\title{
$\xi$
}

20.746 DEPARTMENT OF THE INTERIOR

Hubert Work, Secretary

United Statis Geological Survey, George Otis SMith, Director

\section{Bulletin 746}

\section{GEOLOGIC LITERATURE ON NORTH AMERICA}

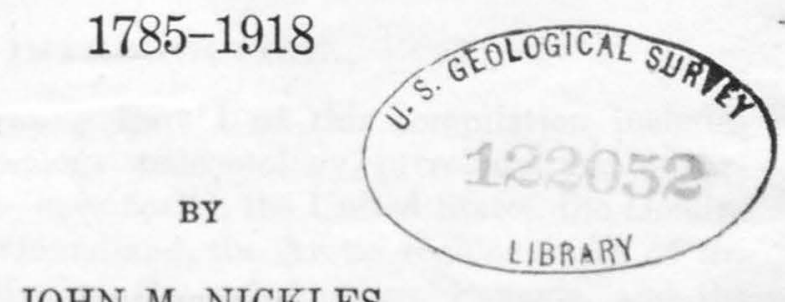

JOHN M. NICKLES

\section{PART I. BIBLIOGRAPHY}

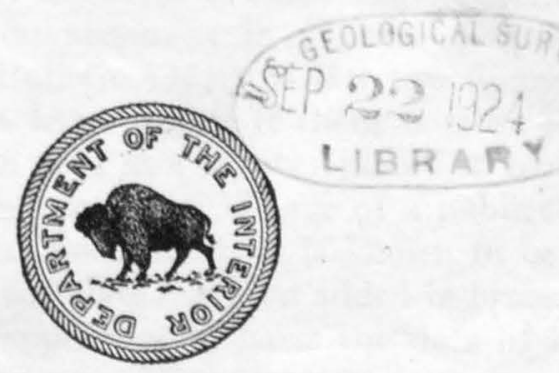

WA SHINGTON

GOVERNMENT PRINTING OFFICE 


\section{CONTENTS.}

Introduction

Page.

List of abbreviations

Serials

Bibliography

II 


\title{
GEOLOGIC LITERATURE ON NORTH AMERICA, 1785-1918.
}

\author{
By John M. Nickles.
}

\section{PART I. BIBLIOGRAPHY.}

\section{INTRODUCTION.}

The bibliography forming Part I of this compilation includes papers relating to the geology, paleontology, petrology, and mineralogy of North America-specifically, the United States, the Dominion of Canada and Newfoundland, the Arctic regions north of the continent, Greenland, Mexico, Central America, Panama, and the West Indies, including Trinidad-and also the Hawaiian Islands. Geographic and descriptive writings and accounts of travels with incidental mention of geologic facts are not included. Textbooks published in America and works general in character by American authors are given, but general papers by foreign writers are excluded unless they have appeared in American publications. Papers by American writers on the geology of other parts of the world are not listed.

The papers of each author are listed in chronologic order by years with no definite order of arrangement in a year. For reference from Part II, the index (Bulletin 747), the last two figures of the year of publication, with a letter added if there is more than one paper in the year, have been used as a number placed in black-faced type before a title. The date on the title page of a publication has been accepted as the date of issue unless it is known to be grossly erroneous; in that case the real date has been added in brackets. In references to publications appearing in parts the date of the part cited has been used if it is given. If no date appears on a publication, the year of issue has been supplied and placed in brackets at the end of the citation; for a few publications, even the approximate year of issue could not be ascertained.

This compilation is in the main a cumulation of the series of bibliographies of North American gcology issued by the United States Geological Survey as Bulletins 44 (1886), 75 (1887-89), 91 (1890), 99 (1891), included in 127 (1732-1891) ; 130, 135, 146, 149, 156, 162, 
and 172 , cumulated in 188 and $189(1892-1900) ; 203,221,240$, and 271 , cumulated in 301 (1901-1905); and 372 (1906-07), 409 (1908), 444 (1909), 495 (1910), 524 (1911), 545 (1912), 584 (1913), 617 (1914), 645 (1915), 665 (1916), 684 (1917), and 698 (1918), not previously cumulated. Many titles not found in these bulletins have been added as a result of the examination of the bibliographies on particular subjects issued by the Survey and many other special bibliographies and from other sources. It is hoped that little of importance has been overlooked.

The magnitude of the work has compelled the elimination of all but the title of the paper, from which unimportant parts have been omitted, and the citation, which has been greatly abbreviated. In the citation of serials a colon immediately follows the number of the volume and is immediately followed by the figures for the inclusive pages. If the volume is in a numbered series other than the first, this number is in parentheses immediately before the volume number. The year of publication is placed in parentheses at the end of the citation. Between the pages and the date "il" means figures of fossils and "map" that a geologic map forms part of the paper or accompanies it. For independent publications the number of pages, the place of publication and date, not in parentheses, are given. An explanation of the abbreviations used follows. 


\section{LIST OF ABBREVIATIONS.}

Abh

abst

Ac.

Agr.

Ak.

Ala.

Alta.

Am.

An.

Anz.

App

Ariz

Ark

As.

B........ bulletin, boletín, etc.

B C....... British Columbia

Bd........ board

Beitr...... Beiträge

Ber....... Berichte

Bien..... biennial

Bot....... botany, etc.

Br........ branch

Brit....... British

Bur...... bureau

c.......... copyright

C R...... compte rendu

Cal........ California

Can....... Canada: Canadian

Centr.... Centralblatt

Cin......... Cincinnati

Co........ county

Col......... collection

Coll....... college

Colo........ Colorado

Cong....... congress

Conn....... Connecticut

cos........ counties

Contr...... contributions

D C...... District of Columbia

Del........ Delaware

Deut..... deutsch, etc.

Diss....... dissertation

Dp....... department

Doc...... document, etc.

Ed........ edition, editor, etc.

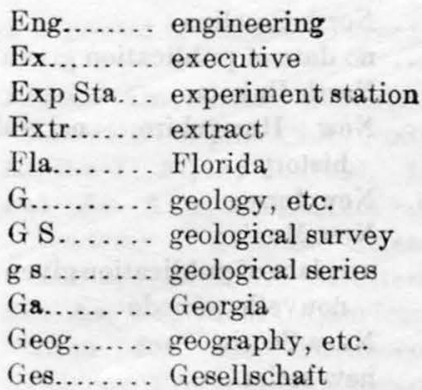


Mitt...... Mitteilungen

Mo...... Missouri; monthly

Mon..... monograph

Mont..... Montana

Mus...... museum

N........ new; north; etc.

N B...... New Brunswick

N C....... North Carolina

n d........ no date of publication given

N Dak.... North Dakota

N H....... New Hampshire; natural history

N J........ New Jersey

N Mex.... New Mexico

n p....... no place of publication given; nouvelle période

N S..... Nova Scotia

n s....... new series

N Sc..... natural science

N W Ter.. Northwest Territories

N Y...... New York

Nat....... national; naturalist

Nebr...... Nebraska

Nev....... Nevada

Newf...... Newfoundland

Oc P...... occasional papers

Okla...... Oklahoma

Ont...... Ontario

Oreg..... Oregon

P........ papers

P E I...... Prince Edward Island

P P...... professional paper

Pa....... Pennsylvania

Phila.... Philadelphia

pls........ plates

port....... portrait

pp........ pages

Pr....... proceedings

priv pr.... privately printed

priv pub. . private publication

pt........ part

Pub....... publications
Q....... quarterly

Que..... Quebec

R........ royal.

R I........ Rhode Island.

rev ed..... revised edition.

Rp....... report.

Rv....... review, revista, etc.

s........... series

S........ Senate; south

S C...... South Carolina

S Dak...... South Dakota

Sask..... Saskatchewan

Sc....... science, scientific, etc.

sc 8...... science series

Sch...... school

sec......... section

sess........ session

St......... Saint; State

St L....... St. Louis

Szb...... Sitzungsberichte

Tech..... technology, etc.

Tenn...... Tennessee

Tex....... Texas

Tr....... transactions

Transl..... translated, etc.

U S....... United States

Univ....... university

v........... volume

Va......... Virginia

Ver........ Verein

Verh....... Verhandlungen

Vt......... Vermont

vol........ volume

W I...... West Indies

W Va..... West Virginia

Wash....... Washington

Wis....... Wisconsin

Wyo...... Wyoming

Y Bk..... yearbook

Zool........ zoology, etc.

Zs........ Zeitschrift

Ztg........ Zeitung 


\section{SERIALS.}

[The abbreviation used in the citation is printed in black-faced type.]

Ac Cienc Méd Habana, An Academia de ciencias médicas, físicas y naturales de la Habana [Cuba], Anales. Ac Gioenia Sc Nat Catania, B. Accademia Gioenia de scienze naturali in Catania. Bollettino delle sedute. Ac Imp Lyon, Cl Sc, Mém Académie impériale des sciences, belles-lettres, et arts de Lyon, Classe des sciences, Mémoires.

Ac Mex Cienc, An Academia mexicana de ciencias exactas, físicas, y naturales, Anuario. México, D. F. Ac N Sc Phila, J; Pr; Min G Sec, Pr Academy of Natural Sciences of Philadelphia, Journal; Proceedings ; Mineralogical and Geological Section, Proceedings.

Ac R Sc Bruxelles, B Académie royale des sciences... de Bruxelles, Bulletins.

Ac Sc Kansas City, Tr Academy of Science of Kansas City [Mo.], Transactions, vol. 1 (1898) [no more published]

Ac Sc Paris, C R Académie des sciences, Paris, Comptes rendus.

Ac Sc Sioux City, Pr Academy of Science and Letters of Sioux City, Iowa, Proceedings.

Ac Sc St. L, Tr Academy of Science of St. Louis, Transactions.

Ala G S Alabama, Geological Survey of. Montgomery and University.

Ala Ind Sc Soc, Pr Alabama Industrial and Scientific Society, Proceedings. University.

Albany Inst, $\mathrm{Pr}$; Tr Albany [N. Y.] Institute, Proceedings; Transactions.

Allgem Berg- u Hüttenm Ztg. Allgemeine berg- und hüttenmännische Zeitung. Quedlinburg
Alpina Americana; published by the American Alpine Club, Philadelphia. Alpine J Alpine Journal. London.

Am Ac Arts, Pr; Mem American Academy of Arts and Sciences, Proceedings; Memoirs. Boston.

Am As, Pr; Mem American Association for the Advancement of Science, Proceedings; Memoirs.

Am As Museums, $\operatorname{Pr}$ American Association of Museums, Proceedings.

Am As Petroleum G, B American Association of Petroleum Geologists, Bulletin.

Am Bur Geog, B American Bureau of Geography, Bulletin. Winona, Wis.

Am Chem Soc, J American Chemical Society, Journal. New York.

Am G American Geologist. Minneapolis.

Am G As, B American Geological Association, Bulletin. Athens, Tenn.

Am Geog Soc, B; J American Geographical Society of New York, Bulletin; Journal.

Am Geog Stat Soc, J American Geographical and Statistical Society, Journal. New York.

Am I M Eng, Tr; B American Institute of Mining Engineers, Transactions; Bulletin. New York.

Am J Agr American Journal of Agriculture and Science. Albany, N. Y. Am J Conch American Journal of Conchology. Philadelphia.

Am $J$ Sc American Journal of Science. New Haven, Conn.

Am M Cong American Mining Congress. See also International Mining Congress.

Am Meteorological J American Meteorological Journal Ann Arbor, Mich. 
Am Micro Soc, $\operatorname{Pr}$ American Microscopical Society, Proceedings.

Am Miner $J$ American Mineralogical Journal (Bruce), vol. 1, 1814 [no more published]. New York.

Am Mineralogist American Mineralogist. Philadelphia and Lancaster, $\mathrm{Pa}$.

Am Mo Mag American Monthly Magazine. New York.

Am Mus J American Museum Journal (American Museum of Natural History).

Am Mus N H, B; Mem American Museum of Natural History, Bulletin; Memoirs. New York.

Am Nat American Naturalist. Salem, Mass., and elsewhere.

Am Ph Soc, Tr; Pr American Philosophical Society, Transactions; Proceedings. Philadelphia.

Am Q J Agr American Quarterly Journal of Agriculture and Science (later American Journal of Agriculture and Science). Albany, New York.

Am Q Micro J American Quarterly Microscopical Journal. New York.

Am Scenic and Historic Preservation Soc, An Rp American Scenic and Historic Preservation Society, Annual Report. Albany, N. Y.

Am Soc Civil Eng, Tr American Society of Civil Engineers, Transactions. New York.

An Bot Annals of Botany. London.

An G Paléont Annales de géologie et de paléontologie. Palermo, Italy.

An Géog Annales de géographie. Paris.

An Iowa Annals of Iowa. Iowa City.

An M Belgique Annales des mines de Belgique. Bruxelles.

An $\mathrm{Mag} \mathrm{N} \mathrm{H}$ Annals and Magazine of Natural History. London.

An Mex Cienc Anales mexicanos de ciencias ... México, D. F.

An Mines Annales des mines. Paris.

An Paléont Annales de paléontologie. Paris.

An Physik Annalen der Physik und Chemie (J. C. Poggendorff). Leipzig.
An Sc, Cleveland Annals of Science, Cleveland, Ohio.

An Sc Géol Annales des sciences géologiques. Paris.

An Sc Nat, Zool Annales des sciences naturelles, Zoologie. Paris,

An Trav Pub Belgique Annales des travaux publies de Belgique. Brux. elles.

Anat Anz Anatomischer Ánzeiger. Jena.

Appalachia. Boston.

Applied Sc Applied Science. Toronto, Ont.

Arch Anat, Phys, wiss Med Archiv für Anatomie, Physiologie, und wissenschaftliche Medicin. Berlin.

Arch Bergbau Archiv für Bergbau und Hüttenwesen (Karsten). Berlin.

Arch Miner Archiv für Mineralogie, Geognosie, Bergbau und Hüttenkunde (Karsten; Dechen). Berlin. Arch Naturg Archiv für Naturge. schichte (Wiegmann). Berlin.

Arch Sc Phys Nat Archives des sciences physiques et naturelles (Bibliothèque universelle de Ge. nève). Geneva.

Archives of Science Orleans Co [Vt] Soc N Sc, Tr Archives of Science and Orleans County [Vt.] Society of Natural Sciences, Transactions. Newport, Vt.

Ariz St Bur Mines, B Arizona State Bureau of Mines, Bulletin. Tueson.

Ark G S Arkansas, Geological Survey of. Little Rock.

As Am G, Rp Association of Ameri. can Geologists and Naturalists, Re. ports,

As Am Geog, An Association of American Geographers, Annals.

As Eng Soc, J Association of Engi. neering Societies, Journal. Philadelphia.

As Franç, C R Association française pour l'avancement des sciences, Compte Rendu. Paris.

Astron Soc Pacific, Pub Astronomical Society of the Pacific, Publica. tions. San Francisco. 
Augustana Libr Pub Augustana Library Publications. Rock Island, III.

Australasian As, Rp Australasian Association for the Advancement of Science, Reports. Sydney.

B Am Pal Bulletins of American Paleontology. Ithaca, N. Y.

B C Bur Mines, An Rp; B; B C Minister Mines, An $\mathbf{R p}$ British Columbia Bureau of Mines, Annual Report; Bulletin; British Columb:a Minister of Mines, Annual Report.

B Sc Nat Bulletin des sciences naturelles et de géologie (Férussac). Paris.

Baltimore Med Phil Lyc Baltimore [Md.] Medical and Philosophical Lycoeum.

Beitr Geoph Beiträge zur Geophysik. Leipzig.

Berg- u Hüttenm Ztg Berg- und hüttenmännische Zeitung. Leipzig.

Berkshire Hist Sc Soc, Four papers of Berkshire Historical and Scientific Society. Pittsfield, Mass.

Bernice Pauahi Bishop Mus, Oc P Bernice Pauahi Bishop Museum, Occasional Papers. Honolulu, H. I.

Biol B Biological Bulletin. Boston.

Biol Centralbl Biologisches Centralblatt. Erlangen.

Biol Soc Wash, Pr Biological Society of Washington, D. C., Proceedings.

Birmingham $\mathrm{Ph}$ Soc, $\mathrm{Pr}$ Birmingham [England] Philosophical Society, Proceedings.

Bol Agr Boletín de agricultura, minería é industrias. México, D. F.

Bol Minero Boletín minero. Organo del Departamento de minas de la Dirección de minas y petróleo. México, Secretaría de fomento, colonización é industria, México, D. F.

Bol Petróleo Boletín del petróleo. México, D .F.

Boston J N H Boston Journal of Natural History.

Boston J Ph Boston Journal of Philosophy and the Arts.
Boston Soc N H, Pr; Oc P; Mem; Anniv Mem Boston Society of Natural History, Proceedings; Occasional Papers; Memoirs; Anniversary Memoirs.

Bot Gaz Botanical Gazette. Chicago. Brit As, Rp British Association for the Advancement of Science, Report. London.

Brookville Soc N H, B Brookville [Ind.] Society of Natural History, Bulletin.

Buffalo Soc N Sc, B Buffalo [N. Y.] Society of Natural Sciences, Bulletin.

Bur Am Ethnology, B Burean of American Ethnology, Bulletin. Washington, D. C.

Cal Ac Sc; Pr; Oc P; Mem California Academy of Sciences; Proceedings; Occasional Papers; Memoirs. San Francisco.

Cal $J$ Tech California Journal of Technology. Berkeley, Cal.

Cal Phys Geog Club, B California Physical Geography Club, Bulletin. Berkeley, Cal.

Cal St M Bur, An Rp; B California State Mining Bureau, Annual Report; Bulletin. San Francisco.

[Cal] Univ Chronicle [California, University of] University Chronicle, Berkeley, Cal.

Crl, Univ, Dp G, B California, University of, Publications, Department of Geology, Bulletin. Berkeley, Cal.

Cal, Univ, Pub Geog California, University of, Publications in Geography.

Cal, Univ, Seism Sta, B. California, University of, Publications, Seismographic Stations, Bulletin.

Cambridge $\mathrm{Ph}$ Soc, $\mathrm{Pr}$ Cambridge [England] Philosophical Society, Proceedings.

Can Alpine $\mathrm{J}$ Canadian Alpine Journal. Banff, Alta.

Can, Dp Interior, $\mathbf{R p}$ Chief Astronomer Canada, Department of the Interior, Report of the Chief Astronomer, Ottawa. 
Can Dp Interior, Sup Mines, $\mathbf{R p}$ Canada, Department of the Interior, Superintendent of Mines, Report.

Can Entomologist Canadian Entomologist. London, Ont.

Can G S; An Rp; Sum Rp; Mem; Mus B; Victoria Mem Mus, B Canada, Geological Survey; Annual Report; Summary Report; Memoirs ; Museum Bulletin; Victoria Memorial Museum, Bulletin.

Can Inst, Pr Canadian Institute Proceedings. Toronto.

Can J Canadian Journal, Toronto.

Can M Inst, B; Q B; J Canadian Mining Institute, Monthly Bulletin; Quarterly Bulletin; Journal. Montreal.

Can M J Canadian Mining Journal. Toronto and Montreal.

Can M Rv Canadian Mining Review. Ottawa.

Can, Mines Br, Sum $\mathbf{R p}$ Canada, Department of Mines, Mines Branch, Summary Report. Ottawa, Ont.

Can Nat Canadian Naturalist and Geologist and Proceedings of the Natural History Society of Montreal.

Can Peat Soc, B Canadian Peat Society, Bulletin. Ottawa.

Can Rec N H Canadian Record of Natural History and Geology. Montreal.

Can Rec Sc Canadian Record of Science. Montreal.

Can Sc Mo Canadian Science Monthly. Kentville, N. S.

Canal Record. Ancon, Canal Zone, Panama.

Carnegie Inst Wash, Y Bk; Pub Carnegie Institution of Washington [D. C.], Year Book; Publications.

Carnegie Mus, An; Mem Carnegie Museum, Annals ; Memoirs. Pittsburgh, Pa.

Cassier's Mag Cassier's Magazine. New York.

Central Ohio Sc As, Pr Central Ohio Scientific Association of Urbana, Ohio; Proceedings.

Centralbl Miner Centralblatt für Mineralogie, Geologie, und Paläontologie. Stuttgart.
Century Mag Century Illustrated Monthly Magazine. New York.

Ch News Chemical News, London.

Chicago Ac Sc; B; Sp Pub; Pr; G N H S, B; N H S, B Chicago Academy of Sciences; Bulletin; Special Publication; Proceedings. Geological and Natural History Survey, Bulletin; later Natural History Survey, Bulletin.

Chicago, Univ. Dec Pub; Walker Mus, Contr Chicago, University of, Decennial Publications; Walker $\mathrm{Mu}$ seum, Contributions.

Cin $\mathbf{Q} \mathbf{J}$ Sc Cincinnati Quarterly Journal of Science, edited by S. A. Miller.

Cin Soc N H, J Cincinnati Society of Natural History, Journal.

Cleveland Ac, Pr Cleveland Academy of Natural Science, Proceed. ings.

Coal Age. New York.

Colliery Eng Colliery Engineer. Scranton, $\mathrm{Pa}$.

Colo Bur Mines, Rp Colorado Bureau of Mines, Report.

Colo Coll Pub, sc s; Colo Coll Studies Colorado College Publications, science series; Colorado Col. lege Studies. Colorado Springs.

Colo G S, B; Rp Colorado Geological Survey, Bulletin; Report. Denver. Colo Sch Mines, An Rp; Bien Rp; B; Mag; Q Colorado School of Mines, Annual Report; Biennial Report; Bulletin; Magazine; Quarterly. Golden.

Colo Sc Soc, Pr Colorado Scientific Society, Proceedings. Denver.

Colo St Bur Mines, Rp Colorado State Bureau of Mines, Report. Denver.

Colo, Univ, Studies Colorado, University of, Studies. Boulder.

Cong Arts and Sc (St. Louis, 1904) Congress of Arts and Science (St. Louis, 1904).

Conn Ac, Tr; Mem Connecticut Academy of Arts and Sciences, Transactions; Memoirs. New Haven. Conn G S, B Connecticut Geological Survey, Bulletin. Hartford. 
Contr Sc Contributions to Science. Charles City, Iowa.

Copenhagen, Univ, Miner G Mus, Contr Miner Copenhagen, University, Mineralogical and Geological Museum, Contributions to Mineralogy.

Cosmos. Paris.

Costa Rica, B Fomento Costa Rica, Boletín de fomento. San José.

Costa Rica, Centro de Estudios Sismológicos, An Costa Rica, Centro de estudios sismologicos, Anales. San José.

Cuba, Dir Montes, B IMinas Cuba, Dirección de montes y minas, Boletín de minas. Habana.

Dansk G Forening, Medd Dansk Geologisk Forening, Meddelelser. Köbenhavn.

Davenport Ac Sc, Pr Davenport [Iowa] Academy of Natural Sciences, Proceedings. Later Davenport Academy of Sciences.

Delaware Co Inst Sc, $\operatorname{Pr}$ Delaware County Institute of Science, Proceedings. Media, Pa.

Denison Univ, Sc Lab, B Den'son University, Scientific Laboratories, Bulletin. Granville, Ohio.

Deut G Ges, Zs; Monatsb Deutsche geologische Gesellschaft, Zeitschrift; Monatsberichte, Berlin.

Deut Geog Blätter Deutsche geographische Blätter. Herausgegeben von der Geographischen Gesellschaft in Bremen.

Deut Oesterr Alpen-Ver, Zs Deutscher und oesterreichischer Alpen-Verein, Zeitschrift. München [etc.].

Deut Rundschau Deutsche Rundschau. Berlin.

Drury Coll, Bradley G Field Sta, B Drury College, Bradley Geological Field Station, Bulletin. Springfield, Mo.

Dublin Q $\mathbf{J}$ Sc Dublin Quarterly Journal of Science.

Durham, Univ, Ph Soc, Pr Durham, University of, Philosophical Society, Proceedings.
E. M. Mus G Coll N J, Contr E. M. Museum of Geology and Archaeology of the College of New Jersey, Contributions. Princeton, N. J.

Ec G Economic Geology. Lancaster, $\mathrm{Pa}$.

Edinb G Soc, Tr Edinburgh Geological Society, Transactions.

Edinb $\mathrm{N}$ Ph J; Edinb $\mathrm{Ph} \mathrm{J}$ Edinburgh New Philosophical Journal. Preceded by Edinburgh Philosophical Journal.

Elisha Mitchell Sc Soc, J Elisha Mitchell Scientific Society, Journal. Chapel Hill, N. C.

Elliott Soc N H Charleston, Pr Elliott Society of Natural History of Charleston [S. C.], Proceedings.

Eng As South, Tr Engineering Association of the South, Transactions. Nashville, Tenn.

Eng Club Phila, Pr. Engineers' Club of Philadelphia, Proceedings.

Eng $M$ J Engineering and Mining Journal. New York.

Eng Mag Engineering Magazine. New York.

Eng Soc W $\mathrm{Pa}, \mathrm{Pr}$ Engineers' Society of Western Pennsylvania, Proceedings. Pittsburgh.

Eng Soc York, Pr Engineering Society of York [Pa.], Proceedings

Entom News Entomological News. Philadelphia.

España, Com Mapa G, B España, Comision del mapa geologico, Boletín. Madrid.

Essex Co $\mathrm{N}$ H Soc, J Essex County Natural History Society, Journal. Salem, Mass.

Essex Inst, B; Pr Essex Institute, Bulletin; Proceedings. Salem, Mass.

Fed Can M Inst, J Federated Canadian Mining Institute (later, Canadian Mining Institute), Journal.

Fed Inst IM Eng, Tr Federated Institution of Mining Eng neers, Transactions. Newcastle-upon-Tyne.

Field (Col) Mus, Pub, g s; zool s Field Columbian Museum (later, Field Museum), Publication, geological series; zoological series. Chicago. 
Fla G S, An Rp Florida Geological Survey, Annual Report. Tallahassee.

Forum, The. New York.

[France], Comm Sc Mex, Arch [France], Commission scientifique du Mexique, Archives. (Archives de 1a Commission scientifique du Mexique, publiées sous les auspices du Ministère de l'instruction publique). 3 vols., Paris, 1865-67.

Frankfurter Ver Geog, Jber Frankfurter Verein für Geographie und Statistik, Jahresbericht. Frankforton-the-Main.

Franklin Inst, J Franklin Institute, Journal. Philadelphia, Pa.

Freunde Naturw, Ber (Haidinger) Freunde der Naturwissenschaften in Wien, Berichte über die Mittheilungen (W. Haidinger).

G As London, Pr Geologists' Association, London, Proceedings.

G Fören Stockholm, Förh Geologiska Föreningens i Stockholm, Förhandlingar.

G IM Soc Am Univ, Y Bk Geological and Mining Society of American Universities, Year Book and Directory. Stanford University, Cal.

G Mag Geological Magazine. London.

G $\mathrm{Pa}$ Geology of Pennsylvania, by H. D. Rogers, 2 vols, maps. Philadelphia. 1858.

G Pal Abh Geologische und paleontologische Abhandlungen. Jena.

G Reichs-Mus Leiden, Samm Geologische Reichs-Museum in Leiden, Sammlungen.

G Rundschau Geologische Rundschau. Leipzig.

G Sc B Geological and Scientific Bulletin. Published by the Texas State Geological and Scientific Association. Vol. 1, 1888-89. Hous. ton, Texas.

G Soc Am, B Geological Society of America, Bulletin. Rochester, N. Y., and elsewhere.

G Soc Dublin, J Geological Society of Dublin, Journal.
G Soc Glas, Tr Geological Society of Glasgow, Transactions.

G Soc London, $\mathrm{Tr} ; \mathrm{Pr} ; \mathbf{Q} \mathrm{J}$ Geologi cal Society of London, Transactions Proceedings; Quarterly Journal.

G Soc Pa, Tr Geological Society of Pennsylvania, Transactions, vol. 1 (1835) [no more published]. Phil. adelphia.

G Soc Tokyo, J Geological Society of Tokyo [Japan], Journal.

Ga G S, B Georgia, Geological Survey, Bulletin. Atlanta.

Gen II As Que, J. General Mining Association of the Province of Que. bec, Journal. Ottawa, Ont.

Geog Ges Hamburg, Mitt Geograph. ische Gesellschaft in Hamburg. Mittheilungen.

Geog Ges München, Jber Geograph. ische Gesellschaft in München, Jahresbericht.

Geog J Geographical Journal. London.

Geog Soc Chicago, B Geographic Society of Chicago, Bulletin.

Geog Soc Phila, B Geographical Society of Philadelphia, Bulletin.

Geologist. 2 vols., 1842, 1843, edited by Charles Maxon. London.

Ges Erdk Berlin, Verh; Zs Gesellschaft für Erdkunde zu Berlin, Verhandlungen; Zeitschrift.

Ges Naturf Freunde Berlin, Szb Gesellschaft naturforschender Freunde zu Berlin, Sitzungsberichte.

Ges Naturw Marburg, Schrift Gesellschaft zur Beförderung der gesammten Naturwissenschaften zu Marburg, Schriften.

Hamilton As, J Pr; Hamilton Sc As, J Pr Hamilton [Ont.] Association (later Hamilton Scientific Association), Journal and Proceedings.

Harper's Mag Harper's New Monthly Magazine New York.

Harvard Coll, Mus C Z, B; An Rp; Mem Harvard College, Museum of Comparative Zoology, Bulletin; Annual Report; Memoirs. Cambridge. Mass. 
Harvard Univ B Harvard University Bulletin. Cambridge, Mass.

Hist Sc Soc Manit, Tr Historical and Scientific Society of Manitoba, Transactions. Winnipeg.

Hist Soc Mont, Contr Historical Society of Montana, Contributions. Helena.

Ill Ac Sc, Tr Illinois Academy of Science, Transactions.

Ill Coal M Investigations, B Illinois Coal Mining Investigations, Cooperative Agreement, Bulletin. Urbana, III.

IIl G S, B Illinois State Geological Survey, Bulletin. Urbana.

Ill G S, Ec G Illinois, Geological Survey of, Economical Geology (reprinted from vols. 1-6). Springfield.

IIl N H Soc, Tr Illinois Natural History Society, Transactions, vol. 1 (1861), second edition [no more published]. Springfield, IIl.

IIl Soc Eng Illinois Soc of Engineers and Surveyors, Report of annual meeting. Chicago.

Ill St Ac Sc, Tr Illinois State Academy of Science (later Illinois Academy of Science), Transactions.

Ill St Lab N H, B Illinois State laboratory of Natural History, Bulletin. Urbana, IIl.

Ill St Mus $\mathbf{N}$ H, B Illinois State Museum of Natural History, Bulletin, nos. 1-12. Springfield.

IIl, Univ, B; Univ Studies. Illinois, University of, Bulletin; University Studies. Urbana.

Imp Earthquake Investigation Com, B Imperial Earthquake Investigation Committee, Bulletin. Tokyo, Japan.

Ind Ac Sc, $\operatorname{Pr}$ Indiana Academy of Science, Proceedings. Indianapolis. Ind G S, An Rp; Ind, Dp Stat G, An $\mathrm{Rp}$; Ind, $\mathrm{Dp}$ G N H, An Rp; Ind, Dp $\mathrm{G} N$ Res, An Rp Indiana Geological Survey, 1st-8-9-10th Annual Reports, 1869-1879; Indiana, Department of Statistics and Geology, 1st and 2d Annual Reports; Indiana, Department of Geology and
Natural History, 11th-16th Annual Reports; Indiana, Department of Geology and Natural Resources. 17th-, Annual Reports. Indianapolis.

Inst Físico-geog Nac Costa Rica, An Instituto físico-geográfico nacional de Costa Rica, Anales. San José.

Inst M Eng, Tr Institution of Mining Engineers, Transactions. Newcastle-upon-Tyne.

Inst $\mathbf{M}$ Met, $\mathrm{Tr}$ Institution of Mining and Metallurgy, Transactions. London.

Inst Mex Minas Met, Inf Instituto mexicano de minas $y$ metalurgia, Informes y memorias. México, D. F. Inst Petroleum Tech, $\mathrm{J}$ Institution of Petroleum Technologists, Journal. London.

Int Cong Zool, Pr International Congress of Zoology, Proceedings.

Int G Cong, Guide Exc; C R; Rp; Guide Book International Geological Congress, Guide des excursions; Comptes rendus; Report; Guide Book.

Int Geog Cong, Rp; Verh International Geographical Congress, Report; Verhandlungen.

Int. $\mathbf{M}$ Cong International Mining Congress; later, American Mining Congress.

Int $\mathbf{Q}$ International Quarterly. New York.

Int $\mathbf{R v}$ International Review. New York.

Int Zool Cong International Zoologieal Congress.

Iowa Ac Sc, Pr Iowa Academy of Sciences, Proceedings. Des Moines.

Iowa G S Iowa Geological Survey. Des Moines.

Iowa Hist Rec Iowa Historical Record. Iowa City.

Iowa Institutions, B Iowa State Institutions, Bulletin. Des Moines.

Iowa Nat Iowa Naturalist. Iowa City.

Iowa, Univ, Lab N H, B Iowa, State University, Laboratories of Natural History, Bulletin. Iowa City, Iowa. 
Iron Steel Inst, J Iron and Steel Institute, Journal. London.

Ist Bologna, R Ac Sc, Cl Sc Fis, Mem Istituto di Bologna, Reale Accademia delle scienze, Classe di scienze fisiche, Memorie.

Italia, R Comitato G, B Italia, Real Comitato geologico, Bollettino. Rome.

J Anat Phys Journal of Anatomy and Physiology. London.

$J$ Bot Journal of Botany. London.

J Chem Phys Journal für Chemie und Physik (Schweigger). Halle

J G Journal of Geology. Chicago, Ill.

J Geog Journal of Geography. Lancaster, Pa. and elsewhere.

$J$ Indus Eng Chem Journal of Industrial and Engineering Chemistry. Easton, $\mathrm{Pa}$.

$J$ Mines Journal des mines. Paris.

J Morph Journal of Morphology. Boston.

J Phys Journal de physique, de chimie, d'histoire naturelle et des arts. Paris.

$J$ Phys Chem Journal of Physical Chemistry. Ithaca, N. Y.

J Sch Geog Journal of School Geography. New York.

J Zool Journal de Zoologie. Paris.

Jb Miner Jahrbuch für Mineralogie, Geognosie, Geologie und Petrefaktenkunde (Leonhard und Bronn). Heidelberg.

Johns Hopkins Univ Cir Johns Hopkins University Circular. Baltimore, Md.

K Ak Wiss, Mat-nat Cl, Szb Kaiserliche Akademie der Wissenschaften. Mathematische - naturwissenschaftliche Classe, Sitzungsberichte. Wien.

K-Bayer Ak Wiss München, Matphys Kl, Szb; Abh Königlich-bayerische Akademie der Wissenschaften zu München, Mathematisch-physikalische Klasse, Sitzungsberichte; Abhandlungen.

K-Böhm Ges Wiss, Mat-nat Cl, Szb Königlich-böhmische Gesellschaft der Wissenschaften in Prag, Mathematisch-naturwissenschaftliche Classe, Sitzungsberichte.
K Danske Vid Selsk, Skrift Kongelige danske Videnskabernes Selskabs, Skrifter. Copenhagen.

K Ges Wiss Göttingen, $\mathbf{A b h}$ König. liche Gesellschaft der Wissenschaf. ten zu Göttingen, Abhandlungen.

K-k G Reichsanstalt, Verh; Jb Kais. erlich-königliche geologische Reichs. anstalt, Verhandlungen; Jahrbuch, Wien.

K-k Geog Ges Wien, Mitt Kaiserlichkönigliche geographische Gesellschaft in Wien, Mittheilungen.

K-k Naturh Hofmus, An Kaiserlich. königliche naturhistorische Hofmu. seum, Annalen. Wiren.

K-k Zool-bot Ges Wien, Verh Kaiserlich-königliche zoologisch-botani. sche Gesellschaft in Wien, Verhand. lungen.

K-Preuss Ak Wiss Berlin, Mber; Szb; $\mathrm{Abh}$ Königlich-preussische Aka. demie der Wissenschaften zu Berlin, Monatsbericht; Sitzungsber i c h t e; Abhandlungen.

K-Sächs Ges Wiss Leipzig, Mat-phys Cl, Ber Königlich-sächsische Gesellschaft der Wissenschaften zu Leipzig, Mathematisch - physische Classe; Berichte über die Verhand. lungen.

K Svenska Vet-Ak Hdl; Öfv Kong. liga svenska Vetenskaps-Akademiens Handlingar; Öfversigt til Handlin. gar. Stockholm.

Kans Ac Sc, Tr Kansas Academy of Science, Transactions. Topeka.

Kans St Bd Agr, Tr; An Rp; Bien Rp Kansas State Board of Agriculture, Transactions; Annual Report; Biennial Report. Topeka.

Kans, Univ G S Kansas, The University Geological Survey. Topeka.

Kans Univ Q Kansas University Quarterly. Lawrence.

Kans Univ, Sc B Kansas University, Bulletin. Science Bulletin. Lawrence.

Kansas City Rv Sc Kansas City [Mo.] Review of Science and Industry. See also Western Review of Science and Industry. 
Kansas City Scientist. Kansas City, Mo.

Ky G S; Rp Prog; B Kentucky Geological Survey; Report of Progress; Bulletin. Frankfort.

I Sup M Inst, Pr Lake Superior Mining Institute, Proceedings.

La Géog La Géographie. Paris.

La Naturaleza. México, D. F.

La St Exp Sta, G Agr La Louisiana State Experiment Stations, Geology and Agriculture of Louisiana. Baton Rouge.

La St Univ, An Rp Sup Louisiana State University, Annual Report of Superintendent. New Orleans.

Lackawanna Inst, Pr Lackawanna Institute of History and Science, Proceedings and Collections. Scranton, $\mathrm{Pa}$.

Leeds G As, Tr Leeds Geological Association, Transactions.

Leland Stanford Jr Univ, Pub Leland Stanford Junior University, Publications.

Linn Soc, J, Zool Linnean Society, Journal, Zoology, London.

Lit Hist Soc Quebec, Tr Literary and Historical Society of Quebec, Transactions.

Lit $\mathrm{Ph}$ Soc $\mathrm{N} \mathbf{Y}, \mathrm{Tr}$ Literary and Philosophical Society of New York, Transactions,

Liverpool G As, Tr [J] Liverpool Geological Association, Transactions [vol. 9 called Journal].

Liverpool G Soc, Pr Liverpool Geological Society, Proceedings.

Liverpool Geog Soc, Tr An Rp Liverpool Geographical Society, Transactions and Annual Report of the Council.

Lyc N H N Y; An; Pr Lyceum of Natural History of New York, Annals; Proceedings. Later New York Academy of Sciences.

M J Mining Journal. London.

M Mag Mining Magazine. London.

M Mag Mining Magazine; later Mining and Statistic Magazine. New York.
M Met Soc Am, B Mining and Metallurgical Society of America, Bulletin. New York.

M Metal Mining and Metallurgy. New York.

M Reporter Mining Reporter. Denver.

M Sc Press Mining and Scientific Press. San Francisco, Cal.

M Science. Min'ng Science. Denver.

M Soc N S, J Mining Society of Nova Scotia, Journal. Halifax.

M Stat Mag See Mining Magazine.

M World Mining World. Later, Mining and Engineering World. Chicago.

Maclurean Lyc, Contr Maclurean Lyceum, Contributions. Philadelphia.

Mag N H Magazine of Natural History (Loudon). London.

Malacol Soc L, Pr Malacological Society of Lendon, Proceedings. London.

Manchester G (M) Soc, Tr Manchester Geological (later, and Mining) Society, Transactions.

Manchester Lit Ph Soc, Mem Manchester Literary and Philosophical Society, Memoirs and Proceedings.

Mazama. Portland, Oreg.

McClure's Mag McClure's Magazine. New York.

McGill Univ, Peter Redpath Mus McGill University, Montreal, Peter Redpath Museum.

Md Ac Sc, Tr Maryland Academy of Sciences, Transactions. Baltimore.

Md G S, Sp Pub Maryland Geological Survey, Special Publication.

Me Bd Agr, An Rp Maine Board of Agriculture, Annual Report. Augusta.

Me St Water Storage Comm, An $\mathbf{R p}$ Maine State Water Storage Commission, Annual Report. Augusta.

Med Grönland Meddelelser om Grönland. Copenhagen.

Med Phys J Medical and Physical Journal. London.

Med Soc Pa, Tr Medical Society of the State of Pennsylvania, Transactions. Philadelphia. 
Meriden Sc As, Tr Meriden [Conn.] Scientific Association, Proceedings and Transactions.

Méx, Com G, B; I G, B; Par México, Comisión geologica, Boletín; Instituto geológico, Boletín; Parergones.

Mex M J Mexican Mining Journal. México, D. F.

Méx, Min Fomento, An Mexico, Ministerio de fomento, Anales.

[Méx], Sec Fomento, Bol [México], Secretaría de fomento, Boletín.

Mich Ac Sc, Rp; An Rp Michigan Academy of Science, Report; Annual Report. Lansing.

Mich G S, Rp Michigan Geological Survey; Michigan State Board of Geological Survey, Report. Lansing.

Mich Miner Michigan Miner. Sag. inaw.

Mich Univ, Mus Zool, Oc P Michigan, University, Museum of Zøology, Occasional Papers. Ann Arbor.

Middlebury Hist Soc, Papers and Pr Middlebury [Vt.] Historical Society, Papers and Proceedings.

Min B Mining Bulletin. Published bimonthly by the Department of Mining Engineering of the Pennsylvania State College.

Min Mex El Minero mexicano. Mé. xico, D. F.

Miner Mag Mineralogical Magazine and Journal of the Mineralogical Society. London.

Miner Mitt (Tschermak) (K-k G Reichsanstalt, Jb) Mineralogische Mittheilungen (Tschermak). Also as Beilage to Kaiserlich-königliche geologische Reichsanstalt, Jahrbuch. Wien.

Mining. Journal of the Northwest Mining Association. Spokane, Wash.

Minn Ac N Sc, B Minnesota Academy of Natural Sciences, Bulletin. Minneapolis.

Minn G S Minnesota, Geological and Natural History Survey. Minneapolis.

Minn Sch Mines, Exp Sta B Minnesota School of Mines, Experiment Station, Bulletin. Minneapolis.
Minn, Univ, Q B Minnesota, University of, Quarterly Bulletin. Min. neapolis.

Miss Agr Exp Sta, B Mississippi Agricultural Experiment Station, Bulletin. Agricultural College.

Miss G S, B Mississippi Geological Survey, Bulletin. Agricultural College.

Mo G S; Mo Bur G Mines Missouri. Geological Survey: Missouri Bureau of Geology and Mines. Jeffer. son City.

Mo Micro J Monthly Microscopical Journal. London.

Mo, Univ, B sc s; Mus B; Studies Missouri, University of, Bulletin scence series; Museum Bulletin; Studies. Columbia, Mo.

Mo, Univ, Sch Mines, B Missouri, University of, School of Mines and Metallurgy, Bulletin. Rolla.

Mont, Univ, B Montana, University of. Bulletin. Missoula.

Monthly Am J G Monthly American Journal of Geology and Natural Science [G. W. Featherstonhaugh]. Philadelphia.

Morph Jb Morphologisches Jahr. buch. Leipzig.

Mus d'Hist Nat, An; B Muséum national d'histoire naturelle, Annales: Bulletin. Paris.

Mus Nac Méx, An Museo nacional de México, Anales. México, D, F.

Mus R d'Hist Nat Belgique, B Musée royal d'histoire naturelle de Belgique, Bulletin. Bruxelles.

N Am Rev North American Review. New York.

N C G S, B North Carolina Geological Survey, Bulletin.

N Dak Agr Coll Exp Sta, Bien Rp North Dakota Agricultural College Experiment Station, Biennial Report. Fargo.

N Dak G S, Bien Rp North Dakota Geological Survey, Biennial Report. Bismarck. 
N Engl Inst M Eng, Tr North of England Institute of Mining Engineers (later, North of England Institute of Mining and Mechanical Engineers), Transactions, Newcastleupon-Tyne.

N H Rv Natural History Review. London.

N H Soc N B, B Natural History Society of New Brunswick, Bulletin. St John.

N J, Dp Conservation, An Rp New Jersey, Department of Conservation and Development, Annual Report. Trenten, N. J.

N J, G S, An Rp; Final Rp; Pal; G N J New Jersey, Geological Sur vey, Annual Report; Annual Report of the State geologist; Final Report of the State geologist; Paleontology ; Geology of New Jersey (Cook), 1868 Trenton.

N Jb; Beil Bd Neues Jahrbuch für Mineralogie, Geologie, und Paläontologie; Beilage Band. Stuttgart.

N Mex, Univ, B g s New Mexico, University, Bulletin, geological series. Albuquerque.

N S, Dp Mines, Rp Nova Scotia, Department of Mines, Report. Halifax.

N S Inst $N$ Sc, Pr Tr Nova Scotia Institute of Natural Science, Proceedings and Transactions. Halifax.

N S Lit Sc Soc, Tr Nova Scotia Literary and Scientific Society, Transactions. Halifax.

N Y Ac Sc, An; Tr; Mem New York Academy of Sciences, Annals; Transactions; Memoirs

N Y, Bd Agr, Mem New York, Board of Agriculture, Memoirs. Albany.

N Y Bot Garden, B New York Botanical Garden, Bulletin.

N Y Comm St Res Niagara, An Rp New York (State), Commissioners of the State Reservation at Niagara, Annual Report. Albany.

N Y G S New York Geological Survey. Albany.

$28737^{\circ}-23-2$
N Y Med Phys J New York Medical and Physical Journal.

N Y Micro Soc, J New York Microscopical Society, Journal.

N Y Miner Club, B New York Mineralogical Club, Bulletin.

N Y St Agr Soc, Tr New York State Agricultural Society, Transactions. Albany.

N Y St Cab, An Rp New York State Cabinet of Natural History, Annual Report of the Regents of the University. Albany.

N Y St G, An Rp New York, State Geologist, Annual Report. Albany.

$N$ Y St Mus, An Rp New York State Museum of Natural Histery, Annual report. Albany.

Nassauischer Ver Naturk, Jb Nassauischer Verein für Naturkunde, Jahrbücher. Wiesbaden.

Nat Ac Sc, Biog Mem; Mem; Pr National Academy of Sciences, Biographical Memoirs; Memoirs; Proceedings. Washington, D. C.

Nat Gas As Am, Pr Natural Gas Asseciation of America, Proceedings.

Nat Geog Mag National Geographic Magazine. Washington, D. C.

Nat Geog Soc, Nat Geog Mon National Geographic Society. National Geographic Monographs, vol 1, 10 nos., 1895. Washington, D. C.

Nat Inst, B Pr; Pr, n s National Institution (later, Institute) for the Promotion of Seience, Bulletin of the Proceedings; Proceedings, new series. Washington, D. C.

Nat Sc Natural Science. London.

Nat Sc As Staten Island, Pr Natural Science Association of Staten Island [N. Y.], Proceedings.

Nat Sc J Natural Science Journal, vol. 1 , nos. 1 and 2 [no more published], 1897. New Bedford, Mass.

Naturaleza (La) Periódico científico de la Sociedad mexicana de historia natural. México, D. F.

Naturaliste Can Le Naturaliste canadien. Quebec. 
Naturalist's Leisure Hour and Monthly Bulletin. A. E. Foote. Philadelphia.

Nature. London.

Naturf Ges Leipzig, Szb Naturforschende Gesellschaft zu Leipzig, Sitzungsberichte.

Naturh Ver Preus Rheinl, Verh Naturhistorischer Verein der preussischen Rheinlande und Westphalens, Verhandlungen. Bonn.

Naturh Ver Preus Rheinl, Verh Niederrhein Ges Bonn, Szb) Naturhistorischer Verein der preussischen Rheinlande ..., Verhandlungen (Niederrheinische Gesellschaft für Naturund Heilkunde in Bonn, Sitzungsberichte).

Naturh-med Ver Heidelberg, Verh Naturhistorisch-medicinischer Verein zu Heidelberg, Verhandlungen.

Naturw Abh Naturwissenschaftliche Abhandlungen (Haidinger). Wien.

Naturw Ges Isis Dresden, Szb; $\mathbf{A b h}$ Naturwissenschaftliche Gesellschaft Isis in Dresden, Sitzungsberichte; Abhandlungen.

Naturw Ver Halle, Jber Naturwissenschaftlicher Verein [für Sachsen und Thüringen] in Halle, Jahresberichte.

Naturw Ver Neuvorpommern und Rügen in Greifswald, Mitt Naturwissenschaftlicher Verein für Neuvorpommern und Rügen in Greifswald, Mittheilungen.

Naturw Ver Steiermark, Mitt Naturwissenschaftlicher Verein für Steiermark, Mitteilungen. Graz.

Naturw Wochensch Naturwissenschaftliche Wochenschrift. Berlin.

Nautilus. Philadelphia.

Nebr Ac Sc, Pub; Pr Nebraska Academy of Sciences, Publications; Proceedings.

Nebr St Bd Agr, An Rp Nebraska State Board of Agriculture, Annual Report. Lincoln, Nebr.

Nebr St Hist Soc, Pr Nebraska State Historical Society, Proceedings and Collections. Lincoln.

Nebr Univ, Studies Nebraska University, University Studies. Lincoln.
Nev, , Univ, Dp G M, B Nevada, University of, Department of Geology and Mining, Bulletin. Reno.

New Orleans Ac Sc, Papers New Orleans [La.] Academy of Sciences, Papers.

Newport N H Soc, Pr Newport [R. I.] Natural History Society, Proceedings.

Niederrhein Ges Bonn, Szb Niederrhe nische Gesellschaft für Naturund Heilkunde zu Bonn, Sitzungsberichte. Issued with Naturhistorische Verein der preussischen Rheinlande und Westphalens, Verhandlungen.

Oesterreichische Zs Berg- u Hüttenw Oesterreichische Zeitschrift für Berg- und Hüttenwesen. Wien.

Ohio G S, B Ohio Geological Survey, Bulletin. Columbus.

Ohio M J Ohio Mining Journal. Columbus.

Ohio Nat Ohio Naturalist, Ohio State University, Columbus.

Ohio St Ac Sc, An Rp; Pr; Sp P Ohio State Academy of Science, Annual Report; Proceedings; Special Papers: Columbus.

Ohio St Univ, B Ohio State University, Bulletin. Columbus.

Okla, Dp G N H, Bien $\mathrm{Rp}$ Oklahoma, Department of Geology and Natural History, Biennial Report. Guthrie.

Okla G S, B Oklahoma Geological Survey, Bulletin. Norman.

Okla, Univ, Research B Oklahoma, State University, Research Bulletin. Norman.

Oneida Hist Soc, Tr Oneida Historical Society at Utica, N. Y., Transactions.

Onondaga Ac Sc, Pr Onondaga Academy of Science, Proceedings. Syracuse, N. Y.

Onondaga Hist As Sc $\mathbf{S}$ Onondaga Historical Association. Seience series. Syracuse, N. Y.

Ont Bur Mines, An Rp; B Ontario Bureau of Mines, Annual Report; Bulletin. Toronto. 
Oreg Bur Mines; Min Res Oreg Oregon Bureau of Mines and Geology; Mineral Resources of Oregon. Corvallis.

Ottawa Field Nat Club, Tr Ottawa Field Naturalists' Club, Transactions.

Ottawa Lit Sc Soc, Tr Ottawa Literary and Scientitic Society, Transactions.

Ottawa Nat Ottawa Naturalist. Continues the Transactions of the Ottawa Field Naturalists' Club.

$\mathbf{P a}$, Dp Agr, An $\mathbf{R p}$ Pennsylvania, Department of Agriculture, Annual Report. Harrisburg.

$\mathrm{Pa}$ G S [2d], An Rp Pennsylvania, Geological Survey, Second, Annual Report. Harrisburg.

$\mathrm{Pa}$ St Coll; An $\mathrm{Rp}$ Pennsylvania State College; Annual Report.

Pa, Top G S; Rp Pennsylvania, Topographic and Geologic Survey, Report. Harrisburg.

$\mathrm{Pa}$, Univ, Lab, Contr Pennsylvania, University of, Laboratory, Contribu. tions from. Philadelphia.

Pahasapa Q Pahasapa Quarterly. Rapid City, S. Dak.

Pal B Paleontological Bulletins (Cope), Nos, 1-40, 1872-1885. Philadelphia.

Palaeont Abh (Dames u Kayser) Palaeontologische $\mathrm{Ab}$ b a $\mathrm{nd}$ lungen (Dames und Kayser). Jena.

Palaeont Zs Palaeontologische Zeitschrift. Berlin.

Palaeontographica. Cassel.

Penn Monthly. Philadelphia, Pa.

Penn St M $\mathbf{Q}$ Penn State Mining Quarterly. Pennsylvania State College.

Petermanns Mitt; Erg Petermanns Mitteilungen; Ergänzungsheft. Gotha.

Pharmaceutical $\mathrm{J}$ Pharmaceutical Journal and Transactions. London.

Ph Mag Philosophical Magazine. Later London and Edinburgh Philosophical Magazine. Later London, Edinburgh, and Dublin Philosophical Magazine.
Ph Soc Glasgow, Pr Philosophical Society of Glasgow, Proceedings.

$\mathrm{Ph}$ Soc Wash, B Philosophical Society of Washington [D. C.], Bulletin.

Phila Med Phys $J$ Philadelphia Medical and Physical Journal.

Polyt Rv Polytechnic Review. Philadelphia, $\mathrm{Pa}$.

Pop Sc Mo Popular Science Monthly. New York.

Pop Sc Rv Popular Science Review. London.

Portland Soc N H, Pr Portland [Maine] Society of Natural History, Proceedings.

Pottsville Sc As, B Pottsville Scientific Association, $\mathrm{Schuylkill}$ County, Pa., Bulletin [only one number published, 1855]

Poughkeepsie Soc N Sc, Pr Poughkeepsie [N. Y.] Society of Natural Science, Proceedings.

Princeton Coll, B Princeton College [N. J.], Bulletin.

Princeton Coll, E. M. Mus G, Contr Princeton College, E. M. Museum of Geology and Archaeology, Contributions.

Psyche. Cambridge, Mass.

Q J Micro Sc Quarterly Journal of Microscopical Science. London.

Q J Sc Quarterly Journal of Science. London.

Q J Sc Quarterly Journal of Science, Literature, and the Arts. London.

Que, Dp Col..., Mines Br, Rp Quebec (Province), Department of Colonization, Mines and Fisheries, Mines Branch, Report on Mining operations. Quebec.

R Ac Cienc Habana, An Real Academia de ciencias médicas, físicas y naturales de la Habana [Cuba], Anales.

R Astron Soc Can, Pr Royal Astronomical Society of Canada, Selected Papers and Proceedings. Toronto.

R Bot Garden Edinb, Notes Royal Botanical Garden of Edinburgh, Notes. 
R Comitato G Italia, B Reale Comitato geologico d'Italia, Bolletino. See Italia.

R Dublin Soc, J; Sc Pr Royal Dublin Society, Journal; Scientific Proceedings.

R Eng $\mathbf{J}$ Royal Engineers Journal. Chatham.

R G Soc Cornwall, Tr Royal Geological Society of Cornwall, Transactions. Penzance.

R G Soc Ireland, J Royal Geological Society of Ireland, Journal. Dublin.

R Geog Soc, Pr Royal Geographical Society, Proceedings. London.

R I Bur Industrial Statistics, An Rp; Nat Res S, B Rhode Island, Bureau of Industrial Statisties, Annual Report; Natural Resources Survey, Bulletin. Providence.

$\mathbf{R}$ Inst, $\operatorname{Pr}$ Royal Institution of Great Britain, Proceedings. London.

R Irish Ac, Pr Royal Irish Academy, Proceedings. Dublin.

R Micro Soc, J Royal Microscopical Society, Journal. London.

R Phys Soc Edinb, Pr Royal Physical Society of Edinburgh, Proceedings.

R Soc Can, Pr Tr Royal Society of Canada, Proceedings and Transactions. Montreal.

R Soc Edinb, Tr; Pr Royal Society of Edinburgh, Transactions; Proceedings.

R Soc London; $\mathbf{P r} ; \mathrm{Ph}$ Tr Royal Society of London, Proceedings; Philosophical Transactions.

R Soc N S Wales, J Pr Royal Society of New South Wales, Journal and Proceedings. Sydney.

Records of the Past. Washington, D. C.

Republic. Washington, D. C.

Rv Gén Sciences Revue générale des sciences pures et appliquées. Paris.

Rv Scient Revue scientifique... Paris,

Rv Trim Can Revue trimestrielle canadienne. Montreal.

Rv Univ Mines Revue universelle des mines... Liége and Paris.
Revista Minera Revista minera, metalurgica y de ingeniería. Madrid.

Rochester Ac Sc, Pr Rochester [N. Y.] Academy of Science, Proceedings.

Russ-k Min Ges St. Petersburg; Verh Russisch-kaiserliche mineralogische Gesellschaft zu st. Petersburg, Ver. handlungen.

S Cal Ac Sc, B Southern California Academy of Sciences, Bulletin. Los Angeles.

S Dak G S, B South Dakota Geological Survey, Bulletin. Sioux Falls.

S Dak Sch Mines, B South Dalsoti School of Mines, Bulletin. Rapid City.

Salt Lake M Rv Salt Lake [Utah] Mining Review.

San Diego Soc $\mathbf{N} \mathbf{H}, \mathbf{T r}$ San Diego [Cal.] Society of Natural History, Transactions.

San Francisco Micro Soc, Tr S:ın Francisco Microscopical Society, Transactions.

Santa Barbara Soc N H, B Santa Barbara [Cal.] Society of Natura] History, Bulletin.

Sc Advocate Science Advocate. Is sued quarterly by the Natural Sci. ence Society of Atco, N. J.

Sc Am; Sc Am Sup Scientific Ameri. can; Scientific American Supplement. New York.

Sc As Trinidad, Pr Scientific Associ ation of Trinidad, Proceedings. Port of Spain.

Sc Conspectus Science Conspectus Massachusetts Institute of Tech. nology. Boston.

Sc Mo Scientific Monthly. New York.

Sc Mo, Toledo, O Scientific Monthly, Toledo, Ohio.

Sc Progress Science Progress. London.

Sc Soc San Antonio, B Scientific Society of San Antonio [Texas], Bulletin.

Sch Mines Q School of Mines Quarterly. Columbia University. New York. 
Schles Ges, Jber Schlesische Gesellschaft für vaterländische Cultur, Jahres-Bericht. Breslau.

Schweiz Naturf Ges, Verh Schweizerische Naturforschende Gesellschaft, Verhandlungen.

Science. Cambridge, Mass, later New York.

Science (ed. John Michels). New York.

Science News. Salem, Mass.

Scottish Geog Mag Scottish Geographical Magazine. Edinburgh.

Scribner's Mag Scribner's Magazine. New York.

Sedalia N H Soc, B Sedalia [Mo.] Natural History Society, Bulletin.

Seism Soc Am, B Seismological Society of America, Bulletin. Stanford University, Cal.

Senckenbergische Nat Ges Frankfurt, Ber Senckenbergische naturforschende Gesellschaft in Frankfurt am Main, Bericht.

Sierra Club B Sierra Club Bulletin. San Francisco, Cal.

Smiths Inst, An Rp; Smiths Contr Knowl; Smiths Misc Col; Q Is Smithsonian Institution, Annual Report; Smithsonian Contributions to Knowledge ; Smithsonian Miscellaneous Collections; Quarterly Is sue. Washington, D. C.

Soc Arts, J Society of Arts, Journal. London.

Soc Belge G, B Sociêté belge de géologie..., Bulletin. Bruxelles.

Soc Bot France, B Société botanique de France, Bulletin. Paris.

Soc Chem Ind, J Society of Chemical Industry, Journal. London.

Soc Cient Ant Alz, Mem Sociedad científica "Antonio Alzate," Memorias y revista, México, D. F.

Soc Cubana Ing, Rv Sociedad cubana de ingenieros, Revista. Habana.

Soc d'Études Sc d'Angers, B Société d'êtudes scientifiques d'Angers, Bulletin.

Soc Española H N, An So cie d a d española de historia natural, Anales. Madrid.
Soc Franç Minér, B Société française de minéralogie, Bulletin. Paris.

Soc Fribourgeoise Sc Nat, B; Mém Societé fribourgeoise des sciences naturelles, Bulletin; Mémoires. Fribourg.

Soc G Belgique, An Sociêté géologique de Belgique, Annales. Liège.

Soc G France, B; Mém Société géologique de France, Bulletin; Mémoires. Paris.

Soc G Italiana, B Società geologica italiana, Bollettino. Roma.

Soc G Mex, B Sociedad geologica mexicana, Boletín. México, D. F.

Soc G Nord, An; Mém Société géologique du Nord, Annales; Mémoires. Lille.

Soc G Normandie, B Société géologique de Normandie, Bulletin. Havre.

Soc Geog Mex, B Sociedad de geografía y estadística de la República mexicana, Boletín. México, D. F.

Soc Géog Paris, B Société de géographie, Paris, Bulletin.

Soc Gêog Qué, B Sociêté de géographie de Québec, Bulletin.

Soc Hongroise Géog, Ałrégé B Société hongroise de géographie, Abrégé du bulletin. Budapest.

Soc Imp Nat Moscou, B Société impériale des naturalistes de Moscou, Bulletin.

Soc Ind Min, B; C R Men Société de l'industrie minérale, Bulletin; Comptes rendus mensuels des réunions. Saint-Etienne.

Soc Ing Civils France, Mém Societé des ingénieurs civils de France, Mémoires. Paris.

Soc Italiana Sc Nat Milano, Atti Società italiana di scienze naturali... in Milano, Atti.

Soc Ligustica Sc Nat Geog, Atti Societa ligustica di scienze naturali e geografiche, Atti. Genoa.

Soc Mex Geog Estadística, B Sociedad mexicana de geografía y estadística, Boletín. México, D. F.

Soc NIalac Belgique, An Société malacologique de Belgique, Annales. Bruxelles. 
Soc Minér France, B Société minéralogique de France, Bulletin. Paris.

Soc Promotion Agr Sc, Pr Soclety for the Promotion of Agricultural Science, Proceedings of the - Annual Meeting.

Soc Roy Belge de Géog, B Société royale belge de géographie, Bulletin. Bruxelles.

Soc Sc Nat Neuchatel, B Societé des sciences naturelles de Neuchatel, Bulletin.

Soc Zool France, B Sociêtế zoologique de France, Bulletin. Paris.

Southern J Med Phys Sc Southern Journal of the Medical and Physica! Sciences. Nashville, Tenn.

Southwestern As Petroleum G, B Southwestern Association of Petre leum Geologists, Bulletin. Continued as American Association of Petroleum Geologists, Bulletin.

St. Louis Univ, B St. Louis [Mo.] University, Bulletin.

Staten Island As, Pr Staten Island [N. Y.] Association of Arts and Sciences, Proceedings.

Stone. Chicago.

Tech $Q$ Technology Quarterly and Proceedings of the Society of Arts. Earlier, Technology Quarterly. Massachusetts Institute of Technvlogy. Boston.

Tech Rv Technology Review. Massachusetts Institute of Technology. Boston.

Tech Soc Pacific Coast, Tr Technical Society of the Pacific Coast, Transactions. San Francisco.

Tenn G S; Res Tenn; B Tennessee State Geological Survey; Resources of Tennessee; Bulletin. Nashville.

Tenn St Bd Health, B; Rp Tennessee State Board of Health, Bulletin; Report. Nashville.

Terr Magn Terrestrial Magnetism and Atmospheric Electricity. Baltimore.

Tex Ac Sc, Tr Texas Academy of Science, Transactions. Austin, Tex.

Tex G S, Rp Prog Texas Geological Survey, Report of Progress. Austin.
Tex, Univ, B; Min S B Texas University of, Bulletin; Mineral Survey Bulletin. Austin.

Toronto, Univ, Studies, g s Toronto, University of, Studies, geological series.

Torrey Bot Club, B Torrey Botanical Club, Bulletin. New York.

Torreya. Lancaster, Pa.

Transylvania $\mathrm{J}$ Med Transylvania Journal of Medicine. Lexington, Ky.

Tschermak's Mitt Tschermak's mineralogische und petrographische Mittheilungen. Wien.

Tufts Coll Studies Tufts College Studies. Tufts, Mass.

U S, Bur Mines, B; Tech $\mathbf{P}$ United States, Bureau of Mines, Bulletin; Technical Paper, Wash ngton, D. C.

U S, Bur Soils, B United States, Bureau of Soils, Bulletin.

U S, Coast S United States, Coast and Geodetic Survey.

[U S], — Cong — Sess, S Ex D; H Ex D [United States], - Con. gress - session, Senate Executive Document No. - ; House of Representatives Executive Doeument No.

U S, Dp Agr, B United States, Department of Agriculture, Bulletin.

U S, Dp Interior, Off Secretary United States, Department of the Interior, Office of the Secretary.

U S G Expl 40th Par (King) United States Geological Exploration of the Fortieth Parallel (King).

U S G Geog S Terr (Hayden) United States Geological and Geographical Survey of the Territories (Hayden) [title varies].

U S G S, An Rp; P P; B; W-S P; Mon; Min Res; G Atlas, Top Atlas. United States Geological Survey, Annual Report; Professional Paper; Bulletin; Water-Supply Paper; Monograph; Mineral Resources; Geologic Atlas, _- folio (No. _-) ; Topo. graphic Atlas. 
U S Geog G S Rocky Mtn Reg (Powell) United States Geographical and Geological Survey of the Rocky Mountain Region (Powell).

U S Geog S W 100th Mer (Wheeler) United States Geographical Surveys West of the One Hundredth Meridian (Wheeler).

U S Land off United States, General Land Office.

U S Nat Mus, An Rp; B; Pr United States National Museum, Annual Report; Bulletin; Proceedings.

U S, Off Pub Roads, B United States, Office of Public Roads, Bulletin.

U S, Pacific R R Expl United States [War Department], Pacific Railroad Explorations (U. S., 33d Congress, 1st session, House of Representatives Ex. Doc. No. 129, vol. 18, pts. 1-4). Reports of explorations and surveys to ascertain the most practicable and economical route for a rallroad from the Mississippi River to the Pacific Ocean, made... in 1853-4... U. S., 33d Congress $2 d$ session, Senate Ex. Doc. No. 78 and H. Ex. Doc. 91.

U S [War Dp], Chief Eng, An Rp United States [War Department], Chief of Engineers, Annual Report.

Upsala, Univ, G Inst, B Upsala, University, the Geological Institution, Bulletin.

Utah Ac Sc, Tr. Utah Academy of Sciences, Transactions. Salt Lake City.

Va G S, B Virginia Geological Survey, Bulletin. Richmond.

Va, Univ, Ph Soc, B sc s Virginia. University of, Philosophical Society, Bulletin, scientific series. Charlottesville.

Vassar Bros Inst, Tr Vassar Brothers Institute, Transactions. Poughkeepsie, N. Y.

Ver Erdk Dresden, Mitt Verein für Erdkunde zu Dresden, Mitteilungen. Ver Erdk Leipzig, Mitt Verein für Erdkunde zu Leipzig, Mitteilungen.
Ver Freunde Naturg Mecklenberg, Arch Verein der Freunde der Naturgeschichte in Mecklenberg. Archiv.

Ver Freunden Erdk Leipzig. Jber Verein von Freunden der Erdkunde zu Leipzig, Jahresbericht.

Ver Vaterl Naturk Württemberg, Jahresh Verein für vaterländisclıe Naturkunde in Württemberg, Jahreshefte. Stuttgart.

Victoria Inst, $\operatorname{Tr}$ Victoria Institute, or Philosophical Society of Great Britain, Journal of the Transactions. London.

Victoria Inst, Trinidad, $\mathrm{Pr} V$, ctoria Institute, Trinidad, Proceedings.

Videnskabs-Selsk Christiania, Eorh Videnskabs-Selskabet i Christiania, Forhandlingar.

Vt St G, Rp Vermont, State Geologist, Report. Rutland.

W Soc Eng, J Western Society of Engineers, Journal. Chicago, Ill.

w Va G S West Virginia Geological Survey, Charleston and Wheeling.

W Va Univ, Rp Bd Reg West Virginia University, Report of the Board of Regents. Morgantown.

Wagner Free I Sc, Tr Wagner Free Institute of Science of Philadelphia, Transactions.

Walker Museum. See Chicag, Iniversity.

Wash Ac Sc; J; Pr Washington [D. C.] Academy of Sciences, Journal : Proceedings.

Wash, St G, An $\mathbf{R p}$; Wash $\mathbf{G} \mathbf{S}, \mathbf{B}$ Washington, State Geologist, Annual Report; Washington Geological Survey, Bulletin. Tacoma.

Wash, Univ, Pub G Washington. University of, Publications in Geology. Seattle.

Washburn Coll Lab N H, B Washburn College Laboratory of Natural History, Bulletin. Topeka, Kans.

Wernerian $\mathrm{N}$ H Soc, Mem Wernerian Natural History Society, Memoirs. Edinburgh.

West Am Sc West American Scientist. San Diego, Cal. 
Western Eng Western Engineering. San Francisco, Cal.

Western Reserve Hist Soc Tracts Western Reserve Historical Society, Tracts. Cleveland, Ohio.

Western $\mathbf{R v}_{\mathbf{v}} \mathbf{S c}$ Western Review of Science and Industry. With vol. 2, no. 7 , Oct., 1878, name changed to Kansas City Review of Science and Industry. Kansas City, Mo.

Wis Ac Sc, Tr Wisconsin Academy of Science, Arts, and Letters, Transactions. Madison.

Wis Engineer Wisconsin Engineer. Madison.

Wis G $\mathbf{~ S , ~ G ~ W i s ; ~ B ~ W i s c o n s i n ~ G e o - ~}$ logical Survey, Geology of Wisconsin. Later Wisconsin Geological and Natural History Survey, Bulletin. Madison.

Wis $\mathbf{N}$ H Soc, B Wisconsin Natural History Society, Bulletin. Milwaukee.

Wis, Univ, B, Sc s; Eng s Wisconsin, University of, Bulletin, Science series; Engineering series. Madison.

Wyo, G Off, B; Wyo, St G Wyoming, Geologist's Office, Bulletin. Wyoming, State Geologist. Cheyenne and Laramie.

Wyo, Univ, Sch Mines, B Wyoming, University of, School of Mines, Bulletin. Laramie.

Wyoming Hist G Soc, Pr; Pub Wyoming Historical and Geological Society, Proceedings and Collections; Publications. Wilkesbarre, Pa.
Yale Bicen Pub Contr Miner Yale [University] Bicentennial Publica. tions. Contributions to mineralogy and petrography..., edited by S. L. Penfield and L. V. Pirsson. New York, Charles Scribner's Sons, 1901. Yale Sc Mo Yale [University] Sci. entific Monthly. New Haven, Conn.

Yorkshire G Polyt Soc, Pr Yorkshire Geological and Polythechnic Society, Proceedings. Leeds.

Zool Anzeiger Zoologischer Anzeiger. Leipzig.

Zool B Zoological Bulletin. Boston, Mass.

Zool Soc London, Pr Zoological Society of London, Proceedings.

Zs Allg Erdk Zeitschrift für allge. meine Erdkunde. Berlin.

Zs Anorg Chem Zeitschrift für anorganische Chemie. Hamburg.

Zs Berg-, Hütten- u Salinen-Wesen Zeitschrift für das Berg-, Hüttenund Salinen-Wesen. Berlin.

Zs Ges Naturw Zeitschrift für die gesammten $\mathrm{N}$ a t u r wissenschaften, Berlin.

Zs Gletscherk Zeitschrift für Gletscherkunde. Berlin.

Zs Kryst Zeitschrift für Krystallo. graphie und Mineralogie. Leipzig.

Zs Miner (Leonhard) Zeitschrift für Mineralogie (Leonhard). Frankfurt am Main.

Zs Prak G Zeitschrift für praktische Geologie. Berlin.

Zs Vulkan Zeitschrift für Vulkanologie. Berlin. 


\section{BIBLIOGRAPHY.}

A., L.

91 Discovery of fish remains in Lower Silurian rocks [Colorado]. Science 17:107 (1891)

Abbe, Cleveland.

92 [Some mechanical conditions of the earth's mass (abst).] $\mathrm{Ph}$ Soc Wash, B $11: 533-536$ (1892)

Abbe, Cleveland, jr.

95 Remarks on the cuspate capes of the Carolina coast. Boston Soc N H, Pr 26 : 489-497 (1895)

98 An episode during the terrace cutting of the Potomac. Johns Hopkins Univ Circ 18: 16-17 (1898)

99 A general report of the physiography of Maryland. Md St Weather Service 1:41-216, maps (1899). Also Thesis, Johns Hopkins Univ (1898)

oo The physiographic features of Maryland. Am Bur Geog, B 1:151-157, 242$248,342-355$ (1900)

O0a The physiography of Allegany Co. Md G S, Allegany Co : 27-56 (1900)

02 The physiography of Garrett County. Md G S, Garrett Co : 27-54 (1902)

03 Die Fall-Linie der südöstlichen Vereinigten Staaten. Vierteljahrsheften Geog Unterricht (Heiderich) Wien, 2: 204-210 (1903)

Abbot, C. G.

13 Do volcanic explosions affect our climate? Nat Geog Mag 24:181-198 (1913)

$13 \mathbf{a}$ (and Fowle, F. E.) Volcanoes and climate. Smiths Misc Col 60 no $29: 24$ pp (1913)

Abbot, Henry Larcom.

61 (with Humphreys, A. A.) Report upon the physics and hydraulics of the Mississippi River... U S Army, Corps of Topographical Engineers, Prof Papers no 4: 456, cxlvi pp, mảps, Phila 1861 [Reprint, with additions], ... Prof Papers no 13: $691 \mathrm{pp,} \mathrm{maps,} \mathrm{Washington} 1876$

Abbott, Charles Conrad.

83 Occurrence of amber near Trenton, N. J. Science 1:594 (1883)

83a Evidences of glacial man. Science $2: 437-438$ (1883)

89 The descendants of paleolithic man in America. Pop Sc Mo $36: 145-153$ (1889)

95 Timothy Abbott Conrad. Pop Sc Mo $47: 257-263$, port $(1895)$
Abbott, Clarence E.

07 The iron-ore deposits of the Ely trough, Vermilion Range, Minn. L Sup M Inst, $\operatorname{Pr} 12: 116-142$ (1907) Eng M J $83: 601-605$ (1907)

Abbott, George.

14 Is "Atikokania lawsoni" a concre tion? Nature, 94:477-478 (1914)

Abbott, James W.

07 Pioche, Nevada. M Sc Press 95 176-179 (1907)

Abel, $\mathrm{O}$.

06 Ueber den als Beckengürtel von Zeugladon beschriebenen Schultergürtel eines Vogels aus dem Eocän von Alabama. [Alabamornis gigantea, bird remains from the upper Eocene of Choctar: Co., Ala, originally described as the pelvic girdle of Zeuglodon]. Centr Miner 1906:450-458.

o9 Neuere Anschaungen über den Bau und die Lebensweise der Dinosaurier [structure and habits of the Dinosauria]. K-k Zool-bot Ges Wien, Verh 59:(117)(123) (1909)

10 Die Rekonstruktion des Diplodocus. K-k Zool-bot Ges Wien, Abh 5 H 3:1-60, il (1910)

Abele, Charles Arthur.

12 Statistics of the mineral production of Alabama for 1910. Ala G S, B 12:51 pp (1912) ; ... 1911; B 13:64 pp (1913)

Abercrombie, W. $R$.

04 The Copper River country, Alaska. Franklin Inst, J 158: 353-366 (1904)

Abert, James William (1820-1897).

46 Journal ... from Bent's Fort to St. Louis in 1845. U S, 29th Cong 1st sess, S Ex Doc 438: $75 \mathrm{pp}$, map (1846)

48 Report of his examination of New Mexico in the years 1846-47. U S, 30th Cong 1st sess, S Ex Doc 23:3-130, map (1848); H Ex Doc 41:417-546, map (1848)

Abert, Sylvanus Thayer.

70 Report of the Arkansas River. U S, 41st Cong 2d sess, H Ex Doc 295: 33 pp (1870)

76 Survey of a line to connect the waters of the Neuse and Cape Fear rivers in North Carolina ... U S, 44th Cong, 1st sess, S Ex Doc $35: 2-38$, maps (1876)

Ackermann, Hermann W.

75 Yellowstone National Park. Naturw Ges Isis Dresden, Szb 1875:49-64 (1875) 
Aekermann, Hermann W.-Continued.

76 Die Kupferführenden Schichten am Lake Superior. Naturw Ges Isis Dresden, Szb 1875 : 101-105 (1876)

Adam, Joseph S.

71 Notes on the geology of the vicinity of Samana [Santo Domingo]. U S, 42d Cong 1st sess, S Ex Doc 8: 70-71 (1871)

Adams, A. Leith.

75 On a fossil saurian vertebra, Arcto. saurus osborni, from the Arctic regions. R Irish Ac, Pr (2) $2: 177-179$, il (1875)

Adams, A. N.

The geology of Vermont as developed along the western border in the oldest fossiliferous rocks of the continent. $12 \mathrm{pp}$ [Fairhaven, Vt., 189-?] Reprinted from ? Adams, Charles Baker (1814-1853).

42 (with Mighels, J. W.) Description of fossil shells (Nucula and Bulla) occurring at Westbrook, Me. Boston $\mathrm{J} \mathrm{N} \mathrm{H}$ $4: 53-54$ (1842)

45 First annual report on the geology of the State of Vermont. $92 \mathrm{pp}$, map, Burlington 1845

45a ... geology of Jamaica (abst). As Am G, Pr $6: 32-33$ (1845)

46 Second annual report on the geology of the State of Vermont. 267 pp, Burling ton 1846

46n Notice of a small ornithichnite. Am $\mathrm{J} \mathrm{Sc} \mathrm{(2)} 2: 215-216$, il (1846)

47 Third annual report on the geology of the State of Vermont. $32 \mathrm{pp}$, Burlington 1847

$47 \mathbf{a}$ Notice of an example of apparent drift furrows dependent on structure. $\Delta \mathrm{m}$ J Sc (2) 3: 433-434 (1847)

47b On claystone concretions. Am J Agr 6: 207 [255] (1847)

$47 \mathrm{c}$ On the Taconic rocks (with discus sion by E. Emmons). Am J Agr 6:212 [260] (1847) Am J Sc (2) 5:108-110 (1848) Can Nat 6:324-325 (1860)

47d Observation on a polished rock. Am J Agr 6:215-216 (1847) Am J Sc (2) 5: 110 (1848)

48 Fourth annual report on the geological survey of Vermont. $8 \mathrm{pp}$, Burlington 1848

51 Suggestions on changes of level in North America, during the drift period. Am As, Pr 4:60-63 (1851)

53 (with Gray, A.) Elements of geology. $354 \mathrm{pp}, \mathrm{N}$ Y 1853

Adams, Elliot $Q$.

18 Note on the fundamental polyhedron of the diamond lattice. Wash Ac Sc, J 8: 240-241 (1918)

Adams, Francls $\mathbf{S}$.

10 The iron formation of Cuyuna range, Minn. Ec G $5: 729-740(1910) ; 6: 60-70$, 156-180 (1911)

Adams, Frank Dawson.

79 On the presence of chlorine in scapolites. Am J Sc (3) $17: 315-320$ (1879)
Adams, Frank, Dawson-Continued.

83 Notes on the microscopic structure of some rocks of the Quebec group. Can G S, Rp Prog 1880-2: A 8-23 (1883)

$\mathbf{8 3 a}$ On the Laurentian system. Ottawa Field Nat Club, Tr no 4: 21-31 (1883)

84 On the occurrence of the Norwegian "Apatitbringer" in Canada, with a few notes on the microscopic characters of some Laurentian amphibolites (abst). Brit As, Rp 54:717 (1885) G Mag (3) 1:518 (1884)

85 On the presence of zones of certain silicates about the olivine occurring in anorthosite rocks from the River Saguenay. Am Nat 19:1087-1090 (1885)

87 On the coal-bearing rocks of Canada. Brit As, Rp 56:639-641 (1887)

87a The anorthosite rocks of Canada (abst). Brit As, Rp 56:666-667 (1887) G Mag (3) 3:506 (1887)

88 Lithological character of some of the rocks collected in the Yukon district and adjacent northern portion of British Columbia. Can G S, An Rp 3: B 235-240 (1888)

88a (and Lawson, A. C.) On some Canadian rocks containing scapolite, with a few notes on some rocks associated with the apatite deposits. Can Rec Sc 3:185201 (1888)

89 On the micrescopical character of the ore of the Treadwell mine, Alaska. Am G $4: 88-93$ (1889)

89a [Observations in Montcalm and Joliette cos., Que.] Can G 3, Sum Rp 1887-8 (An Rp 3) : A 27-28 (1889)

89b [Observations on the Mattawin River region, Quebec.] Can G $\mathbf{S}$, Sum Rp 1887-8 (An Rp 3) : A 85 (1889)

90 [Summary report on the St. Maurice district, eastern townships, Que.] Can G S, Sum Rp 1888-9 (An Rp 4) : A 34-35 (1890)

91 On some granites from British Colum. bia and adjacent parts of Alaska and the Yukon district. Can Rec Sc 4:344-358 (1891)

91 a Notes to accompany a tabulation of the igneous rocks based on the system of Prof. H. Rosenbusch. Can Rec Sc 4:463469 (1891) Abst, Am G 9:268-269 (1892)

92 On the geology of the St. Clair tunnel. R Soc Can, Pr Tr 9, 1v: 67-73 (1892)

92a On a melilite-bearing rock (alnoite) from Ste. Anne de Bellevue near Montreal, Can. Am J Sc (3) 43: 269-279 (1892)

92b [Report on the Laurentian area north of Montreal.] Can G S, Sum Rp 1891 (An Rp 5) : A 39-44 (1892)

93 Ueber das Norian oder Oberlaurentian von Canada. N Jb, Beil Bd 8:419498, maps (1893) Abst, J G 4:374-375 (1896) On the Norian or "Upper Lau- 
Adams, Frank Dawson-Continued. rentian" formation of Canada. Can ReC Sc $6: 169-198,277-305,416-443$, maps (1895-6)

$93 a$ on the typical Laurentian area of Canada. J G 1:325-340 (1893)

94 Preliminary report on the geology of a portion of central Ontario situated in the counties of Victoria, Peterborough, and Hastings, together with the results of an examination of ore deposits occurring in the region. Can G S, An Rp $6: J \quad 15$ pp (1894)

$94 \mathbf{n} .$. nepheline syenite in the township of Dungannon, Ont. Am J Sc (3) 48:10-16 (1864) Abst, Am G 14:189-190 (1894)

94b On the igneous origin of certain ore deposits. Can M Rv 13:8-10 (1894) Gen M As Que, J 2:35-53 [1896]

95 A further contribution to our knowledge of the Laurentian. Am J Sc (3) 50:58-69, map (1895) Abst, Science n s $1: 63$ (1895)

96 Laurentian area in the northwest corner of the Montreal sheet [Que.]. Can G S, An Rp 7: J 93-112 (1896)

96a Report on the geology of a portion of the Laurentian area lying to the north of the Island of Montreal [Que.]. Can G S, An Rp 8: J 184 pp, map (1896)

96b (and Harrington, B. J.) On a new alkali hornblende and a titaniferous andradite from the nepheline syenite of Dungannen, Hastings Co., Ont. Am J Sc (4) $1: 210-218$ (1896) Can Rec Sc $7: 77-$ 88 (1896)

97 (and Barlow, A. E.) On the origin and relations of the Grenville and Hastings series in the Canadian Laurentian, with remarks by $R$. W. Ells. Am J Se (4) 3:173-180 (1897) Can Rec Sc 7:304-316 (1897) Abst, G S Am, B 8:398-401 (1897); J G 5:92-94 (1897); Science n s 5:96-97 (1897)

$97 a$ Notes on the geology of the Admiralty group of the Thousand Islands, Ont. Can Rec Sc $7: 267-272$ [in error for 333-338] (1897)

97b (and Nicolsen, J. T.) Preliminary notice of some experiments on the flow of rocks (abst). G Mag (4) 4:513514 (1897) Brit As, Rp 67:642-643 (1898) Science n s $7: 82-83$ (1898)

$97 \mathrm{e}$ On the structure and origin of certain rocks of the Laurentian system (abst). Brit As, Rp 67:665-666 (1898) G Mag (4) 4:516-517 (1897)

97a (with Bnrlow, A. E.) [Report on field work in the Haliburton area, central Ontario.] Can G S, Sum Rp 1896 (An Rp 9) : $\triangle \quad$ 43-53 (1897)

98 (and Barlow, A. E.) [Report on field work in the Haliburton area, central Ontario.] Can G S, Sum Rp 1897 (An Rp 10) : $\triangle 44-56, \operatorname{map}(1898)$
Adams, Frank Dawson-Continued.

98a Nodular granite from Pine Lake, Ont. G Soc Am, B $9: 163-172$ (1898) Abst, Sclence n s $7: 82$ (1898); Ottawa Nat 11:224 (1898)

98b Notes on the geology of Montreal and vicinity (abst). Science n s $7: 51-52$ (1898)

98e (and Nicolson, J. T.) Experiments on the flow of rock ... (abst). Science n s $7: 82-83$ (1898) Ottawa Nat $11: 224$ (1898)

98d The deformation of rocks under pressure. Abst, Eng M J $65: 522$ (1898)

99 (and Barlow, A. E.) [Report on field work in central Ontario.] Can G S, Sum Rp 1898 (An Rp 11) : a 106-111 (1899)

99a Studies in the geology of the vicinity of Montreal which might be undertaken by members of the Natural History Society. Can Rec Sc 8: 65-70 (1899)

$99 b$ Sir William Dawson. Science $n \mathbf{s}$ 10:905-910, port (1899) J G $7: 727-736$ (1899) Can Rec Sc 8:137-149, port (1900)

oo On the probable occurrence of a large area of nepheline-bearing rocks on the northeast coast of Lake Superior. J G 8. 322-325 (1900)

oon (and Barlow, A. E.) [Report of field work in the Haliburton area, central Ontario.] Can G S, Sum Rp 1899 (An Rp 12) : A 122-131 (1900)

oob Memoir of Sir J. William Dawson. G Soc Am, B 11:550-557, port (1900)

01 (and Nicolsen, J. T.) An experimental investigation into the flow of marble. R Soc London, $\mathrm{Ph} \operatorname{Tr}$ ser $A$ 195:363401 (1901) Abst, G Mag (4) $8: 322-323$ (1901) Summary, Can Rec Sc 8:426-436 (1902)

01 axperimental work on the flow of rocks (abst). G Soc Am, B 12:455-461 (1901) Science n s $13: 95-96$ (1901) Can Rec Sc 8: 471-472 (1902)

01b In memoriam-Sir John William Dawson. R Soc Can, $\operatorname{Pr} \operatorname{Tr}$ (2) 7, iv : 3-14 (1901) [port (2) 6:xvii (1900)]

o1e George M. Dawson. Science $n$ s $13: 561-563$, port (1901)

02 Haliburton and Bancroft areas, Ont. Can G S, Sum Rp 1901 (An Rp 14) : A 147150 (1902)

02a The origin of ore deposits (discussion). Am I M Eng, Tr 31:966-967 (1902)

o3 The Monteregian Hills, a Canadian petrographical province. J Geol 11:239282, map (1903) Can Rec Sc 9:198-245 (1905)

03a Memoir of George M. Dawson (with bibliography by H. M. Ami) G Soc Am, B 13:497-509, port (1903) 
Adams, Frank Dawson-Continued.

04 (and LeRoy, O. E.) The artesian and other deep wells on the Island of Montreal [Que.]. Can G S An Rp 14: o 74 pp, map (1904)

04a On a new nepheline rock from the Province of Ontario, Can. Am J Sc (4) $17: 269-276$ (1904)

04b Geophysical investigations suggested. Carnegie Inst Wash, Y Bk 2:195201 (1904)

04e (with Ami, H. M.) Synoptical table of geological formations about Montreal, Canada. Can G S, An Rp 14: o 2629 (1904)

o5 The artesian and other deep wells on the island of Montreal (with discussion). Can M Inst, J 8: 76-101 (1905)

05a Investigation on flow of rocks. Carnegie Inst Wash, Y Bk 3:119-120 (1905)

06 (and Coker, E. G.) An investigation into the elastic constants of rocks, more especially with reference to cubic compressibility. Carnegie Inst Wash, Pub 46:69 pp (1906) Am J Sc (4) $22: 95-123$ (1906) Abst, G Soc Am, B 16:564-565 (1906) ; Science n s $21: 219-220$ (1905)

06a On the need of a topographical survey of the Dominion of Canada, particularly with reference to the development of the economic resources of the Dominion. Can M Inst J 9:74-86 (1906)

06b Review of The nature of ore deposits, by Richard Beck, translated and revised by W. H. Weed. Ee G $1: 393-401$ (1906)

07 (and others) Report of a special committee on the correlation of the preCambrian rocks of the Adirendack Mountains, the "original Laurentian area" of Canada, and eastern Ontarie. J G 15 : 191-217 (1907)

o8 Bernard J. Harrington. Am J Sc (4) $25: 91-92$ (1908)

OSa On the structure and relations of the Laurentian system in eastern Canada. G Soe London, Q J 64:127-148, map (1908)

Osb Recent studies in the Grenville series of eastern North America, J G 16 : 617-635 (1908)

ose (and Barlow, A. E.) The nepheline and associated alkali syenites of eastern Ontario. R Soc Can, $\operatorname{Pr} \operatorname{Tr}$ (3) 2 iv : 3-76 map (1908) Abst, G Sec Am, B 17 : 695 (1907)

09 Report on the investigation into the flow of rocks. Carnegie Inst Wash, Y Bk 7, 1908: 205-206 (1909)

$09 a$ On the origin of the amphibolites of the Laurentian area of Canada. J G 17\% 1-18 (1909)

09b The basis of pre-Cambrian correlation. J G 17:105-123 (1909) [See also Van Hise, 09]
Adams, Frank Dawson-Continued.

10 An experimental investigation into the flow of diabase $(a b s t)$. Science n s 32 : 190 (1910) G Soc Am, B 21:773 (1910)

10a An experimental investigation into the action of differential pressure of certain minerals and rocks, employing the process suggested by Professor Kick. J G 18: 489-525 (1910)

$10 \mathrm{~b}$ Notes on the occurrence of the ore body at the City of Cobalt mine. Can M Inst, J 12:414-417 (1910)

10e Climatic conditions in the St. Lawrence Valley during and immediately after the glacial period. Int G Cong, XI, Stock. holm 1910, Die Veränderungen des Klimas: 383-384 (1910)

10d (and Barlew, A. E.) Geology of the Haliburton and Bancroft areas, Prov. ince of Ontarie. Can G S, Mem 6:419 pp, maps (1910)

10e (and Coker, E. G.) An experimental investigation into the flow of rocks; the flow of marble. Am J Sc (4) 29:465$487(1910)$

11 The iron-ore resources of the world. Can M Inst, Q B 14:101-120 (1911); J 14: 215-235 (1912)

11 a Continuation of investigation into the flow of rocks. Carnegie Inst Wash, Y Bk 9, $1910: 224$ (1911)

12 An experimental contribution to the question of the depth of the zone of flow in the earth's crust. J G 20:97-118 (1912)

12a The origin of the deep-seated meta. morphism of the pre-Cambrian crystalline schists. Int G Cong, XI, Stockholm 1910, C R : 563-572 (1912)

12b An experimental investigation into the flow of rocks (with discussion). Int $G$ Cong, XI, Stockholm 1910, C R:911-945 (1912)

13 The Morin anorthosite area [Que.] Int $\mathrm{G}$ Cong, XII, Canada, Guide Book no $3: 5-28$, maps (1913)

13a The Monteregian Hills. Int $G$ Cong, XII, Canada, Guide Book no 3:2980 , maps (1913)

13b (and Barlew, A. E.) HaliburtonBancroft area of central Ontario. Int G Cong, XII, Canada, Guide Book no 2:5-98, maps (1913)

14 A graphic method of representing the chemical relations of a petrographic prov. ince. J G $22: 689-693$ (1914) Abst, with discussion, G Soc Am, B $25: 43$ (1914)

15 Problems of the Canadian shield; the Archaeezoic. In Problems of American geology : 43-80, New Haven 1915

15a (and Dick, W. J.) Discovery of phosphate of lime in the Rocky Mountains. Can, Comm Conservation: $\mathbf{3 6}$ pp, maps (1915)

15b Memoir of Alfred Ernest Barlow. G Soc Am, B $26: 12-18$, port (1915) 
Adams, Frank Dawson-Continued.

16 (and Dick. W. J.) The extension of the Montana phosphate deposits northward into Canada. Nat Ac Sc, Pr 2:62-64 (1916) Abst, with discussion by L. D. Burling, G Soc Am, B 27:62 (1916)

17 (and Baneroft, J. A.) Investiga tions into the magnitude of the various forces which are required to induce movements in various rocks under the conditions which obtain in the deeper parts of the earth's crust (abst, with discussion by R. T. Chamberlin and others). G Soc Am, B 28:125-126 (1917)

17a (and Bancroft, J. A.) On the amount of internal friction developed in rocks during deformation and on the relative plasticity of different types of rocks. J G $25: 597-637$ (1917)

17b (and Dick, W: J.) Discovery of phosphate of lime in the Rocky Mountains [Alberta] (with discussion by W. F. Ferrier and L. D. Burling). Can M Inst, Tr 19 : 321-348 [1917].

17e The phosphate discussion [discovery of phosphate in Alberta]. Can M J 38 : $321-322(1917)$

17d Obituary, Robert Bell, 1841-1917. Can M Inst, B 66: 850-852 (1917)

17e Robert Bell. Am I M Eng, B 131: xlix-1 (1917)

18 Experiment in geology. G Soc Am, B 29:167-186 (1918)

See also Bowen (N L), 17a ; Weed, 05 .

Adams, George Irving.

95 Two new specles of Dinictis from the White River beds. Am Nat 29:573-578, il (1895)

96 On the species of Hoplophoneus. Am Nat $30: 46-52$, il (1896)

96a A geologic section from Galena to Wellington; a section from Manhattan to Abilene. Kans Univ G S 1:16-20, 124$128(1896)$

96b The extinct Felidae of North Amer1ca. Am J Sc (4) 1:419-444, il (1896) 97 On the extinct 1 slidae. $A m$ J Sc (4) $4: 145-149$, il (1897)

$\mathbf{9 7 a}$ [Underground waters of Kansas], special areas described. Kans, Bd Irrig S, Rp 1895-6: 104-114, map, Topeka 1897

98 The upper Cretaceous of Kansas; a historical review. Kans Univ G S 4:1327 (1898)

98a A geological map of Logan and Gove cos. [Kans.]. Kans Univ Q 7:19-20, map (1898)

08b Physiography of southeastern Kansas, Kans Univ Q 7:87-102, map (1898) Kans Ac Sc, Tr 16:53-63, map (1899)

98e A geological reconnaissance in Grant, Garfield, and Woods cos,, Okla. Kans Unir Q $7: 121-124, \operatorname{map}$ (1898)

00 Physiography of the Arkansas Valley region (abst). Science n \& 11:508 (1900)
Adams, George Irving-Continued.

O0a (with Tafr, J. A.) Geology of the eastern Choctaw coal field, Indian T. U S (i) S, An Rp 21 pt $2: 257-311$, maps (1900)

o1 Physiography and geology of the Ozark region. U $\mathrm{S}$ G $\mathrm{S}, \quad \mathrm{An}$ Rp 22 pt $2: 69-94$, map (1901)

01 a Oil and gas fields of the western interior and northern Texas coal measures and of the upper Cretaceous and Tertiary of the western Gulf coast. U S G S, B $184: 64 \mathrm{pp}$, maps (1901)

01b The Carboniferous and Permian age of the Red Beds of eastern Oklahoma from stratigraphic evidence. Am J Sc (4) 12 : $383-386$ (1901)

02 Geology and water resources of the Patrick and Goshen Hole quadrangles, in eastern Wyoming and western Nebraska. U S G S, W-S P 70:50 pp, maps (1902)

02a Physiographic divisions of Kansas. Am Geog Soc, B 34:89-104 (1902) Kans Ac Sc, $\operatorname{Tr}$ 18:109-123, map (1903)

02b Note on a Tertiary terrane new in Kansas geology. Am G 29:301-303 (1902)

02e Lithologic phases of the Pennsylvanian and Permian of Kansas, Indian Territory, and Oklahoma (abst). Science n s $15: 545-546$ (1902)

02d Stratigraphic relations of the red beds to the Carboniferous and Permian in northern Texas $(a b s t)$. Science n s 16: 1029 (1902)

03 (and Girty, G. H., and White, D.) Stratigraphy and paleontology of the upper Carboniferous rocks of the Kansas section.

U S G S, B 211: 123 pp, maps (1903)

03a Stratigraphic relations of the red beds to the Carboniferous and Permian in northern Texas. G Soc Am, B 14:191200 (1903) Abst, Science $n$ s $17: 292$ (1903)

03b Principles controlling the geologic deposition of the hydrocarbons (with discussion by D. T. Day.) Am I M Eng, Tr $33: 340-347,1053-1055$ (1903)

03e Zinc and lead deposits of northern Arkansas. U S G S, B 213:187-196 (1903) Am I M Eng, $\mathrm{Tr} 34: 163-174$ (1904)

o3d Origin of bedded breccias in northern Arkansas (abst). Science n $\mathbf{s} 17$ : 792-793 (1903)

04 (assisted by A. H. Purdne and E. F. Burchard) Zinc and lead deposits of northern Arkansas. U S G S, P P 24: 1-89, maps (1904)

o4a (and others) Gypsum deposits in the United States. U S G S, B 223: 129 pp, maps (1904)

04b The Rabbit Hole sulphur mines near Humboldt House, Nev. 497-500 (1904)

o4c (and Haworth, E. Can Crane, W. R.) Economic geolos of the Iola quadrangle, Kans. U $\$$ S $\&$, B 238:83 pp, maps (1904) 
Adams, George Irving-Continued.

04d Gypsum. U S G S, Min Res 1902 : $903-913(1904)$

o5 (and U1rieh, E. O.) Description of the Fayetteville quadrangle [Ark.-Mo.] U S G S, G Atlas Fayetteville fol (no 119):6 pp, maps (1905)

O5a Summary of the water supply of the Ozark region in northern Arkansas. U S G S, W-S P 110: 179-182 (1905)

13 The terms segment and segmentation in geology. Science n s $37: 177-178$ (1913)

Adams, H. T, W.

68 Alphabet of geology and elements of mineralogy ... $70 \mathrm{pp}$, Springfleld, Mass., 1868.

Adams, J. H.

70 Notice of asbestos and corundum with other minerals at Pelham, Mass. Am J Sc (2) $49: 271-272(1870)$

Adams, John [Rev.].

24 New locality of amethyst [Rhode Island]. Am J Sc 8: 199 (1824)

25 ... phenomena of moving rocks ... Am J Sc $9:$ 136-144 (1825)

Adams, L. A.

15 (with Gregory, W. K.) The temporal fossae of vertebrates in relation to the jaw muscles. Science n s $41: 763-765$ (1915)

Adams, L. D.

16 The Weedon or McDonald copper mine [Wolf $\mathrm{Co}$, Que.]. Can M Inst, Tr $18: 79-90$ (1916)

Adams, L. H.

14 (with Johnston, John) Observations on the Daubrée experiment and capillarity in relation to certain geological speculations. J G $22: 1-15$ (1914) Abst, Wash Ac Sc, J 4:5-6 (1914)

16 (with Johnston, J.) On the measurement of temperature in bore holes. Ec G $11: 741-762$ (1916)

Adams, Thomas K.

03 Lower productive coal measures of the bituminous regions of Pennsylvania. Mines and Minerals 23: 348-352 (1903)

Adams, W. H.

82 Coals in Mexico-Santa Rosa district. Am I M Eng, Tr 10:270-273, map (1882)

84 The pyrites deposits of Louisa Co., Va. Am I M Eng, Tr 12:527-535, map (1884)

Adán de Yarza, Ramón.

95 Rocas hipogénicas de la Isla de Cuba España, Com Mapa Geol, B 20:71-88 (1895)

Adger, J. B.

72 Analysis of a compact talc from North Carolina. Ch News 25: 270-271 (1872) Am J Sc (3) 4:419 (1872)

Adkinson, Henry M.

18 The oil shales of Utah and Colorado. Salt Lake M Rv 20, no 8: 21-25 (1918)
Adorno. Juan N.

64 Memoría acerca de los terremotos en México, escrita en octubre de 1864. 136 pp, México 1864 [not seen]

Agassiz, Alexander (1835-1910).

67 On the position of the sandstone of the southern slope of a portion of Keweenaw Point, Lake Superior. Boston Soc N H, Pr 11: 244-246 (1867)

80 Paleontological and embryological de. velopment. Science (ed, Michaels) 1:142149 (1880) Am J Sc (3) 20:294-302, 375-389 (1880) Am As, Pr 29:389-414 (1881)

82 On the connection between the Cretaceous and the recent echinid faunae. Am $J$ Sc (3) 23:40-46 (1882)

85 The Tortugas and Florida reefs. Am Ac Arts, Mem n s 11:107-134, maps (1885)

89 The corat reefs of the Hawailan Islands. Harvard Coll, Mus C Z, B 17: 121-170 (1889)

94 A reconnaissance of the Bahamas and of the elevated reefs of Cuba ... Harvard Coll, Mus C Z, B 26:1-203 (1894) Abst, Am G 13:141 (1894)

$94 n$ Note from the Bermudas. Am J Sc (3) $47: 411-416 \quad(1894)$

95 A visit to the Bermudas in 1894 . Harvard Coll, Mus C Z, B 26:205-281 (1895)

95a Note on the Florida reef. Am J Sc (3) $49: 154-155 \quad$ (1895)

95b On underground temperatures at great depths. Am J Sc (3) 50:503-504 (1895)

96 The elevated reef of Florida. Harvard Coll, Mus C Z, B 28 (g s 3) : 29-62 (1896)

See also Shaler, 90a

Agassiz, Elizabeth Cáry.

85 Louis Agassiz; his life and correspondence. 2 vols, $794 \mathrm{pp}$, port, Boston 1885

Agansiz, Louis (1807-1873).

47 [On the characters of Pygorhynchus.] Boston Soc N H, Pr 2: 193 (1847)

48 [... Dorudon serratus, and Saurocetus gibbesii.] Ac N Sc Phila, Pr 4:4-5 (1848)

49 [Remarks on crocodiles of the green sand of New Jersey and on Atlantochelys.] Ac N Sc Phila, Pr 4: 169 (1849)

49a The terraces and ancient river bars, drift, boulders, and polished surfaces of Lake Superior. Am As, Pr. 1:68-70 (1849)

$49 b$ On the origin of the actual outlines of Lake Superior. Am As, $\mathrm{Pr}$ 1:79 (1849)

50 Lake Superior; its physical char. acter, vegetation, and animals ... 428 pp, Boston 1850 
Agassiz, Louis-Continued.

50a The erratic phenomena about Lake Superior. Chapter X, pp. $395-416$ of his "Lake Superior ..." Am J Sc (2) 10: 83-101 (1850) Arch Sc Phys Nat 16: 5-34 (1851)

50b [On two kinds of drift in Cambridge, Mass.] Boston Soc $\mathrm{N} \mathrm{H}$, Pr. 3: $183(1850)$

50e [On the age of the Connecticut sandstone.] Boston Soc $\mathrm{N} H, \operatorname{Pr} 3: 336$ $337(1850)$

50d On the fossil remains of an elephant found in Vermont. Am As, $\operatorname{Pr} 2$ : 100-101 (1850)

50e ... succession of organized beings through the whole range of geological times. Am As, Pr 2:432-438 (1850) Edinb N Ph J 49:160-165 (1850)

51 Report on the vertebrate fossils exhibited to the Association (abst). Am As, Pr 5 : 178-180 (1851)

52 ... Florida reefs, keys, and coast. U S Coast S, Rp 1851 (U S, 32d Cong 1st sess, S Ex Doc 3):145-160 (1852) ; Rp 1866 (U S, 39th Cong 2d sess, H Ex Doc 87) : 120-130 (1869)

52a Remarks upon the unconformability of the Paleozoic formations of the United States. Am As, Pr 6:254, 256 (1852)

52b [Fossil Cetacea of the United States (abst).] Am Ac Arts, Pr 2: 4-5 (1852)

52c [On the geological position of the coal at Mansfield, Mass,] Am Ac Arts, Pr $2: 270,271$ (1852)

54 The primitive diversity and number of animals in geological times. Am $\mathrm{J}$ Sc (2) $17: 309-324$ (1854) Arch Sc Phys Nat $30: 27-50$ (1855) An Mag N H (2) 14: 350-366 (1854) Edinb N Ph J $57: 271-292$ (1854)

55 Notice of the fossil fishes found in California [Williamson's reconnaissance]. U S, Pacific R R Expl (U S, 33d Cong 1st sess, H Ex Doc 129) Appendix to the preliminary geological report of $W$. P. Blake : 30-34 (1855) Am J Sc (2) 21:272-275 (1856)

57 Notice of the fossil fishes [Williamson's reconnaissance in California]. U S, Pacific R R Expl (U S, 33d Cong 2d sess, $S$ Ex Doc 78 and $H$ Ex Doc 91) 5 pt 2: 313-316, il (1857) [See also Blake (W P), 57]

59 On Marcou's Geology of North America. Am J Sc (2) $27: 134-137$ (1859)

60 [Consecutive faunae and their corre sponding geologic formations (with discussion by W. B. Rogers).] Boston Soc $\mathrm{N} \mathrm{H}$ Pr 7:241-245, 250-252 (1860)

61 [On the age of New Brunswick sandstones and other rocks.] Boston Soc N H Pr 7:398 (1861)

62 [On Megatherium.] Boston Soc N H, Pr $9: 101-102$, (1862)
Agassiz, Louis-Continued.

$62 a$... new sauroid remains [from Nova

Scotia]. Am J Sc (2) $33: 138$ (1862)

63 [On subdivisions of the Tertiary and correlation by fossils.] Boston Soc N H, Pr 9:174 (1863)

$63 a$ [On the mounting of Megatherium.] Boston Soc N H, Pr 9: 193 (1863)

63b America the old world. Atlantic Monthly 11:373-382 (1863)

63e The Sllurian beach. Atlantic Monthly $11: 460-471$, il (1863)

63d The fern forests of the Carboniferous period. Atlantic Monthly 11:615-625, il (1863)

63e Mountains and their origin. Atlantic Monthly 11: 747-756 (1863)

63f The growth of continents. Atlantic Monthly 12:72-81 (1863)

63g The geological Middle Age. Atlan tic Monthly $12: 212-224$, il (1863)

63h The Tertiary age and its characteristic animals. Atlantic Monthly 12:333342 , il (1863)

63i The formation of glaciers. Atlantic Monthly 12:568-576 (1863)

63j Internal structure and progression of the glacier. Atlantic Monthly 12:751767 (1863)

64 External appearance of glaciers. Atlantic Monthly 13:56-65 (1864)

64 a Glacial period. Atlantic Monthly $13: 224-232$ (1864)

64b Ice period in America. Atlantic Monthly 14: 86-93 (1864)

66 Geological sketches. 311 pp, Boston 1866 Second series, 229 pp, Boston 1876 67 Ueber den Ursprung des Löss. N Jb $1867: 676-680$

67a Glacial phenomena in Maine. Atlantic Monthly 19:211-220, 281-287 (1867) Arch Sc Phys Nat 28: 319-352 (1867)

69 On the relation of geological and zoological researches to general interests in the development of coast features. U S Coast S, Rp 1867 (U. S, 40th Cong 2d sess, H Ex Doc 275) : 183-186 (1869)

70 On the former existence of local glaciers in the White Mountains. Am Nat 4:550-558 (1870) Am As, Pr 19:161167 (1871) Also in Hitchcock, C. H., Geology of N H, pt 3 [vol 3] : 234-238 (1878)

72 [On glacial phenomena of the southern hemisphere compared with those of the north.] Am Nat 7:60-62 (1872)

72a [On boulder trains in Berkshire Co., Mass., with discussion on the transportation of boulders by N. S. Shaler, C. T. Jackson, and L. Agassiz.] Boston Soc N H, Pr 14: 385-386 (1872)

72b [On the extent of the glacial sheet.] Boston Soc N H, Pr 14: 386 (1872)

See also Guyot, 50; Jackson, 61c; Rogers (H D), 47; Rogers (W B), 60 
Agraz, Juan S.

09 Estudio químico de una meteorita del Estado de Durango. Soc G Mex, B 6:8991 (1909)

Asthe, Fred $T$.

10 (and Dynan, J. L.) Paint-ore deposits near Lehigh Gap, Pa. U S G S, B $430: 440-454$ (1910)

Aguilar y Santillan, Rafael.

91 (and Puga, G. B.) Geodinámico; catálogo de los temblores de tierra y fenomenos voleánicos verifícados en la Republica mexicana durante el año de 1889 y 1890. Soc Cient Ant Alz, Mem 4:179-191, 323-329 (1891)

$91 a$ (with Puga, G. B.) El temblor del 2 de diciembre de 1890 . Soc Cient Ant Alz, Mem 4:131-154 (1891)

98 Bibliografía geologica y minera de la República mexicana. Mex I G, B 10:158 pp (1898)

02 Bibliography of Mexican geology and mining. Am I M Eng, Tr 32:605-680 (1902)

os Bibliografía geologica y minera de la República mexicana completada hasta el año de 1904 . Mex I G, B 17 : xili, 330 pp (1908)

16 Extracto de la bibliografía geologica y minera de la República mexicana, 19051916. Bol Minero $1: 31-32,64,128,160$, $223-224,255,287 ; 2: 110$ (1916)

18 Bibliografía geologica y minera de la República mexicana. Appendix to Bol Minero (México, Secretaria de Industria ...), t 5 nos $3-4,5-6$, t 6 nos $1-2,3$ : $54 \mathrm{pp}$ (1918)

Aguilera, José Guadalupe.

88 Estudio de los fenómenos seísmicos del 3 de mayo de 1887. México, Ministerio de Fomento, An 10:5-56, maps (1888)

93 (and ordónez, E.) Datos para la geológia de México. 87 pp. Tacubaya, D. F., México, 1893. Reprint of Méx I G, B 4-6:192-270 (1897)

94 (and Ord6ñez, E.) Breve explicación del bosquejo geológico de la República mexicana. La Naturaleza (2) 2 : 385-389, map (1894)

94a Informe sobre los placeres de oro del Río Bravo [Nuevo Laredo, Nuevo Leơn]. Bol Agr Min é Ind 3 no $8: 222$ 231 (1894)

95 (and Ordбñex, E.) Expedicion clentífica al Popocatepetl. Comision geo16gica mexicana : $48 \mathrm{pp}$, map, Mexico 1895

95a (with Castillo, A. del) Fauna fosil de la Sierra de Catorce, San Luis Potosí. Mex Com G, B 1:55 pp, il (1895)

97 (and Ordoñez, E.) Las fumarolas de Popocatepetl. Soc Cient Ant $\mathrm{Alz}$, Mem $10: 185-188$ (1897)

97a Antonio del Castillo. Méx I G, B 4-6:3-7, port (1897)

97b Bosquejo geológico de México. Méx I G, B 4-6:11-15 (1897)
Aguilera, José Guadalupe-Continued. 97e Itinerarios geológicos. Méx I G, B 4-6: 78-166 (1897)

97d Sinopsis de geología mexicana. Méx I G, B 4-6: 187-250 (1897)

97e (and others) El mineral de $\mathrm{P}$. chuca. Méx I G, B 7-9:183 pp (1897)

98 Catálogos sistemático y geográfico de las especies mineralógicas de la República mexicana. Méx I G, B 11:157 pp (1898)

98a Essai d'une évolution contínentale du Mexique. Soc G France, B (3) 26 : 512-516 (1898)

99 Unas cuantas palabras sobre meteoritas. Ac Mex Clene, An 3:239-260 (1899) [not seen]

oo Sobre las condiciones tectónicas de la República mexicana. Ac Mex Cien, An 4: 103-134 (1900) Reprint, 34 pp, México 1901

01 Distribución geográfica y geológica de los criaderos minerales de la Repúblics mexicana. 57 pp. México 1901 Ac Mes Cienc, An 5:1-57 (1901)

02 The geographical and geological dis $t$ tribution of the mineral deposits of Mex ico. Am I M Eng, Tr $32: 497-520$ (1902)

02a Geología de Tehuacán. In Armen daris, Eduardo, Estudio sobre las aguas de Tehuacá, Estado de Puebla: 11-22, Méxiev 1902 [not seen]

o3 Reseña de los principales trabajo: del octavo congreso geologico internacional [Paris]. Ac Mex Cienc, An 1: 1-11 (1903)

o5 Reseña del desarrollo de la geologi en México. Soc G Mex, B 1:35-11i (1905)

06 [Excursion] de México á Tehuacán Int $\mathrm{G}$ Cong, $\mathrm{X}$, Mexico, Guide Exe no $4: 1 i$ pp (1906)

06a Excursion de Tehuacán a Zapot th tlán et San Juan Raya [México]. Int $f^{2}$ Cong, X, Mexico, Guide Exc no $7: 27$ p $\mathbf{A}$ map (1906)

06b Les gisements carboniferes de $\mathrm{Cos}^{\text {in }}$ huila [México]. Int $G$ Cong, $X$, Mexico Guide Exc no $27: 17$ pp (1906)

07 Aperçu sur la géologie du Mexique or pour servir d'explication a la carte gé $\mathbf{Y}$ logique de l'Amérique du Nord [outline of the stratigraphy of Mexico]. Int $\mathrm{G}$ Cons th $\mathrm{X}$. Mexico, C R : 227-248 (1907)

07a Les volcans du Mexique dans leur relations avec le relief et la tectoniqu so générale du pays. Int $\mathrm{G}$ Cong, $\mathrm{X}$, Mexico C $\mathrm{R}: 1155-1168$ (1907)

07b Los volcanes de México en sus t laciones con el relieve y la tectónica get eral del pais. Méx, Sec Fomento, (2) VI : 121-129, 131-139 (1907)

os Los kaolines de la hacienda de Yextb [State of Hidalgo, Mex]. Soc G Mex, 3: 25-33 (1908)

O8a Mármoles. Méx, Sec Fomento, B II : 504-529 (1908) 
Agnilera, José Guadalupe-Continued.

09 Catálogo de los temblores (macroseismos) sentidos en la República mexicana durante los años de 1904 á 1908. Méx I G, Par 2: 389-467 (1909)

09a Algunos fosiles del cretácico mexicano. Soc G Mex, B 5 : 12 (1909)

09b Algunos criaderos de fierro de la Repńblica [iron deposits of Mexico]. Soc G Mex, B 5:67-89 (1909)

09e The carboniferous deposits of northern Coahuila [Mex.]. Eng M J 88:730733 (1909)

09d The Instituto Geologico de México. Eng M J 88: 857-859 (1909)

16 Distribución geográfica de los criaderos minerales de la República mexicana. Bol Minero 2 : 120-125 (1916)

16a Distribución geológica de los criaderos minerales de la Repáblíca mexicana. Bol Minero $2: 178-194$ (1916)

Aichino, Giovanni.

15 I carboni degli Stati Uniti [coals of the United States]. L'Industria Chimica, Mineraria, e Metallurgica Anno 2 nos 2022, Torino 1915.

Aiken, P. B.

03 The mines of Santa Eulalia, Mex. M Sc Press 87: 402 (1903)

Aikin, Arthur.

15 Manual of mineralogy. 1st Am. ed. 275 pp, Phila 1815

Aikin, William E. A.

34 ... geology of the country between Baltimore and the Ohio River, with a section illustrating the superposition of the rocks. Am J Sc 26: 219-232 (1834)

Aitken, Frank W.

06 (and Hilton, Edward) A history of the earthquake and fire in San Francisco. 285 pp, San Francisco 1906

Akerly, Samuel (1785-1845).

14 A geological account of Dutchess Co. In New York. Am Miner J 1: 11-16 (1814)

14a On the improbability of finding coal on Long Island or in the vicinity of New York. Am Miner J 1: 84-86 (1814)

14b On the geology and mineralogy of the island of New York. Am Miner J 1: 191-198 (1814)

20 An essay on the geology of the Hudson River and the adjacent regions ... 69 pp, N Y 1820

Akers, William A.

90 (with Goodale, C. W.) ... notes on the geology of the Flint Creek mining district [Mont.]. Am I M Kng, Tr 18: 242252 (1890)

Akin, A. D.

12 Mineral resources of Honduras, Central America. M World 36: 865-866 (1912)
Aleala, Maximino.

03 Criaderos de petróleo de Pichucalco, Estado de Chiapas [México], Soc Cient Ant Alz, Mem 13:311-326 (1903)

06 Sondeos en las lagunas 6 ciénegas de Almoloya y Lerma, del Valle de Toluca [peat deposits]. Soc G Mex, B 2:15-34 (1906)

Alcock, Frederick James.

15 Geology of the north shore of Lake Athabasca, Alta. and Sask. Can G S, Sum Rp 1914: 60-61 (1915)

16 Lower Churchill River region, Manit. Can G S, Sum Rp 1915 : 133-136 (1916)

17 Black Bay and Beaverlodge Lake areas, Sask. Can G S, Sum Rp 1916: 152-156 (1917)

18 Wekusko Lake area, northern Manit. Can G S, Sum Rp 1917 pt D : 8-17 (1918)

$18 \mathbf{a}$ The origin of the gold deposits of Wekusko Lake. Can M Inst, B 77: 801803 (1918)

Alden, Timothy, jr.

04 On earthquakes [in New Hampshire]. Mass Hist Soc, Coll $9: 232-234$ (1804)

Alden, William Clinton.

99 (with Salisbury, Rollin D.) The geography of Chicago and its environs: Geog Soc Chicago, B 1:64 pp, maps [1899] 02 Description of the Chicago district, U S G S, G Atlas Chicago fol (no 81) : 14 pp, maps (1902)

o3 The stone industry in the vicinity of Chicago, Ill. U S G S, B 213: $357-360$ (1903)

03a (with Fuller, M. L.) Description of the Elkland and Tioga quadrangles [Pa.]. U S G S, G Atlas Elkland-Tioga fol (no 93): 9 pp, maps (1903)

osb (and Fuller, M. L.) Pleistocene geology of the Gaines quadrangle [Pa.N. Y.]. U S G S, G Atlas Gaines fol (no 92) : $9 \mathrm{pp}$, maps (1903)

04 The Delavan lobe of the Lake Michigan glacier of the Wisconsin stage of glaciation and associated phenomena. U S G S, P P 34: $106 \mathrm{pp}$, maps (1904)

05 The drumlins of southeastern Wisconsin. U S G S, B 273: 46 pp, map (1905)

06 Description of the Milwaukee quadrangle, Wis. U S G S, G Atlas, Milwaukee fol (no 140) : $12 \mathrm{pp}$, maps (1906)

08 Pleistocene phenomena of central Massachusetts (abst). Science n s 27 : 694-695 (1908)

09 Concerning certain criteria for discrimination of the age of glacial drift sheets as modified by topographlc situation and drainage relations. J G $17: 694-709$ (1909) Abst, Science n s 29:628 (1909); G Soc Am, B 20: 638-639 (1910)

09a The Pleistocene phen om en of southeastern Wisconsin (abst). Science n s $29: 557,628$ (1909) G Soc Am, B 20: $638(1910)$ 
Alden, William Clinton-Continued.

$09 \mathrm{~b}$ Log of Cheboygan, Mich., well from examination of samples of drillings. Mich G S, Rp 1908: 96 (1909)

10 Certain geological phenomena indicative of climatic conditions in North Amerlca since the maximum of the latest glaclation. Int G Cong, XI, Stockholm: Die Veränderungen des Klimas : $353-363$ (1910)

10a Fuller's earth and brick clays near Clinton, Mass. U S G S, B 430:402-404 (1910)

11 Radiation of glacial flow as a factor in drumlin formation (abst). G Soc Am, B $22: 733-734$ (1911)

12 Pre-Wisconsin glacial drift in the region of Glacier National Park, Mont, (with discussion by A. P. Coleman and W. W. Atwood: 730-731). G Soc Am, B 23: 687-708, map (1912) Abst, Science n s 35 : 314 (1912)

12a Sketch of the geological history of Green Lake Co., Wis. School Q, Berlin, Wis, 3 no $2: 2-14$ (1912)

13 (and Stebinger, E.) Pre-Wisconsin glacial drift in the region of Glacier National Park, Mont. G Soc Am, B 24: 529-572, map (1913)

14 Early Pleistocene glaciation in the Rocky Mountains of Glacier National Park, Mont. Int $\mathrm{G}$ Cong, XII, 1913, C R : 479484, map (1914)

14a Glaciers of Glacier National Park [Mont.] U S Dp Interior, Off Secretary : $48 \mathrm{pp}$, maps (1914)

17 (and Leighton, M. M.) The Iowan drift; a review of the evidences of the Iowan stage of glaciation. Iowa $\mathrm{G} \mathrm{S}$ $26: 49-212$, map (1917)

18 The Quaternary geology of southeastern Wisconsin with a chapter on the older rock formations. U S G S, P P 106: 356 pp, maps (1918) Abst, Wash Ac Sc, J $15: 537$ (1918)

18a The country around Camp Albert L. Mills [Long Island, N. Y.]. [Text on back of topographic map], New York, Camp Mills quadrangle, U S G S (1918)

18b The country around Camp Upton [Long Island, N. Y.]. [Text on back of topographic map], New York (Suffolk County), Moriches quadrangle (Camp Upton ed.), U S G S (1918)

18c (with Lees, J. H.) The country around Camp Dodge. [Text on back of topographic map], Iowa, Camp Dodge quadrangle, U S G S (1918)

See also Kay (G F), 16d; Leonard, 12. Alder, A.

12 Tin; occurrences in the Black Hills and methods of analysis. Pahasapa (Rapld City, S Dak) 1 no 4:22-27 (1912)
Alder \& Company.

16 General map of the anthracite $A$ fields of Pennsylvania and adjoining ow ties showing the position of each collie Scale $1: 126,720,2$ miles to the inch. $P$ 1916.

Alderson, J. Coleman.

o7 A hand book of southers West ginia; The Kanawha or middle meas: of coal; The Coal River basin; The Ald b son Land and Development Compan Survey. $28 \mathrm{pp}$, Charleston, Kanawha 1 W Va, 1907

Alderson, Matt W.

01 Genesis of ore deposits. M Sc Pr $83: 4-5,14,24$ (1901)

09 Some ore deposits connected 5 A placers. M World 31:229-230 (1909)

Alderson, Victor Clifton.

89 Geology in the high school. Am 4: 284-289 (1889)

18 The ofl shale industry. Colo \& Mines Q 13, no 2: 3-30 (1918)

Aldrich, Truman Heminway.

76 Historical account of coal mid operations in Alabama since 1853. \& G S, Rp Prog 1875 : 28-66 (1876)

85 Observations upon the Tertiary Alabama. Am J Sc (3) $30: 300-2$ (1885)

85a Notes on the Tertiary of Alabal and Mississippi, with descriptions of $D$ species. C1n Soc N H, J 8: 145-153, (1885)

$85 b$ Notes on Tertiary fossils rare little known. Cin Soc N H, J 8: 153-1: II (1885)

86 Preliminary report upon the Terti fossils of Alabama and Mississippl. G S, B 1: 15-60, il (1886)

$86 a$ Notes on the distribution of $T$ tiary fossils in Alabama and Mississig Cin Soc N H, J 8: 256-257 (1886)

86b (with Meyer, O.) The Tertis fauna of Newton and Wautubbee, Mis Cln Soc N H, J 9: 40 [104]-50 [114], (1886)

87 Notes on Tertlary fossils with scriptions of new species. Cin Soc N J $10: 78-83,11$ (1887)

90 A new Eocene fossil from Ter [Omalaxis singleyi n. '.] Nautilus 4: il (1890)

94 New Tertiary fossilg from Red Blut Miss. Nautllus, 7: 97-99, 11 (1894)

94a The (Midway) Clayton Tertiary 86 tion and its fossils. In Smith, E. A., as others, Rp on ... Coastal Plain of Als bama : $240-248$, 11, Ala G S, 1894

95 New or little known Tertiary Mo lusca from Alabama and Texas. B Am P no 2: $31 \mathrm{pp}$, il (1895)

95a Descriptions of two new Eocet Solarildae from Alabama. Nautilus $9: 1-$ ? II (1895) 
Aldrich, Truman Heminway-Continued. 97 Notes on Eocene Mollusca, with de scriptions of some new species. B Am Pal no 8: $26 \mathrm{pp}$, il (1897)

$97 \mathbf{a}$ new Cancellaria from the Alabama Eocene. Nautilus 11: 27-28, il (1897)

98 Some new Eocene fossils from Alabama. Nautilus 11:97-98 (1898)

01 A Texas oil well fossil. Nautilus 15: 74, il $(1901)$

02 (with Smith, E. A.) The Grand Gulf formation. Science $n$ s $16: 835-837$ (1902) ; 18: 20-26 (1903)

03 New species of Tertiary fossils from Alabama, Mississippi, and Florida. Nautilus $16: 97-101$, il $(1903)$

03a A new Conus from the Tertiary of Florida. Nautilus 16: 131-132, il (1903) 03b Two new species of Eocene fossils from the lignitic of Alabama. Nautilus $17: 19-20$, il (1903)

04 A new oyster from the Eocene of Alabama. Nautilus $18: 61$, il (1904) or A new fossil Busycon (Fulgur) from Florida. Nautilus 20: 121, il (1907)

o7a Some new Eocene fossils from Alabama. Nautilus 21: 8-11, il (1907)

os A new Eocene fossil from Claiborne [Ala.]. Nautilus 22: 13 (1908)

O8a New Eocene fossils from Alabama and Mississippi. Nautilus 22: $74-76$, il (1908)

10 A new fossil Mitra from west Florida, and a new Eocene Astarte [from Newton Co., Miss.]. Nautilus 23:121-122, il (1910)

10a New Eocene fossils from the south. ern States. Nautilus 24:73-75, il (1910)

11 New Eocene fossils from the Gule States. B Am Pal $22: 24$, il (1911)

11 a Notes on some Pliocene fossils from Georgia with descriptions of new species. Nautilus 24:131-132, 138-140, il (1911)

Aldrich, Truman Heminway, jr.

08 The treatment of the gold ores of

Hog Mountain, Ala. Am I M Eng. B 24: 911-916 (1908) ; $\operatorname{Tr} 39: 578-583$ (1909)

Alexander, Caleb.

85 An account of eruptions and the present appearances in West River Mountain [Chester Co., N. H.]. Am Ac Arts, Mem $1: 316-317$ (1785)

Alexander, John Henry (1812-1867).

34 (with Duentel, J. T.) Report on the projected survey of the State of Maryland ... $43 \mathrm{pp}$, map, Annapolis 1834 [also other editions] Also in Am J Sc 27:1-38 (1834)

34a (with Ducatel, J. T.) Report on a projected geological and topographical survey of the State of Maryland. Am J Sc $27: 1-38$ (1834)

Alexnnder, J. M.

74 The newly discovered crater of Maui. Am J Sc (3) $7: 525-526$ (1874)
Alexander, J. M.-Continued.

86 The craters of Mokuaweoweo on Mauna Loa [Hawaii]. Nature 34: 232-234 (1886)

88 On the summit crater of Mt. Loa in October, 1885. Am J Sc (3) 36:35-39 (1888)

Alexander, W. D.

70 On the erater of Haleakala, Island of Maui, Hawaiian group. Am J Sc (2) 49: $43-48(1870)$

71 On the earthquake at Oahu, Hawaiian Islands on February 18, 1871. Am J Sc (3) $1: 469-471$ (1871)

Alexine, Moxie.

81 The rock formation of Niagara County, N. Y. Sc Advocate 2:3-4, 20-21, 34-36 (1881)

Alfaro, Anastasio.

10 Efectos del terremoto de 4 de mayo de 1910. Informe del Museo Nacional. Costa Rica, Ministerio de Fomento, Orden no. $151,1910: 13$ pp, San Jose, Costa Rica, 1910

11 Relación que existe entre la conformación del suelo y la resistencia de los edificios en los sacudimientos sísmicos. Costa Rica, B Fomento 1: 706-713 (1911) 11 a Comprobaciones geologicas. Costa Rica, B Fomento 1:123-131, il (1911)

12 (and Michaud, G., and Bielley, P.) Informe sobre el terremoto de Toro Amarillo, Grecia [earthquake of August 28, 1911]. Costa Rica, Centro de Estudios Sismolog, An 1911:35-41 (1912)

13 Rocas voleánicas de Costa Rica. Costa Rica, B Fomento 3:549-555 (1913)

$13 a$ Rocas sedimentarias de Costa kica. Costa Rica, B Fomento 3:853-861 (1913) Alger, Francis (1807-1863).

27 ... mineralogy of Nova Scotia. Am J Sc $12: 227-232$ (1827)

28 (with Jnckson, C. T.) ... mineralogy and geology of a part of Nova Scotia. Am J Sc 14:305-330 (1828); 15:132-160, 201-217 (1829)

33 (with Jackson, C. T.) Remarks on the mineralogy and geology of Nova Scotia. Am Ac Arts, Mem n s 1: 217-330 (1833)

44 Beaumontite and lincolnite identical with heulandite. Boston J N H 4:422426 (1844) Am J Sc $46: 233-236$ (1844)

45 On the zinc mines of Franklin, Sussex Co., N. J. Am J Sc 48: 252-264 (1845)

46 Notices of new localities of rare minerals, and reasons for uniting several supposed distinct species. Boston J N H 5: 297-309 (1846) Edinb $\mathrm{N}$ Ph J 42:59 69 (1847)

46a [Notes on certain minerals-phacolite, yttrocerite, ottrelite, polyadelphite.] Boston Soc N H, Pr 2:87-89 (1846)

49 Examination of a mineral from Cherokee Co. in Ga. Boston J N H 6: 123-124 (1849) 
Alger, Francis-Continued.

50 Crystallized gold from California. Am J Sc (2) 10:101-106 (1850)

5oa [On specimens of crystallized gold from California.] Boston Soc N H, Pr 3: 266-267 (1850)

50b [On a singular cavity in a quartz crystal from Waterbury, Vt.] Boston Soc N H, Pr 3: 273-274 (1850)

50e $[O n$ a deposit of phosphorite in Hurdsville, Morris Co., N. J.] Boston Soc $\mathrm{N} H, \operatorname{Pr} 3: 376-378$ (1850)

5od On rutilated quartz erystals from Vermont and phenomena connected with them. Am J Sc (2) 10:12-19 (1850) Am As, Pr 2:426-432 (1850)

56 [On the beryl formation of Grafton. N. H.] Boston Soc N H, Pr 6:22-23 (1856)

61 [On zincite from Mine Hill, Franklin, Sussex Co., N. J.] Boston Soc N H, Pr 8:145 (1861)

61a on a pseudomorphic crystal of native copper from Copper Falls mine, Lake Superior. Boston Soc N H, Pr $8: 171-172$ (1861)

See also Hunt, 49b; Phillips, 44

Allan, Fergus L.

15 (and Faulkner, H. W.) The San Rafael vein at El Oro [Mex.]. M Mag $12: 281-285$ (1915)

Allan, John Andrew.

10 Saltspring Island, and east coast of Vancouver Island, B. C. Can G S, Sum Rp 1909 98-102 (1910)

11 Ice River district, B. C. Can G S, Sum Rp 1910 135-144 (1911)

11 a (with Clapp, C. H.) Southern Vancouver Island, B. C. Can G S, Map $17 \mathrm{~A}$ (1911)

12 Geology of Field map area, Yoho Park, B. C. Can G S, Sum Rp 1911: 175187 (1912)

12a Geology of the Ice River district, B. C. Abstract of thesis, Massachusetts Institute of Technology, $12 \mathrm{pp}$, [Boston?] 1912

13 Rocky Mountains, Bankhead to Golden. Int G Cong, XII, Canada, Guide Book no $8: 167-201$, maps (1913)

14 Geology of Field map area, B. C. and Alta. Can G S, Mem $55: 312 \mathrm{pp}$, map (1914)

14a Rocky Mountain section between Banff, Alta., and Golden, B. C., along the Canadian Pacific Railway. Can G S, Sum Rp 1912 : 165-176 (1914)

15 Rocky Mountains Park, Alta. Can G S, Sum Rp 1914: 42-43 (1915)

15a National parks in the Canadian Cordillera. Seience Conspectus 5: 113-125 (1915)

16 Simpson Pass to Kananaskis, Rocky Mountains Park, Alta. Can G S, Sum Rp 1915 : 100-102 (1916)
Allnn, John Andrew-Continued.

17 Geology of the Canadian Rocky Mous tains. Can Alpine J 8:108-117 (1917)

17a (with Warren, C. H.) A titan ferous augite from Ice River, B. C., with chemical analysis by M. F Conner. Am Sc (4) $43: 75-78$ (1917)

18 Sections along North Saskatchewa: River and Red Deer and South Saskatche wan rivers, between the third and fift meridians. Can G S, Sum Rp 1917 . C : 9-13 (1918)

Allan, Thomas.

12 Remarks on a mineral from Green land, supposed to be crystallized gadolinite R Soc Edinb, $\operatorname{Tr} 6: 345-351$ (1812)

Allen, Carl A.

11 Vanadium deposits in the Caball Mountains, N. Mex. M and Sc Press 103 376-378 (1911)

Allen, Eugene Thomas.

97 Native iron in the coal measures Missouri. Am J Sc (4) 4:99-104 (1897 05 (with Day, A. L.) The isomorphis: and thermal properties of the feldspar: Carnegie Inst Wash, Pub 31: 13-75, Wasb ington 1905

05a (with Day, A. L.) The isomorphis and thermal properties of the feldspar Am J Sc (4) 19:93-142 (1905)

o6 (and White, W. R.) On wollastor ite and pseudo-wollastonite, polymorphi forms of calcium metasilicate, with optics study by F. E. Wright. Am J Sc (4 $21: 89-108$ (1906)

06a (and Wright, F. E., and Clement J. K.) Minerals of the compositio $\mathrm{MgSiO}_{3}$; a case of tetramorphism. J Sc (4) $22: 385-438$ (1906)

os (and clement, J. K.) The role? water in tremolite and certain other min erals. Am J Sc (4) 26:101-118 (1908 Z Anorg Chem 68:317-337 (1910)

09 (and white, W. P.) Diopside an its relations to calcium and magnesius metasilicates; with optical study by F. E Wright and E. S. Larsen. Am J Sc (4 $27: 1-47$ (1909)

10 Criteria of downward sulphide et richment (discussion). Ec G $5: 387-39$ (1910)

11 Studies in ore deposition with specis reference to the sulphides of iron. Was Ac Sc, J 1:170-177 (1911) M Sc Pres $103: 413-414$ (1911)

12 (and Crenshaw, J. L.) The sulphide: of zinc, cadmium, and mercury ; their crys talline forms and genetic conditions; micro scopic study by H. E. Merwin. Am J S (4) $34: 341-396$ (1912) Abst, Wash A Sc, J $3: 114-115$ (1913)

12a (and Crenshaw, J. L., and John. ston, John.) The mineral sulphides of iron; with erystallographic study by E. \& Larsen. Am J Sc (4) 33: 169-236 (1912 Abst (by E. T. A.), Wash Ac Sc, J $2: 9-1$ (1912) 
Allen, Eugene Thomas - Continued.

14 (and Crenshaw, J. L.) The Stokes method for the determination of pyrite and marcasite. Am $J$ Sc (4) 38:371-392 (1914) bst, Wash Ac Sc, J 5:93-94 (1915)

14a (and Crenshaw, J. L.) Effect of temperature and acidity in the formation of mareasite $\left(\mathrm{FeS}_{2}\right)$ and wurtzite $(\mathrm{ZnS})$; a contribution to the genesis of unstable forms. Am J Sc (4) 38:393-431 (1914) Abst, Wash Ac Sc, J 5:94-95 (1915)

15 (with Posnjak, E., and Merwin, II. E.) The sulphides of copper. Ec G $10: 491-535$ (1915)

16 The composition of natural bornite. Am J Sc 41: 409-413 (1916)

$16 a$ Chemical studies in copper sulphide enrichment (alst). Wash Ac Sc, J 6: 2122 (1916)

16b (with Zies, E. G., and Merwin, H. E.) Some reactions involved in secondary copper sulphide enrichment. Ec G 11: $407-503$ (1916)

17 (and Lombard, R. H.) A method for the determination of dissociation pressures of sulphides, and its application to covellite (CuS) and pyrite $\left(\mathrm{FeS}_{2}\right)$. Am J Sc (4) $43: 175-195$ (1917)

See also Tolman, $16 \mathrm{a}$.

Allen, George N.

66 A descriptive catalogue of minerals... $24 \mathrm{pp}$, Oberlin 1866

Allen, Glover Morrill.

13 A new Mylodon [from the Pleistocene of the Niobrara River, Nebr]. Harvard Coll, Mus C Z, Mem 40:319-346 (1913)

17 New fossil mammals from Cuba. Harvard Coll, Mus C $\mathrm{Z}, \mathrm{B}$ 61:3-12, 11 (1917)

18 Fossil mammals from Cuba. Harvard Coll, Mus C Z, B 62:133-148, il (1918)

Allen, Harrison.

so on some homologies in bunodont dentition. Ac N Sc Phila, Pr 1880:226-228

86 On the types of tooth structure in Mammalia. Am Nat 20:295-297 (1886)

Allen, Henry $\mathrm{T}$.

86 Copper River, Alaska, glacial action. Science 8: 145-146 (1886)

Allen, Jamas (1806?-1846).

34 Journal of an "expedition into the Indian country," to the source of the Mississippi... in 1832. U S, 23d Cong 1st sess. H Ex Doc 323: 68 pp, map (1834)

Allen, Joel Asaph (1838-1921).

74 Metamorphism produced by the burnIng of lignite beds in Dakota and Montana territories. Boston Soc N H, Pr 16:246262 (1874) Abst, Am J Sc (3) 8: 141-142 (1874)

76 The American bisons, living and extinct. Harvard Coll, Mus C Z, Mem 4 no 10 and $\mathrm{Ky} \mathrm{G} \mathrm{S,} \mathrm{Mem} 1$ pt $2: 246$ pp, map, II $(1876)$
Allen, Joel Asaph-Continued.

76a Description of some remains of an extinct species of wolf and an extinct speeies of deer from the lead region of the upper Mississippi. Am J Sc (3) 11:47-51 (1876)

$76 b$ The Little Missouri "Badlands." Am Nat 10:207-216 (1876)

7Ge Extinct birds with teeth. Nuttall Ornithol Club, B $1: 49$ (1876)

$\boldsymbol{z} \boldsymbol{7}$ Synoptical list of the extinct Roden tia of North America. U S G S Terr (Hayden), Rp 11:943-949 (1877)

78 Description of a fossil passerine bird from the insect-bearing shales of Colorado. U S G Geog S Terr (Hayden), B 4:443445 , il (1878) Am J Sc (3) 15:381-384, il (1878) Nature 18:204-205, il (1878)

85 On an extinct type of dog from Ely Cave, Lee Co., Va. Harvard Coll, Mus C Z, Mem 10 no $2: 1-8$, il (1885)

87 Note on squalodont remains from Charleston, S. C. Am Mus N H, B $2: 35-$ 39 il (1887)

04 A fossil porcupine from Arizona. Am Mus N H, B 20:383-384 (1904)

16 An extinct octodont from the island of Porto Ríco, W. I. [Isolobodon portoricensis]. N Y Ac Sc, An 27:17-22, il (1916); abst $26: 438-439$ (1916)

Allen, John H.

46 Some facts respecting the geology of Tampa Bay, Fla. Am J Sc (2) 1:38-42 (1846)

Allen, Jonathan A.

21 On the question whether there are any traces of a volcano in the West River Mountain [Vt.]. Am J Se 3:73-76 (1821)

Allen, Joseph $\mathrm{H}$.

8s Western Kentucky coals and cokes. Am I M Eng, Tr 16:581-593 (1888)

Allen, Milton Arthur.

17 Prospecting for petroleum. Ariz Bur Mines, B 69: 18 pp (1917)

18 Oil and its geology. Ariz Bur Mines, B $65: 34$ pp (1918)

18a (and Butler, G. M.) Manganese Ariz, Univ, Bur Mines, B $91: 32$ pp. (1918)

Allen, Oscar D.

77 Chemical constitution of hatchettolite and samarskite from Mitchell Co., N. C. Am J Sc (3) 14:128-131 (1877)

so (and Comstoek, W. J.) Bastnäsite and tysonite from Colorado. Am J Sc (3) 19:390-393 (1880) Yale Bicen Pub, Contr Miner : 126-129 (1901)

Allen, Paul.

14 (editor) History of the expedition under the command of captains Lewis and Clark to the sources of the Missouri, thence across the Rocky Mountains and down the river Columbia to the Pacific Ocean performed during the years 1804 . 5-6 [geological notes, pp. 29, 49-51, 62. 
Allen, Paul-Continued.

$193,230,231,270,333,397,455$ ] In two vols, xxviii, $470 \mathrm{pp}, \mathrm{ix}, 522 \mathrm{pp}$, maps, Phila 1814 [Also other later and foreign editions]

Allen, Rolland Craten.

09 The occurrence and origin of the brown iron ores of Spring Valley, Wis. Mich Ac Sc Rp 11: 95-103 (1909)

09a Iron formation of Woman River area [Ont.]. Ont Bur Mines, An Rp 18 pt $1: 254-262$, map (1909)

09b Geologic map of Iron River district, Mich. Scale : 2 inches $=1$ mile. Mich G S (1909)

10 The Iron River iron-bearing district of Michigan. Mich G S, Pub 3 ( $\mathrm{g}$ s 2) : $151 \mathrm{pp}$, map (1910)

11 Progress of the geological survey of Michigan; geology and topography. Mich Ac Sc, Rp 13:69-78 (1911)

12 (and others) Mineral resources of Michigan with statistical tables of produc tion and value of mineral products for 1910 and prior years. Mich G S, Pub 8 (g s 6) : $465 \mathrm{pp}$ (1912)

12a The iron mining industry of Michigan. Mich G S, Pub 8 (g \& 6) : 117-256 (1912)

12b (and Ruthven, A. G.) Progress of the geological and biological survey of Michigan. Mich Ac Sc, Rp 14:33-36 (1912)

13 Mineral resources of Michigan with statistical tables of production and value of mineral products for 1912 and prior years. Mich G S, Pub 13 (g s 10) : 255 pp (1913 … 1913; Pub 16 (g s 13) : 150 pp (1914) ‥ (1914) Pub 19 (g s 16) : 359 pp (1915) _.. 1915; Pub 21 (g s 17) : 402 pp, map (1916) ... 1916; Pub 24 (g s 20) : 291 pp (1917) ‥ 1917; Pub 27 (g s 22) : $225 \mathrm{pp}$, map (1918)

14 (and Barrett, L. P.) Evidence of the middle-upper Huronian unconformity in the quartzite hills at Little Lake, Mich. J G 22:574-581 (1914) Mich G S, Pub 18 (g s 15) : 153-159 (1915)

$14 a$ The iron ore reserves of Michigan. Mich G S, Pub 16 (g s 13) : 39-77 (1914)

14b Biennial report of the director. Mich G S, Pub 17 (g s 14) : 104 pp, map (1914)

14c Relative to an extension of the Menominee iron range eastward from Waucedah to Escanaba, Mich. Ec G 9:236238 (1914) Mich G S, Pub 18 (g \& 15) : 161-164 (1915)

14d Correlation and structure of the preCambrian formations of the Gwinn ironbearing district of Michigan. J G 22 : 560 573, map (1914) Mich G S, Pub 18 (g s 15) : 141-152, map (1915)

15 (and Barrett, L. P.) Contributions to the pre-Cambrian geology of northern Michigan and Wisconsin. Mich G S, Pub 18 (g s 15) : 13-164, maps (1915)
Allen, Rolland Craten-Continued.

$15 a$ (and Barrett, L. P.) A revisio of the sequence and structure of the $\mathrm{pr}$ Keweenawan formations of the easter Gogebic Iron range of Michigan. Mich $\mathrm{G}$ Pub 18 (g s 15) : 33-61, map (1915). part, J G 23: 689-703, map (1915)

$15 b$ (with Leith, C. K.) Discussion correlation [of pre-Cambrian formations Lake Superior region]. J G 23: 703-72 map (1915)

16 (and Smith, R. A., and Barrett L. P.) Geological map of Michigan. Sca 1: 750,000. Mich G S, Pub 23 (g s) 1916 Allen, Roy Hutchins.

09 Notes on Mother Lode mine in Britis Columbia. Eng M J 88: 1101-1103 (1908

09a Mines of the Granby Consolidate Phoenix, B. C. Eng M J 88:1260-120 (1909)

10 The Center Star group of mines, Ros: land, B. C. Eng M J 89:17-19 (1910)

10a Equipment and methods at the Hed mine [Coeur d'Alene district, Idaho]. Er M J $89: 311-313$ (1910)

10b Mines and mills of the Consolidate Mercur Co. [Utah]. Eng M J 89:1273 1277 (1910)

Allen, $T$.

48 An account of the inflammable ga wells on the banks of the Kanawha Rive? in Virginia, as they appeared in June, 184: Am Ph Soc, Pr 4:366-368 (1848)

Allen, W. C. B.

10 Mineral deposits of western Arkansa Eng M J 89: 1328 (1910)

Alling, A. N.

s7 On the topaz from the Thomas Rang Utah. Am J Sc (3) 33:146-147 (1887) Aling, Harold Lattimore.

16 Glacial lakes and other glacial fer tures of the central Adirondacks. G So Am, B 27:65 (abst), 645-672, map (1916

17 The Adirondack graphite deposits N Y St Mus B 199: 150 pp, maps (1917).

18 Descriptive catalog of a petrographl collection of rocks from Cripple Creet Colo.; a petrographic interpretation of the rocks of an interesting and importat region. 24 pp, Ward's Natural Science Establishment, Rochester N Y, $\$$ 918. Cats $\log$ No. 35

\section{Alling, Mark $\mathrm{N}$}

14 Ancient auriferous gravel channels Sierra Co., Cal. Am I M Eng, B 91: 1700 1728 (1914); $\operatorname{Tr} 49: 238-257$ (1915)

Allorge, Maurice Mancel.

o6 Esquisse geographique du Cap Col (Etats-Unis). An Géog $15: 443-448$ (1906)

08 The newly discovered cave of Atoysc Mexico ; a contribution to the study of car development. Brit As, Rp 77:577 (1908 Alsdorf. Percy $R$.

16 Occurrence, geology, and economl value of the pitchblende deposits of Gllpit Co., Colo. Ec G $11: 266-275$ (1916) 
A1thonse, Harry W.

00 The Buckstown coal fields, Berlin basin, Somerset Co., Pa. Eng M J $69: 291$ (1900)

04 The Norton coals of the Big Sandy basin. Eng M J 77:235-236 (1904)

06 The Pocahontas coals, Pottsville series no. XII, in Raleigh and Wyoming counties of West Virginia. M Mag 13: 201-213 (1906)

07 Geology of the Buck Mountain coal bed. Eng M J 83:668-670 (1907)

$07 \mathbf{a}$ The so-called new supplies of anthracite [Pennsylvania]. Eng M J 84 : 500-503 (1907)

Alvord, Benjamin.

74 On the recent earthquakes in North Carolina. Ph Soc Wash, B 1:101-102 (1874)

Amador, Manuel Gutiérrez.

oo Notas sobre la geología de Zacatecas. Min Mex 36 no 21:- (1900) [not seen]

06 Los principales centros aurfferos del mundo. Soc Cient Ant Alz, Mem 23:355381 (1906)

os Las capas Cárnicas de Zacatecas [Triassic deposits]. Soc G Mex, B 4:29-35 (1908)

16 Criaderos de antimonio en Fresnillo, Zacatecas [Mexico]: Bol Minero 2:1-2 (1916)

Ambrose, A. W.

16 (with Hall, E. B.) Descriptions of new species from the Cretaceous and Tertiary of the Tesla, Pleasanton, San Jose, and Mt. Hamilton quadrangles, Cal. Nautilus $30: 68-71,77-82$ (1916)

Amelung, Fred $M$.

so The geology of the Leadville ore district [Colo.]. Eng M J 29:255 (1880)

Ameriean Association for the Advancement of Science, Paciflc Coast Committee.

15 Nature and science on the Pacific coast ... 302 pp, maps, San Francisco 1915

American Association of Petroleum Geologists.

17 Bulletin. 2 vols, 1917-8. Vol 1 has title Bulletin of the Southwestern Association of Petroleum Geologists. Editor, Charles H. Taylor.

\section{American Bureau of Mines.}

66 Union Pacific Railroad. A geological and agricultural survey of 100 miles west of Omaha [made by Thos. Egleston]. 44 pp, N Y 1866 Notice, Am J Sc (2) 43:114 (1867)

67 On the rock-salt deposit of Petit Anse; Louisiana Rock-Salt Company; report of the American Bureau of Mines [based on examination by C. Fiton Buck and C. A. Goessmann]. 35 pp. map, N $\mathbf{Y}$ 1867
Ameriean Geographical Society.

15 Memorial volume of the transcontinental excursion of 1912, $407 \mathrm{pp}, \mathrm{N}$ Y 1915

American Geological Association.

10 Bulletin no 1, Summer, 1910 [Athens, Tenn.] Editor, G. Elsworth Brown.

Ameriean Geologist; a monthly journal of geology and allied sciences. Vol 1, 1888-vol 36, 1905, Minneapolis, Minn. Editors, N. H. Winchell and others.

8s The international congress of geologists. Reports of the Amrerican committee to the London session. Am G 2:140-143 (1888)

88a Formation of coal seams. Am G $2: 334-336$ (1888)

89 A new glacial theory. Am G $3: 138$ 140 (1889)

89a Geological Society of America. Am G $3: 140-146$ (1889)

89b Unconformity at the Falls of the Montmorenci [Que.]. Am G 3:333-334 (1889)

89c Some recent speculations on the origin of petroleum. Am G 4:371-376 (1889)

90 The Azoic system. Am G 5:106107 (1890)

$90 a$ The prenatal history of the Geological Society of America. Am G 6:181194 (1890)

$90 \mathrm{~b}$ What constitutes the Taconic Range of mountains. Am G 6:247 (1890)

90e Quebec not in conflict with Taconic. Am G 6:310-311 (1890)

91 The crenitic hyopthesis. Am G 8: 110-114 (1891)

91a The international congress of geologists; Washington meeting. Am G 8 : 243-258 (1891)

$91 b$ Recent studies in spherulitic crystallization. Am G $8: 387-392$ (1891)

92 The so-called Laurentian limrestones at St. John, N. B. Am G $9: 198-200$ (1892)

93 [Boring in McDonald region, Pa.]. Am G 12:325-326 (1893)

97 The geological chronology of Renevier. Am G 20:318-321 (1897)

American Journal of Science, New Haven, Conn.

Numerous short notes by various writers treating of the occurrence, etc., of minerals, rocks, fossils, etc., have been omitted. The limits of the work made it impracticable to Include these.

American Mineralogical Journal ... Conducted by Archibald Bruce. Vol 1: 272 pp, N Y 1814

American Mineralogist. Vol 1, July 1916 - Philadelphia, Pa. Editor, Wallace Goold Levison. 


\section{American Year Book:}

The American Year Book; a record of events and progress, 1910-1918 [includes an annual review of progress in different branches of geology and related sciences by various writers]. N Y, D. Appleton and Company, 1911-1919

Ames, Mary Lesley.

09 Life and letters of Peter and Susan Lesley. 2 vols, N Y 1909

Ami, Henry Mare.

82 Notes on an exposure of the Potsdam formation at Buckingham Basin, Lièvre River, Quebec. Ottawa Field Nat Club, Tr no $3: 39$ (1882)

$82 a$ The Utica slate. Ottawa Fidd Nat Club, Tr no 3:61-66 (1882)

$82 b$ Utica slate formation in Canada (abst). Can Nat n s 10:192 (1882)

83 Notes on Triarthrus spinosus Billings. Ottawa Field Nat Club, Tr no $4: 88-89$, Il (1883)

84 List of fossils from Ottawa and vicinity. Ottawa Field Nat Club, Tr no 5:5462 (1884) Reprint, with amended title, 10 pp. (1884)

84a A classified list of Cambro-Silurian and post-Tertiary fossils from Ottawa and vicinity. $10 \mathrm{pp}$, Ottawa, Canada, 1884

84b Report of the geological section for the season of 1883 [notes on Ottawa region]. Ottawa Field Nat Club, $\mathrm{Tr}$ no 5: 118-121 (1884)

s5 Additional notes on the geology and palentology of Ottawa and vicinity. Ottawa Field Nat Club, Tr no 6:251-259 (1885)

87 On the occurrence of Scolithus in rocks of the Chazy formation about Ottawa, Ont. Can Rec Sc 2:304-306 (1887)

$\mathbf{8 7 a}$ The great ice age and subsequent formations at Ottawa, Ont. Ottawa Nat $1: 65-74,81-88$ (1887)

$\mathbf{8 7 b}$ Notes on, and the prec1se geological horizon of Siphonotreta scotica Davidson. Ottawa Nat 1: 121-126 (1887)

87e (and Sowter, T. W. E.) Report of the geological branch. Ottawa Fleld Nat Club, Tr no. $7: 342-349$ (1887)

87d (and sowter, T. W. E.) Report of the geological branch. Ottawa Nat 1 : 93-97 (1887)

88 Systemattc list of fossils [eastern townships of Quebec]. Can G S, An Rp 3 : K 115-120 (1888)

88 a Notes on fossils from the Utica formation at Point-a-Pic, Murray River, Murray Bay, Que. Can Rec Sc 3:101-106 (1888)

88b On Utica fossils from Rideau, Ottawa, Ont. Ottawa Nat 1:165-169 (1888)

8se On the occurrence of "phosphatic nodules" in the Chazy formation about Ottawa, Canada. Ottawa Nat 2:45-46 (1888)

88d [Faulting in the vicinity of Ottawa, Ont.] Ottawa Nat $2: 48$ (1888)
' mi, Henry Marc-Continued.

s8e [Geology of the Government ex. perimental farm, Ottawa, Ont.] Ottawa Nat 2: 71-72 (1888)

ssf On the sequence of the geological formations about Ottawa, with reference to the natural gas question. Ottawa Nat 2: 93-96 (1888)

88g (and others) Report of the gealogical branch for the season of 1887 . Ottawa Nat $1: 172-173$ (1888)

89 Contribution to the geology and paleontology of the townships of Russell and Cambridge, in Russell, Ont.; II, Paleontol. ogy. Ottawa Nat 2:139-140 (1889)

89a On a species of Goniograptus from the Levis formation, Levis, Que. Can Rec Se 3: 422-428 (1889)

S9b Additional notes on Goniograptu thureaui McCoy from the Levis formation, Canada. Can Rec Sc 3:502-503, il (1889)

s9e (and Ells, R. W.) Report of the geological branch [of the Ottawa Field Naturalists' Club]. Ottawa Nat $3: 36-38$ (1889)

90 On the geology of Quebec City. Science 16:317 (1890) Can Rec Sc 4: 315-319 (1891) Abst, Am J Sc (3) 43: $75-77$ (1892)

90a (and Low, A. P.) Report of the geological branch [of the Ottawa Field Naturalists' Club]. Ottawa Nat 4:70-73 (1890)

91 On the geology of Quebec and environs (with discussion by A. R. C. Selwyt and others). G Soc Am, B 2:477-500 (1891)

91a On some extinct Vertebrata from the Miocene rocks of the Northwest Territories of Canada recently described by Professor Cope. Science 18:53 (1891) Ottawa Nat 5: 74-76 (1891)

91b On the sequence of strata forming the Quebec group of Logan and Billings with remarks on the fossils found thereis (abst). Ottawa Nat 6:41-43 (1893) All G $8: 115-117$ (1891)

92 Catalogue of Silurian fossils from Arisaig, N. S. $\mathrm{N} S$ Inst $\mathrm{Sc}, \mathrm{Pr} \mathrm{Tr} 8$ of (2) $1: 185-192$ (1892)

92a Additional notes on the geology and paleontology of Ottawa and its environs Ottawa Nat $6: 73-78$ (1892)

$\mathbf{9 2 b}$ Notes and descriptions of some ner or hitherto unrecorded species of fossils from the Cambro-Silurian (Ordovician) rocks of the Province of Quebec. Can Res Sc 5: 96-103 (1892)

92e Paleontological notes. Can Rec sc 5: 104-108 (1892)

92d The Utica terrane in Canada, Rec Sc 5 : 166-183, 234-246 (1892)

93 On a small collection of fossils from the Trenton limestones of Port Hope [Ont.]. Ottawa Nat 7:100 (1893) 
Ami, Henry Mare - Continued.

93a Notes on the geology and paleon tology of the Rockland quarries and vicinity, in the County of Russell, Ont., Canada. Ottawa Nat $7: 138-147$ (1893)

93b The world's geological congres? [Chicago, August, 1893]. Can Rec Se 5: 480-484 (1893)

93e Notes on Cambrian fossils from the Selkirks and Rocky Mountain region of Canada (abst). Am G 11: 132 (1893).

94 Notes on fossils from Quebec City, Canada. Ottawa Nat 8:82-90 (1894)

$94 \mathbf{a}$ (and others) Report of the geological branch, 1893-94 [of the Ottawa Field Naturalists' Club]. Ottawa Nat 8:102104 (1894)

94b [The geology of Galetta, Ont.] Ottawa Nat 8:109 (1894)

94e Saxicava sands and gravels at Carp, Ont. Ottawa Nat $8: 121-122$ (1894)

95 Notes on Canadian fossil Bryozoa. Can Rec Sc 6:222-229 (1895)

95a Notes on a collection of Silurian fossils from Cape George, Antigonish Co., N. S., with descriptions of four new species. N S Inst Sc, Pr Tr 8 or (2) 1:411-415 (1895)

95b Memorial of Amos Bowman. G Soc Am, B 6 : 441-443 (1895)

95e Report of the geological branch, 1894-95 [of the Ottawa Field Naturalists' Club]. Ottawa Nat 9: 167-169 (1895)

a5d Fossil insects from the Leda clays of Ottawa and vicinity. Ottawa Nat 9: $190-191$, il (1895)

96 Preliminary lists of the organic remains oceurring in the various geological formations comprised in the southwest quartersheet map of the eastern townships of the Province of Quebec. Can G S, An Rp 7: J 113-157 (1896)

96 Notes on some of the fossil organie remains comprised in the geological formations and outliers of the Ottawa Paleozoic basin. R Soc Can, Pr Tr (2) 2, iv:151158 (1896)

961 Notes on some fossils from the Trenton of Highgate Springs, Vt., near the Canadian boundary line. Ottawa Nat 9: 215-216 (1896)

96e Note on Cardinia subangulata Dawson and Area punctifer Dawson. Ottawa Nat $10: 44$ (1896)

96d New species of graptolites from Canada. Ottawa Nat 10:145-147 (1896) 97 (and others) Report of the geological branch of the Ottawa Field Naturalists Club for 1896-97. Ottawa Nat 11:17-19 (1897)

97a Contribution to the paleontology of the post-Pliocene deposits of the Ottawa Valley. Ottawa Nat 11:20-26 (1897)

$97 \mathbf{b}$ Synopsis of the geology of Montreal. Brit Medieal Assoc, Guide and Souvenir : 45-49, Montreal 1897 [not seen]
Ami, Henry Marc-Continued.

98 Note on the physiography and geology of King's Co., N. S. Ottawa Nat $12: 149$ 150 (1898)

9Sa The mastodon in western Ontario (abst). Science n s 7:80 (1898)

981, On some new or hitherto little known Paleozoic formations in northeastern America (abst). Brit As, Rp 67:657 (1898)

99 On some Cambro-Silurian and Silurian fossils from Lake Timiskaming, Lake Nipissing, and Mattawa outliers. Can G S, An Rp 10: I 289-302 (1899)

$99 a$ [Report on field work on islands in Lake Huron and in Nova Scotia.] Can G S, Sum Rp 1898 (An Rp 11) : A 176-182 (1899)

$99 b$ On a new or hitherto unrecognized geological horizon in the gas and oil region of western Ontario, Canada. Can M Inst, J $2: 186-190,207-211$ (discussion) (1899) Abst, Can M Rv 18:90 (1899)

99e The Geological Society of America [New York City, 1898]. Ottawa Nat 12 : 194-198 (1899)

99d Progress of geological work in Canada during 1898 [bibliography]. Ottawa Nat $13: 52-55(1899)$

99e Obituary, O. C. Marsh. Ottawa Nat $13: 135-136$ (1899)

99f Bellinurus grandaevus, a new species of Paleozoic limulid crustacean recently described by Prof. T. R. Jones and Dr. Henry Woodward from the Eo-Carboniferous of Riversdale, N. S. Ottawa Nat $13: 207-208$ (1899)

$99 \mathrm{~g}$ Report of the geological branch for 1898-1899 [of the Ottawa Field Naturalists' Club]. Ottawa Nat 13: 218-223 (1899)

99h on the geology of Wolfville and part of the basin of Minas, N. S. The Evangeline Journal, Wolfville, N. S., 3d ed, season 1899 [not seen]

oo On the geology of the principal eitles in eastern Canada. R Soc Can, Pr Tr (2) 6 , iv : 125-173 (1900)

O0a Synopsis of the geology of Canada; being a summary of the principal terms employed in Canadian geological nomenclature. R Soc Can, Pr Tr (2) 6, iv : 187225 (1900)

0ob on the subdivisions of the Carboniferous system in eastern Canada, with special reference to the position of the Union and Riversdale formations of Nova Scotia, referred to the Devonian system by some Canadian geologists. N S Inst Sc, Pr $\operatorname{Tr} 10$ or (2) $3: 162-178$ (1900) Abst, Brit As, Rp 69: 755-756 (1900)

o0e [Report on field work in Nova Scotia and New Brunswick.] Can G S, Sum Rp 1899 (An Rp 12) : A 200-204(1900)

00d Sir John William Dawson. Am G $26: 1-48$, port (1900) 
Ami, Henry Marc-Continued.

Ooe Memoir of Sir J. William Dawson; bíbliography. G Soc Am, B 11:557-580 (1900)

oof Notes on some of the formations belonging to the Carboniferous system in eastern Canada. Can Rec Sc 8:149-163 (1900)

OOg Progress of geological work in Canada during 1899 [bibliography]. Can Rec Sc $8: 232-246,329-331$ (1900-01)

ooh On some Trenton (Ordovician) fos. sils from the light grey limestones of Cumberland, County of Russell, Ont., Canada. Ottawa Nat $13: 238-240$ (1900)

001 Annual address of the president of the Ottawa Field Naturalists' Club ... Ottawa Nat $13: 263-276,279-294$ (1900)

$00 j$ On the occurrence of a species of Whittleseya in the Riversdale formation (Eo-Carboniferous) of the Harrington River along the boundary line between Colchester and Cumberland cos., N. S. Ottawa Nat 14: 99-100 (1900)

ook Notes bearing on the Devono-Carboniferous problem in Nova Scotia and New Brunswick. Ottawa Nat 14:121-127 (1900)

001 The Paleozolc formations of eastern Canada (abst). Science n s 11:1023 (1900)

01 Preliminary lists of the organic re mains occurring in the various geological horizons comprised in the map of the Ottawa district, including formations in the provinces of Quebec and Ontario, along the Ottawa River. Can G S, An Rp 12: a 4977 (1901)

01 a Lists of fossils obtained from the several formations along the Ottawa River pertaining to the report on sheet no. 121 , Quebec and Ontario (Grenville sheet). Can G S, An Rp 12: J 139-143 (1901)

01b [Notes on Silurian formations in Antigonish County, N. S.] Can G S, Sum Rp 1900 (An Rp 13) : A 179-180 (1901)

o1e Bibliography of Dr. George M. Dawson. Am G 28: 76-86 (1901)

01d Bibliography of Sir John William Dawson. R Soc Can Pr Tr (2) 7, iv: 1544 (1901)

o1e Bibliography of Canadian geology and paleontology for the year 1900. R Soc Can, $\operatorname{Pr} \operatorname{Tr}$ (3) 7, iv : 123-133 (1901); ... for 1901, ibid (2) 8, iv : 169-182 (1902; ... for 1902 , ibid (2) 9 , iv : 173-188 (1902); ... for 1903, ibid (2) 10, iv : 207-219 (1905) ; ... for 1904 , ibid (2) 11, iv : 127$142(1906) ; \ldots$ for 1905 , ibid (2) 12 , iv : 301-326 (1906) ; ... for 1906, ibid (3) 1 , iv : 143-156 (1907) ; ... for 1907 , ibid (3) 3 , iv : 191-204 (1910)

o1f On a new and hitherto unrecognized geological formation in the Devonian system of Canada. Can Rec Sc 8:296-305 (1901)
Ami, Henry Marc-Continued.

O1is Knoydart formation of Nova Scotie G Soc Am, B 12:301-312, map (1901) Abst, Science n s 13: 135 (1901) ; Can Res Se $8: 474-476$ (1902)

orh Esquisse géologique du Canada on matériaux pour servir a la préparatio: d'un chronographe géologique pour le Can. ada. Naturaliste Can 28: 194-202 (1901) $29: 3-14, \quad 19-30, \quad 35-46, \quad 52-61, \quad 73-8$ (1902). Reprinted, 60, ix pp, Quebec, Car ada 1902.

o1i Brief biographical sketch of Elka nah Billings. Am G 27:265-281, port: 28: 132 (1901)

01j Annual address of the president of the Ottawa Fleld Naturalists' Club [me morial of E. Billings]. Ottawa Nat 14: 212, port (1901)

01k The late George Mercer Dawson Ottawa Nat 15:43-52, port (1901)

011 Bibliography of Dr. George Merces Dawson. Ottawa Nat 15: 202-21S (1901) $\mathrm{R}$ Soc Can, $\operatorname{Pr} \operatorname{Tr}(2) 8$ iv : 192-201 (1902) Can Rec Sc 8:503-516 (1902)

$01 \mathrm{~m}$ Stratigraphical note [Devonian and Silurian of Antigonish Co., N. S.]. Scienes n s 13:394-395 (1901)

$01 n$ Notes on some of the Silurian and Devonian formations of eastern Canada and their faunas and floras (abst). Science n s 13:1017-1018 (1901) R Soc Can, P? Tr (2) $7: x$ :vii (1901)

010 On the subdivisions of the Cam brian system of Canada (abst). Science n s 13:1019 (1901) R Soc Can, Pr T: (2) $7: x l v i i(1901)$

01p A dual classification required to the nomenclature of the geological forms tions in different systems in Canadt (abst). Science n s 13:1019-1020 (1901)

02 On the possible occurrence of a cos area beneath the neo-Carboniferous or Pes mian strata of Pictou Co., N. S. Can X Inst, J 5:358-364 (1902) Can M Br 21:160-162 (1902)

02a Description of tracks from the fine grained siliceous mudstones of the Knor dart formation (Eo-Devonian) of Antigo nish Co., N. S. N S Inst Sc, Pr Tr $100^{\circ}$ (2) $3: 330-332$, il (1902)

02b The Cambrian age of the Dictyo nema slates of New Canaan and Kentville N. S. G Mag (4) 9:218-220 (1902)

02e The Union and Riversdale forms tions in Nova Scotia. Science n s $15: 39$. (1902)

02d Field notes on the geology of the country about Chelsea, Que. Ottawa N8: $16: 149-151$ (1902)

o2e Brief description of the map of th Ottawa district. Ottawa Nat $16: 187-18$ (1902)

02f Artesian wells, paleontology, a chaeology, bibliographies, etc. Can G \& Sum Rp 1901 (An Rp 14) : A 260-267 (1902 
Ami, Henry Marc-Continued.

02m Annual report of the geological section of the Ottawa Field Naturalists' Club for the year 1901-1902. Ottawa Nat 15: 254-262 (1902)

02h Notes on the Albany meeting of the Geological Society of America, held December, 1900. Can Rec Sc 8:471-477 (1902)

02i The great Saint Lawrence-Champlain-Appalachian fault of America and some of the geological problems connected with it (abst). G Mag (4) 9:425 (1902) G Soc L, Abst Pr no 764:129-130 (1902)

$02 j$ Ordovician succession in eastern Ontario (abst). Science n s 15: 82 (1902) G Soc Am, B 13: 517-518 (1903)

03 Sketch of the life and work of the late Dr. A. R. C. Selwyn ... Am G 31:121, port (1903) R Soc Can, Pr Tr (2) 10 iv : $173-205$, port (1905)

03a On the upper Cambrian age of the Dictyonema slates of Angus Brook, New Canaan, and Kentville, N. S. . N S Inst Sc, $\operatorname{Pr} \operatorname{Tr} 10$ or (2) $3: 447-450$ (1903)

03b Paleontology and chronological geology. Can G S, Sum Rp 1902 (An Rp 15) : A 319-337 (1903)

03e Meso-Carboniferous age of the Union and Riversdale formations, Nova Scotia (abst). G Soc Am, B 13:533-535 (1903) Science n s $15: 90$ (1902)

03d The first ep-Archean formation (abst with discussion). Science n 8 17: 290-291 (1903)

04 Preliminary lists of fossil organic remains from the Potsdam, Beekmantown (Calciferous), Chazy, Black River, Trenton, Utica, and Pleistocene formations comprised within the Perth sheet (No. 119) in eastern Ontario. Can G S, An Rp. 14: J 80-89 (1904)

04a (and Adams, F. D.) Synoptical table of geological formations about Montreal, Canada. Can G S, An Rp 14: o26-29 (1904)

05 The late Dr. A, R. C. Selwyn; his work in Canada. Can M Rv 24:175-176 (1905)

05a On the geology of Carp [Ont.] and environs. Ottawa Nat $19: 92-93$, (1905)

05b Preliminary list of the fossils collected ... in the Province of New Bruns wick in 1904. Can G S, Sum Rp 1904 (An Rp 16) : A 289-292 (1905)

05e Notes on a collection of organic remains from the ferruginous and friable shales of Messenger Brook, Torbrook ... Nova Scotia ... Can G S, Sum Rp 1904 (An Rp 16) : A 385-387 (1905)

05d Description of a species of Bythotrephis from ... Yukon district, Canada. Can G S, Sum Rp 1904 (An Rp 16) : A 388 (1905) smi, Henry Marc-Continued.

05e (with Penhallow, D. P.) Determinations of fossil plants from various localities in British Columbia and the Northwest Territories ... with notes on the geological horizon indicated ... Can $\mathbf{G}$ S, Sum Rp 1904 (An Rp 16) : A 389-392 (1905)

06 Preliminary lists of organic remains [collected by Mr. A. P. Low from Beechey Island, Southampton Island, and Cape Chidley]. Cruise of the Neptune: 329-336 (1906) [see Low, 06]

O6a On some fossils from northern Canada, collected by Commander Low, during the expedition of 1903-4, together with notes on the geological horizons to which they belong (abst). Science n $\mathbf{s} 23: 973$ (1906)

06b (and Wilson, W. J.) Report of the geological branch of the Ottawa FieldNaturalists' Club for 1905-6. Ottawa Nat $19: 209-214$ (1906)

o6c Notes on an interesting collection of fossil fruits from Vermont, in the Museum of the Geological Survey of Canada. Ottawa Nat $20: 15-17$ (1906)

O6d [Report of work in geology and paleontology.] Can G S, Sum Rp 1906: 176-177 (1906)

07 Preliminary lists of organic remains from the Chazy, Black River, Trenton, and Pleistocene formations comprised within the area of the Pembroke sheet (no. 122). Can G S, Appendix to Ells's Report on the Geology and Natural Resources of the nortliwest quarter-sheet, no $122: 47-71$ (1907)

07a Memorial of A. R. C. Selwyn (abst). Science n s $25: 763-764(1907)$ G Soc Am, B $18: 614(1908)$

09 [Report on] invertebrate palentology. Can G S, Sum Rp 1908: 179-181 (1909)

15 North America; Vol. 1, Canada and Newfoundland. Rev ed, $1069 \mathrm{pp}$, maps, L 1915 Stanford's Compendium of Geography and Travel (new issue)

See also Adams (F D), 03a; Anderson (W P), 82, 83; Cope, 95; Ells, 96d; White ( $\mathrm{T}$ G), 00

Ammen, S. $Z$.

82 History and description of the Luray Cave ... [Va.]. $3 d$ ed., 48 pp, Baltimore 1882

Anda, Manuel M. de.

75 El carbón de pleđra mexicano. La mina del Cristo en la Huasteca. Min Mex $3: 375 \quad(1875)$

76 El petróleo. Min Mex 4 no 43 :(1876?) [not seen]

76a Génesis de las vetas metaliferas. Min Mex 4 no $46:-(1876$ ?) [not seen]

83 Informe relativo a la exploración del distrito de Coalcoman ... 95 pp, map, México 1883 
Andersen, Carl.

95 The Cooney mining district, Socorro Co., N. Mex. E M J $59: 343-344$ (1895)

97 The mineral belt of the Mogollon Range [N. Mex.]. Eng M J 64:276-278 (1897)

Andersen, Olaf.

14 (with Bowen, N. L.) The binary system $\mathrm{MgO}-\mathrm{SiO}_{2}$. Am J Sc (4) $37: 487$ $500(1914)$

15 The system anorthite-forsterite-silica. Am J Sc (4) 39:407-454 (1915)

15a On aventurine feldspar. Am J Sc (4) $40: 351-399$ (1915)

17 Aventurine labradorite from Callfornia. Am Mineralogist 2:91 (1917)

Anderson, Amil A.

12 Lithium, its occurrence, uses, determination, and methods of extraction Pahasapa Q. (Rapid City, S. Dak.) 1 no. 3 : 11-15 (1912)

Anderson, C. B.

15 (and Dewolf, F. W.) Artesian waters in Chicago and surrounding territory. Ill Soc Eng. An Rp 30:69-72 (1915) Anderson, Charles $\mathrm{L}$.

61 (and Clark, T.) Report on geology and plan for a geological survey of the State of Minnesota ... 26 pp, St. Paul 1861 Anderson, Frank Marion.

95 Some Cretaceous beds of Rogue River valley, Oreg. J G 3:455-468 (1895)

99 The geology of Point Reyes Peninsula. Cal Univ, Dp G, B 2:119-153, map (1899)

01 Neocene basins of the Klamath Mountains (abst). G Soc Am, B 12:500-501 (1901) J G 9:75-76 (1901) Am G 27: 131 (1901)

02 Cretaceous deposits of the Pacific coast. Cal Ac Sc, $\operatorname{Pr}$ (3) G $2: 1-54$, il (1902)

02a The physiographic features of the Klamath Mountains. J G 10:144-159 (1902)

02b Ore deposits of Shasta Co., Cal. (abst). Sclence n s 15:412 (190z)

03 Physiography and geology of the Siskiyou Range (abst). J G 11:100 (1903) Eng M J 75:154 (1903)

04 Stratigraphy of the soutnern coast ranges of California (abst). G Soc Am, B 15: 581-582 (1904)

05 A stratigraphic study in the Mount Diablo Range of California. Cal Ac Sc, Pr (3) G $2: 155-248$, il $(1905)$

08 A further stratigraphic study in the Mount Diablo Range of California. Cal Ac Sc. $\mathrm{Pr}$ (4) 3:1-40 (1908)

11 The Neocene deposits of Kern River, California, and the Temblor Basin. Cal Ac Sc, Pr (4) 3:73-146, il (1911)

14 (and Martin, B.) Neocene record In the Temblor Basin, Cal., and Neocene deposits of the San Juan district, San Luis Obispo Co., Cal. Cal Ac Sc, Pr (4) $4: 15-112$, 11, maps (1914)
Anderson, Frank Marion-Continued.

14a Fauna of the Oligocene (?) of Ore gon (abst, with discussion). G Soc Am B 25:154 (1914)

See also Martin (B), 18a; Schrader, 17 Taff, 13

Anderson, G. E.

o7 Studies in the development of ce: tain Paleozole corals. J G $15: 59-69$, (1907)

07a Development of the inner wall Paleozoic corals (abst). Science $\mathrm{n}$ s 2: 184 (1907)

15 Stream piracy of the Provo at Weber rivers, Utah. Am J Sc (4) 40 314-316 (1915)

Anderson, Glenn.

09 Notes on economic geology of th Cobalt area, Ont. Eng M J, 88:78 (1909)

Anderson, James.

s5 An account of Morne Garon, a mous tain in the island of St. Vincent, with description of the volcano on its summ R Soc London, Ph Tr $75: 16-31$ (1785) Anderson, John.

51 The elements of creation. 384 Cincinnati 1851

Anderson, Netta C.

o5 A preliminary list of fossil mastode and mammoth remains in Illinois at Iowa. Augustana Libr Pub no. $5: 8-4$ maps (1905)

Anderson, Robert.

or Earth flows at the time of the s Francisco earthquake. (abst). Science n $25: 769$ (1907); G Soc Am, B 18:6 (1908)

07a (with Arnold, R.) Diatomaceo deposits of northern Santa Barbs: Co., Cal. U S G S, B 315:438-447 (190)

07b (with Arnola, R.) Preliminary port on the Santa Maria ofl district, Sat Barbara Co., Cal. U S G S, B 317:69 (1907)

07e (with Arnold, R.) Geology : oil resources of the Santa Maria oil trict, Santa Barbara Co., Cal. U S G B $322: 161 \mathrm{pp} \mathrm{(1907)}$

o7d (with Arnold, R.) Metamorphi by combustion of the hydrocarbons in oil-bearing shale of California. J G $750-758$ (1907)

08 (with Arnold, R.) Conglomer formed by a mineral-laden stream in C fornia. G Soc Am, B 19:147-154 (19 OSa (with Arnold, R.) Preliminary port on the Coalinga ofl district, Fres and Kings cos., Cal. U S G S, B 357:1 pp (1908)

osb (with Arnold, R.) The Coalin: Cal, oil field (abst). Science n s $28: 1$ ? 128 (1908)

09 An occurrence of asphaltite in nor eastern Nevada. U S G S, B 380:28 285 (1909) 
Anderson, Robert-Continued.

09a Geology and oil prospects of the Reno region, Nev. U S G S, B 381:475489 (1909)

09b Two areas of oil prospecting in Lyon Co., western Nev. U S G S, B 381: 490-493 (1909)

10 (with Arnold, R.) Geology and oil resources of the Coalinga district, Cal. U S G S, B 398: 354 pp, il, map (1910); reprinted 1911 Abst, Wash Ac Sc, J 1: 130-132 (1911)

11 Preliminary report on the geology and oil prospects of the Cantua-Panoche region, Cal. U S G S, B 431: 58-87 (1911)

11a An earthquake in Trinidad, B. W. I. Seism Soc Am, B 1: 170 (1911)

11b A new gas voleano in Trinidad. Science n s $34: 834-835$ (1911)

12 Preliminary report on the geology and possible oil resources of the south end of the San Joaquin Valley, Cal. U S G S, B 471: 106-136, map (1912)

12a [The formation of a new island near Trinidad] (abst). Wash Ac Sc, J 2 : 108 (1912)

12b The origin and geological occurrence of petroleum (abst). Technologist 17: $62-63$ (1912)

13 Some suggestions for general field work. E G 8:289-291 (1913)

15 (and Pack, R. W.) Geology and oil resources of the west border of the San Joaquin Valley north of Coalinga, Cal. U S G S, B 603: 220 pp, map (1915) Abst, Wash Ac Sc, J $5: 647-648$ (1915)

Arolerson, Tempest (1846-1913).

02 (and Flett, J. S.) Preliminary report on the recent eruption of the Soufrière in St. Vincent, and of a visit to Mont Pelé, in Martinique. R. Soc London, Pr 70:423-445 (1902) Nature 66:402-406 (1902) Smiths Inst, An Rp 1902:309330 (1903)

03 (and Flett, J. S.) Report on the eruptions of the Soufriere in St. Vincent in 1902 and on a visit to Montagne Pelée in Martinique. $\mathrm{R}$ Soc London, $\mathrm{Ph} \mathrm{Tr}$ ser A $200: 353-553$ (1903)

03a Recent volcanic eruptions in the West Indies. Geog J 31:265-279 (1903) Yorkshire $\mathrm{Ph}$ Soc, An Rp 1903: 265-279 (1903)

03b Characteristics of recent volcanic eruptions. Nature 67:308 (1903)

or Recent volcanic eruptions in the West Indies. Int G Cong, x, Mexico, 1906, C R : 735-737 (1907)

os Report on the eruptions of the Soufrière in St. Vincent in 1902, and on a visit to Montagne Pelée in Martinique; Part II, The changes in the districts and the subsequent history of the volcanoes. R Soc London, $\mathrm{Ph}$ Tr ser A 208: 275-303 (1908) 08a The volcanoes of Guatemala. Geog J $31: 473-485, \operatorname{map}(1908)$
Anderson, Tempest-Continued.

osb The Soufriere of St. Vincent; the changes subsequent to the eruption of 1902 (abst). G Mag (5) 5:468-469 (1908) Brit As, Rp 78: 706-707 (1909)

09 The volcanoes of Guatemala. Liverpool Geog Soc, Tr An Rp 17:11-15 (1909)

10 An adventure with an eruption of Mont Pele. Can Alpine J 2:114-120 (1910)

12 Volcanic craters and explosions. Geog J 39 : 123-132 (1912)

17 Volcanic studies in many lands .. Second series. $88 \mathrm{pp}, \mathrm{L} 1917$.

Anderson, William.

60 Geology [of Indiana Co., Pa.] Med Soc Pa, Tr n s 5:85-90, map (1860)

Anderson, William James.

64 Gold Fields of Nova Scotia. Lit Hist Soc Quebec, Tr n s 2: 35-50 (1864)

66 On the coal-like substance or " altered bitumen " found in the excavations at Fort No. 3, Point Levis, and the presently accepted theories on the origin of coals, bitumens, and petroleum springs, with an account of the Carboniferous system of British North America. Lit Hist Soc Quebec, Tr n s 4: 19-47 (1866)

Anderson, William $P$.

So Asbestos. Ottawa Field Nat Club, Tr no $1: 32-35$ (1880)

82 (and others) Report of the geolog. ical branch for the season of 1881. Ottawa Field Nat Club, Tr no 3: 19-21 (1882)

83 (and others) Report of the geolog ical and mineralogical branch for the season of 1882. Ottawa Field Nat Club, Tr no $4: 64-66$ (1883)

Andersson, J. G.

06 Solifluction, a component of subaerial denudation. J G $14: 91-112$ (1906)

Andreae, A.

93 (and osann, A.) Tiefencontacte an den intrusiven Diabasen von New Jersey. Naturh-med Ver Heidelberg, Verh (N F) 5 : 16-27 (1893) Rv, N Jb 1893, 1:505

Andrếe, K.

14 Verschiedene Beiträge zur Geologie von Canada. Ges Naturw Marburg, Schrift $13: 407-466$ (1914)

Andrews, C. Irving.

98 The volcanic rock of Alum Hill, Boulder Co., Colo. Colorado Sc Soc, Pr 5: 148-155 [1898] (separate ed, 8 pp, 1895)

Andrews, C. L.

03 Muir Glacier [Alaska]. Nat Geog Mag 14: 441-445 (1903)

Andrews, E. C.

10 An excursion to the Yosemite (Cali. fornia), or studies in the formation of alpine cirques, "steps," and valley " treads," R Soc N S Wales, J Pr $44: 262-315$ (1910)

See also Hilgard, 71a 
Andrews, Ebenezer Baldwin (1821-1880).

60 Relation of the river terraces of southern Ohio to the drift and drift theories. Am As, Pr 13: 319-321 (1860)

60 a An account of the fall of meteoric stones at New Concord, Ohio, May 1, 1860. Am J Sc (2) 30:103-111 (1860)

61 Rock oil, its geological relations and distribution. Am J Sc (2) $32: 85-93$ (1861) Pharmaceutical J (2) 4:73-76 (1862)

64 Observations on a seam of coal [Washington Co., Ohío]. Am J Sc (2) 38 : 194-199 (1864)

65 Report on the economical geology of southern Ohio traversed by the Marietta \& Cincinnati Railroad, including the Portsmouth branch. 26 pp, map, Cincinnati 1865

66 Petroleum in its geological relations. Am J Sc (2) 42:33-43 (1866)

71 [Economic geology of southeastern Ohic.] Ohio, Secretary of State, An Rp 1870: 200-204, Columbus 1871

71a Report of progress in the second district. Ohio G S [Rp Prog 1869], pt. 2 : 55-142, map (1871)

71b Report of labors in the second geological district during the year 1870 . Ohio G S, Rp Prog 1870:55-251 (1871)

71e Lower Carboniferous limestone in Ohio. Am J Sc (3) 1:91-92 (1871)

72 (with Newberry, J. S.) Report of progress of the geological survey of Ohio for the year 1871. Two different editions, $12 \mathrm{pp}$ [Columbus 1872]

73 Report on second geological district: Gallia Co. ; Meigs Co. ; Athens Co. ; Morgan Co.; Muskingum Co. Ohio G S, Rp 1 pt 1 Geology : 225-364 (1873)

74 Report on second district: surface geology of southeastern Ohio; geology of Washington Co.; Noble Co.; Guernsey Co. (southern half); Belmont Co. (southern half) ; Monroe Co.; Pickaway and Fairfield cos. Ohio G S, Rp 2 pt 1 Geology: 439608 (1874)

74a On the parallelism of coal seams. Am J Sc (3) 8:56-59 (1874) Cin Q J Sc $1: 340-342$ (1874)

75 Descriptions of fossil plants from the coal measures of Ohio. Ohio G S, Rp 2 pt 2 Paleontology : 413-426, il (1875)

75a A comparison between the Ohio and West Virginia sides of the Alleghany coal field. Am J Sc (3) 10:283-290 (1875) Am As, Pr 24 pt 2:84-92 (1876)

75b Notice of new and interesting coal plants. Am J Se (3) 10:462-466 (1875) Am As, Pr 24 pt 2:106-109 (1876)

76 On the erosion of rocks. Am J Sc (3) 12:304-305 (1876)

78 Supplemental report on Perry Co., and portions of Hocking and Athens cos. Ohio G S, Rp 3 pt 1:815-882 (1878)
Andrews, Ebenezer Baldwin-Continued.

78a An elementary geology ... 283 pp Cincinnati $1878 R v$, Am J Sc (3) $17: 175$ 176 (1879)

79 Discovery of a new group of Lowe Carboniferous rocks in southeastern Ohio Am J Sc (3) 18:137 (1879)

79a Geologic atlas of the State of Ohio Am J Sc (3) 18:410 (1879)

Andrews, Edmund.

67 ... the glacial drift beneath the bed Lake Michigan, as seen in the Chicag: tunnel. Am J Sc (2) 43:75-77 (1867)

69 On some remarkable relations and characters of the western boulder drift Am J Sc (2) 48:172-179 (1869)

70 The North American lakes considered as chronometers of postglacial time. Ch. cago Ac Sc, Tr 2:1-23, map (1870) Abst Am-J Sc (2) $50: 264-265,424$ (1870)

74 New theory of geyser action as illus trated by an artificial geyser. Am As, P. 22 pt 1:115-118 (1874) Abst, Can Na: n s $7: 165-166$ (1874)

75 Dr. Koch and the Missouri mastodor Am J Se (3) $10: 32-34$ (1875)

83 Glacial markings of unusual forms is the Laurentian Hills [Ont.]. Chicago d Sc, B 1:1-9 (1883) Am J Sc (3) 26:99105 (1883)

Andros, S. O.

15 Coal mining in Illinois. In Coal $\mathbb{N}$ Investigations, B $13: 250 \mathrm{pp}$ (1915)

Angermann, Ernesto.

04 Informe acerca de la fisiografta, geo logía é hidrologia de los alrededores de L Paz, Baja California. Mex I G, Par 1:31. 49, map (1904) Mex, Sec Fomento, B (2 3 , IV : 216-283, map (1904)

O4a Apuntas sobre el Paleozoico en So nora. Mex I G, Par 1:81-90 (1904)

04b EI fierro meteorico de Bacubirite Estado de Sinaloa. Mex I G, Par 1: 113 116 (1904)

O4c Observaciones geologicas en una as censión al Citlaltapetl (Pico de Orizaba [Mexico]. Soc Cient Ant Alz, Mem 21 365-369 (1904)

04d (with B̈se, E.) Informe sobre temblor del 16 de enero de 1902 en Estado de Guerrero. Mex I G, Par 1 125-131 (1904) Mex, Sec Fomento, B (2 4 no 11, iv : 223-229 (1904)

o7 Explicación del plano geológico de region de San Pedro de Gallo, Estado Durango [México]. Mex I G, Par 2: 5-1 map (1907)

o7a Sobre la geología de la Bufa, M pimí, Estado de Durango [México]. Mex G, Par 2:17-25, map (1907)

07b Notas geologicas sobre el Cretace en el Estado de Colima [México]. Mex I Par 2 : 29-35 (1907) 
Annan, Robert.

93 Account of a skeleton of a large an: mal found near Hudson River [Mastodon?] Am Ac Arts, Mem $2:$ 160-164 (1793)

Annes, Erle Chadwick.

15 The geology and economic minerals of Yukon Territory. Mine, Quarry, and Derrick [Calgary, Alta.] 1 : 176-181 (1915)

Annual of Scientife Discovery; edited by David A Wells and others. Boston, 1850-71.

Includes abstracts of articles on geology.

Annual Record of Seience and Industry for 1871 [-1878]; edited by Spencer F. Baird. N Y 1872-9

Includes abstracts of papers on geology and mineralogy.

Anrep, Aleph.

09 (with Nystrom, Erik) Investigation of the peat bogs and peat industry of Canada during the season 1908-9. Can Mines Br, B 1:25 pp (1909)

10 Investigation of the peat bogs, and peat industry of Canada during the season 1909-10. Can, Mines Br, B 4 (2d ed) : 44 pp (1910) [1st ed, see Nyström, 09]

11 On the investigation of the peat bogs of Canada, and manufacture of peat fuel at the government peat plant, Alfred, Ont. Can Mines Br, Sum Rp 1910:115-116 (1911)

12 Investigation of the peat bogs and peat industry of Canada, 1910-11. Can Mines Br. B 8: 53 pp, maps (1912)

14 Investigation of the peat bogs and peat industry of Canada, 1911-12. Can Mines Br, B 9: 47 pp, maps (1914)

15 Investigation of the peat bogs and peat industry of Canada, 1913-14. Can Mines Br, B $11: 185$ pp, maps (1915)

Ansted, David Thomas (1814-1880).

47 The ancient world, or picturesque sketches of creation. $382 \mathrm{pp}$, Phila 1847 . Another ed, $408 \mathrm{pp}, \mathrm{L} 1847$

49 The gold-seeker's manual; ... gold regions of California. $96 \mathrm{pp}, \mathrm{N}$ Y 1849

56 The Cobre (copper) lode of Santiago de Cuba. G Soc London, Q J 12:144-153 (1856)

57 On some remarkable mineral veins; 1, On the San Fernando copper lodes near Cienfuegos, Cuba; 2, On some copper lodes near Sykesville in Maryland; 3 , On the copper lodes of Ducktown, in east Tennessee. G Soc London, Q J $13: 240-254$ (1857)

63 The great stone book of nature. 309 pp, L 1863335 pp, Phila 1863

69 The earth's history, or First lessons In geology. 214 pp, Phila 1869

85 The Cabin Creek Coal Co. lands [Great Kanawha Valley]. The Virginias $6: 129-130 \quad(1885)$ nthony, Harold Elmer.

16 Preliminary diagnosis of an apparently new family of iñsectivores. Am Mus N H $35: 725-728$, il (1916)

16a Preliminary report of fossil mammals from Porto Rico; with descriptions of a new genus of ground sloth and two new genera of hystricomorph rodents. N Y Ac Sc, An 27:193-203, il (1916)

17 New fossil rodents from Porto Rico, with additional notes on Elasmodontomys obliquus Anthony and Heteropsomys insulans Anthony. Am Mus N H, B 37 : 183189, il (1917)

17a Two new fossil bats from Porto Rico. Am Mus N H, B $37: 565-568$, il (1917)

17b Fossil mammals from Porto Rico (abst). G Soc Am, B 28: 209 (1917)

Anthony, John Gould (1804-1877).

38 New trilobite, Ceratocephala ceralepta. Am J Sc 34:379-380, il (1838)

39 Fossil encrinite. Am J Se 35:359360 , il (1839)

39a Description of a new fossil (Caly. mene bucklandii). Am J Sc 36:106-107, il. (1839)

46 (With, Graham, G., and James, U. P.) Two species of fossil Asterias in the Blue Limestone of Cincinnati. Am J Sc (2) $1: 441-442$, il (1846)

47 On an impression of the soft parts of an Orthoceras [Cincinnati, Ohio]. G Soc London, Q J 3:255-257, il (1847) Am J Sc (2) $6: 132-133$, il (1848)

Antisell, Thomas (1817-1893).

55 [On fossilliferous beds in San Luis Obispo Co., Cal.] Cal Ac N Sc, Pr 1:3536 (1855; 2d ed, $1873: 34-35)$

56 Geological report [Parke's surveys in California and near thirty-second parallel]. U S, Pacific R R Expl (U S, 33d Cong 2d sess, S Ex Doc 78 and $\mathrm{H}$ Ex Doc 91) $7 \mathrm{pt}$ $2: 204$ pp, maps (1856)

Apgood, Frederick W.

11 Description of copper deposits of New Jersey. M World 34:298-301 (1911)

Appleby, William R.

13 (and Newton, E.) Preliminary concentration tests on Mesabi ores [Itasca Co., Minn.]. Minn Sch Mines, Exp Sta, B 2: 126 pp (1913)

15 (and Newton, E.) Preliminary concentration tests on Cuyuna ores [Minn.]. Minn Sch Mines, Exp Sta, B 3 : $66 \mathrm{pp} \mathrm{(1915)}$

Arber, E. A. Newell.

10 A note on some fossil plants from Newfoundland. Cambridge $\mathrm{Ph}$ Soc, $\operatorname{Pr} 15$ : $390-392$, il (1910)

12 On Psygmophyllum majus sp. nov. from the Lower Carboniferous rocks of Newfoundland, together with a revision of the genus and remarks on its affinities. Linn Soc, Tr (2) Bot $7: 391-407$, il (1912) 
Archiac, Etienne Jules Adolph d'.

58 [On the Permian in America.] Soc G France, B (2) $15: 532-533$ (1858)

65 Note sur l'existence de restes organiques dans les roches laurentiennes du Canada. Ac Sc Paris, C R 61: 192-194 (1865)

See also Shumard (B F), $58 \mathrm{~g}$

A retowski, Henryk.

15 Volcanic dust veils and elimatic variations. N Y Ac Sc, An 26:149-174 (1915)

Ardley, Edmond.

16 A list of the type fossils in the Peter Redpath Museum (McGill University). Can Rec Sc 9:464-482 (1916)

Ardley, Edward.

12 The occurrence of Ostrea in the Pleistocene deposits of the vicinity of Montreal. Ottawa Nat 26:67 (1912)

16 Note on the discovery of a skeleton of Beluga catodon (white whale) in the Pleistocene (Leda clay) at the town of Montreal East, Que. Can Rec Sc 9:490493 (1916)

Arenas, Pascual F.

49 Descripción geologica y mineralógica del mineral del Fresnillo. $55 \mathrm{pp}$, map, México 1849 [not seen]

60 Descripción geológica $\mathbf{y}^{*}$ minera del mineral del Fresnillo. Anales Mexicanos de Ciencias 1:285-339, 341-346 (1860) [not seen]

71 Minas de plata del Fresnillo en Zacatecas, México. Revista Minera 22:43-49, 69-79, 117-132 (1871) [not seen]

83 Geological and mineralogical description of the mining region of Fresnillo. In Silliman, B., Jr., Sketch of great historic mines of the Cerro de Praño at Fresnillo, State of Zacatecas, Mexico:1-7, New Haven 1883

Arents, Albert.

67 Partzite, a new mineral [Mono Co., Cal.]. Am J Sc (2) $43: 362$ (1867)

Arey, Albert L.

93 Preliminary notice of the discovery of strata of the Guelph formation in Rochester, N. Y. Rochester Ac Sc, Pr 2: 104-107, map (1893)

Arey, Albert L.

11 (and others) Physiography for high schools. 438 pp, Boston 1911.

Arey, Melvin Franklin.

06 Geology of Black Hawk Co. Iowa G

S 16:407-452, map (1906)

10 Geology of Butler Co. Iowa G S 20:1-59, map (1910)

10a Geology of Grundy Co. Iowa G S $20: 61-95$, map (1910)

10b Geology of Wayne Co. Iowa G S 20:199-236, map (1910)

10e Geology of Davis Co. Iowa G S $20: 487-524$, map (1910)

12 History of geology in Iowa for the last twenty-five years. Iowa Ac Se, $\operatorname{Pr} 19$ : $65-72$ (1912)
A raall, George 0 .

10 Recent developments on Iron Hill. Leadville, Colo. Eng M J 89:261-266 (1910)

A rga 11, Philip B. (1854-1922).

95 Nickel; the occurrence, geologic dis. tribution, and genesis of its ore deposits (with discussion by Thomas Charlton). Colo Sc Soc, Pr 4:395-421 [1895] (sepa. rate ed. $32 \mathrm{pp}, 1894$ )

os Notes on the Santa Eulalia mining district, Chihuahua, Mexico. Colo Sc Soc, $\operatorname{Pr}$ 7:117-126 (1903) Abst, Eng M J $76: 350-351$ (1903)

06 Report on the zinc mines of the east and west Kootenays. Can Dp Interior, Mines $\mathrm{Br}, \mathrm{Rp}$ of the Commission to inves. tigate the zinc resources of British Colum. bia : 147-252 (1906)

os Rock oxidation at Cripple Creek [Colo.]. M Sc Press 96:883-886 (1908)

osa The ore deposits of Magdalena, N Mex. Eng M J 86: 366-370 (1908)

14 Hetærolite from Leadville [Colo.] M Mag 10:426-427 (1914)

14a Siderite and sulphides in Leadville [Colo.] ore deposits. M Sc Press 109:5054, 128-134, 148 (1914)

See also Cross, 98a; Purington, 03: Rickard, 95 ; Van Diest, 95 a

Argall, Philip Henry.

03 Pele's obelisk. Eng M J 76:42 (1903)

\section{Arkansas Diamond Company.}

os Diamonds in Arkansas; a brief ac count of the discovery and investigation and the official reports of geologist [H. 8 Washington] and mining engineer [John T Fuller] on the occurrence of diamonds it Pike Co., Ark. 38 pp, Little Rock, Ark. 1908

A rms, Jennie Maria [Mrs. Shclden].

91 Clay concretions of the Connect cut River. Can Rec Sc 4: 237-241 (1891 Armstrong, L. K.

04 The Alberta coal field. M. Rep 50 548-550 (1904)

A rnell, David $\mathrm{R}$.

09 A geological and topographical his tory of Orange Co., N. Y. Medical Reposi tory 6:313-318 (1809)

Arnold, Delos.

02 (and Arnold, Raiph) The marin Pliocene and Pleistocene stratigraphy the coast of southern California. J G 10 117-138, maps (1902)

Arnold, Ralph.

02 Bibliography of Ilterature referrint to the geology of Washington. Wash G \& 1 : 321-338 (1902)

02a (with Arnold, Delos) The marin Pliocene and Pleistocene stratigraphy the coast of southern California. J G 10: 117-138, maps (1902) 
Arnold, Ralph-Continued.

03 The paleontology and stratigraphy of the marine Pliocene and Pleistocene of San Pedro, Cal. Cal Ac Sc, Mem 3: 420 pp, il (1903) Leland Stanford jr Univ, Cont Biol from the Hopkins Seaside Laboratory $31: 420 \mathrm{pp}$, il (1903)

03a (and wiley, D. C.) The Geological Society of American Universities. Science n s 18: 691-693 (1903)

04 The faunal relations of the Carrizo Creek beds of California (abst). Science n s $19: 503$ (1904)

04a (with Haehl, H. L.) The Miocene diabase of the Santa Cruz Mountains in San Mateo Co., Cal. Am Ph Soc, $\mathrm{Pr} 43$ : 16-53, map (1904)

05 (and Strong, A. M.) Some crystalline rocks of the San Gabriel Mountains, Cal, G Soc Am, B 16:183-204 (1905) Abst, Science n s $21: 350$ (1905)

05a Gold placers of the coast of Washington. U S G S, B 260:154-157, map (1905)

05b Coal in Clallam Co., Wash. U S G S, B 260: 413-421 (1905)

06 The Tertiary and Quarternary pectens of California. U S G S, P P $\mathbf{4 7}: 264$ pp il (1906)

06a Geological reconnaissance of the coast of the Olympic Peninsula, Wash. G Soc Am, B 17:451-468, map (1906)

06b Coal in the Mount Diablo Range, Monterey Co., Cal. U S G S, B 285: 223225 (1906)

06e The Salt Lake ofl field near Los Angeles, Cal. U S G S, B 285:357-361 (1906)

o6d (with Spencer, A. C.) The cause of the great eartbquake. World's Work 12: $7678-7681$ (1906)

oт New and characteristic species of fossil mollusks from the oil-bearing Tertiary formations of southern California. U S Nat Mus, Pr 32:525-546 il (1907)

07a Dome structure in conglomerate. J G $15: 560-570$ (1907)

07b Fossils of the oil-bearing formations of southern California. U S G S, B 309 : 219-256, il (1907)

07e (and Anderson, R.) Diatomaceous deposits of northern Santa Barbara Co., Cal. U S G S, B 315: 438-447 (1907) 07d (and Anderson, R.) Preliminary report on the Santa Maria ofl district, Santa Barbara Co., Cal. U S G S, B 317 :

(๖) pp, map (1907)

ore Geology and ofl resources of the Summerland district, Santa Barbara Co., Cal. U S G S, B 321: 93 pp, map (1907) o7f (and Anderson, R.) Geology and oil resources of the Santa Maria oil district, Santa Barbara Co., Cal, U S G S, B $322: 161$ pp, map (1907)

$$
28737^{\circ}-23-4
$$

Arnold, Ralph-Continued.

ozg (and Anderson, R.) Metamorphism by combustion of the hydrocarbons in the oil-bearing shale of California. I G $15: 750-758$ (1907)

07h The Santa Maria oll district, Cal. (abst). Science n s 25:825 (1907)

o7i Daz letzte grosse Erdbeben in California, seine Ursachen und Wirkungen (abst). Technologist $12: 68-71$ (1907)

o7j (with Eldridge, G. H.) The Santa Clara Valley, Puente Hills, and Los An. geles oil districts, southern Cal. U S G S, B $309: 266$ pp (19.07)

os New and characteristic species of fossil mollusks from the oil-bearing Tertiary formations of Santa Barbara Co., Cal. Smith Misc Col 50 (Q Issue 4) : 419447 , il (1908)

OSa Dome structure in conglomerate (abst). G S Am, B $18: 615-616$ (1908)

08b Notes on the occurrence of the recently described gem mineral, benitoite. Science n s 27:312-314 (1908)

oSe The Miner ranch oil fleld, Contra Costa Co., Cal. U S G S, B 340:339-342 (1908)

osd Descriptions of new Cretaceous and Tertiary fossils from the Santa Cruz Mountains, Cal. U S Nat Mus, Pr $34: 345-390$, il (1908)

ose Description of a new brittle star from the upper Miocene of the Santa Cruz Mountains, Cal. U S Nat Mus, Pr 34: $403-406$, il (1908)

osp (and Anderson, R.) Conglomerate formed by a mineral-laden stream in California. G Soc Am, B 19:147-154 (1908)

oss (and Anderson, R.) Preliminary report on the Coalinga oil district, Fresno and Kings cos., Cal. U S G S, B 357: 142 pp, maps (1908)

osh (and Anderson, R.) The Coalinga, Cal., oil field $(a b s t)$. Science n s 2s:127128 (1908)

osi (and Johnson, H. R.) The socalled volcano in the Santa Monica Mountains, near Los Angeles, Cal. Science n s $27: 553-554$ (1908)

09 Notes on some rocks from the Sawtooth Range of the Olympic Mountains, Wash. Am J Sc (4) 28:9-14 (1909)

09a Paleontology of the Coalinga distriet, Fresno and Kings cos, Cal. U S G S, B $396: 173 \mathrm{pp}$, il (1909)

o9b Environment of the Tertiary faunas of the Pacific coast of the United States. J G $17: 509-533$ (1909)

o9e (and Johnson, H. R.) The earthquake rift in eastern San Luis Obispo Co., Cal. (abst). Science n s 29:558 (1909)

09d (and Johnson, H. R.) Sodium sulphate in Soda Lake, Carriso Plain, San Luis Obispo Co., Cal. U S G S, B 380 : 369-371 (1909) 
Arnold, Ralph-Continued.

09e (with Branner, J. C., and Newsom, J. F.) Description of the Santa Cruz quadrangle, Cal. U S G S, G Atlas Santa Cruz fol (no 163) : 11 pp, maps (1909)

10 (and Anderson, R.) Geology and oil resources of the Coalinga district, Cal. U S G S, B 398: 354 pp, il, map (1910) ; reprinted 1911 Abst, Wash Ac Sc, J 1: 130-132 (1911)

10a (and Johnson, H. R.) Preliminary report on the McKittrick-Sunset ofl region, Kern and San Luis Obispo cos., Cal. U S G S, B $406: 225$, pp, maps (1910)

12 A petroleum gas volcano; the upheaval of an island off the coast of Trinidad. Petroleum World, London, 9: 129-131 (1912)

13 (and Hannibal, H.) The marine Tertiary stratigraphy of the north Pacific coast of America. Am Ph Soc, Pr 52: 559-605 (1913)

14 (and Garfas, V. R.) Geology and technology of the California oil fields. Am I M Eng, B 87:383-467, map (1914)

$14 a$ (and Hannibal, H.) Dickerson on California Eocene. Science n s 39: 906-908 (1914)

15 The petroleum resources of the United States. Ec G 10:695-712 (1915) Smiths Inst, An Rp 1916:273-287 (1917)

15a Petroleum resources and industries of the Pacific coast. In Nature and science on the Pacific cosst: 75-87, map, San Francisco 1915 [See Merriam 15]

16 Conservation of the oil and gas resources of the Americas. Ec G 11:203$222,299-326$ (1916)

17 General conditions of the petroleum industry and the world's future supply. G Soc Am, B 28:603-616 (1917)

17a Conservation of the oil and gas resources of the Americas. Pan American Sc Cong, 2d, Pr sec 3, 3: 207-237 (1917)

17b (and Clark, B. L.) An Apalachicola fauna from Lower California (abst). G Soc Am, B 28:223-224 (1917)

18 Topography and fault system of the region of the San Jacinto earthquake [Cal.]. Seism Soc Am, B 8: 68-73 (1918)

18a (with Clark, B. L.) Marine Oligocene of the west coast of North America. G Soc Am, B 29:297-308, 153-154 (abst) (1918)

See also Reagan, 15.

Arreola, José María.

03 The recent eruptions of Colima. J G 11:749-761 (1903)

15 Catalogue des éruptions anciennes du volcan de Colima. Soc Cient Ant $\mathrm{Alz}$, Mem $32: 443-481$ (1915)

Ascoli, W. $\mathrm{S}$.

o9 The Guatemalan earthquakes and eruption of 1902 . Manchester Lit Ph Soc, Mem 53 no $23: 8$ pp (1909)
Ashburner, Charles Albert (1854-1889)

75 Discovery of Vespertine coal beds in Huntingdon Co., Pa. Eng M J 20:548$549(1875)$

76 Section of the Paleozolc strata of Huntingdon Co., Pa. Eng M J 22:105 (1876)

77 A measured section of the Paleozoic rocks of central Pennsylvania, from the top of the Allegheny River coal series, down to the Trenton limestone in the lower, or Cambro-Silurian system. Am Pb Soc, Pr 16:519-560 (1877)

7s Report of the Aughwick Valley and East Broad Top district. $\mathrm{Pa} G \mathrm{~S}, 2 \mathrm{~d}$ F : $141-288$ (1878)

7Sa the oil sands of Pennsylvania, Frankliu Inst, J 105 or (3) $75: 225-233$ (1878)

78b Description of the Wilcox spouting water well [McKean Co., Pa.]. Am J Sc (3) $16: 144-147$ (1878)

79 Oil well records in McKean and Elk cos., Pa. Am Ph Soc, Pr 18: 9-26 (1879) Abst, Am J Sc (3) $16: 393-394$ (1878)

$79 a$ The oil sands of Pennsylvania. Eng Club Phila, Pr 1:3-11 (1879)

79b The Bradford oil district of Penn. sylvania. Am I M Eng, Tr $7: 316-328$ (1879)

79c The Kane geyser well [Pa.] Franklin Inst, J 108 or (3) $78: 347-348$ (1879) Am J Sc (3) 18:394-395 (1879)

so The geology of McKean Co., and its connection with that of Cameron, Elk, and Forest. $\mathrm{Pa}$ G S, 2d, R: xv, $371 \mathrm{pp}$, atlas (18s0)

SOa Notes of a reconnaissance across the hills from Roulet to Sharon ... [Potter Co.]. Pa G S, 2d, GGG : 97-105 (1880)

sob Renovo coal basin [Clinton Co.]. $\mathrm{Pa}$ G S, 2d, G4: 73-78, map (1880)

$80 \mathrm{c}$ On the constitution of the Brad. ford oll sand. Am Ph Soc, $\mathrm{Pr}$ 18:419422 (1880)

sod Oil sands of the Bradford or north ern oil district of Pennsylvania compared with those of the Venango or western dis trict (abst). Am J Sc (3) 19:415-416 (1880)

81 Geological section at St, Mary's, Elk Co., Pa, Am Ph Soc, Pr 19:337-348 (1881)

81a Progress of the second geologica survey of Pennsylvania. Eng Club Phila, Pr 2:108-114 (1881)

81b Map of part of the Mahanoy and Shenandoah basins in the second anthra cite coal fields ... 1881. Pa G S, 2d, A2 (in pocket) (1881) Am I M Eng. Tr 9: pl 1 (to article pp 506-518) (1881)

sie Brazos coal field, Texas. Am I II Eng, Tr 9:495-506 (1881) Eng M J 32 $72-73,89-90$ (1881) 
Ashburner, Charles Albert-Continued. 81d (with Jones, N. F.) Drillings for coal in Sergeant township, McKean Co. $\mathrm{Pa}$ G S, 2d, R Appendix A.: 35 pp (1881) ; RR : $327-362$ (1885)

83 First report of progress in the anthracite coal region; the geology of the Panther Creek Basin or eastern end of the southern field. $\mathrm{Pa} G \mathrm{~S}, 2 \mathrm{~d}, \mathrm{AA}: 407 \mathrm{pp}$, and atlas of maps, etc. (1883)

83a (and others) Atlas of anthracite fields; Northern anthracite field, pts 1-6; Eastern middle anthracite field, pts 1-3; Western middle anthracite field, pts 1-3; Southern anthracite field, pts 1-4, 4B, 5, 6 . $\mathrm{Pa}$ G S, 2d, 1883-5.

S3b The anthracite coal beds of Pennsylvania. Am I M Eng, Tr 11:136-159 (1883)

83e The Allegheny oil sands. Science $2: 20 \quad$ (1883)

83d Anthracite; description and production of the anthracite coal fields of Pennsylvania. U S G S, Min Res [1882] : 7-32 (1883)

84 Brief description of the anthracite coal fields of Pennsylvania. Eng Club Phila, Pr 4:177-208, map (1884)

84a Sketch of the geology of Carbon Co. [Pa.]. In Mathews, Alfred, and Hungerford, Austin N., History of the counties of Lehigh and Carbon in the Commonwealth of Pennsylvania: $650-656$, map, Phila 1884 Reprint: 18 pp [1884]

84b Pennsylvania anthracite. Seience $3: 310-312$ (1884)

84e Notes on the Natural Bridge of Virginia, Am Ph Soc, Pr 21:690, 699-700 (1884)

84d The anthracite coal fields of Pennsylvania. Sc Am Sup 18: 7410-7413 (1884)

84e [On the commingling of Catskill and Chemung faunas (abst with discussion by James Hall).] Science 4:327 (1884)

85 Second report of progress in the anthracite coal region, part $I$; statistics of production and shipment for 1883 and 1884 ; lllustrated by a general map of the anthracite coal fields. Pa G S, 2d, AA : 21 pp, map (1885)

85a The township geology of Elk and Forest cos. Pa G S, 2d, RR: 61-300, atlas (1885)

85b Note on iron ore in Cameron Co. Pa G S, 2d, RR : 363-368 (1885)

85e The natural bridge of Virginia. Science $5: 13-14$ (1885)

85d The geology of natural gas. Science $6: 42-43, \quad 184-185$ (1885) Sc Am Sup 21: $8677-8678$ (1886)

s5e [Description of the publications and maps of the Second Geological Survey of Pennsylvania.] Am Ph Soc, Pr 22:86-s8 (1885)

86 Borings for oil in Jackson and Abbot townships, Potter Co. Pa G S, An Rp 1885: 82-94 (1886)
Ashburner, Charles Albert-Continued.

86a Report on the Tipton Run coal openings, Blair Co. Pa G S, An Rp 1885 : 250-268, map (1886)

$\mathbf{8 6 b}$ Second report of progress in the anthracite coal regions. $\mathrm{Pa}$ G S, An Rp 1885 : 269-436, maps (1886)

86e Report on the Wyoming Valley Car boniferous limestone beds. Pa G S, An Rp 1885: 437-450 (1886) Wyoming Hist G Soc, Pr $2: 254-264$ (1886)

86d Report on the Bernice coal basin in the Loyalsock and Mehoopany coal field, in Sullivan Co. Pa G S, An Rp 1885: 459 490, map (1886)

86e Report on the Brandywine Summit kaolin bed, Delaware Co. [Pa.]. Pa G S An Rp 19e5: 593-614, maps (1886)

86f Description of the Archbald potholes; also of the buried valley of Newport Creek near Nanticoke ... $\mathrm{Pa}$ G $\mathrm{S}$, An Rp 1885: 615-636 (1886)

86g The product and exhaustion of the oil regiens of Pennsylvania and New York. Am I M Eng, Tr 14:419-428, map (1886)

$\mathbf{8 6 h}$ The geology of natural gas. Am I M Eng, $\operatorname{Tr} 14: 428-438$ (1886)

86i The classification and composition of Pennsylvania anthracites. Am I M Eng, Tr 14:706-726 (1886) Eng M J 41: $150-151(1886)$

S6j Coal. U S G S, Min Res 1885: $\begin{array}{lllll}10-73 & (1886) & \ldots 1886: 224-377 & \text { (1887) }\end{array}$ $\ldots 1887: 168-382 \quad(1888) \quad \ldots 1888: 168-394$ (1890)

87 The geologic distribution of natural gas in the United States. Am I M Eng, Tr $15: 505-542$, maps (1887) Eng M J $43: 38-39,58-60,76-77$ (1887) ; abst, 42 : 332 (1886)

87a The product and exhaustion of the oil regions of Pennsylvania and New York : the geology of natural gas. In Crew, B. J., A practical treatise on petroleum... : 457-478, map, Phila 1887

87b Geological explorations for natural gas. Am Manufacturer, Nat Gas Suppl no $2: 3-5,17$, Dec. 30 (1887)

87e Natural gas in the State of New York. Am Manufacturer, Nat Gas Suppl no $2: 8-9$, Dec. 30 (1887) U S G S, Min Res $1887: 474-479$ (1888)

S7d Natural gas in Kansas. Am Manufacturer, Nat Gas Suppl no 2:13, map, Dec. 30 (1887)

87e Natural gas in Missouri. Am Manufacturer 41 no $26: 13$ (1887)

s8 Petroleum and natural gas in New York. Am I M Eng, Tr 16:906-959, maps (1888)

89 The development and statistics of the Alabama coal fields for 1887. Am I M Eng, $\operatorname{Tr} 17: 206-226$ (1889)

89a The geology of Buffato as related to natural gas explorations along the $\mathrm{Ni}$ agara River. Am I M Eng, Tr $17: 398$ 406 (1889) 
Ashbarner, Charles Albert-Continued.

90 Natural gas explorations in the eastern Ontario peninsula. Am I M Eng, Tr 18 : 290-303, map (1890) Abst, Fng M J $49: 313$, map $(1890)$

See also Carll, 87

Ashe, Thomas.

06 Memoirs of mammoth and various other extraordinary and stupendous bones of incognita or nondescript animals found in the vicinity of the Ohio, Wabash, IIIfnois, Mississippi, Missouri, Osage, and Red rivers... $60 \mathrm{pp}$, Liverpool 1806

Ashe, W. A.

87 The diurnal motion of the earth in its relation to geological phenomena $(a b s t)$. Can Rec Sc $2: 434-435$ (1887)

Ashley, George Hall.

93 An illustration of the flexure of rock. Cal Ac Sc, Pr (2) 3:319-324 (1893)

95 Studies in the Neocene of California. J G $3: 434-454$, map (1895)

96 The Neocene stratigraphy of the Santa Cruz Mountains of California. Cal Ac Se (2) $5: 273-367$ (1896) Rv by F. L. Ransome, Am G 17:331-335 (1896)

97 Geology of the Paleozoic area of Arkansas south of the novaculite region (with introduction by J. C. Branner). Am Ph Soc, Pr 36:217-218, maps (1897) Leland Stanford Univ, Contr Biol 11:217318, maps (1897)

98 Note on an area of compressed struc ture in western Indiana. $G$ Soc Am, B 9:429-430 (1898) Abst, J G 6:118-119 (1898) ; Science n s $7: 84$ (1898)

98a Note on fault structure in Indiana. Ind Ac Sc, $\operatorname{Pr} 1897: 244-250$ (1898)

9Sb (with Blatehley, W. S.) Geological scale of Indiana. Ind, Dp G N Res, An Rp $22: 17-23$ (1898)

99 The coal deposits of Indiana. Ind, Dp $\mathrm{G} N$ Res, An Rp 23:1-1428, maps (1899)

99a (with Ashley, M. M.) Paleontology of the Indiana coal field. Ind, $D_{p}$ G N Res, An Rp $23: 131-161$ (1899)

00 Geologic results of the Indiana coal survey. G Soc Am, B 11: 8-10 (1900)

01 (with Blatehley, W. S.) The lakes of northern Indiana and their associated marl deposits. Ind, Dp $\mathbf{G} \mathbf{N}$ Res, An Rp $25: 31-321$, maps (1901).

02 The eastern interior coal field. U S G S, An Rp 22 pt 3:265-306, map (1902) 02a Economic geology of the Ditney quadrangle [Ind.]. U S G S, G Atlas Ditney fol (no 84): 7-8 (1902).

03 The geology of the Lower Carboniferous area of southern Indiana. Ind, Dp G N Res, An Rp 27:49-122, maps (1903).

O3a (with Fuller, M. L.) Recent work in the coal field of Indiana and Illinois. U S G S, B 213: 284-293 (1903)
Ashley, George Hall-Continued.

04 The Cumberland Gap coal field. M Mag 10:94-100 (1904)

04a The Cumberland Gap coal field of Kentucky and Tennessee. U S G S, Bull $225: 259-275$ (1904)

04b [Geologic structure of the region around Middlesboro, Ky.] (abst). Sclence n \& $19: 856$ (1904)

o5 Coal in the Nicholas quadrangle W. Va. U S G S, B 260:422-428 (1905)

O5a Water resources of the Middles. boro-Harlan region of southeastern Ky. U S G S, W-S P 110:177-178 (1905)

O5b Water resources of the Nicholas quadrangle, W. Va, U S G S, W-S P $145: 64-66 \cdot(1905)$

05e Cannel coal in the United States. M World 23: 90-92, 381-383 (1905)

osd The Ohio and Indiana coal fields. M Mag 11: 233-236 (1905)

06 (and Glenn, L. C.) Geology and mineral resources of part of the Cumberland Gap coal fleld, Ky. U S G S, P P $49: 239$ pp, il, map (1906)

06a Clearfield coal field, Pa. U S G 8 , B 285: 271-275 (1906)

06b Notes on clays and shales in central Pennsylvania. U S G S, B 285:442-444 (1906)

o6e The maximum deposition of coal in the Appalachian coal field. Ec G 1: 788793 (1906)

06d The geological prelude to the $\operatorname{San}$ Francisco earthquake. Pop Sc Mo 69: 6975 (1906)

o6e An area of faulting in central Pennsylvania (abstr). Science n \& 23:33 (1906)

06f (with Peck, F. B.) The Punxsutawney and Glen Campbell coal fields of Indiana and Jefferson cos., Pa. U S G 8 , B 285: 276-279 (1906)

06g (with White, D.) Correlation of coals. U S G S, P P 49: 206-212 (1906)

o7 The maximum rate of deposition of coals. Ec G 2: 34-47 (1907)

07a Were the Appalachian and eastern interior coal fields ever connected? Ec G 2: 659-666 (1907)

08 Studies in mechanics of Allegheny structure (abst). Science n s 27:924-925 (1908)

O8a (assisted by Stone, R. W., Butts, C., and Munn, M. J.) Report of progress on geologic work... [in] Pennsylvania ... P Top G S, Rp 1906-8: 81-340 (1908) 09 Supplementary report (to report of 1898) on the eoal deposits of Indians. Ind Dp G N Res, An Rp 33: 13-150 (1909)

O9a Stratigraphy and coal beds of the Indiana coal field. U S G S, B 381: 5-14 (1909)

$09 b$ Significant time breaks in coal deposition (abst). Science n s 30:124 (1909) 
Ashley, George Hall-Continued.

10 The value of coal land. U S G S, B $424: 5-47$ (1910)

10a The establishment, purpose, scope, and methods of the State geological survey. Tenn G S, B 1-A : 33 pp (1910)

10b Outline introduction to the mineral resources of Tennessee. Tenn G S, B 2-A : $1-65$ (1910)

11 Administrative report of State geological survey, 1900. Tenn G S, B 4:59 pp (1911)

11 a Recent drilling for oil and gas at Memphis. Tenn G S, B 2-E : 40-46 (1911)

$11 \mathrm{~b}$ A brief summary of the resources of Tennessee. Tenn G S, B 13: 40 pp. (1911)

11e The Camden chert, an ideal road material. Tenn $G$ S, Res Tenn 1: 34-43 (1911)

11d The gold fields of Coker Creek, Monroe Co, Tenn. Tenn G S, Res Tenn 1: 78-107 (1911)

11e Coal field of Tennessee. Tenn G $\mathbf{S}$, Res Tenn 1:188-202 (1911); B 9:8-22 (1911) [with title, Introductory statement on the relation of the Pikeville special quadrangle to the coal field of Tennessee as a whole]

118 Bauxite mining in Tennessee. Tenn G S, Res Tenn 1:211-219 (1911)

$11 \mathrm{~g}$ Special problems and their study In economic geology (discussion). Ec G 6: 72-73 (1911)

12 Stratigraphic study of the Appalachian and Central states with reference to the occurrence of oil and gas (abst). G Soc Am, B 23: 725-726 (1912); Science n s $35: 312$ (1912)

12a. Where may ofl and gas be found in Tennessee? Tenn G S, Res Tenn 2:262272 (1912)

12b Bauxite mining in the State of Tennessee. M Sclence $65: 8-9$ (1912)

12e Aluminum and bauxtite mining in Tennessee. M World 36:557-558 (1912)

13 (and Campbell, M. R.) Geologie structure of the Punxsutawney, Curwensville, Houtzdale, Barnesboro, and Patton quadrangles, central Pa. U S G S, B 531 : 69-89. map (1913)

14 Rhode Island anthracite. U S G S, B 541: 155-162, map (1914)

15 Rhode Island coal. U S G S, B 615 : $62 \mathrm{pp}$, map (1915) A bst. Wash Ac Se, J 6: 94-95 (1916)

15a Physiographic study of the Cretaceous-Eocene period in the Rocky Mountain front and Great Plain provinces (abst). Science n s 41:150 (1915) G Soc Am, B 26: 105-106 (1915)

15b The physiography of the Rockies in the Cretaceous-Tertiary period (abst). Wash Ac Sc, J 5:332 (1915)
Ashley, George Hall-Continued.

16 Experiment in the graphic presentation of the economie geology of bedded deposits (abst). G Soc Am, B 27:122 (1916)

17 Oil resources of black shales of the eastern United States. U S G S, B 641: 311-324 (1917) Abst, by R. W. S., Wash Ac Sc, J $7: 564-565$ (1917)

17 a Notes on the greensand deposits of the eastern United States. I S G S, B $660: 27-49$, map (1917) Abst, Wash Ac Sc, J $7: 513-514$ (1917)

18 Cannel coal in the United States. U S G S, B 659: 127 pp (1918) Abst, by R. W. Stone, Wash Ac Sc, J 8:502 (1918) 18a The Santo Tomas cannel coal, Webb Co., Tex. U S G S, B 691 : 251-270 (1918)

18b Memorial of Albert Homer Purdue. G Snc Am, B $29: 55-64$, port (1918)

Ashley, Harrison Everett.

09 The colloid matter of clay and its measurement. U S G S, B $388: 65$ pp (1909)

Ashrey, M. M.

99 (and Ashiey, G. H.) Paleontology of the Indiana coal field. Ind, Dp $G \mathbf{~ N}$ Res, An Rp 23:131-161 (1899)

Ashworth, James.

o5 Notes on the Crowsnest coal field, B. C. Manchester G M Soc Tr 29:78-83 (1905) Can M Rv 25:165-167 (1905) Eng M J 81:711-712 (1906)

Askwith, W. R.

01 The West Gore antimony deposits [Hants Co., N. S.] Can M Rv 20:173-175 1901) M Soc N S, J 6:80-87 (1902) Abst, Eng M J 72:255-256 (1901) ; M Se Pres 83: 77 (1901)

Association of Ameriean Geologists and Naturalists.

43 Reports of the first, second, and third meetings...at Philadelphia in 1840 and 1841 , and at Boston in 1842, embracing its proceedings and transactions. $\mathbf{5 4 4}$ pp, Boston 1843

Aston. James.

09 The soliditication of alloys and magmas. J G $17: 569-585$ (1909)

Atherton, Henry Brydge.

97 Topography and surface geology. In Parker, Edward E. (editor), History of the City of Nashua, N. H. (copyright 1895 by H. Reinheimer \& Co.) : 93-105, Nashua, N. H., 1897 Separate, with cover-title, A study of glacial phenomena; retreat of the continental ice cap and the formation of terraces in southern New Hampshire: 15 pp, from the History of Nashua, copyrighted 1595 by H. Reinheimer \& Co.

Atkin, Austin J. R.

04 The genesis of the gold deposits of Barkerville, B. C., and the vicinity. G Soc London, Q J 60:389-393 (1904) ADst, G Mag (5) 1:327 (1904) 
Atkin, Austin J. R.-Continued.

o5 Some notes on the gold occurrences on Lightning Creek, B. C. G Mag (5) 2: 104-106 (1905)

05a An occurrence of scheelite near Barkerville, B. S. G Mag (5) 2:116-117 (1905)

06 Some further considerations on the genesis of the gold depesits of Barkerville, British Columbia, and vicinity. G Mag (5) 3:514-516 (1906)

Atlee, Washington $\mathrm{L}$.

3s On certain cavities in quartz. Am J Sc 35:139-144 (1838)

\section{Atlin Distriet [British Columbia]}

Board of Trade.

13 The gold fields of Atlin, B. C. 36 pp, map, London 1913

Attwood, George.

82 On the geology of a part of Costa Rica, G Soc London, Q J 38:328-339, map (1882)

Attwood, Melville,

88 Lithology of wall rocks. Cal st $\mathrm{M}$ Bur, An Rp 8: 771-784, map (1888)

95 Metalliferous deposits in fissures. M Sc Press $71: 56-57$ (1895)

Atwater, Caleb (1778-1867).

18 On the prairies and barrens of the West. Am J Sc 1: 116-125 (1818)

19 Notice of the scenery, geology, mineralogy, botany, etc., of Belmont Co., Ohio. Am J Sc 1: 226-230 (181

20 On some ancient human bones, etc., with a notice of the bones of the mastodon or mammoth, and of various shells found in Ohio and the West. Am J Sc 2:242246, il (1820)

26 ... geolegy and organized remains of parts of the State of Ohio. Am J Sc 11: 224-231 (1826)

3s A history of the State of Ohio, natural and eivil [geology:10-44], 403 pp, Cincinnati 1838

Atwood, E. H.

91 The movement of ice on Minnesota lakes. Am G 7:251-254 (1891)

Atwood, Wallace Walter.

97 (with Salisbury, R. D.) Drift phenomena in the vicinity of Devil's Lake and Baraboo, Wis. J G $5: 131-147$, maps (1897)

oo (with Salisbury, R. D.) The geography of the region about Devil's Lake and the Dalles of the Wisconsin. Wis $G \mathbf{S}$, B 5 (ed s 1): $151 \mathrm{pp}$, Madison, Wis., 1900

o5 Glaciation of San Francisco Mountain, Ariz. J G 13:276-279, map (1905)

06 Red Mountain, Ariz.; a dissected volcanic cone, J G 14:138-146 (1906)

07 The glaciation of the Uinta Mountains. J G 15:790-804 (1907)

os Lakes of the Uinta Mountains. Am Geog Soc, B $40: 12-17$ (1908)
Atwood, Wallace Walter-Continued.

08a (and Goldthwait, J. W.) Physl. cal geography of the Evanston-Waukegan region. III G S, B 7:102 pp, (1908) abst, B 8: 48-52 (1908)

osb Working hypothesis on the physiog. raphy of Alaska (abst). Science n s 27: 730-731 (1908)

ose Geologic studies in southwestern Alaska (abst). Science n s 28:933 (1908) osa (with Salisbury, R. D.) The in. terpretation of topographic maps. U S G S, P P 60:84 pp (1908)

09 Glaciation of the Uinta and Wasateh Mountains. U S G S, P P 61:96 pp, map (1909)

09 a Mineral resources of southwestern Alaska. U S G S, B $379: 108-152$, map (1909)

o9b Geologic studies in the Alaska Peninsula (abst). Science n 8 29:636 (1909) ; G Soc Am, B 20:700 (1910)

11 Geology and mineral resources of parts of the Alaska Peninsula. U S G S, B $467: 137$ pp, maps (1911) Abst, Wash Ac Sc J 2:85-86 (1912)

11 a Physiographic studies in the San Juan distriet of Colorado. J G 19: $449-453$ (1911) Abst, Wash Ac Sc, J 1 15-46 (1911) ; G Soc Am, B 22:735 (1911)

$11 \mathrm{~b}$ A geographic study of the Mesa Verde [Colo.]. As Am Geog, An 1:95-100 (1911); Am Geog Soc, B 44:593-598 (1912)

12 Some Triassic fossils from southeastern Alaska. J G 20:653-655 (1912)

12a (and Mather, K. F.) The evidence of three distinct glacial epochs in the Pleistocene history of the San Juan Moun tains, Colo. J G 20:385-409, map (1912) Abst, Science n s $35: 315$ (1912); G Soc Am, B 23: 732 (1912)

14 Early Tertiary glaciation in the San Juan region of Colorado (abst, with dis. cussion). G Soc Am, B 25:31-32 (1914)

14a Over the San Juan Mountains to the Mesa Verde $(a b s t)$. Am Geog Soc, B $46: 430$ (1914)

15 Eocene glrcial deposits in southwestern Colorado. U S G S, P P 95: 13-26, map (1915) Abst, by E. S. Bastin, Wash Ac Sc, J 5:608 (1915)

15a Relation of physiographic changes to ore alterations (abst). Science $n \quad 8$ 41:510 (1915) G Soc Am, B 26:106 (1915)

15b (and Mather, K. F.) The grand canyon of the Gunnison River (abst). As Am Geog, An 5 : 138-139 (1915)

16 The physiographic conditions at Butte, Mont., and Bingham Canyon, Utah, when the copper ores in these districts were enriched. Ec G 11:697-740 (1916)

16a (and Mather, K. F.) Geographic history of the San Juan Mountains since the close of the Mesozoic era (abst). G Soc Am, B 27:38-39 (1916) 
Atwood, Wallace Walter-Continued.

17 Another locality of Eocene glaciation in southern Colorado. J G 25:684-686 (1917)

17a Physiographic conditions and copper enrichment (discussion) [age of peneplains in Rocky Mountains]. Ec G 12:545547 (1917)

$17 \mathrm{~b}$ (and Peattie, R.) Saving the silts of the Mississippi River (abst, with discussion by E. W. Shaw). G Soc Am, B 28: 149-151 (1917)

18 Relation of landslides and glacial deposits to reservoir sites in the San Juan Mountains, Colo. U S G S, B 685:38 pp (1918)

See also Alden, 12 ; Sayles, 16.

Aubouin, Carlos.

17 Influencia del clima sobre las formaciones minerales. Cuba, Dir Montes, Bol Minas 2:64-67 (1917)

17 a Memoria sobre las minas de la jurisdicción de Puerto Príncipe. Cuba, Dir Montes, Bol Minas 2: 68-72 (1917)

Aubury, Lewis E.

02 The copper resources of Callfornia Cal St M Bur, B $23: 282$ pp, maps (1902) 03 The quicksilver resources of California. Cal St M Bur, B 27:273, pp, maps (1903)

06 The structural and industrial materials of California. Cal St M Bur, B 38 : 13-378, maps (1906)

0s The copper resources of California. Cal St M Bur, B 50: 366 pp, maps (1908)

Audubon, John James.

31 An earthquake in Kentucky. Ornithological biography $1: 239-241$, Edinburgh, 1831. Mag Am Hist $16: 342-344$ (18s6) Also in Audubon, Maria R., Audubon and his journals $2: 234-237$, N Y 1897

Anerbach, Herbert $\mathrm{S}$.

Os The north side of the Coeur d'Alene district [Idaho]. Eng M J 86:65-70 (1908)

OSa Tungsten ore deposits of the Cour d'Alene [Idaho]. Eng M J $86: 1146-1148$ (1908)

Aughey, Samuel.

76 The superficial deposits of Nebraska. U S Geog S Terr (Hayden), An Rp [8] : 241-269 (1876)

so Sketches of the physical geography and geology of Nebraska. $326 \mathrm{pp}$, Omaha, Nebr., 1880

82 Report on the Wyoming oil springs... $61 \mathrm{pp}$, map, Omaha 1882

82a (with white, C. A.) Artesian wells upon the Great Plains... U S Dp Agr : 38 pp, map, Washington 1882

86 Annual report of the Territorial geologist to the governor of Wyoming, January 1886. 120 pp, Laramie, Wyo., 1886 Also in Wyo, Message of governer... : 83-200, Laramie, Wyo., 1886
Aurin, Fritz.

17 Geology of the red beds of Oklahoma. Okla G S B 30:66 pp, maps (1917)

17a Correlation of the oil sands in Oklahoma. Okla G S, Cire 7: 16 pp (1917)

Austin, Moses.

04 Description of the lead mines in upper Louisiana. Washington 1804 [not seen] American State Papers 28 (cl 8 vol 1) : 206-209 (1832) Mo G S, Rp 1873-4: 686-694 (1874)

Anstin, William Lawrence.

95 Nickel; historical sketch. Colo Sc Soc, Pr 4: 373-394 [1895] (separate ed, 26 pp. 1894)

98 [Copper deposits in Mora Co., $\mathrm{N}$. Mex.] Colo Sc Soc, B 1897 no 11:2-5 [1898] Abst, Eng M J 65:370 (1898)

98a Some telluride reins in La Plata Mountains [Colo.]. Colo Sc Soc, B 1897 no $10: 4-5$ [1898]

98b The nickel deposits near Riddle's Oreg. Colo Sc Soc, Pr 5: 173-196 [1898] (separate ed, $27 \mathrm{pp}, 1896$ ) Abst, Mines and Minerals 19:226 (1898)

98e Boundary and Trail Creek mining districts of British Columbia. Mines and Minerals $18: 268-272$ (1898)

02 Some tellurium veins in La Plata Mountains [Colo.] (with discussion by E. B. Kirby and Regis Chauvenet. Colo Sc Soc, $\operatorname{Pr} 6: 87-90$ [1902]

02a Some New Mexico copper deposits. Colo Sc Soc, Pr 6 : 91-95 [1902]

03 The ore deposits of Cananea [Mex.]. Eng M J $76: 310-311$ (1903) Am I M Eng, Tr 33:1070-1077 (1903)

See also Lindgren, 03d

Averitt, $S . D$.

15 The soils of Kentucky. Ky Agr Exp Sta, B 193: 127-164, map (1915)

Ayers, H. B.

11 Indications of a Huronian continental angle $(a b s t)$. Science $n$ s $33: 465$ (1911)

$11 a$ The Dam Lake quartzite [Minn.] (abst). Science n ns 33:465 (1911)

Ayres, Edward F.

89 Mineralogical notes [thenardite, pyrite]. Am J Sc (3) $37: 235-236$ (1889)

89 Notes on the crystallization of trona (urao). Am J Sc (3) 38:65-66 (1889)

See also Yeates, 92

Ayres, W. 0 .

82 The ancient man of Calaveras [Cal.] Am Nat 16:845-854, il (1882)

Ayres, W. S.

07 Deutschman's cave, near Banff [Glacier], B. C. Am I M Eng, B 13:93-112 (1907); Tr 38:857-876 (1908)

07 a Report on the exploration of Deutschman cave [B. C.] Can, Dp Intevior, Rp Surveyor-General, 1906: 117-120 (1907) 
A yres, W. S.-Continued.

07 b Supplementary report on the ad. ditional exploration of Deutschman cave. Can, Dp Interior, Rp Surveyor-General, 1906: 121-126 (1907)

Babb, Cyrus Cates.

13 Bibliography of Maine geology. Maine, State Water Storage Comm, An Rp $3: 10,185-242$ (1913)

Babb, Percy Andrus.

o9 Dulces Nombres quícksilver deposit [San Luis Potosi], Mexico. Eng M J 88: 684-686 (1909)

09a The Magistral copper district, Mexico. Eng M J 88: 1215-1216 (1909)

10 The relation of economic geology to mining. Soc G Mex, B $6: \mathrm{xxili}-\mathrm{xxv}, 141-$ 146 (1910)

Babbitt, Franc E.

84 Vestiges of glacial man in Minnesota. Am Nat 18:594-605, 697-706 (1884)

Babbitt, James B.

09 Physical history of the earth in outline. Revised ed, with appendix, 229 pp, Boston 1909.

Babeock, E. N.

04 (and Minor, Jessie) The Graydon sandstone and its mineral waters. Drury Coll, Bradley G Field Sta, B 1:22-31 Babeock, Earle Jay.

99 Coal in North Dakota. Mines and Minerals $19: 254$ (1899)

01 Report of the geological survey of North Dakota; First biennial report. 103 pp, Grand Forks, N. D., 1901

02 Water resources of the Devil's Lake region. N Dak G S, Bien Rp 2:208-250, map (1902)

06 (and Clapp, C. H.) Economic geology of North Dakota clays. N Dak G S, Bien Rp 4: 95-189 (1906)

OGa (with Clapp, C. H.) Clay and its properties with special reference to North Dakota elays. N Dak G S, Bien Rp 4: 9-61 (1906)

14 The coal and clay resources of North Dakota. N Dak Univ, Q J 5:52-56 (1914)

Bubcock, Kendric Charles.

10 The published writings of William Phipps Blake, 1850-1910. Reprinted from the President's report to the Board of Regents of the University of Arizona for $1909: 23$ pp (1910)

Bache, Alexander Dallas.

45 Map of Sandy Hook, exhibiting the increase of that headland from the earliest surveys. $\mathrm{Am}$ Ph Soc, $\mathrm{Pr}$ 4:168-169 (1845)

56 Notice of earthquake waves on the western coast of the United States on the 23d and 25th of December, 1854. Am J Sc (2) $21: 37-43$ (1856)
Bache, Franklin.

95 Coal sections by recent operations in Wise Co., Va. Am I M Eng, $\operatorname{Tr} 24: 70-80$, map (1895)

03 The Arkansas-Indian Territory coal field. Eng M J $76: 390-392$ (1903)

Bachellery, A.

oo Les mines de fer du Minnesota. An Mines (9) $18: 154-213$ (1900)

Bacon, Raymond Foss.

16 (and Hamor, W. A.) The Amercan petroleum industry. 2 vols, $963 \mathrm{pp}$, N Y 1916

Bacorn, Frederick W.

14 An amendment to Sales's theory of ore deposition. Am I M Eng, B 92:19851991 (1914) ; Tr 49:300-306 (1915)

Bacorn, H. C.

o5 A complicated fault system [Gib. bonsville, Idaho]. Eng M J 79:324 (1905) Baddeley, Frederic $\mathrm{H}$.

29 Geology of a portion of the Labradur coast. Lit Hist Soc Quebec, Tr 1: 71-79 (1829)

29a On the geognosy of a, part of the Saguenay country [Que.]. Lit Hist Soc Quebec, Tr 1: 79-166 (1829)

30 Mineralogical examination of the sul. phate of strontian from Kingston (U. C.) with miscellaneous notices of the geology of the vicinity. Am J Sc 18:104-109 (1830)

31 Additional notes on the geognosy of St. Paul's Bay [Que.]. Lit Hist Soc Quebec, Tr 2: 76-94 (1831)

31 a An essay on the localities of metal. lic minerals in the Canadas, with some notices of their geological associations and situations. Lit Hist Soc Quebec, Tr 2:332432 (1831)

33 On the Magdalen Islands... Lit Hist Soc Quebec, Tr 3: 128-191, map (1833) Abst, Soc G France, B 5:406-407 (1834)

34 A tabular view of metallic minerals. Am J Sc 25: App 1-16

35 A geological sketch of the most southeastern portion of lower Canada. Lit Hist Soc Quebec, Tr 3: 271-281 (1835)

35a [W. W. in error for F. H.] Mis. cellaneous notices; 1 , On the conjectured buoyancy of boulders at great depths in the ocean; 2, Discovery of gold in lower Canada; 3 , Water lime made from the rock of Quebec. Am J Sc 28: 111-114 (1835)

35b [Notice of the finding of gold in Quebec.] Soc G France, B 6: 104-105 (1835)

36 [On the primitive rocks in the region of Lake Simcoe.] Soc G France, B 7:93 (1836)

37 [Note sur quelques formations de Haut-Canada.] Soc G France, B 8: 133136 (1837)

41 On the geology and mineralogy of Canada $(a b s t)$. Brit As, Rp 10: sec 114 115 (1841) 
Badger, $\mathrm{S}$. $\mathrm{S}$.

11 The Chiricahua Mountains. Eng M J 91 : 663 (1911)

Bäckström, Helge.

93 Causes of magmatic differentiation. J G 1: 773-779 (1893) Abst, Am G 13: 194-195 (1893) ; Am Nat 28:515 (1894)

Baelz, Walter.

11 Reisebericht aus den Goldfeldern des nördlichen Ontario [Porcupine district]. $\mathrm{Z}$ prak G $19: 377-385$ (1911)

12 The gold fields of New Ontario. Can M J $33: 299-304$ (1912)

Bagg, Rufus Mather.

95 [Eocene fauna of the middle Atlantic slope] Protozoa. Johns Hopkins Univ Circ $15: 6(1895)$

95a The Cretaceous Foraminifera of New Jersey, Johns Hopkins Univ Circ $15: 10-12$ (1895)

98 The occurrence of Cretaceous fossils in the Eocene of Maryland. Am G 22: 370-375 (1898)

98a The Cretaceous Foraminifera of New Jersey, U S G S, B 88:89 pp, il (1898)

98b The Tertiary and Pleistocene Foraminifera of the middle Atlantic slope. B Am Pal no $10: 54$ pp, il (1898)

03 Genesis of the ore deposits in Boulder Co., Colo. (abst). G Soc Am, B 14:565 (1904) J G 11:100 (1903) Eng M J 75: 154 (1903)

03a The veins of Boulder Cu., Colo. Abst, Eng M J 75:334 (1903)

04 Secondary enrichment in the Santa Rita district. Eng M J 77: 153-154 (1904)

04a Earthquakes in Socorro, N. Mex. Am G 34:102-104 (1904)

04b Geological conditions in the Dragoon Mountains, Ariz. Practical Miner, St. Louis, Mo. : 8, July 1904 [not seen]

05 Miocene Foraminifera from the Monterey shale of California, with a few species from the Tejon formation [geology by J. C. Branner]. U S G S, B 268:55 pp, il, map (1905)

05a The Sahuayacan district, Mex. Eng M J 79:749-751 (1905)

05b The minerals of Maguarichic [Rayon district, Chihuahua]. Eng M J $80: 2-3 \quad$ (1905)

05e Foraminifera collected from the bluffs at Santa Barbara, Cal. Am G 35 : 123-124 (1905)

06 Fault breccia veins in the Sierra Madre [Mexico]. M Sc Press 92:125(1906)

os Geology of the mining districts of Chihuahua [Mexico]. M Sc Press 97:152153, 187-189 (1908) Abst, Sclence n s $27: 723$ (1908)

Osa Some copper deposits in the Sangre de Cristo Range, Colo. Ec G $3: 739-749$ (1908)
Bags, Rufus Mather-Continued.

09 Notes on the distribution of the mastodon in Illinois. Ill, Univ, B 6 no 17 , Univ Studies 3:45-56 (1909)

09a Casts of Foraminifera in the Carboniferous of Illinois. IIl G S, B 14: $263-271$, il (1909)

11 New method of calculating the date of the glacial epoch. Abst, G Soc Am, B $22: 735$ (1911)

12 Pliocene and Pleistocene Foraminifera from southern California. U S G S, B $513: 153 \mathrm{pp}$, il (1912)

12a Effect of rapid offshore deepening on lake-shore deposits. Abst, G Soc Am, B $23: 746$ (1912)

13 The discovery of pyrrhotite in Wisconsin, with a discussion of its probable origin by magmatic differentiation. Ec G $8: 369-372$ (1913)

18 Discovery of fluorite in the Ordovician limestones of Wisconsin (abst, with discussien by W. A. Tarr), G Soc Am, B $29: 104$ (1918)

18 a Fluorspar in the Ordovician limestone of Wisconsin. G Soc Am, B 29: 393-398 (1918)

See also Clark (W B), 01a, 04a ; Hill (R T), $98 \mathrm{c}$

Bailar, John C.

os The nonmetallic minerals of Colorado. Colo Sch Mines, Bien Rp 1908: 46$54: 1910: 35-40$

Banley, E. G.

97 Eastern Oregon gold fields. M Sc Press $75: 192$ (1897)

Bailey, E. Stillman.

17 The sand dunes of Indiana. $165 \mathrm{pp}$, Chicago 1917

Bailey, Edgar Henry Summerfield.

s5 (and Walter, E. W.) The new artesian well at Fort Scott, Kans. Kansas City Rv Se 8:485-487 (1885)

89 On the newly-discovered salt beds in Ellsworth Co., Kans. Kans Ac Sc, Tr 11: 8-10 (1889)

89a The composition af Kansas coals. Kans Ac Sc Tr 11:46-49 (1889)

9o (and slosson, E. E:) On barite and associated minerals in the concretionary rocks of eastern Kansas. Kans Ac Sc, $\operatorname{Tr} 12: 45-46(1890)$

90a "Feather alum" from Colorado (abst). Kans Ac Sc, Tr 12:101 (1890)

$90 \mathrm{~b}$ On the minerals contained in a Kiowa Co., Kans., meteorite. Science 16: 206 (1890)

91 On halotrichite or feather alum from Pitkin Co., Colo. Am J Sc (3) 41:296297 (1891)

91a The Tonganoxie meteorite. Am J Sc (3) $42: 385-387$ (1891)

93 (and Case, E. C.) On the composition of some Kansas building stones. Kans Ac Sc, $\operatorname{Tr} 13: 78$ (1893) 
Bailey, Edgar Henry Summerfield-Con.

93n (with Failyer, G. H.) A revised list of Kansas minerals. Kans Ac Sc, Tr 13:76-78 (1893)

95 Natural gas and coal oil in Kansas. Kans Univ Q 4:1-14 (1895)

97 (and Whitten, W. M.) On the chemical composition of some Kansas gypsum rocks. Kans Univ Q 6:29-34 (1897)

99 (with Grimsley, G. P.) Special report on gypsum and gypsum eement plasters. Kans Univ G S 5:183 pp, maps, Topeka 1899

02 Special report on mineral waters. Kans Univ G S 7:343 pp, map, Topeka 1902

Bailey, Elbert W.

o5 (and Rath, C. M., and Grider, R. L.) A garnetiferous bed in Golden Gate Canyon, Jeffersen Co., Colo. Colo Sch Mines, B 2 no $4: 80-86$ (1905)

Bailey, Frank.

o5 Copper deposits of the Aspen Grove camp, Similkameen, B. C. M Rep 51: 214-215 (1905)

13 Platinum in British Columbia. M J $100: 207-210$ (1913)

Bailey, Gilbert Ellis.

90 Report of the geology of South Dakota west of the Missouri River and of Wyoming east of the foothills of the Rocky Mountains. U S, 51st Cong 1st sess, S Ex Doc $222: 65-70$ (1890)

02 The saline deposits of California. Cal St M Bur, B 24: 216 pp, maps (1902)

04 The desert dry lakes of California. M Sc Press $89: 138,161,174,192-193$, 205-206, 222-223, 241-242, 255 (1904)

06 The borax deposits of Callfornia. M World 24:4-5 (1906)

Bailey, Irving W.

11 A Cretaceous Pityoxylon with marginal tracheides. An Bot 25:315-325 (1911)

15 (and Sinnott, E. W.) A botanical index of Cretaceous and Tertiary climates. Science n 8 41: 831-834 (1915)

15a (with Sinnott, E. W.) The evolution of herbaceous plants and its bearing on certain problems of geology and climatology. J G 23:289-306 (1915)

Bailey, J. Trowbridge.

83 The copper deposits of Adams Co., Pa. Eng M J 35:88-89 (1883) [See Frazer, 83]

o3 The ore deposits of Contact, Nev. Eng M J 76:612-613 (1903)

Bailey, Jacob Whitman (1811-1857).

37 Account of an excursion to Mount Katahdin in Maine. Am J Sc 32:20-34 (1837)

38 On fossil Infusoria discovered in peat earth at West Point, New York, with some notices of American species of Diatomae. Am J Sc $35: 118-124$, il (1838)
Bailey, Jacob Whitman-Continued.

41 A sketch of the Infusoria of the family Bacillaria, with some account of the most interesting species which have been found in a recent or fossil state in the United States. Am J Sc 41:284-305, il (1841)

41a American Polythalmia from the upper Mississippi and also from the Cretaceous formation on the upper Missouri. Am J Sc 41:400-401, il (1841)

42 A sketch of the Infusoria of the family Bacillaria, with some account of the most interesting species which have been found in a recent or fossil state in the United States. Am J Sc 42:88-105. il (1842) As Am G, Rp: 112-164, il (1843) N Y G S, Geol N Y, First Dist (Mather): $48-79,238-245$, il (1843)

42a Sketch of the Infusoria of the family Bacillaria. Am J Sc $43: 321-332$, il (1842)

43 [On infusorial deposits at Petersburg, Va. (abst)] Am J Sc $45: 313$ (1843)

44 Account of some new infusorial forms discovered in the fossil Infusoria from Petersburg, Va,, and Piscataway, Md. Am J Sc $46: 137-141$, il (1844)

45 New locality of fossil fluviatile in. fusoria in Oregon-(abst). As Am G, Pr $6: 64-66(1845)$

45a On some of the fossil coniferous trees of the United States. As Am G, Pr $6: 81-82$ (1845)

45b Infusorial deposits in America. Am J Sc 48:102 (1845) An Mag N H $15: 214-215$ (1845)

45e Ehrenberg's Observations on the fossil Infusoria of Virginia and Maryland and comparison of the same with those found in the chalk formations of Europe and Africa. Am J Sc 48:201-204 (1845) The Virginias $2: 56-57$ (1881)

45d Notice of some new localities of Infusoria, fossil and recent. Am J S $48: 321-343$, il (1845)

46 On the detection of spirally dotted or scalariform ducts and other vegetable tissues in anthracite coal. Am J Sc (2) $1: 407-410$, il (1846) Abst, G Soc Lotdon, Q J 2 pt 2: 94-95 (1846)

$46 a$ [Report on infusorial deposits from Peacham and Maidstone, Vt.] $\mathbf{G}$ Vt, At Rp 2 : 151-152, il (1846)

48 Notes concerning the minerals and fossils, collected by Lieutenant J. W. Abert while engaged in the geographical examins tion of New Mexico. U S, 30th Cong 1s sess, S Ex Doc 23:131-132; H Ex Dor 41 : 547-548, il, map (1848)

49 New localities of Infusoria in the Tertiary of Maryland. Am J Sc (2) $7: 43^{\text {? }}$ (1849)

50 Discovery of an infusorial stratum ti Florida. Am J Sc (2) $10: 282$ (1850) 
Bailey, Jacob Whitman-Continued.

51 Microscopical observations made in South Carolina, Georgia, and Florida. Smiths Contr Knowl 2 art 8:48 pp, il (1851)

51 a Miscellaneous notices [fossil Infusoria]. Am J Sc (2) 11:85-86 (1851)

54 Notes on new species and localities of microscopical organisms. Smiths Contr Knowl 7 art $3: 16 \mathrm{pp}$ (1854)

$54 a$ on some new localities of fossil Diatomaceae in California and Oregon. Am J Sc (2) 17:179-180 (1854) Q J Micro Sc 3: 91-92 (1855)

55 Notes upon silicified plants found fossil in California by W. P. Blake, geologist of the expedition under the command of Lieutenant A. S. Williamson. U S, Pacific R R Expl (U S, 33d Cong 1st sess, $\mathrm{H}$ Ex Doc 129) Appendix to the preliminary geological report of W. P. Blake: 28-29 (1855)

55a Letter upon infusorial fossils [diatoms from California]... In Beckwith, E G., Report... forty-first parallel. U. S, Pacific R R Expl (U S, 33d Cong 1st sess H Ex Doc 129 v 18 pt 2):135-136 (1855) ; also (U S, 33d Cong $2 \mathrm{~d}$ sess, S Ex Doe 78 and $\mathrm{H}$ Ex Doc 91) 2:111-112 (1855)

56 New method of disintegrating masses of fossil Diatomaceae. Am J Se (2) 21 : 356-357 (1856)

$56 \mathbf{n}$ On the origin of greensand and its formation in the oceans of the present epoch. Boston Soc N H, Pr 5:364-36s (1856) Am J Sc (2) $22: 280-284$ (1856) An Mag N H (2) $18: 425-428$ (1856) Q J Miero Se 5: 83-87 (1857)

57 ... structure of the fossil plant from Posuncula River [Williamson's reconnaissance in California], U $\mathrm{S}$, Pacific R R Expl (U S, 33d Cong 2d sess, S Ex Doc 78 and II Ex Doc 91) 5 pt $2: 337$, il (1857) [See also Blake (W P), 57]

57 a [Microscopic examination of some earths and rocks.] In Emory, W. H., Report on the United States and Mexican boundary survey... (U S, 34th Cong 1st sess, $\mathrm{S}$ Ex Doc 108 and $\mathrm{H}$ Ex Doc 135), v 1 pt $2: 24$ (1857)

See also Ehrenberg, 43.

Bailey, Loring Woart.

62 [On the siliceous marls or diatomaceous earths of Maine.] Me Bd Agr, 7th An Rp : 395-401 (1862)

64 Report on the mines and minerals of New Brunswick... 73 pp, Fredericton 1864

64 Notes on the geology and botany of New Brunswick. Can Nat n s 1:81-97, map (1864)

65 Observations on the geology of southern New Brunswick... with a geological map. $159 \mathrm{pp}$, map, Fredericton 1865 Rv, Can Nat n s $2: 232-239,314$ 318 (1865)
Bailey, Loring Woart-Continued.

66 Report on the produce, export and import trade, etc., of coal and other combustible minerals of New Brunswick. 16 pp, Fredericton 1866

70 (with Matthew, G. F.) Remarks on the age and relations of the metamorphic rocks of New Brunswick and Maine. Am As, Pr 18:179-195 (1870)

71 On the physiography and geology of the Island of Grand Manan [Bay of Funday]. Can Nat n s 6:43-54, map (1871)

72 (and Matthew, G. F.) Preliminary report on the geology of southern New Brunswick. Can G S, Rp Prog 1870-1: 13-240 (1872)

72a Report of progress of geological investigations in New Brunswick. Can G S, Rp Prog 1871-2:142-145 (1872)

73 (and Matthew, G. F.) Report of observations on the Carboniferous system of New Brunswick, in the counties of Queens, Sunbury, and a portion of York. Can G S, Rp Prog 1872-3: 180-230 (1873)

76 (and Matthew, G. F.) Summary report of geological observations in New Brunswick. Can G S, Rp Prog 1874-5 : 84-89 (1876)

76a The useful minerals of New Brunswick. In Bailey, L. W., and Jack, Edward, The woods and minerals of New Brunswick... : 41-51, Fredericton, N. B., 1876.

77 (and Matthew, G. F.) Report of geological observations in southern New Brunswick, Can G S, Prog Rp 1875-6: 348-368 (1877)

7S (and Ells, R. W.) Report on the Lower Carboniferous belt of Albert and Westmoreland cos., N. B. Can G S, Bp Prog 1876-7:351-401, map (1878)

79 Report on the pre-Silurian (Huronian) and Cambrian or Primordial Silurian rocks of southern New Brunswick, 187778. Can G S, Rp Prog 1877-8: DD 34 pp (1879)

So (and Matthews, G. F., and Ells, R. W.) Report on the geology of southern New Brunswick, embracing the counties of Charlotte, Sunbury, Queens, Kings, St. John, and Albert. 1878-79. Can G S, Rp Prog 1878-9: D 26 pp (1880)

81 On the progress of geological investigation in New Brunswick, 1870-1880. Am As, Pr 29:415-421 (1881)

82 (with Matthew, G. F.) ... sur les roches cambriennes du Nouveau-Brunswick, Canada. Int G Cong, II, Bologna 1881, C R : 646-648 (1882)

83 On the physical and geological history of the St. John River, N. B. (abst). R Soc Can, Pr Tr 1, iv : 281-284 (1883)

84 On the Acadian basin in American geology (abst). Brit As, Rp 54:717 (1885) G Mag (3) $1: 478$ (1884) 
Balley, Loring Woart-Continued.

s5 On geological contacts and ancient erosion in southern and central New Brunswick. $\mathrm{R}$ Soc Can, $\operatorname{Pr} \operatorname{Tr} 2$, iv : 91-97 (1885) Abst, Science $3: 676$ (1884)

85a Report of explorations and surveys in portions of York and Carleton cos., N. B. Can G S, Rp Prog 1882-4: G 31 pp (1885)

86 Report of explorations and surveys in portions of the counties of Carleton, Victoria, York, and Northumberland, N. B. Can G S, An Rp 1: g 30 pp, (1886)

86a Geology and geologists in New Brunswick. Can Rec Sc 2:93-96 (1886) 86b The deepest freshwater lake in America [Lake Temiscouata, Quebec]. Sclence $8: 412-413$ (1886)

87 (and MeInnes, W.) Report on explorations in portions of the counties of Victoria, Northumberland, and Restigouche, N. B. Can G S, An Rp 2: s 19 pp, map (1887)

$\mathbf{8 7 a}$ On the Silurian system of northern Maine, New Brunswick, and Quebec. R Soc Can, $\operatorname{Pr} \operatorname{Tr} 4$, iv : $35-41$ (1887)

88 (and MeInnes, W.) Report on explorations and surveys in portions of northern New Brunswick and adjacent areas in Quebec, and in Maine. Can G S, An Rp 3: if 52 pp, map (1888)

88 a Notes on the physiography and geology of Aroostook Co., Me. R Soc Can, Pr $\operatorname{Tr} 5$, iv : 39-44 (1888) Abst, Can Rec Sc 2:430 (1887)

89 (and MeInnes, W.) [Observations in northern New Brunswick.] Can G S, Sum Rp 1887-8 (An Rp 3) : A $91-93$ (1859)

89a On the Acadian and St. Lawrence water shed. Can Rec Sc 3:398-413 (1889)

90 [Summary report on work in northern New Brunswick and Quebec.] Can G S, Sum Rp 1888-9 (An Rp 4) : A 35-38 (1890)

$90 a$ On the progress of geological investigation in New Brunswick. $\mathrm{R}$ Soc Can, Pr Tr 7, iv : 3-17 (1890)

$90 b$ On some relations between the geology of eastern Maine and New Brunswick, $R$ Soc Can, $\operatorname{Pr} \operatorname{Tr} 7$, iv : 57-68 (1890) Abst, Can Rec Sc $3: 165-166$ (1888)

91 Notes on the surface geology of southwestern Nova Scotía. N S Inst Se, Pr Tr 8 or (2) 1:1-8 (1891)

92 The gold-bearing rocks of New Brunswick and the possible discovery of remunerative gold deposits in that province. R Soc Can, Pr Tr 9, iv : 21-27 (1892)

93 (and MeInnes, W.) Report on portions of the Province of Quebec and adjoining areas in New Brunswick and Maine, relating more especially to the counties of Temiscouata and Rimouski, P. Q. Can G S, An Rp 5: M 28 pp, map (1893)
Bailey, Loring Woart-Continued.

94 [Summary report of field work in southwestern Nova Scotia.] Can G S. Sum Rp 1893 (An Rp 6) : A 66-67 (1894)

95 Preliminary report on geological in. vestigations in southwestern Nova Scotia Can G S, An Rp 6: Q 21 pp, map (1895)

95a The mountain systems of America; a comparative study. N H Soc N B, B [3] no 12, App C: 3 pp (1895)

96 [Report on field work in southwest. ern Nova Scotia.] Can G S, Sum Rp 1895 (An $R_{p}$ 8) : A 115-116 (1896) ; Sum $R_{p}$ 1896 (An Rp 9) : A 89-94 (1897)

$96 a$ Notes on the geology and botany of Digby Neck. N S Inst Sc, Pr Tr 9 or (2) $2: 68-82$ (1896)

96b Some Nova Scotian illustrations of dynamical geology. N S Inst Sc, Pr Tr 9 or (2) $2: 180-194$ (1896)

97 The Bay of Fundy trough in Amert. can geological history. R Soc Can, Pr Tr (2) 3 , iv : 107-116 (1897)

9s Report on the geology of southwest Nova Scotia. Can G S, An Rp 9: M 154 pp, map (1898)

08a [Preliminary report on mineral re sources of New Brunswick.] Can G S, Sum Rp 1897 ( $A$ n Rp 10) : A 92-98 (1898)

98b The mineral resources of the Prot ince of New Brunswick. Can G S, An R? 10 : M 129 pp, map (1898)

98e Triassic (?) rocks of Digby basin N S Inst Sc, Pr Tr 9 or (2) $2: 356-360$ (1898)

98d Some typical sections in south western Nova Scotia $(a b s t)$. Brit $\mathbf{A s}, \mathrm{B} q$ $67: 640$ (1898)

99 [Report on field work in New Bruns wick.] Can G S, Sum Rp 1898 (An B 11) : A 137-139 (1899); Sum Rp 1899 (A Rp 12): A 155-162 (1900); Sum Rp 190 (An Rp 13) : A 146-151 (1901)

o1 On some modes of occurrence of the mineral albertite. R Soc Can, $\operatorname{Pr} \operatorname{Tr}(2$ 7, iv: 77-83 (1901) Abst, Science n s 13 1018 (1901)

o1a on some geological correlations if New Brunswick. R Soc Can, Pr Tr (2) iv : 143-150 (1901) Abst, Science n s 13: 1018-1019 (1901)

02 Report upon the Carboniferous sys tem of New Brunswick with special refer ence to workable coal. Can G S, An B 13: м 38 pp (1902)

02a New Brunswick. Can G S, Sum B 1901 (An Rp 14) : A 197-206 (1902)

o3 Geological observations in norther New Brunswick. Can G S, Sum Rp 190. (An Rp 15) : A 384-390 (1903)

O3a Notes on the highlands of norther New Brunswick. N H Soc N B, B no? (5 pt 1): 93-101 (1903)

04 New Brunswick caves. N H So N B, B no 22 (5 pt 2) : 155-169 (1904) 
Bailey, Loring Woart-Continued.

o5 Fossil occurrences and certain economic minerals in New Brunswick. Can G S, Sum Rp 1904 (An Rp 16) :A 279-289 (1905)

05a The voleanic rocks of New Bruns wick. R Soc Can, Pr Tr (2) 10, iv: 123$138(1905)$

06 The gypsum deposits of New Brunswick, R Soc Can, $\operatorname{Pr} \operatorname{Tr}$ (2) 12, iv:3-14, map (1906) Abst, Science n s 23:971-972 (1906)

10 The geological factors in the present configuration of New Brunswick, R Soc Can, $\mathrm{Pr} \operatorname{Tr}$ (3) 3, iv : 45-65 (1910)

10a The history of Curries Mountain, an old New Brunswick volcano. N H Soc N B, B 6 no $28: 189-197$ (1910)

12 Upon some curious structures in the gypsum of Albert Co., N. B. R Soc Can, Pr Tr (3) 5, iv : 121-124 (1912)

Bailey, P. P.

13 The Moyie sills. Can M Inst, Tr $16: 598-607$ (1913)

Bailey, R. K.

16 (with Schnller, W. T, Intumescent kaolinite. Wash Ac Sc, J $6: 67-68$ (1916)

17 (with Hieks, W. B.) Methods of analysis of greensand. U S G S, B 660 ; $51-58(1917)$

Bailey, S. C. H.

65 On the mineralogy of New York Island. Lyc N H N Y An 8: 185-193 (1865)

S5 A new meteoric iron from West Vir. ginia. Science 6:563 (1885)

87 On an aerolite from Rensselaer Co. N. Y. Am J Sc (3) $34: 60-62$ (1887)

91 The Alexander Co. [N. C.] meteoric fron. Elisha Mitchell Sc Soc, J 8: 17-19 (1891)

93 Some current notes upon meteorites. Science 21:352 (1893)

Bailey, Thomas L.

18 Report on the caves of the eastern Highland Rim and Cumberland Mountains. Tenn G S, Res Tenn 8: 85-138 (1918)

Bain, Francis (1842-1894).

81 Notes on fossils from the Red Sand stone system of Prince Edward Island. Can Nat n s 9: 463-464, 473 (1881)

85 (and Dawson, J. W.) Notes on the geology and fossil flora of Prince Edward Island. Can Rec Sc 1: 154-161, il (1885) 85a Glacial moraines in Prince Edward Island. Can Sc Mo 3 no $6:-(1885)$ [not seen ]

85b Bounding the Trias. Can Sc Mo $3: 150-153$ (1885)

87 On a Permian moraine in Prince Edward Island. Can Rec Sc 2:341-343 (1887)

90 Geology. In The Natural history of Prince Edward Island: 9-29, Charlottetown, P. E. Island (1890)
Bain, Francis-Continued.

93 The Permian in Prince Edward Island. Science 21: 132-133 (1893)

Bain, Harry Foster.

93 Distribution and relations of the Saint Louis limestone in Mahaska Co., Iowa. Iowa G S 1, An Rp 1892: 171-179 (1893)

94 Peculiarities of the Mystic coal seam [Iowa]. An G 13:407-411, map (1894)

94a Structure of the Mystic coal basin [Iowa]. Iowa Ac Sc, $\operatorname{Pr} 1$ pt $4: 33-36$ (1894)

94b Sigourney deep well [Keokuk Co., Iowa]. Iowa Ac Se, Pr 1 pt $4: 36-38$ (1894)

95 Notes on Iowa building stones. U S G S, An Rp 16 pt 4: 500-503 (1895)

95a Cretaceous deposits of the Sioux Valley. Iowa G S 3:99-114 (1895)

95b Report [administrative]. Iowa G S $4: 29-30 \quad(1895)$

95e Geology of Keokuk Co. Iowa G S 4:255-311, map (1895) Abst, J G 3: 979-980 (1895)

95d Geology of Mahaska Co, Iowa G S 4:313-380, map (1895) Abst, J G 3: 979-980 (1895)

95e Origin of certain features of coal basins. J G 3:646-654 (1895)

95f Preglacial elevation of Iowa. Iowa Ac Sc, Pr 2: 23-26 (1895)

95g Central Iowa section of the Missis. sippian series. Am G 15:317-325 (1895) $A$ bst, Iowa Ac Sc, $\mathrm{Pr} 2: 174$ (1895)

95h Geologic conditions of economic mining in Iowa. Mo Rv Iowa Weather and Crop Service 6 no $2: 6-9$ (1895)

951 Notes on Iowa building stones, Mo Rv Iowa Weather and Crop Service 6 no $7: 6-7$, no $8: 6-8$, no $9: 4-8$ (1895)

95j (with Todd, J. E.) Interloessial till near Sioux City, Iowa. Iowa Ac Sc, Pr 2: 20-23 (1895)

96 Report [of assistant State geologist]. Iowa $\mathrm{G} \quad \mathrm{S} \quad 5: 27-28 \quad(1896) \quad \ldots 8: 25-29$, map (1898) $\quad \ldots 9: 25-27 \quad(1899) \quad \ldots 10:$ 28-30 (1900)

96a Geology of Washington Co. Iowa G $S 5: 113-173$, map (1896)

96b Geology of Woodbury Co. Iowa G S 5 : 241-299, map (1896)

96e Geology of Appanoose Ce. Iowa G $\mathrm{S} 5: 363-438, \operatorname{map}(1896)$

96d Buried mountains of the prairies. Midland Mo 5: 20-26 (1896)

97 A sketch of the geology of Mexico. J G 5: $384-390$ (1897)

97 a Relations of the Wisconsin and Kansan drift sheets in central Iowa and related phenomena. Iowa G S $6: 429-476$ (1897)

97b Geology of Polk Co. Iowa $\mathbf{G}$ S $7: 263-412$, maps (1897)

97e Geology of Guthrie Co. Iowa G S $7: 413-487$, maps (1897) 
Bain, Harry Foster-Continued.

97d (with Tilton, J. L.) Geology of Madison Co. Iowa G $\mathbf{S} 7: 489-539$, map (1897)

98 (and Leonard, A. G.) The middle coal measures of the western interior coal field. J G 6:577-588 (1898) Abst, Science n s 8:464 (1898); Am G 22:251 (1898) ; G Soc Am, B 10:10-12 (1898)

98a Geology of Decatur Co. Iowa G S $8: 255-309$, map (1898)

98b Geology of Plymouth Co. Iowa G S $8: 315-366$, map (1898)

98e Properties and tests of Iowa build1ng stones. Iowa G S 8:369-416 (1898)

98d Preliminary outline map of the drift sheets of Iowa. Iowa G S 8: pl. 3 (1898)

9se The Aftonian and pre-Kansan deposits in southwestern Iowa. Iowa Ac Sc, Pr 5 : 86-101 (1898) Abst, Am G $21: 255-$ 262 (1898)

98f The Bethany limestone at Bethany, Mo. Am J Sc (4) 5: 433-439 (1898)

98\% The Bonanza Arkansas coal mínes. Eng M J 66 : 579-580 (1898)

98h The western interior coal fleld of America. N Engl Inst M Eng, Tr 48: 55-80, map (1898)

99 Notes on the drift of northwestern Iowa. Am G 23: 168-176 (1899)

99 a Geology of Carroll Co. Iowa G S $9: 49-107$, map (1899)

$99 \mathrm{~b}$ Dubuque lead and zinc mines; the geological position and mode of oceurrence of the ores. Mines and Minerals 20:10-12 (1899)

00 Geology of the Wichita Mountains. G Soc Am, B 11:127-144, map (1900)

$00 a$ (with Calvin, S.) Geology of Dubuque Co. Iowa G S 10:379-622, map (1900)

01 ... lead and zinc deposits of the Ozark region. U S G S, An Rp 22 pt 2 : 23-227, maps (1901)

o1a The origin of the Joplin ore deposits. Abst, Eng M J 71:557 (1901)

02 The origin of ore deposits (discussion). Am I M Eng, Tr 31:936-942 (1902)

02a The western interior coal field. U S G S, An Rp 22 pt $3: 333-366$, map (1902)

02b Individuals of stratigraphic classification. J G 10:139-143 (1902)

02e (with Van Hise, C. R.) Lead and zinc deposits of the Mississippi Valley, U. S. A. Inst M Eng, $\operatorname{Tr} 23: 376-434$, maps (1902)

04 Mineral deposits of Wichita Mountains in Oklaboma. U S, 58th Cong $2 \mathrm{~d}$ sess, S Doc 149:10 pp (1904)

O4a Reported ore deposits of the Wichita Mountains. U S G S, P P 31 : 82-93 (1904)

04b Reported gold deposits of the Wichita Mountains [Okla.]. U S G S, B $225: 120-122$ (1904)
Bain, Harry Foster-Continued.

04c Lead and zinc deposits of Illinols. U S G S, B 225: 202-207 (1904)

o4d Fluorspar deposits of southern IIli. nois. U S G S, B 225:505-511 (1904)

04e Fluorspar deposits of the Kentucky. Illinols district. Mines and Minerals 25: 182-183 (1904)

o4f Fluorspar deposits of southern Illi. nois (abst). Science n s 19:25 (1904)

04g The zinc deposits of Missourl. Lead and Zinc News 8:223-225 (1904)

04h [Nomenclature of geologic formations]. J G 12:65-66 (1904)

04i Physiography and geology [of Iowa]. Iowa G S, Sup $\mathrm{Rp} 1903$ (The grasses of Iowa, pt 2) : 359-373, map (1904)

04j (with Grant, U. S.) A preglacial peneplain in the Driftless Area (abst). Sclence n \& 19:528 (1904)

05 Portland-cement resources of Iowa. U S G S, B 243: 147-165 (1905)

o5a Zinc and lead deposits of north. western Illinois. U S G S, B 246:56 pp, maps (1905)

05b The fluospar deposits of southern Illinois. U S G S, B 255: $75 \mathrm{pp}$, maps (1905)

o5e (and Ulrieh, E. O.) The copper deposits of Missouri. U S G S, B 260: 233-235 (1905)

05d Lead and zinc resources of the United States. U S G S, B 260:251273 (1905)

o5e (and Urich, E. O.) The copper deposits of Missouri. U S G S, B 267:52 pp (1905)

O5f Structural features of the Joplln district [Mo.]. Ec G 1: 172-174 (1905) 05g The progress of economic geology in 1905. M Mag 12:465-473 (1905)

o5h (with Eckel, E. C.) Cement and cement materials of Iowa. Iowa G S, 15: 33-124 (1905)

06 Zinc and lead deposits of the uppet Mississippi Valley. U S G S, B 294:155 pp, maps (1906) Wis G S, B 19:155 pp, maps (1906) [Review, see Buckly, 07c] o6a [The coals of Illinois.] III $G$ S, B 3:9-19, map (1906)

06b A Nevada zinc deposit [Spring Mountains]. U S G S, B 285: 166-169 (1906)

o6e Sedi-genetic and igneo-genetic ores. Ec G 1:331-339 (1906)

o6d What should appear in the report of a state geologist? Ec G 1:484-487, 702-705 (1906)

06e A persistent error [misuse of terms Des Moines and Missourian]. Science $n$ s $23: 919$ (1906).

o8f The southeastern Illinois oil neld. M Sc Press 92:326 (1906)

o6g Zinc and lead ores. U S G S, Min Res 1905 : 379-392 (1906) 
Bain, Harry Foster-Continued.

07 Some relations of paleogeography to ore deposition in the Mississippi Valley. Int G Cong, X, Mexico 1906, C R : 483-499 (1907) Ec G 2:128-144 (1907)

$07 a$ [Review of] Special report on lead and zinc, by E. Haworth and others (Kans Univ G S vol 8). Ec G 2:186-192 (1907)

07b The work of the [Illinois] State Geological Survey. Western Soc Eng, J 12 : 233-239 (1907) Ill Soc Eng, An Rp 22: 51-56 (1907)

ore Petroleum in Illinois. Eng M J 83: 755-756 (1907)

07d Administrative report for 1906. III G S, B 4:9-35 (1907) ...for 1907; B 8: 11-28 (1908) ...for 1908 ; B 14: 1-30, map (1909)

o7e Analysis of certain silica deposits. IIl G S, B 4:185-186 (1907)

ozf Contributions to the study of coal. Ill G S, B 4:187-188 (1907)

08 Occurrence of oil and gas in eastern Illinois. Ill St Ac Sc, Tr 1:63-65 (1908)

0Sa Petroleum fields of Illinois in 1907 .

III G $\mathrm{S}$, B $8: 273-312 \quad(1908) \quad A b s t$, Science n 8 27: 723 (1908)

0sb Some recent literature on petroleum. Ec G 3: 231-246 (1908)

08e Geology of Illinois petroleum fields. Ec G 3:481-491 (1908)

osd Outlook for young men in geology. Science n \& 27:877-879 (1908) IIl St Ac Sc, Tr 1: 43-45 (1908)

OSe (and others). Studies of Illinois coals. Am I M Eng, B 24:1099-1170 (1908); Tr 40:3-74 (1910) Ill G S, B $14: 183-253$ (1909)

09 Petroleum fieids of Illinois. M Sc Press 99 : 153-156 (1909)

10 Special problems and their study in economic geology. Ec G 5:785-790 (1910)

10n Work of State geological surveys. Can M Inst, Q B 10:101-108 (1910); J $13: 364-371$ (1911)

$10 \mathrm{~b}$ Early geological surveying in Kentucky. M Sc Press 101: 435-437 (1910)

11 Samuel Franklin Emmons. M Sc Press 102: 551-552 (1911)

11a Samuel Calvin. J G 19:385-391 (1911)

$11 b$ (and others.) Types of ore deposits. 378 pp, San Francisco 1911

11e Flats and pitches of the Wisconsin lead and zinc districts. In Types of ore deposits (ed, by H. F. Bain) : 77-102 (1911)

15 Mines and mining. In Nature and science on the Pacific coast: 65-74, maps, San Francisco 1915 [See Merriam, 15] 16 Studies of Joplin ore deposits. M Mag 14:206-212, map (1916)

16a $N$. H. Winchell and the American

Geologist. Ec G 11: 51-62 (1916)
Bain, Harry Foster-Continued.

16b Life on an early geological survey [second Geological Survey of Kentucky]. M Sc Press 113: 564-566 (1916)

Bain, J. W.

99 The occurrence of gold in some rocks in western Ontario. Can Inst, $\mathrm{Pr} \mathrm{n}$ s $2: 39-40$ (1899)

01 The iron belt of Lake Nipigon. Ont Bur Mines, Rp 1901: 212-214 (1901)

Baines, A. C.

84 On the sufficiency of terrestrial rotation for the deflection of streams. Am J Sc (3) $28: 434-436$ (1884)

Baird, B. A.

11 Preliminary report of measurements of the earthquake monuments in Marin and San Mateo cos. for the Seismological Society of America, May, 1911. Seism Soc Am, B 1: 35-37 (1911)

Baird, John.

22 Short account of the rocks in the neighborhood of St. John's, Newfoundland. Wernerian N H Soc, Mem 4:151-156 (1823) Ph Mag 60:206-210 (1822)

Baird, Spencer Fullerton (1823-1887).

50 On the bone caves of Pennsylvanla. Am As, Pr 2: 352-355 (1850)

See also Annual record of science and industry.

Baker, Charles Laurence.

11 Notes on the later Cenozoic history of the Mojave Desert region in southeastern California. Cal Univ, Dp G, B 6:333383, il (1911)

12 Physiography and structure of the western El Paso Range and the southern Sierra Nevada. Cal Univ, Dp G, B 7: 117-142 (1912)

12a Notes on the Cenozic history of central Wyo. Abst, G Soc Am, B 23:73-74 (1912)

13 The nature of the later deformations in certain ranges of the Great Basin. J G 21:273-278 (1913)

15 Geology and underground waters of the northern Llano Estacado. Tex, Univ, B 1915 no $57: 225 \mathrm{pp}$, maps (1915)

16 Origin of Texas red beds. Tex, Univ, B 1916 no $29: 8 \mathrm{pp}$ (1916)

16a (with Udden, J. A., and Bose, E.) Review of the geology of Texas. Tex, Univ, B 1916 no $44: 164$ pp, map (1916)

17 (and Bowman, W. F.) Geologic exploration of the southeastern front range of trans-Pecos Texas. Tex, Univ, B 1753: 61-172 (1917)

Baker, E. P.

89 Notes on Mount Loa. Am J Sc (3) $37: 52-53$ (1889)

Baker, Frank Collins.

98 The Mollusca of the Chicago area; the Pelecypoda [includes Pleistocene]. Chicago Ac Sc, $\mathrm{N}$ H $\mathrm{S}, \mathrm{B} 3: 129 \mathrm{pp}$, il (1898) 
Baker, Frank Collins-Continued.

00 Notes on a collection of Pleistocene shells from Milwaukee, Wis. Cin Soc N H, J $19: 175-177$ (1900)

03 Pleistocene mollusks of White Pond, N. J. Nautilus 17:38-39 (1903)

09 Description of a new fossil Lymnaa [nashotahensis n. sp., from marl beds, Waukesha Co., Wis]. Nautilus 23:1921 (1909)

11 The Lymnæidæ of North and middle America, recent and fossil. Chicago Ac Sc, Sp Pub 3:539 pp, il (1911)

12 Postglacial life of Wilmette Bay, Glacial Lake Chicago. Ill Ac Sc, Tr 4: 108-116 (1912)

13 Interglacial records in New York. Science n \& $37: 523-524$ (1913)

$13 a$ Notes on postglacial Mollusca; I, Emmet Co., Mich; II, Waukesha Co., Wis. Nautilus $27: 7-8,68$ (1913)

13b Interglacial mollusks from South Dakota. Science n s 38:858-859 (1913)

15 Pleistocene mollusks from Illinois. Nautilus 29:87-88 (1915)

18 Postglacial Mollusca from the marls of central Illinois. J G 26:659-671 (1918)

Baker, Howard B.

12 The origin of continental forms, $\mathrm{H}$. Mich Ac Sc, Rp 14:116-141 (1912)

13 Origin of continental forms, IV and III. Mich Ac Sc, Rp 15:26-32, 107-113 (1913)

17 Origin of continental forms, v. Mich Ac Sc, Rp 16:99-103 (1914) [1917]

Baker, H. P.

06 The holding and reclamation of sand dunes and sand wastes by tree planting [origin of dunes] Iowa Ac Se, Pr 13: 209-214 (1906)

Baker, I. O.

85 Natural gas in Illinois. Science 6 : $520(1885)$

Baker, James.

94 Annual report of the minister of mines for the year ending 31st December 1893 , being an account of mining operations for gold, coal, etc., in the Province of British Columbia: 1031-1108, Victoria, B. C., $[1894] ; \ldots 1894 \ldots:$ : 721-774 (1895); ... $1895 \ldots: 643-727$ (1896)

Baker, Manley B.

o5 On the occurrence and development of corundum in Ontario. Can M Inst, J $7: 410-421$ (1905)

06 Clay and the clay industry of Ontario. Ont Bur Mines, Rp 1906, 15 pt 2 : 127 pp (1906)

09 Lake Abitibi area [Ont.]. Ont Bur Mines, An Rp 18 pt 1:263-283 (1909)

09a Our visible supply of brick. Can M J $30: 100-102$ (1909)

09b [Clays of Ontario.] Can M J 30 : 244-245 (1909)
Baker, Manley B.-Continued.

11 Iron and lignite in the Mattagaml basin, Ont. Ont Bur Mines, An Rp $20 \mathrm{pt}$ 1: 214-246 (1911)

$11 a$ The iron ores of the Mattagam River [Ont.]. Can Min Inst, Q B 14:145155 (1911) ; J 14:299-309 (1912)

13 Mineral deposits near Kingston, Ont: Int $\mathrm{G}$ Cong, XII, Canada, Guide Book no $2: 119-139$, map (1913)

$13 a$ Clay deposits and works near Toronto: Int $\mathrm{G}$ Cong, XII, Canada, Guide Book no 6 : 49-53 (1913)

16 The geology of Kingston [Ont.] and vicinity. Ont Bur Mines, An Rp 25 pt 3: 1-36 map (1916)

17 Long Lake gold mine, Sudbury district. Ont Bur Mines, An Rp $26: 157-162$, map (1917)

17a Alexo nickel mine, Timiskaming dis. trict. Ont Bur Mines, An Rp 26: 258-274 (1917)

Bakex, Thomas R.

93 A valuable Florida deposit [sandstone rock]. Science 21:327 (1893)

Baker, W. W.

58 [ On a fossil starfish from Lewiston, Me.] Boston Soc N H, Pr 6:394 (1858) Abst, Am J Sc (2) $27 ; 141$ (1859)

BnleweII, Robert (1768-1843).

29 An introduction to geology... 1st $A m$ ed (edited by B. Silliman, with addition, Outline of the course of geological lectures given in Yale College), from 3d L ed, $400,128 \mathrm{pp}$, New Haven $1829 ; 2 d$ Am from 4th $L$ ed, 479 pp, New Haven 1833 ; 3d Am from 5th L ed, 596 pp, New Haven 1839

30 On the Falls of Niagara, and on the physical structure of the adjacent country. Mag N H (Loudon) 3:117-130 (1830)

32 On the recent discovery of gold mines in the United States of America. Mag N H (Loudion) 5: 434-440 (1832)

47 Observations on the whirlpool and on the rapids below the Falls of Niagara. Am J Sc (2) $4: 25-36$ (1847)

57 Observations on the Falls of Niagara with reference to the changes which have taken place, and are now in progress. Am J Sc (2) $23: 85-95$ (1857)

Balarezo, Manuel.

09 Breve reseña sobre las minas de plats y cobre de nuestro pafs. Soc G Mex, B 5: 7-8, 133-145 (1909)

$09 a$ Los yacimientos metaliferos de EI Dorado, Tepic. Soc G Mex, B $6: v-v i, 1-4$ (1909)

10 Estudio geológico-minero de los alrede dores de "El Pingüico," Guanajuato. Soc G Mex, B $7: 61-63$ (1910)

10a Las turbas de San Nicolas Tolen. tino, Puebla. Soc G Mex, B 7:65-66 (1910) 
Baleh, David M.

62 On orthite from Swampscott, Mass. Am J Sc (2) $33: 348-351$ (1862)

63 On tellurbismuth from Dahlonega, Ga. Am J Sc (2) 35:99-101 (1863)

64 On sodalite at Salem, Mass. Essex Inst, $\operatorname{Pr} 4: 3-6$ (1864)

Baleh, Edwin Swift.

00 Glacières or freezing caverns. 337 pp, Phila 1900

17 Early man in America. Am Ph Soc, Pr 56:473-483 (1917)

Baleh, William Ralston,

82 The mines, miners, and mining interests of the United States in 1882. 1191, $50 \mathrm{pp}$, Phila 1882.

\section{Baldacei, L.}

06 Il giacimento solfifero della Louisiana. Italia, Ministero di Agricoltura, Industria e Commercio, Publicazioni del Corpo Reale delle Miniere, 43 pp, Roma 1906.

Baldauf, Richard.

10 Ueber das Kryolith-Vorkommen in Grönland. Zs prak G 18:432-446 (1910)

Baldwin, C. C.

87 Colonel Charles Whittlesey. Western Reserve Hist Soc, Tract (no 68) 2:404434 , port (1887)

Baldwin, Elmer.

77 Economic geology [of Lasalle Co., III.]. In his History of Lasalle County, Ilinois : $25-34$, Chicago 1877

Baldwin, S. Prentiss.

92 Muir Glacier, Alaska. Se Am $66: 227-228$ (1892)

93 Recent changes in the Muir Glacier. Am G 11: 366-375 (1893)

94 Pleistocene history of the Champlain Valley. Am G 13:170-184, maps (1894)

Bull, John.

32 Diluvial scratches on rocks. Am J Sc 22: 166 (1832)

34 Geology and meteorology west of the Rocky Mountains. Am J Sc 25:351-353 (1834)

35 ... geology and physical features of the country west of the Rocky Mountains. Am J Sc 28:1-16 (1835)

Ball, Lionel C.

13 Field and office methods in the preparation of geological reports; some notes on equipment. Ee G $8: 382-383$ (1913)

Ball, Max W.

09 The western part of the Little Snake River coal field, Wyo. U S G S, B 341: 243-255, map (1909)

10 (and Stebinger, Eugene) The eastern part of the Little Snake River coal field, Wyo. U S G S, B 381: 186-21s, map (1910)

Ball, S. Mays.

09 Manganese deposits of Virginia. Eng M J 87: 1056, map (1909)

$$
28737^{\circ}-23-5
$$

Ba11, S. Mays-Continued.

09a Tin deposits of the Carolinas. Eng M J $87:$ 1139-1140 (1909)

09b Review of fossil iron-ore deposits of Georgia. Eng M J 88:200-204 (1909)

Ball, Sydney Hobart.

03 (and Smith, A. F.) The geology of Miller Co., with an introduction by E. R. Buckley. Mo Bur $G$ and Mines (2) 1:207 pp, maps, Jefferson City, Mo., 1903.

03a (with Bnckley, E. R.) - Glacial boulders along the Osage River in Missouri (abst). J G 11:106-107 (1903) G Soc Am, B 14:553 (1904)

04 The deposition of the Carboniferous formations of the north slope of the Ozark uplift. J G 12 : 335-343, map (1904)

06 Pre-Cambrian rocks of the Georgetown quadrangle, Colo. Am J Sc (4) 21 : 371-389 (1906)

OGa Notes on ore deposits of southwestern Nevada and eastern California. U S

G S, B 285 : 53-73 (1906)

$07 \mathrm{~A}$ geologic reconnaissance in southwestern Nevada and eastern California. U S G S, B 308:218 pp, map (1907)

o7a Copper deposits of the Hartville uplift, Wyo. U S G S, B 315:93-107 (1907)

ozb The Hartville iron-ore range, Wyo. U S G S, B 315:190-205 (1907)

07e Titaniferous iron ore of Iron Mountain, Wyo. U S G S, B 315: 206-212 (1907)

07d Portland cement materials in eastern Wyoming. U S G S, B 315:232-244 (1907)

o7e Mica in the Hartville uplift, Wyo. U S G S, B 315:423-425 (1907)

ozf Graphite in the Haystack Hills, Laramie Co., Wyo. U S G S, B 315: 426-428 (1907)

os Geology of the Georgetown quadrangle, Colo. U S G S, P P 63:29-96, map (1908)

OSa The post-Jurassic igneous rocks of southwestern Nevada. J G 16:36-45, map (1908)

11 The Tampico oil field, Mexico. Eng M J 91:959-961 (1911)

13 Sandstone copper deposits at Bent, N. Mex. M Sc Press 107:132-136, map (1913)

16 The lead mines of Washington Co, Mo. M Sc Press 113: 807-810 (1916)

16 a (and Thompson, L. H.) The southwest Virginia lead-zinc deposits. Eng M J $102: 735-737$ (1916)

17 Molybdenite and its occurrences. Eng M J 104:333-338 (1917)

18 [Notes on the occurrence of molybdenum.] Inst M Met, B 162:21-22 (1918) See also Spurr, 08. 
Ball, W. G.

09 (with Clapp, C. H.) The lead-silver deposits at Newburyport, Mass., and their accompanying contact zones. Ec G 4: 239-250 (1909)

Ballard, F. A.

80 Mastodon remains found in Jackson Co., Mo. Kansas City Rv Sc 3:643-644 (1880)

Ballard, H. O

94 (with Crosby, W. O.) Distribution and probable age of the fossil shells in the drumlins of the Boston basin. Am J Sc (3) $48: 486-496 \quad$ (1894)

Balliet, Letson.

14 The geology of Tonopah, Nev. M World $40: 837-841$ (1914)

Ballou, William Hosea.

80 Improvement of the Mississippi River. Science (ed, Michels) 1:232-233 (1880)

82 Niagara River, its canyon, its depth, and its wear. Sc Am Sup 13: 5045-5046 (1882)

97 Strange creatures of the past; gigantic saurians of the reptilian age. Century Mag 55: 15-23 (1897)

$97 \mathbf{a}$ World's geologists at St. Petersburg. Pop Sc Mo 51:212-222, port (1897)

98 The serpentlike sea saurians. Pop Sc Mo 53:209-225, 11 (1898)

Baneroft, George J.

02 Secondary enrichment at Cripple Creek. Eng M J 74:752-753 (1902) ; 75: 111-112 (1903)

03 The Yaqui River country of Sonora, Mexico. Eng M J 76:160-162 (1903)

07 The formation and enrichment of ore-bearing veins. Am I M Eng, B 15: 499-522 (1907); $\operatorname{Tr} 28: 245-268$ (1908); B 31:581-589 (1909); Tr 40:809-817 (1910) Reprinted in Emmons, S. F., Ore deposits: 696-728, N Y 1913 In part, M World 31:177-179 (1909)

07a Ore deposition. M Sc Press 95:580 581 (1907)

11 Genesis of ore deposits. Colo Sc Soc, Pr 10:1-16 (1911). Colo Sch Mines Mag 1 no $7: 3-8$ (1911)

$11 a$ The superficial appearance and alteration of ore deposits. Colo Sc Soc, P $10: 39-54$ (1911) Colo Sch Mines Mag 1 no $12: 3-5$ (1911)

13 The exodus of ore deposits. M Science $67: 181-183$ (1913)

13a The geology of the Moffat tunnel, Colo. M Science 68:23-26 (1913)

Bancroft, Howland.

10 Notes on the occurrence of cinnabar in central western Arizona. U S G S, B $430: 151-153$ (1910)

10a Patinum in southeastern Nevada. U S G S, B 430:192-199 (1910) Abst, Science n s 31:509 (1910)

$10 b$ Notes on tungsten deposits near Deer Park, Wash. U S G S, B 430:214216 (1910)
Bancroft, Howland-Continued.

11 Reconnaissance of the ore deposits in northern Yuma Co,, Ariz. U S G \& B 451:130 pp (1911) Abst, Wash Ac Sc, J $1: 184$ (1911)

$11 a$ Lead and zinc deposits in the Metaline district, northeastern Wash. I S G S, B 470: 188-200 (1911)

$11 b$ (with Irving, J. D.) Geolog! and ore deposits near Lake City, Colo. U S G S, B 478: 128 pp (1911)

12 A nickel deposit in the San Poil min. ing district, Wash. M Sc Press 104: 144145 (1912)

14 The ore deposits of northeastem Washington. U S G S, B $550: 215$ pp (1914) Abst, by A. H. Brooks, Wash Ac Sc, J $5:$ :21-22 (1915)

14a Dip chart. Am I M Eng, B 91: $1767-1769$ (1914) : Tr 49:307-315 (1915)

$14 b$ (with Lindgren, W.) The Re public mining district, Wash. U S G \&, B $550: 133-166$, map (1914)

15 Geology of Gold Road district [near Kingman, Ariz.]. M Sc Press 111:21 (1915)

Bancroft, Joseph Austen.

05 Ice-borne sediments in Minas Basin, N. S. N S Inst Sc, Pr Tr 11:158-16? $(1905)$

os Report on that portion of the coast of British Columbia extending from Pewell River to Kingcome Inlet, including the ad jacent islands. Can G S, Sum Rp 1907 16-18 (1908) B C Minister of Mines, An Rp 1907: 159-161 (1908)

08a (with Evans, N. N.) On the oc currence of gedrite in Canada. Am J S: (4) $25: 509-512$ (1908)

12 Geology and natural resources of th basins of the Harricanaw and Nottawas rivers, northwestern Que. Que, Dp Col.. Mines $\mathrm{Br}$ : $16 \mathrm{pp}$ (French ed $19 \mathrm{pp}$ ), map (1912)

12a Rcport on the Ecology and mineral resources of Keekeek and Kewagama lakes region. Que, Dp Col... Mines $\mathrm{Br} \mathrm{Rp}$ on mining operations $1911: 160-207$, map (1912)

13 Geology of the coast and islands be tween the Strait of Georgia and Queen Charlotte Sound, B. C. Can G S, Mem 23: $146 \mathrm{pp}$, map (1913)

13a A report on the geology and natura resources of certain portions of the drain age basins of the Harricanaw and Notta. way rivers, to the north of the National Transcontinental Ruilway in northwester Quebec. Que, Dp Col... Mines Br, Rp on mining operations $1912: 131-191$, map (1913)

13b Report on the reology and natural resources of an area embracing the besd waters of the Harricanaw River, nortb. western Quebec. Que, Jp Col... Mines Br. P.p on mining operations 1912:199-236, map (1913) 
Baneroft, Joseph Austen-Continued.

14 Preliminary report on some copper deposits of the eastern townships [of Quebec]. Que, Dp Col, Mines and Fish, Mines $\mathrm{Br}, \mathrm{Rp}$ of mining operations 1913: 48-54 (1914)

15 Report on the copper deposits of the eastern townships of the Province of Quebec. Quebec, Dp Col: 295 pp, map (1915) (French ed, $315 \mathrm{pp,} \mathrm{map} \mathrm{(1916))}$

16 The geology of parts of the townships of Montauban and Chavigny and the seigniory of Grondines; including a description of the zinc and lead deposits in the vicinity of Notre Dame des Anges, Portneuf Co. [Que.]. Que, Dp Col, Mines $\mathrm{Br}$, Rp on mining operations, 1915:103143, map (1916)

17 Geology and mineral resources along National Transcontinental Railway, in the Province of Quebec; geological reconnaissance between Hervey Junction and Doucet, and along the Canadian Northern Railway from St. Thecle to Rivière a Pierre. Que, Dp Col, Report on mining operations 1916 : 128-168, map (1917)

17a (with Adams, F. D.) On the amount of internal friction developed in rocks during deformation and on the relative plasticity of different types of rocks. J G 25: 597-637 (1917)

17b (with Adams, F. D.) Investigations into the magnitude of the various forces which are required to induce movements in various rocks under the conditions which obtain in the deeper parts of the earth's crust (abst). G Soc Am, B 28:125-126 (1917)

18 Memorial of Charles Wales Drysdale. G Soc Am, B 29:29-35, port (1918)

Bancroft, M. F.

16 District east of Kootenay Lake [B. C.] Can G S, Sum Rp 1915: 94-97 (1916)

18 Investigations in the slocan district, B. C. Can G S, Sum Rp 1917 pt B : 28-41 (1918)

Bandmann, Charles $J$.

14 The geology of the Battle Mountain mining district, Nev. M Eng World 40:933 (1914)

Bannister, Henry Martyn.

68 Geology of Cook Co. III G S 3:239256 (1868) ; Ec G 2:180-201 (1882)

70 Geology of DeKalb, Kane and Du Page cos.; McHenry and Lake cos.; Kendall Co.; Morgan Co.; Cass and Menard cos. ; Tazewell, McLean, Logan and Mason cos. Ill G S 4:111-189 (1870); Ec G 2: $361-449$ (1882)

73 Report of a geological reconnaissance along the Union Pacific Railroad. U S G S Terr (Hayden), An Rp 6:519-541 (1873)

79 Note on the age of the Laramie group or Rocky Mountain lignitic formation. Am J Se (3) $17: 243-245$ (1879)
Bannister, Henry Martyn-Continued.

97 The drift and geologic time. J G 5: 730-743 (1897)

Bannon, Benjamin.

66 (with Daddow, S. H.) Coal, iron, and oil... $808 \mathrm{pp}$, map, Pottsville, Pa., 1866

Barbee, William J. (1816-1892).

68 The first principles of geology... $2 \mathrm{~d}$ ed, 523 pp, map, Louisville 1868 First ed, with title, The physical and moral aspeets of geology, 1861 [not seen]

Barber, William Burton ( ?-1905).

02 (with Nutter, E. H.) On some glaucophane and associated schists in the coast ranges of California. J G 10:738-744 (1902)

04 On the lamprophyres and associated igneous rocks of the Rossland mining district, B. C. Am G 33: 335-347 (1904)

Barbot, Louis J.

85 The artesian well, depth 1970 feet, Marion Square, Charleston, S. C. $4 \mathrm{pp}$, Charleston, S. C., 1885

Barbour, Carrie Adeline.

98 Some methods of collecting, preparing, and mounting fossils. Nebr Ac Sc, Pub 6: 258-264 (1898) Nebr St Hist Soe, Pr (2) 2:258-264 (1898)

o0 Report on the work of the Morrill geological expeditions of the University of Nebraska. Science n s 11:856-858 (1900)

o1 Observations on the concretions of the Pierre shale. Nebr Ac Sc, Pub $7: 36-38$ (1901)

Barbour, Eleanor.

10 Preliminary notice of a newly discovered bed of Miocene diatoms. Nebr G $\mathbf{S}$ 3 pt $12: 8$ pp (1910)

Barbour, Erwin Hinckley.

89 Ancient inhabitants of the Connecticut Valley. Conn Almanac 1889: 37-58 il

90 Notes on the paleontological laboratory of the United States Geological Survey under Professor Marsh. Am Nat 24, 388400 (1890)

90a (and Torrey, J., jr.) Notes on the microscopic structure of oolite, with analyses. Am J Sc (3) $40: 246-249$ (1890)

$90 b$ Remains of the primitive elephant found in Grinnell, Iowa. Science 16:263 (1890)

91 (with Torrey, J., jr.) The recorded meteorites of Iowa, with special mention of the last, or Winnebago Co., meteorite. Am G 8: 65-72 (1891)

92 Notice of new gigantic fossils. Science 19:99-100, il (1892)

$92 a$ Notes on a new order of gigantic fossils. Nebr Univ Studies $1: 301-335$, il (1892) Abst, J G 1:421 (1893)

95 Is Daemonelix a burrow? Am Nat $29: 517-527$, il (1895)

95a Progress made in the study of Daemonelix. Nebr Ac Sc, Pub $7: 24-28$, il (1895) 
Barbour, Erwin Hinckley-Continued.

95b On soils. Nebr St $\Delta g r$, An Rp 1894:61-92, map (1895)

95e Topographic and geological features of Nebraska. Northwestern J Educ 6:3041 , il (1895)

96 The deposits of volcanic ash in Nebraska. Nebr Ac Sc, Pub 7:12-17, map (1896)

96 a The diatomaceous deposits of Nebraska. Nebr Ac Sc, Pub 7:18-23, map, il $(1896)$

961 Progress made in the soil survey of Nebraska. Nebr St Bd Agr, An Rp 1895 : 273-285 (1896)

97 Nature, structure, and phylogeny of Daemonelix. G Soc Am, F 8:305-314, 1l (1897) Abst, J G $5: 223-224$ (1897); Science n s 5:94-95 (1897)

97 a Report of the geologist [soils and soil moisture]. Nebr St Bd $A \mathrm{gr}$, An Rp 1896: 157-172 (1897)

97b The deposits of volcanic ash in Nebraska. Nebr St Bd Agr, An Rp 1896: 332-337 (1897) Eng M J 64:549 (1897)

97e Progress made in the study of Daimonelix. Nebr St Bd Agr, An $\mathrm{Rp}$ $1896: 338-342$, il (1897)

97d The diatomaceous deposits of Nebraska. Nebr St Bd Agr, An $R_{p}$ 1896: 343-348, il (1897)

98 The value of water as a soil element. Nebr St Bd Agr, An Rp 1897: 195231 (1898)

98a The barites of Nebraska and the Badlands. Nebr Ac Sc, Pub 6:265-268 (1898) Nebr St Hist Soc, Pr (2) 2 : 265268 (1898)

98b Chalcedony-lime nuts from the Badlands; Archihicoria siouxensis gen. et sp. nov. Nebr Ac Sc, Pub 6:272-274, il (1898) Nebr St Hist Soc, Pr (2) 2 : 272-274, il (1898)

98e Discovery of meteoric iron ore in Nebraska, Nebr Ac Sc, Pub 6:275-278 (1898) Nebr St Hist Soc, Pr (2) 2:275278 (1898)

$98 d$ Notes on the ash beds of Nebraska and the Great Plains. Mineral Industry $6: 22-25$ (1898)

99 A preliminary report on the mechanical analyses of the soils of Nebraska. Nebr St Bd Agr, An Rp 1898: 287-320 (1899)

$99 a$ Wells and windmills in Nebraska. U S G S, W-S Paper 29:85 pp (1899)

$99 \mathrm{~b}$ The rapid decline of geyser phenomena in the Yellowstone National Park (abst), Am As, Pr 48:230 (1899) Science n s 10:490-491 (1899)

99e A gold excitement in Nebraska. Eng M J 67:408 (1899)

99d (and Knight, W. C.) The discovery of new invertebrates in the dinosaur beds of Wyoming (abst). Am As, $\mathrm{Pr}$ 48:229-230 (1899). Science n s 10:490 (1899)
Barbour, Erwin Hinckley-Continued.

00 Report on the initial work of th: State geological survey of Nebrasks Science n \& 11:343-344 (1900)

OOa Glaclal grooves and striae i southeastern Nebraska. J G $8: 309-31$ (1900)

o1 Sand crystals and their relation to certain coneretionary forms. G Soc Am B $12: 165-172$ (1901)

O1a The unpublished meteorites of $\mathrm{N}_{t}$ braska. Nebr Ac Sc, Pub 7: 34-35 (1901

01b The State geological survey; report of progress for the summer of 1900. Netr Ac Sc, Pub $7: 166-169$, maps (1901)

02 Volcanic ash in Nebraska solk Nebr St Bd Agr, An Rp 1901:239-24. (1902)

O2n (and Fisher, C. A.) The geologi cal bibliography of Nebraska. Nebr St B Agr, An Rp 1901: 248-266 (1902)

02b (and Fisher, C. A.) A new form of calcite-sand crystal. Am J Sc (4 $14: 451-454 \quad$ (1902)

02c Report of progress of the Nebrask State Geological Survey and the Morril geological expedition of 1901 . Science $n$ $16: 22-23$ (1902)

021 (with Eastman, C. R.) Synops of the Missourian and Permo-Carboniferos fish fauna of Kansas and Nebraska (abst) Science n s 16: 266-267 (1902)

03 Report of the State geologist. Neh G S 1: 258 pp, il, maps (1903)

03a Present knowledge of the distrib tion of Daimonelix. Science n s 18:504 505 (1903)

04 Memoir of Wilbur Clinton Knigh: G Soc Am, B 15: 544-549, port (1904)

05 Notice of a new fossil mammal fros Sioux Co., Nebr. [Syndyoceras cooki, Lot Fork beds]. Nebr G S 2 pt $3: 4$ pp, (1905)

O5a A new Miocene artiodactyl [ $8 y$ ? doceras cooki]. Science n s $22: 797-794$ il (1905)

06 Notice of a new fossil rhinocer from Sioux Co., Nebr. [Diceratherium an karense, Loup Fork beds]. Nebr G $2: 311-318$, il (1906)

o6a (and Ward, H. B.) Preliminar report on the primitive man of Nebraskl Nebr G S $2: 317-327$, il (1906)

06b Report of the tenth geological es pedition of Hon. Charles H. Morrill, seas of 1905. Science n \& 23:114-115 (1906

06e The skull of Syndyoceras. Abs Science n s 23:288-289 (1906); Am . Pr 55: 378 (1906)

06d The skulls of Syndyoceras and $P_{n}$ toceras. Abst, Science n \& 23:623 (1906 o6e A workable bed of coal in [nes Peru] Nebraska. Science n 8 24:51-5 (1906)

06f Notice of a new Miocene rhinocer Diceratherium arikarense. Science $\mathrm{n}$ 24: 780-781, il (1906) 
Barbonr, Erwin Hinckley-Continued.

07 Evidence of loess man in Nebraska. Nebr G S 2:329-348 (1907)

07a Report on the Honey Creek coal mine. Nebr G S 2:349-364 (1907)

07b Biennial report. Nebr, G S $2: 365$ 387 (1907)

07e Report on the geological expedition of Hon. Charles H. Morrill; season of 1906. Science n s $25: 73-74$ (1907)

ozd Evidence of $\operatorname{man}$ in the loess of Nebraska. Science n s 25: 110-112 (1907)

07e Prehistoric man in Nebraska. Putnam's Mo: $413-415,502-503$, il (1907)

o7f Ancient inhabitants of Nebraska. Records of the Past $6: 40-46$, il (1907)

os The skull of Moropus [Sioux Co., Nebr.]. Nebr G S 3 pt 2: 7 pp, il (1908)

09 Skeletal parts of Moropus. Nebr G S $3: 217-222$, il (1909)

09a The flint ballast industry of Gage Co., Nebr. Nebr G S 3: 231-242 (1909)

09b A slab from the bone beds of Sioux Co. Nebr G S 3 pt $7:[251-254]$, il (1909)

09c Restoration of Diceratherium arikarense, a new form of panel mount. Nebr G S 3 pt 8: [255-258], il (1909)

10 List of publications of the Nebraska Geological Survey. Nebr G S 4:7-16 [1910]

10a The development of our natural resources. Nebr G S 4:19-36 [1910]

11 Second financial statement. Nebr G S 3 pt 13: 7 pp (1911)

11a A new Carboniferous coral, Craterophyllum verticillatum. Nebr G S $4: 38-49$, il (1911)

12 Notice of newly discovered eurypterids in Nebraska. Science n s $36: 642-$ 643 (1912)

12a Skull of the giant hog Elotherium; a panel mount. Nebr G S $4: 50-51$, il (1912)

12b Account of the Nebraska Geological Survey to 1912. Nebr G S $7: 7-15$ [1912] 13 A tooth of the Columbian mammoth. Nebr G S 4:58-65, il (1913)

13a An important undeveloped clay bed. Nebr G \& 4: 70-87 (1913)

13b Cement manufacture in Nebraska. Nebr G S 4:91-115 (1913)

13e A minor phenomenon of the glacial drift in Nebraska. Nebr G S 4:161-164 (1913)

14 A new fossil horse, Hypohippus matthewi. Nebr G S $4: 169-173$, il (1914)

14a Mammalian fossils from Devll's Gulch [Brown Co., Nebr.]. Nebr Univ Studies 14:185-202, il (1914) Nebr G S $4: 175-190$, il (1914)

14b Euryterid beds of Nebraska, with notice of a new species, Eurypterus nebraskensis. Nebr G S $4: 193-203$, Il (1914)
Barbour, Erwin Hinckley-Continued.

14e Notice of jelly fishes in the Carboniferous of Nebraska; Medusina valcotti sp. nov. Nebr G S 4:207-209, il (1914)

14d A new longirostal mastodon from Cherry Co. Nebr G S $4: 213-222$, il (1914)

14e (and Cook, H. J.) Two new fossil dogs of the genus Cynarctus from Nebraska. Nebr G S $4: 225-227$, il (1914)

14 Plant tissue in the Carboniferous shales of Nebraska. Nebr G S $4: 231-232$, il (1914)

$14 \mathrm{~g}$ A phenomenon of the Kansan drift in Nebraska. J G 22: $807-810$ (1914)

14h Medusina walcotti, a Carboniferous jellyfish. Am J Sc (4) 38:505-506, II (1914)

$14 i$ Carboniferous eurypterids of Nebraska. Am J Sc (4) 38:507-510, il (1914)

15 (and Cook, H. J.) A new sabertoothed cat from Nebraska. Nebr G $\mathbf{S}$ $4: 235-238$, il (1915)

15 a The round ligament of Nebraska proboscideans. Nebr G S $4: 241-246$, il (1915)

15b Nebraska green quartzite-an important future industry. Nebr G S, 4 : 249-252 (1915)

15e Nebraska minerals which excite common inquiry. Nebr G S 4: 255-276 (1915)

15. Nebraska rocks which excite common inquiry. Nebr G S 4:279-300 (1915)

15e Nebraska fossils which excite common inquiry. Nebr G S $4: 303-324$, il (1915)

15 f A new mammoth, Elephas hayi, from Crete, Nebr. Nebr G S 4:327-331, il (1915)

$15 \%$ A new mount of the fossil tortoise, Testudo orthopygia. Nebr G S 4: $335-336$, il (1915)

15h A new longirostral mastodon, Tetrabclodon lulli: Am J Sc (4) $39: 87-92$, il (1915)

$15 i$ Carboniferous plant tissue. Am J $\mathrm{Se}$ (4) $39: 173-174$, il (1915)

15j A new Nebraska mammoth, Elephas hayi. Am J Sc (4) $40: 129-134$, il (1915)

16 The natural fuels of Nebraska. Nebr G S 4: 339-345 (1916)

16a Nebraska pumicite. Nebr G S 4: $357-401$ (1916)

16b A giant Nebraska bear (Dinarctotherium merriami). Nebr G S 4:349-353, il (1916)

16e A preliminary report on the alkali resources of Nebraska. Nebr G S 4:405438 [1916]

16d Evidence of the ligamentum teres in Nebraska Proboscidea. Am J Sc (4) 41:251-254, il (1916)

16e A new longirostral mastodon from Nebraska, Tetrabelodon osborni sp. nov. Am J Sc (4) $41: 522-529$, il (1916) 
Barbonr, Erwin Hinckley-Continued.

17 Preliminary report on the clay industry of Nebraska. Nebr G S 4:441-493 (1917)

17a The Boyd County mastodon, Tetra. belodon asborni. Nebr G S 4:499-512, 11 (1917)

17b (and Cook, H. J.) Notes on the skull of Meteoreodon. Nebr G S 7:165172, il (1917)

17e (and Cook, H. J.) Skull of Aelurodon platyrhinus sp. nov. Nebr G S $7: 173-180$, il (1917)

Baxbour, I. R.

52 The coal beds in Rhode Island; Mount Hope coal mine. 24 pp, N Y 1852 Barbour, Percy E.

os The Cochiti mining district, N. Mex. Eng M J 86:173-175 (1908)

09 The Los Angeles oil industry [Cal.]. Eng M J 88:365-366 (1909)

Barbour, Percy $P$.

16 (with Wolf, H. J.) The Boulder County tungsten district, Colo. Eng M J 102: 165-169 (1916)

Barbour, $T$.

16 Some remarks upon Matthew's "Climate and evolution," with supplementary note by W. D. Matthew. N Y Ac Sc. An $27: 1-15$ (1916)

Báreena, Mariano.

73 Noticia de los criaderos de azogue del mineral del Doctor [Querétaro]. Soc Geog Mex, B (3) 1:211-213, map (1873) Min Mex 2 no 28 (1874) [not seen]

73a Los ópalos de México. La Naturaleza 2: 297-302 (1873) Abst, Am J Sc (3) $6: 466-467$ (1873)

73b Estudio sobre los pórfiđos cenozoícos de México. Soc Humboldt, An 2: 209-215 (1873) [not seen] Rev Cienc Mex 1874 no $1: 10-11$ [not seen]

73e (with Castillo, A.) Noticia de la existencia del arsénico nativo en la República mexicana. La Naturaleza $2: 313-$ 314 (1873)

74 Informe sobre los minerales platiniferos de Jacala. La Naturaleza 2:369372 (1874)

74a Las rocas de Tecall [Puebla, Méx.]. La Naturaleza $3: 7-9$ (1874)

74b Descubrimiento de una nueva especie mineral de México [livingstonite]. La Naturaleza $3: 35-39, \quad 172-175$ (1874) Am J Sc 8: 145-146 (1874)

74c Viaje a la caverna de Cacahuamilpa: datos para la geología y la flora de los estados de Morelos y Guerrero. La Naturaleza 3:7592 (1874)

74d El wad oolítico. La Naturaleza 3 : 136-138 (1874)

75 Noticias del Ceboruco. Soc Geog Mex, B (3) 2: 232-240 (1875)

75a Los terremotos de Jalísco. Soc Geog Mex, B (3) 2:240-248 (1875)
Barcena, Mariano-Continued.

75b Datos para el estudio de las rocas mesozoicas de México y sus fósiles carac terísticos. Soc Geog Mex, B (3) $2: 369-$ 405 , il (1875) Abst, Am J Sc (3) $10: 386$ 387 (1875)

75e Notas sobre las esferolitas de Me. xico. La Naturaleza 3:190-194 (1875)

75d Descripción de un crustáceo fósil del género Spheroma (Spheroma burkartii). y reseña geológica del Valle de Amera de Jalisco. La Naturaleza $3: 355-361$, il (1875)

75e (with Ramfrez, S.) Informe sobre el fenómeno geologico de Xochitepec Soc Geog Mex, B (3) 2: 48-60 (1875)

76 Noticia geológica de una parte del Estado de Aguascalientes; estudio presen. tado a la Sociedad minera mexicana. $4 \mathrm{pp}$, map, Mexico City 1876

76a On certain Mexican meteorites. Ac N Sc Phila, Pr 1876:122-126

76b The rocks known as Mexican onyr. Ac N Sc Phila, Pr 1876: 166-168

77 Paleontología; consideraciones gene rales sobre la ciencia; introducción al estudio de la paleontología mexicana. Mus Nae Méx, An 1: 43-46 (1877)

$\boldsymbol{7 7 a}$ Materiales para la formación de uns obra de paleontología mexicana. Mus Nac Méx, An 1:85-91, 195-202, 283-286, t (1877-8)

77b Noticia cientifica de una parte de Estado de Hidalgo. México, Ministerio de Fomento, An 1: 331-351, map (1877) Reprint, $50 \mathrm{pp}$, map, Mexico 1877

77e El linarite de México. La Natu raleza $4: 55-56$ (1877)

77d (with Iglesias, M., and Matute J. I.) Informe sobre los temblores de Jalisco y la erupción del volcán Ceboruco. México, Ministerio de Fomento, An 1: 115 204, map (1877)

79 Estudio del terremoto del $\mathbf{1 7}$ dt Mayo de $1879 . \quad 8$ pp, Mexico, 1879

79n Composición química de la living stonita. La Naturaleza 4:268-271 (1879)

$79 \mathbf{b}$ [Ammonites ;ames-danae.] La Natu raleza 4 rev cient : $67-69$ (1879)

81 Noticias geologicas de algunos camt nos nacionales. Mus Nac Méx, An 2 : 267$270,311-314,431-434$ (1881-2)

82 Sobre el origen de algunas rocas [Mt xico]. La Naturaleza 6 : 6-9 (1882)

82 a Descripción de un hueso labrado, de llama fosil, encontrado en los terrenos posterciarios de Tequixquiac, Estado de México. Mus Nac Méx, An 2:439-444, il (1882)

83 Ayuda de memoria para el estudio de un curso de mineralogia aplicada a ls industria $\mathbf{y}$ preparatoxia a la determins cion de las rocas. 49 pp, México 1883 [not seen] 
Barcena, Mariano-Continued.

85 Notice of some human remains found near the city of Mexico. Am Nat 19:739744 , il (1885)

85a (with Castillo, A. del) El hombre del Peñon; noticia sobre el hallazgo de un hombre prehistorico en el valle de México. $20 \mathrm{pp}$, il, México 1885

s6 Tratado de geología; elementos aplicables á la agricultura y á la industria. $435 \mathrm{pp}$, México 1886

86n (and Castillo, A. del) Noticia acerca del hallazgo de restos humanos prehistoricos en el valle de México. La Naturaleza $7: 257-264$, il (1886)

86b Nuevos datos acerca de la antigüedad del hombre en el valle de México. La Naturaleza $7: 265-270$ (1886) México, Min Fomento, B 10:(1886) [not seen]

86e Contestación a las observaciones de la carta anterior [acerca del hombre del Peñon]. La Naturaleza $7: 286-288$ (1886)

86d The fossil man of Peñon, Mex. Am Nat $20.633-635$ (1886)

87 Informe sobre el estado actual de voleán de Colima. $40 \mathrm{pp}$, México 1887 Méx, Min Fomento, An 8:328-365 (1887) La Naturaleza (2) $1: 249-269$ (1889)

91 Ensayo estadistico del Estado de Jalisco ; geologla. México, Min Fomento, An $9: 238-253$, map (1891)

'92 Apuntes relativos á la geología del Estado de Jalisco. La Naturaleza (2) 2: 198-207 (1892)

97 El hombre prehistórico en México. Cong Int Americanistas, XI, Mexico 1895, Actas : 73-78 (1897)

Barek, C.

13 Caves. Mazama:61-69 (1913)

Bard, Darsie Campbell (1878-1920)

10 Absence of secondary copper-sulphide enrichment in calcite gangues. Ec G 5 : $59-61(1910)$

10a The Radersburg mining district of Montana and some interesting features of its geology. As Eng Soc, $J$ 45:14-17 (1910) Abst, Eng M J 90:599-600 (1910)

13 (and Gidel, M. H.) Mineral associations at Butte, Mont. Am I M Eng, B $80: 1627-1631$ (1913) ; Tr $46: 123-127$ (1914)

See also Billingsley, 15, 16.

Barden, Stillman.

66 [On a boulder at Rockville, Mass.] Essex Inst, Pr 4:1v (1866)

Bardwe11, Carlos.

18 (and others) Chemical properties of Utah hydrocarbons. Utah Ac Sc, Tr 1: 7895 (1918)

Barker, Arthur F.

74 Latest observations on Eozoon cana dense by Prof. Max Schultze. An Mag N H (4) $13: 379-380$ (1874)
Barker, Elmer Eugene.

13 Glacial pothholes at Crown Point, N. Y. J G 21:459-464 (1913)

16 Ancient water levels of the Crown Point embayment. N Y St Mus B 187: 165-190, maps (1916)

Barker, F. L.

o7 Structural geology at Leadville [Colo.]. Mines and Minerals 28: 220-222 (1907)

Barker, George F.

61 Report [on rocks of Vermont]. In Report on the geology of Vermont (Hitchcock) 2:706-711 (1861)

02 Memoir of Frederick Augustus Genth, 1820-1893. Nat Ac Sc, Biog Mem 4:201231, port (1902)

Barlow, Alfred Ernest (1861-1914).

90 On the contact of the Huronian and Laurentian rocks north of Lake Huron [descriptions of rocks by A. C. Lawson]. Am G 6:19-32 (1890)

91 On the nickel and copper deposits of Sudbury, Ont. Ottawa Nat 5:51-71 (1891) Can G S, An Rp 5: S 122-139 (1891) Abst, Can Rec Sc 5: 68-69 (1892)

92 On the relations of the Laurentian and Huronian on the north side of Lake Huron. Am J Sc (3) 44:236-239 (1892) 93 [Summary report on field work in the Nipissing region, Ont.] Can G S, Sum Rp 1892 (An Rp 6) : A 34-35 (1893)

93a Relations of the Laurentian and Huronian rocks north of Iake Huron. G Soc Am, B 4:313-332 (1893) Abst, Am G $11: 138$ (1893)

94 [Report on work in the Mattawa River region, Ontario.] Can G S, Sum Rp 1893 (An Rp 6) : A 30-33 (1894)

95 [Report on field work in the Nipissing region, Ontario.] Can G $\mathbf{S}$, Sum $\mathrm{Rp}$ 1894 (An Rp 7) : A 56-57 (1895)

$95 \boldsymbol{a}$ On some dikes containing 'huronite.' Ottawa Nat 9:25-47 (1895) Abst, Science n s 1:62 (1895)

95b (with Ells, R. W.) The physical features and geology of the route of the proposed Ottawa Canal between the St. Lawrence River and Lake Huron. R Soc Can, $\operatorname{Pr} \operatorname{Tr}$ (2) 1, iv : 163-190, map (1895)

96 [Report on field work in the Temiscaming area, Ont.] Can G S, Sum Rp 1895 (An Rp 8) : A 61-63 (1896)

97 (and Adams, F. D.) [Report on field work in the Haliburton area, central Ontario.] Can G S, Sum Rp 1896 (An Rp 9) : ^ $43-53$ (1897)

97a On the occurrence of cancrinite in Canada. Can Rec Sc 7:228 (1897)

97b (with Adams, F. D.) On the origin and relations of the Grenville and Hastings series in the Canadian Laurentian, with remarks by R. W. Ells. Am J Se (4) 3: 173-180 (1897) Abst, G S Am, B $8: 398-401$ (1897); J G $5: 92-94$ (1897) ; Science n s 5:96-97 (1897) 
Barlow, Alfred Ernest-Continued.

97e (with Adams, F. D.) On the origin and relations of the Grenville and Hastings series in the Canadian Laurentian. Can Rec Sc $7: 304-316$ (1897)

98 (and Ferrier, W. F.) On the relatlons and structure of certain granites and associated arkoses of Lake Timiskaming, Canada (abst). Brit As, Rp 67:659-660 (1898) G Mag (4) 5:39-41 (1898)

98a (with Adams, F. D.) [Report on field work in the Hallburton area, central Ontario.] Can G S, Sum Rp 1897 (An Rp 10) : ^ 44-56, map (1898)

99 Report on the geology and natural resources of the area included by the Nipissing and Timiskaming map sheets, comprising portions of the district of Nipissing, Ont., and of the comnty of Pontiac, Que. Can G S, An Rp. 10: I. 1-287 pp, maps (1899)

$99 a$ on the origin of some Archean conglomerates. Ottawa Nat 12:205-217 (1899)

99b (with Adams, F. D.) [Report on field work in central Ontario.] Can G S, Sum Rp 1898 (An Rp 11): A 106-111 (1899)

oO (with Adams, F. D.) [Report of field work in the Haliburton area, central Ontario.] Can G S, Sum Rp 1899 (An Rp 12) : A 122-131 (1900)

o1 Descriptions of rocks collected in 1900 in Great Bear Lake district and thence to Great Slave Lake. Can G S, An Rp 12: c 29-36 (1901)

01 a Microscopic examination of sections of rocks associated with the iron ore deposits of the Kingston and Pembroke railway district. Can G S, An Rp 12: 1 8191 (1901)

02 The Sudbury district [Ont.]. Can G S, Sum Rp 1901 (An Rp 14) : A 143-147 (1902)

02a on the nepheline rocks of Ice River, B. C. Ottawa Nat 16:70-76 (1902) Abst, Science n s 11:1022 (1900)

02b Dr. Alfred R. C. Selwyn... director Geological Survey of Canada, 1869-1894. Ottawa Nat $16: 171-177$, port (1902)

03 The Sudbury mining district [Ontario]. Can G S, Sum Rp 1902 (An Rp 15) : A 254-269 (1903)

04 Report on the origin, geological relations, and composition of the nickel and copper deposits of the Sudbury mining district, Ontario, Canada. Can G S, An Rp 14: H 236 pp, maps (1904)

04a The Timagami district [Ont.]. Can G S, Sum Rp 1903 (An Rp 15) : A 120-133, map (1904)

o5 On corundum in Ontario and on surveys near Lake Timagami. Can G S, Sum Rp 1904 (An Rp 16) : ^ 190-194 (1905)

O5a A landslide on the Lievre River [Que.]. Ottawa Nat 18: 181-190 (1905)
Barlow, Alfred Ernest-Continued.

06 Report on some of the undereloped zine deposits of British Columbia. Can, Dp Interior, Mines Br, Report of the Con. mission to investigate the zinc resources of British Columbia : 273-293 (1906)

06a On the Quebee side of Lake Timt. skaming. Can G S, Sum Rp 1906:113118 (1906)

06b On the nickel deposits of Webster, western N. C. Can M Inst, J 9:303-316, map (1906)

o6e On the origin and relations of the nickel and copper deposits of Sudbury, Ont. Ec G 1: 454-466, 545-553 (1906)

os The origin of the silver of James township, Montreal River mining district [Ont.]. Can M Inst, J 11: 256-272 (1908)

o8a The silver veins of the Montreal River district, Canada. M Sc Press 97: 462-465 (1908)

O8b (with Adams, F. D.) The nepheline and associated alkali syenites of eastern Ontario. $\mathrm{R}$ Soc Can, $\mathrm{Pr} \mathrm{Tr}$ (3) 2, 1v : 3-76 (1908)

09 Report on mining claims in the Montreal River minlng division. Can $\mathrm{M}$ J $30: 51-54$ (1909)

09a Mineral veins in the Montreal Rive district. Can M J 30:57-58, 77 (1909)

09b Repert on mining claims in the Montreal River mining division [silver ores of Nipissing district, Ont.] The German Development Company, Limited [Rp]:521 [1909]

o9e Report on the mining locations be longing to "Miller Lake and Everett Mines, Ltd." [Montreal River mining district, Ont.] The German Development Company, Limited [Rp] : 22-26 [1909]

10 Some notes on the origin of asbestos. Can M Inst, Q B 12: 113-118 (1910); J 13: 438-443 (1911)

10a (with Adams, F. D.) Geology of the Haliburton and Bancroft areas, Prov ince of Ontario. Can C S, Mem 6:419 p? (1910)

11 Memoir of David Pearce Penhallow. 1854-1910. G Soc Am, B 22:15-19, port (1911)

$11 a$ Geology of the Chibougamau region, Quebec, Canada. Abst, G Soc Am, B 22: 738 (1911)

11b (and Gwillim, J. C., and Farl. bault, E. R.) Preliminary report on the geology and mineral resources of the $\mathrm{Chl}$. bougamau mining region, Quebec, by the Chibougamau Mining Commission. Que Dp Col ... 24 pp (1911)

11e (and Gwillim, J. C., and Fari. bault, E. R.) Report on the geology and mineral resources of the Chibougamau re gion, Quebec. Que, Dp Col ... Mines Br : 224 pp, maps (1911) 
Barlow, Alfred Ernest-Continued.

13 The nepheline and alkali syenites of the Port Coldwell area. Int $G$ Cong, XII, Canada, Guide Book no $8: 16-24$ (1913)

15 Corundum, its occurrence, distribution, exploitation, and uses. Can G S, Mem $57: 377 \mathrm{pp}$, map (1915)

Barlow, Scott.

74 Report on the exploration and survey of the Springhill coal field, Cumberland Co., N. S. Can G S, Rp Prog 1873-4 : 147-160 (1874)

77 Report of progress in the exploration and survey of the coal fields of Cumberland Co., N. S. Can G S, Rp Prog 1875-6 : 343347 (1877)

Barnard, Charles.

99 Some recent changes in the shore line of Nantucket (abst). Science n s 10:895 (1899) N Y Ac Sc, An 12:683-684 (1900)

Barnes, Corbin.

13 (and Byler, E. A.) Relation of faulting and mineralization in Goldfield [Nev.]. M Se Press 107 : 59-60 (1913)

Barnes, Daniel Henry (1785-1828).

22 A geological section of the Canaan Mountain [N. Y.]. Am J Sc 5:8-21 (1822)

Barnes, G. W

79 The hillocks or mound formations of San Diego, Cal. Am Nat 13:565-571 (1879)

Barnes, George Orville.

49 Report [on field work in Keweenaw Point region, Lake Superior]. U S, 31st Cong 1st Sess, S Ex Doc 1 pt 3 and $\mathrm{H} \mathrm{Ex}$ Doc 5 pt $3: 509-514$ (1849)

49a Field notes ... on the Ontonagon district [Lake Superior region]. U S, 31st Cong 1st Sess, S Ex Doc 1 pt 3 and $H$ Ex Doc 5 pt $3: 627-636$ (1849)

Barnett, Victor $\mathrm{H}$.

05 Notice of the discovery of a new dike at Ithaca, N. Y. Am J Sc (4) $19: 210$ (1905)

08 A natural bridge due to stream meandering. J G 16: 73-75 (1908)

08a Striations in gravel bars of the Yukon and Porcupine rivers, Alaska. J G 16: 76-78 (1908)

OSb An example of disruption of rock by lightning on one of the leucite hills in Wyoming. J G 16 : 568-571 (1908)

09 (with Kindle, E. M.) The stratigraphic and faunal relations of the Waldron fauna in southern Indiana. Ind $\mathbf{D} \mathbf{G}$ An Rp $33: 393-416$ (1909)

12 Some small natural bridges in eastern Wyoming. J G 20:438-441 (1912)

13 Field methods of geologic mapping in public land states of the west. Ec G 8: 272-279 (1913)

14 The Douglas ofl and gas field, Converse Co., Wyo. U S G S, B 541: 49-88, map (1914)
Barnett, Victor H.-Continued.

$14 \mathbf{a}$ The Moorcroft oil field, Crook Co. Wyo. U S G S, B 581:83-104, maps (1914)

14b Possibilities of oil in the Big Muddy dome, Converse and Natrona cos., Wyo. U S G S, B 581:105-117, map (1914)

14c (with Calvert, W. R., et al.) Geology of the Standing Rock and Cheyenne River Indian reservations, N. and $\mathrm{S}$. Dak. U S G S, B 575: 49 pp, maps (1914) Abst, Wash Ac Sc, J $4: 425$ (1914)

16 Geology of the Hound Creek district of the Great Falls coal field, Cascade Co. Mont. U S G S, B 641:215-231, map (1916) Abst, by R. W. S., Wash Ac Sc, J $7: 133$ (1917)

Barney, W. G.

04 The Silverbell Mountains, Ariz. Eng M J 78: 755-756 (1904)

Barnum, George.

02 Heat and frost in the weathering of stone. Stone 25: 222-228 (1902)

Baron, H. J.

09 Rio Plata mine and mill, western Chihuahua, Mexico. Eng M J 87:147-151 (1909)

09a Mines and works of the Rio Tinto Copper Company [Terrazas, Chihuahua, Mexico]. M World 31:681-684 (1909)

Baron, J. Francis Patch-Le.

02 Some geological notes in Honduras, central America (abst). Selence $n$ s $16: 264-265$ (1902)

Barr, James A.

14 Tennessee phosphate practice. Am I M Eng, B 93:2397-2413 (1914); Tr 50: 917-933 (1915)

Barrande, Joachim (1799-1883).

53 Wiederholung der Silur-Fauna Böhmens in Wisconsin und New York nach D. D. Owen und J. Hall. N Jb $1853: 335$ 347

53a Silur-Gebilde in Texas und am Oberen See. N Jb 1853: 446-447

57 Note relative aux Céphalopodes fossiles du Canada. Soc G France, B (2) 14 : 428-436 (1857)

59 Etat actuel des connaissances acquises sur la faune primordiale. Soc $G$ France, B (2) $16: 516-546 \quad$ (1859) [American : 521-526]

60 Trilobiten der Primordial-Fauna in Massachusetts. N Jb 1860:429-431

60a Neue Beweise einer weiteren Verbreitung der Primordial-Fauna in NordAmerika (On the Primordial fauna and the Taconic system of Emmons). N Jb $1860 ; 769-783$ Boston Soc N H, Pr 7 : $371-374,375-376$ (1860) Am J Sc (2) 31: 212-215 (1861) Can Nat 6:108-113 (1861) Report on the geology of Vermont (Hitcheock) 1:377-379 (1861)

60b Observations sur la faune primordiale. Soc G France, B (2) 17:542-554 (1860) 
Barrande, Joachim-Continued.

61 Documents anciens et nouveaux sur la faune primordiale et le système taconique en Amérique. Soc G France, B (2) $18: 203-321$, il (1861)

$61 a$ Ueber die geologischen und paläontologischen Erscheinungen in Canada. N Jb $1861: 286-293$

62 [Sur la faune primordiale en Amérique.] Soc G France, B (2) 19:721-724, 734-745 (1862) Abst, N Jb 1862: 336-337 See also Dana, 61

Barratt, Joseph.

45 On fossil footmarks in the red sandstone of the Connecticut Valley (abst). As Am G, Pr 6:23 (1845)

45a On the evidence of congelation in the New Red sandstone $(a b s t)$. As Am G, Pr 6:26 (1845)

Barre11, Joseph (1869-1919).

01 Microscopical petrography of the Elkhorn mining district, Jefferson Co., Mont. U S G S, An Rp 22 pt 2:511549 (1901)

02 The physical effects of contact metamorphism. Am J Sc (4) 13:279-296 (1902)

06 Relative geological importance of continental, littoral, and marine sedimentation. J G 14:316-356, 430-457, 524-568 (1906)

o7 Geology of the Marysville mining district, Montana: a study of igneous intrusion and contact metamorphism. U S G S, P P $57: 178$ pp, map (1907)

$07 \mathbf{a}$ Origin and significance of the Mauch Chunk shale. G Soc Am, B 18:449-476 (1907) Abst, Science n s 25:766 (1907)

08 Relations between climate and terrestrial deposits. J G $16: 159-190,255-295$, 363-384 (1908). Abst, Science n s $25: 766$ (1907); G Soc Am B 18:616-621 (1908)

osa Schaeberle and geological climates.

Science n s 28:371-373 (1908)

08b [On flood plain deposits in Old Red Sandstone basins (abst).] Science n s 27:254-255 (1908)

09 Some distinctions between marine and terrestrial conglomerates (abst). Science n s $29: 624$ (1909) G Soc Am, B $20: 620 \quad(1910)$

10 (and Loughlin, G. F.) The lithology of Connecticut. Conn G S, B 13:207 pp (1910)

12 Central Connecticut in the geologic past. Wyoming Hist $\mathrm{G}$ Soc, $\operatorname{Pr} 12: 25-$ 54, map (1912) Conn G S, B 23:44 pp, map (1915)

12a Criteria for the recognition of ancient delta deposits (with discussion by J. M. Clarke, David White, G. W. Stose, Arthur Keith, E. T. Wherry, and H. B. Kümmel : 743-746). G Soc Am, B 23:377446 (1912) Abst, Science n $\quad$ s $\quad 35: 317$ (1912)

\section{Barrell, Joseph-Continued.}

13 Field and office methods in the prepa. ration of geologic reports; measurements by compass, pace, and aneroid. Ec G 8: $691-700$ (1913)

13a The Upper Devonian delta of the Appalachian geosyncline; Part I, the delts and its relations to the interior sea. Am J S (4) $36: 429-472$ (1913)

13b Piedmont terraces of the northem Appalachians and their mode of origin (abst). G Soc Am, B 24:688-690 (1913)

13e Post-Jurassic history of the north. ern Appalachians (abst, with discussion by D. W. Jobnson, W. M. Davis, N. H. Darton, and $\mathrm{J}$. Barrell). G Soc Am, B 24:690-696 (1913)

14 The Upper Devonian delta of the Appalachian geosyncline. Am J Sc (4) $37: 87-109,225-253$ (1914)

14a The strength of the earth's crust; I, Geologic tests of the limits of strength; II, Regional distribution of isostatic compensation; III, Influence of variable rate of isostatic compensation; IV, Hetero. geneity and rigidity of the crust as meas. ured by departures from isostasy; V, The depth of masses producing gravity anoma. lies and deflection reslduals; VI, Relations of isostatic movements to a sphere of weakness-the asthenospere; VII, Varia. tion of strength with depth as shown by the nature of departures from isostasy; VIII, Physical conditions controlling the nature of lithosphere and asthenosphere. J G $22: 28-48, \quad 145-165,209-236, \quad 289-$ $314,441-468,537-555,655-683,729-741$ (1914); $23: 27-44, \quad 425-443, \quad 499-515$ (1915)

14b The status of hypotheses of polar wanderings. Science n s 40:333-340 (1914)

14e (with Schuehert, C.) A revised geologic time-table for North America. Am J Sc (4) $38: 1-27$ (1914)

15 Factors in movements of the strand line and their results in the Plelstocene and post-Pleistocene. Am $\mathrm{J}$ Se (4) 40: 1-22 (1915) Abst, Wash Ac Sc, J 5: 413-420 (1915)

16 Dominantly fluviatile origin under seasonal rainfall of the old Red Sand. stone. Nat Ac Sc, Pr $2: 496-499$ (1916) Abst, G Soc Am, B 27:39-40 (1916); Science n \& 44:502 (1916)

16a Influence of Silurian-Devonian climates on the rise of air-breathing vertebrates. G Soc Am, B $27: 40-41$ (abst), 387-436 (1916) Nat Ac Sc, Pr. 2:499504 (1916) Abst, Science n s $27: 254-255$ (1908); $44: 502$ (1916)

16b The fourteenth New England intercollegiate geological excursion. Science n s 44: 701-703 (1916) 
Barrell, Joseph-Continued.

17 Rhythms and the measurements of geologic time. G Soc Am, B 28: 745-904 (1917)

17a Probable relations of climatic change to the origin of the Tertiary apeman. Sc Monthly 4:16-26 (1917)

1s The origin of the earth. In The evolution of the earth and its inhabitants [edited by R. S. Lull]: 1-44, New Haven 1918.

18a The growth of knowledge of earth structure. Am J Sc (4) $46: 133-170$ (1918) Reprinted in A century of science in America : 153-192, New Haven 1918

See also Chamberlin (T C), 16; Paige, $16 \mathrm{a}$; Sayles, 16 ; Vaughan, 15.

Barrell, Robert W.

96 Elkhorn Mountain and Rock Creek district of the Blue Mountains, Oregon. Eng M J 62:128-129 (1896)

97 The mineral formation of the Golden Leaf mines [Beaverhead Co., Mont.]. Eng M J $64: 64$ (1897)

98 Gold mining in [eastern] Oregon. Mines and Minerals 19:12-15 (1898)

00 The Bear Butte mineral formation [Black Hills, S. Dak.]. Mines and Minerals, 20: 512-514 (1900)

Barrett, Edward.

12 Thirty-sixth annual report of Depart ment of geology and natural resources, Indiana, 1911. $873 \mathrm{pp}$, maps, Indianapolis 1912 Thirty-seventh ... 1912: $485 \mathrm{pp}$, maps (1913) Thirty-eighth … 1913: 231 pp, maps (1914) Thirty-ninth ... 1914: 330 pp, maps (1915) Fortieth ... 1915:279 pp, maps (1916) Eorty-first ...: $123 \mathrm{pp}$, maps (1917)

12n Glaciation in its relation to the soils of Indiana. Ind $\mathrm{Dp} G$, An $\mathrm{Rp} 36$ : 11-30, map (1912)

14 Sullivan Co. [Ind.] oil field. Ind $D p$ G, An Rp $38: 9-40$ (1914)

14n Glass sands of Indiana. Ind $\mathrm{Dp} \mathrm{G}$, An Rp 38:41-59 (1914)

15 Conditions of oil fields and development in Indiana, 1914. Ind $\mathrm{Dp} G, \mathrm{An} \mathrm{Rp}$ $39: 14-19$ (1915)

17 The dunes of northwestern Indiana. Ind, Dp G N Res, An Rp 41:11-27 (1917)

17 a The beautiful Shades. Ind, Dp G N Res, An Rp 41:80-89 (1917)

17b The canyon of McCormick's Creek. Ind, Dp G N Res, An Rp 41: 90-99 (1917)

17e Structural geology [of ofl and gas fields]. Ind, Dp G N Res, An Rp 41:100 112, map (1917)

18 Report of department of geology and natural resources. Ind, Yr Bk 1917: 234241 (1918)

Barrett, L. P.

14 (with Allen, R. C.). Evidence of the middle-upper Huronian unconformity in the quartzite hills at Little Lake, Mich. J G $22: 574-581$ (1914)
Barrett, L. P.-Continued.

15 (with Allen, R. C.) Contributions to the pre-Cambrian geology of northern Michigan and Wisconsin. Mich $\mathbf{G} \mathbf{S}$, Pub 18 ( $\mathrm{g}$ s 15) : 13-164, maps (1915)

15a (and Allen, R. C.) A revision of the sequence and structure of the preKeweenawan formations of the eastern Gogebic iron range of Michigan. Mich G $\mathrm{S}$, Pub 18 (g s 15) : 33-61, map (1915) In part, J G 23:689-703 (1915)

16 (with Allen, R. C., and Smith, R. A.) Geological map of Michigan. Mich G S, Pub 23 (1916)

Barrett, Lucas (1837-1862).

60 On some Cretaceous rocks in the southeastern portion of Jamaica. G Soc London, Q J 16:324-326 (1860)

See also Sawkins, 69

Barrett, Simeon $T$.

76 Description of a new trilobite, Dalmanites dentata. Am J Sc (3) 11:153, 200 , il ; $12: 70-71$ (1876)

76a Notes on the Lower Helderberg rocks of Port Jervis, N. Y., with description of a new pteropod. Lyc N H N Y, An 11: 290-299 (1876) Abst, Am J Sc (3) $13: 385-387 \quad(1876)$

78 Descriptions of new species of fossils from the Upper Silurian rocks of Port Jervis, N Y. ; with notes on the occurrence of the Crystalline Limestone at that 10cality. N Y Ac Sc, An 1:121-124 (1878)

78a The coralline or Niagara limestone of the Appalachian system as represented at Nearpass Cliff, Montague, N. J. Am J Sc (3) $15: 370-372(1878)$

79 Note on the section [at Rondout, N. Y.] Am J Sc (3) 18:409 (1879)

93 Note on ... "a new Oriskany fauna in Columbia Co., N. Y." $\Delta \mathrm{m} J \mathrm{Sc}$ (3) $45: 72$ (1893)

See also Dale, $79 a$

Barringer, Daniel Moreau.

97 A description of minerals of commercial value. $168 \mathrm{pp}, \mathrm{N} \times 1897$

06 Coon Mountain and its crater [Ariz.]. Ac N Sc Phila, Pr 57:861-886 (1906)

O6a (and Tilghman, B. C.) The geology of Coon Butte, Ariz. (abst). Science n s 24:370-371 (1906); Am As, Pr 56-57:271 (1907)

10 Meteor Crater (formerly called Coon Mountain or Coon Butte) in northern cen. tral Arizona. Paper read before the National Academy of Sciences, November 16, 1909. 24 pp [priv pub 1910?]

15 Further notes on Meteor Crater, Ariz. Ac N Sc Phila, Pr 66:556-565, map (1915) Barris, Willis Hervey (1821-1901).

so The local geology of Davenport and vicinity. Davenport Ac Sc, Pr 2:261-269 (1880)

S0a New fossils from the Corniferous formation at Davenport [Iowa]. Davenport Ac Sc, Pr $2: 282-288$, il (1880) 
Barris, Willis Hervey-Continued.

82 Notes on our local geology [Davenport, Iowa]. Davenport Ac Sc, Pr 3:163168 (1882)

83 Description of some new blastoids from the Hamilton group. Ill G S $7: 357-$ 364 , il (1883)

83a (with Wachsmuth, C.) Description of fossil invertebrates [Crinoidea]. Ill G S $7: 339-345$, il (1883)

s4 Descriptions of some new blastoids from the Hamilton group. Davenport Ac Se, $\operatorname{Pr} 4: 88-94$, il (1884)

S4a Descriptions of some new crinoids from the Hamilton group [of Michigan]. Davenport Ac Sc, Pr $4:$ 98-101, il (1884)

84b Stereocrinus Barris (revised). Davenport Ac Sc, Pr 4:102-104 (1884)

89 A defense of our local geology [Davenport, Iowa]. Davenport Ac Sc, Pr 5: 15-22 (1889)

o0 Our local geology [Davenport, Iowa]. Davenport Ac Sc, Pr 7: 14-32 (1900)

Barrois, Charles.

99 Notice sur James Hall. Soc G France, B (3) $27:$ 168-173 (1899)

Barroso, Agustin.

77 Memoria sobre la geología del Istmo de Tehuantepec. México, Ministerio de Fomento, An 3:245-290, map (1877)

Barrow, F. H.

10 The asbestos industry in central Wyoming. Eng M J $90: 559$ (1910)

Barrows, Albert L.

13 Preliminary inquiry into the geological significance of rock-boring shells (abst), G Soc Am, B 24: 130-131 (1913)

17 Geologic significance of fossil rockboring animals. G Soc Am, B 28:199, 965-972 (1917)

Barrows, David P.

00 The Colorado Desert. Nat Geog Mag $11: 337-351$ (1900)

Barrows, Harlan $\mathrm{H}$.

08 Middle portion of the Illinois Valley. IIl G S, B 8:77-80 (1908)

10 Geography of the middle Illinois Valley. IIl G S, B 15: 128 pp (1910)

11 (with Blackwelder, Eliot) Elements of geology. $475 \mathrm{pp} \mathrm{N} \mathrm{Y} \mathrm{(1911)}$

18 (with Salisbury, R. D.) The environment of Camp Grant. IIl G S, B 39: 75 pp (1918)

Barrows, Walter L.

io A fulgurite from the Raritan sands of New Jersey with an historical sketch and bibliography of fulgurites in general. Sch Mines Q $31:$ 294-319 (1910)

Barry, John G.

os (and Melsted, V. J.) The geology of northeastern North Dakota with special reference to cement materials. N Dak G S, Bien Rp 5 : 115-211 (1908)

08a The Bottineau gas field. $N$ Dak G S, Bien Rp $5:$ 245-251 (1908)
Barilett, F. I.

77 Minerals of New England... 46 pp, Portland, Me., 1877

Bartlett, H. H,

11 Botanical evidence of coastal subsid. ence. Science n s 33:29-31 (1911)

16 (with Sinnott, E. W.) Coniferous woods of the Potomac formation. Am J Sc (4) $41: 276-293$, Il (1916)

Bartlett, John.

46 [On Zeuglodon near Natchez, Miss.] Boston Soc N H, Pr 2: 96 (1846)

Barton, Benjamin Smith (1766-1815).

05 Memorandums concerning the earthquakes of North America. Phila Med Phys J 1 pt 1:60-67 (1805)

osa Notice of the sulphur springs in the County of Ontario and State of New York. Phila Med Phys J 1 pt 2:166-168 (1805)

06 Facts, observations, and conjectures relative to the elephantine bones of differ. ent species that are found in various parts of North America. Phila Med Phys J 1st sup : 22-34 (1806)

or Additional facts and observations relative to the extinct species of American elephants. Phila Med Phys $J$ 2d sup: 166-173 (1807)

14 Archaeologiae americanae telluris collectanea et specimina... [on the extinet species of American elephant]. vli, $64 \mathrm{pp}$, Phila 1814

14a Mineralogical notice respecting fluate of lime from Virginia. Am Minet J 1 : $79-80$ (1814)

Barton, David Walker (?-1863).

22 ...geology of the Catskills. Am J Sc 4 : 249-251 (1822)

22a On the Virginia fluorspar. Am Sc 4:277-278 (1822) Transl in Struve. H. von, Beiträge zur Mineralogie und Geo logie des nördlichen Amerikas: 108-110, Hamburg 1822

Barton, Donald Clinton.

13 A new genus of the Cheiruridæ, with descriptions of some new species. Harvard Coll, Mus C Z B 54:547-556, il (1913)

15 A revision of the Cheirurinæ, with notes on their evolution. Wash Univ [St Louis] Studies 3 pt 1: 101-152, il (1915)

16 The geological significance and genetic classification of arkose deposits J G $24: 417-449$ (1916) Abst, G Soc Am B $27: 115$ (1916)

18 Notes on the Mississippian chert of the St. Louis area. J G 26:361-374 (1918)

Barton, George Hunt.

80 (with Crosby, W. O.) Extension of the Carboniferous formation in Masss chusetts. Am J Sc (3) 20:416-420 (1880)

81 Geology of Norfolk County basin [Mass.] Science Observer 3:41-42 (1881) 
Barton, George Hunt-Continued.

84 Notes on the lava flow of $1880-81$ from Mauna Loa. Science 3:410-413 (1884)

S6 (with Crosioy W. O.) On the great dikes at Paradise, near Newport [R. I.]. Boston Soc Y H, Pr 23:325-330 (1886)

s9 A preliminary paper on the drift in portions of Middlesex Co. [Mass.]. Tech Q 2:316-321 (1889)

92 Boulders formed in situ. Tech Q 5 : 401-405 (1892)

94 Glacial origin of channels on drumlins. G Soc Am, B 6:8-13 (1894) Abst, Am G $13: 224$ (1894); Am J Sc (3) 48: $349-350$ (1894)

96 Evidence of the former extension of glacial action on the west coast of Greenland in Labrador and Baffin Land. Am G $18: 379-384$ (1896)

97 Glacial observations in the Umanak district, Greeland. Tech Q 10:213-244 (1897) Abst, J G 5:89-92; Science n s $5: 89$ (1897)

o1 Outlines of elementary lithology. $112 \mathrm{pp}$, Boston 1901 [not seen]

11 Memoir of William Harmon Niles, 1838-1910. G Soc Am, B 22: 8-14 (1911)

12 Bibliography of W. H. Niles. G Soc Am, B 23:34-35, port (1912)

See also Upham, $93 f$.

Barton, J. K.

7s Map of the clay district of Middlesex Co. [N. J.]. See Cook, 78

Bartow, Edward.

05 (and MeCollum, E. V.) Kansas petroleum. Kans Ac Sc, Tr 19:56-59 (1905)

09 (and others) The mineral content of Illinois waters. Ill S G S, B 10:192 pp (1909)

Bartsch, Paul.

96 Notes on the Cretaceous flora of western Iowa. Iowa Univ, Lab N H, B 3:178$182(1896)$

01 (with Dall, W. H.) A new Callfornian Bittium. Nautilus $15: 58-59$ (1901)

04 (with Dall, W. H.) Synopsis of the genera, subgenera, and sections of the family Pyramidellidae. Biol Soc Wash, Pr $17: 1-16$ (1904)

11 The recent and fossil mollusks of the genus Alabina from the west coast of America. U S Nat Mus, Pr $39: 409-418$, il (1911)

$11 a$ The recent and fossil mollusks of the genus Diastoma from the west coast of America. U S Nat Mus, Pr 39:581-584, il (1911)

11b The recent and fossil mollusks of the genus Cerithiopsis from the west coast of America. U S Nat Mus, Pr 40:327-367, il (1911)
Bartsch, Paul-Continued.

11e The recent and fossil mollusks of the genus Bittium from the west coast of America. U S Nat Mus, Pr $40: 383-414$, il (1911)

$11 d$ The recent and fossil mollusks of the genus Alvania from the west coast of America. U S Nat Mus, Pr $41: 333-362$, il (1911)

15 The recent and fossil mollusks of the genus Rissoina from the west coast of America. U S Nat Mus, Pr $49: 33-62$, 11 (1915)

17 A monograph of West American melanellid mollusks. U $\mathrm{S}$ Nat Mus, $\mathrm{Pr}_{\mathbf{r}}$ $53: 295-356$, il (1917)

IS A new West Indian fossil land shell. U S Nat Mus, Pr 54:605-606, il (1918)

Barus, Carl.

91 The contraction of molten rock. Am J Sc (3) $42: 498-499$ (1891)

93 High temperature work in igneous fusion and ebullition, chiefly in relation to pressure. U S G S, B 103:57 pp (1893) 06 Vulcanism. Science n s $24: 400-403$ (1906)

or Note on volcanic activity. Am J Sc (4) $24: 483-484$ (1907)

Bascom, Florence.

93 The structures, origin, and nomenclature of the acid volcanic rocks of South Mountain [Pa.]. J G 1:813-832 (1893)

96 The ancient volcanic rocks of South Mountain, Pa. U S G S, B 136:124 pp (1896)

96a A pre-Tertiary nepheline-bearing rock. J G 4:160-165 (1896)

96b Perido-steatite and diabase [southeastern Pa.]. Ac N Sc Phila, Pr 1896: $219-220$

97 The relation of the streams in the neighborhood of Philadelphia to the Bryn Mawr gravel. Am G 19:50-57 (1897)

$97 \mathbf{a}$ Aporhyolite of South Mountain, Pa. G Soc Am, B 8: 393-396 (1897) Abst, Science n s $5: 95$ (1897)

99 On somre dikes in the vicinity of Johns Bay, Me. Am G 23:275-280, map (1899)

00 Volcanics of Neponset Valley, Mass. G Soc Am, B 11:115-126 (1900)

02 The geology of the crystalline rocks of Cecil County. Md G S, Cecil Co: 83148 (1902)

04 Water resources of the Philadelphia district. U S G S, W-S P 106:75 pp (1904)

o5 Piedmont district of Pennsylvania. G Soc Am, B 16:289-328 (1905)

09 The pre-Cambrian gneisses of the Pennsylvania Pledmont Plateau (abst). Science n \& 30:415 (1909)

O9a (and others) Description of the Philadelphia district. U S G S, G Atlas, Philadelphia folio (no 162): $23 \mathrm{pp}$, maps (1909) 
Bascom, Florence-Continued.

o9b (and others) Description of the Trenton quadrangle, N. J.-Pa. U S G S, G Atlas, Trenton follo (no 167):24 pp (1909)

12 The petrographic province of Neponset Valley, Mass. Ac N Sc Phila, J (2) 15 : 129-161 (1912)

15 Pre-Cambrian igneous rocks of the Pennsylvania Piedmont $(a b s t)$. G Soc Am, B $26: 81-82$ (1915)

15a Magmatic assimilation (abst). G Soc Am, B 26:82 (1915)

16 A correction [neponsetose]. Am J Sc (4) $41: 300-301$ (1916)

See also Dale, 99

Bashore, Harvey B.

89 The Champlain period in the Susquehanna Valley. Science 14:340 (1889)

94 The Harrisburg terraces [Pa.]. Am

J Sc (3) $47: 98-99$ (1894)

96 Notes on glacial gravels, in the lower Susquehanna Valley. Am J Sc (4) 1:281282 (1896)

Baskerville, Charles (1870-1922).

92 (and Mitchell, R. H.) An example of river adjustment [Jackson River, Va.]. Elisha Mitchell Se Soc, J 9:6466 (1892)

03 Kunzite, a new gem. Science n s $18: 303-304$ (1903)

04 (and Kunz, G. F.) Kunzite and its unique properties. Am J Sc (4) $18: 25-28$ (1904)

os The rare metals. Eng M J 86:907, $960,1055,1100,1241-1242$ (1908) ; 87 : $10-11,203,257-258,518-519,548$ (1909)

09 Economic possibilities of American oll shales. Eng M J 88:149-154, 195-199 (1909)

10 Oil shales of Canada. Int Cong Applied Chem, 7 th, London 1909 , Sec IV A 1: 22-31 (1910)

Bassett, D. A.

85 The Crawfordsville crinoids. Kansas City Rv Sc 8: 556-563 (1885)

Bassler, Harvey.

16 A cycadophyte from the North American coal measures. Am J Sc (4) $42: 21$ 26, il (1916)

Bassler, Ray Smith.

96 (with Harper, G. W.) Catalogue of the fossils of the Trenton and Cincinnati periods occurring in the vicinity of Cincinnati, Ohio. $34 \mathrm{pp}$, Cincinnati, 1896

00 (with Nickles, J. M.) A synopsis of American fossil Bryozoa including bibliography and synonymy. U S G S, B 173: 663 pp (1900)

03 The structural features of the bryozoan genus Homotrypa, with descriptions of species from the Cincinnatian group. U S Nat Mus, Pr 26:565-591, il (1903)
Bassler, Ray Smith-Continued.

04 (with U1rich, E. O.) A revision of the Paleozoic Bryozoa; Part I, On genera and species of Ctenostomata. Smiths Misc Col 45 ( $Q$ Is 1) : 256-294, il (1904)

0-4a (with Ulrieh, E. O.) A revision of the Paleozoic Bryozoa; Part II, On genera and species of Trepostomata. Smiths Misc Col 47 (Q Is 2): 15-55, il (1904)

os Portland-cement resources of Virginia. U S G S, B 243: 312-323 (1905)

o5a Cement materials of the Valley of Virginia. U S G S, B 260:531-544, maps (1905)

O5b The subdivisions of the Shenandoah limestone $(a b s t)$. Science n $\mathbf{s} 22: 756$ (1905)

05e (with Schuchert, C., and others Catalogue of the type specimens of fossil invertebrates in the department of geology, United States National Museum. U S Nat Mus, B 53 pt 1: 704 pp (1905)

06 A study of the James types of Ordovician and Silurian Bryozoa. U S Nat Mus, $\operatorname{Pr} 30: 1-66$, il (1906)

O6a The bryozoan fauna of the Rocbester shale. U S G S, B 292: $136 \mathrm{pp}, 1$ (1906)

O6b (with U1rich, E. O.) New Amer can Paleozoic Ostracoda. Notes and de scriptions of upper Carboniferous genen and species. U S Nat Mus, Pr 30:149164 , il (1906)

07 Cement and cement materials [of Vir ginia]. In Watson, T. L., Mineral re sources of Virginia:86-167, Lynchburs Va., 1907

os The formation of geodes, with re marks on the silicification of fossils. U Nat Mus, Pr 35: 133-154 (1908)

08a Cement materials of western Vir ginia. Ec G 3: 503-524 (1908)

osb (with Pate, W. F.) The lat Niagaran strata of West Tennessee. U Nat Mus, $\operatorname{Pr} 34: 407-432$, il (1908)

ose (with Ulrich, E. O.) New Amert can Paleozoic Ostracoda; preliminary vision of the Beyrichiidx, with descrip tions of new genera. U $\$$ Nat Mus, $P$ $35: 277-340$, il (1908)

09 The cement resources of Virgini west of the Blue Ridge. Va G S, B 2.1 309 pp, il (1909)

09a Dendroid graptolites of the N agaran dolomites at Hamflton, Ont. U Nat Mus, B 65: 76 pp, il (1909)

09b The Nettleroth collection of invert brate fossils. Smiths Misc $\mathrm{Col} 52$ (Q 5) : 121-152, il (1909)

o9c Some noteworthy accessions to th Division of Invertebrate Paleontology the National Museum. Smiths Misc Col 5: (Q I 5) : 267-269, il (1909)

10 Adequacy of the paleontologic recor Pop Sc Mo $76: 586-589$ (1010) 
Bassier, Ray Smith-Continued.

11 The early Paleozoic Bryozoa of the Baltic provinces. U S Nat Mus, B 77:382 pp, il (1911)

$11 \mathrm{a}$ The stratigraphy of a deep well at Waverly, Ohio. Am J Sc (4) 31:19-24 (1911)

11b Corynotrypa, a new genus of tubuliporoid Bryozoa. U S. Nat Mus, Pr 39 : $497-527$, il (1911)

11e Proceedings of the second annual meeting of the Paleontological Society, held at Pittsburgh, Pa., December 28-29, 1910. G Soc Am, B 22: 85-102 (1911)

11d The Waverlyan period of Tennessee. U S Nat Mus, $\operatorname{Pr} 14: 209-224$ (1911)

11e Conference on the faunal criteria in Paleozoic paleogeography [Introduction]. G Soc Am, B 22: 217 (1911)

11P Stratigraphic significance of Ostracoda. G Soc Am, B 22:275-278 (1911)

$11 \mathrm{~g}$ The influence of marine currents on deposition in continental seas (abst). Sclence n s $33: 316$ (1911)

12 Proceedings of the third annual meeting of the Paleontologiccal Society held at Washington, D. C., December 28, 29, and 30, 1911. G Soc Am, B 23:77-92 (1912)

12a (and others) Symposium of ten years' progress in vertebrate paleontology. G Soc Am, B 23: 155-266 (1912)

13 Proceedings of the fourth annual meeting of the Paleontological Society, held at New Haven, Conn., December 30 and 31 , 1912. G Soc Am, B 24:99-126 (1913)

13a Notes on an unusually fine slab of fossil crinoids. U S Nat Mus, Pr 46:5759, il (1913)

14 The Paleontological Society [Princeton meeting, 1913-4]. Science n s $39: 187$ (1914)

14a Proceedings of the fifth annual meeting of the Paleontological Society, held at Princeton, N. J., Dec. 31, 1913, and Jan. 1, 1914. G Soc Am, B 25:127-150 (1914)

15 Proceedings of the sixth annual meetIng of the Paleontological Society, held at Philadelphia, Pa., December 29, 30, and 31, 1914. G Soc Am, B 26:141-165 (1915)

15a Bibliographic index of American Ordovician and Silurian fossils. U S Nat Mus, B 92, 2 vols : 1521 pp (1915) Abst, Wash Ac Se, J 6:186 (1916)

15b Unconformities in limestone (abst). Wash Ac Sc, J 5:185 (1915)

16 Proceedings of the seventh annual meeting of the Paleontological Society, held at Washington, District of Columbia, December 29,30 , and 31,1915 . G Soc $\mathrm{Am}$, B $27: 139-167$ (1916)

17 Proceedings of the eighth annual meeting of the Paleontological Society, held at Albany, N. Y., December 27, 28, and 29, 1916. G Soc Am, B 28: 189-222 (1917)
Bassler, Ray Smith-Continued.

17a The value of microscopic fossils in stratigraphy (abst). Wash Ac Sc, J $7: 434$ (1917)

17b (with Canu, F.) Methods of study and the classification of American Tertiary Bryozoa (abst). G Soc Am, B 28:204 (1917)

17e (with Cann, F.) A synopsis of American early Tertiary Cheilostome Bryozoa. U S Nat Mus, B $96: 87 \mathrm{pp}$, il (1917)

18 Proceedings of the ninth annual meeting of the Paleontological Society, held at Pittsburgh, Pa., December 31, 1917, and January 1 and 2,1918 . G Soc Am, B 29 : 119-160 (1918)

18a Paleozolc deposits and fossils on the Piedmont of Maryland and Virginia (abst). G Soc Am, B 29:127 (1918)

18b Paleozoic rocks and fossils on the Piedmont of Maryland (abst). Wash Ac Sc, J $8: 411$ (1918)

1Se (with Canu, F.) Bryozoa of the [Panama] Canal Zone and related areas. U S Nat Mus, B 103:117-122, il (1918)

1Sd (with Cana, F.) Principles of classification of cyclostome Bryozoa (abst). G Soc Am, B 29:151 (1918)

See also Clark (W B), 04a, 16b ; Eastmann, 00 ; Watson, 07e.

Bastin, Edson Sunderland.

o5 Note on baked clays and natural slags in eastern Wyoming. J G 13:408412 (1905)

o6 Some unusual rocks from Maine. J G 14: 173-187 (1906)

06a The lime industry of Knox Co., Me. U S G S, B 285: 393-400 (1906)

06b Clays of the Penobscot Bay region, Me. U S G S, B 285: 428-431 (1906)

07 Feldspar and quartz deposits of Maine. U S G S, B 315:383-393 (1907)

$07 a$ Feldspar and quartz deposits of southeastern New York. U S G S, B 315 : 394-399 (1907)

o7b Quartz (flint) and feldspar. U S G S Min Res 1906:1253-1270; 1907 pt $2: 843-872 ; 1908$ pt $2: 861-868 ; 1909$ pt $2: 907-913 ; 1910$ pt $2: 963-975$ (1907-11)

07e (with Smith, G. O.) Description of the Penobscot Bay quadrangle [Me.]. U S G S, G Atlas, fol 149:14 pp (1907)

os A pyrrhotitic peridotite from Knox Co., Me.-a sulphide ore of igneous origin. J G $16: 124-138$ (1908) Abst, Science n s $27: 426$ (1908)

O8a Description of the Rockland quadrangle, Me. U S G S, G Atlas Rockland folio (no 158): $15 \mathrm{pp}$, maps (1908)

OSb (with Leighten, H.) Road materials of southern and eastern Maine. U S Dp Agr, Off Pub Rds, B 33:56 pp (1908) 
Bastin, Edson Sunderland-Continued.

09 Chemical composition as a criterion in identifying metamorphosed sediments. J G 17:445-472 (1909) Abst, Sclence n 8 29:631-632, 948-949 (1909); G Soc Am, B 20:667 (1910)

09a (and Davis, C. A.) Peat deposits of Maine. U S G S, B 376:127 pp (1909)

09b Graphite. U S G S, Min Res 1908 pt $2: 717-738 ; 1909$ pt $2: 809-840 ; 1910$ pt $2: 901-910 ; 1911$ pt $2: 1079-1112$; 1912 pt $2: 1061-1069 ; 1913$ pt $2: 181-$ 251, map; 1914 pt $2: 159-174 ; 1915$ pt 2: 81-93 (1909-16)

10 Economic geology of the feldspar deposits of the United States. U $\mathbf{S}$ G $\mathbf{S}$, B 420:85 pp, map (1910)

10a Origin of certain Adirondack graphite deposits. Ec G 5:134-157 (1910) Abst, Science n s 31: 758-759 (1910)

$\mathbf{1 0 b}$ Origin of the pegmatites of Matne. J G $18: 297-320$ (1910) Abst, Science n s $31: 321$ (1910)

11 Geology of the pegmatites and associated rocks of Maine, including feldspar, quartz, mica, and gem deposits. U S G S, B 445:1:2 pp (1911)

11a Special problems and their study in economic geology (discussion). Ec G 6: 188-190 (1911)

11b Some features of graphite in the United States. Abst, Wash Ac Sc, J 1:44 (1911)

11e (and Hill, J. M.) The Evergreen copper mine, Colo. Ec G 6:465-472 (1911)

12 The graphite deposits of Ceylon; a review of present knowledge with a description of a similar graphite deposit near Dillon, Mont. Ec G 7:419-443 (1912)

12a Geology of the Penobscot River basin, Me. U S G S, W S P 279:11-12 (1912)

13 Metasomatism in downward sulphide enrichment. Ec G 8:51-63 (1913)

$13 a$ Secondary enrichment in silver (abst). Wash Ac Sc, J 3:52 (1913)

13b Chemical composition as a criterion In identifying metamorphosed sediments. J G 21 : 193-201 (1913)

13e (and Williams, H. S.) Geology of the Eastport quandrangle. Me St Water Storage Comm, An Rp 3:166-169 (1913)

14 (and Willams, H. S.) Description of the Eastport quadrangle, Me. U S G S, G Atlas Eastport fol (no 192): 15 pp, maps (1914)

14a Geology of the pitchblende ores of Colorado. U S G S, P P 90:1-5 (1914) Abst, Wash Ac Sc, J 4:256-257 (1914)

$14 \mathrm{~b}$ Origin of the titaniferous iron ore at Caribou, Colo. (abst). Wash Ac Sc, J $4: 9$ (1914)

15 Experiments with colloidal gold and silver. Wash Ac Sc, J 5 ; 64-71 1915)
Bastin, Edson Sunderland-Continued.

15a (and Hill, J. M.) Some features of the ore deposits of Gilpin Co., Colo. Wash Ac Sc, J 5:160-164, 185-186 (discussion) (1915)

15b Ores of Gilpin Co., Colo. Ec G 10: 262-291 (1915)

16 (and Hill, J. M.) Preliminary te. port on the economic geology of Gilpin Co. Colo. U S G S, B $620: 295-323$, maps (1916)

$16 a$ The Gold Log mine, Talladega $\mathrm{C}_{0}$ Ala. U S G S, B 640:159-161 (1916) $A b s t$, by R. W. S., Wash Ac Sc, J $7 ; 76$ (1917)

16b Occurrence, geology, and economic value of the pitchblende deposits of Gilpis Co., Colo. Ec G 11: 681-685 (1916)

17 (and Hill, J. M.) Economic geologr of Gllpin Co. and adjacent parts of Clea: Creek and Boulder cos., Colo. U S G \& P P 94: 379 pp, maps (1917) Abst, b? R. W. S., Wash Ac Sc, J $7: 266-267$ (1917)

17a Significant mineralogical relations in silver ores of Cobalt, Ont. Ec G 12: 219-236 (1917)

17b Large pyrrhotite deposits in [central] Maine. Eng M J 104: 758-75\% (1917)

18 (and Laney, F. B.) The genesis of the ores at Tonopah, Nev. U S G S, P ? 104: 50 pp (1918)

18a War-time mineral activities t Washington. Ec G $13: 524-537$ (1918)

18b Antimony in 1916. U S G S, Mit Res 1916 pt 1: 723-729 (1918)

See also Atwood, 15; Darton, 15; HII (J M), 15

Bastin, Ellen B.

90 Some geology of Chicago and vicit ity. Harper's Mag $81: 427-436$ (1890)

Bateman, Alan Mara.

12 Geology of Fraser Canyon and vict ity, B. C., Siwash Creek area. Can G : Sum Rp 1911: 125-129 (1912)

12a (with Ferguson, H. G.) Geolog features of tin deposits. Ec G $7: 209-2$ (1912)

14 Exploration between Lillooet at Chilko Lake, B. C. Can G S, Sum : 1912: 177-187, map (1914)

$14 a$ Lillooet map area, B. C. Can G. Sum Rp 1912: 188-210, map (1914)

17 Magmatic ore deposits, Sudbury, 0 : Ec G 12:391-426 (1917)

17 a the geologist in war times-t training of artillery officers. Ec $G 1$ 628-631 (1917)

18 A tungsten deposit near Fairbanl Alaska. Ec G 13:112-115 (1918)

$18 a$ Genesis of the Sudbury nick copper ores (discussion). Am I M E? B 136: 854-855 (1918)

See also Roberts (H M), 18 
Bateman, G. C.

05 Notes on graphite, its occurrences, uses, and production. Can M Inst, J 8 : 343-348 (1905)

17 The Kirkland Lake gold district [Ont.]. M Sc Press 114:657-662 (1917) Bates, Mowry.

18 A concrete example of the use of well logs [Red River-Crichton oil field, La.]. Am I M Eng, B 137 : 979-986 (1918) 1Sa The oil and gas fields of northern Louisiana. Am As Petroleum G, B 2:6169 (1918)

Bateson. Charles E. W.

06 The Mojave mining district of California. Am I M Eng, B $7: 65-82$ (1906) ; Tr 37:160-177 (1907).

Bather, Francis Arthur.

92 Classification of the Cephalopoda. Am G 10:396-397 (1892)

95 Brachiocrinus and Herpetocrinus Am G 16:213-217 (1895)

$\mathbf{9 6}$ On Uintaorinus; a morphological study. Zool Soc London, $\operatorname{Pr}$ 1895: 9741003, il (1896) Abst, G Mag (4) 3:85 (1896)

96a Obituary, Charles Wachsmuth. G Mag (4) 3:189-192 (1896)

os Wachsmuth and Springer's Classifica. tion of crinoids. Nat Sc 12:337-345 (1898)

98n Petalocrinus Weller and Davidson. G Soc London, Q J 54:401-441, il (1898) Abst, G Mag (4) $5: 284$ (1898)

98b Obituary, Samuel A, Miller. G Mag (4) $5: 192$ (1898)

00 Pores in the ventral sac of fistulate crinoids. Am G 26:307-312 (1900)

01 The geologic distribution of Pollicipes and Scalpellum. Science $\mathbf{n}$ s 14 : 112 (1901)

04 The term "Bradfordian." Science n s $19: 434-435$ (1904)

05 Charles Emerson Beecher. G Soc London, Q J 61 Pr : xlix-1 (1905)

06 The species of Botryocrinus. Ottawa Nat 20:93-104 (1906)

09 Visit to the Florissant exhibit in the British Museum (Natural History) [Miocene beds at Florissant, Colo.]. G As, London, Pr 21; 159-165 (1909) -

$13 \mathrm{I}$, The i renton crinoid ottavacrinus W. R. Billings; II, Note on Merocrinus Walcott, Can G S, Victoria Mem Mus, B $1: 1-14$, il (1913)

18 The Triassic crinoids from New Zealand. [Includes Isocrinus from Triassic of Alaska.] G Soc London, Q J 73:247-256, il (1918)

See also Eastman, 00

Bather, William $\mathrm{T}$.

- 18 (with Manchester, J. G.) Famous mineral localities; Mt. Mica, Mt. Apatite, and other localities in Maine. $\mathbf{A m}$ Mineralogist $3: 169-174$ (1918)
Battey, Thomas J.

86 Kames in Rhode Island, Random Notes on Natural History 3:81 (1886)

86a The amethyst locality of Burrillville, R. I. Random Notes on Natural History $3: 90-91$ (1886)

Battle, Kemp P.

05 Diary of a geological tour by Dr. Elisha Mitchell in 1827 and $1828 \ldots \mathrm{N} \mathrm{C}$ Univ, James Sprunt Hist Mon no 6:73 pp, Chapel Hill 1905

Baner, A.

74 Analysen einiger Gesteine aus Ostgrönland. In Die Zweite Deutsche Nordpolarfahrt... (Verein für die Deutsche Nordpolarfahrt in Bremen) 2:508-511, Leipzig 1874

Baner, Clyde Maxwell.

14 Clay in northeastern Montana. U S G S, B 540: 369-372 (1914)

$14 a$ Lignite in the vicinity of Plentywood and Scobey, Sheridan Co., Mont. U S G S, B 541 : 293-315, maps (1914)

15 A sketch of the late Tertiary history of the upper Missouri River. J G 23: 52-58, map (1915)

16 Contributions to the geology and paleontology of San Juan Co., N. Mex.; 1, Stratigraphy of a part of the Chaco River valley. U S G S, P P 98: 271-278 (maps) (1916) Abst, by R. W. S., Wash Ac Sc, J $7: 133-134$ (1917)

Bauer, Louis Agricola.

06 Magnetograph records of earthquakes with special reference to the San Francisco earthquake, April 18, 1906. Terr Magn 11 : 135-144 (1906)

o6a Seismograph and magnetograph records of the San Francisco earthquake, April 18, 1906. Pop Sc Mo $69: 116-127$ (1906)

06b (and Burbank, J. E.) The San Francisco earthquake of April 18, 1906, as recorded by the Coast and Geodetic Survey magnetic observatories. Nat Geog Mag 17 : 298-300 (1906)

Bauerman, Hilary.

60 On the geology of the southeastern part of Vancouver Island. G Soc London, Q J 16: 198-202 (1860) Abst, Ph Mag (4) $18: 475-476(1859)$

66 Remarks on the copper mines of the State of Michigan. G Soc London, Q J 22: $448-463$ (1866) Abst, G Mag 3:225-226 (1866)

85 Report on the geology of the country near the forty-ninth parallel of north latitude west of the Rocky Mountains, from observations made 1859-61. Can G S, Rp Prog 1882-4; B 1-41 (1885)

Baum, G.

os Kohle und Eisen in Nordamerika. 152 pp, Essen (Ruhr) 1908

Banmgarten, Karl.

10 Thunder Mountain landslide [Idaho]. M Sc Press 101: 698-699 (1910) 
Banmhaner, H.

85 Ueber die mikroskcpische Beschaffenheit eines Buntkupfererzes von Chloride, New Mexico. Zs Kryst 10:447-450 (1885) o9 Ueber die Winkelverhältnisse des Benitoit. Centralbl Miner 1909:592-594 (1909)

Baur, George (1859-1898).

83 Der Tarsus der Vögel und Dinosaurier. Morph Jb $8: 417-456$, il (1883)

84 Dinosaurier und vögel. Morph Jb $10: 446-454$ (1884)

84a Note on the pelvis in birds and dinosaurs. Am Nat 18:1273-1275 (1884) Morph Jb 10:613-616 (1885)

85 Zur Vögel - Dinosaurier - Frage. Zool Anzeiger 8:441-443 (1885)

S6 Osteologische Notizen iber Reptilien. Zool Anzeiger 9:685-690, 733-743; 10 $96-102 ; 11: 417-424,736-740 ; 12: 40-47$ (1886-9)

S6a Ueber die Homologien einiger Schädelknochen der Stegocephalen und Reptilien. Anat Anz 1:348-350 (1886)

86b The proatlas, atlas, and axis of the Crocodilia. Am Nat 20:288-293, il (1886)

87 Ueber die Abstammung der amnioten Wirbeltiere. Biol Centralbl 7:481-493 (1887)

\$7a Ueber den Ursprung der Extremitäten der Ichthyopterygia. Oberrhein G Ver, XX Vers, Ber: 17-20, il [1887]

$\mathbf{8 7 b}$ on the phylogenetic arrangement of the Sauropsida. J Morph 1:93-104 (1887)

s7e On the morphology and origin of the Ichthyopterygia. Am Nat 21:837840 (1887)

S7d On the morphology of the ribs. Am Nat 21:942-946 (1887)

89 $0 n$ the morphology of the vertebrate skull. J Morph 3:467-474 (1889)

90 On the characters and systematic position of the large sea lizards, Mosasauridae. Science 16:262 (1890)

$90 a$ A review of the charges against the paleontological department of the U. S. Geological Survey, and of the defense made by Prof. o. C. Marsh. Am Nat 24: 298-304 (1890)

90b Prof. Marsh on Hallopus and other dinosaurs. Am Nat 24:569-571 (1890)

91 Remarks on the reptiles generally called Dinosauria. Am Nat 25:434-454 (1891)

91 a Notes of some little known Ameriean fossil tortolses. Ac N Sc Phila, Pr $1891: 411-430$.

$91 \mathrm{~b}$ The horned saurians of the Laramie formation. Science $17: 216-217$ (1891)

92 On the morphology of the skull in the Mosasauridae. $\cdot \mathrm{J}$ Morph $7: 1-22$, il (1892)
Baur, George-Continued.

93 The discovery of Miocene amphis bænians. Am Nat 27:998-999 (1893)

95 Cope on the temporal part of the skull and on the systematic position of the Mosasauridae. Am Nat 29:998-1002 (1895)

95a Die Palatingegend der Ichthyosauria. Anat Anz 10:456-459, il (1895

95b Das Gebiss von Sphenodon (Hat. teria)... Anat Anz 11:436-439 (1895)

96 The paroccipital of the Squamata and the affinities of the Mosasauridae once more; a rejoinder to Prof. E. D. Cope. Am-Nat $30: 143-147$, il (1896)

96n The Stegocephali. Anat Anz 11: $657-673$, il (1896)

96b Bemerkungen iber die Phylogenie der Schildkröten. Anat Anz 12:561-570 (1896)

97 (and Case, E. C.) On the morphology of the skull of the Pelycosauria and the origin of the mammals. Anat Anz 13: 109-120, il (1897) Abst, Science n s 5: 592-594 (1897)

97a Ueber die systematische Stellung der Microsaurier. Anat Anz 14:148-151 (1897)

97b Archegosaurus. Am Nat 31:975980 (1897)

99 (and Case, E. C.) The history of the Pelycosauria, with a description of the genus Dimetrodon, Cope. $\mathrm{Am} \mathrm{Ph}$ Soc, Tr n s $20: 5-62$, il (1899)

Baverstock, R. S.

02 Quicksilver, M Sc Press 84:4-5 (1902)

Bawden, H. Heath.

o5 Clarence Luther Herrick. Denison Univ, Se Lab, B 13:14-27 (1905)

Baxter, Florus R.

95 Petroleum; a class room talk. $47 \mathrm{pp}$. Vacuum Oil Company, Rochester, N. Y. 1905

Buy, Edv.

96 Geologi [geology of Scoresby Sound region, Greenland]. Med Grönland 19: 145-187, 261-267, map (1896)

Bayfield, Henry Wolsey.

29 Outlines of the geology of Lake Superior. Lit Hist Soc Quebec, Tr $1: 1-43$ (1829)

37 Notes on the geology of the north coast of the St Lawrence. G Soc London, Tr (2) 5:89-103 (1837) Abst, G Soc London, $\mathrm{Pr} 2: 4-5$ (1834); $\mathrm{Ph} \mathrm{Mag}$ (3) 4: 51-52, 453-454 (1834); Soc G France. B $5: 407-408$ (1834)

40 Notes on the geology of the north coast of the St. Lawrence. G Soc London. Tr (2) 5: 89-102 (1840)

45 On the junction of the transition and primary rocks of Canada and Labrador. G Soc London, Q J 1:450-459 (1845) 
Bayley, William Shirley.

s6 [Notes on] mineralogy and petrography. Am Nat vols. 20-36 (1886-1902)

88 Notes of microscopical examinations of rocks from the Thunder Bay silver district [Ont.]. Can G S, An Rp 3: H 115122 (1888)

88a on some peculiarly spotted rocks from Pigeon Point, Minn. Am J Sc (3) $35: 388-393$ (1888)

s8b Synopsis of Rosenbusch's new scheme for the classification of massive rocks. Am Nat 22:207-217, 295-305 (1888)

89 A quartz keratophyre from Pigeon Point and Irving's augite syenites. Am J Sc (3) $37: 54-63$ (1889)

90 (and King, F. P.) Catalogue of the Maine geological collection with a brief outline history of the two surveys of the State. Colby Univ., Geol. Dept: 32 pp, Waterville, Me., 1890

90a The origin of the soda-granite and quartz-keratophyre of Pigeon Point [Minn.]. Am J Sc (3) $39: 273-280$ (1890) 92 Eleolite-syenite of Litchfield, Me., and Hawes' hornblende syenite from Red Hill, N. H. G Soc Am, B 3:231-252, map (1892)

92a Notes on the petrography and geology of the Akeley Lake region in northeastern Minnesota. Minn $\mathrm{G} S$, An $\mathrm{Rp}$ $19: 193-210(1892)$

92b A fulgurite from Waterville, Me. Am J Sc (3) 43:327-328 (1892)

92e A fibrous intergrowth of augite and plagioclase, resembling a reaction rim, in \& Minnesota gabbro. Am J Sc (3) 43 : 515-520 (1892)

92d Striated garnet from Buckfield, Me. Am J Sc (3) 44: 79-80 (1892)

93 The eruptive and sedimentary rocks on Pigeon Point, Minn., and their contact phenomena. U S G S, B 109:121 pp, maps (1893)

93a The basic massive rocks of the Lake Superior region $J$ G $1: 433-456$, $587-596, \quad 688-716 \quad(1893) ; \quad 2: 814-825$ (1894) ; $3: 1-20$ (1895)

93b Actinolite-magnetite schists from the Mesabi iron range, in northeastern Minnesota. Am J Sc (3) 46:176-180 (1893)

93e The classification and naming of igneous rocks. Science 21: $87-88$ (1893)

95 Spherulitic volcanics at North Haven, Me. G Soc Am, B 6: 474-476 (1895 Abst, Science n s 1: 65 (1895)

95a The peripheral phases of the great gabbro mass of northeastern Minnesota (abst). Sclence n s 1:65 (1895)

95b (with Van Hime, C. R.) Preliminary report on the Marquette iron-bearing district of Michigan, with a chapter on the Republic Trough, by H. L. Smyth. U S G S, An Rp 15:477-650, maps (1895)
Bayley, William Shirley-Continued.

97 (with Van Hise, C. R.) The Marquette iron-bearing district of Michigan. U S G S, Mon 28:608 pp, atlas (1897)

99 The Sturgeon River tongue [Mich.].

U S G S, Mon $36: 458-487$ (1899) U S G S, An Rp 19 pt 3:146-151 (1899)

00 The geological features of the Menominee iron district of Michigan (abst). Am As, Pr 49:189-190 (1900) Science n s 12:992-993 (1900)

OOa (with Van Hise, C. R.) Description of the Menominee quadrangle [Mich.]. U S G S, G Atlas Menominee fol (no. 62): $13 \mathrm{pp}$, maps (1900)

04 The Menominee iron-bearing district of Michigan. U S G S, Mon 46:513 pp, maps (1904)

O4a [Notes on water resources of] Maine. U S G S, W-S P 102:27-55 (1904)

o5 [Underground waters of] Maine. U S G S, W-S P 114: 41-56 (1905)

os Note on the occurrence of graphite schist in Tuxedo Park, N. Y. Ec G 3 : 535-536 (1908)

08a The American Association for the Advancement of Science. Section E. Geology and Geography [meeting in Chieago, December 30,1907$]$. Sclence $n$ s $27: 721-733$ (1908)

08b (with Darton, N. H.) Description of the Passaic quadrangle, N. J.-N. Y. U S G S, G Atlas, fol 157:27 pp (1908)

09 Preliminary account of the geology of the Higblands in New Jersey. I1l, Univ, B 6 no 17, Univ Studies 3 no $2: 5-19$ (1909) Abst, Science n s 27:722-723 (1908)

09a Records of deep wells in southern Maine. U S G S, W-S P 223: 238-257 (1909)

10 Elementary crystallography, being part one of general mineralogy. xii, 241 pp, N Y (1910)

10a Iron mines and mining in New Jersey. N J G S, Final Rp 7:512 pp, map (1910)

12 A peculiar hematite ore on the tract of the Durham mine, Durham, Pa. Ec G $7: 179-184$ (1912)

14 (and Salisbury, R. D., and Kümmel, H. B.) Description of the Raritan quadrangle, N. J. U S G S, G Atlas Raritan fol (no 191): 32 pp, maps (1914) Abst, Wash Ac Sc, J 4:371 (1914)

14a The pre-Cambrian sedimentary rocks in the Highlands of New Jersey. Int $G$ Cong. XII, 1913, C R: 325-334, maps (1914)

15 Minerals and rocks; the elements of mineralogy and lithology for the use of students in general geology, $227 \mathrm{pp}, \mathrm{N}$ Y 1915

17 Descriptive mineralogy. 542 pp, N Y 1917

See also Miller (W J), 18a 
Baylies, William.

93 Description of Gay Head [Mass.]. Am Ac Arts, Mem 2:150-155 (1793)

Bax y Dresch, Julio.

10 Notas sobre exploración y prospección de criaderos minerales. Soc Cient Ant Alz, Mem 28: 343-384 (1910)

Beachler, Charles S. (1870-1894).

87 Crinoid beds at Crawfordsville, Ind. Am Nat 21: 1106-1109 (1887)

88 Keokuk group at Crawfordsville, Ind. Am G 2: 407-412 (1888)

89 Corrected list of fossils found at Crawfordsville, Ind. Ind, Dp $\mathrm{G} N \mathrm{H}$, An $\mathrm{Rp} 16: 65-70$ (1889)

$89 a$ Notice of some new and remarkable forms of Crinoidea from the Niagara limestone at St. Paul, Decatur Co., Ind. Am G 4:102-103 (1889)

91 The rocks at St. Paul, Ind., and vicinity. Am G 7:178-179 (1891)

92 Rocks of the Niagara age in Indiana. Am G 9:408-409 (1892)

92a Keokuk group of the Mississippi Valley. Am G 10:88-96 (1892)

93 Erosion of small basins in northeastern Indiana during the time preceding the Pleistocene period. Am G 12:51-53 (1893)

94 An abandoned Pleistocene river channel in eastern Indiana. J G 2:62-65 (1894)

Beadle, H. M.

93 The persistence of ores in lodes in depth - the Empire lode [Marysville. Mont.]. Eng M J 55:154-155 (1893)

95 The Iron Mountain mine iMissoula Co., Mont.]. Eng M J 60:562 (1895)

96 Mineral regions of British Columbia. Eng M J 62:104-105 (1896)

$96 a$ British Columbia mines [Rootenay district]. Eng M J 62:174-176 (1896)

02 Gold mining in eastern Oregon. Eng M J $73: 136$ (1902)

Beal, Carl Hugh.

14. The earthquake in the Santa Cruz Mountains, Ca1., Nov. 8, 1914. Seism Soc Am, B $4: 215-219$, map (1914)

15 The earthquake at Los Alamos, Santa Barbara Co., Cal., Jan. 11, 1915. Seism Soc Am, B 5:14-25 (1915)

15a The earthquake in the Imperial Valley, Cal., June 22, 1915. Seism Soc Am, B 5:130-149 (1915)

17 Geologic structure in the Cushing oil and gas field, Okla., and its relation to the oil, gas, and water. U S G S, B 658: $64 \mathrm{pp}$, maps (1917) Abst, Am I M Eng, B 128:1101-1112 (1917) ; Tr 57:894-905 (1918) Abst, by R. W. Stone, Wash Ac Sc, J $8: 172$ (1918)

Beall, Elias.

30 Georgia meteor and aerolite, Am .J Sc $18: 388$ (1830)
Benls, C. C.

17 (with Erni, C. P.) Soll survey of Carroll Co. Ind, Dp $G$ Nat Res, An Bp 41: 45-66, map (1917)

Beals, William, jr.

97 The building stones of New England. Stone $14: 545-567 ; 15: 1-7, \quad 213-223$ (1897)

o0 The Seven Devils mining district, Idaho. Eng M J 69:345-346 (1900)

\section{Beam, W.}

83. Rocks of the [Yellowstone National] Park. Am J Sc (3) $25: 106,352$ (1883)

Bean, Ernest F.

13 (with Martin, L., and Williams, F. E.) A manual of physical geography excursions, 207 pp, Madison, Wis., 1913. See also Hotehkiss ( W O), 15.

Beard, J. Carter.

01 Three characteristis types of American dinosaurs. Sc Am 84:184-185, I (1901)

O1a Something about ancient American saurians, Sc Am $85: 267$, il (1901)

Benrd, R. E.

17 (with Watson, T. I.) The color of amethyst, rose, and blue varieties of quarts. U S Nat Mus, Pr 53:553-563 (1917)

Beasley, Walter L.

03 Evolution of the horse. Sc Am 88: $451-452$, il (1903)

o3a A remarkable fossil discovery [ $T n$ ceratops 1 . Sc Am 89:87, il (1903)

16 Copper Queen cave in New York Eng M J 102: 379-380 (1916)

Benttie, H. M.

12 Acme graphite mines and mills [Ches ter Co., Pa.]. Eng M J 94: 115-118 (1912)

Beaumont. See Elie de Beaumont.

Beanregard, G. T.

66 [On the cause of the mud lumps is the Mississippi delta.] U S, 39th Conf 1st sess, H Ex Doc $97: 6-7$ (1866)

Bechdolt, A. F.

81 Influence of geological structure of history in the United States. Minn Ac I Sc, B 2:78-86 (1881)

85 Geological notes in Blue Earth Co Minn G S, An Rp 13:141-146 (1885)

89 Notes on the local geology of Mas kato; a preglacial river channel. Mins Ac $N$ Sc, B 3:58-63 (1889)

Beck, Lewis Caleb (1798-1853).

37 Report on the mineralogical agl chemical department of the survey. N G S, An Rp 1:15-60 (1837)

38 Report on the mineralogical and chemical department of the survey 10 New York]. N Y G S, An Rp 2:7-ii (1838)

39 Report on the mineralogical at chemical department of the survey New York]. N Y G $\mathbf{S}$, An Rp 3:9-i (1839) 
Beck, Lewis Caleb-Continued.

39 a Notices of the native copper, ores of copper, and other minerals found in the vicinity of New Brunswick, N. J. Am J Sc $36: 107-114$ (1839)

40 Communication to the governor, relative to the geological survey of the State [of New York]. N Y G S, An Rp 4: 37-43 (1840)

40a Report on the mineralogical and chemical department of the survey [of New York]. N Y G S, An Rp 4:45-111 (1840) In part (Putnam Co.) in Blake, William J., The history of Putnam County, N. Y...: 1722, N Y 1849

41 Report on the mineralogical and chemical department of the survey [of New York]. N Y G S, An Rp 5: 5-23 (1841)

$41 \mathrm{a}$ On the sulphur springs of the State of New York (abst). Am J Sc 41: 162-163 (1841) ; As Am G, Rp : 15-16 (1843)

42 Mineralogy of New York. 534 pp, Albany 1842

43 On some pseudomorphous minerals of the State of New York. As Am G, Rp: 2v1-253 (1843)

43a ... trappean minerals found in New Jersey and New York. Am J Sc 44:5460 (1843)

43b On certain phenomena of igneous action ... (abst with discussion). Am J Sc $45: 143-144$ (1843)

43e Antediluvian climate (abst with discussion). Am J Sc 45:144 (1843)

43d Occurrence of bituminous matter in New York limestones and sandstones. Am J Sc $45: 335-336$ (1843)

44 Views concerning igneous action, chiefly as deduced from the phenomena presented by some of the minerals and rocks of the State of New York. Am J Sc 46: 333-343 (1844)

48 Catalogue of the specimens in the mineralogical department of the geological survey [of New York]. N Y St Cab, An Rp 1:21-33 (1848)

50 Report on the mineralogy of New York; comprising notices of the additions which have been made since 1842 , N Y St Cab, An Rp 3:109-153 (1850)

Beek, Richard.

02 The origin of ore deposits (discussion). Am I M Fing, Tr 31:944-947 (1902)

05 The nature of ore deposits. Transl. and rev. by W. H. Weed. 2 vols, $685 \mathrm{pp}$, N Y 1905

10 Ergebnisse einer mikroskopischen Untersuchung von Ivigtut-Gesteinen. Z prak $\mathrm{G}$ 18:441-443 (1910)

13 Microscopy in economic geology. Eng M J 95: 1087-1089 (1913)

Beck, T. Romeyn.

20 (with Enton, A.) A geological survey of the county of Albany ... 56 pp, Albany 1820
Becke, F.

oo Optische Orientirung des Albit von Amelia, Va. Tschermak's Mitt N F $19: 321-335$ (1900)

09 Uranpecherz von Kirk mine, Bald Mountain, Gilpin City, Colo. Tschermaks Mitt N F 28:188 (1909)

Becker, Arnold.

os Geological possibilities at Goldfield [Nevada]. M Sc Press $96: 846$ (1908)

Becker, Clyde $M$.

14 Sulphur deposits of southwestern Texas. M Sc Press 109: 296 (1914)

$14 a$ Origin of ore bodies in replacement veins of northern Gilpin [Co., Colo.]. M Science 69 Jan: 42-43 (1914)

14b Historical and geological survey of the Florida Mountains [N. Mex.]. M Science 70 Aug : 35-36 (1914)

14e Lead and zine deposits in the Arbuckle Mountains [Okla.]. M Science 70 Dec: 21-22 (1914)

Becker, George Ferdinand (1847-1919).

75 Notes on a new feature in the Comstock Lode. Am J Sc (3) $10: 459-462$ (1875)

75a Gold. M Sc Press 30:78 (1875)

75b Quicksilver and fuel. M Sc Press $30: 98,102$ (1875)

So Reconnaissance of the San Francisco, Eureka, and Bodie districts [Nev.]. U S G S, An Rp 1: 37-47 (1880)

82 Geology of the Comstock lode and the Washoe district [Nev.]. U S G S, An Rp 2: 291-330 (1882)

S2a Geology of the Comstock lode and the Washoe district [Nev.]. U S G S, Mon $3: 422 \mathrm{pp}$, atlas (1882)

83 On the relations of temperature to glaciation. $\Delta \mathrm{m} J \mathrm{Sc}$ (3) $26: 167-175$ (1883)

84 The influence of convection on glaciation. Am J Sc (3) $27: 473-476$ (1884)

84a The relations of the mineral belts of the Pacific slope to the great upheavals. Am J Sc (3) 28: 209-212 (1884)

84b [Notes on California.] Science 3 : 665 (1884)

85 Geological sketch of the Pacific division. U S, 10th Census 13:5-59 (1885)

85 Notes on the stratigraphy of Cal1fornia. U S G S, B 19:28 pp (1885)

85b Impact friction and faulting. Am J Sc (3) 30:116-128, 194-209 (1885)

85e The geometrical form of voleanic cones and the elastic limit of lava. Am J Se (3) $30: 283-293$ (1885)

86 A new law of thermo-chemistry. Am J Sc (3) $31: 120-125$ (1886)

86 a Cretaceous metamorphic rocks of California. Am J Sc (3) $31: 348-357$ (1886)

87 The Washoe rocks [Nev.]. Cal Ac Sc, B 2 no 6:93-120 (1887) Abst, $\Delta \mathrm{m}$ J Se (3) $33: 75-76$ (1887); Am Nat 22: 639-640 (1888) 
Becker, George Ferdinand-Continued.

S7a The texture of massive rocks. Am J Sc (3) $33: 50-58$ (1887)

87b Natural solutions of cinnebar, gold, and associated sulphides. $\mathrm{Am} \mathrm{J}$ Sc (3) $33: 199-210$ (1887)

87e A sketch of the geological development of the Pacific slope. Newport N H Soc, Pr 5: 3-11 (1887)

88 Geology of the quicksilver deposits of the Pacific slope. U S G S, Mon 13: xix, $486 \mathrm{pp}$, atlas (1888)

s9 Summary of the geology of the quicksilver deposits of the Pacific slope. U S G S, An Rp 8: 961-985 (1889)

89a Silicic acids. $A m$ J Sc (3) 38 : 154-157 (1889)

90 An elementary proof of the earth's rigidity. Am J Sc (3) $39: 336-352$ (1890)

91 The structure of a portion of the Sierra Nevada of California. G Soc Am, B 2: 49-74 (1891)

91a Antiquities from under Tuolumne Table Mountain in California (with discussion by G. F. Wright). G Soc Am, B $\because$ : 189-198 (1891)

$91 \mathrm{~b}$ Notes on the early Cretaceous of California and Oregon (with discussion by G. M. Dawson, J. S. Diller, and C. A. White). G Soc Am, B 2:201-206 (1891)

91e The crystalline schists of the Coast Ranges of California. Int $G$ Cong, IV, London 1888, C R : 170-175 (1891)

93 Quicksilver ore deposits. U S G S, Min Res 1892: 139-168 (1893)

$93 a$ Finite homogeneous strain, flow, and rupture of rocks. G Soc Am, B 4:13-90 (1893)

94 On certain astronomical conditions favorable to glaciation. Am J Sc (3) 48 : 95-113 (1894)

95 Reconnaissance of the gold fields of the southern Appalachians. U S G S, An Rp 16 pt $3: 251-331$ (1895) Abst, $\mathrm{Am} \mathrm{J} \mathrm{Sc} \mathrm{(4)} \mathrm{1:57-60} \mathrm{(1896);} \mathrm{J} \mathrm{G} \mathrm{3:}$ 889-990 (1895)

95a The torsional theory of joints (with discussion by C. R. Boyd and R. W. Raymond). Am I M Eng, Tr 24:130-138, 863-867 (1895) Reprinted in Emmons, S. F., Ore deposits (pub by Am I M Eng) : $92-104$, N Y 1913

95b Distribution of gold deposits in Alaska. J G $3: 960-962$ (1895)

96 Schistosity and slaty cleavage. J G 4: 429-448 (1896)

97 The Witwatersrand banket, with notes on other gold-bearing pudding stones. U S G S, An Rp 18 pt $5: 153-184$, map (1897)

$97 \mathbf{a}$ Some queries on rock differentiation. Am J Se (4) 3:21-40 (1897) Abst. Science n \& $4: 927$ (1896)

$97 \mathbf{b}$ Fractional crystallization of rocks. Am J Sc (4) $4: 257-261$ (1897)
Becker, George Ferdinand-Continued.

97e Lewis on the diamond. Science n s $6: 664-667$ (1897)

98 Reconnaissance of the gold fields of southern Alaska, with some notes on gen. eral geology. U S G S, An Rp 18 pt 3: 1-86, maps (1898)

$\mathbf{9 8 a}$ On the determination of plagioclase feldspars in rock sections. Am J Sc (4) 5: $349-354$ (1898)

04 Experiments on schistosity and slaty eleavage. U S G S, B 241:34 pp (1904)

04a Present problems of geophysics. Science n 8 20:545-556 (1904) Am G 35: 4-22 (1904) Cong Arts and Sc (St. Louis 1904) 4:508-522 (1906) Abst, Eng M J $78: 743-744$ (1904)

o5 The isomorphism and thermal properties of the feldspars; introduction. Car negie Inst Wash, Pub $31: 3-12$, Washing. ton 1905

O5a Simultaneous joints. Wash Ac Sc, Pr 7:267-275 (1905) Eng M J 79:11821184 (1905)

o5b (and Day, A. L.) The linear force of growing crystals. Wash Ac Sc, Pr $7: 283-288$ (1905)

o7 Methods of igneous intrusion. Abst, Science n s 25:622 (1907)

$07 \mathbf{a}$ Current theories of slaty cleaverage Am J Sc (4) 24:1-17 (1907) Abst, Scl. ence n s 25:967-968 (1907)

os Age of a cooling globe in which the initial temperature increases directly as the distance from the surface. Science n s $27: 227-233,392$ (1908)

osa Relations of radioactivity to $\cos$ mogony and geology. G Soc Am 19:113146 (1908)

09 Relations between local magnetic dis turbances and the genesis of petroleum U S G S, B 401: 24 pp (1909)

10 The age of the earth. Smiths Mist Col 56 no $6: 1-28$ (1910)

10a Halley on the age of the ocean. Sclence n s 31:459-461 (1910)

10b Reflections on Joly's method of dt termining the ocean's age. Science $\mathrm{n}$, $31: 509-512$ (1910)

11 Biographical notice of Samuel Frank. lin Emmons. Am I M Eng, B 57 : 673-691 port (1911) ; Tr 42:643-661, port (1912) Reprinted in Emmons, S. F., Ore deposits: xxix-xlvii N Y 1913

12 Major C. E. Dutton. Am J Sc (4) 33 : $387-388$ (1912)

14 Note on mean density of fracturel rocks. Wash Ac Sc, J 4:429-431 (1914)

15 Isostasy and radioactivity. G Sol Am, B 26:171-204 (1915) Science n ! $41: 157-160$ (1915)

15a on the earth considered as a heat engine. Nat Ac Sc, Pr 1:81-86, 257-258 (1915) 
Becker, George Ferdinand-Continued.

16 Mechanics of the Panama canal slides. U S G S, P P 98: 253-261 (1916) Abst, Wash Ac Sc, J $7: 13$ (1917)

16a (and Day, A. L.) Note on the linear force of growing crystals. J G 24:313-333 (1916) Centralbl Miner 1916 : $337-346 \quad 364-373$

See also Don, 98 ; Pošepný, 94, 95 ; Powell, $82,83,84,85,85 a, 88,89,89 a, 90,91$, $91 \mathrm{a}, 92,93$

Beekwith, Edward Griffin.

55 Report of explorations for the $\mathrm{Pa}$ cific Railroad on the line of the forty-first parallel of north latitude. U S, Pacific R R Expl (U S, 33d Cong 1st sess, H Ex Doc 129 × 18 pt 2):1-77 (1855); also U S, 33d Cong $2 d$ sess, $\mathbf{S}$ Ex Doc 78 and $\mathbf{H}$ Ex Doc 91) 2:1-66 (1855)

55 a Report of exploration of a route for the Pacific raflroad near the 38 th and 39 th parallels of latitude from the mouth of the Kansas to Sevier River in the Great Basin. U S, Pacific R R Expl (U S, 33d Cong 1st sess, H Ex Doc 129 v 18 pt 2) : 1-98 (1855) ; als J (U S, 33d Cong 2d sess, $\mathrm{S}$ Ex Doc 78 and $\mathrm{H}$ Ex Doc 91) 2: 1-88 (1855)

Beckwith, John.

22 ... the natural walls, or solid dikes, In the State of North Carolina. Am J Sc 5:1-7 (1822)

Beekwith, Leonard Forbes.

80 The Arcadia iron property [Botetourt Co., Va.]. The Virginias 1: 110-112 (1880) Beecher, Charles Emerson (1856-1904).

83 List of species of fossils from an exposure of the Utica slate and associated rocks, within the limits of the City of Albany [N. Y.]. N Y St Mus, An Rp 36: 78 (1883)

84 Ceratiocaridae from the Chemung and Waverly groups of Pennsylvania. Pa G S, 2d, PPP : 1-22, il (1884)

86 A spiral bivalve shell from the Waverly'group of Pennsylvania [Spirodomus insignis]. N Y St Mus, An Rp $39: 161$ 164, il (1886)

S6a (and Hall, C. E.) Field notes on the geology of the Mohawk Valley. N Y St G, An Rp 5:8-10, map (1886); 14: 54-56, map (1895)

86b (and Hall, C. E., and Hall, J. W.) Note on the Oneonta sandstone in the vicin. ity of Oxford, Chenango Co., N. Y. N Y St G, An Rp 5:11 (1886)

88 Synoptical table of the genera and species described in volume VI of the Paleontology of New York. N Y St Mus, An Rp 41:363-375 (1888); 43: 279-291 (1890) N Y St G, An Rp 9: 77-89 (1890)

88 statement of the condition of the work on the Brachiopoda. N Y St Mus, An Rp $41: 383-387$ (1888) ; $43: 299-303$ (1890) N Y St G, An Rp $9: 97-101$ (1890)
Beecher, Charles Emerson-Continued.

89 (and Clarke, J. M.) The development of some Silurian Brachiopoda. N Y St Mus, Mem 1:95 pp, il (1889) Reprinted in Beecher, C. E., Studies in evolution: $310-417$, il, N Y 1901

89a Brachiospongidae; a memoir on a group of Silurian sponges. Yale Univ., Peabody Mus, Mem 2 pt 1: 28 pp, il (1889)

S9b Note on the fossil spider Arthroly. cosa antiqua Harger. Am J Sc (3) 38: 219-223, il (1889)

90 On the development of the shell in the genus Tornoceras Hyatt. Am J Sc (3) $40: 71-75$, il (1890) Reprinted in his Studies in evolution: $435-440$, il, N Y 1901

90a Koninckina and related genera. Am J Sc (3) $40: 211-219$, il (1890)

$90 \mathbf{b}$ On Leptaenisca, a new genus of brachiopod from the lower Helderberg group. Am J Sc (3) $40: 238-240$, il (1890)

90e North American species of Strophalosia. Am J Sc (3) 40:240-246, il (1890)

91 Development of the Brachiopoda. Am J Sc (3) $41: 343-357$, il ; $44: 133-$ 155 , il (1891-2) N Jb 1892, 1:178-197, il Reprinted in his Studies in evolution: 229-273, il, N Y 1901

91a Development of Bilobites. Am J Sc (3) $42: 51-56$, il (1891)

92 Notice of a new lower Oriskany fauna in Columbia Co., N. Y., with an annotated list of fossils, by J. if. Clarke. Am J Se (3) 44:410-414 (1892)

92a (with Dodge, W. W.) On the occurrence of Upper Silurian strata near Penobscot Bay, Me. Am J Sc (3) 43 : 412-418, map (1892)

93 Some correlations of ontogeny and phylogeny in the Brachiopoda. Am Nat 27:599-604 (1893) Reprinted in his Studies in evolution : 286-289, 11, N Y 1901

93a The development of a Paleozoic poriferous coral. Conn Ac, $\operatorname{Tr} 8: 207-$ 214, il (1893) Reprinted in his Studies in evolution : 421-428, il, N Y 1901

93b Symmetrical cell development in the Favositidae. Conn Ac, Tr $8: 215-219$, il (1893) Reprinted in his Studies in evolution : $429-434$, 11, N Y 1901

93e Larval forms of trilobites from the lower Helderberg group. Am J Sc (3) 46:142-147, il (1893)

93d A larval form of Triarthrus. Am J Sc (3) $46: 378-379$, il (1893)

93e On the thoracic legs of Triarthrus. Am J Sc (3) $46: 467-470$, il (1893)

93P (and Sehuchert, C.) Development of the brachial supports in Dielasma and Zygospira. Biol Soc Wash, Pr 8:7178, il (1893) Abst, Am Nat 28:267 (1894) 
Beecher, Charles Emerson-Continued.

94 On the mode of occurrence, and the structure and development of Triarthrus becki. Am G 13:38-43, il (1894) Reprinted in his Studies in evolution : 197202,11, N Y 1901

$94 a$ The appendages of the pygidium of Triarthrus. Am J Sc (3) $47: 298-300$, il (1894)

95 ... Further observations on the ventral structure of Triarthrus. Am G 15 : 91-100, il (1895) Reprinted in his Studies in evolution : 203-212, il, N Y 1901

95a The larval stages of trilobites. Am G 16:166-197, il (1895) Reprinted in his Studies in evolution : 166-196, il, N Y 1901

95b Structure and appendages of Trinuclets. Am J Sc (3) $49: 307-311$, il (1895) Reprinted in his Studies in evolution : 220-225, il, N Y 1901

95e Revision of the families of loopbearing Brachiopoda. Conn Ac, Tr 9: $376-391,395-398$, il (1895) Reprinted in his Studies in evolution : 290-309, 11, N Y 1901

96 The morphology of Triarthrus. Am J Sc (4) 1:251-256, il (1896) G Mag (4) $3: 193-200$, il (1896) Reprinted in his Studies in evolution: 213-219, 11, N Y 1901

96a James Dwight Dana. Am G 17 : 1-16, port. (1896)

962 On a supposed discovery of the antennae of trilobites by Linnaeus in 1759 . Am G $17: 303-306$, il (1896)

s6e On the valldity of the family Bohemillidae, Barrande. Am G $17: 360-362$, 11 (1896)

$96 d$ On the occurrence of Silurian strata in the Bighorn Mountains, Wyoming, and in the Black Hills, S. Dak. Am G 18:3133 (1896)

97 The systematic position of the trilobites. Am G 20:38-40 (1897) Reprinted in his Studies in evolution:163-165, N Y 1901

$97 a$ Outline of a natural classification of the trilobites. $\Delta \mathrm{m} \mathrm{J} \mathrm{Sc} \mathrm{(4)} 3: 89-106$, 181-207, il (1897) Reprinted in his Studies in evolution:109-162, N Y 1901

$97 \mathrm{~b}$ Morphology of the brachia [of Brachlopoda]. U S G S, B 87:105-112 (1897) Reprinted in his Studies in evolution : 274-285, N Y 1901

98 The origin and significance of spines; a study in evolution. Am J Sc (4) 6:1-20, 125-136, 249-268, 329-359, il (1898) Reprinted in his Studies in evolution: 3-105, il, N Y 1901

99 Othniel Charles Marsh. Am J Sc (4) 7:403-428, port (1899) Am G 24:135157, port (1899) G S Am, B 11:521-537 (1900)

Oo On a large slab of Uintacrinus from Kansas, Am J Sc (4) 9:267-268, il (1900)
Beecher, Charles Emerson-Continued.

oor Restoration of Stylonurus lacoanus, a giant arthropod from the Upper Dero. nian of the United States. Am J Sc (4) 10:145-150, il (1900) G Mag (4) 7:481$485,11(1900)$

o1 Studies in evolution ... 638 pp, il, N Y 1901 Yale Bicentennial Publications, O1a Note on the Cambrian fossils of St. Francois Co., Mo. Am J Se (4) 12:362363 (1901) G Mag (4) 8:559-561 (1901)

01b Discovery of eurypterid remains in the Cambrian of Missouri. Am J Sc (4) $12: 364-366$, il (1901) G Mag (4) 8: $561-564$, il (1901)

o1e The restoration of a dinosan: [Claosaurus annectens]. Yale Sc Mo 7: 291-293, il (1901)

02 Notes on a new Xiphosuran from the upper Devonian of Pennsylvania. Am G $29: 143-146$, il (1902)

02a The ventral integument of trilobites. G Mag (4) $9: 152-162$, il (1902) Am J Sc (4) $13: \mathbf{1 6 5 - 1 7 4}$, il (1902)

02b Revision of the Phyllocarida from the Chemung and Waverly groups of Pennsylvania. G Soc London, Q J 58:441-449, il (1902) Abst, G Mag (4) $9: 327-328$ (1902)

02c The reconstruction of a Cretaceous dinosaur, Claosaurus annectens Marsh. Conn Ac, Tr 11:311-324, il (1902)

o3 Observations on the genus Romingeria. Am J Sc (4) $16: 1-11$, il (1903)

04 Note on a new Permian Xiphosuran from Kansas. Am J Sc (4) $18: 23-24$, Il (1904)

See also Eastman, 00

Beede, Joshua William.

97 (with Haworth, E.) The Mc Pherson Equus beds. Kans Univ G S 2: 285-296 (1897)

98 The stratigraphy of Shawnee Co. [Kans.]. Kans Ac Sc, Tr 15: 27-34 (1898) 98a The MePherson Equus beds [Kans.]. Kans Ac Sc, Tr 15:104-110, map (1898)

98b Notes on Kansas physiography. Kans Ac Sc, Tr 15: 114-120 (1898)

98c New corals from the Kansas Carboniferous. Kans Univ Q 7:16-18 (1898)

98d Variations of external appearance and internal characters of Spirifer camer atus Morton. Kans Univ Q $7: 103-105$, « (1898)

98e Notes on Campophyllum torquium Owen and a new variety of Monopteris gibbosa Meek and Worthen. Kans Unir Q $7: 187-190$, il (1898)

98f Preliminary notice on the correla tion of the Meek and Marcou section at Nebraska City, Nebr., with the Kansas Coal Measures. Kans Univ Q 7 : 231-233 (1898) 99 On the correlation of the coal measures of Kansas and Nebraska. Kans Ac Sc, Tr 16: 70-84 (1899) 
Beede, Joshua William-Continued.

99a Description of some new forms of Pseudomonotis from the upper coar meas. ures of Kansas. Kans Univ Q $8: 79-84$, II (1899)

99b New fossils from the Kansas coal measures. Kans Univ Q 8:123-130, il (1899)

99e (and Rogers, A. F.) New and little known pelecypods from the coal meas. ures. Kans Univ Q 8:131-134, il (1899) 00 Carboniferous invertebrates. Kans G S $6: 1-187$, il $(1900)$

00a Two new crinoids from the Kansas Carboniferous. Kans Univ Q 9:21-24, il (1900)

00b A reconnaissance in the Blue Valley Permian. Kans Univ Q 9:191-202, map (1900)

00e (and Rogers, A F) Coal measures faunal studies. Kans Univ Q 9:233254 (1900); Kans Univ Sc B 1: 163-181 (1902) ; $2: 459-473$ (1904) ; $3: 377-388$ (1906)

01 Fauna of the Permian of the central United States [Gage Co., Nebr.]. Kans Ac Sc, $\operatorname{Tr} 17: 185-189$, il (1901)

01a The age of the Kansas-Oklahoma red beds. Am G 28: 46-47 (1901)

02 New fossils from the upper Carboniferous of Kansas. Kans Univ Sc B, 1: 147151, il (1902)

02a Variation of the spiralia in Seminula argentia (Shepard) Hall. Kans Univ Se B 1: 155-157 (1902) Abst, Ind Ac Se, Pr 1901: 221-222 (1902)

02b Fauna of the Shawnee formation (Haworth), the Wabaunsee formation (Prosser), the Cottonwood limestone. Kans Univ, Se B 1: 163-181 (1902)

02e Invertebrate paleontology of the Red Beds. Okla G S, Bien Rp 1, Advance $\mathrm{B}: 11 \mathrm{pp}$, il [1902]

04 (with Prosser, C. S.) Description of the Cottonwood Falls quadrangle [Kans.]. U S G S, G Atlas Cottonwood Falls fol (no 109) : 6 pp, maps (1904)

05 (and Sellards, E. H.) Stratigraphy of the eastern outcrop of the Kansas Permian. Am G 36:83-111, map (1905)

06 Fauna of the Salem limestone; Foraminifera and Anthozoa [see also 06a], Echinoderma, Vermes, Brachiopoda, Pelecypoda. Ind Dp G, An Rp $30: 1201-1218$, $1243-1273,1297-1334$, II (1906)

06a A correction [to above paper on Foraminifera and Anthozoa]. Science n s 24: 594 (1906)

06b (and Rogers, A. F.) Coal measures faunal studies; IV, Upper coal measures, Neosho River section. Kans Univ Sc B 3: $375-388$ (1906)

06e (with Cumings, E. R.) Fauna of the Salem limestone of Indiana. Ind $\mathrm{D} \mathrm{G}$, An Rp 30:1189-1201 (1906)
Beede, Joshua William-Continued.

o7 Invertebrate paleontology of the up per Permian Red Beds of Oklahoma and the Panhandle of Texas. Kans Univ, Sc B $4: 113-171$, il (1907)

o7a (and Shannon, C. W.) [Iron ores of ] Martin Co. Ind D G, An Rp $31: 383-$ 424 (1907)

os (and Rogers, A. F.) Coal measures faunal studies; Faunal divisions of the Kansas coal measures. Kans Univ G $\mathbf{S} 9$ : $318-385$, il (1908)

09 Formations of the Marion stage of the Kansas Permian. Kans Ac Sc Tr 22: 248-256 (1909)

09n The bearing of the stratigraphic history and invertebrate fossils on the age of the anthracolithic rocks of Kansas and Oklahoma. J G 17: 710-729 (1909)

09b Relationships of the Pennsylvanian and Permian faunas of Kansas and their correlation with similar faunas of the Urals (abst). Science n s 29:637-638 (1909) G Soc Am, B 20:702 (1910)

09e The invertebrate faunas and correlation of some so-called Permian rocks of the Mississippi Valley, with remarks on their stratigraphy (abst). Science n s 29: 752 (1909)

10 The correlation of the Guadalupian and the Kansas sections. Am J Sc (4) 30 : 131-140 (1910) Abst, Science n s 32:224 (1910)

11 The Carbonic fauna of the Magdalen Islands. N Y St Mus, B 149: 156-186, il (1911)

11 a The cycle of subterranean drainage as illustrated in the Bloomington, Ind., quadrangle. Ind Ac Sc, Pr 1910:81-103 (1911)

12 [Report on the fossils of the Ames limestone of Harrison Co., W. Va.]. W Va G S, Doddridge and Harrison cos: 254255 (1912)

12a Origin of the sediments and colorlng matter of the red beds of Oklahoma. Science n s $35: 348-350$ (1912) Abst, Science n \& $35: 311$ (1912); (with discussion by I. C. White), G Soc Am, B 23 : 723-724 (1912)

13 Fossil fauna, Conemaugh series [W. Va.]. W Va G S, Marion, Monongalia, and Taylor $\cos : 322-324$ (1913)

13a Influence of bedrock and surface deposits on the potability of well water. Ind Sanitary \& Water Supply As, 6th An Convention, $\mathrm{Pr}$ : 47-54 [1913?]

14 The Neva limestone in northern Oklahoma, with remarks upon the convelation of the vertebrate fossil beds of the State. Okla G S, B 21:37 pp, map (1914)

15 (and others) Geology of the Bloomington quadrangle. Ind $\mathrm{Dp} G, \mathrm{An} \mathrm{Rp} 39$ : 190-312, map (1915) 
Beede, Joshua William-Continued.

16 New species of fossils from the Pennsylvanian and Permian rocks of Kansas and Oklahoma. Ind Univ Studies 3 no $29: 15$ pp (1916)

17 Development of the successive peneplains in Kansas $(a b s t)$. G Soc Am, B 28: 160 (1917)

18 (and Waite, V. V.) The geology of Runnels Co. Tex, Univ, B no $1816 ; 64$ pp, map (1918)

See also Girty, 08 ; $\mathrm{Ha}$ orth, $97 \mathrm{c}$

Beekly, A. L.

12 The Culbertson lignite field, Valley Co., Mont. U S G S, B 471:319-358, maps (1912)

14 (with Calvert, W. R., et al.) Geology of the Standing Rock and Cheyenne River Indian reservations, N. and S. Dak. U S G S, B 575: 49 pp, maps (1914) Abst, Wash Ac Sc, J 4:425 (1914)

15 Geology and coal resources of North Park, Colo. U S G S, B 596:121 pp. map (1915)

Beeler, Henry C.

03 A brief review of the South Pass gold district, Fremont Co., Wyo. 12 pp, 19032 d ed, 16 pp, 1904

04 Wyoming mines and minerals in brief. 15 pp, Cheyenne, Wyo., 1904

04a The north Laramie Peak copper district in Converse, Albany, and Laramie Cos., Wyo. 16 pp, Cheyenne, Wyo., 1904

04b A report to the governor of Wyoming by the State geologist [for 1903 and 1904]. 39 pp, Cheyenne, Wyo., 1904

05 Geology and mineral resources of Wyoming. Am M Cong, 7th, Pr: 113-118 (1505)

05a Mining in the Grand Encampment copper district, Carbon and Albany cos., Wyo. $32 \mathrm{pp}$, Cheyenne 1905

06 Mineral and allied resources of Albany Co., Wyo. Laramie, 80 pp, Wyo. 1906

07 A report by the State geologist to the governor of Wyoming [for 1905 and 1906]. 45 pp, Laramie, Wyo., 1907

08 Wyoming mines, 1907; a summary of the conditions and progress in the copper, gold, placer, iron, asbestos, sulphur, stone, plastic minerals, gravel, oil, natural gas, and coal industries. $46^{\circ} \mathrm{pp}$, Laramie, Wyo. [1908]

08a The South Pass gold mining district [Wyo]. M World 29:953-955 (1908)

10 Asbestos in [Natrona Co.] Wyoming. Eng M J 90:955 (1910]

11 Asbestos deposits of Casper Mountain [Natrona Co.], Wyo: Colo Sch Mines Mag 1 no $10: 5-9$, no $11: 5-9$ (1911)
Beesley, Maurice.

80 A lecture on the antiquity of the sunken cedar forests of Cape May County. N. J., and the territorial encroachments made and still making upon our country bs water. 7 pp, Cape May City, N. J., 1880 [Priv pub]

Beeson, J. J.

15 The disseminated copper ores of Bingham Canyon, Utah. Am I M Eng B $107: 2191-2236$ (1915) ; Tr $54: 356-401$ (1917)

Begbie, Matt. B.

$\boldsymbol{7 1}$ On the "benches" or valley terraces of British Columbia. $\mathrm{R}$ Geog Soc, $\mathrm{P}$ 1870-1:133-145 (1871) In part, Am ? Sc (3) $2: 142-144$ (1871)

Be1, Jean Marc.

04 Voyage minier au nord-ouest cans. dien [Klondike]. Soc Ing Civils France Mém (6) $57: 580-641$ (1904)

o5 Gites auriferes du Klondike, Yukon, Canada. Soc Ind min, B (4) 4:275-316 maps (1905)

Belcher, Edward.

56 Notice of the discovery of Ichthy saurus and other fossils in the late Arctis searching expedition, 1852-54. Brit As Rp 25: sec 79-80 (1856)

62 Remarks on the glacial movements noticed in the vicinity of Mount St. Ellas on the northwest coast of America. Brit As, Rp 31: 186-187 (1862)

Belknap, Jeremy.

85 An account of large quantities of s fossil substance found at Lebanon in thi state of New Hampshire [Lebanon, Yot Co., Me.]. Am Ac, Mem 1: 377 (1785)

Bell, Andrew.

96 Notes on the building stones of east. ern Ontario. Stone $12: 565-567 ; 13: 24-$ 27 (1896)

Be11, Benjamin.

29 Strictures on the hypothesis of It: Joseph Du Commun on voleanoes and earthquakes Am J Sc 16:51-53 (1829) Bell, Isaac Lowthian.

75 Notes of a visit to coal and iro: mines and iron works in the United States 66 pp, Newcastle-on-Tyne 1875

92 On the American iron trade aud its progress during sixteen years. Irc1l and Steel Inst. in America in 1890, special wi of $\operatorname{Pr}: 1-208$, maps [1892]

Bell, J. J.

o7 The Cassiar coal fields in British Co lumbia. Eng M J 83:1007 (1907)

os The Moose Mountain iron rangs [Ont.]. Eng M J 85: 805 (1908)

Bell, James Macintosh.

O1 Report on the topography and geot ogy of Great Bear Lake and of a chain o. lakes and streams thence to Great slart Lake. Can G S, An Rp 12: c 1-28 (1901) 
Bell, James Macintosh-Continued.

01a [Report of explorations in the Great Bear Lake country, Mackenzie district.] Can G S, Sum Rp 1900 (An Rp 13): A 95-103 (1901)

04 Economic resources of Moose River basin. Ont Bur Mines, Rp 1904:135179, map (1904)

05 Iron ranges of Michipicoten west. Ont Bur Mines, Rp 1905, 14 pt 1:278355 , map (1905)

06 The possible granitization of acidic lower Huronian schists on the north shore of Lake Superior. J G 14:233-242 (1906)

13 The occurrence of gold in Ontario (discussion). Inst M Met, B 111:45-46 (1913)

14 The ore deposits of Cobalt [Ont.]. M Mag 10:126-132 (1914)

Bell, Robert (1841-1917).

58 Report for the year 1857. Can G S, Rp Prog 1857 : 95-108 (1858)

61 On the occurrence of freshwater shells in some of our post-Tertiary deposits. Can Nat 6:42-51 (1861)

63 On the superficial geology of the Gaspe Peninsula. Can Nat $8: 175-183$ (1863)

$63 a$ Roofing slate as a source of wealth to Canada; a visit to the Walton slate quarry. Can Nat 8: 358-369 (1863)

65 (and others) Repert on the Canadian gold fields... Canada, Legislative Assembly : $128 \mathrm{pp}$, maps, Quebec 1865

66 Report [on the geology of Manitoulin Island]. Can G S, Rp Prog 1863-6: 165179 (1866)

70 Report [on the geology of the Manitoulin Islands]. Can G S, Rp Prog 1866$9: 109-117$ (1870)

70a Report [on the geology of the northuest coast of Lake Superior and of the Nipigon district]. Can G \&, Rp Prog 1866$9: 313-364$, map (1870) [See also Logan, 701

70b On the Nipigon territory. Can Nat n $8 \quad 5: 118-120 \quad(1870)$

72 Report on the country north of Lake Superior, between the Nipigon and Michipicoten rivers. Can G S, Rp Prog 1870-1 : 322-351 (1872)

72a Report on the country between Lake Superior and the Albany River. Can G S, Rp Prog 1871-2: 101-114 (1872)

73 Report on the country between Lake Superior and Lake Winnipeg. Can G S, Rp Prog 1872-3: 87-111 (1873)

$73 a$ The mineral region of Lake Superior Am J Sc (3) $6: 224-225$ (1873) Can Nat n \& 7:49-51 (1873)

74 Report on the country between Red River and the South Saskatchewan, with notes on the geology of the region between Lake Superlor and Red River [with appendix by C. Hoffmann on analyses of lignites]. Can G S, Rp Prog 1873-4:66-93
Bell, Robert-Continued.

76 Report on the country west of lakes Manitoba and Winnipegosis, with notes on the geology of Lake Winnipeg. Can G S, Rp Prog 1874-5:24-56 (1876)

77 Report on an exploration in 1875 between James Bay and lakes Superior and Hudson. Can G S, 2 p Prog 1875-6: 294-342 (1877)

$77 \mathbf{a}$ Sketch of the geology of the route of the Intercolonial Raflway. Can $\mathbf{J} \mathrm{n} \mathbf{s}$ 15: $381-387$ (1877)

78 Report on geological researches north of Lake Huron and east of Lake Superior. Can G S, Rp Prog 1876-7: 193-220 (1878)

79 Report of an exploration of the east coast of Hudson's Bay, 1877. Can G S, Rp Prog 1877-8: C 37 pp, map (1879)

$79 a$ Report on the country between Lake Winnipeg and Hudson's Bay, 1878. Can G S, Rp Prog 1877-8: cC 31 pp, maps (1879)

so Report on explorations on the Churchill and Nelson rivers and around God's and Island lakes, 1879. Can G S, Rp Prog 1878-9:c 1-44, map (1880)

81 Report on Hudson's Bay and some of the lakes and rivers lying to the west of it. Can G S, Rp Prog 1879-80: c 1-56, map (1881)

81 a on the occurrence of petroleum in the Northwest Territories, with notes on new localities. Can Inst, $\mathrm{Pr} n \mathrm{n}$ 1:225230 (1881)

83 Report on the geology of the basin of Moose River and adjacent country. Can G S, Rp Prog 1880-2 : c 1-9, map (1883)

$83 a$ on the geology of the lake of the Woods and adjacent county. Can G S, Rp Prog 1880-2: c 11-15, map (1883)

s3b The causes of the fertility of the land in the Canadian Northwest Territories. R Soc Can, $\operatorname{Pr} \operatorname{Tr} 1$, iv : 157-162 (1883) Abst, Can Rec $\mathrm{N} H$ 1:14-15 (1884)

84 Observations on the geology, mineralogy, zoology, and botany of the Labrador coast, Hudson's Strait and Bay. In [Canada, Dp of Marine], Report of the Hudson's Bay Expedition under the command of Lieut. A. R. Gordon : 20-40 (1884)

85 The geology of Hudson's Bay and Strait. In [Canada, Dp of Marine], Report of the second Hudson's Bay Expedition under the command of Lieut. A. R. Gordon : $55-70$ (1885)

85a Report on part of the basin of the Athabasea River, Northwest Territory. Can G S, Rp Prog 1882-4: cC 35 pp, map (1885)

85b Observations on the geology, zoology, and botany of Hudson's Strait and Bay, made in 1885. Can G S, An Rp 1: DD 1-20, map (1885) 
Bell, Robert-Continued.

s5e Observations on the geology, mineralogy, zoology, and botany of the Labrador coast, Hudson's Strait and Bay. Can G S, Rp Prog 1882-4: DD 1-37 (1885)

85d The geology and economic minerals of Hudson Bay and northern Canada (abst). R Soc Can, Pr Tr 2, iv : 241-245 (1885) Science 3:755-756 (1884)

s5e On the mode of occurrence of apatite in Canada. Eng M J 39:316-317 (1885) Can Inst, Pr (3) $3: 294-302$ (1886)

85P The topography and geology of the Hudson Bay region. Science 5:256-257 (1885)

86 Marble Island and the northwest coast of Hudson's Bay. Can Inst, Pr 22 or (3) $4: 192-204$ (1886)

86a The mineral resources of the Hudson Bay Territories. Am I M Eng, Tr 14: 690-698 (1886)

86b Metallic ores of the country between the Great Lakes and Hudson Bay. Eng M J $42: 458$ (1886)

87 Report on an exploration of portions of the Attawapiskat and Albany rivers, Lonely Lake to James Bay [Ontario]. Can G S, An Rp 2: a 38 pp (1887)

87a On some points in reference to ice phenomena. R Soc Can, $\operatorname{Pr} \operatorname{Tr} 4$, lii : 8591 (1887)

87b Rock specimens from Cumberland Sound, Baflin Land. Science 10:287 (1887)

87. The sllver mines of Thunder Bay, Lake Superior. Eng M J $43: 23,42$ (1887)

88 The petroleum field of Ontario. R Soc Can, Pr Tr 5, iv : 101-113 (1888)

88 . The origin of some geographical features in Canada (abst). Can Rec Sc $3: 163-165$ (1888) Pop Sc Mo $35: 422-$ 423 (1889)

89 [Summary of explorations in the Lake Timiskaming region.] Can G $\mathrm{S}$, Sum Rp 1887-8 (An Rp 3) : A 22-27 (1889)

89 [Summary of observations between the Montreal River and the northern shores of Lake Huron, Ontario.] Can G S, Sum Rp 1887-8 (An Rp 3) : A 77-80 (1889)

89b The geology of Ontario, with special reference to economic minerals. (Reprinted from the report of the Royal Commission). $57 \mathrm{pp}$, Toronto 1889 Abst, Am G 5 : 238240 (1890) ; Eng M J 49: 468 (1890)

89e Presidential address: The Huronian system in Canada. $\mathrm{R}$ Soc Can, $\operatorname{Pr} \operatorname{Tr} 6$, Iv : 3-13 (1889)

90 [Report on the Sudbury region, Ont.] Can G S, Sum Rp 1888-9 (An Rp 4) : A 29-32 (1890)

$90 a$ On glacial phenomena in Canada. G Soc Am, B 1:287-310 (1890) Abst, Am Nat $24: 207-208$ (1890)
Bell, Robert-Continued.

9ob The origin of gneiss and some othe primitive rocks (abst). Am $\mathrm{As}, \operatorname{Pr} 3$ $227-231$ (1890)

91 Report on the Sudbury distria [Ont.]. Can G S, An Rp 5: F 1-54, my (1891)

$91 \mathbf{a}$ [Summary report of work in th Sudbury region, Ont.] Can G S, Sum $\mathrm{R}$ 1890 (An Rp 5) : A 41-43 (1891)

$91 \mathrm{~b}$ The nickel and copper deposits Sudbury distriet, Can. G Soc Am, B : 125-137 (1891) Abst, Eng M J 51:38 (1891)

92 [Report on field work in the am south of the Sudbury district, Ont.] a G S, Sum Rp 1891 (An Rp 5) : $\Delta$ 31 (1892)

92a The Laurentian and Huronian 87? tems north of Lake Huron. Ont Be Mines, Rp 1:63-94 (1892)

92b Alexander Murray. Can Rec Sc 77-96, port (1892)

93 [Summary report of field work the Byng Inlet sheet, Ont.] Can $G$ : Sum Rp 1892 (An Rp 6) : A 30-34 (189: 93a The contact of the Laurentian a Huronian north of Lake Huron (abst: Am G 11: 135-136 (1893)

93b The succession of the glacial it posits of Canada (abst). Am G $12: 22 \%$ 227 (1893)

94 [Summary report on field work not? of Lake Huron.] Can G S, Sum Rp 180 (An Rp 6) : A 33-39 (1894)

$94 a$ Pre-Paleozoic decay of crystallis rocks north of Lake Huron. G Soe Am, 5: 357-366 (1894) Abst, Am G 13:21: (1894)

95 [Report on field work in the Lal Huron region.] Can G S, Sum Rp 18: (An Rp 7) : A 52-55 (1895)

95a Honeycombed limestones in Lat Huron. G Soc Am, B 6:297-304 (189: Abst, Science n s 1:67 (1895); J G : 869 (1895)

95b A great preglacial river in norther Canada (abst). Am G 16:132 (1895)

95e On the occurrence of lignite at anthracite around Hudson Bay. Can Rv 14:8-10 (1895)

96 [Report of an exploration of t Nottaway River.] Can G S, Sum Rp 18: (An Rp 8) : A 75-85 (1896)

96a Proofs of the rising of the lat around Hudson Bay. Am J Sc (4) 1:219 228 (1896) Smith's Inst, An Rp 1897:35\% 367 (1898) Abst, Am G $17 ; 99$ (1896) Science n s $3: 53$ (1896)

96b On the occurrence of lignite and 8 thracite around Hudson Bay. Gen M ! Que, J 2: 154-159 [1896]

97 [Report on exploration of Nottax: River basin, Que.] Can G S, Sum Rp 180 (An Rp 9) : \& 64-74 (1897) 
Bell, Robert-Continued.

97 a Evidences of northeasterly differential rising of the land along Bell River. G Soc Am, B 8: 241-250, map (1897)

$\mathbf{9 7 b}$ Recent explorations to the south of Hudson Bay. Geog J 10:1-17, map (1897) 97e Observations on Baffinland (abst). Am J Sc (4) 4:476-477 (1897)

98 Report on the geology of the French River sheet, Ont. Can G S, An Rp 9: r $29 \mathrm{pp}$, map (1898)

98a [Report of explorations in Hudson Strait region.] Can G S, Sum Rp 1897 (An Rp 10) : A 75-83 (1898)

9sb on the occurrence of mammoth and mastodon remains around Hudson Bay. G Soc Am, B $9: 369-390$, il (1898) Abst, Science n s $7: 80$ (1898)

98e Fossil-like forms in the Sault Ste. Marie sandstone $(a b s t)$. Science n s $7: 80$ (1898)

99 [Report of an examination of the Michipicoten district, Ont.] Can G S, Sum Rp 1898 (An Rp 11) : A 99-106 (1899)

99a The geological history of Lake Superior. Can Inst, $\operatorname{Tr} 6: 45-60$ (1899)

99b Outline of the geolegy of Hudson Bay and Strait (abst). Am G 23: 92-93 (1899) Science $n$ s 9:101-102 (1899) 0ttawa Nat 12:195 (1899)

00 [Report on explorations in the Great Slave Lake region, Mackenzie district.] Can G S, Sum Rp 1899 (An Rp 12): A 103-110 (1900)

01 Report of an exploration on the northern side of Hudson strait. Can G S, An Rp 11: M 38 pp, map (1901)

01a Laurentian limestones of Baffinland (abst). G Soc Am, B 12:471 (1901) Science n \& 13:100 (1901) Can Rec Sc $8: 472-473$ (1902)

02 Report on the geology of the basin of the Nottaway River with a map of the region. Can G S, An Rp 13: K $11 \mathrm{pp}$, map (1902)

02a Summary report on the operations of the Geological Survey for the year 1901. Can G S, An Rp n s 14: A 3-271, maps (1902) ... for the year 1902, An Rp n s $15:$ A $1-484$ (1903) $\ldots$ for the year 1903 , An Rp n 8 15: A 1-218, maps (1904) ... for the year 1904, An Rp n s $16:$ Ai-xxxvili, 1-392, maps (1905) [Also issued separately.]

03 The work of the Geological Survey of Canada in 1902 (abst). Science $n$ s $17: 299-300 \quad(1903)$

05 The advantages of combining topographical with geological surveying in unexplored regions (abst). Can M Inst, J $8: 56-58 \quad(1905)$

06 Summary report of the Geological Survey department of Canada for the calendar year 1905. 144 pp, maps, Ottawa 1906.

06a [Report on] the Cobalt mining district. Can G S, Sum Rp 1905: 94-104 (1906) Can M Rv 27:116-124 (1906)
Bell, Robert-Continued.

06b Cobalt district and northward. Can G S, Sum Rp 1906: 110-112 (1906)

o6e The occurrence of diamonds in the drift of some of the northern States. Eng M J 82:819 (1906) Can M Inst, J 9: 124-127 (1906)

07 The Cobalt mining district. Can M J 28 (n s 1 no 8) : 246-248 (1907)

os Personal reminiscences of Sir William E. Logan (abst). G Soc Am, B 18: $622(1908)$

O8a The tar sands of the Athabasca River, Canada. Am I M Eng, B 20:157169 (1908) ; $\operatorname{Tr} 38: 836-848$ (1908) Abst, M World 28:753 (1908)

10 The Klondike gold district in the Yukon Valley, Can. Australasian As, Rp $12: 282-296$ (1910)

10a The diversion of the Montreal River (abst). Science n $\mathrm{s} \quad 32: 187$ (1910) G Soc Am, B 21: 762-763 (1910)

11 Memoir of Thomas Chesmer Weston, 1832-1910. G Soc Am, B 22:32-36, port (1911)

See also Coste, 04; Miller (W G), 12 ; Salisbury, 93a ; Wright (G F), 93

Bell, Robert $\mathrm{N}$.

o0 [The Ramshorn mine at Bayhorse, Idaho.] Mines and Minerals 21:174-176 (1900)

01 An outline of Idaho geology and of the principal ore deposits of Lemhi and Custer cos., Idaho. Int $\mathrm{M}$ Cong, $4 \mathrm{th}, \mathrm{Pr}$ : 64-80 (1901)

02 The origin of the fine gold of Snake River. Eng M J 73:143-144 (1902)

02a The geology of Thunder Mountain and central Idaho. Eng Min J 73:791793 (1902)

02b Thunder Mountain and Mackay, Idaho. M Sc Press 84:62-63 (1902)

02e Facts about Thunder Mountain [central Idaho]. Eng M J 74:273-275 (1902)

03 Tin ledges in Alaska. Eng M J 76 : 820 (1903)

04 Geology of Park City, Utah, district. Lead and Zinc News 8:57, 60 (1904)

O4a Report of the mining districts of Idaho for the year 1903. $145 \mathrm{pp}$, Boise, Idaho, 1904.

os Report of the mining districts of Idaho for the year 1904. $139 \mathrm{pp}$, Boise [1905]

o5n The geology and mineral resources of Idaho. Am M Cong, 7th, Pr: 200-226 (1905)

06 Seventh annual report of the mining industry of Idaho for the year 1905: 143 pp (1906) ; Eighth... 1906:175 pp [1907]; Ninth... 1907:217 pp [1908]; Tenth... 1908: 27 pp [1909]; Thirteenth... 1911: 135 pp [1912] ; Fourteenth... 1912: 190 
Bell, Robert N.-Continued.

pp, map [1913] ; Fifteenth... 1913: 225 pp

[1914] ; Sixteenth... 1914:55 pp [1915] ; Seventeenth... 1915: 134 pp [1916] ; Eighteenth... 1916: 56 pp [1917] ; Nineteenth... 1917: 131 pp [1918] [See also Moore (F C), 10]

07 The gold of the Snake River [Idaho]. M Sc Press 94:542-543 (1907)

O7a South Mountain, Idaho. Eng M J $83: 283-284$ (1907)

o7b Sapphires in Idaho. M World 26: 449 (1907)

os Association of igneous intrusions with Idaho ore bodies. Eng M J 85: 127 (1908)

Osa Atlanta gold district, Idaho. Eng M I $86: 176-177$ (1908)

11 The Pioche, Nev., district. Mines

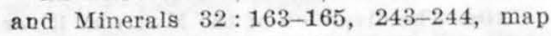
(1911)

16 Rich gold ore found in Idaho [Atlanta district]. Eng M J 102:783-785 (1916)

17 Phosphate deposits of Idaho. Eng M J 104: 293-294 (1917)

18 Quicksilver and antimony discoveries in central Idaho. Idaho, M Dp, B no 1 [12 pp] (1918)

Be11, Thomas J.

82 History of the water supply of the world... also geology and water strata of Hamilton Co., Ohio... 134 pp, Cincinnati 1882

Bell, William A.

12 Joggins Carboniferous section of Nova Scotia. Can G S, Sum Rp 1911: 328-333 (1912)

13 Excursion in eastern Quebec and the maritime provinces; Horton-Windsor; the Joggins Carboniferous section. Int G Cong, XII, Canada, Guide Book no $1: 136$ $144,146-151,326-346$ (1913)

14 Joggins Carboniferous section, N. S. Can G S, Sum Rp 1912 : 360-371 (1914)

15 The Horton-Windsor Carboniferous area, N. S. Can G S, Sum Rp 1914:106107 (1915)

Bell, W. T.

ox The remarkable concretions of $\mathrm{Ot}$ tawa Co., Kans. Am J Sc (4) 11:315-316 (1901)

Bell, William H.

44 Mineral lands of the upper Mississippi. U S, 28th Cong 1st sess, H Ex Doc 43:52 pp (1844)

Belowsky, Max.

os Beiträge zur Petrographie des westlichen Nord-Grönlands. Deut G Ges, Zs 57: 15-90 (1905)

Belt, Thomas (1832-1878).

63 Some recent movements of the earth's surface. N S Inst N Sc, Pr Tr 1 pt 1:1930 (1863)
Belt, Thomas-Continued.

65 The production and preservation lakes by ice action. N S Inst N Sc, Pr T 1 pt 3:70-75 (1865) Abst, G Soc Los don, Q J 20:463-465 (1864); Ph Mag (4) $28: 323$ (1864)

66 The glacial period in North America. N S Inst N Sc, Pr Tr 1 pt $4: 91-106$ (1866)

74 Glacial phenomena in Nicaragua. An J Sc (3) 7:594-595 (1874)

75 Niagara; glacial and postglacial pbe nomena. Q J Sc 12 (n s 5) : 135-156, ma (1875) Reprint, 22 pp, L 1875.

76 Man and the glacial period, Q J \& 13 (n s 6) : 289-304 (1876) Pop Sc H $12: 61-74$ (1877)

78 On the discovery of stone implements in glacial drift in North America. Q J \& 15 (n s 8) : 55-74 (1878)

See also Dana, 75

Bement, Alburto.

05 The necessity for a geological surref of Illinois. Western Soc Eng, J 10:131166 (1905)

o6 Distribution of the coal beds of the State [of Illinois]. Ill S G S. B $3: 19-9$ (1906)

10 The Illinois coal field. Ill St G $\mathrm{S}, \mathrm{B}$ $16: 182-202$, maps (1910) Western Sox Ing, J 14:305-328, maps (1909) Awi Mines and Minerals $30: 709-712$ (1910)

13 The Illinois coal fields. Coal Age 3 558-562, maps (1913)

Bement, Clarence s.

8s Ueber neuere americanische Mineral vorkommen, Zs Kryst 14:256-257 (1888

Bender, George.

32 Specific gravities of the rocks used it the construction of the Delaware break water. Monthly Am J G 1:312-314 (1832)

\section{Bendrat, T. A.}

00 (with Herriek, C. L.) Identifict tion of an Ohio coal measures horizon in New Mexico. Am G 25:234-242 (1900 N Mex Univ, B 2:10 pp (1900)

04 The geology of Lincoln Co,, S. Dak. and adjacent portions. Am G $33: 65-94$ map (1904)

os Physiographic sketch of Lewis Co. N. Y. Science n s 28:380-381 (1908)

Benediet, A. C.

92 Petroleum in Indiana. Ind, Dp GI Res, An Rp 17:306-325 (1892)

92a (with Elrod, M. N.) Geology of Wabash Co. Ind, Dp G N Res, An Rp 17: 192-259 (1892)

94 (with Elrod, M. N.) Geology of Cass Co. Ind, Dp G N Res, An Rp 19:1739 (1894)

98 The Bayport, Mich., quarries. Stope $17: 153-164$ (1898)

Benedict, G. W.

24 Notice of new localities of sahlite augite, ceylanite, etc. $\Delta \mathrm{m} J$ Sc $8: 88-9 \%$ (1824) 
Benge, Elmer.

06 (and Wherry, E. T.) Directory of the mineral localities in and around Philadelphia. Mineral Collector 12:1-3, 49-51, 65-67, 89-91, 105-107, 119-121, 139-142 ; $13: 7-10,21-24,41-43,60-62,65-67,91-$ $93,109-111,129-132,151-154$ (1906) ; 13 : $161-163, \quad 183-184 ; \quad 14: 5-7, \quad 25-27,42$ $(1907) ; 15: 6-17,26-28,44-46,54-56,69-$ $70,85-86,107-109$ (1908)

Bengston, N. A.

15 (with Condra, G. E.) The Pennsylvanian formations of southeastern Nebraska. Nebr Ac Sc, Pub 9 no $2: 60$ pp (1915)

Benjamin, Marcus.

86 Mineral paints. U S G S, Min Res $1885: 524-533 ; 1886: 702-714$ (1886-7)

10 Charles Abiathar White [1826-1910]. Science n s 32 : 146-149 (1910)

10a Edward Drioker Cope, paleontologist, 1840-1897. In Leading American men of science, ed. by David Starr Jordan, pp 313-340, port, N Y 1910.

Benjamin, S. W.

0s Foothill copper belt of the Sierra Nevada. M Sc Press 97:490 (1908)

Benndorf, $\mathrm{H}$.

11 Microseismic movements. Seism Soc Am, B 1 : 122-124 (1911)

Bennett, John (Rev.)

Geology of southeastern Kansas. 17 pp, Monitor Book \& Ptg. Co., Ft. Scott, Kas. [189-?]

96 A geologic section along the Missouri Pacifie Railway from State line, Bourbon Co. to Yates Center; a geologic section along the Kansas River from Kansas City to MeFarland. Kans Univ G S $1: 86-98$, $107-124$ (1896)

96n A preliminary catalogue of the invertebrate paleontology of the Carboniferous of Kansas. Kans Univ G S $1: 270-310$ (1896)

96b (with Haworth, E.) A geologic section from Baxter Springs to the Nebraska State line. Kans Univ G S 1:3571 (1896)

00 (with Haworth, Erasmus) Native copper near Enid, Okla. G Soc Am, B 12 : 2-4 (1900)

08 (with Haworth, E.) History of [geological] fieldwork [in Kansas]. Kans Univ G S $9: 42-56(1908)$

08a (with Havorth, E.) General stratigraphy [of Kansas]. Kans Univ G S 9: 57-121 (1908)

08b (with Havorth, E.) The nomenclature of the Kansas coal measures employed by the Kansas State geological survey. Kans Ac Sc, Tr 21: 71-85 (1908)

Bennett, Lee F.

98 Four comparative cross sections of the Knobstone group of Indiana. Ind $\mathrm{Ac}$ Sc, Pr 1897: 258-262 (1898)
Bennett, Lee F.-Continued.

99 Notes on the eastern escarpment of the Knobstone formation in Indiana. Ind Ac Sc, Pr 1898: 283-287, map (1899)

00 Headwaters of Salt Creek in Porter Co. [Ind.]. Ind Ac Se, $\operatorname{Pr} 1899: 164-166$, $\operatorname{map}(1900)$

Bensley, B. Arthur.

02 On the identification of Meckelian and mylohyoid grooves in the jaws of Mesozoic and recent Mammalia. Toronty Univ Studies, Biol ser no $3: 9$ pp, il (1902)

13 A Cervalces antler from the Toronto interglacial. Toronto, Univ, Studies $\mathbf{g} \mathbf{s} 8$ : 3 pp, il (1913)

Benson, William Noel.

1s The origin of serpentine, a historical and comparative study. Am J Sc (4) 46 : 693-731 (1918)

Benton, Edward R.

78 The Richmond boulder trains. Harvard Coll, Mus C $\mathrm{Z}, \mathrm{B} \quad 5: 17-42$, map (1878)

so The amydaloidal melaphyre of Brighton, Mass. Boston Soc N H, Pr 20: 416-426 (1880)

86a Notes on samples of iron ore collected in northern New England; ... Maryland ; ... Virginia. U S, 10 th Census 15 : 79 $82,245-260,261-288$, maps (1886)

Berekhemer, Fritz.

14 (with Van Tuyl, F. M.) A problematic fossil from the Catskill formation [Delaware Water Gap, Pa.]. Am J Sc (4) $38: 275-276$, il (1914)

Bereman, T. A.

91 What caused the obliquity of the ecliptic? Sclence 17:93-95 (1891)

Berg, G.

os Ueber krystalline Schiefer aus dem Las Animas Canyon südlich von Silverton, Colo. Tschermaks Mitt N F 27:276-284 (1908)

Bergent, Alfred.

94 Zur Kentniss der Jungen Eruptivgesteine der Republik Guatemala. Deut G Ges, Zs $46: 131-157$ (1894)

02 Ein Rückblick auf die vulkanischen Ereignisse in Westindien im Mai 1902. Globus 82: 125-131 (1902)

o3 Die Produkte der letzten Eruption am Vulkan S. Maria in Guatemala (Oktober 1902). Centralbl Miner 1903:112117

03a Einige weitere Bemerkungen über die Produkte des Ausbruchs am Sta. Maria, Guatemala. Centralbl Miner 1903: $290-291$

09 Der Granodiorit von Concepción del Oro im Staate Zacatecas (Mexiko) und seine Kontaktbildungen. N Jb Beil Bd 28:421-573 (1909) Mex I G, B 27:109 pp (1910) 
Bergeat, Alfred-Continued.

09a Nontronit [from Concepcion de] Oro, Mexico], gebildet durch die Einwirkung ven Eisensulfatlösung auf Wollastonit. Centralbl Mineral 1909:161-168 (1909)

\section{Bergemann, C.}

52 Allanite from West Point, N. Y. Am J Se (2) $13: 416-417$ (1852)

Berser, W. F. B.

04 Bauxite in Arkansas. Eng M J 77 : 606-607 (1904)

Berger, Walter R.

18 The relation of the Fort Scott for mation to the Boone chert in southeastern Kansas and northeastern Oklahoma. J G 26:618-621, map (1918)

Berghes, Carlos de.

27 (with Gerolt, F. de) Carta geognostica de los principales distritos minerales del Estado de México ... [Scale 1: $25,000]$ Düsseldorf 1827 Reproduced, reduced, in Egloffstein, 64

See also Bustamante, 34

Bergt, W.

98 Zur Geologie von San Domingo. Nat Ges Isis Dresden, Szb 1897: 61-64 (1898)

Berkey, Charles Peter.

93 An apophyllite geode $(a b s t)$. Minn, Univ, Q B 1:114-115 (1893) Minn Ac N Sc, B 4:28 (1896)

94 Preliminary report of levelling party. Minn G S, An Rp 22: 134-140 (1894)

95 Notes on Minnesota minerals. Minn G S, An Rp 23: 194-202 (1895)

96 The occurrence of datolite on the north shere of Lake Superior (abst). Minn Ac N Sc, B 4:42-43 (1896)

96a The occurrence of copper minerals in hematite ore, Montana mine, Soudan, Minn. L Sup M Inst, $\operatorname{Pr} 4: 73-79$ (1896) Minn, Univ, Engineers Year Book 5:110117 (1897)

97 Geology of the St. Croix Dalles. Am G $20: 345-383$, maps (1897) ; $21: 139-155$, map, $270-294$, il (1898)

$97 \mathbf{a}$ On the occurrence of native copper and other copper minerals in the hematite ore of the Montana mine, Soudan, Minn. (abst). Science n s 6:363-364 (1897)

97b Glacial geology in the vicinity of Taylor's Falls, Minn. (abst). Science n s 5:364 (1897)

97e (with winchell, N. H.) The Fisher meteorite. Am G 20:316-318 (1897)

98 A guide to the Dalles of the St. Croix ... 40 pp, Minneapolis 1898

02 Sacred Heart "geyser spring" [Renville Co., Minn.]. Am G 29:87-88 (1902)

02a Origin and distribution of Minnesota clays. Am G 29:171-177 (1902) Abst, Minn Ac Sc, B 4:241-242 (1906)

04 Mineral resources of the Uinta Mountains. Eng M J 77:841 (1904)
Berkey, Charles Peter-Continued.

O4a A geological reconnaissance of th Uinta Reservation, northeastern एisi (abst). Science n s 19:618 (1904) N! Ac Sc, An 16:323-324 (1905)

05 Laminated interglacial clays Grantsburg, Wis., with chronological de ductions. J G $13: 35-44$, map (1905) Abst, Science n \& $21: 426$ (1905)

o5a Stratigraphy of the Uinta Mon tains. G Soc Am, B $16: 517-530$, mast (1905)

05b Economic geology of the Pembin region of North Dakota. Am G 35:14. 152, map (1905)

o5e [Paleogeography of St. Peter tim (abst).] Science n s 21:221 (1905) \& Am Sup $59: 24327$ (1905)

osd The paleogeography of mid-0 ro vicic time (abst). Science $n$ s $21: 96$ (1905)

06 Paleogeography of Saint Peter tim: G Soc Am, B 17:229-250 (1906)

06a Notes on the preglacial channels the lower Hudson Valley as revealed in recent borings (abst). Sclence n 824 691 (1906) N Y Ac Sc, An 18:294 (1906

06b Some geological features of the if cinity of Franconia, Minn. (abst). Mim Ac Sc, B $4: 194$ (1906)

o7 Structural and stratigraphic feature of the basal gneisses of the Highlands N Y St Mus, B $107: 361-378$ (1907)

07a Interpretation of certain inte glacial clays and their bearings upu measurement of geologic time $(a b s t)$. $\mathrm{Y}$ Ac Sc, An 17:574 (1907)

07b Palæography of North America dur ing mid-Ordovicic time (illustrated maps, diagrams, and lantern views) (abst N Y Ac Sc, An 17:591 (1907)

ore (with Hastings, J. B.) The geo ogy and petrograply of the Goldfield mith ing district, Nev. Am I M Eng, B 8:205314 (1906) ; Tr 37:140-159 (1907)

os Quality of bluestone in the vicinitf of the Ashokan dam [Kingston, N. I] Sch Mines Q 29:149-158 (1908)

08n Joint meeting of geologists of the northeastern United States with the ser tion of geology and mineralogy of the Ner York Academy of Sciences. Science n 828 : 573-576 (1908)

Osb A revised cross-section of the Bor dout Valley along the line of the Catskil Aqueduct (abst). Science n $\mathrm{s} 28: 351$ 352 (1908)

ose The acid extreme of the Cortland: series near Peekskill, N, Y. (abst). Scienct n s 28:575 (1908)

o8d Limestones interbedded with the Fordham gneiss in New York City (atst). Science n s 28: 936 (1908) 
Berkey, Charles Peter-Continued.

09 Areal and structural geology of southern Manhattan Island. N Y Ac Sc, An 19:247-2s2, map (1909) (abst). Science n s $29: 279-280$ (1909)

09a Characteristics of the older crystallines of southeastern New York (abst). Science n s 30:416 (1909)

10 Observations on rate of sea-cliff erosion (abst). G Soc Am, B 21: 778 (1910)

11 Geology of the New York City (Catskill) aqueduct. N Y St Mus, B $146 ; 283$ pp, map (1911)

$11 a$ (and Hyde, J. E.) Original ice structures preserved in unconsolidated sands. J G $19: 223-231$ (1911)

12 Geological features ... of the city tunnel of the Catskill Aqueduct. N Y City, Board of Water Supply, Rp on the eity tunnel : 115-186, map (1912) ; also issued as Columbia Univ, G Dp, Contr 23 no 11

12n (and Healy, John R.) The geology of New York City and its relations to engineering problems (with discussion). Municipal Engineers of the City of New York, $\operatorname{Pr} 1911: 5-39$ (1912)

12b Prominent structure of the northern margin of the Highlands [Moodna Valley] (abst). N Y Ac Sc, An 21: 210 (1912)

13 Field and office methods in the preparation of geologic reports; objects and methods of petrographic description. Ec G 8: 700-711 (1913)

13a Petrographic range of road building material. Sch Mines $Q \quad 35: 22-27$ (1913)

13b Is there fault control of the Hudson River course? (abst). N Y Ac Sc, An $22: 351$ (1913)

13e Geological light from the Catskill aqueduct (discussion by J. W. Spencer). G Soc Am, B 24: 711 (1913)

13a Objects and methods of petrographic description (abst). G Soc Am, B 24: 719 (1913)

14 Origin of some of the complex structures of the ancient gneisses of New York (abst). N Y Ac Sc, An 23: 309 (1914)

15 Origin of some complex structures of the ancient gneiss of New York; igueous contacts and transitions (abst). N Y Ac Sc, An 24: 353-355, 367 (1915)

15a Geological reconnaissance of Porto Rico. N Y Ac Sc, An $26: 1-70$, map (1915) Abst, G Soe Am, B $26: 113-114$ (1915)

16 Proceedings of the twenty-eighth annual meeting of the Geological Society of America, held at Washington, D. C., December 28,29 , and 30,1915 . G Soc $\mathrm{Am}$ B 27:1-138 (1916)

16a [Geological investigations in Porto Rico.] N Y Ac Sc, An 26:457-458 (1916)
Berlkey, Charles Peter-Continued.

17 Proceedings of twenty-ninth annual meeting of the Geological Society of America, held at Albany, N. Y., December 27, 28, and 29,1916 . G Soc Am, B 28:1-188 (1917)

17a Summary of geological investigations connected with the Catskill Aqueduct (abst). G Soc Am, B 28:174 (1917)

17b Unstable conditions exhibited by some of the rock foundations of the Hudson Valley (abst). N Y Ac Sc, An 27:256-257 (1917)

18 Genesis of the Sudbury nickel-copper ores (discussion). Am I M Eng, B 136: 855-857 (1918)

1Sa Charles Richard Van Hise (18571918). Am Mus J 18: 705-706 (1918)

See also Lingren, $15 \mathrm{~b}$; Roberts, 18 ; Roesler, 16; Tolman, $16 \mathrm{a}$

Bernard, Clinton $P$.

16. The cryolite mine at Ivigtut, Greenland. M Mag 14:202-203 (1916)

Bernard, Felix.

97 The principles of paleontology (extracted from Bernard's Eléments de palé. ontologie, Paris, 1895). N Y St G, An Rp 14:127-215 (1895) [1897] N Y St Mus, An $\mathrm{Rp} 48 v 2: 127-215$ (1895) [1897]

Bernard, H. M.

95 The zoological position of the trilobites. Sc Am Sup 40: 16533-16534, 1654916550 (1895)

Berry, Edward Wilber.

02 Notes on the pbylogeny of Liriodendron. Bot Gaz 34:44-63, il (1902)

02a Notes on Sassafras. Bot Gaz 34 : $426-450$, il (1902)

03 The flora of the Matawan formation (Crosswicks clays). N Y Bot Garden, B $3: 45-103$, il (1903)

03a The American species referred to Thinnfeldia. Torrey Bot Club, B 30:438445 (1903)

03b New species of plants from the Matawan formation. Am Nat $37: 677-684$, il (1903)

03e Aralia in American paleobotany. Bot Gaz 36:421-428 (1903)

o3d Notes on the Matawan formation and its flora (abst). Torreya $3: 64-65$ (1903)

04 The Cretaceous exposure near Cliffwood, N. J. Am G $34: 253-260$, il (1904)

04a Additions to the flora of the Matawan formation. Torrey Bot Club, B 31: $67-82$, il (1904)

04b A notable paleobotanical discovery [Lyginodendron]. Science n \& $20: 56-57$, 86-87 (1904)

04e Recent contributions to our knowledge of Paleozoic seed plants. Torreya $4: 185-188$ (1904)

o5 Additions to the fossil flora from Cliffwood, N. J. Torrey Bot Club, B 32 : 43-48, il (1905)

$$
28737^{\circ}-23-7
$$


Berry, Edward Wilber-Continued.

05a A Ficus confused with Proteoides.

Torrey Bot Club, B $32: 327-330$, il (1905)

05b A palm from the mid-Cretaceous [Flabellaria magothiensis from Maryland and Delaware]. Torreya $5: 30-33$, il (1905)

o5e An old swamp bottom. Torreya 5 : 179-182, il (1905)

05a Fossil grasses and sedges. Am Nat $39: 345-348$, il (1905)

05e The ancestors of the big trees. Pop Sc Mo $67: 465-474$ (1905)

06 Isolation and evolution. Seience $\mathrm{n} \mathrm{s}$ 23: 34 (1906)

06a $A$ note on mid-Cretaceous geography. Science n s $23: 509-510$ (1906)

O6b Fossil plants along the Chesapeake and Delaware canal. N Y Bot Garden, J $7: 5-7$ (1906)

o6e A brief sketch of fossil plants. $\mathrm{N} \mathrm{J}$ G S, An Rp 1905: 97-133, il (1906)

06d The flora of the Cliffwood clays. N J G S, An Rp 1905: 135-172, il (1906) o6e (and Gregory, W. K.) Proros marus alleni, a new genus and species of walrus from the upper Miocene of Yorktown, Va. Am J Sc (4) $21: 444-450$, il (1906)

06f Living and fossil species of Comp. tonia. Am Nat 40:485-524, il (1906)

06\& Contributions to the Mesozoic flora of the Atlantic Coastal Plain, I. Torrey Bot Club, B $33: 163-182$, 11 (1906)

O6h Pleistocene plants from Virginla. Torreya $6: 88-90$ (1906)

06i Leaf-rafts and fossil leaves. Torreya $6: 246-248$, il (1906)

o7 Coastal-plain amber. Torreya $7: 4-6$ (1907)

07a A Tilia from the New Jersey Pleistocene. Torreya $7: 80-81$ (1907)

07b Contributions to the Mesozoic flora of the Atlantic Coastal Plain. Torrey Bot Club, B 34: 185-205, il (1907)

07e Contributions to the Pleistocene flora of North Carolina. J G 15 : 338-349 (1907)

o7d Pleistocene plants from Alabama. Am Nat 41:689-700, il (1907)

oze Paleobotanical notes. Johns Hopkins Univ Cire n s 1907 no $7: 79-82$ [667670] (1907)

o7f New species of plants from the Magothy formation. Johns Hopkins Univ Cire n s 1907 no $7: 82-89$ [670-677], il (1907)

07g The stomata in Protophyllocladus subintegrifolius (Lesq.). Johns Hopkins Univ Circ n s 1907 no $7: 89-91$ [677-679] (1907)

os A Mid-Cretaceous species of Torreya [Tumion carolinianum, Cumberland Co., N. C.]. Am J Sc (4) 25:382-386, il (1908)

08 a Some araucarian remains from the Atlantic Coastal Plain. Torrey Bot Club, B $35: 249-260$, il (1908)
Berry, Edward Wilber-Continued.

08b A new Cretaceous Bauhinia. Tot reya $8: 218-219$, il (1908)

ose A Miocene cypress swamp. Torreya 8: 233-235 (1908)

09 A Miocene flora from the Virginis Coastal Plain. J G $17: 19-30$, il (1909)

09a Contributions to the Mesozoic flora of the Atlantic Coastal Plain; III, Ner Jersey. Torrey Bot Club, B 36:245-264, il (1909)

09b Additions to the Pleistocene flora of North Carolina. Torreya 9:71-73, \&] (1909)

09c Juglandacex from the Pleistocene of Maryland. Torreya $9: 96-99$, il (1909)

o9d Pleistocene swamp deposit in Virginia. Am Nat $43: 432-436$, il (1909)

09e The geologic relations of the Crets. ceous floras of Virginia and North Carolina (abst). Science n s 29:629 (1909) G Soc Am, B 20:655-659 (1910)

10 Contributions to the Mesozoic flora of the Atlantic Coastal Plain; IV, Maryland Torrey Bot Club, B 37:19-29, il (1910)

10a Contributions to the Mesozoic flor of the Atlantic Coastal Plain; V, North Carolina. Torrey Bot Club, B 37:181200 , il $(1910)$

10b Contributions to the Mesozoic flora of the Atlantic Coastal Plain; VI, Georgis. Torrey Bot Club, B 37:503-511, il (1910)

10e A new species of Dewalquea from the American Cretaceous. Torreya 10: $34-38$, il (1910)

10d Additions to the Pleistocene flora of New Jersey. Torreya 10:261-267, il (1910)

10e A revision of the fossil plants of the genus Nageiopsis of Fontafne. U \& Nat Mus, Pr 38:185-195, il (1910)

I0f A revision of the fossil plants of the genera Acrostichopteris, Taniopteris, Nilsonia, and Sapindopsis from the Poto mac group. U S Nat Mus, Pr $38: 625-$ 644 (1910)

10g A new Cretaceous Bauhinia frow Alabama. Am J Sc (4) $29: 256-258$, il (1910)

10h Additions to the Pleistocene flora of Alabama. Am J Sc (4) 29:387-398, il (1910)

10i A Cretaceous Lycopodium [Middendorf, S. C.]. $\triangle \mathrm{m} \mathrm{J} \mathrm{Sc} \mathrm{(4)} 30: 275-276$, il (1910)

10j The evidence of the flora regarding the age of the Raritan formation. J G $18: 252-258$ (1910)

101k An Eocene flora in Georgia and the indicated physical conditions. Bot Gat $50: 202-208$, il (1910)

101 The epidermal characters of Frenet. opsis ramossima. Bot Gaz $50: 305-309$, il (1910)

11 The flora of the Raritan formation. N J G S, B 3:233 pp, il (1911) 
Berry, Edward Wilber-Continued.

$11 \mathrm{a}$ The Lower Cretaceous floras of the world. Md G S, Lower Cret : 99-151 (1911)

11b Correlation of the Potomac formations. Md G S, Lower Cret : 153-172 (1911)

11c Systematic paleontology of the Lower Cretaceous deposits of Maryland; Plantæ. Md G S, Lower Cret: 214-508, il (1911)

11d A Lower Cretaceous species of Schizæaceæ from eastern North America. An Bot 25: 193-198, il (1911)

11e A study of the Tertiary floras of the Atlantic and Gulf Coastal Plain. Am Ph Soc, Pr 50:301-315, il (1911)

11f A revision of several genera of gymmospermous plants from the Potomac group in Maryland and Virginia. U S Nat Mus, Pr 40:289-318 (1911)

$11 \mathrm{~g}$ A revision of the fossil ferns from the Potomac group which have been referred to the genera Cladophlebis and Thyrsopteris. U S Nat Mus, $\operatorname{Pr} 41: 307-$ 332 (1911)

$11 \mathrm{~h}$ The age of the type exposures of the Lafayette formation. J G $19: 249-$ 256 (1911)

$11 i$ An Engelhardtia from the American Eocene. Am J Sc (4) $31: 491-496$, il (1911)

11j Contributions to the Mesozolc flora of the Atlantic Coastal Plain, VII. Torrey Bot Club, B $38: 399-424$, il (1911)

$11 k$ Notes on the ancestry of the bald cypress. Plant World 14:39-45 (1911)

111 (with Clark, W. B.) The Lower Cretaceous deposits of Maryland. Md G S, Lower Cretaceous : 23-98 (1911)

$11 \mathrm{~m}$ (with Lull, R. S.) Systematic paleontology of the Lower Cretaceous deposits of Maryland. Md G S, Lower Cretaceous : 179-596 (1911)

12 Geology of the Virginia Coastal Plain: Lower Cretaceous. Va G S, B 4: 61-86, il (1912)

12a American Triassic Nevcalamites. Bot Gaz 53:174-180, il (1912)

12b Notes on the genus Widdringtonites. Torrey Bot Club, B $39: 341-347$, il (1912)

12e Contributions to the Mesozoic flora of the Atlantic Coastal Plain; VIII, Texas. Torrey Bot Club, B $39: 387-406$, il (1912)

12d Pleistocene plants from the Blue Ridge in Virginia. Am J Sc (4) $34: 218-$ 223 , il (1912)

12e The age of the plant-bearing shales of the Richmond coal field. Am J Sc (4) 34: 224-225 (1912)

12f Notes on the geological history of the walnuts and hickories. Plant World $15: 225-240$, il (1912) Smith Inst, An $\mathrm{Rp}$ 1913 : 319-331 (1914)

$12 \mathrm{~g}$ Some ancestors of the persimmon. Plant World 15:15-21, il (1912)
Berry, Edward Wilber-Continued.

12h Notes on the present status of paleobotany. Plant World 15:169-175 (1912)

$12 i$ (with Clark, W. B.) The physiography and geology of the Coastal Plain province of Virginia; Lower Cretaceous. Va G S, B 4 (1912)

13 A fossil flower from the Eocene [ Combretanthites eocenica from Wilcox group, Fayette Co., Tenn.]. U s Nat Mus, Pr $45: 261-263$, il (1913)

13a Contributions to the Mesozoic flora of the Atlantic Coastal Plain; IX, Alabama. Torrey Bot Club, B 40:567-574 (1913)

13b Status of the study of the fossil floras of the Atlantic Coastal Plain (abst). G Soc Am, B 24:114 (1913)

14 The Upper Cretaceous and Eocene floras of South Carolina and Georgia. U S G S, P P 84:200 pp, il (1914) Abst, Wash Ac Sc, J $4: 330$ (1914)

$14 a$ The affinities and distribution of the lower Eocene flora of southeastern North America. Am Ph Soc, Pr 53:129250 (1914)

14b Contributions to the Mesozoic flora of the Atlantic Coastal Plain; X, Maryland. Torrey Bot Club, B 41, 295-300 (1914)

14e Two new Tertiary species of Trapa. Torreya 14 : 105-108, il (1914)

14d Additions to the Pleistocene flora of the Southern States. Torreya 14:159162 (1914)

14e A Nipa palm in the North American Eocene. Am J Sc (4) 37:57-60 (1914)

$14 \mathrm{f}$ Fruits of a date palm in the Tertiary deposits of eastern Texas. Am J Sc (4) $37: 403-406$, il (1914)

$14 \mathrm{~g}$ Notes on the geologic history of Platanus. Plant World $17: 1-8$, il (1914)

14h Fossil plants in the Panama canal zone. Science n s 39:357 (1914)

$14 i$ The geologic and biologic results of a study of the Tertiary floras of southeastern North America (abst). Science n s $39: 843$ (1914)

15 Erosion intervals in the Eocene of the lississippi embayment. U S G S, P P 95: 73-82, maps (1915) Abst, Wash Ac Sc, $\operatorname{Pr} 6: 92-93$ (1916)

15a The age of the Cretaceous flora of southern New York and New England. J G 23:608-618 (1915)

15b The Mississippi River bluffs at Columbus and Hickman, Ky., and their fossil flora, U S Nat Mus, Pr 48:293-303, il (1915)

15e Paleobotanic evidence of the age of the Morrison formation. G Soc Am, B $26: 335-342$ (1915)

15d An Eocene ancestor of the Zapodilla [Eoachras eocenica]. Am J Sc (4) 39 : 208-213, il (1915) 
Berry, Edward Wilber-Continued.

15e The origin and distribution of the family Myrtaceae. Bot Gaz 59:484-490 (1915)

15f Pleistocene plants from Indian Head, Md. Torreya 15:205-208, il (1915)

- 16 The Upper Cretaceous floras of the world. Md G S, Upper Cret:183-313 (1916) Rev by Charles Schuchert, Am J Sc (4) $42: 81-82$ (1916)

16a The lower Eocene floras of southeastern North America. U S G S, P P 91: $481 \mathrm{pp}$, il (1916) Abst, Wash Ac Sc, J $6: 663-664$ (1916)

16b The physical conditions and age indicated by the flora of the Alum Bluff formation. U S G S, P P 98:41-59, il (1916) Abst, Wash Ac Sc, J 6:567 (1916)

16e The physical conditions indicated by the flora of the Calvert formation. U S G S, P P 98:61-73, il (1916) Abst, Wash Ac Sc, J 6:567 (1916)

16d The flora of the Citronelle forma tion. U S G S, P P 98: 193-208, il (1916)

16e The flora of the Catahoula sandstone. U S G S, P P 98:227-251, il (1916)

161 Contributions to the Mesozolc flora of the Atlantic Coastal Plain; XI, Tennessee. Torrey Bot Club, B $44: 283-304$, il (1916)

16g A Zamia from the lower Eocene [of Meridian, Miss.]. Torreya $16: 177-179$, il (1916)

16h A petrified palm from the Cretaceous of New Jersey. Am J Sc (4) 41:193197, il (1916)

161 A fossil nutmeg from the Tertiary of Texas. Am J Se (4) $42: 241-245$, il (1916)

16j Upper Cretaceous floras of the world. Nat Ac Sc Pr 2:186-187 (1916)

16k The geological history of gymnosperms. Plant World $19: 27-41$ (1916)

161 Remarkable fossil fungi. Mycologia $8: 73-79$, il (1916)

$16 \mathrm{~m}$ (with Clark, W. B., and Gardner, J. A.) The age of the middle Atlantic coast upper Cretaceous deposits. Nat Ac Sc, Pr 2:181-187 (1916)

16n (with Clark, W. B., and Gardner, J. A.) Correlation of the Upper Cretaceous formations. Md G S, Upper Cret : 315-341 (1916)

17 Geologic history indicated by the fossiliferous deposits of the Wilcox group (Eocene) at Meridian, Miss. U $\mathbf{S} \mathbf{G}$, P P 108: 61-72, il (1917) Abst, by R. W. Stone, Wash Ac Sc, J 7:601 (1917)

17a Contributions to the Mesozoic flora of the Atlantic Coastal Plain; XII, Arkansas. Torrey Bot Club, B $44: 167-190$, il (1917)
Berry, Edward Wilber-Continued.

17b a middle Eocene Goniopteris. Tor. rey Bot Club, B 44:331-335, il (1917)

17e Pleistocene plants in the marine clays of Maine. Torreya $17: 160-163$, is (1917)

17d The delta character of the Tusca. loosa formation. Johns Hopkins Unfv, Cire n s 1917, no $3: 18-24$ [216-222] (1917) 17e A middle Eocene member of the "sea drift." Am J Sc (4) 43: 298-300, il (1917)

17f A sall fish from the Virginia Miocene [Istiophorus calvertensis]. Am J Sc (4) $43: 461-464$, il (1917)

$17 \mathrm{~g}$ Plants associated with human remains at Vero, Fla. (abst, with discussion by E. H. Sellards). G Soc Am, B 28:197198 (1917)

17h The fossil plants from Vero, Fla. J G 25: 661-666 (1917)

17i The fossil plants from Vero, Fla. Fla G S, An Rp 9:19-33 (1917)

17j William Bullock Clark. Am J Sc (4) $44: 247-248$ (1917)

17k Notes on the bistory of the willows and poplars. Plant World 20:16-28, 1l (1917)

171 The Mississippi Gulf three million years ago. Sc Mo 4:274-283 (1917)

$17 \mathrm{~m}$ Rilly, a fossil lake. Sc Mo 5: 175-185 (1917).

18 The fossil higher plants from the Canal Zone. U S Nat Mus, B 103: 15-44, il (1918)

18a Fossil plants from the late Tertiary sf Oklahoma. U S Nat Mus, Pr 54:627636, il (1918)

18b A restoration of Neocalamites. Am J Sc (4) $45: 445-448$, il (1918)

18e Notes on the fern genus Clathrop. teris. Torrey Bot Club, B $45: 279-285$, Il (1918)

18d Paleogeographic significance of the Cenozoic floras of equatorial America and the adjacent regions. G Soc Am, B 29: 631-636 (1918)

18e The history of the linden and ash. Plant World 21:163-175, il (1918)

18P Geologic history of the locust and its allies. Plant World $21: 284-298$, il (1918)

18e (with Clark, W. B, and Mathews, E. B.) The surface and underground water resources of Maryland, including Delaware and the District of Columbia. Md G S 10:169--542 (1918)

See also Clark (W B), 12a, 16b; Schuchert, 16

Berry, Hattie M.

11 (with Pratt, J. H.) The mining industry in North Carolina during 1908, 1909, and 1910. N C G S, Ec P 23:13ł (1911) 
Swallow, George Clinton-Continued.

65 (and Hawn, F.) Report of the geologieal survey of Miami Co., Kans. 24 pp, map, Kansas City, Mo., 1865. Also in Prel Rp: 71-94 (1866)

66 Preliminary report of the geological survey of Kansas. $198 \mathrm{pp}$, Lawrence, Kans., 1866

66 Notes on some points in the geology of Kansas. Am J Sc (2) 41:405-406 (1866)

66b Some new varieties of spirifer... Ac Sc St L, Tr 2:408-410 (1866)

66c Notice of the remains of the horse in the altered drift of Kansas. Ac Sc St L, Tr 2: 418 (1866)

67 Section of the rocks in eastern $\mathrm{Kan}$ sas. Am As, Pr 15:57-82 (1867)

67a Physical geography of Missouri. Mo St Bd Agr, An Rp 2:58-79 (1867)

67b Geology; mineral and agricultural resources of Missouri. In Parker, Nathan H. Missouri as it is in $1867 \ldots: 109-154$, Phila 1867

$68 \mathrm{Mr}$. Meek's notes on my preliminary report of the geology of Kansas, as edited by Dr. Hayden. Ac Se St L, Tr 2: 507-526 (1868)

71 Remarks on the geological map and section of the rocks of Missouri (abst). Am Nat 5: 541-542 (1871) Am As, Pr $20: 262$ (1872)

73 Geology. In Campbell's new atlas of Missouri... : 106-116, map, Saint Louis 1873

74 Physieal geography [including geology ]. In Campbell, R. A., Gazetteer of Missouri : $755-790$, St. Louis 1874

$7 \boldsymbol{7}$ Geology, mines, minerals, waters, prairies, timber, and soils of Missouri. In The Commonwealth of Missouri (ed. by C. R. Barns) : 497-536, St. Louis 1877 Also in Switzler's Illustrated history of Missouri : 497-536, St. Louis, 1879

83 Geology of Greene Co. In History of Greene County, Missouri... : 573-575, St. Louis, Western Historical Company, 1883 Swartley, Arthur M.

14 Ore deposits of northeastern Oregon. Oreg Bur Mines, Min Res Oreg 1 no 8 : 229 pp, maps (1914)

16 (with Parks, H. M.) Handbook of the mining industry of Oregon. Oreg Bur Mines, Min Res Oreg 2 no 4:306 pp, map (1916)

Swartz, Charles Kephart.

o7 The Ithaca fauna of Maryland. Johns Hopkins Univ Circ n s 1907 no 7 : $50-55$ [638-643]

07 a The relation of the Columbus and Sandusky formations of Ohio. Johns Hopkins Univ Circ n s 1907 no $7: 56-65$ [644-653]

of The succession of faunas in the Portage and Chemung formations of Maryland. J G 16:328-346 (1908)
Swartz, Charles Kephart-Continued.

09 Proposed classification of crys based on the recognition of seven fuid mental types of symmetry. G Soc An 20:369-398 (1909) Abst, Science in s s 631 (1909)

10 Recurrence of the Tropidolept fauna in the Chemung of Maryland. Soe Am, B 20:679-686 (1910) Alt Science, n s 29:635 (1909)

10a A generalized section through to Appalachian Mountains of Maryland (abt Science n s $32: 189$ (1910); (with dise sion), G Soc Am, B 21: 769-770 (1910)

12 (with Stose, G. W.) Descriptin of the Pawpaw and Hancock quadrangl [Md.-W. Va.-Pa.]. U S G S, G Atlas, t 179 (1912) (Abst), Wash Ac Sc, J 2:41] (1912)

13 (and others) Lower Devonian; th troduction. Md G S, Lower Devonian 23-66, map (1913)

13a (and others) Local sections of the Lower Devonian [of Maryland]; Correlk tion of the Lower Devonian. Md G 5 Lower Devonian : 96-190 (1913)

13b Systematic paleontology of the Lower Devonian deposits of Marylad Cœlenterata. Md G S, Lower Devonian: 195-227 (1913)

13e Correlation of the Upper Devonian Local sections of the Upper Devonian [f Maryland]. Md G S, Middle and Lppe Devonian : 410-534 (1913)

13d Systematic paleontology of t Upper Devonian deposits of Maryland Pisces. Md G S, Middle and Upper De vonian : 700-701, il (1913)

16 (and Pronty, W. F.) Silurian st? tem of Maryland ( $a b s t$, with discussion G. W. Stose and G. H. Chadwick). Soc Am, B 27:89 (1916)

Sweet, Edmund Theodore.

76 Catalogue of the Wisconsin State mineral exhibit at Philadelphia 1876 lis cludes descriptions of formations]. Is The State of Wisconsin ... and a catalogut of its exhibits at the Centennial at Phila. delphia, 1876:1-57 [catalogue], Madison, Wis., 1876

76a Notes on the geology of norther Wisconsin. Wis Ac Sc, Tr 3:40-55 (1876)

78 [Report on Douglas and Bayfield cos.] Wis G S, An Rp 1877:4-9 (1878)

80 Geology of the western Lake Superiot district. [Wis G S], G Wis $3: 303-362$ maps (1880)

Sweetser, Nelson W.

10 Geology of the Jarbidge mining dit trict, Nev. M Sc Press 101:871-872 (1910)

Sweezey, R. O.

13 Molybdenite deposit at Turn Back Lake, Que. Can M J 34:190-191 (1913) 
swem, Earl G.

96 A preliminary report on the glaciated area of Kansas. Kans Univ Q 4:153-159 (1896)

Swezey, Goodwin Deloss.

82 On some points in the geology of the region about Beloit. Wis Ac Sc, Tr 5: 194-204 (1882)

93 Evidence of two premorainic glacial movements (abst). Nebr Ac Sc, Pub 3 : 11 (1893) Science 21:216 (1893)

swineford, A. P.

76 History and review of the copper, iron, silver, slate, and other material interests of the south shore of Lake Superior. $280 \mathrm{pp}$, Marquette, Mich., 1876

Sword, J. D.

96 The Trail Creek gold mining district of British Columbia. [Fed] Can M Inst, J $1: 83-95$ (1896) Can M Rv 15:18-19 (1896)

sykes, Godfrey.

15 (with MacDougal, D. T.) The travertine record of Blake Sea [Cal.]. Science n s 42:133-134 (1915)

sylvester, A. H.

08 Evidences of recent volcanic activity and the glaciers of Mt. Hood, Oreg. (abst). Science n \& $27: 585$ (1908)

08a Is our noblest volcano awakening to new life? A description of the glaciers and evidences of volcanic activity of Mount ltood. Nat Geog Mag 19:515-525 (1908) symons, Brenton.

09 Mineral resources of Newfoundland. M Jour, London, 87:167-169 (1909)

10 The mineral resources of Newfoundland. Eng M J 90:360-363 (1910)

11 The Wabana iron mines [Newfoundland]. Eng M J 91:1008-1010, map (1911)

Symons, Thomas W.

82 The upper Columbia River and the Great Plain of the Columbia. U $\mathrm{S}, 47$ th Cong 1st sess, S Ex Doc 186: 133 pp, maps (1882)

Szabo, Joseph.

79 The Tertlary eruptive rocks. Am Nat 13: $399-402$ (1879)

Taber, C. A. M.

07 The cause of geologic periods. $68 \mathrm{pp}$, Baston 1907

10 Our periodic earth. 54 pp, Boston 1910

Taber, Stephen.

06 Some local effects of the San Francisco earthquake. .J G $14: 303-315$ (1906) Reprinted in Jordan, D. S., editor, The California earthquake of $1906: 257-280$, San Francisco 1907

10 (with Watson, T. L.) The Vir ginia rutile deposits. U S G S, B 430 200-213 (1910)

10a (with Watson, T, L.) Nelsonite, a new rock type ... (abst). G Soc Am, B 21:787 (1910)
'Taber, Stephen-Continued.

11 The importance of displaced objects in studying the character of earthquake motion in megaseismic areas. Seism Soc Am, B $1:$ 149-158 (1911)

13 Geology of the gold belt in the James River basin, Va. Va G S, B $7: 271$ pp, map (1913)

13a The South Carolina earthquake of January 1, 1913. Seism Soc Am, B 3: 6-13 (1913)

13b Earthquakes in Buckingham Co., Va. Seism Soc Am, B 3:124-133, map (1913)

14 Seismic activity in the Atlantic Coastal Plain near Charleston, S. C. Seism Soc Am, B 4:108-160 (1914)

15 Earthquakes in South Carolina durlng 1914. Seism Soc Am, B 5:96-99 (1915)

16 The origin of veins of the asbestiform minerals. Nat Ac Sc, Pr 2: 659-664 (1916)

$16 a$ The genesis of asbestos and asbestiform minerals (with discussion by J. C. Branner, J. A. Dresser, R. P. D. Graham, and G. P. Merrill). Am I Eng, B 119: $1973-1998$ (1916); $123: 397-405 ; 125$ : $825-827$ (1917); $\operatorname{Tr} 57: 62-98$ (1918)

16b The earthquake in the southern Appalachians, February 21, 1916. Seism Soc Am, B 6:218-226, map (1916)

16e The growth of crystals under external pressure. Am J Sc (4) 41:532$556(1916)$

17 Pressure phenomena accompanying the growth of crystals. Nat Ac Sc, Pr 3: $297-302$ (1917)

17a The origin of chrysotile veins (dis. cussion). Ee G 12:476-479 (1917)

$\mathbf{1 7 b}$ Origin of veinlets in the limestone, shale, and gypsum beds of central New York (abst). G Soc Am, B 28: 131 (1917)

18 The origin of the veinlets in the Silurian and Devonian strata of central New York. J G 26:56-73 (1918)

18a The mechanics of vein formation. Am I M Eng, B 140:1189-1222 (1918) Discussion by Blamey Stevens, B 144: $1768-1770$ (1918)

18b Pressure in the formation of ore deposits. M Sc Press 116:128-130 (1918)

Tan, Joseph Alexander.

91 The Cretaceous deposits [of El Paso Co.]. Tex G S, An Rp 2: 714-738 (1891) 92 Report [on southern and central Texas]. Tex G S, Rp Prog 2 (1891) : 7077 (1892)

92a Reports on the Cretaceous area north of the Colorado River; I, The Bosque division: II, The Lampasas-Williamson section. Tex G S, An Rp 3: 267-379 (1892)

93 Report on the Cretaceous area north of the Colorado River. Tex $\mathbf{G} \mathbf{S}, \mathbf{\Delta n} \mathrm{Rp}$ 4 pt $1: 241-354$, maps (1893)

93a [On Cretaceous rocks of Mexas]. Am G 11: 128-130 (1893) 
Ta f, Joseph Alexander-Continued.

96 (and Brooks, A. H.) Description of the Buckhannon quadrangle [W. Va.]. U S G S, G Atlas Buckhannon fol (no 34 ): 4 pp, maps (1896)

96a Structure of the Elk Garden coal fields [Md-W. Va.] (abst). Science $\mathrm{n}$ s 3 : 374 (1896)

96b (with Darton, N. H.) Description of the Piedmont sheet [W. Va.-Md.]. U S G S, G Atlas Piedmont fol (no 28):6 pp, maps (1896)

98 Geology of the McAlester quadrangle (abst). Science n s 7:612 (1898)

99 Geology of the McAlester-Lehigh coal field, Indian T. U S G S, An Rp 19 pt 3 : 423-456, maps (1899)

99a An albertite-like asphalt in the Choctaw Nation, Indian Territory. Am J Sc (4) $8: 219-224$, map (1899)

99b Changes in the Canadian River in western Choctaw Nation, Ind. T. (abst.) Science n s 10:26 (1899)

00 (and Adams, G. I.) Geology of the eastern Choctaw coal field, Indian $\mathrm{T}$. U S G S, An Rp 21 pt 2:257-311, maps (1900)

Oon Preliminary report on the Camden coal field of southwestern Arkansas. U S G S. An Rp 21 pt $2: 313-329$, maps (1900)

00 b Structural features of the Ouachita Mountain Range in Indian Territory (abst). Science n \& 11: 187-188 (1900)

01 Description of the Colgate quadrangle [Ind. T.]. U S G S, G Atlas Colgate fol (no 74):6 pp, maps (1901)

O1a A comparison of the Ouachita and Arbuckle Mountain sections, Ind. T. (abst). Science n s 13 : 271-272 (1901)

02 Description of the Atoka quadrangle [Ind. T.]. U S G S, G Atlas A toka fol (no 79): 8 pp, maps (1902)

02a The southwestern coal field. U S G S, An Rp 22 pt $3: 367-413$, maps (1902)

02b Chalk of southwestern Arkansas. U S G S, An Rp 22 pt 3:687-742, il, maps (1902)

03 Description of the Tishomingo quadrangle [Ind. T.]. U S G S, G Atlas Tishomingo fol (no 98) : 8 pp, maps (1903)

04 Preliminary report on the geology of the Arbuckle and Wichita mountains in Indian Territory and Oklahoma. U S G S, P P 31:1-81, maps (1904)

04a Maps of segregated coal lands in the McAlester district, Choctaw 'Nation, Ind. T., with descriptions of the unleased segregated coal lands. U S, Dp Int, Circ no 1:59 pp, maps, Washington 1904

04h Maps of segregat. coal lands in the Wilburton-Stigler district, Choctaw Nation, Ind. $T$, ... U S, Dp Int, Cire no 2: $47 \mathrm{pp}$, maps, Washington 1904
Tan, Joseph Alexander-Continued.

o4e Maps of segregated coal lands the Howe-Poteau distriet, Choctaw Natin Ind. T. ... U S, Dp Int, Circ no $3: 48$ n maps, Washington 1904

04d Maps of segregated coal lands the McCurtain-Massey district, Chocts Nation, Ind. T. ... U S, Dp Int, Circ 4:54 pp; maps, Washington 1904

o4e Maps of segregated coal lands b the Lehigh-Ardmore districts, Choctaw an Chickasaw nations, Ind. T. ... U S, Dp It Cire no $5: 39$ pp, maps, Washington 19 -

O4f Description of the unleased segn gated asphalt lands in the Chickasaw $\mathrm{N}$ tion, Ind. T. ... U S, Dp Int, Circ no $14 \mathrm{pp}$, Washington 1904

o5 Description of the Tahlequah quad rangle [Ind. T.-Ark.]. U S G S, G Ath Tahlequab fol (no 122) : $7 \mathrm{pp}$, maps (1905

osa Portland cement resources of indian Territory. U S G S, B 243:144-14 (1905)

05b Portland cement resources of Terss U S G S, B 243: 307-310 (1905)

05e Progress of coal work in Indian Territory. U S G S, B 260:382-401, maps (1905)

o5d (and Shaler, M. K.) Notes on the geology of the Muscogee oil flelds, Ind. T U S G S, B 260:441-445, map (1905)

o5e Some erratic boulders in middy Carboniferous shale in Indian Territory (abst). Science n s 21:225 (1905)

06 Decsription of the Muscogee quad. rangle [Ind. T.]. U S G S, G Atlas Musct gee fol (no 132): $7 \mathrm{pp}$, maps (1906)

06a Notes on the Weber River coal field, Utah. U S G S, B 285 : 285-288 (1906)

O6b Book Cliff's coal field, Utah, west of Green River. U S G S, B $285: 289-302$ map (1906)

o6e (and Smith, C. D.) Ozokerite deposits in Utah. U S G S, B $285: 369-372$ (1906)

06d Natural coke in the Wasatch Pla. teau (abst). Science n \& 23:696 (1906)

07 The Durango coal district, Colo. U 8 G S, B 316:321-337 (1907)

07a The Pleasant Valley coal district. Carbon and Emery cos., Utah. U S G S, B 316:338-358 (1907)

07b Asphalt and bituminous rock. U S G S, Min Res $1906: 1131-1137 ; 1907$ pt 2 : $723-730 ; 1908$ pt $2: 707-715$ (1907-9)

o9 The Sheridan coal field, Wyo. U \& G S, B 341: 123-150, map (1909)

O9a Grahamite deposits of southeastern Oklahoma. U S G S, B $380: 286-297$ (1909)

o9b Ice-borne boulder deposits in midCarboniferous marine shales $(a b s t)$. Sclence $n$ s, 29:637 (1909) G Soc Am, B $20: 701-702$ (1910) 
Tafi, Joseph Alexander-Continued.

09e (and Reed, W. .J.) The Madill oil pool, Okla. U S G S, B 381: 504-513, map (1909)

13 Eocene of the Coalinga-Cantua district, Fresno Co., Cal. (abst, with discussion by F. M. Anderson, A. C. Lawson, and W. Stalder). G Soc Am, B 24:127-128 (1913)

15 Proceedings of the summer meeting of the Geological Society of America, held at the University of California and at Stanford University, August 3, 4, and 5, 1915

See also Eckel, 13; Ruckman, 13

Taft, H. H.

05 Notes on southern Nevada and Inyo Co., Cal. Am I M Eng, Bi-Mo B 6:12791298 (1905) ; Tr $37: 178-197$ (1907)

06 Goldfield and Tonopah. Eng M J $81: 557-558$ (1906)

06a Notes on Inyo Co., Cal. Eng M J 81: 704-705 (1906)

07 Notes on southern Nevada and Inyo Co., Cal. Am I M Eng, Tr 37:178-197 (1907)

16 Notes on the tungsten ores of the Southwest. M World 44:1047-1048 (1916) 18 A Wyoming platinum mine. Eng M J $106: 900$ (1918)

Tait, James L.

89 Report of geologists for southern Texas. Tex G S, Rp Prog 1 (1888) : 64-69 (1889)

S9a Gas well at San Antonio [Tex.]. G Sc B 1 no 10 (1889)

Talbot, Mignon.

03 A contribution to a list of the fauna of the Stafford limestone of New York. Am J Sc (4) 16:148-150 (1903)

05 Revision of the New York Helderbergian crinoids. Am J Sc (4) 20:17-34, il $(1905)$

11 Podokesaurus holyokensis, a new dinosaur from the Triassic of the Connecticut Valley. Am J Sc (4) $31: 469-479$ (1911)

Talbutt, John H.

76 (with Peter, Robert) Chemical re. port of the soils, marls, clays, ores, coals, iron furnace products, mineral waters, etc., etc. of Kentucky. Ky G S, Rp Prog 1 n s : 137-316 (1876) Reprinted in $\mathrm{Ky} G \mathrm{~S}$, Chemical Analyses A [1]:1-180 (1884)

78 (with Peter, Robert.) Chemical re port of the soils, coals, ores, iron furnace products, clays, marls, mineral waters, rocks, etc., of Kentucky. Ky G S, Rp Prog 4 n s: 1-166 (1878) Reprinted in Ky G S, Chemical Analyses A [1]: 181-345 (1884)

Taliaferro, N. L.

18 (with Moody, C. L.) Anticlines near Sunshine, Park Co., Wyo. Cal Univ, Dp G, B $10: 445-459$ (1918)

Tallman, Clay.

09 The Bullerog district [Nev.]. Am M Cong, 12th An Sess, Rp Pr : 428-437 (1909)
Tallmon, Marion Clover.

04 (with Morgan. W. C.) A peculiar occurrence of bitumen and evidence as to its origin. $\mathrm{Am} \mathrm{J}$ Sc (4) $18: 363-377$ (1904)

$04 a$ (with Morgan, W. C.) A fossil egg from Arizona. Cal Univ, Dp G, B 3 : $403-410$, il (1904)

TaImage, James Edward.

93 A remarkable occurrence of selenite. Science 21:85-86 (1893)

95 Geology as a popular study. Utah Univ Q 1:114-119 (1895)

95a Notes concerning a peculiarly marked sedimentary rock. Utah Univ Q 1: 193-197 (1895) Abst, J G 4:653-654 (1896)

96 The Great Salt Lake, past and present. Utah Univ $Q \quad 2: 73-82, \quad 137-152$ (1896)

00 The great Salt Lake, present and past. 116 pp, Salt Lake City, Utah, 1900

00 a Notes concerning erosion forms and exposures in the deserts of south central Utah (abst). Science n s 11:220 (1900)

oob On certain peculiar markings on sandstones from the vicinity of Glen Canyon, Ariz. (abst). Science n s 11:220 (1900)

ooe Conglomerate "puddings" from the Paria River, Utah (abst). Science n s 11: 220-221 (1900)

01 Geology of Utah. Int $M$ Cong, $4 \mathrm{th}$, Pr : 42-48 (1901)

01a A recent fault slip. Ogden Canyon, Utah. Science n s 13:550 (1901)

01 b The Great Salt Lake [Utab]. Scottish Geog Mag 17:617-644 (1901)

02 Lake Bonneville, the predecessor of the Great Salt Lake. Scottish Geog Mag $18: 449-471$ (1902)

o7 Seismographs in Utah. Science $\mathrm{n} \mathrm{s}$ $26: 556-558 \quad(1907$

11 The Deseret Museum [includes notes on mammoth selenite crystals from southern Utah]. Deseret Museum $\mathrm{B}, \mathrm{n} \mathbf{s}$ no 1 : $32 \mathrm{pp}$ (1911)

Tanton, T. L.

15. The Harricanaw Basin north of the Grand Trunk Pacific Railway, Que. Can G S, Sum Rp 1914: 96-98 (1915); 1915 : 168-170, map (1916)

17 Reconnaissance along Canadian Northern Railway between Gogama and Oba, Sudbury and Algoma districts, Ont. Can G S, Sum Rp 1916:179-182 (1917)

Tappan, Benjamin.

28 on the boulders of primitive rocks found in Ohio and other Western States and Territories. Am J Sc 14 : 291-297 (1828)

Tarr, R. P.

o7 The coal resources of Washington. Mines and Minerals $30: 17-19,108-110$, 135-138, 311-314, map (1907) 
Tarr, Ralph Stockman (1864-1912).

85 Sketch of Professor Alpheus Hyatt. Pop Sc Mo 28:261-267, port (1885)

90 A preliminary report on the coal fields of the Colorado River. Tex $G \mathrm{~S}$, An Rp 1: 199-216 (1890)

90a Drainage systems of New Mexico: Am G 5:261-270 (1890)

$90 \mathbf{b}$ The Carboniferous area of central Texas. Am G 6:145-153 (1890)

90e Origin of some topozraphic features of central Texas. Am J Sc (3) $39: 306-$ $311(1890)$

90d On the Lower Carboniferous limestone series in central Texas. Am J Sc (3) $39: 404(1890)$

90e Superimposition of the drainage in central Texas. Am J Sc (3) 40:359-362 (1890)

900 Erosive agents in the arid regions. Am Nat 24:455-459 (1890)

91 The phenomenon of rifting in granite. Am J Sc (3) 41:267-272 (1891) Eng M J 51:604-605 (1891)

91 a $A$ recent lava flow in New Mexico. $1 \mathrm{~m}$ Nat $25: 524-527$ (1891)

92 Reconnaissance of the Guadalupe Mountains. Tex G S, B 3:42 pp (1892)

92a The Cretaceous covering of the Texas Paleozoic. Am G 9:169-178 (1892)

92b The relation of secular decay of rocks to the formation of sediments. Am G $10: 25-44$ (1892)

92e The Permian of Texas. Am J Sc (3) $43: 9-12 \quad(1892)$

92d The central Massachusetts moraine. Am J Sc (3) 43: 141-145 (1892)

$92 \mathrm{~A}$ hint with respect to the origin of terraces in glaciated regions. Am J Sc (3) $44: 59-61 \quad(1892)$

93 Glacial erosion. Am G 12 : 147-152 (1893)

93a Notes on the physical geography of Texas. Ac N Sc Phila, Pr 1893:313-347

93b The glacial period. Sc Am $68: 86$, 103 (1893)

93e Extinct volcanoes in the United States. Sc Am Sup 36:14657-14658 (1893)

93d The new physical geography. Sc Am Sup $36: 14975-14976$ (1893)

93e (with Wo1n, J. E.) Acmite trachyte from the Crazy Mountains, Mont. Harvard Coll, Mus C Z, B 16 (g s 2): 227-233 (1893)

94 Economic geology of the United States... 509 pp. N Y 1894

94a Lake Cayuga a rock basin. G Soc Am, B 5:339-356, map (1894) Abst, Am G $13: 216$ (1894)

94b The origin of drumlins. Am G 13 : 393-407 (1894)

94e Lake Cayuga a rock basin. Am G 14: 194-195 (1894)

94d The process of segregation as illustrated in the New Jersey Highlands (abst). Am G 14: 196 (1894)
Tarr, Ralph Stockman-Continued.

96 The physical geography of New York State. Am Geog Soc, B 28 : 99-129 (1896); $29: 16-40 \quad(1897) ; \quad 30, \quad 28-56, \quad 183-225$, $375-407$ (1898) ; $31: 1-23,101-117,217-$ $235,315-343,417-443$ (1899)

96a A query concerning the origin of atolls. Nature 54:101 (1896)

$\mathbf{9 6 b}$ Geological history of the Chauta. qua grape belt. Cornell Eniv, Agr Exp Sta. B $109: 127-158 \quad(1896)$

$\mathbf{9 7}$ Elementary geology. $499 \mathrm{pp}$, N T 1897

$\mathbf{9 7 a}$ Elementary physical geography. $488 \mathrm{pp}, \mathrm{N}$ Y 1897

97b First book of physical geographr. $368 \mathrm{pp}, \mathrm{N}$ Y 1897 Questions for first book of physical geography. $56 \mathrm{pp}$. N Y 1897

97 e Suggestions for laboratory and field work in high school geology and questions for use with Tarr's Elementary geology. $100 \mathrm{pp}, \mathrm{N}$ Y 1897

$97 \mathrm{~d}$ Former extension of Cornell Glacier near the southern end of Melville Bay. G Soc Am, B 8:251-268, map (1897) Abst, J G 5:95-96 (1897); Science n \& 5:87 (1897)

97e Rapidity of weathering and stream erosion in the Arctic latitudes. Am G 19 : 131-136 (1897)

97f Evidence of glaciation in Labrador and Baffin Land. Am G 19:191-197 (1897)

$\mathbf{9 7 g}$ Valley glaciers of the upper Nug. suak Peninsula, Greenland. Am G 19 : 262-267 (1897)

97h Changes of level in the Bermuda Islands. Am G 19:293-303 (1897) Abst, G Soc London, Q J 53: 222 (1897) ; G Mag (4) $4: 92-93$ (1897)

971 The margin of the Cornell glacier. Am G 20:139-156 (1897)

97j The Arctic sea ice as a geological agent. Am J Sc (4) 3:223-229 (1897) Sc $\Delta \mathrm{m}$ Sup 44:17941-17942 (1897)

$97 \mathbf{k}$ Difference in the climate of the Greenland and American sides of Davis' and Baffin's bays [includes notes on glaciation]. Am J Sc (4) 3:315-321 (1897)

971 Former extension of Greenland gla. ciers. Science n s $5: 344,515-516,804-$ 805 (1897)

$97 \mathbf{m}$ The glaciers of Greenland. Sc Am 76: 216-218 (1897)

98 The peneplain. Am G 21:351-370 (1898)

9Sa Wave-formed cuspate forelands. Am G $22: 1-12$ (18:8)

OO Glaciation of Mount Katahdin, Me. G Soc Am. B 11 : 433-448 (1900)

00a The Bad Lands of North Dakota. Sc Am Sup 49: 20101-20102 (1900)

02 The physical geography of New York State. $397 \mathrm{pp}$, N Y 1902

02a Syllabus for field and laboratory work in dynamic, structural, and physiographic geology (Geology 1) at Cornell University. 152 pp, Ithaca, N Y 1902 
Tarr, Ralph Stockman-Continued.

03 Postglacial and interglacial changes of level at Cape Ann, Mass. Harpard Coll, Mus C Z, B 42 (g s 6) : 181191, map (1903)

04 New physical geography. 547 pp, N Y 1904

04a Hanging valleys in the Finger Lake region of central New York. Am G 33: 271-291, map (1904)

04b Artesian well sections at Ithaca, N. Y. J G 12 : 69-82 (1904)

05 Water resources of the Watkins Glen quadrangle, N. Y. U S G S, W-S P 110: 134-140 (1905)

05a Moraines of the Seneca and Cayugn Lake valleys. G Soc Am, B 16:215-228, map (1905) Abst, Am G 35: 129 (1905) ; Science n s 21:220 (1905); Sc Am Sup $59: 24326$ (1905)

05b Drainage features of central New York. G Soc Am, B $16: 229-242$, maps (1905) Abst, Am G 35: 52 (1905) ; Science n s $21: 218(1905)$; Sc Am Sup 59: 24326 (1905)

05e Some instances of moderate glacial erosion. J G 13 : 160-173 (1905)

05d The gorges and waterfalls of central New York. Am Geog Soc, B 37: 193-212 (1905)

o5e Gorges and waterfalls of central New York (abst with discussion by J. W Spencer and H. F. Reid). Int Geog Cong. VIII, Rp: 136 (1905)

05f (and Martin, Lawrence) Recent change of level in Alaska. Science n s 22 879-880 (1905)

06 The Yakutat Bay region [Alaska]. U S G S, B 284:61-64 (1906)

06a Glacial erosion in the Finger Lake region of central New York. J G 14:1821 (1906)

06b Watkins Glen and other gorges of the Finger Lake region of central New York. Pop Sc Mo 68:387-397 (1906)

o6e (and Martin, Lawrence) Recent changes of level in the Yakutat Bay region, Alaska. G Soc A1, B 17:29-64 (1906)

06d (and Martin, Lawrence) Recent change of level in Alaska. Geog J 28:3043 (1906)

06e (and Martin, Lawrence) Glaciers and glaciation of Yakutat Bay, Alaska. Am Geog Soc, B 38: 145-167, 99-101 (abst) (1906)

06f Earthquakes and their causes. In San Francisco's Great Disaster, by Sydney Tyler: $17-43$, Phila 1906

06g The physiographic history of Watkins Glen, New York. Am Scenic and Historic Preservation Soc, 11th An Rp: 113-141 (1906) (in Documents of the Assembly of the State of New York, 129th sess, 1906, vol 12, no 74 )
Tarr, Ralph Stockman-Continued.

07 Second expedition to Yakutat Bay, Alaska. Geog Soc, Phila, B 5:1-14 (1907)

$07 \mathbf{a}$ Recent advance of glaciers in the Yakutat Bay region, Alaska. G Soc Am, B $18: 257-286$ (1907)

отb The Malaspina Glacier. Am Geog Soc, B $39: 273-285$ (1907)

07e (and Martin, Lawrence) Position of Hubbard Glacier front in 1792 and 1794 , Am Geog Soc, B 39:129-136 (1907)

07d The advancing Malaspina Glacler. Science n s 25:34-37 (1907)

ore Glacial erosion in Alaska. Pop Sc Mo 70:99-110 (1907)

orf Recent changes in 1 e Malaspina and other glaciers of the Yakutat Bay region, Alaska (abst). Science n s 25: 770 (1907)

os Some phenomena of the glacier margins in the Yakutat Bay region, Alaska. Zs Gletscherk 3: 81-110 (1908)

OSa (and Von Engeln, O. D.) Representation of land forms in the physiography laboratory. $\mathrm{J}$ Geog, $7: 73-85$ (1908)

09 The Yakutat Bay region, Alaska; physiography and glacial geology. U S G S, P P 64 : 11-144 (1909)

09a (and Butler, B. S.) The Yakutat Bay region, Alaska. U S G S, P P 64: $183 \mathrm{pp}$, maps (1909)

o9b (with Williams, H. S.) Description of the Watkins Glen-Catatonk district, N. Y. U S G S, G Atlas, fol $169: 33$ pp (1909)

10 (and Martin, Lawrence) The National Geographic Society's Alaskan expedition of 1909. Nat Geog Mag 21:154 (1910)

10a Oscillations of Alaskan glaciers (abst). Sclence n s 32:185-186 (1910); (with discussion), G Soc Am, B 21:758759 (1910)

$10 b$ (and Von Engeln, O. D.) A laboratory manual of physical geography. xvil, 362 pp, N Y 1910

10e The theory of advance of glaciers in response to earthquake shaking. Zs Gletscherk $5: 1-35$ (1910)

12 The glaciers and glaciation of Alaska, Science n s $35: 241-258$ (1912)

12a The larger physiographic features of New York. J Geog 10:209-213 (1912)

12b (and Martin, Lawrence) The earthquakes at Yakutat Bay, Alaska, in September, 1899 ; with a preface by G. K. Gilbert. U S G S, P P 69: 135 pp (1912) Abst, Wash Ac Sc, J 2:421-422 (1912)

12e (and Martin, Lawrence) Glacial deposits of the continental type in Alaska (abst). Science n s $35: 313$ (1912); (with discussion by C. A. Davis and W. M. Davis), G Soc Am, B 23: 729-730 (1912)

12d (and Rich, I. L.) The properties of ice: experimental studies. Zs Gletscherk 6: 225-249 (1912) 
Tarr, Ralph Stockman-Continued,

13 Glaciers and glaciation of Alaska. As Am Geog, An 2:3-24 [1913]

$13 a$ (and Martin, Lawrence) Glacial deposits of the continental type in Alaska. J G $21: 289-300$ (1913)

13b (and Martin, Lawrence) An effort to control a glacial stream [Kenai Peninsula, Alaska]. As Am Geog, An 2:25-40 [1913]

14 (and Martin, Lawrence) College physiography. 837 pp, N Y 1914

14a (and Martin, Lawrence) Alaskan glacier studies of the National Geographic Society in the Yakutat Bay, Prince William Sound and lower Copper River regions. $x i$, 498 pp, maps, Washington, The National Geographic Society, 1914

15 (and Von Engeln, O. D.) Experimental studies of ice with reference to glacier structure and motion. Zs Gletscherk 9: 81-139 (1915)

Tarr, William Arthur.

10 Copper in the "red beds" of Oklahoma. Ec G 5:221-226 (1910)

12 The lack of association of the irregularities of the lines of magnetic declination and the petroleum fields. Ec G 7:647-661 (1912)

14 Tables for the determination of the common minerals and rocks. $18 \mathrm{pp}$ [Columbia, Mo.1 1914

14a (and Neuman, L. M.) A study of the effects of heat on Missouri granites. Mo Univ, B 15 no $27: 64$ pp (1914)

15 A study of some heating tests, and the light they throw on the cause of the disaggregation of granite. Ec G 10:348367 (1915)

15a Native silver in glacial material at Columbia, Mo. Am J Sc (4) $40: 219$ (1915)

16 Stylolites in quartzite. Science $\mathbf{n} \mathbf{s}$ 43: $819-820$ (1916)

17 Origin of the chert in the Burlington limestone. Am J Sc (4) 44:409-452 (1917)

17a Barite deposits of Missouri (abst). G Soc Am, B 28:132 (1917)

18 The barite deposits of Missouri and the geology of the barite district. Mo Univ, Studies 3 no 1:111 pp, map (1918)

18u Rhythmic banding of manganese dioxide in rhyolite tuff. J G 26:610-617 (1918)

18b Oblites in shale and their origin. G Soc Am, B 29:587-600 (1918)

18e Genesis of Missouri lead and zinc deposits (abst, with discussion by W. H. Emmons, F. R. Van Horn, and H. A. Wheeler). G Soc Am, B 29:86-87 (1918)

18d Siliceous oolites in shale $(a b s t)$. G Soc Am, B $29: 103,104$ (1918)
Tarr, William Arthur-Continued.

18e Glauconite in dolomite and lime stone of Missouri (abst). G Soc Am, B $29: 104$ (1918)

See also Bagg, 18

Tassin, Wirt (1869-1915).

95 Directions for collecting minerals. U S Nat Mus, B 39 pt $\mathrm{H}: 6$ pp (1895)

97 The mineralogical eollections in the U. S. National Museum. Smiths Inst, An Rp 1895, Rp U S Nat Mus: 995-1000 (1897)

99 Classification of the mineral collec tions in the U. S. National Museum. Smiths Inst, An Rp 1897, Rp U S Nat Mus, pt 1: 747-810 (1899)

02 Descriptive catalogue of the collections of gems in the United States National Museum. Smiths Inst, An Rp 1900, Rp U S Nat Mus : 473-670 (1902)

02a Descriptive catalogue of the meteorite collection in the United States National Museum, to January 1, 1902, Smiths Inst, An Rp 1900, Rp U S Nat Mus: 671698 (1902)

02b The Casas Grandes meteorite [Chihuahua, Mexico]. U S Nat Mus, Pr 25: 69-74 (1902)

04 The Persimmon Creek meteorite. U S Nat Mus, Pr $27: 955-959$ (\$904)

o5 The Mount Vernon meteorite. U S Nat Mus, Pr 28: 213-217 (1905)

06 Note on an occurrence of graphitic iron in a meteorite. U S Nat Mus, Pr 31: $573-574$ (1906)

o7 (with Merrill, G. P.) Contribu. tions to the study of Canyon Diablo meteorites. Smith Misc Col 50: 203-215 (1907)

os Analysis and notes on the Ainsworth meteorite. Am J Sc (4) 25:106-107 (1908)

osa on the occurrence of calcium sul. phide (oldhamite) in the Allegan meteorite. U S Nat Mus, Pr $34: 433-434$ (1908)

osb On meteoric chromites. U S Nat Mus, Pr 34: 685-690 (1908)

Tatham, William.

98 Gold mining in Georgia. Franklin Inst, J 146: 19-26 (1898)

Taylor, Alexander S.

69 Historical summary of Lower Callfornia, from its discovery in 1532 to 1867 . $200 \mathrm{pp}$, in J. R. Browne, Resources of the Pacific slope, N Y 1869

Taylor, Arthur E.

$07 \mathrm{On}$ the peat deposits of northern Indiana. Ind Dp G, 31st Ann Rp: 73-298 (1907)

09 Indiana peat, its origin and value. Am Peat Soc, J : 30-33, 64-67 (1909)

Taylor, Charles F.

12 (and Booth, W. M.) The Ontario Iron mine, N. Y. Eng M J 94:893-895 (1912) 
Taylor, Charles H.

15 Granites of Oklahoma, Okla G S, B $20: 108 \mathrm{pp}$, maps (1915)

17 The granites of Kansas (with discussion). Southwestern As Petroleum G, B $1: 111-126$ (1917)

See also Gould, 11b

Taylor, Frank Bursley.

92 The deltas of the Mohawk. Am G $9: 344-345$ (1892)

92a The highest old shore line on Mackinac Island. $\mathrm{Am} \mathrm{J}$ Sc (3) $43: 210-218$ (1892) Abst, Am G 8:235-236 (1891); Am As, Pr $40: 260-261$ (1892)

94 The ancient strait at Nipissing [Ont.]. G Soc Am, B 5:620-626, map (1894) Abst, Am G 13:220-221 (1894)

94a A reconnaissance of the abandoned shore lines of Green Bay [Wis. and Mich.]. Am G $13: 316-327$, map (1894)

94b A reconnaissance of the abandoned shore lines of the south coast of Lake Superior. Am G 13:365-383, map (1894)

94e The limit of postglacial submergence in the highlands east of Georgian Bay. Am G 14: 273-289, map (1894)

95 The Munuscong Islands. Am c 15: 24-33, map (1895)

95a The second Lake Algonquin. Am G 15: 100-120, 162-179, map, 394-395 (1895)

95b The Nipissing beach on the north Superior shore. Am G 15: 304-314 (1895)

95e Changes of level in the region of the Great Lakes in recent geological time. $\mathrm{Am} \mathrm{J} \mathrm{Sc} \mathrm{(3)} 49: 69-71$ (1895)

95d Niagara and the Great Lakes. Am J Sc (3) 49:249-270 (1895)

96 Preliminary notes on studies of the Great Lakes made in 1895 [extinct beaches, etc.]. Am G 17: 253-257 (1896)

96n The Algonquín and Nipissing beaches. Am G 17:397-400 (1896)

96b Notes on the Quaternary geology of the Mattawa and Ottawa valleys [Ont.]. Am G 18:108-120 (1896)

96e Correlation of Warren beaches with moraines and outlets in southeastern Michigan $(a b s t)$. Am G 18:233-234 (1896)

96d Notes on the glacial succession in eastern Michigan (abst). Am G 18:234 236 (1896) Science n \& 4:284 (1896)

97 A short history of the Great Lakes. In Dryer, C. R., Studies in Indiana geography ; first series: 90-110, maps, Terre Taute, Ind., 1897

97a Correlation of Erie-Huron beaches with outlets and moraines in southeastern Michigan. G Soc Am, B $8: 31-58$, map (1897)

$97 \mathrm{~b}$ Moraines of recession and their signifleance in glacial theory. J G 5:421466 (1897) Abst, Am G 19:290 (1897) ; Science n s 5:90-91 (1897)
Taylor, Frank Bursley-Continued.

97e Lake Adirondack. Am G 19:392396 (1897)

97d The Nipissing-Mattawa River, the outlet of the Nipissing Great Lakes (abst). Am G 20:65-66 (1897) J G 5:220-222 (1897) Science n s 5:90 (1897)

97 Notes on the abandoned beaches of the north coast of Lake Superior. Am G $20: 111-128$, map (1897)

97f The scoured boulders of the Mattawa Valley [Ont.]. Am J Sc (4) 3:208218 (1897)

$\mathbf{9 7 g}$ Some features of the recent geology around Detroit (abst). Am As Pr 46: 201-202 (1898) Am G 20:196 (1897) Science n s 6:688-689 (1897)

97h The lower abandoned beaches of southeastern Michigan (abst). Science $\mathbf{n} \mathbf{s}$ $6: 689$ (1897)

97i The glacial drainage of the Simcoe area in Ontario (abst). Science $n$ s 6 : 692 (1897)

98 Origin of the gorge of the Whirlpool Rapids at Niagara. G Soc Am, B 9:5984 (1898) Abst, Am G 20:195 (1897); Science n s 6:692 (1897)

$98 \mathbf{a}$ Notes on the moraines of the Georgian Bay lobe of the ice sheet (abst). Science $n$ \& $7: 51$ (1898) Ottawa Nat 11: 223 (1898)

9sb The Champlain submergence and uplift, and their relations to the Great Lakes and Niagara Falls (abst). Brit As, Rp 67:652-653 (1898)

99 The great ice dams of Lakes Maumee, Whittlesey, and Warren. Am G 24:6-88, map (1899)

99 The Galt moraine and associated drainage [Ontario] (abst). Am As, $\mathrm{Pr}$ $48: 228$ (1899) Science n s $10: 489-490$ (1899)

o1 Glacial phenomena in eastern Ontario (abst). Science n s 13:138 (1901)

02 Surface geology of Lapeer Co., Mich. Mich G S Rp 1901:111-117, map (1902)

03 The correlation and reconstruction of recessional ice borders in Berkshire Co., Mass. J G 11: 323-364, maps (1903)

o3n Studies in the glaciation of the Berkshire Hills, Mass. (abst). Science n s $17: 225$ (1903) Sc Am Sup 55:22666 (1903)

05 Water resources of the Taconic quadrangle, N. Y., Mass., and Vt. U S G S, W-S P 110: 130-133 (1905)

O5a Relation of Lake Whittlesey to the Arkona beaches. Mich Ac Sc, Rp $7: 29-36$ (1905) Abst, G Soc Am, B 16:587-589 (1906)

07 A short history of the Great Lakes. In Dryer, C. R., Studies in Indiana Geography : 90-111, Terre Haute, Ind. 1907. 
Taylor, Frank Bursley-Continued.

ora Distribution of drumlins and its bearing upon their origin $(a b s t)$. G Soc Am, B 17:726 (1907)

os A review of the Great Lakes history, with special reference to the deformation of the ancient water planes $(a b s t)$. Science $n$ s 27:725-726 (1908)

09 Field work on the Pleistocene deposits of southwestern Ontario. Can, G S, Sum Rp 1908: 103-111 (1909)

10 Bearing of the Tertiary mountain belt on the origin of the earth's plan. $G$ Soc Am, B 21:179-226 (1910) Abst, Science n s $29: 624-625$ (1909)

10a Field studies on the Pleistocene deposits of southwestern Ontario. Can G S, Sum Rp 1909: 164-167 (1910)

10b Richmond and Great Barrington boulder trains [Columbia Co., N. Y. and Berkshire Co., Mass.] G Soc Am, B 21 : 747-752 (1910) Abst, Science n $\mathbf{s} 32$ : 186-187 (1910)

10c The glacial recession in western New England (abst). Science n $\mathbf{s} 32$ : 127-128 (1910)

10d Isobases of the Algonquin and Iroquois beaches and their significance ( $a b s t)$. Science n s $32: 187$ (1910)

11 Twenty-foot terrace and sea cliff of the lower St. Lawrence (discussion). G Soc Am, B 22: 724 (1911)

11 a Lake Maumee, in Ohio (discussion). G Soc Am, B 22:726 (1911)

$11 b$ Study of ice-sheet erosion and deposition in the region of the Great Lakes (abst). G Soc Am, B 22:727-728 (1911)

12 Pleistocene deposits of southwestern Ontario. Can G S, Sum Rp 1911:262268 (1912)

12a Recent studies of the moraines of Ontario and western New York (abst). Science n s $35: 315$ (1912); (discussion by H. L. Fairchild), G Soc Am, B 23:736737 (1912)

12b Map of the old distributaries of the St. Clair and Detroit rivers (abst). Mich Ac Sc, Rp 14: 142 (1912)

13 The glacial and postglacial lakes of the Great Lakes region. Smiths Inst, An Rp $1912: 291-327$ (1913)

13a Niagara Falls and Gorge. Int $G$ Cong, XII, Canada, Guide Book no 4:8-70 map (1913)

13b Moraines north of Toronto [Ont.]. Ont Bur Mines, An Rp 22 pt $1: 256-260$, map (1913) Int $G$ Cong, XI, Canada, Guide Book no $6: 35-42$ (1913)

13e The moraine system: of southwestern Ontario. Can Inst, $\operatorname{Tr} 10: 57-79$, maps (1913)

13d Claracters of the older sections of the Niagara Gorge and their correlation with Great Lakes history (abst). G Soc Am, B 24:702-703 (1913)
Taylor, Frank Bursley-Continued,

13e (with Kindle, E. H.) Description of the Niagara quadrangle, N. Y. U S G 8 , G Atlas Niagara fol (no 190) : 25 pp, maps (1913)

14 Time measures in the Niagara Gorge and their application to Great Lake his. tory (abst with discussion). G Soe Am, B $25: 35-36$ (1914)

15 Old shore lines of Mackinac Island and their relations to the lake history (abst). G Soc Am, B 26:68-70 (1915)

Isa (with Leverett, F.) The Pleistocene of Indiana and Michigan and the bistory of the Great Lakes. U S G S, Mon 53: 529 pp, maps (1915) Abst, Wash Ac Se, I $6: 18-20$ (1916)

16 Landslips and laminated lake clays in the basin of Lake Baseom (abst with discussion by G. C. Martin). G Soc Am, B $27: 81$ (1916)

See also Rich, $17 \mathrm{~b}$; Sayles, 16 ; Wright (G F), 17a

Taylor, Frank H.

11 The anticlinal theory [of the occurrence of petroleum]. Oil and Gas J 10 no $10: 2$ (1911)

Taylor, H. B.

12 A study of ores from Austin, Nev. Sch Mines Q 34:32-39 (1912)

Taylor, James W.

67 Gold mines east of the Rocky Mountains. U S, 39th Cong 2 d sess, H Ex Doc $92: 28$ pp (1867)

67a (with Brovne, J. R.) Reports upon the mineral resources of the United States. [U S, Treas Dp] : 360 pp. Wash. ington $\mathbf{1 8 6 7}$

68 Report on the mineral resources of the United States east of the Rocky Mountafns. [U S, Treas Dp] : 72 pp, Washing. ton 1868

Taylor, Joseph H.

18 Pyrite and pyrrbotite resources of Ducktown, Tenn. Am I M Eng, B 134: 529-533 (1918); Tr 59:88-92 (1918)

Taylor, Julius $\mathrm{S}$.

50 Notice of trilobites in the cabinet of Dr. Julius S. Taylor [Carrollton, Montgomery Co., Ohio]. Am J Sc (2) 10:113114 (1850)

Taylor, L. H.

02 Water storage in the Truckee basin, Cal.-Nev. U S G S, W-S P 68:90 pp (1902)

Taylor, Richard Cowling (1789-1851).

32 Section of the Alleghany Mountain and Moshannon Valley, in Centre Co., Pa. Monthly Am J G 1:433-438 (1832)

34 On the geological position of certain beds which contain numerous fossil marine plants of the family Fucoides, near Lewiston, Mifflin Co., Pa. G Soc $\mathrm{Pa}$, Tr $1: 5-$ 15, il (1834) Abst, Am J Sc $27: 347-348$ (1835) 
Taylor, Richard Cowling-Continued.

34a A description of a fossil vegetable of the family Fucoides in the transition rocks of North America, and some considerations in geology connected with it. Mag N H (Loudon) $7: 27-32,163$, il (1834)

35 On the relative position of the transition and secondary coal formations in Pennsylvania, and description of some transition coal or bituminous anthracite and iron ore beds near Broadtop Mountain in Bedford Co., and of a coal vein in Perry Co., Pa. G Soc Pa, Tr 1: 177-193 (1835)

35 a Notice as to the evidences of the existence of an ancient lake which appears to have formerly filled the limestone valley of Kishacoquillas in Mifflin Co., Pa. G Soc Pa, Tr 1: 194-203 (1835)

$35 b$ on the mineral basin or coal field of Blossburg on the Tioga River, Tioga Co., Pa. G Soc Pa, Tr 1:204-223 (1835)

35e Memoir of a section passing through the bituminous coal field near Richmond, in Virginia. $\mathrm{G}$ Soe $\mathrm{Pa}, \mathrm{Tr} 1$ : $275-294$ (1835)

$35 d$... sections in parts of Virginia and Maryland: also notice of certain fossil acotyledonous plants in the secondary strata of Fredericksburg. G Soc $\mathrm{Pa}$, Tr $1: 314-325$, il (1835)

35e On the geology and natural history of the northeastern extremity of the Alleghany Mountain Range in Pennsylvania, U. S. A. Mag N H (Loudon) $8: 529-541$ (1835)

36 On the Carboniferous series of the United States of America. Ph Mag (3) 9: 407-411 (1836)

36 Notes on natural objects observed while staying in Cuba. Mag $\mathrm{N} \mathrm{H}$ (Loudon) $9: 449-457$ (1836)

37 Notes relative to the geology of a portion of the district of Holguin in the Island of Cuba and the mineral region on the northeast coast. Ph Mag (3) 11:1733 (1837)

37a (and Clemson, T. G.) Notice of a vein of bituminous coal in the vicinity of Havana in the Island of Cuba. Ph Mag (3) 10:161-167 (1837) Bibliotheque Universelle de Genève n s 9:199-202 (1837)

39 (and Clemson, T. G.) Notice of a vein of bituminous coal, recently explored in the vicinity of Havana, in the Island of Cuba. Am Ph Soc, $\mathrm{Tr} n$ s $6: 191-196$ (1839)

41 Notice of a model of the western portion of the Schuylkill or southern coal field of Pennsylvania... Am J Sc 41: 80-91 (1841) As Am G, Rp : 81-94 (1843)

43 On fossil arborescent ferns of the family of Sigillaria, occurring ... in Dauphin Co., Pa. Am Ph Soc, Pr 3:149-150 (1843)

$$
28737^{\circ}-23-64
$$

Taylor, Richard Cowling-Continued.

43a On the geology of the northeast part of the Island of Cuba... Am Ph Soc, Pr 3: 154-155 (1843)

46 Memoir on the character and prospects of the copper region of Gibara, and a sketch of the geology of the northeast part of the Island of Cuba. Am Ph Soc, Tr n s $9: 204-218$, map (1846)

46a Notice of fossil arborescent ferns, of the family of Sigillaria and other coal plants, exhibited in the roof and floor of a coal seam, in Dauphin Co., Pa. Am Ph Soc, $\operatorname{Tr}$ n s $9: 219-227$ (1846)

48 Statistics of coal... exlvili, $754 \mathrm{pp}$, map, Phila 1848 2d ed, rev by S. S. Haldeman, 641 pp, Phila 1855

51 On a vein of asphaltum at Hillsborough, in Albert Co., N. B. Am Ph Soc, Pr 5 : 241-243 (1851)

52 ... a geological reconnaissance in the auriferous porphyry region next the Caribbean Sea, in the Province of Veraguas and Isthmus of Panama. Ae N Sc Phila, J (2) 2: 81-86, map (1852)

Taylor, Stephen.

41 Discovery in Virginia of the regular mineral salt formation. Am J Sc 41:214215 (1841)

Taylor, Steuben.

24 Notice of a rocking stone in Warwick, R. I. Am J Sc 7:201-203 (1824)

24a (and others) Notice of miscellaneous localities of minerals. Am J Sc 8: 225-236 (1824)

Taylor, Thomas U.

07 Underground waters of the Coastal Plain of Texas. U S G S, W-S P 190:73 pp (1907)

Taylor, W. B.

S5 On the crumpling of the earth's crust. $\triangle \mathrm{m} \mathrm{J} \mathrm{Sc} \mathrm{(3)} \mathrm{30:249-266} \mathrm{(1885)} \mathrm{Abst,}$ $\mathrm{Ph}$ Soc Wash, B 8:18-19 (1885)

s5a Geological and physical theories (abst). Ph Soc Wash, B 8:6-7 (1885)

86 A probable cause of the shrinkage of the earth's crust. Am As, Pr 34:200202 (1886) Abst, Science 6:220 (1885)

See also Dutton, $80 \mathrm{a}$; Powell, $80 \mathrm{a}$

Taylor, W. Edgar.

88 Geology in our preparatory schools. Am G 1: 316-321 (1888)

Taylor, Walter Penn.

11 A new antelope [Capromeryx minor] from the Pleistocene of Rancho La Brea, Cal. Cal Univ, Dp G, B 6: 191-197 (1911)

14 The problem of aquatic adaptation in the Carnivora, as illustrated in the osteology and evolution of the sea otter. Cal Univ, Dp G, B $7: 465-495$, il (1914)

15 Outline of the history of the Castoridae (abst). G Soc Am, B 26:167 (1915) 
Berry, S. L.

16 An earthquake in Nevada. M Sc Press $113: 52-53$ (1916)

Berryman, B. A.

1s Outline of mining and smelting conditions at San Pedro, N. Mex. Utah Ac Sc, Tr 1:122-127 (1918)

Berté, E.

02 Les éruptions de la Montagne Pelée; recit et observations d'un temoin. La Géog 6:133-141 (1902)

Bertelet, P. G.

56 [Geological features of Oley Valley, Berks Co., Pa.] Med Soc Pa, Tr n s 1: 47, map (1856)

\section{Berthier, $P$.}

20 Analysis of two zinc ores from the United States of America [Franklin, N. J.]. Am J Sc 2 : 319-326 (1820)

Berthoud, Edward L.

66 Description of the hot springs of Soda Creek [Colo.] ... and the geological features of the surrounding locality... Ac N Se Phila, Pr $1866: 342-345$

75 On the occurrence of uranium, silver, iron, etc., in the Tertiary formation of Colorado Terr. Ac N Sc Phila, Pr 1875: $363-365$

76 On rifts of ice in the rocks near the summit of Mt. McClellan, Colo... Am J Sc (3) $11: 108-111$ (1876)

79 On the origin and formation of coal. Kansas City Rv Sc 3 : 23-28 (1879)

81 Artesian wells in Colorado. Kansas City Rv Sc 4: 536-540 (1881)

Bertkan, Philipp.

85. Ueber Planocephalus aselloides Scudd., und Limnochares antiquus v. Heyd. Niedderrhein Ges Bonn, Szb 1885 : 298-299 Bertrand, Émile.

82 Propriétés optiques de la variscite de l'Arkansas. Soc Minér France, B 5:253$254(1882)$

\section{Bertrand, Marcel.}

99 (and Zureher, P.) I, Etude géologique sur l'isthme de Panama. II, Les phénomènes volcaniques et les tremblements de terre de l'Amérique centrale, by $M$. Bertrand. $38 \mathrm{pp}$, maps, Paris [1899] Abst, Soc G France, B (3) $27: 494-495$ (1899) Transl of I (by J. C. Oakes), U S, Bd Consulting Engrs for the Panama Canal, Rp: 149-163. Washington 1906

00 (and zinrcher, P.) Note on the Culebra and Emperador cuts [Panama Canal]. U S, 56th Cong 1st sess, S Doc 188: 8-10 (1900) U S, Bd Consulting Engrs for the Panama Canal, Rp:162-163, Washington 1906

06 (and Züreher, P.) A geological study of the Isthmus of Panama (translation by John, C. Oakes). Board of ConsultIng Engineers for the Panama Canal, Report: 149-163, Washington. 1906
Berwerth, Friedrich.

75 Serpentin von New Jersey. Miner Mitt (Tschermak) 1875:110.

77 Untersuchung zweier Magnesiaglimmer [phlogopite, Edwards Co., N. Y.] Miner Mitt (Tschermak) 1877:109-112.

17. On the origin of meteorites. Smiths Inst, An Rp 1916: 311-320 (1917)

Bethune, George A.

91 Mines and minerals of Washington. Wash St G, An Rp: 122 pp, Olympia, Wash., 1891.

92 Mines and minerals of Washington. Wash St G, 2d An Rp, 1891:187 pp, Olympia, Wash., 1892.

Bettany, G. T.

73 Oreodon remains in the Woodwardian Museum, Cambridge, England [from bad lands, Nebr., Miocene deposits]. Nature 8: 309-311 (1873)

76 On the genus Merycochoerus (family Oreodontidae), with descriptions of two new species [John Day beds, Oregon] G Soc London, Q J 32 : 259-273, il (1876)

Bevier, G. M.

14 The present status of the copper development in the South Mountain region. Pa Top G S, Bien Rp 1912-14: 55-69, map (1914)

Beyer, Samuel Walker.

93 Ancient lava flows in the strata of northwestern Iowa. Iowa $\mathrm{G} S \mathrm{~S}$, An $\mathrm{Rp}$ $1892: 163-169$ (1893)

95 The spotted slates associated with the Sioux quartzite. Johns Hopkins Univ Circ $15: 10$ (1895)

96 Geology of Boone Co. Iowa G S $5: 175-232$, maps (1896)

97 The Sioux quartzite and certain associated rocks. Iowa G S $6: 69-112$ (1897)

97a Geology of Marshall Co. Iowa G S $7: 197-262$, maps $(1897)$

$\mathbf{9 7 b}$ Evidence of a sub-Aftonian till sheet in northeastern Iowa. Iowa Ac Sc, Pr 4:58-62 (1897)

99 Report [administrative]. Iowa G S $9: 28-29(1899) ; \ldots 10: 36-38$ (1900) ; ... 11: 35 (1901)

$99 a$ Mineral production of Iowa in 1898. Iowa G S $9: 31-48(1899) ; \ldots$ in $1899 ; \ldots$ $10: 41-58(1900) ; \ldots$ in $1900, \ldots 11: 37-53$ $(1901) ; \ldots$ in $1901, \ldots 12: 37-61$ (1902); in $1902, \ldots 14: 7-26(1904) ; \ldots$ in $1904, \ldots$ $15: 15-32(1905) ; \ldots$ in $1905, \ldots 16: 17-$ $36(1906) ; \ldots$ in $1906, \ldots .17: 11-25$ $(1907) ; \ldots$ in $1907, \ldots 18: 11-28$ (1908); $\ldots$ in $1908, \ldots 19: 1-20 \quad(1909)$

99h Geology of Story Co. Iowa G S $9: 155-237$, maps (1899)

99e Buried loess in Story Co. [Iowa]. Iowa Ac Sc, $\operatorname{Pr} 6: 117-121$ (1899)

00 Geology of Hardin Co. Iowa G S $10: 241-306$, map (1900)

02 Iowa's iron mine [Allamakee Co.]. Eng M J 73:275-276 (1902) 
Taylor, William Johnson.

56 Examination of the meteoric fron from Xiquipilco, Mex. Ac N Sc Phila, Pr $8: 128-130$ (1856) Am J Sc (2) $22: 374-$ 376 (1856)

57 Investigation on the rock guano from the islands of the Caribbean Sea. Ac N Sc Phila, Pr 1857:91-100 Am J Sc (2) $24: 177-188$ (1857) M Mag 8: 438-449 (1857)

57a Examination of a nickel meteorite, from Oktibbeha Co., Miss. Ac N Sc Phila, Pr 1857:102-104 (1857)

58 Mineralogical notes. Ac N Sc Phila, Pr 1858:172-176

59 Mineralogical notes. Ac N Sc Phila, Pr $1859: 306-310$

Taylor, W. W.

94 The geology and character of the Rainy Lake gold district [Ont.]. Eng M J 58: 509 (1894)

Tays, E, A, H.

o1 Genesis of ore deposits. M Sc Press 83:142-143 (1901)

09 Mining in northern Sinaloa, Mexico. M Sc Press 99: 120-121 (1909)

09a San José de Gracia [State of Sinaloa], a great Mexican gold camp. Eng M J $88: 640-645$ (1909)

10 The Lluvia de Oro mine [Chihuahua, Mexico]. M Sc Press 100:59-60 (1910)

10a The Antigua mines of Real del Sivirijoa, Sinaloa. Eng M J 90:11551156 (1910)

Teall, J. J. Harris.

02 Volcanic dust from the West Indies. Nature 66:130 (1902)

03 The evolution of petrological ideas. Smiths Inst, An Rp 1902:287-308 (1903) Teas, Livingston Pierson.

17 The relation of sphalerite to other sulphides in ore (with discussion by $\mathrm{T}$. L. Watson, L. C. Graton, and H. Ries). Am I M Eng, B 131: 1917-1931 (1917); Tr 59:68-87 (1918)

Teets, D. D., jr.

14 (with Krebs, C. E.) Kanawha County. W Va G S:679 pp, maps (1914)

15 (with Krebs, C. E.) Boone County. W Va G S : $648 \mathrm{pp}$, maps (1915)

16 (with Krebs, C. E.) Raleigh County and the western portions of Mercer and Summers counties. W Va G S : $778 \mathrm{pp}$, maps (1916)

18 (with Reger, D. B.) Barbour and Upshur counties and western portion of Randolph County. W Va G S : ciii, 867 pp, maps (1918)

Teller, Edgar E.

99 (with Monree, C. E.) The fauna of the Deronian formation at Milwaukee, Wis. J G $7: 272-283$ (1899)

00 The Hamilton formation at Milwaukee, Wis. Wis $\mathrm{N}$ H Soc, $\mathrm{B}$ n $81: 47-56$ (1900)
Teller, Edgar E.-Continued.

06 Notes on the fossil fish spine Phlyo tonacanthus telleri Eastman. Wis N H Soe, B n s $4: 162-167$, il (1906)

10 An operculated gastropod from the Niagara formation of Wisconsin. Wis $\mathrm{Ac}$ Sc, $\operatorname{Tr} 16: 1286-1288$, il (1910)

11 A synopsis of the type specimens of fossils from the Paleozoic formations of Wisconsin. Wis $\mathrm{N} H$ Soc, B $9: 170-271$ (1911)

Tello, Rafael M.

16 Informe sobre la constitución geologica del lecho del río Lerma [Estado de México]. Bol Minero 2: 167-177 (1916)

17 Métodos de explotación de algunos materiales de construcción empleados en el Distrito Federal y medios propuestos para mejorarlos. Bol Minero 3: 54-68 (1917)

Tempany, H. A.

14 The ground waters of Antigua. West Indian B 14:281-303 (1914)

Templeton, E. C.

11 The central California earthquake of July 1, 1911. Seism Soc Am, B 1:167169, map (1911)

13 General geology of the San Jose and Mount Hamilton quadrangles (ábst). G Soc Am, B 24:96 (1913)

Templin, L. J.

85 The age of the world. Kansas Cith Rv Sc 8: 570-575 (1885)

Tenne, C. A.

85 Ueber Gesteine des Cerro de las Navajas (Messerberg) in Mexico. Deut $G$ Ges, Zs $37: 610-620$ (1885)

Tennessee Agrienltural Experiment Station.

96 A preliminary agricultural map of Tennessee based on the distribution of geological formations ... 1896

Tenney, J. B.

14 Bisbee [Ariz.] porphyry deposits. Eng M J 97:467-468 (1914)

16 (with Bonillas, Y. S., and Fenchare, L.) Geology of the Warren mining district [Ariz.]. Am I M Eng, B 117: 1397-1465, maps (1916) ; Tr $55: 284-355$ maps (1917)

Tenney, Sanborn (1827-1877).

60 Geology ... 320 pp, Phila 1860 Revised ed, $366 \mathrm{pp}$, Phila 1877

73 On Devonian fossils in the Wasatch Mountains. Am J Sc (3) 5:139-140 (1873)

73a on a few mineral localities which are not mentioned in the books. Am Nat $7: 635$ (1873)

73b Boulders [formed in situ, Califor. nia]. Am Nat $7: 636$ (1873)

74 The quartzite of Williamstown and vicinity, and the structure of the Graylock Range. Am As, Pr 22, pt 2:37-41 (1874) 
Tenney, Sanborn-Continued.

78 Note on some points in the geolog of Stoddard and Marlow, Cheshire Co. $\mathrm{N}$. H. In Hitcheock, C. H., Geology of $\mathrm{N} \mathrm{H}$, pt 3 [vol 3] : 356-357 (1878)

Termier, Pierre.

13 ... la région appalachienne du Canada. Ac Sc Paris, C R 157:621-626 (1913) N Y St Mus, B 173: 75-79 (1914)

13a L'excursion CI du XII Congrès géologique international; les terrains précambriens de la région des Lacs; les problèmes tectoniques des grandes chaines de louest. Ac Sc Paris, C R 157:746-753 (1913)

\section{Tertsch, H.}

07 Optische Untersuchung von Hornblenden und Titanit aus Essexit von Montreal [Canada]. Tschermaks Mitt 25:458482 (1907)

Teschemacher, James Englebert (17901853)

42 (and Hayes, A. A.) On the identity of pyrochlore with the microlite of Professor Shepard. Am J Sc 43: 33-35 (1842)

42a on the occurrence of phosphate of uranium in the tourmaline locality at Chesterfield [Mass.]. Boston J N iI 4: 35-37 (1842)

43 Description of the oxide of tin found at the tourmaline locality, Chesterfield, Mass. As Am G, Rp : 296-297 (1843)

43a [Ferns from the anthracite coal mines at Mansfield, Pa. (with discussion by C. T. Jackson).] Boston Soc N H, Pr 1: $61-62$ (1843)

43b [On slate with dendritic markings at Newton, Mass.] Boston Soc N H, $\mathrm{Pr}$ 1:96 (1843)

44 Mineralogical notices. Boston J N H $4: 498-504$ (1844)

44a [On beryls from Ackworth, N. H.] Boston Soc N H, Pr 1: 191-192 (1844)

45 Remarks on uranium and pyrochlore. Am J Sc 48: 395-397 (1845)

$45 \mathbf{a}$ On the occurrence of uranium in the beryl locality at Acworth, N. H. Boston J N H 5: 87-89 (1845)

46 On the fossil vegetation of America. Boston J N H $5: 370-385$ (1846) Abst, Boston Soc N H, Pr 2:146-147 (1846)

46a [Notes on damourite and pyrrhite.] Boston Soc N H, Pr 2:107-109 (1846)

47 On the fossil vegetation of America. $\Delta \mathrm{m} \mathrm{J} \mathrm{Sc} \mathrm{(2)} 3: 86-90$, il (1847)

48 [On the vegetation of the anthracite coal.] Boston Soc N H, Pr 2:8-9, 35 (1848)

48a [Note on metamorphism, cleavage, and bedding in rocks.] Boston Soc $\mathrm{N} \mathrm{H}$, Pr 3: 28-30 (1848)

49 [On the identity of arkansite with brookite, and the measurement of the angles of the mineral.] Boston Soc $\mathrm{N} \mathrm{H}$, Pr 3:131-132 (1849)
Teschemacher, James Englebert-Contd. 51 On the vanadium minerals from Lake Superior. Am J Se (2) $11: 233-234$ (1851)

52 [On Stigmaria.] Boston Soc N H, Pr $4: 152-154$ (1852)

52a [On coniferous plants during the coal period and on the resinous nature of coal.] Boston Soc N H, Pr 4: 199-202 (1852)

Texas state Geologieal and seientific Association.

85 Geological and Scientific Bulletin, yol. 1, 12 nos., 1888-9. Houston, Tex.

Thacher, W. A.

92 Mining in Honduras. Am I M Eng, $\operatorname{Tr} 20: 394-409$ (1892)

Tharp, W. E.

15 (and others) Soil survey of Clinton Co., Ind. Ind Dp G, $\Delta$ n Rp $39: 89-114$, map (1915)

16 (and Wiley, W. E.) Soll survey of Wells Co. Ind, Dp G Nat Res, An Rp 40 : 44-71, map (1916)

Thayer, Russell.

s6 Earthquakes: a scientific investigation of the method of action of these terrestrial phenomena, and a theory of their primary cause. $13 \mathrm{pp}$, Phila 1886

Thayer, Warren $\mathrm{N}$.

14 A bibliography of Mexican geology. geography, and mining, 1902-1912. M Sclence $70: \Delta u g \quad 52-56$, Sept 53-56, Oct 53-58 (1914)

16 The physiography of Mexice. J G 24:61-94 (1916)

18 The northwarl extension of the physiographic divisions of the United States. J G 26:161-185, 237-254 (1918)

18a The Kentucky oll fields. Eng M J $105: 781-785$ (1918)

Thelen, Paul.

o5 The differential thermal conductivities of certain schists, Cal Univ, Dp G, B $4: 201-226$ (1905)

05a (with Knopf, A.) Sketch of the geology of Mineral King, Cal. Cal Univ, Dp G, B 4:227-262, map (1905)

Thevenet, J. V.

6o Sur les gisements aurifères et platinifères de l'Orégon. Ac Imp Lyon, Clas Sc. Mém 10:129-134 (1860)

Therenin, A.

o6 (with Boule, Marcellin) Types du Prodrome de paléontologie stratigraphique universelle de D'Orbigny. An Paléont 1: 97-101, 165-172 (1906)

Thiele, F. C.

o1 Ueber Texas-Petroleum. ChemikerZeitung, Cöthen, 25:175-176 (1901)

Thiele, L. W.

82 The Grand River, Colo,, coal measures, Eng M J $34: 345$ (1882)

Thierry, J,

02 Sur l'eruption volcanique du $8 \mathrm{mai}$ a la Martinique. Ac Sc Paris, C R 135: $71-72$ (1902) 
Thierry, J.-Continued.

02a La catastrophe de la Martinique. Rv Gén Se 13:664-668 (1902)

Thies, Adolph.

$9 x$ (and Merger, A.) The geology of the Haile mine [Lancaster Co., S. C.]. Am I M Eng, Tr 19:595-601, map (1891)

See also Nitze, $96 \mathrm{~b}$

Thiessen, Reinhardt.

11 Plant remains composing coals (abst). Science n s 33:551-552 (1911)

12 On certain constituents and the genesis of coals (abst). Wash Ac Sc, J 2: 232-233 (1912)

13 On the constitution and genesis of certain lignites and subbituminous coals (abst). Int Cong Applied Chem, Eighth, 25: 203-204 [1913]

$13 a$ (with White, D.) The origin of coal. U S Bur Mines, B 38: 390 pp (1913)

18 The determination of the stratigraphic position of coal seams by means of their spore-exines (abst). Science n s $47: 469$ (1918)

Thom, William Taylor, jr.

17 An Upper Cretaceous seacoast in Montana. Johns Hopkins Univ Circ n s 1917 no $3: 68-73$ [266-271] (1917)

is (with Collier, A. J.) The Flaxville gravel and its relation to other terrace gravels of the northern Great Plains. U S G S, P P 108:179-184, map (1918) Abst, Wash Ac Se, J 8:249 (1918)

Thomae, W. F. A.

02 An ore formation on Prince of Wales Island, southeastern Alaska. Inst M Met, Tr 10:44-48 (1902)

Thomas, Abram Owen.

11 A fossil burrowing sponge from the Iowa Devonian. Iowa, Univ, Lab $\mathrm{N} \mathrm{H}$, B $6: 165-166$, il (1911)

12 Additional evidence of unconformity between the Cedar Valley and Lime Creek stages of the Devonian of Iowa (abst). Science n s 36:569-570 (1912)

12a Some notes on the Aftonian mammals $(a b s t)$. Science n s $36: 570$ (1912)

$12 b$ (with Norton, W. H., and others) Underground water resources of Iowa. U S G S, W-S P 293:994 pp, maps (1912) Iowa G S 21:29-1186, maps (1912)

13 The relation of the Lime Creek shales to the Cedar Valley limestones of Floyd Co., Iowa $(a b s t)$. Science n s $37: 459$ (1913)

14 A new section of the railway cut near Graf, Iowa. Iowa Ac Sc, $\mathrm{Pr} 21$ : 225-229 (1914)

15 A new crinoid fauna from Monticello, Iowa. Iowa Ac Sc, Pr 22: 289-291, il (1915)

15a Some unique Niagaran cephalopods. Iowa Ac Sc, $\operatorname{Pr} 22: 292-300$, il (1915)

16 A highly alate specimen of Atrypa reticularis Linn. Iowa $\mathrm{Ac} \mathrm{Sc}, \operatorname{Pr} 23$ : 173-175, il (1916) Abst, Science n s 44: 69 (1916)
Thomas, Abram Owen-Continued.

$16 a$ Some new Niagaran corals from Monticello, Iowa $(a b 8 t)$. Science n 844 : 69 (1916)

17 A large colony of fossil coral [Cyathophyllum calvini, Niagaran beds, Jones Co.]. Iowa Ac Sc, Pr 24:105-110, il (1917)

17a On a supposed fruit or nut from the Tertiary of Alaska. Iowa Ac Sc, P: 24: 113-116, il (1917)

Thomas, Benfamin Walden.

84 (with Johnson, H. A.) Microscopic organisms in the boulder clays of Chicago and vicinity. Chicago Ac Sc, B $1: 35-40$ (1884) Am J Sc (3) 28:317318 (1884) Abst, Science 3:237 (1884)

85 (with woodward, A.) On the Foraminifera of the bonlder clay taken from a well shaft $22 \mathrm{ft}$. deep, Meeker $\mathrm{C}_{\text {., }}$ central Minn. Minn G S, An Rp 13:164176, il (1885)

93 Diatomaceae of Minnesota interglacial peat. Minn G S, An Rp 20:290293 (1893)

95 (with Woodward, A.) The micro. scopical fruna of the Cretaceous in Min. nesota, with additions from Nebraska and Illinois (Foraminifera, Radiolaria, coceliths, rhabdoliths). Minn G S, Final Rp 3 pt $1: 23-52$, il (1895)

Thomas, David.

30 Diluvial furrows and scratches. An J Se $17: 408$ (1830)

30a Geological facts [dip in western New York]. Am J Sc 18:375-376 (1830)

31 Remarks on Professor Eaton's 0b. servations on the coal formations in the State of New York. Am J Sc 19:326328 (1831)

Thomas, Kirby.

oo Copper mining in northern Wisconsin. Mines and Minerals $21: 102$ (1900)

02 Mining developments in eastern 0 . tario. Eng M J 74:186-187 (1902)

02a Glacial gold in Wisconsin. Eng II J $74: 248$ (1902)

04 Notes on the geology of a new iron district in Minnesota [Aitkin Co.]. Mines and Minerals 25:27 (1904)

09 District of El Chico, State of Hldalgo, Mexico. Mex M J 8: 15-17 (1909)

12 Vanadium in southwestern Colorado. M Sc Press 104:168 (1912)

$12 a$ The Cuyuna iron range. M Sc Press 105: 52-53 (1912)

12b The Sudbury nickel district, Ont. M Sc Press 105: 433 (1912)

13 Zinc ore deposits in Boone and Marion cos., Ark. M Sc Press 107:854855 (1913)

14 The Sudbury nickel district of 0 tario. Eng M J 97: 152-154, map (1914)

18 Principles and problems of oll pros. pecting in the Gulf coast country (discussion). Am I M Eng, B 136:832-833 (1918) 
Thomas, Kirby-Continued.

18a Sulphur deposits in the trans-Pecos region in Texas. Eng M J 106:979-981 (1918)

18b Saline domes and other salt deposits. M Sc Press 117:226 (1918)

See also Matteson, 18

Thomas, N. Wiley.

82 (with Smith, Edgar F.) Corundum and wavellite. Am $\mathrm{Ph}$ Soc, $\operatorname{Pr} 20: 230-$ 231 (1882)

Thomassy, Raymond (1810-1863).

60 Géologie pratique de la Louisiane. 263 pp, New Orleans 1860

60a Hydrologie du Mississippi. Soc G France, B (2) $17: 242-262$ (1860)

$60 b$ [Sur la delta du Mississippi.] Ac Sc Paris, C R 51:133 (1860)

63 Supplément à la Géologie pratique de la Louisiane. Ile Petite-Anse. Soc G France, B (2) 20:542-544, map (1863)

Thompson, A. H.

87 The relation of a State geological survey to the work of the national survey. Kans Ac Se, Tr 10:9-13 (1887)

87a (with Hay, Robert) Historical sketch of geological work in the State of Kansas. Kans Ac Sc, Tr 10:45-52 (1887)

98 In memoriam, Robert Hay. Kans Ac Sc, Tr $15: 131-134$ (1898)

Thompson, Arthur.

12 The Katalla, Alaska, oll fleld, M Sc Press 105: 169-170 (1912)

Thompson, Arthur Beeby.

11 The relationship of structure and petrology to the occurrence of petroleum. Inst $\mathrm{M}$ Met, $\operatorname{Tr} 20: 215-241$ (1911) Min Sc 63: 290-291 (1911)

Thompson, Arthur $G$.

15 Yakataga beach placers [Alaska]. Eng M J $99: 763-765$ (1915)

Thompson, Arthur Perry.

13 The relation of pyrrhotite to chalcopyrite and other sulphides. Sch Mines Q $34: 385-395$ (1913)

14 On the relation of pyrrhotite to chalcopyrite and other sulphides. Ec G 9 : 153-174 (1914)

15 The occurrence of covellite at Butte, Mont. (with discussions by A. S. Eakle, C. F. Tolman, jr., L. C. Graton, A. C. Lawson, J. C. Ray, and A. F. Rogers). Am I M Eng, B 100:645-677; 108: 2464-2471 (1915) ; Tr $52: 563-603$ (1916)

Thompson, Gilbert.

90 An hypothesis for the so-called encroachments of the sea upon the land. Science 15:333 (1890)

Thompson, James D., Jr.

14 The Locust Grove esker, Ohto. Denison Univ, Sc Lab, B $17: 395-398$, map (1914)

Thompson, Joseph L.

70 On the cause of glacier motion. Can J A s 12: 412-414 (1870)
Thompson, Lester H.

16 (with Ball, S. H.) The southwest Virginia lead-zinc deposits. Eng M J 102 : 735-737 (1916)

Thompson, Maurice (1844-1901).

s6 Fifteenth annual report, $1886[\mathrm{com}$ pendium of the geology and mineralogy of Indiana; building stone and clays; glacial deposits; a terminal moraine in central Indiana]. Ind, Dp G N H : $359 \mathrm{pp}$, Indian apolis 1886

86a Fossil mammals of the post-Pliocene in Indiana. Ind, $\mathrm{Dp} \mathrm{G} \mathrm{N} \mathrm{H}$, An $\mathrm{Rp} 15$ : 283-285 (1886)

86b Natural gas. Ind, Dp G $\mathrm{N} \mathrm{H}, \mathrm{An}$ Rp 15: 314-333 (1886)

89 The drift beds of Indiana. Ind, Dp G N H, An Rp 16:20-40 (1889)

89a The Wabash arch. Ind, Dp G N H, An Rp 16:41-53 (1889)

\$9h Gold, silver, and precious stones. Ind, Dp G N H, An Rp 16:87-92 (1889)

89c The formation of soils and other superficial deposits. Ind, Dp $\mathrm{G} \mathrm{N} \mathrm{H,} \mathrm{An}$ Rp 16:93-97 (1889)

89d List of specimens in the State museum. Ind, Dp G N H, An Rp 16:383468 (1889)

92 A report upon the various stones used for building purposes and found in Indiana. Ind, $D p G N$ Res, An Rp 17 : 18-113 (1892)

92n Geological and natural history report of Carroll Co. Ind, Dp G N Res, An Rp $17:$ 171-191 (1892)

Thompson, Phillips.

06 Iron ore in Ontario. Eng M J 81: 719-720 (1906)

o6a The Sudbury nickel region. Eng M J $82: 3-4$ (1906)

06b Coal in Alberta. Eng M J 82:924 (1906)

Thompson, R. 0 .

74 The lead deposits. In Campbell, R. A., Gazetteer of Missouri : 731-745, St. Louis 1874

74a The iron deposits. In Campbell, R. A., Gazetteer of Missouri : 745-754, St. Louis 1874

Thompson, Robert Andrew.

93 Report on soils, water supply, and irrigation of the Colorado coal field. Tex G S, An Rp 4 pt 1:447-481 (1893)

Thompson, W. P.

12 The structure of the stomata of certain Cretaceous conifers. Bot Gaz 54:6367 (1912)

Thompson, Will $\mathrm{H}$.

86 A geological survey of Clinton Co.; Marshall Co. ; ... Starke Co. Ind, Dp G N $\mathrm{H}$, An Rp $15: 154-159,177-182,221-227$ (1886)

86a (and Lee, S. E.) Maxinkuckee [Lake]. Ind, Dp G N H, An Rp 15:182186 (1886) 
Thompson, Will H.-Continued.

89 Fossils and their value. Ind, Dp G N H, An Rp 16:54-76 (1889)

89a Outline sketch of the most valuable minerals of Indiana. Ind, Dp G N H, An Rp 16:77-86 (1889)

89b Partial report of survey of the western division, including sketches of Pulaski and White cos. Ind, Dp G N H, An Rp 16: 131-154 (1889)

Thompson, William A.

31 Scratches on elevated strata of horizontal gravwacke in the Alleghany Range; probably diluvial. Am J Sc 20:125 (1831)

33 Facts relating to diluvial action. Am J Sc 23: 243-249 (1833)

Thompson, Zadock (1796-1856).

45 (with Hall, S. R.) Report [northern Vermont]. In Adams, C. B., First annual report on the geology of the State of Vermont : $68-76 \quad(1845)$

46 Report [Chittenden Co.]. In Adams, C. B.. Second annual report on the geology of the State of Vermont: 259-261 (1846)

4. Geography and geology of Vermont. 220 pp, Burlington 1848

50 An account of some fossil bones found in Vermont in making excavations for the Rutland and Burlington Railroad. $\Delta \mathrm{m} \mathrm{J} \mathrm{Sc}$ (2) $9: 256-263$, il (1850)

$50 a$ [On bones of a cetacean found near Rutland, vt.]. Boston Soc N H, Pr 3: 205-206 (1850)

51 [Lignitic deposit near Burlington, Vt.1 Boston Soc N H, Pr 4:33-34 (1851)

53 Geology and mineralogy of Vermont. In his History of Vermont ... : 222-224 Burlington 1853 With title, Geology of Vermont; In Appendix to Thompson's Vermont : $40-58$, il [1853]

56 Report on the geological survey. In Young, Augustus, Preliminary report on the natural history of the State of Vermont: 55-57 (1856)

$56 a$ Extract from address on the natural history of Vermont. In Young, Augustus, Preliminary report on the natural history of the State of Vermont: 65-68 (1856)

61 Dikes of Chittenden Co. In Report on the geology of Vermont (Hitchcock) 2 : $579-583 \quad(1861)$

Thomson, Elihu.

06 The nature and origin of volcanic heat. Science n \& 24:161-166 (1906)

12 The fall of a meteorite [origin of Meteor Crater (Coon Butte), Ariz.]. Am Ac Arts, Pr 47: 721-733 (1912)

Thomson, Ellis.

17 Dryden gold area. Ont Bur Mines, An Rp 26:163-189, map (1917)

18 A pegmatitic origin for molybdenite ores. Ec G 13:36L-313 (1918)

18a Some Canadian cerusite crystals. Am Mineralogist 3:41-43 (1918)
Thomson, James.

77 (with Nicholson, H. A.) Descrip tions of some new or imperfectly under stood forms of Paleozoic corals (abst). R Soc Edinb, Pr 9:149-150 (1877)

86 The geology of the Territory of Idaho, U. S., and the silver lode of At. lanta $(a b s t)$. G Soc Glasgow, Tr 8:17i177 (1886)

Thomson, Robert Boyd.

12 (and Allin, A. E.) Do the Abje. tineæ extend to the Carboniferous? Bot Gaz 53:339-344 (1912) Abst, Science n s $35: 159$ (1912)

Thomson, R. W.

10 The Portland Canal mining district. B. C. Can M Inst, Q B 10:197-203 (1910) M World 32:1083-1084 (1910)

Thomson, Thomas.

12 A chemical analysis of sodalite, \& new mineral from Greenland. $R$ Soc Edinb, Tr 6:387-395 (1812)

Thore11, $\mathrm{T}$.

86 On Proscorpius osbornei Whitfield. Am Nat 20:269-274 (1886)

Thorne, Joshua.

78 The Rosedale coal vein [Kansas City, Mo.]. Western Rv Sc 2:210 (1878)

79 The Rosedale gas and coal wells [Kansas City, Mo.]. Kansas City Rr Se $3: 410-412$ (1879)

Thornton, E. Q.

58 Reports on portions of the Crets. ceous and Tertiary formations. In Tuomey, M., Second biennial report on the geology of Alabama : 223-252, Montgomery 1858

Thornton, William M., jr.

10 An association of enargite, covellite, and pyrite from Ouray Co., Colo. Am J Sc (4) 29:358-359 (1910)

11 A feldspar aggregate occurring in Nelson Co., Va. Am J Sc (4) 31:218220 (1911)

Thurean, G.

7o Synopsis of a report on mining in California and Nevada, U. S. A. $60 \mathrm{pp}$, Melbourne [1879]

Thurston, L: A.

94 The recent eruption in the crater of Kilauea. Am J Sc (3) $48: 338-342$ (1894) Thwaites, Fredrik Turville.

12 Sandstones of the Wisconsin coast of Lake Superior. Wis G S, B 25 ( $(\mathrm{sc}$ s 8) $117 \mathrm{pp}$, map (1912)

12a (with Hotehkiss, W. O.) Map of Wisconsin showing geology and roads, 1911. Wis G S [1912]

14 Recent discoveries of "Clinton" iron ore in eastern Wisconsin. U S G S, B $540: 338-342$ (1914)

Thwaites, Reuben Gold.

04 (editor) Original journals of the Lewis and Clark expedition, 1804-1806 ... 7 vols and atlas, N Y 1904 
Tibby, Benjamin F.

12 (with Johnson, J. E.) Field classification of igneous rocks. Salt Lake Min Rv $13: 17-19$ (1912)

18 The East Tintic district, Utah. M Sc Press 116: 341-342 (1918)

Tiernan, A. K.

17 The Cedar Range gold district of western Nevada. Salt Lake M Rv 19 no $11: 23-25$ (1917)

\section{Tiffany, A. S.}

s3 The equivalent of the New York water lime group developed in Iowa (abst). Am As, Pr $32: 246-247$ (1884) Science $2: 323-324$ (1883)

85 Geology of Scott Co., Iowa, and Rock Island Co., III., and the adjacent territory ... 34 pp, Davenport, Iowa, 1885 89 The artesian well at City Park, Davenport, Iowa. Am G 3: 117-118 (1889) 90 Deep well at Dixon, Ill. Am G 5 : 124 (1890)

92 Ancient waterways $(a b s t)$. G Soc Am, B 4:10-11 (1892)

Tifrany, J. E.

06 Virginia anthracite field; a region showing coal formations, the values of which have not yet been thoroughly proved by prospecting. Mines and Minerals 26 : $349-350$ (1906)

Tight, William George (1865-1910).

87 (and Herrick, C. L., and Jones. H. L.) Geology and lithology of Michipicoten Bay. Denison Univ, Sc Lab, B 2 : 119-143 (1887) Abst, Am Nat 21:654655 (1887)

91 Some observations on the crushing effects of the glacial ice sheet. Denison Univ, Sc Lab, B 6: 12-14 (1891)

94 A contribution to the knowledge of the preglacial drainage of Ohlo. Denison Univ, Sc Lab, B $8: 35-62$, maps (1894)

94a Lake Licking; a contribution to the buried drainage of Ohio. Ohio St Ac $\mathrm{Sc}$, An Rp $2: 17-20$ (1894)

94b A glacial ice dam and a limit to the ice sheet in central Ohio. Am Nat 28: 488-493 (1894)

95 A preglacial tributary to Paint Creek and its relation to the Beech Flats of Pike Co. [Ohio]. Denison Univ, Sc Lab, B $9: 25-34$ (1895)

97 Some preglacial drainage features of southern Ohio. Denison Univ, Se Lab, B 9 pt $2: 22-32$ (1897)

97a A preglacial valley in Fairfield Co. [Ohio]. Denison Univ, Sc Lab, B 9 pt 2 : $33-37$ (1897)

98 The development of the Ohio River (abst). Am G 22:252 (1898) Science n s $8: 465-466$ (1898)

00 Drainage modifications in Washington and adjacent counties [Ohio]. Ohio St Ac Se, Sp P no 3:11-31, map (1900) 00a Topographic features of Ohio (abst). Sclence n s 11:100 (1900)
Tight, William George-Continued.

oob Drainage modifications in south. eastern Ohio (abst). Selence n s 11:100101 (1900)

o1 Preglacial drainage in southwestern Ohio. Science n s 14:775-776 (1901)

03 Drainage modifications in southeastern Ohio and adjacent parts of West Virginia and Kentucky. U S G S, P P 13 $111 \mathrm{pp}$, maps (1903)

05 Clarence Luther Herrick. Am G 36 : 1-26, port (1905)

05a Bolson plains of the Southwest. Am G 36:271-284 (1905)

or Pleistocene phenomena in the Mississippi basin; a working hypothesis (abst) G Soc Am, B 17: 730 (1907)

07a Preglacial drainage in the Mississippi Valley; a working hypothesis (abst).

Science n s 25:772-773 (1907)

Tilden, Bryant P., jr.

47 Notes on the upper Rio Grande.. 32 pp, maps, Phila 1847

Tilden, George C.

87 Mining notes from Eagle Co. [Colo.]. Colo Sch Mines, Bien Rp 1886:129-133 (1887)

Tilghman, Benjamin Chew.

06 Coon Butte, Ariz. Ac N Sc Phila, Pr 57: 887-914 (1906)

06a (with Barringer, D. M.) The geology of Coon Butte, Ariz. (abst). Science n s 24:370-371 (1906); Am As, Pr 56-57: 271 (1907)

Tillman, S. E.

00 A textbook of important minerals and rocks. $176 \mathrm{pp}, \mathrm{N}$ Y 1900

Tillotson, Edwin Ward, jr.

os (with Farrington, O. C.) Notes on various minerals in the museum collection. Field Mus (g s) 3:131-163 (1908)

osa (with Ford, W. E.) On orthoclase twins of unusual habit. Am J Sc (4) $26: 149-154$ (1908)

Tilton, John Littlefield.

93 Strata between Ford and Winterset [Iowa]. Iowa Ac Sc, $\operatorname{Pr} 1$ pt $3: 26-27$ (1893)

94 Origin of the present drainage system of Warren Co. [Iowa]. Iowa Ac Sc, Pr 1 pt $4: 31-33$ (1894)

95 Geological section along Midale River in central Iowa. Iowa $\mathrm{G}$ S $3: 137$ 146 (1895)

95 On the southwestern part of the Boston Basin. Boston Soc N H, Pr 26: 500-505, map (1895)

96 Geology of Warren Co. Iowa G S 5: 301-359, map (1896)

96a The area of slate near Nashna, N. H. Iowa Ac Sc, $\operatorname{Pr} 3: 66-71$, map (1896)

$96 \mathrm{~b}$ Notes on the geology of the Boston basin [Mass.]. Iowa Ac Se, $\operatorname{Pr} 3: 72-74$, $\operatorname{map}$ (1896)

97 (and Bain, H. F.) Geology of Madi son Co. Iowa G S 7:489-539, map (1897) 
Tilton, John Littlefield Continued.

97 Results of recent geological work in Madison Co. [Iowa]. Iowa Ac Se, $\operatorname{Pr} 4$ : $47-54$ (1897)

10 Pleistocene record of the Simpson College well. Iowa Ac Sc, Pr 17: 159-164 (1910)

11 The Pleistocene deposits in Warren Co., Iowa. Thesis, University of Chieago, 42 pp, Chicago 1911

12 The first reported petrified American Lepidostrobus is from Warren Co., Iowa. Iowa Ac Sc, Pr 19: 163-165 (1912)

13 A new section south from Des Moines, Iowa. Science $n$ s $38: 133-135$, abst 241 (1913)

13a A Pleistocene section from Des Moines south to Allerton. Iowa Ac Sc, Pr 20:213-220 (1913)

13b The proper use of the geologieal name "Bethany." Iowa Ac Sc, Pr 20: 207-211 (1913) Abst, Science n s $38: 241$ (1913)

14 An area of Wisconsin drift further south in Polk Co., Iowa, than hitherto recognized. Iowa Ac Se, Pr 21: 219-220, map (1914) Abst, Science n s $40: 145$ (1914)

15 The extension of the Wisconsin drift southwest from Des Moines [Iowa]. Jowa Ac Sc, Pr 22:229-232 (1915) Abst, Science a s $41: 950$ (1915)

15a The age of the terrace south of Des Moines, Iowa. Iowa Ac Sc, Pr 22:233236 (1915) Abst, Science n $\mathrm{s}$ 41:950 (1915)

Tippenhauer, L. Gentil.

99 Geologische Studien in Haiti. Petermanns Mitt 45:25-29, 153-155, 201-204, maps $(1899) ; 47: 121-127,169-178,193$ 199, maps (1901)

09 Neuer Beitrag zur Topographie, Bevölkerungskunde, und Geologie Haitis. Petermanns Mitt 55: 49-57 (1909)

Titeomb, H. A.

02 The Camp Bird gold mine and mills [San Juan region, Colo.]. Sch Mines Q 24:56-67 (1902)

Toed, Charles A.

12 A problematical geological phenomenon in Colorado $(a b s t)$. Science $\mathrm{n} s \mathrm{~s}$ : 715 (1912)

Todd, J. H.

oo Some observations on the preglacial drainage of Wayne and adjacent counties [Ohio]. Ohio St Ac Sc, Sp P no 3:46-67, map (1900)

Todd, James Edward.

78 On the annual deposit of the Missouri River, during the post-Pliocene (abst). Am As, Pr 26:287-291 (1878)

79 Richthofen's theory of the loess, in the light of the deposits of the Missouri. $\Delta \mathrm{m} \mathrm{As,}$ Pr 27: 231-239 (1879)
Todd, James Edward-Continued.

79n Has Lake Winnipeg discharged through the Minnesota within the last tno hundred years? Am J Sc (3) 17:120 (1879)

so On the relation of loess to drift in southwestern Iowa (abst). Iowa $\mathrm{Ac} S \mathrm{Sc}$ Pr 1875-80:19 (1880)

Soa on certain changes in the Platte River during the Quaternary (abst). Iowa Ac Sc, Pr 1875-80:20 (1880)

81 Quaternary deposits of western Iowa and eastern Nebraska (with discussion by T. C. Chamberlin and C. A. White). Pt Soc Wash, B 4:120-122 (1881)

82 A description of some fossil tracks from the Potsdam sandstone. Wis Ac $8 c$, Tr 5: 276-281, il (1882)

83 On the geological effects of a vary. ing rotation of the earth. An Nat 17: 15-20 (1883)

83a Intermittent wells in Nebraska. Am Nat $17: 533-534$ (1883)

S4 The possible origin of some osar. Science 3: 404 (1884)

85 The Missouri Coteau and its moraines. Am As, $\operatorname{Pr} 33: 381-393$, map (1885)

86 Quaternary voleanic deposits in Ne. braska. Science $7: 373$ (1886)

89 Further notes on a " green quartzite from Nebraska." Am G 3:59-60 (1889)

89a Evidence that Lake Cheyenne con. tinued until the ice age $(a b s t)$. Am As, Pr $37: 202-203(1889) \quad$ Am Nat $23: 436-437$ (1889)

89b The terraces of the Missouri (abst). Am As, Pr $37: 203-205$ (1889) Iowa Ac Sc, $\operatorname{Pr} 1887-89: 11-12$ (1890)

90 The origin of the extramorainic till (abst). Iowa Ac Se, Pr 1887-89:12-14 (1890)

90a The lineage of Lake Agassiz (abst). Iowa Ac Sc, Pr 1887-89:57-58 (1890)

$90 b$ On the folding of Carboniferous strata in southwestern Iowa $(a b s t)$. Iowa Ac Sc, Pr 1887-89:58-62 (1890)

91 Strix and slickensides at Alton, III. (abst). Am G 8:236 (1891) Am As, Pr $40: 254-255$ (1892)

92 Striation of rocks by river lce. Am G 9:396-400 (1892) Iowa Ac Sc, Pr 1 pt $2: 19-20$ (1892)

92a Volcanic dust from Omaha, Nebraska. Am G 10:295-296 (1892) Iowa Ac Sc, Pr 1 pt 2:16 (1892)

92b The shore lines of ancient glacial lakes. Am G 10:298-302 (1892) Iows Ac Sc, Pr 1 pt $2: 17-19$ (1892)

92e Notes on the geology of northwestern Iowa. Iowa Ac Sc, Pr 1 pt 2: 13-16 (1892)

92d Further notes on the Loup and Platte rivers. Science 19: 148-149 (1892) 
Todd, James Edward-Continued.

93 Preliminary report of a reconnais sance in northwestern Minnesota in 1892. Minn G S, An Rp 21: 68-78 (1893) Abst, Minn, Univ, Q B 2:91-92 (1894)

94 Preliminary report of reconnaissance in northwestern Minnesota during 1893. Minn G S, An Rp 22: 90-96 (1894)

94a Pleistocene problems in Missouri. G Soc Am, B 5:531-548 (1894) Abst, Am G $13: 216-217$ (1894)

95 A preliminary report on the geology of South Dakota. S Dak G S, B 1:172 pp, map, Sioux Falls, S. Dak., 1895

95a (and Bain, H. F.) Interloessial till near Sioux City, Iowa. Iowa Ac Sc, Pr 2: 20-23 (1895)

95b Inequalities in the old Paleozoic sea bottom. Am G 15:64 (1895)

95e Volcanic ash bed near Omaha. Am G $15: 130$ (1895)

95d Recent geological work in South Dakota. Am G 16:202 (1895)

96 The moraines of the Missouri Coteau and their attendant deposits. - U S G S, B 144: $71 \mathrm{pp,} \mathrm{map} \mathrm{(1896)}$

96n Formation of the Quaternary deposits. Mo G S 10:111-217, map (1896)

96b Loglike concretions and fossil shores. Am G $17: 347-349$ (1896)

96e The hydraulic gradient of the main artesian basin of the Northwest (abst). Am G 18:219-220 (1896) Seience $n$ s $4: 385$ (1896)

96 A revision of the moraines of Minnesota (abst). Am G 18:225-226 (1896) Science n \& 4:385 (1896)

97 Volcanic dust in southwestern Ne braska and in South Dakota. Science n s 5: 61-62 (1897)

97a The Quaternary of Missouri. Science n s 5:695-696 (1897)

$97 \mathbf{b}$ Is the loess of either lacustrine or semimarine origin? Science n \& 5:993994 (1897)

9s The first and second biennial reports on the geology of South Dakota with accompanying papers, 1893-6. S Dak G S, B 2: 130 pp, Vermilion, S. D., 1898

9Sa A revision of the moraines of Minnesota. Am J Sc (4) 6:469-477, map (1898)

98b Degradation of loess. Iowa Ac Sc, Pr 5:46-51 (1898)

98e The elay and stone resources of South Dakota, Eng M J 66:371 (1898)

99 The moraines of southeastern South Dakota and their attendant deposits. U S G S, B 158: 171 pp, maps (1899)

99a The geology of Hubbard Co. and northwestern portions of Cass Co. ; ... Norman and Polk cos.; ... Marshall, Roseau, and Kittson cos. ; ... Beltrami Co. Minn G S, Final Rp 4:82-155, maps (1899)

$99 \mathrm{~b}$ New light on the drift in South Dakota. Iowa Ac Sc, Pr $6: 122-130$ (1899) Am G 25:96-105 (1900)
Todd, James Edward-Continued.

00 Geology and water resources of a portion of southeastern South Dakota, U S G S, W-S P 34:34 pp, maps (1900)

01 River action phenomena. G Soc Am, B 12: 486-490 (1901)

01 a Some problems of the Dakota arte. sian system $(a b s t)$. Science n s 14:794 (1901)

01b Moraines and maximum diurnal temperature (abst). Science n s 14:794795 (1901)

02 Mineral building material, fuels, and waters of South Dakota, with production for 1900. S Dak G S, B 3: 81-130 (1902) Stone 25:413-418, 521-524; 26:20-27 (1903)

02a Hydrographic history of South $\mathrm{Da}$ kota. G Soc Am. B 13:27-40, map (1902) Abst, Sc Am Sup 52: 21504-21505 (1901)

03 Description of the Olivet quadrangle [S. Dak.]. U S G S, G Atlas Olivet fol (no 96) :6 pp, maps (1903)

03a Description of the Parker quadrangle [S. Dak.]. U S G S, G Atlas Parker fol (no 97): 6 pp, maps (1903)

03b Description of the Mitchell quadrangle [S. Dak.]. U S G S, G Atlas Mitchell fol (no 99): 7 pp, maps (1903)

03e (and Hall, C. M.) Description of the Alexandria quadrangle [S. Dak.]. U S G S, G Atlas Alexandria fol (no 100): 6 pp, maps (1903)

o3d Concretions and their geological effects. G Soc Am, B 14: 353-368 (1903) Abst, Eng M J $75: 153$ (1903)

o3e Further notes on Lake Arickaree [glacial lake, South Dakota]. Seience $n \mathrm{~s}$ $17: 227$ (1903)

osf A newly discovered rock at Sioux Falls, S. Dak. Stone 27:46-48 (1903)

04 Description of the Huron quadrangle [S. Dak.]. U S G S, G Atias Huron fol (no 113): $6 \mathrm{pp}$, maps (1904)

04a (and Hall, C. M.) Deseription of the De Smet quadrangle [S. Dak.]. U S G S, G Atlas De Smet fol (no 114): 6 pp. maps (1904)

04b (and Hall, C. M.) Geology and water resources of part of the lower James River valley, S. Dak. U S G S, W-S P 90:47 pp, maps (1904)

o4e Benton formation in eastern South Dakota. G Soc Am, B 15:569-575, map (1904)

04d The newly discovered rock at Sioux Falls, S. Dak. Am G 33: 35-39 (1904)

04e Sketch of South Dakota geology. Am M Cong, 6th, Pr : 51-57 (1904)

06 Some variant conclusions in Iowa geology. Iowa Ac Se, Pr, I3: 183-186 (1906)

06a More light on the origin of the Missouri River loess. Iowa Ac Sc, Pr 13: 187-194 (1906) 
Todd, James Edward-Continued.

07 Recent alluvial changes in southwestern Iowa. Iowa Ac Sc, Pr 14: 257266 (1907)

07a Effects of eertain characteristics of rocks on their erosion. Iowa Ac Sc, Pr 14:267-270 (1907)

os Description of the Elk Point quadrangle, S. Dak.-Nebr.-Iowa. U S G S, G Atlas Elk Point fol (no 156): 8 pp, maps (1908)

09 Description of the Aberdeen-Redfield district, S. Dak. U S G S, G Atlas Aberdeen-Redfield fol (no 165) : $13 \mathrm{pp}$, maps (1909)

09a Drainage of the Kansas ice sheet. Kans Ac Sc, Tr 22:107-112 (1909)

10 Preliminary report on the geology of the northwest-central portion of South Dakota. S Dak G S, B 4 (Rp St G 1908) : 13-76, 193-207 (1910)

10a A speculation in crystallography. Science n s $32: 216-218$ (1910)

10b (with Udden, Jon A.) Structural materials in Illinois. Ill G S, B $16: 342$ 393 (1910)

11 Is the Dakota formation upper or lower Cretaceous? Kans Ac Sc, Tr 23-24: 65-69 (1911)

11 a History of Wakarusa Creek, Kansas. Kans Ac Sc, Tr 23-24: 211-218 (1911)

12 Pre-Wisconsin channels in southeastern South Dakota and northeastern Nebraska. G Soc Am, B $23: 463-470$ (1912)

13 Evidence of Pleistocene crustal movements in the Mississippi Valley: Kans Univ Sc B 6:375-379 (1912) [1913] Abst, Science n s $33: 466$ (1911)

13a More about septarian structure. G Mag (5) $10: 361-364$ (1913)

13b The "moraines" of Kansas (abst). Science n \& $37: 457$ (1913)

13e Traces of an early Wisconsin flood (abst). Science n s $37: 457$ (1913)

14 The Pleistocene history of the Missouri River. Science n s $39: 263-274$, map (1914)

15 A mnemonic couplet for geologic periods. Science n s 42:908 (1915)

18 Kansas during the ice age. Kans Ac Sc, $\operatorname{Tr} 28: 33-47$, map (1918)

18 aistory of Kaw Lake [Kans.]. Kans Ac Sc, Tr 28: 187-199 (1918)

18b Eolian loess. Kans Ac Sc, Tr 28: 200-203 (1918)

See also Crook, 18; Gordon (C H), 93 ; Kay $(G$ F), 18; Union Pacific Railroad Company, 09; Winslow, 92

Törnebohm, A. E.

86 Karakteristik af bergartsprof, insamlade af den svenska expeditionen till Grönland år 1883: G Fören Stockholm, Förh 8: $431-441$ (1886)
To11, R. H.

o8 La Plata Mountains, Colo. M \& Press 97:741-744 (1908)

12 Mineral Hill, Nev. M Sc Press 104: 888-889 (1912)

Tolman, Cyrus Fischer, jr.

99 The carbon dioxide of the ocean and its relations to the carbon dioxide of the atmosphere. J G 7:585-618 (1899)

06 Methods of investigating problems in faulting. M Mag 13:99-108 (1906)

o7 How should faults be named and classified? Ec G 2:506-511 (1907)

09 The geology of the vicinity of the Tumamoc Hills, Ariz. In Spalding, V. M. Distribution and movements of desert plants (Carnegie Inst Wash, Pub no 113): $67-82$, maps (1909)

O9a Erosion and deposition in the southern Arizona bolson region. J G 17: 136-163 (1909)

09b The southern Arizona copper fields. M Sc Press $99:$ 356-360, 390-393 (1909)

09e Disseminated chalcocite deposits at Ray, Ariz. M Se Press 99:622-624 (1909)

o9d The Miami-Inspiration ore zone [Globe district, Ariz.]. M Sc Press 99: 646-658 (1909)

09e Copper deposits of Silverbell, Ariz. M Sc Press 99: 710-712 (1909)

10 Copper in Arizona in 1909 . M \& Press 100: 71-72 (1910)

10a Geology at Globe, Ariz. M Sc Press $100: 327-328$ (1910)

10b Engineering and economic aspects of low-grade copper deposits. Eng Mag 38 : 893-904 (1910)

11 Graphic solution of fault problems M Sc Press 102:810-812; 103:128-130, $157-160$ (1911) Revised and printed in book form, 43 pp, San Francisco 1911

12 Magmatic origin of ore-forming solt tions. M Sc Press 104: 401-404 (1912)

12a The teaching of economic geologf (discussion). Ec G $7: 393-399$ (1912)

12b Persistence of ore in depth. M Sc Press 105 : 311-312 (1912)

12e An Arizona earthquake [August 18, 1912]. Seism Soc Am, B 2:209-210 (1912)

12d Geological sketch of the Papagueria. In Lumholtz, Carl, New trails in Mexico: 398-399, N Y 1912

13 Secondary sulphide enrichment of ores. M Sc Press 106:38-43, 141-145, 178-181 (1913)

14 (and Clark, J. D.) The oxidation, solution, and precipitation of copper in electrolytic solutions and the dispersion and precipitation of copper sulphides from colloidal suspensions, with a geological discussion. Ec G 9:559-592 (1914)

14a Recent advances in the study of sulphide enrichment. M Sc Press 108: 172-176 (1914) 
Tolman, Cyrus Fischer, jr.-Continued.

14b The laboratory study of secondary enrichment. M Sc Press 109:649-650 (1914)

15 Geology of the west coast of the United States. In Nature and science on the Pacific coast: 41-61, maps San Franciseo 1915 (See Merriam, 15)

15a Bajadas of the Santa Catalina Mountains, Arizona (abst). G Soc Am, B $26: 391$ (1915)

15b (and others) Some physiographic features of bolsons (discussion). G Soc Am, B 26:392-393 (1915)

15e Examples of progressive change in the mineral composition of copper ores (abst). G Soc Am, B 26:394-395 (1915)

16 (and Rogers, A. F.) A study of the magmatic sulfid ores. Leland Stanford Junior Univ Pub, Univ Ser : 76 pp (1916)

16a Observations on certain types of chalcocite and their characteristic etch patterns (with discussion by L. C. Graton, A. C. Lane, J. T. Singewald, C. P. Berkey, and E. Posnjak, E. T. Allen, and H. F. Merwin). Am I M Eng, B 110:401-433 (1916) ; $\operatorname{Tr} 54: 402-441$ (1917)

17 Ore deposition and enrichment at Engels, Cal. Ee G $12: 379-386$ (1917)

17a (and Rogers, A. F.) The origin of the Sudbury nickel ores. Eng M J 103: 226-229 (1917)

17b (and Rogers, A. F.) The magmatic sulfids $(a b s t)$. G Soc Am, B 28: 132-133 (1917)

See also Overbeck, 16; Rogers (A F), 16; Thompson (A P), 15

Tomlinson, C. $\mathrm{H}$.

32 Alluvial deposits of the Mohawk. Am I Se 23: 207 (1832)

Tomlinson, Charles Weldon.

15 Method of making mineralogical analysis of sand. Am I M Eng, B 101:947956 (1915) ; $\mathrm{Tr} 52: 852-861$ (1916)

16 The origin of the red beds; a study of the conditions of origin of the PermoCarboniferous and Triassic red beds of the western United States. J G 24:153-179, 238-253, map (1916)

17 The middle Paleozoic stratigraphy of the central Rocky Mountain region. J G $25: 112-134,244-257,373-394$ (1917)

18 Present status of the problem of the origin of loess (abst, with discussion by Frank Leverett, J. L. Rich, A. R. Crook, I. H. Lees, and W. H. Bucher). G Soc Am, B $29: 73-74$ (1918)

Tomlinson, W. Harold.

06 Determination of minerals by petrographical methods. Mineral Collector 13: $89-90 \quad$ (1906)

14 Commercial petrographic reports. Ec G $9: 67-72$ (1914)
Tondorf, Francis A.

17 The registration of earthquakes at the Georgetown University [D. C.] Station ... January 1,1916 , to January 1,$1917 ; \ldots$ January 1, 1917, to January 1, 1918. Georgetown Univ, Sesismographic Station, B no 1:23 pp (1917) ; no 2:30 pp (1918) Tonge, Alfred J.

14 Coal as seen under the microscope. M Soc N S, J 19:44-48 (1914)

Tonge, James.

07 Coal. 275 pp, N Y 1907

Topham, Harold W.

S9 A visit to the glaciers of Alaska and Mount St. Elias. R Geog Soc, Pr 11:424435 (1889)

Topley, William.

87 Notes on the recent earthquakes in the United States. Brit As, Rp 46:656657 (1887)

92 The geology of petroleum and natural gas (abst). Brit As, Rp 61:637-639 (1892)

Tornier, Gustav.

09 Wie war der Diplodocus carnegii wirklich gebaut? Ges Naturf Freunde Berlin, Szb 1909: 193-209, il

09 arnstes und lustiges aus Kritiken iber meine Diplodocus-Arbeit. Ges Nature Freunde Berlin, Szb 1909:505-536, il

09b War der Diplodocus elefantenfüssig? Ges Naturf Freunde Berlin, Szb 1909: 536557 , il

10 Ueber und gegen neue DiplodocusArbeiten. Deut G Ges, Monatsb 1910: 536576 , il

Torrance, J. Fraser.

85 Report on apatite deposits, Ottawa Co., Que. Can G S, Rp Prog 1882-4: J 32 pp (1885)

Torre, Carlos de la.

92 Observaciones geologicas y paleontologicas en la región central de la Isla [de Cuba]. R Ac Cienc Habana, An 29: 121-124 (1892)

10 Excursión cientifica a Viñales; descubrimiento de Ammonites del período jurásico en Cuba. Ac Cienc Méd Habana, An Rv Cient $47: 187-191$ (1910)

10a Excursión á la Sierra de Jatibonico; osamentas fosiles de Megalocnus rodens 6 Myomorphus cubensis: comprobacion de la naturaleza continental de Cuba a principios de la época cuaternaria. Ac Cienc Méd Habana, An, Rv Clent 47:192203, il (1910)

106 Investigaciones paleontologicas re alizadas en las Sierras de Viñales y Jatibonico. Ac Ciene Méd Habana. An, Rv Cient 47: 204-217, il (1910)

12 Comprobation de l'existence d'un horizon jurassique dans la région oceidentale de Cuba (with discussion). Int G Cong, XI, Stockholm, C R : 1021-1022 (1912) 
Beyer, Samuel Walker-Continued.

o3 (and Young, L. E.) Geology of Monroe Co. Iowa G S $13: 353-422$, map (1903)

04 (and Williams, I. A.) Technology of clays. Iowa G S $14: 29-318$ (1904)

O4a (and Williams, I. A.) The geology of clays. Iowa G S, 14:377-554 (1904)

06 Supplementary report on Portland cement materials in Iowa. Iowa $G \mathrm{~S}$, B $3: 36$ pp, map (1906)

07 Physical tests of Iowa limes. Iowa G S 17:91-150 (1907)

o7a (and Williams, I. A.) The ma terials and manufacture of Portland cement. Iowa G S $17: 29-89$ (1907)

07b (and Williams, I. A.) The geol ogy of the Iowa quarry products. Iowa G S 17:201-525 (1907)

09 Peat deposits in Iowa. Iowa $\mathrm{G} S$ 19:689-730 (1909)

14 (and Wright, H. F.) The road and concrete materials of Iowa. Iowa $G$ S, An Rp 24:33-685 (1914)

Bibbins, Arthur Barneveld.

95 Notes on the paleontology of the Potomac formation. Johns Hopkins Univ Cire $15: 17-20$, il $(1895)$

97 (with Clark, W. B.) The stratigraphy of the Potomac group in Maryland. J G 5:479-506 (1897)

98 A fossil cypress swamp in Maryland. Plant World 1:164-166 (1898)

01 Occurrence of zoisite and thulite near Baltimore. Am J Sc (4) 11:171-172 (1901)

02 (with Clark, W. B.) Geology of the Potomac group in the middle Atlantic slope. G Soc Am, B 13:187-214, maps, il (1902) Abst, Science n s 15:84 (1902)

02a (with Clark, W. B.) The Potomac group in Maryland (abst). Science n 8 15:905 (1902)

05 The buried cypress forests of the upper Chesapeake. Records of the Past 4: 47-53 (1905)

07 Additional evidence of tropical climate on the Middle Atlantic coast during the lower Cretaceous (abst). Science n s $25: 297-298$ (1907)

07a (with Shattuek, G. B.) Description of the Patuxent quadrangle [Md.-D. C.]. U S G S, G Atlas, fol $152: 12$ pp (1907)

09 Occurrence of the Magothy formation on the Atlantic islands (abst). Science n s 29:634 (1909); G Soc Am, B $20: 672$ (1910)

10 Magothy formation of the Atlantic coast (abst). G Soc Am, B 21:780 (1910)

11 (with Clark, W. B.) The Lower Cretaceous deposits of Maryland. Md G S, Lower Cretaceous : 23-98 (1911)
Bibbins, Arthur Barneveld-Continued.

17 (with Miller, B. L., and others) Description of the Tolchester quadrangle, Md. U S G S, G Atlas Tolchester fol (no 204) : $15 \mathrm{pp}$, maps (1917)

See also Ward, 05

Bicknell, E.

69 [On Eozoon canadense from New. bury, Mass. (with discussion by A. Hyatt).] Essex Inst, B 1:141-142 (1869)

Biddle, H. C.

01 The deposition of copper by solutions of ferrous salts. J G 9:430-436 (1901)

Biddle, H. J.

8s Notes on the surface geology of southern Oregon. Am J Sc (3) 35:475483 (1888)

\section{Bierbaner, Bruno.}

91 A check list of the Paleozoic fossils of Wisconsin, Minnesota, Iowa, Dakota, and Nebraska. Minn Ac N Sc, B 3:206-247 (1891)

Blerer, R. W.

11 (and Parker, T. B.) An exper. mental investigation of the resistance of masonry to vibration, with special refer ence to the effect of earthquake waves Seism Soc Am, B 1: 107-108 (1911)

Bigelow, Artemas.

46 Observations upon some sandston rocks in Baldwin County, Ala. Am J se (2) $2: 419-422(1846)$

Bigney, Andrew J.

92 Preliminary notes on the geology of Dearborn Co. Ind Ac Sc, Pr 1891:66-67 (1892)

11 A new bed of trilobites [Calymene in Richmond formation northeast of Moores Hill, Ind.]. Ind Ac Sc, Pr 1910:13? (1911)

16 . Geology of Dearborn Co. Ind, Dp $\mathrm{N}$ Res, An Rp 40:211-222, map (1916)

$16 a$ New cave near Versailles [Ind.] Ind Ac Sc, Pr 1915:183 (1916)

Bigot, Raoul.

os Prospection pour cuivre au sud de l'Etat de Michoacan, Mexique. Soc In Civils France, Mém (6) 61:843-873, ms? (1908) Soc Cient Ant Alz, Rv Cient ? Bib $25: 9-40$, maps (1908)

Bigsby, John Jeremiah (1792-1881).

20 Remarks on the environs of Carthage Bridge, near the mouth of the Geneset River. Am J Sc 2:250-254 (1820)

21 Geological and mineralogical obser vations on the northwest portion of Lake Huron. Am J Sc 3: 254-272 (1821)

22 [Strontianite-bearing limestone of Lake Erie]. Am J Sc 4:280-282 (1822 Transl. in Struve, H. von, Belträge zu Mineralogie und Geologie des nördlichen Amerikas : 114-117, Hamburg 1822

22a Outline of the mineralogy, geologs? etc., of Malbay, in Lower Canada. $\Delta \mathrm{m} J \mathrm{~S}$ $5: 205-222$ (1822) 
Torré, Carlos de la-Continued.

12a Restoration of Megalocnus rodens and discovery of a continental Pleistocene fauna in central Cuba (with discussion by J. W. Spencer). Int G Cong, XI, Stock holm, C R : 1023-1024 (1912)

15 (and Matthew, W. D.) Megalocnus and other Cuban ground sloths (abst). G Soc Am, B 26:152 (1915)

Torrell, Otto.

$\mathbf{7 7}$ On the glacial phenomena of North America. Am J Sc (3) 13:76-79 (1877)

78 On the causes of the glacial phenomena in the northeastern portion of North Amercia. Sveriges G Undersökning, Ser C no $26: 8$ pp, map (1878)

Torrey, John.

23 Notice of a locality of yenite in the United States. Lyc N H N Y, An 1:51 (1823)

37 Discovery of the vauquelinite, a rare ore of chromium, in the United States [Sing Sing, N. Y.] Lye N H N Y, An 4: 76-79 (1837)

Torrey, Joseph, jr.

90 (with Barbour, E. H.) Notes on the microscopic structure of oolite, with analyses. Am J Sc (3) 40:246-249 (1890)

91 (and Barbour, E. H.) The recorded meteorites of Iowa, with special mention of the last, or Winnebago Co., meteorite. Am G 8:65-72 (1891)

Tothill, John D.

16 The ancestry of insects with particular reference to chilopods and trilobites. Am J Sc (4) $42: 373-387$, il (1916) Toula, Franz.

74 Allegemeine Uebersicht der geologischen Beschaffenheit Ostgrönlands. In Die zweite Deutsche Nordpolarfahrt ... (Verein für die Deutsche Nordpolarfahrt in Bremen) 2:475-480, map (by Ferdinand von Hochstetter), Leipzig 1874

74a Beschreibung mesozoischer Versteinerungen von der Kuhn-Insel [Greenland]. In Die zweite Deutsche Nordpolarfahrt ... (Verein für die Deutsche Nordpolarfahrt in Bremen) 2:497-507, il, Leipzig 1874

87 Geologische Forschungsergebnisse aus dem Flussgebiet des Colorado. Ein Vortrag gehalten im Vereine zur Verbreitung naturwissenschaftlicher Kenntnisse in Wien am 5. Jänner 1887. $51 \mathrm{pp}$, Wien 1887

$\mathbf{8 7 a}$ Der Yellowstone-Nationalpark, der vulkanische Ausbruch auf Neu-Seeland, und das Geysir-Phänomen. Ein Vortrag gehalten im Vereine zur Verbreitung naturwissensehaftlicher Kenntnisse in Wien am 19. Jänner 1887 . $79 \mathrm{pp}$, Wien 1887

09 Eine jungtertiäre Fauna von Gatun am Panama-Kanal. K-k G Reichsanstalt, Jb 58: 673-760, il (190)

$09 a$ Die jungtertiäre Fauna von Gatun am Panamakanal und die von Emil Böse beschriebene Pliocänfauna Südmexikos (Isthmus von Tehuantepec und Tuxtepec). K-k G Reichsanstalt, Verh 1909: 159-161
TonIa, Franz-Continued.

10 (with Bose, E.) Zur jungtertiären Fauna von Tehuantepec. K-k G Reichs anstalt, Wien, Jb $60: 215-276$ (1910)

17 Nachträge zur jungtertiären (plio. cilnen) Fauna von Tehuantepec. K- $k$ G Reichsanstalt, Jb $61: 473-486$, il (1911)

11 a Die jungtertiäre Fauna von Gatun am Panamakanal. K-k G Reichsanstalt, Jb $61: 487-530$, il (1911)

Tovote, William L. (1872-1919).

06 Das Pechblende-Vorkommen in Gil. pin Co., Colo. Oesterreichische Zs Berg. u Hüttenw $54: 223-224$ (1906)

06a Ein Ausflug durch Boulder $\mathrm{C}_{0}$ Colo. Oesterreichische Zs Berg- u Hütten $54: 281-283$ (1906)

06b Gold Road, die bedeutendste Goll grube Arizonas. Oesterreichische Zs Bery. u Hüttenw $54: 549-550$ (1906)

07 Mojave Co., Ariz. Oesterreichische Zs Berg- u Hiittenw 55: 9-10 (1907)

10 The Clifton-Morenci district of Ari. zona. M Sc Press 101: 770-773 (1910)

11 Bisbee, Ariz.; a geological sketed M Se Press 102: 203-208 (1911)

12 Magmatic origin of ore-forming solt tions. M Sc Press 104: 601-602 (1912)

12a Types of porphyry copper deposits. M Sc Press 104 (1912)

13 Metallic minerals as precipitants of silver and gold (discussion). Ec G 8: 720 (1913)

14 The Globe mining district [Ariz.] M Sc Press 108:442-449, 487-492 (1914)

17 Detrital copper deposits [Ariz.] If Sc Press 115 : 281-282 (1917)

18 Notes on certain ore deposits of the Southwest. Am I M Eng, B 142: 15991612 (1918)

18a Cunningham Pass district, Ariz. If Sc Press 117:19-20 (1918)

Tower, George Warren, jr.

96 Naval erosion. Science n 8 : $363-$ 564 (1896)

97 (with Emmons, S. F.) Economie geology of the Butte special district [Mont.]. U S G S, G Atlas Butte fol (no 38) : 3-8, map (1897)

99 (and Smith, G. O.) Geology and mining industry of the Tintic district, Utah. U S G S, An Rp 19 pt $3: 601-767$, maps (1899)

Oo Deseription of the Tintic special dis trict; mining industry. $U$ S $\mathrm{G} S, G$ Atlas Tintic fol (no 65) : 4-7 (1900)

Tower, Walter Sheldon.

04 The development of cut-off meanders. Am Geog Soc, B 36:589-599 (1904)

Townley, S. D.

18 The San Jacinto [California] earthquake of April 21, 1918. Seism Soc Am, B $8: 45-62$ (1918)

Townsend, Arthur R.

os Black sands. Eng M J $85: 207-308$ (1908) 
Townsend, Charles Wendell.

11 Coastal subsidence in Massachusetts. Science n s $33: 64$ (1911)

13 Sand dunes and salt marshes. 311 pp, Boston 1913.

Tracy, C. M.

69 Notice of a singular erratic in Lynn, Mass ... Essex Inst., B 1:59-64 (1869)

Transeau, Edgar N.

03 On the geographic distribution and ecological relations of the bog plant societies of northern North America. Bot Gaz $36: 401-420$ (1903)

Traquair, Ramsey Heatley (1840-1912). 90 Notes on the Devonian fishes of Scaumenac Bay and Campbelltown in Canada. G Mag (3) 7:15-22 (1890); (3) $10: 145-149,262-267$, il (1893) A.bst, Brit As, Rp 59:584 (1890)

93 Notes on the Devonian fishes of Campbelltown and Scaumenac Bay in Canada. R Phys Soc Edinb, Pr 12:111-125, il (1893)

Trask, John Boardman (1824-1879).

53 Report on the geology of the Sierra Nevada, or California Range. 30 pp [Sacramento 1853]

53a Geology of the Sierra Nevada, or California Range. M Mag 1:6-23 (1853)

54 Report on the geology of the Coast mountains and part of the Sierra Nevada ... $95 \mathrm{pp}$ [Sacramento 1854]

$54 \mathbf{a}$ Mineral district of central California. II Mag 3:121-136, 239-250 (1854)

55 Report on the geology of the Const mountains ... $95 \mathrm{pp}$ [Sacramento 1855]

55a Report on the geology of the Sierra Nevada, or Californian Range. Pharmaceutical $J$ and $\operatorname{Tr} 14: 20-24$ (1855)

$\mathbf{5 5 b}$ [Description of Ammonites batesii from Shasta Co., and remarks on the occurrence of Carboniferous limestone.] Cal Ac N Sc, Pr 1:40 (1855; 2d ed, 1873: 39)

55e Mines and mining in California. M Mag 5 : 193-215 (1855)

56 Report on the geology of northern and southern California ... 66 pp [Sacramento 1856]

56a On earthquakes in California from 1812-1855. Cal Ac N Se, Pr 1:80-82 (1856; 2d ed, 1873:85-89) Am J Se (2) $22: 110-116(1856)$

56b Description of a new species of ammonite and baculite from the Tertiary rocks of Chico Creek [Cal.]. Cal Ac N Sc. Pr $1: 85-86$ (1856; 2d ed. $1873: 92-93)$

56e Description of three new species of the genus Plagiostoma from the Cretaceous rocks of Los Angeles [Cal.]. Cal Ac N Sc, Pr 1: $86(1856 ; 2$ d ed, $1873: 93-94)$

57 [On earthquakes in Calfornia in the year 1856.] Cal Ac N Sc, Pr 1:93-94 (1857: 2d ed, 1873:102-104) Am J Sc (2) $23: 341-346 \quad(1857)$
Trask, John Boardman-Continued.

$57 \mathbf{a}$ on the direction and velocity of the earthquake in California, January 9, 1857. Cal Ac N Sc, Pr 1:98 (1857; 2d ed, 1873: 109-110)

58 On earthquakes in California during the year 1857. Cal Ac N Sc, Pr 1:108109 (1858; 2d ed, 1873:121-122) Am J Sc (2) $26: 296-298$ (1858)

60 Earthquakes in California during 1858 and 1859 . Cal Ac N Sc, Pr 2:3839 (1860)

63 Earthquakes in California in 1860 . Cal Ac N Sc, Pr 2:90-91 (1863)

64 Earthquakes in California during the year 1863. Cal Ac N Sc, Pr 3:127-128 (1864)

64a Earthquakes in California from 1860-1864. Cal Ac N Sc, Pr $3: 130-153$ (1864)

66 Earthquakes in California during 1864. Cal Ac N Sc, Pr 3: 15 J-192 (1866)

66a Earthquakes in California during 1865. Cal Ac N Sc, Pr $3: 239-240$ (1866)

Travis, Charles.

o6 Pyrite from Cornwall, Lebanon Co., Pa. Am Ph Soc, Pr 45:131-148 (1906) Treadwell. John C.

o5 The Sahuayacan mining district [Chihuahua], Mex. Eng M J 80:12131216 (1905)

Trego, Charles $\mathrm{R}$.

73 Observations on the iron ore de. posits of Buckingham Mt., Bucks Co., Pa. Am Ph Soc, Pr 13: 264 (1873)

Treherne, H. S.

81 An ancient outlet of Lake Manitoba. Minn G S, An Rp 9:388-392 (1881)

Trelease, William.

18 Bearing of the distribution of the existing flora of Central America and the Antilles on former land connections. G Soc Am, B 29:649-656 (1918)

Trimmer, Joshua.

42 Practical geology and mineralogy ... 519 pp. L 1841527 pp, Phila 1842

Tristan, J. Fidel.

12 Continuación de la lista de temblores [list of earthquakes during November and December, 1910, in Costa Rica, continuing list in] Cleto Gonzalez Viquez, Temblores. terremotos, inundaciones, $y$ erupciones volcánicas en Costa Rica, 1608-1910. Costa Rica, Centro de Estudios Sismologicos, An ลก๊o $1911: 16-17$ (1912)

12a Apuntes sobre el temblor del 25 de agosto. Costa Rica, Centro de Estudios Sismologicos, An año 1911: 43-45 (1912)

12b Notas sobre el terremoto de Guatuso 10 de octubre de 1911. Costa Rica, Centro de Estudios Sismologicos, An año 1911: $47-51$ (1912)

12e Actividad sísmica en Costa Rica, 1910-1911. Costa Rica, Centro de Estudios Sismologicos, An año 1911: 53-59 (1912) 
Tristan, J. FYdel-Continued.

12d El temblor del 21 de junio de 1900. Costa Rica, Centro de Estudios Sismologicos, An año 1911: 61-62 (1912)

12e Apuntes acerra del antiguo volcán "Reventado." Costa Rica, Centro de Estudios Sismológicos, An año 1911:63-65 (1912)

$12 f$ (and Biolley, Pablo) Registro de temblores, 1911. Costa Rica, Centro de Estudios Sismologicos, An año 1911: 18-32 (1912)

18g (and Biolley, Pablo, and Cots, Cesar) The Sarchi earthquake, Costa Rica. Seism Soc Am, B 2:201-208 (1912)

14 El voleân de Miravalles [Costa Rica]. Costa Rica, Ministerio de Fomento, B 4: 157-160 (1914)

16 The Costa Rica earthquake of February 27,1916 . Seism Soe Am, B 6:232$235(1916)$

$16 a$ Recent eruptions of Poás Volcano in Costa Rica. Zs Vulkan 2: 140-146 (1916)

17 (and Fernández Peralta. Ricardo) Informe presentado al Señor Ministro de Instrucción Páblica sobre la actividad del voleán Irazá. Colegio de Señoritas Publicaciones, Serie A no 1 (1917) [not seen] La Gaceta, Diario Oficial $39: 662-664$, San José. Costa Riea, December 4, 1917

Troost, Gerard (1776-1850).

21 Description of a variety of amber and of a fossil substance supposed to be the nest of an insect discovered at Cape Sable, Magothy River, Ann Arundel Co.; Md. Am J Sc 3:8-15 (1821) Transl in Struve, H. von, Beltrïge zur Mineralogie und Geologie des nördlichen Amerikas : 8199. Hamburg, 1822

21a Description of some new crystaline fotms of the minerals of the United States. Ac N Sc Phila, J 2:55-58 (1821)

22 ... a new crystalline form of quart\%. Ac N Sc Phila, J $2: 212-214$ (1822)

22a ... some crystals of sulphate of strontian from Lake Erie. Ac N Sc Phila, J $2: 300-302$ (1822)

23 Account of the pyroxene of the United States, and descriptions of some new varieties of its erystalline forms. Ac N Sc Phila, J 3:105-124 (1823)

23a Notice of the yenite of Rhode Island, and several other American minerals. Ac N Se Phila, J 3:222-224 (1823)

24 Description of the American petalite from Lake Ontario [York, Ont.]. Ac N Sc Phila, J 3: 234-237 (1824)

24a Description of a new crystalline form of the chrysoberyl. Ac N Sc Phila, J $3: 293-295$ (1824)

24b Description of a new crystalline form of the andalusite. Ac N Se Pbila, J 4 : 122-123 (1824)

25. Description and chemical analysis of the retinasphalt discovered at Cape Sable. Magothy River, Ann Arundel Co.. Md. Am Ph Soc. Tr n s $2: 110-115$ (1825)
Troost, Gerard-Continued.

25a Notice of a new crystalline form of the yenite of Rhode Island. Am Ph Soc, $\operatorname{Tr}$ n s 2:478-480 (1825)

25b Observations on the zinc ores of Franklin and Sterling, Sussex Co., N. J. Ac N Se Phila, J $4: 220-231$ (1825)

25e Description of a new erystalline form of apphyllite, laumonite, and amphi. bole, and of a variety of pearlstone. Ac I Sc Phila. J 5:51-56 (1825)

26 Geological survey of the environs of Philadelphia ... 40 pp, map, Phila, 1826 Notice, by G. P. Merrill, Science n 8 12: 884 (1900)

27 On pyroxene. Maclurean Lyc, Contr 1: 51-66 (1827)

27 a (and Lesueur, - Calamine in Missouri; lead ores of Missouri. Am J Sc $12: 376-378,379-380$ (1827)

31 [On the mineral resources of Ton. nessee and the utility of a geological survey.] Address delivered before the legit lature of Tennessee at Nashville, Octobet 19th, 1831. Transylvania J Med, Lexing. ton $4: 491-507$ (1831)

33 Analysis of the geologicul descrip. tion of Davidson, Williamson, and Maury $\cos . .$. In Tenn, Legislature. J H R, 20th Gen Assembly : 303-305 (1833)

34 On the localities in Tennessee in which bones of the gigantic Mastodon and Megalonyx jeffersonii are found. $G$ Soc $P_{y}$, Tr 1:139-146, 236-243 (1834-5) Abst, Am J Sc $27: 354$ (1835)

35 Third geological report to the Twenty. first General Assembly of the State of Tennessee. $32 \mathrm{pp}$, map, Nashville 1835

$35 \mathbf{a}$ on the Pentremites reincardtil, a new fossil; with remarks on the genus Pentremites Say and its geognostic pos:tion in the States of Tennessee, Alabama, and Kentucky. G Soc $\mathrm{Pa}$, $\mathrm{Tr} 1: 224-231$, il (1835)

35b Description of a new species of fossil Asterias (Asterias antiqua) [Davidson Co., Tenn.]. G Soc Pa, Tr 1:232235 (1835)

35e Description of some organic remains characterizing the strata of the upper transition which composes midale Ten nessee. G Soc $\mathrm{Pa}$, Tr 1: 244-247 (1835)

$35 d$ On the organic remains which char. acterize the transition series of the valley of the Mississippi. G Soc $\mathrm{Pa}, \operatorname{Tr} 1: 248$ 250 (1835)

37 Fourth geological report ... of the State of Tennesee. 38 pp, map, Nashville 1837

38 Description d'un nouveau genre de fossiles. Soc G France, Mém 3:87-96, Il (1838)

38a Mineralogische Notizen aus Nashville [Tenn.]. N Jb 1838:41-42 
Troost, Gerard-Continued.

40 Fifth geological report... of Tennessee. 75 pp, maps, Nashville 1840 [Organic remains discovered in the State of Tennessee : 45-75]

40a Description and analysis of a meteoric mass, found in Tennessee... Am J Sc $38: 250-254(1840)$

41 Sixth geological reports ... of the State of Tennessee. $48 \mathrm{pp}$, map, Nashville 1841

43 Seventh geological report...of the State of Tennessee. 45 pp, map, Nashville, 1843

45 Eighth geological report... of the State of Tennessee. $20 \mathrm{pp}$, Nashville 1845

45a Description of a mass of meteoric iron which fell near Charlotte, Dickson Co., Tenn., in 1835 ; of a mass of meteoric iron discovered in Dekalb Co., Tenn.; of a mass discovered in Green Co., Tenn.; of a mass discovered in Walker Co., Ala. Am J Sc $49: 336-346$ (1845)

46 Description of three varieties of meteoric iron [Tennessee and Kentucky]. Am J Se (2) 2:356-358 (1846) Edinb N Ph J 42:371-373 (1847)

48 Ninth geological report ... of the State of Tennessee. $39 \mathrm{pp}$, Nashville 1848

48a Description of a mass of meteoric iron discovered near Murfreesboro, Rutherford Co., Tenn. Am J Sc (2) 5:351-352 (1848)

48b Kraurite and cacoxene in Tennessee. Am J Sc (2) 5:421 (1848)

50 A list of the fossil crinoids of Tennessee. Am As, Pr 2: 59-64 (1850)

Tront, L. E.

15 (and Myers, G. H.) Bibllography of Oklahoma geology, with subject index. Okla G S, B 25: 105 pp (1915)

15a (with Shannon, C. W.) Petroleum and natural gas in Oklahoma; Part I, General information concerning ofl and gas; geology of Oklahoma. Okla G S, B $19: 133 \mathrm{pp}$ (1915)

Trowbridge, Arthur Carleton.

os The rock bed near Wheaton. Ill G S, B $8: 72-76$ (1908)

11 The terrestrial deposits of Owens Valley, Cal. J G 19:706-747, map (1911) Abst, Science n s $33: 564$ (1911)

12 Geology and geography of the Wheaton quadrangle. III G S, B 19:79 pp, map (1912)

13 Some partly dissected plains in Jo Daviess Co., III. J G 21: 731-742 (1913)

13a (with Snlisbury, R. D.) The interpretation of topographic maps; a laboratory manual for use in connection with the topographic maps of the United States Geological Survey, to accompany beginning courses in physiography. v, $64 \mathrm{pp}$, New York, 1913
Trowbridge, Arthur Carleton-Contd.

13b (with Salisbury, R. D.) Studies in geology; a laboratory manual based on topographic maps and folios of the United States Geological Survey, for use with classes in physiography and structural geology. v, 68 pp, New York 1913

13e (with Salisbary, R. D.) Laboratory exercises in structural and historieal geology; a laboratory manual based on folios of the United States Geological Survey, for use with classes in structural and historical geology. v, 76 pp, New York 1913

14 A classification of common sediments and some criteria for identification of the various classes. J G 22:420-436 (1914)

14a Preliminary report on geological work in northeastern Iowa. Iowa Ac Sc, Pr 21: 205-209 (1914)

14b The formation of eskers. Iowa Ac Sc, Pr 21:211-218 (1914) Abst, Science n \& 40:145 (1914)

15 Physiographit studies in the Driftless Area (abst). G Soc Am, B 26:76 (1915)

16 (and Shaw, E. W.) Geology and geography of the Galena and Slizabeth quadrangles [III.]. Ill G S, B 26:13-171, il, maps (1916)

16a (with Shaw, E. W.) Description of the Galena and Elizabeth quadrangles, IIl.-Iowa. U S G S, G Atlas GalenaElizabeth fol (no 200): 13 pp, maps (1916)

17 The history of Devil's Lake, Wis. J G 25:344-372, maps (1917)

$17 \mathbf{a}$ The origin of the St. Peter sandstone. Iowa Ac Sc, Pr 24:171-175 (1917)

17b The Prairie du Chien-St. Peter unconformity in Iowa. Iowa Ac Sc, $\operatorname{Pr} 24$ : $177-182$ (1917)

Trowbridge, S. H.

82 Remarks on the classification and distribution of Producti. Am As, $\operatorname{Pr} 30$ : 193-204 (1882)

83 Geological survey of Missouri. Kansas City Rv Sc 6:621-626 (1883)

Troxe11, Edward L.

14 Unios in the Triassic of Massachusetts. Am J Sc (4) $38: 460-462$, il (1914)

15 The vertebrate fossils of Rock Creek, Tex. Am J Sc (4) 39:613-638, il (1915)

15a A fossil ruminant from Rock Creek, Tex., Preptoceras mayfieldi sp. nov. Am J Sc (4) $40: 479-482$ (1915)

16 An early Pliocene one-toed horse. Pliohippus lullianus sp. nov. Am J Sc (4) $42: 335-348$, il (1916) Abst, G Soc Am, B $27: 151-152$ (1916)

16a Oligocene fossil eggs. Wash AC SC, J $6: 422-425$, il (1916)

17 An Oligocene camel, Pocbrotherium andersoni n. sp. Am J Sc (4) $43: 381-$ 389 , il (1917) 
Troxell, Edward L.-Continued.

17a Fossil hunting in Texas [Equus scotti quarry, Rock Creek]. Sc Mo 4:8189 , il (1917)

17b An Oklahoma Pleistocene fauna (abst). G Soc Am, B 28:212-213 (1917) Trude11, Harry W.

18 Famous mineral localities; 2, The gem regions of North Carolina. Am Mineralogist $3: 14-17$ (1918)

True, Frederick William (1858-1914).

o5 Diagnosis of a new genus and species of fossil sea-lion from the Miocene of Oregon [Pontoleon]. Smiths Misc Col 48 ( $Q$ Is 3) : 47-49 (1905)

O5a The first discovery of fossil seals in America. Science n s 22:794 (1905)

o5b New name for Pontoleon [Pontolis]. Biol Soc Wash, Pr 18: 253 (1905)

o6 Description of a new genus and species of fossil seal from the Miocene of Maryland. U S Nat Mus, Pr 30:835-840, il (1906)

o7 Remarks on the type of the fossil cetacean Agarophits pygmous (Miiller). 8 pp, il Smiths Inst 1907

Ora Observations on the type specimen of the fossil cetacean Anoplonassa forcipata Cope. Harvard Coll, Mus C Z, B 51: 97-106, il (1907)

os On the classification of the Cetacea. Am Ph Soc, Pr 47:385-391 (1908)

osn On the occurrence of remains of fossil cetaceans of the genus Schizodelphis in the United States, and on Priscodel phinus? crassangulum Case. Smiths Mise Col 50 (Q Is 4) : 449-460, il (1908)

0sb The fossil cetacean Dorudon serratus Gibbes. Harvard Coll, Mus C $\mathrm{Z}, \mathrm{B}$ $52: 65-78$, il $(1908)$

ose Remarks on the fossil cetacean Rhabdosteus latiradix Cope. Ac N Se Phila, Pr 60:24-29, il (1908)

09 A further account of the fossil sea lion Pontolis magnus, from the Miocene of Oregon. U S G S, P P $59: 143-148$, il (1909)

11 Discovery of a fossil delphinoid cetacean with tuberculate teeth. Biol Soc Wash, Pr 24: 37-38 (1911)

12 Description of a new fossil porpoise of the genus Delphinodon from the Miocene formation of Maryland. Ac N Sc Phila, J (2) $15: 163-194$, il (1912) Abst, Ac N Sc Phila, Pr 64: 135-136 (1912)

12a The genera of fossil whalebone whales allied to Balaenoptera. Smiths Mise Col 59 no $6: 1-8$ (1912)

12b Ten years' progress in vertebrate paleontology ; marine mammals. G Soc Am, B 23: 197-200 (1912)

12e On the correlation of North American and European genera of fossil cetaceans $(a b s t)$. Int Zool Cong, VII, Boston, 1907. Pr : 779-781 (1912)
True, Hiram L.

02 The cause of the glacial period. 162 pp, Cincinnati 1902

True, N. T

62 Grooved boulders in Bethel, Me. Port land Soc N H, Pr 1:92-94 (1862)

69 New localities of minerals in Maine Portland Soc N H, Pr 1 : 163-165 (1869) 69a on surface changes in Main $(a b s t)$. Can Nat n s 4:328-329 (1869)

81 [The geology of Maine, especially th western portion and the White Mountains Portland Soc N H, Pr 1880-1, 10th meet ing : $1-6$ (1881)

82 Columbite in Maine. Portland s N H, Pr 1881-2, 10th meeting : 9 (1882)

Trueman, J. D. ( ?-1912).

11 Gunflint district, Ont. Can G S, Sun Rp 1910: 183-187 (1911)

12 The value of certain criteria for the determination of the origin of foliated crystalline rocks. J G $20: 228-258,300$ 315 (1912)

Truesdell, William $\mathrm{H}$.

09 Ray copper district, Ariz. M \& Press 98: 794-797 (1909)

Truman, Ben C.

02 (and Marais, C. L. P.) Le pétrol en Californie. Cong Intern Pétrole, I, Pari 1900 , Notes ... : 57-59, Paris 1902

Trumbull, Loyal Wingate.

o5 A preliminary report upon the col resources of Wyoming. Wyo, Univ, Sch Mines [Univ G S], B $7: 95 \mathrm{pp}$, map, (1905)

oz Sulphur mining and refining in Wyo ming. Mines and Minerals $27: 314-310$ (1907)

07a Cement-plaster industry in Wyomine M World 26:387 (1907)

13 Prospective oil fields at Upton, Wos ton Co., Buck Creek, Nlobrara Co., Rattle snake Mountains, Natrona Co., La Barge. Lincoln Co. [Wyo.]. Wyo, G Off, Ser B, B no $5: 15$ pp, maps (1913)

14 Atlantic City gold mining district, Fremont Co. [Wyo.]. Wyo, G Off, Ser B B $7: 69-97$, maps (1914)

14a The Salt Creek ofl field. Natrons Co., Wyo. Wyo, G Off, Ser B, B 8:103148, maps (1914)

14b Biennial report, 1913-1914. Wyo, G Off, Ser B, B 9: 149-168 (1914)

14c Atlantic gold mining district, Wyo. M Science 69:45-49 (June 1914)

15 [Geologic map of] Rock Springs up. lift and Dry Lake dome after U. S. G. \& coal reports. Scale 4 miles to one incb. Wyo, Off St G, 1215

16 Light-oil fields of Wyoming. Wyo, 6 Off, B $12: 123-130$, map (1916); $2 d$ ed: 123-134, map (1916)

16a Petroleum in granite [Fremont $\mathrm{CO}_{0}$ Wyo.]. Wyo, G Ofr, B sc s 1:5-16, map (1916) 
Trumbu11, Loyal Wingate-Continued.

$16 \mathrm{~b}$ The effect of structure upon the migration and separation of hydrocarbons. Wyo, G Off, B sc s $1: 17-27$, map (1916)

17 Petroleum geology of Wyoming. 81 pp, map, Cheyenne, Wyoming, 1917

Tsehermak, Gustav.

09 Ein Silicateinschluss im Tolucaeisen. Tsehermak's Mitt 28:107-109 (1909) Una inclusion de silicato en el fierro meteorico de Toluca. Soc Cient Ant Alz, Mem 29, Rv : 25-27 (1910)

Tsehernyschew, Th.

16 (and Stepanow, P.) Obercarbonfauna von König Oscars und Heibergs Land. Second Norwegian Arctic Expedition in the Frame, 1898-1902, Rp no 34 : 67 pp, il, Videnskabs-Selskabet i Kristiania, 1916

Tucker, W. Burling.

15 The counties of Amador County, Calaveras County, Tuolumne County. CaI St M Bur, Rp XIV of the State Mineralogist: 1-172 (1916) [issued as separate July, 1915]

17 El Dorado County. In Mines and mineral resources of the counties of El Dorado, Placer, Sacramento, Yuba (Chapters of State Mineralogist's Rp [15:271308] 1915-16): 1-38, Cal St M Bur (1917)

17a Lassen County. In Mines and mineral resources of the counties of Butte, Lassen, Modoc, Sutter, and Tehama (Chapters of State Mineralogist's Rp [15: 226238] 1915-16):46-58, Cal St M Bur (1917)

17b Modoc County. In Mines and mineral resourees of the counties of Butte, Lassen, Modoc, Sutter, and Tehama (Chapters of State Mineralogist's Rp $[15: 239$ 253] $1915-16$ ) : 59-73, map, Cal St M Bur (1917)

17e Tehama County. In Mines and mineral resources of the counties of Butte, Lassen, Modoc, Sutter, and Tehama (Chapters of State Mineralogist's Rp [15:258266] 1915-16): 78-86, Cal St M Bur (1917)

17d Tulare County. In Mines and min. eral resources of San Bernandino County, Tulare County (Chapters of State Mineralogist's Rp [15:900-954] 1915-16) : 126180, Cal St M Bur (1917)

See also Bradley (W W), 18

Tueker, W. M.

11 The water power of Indiana. Ind Dp G, 35th An Rp: 11-77, maps (1911)

Tuomey, Michael (1805-1857).

42 Discovery of a chambered univalve fossil in the Eocene Tertiary of James River, Va. Am J Sc 43:187 (1842) An Mag N H 10:156-157 (1842)

43 ...discovery of a new locality of the "Infusorial stratum" [Petersburg, Va.]. Am J Sc 44:339-341 (1843)
Tuomey, Michael-Continued.

44 Report on the geological and agricultural survey of the State of South Carolina, 1844. $63 \mathrm{pp}$, Columbia, S. C., 1844

47 Discovery of the cranium of the Zeuglodon. Ac N Se Phila, Pr 3:151-153, il (1847) Am $J$ Sc (2) $4: 283-285$, il (1847) Ac N Sc Phila, J (2) $1: 16-17$, il (1847)

48 Report on the geology of South Carolina. vi, 293, lvi pp, maps, Columbia, S. C., 1848 Rv by Bouvé, T. S., Am J Sc (2) $8: 61-74 \quad(1849)$

49 Results of observations in the Tertiary region of South Carolina. Am As, Pr 1: 32-33 (1849)

50 First biennial report on the geology of Alabama. $176 \mathrm{pp}$, map, Tuskaloosa, 1850.

51. Notice of the geology of the Florida Keys and of the southern coast of Florida. Am J Sc (2) 11:390-394 (1851)

52 Description of some fossil shells from the Tertiary of the Southern States. Ae N Se Phila, Pr 6: 192-194 (1852)

54 Description of some new fossils from the Cretaceous rocks of the Southern States. Ac N Sc Phila, Pr 7:167-172 (1854)

55 A brief notice of some facts connected with the Ducktown, Tenn., copper mines. Am J Se (2) 19:181-182 (1855)

57 (and Holmes, F. S.) Pleiocene fossils of South Carolina... 152 pp, il, Charleston, S. C., 1857

58 Second biennial report on the geology of Alabama. $292 \mathrm{pp}$, map, Montgomery, 1858.

5Sa (and Mallet, J. W.) Lists of fossils from the Cretaceous and Tertiary formations in Alabama and Mississippi. In Tuomey, M., Second biennial report on the geology of Alabama : 253-275, Montgomery 1858

76 Descriptions of the eastern side of the Cahaba coal field. Ala G S, Rp Prog $1875: 205-212$ (1876)

Turgeon, Fremont $\mathrm{N}$.

es (with Ferguson, H. G.) An occurrence of Harney granite in northern Black Hills. Harvard Coll, M C Z, B 49 (g s 8) : 275-283 (1908)

Turnbu11, J. M.

04 Geolegical sketch of the Bankhead coal field [Alta.]. Can M Rv 23: 213-214 (1904)

Turner, George.

99 Memoir on the extraneous fossils, de. nominated mammoth bones; principally designed to show that they are the remains of more than one species of nondescript animal. Am Ph Soc, Tr 4:510-518 (1799, Turner, George M.

87 Novaculite. U S G S, Min Res 1886 : 589-594 (1887) 
Turner, H. H.

06 The times and places of earthquakes. Pop Sc Mo $68: 537-542$ (1906)

Torner, Henry Ward.

91 The geology of Mount Diablo, Cal. G Soc Am. B 2: 384-402, map (1891)

$91 a$ Mohawk lake beds [Plumas Co., Cal.]. Ph Soc Wash, B 11:385-409, map (1891)

92 Glacial potholes in California. Am J Sc (3) 44:453-454 (1892)

92a The lavas of Mount Ingalls, Cal, Am J Sc (3) 44:455-459 (1892)

93 Some recent contributions to the geology of California. Am G 11:307-324 (1893)

93a Mesozoic granite in Plumas Co., Cal., and the Calaveras formation. Am G 11: 425-426 (1893)

93b The coal deposits of California. U S G S, Min Res 1892: 308-310 (1893)

94 Description of the gold belt [Sierra Nevada, C2l.]; description of the Jackson sheet. U S G S, G Atlas Jackson fol (no 11) : $6 \mathrm{pp}$, maps (1894; reprint 1914) In part, Deseription of the gold belt, Sc Am Sup $39: 16197-16198$ (1895) Abst, J G 3 : 969-970 (1895)

$94 \pi$ The rocks of the Sierra Nevada. U S G S, An Rp 14 pt $2: 435-495$, maps (1894) Abst, J G 3:985-986 (1895)

94b Notes on the gold ores of California. Am J Sc (3) $47: 467-473$ (1894)

94e Geological notes on the Sierra Nevada. Am G 13:228-249, 297-316 (1894)

94d (and Stanton, T. W.) Notes on the geology of the Coast Ranges of California. Am G 14: 92-98 (1894)

94 (with Lindgren, W.) Description of the gold belt [Cal.]; description of the Placerville sheet. U S G S, G Atlas Placerville fol (no 3 ) : 3 pp, maps (1894; reprint 1914)

95 The age and succession of the igneous rocks of the Sierra Nevada. J G 3 : 385-414, map (1895)

95a Auriferous gravels of the Sierra Nevada. Am G 15:371-379 (1895)

95b Further notes on the gold ores of California, Am J Sc (3) 49:374-380 (1895)

95e Gold in serpentine. Am $J$ Sc (3) 49: 478 (1895)

95d Volcanic dust in Texas. Science $\mathbf{n}$ s $1: 453-455$ (1895)

95e (with Lindgren, W.) Description of the gold belt; description of the Smartsville sheet [Cal.]. U S G S, G Atlas Smartsville fol (no 18) : 6 pp, maps (1895)

95f (with Lindgren, W.) Description of the Marysville sheet [Cal.] U S G S, G Atlas Marysville fol (no 17): $2 \mathrm{pp}$, maps (1895) Abst, J G 3:976-977 (1895)

96 Further contributions to the geology of the Sierra Nevada. U S G S, An Rp 17 pt $1: 521-762$, map (1896)
Turner, Henry Ward-Continued.

$96 \mathbf{a}$ Notice of some syenitic rocks from California. Am G 17: 375-388 (1896)

96b Archean gneiss in the Sierra No vada (abst). Seience n $\mathrm{s} 3: 606$ (1896) Am G $17: 344-345$ (1896)

97 Description of the gold belt; descrip. tion of the Downieville quadrangle [Cal.]. U S G S, G Atlas Downieville fol (no. $37): 8 \mathrm{pp}$, maps (1897)

97a (and Ransome, F. L.) Descrip. tion of Sonora quadrangle [Cal.]. U \& G S, G Atlas Sonora fol (no. 41):5 pp. maps (1897)

$\mathbf{9 7 b}$ Nomenclature of metamorphic lavas. Science n s 5:226 (1897)

97e A new amphibole-pyroxene rock and some orbicular rocks from California (abst). Science n s 5:811 (1897)

98 Description of the gold belt; descrip. tion of the Bidwell Bar quadrangle [Cal.]. U S G S, G Atlas Bidwell Bar fol (no 43): $6 \mathrm{pp}, \operatorname{maps}(1898)$

98a (and Ransome, F. L.) Description of the gold belt; Description of the Big Trees quadrangle [Cal.]. U S G S, G Atlas Big Trees fol (no 51) : 8 pp, maps (1898)

98b Notes on some igneous, metamorphic and sedimentary rocks of the Coast Ranges of California. J G 6:483-499, map (1898)

98e Notes on rocks and minerals from California. Am J Sc (4) 5:421-428 (1898)

$98 a$ Origin of Yosemite Valley (abst). Science n 8 7:358-359 (1898)

98e The succession of the igneous rocks of the Sierra Nevada (abst). Science n s $7: 612$ (1898)

98f Classification of igneous rocks. Science n \& $7: 622-625$ (1898)

99 The granitic rocks of the Sierra Nevada. J G $7: 141-162$ (1899)

$99 a$ Replacement ore deposits in the Sierra Nevada. J G $7: 389-400$ (1899)

95b The occurrence and origin of diamonds in California. Am G 23: 182-191 (1899) M Sc Press 78:586, 613 (1899)

99e Some rock-forming biotites and amphiboles. Am J Sc (4) 7:294-298 (1899)

99d The occurrence of roscoelite in California. Am J Sc (4) $7: 455-458$ (1899) M Sc Press $79: 93$ (1899)

99e The geology of the Yosemite Na. tional Park (abst). Am G 23:100-101 (1899) Science n s 9: 106 (1899)

99P (with Hillebrand, w. F.) On roscoelite. Am J Sc (4) 7:451-454 (1899)

o0 The Esmeralda formation, a freshwater lake deposit. U S G S, An Rp 21 pt 2:191-208, map (1900)

oOn The Pleistocene geology of the south central Sierra Nevada with especial reference to the origin of Yosemite Valley. Cal Ac Sc, Pr (3) G 1:261-321 (1900) 
Turner, Henry Ward-Continued.

00b The nomenclature of feldspathic granolites. J G 8: 105-111 (1900)

ooc [Hanging valleys, Sierra Nevada.]

G Soc Am, B 11:591-592 (1900)

ood The Esmeralda formation. Am G

$25: 168-170$ (1900)

ooe The Terlingua quicksilver mining district, Brewster Co., Tex. M Sc Press 81: 64 (1900)

oof [On the term Sierran (abst).] Science n s 11:348 (1900)

$00 \mathrm{~g}$ Geology of the Silver Peak district, Nev. (abst). Science n s 11:826 (1900) Sc Am 83: 22 (1900)

01 Perknite (lime-magnesia rocks). J G

9: $507-511$ (1901)

01 a Geology of the Great Basin in California and Nevada (abst). G Soc Am, B $12: 498$ (1901) J G 9:73 (1901) Am G $27: 132$ (1901)

01b The mines of Esmeralda Co., Nev. M Sc Press $82: 73-74$ (1901)

$02 \mathrm{~A}$ sketch of the historical geology of Esmeralda Co., Nev. Am G 29:261-272 (1902)

02a Notes on unusual minerals from the Pacific States. Am J Sc (4) 13:343346 (1902) In part, M Sc Press 84:296 (1902)

02b The Greenback copper mine, Kern Co., Cal. Eng M J 74:547-548 (1902)

02e An instance of variabllity in a rock magma (abst). Science n s 15:411 (1902) 03 Post-Tertiary elevation of the Sierra Nevada. G Soc Am, B $13: 540-541$ (1903) Abst, Science n s 15:414-415 (1902)

03a The copper deposits of the Sierra Oscura, N. Mex. Am I M Eng, Tr 33 : 678-681 (1903)

03b The Cretaceous auriferous conglomerate of the Cottonwood mining district, Siskiyou Co., Cal. Eng M J 76:653-654 (1903)

04 Notes on contact-metamorphic deposits in the Sierra Nevada Mountains. Am I M Eng, Tr 34:666-668 (1904)

04a Native copper in greenstone from the Pacific slope. Eng M J $77: 276$ (1904)

05 The Terlingua quicksilver deposits [Tex.]. Ec G 1:265-281, map (1905)

06 The Terlingua quicksilver deposits. Ec G 1:265-281 (1906)

07 The ore deposits of Copperopolis, Cal. Ec G 2:797-799 (1907)

07a The sodium nitrate deposits of the Colorado. M Sc Press 94:634-635 (1907)

$07 \mathbf{b}$ Faulting in the Red Cloud mine [Idabo]. M Sc Press 95: 747-748 (1907) 08 The vein system of the Standard mine, Bodie, Cal. Am I M Eng, B 22: 623-624 (1908)

08a The ore deposits at Mineral, Idaho. Ec G 3:492-502 (1908)

08b On the Ray mining district, Nev. Ec G $3: 538-539$ (1908)
Turner, Henry Ward-Continued.

ose Waters, meteoric and magmatic. M Sc Press 97 : 805-806 (1908)

09 Contribution to the geology of the Silver Peak quadrangle, Nev. G Soc Am, B $20: 223-264$ (1909)

09a Mining on the Mother Lode [Cal.]. M Sc Press 98:40-41 (1909)

12 Replacement of siliceous rock by pyrite (discussion). Ec G $7: 709$ (1912)

12a Gossan ontcrops of cupriferous pyrite. M Mag $7: 357-361$ (1912)

14 (and Rogers, A. F.) A geologic and microscopic study of a magmatic copper sulphide deposit in Plumas Co., Cal., and its modification by ascending secondary enrichment. Ec G 9:359-391 (1914)

$14 a$ (with Lindgren, W.) Reprints from Placerville, Sacramento, and Jackson folios [Cal.]. (nos 3, 5, and 11):9 pp, maps, U S G S (1914)

15 Association of alunite and pyrophyllite. Ec G 10 : 393-394 (1915)

15a Eruptions of Mount Lassen and Tertiary eruptions of the Sierra Nevada. M Sc Press 110: 955-956, map (1915)

16 Copper in the red beds of New Mexico. Ec G 11:594-597 (1916)

See also Hill (R T), 98c; Lindgren, 03đ; Powell, 95; Prichard, 04

Turner, Homer $\mathrm{G}$.

14 (with Richardson, C. H.) The terranes of Greensboro, Vt. Vt St G, Rp 9 : 277-293, map (1914)

Turner, James W.

12 Wonders of the great Mammoth Cave of Kentucky, containing thorough and accurate historical and deseriptive sketches of this marvelous underground world, with a chapter on the geology of cave formation. 116 pp, Carrier Mills, Ill., 1912

Turner, Lucien $\mathrm{M}$.

s8 Physical and zoological character of the Ungava district, Labrador. R Soc Can, Pr Tr 5, iv : 79-83 (1888)

Turner, Scott.

o7 A simple classification of igneous rocks. M Sc Press 94:404-405 (1907)

Turp, James S.

16 Peat in 1915. U S G S, Min Res 1915 pt $2: 1027-1030$ (1916)

Turrentine, J. W.

13 The occurrence of potassium salts in the salines of the United States. U S Dp Agr, Bur Soils, B 94:96 pp (1913)

Tuttle, Edgar G.

94 The Sabinas coal field [State of Coahuila, Mex.]. Eng M J 58:390-392, map (1894)

94a The Deep River coal field of North Carolina... Eng M J 58: 441 (1894)

12 The Magdalena mining district, $N$. Mex. Mines and Minerals $33: 275-277$ (1912) 
Tnttle, George W.

04 Recent changes in the elevation of land and sea in the vicinity of New York City. Am J Sc (4) $17: 333-346$ (1904)

Tutton, C. H.

02 The laws of river flow. An Eng Soc, J $28: 32-37$ (1902)

Twenhofel, William Henry

09 The Silurian section at Arisaig, Nova Scotia; with a correlation note by Charles Schuchert. Am J Sc (4) 28: 143-164 (1909)

10 Geologic bearing of the peat beds of Anticosti Island. Am J Sc (4) $30: 65-71$ (1910)

10n (with Sehnehert, C.) OrdovicicSiluric section of the Mingan and Anticosti islands, Gulf of St. Lawrence. G Soc Am, B 21: 677-716 (1910) (Abst), Science $n$ s $32: 223$ (1910)

12 Physiography of Newfoundland. Am J Sc (4) 33: 1-24 (1912)

13 Excursion in eastern Quebec and the maritime province; ; Arisaig. Int G Cong, XII, Canada, Guide Book no $1: 288-312$, map (1913)

14 The Anticosti Island faunas. Can G S, Mus B $3: 35$ pp, il (1914)

14a (and Dunbar, C. O.) Nodules with fishes from the Coal Measures of Kansas. Am J Sc (4) 38:157-163 (1914)

14b A new locality and horizon for Pennsylvanian vertebrates. Science $n \mathrm{~s}$ $40: 26-27$ (1914)

15 Notes on black shale in the making. Am J Sc (4) $40: 272-280$ (1915)

16 Expedition to the Baltic provinces of Russia and Scandinavia, 1914 ; Part 2, The Silurian and high Ordovician strata of Esthonia, Russia, and their faunas: Part 3, An interpretation of the Silurian section of Gotland. Harvard Coll, Mus C Z, B 56 (g s 10) : 289-354 (1916)

17 The Silver City quartzites; a Kansas metamorphic area. G Soc Am, B 28:419430, 164 (abst) (1917)

17a Granite boulders in (?) the Pennsylvanian strata of Kansas. Am J Sc (4) $43: 363-380$ (1917)

17b (with whitaker, W. A.) Manganese in the Dakota sandstone of central Kansas. Ee G 12: 473-475 (1917)

18 The Comanchean of central Kansas. Kans Ac Sc, Tr 28: 213-223 (1918)

See also Grabau, 17d

Trining, Alex. C.

71 Earthquake of October 20, 1870, in northeastern America. Am J Sc (3) 1: $47-53$ (1871)

Twitehell, Mayville William.

09 (with Clark, W. B.) The geological distribution of the Mesozoic and Cenozoic Echinodermata of the United States (abst). Science n s 29:635 (1909) G Soc Am, B $20: 686-688$ (1910)
Twitchell, Mayville William-Continued

12 Annual report of the State geologist for 1911. S C G S, Ser 5, First Rp : 38 th, Columbia, S. C., 1912

13 The mineral industry of New Jens for 1912. N J G S, B 11:43 pp, me? (1913).

14 The mineral industry of New Jerser for 1913. N J G S, B 15:46 pp (1914)

15 (with Clark, W. B.) The Mesozol and Cenozoic Echinodermata of the United Stutes. U S G S, Mon 54:341 pp, It (1915)

16 Statisties of the mineral industry of New Jersey for 1914, N J, Dp Conser vation... An Rp 1915: 31-40 (1916)

Tyler, S. W.

65 Analysis of a carbonate of lime and manganese (spartaite of Breithaupt) from Sterling, Sussex Co., N. J. Am J Sc (2) $39: 174-176$ (1865)

66 Analyses of rabtite, marcylite, and moronolite. Am J Sc (2) 41:209-218 (1866)

Tyler, Sydney.

06 San Francisco's great disaster. 424 pp, Phila 1906 [Includes a chapter by $\mathrm{R}$. S. Tarr on earthquakes and their causes See Tarr, 06f]

Tylor, Alfred.

54 On changes of the sea level effected by existing physical causes during stated periods of time. Am J Sc (2) 18:21-32, 216-227 (1854)

Tyndn11, John.

73 Some observations on Niagara. Pop Se Mo 3:210-226 (1873)

Tyrrell, G. W.

14 A review of igneous rock classifics. tion. Se Progress 9:60-84 (1914)

Tyrrell, Joseph Burr.

87 Report on a part of northern At berta, and portions of adjacent districts of Assiniboia and Saskatchewan, embracing the country lying south of the North Sas. katchewan River and north of Lat. $51^{\circ} 6$, between $110^{\circ}$ and $115^{\circ} 15^{\prime}$ west. Can G S, An Rp 2: n 1-152, maps (1887)

87 a Naturally reduced iron. Am J Sc (3) $33: 73$ (1887)

8s Notes to accompany a preliminary map of the Duck and Riding mountains in northwestern Manitoba. Can $G$ S, A Rp 3: E 16 pp, map (1888)

89 [Explorations in Lake Winnipegosis region, Manitoba.] Can G S, Sum Rp 18878 (An Rp 3) : A 72-75 (1889)

89a Gypsum deposits in northern Manitoba. Can Rec Sc 3:353-360 (1889)

s9b On the superficial geology of the central plateau of northwestern Canada (abst). G Mag (3) 6:37-38 (1889) Nature $39: 95$ (1888) 
Tyrre11, Toseph Burr-Continued.

90 [Report of an examination of the shores and islands of Lake Winnipegosis, Manit.] Can G S, Sum Rp 1888-9 (An Rp 4) : A 15-25 (1890)

90a Post-Tertiary deposits of Manitoba and the adjolning territories of northwestern Canada (with diseussion by J. E. Mills and others): G Soc Am, B 1:395410 (1890) Abst, Am G 5:119 (1890) ; Am Nat 24: 208-209 (1890)

90b The Cretaceous of Manitoba, Am J Sc (3) $40: 227-232$ (1890)

91 [Summary report of work in western Manitoba.] Can G S, Sum Rp 1890 (An Rp 5) : A 26-36 (1891)

$91 a$ Eossil resin (" amber") [Cedar Lake, Manit.]. Can G S, An Rp 5: s 1415 (1891)

91b Foraminifera and Radiolaria from the Cretaceous of Manitoba. R Soc Can, Pr Tr 8: 111-115 (1891)

91e Pleistocene of the Winnipeg basin. Am G $8: 19-28$ (1891)

92 Report on northwestern Manitoba, with portions of the adjacent districts of Assiniboia and Saskatchewan. Can G S, An Rp 5: $\mathrm{E} 235 \mathrm{pp}$, map (1892)

$92 a$ [Summary report of a geological examination of the Lake Winnipeg region, Manitoba.] Can G S, Sum Rp 1891 (An Rp 5) : A 19-25 (1892)

92b Three deep wells in Manitoba. $\mathrm{R}$ Soc Can, Pr Tr 9, is : 91-104 (1892)

93 [Summary report of exploration in the country north of the Churchill River.] Can G S, Sum Rp 1892 (An Rp 6) : A 1221 (1893)

93a Pleistocene phenomena in the region southeast and east of Lake Athabasca, Canada (abst). Am G 11:132$133,175(1893)$

93b Deep well at Deloraine, Manit. Am G $11: 332-342$ (1893)

94 Notes on the Pleistocene of the Northwest Territories of Canada, northwest and west of Hudson Bay, G Mag (4) 1:394-399 (1894)

95 [Report on exploration in the region between Athabasca Lake and Hudson Bay.] Can G S, Sum Rp 1894 (An Rp 7) : A $38-48$ (1895)

96 (assisted by D. B. Dowling) Report on the country between Athabasca lake and Churchill River. Can G S, An Rp 6: D 120 pp, map (1896)

96a [Report of an examination of the country northeast of Lake Winnipeg.] Can G S, Sum Rp 1895 (An Rp 8): A $39-45$ (1896)

96h The genesis of Lake Agassiz. J G $4: 811-815 \quad(1896)$; see also $5: 78-81$ (1897)

96e Is the land around Hudson Bay at present rising? Am J Sc (4) 2: 200-205 (1896)
Tyrrell, Joseph Burr-Continued.

97 Report on the Doobaunt, Kazam, and Ferguson rivers and the northeast coast of Hudson Bay. Can G S, An Rp 9: $\mathbf{w} 218$ pp, maps (1897)

$\mathbf{9 7}$ a [Report of work in the country north of Lake Winnipeg, Manit.] Can G S, Sum Rp 1896 (An Rp 9) : A $\quad 31-34$ (1897)

98 [Report of field work in Lake Winnipeg region, Manitoba.] Can G S, Sum Rp 1897 (An Rp 10) : A 35-38 (1898)

98n The glaciation of north central Canada. J G 6:147-160, maps (1898) Abst, G Mag (4) 4:514-515 (1897) ; Brit As, Rp 67:662-663 (1898)

98b The Cretaceous of Athabasea River. Ottawa Nat 12: $37-41$ (1898)

99 [Report on field work in southwestern Yukon.] Can G S, Sum Rp 1898 (An Rp 11) : A 36-46 (1899)

99a Glacial phenomena in the Canadian Yukon district. G Soc Am, B 10:193-198, map (1899)

99b The geology of the Klondike region. Eng M J 67:116 (1899) Sc Am Sup 49: $20101(1900)$

99e (with Meconne11, R. G.) Preliminary note on the gold deposits and gold mining in the Klondike region, Yukon distriet. Can G S, Sum Rp $1898^{\circ}$ (An Rp 11) : A 55-62 (1899)

00 Report on the east shore of Lake Winnipeg and adjacent parts of Manitoba and Keewatin. Can G S, An Rp 11:0 $98 \mathrm{pp}$, map (1900)

O0a The stability of the land around Hudson Bay. G Mag (4) 7:266-267 (1900)

02 Report on explorations in the north. eastern portion of the district of Saskatehewan and adjacent parts of the district of Keewatin. Can G S, An Rp 13: F 48 pp, $\operatorname{map}(1902)$

o: A peculiar artesian well in the Klondike. Eng M J 75: 188 (1903)

04 Crystosphenes or buried sheets of ice in the tundra of North America. J G 12: $2: 2-236$ (1904)

06 A Canadian Department of Mines or Geological Survey. Can M Inst, J 9:107111 (1906)

o7 Concentration of gold in the Klondike. Ee G 2:343-349 (1907) Can M J 28 (n s 1 no 13) : 403-405 (1907)

o7a Vein formation at Cobalt, Ont. Can M J 28 (n \& 1 no 10): 301-303 (1907)

os Minerals and ores of northern Canada. Can M Inst, J 11:348-365 (1908) Can M J 30:149-150 (1909)

OSa Cobalt and northern Ontario. Inst M Eng, Tr 35: 488-500 (1908)

osb Mineral veins in the Montreal River district [Ont.]. Can M J 29:651a-652a (1908); 30:149-150 (1909) 
Bigsby, John Jeremiah-Continued.

24 Notes on the geography and geology of Lake Huron. G Soc London, Tr (2) 1 : 175-209. (1824)

24a Notes on the geography and geology of Lake Superior. Q J Sc 18:1-34, 228269 (1824-5) Abst, B Sc Nat, Paris, 7 : 8-13 (1826)

24b A list of minerals and organic remains occurring in the Canadas. Am J Sc 8: 60-88 (1824)

25 A sketch of the geology of the Island of Montreal. Lye N H N Y, An 1:198219 (1825)

25a Description of a new species of trilobite. Ac N Sc Phila, J $4: 365-368$ (1825)

25b Notice of a cave containing bones in Lanark, Upper Canada. Am J Sc 9: $354-355(1825)$

27 On the fixed rocks of the valley of the St. Lawrence in North America (abst). $\mathrm{Ph}$ Mag n s 2:217-220 (1827) G Soc London, $\operatorname{Pr} 1: 23-25$ (1827)

28 On the geology of Quebec and its vicinity (abst). G Soc London, Pr 1:3738 (1828) Ph Mag n s 3:132-133 (1828)

29 Topography of the River Niagara. Q J Sc 27:39-56 (1829) Abst, B Sc Nat, Paris, 21: 52-54 (1830)

29a A sketch of the topography and geology of Lake Ontario. Ph Mag n s 5 : $1-15,81-87,263-274,339-347,424-431$, $\operatorname{map}(1829)$

51 On the erratics of Canada. G Soc London, Q J $7: 215-238$, map (1851)

52 On the geology of the Lake of the Woods, South Hudson's Bay. G Soc London, Q J 8:400-406, map (1852) Abst, An Sc, Cleveland 1:60-61 (1852)

52a On the physical geography, geology, and commercial resources of Lake Superior. R Inst, $\mathrm{Pr} 1: 154-162$ (1852) Edinb N Ph J $53: 55-62$ (1852)

53 On the geology of Quebec and its environs. G Soc London, Q J 9:82-101, map, il (1853)

54 On the geology of Rainy Lake, south Hudson Bay. G Soc London, Q J 10: 215222, map (1854)

58 On the Paleozoic basin of the State of New York. G Soc London, Q J 14:305$306,335-452$ (1858) ; 15:251-335 (1859) Abst, Am J Sc (2) $27: 272-276$ (1858)

63 On the Cambrian and Huronian formations. G Soc London, Q J 19:3652 (1863)

64 On the Laurentian formation; its mineral constitution, its geographical distribution, and its residuary elements of life. G Mag 1: 154-158, 200-206 (1864)

68 Thesaurus siluricus; the flora and fauna of the Silurian period. $214 \mathrm{pp}, \mathrm{L}$ 1868

78 Thesaurus devonico-carboniferus ... $x$, 447 pp, L 1878
Bilgram, Hugo.

04 Inclusions in quartz. Ac N Sc Phila, Pr 55: 700 (1904)

Billin, Charles E.

85 Ranges of fossil ore through Barree and Jackson townships [Huntingdon Co.] Pa G S, 2d T3 : 239-254 (1885)

See also D'Invilliers, 91.

Billings, Elkanah (1820-1876).

54 On some new genera and species of Cystidea from the Trenton limestone. Can J $2: 215-218,250-253,268-274$, il (1854)

56 ... European and American formations; geographical distribution of the latter in Canada. Can Nat 1:1-25 (1856)

$56 a$ Fossils of the Potsdam sandstone; sea weeds, shells, and footprints on the rock at Beauharnois. Can Nat 1:32-39, il (1856)

56b On some of the characteristic fossils of the Lower Silurian rocks of Canada. Can Nat 1:39-47, il (1856)

56e On the Crinoidea or stone lilies of the Trenton limestone, with a description of a new species. Can Nat $1: 48-57$, il (1856)

56d Fossils of the Upper Silurian rocks, Niagara and Clinton groups. Can Nat 1: $57-60$, il (1856)

56e On the fossil corals of the Lower Silurian rocks of Canada. Can Nat 1 : $115-128$, il (1856)

56f On some of the technical terms used in the description of fossil shells. Can Nat 1:128-131, il (1856)

$56 \mathrm{~s}$ On some of the fossil shells of the Niagara and Clinton formations. Can Nat 1:131-139, il (1856)

56h A chapter on earthquakes. Can Nat 1:189-195 (1856)

56i On some of the common rocks of the British provinces. Can Nat 1:196202 (1856)

56j On some of the Lower Silurian fossils of Canada. Can Nat 1:203-208, il (1856)

56k Description of fossils occurring in the Silurian rocks of Canada. Can Nat $1: 312-320$, il (1856)

561 On the Tertiary [Quaternary] rocks of Canada, with some account of their fossils. Can Nat $1: 321-346$, il (1856)

$56 \mathrm{~m}$ On the mammoth and mastodon. Can Nat $1: 379-390$, il (1856)

57 Report for the year 1856 [fossils from Anticosti, and new species of fossils from the Lower Silurian rocks of Canada]. Can G S, Rp Prog 1853-6: 247-345 (1857)

$57 \boldsymbol{n}$ Lawrencian formation. Can Nat 1 : 464 (1857)

57b Fossils of the Hamilton group. Can Nat $1: 471-479$, il (1857)

57e On the iron ores of Canada... Can Nat 2:20-28 (1857) 
Tyrrell, Joseph Burr-Continued.

10 Changes of climate in northwestern Canada since the glacial period. Int $G$ Cong, XI, Stockholm, Die Veränderungen des Klimas seit dem Maximum der letzten Eiszeit : $389-391$ (1910)

10a Ice on Canadian lakes [origin of lake ramparts]. Can Inst, $\operatorname{Tr} 9: 13-21$ (1910)

10 b "Rock glaciers" or chrystocrenes. J G 18:549-553 (1910)

10c The geology of western Canada (abst). Brit As, Rp 79:471-472 (1910)

$10 d$ Placer gold mining in Canada (abst). Brit As, Rp 79:480-481 (1910)

11 Certain natural associations of gold (discussion). Ec G 6:701-703 (1911)

11 a Study of ice-sheet erosion and deposition in the region of the Great Lakes (discussion). G Soe Am, B 22:728-729 (1911)

12 The Coppermine country. Can M Inst, $\mathrm{Tr}$ 15:508-534, map (1912) Can Inst, Tr 9:201-222 (1912) Can M J 34: 117-121, 147-153, maps (1913)

12a The law of the pay streak in placer deposits. Inst M Met, Tr 21:593-605 (1912) M Sc Press 104: 760-762 (1912)

$12 b$ The gold of the Klondike. $R$ Soc Can, Pr Tr (3) 6 iv : 29-59 (1912)

12e Vein formation in Cobalt. Can M J $33: 171-172$ (1912)

13 Hudson Bay exploring expedition, 1912. Ont Bur Mines, An Rp 22 pt 1: 161-209, maps (1913)

13a The occurrence of gold in Ontario. Inst M Met, B no 110:1-12 (1913) Can M J 35:230-235 (1914) Abst, M. Science 69 , Feb : $32-33$ (1914)

13b The Patrician Glacier south of Hudson Bay. Int G Cong, XII, 1913, C R : 523-534, map (1914) Advance copy 1913

13e Silver veins in South Lorrain, Ont. Can M J 34: 329-330 (1913)

14 (and Graham, R. P. D.) Yukonite, a new hydrous arsenate of iron and calcium, from Tagish Lake, Yukon Terr., Can. ; with a note on the associated symplesite. R Soc Can, $\operatorname{Pr} \operatorname{Tr}$ (3) 7, iv: 13-18 (1914)

14a The Yukon Territory [geology, mineral resources, etc.]. In Canada and its provinces (Adam Shortt and A. G. Doughty, ed.) $22: 583-636$, Toronto 1914

14b The Northwest Territories [geology, mineral resources, etc.]. In Canada and its provinces (Adam Shortt and A. G. Doughty, ed.) $22: 637-660$, Toronto 1914

14e Artesian water in Manitoba. Can Engineer 26:574-575 (1914)

15 Gold-bearing gravels of Beauce Co., Que. Am I M Fng, B $99: 609-620$ (1915); Tr 51:672-683 (1916) Can M J 36:174178 (1915)
Tyrrell, Joseph Burr-Continued.

15r [Geologic conditions in southwesten British Columbia with reference to the possible occurrence of oil.] Am I M Fin B 108:2432-2433 (1915); Tr 52:248-24 (1916)

15b Pre-Cambrian gold fields of centril Canada. R Soc Can, Tr (3) 9 iv : 89-11 (1915) Abst, Ec G 10:475-477 (1915)

15e Gold on the North Saskatchewa River [A1ta.]. Can M Inst, B 34:68-81 (1915) ; Tr 18: 160-173 (1916)

15d Note on the geology of Porcupine [Ont.]. Can M Inst, Mo B 38: 397-388 (1915)

16 Notes on the geology of Nelson and Hayes rivers. $R$ Soc Can, $\operatorname{Tr}$ (3) 10 ir: 1-27 (1916)

17 Frozen muck in the Klondike district, Yukon Territory, Canada. R Soc Can, Tr (3) 11 iv: $39-46$ (1917)

17 a Northern Manitoba as a mining country. In Northern Manitoba (issued br the Province of Manitoba) : 23-25 (1917)

See also Johnston (W A), 17b; Leverett, $12 \mathrm{~b}$; Newberry, $89 \mathrm{~b}$; Weaver, 15

Tyrrell, John F.

65. The oil districts of Canada. $40 \mathrm{pp}$, N Y 1865

Tyson, Philip Thomas (1799-1877).

30 ... localities of minerals in the coun. ties of Baltimore and Harford, Md. Am J Sc $18: 78-81$ (1830)

37 A description of the Frostburg coal formation of Allegany Co., Md., with at account of its geological position. Md Ac Sc, Tr 1:92-98 (1837)

37a A descriptive catalogue of the princpal minerals of the State of Maryland. Md Ac Sc, Tr 1: 102-117 (1837)

50 ... information in relation to the geology and topography of California. U S, 31st Cong 1st sess, S Ex Doc 47:1-7t (1850) [See also next entry]

51 Geology and industrial resources of California. xxxiv, $127,37 \mathrm{pp}$, maps, Baltimore 1851 [The preceding entry, with additional matter]

60 First report of the State agricultu. ral chemist to the House of Delegates of Maryland, January, $1860.145 \mathrm{pp}$, appendix (mineral resources of Md), $20 \mathrm{pp}$, map, Annapolis 1860 Second report.. January 1862:92 pp, Annapolis 1862

60a [On infusorial beds in Maryland.] Ac N Sc Phila, Pr 1860:550-551

69 Section of the Cumberland coal basin [Md.]. In Hodge, James T., Report on the coal properties of the Cumberland coal basin in Maryland:59-63, N Y 1869 Am Ph Soc, Pr 11:9-13 (1869)

Tyssowski, John.

o9 Gypsum on Cape Breton Island, N. S. Eng M J $88: 569-570$ (1909) 
Udden, Anton $D$.

12 On the earthquake of January 2, 1912 , in the upper Mississippi Valley. IIl Ac Sc, Tr 5: 111-115 (1912)

Udden, Johan August.

91 Megalonyx beds in Kansas. Am G $7: 340-345$, map (1891)

93 On a natural formation of pellets. Am G 11:268-271 (1893)

94 Erosion, transportation, and sedimentation performed by the atmosphere. J G 2 : $318-331$ (1894)

95 A geological section across the northern part of Illinois. In Illinois Board of World's Fair Commissioners at the World's Columbian Exposition [Chicago 1893], Report: $117-151$, Springfield 1895

95a Fossil frost cracks. Sc Am 72: 102 (1895)

96 An account of the Paleozoic rocks explored by deep borings at Rock Island, IIl., and vicinity. U S G S, An Rp 17 pt 2:829-849, map (1896)

97 Loess as a land deposit. G Soc Am, B $9: 6-9$ (1897) Abst, Am G 20: 194 (1897) ; Science n s 6:691 (1897)

97a Origin of the loess. Am G 20: 274-275 (1897)

$97 \mathrm{~b}$ A brief description of the section of Devonian rocks exposed in the vicinity of Rock Island, IIl., with a statement of the nature of its fish remains. Cin Soc $\mathrm{N} \mathrm{H}$, J $19: 93-95$ (1897)

98 The mechanical composition of wind deposits. Augustana Libr Pub, no. 1, 69 p) (1898)

98a Fucoids or coprolites. J G 6:193198, il (1898)

98b A ncw. well at Rock Island, III. Am G 21: 199-200 (1898)

9Se Some preglacial solis. Iowa Ac Sc, Pr 5:102-104 (1898) Am G 21:262-264 (1898)

98d A geological romance. Pop Sc Mo $54: 222-229$ (1898)

99 Geology of Museatine Co. Iowa G S $9: 247-380$, maps (1899)

99a The Sweetland Creek beds. J G $7: 65-78 \quad(1899)$

99b Dipterus in the American middle Devonian. J G $7: 494-495$, il (1899)

99c Some Cretaceous drift pebbles in northern Iowa. Am G 24:389-390 (1899) 99d Diatomaceous earth in Muscatine Co. [Iowa]. Iowa Ac Sc, Pr 6:53 (1899) 99e The Pine Creek conglomerate [Iowa]. Iowa Ac Sc, Pr 6:54-56 (1899)

01 Geology of Louisa Co. Iowa G S 11 : 55-126, maps (1901)

O1a Geology of Pottawattamie Co. Iowa G S $11: 199-277$, map (1901)

02 Geology of Jefferson Co. Iowa G S $12: 355-437$, map (1902)

02a Loess with horizontal shearing planes. J G 10:245-251, map (1902)
Udden, Johan August-Continued.

02b On the occurrence of rhizopods in the Pella beds in Iowa. Iora Ac Sc, Pr 9 : 120 (1902)

02c Pleuroptyx in the Iowa Coal Measures. Iowa Ac Sc, Pr 9: 121 (1902)

03 Geology of Mills and Fremont $\cos$. Iowa G S $13: 123-183$, maps (1903)

03a Foraminiferal ooze in the Coal Measures of Iowa. J G 11:283-284, 430 (1903)

04 The geology of the Shafter silvermine district, Presidio Co., Tex. Tex Univ Min S B 8:60 pp, map (1904)

04a (with Hill, B. F.) Geological map of a portion of west Texas. Tex Univ Min S (1904)

05 On the proboscidean fossils of the Pleistocene deposits in Illinois and Iowa. Augustana Libr Pub no. 5:45-57 (1905)

06 The origin of the small sand mounds in the Gulf coast country. Science n s 23: 849-851 (1906)

o7 Report on a geological survey of the lands belonging to the New York and Texas Land Company (Ltd.), in the upper Rio Grande embayment in Texas. Augustana Library Pub no 6:51-107, map (1907)

$07 a$ A sketch of the geology of the Chisos country, Brewster Co., Tex. Tex Univ, B no 93 (sc s no 11) : 101 pp (1907)

os Fossil tracks in the Del Rio clay. Tex Ac Sc, Tr 10:51-52, il (1908)

08n A cycad from the upper Cretaceous in Maverick Co., Tex. Science n s 28:159160 (1908)

0sb Defects in coal number five at $\mathrm{Pe}$ oria. III G S, B 8: 255-267 (1908)

ose Artesian wells in Peoria and vicinity. III G S, B $8: 313-334$ (1908)

osd (and Dewolf, F. W.) Notes on the Belleville-Breese area. Ill G S, B 8:246254 (1908)

09 Geological classification of the waters of Illinois. III G S, B 10:8-21 (1909)

10 Observations on the earthquake of May 26, 1909. Pop Sc Mo 77:154-162 (1910) III Ac Sc, Tr 3: 132-143 (1910)

10a A geologist's notes on the origin of coal. M World 32:1129-1130 (1910)

11 Structural relations of quicksilver deposits [Tex.]. M World 34:973-975 (1911)

12 Geology and mineral resources of the Peoria quadrangle, III. U S G S, B 506: $103 \mathrm{pp}$, maps (1912) Abst, by David White, Wash Ac Sc, J 2:440 (1912); by W. C. Alden, 4:219-221 (1914)

$12 a$ The eastward extension of the Sweetland Creek shale in Illinois. Ill. Ac Sc, $\operatorname{Tr} 4: 103-107$ (1912)

$12 b$ Oil and gas fields of Wichita and Clay cos., Tex. M World $36: 767$ (191L)

12c Potash in the Permian rocks of Texas, American Fertilizer 37 no 12:40-41 (1912) 
Udden, Johan August-Continued.

$12 d$ (assisted by Phillips, D. M.) reconnaissance report on the geology of the oil and gas fields of Wichita and Clay cos., Tex. Tex, Univ, B no 246 (se no 23) : $308 \mathrm{pp}$, maps (1912)

13 On the trail of a catastrophe [depesit of volcanic ash in Kent Co., Tex.]. The Texas Magazine $7: 242-244$ (1913)

13a Blocks and segments. Science n s $37: 709-710$ (1913)

13b The effect of leaching on drift pebbles. J G 21 : 564-567 (1913)

14 Some deep borings in Illinois. IIl G S, B 24:141 pp (1914)

14a The deep boring at Spur [Tex.]. Tex Univ, B 363 (sc s 28): 90 pp (1914)

14b Flattening of limestone gravel boulders by solution. G Soc Am, B 25: 66-68 (1914)

14c Mechanical composition of clastic sediments. G Soc Am, B 25:655-744 (1914)

14d The Buck zinc prospect near Boracho, Tex. M Sc Press 108:493-494 (1914)

15 (and Shaw, E. W.) Description of the Belleville and Breese quadrangles, III. U S G S, G Atlas Belleville-Breese fol (no 195) : $13 \mathrm{pp}$, maps (1915)

15a Potash in the Texas Permian. Tex, Univ, B 1915 no $17: 59$ pp, map (1915)

15b The age of the Castile gypsum and the Rustler Springs formation [Texas] [with note by G. B. Richardson]. Am J Sc (4) $40: 151-156$ (1915)

15e Oil in an igneous rock. Ec G 10 : 582-585 (1915)

16 Geological maps in Texas. Texas, Univ, B 1916 no $35: 17-21$, map (1916)

$16 a$ (and others) Review of the geology of Texas. Tex Univ, B 1916 no 44 : $164 \mathrm{pp}$, map (1916) Geological map of Texas, 1916. Scale 1:1 500000

16b (and Bybee, H. P.) The Thrall oil field. Tex Univ, B 1916 no $66: 3-78$, map (1916)

16c Notes on ripple marks. J G 24 : 123-129 (1916)

17 Notes on the geology of Glass Mountains. Tex Univ, B no $1753: 3-59$, map (1917)

17a The Texas meteor of October 1 , 1917. Tex Univ, B no 1772: 56 pp (1917)

17b The geology of Texas quicksilver de posits. Tex Min Res 1:1-2, 28-29 (1917)

17e Hints to prospective geologists. Sonthwestern As Petroleum G, B 1:127130 (1917)

17d A Texas meteor. Science n s 46 : 616-617 (1917)

18 Fossil ice crystals; an instance of the practical value of "pure science." Tex, Univ, B 1821: 8 pp (1918)

18n The anticlinal theory as applied to some quicksilver deposits. Tex, Univ, B 1822: 30 pp (1918)
Vdden, Johan August-Continued.

18b Funnel and anticlinal ring structure associated with igneous intrusions in the Mexican oil field (discussion). Am I M Eng, B 133 : 93-95 (1918)

18e The theory of volcanic origin of salt domes (discussion). Am I M Eng, B $139: 1147$ (1918)

Udden, Jon Andreas.

05 Geology of Clinton Co. Iowa G S $15: 369-431$, maps (1905)

o7 The Delafield dril] core [Illinois]. III G S, B 4:203-211 (1907)

08 Notes on the Shoal Creek limestene. III G S, B 8: 117-126 (1908)

09 Coal deposits and possible oil field near Duquoin, IH. IH G S, B 14: 254 262 (1909) M World $30: 487-489$ (1909)

10 Diamond drill core from Franklin Co. Ill G S, B 16:300-301 (1910)

10a The oolitic limestone industry at Bedford and Bloomington, Ind. $\mathrm{U} S \mathrm{G} \mathrm{S}$, B $430: 335-345$ (1910)

$10 b$ (and Todd, J. E.) Structural materials in Illinois. IIl G $\mathrm{S}, \mathrm{B} 16: 342-393$ (1910)

Uglow, William Lawrence

11 The Alexo nickel deposit, Ontario. Ont Bur Mines, An Rp 20 pt $2: 34-39$ (1911)

11 a The Alexo mine; a new nickel oc currence in northern Ontario. Can M Inst, Q B 16:151-171 (1911)

13 Port Arthur to Winnipeg via Canadian Northern Railway. Int G Cong, XII, Canada, Guide Book no 8:37-69, maps (1913)

13a A review of the existing hypotheses on the origin of the secondary silicate zones at the contacts of intrusives with limestones. Ec G 8: 19-50, 215-234 (1913)

13b Hydrothermal alteration (discus. sion). Ec G 8: 797-800 (1913)

14 "Secondary silicate zones"... Ec G $9: 175-183$ (1914)

16 Lead and zinc deposits in Ontario and in eastern Canada. Ont Bur Mines. An Rp 25 pt 2:56 pp, maps (1916)

16a Origin of certain ore deposits [lead veins, Ontario and Quebec]. Ec G 11: 87-92 (1916)

16b Ore genesis and contact metamorphism at the Long Lake zinc mine, Ontarie. Ec G 11:231-245 (1916)

17 Gneissic galena ore from the Slocan district, B. C. Ee G 12:643-662 (1917)

Uhler, Philip Reese (1835-1913).

83 Geology of the surface features of the Baltimore area [Md.]. Johns Hopkins Univ Circ 2: 52-53 (1883)

88 The Albirupean formation and its nearest relatives in Maryland. $\mathrm{Am} \mathrm{Ph}$ Soc, Pr 25:42-53 (1888)

$88 a$ Observations on the Eocene Tertiary and its Cretaceous associates in the State of Maryland. Md Ac Sc, Tr n \& 1:11-32 (1888) 
Thler, Philip Reese-Continued.

89 Additions to observations on the Cretaceous and Eocene formations of Maryland. Md Ac Sc, Tr n s 45-72 (1889)

90 Notes and illustrations to "Observations on the Cretaceous and Eocene formations of Maryland." Md Ac Sc, Tr n s 1: $97-104$ (1890)

92 Albirupean studies. Md Ac Sc, Tr n 8 1: 185-201 (1892)

92a A study of Gay Head, Marthas Vineyard. Md Ac Sc, Tr n s $1: 204-212$ (1892)

92b Gay Head [Marthas Vineyard, Mass.]. Science 20:176-177 (1892)

92e Observations on the Cretaceous at Gay Head [Marthas Vineyard, Mass.]. Science $20: 373-374$ (1892)

98 Preliminary notice of a recent series of geological accumulations, the McHenry formation. Md Ac Se, Tr n s 1:395-400 (1898)

o5 The Niagara period and its assoeiates near Cumberland, Md. Md Ac Sc, Tr n $\mathrm{s}$ 2: 19-26 (1905)

08 The Cauda-Galli in the Niagara of Maryland. M Ac Sc, Tr 2:27-30 (1908) Uhlig, Johannes.

09 Untersuchung einiger Gesteine aus dem nordöstlichsten Labrador. Ver Erdk Dresden, Mitt 8:230-236 (1909)

U1ke, Titus.

92 A contribution to the geology of the Dakota tin mines. Fng M J $53: 547$ (1892)

93 A new tin mineral in the Black Hills [cuprocassiterite]. Am I M Eng. Tr 21: 240-241 (1893)

94 The occurrence of tin ore at Kings Mountain [Cleveland Co., N, C.]. U S G S, Min Res 1893: 178-182 (1894)

Ulrich, Edward Oscar.

78 Observations on fossil annelids and descriptions of some new forms. Cin Soc N H, J 1:87-91, il (1878)

78n Descriptions of some new species of fossils from the Cincinnati group. Cin Soc N H, J 1: 92-100, il (1878)

79 Descriptions of new genera and species of fossils from the Lower Silurian about Cincinnati. Cin Soe N H, J 2:830 , il (1879)

$79 n$ Description of a new genus and some new speeies of bryozoans from the Cincinnati group. Cin Soc N H, J 2 : 119131, il (1879)

79b Deseription of a trilobite from the Niagara group of Indiana. Cin Soc $\mathrm{N} \mathrm{H}$, J 2:131-134, il (1879)

82 American Paleozolc Bryozoa. Cin Soc N H, J 5 : 121-175, 232-257; $6: 82-92$, $148-168,245-279 ; 7: 24-51$, il $(1882-4)$

82n Descriptions of two new species of crinolds. Cin Soc N H, J 5:175-177, il (1882)
Urich, Edward Oscar - Continued.

86 Descriptions of new Silurian and Devonian fossils. In Contributions to American Paleontology, vol 1 no $1: 3-35$, published by E. O. Ulrich, Cincinnati, O., May 1, 1886 [no more published]

86a Report on the Lower Silurian Bryozoa with preliminary deseriptions of some of the new species. Minn $G \mathrm{~S}, \mathrm{An} \mathrm{Rp} 14$ : $57-103$ (1886)

s6b Remarks upon the names Cheirocrimus and Calceocrimus, with descriptions of three new generic terms and one new species. Minn G S, An Rp 14:104-113, il (1886)

8S A list of the Bryozoa of the Waverly group in Ohio, with descriptions of new species. Denison Univ, Sc Lab, B $4: 62-96$, il (1888)

S8a A correlation of the Lower Silurian horizons of Tennessee and of the Ohio and Mississippi valleys with those of New York and Canada. Am G $1: 100-110,179-190$. $305-315 ; 2: 39-44$ (1888)

ssb Prof. Amos H. Worthen. Am G 2 : 114-117, port. (1888)

s8e On Sceptropora, a new genus of Bryozoa, with remarks on Helopora Hall, and other genera of that type. Am G 1: $228-234$, il (1888)

88d Nomenclature of some Cincinnati group fossils. Am G 1: $333-335$ (1888)

89 On some Polyzoa (Bryozoa) and Ostracoda from the Cambro-Silurian rocks of Manitoba. Can G S, Contr Micro-Pal pt 2: 27-57, il (1889)

S9a Preliminary description of new Lower Silurian sponges. Am G 3:233248 , il $(1889)$

s9b On Lingulasma, a new genus, and eight new species of Lingula and Trematis. Am G $3: 377-391 ; 4: 21-25$, il (1889)

90 American Paleozoic sponges. Ill G S $8: 209-241$, il $(1890)$

90a Sponges of the Devonian and Carboniferous systems. Ill G S $8: 243-251$, il (1890)

9ob (and Everett, O.) Descriptions of Lower Silurian sponges. Ill $\mathrm{G}$ S 8: 253-282, il (1890)

9oe Paleozoic Bryozoa. Ill G S 8:283688 , il (1890)

$90 d$ New Lamellibranchiata. Am G 5 : $270-284$, il ; $6: 173-181, \quad 382-389$, il $(1890) ; 10: 96-104$, il (1892)

90e New Lower Silurian Bryozoa. Cin Soc N H, J 12:173-198, il (1890)

90R New and little known American Paleozoic Ostracoda. Cin Soc N H, J 13: 104-137, 173-211, il (1890-1)

91 Beecherella, a new genus of Lower Helderberg Ostracoda. Am G 8:197-204, il (1891) 
Elrich, Edward Oscar - Continued.

92 New Lower Silurian Lamellibranchi ata chiefly from Minnesota rocks. Minn G S, An Rp 19:211-248, il (1892) Abst. Minn, Univ, Q B 1:59 (1892)

92a New Lamellibranchiata [Ordovician, Minnesota and Wisconsin]. Am G 10:96104, il (1892) Abst, Minn, Univ, Q B 1: $59-60(1892)$

92b New Lower Silurian Ostracoda. Am G 10:263-270, il (1892)

92e Two new Lower Silurian species of Lichas (subgenus Hoplolichas). Am G 10 : $271-272$, il (1892)

93 New and little known Lamellibranchiata from the Lower Silurian rocks of Ohio and adjacent States. Ohio G S, Rp 7 : $627-693$, il (1893)

95 On the structure and systematic position of "Anomaloides," and a proposal to change the name to Anomalospongia. Minn G S, Final Rp 3, pt 1:68-74, il (1895)

95a On Lower Silurian Bryozoa of Minnesota. Minn G S, Final Rp 3 pt 1:96332, il (1895) Abst, Minn, Univ, Q B $2: 56(1894)$

$95 b$ (with Winchell, N. H.) Historical sketch of investigation of the Lower Silurian in the Mississippi Valley. Minn G S, Final Rp 3 pt 1: ix-liii, map (1895)

97 The Lower Silurian Lamellibranchiata of Minnesota. Minn G S, Final Rp 3 pt 2: 475-628, il (1897) Abst, Minn, Univ, Q B 2:89-91 (1894)

97a The Lower Silurian Ostracoda of Minnesota. Minn G S, Final Rp 3 pt 2: 629-693, il (1897)

97b (and Scofield, W. H.) The Lower Silurian Gastropoda of Minnesota. Minn G S, Final Rp 3 pt 2:813-1081, il (1897)

97e (with winchell, N. H.) The Lower Silurian deposits of the upper Mississippi province; a correlation of the strata with those in the Cincinnati, Tennessee, New York, and Canadian provinces, and the stratigraphic and geographic distribution of the fossils. Minn G S, Pal 3 pt 2: Ixxxiii-cxxviii (1897)

00 New American Paleozoic Ostracoda. Cin Soc N H, J 19:179-186, il (1900)

02 (and Schuchert, C.) Paleozoic seas and barriers in eastern North America. $\mathrm{N}$ X St Mus, B 52:633-663, map (1902)

02a The lithographic stone deposits of eastern Kentucky. Eng M J 73:895-896 (1902)

o3 (and Smith, W. S. T.) Lead, zinc, and fluorspar deposits of western Kentucky. U S G S, B $213: 205-213$ (1903)

03a (with Hayes, C. W.) Description of the Columbia quadrangle [Tenn.]. U S G S, G Atlas Columbia fol (no 95): 6 pp, maps (1903)

04 Determination and correlation of formations [of northern Arkansas]. U S G S, P P 24: 90-113 (1904)
Trich, Edward Oscar-Continued.

04a Fossils and age of the Yakutat formation [A laska]. Harriman Alaska Ex. ped $4: 125-146$, il (1904)

04b (and Bassler, R. S.) A revision of the Paleozolc Bryozoa; Part I, On gen era and species of Ctenostomata. Smiths Misc Col 45 (Q Is 1) : 256-294, il (1904)

04e (and Bassler, R. S.) A revision of the Paleozoic Bryozoa; Part II, On genera and species of Trepostomata. Smiths Misc Col 47 (Q Is 2): 15-55, i (1904)

o5 (and Smith, W. S. T.) The lead, zinc, and fluorspar deposits of western Kentucky. U S G S, P P 36:218 pp. maps, il (1905)

05a Portland-ment resources of Tennessee. U S G S, B $243: 301-307$ (1905)

osb (with Adams, G. I.) Description of the Fayetteville quadrangle [Ark.-Mo.]. U S G S, G Atlas Fayetteville fol (no 119) $6 \mathrm{pp}$, maps (1905)

o5e (with Bain, H. F.) The copper deposits of Missouri, U S G S, B 260 233-235 (1905)

osd (with Bain, H. F.) The copper deposits of Missouri. U S G S: B $267: 52$ pp (1905)

06 Systematic paleontology of the Pleistocene deposits of Maryland; Molluscoidea. Md G S, Pliocene and Pleisto. cene : $210-212$, 11 (1906)

o6a (and Bassler, R. S.) New Ameri. can Paleozoic Ostracoda ; notes and descrip. tions of upper Carboniferous genera and species. U S Nat Mus, $\operatorname{Pr} 30: 149-164$, il (1906)

os (and Bassler, R. S.) New Ameri. can Paleozoic Ostracoda; preliminary re. vision of the Beyrichidas, with descriptions of new genera. U $\mathrm{S}$ Nat Mus, $\mathrm{Pt}$ $35: 277-340$, il (1908)

09 Ordovician paleogeography (abst). Science n \& 29:199-200 (1909)

O9a Revision of the Paleozoic systems in North America (abst). Science n s 29: 630 (1909)

09b Paleozoic erosion channels (abst). Science n s 30:973-974 (1909)

10 List of fossils from St. Hilaire, Que., collected by $\mathbf{R}$. Harvie, jr. Can G S, Mem $7: 29-30$ (1910)

10a (and Cushing, H. P.) Age and relations of the Little Falls dolomite (Calciferous) of the Mohawk Valley. N Y St Mus, B $140: 97-140$ (1910) Abst. Science n s 32:192 (1910); G Soc Am, B $21: 780-781(1910)$

11 Bearing of the Paleozoic Bryozoa on paleogeography. G Soc Am, B 22:252257 (1911)

11a Revision of the Paleozolc systrms. G Soc Am, B 22: 281-680, map (1911) Index, 24: 625-668 (1913) 
virich, Edward Oscar-Continued.

11b The influence of marine currents on deposition in continental seas (abst). Science n s $33: 312-313,316$ (1911)

12 The Chattanoogan series with special reference to the Ohio shale problem. Am J Sc (4) 34: 157-183 (1912)

13 The Ordovician-Silurian boundary. Int $\mathrm{G}$ Cong, XII, 1913 , C R : 593-667, maps (1914) Advance copy 1913

13a The Medina problem (abst). G Soc Am, B 24: 107-108 (1913)

13b Nomenclature, structure, and classification of the Cremacrinidæ (abst). G Soc Am, B 24: 109-110 (1913)

13e (and Bassler, R. S.) Systematic paleontology of the Lower Devonian deposits of Maryland; Bryozoa, Ostracoda. Md G S, Lower Devonian : 259-290, 513542 , il (1913)

13d Systematic paleontology of the Middle Devonian deposits of Maryland; Bryozoa. Md G S, Middle and Upper Devonian : 123-124, il (1913)

13e (and Butts, Charles.) [Geologic sections in southeastern Tennessee]. Tenn G S, B 16:32-43 (1913)

15 Kinderhookian age of the Chattanoogan series (abst). G Soc Am, B 26: 96-99 (1915)

16 Correlation by displacements of the strand line and the function and proper use of fossils in correlation. G Soc Am, B $27: 451-490$ (1916)

16a The Chester controversy (abst). G Soc Am. B 27:157 (1916)

17 The formations of the Chester series in western Kentucky and their correlates elsewhere. Ky G S, Mississippian formations of western Kentucky:272 pp, il (1917)

17a The Ostracoda as guide fossils in the Silurian deposits of the Appalachian region (abst). G Soc Am, B 28:202 (1917)

18 Clinton formations in the Anticosti section (abst). G Soc Am, B 29:82 (1918).

See also Clark (W B), 01a, 04a ; Eastman, 00; Eckel, 13; Stanton, 05d

Umpleby, Joseph Bertram.

10 Geology and ore deposits of Republic mining district, Washington. Wash G S, B 1: $67 \mathrm{pp}$, map (1910).

11. Geology and ore deposits of the Myers Creek mining district. Wash $\mathbf{G} \mathbf{S}$, B $5:$ 9-52, map (1911)

11 a Geology and ore deposits of the Oroville-Nighthawk mining district. Wash G S, B 5 : 53-107, map (1911)

11b Republic mining district [Wash.]. M Sc Press 102:792 (1911)

12 Note on the stratigraphy of east central Idaho. Wash Ac Sc, J 2:49 (1912)
Umpleby, Joseph Bertram-Continued.

12a An old erosion surface in Idaho; its age and value as a datum plane. J G $20: 139-147$ (1912) Abst, Wash Ac Sc, J $2: 109-110$ (1912)

13 Geology and ore deposits of Lemhi Co., Idaho. U S G S, B 528: 182 pp, map (1913) Abst, Wash Ac Sc, J 4:166 (1914)

13a A preliminary account of the ore deposits of the Loon Creek distriet, Idaho. U S G S, B 530:66-74 (1913)

13b Some ore deposits in northwestern Custer Co., Idaho. U S G S, B 539: 104 $\mathrm{pp}$, map (1913) Abst, Wash Ac Sc, J 8: 194-195 (1914)

13e The old erosion surface of Idaho. J G 21: 224-231 (1913)

13d (and Schaller, W. T., and Larsen, E. S.) Custerite; a new contactmetamorphic mineral. Am J Sc (4) 36 : 385-394 (1913) Zis Kryst 53:321-331 (1914)

14 The lead-silver deposits of the Dome district, Idaho. U S G S, B 540:212-222 (1914)

14a Ore deposits in the Sawtooth quadrangle, Blaine and Custer cos., Idaho. U S G S, B 580: 221-249, maps (1914)

14b The genesis of the Mackay copper deposits, Idaho. Ec G 9:307-358, 593594 (1914)

14c Crystallized chrysocolla from Mackay, Idaho. Wash Ac Sc, J 4:181-183 (1914)

14d The contact-metamorphic copper deposits at Mackay, Idaho (abst). Wash Ac Sc, J 4:12-13 (1914)

16 The occurrence of ore on the limestone side of garnet zones. Cal Univ, Dp G, B $10: 25-37$ (1916)

17 Geology and ore deposits of the Mackay region, Idaho. U S G S, P P $97: 129 \mathrm{pp}$, map (1917) Abst, by A. K., Wash Ac Sc, J 7:514-515 (1917)

$17 \mathbf{a}$ Genesis of the Success zinc-lead deposit, Coeur d'Alene district, Idaho. Ec G 12: 138-153 (1917)

17b Manganiferous iron ore occurrences at Red Cliff, Colo. Eng M J 104:11401141 (1917)

17e The manganese deposits of Philipsburg, Mont. M Sc Press 115: 725 (1917)

18 Arsenic, bismutb, selenium, and tellurium. U S G S, Min Res 1916 pt 1: 501-505: 1917 pt $1: 23-35$ (1918)

Underhill, B. M.

o7 The evolution of the horse. Delaware Co Inst Sc, Pr 2:115-127, 11 ' (1907) Sc Am Sup 64:412-414, il (1907)

10 A glance at the mammalian dawn. Delaware Co Inst Sc, Pr 5:75-87 (1910) Underbill, F, S.

90 Report [on artesian wells in North Dakota]. U S, 51st Cong 1st sess, S Ex Doc 222: 105-109 (1890) 
Underhill, James.

97 Vein intersections in Clear Creek Co., Colo. Eng M J 64:339 (1897)

97a The Seaton mine, Colorado. Eng M J $64: 550$ (1897)

05 The correlation of Colorado geolog. Ical formations. M Rep 52:496-497 (1905)

06 Areal geology of the lower Clear Creek (Colo.) Colo Univ Studies $3: 263-$ 376 (1906) Colo Sc Soc, Pr 8: 103-122, map (1906)

10 Chart of Colorado formations. M Science $62: 198$ (1910)

Underwood, Lucien M.

90 A bison at Syracuse, N. Y. Am Nat 24: 953-954 (1890)

Ungemach, Henri.

10 Contribution à la minéralogie du Mexique. Soc Franç Minér, B 33:375-409 (1910) Soc Cient Ant Alz, Mem 31 Rv: 1-36 (1912)

16 Sur la pyrite du comté de Gilpin, Colo. Soc Frang Minér, B 39:226-230 (1916)

Unger, Claude W.

o7 An account of the various contributions made to the knowledge of the fossil flora of the southern antbracite coal field and the adjacent Palæozoic formations in Pennsylvania, with a list of the fossil plants. Historical Soc Schuylkill Co, Pa, Pub 2 : 50-102 (1907)

Union Pacific Railroad Company.

09 The fossil :elds of Wyoming; re ports by members of the Union Pacific expedition. $61 \mathrm{pp}, \mathrm{il}$, Union Pacific Railroad Company, Passenger Department, Omaha, Nebr. 1909 [Includes reports bearing on the geology, physiography, rnd vertebrate paleontology of Wyoming by W. H. Reed, J. A. Yates, J. E. Todd, A. R. Crook, H. L. T. Skinner, G. C. Broadhead, and George L. Collie.]

United states, Department of the Interior.

10 Coal lands in Oklahoma. U S, 61st Cong, 2d sess, Sen Doc no $390: 374$ pp, maps (1910)

16 Regulations governing coal-land leases in the Territory of Alaska...: $86 \mathrm{pp}$, maps, Washington 1916

U. S. Geologieal and Geographical Survey of the Territories (Hayden).

78 General geological map of Colorado. Surveyed in $1873-6$. Scale 12 miles to 1 inch. $n d$ [1878] [Also in Atlas of Colorado]

79 Economic map of portions of Wyoming, Idaho, and Utah. Scale 8 miles to 1 inch. April 1879. [Also in 12th An Rp]

83 [Geologic map of] part of central Wyoming. Surveyed in 1877. Scale 4 miles to 1 inch. $n$ d [1883?] [Also in 12 th An Rp]
U. S. Geologienl and Geographieal Survey of the Territories-Contd.

83a [Geologic map of] parts of western Wyoming and southeastern Idaho. Scale 4 miles to 1 inch. $n$ d [1883?] [Also in 12 th An Rp]

S3b [Geologic map of] parts of western Wyoming, southeastern Idaho, and nurtheastern Utah. Surveyed in 1877. Scale 4 miles to 1 inch. $n$ d [1883?] [Also in 12th An Rp]

83e Geological map of portions of Wyoming. Idaho, and Vtah. Scale 8 miles to 1 inch. $n$ d [1883?] [Also in 12th An Rp]

83d Preliminary geological map of the Yellowstone Natlonal Park. Surveyed in 1878. Scale 2 miles to 1 inch. $n$ d [1883?] [Also in 12th An Rp]

U. S. Geologieal Survey of the Territories (Hayden).

72 [Geologic] map of the sources of Snake River with its tributaries... Scale 5 miles to 1 inch. $n$ d [1872]

U. S. Geologieal Survey.

S3 Mineral resources of the United States [1882]-1917 (1883-1919) [For contents see The publications of the United States Geological Survey, November, 1919 100-110. Volumes for 1894-1899 were pub. lished in the Director's annual report]

03 Contributions to economic reology (short papers and preliminary reports), 1902. U S G S, B 213: 449 pp (1903) ; 1903, B 225: 527 pp (1904) ; 1904, B 260: 620 pp (1905); 1905 , B $285: 506$ pp (1906); 1906, Part I, Metals and nonmetals except fuels, B 315 : 505 pp (1907), Part II, Coal, lignite, and peat, B 316 : 543 pp (1907) ; 1907, Part I, B $340: 482$ pp (1908), Part II, Coal and lignite, B 341 : 444 pp (1909) ; 1908, Part I, B 380 : $406 \mathrm{pp}(1909)$, Part II. Mineral fuels, B 381 : 599 pp (1910) ; 1909, Part I; B 430:

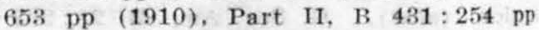
(1911); 1910, Part I, B 470:558 pp (1911), Part II, B 471:663 pp (1912); 1911. Part I, B 530:400 pp (1913), Part II. B $531: 361$ pp $(1913)$; 1912, Part I, B 540:563 pp (1914), Part II, B 541: 532 pp (1914) ; 1913, Part I, B 580:462 pp (1915), Part II, B 581:187 pp (1915); 1915, Part I, B 620:361 pp (1916), Part II, B $621: 375$ pp (1916) ; 1916, Part I, B $640: 255$ pp (1917), Part II, B 641: $3: 3$ pp (1917); 1917, Part I, B 660:304 pp (1918), Part II, B 661: 328 pp (1918) [For contents consult The publications of the United States Geological Survey, November, $1919: 34-70$ ]

04 The United States Geological Survey, its origin, development, organization, and operations. U S G S, B 227:205 pp (1904)

07 The San Francisco earthquake and fire of April 18, 1906, and their effects on structures and structural materials. U S G S, B $324: 170$ pp (1907) 


\section{S. Geologieal Survey-Continued.}

09 Papers on the conservation of min eral resources, U S G S, B 394: 214 pp (1909)

12 Miscellaneous analyses of coal samples from various fields of the United States. U S G S, B 471: 629-655 (1912) ; B $531: 331-335$ (1913)

18 The country around Camp Grant [Illinois]. [Text on back of topographic map], IlHinois, Camp Grant quadrangle, U S G S. 1918

Updyke, Stephen G.

90 Report [on artesian wells of South Dakota]. U S 51st Cong 1st sess, S Ex Doc 222: 110-124 (1890)

Epham, W. E.

11 Specular hematite deposits, Planet, Arie. M Sc Press 102: 521-523 (1911)

Ipham, Warren.

77 The northern part of the Connecticat Valley in the Champlain and terrace periods. Am J Sc (3) 14:459-470 (1877)

77a On the origin of kames or eskers in New Hampshire. Am As, Pr 25: 216-225 (1877)

th Surface geology of the Merrimac Valley. Am Nat 11:524-539 (1877)

77e Notes on the surface geology of New Hampshire. Can Nat $n$ s 8:325-336 (1877)

78 Modified drift in New Hampshire. In Hitchcock, C. H., Geology of $\mathrm{N} H$, pt 3 [vol 3] : 3-176 (1878)

78a Changes in the relative heights of land and sea during the glacial and Champlain periods. In Hitehcock, C. H., Geology of $\mathrm{N}$ H, pt 3 [vol 3] : 329-333 (1878)

79 Terminal moraines of the North American ice sheet. Am J Sc (3) 18:8192, 197-209 (1879)

79a Glacial drift in Boston and its vicinity [Mass.]. Boston Soc N H, Pr 20: 220-234 (1879)

79b. The formation of Cape Cod. Am Nat $13: 489-502,552-565(1879)$

79e The till in New England. G Mag (2) $6: 283-284$ (1879)

so Preliminary report on the geology of central and western Minnesota. Minn G S, An Rp 8: 70-125 (1880)

Soa The sucession of glacial deposits in New England. Am As, $\mathrm{Pr}$ 28: 299-310 (1880)

81 Report of progress in exploration of the glacial drift and its terminal moraines. Minn G S, An Rp 9: 281-356 (1881)

82 Lake Agassiz; a chapter in glacial geology. Minn Ac $N$ Sc, B $2: 290-314$ (1882)

83 The Minnesota Valley in the ice age. Am J Sc (3) $27: 34-42,104-111$ (1883) Am As, $\operatorname{Pr} 32: 213-231$ (1884) Abst, Science $2: 318-319(1883)$
Unham, Warren-Continued.

S4 The geology of Waseca Co, ,..B Blue Earth Co. ;...Faribault Co. ;... Watonwan and Martin cos.;...Cottonwood and Jackson cos. ;...Murray and Nobles cos. ;... Brown and Redwood cos.;...Yellow Medicine, Lyon, and Lincoln cos. ;...Big Stone and Lac qui Parle cos. ;...Le Sueur Co. Minn G S, Final Rp 1:404-532, 562-647, maps (1884)

84a Notes on rock outcrops in central Minnesota. Minn G S, An Rp 11:86-136 (1884)

S4b Lake Agassiz; a chapter in glacial geology. Minn G S, An Rp 11:137-153 (1884)

84e Résumé of the glacial situation at Little Falls [Minn.] Am Nat 18: 706-708 (1884)

$84 d$ Changes in the currents of the ice of the last glacial epoch in eastern Min. nesota. Am As, Pr $32: 231-234$ (1884) Minn Ac N Sc, B 3:51-56 (1889) Abst, Selence $2: 319$ (1883)

S4e [On lakes in Martin Co., Minn.] Science 3:695 (1884)

84f [On belts of knolly and hilly drift in Minnesota.] Science 3: 695-696 (1884)

S5 Notes on the geology of Minnehaha Co.. Dakota. Minn G S, An Rp 13: 88-97 (1885)

S7 The upper beaches and deltas of the glacial Lake Agassiz. U S G S, B $39: 84$ pp. map (1887)

88 The geology of Carver and Scott cos. :...Sibley and Nicollet cos.,....MeLeod Co. :...Renville Co. :...Swift and Chippewa cos. ;... Kandiyohi and Meeker cos. :... Wright Co. :...Chisago, Isanti, and Anoka cos.; Benton and Sherburne cos. :....Stearns Co. :... Douglas and Pope cos. :...Grant and Stevens cos. : Wilkin and Traverse cos. ;...Otter Tail Co. ;... Wadena and Todd eos. ;...Crow Wing and Morrison cos. ;...Mille Làcs and Kanabee cos;...Pine Co, ;...Becker Co.,...Clay Co. Minn G S, Final Rp 2:102-263, 399-671, maps (1888)

SSa The recession of the ice sheet in Minnesota in its relation to the gravel deposits overlying the quartz implements found by Miss Babbitt at Little Falls, Minn. Boston Soc N H, Pr 23:436-447 (1888)

8sb Prof. Henry Carvill Lewis and his work in glacial geology [1853-1888]. Am B 2:371-379, port (1888)

s9 Glaciation of mountains in New England and New York. Appalachia 5:291312 (1889) Am G $4: 165-174,205-216$ (1889)

S9a Marine shells and fragments of shells in the till near Boston, Boston Soc N H, Pr 24:127-141 (1889) Am .J Sc (3) $37: 359-372$ (1889)

89b [6n Indian potholes.] Boston Soc $\mathrm{N} \mathrm{H}, \mathrm{Pr} 24: 226-228$ (1889) 
Upham, Warren-Continued.

89e The structure of drumlins. Boston

Soc N H, Pr 24:228-242 (1889)

s9d Ascents of Camel's Hump and Lincoln Mountain, Vt. Appalachia 5:319326 (1889)

s9e The work of Prof. Henry Carvill Lewis in glacial geology. G Mag (3) 6 : $155-160$ (1889)

89R Probable causes of glaciation. In Wright, G. F., The Ice age in North America : 573-595, N Y 1889

$\mathbf{8 9 g}$ The glacial moraines of Minnesota (abst). Minn Ac N Sc, B 3:12 (1889)

89h Description of maps showing the climate, geography, and geology of Minnesota. Minn Ae N Sc, B 3:151-155 (1889)

90 Report of exploration of the glacial Lake Agassiz in Manitoba. Can G S, An Rp 4: 156 pp, map (1890) In part, with title, History of Lake Agassiz, Am G $7: 188-194,222-231$ (1890)

20a The fiords and Great Lake basins of North America considered as evidence of preglacial continental elevation and of depression during the glacial period. G Soc Am, B 1: 563-567 (1890)

$\mathbf{9 0 b}$ Artesian wells in North and South Dakota. Am G 6: 211-221 (1890)

90e On the cause of the glacial period. Am G 6: $327-339$ (1890)

9os Pleistocene submergence of the Isthmus of Panama. Am G 6:396 (1890)

90e The growth, culmination, and departure of the Quaternary ice sheets. Boston Soc N H, Pr 24:450-455 (1890)

90f Quaternary changes of levels. G Mag (3) $7: 492-497$ (1890)

91 Glacial lakes in Canada (with discussion by G. M. Dawson). G Soc Am, B $2: 243-274$ (1891)

91a Area and duration of Lake Agassiz. Am G 8:127-128 (1891)

$91 \mathrm{~b}$ The ice sheet of Greenland. Am G $8: 145-152$ (1891)

91e Inequality of distribution of the englacial drift (abst). Am G 8:239 (1891)

91d Criteria of englacial and subglacial drift. Am G $8: 376-385$ (1891)

91e A review of the Quaternary era, with special reference to the deposits of flooded rivers. Am J Sc (3) 41:33-52 (1891)

$9 t \mathbf{f}$ Walden, Cochituate and other lakes inclosed by modified drift. Boston Soc N H, Pr $25: 228-242$ (1891)

912 A classification of mountain ranges according to their structure, origin, and age. Appalachia 6:191-207 (1891) Pop Se Mo $39: 665-678$ (1891) Abst, Am As, Pr 40:274-279 (1892); Am G 8:231 (1891)

91h A recent visit to Lake Itasca. Minn Ac N Sc, B $3: 284-292$ (1891)

91i Elevation and subsidence during the glacial period. G Mag (3) $8: 92$ (1891)
Upham, Warren-Continued.

91j Correlation of Quaternary changes of levels in North America and the Carib. bean region, G Mag (3) $8: 330-331$ (1891)

92 Recent fossils of the Harbor and Back Bay, Boston [Mass.]. Boston Soc N H, Pr 25: 305-316 (1892) Am J Se (3) 43: 201-209 (1892)

92a Conditions of a ccumulation of drum. lins. Am G 10:339-362 (1892) Abst, Am G $10: 194-195,218-219(1892) ;$ G Soc Am, B 4:9-10 (1892)

92b Inequality of distribution of the englacial drift. G Soc Am, B 3:134-148 (1892) Abst, Am G 8: 239 (1891)

92e Relationship of the glacial lakes Warren, Algonquin, Iroquois, and Hudson. Champlain (abst). G Soc Am, B 3:484497 (1892)

92d The Champlain submergence (aost). G Soc Am, B 3:508-511 (1892)

92e Submarine valleys on continental slopes $(a b s t)$. Am As, Pr 41:171-173 (1892) Am G 10:222-223 (1892)

93 Comparison of Pleistocene and pres. ent ice sheets. G Soc Am, B 4:191-204 (1893) Abst, with discussion, Am G 11: 241-243 (1893)

93a Epeirogenic movements associated with glaciation. Am J Se (3) 46:114121 (1893) Abst, Minn, Univ, Q B 2: 25-26 (1894) Abst, with title, Altitude as the cause of the glacial period, Science $22: 75-76$ (1893)

93b Estimates of geologic time. Am J Se (3) 45:209-220 (1893) Se Am Sup 35 : 14403-14405 (1893) Abst, Minn, Univ, Q B 1:112-113 (1893)

93e How old is the earth? Pop Sc Mo 44:153-163 (1893) Abst, Minn, Univ, Q B 2: 26-27 (1894)

93d Englacial drift. Am G $12: 36-43$ 1893. Abst, Minn, Univ, Q B $2: 24-25$ (1894)

93e Drumlins near Boston. Appalachia $7: 39-48$ (1893)

931 The origin of drumlins (with dis. eussion by W. M. Davis and G. H. Barton). Boston Soc N H, Pr 26:2-25 (1893)

93m Deflected glacial striae in Somerville [Mass.]. Boston Soe $\mathrm{N} \mathrm{H}, \operatorname{Pr} 26$ : 33-42 (1893)

93h The fishing banks between Cape Cod and Newfoundland. Boston Soc N H, Pr 26:42-48 (1893) Am J Sc (3) 47: 123-129 (1894)

93i Eskers near Rochester, N. Y.; a discussion of the structure and origin of the Pinnacle Hills. Rochester Ac Sc, Pr $2: 181-200$ (1893) Abst, Am G $11: 241$ (1893)

93j [On the cause of the glacial period.] Victoria Inst, Tr 26:254-256 (1893)

93k Man and the glacial period. Am G $11: 189-191$ (1893)

931 Beltrami Island of Lake Agassiz [Minn.]. Am G 11:423-425 (1893) 
Upham, Warren-Continued.

$93 \mathrm{~m}$ Tertiary and Quaternary stream erosion of North America (abst with diseussion). Am G 12:180-181 (1893) Am As, $\operatorname{Pr} 42: \mathbf{1 8 1 - 1 8 3 ~ ( 1 8 9 4 )}$

93n Pleistocene climatic ehanges (abst). Am G 12:228-229 (1893)

93o Geologic time ratios and estimates of the earth's age and of man's ntiquity. Bibliotheca Sacra 50:131-149 (1893)

94 Preliminary report of field work during 1893 in northeastern Minnesota, chiefly relating to the glacial drift. Minn G S, An Rp 22:18-66, map (1894)

94a Wavelike progress of an epeirogenic uplift. J G $2: 383-395$ (1894) Abst, Minn, Univ, Q B 2: 92-93 (1894)

94h Evidences of the derivation of the kames, eskers, and moraines of the North American ice sheet chiefly from its englacial drift (with discussion by $T$. C. Chamberlin, Frank Leverett, and H. F. Reid). G Soc Am, B 5:71-86 (1894) Abst, Am G $12: 169$ (1893); Minn, Univ, Q B 2:57-58 (1894); Am J Se (3) 46 : 304-305 (1893)

94. The succession of Pleistocene formations in the Mississippi and Nelson River basins. G Soc Am, B 5: 87-100 (1894) Abst, Am G 12:170-171 (1893) ; Minn, Univ, Q B 2:58-59 (1894); Am J Se (3) $46: 305$ (1893)

94d Departure of the ice sheet from the Lanrentian lakes. G Soc Am, B 6: 21-27 (1894) Abst, Am G 14:199 (1894)

94e Marine shell fragments in drumlins near Boston. Am J Sc (3) $47: 238-239$ (1894)

94f Diversity of the glacial drift along its boundary. Am J Sc (3) 47:358-365 (1894) Abst, Am G 13:223 (1894)

$\mathbf{9 4} \mathbf{g}$ Quaternary time divisible in three periods, the Lafayette, Glacial, and Recent. Am Nat 28:979-988 (1894) Abst, Am G $14: 203$ (1894); Am As, Pr $43: 219-223$ (1895)

94h Pleistocene climatic changes. G Mag (4) 1:340-349 (1894) Abst, Minn, Univ, Q B 2:94 (1894)

941 Niagara River since the ice age. Nature 50: 198-199 (1894)

94j Causes and conditions of glaciation. Am G 14:12-20 (1894)

94k The Niagara Gorge as a measure of the postglacial period. Am G 14:62-65 (1894)

941 The Madison type of drumlins. Am G $14: 69-83$, map (1894) ; abst, 13:222223 (1894) Abst, Minn, Univ, Q B $2: 93$ (1894)

$94 m$ Tertiary and early Quaternary baseleveling in Minnesota, Manitoba, and northwestward. Am G 14: 235-246; abst 199 (1894) Abst, G Soc Am, B 6:17-20 (1894)
Upham, Warren-Continued.

$94 \mathbf{n}$ Evidence of superglacial eskers in IIlinois and northward. Am G 14:403405 (1894)

95 Late glacial or Champlain subsidence and re-elevation of the St. Lawrence River basin. Am J Sc (3) 49:1-18, map (1895) Minn G S, An Rp 23: 156-193, map (1895)

95a Epochs and stages of the glacial period. Am J Sc (3) $49: 305-306$ (1895)

95b Discrimination of glacial accumulation and invasion. G Soc Am, B $6: 343-352$ (1895) Abst, Am G $15: 200$ (1895); Science n s 1:60-61 (1895)

95e Drumlins and marginal moraines of ice sheets. G Soc Am, B $7: 17-30$ (1895) Abst, Am G 16:237 (1895)

95d Drumlin accumulation. Am G 15 : 194-195 (1895)

95e Climatic conditions shown by North American interglacial deposits. $\mathrm{Am} \mathrm{G} 15$ : 200-201 (abst), 273-295, map (1895) Abst, Science n s $1: 61$ (1895)

95P Secular changes of Arctic climate. Am G 15: 254-259 (1895)

$\mathbf{9 5 g}$ Stages of recession of the North American ice sheet shown by glacial lakes. Am G 15: 396-399 (1895)

$\mathbf{9 5 h}$ Correlations of stages of the ice age in North America and Europe. Am G 16: 100-113, map, abst: 250-251 (1895) Abst, Am As, Pr 44:140-145 (1896); Science n s 2:401 (1895)

95i Warm temperate vegetation near glaciers. Am G $16: 326-327$ (1895)

95j View of the ice age as two epochs, the Glacial and Champlain. Science $n$ s $2: 529-533$ (1895) Am As, $\operatorname{Pr} 44: 140$ 145 (1896)

95k Minor time divisions of the tce age. Am Nat 29:235-241 (1895)

96 The glacial Lake Agassiz. U S G S, Mon 25:658 pp, maps (1896)

96a Preglacial and postglacial valleys of the Cuyahoga and Rocky rivers [Ohio]. G Soc Am, B 7:327-348, map (1896) Abst, Am G 17:105 (1896); J G 4:127128 (1896)

961 Cuyahoga preglacial gorge in Cleveland, Ohfo. G Soc Am, B $8: 7-13,(1896)$ Abst, Science n s 4:385 (1896); Am G 18: 223-225 (1896)

$96 \mathrm{c}$ Causes, stages, and time of the Ice Age. Pop Sc Mo 49:354-:68 (1896)

96d Geologic history of the Rocky Mountains and Great Plains in the region drained by the Missouri River. In J. V. Brower, The Missouri River... : 7-11 (1896)

96e The glacial Lake Agassiz. Northwest Weather and Crops (Minn Weather Service) 1 no $9: 1-2$ (1896)

96f Physical features of Minnesota and the Northwest; their geologic origin and climatic influence. Northwest iveather and Crops (Minneapolis, Minn.) 1 nos 10, 11, $12 ; 2 \operatorname{nos} 1,2$ (1896) 
Billings, Elkanah-Continued.

$57 \mathbf{d}$ On the genera of fossil Cephalopoda occurring in Canada. Can Nat $2: 135-138$, il (1857)

58 Report for the year 1857 [Black River fauna; descriptions of Devonian and Ordovician fossils], Can $\mathbf{G}$ S, Rp Prog 1857: 147-192, il (1858)

5Sa On the Cystideae of the Lower Silurian rocks of Canada. Can $\mathrm{G} S \mathrm{~S}$, Can Organic Remains, decade $3: 9-74$, 11 (1858)

5sb on the Asteriadae of the Lower Silurian rocks of Canada. Can G S, Can Organic Remains, decade $3: 75-85$, il (1858)

5se Geological gleanings. Can Nat 3 : $122-139,182-192,260-276$ (1858)

58d New genera and species of fossils from the Silurian and Devonian formations of Canada. Can Nat 3:419-444, il (1858)

5Se (with Salter, J. W.) On Cyclocystoides, a new genus of Echinodermata from the Lower and midale Silurian rocks. Can G S, Can Organic Remains, decade 3 : 86-90, il (1858)

59 On the Crinoideae of the Lower Silurian rocks of Canada. Can $G \mathrm{~S}$, Can Organic Remains, decade 4:72 pp, il (1859)

$59 a$ on some new genera and species of Brachiopoda from the Silurian and Devonian rocks of Carada. Can Nat 4:131135, il (1859)

59b Description of a new genus of Brachiopoda and on the genus Cyrtodonta. Can Nat 4 : 301-303 (1859)

59e Fossils of the calciferous sandrock including those of a deposit of white limestone at Mingan, supposed to belong to the formation. Can Nat 4:345-367, il (1859)

59d Descriptions of some new species of trilobites from the lower and middle Silurian rocks of Canada. Can Nat $4: 367-$ 383 , il (1859)

59e Fossils of the Chazy limestone, with descriptions of new species. Can Nat 4: $426-470$, il (1859)

59P On the fossil corals of the Devonian rocks of Canada West. Can J n s 4 : 97-140, il (1859) Abst, Am J Sc (2) $28: 152$ (1859)

$59 \mathrm{~g}$ Atrypa hemiplicata. Can Jour n s 4: 316 (1859)

59h Geological formation of the country. In Dawson, S. J., Report on the exploration of the country between Lake Superior and the Red River Settlement... [Canada, Provincial Secretary] : 17-20, Toronto 1859

591 On some of the Silurian and Devonian fossils collected by Professor Henry Y. Hind on the Assiniboine and Saskatchewan exploring expedition. In Hind, H. Y., Northwest Territory; Reports... Assiniboine and Saskatchewan exploring expedition : 186-187, il, Toronto, 1859
Billings, Elkanah-Continued.

60 On the Devonian fossils of Canada West. Can J n \& 5: 249-282 (1860); 6: $138-148,253-274,329-363$, il (1861)

$60 a$ Additional note on the Potsdam fos. sils. Am J Se (2) $30: 242-243,337-338$, il $(1860)$

60b Description of some new species of fossils from the Lower and middle Silurian rocks of Canada. Can Nat $5: 49-69$, il (1860)

60c Description of a new Paleozoic star. fish of the genus Palæaster from Nova Scotia. Can Nat 5:69-70, il (1860)

60d New species of fossils from the Lower Silurian rocks of Canada. Can Nat $5: 161-177$, il $(1860)$

60e On some new species of fossils from the limestone near Point Levi opposite Quebec. Can Nat $5: 301-324$, il (1860)

6or On certain theories of the forma. tion of mountains. Can Nat $5: 409-420$ (1860)

61 Description of the new species of Lingula [from Murray Bay, Quebec]. Can Nat 6:150-151, il (1861)

61a On some of the rocks and fossils occurring near Phillipsburgh, Canada East. Can Nat $6: 310-328$, il (1861)

$61 \mathrm{~b}$ On the occurrence of graptolites in the base of the Lower Sllurian. Can Nat $6: 344-348$ (1861)

61e Note on a new genus of Paleozoic Brachiopoda [Charionella]. Can Jour 6 : 148 (1861)

61d On some new or little known species of Lower Silurian fossils from the Pots. dam group (Primordial zone); on some new species of fossils from the Calciferous Chazy, Black River, and Trenton forma. tions. In Report on the geology of Ver mont (Hitcheock) 2:942-960, il (1861)

62 On the date of the report on the geology of Wisconsin. Can Nat $7: 156-$ 158 (1862)

62a Remarks upon Prof. Hall's recent publication entitled, "Contributions to paleontology." Can Nat 7:389-393 (1862)

62b On the age of the red sandstone formation of Vermont. Am J Sc (2) 32: 232 (1862) Can Nat n s $6: 322-323$ (1872)

62e Further observations on the age of the red sandrock formation (Potsdam group) of Canada and Vermont. Am J Sc (2) $33: 100-105,421-422$ (1862)

62d ... age of the red sandrock series of Vermont. Am J Sc (2) 33:370-376 (1862)

63 On the genus Centronella with remarks on some other genera of Brachio. poda. Am J Sc (2) 36:236-240 (1863)

63a On the parallelism of the Quebec group with the Llandello of England and Australia, and with the Chazy and Calciferous formations. Can Nat 8:19-35 (1863) 
Upham, Warren-Continued.

96g Physical conditions of the flow of glaciers. Am G 17: 16-29 (1896)

96h Philadelphia meeting of the Geological Society of America. Am G 17 : 89-109 (1896)

96i Glacial lakes of the st. Lawrence basin. Am G 17 : 238-241 (1896)

96j Sublacustrine till. Am G 17:371375 (1896)

96k The Ozarkian epoch. Am G 17: 389 (1896)

961 Beaches of Lakes Warren and Algonquin. Am G 17:400-402 (1896)

$\mathbf{9 6 m}$ Origin and age of the Laurentian lakes and of Niagara Falls. Am G 18: 169-177, map (1896)

96n Interglacial change of course, with gorge erosion, of the St. Croix River in Minnesota and Wisconsin (abst). Am G $18: 223$ (1896) Science n $\mathrm{s} \quad 4: 384-385$ (1896)

960 Buffalo meeting of the Geological Society and the American Association. Am G $18: 213-239$ (1896)

96p [On the origin of lake basins in the drift region (abst)]. Minn Ac N Sc, B $4: 40$ (1896)

969 The St. Croix River before, during, and after the ice age. In Lectures, laws, papers, pictures, pointers, Interstate Park, Dalles of the St. Croix, compiled by Geo. H. Hazzard : 45-58, St Paul 1896

96r (with Wright, G. F.) Greenland ice fields...with a new discussion of the causes of the ice age. Xv, 407 pp, N Y 1896. Rv by T. C. Chamberlin, J G 4: 632-636 (1896)

97 The Quaternary era, and its division in the Lafayette, Glacial, and Recent periods. Int $\mathrm{G}$ Cong, VI, Zurich 1894, C R : 238-251 (1897)

$97 \mathbf{a}$ Modified drift in Saint Paul, Minn. G Soc Am, B 8:183-196, map (1897) Abst, J G 5:111-112 (1897)

$\mathbf{9 7 b}$ Relation of the Lafayette or Ozark ian uplift of North America to glaciation. Am G 19: 339-343 (1897)

97e Rhythmic accumulation of moraines by waning ice sheets. Am G 19:411-417 (1897)

97d The glacial Lake Hamline [Minn.] (abst). Am G 19:423 (1897)

97 e Recent estimates of geologic time. Am G 20:268-270 (1897)

97f Drumlins containing or lying on modified drift. Am G $20: 383-387$ (1897)

$\mathbf{9 7 g}$ The topography and glacial geology of the city of St. Paul [Minn.]. Science n s $5: 487-488$ (1897)

98 Niagara Gorge and Saint Davids channel. G Soc Am, B 9:101-110 (1898) Abst, Science n s $7: 84-85$ (1898)

98a Geology and geography at the American Association meeting. Science n s 8: 462-471, 501-506 (1898)
Upham, Warren-Continued.

98b Fluctuations of North American glaciation shown by interglaeial soils and fossiliferous deposits (abst). Am As, Pr 47:297 (1898) Am G 22:258 (1898) Science n s $8: 470$ (1898)

98c Time of erosion of the upper Mississippi, Minnesota, and St. Croix valleys (abst), Am As, Pr 47:297-298 (1898) Science n s $8: 470$ (1898) Am G 22:258259 (1898)

99 The geology of Aitkin Co. ;... Cass $\mathrm{Co}_{\text {, }}$ and of the part of Crow Wing Co. north. west of the Mississippi River ;... of the region around Red Lake and southward to White Earth. Minn G S, Final Rp 4: 25-81, 155-165, maps (1899)

99 Evidences of epeirogenic movements causing and terminating the ice age. G Soc Am, B 10:5-10 (1899) Abst, Am G $22: 250$ (1898); Science n s $8: 463-464$ (1898)

99b Causes of glaciation. Am G 23 258-259 (1899)

99e Modified drift and the Champlain epoch. Am G 23: 319-324 (1899)

99d Englacial drift in the Mississippi basin. Am G 23: 369-374 (1899)

99 Glacial history of the New England islands, Cape Cod, and Long Island. Am G $24: 79-92$ (1899)

99e Greatest area and thickness of the North American ice sheet (abst). Am As, Pr 48:230-231 (1899) Science n s 10: 491 (1899)

oo Pleistocene ice and river erosion in the Saint Croix Valley of Minnesota and Wisconsin. G Soc Am, B 12:13-24 (1900)

OOa Giants' kettles eroded by moulin torrents. G Soc Am, B 12:25-44, map (1900)

Oob Glacial and modified drift in Minneapolis, Minn. Am G 25:273-299, map (1900) Abst, Am As, Pr 48: 229 (1899); Science n s 10:490 (1899)

ooe Recognition of river and flood de. posits. Am G 25: 313-314 (1900)

00d Drift erosion, transportation, and deposition (abst). Am As, Pr 49:190191 (1900) Science $n$ s 12:993-994 (1900)

01 Preglacial erosion in the course of the Niagara Gorge, and its relation to estimates of postglacial time. Am G 28: 235-244 (1901)

O1a The Toronto and Scarboro drift series. $A m$ G 28:306-316 (1901)

O1b Time divisions of the ice age. Victoria Inst, $\operatorname{Tr} 33: 393-410$ (1901)

o1e Artesian wells in North and Soutb Dakota. Minn Ac $\mathrm{N}$ Se, B $3: 370-379$ (1901)

O1d Giant's kettles in the Interstate Park, Taylor's Falls (abst). Science n s $13: 510$ (1901) 
Upham, Warren-Continued.

o2 New evidences of epeirogenic movements causing and ending the ice age. Am G 29:162-169 (1902)

02a Growth of the Mississippi delta. Am G 30:103-111 (1902)

02b Man in the ice age at Lansing, Kansas, and Little Falls, Minn. Am G $30: 135-150$ (1902)

02e Man in Kansas during the Iowan stage of the glacial period. Science $n$ s $16: 355-356$ (1902)

02d The fossil man of Lansing, Kans. Records of the Past $1: 272-275$ (1902)

02e Primitive man in the ice age. Bibliotheca Sacra $59: 730-743$ (1902) Memoirs of Explorations in the Basin of the Mississippl 5 : 116-119 (1902)

02f Primitive man and his stone implements. Am Antiquarian 24:413-420 (1902)

03 Valley loess and the fossil man of Lansing, Kans. Am G $31: 25-34$ (1903) Abst, J G 11:124-126 (1903) ; G Soc Am, B $14: 559-560$ (1904)

03a The life and work of Professor Charles M. Hall. Am G 31:195-198, port (1903)

03b How long ago was America peopled? Am G 31:312-315 (1903)

03e Glacial Lake Nicolet and the portage between the Fox and Wisconsin rivers. Am G $32: 105-115,330-331$ (1903)

03d The antiquity of the fossil man of Lansing, Kans. Am G 32:185-187 (1903)

03e The glacial Lakes Hudson-Champlain and St. Lawrence. Am G $32 \div 223-230$ (1903)

03f The past and future of Niagara Falls. N Y, Comm St Reservation at Niagara, An Rp 19:229-254 (1903) [See also Upham, 01]

03s Geology of Prairie Island, Minn. Memoirs of Exploration in the Basin of the Mississippi $6: 34-38$ (1903)

04 Moraines and eskers of the last glaciation in the White Mountains. Am G $33: 7-14$ (1904)

04a Boulders due to rock decay. Am G $33: 370-375$ (1904)

04b Erosion on the great plains and on the Cordilleran mountain belt. Am G 34: 35-39 (1904)

04e Age of the Missouri River. Am G $34: 80-87$ (1904)

04d Outer glacial drift in the Dakotas, Montana, Idaho, and Washington. Am G $34: 151-162$ (1904)

04e Glacial and modifed drift in and near Seattle, Tacoma, and Olympia. Am G $34: 203-214$, map (1904)

048 The life and work of Professor Charles M. Hall. N Dak Ag Coll S, 2d Bien Rp : 13-16, port (1904)
Upham, Warren-Continued.

o5 The nebular and planetesimal theories of the earth's origin. Am G 35: 202-220 (1905) Victoria Inst, Tr $37: 186-204$ (1905)

05a Fjords and hanging valleys. Am G $35: 312-315$ (1905)

05b Age of the St. Croix Dalles. Am G 35: 347-355 (1905)

o5e Glacial lakes and marine submergence in the Hudson-Champlain Valley. Am G $36: 285-289$ (1905)

05d Geological history of the Great Lakes and Niagara Falls. Int Q 11:248265 (1905)

06 Glacial and modified drift of the Mississippl Valley from Lake Itasca to Lake Pepin. Minn Ac N Sc, B 4:299-305 (1906)

06a Geological time. Popular Astronomy $14: 264-276$ (1906)

06b The origin and antiquity of man. Records of the Past 5: 137-141 (1906)

07 Quaternary history of the upper Mississippi Valley (abst). G Soc Am, B 17 : 725-726 (1907)

07a The San Francisco and Valparaiso earthquakes and their causes. Victoria Inst, $\operatorname{Tr} 39: 43-54$ (1907)

os Fjords of Puget Sound and the Saguenay (abst). Science n $s \quad 27: 732-733$ (1908)

08a Niagara as a measure of postglacial time. Records of the Past $7: 244-246$ (1908)

09 The glacial Lake Agassiz (abst). Can M .J $30: 646$ (1909) G Mag (5) 6: 475-476 (1909) Brit As, Rp 79:472-473 (1910)

10 Birds Hill, an esker near Winnipeg, Manitoba. G S Am, B 21:407-432 (1910)

$10 a$ Englacial and superglacial drift in Minnesota, the Dakotas, and Manitoba (abst). Minn Ac Sc, B 4:428-429 (1910)

11 Modified drift in Minnesota (abst). Science n \& $33: 466$ (1911)

11 aluctuations of the Keewatin and Labradorean ice currents in the vicinity of Minneapolis and St. Paul (abst). Science n s $33: 466-467$ (1911)

$11 b$ Chains of lakes in Martin Co., Minn., as evidence of extensive recession and readvance of the ice-sheet (abst). Science n s $33: 467-468$ (1911)

13 Fields of outflow of the North American ice sheet. Int $\mathrm{G}$ Cong, XII, $1913 \mathrm{C} \mathrm{R}$ : 515-522 (1914) Advance copy 1913

13a The Sangamon interglacial stage in Minnesota and westward. Int $\mathbf{G}$ Cong, XII, 1913, C R : 455-465 (1914) Advance copy 1913 Abst, Science n 8 s7:457 (1913)

13b The relation of the Keewatin and Labrador areas of glaciation (abst). Science n s $37: 457$ (1913) 
Upham, Warren-Continued.

15 Revision of the map of Lake Agassiz. J G $23: 780-784$ (1915)

15a Memoir of Newton Horace Winchell. G Soc Am, B 26:27-46, port (1915)

16 The work of $\mathrm{N}$. H. Winchell in glacial geology and archaeology. Ec G 11: 63-72, port (1916)

See also Chamberlin, 91b, c; Leverett, 12b; McGee, $91 \mathrm{~g}$; Johnston (W A), 17b ; Salisbury, 93, 93a; Shaler, 90c; Spencer (J W), 93a

Urbina, Fernando.

o9 Algunas observaciones acerca de la geografía física del Estado de Yucatán. Soc G Mex, B 5:91-101 (1909)

09a Notas sobre la caverna de Cacahuamilpa, Distrito de Alarcón, Estado de Guerrero. Soc G Mex, B 5:11-12, 151155 (1909)

$09 b$ Nota acerca de unos supuestos yacimientos de cobre $y$ de yeso en el partido de Champotón (Estado de Campeche). Soc G Mex, B 6 : viii, 15-16 (1909)

10 (with Engerrand, J.) Primera nota acerca de la fauna miocénica de Zuluzum, Chiapas. Soc G Mex, B 6:xxvi, 119140 (1910)

13 (and Camacho, H.) La zona megaséismica Acambay-Tixmadeje, Estado de México, conmovida el 19 de noviembre de 1912 [earthquake of November 19, 1912, In the State of Mexico]. Méx I G, B 32 : 125 pp (1913)

15 La cuestión del petróleo en México... 68 pp, México 1915

16 Informe geológico acerca del terreno denominado "Sosa," de la compañfa petrolera “El Manantial," S. A., ubicado dicho terreno en el municipio de Pánuco, cantón de Ozuluama, Estado de Veracruz. Revista Petrolera 1 no $17: 13-18$ (1916)

18 Los yacimientos petrolfferos submarinos. Bol Petróleo $5: 337-377$, maps (1918) Reprint, $45 \mathrm{pp,} \mathrm{maps,} \mathrm{Mexico} 1918$

Urgindi, Juan.

$\mathbf{7 2}$ On the meteorites of the hacienda "La Concepcion" and San Gregorio. Am J Sc (3) 3:207-208 (1872)

Urquiza, Manuel.

82 Exploración de Coalcoman, Estado de Michoacán. México, Ministerio de Fomento, An $7: 195-261$, map, il (1882)

Usera, Gabriel de.

17 Informe sobre las minas de cobre de Manicaragua [copper deposits, Manicaragua, Cuba]. Cuba, Dirección de Montes y Minas, Boletín de Minas no 2:91103 (1917)

Usher, F. C.

37 On the elevation of the banks of the Mississippi in 1811. Am J Sc 31: 294-296 (1837)
Ussing, Niels Viggo (1864-1911).

89 Untersuchungen der Mineralien von Fiskernäs in Grönland. Zs Kryst 15:596615 (1889)

98 Mineralogisk-petrografiske Undersögel. ser af Grönlandske Nefelinsyeniter og beslaegtede Bjaergarter [nepheline syenite and related rocks]. Med Grönland 14: 1-220, 403-407 (1898)

os Kryoliten ved Ivigtut. Geografisk Tidskrift, Kobenhavn 19: 194-200 (1908)

11 Geology of the country around Ju. lianehaab, Greenland. Med Grönland 38: 1-376, map (1912) (Reprint) Copenha. gen, Univ, Mus Miner G, Comm géol no 2 (1911)

12 Beretning om den geologiske Ekspedition til Julianehaab Distrikt i Sommeren 1900. Med Grönland 38: $377-426$ (1912)

Vacher, Antoine.

13 Les environs de Phoenix, Ariz., et le barrage Roosevelt. An Géog, Paris, 22: 197-208 (1913) Am Geog Soc, Memorial Volume of Transcontinental Excursion of $1912: 349-356$ (1915)

Vai1, C. E.

17 Lithologic evidence of climatic pulsations. Science n \& 46:90-93 (1917)

Vail, Isaac Newton.

86 The waters above the firmament, or the earth's annular system. 375 , xxii pp, Cleveland [n d, c 1886] 2d ed, 406 pp, Phila 1902

o5 The deluge and its cause... $133 \mathrm{pp}$ Chicago $\mathrm{n}$ d [c 1905].

Vail, Richard $\mathrm{H}$.

16 Pinar del Rio copper region [Cuba]. Eng M J 102 : 950-952 (1916)

Vaillant, Léon.

02 Sur le présence du tissu osseux che: certains poissons des terrains palaeozolque: de Canyon City, Colo. Ac Sc Paris, C R 134: 1321-1322 (1902)

Valdés Ragués, Pedro.

97 Formación geologica de la Isla de Cuba. R Ac Cienc Habana, An $33: 362-373$ (1897)

Valiant, W. S.

o1 Appendaged trilobites. Mineral Col lector 8: 105-112 (1901)

Valiquette, J. H.

09 Report on an exploration journey to Shining Mountain in the Labrador Penin sula. Que $\mathrm{Dp}$ Col... Mining operation 1908: 32-49 (1909)

12 Report on the Montreal quarries Que, Mines $\mathrm{Br}, \mathrm{Rp}$ on mining operations 1911: 52-70 (1912)

Vallance, John.

11 The Standard nine, Silverton, B. C Can M Inst, Q B 16:55-58 (1911); J 14 212-214 (1912) 
Vallat, B. W.

07 The iron ores and system of mining at Sunrise mine, Wyo. Colo Sc Soc, $\operatorname{Pr} 8$; 315-322 (1907)

08 Methods of mining iron ore at Sunrise, Wyo. Eng M J $85: 399-403$ (1908)

11 The Newport iron mine [Ironwood, Mich.]. Am I M Eng, B 59: 903-921 (1911) ; $\operatorname{Tr} 42: 676-694$ (1911)

Vanatta, E. G.

12 Pleistocene fossils from eastern Cuba. Nautilus 26:69 (1912)

14 [Pleistocene shells from near Sierra Nueva, Santo Domingo]. Nautilus 27:120 (1914)

Van Barneveld, Charles E.

12 Iron mining in Minnesota. Minn, Univ, Sc Mines, Exp Sta, B 1:214 pp (1912)

Van Cleve, John W.

49 Fossil zoophytes of western Ohio, with a few additions from other western localities [preliminary communication]. Am As, Pr 1:19-24 (1849)

Van der Gracht, W.

18 Geosynclines and petroliferous deposits (discussion). Am I M Eng, B 133 : 97-99 (1918)

Van der Meulen, P. A.

17 A study of two so-called halloysites from Georgia and Alabama. Am J Sc (4) $43: 140-144(1917)$

Van Diest, E. C.

98 (and Van Diest, P. H.) Notes on the geology of the western slope of the Sangre de Cristo Range in Costilla Co.. Colo. Colo Se Soc, Pr 5:76-80, map [1898] (separate ed, 5 pp 1895)

Van Diest, Peter H. (1835-1902).

86 Notes on a trip to Telluride, San Miguel Co., Colo. Colo Sc Soc, Pr 2: 28-31 (1886)

87 The mineral resources of Boulder Co., Colo. Colo Sch Mines, Bien Rp 1886 : 23-41, map (1887)

87a Notes on some Boulder Co. veins. Colo Sc Soc, Pr 2:50-55, map (1887)

88 Natural gas in Boulder Co. [Colo.]. Colo Sc Soc, Pr 2: 210 (1888)

88a Address of the retiring president [includes notes on occurrences of gold in Idaho]. Colo Sc Soc, Pr 2: 278-285 (1888)

89 Colorado volcanic craters. Colo Sc Soc, Pr 3: 19-23 (1889)

90 Report on the geological conditions of artesian basins in eastern Colorado and New Mexico. U S, 51st Cong 1st sess, S Ex Doc 222: 87-97, maps (1890)

90 Remarks on the plication of the coal measures in southeastern Colorado and northeastern New Mexico. Colo Sc Soc, Pr 3: 185-190 (1890)

95 On the artesian wells of Denver (with discussion by R. C. Hills). Colo Sc Soc, $\operatorname{Pr} 4: 1-6$ [1895]
Van Diest, Peter H.-Continued.

95 a Evidence bearing on the formation of ore deposits by lateral secretion; the John Jay mine at Providence, Boulder Co., Colo. (with discussion by Franklin Guiterman, Richard Pearce, T. A. Rickard, R. C. Hills, and Philip Argall). Colo Sc Soc, Pr 4:340-354 [1895] (separate ed, $19 \mathrm{pp}$, 1893)

98 (with Van Diest, E. C.) Notes on the geology of the western slope of the Sangre de Cristo Range in Costilla Co., Colo. Colo Sc Soc, Pr $5: 76-80$, map [1898] (separate ed, 5 pp 1895)

02 A mineralogical mistake. Colo Sc Soc, $\operatorname{Pr} 6: 150-156$ [1902] separate ed, 6 pp, 1898)

See also Cross, 98a

Van Gorder, W. B.

16 Geology of Greene Co. Ind Dp G Nat Res, An Rp 40: 240-266 (1916)

Van Hise, Charles Richard (1857-1918).

82 (with Irving, R, D.) Crystalline rocks of the Wisconsin Valley. [Wis G S] G Wis $4: 623-714$, maps (1882)

84 On secondary enlargements of feldspar fragments in certain Keweenawan sandstones. Am J Sc (3) 27:399-403 (1884)

84a (with Irving, R. D.) On secondary enlargements of mineral fragments in certain rocks. U S G S, B 8:56 pp (1884)

85 Enlargements of hornblende fragments. Am J Sc (3) $30: 231-235$ (1885)

86 Upon the origin of the mica schists and black mica slates of the PenokeeGogebic iron-bearing series. Am J Sc (3) 31 : 453-459, map (1886)

87 Note on the enlargement of hornblendes and augites in fragmental and eruptive rocks. Am J Sc (3) $33: 38 \mathrm{~J}-388$ (1887)

89 The iron ores of the Penokee-Gogebic series of Michigan and Wisconsin. Am J Sc (3) $37: 32-48$ (1889)

89a The chemical origin of the Vermilion lake iron ores. Am G 4:382-383 (1889)

90 The pre-Cambrian rock of the Black Hills. G Soc Am, B 1:203-244 (1890) Abst, Am Nat 24:291 (1890)

$90 a$ (with Irving, R. D.) The Penokee iron-bearing series of Michigan and Wisconsin. U S G S, An Rp 10, pt 1:341507, map (1890)

91 An attempt to harmonize some apparently conflicting views of Lake Superior stratigraphy. Am J Sc (3) 41:117-137 (1891)

91a Lake Superior stratigraphy. Am G $7: 383-386$ (1891)

91b (with others) The crystalline schists of the Lake Superior district. Int G Cong, IV, London 1888, C R:156-170 (1891) 
Van Hise, Charles Richard-Continued.

92 Correlation papers; Archean and Algonkian. U S G S, B $86: 549$ pD, maps (1892)

92a The iron ores of the Marquette district of Michigan. Am J Sc (3) $43: 116$ 132 (1892) Abst, Eng M J 54:29 (1892)

$92 b$ The fron ores of the Lake Superior region. Wis Ac Sc, Tr $8: 219-227$ (1892)

92e The relations of the Arehean and the Algonkian in the Northwest (abst). Am As, Pr 40:260 (1892)

92d (with Irving, R. D.) The Penokee iron-bearing series of Wisconsin and Michigan. U S G S, Mon $19: x i x, 534$ pp, maps (1892)

92e (with Pumpelly, R.) ... struetural relations of the Upper Huronian, Lower Huronian, and basement complex on the north shore of Lake Huron. Am J Sc (3) 43: 224-232 (1892)

93 The pre-Cambrian rocks of North America. Int G Cong, V, Washington 1891, C R: 110-150 (1893)

93a Sketch of the pre-Cambrian geology south of Lake Superior, with references to illustrative localities. Int $\mathrm{G}$ Cong, V, Washington 1891, C R:489-512, maps (1893)

93b An historical sketch of the Lake Superior region to Cambrian time. I G 1 : 113-128, map (1893)

93e Some dynamie phenomena shown by the Baraboo quartzite ranges of central Wisconsin. J G 1:347-355 (1893)

93d Summary of current pre-Cambrian North American literature. J G 1:304$314,532-541$ (1893): 2:109-118, 444484 (1894) ; $3: 227-236,709-721$ (1895) ; $4: 362-372,744-756$ (1896)

93e The Huronian volcanies south of Lake Superior (abst). G Soc Am, B 4: 435-436 (1893)

938 The succession in the Marquette iron district of Michigan (abst). G Soe Am, B 5:5-6 (1893)

94 Character of folds in the Marquette iron distriet (abst). Am As, $\mathrm{Pr} 42: 171$ (1894)

95 (and Bayley, W. S.) Preliminary report on the Marquette iron-bearing district of Michigan, with a chapter on the Republic trough, by H. I. Smyth. U S G S, An Rp 15:477-650, maps (1895)

95a The origin of the dells of the Wisconsin. Wis Ac Sc, Tr $10: 556-560$ (1895)

95b Summary of current pre-Cambrian North American literature. J G 3:227236, 709-721 (1895)

95e Analysis of folds (abst). Am G $16: 244$ (1895) Science n s 2:280-281 (1895) Ottawa Nat 9:153 (1895)

95d The relations of primary and secondary structures in rocks $(a b s t)$. Am As, Pr $44: 135-136$ (1896) Am G $16: 247$ (1895) Science n s 2:399-400 (1895)
Van Hise, Charles Richard-Continued.

96 Principles of North American pre Cambrian geology. U S G S, An Rp 16 pt $1: 571-843$ map (1896) Abst, Am J Se (4) $2: 205-213$ (1896) In part, with the title Deformation of rocks; J G 4: 195-213, $\quad 312-353, \quad 449-453, \quad 593-629$ (1896) ; $5: 178-193$ (1897)

96a A central Wisconsin base-level, Science n s 4:57-59 (1896)

96b A northern Michigan base-level. Seience n s 4:217-220 (1896)

o6e Movements of rocks under deformation (abst). Am G 17:99-100 (1890) Science n \& $3: 52-53$ (1896)

96d Primary and secondary structure and the forces that produced them (abst). Science n s $3: 216,294-295$ (1896)

97 (and Bayley, W. S.) The Mar quette iron-bearing district of Michigan U S G S, Mon 28:608 pp, atlas (1897)

98 Estimates and causes of crustal shortening. J G 6:10-64 (1898)

98a Metamorphism of rocks and rock flowage. G Soc Am, B 9:269-328 (1898) Am J Sc (4) 6:75-91 (1898)

98b Earth movements. Wis Ac Sc, Tr 11: 465-516 (1898)

99 The Crystal Falls iron-bearing district of Michigan. U $\mathbf{S}$ G $\mathbf{S}$, Mon 36 : xvii-xxxvi (1899) U S G S, An Rp 19 pt $3: 9-18$ (1899)

99a The naming of rocks. J G $7: 686-$ 699 (1899)

00 (and Bayley, W. S.) Description of the Menominee quadrangle [Mich.]. U S G S, G Atlas Menominee fol (no 62): 13 pp, maps (1900)

OOa Some principles controlling the dep osition of ore. I G 8:730-770 (1900) W Soc Eng J 5: 433-470 (1900)

Oob Buckley on the building and orna mental stones of Wisconsin. Science n 8 11: 191-192 (1900)

01 (and others) The iron ore deposits of the Lake Superior region. U S G S, An Rp 21 pt $3: 305-434$, maps (1901)

o1a ...lead and zine deposits of the Ozark region; introduction. $U$ \& $G S$. An Rp 22 pt $2: 33-60$ (1901)

O1b Some principles controlling the deposition of ores. Am I M Eng, Tr 30 27-177 (1901) Abst, Eng M J 72:699702 (1901) ; M Sc Press $83: 269-270,286$ (1901)

o1e The geology of ore deposits. Science n s 14: 745-757, 785-793 (1901)

o1d Geological excursion in Colorado. G Soc Am, B 13:2-5 (1901)

O1e A study of ore deposits (abst). Am Sup 52:21504 (1901)

o2 Some principles contrelling the depo. sition of ores. Am I M Eng, Tr 31:284302 (1902) 
Van Hise, Charles Richard-Continued.

02a The training and work of a geolo gist. Am G 30:150-170 (1902) Science n s $16: 321-334$ (1902) Am As, Pr 15: $399-420 \quad(1902)$

02b (and Bain, H. F.) Lead and zinc deposits of the Mississippi Valley, U. S. A. Inst M Eng, Tr 23: 376-434, maps (1902)

03 Geological work in the Lake Superior region. L Sup M Inst, Pr 8:62-69 (1903) Abst, M World 21:197-198, map (1904)

04 A treatise on metamorphism. U S G S, Mon 47:1286 pp (1904)

04a The problems of geology. J G 12 : 589-616 (1904) Cong Arts and Sci (St Louis 1904) 4:525-548 (1906)

04b Report on geophysics [laboratory, etc.]. Carnegie Inst Wash, Y Bk 2:173184 (1904)

05 (and others) Report of the special committee for the Lake Superior region [pre-Cambrian nomenclature]. J G 13:89104 (1905) Ont Bur Mines, Rp 1905, 14 pt 1:269-277 (1905) Mich G S, Rp 1904: 133-143 (1905) Can G S, Sum Rp 1904 (An Rp 16) : A xx-xxvii (1905)

05a A correction [of a calculation in A trentise on metamorphism]. J G $13: 280$ (1905)

07 The geology of the Cobalt district [0nt.] (abst). Can M J 28 (n s 1 no 2): 44-45 (1907)

08 The problem of the pre-Cambrian. G Soc Am, B 19:1-28 (1908)

09 Principles of classification and correlation of the pre-Cambrian rocks. I G 17 : 97-104, 118-122 (1909) [See also Adams, F. D., 09b]

09a (and Leith, C. K.) Pre-Cambrian geology of North America. U S G S, B $360: 939$ pp, maps (1909)

11 (and Leith, C. K.) The geology of the Lake Superior region. U S G S, Mon $52: 641$ pp, maps (1911) Abst, Wash Ac Sc, J $1: 157-160$ (1911)

12 The influence of applied geology and the mining industry upon the economic development of the world. Int $\mathrm{G}$ Cong, XI, Stockholm, 1910, C R : 259-261 (1912)

16 (and others) Preliminary report [of the committee of the National Academy of Sciences] upon the possibility of controlling the land slides adjacent to the Panama Canal. Panama Canal, Governor, An Rp 1916:587-598 (1916) Nat Ac Sc, Pr 2: 193-207 (1916)

See also Buckley, 01a; Emmons (S F), 03c, e; Gilbert, $93 \mathrm{~b}$; Powell, $89 \mathrm{a}, 90,91$, 91a, 92, 93, 95; Rickard, 03 ; Walcott, $03 \mathrm{a}$; Winchell (A), 90a

Van Horn, Frank Benjamin.

05 The geology of Monitean Co., with an introduction by R. R. Buckley. Me Bur G Mines (2) 3:104 pp, maps, Jefferson City, Mo. [1905]
Van Horn, Frank Benjamin-Continued,

07 Limestones available for fertilizers.

I11 G S, B 4:177-183 (1907)

os Phosphate rock. U S G S, Min Res 1907 pt $2: 651-657 ; 1908$ pt $2: 629-642$; 1909 pt $2: 655-659 ; 1910$ pt $2: 735-746$; 1911 pt $2: 877-888$ (1908-12)

OSa Fuller's earth. U S G S, Min Res 1907 pt $2: 731-734 ; 1909$ pt $2: 735-738$ (1908-11)

09 The phosphate deposits of the United States. U S G S, B 394: 157-171 (1909) Nat Conservation Comm $\mathrm{Rp}$ (60th Cong, $2 \mathrm{~d}$ sess, Sen Doc no 676) $3: 558-570$ (1909) Abst, M Sc Press 99: 88-90 (1909)

10 A cave-in caused by an underground stream at Staunton, Va. Eng News 64: 238-239 (1910)

11 Phosphate and potash deposits. Am Fertilizer 35:68-70 (1911)

11a Phosphate deposits of the United States (abst). Wash Ac Sc J 1: 293-294 (1911)

Van Horn, Frank Robertson.

00 Andesite rocks near Silverton, Colo. G Soc Am, B 12:4-9 (1900)

os A new occurrence of proustite and argentite [Summit Co, Colo.]. Am J Sc (4) $25: 507-508$ (1908)

osa Occurrence of proustite and argentite at the California mine, near Monte. zuma, Colo. G Soc Am, B 19:93-98 (1908) Abst, Science n s 27:405 (1908)

09 A recent landslide in a shale bank near Cleveland accompanied by buckling (abst). Science n \& 29:626 (1909)

10 Landslide accompanied by buckling, and its relation to local anticlinal folds. G Soc Am, B 20:625-632 (1910)

10a Local anticlines in the Chagrin shales at Cleveland, Ohio (abst). Science n s $32: 190$ (1910); (with discussion), G Soc Am. B 21: 771-773 (1910)

11 A discussion of the formulas of pearcite and polybasite. Am J Sc (4) 32 : 40-44 (1911)

11 a Occurrence of silver, copper, and lead ores at the Veta Rica mine, Sierra Mojada, Coahuila, Mexico (abst). G Soc Am, B $22: 738$ (1911)

11b (and Cook, C. W.) A new occurrence of pearcite. Am J Sc (4) $31: 518-$ 524 (1911)

11c (with Hunt, W. F.) Cerusite twins from the Begoña mine, Cerro de San Pedro, San Luis Potosi, Mex. Am J Sc (4) 32 : 45-47 (1911)

12 The occurrence of silver, copper, and lead ores at the Veta Rica mine, Sierra Mojada, Coahuila, Mexico. Am I M Eng, B $68: 867-881$ (1912); $\operatorname{Tr} 43: 219-233$ (1913)

13 A new occurrence of silver, copper, and cobalt minerals in Mexico [Veta Rica mine, Sierra Mojada, Coahuila]. Am J Sc (4) $35: 23-30 \quad$ (1913) 
Van Horn, Frank Robertson-Continued.

13a New occurrence of pisanite and some large staurolites from Ducktown, Tennessee (abst). G Soc Am, B 24:686 (1913)

14 Notes on a new occurrence of pisanite and arsenopyrite, and some large staurolite crystals from the Ducktown district, Tenn. Am I Sc (4) $37: 40-47$ (1914)

$14 a$ The occurrence of bournonite, jamesonite, and calamine at Park City, Utah. Am I M Eng, B $92: 2223-2230$ (1914) ; Tr $49: 292-299$ (1915) Abst, G Soc Am, B $25: 47-48$ (1914)

15 (and Hunt, W. F.) Bournonite crystals of unusual size from Park City, Utah. Am J Sc (4) 40:145-150 (1915)

15a Natural gas at Cleveland, Ohio (abst). G Soc Am, B 26:102-103 (1915)

16 Clay and shale resources in the vicinity of Cleveland, Ohio. Am Ceramic Soc, $\operatorname{Tr} 18: 450-472$ (1916)

17 Reservoir gas and oil in the vicinity of Cleveland, Ohio. Am I M Eng, B 121 : $75-86$ (1917) ; Tr 56:831-842 (1917)

18 Occurrence of a large tourmaline pegmatite (abst). G Soc Am, B 29:104-105 (1918)

See also Miller (A M), 16; Tarr (W A), $18 \mathrm{e}$; White (I C), 18b

Van Ingen, D. A.

95 Petroleum in New York State. N Y St Mus, B 15:558-560 (1895)

Van Ingen, Gilbert.

96 (and White, T. G.) An account of the summer's work in geology on Lake Champlain. N Y Ac Sc, Tr 15:19-23 (1896)

00 Paleozof faunas of northwestern New Jersey $(a b s t)$. Science n 8 12:923-924 (1900) $\mathrm{N}$ Y Ac Sc, An 13:498-500 (1901)

01 The Siluric fauna near Batesville, Ark. Sch Mines Q $22: 318-329 ; 23: 34$ 74, il, map (1901)

O1a [Paleozoic formations of nort'iwestern New Jersey (abst)]. Am G 27:42-43 (1901)

01b A method of facilitating photography of fossils $(a b s t)$. Science $\mathrm{n}$ s 13 : 710-711 (1901) N Y Ac Sc, An 14:115116 (1902)

02 The Potsdam sandstone of the Lake Champlain basin; notes on field work 1201. N Y St Mus, B 52:529-545, map (1902)

03 (and Clark, P. E.) Disturbed fossiliferous rocks in the vieinity of Rondout, N. Y: N Y St Mus, B $69: 1176-1227$, maps (1903)

05. The rounded sands of Paleozoic formations. $(a b s t)$. Science $\mathrm{n}$ s $\quad$ 21:807 (1905)

08 Stratigraphic observations in the vicinity of Susquehanna Gap, north of Harrisburg, $\mathrm{Pa}$. (abst). Science $\mathrm{n}$ \& $27: 764$ (1908)
Van Ingen, Gilbert-Continued.

09 The stratigrapic position of the oolitic iron ore at Bloomsburg, Pa. (abst). Science n \& $29: 830$ (1909)

11 Shore and offshore deposits of si. lurian age in Pennsylvania (abst). Science $n$ \& $33: 905 \quad(1911)$

14 Cambrian and Ordovician faunas of southeastern Newfoundland (abst). G Soc Am, B 25:138 (1914)

14a Table of the geological formations of the Cambrian and Ordovician systems about Conception and Trinity bays, New. foundland, and their northeastern-American and western-European equivalents, based upon the 1912-1913 field work. Broadside, Princeton, N. J., 1914 [priv pub]

15 Organic origin of some mineral de posits in unaltered Paleozoic sediments (abst). G Soc Am, B 26: 85-86 (1915)

16 Directions for preparing a report on the geelogy of a region: for the use of students in the department of geology of Princeton University. $19 \mathrm{pp}$, Princeton, N. J., 1916 [priv pub]

See also White ( $T$ G), 94 ; Woodman, $13 \mathrm{a}$

Van Lennep, David.

68 Report [of the geologist of the U. P. R. R.]. In Union Pacific Rallroad; Report of the Chief Engineer... for 1866:97-123, Washington, D. C., 1868

Van Mater, J. A.

18 Pyrrhotite deposits of southwest Virginia. Eng M J 105:198-199 (1918)

Van Ness, W. W., jr.

87 Tin in North Carolina. Eng M J $44: 344$ (1887)

Van Orstrand, Charles Edwin.

14 (and Wright, F. E.) The ealcu. lation and comparison of mineral analyses. Wash Ac Sc, J 4:514-525 (1914)

15 (and Dewey, F. P.) Preliminary report on the diffusion of solids. U 8 G S, P P 95: 83-96 (1915)

18 Apparatus for the measurement of temperatures in deep wells and temperature determinations in some deep wells in Pennsylvania and West Virginia. W Va G S, Barbour and Upshur counties: 1xviciil (1918)

Van Rensselaer, Jeremiah.

23 An essay on salt, containing notices of its origin, formation, geological position, and principal localities, embracing a particular description of the American salines... $80 \mathrm{pp}, \mathrm{N}$ Y 1823

25 Lectures on geology... $358 \mathrm{pp}, \mathrm{N} \mathrm{Y}$ 1825

25n Notice of fossil Crustacea from New Jersey. Lyc N H N Y, An 1:195-198, 249 , il (1825)

26 Notice of a recent discovery of the fossil remains of the mastodon [New Jersey]. Am J Sc 11:246-250 (1826) 
Van Rensselaer, Jeremiah-Continued. 27 On the fossil remains of the mastodon lately found in Ontario Co., N. Y. Am J Sc 12:380-381 (1827)

28 On the fossil tooth of an elephant found near the shore of Lake Erie, and on the skeleton of a mastodon lately discovered on the Delaware and Hudson Canal. Am J Sc 14:31-33 (1828)

Van Slyke, L. L.

87 Observations on Kilauea, in July, 1886. Am J Sc (3) $33: 95-98$ (1887)

Van Tuyl, Francis Maurice.

12 The Salem limestone and its stratigraphic relations in southeastern Iowa. Iowa Ac Sc, Pr 19:167-168 (1912) Abst, Science n s $36: 569$ (1912)

12a The origin of the geodes of the $\mathrm{Ke}$ okuk beds. Iowa Ac Sc, Pr 19:169-172 (1912) Abst, Science n s 36:569 (1912)

12b A study of the cherts of the Osage series of the Mississippian system. Iowa Ae Sc, Pr $19: 173-174$ (1912) Abst. Science n $836: 569$ (1912)

14 (and Berekhemer, F.) A problematic fossil from the Catskill formation [Delaware Water Gap, Pa.]. Am J Sc (4) $38: 275-276$, il (1914)

14a Origin of dolomite (abst). G Soc $\triangle \mathrm{m}$, B 25:66 (1914)

$14 b$ The origin of geodes (abst). N Y Ac Sc, An 23: 309 (1914)

15 New points on the origin of dolomites (abst). G Soc Am, B 26:62 (1915)

15a The origin of dolomites (abst). N Y Ac Sc, An 24:362-363 (1915)

15b The mottled Tribes Hill limestone and its bearing on the origin of dolomite $(a b s t)$. N Y Ac Sc, An 24:378 (1915)

15e (with Weller, S.) The Ste. Gene. vieve formation and its stratigraphic relathons in southeastern Iowa. Iowa $\mathrm{Ac} \mathrm{Sc}$, Pr 22 : 241-247 (1915) Abst, Sclence $\mathrm{n} s$ 41: 950 (1915)

16 The origin of dolomite. Iowa $\mathbf{G ~ S}$ $25: 251-421$ (1916)

16a New points on the origin of dolomite. Am J Sc (4) $42: 249-260$ (1916)

$16 \mathrm{~b}$ The present status of the dolomite problem. Science n \& 44:688-690 (1916) Colo Sch Mines Mag 7:185-187 (1917)

16e Mottled limestones and their bearing on the origin of dolomite. Science $\mathrm{n} s$ 43: 24-25 (1916)

$16 d$ A contribution to the oolite problem.

J G 24: 792-797 (1916)

16e An organic oolite from the Ordovician. Science n s $43: 171,396$ (abst) (1916)

16r The geodes of the Keokuk beds. Am J Sc (4) $42: 34-42$ (1916)

$16 \mathrm{~g}$ Brecciation effects in the Saint Louis limestone (abst). G Soc Am, B 27 : $\begin{array}{llll}122-124 & \text { (1916) Science } n \text { \& } & 43: 396\end{array}$ (1916)
Van Tuyl, Francis Maurice Continued.

16h The lithogenesis of the sediments Iowa Ac Sc, $\operatorname{Pr} 23: 163-165$ (1916). Abst, Science n s $44: 69$ (1916)

$16 i$ (with Savage, T. E.) The University of Illinois Hudson Bay expedition. Science n s 44:632 (1916)

17 The western interior geosyncline and its bearing on the origin and distribution of the coal measures. J G 25:150-156 (1917) Abst, Iowa Ac Sc, Pr 23:166 (1916)

17a (with Savage, T. E.) Geology of the area of Paleozoic rocks in the vicinity of Hudson and James bays, Canada (abst). G Soc Am, B 28:171 (1917)

18 The origin of chert. Am J Sc (4) $45: 449-456$ (1918)

18a The depth of dolomitization. Science $n$ \& $48: 350-352$ (1918)

18b (and Crooks, H. F.) Types of North American Paleozoic oolites (abst). G Soc Am, B 29: 102 (1918)

18c The physical history of the upper Mississippi Valley during the late Paleozoic (abst). Ill Ac Sc, Tr 10:280 [1918]

Vanuxem, Lardner $(1 ;, 2-1848)$.

21 On two veins of pyroxene or augite in granite. Ac $\mathrm{N}$ Sc Phila, J 2:146-149 (1821)

21a Description and analysis of the table spar from the vicinity of Wills. borough. Lake Champlain. Ac N Sc Phila, J 2:182-185 (1921) Transl in Struve, $\mathrm{H}$ von, Beiträge zur Mineralogie und Geologie des nördlichen Amerikas: 67-72, Hamburg 1822

22 On a new locality of the automalite. Ac N Sc Phila, J $2: 249-251$ (1822)

22a (and Keating, William H.) On the geology and mineralogy of Franklin, in Sussex Co., N. J. Ac N Sc Phila, J 2 : 277-288 (1822)

23 Deseription and analysis of the zirconite of Buncombe Co., N. C. Ac N Sc Phila, J $3: 59-64$ (1823)

23a Description, analysis, etc., of a lamellar pyroxene. Ac N Sc Phila, J 3: 68-73 (1823)

24 (and Keating, W. H.) Observations upon some of the minerals discovered at Franklin, Sussex Co., N. J. Ac N Sc Phila, J $4: 3-11$ (1824)

26 [Report of a mineralogical and geological examination of South Carolina.] In Mills, Robert, Statisties of South Carolina... : 25-30, Charleston, S. C., 1826 Reprinted in Tuomey, M., Report on the geology of South Carolina: App xxxi-xxxii, Columbia, S. C., 1848

27 Proofs, drawn from geology, of the abstraction of nitrogen from the atmosphere by organization. Am J Sc 12: 84-93 (1827) 
Vanuxem, Lardner-Continued.

29 Analysis of cyanite and fibrolite, and their union in one species, under the name of disthene. Ac N Sc Phila, J 6:41-45 (1829)

29a Geological observations on the Secondary, Tertiary, and Alluvial formations of the Atlantic coast of the United States of America. Ac N Sc Phila, J 6 : 59-71 (1829)

29b Remarks on the characters and classification of certain American rock formations. Am J Sc 16:254-256 (1829)

37 First annual report of the geological survey of the fourth district of the State of New York. N Y G S, An Rp 1:187212 (1837)

38 Second annual report... of the geological survey of the third district of the State of New York... N Y G S, An Rp 2:253286 (1838)

39 Third annual report of the geological survey of the third district. N Y G S, An Rp 3:241-285 (1839)

40 Fourth annual report of the geological survey of the third district. N Y G S, An Rp 4:355-383 (1840)

41 Fifth annual report of the geological survey of the third district. N Y G S, An Rp 5: 137-147 (1841)

41a On the ancient oyster shell deposits observed near the Atlantic coast of the United States. Am J Se 41:168-170 (1841) ; As Am G, Rp : 21-23 (1843)

42 Geology of New York. Part III, comprising the survey of the third geological district. $306 \mathrm{pp}$, il, Albany 1842

43 On the origin of mineral springs. As Am G, Rp : 224-229 (1843)

Van vleet, A. H.

02 Introductory [administrative report].

Okla, Dp G N H, Bien Rp 2: 9-16 (1902)

Van Wagenen, $H$. $R$.

06 Tungsten in Colorado. Colo Sch Mines, B 3:138-169 (1906)

Van Wagenen, Theo. F.

oo Southern Oregon placer conditions.

M Sc Press 80:432 (1900)

02 Nitrate deposits, Humboldt Co., Nev.

M Se Press 84:63 (1902)

Van Wagenen, Thomas $F$.

s2 [Sections of shafts at Leadville, Colo.] Sch Mines Q 3:292 (1882)

Van Wagner, P. S.

84 The formation of Burlington Beach [near Hamilton, Ont.]. Hamilton As, J Pr 1 pt 1:142-145 (1884)

Van Winkle, Katherine E. H.

18 Paleontology of the Oligocene of the Chehalis Valley, Wash. Wash, Univ, Pub in Geology 1 no $2: 69-97$, il (1918)

18a Paleontology and stratigraphy of the Porter division of the Oligocene in Washington (abst). G Soc Am, B 29:166 (1918)
Van Winkle, Walton.

14 Quality of the surface waters of Washington. U S G S, W-S P 339:100 pp (1914) Abst, by R. B. Dole, Wast Ac Sc, J $4: 606$ (1914)

$14 a$ Quality of the surface waters of Oregon. U S G S, W-S P $363: 137$ pp, map (1914) Abst, by R. B. Dole, Wast Ac Sc, J 4:607 (1914)

Varney, B. M.

10 Some long-period deviations of the horizontal pendulums at the Harvard seis. mographic station. Science n 8 31:230232 (1910)

Vaughan, F. E.

18 Evidence in San Gorgonio Pass, Rir. erside Co., of a late Pliocene extension of the Gulf of Lower California (abst), Q Soc Am, B 29:164-165 (1918)

Vaughan, Thomas Wayland.

95 The stratigraphy of northwestern Louisiana. Am G 15:205-229 (1895)

95a Section of the Eocene at old Port Caddo landing, Harrison Co., Tex., with notes upon a collection of plants from that locality by F. H. Knowlton. Am G 16 : 304-309 (1895)

95b [Eocene fauna of the midale Atlantie slope] Coelenterata. Jobns Hopkln Univ Cire 15:6 (1895)

96 ...geology and paleontology of northwestern Louisiana. U S G S, B 142:65 pp, il (1896)

96a Notes on the geology of the Sall Carlos coal field, trans-Pecos Tex (abst). Sclence n 8 3:375 (1896)

$96 b$ (with Stanton, T. W.) Section of the Cretaceous at Fl Paso, Tex. All J Sc (4) $1: 21-26$ (1896)

97 Additional notes on the outlying areas of the Comanche series in Oklahoma and Kansas. Am J Sc (4) 4:43-50, map (1897)

97a The asphalt deposits of western Texas. U S G S, An Rp 18 pt $5: 930-935$ (1897)

97b Geologic notes on Kansas, Okla. homa, and Indian Territory (abst). Sclence n \& $5: 558-559$ (1897)

98 (with Hill, R. T.) Description of the Nueces quadrangle [Tex.]. U S G S. G Atlas Nueces fol (no 42):4 pp, map (1898)

98a (with Hill, R. T.) The Lower Cretaceous Gryphaeas of the Texas region U S G S, B 151: 139 pp, il (1898)

98b (with Hil1, R. T.) Geology of the Edwards Plateau and Rio Grande Plain adjacent to Austin and San Antonio, Texas. with reference to the occurrence of underground waters. U S G S, An Rp 18 pt 2 $193-21$, il, maps (1898)

99 Some Cretaceous and Eocene corals from Jamaica. Harvard Coll, Mus C Z, B 34 (g s 4) : 227-250, il (1899) 
Vanghan, Thomas Wayland-Continued.

99 a Geologic notes on the Wichita Mountains, Okla., and the Arbuckle Hills, Ind. T. Am G 24: 44-45 (1899)

00 Description of the Uvalde quadrangle [Tex.] [petrographic descriptions of igneous rocks by Whitman Cross]. U S \& S, G Atlas Uvalde fol (no 64): 7 pp, maps (1900)

00a The Eocene and lower Oligocene coral faunas of the United States... U S G S, Mon $39: 263 \mathrm{pp}$, il (1900)

$00 b$ Reconnaissance in the Rio Grande coal fields of Texas. U S G S, B 164: 1-88, maps (1900)

00e A new fossil species of Caryophyllia from California... U $\mathrm{S}$ Nat Mus, $\operatorname{Pr} 22$ : 199-203, il (1900)

ood Trochocyathus voolmani, a new coral from the Cretaceous of New Jersey. Ac N Sc Phila, Pr 1900:436-437, il

o0e A Tertiary coral reef near Bainbridge, Ga. Science $n$ \& $12: 873-875$ (1900)

01 Some fossil corals from the elevated reefs of Curaço, Arube, and Bonaire [West Indies]. G Reichs-Mus Leiden, Samm (2) $2: 1-91$ (1901)

01a The locality of the type of Prionastraea vaughani Gregory. An Mag N H (7) 7:300 (1901)

01b The copper mines of Santa Clara Province, Cubs. Eng M J 72:814-816 (1901)

01e Shell Bluff, Ga., one of Lyell's original localities (abst). Science n s 13:270 (1901)

01d (with Hnyes, C. W., and Spencer, A. C.) Report on a geological reconnaissance of Cuba,..: $123 \mathrm{pp}$, map [Habana?] 1901 Also in Civil report of Brig.-Gen. Leonard Wood, Military governor of Cuba, for 1901 vol 1 Transl, with annotations. by Pablo Ortega y Ros, Cuba, Dir Montes y Minas, Bol Minas nos 2 and $3: 132$ pp, map (by Fernández de Castro and Salterain y Legarra) (1917)

02 The stony corals of the Porto Rican waters. U. S. Fish Comm, B 20 pt $2: 289-$ 320 , il (1902)

02a Fuller's earth of southwestern Georgia and western Florida. U S G S, Min Res 1901: 922-934 (1902)

02b Some recent changes in the nomenclature of West Indian corrals. Biol Soc Wash, Pr 15:53-58 (1902)

02e An addition to the coral fauna of the Aquia Eocene formation of Maryland. Biol Soc Wash, Pr $15:$ 205-206 (1902)

02d A redescription of the coral Platytrochus speciosus. Biol Soc Wash, $\operatorname{Pr} 15$ : $207-209$, il (1902)

02e Bitumen in Cuba, Eng M J 73 : $344-347$ (1902)
Vaughan, Thomas Wayland-Continued. $02 f$ (and Spencer, A. C.) The geography of Cuba. Am Geog Soc, B 34:105116 (1902)

02g Notes on Cuban fossil mammals. Science n s 15: 148-149 (1902)

02h Earliest Tertiary coral reefs in the Antilles and United States (abst). Science $n$ \& 15:506-507 (1902)

02i Evidence of recent elevation of the Gulf coast along the westward extension of Florida, Science n s 16:514 (1902)

62j (with Hill, R. T.) Description of the Austin quadrangle [Tex.]. U S G S, G Atlas Austin fol (no 76): $8 \mathrm{pp}$, maps (1902)

03 The corals of the Buda limestone. U S G S, B 205: $37-40$, il (1903)

03a Fuller's earth deposits of Florida and Georgia. U S G S, B 213:392-399 (1903)

03b Corrections to the nomenclature of the Eocene fossil corals of the United States. Biol Soc Wash, Pr 16:101 (1903)

04 A Californian Tertiary coral reef and its bearing on American recent coral faunas (abst). Science n s 19:503 (1904)

05 A critical review of the literature of the simple genera of the Madreporaria Fungida, with a tentative classification. U S Nat Mus, Pr 28: 371-424 (1905)

of Report [on the geologic horizon of human remains in west Florida]. In Bur Am Ethnology, B 33:64-66 (1907)

09 Geology of the Florida Keys and the marine bottom deposits and recent corals of southern Florida. Carnegie Inst Wash, Y Bk 7:131-138 (1909)

$09 n$ The geologic work of mangroves in southern Florida. Smiths Misc Col 52 (Q Is 5) : 461-464 (1909)

10 Geology of the Keys, the marine bottom deposits, and the recent corals of southern Florida. Carnegie Inst Wash, Y Bk $8: 140-144$ (1910)

$10 \mathrm{n}$ The Miocene horizons at Porters Landing, Ga. Science $n$ s $31: 833-834$ (1910)

10b Sketch of the geologic history of the Floridian Plateau. Science n 8 : 24-27, 32 (abst) (1910)

10e A contribution to the geologic history of the Floridian Plateau. Carnegie Inst Wash, Pub no 133, Papers from the Tortugas Laboratory 4:99-185, map (1910)

10a The continuity of development. Pop Sc Mo $77: 478-481$ (1910)

11 Physical conditions under which Paleozoic coral reefs were formed. G Soc Am, B 22: 238-252 (1911) Abst, Wash Ac Sc, J $1:$ 139-140 (1911)

$11 \mathrm{a}$ The influence of marine currents on deposition in continental seas (abst). Science $n$ s $33: 315$ (1911) 
Billings, Elkanah-Continued.

63b Description of a new species of Harpes from the Trenton limestone, Ottawa. Can Nat $8: 36-37$, il (1863)

63c On the internal spiral coils of the genus Cyrtina. Can Nat $8: 37-39$, il (1863)

63d On the remains of the fossil elephant found in Canada. Can Nat $8: 135-$ 147, il (1863)

63e Description of a new species of Phillipsia from the lower Carboniferous rocks of Nova Scotia. Can Nat 8:209210 (1863)

$63 \mathrm{O}$ On the genus Stricklandia; proposed alteration of the name. Can Nat $8: 370$ (1863)

65 Paleozoic fossils, vol. 1; containing descriptions and figures of new or little known species of organic remains from the Silurian rocks. $426 \mathrm{pp}$, il Can G S 1865.

65a Notes on some of the more remarkable genera of Silurian and Devonian fossils. Can Nat n s 2:184-198, 405-409, il (1865)

65b Notice of some new genera and species of Paleozoic fossils. Can Nat n s $2: 425-432$ (1865)

66 Catalogues of the Silurian fossils of the Island of Anticostl, with descriptions of some new genera and species. $99 \mathrm{pp}, \mathrm{ll}$, Can G S 1866 .

67 On the classification of the subdivisions of MeCoy's genus Athyris as determined by the laws of zoological nomenclature. Am J Sc (2) 44:48-61 (1867) An $\mathrm{Mag}$ N H (3) 20:233-247 (1867)

68 [On certain structural features of the Cystidea.] Can Nat n s 3:442-445 (1868)

6Sa Description of two new species of Stricklandinia. G Mag $5: 59-64$, il (1868) 69 Description of some new species of fossils with remarks on others already known from the Sllurian and Devonian rocks of Maine. Portland Soc N H, Pr 1:104-126, il (1869)

69 a Note on the structure of the Blastoidea. Am J Sc (2) 47:353 (1869) Can Nat n s 4:89-90 (1869) An Mag N H (4) $4: 76 \quad(1869)$

69b Notes on the structure of the Crinotdea, Cystidea, and Blastoidea. Am J Sc (2) $48: 69-83 ; 49: 51-58 ; 50: 225-$ 240 , il $(1869-70)$ Can Nat n s $4: 277-$ $293,426-433 ; 5: 180-198$, il $(1869-70)$ An Mag N H (4) $5: 251-266,409-416$; $7: 142-158$, il $(1870-1)$ Can G S, Paleozoic Fossils 2 pt 1:90-128, il (1874)

70 Notes on some specimens of Lower Silurian trilobites. G Soc London, Q J $26: 479-486$, il $(1870)$ Abst, G Mag 7 : 291-292 (1870) ; Can Nat n s 5:90-91 (1870)
Billings, Elkanah-Continued.

71 Notes on Trimerella acuminata. Am J Sc (3) 1:471 (1871) An Mag N H (4) 8: 140-141 (1871)

71a On some new species of Paleozoic fossils. Can Nat n s $6: 213-222$, il (1871) Am J Sc (3) 352-360, il (1872)

71b Proposed new genus of Pteropoda [Hyolithellus]. Can Nat n s 6:240 (1871)

72 On the genus Obolellina. Can Nat n s $6: 326-330$, il (1872)

72a Note on a question of priority. Am J Sc (3) $3: 270-273(1872)$ Can Nat n s $6: 330-333$ (1872)

72b Remarks on the Taconic controversy. Can Nat n s $6: 313-325,460-465$ (1872) Abst, Am J Sc (3) 3:466-468 (1872)

72e Note on the discovery of fosslls in the "Winooski marble" at Scranton, Vt. Can Nat n s 6:351 (1872) Am J Sc (3) $3: 145-146$ (1872)

72d Additional note on Obelellina, etc. Can Nat n s $6: 365-367$ (1872)

72e Additional notes on the Taconic controversy. Can Nat n s 6:460-465 (1872)

72f On some fossils from the Primordial rocks of Newfoundland. Can Nat n s 6 : $465-479$, il (1872)

$72 g$ Fossils probably of the Chazy era in the Eolian limestone of west Rutland. Am J Sc (3) 4:133 (1872)

72h Rejoinder to Prof. Hall's reply to a "Note on a question of priority." Am J Sc (3) $4: 399-400$ (1872)

73 On the Mesozoic fossils from British Columbia ... Can G S, Rp Prog 1872-3 : $71-75 \quad(1873)$

74 Paleozoic fossils, vol. 2, part 1, 144 pp, il, Can G S 1874

74a On some new or little known fossils from the Silurian and Devonian rocks of Ontario. Can Nat n $8 \quad 7: 230-240$, il (1874)

74b On some new genera and species of Paleozoic Mollusca. Can Nat n s $7: 301-$ 302 , il (1874)

74c [On openings in arms of Actinocrinus.] Am J Sc (3) 7:530 (1874)

76 On the structure of Obolella chromatica. Am J Sc (3) 11:176-178 (1876)

82 [Fossils from Avalon Peninsula, Newfoundland, chiefly Cambrian.] Newfoundland G S, Rp Prog 1881: Appendix $16 \mathrm{pp}$, il (1882)

See also Bradley, 60; Hitchcock (E), 61 ; Logan, 67

Billinss, Walter R. (1849-1920).

81 Notes on two species and one genus of fossils from the Trenton limestone, Ottawa. Ottawa Field Nat Club, Tr no 2:34-35 (1881)

83 Notes on, and description of, some fossils from the Trenton limestone. Ottawa Field Nat Club, Tr no $4: 49-52$, il (1883) 
Vanghan, Thomas Wayland-Continued.

11b The keys, corals, and coral reefs of Florida (abst). Science n 8 33: 751-752 (1911)

13 Studies of the geology of the Madreporaria of the Bahamas and of southern Florida. Carnegie Inst Wash, Y Bk 11 : 153-162 (1913)

13a Remarks on the goology of the Bahama Islands, and on the formation of the Floridian and Bahaman oolites (abst). Wash Ac Sc, J 3:302-304 (1913)

14 Investigations of the geology and geologic processes of the reef tracts and adjacent areas in the Bahamas and Florida. Carnegie Inst Wash, Y Bk 12:183-184 (1914)

14a The building of the Marquesas and Tortugas atolls and a sketch of the geologic history of the Florida reef tract. Carnegie Inst Wash, Pub 182 (Papers from the Tortugas Laboratory, vol 5) : 55-67 (1914)

14b Preliminary remarks on the geology of the Bahamas, with special reference to the origin of the Bahaman and Floridian oolite. Carnegie Inst Wash, Pub 182 (Papers from the Tortugas Laboratory, vol, 5) : 47-54 (1914)

14e sketch of the geologic history of the Florida coral reef tract and comparisons with other coral reef areas. Wash Ac Sc, J $4: 26-34$ (1914) Abst, G Soc $A m$, B 25 : 41-42 (1914)

14d (and Cooke, C. W.) Correlation of the Hawthorn formation. Wash Ac Sc, J $4: 250-253$ (1914)

14e The platforms of barrier coral reefs (abst). Am Geog Soc, B 46:426-429 (1914)

14f Memorandum on the geology of the ground waters of the Island of Antigua, B. W. I. West Indian B 14:276-280 (1914)

14g (with Pirsson, L. V.) Contributions to the geology of Bermuda (abst). Science n 8 39:568 (1914)

15 Geological investigations in the $\mathrm{Ba}$ hamas and soutbern Florida. Carnegie Inst Wash, Y Bk $13: 227-233$ (1915)

15a Study of the stratigraphic geology and of the fossil corals and associated organisms in several of the smaller West Indian Islands. Carnegie Inst Wash, Y Bk $13: 358-360 \quad(1915) ; 14: 368-373$ (1916) ; $15: 359$ (1917)

15b Coral reefs and reef corals of the southeastern United States; their geologic history and significance (abst). G Soc Am, B 26:58-60 (1915) Science n s 41:508509 (1915)

15e (and others) Symposium on the factors producing change in position of strand line during Pleistocene and postPleistocene. Wash Ac Sc, J 5:444-447 (1915)
Vaughan, Thomas Wayland-Continued

15d [Correlation of the Cretaceous at Tertiary formations of the Antilles Wash Ac Sc, J $5: 489$ (1915)

15e The geologic significance of th growth-rate of the Floridian and Bahame shoal-water corals. Wash Ac Sc, J 5: $591-600$ (1915)

16 (and Shaw, E. W.) Geologic is vestigations of the Forida coral reef tract Carnegie Inst Wash, Y Bk 14 (1915) : 23?238 (1916)

16a The present status of the investiz. tion of the origin of barrier coral reets Am J Sc (4) 41:131-135 (1916)

$16 \mathrm{~b}$ The results of investigations of the ecology of the Floridian and Bahamat shoal-water corals. Nat Ac Sc, Pr 2:95100 (1916)

16e Some littoral and sublittoral physio graphic features of the Virgin and northen Leeward Islands, and their bearing on th coral reef problem. Wash Ac Sc, J $6: 53$. 66 (1916) Abst, G Soc Am, B $27: 41-4$ (1916)

16d The corals and coral reefs of the Gulf of Mexico and the Caribbean ses (abst). Science n \& 43:250-251 (1916)

16e Summary of the results of investi. gations of the Floridian and Bahamas shoal-water corals (abst). G Soc Am, B $27: 154$ (1916)

17 The reef-coral fauna of Carrin Creek, Imperial Co., Cal. and its signif cance. U S G S, P P 98: 355-395. (1917) Abst, G Soc Am, B 28: 200 (1917

17a Significance of reef coral fauna at Carrizo Creek, Imperial Co., Cal. (abst). Wash Ac Sc, J $7: 194$ (1917)

17b Chemical and organic deposits of the sea. G Soc Am, B 28:933-944 (1917)

$17 \mathrm{e}$ On reported Pleistocene human mains at Vero, Fla. J G 25:40-42 (1917)

18 Study of the stratigraphic geologr and of the fossil corals and associated organisms in several of the small West Indian Islands. Carnegie Inst Wash, Y Bt no $16: 319$ (1918)

18n (and others) Some shoal-water bottom samples from Murray Island, Aus tralia, and comparisons of them with sam ples from Florida and the Bahamas. Car negie Inst Wash, Pub no 213, Papers from the Department of Marine Biology 9:235288 (1918)

18b The temperature of the Florids coral-reef tract. Carnegie Inst Wash, Pub 213, Papers from Dp Marine Biology 9: 319-339 (1918)

18e Geologic history of Central Americs and the West Indies during Cenozolc time. G Soc Am, B 29:615-630 (1918)

18d Correlation of the Tertiary geologle formations of the southeastern United States, Central America, and the West In dies. Wash Ac Sc, J 8: 268-276 (1918) 
Vaughan, Thomas Wayland-Continued.

18e Geologic surveys and the eradica tion of malaria. Southerr inedical J 11: $569-572$ (1918)

$18 f$ (with Hayes, C. W., and Spencer, A. C.) Geology of Cuba ; a reprint...from the "Report on a geological reconnaissance of Cuba,"... Cuba, Direccion de Montes y Minas: $37 \mathrm{pp}$, map, Havana 1918

See also Clark (W B), 01a, 04a ; Eastman, 00; Hill (R T), 98c; McCallie, 08

Vaux, George.

99 (and Vaux, W. S., Jr.) Some observations on the Illecillewaet and Asulkan glaciers of British Columbia. Ac $\mathrm{N}$ Sc Phila, Pr 1899: 121-124

00 (and Vaux, W. S., jr.) The great glacier of the Illicilliwaet [B. C.]. Appalachia $9: 156-165$ (1900)

00a (and Vaux, W. S., jr.) Additional observations on glaciers in British Columbia. Ac N Sc Phila, Pr 1899: 501-512 (1900)

01 (and Vanx, W. S., Jr.) Observa. tions made in 1900 on glaciers in British Columbia. Ac N Sc Phila, Pr 53:213-215 (1901)

04 (and Vaux, W. S., jr.) Les variations périodiques des glaciers, IX; Colomble anglais et Alberta. Arch Sc Phys Nat (4) $18: 194-195(1904)$

06 (and Vanx, W. S., jr.) Les variations périodiques des glaciers, 1905 ; British Columbia and Alberta. Zs Gletscherk 1: 180 (1906)

o7 (and Vaux, W. S., jr.) Observations made in 1906 on glaciers in Alberta and British Columbia. Ac $\mathrm{N}$ Sc Phila, Pr 58:568-579 (1907)

07a (and Vanx, W. S., jr.) Observations made in 1907 on glaciers in Alberta and British Columbia. Ac N Sc Phila, Pr 59: 560-563 (1907)

07b (and Vaux, W. S., jr.) Glacier observations. Can Alpine J $1: 138-148$ (1907)

08 (and Vaux, W. S., jr.) Les variations périodiques des glaciers, XIIme rapport, 1906; Alberta and British Columbia, Zs Gletscherk 2: 185-196 (1908)

10 Observations on glaciers in 1909 . Can Alpine J 2 : 126-130 (1910)

Vaux, Mary M.

11 Observations on glaciers in 1910. Can Alpine I $3: 127-130$ (1911)

13 Observations on glaciers [B. C.]. Can Alpine J 5:59-61 (1913)

Vaux, Roberts.

30 (and MeEven, T.) Notice of the fall of a meteoric stone at Deal in New Jersey. $\Delta c \mathrm{~N}$ Sc Phila, J 6:181-182 (1830)

Vanx, William S., jr. (1872-1908).

99 (with Vanx, G.) Some observations on the Illecillewaet and Asulkan glaciers of British Columbia. Ac $\mathbf{N}$ Sc Phila, Pr 1899: 121-124
Vanx, William S., jr.-Continued.

00 (with Vaux, G.) The great glacier of the Illicilliwaet [B. C.] Appalachia 9: 156-165 (1900)

oon (with Vanx, G.) . Additional observations on glaclers in British Columbia. Ac N Sc Phila, Pr 1899: 501-512 (1900)

01 (with Vaux, G.) Observations made in 1900 on glaciers in British Columbia. Ac N Sc Phila, Pr 53: 213-215 (1901)

04 (with Vanx, G.) Les variations périodiques des glaciers, IX; Colomble anglais et Alberta. Arch Sc Phys Nat (4) 18 : 194-195 (1904)

06 (with Vaux, G.) Les variations périodiques des glaciers, 1905 ; British $\mathrm{Co}$ lumbia and Alberta. Zs Gletscherk 1:180 (1906)

o7 Modern glaciers: their movements and the methods of observing them. Eng Club Phila, Pr 24: 259-283 (1907) Can Alpine J 2:56-78 (1909)

07a (with Vnux, G.) Glacier observations, Can Alpine J 1:138-148 (1907)

os (with Vaux, G.) Les variations périodiques des glaciers, $\mathrm{XII}^{\mathrm{me}}$ rapport, 1906; Aiberta and British Columbia. Zs Gletscherk 2: 185-196 (1908)

Veateh. Arthur Clifford.

98 Notes on the Ohio Valley in southern Indiana. J G 6:257-272 (1898)

9Sa An old river channel in Spencer Co., Ind. Ind $\mathrm{Ac} \mathrm{Sc}, \operatorname{Pr} 1897: 266-271$, map (1898)

99 The Shreveport area; the Five Is. lands. La St Exp Sta, G Agr La pt 5: 149-262, maps [1899]

99a (with Harris, G. D.) A preliminary report on the geology of Loulslana. La St Exp Sta, G Agr La pt 5:354 pp, il, map [1899]

02 The salines of north Louisiana. La St Exp Sta, G Agr La pt 6:41-100, maps (1902)

02a The geography and geology of the Sabine River. La St Exp Sta, G Agr La pt $6: 101-148$, map (1902)

02b Notes on the geology along the Ouachita. La St Exp Sta, G Agr La pt 6: 149-172, maps (1902)

03 The diversity of the glacial period on Long Island [N. Y.]. J G 11:762-776, map (1903)

O3a Notes on the geology of Long Island. Sclence n s 18:213-214 (1903)

o3b (with Fuller, M. L.) Results of the resurvey of Long Island, N. Y. Science n s 18:729-731 (1903)

o4 Some peculiar artesian conditions on Long Island, N. Y. (abst). Seience n $\mathbf{s}$ $19: 795-796$ (1904)

os [Underground waters of] Louisiana and southern Arkansas, U S G S, W-S P 114: 179-187 (1905) 
Veuteh, Arthur Clifford-Continued.

O5a The underground waters of northern Louisiana and southern Arkansas. La St Exp Sta, La G S, B 1:82-91, map (1905)

O5b The question of the origin of the natural mounds of Loulsiana, Arkansas, and Texas (abst). Science n s 21:310$311,350-351$ (1905)

05e (with Fuller, M. L.) Record of deep well drilling for 1904. U S G S, B 264:193 pp (1905)

06 On the human origin of the small mounds of the lower Mississippi Valley and Texas. Science n s 23:34-36 (1906)

O6a Age and type localities of the supposed Jurassic fossils collected north of Fort Bridger, Wyo., by Frémont in 1843. Am J Sc (4) 21:457-460 (1906)

06b Fluctuations of the water level in wells, with special reference to Long Island, N. Y. U S G S, W-S P $155: 83$ pp (1906)

o6e Outlines of the geology of Long Island [N. Y.]: Underground water conditions of Long Island. U S G S, P P 44: 15-85, map (1906)

O6d (and Bowman, I.) Tell records on Long Island. U S G S, P P 44:116337 (1906)

o6e Geology and underground water resources of northern Lonisiana and southern Arkansas. U S G S, P P 46:422 pp, map (1906)

o6f Coal and oil in southern Uinta Co., Wyo. U S G S, B 285:331-353, maps (1906)

06g Geology and underground water resources of northern Louisiana with notes on adjoining districts. La G S, B 4:209 pp (1906)

o7 On the origin and definition of the geologic term "Laramie." J G 15:526549 (1907) Abst, Am J Sc (4) 24:18-22 (1907)

07a Coal fields of east-central Carbon Co., Wyo. U S G S, B $316: 244-260$ (1907)

11 Coal deposits near Pinedale, Navajo Co., Ariz, U S G S, B 431:239-242, map (1911)

Veatch, J. Allen.

14 The genesis of the mercury deposits of the Pacific coast. Am I M Eng, B 86: 209-226, maps (1914)

Veatch, Jethro Otto.

06 The term "colluvial" as applied to clay deposits. Science n s 24:782 (1906) 07 Kaolins and fire elays of central Georgia. U S G S, B 315 : 308-314 (1907)

os Altamaha formation of the Coastal Plain of Georgia. Science n 8 27:71-74 (1908)

08a A new discovery of bauxite in Georgia. Eng M J 85: 688 (1908)
Veateh, Jetbro Otto-Continued.

08b The kaolins of the Dry Branch region, Ga. Ec G 3:109-117 (1208)

09 Second report on the clay deposits of Georgia. Ga G S, B $18: 453$ pp, maps (1909)

11 Graphite in vein quartz. Science ns $33: 38$ (1911)

11a (and Stephenson, L. W.) Pre liminary report on the geology of the Coastal Plain of Georgia. Ga G S, B 26: 466 pp, maps (1911)

15 (with Stephenson, L. W.) Under. ground waters of the Coastal Plain of Georgia. U S G S, W-S P 341:539 pp, maps (1915)

Veateh, John A.

57 Notes of a visit to the "mud vol. canoes " in the Colorado Desert in the month of July, 1857. Cal Ac N Sc, Pr 1 : 104-108 (1857; 2d ed, 1873:116-121) Am J Sc (2) 26:288-295 (1857)

Velasquez de León, Joaquín.

50 Cortes geológicos (México a Puebla) Inst Nac Geog Estad Rep Mex, Bol 1 no 3 $27-3 \theta(1850)$ [not seen]

Velásquez de León, Miguel.

50 Corte geológico en el mineral del Fresnfllo [México]. Inst Nac Geog Estad Rep Mex, Bol 1 no 5:52-60 (1850)

84 Un nuevo mineral de vanadio; su analisis [San, Luis Potosi, México]. La Naturaleza $7: 65-72$ (1884)

85 La ramirita, nueva especie mineral. 32 pp, México 1885

Venable, Francis Preston.

90 Two new meteoric irons [N. C. and Va.]. Elisha Mitchell Sc Soc, J $7: 31-32$ (1890) Am J Se (3) 40:161-163 (1890)

$90 \mathrm{n} A$ list and description of the meteorites of North Carolina. Elisha Mitchell Sc Soc, J 7:33-51 (1890)

92 Occurrence of zirconium. Elishs Mitchell Sc Soc, J 8: 74-78 (1892)

92a The occurrence of platinum in North Carolina. Flisha Mitchell Sc Soc, J 8: 123-129 (1892)

Vennor, Henry George (1840-1884).

67 Ascending section of Laurentian rocks in the County of Hastings, Canada West. G Soc London, Q J 23:256-257 (1867) Can Nat n s $3: 310-311$ (1868)

70 Report [on the geology of parts of Hastings, Peterborough, Addington, and Frontenac cos., Ont.]. Can G S, Rp Prog 1866-9:143-171, map (1870)

72 ... on the geology of parts of the counties of Frontenac, Leeds, and Lapark. Ont. Can G S, Rp Prog 1870-1: 309-315 (1872)

72a Progress report of exploration and surveys in the counties of Leeds. Frontenac, and Lanark, with notes on the gold of Marmora. Can G S, Rp Prog 1871-2 : 120 141, map (1872) 
Vennor, Henry George-Continued.

73 Report of explorations and surveys in the counties of Addington, Frontenac, Leeds, and Lanark [Ontario]. Can G S, Rp Prog 1872-3 : 136-179 (1873)

74 Report of explorations and surveys in Frontenac, Leeds, and Lanark counties, with notes on the Plumbago of Buckingham and apatite of Templeton and Portland townships, Ottawa Co. Can G S, Rp Prog 1873-4: 103-146, map (1874)

75 Notes on some of the galena or sulphuret of lead deposits connected with the Laurentian rocks of Ontario. Can Nat n s $7: 455-462$ (1875)

76 Progress report of explorations and surveys in the rear portions of Frontenac and Lanark cos., together with notes on some of the economic minerals of Ontario. Can G S, Rp Prog 1874-5:105-165, map (1876)

77 Archean of Canada. Am J S (3) 14:313-316 (1877) Can Nat n s $8: 374-$ 376 (1877)

78 Progress report of explorations and surveys made during the years 1875 and 1876 in the counties of Renfrew, Pontiac, and 0 ttawa, together with additional notes on the iron ores, apatite, and plumbago deposits of Ottawa Co. Can G S, Rp Prog $1876-7: 244-320$, map (1878)

82 Phosphates in Canada. Eng M J $33: 69$ (1882)

Vermeule, C. C.

05 East Orange wells at White Oak Ridge, Essex Co. [N. J.]. N J G S, An Rp 1904: 255-263 (1905)

Vernenil, Edouard de (1805-1873).

46 Fusulina in the coal formation of Ohio. Am J Sc (2) $2: 293$ (1846) Am Q J Agr 4: 166 (1846)

47 [Sur une grande orthocère des fitatsUnis.] Soc G France, B (2) 4:556-559 (1847)

47a on the parallelism of the Paleozoic deposits of North America with those of Europe... Soc G France, B (2) 4:646710 (1847) Am J Sc (2) 5:176-184, $359-370$ (1848) ; $7: 45-51,218-231$ (1849) In part, with title, The Carboniferous fauna of America compared with that of Europe, Edinb N Ph J 47:117-121 (1849)

55 Rapport sur un némoire de M. Jules Marcou relatif a la classification des chaines d'une partie de v'Amérique du Nord. Ac Sc Paris, C R 40:734-741 (1855)

Verri, A.

05 Le eruzioni della Montagna Pelée e del vulcano Laziale. Soc G Italiana, B 24 : 84-88 (1905)

Verrill, Addison Emory.

66 [Geologic notes on northern New Hampshire.] Boston [oc N H, Pr 10:386 (1866)
Verrill, Addison Fmory-Continued.

68 On the zoological affinities of the tabulate corals. Am As, Pr $16: 148-151$ (1868)

72 On the affinities of the Paleozoic tabulate corals with existing species. Am J Sc (3) $3: 187-184$ (1872) An Mag N H (4) $9: 355-364(1872)$

75 On the post-Pliocene fossils of Sankoty Head, Nantucket Island. Am J Sc (3) $10: 364-375 \quad(1875$

78 Occurrence oi fossiliferous Tertiary rocks on the Grand Bank and George's Bank. Am J Sc (3) 16:323-324 (1878)

82 Nature and origin of the sediments; occurrence of fossiliferous limestone nodules. Am J Sc (3) $24: 447-452$ (1882); $26: 245$ (1883)

83 The sediments of the Gulf Stream slope (abst). Am Nat $17: 189-190,305$ 308 (1883) Science 2:153-154 (1883)

00 Notes on the geology of the Bermudas. Am J Sc (4) $9: 313-340$, map (1900)

02 Peculiar character of the eruption of Mt. Pele, May 8 [1902]. Am J S: (4) 14: $72-74 \quad(1902)$

02a The Bermuda Islands; their scen. ery, climate, productions, physiography, natural history, and geology... Conn $\mathbf{A c}$, Tr 11: 413-911 (1902)

o7 The Bermuda Islands; Part IV, Geology and paleontology, and Part V, An account of the coral reefs. Conn $\mathbf{A c}$, $\mathrm{Tr}$ $12: 45-348$ (1907)

\section{Versinys, J.}

10 Waren die sauropoden Dinosaurier Pflanzenfresser? Zool Jahrb 29:425-450, il (1910)

Verwiebe, Walter $A$.

16 The Berea formation of Ohio and Pennsylvania. Am J Sc (4) $42: 43-58$ (1916) Abst, Science n s 43:395 (1916)

17 Correlation of the Mississippian of Ohio and Pennsylvania. Am J Sc (4) 43 : 301-318 (1917)

17a Correlation of the Devonian shales of Ohio and Pennsylvania. Am J Sc (4) $44: 33-47$ (1917)

Very, Frank W.

10 Fall of a meteorite in Norwood, Mass. Seience n \& 31:143-144 (1910)

$10 n$ The Norwood "meteorite" a fraud; how meteoritic evidence may be manufactured. Science n s $31: 415-418$ (1910)

Vesa y Fillart, Antonio.

09 Acerca del ballazgo de terrenos geo16 gicos secundarios en la Isla de Cuba. Ac Cienc Méd Habana, An 46: 89-93 (1909) Vespucins, pseud.

41 Geological phenomena of the Falls of Niagara. The Museum of Foreign Literature, Sclence and Art 43 (n s 15): $435-$ 440 (1841) 
Veteh, -

24 Notice accompanying specimens from the Bermuda Islands. $\mathbf{G}$ Soc London, $\mathrm{Tr}$ (2) $1: 172-173$ (1824)

\section{vicaire, $A$.}

04 Développements récents des indus. tries minière et métallurgigue en Colombie Britannique. An Mines (10) 5:297-388 (1904)

o5 Les gisements pétrolifères des Etats Unis. Soc Ind Min, B (4) 4:681-849 (1905) ; $7: 433-485$ (1907)

Vickery, Hubert Bradford.

15 Notes on the analysis of "ironstone," N S Inst Sc, Pr Tr 13:209-215 (1915)

Victorin, Marie.

13 Les "galets"; observations sur la géologie et la flere des terrains désertiques aux environs de St.-Jérôme, P. Q. Soc Géog Québec, B $7: 7-22$ (1913)

Visier, Victor von.

07 (with Böse, E.) Sobre la aplicación de la potasa cáustica a la preparación de fósiles. Méx I G, Par 2:49-59 (1907) Vilanova y Piera, Juan.

74 La estructura de las rocas serpentínicas y el Eozoon canadense. Soc Española $\mathrm{H}$ N, An $3: 261-266$ (1874)

Villada, Manuel María (1841-1921).

87 Sobre el distrito de Sultepec [México]. La Naturaleza (2) 1:36-39 (1887)

Ss La caverna de Ojo de Agua [México]. La Naturaleza (2) 1:81-85 (1888)

88a Relación de un viaje á la caverna de Cacahuamilpa [México]. La Naturaleza (2) $1: 148-156$ (1888)

90 Apuntes de geología y de botánica relativos a México. La Naturaleza $1: 419-433,493-498(1890)$

91 Noticia y explicacíon de la carta geológica que acompaña el trabajo anterior [valleys of Mexico and Toluca]. La Naturaleza (2) $1: 483-484$, map (1891)

$91 a$ La variedad más notable de granate mexicano [garnet, Cuatla, Morelos]. La Naturaleza (2) 1:500-502 (1891)

96 Catáloge de la colección de minerales Gel Museo Nacional. 56 pp, México 1896 [not seen]

97 Catálogo de la colección de fósiles del Museo Nacional. 79 pp, México 1897

99 Reseña de la colección de rocas mexicanas del Museo Nacional. Mus Nac Méx, An 6: Ap 33-44 (1899)

03 Apuntes acerca de la fauna fósil del Valle de México. Mus Nac Méx, An 7 : $441-451$, il (1903)

o3a Consideraciones generales acerca de la flora fosil del Valle de México. Mus Nac Méx, An 7:452-454 (1903)

94 Breve reseña geológica del terreno comprendido en las obras del desagüle del Valle de México $y$ en general de toda esta region. Mus Nac Méx, An (2) 1:172-184 (1904)
Villada, Manuel María-Continued.

o5 Una exploración á la cuenca fosilifera de San Juan Raya, Estado de Puebla [Mexico]. Mus Nac Méx, An (2) $2: 126-$ 164 (1905)

10 Breves apuntes acerca de la paleo. biologica del Valle de México. La Naturaleza (3) $1: 7-13 \quad(1910)$

10a Reseña descriptiva y geológica de la Gruta de Tonsltongo, del mineral del Cardonal...[Hidalgo]. La Naturaleza 1: $25-44$ (1910)

10b Pretendido hallazgo de huesos ho manos fosiles en cierto lugar del Estado de Coahuila. La Naturaleza (3) 1:45-51 (1910)

10e Breve noticia de un viaje de exploración a diversos lugares del Estado de Veracruz. La Naturaleza (3) $1: 53-92$. fl $(1910)$

12 Apuntes recogidos en un viaje de exploración al Estado de México. La Natu. raleza (3) $1: 145-152$ (1912)

Villufaña, Anđớs.

05 Criaderos cupro-argentíferos en Tapalpr, Jalisco. Soc G Mex, B 1:135138 (1905)

o7 El volcán Jorullo, Méx I G, Par 2 73-130 (1907)

os Fuente termal en Cultzeo de Abasolo Estado de Guanajuato, México. Méx I $G_{\text {, }}$ Par 2: 227-287 (1908)

12 Estudio de la inflitración de aguas en las minas de la región noroeste del mineral de Zacatecas. Soc Cient Ant Alz, Mem 32 21-26, map (1912)

12a Algunos datos acerca de la Sierr: Madre Occidental en el Fstado de Durang (abst). Soc G Mex, B 8: vil-vili (1912)

14 Criaderos minerales en la sierra de Almoloya, Estado de Chihuahua. La Naturaleza (3) $1: 168-170$ (1914) [not seen]

16 Reseña minera de la region central y sureste del Estado de Jalisco. Soc Cient Ant Alz, Mem 34:152-327 (1916) Also, 175 pp, Mexico 1916

17 Informe sobre la negociación minera de "El Magistral," S. A. [Zacatecas, Mexico]. Bol Minero 4:626-631 (1917) V111

o9 Las minas de "Coronas y Anexas," pertenecientes a la "Seguranza Mining Co." Soc Cient Ant Alz, Mem 28: 23-51 (1909 Villarello, Juan de D.

02 (and Bäse, Emilio) Criaderos de fierro de la hacienda de Vaquerfas en el Estado de Hidalgo. Méx I G, B 16:15-44, map (1902)

o3 Génesis de los yacimientos mercuriales de Palomas y Huitzuco en los Estados de Durango y Guerrero de la República Mexí cana. Soc Cient Ant Alz, Mem 19:95-186 (1903)

04 Análisis y clasificación de un granate procedente del mineral de Pihuamo, Jalisco. Méx I G, Par 1:75-80 (1904) Méx, Sec Fomento, B (2) 4, IV : 85-90 (1904) 
Villarello, Juan de D.-Continued.

04a Estudio de la teoría qufmica propuesta por el Sr. D. Andres Alamaraz para explicar la formación del petróleo de Arag6n, México, D. F. Méx I G, Par 1: 95-111 (1904)

04b Estudio de una muestra de mineral asbestiforme procedente del rancho del Ahuacatillo, Distrito de Zinapécuaro, Michoacán. Méx I G, Par 1:133-149 (1904)

04c Estudio de la hidrologia interna de los alrededores de Cadereyta Méndez, Estado de Querétaro. Méx I G, Par 1: 155-208, map (1904)

04d Estudio de una muestra de grafita de Ejutla, Estado de Oaxaca. Méx I G, Par 1: 213-228 (1904)

04e Descripción de los criaderos de mereurio de Chiquilistıán, Jalisco [México]. Soc Cient Ant Alz, Mem 20:389-397 (1904)

05 Distribución de la riqueza en los criaderos metaliferos primarios epigenéticos. Soc G Mex, B 1: 175-206 (1905)

05a Descripción de las minas "Santiago Anexas" del Estado de Michoacán México]. Soc Cient Ant Alz, Mem 22: 125-140 (1905)

05b Reseña del mineral de Arzate, Esado de Durango. [Méx), Sec Fom, B (2) (II) : $301-313, \quad 363-381 \quad(1905)$ Soc Cient Ant Alz, Mem 23: 211-240 (1905)

05e Description des mines "La Bella "nion" (Êtat de Guerrero); génèse des sisements de mercure. Soc Clent $\mathrm{Ant} \mathrm{Alz}$, Mem $23: 395-411$ (1905)

05d Hidrología subterránea de los alrededores de Querétaro. Méx I G, Par 1: 239-289, map (1905)

06 Descripción de algunas minas de Zacualpan (Estado de México). Soc Cient dnt Alz, Mem 23: 251-266 (1906)

06a Aplicación de la fluoresceína a cuestiones de salubridad pablica. Soc Cient Ant Alz, Mem 24: 51-62 (1906)

06b Un nuevo fluoroscopío. Soc Cient Ant Alz, Mem $24: 63-72$ (1906)

06e Hidrología subterránea de las cercanfas de Jiutepec (Estado de Morelos) [México]. Soc Cient Ant Alz, Mem 24: 159-171 (1906)

06d (and Flores, T., and Robles, R.) thtude de la Sierra de Guanajuato [Mér. lco]. Int $\mathrm{G}$ Cong, $\mathrm{X}$, Mexico, Guide Exc no $\mathrm{XV}: 33 \mathrm{pp}, \operatorname{map}(1906)$

06e Le minéral de Mapimi [México]. hit $\mathrm{G}$ Cong, $\mathrm{X}$, Mexico, Guide Exc no XVIII : 8 pp (1906)

06f Le minéral d'Aranzazá (État de Pacatecas). Int $\mathbf{G}$ Cong, $X$, Mexico, Guide Pre no XXV: 29 pp (1906)

07 Hidrología subterrínea de los alrede. ores de Querétaro [México]. Méx, Sec pomento, B (2) 7 IV : 65-81, 84-96 (1907)
Villarello, Juan de D.-Continued.

07a Géologie chimique des gisements de soufre de Mapimi, Etat de Durango. Soc Cient Ant Alz, Mem $26: 115-145$ (1907)

o7b Sur le remplissage de quelques gisements métallifères. Int $\mathrm{G}$ Cong, $\mathrm{X}$, Mexico, 1906, C R :533-553 (1907) Soc Cient Ant Alz, Mem 26: 423-447 (1908)

os Datos relativos a varias regiones petroliferas de México. Soc G Mex, B 4: 43-57 (1908)

08a Algunas regiones petrolfferas de México. Méx I G, B 26:120 pp (1908)

09 Hidrología subterránea de los alrededores de Montenegro (Estado de Querétaro). Soc G Mex, B 5 : 37-65 (1909)

09a Los granitos de las eanteras "Leahy," "Red Stone" (N. H.), y "Bienvenue " (Maine), E. U. A. Soc G Mex, B $6: i x-x i, 37-66 \quad(1909)$

09 b Hidrología subterránea de los alre. dedores de Patzeuaro, Michoacan, México. Méx I G, Par 2: 341-362 (1909)

09e El pozo de petróleo de Dos Bocas. Méx I G, Par 3: 5-112 (1909)

09d Some petroleum-bearing regions of Mexico. M J, London, 85: 609 (1909)

09e Principal petroleum-bearing regions of Mexico. M World 31:28-31 (1909)

09f The mode of filling of some Mexican ore deposits. M J, London, 87:169-170, 208-209 (1909)

$09 \mathrm{~g}$ (and Flores, T., and Robles, R.) Geologic study of the Sierra of Guanajuato. Eng M J 88:672-677, map (1909) [see also 06d]

09h (with Burekhardt, C.) Estudio geologico de los alrededores de una parte del Río Nazas en relación con el proyecto de una presa en el cañón de Fernández. Méx I G, Par $3: 117,135$ (1909)

10 Hidrología subterránea de la comarca lagunera del Tlahualilo, Durango. Méx I G, Par 3: 205-251, map (1910)

$10 a$ Diversas zonas mineralizadas, en los principales criaderos metalfferos de México. Soc G Mex, B $7: 9-22$ (1910)

10b Zonas probables de acumulación del petróleo en el subsuelo de las mejores regiones petrollferas de México. Soc G Mex, B 7:23-30 (1910)

10e Circulación subterránea del agua por diaclasas, $\sigma$ cavidades supercapilares. Soc G Mex, B $7: 31-46$ (1910)

10d Algunos datos relativos al mineral de Providencia, San Felipe, Estado de Guanajuato. Soc G Mex, B 7:47-59 (1910)

11 Las aguas subterráneas en el borde meridional de la cuenca de México. Méx I G, B 28: 1-80, map (1911)

13 Apuntes acerca de la hidrología sub. terránea del Estado de Coahuila [México]. Méx I G, Par 5 : 195-208, map (1913)

Villars, J. R.

09 Spheroidal weathering of dikes. M Sc Press 98: 443 (1909) 
Villaneñor, F.

03 Análisis de las cenizas de la erupción del voleán de Santa María (Guatemala)... Méx, Sec Fomento, B (2) 2, II : 279-280 (1903)

Vinageras, Arturo Codeso.

13 Notas de geología aplicada. Ac Cienc Méd Habana, An 50:492-503 (1913)

Viquennel, A.

57 [Sur une collection de roches du Canada.] Soc G France, B (2) 14:419427 (1857)

Virginia, Commissioner of Agrieulture. See Pollard, Thomas; and Harrison, Randolph.

Virginia Geologieal Survey.

09 Map of Virginia showing location of mines and quarries. Scale 12 miles to 1 inch. 1909

Virlet D'A oust, Théodore.

57 Sur des œufs d'insectes servant a l'alimentation de thomme et donnant lieu a la formation doolithes dans des calcaires lacustres an Mexique. Ac Sc Paris, C R 45 : $865-868$ (1857)

58 Nouvelles observations sur le métamorphisme normal. Soc G France, B (2) 15: 119-129 (1858)

58a Observations sur un terraln dorigine météorique ou de transport aérien qui exlste au Mexique, et sur le phénomène des trombes de poussiere auquel $\mathbf{n}$ doit principalement son origine. Soc G France, B (2) 15: 129-139 (1858)

65 Sur les salures différentes et les diffe. rents degrés de salure de certains lacs au Mexique. Soc G France, B (2) 22:464472 (1865)

66 Coup d'œil général sur la topographie et la géologie du Mexique et de l'Amérique central. Soc G France, B (2) $23: 14-50$ (1866)

Visher, Stephen Sargent.

12 (with Perisho, E. C.) A preliminary report upon the geography, geology, and biology or Mellette, Washabaugh, Bennett, and Todd cos., S. Dak. S Dak G S, B 5: $152 \mathrm{pp} \mathrm{(1912)}$

13 The history of the bajadas of the Tucson bolson of Arizona (abst). Science n s $37: 549$ (1913)

18 The geography of South Dakota... S Dak G S, B $8: 1-177$ (1918)

Vivar, Gonzalo.

16 La grafita. Bol Minero $2: 378-385$ (1916)

Vivian, Arthur C.

16 Barytes mining in Georgia. Eng M J $102: 1083-1085$ (1916)

Vivian, Arthur Pendarves.

79 Wanderings in the western lavd. 426 pp, maps L 1879

Vivian, William.

65 Observations on the mining district of Sonora, Tuolumne Co., Cal. R G Soc Cornwall, Tr $7: 216-219$ (1865)
Vogdes, Anthony Wayne.

76 A monograph of American trilobites, part 1. $16 \mathrm{pp,} \mathrm{Tampa,} \mathrm{Fla.,} 1876$ [not seen 1

77 Notes on the genera Acidaspis Murchison, Odontopleura Emmerich, and Cere. tocephala Warder, Ac N Sc Phila, Pr 1877 : 138-141

78 A monograph on the genera Zethus, Cybele, Encrinurus, and Cryptonymus. 35 pp, Il, Charleston, S. C., 1878

78n Cretaceous and Tertiary of Charles. ton, S. C. Am J Sc (3) 16:69-70 (1878)

78b (with Maxyek, Wm. G.) Description of a new fossil from the Cretaceovs beds of Charleston, S. C. Ac N Sc Phila, Pr 1878: 272, il

79 ...geology of Catoosa Co., Ga. Am J Se (3) 18:475-477 (1879)

so Description of a new crustacean from the Upper Silurian of Georgia, with remarks upon Calymene elintoni. Ac N Sc Phila, Pr 1880:176-178, il

84 A new trilobite [Bathyurus stone manii]. Minn G S, An Rp 12:8-9 (1884)

84a Course of science applied to mili. tary art; Part I, geology and military geography ; geology. $176 \mathrm{pp}$, Eort Monroe. Va., 1884

86 Notes on the distribution of iron ores in the United States.. 24 pp, Fort Mon roe, Va., 1886

86a Description of a new crustaceas from the Clinton group of Georgia, with remarks upon others. $5 \mathrm{pp}, \mathrm{il}$, New York City 1886

88 The genera and species of Nortl American Carboniferous trilobites. N Y Ac Se, An $4: 69-105$, il (1888)

88a Description of two new species of Carboniferous trilobites. N Y Ac Sc, Tt $7: 247-250$, il (1888)

88b Some forgotten Taconic literature Am G 2:352-355 (1888)

89 A catalogue of North American Pa. leozoic Crustacea confined to the nontrilobitic genera and species. N Y Ac Sc An 5:1-38, il (1889)

89a (with Saford, J. M.) Descrip tion of new species of fossil Crustacea from the Lower Silurian of Tennessee... Ac I Sc Phila, $\operatorname{Pr} 1889: 166-168$, il

90 A bibliography of Paleozoic Crustacet from 1698 to 1889 . U S G S, B $63: 17$ pp (1890)

92 On the North American species of the genus Agnostus. Am G 9:377-396. il (1892)

92a On some new Sedalia trilobites [Mo.]. Ac Sc St L, Tr 5: 615-618 (1892) 93 A classed and annotated bibliography of the Paleozoic Crustacea, 1698-1892, to which is added a catalogue of North American species. Cal Ac Sc, Oc P 4:41. pp (1893) 
Vogdes, Authony Wayne-Continued.

93a Geological surveys in the State of California, Cal Ac Se, $\operatorname{Pr}$ (2) $3: 325$ 337 (1893)

93b On the genus $A m p y x$ with descriptions of American species. Am G 11:99109 , il (1893)

95 A supplement to the bibliography of the Paleozoic Crustacea. Cal Ac Sc, Pr (2) $5: 53-76$ (1895)

95a On a new trilobite from Arkansas lower Coal Measures. Cal Ac Sc, Pr (2) 4:589-591, il (1895)

96 A bibliography relating to the geology, paleontology, and mineral resources of California. Cal St M Bur, B 10:121 pp, Sacramento 1896

97 Carboniferous trilobites from Missouri. Cal Ac Sc, Pr (2) 6:197-198, il (1897)

99 Biographical sketch of Issachar Cozzens, jr. Am G 24:327-328, port (1899)

04 A bibliography relating to the geology, paleontology, and mineral resources of California. Cal St M Bur, B 30:290 pp, Sacramento 1904

05 ...books relating to geology, mineral resources and paleontology of California. San Diego Soe N H, Tr 1:9-23 (1905)

07 Bibliographical sketch of Dr. John B. Trask, first State geologist of California, San Diego Soe $\mathrm{N} H, \operatorname{Tr} 1: 27-30$, port. (1907)

07a The genus Encrinurus; its history, Its species, its proper division in the family of trilobites. San Diego Soc N H, Tr 1 : $61-82$, il (1907)

17 Paleozoic Crustacea; the publications and notes on the genera and species during the past twenty years, 1895-1917. San Diego Soc N H, Tr 3:1-141, il (1917) Vogt, J. H. L.

02 Problems in the geology of ore deposits. Am I M Eng, Tr 31:125-169 (1902)

Volekening, G. J.

95 (with Luquer, Lea MeI.) On three new analyses of sodalite, from three new localities. Am J Sc (3) $49: 465-466$ (1895) Volk, Ernest ( ?-1919).

11 The geological features of the vicinity of Trenton, N. J. Harvard Univ, Peabody Mus Am Arch and Eth, Papers 5 : 1-13 (1911)

12 Early man in America; thirty years of experience in searching for evidences of the antiquity of man in the Delaware Valley. Am Mus J 12 : 181-185 (1912)

Volney, C. F.

os Tableau du climat et du sol des Etats-Unis d'Amérique. 2 vols, 532 pp. maps, Paris 1803. Transl. by C. B. Brown, A view of the soil and climate of the United States of America: 446 pp, maps, Phila 1804
Von Engeln, Oscar Dledrich.

os The use of a wet laboratory in physiography teaching. N Y, State Edue Dp, B 431:44-49 (1908)

OSa (with Tarr, R. S,) Representation of land forms in the physiography laboratory. J Geog $7: 73-85$ (1908)

10 (with Tarr, R. S.) A laboratory manual of physical geography. xvii, 362 pp N Y 1910

11 Phenomena associated with glacier drainage and wastage, with especial reference to observations in the Yakutat Bay region, Alaska. Zs Gletscherk 6:104-150 (1911) Also, Thesis, Cornell Unlo

$11 a$ Some factors influencing the percentages of mineral plant foods contained in soils. Am J Sc (4) $32: 350-358$ (1911)

$11 b$ A method for combining the topical, regional, and cultural phases of physiographic study in the laboratory (abst). As Am Geog, An 1:148-149 (1911)

12 In Missouri [physiographic features in the vicinity of Columbia]. I Geog 10 : 263-267 (1912)

13 Dynamic geology (with references to structural phenomena in their relation to processes); a recitation text. $160 \mathrm{pp}$, Copyright, 1913. [Priv pub].

14 Effects of continental glaciation on agriculture. Am Geog Soc, B $46: 241-264$, $336-355$ (1914)

15 Experimental studies and observations on ice structure. Am J Sc (4) 40 : 449-473 (1915)

15n (with Tarr, R. S.) Experimental studies of ice with reference to glacier structure and motion. Zs Gletscherk 9: 81-139 (1915)

16 (and Hausman, L. A.) An auto. matic, intermittent eruption, artificial geyser. School Science and Mathematics 16:116-122 (1916)

18 Transportation of débris by icebergs. J G $26 ; 74-81$ (1918)

1Sa Glacial erosion of rock basins; with especial reference to the conditions applying in the Finger Lake region, of central New York (abst). As Am Geog. An $7: 83-85$ [1918]

Von Herrmann, C. F.

is The desiceation of the earth. Sclence n s $47: 417$ (1918;

Von osdel, E. B.

02 The Etzatlan mining district [Jalisco], Mexico. Fng M J $73: 243-244$ (1902)

Von Petersiorf, F. C.

90 Meteorites. Cal St M Bur, An Rp 10: 946-951 (1890)

Vose, George Leonard.

66 Orographic geology; or, the origin and structure of mountains. $135 \mathrm{pp}$, Boston 1866 
Vose, George Leonard-Continued.

68 Traces of ancient glaciers in the White Mountains of New Hampshire. Am Nat $2: 281-291,330$ (1868)

6Sa Traces of ancient glaciers in the White Mountains of New Hampshire... Am As, Pr 16:127-128 (1868)

$68 b$ On the distortion of pebbles in conglomerates, with illustrations from Rangely Lake in Maine. Boston Soc N H, Mem 1: $482-487$ (1868)

6Se On the formation of glaciers. Essex Inst. Pr $6: 13-14$ (1868)

voyle, Joseph.

03 Aurite and a general theory of gold ore genesis. M Sc Press 86:382-383 (1903)

Vrba, Karl.

74 Beiträge zur Kenntniss der Gesteine Süd-Grönland's, K Ak Wiss, Mat-nat Cl, Szb 69 Abt 1: 91-123 (1874)

w., J. T.

89 Notes on the geology of Hardeman Co. [Tex.]. G Sc B 1 no 9 (1889)

Wachsmuth, Charles (1829-1896).

66 (with Niles, W. H.) Evidence of two distinct geological formations in the Burlington limestone. Am J Sc (2) 42: 95-99 (1866)

77 (and Springer, F.) Revision of the genus Belemnoerinus and description of two new species. Am J Sc (3) $13: 253-260$ (1877)

77a Notes on the internal and external structure of Paleozoic crinoids. Am J Sc (3) $14: 115-127,181-191$ (1877)

78 (and Springer, F.) Transition forms in crinoids, and description of flve new specles. Ac N Sc Phila, Pr 1878: 224-266

80 (and Springer, F.) Revision of the Palaeocrinoidea. Ac N Sc Phila, Pr $1879,226-378$, il $(1880) ; 1881: 177-414$, il ; $1885: 225-364$, $11 ; 1886: 64-226$

S0a Preliminary notice of the Sphaeroidocrinidae $(a b s t)$. Iowa Ac Sc, $\operatorname{Pr} 1875$ $80: 22(1880)$

82 Descriptions of two new species of Crinoidea from the Chester limestone and Coal Measures of Illinois. Ill St Mus N H, B $1: 40-43$ (1882)

83 (and Barris, W. H.) Description of fossil invertebrates [Crinoidea]. Ill $\mathrm{G} S$ $7: 339-345$, il (1883)

83a On a new genus and species of blastoids, with observations upon the struc. ture of the basal plates in Codaster and Pentremites. IIl G S $7: 346-357$, il (1883)

83b (and Springer, F.) Remarks on Glyptocrinus and Reteocrinus, two genera of Silurian crinoids. Am J Sc (3) 25: 255-268 (1883)

83e (and Springer, F.) On Hybocrinus, Hoplocrinus, and Baerocrinus. Am J Sc (3) $26: 365-377$, il (1883)
Wachsmuth, Charles-Continued.

84 Description of a new crinoid from the Hamilton group of Michigan [Megitocrinus concavus]. Davenport Ac Sc, $\mathrm{P}$ ? $4: 95-97$, il (1884)

$84 a$ On a new genus and species of blastoids [Heteroschisma gracile]. Daveport Ac Sc, $\operatorname{Pr} 4: 76-87$, Il (1884)

86 The presence or absence of under. basals in crinoids can be ascertained from the column (abst), Am As, Pr 34:341342 (1886)

87 (and Springer, F.) The summit plates in blastoids, crinoids, and cystids, and their morphological relations. AC $\mathbb{A}$ Se Phila, Pr 1887:82-114, il

89 (and Springer, F.) Discovery of the ventral structure of Taxocrinus and Haplocrinus, and consequent modifications in the classification of the Crinoidea. Ac N Sc Phila, Pr 1888: $337-363$, II (1889)

89a (and Springer, F.) Crotalocrinus; its structure and zoological position. Ac N Sc Phila, Pr $1888: 364-390$, il (1889)

90 (and Springer, F.) New species of crinoids and blastoids from the Kinderhook group of the Lower Carboniferous rocks at Le Grand, Iowa. III G S 8:155$205,11(1890)$

90a (and Springer, F.) A new genus (Allocrinus) from the Niagara group of western Tennessee. III G S 8: 206-208, il (1890)

91 (and Springer, F.) The perisomic plates of the crinoids. Ac N Sc Phila, Pr $1890: 345-392$, il (1891)

92 (and Springer, F.) Description of two new genera and eight species of camerate crinoids from the Nlagara group. Am G 10:135-144 (1892)

97 (and Springer, F.) The North American Crinoidea Camerata. Harvard Coll, Mus C Z, Mem 20 and 21:837 pp, il (1897) Rv by F. A. Bather, G Mag (4) $5: 276-283, \quad 318-329, \quad 419-428, \quad 522-527$ (1898) ; 6:32-44, 117-127 (1899) ; reprint with index (1899)

See also Eastman, 00

Waddington, Alfred.

54 Lodes and quartz veins of gold. M Mag 2: 21-24 (1854)

Wade, Bruce.

14 The geology of Perry Co. [Tenn.] and vicinity. Tenn G S, Res Tenn 4:150181 (1914)

17 A remarkable Upper Cretaceous fauna from Tennessee. Johns Hopkins Univ Circ n s 1917 no $3: 73-101$ [271-299], il, map

17a The occurrence of the Tuscaloosa formation as far north as Kentucky. Johns Hopkins Univ Circ n \& 1917 no 3: 102-106 [300-304]

17b The gravels of west Tennessee valley. Tenn G S, Res Tenn 7: 55-89 (1917)

17e An Upper Cretaceous Fulgur. Am J Sc (4) $43: 293-297$, il (1917) 
Wade, Bruce-Continued.

17d New genera and species of Gastropoda from the Upper Cretaceous [of McNairy Co., Tenn.]. Ac Nat Sc, Phila, Pr $68: 455-471$, il (1917)

17e New and little-known Gastropoda from the Upper Cretaceous of Tennessee Ac Nat Sc Phila Pr 69:280-304, fl (1917)

18 New generic names for Upper Cretaceous Gastropoda. Am J Sc (4) 45 : 334 (1918)

Wade, W. M.

98 Copper mining at Kamloops, B. C. Eng M J 66: 698-699 (1898)

Wade, William Rogers.

07 Burro Mountain copper district [N. Mex.]. Eng M J 84:355-356 (1907)

09 The gem-bearing pegmatites of western Maine. Eng M J 87:1127-1129 (1909)

13 Minerals of the Tres Hermanas district [N. Mex.]. Eng M J $96 ; 589-590$ (1913)

14 Apache mining district, N. Mex. Eng M J $97: 597-598$ (1914)

14a Mining district of Pinos Altos, N. Mex. M Sc Press 109: 402-403 (1914)

Wadwworth, Marshman Edward (18471921).

77 Notes on the mineralogy and petrography of Boston and vicinity. Boston Soc $\mathrm{N} \mathrm{H}, \operatorname{Pr} 19: 217-237$ (1877)

77a On the granite of North Jay, Me. Boston Soc N H, Pr 19:237-238 (1877)

78 on the so-called tremolite of New. bury, Mass. Boston Soc N H, Pr 19: 251252 (1878)

78n Notes on the petrography of Quincy and Rockport [Mass.]. Boston Soc N H, Pr $19: 309-316$ (1878)

79 On the classification of rocks. Harvard Coll, Mus C Z, B 5:275-287 (1879) $A b s t, A m$ Nat 13: 531-532 (1879)

80 Notes on the geology of the iron and copper districts of Lake Superior. Harvard Coll, Mus C Z, B 7 (g s 1):1-157 (1880) In part, with title on the jasper and iron ore of the Marquette region. Am $\mathrm{J} \mathrm{Sc}$ (3) $22: 403-408$ (1880)

Soa Danalite from the iron mine, Bartlett, N. H. Boston Soc N H, Pr 20:284 $286(1880)$

80b Picrolite from a serpentine quarry in Florida, Mass. Boston Soc $\mathrm{N} \mathrm{H}$, $\mathrm{Pr}$ $20: 286-287$ (1880)

80c On the origin of the iron ores of the Marquette district, Lake Superior. Boston Soc N H, Pr 20:470-479 (1880) Criticism by J. D. Dana, Am J Sc (3) $22: 320-321.402-403$ (1881)

sod The volcanic dust from Dominica. Nature $22: 266-267 \quad(1880)$

81 Tufa from Florissant [Colo.]. U S G Geog S Terr (Hayden), B 6:286-287 (1881); An Rp 12 pt 1:276-278 (1883)

81a On an occurrence of gold in Maine. Harvard Coll, Mus C Z, B 7 (g s 1): 181 (1881)
Wadsworth, Marshman Edward-Contd.

81b A microscopical study of the iron ore or peridotite of Iron Mine Hill, Cumberland, R. I. Harvard Coll, Mus C Z, B 7 (g s 1) : 183-187 (1881) Science (ed, Michels) $2: 368-370$ (1881) Abst, Boston Soc N H, Pr 21:194-197 (1882); Harvard Univ B no 19 ( $v$ no 6$): 219$ (1881)

s1e on the filling of amygdaloidal cavities and veins in the Keweenaw Point district of Lake Superior; a reply to Prof. James D. Dana. Boston Soc N H, Pr 21: 91-103 (1881)

s1d The appropriation of the name Laurentian by the Canadian geologists. Boston Soc N H, Pr 21: 121-122 (1881)

s1e $\mathrm{O}_{n}$ the age of the copper-bearing rocks of Lake Superior $(a b s t)$. Am As, Pr 29:429-430 (1881) Eng M J 32:270 (1881)

82 Notes in geology and lithology ; 1, The Marblebead diabase; 2, Picotite found in the ground mass and feldspar of basalt ; 3. Zircon syenite; 4, The Stoneham limestone: 5, The Braintree argillite and Quincy granite; 6, On the relations of the so-called felsite to the conglomerate on Central Avenue, Milton, Mass. Harvard Univ B no 22 (v 2 no 9 ) : $359-360$; no 23 (v 2 no 10 ) : 431-432 (1882)

$\mathbf{8 2 a}$ Some points relating to the geological exploration of the fortieth parallel. Boston Soc N H, Pr 21: 243-274 (1882)

82b On the relation of the Quincy granite to the Primordial argillite of Braintree, Mass. Boston Soc N H, Pr 21:274 $277(1882)$

s2e On the tracbyte of Marblehead Neck, Mass. Boston Soc N H, Pr 21: 288-294 (1882) Abst, Harvard Univ B no 20 (v 2 no 7 ) : 267 (1881)

82d Note on the lithology of Marble head [Mass.]. Boston Soc N H, Y : 21: 306 (1882)

82e [On picotite from M.t. Shasta, Cal.] Boston Soc N H, Pr 21:314-315 (1882)

s2f [Zircon syenite from Salem, Mass.] Boston Soc N H, Pr 21: 406 (1882)

s3 The Bishopville and $W$-terville meteorites. Am J Sc (3) 26:32-38 (1883)

83a Note on Professor R. D. Irving's paper on the paramorphic origin of the hornblende of the crystalline rocks of the Northwestern States. Am J Sc (3) $26: 155$ (1883)

83b The argillite and conglomerate of the Boston Basin. Boston Soc N H, Pr 22: 130-133 (1883)

s3e Some instances of atmospheric action on sandstone. Boston Soc N H, Pr 22 : 201-203 (1883)

83d Meteoric and terrestrial rocks. Science 1: 127-130 (1883)

83e Keweenaw Point geology [Mich.]. Science $1: 248-249$ (1883) 
Billings, Walter R.-Continued.

83a (with Whiteaves, J. F.) Report on the paleontological branch for the season of 1882. Ottawa Field Nat Club, Tr no $4: 67-69$ (1883)

85 Two new species of cripoids [Trenton, Ottawa area, Ont.] Ottawa Field Nat Club, Tr no 6: 248-250, il (1885)

85a Report of the paleontological branch [lists of Trenton fossils]. Ottawa Field Nat Club, Tr no 6: 259-262 (1885)

87 A new genus and three new species of crinoids from the Trenton formation with notes on a large specimen of Dendrocrinus proboscidiatus. Ottawa Nat 1:4954, il (1887)

98 Death of a distinguished American amateur geologist and paleontologist-S. A. Miller. Ottawa Nat 11:208 (1898)

See also Anderson (W P), 82

Billingsley, Paul.

10 Structure, origin, and stratigraphic significance of the Shawangunk grit (abst). Science n s 32:125-126 (1910)

13 The Southern Cross mine, Georgetown, Mont. Am I M Eng, B 81: 22892297 (1913) ; Tr 46:128-136 (1914) M World $39: 781-784$ (1913)

15 The Boulder batholith of Montana (with discussion by J. F. Kemp, D. C. Bard, W. Lindgren, H. V. Winchell, and L. C. Graton). Am I M Eng, B 97:31-47, map (1915); 101:1128-1137 (discussion) (1915) ; $\operatorname{Tr} 51: 31-56$, map (1916)

17 (and Grimes, J. A.) Ore deposits of the Boulder batholith of Montana (with discussion by Walter E. Gaby and J. B. Hastings). Am I M Eng, B 124:641-717 ; $130: 1869-1870$ (1917); Tr $58: 284-361$ (1918)

18 (with Kemp, J. F.) Notes on Gold Hill and vicinity, Tooele Co., western Utah. Ec G 13:247-274, map (1918)

Billups, A. C.

02 Fossil land shells of the old forest bed of the Ohio River. Nautilus 16:5052 (1902)

\section{Bingham, Hiram.}

45 ... fall of meteorites in the Sandwich Islands. Am J Sc 49:407-408 (1845)

Binney, Amos (1803-1847).

46 [The bluff formation at Natchez, Miss.] Boston Soc N H, Pr 2: 126-130 (1846)

Biolley, Pablo.

12 (with Tristan, J. F.) Registro de temblores, 1911. Costa Rica, Centro de Estudios Sismologicos, An 1911: 18-32 (1912)

12a (with Tristan, J. F.) The Sarchi earthquake, Costa Rica. Seism Soc Am, B 2: 201-208 (1912)

Bira, Allen $\mathrm{T}$.

16 Resources of Santa Cruz Co. [Ariz.]. Ariz Upiv, Bur Mines, B 29:27 pp (1916)
Bird, R. M.

14 (and Calcott, W. S.) The associs. tion of vanadium with petroleum as: asphalt. Va Univ, $\mathrm{Ph}$ Soc, n s $1: 365-3 i !$ (1914)

Birge, Edward Asahel.

99 Report of the superintendent [late director] of the survey. Wisconsin $G$ H S, First biennial report: 8-28 (1899): Second $\ldots \quad: 7-44$ (1901); Third: $9-25$ (1902) ; Fourth : 9-32 (1904); Fifth : 9-4 (1906) ; Sixth : 9-45 (1908); Seventb:1055 (1910); Eighth : 7-39 (1912); Ninth: $7-40$ (1914); Tenth: $7-29$ (1916); Eler. enth : 9-40 (1918)

14 (and Juday, Chancey) The inlant lakes of Wisconsin. Wis G S, B $27: 137$ pp, maps (1914)

Birkinbine, John (1844-1915).

84 The Durango íron mountain [Mer. ico]. Eng M J 37:199-200 (1884)

85 The Cerro de Mercado (Iron Mour tain) at Durango, Mex. Am I M Eng, T 13: 189-209 (1885)

87 The iron ores east of the Mississippi River. U S G S, Min Res 1886:39-103 (1887)

88 The Iron ores of the United States Franklin Inst, J 96:190-208 (1888)

88a Iron ore mining in 1887 . U $8 \mathrm{G}$ $\mathrm{S}$, Min Res $1887: 30-57$ (1888)

90 Crystalline magnetite in the Port Henry, N. Y., mines. Am I M Eng, Tr 18: 747-762 (1890)

93 Iron ores. U S G S, Min Res 1891: $10-46 ; 1892: 23-45 ; 1893: 23-49 ;$ An Bp 16 pt $3: 21-218 ; 17$ pt $3: 23-43 ; 18$ pt $5: 23-50 ; 19$ pt $6: 23-63 ; 20$ pt $6: 27-59$; 21 pt $6: 31-67$; Min Res $1900: 39-67$; $1901: 43-72 ; 1902: 41-73 ; 1903: 41-73 ;$ $1904: 37-68 ; 1905: 53-87$ (1893-1906)

92 Notes upon American iron ore de posits... Iron and Steel Inst. in Americ in 1890 , Special vol of $\operatorname{Pr}: 361-402$ [1892]

97 Manganese ores. U S G S, An B? 18 pt $5: 291-328 ; 19$ pt $6: 91-125 ; 20$ pt $6: 125-158$; 21:129-162; Min Res 1900: $115-140 ; 1901: 127-155 ; 1902: 133-161$; $1903: 129-156 ; 1904: 113-140 ; 1905: 87-$ 111 (1897-1906)

Birkinbine, J. L. W.

10 Exploration of certain iron-ore and coal deposits in the State of Oaxaca, Mes. ico. Am I M Eng, B 45:671-693 (1910): Tr 41:166-188 (1911) Abst, Eng M J $90: 668-671$ (1910)

Bishop, Alfredo.

16 Los minerales de El Triunfo y Sat Antonio distrito sur de la Baja Californis [Mexico]. Bol Minero 2:55-61 (1916)

Bishop. Irving Prescott.

86 Salt wells of western New York. N Y St G, An Rp 5:12-47 (1886) 
Wadsworth. Marshman Edward-Contd. S3f United States geologists, sandstones, and the Keweenaw series. Science 1:307 (1883)

S3g St. David's rock and universal law. Science 1:541 (1883)

83h The microscopic evidence of a lost continent. Science 1:590-592 (1883)

84 Lithological studies; a description and classification of the rocks of the Cordilleras, Harvard Coll, Mus C Z, Mem 11: xvi, 208, xxxiii pp (1884)

84a The fortieth parallel rocks. Boston Soc N H, Pr 22: 412-432 (1884)

841. On the evidence that the earth's interior is solid. Am Nat 18: $587-594,678-$ 686, 767-773 (1884)

s4e Notes on the rocks and ore deposits in the vicinity of Notre Dame Bay, Newf. Am J Sc (3) 28:94-104 (1884)

s4d Methods of instruction in mineralogy. Pop Sc Mo 24: 754-759 (1884)

S4e Olivine rocks of North Carolina. Science 3: 486-487 (1884)

s4f Some United States geologists and the propylite question. Science 4:111 (1884)

84g The lateral-secretion theory of ore deposits. Eng M J $37: 364-365$ (1884)

Sth (with Dickerman, Q. E.) An olivine-bearing diabase from St. George, Me. Boston Soc N H, Pr 23: 28-29 (1884)

S4i (with Whitney, J. D.) The Azoic system and its proposed subdivisions. Harvard Coll, Mus C Z, B 7 (g s 1): xvi, $331-565$ (1884)

85 On the relation of the Keweenawan series to the eastern sandstone in the vicinity of Torch Lake, Mich. Boston Soc N H, Pr 23:172-180 (1885) Abst, Science $3: 553$ (1884)

85a The theories of ore deposits. Boston Soc N H, Pr 23: 197-208 (1885)

$\mathbf{s 5 b}$ on the presence of syenite and gabbro in Essex Co., Mass. G Mag (3) 2 : 207-210 (1885)

85e Voleanic dust east of the Rocky Mountains. Science B:63 (1885)

86 On a supposed fossil from the copperbearing rocks of Lake Superior. Boston Soc N H, Pr 23: 208-212 (1886)

87 Preliminary description of the peri. dotites, gabbros, diabases, and andesites of Minnesota. Minn G S, B 2:ix, 159 pp (1887)

$\mathbf{8 7 a}$ The Keweenawan system. Science $10: 166(1887)$

$87 b$ The volcanic theory of ore formation. Eng M J 44:392 (1887)

90 A sketch of the geology of the Marquette and Keweenawan districts. In Ralph, Julian, Along the south shore of Lake Superior: 63-82, Copyrighted by C. B. Hibbard of the Duluth, South Shore \& Atlantic R'y, 1890 2d ed: 75-99 (1891)
Wadsworth, Marshman Edward-Contd.

91 The relations of the eastern sandstone of Keweenaw Point to the Lower Silurian limestones. Science 18:25 (1891) Am J Sc (3) 42:170-171 (1891)

$91 \mathbf{n}$ The South Trap Range of the Ke. weenawan series. Am J Sc (3) 42:417419 (1891)

92 Subdivisions of the Azoic or Archean in northern Michigan. Science 20:355 (1892) Am J Se (3) 45: 72-73 (1892)

92n The serpentines of the Coast Ranges in California. Am G 9:277-278 (1892)

92b A sketch of the geology of the iron, gold, and copper districts of Mich igan (abst). G Mag (3) 9:571-572 (1892)

93 Report of the State geologist for 1888-1889. Mich G S, Rp 1891-2; 39$44 ; \ldots$ for $1889-1890: 45-49$; ... for 1890 $1891: 51-57 ; \ldots$ for $1891-1892: 59-73$ (1893)

93a A sketch of the geology of the iron. gold, and copper districts of Michigan. Mich G S, Rp 1891-2:75-174 (1893)

94 A new classification of useful min. erals. Fng M J 58:340, 369 (1894)

96 The copper deposits of Michigan. G Mag (4) $3: 20-23$ (1896)

98 Some methods of determining the positive or negative character of mineral plates in converging polarized light with the petrographical microscope. Am G 21: 170-175 (1898)

$98 \mathrm{n}$ The origin and mode of occurrence of the Lake Superior copper deposits. Am I M Eng, Tr 27:669-696 (1898)

98b Zirkelite; a question of priority. J G 6:199-200 (1898) Am G 21:133134 (1898) Am J Sc (4) $5: 153$ (1898) Science n \& $7: 30$ (1898)

09 Crystallograpby; an elementary man. ual for the laboratory, $299 \mathrm{pp}$, Phila 1909

13 Microscopy in economic geology. Eng M J $96: 31$ (1913)

See also Crosby, 80a; Frazer, 88a ; Hague, 83

Waggaman, William Henry.

10 A review of the phosphate fields of Idaho, Utah, and Wyoming, with special reference to the thickness and quality of the deposits, U S Dp Agr, Bur Solls, B 69:48 pp, map (1910)

11 A review of the phosphate fields of Florida, U S Dp Agr, Bur Soils, B $76: 23$ pp (1911)

12 A report on the natural phosphates of Tennessee, Kentucky, and Arkansas. U S, 62d Cong 2d Sess, Sen Doc no 190:4977 (1912) U S Dp Agr, Bur Solls, B 81: 36 pp (1912)

12a The phosphate deposits of the United States. Am Fertilizer 37:34-36 (1912)

13 A report on the phosphate flelds of South Carolina. U S Dp Agr, B 18:12 pp (1913) 
Wagramsn, William Henry-Continued.

15 (and Fry, W. H.) Phosphate rock and methods proposed for its utilization as a fertilizer. U S Dp Agr, B no 312:37 pp (1915)

16 (and Cullen, J. A.) The recovery of potash from alunite. U S Dp Agr, B 415: 14 pp (1916)

Wagner, George.

98 on some turtle remains from the Fort Pierre. Kans Univ Q $7: 201-203$, il (1898)

99 On Tetracaulodon (Tetrabelodon) shepardii Cope. Kans Univ Q 8:99-103, il (1899)

03 Observations on Platygonus compressus Le Conte. J G 11:777-782, il (1903)

05 On an interesting fossil Unio from Wisconsin. Nautilus 18:97-100, il (1905) Wagner, William.

39 Description of five new fossils of the older Pliocene formation of Maryland and North Carolina. Ac N Sc Phila, J 8:5153 , il (1839)

64 Die Gold-Regionen am "Rivière Chaudiere," Unter-Canada. Ver Freunden Erdk Leipzig, Jber 3:64-68, map (1864) Wagoner, Luther.

82 The geology of the quicksilver mines of Callfornia. Eng M J 34:185-186, 334 (1882)

Wahnschafre, Felix.

92 Mittheilungen über das Glacialgebiet Nordamerikas; die Endmoränen von Wisconsin und Pennsylvanien. Deut G Ges, Zs $44: 107-122$ (1892)

Wailes, Benjamin Leonard Covington (1797-1862).

45 On the geology of Mississippi. As Am G, Pr 6:80-81 (1845)

47 On the formation of the Mississippi Blun, near Natchez (abst). Am J Agr 6 : 208-209 (1847) Am J Sc (2) $5: 249-250$ (1848)

54 Report on the agriculture and geology of Mississippi. 371 pp [Jackson, Miss.] 1854

\section{Wainewright, Wilfrid $B$.}

09 Borate deposits of California. Manchester G M Soc, Tr 31:60-66 (1909) Inst M Eng, Tr 37:156-162 (1909)

Wait, Charles E.

74 Analysis of novaculite, or Ouachita whetstone, from Hot Springs, Ark. Am $\mathrm{J} \mathrm{Sc} \mathrm{(3)} 7: 520 \quad(1374)$

so The antimony deposits of Arkansas. Am I M Eng, Tr 8:42-52 (1880)

Wnit, F. G.

09 Report of analyses of ores, nonmetallic minerals, fuels, etc., made in the chemical laboratories during the years 1906, 1907, 1908. Can Mines B: 126 pp (1909)

Waite, V. V.

18 (with Beede, J. W.) The geology of Runnels Co. Tex, Univ, B no 1816: 64 pp, map (1918)
Waitz, Paul.

06 Phénomènes postparoxysmiques du San Andrés, Michoacán. Int G Cong, X, Mexico, Guide Exc, no X: 29 pp (1906)

$06 a$ Les geysers d'Ixtlán, Maichoacán. Int G Cong, $\mathrm{X}$, Mexico, Guide Exc, no XII : 22 pp (1906)

06b Le volean de Colima. Int $\mathrm{G}$ Cong, X, Mexico, Guide Exc, no XIII: 28 pp (1906)

06e Esquisse géologique et pétrographique des environs de Hidalgo del Parral. Int $\mathbf{G}$ Cong, $\mathrm{X}$, Mexico, Guide Exc, no XXI : $21 \mathrm{pp}$, map (1906)

o6d Algunos experimentos en geyseres artificiales. Soc G Mex, B 2:71-85 (1906)

09 Principios de clasificación y comparacion de rocas macizas (ígneas). Soc G Mex, B 6: xi-xii, 17-36 (1909) Soc Cient Ant Alz, Mem 28:53-78 (1909)

10 Las rocas eruptivas de la region [de San Pedro del Gallo, Durango, México]. Méx I G, Par 3:331-334 (1910)

10a Excursión geologica al Nevado de Toluca. Soc G Mex, B 6:xxviil-xxix, 113117 (1910)

10b Excursión geológica a la Sierra de Santa Catarina, México. Soc G Mex, B $7: 1-7 \quad(1910)$

10e Observaciones geológicas acerca del pico de Orizaba. Soc $G$ ex, B $7: 67-76$ (1910)

$10 d$ El Nevado de Toluca; uno de los dos grandes volcanes de México a que ascendio Humboldt. Memoria Humboldt: 5962 (1910) Der Nerado de Toluca, einer der beiden grossen mexikanischer Vulkane, welche A. ron Humboldt erstieg. Wissenschaftlicho Festschrift Humboldt: 67-92 (1910) [not seen]

11 (and Wittich, E.) Tubos de ezplosión en el Pedregal de San Ángel. Soc G Mex, B 7:169-186 (1911)

12 Notas preliminares relativas a un reconocimiento geológico por el curso del Atoyac (Río Verde) de Oaxaca. Méx I G. Par 4: 2-32 (1912)

12a Excursión geológica a la parte poniente de la Sierra de Santa Catarina. Soc G Mex, B 8:1-8 (1912)

12b (and Hijar y Haro, L.) Algunos datos geologicos sobre la región minera de Yesca (Tepic) de los alrededores de la mina "Nueva Buenavista y Anexas." Soc G Mex, B $8: 71-96$ (1912)

15 Der gegenwärtige Stand der mexikanischen Vulkane und die letzte Eruption des Vulkans von Colima. Zs Vulkan $1: 247-274$ (1915)

15a "Absteigende Eruptionswolken" bei den Ausbrüchen des Jorullo (1759) und des Ceboruco (1870) in Mexico. Zs Vulkan 2: $76-82(1915)$ 
WaIcott, Charles Doolittle.

75 Description of a new specles of trilobite [Spherocoryphe robustus]. Cin Q J Sc $2: 273-274$, il (1875)

$75 a$ New species of trilobite from the Trenton limestone at Trenton Falls, N. Y. [Remopleurides striatulus]. Cin Q J Sc 2 : $347-349$, il (1875)

76 Descriptions of new species of fossils from the Trenton limestone. N Y St Mus, An Rp 28:93-97 [doc ed 1876] (1879)

76a Preliminary notice of the discovery of the remains of the natatory and branchial appendages of trilobites. N Y St Mus, An Rp 28:99-199, il [doc ed 1876] (1879)

76b Notes on Ceraurus pleurexanthemus Green. Lyc N H N Y, An 11:155-159 (1876)

76e Description of the interior surface of the dorsal shell of Ceraurus pleurexanthemus Green. Lyc N H N Y, An 11:159162, il (1876)

79 Notes on some sections of trilobites from the Trenton limestone. N Y St Mus, An Rp 31: 61-64, 11 (1879)

79a Note on the eggs of the trilobite. N Y St Mus, An Rp 31:66-67 (1879)

79b Descriptions of new species of fossils from the Chazy and Trenton limestones. N Y St Mus, An Rp 31:68-71 (1879)

79e Description of new species of fossils from the Calciferous formation. N $\mathrm{Y}$ St Mus, An Rp 32:129-131 (1879)

so The Permian and other Paleozoic groups of the Kanab Valley, Ariz. Am J Sc (3) 20:221-225 (1880)

81 The trilobite; new and old evidence relating to its organization. Harvard Coll, Mus C Z, B 8:191-230, il (1881)

81 a On the nature of Cyathophycus. Am J Sc (3) $22: 394-395$ (188d)

82 Description of a new genus of the order Eurypterida from the Utica slate. $\mathrm{Am} J$ Sc (3) 23:151-152, 213-216, il (1882)

83 The Utica slate and related formations of the same geological horizon. Albany Inst, $\operatorname{Tr} 10: 1-17$ (1883)

$83 a$ Fossils of the Utica slate. Albany Inst, $\operatorname{Tr} 10: 18-38$, il (1883)

83b Injury sustained by the eye of a trilobite at the time of the moulting of the shell. Am J Sc (3) 26:302 (1883)

83e Pre-Carboniferous strata in the Grand Canyon of the Colorado, Ariz. Am J Sc (3) $26: 437-442,484$ (1883)

83d [Investigations in] the Champlain Valley. Science 2:633-634 (1883)

83e Correlation of Cambrian rocks. Science 2 : 801-802 (1883)

831 Freshwater shells from the Paleozolc rocks of Nevada. Science $2: 808,11$ (1883)
Walcott, Charles Doolittle-Continued.

84 Paleontology of the Eureka district, Nev. U S G S, Mon 8: xili, 298 pp, I (1884)

$84 a$ On the Cambrian faunas of North America. U S G S, B 10:72 pp, il (1884)

84b Descriptions of new species of fos. sils from the Trenton group of New York, N Y St Mus, An Rp $35: 207-214$, il (1884)

84c Note on Paleozoic rocks of central Texas. Am J Sc (3) 28:431-433 (1884) 84d Potsdam fauna at Saratoga, N. I. Science $3: 136-137$ (1884)

84e Appendages of the trilobite. Sc. ence $3: 279-281$, il (1884)

84f The Cambrian system in the United States and Canada (abst). Ph Soc Wash, B $6: 98-102$ (1884)

85 Paleontologic notes [St. John fauns, N. B.]. $A m$ J Sc (3) 29:114-117, il (1885)

$85 a$ New genus of Cambrian trilobites, Mesonacis. Am J Sc (3) $29: 328-330$, il (1885)

85b Note on some Paleozoic pteropods. Am J Sc (3) $30: 17-21$, il (1885)

85e Deer Creek coal fleld, White Mous. tain Indian Reservation, Ariz. U S, 48th Cong 2 d sess, S Ex Doc $20: 2-7$ (1885)

86 ... Cambrian faunas of North Ames. ica. U S G S, B 30: $369 \mathrm{pp}$, Il (1886)

s6a Classification of the Cambrian system of North America. Am J Sc (3) 32: $138-157$ (1886)

87 The Taconic system. Am J Sc (3) 33: 153-154 (1887)

87 Note on the genus Archeocyathus of Billings. Am J Sc (3) 34:145-146 (1887)

87b Fauna of the "Upper Taconic" of Emmons, in Washington Co., N Y. Am J Sc (3) 34:187-199, il (1887)

87e Cambrian age of the roofing slates of Granville, Washington Co., N. Y. (abst). Am As, Pr 35:220-221 (1887)

s8 The Taconic system of Emmons, and the use of the name Taconic in geologic nomenclature. Am J Sc (3) $35: 229-242$, $307-327,394-401$, map, Il (1888)

88a Cambrian fossils from Mt. Stephens [B. C.]. Am J Sc (3) 36:161-166 (1888)

88b Section of lower Silurian (Ordovician) and Cambrian strata in central New York, as shown by a deep well near Utica (abst). Am As, Pr 36:211-212 (1888)

88e Discovery of fossils in the lower Taconic of Emmons $(a b s t)$. Am As, $\mathrm{Pr}$ $36: 212-213$ (1888)

89 Description of new genera and species of fossils from the Middle Cambrian. U 8 Nat Mus, Pr 11:441-446, 11 (1889)

89a A simple method of measuring the thickness of inclined strata. U S Nat Mus, Pr 11: 447-448 (1889) 
Walcott, Charles Doolittle-Continued.

89b A fossil Lingula preserving the cast of the peduncle. U S Nat Mus, Pr $11: 480$, il (1889)

89e Stratigraphic position of the Olenellus fauna in North America and Europe. Am J Sc (3) $37: 374-392 ; 38: 29-42$ (1889)

90 The fauna of the Lower Cambrian or olenellus zone. U S G S, in Rp 10, pt 1: $509-760$, il (1890)

$90 a$ Study of a line of displacement in the Grand Canyon of the Colorado, in northern Arizona. G Soc Am, B 1:49-64 (1890)

$90 \mathbf{b}$ The value of the term "Hudson River group" in geologic nomenclature (with discussion by W. M. Davis). G Sec Am, B 1: 335-355 (1890) Abst, Am G 5 : 120 (1890)

90e Descriptive notes of new genera and species from the Lower Cambrian or Olenellus zone of North America. U S Nat Mus, Pr $12: 33-46$ (1890)

90d Description of a new genus and species of Inarticulate brachiopod from the Trenton limestone [Conotreta rusti]. U S Nat Mus, Pr 12:365-366, il (1890)

90e Description of new forms of Upper Cambrian fossils. U S Nat Mus, Pr 13: $267-279$, il $(1890)$

901 ... notes on the "Quebec group." Am J Sc (3) 39:101-115 (1890)

91 Correlation papers; Cambrian. U S G S, B $81: 447 \mathrm{pp}$, maps (1891)

91a The North American continent during Cambrian time. U S G S, An Rp 12 pt $1: 523-568$, maps (1891)

$91 \mathrm{~b}$ Discussion on the geolegical structure of the Selkirk Range [B. C.]. G Soc Am, B 2:611 (1891)

91e La succession stratigraphique des faunes cambriennes dans l'Amérique du Nord. Int G Cong, IV, London 1888, C R : 223-225 (1891)

91d Auffindung von Fischresten in Untersilur. N Jb 1891, I : 284-285

92 Systematic list of fossils found at Eureka, Nev. U S G S, Mon 20:319-333 (1892)

92a Preliminary notes on the discovery of a vertebrate fauna in Silurian (Ordovician) strata [Colorado]. G Soc Am, B $3: 153-172$, il (1892)

92b Notes on the Cambrian rocks of Virginia and the southern Appalachians. Am J Sc (3) 44:52-57 (1892)

92c Notes on the Cambrian rocks of Pennsylvania and Maryland, from the Susquehanna to the Potomac. Am J Sc (3) $44: 469-482$ (1892)

92d Note on Lower Cambrian fossils from Cohasset, Mass. Blol Soc Wash, Pr $7: 155$ (1892)
Walcott, Charles Doolittle-Continued.

93 Geologic time, as indicated by the sedimentary rocks of North America. J G 1:639-676, map (1893). Am G 12:343368, map (1893) Am As, Pr 42:129-169, map (1894) Smiths Inst, An $\mathrm{Rp} 1893$ : 301-334 (1894) Abst, Science 22:104 (1893)

93a The natural bridge of Virginia. Nat Geog Mag 5: 59-62 (1893)

$\mathbf{9 3 b}$ The geologist at Blue Mountain, Md. Nat Geog Mag 5:84-88 (1893)

93e [Correlation of clastic rocks, with particular reference to the Cambrian.] Int $\mathrm{G}$ Cong, $\mathrm{V}$, Washington 1891, $\mathrm{C} \mathrm{R}$ : 168-170 (1893)

94 Pre-Cambrian igneous rocks of the Unkar terrane, Grand Canyon of the Colorado, Ariz.; with notes on the petrographic eharacter of the lavas, by J. P. Iddings. U S G S, An Rp 14 pt 2:497-524, map (1894)

94a Paleozoic intraformational conglomerates. G Soc $\Delta \mathrm{m}, \mathrm{B} 5: 191-198$ (1894) Abst, Am G 13:147 (1894)

$94 \mathrm{~b}$ Note on some appendages of the trilobites. Biol Soc Wash, Pr 9:89-97, il (1894) G Mag (4) $1: 246-251$, il (1894)

94e Discovery of the genus Oldhamia in America. U $\mathbf{S}$ Nat Mus, Pr $17: 313-315$, il (1894)

$94 d$ Notes on the Cambrian rocks of Pennsylvania frem the Susquehanna to the Delaware. Am J Sc (3) $47: 37-41$ (1894)

94e On the occurrence of Olenellus in the Green Pond Mountain series of northern New Jersey, with a note on the conglomerates. Am J Sc (3) $47: 309-311$ (1894)

95 The United States Geological Survey (presidential address before Geological Society of Washington). Pop Sc Mo 46: 479-498 (1895) Also published by the G Soc Washington, March 1895

95a Algonkian rocks of the Grand Canyon of the Colorado. J G $3: 312-330$, map (1895)

95b Lower Cambrian rocks in eastern California. Am J Sc (3) 49:141-144 (1895)

95e The Appalachian type of folding in the White Mountain Range of Inyo Co., Cal. Am J Sc (3) 49:169-174 (1895) Abst, Science n 8 1:58 (1895)

96 Report of the Director for the fiscal year ending June 30,1895 . U S G S, An Rp 16 pt $1: 1-130$ (1896) $\quad \ldots \quad 1896 ; 17$ pt $1: 1-200$ (1896) ... 1897; 18 pt 1 : 11-130 (1897) ... 1898; 19 pt $1: 11-143$ (1898) $\ldots 1899 ; 20$ pt $1: 11-209$ (1899) ... 1900; 21 pt 1:11-204 (1900) ... 1901; 22 pt 1:11-207 (1901) (See also 02)

96a The Cambrian rocks of Pennsylvania. U S G S, B 134:43 pp, map (1896) 
Walcott, Charles Doolittle-Continued. 96b Fossil jellyfishes from the Middle Cambrian terrane. U S Nat Mus, Pr 18: $611-614$, il (1896)

97 The post-Pleistocene elevation of the Inyo Range, and the lake beds of Waucobi embayment, Inyo County, Cal. J G 5 : 340-348, map (1897)

97a Cambrian Brachiopoda; genera Iphidea and Yorkia with descriptions of new species of each, and of the genus Acrothele. U S Nat Mus, Pr 19:707718 , il (1897)

$\mathbf{9 7 b}$ Note on the genus Lingulepis. Am J Se (4) 3:404-405 (1897)

98 Fossil Medusae. U S G S, Mon 30 : $201 \mathrm{pp}$, il (1898)

98a Cambrian Brachiepoda; Obolus and Lingulella, with description of new species. U S Nat Mus, Pr 21: $385-420$ (1898)

98b Note on the brachiopod fauna of the quartzite pebbles of the Carboniferous conglomerates of the Narragansett Basin, R. I. Am J Sc (4) $6: 327-328$ (1898)

99 Cambrian fossils [of Yellowstone National Park]. U S G S, Mon 32 pt 2:440478, il (1899)

99a Pre-Cambrian fossiliferous formations. G Soc Am, B $10: 199-244$, il (1899) Abst, Science n s 9:143 (1899)

oo Random, a pre-Cambrian upper Algonkian terrane. G Soc Am, B 11:3-5 (1900)

OOa Lower Cambrian terrane in the Atlantic province. Wash Ac Sc, Pr 1:301$399(1900)$

Oob Correspondence relating to collecfions of vertebrate fossils made by the late Professor O. C. Marsh. Science n s 11: 21-24 (1900)

o0e The Cambrian formation in the Atlantic province $(a b s t)$. Science $\mathrm{n}$ s 11: 104 (1900)

01 Cambrian Brachlopoda: Obolella, subgenus Glyptias; Bicia; Obolus, subgenus Westonia; with descriptions of new specles. U S Nat Mus, Pr 23:669-695 (1901)

01 a The work of the United States Geological Survey in relation to the mineral resources of the United States. Am I M Eng, Tr 30:3-26, map (1901)

01b Sur les formations pré-cambriennes fossiliferes. Int G Cong, VIII, Paris 1900, C R : 299-312 (1901)

02 Twenty-third annual report of the Director of the United States Geological Survey, 1901-2: 217 pp (1902) Twentyfourth ... 1902-3:302 pp (1903) Twentyfifth ... 1903-4:388 pp (1904) Twentysixth ... 1904-5:322 pp (1905) Twentyseventh ... 1905-6:104 pp, maps (1906)

02a Outlook of the geologist in America. G Soc Am, B 13: 99-118 (1902)

02b Cambrian Brachiopoda; Acrotreta, Linnarssonella, Obolus, with descriptions of new species. U S Nat Mus, Pr 25:577612 (1902)
Walcott, Charles Doolittle-Continued.

o3 New term for the Upper Cambrian series [Saratogian]. J G 11:318-318 (1903)

O3a (and others) John Wesley Porr ell... Wash Ac Sc, Pr 5:99-130, port (1903)

o5 Cambrian Brachiopoda with descrip. tions of new genera and species. U S Nat Mus, Pr 28:227-337 (1905)

06 Algonkian formations of northwest. ern Montana. G Soc Am, B $17: 1-29$ (1906)

o7 Louis Agassiz. Smiths Mise Col 50 ( $Q$ Is 4) : 216-218, port (1907)

os Mount Stephen rocks and fossils Can Alpine J 1: 232-248 (1908)

osa Cambrian geology and paleontol. ogy ; No. 1, Nomenclature of some Cambrian Cordilleran formations; No. 2, Cam. brian trilobites; No. 3 , Cambrian Brachiopoda, deseriptions of new genera and spe. eies; No. 1, Classification and terminology of the Cambrian Brachiopoda; No. 5, Cam. brian sections of the Cordilleran area: No. 6, Olenellus and other genera of the Mesonacidae; No. 7, Pre-Cambrian rocks of the Bow River valley, Alberta, Canads. Smiths Misc Col 53:1-431, il, map (1908-10)

09 Evolution of early Paleozoic faunas in relation to their environment. J G 17 : 193-202 (1909)

10 Cambrian geology and paleontology. II ; Abrupt appearance of the Cambrian fauna on the North American continent; No. 2, Middle Cambrian Merostomata; No. 3 , Middle Cambrian holothurians and Medusae; No. 4, Cambrian faunas of China; No. 5, Middle. Cambrian annelids: No, 6, Middle Cambrian Branchiopoda, Malacost. raca, Trilobita, and Merestomata; No. 7 . Cambro-Ordovician boundary in British Columbia, with description of fossils; No. 8, The Sardinian Cambrian genus Olenopsis in America; No. 9, New York Potsdam. Hoyt fauna; No. 10, Group terms for the Lower and Upper Cambrian series of formations; No. 11, New Lower Cambrian subfauna; No. 12, Cambrian formations of the Robson Peak district, British Columbia and Alberta, Canada; No. 13, Dikelocephalus and other genera of the Dikelocephalinae. Smiths Misc Col 13:1498, 1l, map (1910-14) Abst, of Nos. 11, 12 , and 13 by E. Kirk, Wash Ac Sc, J 4: 371-373 (1914)

11 A geologist's paradise [Field, B. C., region]. Nat Geog Mag 22:509-521 (1911)

11 a Special problems and their study in economic geology (discussion). Ec G 6: 71-72 (1911)

12 Cambrian Brachiopoda. U S G S, Mon 51: 872, $363 \mathrm{pp}$, il (1912) 
Waleott, Charles Doolittle-Continued.

12a Notes on fossils from limestone of Steeprock series, Ontario, Canada. Can G 8, Mem 28:16-22, il (1912) Abst, Science n s $35: 315$ (1912) ; (with discussion by A. P. Coleman), G Soc Am, B 23 : $723(1912)$

12b Cambrian of the Kicking Horse Val ley, B. C. Can G S, Sum Rp 1911:188191 (1912)

12e Inlustrations of remarkable Cambrian fossils from British Columbia ( $a b s t$ ). Science n \& $35: 789$ (1912)

13 The monarch of the Canadian Rockies; the Robson Peak district of BritIsh Columbia and Alberta. Nat Geog Mag 24:626-639 (1913)

13n Cambrian fossils from British Columbia (abst). Science n s 37:724-725 (1913)

14 Cambrian geology and paleontology, III ; No. 1, The Cambrian faunas of eastern Asia; No. 2, Pre-Cambrian Algonkian algal flora; No. 3, Cambrian trilobites; No. 4, Relations between the Cambrian and pre-Cambrian formations in the vicinity of Helena, Mont. ; No. 5, Cambrian trilobites. Smiths Mise Col 64:570 pp, fl $(1914-6)$ Abst, of No. 1, by E. Kirk, Wash Ac Sc, J $4: 423$ (1914); of No. 3, by G. R. B., 6: 501-502 (1916)

14a Is "Atikokania lavsoni" a concre. tion? Nature 94:478 (1914)

15 The Cambrian and its problems in the Cordilleran region. In Problems of American geology : 162-233, 11, New Haven 1915

15a Discovery of Algonkian bacteria. Nat Ac Sc, Pr 1:256-257, il (1915)

15b Pre-Paleozoic algal deposits (abst). Science n \& 41:879 (1915) Wash Ac Sc, J $5: 649$ (1915)

16 Evidences of primitive life. Smiths Inst, An Rp 1915: 235-255, il (1916)

16a Cambrian trilobites. Nat Ac Sc, Pr 2: 101 (1916)

17 Cambrian geology and paleontology, IV ; No. 1, Nomenclature of some Cambrian Cordilleran formations; No. 2, The Albertella fauna in Britisn Columbia and Montana; No. 3, Fauna of the Mount Whyte formation: No. 4, Appendages of trilobites. Smiths Misc Col 67 , no $1: 8$ pp; no $2: 59$ pp, il ; no $3: 61-114$, 11; no $4: 115-216$, il (1917-8) Abst, of no 3 , by G. R. B., Wash Ac Sc, J $7: 565-566$ (1917)

17 a Searching for a doubtful geological zone in the Canadian Rockies [Mount Whyte formation] (abst). Science n s 45: 355 (1917)

See also $A \mathrm{mi}, 91$; Braineru, 90 ; Eastman, 00; Emmons (S F), 93 ; Frazer, 88a ; Geiger, 91; Gilbert, 93b; Hayes, 91; Hill (R T), 91 ; McGee, 90 ; Powell, 84, 85, 85a, $88,89,89 \mathrm{a}, 90,91,91 \mathrm{a}, 92,93,95$; Spencer (J W), 93a ; Williams (H S), 90; Winchell (N H), 88g; Anon, 12h
Waldbanr, Harry.

15 Bemerkungen über Stufenlandschaften. Am Geog Soc, Memorial Volume of Transcontinental Excursion of 1912: 8597 (1915)

Waldo, C. A.

90 The petroleum belt of Terre Haute [Ind.] (abst). Am As, Pr 38:250 (1890)

03 Dikes in the Oklahoma Panhandle (abst). Science n s 17:220 (1903) Eng M J $75: 153$ (1903)

walker, A. E.

91 Stromatoporidae. Hamilton As, J Pr pt $7: 122-126$ (1891)

95 Hamilton [Ont.] sponges. Hamilton As, J Pr 11: 85-87, il (1895)

96 Description of the railway cutting. Hamilton As, J Pr 12:147-150 (1896)

97 Memo. of the cutting on the spur line where it crosses Main Street west [Hamilton, Ont.]. Hamilton As, J Pr 13: 44-45 (1897)

Walker, B. E.

oo Canadian surveys and museums. Can Inst, Pr n s 2: 75-89 (1900)

o1 List of the published writings of Elkanah Billings... Can Rec Sc 8:366398 (1901)

Walker, Bryant.

$\mathbf{0 3}$ On the shells of marls: Mich $\mathbf{G} \mathbf{S}$. 8 pt $3: 97-102$ (1903)

13 The Unione fauna of the Great Lakes [preglacial distribution]. Nautilus 27: $18-23,29-34,40-47,56-59,11$ (1913)

Walker, Francis A.

95 Memoir of William Barton Rogers, 1804-1882. Nat Ac Sc, Biog Mem 3:3-13 (1895)

walker, George Thompson.

15 Petroleum, its history, occurrence, production, uses, and tests. $46 \mathrm{pp}$, Minneapolis 1915

Walker, John A.

83 Graphite. U S G S, Min Res [1882] : 590-594 (1883)

Walker, Joseph B.

89 Notes on the geology of Burnet Co. [Tex.] G Sc B 1 no 10 (1889)

91 [The iron ore district of east Texas ; description of counties.] Tex G S, An Rp 2: 225-302 (1891)

Walker, S. T.

84 On the origin of the fossll bones dis. covered in the vicinity of Tise's Ford, Fla. U S Nat Mus, Pr 6:427-429 (1884)

Walker, Thomas Leonard.

94 Notes on nickeliferous pyrite from Murray mine, Sudbury, Ont. Am $J$ Sc (3) $47: 312-314$ (1894)

95 Diabase dikes in the Sudbury region [Ont.]. Can M Rv 14: 25-26, 43-44 (1895)

96 Notes on sperrylite [Algoma, Ont.]. Am J Sc (4) $1: 110-112$ (1896)

97 Geological and petrographical studies of the Sudbury nickel district, Canada. G Soc London, Q J 53:40-66, map (1897) Abst, G Mag (4) 3:564-565 (1896) 
Walker, Thomas Leonard-Continued.

98 Causes of variation in the composition of igneous rocks. Am J Sc (4) 6 : $410-415$ (1898)

99 The crystal symmetry of the minerals of the mica group. Am J Sc (4) 7 : 199-204 (1899)

o5 The Geological Survey of Canada as an educational institution (with discussion). Can M Inst, J $7: 435-449$ (1905) Can M Rv 23: 137-138 (1904)

06 [Report on] the Muskoka district. Can G S, Sum Rp 1905: 84-86 (1906)

08 The occurrence of tungsten ores in Canada. Can M Inst, J 11:367-371 (1908) Can M J 29:302-303 (1908) Abst, M World $30: 747$ (1909)

08a A review of the minerals tungstite and meymacite. Am J Sc (4) $25: 305-308$ (1908)

09 Report on the -tungsten ores of Canada. Can Mines Br: 56 pp (1909)

11 Report on the molybdenum ores of Canada. Can Mines Br: 64 pp (1911)

$11 a$ On the molybdenum ores of Ontario and British Columbia. Can Mines Br, Sum Rp 1910:65-66 (1911)

$11 b$ Recently discovered wolframite deposits in New Brunswick. Ec G $6: 396-$ 398 (1911)

13 The pre-Cambrian of Parry Island and vicinity. Int $G$ Cong, XII, Canada, Guide Book no 5:98-100, map (1913)

14 Crystallography; an outline of the geometrical properties of crystals. 204 pp New York 1914

14a Temiskamite, a new nickel arsenide from Ontario. Am J Sc (4) $37: 170-172$ (1914) Abst, G Soc Am, B 25: 76 (1914)

15 Certain mineral occurrences in the Worthington mine, Sudbury, Ont., and their significance. Ec G 10:536-542, map (1915)

15a Minerals from Baffin Land. Ottawa Nat $29: 63-66$ (1915)

16 Hopeite from H. B. mine, Salmo, B. C. Wash Ac Sc, J 6:685-688 (1916)

16a Spencerite, a new zinc phosphate from British Columbia. Miner Mag 18: 76 (1916) Abst, G Mag (6) $3: 336$ (1916)

17 The crystal form of spencerite. Wash Ac Sc, J $7: 456-459$ (1917)

18 Mineralogy of the H. B. mine, Salmo, B. C. Toronto, Univ, Studies g s no 10 : 25 pp (1918)

18a (with Ledoux, A.) Cerusite from Salmo, B. C. Ottawa Nat $32: 7-8$ (1918) Wall, G. P.

57 (and Sawkins, J. G.) ... survey of the economic geology of Trinidad. Smiths Inst, An Rp 1856:281-288 (1857)

60 (and Sawkins, J. G.) Report on the geology of Trinidad; or, Part I. of the West Indian Survey. [Great Britain], G s, Mem. 211 pp, map, L 1860
Wall, G. P.-Continued.

$60 a$ On the geology of a part of Vene. zuela and of Trinidad. G Soc London, Q J $16: 460-470$, map (1860)

65 (with Dunern, P. M.) A notice of the geology of Jamaica, especially with reference to the district of Clarendon; with descriptions of the Cretaceous, Eocene, and Miocene corals of the islands. G Soc London, Q J $21: 1-15$, il, map (1865)

12 [Observations on the geology of the West Indies.] $\mathbf{A g}$ Soc Trinidad and To. bago, Pr $12: 207-208$ (1912)

See also Sawkins, 69

Wall, J. Sutton.

84 Report on the coal mines of the Monongahela River region ... Pa G S, 2d, K4 : xxxvili, 231 pp, maps (1884)

Wallace, Alfred Russel (1823-1913).

94 The lce age and its work. Smiths Inst, An Rp 1893: 277-300 (1894) Pop Sc Mo 44: 681-689, 781-791; 45:40-50, 244258 (1894)

Wallace, Charles Montrion.

76 On flint implements from the stratified drift of the vicinity of Richmond, Va. Am J Sc (3) 11: 195-199 (1876)

Wallace, E. C.

01 (with Richardson, Clifford) Pe troleum from the Beaumont, Texas, field. Soc Chem Ind, J 20:690-693 (1901)

Wallace, H. Vincent.

11 Deposits of manganese in Lower California. M World 35:103-104 (1911)

11a Toyah oil fields of Reeves Co., Tex. M World 35:153-154 (1911)

$11 b$ Manganese in Lower Callfornia. M Sc Press 103: 201-202 (1911)

11e Oil fields of the trans-Pecos region in Texas. M Sc Press 103:260-262 (1911)

16 Informe sobre los depósitos de man. ganeso cerca del pueblo de Mulege, Baja California. Bol Minero 1: 209-212 (1916) Wallace, J. P.

00 Horses and breccia. M Sc Press 80 : 608 (1900)

08 A study of ore deposits for the practical miner, with descriptions of ore minerals, rock minerals, and rocks. 349 pp, N Y 1908

Wallace, Robert Charles.

13 Pseudobrecciation in Ordovician limestones in Manitoba. J G 21:402-421 (1913)

13a A physico-chemical contribution to the study of dolomitization. Int G Cong, XII, 1913, C R: 875-884 (1914) Advance copy 1913

13b The Rice Lake gold district of Manttoba. Can M Inst, Tr 16:538-544 (1913)

14 A contribution to the : 1 dy of dolomitization. R Soc Can, $\operatorname{Pr} \mathrm{mr}$ (3) 7 , iv : 139-149 (1914)

$14 a$ Gypsum and anhydrite in genetic relationship. G Mag (6) 1:271-276 (1914) 
Wallace, Robert Charles-Continued.

14b (with MacLean, A.) Gypsum and salt in Manitoba. Can G S, Sum Rp 1913 165-169 (1914)

15 Gypsum and brines in Manitoba. Can G S, Sum Rp 1914: 73-80 (1915)

16 (and DeLnry, J. S.) The mineral belt north of The Pas, northwestern Manitoba and eastern Saskatchewan. Can M Inst, B 54: 884-890 (1916)

17 (and De Lury, J. S.) The mineral belt north of The Pas [Manitoba]. In Northern Manitoba, issued by the Province of Manitoba : 19-22 (1917)

17 a Area between Red River and eastern boundary of Manitoba, and between Winnipeg River and National Transcontinental Railway, Mamitoba. Can G S, Sum Rp 1916: 175-178 (1917)

17b The corrosive action of certain brines in Manitoba. J G 25:459-466 (1917) Abst, Brit As, Rp 85:427 (1916) ; G Mag (6) 3:31-32 (1916)

18 The origin of the gold deposits in the Canadian pre-Cambrian. Can M Inst, B

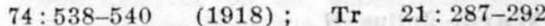
[1919]

Wallace, Samuel Jacob.

69 On the old lake beds of the prairle region. Am As, Pr $17: 342-344$ (1869)

71 Lakes and lake regions. $\mathbf{A m ~} \mathbf{A s}, \mathrm{Pr}$ $19: 182-185$ (1871)

78 On the "geodes" of the Keokuk formation and the genus Biopalla, with some species. Am J Sc (3) $15: 366-370$ (1878)

78 a ... fossil wood from the Keokuk formation, Keokuk, Iowa. Am J Sc (3) $15: 396 \quad(1878)$

80 Geological notes on the region of Silver Cliff, Colo. Kansas City Rv Sc 4: 205-206 (1880)

81 Mountain elevation and changes of tmperature in geology. Science (ed, Michels) 2: 206 (1881)

84 Heat and cold in geology. Am Nat $18: 528$ (1884)

Wallbridge, T. C.

69 On the geology and mineralogy of the County of Hastings, Canada West. G Soc London, Q J 25: 261-271 (1869)

Waller, E.

92 (and Moses, A. J.) A probably new nickel arsenide [Grant Co., N. Mex.]. Sch Mines Q 14:49-51 (1892)

Walling, Henry Francis,

79 The relation of adhesion to horizontal pressure in mountain dynamies. Am As, Pr $27: 179-190$ (1879)

$79 a$ Some indications of recent sensitiveness to unequal pressures in the earth's crust. Am As, Pr $27: 190-197$, map (1879)

83 On the origin of foint cracks (abst). Am As, Pr 31: 417-418 (1883)

84 Topographical indications of a fault near Harper's Ferry. Ph Soc Wash, B 6 : 30-32 (1884)
Wallis, Benjamin Franklin.

15 The geology and economic value of the Wapanucka limestone of Oklahoma. Okla G S, B no $23: 102$ pp, maps (1915)

Walsh, George E.

o7 Prospecting for rare metals and earths. M Sc Press 94 : 218-219 (1907)

Walter, E. W.

85 (with Bailey, E. H. S.) The new artesian well at Fort Scott, Kansas. Kansas City Rev Sc 8:485-487 (1885)

Walter, Emma.

95 Does the Delaware Water Gap consist of two river gorges? Ac N Sc Phila, Pr 1895: 198-205

Walter, Otto.

17 Notes on a decapod crustacean from the Kinderhook shale at Burlington [Iowa]. Iowa Ac Sc, Pr 24:119-124, il (1917)

Walters, Edwin.

91 Mammoth Sigillaria [southern Kansas]. Kansas City Seientist 5:140-142 (1891)

Walther, Johannes.

92 Die Nordamerikanischen Wüsten. Ges Erdk Berlin, Verh 19:52-65 (1892) Transl by Robert Stein, The North American deserts. Nat Geog Mag 4:163-176 (1893)

92a A comparison of the deserts of North America with those of north Africa and northern India. Science 19:158 (1892)

Wang, Yinchang Tsenshan.

15 The formation of oxidized ores of zinc from the sulphide. Am I M Eng, B 105: 1959-2012 (1915); Tr 52:657-710 (1916)

Wankowski, V.

01 The Alamo district, Lower California, Mexico. Mines and Minerals 21:507. (1901)

\section{Wanner, Atreus.}

89 The discovery of fossil tracks, algae, etc., in the Triassic of York Co., Pa. Pa G S, An Rp 1887:21-35, il (1889) Abst, Am As, Pr 37:106 (1889)

90 Casts of Scolithus flattened by pressure. Am G 5:35-38, il (1890)

92 Fossil tracks in the Trias of York Co., Pa. (abst). Am As, Pr 40:286 (1892)

oo (and Fontaine, w. M.) Triassic flora of York Co., Pa. U S G S, An Rp 20 pt $2: 233-255$, il $(1900)$

01 A new species of Olenellus from the Lower Cambrian of York Co., Pa. Wash Ac Sc, Pr 3:267-272, il (1901)

Ward, Freeman.

09 On the Lighthouse granite near New Haven, Conn. Am J Sc (4) 28:131-142, map (1909)

09a (with Ford, W. E.) Calamine crystals from the Organ Mountains, Dona Ana Co., N. Mex. Am J Sc (4) 28:185186 (1909) 
Ward, Freeman-Continued.

14 The "dam" at Cheshire, Conn. Am J Sc (4) 37: 155-156 (1914)

16 The scope, methods, and plans of the State survey. S Dak G S, B $7: 24$ pp (1916)

18 Biennial report of the State geologist, 1916-18. S Dak G S, B 8:179-189 (1918)

18a The possibilities of oil and gas in Harding Co. S Dak $\mathrm{G}$ S, Circ 4:8 pp (1918)

Ward, Henry Augustus (1834-1906)

66 Catalogue of casts of fossils, from the principal museums of Europe and America, with short descriptions and illustrations. $228 \mathrm{pp}$, il, Rochester, N Y., 1866

70 Catalogue of the college series of casts of fossils... 136 pp, il, Rochester, N. Y., 1870

70a Catalogue of the academy series of casts of fossils... 80 pp, il, Rochseter, N. Y., 1870

95 Preliminary notice of the Plymouth meteorite [Marshall Co,, Ind.]. Am J Sc (3) $49: 53-55 \quad(1895)$

oo The Ward-Coonley collection of meteorites. iv, $100 \mathrm{pp}$, Chicago $1900 \quad[2 \mathrm{~d}$ ed], $28 \mathrm{pp}$, Chicago 1901 Catalogue of the Ward-Coonley collection of meteorites. xii, 113 pp, Chicago 1904

01 The Ste. Genevieve meteorite [Mo.]. Rochester Ac Sc, Pr 4:65-66 (1901)

02 On Bacubirito, or the great meteorite of Sinaloa, Mex. Am G 30:203-211 (1902) Rochester Ac Sc, Pr 4:67-74 (1902) Science n s 16:395-398 (1902)

02a Description of four meteorites [Andover, Me.; Cuernavaca, Mex. ; Arispe, Mex.; Bald Eagle, Pa.l. Rochester Ac Sc, Pr 4: 79-88 (1902)

03 The Bath Furnace meteorite [Bath Co., Ky.]. Am J Sc (4) 15:316-319 (1903)

03a The Andover [Me.] meteorite. Am J Sc (4) $15: 395-396$ (1903)

04 The Canyon City meteorite from Trinity Co., Cal. Am J Se (4) 17:383384 (1904)

O4a Willamette meteorite [Clackamas Co., Oreg.]. Rochester Ac Sc, Pr 4: 137148 (1904)

04b Great meteorite collections and their composition. Rochester Ac Sc, $\operatorname{Pr} 4$ : 149-164 (1904)

o5 The Billings meteorite; a new iron meteorite from southern Missouri. Am $J$ Sc (4) $19: 240-242(1905)$

05a Notes on the Bath Furnace aerolite [Bath Co., Ky.]. Rochester Ac Sc, Pr 4:193-202 (1905)

\section{Wara \& Howell.}

78 Catalogue of geology and lithology. 42 pp, Rochester 1878

$78 a$ Catalogue of minerals $48 \mathrm{pp}$, Rochester, N. Y., 1878

78b Catalogue of rocks of the New York system, 44 pp, Rochester, N. Y., 1878
Ward \& Howell-Continued.

7Se College collection of minerals, 39 pp, Rochester, N. Y., 1878

78d College collection of rocks. $24 \mathrm{pp}$, Rochester, N. Y., 1878

s8 A new meteorite from Texas [La Grange]. Science 11:55 (1888)

88a Fayette County [Tex.] meteorite, Science 11: 266 (1888)

Ward, Henry Baldwin.

06 (with Barbour, E. H.) Preliminary report on the primitive man of Nebraska, Nebr G S 2:317-327 (1906)

Ward, Henry L.

99 A new Kansas meteorite. Am J Sc (4) $7: 233 \quad$ (1899)

99 Notice of a new meteorite from Murphy, Cherokee Co., N. C. Am J Sc (4) $8: 225-226$ (1899)

$99 \mathrm{~b}$ Notice of an aerolite that recently fell at Allegan, Mich. Am J Sc (4) 8: 412-414 (1899)

$17 \Delta$ new meteorite [Colby, Clark Co., Wis.]. Science n 8 46:262-263 (1917)

wara, Julius H.

66 Life and letters of James Gates Percival. 579 pp, Boston 1866 [not seen]

Ward, Lester Frank (1841-1913).

82 On the cause of the absence of trees on the Great Plains. Kansas City Rv Sc 5: 697-702 (1882)

83 Plant life, past and present. Science $1: 358-359$ (1883) Glimpses of the cos$\operatorname{mos} 3: 130-133$ (1913)

84 On Mesozoic dicotyledons. Am J Se (3) $27: 292-303$ (1884) Glimpses of the cosmos $3: 306-322$ (1913)

84a The fossil flora of the globe. Bot Gaz $9: 169-174$ (1884) Glimpses of the cosmos $3: 378-385$ (1913)

$\mathbf{8 4 b}$ The upper Missouri River system. Pop Sc Mo 25:594-605 (1884) Glimpses of the cosmos $3: 341-350$ (1913)

84c Caulinites and Zamiostrobus. Science $3: 532-533$ (1884) Glimpses of the cosmos $3: 331-332$ (1913)

85 Sketch of paleobotany. U S G S, An Rp 5:357-452 (1885)

$85 a$ Synopsis of the flora of the Laramie group. U S G S, An Rp 6:399-557, il (1885)

85b Evolution in the $\mathbf{v} \epsilon$ etable kingdom. Am Nat 19:637-644, i45-753 (1885)

85e A glance at the history of our knowledge of fossil plants. Science 5 : 93-95 (1885) Glimpses of the cosmos 3: 389-394 (1913)

85d The ginkgo tree. Science 5:495497 , il (1885) Glimpses of the cosmos $3: 421-426$, il (1913)

85e Historical view of the fossil flora of the globe (abst). Am As, Pr 33:493495 (1885) Glimpses of the cosmos 3: $427-429$ (1913) 
Ward, Lester Frank-Continued.

$\mathbf{8 5 p}$ Geological view of the fossil flora of the globe (abst). Am As, Pr 33:495496 (1885) Glimpses of the cosmos 3 : $430-431$ (1913)

$85 \mathrm{~g}$ Botanical view of the fossil flora of the globe (abst). Am As, $\mathrm{Pr} 33: 496-$ 497 (1885) Glimpses of the cosmos 3: $432-433$ (1913)

86 On the determination of fossil djcotyledonous leaves. Am $\mathrm{J} \mathrm{Sc}$ (3) 31 : $370-375 \quad(1886)$

87 Types of the Laramie flora. U S G S, B $37: 117 \mathrm{pp}$, il (1887)

s8 Evidence of the fossil plants as to the age of the Potomac formation. Am J Se (3) $36: 119-131$ (1888)

88a The paleontologic history of the genus Platanus. U $\mathrm{S}$ Nat Mus, $\mathrm{Pr} 11$ : 39-42, il (1888) Abst, Am As, Pr 37: 201-202 (1889)

s9 The geographical distribution of fossil plants. U S G S, An Rp 8:663-960, map (1889)

89a Remarks on an undescribed vegetable organism from the Fort Union group of Montana (abst.) Am As, Pr 37: 199-201 (1889) [Named Xantholithes propheticus in] Glimpses of the cosmos $4: 149-152$ (1915)

90 The age of the Laramie. G Soc Am, B 1:529-532 (1890) Am Nat 24:564$568(1890)$

90a The age of the Gay Head bluffs at Marthas Vineyard. G Soc Am, B 1:555556 (1890) Am Nat 24:562-563 (1890) Glimpses of the cosmos $4: 220-221$ (1915)

$90 \mathrm{~b}$ The course of biologic evolution. Biol Soc Wash, Pr 5:23-55 (1890) Glimpses of the cosmos 4:198-219 (1915)

92 The plant-bearing deposits of the American Trias. G Soc Am, B 3:23-31 (1892) Abst, Am As, Pr $40: 286-288$ (1892) : Science 18:287-288 (1891)

92a Principles and methods of geologic correlation by means of fossil plants. Am G $9: 34-47$ (1892) Abst, Am As, Pr 40: 288-289 (1892) ; Science 18:282 (1891)

92b [On corrasion in the Missouri River (abst.)]. Ph Soc Wash, B 11:519-520 (1 (1892)

93 Principes et méthodes d'étude de corrélation au moyen des plantes fossiles. Int $\mathrm{G}$ Cong, $\mathrm{V}$, Washington $1891, \mathrm{C} \mathrm{R}: 97-$ 109 (1893)

93a The new botany. Science 21:4344 (1893) Public Opinion 14:474-475 (1893) Glimpses of the cosmos $4: 367$ 372 (1915)

94 The Cretaceous rim of the Black Hills. J G 2: 250-266 (1894)

94a Fossil cycadean trunks of North America, with a revision of the genus Cycadeoidea Buckland. Biol Soc Wash, Pr $9: 75-88$ (1894)
Ward, Lester Frank-Continued.

94b Recent discoveries of cycadean trunks in the Potomac formation of Maryland. Torrey Bot Cl, B 21 : 291-299 (1894)

95 The Potomac formation. U G S G, An Rp 15:307-397 (1895)

95a The Mesozoic flora of Portugal compared with that of the United States. Science n s 1:337-346 (1895)

95b The red hills and sand hills of South Carolina (abst). Science n s 1:669 (1895)

96 Some analogies in the Lower Cretaceous of Europe and America. U S G S, An Rp 16 pt $1: 463-542$, il (1896)

96a Age of the Island series. Science n s $4: 757-760 \quad(1896)$

96b [Reconnaissance in Indian Territory, Okiahoma, and southwestern Kansas (abst).] Science n s 4:883-884 (1896)

97 A new species of Eucalyptus from the Dakota group of southwestern Kansas. Torrey Bot Club, B 24:576-577, il (1897)

97 a Descriptions of the species of Cyeadeoidea, or fossil cycadean trunks, thus far discovered in the iron ore belt, Potomac formation, of Maryland. Biol Soc Wash, Pr 11:1-17 (1897)

97b Professor Fontaine and Dr. Newberry on the age of the Potomac formation. Science n s 5:411-423 (1897)

97 on the Cretaceous formation in southwestern Kansas ( $a b s t$ ). Seience n $\mathbf{s}$ $6: 814-815$ (1897)

98 Descriptions of the species of Cycadeoidea, or fossil cycadean trunks thus far determined from the Lower Cretaceous rim of the Black Hills. U S Nat Mus, Pr 21: 195-229 (1898)

9Sa A new fossil Eucalyptus from Kansas. Plant World 1:75-76, il (1898)

99 The Cretaceous formation of the Black Hills as indicated by the fossil plants. U S G S, An Rp 19 pt 2 : 521-946, maps, il (1899)

00 Status of the Mesozoic floras of the United States: The older Mesozoic. U S G S, An Rp 20 pt 2: 211-748, il (1900)

O0a Report on the petrified forests of Arizona. [U S] Dp Interior : $23 \mathrm{pp}$, Washington 1900. Smiths Inst, An Rp 1899: 289-307 (1901) Glimpses of the cosmos $6: 76-98$ (1918)

Oob Elaboration of the fossil cycads in the Yale Museum. Am J Sc (4) 10:327345, il (1900)

o0e Description of a new genus and twenty new species of fossil cycadean trunks from the Jurassic of Wyoming. Wash Ac Sc, Pr 1:253-300, il (1900)

ood The fossil forests of Arizona (abst). Science $n$ s $11: 30-31$ (1900) Glimpses of the cosmos $6: 71-72$ (1918)

o1 Geology of the Little Colorado Valley. Am J Sc (4) 12:401-413 (1901) 
Bishop, Irving Prescott-Continued.

s6a On certain fossiliferous limestones of Columbia Co., N. Y., and their relation to the Hudson River shales and the $\mathrm{Ta}$ conic system. Am J Sc (3) 32:438-441 (1886)

s7 On certain limestones of Columbia Co., N. Y,.. (abst). Am As, Pr 35:231 (1887)

90 A new locality of Lower Silurian fossils in the limestones of Columbia Co., N. Y. Am J Sc (3) 39:69-70 (1890)

92 Report on the development of the salt industry of central New York for the year 1891. N Y St Mus, An Rp 45:53-61 (1892)

97 The structural and economic geology of Erie Co. [N. Y.]. N Y St G, An Rp $15: 17-18,305-392, \operatorname{map}(1897) \quad$ N Y St Mus, An Rp 49 v 2:305-392, map (1898)

99 Report on petroleum and natural gas in western New York. N Y St G, An Rp 17:9-63, map (1899) N Y St Mus, An Rp 51 v 2:9-63, map (1899)

01 Oil and gas in southwestern New York. N Y St Mus, An Rp 53: r105-134, map (1901)

04 Economic geology of western New York. N Y St Mus, An Rp $56: \mathbf{r} 42-74$, map (1901)

Bishop, Sereno E.

87 The recent eruption of Mauna Loa. Science 9: 205-207 (1887)

92 Kilauea in April, 1892. Am J Sc (3) 44: 207-210 (1892)

96 The temperature of the earth's crust. Science n \& 3:409 (1896)

01 Brevity of tuff cone eruptions. Am G. $27: 1-5$ (1901)

Bishop, Watson L.

$12 \mathrm{R}$ [obert] W[heelock] EHs [18451911]. N S Inst Sc, Pr Tr 13 pt 2 : xxy-xxyl (1912)

Bixby, Maynard.

16 A catalogue of Utah minerals and localities ... 4th ed [Salt Lake City], 1916 Black, George F.

16 List of works relating to the geology, mineralogy, and paleontology of New Jersey. 36 pp, New York Public Library, 1916.

Blackburn, Charles F.

79 The wilderness at the head of the Missouri, Columbia, and Colorado rivers. Se Am Sup 8: 2903-2904 (1879)

81 Glacial observations in the Wind River Mountains. M Sc Press 42:2 (1881) Sc Am Sup 11: 4277 (1881)

Blackman, E. E.

07 Prehistoric man in Nebraska. Records of the Past 6: 76-79 (1907)

Blackmar, Chacles A.

03 Register of oil wells in Los Angeles Co., with map. Cal St M Bur: 13 pp (1903)

\section{Blnckwelder, Eliot.}

03 (with Salisbury, R. D.) Glaciation in the Bighorn Mountains [Wyo.]. J G 11: 216-223 (1903)

$\mathbf{0 7}$ On the probable glacial origin of certain folded slates in southern Alaska. J G $15: 11-14$ (1907)

O7a Reconnaissance on the Pacific coast from Yakutat to Alsek River. U S G S, B 314: 82-88 (1907)

07b Glacial features of the Alaskan coast between Yakutat Bay and the Alsek River. J G 15:415-433 (1907)

os Pre-Cambrian rocks in southeastern Wyoming. Science, n s $27: 787-788$ (1908)

09 The valuation of unconformities. J G $17: 289-299$ (1909)

09a Cenozoic history of the Laramie region, Wyo. J G $17: 429-444$ (1909)

09b The Yakutat coastal plain of Alaska; a combined terrestrial and marine formation. Am J Sc (4) $27: 459-466$ (1909)

10 Phosphate deposits east of Ogden, Utah. U S G S, B $430: 536-551$ (1910)

10a New light on the geology of the Wasateh Mountains, Utah. G Soc Am, B 21:517-542, 767, map (1910) Abst, Science n s $32: 188$ (1910)

$10 b$ (with Darton, N. H.) Description of the Laramie and Sherman quadrangles, Wyo. U S G S, G Atlas, fol 173 (1910)

11 A reconnaissance of the phosphate deposits in western Wyoming. U S G S, B $470: 452-481$, map (1911)

11 a (and Barrows, H. H.) Elements of geology. 475 pp N Y 1911

12 United States of America. Handbuch der regionalen Geologie (Steinmann and Wilckens) Bd 8, Abt 2 (Heft 11) : 258 pp, Heidelberg, 1912 Also issued under the title Regional geology of the United States of North America. $258 \mathrm{pp}, \mathbf{N}$ Y [1913?]

12a The old erosion surface in Idaho; a criticism. J G 20:410-414 (1912)

12b The Gros Ventre slide, an active earth flow. G Soc Am, B 23: 487-492 (1912) ; abst, $23: 739$ (1912)

13 New or little known Paleozoic faunas from Wyoming and Idaho. Am J Sc (4) $36: 174-179$ (1913)

13a Field and office methods in the preparation of geologic reports; a modification of the Walcott method of measuring stratigraphic sections. Ec G 8:489492 (1913)

13b Origin of the Bighorn dolomite of Wyoming. G Soc Am, B 24:607-624 (1913)

13e Coralline algæ in an Ordovician dolomite (abst). G Soc Am, B 24:115 (1913)

14 A summary of the orogenic epochs in the geologic history of North America. J G $22: 633-654$ (1914) 
Ward, Lester Frank-Continued.

03 Correlation of the Potomac formation In Maryland and Virginia (abst). Science n s 17:941-942 (1903)

04 Paleozoic seed plants. Science $n$ s 20:279-281 (1904)

05 (W. M. Fontaine, Arthur Bibbins, and G. R. Wieland, collab.) Status of the Mesozoic floras of the United States (second paper). U S G S, Mon 48:616 pp, pls vol (1905)

05a An example in nomenclature. Science $n$ s $21: 110-111$ (1905)

13 Glimpses of the cosmos. 6 vols., N Y 1913-8

See also Dawson ( $\mathrm{J}$ W), 88 ; Gilbert, 93b; Knowlton, 91a ; Lesquereux, 87b; Newberry, 89b ; Powell, $83,84,85,85 a, 88$, $89,89 \mathrm{a}, 90,91,91 \mathrm{a}, 92,93,95$; White (D), 90

Ward, Robert DeC.

92 Another river pirate. Science 19: 7-9 (1892)

Ward, Thomas.

90 The saIt deposits of the United States of America and Canada. Manchester G Soc, Tr 20:471-498 (1890)

ward, w. S.

$\mathbf{0 5}$ Gold and silver; Colorado. U S G S, Min Res 1904: 177-180 (1905)

Warder, John Aston (1812-1883).

38 New trilobite, Ceratocephala goniata. Am J Sc $34: 377-379$, il (1838)

53 Charter and by-laws of the Cincinnati \& Little Rock Slate Co., with Prof. Warder's geological report (pp. 11-16), 16 pp, Cincinnati 1853

54 A geological reconnaissance of the Arkansas River. 27 pp, Cleveland 1854 Abst, An Sc, Cleveland, 1:234-235 (1853) Warder, Robert Browne.

72 Geology of Dearborn, Ohio, and Switzerland cos. Ind $\mathrm{G} S$, An Rp 3-4: $387-434$, map (1872)

82 Some ochreous deposits of Kentucky and Indiana. Ac $\mathrm{N}$ Sc Phila, Pr 1882: 57-58; Min G Sec, Pr no 2: 24-25 (1882)

83 The silicified stumps of Colorado (abst). Am As, Pr 31:398-399 (1883)

Wardroper, $D$, Lee.

88 The formation of coal beds. Eng M J $45: 473$ (1888)

Warfel, E. C.

15 Kaw Valley [Kans.] anticline. Kans Ac Sc, Tr $27: 53-57$ (1915)

Waring, Clarence Alm (?-1918).

13 Structural geology south of the Santa Susana district [Cal.]. Western Eng 3 : 470-471 (1913)

14 Eocene horizons of California. J G $22: 782-785$ (1914)

15 Minutes of the fifth annual meeting of the Pacific coast section of the Paleontological Society. G Soc Am, B 26:166170 (1915)
Waring, Clarence Alm-Continued.

15a (with MeLaughlin, R. P.) Petro. leum industry of California. Cal St M Bur, B $69: 519$ pp, maps (1915)

17 Stratigraphic and faunal relations of the Martinez to the Chico and Tejon of southern California. Cal Ac Sc, Pr (4) 7 : 41-124, 11, maps (1917)

17a Butte County; Sutter County. In Mines and mineral resources of the countíes of Butte, Lassen, Modoc, Sutter, and Tehama (Chapters of State Mineralogist's Rp [15 : 181-225, 254-257] 1915-16) : 1-45, 74-77, Cal St M Bur (1917)

17b (and Huguenin, E.) Inyo County. In Mines and mineral resources of Alpine County, Inyo County, Mono County (Chapters of State Mineralogist's Rp [15:29-134] 1915-16):25-129, Ca] St M Bur (1917)

17e (and Bradley, W. W.) Monterey County. In Mines and mineral resources of the counties of Monterey, San Benito, San Luis Obispo, Santa Barbara, Ventura (Chapters of State Mineralogist's Rp [15: 595-615] 1915-16):1-21, Cal St M Bur (1917)

17d Placer County; Sacramento County; Yuba County. In Mines and mineral resources of the counties of El Dorado, Placer, Sacramento, Yuba (Chapters of State Mineralogist's Rp [15:309-459] 1915-16) : 39-189, Cal St M Bur (1917)

17e Geological map of Inyo Co., Cal. Cal St M Bur (1917) Scale 1:25,000.

$17 f$ (with Waring, G. A.) Lavas of Morro Hill and vicinity, southern Cal. Am J Sc (4) 44:98-104 (1917)

See also Bradley (W W), 18

Waring, Gerald Ashley.

o5 The pegmatite veins of Pala, San Diego Co., Cal. Am G 35: 356-369, map (1905)

O5a Quartz from San Diego Co., Cal. Am J Se (4) 20:125-127 (1905)

os Geology and water resources of a portion of south-central Oregon. U S G S, W-S P 220:86 pp (1908)

08a Physiographic features of southcentral Oregon (abst). G Soc Am, B 18: 662 (1908)

09 Geology and water resources of the Harney Basin region, Oreg. U $\mathbf{S}$ \& $\mathrm{S}$, W-S P $231: 93$ pp (1909)

13 Geology and water resources of a portion of south-central Washington. U $\mathbf{s}$ G S, W-S P $316: 46$ pp, maps (1913) Abst, by 0 . E. Meinzer, Wash Ac Sc, J 4:226 (1914)

15 Springs of California. U S G S, W-S P 338: $410 \mathrm{pp}$, maps (1915)

17 Mineral springs of Alaska. U S G S, W-S P 418: 114 pp, maps (1917) Abst, Wash Ac Sc, J 8:171 (1918) 
Waring, Gerald Ashley-Continued.

$17 a$ (and Waring, C. A.) Lavas of Morro Hill and vicinity, southern Cal. Am J Sc (4) $44: 98-104$ (1917)

18 Ground water in Reese River basin and adjacent parts of Humboldt River basin, Nev. U S G S, W-S P 425: 95-129, map (1918)

Waring, W. George.

96 The Mercur district [Utah]. Eng M J $62: 27$ (1896)

97 The gold fields of Altar, Mexico. Eng M J 63:257-258 (1897)

Warman, Philip Creveling (1859-1908).

93 Bibliography and index of the publications of the United States Geological Survey. U S G S, B 100: 495 pp (1893)

01 Catalogue and index of the publications of the United States Geological Survey, 1880-1901. U S G S, B 177: 858 pp (1901)

03 Catalogue and index of the publications of the United States Geological Survey, 1901-1903. U S G S, B 215: 234 pp (1903)

03a Catalogue of the published writings of John Wesley Powell. Wash $\Delta c$ Sc, Pr 5: 131-187 (1903)

Warner, A. J.

71 On the oil-bearing rocks of Ohio and West Virginia. Am J Sc (3) 2: 215 (1871)

Warner, J. H.

05 The Waterloo quartzite [southern Wisconsin]. M World $22: 420-422$ (1905)

Warren, Charles Hyde.

98 Mineralogical notes. Am J Sc (4) 6:116-124 (1898) Zs Kryst 30:595-604 (1899)

99 (with Penfield, S. L.) On the chemical composition of parisite and a new occurrence of it in Ravalli Co., Mont. Am J Sc (4) $8: 21-24$ (1899)

99a (with Penneld, S. L,) Some new minerals from the zine mines at Franklin, N. J., and note concerning the chemical composition of ganomalite. Am J Sc (4) 8: 339-353 (1899) Yale Bicen Pub, Contr Miner : 325-342 (1901)

01 Mineralogical notes. Am J Sc (4) $11: 369-373$ (1901)

o3 Mineralogical notes. Am J Sc (4) $16: 337-344$ (1903)

04 Petrographical notes on the rocks of the Weston aqueduct [Mass.]. Tech Q $17: 117-123$ (1904)

06 The mineralogical examination of sands. Tech Q 19:317-338 (1906)

O6a (with Hidden, W. E.) On yttocrasite, a new yttrium-thorium-uranium titanate. Am J Sc (4) $22: 515-519$ (1906)

os Contributions to the geology of Rhode Island; the petrography and mineralogy of Iron Mine Hill, Cumberland. $A m$ J Sc (4) $25: 12-38$ (1908)
Warren, Charles Hyde-Continued.

08a Note on the alteration of augiteilmenite groups in the Cumberland, R. I., gabbro (hessose). Am J Sc (4) $26: 469$ 477 (1908)

08b Über das Vorkommen von Hortonolith bei Cumberland, Rhode Island, U. S. A. Zs Kryst 44:209-211 (1908)

09 Note on the occurrence of an interesting pegmatite in the granite of Quincy, Mass. Am J Sc (4) 28:449-452 (1909)

10 (and Palache, Charles) Pegmatite in the granite of Quincy, Mass (abst). Science n s $32: 220$ (1910); (with discussion), G Soc Am, B 21:784 (1910)

11 The barite deposits near Five Islands, N. S. Ec G 6:799-807 (1911) Abst, G Soc Am, B 21: 786-787 (1910)

11 a (and Palache, Charles) The peg. matites of the riebeckite-ægirite granite of Quincy, Mass., U. S. A. ; their structure, minerals, and origin. Am Ac Arts, Pr 47: 125-168 (1911)

11b (with Palache, Charles) The chemical composition and crystallization of parisite and a new occurrence of it in the granite-pegmatites at Quincy, Mass. Am J Sc (4) 31:533-557 (1911)

12 The ilmenite rocks near St. Urbain, Que.; a new occurrence of rutile and sapphirine. Am J Sc (4) $33: 263-27 /$ (1912)

13 Petrology of the alkali granites and porphyries of Quincy and the Blue Hills, Mass., U. S. A. Am Ac Arts, Pr 49:203331 (1913)

14 (and Powers, Sidney) Geology of the Diamond Hill-Cumberland district in Rhode Island-Massachusetts. G Soc Am, B $25: 75,435-476$, map (1914)

15 A quantitative study of certain perthitic feldspars. Am Ac Arts, Pr 51: $127-154$ (1915)

16 A graduated sphere for the solution of problems in crystal optics. Am J Sc (4) $42: 493-495 \quad$ (1916)

16a George Jarvis Brush (1831-1912). Am Acad Arts, Pr 51: 853-857 (1916)

17 (and Allan, J. A.) A titaniferous augite from Ice River, B. C., with a chemical analysis by M. F. Conner. Am J Sc (4) $43: 75-78$ (1917)

18 on the microstructure of certain titanic iron ores. Ec G 13:419-446 (1918)

Warren, E. R.

97 Vein walls. Eng M J $63: 424$ (1897)

$97 \mathbf{a}$ Some mineral veins of Gunnison Co., Colo. Eng M J 63:597-598 (1897) warren, George $M$.

11 Tidal marshes and their reclamation. U S Dp Agr, Off Exp Stations, B 240: 99 pp (1911) 
Warren, Gouverneur Kemble (18301882).

58 Preliminary account of explorations in Nebraska and Dakota in the years 185556-57. U S, War ' $\mathrm{p}$, An Rp 1858 (U S, 35th Cong 2d sess, H Ex Doc 2):620747 (1858) Reprint, $125 \mathrm{pp}$, map, Washington 1875

59 Preliminary report on explorations in Nebraska 1855-57. U S, 35th Cong 2d sess, H Ex Doc 2 (Rp Sec War) v 2 pt 2 : 620-670 (1859)

68 On certain physical features of the upper Mississippi River. Am Nat 2:497502 (1868)

75 An essay concerning important physical features exhibited in the valley of the Minnesota River and upon their signification. U S, 43 Cong 2 d sess, H Ex Doc 76:6-23 (1875)

76 Report on the transportation route along the Wisconsin and Fox rivers in the State of Wisconsin between the Mississippi River and Lake Michigan. U S, 44th Cong 1st sess, S Ex Doc 28: 114 pp, mzps (1876) U S [War Dp], Chief Eng, An Rp 1876 (U S, 44th Cong 2d sess, H Ex Dca 1 pt 2 v 2 pt 2) App T2: 189-298 (1876) Abst, Am J Sc (3) 13:152-155 (1877)

78 Valley of the Minnesota River and of the Mississippi River to the junction of the Ohio; its origin considered; depth of the bedrock. U S [War Dp], Chief Eng, An Rp 1878 (U S, 45 th Cong 3 d sess, H Ex Doc 1 pt 2 v 2 pt 2), App X: 909-926 (1878) Am J Sc (3) $16: 417-431$, maps (1878)

Warren, John Collins (1778-1856).

46 On the osteology and dentition of some North American mastodons. An Mag N H $17: 145-150$ (1846)

47 On the Mastodon. Am J Agr 6:200 [248]-201 [249] (1847)

49 [on the geological position of the Mastodon giganteus (with discussion by J. W. Foster, H. D. Rogers, and others).] Boston Soc N H, Pr 3:111-117 (1849)

50 On the Mastodon angustidens. Am As, $\operatorname{Pr} 2: 93-94$ (1850)

52 Description of a skeleton of the MasIodon giganteus of North America. 219 $\mathrm{pp}$, il, Boston 1852 Notice, Am J Sc (2) 15: $367-373$ (1853) 2d ed, $260 \mathrm{pp}$, il,

Boston 1855

52a [Remarks on supposed tooth of Mastodon angustidens.] Boston Soc N H, Pr 4:129-131 (1852)

54 Remarks on some fossil impressions in the sandstone rocks of Connecticut River. $54 \mathrm{pp}, \mathrm{il}$, Boston 1854

54 a [On a tooth of Mastodon giganteus from Illinois.] Boston Soc $\mathrm{N} . \mathrm{H}, \mathrm{Pr} 4$ : 376-377 (1854)

54b [On Zeuglodon.] Boston Soc N H, Pr 5 : 91-92 (1854)

55 Supernumerary tooth in Mastodon giganteus. Am J Sc (2) 19:349-353 (1855)
Warren, John Collins-Continued.

55a [On the teeth of the Mastodon gi. ganteus.] Boston Soc N H, Pr 5:146$150(1855)$

55b [On fossil rain drops.] Boston Soc N H, Pr 5: 187-188 (1855)

55e IOn a sandstone slab from Connecticut Valley having impressions on both surfaces.] Boston Soc N H, Pr 5:209210 (1855)

56 [On new remarkable gigantic fossils and footmarks.] Boston Soc N H, Pr 5: 298-306 (1856)

See also Rogers (H D), 55a

Warring, Charles $B$.

76 Studies upon the inclination of the earth's axis. Poughkeepsie Soc $\mathrm{N}$ Sc, $\mathrm{Pr}$ $1: 87-127$ [1876]

85 The uniformity of geological climate in high latitudes (with discussion by J. $\mathrm{S}$. Newberry). N Y Ae Sc, Tr 3:84-97 (1885) 86 Geological climate in high latitudes. Pop Sc Mo 29:352-367 (1886)

87 The evolution of continents (with discussion by W. B. Dwight). Vassar Bros Inst, Tr 4:256-274 (1887)

87a The cutting at Croton Point, N. Y. Vassar Bros Inst, $\operatorname{Tr} 4: 274-278$ (1887)

Warwick, Arthur W.

04 The iron ores of the Uinta Mountains. M Rep 50:166-167 (1904)

o5 The Leadville district [Colo.]. M Mag 11: 430-439 (1905)

06 Notes on mining conditions in and a section across the Sierra Madre Mountains in Mexico. Colo Sc Soc, Pr 8: 123-156 (1906)

o7 Topographical and other notes on the Choix-Guadalupe y Calvo mining districts [Mexico]. M Sc Press 95: 686-688 (1907)

Washburn, William H.

00 Gold in Snake River gravel bars, M Sc Press 81:610 (1900)

\section{washburne, Carleton W.}

16 (and Washburne, H. C.) The story of the earth. $107 \mathrm{pp}, \mathrm{N}$ Y 1916

Washburne, Chester Wesley.

03 Notes on the marine sediments of eastern Oregon. J G 11:224-229 (1903)

04 The distribution of placer gold in Oregon. Oreg Univ, B n \& 1 no $4: 18-19$ (1904)

O4a Beach gold and its source. Oreg Univ, B n s 1 no 4:19-21 (1904)

o7 Thomas Condon. J G $15: 280-282$ (1907)

os Gas fields of the Big Horn Basin, Wyo. U S G S, B 340:348-363 (1908)

09 Coal fields of the northeast side of the Big Horn Basin, Wyo., and of Bridger, Mont. U S G S, B 341:165-199, map (1909)

09a Development in the Boulder ofl field, Colo. U S G S, B 381:514-516 (1909) 
Washburne, Chester Wesley-Continued. 09b The Florence oil field, Colo. U S G S, B 381: 517-544, map (1909)

09c Some observations on Rocky Mountain faults $(a b s t)$. Science n s, 29:555556 (1909)

10 The South Park coal fleld, Colo. U S G S, B 381 : 307-316, map (1910)

10a The Canon City coal field, Colo. U S G S, B 381: 341-378, map (1910)

11 Gas and oil prospects near Vale, Oreg., and Payette, Idaho. U S G S, B 431:26-55, map (1911)

$11 a$ Gas prospects in Harney Valley, Oreg. U S G S, B 431:56-57 (1911)

11b Geological relations of eil pools situated in regions of monoclinal structure (discussion). G Soc Am, B 22:737 (1911)

14 Reconnaissance of the geology and oil prospects of northwestern Oregon. U S G S, B 590: 111 pp, map (1914)

$14 a$ Chlorides in oil-fleld waters. $\Delta \mathrm{m}$ I M Eng, B 87:375-381 (1914) ; B 100: 825-830 (1915) ; Tr 48:687-694 (1915) ; $50: 883-889$ (1915)

14b The capillary concentration of gas and oil (with discussion). Am I M Eng, B $93: 2365-2378$ (1914); $100: 838-846$; 101: 1203-1204 (1915); Tr 50:829-858 (1915)

15 The estimation of oil reserves (with discussion by R. H. Johnsen), Am I M Eng, B 98:469-471; $101: 1169$ (1915); Tr $51: 645-648$ (1916)

15a The rôle and fate of connate water in oil and gas sands (discussion). Am I M Eng, B 105:2057-2060 (1915) ; Tr 51 : $607-610 \quad(1916)$

17 Discussion of "Some effects of capillarity on oil accumulation " by A. W. McCoy. J G 25: 584-586 (1917)

18 [The movements of oil and gas through rocks] (discussion). Ec G 13: 550-551 (1918)

See also Johnson ( $\mathrm{R}$ H), 15; Matteson, 18; Pack, 17; Rogers (G S), 17c

Washington, Henry Stephens.

87 (with Hidden, w. E.) Contributions to mineralogy. Am J Sc (3) 33 : 501-507 (1887)

88 (with Hulebrand, W. F.) Notes on certain rare copper minerals from Utah. Am J Sc (3) 35:298-307 (1888) Colo Sc Soc, Pr $3: 3-16$ (1889)

96 The magmatic alteration of hornblende and biotite. J G 4:257-282 (1896)

97 Catalogue of the collection of meteorites in the Peabody Museum of Yale University. $A m$ J Sc (4) $3: 83-87$ (1897)

98 The petrographical province of Essex Co., Mass. J G 6:787-808 (1898) ; $7: 53-64,105-121,284-294,463-482$, map (1899)

98a The Jerome (Kansas) meteorite. Am J Se (4) 4:447-454 (1898)
Washington, Henry Stephens-Contd. $\mathbf{9 8 b}$ Sölvsbergite and tinguaite from Essex Co., Mass. Am J Sc (4) 6:176-187 (1898)

98c The igneous rocks of Essex Co., Mass. (abst). N Y Ac Sc, An 11:498499 (1898)

00 Igneous complex of Magnet Cove, Ark. G Soc Am, B 11:389-416, map (1900) Abst, Science n s 11:144-145, 427-428 (1900)

00a The composition of kulaite. J G $8: 610-620(1900)$

00b The principles of a genetic classifcation of the igneous rocks. Am J Sc (4) $9: 456-460(1900)$

ooc The statement of rock analyses. Am J Sc (4) 10:59-63 (1900)

ood The rocks of Lake Winnepesaukee, N. H. (abst). Science n s 12:924 (1900) N Y Ac Sc, An 13:501-502 (1901) Am G $27: 44$ (1901)

01 The foyaite-ijolite series of Magnet Cove [Ark.]; a chemical study in differentiation. J G 9:607-622, 645-670 (1901)

O1a A chemical study of the glaucophane schists. Am J Sc (4) $11: 35-59$ (1901)

01b The Magnet Cove laccolith, Arkansas (abst). N Y Ac Sc, An 13: 448-449 (1901)

02 (with others) A quantitative ehemico-mineralogical classification and nomenclature of igneous rocks. J G: 555-690 (1902)

03 Chemical analyses of igneous rocks published from 1884 to $1900 \ldots$ U S G S, P P 14: $495 \mathrm{pp}$ (1903)

03a Quantitative distribution of rock magmas (abst). G Soc Am, B 14:533 (1904) Eng M J 75:153 (1903)

03b The calculation of center points in the quantitative classification ${ }^{*}$ of igneous rocks (abst). Science n s 17:668 (1903)

03e (with Cross, W., and others) Quantitative classification of igneous rocks. 286 pp, Chicago 1903

04 Manual of the chemical analysis of rocks. ix, 183 pp, N Y 1904

04a The superior analyses of igneous rocks ... U S G S, P P 28:68 pp (1904)

o5 (with Pirsson, L. V.) Contributions to the geology of New Hampshire; I, Geology of the Belknap Mountains. Am J Se (4) $20: 344-352$, map (1905)

06 (with Cross, W.) The texture of igneous rocks. J G $14: 692-707$ (1906)

06a (with Pirsson, L. V.) Contributions to the geology of New Hampshire: No. II, Petrography of the Belknap Mountains; No. III, on Red Hill, Moultonboro. Am J Sc (4) $22: 439-457,493-514$ (1906) ; $23: 257-276$ (1907)

07 The formation of leucite in igneous roclis. J G $15: 257-279,357-395$ (1907) 
Washington, Henry Stephens-Contd. O7a (with Kanz, G. F.) Occurrence of diamonds in Arkansas. U S G S, M R 1906: 1247-1251 (1907)

os On kaersutite from Linosa and Greenland, with optical studies by F. E. Wright. Am J Sc (4) $26: 187-211$ (1908)

08 a The distribution of the elements in igneous rocks. Am I M Eng, B 23: 809838 (1908); Tr 39:735-764 (1909) Reprinted in Emmons, S. F., Ore deposits: 729-758, N Y 1913. Smiths Inst, An Rp 1969 : 279-304 (1910)

08b Report [on the property of the Arkansas Diamond Company ] : $31-38$, Little Rock 1908 See Arkansas Diamond Compary, 08

OSe (with Kunz, G. F.) Biamonds in Arkansas. Am I M E, B 20:187-194 (1908)

10 Manual of the chemical analysis of rocks. $2 d$ ed, $200 \mathrm{pp}$, N Y 1910

12 The constitution of some salic silicates. Am J Sc (4) 34:555-571 (1912)

12a A suggestion for mineral nomenclature. Am J Sc (4) 33:137-151 (1912) Abst, G Soc Am, B 23: 729 (1912)

$12 b$ (with Cross, W.) Modifications of the quantitative system of classification of igneous rocks. J G 20:550-561 (1912)

13 (and Larsen, E. S.) Magnetite basalt from North Park, Colo. Wash Ac Sc, J 3: 449-452 (1913)

13a Relations of the feldspars, lenads, and zeolites (abst). N Y Ac Sc, An 22: 345 (1913)

15 The correlation of potassium and magnesium, sodium and iron, in igneous recks. Nat Ac Sc, Pr 1:574-578 (1915)

15a The calculation of calcium orthosilicate in the norm of igneous rocks. Wash Ac Sc, J 5:345-350 (1915)

17 Chemical analyses of igneous recks, published from 1884 to 1913 , inclusive, with a critical discussion of the character and use of analyses; a revision and expansion of Professional Paper 14. U S G S, P P 99:1201 pp (1917) Abst, Wash Ac Sc, J $8: 66$ (1918)

$\mathbf{1 7 a}$ Persistence of vents at Stromboli and its bearing on volcanic mechanism. G Soc Am, B 28:249-278 (1917) Abst, Wash Ac Sc, J 8:207 (1918)

18 A description of the quantitative classification of igneous rocks, with tables for the calculation of the norm. U S G S, Extr from P P 99 (appendixes 1-5) : 1-7, 1151-1180 (1918)

See also Arkansas Diamond Company, 08 ; Cross, 02b

Washington Academy of Sclences.

13 The McGee memorial meeting of the Washington Academy of Sciences held at the Carnegie Institution, Washington, D. C., December 5, 1913. $121 \mathrm{pp}$, port, Baltimore 1916
Washington Geelegical Surrey.

03 The biennial report of the Board of Geological Survey of the State of Wash. ington for the term 1901-1903. $7 \mathrm{pp}$, Tacoma, Wash., 1903

10 The biennial report of the Board of Geological Survey of the State of Wash. ington for the term 1909-11. $24 \mathrm{pp}$, map, Olympia, Wash., 1910. ... 1911-13:24 pp, map (1913) ... 1913-15:31 pp, map (1915) ... 1915-17:29 pp, map (1917)

Wasmuth, Henry A.

87 Studies on the stratification of the anthracite measures of Pennsylvania, Franklin Inst, J 124 or (3) 94:109-126 (1887)

s8 Notes on the Pittsburgh coal bed and its disturbances. Am G 1: 272-277 (1888)

8Sa Notes on the structural geology of the Carboniferous formation of Pennsyl. vania. Am G 2:311-323 (1888)

$\mathbf{8 8 b}$ The southern anthracite coal field of Pennsylrania; its enormous disturb. ances and consequent premature exhaus. tion. Franklin Inst, J 125 or (3) $95: 110$ 114 (1888)

92 Studies on the stratification of the northern anthracite feld of Pennsylvania. Franklin Inst, J 134:354-358 (1892)

Watkins, Joel $H$.

11 (with Watsen, T. L.) Association of rutile and cyanite from a new locality. $\triangle \mathrm{m}$ J Sc (4) $32: 195-201$ (1911)

13 Bauxite near Elizabethtown, Tenn. Eng M J 95:604-605 (1913)

13a New occurrence and use of halloy. site [Chattooga Co., Ga.]. M World 38: 721-722 (1913)

15 White-burning clays of the southern Appalachian States. Am I M Eng, B 98: 391-411 (1915); Tr 51:481-501 (1916)

15a Barytes at Kings Creek, S. C. Eng M J 99:1074-1075 (1915)

15b Occurrence of bauxite in central Georgia. M World 42:1073-1075 (1915)

15e Phosphate rock in Johnsen Co. Tenn. M World 43:217-218 (1915)

16 Manganese in Tennessee. Eng M J $102: 545-546$ (1916)

18 Pyrite mining at Kershaw, S. C. Eng M J 106:517-521 (1918)

Watwon, C. B.

09 Prehistoric Siskiyou Island and Marble Halls of Oregon. 147 pp, Copy. right January 4, 1909, by C. B. Watson [Priv pub]

\section{Watson, D. M. S.}

16 On the structure of the brain case in certain lower Permian tetrapods. Am Mus N H, B 35: 611-636 (1916)

16 a Reconstructions of the skulls of three pelycosaurs in the American Museum of Natural History. Am Mus N H, B 35: $637-648$, il (1916) 
Watson, D. M. S.-Continued.

17 Poikilosakos, a remarkable new genus of brachiopod from the upper Coal Measures of Texas. G Mag (6) $4: 212-219$, il (1917)

See also Gregory (W K), 17

Watson, John Wilbur.

12 (with Watson, T. C.) A contribution to the geology and mineralogy of Graves Mountain Ga. Va Univ, $\mathrm{Ph}$ Soc, B (sc s) 1:200-221 (1912)

13 Abstraction of potassium during sedimentation. Diss, Univ Va: 30 pp [n d, 1913?]

Watson, Lawrence W.

02 Prince Edward Island. Can G S, Sum Rp 1901 (An Rp 14) : A 208-210 (1902)

03 Francis Bain, geologist. R Soc Can, Pr Tr (2) 9, iv : 135-142 (1903)

12 The geological age of Prince Edward Island. N S Inst Sc, Pr Tr 13: 145-149 (1912)

Watson, R. Lind.

01 Black sand auriferous deposits of Wreck Bay, Jordan River, and other localities of Vancouver Island. Mines and Minerals $21: 448-480$ (1901)

Watson, Thomas Leonard.

96 A preliminary petrographic report on some metamorphic rocks in and around Dahlonega, Lumpkin Co., Ga. Ga G S, B 4-A : 320-330 (1896)

97 Evidences of recent elevation of the southern coast of Baffin Land. J G 5:1733, map (1897)

$97 a$ A bibliography of the geological, mineralogical, and paleontological literature of the State of Virginia, B Am Pal no $7: 109$ pp (1897)

97b Lakes with more tian one outlet. Am G $19: 267-270$ (1897)

98 Weathering of diabase near Chatham, Va. Am G 22:85-101 (1898)

99 Some higher levels in the postglacial development of the Finger Lakes of New York State. N Y St Mus, An Rp 51: r55117, maps (1899)

$99 a$ Some further notes on the weathering of diabase in the vicinity of Chatham, Va. Am G 24: 355-369 (1899)

$99 \mathrm{~b}$ Some notes on the lake 3 and valleys of the upper Nugsuak Peninsula, north Greenland. J G 7:655-666 (1899)

01 Weathering of granitic rocks of Georgia. G Soc Am, B 12:93-108, map (1901) Abst, Science n \& $13: 137$ (1901)

o1a on the origin of the phenocrysts in the porphyritic granites of Georgia. J G $9: 97-122$, map (1901)

01b The granitic rocks of Georgia and their relationships. Am G $27: 199-225$ (1901)

o1e The Georgla bauxite deposits; their chemical constitution and genesis. Am G $28: 25-45$, map (1901)
Watson, Thomas Leonard-Continued.

02 A preliminary report on a part of the granites and gneisses of Georgia. Ga G S, B 9-A : 367 pp, maps (1902)

02a On the occurrence of aplite, pegmatite, and tourmalins. bunches in the Stone Mountain granite of Georgia. J G 10:186-193 (1902) Denison Univ, Sc Lab, B $12: 17-24$ (1902)

o2b Copper-bearing rocks of Virgilina copper district, Virginia and North Carolina. G Soc Am, B 13: 353-376 (1902) Denison Univ, Sc Lab, B $12: 97-127$ (1903)

o2e On the occurrence of uranophane in Georgia. Am J Sc (4) 13:464-466 (1902) Denison Univ, Sc Lab, B 12:25-28 (1902)

04 A preliminary report on the bauxite deposits of Georgia. Ga G S, B 11:169 pp, map (1904)

04a The Seminole copper deposit of Georgia. U S G S, B 225: 182-186 (1904)

04b The leopardite (quartz porphyry) of North Carolina. J G 12:215-224 (1904) Denison Univ, Sc Lab, B 12: 223-230 (1904)

04c Orbicular gabbro-diorite from Davie Co., N. C. J G 12:294-363 (1904)

04d Granites of North Carolina. J G 12 : 373-407, map (1904)

04e Geological relations of the manganese ore deposits of Georgia (with discussion by Charles Catlett). Am I M Eng, Tr 34:207-253, 968-973 (1904) Denison Univ, Sc Lab, B 12: 147-198 (1904)

o4f The yellow ocher deposits of the Cartersville district, Bartow Co., Ga. Am I M Eng, Tr 34:643-666, maps (1904) Denison Univ, Sc Lab, B 12:199-221 (1904)

04m Structural relations of the granites of North Carolina (abst). Science n s 19 : 526 (1904)

os Lead and zinc deposits of Virginia. Va G S (g s), B 1:156 pp, map (1905)

06 A preliminary report on the ocher deposits of Georgia. Ga G S, B 13:81 pp, maps (1906)

O6a Lead and zine deposits of the Virginia-Tennessee region. Am I M Eng, Tr $36: 681-737$ (1906) ; B 8:139-195 (1906) $A b s t$, Mines and Minerals $27: 17-19,63-65$ (1906)

O6b Lithological characters of the Virginia granites. G Soc Am, B $17: 523-540$ (1906)

o6e Occurrence of unakite in a new locality in Virginia. Am J Sc (4) $22: 248$ (1906)

o6d The copper deposits of Virginia. Eng M J 82: 824-825 (1906)

o6e (and Laney, F. B., with the col. laboration of G.P. Merrill). The building and ornamental stones of North Carolina. N C G S, B $2: 283$ pp (1906) 
Watson, Thomas Leonard-Continued. ogf (with weed, W. H.) The Virginia copper deposits. Ec G 1:309-330 (1906)

07 Fluorite and barite in Tennessee. Am I M Eng, B 13:77 (1907); Tr 37:890 (1907)

07a On a dike of diabase in the Potsdam sandstone in the Valley of Virginia. Am J Sc (4) $23: 89-90$ (1907)

07b The occurrence of nickel in Virginia. Am I M Eng, B 17:829-843 (1907) ; $\operatorname{Tr} 38: 683-697$ (1908)

07e Geology of the Virginia barite deposits. Am I M Eng. B 18:953-976 (1907) : $\operatorname{Tr} 38: 710-733$ (1908)

07a Occurrence of rutlle in Virginia [near Roseland, Nelson Co.]. Ec G 2:493504 (1907)

o7e Mineral resources of Virginia. The Virginia Jamestown Exposition Commission, 618 pp, maps, Lynchburg, 1907 [The section on cement and cement materials is by R. S, Passler (: $86-167)$, on elays by Heinrich Ries (: 167-187), and on iron by $R$. J. Holden ( : 402-491)]

os A preliminary report on the manganese deposits of Georgia. Ga G S, B 14 : $195 \mathrm{pp}$, maps (1908) Abst, M World 28: 947-948 (1908)

09 Annual report on the mineral production of Virginia during the calendar year 1908. Va G S, B I-A: $141 \mathrm{pp}$, map (1909)

09a The manganese ore deposits of Georgia. Ec G 4:46-55 (1909) M World $30: 643-644$ (1909)

09b Petrology of the South Carolina granites. J G 17: 730-751 (1909)

10 Granites of the southeastern Atlantic States. U S G S, B $426: 282$ pp (1910)

10a Intermediate (quartz monzonitic) character of the central and southern Appalachian granites, with a comparative study of the granites of New England and the western United States. Va, Univ, Ph Soc, B se sec 1:1-40 (1910)

10b (and Powell, S. L.) Discovery of fossils in the Quantico slate belt, and the association of volcano-sedimentary beds with the slates of the Virginia crystalline region (abst). G Soc Am, B 21: 782 (1910)

10e (and Taber, S.) The Virginia rutile deposits. U S G S, B 430: 200-213 (1910)

10 l (and Taber, S.) Nelsonite, a new rock type; its occurrence, association, and compesition (abst). G Soc Am, B 21: 787 (1910)

10e Administrative report of the State geologist for the biennial period 1908-09. 31 pp. Va G S (1910) … 1910-11:25 pp (1912) ‥ 1912-13:49 pp (1914) ... 1914$15: 45$ pp (1916) $\quad . . \quad 1916-17: 36 \quad$ pp (1918)
Watson, Thomas Leenard-Continued.

10f The commercial importance of the Virginia pyrite deposits. Appalachian Mines and Industrial Record 1 no 3 (old number 5 no 2): 8-10, map (1910)

11 A geological map of Virginia. Scale, 1:500,000. Va G S [1911] Revised (1916)

11 a Biennfal report on the mineral pro. duction of Virginia during the calendar years 1909-1910. Va G S, B 6: 123 pp (1911)

11b Underground temperatures. Science n s $33: 828-831$ (1911)

11e West Elizabeth, Pa., deep well. Science $n$ s $34: 125-126$ (1911)

11d Completion of the new geological map of Virginia. M World 35:6-8 (1911)

11e (and Powell, S. L.) Fossil evidence of the age of the Virginia Piednont slates. Am J Sc (4) $31: 33-44$ (1911)

$11 f$ (and Watkins, J. H.) Association of rutile and cyanite from a new locality [Charlotte Co., Va.]. Am J Sc (4) 32 : 195-201, map (1911)

12 (with Clark, W. B.) The physiog raphy and geology of the Coastal Plain province of Virginia; economic geology. Va G S, B 4 (1912)

$12 n$ Economic products of the Virginia Coastal Plain. Va G S, B 4:223-26: (1912)

12b An association of native gold with sillimanite. Am J Sc (4) 33:241-244 (1912)

12e Vanadium and chromium in rutile and the possible effect of vanadium on color. Wash Ac Sc, J $2: 431-434$ (1912)

12d Kragerite, a rutile-bearing rock from Krageroe, Norway. Am J Sc (4) 34 509-514 (1912)

12e (and Hess, F. L.) Zirconiferous sandstone near Ashland, Va., with a sum. mary of the properties, occurrence, and uses of zircon in general. Va, Univ, Ph Soc, B sc s $1: 267-292$, map (1912)

$12 f$ (and Watson, J. W.) A contribution to the geology and mineralogy of Graves Mountain, Ga. Va, Univ, $\mathrm{Pb}$ Soc, B sc s $1: 200-221$ (1912)

13 Biennial report on the mineral production of Virginia during the calendar years 1911 and 1912 . Va G S, B 8:76 pp (1913)

$13 a$ The mineral resources of Virginia. M Sc Press 106:898-900, 947-949; 107 : 14-15 (1913)

13b A meteoric iron from Paulding Co., Ga. Am J Sc (4) $36: 165-168$ (1913)

13e (and Cline, J. H.) Petrology of a series of igneous dikes in central western Virginia. G Soc Am, B $24: 301-334,682-$ 683, (abst), map (1913)

$13 d$ (and Cline, J. H.) Normal faulting in the Cambrian of northern Piedmont, Va. Va, Univ, $\mathrm{Ph}$ Soc, B sc \& 1:341-347, $\operatorname{map}$ (1913) 
Watson. Thomas Leonard-Continued.

13e (and cline, J. H.) Drainage changes in the Shenandoah Vsiley region of Virginia. Va, Univ, $\mathrm{Ph}$ Soc, $\mathrm{B}$ se $\mathrm{s}$ 1: 349-363, map (1913)

$13 f$ (and Hess, F. L.) Zirconiferous sandstone near Ashland, Va. U S G S, B $530: 165-171$ (1913) Va G S, B 8: $40-50 \quad(1913)$

13g (and Taber, S.) Geology of the titanium and apatite deposits of Virginia. Va G S, B 3-A: 308 pp, map (1913)

13h (and Taber, S.) Magmatic names proposed in the quantitative system of dassification for some new rock types in Virginia, Va, Univ, $\mathrm{Ph}$ Soc, $\mathrm{B}$ sc $\mathrm{s}$ 1: $331-333$ (1913)

$13 i$ (and Taber, S.) Igneous complex of high titanium-phosphorus-bearing rocks of Amberst-Nelson cos., Va $(a b s t)$. G Soc Am, B 24:682 (1913)

14 The rutile deposits of the eastern United States, U S G S, B $580: 385-412$, maps (1914)

14a (and others) Examples of intercision type of stream piracy in western Virginfa. Va, Univ, $\mathrm{Ph}$ Soc, B se 8 1:437442 (1914)

14b Memorial of William M. Fontaine. G Soc Am, B 25:6-12, port (1914)

14e (and Grasty, J. S.) The Piedmont limestones of the southeast Atlantic States (abst). Science n s 39:399 (1914)

14d (and Grasty, J. S.) The cement materials and industry of the Southern States (abst). Science n s 39:400 (1914)

14e (with Ries, H.) Engineering geology. xxvi, 672 pp, New York 1914

15 (and Grasty, J. S.) Barite of the Appalachian States. Am I M Eng, B 98 : 345-390, maps (1915) ; Tr 51:514-559, maps (1916)

15a (and Cline, J. H.) Extrusive basalt of Cambrian age in the Blue Ridge of Virginia. $\quad \mathrm{Am} \quad \mathrm{J} \quad \mathrm{Sc}$ (4) $39: 665-669$ (1915)

16 (and Cline, J. H.) Hypersthene syenite and related rocks of the Blue Ridge region, Va. G Soc Am, B 27: 193234, map (1916) ; abst, 26:82-83 (1915)

16a Zircon-bearing pegmatites in Virginia. Am I M Eng, B $115: 1237-1243$ (1916) ; Tr $55: 936-942$ (1917)

17 Weathering of allanite. G Soc Am, B $28: 463-500,152$ (abst) (1917)

17 a (and Beard, R. E.) The color of amethyst, rose, and blue varieties of quartz. U S Nat Mus, Pr 53:553-563 (1917)

17b Titanium; its occurrence and commercial uses. Mineral Foote-Notes 1 no $12: 5-15 \quad(1917)$

18 The Virginia earthquake of April 9 , 1918. Selsm Soc Am, B $8: 105-116$, map (1918)
Watson, Thomas Leonard-Continued.

18a Manganese; its occurrence and commercial uses. Mineral Foote-Note 2 no 6 : 3-12 (1918)

18b The relation of sphalerite to other sulphides in ores (discussion). Am I M Eng, B 136: 843-845 (1918)

18e (and Gooch, S. D.) Vivianite from the land pebble phosphate deposits of Florida. Wash Ac Sc, J 8:82-88 (1918)

18d Pyrolusite from Virginia. Wash Ac Sc, J $8: 550-560$ (1918)

1Se (and Steiger, G.) Titanium-bearing corundum spinellite (rock emery); a preliminary statement of its occurrence and composition in Virginia. Wash Ac Sc, J 8:665-676 (1918)

18f The color change in vivianite and its effect on the optical properties. Am Mineralogist $3: 159-161$ (1918)

See also Clark (W B), 12b ; Teas, 17

Watson, Winslow Cossoul,

53 Mineralogy and geology of the County of Essex. N Y St Agr Soc, Tr 12 : 771-807 (1853)

60 The plains of Long Island. N Y St Agr Soc, $\operatorname{Tr} 19: 485-505$ (1860)

Watts, A. C.

16 Coal mining methods in Utah. Coal Age 10:214-219 (1916) Colo Sch Mines Mag 6:197-201, map (1916)

Watts, A. S.

13 Mining and treatment of feldspar and kaolin in the southern Appalachian region. U S Bur Mines, B 53:170 pp (1913)

16 The feldspars of the New England and north Appalachian States. U. S. Bur Mines, B $92: 181$ pp, maps (1916)

Watts, Francis.

12 Observations on West Indian geology. Agr Soc Trinidad and Tobago, Pr 12:3537 (1912)

watts, O. P.

05 The cause of the moremene of glaciers. Sc Am Sup $39: 16157$ (1895)

Watts, William L.

94 The gas and petroleum yielding formations of the central valley of California. Cal St M Bur, B 3:100 pp, maps, Sacramento 1894

97 Oil and gas yielding formations of Los Angeles, Ventura, and Santa Barbara cos. Cal St M Bur, B 11:94 pp, maps, Sacramento 1897

99 Petroleum in California. In California mines and minerals (pub. by California Miners' Association) : 188-204, San Francisco, Cal., 1899

99 a Notes on the ofl-yielding formations of California. M Sc Press 79:144-146. 172-173 (1899)

oo Petroleum in Callfornia. Am I M Eng, Tr 29:750-756 (1900) 
Watts, William L.-Continued.

o1 $O$ il and gas yielding formations of California. Cal St M Bur, B 19:236 pp, maps, Sacramento 1901

See also Irelan, $90 \mathrm{a}, 93$

Weatherbe, D'Arcy.

02 ...Nictaux iron field. N S Inst Sc, Pr Tr 10 or (2) $3: 350-360$ (1902)

04 Borings in Nova Scotia. N S, Dp Mines, Rp 1903:69-82 (1904)

o5 Boring machines [gives records of borings]. N S Dp Mines, Rp 1904:82-93 (1905)

Weatherby, W. J.

o1 The Mogollon Range; a description of the region near Cooney, N. Mex. Mines and Minerals 22:97-101 (1901)

Weaver, Charles Edwin.

o5 Contribution to the paleontology of the Martinez group. Cal Univ, Dp G, B 4 : 101-123, il (1905)

or Notes on the bedrock geology of the Olympic Peninsula [Wash.]. The Mountaineer, Seattle, Wash., 1 no $3: 58-64$ (1907)

os New echinoids from the Tertiary of California. Cal Univ, Dp G, B 5 : 271-274, 11 (1908)

09 Stratigraphy and paleontology of the San Pablo formation in middle California. Cal Univ, Dp G, B 5:243-269 (1909)

11 Geology and ore deposits of the Blewett mining district, Wash. Wash G S, B $6: 104 \mathrm{pp}$, maps (1911)

12 Geology and ore deposits of the In. dex mining district. Wash G $\mathrm{S}$, B $7: 96$ pp, map (1912)

$12 a$ A preliminary report on the Terti. ary paleontology of western Washington. Wash G S, B 15:80 pp, il, map (1912) Abst, G Soc Am, B 24:131-132 (1913)

13 Geology and ore deposits of the Covada mining district. Wash $G \mathrm{~S}, \mathrm{~B} 16$ : $87 \mathrm{pp} \mathrm{(1913)}$

14 Lower Miocene of Washington (abst). G Soc Am, B 25:153-154 (1914)

15 The possible occurrence of oll and gas fields in Washington (with discussion by Milnor Roberts, J. B. Tyrrell, and others). Am I M Eng, B 103: 1419-1427; 108:2431-2433 (1915); Tr 52:239-249 (1916)

15a Pre-Pleistocene geology in the vicinity of Seattle [Wash.] (abst). G Soc Am, B 26: 130 (1915)

15b Geologic structure in western Washington (abst). G Soc Am, B 26:135-136 (1915)

15c Eocene of the Cowlitz Valley, Wash. (abst). G Soc Am, B 26:136 (1915)

15d Geology of portions of western Washington (abst). G Soc Am, B 26:397 (1915)

16 The Tertiary formations of western Washington. Wash G S, B 13:327 pp, maps (1916)
Weaver, Charles Edwin-Continued.

16a Tertiary faunal horizons of west. ern Washington. Wash Univ Pub, G 1: 1-67, il (1916)

16b Eocene of lower Cowlitz River val. ley, Wash. Cal Ac Sc, Pr (4) 6:1-17, map (1916) Discussion, G Soc Am, B 27 : 174 (1916)

16e The post-Eocene formations of western Washington. Cal Ac Sc, Pr (4) 6: 19-40 (1916)

$16 d$ The Oligocene of Kitsap Co., Wash. Cal Ac Sc, $\operatorname{Pr}$ (4) $6: 41-52$ (1916)

16e Mineral resources of Washington. J Geog 14:343-347 (1916)

Is Paleogeography of the Oligocene of Washington (abst). G Soc Am, B 29:165166 (1918)

Weaver, Thomas.

37 On the Carboniferous series of the States of New York and Pennsylvania. $\mathrm{Ph}$ Mag (3) $10: 365-368$ (1837)

Weaver, W. J.

97 River adjustments in North Caro. lina. Elisha Mitchell Sc Soc, J 13:13-24 (1897)

Webb, Thomas H.

22 ... minerals in the vicinity of Providence, R. I. Am J Sc 4:284-285 (1822) Transl in Struve, $\mathrm{H}$. von, Beitrăge zur Mineralogie und Geologie des nördlichen Amerikas : 122-124, Hamburg 1822

Webb, W. Morton.

11 Genesis of the Leadville [Colo.] ore deposits (discussion of paper by Max Boeh. mer). Am I M Eng, B 50:195-197 (1911); $\operatorname{Tr} 41: 887-889$ (1911)

Webber, Morton.

12 Cross-fractures and ore shoots. M Sc Press 104 : 380-381 (1912)

Webber, Samuel.

42 Sketch of the great geological features of the valley of Connecticut River, at Charlestown, N. H. Nat Inst, Washing. ton, D. C., $\operatorname{Pr} 2: 197-200$ (1842)

44 ... alluvial banks of the Connecticut River (abst). Am J Sc $47: 98$ (1844)

weber,

67 Note sur des ossements fossiles trouvés dans le nord-est du Mexique. [France], Comm Sc Mex, Arch 3:56-61, Paris 1867

Weber, Adolph H.

S8 Natural gas; petroleum and asphaltum, northern California, Cal St M Bur, An Rp $7: 179-202$ (1888)

oo Santa Clara Co. Cal St $M$ Bur, An Rp 9:48-56 (1890)

Weber, $\mathrm{H}$.

oo Die Goldlagerstätten des Cape NomeGebiets [Alaska]. Zs Prak G $8: 133-136$, map (1900)

Webster, Arthur.

o3 Geology of the west coast of Vancouver Island. Can G S, Sum Rp 1902 (An Rp 15) : A 54-76 (1903) 
Webster, Clement Lyon.

87 On the glacial flow in Iowa. Am Nat $21: 758-761$ (1887)

88 Notes on the geology of Johnson Co., Iowa. Am Nat 22:408-419 (1888)

88a Notes on the Rockford shales [Iowa]. Am Nat 22:444-446 (1888)

88b On the glacial drift and loess of a portion of the northern central basin of Iowa. Am Nat 22: 972-979 (1888)

88e Description of new species of fossils from the Rockford shales of Iowa, Am Nat 22:1013-1018 (1888)

88d Description of new and imperfectly known species of Brachiopoda, from the Devonian rocks of Iowa. Am Nat 22: 1100-1104 (1888)

89 A general preliminary description of the Devonian rocks of Iowa ... Am Nat $23: 229-243$ (1889)

89a Contributions to the knowledge of the genus Pachyphyllum. Am Nat 23: 621-625 (1889)

$\mathbf{8 9 b}$ Description of a new genus of corals [Macgeea], from the Devonian rocks of Iowa. Am Nat 23:710-712 (1889)

89e A description of the Rockford shales of Iowa. Davenport Ac Sc, Pr 5: 100-109 (1889)

90 The transitional drift of a portion of northern Iowa. Am Nat 24:1182-1185 (1890)

96 Notes on the geology of southwestern New Mexico. Am G 18:56-57 (1896)

05 Description of a new genus and species of gastropod from the Hackberry group of Iowa [Floyda concentrica]. Iowa Nat $1: 39-40$ (1905)

05a Description of a new genus of gastropod [Westerna] from the Hackberry group of Iowa. Iowa Nat 1:54-55 (1905)

05b On some species of fossils from the Hackberry group of Iowa. Iowa Nat 1: 58-59 (1905)

05e Contributions to the paleontology of the Iowa Devonian [Pachyphyllum n. sp.]. lowa Nat 1:70-71 (1905)

05d Preliminary observations on some of the constituent elements of the glacial drift of northern Iowa. Iowa Nat 1:8283 (1905)

06 Description of new species of gas. tropods from the lower and middle beds of the Hackberry group of Iowa. Iowa Nat $2: 2-4$ (1906)

09 Illustration and description of some fossil species from the Hackberry group of Iowa, Iowa Nat $2: 45-46$, il (1909)

15 Lithographic stone at Lithograph City, Iowa. Contr Sc 21:1-19, maps (1915)

Webster, John White (?-1850).

20 Localities of minerals, observed principally in Haddam, in Connecticut, in Sept. 1819. Am J Sc 2: 239-240 (1820)
Webster, John White-Continued.

24 Remarks on the geology of Boston and its vicinity. Boston $\mathrm{J}$ Ph 2: 277-292 (1824) ; $3: 486-489$ (1826)

Webster, M. H.

24 Catalogue of the minerals which have been discovered in the State of New York, arranged under the heads of the respective counties and towns in which they are found. $32 \mathrm{pp}$, Albany 1824

Webster, N. B.

75 On the physical and geological char. acteristics of the great Dismal Swamp, and the eastern counties of Virginia. Am Nat $9: 260-262$ (1875)

Wedding, $\mathrm{H}$.

92 Die Eisenerze der Insel Cuba. Stah1 und Eisen $12: 545-550$ (1892) Abst, Iron Steel Inst, J 1892 , II : $320-323$

weed, Walter Harvey.

89 Formation of travertine and siliceous sinter by the vegetation of hot springs. U S G S, An Rp 9:613-676 (1889)

$89 \mathbf{a}$ On the formation of siliceous sinter by the vegetation of thermal springs. Am J Sc (3) $37: 351-359$ (1889)

89b The diatom marshes and diatom beds of the Yellowstone National Park. Bot Gaz 14: 117-120 (1889)

89e A deadly gas spring in the Yellowstone Park. Science 13: 130-132 (1889)

90 Geysers. Sch Mines Q 11:289-306 (1890)

91 The Cinnabar and Bozeman coal fields of Montana. G Soc Am, B 2:349364 (1891)

91a The geological work of mosses and algae. Am G 7:48-55 (1891)

91b A gold-bearing hot-spring deposit. Am J Sc (3) 42:166-169 (1891)

91e (and Pirsson, L. V.) Occurrence of sulphur, orpiment, and realgar in the Yellowstone National Park. Am J Sc (3) 42: 401-405 (1891)

91 d Notes on the coal fields of Montana. Sch Mines Q 12:128-131 (1891)

92 Two Montana coal fields. G Soc $A m$, B 3:301-330, map (1892)

92a The fossil forests of the Yellowstone. Sch Mines Q 13:230-236 (1892)

92b The coal fields of Montana. Eng M J 53:520-522, 542-543, (1892); 55 : 197 (1893)

92e The formation of deposits of lime, iron, and sillica by plant life (abst). $\mathrm{Ph}$ Soc Wash, B 11: 537-538 (1892)

93 The glaciation of the Yellowstone Valley north of the Park. U S G S, B 104: 41 pp (1893)

93a The Laramie and the overlying Livingston formation of Montana. $\mathrm{U} \mathbf{S} \mathrm{G} \mathbf{S}$, B $105: 10-41, \operatorname{map}$ (1893)

93b Geysers. Smith Inst, An Rp 1891: 163-178 (1893) 
Blackwelder, Eliot-Continued.

14a Post-Cretaceous history of the mountains of central western Wyoming (abst). Wash Ac Sc, J $4: 445-446$ (1914)

14b Origin of the Rocky Mountain phos phate deposits (abst). M Sc Press 109: 987 (1914)

15 Post-Cretaceous history of the mountains of central western Wyoming. J G 23 : 97-117, 193-217, 307-340, maps (1915)

15a A fully exposed reef of calcareous algae (?) in the middle Cambrian of the Teton Mountains [Wyo.]. Am J Sc (4) $39: 646-650 \quad(1915)$

15b Origin and development of the Rocky Mountains in the United States (abst). As Am Geog, An 5:137 (1915)

15e Origin of the Rocky Mountain phos phate deposits (abst). G Soc Am, B 26 100-101 (1915)

16 The geologic rôle of phosphorus. Nat Ac Sc, Pr 2:490-495 (1916)

16a The geologic rôle of phosphorus Am J Sc (4) 42:285-298 (1916)

16b Geological transformations of phosphorus (abst). G Soc Am, B $27: 47$ (1916)

17 Physiographic conditions and copper enrichment (discussion) [age of peneplains in Rocky Mountains]. Ec G 12:541-545 (1917)

17a Characteristics of continental clastics and chemical deposits. G Soc Am, B $28 ; 917-924$ (1917)

18 The climatic history of Alaska from a new view point. Ill $\mathrm{Ac} \mathrm{Sc}, \operatorname{Tr} 10: 275-$ 280 [1918]

18a The study of the sediments as an aid to the earth historian. Nat Ac Sc, Pr 4: 163-167 (1918) Abst, G Soc Am, B 29 : 84-85 (1918)

$18 b$ New geological formations in western Wyoming. Wash Ac Sc, J 8, 13:417426 (1918)

18e (and Crooks, H. F.) Pre-Cambrian rocks in the Medicine Bow Mountains of Wyoming (abst). G Soc Am, B 29:9798 (1918)

See also Rich, $18 \mathrm{c}$.

Blair, A. A.

73 (with Chauvenet, R.) Analyses of fuels, iron ores, and pig irons. Mo G S, Prel Rp Iron Ores and Coal Fields, 1872 pt $1: 29-44$ (1873)

Blair, A. W.

13 (and Jenning, Henry). The mechanical and chemical composition of the soils of the Sussex area, N. J. N J G S, B $10: 110$ pp (1913)

Blake, Charles Carter.

62 On a fossil elephant from Texas (Elephas texianus). Geologist, London, 5 : 57-58, il (1862)

63 On the geological evidences of horses in the New World. Geologist, London, 6 : 24-28 (1863)
InIke, Charles Carter-Continued.

63a Elephas texianus v. columb. Geol ogist, London, 6:56-60, il (1863)

Blake, F. L.

06 The earth's beginnings. Hamilton \& As, J Pr 22:140-144 (1906)

Blake, Francis Hayes.

84 Vanadinite in Pinal Co., Ariz, An J Sc (3) $28: 145$ (1884)

Blake, James.

52 On the diluvial or Quaternary depos. its in California. Am J Sc (2) $13: 385-$ 391 (1852)

63 On the gradual elevation of the land in the environs of San Francisco. Cal dc N Sc, Pr $3: 45-46$ (1863)

70 Report of the sub-committee on earth. quake topics. San Francisco, Chamber of Commerce, An Rp [20]:14-15 (1870)

73 [On columnar dolerite from Black Rock, Nev.] Cal Ac Sc, Pr 4:183-184 (1873)

73a Remarks on the topography of the Great Basin. Cal Ac Sc, Pr 4:276-278 (1873) Am J Sc (3) 6:59-60 (1873)

73b On nickeliferous sand from Frate River. Cal Ac Sc, Pr 5:200 (1873) An J Sc (3) $7: 238,258$ (1874)

73e On the Puebla range of mountains [Humboldt Co., Nev.]. Cal Ac Sc, Pr 5: 210-214 (1873) Am J Sc (3) $7: 235-230$ (1874)

74 On the structure of the sonorows sand from Kauai. Cal Ac Sc, Pr 5:357 358 (1874)

76 On roscoelite or vanadium mica. Ac $\mathrm{Sc}, \operatorname{Pr} 6: 150$ (1876)

76a On roscoelite, a vanadium mies Am J Sc (3) 12:31-32 (1876)

76b On the results of glacial action at the head of Johnson's Pass in the Sierras. Cal Ac Sc, $\operatorname{Pr} 6: 170-175$ (1876)

Blake, John Charles.

01 A mica-andesite of West Sugarlosf Mountain, Boulder Co., Colo. Colo Sc Soc, Pr 7:1-17 (1901)

O1a Some relations of tetrahedral com. binations to crystalline form. Colo Sc Soc, Pr 7:19-21 (1901)

Blake, John Frederick (1839-1906),

85 First impressions of some pre-Cam brian rocks of Canada (abst). Brit As, Rp 54: 728-729 (1885)

94 On the origin of ancient quarts rocks. Science 23:141-142 (1894)

Blake, John $\mathrm{H}$.

42 Coal mines in Cuba. Am J Sc 42: $388-390 \quad(1842)$

59 (with Jackson, C. T.) [Report of the frozen well in Brandon, Vt.] Bostor Soc N H, Pr $7: 81-84$ (1859)

62 (with Jaclison, C. T., and Rogers, W. B.) $\ldots$ the frozen well of Brandon, it Boston Soc N H, Pr 9: 72-81 (1862) 
Weed, Walter Harvey Continned.

94 (with Iddings, J. P.) Livingston atlas sheet [Mont.] U S G S, G Atlas Livingston fol (no 1): 4 pp, maps (1894; prel ed 1892)

95 Montana coal fields. U S G S, An Rp 16 pt $4: 144-146$ (1895)

95a (and Pirsson, L. V.) Highwood Mountains of Montana. G Soc Am, B 6 : 389-422, map (1895) In part, Yale Bicen Pub, Contr Miner : 436-456 (1901)

95b (and Pirsson, L. V.) On the igneous roeks of the Sweet Grass Hills, Mont. Am J Sc (3) 50:309-313 (1895)

95e (and Pirsson, L. V.) Igneous rocks of Yogo Peak, Mont. Am J Se (3) $50: 467-479$ (1895)

95d The Shonkin sag, an abandoned channel of the Missouri River (abst). Science $n$ \& $1: 559-560$ (1895)

96 Yellowstone National Park; sedimentary rocks. U S G S, G Atlas Yellowstone National Park fol (no 30):4-5 (1896)

96a (and Pirsson, L. V.) Geology of the Castle Mountain mining district, Mont. U S G S, B 139: 164 pp, maps (1896)

96b (and Pirsson, L. V.) The geology of the Little Rocky Mountains [Mont.]. J G $4: 399-428$ (1896)

96e (and Pirsson, L. V.) The Bearpaw Mountains, Mont. Am J Sc (4) 1: 283-301, 351-362; $2: 136-148, \quad 188-189$, map (1896)

$96 d$ (and Pirsson, L. V.) Missourite, a new leucite rock from the Highwood Mountains of Montana. Am J Sc (4) 2 : 315-323 (1896) Yale Bicen Pub, Contr Miner : $457-466$ (1901)

96e The Fort Union formation. Am G $18: 201-211$ (1896)

$96 f$ Ore deposits of the Little Rocky Mountains, Mont. Eng M J 61:423-424 (1896)

$96 \mathrm{~g}$ Mineral resources of the Judith Mountains, Mont. Eng M J 61:496-498 (1896)

$96 h$ Notes on the geology of the Neihart mining district, Mont. Mining 1:25-29 (1896)

97 Description of the Butte [Mont.] special district. U S G S, G Atlas Butte fol (no 38) : 1-3, maps (1897)

97 a Laccoliths in folded strata (abst). Science n s 5:811-812 (1897)

98 (and Pirsson, L. V.) Geology and mineral resources of the Judith Mountains of Montana. U S G S, An Rp 18 pt 3: 437-616, maps (1898)

09 Description of the Fort Benton quadrangle [Mont.]. U S G S, G Atlas Fort Benton fol (no 55): 7 pp, maps (1899)

$99 a$ Description of the Little Belt Mountains quadrangle [Mont.]. U S G S, G Atlas Little Belt Mountains fol (no 56) : 9 pp, maps (1899)
Weed, Walter Harvey-Continued.

99b Geology of the southern end of the Snowy Range, Yellowstone National Park. U S G S, Mon 32 pt 2: 203-214 (1899)

99c Granite rocks of Butte, Mont., and vicinity. J G 7:737-750 (1899)

$99 d$ Laccoliths and bysmaliths (abst). Science n s $10: 25-26$ (1899)

99e (with Iddings, J. P.) Descrip. tive geology of the Gallatin Mountains, U S G S, Mon 32 pt $2: 1-59$ (1899)

99 (with-Iddings, J. P.) Descriptive geology of the northern end of the Teton Range, Yellowstone National Park. U S G S, Mon 32 pt $2: 149-164$, map (1899)

oo Geology of the Little Belt Mountains, Mont. U S G S, An Rp 20 pt 3 : $257-461$, maps (1900)

Q0a Mineral-vein formation at Boulder Hot Springs, Montana. U S G S, An Rp 21 pt $2: 227-255$ (1900)

oob Enrichment of mineral veins by later metallic sulphides. G Soc Am, B 11: 179-206 (1900)

ooe Vein formation at Boulder Hot Springs, Mont. Eng M J 69:321-322 (1900)

01 Geology and ore deposits of the Elkhorn mining district, Jefferson Co., Mont. U S G S, An Rp 22 pt 2:399-510, maps (1901)

01a The El Paso tin deposits [Tex.]. U S G S, B 178:15 pp (1901)

O1b (and Pirsson, L. V.) Geology of the Shonkin Sag and Palisade Butte laccoliths in the Highwood Mountains of Mon. tana. Am J Sc (4) $12: 1-17$ (1901)

o1e The enrichment of gold and silver veins. Am I $M$ Eng, $\operatorname{Tr} 30: 424-448$ (1901)

o1d Types of copper deposits in the southern United States. Am I M Eng. Tr $30: 449-504$, map (1901)

o1e Notes on the Carolina gold deposits. Eng M J 72:494 (1901)

02 Geological sketch of the Hot Springs district, Ark. U S, 57 th Cong 1st sess, S Doc 282:79-94, map (1902) Reprint. U S. Dp Interior : 47-56 (1912)

02a Influence of country rock on mineral veins. Am I M Eng, Tr 31: 634-653 (1902) Am G $30: 170-188$ (1902) Reprinted in Emmons, S. F., Ore deposits (pub. by Am I M Eng) :216-234, N ${ }^{*}$ Y 1913

02b The origin of ore deposits (dis cussion). Am I M Eng, Tr 31:959-962 (1902)

02e Notes on certain mines in the States of Chihuahua, Sinaloa, and Sonora, Mex. Am I M Eng, Tr $32: 396-443$, map (1902)

02d Notes on a section across the Sierra Madre Occidental of Chihuahua and Sinaloa, Mex. Am I M Eng, Tr $32: 444-458$ (1902) 
weed, Walter Harvey-Continued.

02e Recent development of southern copper deposits. Eng M J 74:80-81 (1902)

o2f Contact-metamorphic and other ore deposits near igneous contact. Eng M J $74: 513$ (1902)

02g The Cananea copper deposits, Mexico. Eng M J 74: 744-745 (1902)

03 Gold mines of the Marysville district, Mont. U S G S, B 213:88-89 (1903)

03a Tin deposits at El Paso, Tex. U S G S, B $213: 99-102$ (1903)

03b Ore deposits at Butte, Mont. U s G.S, B 213:170-180 (1903)

03e Copper deposits of the Appalachian States. U S G S, B 213:181-185 (1903)

03d Copper deposits of New Jersey. N J G S, An Rp 1902: 125-139 (1903)

13e Ore deposits near igneous contacts. Am I M Eng, Tr $33: 715-746$ (1903) Reprinted in Emmons, S. F., ore deposits (pub by Am I M Eng) : 364-402, N Y 1913

03f Ore deposition and vein enric lent by ascending hot waters. Am I M Eng, $\operatorname{Tr} 33: 747-754$ (1903) Reprinted in Emmons, S. F., ore deposits (pub. by Am I M Eng) : 403-410, N Y 1913

03s (and others) The genetic classification of ore bodies: a proposal and a diseussion (by S. F. Emmons, J. E. Spurr, Waldemar Lindgren, F. L. Ransome) [See also Rickard, 03] Eng M J 75:256-258 (1903)

03h Secondary enrichment at Cripple Creek [Colo.]. Eng M J 75:553-554 (1903)

03i Cross-vein ore shoots and fractures. Eng M J 76:193 (1903)

03j The Cananea ore deposits [Mex.]. Eng M J $76: 383$ (1903)

03k A genetic classification of ore deposits (abst, with discussion by J. E. Spurr and Waldemar Lindgren). Science n s 17 : $273-274(1903)$

04 Gypsum deposits in Montana, U S G S, B 223:74-75 (1904)

04a Copper deposits in Georgia. U S G S, B 225:180-181 (1904)

04b The Griggstown, N J., copper deposit. U S G S, B 225: 187-189 (1904)

04e Notes on the copper mines of Vermont. U S G S, B 225: 190-199 (1904)

04d Occurrence and distribution of copper in the United States. M Mag 10185 193 (1904)

o4e Original native gold in igneous rocks. Eng M J 77:440-4+1 (1904)

04f Dilation fissures and their contained ores (abst). Science n s 20:761 (1904)

05 The nature of ore deposits, by Dr. Richard Beck. Transl. and rev. by W. H. Weed. 2 vols, 685 pp, map, N Y 1905 Review, by F. D. Adams, Ec G $1: 393-401$ (1906)
Weed, Walter Harrey-Continued.

O5a Cement resources of Montana. U S

G S, B 243: 227-228 (1905)

05b Notes on the gold veins near Great Falls, Md. U S G S B 260: 128-131 (1905)

05e The copper production of the United States. U S G S, B 260:211-216 (1905)

o5d The copper deposits of the eastern United States. U S G S, B 260:217-220 (1905)

o5e Economic value of hot springs and hot-spring deposits. U S G S, B 260: 598604 (1905)

05f Notes on certain hot springs of the southern United States. U S G S, W-S P $145: 185-206 \quad$ (1905)

o5g Copper mines near Havana, Cuba. Eng M J 79:176-177 (1905)

06 The copper mines of the United States in 1905. U S G S, B 285:93124 (1906)

06a (and watson, T. L.) The Virginia copper deposits. Ec G $1: 309-330$ (1906)

06b Ore shoots. Eng M J 82:196 (1906)

66e The copper mines of the United States. M Sc Press 93:484-485 (1906)

o6d Shifting of the Continental Divide at Butte, Mont. (abst). G Soc Am, B 16: 587 (1906)

07 The copper mines of the world. 375 pp, N Y 1907

07a Mutual displacement by intersecting veins. Eng M J 83:1145-1146 (1907)

os Notes on the Tyee copper mine, Vancouver Island, B. C. Eng M J 85:199201 (1908)

10 The Kingman mining district of Ariz. M World 32: 1113-1114 (1910)

11 Copper deposits of the Appalachian States. U S G S, B 455: 166 pp (1911)

11 a The Ray copper-mining district, Ariz. M World $34: 53-56$ (1911)

12 Geology and ore deposits of the Butte district. Mont. U S G S, P P 74 : 262 pp, maps (191/)

$12 \mathrm{a}$ Notes on the Miami copper district, Ariz. M World 36:1043-1044 (1912)

12b A plea for rational classification of ore deposits. M World 36:1088 (1912)

12e Brief notes on the geology of the Ely district, Nev. M World $36: 1198$ (1912)

12d Is geology a success as a guide to ore deposits? M World $36: 1138 ; 37: 245-$ 246 (1912)

12e Geysers. 29 pp. U S Dp Interior (1912)

13 Geology of the copper mines of Butte, Mont. M World 38:110-112, map (1913)

$13 a$ "Chimney" or "pipe" deposits in the porphyries. M World $38: 375-378$ (1913) 
weed, Walter Harvey-Continued.

13b Geology and ore deposits of the Butte district, Mont. (abst). Wash Ac Sc, J 3:363-364 (1913)

14 The copper handbook; a manual of the copper-mining industry of the world. Vol 11, 1912-1913: 1413 pp, Houghton, Mich, 1914

16 The mines handbook; an enlargement of the copper handbook; a manual of the mining industry of North America. Vol $12: 1699 \mathrm{pp}, \mathrm{N}$ Y 1916 Vol $13: 1896 \mathrm{pp}$, N Y 1918

17 Copper in America. Pan American Sc Cong, 2d., Washington, Pr sec 7 v 8 : 416-426 (1917)

See also Adams (F D), 06b; Beck, 05 ; Eckel, 13; Emmons (S F), 93; 03d, e ; Powell, 95 ; Rickard, 03

weeks, Fred Boughton.

96 Bibliography and index of North American geology, paleontology, petrology, and mineralogy for 1892 and 1893 . U S G S, B $130: 210$ pp (1896) ... 1894; B $135: 141$ pp (1896) ... 1895; B $146: 130$ pp (1896) ‥ 1896; B $149: 152$ pp (1897) ... 1897; B 156 : 130 pp (1898) ... 1898: B $162: 163$ pp (1899) ‥ 1899; B 172: 141 pp $(1900) \quad \ldots$ 1901; B 203: 144 pp (1902)

99 [A reconnaissance in Jackson Basin, northwest Wyo. (abst).] Science n s 9: 454 (1899)

99a The duplication of geologic formation names. Science n 8 9:490-491, 625626 (1899) J G $7: 297-299$ (1899) Am G $23: 266-267$ (1899)

o1 An occurrence of tungsten ore in eastern Nevada. U S G S, An Rp 21 pt 6 : 319-320 (1901)

02 Bibliography (and index) of North American geology, paleontology, petrology, and mineralogy for the years 1892-1900, inclusive. U S G S, B 188:717 pp; B 189: 337 pp (1902)

02a North American geologic formation names; bibliography, synonymy, and distribution. U S G S, B 191: 448 pp (1902)

02b Gold-bearing quartzites of eastern Nevada $(a b s t)$. Science n s 15: 546 (1902)

03 Tungsten ore in eastern Nevada. U S G S, B 213:103 (1903)

O3a Occurrence of Paleozoic rocks in the southern portion of the Great Basin region ( $a b s t)$. Science n s $17: 26$ (1903)

04 [Notes on water resources of] New York. U S G S, W-S P 102:169-206 (1904)

05 [Underground waters of] New York. U S G S, W-S P 114: 82-92, map (1905)

07 Stratigraphy and structure of the Uinta Range. G Soc Am, B 18: 427-448, map (1907)
Weeks, Fred Boughton-Continued.

o7a (and Ferrier, W. F.) Phosphate deposits in western United States. U \& G S, B 315:449-462 (1907) Abst, Science n 8 25:620-621 (1907)

08 Geology and mineral resources of the Osceola mining district, White Pine Co., Nev. U S G S, B 340:117-133, map (1908)

OSa (and Heikes, V. C.) Notes on the Fort Hall mining district, Idaho. U S G S, B 340:175-182, map (1908)

osb Tungsten deposits in the Snake Range, White Pine Co., eastern Nev. U S G S, B 340:263-270 (1908)

ose Phosphate deposits in the western United States. U S G S, B $340: 441-447$ (1908) U S Cong, House, Hearings held before the committee on public lands of the House of Representatives ... on H. R. 21873: 101-104, Washington 1910

Weeks, Joseph Dame (1840-1896).

86 Natural gas. U $\mathbf{S}$ G $\mathbf{S}$, Min Res 1885 : $155-179 ; 1886: 488-516 ; 1887: 464-$ $502 ; 1888: 481-512 ; 1889-90: 366-372$; $1891: 436-451 ; 1892: 652-698 ; 1893: 534-$ 541; An Rp 16 pt $4: 405-429 ; 17$ pt 3 : $733-750-(1886-96)$

86a Manganese. U S G $\mathbf{S}$, Min Res $1885: 303-356 ; 1886: 180-213 ; 1887: 144$ 167 ; 1888: 123-143 (1890); 1889-90: $127-136 ; 1891: 126-146 ; 1892: 169-226$; 1893: 119-155; An Rp 16 pt $3: 389-457$; An Rp 17 pt $3: 185-225$ (1886-96)

87 Petroleum. U S G S, Min Res 1886 : $439-487 ; 1887: 436-463 ; 1888: 442-480$; $1889-90: 287-365 ; 1891: 403-435 ; 1892$ : 603-651; $1893: 461-533$; An Rp 16 pt 3 : $315-404 ; 17$ pt $3: 621-731$ (1887-96)

94 The Potomac and Roaring Creek coal fields in West Virginia. U S G S, An Rp 14 pt 2:567-590, map (1894)

95 The Elk Garden and upper Potomac coal fields of West Virginia. Am I M Eng, Tr 24:351-364, maps (1895)

Weeks, Walter Scott.

14 (and Huntington, E. V.) The faultless fault-finder. Eng M J 98: 291296 (1914)

wegemann, Carroll Harvey.

09 Some notes on river development in the vicinity of Danville, III. IIl, Univ, B 6 no 17 , The University Studies 3 no 2 : 21-42 (1909)

09n Notes on the coals of the Custer National Forest, Mont. U S G S, B 381: 108-114, map (1909)

10 (with Gale, H. S.) The Buffalo coal field, Wyo. U $\quad$ S $\quad$ G $\quad$ S, $\quad$ B $\quad 381: 137-169$ (1910)

11 The Salt Creek oil field, Wyo. U S G $\mathrm{S}, \mathrm{B} 452: 37-83$, map (1911)

12 The Powder River oil field, Wyo. U S G S, B 471:56-75, map (1912) 
wegemann, Carroll Harvey-Continued. 12a The Sussex coal field, Johnson, Natrona, and Converse cos., Wyo. U S G S, B 471:441-471, maps (1912)

12b Plane-table methods as adapted to geologic mapping. Ec G, $7: 621-637$ (1912)

13 The Barber coal field, Johnson Co., Wyo. U S G S, B 531:262-284, map (1913)

14 Geology and coal resources of the Sierra Blanca coal field, Lincoln and Otero cos., N. Mex. U S G S, B 541:419-452, maps (1914)

15 The Coalville coal field, Utah. U S G S, B 581: 161-184, map (1915)

15a Anticlinal structure in parts of Cotton and Jefferson cos., Okla. U S G S, B $602: 108$ pp, maps (1915)

15b (and Heald, K. C.) The Healdton oil field, Carter Co., Okla. U S G S, B 621: 13-30, map (1915)

15e The Loco gas field, Stephens and Jefferson cos., Okla. U S G S, B 621 : 3142, maps (1915)

15d The Duncan gas field, Stephens Co., Okla. U S G S, B 621: 43-50, map (1915)

15 e A reconnaissance in Palo Pinto Co., Tex., with special reference to oil and gas. U S G S, B 621:51-59, map (1915)

$15 P$ (and Howell, R. W.). The Lawton oil and gas fleld, Okla. U S G S, B 621: $71-85$, map (1915)

$15 \mathrm{~g}$ A reconnaissance for oil near Quanah, Hardeman Co., Tex, U S G S, B 621: 109-115, map (1915)

16 Notes on the gas fields of central and southern Oklahoma. U S G S, B 629: $121-126$ (1916)

17 Wasatch fossils in so-called Fort Union beds of the Powder River basin, Wyo., and their bearing on the stratigraphy of the region. U S G S, P P 108: 57-60 (1917) Abst, Wash Ac Sc, J 6: 254-255 (1916)

18 The Salt Creek oil field, Wyo. U S G S, B $670: 52 \mathrm{pp}$, maps (1918) Abst, by R. W. Stone, Wash Ac Sc, J 8:538 (1918)

See also Munn, 14

wegener, Georg.

03 Einige neue Aufnahmen vom Mont Pelé. Ges Erdk Berlín, Zs 1903: 431-433

03a Am Mont Pelé im März, 1903. Geog Zs $9: 545-559$ (1903)

04 Reisen im Westindischen Mittelmeer; Fabrten und Studien in den Antillen, Colombia, Panama, und Costarica im Jahre 1903. 2d ed, 302 pp, Berlin 1904

Weidman, Samuel.

95 On the quartz keratophyre and associated rocks of the north range of the Baraboo Bluffs. Wis Univ, B, se s $1: 35-$ 56, map (1895) Abst, Seience n s $1: 67$ (1895)
Weidman, Samuel-Continued.

98 A contribution to the geology of the pre-Cambrian igneous rocks of the Fox River valley, Wis. Wis G S, B 3 (sc s 2) : $63 \mathrm{pp}$, map (1898)

03 Preliminary report on the soils and agricultural conditions of north central Wisconsin. Wis G S, B 11 (ec s 7):68 pp, Madison, Wis., 1903

03a The pre-Potsdam peneplain of the pre-Cambrian of north central Wisconsin. J G 11: 289-313 (1903)

03b Note on the amphibole hudsonite previously called a pyroxene. Am J Sc (4) $15: 227-232$ (1903)

04 The Baraboo iron-bearing district of Wisconsin. Wis G S, B 13 (ec s 8): 190 pp, map, Madison, Wis., 1904

04a Widespread occurrence of fayalite in certain igneous rocks of central Wisconsin. J G 12:551-561 (1904) Abst, G Soc Am, B 15:551-552 (1904); Science n \& $19: 526$ (1904); Sc Am Sup 57: 23446 (1904)

04b Iron ores of Wisconsin with special reference to the Baraboo district. Wis Engineer 9:31-45, map (1904) Abst, Eng M J 79:610-612 (1905)

07 Irvingite, a new variety of lithiamica. Am J Sc (4) 23:451-454 (1907)

07 a The geology of north central Wisconsin. Wis G S, B $16: 697 \mathrm{pp}$, maps (1907)

07b (and Lenher, V.) Marignacite, a new variety of pyrochlore from Wausau, Wis. Am J Sc (4) $23: 287-292$ (1907)

os General petrology of Wisconsin igneous rocks (abst). Science n $\mathrm{s} \quad 27: 723$ (1908)

11 The glacial lake of the Fox River valley and Green Bay and its outlet (abst). Science n s $33: 467$ (1911)

$11 \mathrm{n}$ (and wood, P. O.) Reconnaissance soil survey of Marinette Co. Wis G S, B 24, soil s no $1: 44$ pp, map (1911)

11b (assisted by Hall, E. .., and Musback, F. L.) Reconnaissance soil survey of part of northwestern Wisconsin. Wis G S, B no 23 , ec s 14:102 pp, maps (1911)

13 The Pleistocene succession in $W$ isconsin (abst). Science n s 37:456-457 (1913) G Soc Am, B 24:697-698 (1913)

15 (and Schaltx, A. R.) The underground and surface-water supplies of Wisconsin. Wis G S, B $35: 664$ pp, map (1915)

weidner, Frederico.

77 El Cerro de Mercado de Durango [iron deposits]. México, Ministerio de Fomento, An $3: 155,163-182$ (1877)

84 Der mexikanische Staat Sinaloa. Petermanns Mitt 30:1-9, map (1884) 
Weinsebenk, E.

91 (with Cohen, E.) MeteoreisenStudien. K- $k$ Naturh Hofmus, An 6:131165 (1891)

91 a (with Kunz, G. F.) Meteoritenstudien [Washington, Kans. : Floyd Mountain, Va.]. Tschermak's Mitt N F 12: $177-185 \quad(1891)$

92 (with Kunz, G. F.) Farmington, Washington Co., Kans., aerolite. Am J Sc (3) $43: 65-67$ (1892)

92a (with Kunz, G. F.) On two meteoric irons [Virginia and Chile]. Am J Sc (3) $43: 424-426$ (1892)

16 The fundamental principles of petrology. Transl from 3d German ed. by Albert Johannsen. 214 pp, N Y 1916

Weitzel, R. H.

90 The coal fields of Texas. Ohio M J no $19: 98-103$ (1890) Abst, Eng M J 50 : 214-216 (1890)

weleh, William $\mathrm{L}$.

S6 Opening of Hatteras Inlet [coast of North Carolina]. Essex Inst, B 17:37-42 (1886)

$86 \Omega$... some changes in the coast line lof North Carolina]. Essex Inst, B 17:42-47 (1886)

Weleh, R. Kemp.

09 The placer-mining industry of North Carolina. M World 30:965-967 (1909)

weld, C. M.

09 The residual brown iron ores of Cuba. Am I M Eng, B 32: 749-762 (1909); Tr $40: 299-312$ (1910)

15 The Oriskany iron ores of Virginia. Ec G 10:399-421 (1915)

18 Notes on certain iron-ore resources of the world; Cuba. Am I M Eng, B 141 : 1479-1485 (1918)

Weld, F. A.

57 On the volcanic eruption at Hawail in 1855-56. G Soc London, Q J $13: 163-$ 169 (1857)

weller, Chas. A.

o7 Barytes mines of the Commercial Mining and Milling Company. [Tennessee]. Eng M J 83:851 (1907)

Weller, Stuart.

95 A circum-insular Paleozoic fauna. J G $3: 903-917$ (1895)

95a The succession of fossil faunas at Springfield, Mo. Am J Se (3) 49: 185-199 (1895)

96 (and Davidson, A. D.) Petalocrinus mirabilis (n. sp.) and a new American fauna. J G 4:166-173, il (1896)

97 The Batesville sandstone of Arkansas. N Y Ac Sc, Tr 16:251-282, il (1897) Abst, Science n s 5:560 (1897)

97 a Correlation of the Devonian faunas in southern Illinois. J G 5:625-635 (1897)

$\mathbf{9 7 b}$ On the presence of problematic fossil Medusae in the Niagara limestone of northern Illinois, J G $5: 744-751$, il (1897)
Weller, Stuart-Continued.

97e Cryptodiscus Hall. J G $5: 803$ 808, il (1897)

98 A bibliographic index of North Amer. iean Carboniferous invertebrates. U S G S. B 153,653 pp (1898)

98a Descriptions of Devonian crinoids and blastoids from Milwaukee, Wis. N Y Ac Se, An 11:117-124, il (189s)

98h Description of a new species of Hydreionocrinus from the Coal Measures of Kansas, N Y Ac Sc, Tr $16: 372-374$, il (1898)

98e Classification of the Mississippian series. J G $6: 303-314$, maps (1898)

98d The Silurian fauna interpreted on the epicontinental basis. J G $6: 692-703$, maps (1898)

98e Osage vs. Augusta. Am G 22:1216 (1898)

99 Kinderhook faunal studies; I, The fauna of the vermicular sandstone at Northview, Webster Co., Mo. Ac Sc St L, Tr 9:9-51, il (1899)

99a A peculiar Deronian deposit in northeastern minois. J G 7:483-488 (1899)

99b A century of progress in paleontology. J G $7: 496-508$ (1899)

00 A preliminary report on the strati. graphic paleontology of Walpack Ridge, in Sussex Co., N. J. N J G S, An Rp 1899: 1-46 (1900)

00a Descriptions of Cambrian trilobites from New Jersey with notes on the age of the magnesian limestone series. N J G S, An Rp 1899: 47-53, il (1900)

Oob The succession of fossil faunas in the Kinderhook beds at Burlington, Iowa. Iowa G S 10:59-79 (1900)

00e The paleontology of the Niagaran limestone in the Chicago area: the Crinoidea, Chicago Ac Sc, N H S, B 4:1-153, il (1900)

o0d Kinderhook faunal studies; II, The fauna of the Chonopectus sandstone at Burlington, Iowa. Ac Sc St L, Tr 10:57129 , il (1900)

o0e ... fossils from Wichita Mountains,

G Soc Am, B 11:142-144 (1900)

oof The Gurley collection of fossils. J G $8: 74-75(1900)$

01 A preliminary report on the Paleozoic formations of the Kittatinny Valley in New Jersey. N J G S, An Rp 1900: 1-8 (1901)

o1a Kinderhook faunal studies: III, The faunas of beds No. 3 to No. 7 at Burlington, Iowa. Ac Sc St L, Tr 11:147-214, il (1901)

O1b Correlation of the Kinderhook formations of southwestern Missouri. J G $9: 130-148$ (1901)

o1e (with Kimmel, H. B.) Paleozoic limestones of Kittatinny Valley, N. J. G Soc Am, B 12: 147-164, map (1901) 
weller, Stuart-Continued.

o1d (with Smith, J. P.) Prodromites, a new ammonite genus from the Lower Carboniferous. J G 9:255-268, il (1901)

02 The composition, origin, and relationships of the Corniferous fauna in the Ap. palachian province of North America. J G $10: 423-432$ (1902)

02a Crotalocrinus cora (Hall). J G 10 : 532-534, il (1902)

02b (with Kümmel, H. B.) The rocks of the Green Pond Mountain region. N J G S, An Rp 1901: 1-51 (1902)

03 The Paleozoic faunas. N J G S, Pal 3: 462 pp, il (1903)

05 The fauna of the Cliffwood, New Jersey, clays. N J G S, An Rp 1904: 131144 , il (1905) J G $13: 324-337$, il (1905)

$05 a$ The classification of the upper Cretaceous formations and faunas of New Jersey. N J G S, An Rp 1904: 145-159 (1905) J G 13:71-84 (1905)

05b Paraphorhynchus, a new genus of Kinderhook Brachiopoda. Ac Sc St L, Tr $15: 259-264$, il (1905)

05e A fossil starfish from the Cretaceous of Wyoming. J G $13: 257-258$, il (1905)

05d The northern and southern Kinderhook faunas. J G 13: 617-634 (1905)

05e Classification of the upper Cretaceous formations of New Jersey (abst). Am G 35:176-177 (1905) G Soc Am, B $16: 579(1906)$

05P Fauna of the Cliff wood clays (abst). Am G 35:179 (1905) G Soc Am, B 16: 580 (1906)

06 Kinderhook faunal studies; IV, The fauna of the Glen Park limestone. Ac Sc St. Louis, Tr $16: 435-471$, il (1906)

06a The geological map of Inlinois. III G S, B 1:26 pp, map (1906) [Rev, Irving ( $\mathrm{J}$ D), 06] $2 \mathrm{~d}$ ed, B $6: 34 \mathrm{pp}$, map (1907)

06b Geologic structure of the State [of Illinois]. III G S, B $2: 21-22$ (1906)

07 A report on the Cretaceous paleontology of New Jersey, based upon the stratigraphic studies of George N. Knapp. N J G S, pal s 4:1106 pp, il (1907)

$07 \mathbf{a}$ The paleontology of the Niagaran limestone in the Chicago area; the Trilobita, Chicago Ac Se, N H S, B 4:161281, il (1907)

07b The pre-Richmond unconformity in the Mississippi Valley. J G 15:519-525 (1907)

07c Notes on the geology of southern Calhoun Co. [IIl.]. III G S, B 4:219-233 (1907)

08 The geological map of Illinois (abst). III G S, B $8: 41-47$ (1908)

08a The Salem limestone. III G S, B $8: 81-102$ (1908)

087. The Mississippian section in IIIInois (abst). Science n s 27:726 (1908) weller, Stuart-Continued.

09 Kinderhook faunal studies; $V$, The fauna of the Fern Glen formation. G Soc Am, B 20:265-332, il (1909)

09a Correlation of the middle and upper Devonian and the Mississippian faunas of North America. J G 17:257-285 (1909)

09b Description of a Permian crinoid fauna from Texas. J G $17: 623-635$, il (1909)

09e The fauna of the Fern Glen formation (abst). Science n s 29:636 (1909)

10 Internal characters of some Mississippian rhynchonelliform shells. G Soc Am, B 21: $497-516$, il (1910)

11 Are the fossils of the dolomites indicative of shallow, highly saline, and warm-water seas? G Soc Am, B 22:227231 (1911)

$11 a$ Genera of Mississippian loop-bearing Brachiopoda. J G $19: 439-448$, il (1911)

13 Stratigraphy of the Chester group in southwestern Illinois. Ill Ac Sc, Tr 6 : 118-129 (1913)

14 The Mississippian Brachiopoda of the Mississippi Valley basin. Ill G S, Mon 1: $508 \mathrm{pp}$, il (1914)

14n (and Meh1, M. G.) Western extension of some Paleozoic faunas in south. eastern Missouri $(a b s t)$. G Soc Am, B $25: 135-136$ (1914)

15 Anticlinal structure in Randolph Co. [III.]. III G S, B 31: 69-70, map (1915)

15a (and Van Tuyl, F. M.) The Ste. Genevieve formation and its stratigraphic relations in southeastern Iowa. Iowa Ac Sc, Pr 22: 241-247 (1915) Abst, Science n 8 41:950 (1915)

16 Atactocrinus, a new crinoid genus from the Richmond of Illinois. Chicago Univ, Walker Mus, Contr 1:239-241, il (1916)

16a Description of a Ste. Genevieve limestone fauna from Monroe Co., III. Chicago, Univ, Walker Mus, Contr $1: 243-$ 264 , il (1916)

16b Stratigraphic and faunal succession of the Chester group in Illinois and Kentucky (abst). G Soc Am, B 27:156 (1916)

16e Former extension of the Devonian formations in southeastern Missouri (abst). G Soc Am, B 27:160 (1916)

18 Henry Shaler Williams, 1847-1918. J G $26: 698-700$ (1918)

See also Blatchley (W S), 06

Wells, David Ames (1828-1898).

50 [On the age of the sandstones of the Connecticut Valley.] Boston Soo $\mathrm{N} \mathrm{H}, \mathrm{Pr}$ $3: 339-341$ (1850)

50a $[$ On a vein of phosphate of lime near Crown Point, N. Y.] Boston Soc N H, $\operatorname{Pr} 3: 379$ (1850) 
Wells, David Ames-Continued.

51 On the origin of stratification. Boston Soc N H, Pr 4:108-110 (i851) Am $\Delta s, \operatorname{Pr} 6: 297-299$ (1852) Am J Sc (2) 13: $13-14 \quad(1852)$

60 [On a meteorite, which fell at Bethlehem, Albany Co., N. Y.] Boston Soc N $\mathrm{H}, \operatorname{Pr} 7: 176-179$ (1860)

64 First principles of geology... 333 pp, N Y 1864

90 Evidences of glacial action in southeastern Connecticut. Pop Sc Mo 37:196201 (1890)

92 Remarkable boulders. Pop Sc Mo $40: 340-346$ (1892)

See also Annual of scientific discovery

Wells, E. H.

18 Manganese in New Mexico. N Mex St Sch Mines, B 2:85 pp, map (1918)

Wells, G. M.

96 The Florida rock phosphate deposits. Am I M Eng, Tr 25:163-172, maps (1896) wells, H. G.

93 The making of mountain chains. Sc Am Sup 36:14974-14975 (1893)

Wells, Horace Lemuel.

85 (and Penfleld, S. L.) Gerhardtite and artificial basic cupric nitrates. Am J Sc (3) 30:50-57 (1885) Yale Bicen Pub, Contr Miner : 134-137 (1901)

S7 Bismutosphaerite from Willimantic and Portland, Conn. Am J Sc (3) 34 : 271-274 (1887)

89 Sperrylite, a new mineral. Am J Sc (3) $37: 67-70$ (1889) Yale Bicen Pub, Contr Miner: 151-156 (1901) Zs Kryst 15: 285-289 (1889)

89a (with Dana, :. S.) Description of the new mineral, beryllonite. Am J Sc (3) 37:23-32 (1889) Zs Kryst 15: 275-284 (1889)

90 (with Dana, E. S.) On some selenium and tellurium minerals from Honduras. Am J Sc (3) 40:78-82 (1890)

91 On the composition of pollucite and its occurrence at Hebron, Me. Am J Sc (3) 41:213-220 (1891) Yale Bicen Pub, Contr Miner: 183-192 (1901) Zs Kryst $19: 63-71$ (1891)

92 (and Penfield, S. L.) On herderite from Hebron, Me. Am J Sc (3) 44:114 116 (1892)

94 (with Pirsson, L. V.) On the occurrence of leadhillite in Missouri and its chemical composition. Am J Sc (3) 48: 219-226 (1894)

02 (and Penfield, S. L.) On a new occurrence of sperrylite [Wyoming]. Am J Sc (4) 13: 95-96 (1902)

o6 Samuel Lewis Penfield. Science n s 24: 252-253 (1906)

o7 Biographical memoir of Samuel Lewis Penfield, 1856-1906. Nat Ac Sc, Biog Mem 6:119-146, port (1907)

13 Note on artificial sperrylite. Am J Sc (4) $35: 171-172$ (1913)
Wells, J. Walter.

97 The mispickel gold ores of Deloro, Ont. Fed Can M Inst, J 2:127-133 (1897) Can M Rv 16:120-121 (1897)

02 Arsenic in Ontario. Ont Bur Mines, Rp 1902 : 101-122 (1902)

o3 Molybdenite, its occurrence, concentration, and uses. Can $M$ Inst, J 6:4765 (1904) Can M Rv 22:113-118 (1903)

o5 Preliminary report on the industrial value of the clays and shales of Manitoba. Can, Dp Interior, Mines Br: 41 pp, Ottawa 1905

05a Preliminary report on the limestones and the lime industry of Manitoba. Can, Dp Interior, Mines $\mathrm{Br}: 68 \mathrm{pp}$, Ottawa 1905

05b Preliminary report on the raw ma. terials, manufacture, and uses of hydraulic cements in Manitoba, 1905. Can, Dp Interior, Mines $\mathrm{Br}: 70 \mathrm{pp}$, Ottawa 1905

wells, R. W.

19 On the origin of prairies. Am J Sc 1: 331-337 (1819)

Wells, Roger Clark.

10 The fractional precipitation of sulphides. Ec G 5:1-14 (1910)

10a Criteria of downward sulphide en. richment (discussion). Ec G $5: 479-484$ (1910)

10b A new occurrence of hydrogiobertite [Chiles Valley, Napa Co., Cal]. Am J Sc (4) 30:189-190 (1910)

11 The rôle of hydrolysis in geological chemistry. Ec G 6:211-217 (1911) Abst, Wash Ac Sc, J 1:36 (1911)

$11 \mathrm{n}$ (with Hess, F. L.) An occurrence of strüverite. Am J Sc (4) $31: 432-442$ 577 (1911) Abst, Wash Ac Sc, J $1: 88-89$ (1911)

13 Electrochemical activity between solutions and ores. Ec G $8: 571-577$ (1913)

13a A new occurrence of cuprodescloizite [Bisbee, Ariz.]. Am J Sc (4) 36 : 636-638 (1913)

13b The interpretation of mineral anal yses. Wash Ac Sc, J 3: 416-423 (1913)

14 Electric activity in ore deposits. U S G S, B 548: 78 pp (1914) Abst, Wash Ac Sc, J $5: 23-24$ (1915)

15 The fractional precipitation of some ore-forming compounds at moderate temperatures. U S G S, B 609: 46 pp (1915) Abst, Wash Ac Sc, J 5: 634-635 (1915)

15a The solubility of magnesium carbonate in natural waters (abst). Wash Ac Sc, J 5 : 491 (1915)

15b The solubility of calcite in water in contact with the atmosphere, and its variation with temperature. Wash $\mathrm{Ac} \mathrm{Sc}$, J 5 : 617-622 (1915)

16 Experiments on the extraction of potash from wyomingite. U S G S, P P $98: 37-40$ (1916) Abst, Wash Ac Sc, J $6: 504$ (1916) 
Wells, Roger Clark-Continued.

16a (and Larsen, E. S.) Lorettoite, a new mineral. Wash Ac Sc, J 6:669-672 (1916)

16b (with Larken, E. S.) Some minerals from the fluorite-barite vein near Wagon Wheel Gap, Colo. Nat Ac Sc, Pr 2: 360-365 (1916)

17 (and Butler, B. S.) Tungstenite, a new mineral. Wash Ac Sc, J $7: 596-599$ (1917)

17a (with Mills, R. V. A.) The evaporation of water at depth by natural gases (abst). Wash Ac Sc, J $7: 309-310$ (1917)

18 New determinations of carbon dioxide in water of the Gulf of Mexico. U S G S, P P $120: 1-6$ (1918) Abst, by R. W. Stone, Wash Ac Sc, J 8:539-540 (1918)

18a The solubility of calcite in seawater in contact with the atmosphere, and its variation with temperature. Carnegie Inst Wash, Papers from the Department of Marine Biology 9 (Pub no 213) : 316318 (1918)

18b Tungstenite, disulphide of tungsten, a new mineral (abst). Wash Ac Sc, J 8 : 99 (1918)

Wells, W. E.

04 The topography and geology of Clifton Gorge [Greene Co., Ohio]. Ohio Nat 4: $75-78$ (1904)

Welsh, Jane Kilby.

32 Familiar lessons in mineralogy and geology... 2 vols, 404, 401 pp, Boston 1832-3

Welsh, Norval J.

14 The Organ Mountain district [N. Mex.]. Eng M J 98: 331-334, map (1914) Welsh, T. W. B.

12 (and Stewart, C. A.) Note on the effect of calcite gangue on the secondary enrichment of copper veins (discussion). Ec G $7: 785-787$ (1912)

Welter, Joshua Lewis.

00 Report... on the Lacoe collection of fossils. Wyoming Hist $\mathrm{G}$ Soc, Pr $5: 177$ $204(1900)$

Wemple, Edna $M$.

06 New cestraciont teeth from the westAmerican Triassic. Cal Univ, Dp G, B 5 : $71-73,11$ (1906)

Wendeborn, $B$. A.

03 Der Ducktown-Kupfergrubendistrict in den Vereinigten Staaten von Nordamerika. Berg- u hütt Ztg $62: 86-88$ (1903)

04 Die Tätigkeit heisser Quellen in den Gängen von Wedekind, Nevada [rôle of thermal waters in the veins]. Berg- u hütt Ztg 63:265-266 (1904)

04a Die Quecksilberablagerungen in Oregon. Berg- $u$ hütt Ztg $63: 274-277$ (1904)

Wendt, Arthur Frederick (1852-1893).

85 The iron mines of Putnam Co., N. Y. Am I M Eng, Tr 13:478-488, map (1885)
Wendt, Arthur Frederick-Continued.

86 The pyrites deposits of the Alleghanies. Sch Mines Q 7:154-188, 218-235, 301-323 (1886) Eng M J 41:407-410, $426-428,446-447 ; 42: 4-5,22-24$ (1886)

87 The copper ores of the Southwest. Am I M Eng, $\operatorname{Tr} 15: 25-77$, map (1887) Eng M J 43: 94-96, 112-114, 133-134, $150-152,183-185$ (1887)

Wenström, 0 .

92 (and Sjögren, Hj.) Meddelande rörande jernmalmer m. m. 1 Nord Amerika. G Fören Stockholm, Förh 14:358-362 (1892)

Wentworth, Chester $\mathrm{K}$.

17 A proposed dip protractor. J G 25: 489-491 (1917)

Wentworth, Irving $H$.

12 The San Nicolas mining district, San Nicolas, Tamaulipas, Mexico. Am I M Eng, B $68: 843-852$ (1912); Tr 43:304-313 (1913)

wentworth, R. Preston.

15 Pre-Wisconsin glacial drift in the Boston Basin. Science n s 42:58 (1915)

Wesson, Edward.

85 Niagara Falls; the rate at which they recede southwards. Nature $32: 229_{-}$ 230 (1885)

West, Charles E.

43 Notice of certain siliceous tubes (fulgurites) formed in the earth. $\Delta \mathrm{m} \mathbf{J}$ Sc $45: 220-222$ (1843)

58 On an earthquake in western New York. Am J Sc (2) $26: 177-182$ (1858)

$\Delta \mathrm{m}$ As, Pr 12: 127-133 (1859)

West, E. P.

79 Following the pick and the spade [drainage changes in Kansas City, Mo., area]. Kansas City Rv Sc $3: 328-330$ (1879)

83 Age of the Missouri River. Kansas City Rv Sc $7: 25-28$ (1883)

85 The last submersion and emergence of southeastern Kansas from the Corboniferous seas, or those affecting the Carboniferous formation in Kansas. Kans Ac Sc, Tr 9:106-109 (1885) Kansas City Rv Sc $8: 477-480,565-567$ (1885)

West, H. E.

09 Impressions of a new Ontario camp, Gowganda. Eng M J $87: 900-902$ (1909)

09a Features of a vein formation in Nicaragua. Eng M J $87: 1130-1133$ (1909)

12 The geological progress of twentyfive years. Ohio St Ac Se, Pr 6:20-42 (1912)

West, H. H.

77 Report of discovery of mastodon tusk (Kansas City, Mo.). Western Rv Sc 1: 336-337 (1877)

west, Samuel.

93 A letter concerning Gay Head [Mass.]. Am Ac Arts, Mem 2: 147-150 (1793) 
Westeott, Henry P.

13 Handbook of natural gas. 529 pp, Erie, Pa, 1913

Westgate, Lewis Gardner.

93 The geographic development of the eastern part of the Mississippi drainage system. Am G 11:245-260 (1893)

94 The mineralogical characters of certain New Jersey limestones. Am G 14: 308-313 (1894)

$94 \mathbf{a}$ The age of the crystalline limestones of Warren Co., N. J. Am G 14 : 369-379, map (1894)

96 The geology of the northern part of Jenny Jump Mountain, in Warren Co., N. J. N J G S, An Rp 1895: 21-61, map (1896)

99 A granite gneiss in central Connecticut. J G $7: 638-654$, map (1899)

o5 The Twin Lakes glaciated area, Colo. J G 13 : 285-312 (1905)

07 Abrasion by glaciers, rivers, and waves. J G 15:113-120 (1907)

12 The geological progress of twentyfive years. Ohio St Ac Sc, Pr 6:20-42 (1912)

13 (and Branson, E. B.) The later Cenozoic history of the Wind River Mountains, Wyo. J G 21:142-159 (1913) Abst, Science n s $35: 318$ (1912); G Soc Am, B 23: 739 (1912)

Weston, Thomas Chesmer.

92 Notes on concretionary structure in various rock formations in Canada. N S Inst Sc, Pr Tr 8 or (2) 1: 137-142 (1892)

93 Notes on the Miocene Tertiary rocks of the Cypress Hills, Northwest Territory of Canada. N S Inst Sc, Pr Tr 8 or (2) $1: 223-227$ (1893)

94 Notes on the "Quebec group." Ottawa Nat $8: 81-82$ (1894)

96 Notes on concretions found in Canadian rocks. N S Inst Se, $\mathrm{Pr} \operatorname{Tr} 9$ or (2) $2: 1-9$ (1896)

$96 a$ Notes on the geology of Newfoundland. $\mathrm{N} S$ Inst $\mathrm{Sc}, \mathrm{Pr}$ 't 9 or (2) 2 ; 150-157 (1896)

99 Reminiscences among the rocks in connection with the geological survey of Canada. $328 \mathrm{pp}$, port, Toronto $\mathbf{1 8 9 9}$

99 a Notes on a geological trip over a portion of the Canadian Northwest Territories. Ottawa Nat $13: 177-187$ (1899)

weston, William.

04 The hydrocarbon field of western Colorado and eastern Utah ... 39 pp, map [1904?]

14 The Yampa coal field of Routt Co., Colo., on the line ... of the Denver and Salt Lake Railroad (Moffat road). Report on the above. $62 \mathrm{pp}$, map, 1914

West Virginia Geological Survey.

17 Map of West Virginia showing coal, oil, and gas, iron ore and limestone areas. Scale, 8 miles to one inch. 1917 [also earlier editions]
Wetherby, Albert Gallatin (1833-1902).

7S (with Miekleborough, John.) A elassified list of Lower Silurian fossils, Cincinnati group. Cin Soc N H, J 1: 61-86 (1878)

79 Description of a new family and genus of Lower Silurian Crustacea. Cin Soc N H, J 1: 162-166, il (1879)

79a Remarks on the genus Pteroto. crinus. Cin Soc N H, J 2:3-8 (1879)

$79 \mathrm{~b}$ Descriptions of new species of crinoids from the Kaskaskia group of the Subcarboniferous. Cin Soc N H, J $2: 134$ 140, il (1879)

so Descriptions of new crinoids from the Cincinnati group of the Lower Silurian and the Subcarboniferous of Kentucky, Cin Soc N H, J $2: 245-253$, il (1880)

soa [On the Trenton rocks of Kentucky.] Cin Soc N H, J 3:72-73 (1880)

80b Remarks on the Trenton limestone of Kentucky, with descriptions of new fossils from that formation and the Kaskaskla (Chester) group, Subcarboniferous. Cin Soe N H, J $3: 144-160$, il (1880)

81 Descriptions of crinoids from the up. per Subcarboniferous of Pulaski Co., Ky. Cin Soc N H, J 3:324-330 (1881)

81 a Description of new fossils from the Lower Silurian and Subcarboniferous rocks of Ohio and Kentucky. Cin Soc N H, J 4: $77-85$, il (1881)

81b Descriptions of new fossils from the Lower Silurian and Subcarboniferous rocks of Kentucky. Cin Soc N H, J 4: $177-179$, il (1881)

82 Geological structure and metalliferons deposits of Roan Mountain, N. C. Obio Mechanics' Inst., Se Pr 1:49-50 (1882)

Wethered, Edward.

84 On the structure of English and American Carboniferous coals (abst). Brit As, Rp 54:741 (1885) G Mag (3) $1: 515-516$ (1884) Am J Sc (3) $28: 467-$ 468 (1884)

85 On the structure and formation of certain English and American coals. Cotteswold Naturalists' Field Club, Pr $8: 281$ 298 (1885)

wetherill, Charles Mayer (1825-1871).

52 Examination of molybdate of lead, from Wheatley's mine near Phoenixville, Chester Co., Pa. Ac N Se Phila, Pr 6:55, 119 (1852)

53 Chemical examination of two minerals from the neighborhood of Reading, $\mathrm{Pa}$; and on the occurrence of gold in Pennsylvania. Am $\mathrm{Ph}$ Soc, $\operatorname{Tr} \mathrm{n}$ s 10 : 345-351 (1853); Abst, Pr 5:273-274 (1853)

53a on a new variety of asphalt; (melan-asphalt). Am Ph Soc, $\operatorname{Tr} \mathrm{n}$ s 10: 353-358 (1853)

wetmore, Alexander.

17 The relationships of the fossil bird Palaeochenoides mioceanus. J G 25:555557 (1917) 
Wharton, Joseph.

97 Nickel and cobalt. U S G S, An Rp 18 pt $5: 329-342$ (1897)

Wheat, Alfred W.

78 Report on the geology of Medina Co. Ohio G S, Rp 3 pt $1: 362-380$, map (1878)

Wheatley, Charles M.

61 Remarks on the Mesozoic red sandstone of the Atlantic slope and notice of the discovery of a bone bed therein, at Phoenixville, Pa. Am J Sc (2) 32:41-48 (1861)

71 Notice of the discovery of a cave in eastern Pennsylvania containing remains of post-Pliocene fossils ... Am J Sc (3) 1: 235-237 (1871)

Wheelan, F. H.

90 The gas well at Summerland. Cal St M Bur, An Rp 10:601-603 (1890)

wheeler, Arthur 0 .

o7 Nakimu caves [British Columbia]. Can, Dp Interior, Rp Surveyor-General 1906: 103-117 (1907)

07a Observations on the Yoho Glacier. Can Alpine J 1:149-156 (1907)

os Motion of the Yoho Glacier [B. C.]. Can Alpine J 1:271-275 (1908) ; 2:9799 (1909) ; 2:121-125 (1910)

10 Some characteristics of the Canadian Rockies (abst). Brit As, Rp 79:533-534 (1910)

11 Motion of the Yoho Glacier [B. C.]. Can Alpine J 3: 123-126 (1911)

13 Motion of the Yoho Glacier [B. C.]. Can Alpine J 5:53-58 (1913)

15 Motion of the Yoho Glacier 19121914. Can Alpine J 6:133-138 (1915)

15a Robson Glacier [B. C.]. Can Alpine J $6: 139-142$ (1915)

17 Motion of the Yoho Glacier, 19141916 [B. C.]. Can Alpine J 8:118-120 (1917)

18 Motion of the Yoho Glacier, 19161917. Can Alpine J 9: 76-78 (1918).

Wheeler, Charles Gilbert (1836-1912).

80 An elementary guide to determinative mineralogy... 75 pp, Chicago 1880

Wheeler, Edward S.

76 Scheybichi and the strand, or early days along the Delaware ... to which is appended a geological description of the shore of New Jersey [" geological outlines and items," pp. 94-116]. 116 pp, Phila 1876

wheeler, George $D$.

02 Zinc in Crittenden Co,, Ky. Eng M J $74: 413-414$ (1902)

Wheeler. George Montague (1842-1905). 70 Preliminary report of the general features of the military reconnaissance through southern Nevada. 20 pp [n p, 1870?]
Wheeler, George Montague - Continued.

72 Preliminary report of explorations in Nevada and Arizona. U S, 42d Cong 2d sess, S Ex Doc 65: 94 pp, map (1872)

72a Preliminary report concerning explorations and surveys principally in Nevada and Arizona 1871 [notes on mining districts in part furnished by G. K. Gilbert and others]. $96 \mathrm{pp}$, map, Washington 1872

72b Report of explorations and surveys in Nevada, Utah, Arizona. U S [War Dp], Chief Eng, An Rp 1872 (U S, 42d Cong $3 d$ sess, H Ex Doc 1 pt 2 v 2) App DD : 1124-1176 (1872)

73 Annual report upon the geographical and geological surveys and explorations west of the 100th meridian in Nevada, Utah, Colorado. New Mexico, and Arizona. $11 \mathrm{pp}$, map, Washington 1873 Also in U S [War Dp], Chief Eng, An Rp 1873 (U S, 43d Cong 1st sess, H Ex Doc 1 pt 2 v 2) App EE : 1211-1218 (1873)

74 Annual report upon the geographical explorations and surveys west of the 100 th meridian in California, Nevada, Utah, Arizona, Colorado. New Mexico, Wyoming, and Montana. $130 \mathrm{pp}$, map, Washington 1874 Also in U S [War Dp], Chief Eng, An Rp 1874 (U S, 43d Cong 2d sess H Ex Doc 1 pt 2 ₹ 2 pt 2) App FF : $480-606$ (1874)

74a Progress report upon geographical and geological explorations and surveys west of the one hundredth meridian in 1872 [notes on mining districts in part furnished by G. K. Gilbert, E. E. Howell, and others]. $56 \mathrm{pp}$, Washington 1874

74b Geographical and geological explorations and surveys west of the 100th meridian. Am J Sc (3) $7: 388-391$ (1874)

75 Annual report upon the geographical explorations and surveys west of the one hundredth meridian, in California, Nevada, Nebraska, Utah, Arizona, Colorado, New Mexico, Wyoming, and Montana. 196 pp, maps, Washington 1875 Also in U S [War Dp], Chief Eng, An Rp 1875 (U S, 44th Cong 1st sess, H Ex Doc 1 pt 2 v 2 pt 2) App LL : 921-1108 (1875)

$75 a$ Preliminary report upon a reconnaissance through southern and southeastern Nevada made in 1869 . $72 \mathrm{pp}$, map, Washington 1875

76 Annual report upon the geographical surveys west of the one hundredth meridian in California, Nevada, Utah, Colorado, Wyoming. New Mexico, Arizona, and Montana. $355 \mathrm{pp}$, maps, Washington 1876 Also in U S [War Dp], Chief Eng, An Rp 1876 (U S, 44th Cong $2 d$ sess, H Ex Doc 1 pt 2 v 2 pt 3) App JJ : $219-563$ (1876)

76a (in charge) Geological atlas projected to illustrate geographical explorations and surveys west of the 100 th meridian of longitude... [for sheets published, see U S G S, B 222:63] [1876-] 
Blake, John Marcus (1838-1920).

66 On crystals of gaylussite from Nevada Territory. Am J Sc (2) $42: 221-222$ (1866)

69 (with Brush, G. J.) On hortonolite, a new member of the chrysolite group. Am J Sc (2) $48: 17-23$ (1869)

15 Growing crystals for measurement. Am J Sc (4) $39: 567-570$ (1915)

16 Plotting crystal zones on paper. Am J Sc (4) $42: 486-492$ (1916)

17 Plotting crystal zones on the sphere. Am J Sc (4) $43: 237-242$ (1917)

17a Crystal drawing and modeling. Am J Sc (4) $43: 397-401$ (1917)

18 Means of selving crystal problems. Am J Sc (4) 46:651-662 (1918)

Blake, Theodore Augustus.

68 Topographical and geological features of the northwest coast of America. Am J Sc (2) $45: 242-247$ (1868)

69 General topographical and geological features of the northwestern coast of America from the Straits of Juan de Fuca to the parallel of 60 degrees north latitude. U S Coast S, Rp 1867 (U S, 40th Cong 2d sess, H Ex Doc 275) : 281-290 (1869)

69a Notes on Alaska. Cal Ac Sc, Pr 4: 13-15 (1869)

Blake, William Phipps (1826-1910).

49 The history of Putnam County, N. Y. ... (geology [extracts from Beck, 40 and Mather, 43]: 17-77). $368 \mathrm{pp}, \mathrm{N}$ Y 1849

51 On a method for distinguishing between blaxial and uniaxial crystals when in thin plates; and the results of the examination of several supposed uniaxial micas. Am $A \mathrm{~s}, \operatorname{Pr} 5: 50-54$ (1851) Am J Sc (2) 12:6-9 (1851)

51a Optical and blowpipe examination of the supposed chlorite of Chester Co., Pa. Am J Sc (2) $12: 339-341$ (1851)

52 Mineralogical notices. Am J Sc (2) $13: 116-117 ; 14: 105$ (1852)

53 On the occurrence of crystallized car. bonate of lanthanum [Lehigh Co., Pa.]. $\triangle \mathrm{m} \mathrm{J} \mathrm{Sc} \mathrm{(2)} 16: 228-230$ (1853)

54 Ancient lake in the Colorado Desert. Am J Sc (2) 17:435-438 (1854)

54a Quicksilver mine of Almaden, Cal. Am J Se (2) $17: 438-440$ (1854)

54b Recent earthquake shocks in California, Am J Se (2) 18:151 (1854)

54e on gold and platinum of Cape Blanco [Cal.]. Am J Sc (2) $18: 156$ (1854)

54d Notes on California. Am J Sc (2) $18: 441$ (1854)

55 Remarks in conclusion [of Conrad's report on the fossil shells collected in California]. U S, Pacific R R Expl (U S, 33d Cong 1st sess, H Ex Doc 129) Appendix to the preliminary geological report of W. P. Blake : $20-21$ (1855) Am J Se (2) $21: 270-272$ (1856)
Blake, William Phipps-Continued.

55a Preliminary geological report [Williamson's reconnaissance in California]. U S, Pacific R R Expl (U S, 33d Cong 1st sess, H Ex Doc 129): 80 pp (1855)

55b Remains of the mammoth and mastodon in California. Am J Sc (2) 19:133 (1855)

55e Observations on the extent of the gold region of California and Oregon ... $\Lambda \mathrm{m} \quad \mathrm{J}$ Sc (2) 20:72-85 (1855) M Mag $5: 32-45$ (1855)

55d on the grooving and polishing of hard rocks and minerals by dry sand. Am $\mathrm{J}$ Sc (2) $20: 178-181$ (1855) Am Ac, $\mathrm{Pr}$ $9: 216-220$ (1856)

55e Notice of remarkable strata containing the remains of Infusoria and Polythalmia in the Tertiary formation of Monterey, Cal. Ac N Sc Phila, Pr $7: 328-331$ (1855)

56 Report on the geology of the route near the thirty-second parallel ... [Pope's reconnaissance]. U $S$, Pacific $R \quad R \quad$ Expl (U S, 33d Cong $2 d$ sess, S Ex Doc 78 and H Ex Doc 91) 2:50 pp, map (1856)

56n General report upon the geological collections [made on Whipple's reconnaissance near the thirty-fifth parallel]. U S, Pacific R R Expl (U S, 33d Cong 2d sess, $\mathrm{S}$ Ex Doc 78 and $\mathrm{H}$ Ex Doc 91) 3 pt. 4: 1-119, map (1856)

$\mathbf{5 6 b}$ Observations on the physical geography and geology of the coast of Callfornia from Bodega Bay to San Diego. U S Coast S, Rp 1855 (U S, 34th Cong, 1st sess, S Ex Doc 22) : 376-398 (1856)

56e Notice of the geological collection [made by Shumard on Marcy's expedition on Big Wichita and Brazos rivers]. U S, 34th Cong 1st sess, S Ex Doc 60:46-47 (1856)

56d Geological note on section in ravine of L'Eau qui Court River [Badlands, Nebr.]. In Warren, G. K., Explorations in the Dacota country in the year 1855; U S, 34th Cong 1st sess, S Ex Doc 76: 63-66 (1856)

56e Observations on the characters and probable geological age of the sandstone formation of San Francisco (abst). Am As, Pr $9: 220-222$ (1856)

56f Remarks upon the geology of Callfornia, from observations in connection with the United States surveys and explorations for a railroad route to the $\mathrm{Pa}$ cific. Am As, Pr 9:222-225 (1856)

56 $\approx$ Earthquakes in California. Am J Sc (2) $21: 449$ (1856)

57 Geological report [Williamson's reconnaissance in California]. U S, Pacific R R Expl (U S, 33d Cong 2d sess, S Ex Doc 78 and $\mathrm{H}$ Ex Doc 91) 5 pt 2:370 pp, il, maps (1857) Another ed. with title, Report of a geological reconnaissance in California ... N N Y 1858 
Wheeler, George Montague-Continued.

77 Annual rport upon the geographical surveys west of the one hundredth meridian in the states and territories of California, Oregon, Nevada, Texas, Arizona, Colorado, Idaho, Montana, New Mexico, Utab, and Wyoming. U S [War Dp], Chief Eng, An Rp 1877 (U S, 45th Cong 2d sess, H Ex Doc 1 pt 2 ₹ 2 pt 2), App NN : 1209-1334, maps (1877)

78 Annual report ... 1878; geographical surveys of the territory of the United States west of the one hundredth meridian in the states and territories of California Colorado, Kansas, Nebraska, Nevada, Oregon, Texas, Arizona, Idaho, Montana, New Mexico, Utah, Washington, and Wyoming. viii, $234 \mathrm{pp}$, map, Washington 1878 Also in U S [War Dp], Chief Eng, An Rp 1878 (U S, 45th Cong $3 \mathrm{~d}$ sess, $\mathrm{H}$ Ex Doc 1 pt 2 v 2 pt 3) App NN: 1421-1651 (1878)

79 Annual report ... 1879; geographical surveys of the territory of the United States west of the 100 th meridian in the states and territories of California, Colorado, Kansas, Nebraska, Nevada, Oregon, Texas, Arizona, Idaho, Montana, New Mexico, Utah, Washington, and Wyoming. iv, $340 \mathrm{pp}$, maps, Washington 1879 Also in U S [War Dp], Chief Eng, An Rp 1879 (U S, 46th Cong $2 \mathrm{~d}$ sess, H Ex Doc 1 pt 2 v 2 pt 3) App OO: 1977-2313 (1879)

so Annual report upon the geographical and topographical surveys of the territory of the United States west of the 100th meridian... $40 \mathrm{pp}$, map, Washington 1880 Also in U S [War Dp], Chief Eng, An Rp 1880 (U S, 46th Cong $3 \mathrm{~d}$ sess, H Ex Doc 1 pt 2 v 2 pt 3 ), App PP : 2459-2499 (1880)

84 Annual report upon the geographical and topographical surveys of the territory of the United States west of the 100th meridian... U S [War Dp], Chief Eng, An Rp 1884 (U S, 48th Cong 2 d sess, H Ex Doc 1 pt 2 v 2 pt 3), $\Delta$ pp VV : 2375 2378 (1884)

Wheeler, H. E.

10 A пет Claibornian shell [Ovulactaon aldrichi from ferruginous sand bed, Claiborne, Ala]. Nautilus 24:13-14, il (1910) Wheeler, Herbert Allen.

83 The copper deposits of Vermont. Sch Mines Q 4:219-224 (1883)

86 Temperature observations at the Lake Superior copper mines. Am J Sc (3) 32 : 125-129 (1886)

89 Plattnerite from Idaho. Am J Sc (3) $38: 79$ (1889)

91 Notes on ferro-goslarite, a new variety of zinc sulphate. Am J Sc (3) 41 : 212 (1891)

91 (with Luedeking, C.) Notes on a Missouri barite. Am J Sc (3) 42:495498 (1891)
Wheeler, Herbert Allen-Continued.

95 Note on the glacial drift in St. Louis Ac Se St L, Tr 7:121-122 (1895)

95 a Note on an occurrence of blende in lignite. Ac Sc St L, Tr $7: 123-125$ (1895) Eng M J $59: 248$ (1895)

$\mathbf{9 5 b}$ Recent additions to the mineralogy of Missouri. Ac Se St L, Tr 7:126-131 (1895)

96 Clay deposits. Mo G S 11:622 pp, maps, Jefferson City, 1896

98 Clay resources of Missouri. Eng M J $66: 426-427$ (1898)

04 Notes on the source of the south. east Missouri lead. Eng M J 77:517-518 (1904)

o5 The fire clays of Missouri. Am I M Eng, Tr 35:720-734 (1905) Abst, Eng M J 78: 834-835 (1904)

06 The Wisconsin zinc district; an old lead and zinc producing district which modern machinery and methods have ren. dered profitable. Mines and Minerals 26: 368-372 (1906)

O6a Is the drilling sufficiently deep in the Wisconsin zinc reglon? Eng M J 82: $167-168$ (1906)

os The ore bodies of Etna Hill, Wis. Mines and Minerals 28:320 (1908)

09 Oil and gas in the St. Louis district, As Eng Soc, J 42: 188-199 (1909)

10 The occurrence of ofl and gas about St. Louis. Ac Sc St. Louis, Tr 18: xxixxxxili (1910)

10a Geology of southeast Missouri lead district. Eng M J 89:465-466 (1910)

11 The new oil field at Carlyle, III. Eng M J $92: 63-64$ (1911)

11 a The Illinois oil fields. Eng M J $92: 355-356$ (1911)

12 Developments in the Hlinois oil fields. As Eng Soc, J 48:68-77 (1912)

14 The Illinois oil fields. Am I M Eng, B $89: 881-912$ (1914); Tr $48: 533-563$ (1915)

18 Oil and gas fields of Illinois. Eng M J 105: 181-184 (1918)

$18 \mathbf{a}$ Uncertainties of geological evidence. Eng M J 106: 878-879 (1918)

See also Gordon (C H), 93 ; Hager, 17; Tarr (W A), 18c; Washburne, 14b

Wheeler, Joseph $\mathbf{T}$.

08 The zonal-belt hypothesis; a new explanation of the cause of the ice ages. 401 pp, Phila 1908

wheeler, O. C.

18 (with Christner, D. D.) The geology of Terrell Co. Tex, Univ, B 1819: 1-32, map (1918)

Wheeler. Walter Calhoun.

14 (with Clarke, F. W.) The composition of crinoid skeletons, U S G S, P P $90: 33-37$ (1914) Abst, Wash Ac Sc, J $4: 419$ (1914) 
Wheeler, Walter Calhoun-Continued.

15 (with Clarke, F. W.) The inorganic constituents of echinoderms. U S G S, P P $90: 191-196$ (1915)

15a (with Clarke, F. W.) The composition of brachiopod shells. Nat Ac Sc, Pr 1:262-266 (1915)

15b (with Clarke, F. W.) The inorganic constituents of Alcyonaria. Nat Ac Sc, Pr 1:552-556 (1915)

17 (with Clarke, F. W.) The inorganic constituents of marine invertebrates. U S G S, P P 102:56 pp (1917) Abst, Wash Ac Sc, J $7: 562-563$ (1917)

Wheeler, William.

78 A fossil tusk found in Franklin Co. [Kans.]. Kans Ac Sc, Tr 6:11 (1878); reprint (1906)

Wheeler, William Morton.

99 George Baur's life and writings. Am Nat $33: 15-30$, port (1899)

06 The expedition to Colorado for fossil insects. Am Mus J 6:199-203 (1906)

08 Expedition to Florissant, Colo., for fossil insects (abst). N Y Ac Sc, An 18: 292 (1908)

Wheelock, Charles E.

03 The Oriskany sandstone (abst). Onondaga Ac Sc, Pr 1:39-44 (1903)

05 [Overthrust faults in central New York (abst).] Science n s 22:673 (1905) Wheelock, G. A.

73 Striæ on Mount Monadnock [N. H.]. Am Nat $7: 466-470$ (1873)

Whelpley, James Davenport (?-1872).

45 [Classification of drift phenomena] (abst). As Am G, Pr 6:14-16 (1845)

$45 \mathbf{a}$ [On the relations of the trap and sandstones of the Connecticut Valley]. As Am G, Pr 6:61-64 (1845)

Wherry, Edgar Theodore.

06 (with Benge, E.) Directory of the mineral localities in and around Philadelphia. Mineral Collector 12:1-3, 49-51, $65-67,89-91,105-107,119-121,139-142$; $13: 7-10,21-24,41-43,60-62,65-67,91-$ $93, \quad 109-111, \quad 129-132, \quad 151-154$ (1906) ; $13: 161-163,183-184 ; 14: 5-7,25-27,42$ $(1907) ; \quad 15: 6-17,26-28, \quad 44-46, \quad 54-56$, $69-70,85-86,107-109(1908)$

07 Note on luminescent spodumene. Mineral Collector 14:31-32 (1907)

$07 a$ A new occurrence of scapolite. Mineral Collector 14: 37-39 (1907)

07b How quartz crystals form. Mineral Collector 14:145-151 (1907) Sc Am Sup $65: 110-111$ (1908)

os Radioactive minerals found in Pennsylvania and their effect on the photographic plate. Franklin Inst, J 165: 5978 (1908)

08n The Newark copper deposits of southeastern Pennsylvania. Ec G $3: 726$ 738 , map (1908) Abst, Science $\mathrm{n}$ s 28 : $573-574$ (1908)
Wherry, Edgar Theodore-Continued.

08b A new theory of the earth [Sim. roth's pendulation theory to explain the causes of geologic changes]. Mineral Collector 15: 8-9 (1908)

09 A new occurrence of carnotite (abst). Science n s 29:751 (1909)

09 a Second annual spring conference of the geologists of the northeastern United States. Science n s 30:414-416 (1909)

09b The early Paleozolc of the Lehigh Valley district, $\mathrm{Pa} .(a b s t)$. Science $\mathrm{n} \mathrm{s}$ $30: 416$ (1909)

10 Contributions to the mineralogy of the Newark group in Pennsylvania. Wagner Free Inst Sc, Tr 7:5-27, map (1910)

10a (with Boyer, C.) A comparative study of the radioactive minerals in the collection of the Wagner Free Institute of Science. Wagner Free Inst Sc, Tr $7: 29$ 34 (1910)

11 The copper deposits of FranklinAdams counties, $\mathrm{Pa}$. Franklin Inst, J 171:151-163 (1911) Abst, Ac N Sc Phila, Pr 62 : 454-455 (1910)

12 Crystallographic tables. Science n s $35: 820-821$ (1912)

12a A new occurrence of carnotite [near Mauch Chunk, Pa.]. Am J Sc (4) $33: 574$ 580 (1912)

12b The Triassic of Pennsylvania (abst). Ac N Sc Phila, Pr 64: 156 (1912)

12e Apparent sun-crack structures and ringing-rock phenomena in the Triassic diabase of eastern Pennsylvania. Ac N Sc Phila, Pr 64:169-172 (1912) Abst, G Soc Am, B 22:718 (1911)

12d Silieified wood from the Triassic of Pennsylvania. Ac N Sc Phila, $\operatorname{Pr} 64$ : 366-372 (1912)

12e Age and correlation of the "New Red" or Newark group in Pennsylvania. Ac N Se Phila, Pr 64: 373-379 (1912)

13 North border relations of the Triassic in Yennsylvania. Ac N Se Phila, Pr 65: 114-125, map (1913)

$13 a$ Zur Nomenklatur der Mineralvarietäten und Kolloidmineralien. Centralbl Miner 1913 : 518-519

14 Carnotite near Mauch Chunk, Pa. U S G S, B 580:147-151 (1914)

$14 a$ Notes on wolframite, beraunite, and axinite. U S Nat Mus, Pr 47:501511 (1914)

14b Mineral nomenclature. Science $\mathrm{n} \mathrm{s}$ $39: 575-577$ (1914)

14c Variations in the compositions of minerals. Wash Ac Sc, J 4:111-114 (1914)

14d The occurrence of earnotite in eastern Pennsylvania (abst). Wash Ac Sc, J $4: 296$ (1914)

15 The microspectroscope in mineralogy. Smiths Mise Col 65 no 5:16 pp (1915) Abst, Wash Ac Sc, J 5:521 (1915) 
Wherry, Edgar Theodore-Continued.

15a A peculiar oolite from Bethlehem, Pa. U S Nat Mus, Pr 49:153-156 (1915) Abst, Wash Ac Sc, J $5: 31$ (1915) ; 6:7172 (1916)

15b (and Gordon, S. G.) An arrangement of minerals according to their occurrence. Ac N Sc Phila, Pr 67:426457 (1915)

15e The chemical composition of bornite. Science n s 42:570-571 (1915)

16 Notes on allophanite, fuchsite, and triphylite. U S Nat Mus, Pr 49:463-467 (1915) Abst, Wash Ac Sc, J 6: 149 (1916)

$16 a$ Notes on alunite, psilomelanite, and titanite. U S Nat Mus, Pr 51:81-88 (1916)

16b Two new fossil plants from the Triassic of Pennsylvania. U S Nat Mus, $\operatorname{Pr} 51: 327-329$, il (1916)

16e The composition of bornite. Science n s 42:570-571 (1915) Abst, Wash Ac Sc, J $6: 149$ (1916)

16d Notes on the geology near Reading, Pa. (abst). Wash Ac Sc, J 6:23 (1916)

16e A peculiar intergrowth of phosphate and silicate minerals. Wash Ac Sc, J 6 : 105-108 (1916)

$16 f$ The lozenge-shaped cavities in the First Watchung Mountain zeolite deposits. Wash Ac Sc, J 6:181-184 (1916)

16g Glauberite crystal cavities in the Triassic rocks of eastern Pennsylvania. Am Mineralogist 1:37-43 (1916)

16h (and Brown, G. V.) An American occurrence of miloschite [Ely, Nev.]. Am Mineralogist : 63-67 (1916)

17 A remarkable oceurrence of caleite in silicified wood. U S Nat-Mus, Pr 53: 227-230 (1917) Abst, Wash Ac Sc, J 7 : 433-434 (1917)

$17 \mathbf{a}$ Neodymium as the cause of the red-violet color in certain minerals. Wash Ac Sc, J $7:$ 143-146 (1917)

$\mathbf{1 7 b}$ The indices of refraction of analyzed rhodocbrosite and siderite. Wash Ac Sc, J $7: 365-368$ (1917)

17e Geological areas about Washington (abst). Wash Ac Sc, J 7:435 (1917) Science n s 46: 72 (1917)

17d The nomenclature and classification of the native element minerals. Wash Ac Sc, J $7: 447-456$ (1917)

17 e Clay derived from volcanic dust in the Pierre in South Dakota. Wash Ac Sc, J $7: 576-583$ (1917)

17f (and Glenn, M. L.) Chalcedony mistaken for an iron sulphate mineral. Am Mineralogist $2: 6-7$ (1917)
Wherry, Edgar Theodore-Continued.

$17 \mathrm{~g}$ Note on the nomenclature of the lead monoxide minerals. Am Mineralogist 2: 19 (1917)

17h A tetragonal iron phosphide from the Ruff's Mountain meteorite. Am Miner. alogist $2: 80-81$ (1917)

$17 \mathbf{i}$ Terminated crystals of thaumasite. Am Mineralogist 2: 89 (1917)

17j The occurrence of the native ele. ments. Am Mineralogist 2: 105-108 1917)

17k Merrillite, meteoritic calcium phos. phate. Am Mineralogist 2:119 (1917)

171 Supplementary note on thaumasite. Am Mineralogist 2:125 (1917)

$17 \mathrm{~m}$ Lamellar ealcite at Keystone, $\mathrm{S}$. Dak, Am Mineralogist 2: 139 (1917)

17n Diasporite in Missouri. Am Min. eralogist $2: 144$ (1917)

17o Pre-Cambrian sedimentary rocks in the highlands of eastern Pennsylvania (abst). G Soc Am, B 28: 156 (1917)

17p (with Larsen, E. S.) Halloysite from Colorado. Wash Ac Sc, J $7: 178-180$ (1917)

17q (with Larsen, E. S.) Leverrierite from Colorado. Wash Ac Sc, J 7 : 208-217 (1917)

is Notes on mimetite, thaumasite, and wavellite. U S Nat Mus, Pr 54:373-381 (1918)

18n Pre-Cambrian sedimentary rocks in the Highlands of eastern Pennsylvania. G Soc Am, B 29:375-392 (1918)

$18 b$ The assignment of crystals to symmetry classes. Wash Ac Sc J 8:480-487 (1918)

18e Famous mineral localities; 1 , The Keokuk geode region. Am Mineralogist 3: 3-5 (1918)

18d The life and work of Amos Peaslee Brown. Am Mineralogist $3: 21-23$ (1918)

1Se Famous mineral localities: 5 , The Black Hills of South Dakota. Am Miner. alogist $3: 44-46$ (1918)

18f Some minerals from Sylmar, Pa. Am Mineralogist 3:47 (1918)

18g Field identification of diasporite. Am Mineralogist 3:154 (1918)

18h Note on iron as a cause of blue colors in minerals. Am Mineralogist 3 : 161 (1918)

1si Supplementary note on meteoritic iron phosphide. Am Mineralogist $3: 184$ (1918).

ISj (with Hawkins. A. C.) Famous mineral localities: 4 , The Joplin district. Am Mineralogist $3: 36-37$ (1918)

See also Barrell, 12a; Branson, 12; Grabau, 12b 
Whinery, $S$.

12 Clinton iron-ore deposits in Kentucky and Tennessee. Am I M Eng, B 70:10571058 (1912)

Whipple, A. W.

55 Report of explorations for a railway route near the thirty-fifth parallel of latitude from the Mississippi River to the Pacific Ocean. U S, Pacific R R Expl (U S, 33d Cong 1st sess, H Ex Doc 129 v 18 pt 2) : 1-87 (1855); also (U. S, 33d Cong $2 d$ sess, $\mathrm{S}$ Ex Doc 78 and $\mathrm{H}$ Ex Doc 91) 3 : 3-36, 1-136 (1856)

56 Route near the thirty-fifth parallel ...; report on the topographic features and character of the country. U S, Pacific R R Expl (U. S, 33d Cong 2 d sess, S Ex Doc 78 and $\mathrm{H}$ Ex Doc 91) 3:77 pp (1856)

Whipple, S. H.

44 Notice of mastodon bones from the County of Benton, Mo. Am Ph Soc, Pr 4: $35-36$ (1844)

Whitaker, Milton C.

02 An olivinite dike of the Magnolia district and the associated picrotitanite [Colo.]. Colo Sc Soc, Pr 6:104-119 [1902]

\section{Whitaker, W. A.}

17 (and Twenhofel, W. H.) Manganese in the Dakota sandstone of central Kansas. Ec G 12:473-475 (1917)

18 (and others) The petroleum industry in Kansas. Eng M $J$ 105: 817-821 (1918)

\section{Whitbeek, Roy Hughes.}

02 The preglacial course of the middle portion of the Genesee River [N. Y.]. Am Geog Soc, B 34:32-44, map (1902)

11 Contrasts between the glaciated and the driftless portions of Wisconsin. Geog Soc Phila, B 9 no $3: 12-21$ (114-123) (1911)

13 The geography and industries of Wisconsin. Wis G S, B 26:94 pp (1913)

$13 a$ Mammoth Cave. J Geog 11:327341 (1913)

15 The geography or the Fox-Winnebago Valley. Wis G S, B 42: 109 pp (1915)

White, A. F.

69 Report of the State mineralogist of Nevada for the years 1867 and 1868. 96 pp. Carson City, Nev., 1869

71. Third biennial report of the State mineralogist [of Nevada]. 128 pp [Carson City 1871]

White, Americus Frederic.

06 Composition of the waters of Rockbridge County, Virginia, and their relation to the geological formations. Thesis, Washington and Lee University. $38 \mathrm{pp}$, Winchester, Va. 1906

White, Charles Abiathar (1826-1910).

60 Observations upon the geology and paleontology of Burlington, Iowa, and its vieinity. Boston J N H 7:209-235 (1860)
White, Charles Abiathar-Continued.

62 (and Whitfield, R. P.) Observations upon the rocks of the Mississippi Valley which have been referred to the Chemung group of New York, together with descriptions of new species of fossils from the same horizon at Burlington, Iowa. Boston Soc N H, Pr 8: 289-306 (1862)

62a Description of new species of fossils from the Devonian and Carboniferous rocks of the Mississippi Valley. Boston Soc N H, Pr 9:8-33 (1862)

63 Observations on the summit strueture of Pentremites, the structure and arrangement of certain parts of crinoids, and deseriptions of new species from the Carboniferous rocks at Burlington, Iowa. Boston J N H $7: 481-506$ (1863)

66 Observations on the genus Belem. nocrinus. Boston Soc N H, Pr 10:180 (1866)

67 First annual report of progress of the [Iowa] Geological Survey ... 4 . 4 p, Des Moines 1867

$67 \mathbf{a}$... drift phenomena of southwestern Iowa. Am J Se (2) $43: 301-305 ; 44: 119$ (1867) Iowa G S, An Rp 1-2:143-148 (1868)

67b (and St. John, O. H.) Preliminary notice of new genera and species of fossils. Iowa $\mathrm{G}$ S [3 pp, Iowa City 1867]

67e (and St. John, O. H.) Descriptions of new Subcarboniferous and Coal Measures fossils collected upon the geological survey of Iowa; together with a notice of new generic characters observed in two species of brachiopods. Chicago Ac Sc, Tr 1: 115-127, il (1867)

67 d A sketch of the geology of southwestern Iowa. Am J Sc (2) 44:23-31 (1867)

67e Exogenous leaves in the Cretaceous rocks of Iowa. Am J Se (2) 44:119 (1867)

68 First and second annual report of progress by the State geologist ... on the geological survey of the State of Iowa... 284 pp, Des Moines 1868

68a The lakes of Iowa-past and present. Am Nat $2: 143-155$ (1868) Iowa G S, An Rp 1-2: 151-163 (1868)

68b The Iowa drift. Am Nat 2:615616 (1868)

68e Character of the unconformability of the Iowa Coal Measures upon the older rocks. Am J Sc (2) $45: 331-334$ (1868)

68d On coal in Nebraska ... Am J Sc (2) $45: 399-400$ (1868)

68e Note on the shell structure of certain Naiades. Am J Sc (2) $45: 400-401$ (1868)

68P Note on " cone in cone." Am J Sc (2) $45: 401-402$ (1868)

69 A trip to the Great Red Pipestone quarry [Minn.]. Am Nat $2: 644-653$ (1869) 
White, Charles Abiathar-Continued.

69a Kjoekkenmoeddings in Iowa. Am Nat $3: 54-55$ (1869)

$69 \mathrm{~b}$ Announcement of the existence of Cretaceous rocks in Guthrie Co., Iowa. Am As, Pr $17: 326-327$ (1869)

69c Observation on the red quartzite boulders of western Iowa, and their original ledges of red quartzite in Iowa, Dakota, and Minnesota. Am As, Pr 17:340342 (1869)

70 Report on the geological survey of the State of Iowa ... 2 vols, vol $1: 391$ pp; vol. 2:443 pp, map, Des Moines 1870

70a Geology of southwestern Iowa. Iowa G S 1:296-381 (1870)

$\mathbf{7 0 b}$ Northwestern Iowa; middle region of northern Iowa; geology of the coal counties. Iowa G S 2: 201-274 (1870)

70e Peat, petroleum, etc.; gypsum and other sulphates of the alkaline earths; building materials, metals, and miscellaneous substances. Iowa G S 2:275-342 (1870)

71 [On boulders in Carboniferous rocks.] Am Nat 5:606 (1871)

73 On the eastern limit of Cretaceous deposits in Iowa. Am As, $\operatorname{Pr} 21: 187-192$ (1873) Abst, Am J Sc (3) 5:66-69 (1873)

$\mathbf{7 3 a}$ On spontaneous fission? in Zaphrentis. Am J Sc (3) 5: 72 (1873)

74 Preliminary report upon invertebrate fossils collected by expeditions of 1871, 1872 , and 1873 , with descriptions of new species. U S Geog G S W 100th Mer (Wheeler) : $27 \mathrm{pp}$, Washington 1874

74a The proposed genus Anomalodonta of Miller identical with the earlier Megaptera of Meek. Am J Sc (3) 8:218-219 (1874)

75 Note on the genus opisthoptera Meek, 1872, and Anomalodonta Miller, 1874. Am J Se (3) 9:318-320 (1875)

$75 a$ On the equivalency of the Coal Measures of the United States and Europe. Am As, Pr 23 pt 2:35-38 (1875)

76 Invertebrate paleontology of the Plateau province. In Powell, J. W., Report on the geology of the eastern portion of the Uinta Mountains... (U S G Geog S Terr) : 74-135 (1876)

$76 a$ Description of new species of fossils from Paleozoic rocks of Iowa. Ac N Sc Phila, Pr 1876:27-34

$\boldsymbol{7 7}$ Report upon the invertebrate fossils collected in portions of Nevada, Utah, Colorado, New Mexico, and Arizona... U S Geog S W 100th Mer (Wheeler), 4 pt 1: $219 \mathrm{pp}$, il (1877)

77a Paleontological papers, No. 1; Descriptions of Unionidae and Physidae ... from the Judith River group of Montana Terr... U S G Geog S Terr (Hayden), B 3: 599-602 (1877)
White, Charles Abiathar-Continued.

77b Paleontological papers, No. 2 ; Dh scriptions of new species of Uniones and a new genus of fresh-water Gastropoda from the Tertiary strata of Wyoming and Utab. U S G Geog S Terr (Hayden), B 3:603606 (1877)

77e Paleontological papers, No. 3 ; Catalogue of the invertebrate fossils hitherto published from the fresh- and brackishwater deposits of the western portion of North America. U S G Geog S Terr (Hay. den), B 3:607-614 (1877)

77d Paleontological papers, No. 4; Com. parison of the North American Mesozoic and Cenozoic Unionidae and associated mollusks with living species. U S G Geog S Terr (Hayden), B 3:615-624 (1877)

77e Paleontological papers, No. 5 ; Remarks on the paleontological characteristics of the Cenozolc and Mesozoic groups as developed in the Green Mountain region. U S G Geog S Terr (Hayden), B 3:625629 (1877)

77f Fielding Bradford Meek. Am J Sc (3) $13: 169-171$ (1877)

78 Paleontological papers, No, 6; Descriptions of new species of invertebrate fossils from the Laramie group. I S G Geog S Terr (Hayden), B 4:707-719 (1878)

78a Paleontological papers, No. 7; On the distribution of molluscan species in the Laramie group. U S G Geog S Terr (Hay. den), B $4: 721-724$ (1878)

78b Paleontological papers, No. 8; Remarks upon the Laramie group. U S G Geog S Terr (Hayden), B 4:865-876 (1878)

78e (and Nieholson, H. A.) Bibliography of North American invertebrate paleontology ... $\quad$ U $\quad$ S G $\mathbf{S}$ Terr (Hayden), Misc Pub no 10:132 pp (1878)

78d Report on the geology of a portion of northwestern Colorado. U S G Geog S Terr (Hayden), An Rp 10:1-60, map (1878)

78e Descriptions of new species of invertebrate fossils from the Carboniferous and Upper Silurian rocks of Illinois and Indiana. Ac N Sc Phila, Pr 1878:29-37

79 Paleontological papers, No. 9; Fossils of the Jura-Trias of southeastern Idaho. U S G Geog S Terr (Hayden), B $5: 105-117$ (1879)

79a Paleontological papers, No. 10 ; Conditions of preservation of invertebrate fossils. U S G Geog S Terr (Hayden), B 5:133-141 (1879)

79b Paleontological papers, No. 11; Re. marks upon certain Carboniferous fossils from Colorado, Arizona, Idaho, Utah, and Wyoming, and certain Cretaceous corals from Colorado, together with descriptions of new forms. U S G Geog S Terr (Hayden), B $5:$ 209-221 (1879) 
White, Charles Abiathar Continued.

79e Contributions to invertebrate paleontology, No. 1; Cretaceous fossils of the Western States and Territories. U S G Geog S Terr (Hayden), An Rp 11:273319 , il (1879)

79d Report on the paleontological field work for the season of 1877. U S G Geog S Terr (Hayden), An Rp 11:159-272, il (1879)

79e (and Nicholson, H, A.) Supplement to the bibliogre phy of North American invertebicie paleontology. U S G Geog S Terr (Hayden), B 5: 143-152 (1879)

79P Remarks on the Jura-Trias of western North America. Am J Sc (3) 17 :214218 (1879)

so Descriptions of new species of Carboniferous invertebrate fossils. U S Nat Mus, Pr 2:252-260, il (1880)

80a Note on Endothyra ornata. U S Nat Mus, Pr 2: 291 (1880)

$80 b$ Note on Criocardium and Ethmocardium. U S Nat Mus, Pr 2: 291-292 (1880)

80e Descriptions of new Cretaceous invertebrate fossils from Kansas and Texas. U s Nat Mus, Pr 2:292-298, il (1880)

80d Fossils of the Indiana rocks. Ind, Dp Stat G, An Rp 2:471-522, il (1880)

soe The Permian formation of North America (with discussion by G. K. Gilbert and J. W. Powell). Ph Soc Wash, B 3: 104-106 (1880)

sor on the antiquity of certain subordinate types of freshwater and land Mollusca. Am J Sc (3) 20:44-49 (1880)

$80 \mathrm{~g}$ Progress of invertebrate paleontology in the United States for the year 1879. Am Nat 14:250-260 (1880)

80h Contributions to paleontology, Nos. 2-8 (extracted from the Twelfth annual report of the survey for the year 1878) U S G S (Hayden): 171 pp, il (1880) [See below, 83-83f]

81 Report on the Carboniferous invertebrate fossils of New Mexico. U S Geog S W 100th Mer (Wheeler), 3 Sup, App: xxxviii pp, il (1881)

81a Note on the occurrence of Productus giganteus in California. U S Nat Mus, Pr 3: 46-47, il (1881)

$81 b$ Note on Acrothele. U S Nat Mus, Pr 3:47 (1881)

81e Description of a new Cretaceous Pinna from New Mexico. U S Nat Mus, Pr 3: 47-48 (1881)

81d Note on the occurrence of Stricklandinia salteri and $S$. davidsoni in Georgia. U S Nat Mus, Pr 3:48-49 (1881)

81e Descriptions of new invertebrate fossils from the Mesozoic and Cenozoic rocks of Arkansas, Wyoming, Colorado, and Utah, N S Nat Mus, Pr 3:157-162 (1881)
White, Charles Abiathar-Continued.

81 Description of a very large fossil gastropod [Tylostoma princeps] from the State of Puebla, Mexico. U S Nat Mus, $\operatorname{Pr} 3: 140-142$, il (1881) La Naturaleza $6: 219-221$, il (1883)

$\mathbf{8 1 g}$ Progress of invertebrate paleontology in the United States for the year 1880. Am Nat 15:273-279 (1881)

82 (and Anghey, Samuel) Artesian wells upon the Great Plains... U S Dp Agr : 38 pp, map, Washington 1882

82a On certain Cretaceous fossils from Arkansas and Colorado. U S Nat Mus, Pr $4: 136-139$, il (1882)

82b Fossils of the Indiana rocks, no. 2. Ind, Dp G N H, An Rp 11:347-401, il (1882)

82e Progress of invertebrate paleontology in the United States for the year 1881 . Am Nat 16:887-891 (1882)

s2d On certain conditions attending the geological descent of some North American types of fresh-water gill-bearing mollusks. Am J Sc (3) $23: 382-386$ (1882)

82e Artesian wells upon the Great Plains. N Am Rv 135: 187-195 (1882)

83 Contributions to invertebrate paleontology, No. 2; Cretaceous fossils of the Western States and Territories. U S G Geog S Terr (Hayden), An Rp 12 pt 1: $5-39$, il (1883, advance print 1880 )

83a Contributions to invertebrate paleontology, No. 3 ; Certain Tertiary Mollusca from Colorado, Utah, and Wyoming. U S G Geog S Terr (Hayden), An Rp 12 pt 1 : $41-48$, il (1883, advance print 1880 )

83b Contributions to invertebrate paleontology, No. 4; Fossils of the Laramie group. U S G Geog S Terr (Hayden), An Rp 12 pt $1: 49-103$, il (1883, advance print 1880)

83e Contributions to invertebrate paleontology, No. 5; Triassic fossils of southeastern Idaho. U S G Geog S Terr (Hayden), An Rp 12 pt $1: 105-118$, il (1883, advance print 1880 )

s3d Contributions to invertebrate paleontology, No. 6; Certain Carboniferous fossils from Western States and Territories. U S G Geog S Terr (Hayden), An Rp 12 pt $1: 119-141$, il (1883, advance print 1880)

83e Contributions to invertebrate paleontology, No. 7 ; Jurassic fossils from the Western Territories. U S G Geog S Terr (Hayden), An Rp 12 pt $1: 143-153$, il ( 1883 , advance print 1880 )

83f Contributions to invertebrate paleontology, No. 8 ; Fossils from the Carboniferous rocks of the Interior States. U S G Geog S Terr (Hayden), An Rp 12 pt 1: $155-171$, il (1883, advance print 1880 )

$\mathbf{8 3 g}$ Progress of invertebrate paleontology in the United States for the year 1882 . An Nat $17: 598-603$ (1883) 
White, Charles Abiathar-Continued.

83h New molluscan forms from the Laramie and Green River groups, with discussion of some associated forms heretofore known. U S Nat Mus, Pr 5: 94-99, il (1883)

83i The molluscan fauna of the Truekee group, including a new form. U S Nat Mus, Pr 5: 99-101, il (1883)

83j on the Macrocheilus of Phillips, Plectostylus of Conrad, and Soleniscus of Meek and Worthen. U S Nat Mus, Pr 6 : 184-187, il (1883)

83k A review of the nonmarine fossil Mollusca of North America. U S G S, An Rp $3: 403-550$, il (1883)

831 Glacial drift in the upper Missouri River region. Am J Sc (3) 25:206 (1883)

$83 m$ Late observations concerning the molluscan fauna and the geographical extent of the Laramie group. Am J Sc (3) 25: 207-209 (1883)

83n On the existence of a deposit in northeastern Montana and northwestern Dakota that is possibly equivalent with the Green River group. Am J Sc (3) 25:411414 (1883)

83o The burning of lignite in situ. Am J Sc (3) 26:24-26 (1883)

83p On the commingling of ancient faunal and modern floral types in the Laramie group. Am J Sc (3) 26:120-123 (1883)

84 Fossil Ostreidae of " "orth America ... U S G S, An Rp 4: 273-430, il (1884)

84a on Mesozoic fossils. U S G S, B 4: $36 \mathrm{pp}$, il (1884)

84b The fossils of the Indiana rocks, no. 3. Ind, Dp G N H, An Rp 13 pt $2: 107$ 180, il (1884)

84e Glacial drift in Montana and $\mathrm{Da}$ kota. Am J Sc (3) $27: 112-113$ (1884)

84d The enemies and parasites of the oyster, past and present. Science 3:618 (1884)

85 On the Mesozoic and Cenozoic paleontology of California. U S G S, B 15 : $33 \mathrm{pp}$ (1885)

85a On marine Eocene, fresh-water Miocene, and other fossil Mollusca of western North America. U S G S, B 18: 26 pp, il (1885)

85b On new Cretaceous fossils from California. U $\mathrm{S}$ G S, B $22: 25$ pp, ,1 (1885)

s5e Certain phases in the geological history of the North American continent, biologically considered. Biol Soc Wash, $\mathrm{Pr}$ $2: 41-66$ (1885)

85d Notes on the Jurassic strata of North America. Am J Sc (3) 29 : 228232 (1885)

s5e The genus Pyrgulifera Meek, and its associates and congeners. Am J Sc (3) $29: 277-280$ (1885)
White, Charles Abiathar-Continued.

86 On the fresh-water invertebrates of the North American Jurassic. U S G S, B $29: 41 \mathrm{pp}$, il (1886)

$86 \boldsymbol{a}$ On the relation of the Laramie mol. luscan fauna to that of the succeeding fresh-water Eocene and other groups. I S G S, B 34:54 pp, II (1886)

$86 \mathrm{~b}$ The application of biology to geological history. Biol Soc Wash, Pr 3:120 (1886)

87 On the age of the coal found in the region traversed by the Rio Grande. Am J Sc (3) $33: 18-20$ (1887)

$87 \mathbf{a}$ Remarks on the revision of the Palaeocrinoidea of Wachsmuth and Springer. Am J Sc (3) 33:154-157 (1887)

$\mathbf{8 7 b}$ On the interrelation of contemporaneous fossil faunas and floras. Am J Sc (3) $33: 364-374$ (1887)

87e On new generic forms of Cretaceous Mollusca and their relation to other forms. Ac N Se Phila, Pr $1887: 32-37$, il

s7d On the Cretaceous formations of Texas and their relation to those of other portions of North America. Ac $\mathrm{N}$ Sc Phila, Pr 1887: 39-47

88 Remarks on the genus Aucella, with especial reference to its occurrence in California. U S G S, Mon $13: 226-233$, il (1888)

S8a On the occurrence of later Cretaceous deposits in Iowa. $A m$ G 1:221227 , il (1888)

$\mathbf{8 8 b}$ on the relation of the Laramie group to earlier and later formations. Am J Sc (3) $35: 432-438$ (1888)

s8e On the Puget group of Washington Territory. Am J Sc (3) $36: 443-450$ (1888)

88d Mountain upthrusts. Am Nat 22: 399-408 (1888)

sse [On the fauna of the Permian in Baylor, Areher, and Wichita cos., Tex.]. Am Nat $22: 926$ (1888)

ssf On Hindeastraea, a new generic form of Cretaceous Astraeidae. G Mag (3) $5: 362-364$, il (1888)

89 On the geology and physiography of a portion of northwestern Colorado and adjacent parts of Utah and Wyoming. U S G S, An Rp 9:677-712, map (1889)

s9a on invertebrate fossils from the $\mathrm{Pa}$ cific coast. U S G S, B 51:102 pp, il (1889)

89b The North American Mesozoic [address]. Am As, $\operatorname{Pr} 38: 205-226$ (1890) Science 14: 160-166 (1889)

89e The Lower Cretaceous of the Southwest and its relation to the underlying and overlying formations. Am J.Se (3) $38: 440-445$ (1889) ; 39:70 (1890)

89d On the Permian formation of Texas. Am Nat 23:109-128, il (1889)

89e The Cretaceous deposits of North America (abst). Am As, Pr 37:183 (1889) 
White, Charles Abiathar-Continued.

90 Remarks on the Cretaceous of northern Mexico (abst). Am As, Pr 38:252 (1890)

90a (with Bliss, N. W.) The private life and scientific work of Prof. Amos Henry Worthen. III G S 8: App 3-37, port (1890)

91 The Texas Permian and its Mesozoic types of fossils. U S G S, B $77: 51 \mathrm{pp}$, il (1891)

91 a Correlation papers, Cretaceous. U S G S, B $82: 273$ pp, maps (1891)

$91 b$ On the biological and geological significance of closely similar fossil forms. Am As, Pr 39:239-243 (1891)

92 On the Bear River formation, a series of strata hitherto known as the Bear River Laramle. Am J Sc (3) 43:91-97 (1892)

93 The relation of biology to geological investigation. Smiths Inst, An Rp 1892, Rp U S Nat Mus : 245-368 (1893)

93a Memoir of Ferdinand Vandiveer Hayden, 1839-1887. Nat Ac Sc, Biog Mem $3: 395-413$, port (1893)

94 Notes on the invertebrate fauna of the Dakota formation, with descriptions of new molluscan forms. U S Nat Mus, Pr 17:131-138, 11 (1894)

95 The Bear River formation and its characteristic fauna. U S G S, B 128: $108 \mathrm{pp}$, map, il (1895)

95a Memoir of Amos Henry Worthen, 1813-1888. Nat Ac Sc, Biog Mem 3: 339-362 (1895)

96 Biographical sketch of Fielding Bradford Meek. Am G 18:337-350, port (1896)

02 Memoir of George Engelmann, 18091884. Nat Ac Sc, Biog Mem 4:1-21 (1902)

02a Memoir of Fielding Bradford Meek, 1817-1876. Nat Ac Sc, Biog Mem 4:7591 (1902)

02b The mutation theory of Professor de Vries. Smiths Inst, An Rp 1901: 631640 (1902)

03 De Mutatie-Theorie en de Paleontologie. Album du Natur 1903: 231-238 Die Mutationstheorie und der Paläontologie. Natur und Schule 3: 248-253 (1904) [not seen]

o5 The ancestral origin of the North American Unionidae, or freshwater mussels. Smiths Misc Col 48 (Q Is 3): 75-88, il (1905)

05a The relation of phylogenesis to historical geology. Science n s $22: 105-113$ (1905)

o6 Bibliographical memoir of John Strong Newberry, 1822-1892. Nat Ac Sc, Biog Mem 6:1-24, port (1906)

See also Becker, 91b; Hilgard 71a; Hill (R T), 91 ; Langdon, $91 \mathrm{a}$; Powell, 84, 85, $85 a, 88,89,89 a, 90,91,91 a, 92$; Todd, 81
White, Charles Henry.

94 An examination into the nature of Palaeotrochis. Elisha Mitchell Sc Soc, J 11: $50-66$, il (1894)

04 The Appalachian river versus a Tertiary trans-Appalachian river in eastern Tennessee. J G 12: 34-39 (1904)

05 Autophytography; a process of plant fossilization. Am J Sc (4) 19:231-236 (1905)

White, Charles David.

90 On Cretaceous plants from Marthas Vineyard. Am J Se (3) 39:93-101, il (1890) Abst, with discussion by J. S. Newberry, L. F. Ward, and F. J. H. Merrill, G Soc Am, B 1:554-556 (1890)

92 The Cretaceous at Gay Head, Marthas Vineyard, [Mass.] Science 20:332-333 (1892)

93 Flora of the outlying Carboniferous basins of southwestern Missouri. U S G S, B $98: 139 \mathrm{pp}$, il (1893)

93a A new taeniopterold fern and its allies. G Soc Am, B 4: 119-132, il (1893)

95 The Pottsville series along New River, W. Va. G Soc Am, B 6:305-320 (1895)

96 Report on the fossil plants from the Hindostan whetstone beds in Orange Co., Ind. Ind, Dp G N Res, An Rp 20:354355 (1896)

96a The development of exogenous structure in the Paleozoic lycopods. Science n s 3 : 754-759 (1896)

96b Some new forms of Paleozoic algae from the central Appalachian region (abst). Sclence n \& $3: 331$ (1896)

96e The thickness and equivalence of some basal Coal Measure sections along the eastern margin of the Appalachian basin (abst). Science n s 3:534-535 (1896) Am G $17: 266$ (1896)

97 Age of the lower coals of Henry County, Mo. G Soc Am, B $8: 287-304$ (1897)

9s Omphalophloios, a new lepidodendroid type. G Soc Am, B 9:329-342, il (1898) Abst, Science n s $7: 80$ (1898)

9sa (and schuchert, C.) Cretaceous series of the west coast of Greenland. $\mathrm{G}$ Soc Am, B 9:343-368, map (1898) Abst, Science n s $7: 52-53$ (1898)

98b The probable age of the McAlester coal group (abst). Science n s $7: 612$ (1898)

99 Fossil flora of the lower Coal Meas. ures of Missouri. U S G S, Mon $37: 467$ pp, il (1899)

99a Report on fossil plants from the McAlester coal field, Ind. T... U S G S, An Rp 19 pt $3: 457-538$, il (1899)

oo The stratigraphic succession of the fossil floras of the Pottsville formation in the southern anthracite coal field, Pennsyl. vania. U S G S, An Rp 20, pt 2: 749-930, Il (1900) 
White, Charles David-Continued.

ooa Relative ages of the Kanawha and Allegheny series as indicated by the fossil plants. G Soc Am, B 11:145-178 (1900) Abst, Science n s 11:140-141 (1900)

01 Two new species of algae of the genus Buthotrephis, from the Upper $\mathrm{Si}$ lurian of Indiana. U S Nat Mus, $\operatorname{Pr} 24$ : 265-270, il (1901)

01a Age of the coals at Tipton, Blair Co., Pa. G Soc Am, B 12:473-477 (1901)

o1b Some paleobotanical aspects of the upper Paleozoic in Nova Scotia. Can Rec Sc $8: 271-280$ (1901) Abst, Science n s $12: 885$ (1900)

o1e The Canadian species of the genus Whittleseya and their systematic relations. Ottawa Nat 15:98-110, il (1901)

$01 d \mathrm{Mr}$. Lacoe's relations to science. Wyoming Hist G Soc, Pr 6:55-60 (1901)

02 (and Campbe11, M. R.) The bituminous coal field of Pennsylvania. U S G S, An Rp 22 pt $3: 127-200$, map (1902)

02a The bituminous coal field of Maryland. U S G S, An Rp 22 pt 3:201-214 (1902)

02b Fossil alga from the Chemung of New York, with remarks on the genus Haliserites Sternberg. N Y St Mus, B 52 : 593-605, il (1902)

02e Stratigraphy vs. paleontology in Nova Scotia. Science n $s$ 16:232-235 (1902)

03 Summary of fossil plants recorded from the upper Carboniferous and Permian formations of Kansas. U S G S, B 211: 85-117 (1903)

03a Memoir of Ralph Dupuy Lacoe. G Soc Am, B 13: 509-515 (1903)

03b An anthracite coal field three and a half hours west of Washington [D. C.] Science n s $17: 387$ (1903)

03e Problematic fossils supposed to be seaweeds from the Hudson group (abst). Science n s 17: 264 (1903)

03d Age of the Mercer group (abst). Science n s 17:942 (1903)

o3e (with Adams, G. I.) Stratigraphy and paleontology of the upper Carboniferous rocks of the Kansas section. U S G S, B 211: 123 pp, maps (1903)

04 Deposition of the Appalachian Pottsville. G Soc Am, B 15:267-282, map (1904) Abst, Science n s $19: 24, \quad 532$ (1904)

O4a Permian elements in the Dunkard flora (abst). G Soc Am, B 14: 538-542 (1904) J G 11:105-106 (1903) Science n s $17: 298$ (1903)

04b $A$ new seed-bearing fern (abst). Science n s 20:840 (1904)

05 The seeds of Aneimites. Smiths Misc Col 47 ( $Q$ Is 2) : 322-331, il (1905)

05a Fossil plants of the group Cycadofilices. Smiths Misc Col 47 (Q Is 2) : $377-$ 390, il (1905) Abst, Science n \& 21:664 (1905)
White, Charles David-Continued.

05b The occurrence of glacial epochs in Paleozoic time (abst). Science n s $22: 335$ (1905)

ose The age of the Wise and Harlan formations of southwestern Virginia (abst). Science n s $22: 335-336$ (1905)

05d The American range of the Cycadofilices (abst). Int Geog Cong, VIII, $\mathrm{Rp}$ : 616 (1905)

o5e (with Smith, G. O.) The geology of the Perry Basin in southeastern Maine. U S G S, P P 35: $107 \mathrm{pp}$, map, il (1905)

06 Geological position of the principal insect-bearing localities of the American Paleozoic. U S Nat Mus, Pr 29:664-66s (1906)

06a (and Ashley, G. H.) Correlation of coals. U S G S, P P $49: 206-212$ (1906)

06b Report on fossil plants [from the Cape Lisburne region, Alaska]. U S G S, B $278: 22$, il (1906)

o6e A source of hydrocarbons in the Ordovician (abst). Science n 8 23: 814 816 (1906)

o7 A remarkable fossil tre trunk from the middle Devonic of New York. N Y St Mus, B $107: 327-360$, il (1907)

Ora Report on the field work in the coal districts of the State. III G S, B 4: 201-20: (1907)

07b Report on fossil plants from the Coal Measures of Arkansas. U S G S, B 326: 24-31 (1907)

ore A composite lycopod type from the Devonian (abst). Sclence $\mathrm{n} \quad \mathrm{s} \quad 25: 269$ (1907)

07d Report on field work done in 1907. III G S, : 8:268-272 (1907)

os Some problems of the formation of coal. Ec G $3: 292-318$ (1908) Abst, Science n \& $25: 965-966$ (1907)

08a Correlation of Elkhorn coals [eastern Kentucky ]. U S G S, B 348: 30-32 (1908)

08b Oxygen values and coal alteration (abst). Science n \& 27:537 (1908)

09 The effect of oxygen in coal. U $\mathbf{S}$ G S, B 382: 74 pp (1909)

09a The upper Paleozoic floras, their succession and range. $J$ G $17: 320-341$ (1909)

09b Paleobotanical work in Illinois in 1908. Ill G S, B 14:293-295 (1909)

09e Occurrence of resin in Paleozoic coals (abst). Science n s 29:945 (1909)

09d Graphic methods of representing the regional metamorphism of coals (abst). Science n s $30: 62$ (1909)

10 The regional devolatilization of coal (abst). Science n s $32: 221$ (1910) G Soc Am, B 21: 788 (1910)

10n Permian floras in the western "Red Beds" (abst). Science n s $32: 223$ (1910) 
White, Charles David-Continued.

10b (and Knowlton, F. H.) Evi dences of paleobotany as to geological cli mate $(a b s t)$. Science n s 31:760 (1910)

11. Value of floral evidence in marine strata as indicative of nearness of shores. G Soc Am, B 22: 221-227 (1911)

11a A Carboniferous flora [at St. John, $\mathrm{N} . \mathrm{B}$.$] in the Silurian? Science \mathrm{n}$ s 34 : 440-442 (1911) [See Matthew (G F) 10d]

12 The characters of the fossil plant Gigantopteris Schenk and its occurrence in North America. U S Nat Mus, Pr 41: $493-516$, il (1912)

12a Age of the Worcester phyllite. Wash Ac Sc, J 2:114-118 (1912)

12b [Formation of llmestone near tide level] (abst). Wash Ac Sc, J 2:357 (1912)

12e Resins in Paleozoic coals (abst). Science n s $35: 312$ (1912) G Soc Am, B $23: 728$ (1912)

13 Excursion in eastern Quebec and the maritime provinces; the flora of the Gaspe sandstone; the Horton flora; note on the flora of the Coal Measures. Int $G$ Cong, XII, Canada, Guide Book no 1:108-110, $144-146,250-251$ (1913)

13a The fossil flora of West Virginia. W Va G S 5 (A) : 390-453 (1913)

$13 \mathrm{~b}$ Roots in the underclays of coals (abst), G Soc Am, B 24:114-115, 719 (1913)

13e Pottsville-Allegheny boundary in the interior province $(a b s t)$. G Soc Am, B 24: 716 (1913)

13d (and Thiessen, R.) The origin of coal. U S Bur Mines, B $38: 390$ pp (1913)

13e Resins in Paleozoic coals (abst). Int Cong Applied Chem, Eighth, 25:775776 [1913]

14 Resins in Paleozoic plants and in coals of high rank. U S G S, P P 85: 6583 (1914) Abst, Wash Ac Sc, J 4:10, 225 (1914)

15 Notes on the fossil floras of the Pennsylvanian in Missouri. Mo Bur G (2) $13: 256-262$ (1915)

15 a Some relations in origin between coal and petroleum. Wash Ac Sc, J 5 : 189-212, map (1915)

151. The occurrence of transported boulders in coal beds (abst). Wash Ac Sc, J 5: 407 (1915)

15e Regional alterations of oil shales (abst). G Soc Am, B 26:101-102 (1915)

16 (and others). Natural gas resources of parts of north Texas. U S G S, B 629: 126 pp, maps (1916)

16a Charles Willard Hayes. Science n s $44: 124-126$ (1916)

17 Late theories regarding the origin of oil. G Soc Am, B 28:727-734 (1917)
White, Charles David-Continued.

17a Organization and cost of geological surveys. Pan dmerican Sc Cong, 2d, Washington, $\operatorname{Pr} \sec 7$ × 8:605-612 (1917)

18 Structure and oil and gas resources of the Osage Reservation, Okla.; Introduction. U S G S, B 686: v-xii, map (1918)

See also Barrell, 12a; Branson, 12 ; Collier, 07b; Gordon (C H), 11a ; Grabau, 12b; Powell, 95 ; Stanton, 05d

White, Douglas.

09 The zinc mines of southern Nevada. Am M Cong, 12th An Sess, Rp Pr: 401411 (1909)

White, E. E.

16 Analysis of slate and dike [Marquette Range, Mich.]. Eng M J 101:433434 (1916)

White, E. L.

07 Report of the State Bureau of Mines [of] Colorado for the years 1905-6. 127 pp [Denver 1907]

White, George.

49 Statistics of the State of Georgia... [Geology : 13-27]. $624,77 \mathrm{pp}$, map, Savannah 1849

White, H. C.

81 (with MeAdoo, W. G.) Elementary geology of Tennessee. $118 \mathrm{pp}, \mathbf{N} \mathbf{Y}$ 1881

White, H. T.

10 Chrome-bearing peridotites of Lake Abitibi [Ont.]. Can M Inst, J 12:592597 (1910)

White, Henry.

65 Geology, oil fields, and minerals of Canada West. Toronto, 1865 [not seen] White, Israel Charles.

74 Notes on the Coal Measures of Beaver Co., Pa. Lyc N H N Y, An 11: 14-18 (1874)

74a Notes on the upper Coal Measures of West Virginia and Pennsylvania. Lyc $\mathrm{N}$ H N Y, An 11:46-57 (1874)

76 Beaver Co., south from the Ohio River. $\mathrm{Pa} \mathrm{G} \mathrm{S,} \mathrm{2d,} \mathrm{K} \mathrm{:} \mathrm{334-349} \mathrm{(1876)}$

78 Report of progress in the Beaver River district of the bituminous coal flelds of western Pennsylvania. $\mathrm{Pa}$ G S, 2d, Q : 11, $337 \mathrm{pp}$, maps (1878)

79 The geology of Lawrence Co. To which is appended a special report on the correlation of the Coal Measures in western Pennsylvania and eastern Ohio. $\mathrm{Pa} G \mathrm{~S}$, 2d, QQ: xxxvi, 336 pp, map (1879)

so The geology of Mercer Co. Pa G S, $2 d, Q Q Q$ : xiv, $233 \mathrm{pp}$, map (1880)

soa (with Fontaine, Wm. M.) The Permian or upper Carboniferous flora of West Virginia and southwestern Pennsylvania. $\mathrm{Pa} G \mathrm{~S}, 2 \mathrm{~d}, \mathrm{PP}: \mathrm{ix}, 143 \mathrm{pp}$, il (1880)

81 The geology of Erie and Cranford $\cos$. $\mathrm{Pa} G \mathrm{~S}, 2 \mathrm{~d}, \mathrm{QQQQ}: 1-355$, maps (1881) 
Blake, William Phipps-Continued.

57 a Observations on the orography of the western portion of the United States. Am As, Pr 10 pt 2:119-134 (1857) Abst, Edinb N Ph J n s $5: 370-374$ (1857)

57b Note on the occurrence of telluret of silver in California. Cal Ac N Sc, $\operatorname{Pr} 1$ : 96-97 (1857; 2d ed, 1873:107-108) Am J Sc (2) $23: 270-271$ (1857)

58 The chalchihuitl of the ancient Mexicans; its locality and association, and its identity with turquoise. Am J Sc (2) 25 : 227-232 (1858)

58a On the parallelism between the deposits of auriferous drift of the Appalachian gold field and those of California. Am J Se (2) $26: 128$ (1858)

58b Lanthanite and albanite in Essex Co., N. Y. Am J Sc (2) $26: 245-246$ (1858)

58c Report upon the gold placers in the vicinity of Dahlonega, Ga ... 14 pp, N Y 1858 [Priv pub]

59 Silver and copper mining in Arizona. M Mag (2) 1:1-15, map (1859)

$59 a$ Observations on the mineral resources of the Rocky Mountain ehain, near Santa Fe, and the probable extent southwards of the Rocky Mountain gold field. Boston Soc N H, Pr 7:64-70 (1859) M Mag (2) 1:22-27 (1859)

$59 b$ Observations on the geology of the Rocky Mountain chain in the vicinity of Santa Fe, N. Mex. (abst). Edinb N Ph J n s $10: 301-304$ (1859) Am As, Pr 13:314319 (1860)

59e (and Jaekson, C. T.) The gold placers of the vicinity of Dahlonega, Ga. Report to the Yahoola River and Cane Creek Hydraulic Hose Mining Company. $64 \mathrm{pp}$, Boston 1859 Extract, M Mag (2) 1: $360-366 \quad(1860)$

60 The Washoe silver mines [Nev.]. M Mag (2) 1:221-225 (1860)

60a The Wheatley silver lead mines [near Phoenixville, Pa.] M Mag (2) 1: 411-418 (1860)

60b Report upon the zinc ore of Bald Hill, Union Co., Tenn. M Mag (2) 1:419427 (1860)

60e Report on the Cherokee gold mine [Ga.]. M Mag (2) 1:453-457 (1860)

60d Report on the Hendricks gold lots, Lumpkin Co., Ga. M Mag (2) 1:457-461 (1860)

60e Report upon the property of the Valley River Gold Company [Cherokee Co., N. C.]. M Mag (2) 1:461-466 (1860)

60f Contributions to the mineralogy and geology of Georgia. M Mag (2) $2: 76$ 80 (1860)

61 Notes upon the geology and minerals of the Cherokee Valley, Valley River, N. C. M Mag (2) 2:80-84 (1861)
Blake, William Phipps-Continued.

$61 n$ Descriptions of the various silre ores and minerals ... 181 pp, New Have 1861 [not seen]

64 Notes on the geology and mines of Nevada Territory (Washoe region, U. 8. G Soc London, Q J 20:317-327 (186t Abst, Ph Mag (4) 28:72-73 (1864)

$64 a$ Note on the fossil remains of the horse and elephant, mingled, at Mare is land, San Francísco Bay. Cal Ac N sc $\operatorname{Pr}$ 3: 166 (1864)

64b Note on a large lump of gold foun on the middle fork of the American Rive Cal Ac N Sc, Pr 3:166 (1864)

64e Ammonites or Ceratites from Ore gon Bar, middle fork of the America River. Cal Ac N Sc, Pr 3:167 (1864)

64d Note on the discovery of fossill in the auriferous slate formation of th Mariposa estate, Cal., and the probabl geological age. Cal Ac N Sc, Pr $3: 1 \%$ (1864)

64e Der Stekin-Fluss Im Britiscles Nord-Amerika [Stikine River district, B C.]. Petermanns Mitt 10:171-175 (186t

65 Iron regions of Arizona. Am J \& (2) $40: 388$ (1865)

66 Annotated catalogue of the principel mineral species hitherto recognized in cal fornia and the adjoining states and term tories; being a report to the Califoril State Board of Agriculture [and Notes o the geographical distribution and geolog of the precious metals and valnable mit erals on the Pacific slope of the Unite States: 27-31] 31 pp, Sacramento 186 Also in Cal St $\mathrm{Bd} \mathrm{Agr,} \mathrm{Tr} \mathrm{St} \mathrm{Agr} \mathrm{\&}$ 1864-5 : 335-363 (1866) ; Cal., Legislatur App. to Journals, 16 Sess., vol $3: 335-38$ (1866) Notice, Am J Sc (2) $42: 1 \%$ (1866)

66a Account of an earthquake at \$s: Franciseo, Cal., October 8, 1865. Boste Soc N H, Pr 10:236-237 (1866)

66b Note on the occurrence of gold with cinnabar in the Secondary or Tertiart rocks. Boston Soc $\mathrm{N}$ H, Pr 11:30-3] (1866)

66e Note upon the occurrence of sphex in the granite of the Sierra Nevada. Ac N Sc, Pr 3:193 (1866)

66d New mineral ofl regions in the Tulare valley. Cal Ac $\mathrm{N}$ Sc, Pr 3:19 (1866)

66e Note on the abundance of iron of in northern Arizona. Cal Ac $\mathrm{N}$ Sc, ? 3: 206-207 (1866)

66f Ammonites in the auriferous slat of California. Cal Ac $\mathrm{N}$ Sc, Pr 3:25 (1866)

67 Mineralogical notices. Am $\mathrm{J}$ Sc (?) 43:124-125 (1867) Cal Ac N Sc, $\mathrm{Pr}^{3}$ 297-298 (1867)

67 a The glaciers of Alaska, Rusits America. Am J Sc (2) 44:96-101 (186i? 
White, Israel Charles-Continued.

81a The geology of Susquehanna Co., and Wayne Co. Pa G S, 2d, G5: xi, 243 pp, map (1881)

$81 \mathrm{~b}$ Notes on the place of the Sharon conglomerate in the Paleozoic series. Am Ph Soc, Pr 19: 198-201 (1881)

s1e Notes on the geology of West Virginia. Am Ph Soc, Pr 19:438-446 (1882) The Virginias 2: 130-132 (1881)

s1d The coal beds of Ohie River counties of West Virginia. The Virginias 2: 107 (1881)

82 The geology of Pike and Monroe cos. Pa G S, 2d, G6: xxiv, 407 pp, map (1882)

s2a Notes on the geology of West Virginia. The Virginias $3: 102-103,123-124$, 141-144 (1882)

$82 b$ Notes on the geology of West Virginia. $\mathrm{Am} \mathrm{Ph}$ Soc, $\mathrm{Pr} 20: 479-496$ (1882) The Virginias $3: 188-189 ; 4: 53-54,77-79$ (1822-3)

82e The fossil flora of West Virginia. The Virginias 3:153 (1882)

82d The origin of petroleum. The Virginias $3: 171(1882)$

83 The geology of the Susquehanna River region in the six counties of Wyoming, Lackawanna, Luzerne, Columbia, Montour, and Northumberland. $\mathrm{Pa} G \mathrm{G}$, 2d, G $7: \mathrm{xxx}, 464 \mathrm{pp}$, maps (1883)

83a Geological section at Wheeling. W. Va. The Virginias $4: 15-16$ (1883)

83b Coal sections, Ohio River, W. Va. The Virginias 4:96-97 (1883)

83c Notes on the geology of West Virginia. The Virginias $4: 107-110,123-126$, $140-143,155-158 ; 5: 172-173,187,188$ $190(1883-4)$

83d The glacial period. Kansas City Rv Sc $7: 295-299$ (1883)

83e Physical history [of Monongalia Co.1. In Wiley, Samuel T., History of Monongalia Co., W. Va.:220-239, Kingwood, W. Va., 1883

84 Effects of the glacial dam at Cincinnati along the upper basin of the Ohio. Western Reserve Hist Soc, Tract (no 60) $2: 273-278$ (1884) [another ed, Wright, G. F., The glacial boundary in Ohio, Indiana, and Kentucky] : 81-86 (1884) Kansas City Rv Sc 7:295-299 (1884) [under title, The glacial period] Abst, Am As, Pr 32: 212-213 (1884); Am J Sc (3) 26 : 327 ; Science $2: 319-320$ (1883) ; The Virginias $4: 139-140$ (1883)

84a The Great Kanawha coal field. The Virginias $5: 108,151$ (1884)

85 The geology of Huntingdon Co. Pa G S, 2d T3: xv, $471 \mathrm{pp}$, maps (1885)

85a Résumé of the wark of the U. S. Geological Survey in the Great Kanawha Valley during the summer of 1884 . The Virginias $6: 7-16$ (1885)

85b Nomenclature of Appalachian coal beds. The Virginias $6: 44$ (1885)
White, Israel Charles-Continued.

s5e Report of the Morgantown, w. Va., gas well. The Virginias 6:91-92, 101 (1885)

85d The geology of natural gas. Sci. ence $6: 43-44 \quad(1885)$

85e The geology of natural gas. Science $5: 521-522$ (1885) The Virginias 6:100 101 (1885)

85f The coal beds on Cabin Creek [Great Kanawha Valley], W. Va. The Virginias $6: 115-116 \quad(1885)$

86 The geology of natural gas. Petro. leum Age 5: 1263-1267, 1464-1465 (1886) Abst, Am J Sc (3) $31: 393-394$ (1886)

87 Rounded boulders at high altitudes along some Appalacbian rivers. Am J Sc (3) $34: 374-381$ (1887)

89 The age of the Tipton Run coal of Blair Co., Pa. Am G 4:25-28 (1889)

91 Stratigraphy of the bituminous coal field of Pennsylvania, Ohio, and West Virginia. U S G S, B 65: 212 pp, map (1891)

91 a James Macfarlane [1819-1885]. Am G $7: 145-149$, port (1891)

$\mathbf{9 1 b}$ Oil and gas resources of West Virginia. Am G $7: 302-305$ (1891)

92 The Mannington oil field [W. Va.] and the history of its development. G Soc Am, B 3: 187-216, map (1892)

92a Fossil plants from the Wichita or Permian beds of Texas (with discussion, $p$. 459) G Soc Am, B 3:217-218 (1892)

96 Origin of the high terrace deposits of the Monongahela River. Am G 18:368379,227 (abst) (1896) Abst, Science n s 4: 385 (1896)

97 A complete oil-well record in the McDonald field between the Pittsburg coal and the fifth oil sand (abst). J G 5: 103-104 (1897) Science n \& 5:93 (1897) Am G $19: 422$ (1897)

9S Report of the State geological and economic survey commission to the West Virginia legislature. $24 \mathrm{pp}$, Charleston 1898

9Sa The Pittsburg coal led. Am As, Pr 46: 187-198 (1898) Am G 21:49-60 (1898); abst, 20:196 (1897)

99 Administrative report; levels above tide; petroleum and natural gas. W Va G S 1:392 pp, Morgantown 1899

99a Origin of grahamite. G Soc Am, B $10: 277-284$, map (1899) Abst, Am G

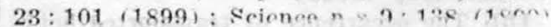

00 Edward Orton. Am G 25:197210 , port $(1900)$

01 The geology of West Virginia. Int M Cong, 4th. Pr:56-61 (1001) Mines and Minerals 22: 153-155 (1901)

02 Biennial report of the state geolog. ical and economic survey, West Virginia, 1902. 51 pp Charleston 1902

O2a Geological horizon of the Kanawha black flint G Soc Am, B 13:119-126 (1902) Abst, Science n s 15:83-84 (1902) 
White, Israel Charles-Continued.

02b Lists of fossils from the lower half of the Conemaugh formation near Morgantown, W. Va., collected in 1870 by Dr. John J. Stevenson, and identified by F. B. Meek. Am G 30:211-214 (1902)

02e The geology of the Pittsburgh district $(a b s t)$. Science $n$ s $16: 258-259$ (1902)

03 Levels above tide; true meridians; report on coal. W Va G S $2: 81-716$ (1903)

04 Petroleum and natural gas; precise levels. W Va G S 1A; 625 pp [Morgantown 1904]

04a Map showing occurrence of coal, oil, and gas in West Virginia. Scale, 8 miles to inch. W Va G S, 1904 Later editions 1908, 1910, 1913, 1914, 1917

os Supplementary coal report. W Va G S $2(\mathrm{~A}): 720$ pp $(1908)$

o9 Shortage of coal in the northern Appalachian coal field. G Soc Am, B 20 : 333-340 (1909)

09a The barren zone of the northern Appalachian coal field and its relations to Pittsburg's industries. Address of Dr. I. C. White, State geologist of West Virginia, before the Am. Min. Congress, Pittsburg, Pennsylvania, on Friday, the 5th day of December, 1908. 20 pp. Also in Am M Cong, 11th An Sess, Papers and Addresses : 166-176 (1909)

09b West Virginia Geological Survey, Coal report (discussion of review by M. R. Campbell). Ec G $4: 261-262$ (1909)

10 Levels; coal analyses. W Va G S, B 2:385 pp (1910)

11 Petroleum and natural gas in West Virginia. Nat Gas As Am, 6th An Meeting : 82-103 (1911)

11 a Petroleum and natural gas in West Virginia. Nat Gas As Am, Pr 3: 159-175 [1911]

13 Petroleum fields of northeastern Mexico between the Tamesi and Tuxpan rivers. G Soc Am, B 24:253-274, 706 (1913)

13a Note on a very deep well near McDonald, Pa. G Soc Am, B 24: 275-282 (1913)

14 Introduction [to the history and physiography of Kanawha Co., W. Va.]. W Va G S, Kanawha Co : xvii-xxviii (1914)

14a Deepest boring in West Virginia (abst). G Soc Am, B 25:48 (1914)

17 The anticlinal theory. Am M Cong, 19th An Sess., Rp Pr:550-556 (1917)

18 Discussion of the records of some very deep wells in the Appalachian oil fields of Pennsylvania, Ohio, and West Virginia. W Va G S, Barbour and Upshur counties: Xxv-lXv, maps (1918)

18a Some definite correlations of West Virginia coal beds in Mingo Co., W. Va., with those of Letcher Co., southeastern Ky (abst). G Soc Am, B 29:96 (1918)
White, Isracl Charles-Continued.

18b Records of three very deep wells drilled in the Appalachian oil fields of Pennsylvania and West Virginia (abst, with discussion by $\mathrm{Mr}$. Decker and $\mathrm{F}$. R. Van Horn). G Soc Am, B 29:96-97 (1918)

18c The deepest well in the world and the next deepest in America. Nat Gas As Am, Pr, 13th An Meeting, Pittsburgh, 1918: 80-99 (1918)

See also Beede, 12a; Case, 17a; Chamberlin. 90 ; Cushing, 13; Emmons (S F), 93 ; Ordбñez, 14 ; Orton (E), 90 a

white, James.

14 Alfred E. Barlow. Can M Inst, Mo B $27: 51-54$ (1914)

White, K. D.

15 (with Kay, F. H.) Coal resources of District VIII (Danville) [III.]. III Coal M Investigations, B $14: 68 \mathrm{pp}$, maps (1915)

White, M. C.

62 Discovery of microscopic organisms in the siliceous nodules of the Paleozoic rocks of New York. Am J Sc (2) 33 : 385386 , il (1862) Can Nat $7: 281-283$ (1862) white, Mark.

01 Geology of the Glass Mountains of western Oklahoma. Kans Ac Sc, Tr 17: $199-200$ (1901)

\section{white, Peter.}

86 The iron region of Lake Superior. Michigan Pioneer Collections 8:145-161 (1886)

White, Theodore Greely (1872-1901).

94 The geology of Essex and Willsboro townships, Essex Co., N. Y. N Y Ac Sc, Tr $13: 214-233$, map (1894)

96 The faunas of the upper Ordovician strata at Trenton Falls, Oneida Co., N. Y. N Y Ac Se, Tr 15: 71-96 (1896) Abst, Science n s $3: 34$ (1896)

96a The original Trenton rocks (abst). Am J Sc (4) 2: 430-432 (1896)

96b (with Kemp, J. F.) [Dikes in the Adirondack region (abst).] Science n s 3 : 214 (1896)

96c (with Van Ingen, G.) An account of the summer's work in geology on Lake Champlain. N Y Ac Sc, Tr 15: 19-23 (1896)

97 A contribution to the petrography of the Boston Basin. Boston Soe N H, Pr $28: 117-156$ (1897)

99 Report on the relations of the Ordovician and Eo-Silurian rocks in portions of Herkimer, Oneida, and Lewis cos. [N. Y.]. N Y St Mus, An Rp 51: r 21-54, maps (1899)

oo Upper Ordovician faunas in Lake Champlain Valley (with discussion by $\mathrm{H}$. M. Ami). G Soc Am, B 10:452-462 (1900) Abst, Am G 23:96 (1899); Science n s $9: 102$ (1899); Ottawa Nat $12: 196-197$ (1899) 
White, Theodore Greely-Continued.

OOa The Glens Falls, N. Y., section of the lower Ordovician (abst). Science n s 12: 924 (1900) Am G 27: 43 (1901) N Y Ac Sc, An 13:500 (1901)

White, W. R.

06 (with Allen, E. T.) On wollastonite and pseudo-wollastonite. Am J Sc (4) 21 : 89-108 (1906)

Whiteaves, Joseph Frederick (18351909).

65 On the fossils of the Trenton limestone of the Island of Montreal. Can Nat n \& 2:312-314 (1865)

74 Notes on the Cretaceous fossils collected ... at Vancouver and the adjacent islands. Can G S, Rp Prog 1873-4:260268, il (1874)

76 On some invertebrates from the coalbearing rocks of the Queen Charlotte Islands. Can G S, Mesozoic Foss 1: 1-92, il (1876)

77 Notes on some of the fossils collected during the expedition [see Selwyn, 77]. Can G S, Rp Prog 1875-6:96-106 (1877)

77a [Notes on fossils from Moose River, Ont.]. Can G S, Rp Prog 1875-6 : 316-320 (1877)

$\boldsymbol{7} \boldsymbol{7 b}$ Obituary notice of Elkanah Billings, F. G. S. Can Nat n s $8: 251-261$ (1877)

78 Notes on some Jurassic fossils collected ... in the Coast Range of British Columbia. Can G S, Rp Prog 1876-7 : 150-159 (1878)

78a On some Jurassic fossils from the Coast Range of British Columbia. Can Nat n s 8:400-410 (1878)

7Sb On some Primordial fossils from southeastern Newfoundland. Am J Sc (3) 16:224-226 (1878)

79 On the fossils of the Cretaceous rocks of Vancouver and adjacent islands in the Strait of Georgia. Can G S, Mesozoic Foss 1:93-190, il (1879)

80 On some Silurian and Devonian fossils from Manitoba and the valleys of the Nelson and Churchill rivers ... Can G S, Rp Prog 1878-9: c 45-51 (1880)

$\mathbf{8 0 a}$ On a new species of Pterichthys ... from the Devonian rocks of the Baie des Chaleurs. Am J Sc (3) 20:132-136 (1880) Can Nat n s $10: 23-27$ (1881)

8ob On some Silurian and Devonian fossils collected by Dr. Bell in Manitoba and Hudson's Bay (abst). Can Nat n s $9: 315 \quad(1880)$

soc Some new and remarkable fossil fishes from the Devonian rocks of the northern side of the Bale des Chaleurs $(a b s t)$. Can Nat n s 9:440-441 (1880)

81 List of fossils collected ... in Manitoba ... Can G S, Rp Prog 1879-80: C 57-58 (1881)
Whiteaves, Joseph Frederick-Contd.

S1a On some remarkable fossil fishes from the Devonian rocks of Scaumenac Bay, in the Province of Quebec. Am J $\mathrm{Sc}$ (3) 21: 494-496 (1881) An Mag N H (5) $8: 159-162(1881)$

81b On some remarkable fossil fishes from the Devonian rocks of Scaumenac Bay, P. Q., with descriptions of a new genus and three new species. Can Nat n 8 $10: 27-35$, il (1881) Abst, Am Nat 15: 252-253 (1881)

81e Description of a new species of Psammodus from the Carboniferous rocks of the Island of Cape Breton. Can Nat n s $10: 36$ (1881)

s1d On some fossil fishes, Crustacea, and Mollusca from the Devonian rocks at Campbelltown, N. B., with descriptions of five new species. Can Nat n s $10: 93-$ 101, II (1881)

82 On the occurrence of Siphonotreta scotica Davidson, in the Utica formation near Ottawa, Ont. Am J Sc (3) $24: 278$ 279 (1882) Can Nat n s 10:396-397 (1883) Abst, Am As, Pr $31: 356-357$ (1883)

83 On the Lower Cretaceous rocks of British Columbia. R Soc Can, $\operatorname{Pr} \operatorname{Tr} 1$, iv: $81-86$, il (1883)

83a On some supposed annelid tracks from the Gaspe sandstones. R Soc Can, $\operatorname{Pr} \operatorname{Tr} 1$, iv : 109-111, il (1883)

83b Recent discoveries of fossil fishes in the Devonian rocks of Canada. Am Nat 17:158-164 (1883) Abst, Am As, Pr $31: 353-356$ (1883)

83e (and Billings, W. R.) Report of the paleontological branch for the season of 1882. Ottawa Field Nat Club, Tr no 4 : $67-69$ (1883)

84 On some new, imperfectly characterized, or previously unrecorded species of fossils from the Guelph formation of Ontario. Can G S, Paleozoic Foss $3: 1-43$, il (1884)

84a On the fossils of the coal-bearing deposits of the Queen Charlotte Islands ... Can G S, Mesozoic Foss 1:191-262, II (1884)

85 Report on the Invertebrata of the Laramie and Cretaceous rocks of the vicinity of the Bow and Belly rivers and adjacent localities in the Northwest Territory. Can G S, Contr Can Pal 1:1-89, il (1885)

S5a Note on a decapod crustacean from the upper Cretaceous of Highwood River, Alberta, N. W. T. R Soc Can, Pr Tr 2, iv : $237-238$ (1885)

85b Description of a new specles of ammonite from the Cretaceous rocks of Fort St. John on the Peace River. R Soc Can, $\operatorname{Pr} \operatorname{Tr} 2$, iv : 239-240 (1885) Abst, Science $3: 676$ (1884) 
Whiteaves, Joseph Frederick-Contd.

85e Notes on the possible age of some of the Mesozoic rocks of the Queen Charlotte Islands and writish Columbia. Am J Sc (3) 29:444-449 (1885)

87 [Report on] paleontology and zoology. Can G S, Sum Rp 1886 (An Rp 2) : A 45-54 (1887); Sum Rp 1887-8 (An Rp 3) : A 105-113 (1889) ; Sum Rp 1888-9 (An Rp 4) : A 51-61 (1890); Sum Rp 1891 (An Rp 5) : A 75-85 (1892) ; Sum Rp 1892 (An Rp 6) : A 81-89 (1893) ; Sum Rp 1893 (An Rp 6) : A 83-92 (1894); Sum Rp 1894 (An Rp 7) : A 106-116 (1895); Sum Rp 1895 (An Rp 8) : A 130-139 (1896) ; Sum Rp 1896 (An Rp 9) : A 123-132 (1897) ; Sum Rp 1897 (An Rp 10) : A $130-144$ (1898) ; Sum Rp 1898 (An Rp 11) : A 173194 (1899) ; Sum Rp 1899 (An Rp 12) : A 198-209 (1900); Sum Rp 1900 (An Rp 13) : A 176-189 (1901); Sum Rp 1901 (An Rp 14) : A 253-260 (1902) ; Sum Rp 1902 (An Rp 15) : A 461-467 (1903) ; Sum Rp 1903 (An Rp 15) : A 201-205 (1904) : Sum Rp 1904 (An kp 16) : A $355-362$ (1905) ; Sum Rp 1905: 131-135 (1906) ; Sum Rp 1906:170-174 (1906); Sum Rp 1907 : 105-109 (1908) ; Sum Rp 1908 : 171175 (1909)

$\mathbf{8 7 a}$ Notes on some Mesozoic fossils from various localities on the coast of British Columbia ... Can G S, An Rp 2: B 108114 (1887)

$\mathbf{8 7 b}$ On some fossils from the Cretaceous and Laramie rocks of the Saskatchewan and its tributaries... Can G S, An Rp 2 : E $153-166$ (1887)

87e Illustrations of the fossil fishes of the Devonian rocks of Canada. R Soc Can, Pr Tr 4, iv : 101-110, 11 (1887)

89 On some fossils from the Hamilton formation of Ontario, with a list of the species at present known from that formation and province. Can $\mathrm{G} \mathrm{S}$, Contr Can Pal 1: 91-125, il (1889)

89 a on some fossils from the Triassic rocks of British Columbia. Can G $\mathbf{S}$, Contr Can Pal 1:127-149, il (1889)

89b On some Cretaceous fossils from British Columbia, the Northwest Territory, and Manitoba. Can G S, Contr Can Pal 1: 151-196, il (1889)

89e Illustrations of the fossil fishes of the Devonian rocks of Canada, Part II. R Soc Can, Pr Tr 6, iv : 77-96, il (1889)

90 Descriptions of eight new species of fossils from the Cambro-Silurian rocks of Manitoba. R Soc Can, Pr Tr 7, iv : 75-83, il (1890)

91 The fossils of the Devonian rocks of the Mackenzie River basin. Can G S, Contr Can Pal 1: 197-253, il (1891)

91 a Descriptions of some new or previously unrecorded species of fossils from the Devonian rocks of Manitoba. $R$ Soc Can, $\operatorname{Pr} \operatorname{Tr} 8$, iv : 93-110, il (1891)
Whiteaves, Joseph Frederick-Contd.

91b Descriptions of four new species of fossils from the Silurian rocks of the southeastern portion of the district of Saskatchewan. Can Rec Sc $4: 293-303$, il (1891)

91c Note on the occurrence of paucispiral opercula of Gastropoda in the Guelph formation of Ontario. Can Rec Sc 4:404407 , il (1891)

$91 d$ Description of a new species of Panenka from the Corniferous limestone of Ontario. Can Rec Sc 4:401-404, il (1891)

92 The fossils of the Devonian rocks of the islands, shores, or immediate vicinity of Lakes Manitoba and Winnipegosis. Can G S, Contr Pal 1:255-359, il (1892)

$92 \mathrm{a}$ The Orthoceratidae of the Trenton limestone of the Winnipeg basin. R Soc Can, $\operatorname{Pr} \operatorname{Tr} 9$, iv : 77-90, il (1892)

92b Description of a new genus and species of phyllocarid Crustacea from the middle Cambrian of Mount Stephen, B. C. Can Rec Sc $5: 205-208$, il (1892)

93 Notes on the Ammonites of the Cretaceous rocks of the district of Athabasca, with descriptions of four new species. R Soc Can, $\operatorname{Pr} \operatorname{Tr} 10$, iv: 111-121, il (1893)

$93 \mathbf{a}$ Notes on the Gastropoda of the Trenton limestone of Manitoba, with a description of one new species. Can Rec Sc $5: 317-328$, il (1893)

93b Descriptions of two new species of Ammonites from the Cretaceous rocks of the Queen Charlotte Islands. Can Rec Sc $5: 441-446$, il (1893)

94 The Cretaceous system in Canada. R Soc Can, Pr Tr 11, iv : 3-19 (1894)

$94 a$ Note on the recent discovery of large Unio-like shells in the Coal Measures at the South Joggins, N. S. R Soc Can, Pr $\operatorname{Tr} 11$, iv: 21-24, il (1894)

95 Revision of the fauna of the Guelph formation of Ontario, with descriptions of a few new species. Can G S, Paleozoic Foss $3: 45-109$, il (1895)

95a Systematic list, with references, of the fossils of the Hudson River or Cincinnati formation at Stony Mountain, Manitoba. Can G S, Paleozoic Foss 3:111-128 (1895)

95b Notes on some of the Cretaceous fossils collected during Captain Palliser's explorations in British North America in 1857-60. R Soc Can, $\operatorname{Pr} \operatorname{Tr}$ (2) 1, iv : 101-117, il (1895)

95e On some fossils from the Nanaimo group of the Vancouver Cretaceous. $\mathbf{R}$ Soc Can, Pr Tr (2) 1, Iv: 119-133, il (1895)

95d Notes on some fossils from the Cretaceous rocks of British Columbia with descriptions of two species that appear to be new. Can Rec Sc $6: 313-318$, il (1895) 
Whitenves, Joseph Frederick-Contd.

96 Descriptions of eight new species of fossils from the (Galena) Trenton limestones of Lake Winnipeg and the Red River valley. Can Rec Sc 6:387-397 (1896)

$96 a$ Canadian stromatoporoids. Can Rec Sc $7: 129-146$ (1896)

97 The fossils of the Galena-Trenton and Black River formations of Lake Winnipeg and its vicinity. Can G S, Paleozoic Foss 3: 129-242, il (1897)

97 a Description of a new genus and species of cystideans from the Trenton limestone at Ottawa [Ont.]. Can Rec Sc 7: 287-292, 395-396, il (1897)

98 On some additional or imperfectly understood fossils from the Hamilton for mation of Ontario, with a revised list of the species therefrom. Can G S, Contr Can Pal 1: $361-418$, il (1898)

98a Revision of the nomenclature of some of the species described or enumerated in previous parts of this volume, and adidtional notes on others, necessitated by the progress of paleontological researches. Can G S, Contr Can Pal 1:419-427 (1898)

$\mathbf{9 8 b}$ On some remains of a sepia-like cuttle-fish from the Cretaceous rocks of the South Saskatchewan. Can Rec Sc 7 : 459-461, il (1898)

98e Note on a fish tooth from the upper Arisaig series of Nova Scotia. Can Rec Se $7: 461-462$, il (1898) Aust, Brit As, Rp $67: 656-657$ (1898)

98d On some fossil Cephalopoda in the museum of the Geological Survey of Canada, with descriptions of eight species that appear to be new. Ottawa Nat 12 :116127 (1898)

99 The Devonian system in Canada. Am As, Pr 48:193-223 (1899) Am G 24: $210-240$ (1899) Science n s 10:402-412, 430-438 (1899) Abst, Can Rc: Sc 8 : 195$198(1900)$

99a Recent discovery of rocks of the age of the Trenton formation at Akpatok Island, Ungava Bay, Ungava, Am J Se (4) $7: 433-434 \quad(1899)$

00 On some additional or imperfectly understood fossils from the Cretaceous rocks of the Queen Charlotte Islands, with a revised list of the species from those rocks. Can G S, Mesozoic Foss 1:263307 , il (1900)

o1 Description of a new species of Unio from the Cretaceous rocks of the Nanaimo field, V[ancouver] I[sland]. Ottawa Nat $14: 177-179$, il (1901)

O1a Note on a supposed new species of Lytoceras from the Cretaceous rocks at Denman Island; in the Strait of Georgia. Ottawa Nat $15: 31-32$ (1901)

02 On the genus Panenka Barrande, with a description of a second species of that genus from the Devonian rocks of Ontario. Ottawa Nat $15: 263-265$, il (1902)
Whiteaves, Joseph Frederick-Contd.

02a on the genus Trimerella, with deseriptions of two supposed new species of that genus from the Silurian rocks of Keewatin. Ottawa Nat $16: 139-143$, Il (1902)

03 On some additional fossils from the Vancouver Cretaceous, with a revised list of the species therefrom. Can G S, Mesozoic Foss 1 : 309-415, il (1903)

03a Description of a fossil Cyrena from Alberta. Ottawa Nat $16: 231-233$, il (1903)

03b Crania of extinct bisons from the Klondike Creek gravels. Ottawa Nat 16 : 240-241 (1903)

o3e Description of a new species of Matheria (M. brevis) from the Trenton limestone at Ottawa. Ottawa Nat $17: 32$ 34, il (1903) G Mag (4) $10: 358-359$, il (1903)

03d Description of a species of Cardioceras from the Crows Nest coal fields. Ottawa Nat $17: 65-67$, il (1903)

o3e Notes on some Canadian specimens of "Lituites undatus." Ottawa Nat 17: 117-122 (1903)

o3f Additional notes on some Canadian specimens of "Lituites undatus." Ottawa Nat $17: 161-163$ (1903)

04 Preliminary list of fossils from the Silurian (Upper Silurian) rocks of the Ekwan River, and Sutton Mill lakes, Keewatin ... with descriptions of such species as appear to be new. Can G S, An Rp 14: F $38-59$ (1904)

04a The Canadian species of Trocholites. Ottawa Nat 18:13-18 (1904)

04b Description of a new genus and species of rugose corals from the Silurian rocks of Manitoba, Ottawa Nat 18:113114 (1904)

O4e Uintaorinus and Hemiaster in the Vancouver Cretaceous, Am J Sc (4) 18 : 287-289 (1904)

o5 Notes on the apical end of the siphuncle in some Canadian Endoceratidae, with descriptions of two supposed new species of Nanno. Am G $35: 23-30,324$, il (1905)

06 The fossils of the Silurian (Upper Silurian) rocks of Keewatin, Manitoba, the northeastern shore of Lake Winnipegosis, and the lower Saskatchewan River. Can G S, Pal Foss $3: 243-298$, il (1906)

06a The Canadian species of Plectoceras and Barrandeoceras. Can G S, Pal Foss 3: 299-312, il (1906)

06b Ilustrations of seven species of fossils from the Cambrian, Cambro-Silurian, and Devonian rocks of Canada. Can G S, Pal Foss 3:313-325, il (1906)

o6c Revised list of the fossils of the Guelph formation of Ontario. Can G S, Pal Foss $3: 327-340$ (1906) 
Whiteares, Joseph Frederick-Contd.

06d Paleozoic fossils; Appendix; Errata et corrigenda. Can $\mathbf{G} \mathbf{S}$, Pal Foss 3 : 341-345 (1906)

OGe Notes on Cyrtoceras cuneatum. Ot. tawa Nat $20: 133-134$, il (1906)

07 Illustrations of the fossil fishes of the Devonian rocks of Canada; Part III. Supplementary notes. R Soc Can, Pr Tr (3) 1 iv : 245-275, il (1907)

07a Description of a Canadian species of Peltoceras. Ottawa Nat 21:80-82, il (1907)

os Notes on the Pelecypoda or bivalve Mollusca of the Chazy formation in Canada, with descriptions of one new genus and four new species from the Chazy sandstone at the Hog's Back, near Ottawa [Ont.]. Ottawa Nat 22:105-115, il (1908)

09 Description of a new species of ammonite, of the genus stepheoceras, from some rocks of presumably Jurassic age in the Nicola Valley, B. C. Ottawa Nat 23 : 21-23, il (1909)

09a Notes on some fossils from the Cambro-Silurian and Silurian rocks of the Albany River drainage system in northwestern Ontario. Can G S, Report on a portion of Algoma and Thunder Bay districts, Ontario, by W. J. Wilson : 34-41 (1909)

10 Preliminary list of fossils from the supposed Utica or Lorraine shales at St. Bruno Mountain, Chambly County, Quebec, collected by J. A. Dresser and R. Harvie, jr., in 1905. Can G S, Mem 7 : 24-28 (1910)

See also Matthew (G F), 86

Whitehead, Cabell.

00 (with Chatard, T. M.) An examination of the ores of the Republic gold mine, Wash. Am I M Eng, Tr 30:419423 (1901) Eng M J 69:497-498 (1900)

Whitehead, Walter Lucius.

14 (with Lindgren, W.) A deposit of jamesonite near Zimapan, Mexico. Ec G $9: 435-462$ (1914)

16 The paragenesis of certain sulphur intergrowths. Ec G 11:1-13 (1916)

17 Notes on the technique of mineragraphy. Ec G 12:697-716 (1917)

Whitehill, Henry R.

73 Blennial report of the State mineralogist of the State of Nevada for the years 1871 and 1872 . $191 \mathrm{pp}$, Carson City $1873 ; \ldots$ for 1873 and $1874: 191 \mathrm{pp}$, Carson City $1875 ; \ldots$ for 1875 and 1876 : 226 pp [Carson City 1877] ; ... for 1877 and $1878: 212 \mathrm{pp}$, San Francisco 1879

whiteside, F. W.

12 The Trinidad district in Colorado. Coal Age 1:632-635 (1912)

12a Central coal fields in Colorado. Coal Age 2:2-5 (1912)
Whiteside, F. W.-Continued.

12b Coal measures of the Front Range of the Rocky Mountains in Colorado. Colo, Univ, J Eng no 8: 50-55 (1912)

17 Yampa coal field in Colorado. Coal Age 11:654-657 (1917)

Whitfield, James Edward.

87 On the Johnson Co., Ark., and Allen Co., Ky., meteorites. Am J Sc (3) 33: $500-501$ (1887)

87a Analyses of some natural borates and borosilicates. Am J Sc (3) 34:281287 (1887)

87b The Rockwood meteorite [Tenn.]. Am J Sc (3) 34:387-390 (1887)

88 (and Merrill, G. P.) The Fayette Co., Tex., meteorite. Am J Sc (3) 36 : 113-119 (1888)

88a (with Gooch, F. A.) Analyses of waters of the Yellowstone National Park. U S G S, B $47: 84 \mathrm{pp} \mathrm{(1888)}$

89 A new meteorite from Mexico. Am $J$ Sc (3) $37: 439-440 \quad(1889)$

Whitfield, Robert Parr (1828-1910).

62 (with White, C. A.) Observations upon the rocks of the Mississippi Valley which have been referred to the Chemung group of New York, together with descriptions of new species of fossils from the same horizon at Burlington, Iowa. Boston Soc N H, Pr 8: 289-306 (1862)

65 Descriptions of new species of Eocene fossils. Am J Conch $1: 259-268$, il (1865)

67 Observations on the internal append. ages of the genus Atrypa. N Y St Cab, An Rp 20:141-144 (1867)

72 (with Hall, J.) Description of new species of fossils from the vicinity of Louisville, Ky., and the Falls of the Ohio. N Y St Mus, An Rp 24:181- 200 (1872)

72a (with Hall, J.) Remarks on some peculiar impressions in sandstone of the Chemung group, N. Y. N Y St Mus, An Rp 24: 201-204, il (1872)

73 (with Ha11, J.) Descriptions of new species of fossils from the Devonian rocks of Iowa. N Y St Cab, An Rp 23: 223-239 (1873)

73a (with Hall, J.) Notice of three new species of fossil shells from the Devonian of Ohio. N Y St Cab, An Rp 23: 240-241 (1873)

73b (with Hall, J.) Notice of two new species of fossil shells from the Potsdam sandstone of New York. N Y St Cab, An Rp $23: 241-242$ (1873)

75 Descriptions of new fossils. In Ludlow, William, Report of a reconnaissance of the Black Hills of Dakota... : 103-104, il, Washington 1875 Also in U S, Chief Eng, An Rp 1875 pt $2: 1202-1203$, il (1875)

75a Fossils from the black slate formations of southern Indiana and adjacent portions of Kentucky. Ind G S, An Rp $6: 179-182(1875)$ 
Whitfield, Robert Parr-Continued.

75b (with Hall, J.) Descriptions of invertebrate fossils, mainly from the Silurian system. Ohio G S, Rp 2 pt 2 Poleontology : 65-157, ill (1875)

75e (with Hall, J.) Crinoids of the Genesee slate and Chemung group. Ohio G S, Rp 2 pt 2 Paleontology: 158-161, il (1875)

75d (with Hall, J.) Crinoidea of the Waverly group. Ohio G S, Rp 2 pt $2 \mathrm{~Pa}-$ leontology : 162-179, il (1875)

76 Descriptions of new species of fossils. In Ludlow, Wm., Report of a reconnaissance ... to the Yellowstone National Park: 126-131, il, Washington 1876 Also in U S [War Dp], Chief Eng, An Rp 1876 (U S, 44th Cong 2d sess, H Ex Doc 1 pt 2 v 2 pt 3 ) App NN : 694-699, il (1876)

z7 Preliminary report on the paleontology of the Black Hills, containing descriptions of new species of fossils from the Potsdam, Jurassic, and Cretaceous formations of the Black Hills of Dakota. U S Geog G S Rocky Mtn Reg (Powell) : $49 \mathrm{pp}$, Washington 1877

77a (with Hall, J.) Paleontology. U S G Expl 40th Par (King), 4:197-302, il (1877)

78 Preliminary descriptions of new species of fossils from the lower geological formations of Wisconsin. Wis G S, An Rp 1877:50-89 (1878)

78 Remarks on some lamellibranchiate shells of the Hudson River group with descriptions of four new species. Cin Soc N H, J $1: 137-141$, il (1878)

79 Discovery of specimens of Maclurea magna, of the Chazy, in the Barnegat limestone near Newburg, N. Y. Am J Sc (3) 18: 227 (1879)

80 Paleontology of the Black Hills of Dakota. In Newton, Henry, and Jenney, Walter P., Report on the geology and resources of the Black Hills of Dakota (U S Geog G S Rocky Mtn Reg) : 325-468, il (1880)

80 a Descriptions of new species of fos sils from the Paleozoic formations of Wis consin. Wis $\mathrm{G}$ S, An Rp 1879:44-71 (1880)

$80 \mathrm{~b}$ Notice of new forms of fossil crustaceans from the upper Devonian rocks of Ohio, with descriptions of new genera and species. Am J Sc (3) $19: 33-42$, il (1880)

soc On the occurrence of true Lingula in the Trenton limestones. Am J Sc (3) $19: 472-475$, il $(1880)$

sod Notice of the occurrence of rocks representing the Marcellus shale of New York, in central Ohio. Am As, Pr 28: 297299 (1880)

81 Description of a new species of crinoid from the Burlington limestone, at Burlington, Iowa. Am Mus N H, B 1:7-9, 1] (1881)
Whitfeld, Robert Parr-Continued.

81a Remarks on Dictyophyton, and descriptions of new species of allied forms from the Keokuk beds, at Crawfordsville, Ind. Am Mus N H, B 1:10-20, il (1881)

$\mathbf{8 1 b}$ Olservations on the purposes of the embryonic sheaths of Endoceras, and their bearing on the origin of the siphon in the Orthocerata. Am Mus N H, B 1:2028 , il (1881)

s1e Notice of a new genus and species of air-breathing mollusk from the Coal Measures of Ohio, and observations on Dawsonella. Am J Sc (3) $21: 125-128$, il (1881)

81d Observations on the structure of Dictyophyton and its affinities with certain sponges. Am J Sc (3) 22:53-54 (1881)

s1e On the nature of Dictyophyton. Am J Sc (3) 22:132 (1881)

82 On the fauna of the Lower Carboniferous limestones of Spergen Hill, Ind... Am Mus N H, B 1:39-97, fl (1882)

82a Paleontology. [Wis G S], G Wis $4: 161-363$, il (1882)

82b Descriptions of new species of fossils from Ohio, with remarks on some of the geological formations in which they occur. N Y Ac Sc, An 2: 193-244 (1882)

83 List of Wisconsin fossils. [Wis G S], G Wis 1:362-375 (1883)

83a Observations on the fossils of the metamorphic rocks of Bernardston, Mass.; with note by J. D. Dana. Am J Sc (3) 25: 368-369 (1883)

84 Notice of some new species of Primordial fossils in the collections of the Museum, and corrections of previously described species. Am Mus N H, B 1:139154, il (1884)

85 Brachiopoda and Lamellibranchiata of the Raritan clays and greensand marls of New Jersey. N J G S, Pal 1: xx, 338 pp, map, 11 (1886) U S G S, Mon $9: \mathbf{x x}$, 338 pp, map il (1885)

85a On a fossil scorpion from the Silurian rocks of America. An Mus N H, B 1: 181-190, il (1885)

$85 \mathrm{~b}$ Notice of a new cephalopod from the Niagara rocks of Indiana. Am Mus N H, B 1: 191-192, il (1885)

85e Notice of a very large species of Homalonotus from the Oriskany sandstone formation. Am Mus N H, B 1: 193-195, il (1885)

85d An American Silurian scorpion [Palaeophonus osborni] Science 6:87-88, il (1885)

85e (with Pohlman, J.) An American Silurian scorpion. Science $6: 183-184$, il (1885)

86 Notice of geological investigations along the eastern shores of Lake Champlain ... with descriptions of the new fossils discovered. Am Mus N H, B 1:293-345, map, il (1886) 
Whitfield, Robert Parr-Continued.

$86 a$ Notice of a new fossil body, probably a sponge related to Dictyophyton. Am Mus N H, B $1: 346-348$, il (1886)

86b Remarks on the fossils [from central Montana] in the following lists. U S 10th Census 15: 712-718 (1886)

see Professor Thorell and the American Silurian scorpion. Science $7: 216-217$ (1886)

86d ...molluscan fossils of the New Jersey marl beds...(abst). Am As, Pr 35 : 215 (1887) Am J Sc (3) 32:320-321 (1886)

s7 New Jersey Cretaceous. Am Nat 21: 66-69 (1887)

S8 Evidence confirmatory of Mastodon obscurus Leidy, as an American species. Am As, Pr $36: 252-253$ (1888)

89 Observations on some imperfectly known fossils from the Calciferous sandrock of Lake Champlain, and descriptions of several new forms. Am Mus $\mathrm{N}$ H, B $2: 41-63$, il (1889)

89a Additional notes on Asaphus canalis, Conrad. Am Mus N H, B 2:64-65 (1889)

S9b Description of a new form of fossil balanoid cirripede from the Marcellus shale of New York. Am Mus N H, B 2: 66-68 (1889)

s9e Note on the faunal resemblance between the Cretaceous formations of New Jersey, and those of the Gulf States. Am Mus N H, B 2:113-116 (1889)

90 Observations on the fauna of the rocks at Fort Cassin, Vt., with descriptions of a few new species. Am Mus N H, B $3: 25-39$, il $(1890)$

$90 a$ Observations on a fossil fish from the Eocene beds of Wyoming. Am Mus N H, B $3: 117-120$ (1890)

901. Description of a new genus of inarticulate brachiopodous shell [Lingulodisoina]. Am Mus N H, B 3:121-122, il (1890)

90e The Fort Cassin rocks and their fauna. G Soc Am, B 1:514-515 (1890)

91 Contributions to invertebrate paleontology [of Ohio]. N Y Ac Sc, An 5:505620 , il (1891) Ohio G S, Rp 7:407-494, il (1893)

91a The common edible crab found fossil in the Hudson River tunnel. Science $18: 300$ (1891)

91b Mastodon remains on New York Island. Science 18:342 (1891)

92 Gastropoda and Cephalopoda of the Raritan clays and greensand marls of New Jersey. N J G S, Pal 2: 402 pp, il (1892) U S G S, Mon 18: $402 \mathrm{pp}$, il (1892)

$92 n$ Visitor's guide to the geological and paleontological collections in the American Museum of Natural History. 68 pp, N Y 1892 [not seen]
Whitfleld, Robert Parr-Continued.

92b Discovery of a second example of the macrouran decapod crustacean Palaeopalaeomon newoberryi. Am G 9: 237-238 (1892)

93 Republication of descriptions of Lower Carboniferous Crinoidea from the Hall collection... Am Mus N H, Mem 1: 1-37, il (1893)

$93 a$ Notice of new Cretaceous fossils from the lower green marls of New Jersey. Nautilus $7: 37-39,51-52$, il (1893)

94 Mollusca and Crustacea of the Miocene formations of New Jersey. U S G S, Mon 24: $195 \mathrm{pp}$, il (1894)

94a on new forms of marine algae from the Trenton limestone, with observations on Buthograptus laxus Hall. Am Mus N H, B $6: 351-358$, il (1894)

95 Republication of descriptions of fossils from the Hall collection... Am Mus $\mathrm{N}$ H, Mem 1:39-74, il (1895)

96 Description of a new genus of fossil brachiopod from the Lower Helderberg limestones. Am Mus N H, B $8: 231-232$, il $(1896)$

$96 a$ Notice and description of new species and a new genus of Phyllocaridae. Am Mus N H, B 8:299-304, il (1896)

97 Note on the hypostome of Lichas (Terataspis) grandis Hall. Am Mus N H, B $9: 45-46$, il (1897)

97 a Descriptions of new species of Silurian fossils from near Fort Cassin [Vt.] and elsewhere on Lake Champlain. Am Mus N H, B 9: 177-184, il (1897)

97b Descriptions of specles of Rudistae from the Cretaceous rocks of Jamaica, W. I. Am Mus N H, B $9: 185-196$, il (1oyi) 97e Observations on the genus Barrettia Woodward, with descriptions of two new species. Am Mus N H, B $9: 233-246$, il (1897) Abst, Science n s 6:690 (1897)

98 (assisted by Hovey, E. O.) Catalogue of the type and figured specimens in the paleontological collection of the geological department, American Museus of Natural History. Am Mus N H, B 1. 500 pp (1898-1901)

99 List of fossils, types and figured specimens used in the paleontological work of R. P. Whitfield, showing where they are probably to be found at the present time. N Y Ac Se, An 12:139-186 (1899)

oo Observations on some "mud flow" markings on rocks from near Albany, N. Y. Am Mus N H, B 12:183-187 (1900)

OOa Observations on and descriptions of Arctic fossils. Am Mus N H, B 13:1922, il (1900)

OOb Description of a new crinoid from Indiana. Am Mus N H, B $13: 23-24$, 11 (1900)

o0e Note on the principal type speclmen of Mosasaurus maximus Cope. Am Mus N H, B $13: 25-29$, il (1900) 
Whitfield, Robert Parr-Continued.

ox Note on a very fine example of Heli. coceras stevensoni preserving the outer chamber. Am Mus N H, B 14:219, il (1901)

02 Description of a new form of Myalina from the Coal Measures of Texas. Am Mus N H, B $16: 63-66$, il $(1902)$

02a Observations on and emended description of Heteroceras simplicostatum Whitfield. Am Mus N H, B $16: 67-72$, il (1902) Abst, Science n s $15: 469$ (1902)

02b Description of a new teredo-like shell from the Laramie group. Am Mus N H, B 16:73-76, il (1902) Abst, Science n \& $15: 469$ (1902)

02e Notice of a new genus of marine algae, fossil in the Nlagara shale. Am Mus N H, B $16: 399-400$, il (1902)

03 Notice of six new species of unios from the Laramie group. Am Mus $\mathrm{N} \mathrm{H}$, B $19: 483-487$, il (1903)

03a Observations on a remarkable specimen of Halysites and description of a new species of the genus. Am Mus N H, B 19 : $489-490$, il (1903)

04 Notice of a new genus and species of Lower Carboniferous bryozoan [Dictyoretmon burlingtonense]. Am Mus N H, B 20 : 469 , il (1904)

$04 a$ Notice of a remarkable case of reproduction of lost parts shown on a fossil crinoid. Am Mus N H, B 20:471-472, il (1904)

04b Note on some worm (?) burrows in rocks of the Chemung group of New York. Am Mus N H, B 20:473-474, il (1904)

o5 Notice of a new crinoid and a new mollusk from the Portage rocks of New York. Am Mus N H, B 21:17-20, il (1905)

05a Descriptions of new fossil sponges from the Hamilton group of Indiana. Am Mus N H, B $21: 297-300$, il (1905)

05b Notice of a new species of Fasciolaria from the Eocene green marls at Shark River, N. J. Am Mus N H, B 21 : 301-303, il (1905)

06 (and Hovey, E. O.) Remarks on and descriptions of [invertebrate] Jurassic fossils of the Black Hills. Am Mus N H, B 22:389-402, il (1906)

or Notice of an American species of the genus Hoploparia McCoy, from the Cretaceous of Montana. Am Mus N H, B 23 : $459-461$, il (1907)

$\mathbf{0 7 a}$ Remarks on and descriptions of new fossil Unionidx from the Laramie clays of Montana. Am Mus N H, B 23:623-628, il (1907)

os Notes and observations on Carboniferous fossils and semifossil shells trought home by members of the Peary expedition of 1905-1906. Am Mus N H, B 24:51-58, il (1908)

See also Booth, 83; Smith (E A), 88a
Whitford, A. C.

14 On a new fossil fungus from the Nebraska Pliocene. Nebr Univ Studies 14: 181-183, il (1914)

16 Some plant cuticles from the Graneros shale [Jefferson Co., Nebr.]. Nebr G S $7: 77-82$, il (1916)

16a A description of two new fossil fungi. Nebr G S 7:85-92, il (1916)

16b Preserved epidermis from the Carboniferous of Nebraska. Nebr G S 7:93101, il (1916)

\section{Whiting, Henry.}

38 Cursory remarks upon east Florida in 1838. Am J Sc 35:47-64 (1838)

Whitlock, Herbert Percy.

02 Guide to the mineralogic collections of the New York State Museum. N Y St Mus, B 58:3-147 (1902)

03 List of New York mineral localities. N Y St Mus, B 70:108 pp (1903)

o5 Contributions from the mineralogic laboratory. N Y St Mus, B 98:36 pp (1905)

O5a Minerals not commercially important. N Y St Mus, An Rp 57:180-192 (1905)

06 Books of reference on geology and paleontology. Cong Arts and Sc (St Louis 1904) 4:757-759 (1906)

o7 Minerals from Lyon Mountain, Clinton Co. [N. Y.]. N Y St Mus, B 107: 55-96 (1907)

07a Kalkspat von Lyon Mountain, Clinton Co., N. Y. Zs Kryst 43:321-330 (1907)

ozb Some new crystallographic combinations of calcite from West Paterson, N. J. Am J Sc (4) 24:426-428 (1907)

09 Some parallel groupings of calcite crystals from the New Jersey trap region. N Y St Mus, B 133: 217-221 (1909)

10 Calcites of New York. N Y St Mus, Mem 13: $190 \mathrm{pp} \mathrm{(1910)}$

10a Contributions to mineralogy. N Y St Mus, B 140:197-203 (1910)

10b Crystallographic notes [datolite and apophyllite from Bergen Hill, N. J., and ealcite crystals from Kelleys Island. Ohio]. Sch Mines Q $31: 225-234$ (1910)

10e A list of new erystal forms of minerals. Sch Mines Q $31: 320-345 ; 32: 51$ 92 (1910)

12 Recent mineral occurrences in New York City and vicinity. N Y St Mus, B 158: 183-187 (1912)

12a Crystallographic tables. Science n s $35: 819-820$ (1912)

13 The Mount Morris meteorite. N Y St Mus, B $164: 78-79$ (1913)

15 A critical discussion of the crystal forms of calcite. Am Ac Arts, Pr 50: 289-352 (1915) 
Whitman, Alfred Russell.

07 A tin deposit near Spokane [Wash.] M Sc-Press v 94:697-698; $95: 49$ (1907)

13 The vadose synthesis of pyrite. Ec G $8: 455-468$ (1913) M Sc Press 107: 928 (1913)

14 Notes on the copper ores at Ely, Nev. Cal Univ, Dp G, B 8 : 309-318 (1914)

15 Structural features of the Poreupine ore deposits [Ont.]. Can M J 36:589-596 (1915)

16 The rocks of the Porcupine district [Ont.]. Can M Inst, Tr 18:256-276 (1916)

17 Geology and mining in northern ontario. Can M J $38: 216-217$ (1917)

Whitman, Alonzo G.

72 (and Keene, J. W.) Notes on min eralogy ... $136 \mathrm{pp}$, Lewiston [Me.] 1872

Whitney, Francis I.

05 The new artesian water supply at Ithaca, N. Y. U S G S, W-S P 110:5564 (1905)

Whitney, Francis Luthur.

11 Fauna of the Buda limestone. Tex, Univ, B se 8 18:54 pp, 11 (1911)

16 The Echinoidea of the Buda limestone. B Am Pal no $26: 36 \mathrm{pp}$, il (1916) whitney, J. P.

67 Le Colorado ... liste des minerais ... a l'exposition universelle de 1867 a Paris .. 71 pp, map, Paris 1867

Whitney, Josiah Dwight (1819-1896).

41 (and Williams, M. B.) Report on the section from Portsmouth to Claremont through Concord. In Jackson, C. T., First Annual report on the geology of New Hampshire : 45-51 (1841)

$41 a$ (and Williams, M. B.) Geology and topography of the northern corner of the State ... In Jackson, C. T., First annual report on the geology of New Hampshire : 83-93 (1841)

47 [Report of work in the Upper Peninsula of Michigan.] U S, Gen Land Office, Rp 1847 (U S, 30th Cong 1st sess, S Ex Doc 2) : 221-230 (1847)

47a Description and analysis of three minerals from Lake Superior. Boston $\mathrm{J}$ N H $5: 486-489$ (1847)

47b Chemische Untersuching einiger Silicate, die Kohlensäure, Chlor, und Schwefelsäure enthalten. An Physik 70:431447 (1847)

47e Analyse des Rothzinkerzes aus Sterling in New Jersey. An Physik 71:169172 (1847)

48 Chemical examination of some Amerlcan minerals. Boston $\mathrm{J}$ N H $6: 36-42$ (1848)

48a Examination of three new mineralogical species proposed by Prof. C. U. Shepard. Boston .J N H 6:42-48 (1848)

48b [On facksonite, a new mineral from the Lake Superior region.] Boston Soc N H, Pr 3:5-6 (1848)
Whitney, Josiah Dwight-Continued.

49 [Report of field work in the Lake Superior land district.] U S, 30th Cong 2 d sess, S Ex Doc 2:154-159 (1849)

49a Notes on the topography, soil, geology, etc., of the district between Portage Lake and the Cntonagon [Lake Superior region]. U S, 31st Cong 1st sess, S Ex Doc 1 pt 3 and $\mathrm{H}$ Ex Doc 5 pt 3: 649-701 (1849)

49b Field notes for 1847 [in the Lake Superior region]. U S, 31st Cong 1st sess, $\mathrm{S}$ Ex Doc 1 pt 3 and $\mathrm{H}$ Ex Doe 5 pt 3 : 713-758 (1849)

49e [On three minerals from Arkansas, arkansite, ozarkite, and schorlomite.] Boston Soc N H, Pr 3:96 (1849)

49d [On the composition of chloritold or chlorite spar, and masonite; and on oxide of copper from Copper Harbor, Lake Superior.] Boston Soc N H, Pr 3:100103 (1849)

49e (with Foster, J. W.) Synopsis of the explorations ... in the Lake Superior land district in the Northern Peninsula of Michigan ... U $\mathrm{S}$, 31st Cong 1st sess, $\mathrm{S}$ Ex Doc 1 pt 3 and $H$ Ex Doc 5 pt 3 : 605-626, maps (1849)

50 [On the mineral lands of the Lake Superior region.] Boston Soc N H, Pr 3: 210-212 (1850)

$50 a$ [On fractured strata at Guilford, Vt.] Boston Soc N H, Pr 3: 226 (1850)

$50 b$ (with Foster, J. W.) Report on the geology and topography of a portion of the Lake Superior land district in the State of Michigan; Part 1, Copper lands. U S, 31st Cong 1st sess, H Ex Doc 69 : 224 pp, maps (1850)

50e (with Foster, J. W.) Mineral reports [Lake Superior land district]. U S, 31st Cong 2d sess, H Ex Doc 9 (Land Office, Rp 1850) : 147-152 (1850)

51 (with Foster, J. W.) Report on the geology of the Lake Superior land district: Part 2, The iron region, together with the general geology. U S, 32d Cong spec sess, S Ex Doc 4: xvi, 406 pp, il, maps (1851) Extracts, Am J Sc (2) 17:1133 (1854)

51 (with Foster, J. W.) On the elevation of mountain chains. In their Report on the geology of the Lake Superior land district, pt 2 (U S, 32d Cong spec sess, S Ex Doc 4) : 274-284 (1851)

$51 \mathrm{~b}$ (with Foster, J. W.) On the Azoic system, as developed in the Lake Superior land district $(a b s t) . \quad \mathrm{Am} \mathrm{As}$, Pr 5: 4-7 (1851)

sle (with Fonter, J. W.) On the age of the sandstone of Lake Superior, with a description of the phenomena of the association of igneous rocks. $\Delta \mathrm{m}$ As, $\operatorname{Pr} 5$ : 22-38 (1851) 
Blake, William Phipps-Continued.

$67 \mathrm{~b}$ Locality of secondary fossils in Oregon. Am J Sc (2) 44:118-119 (1867) 67e Note upon "partzite." Am J Sc (2) $44: 119$ (1867)

67d Sur l'action des anciens glaciers dans la Sierra Nevada de Callfornie et sur l'origine de la vallée de Yo-Semite. Ac Sc Paris, C R 65:179-181 (1867)

67 e Miscellaneous notices.

Sc, Pr $3: 289-291$ (1867)

67f Fossil fish in the Great Basin, Nev. Cal Ac N Sc, Pr 3:306-307 (1867)

67 Notice of fossil elephants' teeth from the northwest coast. Cal Ac N Sc, Pr $3: 325$ (1867)

67h Origin of the submerged forests in the Columbia River, Oregon. Cal Ac N Sc, Pr 3: 339-341 (1867)

67i Note upon the brown coal formation of Washington Territory and Oregon. Cal Ac N Sc, Pr $3: 347$ (1867)

67j Analysis of Mt. Diablo, Cal., coal. Cal Ac N Sc, Pr 3:348 (1867)

68 Notes upon the geography and geology of Russian America and the Stickeen River, from observations made in 1863 . U 8,40 th Cong, 2d sess, H Ex Doc 177 pt 2: 19 pp, map (1868)

68a The Carboniferous age of a portion of the gold-bearing rocks of California. Am J Sc (2) $45: 264-267$ (1868)

68b Note on the occurrence of fossil remains of the tapir in California. Am J Sc (2) $45: 381$ (1868)

68e Upon the gradual desiccation of the surface of the western portion of North America (abst). Am Nat 2: 244 (1868)

68 d Notes upon the universal exposition at Paris, 1867. Report of the [California] Commissioner to the Paris Exposition, 1867 . $99 \mathrm{pp}$, Sacramento 1868

69 Report upon the precious metals; being statistical notices of the principal gold and silver producing regions of the world ... Paris Universal Exposition 1867, Reports of the United States Commissioners:369 pp, Washington 1869 Also an author's edition, N Y 1869

70 The plasticity of pebbles and rocks. $A m$ As, Pr 18:199-205 (1870) Abst, Am Nat $3: 445-446$ (1869)

70a On a fossil tooth from Table Mountain. Am J Sc (2) $50: 262-263 \quad(1870)$ 71 Notes on some points in the mineralogy and geology of Utah. Am J Sc (3) $2: 216$ (1871)

71a Preliminary geological report of observations upon the Peninsula of Samana; Preliminary report of the expedition across the island from Santo Domingo City to Puerto Plata by the western or Banao route; Preliminary report upon the mineral resources of Santo Domingo. U S, 42d Cong 1st sess, S Ex Doc 8: 63-65, 121-127, 144-145 (1871)
Blake, William Phipps-Continued.

73 (with Hiteheock, C. H.) Geological map of the United States. Accompanying the report of Rossiter W. Raymond, United States Commissioner of Mining Statistics. 1873

73a (with Hitcheock, C. H.) [Description of] geolegical map of the United States compiled for the Ninth Census, 1872. G Mag 10:371-373 (1873)

74 Wood tin in Georgia. Am J Sc (3) $8: 392$ (1874)

74a (with Hitchcock, C. H.) Geological map of the United States. In U S, Ninth Census, Statistical Atlas pl 13-14 (1874)

75 Origin of the cascades and of the submerged forest on the Columbia River, Oreg. Am As, Pr 23 pt 2:72-74 (1875)

76 Notes on the occurrence of siderite at Gay Head, Mass. Am I M Eng, Tr 4:112-113 (1876)

77 On itacolumite [Mariposa Co., Cal.]. Ac N Sc Phila, Pr 1876:325-326 (1877)

78 Note sur les gisements de cinabre de la Californie et du Nevada. Soe Minér France, B 1: 81-84 (1878)

79 The ore deposits of Eureka district, eastern Nev. Am I M Eng, Tr 6:554-563 (1879)

so Carte géologique des États-Unis de l'Amérique septentrionale. Int $\mathrm{G}$ Cong, Paris 1878, C R : 199-201 (1880)

S0a Commissions géologiques en exercice aux Etats-Unis en 1878. Int G Cong, Paris 1878, C R : 295 (1880)

sob A winter trip to the mines of the West. Synopsis of a lecture before the Bullion Club of New York. 11 pp, published by members of the club, 1880

81 Occurrence of realgar and orpiment in Uitah. Am J Sc (3) $21: 219$ (1881)

$81 \mathrm{a}$ On the occurrence of vanadates of lead at the Castle vome mines in Arizona. Am J Sc (3) $22: 410-411$ (1881)

$\mathbf{8 1 b}$ Contributions to the geology and mineralogy of California. [Cal] St M Bur : $15 \mathrm{pp}$, Sacramento 1881

82 The geology and veins of Tombstone, Ariz. Am I M Eng. Tr 10:334-345 (1882) Éng M J $33: 145-146,157,231-232,328$; 34: 29-30 (1882) [See Church, 82]

83 New locality of the green turquoise... Am J Sc (3) 25: 197-200 (1883)

83a Cassiterite, spodumene and beryl in the Black Hills, Dakota. Am J Sc (3) $26: 235$ (1883)

83b The Silver King mine [Pinal region, Ariz.] Eng M J $35: 238-239,254-256$ (1883)

83e The discovery of tinstone in the Black Hills of Dakota. Eng M J 36:145146, 163-164, 344 (1883)

83d Glacial phenomena of Mill Rock, near New Haven, [Conn.]. Science 1: 146-147 (1883) 
Whitney, Josiah Dwight-Continued.

51 d (with Foster, J. W.) On the different systems of elevation which have given configuration to North America, with an attempt to identify them with those of Europe. Am As, Pr 5:136-151 (1851)

51e (with Foster, J. W.) Sur les terrains siluriens du district métallifère du lac Supérieur. Soc $G$ France, B (2) 8 : 89-100 (1851)

$51 f$ (with Foster, J. W.) Geological map of the district between Keweenaw Bay and Chocolate River, Lake Superior, Mich. N Y [1851?]

53 Mineral tract of the East Tennessee and Cherokee Copper Mining Company [Polk Co., Tenn.]. M Mag 1:114-121 (1853)

54 The metallic wealth of the U. S... xxxil, $510 \mathrm{pp}$, Phila 1854

54a On the chemical composition of the minerals algerite and apatite. Am J Sc (2) $17: 206-210$ (1854)

55 Catalogue of the rocks, minerals, etc., collected on the district between Portage and Montreal River during the years 1847 and 1848. Smiths Inst, An Rp 9, 1854: 387-392 (1855)

$55 a$ Remarks on the changes which take place in the structure and composition of mineral veins near the surface, with particular reference to the east Tennessee copper mines. Am J Sc (2) 20:53-57 (1855) M Mag 5: 24-28 (1855)

55b Report on the South Echo location of the Canada Mining Co. M Mag 4: 376-378, map (1855)

55e (with Silliman, B., jr.) Notice of the geological position and character of the copper mine at Bristol, Conn. Am J Sc (2) $20: 361-368$ (1855)

56 On the accurrence of the ores of iron in the Azoic system. Am As, $\operatorname{Pr} 9: 209-$ 216 (1856) Am J Sc (2) $22: 38-44$ (1856) M Mag $7: 67-73$ (1856)

$56 a$ The iron deposits of New York State. M Mag 7:255-258 (1856)

56b Remarks on some points connected with the geology of the north shore of Lake Superior (abst). Am As Pr 9:204209 (1856)

57 Remarks on the Huronian and Laurentian systems of the Canada Geological Survey. Am J Sc (2) 23:305-314 (1857)

$\mathbf{5 7 a}$ Notice of a remarkable instance of Inclined straification in Warren Co., N. Y. (abst). Edinb N Ph J n s $5: 363$ (1857)

58 (with Hall, J.) Report on the geological survey of the State of Iowa, embracing the results of investigations made during ... 1855, 56 \& 57. Vol. 1 , pt 1 , Geology : xv, 472, 4, 4 pp, map; pt 2 , $\mathrm{Pa}$ leontology : 473-724, 3, $30 \mathrm{pp}$, il [Albany, N Y] 1858
Whitney, Josiah Dwight-Continued.

59 Notice of new localities and interesting varieties of minerals in the Lakv" Superior region. Am J Sc (2) 28:8-20 (1859) M Mag (2) $1: 32-47$ (1859)

$59 a$ The lead deposits of the Mississippi Valley. M Mag (2) 1:89-102, 169-184 (1859-60) [extracted from the Report on the geological survey of the State of Iowa, vol 1]

60 On the chemical composition of pectolite. Am J Sc (2) 29:205-208 (1860)

60 Note on the geological position of the Lake Superior sandstone. M Mag (2) 1: 435-446 (1860)

$60 \mathrm{~b}$ On the stratigraphical position of the sandstones of the Connecticut River valley (abst). Annual of Scientific Discovery (Wells) $1860: 322$

61 The geological survey of California; an address delivered before the legislature of California... 50 pp, San Francisco 1861

61 a (with Foster, J. W.) On the origin and stratigraphical relations of the trappean rocks of Lake Superior (abst). Annual of Sclentiflc Discovery for 1861: 285 (1861)

62 Report of a geological survey of the upper Mississippi lead region. [Extracted from Report of the geological survey of the State of Wisconsin, vol. I.] Albany 1862 Extract, Ky G S, Rp Prog n s 2 : 293-300 (1877)

62a Lecture on geology, delivered before the legislature of California... $33 \mathrm{pp}$, San srancisco 1862

62b Letter of the State geologist relative to progress of the [California] State geological survey. 7 pp [Sacramento 1862]

62e (with Hall, J.) Report of the cological survey of the State of Wisconsin. Volume I. $455 \mathrm{pp}$, maps [Albany, N. Y.] 1862 [Whitney's part also issued separately. See Whitney, 62]

63 Annual report of the State geologist of California for the year 1862 . $12 \mathrm{pp}$, Sacramento 1863

63a Lecture on geology delivered before the legislature of California at Sacramento, Thursday evening, March 19, 1863. $17 \mathrm{pp}$ [Sacramento 1863]

63b [The progress of the State geological survey of California.] Cal Ac N Sc, Pr 3: 23-29 (1863)

63e [On meteoric iron from Arizona.] Cal Ac N Sc, Pr 3:48-50 (1863)

64 Annual report of the State geologist [of California] for the year 1863. $7 \mathrm{pp}$ [Sacramento 1864]

64a Preface [survey operations; stratigraphic notes]. Cal G S, Paleontology 1: vii-xx (1864)

64b On the progress of the geological survey of California. Am J Sc (2) 37 : $427-431 ; 38: 256-264$ (1864) 
Whitney, Josiah Dwight-Continued.

65 Geological survey of California; Geology, volume I, Report of progress and synopsis of the field work from 1860 to 1864. xxvii, $498 \mathrm{pp}, 1865$

65a Notice of the explorations of the Geological Survey of California in the Sierra Nevada during the summer of 1864 . Am J Sc (2) 39: 10-13 (1865)

66 Letter of the State geologist relative to the progress of the State geological survey during the years 1863-64. $14 \mathrm{pp}$, Sacramento, 1866

66a Recent developments with regard to the geology of California. Am J Sc (2) 41: 252-254 (1866)

66b On borax in California. Am J Sc (2) $41: 255$ (1866)

66e Geology of the lead region. IIl G S 1:153-207, map (1866); Ec G 1: 118-162 (1882)

66d [Remarks on the nature and distribution of meteorites which have been discovered on the Pacific coast and in Mexico.] Cal Ac $\mathrm{N}$ Sc, Pr 3:240-242 (1866)

66e [Remarks on the geology of the State of Nevada.] Cal Ac $\mathrm{N}$ Sc, Pr 3: 266-270 (1866)

66f [Remarks on the absence of the northern drift formation from the western coast of North America.] Cal Ac N Sc, Pr 3: 271-272 (1866)

67 Letter of the State geologist relative to the progress of the [California] State geological survey during the years 1866-7. $15 \mathrm{pp}$ [Sacramento 1867]

67 a Notice of a human skull recently taken from a shaft near Angel's, Calaveras Co., Cal. Cal Ac N Sc, Pr 3:277-278 (1867) Am J Sc (2) 43:265-267 (1868)

$67 \mathbf{b}$ Notice of the occurrence of a tungstate of lime and copper in Lower California. Cal Ac N Sc, Pr 3:287-288 (1867)

67e Notice of the occurrence of the Silurian series in Nevada. Cal Ac $\mathrm{N}$ Sc, Pr 3: 307-309 (1867) Am J Sc (2) 43: 267-269 (1867)

67a On the fresh-water infusorial deposits of the Pacific coast and their connection with the volcanic rocks. Cal Ac N Sc, Pr $3: 319-324$ (1867)

67e [On the geological position of coal (abst).] Cal Ac N Sc, Pr 3:356 (1867)

67p Sur les amas détritiques de la Californie. Soc $G$ France, B (2) 24:624-625 (1867)

68 An address on the propriety of continuing the State geological survey of California ... 23 pp, San Francisco 1868
Whitney, Josiah Dwight-Continued.

68 a Letter of the State geologist relative to the progress of the [California] State geological survey during the years 1864-65. $14 \mathrm{pp}$ [Sacramento 1868]

$68 \mathrm{~b}$ The Yosemite book; a description of the Yosemite Valley and the adjacent region of the Sierra Nevada, and of the big trees of California. Cal G S : $116 \mathrm{pp}$, map, N Y 1868 Another ed, with text figures instead of plates: $155 \mathrm{pp}$, map. Cambridge 1870. Other editions, The Yosemite guidebook ...: 133 pp, maps, Cambridge 1871; $186,3 \mathrm{pp}$, maps, Cambridge 1874

68c [Remarks on the mineral species occurring in California and on the Pacific coast.] Cal Ac N Sc, Pr 3:372-373, 374 376 (1868) Deut G Ges, Zs $21: 741-746$ (1869)

68d [On the depression of Death Valley.] Cal Ac N Sc, Pr 3:376 (1868)

68e [On the Calaveras skull and its geological position.] Am Nat 2:445-447 (1868)

$68 \mathrm{P}$ [Sllurian fossils in the West.] N Jb 1868: 188-189

69 Report of the State geologist on the condition of the geological survey of Californla. $7 \mathrm{pp}$, Sacramento 1869

69a Preface. Cal G S, Paleontology 2 : vii-xiv (1869)

71 Letter of the State geologist relative to the progress of the [California] geological survey during the years $1870-71$. $13 \mathrm{pp}$, Sacramento 1871

71a Earthquakes, volcanoes, and mountain building. Three articles published in the North American Review 1869-1871 [108: 578-610 (1869) ; 109:231-265 (1869) 113 : 235-274 (1871)]. 107 pp, Cambridge 1871

72 Note on the occurrence of the Primordial fauna in Nevada. Am J : (3) 3 : $84-86(1872)$

72a [Remarks on fossils from near Eureka, Nev.] Cal Ac Sc, Pr 4:200 (1872)

72b The Owen's Valley earthquake [Cal.]. Overland Monthly 9:130-140, 266-278 (1872)

72e Erläuterungen der Californischen Bacillarien-Gebirge. $\mathrm{K}$ Preuss Ak Wiss Berlin, Mber 1872:124-128

73 Statement of the progress of the geological survey of California during the years 1872-3. $14 \mathrm{pp}$, [Sacramento] 1873

$73 a$ Geological map of the State of California. Seale, 36 miles to 1 inch. Cal G S 1873

73b Note on the occurrence of the Trias in British Columbia. Am J Sc (3) 5:473474 (1873)

75 Geographical and geological surveys. N Am Rv 121:37-85, 270-314 (1875)

76 Plain, prairie, and forest. Am Nat $10: 577-588,656-667$ (1876) 
Whitney, Josiab Dwight-Continued.

so The auriferous gravels of the Sierra Nevada of California. Harvard Coll, Mus C Z, Mem 6 no 1:659 pp, maps (1880) Another edition is called Contributions to American geology, vol. 1 .

80a The climatic changes of Iater geological times; a discussion based on observations made in the Cordilleras of North America. Harvard Coll, Mus C Z, Mem 7 no 2:394 pp (1880-82) Also in Contributions to American geology, vol 2 .

82 The Coast Ranges. Cal G S, Geology 2 Appendix : 148 pp, Cambridge $\mathbf{1 8 8 2}$

82a List of American authors in geology and paleontology. Harvard Univ B no 22 (2 no 9 ) : $352-356$; no 23 (2 no 10$)$ : 426$429(1882)$

84 (and Wadsworth, M. E.) The Azoic system and its proposed subdivisions. Harvard Coll, Mus C Z, B 7 (g \& 1) : xvi, 331-565 (1884)

89 The United States ... 472 pp, Boston 1889

See also Rémond 66

Whitney, Milton.

95 Report on the examination of some soils from Illinois. In Illinois Board of World's Fair Commissioners at the World's Columbian Exposition [Chicago 1893], Report: 93-114, Springfield 1895

96 Texture and structure of solls ( $a b s t$ ). Science n s 3:879-880 (1896)

oo (and others). Field operations of the Division of Soils, 1899. U S Dp Agr, Rp no $64: 198$ pp, maps (1900)

o1 (and others) Field operations of the Division of Soils, 1900. U S Dp Agr, Div Soils (Second report) : $473 \mathrm{pp}$, maps (1901)

02 (and others) Field operations of the Bureau of Soils, 1901. U S Dp Agr, Bur Soils (Third report):647 pp, maps (1902) Fourth report, 1902:842 pp, maps (1903) Fifth report, 1903: $1310 \mathrm{pp}$, maps (1904) Sixth report, 1904: $1151 \mathrm{pp}$, maps (1905) Seventh report, 1905: 1089 pp, maps (1907) Eighth report, 1906:1033 pp, maps (1908) Ninth report, 1907:1062 pp, maps (1909) Tenth report, 1908:1428 pp, maps (1911) Eleventh report, 1909: $1740 \mathrm{pp}$, maps (1912) Twelfth report, 1910:1772 pp, maps (1912) Thirteenth report, $1911: 2356 \mathrm{pp}$, maps (1914) Fourteenth report, 1912: $2166 \mathrm{pp}$, maps (1915) Fifteenth report, $1913: 2438$ pp, maps (1916) Sixteenth report, 1914:2850 pp, maps (1919) Seventeenth report, 1915: 2733 pp (1919) [For contents see List of soil surveys issued by Bureau of Soils]

09 Soils of the United States. U S, Dp Agr, Bur Soils, B 55:243 pp (1909)

\section{Whitson, A, R.}

13 (and others) Soil survey of Waw. shara Co., Wis. Wis G S, B 28 (soil ser no 2) : $63 \mathrm{pp}$, map (1913)

Waukesha Co. B 29 (soil ser no 3) : $82 \mathrm{pp}$, map (1914)

Iowa Co. B 30 (soil ser no 4):61 pp, map (1914)

Bayfield area. B 31 (soil ser no 5) : $51 \mathrm{pp}, \operatorname{map}(1914)$

North part of northwest Wis. B 32 (soil ser no 6) :92 pp, map (1914)

Fond du Lae Co. B 37 (soll ser no 7) : $85 \mathrm{pp}, \operatorname{map}$ (1914)

Juneau Co. B 38 (soll ser no 8) : $93 \mathrm{pp}, \operatorname{map}$ (1914)

Kewaunee Co. B 39 (soil ser no $9): 84 \mathrm{pp}, \operatorname{map}$ (1914)

La Crosse Co. B 40 (soil ser no 10) : $77 \mathrm{pp}$, map (1914)

Vilas and portions of adjoining cos. B 43 (soil ser no 11): $77 \mathrm{pp}$, map (1915)

Northeastern Wis. B 47 (soil ser no 12$): 87 \mathrm{pp}, \operatorname{map}(1916)$

Jefferson Co. B 48 (soil ser no 13) : $77 \mathrm{pp}$, map (1916)

Columbia Co. B 49 (soil ser no 14) : 84 pp, map (1916)

North part of north central Wis. B 50 (soil ser no 15):78 pp, map (1916)

Dane Co. B 53-A (soil ser no 20) : $86 \mathrm{pp}, \operatorname{map}(1917)$

Buffalo Co. B 54-A (soil ser no 23) : 76 pp, map (1917)

South part of north central Wis. B 52-A (soil ser no 16): 108 pp, map (1918)

Wood Co. B 52-B (soil ser no 17) : $86 \mathrm{pp}$, map (1918)

Portage Co. B 52-C (soil ser no 18) : $79 \mathrm{pp}$, map (1918)

Whittaker, E. J.

18 The relationship of the fossil mar fauna of Mackay Lake, Ottawa, to the present molluscan fauna of the lake. Ottawa Nat $32: 14-18$ (1918)

Whittemore, Charles A.

oo The Subcarboniferous limestone exposure at Grand Rapids, Mich: Mich Ac Sc, Rp 1:62-65 (1900)

Whitten, W. M.

97 (with Bailey, E. H. S.) On the chemical composition of some Kansas gypsum rocks. Kans Univ Q 6:29-34 (1897)

98 "Quicksand pockets" in the "blue clay" of South Bend [Ind.]. Ind Ac Sc, Pr 1897: 234-240 (1898)

whittier, William Harrison.

17 An investigation of the iron ore resources of the Northwest. Wash, Univ, Bur Industrial Research, B 2:128 pp (1917) 
Whittle, Charles Livy.

89 (with Davis, W. M.) The intrusive and extrusive Trassic trap sheets of the Connecticut Valley. Harvard Coll, Mus C Z, B 16 (g s 2): 99-138 (1889)

91 Genesis of the manganese deposits of Quaco, N. B. Boston Soc N H, Pr 25: 253-258 (1891)

91 a The beach phenomena at Quaco, N. B. Am G 7:183-187 (1891)

92 An ottrelite-bearing phase of a metamorphic conglomerate in the Green Mountains. Am J Sc (3) $44: 270-277$ (1892)

93 Some dynamic and metasomatic phenomena in a metamorphic conglomerate in the Green Mountains. G Soc Am, B 1: 147-166 (1893)

94 The occurrence of Algonkian rocks in Vermont and the evidence for their subdivision. J G 2:396-429 (1894)

$94 \mathbf{a}$ The general structure of the main axis of the Green Mountains. Am J Sc (3) $47: 347-355$ (1894)

98 The clays and clay industry of Massachusetts. Eng M J 66:245-246 (1898)

98a The building and road stones of Massachusetts. Eng M J $66: 336-337$ (1898)

99 The Buffalo Hump mining camp, Idaho. Eng M J 68:215-216 (1899)

oO Rifting and grain in granite. Eng M J 70:161 (1900)

Whittlesey, Charles (1808-1886).

38 Report. Ohio G S, 2d An Rp : 41-71 (1838)

43 A statement of elevations in Ohio with reference to the geological formations ... Am J Sc 45: 12-18 (1843)

46 Copper regions of Lake Superior. $64 \mathrm{pp}, 1846$

47 General geology of Ohio. - pp, map, 1847 [not seen]

48 Notes upon the drift and alluvium of Ohio and the West. $A \mathrm{~m} \mathrm{~J} \mathrm{Sc} \mathrm{(2)} 5: 205-$ 217 (1848)

49 Description of a coal plant supposed to be new [from Summit Co., Ohio]. Am $J \mathrm{Sc}$ (2) $8: 375-377$, il (1849)

49n Outline sketch of the geology of Ohio. In Howe, Henry, Historical collections of Ohio ...:577-589, map, Cincinnati 1849 Reproduced with map, Cleveland 1856

50 On the natural terraces and ridges of the country bordering Lake Erie. Am $J$ Sc (2) 10:31-39 (1850) Also in his Fugitive essays:179-191, Hudson, Ohio, 1852

51 Remarks upon the section from the falls of Wolf River, through Navarino to Lake Michigan; The dip, bearing, and thickness of the silurian groups; The ancient and present beaches of Lake Michigan; Artesian wells in the red clay of Green Bay. In Foster, J. W., and Whitney,
Whittlesey, Charles-Continued.

J. D.. Report on the geology of the Lake Superior land district, pt 2 (U S, 32d Cong spec sess, S Ex Doc 4): 174-176, 177-183, $270-273,393-395$ (1851)

$51 a$ On the "superficial deposits" of the northwestern part of the United States. Am As, $\operatorname{Pr} 5: 54-57$ (1851)

$51 b$ On the equivalency of the rocks of northeastern Ohio and the Portage, Chemung, and Hamilton rocks of New York. Am As, Pr 5: 207-221, il (1851)

52 Geological report on that portion of Wisconsin bordering on the south shore of Lake Superior. In Owen, D. D., Report of a geological survey of Wisconsin, Iowa, and Minnesota ... : 421-473, Phila 1852

52a A dissertation upon the origin of mineral coal. In his Fugitive essays... : 97125, Hudson, Ohio, 1852

53 Western Reserve coal field, Ohio. An Sc, Cleveland, 1: 70-72 (1853)

53a Origin of the bitumen of stratified rocks. An Sc, Cleveland, 1:153-157 (1853)

54 Drift etchings, Lake Superior. An Sc, Cleveland, 2:57-59 (1854)

54a The Allegheny coal field. An Sc, Cleveland, 2:127-132 (1854)

56 Geological, railroad, and township map of the State of Ohio. Scale 12 miles to 1 inch. N Y 1856

58 Outline sketch of the geology of Ohio. Ohio St Bd Agr, An Rp 12:533-547 (1858)

58a Report of progress for the region between the Oconto and Menomonee rivers. In Report of the commissioners of the geological survey [of Wisconsin]:5-7, Madison 1858

59 Paleontology and the moral sense. $10 \mathrm{pp}$, maps, Cleveland 1859 [priv pub]

60 On the drift cavities, or "potash kettles" of Wisconsin. Am As, Pr 13: 297-301 (1860)

60a On the origin of the Azoic rocks of Michigan and Wisconsin. Am As, $\operatorname{Pr} 13$ : 301-308 (1860)

63 Ancient mining on the shores of Lake Superior. Smiths Contr Knowl 13 art 4 (155) $29 \mathrm{pp}$ (1863)

$63 a$ Mineral resources of the Cordilleras of North America, particularly as to precious metals. 64 pp, map, Cleveland, Ohio, 1863

63b The Penokee mineral range, Wis, Boston Soc N H, Pr 9:235-244 (1863) [Wis G S], G Wis $3: 216-223$ (1880)

66 On the fresh-water glacial drift of the Northwestern States [Great Lakes region]. Smiths Contr Knowl 15 art 3 (197) : 32 pp, map (1866)

66a Geology and minerals; a report of explorations in the mineral regions of Min. nesota during the years 1848,1859 , and 1864. 54 pp, Cleveland 1866 
Whittlesey, Charles-Continued.

66b St. Louis and Vermilion rivers, Minnesota. Geological Journal, August, 1848. $12 \mathrm{pp}$, Cleveland 1866 [priv pub]

67 On the ice movements of the glacial era in the valley of the St. Lawrence. Am As, $\operatorname{Pr} 15: 43-54$ (1867)

6s Depression of the ocean during the ice period. $\Delta \mathrm{m}$ As, $\operatorname{Pr} 16: 92-97$ (1868) Can Nat n s 3:304-305 (1868)

68n Remarks upon the occurrence of iron in masses (abst) Am As, Pr 16:97107 (1868)

69 The physical geology of eastern Ohio. Boston Soc N H, Mem 1:588-597, map (1869)

69 a Contributions to the geology of Ohio. $48 \mathrm{pp}$, Cleveland 1869

69b On the evidences of the antiquity of man in the United States. $A m \Delta s$, Pr $17: 268-288$ (1869)

71 On the earthquake of October, 1870. Am Nat 5:561-562 (1871)

72 The earthquake of October, 1870 ; its rate of progress. Am As, Pr 20:218-221 (1872)

72a Notice of the "Great Vein" coal region near Straitsville, Perry Co., Ohio. $7 \mathrm{pp}$, map [Cleveland 1872 ?] [priv pub] 72b Glances at the geological survey [of Ohio]. $6 \mathrm{pp}$, [1872?] [priv pub]

73 The dip of the great Straitsville coal seam, Ohio. 4 pp [Cleveland 1873] [priv pub]

74 On the origin of mountain chains. Am As, Pr 22 pt 2:51-54 (1874)

$\mathbf{7 4 a}$ The Alleghany coal field. Cleveland Ac, $\operatorname{Pr} 1: 99-113$ (1874)

74b Gold-bearing rocks of Lake Superior. Cleveland Ac, Pr 1:134-136 (1874)

75 Coal seam No. 6, Ohio geology; Boston Soc N H, Pr 17:183-200 (1875)

76 Physical geology of Lake Superior (abst). Am As, Pr 24 pt 2:60-7:2, map (1876)

76a The physical structure of the Ohio coal field (abst). Am As, Pr 24 pt 2: 73$79(1876)$

77 On the origin of mineral veins. Am As, Pr $25: 213-216$ (1877)

$\mathbf{7 7 a}$ Iron River silver district, south shore of Lake Superior. Eng M J 23: 254, 278-279 (1877)

77b Great Seam coal region, Ohio; comparison of strata. $7 \mathrm{pp}$, Cleveland 1877 [priv pub]

78 Geology of Portage County [Ohio]. $3 \mathrm{pp}$ [Cleveland 1878?] [priv pub]

79 Ancient glacial action, Kelly's Island, Lake Erie. Am As, Pr $27: 239-245$ (1879)

$79 a$ General geology of the counties of Columbiana, Stark, and Tuscarawas. Ohio, Secretary of State, An Rp 1878:561-578 (1879)
Whittlesey, Charles Continued.

so Columbiana Co., Ohio, its geological structure. $2 \mathrm{pp}$, Cleveland 1880 [priv pub]

83 Preglacial channel of Eagle River, Mich. (abst). Am As, Pr 31:352 (1883)

84 Abstract of the bearings of glacial striae and grooves in Ohio. Ohio $\mathrm{G} \mathrm{S}$, Rp 5: 770-771 (1884) Western Reserve Hist Soc, Tract (no 60) 2: 269-272 (1884)

$84 a$ The lower limestone group coal series of northeastern Ohí. Ohio M J 2: 55-62 (1884)

85 The preglacial channel of Eagle River, Keweenaw Point, Lake Superior. Am J Sc (3) 29:392-397 (1885)

85a Personnel of the first geological survey of Ohio. Magazine of Western History $2: 73-87$ (1885)

See also Desor, 50h, 52d, 1; Hilgard, 71a Whymper, Edward.

70 Report of proceedings to obtain a collection of fossil plants in north Greenland... Brit As, Rp $39: 1-8$ (1870)

Whymper, Frederick.

68 Notes on the glaciers of Bute Inlet, B. C. $(a b s t)$. Edinb G Soc, Tr $1: 65-67$ (1868)

Whytock, P. R.

09 The Rawhide district, Nev. M World $31: 266$ (1909)

10 Rawhide, its past, present, and the future. M World 83:89-90 (1910)

Wiard, Edward S.

09 Ore dressing in the Cour d'Alene dis. trict, Idaho. Eng M J 88:1055-1060 (1909)

\section{Wichman, Arthur.}

79 A microscopical study of some $\mathrm{Hu}$ ronian clay slates. G Soc London, Q J 35 : 156-164 (1879)

so Microscopical observations of the iron-bearing (Huronian) rocks from the region south of Lake Superior. [Wis G S], $G$ Wis $3: 600-656$ (1880)

84 Ueber Gesteine von Labrador. Deut G Ges, Zs 36:485-499 (1884)

Wiekersham, C. P.

46 On fossil tracks in the red sandstone of the Connecticut Valley. Ac N Sc Phila, Pr 3:120-121 (1846)

wickersham, W.

68 [On the traveling of rocks.] Boston Soc N H, Pr 11: 285 (1868)

Wickes, C. T.

so Geological section on Fork Run, Low Moor Iron Co.'s lands, Alleghany Co., Va. The Virginias 1 : opp 9 (1880)

wickes, L. Webster.

10 Classification of igneous rocks. M Sc Press 101: 52 (1910)

17 Molybdenum in the Hualpai Mountains [Mohave Co., Ariz.]. M Sc Press $114: 699-700$ (1917) 
Wickham, Henry Frederick.

os New fossil Elateridx from Florissant. Am J Sc (4) $26: 76-78$, il (1908)

09 New fossil Coleoptera from Florissant. Am J Sc (4) 28:126-130 (1909)

10 New fossil Coleoptera from Florissant, with notes on some already described. Am J Sc (4) 29:47-51 (1910)

11 Fossil Coleoptera from Florissant, with descriptions of several new species. Am Mus N H, B 30:53-59 (1911)

12 A report on some recent collections of fossil Coleoptera from the Miocene shales of Florissant. Iowa, Univ, Lab N H, B $6: 3-38$, il (1912)

12a On some fossil rhynchophorous Coleoptera from Florissant, Colo. Am Mus N H, B 31:41-55, il (1912)

13 Fossil Coleoptera from the Wilson ranch near Florissant, Colo. Iowa, Univ, Lab N H, B $6: 3-29$, il (1913)

13a Fossil Coleoptera from Florissant in the United States National Museum. U S Nat Mus, Pr $45: 283-303$, il (1913)

14 New Miocene Coleoptera from Flo. rissant. Harvard Coll, Mus C Z, B 58: 423-494, il (1914)

16 The fossil Elateridae of Florissant [Colo.]. Harvard Coll, Mus C Z, B 60 : 493-527, il (1916)

16a New fossil Coleoptera from the Florissant beds. Iowa, Univ, Lab N H, B 7 no $3: 20 \mathrm{pp}$, il (1916)

17 Some fossil beetles from the Sangamon peat [Champaign Co., IIl.]. Am J Se (4) 44:137-145 (1917)

17 a New species of fossil beetles from Florissant, Colo. U S Nat Mus, Pr 52 : 463-472 (1917)

Wiechert, Fi.

09 Onr present knowledge of the earth. Smiths Inst, An Rp 1908:431-449 (1909)

wiechmann, F. G.

82 Fusion structures in meteorites. N $Y$ Ac Sc, An 2: 289-312 (1882); Abst, Tr $1: 153-155$ (1882)

Wiedersheim, Robert.

81 Zur Palaeontologie Nord-Amerikas [Vertebrata]. Biol Centralbl 1:359-372 (1881)

Wiel, Samuel Charles.

04 A Nevada ore deposit [Shelbourne Range, White Pine Co.], M Sc Press 88: 330-331 (1904)

Wieland, George Reber.

96 Archelon ischyros; a new gigantic cryptodire testudinate from the Fort Pierre Cretaceous of South Dakota. Am J Sc (4) 2: $399-412$, il (1896)

97 The depth of peat in the Dismal Swamp. Am J Sc (4) 4:76 (1897)

$97 \mathbf{a}$ Currituck Sound, Va, and N. C., a region of environmental change. Am J Sc (4) $4: 76-77 \quad(1897)$

97b Eopaleozolc hot springs and the origin of the Pennsylvania siliceous oolite. Am J Sc (4) 4:262-264 (1897)
Wieland, George Reber-Continued.

98 The protostegan plastron. Am J Sc (4) $5: 15-20$, il (1898)

99 A study of some American fossil cycads; Part I, The male flower of Cycadeoidea. $\mathrm{Am} J \mathrm{Sc}$ (4) $7: 219-226$, il (1899) Part II, The leaf structure of Cycadeoidea; (4) $7: 305-308$, il (1899) Part III, The female fructification of Cycadeoidea: (4) $7: 383-391$, il (1899) Part IV, On the microsporangiate fructification of Cycadeoidea; (4) 11:423-436 (1901) Part V, Further notes on seed structures; (4) $32: 133-155$, il (1911) Part VI, On the smaller flower buds of Cycadeoidea; (4) $33: 73-91$, il (1912) Part VII, Further notes on disk structure; (4) $38: 117-136$, il (1914) Part VIII, Notes on young floral structures; (4) 46 : $645-650$, il (1918)

$99 \mathbf{a}$ The terminology of vertebral centra. Am J Sc (4) 8:163-164 (1899)

99b Cycadean monoecism. Am J Sc (4) $8: 164$ (1899)

00 The skull, pelvis, and probable relationships of the huge turtles of the genus Archelon from the Fort Pierre Cretaceous of South Dakota. Am J Se (4) 9:237251, il (1900)

OOn ...stages in the evolution of the testudinate humerus. Am J Sc (4) 9:413424 , il (1900)

Oob The Yale collection of fossil cycads. Yale Sc Mo 6:211-221, il (1900)

02 Notes on the Cretaceous turtles Toxochelys and Archelon, with a classification of the marine Testudinata. Am J Sc (4) $14: 95-108$, il (1902)

03 Notes on the marine turtle Archelon; I, On the structure of the carapace; II, Associated fossils. Am J Sc (4) 15:211216. il (1903)

03a Polar climate in time the major factor in the evolution of plants and animals. Am J Sc (4) 16:401-430 (1903)

03b A grant from the Carnegie Institu. tion for paleobotany [investigation of cycads]. Science n s 17:352-353 (1903)

04 Structure of the Upper Cretaceous turtles of New Jersey. Am J Sc (4) 17 : 112-132； 18:183-196 (1904)； $20: 430$ 444 , il (1905)

$04 a$ The proembryo of the Bennettiteae. Am J Sc (4) 18:445-447, il (1904)

o5 A new Nlobrara Toxochelys. Am J Sc (4) $20: 325-343$, il (1905)

06 The osteology of Protostega. Carnegie Mus, Mem 2: 279-304, il (1906)

06a Plastron of the Protosteginæ. Carnegie Mus, An 4:8-14, il (1906)

06b American fossil cycads. Carnegie Inst Wash, Pub no 34:196 pp, il, Washington, 1906

o6e Dinosaurian gastroliths. Science n s $23: 819-821$ (1906)

07 Gastroliths. Science n \& $25: 66-67$ (1907) 
wieland, George Reber-Continued.

os Historic fossil cycads. Am J Sc (4) $25: 93-101$, il (1908)

09 Revision of the Protostegida. Am J Sc (4) $27: 101-130$, il (1909)

09a A new armored saurian from the Niobrara. Am J Sc (4) $27: 250-252$, il (1909)

09b The Williamsonias of the Mixteca Alta, Mexico. Bot Gaz 48:427-441, il (1909)

10 Two new Araucarias from the western Cretaceous. S Dak G S, B 4 (Rp St G 1908) : 77-81, il (1910)

10a Investigations on American fossil cycads. Carnegie Inst Wash, Y Bk 8:231$232(1910)$

$10 b$ Plesiosaurus (Polyptychodon) mexicanus Wieland. Mex I G, Par $3: 361-365$ (1910)

11 Continuation of investigations on fossil cycads. Carnegie Inst Wash, Y Bk 9 : 229-230 (1911)

11 a Notes on the armored Dinosauria. Am J Sc (4) 31:112-124, il (1911)

11b On the Williamsonian tribe. Am J Se (4) $32: 433-466$, il (1911)

12 On the dinosaur-turtle analogy. Ist Bologna, R Ac Sc, Cl Sc Fis, Mem (6) 9 : $297-300$ (1912)

$12 a$ Note on the dinosaur-turtle analogy. Science n s $36: 287-288$ (1912)

$12 b$ La flora fosil de la Mixteca Alta (abst). Soc G Mex, B 8: vili (1912)

13 The Liassic flora of the Mixteca Alta of Mexico. Am J Sc (4) 36:251-281, map (1913)

14 Further notes on Ozarkian seaweeds and oölites. Am Mus N H, B 33: 237-260, il (1914)

14a La flora liásica de la Mixteca Alta [México]. Méx I G, B $31: 165$ pp, il (1914)

14b Was the Pterophyllum foliage transformed into the leafy blades of dicotyls? Am J Sc (4) 38:451-460, il (1914)

14e (with Elkins, M. G.) Cordaitean wood from the Indiana black shale. Am J Sc (4) $38: 65-78$, il (1914)

16 American fossil cycads; vol. 2, Taxonomy. Carnegie Inst Wash, Pub no 34: $277 \mathrm{pp}$, il, Washington 1916

16a Continuation of investigations on fossil cycads. Carnegíe Inst Wash, Y Bk $14: 387$ (1916)

18 Cycadeoid wood structure. Seience $\mathrm{n}$ s 47: 141-142 (1918)

18a The origin of dicotyls. Science n s 48:18-21 (1918)

18b The Vero man and the sabre tooth [tiger]. Science n s 48: 93-94 (1918)

See also Ward, 05

Wigrlesworth, Edward.

15 The serpentines of Vermont. Boston Soc N H, Pr 35: 95-107, map (1915) Vt, St G, Rp 10:281-292, map (1916)
Wight, O. W.

77 Report of progress and results for the year 1875 . [Wis $G \mathrm{~S}$ ], $G$ Wis $2: 67$ 89 (1877)

Wilber, Charles Dana (1831-1893?).

61 Mastodon giganteus [Aurora, III.]. III $\mathrm{N}$ H Soc, Tr 1:59-64, il (1861)

7o Mineral wealth of Missouri; two lectures ... 1. Mines and mining education: 2. Coal and iron. $67 \mathrm{pp}$, St Louis [1870]

Wilber, F. A.

83 Clays; fire-clay in the eastern dIvision. U S G S, Min Res [1882] : 465469 (1883)

83a Apatite; marls. U S G S, Min Res [1882] : 521-526 (1883)

85 Clays. U S G S, Min Res 1883-4 : $676-711$ (1885)

Wileox, Walter Dwight.

99 A certain type of lake formation in the Canadian Rocky Mountains. J G 7 : 247-260, map (1899)

Wilder, Burt Green.

71 Mastodon remaing in central New York. Am J Sc (3) 2:58 (1871)

Wilder, Frank Alonzo.

Oo Geology of Lyon and Sioux cos. lowa G S 10:85-155, maps (1900)

00a Observations in the vicinity of Wall Lake [Sac Co., Iowa]. Iowa Ac Sc, Pr $7: 77-82(1900)$

02 Geology of Webster Co. Iowa G S $12: 63-191$, maps (1902)

02a Second biennial report of the State geological survey of North Dakota. N Dak, St Univ, B 1 no $1: 262 \mathrm{pp}$, maps, Bismark 1902 2d ed, 1903

02b The lignite coal fields of North Dakota. N Dak G S, Blen Rp 2:33-55 (1902)

02e (and wood, L. H.) Report on the lignite by counties, N Dak G S, Bien Rp 2:56-162, map (1902)

02d The lignite deposits of North Dakota. Eng M J 74:674-675 (1902)

03 The age and origin of the gypsum of central Iowa. J G 11:723-748 (1903)

03a A possible origin for the lignites of North Dakota. Iowa Ac Sc, $\operatorname{Pr} 10$ : 129-135 (1903)

O4 The lignite on the Missouri, Heart, and Cannonball Rivers ... N Dak $\mathrm{G}$ S, Bien Rp 3: 9-40, map (1904)

O4a Gypsum deposits in Iowa. U S G S, B $223: 49-52$ (1904)

04b The Laramie and Fort Union beds in North Dakota. J G 12:290-293 (1904)

os Thirteenth annual report of the State geologist. Iowa G S 15:3-11 (1905) ; Fourteenth annual report ... 16: $1-12(1906)$

O5n The lignite of North Dakota and its relation to irrigation. U $\mathrm{S}$ G $\mathrm{S}, \mathrm{W}-\mathrm{S} \mathrm{P}$ $117: 59 \mathrm{pp}(1905)$

06 The lignite coals of North Dakota. Ec $G$ 1:674-681 (1906) 
wilder, Frank Alonzo-Continued.

o7 Memoir of Albert Allen Wright [1846-1905]. G Soc Am, B 17:687-690 (1907)

09 Fuel values of Iowa coal. Iowa G S $19: 397-475$ (1909)

14 The gypsum resources of the Southern States (abst). Science n s 39:400 (1914)

wiley, De witt C.

03 (with Arnold, R.) The Geological Society of American Universities. Science n 8 18:691-693 (1903)

wiley, W. E.

16 (with Tharp, W. E.) Soil survey of Wells Co. Ind, Dp $G$ Nat Res, An Rp $40: 44-71$, map (1916)

wilke, R. M.

os Benitoite and neptunite. Mineral Collector 14: 167-168 (1908)

Wilkens, Henry A. J.

96 (with Nitze, H. B. C.) The present condition of gold mining in the southern Appalachian States. Am I M Eng, Tr $25: 661-796,1016-1027$ (1896)

97 (with Nitze, H. B. C.) Gold mining in North Carolina and adjacent south Appalachian regions. N C G S, B $10: 164$ pp, Raleigh 1897

winkes, Charles.

59 Report on the examination of the Deep River district, N. C. U S, 35th Cong $2 d$ sess, \& Ex Doc 26:2-25 maps (1859) Reprinted in Hale, P. M., In the coal and fron counties of North Carolina: 147-181, Raleigh 1883

wilkins, D. F, H.

76 Notes upon the superficial deposits of Ontario. Can Nat n s 8: 82-86 (1876)

$76 \mathrm{a}$ Note on the geology of the Labrador coast. Can Nat n $88: 87-88$ (1876)

77 Notes upon the occurrence of Eozoic rocks in the South Riding of Hastings Co., and in Prince Edward Co., Ont. Can Nat n s $8: 278-282$ (1877)

oo River valleys of the Niagara escarpment [Ontario]. Hamilton As, J Pr pt $6: 128-136$ (1890)

91 Notes upon the surface geology of Lincoln Co., Ont. Hamilton As, J Pr pt 7:23-30 (1891)

Wilkinson, Ernest.

85 On the occurrence of native mercury in alluvium in Louisiana. Am J Sc (3) $29: 280-281$ (1885)

Willard, Daniel Everett.

93 Some geological features of Jackson Park, Chicago. Science $22: 309-310$ (1893)

02 The story of the prairies, or, the landscape geology of North Dakota. 256 pp, Chicago 1902 5th ed, 377 pp, Chicago 1907

04 The surface formations of southeastern North Dakota. N Dak Agr Coll s, 2d Bien Rp: 128-184 (1904)
Willard, Daniel Everett-Continued.

04a The geology of the soils of southeastern North Dakota. N Dak Agr Coll S, 2d Bien Rp : 135-138 (1904)

04b Geologic history of eastern North Dakota. N Dak Agr Coll S, 2d Bien Rp : 138-144 (1904)

04c The water supply [of North Dakota]. N Dak Agr Coll S, $2 d$ Bien $R p$ : 144-152 (1904)

04d (and Erickson, M. B.) A survey of the coteaus of the Missouri. N Dak Agr Coll S, 2d Bien Rp : 17-27, map (1904)

05 (with Hall, C. M.) Description of Casselton and Fargo quadrangles [N. Dak. Minn.] U S G S, G Atlas CasseltonFargo fol (no 117) : 7 pp, maps (1905)

06 A description of geologic formations in eastern North Dakota. N Dak Agr Coll S, $3 d$ Bien Rp: 6-9 (1906)

06n Geologic history of the Tower quad. rangle. N Dak Agr Coll $\mathrm{S}$, 3d Bien Rp : 28-37 (1906)

06b Notes on the water supply of a portion of Cass, Barnes, and Ransom cos. $N$ Dak Agr Coll $\mathrm{S}$, 3d Bien $\mathrm{Rp}: 38-43$ (1906)

o6e Notes on the wells of a portion of the Dakota artesian basin. N Dak Agr Coll S, 3d Bien Rp: 44-46 (1906)

06d The soils of the Tower quadrangle. N Dak Agr Coll $\mathrm{S}$, 3d Bien Rp:47-50 (1906)

o6e The history of Maple River. N Dak Agr Coll S, 3d Bien Rp : 51-54 (1906)

o6f (and Hibbard, $H$. ) The Quaternary (drift) formations of the Towet quadrangle. N Dak Agr Coll S, 3d Bien Rp : $10-20$ (1906)

06\% (and Hibbard, H. V.) Late glaeial and postglacial deposits of the Sheyenne and Maple Rivers. N Dak Agr Coll S, 3d Bien Rp: 21-27 (1906)

o6h (and Hibbard, H. V.) A peculiar type of hills. N Dak Agr Coll S, 3d Bien Rp : 55 (1906)

09 Description of the Jamestown-Tower district, N Dak. U S G S, G Atlas Jamestown-Tower fol (no. 168): 10 pp, maps (1909) N Dak Agr Coll $\mathrm{S}$, 4th Bien Rp : 173-233, maps (1910)

willard, J. T.

85 Note on a new Kansas mineral [menaccanite]. Kans Ac Sc, Tr 9:25-26 (1885)

Willeox, Joseph (1829-1918).

73 [Glacial scorings in St. Lawrence Co., N. X.] Ac N Sc Phila, Pr 1872:275 (1873)

74 Mountain drainage of eastern Tennessee and western North Carolina. Ac N Sc Phila, $\operatorname{Pr} 1874: 164-165$

75 On samarskite [Mitchell Co., N. C.] Ac N Sc Phila, Pr $1875: 263$

76 On mineral localities in North Carolina. Ac N Sc Phila, Pr 1875:467-468 (1876) 
Willeox, Joseph-Continued.

83 Notes on the serpentine beds of Chester and Delaware cos., with their associated minerals, corundum, chrome, etc. $\mathrm{Pa}$ G S, 2d, C4: 346-351 (1883)

83a Canadian notes. Ac N Sc Phila, Pr 1883: 96

84 Notes on glacial action in northern New York and Canada. Ac N Sc Phila, Pr 1883: 257-259 (1884)

84a Notes on the geology and natural history of the west coast of Florida. Ac N Sc Phila, Pr 1884: 188-192

85 [Glacial action north of the St. Lawrence.] Science 6:388 (1885)

93 Metamorphism of sedimentary rocks. Ac N Sc Phila, Pr 1893: 10

08 A half hour's talk on mineralogy. Delaware Co Inst Sc, Pr 4:1-11 (1908)

willeox, Oswin W.

04 On certain aspects of the loess of southwestern Iowa. J G 12:716-721 (1904)

05 The so-called alkali spots of the younger drift sheets. J G 13: 259-263 (1905)

06 The viscous vs. the granular theory of glacial motion. 23 pp. Long Branch, N. J. 1906 [Priv pub] [Rv, Chamberlin, 07f]

06a The iron concretions of the Redbank sands. J G 14:243-252 (1906)

willet, J. E.

54 Description of meteoric iron from Putnam Co., Ga. Am J Sc (2) $17: 331$ $3 3 2 \longdiv { ( 1 8 5 4 ) }$

Villey, Day Allen.

04 New Texan oil deposits. Sc Am 90: 96 (1904)

05 The oil fields of the West. Sc Am $93: 484$ (1905)

os Sand waves and their work. Sc Am Sup 65:120-121 (1908)

13 The world's greatest iron-ore deposits. Eng Mag 44: 867-883 (1913)

Williams, Albert, jr.

83 Mineral resources of the United States [1882]. U S G S: 813 pp (1883) ...calendar years 1883 and $1834 ; \mathrm{U}$ S G S : 1016 pp (1885) ...calendar year 1885 ; U S G S : 576 pp (1886)

84 Popular fallacies regarding preciousmetal ore deposits. U S G S, An Rp 4: 253-271 (1884) Eng M J 37:465-466, 481-483 (1884)

88 Useful minerals of the United States.

U S G S, Min. Res 1887:688-812 (1888)

92 Why dip is more likely to be regular than strike with fissure veins. Eng M J $53: 398$ (1892)

98. Faults. Mines and Minerals 18 : 298-301 (1898)

99 Popular fallacies regarding ore deposits. Can M Rv 18:293-294 (1899)

See also Powell, 84, 85, 85a, 88
Wilinms, Charles C.

72 Contribution to a knowledge of the iron ores of Missouri. 15 pp [Rolla, Mo.] 1872

Williams, Charles P.

62 (and Blandy, J. F.) ...the copper range of Lake Superior. Am J Sc (2) $34: 112-120$ (1862)

63 (with Stevens, W. H., and Hill, S. W.) Geological map of the trap range of Keweenaw Point, Lake Superior. Phila [1863] [not seen]

74 Note on the occurrence of antimony in Arkansas. Am I M Eng, Tr $3: 150-151$ (1875) Eng M 17:386 (1874)

77 Industrial report on lead, zinc, and iron, together with notes on Shannon Co. and its copper deposits. Mo G S : $183 \mathrm{pp}$, Jefferson City 1877

Williams, E. G.

03 The manganese industry of the Department of Panama, Republic of Colombia. Am I M Eng, $\operatorname{Tr} 33: 197-234$, map (1903)

Williams, Edward Higginson, jr.

76 On crystals of tourmaline with enveloped orthoclase. Am J Sc (3) $11: 273-$ 275 (1876)

86 A manual of lithology. 135 pp, N Y $18862 d$ ed, $418 \mathrm{pp}, \mathrm{N}$ Y 1895

90 Data for the determination of earth movements. Am G 6:400 (1890)

91 Geology from a business point of view. Eng Mag 2:311-317 (1891)

93 Sonth Mountain glaciation [Pennsy]vania]. G Soc Am, B 5:13-15 (1893) Abst, Am G 12: 166 (1893)

93a Glaciation in Pennsylvania. Science $21: 343$ (1893)

94 Extramorainic drift between the Delaware and the Schuylkill. G Soc Am, B 5: 281-296, map (1894) Abst, Am G 13:221 (1894)

94a The age of the extramoraine fringe in eastern Pennsylvania. Am J Sc (3) 47 : $34-37$ (1894)

95 Notes on the southern ice limit in eastern Pennsylvania. Am J Sc (3) 49 : 174-185, map (1895)

96 The mammoth bed at Morea, $\mathrm{Pa}$. Science n s 3:782-783 (1896)

96a The "Kansan" glacial border. Science n \& 4:229-230 (1896)

$96 b$ Notes on Kansan drift in Pennsylvania $(a b s t)$. Am G 18:237-238 (1896)

97 Greenland glaciers. Science n 8 5: 448 (1897)

98 Notes on Kansan drift in Pennsylvania. Am $\mathrm{Ph}$ Soc, $\mathrm{Pr} 37: 84-87$ (1898)

o1 The alleged Parker channel. G Soc Am, B 12: 463 (1901) Abst, Science n s $13: 99$ (1901)

02 Kansas glaciation and its effect on the river system of northern Pennsylvania. Wyoming Hist G Soc, $\operatorname{Pr} 7: 21-28$ (1902) 
Williams, Edward Higginson, jr.-Contd. 12 The heating in the Culebra cut [Cana] Zone]. Science n s $35: 892-893$ (1912)

13 Alleghany Valley erosion. Science n s $37: 447-450$ (1913)

17 Pennsylvania glaciation, first phase; materials for a discussion of the attenuated border of the moraine described in volume $Z$ of the Second Geological Survey of Pennsylvania. $101 \mathrm{pp}$, Woodstock, Vt., 1917 [copyright, by the author]

See also Branner, 98; Wright (G F), 17

Williams, Frank Ernest.

13 The petrified forests of Arizona. J Geog 11: 329-332 (1913)

$13 a$ (with Martin, L., and Bean, E. F.) A manual of physical geography excursions. 207 pp, Madison, Wis., 1913

15 Fiords of southeastern Alaska (abst). As Am Geog, An 3:113 [1915]

Willams, George Huntington (18561894).

84 On the paramorphosis of pyroxene to hornblende in rocks. Am J Sc (3) 28 : 259-268 (1884)

84a Barite crystals from De Kalb, N. Y. Johns Hopkins Univ Circ 3:61 (1884)

84b Preliminary notice of the gabbros and associated hornblende rocks in the vicinity of Baltimore [Md.] Johns Hopkins Univ Circ 3: 79-80 (1884)

s4e Note on the so-called quartz porphyry at Hollins Station, north of Baltimore. Johns Hopkins Univ Cire 3:131 (1884)

85 Cause of the apparently perfect cleavage in American sphene (titanite). Am J Se (3) 29:486-490 (1885)

85a The microscope in geology. Science 5 : 190-191 (1885)

85b Hypersthene basalt [discovery of]. Am Nat 19:601 (1885)

85e Dikes of apparently eruptive granite in the neighborhood of Baltimore. Johns Hopkins Univ Circ 4:65-66 (1885)

85d [Notes on] mineralogy and petrography. Am Nat vol. 19 (1885)

s5e Hornblende aus St. Lawrence Co., N. Y.; Amphibol-Anthophyllite aus der Gegend von Baltimore; iber das Vorkommen des von Cohen als "Hudsonit" bezeichneten Gesteines am Hudson-Fluss. N Jb 1885 II : $175-177$

85P Notice of an important work on the origin of the crystalline schists by Dr. J. Lehmann...(abst). Am As, Pr 33:405-407 (1885)

85g The methods of modern petrography (abst). Ph Soc Wash, B $7: 36$ (1885)

86 The gabbros and associated hornblende rocks occurring in the neighborhood of Baltimore, Md. U S G S, B 28 : $78 \mathrm{pp} \mathrm{(1886)}$

$\mathbf{8 6 a}$ Modern petrography; an account of the application of the microsccpe to geology. $35 \mathrm{pp}$, Boston 1886 (Monographs on education, D. C. Heath \& Co.)
Williams, George Huntington-Contd.

S6b The peridotites of the "Cortlandt series" on the Hudson River near Peekskill, N Y. Am J Sc (3) 31:26-41, map (1886)

86e On a remarkable crystal of pyrite from Baltimore Co., Md. Johns Hopkins Univ Cire 6:30-31 (1886)

$8 \boldsymbol{7}$ Notes on the minerals occurring in the neighborhood of Baltimore. $18 \mathrm{pp}$, Baltimore 1887

87a The norites of the "Cortlandt series" on the Hudson River near Peekskill, N. Y. Am J Sc (3) 33: 135-144, 191-199 (1887)

87b On the chemical composition of the orthoclase in the Cortlandt norite. Am J Sc (3) $33: 243$ (1887)

87e Holocrystalline granitic structure in eruptive rocks of Tertiary age. Am J Sc (3) $33: 315-316$ (1887)

87d On the serpentine (peridotite) occurring in the Onondaga salt group at Syracuse, N. Y. Am J Sc (3) 34:137-145 (1887) Abst, Science 9:232-233 (1887)

87 Note on some remarkable crystals of pyroxene from Orange Co., N. Y. Am J Sc (3) $34: 275-276$ (1887)

87f On a plan proposed for future work upon the geological map of the Baltimore region. Johns Hopkins Univ Circ 6:122123 (1887)

87g Rutil nach Ilmenit in verändertem Diabas; Pleonast (Hercynit) in Norit vom Hudson-Fluss; Perowskit in Serpentin (Peridotit) von Syracuse, N. Y. N Jb 1887 , II : $263-267$

S8 On a new petrographical microscope of American manufacture. Am J Sc (3) 35 : 114-117 (1888)

88a The gabbros and diorites of the "Cortlandt series" on the Hudson River near Peekskill, N. Y. Am J Sc (3) 35: 438-448 (1888)

88b The contact metamorphism produced in the adjoining mica schists and limestones by the massive rocks of the "Cortlandt series," near Peekskill, N. Y. Am J Sc (3) 36 : 254-259 (1888)

8Se Progress of the work on the Archean geology of Maryland. Johns Hopkins Univ Cire 7:61-63 (1888)

$88 d$ The massive rocks and contact phenomena of the "Cortlandt series," near Peekskill, N. Y. Johns Hopkins Univ Cire $7: 63-65$ (1888)

8se Geology of the Baltimore region (abst). Johns Hopkins Univ Circ $7: 73$ (1888)

88f Some examples of the dynamic metamorphism of the ancient eruptive rocks on the south shore of Lake Superior (abst). Am As, Pr 36:225-226 (1888)

89 On the possibility of hemihedrism in the monoclinic crystal system, with especial reference to the hemihedrism of pyroxene. Am J Sc (3) 38:115-120 (1889) 
Blake, William Phipps-Continued.

83e Nickel. U S G S, Min Res [1882] :

$399-420 ; 1883-4: 537-543$ (1883-5)

84 Crystallized gold in prismatic forms. Am J Sc (3) 28:57-58 (1884)

s4a Columbite in the Black Hills of Dakota. Am J Se (3) 28:340-341 (1884) Eng M J 38: 362 (1884)

84b Columbite and tantalite with the tin ore of the Black Hills. Eng M J 38:376 (1884)

84e The Carson City ichnolites. Science $4: 273-276$, il (1884)

85 Uintahite, a new variety of asphaltum from the Uinta Mountains, Utah. Eng M J $40: 431$ (1885)

85a Spodumene crystals of gigantic size. Am J Sc (3) 29:71 (1885)

$85 \mathrm{~b}$ New localities of erythrite. Am J Sc (3) $30: 163$ (1885)

85e Tin ore veins in the Black Hills of Dakota. Am I M Eng, Tr 13:691-696 (1885)

85d Tantalite and columbite in the Black Hills of Dakota. Am I M Eng, Tr 13: 696-697 (1885)

s5e Tin. U S G S, Min Res 1883-4: 592-640 (1885)

85P Antimony. U S G S, Min Res 18834: $641-153$ (1885)

86 Description of a meteorite from Green Co., Tenn. Am J Sc (3) 31: 41-46 (1886)

86a Iron ore deposits of southern Utah. Am I M Eng, Tr 14: 809-811 (1886)

87 The Rainbow lode, Butte City, Mont. Am I M Eng, Tr 16:65-80 (1887)

87a Wood River, Idaho, silver-lead mines. Eng M J 44:2-3 (1887)

89 The copper deposits of Copper Basin, Ariz., and their origin. Am I M Eng, Tr $17: 479-485$ (1889)

90 Wurtzilite [Uinta Mountains, Wasatch Co., Utah]. Eng M J 48:542-543 (1889) Am G 5:63-64 (1890)

90a Wurtzilite from the Uintah Mountains, Utah. Am I M Eng, Tr 18:497$503(1890)$

90b Uintaite, albertite, grahamite, and asphaltum described and compared, with observations on bitumen and its compounds. Am I M Eng, Tr 18:563-582 (1890)

90e Mineralogical notes. Am J Sc (3) $39: 43-45 \quad(1890)$

91 Columbite of the Black Hills, S. Dak. Am J Sc (3) 41:403-405 (1891)

92 Age of the limestone strata of Deep Creek, Utah, and the occurrence of gold in the crystalline portions of the formation. Am G 9:47-48 (1892) Eng M J 53:253 (1892)

92a Reletive abundance of gold in different geological formations. Am $\mathrm{G} 9$ : 166-168 (1892) Eng M J $53: 348-349$ (1892)
Blake, William Phipps-Continued.

93 Wisconsin lead and zine deposits (with discussion by J. F, Kemp and T, C Chamberlin). G Soc Am, B $5: 25-3$ ? (1893) Abst, Am J Sc (3) $46: 306$ (1893)

93a Association of apatite with beds of magnetite. Am I M Eng, Tr 21:159160 (1893)

93b The mineral deposits of southwest Wisconsin. Am I M Eng, Tr 22:558-568 (1894) Am G 12:237-248 (1893)

93e The progress of geological surren in the State of Wisconsin; a review and bibliography (abst). Wis Ac Sc, Tr 9:225231 (1893)

93d The persistence of ores in lodes in depth. Eng M J 55:3 (1893)

94 Trilobites in the "oil-rock" horizs of the Trenton limestones [Wisconsin]. Am G 14:133-134 (1894)

94a Alunogen and bauxite of New Mer. ico, with notes on the geology of the upper Gila region (abst). Am G 14:196 (184) Am I M Eng, Tr 24:571-573 (1895)

94b The gold of Cripple Creek [Colo.], Eng M J $57: 30$ (1894)

95 The zinc ore deposits of southwesten New Mexico. Am I M Eng, Tr 24:187195, map (1895) Abst, Eng M J 57:53! (1894)

95a Notes on the structure of the frank. linite and zinc ore beds of Sussex Co., N. J. Am I M Eng, Tr 24: 521-524 (1895)

95b Alunogen and bauxite of New Mer. ico. Am I M Eng, Tr 24:571-573 (1895)

96 Mines and mining [of Arizona]. Is Report of the Governor of Arizona to the Secretary of the Interior, 1896:32-4t Washington 1896

96a Cinnabar in Texas. Am I M Enc Tr 25:68-76 (1896)

96b Notes and recollections concernint the mineral resources of northern Georgis and western North Carolina. Am I M Ens Tr 25: 796-811 (1896)

96c Gypsum beds in southern Arizon: Am G 18:394 (1896)

97 Mines and mining [of Arizona]. Is Report of the Governor of Arizona to the Secretary of the Interior, $1897: 31-4$ ? Washington 1897

$\mathbf{9 7} \mathbf{a}$ Gold in granite and plutonic rocks Am I M Eng, Tr 26:290-298 (1897) Abst M Sc Press $73: 296$ (1896)

97b The Fortuna gold mine, Ariz. Et? M J $63: 664-665$ (1897)

98 Distribution of metallic wealth is Arizona, In Report of the Governor Arizona to the Secretary of the Interiot 1898: 19-86, Washington, 1898

98a Oscillations of level of the Pacif coast of the United States. Am G 21 164-165 (1898)

98b Anthracite coal in Arizona. Am 21: 345-346 (1898) 
Williams, George Huntington-Contd.

89a Some modern aspects of geology. Pop Sc Mo $35: 640-648$ (1889)

$89 \mathrm{~b}$ Contributions to the mineralogy of Maryland. Johns Hopkins Univ Circ 8: 99-100 (1889)

90 The greenstone schist areas of the Menominee and Marquette regions of Michigan; a contribution to the subject of dynamic metamorphism in eruptive rocks, with an introduction by $R$. D. Irving. U S G S, B 62:241 pp, maps (1890)

90a Elements of crystallography ... 250 pp, N Y 1890

90b Celestite from Mineral Co., W. Va. Am J Sc (3) $39: 183-188$ (1890) Zs Kryst 18: 1-6 (1890)

90c On the hornblende of St. Lawrence Co., N. Y., and its gliding planes. Am J Se (3) $39: 352-358 \quad(1890)$

9od Note on the eruptive origin of the Syracuse serpentine (with discussion by James Hall and J. F. Kemp). G Soc Am, B $1: 533-534(1890)$

90e Geological and petrographieal observations in southern and western Norway (abst, with discussion by J. S. Newberry and B. K. Emerson). G Soc Am, B 1: $551-553(1890)$

901 The nonfeldspathic intrusive rocks of Maryland and the course of their alteration. Am G 6: $35-49$ (1890)

$90 \mathrm{~g}$ [Origin of serpentine of Syracuse, [N. Y.] (abst). Am G 5: 118 (1890)

90h On a geological excursion in the northern Appalachian chain. Johns Hopkins Univ Circ 10:27-28 (1890)

91 Notes on the microscopical character of rocks from the Sudbury mining district, Canada. Can G S, An Rp 5: F $\quad 55-82$ (1891)

91a The silicified glass breccia of Vermilion River, Sudbury district [Ont.]. G Soc Am, B 2:138-140 (1891)

911. The petrography and structure of the Piedmont Plateau in Maryland (with discussion by W. M. Davis and others). G Soc Am, B 2 : 301-318 (1891)

91e Anatase from the Arvon slate quarries, Buckingham Co., Va. Am J Sc (3) $42: 431-432$ (1891)

91 d Anglesite, cerusite, and sulphur from the Mountain View lead mine, near Union Bridge, Carroll Co., Md. Johns Hopkins Univ Circ 10:73-75 (1891)

91e The geological excursion ... across the Appalachians in May, 1891. Johns Hopkins Univ Cire 11:25-27 (1891)

911 (with MeGee, W J, and others) The geology of Washington and vicinity. In Guide to Washington ... International Congress of Geologists, fifth session, Washington 1891: 38-64, map [1891]
Williams, George Huntington-Contd.

92 The volcanic rocks of South Mountain in Pennsylvanía and Maryland. Am J Sc (3) $44: 482-496$, map (1892) Abst, Am Nat 26: 1057-1058 (1892); Johns Hopkins Univ Cire 12: 45-47 (1893)

92a The geology of Baltimore and its vicinity; geology of the crystalline rocks. In Guide to Baltimore (Am. Iust. Min. Eng., Baltimore meeting): 77-124, map [Baltimore 1892]

92b Notes on some eruptive rocks from Alaska. Nat Geog Mag 4:63-74 (1892)

92e (and Clark, W. B.) Reports on short excursions made by the geological department of the University during the autumn of 1891. Johns Hopkins Univ Cire $11: 37-39$ (1892)

93 (and Clark, W. B.) Geology [of Maryland]. In Maryland, its resources, industries, and institutions, prepared for the Board of World's Fair [Chicago 1893] Managers... : 55-88, Baltimore 1893

93a Mines and minerals [of Maryland]. In Maryland, its resources, industries, and institutions, prepared for the Board of World's Fair [Chieago 1893] Managers... : 89-153, Baltimore, 1893

93b A new machine for cutting and grinding thin sections of rocks and minerals. Johns Hopkins Unív Cire 12:47 (1893) Am J Se (3) 45:102-104 (1893)

93e Piedmontite and scheelite from the aneient rhyolite of South Mountain, $\mathrm{Pa}$. Am J Sc (3) 46:50-57 (1893)

93d On the use of the terms poikilitic and micropoikilitic in petrography. J G 1: 176-179 (1893)

93e The microscope and the study of the crystalline schists. Science 21:1-2 (1893)

94 The distribution of ancient volcanic rocks along the eastern border of North America. J G 2:1-31, map (1894) Abst, Am G 13:212-213 (1894); Am J Sc (3) 47:140-141 (1894)

94a Johann David Schoepf and his contributions to North American geology. G Soc Am, B 5:591-593 (1894) Abst, Am G $13: 140$ (1894)

94b Sixth annual excursion of the geological department, May. 29-June 5, 1893 [Pennsylvania and Maryland]. Johns Hopkins Univ Circ 13:26-27 (1894)

95 General relations of the granitic rocks in the middle Atlantic Pledmont Plateau. U S G S, An Rp 15:657-684 (1895)

See also Campbell (H D), 91 ; Emmons (S F), 93; Frazer, 88a ; Hitcheock (C H), 90a ; Powell, 95 ; Pumpelly, 91

Willams, H. J.

96 Slate; its formation. extraction; and uses. Gen M As Que, J 2:92-100 [1896] 
Williams, H. J. Carnegie.

07 The Bruce Mines, Ontario, 18461906. Can M J 28 (n s 1 no 2 ) : 47-51 (1907)

Williams, Henry Shaler (1847-1918).

so Abstract of some paleontological studies of the life history of Spirifer laevis H. Am J Sc (3) $20: 456-459$ (1880)

Soa Paleontological researches [Devonian, Cayuga Lake, N. Y.] Science (ed, Michels) 1:190-191 (1880)

81 The life history of Spirifer laevis; a paleontological study. N Y Ac Sc, An 2: $140-160$, il (1881)

$81 a$ on the occurrence of Proetus longicaudus Hall [Madison, Greenwood Co., Kans.]. Am J Sc (3) 21:156 (1881)

811 Channel fillings in upper Devonian shales. Am J Sc (3) 21:318-320 (1881)

82 Catalogue of the fossils of the Chemung period of North America. 14 pp [Ithaca, N. Y., 1882]

82a New crinolds from the rocks of the Chemung period of New York State. Ac N Sc Phila, $\operatorname{Pr} 1882: 17-34$, il

82b The recurrence of faunas in the Devonian rocks of New York. Am As, Pr 30: 186-191 (1882)

82e Note on some fish remains from the upper Devonian rocks in New York State (abst). Am As, Pr $30: 192-193$ (1882)

83 On a remarkable fauna at the base of the Chemung group in New York. Am J Sc (3) $25: 97-104$ (1883)

$83 n$ Equivalency of the Lime Creek beds of Iowa. $\mathrm{Am} \mathrm{J} \mathrm{Sc} \mathrm{(3)} 25: 311$ (1883)

83h Comparative paleontology of the Devonian formation. Science 2: 836-837 (1883)

83e The undulations of the rock masses across central New York State (abst). Am As, Pr 31:412 (1883)

84 On the fossil faunas of the upper Devonian... U S G S, B $3: 36$ pp (1884)

84a The age of the sandrock at Austin, Mower Co. Minn G S, An Rp 12:9-11 (1884)

84b On a crinoid with movable spines [Arthroacantha ithacensis]. Am Ph Soc, Pr 21:81-88, il (1884)

s4e The spirifers of the upper Devonian. Science $3: 374-375$ (1884)

84d [On the Devonian in Genesee and Wyoming cos., N. Y.] Science 3:421 (1884)

84e Geographical and physical conditions as modifylng fossil faunas (abst). Am As, $\operatorname{Pr} 33: 422-423$ (1885) Science 4: 326-327 (1884)

85 Notice of a new limuloid crustacean from the Devonian. Am J Sc (3) 30:4549 , il (1885) G Mag (3) 2:427-429 (1885)

$28737^{\curvearrowleft}-23-71$
Williams, Henry Shaler-Continued.

86 On the classification of the Upper Devonian. Am As, $\mathrm{Pr} 34: 222-234$ (1886) Abst, Science 6:220-221 (1885)

86a Devonian Lamellibranchiata and species making. Am J Sc (3) 32: 192-198 (1886)

86b ...Cayuga Lake section of the Deronian (abst). Am J Sc (3) 32:321 (1886) Am As, Pr 35: 215 (1887)

87 On the fossil faunas of the upper Devonian; the Genesee section, N. Y. U S G S, B $41: 123 \mathrm{pp}$, il (1887)

$\mathbf{8 7 a}$ Methods of instruction in general geology. Am Nat 21:616-626 (1887)

$\mathbf{8 7 b}$ The Strophomenidae; a paleontological study of the method of initiation of genera and species (abst). Am As, Pr 35 : 227-228 (1887)

88 Report of the subcommittee on the upper Paleozoic (Devonic). In International Congress of Geologists, American Committee, Reports... C 31 pp, Phila 1888 Am G 2:225-247 (1888) Int G Cong, IV, London 1888, C R App A: 121-145 (1891)

88a International Geological Congress; Report of the subcommittee on the upper Paleozoic (Devonic). Am G 2:225-247 (1888)

ssb on the different types of the Devonian system in North America. Am $\mathbf{J}$ Sc (3) 35:51-59 (1888) Abst, Am As, Pr $36: 207-208$ (1888)

89 On the relation of the Devonian faunas of Iowa. Am G 3:230-233 (1889)

89a The use of fossils in determining the age of geologic terranes (abst). Am As, $\operatorname{Pr} 37: 206$ (1889)

90 The Cuboides zone and its fauna; a discussion of methods of correlation (with discussion by C. D. Walcott). G Soc Am, B 1:481-500 (1890) Abst, Am G 5:120 (1890) ; Am Nat 24: 290 (1890)

90a North American paleontolory for 1887 and 1888. Smiths Inst, An Rp 1888 : 261-326 (1890)

001 The Devonian system of North and South Devonshire [and comparison with the Devonian of the Appalachian basin]. Am J Sc (3) $39: 31-38$ (1890) Abst, Nature $40: 557$ (1889); Am As, Pr 38: 233-234 (1890)

90e The American committee of the International Congress of Geologists. Am $\mathrm{J}$ Sc (3) $40: 166-168$ (1890)

91 Correlation papers; Devonian and Carboniferous. U S G S, B $80: 279$ pp (1891)

91a What is the Carboniferous system? (abst). G Soc Am, B 2:16-19 (1891)

$91 \mathrm{~b}$ On the plates of Holonema rugosa (abst). Am As, Pr 39:337 (1891)

92 The scope of paleontology and its value to geologists. Am G 10:148-169 (1892) Am As, Pr 41: 149-170 (1892) 
Williams, Henry Shaler-Continued. 93 Geology as a part of a college curriculum. J G $1: 37-46$ (1893)

93a The making of the geological time scale. J G 1:180-197 (1893)

93b The elements of the geological time scale. J G 1:283-295 (1893)

93e On the ventral plates of the carapace of the genus Holonema of Newberry. Am J Sc (3) 46:285-288, 11 (1893)

93d [Correlation of clastic rocks; biotic conditions.] Int $\mathrm{G}$ Cong, $\mathrm{V}$, Washington, 1891, C R: 170-171 (1893)

93e On the brachial apparatus of hinged Brachiopoda and on their phylogeny. Rochester Ac Sc, Pr 2:113-118, il (1893)

94 Dual nomenclature in geological classification. J G $2: 145-160$ (1894) Abst, Am G 13:139-140 (1894); Am J Sc (3) $47: 143-145$ (1894)

$94 a$ The age of the white limestones near Warwick, Orange Co., N. Y. Am J Sc (3) $47: 401-402$ (1894)

$94 \mathbf{b}$ On the age of the manganese beds of the Batesville region of Arkansas. Am J Sc (3) $48: 325-331$ (1894)

95 Geological biology; an introduction to the geological history of organisms. $395 \mathrm{pp}, \mathrm{N}$ Y 1895

95a On the recurrence of Devonian fossils in strata of Carboniferous age. Am J Sc (3) 49:94-101 (1895) Abst, Science n s $1: 64$ (1895)

95b James Dwight Dana and his work as a geologist. J G $3: 601-621$ (1895)

96 On the origin of the Chouteau fauna. J G 4:283-290 (1896)

97 On the southern Devonian formations. Am J Sc (4) 3:393-403, map (1897) Abst, Science n s 5:92-93 (1897)

98 The classification of stratified rocks. J G $6: 671-678$ (1898)

99 On the occurrence of Paleotrochis in volcanic rocks in Mexico. Am J Sc (4) 7:335-336 (1899)

$99 a$ The Devonian interval in northern Arkansas. Am J Sc (4) $8: 139-152$ (1899) 00 The Paleozoic faunas of Maine. U S G S, B 165: 15-92, il (1900)

00a The Paleozoic faunas of north Arkansas. Ark G S, An Rp 1892, 5 : 268$362(1900)$

oob Silurian-Devonian boundary in North America. G Soc Am, B 11: 333-346 (1900) Am J Sc (4) $9: 203-213$ (1900) Abst, Science n s 11:104-105 (1900)

o0e [Catskill formation sedimentation].

G Soc Am, B 11:594-595 (1900)

o1 The discrimination of time values in geology. J G 9:570-585 (1901)

o1a The photography of fossils. Science n s 13:790 (1901)

01b Points involved in the Siluro-Devonian boundary question (abst). G Soc Am, B $12: 472-473$ (1901)
Willams, Henry Shaler-Continued.

02 Fossil faunas and their use in correlating geological formations. Am J Sc (4) 13: 417-432 (1902)

03 The correlation of geological faunas; a contribution to Devonlan paleontology.

U S G S, B 210:147 pp (1903)

03a Shifting of faunas as a problem of stratigraphic geology. G Soc Am, B 14: 177-190 (1903) Abst, Science n s $17: 218$, 296-297 (1903)

04 Fote on the Devonian fossils [of the Bisbee quadrangle, Ariz.]. U S G S, P P $21: 35-42$, il (1904)

04a Preliminary report on the classification of the rocks of the Watkins Glen $\left(30^{\circ}\right)$ quadrangle (U. S. Geological Survey). Science n s 19:234-236 (1904)

o5 (and Kindle, E. M.) Contributions to Devonian paleontology, 1903. U S G S, B 244: 144 pp (1905)

O5a Bearing of some new paleontologic facts on nomenclature and classification of sedimentary formations. G Soc Am, B 16 : $137-150$ (1905)

06 The Devonian section of Ithaca, N. Y. J G $14: 579-598$ (1906) ; 15:93-112 (1907) Abst, Science n s 24:365-367 (1906); Am As, Pr 56-57:265-267 (1907)

07 A new brachiopod, Rensselaeria mainensis, from the Devonian of Maine. U S Nat Mus, Pr $32: 267-269$, il (1907)

08 The Dalmanellas of the Chemung formation, and a closely related new brachiopod genus Thiemella. U S Nat Mus, Pr $34: 35-64$, il (1908)

08a On the revision of the mollusk genus Pterinea, Goldfuss. U S Nat Mus, Pr 34: 83-90 (1908)

09 (and Tarr, R. S., and Kindle, E. M.) Description of the Watkins GlenCatatonk district, N Y. U S G S, G Atlas Watkins Glen-Catatonk fol (no 169) : $33 \mathrm{pp,}$ maps (1909)

10 On the fossil faunas of the St, Helen's breceias. R Soc Can, Pr Tr (3) 3 iv : $205-247$, il (1910)

10a Age of the Gaspe sandstone. G Soc Am, B 20:688-698 (1910) Abst, Science n s 29:635 (1909)

10b Migration and shifting of Devonian faunas. G Soc Am, B $21: 285-294$ (1910) Pop Sc Mo $77: 70-77$ (1910)

10e Persistence of fluctuating variations as illustrated by the fossil genus Rhipidomella. G Soc Am, B $21: 295-312$ (1910) Abst, Science $32: 223$ (1910)

12 Some new Mollusca from the Silurian formations of Washington Co., Me. U S Nat Mus, Pr 42: 381-398, il (1912)

12a Ralph Stockman Tarr. Am J Sc (4) $33: 515-516 \quad(1912)$

$12 b$ Correlation of the Paleozoic faunas of the Eastport quadrangle, Me. G Soc Am, B $23: 349-356$ (1912) 
Williams, Henry Shaler-Continued.

13 Recurrent Tropidoleptus zones of the upper Devonian in New York. U S G S, P P 79: $103 \mathrm{pp}$, il (1913)

$13 a$ New species of Silurian fossils from the Edmunds and Pembroke formations of Washington Co., Me. U S Nat Mus, Pr 45:319-352, il (1913)

13b Correlation problems suggested by a study of the faunas of the Eastport quadrangle, Me. G Soc Am, B 24:377398 (1913)

14 (with Bastin, E. S.) Description of the Eastport quadrangle, Me. U S G S, G Atlas fol 192 (1914)

16 (assisted by Breger, C. L.) The fauna of the Chapman sandstone of Maine, including descriptions of some related species from the Moose River sandstone. U S G S, P P 89:347 pp, il, map (1916) Abst, Wash Ac Sc, J 6:564 (1916)

$16 n$ New brachlopods of the genus Spirifer from the Silurian of Maine. U S Nat Mus, Pr 51:73-80, il (1916)

17 Nuculites from the Silurian formations of Washington Co., Me. U S Nat Mus, Pr 54:27-58, il (1917)

See also Gilbert, 93b ; Willis, 01e

Wiuiams, Herbert.

65 Copper mining in Canada East. Lit Hist Soc Quebec, Tr n s 3:37-50 (1865)

Williams, Herbert Upham.

86 Notes on the fossil fishes of the Genesee and Portage black shales. Bufralo Soc N Sc, B 5:81-84, il (1886)

86a (with Mixer, F. K.) Fish remains from the Carboniferous near Buffao [N. Y.]. Buffalo Soc N Sc, B 5:84 (1886)

Williams, Ira Abraham.

00 Geelogy of Worth Co. Iowa G S 10 : 317-377, maps (1900)

04 (with Beyer, S. W.) Technology of clays. Iowa G S 14: 29-318 (1904)

O4a (with Beyer, S. W.) The geology of clays. Iowa G S 14:377-554 (1904)

o5 Geology of Jasper Co. Iowa G S 15 : 277-367, maps (1905)

O5a The comparative accuracy of the methods for determining the percentages of the several components of an igneous rock. Am G 35: 34-46 (1905)

06 Geology of Franklin Co. Iowa G S $16: 453-507$, maps (1906)

07 (with Beyer, S. W.) The materials and manufacture of Portland cement. Iowa G S $17: 29-89$ (1907)

14 The occurrence of coal in Squaw Creek Basin, Coos Co., Oreg. Oreg Bur Mines, Min Res 1 no $1: 28-48$, map (1914)

14n Limestone deposits in Oregon. Oreg Bur Mines, Mín Res 1 no $7: 52-70$ (1914)

15 Oregon Bureau of Mines and Geology (abst). G Soc Am, B 26:137-138 (1915)
Williams, Ira Abraham-Continued.

16 Some little-known scenic pleasure places in the Cascade Range in Oregon. Oreg Bur Mines, Min Res Oreg 2 no 1: 114 pp, map (1916)

16a The Columbia River gorge; its geologic history interpreted from the Columbia River highway. Oreg Bur Mines, Min Res Oreg, 2 no $3: 130$ pp (1916)

16b Geology of the Clarno dam site. [Oreg, State Engineer], Oreg Cooperative Work, John Day Project: $82-88$, Portland 1916

16e Glaciers of the Three Sisters [Oreg.]. Mazama 5:14-23 (1916)

18 Nitrate deposits of southeastern Oregon. M Sc Press 117:285-289 (1918)

Williams, J. C.

18 Chromite. Colo Sch Mines Mag 8: $157-159$ (1918)

Williams, J. Lawton.

91 On cycles of sedimentation. Am G $8: 315-324$ (1891)

Williams, John.

87 The mining district of San Jose, Mexico. Eng M J 44: 447 (1887)

Williams, John Francis (1862-1891).

90 Eudialite and eucolite, from Magnet Cove, Ark. Am J Sc (3) $40: 457-462$ (1890)

90a Manganopektolith, ein neues Pektolithăhnliches Mineral von Magnet Cove, Ark. Zs Kryst 18:386-389 (1890)

91. The igneous rocks of Arkansas. Ark G S, An Rp 1890, 2:1-391, 429-457, maps, Little Rock 1891

$91 a$ (with Brackett, R. N.) Newtonite and rectorite-two new minerals of the kaolinite group. Am I Sc (3) 42 : 11-21 (1891) In part, Ark G S, An Rp 1892, 5: 256-261 (1900)

91b (with Kemp, J. F.) Tabulation of the dikes of igneous rocks of Arkansas. Ark G S, An Rp 1890, 2:407-427 (1891)

Williams, John H.

10 The mountain that was "God," being a little book about the great peak which the Indians named "Tacoma" but which is officially called "Rainier." $111 \mathrm{pp}$, Tacoma 1910 [priv pub]

11 Tungsten deposits in San Bernardino Co., Cal. M Sc Press 103: 545 (1911)

14 Yosemite and its high Sierra. 147 pp, Tacoma 1914

Williams, Merton Yarwood.

11 Arisaig-Antigonish district, N. S, Can G S, Sum Rp 1910: 238-247 (1911)

12 Geology of Arisaig-Antigonish district, N. S. Am J Sc (4) $34: 242-250$, (1912)

13 The Hamilton formation at Thedford and vicinity [Ont.]. Int $G$ Cong, XII, Canada, Guide Book no 4:101-110, map (1913) 
Williams, Merton Yarwood-Continued.

13a The Silurian of the eastern part of Manitoulin Island. Int $\mathrm{G}$ Cong, XII, Canada, Guide Book no 5:89-98, map (1913)

13b Revision of the Silurian of southwestern Ontario. Ottawa Nat $27: 37-38$ (1913)

14 Arisaig-Antigonish district, N. S. Can G S, Mem 60:173 pp, maps (1914)

14a The Silurian of Manitoulin Island and western Ontario. Can G S, Sum Rp $1912: 275-281$ (1914)

14b Thedford and vicinity, Ont. Can G S, Sum Rp 1912 : 282-285 (1914)

14e Stratigraphy of the Niagara escarpment of southwestern Ontario. Can G S, Sum Rp 1913: 178-188 (1914)

$14 d$ Sections illustrating the lower part of the Silurian system of southwestern Ontario (abst). G Soc Am, B 25:40-41 (1914)

15 The Ordovician rocks of Lake Timiskaming [Que.]. Can G S, Mus B 17:9 pp (1915)

15a An eurypterid horizon in the Niagara formation of Ontario. Can G S, Mus B 20:21 pp, il (1915)

15b The middle and upper Silurian of southwestern Ontario. Can G $\mathbf{S}$, Sum Rp $1914: \$ 2-86$ (1915)

16 Formations adjacent to the Niagara escarpment of southwestern Ontario. Can G S, Sum Rp 1915 : 139-142 (1916)

16 a Guelph formation of Ontario (abst). G Soc Am, B $27: 148-149$ (1916)

17 Investigations in Ontario. Can $G \mathrm{~S}$, Sum Rp 1916: 186-188 (1917)

17a The Rockwood anticline [Ont.]. Can M J 38: 290 (1917)

18 The late Dr. C. W. Drysdale. Can M Inst, B $69: 66-69$, port (1918)

$18 \mathrm{a}$ The geologist and the development of our oil fields. Can M. Inst, B 74:528538 (1918); $\operatorname{Tr} 21: 259-268$ [1919]

18b Oil prospecting in southwestern ontario. Can M J 39: 48-49 (1918)

See also Chadwick, 17b, c; Grabau, $17 \mathrm{~d}$ Williams, Moses B.

41 (with Whitney, J. D.) Report on the section from Portsmouth to Claremont through Concord. In Jackson, C. T., First annual report on the geology of New Hampshire: $45-51$ (1841)

41 a (with Whitney, J. D.) Geology and topography of the northern corner of the State... In Jackson C. T., First annual report on the geology of New Hampshire: 83-93 (1841)

Williams, Samuel.

85 Observations and conjectures on the earthquakes of New England. Am Ac Arts, Mem 1: 260-311 (1785)

Williams, Samuel Gardner.

76 Notes on the geology of some localities near Canon City, Fremont Co., Colo. U S G Geog S Terr (Hayden), B [1] no 5 (2) : 249-251 (1876)
Williams, Samuel Gardner-Continued.

83 Dip of the rocks in central New York. Am J Sc (3) $26: 303-305$ (1883)

85 Geological relations of the gypsum deposits in Cayuga Co., N. Y. Am J Sc (3) $30: 212-218$ (1885) Abst, Science 4:325 (1894) ; Am As, Pr $33: 402$ (1885)

86 Applied geology ; a treatise on the industrial relations of geological structure, and on the nature, occurrence, and uses of substances derived from geological sources. 386 pp. N Y 1886

86a The westward extension of rocks of Lower Helderberg age in New York. Am J Se (3) 31: 139-145 (1886) Abst, Am As, Pr 34:235-236 (1886); Science 6:221 (1885)

87 Note on the Lower Helderberg rocks of Cayuga Lake [N. Y.]. N Y St C, An Rp $6: 10-12$ (1887) Abst, Am As, Pr 35: 214-215 (1887)

87a The Tully limestone, its distribution and its known fossils. N Y St G, An Rp 6:13-29, map (1887) Abst, Am As, Pr 35: 213-214 (1887) ; Am J Sc (3) 32: 320 (1886)

\section{Williams, Stephen R.}

10 Some principles of zoology as illustrated by the fossil remains of southwestern Ohio. Miami B, Oxford, Ohio (8) no $7: 20 \mathrm{pp}$, il $(1910)$

14 A starfish found in the Whitewater division of the Richmond on Blue Creek, Adams Co., Ohio. Ohio Nat 14:221-224, il (1914)

18 Concerning the structure of Agela. crinites and streptaster, Edrioasteroidea of the Richmond and Maysville divisions of the Ordovician. Ohio J Sc 19:59-86, il (1918)

\section{Williams, $T$.}

96 (and others) George Huntington Williams...1856-1894. $150 \mathrm{pp}$, port [N I] 1896

Williamson, C. G.

69 On the rolcanic phenomena of Hawaif. G Soc London, Q J 25:432-434 (1869)

\section{Williamson, E. D.}

16 (with Johnston, J.) The role of inorganic agencies in the deposition of calcium earbonate. J G 24:729-750 (1916)

16a (with Johnston, J., and Merwin, H. E.) The several forms of calcium carbonate. Am J Sc (4) 41:473-512 (1916)

\section{Williamson, R. S.}

55 Report of a reconnaissance and survey in California in connection with explorations for a practicable rallway route from the Mississippi River to the Pacific Ocean in 1853 . $\mathrm{C} S$, Pacific $R$ Expl (U S, 33d Cong 1st sess, H Ex Doc 129) : 61 pp (1855); also (U S, 33d Cong 1st sess, $\mathrm{S}$ Ex Doc 78 and $\mathrm{H}$ Ex Doc 91) 5 pt 1:43 pp (1856)

\section{Williamson, W. C.}

83 The vegetation of the Carboniferous age. Science $2: 529-538$ (1883) 
Willig, H. L.

18 Limonite pseudomorphous after pyrite from Lancaster Co., Pa. Am Mineralogist $3: 2$ (1918)

Willimott, Charles William.

83 Notes on some of the mines in the Province of Ontario. Can G S, Rp Prog 1880-2: g 14 pp (1883)

85 Report of observations in 1883 , on some mines and minerals in Ontario, Quebec, and Nova Scotia. Can G S, Rp Prog 1882-4: L 28 pp (1885)

s5a Minerals of the Ottawa district. Ottawa Field Nat Club, Tr no $6: 189-210$ (1885)

91 Canadiun gems and precious stones. Ottawa Nat $5: 117-142$ (1891)

04 Notes on molybdenite. Can G S, B on molybdenum and tungsten (Johnston, R. A. A.) : 15-16 (1904)

o5 Minerals of the Ottawa Valley. Can G S, Sum Rp 1904 (An Rp 16) : $\triangle 229$ $232(1905)$

06 The mineral pigments of Canada. Can G S : 29 pp (1906)

Willis, Bailey.

84 Mount Tacoma in Washington Terri tory. Newport N H Soc, Pr $2: 13-21$ (1884)

85 The lignites of the Great Sioux Reservation; a report on the region between the Grand and Moreau rivers, Dakota. U S G S, B 21: 16 pp (1885)

86 Report on certain magnetites in eastern Pennsylvania. U S, 10 th Census 15 : $223-234$ (1886)

86a Notes on the samples of iron ore collected in Ohlo; ... North Carolina ; ... east Tennessee ; ... Georgia ; ... Alabama. U S, 10th Census 15:235-243, 301-329; 331$350 ; 367-378,400-401$, maps (1886)

86b Notes on the samples of the manganese ore collected in Georgia. U S, 10th Census $15: 379-382$ (1886)

86e Report of a trip on the upper Mississippi and to Vermilion Lake, Minnesota. U S, 10th Census 15:457-467, map (1886)

86d Report on the coal fields of Washington Territory. U S, 10th Census 15: 759-771, maps (1886)

87 Changes in river courses in Washington Territory due to glaciation. U S G S, B $40: 10 \mathrm{pp}$, maps (1887)

87a Topography and structure in the Bays Mountain, Tenn. Sch Mines Q 8: 242-252 (1887)

88 The marble of Hawkins Co., Tenn. Sch Mines Q 9: 112-123 (1888)

88 Notes on the geology of the Cascade Range. Science 11:122 (1888)

88b Mount Rainier and its glaciers (abst). Ph Soc Wash, B 10:10 (1888)

89 Round about Asheville [N. C.] Nat Geog Mag 1: 291-300, map (1889)

91 Graphic field notes for areal geology. G Soc Am B 2:177-188 (1891) Sch Mines Q $12: 319-333$ (1891)
Willis, Bailey-Continued.

91a (with MeGee, W $J$, and others) The geology of Washington and vicinity. In Guide to Washington... International Congress of Geologists, flfth session, Washington 1891: 38-64, map [1891]

92 Outlines of Appalachian history. U S G S, G Atlas, Kingston, Chattanooga, and Ringgold sheets, prel ed 1892

92a Determination of fault hades (abst). Ph Soc Wash, B 11:500-501 (1892)

92b The mechanism of the overthrust fault (abst). Ph Soc Wash, B 11:529 (1892)

93 Conditions of sedimentary deposition.

J G 1:476-520 (1893)

93a (and Hayes, C. W.) Conditions of Appalachian faulting. Am J Sc (3) $46: 257-268$ (1893)

93b The mechanics of Appalachian structure. U S G S, An Rp 13 pt 2:211281, maps (1893) (In part, with title, Studies in structural geology) Am I M Eng, Tr 21:551-566 (1893); Abst, J G 1:96-97 (1893); Eng M J 54:390-391 (1892)

94 Relations of synclines of deposition to ancient shore lines( abst). Am G 13 : 140-141 (1894)

95 The northern Appalachians: Nat Geog Soc, Nat Geog Mon 1 no $6: 169-202$, map (1895) Also in The physiography of the United States (Nat Geog Soc) : 169202, N Y, American Book Co., 1896

95a The development of the Geologic Atlas of the United States. Am Geog Soc, B $27: 337-351$ (1895)

96 The geology of the Cascade Mountains. Johns Hopkins Univ Circ 15:90 (1896)

$96 \mathbf{a}$ Fvidences of ancient shores (abst). Science n \& $3: 534$ (1896) Am G 17: 265-266 (1896)

97 Stratigraphy and structure of the Puget group, Wash. G Soc Am, B 9:2-6 (1897) Abst, Am G 20:194 (1897) ; Science n s 6:691 (1897)

$97 \boldsymbol{a}$ Glaciation in the Puget Sound region [Wash.] (abst). Am G 19:144-145 (1897) Science n s 5:238-239 (1897)

97b Preliminary note on the Pleistocene history of Puget Sound (abst). J G 5 : 99-100 (1897)

98 Some coal fields of Puget Sound. U S G S, An Rp 18 pt $3: 393-436$, maps (1898)

98a Drift phenomena of Puget Sound. G Soc Am, B 9:111-162, maps (1898)

98b Drift phenomena of Puget Sound and their interpretation (abst). Brit As, Rp 67:653 (1898)

99 (and Smith, G. O.) Deseription of the Tacoma quadrangle [Wash.]. U S G S, G Atlas Tacoma fol (no 54): $10 \mathrm{pp}$, maps (1899)

99a Work of the U. S. Geological Survey. Science n s 10:203-213 (1899) 
Willis, Bailey-Continued.

oo Paleozoic Appalachia or the history of Maryland during Paleozoic time. Md G S $4: 23-93$, maps (1902; advance separate 1900 )

OOa Some coast migrations, Santa Lucia Range, Cal. G Soc Am, B 11: 417-432, map (1900) Abst, Science n s 11:99, 221 (1900)

OOb Work of the U. S. Geological Survey, 1899-1900. Science n s 12:241-246 (1900)

ooe Notes on Lake Chelan and vicinity (abst). Science n s 11:884 (1900)

o1 Individuals of stratigraphic classification. J G 9:557-569 (1901)

O1a Oil of the northern Rocky Mountains. Eng M J 72: 782-784 (1901)

01b Thomas Benton Brooks. Science n s 13: 460-462 (1901)

o1c (and others) Discussion of geologic units-formation, stage, and age (abst). Science n \& 13:585 (1901)

o1d (with Smith, G. O.) The Clealum iron ores, Wash. Am I M Eng, Tr 30: $356-366$, map (1901)

02 Stratigraphy and structure, Lewis and Livingston ranges, Mont. G Soc Am, B $13: 305-352$, map (1902) Abst, Science n s $15: 86-87$ (1902)

02a Conditions of overthrust in the northern Rockies (abst). Science n s 15 : 507 (1902)

O2b Mountain growths of the Great Plains (abst). Science n s 16: 1028-1029 (1902)

03 Physiography and deformation of the Wenatchee-Chelan district, Cascade Range [Wash.]. U S G S, P P 19:41-97, maps (1903)

O3a Ames Knob, North Haven, Me. G Soc Am, B 14:201-206 (1903) Abst, Am G 31:159 (1903); Science n s 17: 294 (1903) ; J G 11: 104-105 (1903)

03b Post-Tertiary deformation of the Cascade Range (abst). Science n s 17: 740 (1903)

04 Ueberschiebungen in den Vereinigten Staaten von Nordamerika. Int $\mathrm{G}$ Cong, IX, Vienna 1903, C R : 529-540 (1904)

o5 Mountain growth and mountain structure $(a b 8 t)$. Am G $35: 52-53$ (1905) Science n s 21:219 (1905) Sc Am Sup $59: 24326$ (1905)

06 Geologic research in continental histories. Carnegie Inst Wash, Y Bk 4:204214 (1906)

06a Carte géologique de l'Amérique du Nord, 1906. Scale 1:5,000,000. Prepared for the Congrès géologique international, $\mathrm{X}^{\mathrm{e}}$ session, Mexico, 1906

o6b Carte géologique de l'Amérique du Nord; Geological map of North America. 12 pp. Mexico, 1906 [Descriptive text accompanying the map (06a above); reprinted in French (see 07)
Willis, Bailey-Continued.

07 Carte géologique de l'Amérique du Nord. Int G Cong, X, Mexico, C R : 211225 (1907)

07a Geographic history of Potomac River. U S G S, W-S I P 192: 7-22 (1907)

07b How should faults be named and classified? Ec G 2: 295-298 (1907)

ore A theory of continental structure applied to North America. G Soc Am, B 18: 389-412 (1907)

o7d Thrusts and recumbent folds, a suggestion bearing on Alpine structure. Science n s 25:1010-1011 (1907)

o7e The Appalachian revolution (abst). Science n s 25:867 (1907)

ozf Current theories of slaty cleavage (abst). Science n s 25:968 (1907)

os Memoir of Israel C. Russell. G Soc Am, B 18: 582-592, port (1908)

osa The American Association for the Advancement of Science, Hanover meeting, Section E, July 1-3, 1908. Science n s 28: 381-384 (1908)

osb Lines of inference in paleogeographic studies (abst). Science n s $28: 934$ (1908)

09 Paleogeographic maps of North America. J G $17: 203-208,253-256,286-288$, $342-343,403-405,406-407,408-409,424-$ $425,426-428$, 503-505, 506-508, 600-602, paleogeographic maps (1909)

o9a [Report on symposium on correlation] Science n s 29:748-750 (1909)

10 Principles of paleogeography. Science n s $31: 241-260$ (1910)

10a (and Salisbury, R. D.) Outlines of geologic history with especial reference to North America. A series of essays involving a discussion of geologic correlation presented before section $\mathrm{E}$ of the American Association for the Advancement of Science in Baltimore, December, 1908. Symposium organized by Bailey Willis; compilation edited by Rollin D. Salisbury. $306 \mathrm{pp}$, University of Chicago Press 1910

11 What is terra firma? A review of current research in isostasy. Smiths Inst, An Rp 1910:391-406 (1911)

11a The influence of marine currents on deposition in continental seas (abst). Science $n$ s $33: 313-314$ (1911)

12 Index to the stratigraphy of North America. U S G S, P P 71:894 pp, map (1912) Abst, Wash Ac Sc, J 3:118-119 (1913)

See also Hayes (C W), 91; Merrill (F J H), 02 ; Powell, 90, 91, 91a, 92, 93, 95 ; Russell, 87 ; Sallsbury, 98b ; Vaughan, $15 \mathrm{c}$

Willis, C. E.

94 The asbestos fields of Port au Port, Newfoundland (with discussion). M Soc N S, J 2: 166-173 (1894)

98 A peculiar lode formation [contorted strata, Gold River district, Nova Scotia]. Can M Rv 17:138-140 (1898) M Soc N S, J $4: 22-26$ (1899) 
Willis, Charles Francls.

15 Directory of Arizona minerals. Ariz St Bur Mines, B 3:16 pp (1915)

15a Arizona [mineral resources, etc.]. Ariz St Bur Mines, B 6:16 pp (1915)

16 Mineralogy of useful minerals in Arizona. Ariz, Univ, Bur Mines, B 41: 70 pp (1916)

16a Tungsten mining in Arizona. M Sc Press 112:824-825 (1916)

Williston, Samuel Wendell (1852-1918). 78 American Jurassic dinosaurs. Kans Ac Sc, Tr 6: 42-46 (1878, reprint 1906)

79 Are birds derived from dinosaurs? Kansas City Rv Se 3: 457-460 (1879)

90 On the structure of the Kansas chalk. Kans Ac Sc, Tr 12:100 (1890)

90a A new plesiosaur from the Niobrara Cretaceous of Kansas [Cimoliosaurus 8nowii]. Kans Ac Sc, Tr 12:174-178, il (1890)

$90 \mathrm{~b}$ Note on the pelvis of Cumnoria (Camptosaurus). Am Nat $24 ; 472-473$ (1890)

90e Chalk from the Niobrara Cretaceous of Kansas. Science $16: 249$ (1890)

90d Structure of the plesiosaurian skull. Science $16: 262,290$ (1890)

91 The skuIl and hind extremity of Pteranodon. Am Nat 25: 1124-1126 (1891)

91 a Kansas mosasaurs. Science 18: 345 (1891)

92 Kansas pterodactyls. Kans Univ Q 1: 1-13, il (1892) ; $2: 79-81$, il (1893)

92a (and Case, E. C.) Kansas mosasaurs. Kans Univ Q $1: 15-32$, il (1892) ; $2: 83-84$, il (1893)

92b Volcanic dust in Kansas and Indian Territory. Am G 10:396 (1892)

93 The Niobrara Cretaceous of western Kansas. Kans Ac Sc, Tr 13:107-111 (1893)

93a An interesting food habit of the plesiosaurs. Kans Ac Sc, Tr $13: 121-122$, il (1893)

94 Restoration of Aceratherium fossiger Cope. Kans Univ Q 2:289-290, il (1894)

$\mathbf{9 4 a}$ On various vertebrate remains from the lowermost Cretaceous of Kansas. Kans Univ Q 3:1-4, il (1894)

94b A new turtle from the Benton Cretaceous [Desmatochelys lowi]. Kans Univ Q 3:5-18, il (1894)

94e Notes on Uintacrinus socialis Grinnell. Kans Univ Q 3:19-20 (1894)

94d Restoration of Platygonus. Kans

Univ Q 3:23-39, il (1894)

94e A new dicotyline mammal from the Kansas Pliocene. Science 23: 164 (1894)

95 New or little known extinct vertebrates. Kans Univ Q 3:165-176, II (1895)

95a "Semi-arid Kansas." Kans Univ Q 3:209-216, map (1895)

95b Note on the mandible of Ornithostoma. Kans Univ Q 4:61, Il (1895)
Williston, Samuel Wendell-Continued. 96 On the skull of Ornithostoma. Kans Univ Q 4:195-197, il (1896)

$96 a$ On the dermal covering of Hesperornis. Kans Univ Q 5:53-54, il (1896)

97 The Kansas Niobrara Cretaceous. Kans Univ G S 2:235-246 (1897)

$\mathbf{9 7 a}$ The Pleistocene of Kansas. Kans Univ G S $2: 299-308$, il (1897)

97b Restoration of Ornithostoma (Pteranodon $)$. Kans Univ Q 6:35-51, il (1897)

$97 \mathbf{e}$ Notice of some vertebrate remains from the Kansas Permian. Kans Univ $Q$ $6: 53-56$, il (1897)

$97 d$ A new plesiosaur from the Kansas Comanche Cretaceous. Kans Univ Q 6: 57 (1897)

97 e Brachysaurus, a new genus of mosasaurs. Kans Univ Q 6:95-99, il (1897) $9 \boldsymbol{7 f}$ On the extremities of Tylosaurus. Kans Univ Q 6:99-102, il (1897)

$97 \mathbf{g}$ Restoration of Kansas mosasaurs. Kans Univ Q 6:107-110, il (1897)

97h Range and distribution of the mosasaurs, with remarks on synonymy. Kans Univ Q 6:177-185, il (1897)

97i A new labyrinthodont from the Kansas Carboniferous. Kans Univ Q 6: 209-210, il (1897)

97j Vertebrates from the Kansas Permian. Science n s 5:395 (1897)

9s Paleontology [of Kansas]; Part I, Upper Cretaceous. Kans Univ G S 4:594 pp, il, Topeka 1898

9Sa The sacrum of Morosaurus. Kans Univ Q 7: 173-175, il (1898)

98b [On Platecarpus from Elkader, Kans.] Kans Univ Q 7:235 (1898)

98e The Pleistocene of Kansas, Kans Ac Sc, $\operatorname{Tr} 15: 90-94$ (1898)

9sd Notice of some vertebrate remains from the Kansas Permian. Kans Ac Sc, Tr 15:120-122 (1898)

98e Saber-toothed eats. Pop Se Mo 53: $348-351$, il (1898)

98f Miocene edentates. Science $n$ s 8 : 132 (1898)

99 Some additional characters of the mosasaurs. Kans Untv $Q$ 8:39-41, il (1899)

99a A new genus of fishes from the Niobrara Cretaceous. Kans Univ Q 8: $113-115$, il (1899)

99b A new species of Sagenodus from the Kansas Coal Measures. Kans Univ Q 8:175-181, il (1899)

99e Notes on the coraco-scapula of Eryops Cope. Kans Unlv Q 8:185-186, il (1899)

99d Prof. Benjamin F. Mudge. Am G $23: 339-345$, port. (1899)

99e The geology of Kansas. In Hellprin, Angelo, The earth and its history ... 269-288, map, Boston 1899

99f The red beds of Kansas. Science n $89: 221$ (1899) 
Williston, Samuel Wendell-Continued.

oo Cretaceous fishes; selachians and pycnodonts; Dercetidae. Kans Univ G S 6 : 235-256; 380-382, il (1900)

ooa Some fish teeth from the Kansas Cretaceous. Kans Univ Q $9: 27-42$, il (1900) Kans Univ G S $6: 237-254$, il (1900)

01 A new turtle from the Kansas Cretaceous [Porthochelys laticeps]. Kans Ac Sc, $\operatorname{Tr} 17: 195-199$, il (1901)

$01 a$ The dinosaurian genus Creosaurus, Marsh. Am J Sc (4) 11:111-114 (1901) 02 Restoration of Dolichorhynchops osborni, a new Cretaceous plesiosaur. Kans Univ, Sc B 1: 241-244, il (1902)

$02 a$ Notes on some new or little-known extinct reptiles. Kans Univ, Sc B 1 : 247254, il (1902)

02b On certain homoplastic characters in acquatic air-breathing vertebrates. Kans Univ, Se B 1:259-266 (1902)

02e On the hind limb of Protostega. Am J Sc (4) $13: 276-278$, il (1902)

02d On the skull of Nyctodactylus, an Upper Cretaceous pterodactyl. J G 520531, il (1902)

02e An arrow head found with bones of Bison occidentalis Lucas, in western Kansas. Am G $30: 313-315$ (1902)

o2f On the skeleton of Nyctodactylus with restoration. Am $J$ Anatomy 1 : 297305, il (1902)

02g Winged reptiles. Pop Sc Mo 60 : 314-322, il (1902)

02h A fossil man from Kansas. Science n s $16: 195-196$ (1902)

021 The Laramie Cretaceous of Wyoming. Science n s 16:952-953 (1902)

03 North American plesiosaurs, part 1 . Field Col Mus, Pub g s $2: 1-77$, il (1903)

03a On the osteology of Nyctosaurus (Nyctodactylus), with notes on American pterosaurs. Field Col Mus, Pub g s 2 : 125-163, il (1903)

03b The fossil man of Lansing, Kans. Pop Sc Mo $62: 463-473$ (1903)

03e On the structure of the plesiosaurian skull. Science n s $17: 980$ (1903)

o3d Some osteological terms. Science n s $18: 829-830$ (1903)

04 The relationships and habits of the mosasaurs. J G $12: 43-51$ (1904)

04a Notice of some new reptiles from the upper Trias of Wyoming. J G 12 : 688-697, il (1904)

04b Wilbur Clinton Knight. Am G 33 : 1-6, port. (1904)

04e The fingers of pterodactyls. G Mag (5) $1: 59-60(1904)$

04d The stomach stones of the plesiosaurs. Science n \& 20:565 (1904)

05 The Hallopus, Baptanodon, and $A t$ lantosaurus beds of Marsh. J G 13 : 338350 (1905)
Williston, Samuel Wendell-Continued.

05a On the Lansing man. Int Cong Americanists, 13th, N Y, 1902, Pr : 85-89 (1905) Am G 35: 42-346 (1905)

05b [New locality for Triassic vertebrates near Lander, Wyo. (abst).] Seience n s $21: 297-298$ (1905)

ose A new armored dinosaur from the upper Cretaceous of Wyoming (Stegopelta landerensis). Sclence n s 22:503-504 (1905)

06 American amphiccelian crocodiles, J G $14: 1-17$, il (1906)

O6a North American plesiosaurs; Elasmosaurus, Cimoliasaurus, and Polycotylus. Am J Sc (4) $21: 221-236$, il (1906)

07 The skull of Brachauchenitus, with observations on the relationships of the plesiosaurs, U S Nat Mus, Pr 32:477-489, il (1907)

os The Cotylosauria. J G $16: 139-148$, il (1908)

o8a "The oldest known reptile." Iso. dectes punctulatus Cope. J G $16: 395-400$ 11 (1908)

08b North American plesiosaurs, Trinacromerum. J G 16:715-836, il (1908)

ose Lysorophus, a Permian urodele. Biol B $15: 229-240$, il (1908)

08d The evolution and distribution of the plesiosaurs (abst). Science n s 27: $726-727$ (1908)

ose A new group of Permian amphibians. Science n s $28: 316-317$ (1908)

osf Review of The fossil turtles of North America, by O. P. Hay. Science n s 28 : 803-804 (1908)

09 The skull and extremities of Diplocaulus. Kans Ae $\mathrm{Sc}, \operatorname{Tr} 22: 122-131$, il (1909)

09a The faunal relations of the early vertebrates. J G $17: 389-402$ (1909)

$09 b$ New or little-known Permian vertebrates; Trematops, new gen. J G 17 : 636-658, il (1909)

09e Discussion of paper by R. S. Lull, Dinosaur societies (abst). Science n $\mathbf{s}$ $29: 194$ (1909)

10 Cacops, Desmospondylus; new genera of Permian vertebrates. G Soc Am, B 21: 249-284, il (1910)

10a Dissorophus Cope. J G 18:526536 , il (1910)

$10 \mathrm{~b}$ A mounted skeleton of Platecarpus. J G 18:537-541, 11 (1910)

10e New Permian reptiles; rhachitomous vertebræ. J G $18: 585-600$, il (1910)

10d The birthplace of man. Pop Sc Mo $77: 594-597$ (1910)

10e Varanosaurus species, a Permian pelycosaur (abst). Science n s $32: 223$ (1910)

11 American Permian vertebrates. 145 pp, il, Chicago 1911 
Williston, Samuel Wendell-Continued.

11 a Permian reptiles. Science n s 33 : 631-632 (1911)

$11 b$ A new family of reptiles from the Permian of New Mexico. Am J Sc (4) 31 : 378-398 (1911)

11e Restoration of Seymouria baylorensis Broili, an American cotylosaur. J G $19: 232-237$, il (1911)

11d The wing finger of pterodactyls, with restoration of Nyctosaurus. J G 19: $696: 705$, il (1911)

12 'Ten years' progress in vertebrate paleontology; evolutionary evidences. G Soc Am, B 23: 257-262 (1912)

$12 a$ Restoration of Limnoscelis, a cotylosaur reptile from New Mexico. Am J Sc (4) $34: 457-468$ (1912)

12b Primitive reptiles. J Morphology 23 : $637-666$ (1912)

12e (and Case, E. C.) The PermoCarboniferous of northern New Mexico. J G 20:1-12, maps (1912)

12d (with Case, E. C.) A description of the skulls of Diadectes lentus and Aninasaurus carinatus. Am J Sc (4) 33 : 339-348 (1912)

13 Ostodolepis brevispinatus, a new reptile from the Permian of Texas. J G 21 : 363-366, il (1913)

13a The primitive structure of the mandible in amphibians and reptiles. J G 21 : 625-627, il (1913)

13b The skulls of Araoscelis and Casea, Permian reptiles. J G $21: 743-747$, il (1913)

13e The pelycosaurian mandible. Science n $8 \quad 38: 512$ (1913)

$13 d$ An ancestral lizard from the Permian of Texas. Science n s $38: 825-826$ (1913)

13e (and Moodie, R. L.) New plesiosaurian genus from the Niobrara Cretaceous of Nebraska (abst). G Soc Am, B $24: 120-121$ (1913)

14 Water reptiles of the past and present. vii, 251 pp, 11, Chicago 1914

14a Restorations of some American Permocarboniferous amphibians and reptiles. J G 22:57-70, il (1914)

$14 b$ Broiliellus, a new genus of amphibians from the Permian of Texas. I G 22:49-56, il (1914) Chicago Univ, Walker Mus, Contr 1: 107-162, il (1914)

14e The osteology of some American Permian vertebrates. J $\mathrm{G} \quad 22: 364-419$, 11 (1914)

14d The American land vertebrate fauna and its relations $(a b s t)$. Science $\mathrm{n} s 40$ : 777-778 (1914)

15 Trimerorhachis, a Permian temnospondyl amphibian. J G $23: 246-255$, il (1915)

15a A new genus and species of American Theromorpha, Mycterosaurus longiceps. J G 23:554-559, il (1915)
Williston, Samuel Wendell-Continued.

$15 \mathrm{~b}$ New genera of Permian reptiles. Am J Sc (4) $39: 575-579$. il (1915)

16 The osteology of some American Permian vertebrates, II. Chicago Univ, Walker Mus, Contr 1:165-192, il (1916)

$16 a$ Synopsis of the American Permocarboniferous Tetrapoda, Chicago Univ, Walker Mus, Contr 1: 193-236, il (1916)

16b The skeleton of Trimerorhachis. J G 24:291-297, il (1916)

16e Sphenacodon Marsh, a Permocarboniferous theromorph reptile from New Mexico. Nat Ac Se, $\operatorname{Pr} 2: 650-654$, il (1916)

16d Origin of the sternum in the reptiles and mammals $(a b s t)$. G Soc Am, B $27: 152$ (1916)

17 Labidosaurus Cope, a lower Permian cotylosaur reptile from Texas. J G 25: $309-321$, il (1917)

17a The phylogeny and classification of reptiles. J G 25:411-421, il (1917)

17b (and Moodie, R. L.) Ogmodirus martinii, a new plesiosaur from the Cretaceous of Kansas. Kans Univ Se B 10: 61-73, il (1917)

18 The evolution of vertebrae. [Chicago, Univ], Walker Mus, Contr 2:75-85, il (1918) Abst, G Soc Am, B 29: 146 (1918)

$18 \mathrm{a}$ The osteology of some American Permian vertebrates, III. [Chicago, Univ], Walker Mus, Contr 2:87-112, il (1918)

See also Gregory (W K), 17; Heilprin, 96 ; Osborn, 05i ; Salisbury, 98b

Willmott, Arthur Brown (1866-1914).

97 The mineral wealth of Canada; a giude for students of economic geology. 201 pp, Toronto 1897

98 Michipicoten mining division. Ont Bur Mines, Rp 7:184-206, map (1898)

98a Notes on the Michipicoten gold field [Ont.]. Fed Can M Inst, J 3:100102 (1898) Can M Rv $17: 73-74$ (1898)

99 (with Coleman, A. P.) Michipicoten iron range. Ont Bur Mines, Rp 8: $254-$ 258 (1899)

o1 The Michipicoten Huronian area [Ont.]. Am G 28:14-19, map (1901)

02 The nomenclature of the Lake Superior formations. J G 10:67-76 (1902)

02a (with Coleman, A. P.) The Michipicoten iron region. Ont Bur Mines, Rp 1902:152-185, map (1902)

02b (with Coleman, A. P.) The Michipicoten fron ranges [Ont.]. Toronto, Univ, Studies, $g$ s no $2: 47$ pp, maps (1902)

04 The exploration of the Ontario iron ranges. Can M Inst, J $7: 257-269$ (1905) Can M Rv $23: 154-156$ (1904)

04a The contact of the Archean and post-Archean in the region of the Great lakes. J G 12:40-42, map (1904) 
Blake, William Phipps-Continued.

98e Remains of a species of $B o s$ in the Quaternary of Arizona. Am G 22: 65-72 (1898)

98d Bison latifrons and Bos arizonica. Am G 22: 247-248 (1898)

98e Native sodium carbonate [Sonora, Mex.]. Eng M J 65: 188 (1898)

9se Wolframite in Arizona. Eng M J $65: 608$ (1898)

99 Historical sketch of mining in Arizona. In Report of the Governor of Arizona to the Secretary of the Interior, 1899 : 43-153, Washington 1899

99a The Pliocene skull of California and flint implements of Table Mountain. J G 7:631-637 (1899)

99b Hübnerite in Arizona. Am I M Fing, $\operatorname{Tr} 28: 543-546$ (1899)

99e The occurrence and production of wolframite in Arizona. Mineral Industry 7: 720-722 (1899)

00 Glacial erosion and the origin of the Yosemite Valley [Cal.]. Am I M Eng, Tr 29:823-835 (1900)

00a Remains of the mammoth in Arizona. Am G $26: 257$ (1900)

01 Notes on the mining industry. In Beport of the Governor of Arizona to the Secretary of the Interior, 1901: 99-112, Washington 1901.

01a Some salient features in the geology of Arizona with evidences of shallow seas in Paleozoic time. Am G 27 : 130 (abst), 160-167 (1901) Abst, G Soc Am, B 12:493 (1901); J G $9: 68-69$ (1901)

01b The caliche of southern Arizona ; an example of deposition by the vadose circulation. Am I M Eng, Tr 31:220226 (1902) Eng M J 72:601-602 (1901) M Sc Press $82: 294$ (1901)

01e Sketch of mineral wealth of the region adjacent to the Santa Cruz Valley, Ariz. 22 pp, 1901 [not seen]

02 [Mining in Arizona in 1902.]. In Report of the Governor of Arizona to the Secretary of the Interior, 1902: 51-54, Washington 1902

02a The geology of the Galiuro Mountains, Ariz., and of the gold-bearing ledge known as Gold Mountain. Eng M J 73 : 546-547 (1902)

02b Notes on the mines and minerals of Guanajuato, Mex. Am I M Eng, Tr $32: 216-223$ (1902)

02e Lake Quiburis, an ancient Pliocene lake in Arizona. Ariz, Univ, Mo 4:107108 (1902) Abst, Science n s 15: 413414 (1902)

02d Tombstone and its mines; a report upon the past and present condition of the mines of Tombstone, Cochise Co., Ariz., to the Development Company of America. 83 pp, N Y 1902
Blake, William Phipps-Continued.

03 Geology of Arizona. In Report of the Governor of Arizona to the Secretary of the Interior, 1903:126-135, Washington 1903

03a Arizona diatomite. Wis Ac Sc, Tr $14: 107-111$, il (1903)

03b Diatom earth in Arizona. Am I M Eng, Tr 33: 38-45 (1903)

03e Origin of pebble-covered plains in desert regions. Eng M J 75:632 (1903) Am I M Eng 34:161-162 (1904)

04. Geology of Arizona. In Report of the Governor of Arizona to the Secretary of the Interior, 1904:66-72, Washington 1904

04a Tombstone [Ariz.] and its mines. Am I M Eng, Tr 34: 668-670 (1904)

04b Copper ore and garnet in association. Am I M Eng, Tr 34: 886-890 (1904) M Sc Press 89:72-73 (1904) M World $21: 175$ (1904)

04c Evidences of plication in the rocks of Cananea, Sonora [Mex.] Am I M Eng, $\operatorname{Tr} 35: 551-552$ (1905) M Rep 50:586587 (1904) Eng M J 78: 904 (1904)

04d Gypsum deposits in Arizona. U S G S, B 223: 100-101 (1904)

o5 Notes on the year's progress in mining. In Report of the Governor of Arizona to the Secretary of the Interior, 1905:3542, Washington 1905

o5a Superficial blackening and discoloration of rocks especially in desert regions (with discussion by T. B. Comstock). Am I M Eng, T'r $35: 371-375,1014-1017$ (1905)

05b Origin of orbicular and concretionary structure. Am I M Eng, Bi-Mo B 4: $677-682$ (1905) ; Tr $36: 39-44$ (1906)

05e Iodobromite in Arizona. Am J Sc (4) $19: 230$ (1905)

06 Origin of the depression known as Montezuma's Well, Ariz. Science n 8 24: 568 (1906)

07 The flanking detrital slopes of the mountains of the Southwest. Science $n \mathbf{s}$ 25: $975-978,294$ (abst) (1907)

os Destruction of the salt works in the Colorado Desert by the Salton Sea. Am I M Eng, B 19:81-82 (1908)

08a Tourmaline of Crown Point, N. Y. Am J Sc (4) 25:123-124 (1908)

osb Note upon the structure of the Santa Catalina gneiss, Ariz. Science $\mathbf{n} \mathbf{s}$ 28: 379-380, 382 (abst) (1908)

ose Geological sketch of the region of Tucson, Ariz. In MacDougal, D. T., Botanical features of North American deserts (Publ no 99 of the Carnegie Institution of Washington) : 45-68, map (1908)

09 Minerals of Arizona; their occurrence and association, with notes on their composition. A report to the Governer of Arizona. $64 \mathrm{pp}$, Tucson 1909

$$
28737^{\circ}-23-8
$$


Willmott, Arthur Brown-Continued.

07 Michipicoten Island [Ont.]. Can M J 28 (n s 1 no 13) : 398-400 (1907)

07a The origin of deposits of pyrites. Can M J 28 (n s 1 no 16) : 500-503 (1907)

os The iron ores of Ontario. Can M Inst, J 11: 106-124 (1908) Can M J 29: $77-84,308-309$ (1908)

11 The undeveloped iron resources of Canada. Can M Inst, Q B 14:121-143 (1911); J 14:236-258 (1912) Abst, Can M J $32: 519-524$ (1911)

Wills, J. Lainson.

92 On natural phosphates. Ottawa Nat $6: 7-22 \quad$ (1892)

Wilson, Alfred William Gunning.

01 Physical geology of central Ontario. Can Inst, Tr $7: 139-186$ (1901)

01a The Medford dike area [Boston Basin, Mass.] Boston Soc N H, Pr 30 : 353-374, map (1901)

02 The country west of Nipigon Lake and River [Ont.]. Can G S, Sum Rp 1901 (An Rp 14) : A 96-105 (1902)

02a Some recent folds in the Lorraine shales. Can Rec Sc 8:525-531 (1902)

o3 A geological reconnaissance about the headwaters of the Albany River [Ont.]. Can G S, Sum Rp 1902 (An Rp 15): A 203-208 (1903)

03a The Laurentian peneplain. J G $11: 615-669$ (1903)

03b The theory of the formation of sedimentary deposits. Can Rec Sc 9:112132 (1903)

04 Trent River system and Saint Lawrence outlet. G Soc Am, B $15: 211-242$, maps (1904) Abst, Science n s $19: 528$ 529 (1904)

04a Cuspate forelands along the Bay of Quinte [Lake Ontario]. J G 12:106-132, map (1904)

o5 Physiography of the $\Delta$ rchean areas of Canada. Int Geog Cong, VIII, Rp:116135 (1905)

05a A forty-mile section of Pleistocene deposits north of Lake Ontario. Can Inst, Tr 8:11-21 (1905)

06 James Bay exploration, 1905 ; report of the geologist. Temiskaming and Northern Ontario Rallway Commission, 4th An Rp : 57-65, Toronto 1906

$06 a$ On the glaciation of Orford and Sutton mountains, Que. Am J Sc (4) 21 : 196-205 (1906)

os Shore-line studies on Lakes Ontario and Erie. G Soc Am, B 19:471-500 (1908) Abst, Science n s 27:411 (1908)

09 Trap sheets of the Lake Nipigon basin [Ont.]. G Soc Am, B 20:197-222 (1909) Abst, Science n s $29: 635-636$ (1909)

09a The region in the vicinity of Lake Nipigon, Thunder Bay district, Ont. Can G S, Sum Rp 1908: 95-96 (1909)
Wilson, Alfred William Gunning-Contd. 09b Report on a traverse through the southern part of the Northwest Territories from Lac Seul to Cat Lake in 1902. Can G S : 25 pp (1909)

10 Geology of the Nipigon basin, Ont. Can G S, Mem 1: 152 pp, map (1910)

10a The Department of Mines of Canada, its organization and its work. Ec G $5: 640-651$ (1910)

11 On the copper mining industry in Ontario, 1910. Can Mines Br, Sum Rp 1910: 67-75 (1911)

12 Pyrites in Canada, its occurrence, exploitation, dressing and uses. Can Mines Br : 202 pp, map (1912)

12a Copper and pyrites. Can Mines $\mathrm{Br}$, Sum Rp 1911: 90-94 (1912)

13 Report on mineral deposits in the vicinity of St. Mary Bay, Nova Scotia, Can Mines Br, Sum Rp 1912: 81-83 (1913)

See also Lane, 12 ; Miller (W G), 12

Wilson, Alice E.

13 A new brachiopod from the base of the Utica [Oxopleoia calhouni]. Can G S, Victoria Mem Mus, B 1:81-84, il (1913)

14 A preliminary study of the variations of the plieations of Parastrophia hemipli. cata, Hall. Can G S, Mus B 2:131-139, il (1914)

15 A new Ordovician pelecypod from the Ottawa district [Rhytimya granulosa]. Ottawa Nat 29:85-86, il (1915)

16 (and Mather, K. F.) Synopsis of the commion fossils of the Kingston area [Ont.]. Ont Bur Mines, An Rp 25 pt 3 : 45-62 (1916)

wilson, Andrew Gordon.

95 The Upper Silurian in northeastern Iowa. Am G 16:275-281 (1895) Abst, Am As, $\operatorname{Pr} 44: 137$ (1896); Science n s $2: 401$ (1895)

96 Frozen streams of the Iowa drift border. Am G 17:364-371 (1896)

wilson, B. C.

94 Notes on some special features in lode formation and deposition of gold as presented in the Waverley gold district, Halifax Co., N. S. (with discussion). Min Soc N S, J 2: 32-46 (1894)

wilson, Daniel.

77 Supposed evidence of the existence of interglacial American man. Can $\mathrm{J}$ n s 15 : $557-573$ (1877)

wilson, E. H.

82 Report upon the results of borings ... [in the lower Mississippi Valley]. U S, 47th Cong 1st sess, S Ex Doc 10:139-239 (1882)

17 A visit to the zeolite locality at North Table Mountain, Colo. Am Mineralogist $2: 29-30 \cdot(1917)$ 
Wirson, Eduardo M.

17 Petróleo crudo como combustible. Bol Petroleo 4: 104-181 (1917) Also separate $80 \mathrm{pp}$

Wilson, Eugene Benjamin.

92 Faulting in veins. Eng M J $53: 638$ (1892)

04 The theory of ore deposits. Mines and Minerals $24: 386-387,527-529$ (1904)

o6 Cape Nome placers. Eng M J 82 : 680-681 (1906)

os Geological nomenclature [dip, pitch, and hade]. M Science $57: 460-461$ (1908)

09 Boron. Mines and Minerals $30: 168$ 170 (1909)

10 Iron ores of Santiago, Cuba. Mines and Minerals $31: 245-249$ (1910)

11 The Cornwall, Pa., magnetite deposits.

L. Sup Mb Inst, Pr $16: 227-238$ (1911)

$11 a$ Some notes on pyrite and marcasite. Can M Inst, Q B 14:173-178 (1911); J $14: 310-315$ (1912)

12 Formation of magmas. Mines and Minerals $33: 115$ (1912)

wilson, F. L.

11 The Seneca mining district, Cal. M Sc Press 103: 682-683 (1911)

Wilson, Floyd B.

92 The phosphate industry of Florida. Eng Mag 4:80-94 (1892)

Wilson, G. B.

os Geology of the Honarine mine, Stockton, Utah. Eng M J $85: 869-870$ (1908)

Wilson, Guy West.

06 A travertine deposit in Tippecanoe Co., Ind. Ind Ac Sc, $\mathrm{Pr}$ 1905: 183-184 (1906)

Wi1son, Herbert M. (1860-1920).

97 Topography of Mexico. Am Geog Soc, B $29: 249-260$ (1897)

99 Water resources of Puerto Rico. U S G S, V.S P 32:48 pp, maps (1899)

oo A dictionary of topographic forms. Am Geog Soc, B 32:32-41 (1900)

00a Porto Rico; its topography and aspects. Am Geog Soc, B 32 : 220-238 (1900)

01 Topographic forms of the United States. Am Geog Soc, B 33:301-304 (1901)

Wilson, Herrick East.

16 Evolution of the basal plates in monocyclic Crinoidea Camerata. I G 24:488$508,533-553,665-684$, il (1916)

Wilson, J. F.

10 Earthquakes and volcanoes, hot springs. Supplementary edition, including the theory of gravitation. $173 \mathrm{pp}$, [Knoxville? Tenn. 1910 Priv pub]

wilson, J. W.

98 Geology of Efingham Ridge [Atchison Co., Kans.]. Kans Ac Sc, Tr 15:113-114 (1898)

Wilson, James $\mathrm{S}$.

54 On the gold regions of California. G Soc London, Q J 10:308-321, map (1854)
Wilson, John D.

o1 The fauna of the goniatite limestone. Science n s 13:825 (1901)

03 Fauna of the agoniatite limestone of Onondaga Co., N. Y. Onondaga Ac Sc, $\mathrm{Pr}$ $1: 84-88$, il (1903)

Wilson, John Howard.

05 The Pleistocene formations of Sankaty Head, Nantucket. J G 13: 713-734, il (1905) Abst, Science n s 21:989-990 (1905)

06 The glacial history of Nantucket and Cape Cod; with an argument for a fourth center of glacial dispersion in North America. 90 pp, N Y 1906 Abst, G Soc Am, B 17:710-711 (1907); N Y Ac Sc, An 17: 624-625 (1907); Science $n$ s $23: 389$ (1906)

O6a Deposit of Venus shells in New York City. Science n s 23: 821-822 (1906)

07 The Pleistocene beds of Sankaty Head, Nantucket $(a b s t)$. N Y Ac Sc, An $17: 594-595$ (1907)

os Was there a Newfoundland ice sheet? (abst). N Y Ac Sc, An 18:277 (1908)

14 A glacially formed lake in Susquehanna Co., Pa. Am Geog Soc, B 46:659661, map (1914)

Wilson, Joseph D.

83 Observations on fluviatile deposits in Peoria Lake, Ill. Chicago Ac Sc, B 1:1329 (1883)

Wilson, L. M.

16 Petroleum and natural gas; a short treatise on their early history, origin, distribution, accumulation, and surface indications; relating more especially to the Gulf Coast country. $64 \mathrm{pp}$, Houston, Texas, 1916

\section{wilson, M. Estelle.}

o7 Shore topography near Davenport, Santa Cruz Co. [Cal.]. Cal Phys Geog Club, B 1, no 2: 11-17 (1907)

wilson, Malcolm Earl.

18 Oil and gas possibilities in the Belton area. Mo Bur G Mines: 39 pp, maps (1918)

See also Grout, $18 b$

Wilson, Morley Evans.

os An area from Lake Timiskaming eastward [Quebec]. Can G S, Sum Rp 1907: 59-63 (1908)

09 Lake Opasatika and the Height of Land. Can G S, Sum Rp 1908: 121-123 (1909)

10 Larder Lake and eastward. Ontario. Can G S, Sum Rp 1909:173-179 (1910)

10a Geology of an area adjoining the east side of Lake Timiskaming, Quebec. Can G S : 46 pp (1910)

11 Northwestern Quebec adjacent to the interprovincial boundary and the National Transcontinental Rallway. Can G S, Sum Rp 1910:203-207 (1911) 
Wilson, Morley Evans-Continued.

12 Geology and economic resources of the Larder Lake district, Ont., and adjoining portions of Pontiac Co., Que. Can G S, Mem 17:62 pp, maps (1912)

12a Kewagama Lake map area, Pontiac and Abitibi, Que. Can G S, Sum Rp 1911: 273-279 (1912)

13 The Cobalt series; its character and origin. J G 21:121-141 (1913)

13a The significance of recent developments in the pre-Cambrian stratigraphy of the Lake Superior-Lake Huron region. J G 21:385-398 (1913)

13b The banded gneisses of the Laurentian highlands of Canada. Am J Sc (4) 36 : 109-122 (1913)

13e Kewagama Lake map area, Que. Can G S, Mem 39: 134 pp, map (1913)

14 A geological reconnaissance from Lake Kipawa via Grand Lake Victoria to Kanikawinika Island, Bell River, Que. Can G S, Sum Rp 1912:315-336, map (1914)

$14 a$ Southeastern portion of Buckingham map area, Que. Can G S, Sum Rp 1913: 196-207 (1914)

15 Northern portion of Buckingham map area, Que. Can G S, Sum Rp 1914:94 (1915)

16 Southwestern portion of the Buckingham map area, Que. Can G S, Sum Rp $1915: 156-162$ (1916)

17 Magnesite deposits of Grenville district, Argenteuil Co., Que. Can G S, Mem $98: 88$ pp, maps, (1917)

17a Grenville district, Argenteuil Co.; Part of Amberst township, Labelle Co., Que. Can G S, Sum Rp 1916: 208-219, maps (1917)

17b The mineral deposits of the Buckingham map area, Que. Can M Inst, Tr 19:349-370 [1917]

17c The magnesite deposits of the Grenville district, Que. Am Ceramic Soc, Tr. 19:254-259 (1917)

18 Timiskaming Co., Que. Can G S, Mem 103: $197 \mathrm{pp}$, map (1918)

18a The subprovincial limitations of preCambrian nomenclature in the St. Lawrence basin. J G 26:325-333 (1918) $A b s t$, with discassion by A. P. Coleman and W. J Miller. G Soc Am, B 29:90-92 (1918)

$18 \mathrm{~b}$ Molybdenite deposits of Quyon district, Que. Can M J 39:78-80 (1918)

Wilson, Philip D.

14 A cavern in the Shattuck mine [Bisbee, Ariz.] Eng M J $97: 743-744$ (1914) Wilson, Roy Arthur.

15 (with Rowe, J. P.) Bull Mountain coal field, Mont. Colliery Eng 36 no 1 : 7-11; no $2: 74-79$ (1915)

16 (with Rowe, J. P.) Geology and economic deposits of a portion of eastern Montanar Mont Univ Studies, Ser no 1: 58 pp, map (1916)
Wilson, Thomas.

92 Man and the Mylodon; their possible contemporaneous existence in the Missis sippi Valley. Am Nat 26:628-631 (1892) wilson, W. B.

16 The origin of clay slips. Ec G 11: 381-389 (1916)

Wilson, William James (1851-1920).

98 Notes on the Pleistocene geology of a few places in the Ottawa Valley. Ottawa Nat 11: 209-220 (1898)

02 Western part of the Abitibi region [Nipissing district, Ont.]. Can G S, Sum Rp 1901 (An Rp 14): A 117-130, map (1902)

o3 Reconnaissance surveys of four riv ers southwest of James Bay [Ont.]. Can G S, Sum Rp 1902 (An Rp 15): A 222241, map (1903)

04 The Nagagami River and other branches of the Kenogami [Ont.]. Can G S, Sum Rp 1903 (An Rp 15) : A 109-120, map (1904)

05 The Little Current and Drowning rivers, branches of the Albany, east of Lake Nipigon [Ont.]. Can G S, Sum Rp 1904 (An Rp 16) : A 164-173 (1905)

06 [Report on] the region between Lake Temagami and Spanish River. Can G S, Sum Rp 1905: 82-84 (1906)

06a On explorations along the proposed line of the Transcontinental Rallway from Lake Abitibi eastward. Can G S, Sum Rp 1906: 119-123 (1906)

O6b (with Ami, H. M.) Report of the geological branch of the Ottawa FieldNaturalists' Club for 1905-6. Ottawa Nat $19: 209-214$ (1906)

os Report on the district along the $\mathrm{Na}$ tional Transcontinental Railway from Bell River eastward [Que.] Can G S, Sum Rp $1907: 64-66$ (1908)

09 Geological reconnaissance of a portion of Algoma and Thunder Bay districts, Ont. Can G S : 49 pp, map (1909)

09a Summary report dealing with the field work in connexion with the collection of paleontological material from the Devonian and lower Carboniferous of New Brunswick. Can G S, Sum Rp 1908:183185 (1909)

10 Geological reconnaissance along the line of the National Transcontinental Railway in western Quebec. Can G S, Mem 4:56 pp, map (1910)

10a Paleontological material from the Devonian and Carboniferous of southern New Brunswick. Can G S, Sum Rp 1909 ; 274-276 (1910)

11 Paleontological work in southern New Brunswick. Can G S, Sum Rp 1910: 275-276 (1911)

12 [Report of the] Paleontological division; paleobotany. Can G S, Sum Rp 1911 : 358-359 (1912) 
Wilson, William James-Continued.

13 A new genus of dicotyledonous plant from the Tertiary of Kettle River, B. C. Can G S, Victoria Memorial Mus, B 1:8788, il (1913)

$13 a$ A new species of Lepidostrobus. Can G S, Victoria Memorial Mus, B 1: 89-92, il (1913)

14 Paleobotany [report on]. Can G S, Sum Rp $1912: 407-410$ (1914) ; $1913: 322-$ 326 (1914) ; 1914:130-134 (1915) ; 1915 : 205-209 (1916); $1916: 300-302$ (1917)

18 Notes on some fossil plants from New Brunswick. Can G S, Sum Rp 1917 pt F : 15-17 (1918)

See also Miller (W G), 12

wiltsee, Ernest.

93 Notes on the geology of the HalfMoon mine, Pioche, Nev. (with discussion). Am I M Eng, Tr 21: $867-871$ (1893)

\section{wiman, Carl.}

16 Notes on the marine Triassic reptile fauna of Spitzbergen. Cal Univ, Dp G, B $10: 63-73$, il (1916)

Winchell, Alexander (1824-1891).

56 On the geology of the Choctaw Bluff [Greene Co., Ala.]. Am As, Pr $7: 150-153$ (1856)

57 Notes on the geology of middle and southern Alabama. Am As, Pr 10 pt 2: $82-93(1957)$

$\mathbf{5 7 a}$ Statistics of some artesian wells of Alabama. Am As, Pr 10 pt 2:94-103 (1857)

58 Synoptical view of the geological succession of organic types. $7 \mathrm{pp}$, Ann Arbor 1858 [not seen] $2 d$ ed, 10 pp, Ann Arbor 1867

59 Scenes and incidents of the coal period. Mich J Educ 6:13-20 (1859)

61 First biennial report of the progress of the geological survey of Michigan ... Lower Peninsula. 339 pp, Lansing 1861

62 Notice of the rocks lying between the Carboniferous limestone of the Lower Peninsula of Michigan and the limestones of the Hamilton group; with descriptions of some cephalopods supposed to be new to science. Am J Sc (2) $33: 352-366$ (1862)

62n on the saliferous rocks and salt springs of Michigan. Am J Sc (2) 34 : 307-311 (1862)

62b Descriptions of fossils from the Marshall and Huron groups of Michigan. Ac N Sc Phila, Pr 1862:405-430

63 On the identification of the Catskill red sandstone group with the Chemung. $\mathrm{Am} \mathrm{J} \mathrm{Sc} \mathrm{(2)} 35: 61-62$ (1863)

$63 n$ Descriptions of fossils from the yellow sandstones lying beneath the "Burlington limestone" at Burlington, Iowa. Ac N Se Phila, Pr 1863:2-25

636 Description of elephantine molars in the museum of the University [of Michigan]. Can Nat $8: 399-400$ (1863)
Winchell, Alexander-Continued.

64 Notice of a small collection of fossils from the Potsdam sandstone of Wisconsin and the Lake Superior sandstone of Michigan. Am J Sc (2) 37:226-232 (1864)

$64 a$ Notice of the remains of a mastodon recently discovered in Michigan. Am J Sc (2) $38: 223-224$ (1864)

$64 \mathrm{~b}$ On the origin of the prairies of the valley of the Mississippi. Am J Sc (2) $38: 332-344,444-445$ (1864)

64c Report, historical and statistical, on the collections in geology, zoology, and botany in the museum of the University of Michigan ... (incl. a report on the White collection). $26 \mathrm{pp}$, Ann Arbor 1864

64d Map of the State of Michigan, colored to show the geological formations. 15 by 18 inches [n p, n d, 1864?] Notice. N Jb 1868: 99-101

65 On the oil formation in Michigan and elsewhere. Am J Sc (2) 39:350-353 (1865)

65a Some indications of a northward transportation of drift materials in the Lower Peninsula of Michigan. Am J Sc (2) $40: 331-338$ (1865)

$65 \mathrm{~b}$ Descriptions of new species of fossils, from the Marshall group, and its supposed equivalent, in other States ... Ac N Sc Phila, Pr 1865: 109-133

65e The soils and subsolls of Michigan.. $30 \mathrm{pp}$, Lansing 1865

66 The Grand Traverse region; a report on the geological and industrial resources of the counties of Antrim, Grand Traverse, Benzie, and Leelanaw in the Lower Peninsula of Michigan. $97 \mathrm{pp}$, map, Ann Arbor 1866

66a (and Marey, O.) Enumeration of fossils collected in the Niagara limestone at Chicago, Ill., with descriptions of several new species. Boston Soc N H, Mem 1: 81114, il (1866)

66b Note on the geology of petroleum in Canada West. Am J Sc (2) 41:176-178 (1866)

67 Stromatoporidae; their structure and zoological affinities. Am As, $\operatorname{Pr} 15: 91-99$ (1867)

67a Address on public geological surveys, and the geological survey of Kentucky, in particular... 21 pp, Erankfort, Ky., 1867

68 On the geological age and equivalents of the Marshall group (abst). Am Nat 2: 445 (1868)

69 Outline of a proposed final report of a survey of the State of Michigan... $8 \mathrm{pp}$. Ann Arbor 1869

69a On the geological age and equivalents of the Marshall group. Am Ph Soc, Pr 11:57-82 (1869) ; 385-418 (1870)

69b Table of geological equivalents. In Safford, J. M., Geology of Tennessee : 364365, Nashville 1869 
Winche11, Alexander-Continued.

69c Notes on fossils from Tennessee collected from strata immediately overlying the black shale. In Safford, J. M., Geology of Tennessee: 440-446, Nashville 1869

69d Ths old age of continents. Western Monthly $1: 210-215$ (1869)

69e A grasp of geologic time. Western Monthly 1:369-374 (1869)

70 Sketches of creation... 459 pp, N Y 1870

70a Syllabus of a course of lectures on geology to be delivered in the University of Michigan, in the months of February and March, 1870, $18 \mathrm{pp}, \mathrm{Ann}$ Arbor 1870

70b Schedules of instructions for observers and collaborators [on the Michigan State geological survey]. $7 \mathrm{pp}$ [1870]

70e A geological chart; exhibiting the classification and relative positions of the rocks... $4 \mathrm{ft} \times 7 \mathrm{ft}$. Key, 18 pp. N Y, 1870 [not seen]

70d Notes on some post-Tertiary phenomena in Michigan (abst). Am Nat 4: 504-505 (1870)

71 Report on the progress of the State geological survey of Michigan... 64 pp, Lansing 1871

71a Geology of Berrien Co., [Mich.]. In Cowles, Ed. B., Berrien County directory and history : 21-26, Buchanan, Mich., 1871

$\mathbf{7 1 b}$ Notices and descriptions of fossils, from the Marshall group of the Western States... Am Ph Soc, Pr 11:245-260 (1871)

71e [On a boulder in a coal bed in Ohio.] Am Nat 5:606 (1871)

72 Report of a geological survey of the vicinity of Belleplaine, Scott Co., Minn. $16 \mathrm{pp}$, St Paul 1872

73 The diagonal system in the physical features of Michigan. Am J Sc (3) 6: 36-40 (1873)

73a Michigan; being condensed popular sketches of the topography, climate, and geology of the state. (Extracted from Walling's Atlas of Michigan.) 121 pp, maps, [Claremont, N. H.] 1873

73b The geology of the stars. In Halfhour recreations in popular science (Dana Estes, ed), no $7: 255-286$, Boston [1873]

74 The doctrine of evolution... $148 \mathrm{pp}$, N Y 1874

75 Syllabus of a course of lectures on geology to be delivered in the Syracuse University during the winter term of 1874-5. $32 \mathrm{pp}$, Syracuse 1875

$75 a$ Supposed agency of ice floes in the Champlain period. Am J Sc (3) $11: 225-$ 228 (1876) Sc Mo, Toledo, O, 1:14-17 (1875)

76 Rectification of the geological map of Michigan. Am As, Pr 24 pt 2:27-43 (1876)

78 Adamites and pre-Adamites. $52 \mathrm{pp}$, Syracuse, N. Y., 1878.
Winchell, Alexander-Continued.

78a Mastodon and mammoth. Reprinted by H. A. Ward from articles in New York Tribune, $10 \mathrm{pp}, 1878$ [not seen]

79 Syllabus of courses of lectures and instruction in general geology with references to sources of information, $115 \mathrm{pp}$, Ann Arbor 1879

79a The sanitary geology of Nashville [Tenn]... Nashville, Bd Health, Rp 3: 135-150, Nashville, Tenn., 1879

so Pre-Adamites... xxvi, $500 \mathrm{pp}$, Chicago 1880 5th ed, xxvi, 526 pp. Chicago 1890

81 Sparks from a geologist's hammer. $400 \mathrm{pp}$, Chicago 1881

81a Geology of Washtenaw Co., ich. In History of Washtenaw County : 141-172, Chicago 1881

83 World-life, or comparative geology. xxiv, 642 pp, Chicago 1883

S3a Secular increase of earth's mass. Science $2: 820-821$ (1883)

84 Geological excursions, or the rudiments of geology for young learners. 234 pp, Chícago 1884

S4a Limits of Tertiary in Alabama. Science $3: 32$ (1884)

85 Sources of trend and crustal surplusage in mountain structures. Am J Sc (3) $30: 417-420$ (1885) Am As, $\mathrm{Pr} 34$ : 209-212 (1886) Abst, Science $6: 220$ (1885)

85a Notes on some of the geological papers presented at the meeting of the American Association at Ann Arbor. Am J Sc (3) $30: 315-317$ (1885)

85b Coenostroma and Idiostroma and the comprehensive character of stromatoporoids (abst). Am J Sc (3) $30: 317$ (1885) Am As, Pr 34:342 (1886)

85e On the geology of Ann Arbor, Mich. (abst). Am J Sc (3) $30: 315$ (1885)

86 Geological studies... xxv, 513 pp, Chicago 1886

s6a Walks and talks in the geological field. $329 \mathrm{pp}, \mathrm{N}$ Y 1886 Revised ed, by Frederick Starr, 353 pp, Meadville, Pa,, 1898

87 Report of geological observations made in northeastern Minnesota during the season of 1886. Minn G S, An Rp 15: 7207, map (1887)

88 Report of a geological survey in Minnesota during the season of 1887 . Minn G S, An Rp 16:133-391 (1888)

88a The unconformities of the Animikie in Minnesota, Am G 1: 14-24 (1888)

88b Some effect of pressure of a continental glacier. Am G 1:139-143 (1888)

88c The Taconic question. Am G 1: $347-363$ (1888)

88d Geology as a means of culture. Am G $2: 44-51,100-114$ (1888)

89 Shall we teach geology? A discussion of the proper place of geology in modern education. $217 \mathrm{pp}$, Chicago 1889 
Winchell, Alexander-Continued.

89 . Field studies in the Archean rocks of Minnesota, with accessory observations in Ontario, Michigan, and Wisconsin. 504 pp, Ann Arbor, Mich., 1889 (Reprint of reports in Minn G S 1886 and 1887)

$\mathbf{8 9 b}$ Conglomerates inclosed in gneissic terranes. Am G $3: 153-165, \quad 256-261$ (1889)

89c [Foliation and sedimentation in the Lake Superior region]. Am G 3:193-195 (1889)

89d Two systems confounded in the Huronian. Am G 3:212-214 (1889)

S9e Douglass Houghton. Am G 4:129 139, port. (1889)

89f Charles Whittlesey. Am G 4:257268 , port (1889)

$\mathbf{8 9 g}$ Systematic results of a field study of the Archean rocks of the Northwest (abst). Am As, Pr 37:205-206 (1889)

90 Organization of the Geological Society of America. G Soc Am, B 1:1-6 (1890)

$90 n$ Some results of Archean studies (with discussion by C. R. Van Hise). G Soc Am, B 1:357-393 (1890) Abst, Am G $5: 121(1890) ; \Delta m$ Nat $24: 291-292$ (1890)

90b Winter meeting of the Geological Society of America [New York, December, 1889]. Am G 5:117-124 (1890)

90e Recent observations on some Canadian rocks. Am G $6: 360-370$ (1890)

90d Recent views about glaciers. The

Forum 10:306-314 (1890)

90e The geological position of the Ogishke conglomerate (abst). Am As, Pr 38 : 234-235 (1890)

91 American opinion on the older rocks. Minn G S, An Rp 18:65-219 (1891)

$91 a$ A last word with the Huronian.

G Soc Am, B 2:85-124 (1891)

See also Chamberlin, 90a; Gilbert, 90b; Hilgard, 71a ; Smith (E A), 88a; Winchell (N H) , $88 \mathrm{~g}$

Winche11, Alexander Newton.

97 The age of the Great Lakes of North America ; a partial bibliography, with notes. Am G 19:336-339 (1897)

$97 \mathbf{n}$ The Koochiching granite [Minnesota]. Am G 20:293-299 (1897)

oo Mineralogical and petrographic study of the gabbroid rocks of Minnesota, and more particularly, of the plagioclasytes. Am G 26:151-188, 197-245, 261-306, 348-388, map (1900) (Reprinted in French-Diss. Univ. Paris, 164 pp.)

01 Notes on certain copper minerals. Am G 28: 244-246 (1901)

o3 Note on titaniferous pyroxene. Am G $31: 309-310$ (1903)

o5 Gold and silver: Montana. U S G S, Min Res $1904: 191-196 ; 1905: 242-$ $259 ; 1906: 267-287$ (1905-7)
Winchell, Alexander Newton-Continued.

07 The oxidation of pyrite. Ec G 2: 290-294: 799-800 (1907) Mines and Minerals 28:61 (1907)

os Review of nomenclature of Keweenawan igneous rocks. J G $16: 765-774$ (1908) U S G S, Mon 52:395-407 (1911)

09 (with Winchell, N. H.) Elements of optical mineralogy. 502 pp (1909)

10 Use of "ophitic" and related terms in petrography. G Soc Am, B 20:661-667 (1910)

$10 a$ Notes on tungsten minerals from Montana. Ec G 5: 158-165 (1910)

10b Criteria of downward sulphide enrichment (discussion). Ec G 5:488-491 (1910)

11 Directions for laboratory work in optical mineralogy. 36 pp, Madison, Wis. 1911

11n A theory for the origin of graphite as exemplifled in the graphite deposit near Dillon, Mont. Ec G $6: 218-230$ (1911)

11b Graphite near Dillon, Mont. U S G S, B 470:528-532 (1911)

11e The geothermal gradient (abst). Science n s $33: 464-465$ (1911)

12 Brun's new data on volcanism. Ec G $7: 1-14$ (1912)

12a Geology of the National mining district, Nev. M Sc Press 105:655-659 (1912)

12b (with winchell, H. V,) Notes on the Blue Bird mine [Wickes, Mont.]. Ec G $7: 287-294$ (1912)

13 Rock classification on three coordinates. J G 21:208-223 (1913) Abst, Science n 8 37:460 (1913)

14 Mining districts of the Dillon quadrangle, Mont., and adjacent areas. U S G S, B 574:191 pp, map (1914) Abst, by A. H. Brooks, Wash Ac Sc, J $5: 23$ (1915)

$14 a$ Petrology and mineral resources of Jackson and Josephine cos., Oreg. Oreg Bur Mines, Min Res 1 no $5: 265$ pp (1914)

18 (and Miller, E, R.) The dust fall of March 9, 1918. Am J Sc (4) 46:599609 (1918)

18n (and Miller, E. R.) The dust falls of March, 1918. Mo Weather Rv 46:502506 (1918)

18b Racewinite, a peculiar mineral from ore deposits in Utah. Ec G 13:611-615 (1918)

See also Spurr, 03c

winchell, Horace Vaughan (1865-1923). 87 Notes of reconnaissances. Minn G S, An Rp 15: 403-419 (1887)

88 Report of observations made during the summer of 1887 [northern Minnesota]. Minn G S, An Rp 16:395-478, map (1888) 
Winchell, Horace Vaughan-Continued.

S8a Additions to the minerals of Minnesota. Am G 1:132 (1888)

s9 Report of field observations made during the season of 1888 in the iron regions of Minnesota. Minn $G \mathrm{~S}, \mathrm{An} \mathrm{Rp}$ $17: 77-145$ (1889)

S9a The diabasic schists containing the jaspilite beds of northeastern Minnesota. Am G 3: 18-22 (1889)

s9b (with winehell, N. H.) On a possible chemical origin of the iron ores of the Keewatin in Minnesota. Am G 4: 291-300, 383-386 (1889) Am As, Pr 38: 235-242 (1890) Minn G S, B 6:391-399 (1891)

90 (with winehell, N. H.) The Taconic iron ores of Minnesota and of western New England. Am G 6:263-274 (1890) Minn G S. B $6: 400-410$ (1891)

91 Geological age of the Saganaga syenite. Am J Sc (3) 41:386-390 (1891)

$91 \mathrm{a}$ The iron-bearing rocks of Minnesota (abst). Minn Ac $\mathrm{N}$ Sc, B $3: 277-280$ (1891)

$91 b$ (with winchell, N. H.) The iron ores of Minnesota, their geology, discovery, development, qualities and origin, and comparison with those of other iron districts... Minn G S, B 6: $430 \mathrm{pp}$, map (1891)

92 Classification of the theories of the origin of iron ores. Am G 10:277-278 (1892)

93 The Mesabi iron range. Minn $G \mathrm{~S}$, An Rp 20:111-180 (1893) Abst, Minn, Univ, Q B 1:94-95 (1893)

$93 \mathbf{a}$ Note on Cretaceous in northern Minnesota. Am G 12:220-223 (1893) Abst, Minn, Univ, Q B 2:50-51 (1894)

93b The Mesabi iron range [Minn]. Am I M Eng, Tr 21:644-686, map (1893) Abst, Eng M J 55:177-178 (1893)

93e (and Jones, J. T.) The biwabik mine [Minn.]. Am I M Eng, Tr 21:951961 (1893) Abst, Mínn, Univ, Q B 1 : 120-121 (1893)

94 Historical sketch of the discovery of mineral deposits in the Lake Superior region. L Sup M Inst, Pr $2: 33-78$ (1894) Minn G S, An Rp 23:116-155 (1895)

94a Additional facts about Nicollet. Am G 13: 126-128 (1894)

$94 b$ A bit of iron-range history. Am G 13: 164-170 (1894)

95 (and Grant, U. S.) Preliminary report on the Rainy Lake gold region. Minn $G$ S, An Rp 23:36-105 (1895) Abst, Zs prak G $1897: 92-94$

95a The iron ranges of Minnesota. L Sup 2I Inst, Pr 3: 15-32 (1895)

97 The gold fields of the Rainy River district [Ont.]. Eng M J 64: 485-486, map (1897)
Winchell, Horace Vaughan-Continued. 98 The Lake Superior iron-ore region, U. S. A. Fed Inst M Eng, Tr 13:493562 , map (1898)

98a on the occurrence of cubanite at Butte, Mont. Am G 22:245 (1898)

99 (and Grant, U. S.) Preliminary report on the Rainy Lake gold region. Minn G S, Final Rp 4:192-211 map (1899)

02 The ore deposits of Monte Cristo, Washington (review of Spurr, U S G S, An Rp 22, pt $2: 779-865)$. Am G 30 : 113-118 (1902)

03 Synthesis of chalcocite and its genesis at Butte [Montana]. G Soc Am, B $14: 269-276$ (1903 Eng M J 75:782-784 (1903) Abst, J G 11:94 (1903)

03a The Mesabi iron range [Minn.]. Eng M J 76: 343-344 (1903)

04 Butte copper veins [Mont.] Eng M J $78: 7-8$ (1904)

o5 Notes on Goldfield, Nev. Am G 35 : 382-385 (1905)

07 The genesis of ores. M Sc Press 95: 55-58 (1907) Eng M J 84:1067-1070 (1907) Pop Se Mo 72:534-542 (1908) Glückauf $44: 784-787$ (1908)

os The localization of values in ore bodies and the occurrence of shoots in metalliferous deposits. Ec G $3: 425-428$ (1908)

08a A theory of ore deposition. M Sc Press $96: 385-387$ (1908)

10 Prospecting in the North. M Mag, London, 3:436-438 (1910) ; 4:359-360 (1911)

12 Secondary sulphide enrichment. Eng M J $93: 364-367$ (1912)

12a The St. Helens mining district, Wash. Am I M Eng, B 70:1037-1044, map (1912) ; $\operatorname{Tr} 44: 580-587$, map (1913)

12b (and Winchell, A. N.) Notes-on the Blue Bird mine [Wickes, Mont.]. Ec G $7: 287-294$ (1912)

13 Persistence of ore deposits in deptl. M Sc Press 107:332-334 (1913)

See also Billingsley, 15; Graton, 13b ; Pošepny, 94, 95

winchell, Newton Horace (1839-1914).

71 The glacial features of Green Bay of Lake Michigan, with some observations on a probable former outlet of Lake Superior. Am J Sc (3) 2:15-19 (1871)

73 Reports on the geology of Sandusky, Seneca, Wyandot, and Marion cos. Ohio G S, Rp 1 pt 1 Geology : 591-645, maps (1873)

73a The geological and natural history survey of Minnesota; the first annual report for the year 1872 [histoxical; bibliography; surface contour; surface and general geology]. In Minn, Univ, An Rp 1872: 17-130, maps, Saint Paul 1873 2d ed, Minneapolis 1884 
Winchell, Newton Horace-Continued. 73b Address [administrative report]. Minn G S, An Rp 1:19-21 (1873) ...2: 75-78 (1874) $\quad$...3:3-4 (1875) ...4:512 (1876)

73e The surface geology of northwestern Ohio. Am As, Pr 21:152-186 (1873) Abst, Am J Sc (3) 4:321-322 (1872)

73d The drift deposits of the Northwest. Pop Sc Mo 3: 202-210, 286-297 (1873)

74 Reports on the geology of Ottawa, Crawford, Morrow, Delaware, Van Wert, Union, Paulding, Hardin, Hancock, Wood, Putnam, Allen, Auglaize, Henry, Mercer, and Defiance cos. Ohio G S, Rp 2 pt 1 Geology : 227-438, maps (1874)

74a Preliminary geological report [of the Black Hills exploration]. U S [War Dp], Chief Eng, An Rp 1874 (U S, 43d Cong 2 d sess, H Ex Doc 1 pt 2 v 2 pt 2), App KK: 630-632 (1874)

74b The geological and natural history survey of Minnesota; the second annual report for the year 1873 [Belle Plaine salt well; peat; geology of the Minnesota Valley]. In Minn, Univ, An Rp 1873:73219, map, Saint Paul $\mathbf{1 8 7 4}$

74e Geological notes from early explorers in the Minnesota valley. Minn Ac N Sc, B 1874:89-101; 1875:153-156 (1874-6)

$\mathbf{7 4 d}$ On the Hamilton in Ohio. Am $\mathbf{J}$ Sc (3) $7: 395-398$ (1874)

74e The Devonian limestones in Ohio. Am As, Pr 22 pt 2:100-104 (1874)

75 Geological report. In Ludlow, William, Report of a reconnaissance of the Black Hills of Dakota...:21-66, map, Washington 1875. Also in U S, Chief Eng, An Rp 1875 pt 2:1131-1172, map (1875)

75a The economical geology of the region of Cheboygan and Old Mackinac in the counties of Presque Isle, Cheboygan, and Emmet, State of Michigan. Mich, St Bd Agx, 12th An Rp 1873: 103-107 (1875)

75b Report on the geology of Freeborn Co. Minn G S, An Rp 3:5-19, map (1875)

75e Report on the geology of Mower Co. Minn G S, An Rp 3:20-36, map (1875)

75d Note on lignite in the Cretaceous of Minnesota. Am J Sc (3) 10:307 (1875)

76 Report on the geology of Fillmore Co. Minn G S, An Rp $4: 13-74$, map (1876)

76a Notes on the deep well drilled at East Minneapolis, Minn., in 1874-1875. Minn Ac N Sc, B 1875: 187-189 (1876)

76b Vegetable remains in the drift deposits of the Northwest. Am As, Pr 24 pt $2: 43-56(1876)$

76e On the parallelism of Devonian outcrops in Michigan and Ohio. Am As, Pr 24 pt $2: 57-59$ (1876)
Winchell, Newton Horace-Continued.

77 Report [administrative]. Minn G S, An Rp $5: 5-8$ (1877) $\quad \ldots 6: 5-8$ (1878) $\ldots$ $\begin{array}{lllll}7: 7-8 & (1879) & \ldots 8: 7-9 & (1880) \quad \ldots 9: 7-9\end{array}$ (1881) $\quad \ldots 10: 5-8 \quad(1882) \quad \ldots 12: 5-7 \quad$ (1884) ...13:5-9 (1885) ...14:5-10 (1886) $\ldots 15$ : $\begin{array}{llllll}1-4 & \text { (1887) } & \ldots 16: 9-11 & (1888) & \ldots 17: 1-4\end{array}$ (1889) $\ldots 18: 3-7(1890) \quad \ldots 20:$ vi-vii $(1893)$ ...21:1-3 (1893) ...22: 1-4 (1894) ...23 : 1-3 (1895) ...24: vii-xxviii (1899)

77a The geology of Houston Co. Minn G S, An Rp 5:9-50, map (1877)

$\boldsymbol{7} \boldsymbol{7 b}$ The geology of Hennepin Co. Minn G S, An Rp 5:131-201, maps (1877)

78 The water supply of the Red River Valley, Minn G S, An Rp 6:9-42 (1878)

78a Reconnaissances [Wright Co., Rice Co., Goodhue Co., Northern Pacific Railroad]. Minn G $\mathrm{S}$, An Rp 6:43-49 (1878)

$\mathbf{7 s b}$ The geology of Morrison Co. Minn G S, An Rp 6:50-65 (1878)

7se The geology of Ramsey Co. Minn G S, An Rp 6: 66-92, map (1878)

78d The geology of Rock and Pipestone cos. Minn G S, An Rp 6:93-111, map (1878)

$7 \mathrm{Se}$ The recession of the Falls of $\mathrm{St}$. Anthony. G Soc London, Q J 34:886901 (1878)

7SP The Cretaceous in Minnesota. Minn Ac N Sc, B 1877: 347-350 (1878)

79 Sketch of the work of the season of 1878. Minn G S, An Rp $7: 9-25$ (1879)

so Preliminary report on the building stones, clays, limes, cements, roofing, flagging, and paving stones of Minnesota. Minn G S, Misc Pub $8: 37$ pp, St. Paul 1880

80a Lithology. Minn G S, An Rp 8: 10-26 (1880)

sob Descriptions of new species of Brachiopoda from the Trenton and Hudson River formations in Minnesota. Minn G $\mathbf{S}$, An Rp 8:60-69 (1880)

80c Section of a deep well at Emmetsburg, Iowa. Minn Ac N Sc, B 1878-9: $387-388$ (1880)

81 Preliminary list of rocks. Minn G S, An Rp 9: 10-114 (1881)

s1a New Brachiopoda from the Trenton and Hudson River formations in Minnesota. Minn G S, An Rp 9: 115-122 (1881)

81b The cupriferous series in Minnesota. Am As, Pr 29:422-425 (1881) Minn G S, An Rp 9:385-387 (1881) Abst, Science (ed, Michels) 1:197 (1880)

81e Dall's observations on Arctic ice, and the bearing of the facts on glacial phenomena in Minnesota. Am J Sc (3) 21 : $358-360$ (1881)

s1d The geology of the upper Mississippi and Saint Louis valleys. In History of the upper Mississippi Valley:700-707, Minneapolis, Minnesota Historical Company, 1881 
Winchell, Newton Horace-Continued. 82 Preliminary list of rocks. Minn G S, An Rp 10:9-122 (1882)

82a The Potsdam sandstone. Minn G S, An Rp 10:123-136 (1882)

s2b The geology of the deep well drilled... at Minneapolis... Minn G S, An Rp $10: 211-217$ (1882)

82e Typical thin sections of the rocks of the cupriferous series in Minnesota. Am As, Pr 30:160-166 (1882) Minn G $\mathrm{S}$, An Rp 10:137-143 (1882) Abst, Science (ed, Michels) 2:441 (1881)

82d ... sur la nomenclature géologique dans l'échelle stratigraphique. Int G Cong, II, Bologna 1881, C R : 642-646 (1882)

83 The Lake Superior rocks. Science 1 : 334 (1883)

83a Clay pebbles from Princeton, Minn. (abst). Am As, Pr 32:238 (1884) Science $2: 324$ (1883)

84 Historical sketch of explorations and surveys in Minnesota; The general physical features of Minnesota; The building stones of Minnesota. Minn G S, Final Rp 1: 1-203 (1884)

84a The geology of Houston Co.: Winona Co.; ...Fillmore Co. ; ...Mower Co. ; ...Freeborn Co. ; ...Pipestone and Rock cos. ; ...Rice Co. Minn G S, Final Rp 1:207$324,347-366$, 376-393, 533-561, 648-673, maps (1884)

84b The mineralogy of Minnesota. Minn G S, An Rp 11:5-29 (1884) Minn Ac N Sc B 2:390-416 (1885)

84c Note on the age of the rocks of the Mesabi and Vermilion iron districts. Minn G S, An Rp 11: 168-170 (1884)

84d The comparative strength of Minnesota and New England granites. Minn G S, An Rp 12: 14-18 (1884) Abst, Am As, Pr 32: 249-250 (1884) ; Science 2:324325 (1883)

84e The crystalline rocks of the Northwest. Am Nat 18:984-1001 (1884) Am As, Pr $33: 363-379$ (1885) Abst, Science 4: $238-240$ (1884)

84f The salt well at Humboldt, Minn. (abst). Am As, Pr $33: 399-400$ (1885) Science 4:325 (1884)

85 Reconnaissances [Pope Co.; Mesabi range]. Minn $G$ S, An Rp 13:10-24 (1885)

85a The Vermilion iron ores. Minn G S, An Rp 13:25-35 (1885)

85b The crystalline rocks of Minnesota. Minn G S, An Rp 13: 36-40 (1885)

85e The Humboldt salt well in Kittson Co. Minn G S, An Rp 13:41-47 (1885)

85d The deep well at Lakewood Cemetery, Minneapolis. Minn G S, An Rp 13 : 50-54 (1885)

s5e Notes on the artesian wells at Mendota, Hastings, Red Wing, Lake City, and Brownsville, and on the deep wells at St. Paul. Minn G S, An Rp 13:55-64 (1885)
Winche11, Newton Horace-Continued. 85P Fossils from the red quartzite at Pipestone. Minn G S, An Rp 13:65-72, il (1885)

$\mathbf{8 5 g}$ The crystalline rocks of the Northwest. Minn G S, An Rp 13:124-140 (1885)

$\mathbf{8 5 h}$ Report of the section of mineralogy. Minn Ac N Sc, B 2:390-416 (1885)

851 Note on the sandstones of Taquamenon Bay, Lake Superior. Am J Sc (3) $29: 339-340$ (1885)

86 Notes on some deep wells in Minnesota. Minn G S, An Rp 14:11-16, 348353 (1886)

86 a New species of fossils. Minn G $\mathbf{S}$, An Rp 14: 313-318, il (1886)

86b Revision of the stratigraphy of the Cambrian in Minnesota. Minn G S, An Rp $14: 325-337$ (1886)

s6e The Taconic controversy in a nutshell. Science $7: 34$ (1886)

$86 d$ Notice of Lingula and Paradoxides from the red quartzites of Minnesota (abst). Am As, Pr 34: 214 (1886)

87 Geological report [iron ores, Vermilion range]. Minn G S, An Rp 15 : 211399 , map (1887)

87a Notes on classification and nomenclature for the American committee of the International Geological Congress, March, 1887. Am Nat $21: 693-700$ (1887)

s8 Preface [stratigraphical notes]. Minn G S, Final Rp 2 : xili-xxiv (1888)

SSa The geology of Wabasha Co.; . Goodhue Co. ; ... Dakota Co. ; ... Hennepin Co. ; ... Ramsey Co. ; ... Washington Co. Minn G S, Final Rp 2:1-101, 264-398, maps (1888)

$\mathbf{8 8 b}$ Report [on field work in northeastern Minnesota]. Minn $G \mathrm{~S}$, An $\mathrm{Rp} 16$ : 13-129 (1888)

88e The Animikie black slates and quartzites, and the Ogishke conglomerate of Minnesota, the equiralent of the "original Huronian." Am G 1:11-14 (1888).

88d Irving and Chamberlin on the Lake Superior sandstones. Am G 1:44-57 (1888)

s8e Some objections to the term Taconic considered. Am G 1: 162-172 (1888)

88f A great primordial quartzite. Am G $1: 173-178$ (1888)

88g (and others) Report of the subcommittee on the lower Paleozoic. In International Congress of Geologists, American Committee, Reports... B : 37 pp Phila 1888 Am G 2:193-224 (1888) Int G Cong, IV, London 1888, C R App A : $87-120$ (1891)

$\mathbf{8 8 h}$ The granite and quartzite contact at the Aurora mine, Gogebic iron range, at Ironwood, Mich. (abst). Am As, $\mathrm{Pr} 36$ : 211 (1888)

89 The history of geological surveys in Minnesota. Minn G S, B 1:37 (1889) 
Winche11, Newton Horace-Continued.

89a Natural gas in Minnesota. Minn G S, B 5:39 pp, map (1889)

$89 b$ Report (the crystalline rocks of Minnesota...). Minn G S, An Rp 17:5-74 (1889)

89e List of recent geological publications relating to the crystalline rocks. Minn G S, An Rp $17: 233-265$ (1889)

89d American petrographical microscopes. Am G 3:225-230 (1889)

89e Benjamin Franklin Shumard [18201869]. Am G 4:1-6, port. (1889)

$89 f$ (and winehell, H. V.) On a possible chemical origin of the iron ores of the Keewatin in Minnesota. Am G 4: 291-300, 383-386 (1889) Am As, $\operatorname{Pr} 38$ : 235-242 (1890) Minn G S, B 6:391-399 (1891)

$\mathbf{8 9 g}$ Methods of stratigraphy in studying the Huronian. $\mathrm{Am}$ G $4: 342-357$ (1889)

$\mathbf{8 9 h}$ Notice of the discovery of Lingula and Paradoxides in the red quartzites of Minnesota. Minn Ac N Sc, B 3:103-105 (1889)

S9i Some thoughts on eruptive rocks with special reference to those of Minnesota. Am As, Pr 37: 212-221 (1889)

90 A sketch of Richard Owen [18101890]. Am G 6:135-145, port (1890)

90a (and Dodge, J. A.) The Brenham, Kiowa Co., Kans., meteorites. Am G 5: $309-312 ; 6: 370-377$ (1890)

$90 b$ (and Winchell, H. V.) The Taconic iron ores of Minnesota and of western New England. Am G 6:263-274 (1890) Minn G S, B 6:400-410 (1891)

90e What constitutes the Taconic Mountains? (abst). Am G $6: 247$ (1890) Am As, $\operatorname{Pr} 39: 246-247$ (1891)

91 (and winchell, H. V.) The iron ores of Minnesota, their geology, discovery, development, qualities and origin, and comparison with those of other iron districts ... Minn G S, B 6:430 pp, map (1891)

91a The eastern equivalents of the Minnesota iron ore. Minn G S, B 6:411-419 (1891)

$91 \mathrm{~b}$ Record of field observations in 1888 and 1889. Minn G S, An Rp 18:7-63 (1891)

91e [Alexander Winchell, 1824-1891]. Am G 7:195 (1891)

91d Jean N. Nicollet. Am G $8: 343-$ 352 , port (1891)

91e The iron-bearing formations of northeastern Minnesota (abst). Minn Ac N Sc, B 3: 168-169 (1891)

$91 \mathrm{p}$ The so-called Huronian rocks in the vicinity of Sudbury, Ont. Minn Ac N Sc, B 3:183-185 (1891)

92 Catalogue of the meteorites in the University [of Minnesota] collection... Minn G S, An Rp 19:170-192 (1892)
Winche11, Newton Horace-Continued. 92a Memorial sketch of Alexander Winchell. G Soc Am, B 3:3-13, port (1892)

92b The geology of the iron ores of Minnesota, U.S.A. Australasia G Soc, Tr 1: 171-180 (1892) Abst, Minn, Univ, Q B 1: $92-94$ (1893)

92e Alexander Winchell. Am G 9:71$148,273-276$, port (1892)

92d (and Schuchert, C.) Preliminary descriptions of new Brachiopoda from the Trenton and Hudson River groups of Minnesota. Am G 9:284-294 (1892)

92e The Kawishiwin agglomerate at Ely, Minn. Am G 9:359-368 (1892)

$92 f$ An approximate interglacial chronometer. Am G 10:69-80, map (1892) Abst, Minn, Univ, Q B 1:58-59 (1892)

$92 \mathrm{~g}$ Some problems of the Mesabi iron ore. Am G 10:169-179 (1892) Abst, Minn, Univ, Q B 1:58 (1892)

93 The Norian of the Northwest. Minn G S, B 8: i1-xxxiv (1893) Abst, Minn, Univ, Q B 1:118 (1893)

93a The crystalline rocks, some preliminary considerations as to their structures and origin. Minn G S, An Rp 20:1-28 (1893) Abst, Minn, Univ, Q B 1:92 (1893)

93b Field notes of N. H. Winchell in 1890. Minn G S, An Rp 20:29-34 (1893)

93e Oxide of manganese. Minn G $\mathrm{S}$, An Rp 20:321-322 (1893)

93a Summary statement and comparative nomenclature. Minn $\mathrm{G} S \mathrm{~S}$, An $\mathrm{Rp} 21$ : 1-4, table (1893) Abst, Minn, Univ, Q B $2: 88-89$ (1894)

93e Field observations of N. H. Winchell in 1892. Minn G S, An Rp 21: 79-160 (1893) Abst, Minn, Univ, Q B 2: 92 (1894)

93f Frondescent hematite. Am G 11: 20-21 (1893)

93g The geology of Hennepin Co. In History of the City of Minneapolis, Minnesota : 49-62, N Y 1893

94 A sketch of geological investigations in Minnesota. J G 2:692-707 (1894)

$94 \Omega$ Increase Allen Lapham. Am G 13: $1-38$, port (1894)

94b The crystalline rocks. Am G 14: 46-47 (1894)

94e The origin of spheroidal basalt. Am G $14: 321-326$ (1894)

94d Sketch of Dr. John Locke. Am G $14: 341-356$, port (1894)

94e A new meteorite; Minnesota no. 1. Am G 14: 389 (1894)

$94 \mathrm{f}$ Pebbles of clay in stratified gravel and sand. Glacialists' Mag 1:171-174 (1894)

95 (and Ulrieh, E. O.) Historical sketch of investigation of the Lower Silurian in the Mississippi Valley. Minn G S, Final Rp 3 pt 1: ix-liii, map (1895) 
Blake, William Phipps-Continued.

10 Manganese ore in an unusual form. Am I M Eng, B 45: 763-765 (1910); Tr 41:647-649 (1911) M World $33: 614$ (1910)

14 The Cahuilla Basin, and Desert of the Colorado. Carnegie Inst Wash, Pub 193 (MacDougal, The Salton Sea) : 1-12 (1914)

15 Sketch of the region at the head of the Gulf of California. In Cory, H. T., The Imperial Valley and the Salton Sink : 1-35, San Francisco 1915

See also Don, 98; Jenney, 94; Marcou, 55c ; Pošepný, 94, 95 ; Smock, 74; Spencer (J W), 93a.

Blakemore, William.

o1 Pioneer work in the Crowsnest coal areas [B. C.]. Can M Inst, J $4: 230-243$ (1901) Can M Rv 20:127-132 (1901)

02 The iron ore deposits near Kitchener, B. C. Can M Inst, J 5: 76-80 (1902)

03 The Frank disaster [landslide, Frank, Alta.]. Can M Rv 22:121-122 (1903)

04 Graham Island coal [B. C.]. Eng M J $78: 631$ (1904)

Blanchard, Émile.

91 Les preuves de communications terrestres entre l'Europe et l'Amérique pendant l'âge moderne de la terre. Ac Sc Paris, C R 113: 115-118 (1891)

Blanchard, Ralph C.

13 The geology of the western Buckskin Mountains, Yuma Co., Ariz. Thesis, Columbia University. $80 \mathrm{pp}$ (1913) [Priv pub]

Bland, John.

17 Tin and tungsten in South Dakota. M Sc Press 114: 441-444 (1917)

Bland, Thomas.

$52 \ldots$ the origin and the geographical distribution of Mollusca. Am J Se (2) 14: $389-404$ (1852)

71 Notes relating to the physical geography and geology of, and the distribution of terrestrial Mollusca, in certain of the West India Islands. Am Ph Soc, Pr 12: 56-73 (1871)

Blandy, John F.

62 (with Williams, C. P.) ... the copper range of Lake Superior. Am J Sc (2) $34: 112-120$ (1862)

73 Topography with especial reference to the Lake Superior copper district. Am I M Eng, Tr 1:75-82 (1873)

76 On evidence of streams during deposition of coal. Am I M Eng, Tr 4:113116 (1876) Eng M J 21:392-393 (1876)

79 The Lake Superior copper rocks in Pennsylvania (with discussion by T. S. Hunt and P. Frazer). Am I M Eng, Tr 7 : 331-339 (1879)

83 The mining region around Prescott, Ariz. Am I M Eng, Tr 11:286-291, map (1883) Eng M J 36:33-34, map (1883) Abst, Science $2: 86$ (1883)
Blandy, John F.-Continued.

93 The persistence of ores in lodes in depth. Eng M J 55:75-76 (1893)

93a Some notes on the geology of Ari. zona. Eng M J 56:473-474 (1893)

93b A peculiar case of stratification [in Grand Canyon, Coconino Co., Ariz.]. Eng M J $56: 638$ (1893)

97 The mines of Yavapai Co., Ari. Eng M J 63:632-634 (1897)

97a An Arizonta copper deposit [Colo rado Plateau, near Grand Canyon]. Ens M J 64:97 (1897)

98 Mining in Yavapai Co., Ariz. Eng M J $66: 547-548$ (1898)

oo The origin of the native copper in the Michigan deposits. Eng M J 70:278-279 (1900)

BIaney, Dwight.

16 (and Loomis, F. B.) A Pleistocene locality on Mt. Desert Island, Maine. An J Sc (4) $42: 399-401$ (1916)

Blaney, J. V. Z.

66 Chemical report for the geological survey of Illinois. Ill G S 1:255-27! (1866) ; Ec G 1: 191-209 (1882)

68 Chemical analyses [hydraulic lime stone, coall. Ill G S 3:573-574 (1868) Blanford, W. T.

84 The correlation of geological formt. tions $(a b s t)$. Science 4: 208-209 (1884)

Blankinship, J. W.

92 On the natural history of the Farallon Islands; notes on the geology. Zoe 3: 144-146 (1892)

Blasdale, Walter C.

o1 Contributions to the mineralogy of California. Cal Univ, Dp G, B 2:327-344 (1901)

os The chemical formula of the minetal benitoite. Science n s 28: 233-234 (1908)

OSa (with Louderback, G. D.) Bent toite, its mineralogy, paragenesis, and ger logical occurrence (abst). Science n s 27: 411 (1908)

10 (with Louderback, G. D.) Rubf corundum from San Bernardino Co., Cal (abst). Science n s 32:31 (1910) G $5 \propto \alpha$ Am, B 21: 793 (1910)

Blatehford, John.

03 The Potsdam formation of Ball Mountain district [Black Hills, S. Dak.]. M Sc Press 87:167 (1903)

04 The Potsdam or Flat formation of the Bald Mountain district [Black Mouttains, S. Dak.]. Am M Cong, 6th ti Sess, Rp Pr: 60-62 (1904) Mines and Minerals 24: 394 (1904)

Blatchley, Ralph F.

11 The Oakland City, Ind., ofl fiell in 1910. Ind $D$ G, An Rp $35: 81-1+1$ (1911)

\section{Blatchley, Raymond Silliman.}

07 The Princeton petro'sum ficld of it: diana. Ind $\mathrm{Dp} G$, An $\mathrm{R}_{\mathrm{p}} 31: 559-593 \mathrm{i}$ map (1907) 
Winchell, Newton Horace-Continued.

95a Other Cretaceous fossils in Minnesota. Minn G S, Final Rp 3 pt $1: 53-$ $54(1895)$

95b (and Sehuehert, C.) Sponges, graptolites, and corals from the Lower Silurian of Minnesota. Minn G S, Final Rp 3 pt 1:55-95, il (1895) Abst, Minn, Univ, Q B 2: 52 (1894)

95e (and Schuchert, C.) The Lower Silurian Brachiopoda of Minnesota. Minn G S, Final Rp 3 pt $1: 333-474$, il (1895) Abst, Minn, Univ, Q B 2:56-57 (1894)

95d The origin of the Archean greenstones. Minn G S, An Rp 23:4-35 (1895)

95e The age of the Galena limestone. Am G 15:33-39 (1895); abst, 14:203 (1894)

95f The stratigraphic base of the Taconic or Lower Cambrian. Am G 15:153162 (1895)

$95 \mathrm{~g}$ The paleontologic base of the Taconic or Lower Cambrian. Al4 G 15:229234 (1895)

95h The eruptive epochs of the Taconic or Lower Cambrian. Am G 15:295-304 (1895)

95i Canadian localities of the Taconic eruptives. Am G 15:356-363 (1895)

95j Steps of progressive research in the geology of the Lake Superior region prior to the late Wisconsin survey. Am G 16 : 12-20 (1895)

95k The feldspars. Am G 16:51-58 (1895)

951 The Keweenawan according to the Wisconsin geologists. Am G 16:75-86 (1895)

$95 \mathrm{~m}$ A rational view of the Keweenawan. Am G 16:150-162 (1895)

95n The synchronism of the Lake Superior region with other portions of the North American continent. Am G 16:205213, map (1895)

95o The latest eruptives of the Lake Superior region. Am G 16:269-274 (1895)

95p Comparative taxonomy of the rocks of the Lake Superior region. Am G 16 : $331-337$ (1895)

96 Lacroix' axial goniometer. Am G $17: 79-82$ (1896)

96a Microscopic characters of the Fisher meteorite (Minnesota no. 1). Am G 17: 173-176, 234-238 (1896)

96b The Arlington iron-Minnesota no. 2. Am G $18: 267-271$ (1896)

96e The Black River limestone at Lake Nipissing [Ont.]. Am G 18:178-179 (1896)

96d (and Grant, U. S.) Volcanic ash from the north shore of Lake Superior. Am G 18: 211-213 (1896)

$96 e$ Sur la météorite tombée le 9 avril 1894 près de Fisher, Minn. Ac Sc Paris, C R $122: 681-682$ (1896)
Winehell, Newton Horace-Continued. 961 Sur un cristal de labrador du gabbro de Minnesota. Soc Franç Minér, B 19 : 90-92 (1896)

97 (and Ulrieh, E. O.) The Lower Silurian deposits of the upper Mississippl province; a correlation of the strata with those in the Cincinnati, Tennessee, New York, and Canadian provinces, and the stratigraphic and geographie distribution of the fossils. Minn G S, Pal 3 pt 2 : 1xxxiiicxxviii (1897)

$\mathbf{9 7 a}$ Some new features in the geology of northeastern Minnesota. Am G 20:4151 (1897) Abst, Minn Ac Sc, B 4:201 (1906)

97b (and Berkey, C. P.) The Fisher meteorite. Am G 20:316-318 (1897)

97e The Taconic according to Renevier. Am G 20:405-407 (1897)

97 d L'extension du système taconique vers l'ouest. Int G Cong, VI, Zurich 1894 , C R : 272-308, map (1897)

98 The determination of the feldspars. Am G 21: 12-49 (1898)

$98 a$ Some resemblances between the Archean of Minnesota and of Finland. Am G 21: 222-229 (1898)

98b The significance of the fragmental eruptive débris at Taylor's Falls, Minn. Am G 22: 72-78 (1898)

98e The question of the differentiation of magmas. Am G 22:113-123 (1898)

98d Note on the characters of mesolite from Minnesota. Am G 22:228-230 (1898)

98e The origin of the Archean igneous rocks. Am G 22:299-310 (1898) Abst, Am As, Pr 47:303-304 (1898); Science n s $8: 504-505$ (1898)

98f Thomsonite and lintonite from the north shore of Lake Superior. Am G 22 : 347-349 (1898)

$98 \mathrm{~g}$ A new iron-bearing horizen in the Keewatin in Minnesota. L Sup M Inst, Pr 5:46-48 (1898)

98h The discovery and development of the iron ores of Minnesota. Minn Hist Soc, Col 8: 25-40, map (1898)

98i The oldest known rock (abst). Am As, Pr 47:302-303 (1898) Am G 22: 262-263 (1898) Science n \& 8:504 (1898)

99 Preface [including stratigraphical notes]. Minn G $\mathrm{S}$, Final $\mathrm{Rp} 4: x i i i-x x$ (1899)

99 The geology of Carlton Co. ; ...St. Louis Co.; ...Lake Co. ; ...Hibbing plate of the Mesabi iron range; ...Mountain Iron plate of the Mesabi iron range; ...Virginia plate of the Mesabi iron range; ...Partridge River plate of the Mesabi iron range; ...of the Dunka River plate of the Mesabi iron range; ...Pigeon Point plate; ...Vermilion Lake plate; ...Carlton plate; ...Duluth plate. Minn G S, Final Rp 4: $1-24, \quad 212-312, \quad 358-398, \quad 502-580$, maps (1899) 
Winche11, Newton Horace-Continued.

99b Rock samples collected to illustrate notes of N. H. Winchell in 1896 , with annotations. Minn G S, An Rp 24:1-84 (1899)

99e General index of the annual reports of the Minnesota Survey. Minn G S, An Rp 24 : 179-284 (1899)

99d Thalite and bowlingite from the north shore of Lake Superior. Am G 23 : 41-44 (1899)

99e Chlorastrolite and zonochlorite from Isle Royale. Am G 23:116-118 (1899)

99r Common zeolites of the Minnesota shore of Lake Superior. Am G 23:176177 (1899)

99g The optical characters of jacksonite. Am G 23: 250-251 (1899)

99h Adularia and other secondary minerals of copper-bearing rocks. Am G 23 : 317-318 (1899)

00 Preface [notes on Archean rocks]. Minn G S, Final Rp 5: xxili-xxvil (1900) O0a Structural geology. Minn G S, Final Rp $5:$ 1-74 (1900)

oob (and Grant, U. S.) The petrographic geology of the crystalline rocks of Minnesota. Minn G S, Final Rp 5:75936 (1900)

ooc Mineralogy and petrology of Minnesota. Minn G S, Final Rp 5:937-1006 (1900)

01 Geological atlas with synoptical descriptions. Minn G S, Final Rp 6:88 pls and text, maps (1901)

O1a Glacial lakes of Minnesota. G Soc Am, B 12:109-128, map (1901)

o1b Edward Waller Claypole. Am G $28: 247-248$ (1901)

01c Fundamental changes in the Archean and Algonkian, as understood by Prof. Van Hise, of the United States Geological Survey [see Van Hise, 01]. Am G 28:385388 (1901)

O1d Sketch of the iron ores of Minnesota. Int M Cong, 4th, Pr: 136-140 (1901) Am G 29:154-162 (1902)

01e The retreat of the ice margin across Minnesota. (abst). Science n s 13:509510 (1901).

02 "The Monthly American Journal of Geology and Natural Science." Am G 30 : 62-64 (1902)

02a The Sutton Mountain [Que.]. Am G $30: 118-120 \quad(1902)$

O2b The Lansing skeleton. Am G 30 : 189-194 (1902)

02c The geology of the Mississippi Valley at Little Falls, Minn. Memoirs of Explorations in the Basin of the Mississippi 5: $89-104$ (1902)

o3 Regeneration of clastic feldspar. G Soc Am, B 13:522-525 (1903) Abst, Science n \& 15:85 (1902)

03a Was man in America in the glacial period? G Soc Am, B 14:133-152 (1903)
Winchell. Newton Horace-Continued. 03b Some results of the late Minnesota geological survey. Am G 31:246-253 (1903) Abst, Science n s 17:218-219 (1903); J G 11:130-131 (1903) ; Eng M J $75: 152$ (1903) ; Sc Am Sup $55: 22646-$ 22647 (1903)

o3e The Pleistocene geology of the Concannon farm, near Lansing, Kansas. Am G $31: 263-308$ (1903)

o3d Metamorphism of the Laurentian limestones of Canada. Am G 32:385-392 (1903)

o3e Granite [origin, Archean geologic history]. Memoirs of Exploration in the Basin of the Mississippi $7: 87-91$ (1903)

o3f (and others) Geological and archeological excursion to Nehawka, Nebr., August 14, 1902. Nebr St Bd Agr, An Rp 1902: 314-316 (1903)

04 The evolution of climates. Am G 33 : 116-122 (1904)

04a Where did life begin? Am G 33 : 185-189 (1904)

04b Peléliths. Am G $33: 319-325$ (1904)

04e The colossal bridges of Utah. Am G 34: 189-192 (1904)

04d The Baraboo iron ore. Am G 34: 242-253 (1904)

04e Notes on the geology of the Hellgate and Big Blackfoot valleys, Mont. (abst). G Soc Am, B 15:576-578 (1904) Science n s 19:524-525 (1904)

o5 Deep wells as a source of water supply for Minneapolis. Am G 35: 266-291, il (1905)

05a The Willamette meteorite. Am G $36: 250-257$ (1905)

06 The Keweenawan at Lake of the Woods in Minnesota (abst). Science $\mathrm{n} \mathrm{s}$ $23: 289$ (1906) Am As, Pr $55: 378$ (1906)

O6a Glacial lakes of St. Louis and Nemadji (abst). Minn Ac Sc, B 4: 208 (1906)

06b Deep wells as a source of water for Minneapolis (abst). Minn Ac Sc, B 4: 266 (1906)

o7 The Cuyuna iron range. Ec $G$ 2: 565-571 (1907)

$07 a$ Pre-Indian inhabitants of North America. Records of the Past 6:145-157, 163-181 1907)

os Structures of the Mesabi iron ors. I. Sup M Inst, Pr 13:189-204 (1908)

o9 A diamond drill core section of the Mesabi rocks. L Sup M Inst, Pr 14:156178 (1909) ; $15: 100-141$ (1910); $16: 61-$ 69 (1911)

o9a (and winchell, A. N.) Elements of optical mineralogy ... 502 pp, N Y 1909

09b Possible preglacial human remains about Washington, D C. Records of the Past 8: 249-252 (1909)

10 Extinct Pleistocene mammals of Minnesota. Minn Ac Sc, B 4:414-422, il (1910) 
Winche11, Newton Horace-Continued.

11 The iron-ore ranges of Minnesota, and their differences. Minn Ac Sc, B 5:4368 (1911)

$11 a$ The genesis of certain greensands of Minnesota (abst). Science n s $33: 462-$ 463 (1911)

12 Memoir of Christopher Webber Hall. G Soc Am, B 23: 28-30, port (1912)

12a Progress of opinion as to the origin of the Lake Superior iron ores. G Soc Am, B $23: 317-328$ (1912)

12b Saponite, thalite, greenalite, greenstone. G Soc Am, B 23: 329-332 (1912)

13 The weathering of aboriginal stone artifacts, no. 1; a consideration of the paleoliths of Kansas. Minn Hist Soc, Col 16 pt $1: x i v, 186 \mathrm{pp}$, il (1913)

13a The age of the Mesabi iron-bearing rocks of Minnesota $(a b s t)$. Science n $\mathrm{s}$ $37: 457$ (1913)

14 The foundation of the Geological Society of America. Science n s $39: 819-821$ (1914)

14a Review of the formation of geological societies in the United States. G Soc Am, B 25 : 27-30 (1914)

14b Delaware terraces (abst). G Soc Am, B 25: 86 (1914)

See also Branner, 98; Graton, 03a; Hawes, 84; Hitcheock (C H), 91

Winchester, Dean Eddy.

12 The Lost Spring coal field, Converse Co., Wyo. U S G S, B $471: 472-515$, maps (1912)

$12 a$ (with Woodrufr, E. G.) Coal fields of the Wind River region, Fremont and Natrona counties, Wyo. U S G S, B 471: $516-564$ (1912)

13 Cross-bedding in the White River formation of northwestern South Dakota. J G 21: 550-556, map (1913)

14 The Upper Cretaceous formations of western New Mexico and their relations to the underlying rocks (abst). Wash Ac Sc, J $4: 300$ (1914)

16 (and others) The lignite field of northwestern South Dakota. U S G S, B $627: 169 \mathrm{pp}$, maps (1916) Abst, Wash Ac Sc, J $7: 36-37$ (1917)

$16 \mathbf{a}^{*}$ Oll shale in northwestern Colorado and adjacent areas. U S G S, B 641: 139198, maps (1916) Abst, by R. W. S., Wash Ac Sc, J $7: 265$ (1917)

17 Oil shale in the United States. Ec G 12 : 505-518 (1917) Reprinted in The Railroad Red Book (Denver \& Rio Grande Railroad) $35: 33-38$ (1918) Abst, Wash Ac Sc, J $7: 432-33$ (1917)

18 Structure and oil and gas resources of the Osage Reservation, Okla.; T. $27 \mathrm{~N}$, R. 9 E. U S G S, B $686: 11-15$, map (1918)

18a (and Heald, K. C., and others) Structure and oil and gas resources of the Osage Reservation, Okla.; T. 25 N., R. 10 E. U S G S, B $686: 59-73$, map (1918)
Winchester, Dean Eddy-Continued.

18b Oil shale of the Uinta Basin, northeastern Utah. U S G S, B 691:27-50, map (1918) Abst, by R. W. Stone, Wash Ac Sc, J 8:501 (1918)

1Se Results of dry distillation of miscellaneous shale samples [includes sections of Green River formation in northwestern Colorado]. U S G S, B 691:51-55 (1918)

Winslow, Arthur.

s4 Peculiarities of weathering in the Pottsville conglomerate. Science $3: 12-14$ (1884)

85 Phosphate deposits of North Carolina. Eng M J 39: 193 (1885)

85a Tin ore in Virginia. Eng M J 40: 320 (1885)

86 Report on pyrites in North Carolina. N C Agr Exp Sta, An Rp 1885:93-106 (1886)

87 The Lehigh River cross section ... Pa G S, An Rp 1886 pt 4:1331-1371 (1887)

88 A preliminary report on a portion of the coal regions of Arkansas. Ark G s, An Rp 1888, 3: 109 pp, map, Little Rock 1888

89 The relations of geology and engineering practice; an address. $17 \mathrm{pp}$, Little Rock 1889

90 Administrative report. Mo G S, B 1 : 1-13 (1890)

$90 a$ Notes on the coal beds of Lafayette Co. Mo G S, B 1: 14-21, map (1890)

90b Charles Albert Ashburner [18541889]. Am G 6:69-78, port (1890)

91 Biennial report of the State geologist ...: 53 pp, Jefferson City, Mo., 1891 [Second] biennial report ...: $\mathbf{3 7} \mathrm{pp}$, Jefferson City, Mo., 1893

91 a A preliminary report on the coal deposits of Missouri... Mo G S: 227 pp, map. Jefferson City 1891

91b The geotectonic and physiographic geology of western Arkansas. G Soc Am, B $2: 225-242$ (1891)

91e The relations of geological surveys to successful mining. Science $18: 351-353$ (1891)

91d Remarks on the construction of topographic maps for geologic purposes (abst). Am As, Pr 39:252-255 (1891)

92 The Higginsville sheet in Lafayette Co. Mo G S:18 pp, map, Jeffersonville 1892 Also in Mo G S 9, Sheet Rp no 1: 99 pp (1892) [Quaternary geology, by J. E. Todd]

92a The mapping of Missouri. Ac Sc St L, Tr 6:57-99, map (1892)

92b An illustration of the flexibility of limestone. $A m$ J Sc (3) 43:133-134 (1892)

92e The Missouri coal measures and the conditions of their deposition $(a b s t)$. G Soc Am, B 3:109-121, map (1892)

93 Notes on the lead and zine deposits of the Mississippi Valley and the origin of the ores. J G 1:612-619 (1893) 
Winslow, Arthur-Continued.

93a Notes on the Cambrian in Missouri and the classification of the Ozark series. Am J F (3) $45: 221-226$ (1893)

93b The coal measures of Missouri. U S G S, Min Res 1892:429-436 (1893)

93e The Osage River and its meanders. Science $22: 31-32$ (1893)

94 Lead and zine deposits. Mo G S 6 and $7: 763 \mathrm{pp}$, maps, Jefferson City 1894

94a (and Haworth, E., and Nason,

F. L.) A report on the Iron Mountain sheet, including portions of Iron, St. Francois, and Madison cos. Mo G S 9, Sheet Rp no $3: 85$ pp, map [under separate cover], Jefferson City 1894

$94 b$ Geological surveys in Missouri. J

G 2 : 207-221 (1894)

95 The geologic history of Missouri. Am G 15:81-89 (1895)

95a Lead and zinc deposits of Missouri (with discussion by F. L. Clerc). Am I M Eng, Tr 24:634-689, 931-933, maps (1895)

95b A Paleozoic eruptive in Missouri (abst). Am As, Pr 43:227-229 (1895)

96 The disseminated lead ores of southeastern Missouri. U S G S, B 132: $31 \mathrm{pp}$, maps (1896)

98 A natural bridge in Utah. Science n 8 $7: 557-558$ (1898)

oo The Liberty Bell gold mine, Telluride, Colo. Am I M Eng, Tr 29:285307, maps (1900)

See also Don, 98 ; Emmons (S F), $94 \mathrm{a}$; Gordon (C H), 93 ; Jenney, 94; Pošepny, 95

Winslow, Charles Frederick (1811-1877).

53 On the supposed bed of coral at a high elevation on the island of Maui. Am J Sc (2) $15: 450-451$ (1853)

57 On human remains along with those of Mastodon in the drift of Californla. Boston Soc N H, Pr 6:278-279 (1857) Am J Sc (2) $46: 407-408$ (1857)

$57 \mathbf{n}$ On the volcanic phenomena of Kilauea and Mauna Loa $(a b s t)$, Edinb $N$ Ph J n s 5:359 (1857)

65 The cooling globe; or, the mechanics of geology. 63 pp, Boston 1865

70 [On the dynamics of geology.] Essex Inst, B 2:111-112, 116 (1870)

73 [Particulars relating to the discovery of human remains in Table Mountain, Cal.1 Boston Soc N H, Pr 15:257-259 (1873)

winsted, Huldah L.

13 The sea caves at La Jolla, California. J Geog 12:125-126 (1913)

winston, W, B.

09 Arteaga district, Chihuahua, Mexico. M Sc Press 98:829-830 (1909)

Winterton, J.

03 The volcanic eruptions in Guatemala

Sc Am $89: 84$ (1903)
Winther, Chr.

01 (with Böggild, O. B.) On some minerals from the nephelite syenite at Julianehaab, Greenland (epistolite, britholite, schizolite, and steenstrupite). Med Grönland 24:181-213 (1901)

Wintringham, J. P.

17 An elementary introduction to crys. tallography. Am Mineralogist 2:49-50, $65-66,82-83,93-94,109-110,118,126-$ 127 (1917)

winwood, H. H.

85 Geological age of the Rocky Mountains. G Mag (3) $2: 240$ (1885) Abst, Am J Sc (3) 30:79 (1885)

\section{Wisconsin Geologieal and Natural}

History Survey.

99 First biennial report of the commissioners of the geological and natural history survey. $31 \mathrm{pp}$, Madison 1899 Second...: 44 pp (1901); Third:35 pp (1902) ; Fourth : 42 pp (1904); Fitth : 45 pp (1906); Sixth : 45.pp (1908); Seventh : 55 pp (1910); Eighth : 39 pp (1912) ; Ninth : $40 \mathrm{pp}$ (1914); Tenth: $12 \mathrm{pp}(1 \mathrm{f} / 6)$; ; Eleventh : 40 pp (1918)

Wislizenus, $A$.

48 Memoir of a tour to aoethern riexico...in 1846 and 1847. U. S. 80th Cong 1 st sess, S Misc Doc 26: I 11 pp, maps (1848)

wissler, Clark.

16 The present status of the antiquity of man in North America. Bc Mo 2:234 238 (1916)

Wistar, Caspar.

99 A description of the bnnes deposited by the President in the museum of the society and represented is the annexed plates. Am Ph Soc, Tr 4:526-531, il (1799)

18 An account of two heads found in the morass called the Big Bow Lick... Am Ph Soc, Tr n s $1: 375-380$, il (1818)

Wistar, Isaac J.

96 Iron oxide as colorlag matter in the rocks of the anthracite region (abst). Am G $17: 261-262$ (1896) Fcience n s $3: 488$ 489 (1896)

wister, Charles I.

14 Description of melanite from Pennsylvania and amber frum New Jersey. Am Miner J 1: 31 (1814)

witherbee, $T$. $F$.

02 The Iron Mountain and the plant of the Mexican National Iron and Steel Co., Durango, Mex. Am I M Eng, Tr 32: 156-163 (1902)

Withers, Robert W.

33 Geological notices respecting a part of Greene County, Ala. Am J Sc 24:187189 (1833)

Withrow, James Renwick.

99 (with Hamilton, S. H.) The prog. ress of mineralogy in 1898. Am I M Eng, B 1:33 pp (1899) 
Withrow, James Renwick-Continued.

00 (with Hamilton, S. H.) The prog. ress of mineralogy in 1899. Am I M Eng, B 2:96 pp (1900)

Witter, F. M.

79 Geographic and geologic features. In History of Muscatine County [Iowa] : 323334, Chicago, IIl, 1879

79a Notes on Wyoming Hills [Muscatine Co., Iowa]. Read before Muscatine Academy of Sciences. 4 pp [Muscatine 1879] [priv pub]

79b Notes on the loess. Read before the Muscatine Academy of Science. $4 \mathrm{pp}$ [Muscatine 1879] [priv pub]

90 Some additional observations on the loess in and about Muscatine [Iowa]. Iowa Ac Sc, Pr 1887-89:45 (1890)

92 Gas wells near Letts, Iowa. Am G 9 : 319-321 (1892) Iowa Ac Sc, Pr 1 pt 2 : 68-70 (1892)

99 Observations on the geology of Steamboat Springs, Colo. Iowa Ac Sc, Pr 6 : 93-98 (1899)

wittieh, Ernst.

09 Contribuciones a la geología de la región meridional de la Baja California. Soc G Mex 6: xii-xiil, 5-14 (1909)

10 Notas mineralogicas sobre el distrito de Guanajuato; Mineralogische Notizen über den Minendistrikts von Guanajuato. Soc Cient Ant Alz, Mem 28:247-270 (1910)

10a Algunos datos preliminares sobre diques de aplito-pegmatita, cerca de Silao, Guanajuato. Soc G Mex, B $6: \mathbf{x x i x}-\mathbf{x x x}$, 173-178 (1910)

10b Los criaderos de contacto de Harperos, cerca de Silao, E. de Guanajuato. Soc G Mex, B 6 : xxx, 179-181 (1910)

10e Geysers y manantiales termales de Comanjilla, Guanajuato. Soc G Mex, B 6 : xxx-xxxi, $183-188$ (1910)

10d El estaño en la Sierra de Guanajuato. Soc G Mex, B 6: xxxii-xxxiii, 189194 (1910)

10e Las especies minerales de la Sierra de Guanajuato. Soc G Mex, B 6 : xxxixxxii, 195-221 (1910)

10 Una ceniza volcánica de Guanajuato. Soe G Mex, B $7: 77-78$ (1910)

$10 \mathrm{~g}$ Algunos apuntes sobre la distribución de distintos elementos químicos en la Sierra de Guanajuato. Soc G Mex, B 7 : 79-84 (1910)

10h Neue Aufschlüsse im Lavafeld von Coyoacán bei Mexiko. N Jb Bd 2:131137 (1910)

101 Aplit-Pegmatitgänge im Granitgebiet von Silao, Staat Guanajuato, Mexiko. Centralbl Miner 1910:436-440

10j Ueber das Vorkommen von Wismut in der Sierra von Sta. Rosa, Staat Guanajuato in Mexico. Zs Prak G 18:119-121 (1910)

10k Zinnerze in der Sierra von GuanaJuato, Mexiko. Zs Prak G 18:121-123 (1910)
Wittich, Ernst-Continued.

101 Strandlinien an der Sïdküste von Niederkalifornien. Globus 97:379 (1910)

$10 \mathrm{~m}$ Skizze der Entwicklung des Bergwesens in Mexiko. In Festschrift Humboldt : 227-261, Mexico, 1910

11 Seltene silikate in der Veta Madre von Guanajuato, Mexiko. Deut G Ges, Zs, Monatsb 1911: 420-425

$11 a$ Über das Vorkommen von Raspit in Nord-Amerika. Deut G Ges, Zs, Monatsb $1911: 425-427$

11 b Beitrăge zur Geologie der Kapregion von Nieder-Californien. Deut $\mathrm{G}$ Ges, Zs, Monatsb 1911: 578-587

11e (with Waitz, P.) Tubos de explosión en el Pedregal de San Ángel. Soc G Mex, B $7: 169-186$ (1911)

12 Ueber Meeresschwankungen an der Küste von Kalifornien. Deut $\mathbf{G}$ Ges, Zs, Monatsb 1912 : 505-512

12a (and Pantor y Giraud, A.) Riesengipskristalle aus Chihuahua, NordMexiko. Centralb Miner 1912: 731-733

12b Observaciones sobre el postplioceno a lo largo de los ríos Papaloapam, Tezechoacán y Manso. Soc G Mex, B 8:ix, 41-46 (1912)

12e Estudio de algunos minerales raros del Estado de Chihuahua. Soc G Mex, B $8: \mathrm{ix}-\mathrm{x}, 47-51$ (1912)

12d (and Pastor y Giraud, A.) Reseña acerca de los topacios de México. Soc G Mex, B $8: x-x i, 53-59$ (1912)

12e (and Pastor y Giraud, A.) Unos cristales gigantes de yeso, procedentes de la mina Naica, Chibuahua. Soc G Mex, B 8: xi-xil, $61-70$ (1912)

14 Ueber Edelsteinfunde auf der Halbinsel Nieder-Kalifornien. Centralbl Miner 1914: $449-456$

$14 a$ Nuevas observaciones acerca de levantamientos modernos en la Baja California; Restos de selacios del terciario de la division norte de la Baja California. Del Acta de la sesión de verano (12 de jullo de 1913) de la Sociedad Geologica Mexicana : i-iil [n p, n d, 1914?] [priv pub ?]

14b (and Vivar, G.) La celestita de Atotonilco el Grande, Hgo. Del Acta de la asamblea general de invierno (27 de diciembre de 1913) de la Sociedad Geológica Mexicana : v-vi [n p, n d, 1914?] [priv pub?]

14e Observaciones geológicas en los alrededores de Atotonilco el Grande, Hgo. Del Acta de la asamblea general de invierno (27 de diciembre de 1913) de la Sociedad Geologica Mexicana: vi-vili $[\mathrm{n} p, \mathrm{n}$, 1914?] [priv pub?]

$14 d$ (with Bose, E.) Las salinas de Ojo de Liebre, Baja California. México, Min Fomento, Mem 1912-3: 109-122 (1914) [not seen] 
Wittich, Frnst-Continued.

15 Ueber Eisenerzlager a 1 der Nordwestküste von Nieder-Kalifornien. Centralbl Miner 1915: 389-395

15a Ueber lakustre Tertiärbildungen auf dem Hochplateau von Mexiko. Centralbl Miner 1915: $467-475$

16 Die Salzlager am Ojo de Liebre an der Westküste von Nieder-Kalifornien. Centralbl Miner 1916: 25-32

16a Estudio sobre las piedras preciosas en el territorio de la Baja California. Bol Minero 1: 69-74 (1916)

16b Los criaderos de fierro en la costa occidental de la Baja California. Bol Minero 1: 102-107 (1916)

16e Las salinas de Ojo de Liebre en la bahia Sebastián Vizcaino, Baja California. Bol Minero 2 : 235-240 (1916)

16d Ueber Lavahölen im Pedregal von San Ángel bei Mexiko. N Jb 1916:126133

18 Contribuciones á la mineralogía mexicana. Soc Cient Ant Alz, Mem 37:23-42 (1918)

18a Fenómenos desérticos en los alrededores de San Luis Potosí. Soe Cient Ant Alz, Mem 37:65-70 (1918)

18b Morfologia y origen de la Mesa Central de Mexico. Soc Mex Geog y Estad, B (5) $8: 128-140$ (1918) Disertaciones científicas de autores alemanos $1: 1-16$, Mexico 1918

Wittich, Lueius $\mathrm{L}$.

10 Developing a new ore horizon. Mines and Minerals $30: 637-639$ (1910)

10a Zinc and lead in Arkansas, Mines and Minerals $31: 10-11$ (1910)

11 Southern Kansas coal district. Mines and Minerals 31 : 668-671 (1911)

11 a Petroleum in Oklahoms. Mines and Minerals 32: 291-294 (1911)

12 Barytes in Missouri. Mines and Minerals 33: 95-97 (1912)

$12 a$ Iron mining in Missouri. Mines and Minerals $33: 227-228$ (1912)

Wittman, Ernest.

o5 The geological and topographical features of the City of Monterey, Nuevo Leon, Mex., and its vicinity. Am G 35:171-176 (1905)

wohler, $\mathbf{F}$.

56 Über das Meteoreisen von Toluca in Mexico. K Ak Wiss, Mat-nat Cl, Szb 20 : 217-224 (1856)

\section{Woeikof, A.}

86 Examination of Dr. Croll's hypothesis of geological climates. Am J Sc (3) 31 : 161-178 (1886)

Wolcott, E. R.

04 Radioactivity and some radioactive minerals and springs of Colorado. Colo Sch Mines, Bien Rp: 25-36 (1904)

woleott, G. E.

09 Mining and milling at Rawhide, Nev. Eng M J $87: 345-348$ (1909)
Woleott, H. N.

17 The replacement of sulphides by quartz. Am I M Eng, B 126: 959-962 (1917) ; Tr $58: 385-388$ (1918)

Wolf, August.

10 Tungsten ore in Washington. Mines and Minerals $31: 307-308$ (1910)

Wolf, F., jr.

10 Stanley Butte district [Graham Co. Ariz.]. M Sc Press 101:13 (1910)

wolf, Harry J.

15 (with Patton, H. B.) Preliminary report on the Cresson gold strike at Cripple Creek, Colo. Colo Sch Mines, Q 9 no 4: $1-15$ (1915)

16 (and Barbonr, P. P.) The Boulder County tungsten district, Colo. Eng M J $102: 165-169$ (1916)

18 Molybdenum. Colo Sch Mines Mag 8: $71-74$ (1918)

18a Mining in the Telluride district of Colorado. Eng M J 106:395-399 (1918)

Wolf, J, H. G.

13 The Mother Lode of California. M Sc Press 106: 934-938, 983-986 (1913)

Woln, Arthur.

os Die Erdbeben-Katastrophe in San Franzisko. 39 pp Berlin 1908

woln, Henry C.

06 (with slichter, C. S.) The underflow of the South Platte Valley. U S G S, W-S P 184 (1906)

11 Utilization of the underflow near St. Francis, Kans. U S G S, W-S P 258; 58119 (1911)

Wolf, John Eliot.

84 The great dike at Hough's Neck, Quincy, Mass. Harvard Coll, Mus C Z, B 7 (g 8 1) : 231-242 (1884)

85 Notes on the petrography of the Crazy Mountains and other localities in Montana Terr. Northern Transcontinental Survey, Raphael Pumpelly, Director. 19 pp, n p, n d [1885 ?]

85a Nephelingesteine in den Vereinigten Staaten. N Jb 1885, I : 69

90 On some occurrences of ottrelite and ilmenite schist in New England. Harvard Coll, Mus C Z, B 16 (g s 2):159-165 (1890)

91 Metamorphism of clastic feldspar in conglomerate schist. Harvard Coll, Mus C Z, B 16 (g \& 2): 173-184 (1891)

$91 a$ On the Lower Cambrian age of the Stockbridge limestone (with discussion by J. F. James). G Soc Am, B 2:331-337 (1891)

92 The geology of the Crazy Mountains, Mont. G Soc Am, B 3:445-452 (1892)

93 (and Tarr, R. S.) Acmite trachyte from the Crazy Mountains, Mont. Harvard Coll, Mus C Z, B 16 (g \& 2 ): 227-233 (1893)

94 The geology of Hoosac Mountain and adjacent territory. U S G S, Mon 23:35118, map (1894) 
Wolf, John Eliot-Continued.

94a Report on Archean geology.

N J

G S, An Rp 1893: 357-369 (1894)

$94 \mathrm{~b}$ Notes on apparatus for the geological laboratory. Am J Sc (3) 47:355358 (1894)

94e The Hibernia fold, New Jersey (abst). Am G 13:142-143 (1894)

96 Report on Archean geology. N J G S, An Rp 1895:17-20 (1896)

$96 \mathbf{a}$ On an occurrence of theralite in Costa Rica, Central America, Am J Sc (4) 1: 271-272 (1896)

96b Some occurrences of eruptive granite in the Archean Highlands of New Jersey (abst). Science n s $3: 179$ (1896) 97 Report on Archean geology. N J G S, An Rp 1896: 89-94, map (1897)

$97 \mathbf{a}$ (and Brooks, A. H.) Age of the white limestone of Sussex Co., N. J. (abst). G Soc Am, B $8: 397$ (1897) J G $5: 322$ (1897) Science n s 5:96 (1897)

98 (and Brooks, A. H.) The age of the Franklin white limestone of Sussex County, New Jersey. U S G S, An Rp 18 pt $2: 425-457$, map (1898)

98a Occurrence of native copper at Franklin Furnace, N. J. Am Ac Arts, Pr $33: 429-430$ (1898)

$98 \mathrm{~b}$ The relation of the granite to the ore deposits at Franklin Furnace, N. J. (abst). Science n s 8:560 (1898)

99 On hardystonite, a new calcium-zinc silicate from Franklin Furnace, N. J. Am Ac Arts, Pr 34:477-481 (1899) Abst, Science n s $9: 519$ (1899)

oo On hardystonite and a zinc schefferite from Franklin Furnace, N. J. Am Ac Arts, Pr 36:111-115 (1900) Zs Kryst $33: 147-151$ (1900)

02 (and Palache, C.) Apatite from Minot, Maine. Am Ac Arts, Pr $37: 517-$ 528 (1902) Zs Kryst $36: 438-448$ (1902)

02a Leucite tinguaite from Beemerville, N. J. Harvard Coll, Mus C Z, B 38 (g s 5) : 273-277 (1902)

03 Zine and manganese deposits of Franklin Furnace, N. J. U S G S, B 213 : 214-217. (1903)

os Post-Ordovician igneous rocks of the Franklin Furnace quadrangle, N. J. U S G S, G Atlas, Franklin Furnace fol (no 161) : 12-13 (1908)

O8a Memoir of Nathaniel Southgate Shaler. G Soe Am, B 18:592-609, port (1908)

08b Notes on the Crazy Mountains, Mont. (abst.) Science n s 27:409 (1908) G Soc Am, B 19:557-558 (1909)

osc (with Spencer, A. C.) Description of Franklin Furnace quadrangle, N. J. U S G S, G Atlas, fol 161:27 pp (1908)

12 A new chlorite from northern Wyoming. Am J Sc (4) $34: 475-476$ (1912)

17 The Hancock mineral collection. Science n s $45: 161$ (1917)
Wo1n, John Eliot-Continued.

See also Powell, 95 ; Grabau, 98 ; Hawes, 84; Hill (R T), $98 \mathrm{c}$

Wolm, Julius Frederic.

09 Open-pit iron mining on the Mesabi Range of northern Minnesota. Mines and Minerals $29:$ 291-293 (1909)

15 Ore bodies of the Mesabi range. Eng M J 100:89-94, 135-139, 178-185, 219224 (1915)

16 Recent geologic developments on the Mesabi iron range, Minn. L Sup M Inst, Pr 21:229-257 (1917); (with discussion by Carl Zapffe and Edwin J. Collins) Am I M Eng. Tr 56:142-169 (1917) ; B 118: 1763-1787 (1916) ; 123:376-379 (1917)

18 Recent geologic development on the Mesabi iron range, Minn discussion). Am I M Eng, B 141: 1523-1524 (1918)

Wolr, wilhelm.

14 Glazialgeologische Exkursionen des XII Internationalen Geologenkongresses zu Toronto 1913. Centralbl Miner 1914: 334$350,374-384,405-416,431-443$

15 Ueber die Grossgletscher von Alaska und die diluviale Vereisung von Nordamerika. Geog Zs 21:684-700 (1915)

wood, Edgar.

99 Eruption of Mauna Loa, 1899 Am G 24:300-304, map (1899)

04 Eruption of Mauna Loa, 1903. Am G 34: 62-64 (1904)

Wood, Elvira.

01 Marcellus (Stafford) limestones of Lancaster, Erie Co., N. Y. N Y St Mus, B $49: 139-181$, il (1901)

01a A new crinoid from the Hamilton of Charlestown, Ind. Am J Sc (4) 12: $297-300$, il (1901)

04 On new and old midale Devonic crinoids. Smiths Misc Col 47 (Q Is 2) : 5684, il (1904)

09 A critical summary of Troost's unpublished manuscript on the crinoids of Tennessee. U S Nat Mus, B 64:150 pp, il (1909)

10 The phylogeny of certain Cerithiidr. N Y Ac Sc, An 20:1-92, il (1910) Abst, Science n 8 32:224 (1910)

$11 \mathrm{M}$. Cossman on the phylogeny of Cerithium. Science n $\mathrm{s}$ 34:346-347 (1911)

14 The use of crinoid arms in studies of phylogeny. N $\mathrm{X}$ Ac Sc, An 24: 1-17, il (1914) Abst, G Soc Am, B 25: 135 (1914)

\section{wood, George McLane.}

16 Suggestions to authors of papers submitted for publication by the United States Geological Survey ... U S G S, 3d ed : 120 pp (1916)

\section{wood, Harry 0 .}

04 (with Palache, C.) A crystallographic study of millerite. Am J Sc (4) $18: 343-359$ (1904) 
Wood, Harry O.-Continued.

09 (with Palache, C.)

Mass. Am Ac, Pr 44:641-652 (1909)

10 California earthquakes, a synthetic study of the recorded shocks $(a b s t)$. G Soc Am, B 21: 791 (1910)

11 The observation of earthquakes. Seism Soc Am, B 1:48-82 (1911)

12 The registration of earthquakes at the Berkeley station from October 30,1910 , to March 31, 1911. Cal, Univ, Seism Sta, B $1: 1-10$ (1912)

$12 a$ The registration of earthquakes at the Berkeley station from April 1 to September 30,1911 , and at the Lick Observatory station from May 23 to September 30, 1911. Cal, Univ, Seism Sta, B 2:1148 (1912)

12b The registration of earthquakes at the Berkeley station and at the Lick Observatory station from October 1, 1911, to March 31, 1912. Cal, Univ, Seism Sta, B $3: 49-67$ (1912)

12e On the region of origin of the central California earthquakes of July, August, and September, 1911. Seism Soc Am, B 2:31-39 (1912)

12d Seismographic bookkeeping. Seism Soc Am, B 2: 118-123 (1912)

13 The Hawailan volcano observatory. Seism Soc Am, B 3: 14-19 (1913)

14 Concerning the perceptibility of weak earthquakes and their dynamical measurement. Seism Soc Am, B 4:29-38 (1914)

14a On the earthquakes of 1868 in Hawait. Seism Soc Am, B 4:169-203 (1914)

15 The seismic prelude to the 1914 eruption of Mauna Loa [Hawaii]. Seism Soc Am, B $5: 39-51$ (1915)

15a On a possible causal mechanism for heave-fault slipping in the California coast range region. Seism Soc Am, B 5:214229 (1915) Abst, G Soc Am, B 26: 404 (1915)

16 Effects in Mokuaweoweo [Mauna Loa, Hawaii] of the eruption of 1914, Am J Se (4) $41: 383-408$ (1916)

16a California earthquakes; a synthetic study of recorded shocks. Seism Soc Am, B $6: 55-180$, map (1916)

16b The earthquake problem in the western United States. Selsm Soc Am, B 6: 197-217 (1916)

16e Reconnaissance of the Kahuku flow of 1916. Hawalian Volcano Observatory, Weekly B $4: 51-57$ (1916)

16d (with Jaggar, T. A., Jr.) [Observations on Hawailan volcanoes]. Hawaían Volcano Observatory, Weekly B 4, nos 1-12 (1916)

17 Notes on the 1916 eruption of auna Loa. J G $25: 322-336,467-488$ (1917)

17 a $A$ further note on seismometric bookkreping. Seism Soc Am, B 7:106112 (1917)
Wood, Harry O.-Continued.

$17 b$ On cyclical variations in eruption at Kilauea. Second Report of the Hawailan Volcano Observatory : $59 \mathrm{pp}$, published by the Mass Inst Tech, Cambridge, Mass. 1917

1s The study of earthquakes in southern California. Seism Soc Am, B 8:28-33 (1918)

Wood, Harry Warren.

16 The history of Indiana during the Glacial period. Ind, Dp G Nat Res, Rp $40: 11-43$, map (1916)

Wood, Herbert $R$.

90 Kamanistiquia silver-bearing belt [Port Arthur region, Ont.]. Can Inst, $\mathrm{Pr}$ (3) $7: 245-259$ (1890)

92 A note on the Cretaceous of northwestern Montana. Am J Sc (3) 44:401406, map (1892)

92a Gold in placers. Am G 9:371-377 (1892)

92b Glaciation in western Montana. Science 20: 162 (1892)

92e Flathead coal basin, Montana. Eng M J 54:57 (1892)

92d Mineral zones in Montana. Eng M J $54: 292$ (1892)

92e Fissure veins in the Cabinet anticlinal, Libby, Mont. Eng M J 54:605 (1892)

93 The Cabinet anticlinal [Idaho-Montana]. Can Rec Sc 5:261-266 (1893)

Wood, Horatio Charles, jr.

60 Contributions to the Carboniferous flora of the United States. Ac N Sc Phila, Pr $1860 ; 236-240,519-522$, il

60n Catalogue of Carboniferous plants in the museum of the Academy of Natural Sciences, with corrections in synonomy, descriptions of new species, etc. Ac N Sc Phila, Pr $1860: 436-443$

69 A contribution to the knowledge of the flora of the coal period in the United States. Am Ph Soc, Tr n s $13: 341-349$, il (1869)

wood, J.

25 Remarks on the moving of rocks by ice. Am J Sc 9:144-145 (1825)

Wood, J. Walter, jr.

90 (with Duvis, W. M.) The geographic development of northern New Jersey. Boston Soc N H, Pr 24:365-423 (1890)

Wood, John R.

10 Rare metals in Boulder Co., Colo. M Science 62:11 (1910)

Wood, Katharine Hill.

09 (with Laney, F. B.) Bibliography of North Carolina geology, mineralogy, and geography, with a list of maps. N C G S, B 18:428 pp (1909)

Wood, Leslie $\mathrm{H}$.

02 (with Wilder, F. A.) Report on the lignite by counties. N Dak G S, Bien Rp 2:56-162, map (1902) 
Wood, Leslie H.-Continued.

04 Report on the region between the Northern Pacific Railroad and Missouri River; its topography, climate, vegetation, irrigation possibilities, and coal deposits. N Dak G S, Bien Rp 3:41-125, map (1904)

Wood, Robert $\mathrm{H}$.

13 Oil and gas development in northcentral Oklahoma. U S G S, B 531:27-53, map (1913)

Wood, Searles V.

77 American "surface geology," and its relation to British. G Mag (2) 4:481$496,536-551$ (1877) ; 5:13-29 (1878)

Woodbridge, Dwight Edwards.

o5 The Mesabi iron-ore range. Eng M

J $79: 698-700(1905)$

06 Arizona and Sonora. Eng M J 81: $896-897,990-992,1134-1135,1180-1182$, 1229-1232 (1906)

OGa La Cananea mining camp [Sonora, Mexico]. Eng M J $82: 623-627$ (1906)

07 Iron ore in Crow Wing Co., Minn. Eng M J 84:775-776 (1907)

11 Exploration of Cuban iron-ore deposits. Am I M Eng, B 51:269-282 (1911) ; Tr 42:138-152 (1912)

11a Cuban iron-ore deposits. Can M J $32: 738-741$ (1911)

14 The possibilities of the Cuban iron deposits. M World 40:511-513 (1914)

Woodhouse, C. C., jr.

96 Coal fields of Washington. Mining 1: $67-71$ (1896)

Woodhull, Alfred A.

72 On the elephant in Colorado. Am J Sc (3) $3: 374$ (1872)

Woodman, E. E.

82 The pipestone of Devil's Lake. Wis Ac Sc, Tr 5: 251-254 (1882)

Woodman, Joseph Edmund.

96 Preliminary notes on the north Jersey coast (abst). Science n $8 \quad 3: 144$ (1896)

96a 'Longshore transportation on the north Jersey coast $(a b s t)$. Science n s 3 : 679-680 (1896)

99 Ore-bearing schists of middle and northern Cape Breton. N S, Dp Mines, Rp 1898: 39 pp (1899)

99a Shore development in the Bras d'Or lakes. Am G 24:329-342 (1899)

$99 \mathrm{~b}$ Studies in the gold-bearing slates of Nova Scotia. Boston Soc N H, Pr 28:375408 (1899)

99e Notes on the glacial geology of Nova Scotia (abst). Science n s 9:786 (1899)

04 Nomenclature of the gold-bearing metamorphic series of Nova Scotia. Am $G$ $33: 364-370$ (1904)

$04 a$ The sediments of the Meguma series of Nova Scotia. Am G 34:13-34 (1534)

o5 Geology of the Moose River gold district, Halifax Co., N. S. N S Inst Sc, Pr Tr 11:18-88, map (1905)
Woodman, Joseph Edmund-Continued.

06 Distribution of bedded leads in relation to mining policy. N S Inst Sc, Tr 11: 163-178 (1906) M Soc N S, J $10: 79-94$ (1907)

06n The earthquake of March 21, 1904, in Nova Scotia. N S Inst Sc, Tr 11:227235 (1906)

07 Preliminary report on iron-ore deposits of parts of Nova Scotia. Can, Dp Interior, Rp Supt Mines 1907:18-32 (1907)

07a The Cumberland coal basin, N. S. (abst). Science n \& 25:296-297 (1907)

os Probable age of the Meguma (goldbearing) series of Nova Scotia. G Soc Am, B $19: 99-112$ (1908), abst 18:636-637 (1908)

09 Report on the iron-ore deposits of Nova Scotia (Part I). Can Mines Br : 226 pp (1909) Can M J $30: 496-498,550-556$, 621-627 (1909)

11 On the geology of Trenton, N. J. Harvard Univ, Peabody Mus Am Arch, Papers 5:233-236 (1911)

13 Forelands of the Bras d'Or Lakes, Cape Breton Island, N. S. $(a b s t)$. N Y Ae Se, An $22: 351$ (1913)

13a The interbedded iron ores of Nova Scotia (abst, with discussion by J. F. Kemp and G. Van Ingen). Science n s 38 : 281 (1913) N Y Ac Sc, An 23: 274 (1914)

16 Metallurgical limestones of Nova Scotia (abst). N Y Ac Sc, An 26:445 (1916)

See also Earle, 13; Grabau, 98

Woodring, Wendell Phillips.

17 The pelecypods of the Bowden fauna [Jamaica]. Johns Hopkins Univ Cire n s 1917 no $3: 44-56$ [242-254] (1917)

Woodrufr. Elmer Grant.

04 Present status of the mining industry in the Wichita Mountains of Oklahoma. Okla, Dp G N H, Bien Rp 3: 23-24 (1904)

06 The geology of Cass Co., Nebr. Nebr G S 2:171-302, map (1906)

o7 The Lander coal field, Wyo. U S G S, B $316: 242-243$ (1907)

os Sulphur deposits at Cody, Wyo. U S G S, B 340: 451-456 (1908)

09 The Red Lodge coal field, Mont. U S G S, B 341: 92-107, map (1909)

O9a Coal fields of the southwest side of the Bighorn Basin, Wyo. U S G S, B 341 : 200-219, map (1909)

09b Sulphur deposits near Thermopolis, Wyo. U S G S, B $380: 373-380$ (1909)

10 The coal field in the southeastern part of the Bighorn Basin, Wyo. U S G S, B 381: 170-185, map (1910)

11 The Lander oil field, Wyo. U S G S, B 452: 7-36, map (1911)

11 a (with Campbell, M. R.) The Powell Mountain coal field, Scott and Wise cos., Va. U S G S, B 431: 147-162 (1911) 
Woodrufr, Elmer Grant-Continued.

12 Geology of the San Juan oil field,

Utah. U S G S, B 471:76-104, maps (1912)

12a Marsh gas along Grand River near Moab, Utah. U S G S, B 471: 105 (1912)

12b The coal resources of Gunnison Valley, Mesa and Delta cos., Colo, U S G S, B 471:565-573, map (1912)

12e (and winchester, D. E.) Coal fields of the Wind River region, Fremont and Natrona cos., Wyo. U S G S, B 471 : 516-564, maps (1912)

13 Measurement of the thickness of strata with the plane table and telescopic alidade. Ec G 8:291-297 (1913)

13a Geology and petroleum resources of the De Beque oil field, Colo. U S G S, B 531: 54-68, map (1913)

13b Cone in cone structure in coal from St. Anthony, Idaho (abst). Wash Ac Sc J $3: 237$ (1913)

14 The Horseshoe Creek district of the Teton Basin coal field, Fremont Co., Idaho. U S G S, B 541: 379-388, map (1914)

14a The Glacier coal field, Whatcom Co., Wash. U S G S, B 541:389-398, map (1914)

14b (and Day, D. T.) Oil shale of northwestern Colorado and northeastern Utah. U S G S, B 581: 1-21 map (1914) Abst, Wash Ac Sc, J 4:170-171 (1914)

See also Bucher, 18a

woodrufr, Lorande Loss.

1s The origin of life. In The evolution of the earth and its inhabitants [edited by R, S. Lull] : 82-108, New Haven, , 1918 woods, Henry.

99 Note on the genus Grammatodon Meek and Hayden. An Mag N H (7) 3: 47-48 (1899)

woodward, A. E.

90 The mineral waters of Saline Co. Mo G S, B 1: 45-59 (1890)

$90 \mathbf{n}$ The mineral waters of Henry, St. Clair, Johnson, and Benton cos. Mo G S, B 3: 85-101 (1890)

woodward, Anthony.

85 (and Thomas, B. W.) On the Foraminifera of the boulder clay taken from a well shaft 22 feet deep, Meeker Co., central Minn. Minn G S, An Rp 13:164-176, il (1885)

86 The bibliography of the Foraminifera, recent and fossil, including Eozoon and Receptaculites. Minn G S, An Rp 14: 167-311 (1886)

89 Preliminary list of the Foraminifera from the post-Pliocene sand at Santa Barbara, Cal. N Y Micro Soc, J 5:24-25 (1889)

94 The Cretaceous Foraminifera of New Jersey. N Y Micro Soc, J 10:91-141 (1894)
Woodward, Anthony-Continued.

95 (and Thomas, B. W.) The microscopical fauna of the Cretaceous in Minnesota, with additions from Nebraska and Illinois (Foraminifera, Radiolaria, coccoliths, rhabdoliths). Minn $\mathbf{G} \mathbf{S}$, Final Rp 3 pt $1: 23-52$, il (1895) Abst, Minn, Univ, Q B 1:119-120 (1893)

Woodward, Arthur Smith.

89 Acanthodian fishes from the Devonian of Canada. An Mag N H (6) 4:183-184 (1889)

90 Vertebrate paleontology in some American and Canadian museums. G Mag (3) $7: 390-395,455-460 \quad$ (1890)

92 On the Lower Devonian fish fauna of Campbellton, N. B. G Mag (3) 9:1-6, il (1892)

92a Further contributions to knowledge of the Devonian fish fauna of Canada. G Mag (3) 9:481-485, il (1892)

96 On some extinct fishes of the teleostean family Gonorhynchidae [Eocene fish, Wyo.]. Zool Soc London, $\operatorname{Pr} 1896$ : 500504 , il (1896)

97 Edward Drinker Cope. Nat Sc 10: $377-381$, port. (1897)

oo On a new ostracoderm (Euphanerops longaevus) from the upper Devonian of Scaumenac Bay, Province of Quebec, Canada. An Mag $\mathrm{N} H$ (7) $5: 416-419$, il (1900)

06 The relations of paleontology to other branches of science. Cong Arts and Sc (St. Louis 1904) : 551-565 (1906)

09 Address of the president to the geological section of the British Association for the Advancement of Science. Science n s $30: 321-331$ (1909)

13 On a new specimen of the Cretaceous fish Partheus molossus, Cope [from Kansas]. G Mag (5) 10:529-531, il (1913)

17 Henry Fairfield Osborn. G Mag (6) 4: 193-196, port (1917)

woodward, Henry.

66 Note on a new species of Ranina (R. porifera) from the Tertiary strata of Trinidad. G Soc London, Q J 22: 591-592 (1866)

70 Note on the palpus and other appendages of Asaphus from the Trenton limestone. G Soc London, Q J 26:486488 , il (1870) Abst, G Mag $7: 292-293$ (1870)

71 On a new fossil crustacean from the Devonian rocks of Canada. Can Nat $n$ s 6 : 18-19 (1871)

71a On the Canadian trilobite with legs. Can Nat n s 6:227-231 (1871)

78 Notes on some Arctic Silurian or Devonian (?) fossils from Beechey Island... G Mag (2) $5: 385-390$, il (1878)

so Notes on the Anomalocystidae, a remarkable family of Cystoidea found in the Silurian rocks of North America and Britain. G Mag (2) 7:193-201, il (1880) 
Blatehley, Raymond Silliman-Continued. 08 The Indiana oolitic limestone industry in 1907. Ind Dp G, An Rp $32: 299$ 459, maps (1908)

09 Drilling for oil in eastern Illinois. M Sc Press 99:613-617 (1909)

10 Oil resources of Illinois with special reference to the area outside the southeastern fields. In G S, B 16:42-176, map (1910)

11 Oil investigations in Illinois. Western Soc Eng, J $16: 369-396$, maps (1911) IIl Ac Sc, $\operatorname{Tr} 4: 85-97$, maps (1912)

12 The structural relations of the oil fields of Crawford and Lawrence cos., IIl. Ec G $7: 574-582$, map (1912) Ill Ac Sc, $\operatorname{Tr} 5: 81-87$ (1912) M World $37: 1098$ 1099, map (1912)

12a Illinois oil industry, its history and development. M Eng World 36:12931295 (1912)

12b The Illinois petroleum fields, Am Geog Soc, B 44:417-426, map (1912)

13 The ofl flelds of Crawford and Lawrence cos. III G S, B $22: 442 \mathrm{pp}$, maps (1913)

14 The Plymouth oil field [IIl.]. IIl G S, Extract B 23:5-7 (1914)

14a Oil and gas in Bond, Macoupin, and Montgomery cos., Ill. III G S, B 28:51 pp, maps (1914)

17 Plymouth oil field. Ill G S, B 23: 51-53 (1917)

\section{Blatchley, Willis Stanley.}

96 Twentieth annual report, 1895 . Ind, Dp G N Res: 520 pp, maps, Indianapolis 1896 Twenty-first ... 1896:719 pp, maps (1897) Twenty-second ... 1897: $1197 \mathrm{pp}$ maps (1898) Twenty-third ... 1898: xxvii, $1741 \mathrm{pp}$, maps (1899) Twenty-fourth ... 1899: $1078 \mathrm{pp,} \mathrm{map} \mathrm{(1900)} \mathrm{Twenty-fifth}$ ... 1900 : xili, $782 \mathrm{pp}$, maps (1901) Twentysixth ... 1901 : 448 pp, maps (1903) Twentyseventh ... 1902:680 pp, maps (1903) Twenty-eighth ‥ $1903: \mathbf{5 6 5} \mathrm{pp}, \mathbf{1 1}$, maps (1904) Twenty-ninth ... 1904:888 pp, maps (1905) Thirtieth ... 1905:1494 pp, il, maps (1906) Thirty-first ... 1906: 772 pp, maps (1907) Thirty-second ... 1907 : $1258 \mathrm{pp}$. il, maps (1908) Thirty-third ... 1908: $663 \mathrm{pp}$, maps (1909) Thirty-fourth 1909: 392 pp, maps (1910) Thirtyfifth ... 1911: 242 pp, maps (1911)

96a A preliminary report on the clays and clay industries of the coal-bearing countles of Indiana. Ind, Dp G N Res, An Rp 20:23-185 (1896)

97 The natural resources of Indiana. Ind, Dp G N Res, An Rp 21: 7-25 (1897)

07a The petroleum industry in Indiana. Ind, Dp G N Res, An Rp 21:27-96, map (1897)

97b Indiana caves and their fauna. Ind, Dp G N Res, An Rp 21:121-212 (1897)
Blatchley, Willis Stanley-Continued.

$97 \mathrm{e}$ The natural resources of Indiana. In Dryer, C. R., Studies in Indiana geography; first series:61-71, Terre Haute, Ind., 1897

98 (and Ashley, G. H.) Geological scale of Indiana. Ind, Dp G N Res, An Rp $22: 17-23$ (1898)

98a The geology of Lake and Porter cos., Ind. Ind, Dp $G$ N Res, An Rp 22 : 25-104, map (1898)

98b The clays and clay industries of northwestern Indiana. Ind, Dp G N Res, An Rp 22: 105-153 (1898)

9Se The petroleum industry in Indiana in 1897. Ind, $\mathrm{Dp} G \mathrm{~N}$ Res, $\mathrm{An} \mathrm{Rp} 22$ : 155-184 (1898)

oo The natural resources of the State of Indiana. Ind, $\mathrm{Dp} G \mathrm{~N}$ Res, An Rp $24: 3-40$ (1900)

o1 Portland cement. Ind, Dp G N Res, An Rp 25:1-30 (1901)

o1n (and Ashley, G. H.) The lakes of northern Indiana and their associated marl deposits. Ind, $\mathrm{Dp} G \mathrm{~N}$ Res, An Rp $25: 31-321$, maps (1901)

01b Oolite and oolitic stone for Portland cement manufacture. Ind, Dp G N Res, An Rp 25: 322-330 (1901)

01e The petroleum industry in Indiana in 1900. Ind, $\mathrm{Dp} G \mathrm{~N}$ Res, An $\mathrm{Rp} 25$ : 481-527, map (1901) ...in 1901; 26:303331 (1903) ...in $1902 ; 27: 571-576$ (1903) ...in $1903 ; 28: 79-209$ (1904) ...in 1904; $29: 781-799$ (1905)

03 The mineral waters of Indiana; their location, origin and character. Ind, Dp G N Res, An Rp 26:11-158 (1903)

03a Gold and diamonds in Indiana. Ind, Dp G N Res, An Rp 27:11-47 (1903)

03b (and Sheak, W. H.) Trenton rock petroleum. Sc Am Sup 55: 22775 (1903)

04 The Indiana of nature; its evolution. Ind Ac Sc, Pr 1903: 33-59 (1904)

O4a The lime industry in Indiana. Ind Dp G N Res, An Rp 28:211-257 (1904)

05 The clays and clay industries of Indiana. Ind, Dp $G N$ Res, An Rp 29 : 13-657 (1905)

06 The petroleum industry of southeastern Illinois [with contributions by Stuart Weller, F. F. Grout, and T. E. Savage]. III G S, B 2: 109 pp (1906)

O6a The geologic distribution of the road materials of Indiana. Ind, $\mathrm{Dp} G, \mathrm{An}$ Rp $30: 120-160$ (1906)

о7 The natural resources of the State of Indiana. Ind, Dp $G$, An $R p$ 31:13-72 (1907)

07a The petroleum industry in Indiana in 1906. Ind Dp G, An Rp 31:429-558, map (1907)

11 General geology of the Oakland City. Indiana, area relating to occurrence of ofl and gas. Oil and Gas J 10 no $19: 12$ (Oct. 19,1911 ) 
woodward, Henry-Continued.

84 Notes on appendages of trilobites.

G Mag (3) 1:162-165, il (1884)

s8 Obituary, Prof. Henry Carvill Lewis.

G Mag (3) $5: 428-430$ (1888)

89 On the dicovery of Turrilepas in the Utica formation (Ordovician) of Ottawa, Canada. G Mag (3) 6:271-275, il (1889)

95 On some decapod crustacea from the Cretaceous formation of Vancouver's Island, etc. $(a b s t)$. Brit As, 65:696-697 (1895)

96 On some podophthalmatous Crustacea from the Cretacequs formations of Vancouver and Queen Charlotte islands. G Soc London, Q J 52:221-228, il (1896) Abst, G Mag (4) $3: 88$ (1896)

99 Alfred Richard Cecil Selwyn. G Mag (4) $6: 49-55$, port (1899)

99a Othniel Charles Marsh. G Mag (4) $6: 237-240$, port (1899)

99b (with Jones, T. R.) Contributions to fossil Crustacea. G Mag (4) 6:388395 , il (1899)

oo Further note on podophthalmous crustaceans from the upper Cretaceous formation of British Columbia, etc. G Mag (4) $7: 392-401,433-435$, il $(1900)$

02 On a collection of middle Cambrian fossils ... from Mount Stephen, B. C. G Mag (4) 9:502-505, 529-544, il (1902)

03 Note on some fragmentary remains of fossils from the upper part of Mount Noyes, Canadian Rockies. G Mag (4) 10 : $297-298$, il (1903)

Woodward, Robert Simpson.

86 Recession of Niagara River (abst). Am J Sc (3) $32: 322-323$ (1886) Science $8: 205$ (1886)

s9 The mathematical theories of the earth. Science 14:167-172 (1889) Am J Sc (3) 38:337-355 (1889) Am G 4: 268-284 (1889) Am As, Pr 38:49-69 (1890) Smiths Inst, An Rp 1890:183200 (1891)

92 Some mechanical conditions of the earth's mass (abst). Ph Soc Wash, B 11 : $532-533(1892)$

95 The condition of the interior of the earth. N Y Ac Sc, Tr 14:72-74 (1895) Science n s $1: 193-195$ (1895)

03 (and others) Report of advisory committee on geophysics [problems and methods of investigation]. Carnegie Inst Wash, Y Bk 1: 26-70 (1903)

See also Dutton, 89a; Powell, 89, 89a, $90,91,91 \mathrm{a}$

Woodwaxd, S. F.

78 Altitude of the Blue limestone formation at Osborn, Ohio. Central Ohio Sc As (Urbana), Pr 1: 50-51 (1878)

woodward, S. P.

62 Some account of Barrettia, a new and remarkable fossil shell from the Hippurite limestone of Jamaica. Geologist, London, $5: 372-377$, il (1862)
Woodworth, Jay Backus.

92 Note on the occurrence of erratic Cambrian fossils in Neocene gravels of the island of Marthas Vineyard. Am G 9 : 243-247 (1892)

93 An attempt to estimate the thickness of the ice blocks which gave rise to lakelets and kettleholes. Am G 12:279284 (1893)

93a The ice wall on the beach at Hull, Mass., January, 1893. Seience 21:71-72 (1893)

93b On traces of a fauna in the Cambridge slates $(a b s t)$. Boston Soc N H, Pr $26: 125-126$ (1893)

94 The relation between base-levellng and organic evolution. Am G 14: 209-235 (1894)

94a Postglacial eolian action in Southern New England. Am J Sc (3) $47: 63-71$ (1894)

94b Carboniferous fossils in the Norfolk County Basin [Mass.]. Am J Sc (3) 48 : 145-148 (1894)

94e Some typical eskers of southern New England. Boston Soc $\mathrm{N} H, \operatorname{Pr} 26$ : $197-220$ (1894)

94d A new geological map of Pennsylvania. Science $23: 143-144$ (1894)

95 Three-toed dinosaur tracks in the Newark group at Avondale, N. J. Am J Sc (3) $50: 481-482$ (1895)

96 The retreat of the ice sheet in the Narragansett Bay region. Am G 18:150168, 391-392, map (1896)

96a On the fracture system of joints, with remarks on certain great fractures. Bostón Soc N H, Pr 27:163-184 (1896)

96b (and Marbut, C. F.) The Queen's River moraine in Rhode Island. $J$ G 4: 691-703 (1896)

96e (with Shaler, N. S.) The glacial brick clays of Rhode Island and southeastern Massachusetts. U S G S, An Rp 17 pt 1: 951-1004 (1896)

97 Unconformities of Marthas Vineyard and of Block Island. G Soc Am, B 8:197212, map (1897) Abst, J G $5: 96-97$ (1897) ; Sclence n s 5: 86-87 (1897)

$97 a$ Charles Thomas Jackson. Am G $20: 69-110$, port (1897)

$\mathbf{9 7 b}$ Homology of joints and artificial fractures (abst). J G $5: 97-98$ (1897) Science n s 5:84 (1897)

98 Some glacial wash plains of southern New England. Essex Inst, B 29:71-119 (1898)

99 The ice contact in the classification of glacial deposits. Am G $23: 80-86$ (1899)

$99 a$ (with Curtis, G. C.) Nantucket, a morainal island. $J$ G $7: \cap 26-236$, map (1899)

$99 b$ (with Shaler, N. S.) Geology of the Narragansett Basin. U S G S, Mon $33: 402$ pp, maps (1899) 
Woodworth, Jay Backus-Continued. 99e (with Shaler, N. S.) Geology of the Richmond Basin, Virginia. U S G S, An Rp 19 pt $2: 385-515$, maps (1899)

oo Vertebrate footprints on Carboniferous shales of Plainville, Mass. G Soc Am, B 11: 449-454, map, il (1900)

OOa Glacial origin of older Pleistocene in Gay Head cliffs, with note on fossil horse of that section. G Soc Am, B 11: 455-460 (1900) Abst, Science n s $11: 102$ (1900)

o1 Pleistocene geology of portions of Nassau County and Borough of Queens [N. Y.]. N Y St Mus, B 48: 618-670, map (1901)

01a Original micaceous cross banding of strata by current action. Am G $27: 281-$ 283 (1901)

02 The Atlantic coast Triassic coal field. U S G S, An Rp 22 pt 3:25-53, maps (1902)

02a The history and conditions of mining in the Richmond coal basin, Va. Am I M Eng, Tr 31: 477-484, map (1902)

03 The Northumberland volcanic plug [Saratoga Co., N. Y.]. N Y St Mus, An Rp $55:$ r17-24 (1903)

o3a On the sedentary impression of the animal whose trail is known as Climactichnites. N Y St Mus, B $69: 959-966$, il (1903)

03b Note on the elevated beaches of Cape Ann, Mass. Harvard Coll, Mus C Z, B 42 ( g \& 6) : 191-194 (1903)

04 The Brandon clays. Vt, St G, Rp 4: $167-173$ (1904)

o5 Pleistocene geology of Mooers quadrangle (N. Y.]. N Y St Mus, B $83: 3-60$, maps (1905)

o5a Ancient water levels of the Champlain and Hudson valleys [N. Y.]. N Y St Mus, B 84:265 pp, maps (1905)

07 Postglacial faults of eastern New York. N Y St Mus, B 107:5-28 (1907)

O7a Abandoned shore lines (abst). Science n \& 26:397-398 (1907)

o9 Report on the Harvard seismographic station. Harvard Coll, Mus C Z, An Rp Curator 1908-09; 28-32 (1909) Second annual report ...; 1909-10:27-34 (1910) [Third ...] ; 1910-11:24-26 (1911)

11 The nomenclature of seismological reports. Seism Soc Am, B 1:21-22 (1911)

$11 \mathrm{n}$ On the geology of vicinity of Trenton, N. J. Harvard Univ, Peabody Mus Am Arch, Papers 5:237-241 (1911)

12 Boulder beds of the Caney shale at Talihina, Okla, G Soc Am, B 23:457462 (1912) Abst, Science n $8 \quad 35: 319$ (1912)

12a Harvard seismographic station [annual reports]. Harvard Coll, Mus C Z, B 55 (g s 9):3-23, 27-51, 55-57, 81-107, 111-161 (1912-7)

13 (and others) "The pre-Cambrian nomenclsture," Ec G 8:309 (1913)
Woodworth, Jay Backus-Continued.

13a Memoir of Ralph Stockman Tarr.

G Soc Am, B 24: 29-43, port (1913)

See also Davis (C A), 12; Goldthwait, 13 ; Sayles, 16 ; Spencer (J W), 12b

Woolacott, David.

10 Note on the structure and surface features of a portion of the Rocky Mountains. Durham, Univ, $\mathrm{Ph}$ Soc, $\operatorname{Pr} 3: 327-$ 329 (1910)

\section{wooldridge, A. S.}

42 ... coal mines in the vicinity of Richmond, Va. Am J Sc 43:1-14 (1842)

Wooldridge, $C$. W.

84 Recent geological changes in western Michigan. Pop Sc Mo 24:826-830 (1884)

88 The river-lake system of western Michigan. Am G 1:143-146 (1888)

88a The postglacial geology of Ann Arbor, Mich. Am G 2:35-39 (1888)

Woolford, Frederick.

48 [Clays of Washington Co., Mo.]. Western J (St. Louis) 1.168-169, 193195 (1848)

Woolman, Lewis.

86 Oriskany sandstone in Lycoming Co., Pa. Ac N Sc Phila, Pr 1886: 296-297

88 Geological results of the boring of an artesian well at Atlantic City, N. J. Ac N Sc Phila, Pr 1887:339-342 (1888)

89 Artesian wells, Atlantic City, N. J. N J G S, An Rp 1889: 89-99 (1889)

90 Geology of artesian wells at Atlantic City, N. J. Ac N Sc Phila, Pr 1890:132147,444

90a Marine and fresh-water diatoms and sponge splcules from the Delaware River clays of Philadelphia. Ac N Sc Phila, Pr 1890:189-191

91 Artesian wells and water-bearing horizons of southern New Jersey. N J G S, An Rp 1890: 269-283 (1891)

92 A review of art ian well horizons in southern New Jersey. N J G S, An Rp 1891: 223-232 (1892)

92a (and Kain, C. H.) Fresh-water diatomaceous deposit from Staked Plains, Texas. Am Nat 26:505-506:1892)

93 Artesian wells in southern New Jersey. N J G S, An Rp 1892:273-311; $1893: 387-421 ; 1894: 151-221$ (1893-5)

93a Cretaceous ammonites and other fossils near Moorestown, N. J.; their stratigraphic position shown by an artesian well section at Maple Shade, N. J. Ac N Sc Phila, Pr 1893: 219-224

96 Report on artesian wells. N J G S, An Rp $1895: 63-95 ; 1896: 95-200 ; 1897$ : 211-295; 1898:59-144; 1899:55-139; $1900: 103-171 ; 1901: 53-128 ; 1902: 59$ 95 (1896-1903)

97 Stratigraphy of the Fish House black clay and associated gravels. N J G S, An Rp 1896: 201-254, il (1897) 
Woolman, Lewis-Continued.

9s Fossil mollusks and diatoms from the Dismal Swamp, Virginia and North Carolina, indication of the geological age of the deposit; with notes on the diatoms by Charles $\mathrm{S}$. Boyer. Ac $\mathrm{N}$ Sc Phila, $\mathrm{Pr}$ $1898: 414-428$

Woolsey, Lester Hood.

o4 Clays of the Ohio Valley in Pennsylvania. U S G S, B 225:463-480 (1904)

04a Extramorainic pebbles in western Pennsylvania $(a b s t)$. Science n s 19:733 (1904)

o5 Description of the Beaver quadrangle [Pa.]. U S G S, G Atlas Beaver fol (no 134) : $15 \mathrm{pp}$, maps (1905)

06 Volcanic ash near Durango, Colo. U S G S, B 285:476-479 (1906)

06a Economic geology of the Beaver quadrangle, Pa. (southern Beaver and northwestern Allegheny cos.). U S G S, B $286: 132$ pp (1906)

o7 Lake Fork extension of the Silverton mining area, Colo. U S G S, B $315: 26-$ $30(1907)$

09 The Bull Mountain coal field, Mont. U S G S, B 341:62-77, map (1909)

17 (and Richards, R. W., and Lupton, C. T.) The Bull Mountain coal field, Musselshell and Yellowstone cos., Mont. U S G S, B $647: 218$ pp, maps (1917) Abst, by R. W. Stone, Wash Ac Sc, J 7 : 602-603 (1917)

See also Boutwell, 12

woolsey, W. J.

10 Notes on recent developments in asbestos mining in Quebec. Can M Inst, Q B $10: 205-210(1910) ;$ J $13: 408-413$ (1911) Abst, Can M J 31:434-435 (1910)

13 Notes on asbestos veins and the mineral nephrite. Can M J 34:519 (1913)

14 Asbestos resources of the Thetford area [Que.]. Can M Inst, Mo B $27: 103-$ 106 (1914)

Woolworth, Samuel.

47 Description of a tooth of the Elephas americanus [Homer, Cortlandt Co., N. Y.]. Am J Agr 6:31-37, il (1847)

Wooster, Lyman C.

78 Work in St. Croix, Dunn, and adjacent cos. Wis G S, An Rp 1877: 36-41 (1878)

82 Geology of the lower St. Croix district. [Wis G S], G Wis 4:99-159 (1882)

83 The thickness of the ice in New England in glacial times. Science 2:685 (1883)

84 Transition from the copper-bearing series to the Potsdam. Am J Sc (3) 27 : 463-465 (1884)

84a Kames near Lansing, Mich. Science $3: 4$ (1884)

84b Ripple marks in limestone. Science $3: 274$ (1884)
Wooster, Lyman C.-Continued.

88 The Coal Measures of Kansas. Science 12:119 (1888) Eng M J 46:240 (1888)

88a The limit of drift [in Kansas]. Science $12: 132$ (1888)

90 The Permo-Carboniferous of Greenwood and Butler cos., Kans. Am G 6: 9-18 (1890)

92 Glacial striae in Kansas. Am G 10 : 131 (1892)

00 The geological story of Kansas. 139 pp, Topeka, Kans., 1900

o5 The Carboniferous rock system of eastern Kansas. 12 pp, Emporia, Kansas, 1905 [priv pub]

O5a Some notes on Kansas geology. Kans Ac Sc, Tr 19:118-121 (1905)

06 Additional observations on the geology of Kansas. Kans Ac Sc, Tr 20 pt 1: 75-82 (1906)

11 An esker at Mason, Mich. Kans Ac Sc, Tr 23-24: 91-94 (1911)

13 Notes on the moraine of the glacier southwest of Topeka. Kans Ac Sc, Tr 25 : 43-44 (1913)

14 Geological development of Kansas. Kans Ac Sc, Tr 26:55-69 (1914)

15 The chert gravels of eastern Kansas. Kans Ac Sc, Tr 27:58-62 (1915)

18 Glacial moraines in the vicinity of Estes Park, Colo. School Science and Mathematics 18:263-267 (1918)

Wooton, Paul.

12 Louisiana salt mines; their operation and output. M World $36: 401-402$ (1912)

12a History and development of Louisiana's oil fields. M World 36:1296-1298 (1912)

worcester, P. G.

16 (with Crawford, R. D.) Geology and ore deposits of the Gold Brick dis. trict, Colo. Colo G S, B 10:116 pp, maps (1916)

Wormley, T. G.

71 Report of chemical department. Ohlo G S, Rp Prog 1870:401-462 (1871)

wornester, L., Jr.

07 Zinc in Chihuahua. Mineral Collector 13: 169-171 (1907)

worre11, s. $\mathrm{H}$.

11 (with Phillips, W. B.) The com position of Texas coals and lignites. Tex Univ, B (sc s) $19: 5-57$ (1911)

13 (with Phillips, W. B.) The fuels used in Texas. Tex Univ, B 307 (sc s 35) : $287 \mathrm{pp}$ (1913)

Worthen, Amos Henry (1813-1888).

$\mathbf{5 7}$ On the occurrence of fish remains in the Carboniferous limestone of Illinols. Am As, Pr 10 pt $2: 189-192$ (1857) Abst, Edinb N Ph J n s 5:367-369 (1857)

58 Geology of the Des Moines Valley; geology of certain counties. Iowa G S 1 pt $1: 147-258$ (1858) 
Worthen, Amos Henry-Continued.

60 Notice of a new species of Platy. crinus and other fossils from the Mountain Limestone of Illinois and Iowa... Ac Sc St L, Tr 1:569-571 (1860)

$60 a$ Review of some points in Dr. B. F. Shumard's Report on the geology of Ste. Genevieve Co., Mo. Ac Sc St L, Tr 1: 696-698 (1860)

$60 \mathrm{~b}$ Remarks on the discovery of a terrestrial flora in the mountain limestone of Illinois (abst). Am As, $\operatorname{Pr} 13: 312-313$ (1860)

60e (with Meek, F. B.) Descriptions of new species of Crinoidea and Echinoidea from the Carboniferous rocks of Illinois, and other Western States. Ac N Sc Phila, Pr 1860: 379-397

60d (with Meek, F. B.) Descriptions of new Carboniferous fossils from Illinois and other Western States. Ac N Sc Phila, Pr $1860: 447-472$

61 (with Meek, F. B.) ... age of the Goniatite limestone at Rockford, Indiana, and its relation to the "black slate" of the Western States, and to some of the succeeding rocks above the latter. Am J Sc (2) $32: 167-177,288$ (1861)

$61 \mathrm{n}$ (with Meek, F. B.) Descriptions of new Paleozoic fossils from Illinois and Iowa, Ac N Sc Phila, Pr 1861: 128-148

62 Remarks on the age of the so-called "Leclare limestone" and "Onondaga salt group" of the Iowa report. Am J Sc (2) $33: 46-48$ (1862)

65 (with Meek, F. B.) Note in relation to a genus of crinoids [Erisocrinus] from the Coal Measures of Illinois and Nebraska. Am J Sc (2) $39: 350$ (1865)

65a (with Meek, F. B.) Notice of some new types of organic remains, from the Coal Measures of Illinois. Ac N Sc Phila, Pr 1865:41-53

65b (with Meek, F. B.) Remarks on the genus Taxocrinus (Phillips) McCoy, 1844; and its relations to Forbesiocrinus, Koninck and Le Hon, 1854, with descriptions of new species. Ac N Sc Phila, Pr $1865: 138-143$

65e (with Meek, F. B.) Description of new species of Crinoidea, etc., from the Paleozoic rocks of Illinois and some of the adjoining States. Ac N Sc Phila, Pr 1865: 143-155

65d (with Meek, F. B.) Descriptions of new Crinoidea, etc., from the Carboniferous rocks of Illinois and some of the adjoining States. Ac N Sc Phila, Pr 1865: $155-166$

65e (with Meek, F. B.) Contributions to the paleontology of Illinois and other Western States. Ac N Sc Phila, Pr 1865: 245-273

$$
28737^{\circ}-23-73
$$

Worthen, Amos Henry-Continued.

66 [Geology of Illinois: Physical features, surface deposits; stratigraphical geology, Tertiary deposits, and Coal Measures ; Subcarboniferous limestone; Devonian and Silurian systems.] III G S 1:1-152 (1866) ; Ec G 1:1-117 (1882)

66a Geology of Randolph Co.; St. Clafr Co.; Madison Co.; Hancock Co. IIl G S $1: 278-349$ (1866); Ec G 1:210-290 (1882)

66b (and Engelmann, H.) Hardin Co. Ill G S $1: 350-375$, map (1866) ; Ec G 1:291-319 (1882)

66e Remarks on the occurrence of fossil fishes in Illinois. III G S $2: 11-16$ (1866)

66d (with Meek, F. B.) Introduction to volume II, Paleontology [includes discussion of nomenclature of Illinois formations]. Ill G S 2: iii-xix (1866)

66e (with Meek, F. B.) Descriptions of invertebrates from the Carboniferous system. Ill G S 2:143-411, il (1866)

66f (with Meek, F. B.) Descriptions of Paleozoic fossils from the Silurian, Devonian, and Carboniferous rocks of Illinois, and other Western States. Chicago Ac Sc, Pr 1: 11-23 (1866)

66ณ (with Meek, F. B.) Contributions to the paleontology of Illinois and other Western States. Ac N Sc Phila, Pr 1866: $251-275$

66h (with Newberry, J. S.) Descriptions of new species of vertebrates, mainly from the Subcarboniferous limestone and Coal Measures of Illinois. Ill G S, 2:9134, il (1866)

68 Coal Measures and Lower Carboniferous limestones. III G S, 3:1-19 (1S68)

6Sa Geology of Alexander Co.; Union Co. ; Jackson Co. ; Perry Co. ; Jersey Co. ; Greene Co.; Scott Co. III G S, 3: 20-144 (1868) ; Ec G $1: 456-531 ; 2: 1-71$ (1882)

$68 b$ On the Coal Measures of Illinois, with a vertical section of the strata (abst). Am Nat 1:619-620 (1868) Can Nat n \& 3:295 (1868)

68c (with Meek, F. B.) Paleontology: Lower Silurian species; Upper Silurian species; Devonian species; Carboniferous species. III G S, 3: 291-565, il (1868)

68d (with Meek, F. B.) Preliminary notice of a scorpion, a Eurypterus?, and other fossils from the Coal Measures of Illinois. Am J Sc (2) 45:19-28 (1868)

68e (with Meek, F. B.) Remarks on some types of Carboniferous Crinoidea, with descriptions of new genera and species of the same, and of one echinoid. Ac N Sc Phila, Pr 1868: 335-359

69 (with Meek, F. B.) Descriptions of new Crinoidea and Echinoidea, from the Carboniferous rocks of the Western States, with a note on the genus Onychaster. Ac N Sc Phila, Pr 1869: 67-83 
Worthen, Amos Henry-Continued.

$69 a$ (with Meek, F. B.) Notes on some points in the structure and habits of Paleozoic Crinoidea. Ac N Sc Phila, Pr 1868: 323-334 (1869) Can Nat n s 4:434-452 (1809) Am J Sc (2) 48:23-40 (1869)

$69 b$ (with Meek, F. B.) Remarks on the Blastoidea, with descriptions of new species. Ac N Se Phila, $\operatorname{Pr} 1869: 83-91$

69e (with Meek, F. B.) Descriptions of new Carboniferous fossils from the Western States. Ac N Sc Phila, Pr 1869: $137-172$

70 Geology of Calhoun Co.; Pike Co.; Adams Co.; Brown Co.; Schuyler Co.; Fulton Co. Ill G S 4:11-110 (1870); Ec G $2: 237-360$ (1882)

70a (with Meek, F. B.) Note on the relations of Synocladia, King, 1849, to the proposed genus Septopora, Prout, 1858. Ac N Se Phila, Pr 1870:15-18

70b (with Meek, F. B.) Descriptions of new species and genera of fossils from the Paleozoic rocks of the Western States. Ac N Sc Phila, Pr 1870:22-56

70c (with Newberry, J. S.) Deseriptions of fossil vertebrates. Ill $\mathrm{G} S, 4$ : $343-374$, il (1870)

71 Remarks on the relative age of the Niagara and the so-called Lower Helderberg groups. Am As, Pr 19:172-175 (1871)

71a [Coal Measures of Illinois and Kentucky.] Am Nat 5:558 (1871)

71b [On the occurrence of the mammoth and mastodon.] Am Nat 5: 606-607 (1871)

73 (and Shaw, J.) Geology of Rock Island Co. I11 G S 5:217-234 (1873); Ec G $3: 226-246$ (1882)

73a Geology of Peoria Co.; McDonough Co. ; Monroe Co; Macoupin Co. ; Sangamon Co. Ill G S $5: 235-319$ (1873); Ec G 3 : 246-337 (1882)

73b (with Meek, F. B.) Descriptions of invertebrates from Carboniferous system. Ill G S 5:321-619, il (1873)

75 Coal Measures. Ill G S $6: 1-8$ (1875)

75a Geology of Clark Co.; Crawford and Jasper cos.; Lawrence and Richland cos.; Wabash and Edwards cos. ; White and Hamilton cos. ; Wayne and Clay cos. ; Cumberland, Coles, and Douglas cos. ; Williamson and Franklin cos. III G S 6:9-127 (1875) ; Ec G 3:337-467 (1882)

$\mathbf{7 5 b}$ Geological map of the State of Illinois. Scale, 6 miles to 1 inch. Accompanies vol. 6,1875

$75 \mathrm{c}$ (with Meek, F. B.) Descriptions of invertebrates. Ill G S, 6:489-532, il (1875)

754 (with St. John, O. H.) Deseriptions of fossil fishes. III G S, 6:245488, il (1875)
Worthen, Amos Henry-Continued.

82 Descriptions of fifty-four new species of crinoids from the Lower Carboniferous limestones and Coal Measures of Illinois and Iowa. Ill St Mus $\mathrm{N}$ H, B 1:3-38 (1882)

82a Corrections and proposed new names for species described in the geological reports of Illinois, under names that were preoccupied; and descriptions of two new species of fossil shells from the Coal Measures of Illinois and Kansas. Ill St Mus N H, B 1: 38-40 (1882)

83 Economical geology; Notes on La Salle Co. IIl G S 7:1-51 (1883)

83a Description of fossil invertebrates. Ill G S $7: 265-322$, il (1883)

83b Descriptions of some new species of fossil shells from Lower Carboniferous limestones and Coal Measures of Illinois. III G S $7: 323-326$ (1883)

83e (and Miller, S. A.) Descriptions of new Carboniferous echinoderms. Ill G S $7: 327-338$, il (1883)

83d (with St. John, O. H.) Descriptions of fossil fishes. III G S 7:55-264, il (1883)

84 Descriptions of two new species of Crustacea, fifty-one species of Mollusea, and three species of crinoids, from the Carboniferous formations of Illinois and adjacent states. IIl St Mus N H, B 2:27 pp (1884)

85 Quaternary deposits of central and southern Illinois (abst). Science $6: 221$ (1885)

90 Drift deposits of Illinois. Ill $\mathrm{G}$ S $8: 1-24$ (1890)

90a Economical geology; coal, natural gas and oil, artesian water. Ill G S 8: 25-67 (1890)

90b Description of fossil invertebrates. Il1 G S 8: 69-154, il (1890)

90c Approximate geological map of the State of Illinois, reduced from the map published in 1875 with vol. VI. Scale, 32 miles to one inch. III G S 8 (1890)

Wortman, Jacob Lawson.

82 The geology of the Big Horn Basin. Am Ph Soc, Pr 20:139-142, map (1882)

$\mathbf{8 2 a}$ On the origin and development of the existing horses. Kansas City Rv Sc $5: 719-726 ; 6: 67-75$, il (1882)

83 Lorigine du cheval. Rv Scient 31 ((3) 5) : 705-714, il (1883)

83a Remarks on Ursus amplidens. Ac N Sc Phila, Pr 1882:286-288 (1883)

84 Recent discoveries of fossil horses. In Clarke, William H., Horses' teeth ... 2d ed: $257-269$, N Y 1884 Separate with cover-title, Fossil horses; a summary of their history. From the revised edition of W. H. Clarke's work on Horses' teethappendix : $257-269, \mathrm{~N}$ Y 1883 
Wortman, Jacob Lawson-Continued.

84a (with Cope, E. D.) Post-Pliocene vertebrates of Indiana. Ind, $D p G \mathrm{~N} \mathrm{H}$, An Rp 14 pt $2: 1-54$, il (1884)

92 (with osborn. H. F.) Fossil mammals of the Wasatch and Wind River beds. Am Mus N H, B 4:81-147, il (1892)

92n (with osborn, H. F.) Characters of Protoceras (Marsh), the new artiodactyl from the lower Miocene. Am Mus N H, B $4: 351-371$, il (1892)

93 On the divisions of the White River or lower Miocene of Dakota. Am Mus N H, B 5: 95-105 (1893)

93a (and Earle, C.) Ancestors of the tapir from the lower Miocene of Dakota. Am Mus N H, B 5:159-180, il (1893)

93b A new theory of the mechanical evolution of the metapodial keels of Diplarthra. Am Nat 27:421-434, il (1893)

94 Osteology of Patriofelis, a middle Eocene creodont. Am Mus N H, B 6:129164, il (1894)

$94 \mathrm{a}$ On the affinities of Leptarctus primus of Leidy. Am Mus N H, B 6:229231 (1894)

94b (with osborn, H. F.) Fossil mammals of the lower Miocene White River beds. Am Mus N H, B $6: 199-228$, il (1894)

95 On the osteology of Agriochoerus. Am Mus N H, B 7:145-178, il (1895)

ora (with Osborn, H. F.) Perissodactyls of the lower Miocene White River beds. Am Mus N H, B 7:343-375, il (1895)

96 Species of Hyracotherium and allied perissodactyls from the Wasatch and Wind River beds of North America. Am Mus N H, B $8: 81-110$, il (1896)

96a Psittacotherium, a member of a new and primitive suborder of the Edentata. Am Mus N H, B 8:259-262 (1896)

96b The North American origin of the edentates. Science n s 4:865-866 (1896) 97 The Ganodonta and their relationship to the Edentata. Am Mus N H, B 9 : $59-110$, il (1897)

98 The extinct Camelidae of North America and some associated forms. Am Mus N H, B $10: 93-142$, il (1898)

99 Othniel Charles Marsh. Science n s $9: 561-565$, port (1899)

00 (and Matthew, W. D.) The ancestry of certain members of the Canidae, the Viverridae, and Procyonidae. Am Mus N H, B 12:109-138, il (1900)

oOa Restoration of Oxyaena lupina Cope, with descriptions of certain new species of Eocene creodonts. Am Mus N H, B $12: 139-148$, il $(1900)$

oob The new department of vertebrate paleontology of the Carnegle Museum. Science n s $11: 163-166$ (1900)
Wortman, Jacob Lawson-Continued.

01 A new American species of $A m$ phicyon. Am J Sc (4) 11:200-204, il (1901)

O1a Studies of Eocene Mammalia in the Marsh collection, Peabody Museum. Am J Sc (4) $11: 333-348,437-450 ; 12: 143-$ $154,193-206,281-296,377-382,421-432$; $13: 39-46,115-128,197-206,433-448 ; 14$ : $17-23 ; \quad 15: 163-176, \quad 399-414, \quad 419-436$; 16 : 345-368 ; $17: 23-33,133-140,203-214$, il (1901-4)

01b The probable successors of certain North American primates. Science n s 13: 209-211 (1901)

06 A new fossil seal from the marine Miocene of the Oregon coast region. Science n \& 24:89-92 (1906)

See also Cope, 84

Wrather, W. E.

17 Notes on the Texas Permian. Southwestern As Petroleum G, B 1:93-106 (1917)

Wright, Albert Allen (1846-1905).

S4 Mines of Holmes Co. Ohio G S, Rp 5: $816-842 \quad$ (1884)

92 Extra-morainic drift in New Jersey. Am G 10:207-216, map (1892) Abst, Am As, Pr 41:175 (1892)

93 On the ventral armor of Dinichthys. Ohio G S $7: 620-626$, il (1893)

$93 n$ Limits of the glaciated area in New Jersey (with discussion by T. C. Chamberlin and others): G Soc Am, B 5:7-13, map (1893) Abst, Am G $12: 166$ (1893)

93b older drift in the Delaware Valley. Am G 11: 184-186 (1893)

94 The ventral armor of Dinichthys. Am G 14:313-320, il (1894)

97 New evidence upon the structure of Dinichthys (abst). Ohio St Ac Sc, An Rp $5: 59-60$ (1897)

97a Ohio boulders containing "huronite." Ohio St Ac Sc, An Rp 5:60-61 (1897)

Wright, Arthur Williams (1836-1915).

81 On the gaseous substances contained in the smoky quartz of Branchville, Conn. Am J Se (3) $21: 209-216$ (1881) Can Nat n s 10:12-19 (1881)

11 Benjamin Silliman, 1816-1885. Nat Ac Sc, Biog Mem $7: 115-141$, port (1911)

Wright, Benjamin.

21 Lime for water cement. Am J Sc 3: 230-231 (1821)

Wright, Berlin $H$.

84 Notes on the geology of Yates Co., N. Y. N Y St Mus, An Rp $35: 195-206$, map (1884)

Wright, C. T.

09 The laboratories for physical geography in two California high schools. J Geog 8:10-14 (1909) 
Wright, Charies E. (1843-1888).

73 Lithology [of the Upper Peninsula]. Mich G S, 2: 213-231 (1873)

76 Geology of the Lake Superior iron region. In Swineford, A. P., History and review of the copper, iron, silver, slate, and other material interests of the south shore of Lake Superior : 132-150, Marquette, Mich., 1876

77 Report [on the Menominee and Penokee regions]. Wis $\mathrm{G} \mathrm{S}$, An Rp 1876:1823 (1877)

77a Microscopic lithology. [Wis G S], G Wis $2: 637-642$ (1877)

78 [Report on iron deposits in Oconto Co.] Wis G S, An Rp 1877:33-36 (1878)

79 First annual report of the Commissioner of mineral statistics of the State of Michigan for $1877-8$ and previous years. 229 pp, Marquette 1879

80 The Huroninn series west of Penokee Gap. [Wis G S], G Wis $3: 239-301$, maps (1880)

80a The geology of the Menominee iron range. [Wis $\mathrm{G}$ S], G Wis $3: 665-734$ (1880)

93 Report of the State geologist from May 1, 1885 to January 1, 1888. Mich G S, Rp 1891-2: 33-37 (1893)

See also Lane, 95

Wright, Charles Will.

04 The Porcupine placer mining district, Alaska. U S G S, B 225:60-63 (1904)

04a The Porcupine placer đistrict, Alaska. U S G S, B 236, 35 pp, map (1904)

05 (with Wright, F. E.) Economic developments in southeastern Alaska. U S G S, B 259: 47-68 (1905)

06 Nonmetallic products of southeastern Alaska, U S G S, B 284: 55-60 (1906)

06a A reconnaissance of Admiralty Island. U S G S, B $287: 138-161$, map (1906)

06b (with Wright, F. E.) Lode mining in southeastern Alaska. U S G S, B $284: 30-54$ (1906)

07 Lode mining in southeastern Alaska. U S G S, B 314: 47-72 (1907)

$\mathbf{0 7 a}$ Nonmetalliferous mineral resources of southeastern Alaska. U S G S, B 314 : 73-81 (1907)

$\mathbf{0 7 b}$ Recent changes in the ice fields of Glacier Bay, Alaska (abst). Science n s 26: 148-149 (1907)

08 Lode mining in southeastern Alaska, 1907. U S G S, B 345: 78-97, map (1908)

osa The building stones and materials of southeastern Alaska. U S G S, B 345: 116-126 (1908)

08b The copper deposits of Kasaan Peninsula, Alaska. Ec G $3: 410-417$ (1908) Abst, Science n s 28:96 (1908)
Wright, Charles Will-Continued.

ose (and Paige, Sidney) Copper deposits on Kasaan Peninsula, Prince of Wales Island. U S G S, B 345: 98-115 (1908)

osd (with Wwight, F. E.) The Ketchikan and Wrangell mining districts, Alaska. U S G S, B $347: 210$ p (1908) o9 Mining in southern Alaska. U S G S, B $379: 67-86$, map (1909)

11 Prospecting in the North (discussion). M Mag 4:359 (1911)

15 Geology and ore deposits of Copper Mountain and Kasaan Peninsula, Alaska. U S G S, P P 87: 110 pp, maps (1915)

Wright, Clarence A.

13 Mining and treatment of lead and zinc ores in the Joplin district, Missouri; a preliminary report. U S Bur Mines, Tech P 41: 43 pp (1913)

15 Mining and milling of lead and zinc ores in the Wisconsin district, Wis. U $\mathrm{s}$ Bur Mines, Tech P 95: 38 pp (1915)

18 Mining and milling of lead and zinc ores in the Missouri-Kansas-Oklahoma zinc district. U S Bur Mines, B 154:134 pp (1918)

Wright, Floyd E.

16 Oil and gas [in Indiana]. Ind, Dp G Nat Res, An Rp $40: 267-273 ; 41: 114$ 121, maps (1916-7)

Wright, Frederick Bennett.

96 The origin of the Wind Gap [Pa.]. Am G 18:120-123, map (1896)

oo Erosion of mountains in southern California. Am G 25:326-327 (1900)

03 The mastodon and mammoth contemporary with man. Records of the Past $2: 243-253$ (1903)

Wright, Fred Eugene.

00 Der Alkalisyenit von Beverly, Mass., U. S. A. Tschermak's Mitt N F 19:308320 (1900)

02 A new combination wedge for use with the petrographical microscope. J G $10: 33-35$ (1902)

04 Two microscopic petrographic methods. Am J Sc (4) 17:385-391 (1904)

05 Notes on the rocks and minerals of Michigan; to accompany the loan collection issued by the Michigan College of Mines. Prepared by the Department of geology. $105 \mathrm{pp}$, map, Houghton 1905

05a Report of progress in the Porcupines. Mich G S, Rp 1903: 33-44 (1905)

osb (and wright, C. W.) Economic developments in southeastern Alaska. U S G S, B 259: 47-68 (1905)

o5e The determination of the optical character of birefracting minerals. Am J Sc (4) $20: 285-296$ (1905)

06 [Report on] the Unuk River mining region of British Columbia. Can G S, Sum Rp 1905: 46-53 (1906) B C, Minister of Mines, An Rp 1906: 68-74 (1907) 
Wright, Fred Eugene-Continued.

06a The determination of the feldspars by means of their refractive indices. Am J Sc (4) $21: 361-363$ (1906)

06b A modification of the Lasaulx method for observing interference figures under the microscope. Am J Sc (4) 22 : 19-20 (1906)

06e Schistosity by crystallization; a qualitative proof. Am J Sc (4) 2:224230 (1906)

o6d Optical study of the lime-silica series of minerals. Am J Sc (4) 22 : 293302 (1906)

o6e (and wright, C. W.) Lode mining in southeastern Alaska. U S G S, B 284: 30-54, map (1906)

06f Artificial wollastonite and pseudowollastonite $(a b s t)$. Science n s 23:3233 (1906)

06g (with Allen, E. T.) Minerals of the composition $\mathrm{MgSiO}_{3}$; a case of tetramorphism. Am J Se (4) 22:385-438 (1906)

07 The measurement of the optic axial angle of minerals in the thin section. Am J Sc (4) $24: 317-369$ (1907)

o7a Artificial magnesian-pyroxenes and amphiboles $(a b s t)$. Science n s 25:389$390(1907)$

07b Methods of igneous intrusion (abst). Science n s 25:623 (1907)

o7e Artificial production of gneissic structures by crystallization under stress $(a b s t)$. Science n s 25:768 (1907)

ord Recent changes in the glaciers of Glacier Bay, Alaska (abst). Science n $\mathbf{s}$ 25: 770 (1907)

os (and Wright, C. W.) The Ketchikan and Wrangell mining districts, Alaska. U S G S, B $347: 210$ pp, maps (1908)

osa on the measurement of extinction angles in the thin section. Am J Sc (4) $26: 349-390$ (1908)

osb The bi-quartz wedge plate applied to polarimeters and saccharimeters. Am J Sc (4) $26: 391-398$ (1908)

ose A telemeter with micrometer screw adjustment. $\mathrm{Am}$ J Sc (4) 26:531-535 (1908)

osd A device to aid in the explanation of interference phenomena. Am J Sc (4) $26: 536$ (1908)

ose on three contact minerals from Velardeña, Durango, Mexico (gehlenite, spurrite, and hillebrandite). Am J Sc (4) $26: 545-554$ (1908)

09 Über Enstatit und Klinoenstatit. Zs Kryst $46: 599-600$ (1909)

09a (and Larsen, E. S.) Quartz as a geologic thermometer. Am J Sc (4) 27 : 421-447 (1909) Zs anorg Chemie 68: 338-369 (1910) Abst, Science n s 29 : $556,634 .(1909)$; G Soc Am, B 20:671$672(1910)$
Wright, Fred Eugene-Continued.

09b The intrusive rocks of Mount Bohemia, Michigan. Mich G S, Rp 1908: 355-402, map (1909) Abst, Scinnce n s $27: 768$ (1907)

09e (and Lane, A. C.) Preliminary geological map of the Porcupine Mountains and vicinity. Mich G S, Rp 1908:pl 1, opp p 8 (1909)

10 A new petrographic microscope. Am J Sc (4) 29:407-414 (1910) Tschermaks Mitt 29:489-497 (1910)

10a A new ocular for use with the petrographic microscope. Am J Sc (4) $29: 415-426$ (1910)

10b Geologic thermometry (abst). Sclence n s $31: 320 ; 32: 219$ (1910); (with discussion), G Soc Am, B 21:783-784 (1910)

10e (with Hillebrand, W. F.) A new occurrence of plumbojarosite. Am J Sc (4) 30: 191-192 (1910)

11 The methods of petrographic-microscopic research; their relative accuracy and range of application. Carnegie Inst Wash, Pub no 158:204 pp (1911) Abst, Wash Ac Sc, J $2: 83-84$ (1912)

11 a Neuere Verbesserungen am petrographischen Mikroskop. Centralbl Miner $1911: 555-559,581-588$

11b The stability ranges of minerals with special reference to the geologic thermometer scale (abst). Wash Ac Sc, J 1 : 45 (1911)

12 Microscopical petrography from the quantitative viewpoint. J G 20:481-501 (1912) N Jb Beil Bd 35:735-775 (1913) Abst, Wash Ac Sc, J 3:115 (1913)

12a Granularity limits in petrographicmicroscopic work (abst). Science n s 35 : 312 (1912) G Soc Am, B 23:726 (1912)

13 Oblique illumination in petrographic microscope work. Am J Sc (4) 35:63-82 (1913)

13a Ths index ellipsoid (optical indicatrix) in petrographic microscope work. Am J Sc (4) $35: 133-138$ (1913) Abst, Wash Ac Sc, J 3:503 (1913); (with discussion by E. B. Mathews), G Soc Am, B 24:681682 (1913)

13b A new thermal microscope for the measurement of the optical constants of minerals at high temperature. Wash Ac Sc, J $3: 232-236$ (1913)

13e Yukon and Malaspina, Prince RupertSkagway section. Int $G$ Cong, XII, Canada, Guide Book no 10:41-51, maps (1913)

13d Graphical methods in microseopical petrography. Am J Sc (4) $36: 509-539$ (1913)

13e A graphical plot for use in the microscopical determination of the plagioclase feldspars. $A \mathrm{~m}$ J Sc (4) $36: 540-542$ (1913) 
Wright, Fred Eugene-Continued.

13f The change in the crystal angles of quartz with rise in temperature. Wash Ac Sc, J 3: 485-494 (1913)

13g Experimental geology, one of the large subdivisions of geology (abst, with discussion by A. W. Grabau). G Soc Am, B 24:671-672 (1913)

13h (and Van Orstrand, C. E.) The determination of the order of agreement between observation and theory in mineral analyses. Wash Ac Sc, J 3:223-231 (1913)

14 The optical properties of roscoelite. Am J Sc (4) $38: 305-308$ (1914) Abst, Wash Ac Sc, J 5 : 95-96 (1915)

14a Change in the crystallographical and optical prcperties of quartz with rise in temperature (abst, with discussion). G Soc Am, B 26: 44 (1914)

14b (and Rankin, G. A.) Physicalchemical system, lime-alumina-silica and its geological significance $(a b 8 t)$. G Soc Am, B 25:92 (1914)

14e (with Hillebrand, W. F.) Hewettite, metahewettite, and pascoite, hydrous calcium vanadates. $\mathrm{Am} \mathrm{Ph}$ Soc, $\mathrm{Pr} 53$ : 31-34 (1914)

14d (with Van Orstrand, C. E.) The calculation and comparison of mineral analyses. Wash Ac Sc, J 4:514-525 (1914)

15 Obsidian from Hrafntinnuhryggur, Iceland; its lithophysae and surface markings. G Soc Am, B 26:255-286 (1915)

15a A new crystal-grinding goniometer. Wash Ac Sc, J 5 : 35-40 (1915)

15b The position of the vibration plane of the polarizer in the petrographic microscope. Wash Ac Sc, J 5 : 641-644 (1915)

16 A geological protractor. Wash Ac Sc, J $6: 5-7$ (1916)

16a Crystals and crystal forces. Wash Ac Sc, J 6:326-332 (1916) Abst, G Soc Am, B 27:62 (1916)

16b Note on the lithophysae in a specimen of obsidian from California. Wash Ac Sc, J $6: 367-369$ (1916)

17 (and Hostetter, J. C.) The thermodynamic reversibility of the equilibrium relations between a strained solid and its liquid. Wash Ac Sc, J $7: 405-417$ (1917)

17a The petrographic microscope. Optical Soc Am, J 1: 15-21 (1917)

See also Allen (E T), 06, 09 ; König, 04 Wright, George Frederick (1838-1921).

$\mathbf{7 7}$ Some remarkable gravel ridges in the Merrimac Valley. Boston Soc N H, Pr 19: 47-63 (1877)

79 The kames and moraines of New England. Boston Soc N H, Pr 20:210-220 (1879)
Wright, George Frederick-Continued.

81 An attempt to calculate approximately the date of the glacial era in eastern North America, from the depth of sediment in one of the bowl-shaped depressions abounding in the moraines and kames of New England. Am J Sc (3) 21:120-123 (1881) Abst, Am As, Pr 29:426 (1881)

81a An attempt to estimate the age of the paleolithic-bearing gravels in Trenton, N. J. Boston Soc N H, Pr 21: 137-145 (1881)

81b The glacial phenomena of North America and their relation to the question of man's antiquity in the valley of the Delaware. Essex Inst, B 13:65-72 (1881) 82 [The terminal moraine in Pennsylvania.] Essex Inst, B 14: 71-73 (1882)

82a The southern limit of ancient glaciers in Pennsylvania (abst). An Nat 16 : 753-754 (1882)

83 Recent investigations concerning the southern boundary of the glaciated area of Ohio. Am J Sc (3) 26:44-56 (1883) Abst, Science 1:269-271, map (1883)

83a Depth of ice during the glacial age. Science 2:436 (1883)

83b Supposed glacial phenomena in Boyd Co., Ky. Science 2:654 (1883)

83e Result of explorations of the glacial boundary between New Jersey and Illinois (abst). Am As, Pr 32: 202-208 (1884) Science $2: 316-317$ (1883)

84 The glacial boundary in Ohio, Indiana, and Kentucky. Western Reserve Hist Soc, Tract (no 60) 2:193-268, [another ed:1-76] maps (1884) Pa G S, 2d, Z : 203-243 (1884)

84a The glacial boundary in Ohio. Ohio G S, Rp 5: 750-772, map (1884)

84b The Niagara River and the glacial period. Am $J$ Sc (3) $28: 32-35$, map (1884)

84e The theory of a glacial dam at Cincinnati and its verification. Am Nat 18: 563-567 (1884)

84d The glaciated area of North America. Am Nat $18: 755-767$, maps (1884)

84e The Nlagara Gorge as a chronometer. Bibliotheca Sacra $41: 369-376$ (1884) Science $5: 399-401$ (1885)

86 A salt mine in western New York. Science $8: 52$ (1886)

87 The Muir Glacier. Am J Sc (3) 33 : 1-18 (1887) Sc Am Sup 23:9252-9254 (1887)

$87 \mathbf{a}$ Notes on the glaciation of the $\mathrm{Pa}$ cific coast. Am Nat 21:250-256 (1887)

s8 On the age of the Ohio gravel beds. Boston Soc N H, Pr 23:427-436 (1888)

89 The ice age in North America... 622 pp, N Y 1889 5th ed, 763 pp, Oberlin, Ohio, 1911 Review by W. M. Davis, Science 14:118-119 (1889) 
Wright, George Frederick-Continued.

89a [The Nampa image]. Am G 4: 387-388 (1889)

89b The age of the Philadelphia red gravel. Boston Soc N H, Pr 24:152-157 (1889)

89e The glacial boundary in southeastern Dakota (abst). Am As, Pr 37:208212 (1889)

90 The glacial boundary in western Pennsylvania, Ohio, Kentucky, Indiana, and Illinois, with an introduction by $T$. C. Chamberlin. U $\quad$ S $\quad$ G $\quad$ S, B $58: 112$ pp (1890)

$90 a$ A moraine of retrocession in ontario (abst, with discussion by J. W. Spencer). G Soc Am, B 1:544-546 (1890) Am G 5:119-120 (1890) Am Nat 24:209 (1890)

90b The Nampa image. Boston Soc N H, Pr 24:424-451 (1890)

90c Glacial man in Ohio. In Howe, Henry, Historical collections of Ohio 1: 90-99, Columbus 1890

90d The lake ridges of Ohio and their probable relations to the lines of glacial drainage into the valley of the Susquehanna (abst). Am As, Pr 38: 247 (1890) 91 ... the Muir glacier. Am G 8:330331 (1891)

91 a Additional notes concerning the Nampa image. Boston Soc N H, Pr 25: 242-246 (1891)

91b Glacial grooves on Kelly's Island [Ohio]. Science 17:358-359 (1891) Am G $8: 266$ (1891)

91e Man and the glacial period. Pop Sc Mo $39: 314-319$ (1891)

$92 \mathrm{Man}$ and the glacial period. The International Scientific Series, vol. $69: 385$ pp, N Y 1892 Rv by R. D. Salisbury, Am G $11: 13-20$ (1893)

92n Unity of the glacial epoch. Am J Sc (3) 44:351-373 (1892)

92b The extramorainic drift of the Susquehanna Valley (abst with discussion), Am G 10: 219 (1892)

92e The movements of the Muir glacier. Am G 10:397 (1892)

92d Recent discoveries concerning the relation of the glacial period in North America to the antiquity of man (abst). Brit As, Rp 61 : 647-649 (1892)

92e The lava beds of California and Idaho and their relation to the antiquity of man (abst). Brit As, Rp 61:651 (1892)

92p Man and the glacial period. Science $20: 275-277$ (1892)

92m Excitement over glacial theories. Science $20: 360-361$ (1892)

93 The supposed postglacial outlet of the Great Lakes through Lake Nipissing and the Mattawa River (with discussion by Robert Bell). G Soc Am, B 4:423-425 (1893)
Wright, George Frederick-Continued.

93a Some of Prof. Salisbury's criticisms on "Man and the glacial period." Am G 11: 121-126 (1893)

93b Additional evidence bearing upon the glacial history of the upper Ohio Valley. Am G 11: 195-199 (1893)

93e The postglacial outlet of the Great Lakes through Lake Nipissing and the Mattawan River (abst with discussion). Am G 11: 243-244 (1893)

93d Extramorainic drift in New Jersey (abst). Am G 12:166-167 (1893) Am J Sc (3) $46: 304$ (1893)

93e The evidence of glacial man in America (abst). Am G 12:173-174 (1893)

$93 \mathbf{f}$... unity of the glacial period (abst). Am G 12: 178-179 (1893)

93\% Extramorainic drift in the Susquehanna, Lehigh, and Delaware valleys. Ac N Sc Phila, Pr 1892: 469-484 (1893)

$\mathbf{9 3 h}$ Some detailed evidence of an iceage man in eastern America. Science 21: 65-66 (1893)

$93 i$ Mr. Holmes' criticism upon the evidence of glacial man. Scíence 21:267268 (1893)

93j Recent volcanic eruptions in California. Am Nat 27:813-816 (1893)

931k Evidences of glacial man in Ohio.

Pop Sc Mo 43 : 29-39 (1893)

94 Continuity of the glacial period. Am J Se (3) 47:161-187, maps (1894)

$94 \mathbf{a}$ Report of the boulder committee of the Ohio Academy of Sciences. Ohio St Ac Sc, An Rp $2: 5-10 ; 3: 6-7$ (1894-5)

94b The Cincinnati ice dam. Pop Sc Mo $45: 184-198$ (1894)

94e Glacial history of western Pennsylvania (abst), Am G $13: 219-220$ (1894)

95 Observations upon the glacial phenomena of Newfoundland, Labrador, and southern Greenland. Am J Sc (3) 49 : 86-94 (1895) Abst, Am G 15:198-199 (1895); Science n s 1:60 (1895)

95a Glacial phenomena between Lake Champlain, Lake George, and Hudson River. Science n s 2: 401-402 (abst), 673678 (1895) Abst, Am G 16:251 (1895)

95b Dr. Holst on the continuity of the glacial period. Am G 16:396-399 (1895)

95e New evidence of glacial man in Ohio. Pop Sc Mo 48: 157-165 (1895)

96 (and Upham, W.) Greenland ice fields... with a new discussion of the causes of the ice age. $x v, 407 \mathrm{pp}, \mathrm{N}$ Y $1896 \mathrm{Rv}$ by T. C. Chamberlin, J G 4:632-636 (1896)

96n The age of the second terrace on the Ohio at Brilliant, near Steubenville. J G $4: 218-219$ (1896)

$96 \mathrm{~b}$ Fresh relics of glacial man at the Buffalo meeting of the A. A. A. S. Am Nat $30: 781-784$ (1896) 
Blatchley, Willis Stanley-Continued.

17 A century of geology in Indiana. Ind Ac Sc, Pr 1916:89-177 (1917)

Blauvelt, Harrington.

89 The Reymert manganiferous lode, Arizona, and its formation. Eng M J 47: 139-140 (1889)

96 Mineral in basalt [Castle Creek district, Yavapal Co., Ariz.]. Eng M J 61: 111 (1896)

Bleasde11, William.

70 Observations on modern glacial action in Canada. G Soc London, Q J 26:669$671(1870) ; 28: 392-396$ (1872) Abst, G Mag $7: 393-394$ (1870), 9 : 330-331 (1872) ; Ph Mag (4) 41:78 (1871); (4) 44:542 (1872)

76 Recent glacial and aqueous action in Canada and the drift uplands of the Province of Ontario (abst). Ph Mag (5) 2: 394-395 (1876)

Bleininger, Albert Victor.

04 The manufacture of hydraulic cements. Ohio G S (4) B 3:391 pp, Columbus, Ohio, 1904

12 (and Lines, E. F., and Layman, F. E.) Portland-cement resources of Illinols. Ill G S, B 17: 121 pp (1912)

Bliss, Edward.

64 A brief history of the new gold regions of Colorado Territory ... 31 pp, N Y 1864

Bliss, Eleanora Frances.

13 Glaucophane from eastern Pennsylvania. Am Mus $\mathrm{N}$ H, B $32: 517-526$, map (1913)

14 (and Jonas, Anna I.) Relation of the Wissahickon mica gneiss to the Shenandoah limestone and to the Octoraro mica schist, of the Doe Run-Avondale district, Coatesville quadrangle, $\mathrm{Pa}$. Dissertation ... Bryn Mawr College. $64 \mathrm{pp}$, maps (1914) [?Priv pub]

16 (and Jonas, Anna I.) Relation of the Wissahickon mica gneiss to the Shenandoah limestone and Octoraro schist of the Doe Run and Avondale region, Chester Co., Pa. U S G S, P P 98: 9-34, maps (1916)

Bliss, J. S.

65 On buried stems and branches in I11inois. Am J Sc (2) 39:95-96 (1865)

66 Notes on Wisconsin drift. Am J Sc (2) $41: 255$ (1866)

B1iss, N. W.

90 (and White, C. A.) The private life and scientific work of Prof. Amos Henry Worthen. Ill G S 8: App 3-37, port (1890)

Bliss, Richard, jr.

72 Glaciers in the Rocky Mountains. Am Nat $6: 310-312$ (1872)

Blodget, J. B.

76 (and others) On the clays and gravels underlying the city [Philadelphia, Pa.] Am Ph Soc, Pr 16:180-181 (1876)
Blodgett, Lorin.

53 The earthquake of April 29, 1852 An Sc, Cleveland, $1: 231-233$ (1853)

Blodgett, Mildred E.

os (with Shimer, H. W.) The strat. graphy of the Mt. Taylor region, N. Mer Am J Sc (4) 25: 53-67 (1908)

Bloesch, Edward.

17 North-south correlation of the Penp. sylvanian of Oklahoma. Southwestern As Petroleum G, B 1:134-135 (1917)

$17 \mathbf{a}$ Observations on post-Permian is posits in north-central Oklahoma. Southwestern As Petroleum G, B 1:136-139 (1917)

18 Value of oil geology in the Mis. Continent field. Am As Petroleum G, B 2: 124-132 (1918)

Blood, Clifford C.

16 Pinos Altos district, Grant $\mathrm{CO}_{4}$ N. Mex. M World 45:659-660 (1916) Blow, A. A.

8s The ore chutes and recent develor ments of Iron Hill, Leadville, Colo. Colo Sch Mines, An Rp 1887: 61-85 [1888]

90 The geology and ore deposits d Iron Hill, Leadville, Colo. Am I M Eng Tr 18:145-181, maps (1890)

95 The Leadville gold belt [Colo.]. Ens M J 59:77 (1895)

B1ue, Archibald.

92 First report of the [Ontario] Burea of Mines. $253 \mathrm{pp}$, Toronto 1892

93 Second report of the [Ontario] B. reau of Mines. $264 \mathrm{pp}$, Toronto 1893

94 Third report of the [Ontario] Bureau of Mines, $1893.205 \mathrm{pp}$, Toronto 1894

95 Fourth report of the [Ontario] Bt reau of Mines, 1894. $261 \mathrm{pp}$, maps, To ronto 1895

96 Fifth report of the [Ontario] Bureat of Mines, $1895.297 \mathrm{pp}$, Toronto 1896

97 Sixth report of the [Ontario] Bureat of Mines, $1896.289 \mathrm{pp}$, maps, Toronto 1897

9s Report of the [Ontario] Bureau of Mines, volume VII, 1898. $265 \mathrm{pp}$, maps, Toronto 1898

99 Report of the [Ontario] Bureau of Mines, volume VIII, 1899. $205 \mathrm{pp}$, maps, Toronto 1899.

99a Corundum in Ontario. Can Inst, $\mathrm{Pt}$ n s 2: 15-22 (1899) Am I M Eng, Tr 28: 565-578 (1899) Ont Bur Mines Rp 8: 241-249 (1899)

oo Report of the [Ontario] Bureau of Mines, 1900. $239 \mathrm{pp}$, maps, Toronto 1900 OOa Are there diamonds in Ontario! Can M Inst, J $3: 149-160$ (1900) Ont Bu? Mines, Rp 1900: 119-124 (1900)

Blum, R.

30 Ueber einige Nord-Amerikanische Mineralien. Jb Miner 1:49-59 (1830) 
Wright, George Frederick-Continued.

96e The age of the Philadelphia brick clay. Science n s 3:242-243 (1896)

96d High-level terraces of the middle Ohio and its tributaries $(a b s t)$. Am G 17 : 103 (1896) Science n s 3:55 (1896)

97 Special explorations in the implement-bearing deposits on the Lalor farm, Trenton, N. J. Science n $8 \quad 6: 637-645$ (1897)

98 Agassiz and the ice age. Am Nat $32: 165-171$ (1898)

98a Glacial observations in the Champlain-St. Lawrence Valley. Am G 22 : 333334 (1898)

98b Clayey bands of the glacial delta of the Cuyahoga River at Cleveland, Ohio, compared with those of the implementbearing deposits of the glacial delta at Trenton, New Jersey (abst). Am G 22: 250 (1898) Science n s 8:464 (1898)

98e Supposed "corduroy road" of late glacial age, at Amboy, Ohio (abst). Am As, Pr 47:298 (1898) Am G 22:259 (1898) Science n s $8: 470$ (1898)

98d The age of Niagara Falls as indicated by the erosion at the mouth of the gorge (abst). Am As, Pr 47:299-300 (1898) Am G 22:260-261 (1898) Science $n$ s $8: 502$ (1898)

98e A recently discovered cave of celestite crystals at Put-in-Bay, Ohio (abst). Am As, Pr $47: 300$ (1898) Am G 22:261 (1898) Science n s 8:502-503 (1898)

99 The truth about the Nampa figurine. Am G $23: 267-272$ (1899)

$99 a$ New method of estimating the age of Niagara Falls. Pop Sc Mo 55: 145-154 (1899)

99b Lateral erosion at the mouth of the Niagara gorge $(a b 8 t)$. Science n s $10: 488$ (1899)

02 The rate of lateral erosion at Niagara. $A m$ G 29:140-143 (1902)

o3 The age of the Lansing skeleton. Records of the Past 2: 119-124 (1903)

03a Glacial man. Records of the Past 2: 259-271 (1903)

03b The Lansing skull and the early history of mankind. Bibliotheca Sacra, $73: 28-32$ (1903)

o3e The revision of geological time [length of postglacial time]. Bibliotheca Sacra, 73:578-582 (1903)

03d The problem of the loess in the Missouri Valley compared with that in Europe and Asia (abst). Science n s 17: 227-228 (1903) Sc Am Sup 55:22666 (1903)

o3e Another glacial wonder [boulders near Tuscumbia, Mo.]. The Nation 77: 461-462 (1903)
Wright, George Frederick-Continued.

04 Evidence of the agency of water in the distribution of the loess in the Missouri Valley. Am G $33: 205-222$, maps (1904) Abst, G Soc Am, B 15:575-576 (1904); Seience n s 19:533 (1904); Sc Am Sup $57: 23447$ (1904)

o5 Prof. Shimek's criticism of the aqueous origin of loess. Am G 35:236-249 (1905)

05a Albert Allen Wright. Am G 36 : 65-68, port (1905)

05b The physical conditions in North America during man's early occupancy. Records of the Past 4:15-26 (1905)

ose Recent date of lava flows in California. Records of the Past 4:195-198 (1905)

o5d The ancient gorge of Hudson River. Records of the Past 4:167-171 (1905)

06 Submerged trees in the Columbia River. Records of the Past 5:243-248 (1906)

07 recent geologic changes as affecting theories of man's development. Am Anthropologist n s 9:529-532 (1907)

os The influence of the glacial epoch upon the early bistory of mankind. Records of the Past $7: 22-37$ (1908) Victoria Inst, $\operatorname{Tr} 40: 51-76$ (1908)

O8a The latest concerning prehistoric man in California. Records of the Past $7: 183-187$ (1908)

08b Chronology of the glacial epoch in North America (abst). G Soc London, Q J $64: 149-151$ (1908)

09 Recent variations of glaciers. Records of the Past 8:113-117 (1909)

09a Geological facts bearing on the place of the origin of the human race (abst). Science n \& 29:512 (1909)

11 Note on the geology of the Trenton gravel near mouth of Crow Creek [N. J.]. Harvard Univ, Peabody Mus Am Arch, Papers 5 : 242-243 (1911)

11 Glacial man at Trenton, N. J. Records of the Past $10: 273-282$ (1911)

$11 \mathrm{~b}$ Computing the age of terrace gravels. Records of the rast $10: 332-333$ (1911)

12 Origin and antiquity of man. ix, 547 pp, Oberlin, Ohio 1912

12a Postglacial erosion and oxidation (abst). Science n s $35: 316-317$ (1912) G Soc Am, B 23:277-296 (1912)

13 Recent date of the attenuated glacial border in Pennsylvania. Int $\mathrm{G}$ Cong, XII, 1913, C R : 451-453, map (1914) Advance copy 1913

$13 \mathbf{a}$ Work of natural forces in relation to time. Nature $92: 346$ (1913)

14 Age of the Don River glacial deposits, Toronto, Ont. G Soc Am, B 25: 71-73, 205-214 (1914) 
Wright, George Frederick-Continued.

14a Evidence of a glacial dam in the Allegheny River betwecn warren, $\mathrm{Pa}$, and Tionesta. G Soc Am, B 25:84-85, 215218 (1914)

16 Ohio's contributions to archaeology. Ohio Ac Sc, Pr 6:388-406 (1916)

17 Report of Dr. E. H. Williams on the first phase of Pennsylvania glaciation. Science n s $46: 37-39$ (1917)

17 a Explanation of the elevated beaches surrounding the south end of Lake Michigan (abst, with discussion by F. B. Taylor). G Soc Am, B 28: 142 (1917)

18 Explanation of the abandoned beaches about the south end of Lake Michigan. G Soc Am, B 29: 235-244 (1918)

18a Evidence from Alaska of the unity of the Pleistocene glacial period. Science n 8 47:364 (1918)

See also Becker, 91a; Chamberlin, 90a ; Goldthwait, 17; Leverett, $17 \mathrm{c}$; Russell, 92b; Shimek, 12c

Wright, H. F.

14 (with Beyer, S. W.) The road and concrete materials of Iowa. Iowa $\mathbf{G} \mathbf{S}$, An Rp 24:33-685 (1914)

Wright, Ira L,

15 The Pinos Altos district, N. Mex. Eng M J 99: 133-135 (1915)

Wright, J. W.

09 The Black Range mining district, N. Mex. M World 31:979-981 (1909)

Wright, Lewis $T$.

os Diffusion as a factor in ore deposition. M Sc Press 96:844-845; $97: 250$ 251 (1908)

Wright, Park.

17 Granite in Kansas wells. Am I M Eng, B 128: 1113-1120 (1917) ; Tr 57: 906-913 (1918)

Wright, William Josiah.

12 Lahave Valley and Starrs Point, N. S. Can G $\mathrm{S}$, Sum Rp 1911:341-342 (1912)

14 Geology of the neighborhood of New Ross, Lunenburg Co., N. S. Can G S, Sum Rp 1912:384-389 (1914)

$14 a$ Geology of the Moncton map area, N. B. Can G S, Sum Rp $1913: 223-227$ (1914)

14b Geology of Clyburn Valley, Cape Breton [Island, N. S.]. Can G S, Sum Rp $1913: 270-283$, map (1914)

15 Moncton map area, N. B. Can G S, Sum Rp 1914:101-102; 1915:179-185 (1915-6)

Wright, W. H.

14 A journey to Lassen Peak [Cal.].

Eng M J 98: 97-100 (1914)

15 Seneca mining district, Cal. Eng M J $99: 1072-1074$, map (1915)

Wright, William.

65 The oil regions of Pennsylvania... $275 \mathrm{pp}, \mathrm{N}$ Y 1865
Wright, William B.

14 The Quaternary ice age. 464 pp, London 1914

Wrigley, Henry E.

75 Special report on the petroleum of Pennsylvania, Pa G S, 2d, J:1-78, maps (1875)

79 On the present and prospective conditions of the petroleum fields of Pennsylvania. Eng M J 28:70-71 (1879)

82 The amount of oil remaining in Pennsylvania and New York. Am I M Eng, Tr $10: 354-360$ (1882)

Wroth, James $\mathrm{S}$.

08 Geology of the Lucky Boy mine, Nev. M Sc Press $97: 251$ (1908)

Wuenseh, A. F. (1856-1910).

03 The Arizpe meteorite [Sonora, Mexico ]. Colo Sc Soc, Pr 7:67-68 (1903)

wuenseh, C. Erb.

17 Recent volcanism in Salvador. M Sc Press 115: 22 (1917)

17a Geology of the San Sebastian mine, alvador. M Sc Press $115: 345-350$ (1917)

Wnestner, Herman.

06 Pisolitic barite [from Texas]. Cin Soc N H, J 20:245-250 (1906)

Wuisten, Carl.

76 The silver region of the Sierra Mojada (Wet Mountain) and Rosita, Fremont Co., Colo. $101 \mathrm{pp}$, map, Denver 1876

Wurtx, Henry.

55 Report of chemist and mineralogist. N J G S, An Rp 1: 79-95 (1855)

59 On the occurrence of cobalt and nickle in Gaston Co., N. C. Am As, Pr 12: 221-227 (1859) Am J Sc (2) 27:24-31 (1859)

7o Studies in chemical geogony. Am As, Pr 18: 216-227 (1870)

70a Progress of an investigntion of the structure and lithology of the Hudson River Palisades. Lyc N H N Y, Pr 1:99105,283 (1870)

70b On the grahamite of West Virginia, and the new Colorado resinoid. Am As, Pr 18:124-135 (1870)

71 Analyses of sandstones from New Jersey. Lyc N H N Y, Pr 1: 196 (1871)

71a The gas well at West Bloomfield, N. Y. Lyc N H N Y, Pr 1: 260-265 (1871)

72 Triassic sandstone of the Palisade Range. Am J Sc (3) 3:57 (1872)

73 Metamorphism as a consequence of the transformation of motion into heat. Am J Sc (3) 5:385-386 (1873)

75 Preliminary note upon the carbonite, or so-called "natural coke" of Virginia. Am I M Eng, Tr 3:456-458 (1875) Eng M J 20:188-189 (1875)

90 Wurtzilite. Eng M J 49:59, 106107 (1890)

94 Gold genesis. Se Am Sup 38 : 15644-15645 (1894) 
Wyatt, Francis.

87 Salt. Eng M J 44:411, 432-433, 448-449 (1887)

90 Notes on Florida phosphate beds. Eng M J 50:218-220 (1890)

91 The phosphates of America... 187 pp, N Y 1891

92 The phosphates of Florida. Eng $\mathbf{M}$ J $53: 202-204$ (1892)

Wyer, Samuel $\mathrm{S}$.

18 Natural gas; its production, service, and conservation. U S Nat Mus, B 102 pt $7: 66 \mathrm{pp} \mathrm{(1918)}$

wylie, T. A.

59 Teeth and bones of Elephas primigenius, lately found near the western fork of White River, in Monroe Co, Ind. Am J Sc (2) 28:283-284 (1859)

Wyman, Jeffries (1814-1874).

45 [On Hydrarchos sillimani.] Boston Soc N H, Pr 2:65-68 (1845)

46 An anatomical description of the cranium of the Castoroides ohioensis. Boston J N H 5: 391-401 (1846)

46a [On a cranium and lower jaw or an extinct rodent from Wayne Co., N. Y J Boston Soc N H, Pr 2:138-139 (1846)

50 Notice of fossil bones from the neighborhood of Memphis, Tenn. Am J Sc (2) $10: 56-64$, il $(1850)$

50a Notice of remains of vertebrate animals found at Richmond, Virginia. Am J Sc (2) $10: 228-235$, il (1850)

50b [On boulder accumulations on the coast of Laborador.] Boston Soc N H, Pr $3: 182-183$ (1850)

50c [On teeth of fishes from the Tertiary deposit of Richmond, Va. (with discussion by H. D. Rogers and E. Desor).] Boston Soc N H, Pr 3: 246-247 (1850)

50d [Vertebrate fossils from the Mississippi alluvium at Memphis, Tenn.] Boston Soc N H, Pr 3:280-281 (1850)

50e $[O n$ the remains of seals and a coprolite from Richmond, Va.] Boston Soc N H, Pr 3: 323 (1850)

50P [On bones of Zeuglodon from Washington Co., Ala.] Boston Soc N H, Pr $3: 328-329$ (1850)

53 Description of the interior of the cranium and of the form of the brain of Mastodon giganteus. Am J Sc (2) 15 : $48: 55$, il (1853)

53a (and owen, R.) Notes on the reptilian remains [from the Coal Measures of Nova Scotia]. G Soc London, Q J 9 : 64-67, 11 (1853)

54 [On the American fossil elephant.] Boston Soc N H, Pr 4:377-378 (1854)

55 Notice of fossil bones from the Red Sandstone of the Connecticut River valley. Am J Se (2) 20:394-397 (1855)

55a [On fossil bones from the sandstone of the Connecticut Valley.] Boston Soc N H, Pr 5: 238 (1855)
Wyman, Jeffries-Continued.

55b [On the formation of rain impressions in clay.] Boston Soc N H, Pr 5: 253-254 (1855)

55e Fossil footprints. Boston Soc $\mathrm{N} \mathrm{H}$, Pr 5: 258-259 (1855) Am J Se (2) 21 : 444 (1855)

57 On the internal structure of the cranium of the mastodon. Am Ac Arts, Pr $3: 25-26$ (1857)

$57 \mathbf{a}$ Note on the teeth of an elephant discovered near Zanesville, Ohio. Am As, Pr 10 pt 2: 169-172 (1857)

57b On a batrachian reptile from the coal formation [Ohio]. Am As, $\operatorname{Pr} 10$ pt 2:172-173 (1857) Abst, Edinb N $\mathrm{Ph} J$ n s $5: 360-361$ (1857)

58 On some remains of batrachian reptiles discovered in the coal formation of Ohio ... Am J Sc (2) 25:158-163, il (1858)

62 Observations upon the remains of extinct and existing species of Mammalia found in the crevices of the lead-bearing rocks and in the superficial accumulations within the lead region of Wisconsin, Iowa, and Illinois. In Hall, James, and Whitney, J. D., Report of the geological survey of the State of Wisconsin, vol. I : 421-423 (1862)

66 [On ripple marks in Potsdam sandstone at Keeseville N. Y.: Boston Soc $\mathrm{N} \mathrm{H}, \operatorname{Pr} 10: 186-187$ (1866)

See also Perley, 50

Wyman, L. E.

18 Notes on the pleistocene fossils obtained from Rancho La Brea asphalt pits, Los Angeles Co. [Cal.] Mus ... Dp N Sc, Misc Pub no $2: 35 \mathrm{pp}$, il (1918)

wynkoop, W. C.

oo The Cochiti district, N. Mex. Eng M J $70: 215-216$ (1900)

Wyoming, State Geologist.

15 [Map of] Big Muddy and Douglas oil and gas fields [Wyo.]. Scale 1 in $=2$ miles, 1915

Wysor, D. C.

16 Aluminum hydrates in the Arkansas bauxite deposits (see also discussion by L. L. Fermor: 686-690). Ec G $11: 42-50$ (1916)

17 Aluminium hydrates (discussion). Ec G 12:282-285 (1917)

Yale, Charles Gregory.

92 Borax. U S G S, Min Res 1889$90: 494-506$ (1892)

99 The mineral industry of California. In California mines and minerals (pub. by California Miners' Association) : 1-56, San Francisco, Cal., 1899

oo The gold deposits of Cape Nome. Sc Am Sup 49:20381-20382 (1900)

04 Boráx. U S G S, Min Res 1903: 1017-1028 ; 1905 : 1091-1096； 1906 : 1059$1062 ; 1907$ pt $2: 631-635 ; 1908$ pt $2: 603-$ $605 ; 1909$ pt $2: 631-632 ; 1910$ pt $2: 701-$ 702 (1904-11) 
Yale, Charles Gregory-Continued,

04a Magnesite. U S G S, Min Res 1903: 1131-1135; 1904 : 1169-1174; 1905 : 1273-1278; $1906: 1145-1147 ; 1907$ pt 2 : $737-740 ; 1908$ pt $2: 739-741 ; 1909$ pt 2 : $841-843 ; 1910$ pt $2: 911-914$ (1904-11)

o5 Gold and silver; California, Nevada, Oregon, Washington. U S G S, Min Res $1904: 165-177, \quad 196-200, \quad 203-206, \quad 217-$ $219 ; \quad 1905: 162-185, \quad 259-275, \quad 284-293$, $331-337$; 1906 : 178-198, 287-300, 312-318, 362-368 (1905-8)

O5a Gold and silver; Alaska. U S G S, Min Res 1904: 155-157 (1905)

07 General index to publications of the California State Mining Bureau. Cal St M Bur, B 46: 7-42 (1907)

os Gold, silver, copper, lead, and zinc; California; Oregon, U S G S, Min Res 1907 pt $1: 187-235,414-427 ; 1908$ pt 1 : $314-359, \quad 520-534 ; 1909$ pt $1: 259-290$, $441-450 ; 1910$ pt $1: 347-384,553-565$; 1911 pt $1: 462-505,721-733 ; 1912$ pt 1 : $569-634,847-866 ; 1913$ pt $1: 459-522$; 1914 pt $1: 353-414 ; 1915$ pt $1: 207-257$; 1916 pt $1: 215-267(1908-17)$

osa Gold, silver, copper, lead, and zinc ; Nevada. U S G S, Min Res 1907 pt 1: 337-398 (1908)

osb Gold, silver, copper, lead, and zine ; Washington. U S G S, Min Res 1907 pt 1: $468-477 ; 1908: 573-582 ; \quad 1909: 485-491$ (1908-11)

09 (with Naramore, C.) Gold, silver, copper, lead, and zinc; Nevada. U S G S, Min Res 1908 pt 1: 462-506 (1909)

13 (and Gale, H. S.) Borax. U S G S, Min Res 1912 pt $2: 839-846 ; 1913$ pt 2 : $521-536$, map; 1914 pt $2: 839-846 ; 1913$ pt $2: 521-536, \operatorname{map} ; 1914$ pt $2: 285-290$, map ; 1916 pt $2: 387-389$, map (1913-8)

13a (and Gale, H. S.) Magnesite. U S G S, Min Res 1912 pt 2:1071-1077; 1913 pt $2: 441-454$, map ; 1914 pt $2: 569$ 586, map; 1916 pt $2: 391-401$ (1913-8)

16 Borax in 1915. U S G S, Min Res 1915 pt $2: 1017-1018$, map (1916)

16a Magnesite in 1915. U .S G S, Min Res 1915 pt 2:1019-1026 (1916)

18 (and stone, R. W.) Magnesite in 1917. U S G S, Min Res 1917 pt $2: 63-79$ (1918)

Yale University, Silliman Foundation.

15 Problems of American geology; a series of lectures dealing with some of the problems of the Canadian shield and of the Cordilleras, delivered at Yale University on the Silliman Foundation in December, 1913, by William North Rice, Frank D. Adams, Arthur P. Coleman, Charles D. Walcott, Waldemar Lindgren, Frederick L. Ransome, William Diller Matthew. $505 \mathrm{pp}$, New Haven 1915
YandeII, Lunsford Pitts (1805-1878).

47 (and Shumard, B. F.) Contributions to the geology of Kentucky. $36 \mathrm{pp}$, il, Louisville 1847

48 [Sur une pentrémite des États-Unis.] Soc G France, B (2) 5: 296-297 (1848)

51 On the distribution of the Crinoidea in the Western States, $\mathrm{Am} \mathrm{As,} \operatorname{Pr} 5$ : 229-235 (1851)

55 Description of a new genus of crinoidea [Acrocrinus, from Grayson Co., Ky.]. Am J Sc (2) $20: 135-137$, il (1855)

56 (with Shumard, B. F.) Notice of a new fossil genus belonging to the family Blastoidea, from the Devonian strata near Louisville, Ky. Ac N Sc Phila, Pr 8:7375 , il (1856) Am J Sc (2) $22: 120-122$ (1856)

Yarrow, H. C.

73 Explorations west of the 100 th meridian. Am J Sc (3) 5:290-291*(1873)

Yates, J. A.

03 The Ottawa gas wells [Kans.]. Kans Ac Sc, Tr 18:106-108 (1903)

09 Study of certain features of the Lawrence shales, Kans Ac Sc, Tr 22 : 117-121 (1909)

11 A description of the changes in the Cottonwood limestone south of Cottonwood Falls, Kans. Kans Ac Sc, Tr 23-24: 75-90 (1911)

See also Union Pacific Rallroad Company, 09

Yates, Lorenzo Gordin.

74 [Mammalian fossils in California.] Ac N Sc Phila, Pr 1874: 18-21 Abst, Am $\mathrm{J}$ Se (3) $8: 143$ (1874)

86 Catalogue of minerals in Lorenzo G. Yates' collection, Santa Barbara, Cal. 71 pp, Santa Barbara, Cal,, 1886

87 Fossil botany. West Am Sc 3:180$181,201-203,213-215$ (1887) ; 4:20-22 (1888)

90 Notes on the geology and scenery of the islands forming the southerly line of the Santa Barbara channel. Am G 5:43$52(1890)$

90 Stray notes on the geology of the Channel Islands. Cal St M Bur, An Rp 9 : 171-174 (1890)

02 Prehistoric California; its topography, flora, and fauna ... S Cal Ac Sc, B 1: $81-86,97-100,113-118,129-137$ (1902) ; $2: 145-155,17-22, \quad 44-51,74-75,87-93$, 97-101, 113-118, il (1903) ; 3:6-10 (1904)

Yeandle, W. H.

o9 Notes on the effect of earthquakes on deep underground water circulation. Eng M J 88: 871 (1909)

Yertes, William S.

89 Pseudomorphs of native copper after azurite, from Grant Co., N. Mex. Am J Sc (3) $38: 405-407$ (1889)

90 New localities for phenacite. Am J Sc (3) $39: 325$ (1890) 
Yeates, William S.-Continued.

92 Plattnerite, and its occurrence near Mullan, Idaho. Am J Sc (3) 43:407-412 (1892)

93 Report of the State geologist as to the progress and conduct of the geological survey [of Georgia]. 8 pp, Atlanta 1893

94 Administrative report of the State geologist for the year ending October 23, 1894. Ga G S: 9 pp, Atlanta, Ga., 1894 ... from October 24,1894 , to October 15 , $1896 ; \ldots 45 \mathrm{pp}(1896) \quad \ldots$ for the year ending October 15,$1897 ; \ldots 20$ pp (1897) ... for the year ending October 15,1898 ; ... 19 pp (1898) ... for the year ending October 15,$1899 ; \ldots 21$ pp (1899) ... for the year ending October 15,$1900 ; \ldots 27$ pp (1900)

96 (and others) A preliminary report on a part of the gold deposits of Georgia. Ga G S, B 4-A : 542 pp (1896)

Yonge, Allen Murray.

17 Manganese deposits in Costa Rica. Eng M J 104: 739-741 (1917)

Young, A. A.

82 On sandstones having the grains in part quartz crystals. Am J Sc (3) 23 : 257 (1882)

82a Further observations on the crystallized sands of the Potsdam sandstone of Wisconsin. Am J Sc (3) $24: 47-49$ (1882) Young, Augustus (1785-1857).

56 Preliminary report on the satural history of the State of Vermont. $88 \mathrm{pp}$, Burlington 1856

Young, C. C.

11 Note on the waters from the sandstone in the Lawrence shales. Kans Ac Sc, Tr 23-24: 199-200 (1911)

Young, C. M.

17 The coal industry of Illinois. Am I M Eng, B 129:1369-1384 (1917) ; Tr $57: 560-578$ (1918)

Young, Charles Augustus (1834-1908).

75 The occurrence of celestine in Blair Co., Pa. Ac N Sc Phila, Pr 1875:127128

r 7 On conglomerate No. XII. Ac N Se Phila, Pr 1876: 262 (1877)

79 The New River coal field, W. Va. Eng Elub Phila, Pr 1: 125-129 (1879)

Young, George Albert.

01 [Report on field work in the Lake St. John district, Que.] Can G S, Sum Rp 1900 (An Rp 13) : A 143-146 (1901)

04 Geology of Yamaska Mountain [Que.]. Can G S, Sum Rp 1903 (An Rp 15) : A 144-146 (1904)

05 On surveys between Rabbit and Timagami lakes [Ont.]. Can G S, Sum Rp 1904 (An Rp 16) : ^ 195-198 (1905)

06 The geology and petrography of Mount Yamaska, Province of Quebec. Can G S, An Rp 16: H 43 pp, map (1906)

06a sketch geological map of the City of Rossland and vicinity, B. C. ... Scale 1600 feet to 1 inch. Can G S 1906
Young, George Albert-Continued.

os The tin-bearing locality at New Ross, N. S. Can G S, Sum Rp 1907: 77 (1908)

09 A descriptive sketch of the geology and economic minerals of Canada. Can G S:151 pp, maps (1909) Abst, Can M J $30: 684-685$ (1909)

09a Summary report on a district near Bathurst, N. B., and on the reported occurrence of gold in the Tobique country, Victoria Co., N. B. Can G S, Sum Rp 1908: 129-131 (1909)

10 Bathurst district, N. B. Can G S, Sum Rp 1909: 217-224 (1910) Can M J 31 : 488-492 (1910)

10a La Canada géologique. Soc Géog Qué, B $4: 229-234$ (1910)

10b L'archipel arctique. Soc Géog Qué, B $4: 322-325$ (1910)

11 Tobique district, N. B. Can G S, Sum Rp 1910: 234-237 (1911)

11 a Bathurst district, N. B. Can G S, Mem 18: 96 pp, maps (1911)

12 Geology of the Moncton map area, Westmorland and Albert cos., N. B, Can G S, Sum Rp 1911: 309-321 (1912)

13 (and others) Excursion in eastern Quebec and the maritime provinces. Int G Cong, XII, Canada, Guide Book no 1 : 1-207, 209-407, maps (1913)

16 Hydromagnesite deposits of Atlin, B. C. Can G S, Sum Rp 1915:50-61 (1916)

18 Burnthill Brook map area, N. B. Can G S, Sum Rp 1917 pt F:1-15, maps (1918)

Young, George Joseph.

14 Potash salts and other salines in the Great Basin region. U S Dp Agr, B 61: 96 pp (1914)

15 A cave deposit [Battle Mountain, Nev.]. Ec G 10:186-190 (1915)

18 The sink of the Amargosa [Death Valley, Inyo Co., Cal.]. Eng M J 105: 985-986 (1918)

Young, J. P.

31 Oolite in situ, in Edenville, Orange Co,, N. Y. Am J Sc 19:398 (1831)

Young, Jacob W.

18 The halogen salts of silver at Wonder, Nev. (discussion). Ec G $13: 224$ 225 (1918)

Young, Lewis E.

03 (with Beyer, S. W.) Geology of Monroe Co. Iowa G S $13: 353-422$, map (1903)

16 Surface subsidence in Illinois resulting from mining. Ill $\mathrm{G} \mathrm{S}$, Cooperative Coal Mining Series, B 17:112 pp (1916)

16a (and Stoek, H. H.) Subsidence resulting from mining. IIl Univ, B 13 no $49: 205$ pp (1916)

Young, S. W.

15 Some chemical factors affecting secondary sulphide ore enrichment (abst). G Soc Am, B $26: 393-394$ ( 1915 ) 
Young, S. W.-Continued.

16 (and Moore, N. P.) Laboratory studies on secondary sulphide ore enrichment. Ec G 11:349-365, 574-581 (1916)

Youngs, L. J.

12 (with Kraus, E. H.) Ueber die Aenderungen des optischen Achsenwinkels in Gips mit der Temperatur. $\mathrm{N}$ Jb 1 : 123-146 (1912)

Youtz, L. A.

96 Clays of the Indianola brick, tile, and pottery works [Warren Co., Iowa]. Iowa Ac Sc, Pr 3:40-44 (1896)

Yuill, Harry H.

08 The "White Bear mine," Rossland, B. C. Can M Inst, J $11: 525-543$ (1908)

Yung, Morrison B.

03 (and MeCaffery, R. S.) The ore deposits of the San Pedro district, N. Mex. Am I M Eng, Tr $33: 350-362$, maps (1943) Eng M J 75:279-299 (1903)

Zalinski, Edward R.

O7 Some notes on Greenwater; the new copper district of California. Eng M J 83 : $77-82$ (1907)

$07 \mathbf{a}$ The mines of the Fairview district, Nev. Eng M J 83:699-703 (1907)

o7b Mining in the Wonder district, Nev.

Eng M J 83:763-765 (1907)

07e Turquoise in the Burro Mountains,

N. Mex. Ec G 2:464-492 (1907)

os Occurrence of vanadium near Telluride, Colo. Eng M J 85 : 1152-1153 (1908) 0Sa Turquoise mining, Burro Mountains, N. Mex. Eng M J 86:843-846 (1908)

08b Ore occurrence at Fortuna mine, Bingham [Utah]. Fng M J 86:1191-1195 (1908)

09 Amatrice, a new gem stone of Utah. Eng M J 87:1038-1039 (1909)

11 Ore occurrence at Little Bell mine [Park City, Utah]. Eng M J 91:11011103 (1911)

13 Ore occurrence at Prince Consolidated [mine, Pioche, Nev.]. Eng M J 95 : 809-812 (1913)

13a Occurrence of oxidized zinc ores at Tintic [Utah]. Eng M J 95: 1227-1228 (1913)

Zambonini, F.

01 Brochantit von Utah. Zs Kryst 34 : 238 (1901)

09 Über Enstatit und Klinoenstatit. Zs Kryst $46: 601-602$ (1909)

Zapre, Carl.

11 Geology of the Cuyuna iron ore district, Minn. M World 34: 585-588, map (1911) Abst, Science n s $33: 463$ (1911)

12 The effects of a basic igneous intrusion on a Lake Superior iron-bearing formation. Ec G 7:145-178 (1912)

$12 a$ The geology of the St. Helens mining district of Washington. Ec G $7: 340$ 350 (1912)
Zapfre, Carl-Continued.

13 (and Barrows, W. A., jr.) The iron ores of the South Range of the Cuyuna district, Minn. Am I M Eng, B 74:215-225 (1913) : Tr 44:3-13 (1913)

See also Wolff ( $\mathrm{J}$ F), 16

Zarate, José C.

17 Las salinas de México y la industria de la sal común. Méx I G, An no $2: 71$ pp (1917)

Zehring, W. S.

09 The Nevada-Douglas copper properties, Nev. M World 30:736-738 (1909)

Zepharovich, V. von.

85 (with Moore, G. E.) Kallait pseudomorph nach Apatit aus Californien. Zs Kryst 10:240-251 (1885)

Zêrega, Francisco.

75 Informe sobre el aerolito de la Descubridora. Soc Geog Mex, B (3) 2: 121128 (1875)

ziegler, Victor.

Ix The Ravenswood granodiorite. N Y Ac Sc, An 21:1-10 (1911)

11 a Factors influencing the rounding of sand grains. J G 19:645-654 (1911)

12 The siliceous oolites of central Pennsylvania. Am J Sc (4) 34:113-127, map (1912)

13 The order of crystallization in igneous rocks. J G 21:181-185 (1913)

13a Lithia deposits of the Black Hills. Eng M J 96: 1053-1056 (1913)

14 The minerals of the Black Hills [S. Dak.]. S Dak Sch Mines, B 10:250 pp (1914)

14a The differentiation of a granitic magma as shown by the paragenesis of the minerals of the Harney Peak region, S. Dak. Ec G $9: 264-277$ (1914)

$14 \mathrm{~b}$ The mineral resources of the Harney Peak [S. Dak.] pegmatites. M Sc Press 108: 604-608, 654-656, map (1914)

14e A note on two new Black Hills minerals. Pahasapa Q 4 no $1: 14-16$ (1914)

15 The potash deposits of the sand hills region of northwestern Nebraska. Colo Sch Mines Q 10 no 3:6-26 (1915)

16 The Pilot Butte oil field, Fremont Co. Wyo, St G of, B $13: 139-178$, maps (1916)

17 The Byron oil and gas field, Bighorn Co. Wyo, G Off, B 14:181-207, map (1917)

17a The Oregon Basin oil and gas field, Park Co. Wyo, G Ofr, B $15: 211-242$, map (1917)

17b Foothills structure in northern Colorado. Colo Sch Mines Q 12 no 2:39 pp (1917)

17e Foothills structure in northern Colorado. J G 25:715-740 (1917)

17d Rôle of geology in petroleum discovery. Colo Sch Mines Mag 7:171-172 (1917) 
Ziegler, Victor-Continued.

18 Popular oil geology. 149 pp, Golden, Colo., 1918

18a The movements of oil and gas through rocks. Ee G $13: 335-348$ (1918)

18b Colorado's future as an oil producer. Colo Sch Mines, Q 13 no $4: 3-19$ (1918)

18e Oil shales and their utilization. The Railroad Red Book of the Denver \& Rio Grande Railroad 35 no $3: 13-20$ (1918) zies, E. G.

16 (and others) Some reactions involved in secondary copper sulphide enrichment. Ec G 11:407-503 (1916)

Zimányi, K.

oo Ueber einen Pyrit von Montana.

Zs

Kryst $32: 243-245$ (1900)

12 Ueber Pyritkrystalle von Spanish Peaks in Colorado. Zs Kryst 51:146-148 (1912)

Zirkel, Ferdinand (1838-1912).

76 Microscopical petrography. U S G Expl 40th Par (King), 6:297 pp (1876)

77 Ueber die krystallinischen Gesteine längs des 40. Breitegrades in Nordwest Amerika [crystalline rocks of fortieth parallel]. K Sächs Ges Wiss Leipzig, mat Cl, Ber $29: 156-243$ (1877)

83 Some remarks upon the petrographical collection of the geological exploration of the fortieth parallel. Boston Soc N H, Pr 22:109-116 (1883)

04 Über die gegenseitigen Beziehungen zwischen der Petrographie und angrenzenden Wissenschaften [relations of petrography with other sciences]. J G 12:485500 (1904) Cong Arts and Sei (St Louis 1904) $4: 591-603$ (1906)

06 Works of reference on petrology and mineralogy. Cong Arts and Sc (St. Louis 1904) $4: 760-761$ (1906)

Zittel, Karl A. von.

90 Vulkane and Gletscher im nordamerikanischen Westen. Deut Österr AlpenVer, Zs 21:1-20 (1890)

96 Paleontology and the biogenetic law. Am G 18:140-150 (1896)

00 Textbook of paleontology, transl by Charles R. Eastman. See Eastman 00

Zuber, Rudolf.

10 The origin of petroleum; discussion of a paper by L. V. Dalton. Ec G 5 : 194-195 (1910)

\section{Ziircher, Philippe.}

99 (with Bertrand, M.) I, Etude géologique sur l'isthme de Panama; II, Les phénomènes volcaniques et les tremblements de terre de l'Amérique centrale, by M. Bertrand. 38 pp, maps, Paris [1899] Abst, Soc G France IB (3) 27:494-495 (1899) Transl of I (by J. C. Oakes), U S, Bd Consulting Engrs for the Panama Canal Rp : 149-163, Washington 1906
Zïrcher, Philippe-Continued.

00 (with Bertrand, M.) Note on the Culebra and Emperador cuts [Panama Canal], U S, 56th Cong 1st sess, S Doc 188: 8-10 (1900) U S, Bd Consulting Engrs for the Panama Canal, Rp : 162-163, Washington 1906

06 (with Bertrand, M.) A geological study of the Isthmus of Panama (translation by John C. Oakes). Board of Consulting Engineers for the Panama Canal, Report : 149-163, Washington, 1906

Zuleh, W. G.

14 (with Smith, R. W.) Solution of a landslide fault. Eng M J 97:1090-1091 (1914)

\section{Anonymous.}

14 An inquiry into the chemical characters and properties of that species of coal lately discovered at Rhode Island. Am Miner J 1: 34-40 (1814)

14a Geological inquiries. Am Miner $\mathrm{J}$ $1: 43-53$ (1814)

20 American Geological Society. Am J Sc 2: 139-144 (1820)

20n A geological survey of the county of Albany ... See Eaton (A), 20

30 ... geology of the Arctic regions... Am J Sc 17:1-15 (1830)

37 Fossil remains of the elephant, Elephas primigeneus [New York]. Am J Sc $32: 377-379$ (1837)

40 [?Beck, L. C.] [Proceedings of] Association of American Geologists [Philadelphia, 1840]. Am J Sc 39:189-191 (1840) As Am G, Rp : 9-11 (1840)

40a Earthquake in Connecticut Am J Sc $39: 335-342(1840)$

41 [?Beck, L. C.] [Proceedings of the] Association of American Geologists [second annual meeting, Philadelphia, 1841]. Am J Sc 41:158-189 (1841) As Am G, Rp : 11-41 (1843)

42 [?Jackson, C. T.] Third annual meeting of the Association of American Geologists and Naturalists. Am J Sc 43:146184 (1842) As Am G, Rp: 42-76 (1843)

43 Association of American Geologists and Naturalists [3d annual session at Boston in 1842]. Geologist 1843:32-40

44 [?Silliman, B., jr.] Abstract of the proceedings of the fifth session of the Association of American Geologists and Naturalists [held in Washington, D. C., May, 1844]. Am J Sc 47:94-160, 247-278 (1844)

45 [?Silliman, B., jr.] Abstract of the proceedings of the sixth annual meeting of the Association of American Geologists and Naturalists held in New Haven, Conn., April, 1845. 87 pp. New Haven (1845)

45a Large skeleton of the Zeuglodon of Alabama. $\Delta \mathrm{m}$ J Se $49: 218$ (1845) 
Anonymous-Continued.

45b Sixth annual meeting of the Association of American Geologists [New Haven, 1845]. Am J Sc 49: 219 (1845)

47 American Association of Geologists and Naturalists [Boston meeting, 1847]. Am J Agr 6: 208-219, 198 [246]-219 [267] (1847)

48 A memoir of Dr. Douglass Houghton. Am J Sc (2) 5: 217-227 (1848)

53 Belcher's artesian well in St. Louis [Mo.]. Am J Sc (2) 15:460-462 (1853) 53a The silver of the Lake Superior mineral region. M Mag $1: 447-454$ (1853)

55 Mines of New Jersey. M Mag 4: 121-134 (1855)

58 Franklinite iron ores; their uses and quiantity [Franklin, Sussex Co., N. J.], M Mag 10:105-108 (1858)

59 A few facts regarding the geological survey of Pennsylvania, exposing the erroneous statements and claims of J. P. Lesley... 22 pp, Phila 1859

61 David Dale Owen. Am J Sc (2) 31 : 153-155 (1861)

65 Benjamin Silliman. Am J Sc (2) $39: 1-9(1865)$

$65 a$ Notices of earthquakes. Am J Sc (2) $40: 362-366$ (1865)

66 [Geological notes on Lycoming Co., Pa.] Med Soc Pa, Tr (4) 2:88-89 (1866) 67 A catalogue of official reports upon geological surveys of the United States and British provinces. Am J Sc (2) $43: 116-$ 121, 399-404 (1867)

70 Discovery of a mastodon [in Illinois]. Am J Sc (2) 50:422-423 (1870)

72 Wyoming coal formations. Am J Sc (3) $4: 489$ (1872)

73 River and lake terraces. Pop Sc Mo 2: 661-665 (1873)

73a The geysers of Montana [Yellowstone National Park]. Am Nat 7:279$290(1873)$

77 Elkanah Billings. Am J Sc (3) 14: $78-80$ (1877)

77a Wonderful discoveries in the sandstone rocks of Colorado [Reptilia, Morrison]. Western Rv Sc 1:564-565 (1877)

77b The wonderful fossil beds of Oregon. Western Rv Sc 1:608-610 (1877)

78 Geographical and geological survey of the Rocky Mountain region under the direction of Professor J. W. Powell; account of work performed during the year 1877. Am J Sc (3) $15: 342-358$ (1878)

78n A fossil walrus discovered at Portland, Maine. Am Nat 12:633 (1878)

79 A gigantic Conularia of the Niagara group of Hamilton, Ont. Can Nat n s 9: $62-63 \quad(1879)$

so The Comstock lode. Am Nat 14: 884-385 (1880)

80a Sketch of Benjamin Silliman. Pop Sc Mo 16:550-553, port (1880)
Anonymous-Continued.

Sob The Richmond diatomaceous earth. Science (ed, Michels) 1:222 (1880)

81 Report of a visit to the Luray Cavern in Page Co., Va... Smiths Inst, An Rp $1880: 449-460$ (1881)

82 Professor John W. Powell. Pop Sc Mo $20: 390-397$, port (1882)

82a The mineral resources of the Dominion of Canada... [Canada, Dp Agr] : 72 pp, Ottawa 1882

83 Iron mines of New Jersey. Sch Mines Q 4:111-121 (1883)

83a Baltimore [Md.] surface geology. Science 1:277 (1883)

83b American Association for the Advancement of Science; proceedings of Section E-geology and geography [Minneapolis, 1883]. Science 2:314-327 (1883)

84 Sketch of Professor James Hall. Pop Sc Mo 26:120-123, port (1884)

84a [Topographic features of southern West Virginia.] Science 3:603-605 (1884)

84b The new Bogosloff Volcano. Science 4: 138 (1884)

84e Proceedings of the section of geology [of the British Association for the Advancement of Science, Montreal meeting, 1884]. Science 4:257-260 (1884)

84d Proceedings of the section of geology and geography [of the American Association for the Advancement of Science, Philadelphia, 1884]. Science 4:325-329 (1884)

84e The new volcano of the Bering Sea [Bogosloff Island and Hague Volcano]. Science 4: 432-434 (1884)

S4f [Geology of Snyder Co., Pa.] Med Soc $\mathrm{Pa}$, Tr 16:510-512 (1884)

85 Benjamin Silliman [jr.]. Am J Sc (3) $29: 85-92(1885)$

85n The oldest air breathers. Pop Sc Mo $27: 395-400$ (1885)

85b Proceedings of the section of geology and geography [American Association for the Advancement of Science, Ann Arbor meeting, August, 1885] Science 6:219222 (1885)

85e The international geological congress at Beriin. Science $6: 376-379$ (1885)

86 Proceedings of the geological section of the American Association for the Advancement of Science [Buffalo, 1886]. Science $8: 205-206$ (1886)

s6a Isaac Lea. Science 8:556-558, port (1886)

87 Proceedings of the American Association: Section E. Science 10:87-88 (1887)

$\mathbf{8 7 a}$ Gogebic iron ore mines. Eng M J $43: 182$ (1887)

88 [Bison latifrons from Antelope Creek, Nebr.]. Am G 2: 439 (1888)

88a Ferdinand Vandeveer Hayden. Science $11: 1-2$ (1888)

S8b The international geological congress. Science $12: 193-194$ (1888) 
Anonymous-Continued.

88e [Boring at Saybrook, IIl.] Eng M J $46: 193$ (1888)

89 Sketch of the life of David Dale Owen, M. D. Am G 4:65-72, port (1889) 89a Zinc mining in Arkansas [Marion

Co.]. Eng M J 47:431 (1889)

90 Description géologique des terrains traversés par le Canal. Canal interocéanique de Panama. Commission d'études instituée par le liquidateur de la Compagnie universelle. $30 \mathrm{pp}$, Paris 1890

90a Henry Rowe Schoolcraft. Am G 5 : $1-9$, port (1890)

$90 b$ Obituary notice; George H. Cook.

G Soc Am, B 1:519-520 (1890)

90e Sketch of Amos Eaton. Pop Sc Mo $38: 113-118$ (1890)

90d American Geological Society [Geological Society of America, New York meeting, December, 1889]. Science 15:10-11 (1890)

90e The Crimora manganese mine of Virginia. Eng M J 49:333-334 (1890)

91 John Francis Williams. Science 18: 300 (1891)

92 Review of the oricin of the basins of the Great Lakes. Science 19:312-313 (1892)

93 The Geological Society of America. Science 21: 17-18 (1893)

95 Sketch of Charles Upham Shepard. Pop Sc Mo $47: 548-553$, port (1895)

95a Edward Hitcheock. Pop Sc Mo 47 : 689-696, port (1895)

96 Sketch of Ebenezer Emmons. Pop Sc Mo 48: 406-411, port (1896)

96a Sketch of Henry Darwin Rogers. Pop Sc Mo $50: 258-264$, port (1896)

98 Sketch of Charles D. Walcott. Pop Sc Mo 52: 547-553, port (1898)

98 a Sketch of Charles Henry Hitchcock. Pop Sc Mo 54: 260-268, port (1898)

99 Metamorphism of rocks. M Sc Press $79: 313-314$ (1899)

$99 a$ Dr. Douglass Houghton. Mich Miner

2 no $1: 26-27$, port (1899)

oo Sketch of Edward Orton. Pop Sc Mo 56:607-613, port (1900)

OOa [Catalog of the] Lacoe collection of Paleozoic fossils ... Wyoming Hist G Soc, Pr 5: 179-204 (1900)

01 Geology, etc, of the Coosa Valley, Ala. U S, 56th Cong $2 d$ sess, S Doc 65:4 pp (1901)

02 International catalogue of scientific literature; G (Mineralogy, including petrology and crystallography); $\mathrm{H}$ (Geology); J (Geography); K (Paleontology). Annual issues 1-14. Royal Society, London, 1902-1919

o3 Economic minerals of Nova Scotia; catalogue and description. Provincial exhibition, 1903. N S., Dp Public Works and Mines : 39 pp, Halifax, N. S., 1903
Anonymous-Continued.

o5 Bibliography of C. L. Herrick. Dentson Univ, Sc Lab, B 13: 28-33 (1905)

06 The Californian earthquake of April

18. Nature 74:178-179 (1906)

O6a Joseph Frederick Whiteaves. G Mag (5) 3:433-442, port (1906)

06b After earthquake and fire. See

Rickard, 06

07 Angelo Heilprin. Geog Soc Phila, B $5: 67-68$ (1907)

o7a Angelo Heilprin. Am Geog Soc, B $39: 666-668$ (1907)

07b The Mayari iron ore district of Cuba. Iron Age 80:421-426 (1907)

os The geology of Stateline district, Utah. Salt Lake M Rv 9 no $23: 15-17$ (1908)

O8a Iron mining in Cuba. Iron Age 81: 1149-1157 (1908)

09 Geologic note on Liberty Bell [mine, at Telluride, Colo.]. M Sc Press 98:793 (1909)

09a Rutile deposits of Virginia. Min Sc Press 98: 896 (1909)

10 Notes on the Archean rocks of Mexico. Eng M J 90:821-822 (1910)

10a The oil fields of Trinidad. Petroleum Rv, London, $22: 361-364 ; 23: 17-19$ (1910)

10b William Phipps Blake [1826-1910]. Am J Sc (4) 30:95-96 (1910) Eng M J $89: 1099$ (1910)

11 Samuel Franklin Emmons. Eng M J 91 : 701-702, port (1911)

$11 a$ Obituary, Samuel Franklin Emmons. M Met Soc Am, B no 35 (4 no 4) : $64-69$ (1911)

$11 b$ Obituary, Samuel Hubbard Scudder. Appalachia 12:276-279, port (1911)

11e Notes on the California earthquake of July 1, 1911. Seism Soc Am, B 1:110121 (1911)

11d A field school of geology [Montrose quadrangle, southwestern Colorado]. Science $n$ s $34: 706$ (1911)

12 Ernest Robertson Buckley [obituary notice]. M World $36: 306$, port (1912) M Met Soc Am, B no 45 (5 no 2): $37-38$ (1912)

12a Obituary notice, W J McGee. Eng M J 94:484 (1912) Am J Sc (4) 34: 496 (1912)

12b Ralph Stockman Tarr. Am Geog Soc, B $44:$ :283-285 (1912)

12c David White. Eng M J 94:1066, port (1912)

12d Patricia district, Ont. Eng M J 94: 973-974, map (1912)

12e Development of the Green River oil fields [Utah]. Salt Lake M Rv 14 no 4 : 11-14 (1912)

$12 f$ Seismological notes. Seism Soc Am, B 2: 209-212 (1912)

12m Volcanoes of Alaska. Nat Geog Mag 23: 824-832 (1912) 
Anonymous-Continued.

12h Expeditions organized or participated in by the Smithsonian Institution in 1910 and 1911 ; Studies in Cambrian geology aud paleontology in the Canadian Rockies. Smiths Misc Col 59 no $11: 39$ 45 (1912)

13 Mastodon remains. Tenn G S, Res Tenn $3: 110$ (1913)

13a The Twelfth International Geological Congress. Can M J 34:455-472, 504517 (1913)

13b Prospecting for potash in Death Valley, Cal. M World $38: 855-856$ (1913) Translated by G. Bentz in Zs Prak G 21 : 419-422 (1913)

13e The Cape Breton, N. S., coal fields. Coal Age 4:805-806, maps (1913)

16 Nature and science on the Pacific voast ... Edited under the auspices of the Pacifle coast committee of the American Association for the Advancement of Seience. 302 pp, maps, San Francisco 1915

15a The United States Geological Survey at the Panama exposition. Science $\mathbf{n} \mathbf{s}$ 41: 383-384 (1915)

15b Obituary, Doctor Joseph Austin Holmes. M Met Soc Am, B 86:179-181, port (1915)

$$
28737^{\circ}-23-74
$$

Anonymous-Continued.

16 Geology of Tonopah [Nev.]. M Sc Press 112: 498-499 (1916)

16a Origin of the Sudbury nickel-copper ores. Can M J 37:390 (1916)

16b The earthquake at Volcano Iake, Mexico, November 20, 1915. Selsm Soc Am, B 6:181-184 (1916)

16e Old New England; a geologieal interpretation and retrospect. In Sargent, P. E., A handbook of New England: 24-29, Boston 1916

17 William Bullock Clark. Science $\mathbf{n ~ s}$ 46:104-106 (1917) Smiths Inst, An Rp 1917:663-666 (1919)

17a Apuntes acerca de criaderos estaníferos en México. Bol Minero 4:605-617 (1917)

18 Some tungsten ores in the National Museum. Science n s 47:412-413 (1918)

18a Manganese ore in Georgia. Science n s $48: 360-362$ (1918)

18b Manganiferous ore in Oregon. Sclence n \& 48:439-440 (1918)

18c Charles Richard Van Hise. Eng M J 106:999-1000, port (1918)

18d The Guatemala earthquake of December, 1917, and January, 1918. Geog Rv 5:459-460 (1918)

ADDITIONAL COPIES

OF THIS PUBLICATION MAY BE PROCURED FROM THE SUPERINTENDENT OF DOCUMENTS GOVERNMENT PRINTING OFFICE WASHINGTON, D. C.

\section{$\$ 1.25$ PER COPY}

PURCHASER AGREES NOT TO RESELL OR DISTRIBUTE THIS COPY FOR PROFIT.-PUB, RES. 57, APPROVED MAY 11, 1922 
Blytt, A.

90 On the movements of the earth's crust. Smiths Inst, An Rp 1889 : 325-375 (1890) Boalich, Edwin Snow.

14 Mineral production [of California] for 1913. Cal St M Bur, B 68:138 pp, maps (1914)

17 Manganese and chromium. Cal St M Bur, Prel Rp 3:32 pp (1917) 2d ed, 46 pp (1918)

18 (and Castello, W. O.) Tungsten, molybdenum, and vanadium. Cal $S t M$ Bur, Prel Rp no $4: 34$ pp (1918)

18a (and Castello, W. O.) Antimony, graphite, nickel, potash, strontium, tin. Cal St M Bur, Prel Rp no 5: 44 pp (1918)

$18 \mathrm{~b}$ Catalogue of the publications of the California State Mining Bureau, 1880-1917. Cal St M Bur, B $77: 44$ pp (1918)

Boaz, Franz.

88 On the geography and geology of Baffinland. R Soc Can, Pr Tr 5, iv : 75-78 (1888)

Bodewig, C.

85 (and Rath, G. vom.) Colemanit aus Californien. Zs Kryst 10:179-186 (1885)

Böggild, Ove Balthasar.

01 (and Winther, Chr.) On some minerals from the nephelite syenite at Julianehaab, Greenland (epistolite, britholite, schizolite, and steenstrupite). Med Grönland 24:181-213 (1901)

02 On ilvaite from Siorarsuit at Julianehaab, Greenland. Med Grönland 25:43-89 (1902) Copenhagen Univ, Min G Mus, Contr Min, no 1 (1902)

03 On some minerals from the nephelite syenite at Julianehaab, Greenland (erikite and schizolite). Med Grönland 26:91-139 (1904) Copenhagen Univ, Min G Mus, Contr min, no 2 (1903)

03a Samples of the sea floor along the coast of east Greenland, $74 \frac{1}{2}-70$ N. L. Med Grönland 28:17-95 (1904) Copenhagen, Univ, Min G Mus, Contr Miner no 3 (1903)

05 The minerals from the basalt of east Greenlanđ. Med Grönland 28: 97-129 (1909) Copenhagen, Univ, Min G Mus, Contr Miner no 5 (1905)

05a Mineralogia Groenlandica (with a short summary of contents). Med Grornland $32: 625 \mathrm{pp}$, map (1905) Copenhagen, Univ, Min G Mus, Contr Miner no 6 (1905)

06 On some minerals from Narsarsuk at Julianehaab, Greenland. Med Grönland 33: 97-120 (1907) Copenhagen. Univ, Min Mus, Contr Miner no 7 (1906)

$070 \mathrm{~m}$ Dansk-Vestindiens geologi. [In Danish.] Geografisk Tidskrift, Copenhagen 19:6-11 (1907)

08 On gyrolite from Greenland. Med Grönland $34: 91-114$ (1910) Copenhagen, Univ, Min G Mus, Contr Miner no 8 (1908)
Bogsild, Ove Balthasar-Continued.

11 Om Britolitens Krystalform [Julianehaab district, Greenland]. Med Grönland $47: 275-282$ (1911) Zs Kryst 50:430436 (1912)

12 Krystalform og tvillingdannelser hos kryolit, perovskit, og boracit. Med Grönland 50:1-95 (1912) Zs Kryst 50:349429 (1912)

12a Iagttagelser over kryolitgruppens mineraler. Med Grönland 50:105-129 (1912) Zs Kryst 51:591-613 (1912)

12b De stalaktitiske mineraler fra Ivigtut. Med Grönland 50:175-185 (1912) Zs Kryst 51:614-623 (1912)

14 Ussingit, ein neues Mineral von Kangerdluarsuk [Grönland]. Zs Kryst 54: 120-126 (1914) Med Grönland 51:105110 (1914)

15 Leifit, et nyt mineral fra Narsarsuk [Greenland]. Med urön'and 51:427-433 (1915)

15a Dahllit fra Kangerdluarsuk [Greenland]. Med Grönland 51:435-443 (1915)

17 Grönland, In Steinman G., and Wilckens, O., Handbuch der regionalen Geologie, H 21 Bd IV, 2a:38 pp, maps, Heidelberg 1917

See also Dreyer, 10

$\mathbf{B} \boldsymbol{b h m}$, C. Richard.

06 Monazite sand [in North Carolina and South Carolina]. Eng M J 81:842 (1906)

Boehm, G.

98 Ueber Caprinidenkalke aus Mexico. Deut G Ges Zs 50:323-332, il (1898)

99 Beiträge zur Kenntniss mexicanischer Caprinidenkalke. In Felix, J., and Lenk, H., Beiträge zur Geologie und Paläontologie der Republik Mexico, Th 2:143154, il, Leipzig 1899

B̈hm, Joh.

12 Literarische Bemerkung über Porocystis pruniformis Cragin [synonym for Porocystis globularis Giebel sp.]. Centralbl Miner 1912: $86-87$ (1912)

Boehmer, Max (1847-1913).

04 Some practical suggestions concerning the genesis of ore deposits. Am I M Eng, Tr 34:449-453 (1904)

os The localization of values in ore bodies and the occurrence of shoots in metalliferous deposits; Secondary enrichment and impoverishment. Ec G 3:337340 (1908)

10 The genesis of the Leadville ore deposits. Am I M Eng, B 38:119-122 (1910) ; Tr 41:162-165 (1911)

Boeke, H. E.

14 Die Erzlagerstatte Nord Ontarios, insbesondere die Nickellagerstätte von Sudbury. Naturf Ges Halle, Mitt $3: 25-33$ (1914) 
Boerker, Richard $\mathrm{H}$.

15 the Mt. Lassen eruption. Am Forestry 21:51-55 (1915) Pan Am Union, B 11: $228-232$ (1915)

Böse, Emil.

98 Ueber Lias in Mexico. Deut G Ges, Zs 50 : 168-175 (1898)

99 Geologla de los alrededores de Orizaba con un perfil de la vertiente de la mesa central de México. Mex I G, B 13:52 pp (1899)

$99 a$ (with Ord6ñez, E.) Apuntes para la geología del valle de Chilpaneingo [Guerrero, México]. Soc Cient Ant Alz, Mem 14:5-12 (1899)

oo Sobre la independencia de los volcanes de grietas preexistentes. Soc Cient Ant Alz, Mem 14:199-231 (1900)

01 Ein Profil durch den Ostabfall der Sierra Madre Oriental von Mexico. Deut G Ges, Zs 53 : 173-210 (1901)

02 Sobre las regiones de temblores en México. Soc Cient Ant Alz, Mem 18:159184 (1902)

02a Breve noticia sobre el estado actual del volcán de Tacaná, Chiapas [México]. Soc Cient Ant Alz, Mem 18: 267-270 (1902)

$02 b$ (with Villarello, J. de D.) Criaderos de fierro de la hacienda de Vaquerías en el Estado de Hidalgo. Méx I G, B 16: 15-44, map (1902)

03 Informe sobre los temblores de $\mathrm{Za}$ natepec á fines de septiembre de 1902, y sobre el estado actual del volcán de Tacaná. Méx I G, Par 1: 5-25 (1903) Méx. Sec Fomento, B (2) 3 no 5, IV : 59-79 (1903)

04 El área cubierta por la ceniza del volcán de Santa Marfa, octubre 1902. Méx I G, Par 1:51-54 (1904) Méx, Sec Fomento, B (2) 4, IV : 73-78 (1904)

04a (and Angermann, E.) Informe sobre el temblor del 16 de enero de 1902 en el Estado de Guerrero. Méx I G, Par 1:125-131 (1904.) Méx, Sec Fomento, B (2) 4 no 11 , IV : 223-229 (1904)

o5 Reseña acerca de la geología de Chiapas y Tabasco. Méx I G, B 20:5-100, maps (1905)

O5a Noticia preliminar sobre la fauna pliocénica de Tuxtepec, Oaxaca. Soc G Mex, B $1:$ 139-149 (1905)

06 Sobre algunas faunas terclarias de México. Méx I G, B 22:97 pp, il (1906)

06a La fauna de moluscos del Senoniano de Cárdenas, San Luis Potosi [México]. Méx I G, B 24: $95 \mathrm{pp}$, il (1906)

06b Excursions a Chavarrillo, Santa Maria Tatetla, Vera Cruz, et Orizaba [Mexico], Int $\mathrm{G}$ Cong, $\mathbf{X}$, Mexico, Guide Exc II : $11 \mathrm{p}$ (1906)

o6e Excursions aux mines de soufre de la Sierra de Banderas [Mexico]. Int $G$ Cong, X, Mexico, Guide Exc XIX: 8 pp (1906) röse, Emil-Continued.

o6d Excursion au Cerro de Muleros pro ciudad Juarez (Chíhuahua). Int $\mathrm{G}$ Cons $\mathrm{X}$, Mexico, Guide Exc XX: 24 pp, ma (1906)

o6e Excursion dans les environs de Par. ras [Mexico]. Int $G$ Cong, $X$, Mexice Guide Exc XXIII : 16 pp, map (1906)

o6e Excursions dans les environs d: Monterrey et Saltillo [Mexico]. Int $\theta$ Cong X, Mexico, Guide Exc XXIX:1 pp (1906)

06r De San Luis Potosí à Tampio [Mexico]. Int $G$ Cong $X$, Mexico, Guid Exc XXX : 16 pp (1906)

o6h Excursion a l'Isthme de Tehua tepec. Int $\mathrm{G}$ Cong $\mathrm{X}$, Mexico, Guide $\mathrm{Er}$ XXXI : 40 pp (1906)

06i Nota preliminar sobre la fauna pli cénica de Santa María Tatetla, Ver. \& G Mex, B 2:51-64 (1906)

o7 Sobre algunos fosiles pleistocéniou recogidos por el Sr. Dr. E. Angermann e la Baja California. Méx I G, Par 2:41. 45 (1907)

oza Un appareil perfectionné pour reproduction photographique des sutur d'ammonites et d'ambulacres des ourvis Soc Cient Ant Alz, Mem 24:467-4t (1907) Centralbl Miner 1907:422-429

o7b (and Vigier, Victor von.) Sobr la aplicación de la potasa cáustica á preparación de fosiles. Méx I G, Par 49-59 (1907)

os (and others) E1 temblor del 14 abril de 1907. Méx I G, Par 2:131-? (1908)

o9 Zur Frage der Entstehung des $80 \%$ nannten mexikanischen Zentralplateaus. Jb 1908, 2: 114-135 (1909)

09a Ueber eine durch vulkaniscir Druck entstandene Faltungszone im ? von Mexiko. N Jb 1909, 1:28-42 (190)

10 Monografía geologica y paleontolog del Cerro de Muleros cerca de cind Juárez, Estado de Chihuahua, y desctil ción de la fauna cretácea de la Encantśt placer de Guadalupe, Estado de Chihuabt Méx I G, B $25: 193$ pp, il, map (1910)

10a Nuevos datos para la estratignt del cretácico en México. Méx I G, $3: 257-280$ (1910)

10b Neue Beiträge zur Kenntniss mexikanischen Kreide. Centralbl Jit 1910:616-622, 652-662 (1910)

10e (and Toula, Franz) Zur jor tertiären Fauna von Tehuantepec. Stratigraphie, Beschreibung, und Vergle mit amerikanischen Tertiärfaunen, $\vee 00$ Böse. II. Vergleichung hauptsächlich europäischen und lebenden Arten, Franz Toula. K-k G Reichsanstalt, Jb 215-276, il (1910) 
Böse, Emil-Continued.

11 Sobre el origen de los ultimos grandes temblores de California $y$ de la costa de Guerrero, México. Soc Cient Ant Alz, Mem 30:135-162, 163-170 (abst in German) (1911)

13 Algunas faunas del Cretácico superior de Coahuila y regiones limitrofes. Méx I G, B $30: 56 \mathrm{pp}$, il (1913)

13a (and Wittich, E.) Informe relativo a la exploración de la region norte de la costa occidental de la Baja California. Méx I G, Par 4:307-529 (1913)

14 (and Wittich, E.) Las salinas de 0jo de Liebre, Baja California. México, Min Fomento, Mem 1912-3: 109-122 (1914) [not seen]

16 Contributions to the knowledge of Richthofenia in the Permian of West Texas. Tex, Univ, B 1916 no $55: 50 \mathrm{pp}$, il (1916) 16a Las aguas subterráneas de la región de Tehuacán, Puebla. Bol Minero, 1 : 165$168,195-198,228-231,259-262,294-296$, $325-328,355-359$ (1916)

16b (with Udden, J. A., and Bnker, C. L.) Review of the geology of Texas. Tex, Univ, B 1916 no $44: 164$ pp, map (1916)

17 Geological conditions near Bridgeport and Chico, Wise Co., Tex., with special reference to the occurrence of oil. Tex, Univ, B no 1758: 31 pp (1917)

17a The Permo-Carboniferous ammonoids of the Glass Mountains, west Texas, and their stratigraphical significance. Tex, Univ, B 1762: 241 pp, il (1917)

Bogart, John.

91 Report on the outline of the crest of the Falls of Niagara in 1890 and the recession of the Falls since 1842. N Y, Comm St Reservation at Niagara, An Rp 7:89116 (1891)

Bogdanovieh, Karl Ivanovich.

01 [Sketch of Nome.] 116 pp, St. Petersburg 1901 [In Russian. Includes notes on gold resources and geology of Cape Nome region, Alaska.]

09 Earthquakes of Messina and San Francisco [In Russian]. 160 pp, St. Petersburg 1909.

Boilean, John W.

07 Coal fields of southwestern Pennsylvania, Washington, and Greene cos. $90 \mathrm{pp}$, maps, [Priv pub] 1907

Boll, Jacob.

79 Texas in its geognostic and agricultural aspect. Am Nat 13:375-384 (1879) 80 Geological examinations in Texas. Am Nat 14:684-686 (1880)

Bollaert, William.

51 Observations on the geography of Texas. R Geog Soc, J 20:113-135 (1851) Bolton, $\mathrm{H}$.

96 The metamorphism of coal. Colliery Ing $16: 254-255 \quad(1896)$
Bolton, Henry Carrington (1843-1903). 77 Application of organic acids to the examination of minerals. N $\mathrm{Y}$ Ae Sc, An 1:1-34 (1877) ; $2: 1-18$ (1880)

83 (and Julien, A. A.) The singing beach of Manchester, Mass. (abst). Science $2: 325$ (1883) Am As, Pr 32:251252 (1884)

S3a (and Julien, A. A.) Musical sand. Science 2: 713 (1883)

S4 (and Julien, A. A.) Musical sand, its wide distribution and properties (abst). Am As, Pr 33: 408-413 (1885) Science 4: 329 (1884)

85 (with Julien, A. A.) Notice on the microscopical examination of a series of ocean, lake, river, and desert sands (abst). Am As, Pr 33:413-415 (1885)

8s Notes on the great salt deposit of Petite Anse, La. N Y Ac Sc, Tr $7: 122-$ 127 (1888) Sc Am Sup 26:10475-10476 (1888)

88n (with Julien, A. A.) The true cause of sonorousness in sand. $\mathrm{N} \mathrm{Y} \mathrm{Ac} \mathrm{Sc,}$ Tr $8: 9-11$ (1888)

90 The "barking sands" of the Hawailan Islands. Science 16:163-164 (1890) Am As, Pr $39: 257-259$ (1891)

oon Researches on musical sand in the Hawailan Islands and in California. N Y Ac Sc, Tr 10:28-35 (1890)

91 Notes on the occurrence of musical sand on the Pacific coast of the United States (abst). Am As, Pr 39:255-257 (1891)

Bolton, Launcelot Lawrence.

03 Round Lake to Abitibi River. Ont Bur Mines, Rp 1903:173-190 (1903)

17 (with Lindeman, E.) Iron ore occurrences in Canada. Vol. 1, Descriptions of principal iron ore mines: 23-71, maps (in case) ; vol. 2, Descriptions of iron ore occurrences : $222 \mathrm{pp}$, maps (in case), Can Mines $\mathrm{Br}$, Ottawa 1917

Bolton, Richard.

49 On the physical geography and geology of the northern portion of the State of Mississippi. Am As, Pr 1: 71-74 (1849)

Boltwood, Bertram B.

05 On the ultimate disintegration products of the radioactive elements. Am J Sc (4) $20: 253-267$ (1905)

\section{Bomford, George.}

22 [On lead mines in Missouri.] U $\mathrm{S}$, 17th Cong, 1st sess, S Doc 94:14-17 (1822)

Bond, Josiah.

10 A silver-bearing diorite in southern Arizona. Eng M J $89: 1268-1269$ (1910)

$1 x$ Problems on the strike. Eng M J 92:1046-1048 (1911) 
Bond, Josiah-Continued.

13 Influence of joints on the location of ore shoots [notes on geology of First Watchung Mountain, N. J., and the genesis of copper ores there]. Mex M J 16:19-21 (1913)

Bone, J. H. A.

65 Petroleum and petroleum wells ... $95 \mathrm{pp}, \mathrm{N}$ Y 1865

Bonillas, Ygnacio S.

10 Estudio químico y óptico de una labradorita del Pinacate, Sonora. Méx I G, Par 3 : 427-432 (1910)

11 Reconocimiento de algunos criaderos de fierro del Estado de Oaxaca, Mexico. Méx I G, Par 3: 499-524 (1911)

11a Algunos datos geológicos sobre el mineral La Campana, Distrito de Altar Sonora. Soc G Mex, B 7:155-168 (1911)

$11 b$ (with Lord, P. B.) Algunos criaderos argentiferos de cerca de Reyes, Durango. Soc G Mex, B 7:149-154 (1911)

12 Algunas aplicaciones prácticas de la geologia (abst). Soc G Mex, B $8: 1 v-v$ (1912)

13 (and Urbina, F.) Informe acerca de los recursos naturales de la parte norte de la Baja California, especialmente del Delta del Rfo Colorado. Méx I G, Par 4: 161-235 (1913)

16 (and others) Geology of the Warren mining district [Ariz,]. Am I M Eng, B 117: 1397-1465, maps (1916); (with discussion by Ira B. Joralemon, F. L. Ransome, and L. C. Graton), Tr 55:284355 , maps (1916)

18 Clásificación [de rocas del Estado de Guerrero]. Bol Minero 6:498-504 (1918)

Bonine, Chesleigh Arthur.

14 (with Stone, R. W.) The Elliston phosphate field, Mont. U S G S, B 580 : 373-383 (1914)

15 Anticlines in the Clinton sand near Wooster, Wayne Co., Ohio. U S G S, B 621: 87-98, map (1915)

Bonnell, Clarence.

17 The variety of physiographic material in a few counties of southern Illinois. Ill Ac Sc, Tr 9:203-208 [1917]

Bonney, Thomas George.

79 On Professor Dana's classification of rocks. G Mag (2) 6:199-203 (1879)

88 Notes on a part of the Huronian series in the neighborhood of Sudbury, Canada. G Soc London, Q J 44:32-45 (1888)

95 On the mode of occurrence of Eozoon canadense at Cote St. Pierre [Que.]. G Mag (4) 2 : 292-299 (1895)

96 Pyroxene and serpentine in association with Eozoon canadense. G Mag (4) $3: 47$ (1896)

02 On a sodalite syenite (ditroite) from Ice River valley, Canadian Rocky Mountains. G Mag (4) 9:199-206 (1902)
Bonney, Thomas George-Continued.

02n On some rock specimens collected. in the Canadian Rocky Mountains. G Maz (4) $9: 544-550$ (1902)

o3 Notes on some specimens collected... in the Canadian Rocky Mountains. G Maz (4) $10: 289-297$ (1903)

03a Note on rock specimens from the Canadian Rocky Mountains. Geog J 21: 498-499 (1903)

o3b On specimens from Desolation $\mathrm{Va}$. ley Glacier, Canada. G Soc London, Q J 59: c-ci (1903)

o3e March dust from the Soufrière $[0 t$ St. Vincent]. Nature $67: 584$ (1903)

Bonnyeastle, R. E.

29 Desultory observations on a few of the rocks and minerals of Upper Canada. Lit Hist Soc Quebec, Tr 1: 62-70 (1829)

30 On the transition rocks of the Cata. raqui [Ontario]. Am J Sc 18:85-104, it (1830)； 20:74-82 (1831); 24:97-104 (1833) ; $30: 233-248$ (1836)

Bonnycastle, Richard Henry.

42 Newfoundland in $1842 \ldots$ [geolog and geological relations $1: 179-222]$. ? vols, $367,351 \mathrm{pp}$, map, L 1842

Bonsteel, Jay A.

07 The soils of St. Mary's Co. [Md.]. Md G S, St. Mary's Co:125-146 (1907)

O7a (and Burke, R. T. A.) The solls of Calvert Co. [Md.]. Md G S, Calvert Co : 135-167 (1907)

\section{Booth, Henry.}

83 On the discovery of Utica slate grap tolites on the west side of the Hudson : few miles north of Poughkeepsie, N. Y. [identified by R. P. Whitfield]. Am J Sc (3) $26: 380$ (1883)

Booth, James Curtis (1810-1888).

39 First and second report of the get logical survey of Delaware. $25 \mathrm{pp}$, Dovet 1839 [not seen]

40 (and Lea, M. C.) Analysis of : chromic iron ore ... from Mahobal, near Gibara, Island of Cuba. Am J Sc 38:243245 (1840)

41 Memoir of the geological survey of the Delaware ... 188 pp, Dover 1841 Also in Journal of the Senate of the State of Delaware, 1841:41-170, index $347-352$, Dover 1841

41a Analysis of various ores of lead, silver, copper, zinc, iron, etc., from King's mine, Davidson Co., N. C. Am J Sc 41: 348-352 (1841)

$41 b$ (with Boyé, M. H.) Results of the analysis of three different varieties of feld. spar from the primary rocks of the State of Delaware. Am Ph Soc, Pr $2: 53-56$ (1841)

52 On remingtonite, a new cobalt min eral [Carroll Co., Md.]. Am J Sc (2) $14: 48$ (1852) 
Booth, John C.

55 (and Hulbert, E. J.) Geological and topographical map of the mineral district of Lake Superior, Mich. N Y 1855

Booth, William M.

12 (with Taylor, C. F.) The Ontario iron mine, New York. Eng M J 94 : 893895 (1912)

Bordeaux, Albert F. J.

01 Les mines d'or de la Californie. Rv Univ Mines (3) 53:30-82, 245-307 (1901)

02 Les anciens chenaux aurifères de Californie. An Mines (10) 2:217-258 (1902)

07 Les mines de cuivre et les mines d'argent du Mexique. Rv Univ Mines (4) 20:101-132 (1907) Abst, Soc Cient Ant Alz, Mem y Rv 28:5-32 (1910)

08 The silver mines of Mexico. Am I M Eng, B 23:629-640 (1908) ; Tr 39: 357368 (1909) ; Abridged, M World 31:9-11 (1909)

Borden, William Wallace.

74 Report of a geological survey of Clark and Floyd cos., Ind. Ind $\mathrm{G}$ S, An Rp 5:134-189, map (1874)

75 [Geology of] Scott Co. Ind G S, An Rp 6:112-186, map (1875)

$75 a$ [Geology of] Jefferson Co. Ind G S, An Rp 6:135-186, map (1875)

76 Jennings $\mathrm{Co}$; Ripley $\mathrm{Co}$. Ind $\mathrm{G} \mathrm{S}$, An Rp $7: 146-202$ (1876)

Borgström, L. H.

05 The Shelburne meteorite [Grey Co., Ont.]. R Astron Soc Can, Pr 1904:69-94 (1905)

Borhek, R. J.

15 Sand and gravel deposits of the Puget Sound territory [Wash.]. West Eng 5: 387-390 (1915)

Borieky, Emanuel.

92 The elements of a new method of chemico-microscopic analysis of rocks and minerals. Minn G $\mathrm{S}$, An Rp 19:1-77 (1892)

Borie, Jules.

60 Notice sur le lac Supérieur et ses mines de cuivre de la rive américaine. Soc Ind Min, B $6: 233-284$ (1860) ; $7: 185$ 251 (1861) ; 8:270-271 (1862) Allgem Berg- und Hüttenm Ztg 4:448-450, 457$460,469-471$ (1862) [not seen]

Boright, Sherman $\mathrm{H}$.

04 Notes on the geology of the northern portion of the Boisdale Hills anticline [Cape Breton Island, N. S.]. Can M Inst, J 6:411-434, map (1904)

Borron, E. B.

90 Report on the basin of Moose River and adjacent country belonging to the Province of Ontario. $95 \mathrm{pp}$, Toronto 1890

Boss, C. M.

98 Some dike features of the Gogebic Iron range [Mich.]. Am I M Eng, Tr 27: $556-563(1898)$
Boston Society of Natural History.

02 Memorial of Professor Alpheus Hyatt. Boston Soc N H, Pr 30:413-433 (1902)

Bosworth, T. 0 .

12 Birth of an island near the coast of Trinidad. G Mag n $\mathrm{s}$ (5) $9: 159-163$ map (1912)

13 Notes on the semiarid conditions in a part of southern Texas. G Mag n s (5) $10: 481-485$ (1913)

Botsford, C. A.

13 A possible Arizona oil field [Tonto Basin]. Western Eng 3:187-189 (1913) Botsford, C. W.

o9 Geology of the Guanajuato district, México. Eng M J 87:691-694 (1909)

$09 a$ The Zacatecas district and its relation to Guanajuato and other camps. Eng M J $87: 1227-1228$ (1909)

09b Loreto mine and the Pinguico district, Guanajuato. Eng M J 88: 650 (1909)

10 Geological notes on the west coast of Mexico. Eng M J $89: 223-224$ (1910)

10n Geology of the Guanajuato district. Mex M J 11 no 4:30-33, map (1910)

11 Southern Sonora and Chihuahua [Mexico]. Eng M J 92: 704-706 (1911)

13. Disseminated replacement copper deposits. Eng M J 95:620-622 (1913)

Boucheporn, Félix de.

51 Considérations générales sur le terrain erratique et le phénomène glaciaire. Soc G France, B (2) 8:401-413 (1851)

Boué, Amí.

66 Einige Bemerkungen über amerikanisch-mexikanische Geographie und Geologie ... $\mathrm{K}$ Ak Wiss, Mat-nat $\mathrm{Cl}, \mathrm{Szb} 53,1$ : 325-336 (1866)

Boule, Marcellin,

93 Une excursion géologique dans les montagnes rocheuses. As Franc, 22 sess, C R pt 1:39-54 (1893)

06 (and Thevenin, A.) Types du Prodrome de paléontologie stratigraphique universelle de D'Orbigny [includes fossils described by D'Orbigny from Cincinnati, Ohio, and from the Falls of the Ohio]. An Paléont 1:97-101, 165-172, il (1906)

Bourdariat, Alexandre $\mathrm{J}$.

93 Esquisse géologique et minéralogique du district aurifère de Santa Cruz, Honduras. Soc Belge G, B $7:$ M 35-40 (1893)

Bourne, William Oland.

41 Notice of a locality of zeolites, etc., at Bergen, Bergen County, N. J. Am J Sc 40:69-73 (1841)

Bontwe11, John Mason.

03 Progress report on the Park City mining district, Utah. U S G S, B 213: $31-40$ (1903)

03a Ore deposits of Bingham, Utah. U S G S, B 213: 105-122 (1903)

04 [Notes on water resources of] New Hampshire. U S G S, W-S P 102: 56-72 (1904) 
Boutwell, John Mason-Continued.

04a Gypsum deposits in Utah. U S G S, B $223: 102-110$ (1904)

04b Progress report on the Park City mining district, Utah. U S G S, B 225 : 141-150 (1904)

04e Iron ores in the Uinta Mountains, Utah. U S G S, B 225: 221-228 (1904)

04d Rock gypsum at Nephi, Utah. U S G S, B 225 : 483-487 (1904)

o5 Progress report on Park City mining district, Utah. U S G S, B 260: 150-153 (1905)

05a Vanadium and uranium in southeastern Utah. U S G S, B 260: 200-210, map (1905)

05b Ore deposits of Bingham, Utah. U S G S, B 260 : 236-241 (1905)

05e Oil and asphalt prospects in Salt Lake basin, Utah. U S G S, B 260: 468479, map (1905)

o5d Genesis of the ore deposits at Bingham, Utah. Am I M Eng, Bi-Mo B 6: 1153-1192 (1905); Tr 36:541-580 (1906)

o5e Economic geology of the Bingham mining district, Utah. U S G S, P P 38 : 71-385, map (1905) Abst, Eng M J 79: 1176-1178 (1905)

osf Genesis of the ore deposits at Bingham, Utah (abst). Science n s 21:662 (1905)

o7 Stratigraphy and structure of the Park City mining district, Utah. J G 15 : 434-458, map (1907)

о7a Lead; zinc; quicksilver. U S G S, Min Res 1906 : 439-499 (1907)

11 The Calaveras skull [shown to be of recent origin] (See also Koch 11). U S G S, P P 73:51-55 (1911)

12 Geology and ore deposits of the Park City district, Utah, with contributions by L. H. Woolsey. U S G S, P P $77: 231$ pp, map (1912) Abst, Wash Ac Sc, J 3: 445-447 (1913)

Bouve, Thomas Tracy.

45 Review of Dr. C. T. Jackson's Final report on the geology and mineralogy of the State of New Hampshire. Am J Sc 49: 27-37 (1845)

46 Pygorhynchus gouldii, a new Echinus from the Millstone grit of Georgia. Am J Sc (2) $3: 437$ (1847) Boston Soc N H, Pr 2:192 (1846) An Mag N H 20:142 (1847)

51 [New species of echinoderms from the lower Tertiary rocks of Georgia.] Boston Soc N H, Pr $4: 2-4$, il (1851)

54 [On slabs showing Ornithichnites and other markings (with discussion by H. D. Rogers and J. B. S. Jackson).] Boston Soc N H, Pr 5:29-30 (1854)

57 [On a landslide near Portland, Me.] Boston Soc N H, Pr 6:131-133 (1857)

58 [Sketch of the life and labors of James Deane.] Boston Soc N H, Pr 6 : 391-394 (1858)
Bouvé, Thomas Tracy-Continued.

59 [On Zeuglodon cetoides.] Boston Soc N H, 6: 421-422 (1859)

$59 a$ [On the footprints of the Connect. cut Valley.] Boston Soc N H, Pr 7:4q 53 (1859)

62 [Altered conglomerate near Hing. ham, Mass.] Boston Soc N H, Pr 9:5: (1862)

67 [On minerals from Warren, N. H. Boston Soc N H, Pr 11:215-216 (1867)

76 On the origin of porphyry. Boston Soc N H, Pr. 18: 217-220 (1876)

84 The genesis of the Boston Basin and its rock formation. Boston Soc $\mathrm{N} \mathrm{H}, \mathrm{Pt}$ $23: 29-36$ (1884)

89 Indian potholes, or giants' kettles of foreign writers. Boston Soc N H, Pr 24: 218-226 (1889)

91 Kamre ridges, kettle holes, and other phenomena attendant upon the passing away of the great ice sheet in Hingham, Mass. Boston Soc N H, Pr 25:173-182, map (1891)

Bovard, John F.

or Notes on Quaternary Felidæ from California. Cal, Univ, Dp G, B $5: 155-170$, il (1907)

Bovee, Gladys G.

1s Bibliography and Index of Wyoming geology, 1823-1916. Wyo, G Office, B 17: $317-446$ (1918)

Bouviex, E. L.

99 Calappa zurcheri, crabe nouveau des terrains miocènes de Panama. Mus d hist nat, B 5:189-192, il (1899)

Bow, James A.

99 Lower Seine gold mines [Ontario]. Ont Bur Mines, Rp 8: 263-274 (1899)

Bowen, Charles Franklin.

12 The Baker lignite field, Custer $\mathrm{Cl}_{0}$. Mont. U S G S, B 471:202-226, map (1912)

13 Coal at Horseshoe Bend and Je rusalem Valley, Boise Co., Idaho. U S 0 S, B 531: 245-251, map (1913)

13a Lignite in the Goose Creek district Cassia Co., Idaho, U S G S, B 531:252262, map (1913)

14 Coal discovered in a reconnaissance survey between Musselshell and Judith, Mont. U S G S, B 541:329-337, map (1914)

14a The Cleveland coal field, Blaine $\mathrm{CO}_{4}$ Mont. U S G S, B 541:338-355, map (1914)

14b The Big Sandy coal field, Chouteal Co., Mont. U S G S, B 541:356-378, map (1914)

15 The stratigraphy of the Montans group with special reference to the position and age of the Judith River forms: tion in north-central Montana. U S G \&, P P $90: 95-153$, map (1915) Abst, Was Ac Sc, J $6: 92$ (1916) 
Bowen, Charles Franklin-Continued.

15a Possibilities of oil in the Poreu. pine dome, Rosebud Co., Mont. U S G S, B 621: 61-70, map (1915)

16 Review of the stratigraphy and structure of the Hanna Basin, Wyo. (abst). Wash Ac Sc, J 6: 253-254 (1916)

18 Stratigraphy of the Hanna Basin, Wyo, U S G S, P P 108: 22 ‘-241 (1918)

18a Phosphatic oil shales near Dell and Dillon, Beaverhead Co., Mont. U S G S, B 661: 315-320 (1918) Abst, by R. W. Stone, Wash Ac Sc, J 8: 248 (1918)

18b Structure and oil and gas resources of the Osage Reservation, Okla.; T. 24 N., R. 10 E. U S G S, B $686: 17-26$, map (1918)

1Se Structure and oil and gas resources of the Osage Reservation, Okla.; T. $28 \mathrm{~N}$., R. 9 and 10 E.; T. 29 N., R. 10 E. U S G S, B $686: 43-58$, map (1918)

$18 d$ Structure and oil and gas resources of the Osage Reservation, Okla. : Tps. 24, 25 , and 26 N., Rs. 6 and 7 E., Tps. 25 and 26 N., R. 5 E., T. 26 N., R. 4 E. U S G S, B $686: 137-148$, maps (1918)

18e Anticlines in a part of the Musselshell Valley, Musselshell, Meagher, and Sweetgrass cos., Mont. U S G S, B 691 : 185-209, map (1918)

Bowen, Eli.

48 The coal regions of Pennsylvania.. [anthracite region]. $72 \mathrm{pp}$, map, Pottsville, $\mathrm{Pa}$., 1848

52 The pictorial sketch book of Pennsylvania... [pt 2 , the anthracite coal formation : $120-235] .268 \mathrm{pp}$, Phila 1852

55 The McGinnes theory of the Schuylkill coal formation... $56 \mathrm{pp}$, Pottsville, $\mathrm{Pa}, 1855$ [not seen]

62 Coal and the coal trade; a series of letters on the origin of coal and oil springs... with a geological cross section from the Locust Mountain to the Sharp Mountain [Pa.]. $\quad 36 \mathrm{pp}$, Phila 1862

65 Coal and coal oil or the geology of the earth... $494 \mathrm{pp}$, Phila [1865]

Bowen, George $T$.

24 bescription and analysis of the sillimanite, a new mineral [from Connecticut]. Ac N Sc Phila, J 3: 375-381 (1824) Am J Se 8: 113-118 (1824)

24a Analysis of a siliceous hydrate of copper from New Jersey, with a notice of the discovery of two localities of spodu. mene in the United States. Am $J$ Sc 8:118-121 (1824) Ac $\mathrm{N}$ Se Phila, J 3: 285-286, 295-297 (1824)

Bowen, H. G.

56 On the geology of Trinidad. G Soc London, Q J 12:389 (1856)

Bowen, Norman Levi.

10 Diabase and granophyre of the Gowganda Lake district, Ont. J G 18:658$674(1910)$
Bowen, Norman Levi-Continued.

10a Diabase and aplite of the cobaltsilver area. Can M Inst, J 12:517-52s (1910)

11 Silver in Thunder Bay district, Ont. Ont Bur Mines, An Rp 20 pt $1: 119-132$, map (1911)

11 a Notes on the salt industry of Ontario. Ont Bur Mines, An Rp 20 pt $1: 247$ 258 (1911)

12 The composition of nephelite. Am J Se (4) 33:49-54 (1912)

12a The binary system; $\mathrm{Na}_{2} \mathrm{Al}_{2} \mathrm{Si}_{2} \mathrm{O}_{8}$ (nephelite, carnegieite) - $\mathrm{CaAl}_{2} \mathrm{Si}_{2} \mathrm{O}_{3}$ (anorthite). Am J Se (4) $33: 551-573$ (1912)

$12 \mathrm{~b}$ The order of erystallization in igneous rocks. J G 20:457-468 (1912); $21: 399-401$ (1913)

13 Columnar sections, Coast Range, eastern part, Lytton to Hope, western part, Hope to Vancouver [B. C.]. Int G Cong XII, Canada, Guide Book no $8: 257-258$ (1913)

$13 n$ The melting phenomena of the plagioclase feldspars. Am J Sc (4) $35: 577$ 599 (1913)

14 A geological reconnaissance of the Fraser River Valley from Lytton to Vancouver. B. C. Can G S, Sum Rp 1912: 108-114 (1914)

14a Crystallization of certain pyroxenebearing artificial melts (abst). G Soc Am, B 25:91 (1914)

14b (and Andersen, Olaf) The binary system $\mathrm{MgO}-\mathrm{SiO}_{2}$. Am J Sc (4) $37: 487$ 500 (1914)

14e The ternary system; diopside-forsterite-silica. Am J Sc (4) 38: 207-264 (1914)

15 Crystallization-differentiation in silicate liquids. Am J Sc (4) $39: 175-191$ (1915)

15a The crystallization of haplobasaltic, haplodioritic, and related magmas. Am J Se (4) $40: 161-185$ (1915)

15b The later stages of the evolution of the igneous rocks. J G 23 no 8 , suppl : 91 pp (1915)

15e The importance of crystallization in the differentiation of igneous rocks (abst). Wash Ac Sc, J 5: 29 (1915)

16 Diffusion in silicate melts (abst, with discussion by J. P. Iddings). G Soc Am, B $27: 48$ (1916)

17 The sodium-potassium nephelites. Am J Sc (4) $43:$ 115-132 (1917)

$17 \mathbf{a}$ The problem of the anorthosites. J G 25: 209-243 (1917) Abst, with discussion by F. D. Adams and J. A. Dresser, G Soc Am, B 28:154-155 (1917); Wash Ac Sc. J 8: 205-206 (1918)

17b Adirondack intrusives. $J$ G 25: 509-512 (1917) 
Bowen, Norman Levi-Continued.

18 The significance of glass-making processes to the petrologist. Wash Ac Sc, J 8 : 88-93 (1918) Abst, G Soc Am, B 29: 102 (1918)

See also Powers, 16a

Bowers, Stephen.

90 San Nicolas Island. Cal St M Bur, An Rp 9:57-61 (1890)

01 Reconnaissance of the Colorado Desert mining distriet. Cal St M Bur: $12 \mathrm{pp}$ (1901)

See also Irelan, $88 a, 90 a$

Bowie, A. J.

79 Hydraulic mining in California. Am I M Eng, $\operatorname{Tr} 6: 27-100$ (1879)

Bowie, Alexander.

14 The burning of coal beds in place. Am I M Eng, B 86:195-204 (1914); Tr 48:180-193 (1915)

Bowie, William.

12 Effect of topography and isostatic compensation upon the intensity of gravity (second paper). U S Coast S, Special Pub no $12: 28 \mathrm{pp}$ (1912)

$12 a$ Some relations between gravity anomalies and the geologic formations in the United States. Am J Sc (4) $33: 237-$ 240 (1912) Abst, Science n s $35: 320$ (1912)

12b Some results of the Hayford method of gravity reduction. Wash Ac Sc J 2 : 499-504 (1912)

14 Isostasy and the size and shape of the earth. Science n s 39:697-707 (1914)

$14 a$ Some geodetic evidence of isostasy (abst). Wash Ac Sc, J 4:382-383 (1914)

17 Investigations of gravity and isostasy. U S Coast S, Spec Pub no $40: 196$ pp, maps (1917) Abst, Wash Ac Sc, J 7: 159-160 (1917)

$\mathbf{1 7 a}$ The gravimetric survey of the United States. Nat Ac Sc, Pr 3:171-177 (1917)

17b Local versus regional distribution of isostatic compensation. Am J Sc (4) 43:471-475 (1917)

17e Our present knowledge of isostasy from geodetic evidence. J G 25:422-445 (1917) Abst, Wash Ac Sc, J 7:267-268 (1917)

17d Some evidence of isostasy (abst). Wash Ac Sc, J $7: 311-312$ (1917)

See also Vaughan, $15 \mathrm{c}$

Bowles, Oliver.

09 Pyromorphite from British Columbia, Canada. Am J Sc (4) $28: 40-44$ (1909)

10 Tables for the determination of common rocks. vil, $64 \mathrm{pp}, \mathrm{N} \cdot \mathrm{Y} 1910$

11 Crystal forms of pyromorphite. Am J Sc (4) 32: 114-116 (1911)

11a An example of limonite deposition (abst). Science n s 33: 463 (1911)

12 Crystallographic tables. Science n s 35 : $576-577$ (1912)
Bowles, Oliver-Continued.

16 The technology of marble quarrying [incl. notes on occurrence, etc.]. U S Bur Mines, B 106:174 pp (1916)

17 Sandstone quarrying in the United States. U S Bur Mines, B 124:143 pp (1917)

18 Rock quarrying for cement manufac ture [notes on cement materials]. U S Bur Mines, B 160: 160 pp (1918)

18a The structural and ornamental stones of Minnesota. U S G S, B 663:225 pp, maps (1918) Abst, by R. W. Stone, Wash Ac Sc, J 8: 453 (1918)

Bowman, Amos (1839-1894).

73 The Pliocene rivers of California. Is Raymond, R. W., Statisties of mines and mining ..., 5th An Rp : 377-389 (1873)

73a On coast, surface, and scenic geolog [California]. Cal Ac Sc, Pr 4:244-245 (1873)

74 Report on the properties and domain of the Callfornia Water Company, situated on Georgetown Divide ... El Dorado $\mathrm{CO}_{0}$, Cal. 225 pp, maps, San Francisco 1874

75 Geology of the Sierra Nevada in lts relation to vein mining. In Raymond, R. W., Statistics of mines and mining 7 th An Rp: 441-470, map (1875)

87 [Preliminary report on the Cartboo gold-bearing district, B. C.]. Can G B, Sum Rp 1886 (An Rp 2) : A 5-7 (1887)

$\mathbf{8 7 a}$ Mining developments on the north. western Pacific coast, and their wider bear ing. Am I M Eng, Tr 15: 707-717 (1887)

S7b On the gold-bearing rocks of British Columbia (abst). Can Rec Sc 2:432-433 (1887)

s8 Report on the geology of the mining district of Cariboo, B. C. Can G S, An Rp 3: c 49 pp, map (1888)

SSa Testimony of Ottawa clays and gravels to the expansion of the Gulf of St. Lawrence and Canadian lakes within the human period. Ottawa Nat 1:149-161 (1888)

89 [Examination of New Westminste: district, B. C.] Can G S, Sum Rp 1887-8 (An Rp 3) : A 66-69 (1889)

Bowman, H. L.

02 On an occurrence of minerals at Haddam Neck, Conn. Miner Mag 13: 97-121 (1902) Zs Kryst 37:97-119 (1902)

03 Note on the refractive indices of $\mathrm{pr}$. romorphite, mimetite, and vanadinite. Miner Mag 13: 324-329 (1903)

Bowman, Isaiah.

04 A typical case of stream capture in Michigan. J G $12: 326-334$, map (1904)

O4a Deflection of the Mississippi. Sctence n s $20: 273-277$ (1904)

os Pre-Pleistocene deposits at Third Cliff, Mass. Science n s 21:993-994 (1905) 
Bowman, Isalah-Continued.

06 Northward extension of the Atlantic preglacial deposits. Am J Sc (4) 22 : 313-325 (1906)

06a (with Veateh, A. C.) Well records on Long Island. U S G S, P P $44:$ 116-337 (1906)

07 (and Reeds, C. A.) Water resources of the East St. Louis district. Ill $\mathrm{G}$ S, B $5: 128 \mathrm{pp}$, map (1907); Abst, B 8 : $30-40(1908)$

07a (with Davis, W. M., and Johnson, D. W.) Current notes on land forms. Science n s 25: 70-73, 229-232, 394-396, $508-510,833-836, \quad 946-949 ; \quad 26: 90-93$, $152-154,226-228,353-356,450-453,837-$ 839 (1907) ; $27: 31-33$ (1908)

11 Forest physiography : physiography of the United States and principles of soils in relation to forestry. $750 \mathrm{pp}$, map, N Y 1911

$11 a$ Well-drilling methods [notes on underground waters]. U S G S, W-S P 257: 139 pp, (1911)

Bowmnn, W. F.

17 (with Baker, C. L.) Geologic exploration of the southeastern front range of trans-Pecos Texas. Tex Univ, B 1753: 61-172 (1917)

Bownocker, John Adams.

95 Hypotheses proposed to explain the cause of the glacial period. Yale Sc Mo, May and June 1895 [not seen]

98 The paleontology and stratigraphy of the Corniferous rocks of Ohio. Denison Univ, Sc Lab, B $11: 12-40$, map (1898)

99 A deep preglacial channel in western Ohio and eastern Indiana. Am G 23: 178182 , map (1899)

99a The earth's interior. J Sch Geog $3: 250-256$ (1899)

00 History of the Little Miami River [Ohio]. Ohio St Ac Sc, Sp P no $3: 32-45$, map (1900)

01 The Corning oil and gas field [Ohio]. Ohio Nat 1:49-59, map (1901)

02 The oil- and gas-producing rocks of Ohio. J G $10: 822-838$ (1902)

03 The occurrence and exploitation of petroleum and natural gas in Ohio. Ohio G S (4) B 1:325 pp, maps, Columbus, Ohio, 1903

03a The central Ohio natural gas fields: Am G 31: 218-231, map (1903)

05 The salt deposits of northeastern Ohio. Am G 35 : 370-376, map (1905)

06 Salt deposits and the salt industry in Ohio. Ohio G S (4) B 8:42 pp (1906)

08 Coals of the Monongahela formation or upper productive coal measures. Ohio G S (4) B 9:342 pp, maps (1908)

08a (and Condit, D. D.) The Pomeroy coal in Ohio. Ec G $3: 183-199$ (1908)
Bownoeker, John Adams-Continued.

09 Geology as applied to the formations in which natural gas is found in the Appalachian regions. Nat Gas $\mathrm{As} A \mathrm{~m}, \operatorname{Pr} 1$ : 491-507 (1909) Am Gas Light J 90: 1160-1163 (1909) Progressive Age 27: $541-544$ (1909)

10 The Bremen oil field, Ohio. Ohio G S (4) B $12: 68 \mathrm{pp} \mathrm{(1910).}$

11 Memoir of William George Tight, 1865-1910. G Soc Am, B 22:19-22 (1911)

11 a The Clinton sand as a source of oil in Ohio. Ec G 6:37-50 (1911) Abst, G Soc Am, B 22: 736-737 (1911)

11b Mineral resources of Ohio. J Geog $9: 175-179$ (1911)

11e (with Stauffer, C. R.) Geology of the Columbus quadrangle. Ohio G S (4) B 14:133 pp (1911)

15 Building stones of Ohio. Ohio G S (4) B $18: 160 \mathrm{pp}$, map (1915)

16 Natural gas in Ohio. Cleveland Eng Soc, J $8: 313-332$, map (1916)

$16 a$ The Cleveland gas field [Ohio] (abst). Science n s $43: 397$ (1916)

17 The coal fields of Ohio. U S G S, P P $100: 35-88$, maps (1917)

17a Petroleum in Ohio and Indiana. $\mathbf{G}$ Soc Am, B 28:607-676 (1917)

See also Hubbard (G D), 15

Bowron, William M.

S6 The geology and mineral resources of Sequatchie Valley, Tenn. Am I M Eng, Tr $14: 172-181$, map (1886)

o5 The origin of Clinton red fossil ore in Lookout Mountain, Ala. Am I M Eng, Bi-Mo B 6:1245-1262 (1905); Tr 36: $587-604$ (1906)

Boyee, Edward.

14 Impressions of Mt. Lassen [Cal.]. Mazama $4: 60-62$ (1914)

Boyd, Charles Rufus (1841-1903).

76 The mineral wealth of southwestern Virginia. Am I M Eng, Tr 5:81-92 (1877) ; $8: 338-348$ (1880) Eng M J 22 : $316-317,329-330$ (1876)

s1 Resources of southwest Virginia, showing the mineral deposits of iron, coal, zinc, copper, and lead... $321 \mathrm{pp}$, map N Y 1881

83 [Map of] southwest Virginia; mineral resources and railway facllities. Scale 6 miles $=1$ inch. 1883 [also later editions]

84 The ores of Cripple Creek, Va. Am I M Eng, Tr 12:27-40 (1884)

87 The economic geology of the Bristol and Big Stone Cap section of Tennessee and Virginia... Am I M Eng, Tr 15:114121 (1887)

90 Middlesboro [Bell Co.], Ky. [coal and iron deposits]. Eng $M$ J $49: 171-173$ (1890)

93 The Indiana natural gas field. Eng M J $55: 440-441$ (1893) 
Boyd, Charles Rufus-Continued.

93a The Wythe lead and zinc mines, Va. Eng M J 55:561-562, 586 (1893)

95 Correlations in the coal rocks west of Pocahontas, Flat Top, Va. Am I M Eng, $\operatorname{Tr} 24: 254-257$ (1895)

97 Grayson County, Virginia... $43 \mathrm{pp}$, map, Independence, Va., 1897

See also Becker, $95 \mathrm{a}$

Boyd, E. F.

76 Remarks on the coal measures and oil produce of the United States of America... N Engl Inst M Eng, Tr $25: 145-175$, maps (1876)

Boyd, George W. (?-1840).

38 Local and economical geology, Wayne Co., and Orleans Co. [N. Y.]. N Y G S, An Rp 2: 312-326, 347-359 (1838)

Boyd, J. T.

18 Characteristics of zine deposits of North America (discussion). Am I M Eng, B 133: 63-67 (1918)

See also Nason, 17

Boyd, W. W.

12 The Joplin mining district [Mo.Ark.]. Can M Inst, $\operatorname{Tr} 15: 617-630$ (1912) Boyé, Martin H.

41 (and Booth, J. C.) Results of the analysis of three different varieties of feldspar from the primary rocks of the State of Delaware. $\mathrm{Am} \mathrm{Ph}$ Soc, $\mathrm{Pr} 2$ : 53-56 (1841)

52 Analysis of a magnetlc iron pyrites containing nickel from Gap mine, Lancaster Co., Pa. Am J Sc (2) 13:219-222 (1852)

Boyer, Carl.

10 (and Wherry, E. T.) A comparative study of the radioactive minerals in the collection of the Wagner Free Institute of Science. Wagner Free I Sc, Tr 7:2934 (1910)

Boyer, Charles S.

95 A fossil marine diatomaceous deposit at St. Augustine, Fla. Torrey Bot Club, B $22: 171-174$ (1895)

95a A diatomaceous deposit from an artesian well at Wildwood, N. J. Torrey Bot Club, B $22:$ 260-266 (1895)

00 The biddulphoid forms of North American Diatomaceae. Ac N Sc Phila, Pr 1900:685-748

See also Clark (W. B.), 04a

Boyle, Albert C., jr.

14 The geology and ore deposits of the Bully Hill mining district, Cal. Am I M Eng, B 85:57-105, map (1914) ; Tr 48: 67-117, map (1915)

Boyle, Cornelius Breckenridge.

93 A catalogue and bibliography of North American Mesozoic Invertebrata. U S G S, B 102: 315 pp (1893)

Boyle, O. M., jr.

o7 The Greenwater mining district, $\mathrm{Cal}$. Cal J Tech 10:29-32 (1907)
Boynton, C. H.

o6 The Little Rockies mining district. Eng M J 81:181 (1906)

Brace, John P.

19 Observations on the minerals con. nected with the gneiss range of Iitchfield Co., Conn. Am J Sc 1: 351-355 (1819)

20 The geology and mineralogy of Litch. field, Conn. Am J Sc 2: 370 (1820)

Brackenbury, Cyril.

oo The Mesabi range [Minn.]. Mines and Minerals 21:150-152 (1900)

14 Notes on the rocks at Levack [Ont.]. Ont Bur Mines, Rp 23:194-201 (1914)

Brackett, Richard Newman.

89 (with Branner, J. C.) The peridotites of Pike Co., Ark. Am As, Pr 37: 188-189 (1889)

89a (with Branner, J. C.) The peridotite of Pike Co., Ark. Am J Sc (3) 38: $50-59$ (1889)

91 (and Williams, J. F.) Newtonite and rectorite-two new minerals of the kaolinite group. Am J Sc (3) 42:11-21 (1891) In part, Ark G S, An Rp 1892, 5: 256-261 (1900)

Braden, William.

02 Certain conditions in veins and faults in Butte, Mont. Can M Inst, J $5: 296-308$ (1902) Can M Rv 21:149-152 (1902)

Bradford, A. H.

09 (and Curtis, R. P.) Dredging at Breckenridge, Colo. M Sc Press 99:361366 (1909)

Bradford, Robert $\mathrm{H}$.

o9 Some Utah mineral deposits and theit metallurgical treatment. Am M Cong, 11th An Sess, Papers and Addresses: 101-118 (1909)

Bradford, William.

04 Gold deposition by drainage. Eng M J 78:554-555 (1904)

Bradish, Alva.

89 Memoir of Douglass Houghton, first State Geologist of Michigan; with an ap pendix containing reports or abstracts of the first geological survey, and a chronological statement of the progress of geo logical exploration in Michigan. $302 \mathrm{PA}$ port, Detroit 1889

Bradley, Frank Howe (1838-1879).

60 Description of a new trilobite frofl the Potsdam sandstone [New York]; with a note by E. Billings. Am J Sc (2) 30 241-243, il (1860) Can Nat 5:420-425, il (1860) Am As, $\mathrm{Pr} 14: 161-166$, (1861)

61 Trilobites of the Wisconsin "Pots dam". Am J Sc (2) 31:294-295 (1861)

66 Preliminary notice of certain beds fish remains in the Hamilton group of western New York. Am J Sc (2) 42: 7072 (1866)

69 Geology of Vermilion Co. Ind $G$ \& An Rp 1: 138-174, map (by John Collett) (1869) 
Bradley, Frank Howe-Continued.

70 Geology of Grundy Co.; Will Co. ; Kankakee and Iroquois cos. ; Vermilion Co. ; Champaign, Edgar and Ford cos. Ill G S 4:190-275 (1870) ; Ec G $2: 450-542$ (1882)

72 Description of two new land snails from the coal measures. Am J Sc (3) 4: $87-88$, il (1872)

72a $0 n$ the discovery of the Quebec formation in the Territory of Idaho. Am J Sc (3) $4: 133 \quad$ (1872)

72b On the Quebec and Carboniferous rocks in the Teton Range. Am J Sc (3) 4: 230-231 (1872)

72e [Geologic] map of the sources of Snake River... Scale 5 miles to 1 inch. U S G S Terr (Hayden), n d [1872]

73 Report [on the Snake River region]. U S G S Terr (Hayden), An Rp 6:189271 (1873)

73a Explorations of 1872: U. S. Geological Survey of the Territories, under Dr. F. V. Hayden; Snake River division. Am J Sc (3) 6:194-207 (1873)

73b [Remarks on the Yellowstone region.] Cal Ac Sc, Pr 4:292-293 (1873)

74 Note on Anomphalus meeki. Am J Sc (3) $7: 151$ (1874)

74a On unakite, an epidotic rock from the Unaka Range, on the borders of Tennessee and North Carolina. Am J Sc (3) $7: 519-520(1874)$

74b Note on the recent earthquakes of Bald Mountain in Rutherford Co., N C. Am J Sc (3) 8: 79 (1874)

74c Note on the occurrence of metamorphic Silurian rocks in North Carolina. Am J Sc (3) $8: 390$ (1874)

75 On the Silurian age of the southern Appalachians. Am J Sc (3) 9:279-288, 370-383 (1875)

76 Geological chart [map] of the United States east of the Rocky Mountains and of Canada, compiled 1875. $16 \times 24$ inches, in cover. N Y 1876

$76 a$ On a geological chart of the United States east of the Rocky Mountains and of Canada. Am J Sc (3) 12:286-291 (1876)

Bradley, P. R.

13 Pyrites deposit in Plumas Co., Cal. M Met Soc Am, B 65 (vol 6) : 276-278 (1913)

Bradley, Walter Minor.

09 On the analysis of the mineral neptunite from San Benito Co., Cal. Am J Sc (4) $28: 15-16$ (1909) Z Kryst 46:516-517 (1909)

10 (with Ford, W. E.) Chemical and optical study of a labradorite. Am J Sc (4) $30: 151-153(1910)$

11 (with Foote, H. W.) On solid solution in minerals with special reference to nephelite, $\mathrm{Am} \mathrm{J}$ Sc (4) $31: 25-32$ (1911)
Bradley, Walter Minor-Continued.

12 (with Foote, H. W.) On solid solution in minerals; II, The chemical composition of analcite. Am J Sc (4) 33: 433439 (1912)

12a (with Foote, H. W.) The chemical compesition of nephelite. Am J Sc (4) $33: 439-441$ (1912)

12b (with Ford, W. E.) Pseudomorphs after stibnite from San Luis Potosi, Mex. Am J Sc (4) 34:184-186 (1912)

13 (with Foote, H. W.) On solid solution in minerals; III, The constant composition of albite. Am J Sc (4) $36: 47-50$ (1913)

13a (with Foote, H, W.) On solid solution in minerals; IV, The composition of amorphous minerals as illustrated by chrysocolla. Am J Sc (4) $36: 180-184$ (1913)

14 Empressite, a new silver-tellurium mineral from Colorado. Am J Sc (4) 38 : 163-165 (1914)

$14 a$ (with Foote, H. W.) On solid solution in minerals; $\mathrm{V}$, The isomorphism between calcite and dolomite. Am J Sc (4) $37: 339-345$ (1914)

15 On the mineral empressite. Am J Sc (4) $39: 223$ (1915)

15a (with Ford, W. E.) On the identity of footeite with connellite together with the description of two new occur rences of the mineral. Am J Sc (4) 39 : $670-676$ (1915)

16 (with Ford, W. E.) On hydrozincite. Am J Sc (4) 42:59-62 (1916)

16a (with Ford, W. E.) MargarosanIte, a new lead-calcium silicate from Franklin, N. J. Am J Sc (4) $42: 159-162$ (1916)

Bradley, Walter Wadsworth.

15 (and others) The counties of Fresno, Kern, Kings, Madera, Mariposa, Merced, San Joaquin, Stanislaus. Cal St M Bur, Rp XIV of St. Mineralogist: 427 634 (1916) [issued as separate (1915)]

15n Mines and mineral resources of Fresno and Kings cos., Cal. CaI St M Bur, Chapters of St Mineralogists's Rp 1913-14, Fresno...counties : 3-44, 99-104 (1915)

15b Mines and mineral resources of the counties of Colusa, Glenn, Lake, Marin, Napa, Solano, Sonoma, Yolo, Cal. Cal St M Bur, Chapters of St Mineralogist's Rp 1913-14:20£ pp (1915) Rp XIV of St Mineralogist : 173-370 (1916)

15e (with MeLaughlin, R. P.) Mines and mineral resources of Madera Co., Cal Cal St M Bur, Chapters of St Mineralogist's Rp 1913-14, Fresno... counties : 105-142 (1915)

16 California mineral production for 1915. Cal St M Bur, B 71:193 pp (1916)

17 California mineral production for 1916, with county maps. Cal St M Bur, B $74: 179$ pp, maps (1917) 
Bradley, Walter Wadsworth-Continued,

17a (and Logan, C. A.) San Benito County. In Mines and mineral resources of the counties of Monterey, San Benito, San Luis Obispo, Santa Barbara, Ventura (Chapters of St Mineralogists's Rp [15: 616-673] 1915-16;22-79. Cal St M Bur (1917)

17b (with Waring, C. A.) Monterey County. In Mines and mineral resources of the counties of Monterey, San Benito, San Luis Obispo, Santa Barbara, Ventura (Chapters of State Mineralogist's report, 1915-16) : 1-21, Cal St M Bur (1917)

18 (and others) Manganese and chromium in California. Cal St M Bur, B 76 : 248 pp, maps (1918)

18a Quicksilver resources of California, with a section on metallurgy and ore dressing. Cal St M Bur, B $78: 389 \mathrm{pp}$, maps (1918)

18b California mineral production for 1917, with county maps. Cal St M Bur, B $83: 179 \mathrm{pp}$, maps (1918)

Brady, Frank W.

05 The white sands of New Mexico [formation of nearly pure gypsum sand]. Mines and Minerals 25:529-530 [1905]

Brady, George Stewardson.

71 (and Crosskey, H. W.) Notes on fossil Ostracoda from the post-Tertiary deposits of Canada and New England. G Mag $8: 60-65$, il (1871) Can Nat n s $5: 385-388$ (1870 [1871])

Brady, H. B.

76 Description d'une nouvelle espèce de foraminifère des couches miocènes de la Jamaique [W. I.]. Soc malac Belgique, An $11: 103$ (1876)

Brainard, Robert $L$.

16 Antimony mining in Coeur d'Alene district, Idaho. $\mathrm{M}$ World 44:351-353 (1916)

Brainerd, Alfred F.

85 Hematite of Franklin Co., Vt. Am I M Eng, Tr 13:689-691 (1885)

86 Note on a deposit of fire sand in Clinton Co., N. Y. Am I M Eng, Tr 14: 757-759 (1886)

87 A new discovery of carbonate iron ore at Enterprise, Miss. Am I M Eng, Tr 16:146-149 (1887)

89 Notes on the iron ores, fuels, ... of the Birmingham district. Am I M Eng, Tr 17:151-155 (1889)

Brainerd, Arthur E.

14 (with Richardson, C. H.) The geology and mineralogy of Hardwick and Woodbury, Vt. Vt St G, Rp 9:294-336, maps (1914)

Brainerd, Ezra.

85 The geological features of the marble belt [of western New England]. Middlebury Hist Soc, Papers and Pr 1 pt 2:9-21, map (1885)
Brainerd, Ezra-Continued.

88 (and Seely, H. M.) The original Chazy rocks. Am G $2: 323-330$ (1888)

90 (and Seely, H. M.) The Calciferom formation in the Champlain Valley (with discussion by C. D. Walcott and C. H. Hitchcock), G Soc Am, B 1:501-513 (1890) Abst, Am J Sc (3) 39:235-238 (1890)

90a (and Seely, H. M.) The Calcif erous formation in the Champlain Valler. Am Mus N H, B 3:1-23, maps (1890)

91 The Chazy formation in the Cham plain Valley. G Soc Am, B 2:293-300 (1891)

96 (and Seely, H. M.) The Chazy of Lake Champlain. Am Mus N H, B $8: 305^{5}$ 315 , maps (1896)

See also Ami, 91, 97

Brainerd, Jehu.

51 On quartz pebbles, of the sandstone conglomerate, and reasons for rejecting the theory of "water detrition". Am As $\operatorname{Pr} 5: 222$ (1851)

52 On some fossils of northern 0hit Am As, $\operatorname{Pr} 6: 304-306$, il (1852)

53 Fossil fishes [Cuyahoga Co., Obio]. An Se, Cleveland, 1: 18-20, il (1853)

$\mathbf{5 3 a}$ Origin of quartz pebbles in the sandstone conglomerate, and the forms. tion of the siliceous stratified rocks (ask with discussion by J. S. Newberry and James Hall). An Sc, Cleveland, 1:235237 (1853)

74 Analysis of Berea sandstones. Clere land $\mathrm{Ac}, \operatorname{Pr} 1: 144-146$ (1874)

Branner, John Casper (1850-1922).

86 The glaciation of parts of the Wyoming and Lackawanna valleys. Am Ph Soc, $\operatorname{Pr} 23: 337-357$, maps (1886) Abri, Science $6: 221-222$ (1885) ; $8: 422$ (1886); Am As, Pr 34: 212-214 (1886)

86a Origin of the Pottsville and othes conglomerates (abst). Am J Sc (3) 32: 324 (1886)

86b The thickness of the ice in nort eastern Pennsylvania during the glacial epoch. Am J Sc (3) 32:362-366 (1886)

86e Coloring geological maps. Scienct $8: 455$ (1886)

86a [Map showing] geology of Indiand. Scale, 1 inch $=77$ miles [1886]

87 Glaciation; its relations to the Lackawanna-Wyoming region. Lacks. wanna Inst, Pr 1: 3-18 (1887)

$\mathbf{8 7 a}$ Notes upon the glacial striæ of served in the Wyoming-Lackawanna region. Lackawanna Inst, $\operatorname{Pr} 1: 19-27$ (1887)

$\mathbf{8 7 b}$ Annual report of the geological sut: vey of Arkansas for $1887.15 \mathrm{pp}$, Little Rock, Ark., 1887.

s8 Administrative report and Introduc tion to the report upon western central Arkansas. Ark G S, An Rp 1888, 1: $\mathbb{T}^{-}$ xxxi, Little Rock, 1888 
Branner, John Casper-Continued.

$88 \mathrm{a}$ On the manufacture of Port'and cement. Ark G S, An Rp 1888, $2: 291$ 302 (1888)

89 (and Brackett, R. N.) The peridotite of Pike Co., Ark. Am J Se (3) 38:50-59 (1889) Abst, Am As, Pr 37: 188-189 (1889)

$89 \mathrm{a}$ The age of the crystalline rocks of Arkansas (abst). Am As, Pr $37: 188$ (1889)

90 The training of a geologist. Am G 5:147-160 (1890) 3d ed, 19 pp, San Francisco, 1892

$90 \mathrm{a}$ The relations of the State and national geological surveys to each other and to the geologists of the country. Am G 6:295-309 (1890) Science $16: 120-123$ (1890) Am As, Pr 39:219-237 (1891)

91 Introduction [to The geology of Washington Co.]. Ark G S, An Rp 1888, 4: xi-xiv (1891)

91a Preface [to The geology of Crowley's Ridge]. Ark G S, An Rp 1889, 2 : xi-xix (1891)

91b Bauxite in Arkansas. Am G 7 : 181-183 (1891) Science 17:171 (1891)

92 The mineral waters of Arkansas. Ark G S, An Rep 1891, 1: 144 pp, map, Little Rock 1892

93 Observations upon the erosion in the hydrographic basin of the Arkansas River above Little Rock. The Wilder Quartercentury Book, 1868-1893: 325-327 Ithaca, N. Y., 1893 Ark G S, An Rp 1891, 2 : 153166 (1894)

93a The coal fields of Arkansas. U S G 8, Min Res 1892 : 303-306 (1893)

94 Bibliography of the geology of Arkansas. Ark G S, An Rp 1891, 2:319-340 $(1894)$

94a The geological surveys of Arkansas. J G $2: 826-836$ (1894)

95 (and Newsom, J. F.) Syllabus of lectures on economic geology. $270 \mathrm{pp}$ (one half blank), Palo Alto, Cal., $18952 d$ ed, $368 \mathrm{pp}$ fone half blank), Stanford University 1900

96 Bibliography of clays and the ceramic arts, U S G S, B 143:114 pp (1896)

96a Thickness of the Paleozoic sediments in Arkansas. Am J Sc (4) $2: 229$ 236, map (1896)

97 The bauxite deposits of Arkansas, J G $5: 263-289$, map (1897)

97a Bacteria and the decomposition of rocks. Am J Se (4) 3:438-442 (1897)

$97 \mathrm{~b}$ The former extension of the Appalachlans across Mississippi, Louisiana, and Texas. Am J Sc (4) 4:357-371, maps (1897) Abst, Brit As, Rp 67:643-644 (1898)

97c The phosphate deposits of Arkansas. Am I M Eng, Tr 26:580-598, map (1897) $4 b s t$, Zs prak G $1897: 101-102$
Branner, John Casper-Continued.

97d The introduction of new terms in geology. Science n s 5:912-913 (1897); $6: 133-134$ (1897)

98 Geology in its relations to topography (with discussion). Am Soc Civil Eng, Tr $39: 53-95$ (1898)

9Sa The cement materials of southwest Arkansas. $\triangle \mathrm{m}$ I M Eng, $\operatorname{Tr} 27: 42-63$, 944-946, map (1898)

9Sb On the origin of novaculites and related rocks. J G 6:368-371 (1898)

00 The zinc and lead region of North Arkansas. Ark G S, An Rp 1892, 5:395 pp, maps, atlas of raps, Little Rock 1900

60a The origin of beach cusps. J G 8: 481-484 (1900)

01 Ripples of the Medina sandstone. J G 9:535-536 (1901)

o1a The origin of travertine falls and reefs. Science n s 14: 184-185 (1901)

02 Syllabus of a course of lectures on elementary geology. $2 d$ ed, 369 pp (part blank), Stanford University 1902 [First ed not seen]

02a (and Newsom, J. F.) The phosphate rocks of Arkansas. Ark Agr Exp Sta, B 74:61-123 (1902)

02b The zine and lead deposits of north Arkansas. Am I M Eng, Tr 31:572-603 (1902) Abst, Eng M J 72:718-719 (1901) o3 Notes on the geology of the Hawaiian Islands. Am J Sc (4) 16:301-316, maps (1903)

03a A topographic feature of the hang. ing valleys of the Yosemite. J G 11: $547-553$ (1903)

04 Memoir of James E. Mills. G Soc Am, B 14:512-517, port (1904)

05 Natural mounds or ' hog wallows.' Science n s 21:514-516 (1905)

06 The university training of engineers in economic geology. Ec G 1:289-294 (1906)

OGa A bibliography of clays and the ceramic arts. $451 \mathrm{pp}$, Am Ceramic Soc, 1906

06b [Fault lines in the Santa Cruz Mountains, Cal.] M Sc Press 92:347 (1906)

o6e The California earthquake: movements along the Santa Cruz fault line. Falo Altan May 1, 1906 [not seen] Eng News 55: 542 (1906) Mines and Minerals $26: 536$ (1906)

o6d Geology and the earthquake. Out West 24:513-518 (1906) Reprinted in Jordan, D. S., editor, The California earthquake of 1906:63-78, San Francisco 1907

07 A drainage peculiarity of the Santa Clara Valley [Cal.] affecting fresh-water faunas. J G 15:1-10 (1907) Abst, Sclence n s 24:369-370 (1906); Am As, Pr 56-57:270 (1907)

os The clays of Arkansas. U S G S, B $351: 247 \mathrm{pp}, \operatorname{map}(1908)$ 
Branner, John Casper-Continued.

09 Bibliography of the geology of Arkansas. Ark G S, Slates of Arkansas (Purdue) : 97-164 (1909)

09a Some facts and corrections regarding the diamond region of Arkansas. Eng M J $87: 371-372$ (1909)

09b (and Newsom, J. F., and Arnold, Ralph) Description of the Santa Cruz quadrangle, Cal. U S G S, G Atlas, Santa Cruz fol (no 163) : 11 pp, maps (1909)

11 Special problems and their study in economic geology (discussion). Ee G 6 : $73-75$ (1911)

11 a Impressions regarding the relations of surface geology to intensity in the Mendoza, Valparaiso, Kingston, and San Francisco earthquakes. Seism Soc Am, B $1: 38-43$ (1911)

11b Syllabus of a course of lectures on economic geology. 3d ed, $503 \mathrm{pp}$ (onehalf blank), Stanford University 1911

12 An early discovery of fuller's earth in Arkansas. Am I M Eng, B 67: 747749 (1912) ; Tr $43: 520-522$ (1913)

12 a Report of the geology of Livermore Valley [Cal.]. In The future water supply of San Francisco; a report... by the Spring Valley Water Company, San Francisco, Cal, pp 203-208, 1912

12b Report on the underground water conditions of the Livermore Valley and of Sunol Valley [Cal.]. In The future water supply of San Francisco ; a report... by the Spring Valley Water Company, San Francisco, Cal, pp 209-222, map, 1912

13 Earthquakes and structural engineering. Seism Soc Am, B 3:1-5 (1913)

$13 a$ Influence of wind on the accumulation of oil-bearing rocks (abst). G Soc Am, B 24: 94-95 (1913)

15 Earthquakes. In Nature and science on the Pacific coast: 62-64, San Francisco 1915 (See Merriam, 15)

15a The untrustworthiness of personal impressions of direction in earthquakes. Seism Soc Am, B 5 : 26-29 (1915)

15b Geologia elementar. 2d ed, 396 pp, Rio de Janeiro, 1915 [First ed., English, 1906, not seen]

16 Orville A. Derby. J G 24: 209-214 (1916)

16a Memorial of Orville A. Derby. G Soc, Am B $27: 15-21$, port (1916)

$16 \mathrm{~b}$ Can we keep the canal open? An analysis of the causes of the slides on the Panama Canal and a suggestion for their prevention. Sunset 36 no $6: 13-15,70-71$ (1916)

17 One of the scientific problems at our doors [earthquakes]. Seism Soc Am, B 7:45-48 (1917)

17a The Tejon Pass earthquake of October 22, 1916. Seism Soc Am, B 7:51-59 (1917)
Branner, John Casper-Continued.

See also Ashley, 97 ; Bagg, 05 ; Gilbert, $90 \mathrm{~b}$; Hedburg, 02 ; Newsom, 97; Tabe, $16 a, 17,18$

Brannt, William T

95 Petroleum; its history, origin, occos rence... $715 \mathrm{pp}$, Phila 1895

Branson, Edwin Bayer.

o5 Notes on some Carboniferous cochlis donts with descriptions of seven new sps cies. J G 13:20-34, il (1905) Chicag Univ, Walker Mus, Contr 1 no $7: 89-103,1$ (1905)

o5a Structure and relationships o American Labyrinthodontidæ. J G $13: 56 \%$ 610 , il (1905)

06 Fish remains from the Salem lime stone of Indiana. Ind $\mathrm{Dp} \mathbf{G} A \mathrm{Rp}$ 34: 1376-1394 (1906)

os Cladodus cempressus, a correction. Science n s 27: 311-312 (1908)

o8a Dinichthys intermedius Newberm, from the Huron shale [of Ohio]. Sciend n s 28:94 (1908)

08b Notes on Dinichthys terrelli New berry, with a restoration. Ohio Nat 8: $363-369$, il (1908)

09 The fauna of the residuary Aubun chert of Lincoln Co., Mo. Ac Sc St. Louks Tr 18:39-52, il (1909)

O9a Notes on some dinichthyids frot northern Ohio (abst). Science n s 2s: 197 (1909)

10 Amphibian footprints from the Mis sissippian of Virginia. J G $18: 356-358$, 1 (1910)

11 Notes on the osteology of the skrll of Pariotichus. J G 19:135-139. il (1911)

$11 a$ Notes on the Ohio shales and thet faunas. Mo, Univ, B sc s $2: 21-32$, (1911)

12 A Mississippian delta (with disevs sion by J. M. Clarke, David White, G. $\mathbb{T}$. Stose, Arthur Keith, E. T. Wherry, and H. B. Kümmel, on pp 744-746). G Soc Am B $23: 447-456$ (1912) Abst, Science n s $35: 317$ (1912)

12n (with Westgate, L. G.) The Co nozoic history of the Wind River Mouth tains, Wyo. (abst). Science n s $35: 318$ (1912) G Soc Am, B 23: 739 (1912)

13 Devonian fishes of Missouri (abst). G Soc $\Delta \mathrm{m}, \mathrm{B}$ 24:119 (1913)

13a $\Lambda$ four mile section along the Mir souri River south of Columbia, Missout (abst). Science n s 37:459 (1913)

14 The Devonian fishes of Missouri. It Univ, B 15 (sc s 2) : 59-74, il (1914)

15 Origin of the red beds of western Wyoming. G Soc Am, B 26:61-62 (abst), 217-230 (1915)

15a Origin of thick gypsum and salt dt posits. G Soc Am, B 26:103-104 (abst), 231-242 (1915) 
Branson, Edwin Bayer-Continued.

15b (and Greger, D. K.) Devonian of central Missouri (abst). G Soc Am, B 26: 112 (1915)

16 The lower Embar of Wyoming and its fauna. J G 24 : 639-664, il (1916)

17 Remarkable geologic section near Columbia, Mo. (abst). G Soc Am, B 28:170 (1917)

17a Bull Lake Creek rock slide in the Wind River Mountains of Wyoming. G Soc Am, B 28:347-350, 149 (abst) (1917)

18 (and Greger, D. K.) Amsden formation of the east slope of the Wind River Mountains of Wyoming and its fauna. G Soc Am, B 29:309-326, il (1918); abst, 28:170 (1917)

15a Geology of Missouri. Mo, Univ, B 19 no $15: 172 \mathrm{pp}$, il (1918)

$18 \mathrm{~b}$ Notes on the stratigraphy and faunas of the lower Kinderhookian in Mis. souri (abst). G Soc Am, B 29:93 (1918) See also Knight (S H), 17a

Brantley, J. E.

16 A report on the limestones and marls of the Coastal Plain of Georgia. Ga G S, B 21:300 pp, map (1916)

Brasch, Frederick E.

16 An earthquake in New England durIng the Colonlal period (1755) [Gives a reprint of A lecture on earthquakes, by John Winthrop, Boston 1755] Seism Soc Am, B 6: 26-42 (1916)

Bratnober, $\mathrm{H}$.

97 The Klondike gold fields [Yukon]. Eng M J 64: 484 (1897)

Braun, E. Lucy.

16 The Cincinnatian series and its brachlopods in the vicinity of Cincinnati [Ohio]. Cin Soc N H, J $22: 18-42$ (1916)

Braun, Frederick (1841-1918).

73 Collection of crinoids from the subcarboniferous Keokuk group, Montgomery Co.. Ind. $7 \mathrm{pp}, \mathbf{n} \mathbf{d}$ [priv pub]

Brauns, R.

03 Asche des Vulkans Sta. Maria in Guatemala. Centralbl Miner 1903:132134,290

Bray, W.

55 On the occurrence of copper in Tennessee (abst). G Soc London, Q J 11:8 (1855)

Breed, Robert $\mathbf{S}$.

02 "The Sunset trachyte" from near Sunset, Boulder Co., Colo. Colo Sc Soc, Pr 6:216-230 [1902] (separate ed, $15 \mathrm{pp}$. 1899)

\section{Breeze, Fred J.}

02 The valley of the lower Tippecanoe River. Ind Ac Sc, Pr 1901:215-216 (1902)

03 Some topographic features in the lower Tippecanoe Valley [Ind.]. Ind AC Sc, Pr 1902: 198-200 (1903)
Breger, Carpel Leventhal.

04 (with Kindle, E. M.) Paleontology of the Niagara of northern Indiana. Ind, Dp G N Res, An Rp 28: 428-486, il (1904)

06 On Eodevonaria, a new subgenus of Chonetes. Am J Sc (4) $22: 534-536$ (1906)

10 The salt resources of the Idaho-Wyoming border, with notes on the geology. U S G S, B 430: 555-569 (1910)

11 Origin of some mineral deposits by bacteria. M World 35:289-291 (1911)

11a Origin of Lander oil and western phosphate. M World 35:631-633 (1911)

$11 \mathrm{~b}$ The rarious theories of origin of petroleums. M World $35: 1219-1221,1321$ 1324 (1911)

12 Potash in the United States and foreign countries. M World $36: 297-298$ (1912)

12a Index to the world's current oil literature. M World 36:1310-1316 (1912)

16 (with Williams, H. S.) The fauna of the Chapman sandstone of Maine, including descriptions of some related species from the Moose River sandstone. U S G S, P P $89: 347$ pp, il, map (1916)

Breidenbaugh, E. $\mathrm{S}$.

73 On the minerals found at the Tilly Foster iron mines, N. Y. Am J Sc (3) 6: $207-213$ (1873)

Brent, Charles.

88 The Beaver mine, Ontario, Canada. Eng M J 45:123 (1888)

03 Notes on the gold ores of western Ontario. Can M Rv 22: 33-35 (1903) Can M Inst, J 6:327-335 (1904) M Sc Press $86: 383,397-398 \quad(1903)$

Bretz, J. Harlen.

10 Glacial lakes of Puget Sound (preliminary paper). J G 18:448-458 (1910)

11 The terminal moraine of the Puget Sound glacier. J G $19: 161-174$, map (1911)

13 Glaciation of the Puget Sound region. Wash G S, B 8: 244 pp (1913)

15 Pleistocene of western Washington (abst). G Soc Am, B 26:131 (1915)

17 The Satsop formation of Oregon and Washington. J G 25:446-458 (1917) (abst). G Soc Am, B 28:170-171 (1917)

Brevoort, James Carson.

59 Remains of the American Mastodon found on Long Island, near New York. Am As, Pr $12: 232-234$ (1859)

Brewer, William Henry (1829-1910).

66 Whitney's Geology of California. Am J Sc (2) $41: 231-246,351-368$ (1866)

$66 a$ on the age of the gold-bearing rocks of the Pacific coast. Am J Sc (2) 42 : 114-118 (1866)

$66 \mathrm{~b}$ Alleged discovery of an ancient human skull in California. Am J Sc (2) $42: 424$ (1866)

66e Occurrence of fossils in the auriferous slates of California. Cal Ac N Sc, Pr 3:198 (1866) 
Brewer, William Henry-Continued.

68 On the age of the gold-bearing rocks of California. Am J Se (2) 45:397-399 (1868)

85 On the suspension and sedimentation of clays. Am J Sc (3) $29: 1-5$ (1885)

89 The Great Basin. Am Geog Soc, B $21: 197-227$ (1889)

02 John Wesley Powell. Am J Se (4)

$14: 377-382$ (1902)

Brewer, William M.

93 The brown ore deposit of Baker Hill,

Ala. Eng M J 55: 77-78 (1893)

93a The Warwhoop bauxite bank, Ala.

Eng M J 55:461 (1893)

93b Some Alabama gold mining districts. Eng M J 55: 486 (1893)

93e The Coosa coal field in Alabama. Eng M J 56: 7-8 (1893)

94 Notes on the Alabama gold belt. Eng M J $57: 57-58$ (1894)

95 Ducktown, Tenn., copper mining district. Eng M J 59: 271 (1895)

95a The Arbacoochee gold district, Ala. Eng M J $60: 148$ (1895)

95b Mineral resources on the Southern Railway from Atlanta to Birmingham. Eng M J 60:610-611 (1895)

96 Mineral resources along the line of the East Tennessee, Virginia \& Georgia division of the Southern Railway. Eng M J 61 : $65-66$ (1896)

96a A preliminary report on the upper gold belt of Alabama in the counties of Cleburne, Randolph, Clay, Talladega, Elmore, Coosa, and Tallapoosa. Ala G S, B 5:1-105 (1896)

96b The gold regions of Georgia and Alabama. Am I M Eng, Tr 25:569-587 (1896) Abst, Eng M J 60:539, 563 (1895).

96e Gold mining in Alabama. Ala Ind Sc Soc, Pr 6: 42-49 (1896)

96d The manganese ores of Georgia. Ala Ind $\mathrm{Sc}$ Soc, $\operatorname{Pr} 6: 72-78$ (1896)

97 Further notes on the Alabama and Georgia gold fields. Am I M Eng, Tr 26: $464-472$ (1897)

97a Metal mining in Alabama. Eng M J 63:256 (1897)

$97 \mathrm{~b}$ Gold mining in Georgia. Eng M J $63: 280$ (1897)

97e The Villa Rica mining district, Ga. Eng M J 63:483 (1897)

97d Some auriferous quartz bodies in Alabama. Eng M J 64: 458-459 (1897)

$97 \mathrm{e}$ Copper mining in Alabama. Ala Ind Sc Soc, Pr $7: 13-16$ (1897)

97f Gold fields of the South [Georgia and Alabama]. Colliery Eng 17:333-335 (1897)

98 The West Kootenay district, B. C. Eng M J $65: 579$ (1898)

98a Harrison Lake, B. C. Eng M J 65 : 640-641 (1898)
Brewer, William M.-Continued. 98b The Sandon district, B. C. En M J 65: 731-732 (1898)

98e Lillooet River and tributaries, $B$. Eng M J 66: 9, 62-63, 185, 515 (1898)

98d Rossland, B. C. Eng M J 66:40-4] (1898)

98e Pemberton Meadows and the Blact water, B. C. Eng M J 66: 281 (1898)

98f The mineral resources of Vancoure Island, B. C. Eng M J 66: 638 (1898) 99 The copper deposits of Vancoure Island. Am I M Eng, Tr 29:483-48s (1900) Can M Rv 18:270-271 (1899)

$99 \mathbf{a}$ The west coast of Vancouver Island, B. C. Eng M J 67:176 (1899)

99b Mining on Vancouver and Texad Islands, B. C. Eng M J 67:529-53 (1899)

99e Leech River, Alberni, and Skirt Mountain, B. C. Eng M J 68:36 (1899) 99d Windermere mining division, East Kootenay district, B. C. Eng M J 68: 127-128 (1899)

99e Mineral resources and development of the upper Columbia, B. C. Eng If J $68: 515-516,549(1899)$

oo Mineral resources around Kamloops B. C. Eng M J 69: 165-166 (1900)

OOa Van Anda, Texada Island, B. C Eng M J 69:259-260 (1900)

oob Prospects on Howe Sound, West coast, B. C. Eng M J $69: 315-316$ (1900) o0e Vancouver Island, Alberni distrit. B. C. Eng M J $69: 465-466$ (1900)

ood Iron ore deposits of Vancouver and Texada islands, B. C. Eng M J 69:58\% (1900)

o0e Progress on Vancouver and Texadt islands, B, C. Eng M J 70:34-35 (1900) oof Mount Sieker district, Vancouret Island, B. C. Fing M J $70: 65-66$ (1900) OOg Howe Sound division New West minster mining district, B. C. Eng M I $70: 189(1900)$

Ooh Similkameen mining division, Kam loops mining district, B. C. Eng M I $70: 458-459$ (1900)

o1 Cadwallader Creek mining camp, Lillooet mining district, B. C. Eng M J 71: 644-645 (1901)

O1a Auriferous black sands of Vancot ver Island, B. C. Eng M J 71:649-650 (1901)

01b Texada Island, B. C. Eng M I $72: 665-667$ (1901)

o1e Vancouver Island mines and pros pects, B. C. Eng M J 72:846-848 (1901)

02 White Horse mining district, Yukon

Terr. Eng M J 73:167-168 (1902)

O2a British Columbia coal flelds. Bn M J 73:408-410 (1902)

02b The Crowsnest Pass coal flelds [B. C.]. Eng M J 73:549-552 (1902)

o2e Boundary mining district, B. C. Eng M J $73: 617-620$ (1902) 
Brewer, William M.-Continued.

02d Coal fields on Crowsnest Pass branch of the Canadian Pacific Railway, Alberta Terr. Eng M J 73: 757-758 (1902)

02e Mining industry and mineral resources of British Columbia. Eng Mag 23:831-846, map (1902)

02f British Columbia iron and coal. Mines and Minerals 23:1-4 (1902)

03 Whitehorse district in Yukon Territory. Mines and Minerals 24:28-31 (1903)

03a Mineral resources of southeastern Alaska. Min Sc Press, $86: 315$ (1903)

03b Mount Sicker mining district, B. C. M Sc Press $87: 7-8$ (1903)

03e The rock slide at Frank, Alberta Terr., Canada. Inst M Eng, Tr 26:34-39, 157-163 (1903)

04 Whitehorse copper camp, Yukon Terr. M Sc Press 89: 308-309 (1904)

04a Mineral resources of Vancouver Island [B. C.]. Can M Inst, J 6: 188-199 (1904) Can M Rv 21: 231-234 (1902)

05 Bornite ores of British Columbia and the Yukon Territory (with discussion). Can M Inst, J 8:172-182 (1905) Can M Rv $24: 76-79$ (1905)

06 Some observations relative to the occurrence of deposits of copper ore on Vancouver Island, and other portions of the Pacific coast. Can M Inst, J 9:39-48 (1906)

os Some notes on the Copper River district, Alaska. Can M Inst, J 11:415-422, map (1908)

0Sa The Copper River district, Alaska. M Sc Press 96: 71-72, 101-102 (1908)

12 Mineral resources of the Kenai Peninsula [Alaska]. M Sc Press 105:662 (1912)

15 The mineral resources of the Atlin mining division [B. C.]. B C Bur Mines, B 2 (1915) : 24 pp, map

15a Mineral resources of portions of the Skeena and Omineca mining divisions [B. C.]. B C Bur Mines, B 3 (1915) : 56 pp. map

$15 \mathrm{~b}$ The Omineca mining division, B. C. M Sc Press $110: 443-444$ (1915)

17 Report on the occurrences of iron ore deposits on Vancouver and Texada isiands, B. C. B C, Minister of Mines, An Rp 1916:274-303, map (1917)

17a Report on the copper-gold-silver ore deposits on Vancouver and adjacent islands. B C, Minister of Mines, An Rp 1916:304360 (1917)

Brewster, David.

23 Fluids in the cavities of minerals. Edinb Ph J 9:94-107 (1823) Am J Sc $12: 214-227$ (1827)
Brewster, Edwin Tenney.

09 Life and letters of Josiah Dwight Whitney [1819-1896]. 411 pp, port, Boston 1909

Brezina, Aristides.

81 Ueber die Meteoreisen von Bolson de Mapimi [Mexico]. $\mathrm{K}$ Ak Wiss, Mat-nat Cl, Szb $83: 471-477$ (1881)

04 The arrangement of collections of meteorites. Am Ph Soc, Pr 43:211-247 (1904)

O4a (and Cohen, Emil). Über Meteoreisen von De Sotoville [Choctaw Co., Ala.]. K Ak Wiss, Mat-nat K1, Szb 113, 1: 89-103 (1904)

Bridge, Josiah.

17 A study of the faunas of the residual Mississippian of Phelps Co. (central Ozark region), Mo. J G $25: 558-575$ (1917)

Bridges, J. H.

11 (with Richards, R. W.) Sulphur deposits near Soda Springs, Idaho. U S G S, B 470:499-503 (1911)

Bridgman, P. W.

1s The fallure of cavities in crystals and rocks under pressure. Am J Sc (4) 45: 243-268 (1918)

Briggs, Charles, jr.

38 Report [Scioto and Hocking valleys]. Ohio G S, 1st An Rp: 71-98 (1838)

38a Report [on Wood, Crawford, Hocking and Athens, and Tuscarawas cos.] Ohio G S, 2d An Rp: 109-154 (1838)

Brigham, Albert Perry.

89 The geology of Oneida Co. [N. Y.]. Oneida Hist Soc, Tr 1887-89:102-118 (1889)

92 Rivers and the evolution of geographic forms. Am Geog Soc, B $24: 23-43$ (1892)

93 The Finger Lakes of New York. Am Geog Soc, B 25: 203-223 (1893)

95 Drift boulders between the Mohawk and Susquehanna rivers. Am J Sc (3) $49: 213-228$, maps (1895)

95a The composite origin of topographic forms. Am Geog Soc, B 27:161-173 (1895)

97 Glacial flood deposits in Chenango Valley. G Soc Am, B 8:17-30, map (1897) Abst, Am G 18:229-230 (1896)

07a Lakes; a study for teachers. J Sch Geog 1:65-72 (1\&97)

98 Note on trellised drainage in the Adirondacks. Am G 21:219-222, map (1898)

9Sa Topography and glacial deposits of Mohawk Valley [N. Y.]. G Soc Am, B 9: 183-210, map (1898) Abst, J G 6:211212 (1898) : Science n s $7: 50$ (1898)

01 A text-book of geology. $477 \mathrm{pp}, \mathrm{N} \mathrm{Y}$ 1901

02 (with Gilbert, G. K.) An introduction to physical geograpby. $380 \mathrm{pp}, \mathrm{N} \mathrm{Y}$ $19022 \mathrm{~d}$ ed, 412 pp, N Y 1907 
Brigham, Albert Perry-Continued.

o5 Students' laboratory manual of physical geography. $153 \mathrm{pp}, \mathrm{N}$ Y 1905

05a Early interpretations of the physiography of New York State (abst). Seience n s $21: 136$ (1905)

10 Scenery, soil, and the atmosphere. Pop Sc Mo 76: 570-580 (1910)

11 Mohawk glacial lobe (abst). G Soc Am, B $22: 725-726$ (1911)

15 Memoir of Ralph Stockman Tarr. As Am Geog, An 3: 93-98, port (1915)

15a The new glacier park [near Syracuse, N. Y.]. Science n s $41: 611$ (1915)

Brigham, William Tufts.

67 The Volcano of Kilauea, Hawailan Islands, in 1864-65. Am Nat 1: 16-23 (1867)

68 Notes on the rolcanic phenomena of the Hawailan Islands, with a description of the modern eruptions. Boston Soc N H, Mem 1: 341-472 (1868)

$68 a$ on the form of volcanic craters as influenced by a supposed line of fracture in the earth's crust. Boston Soc N H, Pr 11 : 321-322 (1868)

68b Eruption of Mauna Loa on the Hawalian Islands. Boston Soc N H, Pr $12: 82-83$ (1868)

68c [On the motion of rocks imbedded in the bottom of a glacier.] Boston Soc N H, Pr 12:150-151 (1868)

68d Earthquakes. Am Nat 2:539-547 (1868)

69 The eruption of the Hawailan volcanoes, 1868. Boston Soc N H, Mem 1: 564-587 (1869)

71. Volcanic manifestations in New England; being an enumeration of the principal earthquakes from 1638 to 1869 . Boston Soc N H, Mem 2:1-28 (1871)

71a On volcanoes in Mexico. Boston Soc N H, Pr 14:127-128 (1871)

87 Kilauea in 1880 . Am J Sc (3) 34 : 19-27 (1887)

$\mathbf{8 8}$ On the summit crater of Mt. Loa in 1880 and 1885. Am J Sc (3) 36:33-35 (1888)

91 On the recent eruption of Kilauea. Am J Sc (3) 41:507-510 (1891)

09 The volcanoes of Kilauea and Manna Loa. Bernice Pauahi Bishop Mus, Mem 2 no $4: 222$ pp (1909)

See also Niles, 71b; Pickering, 71a

Brinegar, T. P.

10 Alamos-Promonitos district, Sonora, Mexico. M Sc Press $100: 553-554$ (1910) Bringier, L.

21 ...geology, mineralogy, ...of the regions around the Mississippi and its confluent waters. Am J Sc 3: 15-46 (1821)

Brinker, Arthur C.

13 Geology at Santa Eulalia, Chihuahua. M Sc Press 106:895-896 (1913)
Brinsmade, Robert Bruce.

05 Talc in northern New York. M J 80:1155-1157 (1905)

06 Hematite mining in New York. Bn M J $82: 493-495,554-556$ (1906)

06a Kelly, N. Mex.; a zine camp. Mines and Minerals 27:49-53 (1906)

07 Lead deposits in northern Kentudu Eng M J 83:658-659 (1907)

o7a A curious deposit of cerussite Colorado. Eng M J 83: 844-845 (1907)

07b Lead-silver deposits of Mowry, Ari

Mines and Minerals $27: 529-531$ (1907) o7e Copper mining at Bisbee, Ari Mines and Minerals 27:289-293 (1907) o7d Tombstone, Ariz., restored. Yina and Minerals 27:371-374 (1907)

ore The Cananea copper deposits [Met ico]. Mines and Minerals $27: 422-424$ 465-469 (1907)

Ozf Mining at Bingham, Utah; histor and geology of the region. Mines ati Minerals 28:90-93, 105-108 (1907)

08 Mines of Tintic district, Dtah Mines and Minerals 28:291-295 (1908)

osa Daly-West mine and mill [Park Citg Utah]. Mines and Minerals 28:353-35? (1908)

08b Mining and milling at Stocktos Utah. Eng M J 85 : 611-612 (1908)

o8e The Utah copper mill near Garfell Utah. M World 28:553-556 (1908)

osd Development of San Pedro Mons tain, N Mex. M World 28:1021-10. (1908)

ose Mining and milling near Silver City N Mex. M World 29: 947-950 (1908)

osf Lead and zinc fields of southwesten Wisconsin. M Science 58:305-307, 324 325 (1908)

$\mathbf{0 8 g}$ The great iron fields of the Lail Superior district. M Science 58:425-42\% $444-446,465-467,484-485,505-507,528$ 530 (1908) ; $59: 127-129,149-151,304$ $306,325-327$, map (1909)

10 The Michigan copper mines and mett. ods. M World $32: 549-552$ (1910)

10a The gold district of Wabigoon Lake Ont. M World 33:215-216 (1910)

13 The copper mines of the Sierra Magls tral [Puebla, Mexico]. Mex M J 17:394 397 (1913)

16 The contact mines of Vera Crus Mex M J, 21: 119-121 (1916)

18 Iron in Santo Domingo. M Sc Press $117: 356-358$ (1918)

Brinton, D. G.

8s On an ancient human footprint fros Nicaragua. $\mathrm{Am}$ Ph Soc, Pr 24:437-444 il (1888)

Briscoe, Rufus Janvier

14 The two oldest trees, one dead, os living. $63 \mathrm{pp}, \mathrm{il}, \mathrm{Riverside,} \mathrm{Cal,} 1914$ 
Bristol, Charles L.

01 Notes on the Bermudas. Am Geog Soc, B $33: 242-248$ (1901)

Bristol, T. W.

46 (with Honghton, J., jr.) Reports of Wm. A. Burt and Bela Hubbard on the geography, topography, and geology ... of the south shore of Lake Superior ... $109 \mathrm{pp}$, map, Detroit 1846

Brittain, Doss.

07 The new sheet ground of the Joplin district. M World 27:841-844 (1907)

08 The minerals of Joplin and their association. M World 28:289-291 (1908)

Britton, Elizabeth G.

98 (with Hollick, A.) A description of a new fossil moss from Seattle, Wash. (abst). Science n s 8: 83-84 (1898)

99 A new Tertiary fossil moss [Rhynchostegium knowltoni from Kittitas Co., Wash.]. Torrey Bot Club, B 26:79-81, il (1899) With title, Fossil mosses. Plant World $2: 108-109$, il (1899)

07 (and Hollick, A.) American fossil mosses, with description of a new species from Florissant, Colo. Torrey Bot Club, B 34:139-142, il (1907) N Y Bot Garden, Contr 93 (1907) Abst, Science n s 25:292 (1907)

15 (and Holliek, A.) A new American fossil moss [Plagiopodopsis scudderi from Florissant, Colo.]. Torrey Bot Club, B 42 : $9-10$, il (1915)

Britton, J, Blodget.

73 [On the lignite of Arkansas.] Am I M Eng, Tr $1: 223-224$ (1873)

81 Analyses of Campbell and Appomattox cos., Va., iron and manganese ores and limestones. The Virginias $2: 170-171$ (1881)

Britton, Nathaniel Lord.

$\mathbf{8 1}$ The true geological age of the metamorphic rocks of New York Island and Westchester Co. [N. Y.]. Sch Mines Q 2: 141-142 (1881)

81a On the geology of Richmond Co., N. Y. N Y Ac Sc, An 2:161-182, map (1881) Abst, Sch Mines Q 2:165-173, map (1881)

82 Additional notes on the geology of Staten Island [N. Y.] (with discussion by D. S. Martin, J. S. Newberry, and A. A. Julien). N Y Ac Sc, Tr 1: 56-58 (1882)

$82 a$ on some large potholes near Williamsbridge, N Y. N Y Ac Sc, Tr 1:181183 (1882)

82b Notes on the Cretaceous marl belt of New Jersey. N Y Ac Sc, Tr 2: 9-13 (1882)

83 On a post-Tertiary deposit containing impressions of leaves, in Cumberland Co., N. J. (abst). Am As, Pr 31:357-359 (1883)

84 [Plants on Long Island.] Science 3 : 25 (1884)
Britton, Nathaniel Lord-Continued.

S5 Leaf-bearing sandstones on Staten Island, N. Y. N Y Ac Sc, Tr $3: 30-31$ (1885)

S5a [Fossil leaves in Cretaceous clays of Kreisherville, Staten Island, N. Y.] N Y Ac Sc, Tr $5: 28-29$ (1885)

851 [On the Archean rocks of New Jersey.] N J G S, An Rp 1885; 36-55 (1885)

s5e [On schistose rocks in the Adirondacks.] N Y Ac Sc, Tr 5: 72 (1885)

86 Geological notes in western Virginia, North Carolina, and eastern Tennessee. N Y Ac Sc, Tr 5:215-223 (1886)

86u Drift at the south end of the Rapid Transit Railway tunnel at Tompkinsville [N. Y.]. N Sc As Staten Island, Pr 1:33 (1886)

86b Results of a cruise along the shores of Staten Island and New Jersey. N Sc As, $\operatorname{Pr} 1: 38-39$ (1886)

86e [Additional notes on the geology of Staten Island, N. Y.] N Sc As Staten Island, $\operatorname{Pr} 1: 40-41$ (1886)

87 [On the Archean rocks of New Jersey.] N J G S, An Rp 1886: 74-112, maps (1887)

S7a On recent field work in the Archean areas of northern New Jersey and southeastern New York. Sch Mines Q 9:33-39 (1887)

S7b Notes on the glacial and preglacial drifts of New Jersey and Staten Island [N. Y.]. N Y Ac Se, Tr 4: 26-33 (1887)

87e [On the origin of serpentines of the vicinity of New York City.] N Y Ac Sc, $\operatorname{Tr} 4: 79$ (1887)

87d Additional notes on the geology of Staten Island [N. Y.]. N Y Ac Sc, Tr $6: 12-18$ (1887)

s8 [On hormblende granite, a bullding stone from the Powerville quarries, Morris Co., N. J.] N Y Ac Sc, Tr 7:138 (1888)

88a On an Archean plant from the white crystalline limestone of Sussex Co., N. J. N Y Ac Sc, An 4:123-124 (1888) Can Rec Sc 3:184 (1888)

Ssb Modified drift [of Staten Island, N. Y.]. N Sc As Staten Island, $\operatorname{Pr} 1$ : 61 (1888)

89 [Recent discovery of another exposure of Cretaceous strata, Staten Island, N. Y.]. N Sc As Staten Island, $\operatorname{Pr} 2: 8$ (1889)

89a [On the origin of the Yellow Gravel or preglacial drift, Cretaceous of Staten Island and New Jersey.] N Sc As Staten Island, $\operatorname{Pr} 2: 9$ (1889) Am Nat 23:10321033 (1289)

89b Remarks on recent discoveries in local Cretaceous and Quaternary geology [Staten Island, N. Y.] N Y Ac Sc, Tr 8: 177-181 (1889)

93 John Strong Newberry. Torrey Bot Club, B 20:89-98, port (1893)

See also Rand, 89 
Broadhead, Garland Carr (1927-19i2). 66 Coal Measures in Missouri. Ac Sc St L, Tr 2: 311-333 (1866)

67 Cass Co. Mo St Bd Agr, An Rp 2: $226-229(1867)$

71 Quaternary deposits [Missouri and Illinois]. Am Nat 4:61-62 (1871)

71a Note on coal measure fucoids. Am J Sc (3) $2: 216-217$ (1871)

73 Geology of northwestern Missouri. Mo G S. Prel Rp Iron Ores and Coal Fields, 1872 pt:1-213 (1873)

73a Geo'ogy of Livingston Co. ; ... Clay Co. ; ... Platte Co. ; ... Buchanan Co.; ... Holt Co. : ... Atchison Co. : ... Nodaway Co. Mo G S, Prel Rp Iron Ores and Coal Fields, 1872 pt $2: 209-402$ (1873)

731. Notes on such rocks of Missouri as admit of a fine polish. Mo G S, Prel Rp Iron ores and Coal Fields 1872 pt 2 : 414 415 (1873)

73e Schedule showing depth of coal seams below given horizons. Mo G S, Prel Rp Iron Ores and Coal Fields, 1872 pt $2: 421$ (1873)

73a Maries Co; Osage Co.; Warren Co.; Shelby Co.; Macon Co.; Randolph Co. In Reports on the geological survey of the State of Missouri, 1855-1871: 7-110 Jefferson City 1873.

73e Fossil horse in Missouri. Ac Sc St L, Tr 3: $\mathbf{x x}-\mathbf{x x i} \quad$ (1873)

73f Bones of large mammals in drift; vegetable remains in drift; boulders. Ac $\mathrm{Sc}$ St L, Tr 3: xxii-xxiii (1873)

73g Mineralogy of Cole Co, Mo. Ac Sc St L, Tr 3 : xxxiii-xxxiv (1873)

74 Report of the geological survey of the State of Missouri, including field work of 1873-1874. 734, xlix pp, maps (in atlas), Jefferson City 1874

Ta Note on pickeringite from Missouri. Am J Sc (3) $7: 520$ (1874)

75 Geology of Bond Co.; Fayette Co.; Montgomery Co.; Christian Co.; Shelby Co.; Effingham Co.; Moultrie, Macon, and Platt cos. Ill G S $6: 128-196 \quad$ (1875) ; Ec G $3: 467-544$ (1882)

$75 a$ On the well at the insane asylum, St. Louis Co. [Mo.]. Ac Sc St L, Tr 3: 216-223 (1875) Abst, Am J Sc (3) 9:6162 (1875)

75b Occurrence of bitumen in Missouri. Ac Sc St L. Tr $3: 224-226$ (1875)

75e On a discovery of meteoric iron in Missouri. Am J Sc (3) 10:401 (1875)

76 The southeast Missouri lead district. Am I M Eng, Tr 5:100-107 (1877) Eng M J 22:59-60 (1876)

76a Age of our porphyries. Ac Sc St L, $\operatorname{Tr} 3: 366-370$, ccxix (1876)

76 brift formation and gold in Missouri. Am J Sc (3) 11:150 (1876)

76e Age of Missouri porphyries. The Western n s 2:448 (1876)
Brondhead, Garland Carr-Continued. 77 Bitumen, asphaltum, petroleum, roschists, and certain other solid hydr carbons. Western Rv Sc 1:209-2 (1877)

z7a Thickness of the Missouri of measures. Western Rv Sc $1: 392-38$ (1877)

77b On barite crystals from the Let Chance mine, Morgan Co., Mo., and göthite from Adair Co., Mo. Am J \& (3) $13: 419-420$ (1877)

77e Meteor of January 3, 1877. Th Western n s $3: 245-246$ (1877)

78 Missouri iron ores of the Carbonifes. ous age. Western Rv Sc 1:650-654 (1878)

7Sa Meteoric st nes and shooting stank Western Ry Sc 1: 724-742 (1878)

7Sb Jackson Co., Mo.; a few notes on its geology. Western Rv Sc $2: 204-211$ (1878)

79 Origin of the loess. Am J Sc (3) 18: 427-428 (1879)

79a Remarks on Hunt's and Dana's ser tions. Kansas City Rv Sc $2: 666-668$ (1879)

79b The walled lakes of Iowa. Kanses City Rv Sc 2:688-689 (1879)

79e Notes on surface geology of south west Missouri and southeast Kansas Kansas City Rv Sc 3: 460-461 (1879)

so Geologieal report upon the mineral lands of Major R. H. Melton [Benton and Hickory cos., Mo.]. $12 \mathrm{pp}$, Sedalia, Mo, 1880 [priv pub]

81 The mastodon. Kansas City Rv \& 4: 519-530 (1880)

81a Geological notes on the central branch, Union Pacific Railroad. Kanas City Rv Sc 5: 129-132 (1881)

81b The Carboniferous rocks of sout east Kansas. Am J Sc (3) $22: 55-5 t$ (1881) Kansas City Rv Sc $5: 273-275$ (1881)

82 Marble of southeast Missouri. Kan sas City Rv Se 5: 523-526 (1882)

82a The chalk beds of Wakeeney, Kans. Kansas City Rv Sc 5: 616 (1882)

82b Archean rocks of Missouri. Kansas City Rv Sc 5 : 735-738 (1882)

82c Geologieal notes on a part of south. east Kansas. Kansas City Rv Sc 6:172175 (1882)

82d North Park, Colo. Kansas City Rv Sc 6: 197-204 (1882)

83 Juratrias. Kansas City Rv Sc 6: 534-540 (1883)

S3a Physical fatures and geological survey [of Bates Co., Mo.]. In The bistory of Cass and Bates Counties, Missouri ...: $759-781$. St. Joseph, Mo., Na. tional Historical Company, 1883

84 Mines of Carterville, Jasper Co., Mo. Kansas City Rv Sc 8: 70-72 (1884) 
Broadhead, Garland Carr-Continued.

$84 \mathrm{a}$ The gravels of southern Kansas. Kansas City Rv Sc 8: 453-454 (1884)

84b Carboniferous rocks of eastern Kansas. Ac Sc St L, Tr 4: 481-493 (1884)

$84 \mathrm{c}$ The relation of the solls of Missouri to geology. Mo St Bd Agr, An Rp 17: 159-168 (1884)

85 Sketch of geology of Missouri. Mo St Bd Agr, An Rp 18:250-259 (1885)

86 Missouri geological surveys. Ac Sc St $\mathrm{L}, \operatorname{Tr} 4: 611-624$ (1886)

88 Mitchell Co., Tex. Am G $2: 433-436$ (1888)

89 The geological history of the Ozark uplift. Am G 3:6-13 (1889)

89a The Missouri River. Am G 4: 148155 (1889)

91 The Ozark series [Mo.]. Am G 8: 33-35 (1891)

93 The Cambrian and the Ozark series. Am J Sc (3) 46:57-60 (1893)

93a The correct succession of the Ozark series. Am G 11: 260-268 (1893)

93b A critical notice of the stratigraphy of the Missouri Paleozoic. Am G 12:7489 (1893)

94 Geological history of the Missouri Paleozoic. Am G 14: $380-388$ (1894)

95 Coal measures of Missouri. Mo $\mathrm{G} \mathrm{S}$ $8: 353-395 \quad(1895)$

95a Joseph Granville Norwood, M. D., LL. D. $\mathrm{Am} \mathrm{G} 16: 69-74$, port (1895)

96 The Devonian of north Missouri, with notice of a new fossil. Am J Se (4) 2 : $237-239$, il (1896)

98 Reports on Boone County and the Ozark uplift. Mo G S 12 pt $3: 373-409$, map (1898)

98a Major Frederick Hawn. Am G 21: 267-269, port. (1898)

99 Biographical sketch of George Clinton Swallow. Am G 24:1-6, port. (1899)

01 Geological surveys [of Missouri] Encyclopedia of the History of Missouri, 3: $27-31$, N Y 1901

01a Mineralogy [of Missouri]. Encyclopedia of the History of Missouri, $4: 390$ 393, N Y 1901

02 The New Madrid earthquake: Am G $30: 76-87$ (1902)

03 Bituminous and asphalt rocks of the United States. Am G 32:59-60 (1903)

01 Bitumen and oil rocks. Am G 33 : $27-35$ (1904)

04a The loess. Am G 33:393-394 (1904)

04b Surface deposits of western Missouri and Kansas. Am G 34: 66-67 (1904)

04e The saccharoidal sandstone. Am G $34: 105-110$ (1904)

07 Cone in cone. Science n s 26:597 (1907)

See also Hawes, 84 ; U. P. R. Co., 09
Brock. Reginald Walter.

96 (with Miller, W. G.) Some dikes cutting the Laurentian system in the counties of Frontenac, Leeds, and Lanark, Ont. Can Rec Sc 6:481-488 (1896)

99 [Report on field work in West Kootenay district, B. C.] Can G S, Sum Rp 1898 (An Rp 11) : ^ 63-71 (1899)

99 . West Kootenay ore bodies. Can M Inst, J 2:72-86 (1899) Can M RV 18: 61-64 (1899) M Sc Press, 79:201, 230231 (1899)

oo [Report on the West Kootenay district, B. C.] Can G S, Sum Rp 1899 (An Rp 12) : A 75-103 (1900)

OOa British Columbia, West Kootenay sheet, economic minerals and glacial striae. Scale, 4 miles $=1$ inch. Can G S, An Rp 14 (1900)

0өb West Kootenay notes [B. C.]. Can M Inst, J 3:141-144 (1900) Can M Rv $19: 51$ (1900)

o1 [Report of field work in the West Kootenay district, B. C.] Can G S, Sum Rp 1900 (An Rp 13) : ^ 62-84 (1901)

O1a (with MeConnell, R. G.) British Columbia, West Kootenay sheet, geologically coloured. Scale, 4 miles $=1$ inch. Can G S, An Rp 14 [n d, about 1901]

02 The Boundary Creek district, B. C. Can G S, Sum Rp 1901 (An Rp 14) : A 51-69 (1902)

02n The ore deposits of the Boundary (Creek) district, B. C. Can M Inst, J 5:365-378 (1902) Can M Rv 21:156160 (1902)

03 Preliminary report on the Boundary Creek district, B. C. Can G S, Sum Rp 1902 (An Rp 15) : A 92-138 (1903)

O4 The Lardean district, B. C. Can G S, Sum Rp 1903 (An Rp 15) : A 42-81, map (1904)

O4a Platinum in British Columbia. Eng M J $77: 280-281$ (1904)

04b Original native gold in igneous rocks. Eng M J 77:511 (1904)

o4e (with MeConneII, R. G.) Report on the great landslide at Frank, Alta. Canada, Dp Interior, An Rp 1902-3 pt 8 App, 17 pp (1904)

o5 The Lardeau mining district [B. C.]. Can G S Sum Rp 1904 (An Rp 16):A 80-91 (1905)

05a Poplar Creek and other camps of the Lardeau district B. C. Can M Inst, J 7: 87-113 (1905)

06 Preliminary report on the Rossland, B. C., mining district. Can G S: 40 pp (1906) Sum Rp 1906:56-65 (1906)

o7 The Larder Lake district. Ont Bur Mines, An Rp 16 pt $1: 202-218$, map (1907) Can M J n s, 1 no 20 , old s 28 no 22 [29 no 1]: 621-624, 29 no $2: 656$ 659 (1908) 
Brock, Reginald Walter-Continued.

orn The geology and ore deposits of Franklin Camp, B. C. Can M J 28 (n s 1) : 233-236 (1907)

os Summary report of the Department of Mines, Geological Survey for the calendar year 1907 : 132 pp, Ottawa 1908 Summary report of the Geological Survey branch of the Department of Mines for the calendar year 1908:220 pp, Ottawa 1909 ...for the calendar year 1909:307 pp, Ottawa 1910 ...for the calendar year $1910: 314$ pp, maps, Ottawa 1911 ...for the calendar year $1911: 412 \mathrm{pp}$, maps, Ottawa 1912 ...for the calendar year 1912 : 544 pp, maps, Ottawa 1914 ...for the calendar year 1913:417 pp, maps, Ottawa 1914.

OSa The Lardeau district, B. C. Can G S, Sum Rp 1907:84-90 (1908)

09 The geology of Canada. In A Handbook to Winnipeg and the Province of Manitoba, prepared for the 79 th annual meeting of the British Association for the Advancement of Science, 1909:104-148 Winnipeg 1909.

O9a A descriptive sketch of the geology and economic minerals of Canada; Introduction. Can G S, Pub no 1085: 7-22 (1909)

00b Hugh Fletcher [1848-1909]. Can M J 30:677-678 (1909)

10 Climatic changes in British Columbia since the glacial period. Int $\mathrm{G}$ Cong, XI, Stockholm, Die Veränderungen des Klimas seit dem letzen Eiszeit: 393-394 (1910)

10a The Porcupine district, Ont. Eng M J $90: 221-222$ (1910)

11 Tin and topaz in New Brunswick. Can M J 32:549-551, map (1911) M Soc N S, J $17: 50-54$ (1912)

11 a Special problems and their study in economic geology (discussion). Ec G 6: 72 (1911)

11b Prospecting in the North (discussion). M Mag 4:203-204; 5:222-223 (1911)

15 Notes on some hitherto unrecorded occurrences in British Columbia, of uncommon minerals ... R Soc Can, $\operatorname{Tr}$ (3) 9, iv : 119-120 (1915)

15a A British Columbia example of the contact metamorphism of a granite to a garnet. R Soc Can, Tr (3) 9, iv : 175-180 (1915) Abst, Science n s 42: 468 (1915)

Brockway, Charles J.

75 Mineral deposits in Essex Co., Mass... $60 \mathrm{pp}$, map, Newburyport 1875

Broderick, Thomas Monteith.

16 Some experiments bearing on the secondary enrichment of mercury deposits. Ec G 11:645-651 (1916)

16a Rock quarrying industry in Minnesota. J G $14: 187-188$ (1916)
Broderiek, Thomas Monteith-Continud 17 The relation of the titaniferous mas netites of northeastern Minnesota to th Duluth gabbro. Ec G 12:663-696 (1917)

18 Some features of magnetic survers the magnetite deposits of the Duluth gabbor Ee G $13: 35-49$ (1918)

Brodie, W. S.

12 Some effects of ice action near Grand Lake, Cape Breton. N S Inst Sc, Pr Tr 12 253-257 (1912)

Brodie, Walter $M$.

10 Native silver in southwestern $\mathrm{CH}$ huahua. Eng M J 89:664-665 (1910)

10a South of the Rio Grande Rive Mexico. M World 33:1083-1086 (1910) Brödermunn, Jorge.

17 Existencia de yacimientos petrolfero en la provincia de la Habana. Soc Cubas Ing, Rv $9: 153-156$ (1917)

17 a El petróleo en la región de Baw ranao [Cuba]. Soc Cubana Ing, $\mathrm{Br} 9:$ 591-622 (1917) Fomento, Habana, 1:5364, 87-94 (1917)

17b Yacimientos petrolfferos de Cuba Fomento, Habana, 1:11-14 (1917)

17e El petroleo en Pinar del Rio; istencia probable de grandes yacimientos Fomento, Habana, 1: 112-115 (1917)

17d Reconocimiento petrolffero de is región del Caimito [Cuba]. Fomento, Ha bana, 1: 161-163 (1917)

18 Los yacimientos petrolfferos al sor de la Sierra "Fl Rosario" en la Provind de Pinar del Rio [Cuba]. Fomento, Hs bana, $1: 192-196$ (1918)

18a Nueva zona petrolsfera en la Hz bana. Fomento, Habana, $1: 220-222$ (1918)

18b (and Medley, E.) Reconocimiento petrolifero en la Provincia de Santa Clar [Cuba]. Fomento, Habana, 1:255-258 (1918)

18c Cuba, país eminentemente petrolffero. Heraldo Minero, número extraord: nario, 20 mayo 1918.

Brogger, Waldemar Christopher.

\$6 Om alderen af Olenelluszonen I Nor amerika [age of the olencllus zone], f Fören Stackholm, Förh 8:182-213 (1886) 94 On the formation of pegmatite reins Can Rec Sc 6: 33-46, 61-71 (1894)

Broili, Ferdinand.

99 Ein Beitrag zur Kenntniss von Bryope megacephalus Cope. Palæontographica 46: $61-84$, il (1899)

02 Ein Beitrag zur Kentniss von Diplo. caulus Cope. Centralbl Miner 1902: 536541, il

O4 Permische Stegocephalen und Reptilien aus Texas. Palæontographica 51:1120 , il (1904)

O4a Ueber Diacranodus texensis Cope (= Didymodus? compressus Cope). N Jb, Beil Bd $19: 467-484$, il (1904) 
Broili, Ferdinand-Continued.

04b Pelycosaurierreste von Texas. Deut G Ges, Zs $56: 268-274$, il (1904)

os Ein montiertes Skelett von Labidosaurus hamatus Cope, einem Cotylosaurier aus dem Perm von Texas. Deut G Ges, Zs $60: 63-67$, il (1908)

13 Über zwei Stegocephalenreste aus dem texanischen Perm. N Jb. 1913, 1: 96-100, il (1913)

Brokaw, Albert Dudley.

10 The solution of gold in the surface alterations of ore bodies. J G $18: 321-326$ (1910)

13 The secondary precipitation of gold in ore bodies. J G 21:251-267 (1913)

16 Preliminary oil report on southern Illinois; parts of Saline, Williamson, Pope, and Johnson cos. III G S, Extract from B $35: 13$ pp, map (1916)

16a (and Smith, L. P.) Zonal weather. Ing of a hornblende gabbro. J G 24:200205 (1916)

16b A stage attachment for the metallographic microscope. J G 24:718-719 (1916)

17 Oil investigations in Illinois in 1916; parts of Saline, Johnson. Pope, and Williamson cos. III G S, B $35: 19-37$, map (1917)

18 An interpretation of the so-called paraffin dirt of the Gulf coast ofl fields. Am I Eng, B 136:947-950 (1918) Discussion by Lee Hager, B $140: 1158-1162$ (1918)

\section{Brongniart, Alexandre.}

21 Miscellaneous observations relating to geology, mineralogy, and some connected topics, with remarks by the editor [B. Silliman]. Am J Sc 3:216-226 (1821) In part, with title, Vorkommen von geliegnem Kupfer und von Fischabdrücken unter der Trapp-formation von New England, An Physik (Gilbert) 70:349-360 (1822)

Brook, W, M.

99 The Atlin district in British Columbla. Eng M J 68: 605-606 (1899)

Brooks, Alfred Hulse.

96 Preliminary petrographic notes on some metamorphic rocks from east $\mathrm{rn}$ Alabama. Ala G S, B 5:177-197 \$1896)

96a (with Tafr, J. A.) Description of the Buckhannon quadrangle [W. Va.]. U 8 G S, G Atlas Buckbannon fol (no 34): $4 \mathrm{pp}$, maps (1896)

97 (with Hayes, C. W.) The crystalline and metamorphic rocks of northwest Georgia (abst). J G 5:321-322 (1897) Sclence n s $5: 97$ (1897)

97a (with Woln, J. E.) Age of the white limestone of Sussex Co., N. J. (abst). G Soc Am, B $8: 397$ (1897) J G $5: 322$ (1897) Science n \& $5: 96 \quad$ (1897)
Brooks, Alfred Hulse-Continued.

98 (with wolf, J. E.) The age of the Franklin white limestone of Sussex County, New Jersey. U S G S, An Rp 18 pt 2: 425-457, map (1898)

99 Notes on the geology of the Tanana and White River basins [Alaska] (abst). Science n s 9:622 (1899)

Oo A reconnaissance in the Tanana and White River basins, Alaska, in 1898. U $\mathrm{S}$ G S, An Rp 20 pt $7: 425-494$, maps (1900)

O0a A reconnaissance from Pyramid Harbor to Eagle City, Alaska, including a description of the copper deposits of the upper White and Tanana rivers. U S G $\mathrm{S}$, An Rp 21 pt $2: 331-391$, maps (1900)

oob A reconnaissance from Pyramid Harbor to Fortymile River, Alaska (abst). Science n s 11:825-826 (1900)

ooc (with sehrader, F. C.) Preliminary report on the Cape Nome gold region, Alaska. U S G S: $56 \mathrm{pp}$, maps (1900) $A b s t$, Mines and Minerals 20:534-537 (1900)

ood (with Hayes, C. W.) Ice cliffs on White River, Yukon Terr. Nat Geog Mag 11: 199-201 (1900)

01 (assisted by G. B. Richardson and A. J. Collier) A reconnaissance of the Cape Nome and adjacent gold fields of Seward Peninsula, Alaska, in 1900. U S G S, Reconnaissances in the Cape Nome and Norton Bay regions, Alaska, in 1900: 1-185, maps (1901)

$01 \Omega$ An occurrence of stream tin in the York region, Alaska. U S G S, Min Res $1900: 267-271$ (1901)

01b (and Collier, A. J.) Glacial phenomena of the Seward Peninsula [Alaska] (abst). Science n s 13:188-189 (1901)

01e $A$ new occurrence of cassiterite in Alaska. Science n s 13:593 (1901)

O1d The placer gold flelds of the Nome region [Alaska]. M and Metal 24:249252 (1901)

ox (with Schrader, F. C.) Some notes on the Nome gold region of Alaska. Am I M Eng, Tr $30: 326-247$, map (1901)

02 The coal resources of Alaska. U S G S, An Rp 22 pt 3:515-571, map (1902) 02a Preliminary report on the Ketchikan mining district, Alaska, witn an introductory sketch of the geology of southeastern Alaska. U S G S, P P 1:120 pp, maps (1902)

02b Geological reconnaissances in southeastern Alaska. G Soc Am, B 13:253266. map (1902)

02e Nortbwestern America and northeastern Asia; a criticism. Science n s 15 : 909-910 (1902)

02d A reconnaissance in the Mount McKinley region, Alaska (abst). Science $\mathbf{n} \mathbf{s}$ $16: 985-986$ (1902) 
Brooks, Alfred Hulse-Continued.

03 Placer gold mining in Alaska in 1902.

U S G S, B 213: 41-48 (1903)

o3a Stream tin in Alaska. U S G S,

B 213: 92-93 (1903)

04 Placer mining in Alaska in 1903. U S G S, B 225: 43-59 (1904)

o5 (and others) Report of progress of investigations of mineral resources of Alaska in 1904. U S G S, B 259: 196 pp, maps (1905) ... in 1905; B 284: 169 pp, maps (1906) ... in 1906 ; B 314:235 pp, maps (1907) Mineral resources of Alaska ; report on progress of investigations in 1907 ; B 345: $294 \mathrm{pp}$, maps (1908) ... in 1908 ; B $379: 411 \mathrm{pp}$, maps $(1909) \quad \ldots$ in 1909 ; B $442: 426 \mathrm{pp}$, maps (1910) ... in 1910 ; B $480: 325 \mathrm{pp}$, maps (1911) $\ldots$ in 1911; B 520:352 pp, maps (1912) ... in $1912 ; \mathrm{B} 542: 308 \mathrm{pp}$, maps (1913)

05a Administrative reports on investigations of mineral resources of Alaska. U S G S, B 259:13-17 (1905); B 284: 1-3 (1906) ; B 314:11-18 (1907) ; B 345: 5-17 $(1908) ;$ B $379: 5-20(1909) ;$ B $442: 5-19$ (1910) ; B $480: 5-14$ (1911) ; B 520:7-16 (1912); B $542: 7-17$ (1913)

05b Placer mining in Alaska in 1904 U S G S, B 259: 18-31 (1905)

o5e The geography of Alaska, with an outline of the geomorphology. Int Geog Cong, VIII, Rp : 204-230, map (190b)

o5d The investigation of Alaska's mineral wealth. Am I M Eng, Tr 35:376-396 (1905)

o5e The outlook for coal mining in Alaskя. Am I M Eng, Bi-Mo B 4:683702, map (1905); $\operatorname{Tr} 36: 489-507$, map (1906)

06 The geologic survey of Alaska. Pop Sc Mo $68: 42-54$ (1906)

06a The mineral resources of Alaska. Am M Cong, 8th An Sess Pr: 194-214 (1906)

06b Recent publications on Alaska and Yukon Territory. Ec G 1 : 340-359 (1906)

o6e Gold and silver; Alaska. U S G S,

Min Res 1905:127-134; 1906:134-146 (1906-7)

o6d The mining industry [in Alaska] in 1905 [and succeeding years]. U S G S, B $284: 4-9 ; 314: 19-39 ; 345: 30-53 ; 379$ : 21-62; $442: 20-46 ; \quad 480: 21-42 ; 520$ : $17-44 ; 542: 18-51 ; 592: 45-74 ; 622$ : $15-68 ; 642: 16-71, \operatorname{map}(1906-16)$

o7 The geology and geography of Alaska; a summary of existing knowledge. U S G S, P P 45:327 pp. maps (1906) Abst, Science n s 25:946-947 (1907)

07a The Kougarok region [Alaska].

U S G S, B 314:164-181 (1907)

07b The Circle precinct [Alaska]. U S

G S, B 314:187-204 (1907)

oze (and Kindle, E. M.) The Paleozoic section of the upper Yukon (abst). Science n s 25 : 181-182 (1907)
Brooks, Alfred Hulse-Continued.

07d Geologic reconnaissance map of Alaska (abst). G Soc Am, B 17:695-70 (1907)

08 The distribution of mineral resoum in Alaska. U S G S, B 345:18-29, map (1908)

08 (and Kindle, E. M.) Paleozoic as associated rocks of the Upper Yukon, Alaska. G Soc Am, B 19:255-314, map (1908)

osb Gold, silver, copper, lead, and zinc; Alaska. U S G S, Min Res 1907: 139-150; 1908: 277-285; $1909: 223-232 ; \quad 1910$; $307-320 ; 1911$ pt $1: 406-420 ; 1912$ pt 2 : 523-535 (1908-13)

o8e Sketch of geology of Mt. McKinles region. In Cook, Frederick A., To the top of the continent... : 237-259, N Y 1908

o8d (with Collier, A. J.) The gold placers of parts of Seward Peninsula Alaska, including the Nome, Council, Kotgarok, Port Clarence, and Goodhope pre cincts. U S G S, B 328: $\$ 43$ pp (1908)

09 Mineral resources of Alaska. U S G S, B 394: 172-207 (1909). Nat Conserrs. tion Comm Rp (60th Cong 2d Sess, Sen Doc 676), 3:572-603 (1909)

09a Alaska and its mineral resources Am M Cong, 11th An Sess, Papers asi Pr : 258-268 (1909)

O9b Mining and mineral wealth of Alaska. Alaska-Yukon-Pacific Exposition Seattle, Washington 1909. Department the Interior, Alaskan Exhibit. $46 \mathrm{p}$ Washington, D. C., 1909.

10 Alaska coal and its utilization. I 8 G S, B 442:47-100, map (1910)

11 The Mount McKinley region, Alaska with descriptions of the igneous rocks an of the Bonnifield and Kantishna districts by L M Prindle. U S G S, P P 70:24t pp, map (1911)

11 a Geologic features of Alaskan metal liferous lodes. U S G S, B $480: 43-8 \%$ maps (1911)

11b The future of Alaska coal. Am If Cong, 14th An Sess, Rp. Pr 291-298 (1911)

11e Geography in the development of the Alaska coal deposits. As Am Geog, As 1: 85-94 (1911)

12 Applied geology. Wash Ac Sc, J 2: 19-48. (1912) Smiths Inst, An Rp 1912: 329-352 (1913)

12a Railway routes from the Pacific set. board to Fairbanks [Alaska]. U $\mathrm{S} G \mathrm{G}, \mathrm{B}$ 520:45-88, maps (1912)

12b Gold deposits near Valdez [Alaska]. U S G S, B 520: i08-130, map (1912)

13 A description of methods of placer mining. U S G S, W S P $314: 269-303$ (1913)

$13 a$ (and Martin, G. C.) The coal re sources of Alaska. Int $\mathbf{G}$ Cong, XII, Canada, The Coal Resources of the World 1: 1xiv-1Xv, 2: 541-552, map (1913) 
Brooks, Alfred Hulse-Continued.

14 The Chisana placer district, Alaska.

U S G S, B 592 : 309-320, maps (1914)

14a Gold, silver, and copper in Alaska. U S G S, Min Res, 1913 pt $1: 213-225$; 1914 pt. $1: 125-137 ; 1915$ pt $1: 175-186$; 1916 pt $1: 171-183(1914-7$ )

14b Mountain exploration in Alaska. Alpina Americana $3: 22 \mathrm{pp}$, maps (1914)

15 The future of gold placer mining in Alaska. U S G S, B 622:69-79 (1915)

15a The petroleum fields of Alaska. Am I M Eng, B 98: 199-207, maps (1915) ; Tr 51:611-619, maps (1916)

16 Preliminary report on the Tolovana district, Alaska. U S G S, B 642; 201209, map (1916)

16a Antimony deposits of Alaska. U S G S, B 649:67 pp, maps (1916) Abst, Wash Ac Sc, J $6: 567-568$ (1916)

16b The physiographic provinces of Alaska (abst). Wash Ac Sc, J $6: 252-253$ (1916) As Am Geog, An 6: 123 [1917]

17 Memorial of Charles Willard Hayes. G Soc Am, B 28:81-123, port (1917)

See also Bancroft (H), 14; Eldridge, 99; Grant (U S), 13; Irving, 11a ; Shaw, 13; Winchell (A N), 14

Brooks, E. W.

07 Geology and mineralogy of LondonArizona mine [Banner mining district, Gila Co.] Ariz. M Reporter 56:117-118 (1907)

Brooks, Thomas Benton (1836-1900).

72 (and Pumpelly, R.) On the age of the copper-bearing rocks of Lake Superior. Am J Sc (3) 3:428-432 (1872)

72a On certain Lower Silurian rocks in St. Lawrence Co., N. Y., which are probably older than the Potsdam sandstone. Am J Sc (3) $4: 22-26$ (1872)

73 Iron-bearing rocks (economic). Mich G S, Upper Peninsula 1 pt $1: 319$ pp (1873) ; 2 (appendices to 1 pt 1):298 pp (1873)

73a (and Jnlien, A. A.) Lithology [of the Upper Peninsula]. Mich G S 2:199212 (1873)

73b Contortions of laminae. Mich G S 2: 283-292 (1873)

76 On the youngest Huronian rocks south of Lake Superior and the age of the copper-bearing series. Am J Sc (3) 11: 206-211 (1876)

76a Classified list of the rocks observed in the Huronian series south of Lake Superior ... Am J Sc (3) 12: 194-204 (1876)

79 Work in the Menominee iron region. Wis G S, An Rp 1878: 40-42 (1879)

So The geology of the Menominee iron regiox, Oconto Co., Wis. [Wis G S] G Wis 3:423-599, maps (1880)

80 sketch of the Laurentian rocks of Michigan, [Wis G S] G Wis $3: 661-663$ (1880)
Brooks, Thomas Benton-Continued.

91 Geology of the Marquette iron region ; a correction. Am J Sc (3) 41: 160 (1891)

Brooks, William Kelth.

94 The origin of the oldest fossils and the discovery of the bottom of the ocean. Johns Hopkins Univ Circ 14: 11-16 (1895) J G 2:455-479 (1894) Smiths Inst, An Rp 1894:359-376 (1896)

от Joseph Leidy. Pop Sc Mo 70:311314 , port (1907)

09 Biographical memoir of Alpheus Hyatt, 1838-1902. Nat Ac Sc, Biog Mem 6: $311-325$, port (1909)

Broom, Robert.

10 A comparison of the Permian reptiles of North America with those of South Africa. Am Mus N H, B 28:197-234, il (1910)

13 On the squamosal and related bones in the mosasaurs and lizards. Am Mus N H, B $32: 507-508$, il (1913)

13a On the structure and affinities of Bolosaurus. Am Mus N H, B 32:509-516, il (1913)

13b On the cotylosaurian genus Pantylus Cope. Am Mus N H, B $32: 527-532$, il (1913)

13e Studies on the Permian temnospondylous stegocephalians of North America. Am Mus N H, B $32: 563-595$, il (1913)

14 Some points in the structure of the diadectid skull. Am Mus N H, B 33: 109-114, il (1914)

14a On the structure and affinities of the Multituberculata, Am Mus N H, B 83:115-134, il (1914) Abst, G Soc Am, B $25: 140-141$ (1914)

14b A further comparison of the South African dinocephallans with the American pelycosaurs. Am Mus N H, B 33:135141 (1914)

14e The origin of mammals (abst). N Y Ac Sc, An 23:302-306 (1914)

See also Gregory (W K), 17

Broome, Gordon.

71 The Laurentian apatites of Canada. Am As, Pr 19:149-156 (1871)

72 Notes on the phosphate of lime and mica found in North and South Burgess and North Emsley, Ont. Can G S, Rp Prog 1870-1:316-321 (1872)

Bross, William.

81 Canyons, their character and origin. Science (ed., Michels) 2:468-470 (1881)

Broughton, Samuel H. (1830-1860).

63 Remarks on the mining interest and details of the geology of Ontonagon Co. [Mich.]... 24 pp, map, Phila 1863

Brower, Jacob Vradenberg (1844-1905). 96 The Missouri River and its utmost source... 150 pp, St. Paul, Minn. 1896 02 Kakabikansing (Little Falls, Minn.]. Memoirs of Explorations in the basin of the Mississippl, vol. 5:126 pp, St. Paul, Minn., 1902 
Brown, A. J

74 The formation of fissures and the origin of their mineral contents. Am I M Eng, Tr 2: 215-219 (1874)

74a Carboniferous coal in Nevada. Am I M Eng, Tr $3: 31-33$ (1875) Eng M J $18: 2-3(1874)$

Brown, Alexander.

94 On the structure and affinities of the genus Solenopora... G Mag (4) 1: 145-151, 195-203, il (1894)

Brown, Amos Peaslee (1864-1917).

ss Modes of occurrence of pyrite in bituminous coal. Am I M Eng, $\operatorname{Tr} 16$ : 539-546 (1888)

91 On the young of Baculites compressus Say. Ac N Sc Phila, Pr 1891:159160 , il (1891) Nautilus $5: 19-21$, il (1891)

92 The development of the shell in the colled stage of Baculites compressus Say. Ac N Sc Phila, Pr 1892:136-141, il

96 The crystallization of molybdenite. Ac N Se Phila, Pr 1896: 210-211

96a [On the red color of certain formations.] Am G 17:262 (1896)

os (with Erni, H.) Mineralogy simpllfied. 4th ed. $414 \mathrm{pp}$ (1908)

10 (with Frazer, Persifor) Tables for the determination of minerals. Sixth ed. 125 pp. Phila (1910)

11 New cycads and conifers from the Triàs of Pennsylvania. Ac N Sc Phila, Pr 63: 17-21 il (1911)

11a (and Pilsbry, H. A.) Fauna of the Gatun formation, Isthmus or Panama. Ac N Sc Phila, Pr 63:336-373, il (1911) ; $64: 509-519$, Il (1913)

12 The formation of ripple marks, tracks and trails. Ac N Sc Phila, Pr 63: 536-547 (1912)

12a (and Pilsbry, H. A.) Note on a collection of fossils from Wilmington, N. C. Ac N Sc Phila, Pr 64:152-153, il (1912)

13 (and Ehrenfeld, Frederick) Minerals of Pennsylvania. $\mathrm{Pa}$ Top $\mathrm{G} \mathrm{S}, \mathrm{Rp}$ $9: 160 \mathrm{pp}$, maps (1913)

$13 a$ (and Pilsbry, H. A.) Two collections of Pleistncene fossils from the Isthmus of Panama. Ac N Sc Phila, Pr 65: $493-500$, il (1913)

14 Notes on the geology of the Island of Antigua. Ac N Se Phila, Pr 65:584616, il (1914)

14a (and Pilsbry, Henry A.) Freshwater mollusks of the Oligocene of Antigua. Ac N Sc Phila, Pr 66: 209-213, il (1914)

See also Frazer, 75

Brown, Andrew.

49 (and Dickeson, M. W.) The sediment of the Mississippi River. Am As, Pr 1: 42-55 (1849)

Brown, Arthur Erwin.

o1 On some points in the phylogeny of the primates. Ac N Sc Phila, Pr 53:119125 (1901)
Brown, Barnum.

03 A new genus of ground sloth from the Pleistocene of Nebraska. Am Mus N H B $19: 569-583$, il (1903)

04 Stomach stones and food of plesis saurs. Science n s 20:184-185 (1904)

05 The osteology of Champsosaurus Cop Am Mus N H, Mem 9:1-26, il (1905)

05a Recent exploration of a Pleistoces fissure in northern Arkansas (absi). Science n s 21:300 (1905)

06 New notes on the osteology of $7 \mathrm{~m}$. ceratops. Am Mus N H, B 22:297-300, 11 (1906)

o7 The Hell Creek beds of the uppe Cretaceous of Montana; their relation th contiguous deposits, with faund and flor lists, and a discussion of their correlation. Am Mus N H, B 23: 823-845 (1907)

07a Gastroliths. Science n s $25: 30$ (1907)

os The Conard fissure, a Pleistocene boo deposit in northern Arkansas; with descrip tions of two new genera and twenty ner species of mammals. Am Mus $\mathrm{N} \mathrm{H}$, Met $9: 155-208$, il (1908)

osa Trachodont, the duck-billed dist saur; skeletons of prehistoric reptiles mon: than three million years old. Sc Am 98 262-263, il (1908)

08b The Trachodon group. Am Mus : $8: 51-56$, il $(1908)$

ose The Ankylosauridæ, a new family armored dinosaurs from the upper $\mathrm{Cr}$ taceous. Am Mus N H, B 24: 187-201, (1908)

10 The Cretaceous Ojo Alamo beds d New Mexico with description of the net dinosaur genus Kritosaurus. $\mathrm{m}$ Mus $\mathrm{N}$ B 28: 267-274, il (1910)

$10 \Omega$ Notes on the restorations of the Crt taceous birds Hesperornis and Baptoni (Abst.) Science n s 31:440 (1910)

11 Fossil hunting by boat in Cans [Red Deer River, Alberta]. Am Mus J 11 273-282 (1911)

12 A discovery in the fossil fields o Mexico [glyptodont, Jalisco]. Am Mus $12: 177-180$, il (1912)

12a The osteology of the manus in the family Trachodontidx. Am Mus N H, $31: 105-108$, il (1912)

12b A crested dinosaur from the monton Cretaceous [Saurolophus osborni]. Am Mus N H, B 31:131-136, il (1912)

12e Brachyostracon, a new genus a glyptodonts from Mexíco. Am Mus N H. B $31: 167-177$, il (1912)

13 A new crested dinosaur [Alberta] Am Mus J 13:139-144, il (1913)

13a Some Cuban fossils: a hot sprist yields up the bones of animals that lloed before the advent of man. Am Mus J 18 221-228, il (1913) 
Brown, Barnum-Continued.

13b The skeleton of Saurolophus, a crested duck-billed dinosaur from the Edmonton Cretaceous. Am Mus N H, B 32 : 387-393, il (1913)

13e A new trachodont dinosaur, Hypacrosaurus, from the Edmonton Cretaceous of Alberta. An Mus N H, B 32:395406 , il (1913)

13d A new plesiosaur, Leurospondylus, from the Edmonton Cretaceous of Alberta. Am Mus N H, B 32:605-615, il (1913)

13e The manus of trachodont dinosaurs. Science n s $38: 926-927$ (1913)

14 Cretaceous-Eocene correlation in New Mexico, Wyoming, Montana, Alberta. G Soc Am, B $25: 355-380$ (1914)

14a Anchiceratops, a new genus of horned dinosaurs from the Edmonton Cretaceous of Alberta, with discussion of the ceratopsian crest and the brain casts of Anchiceratops and Trachodon. Am Mus $\mathrm{N}$ H, B $33: 539-548$, il (1914)

14b A complete skull of Monoclonius, from the Belly River Cretaceous of Alberta. Am Mus N H, B $33: 549-558$, il (1914)

14e Corythosaurus casuarius, a new crested dinosaur from the Belly River Cretaceous, with provisional classification of the family Trachodontidae. Am Mus N H, B $33: 559-565$, II (1914)

14d Leptoceratops, a new genus of Ceratopsia from the Edmonton Cretaceous of Alberta. Am Mus N H, B $33: 567-580$, il (1914)

15 Tyrannosaurus, the largest flesh-eatIng animal that ever lived. Am Mus J 15 : 271-280, il (1915)

15a Tyrannosaurus, a Cretaceous carniverous dinosaur. Sc Am 113:322-323, il (1915)

15b (with Matthew, W. D.) Corythosaurus, the new duck-billed dinosaur. Am Mus J $15: 427-428$ (1915)

16 A new crested trachodont dinosaur, Prosaurolophus maximus. Am Mus N H, B $35: 701-708$, il (1916)

$16 a$ Corythosaurus casuarius; skeleton, musculature, and epidermis. Am Mus N H, B $35: 709-716$, il (1916)

17 A complete skeleton of the horned dinosaur Monoclonius, and description of a second skeleton showing skin impressions. Am Mus N H, B $37: 281-306$, il (1917)

17 a Monoclonius, a Cretaceous horned dinosaur. Am Mus J 17:135-140 (1917)

18 Samuel Wendell Williston (18521918). Am Mus J 18: 611, port (1918)

Brown, C. Newton.

84 The Meigs Creek coal seam in Morgan, Muskingum, Fuernsey, and Noble cos. Ohio G S, Rp 5:1059-1086, map (1884)

88 The Pittsburg coal seam in Jefrerson. Belmont, and Guernsey cos. Ohio G S, Rp 6:595-626, map (1888)
Brown, C. Newton-Continued.

oo Report upon the mineral wealth of the Big Sandy Valley from Louisa to the head of navigation [Ky.]. U S [War Dp], Chief Eng, An Rp 1900 pt 5 (U S, 56th Cong 2d sess, H R Doc no 2) : 3413-3461 (1900). Also in U S, 56th Cong 1st sess, H R Doc no 326:14-62 (1900)

Brown, Calvin $\mathrm{S}$.

92 Contributions to the coal flora of Tracy City, Tenn. Thesis, Vanderbilt Univ. 31 pp, il, Nashville, 1892

o7 Lignite of Mississippi. Miss G S, B $3: 71 \mathrm{pp}, \operatorname{map}$ (1907)

os The lignite of Mississippi. Ec G 3: 219-223 (1908) Abst, Science n s $27: 727$ (1908)

13 The petrified forest of Mississippi [near Flora]. Pop Sc Mo 83:466-470 (1913)

Brown, Charles L.

88 (with Crosby, W. O.) Gahnite or zine spinel from Rowe, Mass. Tech Q 1: 408 (1888)

Brown, Charles Wilson.

o7 The Jamaica earthquake. Pop Sc Mo $70: 385-493$ (1907) Scottish Geog Mag 23: $535-543$ (1907)

07a (with Smith, G. O.) Description of the Penobscot Bay quadrangle [Me.]. U S G S, G Atlas, fol 149: 14 pp (1907)

10 Preliminary report of the natural resources survey of Rhode Island. R I Bur Industrial Statistics, An Rp 1909 pt 3 (Nat Res S, B 1) : 59-128, maps (1910)

10a Rhode Island coal (abst). G Soc Am, B 21: 783 (1910)

15 (with Hawkins, A. C.) Basic rocks of Rhode Island; their correlation and relationships (abst). G Soc Am, B 26: 92-93 (1915)

Brown, E. Percy.

09 Notes on geological structure at the Richardson mine as shown by the plans and models of the same [Guysborough Co., N. S.]. M S N S, J 13:17-26 (1909)

13 Some characteristics of the gold bearing veins of Nova Scotia. Can M J 34 : $345-347$ (1913)

Brown, Edward.

77 Man, his place in geological time, his origin and date. District Hist Soc [Akron, Ohio], First Report, n. d. [1877 ?]

Brown, F. A.

06 A contribution to Madison County geology. Iowa Ac Sc, Pr 13:203-206 (1906)

Browvn, G. Chester.

15 Mines and mineral resources of Shasta, Siskiyou, and Trinity cos, Cal. Cal St M Bur, Chapters of St Mineralogist's Rp 1913-14: 192 pp (1915)

15a The counties of Shasta, Siskiyou, Trinity. Cal St M Bur, Rp XIV of the State Mineralogist : 745-925 (1916) [separate 1915] 
Brown, G. Chester-Continued.

15b Mines and mineral resources of Kern Co., Cal. Cal St M Bur, Chapters of St Mineralogist's Rp 1913-14, Fresno... counties : 45-104 (1915)

See also Bradley (W W), 15

Brown, Geo. M.

13 The McAlester coal field in Oklahoma.

Coal Age 4:153-155 (1913)

Brown, Gerald Culmer.

85 The apatite deposits of the Province of Quebec (abst) Brit As, Rp 54:716717 (1885)

Brown, Glenn V.

16 Composition of the selensulphur from Hawail. Am J Sc (4) $42: 132-134$ (1916)

$16 n$ The composition of thaumasite from Great Notch, N. J. Am Mineralogist 1:81 (1916)

$16 b$ (with Wherry, E. T.) An American occurrence of miloschite [Ely, Nev.]. Am Mineralogist 1: 63-67 (1916)

17 The composition of seleniferous sulphur. Am Mineralogist 2:116-117 (1917)

17a (with Larsen, E. S.) Gilpinite, a new uranium mineral from Colorado. Am Mineralogist 2:75-79 (1917)

Brown, H. L.

18 (and Fiayward, M. W.) Molybde. num mining at Climax, Colo. Eng M J $105: 905-907$ (1918)

Brown, H. S.

os (and Mudgett, F. G.) The De Lamar mine of southwestern Idaho. Cal J Teeh $12: 35-41$ (1908)

Brown, Harriet Connor.

02 Report on the mineral resources of Cuba in 1901. Civil Report of BrigadierGeneral Leonard Wood, Military Governor of Cuba, January 1st to May 20th, 1902 . vol 5 pt 2: 121 pp [1902?]

Brown, J. F. Kellock.

17 The mining of thin-coal seams as applied to the eastern coal fields of Canada. Can Mines Br, B 15: 135 pp, map (1917)

Brown, Lucius P.

04 Notes on the anthracite of the Sudbury district, Ont. Eng As South, Tr 14 114-116 (1904)

o5 The phosphate deposits of the Southern States. Eng As South, Tr 15: 53-128 (1905)

13 The phosphate deposits of continental North America. Int Cong Applied Chemistry, VIII, 1912, 26:87-117 [1913?]

14 The brown and blue phosphate deposits of south-central Tennessee (discussion). Tenn G S, Res Tenn 4:83-86 (1914)

14a Recent developments in the Tennessee phosphate industry. Tenn Ac Sc, Tr 1:74-80 (1914)

Brown, Lytle.

94 (with Meadows, T. C.) The phosphates of Tennessee. Eng M J 58:365366, map (1894)
Brown, Lytle-Continued.

95 (with Meadows, T. C.) The phos phates of Tennessee. Am I M Eng, If $24: 582-594$, map (1895)

Brown, R.

34 [Coupé géologique du pays entr. Philadelphia et Norristown.] Soc France, B 5:429 (1834)

Brown, R. G.

94 The Georgetown mining district Montana. Eng M J 58:345-346 (1894)

95 The ore deposits of Butte City [Mont.]. Am I M Eng, Tr 24:543-50 map (1895)

97 Vein walls (discussion). Am I y Eng, Tr 26: 1053-1056 (1897)

97a A mineralized dike [Sahuaripa, \& nora, Mex.]. Sch Mines Q 19:90-8 (1897)

\section{Brown, R, Gilman.}

o7 The vein-system of the Standart mine, Bodie, Cal. Am I M Eng, B 16. 587-601 (1907) ; Tr 38: 343-357 (1908)

Brown, R. J.

85 Is a geological survey of the Stat a necessity? Kans Ac Sc, Tr. 9:49-7 (1885)

\section{Brown, Richard.}

29 (and Smith, R.) Geology and mir tralogy of Nova Scotia. In Haliburten T. C., An historical and statistical 8 . count of Nova Scotia, vol $2: 414-454$ Halifax 1829

45 On the geology of Cape Breton. Soc London, Q J 1:23-26, 207-213, mil (1845)

46 On a group of erect fossil trees the Sydney coal field of Cape Breton. Soc London, Q J 2:393-396 (1846)

47 On the gypsiferous strata of Cap Dauphin in the Island of Cape Breton. Soc London, Q J 3:257-260 (1847)

48 Description of an upright Lepidode dron with Stigmaria roots in the roof the Sydney main coal in the Island Breton. G Soc London, Q J 4:46-50,1 (1848)

49 Description of erect Sigillaria with conical tap roots found in the roof of the Sydney main coal in the Island of Cap Breton. G Soc London, Q J 5:354-360, I (1849)

50 Section of the lower Coal Measure of the Sydney coal field in the Island of Cape Creton. G Soc London, Q J 6:115133 (1850)

71 The coal fields and coal trade of th Island of Cape Breton. 166 pp, maps, 1871

Brown, Richard H.

or Record of borehole no. 1 of the Stand ard Coal and Railway Company, Limited about one mile north of Halfway Rire Lake, Cumberland Co., N. S. M Soc N \& J $10: 162-169$ (1907) 


\section{Brown, Robert.}

68 Observations on the Miocene beds of Greenland. Edinb G Soc, Tr 1: 194-196 (1868)

70 on the geographical distribution and physical characteristics of the coal fields of the north Pacific coast. Edinb G Soc, Tr 1:305-325 (1870)

70a On the supposed absence of the northern drift from the Pacific slope of the Rocky Mountains. Am J Sc (2) 50 : 318$324(1870)$

75 Geological notes on the Noursoak Peninsula, Disco Island, and the country in the vicinity of Disco Bay, north Greenland. G Soc Glasgow, Tr 5:55-112, map (1875)

83 Greenland geology. Science 2:539 (1883)

Brown, Robert Marshall.

02 The Mississippi River from Cape Girardeau to the head of the passes. Am Geog Soc, B 34: 371-383 (1902) ; 35 : 8-16 (1903)

02a The clays of the Boston basin. Am J Sc (3) $14: 445-450$ (1902)

02b Gaspee Point; a type of cuspate foreland. J Geog 1:343-352 (1902)

05 Cirques; a review. Am Geog Soc, B 37: 86-91 (1905)

09 The New England geological excursion. Science n s 30:591-592 (1909)

Brown, Ryland Thomas.

54 Geological survey of the State of Indiana. In Ind St Bd Agr, An Rp 3:299 332. Indianapolis 1854

82 Fountain Co.; geology, geography, ete. Ind, Dp G N H, An Rp 11: 89-125, map (1882)

83 Report of a geological and topographical survey of Marion Co., Ind. Ind. Dp G N H, An Rp 12: 79-99 (1883)

84 Geology of Morgan Co. Ind, Dp G $\mathrm{N}$ H, An Rp 13 pt 1: 71-85 (1854)

Sia Geological and topographical survey of Hamilton and Madison cos., Ind. Ind. Dp G N H, An Rp 14 pt 1: 20-40 (1884)

86 [Geology of] Hancock Co. Ind, Dp G N H, An Rp 15: 187-197 (1886)

Brown, Samuel.

09 A description of a cave on Crooked Creek [Madison Co., Ky.], with remarks and observations on nitre and gunpewder. An Ph Soc, Tr 6:235-247 (1809) Am Miner J $1: 100-113$ (1814)

18 On a curious substance which accompanies the native nitre of Kentucky and of Africa. Am J Sc 1: 146-148 (1818)

Brown, Samuel Boardman.

92 The lower coal measures of Monongalia and Preston counties, W. Va. Am G 9: 224-228 (1892)

01 A bibliography of works upon the geology and natural resources of West Virginia from 1764 to 1901 and also a cartography of West Virginia from 1737 to 1901 . W Va G S, B 1: 85 pp, Morgantown 1901
Brown, Samuel Boardman-Continued.

1s The Saltsburg sandstone as a building stone (abst). Science n s $47: 467-468$ (1918)

Brown, Thomas A.

12 The placer mines of Summit County, Colorado, and geological structure thereof. M Science 65:171 (1912)

Brown, Thomas Clachar.

05 A new lower Tertiary fauna from Chappaquiddick Island, Marthas Vineyard, Am J Sc (4) $20: 229-238$, il (1905) Abst, Science n s 21 : 990-991 (1905)

06 Columbia field work in 1905 intercollegiate field courses in geology. Science n s $23: 587-590$ (1906)

o7 Developmental stages in Streptelasma rectum, Hall. Am J Sc (4) $23: 277-284$ (1907)

o7a A new Tertiary fauna from the Atlantic coast province $(a b s t)$. N Y Ac Sc, An 17:596-597 (1907)

o9 Studies on the morphology and development of certain rugose corals. N Y Ac Sc, An 19:45-97, il (1909)

13 Notes on the Silurian limestone of Milesburg Gap, near Bellefonte, Pa. Am J Sc (4) $35: 83-89$ (1913)

$13 n$ Notes on the origin of certain Paleozoic sediments, illustrated by the Cambrian and Ordovician rocks of Center Co., Pa J G 21:232-250 (1913) Abst, G Soc Am, B 24: 112 (1913)

14 Origin of oolites and the oolitic tex. ture in rocks. G Soc Am, B 25:58-59. $745-780 \quad(1914)$

14a The Shawangunk conglomerate and associated beds near High Falls, Ulster Co., N. Y. Am J Sc (4) $37: 464-474$, map (1914)

15 The development of the mesenteries in the zooids of Anthozea and its bearing upon the systematic position of the Rugosa. Am J Sc (4) $39: 535-542$, il (1915)

15n Evolution of the Anthozoa and the systematic position of Paleozoic corals (abst). G Soc Am, B 26:157 (1915)

16 Importance of " coral reefs" and reef deposits in the formation of Paleozoic limestones (abst). G Soc Am, B 27: 147 (1916)

Brown, W. G.

77 Analysis of a new mineral containing niobium from Amherst Co., Va. Ch News $36: 158-159$ (1877)

84 On cassiterite from Irish Creek, Rockbridge Co., Va. Am Ch J 6:185-187 (1884)

85 On a quartz twin from Albemarle Co., Va. Am J Sc (3) 30:191-194 (1885)

91 (with Campbell, H. D.) Composition of certain Mrozolic igneous rocks of Virginia. G Soc Am, B 2:339-348 (1891)

$$
28737^{\circ}-23-10
$$


Browne, David $\mathrm{H}$.

S9 The distribution of phosphorus in the Ludington mine, Iron Mountain, Mich.; a study in isochemic lines. Am I M Eng, Tr 17:616-632 (1889) Am J Sc (3) 37: 299-310 (1889) with title, Isochemic lines in ore deposits, Eng M J $49: 446-448$ (1890)

95 Segregation in ores and mattes (with note by J. F. Kemp). Sch Mines Q 16: 297-312 (1895) Can Rec Sc 7:176-190 (1896)

o6 Notes on the origin of the Sudbury ores. Ec G 1 : $467-475$ (1906)

Browne, John Ross.

67 (and Taylor, James W.) Reports upon the mineral resources of the United States. [U S, Treas Dp] : 360 pp, Wash. ington 1867

68 Report on the mineral resources of the States and Territories west of the Rocky Mountains. [U S, Treas Dp]:674 pp, Washington 1868

69 Resources of the Pacific slope... $678,200 \mathrm{pp}, \mathrm{N}$ Y 1869

Browne, Peter A.

32 On the geological character of the beds upon which the city of Philadelphia stands. Monthly Am J G 1:363-367 (1832)

32a On the rocks found in the vicinity of Philadelphia (abst). Monthly Am J G 1 : 517-519 (1832)

49 Some notice of the fossil Cephalopoda Belemnosepia ... and of the diphospate of iron called "mullicite," found together at Mullica Hill [N. J.]. Am As, Pr 1: 13-16 (1849)

49a Meteorites (abst). Am As, Pr 1: 80-82 (1849)

Browne, Ross E.

84 A criticism of Becker's theory of faulting. Technical Soc Pacific Coast, $\mathrm{Tr}$ 1:159-167 (1884) Am J Sc (3) 28:348354 (1884)

90 The ancient river beds of the Forest Hill divide [Placer Co.]. Cal St M Bur. An Rp 10:435-465, map (1890) Abst, M Se Press $66: 19,33,49$ (1893)

95 California placer gold. Eng M J 59 : 101-102 (1895)

98 The Mother Lode of California. M Sc Press, 76: 105-106 (1898) Also in Callfornia Mines and Minerals (pub. by Callfornia Miners' Association) : 57-72, San Francisco, Cal., 1899

Browning, Philip Embury.

90 Analysis of rhodochrosite from Franklin Furnace, N. J. Am J Sc (3) $40: 375-$ $376(1890)$

17 Caesium and rubidium. Mineral Foote-Notes 1 no $7: 1-3$ (1917)

17a Thallium. Mineral Foote-Notes, 1 no $7: 3-5$ (1917)

17b Indium, gallium, germanium. Mineral Foote-notes 1 no $9: 3-10$ (1917)
Bruce, Adam Todd.

83 Observations upon the brain casts of Tertiary mammals. Princeton Coll, E. y Mus G, Contr, B no $3: 36-45$, il (1883)

Bruce, Archibald (1777-1818).

14 On native magnesia from New Jer sey. Am Miner J 1: 26-30 (1814)

14a Mineralogical notice respecting American fluates of lime. Am Miner J 1: 32-33 (1814)

14b Description and chemical examina tion of an ore of zinc from New Jerser. Am Miner J 1:96-100 (1814)

14e Description of some of the combl. nations of titanium occurring within the United States. Am Miner J I : 233-243 (1814)

14d Emerald. Am Miner J 1:263-265 (1814)

Bruce, Everend Lester.

12 The Swastika gold area. Ont Bur Mines, An Rp 21 pt 1: 256-265 (1912)

12a Cripple Creek gold area [Ont.] Ont Bur Mines, An Rp 21 pt $1: 266-270$ (1912)

14 The Swastika gold area [Canada] Sch Mines Q 35: 154-165 (1914)

14a Microscopic tests on opaque mlnerals. Sch Mines Q 35: 187-193 (1914)

14b Beaver Lake mining distrdet, Sask. Can M J 35:504-505 (1914)

15 Amisk Lake district, northern Sas katchewan and Manitoba. Can G S, Sum Rp 1914: 67-69 (1915)

16 Amisk-Athapapuskow Lake ares, northern Saskatchewan and northern Maniitoba. Can G S, Sum Rp 1915:126-130 (1916)

16a A new gold area in northern Sas. katchewan and Manitoba. Can M Inst, Tr 18: 174-181 [1916]

17 Schist Lake and Wewusko Lake areas, northern Manitoba. Can G S, Sum Rp 1916: 159-169, maps (1917)

17a Geology and ore deposits of Rossland. B C, Minister of Mines, An Rp 1916: 214-244 (1917) B C, Dp Mines, B 4:35 pp (1917)

18 Amisk-Athapapuskow Lake district [Saskatchewan-Manitoba]. Can G S, Mem 105: $91 \mathrm{pp}, \operatorname{map}$ (1918)

18a Schist Lake district, northern Manitoba. Can G S, Sum Rp 1917 pt D:1-8 (1918)

181. Molybdenite near Falcon Lake. Manitoba. Can G S, Sum Rp 1917 pt D: 22-25 (1918)

18e Mining in northern Manitoba. Can M Inst, B 71:262-270 (1918); Tr 21 279-286 [1919]

Brues, Charles Thomas.

o6 Fossil parasitic and phytophagous Hymenoptera from Florissant, Colo. Am Mus N H, B $22: 491-498$, il (1906) 
Brues, Charles Thomas-Continued.

os New phytophagous Hymenoptera from the Tertiary of Florissant, Colo. Harvard Coll, Mus C Z, B $51: 259-276$, il (1908)

0Sa Two fossil Phoridæ from the Miocene shales of Florissant, Colo. Am Mus N H, B $24: 273-275$, il (1908)

08b (and Brues, B. B.) A new fossil grass from the Miocene of Florissant, Colo. [Melica primeva]. Wis $\mathrm{N}$ H Soc, B 6: $170-171$, il (1908)

10 The parasitic Hymenoptera of the Tertiary of Florissant, Colo. Harvard Coll, Mus C Z, B 54:1-125, il (1910)

10a Some notes on the geological history of the parasitic Hymenoptera. N Y Entom Soc, J 18:1-22, il (1910)

Brumbnek, A. M.

os (with Carney, F.) The deposits of glass sand at Toboso, Ohio. Ohio Nat 8: 358-361 (1908)

Brumby, Richard $T$.

39 Mineral resources of Alabama; mineral waters, etc. In [F. A. P. Barnard's] Alabama State Almanac for the year 1839: 65-80. Tuscaloosa [1839?]

Brumell, H. Peareth H.

88 Report on the mining and mineral statistics of Canada for the year 1888. Can G S, An Rp 4: s 93 pp (1888)

88a Natural gas. Can $G \mathrm{~S}$, An $\mathrm{R}_{\mathrm{p}} 4$ : s 71-76 (1888) ; An Rp 7: s 89-93 (1895)

88b Petroleum. Can G S, An Rp 4: s $77-93$ (1888) ; An Rp $5:$ s 120-127 (1893)

92 Report on natural gas and petroleum in Ontario prior to 1891. Can G S, An Rp 5: Q 94 pp, maps (1892)

92a Notes on manganese in Canada. Am G 10:80-88 (1892)

93 Petroleum [in Canada]. Can G S, An Rp 5: ss 120-133 (1893)

93a On the geology of natural gas and petroleum in southwestern Ontario. G Soc Am, B 4:225-240 (1893)

93b Notes on the occurrence of petroleum in Gaspe, Que. G Soc Am, B 4:241244 (1893)

03 Canadian graphite. Fng M J 75 : 485 (1903)

07 Canadian graphite. Can M J 28 no 8 (n s 1 no 6) 163-171 (1907)

08 Modes of occurrence of Canadian graphite. Can M Inst, J 11:236-250 (1908) Can M J 29:70-72 (1908)

09 Occurrence and geology of Canadian graphite. M World 30:933-934 (1909)

Brun, Albert.

13 Note on the lava taken from the Halemaumau pit by Mr. Frank A. Perret in July, 1911, with gas analyses and remarks. Am J Sc (4) $36: 484-487$ (1913)

Bruncken, Ernest.

00 Physiographical field notes in the town of Wauwatosa. Wis N H Soc, B n s 1:95-99 (1900)
Brunton, David William.

88 Aspen Mountain [Colo.]; its ores and their mode of occurrence. Eng M J $46: 22-23,42-45$ (1888)

o5 Geological mine maps and sections. Am I M Eng, Bi-Mo B 5: 1027-1031 (1905) ; Tr 36:508-540 (1906) M Rep 52 : 363-365 (1905) Abst, Eng M J 80 : 337 (1905)

\section{Brunton, Stopford.}

13 Some notes on titaniferous magnetite. Ec G 8:670-680 (1913)

15 Investigation of the occurrence of radioactive minerals in Ontario. Can $\mathbf{G} \mathbf{S}$, Sum Rp 1914: 91-94 (1915)

Brush, George Jarvis (1831-1912).

50 On American spodumene. Am J Sc (2) $10: 370-371$ (1850) Am As, Pr 4: 148-150 (1851) Yale Bicen Pub, Contr Miner : 30-32 (1901)

52 Note on the fluorspar locality of Gallatin Co, Ill. Am J Sc (2) 14:112 (1852)

53 (with Smith, J. L.) Re-examination of American minerals. Am J Sc (2) $15: 207-215 ; 16: 41-53,365-373$ (1853); $18: 372-381$ (1854); $20: 242-253$ (1855)

$\mathbf{5 3 a}$ (with Smith, J. Lawrence) Danburite, a silicoborate of lime. An Sc, Cleveland, $1: 251-252$ (1853)

54 On the chemical composition of clintonite [New York]. Am J Sc (2) 18:407409 (1854)

58 On chalcodite. Am J Sc (2) 25 : $198-201$ (1858)

58a Mineralogical notices. Am J Sc . (2) $26: 64-70 \quad(1858)$

59 On boltonite. Am J Sc (2) 27 : 395-398 (1859)

60 Eighth, ninth, and tenth supplements to Dana's Mineralogy. Am J Sc (2) 29 : 363-383 (1860) ; 31: 354-371 (1861) ; 34 : 202-224 (1862)

62 On amblygonite from Hebron in Maine. Am J Sc (2) 34:243-245 (1862)

62a On the occurrence of triphyline at Norwich in Massachusetts. Am J Sc (2) $34: 402$ (1862)

63 On a variety of galena from Lebanon Co., Pa. Am J Sc (2) 35:126-129 (1863) 63a Arsenids of copper from Lake Superior. Am J Sc (2) $35: 296-297$ (1863)

63b Discovery of childrenite at Hebron in Maine. Am J Sc (2) 36:122-123, 257 (1863)

63e [Examination of meteoric iron from Tucson, Ariz.] Cal Ac N Sc, Pr 3:30-32 (1863)

64 On tephroite. Am J Sc (2) $37: 66-$ $70 \quad(1864)$

66 Mineralogical notices. Am J Sc (2) 41: 246-248 (1866)

66a Report on the mineralogical characters of geodes from the Keokuk limestone. III G S 1:90-96 (1866); Ec G 1:70-74 (1882) 
Brush, George Jarvis-Continued.

67 (and Rodman, C. S.) Observations on the native hydrates of iron. Am J Sc (2) $44: 219-222$ (1867)

6s On sussexite, a new borate from Mine Hill, Franklin Furnace, Sussex Co., N. J. Am J Sc (2) 46:240-243 (1868) Yale Bicen Pub, Contr Miner: 33-36 (1901)

69 (and Blake, J. M.) On hortonolite, a new member of the chrysolite group. Am J Sc (2) 48:17-23 (1869) Yale Bicen Pub, Contr Miner : 37-41 (1901)

69a On durangite, a fluo-arsenate from Durango in Mexico. Am J Sc (2) 48: 179$182(1869)$

69b On the meteoric stone which fell Dec. 5, 1868, in Franklin Co., Ala. Am J Sc (2) $48: 240-244$ (1869)

69c (with Dana, James D.) On the magnetite in the mica of Pennsbury, $\mathrm{Pa}$. Am J Sc (2) 48: 360-362 (1869)

71 On gahnite from Mine Hill, Franklin Furnace, N. J. Am J Sc (3) 1:28-29 (1871) Yale Bicen Pub, Contr Miner : 4244 (1901)

71a On ralstonite, a new fluoride from Arksut Fiord [Greenland]. Am J Sc (3) $2: 30-31$ (1871)

73 On a compact anglesite from Arizona. Am J Sc (3) 5:421-422 (1873)

74 Manual of determinative mineralogy, with an introduction on blowpipe analysis. 104 pp. N Y 1874 14th ed, 163, 63-108 pp, N Y 1896 15th ed, revised by S. L. Penfield, $312 \mathrm{pp}, \mathrm{N}$ Y 1898

76 On the chemical composition of durangite. Am J Sc (3) $11: 464-465$ (1876) Yale Bicen Pub, Contr Miner: 45-47 (1901)

78 (and Dana, E. S.) Notice of three new phosphates from Fairfield Co., Conn. Am J Sc (3) 15: 398-399 (1878)

78a (and Dana, E. S.) Notice of a fourth new phosphate from Fairfield Co., Conn. Am J Sc (3) 15:481-482 (1878)

78b (and Dana, E. S.) On a new and remarkable mineral locality in Fairfield Co., Conn., with a description of several new species occurring there. $\Delta \mathrm{m} \mathrm{J} \mathrm{Sc} \mathrm{(3)} 16$ : 33-46, 114-123 (1878) Zs Kryst 2:529551 (1878) Yale Bicen Pub, Contr Miner : 48-71 (1901)

79 (and Dana, E. S.) On the mineral locality in Fairfield Co., Conn., with the description of two additional new species. Am J Se (3) 17:359-368 (1879) Zs Kryst 3:577-587 (1879) Yale Bicen Pub, Contr Miner : 72-80 (1901)

79a (and Dana, E. S.) On the mineral locality in Fairfield Co., Conn. Am J Sc (3) 18:45-50 (1879) Zs Kryst 4:6975 (1879) Yale Bicen Pub, Contr Miner: $81-85$ (1901)
Brush, George Jarvis-Continued.

so (and Dana, E. S.) On erystallized danburite from Russell, St. Lawrence Co. N. Y. Am J Sc (3) 20:111-118 (1880) Zs Kryst 5: 183-190 (1880)

Soa (and Dana, E. S.) On the mineral locality at Branchville, Conn.; spodu. mene and the results of 1 ts alteration. An J Sc (3) 20:257-285 (1880) Zs Kryst 5: 190-221 (1880) Yale Bicen Pub, Contr Miner : 86-104 (1901)

81 On American sulpho-selenides of mer eury. Am J Sc (3) $21: 312-316 \quad$ (1881 Zs Kryst 5:467-471 (1881)

82 The progress of American mineralogy. Can Nat n s 10:321-338 (1882 Am As, Pr $31: 1-28$ (1883) Pop Sc $\mathrm{M}$ $21: 795-809(1882)$

83 (and Penfield, S. L.) On scovillite, a new phosphate of didymium, yttrium, and other rare earths, from Salisbury, Conn. Am J Sc (3) 25:459-463 (1883) Zs Kryst $8: 226-230$ (1883)

84 (and Penfield, S. L.) On the identity of scovillite with rhabdophane. Am J Sc (3) $27: 200-201$ (1884)

90 (and Dana, E, S.) On the mineral locality at Branchville, Conn. Am J Sc (3) $39: 201-216(1890)^{-}$Zs Kryst 18:723 (1890) Yale Bicen Pub, Contr Miner 105-120 (1901)

See also Dana, 37

Bryan, Kirk.

09 Geology of the vicinity of Albu. querque. N Mex, Univ, B g s 3:1-24, map (1909)

15 Ground water for irrigation in the Sacramento Valley, Cal. U S G S, W-S P $375: 1-49$, maps (1915)

Bryan, Oliver N.

89 The Cretaceous formation of south western Maryland. Am Nat 23:713-714 (1889)

Bryan, St. George T.

77 Analysis of auriferous cobalt ore from Grant Co., Oreg. Ch News 36:167 (1877)

Bryan, William Alanson.

03 A monograph of Marcus Island. Bernice Pauahi Bishop Mus, Honolulu, Occ $\mathrm{P}$ $2: 77-139$ (1903)

Is Report on the diseovery of ancient glaciation on Mount Kea, Hawaii (abst) Science n s $47: 492$ (1918)

Bryant, $H$.

59 [Observations on the Bahama is lands.] Boston Soc N H, Pr 7:85 (1859) Bryant, Harold C.

11 (with Merriam, J. C.) Notes of the dentition of Omphalosaurus. Cal Univ, Dp G, B $6: 329-332$ (1911)

14 Teeth of a cestraciont shark from the upper Triassic of northern California. Cal Univ, Dp G, B $8: 27-30$, II (1914) 
Bryant, Harold C.-Continued.

$14 a$ Vertebrate fauna of the Triassic limestones at Cow Creek, Shasta Co., Cal. (abst). G Soc Am, B 25:155 (1914)

Bryant, J. Owen.

14 The economic geology of a portion of Edmonson and Grayson cos. [Ky.]. Ky G S (4) 2 pt $1: 155-218$ (1914) Also separate 66 pp (1914)

Bryant, J. W.

12 A new copper district [Klehini Valley, B. C.]. M Mag $7: 448-449$ (1912)

Bryant, $W$. L.

15 (with Hussakof, L.) The fauna of the conodont bed (basal Genesee) at Eighteen-Mile Creek, N. Y. (abst). G Soc Am, B 26:154 (1915)

18 (with Hussakof, L.) Catalog of the fossil fishes in the museum of the Buffalo Society of Natural Sciences. Buffalo Soc N Sc, B $12: 346$ pp, il (1918)

\section{Bryee, George.}

91 Surface geology of the Red River and Assiniboine valleys [Manitoba]. Hist Sc Soc Manit, $\operatorname{Tr} 41: 7$ pp (1891)

91a Older geology of the Red River and Assiniboine valleys [Manitoba]. Hist Sc Soc Manit, $\operatorname{Tr} 42: 10$ pp (1891)

97 The Lake of the Woods, its history, geology, mining, and manufacturing. Hist Sc Soc Manit, Tr 49:17 pp (1897)

or Everyman's geology of the three prairie provinces of the Canadian West [Manitoba, Saskatchewan, and Alberta]. 68 pp, maps, Winnipeg 1907

Bryee, P. H.

91 Some points in the natural history of ground waters. Can Inst, $\operatorname{Tr} 1: 149-$ 169 (1891)

\section{Bryson, John.}

83 The glacial phenomena of North America as studied in Long Island, N. Y., U. S. G Mag (2) $10: 169-171$ (1883)

85 The geological formation of Long Island, N. Y., with a description of its old water courses. $18 \mathrm{pp}$, map, N Y 1885

88 [Drift deposits on Long Island, N. Y,]. Am G 2:64-65 (1888)

88a [Eoring on Long Island, N. Y.]. Am G 2:136-137 (1888)

89 Artesian well, Woodhaven, Long Island, N. Y. Am G 3:214-215 (1889)

89a The terminal moraine near Louisville, $\mathrm{Ky} . \quad \mathrm{Am} \mathrm{G} \mathrm{4:125-126} \mathrm{(1889)}$

90 Preglacial channels at the Falls of the Obio. Am G 5:186-188 (1890)

90a The Wetwoods [near Louisville, Ky.]. Am G 6:254-255 (1890)

91 Excursion across Long Island [drift deposits]. Am G $7: 332-333$ (1891)

91a The so-called sand dunes of East Hampton, Long Island, New York. Am G 8: 188-190 (1891)

92 Englacial drift, Long Island, N. Y. Am G $9: 278-280$ (1892)
Bryson, John-Continued.

93 The glacial geology of Marthas Vineyard compared with that of Long Island. Am G 11:210-212 (1893)

$\mathbf{9 3 a}$ The drift mounds of Olympia and of Long Island. Am G 12:127-129 (1893)

93b Origin of Peconic Bay and of Shinnecock Hills [Long Island, N. Y.]. Am G 12 : 402-403 (1893)

94 Lake Ronkonkoma and other glacial features of Long Island [N. Y.]. Am G 13: 390-392 (1894)

95 The ups and downs of Long Island [glacial phenomena] Am G 15:188-192 (1895)

95a Rock Hill, Long Island, N. Y. [drift deposits]. Am G 16:228-233 (1895)

96 Good Ground, Long Island, N. Y. [glacial phenomena]. Am G 18:329-331 (1896)

97 The Hempstead plains, Long Island, N. Y. Am G 20:61-65 (1897)

98 Drift formations of Long Island, N. Y. Am G 22: 245-247 (1898)

Bueh, Leopold von.

49 Betrachtungen über die Verbreitung und die Grenzen der Kreide-Bildungen. Naturh Ver Preus Rheinl, Verh $6: 210-242$ (1849)-

53 [Cretaceons fossils from the Black Hills.] Deut G Ges, Zs 5: 11 (1853)

Buchan, I. S.

00 The rock formation of the Bermudas. Can Rec Sc 8: 219-223 (1900)

o1 Was Mount Royal an active voleano? Can Rec Sc 8: 321-328 (1901)

02 Some notes on Mount Royal [Que.]. Can Rec Sc 8: 517-525 (1902)

o5 The Pleistocene of Montreal and the Ottawa Valley from a railway carriage. Can Rec Sc 9: 190-195 (1905)

14 Mount Royal [Montreal, Can.] once an active volcano. Can Rec Sc $9: 338-\mathbf{3 4 5}$ (1914)

Bucher, Walter $\mathrm{H}$.

16 Study of ripple marks (abst). G Soc Am, B 27:109 (1916)

17 Large current-ripples as indicators of paleogeography. Nat Ac Sc, Pr $3: 285$ 291 (1917)

17a "Giant ripples" as indicators of paleogeography (abst, with discussion by A. W. Grabau and G. H. Cnadwick). G Soc Am, B 28: 161-162 (1917)

18 On oolites and spherulites. J G 26 : 593-609 (1918)

18a Inorganic production of oolitic structures (abst, with discussion by E. G. Woodruff, G. H. Cox, A. R. Crook, and E. V. Emerson). G Soc Am, B 29: 103 (1918)

See also Tomlinson, 18

Buck, C. Elton. See American Bureau of Mines, 67 
Bnek, L. L.

94 A few remarks about the Niagara Gorge. Am Soc Civil Eng, $\operatorname{Tr} 32$ : 205208, map (1894)

Buek, Stuart M.

$\mathbf{8 1}$ Notes on the hard-splint coal of the Kanawha Valley (W. Va.). Am I M Eng, Tr 10:81-85 (1882) The Virginias 2: 136 (1881)

Bueke, Horace W.

07 The meaning of striations [occurrence of ores]. M Sc Press 94: 432 (1907)

Buekhont, William A.

96 An estimate of geological time. Min B $2: 28-37$ (1896)

Buekland, William (1784-1856).

21 [Geological notes on the Great Lakes region.] Am J Sc 4:186 (1821)

31 On the occurrence of the remains of elephants and other quadrupeds in the eliffs of frozen mud in Eschscholtz Bay within Bering's Strait ... In Beechey, F. W., Narrative of a voyage to the Pacific ... : 593-612, 11, L 1831

39 Geology. In The zoology of Captain Beechey's voyage ...: 157-180, maps L 1839 Extract, Geology of the Bay of San Francisco, in Cal St M Bur, B 30:145-147 (1904)

Buckley, Ernest Robertson (1872-1912).

$98 \mathrm{On}$ the building and ornamental stones of Wisconsin. Wis G S, B 4 (ec s 2):544 pp, map, Madison 1898

00 The properties of building stones and methods of determining their value. J G $8: 160-185,333-358$ (1900)

00 a Results of tests of Wisconsin building stone. J G 8:526-567 (1900)

01 The clays and clay industries of Wisconsin. Wis G Sur, B 7 (ec s 4) : 304 pp, map, Madison, Wis., 1901

o1a Ice ramparts (with discussion by C. R. Van Hise). Wis Ac Sc, Tr $13: 141$ 162 (1901)

03 Highway construction in Wisconsin. Wis G S, B 10 (ec s 6) : xvi, 339 pp, Madison, Wis., 1903

03a Biennial report of the State geo'ogist ... $83 \mathrm{pp}$, map, Jeffcrson City, Mo. 1903 Biennial report ... 56 pp, map. Jefferson City, Mo. [1905] Biennial report .. 57 pp, Jefferson City, Mo. [1907]

03b (and Ball, S. H., and Smith, A. F.) Glaclal boulders along the Osage River In Missouri (abst). J G 11:106-107 (1903) G Soc Am, B 14:553 (1904)

04 (and Buehler, H. A.) The quarrying industry of Missouri. Mo Bur G Mines (2) $2: 371 \mathrm{pp}$, maps, Jefferson City, Mo., 1904

04a A system of keeping the records of a State geological survey (abst). Science n s $19: 527$ (1904)

06 (and Buehler, H, A.) The geology of the Granby area. Mo Bur G Mines, (2) 4: $120 \mathrm{pp,} \mathrm{map} \mathrm{[1906]}$
Buckley, Ernest Robertson-Continued.

o7 The geology of the Granby area. Bc G 2: 311-314 (1907)

ora The genesis of the lead and zinc ores of the Mississippi Valley. Ec G 2: $427-433$ (1907)

07b Reviem of Joplin District folio by W. S. T. Smith and C. E. Siebenthal. Ec G 2:518-529 (1907)

o7c Review of Zinc and lead deposits of the Upper Mississippi Valley, by H. P. Bain (U S G S, B 294). Ec G $2: 617-624$ (1907)

07d Public roads, their improvement and maintenance. Mo Bur G Mines (2) 5:124 pp [1907]

os Lead and zinc resources of Missouri. Am M Cong. Rp Pr, 10th An Sess:282297 (1908)

09 Geology of the disseminated lead deposits of St. Francols and Washington $\cos _{\text {, }}$ Mo. Mo Bur G Mines 9 pt 1:259 pp, map (1909)

09a Discussion of paper by C. R. Keyes, Ozark lead and zinc deposits, their genesis, localization, and migration. Am I M Eng B $34: 949-954$ (1909); Tr $40: 856-861$ (1910)

O9b Lead and zinc mining in the Cen tral States in 1907. Ec G 4:175-177 (1909)

10 Discussion of review by F. L. Ransome of paper on The disseminated lead deposits of Missouri. Ec G $5: 192-194$ (1910)

11 Special problems and their study in economic geology (discussion). Ec G 6: 75-77 (1911)

11a Lead and zinc deposits of the Ozark region. In Types of ore deposits (ed. by H. F. Bain) : 103-132 (1911)

$11 \mathrm{~b}$ Geology of the Jarbridge mining district. Nev. M World 45:1209-1210 (1911)

See also Van Horn (F B) : 05

Buckley, Samuel Botsford (1809-1884)

43 ... discovery of a nearly complete skeleton of the Zygodon of Owen (Basilo. saurus of Harlan) in Alabama. Am J Sc 44: 409-412 (1843)

46 On the Zeuglodon remains of Alabama. Am J Sc (2) $2: 125-131$, il (1846)

66 A preliminary report of the geological and agricultural survey of Texas. $81,4 \mathrm{pp}$, Austin 1866

66a Geological resources of Texas. In The Texas Almanac for 1867 (W. Richardson \& Co.) 10: 63-66, Galveston 1866

68 The mineral resources of Texas. Texas Almanac for 1868: 79-82 (1868)

$\mathbf{7 4}$ First annual report of the geological and agricultural survey of Texas. $142 \mathrm{pp}$, Houston 1874

75 Geological resources of Texas. (From Texas Almanac.). In Baker, D. W. C., A Texas scrap book: 488-501, N Y 1875 
Buckley, Samuel Botsford-Continued.

76 Second annual report of the geologfcal and agricultural survey of Texas. 96 pp, Houston 1876

See also Calkins, 09; Van Horn (F B) 05

Buckman, H. O.

11 The chemical and physical processes involved in the formation of residual clay. Am Ceramic Soc, Tr 13:336-384 (1911)

Buekman, S. S.

05 (with Schuchert, C.) The nomenclature of types in natural history. Science n s 21: 899-901 (1905)

06 Brachiopod nomenclature. Seience $\mathrm{n}$ s $24: 742-743$ (1906)

11 A method of removing tests from fossils. Am J Sc (4) $32: 163$ (1911) ; $33: 593-594$ (1912)

Budden, H. A.

84 On the coals of Canada (abst) Brit As, Rp 54: 713-714 (1885) G Mag (3) 1 : 560-561 (1884)

Buddington, Arthur F.

14 Reconnaissance of the Algonkian rocks of southeast Newfoundland (abst). G Soc Am, B 25: 40 (1914)

16 Pyrophyllitization, pinitization, and sllicification of rocks around Conception Bay, Newfoundiand. J G 24:130-152 (1916)

17 Report on the pyrite and pyrrhotite veins in Jefferson and St. Lawrence cos., N. Y. N Y State Defense Council, B no 1 : $40 \mathrm{pp}$ (1917)

18 (and Smyth, C. H., jr.) Lake Bonaparte quadrangle, N Y St Mus B 196:30 32 [1918]

Bieking, H

87 Topas von San Luis Potosi und vom Durango in Mexico. Zs Kryst 12:424 $434,451-452$ (1887)

Buehler, Henry Andrew.

04 (with Buekley, E. R.) The quarry lng industry of Missouri. Mo Bur G Mines (2) 2:371 pp, maps, Jefferson City, Mo., 1904

06 (with Buckley, E. R.) The geology of the Granby area [Mo.]. Mo Bur G M (2) $4: 120 \mathrm{pp}[1906]$

07 The lime and cement resources of Missouri. Mo Bur G Mines (2) 6:255 pp [1907]

09 Biennial report of the State geologist... 59 pp, Jefferson City, Mo. [1909] Biennial report... $68 \mathrm{pp}$, maps, Jefferson City, Mo. [1911] Biennial report... 54 pp, maps, Jefferson City, Mo. [1913] Biennial report... [1913-4], Mo Bur G M: 62 pp, maps (1915) Biennial report... [19156]... : 75 pp (1917)

10 (and Gottschalk, V. H.) Oxidation of sulphides. Ec G 5:28-35 (1910)

12 (with Gottsehalk, V. H.) Oxidation of sulphides (second paper). Ec G $7: 15-34$ (1912)
Buehler, Henry Andrew-Continued.

13 Memoir of Ernest Robertson Buck-

ley, G Soc Am, B 24:44-48, port (1913)

17 Geology and mineral deposits of the Ozark region. Am I M Eng, B 130:16991718 (1917) ; Tr 58:389-408 (1918)

18 The characteristics of zinc deposits of North America (discussion). ¿m I M Eng. B 133: 62-63 (1918)

1Sa Mineral resources of Missouri. Mo Bur G Mines: 34 pp [1918?]

See also Nason, 17

Buell, Ira M.

82 The corals of Delafield. Wis Ac Sc, $\operatorname{Tr} 5: 185-193$ (1882)

93 Geology of the Waterloo quartzite area. Wis Ac Sc, Tr $9: 255-274$ (1893)

95 Boulder trains from the outcrops of the Waterloo quartzite area. Wis Ac Sc, Tr 10:485-509, maps (1895)

11 Notes on fossil Californian Pleurotomidæ. Nautilus 24:142-144 (1911)

Buelna, Ramón Félix.

94 Informe sobre los criaderos de oro del Cerro de los Ocotes del Distrito de Sultepec del Estado de México. Bol Agr Min ê Ind 3 no $7: 229-239$ (1894)

94a Informe sobre la exploración geologica de una parte del Estado de Durango. Bol $\mathrm{Agr}$, Min é Ind 3 no $8: 231-243$ (1894)

97 The Copalquin and Lemon mineral zone, Durango, Mex. Eng M J 64:217 (1897).

97a Estados de Durango, Chihuahua, Sonora, y Sinaloa. Mex I G, B 4-6: 19-29 (1897)

Bumet, Edward P.

03 Some glacial conditions and recent changes on Long Island. J Geog 2: 95-101 (1903)

Bugre, Carl.

10 Petrographische Resultate der 2ten Fram-Expedition. Second Norwegian Arctic Expedition in the Fram, Rp no $22: 38$ $\mathrm{pp}$, map (published by Videnskabs-Selskabet i Kristiania) 1910

Bulkley, Fred G.

85 The separation of strata in folding. Am I M Eng, Tr 13:384-388 (1885)

Bullen, R. Ashington.

11 Some notes on the geology of the Bermuda Islands. G Mag (5) $8: 385-395$, 433-442 (1911)

Bullock, William Starr.

o7 Copper deposits at Ely, Nev. Mines and Minerals 27:518-520 (1907)

Bunbury, Charles J. F.

46 Deseription of Alabama coal plants. Am J Sc (2) 2: 230-233, il (1846)

46a On some remarkable fossil ferns from Frostburg, Md. G Soc London, Q J 2:82-91, il (1846) Abst, Am J Sc (2) 2 : 427-428 (1846)

$46 \mathrm{~b}$ Notes on the fossil plants ... from Nova Scotia. G Soc London, Q J 2:136139 (1846) 
Bunbury, Charles J. F.-Continued.

47 Descriptions of fossil plants from the coal field near Richmond, Va. G Soc London, Q J 3:281-288, il (1847) Abst, Am J Sc (2) $4: 114-115$ (1847)

$47 a$ on fossil plants from the coal formation of Cape Breton. G Soc L, Q J $3: 423-438$, il $(\mathbf{1 8 4 7})$

52 Description of a peculiar fossil fern from the Sydney coal field, Cape Breton. G Soc London, Q J 8:31-35, il (1852)

Bunker, James Madison.

33 Vegetable origin of anthracite, Am J Sc $24: 172-173$ (1833)

Burbank, John Emerson.

o5 Earthquake disturbances recorded on the magnetographs at the observatories of the United States Coast and Geodetic Survey; no. 1. Terr Magn 10:113-124 (1905)

06 (with Bauer, L. A.) The San Francisco earthquake of April 18, 1906. Nat Geog Mag 17: 298-300 (1906)

12 One phase of microseismic motion. Am J Se (4) 33:470-473 (1912)

12a Microseisms caused by frost action. Am J Sc (4) 33:474-475 (1912)

Burbank, Levi Summer (1828-1880)

71 On Eozoỏn canadense in the crystalline limestones of Massachusetts. Am Nat $5: 535-538$ (1871) Am As, Pr 20:262266 (1872)

72 On eozoonal limestones of eastern Massachusetts. Boston Soc N H, Pr 14: 190-193, il (1872)

$\mathbf{7 4}$ Observations on the surface geology of North Carolina, with special reference to some phenomena of the drift of the northern United States. Boston Soc N H, $\operatorname{Pr} 16: 150-155 \quad(1874)$

75 Minerals from Athol, Mass. Boston Soc N H, Pr 17: 181-182 (1875)

76 On the conglomerate of Harvard, Mass. Boston Soc N H, Pr 18: 224-225 (1876)

76a Geology of the Nashua Valley. In Crosby, W. O., Report on the geological map of Massachusetts (Massachusetts Commission to the Centennial Exposition) : 43-52, Boston 1876

Burchard, Ernest Francis.

04 Geology of Dakota Co., Nelur., with special reference to the lignite deposits. Ac Sc Sioux City, Pr 1:135-184, map (1904)

04a Lignites of the middle and upper Missouri Valley. U S G S, B 225:276288 (1904)

05 Iron ores in the Brookwood quadrangle, Ala. U S G S, B 260:321-334 (1905)

06 The requirements of sand and limestone for glass making. U S G S, B 285 : 452-458 (1906)

o6n Glass sand of the middle Mississippi basin. U S G S, B 285:459-472 (1906)
Burchard, Ernest Francis-Continued.

o7 The Clinton or red ores of the Bir. mingham district, Ala. U S G S, B 315 : 130-151 (1907)

07a The brown iron ores of the Russell. ville district, Ala. U S G S, B 315:152160 (1907)

07b Portland cement materials near Dubuque, Iowa.-U S G S, B 315: 225-231 (1907)

07e Glass-sand industry of Indiana, Kentucky, and Ohio. U S G S, B 315: 361-376 (1907)

o7d Notes on various glass sands, mainly undeveloped. U S G S., B 315: $377-382$ (1907)

oze Southern red hematite as an ingredient of metallic paint. U S G \& B $315: 430-434$ (1907)

Ozf Bauxite and aluminum. U S G 8 , Min Res 1906: 501-510 (1907)

o7s Glass sand, sand, and gravel. D S G S, Min Res 1906: 993-1000 (1907)

07h Fluorspar and cryolite. U S G S, Min Res 1906 : 1063-1067; 1907 pt 2 : 637$641 ; 1908$ pt $2: 607-620 ; 1909$ pt $2: 633-$ $638 ; 1910$ pt $2: 703-716 ; 1911$ pt $2: 867-$ $875 ; 1912$ pt $2: 847-853 ; 1913$ pt $2: 373-$ $381 ; 1914$ pt $2: 123-129 ; 1915$ pt $2: 33-$ $41 ; 1916$ pt $2: 309-325 ; 1917$ pt $2: 293-$ 304 (1907-18)

07i Gypsum and gypsum produets. U \& G S, Min Res $1906: 1069-1078 ; 1907$ pt 2 : $643-650 ; 1908$ pt $2: 621-628 ; 1909$ pt 2 : $639-647 ; 1910$ pt $2: 717-733 ; 1911$ pt 2 : $639-644 ; 1912$ pt 2 : $637-649$ (1907-13)

07j Barytes, with a note on strontium. U S G S, Min Res 1906:1109-1114 (1907)

ozk (with Girant, U. S.) Description of the Lancaster and Mineral Point quadrangles [Wis.-Iowa-III.]. U S G S, 6 Atlas, fol 145: 14 pp (1907)

os An estimate of the tonnage of avail able Clinton iron ore in the Birmingham district, Ala. U S G S, B $340: 308-317$ (1908)

OSa Concrete materials produced in the Chicago district. U S G S, B $340: 383-$ 410 (1908) III St G S, B $8: 345-372$ (1908)

08b The Clinton iron-ore deposits in Alabama. Am I M Eng. B 24:997-1055 (1908) ; Tr 40: 75-133 (1910)

ose Barytes and strontium, U S G S. Min Res 1907 pt $2: 685-696 ; 1908$ pt 2 : $669-673 ; 1909$ pt $2: 697-700 ; 1910$ pt 2 : 799-802 (1908-11)

08d Mineral paints. U S G S, Min Res 1907 pt $2: 697-709 ; 1908$ pt $2: 675-696$; 1909 pt $2: 701-720 ; 1910$ pt $2: 803-821$ (1908-11)

o9 Tonnage estimates of Clinton iron ore in the Chattanooga region of Tennessee, Georgia, and Alabama. U S G S, B 380: 169-187 (1909) 
Burchard, Ernest Francis-Continued.

09a Clinton iron ores in the Birmingham district, Ala. (abst). Science n $\mathrm{s} 29$ : $557-558$ (1909)

09b Fluorspar in Colorado. M Sc Press 99:258-261 (1909)

10 Field investigations of structural materials. U S G S, B 430:275-279 (1910) Am I M Eng, B 42:499-503 (1910); Tr $41: 490-494$ (1911)

10a Structural materials available in the vicinity of Minneapolis, Minn. U S G S, B $430: 280-291$ (1910)

10b Structural materials available in the vicinity of Austin, Tex. U S G S, B 430 : 292-316 (1910)

10c (and Butts, Charles) Iron ores, fuels, and fluxes of the Birmingham district, Ala., with chapters on the origin of the ores, by Edwin C. Eckel. U S G S, B 400: 204 pp, map (1910)

11 Gypsum deposits in Eagle Co., Colo. U S G S, B 470:354-365, maps (1911)

$11 a$ (with Darton, N. H.) Fluorspar near Deming, N. Mex. U S G S, B 470 : 533-545 (1911)

11b Fluorspar mining of Rosiclare, III. Eng M J 92: 1088-1090 (1911)

11e Fluorspar in New Mexico. M Sc Press 103: 74-76, map (1911)

11d Iron ore, pig iron, and steel. U S G S, Min Res 1909 pt 1 : 71-99; 1910 pt 1 : 69-102; 1911 pt $1: 119-174 ; 1912$ pt 1 : $147-202 ; 1913$ pt $1: 291-338 ; 1914$ pt 1 : $477-539 ; 1915$ pt $1: 279-342 ; 1916$ pt 1 : 507-564 (1911-8)

11e Manganese ore. U S G S, Min Res 1909 pt $1: 107-119 ; 1910$ pt $1: 103-115$; 1911 pt 1: 191-208 (1911-2)

$11 \mathrm{f}$ Chromic iron ore. U S G S, Min Res 1909 pt $1: 591-593 ; 1910$ pt $1: 769$ 771 (1911)

$11 \mathrm{~g}$ Cement. U S G S, Min Res 1909 pt $2: 433-452 ; 1910$ pt $2: 469-535 ; 1911$ pt $2: 485-519$, map; 1912 pt $2: 503-524$; 1913 pt $2: 117-143 ; 1914$ pt $2: 221-259$; 1915 pt $2: 189-212 ; 1916$ pt $2: 341-375$ (1911-8)

11h Glass sand, other sand, and gravel. U S G S, Min Res 1909 pt 2:519-542; 1910 pt $2: 601-621 ; 1911$ pt $2: 585-638$ (1911-2)

$11 i$ Stone, U S G S, Min Res 1909 pt $2: 569-608 ; 1910$ pt $2: 643-682 ; 1911$ pt $2: 741-833$, maps; 1912 pt $2: 709-818$, maps; 1913 pt $2: 1285-1410$, maps (191114)

12 Granite, marbles, and other building stones of the South. Manufacturers Record 61 no 7 pt $2: 59-60$ (1912)

13 Marble resources of Ketchikan and Wrangell districts [Alaska]. U S G S, B $542: 52-77$, map (1913)

13a The red iron ores of east Tennessee. Tenn G S, B 16:173 pp, maps (1913)
Burchard, Ernest Francis-Continued.

14 (and Emley, W. E.) The source, manufacture, and use of lime. U S G S, Min Res 1913 pt 2: 1509-1593, map (1914)

14a Preliminary report on the red iron ores of east Tennessee, northeast Alabama. and northwest Georgia. D S G S, B 540: 279-328 (1914)

14b Marble resources of the Juneau, Skagway, and Sitka districts, Alaska. U S G S, B 592: 95-107, map (1914)

14c A barite deposit near Wrangell, Alaska. U S G S, B 592:110-117 (1914) M Sc Press 109, 371-374 (1914)

15 Iron ore in Cass, Marion, Morris, and Cherokee cos., Tex. U S G S, B 620 : 69-109, map (1915)

15a Iron-bearing deposits in Bossier, Caddo, and Webster parishes, La. U S G S, B 620: 129-150, map (1915)

See also Adams (G I), 04 ; Eckel, 13

Burekhardt, Carlos.

04 Les masses éruptives intrusives et la formation des montagnes. Soc Cient Ant Alz, Mem 21:5-8 (1904)

o5 (and Sealia, Salvador) La fauna marine du Trias superieur de Zacatecas. Mex I G, B 21: 44 pp, il (1905)

06 (and Scalia, S.) Géologie des environs de Zacatecas. Int $G$ Cong, $X$, Mexico, Guide Exc no XVI : 25 pp, map (1906)

o6a Géologie de la Sierra de Concepción del Oro [México]. Int $G$ Cong, $X, M e x i c o$, Guide Exc no XXIV : 24 pp, map (1906)

06b Géologie de la Sierra de Mazapil et Santa Rosa [México]. Int G Cong, $\mathrm{X}$, Mexico, Guide Exe no XXVI: 40 pp, maps (1906)

06e La faune jurassique de Mazapil avec un appendice sur les fossiles du crétacique inferieur. Mex I G, B $23: 216 \mathrm{pp}$, il (1906)

06d Sobre el descubrimiento del Trias marino en Zacatecas. Soc G Mex, B 2 : $43-45$ (1906)

o7 Sobre las rocas fosforfticas de las sierras de Mazapil y Concepción del Oro, Zacatecas. Mex I G, Par 2:63-67 (1907)

oza Sur le climat de l'époque jurassique. Soc Cient Ant Alz, Mem 25:45-49 (1907)

09 (and Villarello, J. D.) Estudio geológico de los alrededores de una parte del Río Nazas en relación con el proyecto de una presa en el cañon de Fernández. Méx I G, Par 3: 117-135 (1909)

10 Nuevos datos sobre el jurásico y el cretácico en México. Méx I G, Par 3 : 281-301 (1910)

10a Estudio geológico de la región de San Pedro del Gallo, Durango. Méx I G, Par 3:307 $\rightarrow 357$ (1910)

10b Neue Unterschungen über Jura und Kreide in Mexiko. Centralbl Miner 1910: 622-631, 662-667 (1910) 
Burckhardt, Carlos-Continued.

11 Bemerkungen über die russisch-borealen Typen im Oberjura Mexikos und Südamerikas. CentralbI Miner 1911:477483

11 a Schlüsswort zu der Diskussion über die russisch-borealen Typen im Oberjura Mexikos und Südamrerikas. Centralbl Miner 1911: 771-773

11b Remarques sur quelques travaux recents relatifs a des questions de paléoclimatologie. Soc Cient Ant Alz, Mem 31: 107-115 (1911)

12 Faunes jurassiques et crétaciques de San Pedro del Gallo [1Etat de Durango, México] Méx I G, B 29:260 pp, il (1912)

12a Les mollusques de type boréal dans le Mésozoique mexicain et andin. Soc Cient Ant Alz, Mem $32: 79-84$ (1912)

15 Resumen de los conocimientos actuales del terreno jurásico en México. Revista Petrolera 1 no $3: 4-5$ (1915)

\section{Burekhardt, Rudole.}

92 Das Gehirn von Triceratops flabellatus Marsh. N Jb 1892, II : 71-72, il

Burdick, Arthur J.

17 Chemical tests for minerals. $93 \mathrm{pp}$, Beaumont, Cal., Gateway Publishing Company, 1917.

Burdsal, C. W.

96 Cedar Canyon mining district [B. C.]. Mining 1: 191-192 (1896)

Bureau, Ed.

03 Sur une collection de végétaux fossiles des Etats-Unis. Mus d'Hist Nat, Paris, B $9: 250-251$ (1903)

Burgess, J. A.

09 The geology of the producing part of the Tonopah mining district [Nev.]. Ec G 4:681-712, map (1909)

11 The halogen salts of silver and associated minerals at Tonopah, Nev. Ec G 6:13-21 (1911)

17 The halogen salts of silver at Wonder, Nev. Ec G 12:589-593 (1917)

18 [Halogen salts of silver at Wonder, Nev.,] (discussion). Ec G $13: 546-549$ (1918)

Burgess, John D.

o3 secondary enrichment. Eng M J 76: 153 (1903)

03a Recent discoveries in Arizona. [gold, Pinal Co.]. Eng M J 76:936 (1903)

Burk, William E.

01 The fluorspar mines of western Kentucky and southern Illinois. Mineral Industry $9: 293-295$ (1901)

03 Asphalt rock in Kentucky. Eng M J 75: 969-970 (1903)

Burkart, Hermann Joseph (1798-1874).

26 Geognostische Beobachtungen auf Reisen in Mexiko gesammelt. Zs Miner (Leonhard) 1826 , II : 1-35 Arch Bergb IIüttenw $14: 67-92$ (1827)
Burkart, Hermann Joseph-Continued.

27 Geognostiche Beobachtungen auf elner Reise nach dem Nevado (Schnee. berge) oder dem erloschenen Vulkan von Toluca in Mexiko. Arch Bergb Hüttent 14: 93-112 (1827)

28 Ueber die geognostischen Verhält: nisse und die Bergwerke zu Angangeo in Mexiko. Zs Miner (Leonhard) 1827, II: 401-410 (1828)

31 Reise nach den Bergwerksorten ros Ramos, Catorze, und Chareas in dem Staate San Luis Potosi in der Republik von Mer. ico. Arch Miner 3:123-176 (1831)

32 Geognostische Bemerkungen, gesam. melt auf einer Reise von Tlalpujahua nach Huetamo, dem Jorullo, Patzcuaro, und Valladolid, im Staate von Michoacan [Mer. iko]. Archiv Miner (Karsten) 5:159-20" (1832)

33 Ueber die geognostischen Verhält. nisse und Betriebs-Resultate der Silber. bergwerke von Veta grande in der Prorint Zacatecas in Mexico. Arch Miner 6:319342 (1833) ; 8:230-231 '835)

33a Geognostische Bemerkungen ilber die Berge von Santiago östlich von Zaca. tecas im Staate von San Luis Potosi. Arch Miner $6: 413-421$ (1833)

33b Beobachtungen auf einer Reise von Ramos nach Catorze und Bemerkungen ïber die Grube Veta grande. Arch Minet $6: 422-430$ (1833)

35 Ueber die Ausbrüche des Jorullo und des Tustla. N Jb $1835: 36-45$

35 a Deseription du filon et des mines de Veta Grande près de la ville de Zacatecas, dans l'État du même nom au Mexique. As Mines (3) $8: 55-87$ (1835)

36 Aufenthalt und Reisen in Aexico in den Jahren 1825 bis $1834 \quad \ldots \quad 2$ vols, 392 $286 \mathrm{pp}$, maps, Stuttgart 1836

39 Excursion au volcan de Jorullo [en 1827]. Nouvelles Annales des Voyags (3) $22: 92-101$ (1839)

56 Gediegenes Gold und ZInnober as Callfornien, so wie Manganblende und Fallerz aus Mexico. Naturh Ver Preus Rhein Verh (Niederrhein Ges Bonn, Szb) 13 $\mathrm{x} v-\mathrm{xx}$ (1856) Abst, N Jb 1857:461-46:

56a Ueber die Fundorte der bis jett bekannten mexikanischen Meteoreisen-Mar $\operatorname{sen} \ldots \quad N$ Jb $1856: 257-307 ; 1857: 53-$ 54 Naturh Ver Preus Rheinl, Vert (Niederrhein Ges Bonn, Szb) $13: x 1$-xlvil (1856)

57 Ueber die Erscheinungen bel dest Ausbruche des mexicanischen Feuerberge Jorulla im Jahre 1759. Deut G Ges, Zs 9: 274-297 (1857)

57 a Ueber einen neuen Feuerausbruch in dem Gebirge von Real del Monte is Mexico. Deut $G$ Ges, Zs $9: 729-736$ (1857) ; 11:24-26 (1859) 
Burkart, Hermann Joseph-Continued.

5s Ueber die Fundorte der mexikanisch. en Meteoreisen-Massen, als Nachtrag zu den früheren Angaben über diesen Gegenstand, unter Anschluss eines Berichts von Freidr. G. Weidner ïber das Magneteisenstein-Vorkommen an dem Cerro del Mercado bei Durango in Mexiko. N Jb 1858: 769800

59 Untersuchung eines Meteoreisens von Zacatecas in Mexico. Naturh Ver Preus Rheinl, Verh (Niederrhein Ges Bonn, Szb) $16: 84-89$ (1859)

66 Ueber einige neue Fundorte mexicanischer Meteoriten. N Jb 1866:401-408

66a. Ueber einige mexicanische Mineralien. N Jb 1866:409-417

67 Ueber das Vorkommen des Domeykit in Mexico. Naturh Ver Preus Rheinl, Verh (Niederrhein Ges Bonn, Szb) 24:64-67 (1867)

67a Nähere Angaben über die Fundorte des Domeykits und der Manganblende in Mexico. N Jb $1867: 826-828$

65 Die Quaternärschichten des Beckens oder Hochthales von Mexico. N Jb 1868: 513-539

69 Descripcion del distrito de minas de Tlalpujahua y de su constitución geológica. Soc Geog y Estad Rep Mex, B (2) $1: 82-$ 111, map (1869)

69a Der Mineralreichthum Californiens und der angrenzenden Staaten und Territorlen. Berg- u Hütt $\mathrm{Ztg} 28: 3-5,21-22$, $51-52, \quad 83-85, \quad 94-95, \quad 103-104, \quad 198-199$, 212-215, 221-223 (1869)

69b Ueber die geologische Erforschung der central-amerikanischen Republiken Guatemala und Salvador durch A. Dollfuss und E. de Montserrat. N Jb 1869:769807

70 Das Petroleum und seine Production in Nord-Amerlka. Berg- $\mathrm{u}$ Hitt Ztg 29: 373-376 (1870) Abst, N Jb 1871:87-90

70a Die Goldlagerstätten Californiens. N Jb 1870: 21-50, 129-182

$70 b$ Ueber die Fundorte mexicanischer Meteoriten. N Jb $1870: 673-692$

70c Ueber Vulcane in Mexico. N Jb $1870: 880-885$

71 Ueber Fundorte mexicanischer Meteoriten und uber Apatit von Durango. N Jb $1871: 851-855$

72 Ueber den Guadalcazarlt [Mexico]. Miner Mitt (Tschermak) (K-k G Reichsanstalt, Jb 22) $1872: 243-244$ La Natu raleza $3: 236-238$ (1875)

73 Ueber das Vorkommen verschiedener Tellur-Minerale in den Vereinigten Staaten von Nordamerika. N Jb $1873: 476-495$

74 Die Meteoreisenmasse von dem Berge Descubridora bel Poblazon unweit Catorze im Staate San Luis Potosi der Republik Mexico. N Jb 1874: 22-28
Burkart, Hermunn Joseph-Continued.

74a Ueber das Vorkommen verschiedener Tellur- und Wismuth-Minerale in den Vereinigten Staaten von Nordamerika. N Jb $1874: 29-32$

74b Ueber neue mexicanische Fundorte einiger Mineralien. N Jb 1874: 587-599

74e Das Borax-Vorkommen in den westlichen Staaten von Nordamerika. N Jb $1874: 716-720$

75 Examen y clasificación de algunas especies minerales de México. La Naturaleza 3 : 248-253, 288-291, 336-342 (1875)

Burke, Milo Darwin.

88 Drift; its distribution and character in the vicinity of Cincinnati ... Cin Soc N H, J 11:6975 (1888)

Burke, Robert E.

00 (with Burr, H. T.) The occurrence of fossils in the Roxbury conglomerate. Boston Soc N H, Pr 29:179-184, il (1900)

\section{Burleson, Richard.}

74 Report of asisstant State geologist [eastern, northern, and middle Texas]. In Buckley, S. B., First annual report of the geological and agricultural survey of Texas : 120-136, Houston, 1874

Burling, Lancaster D.

09 The landslide at Frank, Alta (abst). Science n s 29: $947-948$ (1909)

10 The mechanical part of a paleontologic monograph (abst). Science n $\mathbf{s} 31$ : $517-518$ (1910)

11 Photographing fossils by reflected light. Am J Sc (4) 31:99-100 (1911)

12 A key to basin-range structure in the Cricket Range, Utah. Science n s $36: 240$ (1912)

12a [The relations of the Sherbrooke formation to the Ordovician in British Columbia]. Wash Ac Sc, J 2:357 (1912)

12b The nomenclature of types. Wash Ac Sc, J $2: 519-520$ (1912)

13 The habitat of the Cambrian Brachiopoda (abst). Wash Ac Sc, J $3: 199$ (1913)

14 Early Cambrian stratigraphy in the North American Cordillera, with discussion of Albertella and related faunas. Can G $\mathbf{S}$, Mus B 2 : 93-129 (1914)

14a Cambrian and related Ordovician Brachiopoda ; a study of their inclosing sediments. G Soc Am, B 25:137, 421-434 (1914)

14b Report [on field and office work]. Can G S, Sum Rp 1913:314-321 (1914)

14e Fossils of the Rocky Mountains Park. Canada, Dp Interior, Dominion Parks Branch, Hundbook of the Rocky Mountains Park Museum : 102-104, Ottawa, 1914.

14d The popularization of paleontology. Am As Mus, Pr 8:92-97 (1914)

15 Shallow-water deposition in the Cambrian of the Canadian Cordillera, Ottawa Nat $29: 87-88$ (1915) 
Burling, Lancaster D.-Continued.

15a (with Kindle, E. M.) Structural relations of the pre-Cambrian and Paleozoic rocks north of the Ottawa and $\mathrm{St}$. Lawrence valleys. Can G S, Mus B 18: 23 pp, maps (1915)

16 Notes on the stratigraphy of the Rocky Mountains Alta, and B C. Can G S, Sum Rp 1915: 97-100 (1916)

16a Ellipsoidal lavas in the Glacier National Park, Mont. J G 24:285-237 (1916)

16b Paedeumias and the Mesonacidae, with description of a new species, having at least 44 segments, from the Lower Cambrian of British Columbia. Ottawa Nat $30: 53-58$, il (1916)

16e The Albertella fauna located in the middle Cambrian of British Columbia and Alberta. Am J Sc (4) 42:469-472, il (1916)

16d Stratigraphy of the Canadian Cordillera (abst). G Soc Am, B 27:158 (1916)

16e New species of Mesonacidae with twenty-nine rudimentary segments posterior to the fifteenth (abst). G Soc Am, B $27: 158-159$ (1916)

17 Downwarping along joint planes at the close of the Niagaran and Acadian. J G 25:145-149 (1917)

17a Protichnites and Climactichnites; a critical study of some Cambrian trails. Am J Sc (4) 44:387-398, il (1917)

17b Was the Lower Cambrian trilobite supreme? Ottawa Nat $31: 77-79$, il (1917)

17. Criteria of attitude in bedded deposits (abst). G Soc Am. B 28:208 (1917)

18 Further light on the earlier stratigraphy of the Canadian Cordillera ( $a b s t$ ). G Soe Am, B 29:145-146 (1918)

18a The A B C of fossils. Ottawa Nat $32: 43-46$ (1918)

$18 b$ (with Drysdale, C. W.) Rocky Mountains section in the vicinity of Whitemans Pass (abst). G Soe Am, B 29:145 (1918)

See also Adams (F D), 16, 17b; Hotchkiss ( W O ) 17

Burnett, Jerome Benjamin.

16 Barite "dollars" from Franklin Co., Nebr. Nebr G S 7:105-111 (1916)

16a Certain Dakota concretions and their mineral contents. Nebr G S $7: 113$ 123 (1916)

Burnham, Sarah Maria (1818-1901).

83 History and uses of limestones and marbles. 392 pp, Boston 1883

Burns, David.

04 On the phenomena accompanying the volcanic eruptions in the West Indies (abst). Brit As, Rp 73:567-568 (1904)

Burns, Frank.

99 Viviparous Miocene Turritellicae. Nautil :s 13:68-69 (1899)
Burns, James A.

87 An outline of the structural, sot face, and economic geology of northwest Georgia. 22 pp, Atlanta, Ga., 1887

Burr, Freeman F.

15 Occurrence of Amazon stone at North White Plains, N. Y. Sch Mines Q 38: 186-188 (1915)

17 Report [on the economic geology Maine]. Me, Public Utilities Commissios An Rp 2:17-103 (1917)

Burr, Henry T.

99 A drainage peculiarity in Andre coggin Co., Me. Am G 24:369-3i! (1899) Abst. Science n 8 9:519 (1899

00 A new lower Cambrian fauna fro eastern Massachusetts. Am G $25: 41-5$ (1900)

Oon (and Burke, R. E.) The ocen rence of fossils in the Roxbury conglow erate. Boston Soc N H, Pr 29:179-184 il (1900)

o1 The structural relations of th amygdaloidal melaphyr in Brookline, Ner ton, and Brighton, Mass. Harvard Col Mus C Z, B 38 (g s 5) : 53-69, map (1901

04 Pbysical geography of the Conneet. cut lowland. Conn School Doc no (1904) whole no 251:17 pp (1904)

Burroughs, Elizabeth Harding.

is Bibllography of petroleum and allit substances, 1915. U S Bur Mines, B 148 $147 \mathrm{pp} \mathrm{(1918)}$

Burroughs, Wilbur Greeley.

10 The petroleum fields of the Unitel States. Eng M J 89:921-924 (1910)

11 The unconformity between the Bet ford and Berea formations of northern obil J G 19: 655-659 (1911)

$11 a$ The formation of petroleum ace mulations. Cassier's Mag 40:597-6 (1911)

13 Economic geology of the Berea sat stone formation of northern Ohio. Ec 8: 469-481 (1913)

13a The Pittsfield oil fleld [Lorain a Ohio] M Mag 9:354-361 (1913)

13b The eoal fields of Ohio. Colliet Fing $33: 544-547$ (1913)

13e The origin of coal. Colliery Eas $34: 271-274$ (1913)

14 Berea sandstone in eroded Clevelast shale. J G 22: 766-771 (1914)

14a The origin of coal. Coll Eng it 351-353 (1914)

14b [Hocking Valley coal field, obial coll Eng 34: 421-424 (1914)

14e The Pittsburgh coal bed. Coal Af $5: 440-442$, map (1914)

Burrows, Alfred Granville.

o7 Eldorado copper mine [Ont.]. Canl J 28 no 5 (n s 1 no 3 ) : 76 (1907)

o9 The Gowganda and Miller lakes sf ver area Ont Bur Mines, An Rp $18 \mathrm{pt}$ ? 1-20, maps (1909) Abst, M World 81 181-183 (1909) 
Burrows, Alfred Granville-Continued.

09a The South Lorraine silver area. Ont Bur Mines, An Rp 18 pt $2: 21-31$ (1909)

11 The Porcupine gold area, Ont. Ont Bur Mines, An Rp 20 pt 2:1-33, maps (1911) Can M Inst, Q B 16:59-62 (1911); J 14 : 203-206 (1912)

12 The Porcupine gold area (second report). Ont Bur Mines, An Rp 21 pt 1: 205-249, map (1912)

13 The Porcupine area [Ont.]. Int $\mathrm{G}$ Cong. XII, Canada, Guide Book no 7:109138 (1913)

13a Annotated guide, Nipigon to Iroquois Falls. Int $\mathbf{G}$ Cong, XII, Canada, Guide Book no 9:159-162, maps (1913)

13b The outlying cobalt-silver areas [Ontario]; South Lorrain silver area; the Gowganda silver area; township of Langmuir, Porcupine area; Otter township. Ont Bur Mines, An Rp 19 pt 2:134-144, 165-186, 195-196, maps (1913)

14 (and Hopkins, Percy E.) The Kirkland Lake and Swastika gold areas and Maisonville, Grenfell, and Eby townships. Ont Bur Mines, An Rp 23 pt 2: 1-39, maps (1914)

15 The Porcupine gold area (third report). Ont Bur Mines, An Rp 24 pt 3 : 1-57, maps (1915)

15a (and Hopkins, P. E.) The Kamiskotia Lake area [Ont.]. Ont Bur Mines, An Rp 24 pt 3:58-60, map (1915)

16 (and Hopkins, P. E.) Boston Creek gold area. Ont Bur Mines, An Rp 25 pt 1 : 244-259 (1916)

16a (and Hopkins, P. E.) Goodfish Lake gold area. Ont Bur Mines, An Rp 25 pt 1:260-263 (1916)

16b (and Hopkins, P. E.) Boston Creek gold area and Goodfish Lake gold area. Ont Bur Mines, B 29:24 pp, maps (1916)

16e (and Hopkins, P. E.) Boston Creek gold area [Ont.]. Can M J 37 : 399402 (1916)

17 Longuelac to Jellicoe and Orient Bay. Ont Bur Mines, An Rp 26:227-247, map (1917)

17a Gold-bearing veins in Benoit township. Ont Bur Mines, An Rp $26: 248-251$ (1917)

17b Gold in Gauthier Township. Ont Bur Mines, An Rp 26: 252-257, map (1917)

18 The Matachewan gold area. Ont Bur Mines, An Rp : 215-240, map (1918) ; B 34 : $30 \mathrm{pp}$, map (1918)

Burrows, John Shober.

04 The Barnesboro-Patton coal fleld of central Pennsylvania. U S G S, B 225 : 295-310 (1904)

08 Mine sampling and chemical analyses of coals tested at the United States fueltesting plant, Norfolk, Va, in 1907. U S G S, B $362: 23$ pp (1908)
Burrows, John Shoher-Continued.

14 Geology and location of the coal fields of Pennsylvania. Coal Age 6:459461, map (1914)

15 The coal fields of Ohio. Coal Age 7 : 124-125 (1915)

15a The coal fields of West Virginia. Coal Age 7:670-672 (1915)

Burrows, R. H.

07 The Lluvia de Oro district, Mexico. M Sc Press 94:664-667 (1907)

09 Geology of northern Mexico. M Sc Press 99: 290-294, 324-327 (1909)

10 Prospecting in Chihuahua. M Sc Press 100:392-393, map (1910)

10a Geology of northern Mexico. Soc G Mex, B 7:85-103, map (1910)

Burt, William A.

46 Topography and geology of the survey of a district of township lines, south of Lake Superior, 1845. U S, 29th Cong 1st sess, S Ex Doc 357:2-19 (1846)

49 Geological report of survey [in Lake Superior region]. U S, 31st Cong 1st sess, $S$ Ex Doc 1 pt 3 and $H$ Ex Doc 5 pt 3 : 811-832, 842-875, 933-935, maps (1849)

See also Houghton $(J), 46$

Burthe, L.

74 Mines de soufre dans l'Etat de Louisiana. Soc Géog, Paris, B (6) 8:433-437 (1874)

Burton, Beverly S.

6S Contributions to mineralogy. Am J Sc (2) $45: 34-38$ (1868)

76 Notice of a meteorite from Madison Co., N. C. Am J Sc (3) $12: 439$ (1876)

Burton, George E.

18 The work of the petroleum geologist. Eng M J 105: 822-824 (1918)

18a New development for oil and gas in Oklahoma during the past year and its geological significance. Am As Petroleum G, B 2:53-59 (1918)

Burwash, Edward Moore Jackson.

97 Geology of the Nipissing-Algoma line. Ont Bur Mines, Rp 6:167-184, map (1897)

05 The geology of Michipicoten Island [Ont.]. Toronto, Univ, Studies, g $s$ no $3: 48 \mathrm{pp}$, maps (1905)

09 Structures in the vicinity of Rogers Pass, B. C. Can Alpine J 2:79-84 (1909)

11 The origin and history of the Selkiks [B. C.]. Can Alpine J 3:121-122 (1911)

14 On some new species of marine invertebrates from the Cretaceous of Queen Charlotte Islands [B. C.]. R Soc Can, Pr Tr (3) 7 , iv: 77-89, il (1914)

$14 a$ Pleistocene vulcanism of the Coast Range of British Columbia. J G 22:260 267 (1914)

14b A review of British Columbia geology. B C Ac Sc, Papers 1910-1914: 61-66 (1914) 
Burwash, Edward Moore Jackson-Contd. 14e The Pleistocene volcanoes of the Coast Range of British Columbia. B C Ac Sc, Papers 1910-1914:67-75, map (1914)

18 The geology of Vancouver and vicinity. $106 \mathrm{pp}$, map, University of Chicago Press, 1918

Burwash, John.

77 Geology of the site of the Belleveau mining operations. N S Inst N Sc, Pr Tr 4: 309-311 (1877)

Bush, B. F.

05 The coal fields of Missouri. Am I M Eng, Bi-Mo B 1: 165-179; Tr 35: 903-917, map (1905)

Bush, E. Renshaw.

94 The Sudbury nickel region. Eng M J $57: 245-246$ (1894)

Bush, Faris V.

14 Phelps-Dodge in the Burro Mountains [N. Mex.]. Eng M J 98:375-377, maps (1914)

15 Mining in the Pinos Altos district of New Mexico. M World 42:165-168 (1915)

15a Red River mining district, Taos Co., N. Mex. M World 42:541-543 (1915)

15b The Steeple Rock mining district, N. Mex. M World 42:845-846 (1915)

15e Meerschaum deposits of New Mexico. Eng M J 99: 941-943 (1915)

Bush, Lucy P.

03 Note on the dates of publication of certain genera of fossil vertebrates. Am J Sc (4) $16: 96-98$ (1903)

Bushnell, D. I., jr.

05 The small mounds of the United States. Science n s $22: 712-714$ (1905)

Bushnell, T. M.

16 (and Erni, C. P.) Soil survey of White Co. Ind, Dp $\mathrm{G} N$ Res, An Rp 40: 109-155, map (1916)

Bushong, F. W.

99 The deep well at Madison, Kans.

Kansas Ac Sc, Tr 16:67-70 (1899) $14 \mathrm{~b}$

See also Johnson ( $\mathrm{R} \mathrm{H}), 15$; Washburne,

Bustamante, I. M.

34 Descripción de la serrania de Zacatecas [Mexico], 1828 y 1829; aumentada y combinada ... por C. de Berghas. 39 pp, Mejico 1834

Bustamante, Miguel.

82 Informe sobre criaderos carboniferos de las Huastecas. México, Ministerio de Fomento, An 7: 538-547 (1882)

98 Estudio sobre algunos criaderos metaliferos del Estado de Michoacán. Min Mex 33 no 6 (1898) [not seen]

06 Ligero estudio sobre los pozos de "El Ebano," explotados por la Mexican Petroleum Co. [petroleum at Ebano, San Luis Potosi, Mexico]. Soc G Mex, B 2: 111-181 (1906)

\section{Bustamante, Miguel-Continued.}

o6n Climas de los tiempos geológicos ? la división en eras (trabajo leído el 19 de octubre de 1906 en la Sociedad geologies mexicana). 28 pp, Mexico 1906

09 Critica y teorias nuevas sobre el período carbontfero. 39 pp, Mexico 1909

11 Observaciones sobre la edad relatim de dos sistemas de vetas que se cortan; consideraciones sobre la formación de los saltos $y$ experiencias para producir en losetas grietas que simulan perfectamente los saltos que se observan en las vetas Inst Mex Minas Met, Inf $2: 222-230$ (1910-11)

18 El petróleo en la República mexicana: estudio geologico económico sobre los yacmientos petrolfferos mexicanos. Méx I $\theta$ B $35: 216 \mathrm{pp}$, maps (1918)

Butler, Bert Sylvenus.

09 The Yakutat Bay region, Alaska petrographic study of rocks. U S G S, P P 64:171-178 (1909)

09a Pyrogenetic epidote. Am J Sc (4) 28: 27-32 (1909)

09b Copper. U S G S, Min Res 1908 t $1: 185-226 ; 1909$ pt $1: 151-180 ; 1910$ pt $1: 155-220 ; 1911$ pt $1: 255-313 ; 1912$ pt $1: 275-334 ; 1913$ pt $1: 523-581 ; 1914$ p $1: 541-596 ; 1915$ pt $1: 655-722$, map 191 pt $1: 623-677(1909-18)$

09e (and Siebenthal, C. E.) Silver, copper, lead, and zinc in the Central States U S G S, Min Res 1908 pt 2: 587-643; 1909 pt 2 : 495-531 (1909-11)

09d (with Tarr, R. S.) The Yakutat Bay region, Alaska. U S G S, P P 64: $183 \mathrm{pp}$ (1909)

11 Geological classification of copper de posits. U S G S, Min Res, 1910, Pt I, pp 159-163 (1911)

$11 a$ (and Schaller, W. T.) Thaums. site from Beaver Co., Utah. Am J Sc (4) 31: 131-134 (1911) Zs Kryst 49:236238 (1911) Abst, Wash Ac Sc J 1:3t (1911)

$11 b$ (and Sehaller, W. T.) Beaverite, a new mineral. Wash Ac Sc, 1:26-27 (1911)

11e (and Schaller, W. T.) Some min erals from Beaver Co., Utah. Am J Sc (4) $32: 418-424$ (1911) Zs Kryst 50:114-119 (1912)

$11 d$ (and Dunlop, J. P.) Silver, cop per, lead, and zinc in the Central States. U S G S, Min Res 1910 pt 1:611-674; 1911 pt $1: 793-872 ; 1912$ pt $1: 437-521$; 1913 pt $1: 81-171 ; 1914$ pt $1: 27-124$ (1911-5)

12 The Morenci-Metcalf district [Ariz.]. M Science 65:154 (1912)

12a Geological classification of coppet deposits. U S G S, Min Res U S, 1911, $t^{t}$ 1. pp 257-262 (1912) 
Butler, Bert Sylvenus-Continued.

12b (and Gale, H. S.) Alunite; a newly discovered deposit near Marysvale, Utah. U S G S, B 511:64 pp (1912) Abst, Wash Ac Sc, J $2: 193$ (1912)

13 Geology and ore deposits of the San Francisco and adjacent districts, Utah. U S G S, P P 80:212 pp, map (1913) d bst, Wash Ac Sc, J $4: 222-223$ (1914)

13a [Notes on the] San Francisco region, Utah, U S G S, B 529:197-199 (1913)

131. Occurrence of complex and little known sulphates and sulpharsenates as ore minerals in Utah. Ec G 8: 311-322 (1913)

14 (and Mecaskey, H. D.) Copper ores of the New London mine [Frederick Co., Ma.]. Am I M Eng, B 91: 1681-1688 (1914); Tr $49: 284-291$ (1915)

14a Geology and ore deposits of the San Francisco and adjacent districts, Utah. Ee G $9: 413-434,529-558$, map (1914)

14b Notes on the Unaweep copper district, Colo. U S G S, B 580: 19-23 (1914)

15 (and Loughlin, G. F.) A reconnaissance of the Cottonwood-American Fork mintng region, Utah. U S G S, B 620 : 165-226, map (1915)

15a Potash in certain copper and gold ores. U S G S, B 620:227-235 (1915)

15b Relation of ore deposits to different types of intrusive bodies in Utah. Ee G 10:101-122 (1915) Abst, Wash Ac Sc, J $5: 407-408$ (1915)

16 (and Heikes, V. C.) Notes on the Promontory district, Utah. U S G S, B 640:1-10 (1916)

17 (and Schaller, W. T.) Magnesioludwigite, a new mineral. Wash Ac Sc, J $7: 29-31$ (1917)

17 a (with Wells, R. C.) Tungstenite, a new mineral. Wash Ac Sc, J $7: 596-599$ (1917)

See also Daly, 15

Butler, Gurdon Montague.

0s A pocket handbook of minerals ... First ed, 298 pp, N Y 1908

09 An outline for the examination of mines from a geological standpoint. Colo Sch Mines, B 5 no 1: 7-14 (1909)

12 Recent developments in geology. Colo Sch Mines Mag 2:93-95, 115-117 (1912) M Science 65:213-214 (1912)

12a The gold of Newlin's Gulch, near Denver, Colo. ... M Science $65: 486-487$ (1912)

12b Some recent developments at Leadville [Colo.]; a Leadville fissure vein. Ec G 7:315-323 (1912) Colo Sch Mines Q 8:1-8 (1913)

12e (with Patton, H. B.) Geology and ore deposits of the Alma district, Park Co., Colo. Colo G S, B 3:284 pp (1912)

13 some recent developments at Leadville; Second paper, The oxidized zinc ores. Ec G 8:1-18 (1913) Colo Sch Mines Q 8:9-21 (1913)
Butler, Gurdon Montague-Continued.

15 The clays of eastern Colorado. Colo G S, B 8:353 pp, maps (1915)

15a Plea for uniformity and simplicity in petrologic nomenclature (abst and discussion). G Soc Am, B 26:134-135 (1915)

16 (and Mitchell, G. J.) Preliminary survey of the geology and mineral resources of Curry Co., Oreg. Oreg Bur Mines, Min Res Oreg no 2:134 pp, map (1916)

18 A manual of geometrical crystallography; treating solely of those portions of the subject useful in the identification of minerals. $155 \mathrm{pp}, \mathrm{N}$ Y 1918

1Sa Handbook of mineralogy, blowpipe analysis, and geometrical crystallography. Contains A pocket handbook of minerals ..., 2d edition, $311 \mathrm{pp}$; Pocket handbook of blowpipe analysis. $\quad . .80 \mathrm{pp}, \mathrm{N}$ Y 1916 ; A manual of geometrical crystallography. ... $155 \mathrm{pp}, \mathrm{N}$ Y 1918

18b (with Allen, M. A.) Manganese. Ariz Univ, Bur Mines, B 91: 32 pp (1918) Butters, R. M.

13 Permian or "Permo-Carboniferous" of the eastern foothils of the Rocky Mountains in Colorado. Col G S, B 5 pt 2: 61-94 (1913)

Buttervorth, Emerson M.

16 A new mustelid from the Thousand Creek Pliocene of Nevada. Cal Univ, Dp G, B $10: 21-24$, il (1916)

Buttram, Frank.

13 The glass sands of Oklahoma. Okla G S, B 10:91 pp, map (1913)

14 Volcanic dust in Oklahoma. Okla G S, B 13:49 pp (1914)

14a The Cushing oil and gas field, Okla. Okla G S, B 18: 107 pp, maps (1914)

Butts, Charles.

o2 Recent structural work in western Pennsylvania (abst). Science n s 15:823 (1902)

03 Fossil faunas of the Olean quadrangle [N. Y.]. N Y St Mus, B 69:990995 (1903)

04 Description of the Kittanning quadrangle [Pa.]. U S G S, G Atlas Kittan ning fol (no 115): 15 pp, maps (1904)

O4a Coal mining along the southeastern margin of the Wilmore basin, Cambria Co., Pa. U S G S, B 225: 325-329 (1904)

05 The Warrior coal basin in the Brookwood quadrangle, Ala. U S G S, B 260: 357-381, map (1905)

O5a Description of the Rural Valley quadrangle [Pa.]. U $\mathrm{S}$ G S, G Atlas Rural Valley fol (no 125): 11 pp, maps (1905)

O5b Description of the Ebensburg quadrangle [Pa.]. U S G S, G Atlas Ebensburg fol (no 133) : $9 \mathrm{pp}$, maps (1905)

06 The Devonian section near Altoona, Pa. J G 14:618-630 (1906) 
Butts, Charles-Continued.

O6a Economic geology of the Kittanning and Rural Valley quadrangles, Pa. U S G S, B 279:198 pp, map (1906)

O6b The Warrior coal basin in the Birmingham quadrangle, Ala. U S G S, B 285:211-222, map (1906)

or Limestone and dolomite in the Birmingham district, Ala. U S G S, B 315 : 247-255 (1907)

07a Sand-lime brickmaking near Birmingham, Ala. U S G S, B $315: 256-258$ (1907)

07b Clays of the Birmingham district, Ala. U S G S, B $315: 291-295$ (1907)

oze The northern part of the Cahaba coal field Ala. U S G S, B 316:76-115 (1907)

os The unconformity between the Mississippian and Pennsylvanian, and its bearing on questions of geologic correlation (abst). Science n s 27: 92-993 (1908)

08a Pre-Pennsylvanian stratigraphy of southwestern Pennsylvania. 2a Top G S Comm, Rp 1906-08: 190-204 (1908)

08b (with Ashley, G. H.) Report of progress on geologic work under the Topographic and Geologic Survey Commission of Pennsylvania. Pa G S, Rp 1906-08; 81-340 (1908)

o9 Ganister in Blair Co., Pa. U S G S. B $380: 3: 7-342$ (1909)

10 Description of the Warren quadrangle, Pa.-N. Y. U S G \$, G Atlas, Warren fol (no 172) : 11 pp, maps (1910)

10a Description of the Birmingham quadrangle, Ala. U S G S, G Atlas, Birmingham fol (no 175) : 24 pp, maps (1910) Abst, Wash Ac Se, J $2: 160-161$ (1912)

10b (with Burehard, Ernest F.) Iron ores fuels and fluxes of the Birmingham district Ala. U S G S, B $400: 204$ pp (1910)

11 The southern part of the Cahaba coal field, Ala. U S G S, B 431: 89-146. map (1911)

$11 a$ Iron ores in the Montevallo-Colum. biana region, Ala. U S G S, B 470:215230, maps (1911)

$11 b$ Variegated marble southeast of Calera, Shelby Co., Ala. U S G S, B 470 : 237-239 (1911)

11e Dolomite for flux in the vicinity of Montevallo, Shelby Co., Ala. U S G S, B 470:525-527 (1911)

12 New dolomite formations in Alabama (abst). Wash Ac Sc, J 2:231 (1912)

13 Contributions to the black shale problem (abst). G Soe Am, B 24:113 (1913)

14 The coal resources and general geology of the Pound quadrangle of Virginia and Kentucky. U S G S, B 541: 165-221, map (1914)

14a The coal resources and general geology of the Pound quadrangle in Virginia. Va G S, B 9:61 pp, map (1914)
Butts, Charles-Continued.

15 Geology and mineral resources of Jefferson Co., Ky. Ky G S (4) 3 pt 2:270 pp, il, map (1915)

16 Mississippian section in west central Kentucky (abst). G Soc Am, B 27:155156 (1916)

16a Structure of the southern part of Cumberland Co., Tenn., in relation to the possible occurrence of ofl and gas. Tenn G S, Res Tenn 6:107-110, map (1916)

16b Faults of unusual character in cen. tral Pennsylvania (abst). Wash Ac Sc, J 6: 251 (1916)

17 Coals in the area between Bon Atr and Clifty, Tenn. U S G S, B 641:307310 (1917)

17a Oil investigations in Illinois in 1916 ; parts of Hardin, Pope, and Saline cos. Ill G S, B 35: 75-78, map (1917)

17b Descriptions and correlation of the Mississippian formations of western Kentucky. Ky G S, Mississippian formations of western Kentucky:119 pp, il, map, Frankfort, 1917.

18 Geologic section of Blair and Hunt. ingdon cos., central Pa. Am J Sc (4) 46: $523-537$ (1918)

18a The country in and around Camp Taylor $[K y]$. [Text on back of topographic man $\mathrm{Kr}$ Camp Taylor and vidin. ity. U S G S 1918

See aiso Ashley, 08a.

\section{Butts, E.}

91 Recently discovered foot prints of the amphibian age in the upper Coal Measure group of Kansas City, Mo. Kansas City Scientist $5: 17-19,44$, il (1891)

91 a A description of a new species of Echinodermata from the upper Coal Meas. ures of Kansas City [Mo.]. Kansas City Scientist $5: 144$, il (1891)

98 Description of some new species of crinoids from the upper Coal Measures of the Carboniferous age at Kansas City Mo. Ae Se Kansas City, Tr 1: 13-15, il (1898) Buvalda, John Peter.

13 Faunal zones of the San Pablo formation east of Walnut Creek, near Mount Diablo, Cal $(a b s t)$. G Soc Am, B $24: 130$ (1913)

14 Pleistocene beds at Manix in the eastern Mohave Desert region. Cal Unir, Dp G, B $7: 443-464$ (1914)

14 a A proboscidean tooth from the Truckee beds of western Nevada. Cal Lniv, Dp G, B 8:305-308, il (1914)

14b Tertiary mammal beds of Stewart and lone valleys in west central Nevada. Cal Univ, Dp G, B $8: 335-363$, maps (1914)

15 Structure of the southern Sierra Ne. vada $(a b s t)$. G Soc Am, B $26: 403$ (1915) 
Buwalda, John Peter-Continued.

16 New mammalian faunas from Miocene sediments near Tehachapi Pass in the southern Sierra Nevada. Cal Univ. Dp G, B $10: 75-85$ (1916) Abst, with discussion by J. C. Merriam, G Soc Am, B 27 : 170 (1916)

16a Note on the geology of the Tejon Hills [Cal.]. Cal Univ, Dp G, B 10:113114 (1916)

17 (with Merriam, J. C.) Age of strata referred to the Ellensburg formation in the White Bluffs of the Columbia River. Cal Univ, Dp G, B 10:255-266 (1917)

Bybee, H. P.

16 (with Udden, J. A.) The Thrall oil field. Tex Univ, B 1916 no $66: 3-78$, map (1916)

Byers, Charles Alma.

$05 \mathrm{~A}$ petrified forest covering thousands of acres. Sc Am 92:388 (1905)

Byers, H. G.

02 (and Ruddy, C. A., and Heine, R. E.) The water resources of Washington. Wash G S 1: 285-320 (1902)

Byler, E. A.

13 (and Davis, L. W.) Topographic model of Cripple Creek district. M Sc Press $107: 144$ (1913)

Byrne, $\mathrm{P}$.

02 Marble formations of the Cahaba River in Alabama. Eng As South, Tr 12 : 48-59, map (1902) Abst, Eng M J 72 : 400 (1901)

10011 and gas prospects in the state of Alabama. Eng As South, Pr 21:167-177 (1910)

C., T. J.

55 The Mastodon giganteus [Ontario]. Can J $3: 405-406$ (1855)

Caballero, Gustavo de J.

02 Le cobalt au Mexique. Soc Cient Ant Alz, Mem 18:197-201 (1902)

03 La domeykita de Chihuahua. Soc Clent Ant Alz, Mem 18: 243-245 (1902) [1903]

03a El vanadio de Charcas, E. de San Luis Potosi, México. Soc Cient Ant Alz, Mem 20:87-98 (1903)

05 Los yacimientos de fierro del $\mathrm{Ca}$ rrizal, Estado de Nuevo León [México]. Soc Cient Ant Alz, Mem 22 : 183-186 (1905) 05a La región geisseriana al $\mathrm{N}$. del Estado de Michoacán [México]. Soc Cient Ant Alz, Mem $22: 203-208$ (1905)

06 Los hervideros de la Sierra de Ozumatlân. Soc G Mex, B 2: 35-41 (1906)

10 Notas geologicas sobre la región norte del Estado de Michoacán. La Naturaleza (3) 1:1-6 (1910) Soc Cient Ant Alz, Mem $30: 215-222$ (1911)

Cable, E. J.

16 Bibllography of the loess. Iowa $\mathrm{Ac}$ Sc, Pr 23:159-162 (1916)

$$
28737^{\circ}-23-11
$$

Cabot, Edward C.

48 [Glacial scratches in Brookline, Mass.] Boston Soc N H, Pr 3:28 (1848)

49 (with Desor, E.) On the Tertlary and more recent deposits in the Island of Nantucket [Mass.]. G Soc London, Q J 5: $340-344$ (1849)

50 [Ripple marks on a rock from Brookline, Mass.] Boston Soc N H, Pr 3:208 (1850)

Cabot, Godfrey L.

08 Pyritic origin of iron ore deposits. Eng M J $86: 630$ (1908)

Cabrera, Raimundo.

98 Mineral resources of Cuba (with discusison by E. V. d'Invilliers and F. L. Garrison). Franklin Inst, J 146:26-45 (1898) Abst, Eng M J $66: 308-309$ (1898) ; Mines and Minerals 19: 158-159 (1898)

Cadell, Henry M.

87 The Colorado River of the West. Scottish Geog Mag 3:441-460, map (1887)

91 A visit to the coal, oil, and anthracite districts of Pennsylvania, August, 1891. M Inst Scotland, Tr $13: 242-262$ (1891)

92 The Yellowstone region and its geysers. Scottish Geog Mag 8:233-248, map (1892)

o7 Some old Mexican volcanoes. Scottish Geog Mag 23: 281-312 (1907)

See also Emmons (S F), 93

14 The Klondike and Yukon gold field in 1913. Scottish Geog Mag 30:337-356, map (1914) Smiths Inst, An Rp 1914: 363-382 (1915)

\section{Cadman, John.}

o5 Cunapo coal field. Trinidad, Legislative Council, Council Paper no 138 of 1905: 4 pp (1905)

os Mineral resources of Trinidad. Inst M Eng. Tr 35:453-475 (1908)

15 Notes on the development of the Trinidad oil fields. Inst Petroleum Tech, J $1: 99-116$ (1915)

Cady, Gllbert Haven.

os Cement-making materials in the vicinity of La Salle. III G S, B 8:128-134 (1908)

10 The geology and coal resources of the West Frankfort quadrangle. III G S, B $16: 244-265$, map (1910)

12 Geological sequence in the vicinity of La Salle [III.] as revealed by recent drilling. Ill Ac Sc, Tr 5: 87-96 (1912)

14 (with Grant, U. S.) Preliminary report on the general and economic geology of the Baker district of eastern Oregon. Oreg Bur Mines, Min Res Oreg 1 no 6 : 129-161 (1914)

15 Coal resources of District I (Longwall) [Illinois]. Ill Coal M Investigations, B $10: 149$ pp (1915)

15a Mineral production of lllinois in 1909 and 1910 . III G S, B $20.19-42$ (1915) 
Cady, Gilbert Haven-Continued.

16 Coal resources of District VI [III.].

In Coal M Investigations, B 15:94 pp (1916)

17 Coal resources of district II (Jackson Co.). Ill G S, Cooperative Coal M S, B 16 53 pp (1917)

17a Geology of the La Salle and Henne. pin quadrangles. III $\mathbf{G}$ S, B 23:55-65 (1917)

17b Lateral erosion in the upper Illinois Valley by the Chicago outlet (abst). III Ac Sc, Tr 9:210 [1917]

17e The New Richmond sandstone of northern Illinois (abst), Ill Ac Sc, Tr $9: 210$ [1917]

18 Starved Rock State Park and its environs; geology, Geog Soc Chicago, B 6 : 85-128, map (1918)

Cahen, Edward.

18 Uranium. Mineral Foote-Notes 2 no 4: 2-11 (1918)

Cahill, Edward G.

04 ... silver-lead mines of Santa Eulalia, Chihuahua, Mex. Cal J Tech $3: 145-149$ (1904)

Cairnes, Delorme Donaldson (1879-1917).

06 [Report on] the foothills of the Rocky Mountains south of the main line of the Canadian Pacific Railway. Can G S, Sum Rp 1905:62-67 (1906)

06a Explorations in a portion of the Yukon south of Whitehorse. Can G S, Sum Rp 1906: 22-30 (1906)

or Moose Mountain district of southern Alberta. Can G S : 55 pp, maps (1907) 2d ed (1914)

07a Recent developments in mining in the southern Yukon. Can M J 28 (n s 1) : 87-88, 121-122 (1907)

os Report on portions of the Yukon Territory, chiefly between Whitehorse and Tantalus. Can G S, Sum Rp 1907:10-15 (1908)

OSa Report on a portion of Conrad and Whitehorse mining districts, Yukon. Can G $\mathbf{S}: 38, \mathrm{pp}$, map (1908)

08b Preliminary geological map of lower Lake Laberge and vicinity, Yukon Territory. Scale 1 mile to 1 inch. Can G S 1908.

o9 Preliminary report on a portion of the Yukon Territory, west of the Lewes River and between the latitudes of Whitehorse and Tantalus. Can G S, Sum Rp 1908: 26-32 (1909) Abst, M Sc Press 99: 29-30 (1909)

10 The Wheaton River district, Yukon Terr. Can G S, Sum Rp 1909:47-60 (1910)

10a Preliminary memoir on the Lewes and Nordenskiöld Rivers coal district, Yukon Terr. Can G S, Mem 5:70 pp, maps (1910)

10b Forestry and the coal areas of the Yukon Terr. Can M J 31:131-132 (1910)
Cairnes, Délorme Donaldson-Continud 10c Antimony deposits in the Yuth Terr. M World 32:1183-1184 (1910) 11 Portions of Atlin district, B. Can G S, Sum Rp 1910:59-89 (1911)

11a The Wheaton River antimony posits, Yukon Terr. Can if Inst, Q B 16 177-188 (1910) ; J $13: 297-308$ (1911)

$11 b$ Canadian tellurium-containing ose Can M Inst, Q B 13:89-104 (1911); $14: 185-202$ (1912) Can M J $32: 215-21$ (1911)

12 Wheaton district, Yukon Terr. (2) G S, Mem $31: x, 153$ pp, maps (1912)

12a Geology of a portion of the Yukt Alaska boundary between Porcupine 2 Yukon rivers. Can G S, Sum Rp 1911 17-33, map (1912)

12b Quartz mining in the Klondiled trict. Can G S, Sum Rp 1911:33(1912)

12c Some suggested new physiographi terms [equiplanation, deplanation, and planation]. Am J Sc (4) $34: 75-5$ (1912)

12d Differential erosion and equiplan. tion in portions of Yukon and Alaska. Soc Am, B 23:333-348 (1912). Aht Science n $8 \quad 35: 318$ (1912)

12e Banded slates of the Orange groat G Soc Am, B 23:424-425 (1912)

$12 f$ The ore and coal-bearing formatin of the Yukon. Can M J 33:407-4: (1912)

12g The Yukon coal fields. Can M ls Tr 15:364-395, map (1912)

13 Portions of Atlin district, B. C: with special reference to lode mining. Car G S, Mem 37:129 pp, map (1913)

13a Yukon and Malaspina, general th troduction (pp 39-40); the Skagwat Whitehorse-Dawson section (pp 51-121 Int G Cong, XII, Canada, Guide Book : 10, maps (1913)

13b Yukon coal fields. Int $G$ Cont XII, Canada, The Coal Resources of th World, 2: 516-520, map (1913)

13e Geological section along the Yukot Alaska boundary between Yukon and Po: cupine rivers (abst). G Soc Am, B 2t 678-679 (1913)

13d The Chisana placer-gold strike th Alaska. M Eng World 39:935-936 (1915

14 The Yukon-Alaska international boud ary, between Porcupine and Yukon rives Can G S, Mem 67:161 pp, maps (1914)

14a Chisana gold fields, Alaska. Co M Inst, B 24:33-64, map (1914): $17: 11-32$, map (1914) M Eng World 4) 559-562 (1914)

14b Geological section along the Yuk0 Alaska boundary line between Yukon at Porcupine rivers. G Soc Am, B 25:17204, map (1914) 
Cairnes, Delorme Donaldson-Continued.

14e Geology of a portion of the YukonAlaska boundary, between Porcupine and Yukon rivers. Can G S, Sum Rp 1912: 9-11 (1914)

14d Upper White River district, Yukon. Can G S, Sum Rp 1913: 12-28, map (1914) 14e The lime belt, Quadra (South Valdes) Island, B. C. Can G S, Sum Rp $1913: 58-75$, map (1914)

15 Upper White River district, Yukon. Can G S, Mem 50:191 pp, maps (1915)

15a Exploration in southwestern Yukon. Can G S, Sum Rp 1914: 10-33, map (1915)

16 Mayo area; Scroggie, Barker, Thistle, and Kirkman creeks; Wheaton district; Yukon Territory. Can G S, Sum Rp 1915: 10-49, maps (1916)

16a The economic possibilities of Yukon. Can M Inst, Tr 18:45-78, map [1916]

17 Scroggie, Barker, Thistle, and Kirkman creeks, Yukon Terr. Can G S, Mem $97: 47 \mathrm{pp}$, map (1917)

17a Investigations and mapping in Yukon Terr. Can G S, Sum Rp 1916:1244 (1917)

$17 \mathrm{~b}$ Investigations in New Brunswick and Nova'Scotia. Can G S, Sum Rp 1916 : 251-260 (1917)

Caldeleugh, Alexander.

36 Some account of the volcanic eruption of Cosiguina in the Bay of Fonseca ... on the western coast of Central America. $\mathrm{Ph}$ Mag (3) 8:414-415 (1836)

Calderón y Arana, Salvador.

82 Los grandes lagos nicaragüenses (en la América central). Soc Española H N, An 11:193-240, map (1882)

07 Sobre los fenómenos de las pegas. Méx, Secretarfa de Fomento, B (2) 6, VI, no $10: 141-158$ (1907) Int $G$ Cong $X$, Mexico, C R : 1187-1200 (1907)

Caldwell, M. M.

09 Lead and zinc ores of Virginia. Mines and Minerals $30: 269-270$ (1909)

Caldwell, William B.

78 Notes on the coal and iron ores of western Kentucky. Ky G S:17 pp [1878] Also in its B 1:46-59 [1879?]

80 Report on the limenite ores of Trigg, Lyon, and Caldwell cos., known as the "Cumberland River ores." Ky G S, Rp, Prog 5 n s: 251-263 (1880) ; Western Coal Field D:179-191 (1884)

Calhonn, Fred Harvey Hall.

06 The Montana lobe of the Keewatin ice sheet. U S G S, P P 50:62 pp, map (1906)

15 Limestone and marl deposits of South Carolina. S C Agr Exp Sta, B 183: 27 pp (1915)

\section{California Academy of Seiences.}

76 Memcrial [on the continuance of the State geological survey]. Cal Ac Sc, Pr 6:206-207 (1876)

\section{California Miners' Association.}

99 California mines and minerals. 450 pp, maps, San Francisco, Cal., 1899

\section{California State Mining Bureau.}

oo Register of mines and minerals, with map [of each of the following counties,

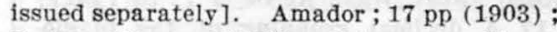
Butte: 13 pp (1903); Calavaras: $50 \mathrm{pp}$ (1900) ; El Dorado: 32 pp (1902); Inyo: 24 pp (1902) ; Kern : 37 pp (1904); Lake : $14 \mathrm{pp}$ (1901); Mariposa : 19 (1903); Nevada: $18 \mathrm{pp}$ [190-] ; Placer : $21 \mathrm{pp} \mathrm{(1902);}$ Plumas: 36 pp (1900) ; San Bernardino: 35 pp (1902) ; San Diego: 15 pp (1902) ; Santa Barbara : 12 pp (1906); Shasta: 27 pp (1902) ; Sierra: 24 pp (1903) ; Siskiyou : 50 pp (1900); Tuolumne: 24 pp (1903) ; Yuba : 20 pp (1905)

os Mineral productions of California. Cal St M Bur, B 53:62 pp (1908)

10 Gold dredging in California. Cal St M Bur, B $57: 312$ pp, maps (1910)

Calkins, Frank Cathcart.

02 A contribution to the petrography of the John Day Basin [Oreg.]. Cal Univ, Dp G, B 3: 109-172 (1902) Abst, Science n s $15: 416-417$ (1902)

03 Soils of the wheat lands of Washington (abst). Science n s 17:669 (1903)

04 (with Smith, G, O.) A geological reconnaissance across the Cascade Range near the forty-ninth parallel. U S G S, B 235: $103 \mathrm{pp}$, map (1904)

05 Geology and water resources of a portion of east central Washington. U S G S, W-S P 118: 96 pp, map (1905)

06 (with Smith, G. O.) Description of the Snoqualmie quadrangle [Wash.]. U S G S, G Atlas, fol 139: 14 pp (1906)

08 (with Ransome, F. L.) The geology and ore deposits of the Cœur d'Alene district, Idaho. U S G S, P P 62:203 pp (1908)

09 A geological reconnaissance in northern Idaho and northwestern Montana. U S G S, B 384: 7-91, map (1909)

Ona Geology and ore deposits of the Cour d'Alene district; discussion of review by E. R. Buckley. Fe G 4:258-261 (1909)

09b Primary seapolite in igneous rocks ( $a b s t)$. Science n s 29:946-947 (1909)

13 Field and office methods in the preparation of geological reports; the Penfield protractor. Ec G $8: 373-376$ (1913)

13a (and Jones, E. L., jr.) Geology of the St. Joe-Clearwater region, Idaho. U S G S, B 530: 75-86, map (1913)

14 (and Jones, E. L., jr.) Economic geology of the region around Mullan, Idaho, and Saltese, Mont. U S G S, B 540: 167211, map (1914)

15 (and Emmons, W. H.) Description of the Philipsburg quadrangle, Mont. U S G S, G Atlas Philipsburg fol (no 196) : $25 \mathrm{pp}$, maps (1915) 
Calkins, Frank Cathcart-Continued.

16 Molybdenite near Ramona, San Diego Co., Cal. U, S G S, B 640: 73-76 (1916) Abst, Wash Ac Sc, J 7:78 (1917)

16a An occurrence of nickel ore in San Diego Co., Cal. U S G S, B 640:77-82 (1916) Abst, Wash Ac Sc, J $7: 78$ (1917)

17 A decimal grouping of the plagioclases. J G 25:157-159 (1917)

Calkins, William Wirt.

77 The geological formations of Lasalle Co., III., and their organic remains. In Baldwin, Flmer, History of Lasalle County, Illinois : 503-513, Chicago 1877

CaI1, Richard Ellsworth (1856-1917).

so Geology and natural history of Fremont Co., Iowa. (Extracted from History of Fremont County.) 37 pp, Des Moines, Iowa, 1880

81 Fossils of the Iowa loess. Am Nat $15: 585-586$ (1881)

S1a The loess in central Iowa. Am Nat $15: 782-784$ (1881)

82 The loess of North America. Am Nat 16:369-381, 542-549 (1882)

82a (with MeGee, W J) On the loess and associated deposits of Des Moines, Iowa. Am J Sc (3) 24:202-223, map (1882)

85 On the Quaternary and recent Mollusca of the Great Basin, with descriptions of new forms. U S G S, B 11:66 pp, 11 (1885)

86 On the genus Campeloma Rafinesque with a revision of the species, recent and fossil. Washburn Coll Lab N H, B 1: 149165, il (1886)

88 On a new post-Pliocene limnaeid [California]. Am G 1: 146-148, il (1888) Abst, Iowa Ac Sc, Pr 1887-9: 17 (1890)

90 The geology of Crowley's Ridge, Ark. (abst). Iowa Ac Sc, Pr 1887-89:52-53 (1890)

90a On the geology of eastern Arkansas (abst). Iowa Ac Sc, Pr 1887-89:85-90 (1890)

91 The geology of Crowley's Ridge. Ark G S, An Rp 1889, 2:1-223, maps, Little Rock 1891

91a The Tertiary silleified woods of eastern Arkansas. Am J Sc (3) 42:394401 (1891) Iowa Ac Sc, Pr 1 pt $2: 37-43$ (1892)

91b A sketch of the physical geography of Iowa. Iowa Weather and Crop Service, An Rp 1890:12-18, map (1891)

91e The cost of a geological survey of Iowa. U S Dp Agr, Weather Bur, Mo Rv Iowa Weather and Crop Service 2 no 3 : 2-3 (1891)

91d Preliminary paper on artesian wells in Iowa. Mo Ry Iowa Weather and Crop Service 2 no 4:1-6 (1891)

92 Artesian wells in Iowa (abst). Iowa As Sc, Pr 1 pt 2:57-63, map (1892) Science $19: 310-311$, map (1892)
CaI1, Richard Ellsworth-Continued.

92n Iowa artesian wells. Mo Rv Ioms Weather and Crop Service 3 no $3: 1-15$, map (1892)

$92 b$ (with Keyes, C. R.) On a Qus. ternary section eight miles sontheast of Des Moines, Iowa. Iowa Ac Sc, Pr 1 pt 2: 30 (1892)

94 On the Induration of certain Tertiar rocks in northeastern Arkansas. Ind Ac Sc, Pr 1893: 219-224, map (1894)

97 The evolution of the map of Mam moth Cave, Ky. Ind Ac Sc, Pr 1896:4655 , maps (1897)

97a (with Hovey, H. C.) Mammoth Cave of Kentucky ... 112 pp, Louisville 1897

oo Some preliminary notes on crystal growths in Mammoth Cave (abst). Selence n s 11:750 (1900)

14 (with Hovey, H. C.) Bibliographle chronologique et analytique de Mammoth Cave, Ky., Etatg-Unis d'Amérique, 18151914, traduite et ordonnée par E. A. Martel. Speluṇca 9:3-49 (1914)

Callaway, Charles.

76 The geological evidence of the origin of species by evolution. Albany Inst, $T$ t $8: 207-214$ (1876)

78 On the correlation of the Lower Helderberg group of New York. G Mag (2) $5: 271-277$ (1878)

78n [General observations on the geolog of New York.] Albany Inst, Pr 2:41-43 (1878)

87 On parallel structure in rocks as is dicating a sedimentary origin [see also Dana 81]. G Mag (3) 4:351-354, 479 (1887)

94 Is granite ever metamorphlc? Scence $23: 157$ (1894)

Callen, Alfred C.

10 (with Stoddard, J. C.) Ocher de posits of eastern Pennsylvania. U S G \&, B $430: 424-439$ (1910)

Callender, John A.

54 The Lake Superior copper mines, I Mag 2: 249-253 (1854)

Callinan, John W.

17 Flin-Flon Lake copper district [Mant. toba]. Eng M J 103:303-304 (1917)

Calvert, Jobn.

54 On the decomposition of rocks and the re-composition of their metallic cors stituents. M Mag 3:371-376 (1854) Abst, Can J 3:39 (1854)

Calvert, Philip $P$.

13 The fossil odonate Phenacolestes, with a discussion of the ranation of the legion Podagrion Selys. Ac Nat Sc Pbila, Pr 65:225-272 (1913)

18 Eruptions of the Costa Rican voleano Irazu in 1917-18. Ac N Sc Phila, Pr 70: 73 (1918)

Calvert, William $\mathrm{R}$.

09 The Lewistown coal field, Mont. $\square$ S G S, B 341: 108-122, map (1909) 
Calvert, William R. Continued.

09a Geology of the Lewistown coal field, Mont. U S G S, B 390:83 pp, map (1909)

10 (with Stone, R. W.) Stratigraphic relations of the Livingston formation of Montana. Ec G 5: 551-557, 652-669, 741764 (1910)

11 Land classification, its basis and methods. Ec G 6:473-492 (1911)

12 Geology of certain lignite fields in eastern Montana. U S G S, B 471; 187201, map (1912)

12a The L.ivingston and Trail Creek coal fields, Park, Gallatin, and Sweetgrass counties, Mont. U S G S, B 471:384-405, map (1912)

12b The Electric coal field, Park Co., Mont. U S G S, B 471:406-422, map (1912)

14 (and others) Geology of the Standing Rock and Cheyenne River Indian reservations, N. and S. Dak. U S G S, B 575 : 49 pp, maps (1914) Abst, Wash Ac Sc, J $4: 425$ (1914)

14a (with Fisher, C. A.) Geology of the Bering River field and its relations to coal mining conditions. U $\mathrm{S}$ 63d Cong. 2d Sess H R Doe 876: 29-50, maps (1914)

16 Geology of the upper Stillwater basin, Stillwater and Carbon cos., Mont., with special reference to coal and oil. U S G S, B 641: 199-214, maps (1916) Abst, by R. W. S., Wash Ac Sc, J $7: 135$ (1917)

Calvin, Samuel (1840-1911).

78 On some dark shale recently discovered below the Devonian limestones, at Independence, Iowa: with a notice of its fossils and description of new species. U S G Geog S Terr (Hayden), B 4:725730 (1878) In part, Am J Se (3) 15: $460-462$ (1878)

81 A piece of coal. Pop Sc Mo 18: $610-624$, il (1881)

83 On the fauna found at Lime Creek. Iowa, and its relation to other geological faunas. $\mathrm{Am} \mathrm{J} \mathrm{Sc} \mathrm{(3)} 25: 432-436$ (1883)

85 Iowa : notes on the geological formations. World's Exposition at New Orleans [1884-5]. 8 pp [n p, nd, 1885?]

85a Fragments of geological history ; Johnson Co. [Iowa], Iowa Hist Rec 1: 100-106 (1885)

88 On a new genus and new species of tubleolar Annelida [Iowa]. Am G 1:2428 (1888)

88 a Notes on the formations passed through in boring the deep well at Washington, Iowa. Am G 1:28-31 (1888)

$\mathbf{8 8 b}$ Observations on the vertical range of certain species of fossils of the Hamilton period, in western Ontario. Am G $1: 81-86$ (1888)

88e on the chert of the upper Coal Measures in Montgomery County, Iowa. Am G 1:116-117 (1888)
CaIvin, Samuel-Continued.

s8d Some geological problems in Muscatine County, Iowa, with special reference to the rectification of the supposed Kinderhook near the mouth of Pine Creek. Iowa Univ, Lab N H, B 1:7-18 (1888) Am G 3:25-36 (1889)

s8e Notes on the synonymy, characters, and distribution of Spirifera parryana, Hall. Iowa Univ, Lab N H, B $1: 19-28$ (1888)

s8f Description of a new species of Spirifer from the Hamilton group, near Iowa City, Iowa. Iowa Univ, Lab $\mathrm{N} \mathrm{H}$, B $1: 28-29$ (1888)

89 Iron Butte, Montana. Am G 4:9597 (1889)

90 Note on a specimen of Conularia missouriensis Swallow, with crenulated costae. Am G 5:207-208 (1890)

90a Some new species of Paleozoic fossils. Iowa Univ, Lab N H, B 1:173-181, il (1890)

91 Additional notes on the Devonian rocks of Bucbanan Co., Iowa. $\mathrm{Am} \mathrm{G} \mathrm{8:}$ 142-145 (1891) ; $9: 345$ (1892)

91 a Section on west side of Wapsipinicon River, about one-quarter mile below the dam at Littleton, Iowa. N Y St G, An Rp 10:99 (1891)

92 Note on the differences between Acervutaria profunda $\mathrm{Hall}$ and Acervularia davidsoni Edwards and Haime. Am G 9: 355-358 (1892) Iowa Ac Sc, Pr 1 pt 2: $30-32 \quad(1892)$

92a Report on some fossils collected in the Northwest Terr., Can. Iowa Univ, Lab N H, B 2: 163-165 (1892)

92b Two unique spirifers from the Devonian strata of Iowa. Iowa Univ, Lab N H. B 2: 165-167, il (1892)

92e A geological reconnaissance in $\mathrm{Bu}$ chanan Co., Iowa. Iowa Univ, Lab $\mathrm{N}$ H, B 2: 177-189 (1892)

$92 d$ Notes on a collection of fossils from the Lower Magnesian limestone from northeastern Iowa. Am G 10:144-148 (1892) Iowa Univ, Lab N H, B 2:189-193 (1892)

02e Prehistoric Iowa. Iowa Historical Lectures : 5-29 (1892) [Not seen]

93 The relation of the Cretaceous deposits of Iowa to the subdivisions of the Cretaceous proposed by Meek and Hayden. Am G 11:300-307 (1S93) Iowa Ac Sc, Pr 1 pt $3: 7-12$ (1893)

$93 a$ on the structure and probable affinities of Cerionites dactylioides owen. $\mathrm{Am} \mathrm{G} 12: 53-57$, il (1893) Iowa Ac Sc, Pr 1 pt $3: 13-15$ (1893)

931 ... fossil corals described by David Dale Owen ... with observations on the Devonian species Plillipsastrea gigas of later authors. Am G 12:108-112, il (1893) 
Calvin, Samuel-Continued.

93e First annual report of the State geologist [administrative]. Iowa G S 1, An Rp $1892: 3-5$, Des Moines, 1893 . Second annual report ... $3: 19-27 \quad$ (1895) Third annual report $\ldots .4: 19-26 \quad$ (1895) Fourth annual report ... 5: 11-25 (1896) Fifth annual report ... $7: 11-27$, map [also in v. 6] (1897) Sixth annual report ... 8: 11-23, maps (1898) Seventh annual report ... 9:11-24 (1899) Eighth annual report ... 10:11-27, map (1900) Ninth annual report ... 11:11-30, map (1901) Tenth annual report ... 12: 11-27 (1902) Eleventh annual report ... 13:11-13 (1903) Twelfth annual report ... 14:3-6, maps (1904) Fifteenth annual report ... 17: 1-6 (1907) Sixteenth annual report ... 18: 1-5 (1908) Seventeenth annual report ... $19: x i-x v i$, map (1909) Eighteenth annual report ... $20: x i-x v$ (1910)

93d Cretaceous deposits of Woodbury and Plymouth cos., with observations on their economic uses. Iowa G S 1, An Rp 1892: 145-161 (1893)

94 On the geological position of Bennettites dacotensis Macbride, with remarks on the stratigraphy of the region in which the species was discovered [Black Hills, South Dakota]. Am G 13:79-84 (1894) Iowa Ac Sc, Pr 1 pt 4:18-22 (1894)

94a on a new horizon and some new localities for friable sandstone in which the grains are enlarged by secondary deposition of silica in optical continuity with the original nucleus. Am G 13: 225-227 (1894)

94b The Niobrara chalk. Am G 14: 140-161 (1894) Am As, Pr 43:197-217 (1895)

95 Composition and origin of Iowa chalk. Iowa G S $3: 211-236$, il (1895)

95a Geology of Allamakee Co., Iowa. Iowa G S 4:35-120, map (1895) Abst, J G $3: 978-979$ (1895)

95b Maquoketa shales in Delaware Co. [Iowa] (abst). Iowa Ac Sc, Pr 2: 40-42 (1895)

95e Some Iowa dolomites. U S Dp Agr, Weather Bur, Mo Rv Iowa Weather and Crop Service 6 no 10:8-9 (1895)

95d The soils of northeastern Iowa, their history and genesis. U S Dp Agr, Weather Bur, Mo Rv Iowa Weather and Crop Service 6 no $11: 7-9$ (1895)

95e The Switzerland of Iowa. Midland Mo $3: 403-414$ (1895)

96 Geology of Jones Co. Iowa G S 5 : 33-112, map (1896)

96a The Leclaire limestone. Iowa Ac Sc, $\operatorname{Pr} 3: 52-58$ (1896) Iowa Univ, Lab N H, B 3 : 183-189 (1896)

96b The Buchanan gravels; an interglacial deposit in Buchanan Co., Iowa. Am G $17: 76-78$ (1896) Iowa $\Delta c$ Sc, $\mathrm{Pr} 3$ : 58- 60 (1896)
Calvin, Samuel-Continued.

96e Apparent anomalies of stratification in the Postville well [Iowa]. Am G17: 195-203 (1896)

96d The Cedar Valley quarry [Iowa]. Eng M J 61 : $544-545$ (1896)

96e The Devil's Backbone [Delawart Co., Iowa]. Midland Mo 6:20-26 (1898) 97 Geology of Johnson Co. Iowa $G$ s $7: 33-104$, maps (1897)

97a Geology of Cerro Gordo Co. In: G S $7: 117-195$, maps (1897)

$\mathbf{9 7 b}$ The State quarry limestone [Iows] Iowa Ac Sc, Pr 4;16-21 (1897)

97e [On the subdivision of the drift it posits of Iowa.] Iowa Ac Se, $\operatorname{Pr} 4: 66-6$; (1897)

97d Memoir of Charles Wachsmuth. $\theta$ Soc Am, B 8: 374-376 (1897)

97e Synopsis of the drift deposits $d$. Iowa. $A \mathrm{~m}$ G $19: 270-272$ (1897) Iоตี G S $7: 17-19$ (1897)

$97 \mathbf{f}$ Pleistocene Iowa. Annals of Iow (3) $3: 1-22$, map (1897)

98 Geology of Delaware Co. Iowa 68 $8: 119-192$, map (1898)

98a Geology of Buchanan Co. Iowa $\theta$ S 8:201-253, map (1898)

98b The interglacial deposits of nott eastern Iowa (abst) Iowa $\mathrm{Ac} \mathrm{Sc}, \mathrm{Pt} 5$ 64-70 (1898) Am G 21:251-254 (1898

98e Iowa geology from an engineeris point of view. Iowa Eng Soc, Pr 10:8996 (1898)

98d Prehistoric Iowa; the relation of prehistoric events to soil-making. Ior: St Horticultural Soc, Rp $32: 183-184$ (1898)

99 Iowan drift. G Soc Am, B 10:10\%120 (1899)

99a A notable ride from driftless ate to Iowan drift [Iowa]. Am G 24:37\% 376 (1899) Iowa Ac Sc, Pr $7: 72-\pi$ (1900)

99b What glaciers have done for Iort Annals of Iowa (3) $4: 138-142$ (1899)

00 (and Bain, H. F.) Geology of Dr buque Co. Iowa G S $10: 379-622$, mas (1900)

01 Geology of Page Co. Iowa G S 11: $397-460$, map (1901)

O1a Concerning the occurrence of goll and some other mineral products in Iom Am G $27: 363-372$ (1901)

01b The geology and geological it sources of Iowa. Int M Cong, 4th, Pr: 52-56 (1901) Mines and Minerals 22: $560-561$ (1902)

02 Concrete examples from the topos raphy of Howard Co., Iowa. Am G 30: 375-381 (1902)

O2a The geological formations of lowi Stone 25:118-124 (1902)

02b Artesian wells i: Iowa. Iowa It stitutions, B 4:402-408 (1902)

o3 Geology of Howar! Co. Iowa G 8 $13: 21-79$, maps (1903) 
Calvin, Samuel-Continued.

03a Geology of Chickasaw Co. Iowa G S 13:255-292, map (1903)

03b Geology of Mitchell Co. Iowa G S $13: 293-338$, map (1903)

03e Physiography of Iowa. Iowa Weather and Crop Service, An Rp 1902: App 3-11 (1903)

05 The Aftonian gravels and their relations to the drift sheets in the region about Afton Junction and Thayer [Iowa]. Davenport Ac Sc, Pr 10:18-31 (1905)

06 Geology of Winneshiek Co. [Iowa]. Iowa G S 16 : 37-146, maps (1906)

06a Notes on the geological section of Iowa. J G 14:571-578 (1906) Iowa G S $17: 192-200$ (1907)

07 Some features of the channel of the Mississippi River between Lansing and $\mathrm{Du}$ buque, and their probable history. Iowa Ac Sc, Pr 14: 213-220 (1907)

09 Geology and revelation; an address... $27 \mathrm{pp}$, port (of the author), privately printed for the students of the Lakeside Laboratory 1909

09a Present phase of the Pleistocene problem in Iowa. G Soc Am, B 20: 133152 (1909)

09b Aftonian mammalian fauna. G Soc Am, B $20: 341-356$ (1909)

09e The work of the Iowa geological survey (president's address). Iowa $\mathrm{Ac} \mathrm{Sc}$ Pr 16:11-18 (1909)

09d Bone beds in western Iowa. Iowa Nat 2:62-65 (1909)

10 The Aftonian age of the Aftonian mammalian fauna. Iowa Ac Sc, Pr 17: 177-180 (1910)

10a Adequacy of the paleontologic record. Pop Sc Mo 76:582-586 (1910)

11 Aftonian mammalian fauna, II. G Soc Am, B 22: 207-216 (1911)

11a The Iowan drift. J G 19:577602 (1911) Abst, G Soc Am, B 22:729730 (1911)

See also Chamberlin, 02 ; Salisbury, $98 \mathrm{~b}$. Camacho, Heriberto.

10 Interpretación de algunos diagramas de temblores de focos cercanos al $S$. de Tacubaya, D. F. Soc G Mex, B $7:$ iii-v (1910), 187-199 (1911)

13 (with Urbina, F.) La zona megasefsmica Acambay-Tixmadeje, Estado de México, conmovida el 19 de noviembre de 1912. Mex I G, B 32: 125 pp (1913)

17 Captación de aguas potables en el mineral de Jacala. Mex I G, An 4: $39-47$ (1917)

Camacho, L. A.

97 A 150 feet well in the soapstone [Staten Island, N. Y.]. N Sc As Staten Island, $\operatorname{Pr} 6: 45$ (1897)
Cameron, A.

S1 Notes on the geology of Point Pleasant. $N$ S Inst $N$ Sc, $\operatorname{Pr}$ Tr 5:307-309 (1881)

Cameron, A. E.

17 Reconnaissance on Great Slave Lake, Northwest Teritories. Can G S, Sum Rp 1916: 66-76 (1917)

Is Explorations in the vicinity of Great Slave Lake. Can G S, Sum Rp 1917 pt C : $21-28$ (1918)

Cameron, Frank K.

10 The composition of the soil solution (abst). Science n s 32:62-63 (1910)

12 (and others) A preliminary report on the fertilizer resources of the United States. U S $62 d$ Cong $2 d$ sess S Doc no $190: 290 \mathrm{pp}$, maps (1912)

Cameron, J. M.

11 The Cranberry iron-ore mine; large deposit of high grade magnetite [Iron Mountain, Mitchell Co., N. C.]. Mines and Minerals 32:42-44 (1911)

Cameron, R. Clyde.

13 Graphical determination of dip and strike. M Sc Press 106:814-815 (1913)

Camp, Charles Lewis.

16 (with Merriam, J. C.) Recent studies on skull structure of Thalottosaurus (abst). G Soc Am, B 27:171 (1916)

17 An extinct toad from Rancho La Brea. Cal, Univ, Dp G, B $10: 287-292$, il (1917)

Campbell, A. C.

so Ore deposits. Eng M J $30: 39-40$ (1880)

Campbell, C. M.

02 Mining in the Rossland district [B. C.]. Can M Inst, J $5: 447-483$ (1902) Can M Rv 21: 183-194 (1902)

Campbe11, Donald F.

06 The iron ore of Shasta Co., Cal. M Sc Press 93:603 (1906)

o7 The copper of Shasta Co., Cal. M Sc Press 94: 28-30, 55-58 (1907)

Campbell, F. W.

18 (with Whitaker, W. A., and Estes, C.) The petroleum industry in Kansas. Eng M J 105: 817-821 (1918)

Campbell, Henry Donald.

84 (with Campbell, J. L.) The Snowdon [Amherst Co., Va.] slate quarries. The Virginias 5:162-163, map (1884)

85 The Potsdam group east of the Blue Ridge at Balcony Falls, Va. Am J Sc (3) 29:470-474 (1885) The Virginias 6:99$100(1885)$

S5a (with Campbell, J. L.) William B. Rogers' Geology of the Virginias; a review, $\mathrm{Am} \mathrm{J} \mathrm{Sc} \mathrm{(3)} 30: 357-374$ (1885) ; $31: 193-202$ (1886)

91 (and Brown, W. G.) Composition of certain Mesozoic igneous rocks of Virginia (with discussion by W. M. Davis and others). G Soc Am, B 2:339-348 (1891) 
Campbell, Henry Donald - Continued.

96 (with Howe, J. L.) Examination of specimens from Chichan-Kanab, Yucatan. Am J Sc (4) 2:413-415 (1896)

o3 (and Howe, J. L.) A new (?) meteoric iron from Augusta Co., Va. Am $\mathrm{J}$ Se (4) $-15: 469-471$ (1903)

05 The Cambro-Ordovician limestones of the middle portion of the Valley of Virginia. Am J Sc (4) $20: 445-447$ (1905)

Campbell, J. A.

17 Copper and gold in Manitoba. Can M J 38:274-276 (1917)

Campbell, J. B.

45. [Lake Superior region.] U S, 28th Cong spec sess. S Ex Doc 175:4-8 (1845)

CampbeIl, J. K.

85 Highland $\mathrm{Co}$., Va. The Virginias 6 : 115-119, map (1885)

Campbe11, John.

62 [Gold fields of eastern Nova Scotia.] N S, Legislative Council, J Pr 1862, App no 2:61-68, Halifax, N. S., 1862

63 Nova Scotia gold fields. [Nova Scotia, Legislative Doc] : $12 \mathrm{pp}$ [Halifax 1863]

64 Report on the property of the Chebucto Gold Mining Company of Nova Scotia; with a sketch of the gold region of Nova Scotia, by Benjamin Silliman, jr. 33 pp, 1864

Campbell, John H.

92 A new fossil Cypraea [Cretaceous, Montana]. Nautilus $6: 50-51$ (1892); 7 : 52 , il (1893)

Campbell, John Lyle (1818-1886).

79 Silurian formation in central Vir ginia, Am J Sc (3) $18: 16-29$ (1879) The Virglnias $1: 41-45$, $: 1-56 \quad(18 \times 0)$

79a Geology of Virginia; continuation of section across the Appalachian chain. Am J Sc (3) 18:119-128, 239 (1879)

79b Geology of Virginia; Balcony Falls; the Blue Ridge and its geological connections. Am J Sc (3) 18:435-445 (1879) The Virginias 1: 86-87, 94 (1880)

80 The mineral resources apd advantages of the country adjacent to the James River \& Kanawha Canal and the Buchanan \& Clifton Forge Railway. The Virginias 1: 2-8, map (1880)

80 Geological features of the Arcadia iron property [Botetourt Co., Va.] The Virginias 1:104-105, map (1880)

Sob The resources of Brock's Gap, Va. [Rockingham Co.]. The Virginias 1:140141, map (1880)

80e The Purgatory iron property, Bote tourt Co.. Va. The Virginias 1: 156-158, $\operatorname{map}(1880)$

sod The geology, etc., of the Rich-patch, Va., iron region. The Virginias 1:185, 188-189. 192-193 (1880)

81 On dufrenite from Rockbridge Co., Va. Am J Sc (3) 22:65-67 (1881)

81a Ricepatch iron region. The Virginias $2: 7$ (1881)
Campbe11, John Lyle-Continued.

81b The mineral "dufrenite" in Roct. bridge Co., Va. The Virginias 2 : 76 (1881)

82 Geology and mineral resources of the James River Valley, Virginia, U.S.A. 119 pp, map, N Y 1882 Also in The Vir. ginias 3 : 54-55, 119, 120-121, 126-129, 160, 161 (1882)

S3 (and Rufrner, W. H.) A physical survey extending from Atlanta, Ga., across Ala. and Miss. to the Mississippi Riret along the line of the Georgla Pacific Rail. way... 147 pp, map, N Y 1883

83a Report on the mineral prospects of the St. Mary iron property [Augusta $\mathrm{Co}_{0}$ Va.] The Virginias 4:19-20, map (1883)

83b The Virginia papers of Prof, Wm. B, Rogers. The Virginias 4:72 (1883)

84 Geology of the Blue Ridge near Bal. cony Falls, Va. Am J Sc (3) 28:221-223 (1884)

84a The geological section of Little North Mountain [Augusta Co., Va.]. The Virginias $5: 37$ (1884)

$\mathbf{8 4 b}$ Geology of the Blue Ridge in James River Gap, Va. The Virginias 5:145 (1884)

s4e (and Campbell, H. D.) The Snowden [Amherst Co., Va.] slate quar ries. The Virginias $5: 162-163$, ma? (1884)

S5 (and Campbe11, H. D.) William B. Rogers' Geology of the Virginias; a review. Am J Sc (3) $30: 357-374 \quad$ (1885); $31:$ 193-202 (1886)

Campberl, John T.

84 Topographical phenomena in Indians. Am Nat 18: $367-379$ (1884)

89 Origin of the loess. Am Nat 23: 785-792 (1889)

92 Source of supply to lateral and medial glacial moraines (abst), Am As. Pr 40:255-256 (1892)

O1 Evidence of local subsidence in the interior [Indiana]. J G 9:437-438 (1901)

Campbell, Marius Robison.

93 Geology of the Big stone Gap coal field of Virginia and Kentucky. U S G S, B $111: 106 \mathrm{pp}$, maps (1893) Abst, Am G 14: 392-393 (1894)

94 Description of the Estillville sheet [Ky.-Va.-Tenn.]. U S G S, G Atlas Estillville fol (no 12):5 pp, maps (1894) Abst, J G 3:970-972 (1895)

94 a Paleozoic overlaps in Montgomery and Pulaski counties, Va. G Soc Am, B 5 : 171-190, map (1894) Abst, Am G 13: $147-148 \quad(1894)$

94b Tertiary changes in the drainage of southwestern Virginia. Am .J Sc (3) 48: 21-29 (1894)

94e (with Hayes, C. W.) Geomorph. ology of the southern Appalachians. Nat Geog Mag 6 : 63-126, maps (1894) 
Campbe11, Marius Robison-Continued.

96 (and Mendenhall, Walter C.) Geologic section along the New and Kanawha rivers in West Virginia. U S G S, An Rp 17 pt $2: 473-511$ (1896)

96a Description of the Pocahontas sheet [Va.W. Va.]. U S G S, G Atlas Pocahontas fol (no. 26); 5 pp. maps (1896) Abst, J G 5: 414-416 (1897)

96b Drainage modifications and their interpretation. J G 4:567-581, 657-678 (1896) Abst, Am G 17:98 (1896); Science n s 3:51-52 (1896)

96e The origin of some mountain scarps (abst). Science $n$ s $3: 714-715$ (1896) Am G $17: 408$ (1896)

97 Deseription of the Tazewell quadrangle [Va.-W. Va.]. U S G S, G Atlas Tazewell fol (no 44) : 6 pp, maps (1897)

97 a Erosion at base level. G Soc Am, B 8:221-226 (1897) Abst, J G $5: 322-323$ (1897); Science n s 5: 83 (1897)

97b Rapid section work in horizontal rocks. Am I M Eng, Tr 26:298-315 (1897)

97e The origin of certain topographic forms (abst). J G 5:323-324 (1897) Science n s $5: 83-84$ (1897)

98 Description of the Richmond quadrangle [Ky.]. U S G S, G Atlas Richmond fol (no 46) : 4 pp, maps (1898)

98a Description of the London quadrangle [Ky.]. U S G S, G Atlas London fol (no 47) : 3 pp, maps (1898)

98b Earthquake shocks in Giles Co., Va. Science n 8 7:233-235 (1898)

99 Description of the Standingstone quadrangle [Tenn.]. U S G S, G Atlas Standingstone fol (no 53):5 pp, maps (1899)

99a Description of the Bristol quadrangle [Va.-Tenn.]. U S G S, G Atlas Bristol fol (no 59) : 8 pp, maps (1899)

00 (and Leverett, Frank.) Description of the Danville quadrangle [III.-Ind.]. U S G S, G Atlas Danville fol (no 67): 10 pp, maps (1900)

00n Description of the Huntington quadrangle [W. Va,-Ohio]. U S G S, G Atlas Huntington fol (no 69) : 6 pp, maps (1900)

00b Stratigraphy of the Pottsville series in Kentucky (abst). Science $\mathrm{n}$ s 11: $140(1900)$

00c (with Hayes, C. W.) The relation of biology to physiography. Seience n s 12:131-133 (1900)

01 Description of the Charleston quadtangle [W. Va.]. U S G S, G Atlas Charleston fol (no 72) : 9 pp, maps (1901) 01a Hypothesis to account for the extra-glacial abandoned valleys of the Ohio basin (abst). G Soc Am, B 12:462 (1901) Science n 8 13:98-99 (1901)

02 Description of the Raleigh quad. rangle [W. Va.]. U $\mathrm{S}$ G S, G Atlas Raleigh fol (no 77 ) : 8 pp, mas $(1902)$
Campbel1, Marius Robison-Continued.

02a Description of the Masontown and Uniontown quadrangles [Pa.]. U S G S, G Atlas Masontown-Uniontown fol (no 82) : 21 pp. maps (1902)

02b Reconnaissance of the borax deposits of Death Valley and Mohave Desert. U S G S, B 200: 23 pp, map (1902)

02e Recent geological work in Pennsylvania. Eng M J . $73: 245$ (1902) Abst, Science n s 15:189 (1902)

02d (with White, D.) The bituminous coal field of Pennsylvania. U S G S, An Rp 22 pt 3:127-200, map (1902)

o3 Description of the Brownsville and Connellsville quadrangles [Pa.]. U S G S, G Atlas Brownsville-Connellsville fol (no 94) : $19 \mathrm{pp}$, maps (1903)

O3a Geographic development of northern Pennsylvania and southern New York. G Soc Am, B 14:277-296 (1903) Alst, Science n s $17: 220$ (1903); Sc Am Sup $55: 22647$ (1903)

031. Variation and equivalence of the Charleston sandstone. J G 11:459-468 (1903)

o3e Recent work in the bituminous coal field of Pennsylvania. U S G S, B 213 : 270-275 (1903)

03d Borax deposits of eastern California. U S G S, B 2.3:401-405 (1903)

o3e Basin range structure in the Death Valley region of southeastern Callfornia (abst). Science n s 17: 302 (1903) G Soc Am, B 14: $551-552$ (1904) Am G $31: 311-312$ (1903)

03f Pocono rocks in the Allegheny Valley (abst). Seience n s 17:942 (1903)

04 Deseription of the Latrobe quadrangle [Pa.]. U S G S, G Atlas Latrobe fol (no 110) : 15 pp, maps (1904)

Q4a The Meadow Branch coal fleld of West Virginia. U S G S, B 225: 330-344 (1904)

04b The Deer Creek coal field, Ariz. U S G S, B 225: 240-258 (1904)

o4e Conglomerate dikes in southern Arizona. Am G 33: 135-138 (1904)

04d Glacial erosion in the Finger Lake region (abst). Seience n s 19:531-532 (1904)

o5 Hypothesis to account for the transformation of vegetable matter into the different grades of coal. Ec G 1:26-33 (1905) Mines and Minerals 26:565-566 (1906)

O5a The classification of coals. Am I M Eng, Bi-Mo B 5: 1033-1049 (1905) ; Tr $36: 324-340$ (1906)

06 The Santa Fe peneplain (abst). Sclence n s $23: 267$ (1906)

06a Fractured boulders in conglomerate. Am J Sc (4) $22: 231-234$ (1906)

o6b Natural mounds. J G 14:708-717 (1906)

o6e Rock folds due to weathering. J G $14: 718-721$ (1906) 
Campbell, Marius Robison-Continued. o6d Survey work on coal during 1905. U S G S, B 285 : 203-210 (1906)

o6e Character and use of the Yampa coals. U S G S, B 297: 82-91 (1906)

06f Peat. U S G S, Min Res 1905 : 1319-1322 : 1906 : 1211-1212 (1906-7)

o6g (with Parker, E. W.) Report on the operations of the coal-testing plant of the U. S. Geol. Survey at the Louisiana Purchase Exposition, St. Louis, Mo., 1904. Parts I-III. U S G S, P P 48: 1492 pp (1906)

07 How long will the coal reserves of the United States last? Nat Geog Mag 18: 129-138 (1907)

$\mathbf{0 7 n}$ Contributions to economic geology, 1906 ; Part II, Coal, lignite, and peat. U S G S, B 316:543 pp, maps (1907) ... 1907, Part II, Coal and lignite; B $341: 444 \mathrm{pp}$, maps (1909) ... 1908, Part II, Mineral fuels ; B 381: 559 pp, maps (1910) ... 1909, Part II, Mineral fuels; B 431:254 pp, maps (1911) ... 1910, Part II, Mineral fuels; B 471: 663 pp, maps (1912)

1911, Part II, Mineral fuels; B $531: 361$ pp, maps (1913) ... 1912, Part II, Mineral fuels; B 541 : $532 \mathrm{pp}$, maps (1914)

o7b The Una del Gato coal field, Sandoval Co., N. Mex. U S G S, B $316: 427$ 430 (1907)

oze Coal in the vicinity of Fort Stanton Reservation, Lincoln Co., N. Mex. U S G S, B 316: 431-434 (1907)

07a Coal of Stone Canyon, Monterey Co., Cal. U S G S, B 316:435-438 (1907)

os the origin of limestone breccias (abst). Science n s $27: 348$ (1908)

08a Coal fields of the United States. Map, with explanation. U S G S, 1908

08b A practical classification for lowgrade coals. Ec G $3: 134-142$ (1908) Mines and Minerals $28: 535-536$ (1908)

09 (and Parker, E. W.) Coal fields of the United States. U S G S, B 394: 7-26 (1909) Nat Conservation Comm $\mathrm{Rp}$ (60th Cong 2d Sess Sen Doc no 676), vol $3: 426$ 442 (1909) Am I M Eng, B 28: 365-372 (1909) ; $\operatorname{Tr} 40: 253-260$ (1910)

11 Coal in San Benito Co., Cal. U S G S, B $431: 243-247$ (1911)

11a Historical review of theories advanced by American geologists to account for the origin and accumulation of oil. Ec G $6: 363-395,812$ (1911)

$11 \mathrm{~b}$ A plea for revision of the rules of the American Chemical Society governing the proximate analysis of coal. Ec $G 6$ : 562-567 (1911)

11e (and Gregory, H. E.) The Black Mesa coal field, Ariz. U S G S, B 431 : 229-238, map (1911)

11d (and Woodruf, E. G.) The Powell Mountain coal field, Scott and Wise cos., Va. U S G S, B 431:147-162, map (1911)
Campbel1, Marius Robison-Continued,

13 The coal reserves of the United States. Int $\mathrm{G}$ Cong, XII, Canada, The Coal Resources of the World, vol 1: lrifflxiv, vol $2: 525-539$, map (1913)

13a (and Clapp, F. G., and Butts Charles.) Description of the Barnesbon and Patton quadrangles, Pa. U S G S. G Atlas, Barnesboro-Patton fol (no 189):1 pp, maps (1913)

14 Coking coal in Powell Mountain Scott Co., Va. U S G S, B 541: 163-164 (1914)

14a Analyses of coal samples from various fields in the United States. U S G 8 B 541: 491-526 (1914)

14b The Glacier National Park; a pops. lar guide to its geology and scenery. is G S, B 600:54 pp, map (1914)

14e Origin of the scenic features of the Glacier National Park. U S Dp Interiot Off Secretary: 42 pp, map (1914)

15 (and others) Guidebook of the west. ern United States. Part A, The Northen Pacific route with a side trip to Yellow. stone Park. U S G S, B 611 : 212 pp, mapi (1915) Abst (by F. L. Ransome), Wast Ac Sc, J $5: 579-580$ (1915)

15a Movement of sand dunes on the California coast (abst). Wash $\Delta \mathrm{c}$ Sc, J5: 328 (1915)

16 (and Clark, F. R.) Analyses of coal samples from various parts of th United States. U S G S, B 621:251-3il (1916)

17 Coal fields of the United States cor sidered as sources of supply for the westen hemisphere. Pan American Sc Cong, 24. Washington, Pr sec 7 vol 8: 163-174 (1917)

17a The coal fields of the United State: general introduction. U S G S, P P 100 1-33, map (1917)

18 The country around Camp Shermat [Ohio]. [Text on back of topographic map], Ohio, Camp Sherman quadragle U S G S (1918)

See also Clapp (F G), 14 ; Clark (W B), 05 ; Hodge ( $\mathrm{J} \mathrm{M}$ ), 93 ; Powell, 95

\section{Campbell, William.}

06 The microscopic examination opaque minerals. Ec G 1: 751-766 (1906 Abst, Science n s 24:691 (1906)

06a (and Knight, C. W.) A mietr scopic examination of the cobalt nicke arsenides and silver deposits of Timiskat ing. Ee G 1: $767-776$ (1906)

06b (and Knight, C. W.) The par genesis of the cobalt-nickel arsenides and silver deposits of Timiskaming [0nt] Eng M J 81: 1089-1091 (1906)

o6e (and Knight, C. W.) Microscopit examination of nickeliferous pyrrhotites Eng M J 82:909-912 (1906)

or on the microstructure of nickelife ous pyrrhotites. Ee G 2:350-366 (1907) 
Camphell, William-Continued.

09 The microstructure of a complex ore from the Frisco mine, Gem, Idaho. Eng M J $87: 260-261$ (1909)

Campbell, William Wallace.

06 On the earthquake of April 18, 1906. Astron Soe Pacific, Pub 18: 213-217 (1906)

Camsell, Charles.

03 The region southest of Fort Smith, Slave River, Northwest Terr. Can G S, Sum Rp 1902 (An Rp 15) : A $151-169$ (1903)

05 Country around the headwaters of the Severn River. Can G S, Sum Rp 1904 (An Rp 16) : A 143-152, map (1905)

06 [Report on the] Peel River, in the Yukon and Mackenzie district. Can G S, Sum Rp 1905: 36-46 (1906)

06a The Similkameen district, B. C. Can G S, Sum Rp 1906:43-55 (1906)

06b Report on the Peel River and tributaries, : ukon and Mackenzie. Can G S, An Rp 16 CC : 49 pp (1906)

07 Preliminary report on a part of the Similkameen district, B. C. Can G S: 41 pp, map (1907)

os Observations on the geology and ore deposits of Camp Hedley, B. C. Can M Inst, J $11: 423-432$ (1908)

0Sa Camp Hedley, Osoyoos mining division, B. C. Can G S. Sum Rp 1907:2431 (1908) B C, Minister of Mines, An Rp 1907:121-127 (1908)

09 0soyoos and Similkameen mining divisions [B. C.]. Canada G S, Sum Rp 1908:61-64 (1909) B C, Minister of Mines, An Rp 1908: 135-139 (1909)

10 Tulameen district, B. C. Can G S, Sum Rp 1909: 104-117 (1910)

10a The geology and ore deposits of Hedley mining district, B. C. Can G S, Mem 2:218 pp, maps (1910)

101) The mineral resources of a part of the Yale district, B. C. Can M Inst, Q B 12:119-134 (1910) ; J $14: 596-611$ (1912)

10e Platinum mining in the Tulameen district, B. C. Can M Inst, Q B 9:29-44 (1910) ; J 13: 309-324 (1911)

11 Parts of the Similkameen and Tulameen districts. Can G S, Sum Rp 1910 : 111-119 (1911)

11a A new diamond locality in the Tulameen district, B. C. Ec G 6: 604-611 (1911)

12 Fraser Canyon and vicinity. Can G 8, Sum Rp 1911: 108-111 (1912)

12a Geology of a portion of Lillooet mining division, Yale district, B. C. Can G S, Sum Rp 1911: 111-115, map (1912)

12b Geology of Skagit Valley, Yale District, B. C. Can G S, Sum Rp 1911: 115123, map (1912)

12e Note on the occurrence of diamonds at Tulameen and Scottie Creek, near Ashcroft, B. C. Can G S, Sum Rp 1911:123124 (1912)
Camsel1, Charles-Continued.

13 Geology and mineral deposits of the Tulameen district, B. C. Can G S, Mem $26: 188 \mathrm{pp}$, maps (1913)

13a Coast Range, Lytton to Vancouver; fire clay deposits at Clayburn, B. C. Int $G$ Cong, XII, Canada, Guide Book no 8:256274, 343-349, maps (1913)

136 The Similkameen district. Int $G$ G Cong, XI1, Canada, Guide Book no 8: 256-274, 343-349, maps (1913)

14 Guide to the geology of Canadian National Parks on the Canadian Pacific Railway between Calgary and Revelstoke. Can, Dp Int: $70 \mathrm{pp}$, maps, Ottawa 1914

14a The geology of certain portions of Yale district, B. C. Can G S, Sum Rp 1912 : 211-220 (1914)

14b Notes on mining developments in Similkameen district, B. C., and on a reported occurrence of oil at Kelowna, B. C. Can G S, Sum Rp 1913: 127-128 (1914)

15 An exploration of the region between Athabaska and Great Slave lakes, Alberta and Northwest Territories. Can G S, Sum Rp 1914: 55-60 (1915)

15a The Mackenzie River region [Canada]. Science Conspectus 5 no $1: 1-9$, map (1915)

16 An exploration of the Tazin and Taltson rivers, Northwest Territories. Can G S, Mem 84:124 pp, map (1916)

$16 a$ Exploration in the northern interior of British Columbia. Can G S, Sum Rp $1915: 70-75$, map (1916)

$16 \mathbf{b}$ Reported occurrence of silver in the neighborbood of Fond du Lac, Iake Athabasca, Saskatchewan. Can G S, Sum Rp 1915: 120-126 (1916)

17 Salt and gypsum deposits of the region between Peace and Slave rivers, northern Alberta. Can G S, Sum Rp 1916: 134-145 (1917)

17a Molybdenite deposits of the Moss mine, Quyon, Que. Can G S, Sum Rp $1916: 207-208$ (1917)

17b Tungsten deposits of New Brunswick and Nova Scotia. Can G S, Sum Rp $1916: 247-251$ (1917)

18 Reconnaissance along the Pacific Great Eastern Railway between Squamish and Lillooet [B. C.]. Can G S, Sum Rp 1917 pt B : 12-23 (1918)

18a Indian River copper deposits, Vancouver mining division [B. C.]. Can G S, Sum Rp 1917 pt B : 23-25 (1918)

$18 b$ Note on the occurrence of diatomaceous earth, clay, and magne-ite along the route of the Pacific Great Eastern Railway. Can G S, Sum Rp 1917 pt B : 25-28 (1918)

18e Memorial of Delorme D. Cairnes. G Soc Am, B 29:17-20, port (1918)

18d Robert Bell. R Soc Can, Tr (3) 12: $x$-xiv, port (1918)

See also Miller (W G), 90, 12 
Canada, Department of the Interior, Mines Brnneh.

06 Report of the Commission appointed to investigate the zine resources of British Columbia and the conditions affecting their exploitation. $300 \mathrm{pp}$, Ottawa 1906

Canada, Department of Mines, Mines Branch.

os Report on the mining and metallurgieal industries of Canada, 1907-8. 972 pp, Ottawa 1908

13 Economic minerals and mining industries of Canada. 77 pp, map Ottawa 1913 $2 d$ ed 1914

Summary report. See Haanal, 11

\section{Canada, Geological Survey.}

50 Catalogue of some of the economic minerals and deposits of Canada with their localities. Can G S, Rp Prog 1849-50: 107-115 (1850)

55 Carte géologique du Canada. Scale, 150 miles to 1 inch. [Can G S] 1855

66 List of localities in which ores of copper have been met with in rocks of the Quebec group in eastern Canada. Can G S, Rp-Prog 1863-6 : 293-321 (1866)

76 Descriptive catalogue of a collection of the economic minerals of Canada and [by A. R. C. Selwyn] notes on a stratigraphical collection of rocks: Philadelphia International Exhibition. 1876. [Can G S] : 152 pp, Montreal 1876.

84 Map of the Dominion of Canada, geologically colored from surveys made by the geological corps, 1842 to 1882 . Seale [45 miles to 1 inch] [Can G S 1884]

S6 Descriptive catalogue of a collection of the economic minerals of Canada by the geological corp3; Colonial and Indian $\mathrm{Ex}$ hibition, London 1886. [Can G S] : 172 pp (1886)

oo Descriptive catalogue of a collection of the economic minerals of Canada; Paris International Exhibition, 1900. [Can G S] $217 \mathrm{pp} \mathrm{[1900]}$

01 Economic minerals of Canada; PanAmeriean Exposition, Buffalo, 1901. 57 pp (1901)

01a Geological map of the Dominion of Canada (western sheet). Scale 50 miles to 1 inch. Can G S 1901

04 Economic minerals of Canada ; Louisiana Purchase Exposition, St. Louis, 1904 55 pp (1904)

09 Catalogue of publications of the Geological Survey, Canada (revised to January 1, 1909) $181 \mathrm{pp}$, Ottawa 1909 Supple mentary list, $12 \mathrm{pp}$, Ottawa 1912

10 [Geological map of] Province of Nova Scotia, Kings Co., Hall Harbour sheet, no 99. Can G S, Pub 1134. Scale 1 mile to 1 inch. 1910

11 [Geological map of] Province of Nova Scotia, Hants and Kings cos., Kingsport sheet no 84. Can G S, Pub 1133. Scale 1 mile to 1 inch. 1911
Canada, Geologieal Survey-Contd.

12 [Geological map of Canada]. Can G S, Pub 1084 (to accompany pub 1085 and 1086). Scale 1: 6336000 [1912]

13 Guide book, nos 1-10. [Issued for the Twelfth International Geological Cos gress.] Ottawa 1913

The papers, descriptive of the regions to be visited in the excursions, have bee listed under the individual authors.

13a Geological map of the Dominion of Canada and Newfoundland. Scale, 1 6,336,000. Geology compiled by G. A Young. 1913

15 Geological map of the Dominion of Canada [east and west sheets]. Scale 100 miles to 1 inch. In Atlas of Canada (Caada, Dp Interior) : 9-12 (1915)

\section{Canada, Parliament.}

55 Report of the select committee on the geological survey. $63 \mathrm{pp}$, Quebec 1855

84 Report of the select committee appointed by the House of Commons to obtain information as to geological surveys, etc, ete. 207 pp, Ottawa 1884 .

Canby, H. S.

97 The cryolite of Greenland. Yale So Mo 4:15-19 (1897) Se Am Sup 50: 20814 (1900)

Canfield, Frederick A.

S9 Catalogue of minerals found in Ner Jersey. N J G S, Final Rp 2:1-24t (1889)

o7 Mineralogical notes [Willemite N. J.]. Am J Sc (4) $23: 20-22$ (1907)

10 (and Hillebrand, W. F., and Schnller, W. T.) Mosesite, a new met cury mineral from Terlingua, Tex. Am ? Sc (4) $30: 202-208$ (1910) Zs Kryst 49 $1-8 \quad(1911)$

11 Thomsonite in New Jersey. Sct Mines Q 32:215-216 (1911)

17 Twinning in the New Jersey "pseudomorphs." Am Mineralogist 2: 48 (1917)

$17 a$ Crystals of water. Am Mineralogist $2: 90(1917)$

Cannon, George L., jr.

89 The Quaternary of the Denver basid. Colo Se Soc, Pr 3: 48-70 (1889)

89a On the Tertiary Dinosauria found in Denver beds. Colo $\mathrm{Sc}$ Soc, $\operatorname{Pr} 3: 140-$ 147 (1889)

90 [On stegosaurs near Golden, Colo.]. Colo Sc Soc, Pr 3: 190 (1890)

90a Notes on formations in eastert Colorado. Colo Sc Soc, Pr 3:215-210 (1890)

91 Identification of a dinosaur from the Denver group. Colo Sc Soc, Pr $3: 253-$ 254 (1891)

91 a Notes on the geology of Perry Park, Colo. Colo Sc Soc, Pr 3: 308-315 (1891)

95 Notes on a discovery of Radiolites austinensis Roemer (?) [Denver, Colo.]. Colo Sc Soc, $\operatorname{Pr} 4: 75-76$ [1895] 
Cannon, George L., fr.-Continued.

95a Notes on the geology of Palmer Lake, Colo., and the Paleozoic exposures along the Front Range. Colo Sc Soc, $\mathrm{Pr}$ 4:224-234, map [1895] (separate ed, 11 pp, 1893)

95b The geology of Denver and vicinity. Colo Sc Soc, $\operatorname{Pr} 4: 235-270$ [1895].

06 Notes on some [vertebrate] fossils recently discovered near Denver, Colo. Colo Sc Soc, Pr 8: 194-198 (1906)

06a Sauropodan gastroliths. Science $\mathrm{n}$ s $24: 116$ (1906)

\section{Cantley, Thomas.}

11 The Wabana iron mines of the Nova Scotia Steel and Coal Company Limited. Can M Inst, Q B $15: 31-56$, maps (1911) ; J 14: 274-298, maps (1912)

Cantwell, H. J.

14 The disseminated lead district of southeast Missouri. Eng M J $97: 287-290$ (1914)

Canu, Eugène.

s6 L'articulé problématique des dépôts tertiaires de Florissant (Planocephalus aselloides Scudder). Soc G Nord, An 13 : 148-151, il (1886)

Canu, Ferdinand,

17 (and Bassler, R. S.) A synopsis of American early Tertiary cheilostome Bryozoa. U S Nat Mus, B 96:87-pp, il (1917)

17a (and Bassler, R. S.) Methods of study and the classification of American Tertiary Bryozoa $(a b s t)$. G Soc Am, B $28: 204$ (1917)

18 (and Bassler, R. S.) Principles of classification of cyclostome Bryozoa (abst). G Soc Am, B 29:151 (1918)

18n (and Bassler, R. S.) Bryozoa of the [Panama] Canal Zone and related areas. U S Nat Mus, B 103:117-122, il (1918)

\section{Capellini, G.}

64 Relazione di un viaggio scientifico fatto nel 1863 nell America settentrionale. $44 \mathrm{pp}$, map, Bologna 1864

\section{Capellini, J.}

66 (and Heer, O.) Les phyllites crétacées du Nebraska. See Helvétique Sc Nat, Nouv Mém $22: 22$ pp, 11 (1866)

\section{Capilla, Alberto.}

04 Los yacímientos de fierro de Tatatila, Cantón de Jalapa, Estado de Vera Cruz [México]. Soc Cient Ant Alz, Mem 19 : 341-346 (1904) Méx, Sec Fomento, B (2) aก̃o 3 , II : $535-542$ (1904)

10 Criaderos aurfferos del arcaico en Oaxaca. Soc G Mex, B $6: x x y-x x v i, 147-$ 156 (1910)

10a Deposito de antiguos aluviones argentiferos en el río de Santiago, Jalísco, Mexico. Soc G Mex, B $7: v, 135-139$ (1910-11)
Capps, Stephen Reid.

04 (and Leflingwell, E. D. K.) Pleistocene geology of the Satwatch Range, near Leadville, Colo. J G 12:698-706 (1904)

or The girdles and hind limb of Holosaurus abruptus Marsh. J G 15:350-356 (1907)

09 Pleistocene geology of the Leadville quadrangle, Colo. U S G S, B 386:99 pp, map (1909) Abst, Science n s 29: 946 (1909)

10 Glaciation on the north side of the Wrangell Mountains, Alaska. J G 18: $33-57$, map (1910)

10a Rock glaciers in Alaska. $J$ G 18 : 359-375 (1910) Abst, Science n s $30: 974$ (1909)

10b The underground waters of northcentral Indiana. U S G S, W S P 254: 279 pp, map (1910)

10e Quaternary deposits and glaciation in the Nabesua-White Rirer district, Alaska. U S G S, B $417:$ :6-42 (1910)

11 Mineral resources of the Bonnifield region [Alaska]. U S G S, B 480:218235, map (1911)

11 a (with Moffit, F. H.) Geology and mineral resources of the Nizina district, Alaska. U S G S, B 448:111 pp (1911) (Abst), Wash Ac Sc, J 1:130 (1911)

12 The Bonnifield region, Alaska. U S G S, B 501:64 pp, maps (1912) Abst, Wash Ac Sc, J 2:326 (1912)

12a Gold placers of the Yentna district [Alaska]. U S G S, B 520:174-200, maps (1912)

12b Glaciation of the Alaska Range. J G $20: 415-437$, map (1912)

13 The Yentna district, Alaska. U S G S, B 534:75 pp, maps (1913) Abst, Wash Ae Sc, J 3:466 (1913)

13a (and Johnson, B. L.) Mineral deposits of the Ellamar district [Alaska]. U S G S, B 542: 86-124, map (1913)

14 Gold lodes and placers of the Willow Creek district [Alaska]. U S G S, B $592: 245-272$, map (1914)

14a Some ellipsoidal lavas on Prince William Sound, Alaska (abst). Wash Ac Sc, J 4:169 (1914)

15 An ancient volcanic eruption in the upper Yvkon basin. U S G S, P P 95: 59-64, map (1915) Alst, Wash Ac Sc, $6: 72$ (1916)

$15 a$ (and Johnson, B. L.) The Ellamar district, Alas.a. U S G S, B 605: $125 \mathrm{pp}$, maps (1915) Abst, Wash Ac Sc, J $6: 93-94$ (1916)

15b The Willow Creek district, Alaska. U S G S, B 607: 86 pp, maps (1915) Abst, Wash Ac Sc, J 6:93 (1916)

15e Mineral resources of the ChisanuWhite River district [Alaska]. U S G S, B $622: 189-228$, map (1915)

15d Some ellipsoidal lavas on Prince William Sound, Alaska. J G 23:45-51 (1915) 
Capps, Stephen Reid-Continued.

15e An estimate of the age of the last great glaciation in Alaska. Wash Ac Sc, J $5: 108-115,186$ (discussion) (1915)

15f Two glacial stages in Alaska. $\mathrm{J} \mathrm{G}$ $23: 748-756$ (1915)

15g An unusual exposure of a great thrust fault [Nizina River, Alaska] (abst). Wash Ac Sc, J $5: 252$ (1915)

16 The Chisana-White River district, Alaska. U S G S, B 630:130 pp, maps (1916) Abst, Wash Ac Se, J 6:505-506 (1916)

16a The Turnagain-Knik region, Alaska. U S G S, B 642: 147-194, maps (1916)

161. Gold mining in the Willow Creek district [Alaska]. U S G S, B 642:195200 (1916)

17 Mineral resources of the Kantishna region, Alaska. U S G S, B 662:279331, maps (1917) Abst, by R. W. Stone, Wash Ac Sc, J $7: 603-604$ (1917)

See also Knopf, 10; Moffit, 10a

Caracristi, Charles F. Zeilinger.

05 The trans-Pecos sulphur field; a report on their economic geology and value. 44 pp, Bloomington, Ill., 1905 [Priv pub]

09 The economic geology of the Sierra Rica, Sierra San Carlos, and Las Orientales and a railway survey in the Municipality of Ojinaga, District of Iturbide, State of Chihuahua, Mexico. 85 pp [N Y 1909] [priv pub]

10 The geology of the Sierra Ricatrans-Concho country, Chihuahua, Mexico. $80 \mathrm{pp}, \mathrm{N}$ Y 1910 [not seen] [priv pub]

10a Iron deposits of San Carlos, Mexico. M World $32: 54$ (1910)

Caravantes, $A$.

70 El Ceboruco; observaciones sobre este voleán [México]. La Naturaleza 1: 248-252 (1870)

Carden, A. D.

or (and Goldney, G. F. B.) Notes on the Jamaiea earthquake, 14th January, 1907, R Eng J 6:213-217 (1907)

Cardeza, J. T. M.

92 (with Rand, T. D.) Mineral localities of Philadelphia and vicinity. Ac N Sc Phila, Pr 1892: 174-202

Carey, Everett P.

96 Ice phenomena in Green Bay, Lake Michigan (abst). Science n s 3:715-716 (1896)

06 The great fault of California and the San Francisco earthquake, April 18, 1906. J Geog 5:289-301 (1906)

of (and Miller, W. J.) The crystalline rocks of the Oak Hill area, near San José, Ca]. J G 15: 152-169 (1907)

10 (with Fairbanks, H. W.) Glacia tion in the San Bernardino Range, Cal. Science n s $31: 32-33$ (1910)

Car11, John Franklin (1828-1904).

75 Report of progress in the Venango oil district. $\mathrm{Pa} G \mathrm{~S}, 2 \mathrm{~d}, \mathrm{I}: 1-49$, map
Car11, John Franklin-Continued.

7 7 Oil well records and levels. $\mathrm{Pa} \mathrm{G}$ 2d, II - 398 pp (1877)

so The geology of the ofl regions to Warren, Venango, Clarion, and Butler coe. Pa G S, 2d, III : xxiv, 482 pp and ath (1880)

$\mathbf{8 3}$ Geological report on Warren $\mathrm{C}_{0}$, ad the neighboring oil regions with additioul oil well records. $\mathrm{Pa} G \mathrm{~S}, 2 \mathrm{~d}, \mathrm{I} 4: \mathrm{xx}$, 4क्ष pp, maps (1883)

86 Preliminary report on oll and gat Pa G S, An Rp 1885: 1-81, map (1886)

87 Report on the oil and gas regions Pa G S, An Rp 1886 pt 2:575-786, ma; (by C. A. Ashburner and E. V. D'Invillies (1887)

87a Natural gas in Pennsylvania. In Manufacturer, Nat Gas Suppl no 2:5, 1 . ntap, Dec 30 (1887)

90 Seventh report on the oil and ge flelds of western Pennsylvania. $\mathrm{Pa}$ \& \& 2d, I5 : viii, $356 \mathrm{pp}, \operatorname{map}(1890)$

See also Nettleton, 77 .

Carlyle, E. J.

o5 The Pioneer iron mine, Ely, Min Can M Inst, J $7: 335-367$ (1905)

Carlyle, Whilam A.

93 Notes on a great silver camp [Les] ville, Colo.]. Can Rec Sc 5:403-4h (1893)

96 Report on Alberni mining distric B C, Bur Mines, B 1:8 pp, Victoria, B. C 1896

96 Report on the Trail Creek minity dictrict. B C, Bur Mines, B $2: 32 \mathrm{pp}$, Th toria, B. C., 1896 Mining 2:95-100, 12t 128, 143-151 (1896) M Sc Press $73: 23$ 237 (1896)

97 Report on the Slocan, Nelson, ad Ainsworth mining districts in West Koote nay, B. C. B C, Bur Mines, B $3: 5$ vil pp, map, Victoria, B. C., 1897

97a Reports. In Annual report of th minister of mines for the year ending $31 \mathrm{~s}$ December 1896 , being an account of mining operations for gold, coal, etc, in the Pror ince of British Columbia:497-596, Wh toria, B. C., $1897 ; \ldots 1897 \ldots$ : $451-64$. map (1898)

Carman, Joel Ernest.

09 The Mississippi Valley between $\mathrm{St}$. vanna and Davenport. III G S, B $13: 96$ pp, map (1909)

12 A grooved and striated contact plap between the Nebraskan and Kansan drift (abst). Science n s 35:316 (1912); (wit) discussion by Frank Leverett), G Soc At B 23:735-736 (1912)

12a The Nebraskan drift of the Little sioux Valley in northwest Iowa (abst). Science n s 35 : 316 (1912) G Soc Am, B $23: 735$ (1912)

13 Notes on the Nebraskan drift of the Little Sioux Valley, in Cherokee Co. [Iowa]. Iowa Ac Sc, Pr $20: 231-235$, map (1913) 
Carman, Joel Ernest-Continued.

13a The Wisconsin drift plain in the region about Sioux Falls [S. Dak.]. Iowa Ac Sc, Pr 20:237-250, maps (1913) Abst, Science $n$ s $37: 456$ (1913)

17 The Pleistocene geology of northwestern Iowa. Iowa G S $26: 233-445$, map (1917)

Carmichael, Alfred.

07 Placer mining methods in the Atlin district [B. C.]. Mines and Minerals 27 : 241-244 (1907)

Carmichael, Henry.

78 Geological features and minerals [of Brunswick and Topsham, Me.]. In Wheeler, George A., and Wheeler, H. W., History of Brunswick, Topsham, and Harpswell, Maine ...: $95-98$, Boston 1878

Carmody, P.

05 (and Craig, E. H. C.) Portland cement as a local industry. Joint report by the government analyst and government geologist. Trinidad, Legislative Council, Council Paper no. 4 of 1905.6 pp, Trinidad 1905

Carmony, F. A.

03 Jefferson Co. Nebr G S 1: 235-242, map (1903)

Carney, Frank.

03 A type case in diversion of drainage.

J Geog 2: 115-124, map (1903)

04 Direction of preglacial stream flow In central New York. Am G 33: 196-198 (1904)

06 The geology of Perry township, LickIng Co., Ohio. Denison Univ, Sc Lab, B 13:117-130, map (1906)

06a Valley dependencies of the Scioto Illinoian lobe in Licking Co., Ohio. J G 15:488-495 (1907) Denison Univ, Sc Lab, $13: 131-137$ (1907)

07 Pre-Wisconsin drift in the Finger Lake region of New York. J G 15:571585 (1907) Denison Univ, Sc Lab, B $14: 3-18$ (1908)

07a Glacial erosion in longitudinal valleys [Owasco Lake Valley, N. Y.]. J G $15: 722-730$ (1907)

07b Wave-cut terraces in Keuka Valley, older than the recession stage of Wisconsin ice. Am J Sc (4) $23: 325-335$ (1907) Denison Univ, Sc Lab, B $14: 35-46$ (1908) 07e A form of outwash drift [Penn Yan quadrangle, N. Y.]. Am J Sc (4) $23: 336-341$ (1907) Denison Univ, Sc Lab, B $14: 47-53$ (1908)

07d The glacial dam at Hanover, Ohfo. Denison Univ, Sc Lab, B 13:139-153 (1907)

08 A possible overflow channel of ponded waters, antedating the recession of Wisconsin ice. Am J Sc (4) 25:217223 (1908)

08a State gealogical surveys and practical geography. Am Geog Soc, B 40:530535 (1908) Denison Univ, Se Lab, B 14 : 55-60 (1908)
Carney, Frank-Continued.

Osb The alteration of glacial deposits by later ice invasions $(a b s t)$. Science $\mathrm{n} \mathbf{s}$ $27: 729$ (1908)

ose (and Brumback, A. M.) The deposits of glass sand at Toboso, Ohio. Ohio Nat 8: 358-361 (1908)

09 A stratigraphic study of Mary Ann Township, Licking Co., Ohio. Denison Univ, Sc Lab, B 14:127-155 (1909)

09a The development of the idea of glacial erosion in America. Denison Univ, Sc Lab, B 14: 199-208 (1909)

$09 \mathrm{~b}$ The raised beaches of the Berea, Cleveland, and Euclid sheets, Ohio. Denison Univ, Sc Lab, B 14:262-287 (1909) Ohio St Ac Sc, Pr 5 (17th An Rp) : 225253 (1909)

o9e Pleistocene geology of the Moravia quadrangle, N. Y. Denison Univ, Sc Lab, B 14: 335-442, map (1909)

09d The metamorphism of glacial deposits. J G 17:473-487 (1909) Denison Univ, Sc Lab, B 16:1-14 (1910) Abst, Sclence n s 29:750-751 (1909)

10 Glacial erosion on Kelleys Island, Ohio. G Soc Am, B 20:640-645 (1910) Abst, Science n s 29:629 (1909)

10a The abandoned shore lines of the Oberlin quadrangle, Ohio. Denison Univ, Sc Lab, B 16:101-117 (1910) Abst, Science n s $32: 187$ (1910)

10b The economic mineral products of Ohio. Denison Univ, Sc Lab, B 16:137181 (1910)

10e Glaciation in Ohio. Denison Univ, Sc Lab, B 16:183-231 (1910)

11 The abandoned shore lines of the Vermilion quadrangle, Ohio. Denison Univ, Sc Lab, B 16:233-244, map (1911)

11a The geologic development of Ohio. Denison Univ, Sc Lab, B 16:365-380 (1911)

11b The relief features of Ohio. Denison Univ, Sc Lab, B 16:381-402, map (1911)

11e Lake Maumee, in Ohio (abst). G Soc Am, B 22: 726 (1911)

13 Some proglacial lake shorelines of the Bellevue quadrangle, Ohio. Denison Univ, Sc Lab, B $17: 231-246$ (1913)

16 The progress of geology during the period 1891-1915. Ohio Ac Sc, Pr 6: 299 308 (1916) Denison Univ, Sc Lab, B 18 : $370-378$ (1916)

16a The shore lines of glacial lakes Lundy, Wayne, and Arkona, of the Oberlin quadrangle, Ohio. Denison Univ, Sc Lab, B $18: 356-361, \operatorname{map}(1916)$

16b The abandoned shore lines of the Ash tabula quadrangle, Ohio. Denison Univ, Sc Lab, B 18: 362-369, maps (1916)

Carnot, Adolphe.

96 Sur les variations observées dans la composition des apatites, des phosphorites, et des phosphates sédimentaires. An Mines (9) $10: 137-231$ (1896) 
Carpenter, Everett.

13 Ground water in Boxelder and Tooele cos., Utah. U S G S, W-S P $333: 90$ pp, maps (1913)

15 Ground water in southeastern Nevada. U S G S, WW-S P $365: 86 \mathrm{pp}$, maps (1915)

Carpenter, Franklin R.

ss Preliminary report of the Dakota School of Mines upon the geology, mineral resources, and mills of the Black Hills of Dakota. 171 pp, map, Rapid City 1888 Abst, Am G 3:202-204 (1888)

89 Ore deposits of the Black Hills of Dakota. Am I M Eng, $\operatorname{Tr} 17: 570-598$, map (1889)

04 The new geology and vein formation. Colo Sc Soc, Tr $7: 253-266$ (1904) Eng M J $77: 312$ (1904)

06 Tin in the Black Hills, S. Dak. M World 25:600-601 (1906)

Carpenter, George W.

28 on the mineralogy of Chester Co. [Pa.], with an aceount of some of the minerals of Delaware, Maryland, and other localities. Am J Sc 14:1-14 (1828)

Carnenter, Jay A.

10 Kimberly, Nev. M Se Press 100: 482-483 (1910)

10a The Yerington copper district [Nev]. M Sc Press 101:4-9 (1910)

Carpenter, L. G.

90 Report [on artesian water in Colorado]. U S, 51st Cong 1st sess, S Ex Doc 222: 173-232 (1890)

90a Report on New Mexico [arteslan water]. U S, 51st Cong 1st sess. S Ex Doc 222 : 232-241 (1890)

Carpenter, Philip Herbert (1852-1891).

91 Some publications on American Carboniferous echinoderms. An Mag $\mathrm{N}$ H (6) 8: 94-100 (1891)

Carpenter, Philip Pearsell.

66 On the Pleistocene fossils collected ... at Sta. Barbara, Cal,, with descriptions of new species. An Mag N H (3) 17 : 274-278 (1866) Smiths Misc Coll [252] 10:319-325 (1872) U S G S, P P 59 : 189-191 (1909)

See also Dawson ( $\mathrm{J}$ W), 67

Carpenter, W. L.

78 Report on the geology and natural history of the Bighorn Mountains [Wyo.]. In Reports of inspection made in the summer of 1877 by Generals P. H. Sheridan and W. T. Sherman of country north of the Union Pacific Railroad [U S, War Dp] : 11-15, Washington 1878

Carpenter, William Benjamtn.

65 On the structure and affinities of Eozoon canadense. $\mathrm{R}$ Soc London, $\mathrm{Pr} 13$ : $545-549$ (1865)

65a On the structure, affinities, and geological position of Eozoon canadense. Intellectual Observer, London, $7: 278-302$, il (1865)
Carpenter, William Benjamin-Continued 65b Notes on the structure and aflinitio of Eozoon canadense. Can Nat n \& ? 111-119, il (1865)

65e Additional note on the structure and affinities of Eozoon canadense. G Soc London, Q J 21:59-66, il (1865)

66 Supplemental notes on the structure and affinities of Eozoon canadense. G Soc London, Q J 22:219-228 (1866) Abst, G Mag S : 80-81 (1866); Ph Mag (4) $31: 159-160$ (1866)

67 Further observations on the strue ture and aftinities of Eozoon canadens R Soc London, Pr 15:503-508 (1867)

$\mathbf{7 4}$ Remarks ... on the structure of the so-called Eozoon canadense. An Mag N (4) $13: 277-284$, il $(1874)$

74a New observations on Eozoon cano. dense. An Mag N H (4) 13:456-470, it (1874)

74b Final note on Eozoon canadense. An Mag N H (4) $14: 371-372$ (1874)

75 Further researches on Eozoon cans. dense. Brit As, $\mathrm{Rp}_{\mathrm{p}}$ 44: sec 136-13\% (1875)

76 Notes on Otto Hahn's " Microgeolog ical investigation of Eozoon canadense." An Mag N H (4) 17:417-422 (1876)

Carpenter, William M.

38 Interesting fossils found in Louls: ana. Am J Sc $34: 201-203$, il (1838)

39 Miscellaneous notices in Opelonss, Attakapas, etc. Am J Sc $35: 344-346$ (1839)

39 account of the bituminization of wood in the human era. Am J Sc 36: 118-124 (1839)

46 Remarks on some fossil bones re cently brought to New Orleans from Ten. nessee and from Texas. Am J Sc (2) 1: 244-250, il (1846)

Carr, Ezra Slocum (1819-1894).

40 [Economic geology of the third dis trict of New York.] N Y G S, An Rp 4: 385-388 (1840)

Carr, Henry C.

09 Vein structure in the Monument mine [Salmon River Mountains, Lemhi co. Idaho]. M Sc Press 98:557-558 (1909) Carr, Lucien.

76 (and Shaler, N. S.) On the prebistoric remains of Kentucky. Ky G 8 , Mem 1 pt $4: 31$ pp, il, Cambridge 1876

Carranco, Alberto.

07 La región minera de Trinldad y Anexas [Zacatecas, México]. Soc G Mer $3: 15-23$ (1907)

Carroll, Fred.

16 Fourteenth biennial report issued by the Bureau of Mines of the State of Colorado for the years 1915 and 1916. $116 \mathrm{pp}$. maps, Denver, Colo., 1916

Carruth, J. A.

10 New Mexico gold gravels. Mines and Minerals 31: 117-119 (1910) 
Carson, J. P.

91 Notes on the excavation of the New Croton aqueduct [New York City]. Am I M Eng, Tr 19: 705-760, map (1891)

Carstarphen, F. C.

11 Modification of former Cretaceous classifications on the western slope of the Continental Divide. Colo Sch Mines Mag 1 no $7: 8-10$ (1911)

Carter, H. J.

74 On the structure called Eozoon canadense in the Laurentian limestone of Canada. An Mag N H (4) $13: 189-193$, 376378, il (1874)

75 Relation of the canal system to the tabulation in Foraminifera, with reference to Dr. Dawson's "Dawn of Life" [Eozoon]. An Mag N H (4) 16:420-424 (1875)

Carter, Oscar C. S. (?-1917).

84 Ores, minerals, and geology of Montgomery Co. In History of Montgomery County, Pennsylvania, edited by Theodore W. Bean : 8-83, map, Phila, 1884

91 Artesian well in lowest Trias at Norristown [Pa.]. Am Ph Soc, Pr 29:4345, 47-49 (1891)

91a Feldspar bed in Laurentian(?) gneiss [Montgomery Co., Pa.] Am Ph Soc, Pr 29: 49-50 (1891)

93 Artesian wells as a water supply for Philadelphia. Franklin Inst, J 135: 58-61 (1893)

93a Artesian wells. Franklin Inst, J $136: 230-239,298-305$ (1893)

93b [Diamonds in meteorites]. Am Chem J 15: 678 (1893)

94 Anthracite coal near Perkiomen Creek [Pa.]. Franklin Inst, J 138:152156 (1894) Abst, Eng M J $58: 147-148$ (1894)

94a Drilling for oil and natural gas in the vicinity of Philadelphia. Franklin Inst, J $138: 230-236$ (1894)

96 A ferruginised tree [Three Tuns, Montgomery Co., Pa.]. Franklin Inst, J 141: 227-229 (1896)

99 Coastal topography of the United States. Eng Club Phila, Pr 16:273-300, map (1899)

04 The petrified forests and Painted Desert of Arizona. Franklin Inst, J 157 : 293-311 (1904)

09 Earthquakes in the light of the new selsmology. Franklin Inst, J 167:434 472 (1909)

09a The interior of the earth in the light of the new seismology. Franklin Inst, J $168: 303-310$ (1909)

Carter, T. Lane.

10 The gold mining industry in Nicaragua. Eng M J 90:1204-1206 (1910)

10a Mining in Nicaragua. Am I M Eng, B 48: 965-1001 (1910); Tr 41: 594 630 (1911)

11 Gold placers in Arizona, Eng M J 91: 561-562 (1911)
Carter, T. Lane-Continued.

11 a Nicaragua and its gold industry. M Sc Press 103:195-199 (1911)

12 Gold placers of Arizona. M Sc Press 105 : 166-168 (1912)

Carter, William E. H. (1877-1920).

05 The mines of Ontario. Can M Inst, J $7: 114-167$ (1905) Can M Rv 23:193$200,222-227$ (1904) ; 24:34-37, 57-59 (1905)

10 The Poreupine gold area, Ont. Can M J 31:361-366 (1910)

Carus, C. G.

47 (and others) Resultate geologischer, anatomischer, und zoologischer Untersuchungen über das unter dem Namen $H y$ drarchos von Dr. A. C. Koch zuerst nach Europa gebrachte ... Skelett [Basilosaurus]. $16 \mathrm{pp}$, fol, il, Dresden 1847

Carver, Samuel D.

25 Notice of a meteoric stone which fell at Nanjemoy, Md. Am J Sc 9:351-353 (1825)

Cary, Austin.

91 Geological facts noted on Grand River, Labrador. Am J Sc (3) 42:419421, 516 (1891)

92 A study in foot structure lPalaeosyops and Menodus] J Morph $7: 305-315$, il $(1892)$

Cary, L. R.

18 The Gorgonaceae as a factor in the formation of coral reefs. Carnegie Inst Wash, Pub 213, Papers from Dp Marine Biology 9:341-362 (1918)

Case, Ermine Cowles.

92 (with Williston, S. W.) Kansas mosasaurs. Kans Univ Q 1:15-32, il (1892) ; 2:83-84, il (1893)

93 (with Bailey, E. H. S.) On the composition of some Kansas building stones. Kans Ac Sc, Tr 13:78 (1893)

94 A geological reconnalssance in southwest Kansas and No Man's Land. Kans Univ Q 2: 143-147 (1894)

94a Traces of a glacier at Kansas City, Mo. Kans Univ Q 2: 149-150 (1894)

95 Experiments in ice motion. J G 3 : 918-934 (1895)

95a On the mud and sand dikes of the White River Eocene. Am G 15:248-254 (1895)

97 On the foramina perforating the cranial region of a Permian reptile and on a cast of its brain cavity. Am J Sc (4) $3: 321-326$, il (1897)

$97 \mathbf{a}$ On the osteology and relationships of Protostega. J Morph 14:21-60, il (1897)

$97 \mathrm{~b}$ The cranial region of Dimetrodon (abst). Science n s 5:594 (1897)

97e (with Baur, G.) On the morphology of the skull of the Pelycosauria and the origin of the mammals. Anat $\mathrm{Anz}$ 13:109-120, il (1897) Abst, Science n s 5: $592-594$ (1897)

$$
28737^{\circ}-23-12
$$


Case, Ermine Cowles-Continued.

98 The development and geological relations of the vertebrates. J G $6: 393-$ $416,500-523,622-646,711-736,816-839$ (1898); $7: 163-187$ (1899)

9Sa Toxochelys. Kans Univ G S 4: $370-385$, il (1898)

98b The significance of certain changes in the temporal region of the primitive Reptilia. Am Nat $32: 69-74$, il (1898)

99 A redescription of Pariotichus incisivus Cope. Zool B 2:231-245, il (1899)

99a (with Banr, G.) The history of the Pelycosauria, with a description of the genus Dimetrodon, Cope. Am Ph Soc, $\mathrm{Tr}$ n s $20: 5-62$, il (1899)

00 The vertebrates from the Permian bone bed of Vermilion Co., IIl. J G 8: 698-729, il (1900) Chicago Univ, Walker Mus, Contr 1 no 1:29 pp, il (1901)

02 On some vertebrate fossils from the Permian beds of Oklahoma. Okla, Dp G N H, Bien Rp 2:62-68 (1902)

02a Paleontological notes. J G 10 : 256-261, il (1902) Chicago Univ, Walker Mus, Contr 1 no $3: 45-50$, il (1902)

03 The osteology of Embolophorus dollovianus, Cope, with an attempted restoration. J G 11:1-28, il (1903)

03a New or little known vertebrates from the Permian of Texas. J G 11: $394-402$, il (1903) Chicago Univ, Walker Mus, Contr 1 no $4: 53-61$, il (1903)

$\mathbf{0 3 b}$ The structure and relationships of the American Pelycosauria. Am Nat 37 : 85-102, il (1903)

04 The osteology of the skull of the pelycosaurian genus, Dimetrodon. J G 12 : 304-311, il (1904) Chicago Univ, Walker Mus, Contr 1 no 6:75-82, il (1904)

04a On the structure of the fore foot of Dimetrodon. J G $12: 312-315$, il (1904) Chicago Univ, Walker Mus, Contr 1 no 6 : $83-86$, il (1904)

04b A remarkably preserved specimen of pelycosaur collected during the last summer in Texas $(a b s t)$. Science n $\mathrm{s} 19$ : 253 (1904)

05 The osteology of the Diadectidae and their relations to the Chelydosauria. J G $13: 126-159$, il (1905)

05a The morphology of the skull of the pelycosaurian genus Dimetrodon. Am Ph Soc, Ir n s 21:1-29, il (1905)

o5b Decological features of evelution. Wis N ki Soc, B n s 3:169-180 (1905)

o5e Characters of the Chelydosauria (abst). Science n \& 21:298 (1905)

o5d Bathygnathus borealis Leidy and the Permian of Prince Edwards Island. Science n s $22: 52-53$ (1905)

06 A peculiar formation of shore ice. J G 14: 134-137 (1906)

o6a On the skull of Edaphosaurus pogonias Cope. Am Mus N H, B 22:1926, il (1906)
Case, Ermine Cowles-Continued.

07 Restoration of Diadectes. J G 15 : $556-559$, il (1907)

O7a Revision of the Pelycosauria of North America. $176 \mathrm{pp}, 11$, Carnegie ins Wash, Pub no 55, 1907

07b Description of the skull of Bole saurus striatus Cope. Am Mus N H, B $23: 653-658$, il (1907)

07e The character of the Wichita and Clear Fork divisions of the Permian Red Beds of Texas. Am Mus N H, B 23:65664 , il (1907)

o7d Additional description of the genss Zatrachys Cope, Am Mus N H, B 23: 665-668, il (1907)

o7e Wisconsin; its geology and physical geography. $197 \mathrm{pp}$, Milwaukee, Wis, 190

08 Notes on the skull of Lysorophus tricarinatus Cope. Am Mus N H, B 24:531533, il (1908)

osa on the value of the evidence fur. nished by vertebrate fossils of age of cer tain so-called Permian beds in America. J G 16:572-580 (1908)

osb Description of vertebrate fossils from the vicinity of Pittsburgh, $\mathrm{Pa}$ Carnegle Mus, An 4:234-241, il (1908)

ose A great Permian delta and its rerte brate life ... Pop Sc Mo $73: 557-568$, I (1908)

08d Permian glaciation and distribution of Permian reptiles (abst). Science n $27: 255-256$ (1908)

09 Notes on a collecting trip in the Permian of Texas, during the summer ot 1908 [stratigraphy and mode of deposition of the red beds] (abst). Seience n s 29: 195 (1909)

09a American palentology and netLamarckism. Michigan Ac Sc, Rp 11:1823 (1909)

10 Permian reptiles of North Americe. Carnegie Inst Wash, Y Bk $8: 231$ (1910)

10a New or little known reptiles and amphibians from the Permian (?) of Texas Am Mus N H, B 28:163-181, il (1910)

10b The skeleton of Pacilospondyly francisi, a new genus and species of Pelf: cosauria. Am Mus N H, B $28: 183-188$, (1910)

10e Description of a skeleton of Dise trodon incisivus Cope. Am Mus $\mathrm{N} \mathrm{H,} \mathrm{B}$ 28: 189-196, il (1910)

11 A revision of the Cotylosauria of North America. 122 pp, il, Carnegie Inst Wash, Pub no 145,1911

11 a Revision of the Amphibia and Plsces of the Permian of North America; with s description of Permian insects by E. H. Sellards, and a discussion of the fossll fishes by Louis Hussakof. $179 \mathrm{pp}$, Carnegie Inst Wash, Pub no 146, 1911

111. Continuation of the work on the Permian reptiles and amphibia of North America. Carnegie Inst Wash, Y Bk 9 : 228-229 (1911) 
Case, Frmine Cowles-Continued.

12 Ten years' progress in vertebrate paleontology; Paleozoic Reptilia and Amphibla. G Soc Am, B $23:$ 200-204 (1912)

12a (and Williston, $S$. W.) A description of the skulls of Diadectes lentus and Animasaurus carinatus. Am J Sc (4) $33: 339-348$, il (1912)

12b Notes on the geology of the Gallina, N. Mex., quadrangle. Mich Ac Sc, Rp 14 : 114-115 (1912)

12e (with Williston, S. W.) The Permo-Carboniferous of northern New MexIco. J G $20: 1-12$ (1912)

13 Red beds between Wichita Falls, Tex., and Las Vegas, N. Mex., in relation to their vertebrate fauna (abst). G Soc Am, B 24: 679 (1913)

13a (and Williston, S. W., and Mehl, M. C.) Permo-Carboniferous vertebrates from New Mexico. $81 \mathrm{pp}$, il, Carnegie Inst Wash, Pub no 181, 1913

14 The red beds between Wichita Falls, Tex., and Las Vegas, N. Mex., in relation to their vertebrate fauna. J G 22:243-259 (1914)

14a Restoration of Edaphosaurus cruciger Cope. Am Nat 48:117-121, il (1914)

14b On the structure of the inner ear in two primitive reptiles. Biol B $27: 213-216$, il (1914)

14e Evidence of climatic oscillations in the Permo-Carboniferous beds of Texas (abst). G Soc Am, B 25: 41 (1914)

15 The Permo-Carboniferous red beds of North America and their vertebrate fauna. Carnegie Inst Wash, Pub 207:176 pp, il, maps (1915)

15a (and Robinson, W. I.) The geology of Limestone Mountain and Sherman Hill in Houghton Co., Mich. Mich $\mathbf{G} \mathrm{S}$, Pub 18 (g s 15) : 165-181 (1915) J G 23: 256-260 (1915)

15b A mounted specimen of Dimetrodon incisivus Cope, in the Univensity of Michigan. Am J Sc (4) 40:474-478 (1915)

$15 \mathrm{e}$ On a nearly complete skull of $\$ y m$ bos cavifrons Leidy from Michigan. Mich Univ, Mus Zool, Oc P 13: 3 pp, 11 (1915)

$15 d$ Notes on the Permo-Carboniferous genus Oricotus Cope. Science n s 42:797798 (1915)

16 Further evidence bearing on the age of the red beds in the Rio Grande valley, N Mex. Science n s 44:708-709 (1916)

16a Study of the vertebrate fauna and paleogeography of North America in the rermian period, with especial reference to world relations. Carnegie Inst Wash, Y Bk $14: 386$ (1916)

17 The environment of the amphibian fauna at Linton, Ohio. Am J Sc (4) 44 : 124-136, il (1917)
Case, Ermine Cowles-Continued.

$17 \mathbf{a}$ Notes on the possible evidence of the presence of a Pareiasaurus-like reptile in the Conemaugh series of West Virginia, with note by I. C. White. In Braxton and Clay counties: $817-829$, il, W Va G S (1917)

$\mathbf{1 7 b}$ Study of the vertebrate fauna and paleogeography of North America in the Permian period, with especial reference to world relations. Carnegie Inst Wash, Y Bk $15: 373-374$ (1917)

18 A mounted skeleton of Edaphosaurus cruciger Cope, in the geological collection of the University of Michigan. Mich Univ, Mus Zoology, Oc P no $62: 8$ pp, il (1918)

18a Permo-Carboniferous conditions versus Permo-Carboniferous time. J G 26 : 500-506 (1918)

18b Permo-Carboniferous time versus Permo-Carboniferous conditions. Mich Ac Sc, An Rp 20:82 (1918)

18c Study of the vertebrate fauna and paleogeography of North America in the Permian period, with especial reference to world relations. Carnegie Inst Wash, Yr Bk 16, $1917: 331$ (1918)

See also Clark (W B), 01a, 04a

Case, Theodore S.

77 The Wyandotte, Kans., gas well. Western Rv Sc 1:321-324 (1877)

$\boldsymbol{7 7 a}$ The mineral region of southwest Missouri and southeast Kansas. Western Rv Sc 1: 385-391 (1877)

Case, William H.

94 The Bertha zinc mines at Bertha, Va. Amr I M Eng, Tr 22:511-536, map (1894) Abst, Eng M J 56:292-294 (1893)

Casey, Thomas L.

01 On the probable age of the Alabama white limestone. Ac N Sc Phila, Pr 53: 513-518 (1901)

02 The Jackson outcrops on Red River [La.]. Science n s 15: 716-717 (1902)

02a A new genus of Eocene Eulimidae [from Louisiana]. Nautilus $16: 18-19$, il (1902)

03 Notes on the Conrad collection of Vicksburg fossils, with descriptions of new species. Ac N Se Phila, Pr $55: 261-283$ (1903)

04 Notes on the Pleurotomidae with description of some new genera and species. Ae Se St L, Tr 14:123-170 (1904)

o5 The mutation theory [includes notes on stratigraphy of Vicksburg, Miss.]. Science n s $22: 307-309$ (1905)

11 Subsidence of Atlantic shore line. Science n s 34: 80-81 (1911)

Casseday, S. A. . ( ? -1860).

54 Beschreibung eines neuen Crinoideengeschlechts aus dem Kohlenkalkstein Nordamerikas. Deut G Ges, Zs 6:237-242, il (1854) 
Casseday, S. A,-Continued.

59 (with Lyon, S. S.) Description of nine new species of Crinoidea from the Subcarboniferous rocks of Indiana and Kentucky. Am J Sc (2) 28:233-246 (1859)

60 (with Lyon, S. S.) Description of nine new species of Crinoidea from the Subcarboniferous rocks of Indiana and Kentucky. Am J Sc (2) $29: 68-79$ (1860)

60a (with Lyon, S. S.) A synonymic list of the Echinodermata of the Paleozoic rocks of North America. Am Ac Arts, Pr 4: 282-304 (1860)

62 (with Lyon, S. S.) Description of two new genera and eight new species of fossil Crinoidea from the rocks of Indiana and Kentucky. Am Ac Arts, Pr 5: 16-31 (1862)

Casselberry, Isaac.

45 A description of certain fossil bones found near Evansville, Ind. ... : 8 pp, Evansville [Ind], 1845

Castello, W. O.

18 (with Boalieh, E. S.) Tungsten, molybdenum, and vanadium. Cal $\mathrm{St} M$ Bur, Prel Rp no 4:34 pp (1918)

18a (with Boalich, E. S.) Antimony. graphite, nickel, potash, strontium, tin. Cal St M Bur, Prel Rp no 5 : 44 pp (1918) Castelnau, Francis de (1812-1880).

43 Essai sur le système silurien de l'Amérique septentrionale. $\mathrm{xv}, 56 \mathrm{pp}, \mathrm{il}$, Paris 1843

43a Mémoire relatif au systeme silurten de l'Amérique septentrionale. Ac Sc Paris, C R 16:528-538 (1843)

Castillo, Antonio del (1820-1895).

50 Rápida esploración geológica de las montanas inmediatas al norte de la ciudad de Tehuacán y del cerro de Tlachiaque al sur de Tepeyahualco. Inst Nac Geog y Estad Rep Mex, B 1: 300-306 (1850)

52 De las minas y criaderos de hierro ... situados entre los pueblos de Xonacatepec y Xalostoc de oriente a poniente con una rápida esploración geológica ... [ [ Mexico]. Soc Mex Geog, B 3:64-70, maps (1852)

61. Riqueza míneral de la República; Península de la Baja California. $46 \mathrm{pp}$, México 1861 [not seen]

65 Descripción de la masa de hierro meteórico de Yanhuitlan ... [Mexico]. Soc Mex Geog, B 10:661-665 (1865)

66 Ueber den Erzreichthum Nieder-Californiens. Zs Berg-, Hütten- u Salinenwesen 14: Abh 105-119 (1866)

69 Los criaderos de azufre de México y su explotación. La Naturaleza $1: 44-50$ (1869)

69a Säugethierreste aus der QuartärFormation des Hochthales von Mexico. Deut G Ges, Zs 21 : 479-482 (1869)
Castillo, Antonio del-Continued.

71 Resumen de los trabajos que sol reconocimientos de criaderos $y$ minas azogue se practicaron el año de 1844 [quik silver deposits]. La Naturaleza 2:39-14 (1871)

73 Deseubrimiento de una nueva esper mineral de bismuto. La Naturaleza ? 274-276 (1873) N Jb 1874:225-229

73a (and Bárcena, Mariano) Notde de la existencia del arsénico nativo en al Republica mexicana. La Naturaleza $2: 318$ 314 (1873)

74 Acerca de la nueva especie minen de mercurio... La Naturaleza $3: 37$ (1874)

74a Descripcion del mineral bismutfent de San Luis Potosi ... [México]. La Natt. raleza 3: 92-94 (1874)

75 Noticia sobre los criaderos de grefit 6 plombagina de México, y su explotací La Naturaleza $3: 275-281$ (1875)

85 Riqueza mineral de la república; to gión austral de la península de la Baj California [mineral resources and geolog] of southern Lower California]. 86 of Mexico 1885

S5a (and Báreena, Mariano) El bos bre del Peñon; noticia sobre el hallazgo of un hombre prehistorico en el Valle of México. $20 \mathrm{pp}$, il, México $1885 \mathrm{La}$ Nato raleza $7: 257-270$, il (1886)

86 (with Bareena, M.) Noticia acera del hallazgo de restos humanos prehistorion en el valle de Méxíco. La Naturaleza 1 $257-264$, il (1886)

89 Catalogue descriptif des météorita (fers et pierres météoriques) du Mexique. $15 \mathrm{pp}$, map, Paris 1889

89a Bosquejo de una carta geologica de la Republica mexicana ... Scale $1: 1,000$, 000. Paris 1889

90 Catálogo descriptivo de los meteorits (tierras y piedras meteóricas) de Mérich La Naturaleza (2) $1: 378-392$, map (1890)

93 Bosquejo de una carta geológica de la República mexicana ... Scale $1: 1,000$ 000. México [1893]

95 (and Aguilera, J. G.) Fauna fosil de la Sierra de Catorce, San Luis Potost. Mex Com G, B 1:55 pp, il (1895)

16 Descripción de los distritos de minas de San Antonio, Triunfo, Las Vírgenes Cacachílas, ubicados al sur de La Paz, capttal del Territorio de la Baja Californis [México]. Bol Minero 2: 501-511 (1916)

Castleman, J. W.

99 The brown iron ore mines near Leeds. in Jefferson Co., Ala. Ala Ind Sc Soh Pr 9: 13-18 (1899)

Castro, Carlos.

09 Analisis y estudio de una kaolinita encontrada en un carbon de Villafuente Estado de Coahuila. Soc G Mex, B 5: $10,147-150$ (1909) 
Castro, Carlos Continued.

17 Nota sobre un corundo de una nueva localidad de México [Fresnillo, Zacatecas] Mex I G, An 4:31-36 (1917)

Castro, Manuel Fernández de. See Fernández de Castro, Manuel.

Caswell, Alexis.

77 Memoir of Benjamin Silliman, Sr. 1779-1864. Nat Ac Sc, Biog Mem 1:99$112(1877)$

Caswell, J. H,

80 Microscopic petrography of the Black Hills of Dakota. In Newton, Henry, and Jenney, Walter P., Report on the geology and resources of the Black Hills of Dakota (D S Geog G S Rocky Mtn Reg) : 469$527(1880$

Catherall, A. P.

13 The coal fields of Trinidad. Int $G$ Cong, XII Canada, The Coal Resources of the World, vol 1: 1xix, vol $2: 569-573$, map (1913)

Catherinet, Jules.

05 Copper Mountain, B. C. Eng M J $79: 125-127 \quad(1905)$

Catlett, Charles.

89 (with Clarke, F. W.) A platiniferous nickel ore from Canada. Am J Sc (3) $37: 372-374 \quad(1889)$

97 Some of the manganese deposits of the Valley of Virginia, Eng M J 64:156157 (1897)

00 Iron ores of the Potsdam formation in the Valley of Virginia. Am I M Eng. Tr 29: 308-317 (1900) Abst, Eng M J 68: $157-158$ (1899)

00a The Donald iron ore mine, Va. Eng M J 70:485 (1900)

04 Cement resources of the Valley of Virginia. U S G S, B 225: 457-461 (1904) 07 Occurrence of rutile in Virginia. Ee G 2: 796-797 (1907)

07n Quantitative field test for magnesia in cement rock and limestone. Am I M Eng, B 18:947-951 (1907); Tr 38: 705709 (1908)

0s Barite associated with iron ore in Pinar del Rio Province, Cuba. Am I M Eng, $\operatorname{Tr} 38: 358-359$ (1908)

08a Discussion of paper by H. M. Chance, A new theory of the genesis of brown hematite ores; and a new source of sulphur supply. Am I M Eng, B 24:11791183 (1908)

11 Pho phorus in coking coal [evansite from coal near Columbiana, Ala.] Am I II Eng, B 59:901 (1911)

See also Watson, 04e

Catlin, George.

40 Account of a journey to the Coteau des Prairies, with a description of the red bipe stone quarry and granite boulders found there. Am J Sc 38:138-146 (1840) 70 The lifted and subsided rocks of America ... xil, 228 pp, L 1870.
Caton. John D.

69 Origin of the prairies. Ottawa [III] Ac N Sc, Tr : $30 \mathrm{pp} \mathrm{(1869)}$

Cayenx, L.

oт Structure et classification des grès et quartzites; pluralité des origines du type quartzite. Int $\mathrm{G}$ Congr, $\mathrm{X}$, Mexico, $\mathrm{C} \mathrm{R}$ : 1211-1222 (1907)

07a Les œufs d'insects des lacs de Chalco et Texcoco, des environs de Mexico, et la formation des oolithes. Int $\mathrm{G}$ Cong, $\mathrm{X}$, Mexico, C R : 1223-1227 (1907)

11 Existence de restes organiques dans les roches ferrugineuses associées aux minerais de fer buroniens des Etats-Unis. Ac Sc Paris, C R 153: 910-912 (1911)

Cazin, F. M. F.

so New Mexico vs. Lake Superior as copper producer. Eng M J 30:87-88, 108 $(1880) ; 31: 300$ (1881)

See also Pošepný, 94, 95

Cessac, J. Léon de.

75 Etude microscopique et analyse de quelques roches de l'Alaska. In Pinart, Alph. L., Voyages à la côte nord-ouest de l'Amérique : $19-27$, Paris 1875

\section{Chadbourne, P. A.}

71 The discovery of a skull of a muskox in Utah. Am Nat $5: 315-316$ (1871)

Chadwielk, George Halcott.

os Revision of "the New York series." Sclence n s $28: 346-348$ (1908)

10 Downward overthrust fault at Saugerties [Ulster Co.], N. Y. N Y St Mus, B $140: 157-160$, map (1910)

10a Glacial lakes of the Catskill Val. ley. Science n s 32:27-28 (1910)

11 Reciprocal intercision by parallel streams (abst). Science n $\mathrm{s} \quad 33: 468$ (1911)

12 Color scheme for crystal models (abst). G Soc Am, B 23:728 (1912)

13 Angular unconformity at Catskill (abst). G Soc Am, B 24:676 (1913)

15 Post-Ordovician deformation in the Saint Lawrence Valley, N. Y. G Soc Am, B 26:115 (abst), 287-294, maps (1915)

16 Rectilinear features in the eastern Catskills (abst, with discussion by J. L. Rich and W. J. Miller). G Soc Am, B $27: 107$ (1916)

17 The lake deposits and evolution of the lower Irondequoit Valley [N. Y.]. Rochester Ac Sc, Pr 5:123-160, maps (1917)

17a Hypothesis for the relation of normal and thrust faults in eastern New York (abst, with discussion by B. K. Emerson and W. J. Miller). G Soc Am, B 28: 160161 (1917)

$\mathbf{1 7 b}$ Lockport-Guelph section in the barge canal at Rochester, N. Y. (abst with discussion by M. Y. Williams and Marjorie O'Connell). G Soc Am, B $28: 172-173$ (1917) 
Chadwick, George Halcott-Continued. 17e Cayugan water limes of western New York (abst, with discussion by M. Y. Williams). G Soc Am, B 28: 173-174 (1917) 17d American diphyphylloid corals (abst). G Soc Am, B 28:208 (1917)

18 Stratigraphy of the New York Clinton. G Soc Am, B $29: 327-368$ (1918)

1Sa Further studies in the New York Siluric (abst). G Soc Am, B 29:92 (1918)

See also Bucher, 17a; Swartz, 16 Chaix, Emile.

15 Quelques observations sur deux petits geysers du Yellowstone National Park. Am Geog Soc, Memorial Volume of Transcontinental Excursion of 1912:251-258 (1915)

Chalmers, Robert (?-1908).

81. On the glacial phenomena of the Bay Chaleur region. Can Nat n s $10: 37-54$, map (1881)

82 On the surface geology of the Baie de Chaleur region. Can Nat n s 10:193212 (1882)

83 On erosion from coast ice and floatIng ice in the Baie des Chaleurs (abst). R Soc Can, Pr Tr 1, iv : 285-286 (1883)

s5 Report on the surface geology of western New Brunswick with special reference to the area included in New York and Carleton cos. Can G S, Rp Prog 1882-4: GG 47 (1885)

85a Preliminary renort on the surface geology of New Brunswick. Can G S, An Rp 1: GG 58 pp (1885)

87 Report ... surface geology, northern New Brunswick and southeastern Quebec. Can G S, An Rp 2: M 39 pp, maps (1887)

$\mathbf{8 7 a}$ On the glaciation and Pleistocene subsidence of northern New Brunswick and southeastern Quebec. R Soc Can, Pr Tr 4, iv : 139-145 (1887)

s8 Report on the surface geology of northeastern New Brunswick. Can G S, An Rp 3: N 33 pp, map (1888)

89 [Observations on the surface rocks of southern New Brunswick.] Can G S, Sum Rp 1887-8 (An Rp 3) : A 94-96 (1889)

S9a Glaciation of eastern Canada. Can Rec Sc 3:319-333 (1889) Abst, Am G 6: 240-244 (1890) G Mag (3) 6:211-214 (1889)

90 Report on the surface geology of southern New Brunswick. Can G S, An Rp 4: N 92 pp, maps (1890)

$90 a$ [Summary report on the surface deposits of southern New Brunswick.] Can G S, Sum Rp 1888-9 (An Rp 4): A 38-43 (1890)

90b The glaciation of the Cordillera and the Laurentide. Am G 6:324-325 (1890)

91 [Summary report of investigation of surface geology in eastern New Brunswick.] Can G S, Sum Rp 1890 (An Rp 5) : A 53-57 (1891)
Chalmers, Robert-Continued.

02 [Report on surface geology in east. ern New Brunswick.] Can G S, Sum Rp 1891 (An Rp 5) : A 48-52 (1892)

93 [Report on investigation of surface geology of central and eastern New Bruns wick.] Can G S, Sum Rp 1892 (An $\mathrm{B}_{\text {p }}$ 6) : 4 48-54 (1893)

93a Height of the Bay of Fundy coast in the glacial period relative to sea level, as evidenced by marine fossils in the boul. der clay at Saint John, New Brunswick. $\theta$ Soc Am, B $4: 361-370$ (1893) Abst, Am G $11: 134,176-177$ (1893)

94 [Summary report on investigations of surface geology of southeastern Ner Brunswick and adjacent parts of Nors Scotia and Prince Edward Island. $\operatorname{Can} \theta$ S, Sum Rp 1893 (An Rp 6) : A 52-57 (1894) 95 Report on the surface geology of eastern New Brunswick, northwestern Nora Scotia and a portion of Prince Edward Island. Can G S, An Rp 7 : M 149 pp, map (1895)

95a [Report on investigations of the surface geology of New Brunswick.] Can G S, Sum Rp 1894 (An Rp 7) : A 80-88 (1895)

95b On the glacial Lake St. Lawrence.. Am J Sc (3) $49: 273-275$ (1895)

96 [Report on an investigation of the auriferous districts of Quebec.] Can $\theta$ S, Sum Rp 1895 (An Rp 8): A $85-98$ (1896)

96a Pleistocene marine shore lines on the south side of the St. Lawrence Valley. Am J Sc (4) 1:302-308 (1896)

97 [Report on field work in the eastern townsbips of Quebec.] Can G S, Sum Rp 1896 (An Rp 9): A 74-83 (1897)

$97 \mathbf{a}$ The gold-bearing deposits of the eastern townships of Quebec. Fed Can M Inst, J 2:13-28 (1897) Can M Rv 16: 74-77 (1877)

98 Report on the surface geology and auriferous deposits of southeastern Quebec. Can G S, An Rp 10: J 160 pp, map (1898)

98 a [Report on field work in the St. Lawrence Valley.] Can G S, Sum Rp 1897 (An Rp 10) : A 62-74 (1898)

98b The preglacial decay of rocks in eastern Canada. Am J Sc (4) 5:273282 (1898) Abst, Brit As, Rp 67:655656 (1898)

99 [Report on a landslip in Portneuf Co., Que.] Can G S, Sum Rp 1898 (An Rp 11) : ^ 121-124 (1899)

99a [Report on field wo:k in New Brunswick.] Can G S, Sum Rp 1898 (An Rp 11) : $\triangle 133-137$ (1899)

00 Notes on the Pleistocene marine shore lines and landslips of the north side of the St. Lawrence Valley. Can G S, An Rp 11: J 63-70 (1900) 
Chalmers, Robert-Continued.

00a [Report on the investigation of the surface geology of New Brunswick.] Can G S, Sum Rp 1899 (An Rp 12) : A 148155 (1900)

01 [Report on the surface geology of northwestern New Brunswick.] Can G S, Sum Rp 1900 (Am Rp 13): A 151-161 (1901)

01a The sources and distribution of the gold-bearing alluvions of Quebec. Ottawa Nat 15:33-36 (1901)

02 Report on the surface geology shown on the Fredericton and Andover quartersheet maps, N. B. Can G S, An Rp 12: M $41 \mathrm{pp}$, map (1902)

02a On borings for natural gas, petroleum and water; also notes on the surface geology of part of Ontario. Can G S, Sum Rp 1901 (An Rp 14) : A 160-171 (1902)

03 Artesian borings, surface deposits, and ancient beaches in Ontario. Can G S, Sum Rept 1902 (An Rp 15) : A 270-281, map (1903)

04 Bulletin on peat. Can G S : 40 pp (1904)

04a The geomorphic origin and development of the raised shore lines of the St. Lawrence Valley and Great Lakes. Am J Sc (4) 18: 175-179 (1904)

04b Surface geology of the southern part of the Province of Quebec. Can G S, Sum Rp 1903 (An Rp 15) : A 140-143 (1904)

05 Surface geology of eastern Quebec. Can G S, Sum Rp 1904 (An Rp 16) : A 250263 (1905)

05a The glaciation of Mount Orford, P. Q. Ottawa Nat $19: 52-55$ (1905)

06 The surface geology of Manitoba, Saskatchewan, and Alberta. Can G S, Sum Rp 1905: 67-69 (1906)

06a Surface geology of the ${ }^{*}$ Great Plains and British Columbia, etc. Can G S, Sum Rp 1906: 74-80 (1906)

08 Surface geology of the St. Lawrence Valley. Can G S, Sum Rp 1907:69-71 (1908)

Chaloner, A. D.

43 On some fossil bones from Missouri. Ac N Sc Phila, Pr 1: 321-322 (1843)

Chamberlain, Charles J.

15 A phylogenetic study of cycads. Nat Ac Sc, Pr. 1:86-90 (1915)

Chamberlin, Benjamin B. (1831-1888).

83 The minerals of the Weehawken tunnel [N. J.] N Y Ac Sc, Tr 2: 88-90 (1883)

85 Field work in local mineralogy [minerals of New York City]. N Y Ac Sc, Tr 3: 48-50 (1885)

86 Minerals of Harlem and vicinity [N. Y.] N Y Ac Sc, Tr 5: 74-77 (1886)

86 a Minerals of Staten Island (N. Y.). N Y Ac Sc, Tr 5:227-230 (1886)

87 Notes on minerals from the French Creek mines, Chester Co., Pa. N Y Ac Sc, Tr 4: 41-42 (1887)
Chamberlin, Benjamin B.-Continued.

88 The minerals of New York Co., including a list complete to date. N. Y. AC Sc, Tr 7:211-235 (1888)

Chamberlin, P. W.

03 The volcanoes of Nicaragua. U S, 57 th Cong $2 \mathrm{~d}$ sess, Sen Doc no $131: 27-33$ (1903)

Chamberlin, Rollin Thomas.

05 The glacial features of the St. Croix Dalles region. J G $13: 238-256$, maps (1905)

os Contributions to cosmogony and the fundamental problems of geology; the gases in rocks. $80 \mathrm{pp}$, Carnegie Inst Wash, Pub no 106,1908

08a (with Chamberlin, T. C.) Early terrestrial conditions that may have favored organic synthesis. Science n s 28 : 897-911 (1908)

09 The gases in rocks. J G $17: 534$ 568 (1909) Abst, Science n s 27:731-732 (1908)

10 The Appalachian folds of central Pennsylvania. J G 18: 228-251 (1910)

10a Older drifts in the St. Croix region, J G 18: 542-548 (1910)

10b (with Chamberlin, T. C.) Certain valley configurations in low latitudes. J G 18: 117-124 (1910)

11 (with Chamberin, T. C.) Certain phases of glacial erosion. J G 19 : 193-216 (1911)

14 Diastrophism and the formative processes; VII, Periodicity of Paleozoic orogenic movements. J G $22: 315-345$ (1914)

17 Interpretation of the formations containing human bones at Vero, Fla. J G $25: 25-39$ (1917)

17a Further studies at Vero, Fla. J G $25: 667-683$ (1917)

18 (and Miller, W. Z.) Low-angle faulting. J G 26:1-44 (1918)

18 a On the mechanics of the great overthrusts (abst). Science n s $47: 470$ (1918)

18b (and Richards, J. T.) Preliminary report on experiments relating to continental deformation (abst). Science $\mathbf{n} \mathbf{s}$ $47: 492$ (1918)

See also Adams (F D), 17

Chamberlin, Thomas Chrowder.

74 Some evidences bearing upon the method of the upheaval of the quartzites of Sauk and Columbia cos. Wis Ac Sc, Tr 2: 129-132 (1874)

74a On fluctuations in level of the quartzites of Sauk and Columbia cos. Wis Ac Sc, Tr 2:133-138 (1874)

77 Annual report of progress and results of the Wisconsin geological survey for the year 1876. $40 \mathrm{pp}$, Madison 1877

77a Geology of eastern Wisconsin. [Wis $G$ S], $G$ Wis $2: 91-405$, maps [in atlas] (1877)

77b (and others) Atlas of the geological survey of Wisconsin. 45 pls [Milwaukee 1877-1882] 
Chamberlin, Thomas Chrowder-Contd.

78 Annual report of the Wisconsin geological survey for the year 1877. $93 \mathrm{pp}$. Madison, Wis., 1878

78a The Kettle Moraine of the Great Lake district of North America. 20 pp, map, Paris 1878

78b On the extent and significance of the Wisconsin kettle moraine. Wis Ac Sc, Tr 4:201-234, map (1878)

79 Annual report of the Wisconsin geological survey for the year 1878. $52 \mathrm{pp}$, Madison, Wis., 1879

80 Annual report of the Wisconsin geological survey for the year 1879 . $72 \mathrm{pp}$, Madison, Wis., 1880

soa Le Kettle moraine et les mouve ments glaciaires qui lui ont donné nais sance. Int G Cong, Paris 1878, C R : 254 268, map (1880)

s2 The bearing of some recent deter minations on the correlation of the eastern and western terminal moraines. Am J Sc (3) $24: 93-97 \quad(1882)$

S2a On a proposed system of lithological nomenclature. Wis Ac Sc, Tr 5 : 234-247 (1882)

82b Observations on the recent glacial drift of the Alps. Wis Ac Sc, Tr 5:258270 (1882)

82e The ore deposits of southwestern Wisconsin. [Wis G S], G Wis $4: 365-$ 571, maps (1882)

82d (and others) The quartzites of Barron and Chippewa cos. [Wis G S] G Wis $4: 573-581$ (1882)

83 General geology; I, Chemical-geology ; II, Lithological geology ; III, Historical geology. [Wis G S], G Wis $1: 1$ 300, map (1883)

$83 a$ Economic suggestions in regard to copper, silver, and other ores; Building materials; Soils and subsoils of Wisconsin; Artesian wells. [Wis G S], G Wis $1: 656-701$ (1883)

83b Terminal moraine of the second glacial epoch. U S G S, An $R_{p} 3: 291-$ 402, maps (1883)

83e The terminal moraine west of Ohio (abst with discussion). Science 2:317318 (1883)

83d The copper-bearing series of Lake Superior. Science 1:453-455 (1883)

84 Hillocks of angular gravel and disturbed stratification. Am J Sc (3) 27 : 378-390 (1884)

84a Genetic classification of the stony drift clays (abst). Am As, Pr 32:208209 (1884)

84b The character of the outer border of the drift (abst). Am As, $\mathrm{Pr} 32: 210$ (1884.)

s4e The terminal moraines of the later epoch (abst). Am As, Pr 32:211-212 (1884)
Chamberlin, Thomas Chrowder-Contd

85 The requisite and qualifying condtions of artesian wells. U S G S, An b 5:125-173 (1885)

s5a (and Salisbary, R. D.) On the driftless area of the Upper Mississipst Valley. U S G S, An Rp 6:199-322, map (1885)

85b (with Irving, R. D.) Obserr. tions on the junction between the easten sandstone and the Keweenaw series on Keweenaw Point, Lake Superior. U S G S, B 23:124 pp (1885) Rv, Am G 1: $44-57$ (1888)

86 An inventory of our glacial drift (abst). Science 8:156-159 (1886) An As, Pr 35: 195-211 (1887)

86a The artesian well at jelle Plaine, Iowa. Seience 8:276-277 (1886)

88 The rock-scorings of the great le invasions. U S G S, An Rp $7: 147-24$, map (1888)

S8a Note respecting the term Anotozoic. Am J Se (3) 35: 254-255 (1888)

89 Roland Duer Irving [1847-1889]. Am G 3:1-6, port (1889) Wis Ac Sc, $\operatorname{Tr} 8: 433-437$, port (1892)

90 Some additional evidences bearing on the interval between the glacial epochs (with discussion by W J McGee, J. C Procter, F. J. H. Merrill and I. C. White) G Soc Am, B 1:469-480 (1890)

90a Boulder belts distinguished frow boulder trains; their origin and significance (abst, with discussion by $\mathrm{A}$. Winchell and others). G Soc Am, B 1:27-31 (1890)

90b Additional evidences bearing on the intervals between the leading glacial epochs (abst). Am G 5:118 (1890)

91 (and Salisbury, R. D.) On the relationship of the Pleistocene to the prePleistocene formations of the Mississippi Basin, south of the limit of glaciation. Al J Sc (3) $41: 359-377$ (1891)

91 a A proposed system of ehronologic cartography on a physiographic basis, G Soc Am, B 2:541-544. (1891)

$91 \mathbf{b}$ The attitude of the eastern and central portions of the United States dur ing the glacial period (also abst, with dis cussion by W. Upham). Am G 8:233, $267-275$ (1891) Am As, Pr 40:250 (1892)

91c The present standing of the several lypotheses of the cause of the glacial p.riod (abst, with diseussion by C. H. Hitchcock, N. S. Shaler, and W. Upham). Am G 8:195, 237 (1891)

91d Proposed genetic classification of Pleistocene glacial formations (abst, with discussion). $\mathrm{Am}$ G $8: 240,248$ (1891)

91e (with others) The crystalline schists of the Lake Superior district. Int G Cong, IV, London 1888, C R : 156-170 (1891)

92 Some additional evidences bearing on the interval between the glacial epochs. Wis Ac Sc, Tr $8: 82-86 \quad(1892)$ 
Chamberlin, Thomas Chrowder-Contd.

93 The nature of the englacial drift o1 the Mississippi basin. J G 1:47-60 (1893) 93a The horizon of drumlin osar, and kame formation. J G 1: 255-265 (1893)

93b [Englacial drift]. J G 1:521-524 1893)

93e [Divisibility of the glacial period]. J G 1: $847-849$ (1893)

93d The diversity of the glacial period, Am J Sc (3) 45:171-200 (1893)

98e (and others) Discussion sur la classification génétique des dépóts pléistoènes, Int $\mathrm{G}$ Cong, $\mathrm{V}$, Washington 1891 , C R: 62-66, 176-207 (1893)

93f Some questions respecting glacial henomena about Madison, Wis. (abst). Am G $12: 176$ (1893)

93g Glacia: succession in the United States (abst). Am G $12: 227-228$ (1893)

93h Professor Wright and the geological survey. The Dial 14: 7-9 (1893)

94 Glacial studies in Greenland. $\mathrm{J} G$ 2:649-666, 768-788 (1894); 3:61-69, $198-218,469-480,565-582$, 668-681, 833843, maps (1895) ; 4:582-592 (1896] ; :229-240 (1897)

9ia Glacial phenomena of North Amerca. In Geikie. James, The great ice age 3d ed: 724-774, L 1894

94b Proposed genetic classification of Pleistocene glacial formations. Submitted to the International Congress of Geologists for disenssion. $4 \mathrm{pp}, \mathrm{n} \mathrm{p}, \mathrm{n}$ d [1894?] atc The relations of geology to pbysiography in our educational system. Nat feog Mag 5 : 154-160 (1894)

94d (and Leverett, Frank) Certain features of the past drainage systems of the upper Ohio basin (abst with discussion). At 6 13:217-219 (1894)

94e (and Leverett, Frank) Further studies of the drainage features of the upper Obio basin. Am J Sc (3) 47:247283, 483 (1894)

94f Pseudo-cols. J G $2: 205-206$ (1894) dbet, Am G $13: 217$ (1894)

945 Proposed genetic classification of Pleistocene lacial formations. J G 2 : $517-538$ (1594)

95 Recent glacial studies in Greenland. G Soc Am, B 6: 199-220 (1895) Sc Am Sup $39: 15876 ; \quad 40: 16275-16276 \quad$ (1895) Abst, Science, n s $1: 66$ (1895) ; Am G $5: 197-198$ (1895)

95a The classification of American glacial deposits. I G $3: 270-277$ (1895) $95 \mathrm{~b}$ Notes on the glaciation of Newfoundland (abst). G Soc Am, B 6:467 1895) Am G $15: 203$ (1895) Science n $81: 63(1895)$

96 The age of the second terrace on the Ohio at Prilliant, near Steubenville. J G :219-221 (1896)

$96 a$ [Nomenclature of glacial formathons]. J G 4:872-876 (1896)
Chamberlin, Thomas Chrowder-Contd.

96h Memoir of Henry Bradford Nason.

G Soc Am, B $7: 479-481$ (1896)

96e The Natchez formation [Mississippi] (abst). Am G 17:108-109 (1S96)

96a Alternative interpretations [history of Lake Agassiz]. U S G S, Mon 25: 244251 (1896)

$\mathbf{9 7}$ The limit of Greenland glaciation. J G 5:81-85 (1897)

97a A group of hypotheses bearing on climatic changes. J G $5: 653-683$ (1897) Abst, Brit As, Rp 67:644-647 (1898)

9тb Supplementary hypothesis respecting the origin of the loess of the M'ssissippi Valley. J G 5:795-802 (1897) Abst, Am As, Pr 46:204-205 (1898); Am G 20:197 (1897); Science n s 6:689 (1897)

97e The metlod of multiple working hypotheses. J G 5:837-848 (1897)

97d Former extension of Greenland glaciers. Science n s 5:400-401 (1897)

97e Former extension of Cornell Glacier near the sonthern end of Melville Bay. Science n s 5:748-753 (1897)

98 The ulterior basis of time divisions and the classification of geologic history. J G $6: 449-462$ (1898)

9Sa Continental shelf distinguished from sea shelf. J G 6:524-526 (1898)

981 A systematic source of evolution of provincial faunas. J G 6:597-608 (1898)

98e The influence of great epochs of limestone formation upon the constitution of the atmosphere. J G 6:609-621 (1898)

99 Doctrine of crustal quiescence and readjustment. J G $7: 295-297$ (1899)

$99 a$ An attempt to frame a working bypothesis of the cause of glacial periods on an atmospheric basis. I G $7: 545-584$, 667-685. 751-787, maps (1899)

99t. Lord Kelvin's address on the age of the earth as an abode fitted for life. Science n \& 9:8:9-901; $10: 11-18$ (1899) Smiths Inst, An Rp 1899:223-246 (1901)

oo $\Delta \mathrm{n}$ attempt to test the nebular hypothesis by the relations of masses and momenta. J G 8:58-73 (1900)

OOa (and Moulton, F. R.) Certain recent attempts to test the nebular hypothesis. Science n s 12: 201-208 (1900)

Oob On the habitat of the early vertebrates. J G 8:400-412(1900)

ooc Proposed international geologic institute. I G 8:596-609 (1900)

oOd Some recent studies of fundamental problems in geology (abst). Sclence $\mathrm{n} \mathrm{s}$ $11: 311-312(1900)$

o1 Nomenclature in geology. J G 9: 267-270 (1901)

o1a on a possible function of disruptive approach in the formation of meteorites, comets, and nebuls. J G 9:369-392 (1901) 
Chamberlin. Thomas Chrowder-Contd.

01b On Lord Kelvin's address on the age of the earth as an abode fitted for life. Smithsonian Inst, An Rp 1899: 223-246 (1901) Science n s 9:889-901 (1899; $10: 11-18$ (1899)

01e Report on some studies relative to primal questions in geology (abst). Sc Am Sup 52:21504 (1901)

02 The geologic relations of the human relics of Lansing, Kans. J G 10:745-779, map (1902)

03 The eriteria requisite for the reference of relics to a glacial age. J G 11 : 64-85 (1903) Abst, Science n s $17: 223-$ 224 (1903)

$03 n$ The origin of ocean basins on the planetessimal hypothesis (abst). Am G $32: 14$ (1903) Science n $\mathrm{s} \quad 17: 300-301$ (1903) G Soc Am, B 14:548 (1904) Sc Am Sup 55:22665-22666 (1903)

04 (and Salisbury, R. D.) Geology. 3 vols, N Y 1904-06 Vol 1, Geologic processes and their results, xix, 654 pp, 1904 ; $2 d$ ed, xix, 684 pp, 1905 Vol. 2, Earth history; genesis-Paleozoic, $\mathrm{xxvi,} 692 \mathrm{pp}, \mathrm{il}$, map, 1906 Vol. 3, Earth history ; Mesozoic, Cenozolc, xI, 624 pp, II, 1906

04a A contribution to the theory of glacial motion. Chicago Univ, Decennial Pub (1) 9:191-206 (1904)

04b Fundamental problems of geology. Carnegie Inst Wash, Y Bk 2:261-270 (1904)

04e The methods of the earth sciences. Pop Sc Mo 66:66-75 (1904) Cong Arts and Sci (St. Louis 1904) 4:477-487 (1906)

05 Fundamental problems of geology. Carnegie Inst Wash, Y Bk 3 : 195-258, 117118 (abst) (1905)

06 On a possible reversal of deep-sea circulation and its influence on geologic climates. Am Ph Soc, $\operatorname{Pr} 45: 33-43$ (1906) J G 14:363-373 (1906) Abst, Science n s $23: 930-931$ (1906)

o6r Fundamental problems of geology. Carnegie Inst Wash, $Y$ Bk $4: 171-185$ (1906)

06b "An ignored theory of the Ice age." Science n s 24: 531-532 (1906)

07 The fault problem. Ec G $2: 585-601$, 704-724 (1907)

07a [Geologic nomenclature.] J G 15: $817-819$ (1907)

07b On the growth of the earth by accretion under the planetesimal hypothesis (abst). Carnegie Inst Wash, Y Bk 5 : 169 (1907)

07e On certain problems of the lithosphere (abst). Carnegie Inst Wash, Y Bk $5: 170$ (1907)

07d On the former rates of rotation of the earth (abst). Carnegie Inst Wash, Y Bk $5: 170$ (1907)

oze On certain problems of the hydrosphere and atmosphere (abst). Carnegie Inst Wash, Y Bk 5:171 (1907)
Chamberlin, Thomas Chrowder-Contd, O7f Review of The viscous vs. the gras ular theory of glacial motion, by $0, \pi$ Willeox. J G 15:188-190 (1907)

os (and Chamberlin, R. T.) Eati terrestrial conditions that may have farow organic synthesis. Science n s 28:89\%911 (1908)

OSa The influence of the tides on the earth's rotation (abst). Science $n \& 2$ : 727-728 (1908)

o9 The former rates of the earth's rots. tion and their bearings on its deformation In The tidal and other problems, Carnegt Inst Wash, Pub no $107: 3-59$ (1909)

09a Diastrophism as the ultimate bas of correlation. J G 17:685-693 (1909)

09b A geologic forecast of the futur opportunities of our race. Science n 8 : 937-949 (1909) [Revised and with tith The future habitability of the earth] Smiths Inst, An Rp 1910: 371-389 (1911)

09e Soil wastage. Governors, conferest of, in the White House, Washington, D. C, May $13-15,1908$, Pr: 75-83, Washingto: 1909

10 Review of Comparison of Noth American and European glacial deposity by Frank Leverett [nomenclature of Amert can drift sheets]. J G $18: 470-474$ (1910)

10a Special problems and their study it economic geology. Ec G $5: 782-78$ (1910)

10b Certain valley configurations in lor latitudes, J G 18:117-124 (1910)

11 Sofl productivity. Zsience n 8 35: 225-227 (1911)

11a The bearings of radioactivity of geology. J G 19:673-695 (1911)

11b (and Chamberlin, R. T.) Cer tain phares of glacial erosion. $J$ G 19: 193-216 (1911)

12 The bearings of radioactivity on fo ology. Ill Ac Sc, Tr 4:57-75 (1912)

13 Map of North America during th great ice age. Scale, 104 miles $=1$ inch Chicago 1913

13a Contributions from allied scienca to geologic fundamentals (editorial). J 6 $21: 279-283$ (1913)

13b Diastrophism and the formatir processes; I, introduction; II, Shelf ent and certain limitations of diastrophism: III, The lateral stresses within the of tinental protuberances and their relatios: to continental creep and sea-transgression: IV, Rejuvenation of the continents: The testimony of the deep-sea deposits: VI, Foreset beds and slope deposits; VIIl. The quantitative element in circumcont? nental growth; IX, A specific mode of selt promotion of periodic disastrophism. J6 $21: 517-522, \quad 523-533, \quad 577-587,673-6$ s (1913) ; 22: 131-144, 266-274, 516-58 (1914) ; $26: 193-197$ (1918) 
Chamberlin, Thomas Chrowder-Contd. 13e Report on the study of fundamental problems of geology (abst). Carnegie Inst Wash, Y Bk 12:292-293 (1913)

14 (and Salisbury, Rollin D.) Introductory geology. 708 pp, N Y 1914

14a The shelf-seas of the Paleozoic and their relations to diastrophism and time divisions. Int $\mathrm{G}$ Cong, XII, 1913, C R : 539-553 (1914)

14b The fundamental segmentation of the earth (abst). Science n s $40: 774-775$ (1914)

15 The interior of the earth from the riew point of geology. Am $\mathrm{Ph} \mathrm{Soc,} \mathrm{Pr} 54$ : 279-289 (1915) Smiths Inst, An Rp 1916 : 225-234 (1917)

15a Study of fundamental problems of geology. Carnegie Inst Wash, Y Bk 13 : 356-367 (1915)

16 The origin of the earth. $\mathrm{X}, 271 \mathrm{pp}$, University of Chicago Press, 1916. Review by Joseph Barrell, n s 44: 239-244 (1916)

16a The evolution of the earth. Sc Monthly $2: 417-437,536-556$ (1916)

16b Isostasy in the light of the planetesimal theory. Am J Sc (4) $42: 371$ (1916)

17 Study of fundamental problems of geology. Carnegie Inst Wash, Y Bk 15 : 358-359 (1917)

18 Earth genesis. Ill Ac Sc, Tr 10 : 48-69 [1918]

18a Study of fundamental problems of geology. Carnegie Inst Wash, Y Bk 16: $307-318$ (1918)

18b Charles Richard Van Hise, 18571918. J G 26:690-697 (1918)

See also Blake (W P), 93 ; Hayford, 07 ; Powell, 83, 84, 85, 85a, 88, 89, 89a, 90, 91, 91a, 93, 95; Russell, 85d, 90 ; Tarr, 971; Todd, 81; Tyrrell, 90a ; Upham, 94b; Wright (A A), 93a; Wright (G F), 90.

Chambers, E. $\mathrm{T}$.

89 Notes on the Lake St. John country [Quebec]. Can Rec Sc 3:388-394 (1889)

Chambers, R. E.

96 A Newfoundland iron deposit. [Fed] Can M Inst, J 1:41-52 (1896) Can M Rv $15: 69-72$ (1896)

09 (and Chambers, A. R.) Sinking of Wabana submarine slopes [iron ores, Newfoundland]. Can M J 30:110-114 (1909)

Chambers, Robert.

47 Ancient sea margins. Am J Sc (2) $4: 323-325$ (1847) ; 8:33-35 (1849)

Chance, Henry Martyn.

78 A measured section of the Paleozolc rocks between Lock Haven and Farrandsville in Clinton Co., Pa. Pa G S, 2d, F : 265-269 (1878)

78 a Hyner's Station oil well section ... in the vicinity of Renovo, Clinton. Co., Pa. $\Delta \mathrm{m}$ Ph Soc, Pr 17:670-672 (1878)
Chance, Henry Martyn-Continued.

79 The northern townships of Butler Co.; a special survey along the Beaver and Shenango rivers in Beaver, Lawrence, and Mercer cos. Pa G S, 2d, $\nabla$ : xvii, 248 pp, map (1879)

so The geology of Clinten Co. Pa G S, 2d, G4: 1-72, map (1880)

80a A special survey of the Subearboniferous from the Allegheny Mountains to the Clarion-Venango oil district along the Susquehanna. $\mathrm{Pa}$ G S, 2d, G4: 79-152 (1880)

80b The geology of Clarion Co. Pa G S, 2d, VV : $\mathbf{x v}, 232 \mathrm{pp}$, maps (1880)

81 The construction of geological cross sections. Am I M Eng, Tr 9:402-409 (1881) Rv univ Mines (2) $10: 576-584$ (1881)

81a The Millstone grit in England and Pennsylyania. Am J Sc (3) 21:134-135 (1881)

81b [The conglomerate coal series.] The Virginias 2:153 (1881)

S2 The avallable tonnage of the bituminous coal fields of Pennsylvania. Am I M Eng, Tr 10:144-162 (1882)

S2a A survey of the Schuylkill water gap in the counties of Sehuylkill and Berks. $\mathrm{Pa} G \mathrm{~S}, 2 \mathrm{~d}, \mathrm{G} 6: 334$ and $\mathrm{pl}$ in pocket (1882)

82b Special survey of the Delaware water gap. Pa G S, 2d, G6:334-348, map (1882)

82e Special survey of the Lehigh water gap. Pa G S, 2d, G6:349-363, map (1882)

82d The auriferous gravels of North Carolina. Anr Ph Soc, Pr 19:477-481 (1882)

83 Report on the mining methods and appliances used in the anthracite coal fields. $\mathrm{Pa} \mathrm{G} \mathrm{S}, 2 \mathrm{~d}, \mathrm{AC}: 574 \mathrm{pp}$, atlas (1883)

84 A revision of the bituminous coal measures of Clearfield Co. $\mathrm{Pa}$ G S, 2d, H7 : xv, $197 \mathrm{pp}$, maps (1884)

85 Report on an exploration of the coal fields of North Carolina made for the State Board of Agriculture. 66 pp, maps, Raleigh 1885

85a The Deep River coal fleld of North Carolina. Am I M Eng, Tr 13:517-520 (1885)

85b [Nomenclature of the Pennsylvanian in Pennsylvania]. The Virginias 6 : 40-41 (1885)

s6 The anticlinal theory of natural gas. Am I M Eng. Tr 15:3-13 (1887) Petroleum Age 5: 1309-1312 (1886)

90 The Rush Creek. Ark., zinc district. Am I M Eng, Tr 18:505-508 (1890)

$90 a$ Geology of the Choctaw coal field. Am I M Eng, Tr 18:653-661, map (1890)

90b Coal Measures of the Indian Territory. Am G 6:238-240 (1890) 
Chance, Henry Martyn-Continued.

91 The resources of the Black Hills and Big Horn Co., Wyo. Am I M Eng, Tr 19: 49-58 (1891)

oo The Rich Patch iron tract, Va. Am I M Eng, Tr $29: 210-223$ (1900)

Ooa The discovery of new gold districts. Am I M Eng, Tr 29:224-230, 1035-1038 (1900)

0ob Gold ores of the Black Hills, S.

Dak. Eng M J 69:227-228 (1900)

o1 Gold ores of the Black Hills, S. Dak.

Am I M Eng, Tr $30: 278-285$ (1901)

o1a The iron mines of Hartville, Wyo.

Am I M Eng, Tr 30:987-1003, map (1901)

06 A biographical notice of J. Peter

Lesley. Am Ph Soc, Pr 45 : i-xiv (1906)

os The silver-lead deposits of Eureka,

Nev. Eng M J 85: 123-124 (1908)

OSa The origin of coal. Eng M J 86:

$27-28$ (1908)

08b The pyritic origin of iron ore de-

posits. Eng M J 86:408-410 (1908)

ose Rock pressure and metamorphism.

M Sc Press $97: 299-302$ (1908)

osd The origin of bombshell ore. Am

Ph Soc, Pr 47:136-140 (1908) Can M J 29:402-403 (1908)

ose A new theory of the genesis of brown hematite ores; and a new source of sulphur supply. Am I M Eng, B 23: 791808 (1908); $\operatorname{Tr} 39: 522-539$ (1909)

See also Catlett, 08a; Lesley, 83a

Chancourtois, E. B. de.

57 (and Ferri-Pisani, Camille) Géologie du Groenland. In Choieçi, Charles Edmond, Voyage dans les mers du nord a bord de la corvette La Reine Hortense, Notices scientifiques: 103-146, Paris 1857

\section{Chandler, Asa C.}

14 Antelopes in the fauna of Rancho La Brea (abst). G Soc Am, B 25:155 (1914)

16 Notes on Capromeryx material from the Pleistocene of Rancho La Brea [Cal.]. Cal Univ, Dp G, B $9: 111-120$, il (1916)

I6a A study of the skull and dentition of Bison antiquus Leidy, with special reference to material from the Pacific coast. Cal Univ, Dp G, B $9: 121-135$, il (1916)

16b The bison of Rancho La Brea (abst). G Soc Am, B 27:170 (1916)

Chaney, L. W., jr.

92 Cryptozoon minnesotense in the Shakopee limestone at Northfield, Minn. Minn Ac N Sc, B $3: 280-284$ (1892)

95 A glacier in the Montana Rockies. Science n s 2:792-796 (1895)

96 Glaciers in the Montana Rockies.

Science n s $4: 761-762$ (1896)

05 Glacial exploration in the Montana Rockies. Int Geog Cong, VIII, Rp : 493496 (1905)

Chaney, Ralph Works.

18 The ecological significance of the Eagle Creek flora of the Columbia River gorge. J G 26 : 577-592 (1918)
Channing, William F.

47 [St. Marys River, Mich.] U S, Ga Land Off, Rp 1847 (U S, 30 Cong, 1 Sex S Ex Doc 2) : 199-209 (1847)

Chapin, A. B.

34 Junction of trap and sandstone, $\pi_{t}$. lingford, Conn. Am J Sc 27:104-11: (1834)

Chapin, James Henry (1832-1892).

87 The Hanging Hills [Meriden, Conn], Meriden Sc As, Tr 2: 23-28 (1887)

88 The trap ridges of Meriden agin [Conn.]. Meriden Sc As, Tr $3: 35-8$ (1888)

91 Some geological features of Meride [Conn.]. Meriden Sc As, Tr 4:58-6! (1891)

91 a Cycadinocarpus chapinii [Durbas] Conn.]. Meriden Sc As, $\operatorname{Tr} 4: 62$, il (1891) Chapin, Theodore.

13 The McKinley Lake district [Alask], U S G S, B 542: 78-80, map (1913)

14 Quaternary deposits of the Hanagits. Bremner region, Alaska. U S G S, B 576: 27-32 (1914)

14a Lode mining near Fairbanks [Alaska]. U S G S, B $592: 321-335$, map (1914)

14b Placer mining in the Yukon-Tanat region [Alaska]. U S G S, B 592:35i362 (1914)

14e Placer mining on Seward Peninsule Alaska. U S G S, B 592: 385-395 (1914)

14d Lode developments on Seward Pe ninsula, Alaska. U S G S, B 592:39i407, map (1914)

15 Auriferous gravels of the Nelchins. Susitna region [Alaska]. U S G S, B 622: 118-130, map (1915)

16 Mining developments in southeasten Alaska. U S G S, B 642:73-104, map (1916)

17 Mining developments in the Ketchlkan and Wrangell mining districts [Alas ka]. U S G S, B 662: 63-75, map (1917) 18 The Nelchina-Susitna region, Alaska. U S G S, B 668:67 pp, maps (1918)

18a The structure and stratigraphy of Gravina and Revillagigedo islands, Alaska. U S G S, P P 120: 83-100 (1918)

Chapman, Edward John (1821-1904).

52 Mineralogical notes. $\mathrm{Ph}$ Mag (4) 3 : 141-145 (1852)

53 Mineralogical notes; second series Ph Mag (4) 6:115-121 (1853)

56 A review of the trilobites; theit characters and classification. Can $J$ is 1: 271-286 (1856)

56a Asaphus canadensis. Can J n I 1: $482-483$ (1856)

57 Fossils from Anticosti-A saphus lati. marginatus. Can J n s 2:47-49 (1857)

57a On the occurrence of the genus Cryptoceras in Silurian rocks. Can $\mathrm{J}$, 2: 264-268 (1857) An Mag N H (2) 20: 114-117 (1857) 
Chapman, Edward John-Continued.

$57 \mathrm{~b}$ On atomic constitution and crystalline form as classification characters in mineralogy. Can J n s 2:435-439 (1857)

57c The deposition of native metals in rein fissures, etc., by electro-chemical agency. Can Nat 2:274-277 (1857) Can J n s $3: 75-77$ (1858)

57d Trinucleus concentricus. Can $\mathrm{J}$ n s s: 514-515, il (1857)

58 [Classification of the] Brachiopoda. Can J n s $3:$ 158-163 (1858)

58a On some new trilobites from Canadian rocks. Can J n s $3: 230-238$, il (1858)

An Mag N H (3) $2: 9-16$, il (1858)

59 On the hypostoma of Asaphus canadensis and of a third new species of Asaphus from Canadian rocks. Can $\mathrm{J}$ n s $4: 1-4$, il $(1859)$

59 a Note on the occurrence of Asaphus megistos in Canadian rocks, with additional remarks on Asaphus hincksii. Can J $\mathrm{n}$ s 4:140-142 (1859)

$59 \mathrm{~b}$ Local geological notes [occurrence of Ordovician fossils]. Can J n s 4:493 (1859)

60 A popular exposition of the minerals and geology of Canada. Can J n s 5: 1-19, $168-182,517-531(1860)$; $6: 149-165,425-$ $455,500-518$ (1861) ; $7: 108-121$ (1862) ; $8: 17-33, \quad 111-127, \quad 185-216, \quad 473-462$ (1863) ; 9:1-10, il (1864)

$60 a$ On the geology of Belleville [Ont.] and the surrounding district. Can $\mathrm{J} n \mathrm{~s}$ $5: 41-48$ (1860)

$60 \mathrm{~b}$ Agelacrinites billingsii, a new species; preliminary notice of. Can $\mathrm{J} n \mathrm{~s}$ 5:204-205 (1860)

60e Notes on the geology of the Blue Mountain escarpment, in Collingwood township, Canada West. Can J n s 5: 304-305 (1860)

$60 d$ On a new species of Agelacrinites billingsii, and on the structural relations of that genus. Can J n s $5: 358-365$, il (1860) An Mag N H (3) 6:157-162, il (1860)

60e Sketch of the geology of Hastings Co., Canada West. Can J n s 5: $\mathbf{4 7 0 - 4 7 3}$ (1860)

60P Simple rules for calculating the thickness of inclined strata. Can J n s $5: 544-545 \quad(1860) ; 6: 72-73$ (1861)

61 Some notes on the drift deposits of western Canada, and on the ancient extension of the lake area of that region. Can J n 8 6:221-229 (1861) Ph Mag (4) $21: 428-435 \quad(1861)$

$61 \mathrm{n}$ On the klaprothine or lazulite of North Carolina. Can J n s 6:363-368, $455-456$ (1861) Ph Mag (4) $22: 81-85$ (1861)

61b Additional note on the occurrence of fresh-water shells in the upper drift deposits of western Canada. Can J n s 6 : $497-498$ (1861)
Chapman, Edward John-Continued.

62 On the position of lievrite in the mineral series. Can $J$ n $s \quad 7: 42-47$ (1862)

64 A popular and practical exposition of the minerals and geology of Canada. xii, $236 \mathrm{pp}$, Toronto 1864; 2d ed, 295 pp, Toronto 1871; $3 \mathrm{~d}$ ed, $371 \mathrm{pp}$, Toronto 1888. [Second and third editions have title: The minerals and geology of central Canada, comprising the provinces of Ontario and Quebec.]

$64 a$ Note on the occurrence of allanite in Canadian rocks. Can $\mathrm{J} n$ s 9:103-105 (1864)

65 On some minerals from Lake Superior. Can J n s 10:406-411 (1865)

69 Notes on the silver locations of Thunder Bay [Lake Superior]. Can J n \& $12: 218-226$ (1869)

69a Analyses of some Canadian minerals. Can J n s $12: 265-268$ (1869)

72 On the occurrence of copper ore in the Island of Grand Manan, Bay of Fundy. Can J n s 13:234-239 (1872)

72a Note on a remarkable belt of auriferous country in the township of Marmora in Ontario. Can $J$ n s $13: 330-334$ (1872)

73 Analyses of Canadian minerals. Can J n s 13:507-509 (1873)

75 An outline of the geology of Ontario. Can J n s 14:580-588 (1875)

76 An outline of the geology of Canada

xxxil, $105 \mathrm{pp}, \mathrm{il}$, Toronto 1876

$76 a$ on the leading geological areas of Canada. Can $J$ n $s$ 15:13-22, 92-121 (1876)

77 On the probable nature of the supposed fossil tracks known as Protichnites and Climactichnites. Can J n s 15:486490 (1877). Abst, Am J Sc (3) 14:240 (1877)

83 A classification of crinoids. R Soc Can, $\operatorname{Pr} \operatorname{Tr} 1$, iv : 113-116 (1883)

85 On some deposits of titaniferous iron ore in the counties of Hallburton and Hastings, Ont. R Soc Can, $\operatorname{Pr} \operatorname{Tr} 2$, iv : 159160 (1885) Abst, Science 3:676 (1884)

s5a On mimetism in inorganic nature. R Soc Can, $\operatorname{Pr}$ Tr 2, iv : 161-162 (1885) Abst, Science 3:676 (1884)

86 On some iron ores of central Ontario. R Soc Can, Pr Tr 3, iii : 9-14 (1886)

86a On the Wallbridge hematite mine as illustrating the stock-formed mode of occurrence of certain ore deposits. $R$ Soc Canada, $\operatorname{Pr} \operatorname{Tr} 3$, iv . 23-26 (1886)

s7 On the classification of the trilobites (abst). Can Rec Sc 2:431 (1887)

90 Some remarks on the classification of the trilobites as influenced by stratigraphical relations; with outline of a new grouping of these forms. R Soc Can, Pr Tr 7, iv : 113-120 (1890) 
Chapman, Edward John-Continued.

03 On the Mexican type in the crystallization of the topaz. $\mathrm{R}$ Soc Can, Pr Tr 10, iil : $25-28$ (1893)

93a On the corals and coralliform types of Paleozoic strata. R Soc Can, Pr Tr 10, iv : $39-48$ (1893)

94 Note on the Belmont gold veins of Peterborough Co., Ont. R Soc Can, Pr Tr 11. iv : 51-52 (1894)

04 Mineral systems; a review with outline of an attempted classification of minerals in natural groups. xi, $144 \mathrm{pp}, \mathrm{L}$ 1904

See also Dawson ( $\mathrm{J}$ W), 55

Chapman, Frederick.

96 On some Pliocene Ostracoda from near Berkeley, Cal. Cal Univ, Dp G, B 2:93100 , il (1896)

98 Appendix on the Foraminifera from Bissex Hill and Bowmanston [Barbados] G Soc London, Q J 54:550-555 (1898)

00 Foraminifera from the Tertiary of California. Cal Ac Sc, $\operatorname{Pr}$ (3) G 1:241260 , il (1900)

Chapman, Henry C.

93 Note on the geology of Mount Desert Island [Me.]. Ac N Sc Phila, Pr 1892: 350 (1893)

07 The life and work of Joseph Leidy. Science n s $26: 812-814$ (1907)

Chapman, Robert Hollister (1868-1920).

00 Notes on the structure of the Rocky Mountains in the Lewis and Clarke timber reserve, Mont. Am I M Eng, Tr 29:153156, map $(1900)$

06 The deserts of Nevada and the Death Valley. Nat Geog Mag 17:483-497 (1906) Sci Am Sup 63: 26126-26129 (1907)

os Earth movements at Butte, Mont. M Se Press 96: 493 (1908)

08a Preliminary notes on recent earth movements at Butte, Mont., as shown by precise levels of the U. S. Geological Survey (abst). Science n s 27:694 (1908)

10 The United States Geological Survey. Can M Inst, Q B 10:109-129 (1910); J $13: 372-392$ (1911)

Chapman, Temple.

12 The Miami zinc-lead district, Oklahoma. Eng M J 93:1146-1147 (1912)

Chapman, W. H.

87 Geology of Peoria Co. [IIl.]. Sc As Peoria, B 1:14-21 (1887) [Not seen]

Charles, H. W.

01 Dakota sandstone in Washington Co,

[Kans.]. Kans Ac Sc, Tr 17: 194 (1901)

Charleston (City), S. C.

82 Municipal report of the City of Charleston, S. C., 1881 ; artesian wells. 61 pp, Charleston, S. C., 1882

Charleton, A. G.

94 Nickel, its history, uses, and distribution. Soc Arts, J 42:496-511 (1894) Sc Am Sup 37:15418-15419 (1894)
Chariton, 0. C.

90 On the occurrence of mammoth on mains in Franklin Co., Kans. Kans Ac s Tr 12:74 (1890)

01 Note on the Mart and Blot meteorites [Tex.]. Tex Ac Sc, Tr 4:8\%84 (1901)

Chariton, Thomas.

90 Notes on the occurrenc of charoes at a depth of 630 feet in the Silver Cin mining District, Custer Co,, Colo, Eng $/$ J $49: 332$ (1890)

See also Argall, 95.

Chariton, W. A., jr.

99 Goulais River to Dalton [Ontario.] Ont Bur Mines, Rp 8: 197-204 (1899)

Chase, A. W.

73 On the artesian wells of Los Angeles Co. Cal Ac Sc Pr 5: 104-107 (1873)

$73 \boldsymbol{a}$ On the Oregon borate of line (cryptomorphite?) Am J Sc (3) 5:28i290 (1873)

73b On the lower Klamath River mines: remarkable gravel deposits of the low Klamath. Am J Sc (3) 6:56-59 (1873)

$\mathbf{7 4}$ The auriferous gravel deposit of Goll Bluffs [Klamath Co., Cal.]. Am J Se (3) $7: 379-384$ (1874)

74a [Remarks on the auriferous sands of Gold Bluff, Cal.]. Cal Ac Sc, Pr 5: 246 (1874)

Chase, Edwin E.

09 Ore shoots in Nevada. Ec $64: 173-$ 174 (1909)

10 The Santa Gertrudis mine, Pachues, Mexico. M Science 61:125-126 (1910)

Chase, Harvey S.

96 Southern magnetites and magnetic separation. Am I M Eng, Tr 25:551557 (1896)

Chase, R. L.

18 The oil shale of Colorado. M Sc Press 116: 445-446 (1918)

Chase, Thorington.

09 Concepcion del Oro district, State of Zacatecas, Mexico. M World 31:1068 (1909)

O9a Theory of volcanic action and ore deposition. M Sc Press 99: 794 (1909)

Chatard, Thomas Marean.

84 (with Clarke, F. W.) A report of work done in the Washington laboratory. 1883-84 U S G S, B 9:40 pp (1884)

84a (with Clarke, F. W.) Minera logical notes from the laboratory of the U. S. Geological Survey. Am J Sc (3) $28: 20-25$ (1884)

86 Lucasite, a new variety of verml. culite. Am J Sc (3) $32: 375-377$ (1886)

87 The gneiss dunite contacts of Cor undum Hill, N. C., in relation to the origin of corundum. U S G S, B 42:4563 (1887)

88 Analyses of the waters of some Amer ican alkali lakes. Am J Sc (3) $36: 146-$ 150 (1888) 
Chatard, Thomas Marean-Continued. 95 The natural soda deposits of the United States. Franklin Inst, J 139:271283, 341-351 (1895)

00 (and Whitehead, C.) An examination of the ores of the Republic gold mine, Wash. Am I M Eng, Tr 30: 419-423 (1901) Eng M J 69:497-498 (1900)

Chautard, Jean.

13 Sur l'origine du pétrole au Wyoming (États-Unis d'Amérique). Ac Sc Paris, C R 156: 1417-1419 (1913)

15 L'origine des mounds pétrolifères du Texas et de la Louisiane (contribution a la recherche de l'origine des pétroles). Ac Sc, Paris, C R 160: 69-72 (1915)

Chauvenet, Regis (1842-1920).

73 (and Blair, A. A.) Analyses of fuels, iron ores, and pig irons. Mo G S, Prel Rp Iron Ores and Coal Fields, 1872 pt 1: 29-44 (1873)

74 Chemical analyses. Mo G S, Rp 1873-4: $706-734$ (1874)

86 Preliminary notes on the iron resources of Colorado. Colo Sch Mines, An Rp Fieldwork... : 5-16 (1886)

87 Notes on iron prospects in northern Colorado. Colo Sch Mines, Bien Rp 1886 : 13-21 (1887)

88 Iron resources of Gunnison Co [Colo.]. Colo Sch Mines, An Rp 1887: 7-26 [1888]

90 The iron resources of Colorado. Am I M Eng, Tr 18:266-273 (1890)

10 Franklin Mountain tin prospects [near El Paso, Tex.] Mines and Minerals $30: 529-531$ (1910)

11 Tin deposits of El Paso Co., Tex. Colo Sc Soc, Pr 9:451-458 (1911) Mines and Minerals $32: 111-112$ (1911)

See also Austin, 02

Chauvenet, W. M.

86 Notes on the samples of iron ore collected in Kentucky; ...Tennessee ; ...Alabama; ...Missouri. U S 10th Census 15 : $282-300 ; \quad 351-365 ; \quad 383-399$; $\quad 403-420$, maps $(1886)$

Chazal, Philip E.

04 The century in phosphates and fertilizers; A sketch of the South Carolina phosphate industry. 71 pp, Charleston, 8. C., 1904

Cheney, Charles A., Jr.

15 Structure of the Cuyuna iron ore district of Minnesota. Eng M J 99:11131115 , map (1915)

Cheney, T. A.

72 The Chautauqua mastodon [N. Y.]. Am Nat 6:178-179 (1872)

Cherry, Cummings.

66 Geological report and map of the San Juan del Rio Ranche in Sonora, Mexico. Cincinnati \& Sonora Mining As sociation. $86 \mathrm{pp}$, map, Cincinnati 1866
Chester, Albert Huntington (1843-1903). $\boldsymbol{7 7}$ On the identity of the so-called peganite of Arkansas with the variscite of Breithaupt and eallainite of Damour. Am J Sc (3) $13: 295-296$ (1877)

$\boldsymbol{7 7 a}$ On a fibrous variety of sepiolite from Utah. Am J Sc (3) 13:296-297 (1877)

81 The iron region of central New York. 20 pp, Utica, N. Y., 1881

84 The iron region of northern Minnesota. Minn G S, An Rp 11:155-167 (1884)

86 A catalogue of minerals, alphabetically arranged, with their chemical composition and synonyms. 52 pp, N Y 1886 3d ed, 56 pp, N Y 1897

87 (and Cairns, F. I.) Crocidolite from Cumberland, R. I... Am J Se (3) 34:108-116 (1887)

87 Mineralogical notes from the laboratory of Hamilton College. Am J Se (3) $33: 284-291$ (1887)

ss Rhodonit-Veränderungsproducte. N Jb 1888 , I : $187-190$

92 The origin and history of mineralogical names. $N$ Y Ac Sc, Tr 11:49-57 (1892)

94 [On the minerals of Franklin Furnace, N. J.] N Y Ac Sc, Tr 13:97-98 (1894)

94a On caswellite, an altered biotite from Franklin Furnace, N. J. ; quartz crystals from Ellenville, N. Y. N Y Ac Sc, Tr 13 : 181-184 (1894)

94b Acanthite from Coloraco. Sch Mines Q 15: 103-104 (1894)

96 A dictionary of the names of minerals including their history and etymology. 320 pp. N Y 1896

$96 \mathbf{a}$ on caswellite, an altered biotite from Franklin Furnace, N. J. N J G S, An Rp 1895: xxxvii-xl (1896)

98 On krennerite, from Cripple Creek, Colo. Am J Sc (4) $5: 375-377$ (1898)

Zs Kryst 30:592-594 (1899)

01 Mineralogical notes and explorations. N J G S, An Rp 1900:173-188 (1901)

Chester, Frederick Dixon.

83 On boulder drift in Delaware. Am J Sc (3) 25: 18-21 (1883)

83a Observations upon stratified drift in Delaware. Am J Sc (3) 25:436-440 (1883)

84 A review of the geology of Delaware; results of a survey now in progress $(a b s t)$. Am As, Pr 33:400-401 (1885) Science $4: 325$ (1884)

S4a Preliminary notes on the geology of Delaware; Laurentian, Paleozoic, and Cretaceous areas. Ac N Sc Phila, Pr 1884: 237-259, map

84b The Quaternary gravels of northern Delaware and eastern Maryland. Am J Sc (3) $27: 89-199$, map (1884)

85 The gravels of the southern Delaware Peninsula. Am J Sc (3) $29: 36-44$ (1885) 
Chester, Frederick Dixon-Continued.

S6 Results from a study of the gabbros and associated amphibolites in Delaware (abst). Am As, Pr 34:215-216 (1886)

ss The state line serpentine and associated rocks; a preliminary notice of the serpentines of southeastern Pennsylvania (abst). Am As, Pr $36: 224$ (1888)

89 The State line serpentine and associated rocks. Pa G S, An Rp 1887:93-105 (1889)

90 The gabbros and associated rocks in Delaware. U S G S, B 59:45 pp, map (1890)

Chibas, Eduardo J.

01 Manganese mining in Cuba. Mines and Minerals 21: 295 (1901)

Chickering, J. W., jr.

82 Contrasts of the Appalachian Mountains. Saturday lectures, No. 3.16 pp [Washington, D. C., 1882]

s8 The Muir Glacier, Alaska. Sc Am Sup 26:10789-10790 (1888)

Child, A. L.

so The loess of the western plains - subaerial or subaqueous? Kansas City Rv Sc 4 : 293-294 (1880)

Chilton, George.

14 Chemical examination of heavy spar from New Jersey. Am Miner J 1:16-19 (1814)

Chipman, Nathaniel.

28 On moving stones in lakes, ponds, etc. Am J Sc 14:303-305 (1828)

Chism, Richard E.

85 The Vallecillo mines [Nuevo Leon], Mex. Am I M Eng, Tr 13:351-368 (1885)

87 Sierra Mojada, Mex. Am I M Eng, Tr 15:542-587, map (1887)

88 The drainage of the valley of Mexico. Eng M J 46:478-480, 500-501, 522-524 (1888)

89 The mining district of Tasco, State of Guerrero, Mexico. Eng M J 48:27-28, 51-52 (1889)

89a The Catorce mining district [San Luis Potosi, Mex.] Eng M J 48:340-342, 388-389, 476-478, map (1889)

Chisolm, Frederic F.

85 Data concerning the Denver wells. Colo Se Soc, Pr 1: 83-98 (1885)

87 The Elk Head anthracite coal field of Routt Co., Colo. Colo Sc Soc, Pr 2:147149 (1887)

89 Notes on some unusual occurrences of galena crystals [Sierra Co., N. Mex.]. Colo Sc Soc, $\operatorname{Pr} 3: 36-37$ (1889)

91 Iron ore beds at the Province of Santiago, Cuba. Colo Sc Soc, Pr $3: 259-263$ (1891)

Chittenden, A. Pereival.

97 Mountain structures of Pennsylvania. Am Geog Soc, B 29:175-180 (1897)

Chittenden, L. E.

87 [On earthquakes]. N Y Ac Sc, Tr 6: 36-39 (1887)
Christner, Drue De Garmo.

18 (and wheeler, O. C.) The geolog of Terrell Co. Tex, Univ, B 1819:1-32, the (1918)

Christy, David.

47 Some views relating to North Amer: can geology, communicated in a letter fro David Christy, Oxford, Ohio, to M. de Ves neuil ... 12 pp [Oxford, Ohio, 1847]

48 Letters on geology ... giving an out line of the geology of the West and South. west, together with an essay on the errati rocks of North America ... 68, 11 pp, Rost ville [Ohio] 1848

48a Letter on geology [to M. de Ve: neuil]; Erratic rocks of North America $11 \mathrm{pp}$ [Rossville?, 1848?]

51 On the Goniatite limestone of Rod. ford, Jackson Co., Ind. Am As, Pr 5 76-80 (1851)

56 Preliminary report on the lands of the Nantahala \& Tuckasege Land and Mir eral Association [western North Carolina] 24 pp, Cincinnati, 1856

58 [On the occurrence of Orthis in sculpta near Oxford, Ohio.] Ac N B Phlla, Pr 1858: 190

58a Report of the geologist... Second preliminary report of the Nantabala $t$ Tuckasege Land and Mineral Company, for 1858: 8-24. Cincinnati 1858

Christy, Samue! Benedict (1853-1914).

79 On the genesis of cinnabar deposits Am J Sc (3) 17:453-463 (1879)

02 Biographical notice of Joseph t Conte. Am I M Eng, Tr 31:765-703, port. (1902)

Chrustschof, K. v.

78 Einiges über den Cerro del Mercado bei Durango in Mexico. $60 \mathrm{pp}$. Wirtzbure 1878

86 Ueber die Eruption des Vulkans ron Colima in Mexiko im August 1872. Schles Ges, Jber $63: 187$ (1886) Abst, N Jb 188i. $1: 82$

Chrysler, M. A.

06 (with Jefrey, E. C.) The lignites of Brandon [Vt.]. Vt G S, Rp $5: 195-201$ (1906)

Chareh, A. H.

89 Note on Colorado hydropbane. Minet Mag 8:181 (1889)

Church, George Earl.

97 Costa Rica. Geog J 10:56-84, map (1897)

Chureh, John Adams (1843-1917).

79 The Comstock lode, its formation and bistory. 226 pp, N Y 1879

79a Deep mining on the Comstock. Eng M J 28:35-36 (1879)

79b Underground temperatures on the Comstock lode. Am J Sc (3) 17:289-296 (1879)

82 The geology and veins of Tombstone, Ariz. Eng M J $33: 218-219,313$ (1882) [See Blake, 82] 
Chnreh, John Adams-Continued.

86 The geological battle of the Comstock. Eng M J 41:52 (1886)

92 Faulting in veins. Eng M $J 53$ : $469-470,613-613,637-638$ (1892)

93 The cause of faulting. Am I M Eng, Tr 21:782-792 (1893)

03 The Tombstone, Ariz., mining district. Am I M Eng, Tr 33:3-37, map (1903)

05 Enrichment in veins. Eng M J 80 : 695 (1905)

06 The Pinguico mine, Guanajuato, Mexico. Eng M J 82: 959-960 (1906)

07 Proano, a famous mine of Fresnillo, Yexico. Eng M J 84:53-56 (1907)

$07 a$ The mines of La Luz, Guanajuato, Mexico. Eng M J $84: 105-110,153-156$ (1907)

See also Emmons (S F), 94a; Jenney, 03a; Pošepný, 94, 95

Chute, A. P.

56 On newly discovered minerals at Lynnfield, Mass. Essex Inst, Pr 1:151154 (1856)

Cia, Pollcarpo.

54 Observaciones geologicas de una gran parte de la isla de Cuba. Revista Minera, Madrid, $5: 365-382, \quad 393-405, \quad 419-426$, 451-460 (1854) [not seen]

17 Noticia sobre el criadero $y$ minas del Cobre [copper deposits, Cobre, near Santiago, Cuba]. Cuba Dir Montes, Bol Minas 2: 84-90 (1917)

Cirkel, Eritz.

00 The Bridge River gold mining camp [Lillooet district, B. C.]. Can M Inst., J $3: 21-29$ (1900) Can M Rv 18:266269 (1899)

03 Vorkommen und Gewinnung von Asbest in Canada. Zs prak G 11:123-131, map (1903)

04 Mica deposits. Can M Rv 23 : $82-86$, 104-108, 128-133 (1904)

05 Mica; its occurrence, exploitation, and uses. Can, Dp Interior, Mines Br: $148 \mathrm{pp}$, map, Ottawa 1905

05a Asbestos; 1ts occurrence, exploitation, and uses. Can, Dp Interior, Mines Br: 169 pp, map, Ottawa 1905 [2d ed, see below, 10]

07 Preliminary report on the examination of the iron ore deposits in the Ottawa Valley. Canada, Dp Interior, Rp Supt Mines, $1907: 11-13$ (1907)

07n Graphite, 1ts properties, occurrence, refining, and uses. Can, Mines $\mathrm{Br}$ : $307 \mathrm{pp}$, maps (1907)

09 Report on the Iron-ore deposits along the Ottawa (Quebec side) and Gatineau rivers. Can, Mines $\mathrm{Br}: 147$ pp, maps (1909)

09a Report on the chrome iron-ore deposits in the eastern townships, Proyince of Quebec. Can, Mines Br: 141 pp (1909)
Cirke1, Fritz-Continued.

09b The Opasatika Lake district, Province of Quebee. Eng M J 87:455-456 (1909)

09e Depth of asbestos deposits. Can M J 30:132-135 (1909) M World $30: 435$ 437 (1909) Can M Inst, J 12:194-203 (1910)

10 Chrysotile asbestos, its occurrence, exploitation, milling, and uses. $2 \mathrm{~d}$ ed. Can, Mines Br: 316 pp, maps (1910)

10a The quarries of the Canadian asbestos district. Eng M J 89:918-920 (1910)

11 Alluvial gold deposits in Quebec. Eng M J $92: 1035-1038$ (1911)

11 a The Amberst, Quebec, graphite de. posits. Can M Inst, Q B 17:107-115 (1911) ; Tr 15:261-269 (1912) M World $36: 295-296 \quad(1912)$

Cist, Jacob.

21 New locality of manganese [Pennsylvania]. Am J Sc 4:38-39 (1821)

21a Account of the mines of anthracite in the region about Wilkesbarre, $\mathrm{Pa}$. $\Delta \mathrm{m}$ J Sc 4:1-16 (1821) Wyoming Hist G Soc, Pr 10:98-114 (1909)

Claassen, Edward.

98 On erratic boulders in the valley of the Rocky River, Cuyahoga Co,, Ohio. Ohio St Ac Sc, An Rp $6: 43-44$ (1898)

Claghorn, Clarence R.

89 Notes on the Bernice anthracite coal basin, Sullivan Co., Pa. Am I M Eng, Tr $17: 606-616$, map (1889)

Clapp, A.

41 [Geological equivalents of the rocks of the Falls of the Ohio and other strata in western states.] Ac $\mathbf{N}$ Sc Phila, Pr 1 : $18-19,177-178$ (1841)

Clapp, Charles Horace.

06 (and Babeoek, E. J.) Clay and its properties with special reference to North Dakota clays. N Dak G S, Bien Rp, 4 : 9-61 (1906)

O6n (with Babeoek, E. J.) Economic geology of North Dakota clays. N Dak G S, Bien Rp 4: 95-189 (1906)

o 7 The clays of North Dakota. Ec G 2 : 551-564 (1907)

o9 Southeastern portion of Vancouver Island. Can G S, Sum Rp 1908:52-60 (1909) B C, Minister of Mines, An Rp 1908: 158-166 (1909)

09a (and Ball, W. G.) The lead-silver deposits at Newburyport, Mass., and their accompanying contact zones. Ec G 4:239250 (1909)

10 Southern Vancouver Island, B C. Can G S, Sum Rp 1909:84-97 (1910)

10a The igneous rocks of Essex Co., Mass. Abstract of thesis, Massachusetts Institute of Technology. $12 \mathrm{pp}, 1910$

11 Geology of the Victoria and Saanich quadrangles, Vancouver Island, B. C. Can G S, Sum Rp 1910:102-109 (1911) 
Clapp, Charles Horace Continued.

$11 a$ (and Shimer, H. W.) The Sutton Jurassic of the Vancouver group, Vancouver Island, B. C. Boston Soc N H, Pr 34: 425-438, il (1911)

12 Southern Vancouver Island. Can G S, Mem $13: 208$ pp, map (1912)

12a Geology of the Nanaimo sheet, Nanaimo coal field, Vancouver Island, B. C. Can G S, Sum Rp 1911:91-105, map (1912)

12b Notes on the geology of the Comox and Suquash coal flelds, Vancouver Island. Can G S, Sum Rp 1911: 105-107 (1912)

12e The geology of the Nanaimo coal district [Vancouver Island, B. C.]. Can M Inst, $\operatorname{Tr} 15: 334-353$ (1912)

13 Field and office methods in the preparation of geological reports (discussion); a modification of the ordinary field method. Ec G 8:177-181 (1913)

13a Contraposed shorelines. J G 21: $537-540$ (1913) ; abst, G Soc Am, B 24: 700 (1913)

131. Vancouver Island. Int G Cong, XII, Canada, Guide Book 8:280-342, maps (1913)

13e Coal flelds of Vancouver Island. Int $\mathrm{G}$ Cong, XII, Canada, The Coal Resources of the World, vol 2:509-513, map (1913)

13d The coal fields of Queen Charlotte Islands. Int $\mathrm{G}$ Cong, XII, Canada, The Coal Resources of the World, vol 2:513515 (1913)

13e Geology of the Victoria and Saanich map areas, Vancouver Island, B C. Can G S, Mem 36: 143 pp, maps (1913)

14 Geology of the Nanaimo map area [B. C.]. Can G S, Mem 51: 135 pp (1914)

14a A geological reconnaissance on Graham Island, Queen Charlotte group, B. C. Can G S, Sum Rp 1912: 12-40, map (1914)

14b Geology of portions of the Sooke and Duncan map areas, Vancouver Island, B. C. Can G S, Sum Rp 1912: 41-54 (1914)

14e Sharp Point hot spring, Vancouver Island, B. C. Can G S, Sum Rp 1913: 80-83 (1914)

$14 d$ (and Cooke, H. C.) Geology of a portion of the Duncan map area, Vancouver Island, B. C. Can G S, Süm Rp 1913: 84-106 (1914)

14e The geology of the alunite and pyrophyllite rocks of Kyuquot Sound, Vancouver Island [B. C.] Can G S, Sum Rp 1913: 109-126 (1914)

148 Coal formation on Galiano, Mayne, and Saturna islands [B. C.]. B C, Minister of Mines, Ann Rp 1913:292-299, map (1914)

15 Alunite and pyrophyllite in Triassic and Jurassic volcanies at Kyuquot Sound, B C. Ec G 10:70-88 (1915)
Clapp, Charles Horace-Continued.

15a Deformation of the coast region of British Columbia (abst). G Soc Am, B $26: 406-407$ (1915)

17 Sooke and Dunkan map areas, Var. couver Island. Can G S, Mem 96:445 pp. maps (1917)

See also Spencer (A C), 17

Clapp, Frederick Gardrer.

01 Geological history of the Charles River in Massachusetts. Tech Q 14:171. 201, 255-269, map (1901) Am G 29: 218-233, map (1902)

03 (with Fuller, M. L.) Marl-loes of the lower Wabash Valley. G Soc As, B 14:153-176, map (1903) Abst, Am G $31: 158$ (1903); Sclence n $s \quad 17: 293$ (1903)

04 Relations of gravel deposits in the northern part of glacial Lake Charles. J G 12:198-214 (1904)

04a (with Fuller, M. L.) Description of the Patoka quadrangle [Ind.-Ill.]. S G S, G Atlas Patoka fol (no 105): $12 \mathrm{pp}$, maps (1904)

o5 Limestones of southwestern Pennsyl. vania. U S G S, B 249:52 pp, map (1905)

05a Water resources of the Curwens. ville, Patton, Ebensburg, and Barnesboto quadrangles, $\mathrm{Pa}$. U S G S, W-S P 110: 159-163 (1905)

06 The Nineveh and Gordon ofl sads in western Greene Co., Pa. U S G S, B 285 : 362-366 (1906)

06a Evidences of several glacial and interglacial stages in northeastern Nell England. Science n s 24:499-501 (1906)

07 Clay of probable Cretaceous age at Boston, Mass. Am J Sc (4) $23: 183-188$ (1907)

07a Description of the Amity quadrangle [Pa.]. U S G S, G Atlas Amity fol (no 144) : $15 \mathrm{pp}$, maps (1907)

07b Description of the Rogersville quad. rangle $[\mathrm{Pa}]$. U $\mathbf{S}$ G $\mathbf{S}, \mathrm{G}$ Atlas Rogers. ville fol no $14614 \mathrm{pp}$, maps (1907)

07e Economic geology of the Amity quadrangle, eastern Washington Co., Pa. U S G S, B 300: 145 pp, map (1907)

ord Local glaciation in Maine (abst). Science n s 25:390 (1907)

o7e (with Stone, R. W.) Oil and gas fields of Greene County, Pa. U S G S, B 304:110 pp (1907)

o8 Complexity of the glacial period in northeastern New England. G Soc Am, B 18: 505-556 (1908)

08a The Grand Gulf and Lafayette formations in northern Florida (abst). Science n s $27: 993$ (1908)

09 Underground waters of southern Maine; with records of deep wells, by W. S. Bayley. U S G S, W S P 223:268 $\mathrm{pp}$, map (1909) 
Clapp, Frederick Gardner-Continued.

09a Studies in the application of the anticlinal theory of oil and gas accumulatíon. Ec G 4:565-570 (1909)

09b Influence of geological structure on the occurrence of oil and gas (abst). Science n s $29: 440$ (1909)

09e Underground water in crystalline rocks. Eng Record 60:525-527 (1909)

09d (with Matson, G. C.) A preliminary report on the geology of Florida with special reference to the stratigraphy. Fla G S, An Rp 2: 25-173 (1909)

10 The use of geological science in the petroleum and natural gas business. Eng Soc W Pa, Pr 26: 87-111 (1910) Abst, M World $33: 505-509$ (1910)

10a A proposed elassification of petroleum and natural gas fields based on structure. Ec G 5:503-521 (1910) Abst, Science n s $31: 718$ (1910)

$10 \mathrm{~b}$ Present and future of natural gas flelds in the northern Appalachians. Nat Gas J 4 no 3:2-6 (1910) Abst, G Soc Am, B 21:788 (1910) Science n $\mathrm{s} 32: 221$ (1910)

10e Structure of the northern portion of the Burning Springs-Volcano anticllne in Pleasants, Wood, and Ritchie cos., W. Va. (abst). Science n s 32:189 (1910) Abst, with discussion. G Soc Am, B 21 : 769 (1910)

10d Somre instances of flowing wells on anticlines (abst). Science n s 32:189-190 (1910) G Soc Am, B 21:770 (1910)

11 Occurrence and composition of well waters in the slates of Maine. U S G S, W-S P 258: 32-39 (1911)

11 a Occurrence and composition of well waters in the granites of New England. U S G S, W-S P 258: 40-47 (1911)

$11 \mathrm{~b}$ Composition of mineral springs in Maine. U S G S, W-S P 258:66-74 (1911)

11e Underground waters near Manassas, Va. U S G S, W-S P 258: 94-97 (1911)

11 the present status of natural gas development in Pennsylvania flelds. Pa Top G S Comm, Rp 1908-10:73-80 (1911)

11e Notes on the occurrence of oil and gas accumulations in formations having monoclinal dips. Ec G $6: 1-12$ (1911) Oil and Gas J 9 no $46: 6,8$ April 27 (1911)

118 Clinton sand as a source of oil in Ohio (discussion). G Soc Am, B 22:737 (1911)

$11 \mathrm{~g}$ Geological relations of oil pools situated in regions of monoclinal structure (abst). G Soc Am, B 22:737 (1911)

12 The occurrence of oil and gas deposits associated with quaquaversal strueture. Ec G $7: 364-381$ (1912)

$12 a$ Occurrence of petroleum associated with faults and rikes (abst). G Soc Am, B $23: 728$ (1912)
Clapp, Frederick Gardner-Continued.

$12 b$ (with Fuller, Myron L.) The underground waters of southwestern Ohio. U S G S, W-S P 259:228 pp (1912)

13 Outline of the geology of natural gas in the United States. Ec G 8:517-542 (1913)

13a (and Huntley, L. G.) Petroleum and natural gas resources of Canada. Can Mines Br, Sum Rp 1912: 48-57 (1913)

14 (and others) Petroleum and natural gas resources of Canada. Can Mines $\mathrm{Br}$, 2 vols., vol. 1:378 pp (1914) [Includes sections by M. R. Campbell, Theories of origin, and James H. Gardner, Surface indications] Vol 2:404 pp, maps (1915)

16 The geology of petroleum. In Bacon, R. F., and Hamor, W. A., The American petroleum industry : 34-68 (1916)

17 Revision of the structural classification of the petroleum and natural gas fields. G Soc Am, B 28:158 (abst), 553602 (1917)

17 a Ethies of the petroleum geologist. Ec G $12: 105-137$ (1917)

18 Geosynclines and petroliferous deposits (discussion). Am I M Eng, B 133 : 99 (1918)

See also Daly (M R), 16

Clapp, William F.

14 A new fossil Vitrinella from Boston, Mass. Nautilus $26: 38-40$, il (1914)

Clark, A. C.

78 Work in north central Wisconsin. Wis G S, An Rp 1877: 41-43 (1878)

82 Superficial geology of the upper Wisconsin Valley. [Wis G S], G Wis $4: 715-$ 723 (1882)

Clark, Austin Hobart.

11 The systematic position of the crinoid genus Marsupites. U S Nat Mus, $\operatorname{Pr} 40$ : 649-654 (1911)

13 Restoration of the genus Eldonia, a genus of free-swimming holothurians from the Middle Cambrian. Zool Anzeiger 39: 723-725 (1912) Abst, Wash Ac Sc J 3: 167 (1913)

13a Cambrian holothurians. Am Nat 47: 488-507 (1913)

13b The systematic position of the crinoid family Plicatocrinidae. Wash Ac Sc J 3:494-499 (1913)

See also Eastman, 00

Clark, B. W.

14 The peridotite dikes of Syracuse and vicinity [N. Y.]. N Y St Mus, B 171: $45-56$ (1914)

Clark, Bruce Lawrence.

12 The Neocene section at Kirker Pass on the north side of Mount Diablo. Cal Univ, Dp G, B $7: 47-60$, map (1912)

13 San Pablo formation on the north side of Mount Diablo, Cal. (abst). G Soc Am, B $24: 130$ (1913)

14 Fauna of the Scutella breveriana zone of the upper Monterey series (abst). G Soc Am, B 25: 151 (1914) 
Cark. Buce Lawrence-Continued.

$14 a$ Fauna of the San Pablo serles (abst). G Soc Am, B 25:152-153 (1914)

15 Fauna of the San Pablo group of midale Californla. Cal Univ, Dp G, B 8 : $385-572$, il, map (1915)

$15 \mathrm{a}$ The occurrence of Oligocene in the Contra Costa hills of middle California. Cal Univ, Dp G, B 9:9-21 (1915)

16 Note on the marine Tertiary faunas of the Tejon Hills section. Cal Univ, Dp G. B 10:115 (1916)

17 Astoria serles (Oligocene) in the region of Mount Dlablo, middle California (abst), G Soc Am, B 28:227-229 (1917)

17a (with Arnold, R.) An Apalachicola fauna from Lower California (abst). G Soc Am, B 28: 223-224 (1917)

18 Meganos group, a newly recognized division in the Eocene of California. G Soc Am, B 29:94 (abst), 281-296 (1918)

18a (and Arnold, R.) Marine Oligocene of the west coast of North America. G Soc Am, B 29:297-308, 153-154 (abst) (1918)

18b The San Lorenzo series of middle Callifornia. Cal Univ, Dp G, B 11: $45-234$ (1918)

See also Martin (B), 13a; Rich, $18 \mathrm{c}$

Clark, Clifton W.

17 The geology and ore deposits of the Leona rhyolite [Cal.]. Cal Univ, Dp G, B $10: 361-382$ (1917)

17a Lower and Middle Cambrian faunas of the Mohave desert $(a b s t)$. G Soc $\mathrm{Am}$, B 28:230 (1917)

Clark, Edgar F.

84 Studies in the Rhode Islezd Coal Measures. Newport $\mathrm{N}$ H Soc, $\operatorname{Pr} 2: 9-12$ (1884)

Clark, Ellis, Jr.

75 The subterraneous watercourses in the magnesian limestones of Lehigh Co., Pa. Eng M J 19: 433 (1875)

95 the silver mines of Lake Valley, N. Mex. Am I M Eng, Tr $24: 138-167$, maps (1895)

Clark, Frank R.

14 Coal near Thompson, Grand Co., Utah. U S G S, B 541:453-477, map (1914)

14a Coal near Wales, Sanpete Co., Utah. U S G S, B 541: 478-489, map (1914)

16 (with Campbell, M. R.) Analyses of coal samples from various parts of the United States. U S G S, B 621 : 251-370 (1916)

17 Original coal content of the [Ohio coal] fields. U S G S, P P 100:88-96 (1917)

18 Structure and oil and gas resources of the Osage Reservation, Okla, T. $26 \mathrm{~N}$., R. 9,10 , and 11 E. I S G S, B 686:91118, maps (1918)

18 a Geology of the Lost Creek coal field, Morgan Co., Utah. U S G S, B 691 : 311322, map (1918) [1919]
Clark, Galen.

10 The Yosemite Valley; its histor characteristic features, and theories is garding its origin. 108 pp. Nelson L Salter, Yosemite Valley, Cal., 1910

Clark, George Archibald.

12 The Katmai eruption [June 1912.] Seism Soc Am, B 2: 226-229 (1912)

Clark, Heber $R$.

62 [On coal oil localities in Pennsj. vania.] $\mathrm{Am} \mathrm{Ph} \mathrm{Soc,} \mathrm{Pr} 9: 56-57$ (1862)

Clark, Howard.

11 A case of preglacial stream diversios near St. Louisville, Obio. Denison Unir, Se Lab, B 16:339-346, map (1911)

Ciark, Hubert Lyman.

12 Fossil holothurians. Sclence n s 35 : 274-278 (1912)

CInrk, I C.

18 Recently recognized alunite deposit at Sulphur, Humboldt, Co., Nev, Ens M J 106: 159-163 (1918)

Clark, John Dustin.

14 A chemical study of the enrichment of copper sulphide ores. N Mex Univ, B 75 (chem s 1 no 2): 77-150 (1914)

$14 a$ (with Tolman, C. F.) The of dation, solution, and precipitation of cop per in electrolytic solutions and the dis. persion and precipitation of copper strphides from colloidal suspensions, with t geological discussion. Ec G 9:559-59? (1914)

15 Rôle of colloidal migration in ote deposits (abst and discussoin). G Soc Am. B $26: 394$ (1915)

16 (and Menaul, P. L.) The role of colloidal migration in ore deposits. B G $11: 37-41$ (1916)

Clark, K. A.

17 Road materials available for the Toronto-Montreal road between Trentos and Napanee, Ont. Can G S, Sum Bp $1916: 195-198$ (1917)

Clark, L. J.

91 The formation of Toronto Island [Ont.]. Can Inst, Tr 1:37-38, 239-246 (1891)

Clark, Maurice.

97 Notes on mining in Oaxaca, Mes. Eng M J 64: 35-36 (1897)

Claxk, P. Edwin.

o3 (with Van Ingen, Gilbert) Dis turbed fossillferous rocks in the vicinity of Rondout, N. Y. N Y St Mus, B 69: 1176-1227, maps (1903)

Clark, R. Neilson.

73 The Tertiary coal beds of Canyos City, Colo. Am I M Eng, Tr 1:293-296 (1873)

79 The Humboldt-Pocahontas rein, Rosita, Colo. Am I M Eng, Tr $7: 21-33$ (1879)

Clark, Robert W.

12 Heat conductivity of cryetals. Science n s $36: 415$ (1912) 
Clark, Robert W.-Continued.

15 (and Hunt, W. F.) Ungewöhnliche optische Eigenschaften des Muscovits in dem Mar Villa Marmor von Cockeysville, Md. Centralbl Miner 1915: 666-668

16 Descriptive catalogue of a petrographic collection of American rocks. 46 pp, Rochester, N. Y., Ward's Natural Science Establishment, 1916.

16a A new occurrence of crystallized ॠillemite. [Star district, Beaver Co., Utah]. Am Mineralogist 1:89-91 (1916) Abst, Science n s $43: 399$ (1916)

Clark, Thomas.

61 (with Anderson, C. L.) Report on geology and plan for a geological survey of the State of Minnesota ... 26 pp, St. Paul 1861

\section{Clark, Thomas H.}

17 New blastoids and brachiopods from the Rocky Mountains. Harvard Coll, Mus C Z, B 61:361-380, il (1917)

Clark, W. Blair.

02 Drainage modifications in Knox, Licking, and Coshocton cos., Ohio. Denison Univ, Sc Lab, B 12 : 1-16, maps (1902)

Clark, W. C.

00 Cœur d'Alene mining region [Idaho]. Mines and Minerals 20:561-562 (1900)

Clark, W. O.

15 Ground-water resources of the Niles cone and adjacent areas, Cal. U S G S, W-S P $345: 127-168$, maps (1915)

16 (with Lee, C. H.) Report of Soda Lakes Investigation, Truckee-Carson project, near Fallon, Nev. Report of an investigation made by the U. S. Geological Survey : 657-706, Washington, 1916.

17 Ground water for irrigation in the Morgan Hill area, Cal, U S G S, W S P 400:61-108, maps (1917) Abst, Wash Ac Sc, J $8: 128-129$ (1918)

Clark, William (1770-1838).

04 (with Lewis, M.) Original Journals of the Lewis and Clark expedition, 18041806 ... See Thwaites, 04

14 (with Lewis, M.) History of the expedition to the sources of the Missouri ... See Allen (P), 14

Clark, William.

98 Some new points on the fin attachment of Dinichthys and Cladodus (abst). Ohio St Ac Sc, An Rp 6:46-48, il (1898)

See also Claypole, 94b

Clark, Willam Bullock (1860-1917).

88 A synopsis of a course of lectures on the origin, structure, and sequence of the sedimentary rocks delivered at Johns Hopkins University, $1888-89.45 \mathrm{pp}$, Baltimore 1888

88a On three geological excursions made during the months of October and November, 1887, Into the sonthern counties of Maryland. Johns Hopkins Univ Cire 7 : 65-67 (1888)
Clark, Willian. Bullock-Continued.

s8b Geology of eastern Maryland ( $a b s t$ ). Johns Hopkins Univ Circ $7: 73-74$ (1888)

89 Discovery of fossil-bearing Cretaceous strata in Anne Arundel and Prince George cos., Md. Johns Hopkins Univ Cire 8: 20-21 (1889)

90 Third annual geological expedition into southern Maryland and Virginia. Johns Hopkins Univ Circ 9:69-71 (1890)

90a The geologieal features of Gay Head, Mass. Johns Hopkins Univ Circ $10: 28$ (1890)

9ob on the Tertiary deposits of the Cape Fear River region. G Soc Am, B 1: $537-540$ (1890) Abst, Am G 5: 119 (1890) Am Nat 24: 289 (1890)

91 Correlation papers; Eocene. U S G S, B 83:173 pp, maps (1891)

91a A revision of the Cretaceous Echinoidea of North America. Johns Hopkins Univ Circ 10:75-77 (1891)

91b Report of the scientific expedition into southern Maryland. Johns Hopkins Univ Circ 10: 105-108 (1891)

02 A preliminary geological map of portions of Monmouth and Middlesex cos., N. J. Scale 1 mile to 1 inch. $N$ J G S (1892)

$02 a$ (with Williams, G. H.) Reports on short excursions made by the geological department of the University during the autumn of 1891. Johns Hopkins Univ Circ 11: 37-39 (1892)

93 The Mesozoic Echinodermata of the United States. U S G S, B 97:207 pp, il (1895) Abst, Johns Hopkins Univ Circ $12: 51-52$ (1893)

93a A preliminary report on the Cretaceous and Tertiary formations of New Jersey. N J G S, An Rp 1892:167-245, 11, map (1893)

93b The Eocene of the United States. Johns Hopkins Univ Circ 12: 50-51 (1893)

93e The annual expedition of the students in geology, 1892 [Yorktown, Va., and eastern New Jersey]. Johns Hopkins Univ Circ $12: 53-54$ (1893)

93d (with Williams, G. H.) Geology [of Maryland]. In Maryland, its resources, industries, and institutions, prepared for the Board of World's Fair [Chlcago 1893] Managers... : 55-88, Baltimore 1893

94 Cretaceous and Tertiary geology; report of progress. N J G S, An Rp 1893 : 329-355 (1894)

$94 \mathrm{n}$ Origin and classification of the greensands of New Jersey. J G 2:161177 (1894) Abst, Am G 13: 210 (1894)

94b The climatology and physical features of Maryland. Md St Weather Service, Bien Rp 1: 140 pp, maps (1894)

95 Memorial of George Huntington Williams. G Soc Am, B 6:432-440, port. (1895) 
Clark, William Bullock-Continued.

95a Cretaceous deposits of the northern half of the Atlantic Coastal Plain. G Soc Am, B 6:479-482 (1895) Abst, Science n s $1: 64$ (1895)

95b Description of the geological excursions made during the spring of 1895 [Potomac River and Appalachian region]. Johns Hopkins Univ Circ 15: 1-3 (1895)

95e Two new brachiopods from the Cretaceous of New Jersey. Johns Hopkins Univ Cire 15:3, il (1895)

95d Contributions to the Eocene fauna of the middle Atlantic slope. Johns Hopkins Univ Circ $15: 3-6$ (1895)

95e Additional observations upon the Miocene (Chesapeake) deposits of New Jersey. Johns Hopkins Univ Circ 15:6-8 (1895)

95P The marginal development of the Miocene in eastern New Jersey (abst). Science n s 1:66 (1895)

$95 \%$ Eocene fauna of the middle Atlantic slope $(a b s t)$. Am G 16:239 (1895) Science n \& 2:279 (1895)

96 The Potomac River section of the Middle Atlantic coast Elocene. Am J Sc (4) $1: 365-374$ (1896)

9.6a The Eocene deposits of the middle Atlantic slope in Delaware, Maryland, and Virginia. U S G S, B 141:167 pp, il $\operatorname{map}$ (1896)

97 Preface [and] introduction. Md G S 1: $17-42$ (1897)

97 a Historical sketch embracing an account of the progress of investigation concerning the physical features and natural resources of Maryland. Md G S 1:43138, map (1897)

$97 \mathbf{b}$ Outline of present knowledge of the physical features of Maryland, embracing an account of the physiography, geology, and natural resources. Md G $\mathrm{S}$ 1:139228, map (1897)

97e Upper Cretaceous formations of New Jersey, Delaware, and Maryland. G Soc Am, B $8: 315-358$ (1897) Abst, J G 5:217-219 (1897); Science n $\quad$ s $5: 94$ (1897)

97d (and Bibbins, Arthur) The stratigraphy of the Potomac group in Maryland. J G 5 : 479-506 (1897)

97e (and Shattuck, G. B.) The geology of the Sand Hills [Middlesex Co.] of New Jersey. Johns Hopkins Univ Cire 16 : 13-16, map (1897)

97 Geology of Baltimore and the region adjacent to the lower Patapsco River. Baltimore City, Sewerage Commission, Rp 199-204, Baltimore 1897

98 Report upon the Upper Cretaceous formations. N J G S, An Rp 1897:161210 (1898)

98a Administrative report... Md $G$ S $2: 25-43$ (1898)
CIark, William Bullock-Continued.

9Sb Collection of Eocene fossils. Johns Hopkins Univ Cire 18:18 (1898)

99 The relations of Maryland topos. raphy, climate, and geology to highwa construction. Md G S 3:47-106, maps (1899)

oo (and others) Allegany County. Id G S : 323 pp, maps [in Physical Atlas of Md, Allegany Co], Baltimore 1900

ooa (and others) The mineral $p$ sources of Allegany Co. Md G S, Allegany Co, : 165-194 (1900)

01 (and Martin, G. C.) The Eocene deposits of Maryland. Md G S, Eocene: 21-92, map (1901)

O1a (and others) Systematic paleos. tology, Eocene [Reptilia by E. C. Case; Pisces, by C. R. Eastman; Arthropoda Bryozoa, by E. O. Ulrich; Molluses, Brachiopoda, Echinodermata, by W. B. Clark and G. C. Martin; Coelenterats, by T. W. Vaughan; Protozoa, by R. M. Bage. jr: Plantae, by Arthur Hollick]. Md G \&, Eocene : 93-316, il (1901)

02 (and others) Cecil County. Ma G $\mathrm{S}: 322 \mathrm{pp}$, maps (in atlas), Baltimore 1902

02a (and others) Garrett County. MC G $\mathrm{S}: 340 \mathrm{pp}$, maps (in atlas), Baltimore 1902

02b (and Bibbins, A.) Geology of the Potomac group in the middle Atlantic slope. G Soc Am, B 13:187-214, maps il (1902) Abst, Science n s $15: 84$ (1902)

02e (and Martin, G. C.) Correlation of the coal measures of Maryland. G $\mathrm{Sor}$ Am, B 13:215-232, map (1902) Abst, Science n \& 15:84 (1902)

ozd (and Bibbins, A.) The Potomac group in Maryland (abst). Science is s $15: 905$ (1902)

02e (and Martin, G. C.) The correls. tion of the coal measures in Maryland (abst). Science n s 15:905-906 (1902)

03 Cretaceous-Eocene boundary in the Atlantic Coastal Plain (abst). Science is $17: 293$ (1903)

04 (and others) The Mlocene deposits of Maryland. Md G S: Miocene: xxi-cli, map (1904)

O4a (and others. Systematic paleot. tology of the Miocene deposits of Mars. land [Mammalia, Aves, Reptilia, by E. C Case; Pisces, by C. R. Eastman; Arthrop oda, Mollusca, Brachiopoda, Vermes. Radiolaria, by G. C. Martin; Ostracoda Bryozoa, by E. O. Ulrich and R. \$ Bassler; Pelecypoda, by L. C. Glenn: Echinodermuta, by W. B. Clark; Hydrozoa, by E. O. Ulrich; Anthozoa, by T. N Vaughn; Foramínifera, by R. M. Bagg, jr.i Anglospermae, by Arthur Hollick; Thallo phyta, Diatomacea, by C. S. Boyer]. Mo G S, Miocene: 1-507, il (1904) 
Clark, William Bullock-Continued.

04b The Matawan formation of Maryland, Delaware, and New Jersey... Am J $\mathrm{Sc}$ (4) $18: 435-440$ (1904) Johns Hopkins Univ Circ n s 1904 no $7: 28-35$ [692699] (1904)

05 Origin, distribution, and uses of coal. yd G S 5:221-240, maps (1905) RV by M. R. Campbell, Ec G 1: $502-508$ (1906)

05a (and Martin, G. C.) Correlation of the formations and members [of the coal measures of Maryland]. Md G S 5 : 291-315, map (1905)

$05 \mathrm{~b}$ (and others) Distribution and character of the Maryland coal beds. Md G S 5: $317-512$, maps (1905)

06 The Pleistocene fauna [of Maryland]. Md $G \mathrm{~S}$, Pliocene and Pleistocene: 139-148 (1906)

06a (and Hollick, Arthur, and Lueas, F. A.) The Pliocene and Pleistocene depesits of Maryland; the interpretation of the paleontological criteria. Md G S, Pliocene and Pleistocene: $139-152$ (1906)

06b (and others) Systematic paleontology of the Pleistocene deposits of Maryland [Mammalia, by F. A. Lucas; Reptilia, by 0. P. Hay; Insecta, by E. H. Sellards; Crustacea, Mollusca, Coelenterata, Protozoa, by W. B. Clark; Molluscoidea, by E. 0. Ulrich; Pteridophyta, Spermatophyta, by Arthur Hollick]. Md G S, Pliocene and Pleistocene: 153-291, il (1906)

06e (and Mathews, E. B.) Report on the physical features of Maryland, together with an account of the exhibits of Maryland mineral resources made by the Maryland Geological Survey. Md G S, Spee Pub 6:284 pp, map (1906)

06d (and Miller, B. L.) A brief summary of the geology of the Virginia coastal plain. Va G S, g \& B 2:11-24 (1906)

06e What should appear in the report of a state geologist? Ec G 1:489-498 (1906)

07 The classification adopted by the $U$. \$. Geological Survey for the Cretaceous deposits of New Jersey, Delaware, Maryland, and Virginia. Johns Hopkins Univ Circ n s 1907 no $7: 1-4$ [589-592] (1907)

07a Report on the Maryland geological survey. Johns Hopkins Univ Cire 1907 no $1: 99-101 ; 1908$ no $1: 90-92 ; 1909$ no 1 : $86-88 ; 1910$ no $10: 98-99 ; 1912$ no $1: 99$ 100 ; 1913 no 1 : $104-105 ; 1914$ no 1 : $101-$ $102 ; 1915$ no $1: 102-103 ; 1916$ no $1: 129-$ $180 ; 1917$ no $1: 138-139 ; 1917$ no 10 : $148-149$.

09 (and Mathews, E. B.) Maryland mineral industries, 1896-1907. Md G S 8: $97-223$ (1909)

09 a Some results of an investigation of the coastal plain formation of the area between Massachusetts and North Carolina (abst). Sclence n s 29:629 (1909) G Soc Am, B 20:646-654 (1910)
CIark, William Bullock-Continued.

09b (and Twitchell, M. W.) The geological distribution of the Mesozoic and Cenozoic Eehinodermata of the United States (abst). Science n s 29:635 (1909) G Soc Am, B 20:686-688 (1910)

10 Contributions to morphology from paleontology. Pop Sc Mo 77:145-150 (1910)

11 (and Bibbins, A. B., and Berry, E. W.) The Lower Cretaceous deposits of Maryland. Md G S, Lower Cretaceous : 2398, map (1911)

11a (with LuI1, R. S., and Berry, E. W.) Systematic paleontology of the Lower Cretaceous deposits of Maryland. Md G S, Lower Cretaceous: 179-596 (1911)

12 The physlography of the Coastal Plain of North Carolina; the correlation of the Coastal Plain of North Carolina. N C G S 3:23-33, 304-330 (1912)

$12 a$ (and Miller, B. L., and Stephenson, L. W. The stratigraphy of the Coastal Plain of North Carolina; the geological history of the Coastal Plain of North Carolina. N C G S 3:34-44, 291303 (1912)

$12 b$ (and Miller, B. L.) The physiography and geology of the Coastal Plain province of Virginia, with chapters on the Lower Cretaceous, by Edward W. Berry, and the economic geology, by Thomas Leon. ard Watson. Va G S, B $4: 13-222$, map (1912)

13 (and others) Devonian; Lower, Middle and Upper, and plates. Md G S, 3 vols., Lower (text), $560 \mathrm{pp}$, il.; Middle and Upper (text), 720, $156 \mathrm{pp}, \mathrm{il}$, Baltimore 1913

15 (and Twitehell, M. W.) The Mesozoic and Cenozoic Echinodermata of the United States. U S G S, Mon 54:341 pp, il (1915)

15a The Brandywine formation of the middle Atlantic Coastal Plain. Am J Sc (4) $40: 499-506$ (1915)

16 The Upper Cretaceous deposits of Maryland. Md G S, Upper Cret: 33-110, map (1916)

16a (and others) Correlation of the Upper Cretaceous formations. Md G S, Upper Cret : 315-341 (1916)

16b (and others) Systematic paleontology of the Upper Cretaceous deposits of Maryland (Vertebrata and Plantae by E. W. Berry; Arthropoda by H. A. Pilsbry; Mollusca, Brachiopoda and Vermes by Julia A. Gardner; Bryozoa by R. S. Bassler; Echinodermata by W. B. Clark; Coelenterata by L. W. Stephenson). Md G S Upper Cret : 343-986, 11 (1916)

16e (and others) The age of the middle Atlantic coast upper Cretaceous deposits. Nat Ac Sc, Pr 2: 181-187 (1916) 
Clark, William Bullock-Contlnued.

17 Geological surveys with special reference to the work of the Maryland Geological Survey. Johns Hopkins Univ Circ n s 1917 no 3: 3-12 [201-210] (1917)

18 The geography of Maryland. Md G S $10: 39-167$ (1918)

18a (and Mathews, E. B., and Berry, E. W.) The surface and underground water resources of Maryland, including Delaware and the District of Columbia. Md G S $10: 169-542$ (1918)

See also Bascom, 09a, b; Campbell (M R), 06f; Powell, 96; Sallsbury, 98; Williams (T), 96

Clark, William S.

52 On metallic meteorites. Inaug Diss, 80 pp, Göttingen 1852 Notice, Am J Sc (2) $15: 7-22 \quad(1853)$

Clarke, C. H.

03 Notes on the Michipicoten gold belt [Ont.]. Eng M J 76: 735-736 (1903)

Clarke, E. S.

88 (with Herrick, C. L., and Deming, J. L.) Some American norites and gabbros. Am G 1:339-346 (1888)

Clarke, Frank Wigglesworth.

68 On a new process in mineral analysis. Am J Sc (2) 45: 173-180 (1868)

82 (and Perry, N. W.) A new mineral from Colorado [gunnisonite]. Am Chem J 4: 140-142 (1882)

84 (and Chatard, T. M.) A report of work done in the Washington laboratory ... 1883-84. U S G S, B 9:40 pp (1884)

84a (and Chatard, T. M.) Mineralogical notes from the laboratory of the U. S. Geological Survey. Am J Sc (3) 28:20-25 (1884)

85 (and Diller, J. S.) Topaz from Stoneham, Me. Am J Sc (3) 29:378384 (1885)

85a Mica. U S G S, Min Res 1883-4: 906-912 (1885)

86 Report of work done in the division of chemistry and physics ... 1884-85. U S G S, B $27: 80$ pp (1886)

$86 a$ The minerals of Litchfield, Me. Am $\mathrm{J}$ Sc (3) $31: 262-272$ (1886)

$\mathbf{8 6 b}$ (and Diller, J, S.) Turquoise from New Mexico. Am J Sc (3) $32: 211$ 217 (1886)

86e Researehes on the lithia micas. Am

$\mathrm{J}$ Sc (3) $32: 353-361$ (1886)

87 Report of work done in the division of chemistry and physics ... 1885-86. U S G S, B 42:152 pp (1887)

87a Studies in the mica group. Am J Sc (3) $34: 131-137$ (1887)

88 (and Merrill, G. P.) On nephrite and jadeite. U S Nat Mus, Pr 11:115130 (1888)

88a Some nickel ores from Oregon, Am J Sc (3) $35: 483-488$ (1888)

89 Report of work done in the division of chemistry and physies ... 1886-87. U S G S, B 55:96 pp (1889)
Clarke, Frank Wigglesworth-Continue! 89a The meteorite collection in the 0.8 National Museum. Smiths Inst, An 1886 pt $2: 255-265$ (1889)

89 b (and Catlett, Charles) A pltt. niferous nickel ore from Canada. Am Se (3) $37: 372-374$ (1889)

s9e A new oecurrence of gyrolite. st J Se (3) 38: 128-129 (1889)

S9d A theory of the mica group. As $\mathrm{J} \mathrm{Sc} \mathrm{(3)} 38: 384-393$ (1889)

90 Report of work done in the divisio of chemistry and physies ... $1887-8 \%$ U S G S, B 60:174 pp (1890)

$90 a$ A report of work done in the e vision of chemistry and physics... 1888U S G S, B 64:60 pp (1890)

$90 \mathrm{~b}$ (and Sehneider, E. A.) Exper ments upon the constitution of the nath ral silleates. Am J Sc (3) $40: 303-31$. $405-415,452-457$ (1890) Zs Kryst 18 $390-418$ (1890)

91 Report of work done in the divisin of chemistry and physics... 1889-90. G S, B 78:131 pp (1891)

oin (and Sehneider, F. A.) On the constitution of certain micas, vermiculits and chlorites, Am J Sc (3) $42: 242-2:$ (1891) Zs Kryst 19:465-477 (1891)

92 Report of work done in the dirisie of chemistry and physics... 1890-91. If G S, B 90:77 pp (1892)

$92 \mathbf{a}$ Note on the constitution of ptilolit and mordenite. Am J Sc (3) $44: 101-11$. (1892)

93 Report of work done in the divist: of chemistry... 1891-93. U S G S, B 11: $115 \mathrm{pp} \mathrm{(1893)}$

94 An occurrence of anorthite th epidote. Am J Sc (3) 48:429 (1894)

95 The constitution of the silicates.

S G S, B 125:109 pp (1895)

97 (and Hillebrand, W. F.) Analye of rocks, with a chapter on analytic methods, laboratory of the United State Geological Survey, 1880 to 1896 . U S G ? B 148: $306 \mathrm{pp} \mathrm{(1897)}$

99 (and Darton, N. H.) On a dromica from New Jersey. Am J Sc 7: 365-366 (1899) U S G S, B 167:15t $155(1900)$

99a The constitution of tourmaline. J Sc (4) 8: 111-121 (1899) U S G S $167: 26-36 \quad(1900)$

996 (and Steiger, George) Experi ments relative to the constitution of per tolite, pyrophyllite, calamine, and analett $A m \alpha$ S Sc (4) $8: 245-257$ (1899) U S G B $167: 13-25$ (1900)

00 Contributions to chemistry and mit eralogy from the laboratory of the Unit States Geological Survey. U S G S, $167: 166 \mathrm{pp}(1900)$

00a Analyses of rocks from the laboth tory of the United States Geological so vey, 1880-1899. U S G S, B 168: 308 (1900) 
Clarke, Brank Wigglesworth-Continued. 02 (and Steiger, George). The action of ammonium chloride upon silicates. U S G S, B 207:57 pp (1902)

03 Mineral analyses from the laboratories of the United States Geological Survey, 1880-1903. U S G S, B 220:119 pp (1903)

03a The composition of glauconite and greenalite. U S G S, Mon 43:243-247 (1903)

03b A psendoserpentine from Stevens Co., Wash. Am J Sc (4) 15:397-398 (1903) U S G S, B 262:69-71 (1905)

04 Analyses of rocks from the laboratory of the United States Geological Survey, 1880-1903. D S G S, B 228:375 pp (1904)

05 (and Steiger, George) On " californite." U S G S, B 262: 72-74 (1905)

06 The statistical method in chemical geology [average chemical composition of the earth's crust]. Am Ph Soc, Pr 45 : 14-32 (1906) Abst, Science n s $23: 929$ 930 (1906)

07 The composition of the red clay. J G 15: 783-789 (1907) R Soc Edinb, Pr $27: 167-171$ (1907)

08 The data of geochemistry. U S G S, B $330: 716 \mathrm{pp}(1908) ; 2 d$ ed, B $491: 782$ pp (1911) ; 3d ed, B 616: 821 pp (1916)

09 The chemical work of the U S. Geological Survey. Science n s $30: 161-171$ (1909)

10 A preliminary study of chemical denudation. Smlths Misc Col 56 no $5: 1-19$ (1910)

10a Analyses of rocks and minerals from the laboratory of the United States Geological Survey, 1880 to 1908 . U S G S, B $419: 323$ pp (1910)

10b The chemical work of the United States Geological Survey. Int Cong Applied Chemistry, VII, London, 1909, sec. 2 : 146-161 (1910)

11 (and Steigex, George) Note on the composition of sea water. Wash Ac Sc J $1: 4-5$ (1911

12 Some geochemical statisties [average composition of Igneous and sedimentary rocks and character and magnitude of marine sedimentation]. Am Ph Soc, Pr 51: 214-234 (1912) Abst, Science n s 35: 791 (1912)

12a An aluminum arsenate from Dtah. Wash Ac Sc, J 2 : 516-518 (1912)

14 The constitution of the natural silicates. U S G S, B 588:128 pp (1914) Abst, Wash Ac Sc, J 4:607 (1914)

14a Water analyses from the laboratory of the United States Geological Survey. U S G S, W-S P 364:40 pp (1914) Abst, Wash Ae Se J 4:606 (1914)
Clarke, Frank Wigglesworth-Continued.

14b (and Steiger, George) The relative abundance of several metallic elements. Wash Ac Sc, J 4 : 58-62 (1914)

14e (and wheeler, W. C.) The composition of crinoid skeletons. U S G S, P P $90: 33-37$ (1914) Abst, Wash $\mathrm{Ac} \mathrm{Sc}$, J 4:419 (1914)

15 Analyses of rocks and minerals from the laboratory of the U. S. Geological Survey, 1880 to 1914 . U S G S, B 591: 376 pp (1915)

15a (and wheeler, W. C.) The inorganic constituents of echinoderms. U S G S, P P 90:191-196 (1915)

15b (and wheeler, W. C.) The composition of brachiopod shells. Nat Ac Sc, Pr 1: 262-266 (1915)

15e (and wheeler, W. C.) The inorganic constituents of Alcyonaria. Nat Ac Sc, Pr 1: 552-556 (1915)

16 Geochemical evidence as to early forms of life. Wash Ac Sc, J 6:603-605 (1916)

17 (and Wheeler, w. C.) The inorganic constituents of marine invertebrates. U S G S, P P 102:56 pp (1917) Abst, Wash Ac Sc, J $7: 562-563$ (1917) ; Science n s $43: 723$ (1916)

17a (and Kamm, R. M.) New analyses of echinoderms. Nat Ac Sc, Pr 3: 401-404 (1917)

17b The constitution of melilite and gehlenite. Am J Sc (4) 43:476-484 (1917)

18 (and Salkover, B.) Note on the Inorganic constituents of two small crustaceans. Wash Ac Sc, J 8: 185-186 (1918)

See also Powell, 88, 89, 89a, 90, 91, 91a, 92, 93,95

\section{Clarke, Galen.}

73 Explorations in the region of Yosemite Valley. Boston Soc N H, Pr 15: 259-261 (1873)

Clarke, John Mason.

82 New phyllopod crustaceans from the Devonian of western New York. Am J Sc (3) $23: 476-478$ (1882)

82a Cirriped crustacean from the Devonlan. Am J Sc (3) $24: 55-56$, il (1882)

83 New discoveries in Devonian crustacea. Am J Sc (3) $25: 120-125$, 11 (1883)

s5 On Devonian spores, Am J Sc (3) $29: 284-289$, il (1885)

S5a On the higher Devonian faunas of Ontario Co., N. Y. U S G S, B 16:86 pp, 11 (1885)

S5b A brief outline of the geological succession in Ontario Co., N. Y., to accompany a map. N Y St G, An Rp 4: 9-22, map (1885)

87 Annelld teeth from the lower portion of the Hamilton group and from the Naples shales of Ontario Co, N. Y. N Y St G, An Rp 6:30-33, 11 (1887) 
Clarke, John Mason-Continued.

87a Note on the supposed Mastodon bones found at Attica, Wyoming Co. [N. Y.]. N $\mathrm{Y}$ St G, An Rp $6: 34-35$ (1887)

S7b A noteworthy specimen of Devonian lepldodendron. Sclence $9: 516$ (1887)

s8 Report on the bones of Mastodon or Elephas found associated with charcoal and pottery at Attica, Wyoming Co., N. Y. N Y St Mus, An Rp 41:388-390 (1888) ; 43:304-306 (1890) N Y St G, An Rp 9: 102-104 (1890)

S8a The structure and development of the visual area in the trilobite, Phacops rana Green. J Morph 2:253-270 (1888)

S8b (with Hall, J.) Descriptions of the trilobites and other Crustacea of the Oriskany, Upper Helderberg, Hamilton, Portage, Chemung, and Catskill groups. N Y G S, Pal 7 : 1xiv, $236 \mathrm{pp}$, il (1888)

89 The genera of the Paleozoic Brachiopoda. N Y St G, An Rp $8: 43-46$ (1889) N Y St Mus, An Rp 42:389-395 (1889)

S9a The genus Bronteus in the Chemung rocks of New York. N Y St G, An Rp $8: 57-60$, il (1889) N Y St Mus, An Rp 42: 403-405, il (1889)

S9b A list of the species constituting the known fauna and flora of the Marcellus epoch in the State of New York. N Y St G, An Rp 8:60-61 (1889) N Y St Mus, An Rp 42:406-407 (1889)

89c The Hercynian question; a brief review of its development and present status, with a few remarks upon its relation to the current classification of American Paleozoic faunas. N $\mathrm{Y}$ St G, An Rp 8: 62-91 (1889) N Y St Mus, An Rp 42: 408-437 (1889)

89d (with Beecher, c. E.) The development of some Silurian Brachiopoda. N Y St Mus, Mem 1: 95 pp, il (1889)

91 Report on the condition of the paleontological department of the New York State Museum, 1890. N Y St G, An Rp $10: 27-34$ (1891) N $\mathrm{Y}$ St Mus, An Rp $44: 57-64$ (1892)

91a Notes on the genus Acidaspis. N Y St G, An Rp 10:61-78, il (1891) N Y St Mus, An Rp $44: 91-104$, il (1892)

$91 \mathrm{~b}$ Note on Coronura aspectans Conrad (sp.), the Asaphus diurus Green. N Y St G, An Rp 10:79-86, il (1891) N Y St Mus, An Rp $44: 105-110$, il (1891)

91e Observations on the Terataspis grandis Hall, the largest known trilobite. N Y St G, An Rp 10:87-90, il (1891) N Y St Mus, An Rp 44:111-114, il (1892)

$91 d$ The "Hercyn-Frage" and the Helderberg limestones in North America. Am G 7:109-113 (1891)

91e The fann ith Goniatites in tumenscens Beyrich in western New York. Am G 8:86-105 (1891) N Jb 1891, I: 161-168
Clarke, John Mason-Continued.

92 Catalogue of the collection of 30 logical and paleontological specimens, of nated by the Albany Institute to the Stat? Museum. N Y St G, An Rp 11: 31-it (1892) N Y St Mus, An Rp 45:347-30 (1892)

52a Report of the assistant paleontolegist. N Y St G, An Rp 11:54-55 (189?) N Y St Mus, An Rp 45:370-371 (1892)

92b List of the original and illustratel specimens in the paleontological colles. tions; Part I, Crustacea. N Y St G, in Rp 11:57-121 (1892) N Y St Mus, An Rp $45: 373-437$ (1892)

92e On Cordania, a proposed new genos of trilobites. N Y St Mus, An Rp 45: 440-443 (1892) N Y St G, An Rp 11: 124-127 (1892)

92d The discovery of Clymenia in the fauna of the intumescens zone (Naples beds) of western New York, and its geological significance. Am J Sc (3) 43:5i63 , il (1892)

92e (with Hall, James) An introduc tion to the study of the Brachiopoda, in. tended as a hand book for the use o? students. N Y St G, An Rp 11:133-222, Il (1892) N Y St Mus, An Rp. 45:449616 , il (1892)

93 Report of the assistant paleontologist, 1892. N Y St G, An Rp 12:43-53 (1893) N Y St Mus, An Rp 46:189-199 (1893)

$93 a$ List of the original and illustrated specimens in the paleontological collec tions. N Y St G, An Rp 12:57-104 (1893) N Y St Mus, An Rp 46:201-250 (1893)

93b The protoconch of Orthoceras. Am G $12: 112-115$, Il (1893)

93e On the structure of the carapace in the Devonian crustacean Rhinocaris: and the relation of the genus to Mesothyro and the Phyllocarida. Am Nat 27:793801, Il (1893)

93d (with Hall, James) An fntroduction to the study of the genera of Paleozolc Brachiopoda. N $\quad$ Y $\mathrm{G}$ S, Pal 8 pt $1: 367$ pp, il (1893) ; pt 2: 394 pp, 11 (1894)

94 The suecession of the fossil faunas in the section of the Livonia salt shath N Y St G, An Rp 13:131-158 (1894) N Y St Mus, An Rp $47: 325-352$ (1894)

$94 a$ New or rare species of fossils from the horizons of the Livonia salt shaft. N Y St G, An Rp 13:159-189, il (1894) N Y St Mus, An Rp $47: 353-383$, il (1894) 94b Report on field work in Chenango Co. [N, Y.]. N Y St G, An Rp 13:529557 (1894) N Y St Mus, An Rp 47:723751 (1894)

94c $\mathbf{A}$ list of publications relating to the geology and paleontology of the State of New York, 1876-1893. N Y St G, An R? $13: 559-597$ (1894) N Y St Mus, An RP $47: 753-791$ (1894) 


\section{BIBLIOGRAPHY.}

Clarke, John Mason-Continued.

94d Composite generic fundamenta. Am G $13: 286-289$ (1894)

94e American species of Autodetus and some paramorphic shells from the Devonian. Am G $13: 327-335$, il (1894)

off The early stages of Bactrites. Am G $14: 37-43$, il (1894)

94 Nanno, a new cephalopodan type. Am G $14: 205-208$, il (1894)

94h (with Hall, James) Report of de. partment of paleontology. N Y St G, An Rip 13:599-657 (1894) N Y St Mus, An Rp $47: 793-851$ (1894)

941 (with Hanl, James) An introduc tion to the study of the Brachiopoda, intended as a handbook for the use of students, Part II. N Y St G, An Rp $13: 749$ 1015, il (1894) N Y St Mus, An Rp 47 : 945-1137, il (1594)

95 George Huntington Williams. Am G $15: 69-81$, port. (1895)

25a The fossil fishes of Canon City, Colo. Am G 15: 121 (1895)

951 Cephalopod beginnings. Am G 15: 125-128 (1895)

96 The structure of certain Paleozole barnacles, Am G 17:137-143, il (1896)

97 The stratigraphic and faunal rela tions of the Oneonta sandstones and shales, the Ithaca and the Portage groups in central New York. N Y St G, $\Delta$ n Rp 15: 11-12,27-81, maps (1897) N Y St Mus, An $\mathrm{Rp} 49$ v 2:11-12, 27-81, maps (1898)

97 a Notes on some crustaceans from the Chemung group of New York. N Y St $\mathbf{G}$, An Rp $15: 729-738$, il (1897) N $\quad$ St Mas, An Rp 49 v $2: 729-738$, il (1898)

$97 \mathrm{~b}$ The Lower Silurian trilobites of Minnesota. Minn G S, Final Rp 3 pt 2 : $695-759$, il (1897)

97e The Lower Silurian Cephalopoda of Minnesota. Minn G S, Final Rp 3 pt 2 : 761-812, fl (1897)

97d A sphinctozoan calcisponge from the upper Carboniferous of eastern Nebraska. Am G 20:387-392, fl (1897)

97 e The geologic conditions at the site of the proposed dam and storage reservoir on the Genesee River at Portage. N Y, St Engineer and Surveyor, Genessee River Storage Surveys: 106-122 (1897) N Y, St Engineer and Surveyor, An Rp 1596:730746 (1897)

971 (with Hall, James) The new species of Brachiopoda described in Paleontology of New York, vol. VIII, parts 1 and $2,1892-1894$. N $\mathrm{Y}$ St G, An Rp 14: $323-402,11$ (1895) [1897] N Y St Mus, An Rp 48 v 2: $323-402$, il (1895) [1897]

98 (with Fall, James) A memoir on the Paleozoic reticulate sponges constitutfng the family Dictyospongidae. N $\mathbf{Y}$ St G, An Rp 15 pt 2: 741-984, il (1898); 16 : $341-448,11$ (1899) N Y St Mus, An Rp 49 v $3: 741-984$, il $(1898) ; 50$ v $2: 341-448$, il $(1899$,
Clarke, John Mason-Continued.

98a (with Ha11, James). A memoir on the Paleozoic reticulate sponges constituting the family Dictyospongidre. N Y St Mus, Mem 2:350 pp, if (1898)

99 The Naples fauna (fauna with Manticocoras intumescens) in western New York. N Y St G, An Rp 16:29-161, il (1899) N Y St Mus, An Rp 50 v. 2:29161, il (1899)

$99 a$ Notes on the early stages of certain Goniatites. N Y St G, An Rp 16:163169 , il (1899) N Y St Mus, An Rp $50 v$ $2: 163-169$, il $(1899)$

99 Eighteenth annual report of the State geologist [of New York] for the year 1898: $169 \mathrm{pp}$ (1899) Also as N Y St Mus, An Rp $52 v 2: 169$ pp (1900)

99e Paleontology. N Y Univ [St Mus] Habk $13: 8 \mathrm{pp} \mathrm{(1899)}$

99d Guide to excursions in the fossiliferous rocks of New York State. N Y Univ [St Mus] Hdbk 15:120 pp (1899)

99e Relation of New York State paleontology to the schools and colleges. N Y, Univ, Regents B no $48: 359-364$ (1899)

99 James Hall. N Y, Univ, Regents B no. $48: 382-385$ (1899)

99\% (a) Paropsonema; a peculiar echinoderm from the Intumescens fauna, New York: (b) Remarkable occurrence of orthoceras in the Oneonta sandstones of New York; (c) The Squaw Island "water biscuit," Canandaigua Lake, New York (abst). $\mathrm{Am}$ As, $\mathrm{Pr} 48: 226$ (1899) Science n s $10: 488-489$ (1899)

99h Geological time. Science n s 10: 695 (1899)

99i (and Schnehert, C.) The nomenclature of the New York series of geológical formations. Science n s 10:874878 (1899) Am G 25:114-119 (1900)

o0 The Oriskany fauna of Becraft Mountain, Columbia Co., N. Y. N Y St Mus, Mem $3: 5-128$, il (1900)

O0a A remarkable occurrence of Orthoceras in the Oneonta beds of the Chenango Valley, N. Y. N Y St Mus, B $39: 167-171$, il (1900)

oob Paropsonema cryptophya, a pecullar echinoderm from the intumescens zone (Portage beds) of western New York. N Y St Mus, B 39:172-186, il (1900)

ooe Dictyonine hexactinellid sponges from the upper Devonic of New York [Nepheliospongia]. N Y St Mus, B 39 : 187-194, il (1900)

ood The water biscuit of Squaw Island, Canandágua Lake, N. Y. N Y St Mus, B $39: 195-198$ (1900)

00e Notes on the Siluro-Devonic boundary. Science n s $12: 406-408$ (1900)

oof Lenticular deposits of the Oriskany formation in New York $(a b s t)$. Am As, Pr $49: 188(1900)$ Science n s 12:991-992 (1900) 
Clarke, John Mason-Contlnued.

$00 \mathrm{~g}$ The fauna of the arenaceous Lower Devonian of Aroostook Co., Me. (abst). Am As, Pr 49:188 (1900) Science n s $12: 992$ (1900)

o1 Limestones of central and western New York, interbedded with bituminous shales of the Marcellus stage; with notes on the nature and origin of their faunas. N Y St Mus, B 49:115-138, il (1901)

O1a New Agelacrinites. N Y St Mus, B $49: 182-198$, il (1901)

01b Value of Amnigenia as an indicator of fresh-water deposits during the Devonic of New York, Ireland, and the Rhineland. N $\mathrm{X}$ St Mus, B $49: 199-203$, il (1901)

02 Report of the State paleontologist, 1900. N Y St Mus, An Rp $54 v 1$ App I : 3-81 (1902)

02a Notes on Paleozoic crustaceans [Pseudoniscus and Phyllocarida]. N Y St Mus, An Rp $54 \quad v \quad 1$ App $3: 83-124$, il (1902)

02b Report of the State paleontologist, 1901. N Y St Mus, B 52:419-456 (1902)

02e George Bancroft Simpson, 18441901. N Y St Mus, B 52:457-460 (1902)

02d (and Ruedemann, R., and Luther, D. D.) Contact lines of upper Siluric formations on the Brockport and Medina quadrangles [N. Y.]. N Y St Mus, B 52:517-523 (1902)

02e Preliminary statement of the paleon. tologic results of the areal survey of the Olean quadrangle [N. Y.]. N $\mathbf{Y}$ St Mus, B 52: 524-528 (1902)

02f A new genus of Paleozoic brachlopods, Eunoa; with some considerations therefrom on the organic bodies known as Discinocaris, Spathiocaris, and Cardiocaris. N Y St Mus, B 52 : 606-615, il (1902)

$02 \mathrm{~g}$ The indigene and allen faunas of the New York Devonic. N Y St Mus, B $52: 664-672$ (1902)

03 (and Ruedemann, R.) Catalogue of type specimens of Paleozoic fossils in New York State Museum. N Y St Mus, B $65: 847$ pp (1903)

03a Report of the State paleontologist, 1902. N Y St Mus, B 69: 851-891 (1903)

$03 \mathrm{~b}$ Mastodons of New York; a list of discoveries of their remains, 1705-1902. N Y St Mus, B 69: 921-933, map (1903)

03e Construction of the Olean rock section. N Y St Mus, B 69: 996-999 (1903) o3a Some Devonic worms. N Y St Mus,

B $69: 1234-1238$, il (1903)

03e Torsion of the lamellibranch shell; an fllustration of Noetling's law. N Y St Mus, B $69: 1228-1233$, il (1903)

O3f (and Ruedemann. R.) 'Guelph fauna in the State of New York. N Y St Mus, Mem 5: 195 pp, il (1903)

03g Classification of New York series of geologic formations. N Y St Mus, Hdbk $19: 28 \mathrm{pp} \mathrm{(1903)}$
Clarke, John Mason-Continued.

03h Report of committee...on the $\mathrm{B}_{\mathrm{s}}$ mons House memorial [organization Association of American Geologists]. Soc Am, B 14:10-13 (1903)

o31 Origin of the limestone faunas of the Marcellus shales of New York (abst) G Soc Am, B 13:585 (1903) Science D : $15: 90 \quad(1902)$

03j Current work in paleontology in New York State (abst). Science n s 17 219 (1903)

03k Distribution of mastodon remains in New York $(a b s t)$. Science n s 17:297298 (1903) G Soc Am, B 14:537 (1904)

04 Naples fauna in western New Yort N Y St Mus, Mem 6:199-454, map, (1904)

04a Nomenclature of the New Yort geologic formations. University of the State of New York, High School Dp, B 25:495508 (1904)

04b (and Luther, D. D.) Stratigraphic and paleontologic map of Canandaigua and Naples quadrangles [N. Y.], N Y St Mus, B 63: 76 pp, map (1904)

04e Charles Emerson Beecher [with bibliography by Lucy P. Bush]. Am G 34: $1-18$, port (1904)

04d Paleontological work in New York (abst). G Soc Am, B 14:536-537 (1904)

05 Report of the State paleontologist, 1903. N Y St Mus, B $80: 3-133(1905)$

o5a Percé; a brief sketch of its geolorg. N $Y$ St Mus, B $80: 134-171$, 11, maps (1905)

O5b (and Luther, D. D.) Geology of the Watkins and Elmira quadrangles [N. Y.]. N Y St Mus, B $81: 3-29$, map (1905)

Ose (and Luther, D. D.) Geologie map of the Tully quadrangle [N. Y.]. N I \& Mus, B $82: 35-52$ (1905)

O5d Ithaca fauna of central New York N Y St Mus, B $82: 53-70$ (1905)

ose With regard to Portage crinolds

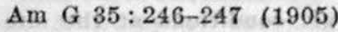

ose Prof. James Hall and the Troost manuscript. Am G 35:256-257 (1905)

06 Report of the director, 1904 [inclnding State geologist and paleontologist]. N Y St Mus, An Rp 58:5-136 (1906)

06a Report of the State geologist and paleontologist [of New York] for 1905. N Y St Mus, An Rp 59, 1: 10-41, 11 (1906)

06b What should appear in the report of a State geologist? Ec G 1: 488-489 (1906)

07 Evidences of a Coblenzian invasion in the Devonic of eastern North America. Festschrift, Adolf v. Koenen : 359-368, Stuttgart 1907

oтa Some new Devonic fossils [Quebec, New Brunswick, and Maine]. N Y St Mus, B $107: 153-291$, il (1907)

отb An interesting style of sand-filled vein. N Y St Mus, B $107: 293-294$ (1907) 
Clarke, John Mason-Continued.

07e The Eurypterus shales of the Shawangunk Mountains in eastern New York. N Y St Mus, B 107: 295-326, il (1907)

07d Third report of the director of the science division 1906, including the 60th report of the State Museum, the 26th report of the State geologist, and the report of the State paleontologist for 1906. Reprinted from the 60th An Rp N Y St Mus. $182 \mathrm{pp}, 11$ Albany 1907

07e Eurypterus fauna of the Shawangunk grit (abst). Science n s $25: 294-295$ (1907)

07f Lake Champlain (abst). Science n 8 26:400 (1907)

07g Barachois, bar, and tickle. N Y St Educ Dp, B 412 (Secondary Educ B 34): 123-131 (1907)

08 Fourth report of the director of the science division, including the 61 st report of the State Museum, the 27 th report of the State geologist, and the report of the State paleontologist for 1907. N Y St Mus, B $121: 203 \mathrm{pp}$, il (1908)

OSa The beginnings of dependent life. N Y St Mus, B 121: 146-169, il (1908)

08b Early Devonic history of New York and eastern North America. N Y St Mus, Mem $9: 366 \mathrm{pp}$, maps (1908)

0Se (and Luther, D. D.) Geologic map and descriptions of the Portage and Nunda quadrangles. N Y St Mus, B 118:43-69, maps (1908)

08ıl Sketches of Gaspé. 85 pp, Albany 1908

09 Fifth report of the director of the sclence division, including the $62 d$ report of the State Museum, the 28th report of the State geologist, and the report of the State paleontologist for 1908; director's report for 1908. N Y St Mus, B 133: 5114, il (1909)

09a Early Devonic history of New York and eastern North America, Part 2, N Y St Mus, Mem 2: 250 pp, maps, il (1909)

10 Sixth report of the director of the science division, including the $63 d$ report of the State Museum, the 29th report of the State geologist, and the report of the State paleontologist for 1909. N Y St Mus, B $140: 229 \mathrm{pp}, 11$ (1910)

10a (and others) The paleontologic record, The Paleontological Society con. ference papers, Pop Sc Mo $76: 581-603$; $77: 67-81, \quad 142-153, \quad 292-307, \quad 333-341$, 473-481, 594-601 (1910)

10b Paleontology and isolation. Pop Se Mo $77: 338-341$ (1910)

10e Age of the Gaspe sandstone (dis. cussion) G Soc Am, B 20:696-697 (1910)

10d (and Ruedemann, Rudolf) Mode of life of the Eurypterida (abst). Science D $832: 224(1910)$
Clarke, John Mason-Continued.

11 Seventh report of the direetor of the science division, including the 64 th report of the State Museum, the 30th report of the State geologist, and the report of the State paleontologist for 1910. N Y St Mus, B $149: 5-31$ (1911)

11 a Notes on the geology of the Gulf of St. Lawrence. N Y St Mus, B 149:121133, il, map (1911)

11b Observations on the Magdalen Islands. $N$ Y St Mus, B 149:134-155 (1911)

11e The Paleontological Society; Address of the president. Science $\mathrm{n}$ s 33 : 284-296 (1911)

$11 d$ Relation of the Paleozoic arthropods to the strand line. G Soc Am, B 22:279280 (1911)

11 Memoir of Joseph Clovis Kemner Laflamme, 1849-1910. G Soc Am, B 22: 4-8, port (1911)

11 Memoir of Robert Parr Whitfield. 1828-1910. G Soc Am, B 22: 22-32, port (1911)

12 Eighth report of the director of the science division, including the 65 th report of the State Museum, the 31st report of the State geologist, and the report of the State paleontologist for 1911. N Y St Mus, B 158: 5-50 (1912)

12a Notes on the geology of the Gulf of St. Lawrence. N Y St Mus, B 158: 111126 (1912)

12b Early adaptation in the feeding habits of starfishes. Ac N Sc Phila, J (2) $15: 113-118$, il (1912)

12e (and Ruedemann, Rudolf) The Eurypterida of New York. N Y St Mus, Mem 14: 439 pp, il (1912)

13 Ninth repert of the director of the sclence division, including the 66 th report of the State Museum, the $32 d$ report of the State geologist, and the report of the State paleontologist for 1912. N Y St Mus, B $164: 5-33$ (1913)

13a The origin of the Gulf of St. Lawrence. $\mathrm{N}$ Y St Mus, B 164:132-137 (1913) Soc Géog Qué, B 7:29-36, map (1913)

13b A notable trilobite from the Perce rock. N Y St Mus, B 164:138-139, il (1913)

13e Dana, the zoologist. G Soc Am, B 24:68-69 (1913)

13d Excursion in eastern Quebec and the maritime provinces; Dalhousle and the Gaspe Peninsula. Int G Cong, XII, Canada, Guide Book no $1: 85-108,110-118$, map (1913)

13e (tand Swartz, C. K.) Systematic paleontology of the Upper Devonian deposits of Maryland. Md G S, Middle and Upper Devonian : 539-699, il (1913)

13P The heart of Gaspé; sketehes in the Gulf of St. Lawrence. xiv, $292 \mathrm{pp}$, New York, 1913. 
Clarke, John Mason-Continued.

14 Tenth report of the director of the State Museum and science department, including the 67 th report of the State Museum, the $33 d$ report of the State geologist, and the report of the State paleontologist for 1913. N Y St Mus, B 173: 3-141, il (1914)

$14 a$ Newton Horace Winchell. Seler a n s $40: 127-130$ (1914)

14b A fossil botanical garden [Greenfield, N. Y.]. Science n s 40:884 (1914)

14e Illustrations of intraformational corrugation (abst, with discussion). G Soc Am, B 25:37 (1914)

14d Illustrations of the recent exposure of the Saratega Springs (abst). G Soc Am, B 25:38 (1914)

15 Eleventh report of the director of the State Museum and science department, including the sixty-eighth report of the State Museum, the thirty-fourth report of the State geologist, and the report of the State paleontologist for 1914. N Y St Mus, B $177: 173 \mathrm{pp}$, il (1915)

15a Conceptions regarding the American Devonic. N Y St Mus, B 177:115-133 (1915)

15b The Oriskany-Pic d'Aurore episode of the Appalachain Devonic. N Y St Mus, B $177: 147-153$ (1915)

15e The rifted relict-mountain, a type of "Old Red" orogeny. N Y St Mus, B 177: 155-161 (1915) Abst, G Soc Am, B 26: 90-91 (1915)

15d Memoir of Horace Carter Hovey G Soc Am, B 26:21-27 port (1915)

15e Causes producing scratched, impressed, fractured, and recemented pebbles in ancient conglomerates (abst). G Soc Am, B 26:60-61 (1915) Science n s $41: 509$ (1915)

15P A new glacial park [Clark Reserva. tion, near Syracuse, N. Y.]. Science $n$ 41: $382-383$ (1915)

16 Twelfth report of the director of the State Museum and science department, including the sixty-ninth report of the State Museum, the thirty-fifth report of the State geologist and the report of the State paleontologist for 1915. N Y St Mus, B 187: 192 pp (1916)

16a Charles Smith Prosser. Science n s $44: 557-559$ (1916)

$16 \mathrm{~b}$ The reincarnation of James Eights, Antarctic explorer. Sc Mo $2: 189-202$ (1916)

17 The philosophy of geology and the order of the state (presidential address). G Soc Am, B 28: 235-248 (1917) Science n s $45: 125-135$ (1917) N Y St Mus, B 196 : 93-106 [1918]

18 Report on the geological survey. N Y St Mus, B 196: 24-49 (1917) [1918]

18a Devonian glass sponges. N Y St Mus, B 196:177-198, il (1917) [1918]
Clarke, John Mason-Continued.

18b Strand and undertow marking of upper Devonian time as indications of the prevalling climate. N Y St Mus, B 198: 199-238 (1917) [1918]. Abst, G Soc dn B $29: 83$ (1918)

18e Primary and secondary stresses corded by the vein systems in the Pend rock. N Y St Mus, B $196: 239-240$ (1917) [1918]

18d Memorial of William Bullock Clar G Soc Am, B 29: 21-29, port (1918)

18e Possible derivation of the lepadid barnacles from the phyllopods. Nat Ac \& Pr 4: 384-386 (1918)

See also Barrell, 12a; Beecher, 82 ; Branson, 12; Eastman, 00 ; Emerson, 98 ; Grabau, 12b; Johns Hopkins University. 94; Luther, 02; Powell, 95; Salísburs. $98 \mathrm{~b}$; Williams ( $\mathrm{T}$ ), 96

Clarke, Robert E.

53 Notes from the copper region [Labs Superior]. Harpers Mag 6:433-448, 5\%588 (1853)

Clarke, W. C.

07 Zine in eastern Tennessee. Minc and Minerals 27:395 (1907)

07a The zinc belt of Claiborne asd Union cos., Tenn. Mines and Minerals 27: 567 (1907)

C1aypole, Edward Waller (1835-1901).

74 Glossary of a few paleontologial terms, the accent and pronunciation of which are not obvious, Cin Q J Sc 1 : 285-286 (1874)

75 Review of the present state of the controversy regarding the motion of th glacier. Cin Q J Se 2:72-77, 134-15! (1875)

77 On the preglacial geography of th region of the Great Lakes. Can Nat DI $8: 187-206$ (1877)

78 On the occurrence of a tree-lik fossil plant, Glyptodendron, in the Uppe Silurian (Clinton) rocks of Ohio. Adu ? Sc (3) $15: 302-304$ (1878) G Mag (?) $5: 558-564$ (1878)

79 Preglacial formation of the beds of the great American lakes. Can Nat is $9: 213-227$ (1879)

82 Evidence from the drift of 0 bla Indiana, and Illinois, in support of the preglacial origin of the basins of Lakd Erie and Ontario. Am As, Pr 30:14t. 159 (1882)

82a On the occurrence of an archimet form fenestellid in the Upper Silurlat rocks of Ohio (abst). Am As, $\operatorname{Pr~30:19:1}$ (1882)

8. On Hellcopora, a new spiral gens (with three species) of North Americas fenestellids. G Soc London, Q J 39:3t38 , il (1883) Abst, G Mag (2) $9: 3 \pi$ 378 (1882) 
Claypole, Edward Waller-Continued. 83a on the occurrence of fossilliferous strata in the lower Ponent (Catskill) group of middle Pennsylvania. Am Nat $17: 274-282$ (1883)

83b Geological notes: $A$, On an error in identifying two distinct beds of iron ore in Report $G$ of the geological survey of Bradford Co. ; $B$, Note on the occurrence of Holoptychius, about $500 \mathrm{ft}$. below the recognized top of the Chemung gr., in Bradford Co.; $C$, On a mass of Catskill rocks supposed to exist on the north bank of Towanda Creek, near Franklin; $D$, On two small patches of Catskill represented near Leroy; $E$, On the equivalent of the Schoharie grit of New York, in middle Pennsylvania. Am Ph Soc, Pr 20; 529536 (1883)

83e Note on a large fish-plate from the upper Chemung (?) beds of northern Pennsylvania. Am $\mathrm{Ph}$ Soc, $\operatorname{Pr} 20: 664$ 666 , il (1883)

83d On the Kingsmill white sandstone [Perry Co., Pa.]. Am Ph Soc, Pr 20: 666-673, il (1883)

83e On a large crustacean from the Catskill group of Pennsylvania (abst). Am As, Pr $32: 265$ (1884) Science 2:327 (1883)

83f Rensselaeria from the Hamilton group of Pennsylvania (abst). Am As, $\mathrm{Pr}$ $32: 266$ (1884) Science 2:327, 471-472 (1883)

84 Preliminary note on some fossil fis' es recently discovered in the Silurian tocks of Nerth America. Am Nat 18: 1222-1226 (1884)

84a The Perry County fault; note on an important correction in the geological map of Pennsylvania. Am Ph Soc, Pr 21:218225 (1884)

84b 0 n the equivalent of the New York Portage, in Perry Co., middle Pa. Am Ph Soc, $\operatorname{Pr} 21: 230-235$ (1884)

84e Note on the genus Ze:sselaeria in the Hamilton group in Perry Co., [Pa.]. Am Ph Soc, Pr 21::35-236 (1884)

$84 d$ Note on a large erustacean from the Catskill group of Pennsylvania [Dolichocephala lacoana]. Am $\mathrm{Ph}$ Soc, $\operatorname{Pr} 21$ : 236-239, il (1884)

84e On the Clinton and other shales, etc., composing the fifth group of Rogers... [Perry Co., Pa.]. Am Ph Soc, Pr 21:492502 (1884)

84f $O$ a the occurrence of the genus Dalmanites in the Lower Carboniferous rocks of Ohlo. G Mag (3) 1:303-307, il (1884)

84g Pennsylvania before and after the elevation of the Appalachian Mountains (abst). Brit As, Rp $54: 718$ (1885) G Mag (3) $1: 466-467$ (1884)
Claypole, Edward Waller-Continued.

84h On some remains of fish from the Upper Silurian rocks of Pennsylvania (abst). Brit As, Rp 54:733-734 (1885) G Mag (3) 1:519-521 (1884)

84i Dalmanites in the Lower Carboniferous rocks. Science 3:563 (1884)

84j Fish remains in the North American Silurian rocks. Science 4:3: (1884)

$84 k$ On the Hamilton sandstone of middle Pennsylvania (abst). Am As, Pr 32 : 244-246 (1884)

841 [On the crumpling of the earth's crust as shown by a section across Huntingdon, Juniata, and Perry counties in Pennsylvania.] Science 4:258 (1884)

$\mathbf{8 4 m}$ On some fish remains recently discovered in the Silurian rocks of Pennsylvania (abst). Am As, $\operatorname{Pr} 33: 424-428$ (1885) Science 4:326 (1884)

S5 A preliminary report on the paleontology of Perry Co., describing the order and thickness of its formations and its folded and faulted structure. $\mathrm{Pa} \mathrm{G} \mathrm{S,} \mathrm{2d,}$ F2 : xxii, $437 \mathrm{pp}$, maps (1885)

S5a On the recent discovery of pteraspidian fish in the Upper Silurian rocks of North America. G Soc London, Q J 41: 48-64, il (1885) Abst, G Mag (3) 2: 89-90 (1885)

85b Pennsylvania before and after the elevation of the Appalachian Mountains; a study in dynamical geology. Am Nat 19 : $257-268$ (1885)

s5e On the vertical range of certain fossil species in Pennsylvania and New York. Am Nat 19:644-654 (1885)

85d On the materials of the Appalachians (abst). Am J Se (3) $30: 316$ (1885) Science 6:221 (1885)

85e On Ctenacanthus and Gyracanthus from the Chemung of Pennsylvania (abst). Am As, Pr 33: 489-490 (1885)

86 Report on some fossils from the lower Coal Measures near Wilkes-Barre, Luzerne Co., Pa. Wyoming Hist G Soc, Pr 2:239253, 11 (1886)

86a The old gorge at Niagara. Science $8: 236$ (1886)

86b Buffalo and Chicago, or "what might have been " [outlet of Great Lakes]. Am Nat 20:856-862 (1886)

87 The lake age in Ohio; or, Some episodes in the retreat of the North American glacier. Edinb G Soc, Tr $5: 421-458$, maps (1887) Reprint, 42 pp, maps, Edinburgh 1887

87a The materials of the Appalachians. Am Nat 21:955-962, 1054-1060 (1887)

s7b Preliminary note on some fossil wood from the Carboniferous rocks of Ohio (abst). Am As, Pr 35:219-220 (1887)

88 The eccentricity theory of glacial cold versus the facts. Edinb $G$ Soc, Tr 5: 534-548 (1888) 
Claypole, Edward Waller-Continued. S8a The future of natural gas. Am G $1: 31-36$ (1888)

88b Singular subterranean commotion near Akron, Ohio. Am G 1:190-192 (1888)

sse on some Investigations regarding the condition of the interior of the earth. Am G $1: 382-386 ; 2: 28-35$ (1888) Abst, Brit As, Rp 58: 669-670 (1889)

s8a [Fossils from the Ohio shale]. Am G $2: 62-64$ (1888)

8se [Earthquake shocks at Charleston, S. C.] Am G 2: 135-136 (1888)

SSP "Lake Cuyahoga"; a study in glacial geology (abst). Am As, Pr $36: 218$ (1888)

88\% The four great sandstones of Pennsylvania (abst). Am As, Pr $36: 227$ (1888)

89 Glaciers and glacial radiants in the 1ce age. Am G 3:73-94 (1889)

89a The story of the Mississippi-Missouri. Am G 3:361-377 (1889)

89b Gilsonite or uintaite. $A m$ G 4 : 386-387 (1889)

89e Falls of rock at Niagara. Nature $39: 367$ (1889)

5o lllustration of the "level of no strain" in the crust of the earth. Am G 5: $83-88$ (1890)

90a The making of Pennsylvania. Am C $5: 225-234$ (1890)

oob Paleontological notes from Indianapelis (A. A. A. S.) ; Pterichthys; Castoroides; Eurysoma. Am G $6: 255-260$, il (1890)

9oe Carcinosoma newolini. Am G 6: 400 (1890)

$90 a$ The reality of a level of no strain In the crust of the earth (abst). Am As, Pr 38: 232 (1890)

91 Traces of the ice age in the flora of the Cuyahoga Valley. Western Reserve Hist Soc, Tract (no 84) $3: 367-379$ (1891)

$91 a$ Megalonyx in Holmes Co., Ohio, 1890. Am G $7: 122-132,149-153$ (1891)

91b An episode in the Paleozoic history of Pennsylvania. Am G 8:152-159 (1891)

91c On a deep boring near Akron, Ohio, and its significance $(a b s t)$. Am G $8: 239$ (1891)

91a The continents and the deep seas (abst). G Soe Am, B 2:10-16 (1891)

$92 \mathrm{~A}$ deep boring in the Pleistocene near Akron, Ohio. G Soc Am, B 3:150-151 (1892) Abst, Am G $8: 195$ (1891)

$92 a$ On the structure of the American pteraspidian, Palaeaspis Claypole, with remarks on the family. G Soc London, Q J $48: 542-561$, il (1892) Abst, G Mag (3) $9: 380-381$ (1892); Am Nat $27: 375-$ 376 (1893)

92b The tin islands of the Northwest

[Black Hills]. Am G $9: 228-236$ (1892)

92e A new gigantic placoderm from Ohio. Am G 10: 1-4, il (1892)
Claypole, Edward Waller-Continued. 92d The head of Dinichthys. Am G 10: 199-207, il (1892)

92e The dentition of Titanichthys and its allies (abst). Am G 10:193 (1892)

$92 \mathrm{f}$ A passage in the history of th Cuyahoga River (abst). Am G 10:20 (1892)

92s On a deep preglacial river bed near Akron, Ohio (abst). Am As, $\operatorname{Pr} 40$ 259 (1892)

92h An episode in thin history of the Cuyahoga River (abst). Am As, Pr 41:176 (1892)

93 The fossil fishes of Ohio. Ohio G \& Rp $7: 602-619$, il (1893)

93 The upper Devonian fishes of Obia G Mag (3) $10: 433-448, "$ ( .893$)$

93b A new coccostean-Coccosteus cur hogae. $\triangle \mathrm{m}$ G 11: 167-171 (1893)

93e Preglacial man not improbable. As G $11: 191-194$ (1898)

93d The cladodont sharks of the Clere land shale. Am G 11:325-331, il (1893) 93e The three great fossil placoderms of Ohio. Am G 12:89-99 (1893)

931 On three new species of Dinichthy. Am G 12: 275-279, il (1893)

939 Prof. G. F. Wright and his critio Pop Sc Mo 42: 764-681 (1893)

94 A new species of Carcinosoms [Kokomo, Ind.]. $\Delta \mathrm{m} G$ 13:77-79, (1894)

$94 a$ Cladodus? magnificus, a new sels. chian. Am G 14:137-140, il (1894)

94b On a new placoderm, Brontichthy clarki, from the Cleveland shale. $A m G$ $14: 379-380$, il (1894) Abst, with disen sion by Wm. Clark, Ohio St Ac Sc, An $\mathbb{R}_{\text {p }}$ 3 : 8-9 (1895)

94e Structure of the bone of Dinichtlyg. Am Micro Soc, Pr 15:189-191, fl (1894) 95 On a new specimen of Cladods clarki. Am G 15:1-7, il (1895)

95a The Shaw mastodons [southwesten Obio]. Am G 15:325-326 (1895)

95b Recent contributions to our knorledge of the eladodont sharks. Am G 15: 363-368 (1895)

95e Actinophorus clarki Newberry. At G $16: 20-25$, il (1895)

95a On an unrecognized coal horizon in northeastern Ohio. Ohio St Ac Sc, An Rp 3 : 9-12 (1895)

95e On the Salina group in northeasten Ohio. Ohio St Ac Sc, An Rp $3: 12-13$ (1895)

95f On the structure of the teeth o! the Devonian cladodont sharks. Am Micto Soc, Pr 16:191-195, il (1895)

$\mathbf{9 5} \mathbf{m}$ The cladodonts of the upper Devonian of Ohio (abst). Brit As, Rp 65: 694 (1895) G Mag (4) $2: 473$ (1895)

95h The great Devonian placoderms of Ohio (abst). Brit As, Rp 65:695 (1895) G Mag (4) 2:473-474 (1895) 
Claypole, Edward Waller-Continued. 96 The timeplece of geology. Am G 17 : 40-45 (1896)

96a A new Titanichthys. Am G 17 : 166-169, il (1896)

96b The ancestry of the upper Devonian placoderms of Ohlo. Am G 17:349-360 (1896)

96e Dinichthys prentis-clarki. Am G $18: 199-201$, il (1896)

96d Human relics in the drift of Ohio. Am G $18: 302-314$ (1896)

97 A new Dinichthys-Dinichthys kepleri, Am G 19:322-324, il (1897)

97a Man and the Megalonyx in North America. Am G 20:52-54 (1897)

97b A fossiliferous stalagmite in the Cuyahoga Glen [Ohio]. Ohio St Ac Sc, An $\mathrm{Rp} 5: 53-55$ (1897)

$97 \mathrm{e}$ On the teeth of Mazodus.

Yicro Soc, $\operatorname{Pr} 18: 146-148$, il (1897)

$97 \mathrm{~d}$ On the structure of some Paleozoic spines from Ohio. Am Micro Soc, $\mathrm{Pr} 18$ : 151-154, il (1897)

98 Microscopical light in geologieal darkness. Am G 22: 217-228 (1898) Am Micro Soc, $\operatorname{Pr} 19: 3-27$ (1898)

98a Glacial theories-cosmical and terrestrial. Am G 22:310-315 (1898)

00 The earthquake at San Jacinto, December 25,1899 . Am G $25: 106-108,192$ (1900)

00a A white-hot liquid earth and geological time. Am G 25: 310-312 (1900)

01 Notes on petroleum in California. Am 6 27:150-159 (1901)

01a Slerra Madre near Pasadena, Cal. (abst). G Soc Am, B 12:494 (1901) J G 9:69-70 (1901) Am G 27:130-131 (1901)

03 The Devonian era in the Ohio basin. Am G $32: 15-41,79-105,240-250,312$ $322,335-353$, maps (1903)

See also Gilbert, 93b

Clayton, Joshua E. (1820-1889).

70 Earthquakes on Kern River, in the central portion of the Sierra Nevada. Cal Ac Sc, Pr $4: 38-40(1870)$

$70 \mathrm{a}$ [Geology and silver ores of White Pine distriet, Nev.] Cal Ac Sc, Pr 4:89 (1870)

76 The glacial period, its origin and development. Cal Ac Sc, Pr 6:123-131 (1876)

77 Atlanta district [Alturas Co., Idaho]. Am I M Eng, Tr 5:468-473 (1877) Eng M J $23: 374-375$ (1877)

78 The coal field of La Plata Co., Colo. Eng M J 25:441 (1878)

79 Utah mineral wax. Eng M J 27 : 216-217 (1879)

85 Ofl shales of Utah. Eng M J 39: 168-169 (1885)

88 The Coeur d'Alene sllver-lead mines [Idaho]. Eng M J 45:108-109 (1888)

$$
28737^{\circ}-23-14
$$

Clayton, Joshua E.-Continued.

8Sa The Drumlummon group of veins and their mode of formation [Helena, Mont.]. Eng M J 46:85-86, 106-108 (1888)

Clearman, Harriet M.

04 A geological situation in the lava flow [Idaho], with reference to the vegetation. Iowa Ac Sc, Pr 11:65-68 (1904)

Cleaveland, Parker (1780-1858).

09 Account of fossil shells ... [Pleistocene deposits, Maine]. Am Ac Arts, Mem $3: 155-158$ (1809)

16 An elementary treatise on mineralogy and geology. $668 \mathrm{pp}$, Boston 1816 2d ed, 2 vols, 818 pp, map, Boston 1822

23 Notice of the late meteor in Maine [Nobleboro]. Am J Sc 7:170-171 (1823) Cleland, Herdman Fitzgerald.

00 The Calciferous of the Mohawk Valley. B Am Pal no 13:26 pp, il (1900)

02 The landslides of Mt. Greylock and Briggsville, Mass. J G 10: 513-517 (1902)

03 Further notices on the Calciferous (Beekmantown) formation of the Mohawk Valley, with descriptions of new species. B Am Pal no $18: 24 \mathrm{pp}$, il (1903)

$03 a$... fauna of the Hamilton formation of the Cayuga Lake section in central New York. U S G S, B 206 : 112 pp, map (1903)

05 The formation of natural bridges. $\triangle \mathrm{m} \mathrm{J} \mathrm{Sc} \mathrm{(4)} \mathrm{20:119-124} \mathrm{(1905)}$

06 A brief history of the geology of the Berkshires. 8 pp (Reprinted from North Adams Transcript of December 24, 1906.)

07 Restoration of certain Devonian cephalopods, with description of new species. J G 15:459-469, il (1907)

07a Some little-known Mexican volcanoes. Pop Sc Mo 71:179-187 (1907)

09 Curaça, a losing colonial venture. Am Geog Soc, B 41: 129-138 (1909)

$09 n$ Some features of the Wisconsin middle Devonic (abst). Science $n$ s 29: 637 (1909) G Soe Am B 20:701 (1910)

10 North American natural bridges, with a discussion of their origin. G Soc Am, B 21 : 313-338 (1910); (discussion) 21: 765-766 (1910) Abst, Science n s 32: 188 (1910)

10a The tenth annual New England intercollegiate geological excursion. Science n \& 32:460-461, 709 (1910)

11 The fossils and stratigraphy of the midale Devonic of Wisconsin. Wis $G \mathbf{S}$, B 21 (sc s 6) : $222 \mathrm{pp}, \operatorname{map}$ (1911)

11 a The formation of North American natural bridges. Pop Sc Mo $78: 417-427$ (1911)

11b Siphon springs and sink holes. Sclence n s $34: 845-846$ (1911)

12 Twelfth annual intercollegiate excursion of New England. Science $n$ s 36 : 508-509 (1912)

$12 a$ The New England geological excursion. Science n s $36: 624-625$ (1912) 
Cleland, Herdman Fitzgerald-Contd.

15 The thirteenth New England intercollegiate geological excursion. Sclence n s 42:634-635 (1915)

16 Geology, physical and historical. 718 pp, N Y 1916

16r Geological excursions in the vicinity of Williams College. $72 \mathrm{pp}$, Willlamstown, Mass., 1916

16b Field meetings of the Association of American State Geologists. Science n s 44: 488-490 (1916)

\section{clem, Harry M.}

11 The preglacial valleys of the upper Mississippi and its eastern tributaries. Ind Ac Sc, Pr 1910:335-352, map (1911)

12 Laboratory work in physiography in the Chicago high schools. J Geog 10:290295 (1912)

clement, J. K.

06 (with Allen, E. T.) Minerals of the composition $\mathrm{MgSiO}_{3}$; a case of tetramorphism. Am J Sc (4) $22: 385-438$ (1906)

Clements, Frederic C.

18 Scope and significance of paleo-ecology. G Soc Am, B $29: 369-374$ (1918)

Clements, Julius Morgan.

95 The volcanics of the Michigamme district of Michigan. J G $3: 801-822$, map (1895)

96 Notes on the microscopical character of certain rocks from northeast Alabama. Ala G S, B 5 : 133-176 (1896)

96a Some stages in the development of rivers as illustrated by the Deer River, Mich. (abst). Am G 17:126-127 (1896)

98 A study of some examples of rock variation. J G 6:372-392 (1898)

99 (and Smyth, Henry Lloyd) The Crystal Falls iron-bearing district of Michigan. U S G S, Mon 36: xxxvi, 512 pp, maps (1899) Abst, C S G S, An Rp 19 pt $3: 19-151$, maps (1899)

99a A contribution to the study of contact metamorphism. $\Delta \mathrm{m} \mathrm{J} \mathrm{Sc} \mathrm{(4)} 7: 81-91$ (1899)

02 Ellipsoidal structure in pre-Cambrian rocks of Lake Superior region (abst). Science n s 16:260-261 (1902) G Soc Am, B 14:8 (1903)

02a Vermilion district of Minnesota (abst). Science n s 16:261 (1902) G Soc Am, B 14:9 (1903)

03 The Vermilion iron-bearing district of Minnesota. U S G S, Mon 45:463 pp, atlas (1903)

04 Geological history of the Vermilion iron-bearing district of Minnesota ( $a b s t)$. G Soc Am, B 14:555 (1904)

See also Van Hise, 01

Clemson, Thomas G.

34 Flemington copper ore [Hunterdon Co., N. J.]. G Soc Pa, Tr 1: 167 (1834)
Clemson, Thomas G.-Continued.

35 Notice of a geological examination the country between Fredericksbur? Winchester in Virginla, including the region. G Soc $\mathrm{Pa}$, Tr 1 : 298-313 (1895)

$35 a$ Notice of native iron from $P$ Yan, Yates Co., N. Y. G Soc Pa, Tr 1:? 359 (1835)

37 (with Taylor, R. C.) Notice of vein of bituminous coal in the vicinity Havana in the Island of Cuba. $\mathrm{Pb} y$ (3) $10: 161-167$ (1837)

39 (with Taylor, R. C.) Notice of vein of bituminous coal, recently explose in the vicinity of the Havana, in the isto of Cuba. Am Ph Soc, Tr n s 6:191-1h (1839)

Clendenin, William Wallace.

96 A preliminary report upon t Florida parishes of east Louisiana 2 the bluff, prairle, and hill lands of soot west Louisiana. La St Exp Sta, G is La pt $3: 159-247$ [1896]

97 A preliminary report upon the but and ississippi alluvial lands of Louisiat La St Exp Sta, G Agr La, pt $4: 257-8$ [1897]

98 Clays of Louisiana. Eng M J \% 456-457 (1898)

Clere, Frank Laurent.

S3 The mining and metallurgy of th in the United States. U S G S, Min BA [1882] : $358-386$ (1883)

87 The lead and zinc ores of southrs Missouri. Eng M J 43: 397-398 (1887)

06 Ore deposits of the Joplin distric Colo Sc Soc, Pr 8: 199-220 (1906)

o7 The ore deposits of tae Joplin regin Mo. Am I M Eng, B 14:353-376 (1907) Tr 38:320-343 (1908)

See also Winslow, 95a

Clere, $\mathrm{M}$.

o5 The Moctezuma district [Sonon], Mex. Eng M J 79:1007-1009 (1905)

Cleve, Per Teodore (1840-1905).

71 On the geology of the northeasten West India islands. K Svenska Vet-1t Hdl 9 no $12: 48$ pp, maps (1871) Notio Am J Se (3) 4: 234-236 (1872)

s1 Outlines of the seology of the noth eastern West India Islands (abst) [ritt discussion by A. A. Julien and J. S. Ne berry]. N $\mathbf{Y}$ Ac Sc, Tr 1:21-24 (1851 Science (ed, Michels) 2:570-571 (1881)

82 Outline of the geology of the nott eastern West India islands. N Y Ac s An 2: 185-192 (1882)

Clevenger, G. $H$.

15 Note upon the occurrence of metcort in Cobalt ores. Ec G $10: 770-773$ (1915) Cliford, James $O$.

11 Vanadium in New Mexico; Cabalie Mountains deposits. M World $35: 857-\$ 5$. (1911) 
Clifford, James O.-Continued.

13 Formation and growth of disseminate 1 copper deposits. Mines and Methods $4: 189-191,221-223$ (1913)

clifford, William.

ss Richmond coal field, Virginia. Manchester G Soc, $\operatorname{Tr} 19: 326-353,431-433$, maps $(1888) ; 20: 247-256$ (1889)

Cline, Justus $\mathrm{H}$.

14 (with Grasty, J. S.) The late deposits of the Southern States (abst). Science n \& $39: 399-400$ (1914)

14a (with Watson, T. L.) Examples of intercision type of stream piracy in western Virginia. Va Univ, Pub, B Ph Soc, se s $1: 437-442$ (1914)

15 (with Watson, T. L.) Extrusive basalt of Cambrian age in the Blue Ridge of Virginia. Am J Sc (4) $39: 665-669$ (1915)

15a (with Watson, T. L.) Hypersthene syenite (akerite) of the middle and northern Blue Ridge region, Va. (abst). G Soc Am, B 26:82-83 (1915)

16 (with Watson, T. L.) Hypersthene syenite and related rocks of the Blue Ridge region, Va. G Soc Am, B 27 : 193-234, map (1916)

Clingman, Thomas Lanier.

75 Earthquakes of North Carolina. Am J Sc (3) $9: 55-58$ (1875)

Clinton, De Witt.

25 On certain phenomena of the Great Lakes of North America. Lit $\mathrm{Ph}$ Soc N Y, Tr 2:1-33 (1825)

Clinton, George W.

30 Notice of the graphite of Ticonderoga. Albany Inst, Tr 1:233-235 (1830)

Cloizeaux, Alfred. See Des Clolzeaux, Alfred.

Clondman, H. C.

17 (and others) San Bernardino County. In Mines and mineral resources of San Bernardino County, Tulare County (Chapters of State Mineralogist's Rp [15: 775-899] 1915-16) : 1-125, Cal St M Bur (1917)

Coan, Titus.

52 On the eruption of Mauna Loa in 1851. Am J Sc (2) $13: 395-397$ (1852) $52 a$ On the eruption of Mauna Loa, Hawali, February, 1852. Am J Sc (2) 14: 219-224 (1852)

53 Notes on Kllauea and the recent eruption of Mauna Loa. Am J Sc (2) $15: 63-65$ (1853)

54 On the present condition of the crater of Kilatea, Hawail. $\mathrm{Am}$ J Sc (2) 18: $96-98$ (1854)

56 On Kilauea. Am J Sc (2) $21: 100$ 102 (1856)

56a On the recent eruption of Mauna Loa. Am J Sc (2) $21: 139-144,237-241$ (1856)
Coan, Titus-Continued.

561 On the eruption at Hawali. Am J Sc (2) $22: 240-243$ (1856)

57 Volcanic action on Hawail. Am J Sc (2) $23: 435-437$ (1857)

$57 \mathbf{a}$ On the volcanic eruptions in $\mathrm{Ha}$ waii. G Soc London, Q J 13:170-176 (1857)

63 On the present condition of the crater of Kilauea on the island of Hawaii. Am J Sc (2) 35:296 (1863)

64 Volcano of Kilauea, Hawail. Am J Sc (2) $37: 415-416$ (1864)

67 Voleanic eruptions in Hawail. Am

J Sc (2) 43:264-265 (1867)

69 Notes on the recent volcanic disturbances of Hawail. Am J Se (2) 47 : 89-98 (1869)

70 The volcano of Kilauea and great earthquake waves. Am J Sc (2) $49: 269-$ 270 (1870)

70a Volcanic action on Hawaii. Am J Sc (2) $49: 393-394$ (1870)

71 On Kilauea and Mauna Loa. Am J Sc (3) $2: 454-456$ (1871)

72 Recent eruption of Mauna Loa. Am

J Sc (3) 4:406-407 (1872)

73 Volcanoes of Hawaii. Am J Sc (3) $5: 476-477$ (1873)

74 Note on the recent volcanic action in Hawail. Am $\mathrm{J}$ Sc (3) $7: 516-517$ (1874)

74a Note on the Hawalian volcanoes. Am J Sc (3) 8:467 (1874)

77 Volcanic eruptions on Hawail. Am

J Se (3) 14:68-69 (1877)

79 On a recent silent discharge of

Kilauea. Am J Sc (3) 18:227-228 (1879) So Recent action of Mauna Loa and Kilauea, Am J Sc (3) 20:71-72 (1880) 81 Volcanic eruptions of Mauna Loa, Hawail. Am J Sc (3) $21: 79$ (1881)

s1a ...volcaulc eruption on Hawail. Am J Sc (3) $22: 226-229,322$ (1881)

See also Dana, 68

Conn, Titus Munson.

89 The Hawailan Islands, their geography, their volcanoes, and their people. Am Geog Soc, B 21: 149-166 (1889)

10 Eruptions of Kilauea [in July, 1855]. Science n s $32: 716-718$ (1910)

Cobb, Collier.

93 Notes on the deflective effect of the earth's rotation as shown in streams. Elisha Mitchell Sc Soc, J 10:26-32 (1893)

93a A recapture from a river pirate. Science 22:195 (1893)

94 On the geological history of certain topographical features east of the Blue Ridge [N. C. and S. C.]. Elisha Mitchell Sc Soc, J 10:94-97 (1894)

94a [Native sulphur in York Co., S. C.]. Elisha Mitchell Sc Soc, J 11: 30-31 (1894)

97 North Carolina. J Seh Geog 1 : 257266, 300-308 (1897) 
Cobb, Collier-Continued.

03 Origin of the sand-hill topography of the Carolinas (abst). Science n s 17: 226-227 (1903) Se Am Sup 55:22666 (1903)

03a Recent changes in the North Carolina coast, with special reference to Hatteras Island (abst). Science n s 17:227 (1903) Sc Am Sup 55:22666 (1903)

04 A new Palaeotrochis locality, with some notes on the nature of Palaeotrochis. Elisha Mitchell Sc Soc, J 20:11-12 (1904)

$04 a$ The forms of sand dunes as influenced by neighboring forests. Elisha Mitchell Sc Soc, J 20:14 (1904)

04b A Liriodendron from the Deep River Triassic, North Carolina. Elisha Mitchell Sc Soc, J $20:$ 116-117 (1904)

o6 Where the wind does the work [ const of North Carolina]. Nat Geog Mag 17: 310-317 (1906) Elisha Mitchell Sc Soc, J $22: 80-85$ (1906)

06a Notes on the geology of Currituck Banks [N. C.] Elisha Mitchell Sc Soc, J $22: 17-19$ (1906)

06b Autophytographs (abst). Elisha Mitchell Sc Soc, J 22:58 (1906)

06e Rhætlc flora of Moncure shales [North Carolina] (abst). Elisha Mitchell Sc Soc, $22: 60$ (1906)

o7 Notes on the geology of Core Bank, N. C. Elisha Mitchell Sc Soc, J 23: 26-28 (1907) Abst, Science n s 25:298 (1907)

15 Pocket dictionary of common rocks and minerals. 2d ed, 59 pp, Chapel Hill, N. C., 1915

Coub, J. C. H.

s7 The Hanging Roek iron district. Ohio M J 5: 112-116 (1887) [not seen]

Cochrane, H. E.

95 Rocks and minerals of Connecticut. Conn Sch Doc no 104:1-26 (1895) [not seen]

Cocke, John H., Jr.

29 Virginia aerolite. Am J Sc 15: 195196 (1829)

Cockere11, Theodore Dru Alison.

24 A list of the Brachiopoda, Pelecyp oda, Pteropoda, and Nudibranchiata of Ja maica, living and fossil. Nautilus $7: 103$ $107,113-118$ (1894)

03 A new fossil Ashmunella [New Mex1co]. Nautilus $16: 105$ (1903)

03a The publication of rejected names [nomenclature of a fossil fruit from Vermont]. Science n s 17: 189 (1903)

04 The origin of the horse. Nature 70 : 53-54 (1904)

o5 A fossil form of Oreohelix yavapai Pilsbry. Nautilus 19:46-47 (1905)

05a The snalls of New Mexico and Arlzona [Pleistocene]. Nautilus 19:68-71 (1905)

05b Two Carboniferous genera. Am G $36: 330$ (1905)
Cockerell, Theodore Dru Alison-Contd, 06 A new fossil ant, Ponera hendersoni Florissant, Colo. Entom News 17:27-25 (1906)

06a A new Tertiary Planorbis. Nautilus $19: 100-101$ (1906)

O6b Fossil plants from Florissant, Colo. Torrey Bot Club, B $33: 307-312$, il (1906) 06e A fossil water bug [Corixa floris. santella]. Entomologist 38: 209 (1906)

06d The fossil fauna and flora of the Florissant (Colo.) shales. Colo Unir, Studies $3: \mathbf{1 5 7 - 1 7 5}$, il (1906)

o6e Fossil Hymenoptera from Florissant, Colo. Harvard Coll, Mus C Z, B 50:33-58 (1906)

06e A fossll Cicada from Florissant, Colo. Am Mus N H, B $22: 457-458$, il (1906)

o6g The fossil Mollusca of Florissant, Colo. Am Mus N H, B $22: 459-462$ (1906) 06h Fossil sawflies from Florissant, Colo. Am Mus N H, B 22:499-501, il (1906)

o7 A new fly (fam. Mycetophilldæ) from the Green River beds. Am J Sc (4) 23: 285-286, il (1907)

07a Some old-world types of insects in the Miocene of Colorado. Science n 8 26: 446-447 (1907)

07b An enumeration of the localities in the Florissant basin, from which fossils were obtained in 1906. Am Mus $\mathrm{N} \mathrm{H,} \mathrm{B}$ $23: 127-132$, il (1907)

07e Fossil dragon flies from Florisant, Colo. Am Mus N H, B $23: 133-139$, il (1907)

07d Some fossil arthropods from Flotis sant, Colo. Am Mus N H, B 23:605-616, il (1907)

07e Some Coleoptera and Arachnida from Florissant, Colo. Am Mus N H, B $23: 617-621$ (1907)

o7f A fossil caterplllar [from the Miocene shales of Florissant, Colo.]. Can Edtomologist $39: 187-188$ (1907)

org A fossil butterfly of the genus Chlorippe [Florissant, Colo.]. Can Entomologist $39: 361-363$, il (1907)

oth A fossil tortricld moth [Tortris florisantana, Florissant, Colo.]. Can Ento mologist $39: 416$ (1907)

07i A fossil tsetse fly in Colorado. Nature $76: 414$ (1907)

ozj A Miocene wasp. Nature $77: 80$ (1907)

ork A new zonitoid shell fron the Miocene, Florissant, Colo. [Vitrea fagalis]. Nautilus 21: 89 (1907)

o71 A new plant (Ficus) from the For Hills Cretaceous [Colo.]. Colo Unir, Studies $4: 149-152$ (1907)

$07 \mathrm{~m}$ A redwood described as a moss [Hypnum haydenii from Florissant, Colo.]. Torreya $7: 203-204$ (1907) 
Coekerell, Theodore Dru Allson-Contd. 0s The fossil sawfly Perga coloradensis [Florissant, Colo.]. Science n s $27: 113-$ 114 (1908)

08a Descriptions of Tertiary insects. Am J Sc (4) $25: 51-52,227-232,309-312$; $26: 69-75 ; 27: 53-58,381-387$; $28: 283-$ 286, il (1908-09)

0sb Fossil Cercopidæ (Homoptera). Wis N I I Soc, B $6: 35-38$, il (1908)

0se The fishes of the Rocky Mountain region. Colo Univ Studies 5:159-178, il (1908)

0sa A fossil leaf-cutting bee [Megachile predieta, Florissant, Colo.] Can Entomologist $40: 31-32$ (1908)

08e Fossil Chrysopidæ [Florissant, Colo.]. Can Entomologist 40:90-91 (1908)

0se Two fossil Diptera [Florissant, Colo.]. Can Entomologist $40: 173-175$, 11 (1908)

08g Fossil Osmylidae (Neuroptera) in America. Can Entomologist $40: 341-342$ (1908)

08h The first American fossil Mantis [Lithophotina floccosa, Florissant, Colo.]. Can Entomologist $40: 343-344$, il (1908)

08i A fossil Orthopterous insect with the media and cubitus fusing [Palaorehnia naculata, Florissant, Colo.]. Entom News $19: 126-128$ (1908)

08j Descriptions of Tertiary plants [Florissant, Colo.]. Am J Sc (4) $26: 65-$ $68,537-544 ; 29: 76-78$, il $(1908-10)$

08k Fossil Aphididæ from Florissant, Colo, Nature $78: 318-319$ (1908)

081 Florissant; a Miocene Pompeil. Pop Sc Mo $73: 112-126$, il (1908)

$08 \mathrm{~m}$ Some results of the Florissant expedition of 1908. Am Nat 42:569-581, Il (1908)

08n Fossil Insects from Florissant, Colo. Am Mus N H, B 24:59-69, il (1908)

08o The fossll flora of Florissant, Colo. Am Mus N H, B 24:71-110, il (1908)

08p A new locality for Miocene mammals [Parahippus, Middle Park, Colo.]. Sclence n s 28:683 (1908)

$08 \alpha$ The Miocene species of Lymnaa. Nautilus $22: 69-70$ (1908)

08r A dragon-fly puzzle and its solution. Entom News 19:455-459 (1908)

08s The dipterous family Nemestrinidæ. Am Entom Soc, Tr 34:247-253, II (1908)

08t Another fossil nemestrinid fly [Hirmoneura occultator, Florissant, Colo.]. Am Entom Soc, $\operatorname{Tr} 34: 254$ (1908)

08u A fossil fly of the family Blepharocerida [Philorites johannseni, Eocene near Rifle, Colo.]. Entomologist 41 : 262265, 11 (1908)

09 A fossil ground sloth in Colorado. Colo Univ Studies $6: 309-312$, il (1909)

09a Fossil Diptera from Florissant, Colo. Am Mus N H, B $26: 9-12$, il (1909)
Coekere11, Theodore Dru Allson-Contd. 09 b Fossil insects from Florissant, Colo. Am Mus N H, B 26:67-76, il (1909)

09e Another fossil tsetse fly [Glossina osborni, Florissant, Colo.]. Nature $80: 128$ (1909)

o9d New fossil insects from Florissant, Colo. Entom Soc Am, An 2:251-256, il (1909)

09e Two fossil bees [Florissant, Colo.]. Entom News 20:159-161 (1909)

o9r Fossil insects from Colorado. Entomologist $42: 170-174$, il (1909)

09g Two fossil Chrysopidæ. Can Entomologist $41: 218-219$, il (1909)

09h New North American bees [Includes Melitta willardi, Florissant, Colo.]. Can Entomologist 41:393-395 (1909)

091 A catalogue of the generic names based on American insects and arachnids from the Tertiary rocks, with indications of the type species. Am Mus N H, B 26: $77-86$ (1909)

09j Eocene fossils from Green River, Wyo. Am J Sc (4) 28:447-448, il (1909) 09k A fossil gar-pike from Utah. Science n s 29:796 (1909)

091 Fossil Euphorbiacs, with a note on Saururacex. Torreya 9:117-119, il (1909) $09 \mathrm{~m}$ Amber in the Laramie Cretaceous. Torreya $9: 140-142$, il (1909)

09n Two new fossil plants from Florissant, Colo. Torreya $9: 184-185$, il (1909)

10 Fossil plants from the Mesa Verde, Cretaceous. Colo Univ Studies 7: 149151, il (1910)

$10 \mathrm{a}$ The Miocene trees of the Rocky Mountains. Am Nat $44: 31-47$, il (1910) $10 \mathrm{~b}$ Fossil insects and a crustacean from Florissant, Colo. Am Mus $\mathrm{N}$ H, B 28: 275-288, il (1910)

10e The fossil Crabronidæ. Entomologist 43: 60-61 (1910)

10d A Tertiary leaf-cutting bee. Nature $82: 429$, il (1910)

10e Magnolia at Florissant. Torreya $10: 64-65$, il (1910)

$10 \mathrm{f}$ Notes on the genus Sambucus. Torreya $10: 125-128$, il (1910)

$10 g$ A fossll flg [Ficus bruesi, Florissant, Colo.]. Torreya 10:222-224, il (1910)

11 Fossil insects from Florissant, Colo. Am Mus N H, B $30: 71-82$, il (1911)

11 a Descriptions and records of bees [Includes Lithanthidium pertriste, Florissant, Colo.]. An Mag N H, (8) $7: 225-$ 237 (1911)

$11 \mathrm{~b}$ Note on Lymnea florissantica. Nautilus 25:24 (1911)

11e Additional note on reticulated fish scales [Sagenodus, Mazon Creek, Ill.]. Science n s $34: 126-127$ (1911)

11d Samuel Hubbard Scudder. Science n 8 34:338-342 (1911) 
Cockerel1, Theodore Dru Alison-Contd.

11e Fossil flowers and fruits. Torreya $11: 234-236 ; \quad 12:, 2-33 ; 13: 75-77$, il (1911-13)

118 New names in Ilex. Torreya 11 264 (1911)

11s The name Glossina [preoccupied for a brachiopod, Palaoglossa proposed]. Nautilus 25:96 (1911)

11h Scudder's work on fossil insects. Psyche 18:181-186 (1911)

12 The Miocene fauna of Florissant, Colo. (abst). Int Zool Cong, VII, Boston, 1907, Or : $745-747$ (1912)

12n (and Henderson, Junius). Mollusca from the Tertiary strata of the West. Am Mus N H, B $31: 229-234$, il (1912)

12b $T$ t: oldest American homopterous Insect [Petropteron mirandum from Plerre formation at Boulder, Colo.]. Can Entomologist $44: 93-95$, il (1912)

12e A fossil Raphidia [Florissant, Colo.]. Entom News $23: 215-216$, il (1912)

12d Fossil cockroaches from Texas (Orthop.). Entom News 23:228-229 (1912)

13 The genera Parotermes and Hodotermes (Isoptera), Entom News 24:6-8 (1913)

13n The first fossil anthomyid fly from Florissant (Dipt.). Entom News 24 :295296 (1913)

13b The fauna of the Florissant, Colo., shales. Am J Sc (4) $36: 498-500$ (1913)

13e Ordovician (?) fish remains in Colorado. Am Nat $47: 246-247$ (1913)

18 d Some fossil insects from Florissant, Colo. U S Nat Mus, Pr 44:341-346, il (1913)

13e Two fossil insects from Florissant, Colo., with a discussion of the venation of the aeshnine dragon flies. U S Nat Mus, $\operatorname{Pr} 45: 577-583$, il (1913)

$13 \mathrm{f}$ The genus Phryganea (Trichoptera) in the Florissant shales. Psyche 20:95-96 (1913)

$13 \mathrm{~g}$ Remarks on fossil insects (abst, with discussion). Entom Soc Wash, $\mathrm{Pr}$ 15 : 123-128 (1913)

13h The first fossil mydaid fly. Entomologist $46: 207-208$ (1913)

131 A fossil asilid fly from Colorado. Entomologist $46: 213-214$ (1913)

13j Some fossil insects from Florissant, Colo. Can Entomologist $45: 229-233$, il (1918)

13k Observations on fish scales. U S Bur Fisheries, B 32 : 117-174, il (1913)

14 Tertiary Mollusca from New Mexico and Wyoming. Am Mus N H, B 33:101107, il (1914)

14a The fossil and recent Bombylidae compared. Am Mus N H, B 33:229-236, il (1914)

14h Land shells from the Tertiary of Wyoming. Am Mus N H, B 33:323-325, il (1914)
Cockerell, Theodore Dru Allson-Contd 14e The fossil Orthoptera of Florisent Colo. Entomologist $47: 32-34$, il (1914)

14d A new fossil sawfly from Florissant, Colo. [Tenthredella toddi]. Can Entomoia gist $46: 32$ (1914)

14e Three Diptera from the Miocene of Colorado. Can Entomologist 46:101-10 (1914)

14f New and little-known insects fron the Miocene of Florissant, Colo. J G 22: 714-724, il (1914)

$14 \mathrm{~g}$ Two new plants from the Tertiary rocks of the West. Torreya 14:135-13?. il (1914)

14h Some fossil fish scales. Zool ds zeiger $45: 189-192$, il (1914)

15 Gastropod Mollusca from the Ter. tiary strata of the West. Am Mus NB, B $34: 115-120$, il (1915)

15a New species of Unio from the Ter. tiary rocks of Wyoming. Am Mus $\mathrm{N}$, B 34: 121-126, il (1915)

15b Miocene fossil insects. Ac N \& Phila, Pr 66:634-648, il (1915)

15c Notes on orchids [includes $A$. tholithes pediloides, from Florissant, Colo.]. Bot Gaz 59:331-33\%, il (1915)

15 a Equisetum in the Florissant Mlo cene. Torreya $15: 265-267$, il (1915)

15e A fossil fungus-gnat [Mycetophiti bradenae from Florissant, Colo.]. Can Entomologist 47:159 (1915)

15P The Solenopsidae. Nauttlus 20:84 (1915)

15g Fossil insects and evolution (abst), Science n s $42: 624$ (1915)

15h Fossil Tertiary Mollusca of the Rocky Mountain region (abst). Science n s $42: 660$ (1915)

16 Some American fossil insects. I \& Nat Mus, Pr 51:89-106, il (1916)

$16 a$ A lower Cretaceous flora in Cols rado. Wash Ae Sc, J 6:109-112, (1916)

16b The uropods of Acanthotelsos stimpsoni. Wash Ac Sc, J 6:234-236, (1916)

16e The third fossil tsetse-fly [Glosins veterna n. sp., Floríssant, Colo]. Nature $98: 70$ (1916)

16a Progress; a drama of evolution is five acts. Am Mus J 16:183-191, (1916)

16e Colorado a million years ago. At Mus J $16: 443-450$, il (1916)

17 New Tertiary insects. U S Nat Mos. Pr $52: 373-384$, il (1917)

17a Some fossil insects from Florisant Colo. U S Nat Mus, Pr 53: 389-392 (1917)

$17 \mathrm{~b}$ Descriptions of fossil insects. Biol Soc Wash, Pr 30:79-82, fl (1917)

17e A fossil tsetse fly and other Dipterl from Florissant, Colo. Biol Soc Wash, Pt $30: 19-22$ (1917)

17a Fossil insects. Entomological So Am, An 10:1-22 (1917) 
Cockerell. Theodore Dru Alison-Contd. 18 New species of North American fossil beetles, cockroaches, and tsetse flies. U S Nat Mus, Pr 54:301-311, il (1918)

1Sa Invertebrate paleontology. Science D s $47: 319-320$ (1918)

Cockfield, William E.

18 Explorations in Yukon Terr. Can G S, Sum Rp 1917 pt B : 1-9 (1918)

Coekrill, Elizabeth.

11 Bibliography of Tennessee geology, soils, drainage, forestry, etc., with subject index. Tenn G S, B 1-B : 117 pp (1911)

Codington, E. W.

96 The Florida pebble phosphates. Am I M Eng, $\operatorname{Tr} 25: 423-431$ (1896)

Coffey, George N.

09 Clay dunes [southern Texas]. J G 17:754-755 (1909)

14 Changes of drainage in Ohio. Science to s $40: 607-609$ (1914)

Coffin, Frederick F. B.

90 Report [on artesian wells of South Dakota]. U S, 51st Cong 1st sess, S Ex Doc 222:125-140 (1890)

Coghill, Will H.

12 A peculiar occurrence of silver (discussion). Ec G $7: 783-785$ (1912)

Cohen, Emil Wilhelm (1842-1905).

80 Ueber Laven von Hawali und einigen anderen Inseln des Grossen Oceans nebst einigen Bemerkungen über glasige Gesteine in allgemeinen. N Jb 1880 , II : 23-62

85 Das labradoritführende Gestein der Küste von Labrador. N Jb 1885, I : 183185

91 (and Weinschenk, E.) MeteoreisenStudien. K-k Naturh Hofmus, An 6:131165 (1891)

92 Meteoreisen-Studien, II-XI, K-k Naturh Hofmus, An $7: 143-162$ (1892); $9: 97-118(1894) ; 10: 81-93 \quad(1895) ; 12$ : 42-62 (1897) ; $13: 45-58,118-158$ (1898) ; $15: 75-94,351-391 \quad(1900)$

94 Meteoritenkunde. 419 pp, Stuttgart 1894

97 Über ein neues Meteoreisen von Locust Grove, Henry Co., Nord-Carolina, Vereinigte Staaten. $\mathrm{K}$ Preuss Ak Wiss Berlin, Szb 1897: 76-81

97a Das Meteoreisen von Forsyth Co., Georgia, Vereinigte Staaten. K Preuss Ak Wiss Berlin, Szb $1897: 386-396$

9s Über das Meteoreisen von Cincinnath, Vereinigte Staaten. $\mathrm{K}$ Preuss Ak Wiss Berlin, Szb 1898: 428-430

98a Ueber ein angebliches Meteoreisen ron Walker Co., Alabama, Vereinigte Staaten. Naturw Ver Neuvorpommern und Rugen in Greifswald, Mitt $29: 35-39$ (1898)

98b Über das Vorkommen von Eisencarbid (Cohenlt) im terrestrischen Nickeleisen von Niakornak bei Jakobshavn in NordGrönland. Med Grönland 15:291-304 (1898)
Cohen, Emil Wilhelm-Continued.

o3 Ueber die Meteoreisen von Cuernavaca [Morelos, Mex.] und Iredell [Bosque Co., Tex.]. Naturw Ver Neuvorpommern und Rügen in Greifswald, Mitt 34:98-102 (1903)

04 Die Meteoreisen von Ranchito und Casas Grandes [Mex.]. Naturw Ver Neuvorpommern und Rügen in Greifswald, Mitt 35: 3-13 (1904)

O4a Das Meteoreisen von Millers Run bei Pittsburgh, Pa. Naturw Ver Neuvorpommern und Rïgen in Greifswald, Mitt 35 : $39-42$ (1904)

04b Die Meteoreisen von Nenntmannsdorf und Persimmon Creek [Cherokee Co., N. C.]. Naturw Ver Neuvorpommern und Rügen in Greifswald, Mitt $35: 57-60$ (1904)

04c (with Brezina, A.) Über Meteoreisen ron De Sotoville [Choctaw Co., Ala.]. K Ak Wiss, Math-nat Kl, Szb 113, 1: 89-103 (1904)

Coker, Ernest G.

OG (with Adams, F. D.) An invest1gation into the elastic constants of rocks. Am J Sc (4) $22: 95-123$ (1906)

06a (with Adams, F. D.) An investigation into the elastic constants of rocks. Carnegie Inst Wash, Pub 46 (1906)

OGb (with Adams, F. D.) Experimental Investigation of the compressibility and plastic deformation of certain rocks (abst). G Soc Am, B 16:564-565 (1906)

10 (with Adams, F. D.) An experimental investigation into the flow of rocks; First Paper, The fiow of marble. Am I Sc (4) $29: 465-487$ (1910)

Colburn, E. A.

04 A peculiar ore deposit [Ajax mine, Victor, Colo.]. M Sc Press 88: 196 (1904)

13 Replacement deposits in the Ajax mine [Victor, Colo.]. Eng M J 95:739741 (1913)

13a Influence of flat dike on ore formation [Cripple Creek, Colo.]. Eng M J 96 : 599-600 (1913)

Coldwell, A, E.

96 Notes on the superficial geology of Kings Co., N. S. N S Inst Sc, Pr Tr 9 or (2) $2: 171-174 \quad$ (1896)

Cole, Arthur A.

98 Graphite deposits of Quebec. Can

G S, An Rp, 10: s 66-73, map (1898)

10 Colbalt [Ont.] in 1910. Eng Mag $40: 15-30 \quad(1910)$

Cole, A. D.

04 Clarence L. Herrick. Science n s $20: 600-601$ (1904)

05 C. L. Herrick as a maker of scientific men. Denison Univ, Sc Lab, B 13:1-13, port (1905)

Cole, Aaron Hodgman.

92 Paleaster eucharis Hall. G Soc Am, B $3: 512-514$, il (1892) Abst, Am G 11 : 120 (1893) 
Cole, G. G.

18 The Holmesville, Obio, glacial terrace and moraine (abst). Science n s 47 : 469 (1918)

Cole, Lionel Heber.

11 Investigation of reported discovery of tin ore in the vicinity of Arnprior, Ont. Can, Mines Br, Sum Rp 1910:93-101 (1911)

12 The gypsum and salt industries of central and western Canada. Can, Mines Br, Sum Rp 1911: 108-116 (1912)

13 Gypsum in Canada; its occurrence, exploitation, and technology. Can, Mines Br : 256 pp, maps (1913)

14 Saline springs of Manitoba. Can, Mines Br, Sum Rp 1913: 50-53 (1914)

15 Report on the salt deposits of Canada and the salt industry. Can, Mines Br: 152 pp, maps (1915)

17 The occurrence and testing of foundry molding sands, Can, Mines $\mathrm{Br}, \mathrm{B} 21$ : 17 pp (1917) Can M Inst, Tr 20:265291 (1917)

$\mathbf{1 7 a}$ Investigation of the sands and sandstones of Canada. Can, Mines Br, Sum Rp 1916:35-55 (1917)

18 Investigation of certain sand and sandstone deposits. Can, Mines $\mathrm{Br}$, Sum Rp 1917 : 51-52 (1918)

Cole, Leon J.

03 The delta of the St. Clair River. Mich G S 9 pt 1:28 pp (1903)

Coleman, Arthur Philemon.

87 A meteorite from the Northwest. R Soc Can, Pr Tr 4, 1ii: 97 (1887)

88 Microscopic petrography of the drift of central Ontario. R Soc Can, $\operatorname{Pr} \operatorname{Tr} 5$, Iii : 45-59 (1888) Abst, Can Rec Sc 2: 435 (1887)

90 Notes on the geography and geology of the Big Bend of the Columbia. R Soc Can, Pr Tr 7, iv: 97-108 (1890)

91 Drift rocks of central Ontario. $R$ Soc Can, $\operatorname{Pr} \operatorname{Tr} 8$, ili : 11-18 (1891)

92 Some Laurentian rocks of the Thousand Islands. Can Rec Sc 5 : 127-131 (1892)

93 Ontario's minerals at the World's Fair. Ont Bur Mines, Rp $2: 185-194$ (1893)

93a The rocks of Clear Lake near Sudbury [Ont.]. Can Ree Sc 5:343-346 (1893)

94 Interglacial fossils from the Don Valley, Toronto, Am G 13:85-93 (189x)

$94 a$ Notes on the geology of the Rocky Mountains between the Saskatchewan and the Athabasca. Am G 14:83-92 (1894)

94b Antholite from Elzivir, Ont. Am J Sc (3) $48: 281-283$ (1894)

95 Gold in Ontario; 1ts associated rocks and minerals; report on the Rainy Lake gold region. Ont Bur Mines, Rp 4 : 35-100, maps (1893) In part, Can M Rv 14: $42-43$ (1895)
Coleman, Arthur Philemon-Continued. $95 a$ Glacial and interglacial deposit near Toronto [Ont.]. J G 3:622-6ts (1895)

96 Second report on the gold fields western Ontario. Ont Bur Mines, $R_{p}$ ? 47-106 (1896)

96a The gold felds of Ontario. Ont Bt Mines, B 1:- pp (1896) [not seen]

96b The anorthosites of the Rainy Laty region. J G 4:907-911 (1896) Can Bu Sc $7: 230-235$ (1897)

96e Ontario as a mining country. [Pet] Can M Inst, J 1:1-11 (1896) Can \& B $15: 55-57$ (1896)

96d The gold flelds of western Ontari Can M Rv 15: 233-235 (1896)

97 Third report on the west Ontarlo goll region. Ont Bur Mines, $\mathrm{Rp}$ 6:71-1.4 maps (1897)

97a Anthraxolite or anthracitic carbe Ont Bur Mines, Rp 6:159-161 (1897)

$\mathbf{9 7 b}$ Notes on the restern Ontario goll fields. Fed Can M Inst, J 2:278-24 (1897) Can M Rv 16:115-116 (1897)

97e Glacial and interglacial deposits it Toronto [Ont.] (abst). Brit As, Rp 67: 650-651 (1898) G Mag (4) 4:515-51! (1897)

9s Fourth report on the west Ontat gold region. Ont Bur Mines, Rp $7: 109-15$ (1898)

98a Notes on the petrology of Ontati Ont Bur Mines, Rp 7:145-150 (1898)

98b Clastic Huronian rocks of westen Ontario. G Soc Am, B $9: 223-228$, at (1898) Ont Bur Mines, Rp $7: 151-1$ हो (1898) Abst, J G 6:212-214 (1898); \& ence n s 7:81 (1898)

99 Copper regions of the upper laks Ont Bur Mines, Rp $8: 121-174$, 때내 (1899)

99a Corundiferous nepheline syenite Ont Bur Mines, Rp 8:250-253 (1899)

99b Copper in Parry Sound district 100 tario]. Ont Bur Mines, Rp $8: 259-90$ (1899)

99e (and Willmott, A. B.) Michis coten iron range. Ont Bur Mines, Rp 8 254-258 (1899)

99d The Iroquois beach. Can Inst, It 6:29-44 (1899)

99e Canadian Pleistocene flora att fauna. Brit As, Rp 68:522-525 (1899) $69: 411-414(1900) ; 70: 328-339$ (1900)

$99 \mathrm{f}$ Lake Iroquois and its predecessots at Toronto. G Soc Am, B 10:165-17i (1899) Abst, Am G 23:103-104 (1899): Science n s 9:143 (1899); Ottawa Nit $12: 195$ (1899)

$99 \mathrm{~g}$ A new analcite rock from Lakt Superior. J G 7:431-436 (1899)

99h Corundiferous nepheline syenitt from eastern Ontario. J G $7: 437$-4t (1899) 
Coleman, Arthur Philemon-Continued.

00 Copper and iron regions of Ontario. Ont Bur Mines, Rp 1900:143-191, map (1900)

00a Upper and lower Huronian in Ontario. G Soc Am, B 11: 107-114 (1900) Abst, Science n s 11: 104 (1900)

$00 \mathrm{~b} \mathrm{~A}$ ferriferous horizon in the $\mathrm{Hu}$ ronian, north of Lake Superior (abst). Brit As, Rp 70:722 (1900)

$00 \mathrm{e}$ Heronite and its related rocks (abst). Science n s 11:144 (1900)

01 The Vermilion River placers. Ont Bur Mines, Rp 1901 : 151-159 (1901)

01 Iron ranges of the lower Huronian. Ont Bur Mines, Rp 1901: 181-212 (1901) 01b Sea beaches of eastern Ontario. ont Bur Mines, Rp 1901: 215-227 (1901) 01e Marine and freshwater beaches of Ontario. G Soc Am, B 12:129-146, maps (1901) Abst, Science n s $13: 136$ (1901); Can Rec Sc 8: 473 (1902)

01d Glacial and interglacial beds near Toronto. J G $9: 285-310$, map (1901)

02 Iron ranges of northwestern Ontario. Ont Bur Mines, An Rp 1902:128-151 (1902) Abst, with title, Types of ironbearing rocks in Ontario, Eng M J 74: 42 (1902); $75: 294-295$ (1903)

$02 \mathrm{a}$ (and Willmott, A. B.) The Michficoten iron region. Ont Bur Mines, Rp 1902:152-185, map (1902)

02b Syenites near Port Coldwell. Ont Bur Mines, Rp 1902: 208-213 (1902)

02e (and wilmott, A. B.) The Michipicoten Iron ranges [Ont.]. Toronto, Univ, Studies, g s no $2: 47$ pp, maps (1902) 02d Rock basins of the Helen mine, Michipleoten, Can. G Soc Am, B 13: 293304 (1902) Abst, Science n s $15: 87-88$ (1902)

02e The classification of the Archean. R Soc Can, Pr Tr (2) 8, iv: 135-148 (1902)

02f The duration of the Toronto interzlacial period. $\mathrm{Am} \mathrm{G} \mathrm{29:71-80} \mathrm{(1902)}$

02g The Huronian question. Am G 29: 7-334 (1902)

$02 \mathrm{~h}$ The relation of changes of level interglacial periods, G Mag (4) $9: 59$ $62(1902)$

$02 i$ Nepheline and other syenites near Port Coldwell, Ont. Am J Sc (4) 14:1475 (1902)

03 The Sudbury nickel deposits. Ont ur Mines, Rp 1903: 235-299, maps (1903) 04 Durbam County; geological features. Ontario Bur Archives, 1st Rp 1903: 46-47 (1904)

04a The northern nickel range. Ont Bur Mines, Rp 1904: 192-222, map (1904) 04b The Iroquois beach in Ontario. Ont Bur Mines, Rp 1904:225-244, map (1904) Abst, Se Am Sup 57:23447
Coleman, Arthur Philemon-Continued.

04c Iroquois Beach in Ontario. G Soc Am, B 15:347-368, map (1904) Abst, Science n s 19: 532 (1904)

04d Sudbury nickel-bearing ernptive (abst). G Soc Am, B 15:551 (1904) Sclence n s 19:526 (1904) Sc Am Sup $57: 23446$ (1904)

05 The Sudbury nickel field. Ont Bur Mines, Rp 1905, 14 pt $3: 188$ pp, maps (1905)

O5a Glacial lakes and Pleistocene changes in the St. Lawrence Valley. Int Geog Cong, VIII, Rp : 480-486 (1905)

O5b Theories of world building. R Astron Soc Can, Sel Papers and $\operatorname{Pr} 1904$ : 53-56 (1905)

05e Geology of the Sudbury district. Eng M J 79:189-190 (1905)

06 Iron ranges of eastern Michipicoten. Ont Bur Mines, Rp 15 pt 1: 173-199, map (1906)

06a Pre-Cambrian nomenclature. J G 14: 60-64 (1906)

o6b The Helen iron mine, Michipicoten. Ec G 1: 521-529 (1906)

06e Magmatic segregation of sulphide ores (abst). Brit As, Rp $75: 400$ (1906)

07 Iron ranges east of Lake Nipigon. Ont Bur Mines, An Rp 16 pt 1 : 105-135 (1907)

07a The Sudbury laccolithic sheet. J G 15: $759-782$ (1907)

07b Interglacial periods in Canada. Int G Cong X, Mexico, 1906, C R : 1237-1258 (1907)

07e A lower Huronian ice age. Am J Sc (4) $23: 187-192$ (1907) Abst, Science n s $25: 769$ (1907)

07d Die Sudbury-Nickelerze. Zs prak $\mathbf{G}$ $15: 221$ (1907)

$07 \mathrm{e}$ The need of field work in the study of ore genesis. Eng M J $83: 295-296$ (1907)

os The Sudbury nickel ores G Mag n s (5) 5: 18-19 (1908)

08a Glacial periods and their bearing on geological theorles. G Soc Am, B 19: 347-366 (1908) Abst, Science n s 27:406 (1908)

osb Ancient ice ages and their bearing an astronomical theories. $R$ Astron Soc Can, J 2: 132-135 (1908)

ose The lower Huronian ice age. $J$ G 16:149-158 (1908)

08d The causes of mountain forms in the Canadian Rockies. Can Alpine J 1: 224-231 (1908)

ose (assisted by Moore, E. S.) Iron ranges east of Lake Nipigon. Ont Bur Mines, An Rp 17:136-169 (1908)

09 Iron ranges of Nipigon district [Ont.]. Ont Bur Mines, An Rp 18 pt 1 : 141-153 (1909)

O9a Black Sturgeon iron region [Ont.]. Ont Bur Mines, An Rp 18 pt 1:163-179, map (1909) 
Coleman, Arthur Philemon-Continued.

09b Lake Ojibway; last of the great glacial lakes. Ont Bur Mines, An Rp : pt $1: 284-293$ (1909) Abst, Science n s $29: 628$ (1909)

09e Classification and nomenclature of Ontario drift. Ont Bur Mines, An Rp 18 pt 1:294-297 (1909)

o9d The bearing of pre-Cambrian geology on uniformitarianlsm $(a b s t)$. Can M J $30: 646-647$ (1909) Brit As, Rp $79: 473-474 \quad(1910)$

o9e [On the Lower Huronian ice age.] Can M J 30:694-695 (1909)

10 Changes of climate in southern and western Ontario since the maximum of the last glaciation. Int $\mathrm{G}$ Cong, XI, Stockholm; Die Veränderungen des Klimas seit dem Maximum der letzten Eiszeit : $385-387$ (1910)

10a Geology and glacial features of $\mathrm{Mt}$. Robson. Can Alpine J 2:108-113 (1910)

10b The history of the "Canadian shield." Nature $84: 333-339$ (1910) Brit As. Rp 80:591-602 (1911)

10e The drift of Alberta and the relations of the Cordilleran and Keewatin ice sheets. R Soc Can, Pr Tr (3) 3 iv : 3-12 (1910)

10d The Alexo nickel deposit [Ont.]. Ec G 5: 373-376 (1910)

10e Lake Ojibwa, last of the great glacial lakes $(a b s t)$. G Soc Am, B 20:639 (1910)

$10 f$ The distribution of the ice sheets in western Canada $(a b s t)$. Brit As, Rp 79 : 472 (1910)

10g Copper and nickel deposits of Canada $(a b s t)$. Brit $\mathrm{As}, \mathrm{Rp} 79: 479-480$ (1910)

11 Climate and physical conditions of the Keewatin. J G $19: 1-14$ (1911) Abst, Science n s 32: 190-191 (1910); G Soc Am, B 21: 778-779 (1910)

11a Note on the geology of the Selkirk Mountains [B. C.]. Can Alpine J 3:119120 (1911)

12 Summary report on the Sudbury nickel field. Can, Mines $\mathrm{Br}$, Sum Rp 1911: 87-89 (1912)

12a Metamorphism in the pre-Cambrian of northern Ontario. Int $\mathrm{G}$ Cong, XI, Stockholm, 1910, C R: 607-616 (1912)

12b Methods of classification of the Archean of Ontario. Int $G$ Cong, $X I$, Stockholm, 1910, C R : 721-728 (1912)

12c The Lower Huronian ice age (with discussion). Int $\mathrm{G}$ Cong, XI, Stockholm, 1910, C R: 1069-1072 (1912)

13 The nickel industry, with special reference to the Sudbury region, Ont, Can, Mines Br: 206 pp, maps (1913)

13a The Whiskey Lake area. Ont, Bur Mines, An Rp 22 pt 1 : 146-154, map (1913)

13b The Massey copper mine area. Ont, Bur Mines, An Rp 22 pt 1:155-160, map (1913)
Coleman, Arthur Philemon-Continox Col 13e Glacial phenomena of Torosto vicinity. Ont, Bur Mines, An Rp 22 \% 238-255 (1913)

13d Iroquois beach. Int $\mathrm{G}$ Cong If Canada, Guide Book no 4:71-74, (1913)

13e Toronto and vicinity. Int $G \mathrm{Co}$ ti XII, Canada, Guide Book no 6:7-34, B (1913)

13P The Sudbury area [Ont.]. Cong, XII, Canada, Guide Book no $?$ 48, maps (1913)

$13 \mathrm{~g}$ Sudbury to Cartier, annotated g Int G Cong, XII, Canada, Guide Book at 13-14 (1913)

13h Cirques and U-shaped mountain v leys. Can Alpine J 5 : 49-52 (1913)

13i Classification of the Sudbury one posits. Can M Inst, Tr 16:283-288, (1913)

13j Geology of the Toronto region. The natural history of the Toronto resi Ontario, Canada, ed. by J. H. Faull:51map. Toronto, published by the Canat: Institute, 1913

14 The pre-Cambrian rocks north Lake Huron with special reference to Sudbury series. Ont Bur Mines, An R? pt 1:204-236, map (1914)

14a The Sudbury series and its beati on pre-Cambrian classification. Int $G$ O XII, 1913, C R : 387-398 (1914)

14b An estimate of postglaclal and int glacial time in North America. Int $G \mathrm{Cu}$ XII, 1913, C R : 435-449 (1914)

14e Length and character of the eart interglacial beds (abst, with discuss: G Soc Am, B 25: 71, 73 (1914)

15 The Proterozoic of the Cansin shield and its problems. In Problems American geology:81-161, New Harti 1915

15a Length and character of the eatlix interglacial period. G Soc Am, B 26:26? 254, map (1915)

15b Glaciers of the Rockies and 8 kirks. Can M J 36 : 361-366 (1915)

15e [The origin of the Sudbury nit deposits.] Ee G 10:390-393 (1915)

15d The climatic conditions of the ent pre-Cambrian $(a b s t)$. Brit $\mathbf{A s}$, Rp $84:{ }^{3}$ (1915)

16 Dry land in geology. G Soc $d D$, 27:174-192 (1916) Smiths Inst, An 1916 : 255-272 (1917)

16a Memorial of A. B. Willmott. Gs Am, B 27: 37-38, port (1916)

$16 \mathrm{~b}$ Geological relations of the Sudot nickel ores. Eng M J 102: 104-105 (1916)

16e Chief minerals of the Sudort nickel ores. Can M J 37 386-389 (191 16d The building of the Torngats if brador] Can Alpine J 7:67-70 (1916) 17 Wave work as a measure of time; study of the Ontario basin. Am J Sc ( 44: 351-359, 487 (1917) 
Coleman, Arthur Philemon-Continued. 17a Magmas and sulphide ores [Sudbury, ont., deposits]. Ec G 12: 427-434 (1917) With title, The origin of Sudbury nickelcopper deposits, Can M J 38:424-426 (1917)

$17 \mathrm{~b}$ Glaciers of the Rockies and Selkirks. Can, Dp Interior, Dominion Parks Branch : 29 pp [1917?]

17e Northeastern Peninsula of Labrador. ian G S, Sum Rp 1916:245-247 (1917)

1s La péninsule du Labrador. Soc Géog Qué, B 12:143-145 (1918)

See also Alden, 12 ; Ekblaw, 18a ; Leverett, 13d; Walcott, 12a ; Wilson (M E), $18 \mathrm{a}$

Coleman, E. T.

77 Mountains and mountaineering in the Far West [including notes on glaciers of Pacific slope]. Alpine J 8: 233-242 1877)

Coll, H, E.

os Coal mining in Pictou Co., N. S. Eng M J $85: 1101-1103$ (1908)

Collen, M.

07 Copper deposits in the Belt formation in Montana. Ec G, 2: 572-575 (1907)

Colles, George Wetmore.

05 Mica and the mica industry. Franklin Inst, J 160: 191-210, 275-294 (1905) ; 161:43-58, 81-100 (1906) Reprinted, 130 pp, Phlla 1906

Collett, John (1828-1899).

71 Geology of Sullivan Co., Ind. Ind G , An Rp 2:191-240, map (1871)

72 Geology of Dubois Co., Ind. Ind G S, An Rp 3-4: 192-237, map (1872)

72a Geology of Pike Co., Ind. Ind G S, An Rp 3-4: 239-287, map (1872)

72b Geological reconnaissance of Jasper, White, Carroll, Cass, Miami, Wabash, and Howard cos. Ind $\mathrm{G} S$, $A \mathrm{n}$ Rp 3-4:291$337(1872)$

74 Geology of Warren Co. Ind G S, An Rp $5: 191-259$, map (1874)

74a Geology of Lawrence Co. Ind G S, An Rp 5: 260-312, map (1874)

74b Geology of Knox Co. Ind G S, An Bp 5:315-382, map (1874)

74e Geology of Gibson Co. Ind $\mathrm{G}$ S, An Rp $5: 382-422$, map (1874)

75 Geology of Brown Co. Ind G S, An Rp 6: 77-110, map (1875)

76 Geological report on Vanderburgh, Owen, and Montgomery cos. Ind $\mathrm{G} \mathbf{S}, \mathbf{A n}$ Rp $7: 240-422$, maps (1876)

$76 a$ Geology of the southeastern part of Clay Co. Ind $\mathrm{G} S$, An $\mathrm{Rp} \quad 7: 423-462$ (1876)

$76 \mathrm{~b}$ Geological reconnaissance of the coal measure rocks of Putnam Co. Ind $G$ S, An Rp 7:463-468 (1876)

79 Geological report on Harrison and Crawford cos. Ind $\mathrm{G} S$, An Rp 8-9-10: 291-522, maps (1879)

80 Geological report, 1879-1880. Ind, Dp Stat G, An Rp 2: $369-544(1880)$
Collett, John-Continued.

80a Geology of Putnam Co. Ind, Dp Stat G, An Rp 2: 397-426, map (1880)

82 Eleventh annual report. Ind, $\mathrm{Dp} \mathrm{G}$ N H : 414 pp, maps, il, Indianapolis, 1882 82a Geology of Shelby Co. Ind, Dp G N H, An Rp 11:55-88, map (1882) 83 Twelfth annual report. Ind, Dp G N H : $400 \mathrm{pp}$, maps, il, Indianapolis, 1883 S3a Geological survey of Newton Co. Ind, Dp G N H, An Rp $12: 48-64$ (1883) 83b Geological survey of Jasper Co. Ind, Dp G N H, An Rp 12 : 65-76 (1883)

84 Thirteenth annual report. Ind, Dp G N H : xvi, 169, $264 \mathrm{pp}$, il, map, Indianapolis 1884

S4a Geology of Posey Co. Ind, Dp G N H, An Rp 13 pt $1: 45-68$ (1884)

84b Fourteenth annual report. Ind, Dp G N H; 122, $62 \mathrm{pp}$, il, map, Indianapolis 1884

Collie, George Lucius.

95 The geology of Conanicut Island, R. I.

Wis Ac Sc, Tr 10:199-230 (1895)

96 Origin of conglomerates $(a b s t)$. Am

G $17: 126$ (1896)

o1 Wisconsin shore of Lake Superior. G Soc Am, B 12 : 197-216 (1901)

01a Physiography of Wisconsin. Am Bur Geog, B 2:270-287 (1901)

03 Ordovician section near Bellefonte, Pa. G Soc Am, B 14:407-420, il (1903) Abst, J G 11:111-112, (1903)

See also Union Pacific R. Co., 09

Collfer, Arthur James.

01 (with Brooks, A. H.) Glacial phenomena of the Seward Peninsula [Alaska] (abst). Science n s 13:188-189 (1901)

01a (with Brooks, A. H., and Richardson, G. B.) A reconnaissance in the Cape Nome and adjacent gold fields of Seward Peninsula, Alaska, in 1900. U S G S, Reconnaissances in the Cape Nome and Norton Bay regions, Alaska, in 1900: 1-185, maps (1901)

02 A reconnaissance of the northwestern portion of Seward Peninsula, Alaska. U S G S, P P 2:70 pp, maps (1902)

03 The Glenn Creek gold mining district, Alaska. U S G S, B 213:49-56 (1903)

O3a Coal resources of the Yukon basin, Alaska. U S G S, B $213: 276-283$ (1903) ;

B 218:71 pp, maps (1903)

03b Coal-bearing series of the Yukon (abst). Science n s 17:668 (1903)

03e Tin in the York region, Alaska.

Eng M J 76:999-1000, map (1903)

04 Tin deposits of the York region, Alaska. U S G S, B 225: 154-167 (1904); B $229: 61 \mathrm{pp}$, map (1904)

04a The tin deposits of the York region, Alaska (abst). Science n s 19:305-306 (1904) 
Collier, Arthur James-Continued.

04b The coalfields of Cape Lisburne, Alaska. Am G 34:401-402 (1904)

05 Auriferous quartz veins on Unalaska Island [Alaska]. U S G S, B 259:102103 (1905)

O5a Recent development of Alaskan tin deposits. U S G S, B 259:120-127 (1905)

05b Coal fields of the Cape Lisburne region [Alaska]. U S G S, B 259:172185 (1905)

06 Geology and coal resources of the Cape Lisburne region, Alaska. U S C $\mathbf{S}$, B 278:54 pp, map (1906)

06a Ore deposits in the St. Joe River basin, Idaho. U S G S, B 285: 129-139 (1906)

07 Gold-bearing river sands of northeastern Fiashington. U S G S, B 315:5670 (1907)

07a The Arkansas coal field. U S G S, B 316: 137-160 (1907)

07b The Arkansas coal field. With reports on the paleantology by David White and G. H. Girty. U S G S, B 326: 158 pp, il, map (1907)

07e Chromite or chromic fron ore. U S G S, Min Res 1906: 541-542 (1907)

ord Talc and soapstone. U S G S, Min Res 1906: 1273-1275 (1907)

os Tin ore of Spokane, Wash. U S G S, B $340: 295-305$ (1908)

08a (and Hess, F. L., Smith, P. S., and Brooks, A. H.) The gold placers of parts of Seward Peninsula, Alaska, including the Nome, Council, Kougarok, Port Clarence, and Goodhope precincts. U $\mathrm{S}$ G S, B 328:343 pp (1908)

09 Classification of low grade coal; discussion of paper by M R Campbell. Ec G 4: 262-264 (1909)

09a (and Smith, C. D.) The Miles City coal field, Mont. U S G S, B 341: 36 61, map (1909)

13 Coal resources of Cowlitz River valley, Cowlitz and $\mathrm{L}$.wis cos., Wash. U S G S, B 531: 323-330, map (1913)

14 The geology and mineral resources of the John Day region. Oreg Bur Mines, Min Res Oreg I no $3: 47$ pp, maps (1914)

16 [Geology of the Columbia River basin, between the John Day River and the Umatilla River]. [Oreg. State Engineer], Oregon Cooperative Work, John Day Project : 31-35, Portland 1916

16a Geology of Dayville reservoir and dam site. [Oreg, State Engineer], Oregon Cooperative Work, John Day Project:9093, Portland 1916

17 The Bowdoin dome, Mont.; a possible reservoir of oll or gas. D S G S, B 661 : 193-209, map (1917) Abst, by R. W. Stone, Wash Ac Sc, J $8: 36$ (1918)

17a Age of the high gravels of the northern Great Plains $(a b s t)$. Wash Ac Sc, J $7: 194-195$ (1917)
Collex, Arthur James-Continued.

18 (and Thom, W. T., jr.) The F. ville gravel and its relation to other race gravels of the northern Great Plain U S G S, P P 108: 179-184, map (1911) $A b s t$, by R. W. Stone, Wash Ac Sc, Ji 249 (1918)

18a Geology of northeastern Montsu U S G S, P P 120: 17-39, map (1918)

18b The Nesson anticlkne, Williams a N. Dak. U S G S, B 691:211-217, (1918)

18e A formation hitherto unaccouts for in North Dakota $(a b s t)$. Wash Ac \& J $8: 412-413$ (1918)

Collier, D. C.

66 Notes on chalk and Cretaceous \& posits in eastern Colorado. Am J Sc i? 41: 401-403 (1866)

Collier, H. B.

13 Meteorites. Roy Astron Soc Can, $7: 313-322$ (1913)

Collier, J. H.

o0 Deep mining at the Utica min Angels, Cal. Am I M Eng, Tr 29:83:$852(1900)$

Collins, Arthur L.

02 The origin of ore deposits (disce sion). Am I M Eng, $\operatorname{Tr} 31: 951-95$ (1902)

Collins, Edgar A.

06 A prospecting shaft in the Goldsel district, Goldfield, Nev. Inst M Met, ? 15 : 540-542 (1906)

o7 The Combination mine; Early dere' opments and geologic structure [Goldtel district, Esmeralda Co., Nev.]. M Sc Pres $95: 397-399,435-438$ (1907)

Collns, George E.

01 Vein structure at the Reynolds mit: Ga. Inst M Met, Tr 9:365-371 (1901) Eng M J 72:68-70 (1901)

12 Persistence of ore in depth. I \& Press 105 : 409-410 (1912)

13 The application of genetic theories th the search for local enrichments in veiss Colo Sc Soc, Pr 10:211-232 (1913)

Collins, H. C.

73 Geological notes [surveys of Rd River raft region]. U S [War Dp], Chit' Eng, An Rp 1873 (U S, 43d Cong 1st sers H Ex Doc 1 pt 2 v 2): 651-664 (1873)

Collins, Henry F.

92 Mineralogical notes from Torreos State of Chihuahua, Mexico. Miner Mas $10: 15-19$ (1892)

03 Notes on the wollastonite rock mass and its associated rinerals, of the Sapts Fe mine, State of Chiapas, Mexico. Mag 13: 356-362 (1903)

Collins, J. H.

88 On the Sudbury copper deposits. Soc London, Q J 44:834-838 (1888) Abst, G Mag (3) $5: 375$ (1888) 
Collins, J. H.-Continued.

93 Geological notes on the Bridgewater district in eastern Ontario (abst). G Soc London, Q J $49: \operatorname{Pr}$ 6-7 (1893) G Mag (3) $10: 47-48$ (1893)

Collins, W. F.

09 Occurrence of gold in placers. M Sc Press $98: 850$ (1909)

Collins, William Henry.

06 [Report on] the Lake Superior region between the Pic and Nipigon rivers. Can GS. Sum Rp 1905: 80-82 (1906)

06a On surveys along the National Transcontinental Raflway location between Lake Nipigon and Lac Seul. Can G S, Sum Rp 1906: 103-109 (1906)

08 Explorations along the National franscontinental Railway location from Sturgeon River westward. Can G S. Sum Rp 1907 : 48-54 (1908)

08a Report on a portion of northwestern Dntario traversed by the National Transcontinental Railway between Lake Nipigon and Sturgeon Lake. Can G S: 23 pp, map (1908)

09 Preliminary report on Gow ganda minng division, distriet of Nipissing, Ontario. Can G S 47 pp, map (1909) Abst, Can I J $30: 369-371,392-394$ (1909)

09a A geological reconnaissance of the egion traversed by the National Transcon. inental Railway between Lake Nipigon and lay Lake, Ont. Can G S: 67 pp, maps 1909)

09b Report on the region lying north of Lake Superior between the Pic and Nipigon rivers, Ont. Can G S:24 pp, map 1909)

09c Montreal River district. Can G S, Sum Rp 1908 : 115-120 (1909) M Sc Press $98: 895(1909)$

10 The Florence Lake and Montreal River districts, Ont. Can G S, Sum Rp 1909: 168-172 (1910)

10a The quartz diabases of Nipissing district, Ont. Ec G 5:538-550 (1910)

11 Montreal River district [Ont.]. Can G S, Sum Rp 1910: 196-202 (1911)

12 Geology of Onaping sheet, Ont, portion of map area between West Shiningtree and Onaping lakes. Can G S, Sum Rp 1911: 244-252, map (1912)

13 The geology of Gowganda mining divislon [Ont.]. Can G S, Mem 33:121 pp, map (1913)

13a The outlying cobalt-silver areas [Ontario]; Florence Lake, Shining Tree and Rose Creek areas. Ont Bur Mines, An Rp 19 pt 2:194 (1913)

13b Annotated guide, Winnipeg to Nipigon. Int G Cong, XII, Canada, Guide Book 10 $9: 153-159$, maps (1913)

13e (and Camse11, Charles.) Sudbury, Ontario, to Dunmore, Alberta. Int $\mathrm{G}$ Cong, XII, Canada, Guide Book no $9: 11-15$ (1913)
Collins, William Henry-Continued.

13d (and Wilson, M. E.) Winnipeg to Cochrane via National Transcontinental Railway. Int G Cong, XII, Canada, Guide Book no $9: 149-153$ (1913)

13e A classification of the pre-Cambrian formations in the region east of Lake Superior. Int $\mathrm{G}$ Cong, XII, Canada, C R : 399 407, map (1914) Advance copy 1913

14 Geology of Onaping sheet, Ont. Can G S, Sum Rp 1912: 301-314, map (1914)

14a Geology of a portion of Sudbury map area, south of Wanapitei Lake, Ont. Can G S, Sum Rp 1913:189-195, map (1914)

14b The Huronian formations of Timiskaming region, Can. Can G S, Mus B 8: 27 pp, maps (1914)

15 A reconnaissance of the north shore of Lake Huron. Can G S, Sum Rp 1914 : 81-82 (1915)

16 North shore of Lake Huron, Ont. Can G S, Sum Rp 1915:136-137 (1916) ; 1916: 183-185 (1917)

$16 a$ The age of Killarney granite [Ontario]. Can G S, Mus B 22:12 pp (1916) 17 Onaping map area [Ont.]. Can G S, Mem 95: 157 pp, maps (1917)

Collister, M. C.

12 (with Richardson, C. H.) The terranes of Albany, Vt. Vt St G, Rp 8: 184-195 (1912)

Colquhoun, A. J.

99 Notes on the occurrence of quicksilver in Canada. Can M Inst, J 2: 13-16 (1899) Can M Rv 18:41-42 (1899) M Sc Press $79: 288$ (1899)

Colton, Geo. H.

02 A possible cause of osars. Ohio Nat $2: 257$ (1902)

Colton, Henry E.

83 Report on the coal mines of Tennessee and other minerals... [Tenn, Dp Agr ] : 128 pp, Nashville 1883

S6 The Upper Measure coal field of Tennessee. Am I M Eng, Tr 14:292-305, map (1886)

88 Notes on the topography and geology of western North Carolina-the Hiawassee Valley. Am I M Eng, Tr 16:830-851, map (1888)

Columbia College, School of Rlines. See Anon., 83, and Shumway, 81

Colvocoresses, G. M.

10 Present developments at Gowganda, Ont. Can M J 31:584-589 (1910)

13 Cobalt conglomerate [Ont.]. M Mag $8: 43-44$ (1913)

Coman, C. W.

D1 Geological work in the southern part of the State; terrace formations of the Atlantic coast and along the Delaware River. N J G S, An Rp 1890:129-135 (1891)

02 Geological work in southern New Jersey. N J G S, An Rp 1891:111-140 (1892) 


\section{Combes, Charles.}

67 Rapport sur les travaux de M. Guillemin. [France], Comm Sc Mex, Arch 2 : 347-354, Paris 1867

Combes, Paul.

96 Exploration de l'nle d'Anticosti [géo. logie: 8-11] $46 \mathrm{pp}$, map, Paris 1896

Comstoek, Frank Mason.

oo An example of wave-formed cusp at Lake George, N. Y. Am G 25:192-194 (1900)

03 A small esker in western New York. Am G 32:12-14 (1903)

o4 Ancient lake beaches on the islands in Georgian Bay. Am G $33: 312-318$, map (1904)

Comstock, John Lee (1789-1858).

27 Elements of mineralogy... Ixxvi, 338 pp, Boston 1827

34 Outlines of geology... 336 pp, Hartford $18342 d$ ed, N Y 1836 3d ed, 384 pp, N Y 1838

41 An introduction to mineralogy... 3d ed, $369 \mathrm{pp}, \mathrm{N}$ Y 1841

47 Elements of geology... 432 pp, N Y 1847

49 A history of the precious metals... 222 pp, Hartford 1849

Comstock, Theodore Bryant (1849-1915).

73 On the geology of western Wyoming. Am J Sc (3) 6:426-432 (1873) ; 7:151 (1874)

74 Geological report. In Jones, Wil liam A., Report upon the reconnaissance of northwestern Wyoming... (C) S, 43d Cong 1st sess, H Ex Doc 285) : 85-184, map (1874) With additional chapters in a later ed: 85-292, map, Washington 1875

74a The northwestern Wyoming expedition. Am Nat 8:124-125 (1874)

74b The Yellowstone Park. Paper read before the Kirtland Society, Cleveland, Ohio, October 20, 1874. 9 pp [n d, 1874?]

76 Formation of geyserite pebbles in pools adjacent to the geysers of the Yellowstone Park (abst). Am As, Pr 24 pt 2:97 (1876)

76a Remarks on the hot springs and geysers and other topics illustrating the scientific value of the Yellowstone Park (abst). Am As, Pr 24 pt 2:97-99 (1876)

77 On some unexplained phenomena in the geyser basins of the Yellowstone $\mathrm{Na}$ tional Park. Am As, Pr 25:235-239 (1877)

78 An outline of general geology... 82 pp, Ithaca, N Y, 1878

83 Notes on the geology and mineralogy of San Juan Co., Colo. Am I M Eng. Tr $11: 165-191$, map (1883)

S4 The distribution of San Juan Co. [Colo.] ores. Eng. M J 38: 208-209, 229, $245-247, \quad 298-299, \quad 315-316, \quad 328-329$ (1884) ; 39:38-39 (1885)
Comstock, Theodore Bryant-Continuet

S6 Some peculiarities of the local dr of the Rocky Mountains. Am Nat : 925-927 (1886)

s6a A remarkable extinct geyser baci in southwestern Colorado. Am Nat : 963-965 (1886) Abst, Am J Sc (3) 3\% 320 (1886) ; Am As, Pr $35: 232$ (1887)

86b Super-metamorphism and volcaniso Am Nat 20:1006-1008 (1886) Abbt, do As, Pr 35:232-233 (1887)

s6e The veins of southwestern coh rado. Am Nat 20:1043-1044 (1886)

87 The geology and vein structure southwestern Colorado. Am I M Eng, $15: 218-265$, maps (1887)

$\mathbf{8 7 a}$ Notes on the region north of th Vermilion Lake district, in British Ame ica. Am I M Eng, Tr 16:109-111 (188) 87b The fossil fuels of Illinols at their exploitation. Fng M J 44:24 (188)

87e Natural gas in Illinois. Am Mam facturer 41 no $26: 13$ (1887)

87 Hints towards a theory of tor canism (abst). Am As, Pr $35: 233$ (1868

s7e Peculiarities of the drift of th Rocky Mountains (abst). Am As, Pr 3 233 (1887)

88 A preliminary examination of t geology of western central Arkansas. G S, An Rp 1888, 1:1-299, maps, Litt Rock 1888

s9 Hot spring formations in Red Mon tain district. Colo.; a reply to th cirticisms of Mr. Emmons. Am I M Ent Tr $17: 261-264$ (1889)

89a The fossil fuels of Illinois and the: exploitation: petroleum and natural ga Eng M J 48: 565-566 (1889)

90 A preliminary report on the geolog of the central mineral region of Tess Tex G S, An Rp 1:237-391 (1890)

$90 a$ The geological survey of Teras Eng M J 49:384-386 (1890)

91 Report on the geology and mineri resources of the central mineral regio of Texas... Tex G S, An Rp 2:553-664 maps (1891)

91 a Tin in central Texas. Eng If $51: 117-118$ (1891)

$91 b$ Occurrence of tin in central Tess Am J Sc (3) 41:251 (1891)

- 92 Report [on southwestern Texs Tex G S, Rp Prog 2 (1891) : 43-54 (189.

92a Valuable experiments in vein form tion. Science $19: 214$ (1892)

94 Mineral resources [of Arizona]. Report of the Governor of Arizona to th Secretary of the Interior, 1894:32-36, Washington, 1894

95 Notes on Arizona geology. Eng If $60: 369$ (1895)

oo The Chloride district, Ariz. Eng NI $70: 97-98$ (1900) 
Comstock, Theodore Bryant-Continued. 01 The geology and vein phenomena of Arizona. Am I M Eng, Tr $30: 1038-1101$, map (1901)

02 (and others) Edward Claypole. Am $29: 1-47$, port (1902)

02a Geological notes [subsidence and elevation in California and later geological istory]. S Cal Ac Sc, B 1: 74-77 (1902) 03 Memoir of Edward Waller Claypole. Soc Am, B $13: 487-497$ (1903)

07 The U. S. Geological Survey. Science is $25: 309-311$ (1907)

See also Blake (W P), 05a

Comstock, W. J.

So (with Allen, O. D.) Bastnäsite and tysonite from Colorado. Am J Sc (3) 19 : 390-393 (1880) Yale Bicen Pub, Contr Miner : $126-129$ (1901)

Condit, D. Dale.

0S (with Bownocker, J. A.) The Pomeroy coal in Ohio. Ec G 3:183-199 (1908) 09 The Conemaugh formation in southern Ohio. Ohio Nat $9: 482-488$ (1909)

12 The petrographic character of Ohio sands with relation to their origin. $\mathbf{J} \mathbf{G}$ $20: 152-163$ (1912) Abst, N Y Ac Sc, An $21: 210$ (1912)

12a Conemaugh formation in Ohio. Ohio G S (4) B $17: 363 \mathrm{pp}$, maps (1912)

13 Deep wells at Findlay, Ohio. Am J (4) $36: 123-130$ (1913)

14 Oil and gas in the northern part of the Cadiz quadrangle, Ohio. U S G S, B $541: 9-17$, map (1914)

16 Relations of the Embar and Chugwater formations in central Wyoming. U S G S, P P 98:263-270, map (1916) Abst, by R. W. S., Wash Ac Sc, J $7: 162$ (1917) 16a Structure of the Berea oil sand in the Summerfield quadrangle, Guernsey, Noble, and Monroe cos., Ohio. U S G S, B $621: 217-231$, maps (1916)

16b Structure of the Berea oil sand in the Woodsfield quadrangle, Belmont, Monroe, Noble, and Guernsey cos., Ohio. U S A S, B 621: 233-249, maps (1916)

16e A shelf of geologic literature for the small library, with a guide to the more important reports on Ohio. Ohio J Sc 17 : 52-63 (1916)

16d (with Lupton, C. T.) Gypsum in the southern part of the Bighorn Mountains, Wyo. U S G S, B 640:139-157, map (1916) Abst, by R. W. Stone, Wash Ac Sc, J $7: 78$ (1917)

17 Evidence in the Helena-Yellowstone Park region, Mont., of the great Jurassic erosion surface (abst). G Soc Am, B 28: 161 (1917)

18 Relations of late Paleozoic and early Mesozolc formations of southwestern Montana and adjacent parts of Wyoming. U S GS, P P 120: 111-121, map (1918)
Condon, Thomas (1822-1907).

69 Geological notes from Oregon. Overland Monthly $3: 355-360$ (1869) Reprinted, with title The geology of Oregon in Raymond, R. W., Statisties of mines and mining...[2d report]; [U S, Treas Dp] ; 205-210, Washington 1870

71 The rocks of the John Day Valley [Oreg.]. Overland Monthly 6:393-398 (1871)

71a The Willamette Sound. Overland Monthly $7: 468-473$ (1871)

74 Prelliminary report of the State geologist [of Oregon]... $22 \mathrm{pp}$, Salem, Oregon, 1874

79 On some points connected with the igneous eruptions along the Cascade Mountains of Oregon. Am J Sc (3) 18:406408 (1879)

96 Scientific description of two new fossil dogs. Oreg Univ, B 2 no $6: 10-11$, il (1896)

96a The ice caves of Mount Adams [Wash.]. Mazama 1:102-103 (1896)

02 The two islands... 211 pp, Portland, Oregon, 1902

06 A new fossil pinniped (Desmatophoca oregonensis) from the Miocene of the Oregon coast. Oreg Univ B, Suppl to rol 3 no $3: 14 \mathrm{pp}$, il (1906)

10 Oregon geology; a revision of "The two islands." Ed by Ellen Condon McCornack. 187, xvll pp, il, Portland, Oreg., 1910

Condra, George Evert.

02 New Bryozoa from the coal measures of Nebraska. Am G 30:337-359, il (1902)

03 The coal measure Bryozoa of Nebraska. Nebr G S 2:11-163, il (1903)

03a On Rhombopora lepidodendroides

Meek. Am G 31:22-24, il (1903)

03b An old Platte channel. Am G 31 : 361-369, map (1903)

04 Stratigraphic delineation of the Benton and Niobrara formations of Nebraska (abst). Science n s 19:925 (1904)

06 Geography of Nebraska. 192 pp, Lincoln, Nebr., 1906

O6a Observations on glacial accumulations of Nebraska (abst). Science n s 23: 620 (1906)

06b Oil and gas possibilities in $\mathrm{Ne}$ braska (abst). Science n 8 23:621 (1906)

o6e A new limestone in the Indian Territory $(a b s t)$. Science n s 23:624 (1906)

07 Geology and water resources of the Republican River valley and adjacent areas, Nebraska. U S G S, W-S P 216:71 pp, map (1907)

os Geology and water resources of a portion of the Missouri River valley in northwestern Nebraska. U S G S, W-S P $215: 59$ pp (1908) 
Condra, George Evert-Continued.

OSa The sand and gravel resources and industries of Nebraska. Nebr G S 3 pt 1: 1-206, map (1908)

15 (and Bengston, N. A.) The Pennsylvanian formations of southeastern $\mathrm{Ne}$ braska. Nebr Ac Sc, Pub 9 no $2: 60$ pp (1915)

17 Road materials of Nebraska; Part 2, Sand. Nebr Conservation and Soll $\mathrm{S}$, B $6: 63$ pp (1917)

18 Preliminary report on the potash industry of Nebraska. Nebr Univ, Nebr Conservation and Soll S, B 8:39 pp (1918)

Congrès géologique international.

See International Geological Congress.

Conkling, Alfred Ronald.

76 Report on the geology of the mountain ranges from La Veta Pass to the head of the Pecos. In Wheeler, G. M., Annual report... surveys west of the 100 th mreridian... : 199-202 (1876) Also in U S [War Dp], Chief Eng, An Rp 1876 (44th Cong 2d sess, H Ex Doc 1 pt 2 v 2 pt 3) App JJ : 419-422 (1876)

77 Geological report on the portions of western Nevada and eastern Callfornia... In Wheeler, G. M., Annual report upon the geographical survey west of the one hundredth meridian... U $\mathrm{S}$ [War Dp], Chlef Eng, An Rp 1877 (U S, 45th Cong 2d sess, H Ex Doc 1 pt 2 ₹ 2 pt 2), App NN : 1285-1295-(1877)

77a Report on the lithology of portions of southern Colorado and northern New Mexico. In Wheeler, G M., Annual report upon the geographical surveys west of the one hundredth meridian... U S [War Dp], Chief Eng, An Rp 1877 (U s, 45th Cong 2d sess, H Ex Doc 1 pt 2 v 2 pt 2), App NN : 1295-1298 (1877)

77b Report on the foothills facing the plains... [N. Mex, and Colo.]. In Wheeler, G. M., Annual report upon the geographical surveys west of the one hundredth meridian... U S [War Dp:, Chlef Eng, An Rp 1877 (U S, 45th Cong 2d sess, H Ex Doc 1 pt 2 ₹ 2 pt 2), App NN : 1298-1303 (1877)

78 Geological report on portions of western Nevada and eastern California including part of the Sierra Nevada Range, 1877. In Wheeler, G. M., Annual report... surveys west of the 100 th meridian... : 167183 (1878) Also in U S [War Dp], Chief Eng, An Rp 1878 (U S, 45th Cong 3d sess, H Ex Doc 1 pt 2 ₹ 2 pt 3), App NN : 1589-1605 (1878)

78a Report on the lithology and mineralogy of portions of Nevada and Callfornla, 1877. In Wheeler, G. M., Annual report... surveys west of the 100 th meridian...; 184-185 (1878) Also in U S [War Dp], Chief Eng, An Rp 1878 (U S, 45th Cong 3d sess, H Ex Doc 1 pt 2 v 2 pt 8 ), $\triangle p p$ NN : 1606-1607 (1878)
Conkling, Rlchard A.

16 The influence of the novement shales on the area of the oil productin [Cushing fleld, northeastern Okla.] (with discussion by D W. Othern, Dorsey Haga. and the author). Am I M Eng, B 118: 1969-1972 (1916); B 123:389-390; 124 : 620 ; B 126 : $985-986$ (1917); Tr 5 : $876-880$ (1917)

Connectient, Geologicnl Survey.

04 First biennial report of the commls sioners of the State geological and natur history survey of Connecticut, 1903-1904 Conn G S, B 1:18 pp (1904) Second bies nial... 1905-1906;... B $9: 23$ pp (1906) Third biennal... 1907-1908; ... B 12:30 ph (1908) Fourth blennial... 1909-1910 ;... B $17: 31$ pp (1910) Fifth biennial... 1911$1912 ; \ldots$ B $21: 27$ pp (1912) Sixth biennil $1913-1914 ; \ldots$ B $25: 24$ pp (1915) Seventh biennial... 1915-1916;... B 27: pp (1917)

Connelly, W. A.

10 Piz-Piz district, Niacaragua. If \& Press 100:350-351 (1910)

Conner, Ell T.

12 (with Griflith, W.) Mining ditions under the City of Scranton, Pa. S Bur Mines, B 25:89 pp (1912)

Conner, M. F.

13 Some notes on rock analysis. Int 6 Cong, XII, 1913, C R: $885-890$ (1914) Adrance copy 1913

Conrad, C. P.

80 Silver in Arkansas. Eng M J W: $172,186-187,203-204$ (1880)

Conrad, Solomon W.

14 Mineralogical notice respecting rirot from Trenton, N. J. Am Minet J 1:1\% 128 (1814)

Conrad, Timothy Abbott (1803-1877).

30 On the geology and organie remals of a part of the Peninsula of Marylad Ac N Se Phila, J $6: 205-230,11$ (1830)

$30 a$ Description of fifteen new species if recent, and three of fossil shells, chiet? from the coast of the United States. ACI Sc Phila, J 6 : 256-268, il (1830)

32 Fossil shells of the Tertiary form tions of North America ... 56 pp, 11, Ptil 1832-35 Republished by G. D. Harris, 12 pp, il, Washington 1893

33 On some new fossil and recent sbels of the United States. Am J Se 23:335 346 (1833)

34 Observations on the Tertiary it: more recent formations of a portion of th Sonthern States. Ac N Sc Phila, J 116-129 (1834)

34a Descriptions of new Tertiary fosel from the Southern States. $\mathrm{Ac} \mathrm{N} \mathrm{Sc} \mathrm{Pbla}$ J $7: 130-157$ (1834)

35 Observations on the Tertiary strit? of the Atlantic coast. $\Delta m$ J Sc 28:10t $111,280-282$ (1835) 
Conrad, Timothy Abbott-Continued. 35a Description of five new species of fossil shells ... [coal measures, Pennsylrania]. G Soc Pa, Tr 1:267-270, il (1835)

35b Observations on a portion of the Atlantic Tertiary region. G Soc $\mathrm{Pa}, \mathrm{Tr} 1$ : 335-341, 11 (1835)

37 First annual report on the geological survey of the third district of the State of New York. N Y G S, An Rp 1: 155-186 (1837)

37a (with Mather, W. W.) Queries proposed by the geologists of the new survey of the State of New York. Am J Sc 33: 124-133 (1837)

38 Fossils of the Tertiary formations of the United States ... $\times \mathbf{x i}, 86 \mathrm{pp}, 11$, Phila 1838 Republished by W. H. Dall, xvili, 136 pp, II, Phila 1893

38a Report on the paleontological department of the survey [of New York]. N Y G S, An Rp 2:107-119 (1838)

39 Second annual report on the paleontological department of the survey [of New York]. N Y G S, An Rp 3:57-66 (1839)

39a Notes on American geology (with remarks by the editors). Am J Sc 35: 237-251 (1839)

40 Third annual report on the paleontological department of the survey [of New York]. N Y G S, An Rp 4:199-207 (1840)

40a On the Silurian system, with a table of the strata and characteristic fossils. Am J Sc 38:86-93 (1840)

$40 \mathrm{~b}$ On the geognostic position of the Zeuglodon, or Basilosaurus of Harlan. Am J Sc $38: 381-382$ (1840)

40e New fossil shells from North Carolins. Am J Sc $39: 387-388$ (1840)

41 Fifth annual report on the paleontology of the State of New York. N Y G S, An Rp 5:25-57 (1841)

41n [Descriptions of Tertiary fossils from the Carolinas]. Am J Sc 41: 344-348, 11 (1841) As Am G, Rp: 108-111, il (1843)

$41 \mathrm{~b}[\mathrm{On}$ new species of fossil shells from the medial Tertiary deposits of Calvert Cliffs, Md.]. Ac N Se Phlla, Pr 1: 28-33 (1841)

42 Description of twenty-four new specles of fossil shells, chiefly from the Tertiary deposits of Calvert Cliffs, Md. Ac N Sc Phila, J 8: 183-190 (1842)

42a Observations on the Silurian and Devonian systems of the United States, with descriptions of new organic remains. Ac N Sc Phila, J 8:228-280, il (1842)

42b Observations on a portion of the Atlantic Tertiary region, with a descripthon of new species of organic remains. Nat Inst Washington, D C., Pr 2: 171-194 (1842)

$28737^{\circ}-23-15$
Conrad, Timothy Abbott-Continued.

43 Descriptions of a new genus and of twenty-nine new Miocene, and one Eocene, fossil shells of the United States. Ac N Sc Phila, Pr 1: 305-311 (1843)

$43 a$ Descriptions of nineteen species of Tertiary fossils of Virginia and North Caroline. Ac N Sc Phila, Pr 1:323-329 (1843)

43b Observations on the lead-bearing limestone of Wisconsin and descriptions of a new genus of trilobites and fifteen new Silurian fossils. Ac N Sc Phila, Pr $1: 329-335$ (1843)

44 Deseriptions of eight new fossil shells of the United States. Ac N Sc Phila, Pr 2:173-175 (1844)

46 Descriptions of new species of fossil and recent shells and corals. Ac $\mathrm{N}$ Sc Phila, Pr $3: 19-27$, 11 (1846)

46a Observations on the Eocene formation of the United States, with descriptions of species of shells, etc., occurring In it. Additional remarks [on corals], by J. D. Dana (pp. 220-221). Am J Sc (2) $1: 209-220,395-405$, il (1846)

$46 \mathrm{~b}$ Observations on the geology of a part of east Florida. Am J Sc (2) 2 : 36- 48 (1846)

46e Tertiary of Warren Co., Miss. Am J Sc (2) 2:124-125 (1846)

46d Eocene formation of the Walnut Hills, etc, Miss. Am J Sc (2) $2: 210-215$ (1846)

46e Descriptions of new species of organie remains from the upper Eocene limestone of Tampa Bay, Fla. Am J Sc (2) $2: 399-400$ (1846)

47 Observations on the Eocene formation, and description of one hundred and five new fossils of that period, from the vicinity of Vicksburg, Miss. Ac N Sc Phlla, Pr 3:280-299 (1847); J (2) 1: 111-134, il (1848)

48 Fossil shells from Tertiary deposits on Columbla River, near Astoria. Am J Sc (2) $5: 432-433$, il (1848) U S G S, P P $59: 150-151$, il (1909)

49 Descriptions of new fossil and recent shells of the United States. Ac N Sc Phila, J (2) $1: 207-209$ (1849)

$49 a$ Fossils from northwestern America (fossil shells of Astoria, Oreg.) In Dana, J. D., Geology, vol. $x$ of the United States exploring expedition...under Charles Wilkes : 723-728, Phila 1849

50 Descriptions of one new Cretaceous and seven new Eocene fossils. Ac $\mathrm{N}$ Sc Phila, J (2) 2:39-41, il (1850)

52 Remarks on the Tertiary strata of St. Domingo and Vicksburg, Miss. Ac $\mathrm{N}$ Sc Phila, Pr 6: 198-199 (1852)

52a Notes on shells, with descriptions of new species. Ac N Sc Pbila, Pr 6: 199-200 (1852) U S G S, P $\quad$ P $59: 158$ (1909) 
Conrad, Timothy Abbott-Continued.

53 Monograph of the genus Fulgur. Ac N Se Phila, Pr 6:316-319 (1853)

53a Notes on shells. Ac N Sc Phila, Pr $6: 320-321$ (1853)

53b Synopsis of the genera Cassidula, Humph., and of a proposed new genus Athleta. Ac N Sc Phila, Pr $6: 448-449$ (1853)

53e Descriptions of new fossil shells of the United States. Ac N Sc Phila, J (2) $2: 273-276$, il (1853) U S G S, P P 59: 159-161 (1909)

54 Descriptions of new fossil shells of the United States. Ac N Sc Phila, J (2) $2: 299-300$ (1854)

$54 a$ Rectiflcation of the generic names of Tertiary fossil shells. Ac N Sc Phila, Pr $7: 29-31$ (1854)

54b Notes on shells, with descriptions of three recent and one fossil species. Ac N Sc Phila, Pr $7: 31-32$ (1854) U S G S, P P 59: 162 (1909)

55 Report on the fossil shells collected in California by W. P. Blake, geologist of the expedition under the command of Lieutenant R. S. Williamson. U S, Pacific R R Expl (U S, 33d Cong 1st sess, H Ex Doc 129) Appendix to the prellminary geological report of W. P. Blake:5-20 (1855) In part, Am J Sc (2) $21: 268-270$ (1856) U S G S, P P $59: 163-171$ (1909)

55a Observations on the Eocene deposit of Jackson, Miss., with descriptions of thirty-four new species of shells and corals. Ac N Sc Phila, $\operatorname{Pr} 7: 257-263$ (1855)

55b Descriptions of eighteen new Cretaceous and Tertiary fossils, etc. Ac N Sc Phila, Pr 7 : 265-268 (1855)

55e Description of one Tertiary and eight new Cretaceous fossils from Texas... Ac N Sc Phila, Pr 7: 268-269 (1855)

55d Description of a new species of Pentamerus. Ac $\mathrm{N}$ Sc Phila, Pr $7: 441$ (1855)

55e Note on the Miocene and postPliocene deposits of California, with descriptions of two new fossil corals. Ac N Sc Phila, Pr 7:441 (1855) U S G S, P P 59: 172 (1909)

56 Description of the Tertiary fossils collected on the survey [Williamson's survey in California and Oregon]. U $\mathbf{S}$, Pacific R R Expl (U S, 33d Cong 2d sess, $\mathrm{S}$ Ex Doc 78 and $H$ Ex Doc 91) 6 pt 2 : 69-73, il (1856) U S G S, P P 59:176179 (1909)

56a Report on the paleontology of the survey [Parke's surveys in California]. U S, Pacific R R Expl (U S, 33d Cong, $\mathrm{S}$ Ex Doc 78 and $\mathrm{H}$ Ex Doc 91) 7 pt 2: 189-196, il (1856) U S G S, P P 59:180185 (1909)
Con rad, Timothy Abbott-Continued.

56b Descriptions of three new genera; twenty-three new species middle Tertiang fossils from California, and one from Texas. Ac $\mathrm{N}$ Se Phila, Pr 8:312-316 (1856) U S G S, P P 59:173-175 (1909)

57 Descriptions of the fossil shells [Williamson's reconnaissance in Call. fornia]. U S, Pacific R R Expl (U S, 33d Cong $2 d$ sess, $\mathrm{S}$ Ex Doc 78 and $\mathrm{H}$ Ex Doe 91) 5 pt $2: 317-329$, il (1857) [See also Blake (W P), 57]

57a Descriptions of Cretaceous and Tertiary fossils. In Emory, W H., Report on the United States and Mexican boundary survey... (U S, 34th Cong 1st sess, S Ex Doc 108 and $H$ Ex Doc 135), v 1 pt 2? 141-174, il (1857)

$57 b$ Descriptions of two new genera of shells. Ac N Sc Phila, Pr 1857:165-166

57e Rectification of some of the get eric names of American Tertiary fossils. Ac N Sc Phila, Pr 1857:166

57d Descriptions of a new species of Myacites [Triassic, Pennsylvania]. Ac N Se Phlla, $\operatorname{Pr} 1857$ : 166

58 Observations on a group of cre taceous fossil shells, found in Tippah Co. Miss., with descriptions of fifty-six ner species. Ac N Sc Phila, J (2) 3:323-336 il $(1858)$

60 (and Gabb, W. M.) Illustrations of some fossils described in the Proceedings of the Academy of Natural Sciences. Ac N Sc Phila, Pr 1860:55, il

60a Notes on shells. Ac N Sc Phila, Pr $1860: 231-232$

$60 b$ Descriptions of new species of Cretaceous and Eocene fossils of Mississippl and Alabama. Ac N Sc Phila, J (2) 4: 275-298, il (1860)

62 Descriptions of new genera, subgenera, and species of Tertiary and Recent shells. Ac N Sc Phila, Pr 1862 : 284-291

62a Catalogue of the Miocene shells of the Atlantic slope. Ac N Se Phila, Pt $1862: 559-582$

62b Descriptions of new, Recent, and Miocene shells. Ac N Sc Phila, Pr 1862: $583-586$

64 Notes on shells, with descriptions of new fossil genera and species. Ac N Sc Phila, Pr 1864:211-214, il

65 Observations on the Eocene lignite formation of the United States. Ac N Sc Phila, Pr 1865: 70-73 Am J Sc (2) 40: 265-268 (1865)

65a Catalogue of the Eocene Annulata. Foraminifera, Echinodermata, and Cirr pedia of the United States. Ac N Sc Phila, Pr 1865: 73-75

65b Descriptions of new species of Echt nidae. Ac N Sc Phila, Pr 1865: 75

65e Observations on American fossils. with descriptions of two new species. Ac $D$ Sc Phila, Pr 1865: 184 
Conrad, Timothy Abbott-Continued. 65d Catalogue of the Eocene and Oligocene Testacea of the United States. Am J Conch 1:1-35 (1865)

65e Descriptions of new Eocene shells from Enterprise, Miss. Am J Conch 1: $137-141,149$, il $(1865)$

$651^{\circ}$ Descriptions of new Eocene shells of the United States. Am J Conch 1:142149 , il (1865)

65g Catalogue of the older Eocene shells of Oregon. Am J Conch 1: 150-154 (1865) 65h Descriptions of new Eocene shells, and references with figures to published species. Am J Conch 1:210-212, 215, il (1865)

65i Deseriptions of five new species of older Eocene shells from Shark River, Monmouth Co., N. J. Am J Conch 1: 213-215, il (1865)

65j Observations on certain Eocene fossils described as Cretaceous by Mr. W. M. Gabb... Am J Conch 1: 362-365 (1865)

66 Check list of the invertebrate fossils of North America; Eocene and Oligowe. Smiths Misc Col 7 (200): 41 pp (1866)

66a [Chalk at Smoky Hill, Colo.] Smiths Inst, An Rp 1865: 125 (1866)

$66 \mathrm{~b}$ Illustrations of Miocene fossils with descriptions of new species. Am $J$ Conch 2:65-74, il (1866)

66e Note on the genus Gadus, with descriptions of some new genera and species of American fossll shells. Am J Conch 2 : 75-78 (1866)

66a Further observations on Mr. Gabb's Paleontology of Callfornia. Am $\mathbf{J}$ Conch 2:97-100 (1866)

66e Observations on recent and fossil shells, with proposed new genera and spe. cies. Am J Conch 2: 101-103 (1866)

66f Descriptions of new species of Tertlary, Cretaceous, and recent shells. Am J Conch 2:104-106 (1866)

$66 \mathrm{~g}$ Notice of a new group of Eocene shells. Am J Sc (2) 41:96 (1866)

67 Tertiary of North and South Caro. llna. $A m$ J Sc (2) $43: 260$ (1867)

67a ... on the Cretaceous rocks of California. Am J Sc (2) $44: 376-377$ (1867)

$67 \mathrm{~b}$ Paleontological miscellanies. Am J Conch $3: 5-7$ (1867)

67e Descriptions of new genera and species of fossil shells. Am J Conch $3: 8-16$ (1867)

67d Synopsis of the genera Sycotypus Browne and Busycon Bolten. Am J Conch 3:182-185 (1867)

67e Descriptions of new Miocene shells. Am J Conch $3: 186-187$ (1867)

67f Notes on fossil shells and descripthons of new species. Am J Conch 3:188$190(1867)$
Conrad, Timothy Abbott-Continued.

68 Descriptions of new genera and species of Miocene shells, with notes on other fossil and recent species. Am J Conch $3: 257-270$, il (1868)

68a Descriptions of Miocene shells of the Atlantic slope. Am J Conch 4:64-68, il (1868)

68b Synopsis of invertebrate fossils [Cretaceous and Eocene]. N J G S, G N J : 721-732 (1868)

69 Notes on American fossiliferous strata [New Jersey]. Am J Sc (2) 47: 358-364 (1869)

$69 a$ Notes on recent and fossil shells, with descriptions of new genera. Am J Conch $4: 246-249$ (1869)

$69 b$ Descriptions of and references to Miocene shells of the Atlantic slope, and descriptions of two new supposed Cretaceous species. Am J Conch 4:278-279 (1869)

69e Description of a new Unio and fossil Goniobasis. Am J Conch 4:280, il (1869)

69d Descriptions of Miocene, Eocene, and Cretaceous shells. Am J Conch $5: 39$ 45 , il (1869)

69e Observations on the genus Astarte, with descriptions of three other genera of Crassatellide. Am J Conch 5 : 46-48 (1869)

69 Descriptions of new fossil Mollusca, principally Cretaceous. $A \mathrm{~m} \mathrm{~J}$ Conch 5 : $96-103$, il (1869)

70 Notes on recent and fossil shells, with descriptions of new species. Am J Conch 6:71-78, il (1870)

70a On the mixture of Cretaceous and Eocene fossils. Am J Sc (2) $49: 275$ (1870)

71 On the Eocene beds of Utah. Am J Sc (3) 1:381-383 (1871)

71a On some points connected with the Cretaceous and Tertiary of North Carolina. Am J Sc (3) 1:468-469 (1871)

71b Descriptions of new Tertiary fossils, with notes on two genera of Lamellibranchiata. Am J Conch 6:199-201, il (1871)

71e Paleontological notes. Am J Conch 6: $314-315$ (1871)

72 Descriptions and illustrations of genera of shells. Ac N Sc Phila, $\mathrm{Pr} 1872$ : $50-55$, il

72a Descriptions of a new Recent species of Glycimeris from Beaufort, N. C., and of Miocene shells of North Carolina. Ac N Se Phila, Pr 1872:216-217

74 Descriptions of new mollusks from Cretaceous beds of Colorado. U S G Geog S Terr, An Rp [7]: 455-456 (1874)

75 [Descriptions of Haploscaphae from Niobrara beds.] U S G S Terr (Hayden), Rp $2: 23-24$ (1875) 
Conrad, Timothy Abbott-Continued.

75a Descriptions of new genera and species of fossil shells of North Carolina ... In Kerr, W. C., Report of the geological survey of North Carolina 1, App:1-28, il, Raleigh 1875

76 Notes on the genus Catillus, Brongn. Ac N Se Phila, Pr 1875: 466-467 (1876)

77 Note on the relations of Balamus estrallanus (Tamiosoma gregaria) with the Rudistae. Am J Se (3) 13:156-157 (1877)

$77 \mathbf{a}$ Note on a cirripede of the Callfornia Miocene, with remarks on fossil shells. Ac N Sc Phila, $\mathrm{Pr} 1876: 273-275$ (1877)

77b On certain generic names proposed by Zittel, Stoliczka, and Zekell. Ac N Sc Phila, Pr $1877: 22-23$

77e Notes on shells. Ac N Sc Phila, Pr $1877: 24-25$

Conway, E. F.

12 (with Richardson, C. H.) The terranes of Irasburg, Vt. Vt St G, Rp $8: 141-161$ (1912)

Conwentz, $H$.

78 Ueber ein tertiäres Vorkommen cy. pressenartiger Holzer bel Calistoga in Callfornien. N Jb 1878: $800-813$ il

$78 a$ Cupressinoxylon taxodiodes, ein vorweltliches cypressenähnliches Holz aus Callfornien. Naturf Ges Danzig, Sebrift (N F) 4 H $3: 122-124$ (1878)

\section{Conzatti, C.}

os Los yacimientos fosilfferos del Valle de Oaxaca. Soc Cient Ant Alz, Mem 26: 353-358, il (1908)

Cook, Alfred N.

04 A new deposit of fuller's earth. Iowa Ac Sc, Pr 11:135-137 (1904)

Cook, Charles Wilford.

06 (with Kraus, E. H.) Datolite from Westfield, Mass. Am J Sc (4) 22:21-28 (1906)

09 (with Kraus, E. H.) Iodyrite from Tonopah, Nev., and Broken Hill, N. S. Wales. $\mathrm{Am} J \mathrm{Sc}$ (4) $27: 210-222$ (1909)

11 Preliminary report on the salt industry of Michigan. Mich Ac Sc, kp 13: 81-86 (1911)

11 (with Van Horn, F. R.) A new occurrence of pearceite. Am J Sc (4) 31: 518-524 (1911)

14 The brine and salt deposits of Micbigan; their origin, distribution, and exploitation. Mich G S, Pub 15 (g s 12) : $188 \mathrm{pp} \mathrm{(1914)}$

15 (and Kraus, E. H.) Datolite from Great Notch, N. J. Am J Sc (4) $39: 642$ 645 (1915)

Cook, Edward $\mathrm{H}$.

05 I.a mina Santa Francisca [Aguascalientes], México. M Mag 11:424-429 (1905)
Cook, Edward H.-Continued.

07 La mina Santa Francisca [Aquas. ealientes, Mexico]. Méx, Sec Fomento, B (2) 6 II : 562-569 (1907)

os The saline deposits of Carmen is. lands [Lower California]. Eng M J 85: 545-546 (1908)

Cook, George Hammell (1818-1889).

55 Report [on the southern division of New Jersey]. N J G S, An Rp 1:56-78 (1855)

$55 a$ The marls of New Jersey. M Mag 5: 132-146 (1855)

56 Report on the geology of the south. ern division of the State. N J G S, Rp $2: 55-108$ (1856)

57 Report on the geology and agrcultural resources of the southern divi. sion of the State [New Jersey]. $30 \mathrm{pp}$ Trenton 1857 Also in N J G S, An Rp 3 : 39-68 (1857)

57 a Geology of the County of Cape May, State of New Jersey. [N J G S] 208 pp, map, Trenton 1857

$57 b$ On a subsidence of the land on the sea coast of New Jersey and Long Island, Am J Sc (2) 24:341-355 (1857) Abst, Can Nat 2: 258-261 (1857); Can J a 8 2: 480-481 (1857); Edinb N Ph $J$ a 8 6: 349-350 (1857)

59 Geology of New Jersey. Am Geog Stat Soc, J 1: 107-112 (1859)

61 Note on the probable age of the white limestone at Sussex and Franklin zinc mines, New Jersey. Am J Sc (2) 32:206209 (1861)

64 Report upon the geological survey of New Jersey and its progress during the year 1863. $13 \mathrm{pp}$, Trenton 1864

65 Annual report of the State geologist for the year 1864, $24 \mathrm{pp}$, map, Trentos $(1865)$ : 66 For 1865,12 pp $(1866) ; 67$ For 1866,27 pp (1867); 68 For 1867, 28 pp (1868); 70 For $1869,57 \mathrm{pp}$, maps $(1870) ; \mathbf{7 1}$ For $1870,75 \mathrm{pp}$, map (1871); 72 For $1871,46 \mathrm{pp}, \operatorname{map}(1872) ; 72 \mathrm{a}$ For 1872, $44 \mathrm{pp}(1872) ; \mathbf{7 3}$ For 1873,128 pp [German ed 141 pp] (1873); 74 For $1874,116 \mathrm{pp}(1874)$; 75 For $1875,41 \mathrm{pp}$. map (1875); $\boldsymbol{7 6}$ For $1876,56 \mathrm{pp}$, map $(1876) ; \mathbf{7 7}$ For $1877,56 \mathrm{pp}$, map (1877): 78 For $1878,131 \mathrm{pp}, \operatorname{map}(1878)$; 79 Fot 1879, $199 \mathrm{pp}, \operatorname{map}(1879)$; So For 1880 , 220 pp. maps $(1880) ; \mathbf{8 1}$ For 1881, 87 107 , xiv pp, map (1881); 82 for 188 . $191 \mathrm{pp}$, map (1882) ; $\mathbf{8 3}$ For $1883,188 \mathrm{DP}$ (1883); 84 For 1884,168 pp $(1884) ; 85$ For $1885,228 \mathrm{pp}(1885)$; 87 For 1886. 254 pp, maps (1887); $\mathbf{8 7 a}$ For 1887,45 pp, map (1887) ; 89 For 1888,87 pp (1889)

68 Geology of New Jersey. N J G \&: 900 pp, Newark, 1868

74a (and Smoek, J. C.) [Map of] northern New Jersey showing the iron-ore and limestone districts. Scale 2 miles to 1 inch. N J G S, 1874 
Cook, George Hammell-Continued.

76a Catalogue of Centennial exhibit of the Geological Survey of New Jersey. International Exhibition, Philadelphia, 1876. 84 pp, New Brunswick, N. J., 1876 Also in Report of the New Jersey Commissioners on the Centennial Exhibition : 217-304, Trenton, N. J., 1877

78a (and Smoek, J. C.) Report on the clay deposits of Woodbridge, South Amboy, and other places in New Jersey. N J G S : $381 \mathrm{pp}$, maps, Trenton, 1878

$79 \mathrm{a}$ on the southern limit of the last glacial drift across New Jersey, and the adjacent parts of New York and Pennsylvania. Am I M Eng, Tr 6:467-470, map (1879)

$83 a$ The change of relative level of the ocean and the uplands on the eastern coast of North America (abst). Am As, Pr 31: 400-408 (1883)

84a Uneonformability between the Upper and Lower Silurian formations in New Jersey, bearing on the question as to the limits of the Green Mountain disturbance. Am J Sc (3) $27: 153$ (1884)

$85 \mathrm{n}$ Sketch of the geology of the Cretaceous and Tertlary formations of New Jersey. U S G S, Mon 9: $1 \mathbf{x}-\mathrm{x} i 1$ (1885)

88 (and Cope, E. D.) Report of the subcommittee on the Mesozoic. In International Congress of Geologists, American Committee, Reports ... E 16 pp, Phlla 1888 Am G 2: 257-268 (1888) Int G Cong, IV, London 1888, C R App A : 159-173 (1891)

$88 a$ On the international geological congress and our part in it as American geologists. Selence 12:92-93 (1888) Am As, Pr $37: 159-177 \cdot(1889)$

89 a Geological map of New Jersey. Scale 5 miles to 1 inch. Atlas sheet no 20 In Atlas of New Jersey. N J G S (1889)

See also Hawes, 84

Cook, Harold James.

09 Notice of a new camel from the lower Mocene of Nebraska [Oxydactylus campestris]. Am Nat 43:188-189 (1909)

09a A new proboscidean from the lower Miocene of Nebraska [Gomphotherium cono. don]. Am J Sc (4) $28: 183-184$, 11 (1909)

$09 \mathrm{~b} A$ new genus of rhinoceros from Sloux Co., Nebr [Metacoenopus egregius]. Nebr G S 3:243-248, 11 (1909)

09e Some new Carnivora from the lower Miocene beds of western Nebraska. Nebr G S 3:259-272, Il [1909?]

09d (with Matthew, W. D.) A Pliocene fauna from western Nebraska. Am Mus N H, B 26: 361-414 (1909)

$12 \mathrm{~A}$ new genus and species of rhinoceros, Epiaphelops virgasectus, from the lower Miocene of Nebraska. Nebr G S 7 : 21-22, il (1912)

12a A new species of rhinoceros, Dioera. flicritu loomisi, from the lower Miocene of Nebraska. Nebr G S $7: \mathbf{2 9 - 3 2}$, il (1912)
Cook, Harold James-Continued.

$12 \mathrm{~b}$ Faunal lists of the Tertiary formations of Sioux Co., Nebr. Nebr G S $7: 33-$ 45 (1912)

12e Notice of a new genus of rhinoceros from the lower Miocene [Epiaphelops virgasectus]. Science n s $35: 219-220$ (1912)

14 Note on the occurrence of the mammoth in Sioux Co., Nebr. Nebr G $\mathrm{S} 7$ : $47-48$, il (1914)

14a A new canid from the lower Pliocene of Nebraska, Tephrocyon mortifer. Nebr G S $7: 49-50$, il (1914)

$14 b$ (with Barbour, E. H.) Two new fossil dogs of the genus Cynarctus from Nebraska. Nebr G S $4: 225-227$, il (1914)

15 Note on the dentition of Amphicyon amnicola, a gigantic fossil dog. Nebr G S $7: 57-58$, il (1915)

15a Notes on the geology of Sioux Co., Nebr., and vicinity. Nebr G S $7: 59-75$ (1915)

15b (with Barbonr, E. H.) A new saber-toothed cat from Nebraska. Nebr G S $4: 235-238$, il (1915)

17 First recorded amphibian from the Tertiary of Nebraska (abst). G Soc Am, B 28: 213 (1917)

17 a (with Barbour, E. H.) Notes on the skull of Meteoreodon. Nebr G S 7: 165-172, il (1917)

17b (with Barbour, E. H.) Skull of Aelurodon platyrhinus sp. nov. Nebr G S $7: 173-180$, il (1917)

Cook, J. P.

84 The terminal moraine in New Jersey. Pa G S, 2d, Z : 246-269 (1884)

Cook, John H.

09 Some preglacial valleys in eastern New York and their relation to existing drainage $(a b s t)$. Science n $s$ 29:750 (1909)

Cook, W. A.

14 Lowering of the ground-water table. Kans Ac Sc, Tr 26:84-86 (1914)

Cooke, C, Montague, jr.

17 Some new species of Amastra. Bernice Pauahi Bishop Mus, Oc P $3: 221-247$, il (1917)

Cooke, Charles Wythe.

14 (with Vaughan, T. W.) Correlation of the Hawthorn formation. Wash Ac Sc, J 4:250-253 (1914)

15 The age of the Ocala limestone. U S G S, P P 95:107-117 (1915) Rv, by G. D. Harris, Science n s $43: 72$ (1916)

16 The age of the Ocala limestone of Florida (abst). Wash Ac Sc, J 6:22 (1916)

17 The stratigraphic position and faunal associates of the orbitoid Foraminifera of the genus Orthophragmina from Georgia and Florida. U S G S, P P 108: 109-113 (1917) Abst, Wash Ac Sc, J $8: 96$ (1918) 
Cooke, Charles Wythe-Continued.

18 (and Shearer, H. K.) Deposits of Claiborne and Jackson age in Georgia. U S G S, P P 120:41-81, map (1918) Abst, Wash Ac Sc, J 8:540 (1918)

18 a Correlation of the deposits of Jackson and Vicksburg ages in Mississippi and Alabama. Wash Ac Sc, J 8:186-198 (1918)

Cooke, Harold Caswell.

13 The secondary enrichment of silver ores. J G 21:1-28 (1913)

14 An exploration of the headwaters of the Broadback or Little Nottaway River, northwestern Quebec. Can G S, Sum Rp $1912: 337-341$, map (1914)

14a Geology of the Sooke special map area, Vancouver Islend, B. C. Can G S, Sum Rp 1913:106-108 (1914)

141 (with Clapp, C. H.) Geology of a portion of the Duncan map area, Vancouver Island, B. C. Can G S, Sum Rp 1913: 84-106 (1914)

15 The basins of the Nottaway and Broadback rivers, northwestern Quebec. Can G S, Sum Rp 1914:95 (1915)

16 Headwaters of the Broadback and Nottaway rivers, northwestern Quebec. Can G S, Sum Rp i915: 170-172 (1916)

17 Sicker series and the gabbros of East Sooke and Rocky Point [Vancouver Island, B C]. Can G S, Mem 96:125-173, 304-329 (1917)

17a Headwaters of Nottaway, Ashuapmuchuan, St. Maurice, and Gatineau rivers, northwestern Quebec. Can G S, Sum Rp 1916: 228 (1917)

Cooke, Josiah Parsons (1827-1894).

63 Crystallographic examination of the Hebron [Maine] mineral and comparison of it with the childrenite from Tavistock. Am J Sc (2) $36: 258-259$ (1863)

66 On danalite, a new mineral species from the granite of Rockport, Mass. Am J Sc (2) $42: 73-79$ (1866)

67 On cryophyllite, a new mineral specles of the mica family, with some associated minerals in the granite of Rockport, Mass. Am J Sc (2) $43: 217-230$ (1867) Abst, Am As, Pr 15:37-42 (1867)

67a Crystallographic examination of some American chlorites. Am J Sc (2) 44:201-206 (1867)

$\mathbf{7 4}$ The vermiculites, their crystallographic and chemical relations to the micas. Am Ac Arts, Pr 9:35-67 (1874) Ph Mag (4) $47: 241-272$ (1874)

75 Melanosiderite, a new mineral specles from Mineral Hill, Delaware Co., Pa. Am Ac Arts, Pr 10:451-452 (1875)

75a On two new varieties of vermiculites, with a revision of the other members of this group. Am Ac Arts, Pr 10:453462 (1875)

Coolbaugh, W. F.

18 Potash. Colorado Sch Mines Mag $8: 97-99$ (1918)
Cooledge, $C$. W.

09 (and Overspeck, L. S.) The fron deposits of the Black Hills, S. Dak, y Science 60:319-321 (1909)

Cooper, Augustus $\mathrm{S}$.

93 The genesis of petroleum and asphalt in California. Sc Am Sup 36:14738 14740 (1893)

98 A bituminous rock deposit in Santa Barbara Co., Cal. Eng M J 66:278-279 (1898)

98a Southern Callfornia petroleum. If Sc Press $77: 372$ (1898)

99 The genesis of petroleum and as. phaltum in Callfornia. M Sc Press, 78 : 124, 149, 182, 205, 236, 264, 289-290, 320, $344,377,401-402,432,460$ (1899) Cal St M Bur, B 16:3-66 (1899) Also in California mines and minerals (pub. by California Miners' Association) : 114-174. San Francisco, Cal., 1899

99 a Phenomena attending the accumu lations of bitumen. M Sc Press 79:632 633, 665, 691, 721 (1899) Cal St M Bur. B $16: 66-82$ (1899)

01 The origin and occurrence of pe. troleum in California. Mineral Industry $9: 505-509$ (1901)

06 The [San Francisco] earthquake explained. M Sc Press 92: 401-402 (1906 Reprinted in After earthquake and fire 161-170, San Francisco 1906

Cooper, C. A.

99 The tungsten ores of San Juan Co., Colo. Eng M J 67:499 (1899)

Cooper, H. C.

12 (with Kraus, E. H.) Die optischen Eigenschaften einlger Bleisilikate. Centt Min : 289-295 (1912)

Cooper, James Graham (1830-1902).

71 Catalogue of the invertebrate fosils of the western slope of the United States. Part II. Cal - G S: 30 pp, San Francisco 1871

74 Remarks on California cosl. Cal Ac Sc, $\operatorname{Pr} 5:$ 384-386 (1874)

74a California during the Pliocene epoch. Cal Ac Sc, Pr $5: 389-392$ (1874)

74b California in the Miocene epocb. Cal Ac Sc, Pr 5 : 401-404 (1874)

74c The Eocene epoch in Californla: are there really no Eocene strata? Cal di Sc, $\operatorname{Pr} 5: 419-421$ (1874) Abst, Am J Sc (3) $14: 321-322$ (1877)

74d Note on Tertiary formation of Call fornia. Cal Ac Sc, Pr 5: 422 (1874)

86 On fossil and subfossil land shells of the United States ... Cal Ac Sc, B [1] no $4: 235-255$ (1886)

87 West coast Pulmonata, fossil and lis. ing. Cal Ac Sc, B 2 nos $7,8: 355-376$, $497-514$ (1887); $\operatorname{Pr}$ (2) $1: 11-24$ (1888)

88 Catalogue of Callfornia fossils. Cal St M Bur, An Rp $7: 221-308$ (1888)

90 The value of fossils as indications of important mineral products. Cal st If Bur, An Rp 9:284-286 (1890) 
Cooper, James Graham-Continued.

94 Catalogue of Californian fossils (parts II, III, IV, and V). Cal St M Bur, B 4:65 pp, 11, Sacramento 1894

94a On some Pliocene fresh-water fossils of California. Cal Ac Sc (2) $4: 166$ 172 , il (1894)

97 On some new Cretaceous (and Eocene?) Mollusca of California. Cal Ac Sc, $\operatorname{Pr}$ (2) 6:330-337, 11 (1897)

Cooper, Theodore.

81 New theory of the formation of coal. Eng M J $32: 103$ (1881)

Cooper, Thomas (1759-1840).

21 Syllabus of a course of lectures on the elements of geological mineralogy ... $8 \mathrm{pp}$, Columbia [S C] 1821

22 on volcanoes and volcanic substances, with a particular reference to the origin of the rocks of the floetz trap formation. Am J Sc $4: 205-243 \quad$ (1822)

36 On the connection between geology and the Pentateuch ... 64 pp, Columbia 1836

Cooper, William (?-1864).

24 On the remains of the Megatherium recently discovered in Georgia. Lyc $\mathrm{N} \mathrm{H}$ N Y, An 1:114-124 (1824) Also in Godman, John D., American Natural History 2:187-196, Phila. 1826.

27 Further discovery of fossil bones in Georgia and remarks on their identity with those of the Megatherium of Paraguay. Lyc N H N Y, An $2: 267-270$ (1827)

31 Notices of Big Bone lick [Ky.]. Monthly Am J G 1:158-174, 205-214, map (1831)

$27 a$ (with Mitehill, S. L., and Smith, J. A.) Discovery of a fossil walrus in Virginia, Lyc N H N Y, An 2:271-272 (1827)

31a (and others.) ... fossil bones disinterred at Big Bone Lick, Ky.... Am J Sc 20:370-372 (1831)

36 A report on some fossil bones of the Megatonyx from Virginla ... Lye N H N Y, An $3: 166-173 \quad(1836)$

Cooper, William Funk.

88 Tabulated list of fossils known to occur in the Waverly of Ohio. Denison Univ, Sc Lab, B 4: 123-130 (1888)

90 The Waverly group. Denison Univ, Se Lab, B $5: 24-34$ (1890)

95 The Paleozoic formation. Denison Univ, Sc Lab, B 9:1-10 (1895)

00 [Geology of Huron o.] Ohio correlations. Mich G S 7 pt 2:285-294 (1900) $00 a$ (with Lane, A. C.) Fossils of the Marshall and Coldwater. Mich G S 7 pt $2: 252-285$, il $(1900)$

04 [Notes on water resources of] lower Michigan. U S G S, W S P 102:489512 (1904)

05 Water supply of the Lower Peninsula of Michigan. Mich G S, Rp 1903: 47-109, maps (1905)
Cooper, William Eunk-Continued.

05a The coal formation of Bay Co.

Mich Miner 7 nos 9-12 (1905)

06 Geological report on Bay Co. [Mich.]. Mich G S, An Rp 1905: 135-426 (1906)

07 Geology and physical geography of Michigan. Mich Ac Sc, Rp 9:136-144 (1907)

os Pleistocene beaches of Saginaw Co. Mich Ac Sc, Rp 10:90-98 (1908)

09 (and Lane, A. C.) Report on the geology of Tuscola Co., Mich.; Paleozoic geology. Mich G S, Rp 1908:175-196 (1909)

Cope, Edward Drinker (1840-1897).

65 On Amphibamus grandiceps, a new batrachian from the Coal Measures. Ac N Sc Phila, Pr 1865: 134-137

66 Supplement to the descriptions of vertebrates. III G S $2: 135-141$, il (1866)

$66 a[O n$ vertebrates of the Mesozoic red sandstone from Pnoenixville, Pa.] Ac N Sc Phila, Pr 1866: 249-250

66b [On a gigantic dinosaur from the Cretaceous of New Jersey.] Ac N Sc Phila, Pr 1866:275-279 Abst, Am J Sc (2) $42: 425$ (1866)

66c [On the Triassic age of the Mesozoic sandstone of Pennsylvania.] Ac N Sc Phila, Pr 1866:290

66d [On the genus Laelaps.] Ac N Sc Phila, Pr 1866:316-317

67 The fossil reptiles of New Jersey. Am Nat $1: 23-30$ (1867) ; 3:84-61, il (1868)

67a On Euclastes, a genus of extinct Chelonifdae. Ac N Sc Phila, Pr 1867: $39-42$

67b [On four extinct species of Mammalia from Miocene deposits of Charles Co., Md.] Ac N Se Phila, Pr 1867: 131132

67e An addition to the vertebrate fauna of the Miocene period, with a synopsis of the extinct Cetacea of the United States. Ac N Sc Phila, Pr 1867: 138-156

67d [Account of extinct reptlles which approach birds.] Ac N Se Phila, Pr 1867: 234-235

68 Synopsis of the extinct Reptilia found in the Mesozoic and Tertiary strata of New Jersey, N J G S, G N J : 733-738 (1868)

68 a Synopsis of the extinct Mammalia of New Jersey, N J G S, G N J : 739-742 (1868)

6Sb [On remains of a large enaliosaur, Elasmosaurus, from Fort Wallace, Kans.] Ac N Sc Phila, Pr 1868: 92-93

68e [On Osteopygis, a new genus of Cheloniidae.] Ac N Sc Phila, Pr 1868: 147 68d [Remarks on Palaeophis littoralis from Monmouth Co., N. J.] Ac N Sc Phila, Pr 1868: 147

68e [On the fresh-water origin and the relations of certain sands and clays in New Jersey, Maryland, and Virginia.] Ac N Sc Phila, Pr 1868: 157-158 
Cope, Edward Drinker-Continued.

68f [Remarks on extinct Cetacea from the Miocene of Maryland.] Ac N Sc Phila, Pr 1868: 159-160

68g $[$ On reptllian remains from New Jersey.] Ac N Sc Phila, Pr 1868: 181

$68 h$ Second contribution to the history of the Vertebrata of the Miocene period of the United States. Ac N Sc Phila, Pr 1868: 184-194

68i Synopsis of the extinct Batrachia of North America. Ac $\mathrm{N}$ Sc Phlla, Pr $1868: 208-221$

68j On some Cretaceous Reptilia. Ac N Sc Phila, Pr 1868:233-242

68k on the origin of genera. Ac $\mathrm{N}$ Sc Phila, Pr 1868: 242-300

681 [On reptilian remains from New Jersey and Maryland.] Ac $\mathrm{N}$ Sc Phila, Pr $1868: 313$

$68 m$ on the genus Laelaps. Am J Sc (2) $46: 415-417$ (1868)

$68 n$ Note on the fossil reptiles near Fort Wallace [Kans.]. In Le Conte, John L., Notes on the geology of the survey for the extension of the Union Pacific Railway...: 68 , Phila 1868

69 On the reptilian orders, Pythonomorpha and Streptosauria. Boston Soc N H, Pr 12: 250-266 (1869)

69a Descriptions of some extinct fishes previously unknown. Boston Soc $\mathrm{N}$ H, Pr $12: 310-217$ (1869)

$69 b$ Third contribution to the fauna of the Miocene period of the United States. Ac N Sc Phila, Pr 1869:6-12

69e [On reptilian remains from New Jersey and Kansas.] Ac N Sc Phila, Pr $1869: 123$

69d [On reptilian remains from North Carolina.] Ac N Sc Phila, Pr 1869: 192

69e [On Cretaceous tortoises and relathons of the Dinosauria to the birds. Am Ph Soc, Pr 11: 16 (1869)

698 On some reptilian remains. Am Ph Soc, Pr 11:116-117 (1869) Am J Se (2) $48: 278$ (1869)

$69 \mathrm{~g}$ Synopsis of the extinct Mammalia of the cave formations in the United States ... Am Ph Soc, Pr 11: 171-192, il (1869)

$69 h$ On two new genera of extinct Cetacea (abst). Am Nat $3: 444$ (1869) Can Nat n s $4: 320-321$ (1869)

ro Extinct Batrachia, Reptilia, and Aves. Am Ph Soc, Tr n s 14:1-252, 11 (1870)

70a On the Megadactylus polyzelus of Hitchcock. Am J Sc (2) 49:390-392 (1870) An Mag $\mathrm{N} H$ (4) $5: 454-455$ (1870)

7Ob [Review of] Maack, G. A., Die bis jetzt bekannten Schildkröten ... [íncludes notes on American forms]. Am J Sc (2) 50: 136-139 (1870)

70c On Elasmosaurus platyurus Cope. Am J Sc (2) 50:140-141, 268-269 (1870)
Cope, Edward Drinker-Continued.

rod Second addition to the history of the flishes of the Cretaceous of the United States, Am Ph Soc, Pr 11:240-244, I] (1870)

70e On some Reptilia of the Cretaceous formation of the United States. Am $\mathrm{Ph}$ Soc, Pr 11: 271-274 (1870)

70r Fourth contribution to the history of the fauna of the Mlocene and Eocene periods of the United States, Am $\mathrm{Pb}$ Soc, Pr 11: 285-294 (1870)

70g On Adocus, a genus of Cretaceous Emydidae. Am Ph Soc, Pr 11:295-298 (1870)

70h Observations on the fishes of the Tertiary shales of Green River, Wyo. Am $\mathrm{Ph}$ Soc, Pr 11:380-384 (1870)

70i Supplementary notice of a nеw chimaeroid from New Jersey, Leptomylus cookii Cope. Am Ph Soc, Pr 11:384 (1870)

70j On the Reptilia of the Triassic formations of the Atlantic region. Am Ph Soc, Pr 11:444-446 (1870) An Mag N H (4) $6: 498-500$ (1870)

70k [Liodon perlatus; and the results of studies of the crania ... of Reptilia and Batrachia, recent and extinct.] $\mathrm{Am} \mathrm{Pb}$ Soc, $\operatorname{Pr} 11: 497-498$ (1870)

701 [On Cretaceous reptiles from Kan. sas.] Ac N Sc Phila, Pr 1870: 132

70m Discovery of a huge whale in North Carolina [Mesoteras kerrianus]. Am Nat $4: 128(1870)$

7On Reptilia of the Triassic formation of the United States (abst). Am Nat 4: $562-563$ (1870)

71 On the fossil reptiles and fishes of the Cretaceous rocks of Kansas. U S G 8 Wyo (Hayden), Prel Rp [4]:385-424 (1871)

71a On the flshes of the Tertiary shales of Green River, Wyo. T. U S G S Wyo (Hayden), Prel Rp [4] : 425-431 (1871)

71b On the homologies of some of the cranial bones of the Reptilia, and on the systematic arrangement of the class. All As, Pr $19: 194-247,11$ (1871)

71e On the remains of a new Cretaceots tortoise [Adocus synthetious]. Am Ph Soc. Pr 11: 515 (1871)

71d On the Saurodontidae. $A \mathrm{~m} \mathrm{Ph} \mathrm{Soc}$ Pr 11: 529-538 (1871)

71e On the fishes of a fresh-water Tep. tiary in Idaho. $\mathrm{Am} \mathrm{Ph}$ Soc, Pr 11:538547 (1871)

71P On the Adocidae. Am Ph Soc, $\mathrm{Pt}$ $11: 547-553$ (1871)

71\% [On reptilian fossils from Ner Jersey, New Mexico, and Kansas.] Am Ph Soc, Pr 11: 571-572 (1871)

71h On some species of Pythonomorpbs from the Cretaceous beds of Kansas and New Mexico. Am Ph Soc, Pr 11:574-584 (1871) 
Cope, Edward Drinker-Continued.

711 On three extinct Astaci from the fresh-water Tertiary of Idaho. Am Ph Soc, Pr 11:605-607 (1871)

71] Note on Saurocephalus Harlan [and rertebrates from caves in the island of Anguilla, W. I.]. Am Ph Soc, Pr 11:608 (1871)

71k Supplement to the "Synopsis of the extinct Batrachia and Reptilia of North America." Am Ph Soc, Pr 12:41-52 (1871)

711 On the occurrence of fossil Cobitidae In Idaho. Am Ph Soc, Pr 12:55 (1871)

$71 \mathrm{~m}$ Preliminary report on the Vertebrata discovered in the Port Kennedy bone cave [Pa.]. Am Ph Soc, $\operatorname{Pr} 12: 15,73-102$ (1871)

71n Note on some Cretaceous Vertebrata in the State Agricultural College of Kansas, U. S. A. Am Ph Soc, Pr 12:168170 (1871)

71o Brief account of an expedition in the valley of the Smoky Hill River in Kansas, $\mathrm{Am} \mathrm{Pb} \mathrm{Soc,} \mathrm{Pr} \mathrm{12:174-176} \mathrm{(1871)}$

71p On the extinct batrachian fauna of the Carboniferous of Linton, Ohio. Am Ph Sec, Pr 12: 177 (1871)

71q Observations on the distribution of certain extinct Vertebrata in North Carolina. $\Delta \mathrm{m}$ Ph Soc, Pr $12: 210-216$, il (1871)

$71 \mathbf{r}$ [On Sauropleura remex from the coal measures.] Ac N Sc Phila, Pr 1871:53

71s On the extinct tortoises of the Cretaceous of New Jersey. Am Nat 5:562564 (1871)

71t Geological expedition to Kansas. $\Delta \mathrm{m}$ Nat 5:792-795 (1871)

72 On the geology and paleontology of the Cretaceous strata of Kansas. U S G S Mont (Hayden), An Rp 5:318-349 (1872)

$72 \mathrm{a}$ On the vertebrate fossils of the Wasatch strata. U S G S Mont (Hayden), An $\mathrm{R}_{\mathrm{p}} 5: 350-353$ (1872)

$72 b$ Catalogue of the Pythonomorpha found in the Cretaceous strata of Kansas. $\triangle \mathrm{m}$ Ph Soc, Pr $12: 264-287$ (1872)

72c on a nex testudinate from the chalk of Kansas [Cynocercus incisus]. Am $\mathrm{Ph} \mathrm{Soc}, \operatorname{Pr} 12: 308-310$ (1872)

72d On the families of fishes of the Cretaceous formation of Kansas. $\mathrm{Am} \mathrm{Ph} \mathrm{Soc,}$ Pr 12:327-357 (1872)

72e On Bathmodon, an extinct genus of ungulates. Am Ph Soc, Pr 12:417-420 (1872)

722 On two new ornithosaurians from Kansas. Am Ph Soc, Pr 12:420-422 (1872)

$72 \mathrm{~g}$ A description of the genus Protostega, a form of extlnct Testudinata. Am $\mathrm{Ph}$ Soc, $\mathrm{Pr} 12: 422-433$ (1872)

$72 h$ [On new fossil reptiles from the Cretaceous of Kansas.] Ac N Sc Phila, Pr 1871:297-298 (1872)
Cope, Edward Drinker-Continued.

721 [On Holops pneumaticus from th $\theta$ Cretaceous green sand of New Jersey.] Ac N Sc Phila, Pr 1872: 11-12

72j List of the Reptilia of the Eocene formation of New Jersey. Ac N Sc Phila, Pr 1872: 14-18

72k on an extinct whale from California. Ac N Sc Phila, Pr 1872:29-30

721 [On Bathmodon radians from the Wasatch group.] Ac N Sc Phila, $\operatorname{Pr} 1872$ : 38 (1872) Am J Sc (3) 4:238-239 (1872) Am Nat 6:438 (1872)

72m [On Plesiosaurus guto and other reptilian remains from Sheridan, Kans.] Ac N Sc Phila; Pr 1872:127-129

72n [On Pythonomorpha and other reptiles from the Kansas Cretaceous.] Ac N Sc Phila, Pr 1872: 140-141

720 Carboniferous reptiles of Ohio. Am Nat $6: 46$ (1872)

72p Food of Plesiosaurus. Am Nat 6 : 439 (1872)

72q The geological age of the coal of Wyoming. Am Nat 6:669-671 (1872)

72r The Eocene genus synoplotherium. Am Nat 6:695 (1872)

72s The probascidians of the American Eocene. Am Nat $6: 773-774$ (1872); 7 : 49 (1873)

72t The armed Metalophodon. Am Nat 6: 774-775 (1872)

72n The fish beds of Osino, Nev. Am Nat $6: 775$ (1872)

$72 v$ On the extinct tortoises of the Cretaceous of New Jersey (abst). Am $\mathbf{A s}, \mathrm{Pr}$ $20: 344-345$ (1872)

73 On the extinct Vertebrata of the Eocene of Wyoming ... with notes on the geology. U S G S Terr (Hayden), An Rp 6: 543-649, il (1873)

73a Synopsis of new Vertebrata from the Tertiary of Colorado obtained during the summer of 1873 . $19 \mathrm{pp}$, Washington 1873 [Printed in advance as extract from the seventh annual report of the U S G S Terr (Hayden)]

73b Paleontological Bulletíns [Nos. 140] ; Preliminary [to Nos, 1-13], $2 \mathrm{pp}$, Phila, 1873

73e Descriptions of some new Vertebrata from the Bridger group of the Eocene. Am Ph Soc, Pr 12:460-465 (1873) Pal B no 1: 6 pp (1872)

73d Second account of new Vertebrata from the Bridger Eocene. $\mathrm{Am} \mathrm{Ph} \mathrm{Soc}, \mathrm{Pr}$ 12: 466-468 (1873) Pal $B$ no $2: 3 \mathrm{pp}$ (1872)

73e Third account of new Vertebrata from the Bridger Eocene of Wyoming Territory. $\triangle \mathrm{m}$ Ph Soc, $\operatorname{Pr} 12: 469-472$ (1873) Pal B no $3: 4$ pp (1872)

73f On the existence of Dinosauria in the transition beds of Wyoming [Aga. thaumas sylvestris]. Am $\mathrm{Ph}$ Soc, $\operatorname{Pr} 12$ : 481-483 (1873) Pal B no $4: 2$ pp n d [1872] 
Cope, Edward Drinker-Continued.

73g Notice of proboscidians from the Eocene of southern Wyoming. Am Ph Soc, Pr 12:580 (1873) Pal B no 5:1 p (1872)

73h Notices of new Vertebrata from the upper waters of Bitter Creek, Wyoming Ter. Am Ph Soc, Pr 12:483-486 (1873) Pal B no $6: 4 \mathrm{pp}, \mathrm{n}$ d [1872]

73i Second notice of extinct vertebrates from Bitter Creek, Wyo. Am Ph Soc, Pr $12: 487-488$ (1873) Pal B no $7: 2$ pp (1872)

73j On a new vertebrate genus from the northern part of the Tertiary basin of Green River [Anaptomorphus aemulus]. Am Ph Soc, $\operatorname{Pr} 12: 554$ (1873) Pal B no $8: 1 \mathrm{p}$ (1872)

731k Descriptions of new extinct reptiles from the upper Green River Eocene basin, Wyo. Am Ph Soc, Pr 12:554-555 (1873) Pal B no $9: 1 \mathrm{p}(1872)$

731 [Age of the coal series of Bitter Creek, Wyo.] Ac N Sc Phila, Pr 1872: 279-280 (1873) Pal B no $10: 2$ pp [1873]

$73 \mathrm{~m}$ On the new perissodactyles from the Bridger Eocene. Am Ph Soc, Pr 13: $35-36$ (1873) Pal B no $11: 2$ pp (1873)

73n On some Eocene mammals obtained by Hayden's geological survey of 1872 . Pal B no 12:6 pp (1873)

73o On some of Prof. Marsh's critieisms. Am Nat $7: 290-299$, il (1873) Pal B no $13: 8$ pp (1873)

73p on some new extinct Mammalia from the Tertiary of the Plains. Pal B no $14: 2$ pp (1873)

73q Second notice of extinct Vertebrata from the Tertiary of the Plains, Pal B no $15: 6$ pp (1873)

73r Third notice of extinct Vertebrata from the Tertiary of the Plains. Pal $B$ no $16: 8 \mathrm{pp} \mathrm{(1873)}$

73s Fourth notice of extinct Vertebrata from the Bridger and the Green River Tertiaries. Pal B no 17:4 pp (1873)

73t The monster of Mammoth Buttes [Loxolophodon cornutus Cope]. Penn Monthly 4:521-534, il (1873)

73u On a new genus of Pleurodira from the Eocene of Wyoming. $\mathrm{Am} \mathrm{Ph}$ Soc, Pr 12:472-477 (1873)

$\mathbf{7 3 v}$ on the Tertiary coal and fossils of Osino, Nev. Am Ph Soc, Pr $12: 478-481$ (1873)

$\mathbf{7 3 w}$ On the dentition of Metalophodon. $\mathrm{Am} \mathrm{Ph}$ Soc, Pr 12:542-545 (1873)

$\boldsymbol{7 3 x}$ Note on the Cretaceous of Wyoming. $\Delta \mathrm{m} \mathrm{J} \mathrm{Sc} \mathrm{(3)} 5: 230-231$ (1873)

73y On the short footed Ungulata of the Eocene of Wyoming. $\mathrm{Am} \mathrm{Ph}$ Soc, $\mathrm{Pr}$ 13: 38-74 (1873) J : :ool, Paris, 2:168185 , 11 (1873)

73z On the flat-clawed Carnivora of the Eocene of Wyoming. Am $\mathrm{Ph}$ Soc, Pr 13 : 198-209 (1873)
Cope, Edward Drinker-Continued.

73xa on the osteology of the extinct tapirold Hyrachyus. Am Ph Soc, Pr 13: 212-224 (1873)

$\mathbf{7 3 x b}$ [On saurodont fishes from the Niobrara of Kansas.] Ac N Sc Phila, Pr $1872: 280-281$ (1873)

73ze [Remarks on additional specimens of Toxoehelys latiremis from the Cretaceous of Kansas.] Ac N Sc Phíla, Pr 1873:10

73xd [Observations on the structure and systematic position of the genus Eobas. leus.] Ac N Se Phila, Pr 1873: 10-12

73ze [On proboscidlan remains from Wyoming.] Ac N Sc Phlla, Pr 1873:102

73zf [On bones of Sus soropha from the Miocene of Wilson Co., N. C.] Ac N Sc Phila, Pr 1873:207

73zg [On batrachian remains from the Green River shale, Eocene, of Wyoming.] Ac N Sc Phila, Pr 1873:207-208

73xh Extinct turtles from the Eocene strata of Wyoming. Ac $\mathrm{N}$ Sc Phila, Pr $1873: 277-279$

73xi On two new species of Saurodor. tidae. Ac N Sc Phila, Pr 1873: $337-339$

73zk On some new Batracbia and fishes from the Coal Measures of Linton, Obio. Ac N Se Phila, Pr 1873:340-343

73xl The gigantic mammals of the genus Eobasileus. Am Nat 7:157-160 (1873)

$73 \mathbf{z m}$ The Eobasileus again. Am Nat $7: 180$ (1873)

$\boldsymbol{7 3 x n}$ On the tusk of Loxolophodos cornutus. Am Nat $7: 315$ (1873)

73zo On Professor Marsh's criticisms. Am Nat 7 : appendix to July no: 1 p (1873)

$\mathbf{7 4}$ Report on the vertebrate paleontolog of Colorado. U S G Geog S Terr (Hayden), An Rp [7] : 427-533, il (1874)

$\mathbf{7 4 a}$ Report on the stratigraphy and Pll. ocene vertebrate paleontology of northern Colorado. U S G Geog S Terr (Hayden), B [1] no. 1:9-28 (1874)

74b Review of the Vertebrata of the Cretaceous period found west of the Mils. sissippi River. U S G Geog S Terr (Has. den), B [1] no 2:5-48 (1874)

74c Supplementary notices of fisbes from the fresh-water Tertiaries of the Rocky Mountains. U S G Geog S Tert (Hayden), B [1] no 2:49-51 (1874)

74d Notes on the Eocene and Pliocene lacustrine formations of New Mexico, including descriptions of certain new species of vertebrates. In Wheeler, G. M., Annual report ... surveys west of the 100 th merld. ian ... : $115-130 \quad(1874) \quad$ Also in $U$ \& [War Dp], Chief Eng, An Rp 1874 (U \& 43d Cong $2 d$ sess, H Ex Doc 1 pt 2 v 2 pt 2) App FF: $591-606$ (1874) Extract, with title, Report upon vertebrate fossils discovered in New Mexico ...: 18 pp, Washington 1874 
Cope, Edward Drinker-Continued.

74e On the homologies and origin of the types of molar teeth of Mammalia educabilia. Ac N Sc Phila, J (2) $8: 71-89$, il (1874)

$\mathbf{7 4 f}$ On the types of molar teeth. Ac N Sc Phila, Pr 1873: 371 (1874)

74g [Remarks on fishes from the coal measures at Linton, Ohio.] Ac N Sc Phila, Pr 1873: 417-419 (1874)

$\mathbf{7 4 h}$ [On vertebrate fossils from the Miocene of Colorado. Ac N Sc Phila, Pr 1873; 419-420 (1874)

$\mathbf{7 4 1}$ [On the Cretaceous age of the lignites of the West.] Ac N Sc Phila, Pr $1874: 10-11,12-13$

$\mathbf{7 4 j}$ [On Symborodon from the Miocene of Colorado.] Ac N Sc Phila, Pr 1874: 89- 90

$\mathbf{7 4 k}$ [On Ctenodus, a dipnoan fish, from the coal measures of Ohio.] Ac $N$ Sc Phila, Pr 1874: 91-92

741 [Observations on vertebrate fossils of Colorado.] Ac N Sc Phila, Pr 1874: 116-117

$74 \mathrm{~m}$ Notes on the Santa Fe marls, and some of the contained vertebrate fossils. Ac N Se Phila, Pr 1874: 147-152 (1874) Pal B [no 18] : 147-152 (1874)

$74 \mathrm{n}$ On Eobasileus galeatus from Wy. oming and a walrus fossil cranium from Virginia. Am Ph Soc, Pr 14:17-18 (1874)

74o [On the anatomy and relations of Poebrotherium Leldy.l Am Ph Soc, Pr $14: 110$ (1874)

74p The succession of life in North America. Penn Monthly 5: 138-145 (1874) An $\mathrm{Mag} \mathrm{N}$ H (4) $13: 326-331$ (1874)

74 On some extinct types of horned Perissodactyles. Am As, Pr 22, pt 2:108109 (1874) An Mag N H (4) 13:405406 (1874) Can Nat n $\mathrm{s} 7: 169-171$ (1874)

75 The Vertebrata of the Cretaceous formations of the West. U S G S Terr (Hayden), Rp 2:303 pp, il (1875)

$75 \mathrm{a}$ On the fishes of the Tertiary shales of the South Park [Colo.]. U S G Geog 8 Terr (Hayden), B [1] (2) $1: 3-5$ (1875)

75b Systematic catalogue of Vertebrata of the Eocene of New Mexico, collected in 1874, U S Geog S W 100th Mer (Wheeler) : $37 \mathrm{pp}$, Wasbington 1875

$75 \mathrm{e}$ Report on the geology of that part of north-western New Mexico examined during the field season of 1874 . In wheeler, G M., Annual report ... surveys west of the 100th meridian ...: $61-97$, il (1875) Also in U S [War Dp], Chlef Eng, An Rp 1875 (U S, 44th Cong 1st sess, H Ex Doc 1 pt 2 v 2 pt 2) App LL : 981-1017, il (1875) [Includes description of Unio cristonensis from Triassic beds by F. B. Meek.]

$75 d$ Check list of North American Batrachia and Reptilia. ... U S Nat Mus, B 1:104 pp (1875)
Cope, Edward Drinker-Continued.

75e Synopsis of the extinct Batrachia from the coal measures. Ohio G S. Rp 2 pt 2 Paleontology: 349-411, il (1875)

75f Report on the vertebrate fossils from the Fort Union group of Milk River. In Dawson, G. M., Report on the geology ... of the forty-ninth parallel, British N Am Boundary Comm:333-337, Montreal 1875

$\mathbf{7 5 g}$ Synopsis of the Vertebrata whose remains have been preserved in the formations of North Carolina. In Kerr, W. C., Report of the geological survey of North Carolina 1, App : 29-52, il, Raleigh 1875

75h Supplement to the extinct Batrachia and Reptilia of N. America; I, Catalogue of the air breathing Vertebrata from the Coal Measures of Linton, Ohio. $\mathrm{Am} \mathrm{Ph}$ Soe, Tr n s 15: 261-278 (1875)

75i Synopsis of the Vertebrata of the Miocene of Cumberland Co., N. J. Am Ph Soe, $\operatorname{Pr} 14:$ 361-364 (1875)

75j on a new mastodon and rodent. Ac N Se Phila, Pr 1874:221-223 (1875)

$75 \mathrm{k}$ On the characters of Symborodon. Ac N Sc Phila, Pr 1874: 224-225 (1875)

751 On the transition beds of the Saskatchewan district. $\Delta c \mathrm{~N}$ Sc Phila, Pr $1875: 9-10$

$75 \mathrm{~m}$ The extinct Batrachia of Ohio. Ac N Sc Phila, Pr 1875: 16

$75 n$ On green sand Vertebrata. Ac $\mathrm{N}$ Sc Phila, Pr 1875: 19

75o On the homologies of the sectorial tooth of Carnivora. Ac N Sc Phila, Pr $1875: 20-23$

75p The feet of Bathmodon. Ac N Sc Phila, Pr 1875:73

$75 \mathbf{\alpha}$ On fossil lemurs and dogs. Ac $\mathrm{N}$ Sc Phila, Pr 1875: 255-256

$75 \mathbf{r}$ On the antelope deer of the Santa Fe marls. Ac N Sc Phila, Pr 1875:257

$75 \mathrm{~s}$ On some new fossil Ungulata. Ac N Sc Phila, $\operatorname{Pr} 1875: 258-261$ (1875) Pal $\mathrm{P}$ [no 19]: $8 \mathrm{pp}$ (1875)

75t The phylogeny of the camels. Ac N Sc Phila, Pr 1875:261-262

$75 u$ The geology of New Mexico. Ac N Sc Phila, Pr 1875: 263-267, 269 (1875) Abst, Am J Sc (3) 10:152-153 (1875)

$75 \mathrm{v}$ On an extinct vulturine bird. Ac N Sc Phila, Pr 1875: 271

$75 w$ On the Cretaceous beds of the Galisteo [sandstones of New Mexico]. Ac N Sc Phila, Pr 1875:359-360

$75 x$ on fossil remains of Reptilia and fishes from Illinois. An N Sc Phila, Pr 1875: 404-411 (1875) An Mag N H (4) $17: 178-184$ (1875)

75y The value of paleontology. Penn Monthly $6: 55-62$ (1875)

$75 x$ The relation of man to the Tertiary Mammalia. Penn Monthly 6:879-886 (1875) 
Cope, Edward Drinker-Continued.

75za The Wheeler geological survey of New Mexico for 1874. Am Nat 9:49-52 (1875)

$75 \mathbf{x b}$ A new mastodon $[M$. productus Cope, Santa Fe marls1. Am Nat 9:56 (1875)

75ze futeresting fossils from tllinols [saurians and fishes]. Am Nat 9:573 (1875)

75zd Note on the genus Calamodon. $\mathrm{Am} \mathrm{J} \mathrm{Sc} \mathrm{(3)} \mathrm{9:228} \mathrm{(1875)}$

76 On the supposed Carnivora of the Eocene of the Rocky Mountains. Ac N Sc Phila, Pr 1875:444-448 (1876) Pal B [no 20]: 4 pp (1875)

$76 a$ On a gigantic blrd from the Eocene of New Mexico. Ac N Sc Pbila, Pr 1876: 10-11

76b On the Trenlodonta, a new group of Eocene Mammalia. Ae $\mathbf{N}$ Se Phlla, Pr $1876: 39$

F6e On the geologic age of the vertebrate fauna of the Eocene of New Mexico. Ac N Sc Phila, Pr 1876:63-66 Am J Sc (3) $12: 297-298$ (1876) Pal B no $21: 3$ pp (1876) J Zool, Paris, 5:307-311 (1876)

76d On some supposed lemurine forms of the Eocene period. Ac N Sc Phila, Pr 1876 : 88-89

76e On a new genus of fossil fishes. Ac N Sc Phila, Pr 1876:113

76f On a new genus of Camelidae. Ac N Sc Phfla, Pr 1876:144-14

$76 \mathrm{~g}$ Descriptions of some vertebrate remains from the Fort Jnion beds of Montana. Ac N Sc Phila, P 1876: 248-261 (1877) Pal B no 22:14 pp (1876)

77 Report upon the extinct Vertebrata obtained in New Mexico ... U S Geog S W 100th Mer (Wheeler), 4 pt 2:371 pp, il (1877)

77a Report on the geology of the region of the Judith River, Mont., and on vertebrate fossils obtained on or near the Missouri Kiver. U S G Geog S Terr (Hayden), B $3: 565-598$, il (1877)

77. On a carnivorous dinosaurian from the Dakota beds of Colorado. U S G Geog S Terr (Hayden), B 3:805-806 (1877)

$77 \mathrm{e}$ A contribution to the nowledge of the ichthyological fauna of the Green River shales. U S G Geog S Terr (Hayden), B $3: 807-819$ (1887)

77d On the genus Erisichte. U S G Geog S Terr (Hayden), B 3: 821-823 (1877)

77e On rome extinct reptiles and Batrachia from the Judith River and Fox Hills beds of Montana. Ac N Sc Phila, Pr 1876:340-359 (1877)

77p Cretaceous vertebrates of the upper Missouri. Ac N Sc ila, Pr 1876: 266 (1877)
Cope, Edward Drinker-Continued.

$\mathbf{7 7 g}$ Vertebral column of an Elasmo. saurus [E. serpentinus]. Am Ph Soc, $\mathrm{Pt}$ $16: 393-394$ (1877)

77h A contintation of researches among the Batrachia of the Coal Measures of Ohío, Am Ph Soc, Pr 16:573-578 (1877) Pal B no 24:573-578 (1877)

771 On a dinosaurian from the Trias of Utah [Dystrophaeus]. Am Ph Soc, P? 16:579-584 (1877) Pal B no 24:572$584(1877)$

77f On a new proboscidian [Caenoba. sileus ]. Am Ph Soc, Pr $16: 584-585$ (1877) Pal B no 24:584-585 (1877)

77k On the brain of Coryphodon, Am Ph Soc, Pr 16:616-620 (1877)

771 ... new locality of the Green River shales containing fishes, insects, and plants in a good state of preservation. $\mathrm{Pal} B$ no $25: 1$ (1877)

$77 \mathbf{m}$ On a gigantic saurian from the Dakota epoch of Colorado [Camarasaurus supremus]. Pa1 B no 25:5-10 (1877)

$\boldsymbol{7 7 n}$ On Amphicoeiias, a genus of sauth ans from the Dakota epoch of Colorado. Pal B no 27:2-5 (1877)

770 The Suessonian fauna in North America. Am Nat 11:95-99 (1877)

77p The discovery of Laelaps in Moptana. Am Nat 11:311 (1877)

77q The sea serpents of the Cretaceous period. Am Nat 11:311 (1877)

77r The dentition of the herbivorous Dinosauria of the lignitic period. Am Nat 11: 311-312 (1877)

77s The lowest mammalian brain. Am Nat 11:312-313 (1877)

77t On the classification of the recent and fossil fishes (abst). Am Nat 11:501 (1877)

77u New fossil fishes from Wyoming (abst). Am Nat 11:570 (1877)

$77 \mathbf{v}$ The largest known saurian [Camaersaurus supremus]. Am Nat 11:629 (1877)

$\mathbf{7 7 w}$ Remains of a huge saurian in Pentsylvania [Palaeoctonus appalachianus], Am Nat 11:629 (1877)

78 Descriptions of fishes from the Cre taceous and Tertiary deposits west of the Mississippl River. U S G Geog 8 Tert (Hayden), B 4:67-77 (1878)

78a Professor Owen on the Pythono. morpha. U S G Geog S Terr (Hayden), B 4:299-311 (1878)

78b Descriptions of new extinct Vertebrata from the upper Tertiary and Dakots formations. U S Geog S Terr (Hayden), B 4:379-396 (1878)

78c On the brain of Procameliss oct dentalis. $\triangle \mathrm{m}$ Ph Soc, $\mathrm{Pr} 17: 49-52$, (1878)

$\mathbf{7 8 d}$ On the Vertebrata of the bone bed in eastern Illinois. $\mathrm{Am} \mathrm{Ph}$ Soc, $\mathrm{Pr} 17$ : 52-63 (1878) 
Cope, Edward Drinker-Continued.

78 e On a new species of Adocidae from the Tertiary of Georgia. Am Ph Soc, Pr $17: 82-84(1878) \quad$ Pal B no $25: 2-4$ (1877)

781 On some new or little known reptiles and fishes of the Cretaceous No. 3, of Kansas. $\mathrm{Am} \mathrm{Ph}$ Soc, $\mathrm{Pr}$ 17:176-181 (1878) Pal B no 26:176-181 (1877)

$78 \mathrm{~g}$ Descriptions of extinct Vertebrata from the Permian and Triassic formations of the United States. Am Ph Soc, Pr 17 : 182-193 (1878) Pal B no 26:182-193 (1877)

78h On reptilian remains from the Dakota beds of Colorado. Am $\mathrm{Ph} \mathrm{Soc,} \mathrm{Pr}$ $17: 193-196$ (1878) Pal B no 26:193196 (1877)

781 Descriptions of new Vertebrata from the upper Tertiary formations of the West. Am Ph Soc, Pr $17: 219-231$ (1878) Pal $B$ no $28: 219-231$ (1878)

$78 \mathrm{j}$ On some saurians found in the Triassic of Pennsylvania. Am $\mathrm{Ph}$ Soc, $\mathrm{Pr}$ 17:231-232 (1878) Pal B no 28:231$232(1878)$

78k On the Vertebrata of the Dakota epoch of Colorado. Am Ph Soc, Pr 17 : 233-247 (1878) Pal B no $28: 233-247$ (1878)

781 Descriptions of extinct Batrachia and Reptilia from the Permian formation of Texas. Am Ph Soc, Pr 17:505-530 (1878) $\mathrm{Pal} B$ no $29: 505-530$ (1878)

$78 \mathrm{~m}$ On the classification of the extinct fishes of the lower types. Am As, Pr 26: 292-300 (1878)

$78 n$ The saurians of the Dakota epoch. Am Nat 12:56-57 (1878)

780 New artiodactyles of the upper Tertlary. $A \mathrm{~m}$ Nat 12:58 (1878)

78 p 0 the saurians recently discovered in the Dakota beds of Colorado. Am Nat 12: 71-85, il (1878)

$78 q$ A new mastodon [Tetralophodon campester]. Am Nat 12:129 (1878)

$78 \mathrm{r}$ A new genus of Dinosauria from Colorado [Hypsirophus discurus]. Am Nat 12 : 188-189 (1878)

78s A new deer from Indiana [Cariacus dolichopsis]. Am Nat 12:189 (1878)

$78 t$ [Review of] contributions to the fossil flora of the western territories; Part II, The Tertiary flora by $L$. Lesquereux. Am Nat $12: 243-246$ (1878)

$78 u$ The homology of the chevron bones. Am Nat 12:319 (1878)

$78 \mathrm{v}$ The structure of Coryphodon. Am Nat $12: 324-326 \quad(1878)$

78w A new fauna [Permian]. Am Nat $12: 327-328$ (1878)

$78 \times$ A new oplsthocoelous dinosaur [Epanterias amplexus]. Am Nat 12:406 (1878) An Mag N H (5) 2:194 (1878)

78 y Prof. Marsh on Permian reptiles. Am Nat 12:406-408 (1878)
Cope, Edward Drinker-Continued.

$\mathbf{7 8 z}$ The species of rhinoceros of the Loup Fork epoch. Am Nat 12:488-489 (1878)

78za A new species of Amphicoelias [A. fragillimus]. Am Nat $12: 563-564$, il (1878)

7Szb A new Diadectes [D. molaris]. Am Nat 12:565 (1878)

78ze The vertebrae of Rachitomus. Am Nat 12:633 (1878)

78zd The theromorphous Reptilla. Am Nat 12:829-830 (1878)

79ze On the saurians of the Dakota Cretaceous rocks of Colorado (abst). N2ture 18: 476 (1878)

78ze On the remains of a Permian fauna in North America (aost). Nature 18:482 (1878)

78zg Theromorphous reptiles, Science News 1: 40 (1878)

79 The relations of the horizons of extinct Vertebrata of Europe and North America. U S G Geog S Terr (Hayden), B $5: 33-54$ (1879)

79n Observations on the faunae of the Miocene Tertiaries of Oregon. U S G Geog S Terr (Hayden) B 5:55-69 (1879)

79b On the extinct species of Rhinoc. eridae of North Ameriza and their allies. U S G Geog S Terr (Hayden), B $5: 227-$ 237 (1879)

79e On some of the characters of the Míocene fauna of Oregon. Am Ph Suc, $\mathrm{Pr}$ 18:63-78 (1879) Pal B no $30: 16$ pp (1878)

79d On the genera of Felidae and Canidae. Ac $N$ Se Phila, Pr 1879:168-194 An Mag N H (5) $5: 36-45,92-107$ (1880) 79e The necks of the Sauropterygia. Am Nat 13: 132 (1879)

79f The origin of the specialized teeth of the Carnivora. Am Nat 13:171-173 (1879)

79g Merycopater and Hoplophoneus. Am Nat 13:197 (1879)

79h A new genus of Perissodactyla [A $n$ chisodon]. Am Nat 13:270-271 (1879)

791 A new genus of Iehthyopterygia. Am Nat 13:271 (1879)

79j The Amyzon Tertiary beds [Nev.]. Am Nat 13:332 (1879)

79k A sting ray from the Green River shales of Wyoming. Am Nat 13:333 (1879)

791 American Aceratheria. Am Nat 13: 333-334 (1879)

$79 \mathrm{~m}$ The lower jaw of Loxolophodon. Am Nat 13:334 (1879)

79n New Jurassic Dinosauria, Am Nat $13: 402-404$, il (1879)

79o $\mathbf{A}$ new Anchitherium [A, praestans]. Am Nat $13: 462-463$ (1879)

79p On the extinct American rhinoceroses and their allies. Am Nat 13:771a771j, Il (1879) 
Cope, Edward Drinker-Continued.

79q The cave bear of California. Am Nat 13:791 (1879) An Mag N H (5) 5: 260-261 (1880) Am J Sc (3) 19:155 (1880)

79r [A vertebrate collecting trip.] Am Nat $13: 798 a-798 b(1879)$

79s ... priorité relative à l'empló des noms de Dinoceras et de Brontotherium. Le Naturaliste, Paris, $1: 2-3$ (1879)

79t On extinct rhinoceroses. Sclence News 1:221 (1879)

so Second contribution to a knowledge of the Miocene fauna of Oregon. Am Ph Soc, $\operatorname{Pr} 18: 370-376$ (1880) Pal $B$ no 31: 7 pp (1879)

Soa On the foramina perforating the posterior part of the squamosal bone of the Mammalia. Am Ph Soc, $\mathrm{Pr} 18: 452$ $461(1880)$

sob Sur les relations des niveaux de vertébrés éteints dans l'Amérique du Nord et en Europe. Int G Cong, Paris 1878, C $\mathrm{R}: 144-163$ (1880)

soe [Observations on fossi] vertebrates from California, Am Nat 14:62 (1880)

Sod Hill's Kansas explorations. Am Nat $14: 141-142$ (1880)

soe Notes on sabre-tooths. Am Nat 14 : 142-143 (1880)

Sof A new Hippidium [H. spectans from the Loup Fork beds of Oregon]. Am Nat $14: 223(1880)$

$80 \mathrm{~g}$ The Manti beds of Utah. Am Nat 14: 303-304 (1880)

SOh The skull of Empedocles. Am Nat $14: 304 \quad(1880)$

S0i A new genus of tapiroids [Triplopus cubitalis]. Am Nat 14:382-383 (1880)

80j The structure of the Permian Ganocephala. Am Nat 14: 383-384 (1880)

sok Corrections of the geological maps of Oregon. Am Nat 14:457-458 (1880)

801 A new genus of Rhinocerontidae [Peraceras]. Am Nat 14:540 (1880)

$80 \mathrm{~m}$ Extinct Batrachia. Am Nat 14: 609-610 (1880)

80n The genealogy of the American rhinoceroses. Am Nat 14:610-611 (1880)

80o The badlands of the Wind River and their fauna. Am Nat 14:745-748 (1880)

80p on the extinct cats of America. Am Nat 14:833-858, il (1880)

80q The northern Wasatch fauna. Am Nat 14:908-909 (1880)

sor Nimravidae and Miocene Canidae (abst). Science (ed, Michels) 1:303 (1880)

81 On some new Batrachia and Reptilia from the Permian beds of Texas. U S G Geog S Terr (Hayden), B 6:79-82 (1881)

s1a On a wading bird from the Amyzon shales. U S G Geog S Terr (Hayden), B $6: 83-85$ (1881)
Cope, Edward Drinker-Continued.

$81 b$ On the Nimravidae and Canidae of the Miocene period. U S G Geog S Ter: (Hayden), B 6:165-181'1881)

s1e On the Vertebrata of the Wind River Eocene beds of Wyoming. U S G Geog S Terr (Hayden), B 6:183-202 (1881)

S1d Review of the Rodentia of the Mio. cene period of North America. U S G Geog S Terr (Hayden), B 6:361-386 (1881)

sie On the Canidae of the Loup Fork epoch. U S G Geog S Terr (Hayden), B $6: 387-390 \quad(1881)$

S1e Second contribution to the history of the Vertebrata of the Permian forma tion. Am Ph Soc, Pr $19: 38-58$, il (1881 Pal B no $32: 22 \mathrm{pp}$, il $(1880,1881)$

$\mathbf{8 1} \mathbf{g}$ On certain Tertiary strata of the Great Basin. Am Ph Soc, Pr 19:60-6? (1881)

81h On the genera of the Creodonta. Am Ph Soc, Pr 19:76-82 (1881)

811 The systematic arrangement of the order Perissodactyla. Am Ph Soe, Pr 19 $377-401$ (1881)

81j Catalogue of Vertebrata of the Permian formation of the United States. An Nat 15:162-164 (1881)

81k On the origin of the foot structures of the ungulates. Am Nat 15:269-273, il (1881)

811 Mammalla of the lower Eocene beds Am Nat 15:337-338 (1881)

$81 \mathrm{~m}$ Miocene dogs. Am Nat 15:497 (1881)

$81 n$ On the effect of impacts and strains on the feet of Mammalia. Am Nat 15 $542-548$, il (1881)

810 The Rodentia of the American Miocene. Am Nat 15:586-587 (1881)

81p A new Clidastes from New Jerser [C. conodon]. Am Nat 15:587-588 (1881

s1a The temporary dentition of a ner creodont [Trisisodon quivirensis]. Am Nat $15: 667-669$ (1881)

81r A Laramie saurian in the Eocene [Champsasaurus australis]. Am Nat 15: 669-670 (1881)

S1s Mammalia of the lowest Eocene. $A \mathrm{~m}$ Nat $15: 829-831$ (1881)

$81 \mathrm{t}$ Geology of the Lake Valley mining district [N. Mex.]. Am Nat 15:831-832 (1881)

81 Eocene Plagiaulacidae. Am Nat 15: 921-922 (1881)

81v Belodon in New Mexico. Am Nat 15: 922-923 (1881)

81w A new type of Perissodactyla. Am Nat $15: 1017-1018$ (1881)

$81 \times$ New genus of Perissodactula Diplarthra [Systemodon]. Am Nat 15:1018 (1881)

81y Notes on Creodonta. Am Nat 15: 1018-1020 (1881) 
Cope, Edward Drinker-Continued.

S1x The Permian formations of New Mexico. Am Nat 15: 1020-1021 (1881)

82 On some Mammalia of the lowest Eocene beds of New Mexico. Am Ph Soc, Pr 19:484-495 (1882) Pal B no $33: 484$ 495 (1881)

82a Contributions to the history of the Vertebrata of the lower Eocene of Wyoming and New Mexico, made during 1881. Am Pb Soc, Pr 20:139-197 (1882) Pal B no $34: 139-197$ (1882)

s2b The classification of the ungulate Mammalia. $\mathrm{Am} \mathrm{Ph}$ Soc, $\operatorname{Pr} 20: 438-447$, il (1882) Pal B no $35: 438-447$, il (1882)

82e Third contribution to the history of the Vertebrata of the Permian formation of Texas. Am Ph Soc, Pr 20:447461 (1882) Pal B no $35: 447-461$ (1882) s2d Synopsis of the Vertebrata of the Puereo Eocene epoch. Am Ph Soc, Pr 20: $461-471$ (1882) Pal B no $35: 461-471$ (1882)

82e On the systematic relations of the Carnivora Fissipedia. $\triangle \mathrm{m} \mathrm{Ph}$ Soc, Pr 20 : 471-475 (1882) Pal B no $35: 471-475$ (1882)

82f On the Condylarthra, Ac N Sc Phila, Pr 1882:95-97 Am Mag N H (5) $10: 76-79 \quad(1882)$

82g The oldest artfodactyle [Mioclaenus brachystomus]. Am Nat 16:71 (1882) An Mag N H (5) 9:204-205 (1882)

82h The characters of the Taeniodonta. Am Nat 16:72 (1882) An Mag N H (5) 3:205-206 (1882)

\$2i New forms of Coryphodontidae. Am Nat $16: 73(1882)$

82j An anthropomorphous lemur. Am Nat $16: 73-74(1882)$

82k Recent extinction of the mastodon. Am Nat 16:74-75 (1882)

821 A new genus of Tillodonta [Psitta cotherium ]. Am Nat $16: 156-157$ (1882)

$82 \mathbf{m}$ A great deposit of mud and lava. [New Mexico]. Am Nat 16:157-158 (1882)

$82 n$ The Tertiary formations of the central region of the United States. Am Nat $16: 177-195$ (1882)

82o Marsh on the classification of the Dinosauria, Am Nat 16:253-255 (1882)

82p New characters of the Perissodactyla Condylarthra. Am Nat 16:334 (1882)

82q Mesonyx and Oxyaena. Am Nat $16: 394$ (1882)

82r The rhachitomous Stegocephall. Am Nat $16: 334-335$ (1882)

82s A second genus of Eocene Plagiaulacidae. Am Nat $16: 416-417$ (1882)

82t Two new genera of the Puerco Eocene [Haploconus and Pantolambda]. Am Nat $16: 417-418$ (1882)

$\mathbf{8 2 \pi}$ The ancestry and habits of Thylacoleo. Am Nat 16:520-522 (1882)

82v Notes on Eocene Mammalia. Am Nat $16: 522(1882)$
Cope, Edward Drinker-Continued.

$82 w$ on the Taxeopoda, a new order of Mammalia. Am Nat 16:522-523 (1882) 82x A new genus of Taeniodonta [Taeniolabis]. Am Nat 16:604-605 (1882) 82y New marsupials from the Puerco Eocene. Am Nat 16:684-686 (1882)

82z Mammalia in the Laramie formation [Meniscoëssus conquistus]. Am Nat $16: 830-831$ (1882)

S2za A new form of Taeniodonta [ $\mathrm{Hemi}$ ganus vultuosus]. Am Nat 16:831-832 (1882)

82zb The Periptychidae. Am Nat 16 : 832-833 (1882)

s2ze Some new forms from the Puerco Eocene. Amr Nat 16:833-834 (1882)

82zd Theories of the origin of the loess. Am Nat 16:920-921 (1882)

s2xe The reptiles of the American Eocene. Am Nat 16:979-993, il (1882)

S2xf Two new genera of Mammalia from the Wasatch Eocene [Diacodexis and Heptodon]. Am Nat 16: 1029 (1882)

82xg Geological age of the Lake Valley mines of New Mexico. Eng M J 34:214 (1882)

83 On the contents of a bone cave in the Island of Anguilla (West Indies). Smiths Cont Knowl 25 art 3 (489) : 30 pp, il (1883)

S3a On a ner extinct genus and species of Percidae from Dakota Territory. Am J Sc (3) 25: 414-416 (1883)

S3b First addition to the fauna of the Puerco Eocene. Am Ph Soc, Pr 20:545563 (1883) Pal B no $36: 545-563$ (1883)

83e On the brains of the Focene Mammalia Phenacodus and Periptychus. $\mathrm{Am} \mathrm{Ph}$ Soc, $\operatorname{Pr} 20: 563-565$, il (1883) Pal B no $36: 563-565$, il (1883)

83d Fourth contribution to the history of the Permian formation of Texas. Am $\mathrm{Ph}$ Soc, $\operatorname{Pr} 20: 628-636$ (1883) Pal B no $36: 628-636$ (1883)

s3e [On the antiquity of man.] Ac $N$ Sc Phíla, Pr 1882: 291-292 (1883)

88f On Uintatherium, Bathmodon, and Triisodon. Ac N Sc Phila, Pr 1882:294300 (1883)

83w On a new extinct genus of Sirenia, from South Carolina. Ac N Sc Phila, Pr $1883: 52-54$

83h The tritubercular type of superior molar tooth. Ac N Sc Phila, Pr 1883: 56

83i Permian fishes and reptiles. Ac N Sc Phila, Pr 1883: 69

83j On the mutual relations of the bunotherian Mammalia. Ac N Sc Phila, Pr 1883: 77-83 An Mag N H (5) $12: 20-26$ (1883)

s3k On the characters of the skull in the Hadrosauridae. Ac N Sc Phila, Pr $1883: 97-107$, il

831 On some Vertebrata from the Permian of Illinois. Ac N Sc Phtla, Pr 1883 ; 108-110 
Cope, Edward Drinker-Continued.

$\mathbf{8 3 m}$ On the fishes of the recent and Pliocene lakes of the western part of the Great Basin, and of the Idaho Pliocene lake. Ac N Sc Phila, Pr 1883: 134-166

s3n On some fossils of the Puerco formation. Ac N Sc Phila, Pr 1883: 168-170 83o The extinct kodentia of North America. Am Nat 17:43-57, 165-174, $370-381$, il (1883)

S3p On Uintatherium and Bathmodon. Am Nat $17: 68$ (1883)

83q The Nevada biped tracks. Am Nat $17: 69-71$, il (1883)

83r New Mammalia from the Puerco Eocene. Am Nat 17:191 (1883)

83s On the extinct dogs of North America. Am Nat 17:235-249, il (1823)

83t A new fossil sirenian [Diplotherium manigaulti]. Am Nat 17:309 (1883)

83n The ancestor of Coryphodon. Am Nat 17:406-407 (1883)

83v Note on the trituberculate type of superior molar and the origin of the quadrituberculate. Am Nat 17:407-408 (1883)

83w The genus Phenacodus. Am Nat $17: 535$, il $(1883)$

$\mathbf{8 3 x}$ Tre structure and ppearance of a Laramie dinosaurian [Diclonius mirabilis]. Am Nat $17: 774-777$, il (1883)

83y A new Pliocene formation in the Snake River valley. Am Nat $17: 867-868$ (1883)

$\mathbf{8 3 z}$ The "third trochanter" of the dinosaurs. Am Nat 17:869 (1883)

83za Some new Mammalia of the Puerco formation. Am Nat 17:968 (1883)

$\mathbf{8 3 x b}$ The progress of the ungulates in Tertiary time. Am Nat 17:1055-1057 (1883)

83ze A new chondrostean from the Eocene [Crassopholis]. Am Nat 17:11521153 (1883)

83zd The Carson footprints. Am Nat $17: 1153$ (1883)

$83 z e$ The classification of the Ungulata (abst). Am As, Pr 31:477-479 (1883)

83ze The fauna of the Puerco Eocene (abst). Am As, Pr 31:479-480 (1883)

83zg. The evidence for evolution in the histroy of the extinct Mammalia. Science 2:272-279 (1883) Nature 29:227-230, 248-250 (1884)

$83 x h$ The structure of the skull in $D i$. clonius mirabilis a Laramie dinosaurian. Science 2:238 (1883)

84 The Vertebrata of the Tertiary formations of the West. U S G S Terr (Hayden), Rp 3: xxxv, 1009 pp, il (1884) Notice, by J. L. Wortman, Am J Sc (3) $30: 295-299$ (1885)

$84 a$ (and Wortman, J. L.) PostPliocene vertebrates of Indiana. Ind, Dp G N H, An Rp 14 pt 2:1-54, 11 (1884)
Cope, Edward Drinker-Continued.

84b [White River beds near Sully Springs, Dakot2.] Am $\mathrm{Ph}$ \& p c, $\mathrm{Pr} 21$ 216-217 (1884) Pal B no 37:216-217 (1884)

84e On the distribution of the Loup Fork formation in New Mexico. Am Pb Soc, Pr 21 : 308-309 (1884) Pal B no 37: 308-309 (1884)

84 Second addition to the knowledge of the Puerco epoch. Am Ph Soc, Pr 21: 309-324 (1884) Pal B no $37: 309-324$ (1884)

84e On the trituberculate type of molar tooth in the Mammalia. Am Pb Soc, $\mathrm{Pr}$ 21:324-326 (1884) Pal B no $37: 324$ 326 (1884)

S4f Synopsis of the species of Oreodon. tidae. Am Ph Soc, $\operatorname{Pr} 21: 503-572,1$ (1884) Pal B no $38: 503-572$, il (1884)

$\mathbf{8 4} \mathbf{g}$ On the structure of the skull in the elasmobranch genus Didymodus. Am Pb Soc, Pr 21:572-590, il (1884) Pal B no $38: 572-590$, il (1884)

84h The extinct Mammalia of the $\nabla \mathrm{a}$. ley of Mexico. Am Ph Soc, Pr 22:1-21 (1884) Pal B no $39: 1-21$ (1884) Mus Nac Méx, An 3: 325-344 (1886)

84i On the structure of the feet in the extinct Artiodactyla of North America. $\Delta \mathrm{m}$ Ph Soc, Pr 22:21-27 (1884) Pal B no $39: 21-27$ (1884)

84j Fifth contribution to the knowledge of the fauna of the Permian formation of Texas and the Indian Territory. $\mathrm{Am} \mathrm{Ph}$ Soc, $\operatorname{Pr} 22: 28-47$, il (1884) Pal B no $39: 28-47$, 11 (1884)

84k On extinct Rhinocerl from the Southwest. Ac N Sc Phila, Pr 1883:301 (1884)

841 The Batrachia of the Permian period of North America. Am Nat 18:26-39, ll (1884)

S4m The Loup Forks beds on the Gila River. $\triangle \mathrm{m}$ Nat 18:58-59 (1884)

$84 n$ On new lemuroids from the Puerco formation. Am Nat 18: 59-62 (1884)

S40 The Creodonta. Am Nat 18:255267, 344-353, 478-485, il (1884)

84p The history of the Oreodontidae. Am Nat 18: 280-282 (1884)

84q The skull of a still living shark of the Coal Measures. Am Nat 18:412-413, il (1884)

84r The mastodons of North America. Am Nat 18: 524-526 (1884)

84. Marsh on Diplodus. Am Nat 18: 526 (1884)

84t The Tertlary Marsupialia, Am Nat $18: 686-697$, il (1884)

84u The Condylarthra. Am Nat 18: $790-805,892-906$, il (1884)

84v The Choristodera. Am Nat 18: 815-817 (1884)

$84 w$ The genus Pleuracanthus. $A \mathrm{~m}$ Nat $18: 818$, il $(1884)$ 
Cope, Edward Drinker-Continued.

84x Observations on the phylogeny of the Artiodactyla derived from American fossils. Am Nat 18:1034-1036 (1884)

$84 \mathbf{y}$ The Amblypoda. Am Nat $18: 1110$ $1121,1192-1202$ (1884) ; 19:40-55, il (1885)

$84 \mathrm{z}$ The origin of the Mammalia (abst). im Nat $18: 1136-1137$ (1884)

84za The structure of the columella auris in Clepsydrops leptocephalus (abst). Im Nat $18: 1253-1255$, il (1884)

$84 z b$ Note on the phylogeny of the Vertebrata. Am Nat 18:1255-1257 (1884)

84zc The evidence for evolution in the bistory of the extinct Mammalia. Am As, Pr $32: 32-48$ (1884)

S4zd On the trituberculate type of molar tooth in the Mammalia (abst). Am As, Pr $32: 313-315$ (1884)

84xe On the structure of the skull in Diclonius mirabilis, a Laramie dinosaur (abst). Am As, Pr 32:315-316 (1884)

84xf Pleuracanthus and Didymodus. Science 3:645-646 (1884)

85 The Vertebrata of the Swift Current Creek region of the Cypress Hills [Saskatchewan]. Can G S, An Rp 1: c 79-85 (1885)

85a The genealogy of the Vertebrata as learned from paleontology. Vassar Bros Inst, Tr 3:60-80 (1885)

$85 \mathrm{~b}$ The structure of the columella auris In the. Pelycosauria. Nat Ac Sc, Mem 3 pt $1: 91-95$, il (1885)

85e Origin of man and other vertebrates. Pop Sc Mo 27 : 605-614 (1885)

$85 \mathrm{~d}$ The relations between the theromorphous reptiles and the monotreme Mammalla. Am As, $\operatorname{Pr} 33: 471-482$, il (1885) Abst, Science 4:340 (1884)

85 e On the strueture of the feet in the extinct Artiodactyla of North America. Am As, $\operatorname{Pr} 33: 482-489$ (1885) Abst, Sclence $4: 339$ (1884)

$85 \mathrm{f}$ The occurrence of man in the upper Mlocene of Nebraska $(a b s t)$. Am As, Pr $33: 593$ (1885)

$85 \mathrm{~g}$ Second continuation of researches among the Batrachia of the Coal Measures of Ohio. Am Ph Soc, Pr 22:405-408 (1885) Pal B no 40:405-408 (1885)

$85 \mathrm{~h} \mathrm{Mr}$. Lydekker on Esthonyx. G Mag (3) $2: 526-527$ (1885)

851 Paleontological nomenclature.

Mag (3) 2:572-575 (1885)

$85 j$ On the evolution of the Vertebrata, progressive and retrogressive. Am Nat 19 : 140-148, 234-247, 341-353 (1885)

$85 k$ The White River beds of Swift Current River, Northwest Territory. $\Delta \mathrm{m}$ Nat $19: 163$ (1885)

851 The position of Pterichthys in the system. Am Nat 19:289-291, il (1885)

$85 \mathrm{~m}$ The oldest Tertlary Mammalia. Am Nat $19: 385-387$ (1885)
Cope, Edward Drinker-Continued.

$85 \mathrm{n}$ The Lemuroidea and the Insectvora of the Eocene period of North America. Am Nat $19: 457-471$, 11 (1885)

85o The mammalian genus Hemiganus. Am Nat 19:492-493 (1885)

85p Marsupials from the lower Eocene of New Mexico. Am Nat 19:493-494 (1885)

85q The Loup Fork Miocene in Mexico. Am Nat $19: 494-495$ (1885)

85r The genera of the Dinocerata. Am Nat 19:594 (1885)

85s Marsh on the Dinocerata. Am Nat $19: 703-705 \quad(1885)$

85t Garman on Didymodus. Am Nat $19: 878-879$ (1885)

85n The relations of the Puerco and Laramie deposits. $\Delta m$ Nat 19:985-986 (1885)

85v Eocene paddlefish and Gonorhynchidae. Am Nat 19:1090-1091 (1885)

$85 \mathrm{w}$ The ankle and skin of the dinosaur Diclonius mirabilis. Am Nat 19:1208, il (1885)

85x Pliocene horses of southwestern Texas. Am Nat $19: 1208-1209$, il (1885)

86 On two new forms of polyodont and gonorhynchid fishes from the Eocene of the Rocky Mountains. Nat Ac Sc, Mem 3 pt 2:159-165, il (1886)

86a Report on the coal deposits near Zacualtipan in the State of Hidalgo, Mexico [and description of mammalian fossils from Tehuichila, Vera Cruz]. Am Ph Soc, Pr 23:146-151, il (1886) La -taturaleza (2) $1: 3,-397$, il $(1890)$

86b 0, the structure of the brain and auditory apparatus of a theromorphous reptile of the Permian epoch. Am Ph Soc, Pr 23:234-238, il (1886) Am As, Pr 34:336-341 (1886) Abst, Science 6:224 (1885)

s6e On two new species of three-toed horses from the upper Miocene, with notes on the fauna of the Ticholeptus beds. Am Ph Soc, Pr $23: 357-361$ (1886)

86d On a new type of periszodactyl ungulate from the Wasatch Eocene of Wyoming Terr. [Phenacodu-]. G Mag (3) 3: $49-52$, il (1886)

86e Edestus and Pelecopterus, etc. G Mag (3) 3:141 (1886)

86r Note on Phenacodus. G Mag (3) 3: 238-239 (1886)

$\mathbf{8 6 g}$ Note on Erisichthe. G Mag (3) 3 : 239 (1886)

86h The batrachian intercentrum. Am Nat $20: 76-77$ (1886)

86i The sternum of the Dinosauria. Am Nat 20:153-155, il (1886)

86j Corrections of notes on Dinocerata. $\Delta \mathrm{m}$ Nat 20:155 (1886)

861 The intercentrum in sphenodon. Am Nat 20:175 (1886)

$$
28737^{\circ}-23-16
$$


Cope, Edward Drinker-Continued.

S61 [On Tinoceras stenops and Tethe. opsis.] Am Nat 20:316 (1886)

$\mathbf{s 6 m}$ The vertebrate fauna of the Ticholeptus beds. Am Nat 20:367-369 (1886)

$86 n$ The Plagiaulacidae of the Puerco epoch. Am Nat 20:451 (1886)

s6o The long-spined Theromorpha of the Permian epoch. Am Nat 20:544-545 (1886)

86p The phylogeny of the Camelidae. Am Nat 20:611-624, il (1886)

86q The recent earthquake in the United States [Charleston, S. C.] Am Nat 20: $869-870,883-884$ (1886)

s6r Schlosser on Creodonta and Phenacodus. Am Nat 20:965-967 (1886)

86s Dollo on extinct tortoises. Am Nat 20: $967-968$ (1886)

86t An interesting connecting genus of Chordata [Mycterops]. Am Nat 20:10271031, il (1886)

S6u A giant Armadillo from the Miocene of Kansas. Am Nat 20:1044-1046 (1886)

87 The origin of the fittest; essays on evolution. $467 \mathrm{pp}$, 11, N Y 1887

87a ... on fossil tortoises. G Mag (3) 4: $572-573$ (1887)

$\mathbf{8 7 b}$ The dinosaurian genus Coelurus. Am Nat 21: 367-369 (1887)

s7e The Mesozoic and Cenozoic realms of the interior of North America. Am Nat 21: 445-462 (1887)

87d American Triassic Rhynchocephalla. Am Nat 21:468 (1887)

ste Some new Taenlodonta of the Puerco. Am Nat 21:469 (1887)

87f Mr. Hill on the Cretaceous of Texas. Am Nat 21: 469-470 (1887)

87\% The sea saurians of the Fox HIlls Cretaceous. Am Nat 21:563-566 (1887) 87h The marsupial genus Chirox. Am Nat 21:566-567, il (1887)

87i [Geologic mapping.] Am Nat 21: 643-645 (1887)

S7j Pavlow on the ancestry of ungulates. Am Nat 21:656-658 (1887)

87k Scott and Osborn on White River Mammalla. Am Nat 21:924-926 (1887) 871 Marsh on new fossil Mammalia. Am Nat 21: 926-927 (1887)

$87 \mathrm{~m}$ Scott on Creodonta. Am Nat 21 : 927 (1887)

87n The Perissodactyla. Am Nat 21 : 985-1007, 1060-1076 (1887)

87o Zittel's Manual of paleontology. Am Nat 21:1014-1019 (1887)

87p A saber-tooth tiger from the Loup Fork beds. Am Nat 21:1019-1020 (1887)

s8 (with Cook, G. H.) Report of the subcommittee on the Mesozoic. In International Congress of Geologists, American Committee, Reports ... E 16 pp, Phila 1888 Am G 2:257-268 (1888) Int G Cong, IV, London 1888, C R App A: 159-173 (1891)
Cope, Edward Drinker-Continued.

SSa Report of the subcommittee on the Cenozoic (interior). In International Congress of Geologists, American Committer, Reports ... G 20 pp, Phila 1888 Am G 2: 285-299 (1888) Int G Cong, IV, Londo 1888, C R App A : 193-210 (1891)

$\mathbf{8 8 b}$ On the intercentrum of the terre: trial Vertebrata. Am Ph Soc, Tr n s 16: 243-253, il (1888)

88e Species of Vertebrata found in the beds of the Permian epoch in North Amer ica, with notes and descriptions. Am P Soc, Tr n s 16: 285-297, 11 (1888)

8sd Synopsis of the vertebrate fauna of the Puerco series. $A m$ Ph Soc, Tr n $s 16$ 298-361, il (1888) Abst, Am Nat 22:161163 (1888)

8se on the shoulder girdle and extremt ties of Eryops. Am $\mathrm{Ph}$ Soc, $\mathrm{Tr} \mathrm{n}$ s 16 $362-367$, il (1888)

SSf A contribution to the history of th: Vertebrata of the Trias of North Americs Am Ph Soc, Pr 24: 209-228, il (1888)

8Sg: The classiflcation and phylogeny of the Artiodactyla. Am Ph Soc, Pr 24:37i400 (1888)

8sh On the Dicotylinae of the John Day Miocene of North America. Am Ph Soc, Pr 25: 62-79 (1888)

s8i On the mechanical origin of the dettition of the Amblypoda. Am Ph Soc, Pr 25: 80-89 (1888)

88j The mechanical origin of the secto rial teeth of the Carnivora. Am $\mathrm{As}, \mathrm{Pr} 36$ : 254-257 (1888)

88k The mechanical causes of the origit of the dentition of the Rodentia. Am Yat $22: 3-13$, il (1888)

s81 Glyptodon from Texas. Am Nat 22 345-346 (1888)

$88 \mathrm{~m}$ Topinard on the latest steps in the genealogy of man. Am Nat $22: 660-665$ (1888)

88n Rutimeyer on the classification of Mammalia, and on American types recently found in Switzerland. Am Nat 22:831835 (1888)

85o The pineal eye in extinct verte brates. Am Nat 22:914-917, il (1888)

88p Sketches of the Cascade Mountains of Oregon. Am Nat 22:996-1003 (1888) Sc Am Sup 27: 10981-10982 (1889)

88a The Artiodactyla. Am Nat 22 $1079-1095$, il $(1888) ; 23:$ Mar $111-136$, th (1889)

88r Goniopholis in the Jurassic of Colorado. Am Nat 22:1166-1107 (1888)

88s A horned dinosaurian reptile. At Nat 22:1108-1109 (1888)

88t Vertebrate fauna of the Puerco stries. Science 11:198 (1888)

88 u. V. Hayden [1829-1887]. Am t 1: 110-113 (1888)

89 A review of the North American spt: cies of Hippotherium. $\mathrm{Am} \mathrm{Ph} \mathrm{Soc,} \mathrm{Pr} \mathrm{26:}$ $429-458$, if (1889) 
Cope, Edward Drinker-Continued.

89a The Vertebrata of the Swift Current River, II. Am Nat 23: Mar 151-155 (1889)

89b The vertebrate fauna of the Equus beds. Am Nat $23: 160-165$ (1889)

89e The Proboscidia. Am Nat $23: 191-$ 211, il (1889) G Mag (3) $6: 438-448$, il (1889)

89d An intermediate Pliocene fauna [0regon]. Am Nat 23:253-254 (1889)

89e Marsh on Cretaceous Mammalia. Am Nat 23: 490-491 (1889)

$89 f$ on a species of Plioplarchus from Oregon. Am Nat 23:625-626 (1889)

$89 \mathrm{~g}$ On a new genus of Triassic Dinosauria [Coelophysis]. Am Nat 23:626 (1889)

89h Vertebrata of the Swift Current River, III. Am Nat 23:628-629 (1889) 89i The Edentata of North America. Am Nat $23: 657-664$, il (1889)

89: The horned Dinosauria of the Laramie. Am Nat $23: 715-717$, il (1889)

89k Synopsis of the families of Vertebrata. Im Nat 23:849-877 (1889)

891 Notes on the Dinosauria of the Laramie. Am Nat 23:904-906 (1889)

$89 \mathrm{~m}$ The Silver Lake of Oregon and its region. Am Nat 23:970-982 (1889)

89n The age of the Denver formation. Science $13: 290(1889)$

89o Mr. Lydekker on Phenacodus and the Athecae. Nature $40: 298$ (1889)

90 Syllabus of lectures on geology and paleontology; Part I, Geology. 47 pp Pbila (1890)

$90 \mathrm{a}$ The homologies of the fins of fishes. Am Nat 24:401-423, il (1890)

$90 \mathrm{~b}$ Scott and Osborn on the fauna of the Brown's Park Eocene. Am Nat 24: $470-472(1890)$

90e The age of the Laramie. G Soc Am, B 1:532 (1890) Am Nat 24:569 (1890)

90d The Cetacea. Am Nat 24:599-616 (1890)

90e The extinct Sirenia. Am Nat 24 : $697-702(1890)$

908 On two new species of Mustelidae from the Loup Fork Miocene of Nebraska. Am Nat 24:950-952 (1890)

$90 \mathrm{~g}$ On a new dog from the Loup Fork Hiocene [Nebr.]. Am Nat 24:1067-1068 (1890)

91 Syllabus of a course of lectures on geology and paleontology; Part III, Paleontology of the Vertebrata. $90 \mathrm{pp}, 11$, Phila 1891

91a on Vertebrata from the Tertiary and Cretaceous rocks of the Northwest Territory; I, The species from the Oligocene or Lower Miocene beds of the Cypress Hills, Can G S, Contr Can Pal $3: 1-25$, 1] (1891)
Cope, Edward Drinker-Continued.

$91 \mathrm{~b}$ On the characters of some Paleozoic fishes. U S Nat Mus, Pr 14:447-463, il (1891)

91e On two new perissodactyles from the White River Neocene of Nebraska. Am Nat 25: 47-49 (1891)

$91 d$ On the non-actinopterygian Teleostomi. Am Nat 25:479-481 (1891)

91e On some new fishes from South $\mathrm{Da}$ kota. Am Nat 25:654-658 (1891)

$91 \mathrm{f}$ On a skull of the Equus excelsus Leidy from the Equus bed of Texas. Am Nat 25:912-913 (1891)

91g The Californian cave bear. Am Nat 25:997-999, il (1891)

91h On the structure of certain Paleozoic fishes (abst). Am As, $\operatorname{Pr} 39: 336$ (1891)

$91 i$ On the cranial characters of Equus excelsus (abst). Am As, Pr 40:285 (1892) A m G 8: 231-232 (1891)

$92 \mathrm{~A}$ contribution to the vertebrate paleontology of Texas. $\mathrm{Am} \mathrm{Ph}$ Soc, $\mathrm{Pr}$ 30:123-131 (1892) Tex G S, An Rp 3: 249-259 (1892)

$92 \mathbf{a}$ On the homologies of the posterior cranial arches, in the Reptilia. $\mathrm{Am} \mathrm{Ph}$ Soc, Tr n s 17:11-26, il (1892) Abst, Am Nat 26:407-408, il (1892)

$92 b$ on some new and little known Paleozoic vertebrates. $\mathrm{Am} \mathrm{Ph}$ Soc, $\mathrm{Pr} 30$ : 221-229, il (1892)

92c On the skull of the dinosaurian Laelaps incrassatus Cope. $\mathrm{Am} \mathrm{Ph}$ Soc, Pr 30:240-245 (1892)

92d On the phylogeny of the Vertebrata. Am Ph Soc, Pr 30:278-279 (1892)

92e A contribution to a knowledge of the fauna of the Blanco beds of Texas. Ac N Sc Phila, Pr 1892:226-229

92f On the permanent and temporary dentitions of certain three-toed horses. Ac N Sc Phila, Pr 1892:325-326 Am Nat 26: 942-944 (1892)

92g A hyena and other Carnivora from Texas. Ac N Sc Phila, Pr 1892:326-327 Am Nat 26: 1028-1029 (1892)

92h The age of the Staked Plain of Texas. $A m$ Nat 26:49-50 (1892)

92i Fossil Vertebrata. Am Nat $26: 89$ 91 (1892)

92j Professor Marsh on extinct horses and other Mammalia. Am Nat 26:410412 (1892)

92k Fourth note on the Dinosauria of the Laramie. Am Nat 26:756-758 (1892) 921 On a new genus of Mammalia from the Laramie formation [Thlaeodon padanicus]. Am Nat 26:758-762, il (1892) Abst, Am As, Pr 41:177 (1892)

$92 \mathrm{~m}$ Crook on Saurodontidae from Kansas. Am Nat 26:941-942 (1892)

92n The fauna of the Blanco epoch (abst). Am Nat 26:1058-1059 (1892) 
Cope, Edward Drinker-Continued.

920 In the Texas Panhandle [occurrence of vertebrate fossils]. Am G 10:131132 (1892)

92p On a new horizon of fossil fishes (abst). Am As, Pr 40:285 (1892)

92q The Cenozoic beds of the Staked Plains of Texas (abst). Am As, Pr 41:177 (1892)

93 A preliminary report on the vertebrate paleontology of the Llano Estacado. Tex G S, An Rp 4 pt 2:11-87, il (1893)

93a On the genus Tomiopsis [Lapara Creek, Tex.]. Am Ph Soc, Pr 31:317-318 (1893)

93b $\Delta$ new extinct species of Cyprinldae. Ac N Sc Phila, Pr 1893: 19-20

93e Description of a lower jaw of Tetrabelodon shepardii Leidy. Ac N Sc Phila, Pr 1893: 202-204

93d $\Delta$ remarkable artiodactyle from the White River epoch. Am Nat 27:147-148 (1893)

93e Earle on the species of Coryphodontidae. Am Nat $27: 250-252$ (1893)

93f The genealogy of man. $\Delta m$ Nat 27: $321-335$, il (1893)

$93 \mathrm{~g}$ [Note on Tetrabelodon shepardi and Mastodon oligobunis]. Am Nat 27: 473 (1893)

93h A new Pleistocene sabre-tooth. Am Nat 27:896-897 (1893)

93i On Symmorium and the position of the cladodont sharks. Am Nat 27:9991001 (1893)

93j ... on the theory of dental evolution. Am Nat 27:1014-1016 (1893)

94. On the structure of the skull in the plesiosaurian Reptilia, and on two new species from the upper Cretaceous. Am Ph Soc, Pr 33:109-113, il (1894)

94a Fossil fishes from British Columbia. Ac N Sc Phila, Pr 1893 : 401-402 (1894)

94b Observations on the geology of adfacent parts of Oklahoma and northwest Texas. Ac N Sc Phila, Pr 1894: 63-68

95 New and little known Paleozoic and Mesozolc fishes. Ac N Sc Phila, J (2) 9: 427-448, il (1895)

95a On Cyphornis, an extinct genus of birds. Ac N Sc Phila, J (2) 9:449-452, Il (1895) Abst, Can Rec Sc $8: 331-332$ (1901)

95b Extinct Bovidae, Canidae, and Felldae from the Pleistocene of the Plains. Ac N Sc Phila, J (2) 9:453-459, il (1895)

95c The fossil Vertebrata from the fissure at Port Kennedy, Pa. Ac N Sc Phila, Pr 1895: 446-450

95d Fourth contribution to the marine fauna of the Miocene period of the United States. $\Delta \mathrm{m} \mathrm{Ph}$ Soc, Pr $34: 135-155$, il (1895)

95e The reptilian order Cotylosauria. Am Ph Soc, Pr 34: 436-457, il (1895)
Cope, Edward Drinker-Continued.

95e On some Pleistocene Mammalia from Petite Anse, La. Am Ph Soc, Pr 34:458 468, il (1895)

95 $\mathrm{g}$ Dean on coprolites. Am Nat 28 : 159 (1895)

95h The antiquity of man in North America. Am Nat 29:593-599 (1895)

95i A batrachian armadillo. Am Nat $29: 998$ (1895)

95j Reply to Dr. Baur's critique on $m$ paper on the parocclpital bone of the scaled reptiles and the systematic position of the Pythonomorpha. Am Nat 29:1003-1005 (1895)

95k On the Paleozolc reptllian order of the Cotylosauria (abst). Science n s 2: $637-638$ (1895)

951 On a bone cave at Port Kennedy, Pa. (abst). Science n s 2:638 (1895)

96 The primary factors of organic ero. lution. $547 \mathrm{pp}$, il, Chicago 1896

$96 a$ Second contribution to the history of the Cotylosauria. Am Ph Soc, Pr 35: $122-139$, il (1896)

96b Sixth contribution to the knoml. edge of the marine Miocene fauna of North America. Am Ph Soc, Pr 35:139146, il (1896)

96e New and little known Mammalis from the Port Kennedy bone deposit. At N Sc Phila, Pr 1896: 378-394.

96d Criticism of Dr. Baur's rejoindet on the homologies of the paroccipital bone, etc.; I, The paroccipital bone. Am Nat $30: 147-149$ (1896)

96e The Paleozoic reptilian order Cots. losauria. Am Nat $30: 301-304$, il (1896) 96e The ancestry of the Testudinati. Am Nat $30: 398-400$ (1896)

96g Permian land Vertebrata with carapaces. Am Nat 30:936-937, il (1896) $\mathbf{9 6 h}$ [On Reptilia from the Permian and Triassic (abst).] Science n s $3: 373-374$ (1896)

97 On new Paleozoic Vertebrata from Illinois, Ohio, and Pennsylvania. Am Pb Sac, $\operatorname{Pr} 36: 71-91$, il (1897)

$\mathbf{9 7 a}$ Recent papers relating to vertebrate paleontology. Am Nat $31: 315-323$ (1897)

97b The position of the Periptychidat

Am Nat 31:335-336 (1897)

97e Toxodontia. Am Nat $31: 485-49 ?$ (1897)

98 Syllabus of lectures on the Vertebrata. with an introduction [biography of Cope] bs H. F. Osborn. $135 \mathrm{pp}$, il, port, Phila, 1808

99 Vertebrate remains from Port Ked nedy [Pa.] bone deposit. Ac N Sc Phill, J (2) $11: 193-267$, il (1899)

15 (and Matthew, W. D.) Hitherto unpublished plates of Tertiary Mammalis and Permian Vertebrata, Am Mus $\mathrm{N}$ 日. Mon s 2 : pls and expl (1915)

See also Marsh, 94; Newberry, 89b; Scott, 95b 
Coppock, John Bridgeford.

03 Analysis of volcanic dust from La Soufflère. Ch News $87: 233-234$ (1903)

Cordeiro, F. J. B.

10 The volcanoes of Alaska. Appalachia 12: 130-135 (1910)

Cordier, Louis.

49 Note sur une masse de cuivre natif provenant des rives du lac Supérieur aux États-Unis d'Amérique. Ac Sc Paris, C R 28:161-162 (1849)

Corey, G. W.

06 The Nonesuch sandstone [Porcupine district, Mich.]. Eng M J $82: 778$ (1906)

Corey, T. B.

$93 \mathrm{Coal}$ fields of western Washington. III M Inst, J 2:14-30 (1893) [not seen] Corkin, E. T.

05 Petroleum and natural gas [in Ontario]. Ont Bur Mines, Rp 1905, 14 pt 1: 59-117 (1905)

05a Notes on the occurrences, production, and uses of mica (with discussion). Can M Inst, J 7:284-307 (1905)

06 Mines of Ontario. Ont Bur Mines,

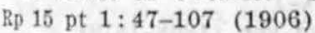

07 Miea in Ontario. Can M J 28: (n s 1): $196-200 \quad$ (1907)

10 Mines of Ontario. Ont Bur Mines, An $\mathrm{Rp} 19$ pt 1:78-130 (1910)

Corless, C. V.

01 The Coal Creek colllery of the Crow's Nest Pass Coal Co. Can M Inst, J 4:155173 (1901) Can M Rv 20:60-67 (1901)

02 Notes on the geology and a few ore deposits of southeastern British Columbia. Can M Inst, J 5:503-527 (1902) Can M Rv $21: 211-218$ (1902)

16 Origin of Sudbury nickel-copper deposits. Eng M J 102:517-518 (1916)

17 On the origin of Sudbury nickel deposits, Can M J 38:268-269 (1917)

Cormaek, William C.

24 Account of a journey across the Island of Newfoundland. Edinb $\mathrm{Ph}$ J 10 : 156-162, map (1824)

Cornejo, Ignacio.

70 Los flerros meteóricos de Méxlco. La Naturaleza $1: 252-267$ (1870)

Cornelius, Ellas (1794-1832).

19 On the geology, mineralogy, scenery, and curlosities of parts of Virginia, Tennessee, and the Alabama and Mississippi territories. Am J Sc 1: 214-226, 317-331 (1819)

20 Account of a singular position of a granite rock. $\Delta \mathrm{m}$ J Sc $2: 200-201$ (1820) Annalen der Physik (Gilbert) $70: 361-362$ (1822)

Cornell, Russell T.

11 Special problems and their study in economic geology (discussion). Ec G 6:7778 (1911)

Cornett, W. T. S.

75 List of fossils found in Jefferson Co., Ind. Ind $G$ S, An Rp 6:182-186 (1875)
Cornett, W. T. S.-Continued.

84 A glossary of terms commonly used in geological reports. Ind, $\mathrm{Dp} \mathrm{G} \mathrm{N} \mathrm{H}, \mathbf{A n}$ Rp 13 pt 1 : 154-160 (1884) ; 14 pt 2 : 103109 (1884)

Corning, Frederick G.

86 The gold quartz mines of Grass Val. ley, Nevada Co., Cal. Eng M J 42 : 418-420 (1886)

Cornish, R. H.

90 Glacial scratches in the vicinity of Norfolk, Conn. Am J Sc (3) 39:321 (1890)

Cornish, Vaughan.

os The Jamaica earthquake (1907). Geog J 31: 245-270 (1908)

10 Waves of the sea and other water waves. $374 \mathrm{pp}$, Chicago 1910

12 On the cause of the Jamaica earthquake of January 14, 1907. Geog Jour 40: 299-303, map (1912)

13 On the Panama Canal, and the formation of gravitation waves in the Culebra cut. Geog J 41:239-243 (1913)

13a The Panama Canal and the philosophy of landslldes. Edinb Rv 217:21-42 (1913)

Cornwall, H. B.

02 Occurrence of greenockite on calcite from Joplin, Mo. Am J Sc (4) 14:7-8 (1902)

Corral, José Isaac del.

11 Reconocimiento geológico-minero del valle de Viñales, Pinar del Río. Cuba, Secretaría Agr, Com y Trabajo, B of, año 6, 11:101-110 (1911)

13 Excursión geológica al placer de Batabano [phosphate deposits and other geologic features of coral islands south of Batabano, Cuba]. Soc Cubana Ing, Rv 5: $32-42$ (1913)

17 El hombre fosil $y$ el arte cuaternario. Soc Cubana Ing, Rv $9: 421-486$ (1917)

Corss, Frederic.

00 Fossils in the river drift at Pittston [Pa.]. Wyoming Hist G Soc, Pr 5:163167 (1900)

Ooa Buried valley and potholes in the Wyoming coal field [Pa.]. Wyoming Hist G Soc, Pr $5: 168-176$ (1900)

04 The buried valley of Wyoming, Pa. Wyoming Hist G Soc, Pr $8: 42-45$ (1904) 09 A study of the glacial rock on Shawnee Mountain [ $\mathrm{Pa}$.$] . Wyoming Hist \mathrm{G} \mathrm{S}$, Pr 10:115-117 (1909)

\section{Cortazar, Daniel de.}

80 Descripcia de un nuevo equinodermo de la Isla de Cuba, Encope cioe n. sp. España, Com Mapa Geol, B $7: 227-232$, il (1880) Also in Salterain y Legarra, Pedro, Apuntes para una descripción físicogeologlca de las jurisdicciones de la Habana y Guanabacoa, Isla de Cuba: 67-72, 1l, Madrid 1880. 
Coryell, Horace Noble.

15 (and Rose, C. M.) Soil survey of Howard Co. Ind Dp G, An Rp 39:20-54, map (1915)

15a Correlation of the outcrop at Spades, Ind. Ind Ac Sc, Pr 1914:389393 (1915)

16 A study of the collections from the Trenton and Black River formations of New York. Ind Ac Sc, Pr $1915: 249-268$ (1916)

Corye11, Martin.

75 Eastern Virginia coal field. Am I M Eng, $\operatorname{Tr} 3: 228-231$ (1875)

76 Diatomaceous sands of Richmond, Va. Am I M Eng, Tr 4:230-232 (1876) Eng M J 22:281-282 (1876) The Virginias $2: 6-7$ (1881)

Cosgrove, James Francis.

16 Coal, its economical and smokeless combustion. $284 \mathrm{pp}$, Phila 1916

Cossman, Maurice.

93 Notes complémentaires sur la faune eocénique de l'Alabama. An G Palónt $12: 52 \mathrm{pp}$, Il (1893)

13 Etude comparative de fossiles miocéniques recueillis à la Martinique et a l'Isthme de Panama. J Conchyliologle 61: 1-64, il (1913)

Coste, Eugene.

85 Report on the gold mines of the Lake of the Woods. Can G S, Rp Prog 1882-4: K 22 pp (1885)

87 Statistical report on the production, value, exports, and imports of minerals in Canada during the year 1886 and previous years. Can G S, An Rp 2: s 85 pp (1887)

88 Report on the mining and mineral statistics of Canada for the year 1887. Can G S, An Rp 3: s 110 pp (1888)

88a The iron ores and phosphate deposits in the Archean rocks of Canada. Can G S, An Rp 3: s 62-64 (1888)

00 Natural gas in Ontario. Can M Inst, J 3:68-89 (1900) Can M Rv 19:70-76 (1900)

04 Volcanic origin of natural gas and petroleum (with discussion by G. R. Mickle and Robert Bell) Can M Inst, J 6:73128 (1904) Abst, Eng M J $75: 439$ (1903)

$04 a$ Volcanic origin of oil. Franklin Inst, J 157:443-454 (1904) Am I M

Eng, $\operatorname{Tr} 35: 288-297$ (1905)

06 Natural gas and petroleum [in Ontario]. Ont Bur Mines, Rp 15 pt $1: 108$ 115 (1906)

07 The new Tilbury and Romney oil flelds of Kent Co., Ont. Can M J 28 (n s 1) : 265-268 (1907)

о7a The Tilbury oil field, Ont. Eng M J $84: 779$ (1907)

09 Petroleums and coals compared in their nature, mode of occurrence, and origin. Can M J $30: 295-300,330-334$ (1909) Can M Inst, J $12: 273-301,643-$ 645. (1910)
Coste, Eugene Continued.

09a The voleanic or organic origin of ofl. M Science 60:367-368 (1909)

12 Fallacies in the theory of the organic origin of petroleums [with discussion of various writers]. Inst $M$ Met, $\operatorname{Tr} 21: 91$ 192 (1912)

14 Rock disturbances theory of petroleum emanations vs. the anticlinal or structural theory of petroleum accumulations (with discussion by Hans von Höfer), An I M Eng, B 93: 2415-2431 (1914); Tt $48: 504-520$ (1915) Can M J 35:647652 (1914)

18 Principles and problems of oil pros pecting in the Gulf coast country (disens. sion). Am I M Eng, B 136:830-832 (1918)

See also Daly (M R), 16; Matteson, 18; Washburn, 14a

Cots, Cesar.

12 (with Tristan, J. F.) The Sarchl earthquake, Costa Rica. Seism Soc Am, B 2 : 201-208 (1912)

Cotta, Bernhard von (1808-1879).

54 General observations on the forma. tion of metalliferous veins (transl. by Oscar M. Lleber). M Mag $3: 386-392$. 465-470 (1854)

70 A treatise on ore deposits. Trans, from 2d German ed, by Frederick Prime. jr. $x v, 575 \mathrm{pp}, \mathrm{N}$ Y 1870 .

Cottean, Gustave Honoré (1818-1894).

$\mathbf{7 1}$ Notice sur le genre Asterostoms [from Cuba]. Soe G France, Mem (2) 9: $177-184$, il (1871)

74 Sur les oursins des Antilles suédoises. Soc G France, B (3) 2:125-126 (1874)

75 Description des echinides tertiaires des iles St. Barthélemy et Anguilla [W. I] K Svenska Vet-Ak Hdi N F 13 no $6: 47$ pp. il $(1875)$

81 Description des échinides fossiles de l'nle de Cuba. Soc G Belgique, An 9:3-49, il (1881)

90 Note sur quelques échinides du ter rain crétacé du Mexique. Ac Sc Paris, CB $110: 621-623(1890)$ Soe G France, B (3) $18: 292-299$, il, (1890)

97 (and Egozeue y Cra, J) Descrip ción de los equinoldes fosiles de la Isla de Cuba España, Com Mapa Geol, B $22=(2)$ $2: 1-99$, il (1897)

Cotting, John Ruggles (1784-1868).

35 A synopsis of lectures on geology ... $120 \mathrm{pp}$, Taunton 1835

36 Report of a geological and agricul. tural survey of Burke and Richmond cos. Ga. 198 pp, Augusta 1836.

Cottle, Thomas.

52 Fossil Pachydermata in Canada [Ele phas primigenius?, head of Lake Ontario]. An Mag N H (2) $10: 395-396$ (1852) Am J Sc (2) $15: 282-283$ (1852) 


\section{Cotton, C. A.}

18 Conditions of deposition on the continental shelf and slope. J G $26: 135-$ 160 (1918)

Conlter, John M.

$\mathbf{8 3}$ Some glacial action in Indiana. Science $2: 6$ (1883)

84 Some Indiana glaciology. Science 3 : 748-749 (1884)

11 (and Land, W. J. G.) An American Lepidostrobus [coal measures of Warren Co., Iowa.] Bot Gaz 51:449-453, II (1911) Abst, Ill Ac Sc, Tr $\therefore: 107-108$ (1912)

12 The history of gymnosperms. Pop Sc Mo $80: 197-203$ (1912)

12a The relations of paleobotany to botany; phylogeny and taxonomy. Am Nat 46:215-225 (1912) Abst, Science n s 35 : 148-149 (1912)

Couper, J. Hamilton.

42 [On fossil bones and shells from the Brunswick Canal, Ga.] Ac N Sc Phila, Pr 1:216-217 (1842)

430 n fossil bones found in digging the New Brunswick Canal in Georgia. G Soc London, Pr $4: 33-34$ (1843) Ph Mag (3) 23:189-190 (1843) Geologist 1843:163165 Mag N H 12: 70-71 (1843)

46 On the age of the burr mill stone, Bainbrldge, Ga.] Boston $\mathrm{Soc} N \mathrm{H}, \operatorname{Pr} 2$ : 123-124 (1846)

46a Observations on the geology of a part of the seacoast of the State of Georgia ... In Hodgson, W. B., Memoir on the Megatherium ... : 31-47, N Y 1846

Conper, Robert H.

00 The yellow ocher mines of the Cartersville district, Ga. Eng M J 69:738 (1900)

Courtis, William Munroe.

77 The north shore of Lake Superior as a mineral-bearing district. Am I lf Eng, Tf 5:473-487 (1877)

84 Gold in fossiliferous limestone in the Judith Mountains, Mont. Eng M J 37 : 478-479 (1884)

87 The Animikie rocks and their vein phenomena, as shown at Duncan mine, Lake Superior. Am I M Eng, Tr 15:671677 (1887)

90 Gold quartz. Am I M Eng, Tr 18: 639-644 (1890)

00 Some notes on Alaska [Ketchikan district]. Eng M J 70:548 (1900)

06 The Cobalt mining district [Ont.]. Eng M J $82: 5-6$ (1906)

06a The Priest Lake mining district, Idaho, Eng M J 82: 866 (1906)

07 Gold in Michigan. Mich $\mathrm{G} S, \mathrm{Rp}$ 1900: 581-584 (1907)

See also Smith ( $\mathrm{G}$ O), 01a

Courtney, Wilshire S.

80 The gold flelds of St. Domingo ... 144 DD, N Y 1860
Couthouy, Joseph Pitty (1808-1864).

41 Volcanic phenomena in Hawail. Am J Sc 41:200 (1841)

42 Remarks upon coral formations in the Paciflc ... Boston J N H 4:66-105, 137-162 (1842)

42a [On icebergs and diluvial phenomena]. Am J Sc 43:154-165 (1842); As Am G, Rp : 49-59 (1843) Abst, Geologist 1843: 35-37

See also Hitchcock (E.), 42

Cowan, Frank.

85 $\Delta$ visit in verse to Halemaumau [Hawaii]. $21 \mathrm{pp}$, Honolulu, 1885

Cowan, John L.

04 The arsenic mines at Brinton, Va.

Eng M J 78:105-106 (1904)

os Turquoise mines of New Mexico.

Mineral Collector 15:110-112 (1908)

10 Tourmaline in California. M Sc Press 100:864-865 (1910)

Cowlam, George b.

s8 The extent and value of east Tennessee's minerals. Eng M J 45:19-21 (1888)

Cox, Charles F.

93 On recently discovered deposits of diatomaceous earth in the Adirondacks. N Y A $\mathrm{Sc}$, Tr $12: 219-220$ (1893)

94 Additional notes on recently discovered deposits of diatomaceous earth in the Adirondacks. N Y Ac Sc, Tr 13:98-101 (1894)

Cox, Edward Travers (1821-1907).

57 Paleontological report of coal measure Mollusca. Ky G S, Rp 3:557-576, il [pls. issued in brochure titled, Maps and illustrations referred to in vols. II \& III of the report of the geological survey of Kentucky, 1857] (1857)

58 Report of a geological reconnaissance of a part of the State of Arkansas made during the years 1857 and 1858. In Owen, D, D., First report of a geological reconnaissance of the northern counties of Arkansas: 193-244, Little Rock, 1858

60 Second report of a geological reconnaisance of a part of the State of Arkansas, made during the years 1859 and 1860 . In Owen, D. D., Second report of a geological reconnaissance of the middle and southern counties of Arkansas: 401-420, Phila 1860

65 (with Owen, R. E.) Report on the mines of New Mexico. 59 pp, Washington 1865

69 First annual report of the geological survey of Indiana made during the year 1869. 240 pp, Indianapolis 1869 Accompanied by Maps and colored section referred to in the Report of State Geologist of Indiana, 1869

71 Second report of the geological survey of Indiana made during the year 1870 . $304 \mathrm{pp}$, maps, Indianapolis 1871 
Cox, Edward Travers-Continued.

71a Western caal measures and Indiana coal. Ind G S, An Rp $2: 164-187$ (1871 Am As, Pr 20:236-252 (1872) Am Nat 5: $547-559$ (1871)

72 Third and fourth annual reports of the geological survey of Indiana made during the years 1871 and $1872,488 \mathrm{pp}$, maps, Indianapolis 1872

74 Fifth annual report of the geological survey of Indiana made during the year 1873. $494 \mathrm{pp}$, maps, Indianapolis 1874

$\mathbf{7 4 a}$ Geological report. Ind $\mathrm{G} \mathrm{S}, \boldsymbol{\Delta} \mathrm{n} \mathrm{Rp}$ 5 : 102-132 (1874)

74b Collettosaurus indianensis Cox. Ind G S, An Rp 5:247-248, il (1874)

75 Sixth annual report of the geolagical survey of Indiana made during the year 1874. $288 \mathrm{pp}$, maps, Indianapolis 1875

75a Geology of Gallatin Co.; Saline Co. IIl G S 6:197-234 (1875); Ec G $3: 544$ 586 (1882)

76 Seventh annual report of the geological survey of Indiana made during the year 1875. $601 \mathrm{pp}$, maps, Indianapolis 1876

79 Eighth, ninth, and tenth annual reports of the geological survey of Indlana made during the years 1876-77-78. 542 pp, maps, Indianapolis 1879

80 Influence of geology upon local diseases. Ind, Dp Stat G, An Rp 1:482-483 (1880)

o0a The discovery of oxide of antimony in extensive lodes in Sonora, Mex. Am J Sc (3) $20: 421-423$ (1880) Am As, Pr 29 : 343-344 (1881)

80b The geology of southern Arizona. $\Delta \mathrm{m}$ Nat $14: 541-542(1880)$

84 West Virginia, Barbour County, iron and coal lands; geological report. $10 \mathrm{pp}$, Mechaniesburg, Pa. 1884

88 [On a salt deposit in Kansas.] $N \mathrm{Y}$ Ac Sc, Tr $7: 127$ (1888)

90 An extensive deposit of phosphorite rock in Florida. Am Nat 24:1185-1186 (1890)

91 Floridite; a new variety of phosphate of lime. Am As, Pr 39:260-262 (1891)

91a Florida pebble and nodular phos. phate of lime. Eng M J 52:359-360 (1891)

93 The origin of Florida phosphates. Eng M J 55: 125 (1893)

96 Geological sketch of Florida, Am I M Eng, Tr 25:28-36 (1896)

$96 \mathbf{a}$ The Albion phosphate district [Lery Co., Fla.]. Am I M Eng, Tr 25:36-40 (1896)

See also Frazer, $74 b$

Cox, Guy Henry (1881-1922),

09 Copper in southwestern Wisconsin.

M Sc Press 99: 592 (1909)

10 Elizabeth sheet of the lead and zinc district of northern Illinois. Ill S G $\mathbf{~}$, B $16: 24-41$, map (1910)
Cox, Guy Henry-Continued.

10a (and Murray, E. P.) Some re: tions between the composition of a mineri and Its physical properties. Mo, Univ, sct Mines, B 3 no 1:3-39 (1910)

11 The origin of the lead and zinc ore of the upper Mississippi Valley district Ec G $6: 427-448,582-603$ (1911)

12 New type of Wisconsin zinc deposit Eng M J 94: 1040-1041 (1912)

14 Lead and zinc deposits of northwest ern Ill. Ill G S, B 21:120 pp, mass (1914)

16 (and Dake, C. L.) Geological ert teria for determining the structural post tion of sedimentary beds. Mo Univ, Sct Mines, B 2 no $4: 59$ pp (1916)

16a (and others) Studies on the origh of Missourl cherts and zinc ores, If Univ, Sch Mines, B, Tech s 3 no $2: 34$ ph (1916)

See also Bucher, 18a; Dake, 15 Cox, Jennings S., jr.

11 The fron-ore deposits of the $\mathrm{Yar}$ district, Oriente Province, Island of Cuh Am I M Eng, B 51: 199-216 (1911); ? 42: 73-90 (1912)

Cox, N. H.

11 (with Sellards, E. H.) Roads ant road materials of Florida. Fla G S, B ? 31 pp (1911)

Comzens, Issachar (1780-1865).

25 Examination of fron ores from the northern part of the State of New Yoth. Lyc N H N Y, An 1: 378-383 (1825)

43 A geological history of Manhattan or New York Island ... 114 pp, map, N 1843

46 Description of three new fossils fros the Falls of the Ohio. Lyc N H N Y, di 4:157-159 (1846)

Crabb, G. A.

14 (and Morrison, T. M.) Soll surres of Orange Co., N. Y. Cornell Univ, $\Delta$ Ft Exp Sta, B 251:745-800, map (1911)

Cragin, Francis Whittemore.

85 Notes on the geology of souther Kansas. Washburn Coll Lab N H, B 1 85-91 (1885)

85a Tertiary in Harper $\mathrm{Co}$, Kans Kansas City Rv Sc 8:652 (1885)

85b Some geological and topographica features of southern Kansas. Kansas Cit Rv Sc 8:678-682 (1885)

86 Further notes on the Dakota gypsum of Kansas. Washburn Coll Lab N H, B 1 166-168 (1886)

s8 Prellminary description of a netr of ifttle known saurian from the Benton o! Kansas. $\triangle \mathrm{m}$ G 2:404-407 (1888)

89 Geological notes on the region soutb of the great bend of the Arkansas [Kans] Washburn Coll Lab N H, B $2: 33-31$ (1889)

89 Contributions to the paleontology o? the Plains, No. 1 . Washburn Coll Lab N B 2: 65-68 (1889) 
Cragin, Francis Whittemore-Continued. 90 On the Cheyenne sandstone and the Neocomian shales of Kansas. Washburn Coll Lab N H, B 2:69-80 (1890) Am G 6:233-238 (1890) ; $7: 23-33$ (1891)

91 Further notes on the Cheyenne sandstone and Neocomian shales [Kans.]. Am G 7:179-181 (1891)

$91 \mathrm{a}$ On a leaf-bearing terrane in the Loup Fork [Kans.]. Am G 8:29-32 (1891)

91b New observations on the genus Trinacromerum. Am G 8:171-174 (1891) 92 Observations on llama remains from Colorado and Kansas. Am G 9:257-260 (1892)

92a A new sabre-toothed tiger from the Loup Fork Tertiary of Kansas. Science 19: 17 (1892)

$93 \mathrm{~A}$ contribution to the invertebrate paleontology of the Texas Cretaceous. Tex GS, An Rp 4 pt $2: 139-246$, il (1893)

94 ... Invertebrata from the Neocomian of Kansas. Am G 14: 1-12, il (1894)

94a The Choctaw and Grayson terranes of the Arietina [Texas]. Colo Coll Studies, An Pub 5:40-48 (1894)

94b Descriptions of invertebrate fossils from the Comanche series in Texas, Kansas, and Indian Territory. Colo Coll Studies, An Pub 5 : 49-68 (1894)

$94 \mathrm{c}$ Vertebrata from the Neocomian of Kansas. Colo Coll Studies, An Pub $5: 69-$ 73 , il (1894)

95 A new Cretaceous genus of Clypeastridae. Am G 15:90-91 (1895)

$95 a$ The Mentor beds, a central Kansas terrane of the Comanche series. Am G $16: 162-165$ (1895)

95b A study of the Belvidere beds. Am G $16: 357-385$ (1895)

96 The Plains Permian. Am G 18 : 131132 (1896)

96a The Permian system in Kansas. Colo Coll Studies $6: 1-48$ (1896)

$96 \mathrm{~b}$ On the stratigraphy of the Platte series, or Upper Cretaceous of the plains. Colo Coll Studies 6:49-52 (1896)

96e Preliminary notice of three late Neocene terranes of Kansas. Colo Coll Studies 6:53-54 (1896)

97 Observations on the Cimarron series. Am G 19:351-363 (1897)

97a Discovery of marine Jurassic rocks in southwestern Texas. J G $5: 813-820$ (1897)

$97 \mathrm{~b}$ Notes on some fossils of the Comanche series; Stratigraphic names for $\mathrm{Ca}$ prina and Caprotina (or Requienia)-bearing beds of northern Texas. Science $\mathbf{n} \mathbf{s}$ 6:134-136 (1897)

00 Goat-antelope from the cave fauna of Pikes Peak region. G Soc Am, B 11:610612 , il (1900) Abst, Science n s 11:219
Cragin, Francis Whittemore-Continued.

ooa Buchiceras (Sphenodiscus) belviderensis and its varieties [Cretaceous, Kansas and Texas]. Colo Coll Studies 8:2731, il (1900)

01 A study of some teleosts from the Russell substage of the Platte Cretaceous series. Colo Coll Studies $9: 25-37$, il (1901)

05 Paleontology of the Malone Jurassic formation of Texas. U S G S, B 266: $172 \mathrm{pp}$, il (1905)

Craig, E. Hubert Cunningham.

05 The San Fernando [Trinidad] manjak field. Report by the government geologist. Council Paper no 3 of 1905. 10 pp, Trinidad 1905

05a Cacao soils. Geological notes on by the government geologist. Council Paper no 5 of 1905 . $6 \mathrm{pp}$, Trinidad 1905

05b Mayara-Guayaguayare oil field. Report by the government geologist upon. Council paper no 25 of $1905.14 \mathrm{pp}$, Trinidad 1905

o5e Ofl flelds of Trinidad. Report by the government geologist. Council Paper no 119 of $1905.14 \mathrm{pp}$, Trinidad 1905

o5d Government geologist; annual report from 24th November 1904 to 23 d November 1905. Trinidad, Legislative Council, Council Paper no 137 of 1905: 4 pp (1905)

o5e Geological structure of Trinidad. Publications of Victoria Inst Trinidad: 8 $\mathrm{pp}$ (1905) [not seen] Imperial Inst, B 5: 175-179 (1907)

O5f (with Carmody, P.) Portland cement as a local industry. [Trinidad, Legisative Council], Council Paper no 4 of $1905: 6 \mathrm{pp} \mathrm{(1905)}$

06 Oil fields of Trinidad. Special report of the government geologist on the Cedros district. Council paper no 12 of 1906: $7 \mathrm{pp}$, Trinidad 1906

06a Oil fields of Trinidad; preliminary report by the government scologist on the Guapo and La Brea district. Trinidad, Legislative Council, Council Paper no 30 of $1906: 4 \mathrm{pp} \mathrm{(1906)}$

06b Supplementary report on the San Fernando manjak field. Trinidad, Legislative Council, Council Paper no 35 of 1906: 6 pp (1906)

06e Annual report by the government geologist for the year ending 23d November, 1906. Trinidad, Legislative Council, Councll Paper no 146 of $1906: 4$ pp, map, Trinidad .906

o6d Trinidad oil fields. Special reports by the government geologist on the oil fields of Trinidad; district east of Erin. Council Paper no 147 of 1906 . 6 pp, map, Trinidad 1906

06e The oil fields of Trinidad. $\mathrm{R}$ Colonial Inst, J $37: 487-498$ (1906) 
Crais, E. Hubert Cunningham-Continued. o7 Preliminary report ... on the Island of Tobago. Trinidad, Council Paper no 9 of $1907,5 \mathrm{pp}$, map, Trinidad 1907

07a Trinidad oil fields. General report by the government geologist on the central and northern anticlines (western districts). Council Paper no 60 of 1907. 19 pp, map, Trinidad 1907

07b Report by the government geologist on the metamorphic rocks of Trinidad. Council Paper no 76 of 1907 . 9 pp, Trinidad 1907

07e Trinidad oil fields. Report on the oil fields of the central anticline (central district). Council paper no 131 of 1907 . $7 \mathrm{pp}$, map, Trinidad 1907

ord Gcological structure of Trinidad. Imperial Inst, B 5:175-179 (1907)

13 Report on the oilfields of Barbados. $14 \mathrm{pp}$, maps, Barbados 1913

14 The oil flelds of Canada (with special reference to Alberta). United Empire n 8 5:261-269 (1914)

14a Oll prospects in Alberta. M J 104: $118-120$ (1914)

15 The prospective oil fields of western Canada (with discussion). Inst Petroleum Tech, J 1:128-145 (1915)

18 The prospective oil fields of Barbados. Inst Petroleum Technologists, J 4 : 68-78 (1918)

Craig, W.

S9 Contribution to the geology and pale. ontology of the townships of Russell and Cambridge, in Russell, Ont.; I, Physiography and general geology. Ottawa Nat 2 : 136-139 (1889)

Cramer, C.

68 Fossile Hölzer der arktischen Zone; II, Fossile Hölzer des Bankslandes. In Heer, O., Flora fossilis aretica vol 1:170 175, il (1868)

Cramer, Frank.

90 On a recent rock flexure. Am J Sc (3) $39: 220-225$ (1890)

91 On the rock fracture at the Combined Locks mill, Appleton, Wis. Am J Sc (3) 41: 432-434 (1891)

Crampton, Frank A.

16 Platinum at the Boss mine, Goodsprings, Nev. M Sc Press 112:479-482 (1916)

Crampton, Henry E.

10 Two active volcanoes of the south seas [Kilauea in the Hawailan Islands]. Am Mus J 10: 171-180 (1910)

Crandall, Albert Rogers.

77 Report on the geology of Greenup, Carter, and Boyd cos., and a part of Law rence. $\mathrm{k} y \mathrm{G} \mathrm{S}, \mathrm{Rp}$ Prog $2 \mathrm{n} \mathrm{s}: 1-77$, map (1877) ; Eastern Coal Field C: 1-77 (1884)

77a Report on the geology of the proposed line of the Elizabethtown, Lexington, and Big Sandy Railroad, from Mt. Sterling to the Big Sandy River. Ky G S, Rp Prog 2 y s: $351-360$ (1877)
Crandall, Albert Rugers-Continued.

7s Report on the geology of Menifee Co Ky G S, Rp Prog 4 n s: 167-181, map (1878) ; Eastern Coal Field C:195-20? (1884)

78n (and Moore, P. N.) On the ge. ology of portions of the upper Cumberland River valley in Bell and Harlan cos. K G S, Rp Prog 4 n s : 445-453 (1878)

so Report on the Chinn's Branch cannel coal district. Ky G S, Rp Prog 5 n s: $385-$ 394 (1880) ; Eastern Coal Field C:289298 (1884)

80a Preliminary report on the geolog of Morgan, Johnson, Magoffin, and Floyd cos., with map. Ky G S [Rp Prog] 6 n s $315-338$ [1880?]

85 The occurrence of trap rock in east. ern Kentucky (abst). Am As, Pr 34:236237 (1886) Science 6:222 (1885)

S7 Report on the Pound Gap region Ky G S, Preliminary reports on the southeastern Ky coal fleld: 1-29 (1887)

87 . Report on the geology of Elliott $\mathrm{Co}$. also. Notes on the trap dikes of Elliott $C_{0}$ Ky G S : 28 pp, map [1887?]

91 Report on the geology of Whitley Co and a part of Pulask1. Ky G S: 44 p $\operatorname{map}$ [1891?]

o5 The coals of the Big Sandy Valley south of Louisa and between Tug Fork and the headwaters of the north fork of Ken tucky River. Ky G S, B 4:141 pp (1905)

10 Report on the coal beds of the Tus Fork region, Martin and Pike cos.. $\mathrm{K}$. Ky G S, Rp Prog 1908-9: 36-54 (1910)

$10 \mathrm{a}$ Coals of the Licking Valley reglon and of some contiguous territory. including also an account of Elliott $\mathrm{Co}$, and its dikes. Ky G S, B 10:90 pp, maps (1910) [dis. tributed 1912 or 1913].

12 (and Sulivan, G. M.) Report on the coal field adjacent to Pineville Gap in Bell and Knox cos, Ky G S, B 14:130 pp, maps (1912)

Crandall, Roderic.

07 The Cretaceous stratigraphy of the Santa Clara Valley region in California Am J Sc (4) 24:33-54 (1907)

O7a The geology of the San Francisen Peninsula. Am Ph Soc, $\operatorname{Pr} 46: 3-58$, maps (1907)

\section{Crane, Agnes.}

93 The generic evolution of the Paleozoli Brachiopoda. Science 21:72-74 (1893) Am G 11: 400-406 (1893)

93a New classifications of the Brachiopoda. G Mag (3) $10: 318-323$ (1893)

\section{Crane, Guy Walter.}

12 The iron ores of Missouri. Mo But G Mines (2) 10:xvi, 434 pp, map [1912]

15 Geology of the ore deposits of the Tintic mining district, Utah. Am I M Eng B $106: 2147-2160$ (1915); Tr $54: 342$ 355 (1917) Abst, Eng M J̀ 100:753-757 (1915) 
Crane, Walter Richard.

96 "Horsebacks" in the Kansas Coal Yeasures. Kans Univ Q 4: 145-151 (1896) 01 Kansas coal mining. Eng M J 72 : 74-752, map (1901)

02 Geological distribution of mineral springs and wells. Kans Univ G S 7: $323-330$ (1902)

02a The Kansas coal mines of the Missouri Valley. Eng M J 74:514-516 (1902) 03 Coal mining in the Indian Territory-the southwestern field. Eng M J $76: 577-581$ (1903)

03a [Asphalt deposits near Comanche, Ind. T.] Mines and Minerals $23: 337-341$ (1903)

03b Coal fields of [north central] Kansas, Mines and Minerals $24: 94$ (1903)

04 (with Adams, G. I.) Economic geology of the Iola quadrangle, Kans. U S G S, B 238: 83 pp, maps (1904)

05 The Pratt coal mines in Alabama. Eng If J 79: 177-180 (1905)

05a Coal mining in Arkansas. Eng M J $80: 774-777$ (1905)

06 Asphaltic coals in the Indian Territory. Mines and Minerals 26:252-254 (1908)

07 Lead and zinc mining in the Quapaw district, Okla. Mines and Minerals 27 : $445-446$ (1907)

08 Gold and silver, comprising an economic history of mining in the United States ... 727 pp. N Y 1908

13 The Bering River coal field, Alaska. Coal Age $3: 212-214$ (1913)

13a The soft coals of the Bering field. Coal Age $3: 298-300$ (1913)

13b Original impurities of Bering coals. Coal Age 3:444-445 (1913)

13e Folding troubles in the Bering [coal] field. Coal Age 3:568-570 (1913) 13d A brief account of the Matanuska [coal] field [Alaska]. Coal Age 3:630632 (1913)

13e The Matanuska River coal field by districts [Alaska]. Coal Age 4:148-152 (1913)

14 The coal resources of Alaska. Am If Cong, Rp 16th An Sess, 1913: 192-205 (1914)

14a The lignite fields of the Cook Inlet and Kachemak Bay region, Alaska. Penn 8t M Q 1:101-111 (1914)

15 Occurrence of lignite in Cook Inlet and Kachemak Bay region, Alaska. M Eng Torld $42: 209-213$ (1915)

15a Chignik Bay, Alaska, cosl fields. Colllery Eng 35: 457-461 (1915)

See also Adams (G I), 04

Oraw, W. J.

52 On the "chlinochlore" of Chester $\mathrm{Co}, \mathrm{Pa}$. Am J Sc (2) $13: 222-223$ (1852)
Crawe, J. B.

34 (and Gray, Asa) ... mineralogy of a portion of Jefferson and St. Lawrence cos. (N. Y.). Am J Sc $25: 346-350$ (1834)

Crawford, J.

90 The geological survey of Nicaragua. Am G 6:377-381 (1890)

91 Recent earthquake in Nicaragua. Am G $7: 77-86(1891)$

$91 a$ Neolithic man in Nicaragua. Am G $8: 160-166$ (1891)

$91 \mathbf{b}$ Viejo Range of Nicaragua. Am G $8: 190$ (1891)

91e Evidences of a glacial epoch in Nicaragua. Am G 8:306-314 (1891)

91d Human footprints in recent vocanic mud in Nicaragua (abst). Brit $\mathrm{As}, \mathrm{Rp} 60$ : 812 (1891)

91e On the geology of Nicaragua (abst). Brit As, Rp 60:812-813 (1891)

92 The geology of Nicaragua (abst). Am As, Pr $40: 261-270$ (1892)

92a The peninsula and voleano of Coseguina (abst). Am As, $\operatorname{Pr} 40: 270-274$ (1892)

92b Notes on earthquakes in Niearagua, February 6, 1892, Am G 10:115-118 (1892)

92e Notes from a geological survey in Nicaragua (abst). G Soc London, Q J 48 : Pr 191-192 (1892) G Mag (3) 9:382383 (1892)

93 Recent discoveries in northeastern Nicaragua; granite bills, moutonnéd ridges and gold-containing lodes or reefs, and leads or placer mines. Science 22:269272 (1893)

93a Minerals and resources of northeastern Nicaragua. Bur Am Republics, Mo B, Dec. $1893: 7-17$

95 Cerro Viejo and its volcanic cones. Boston Soc N H, Pr $26: 546-557$ (1895)

98 Recent severe seismic disturbances in Nicaragua. Am G 22: 56-58 (1898)

02 Earthquakes in Nicaragua. Am G $29 ; 323,395$ (1902)

$02 a$ List of the most important volcanic eruptions and earthquakes in western Nicaragua within historic time. Am G 30: 111-113 (1902)

02b Additions to the list of Nicaraguan rolcanic eruptions in historic-time. Am G $30: 395-396$ (1902)

Crawfora, John Jones.

94 Twelfth report of the State mineralogist (second biennial), two years ending September 15, 1894. Cal St M Bur, Rp $12: 1-412$, maps, Sacramento 1894

96 Thirteenth report (third biennial) of the State mineralogist, for the two years ending September 15, 1896. Cal St M Bur : 726 pp, map, Sacramento 1896 
Crawford, Ralph Dixon.

09 Geology and petrography of the Sugarloaf district, Boulder Co., Colo, Colo Univ, Studies 6:97-131, map (1909)

09 a Notes on the intrusive rocks of Boulder Co., Colo. Colo G S, 1st Rp 1908: 23-26 (1909)

o9b (with George, R. D.) The Hahns Peak region, Routt Co., Colo. Colo G S, Rp 1:189-229 (1909)

10 A preliminary report on the geology of the Monarch mining district, Chaffee Co., Colo. Colo G S, B 1:78 pp, map (1910)

11 (with Ford, W. E.) On a rhodonite (fowlerite) crystal from Franklin, N. J. Am J Sc (4) 32: 289-290 (1911)

13 Geology and ore deposits of the Monarch and Tomichi districts, Colo. Colo G $\mathrm{S}, \mathrm{B} 4: 317 \mathrm{pp}$, maps (1913)

13a Field and office methods in the preparation of geological reports; some methods of geologic fleld work. Ee G 8: 386-389 (1913)

16 (and worcester, P. G.) Geology and ore deposits of the Gold Brick district, Colo. Colo G S, B 10:116 pp, maps (1916)

Credner, Georg Rudolf.

75 Ceratites fastigatus und Salenia texana. Zs Ges Naturw N F 12:105-116, il (1875)

78 Die Deltas, ihre Morphologie geographische Verbreitung und EntstehungsBedingungen. Petermanns Mitt, Erg 56: $74 \mathrm{pp}$, maps (1878)

Credner, Hermann.

65 Geognostische Reiseskizzen aus New Brunswick in Nord-Amerika. N Jb 1865 : 803-821

65a Geognostische Skizze der Umgegend von New York. Deut G Ges, Zs 17:388398 (1865)

66 Geognostische Skizzen aus Virginia, Nordamerika. Deut G Ges, Zs 18:77-85 (1866)

66a Beschreibung von Mineralvorkommen in Nordamerika. Berg-u hütt Ztg 25 : $3-5, \quad 16-17,29-30,55-56,79-80,93-94$, $118-119,143-146,209-210,221-223$ (1866)

67 Geognostische Skizze der Goldfelder von Dahlonega, Ga. Deut $G$ Ges, Zs 19 : $33-40$ (1867)

68 Die Gliederung der eozoischen (vorsilurischen) Formationsgruppe Nord-Amerikas. Zs Ges Naturw 32:353-405 (1868) Also, Habilitationsschrift, Leipzig Univ : 54 pp, Halle 1869

69 Die vorsilurischen Gebilde der "Oberen Halbinsel von Michigan" in Nord-Amerika. Deut G Ges, Zs $21: 516-554$ (1869)

69a Beschreibung einiger charakteristischer Vorkommen des gediegenen Kupfers auf Keweenaw Point am Oberen See NordAmerika's. N Jb $1869: 1-14$

70 Die Kreide von New Jersey. Deut $G$ Ges, Zs 22:191-251, map (1870)
Credner, Hermann-Continued.

70a Geognostische Aphorismen aus Yord. Amerika: 1. Ueber ein Eisensteinrorkommen auf Contaktgüngen in Süd-Carolina: 2, Uder Erzvorkommen im untersilurischen Dolomite Virginias und einiger anderer L 0 . kalitäten. Zs ges Naturw 35:20-32 (1870)

70b Gewaltige Kupfermassen am Lake Superior. N Jb 1870:86

70e Ueber nordamerikanische Schiefer. porphyroide. N Jb 1870:970-984

71 Die Geognosie und der Mineral. relchthum des Alleghany-Systems. Petermanns Mitt 17:41-50, map (1871)

Creelman, Samuel.

63 Report of the chief gold commis. sioner for the Province of Nova Scotla 1ot the year 1862. $39 \mathrm{pp}$, Halifax, N S., 1863 Another ed, 37 pp, Halifax, N S, 1868

Crenshaw, J. L.

14 (with Allen, E. T.) The Stokes method for the determination of pyrite and marcasite. Am J Sc (4) 38:371-39? (1914)

14a (with Allen, E. T.) Effect of tem. perature and acidity in the formation of marcasite $\left(\mathrm{FeS}_{2}\right)$ and wurtzite $(\mathrm{ZnS}) ; 2$ contribution to the genesis of unstable forms. Am J Sc (4) 38:393-431 (1914) Crespi, R. A.

or Geology and development of Aguacate mines, Costa Rica. M World 27:847-818 (1907)

Cresson, Hilborne $\mathrm{T}$.

89 Early man in Delaware Valley. Bos ton Soc N H, Pr 24:141-150 (1889)

89a Remarks upon a chipped implement found in modifled drift, on the east fort of the White River, Jackson Co., Ind. B 0 s ton Soc N H, Pr 24:150-152 (1889)

91 A fallen forest and peat layer under lying aqueous deposits in Delaware $G$ Soc Am, B 2 : 640-642 (1891)

Crevecoen r, F. F.

03 List of fossil plants collected in the vicinity of Onaga, Kans. Kans Ac Sc, Tr 18:124-128 (1903)

Crew, Benjamin J.

87 A practical treatise on petroleum comprising its origin, geology, geographica distribution, history ... 508 pp, Phila 188i Crider, Albert Foster.

o5 Cement resources of northeast Mis sissippi. U S G S, B 260: 510-521 (1905)

O5a (with Eekel, E. C.) Geology and cement resources of the Tombigbee River district, Miss.-Ala. U S 58th Cong $3 d$ sess, $\mathrm{S}$ Doc 165: 23 pp, map (1905)

06 Geology and mineral resources of Mississippi. U S G S, B 283:99 pp, map (1906)

06a Clays of western Kentucky and Tennessee. U S G S, B 285:417-427 (1906) 
Crider, Albert Foster-Continued.

06b (and Johnson, L.C.) Summary of the underground water resources of Mlssissippi. U S G S, W S P 159: 86 pp, map (1906)

07 Cement and Portland c ment materials of Mississippi. Miss $\mathrm{C}$ S, B 1:73 pp, (1907)

13 Economic geology of Tell City and orensboro quadrangles. Ky G S (4) 1: 263-316 (1913)

13a The fireclays and fire clay industries of the Olive Hill and Ashland districts of northeastern Kentucky. Ky G S (4) $1: 589-711$ (1913)

14 Report on the geology and mineral resources of the Da\%son Springs quadrangle [Ky.]. Ky G S (4) pt 1:7-67, map (1914)

$14 a$ Geology and economic products of the Earlington quadrangle [Ky.]. Ky G $\$$ (4) 2 pt 1:69-153, map (1914)

15 Coals of the Nortonville quadrangle [ky.]. Ky G S (4) 3 pt 1:7-64, map (1915)

15a The coals of the Drakesboro quadrangle [Ky.]. Ky $\mathrm{G}$ S (4) 3 pt $1: 65$ 111, map (1915)

15b Coals of the Durmor quadrangle [Ky.]. Ky G S (4) 3 pt - : 113-153, map (1915)

15e The coals of the Little Muddy quadrangle [Ky.]. Ky G S (4) 3 pt 1:155182, map (1915)

16 The coals of Letcher Co. Ky G S (4) 4 pt 1:234 pp, maps (1916)

16a (with Stephenson, L. W.) Geology and ground waters of northeastern Arkansas. U S G S, W.S P 399:309 pp, maps (1916) Abst, Wash Ac Sc, J $6: 662-$ 663 (1916)

17 Oil and gas possibilities in Missis8ippl. Southwestern As Petroleum G, B 1: $152-155$ (1917)

See also Eckel, 13

Croft, Henry.

53 The mineral springs of Canada. Can J 1:151-154 (1853)

Crofton, Denis.

53 Genesis and geology ... with an intro. duction by Edward Hitchcock. 99 pp, Boston 1853

Croll, James.

66 On the reason why the change of cllmate in Canada since the glacial epoch has been less complete than in Scotland. G Soc Glasgow, $\operatorname{Tr} 2: 138-141$ (1866)

83 On some controverted points in geological climatology. Am J Sc (3) $26: 249-$ 271 (1888)

Cronise, Adelbert.

94 The pitch lake of Trinidad. Rochester Ac Sc, Pr 2: 278-285 (1894)

Crook, Alja Robinson.

92 Ueber einige fossile Knochenfische a:3 der mittleren Kreide von Kansas. Palaeontographica $39: 107-124$, il (1892)
Crook, Alja Robinson-Continued.

97 Some geological causes of the scenery of the Yellowstone National Park. Am G $20: 159-167$ (1897)

99 Oliver Marcy, LL. D. Am G 24:6772 , port. (1899)

00 Memoir of Ollver Marcy. G Soc Am, B $11: 537-542$ (1900)

01 Minerals of the Chicago area (abst). Science n s $13: 587-588$ (1901)

02 The mineralogy of the Chicago area. Chicago Ac Sc, N H S, B 5:57 pp (1902)

04 Molybdenite at Crown Point, Wash. G Soc Am, B $15: 283-288$ (1904) Abst, Science n s 19:527 (1904); Sc Am Sup $57: 23446$ (1904)

04a Missouri lead and zinc regions visitel by the Geological Society of America. Science n s 19:197-198 (1904)

12 Geology of Sangamon Co. [III.]. 24 pp, Springfield, IIl. 1912 [Reprinted with some revision from Historical Encyclopedia of Illinois vol $2: 814-822$ ]

12a Notes on Sangamon Co. [III.] limestones. III Ac Sc, Tr 5:115-118 (1912)

15 Origin of Monks Mound (abst). G Soc Am, B 26:74-75 (1915)

17 The composition and origin of Monks Mound [St. Clair Co., IH.]. Ill Ac Sc, Tr $9: 82-84$ [1917]

18 Additional note on Monks Mound (abst), with discussion by J. E. Todd). G Soc Am, B 29:80-81 (1918)

See also Bucher, 18a; Tomlinson, 18; U. P. R. R. Co., 09

Crooks, Harold F.

18 (with Blackwelder, E.) Pre-Cambrian rocks in the Medicine Bow Mountains of Wyoming (abst). G Soc Am, B 29:9798 (1918)

$18 a$ (with Savage, T. E.) Early Silurian rock; of the northern Peninsula of Michigan. Am J Sc (4) $45: 59-64$ (1918)

18b (with Van Tuyl, F. M.) Types of North American oolites $(a b s t)$, G Soc Am, B 29: 102 (1918)

Croom, H. B.

$34 \ldots$ organic remains found in the marl pits in Craven County, N. C. Am J Sc 27 : 168-171 (1834)

Crosby, William Otis.

76 Report on the geological map of Massachusetts (Massachusetts Commission to the Centennial Exposition): 1-42, Boston 1876

77 Notes on the surface geology of eastern Massachuseets. Am Nat 11:577-587 (1877)

79 Notes on the physical geography and geology of Trinldad. Boston Soc N H, Pr $20: 44-55$ (1879)

$79 a$ On the occurrence of fossillferous boulders in the drift of Truro on Cape Cod, Mass, Boston Soc N H, Pr 20:136-140 (1879) 
Crosby, William Otis-Continued.

$\mathbf{7 9 b}$ On the possible origin of petrosili. clous rocks. Boston Soc N H, Pr 20:160169 (1879)

79e Native bitumens and the Pitch Lake of Trinidad. $\Lambda \mathrm{m}$ Nat $13: 229-246$ (1879,

Sc Am Sup 7 : 2771-2772, 2785-2788 (1879)

so Contributions to the geology of east. ern Massachusetts. Boston Soc N H, Oc P 3 : $286 \mathrm{pp}$, map (1880)

son on the evilfence of compression in the rocks of the Boston basin (with discussion by M. E. Wadsworth : 313-318) Boston Soc N H, Pr 20:308-313 (1880)

sob Distorted pebbles in conglomerate. Boston Soc N H, Pr 20:368-378 (1880)

soc Pinite in eastern Massachusetts, its origin and geological relations. Am $\mathbf{J}$ Se (3) $19: 116-122(1880)$

sod (and Barton, G: H.) Extension of the Carboniferous formation in Massa. chusetts. Am J Sc (3) 20:416-420 (1880)

81 Common minerals and rocks. Boston Soc N H, Guides for Sclence teaching. No. XII : $130 \mathrm{pp}$, Boston 1881 [2d ed], $205 \mathrm{pp}$, Boston 1893

81a Geology of Frenchman's Bay, Me. Boston Soc N H, Pr 21: 109-117 (1881)

S1b On the absence of joint structure at great depths and its relations to the forms of coarsely erystalline eruptive masses. G Mag (2) 8:416-420 (1881)

82 On the classification of the textures and structures of rocks, Boston Soc N H, Pr 21:280-288 (1882)

83 On the classification and origin of joint structures. Boston Soc N H, Pr 22 : 72-85 (1883) Abst, Am As, Pr 31:409411 (1883)

S3a On the elevated coral reefs of Cuba. Boston Soc N H, Pr 22:124-130 (1883)

83b Origin of continents. G Mag (2) $10: 241-252$ (1883) ; (3) $1: 46-47$ (1884)

s3e On the mountains of eastern Cuba. Appalachia $3: 129-142$ (1883)

S3a Probable occurrence of the Taconian system in Cuba. Science 2: 740 (1883)

84 On the chasm called "Purgatory" in Sutton, Mass. Boston Soc N H, Pr 22: 434-436 (1884)

84a Origin and relations of continents and ocean basins. Boston Soc N H, Pr $22: 443-485$ (1884)

$\mathbf{8 4 b}$ On the relations of the conglomerate and slate in the Boston basin. Boston Soc N H, Pr 23: 7-27 (1884)

84e Chemical geology. Science $3: 59$ (1884)

s6 Geological collections; mineralogy. $184 \mathrm{pp}$, Boston 1886 [not seen]

$86 a$ Colors of solls. Boston Soc N H, Pr 23: 219-222 (1886)

86b Notes on joint structure. Boston Soc N H, Pr 23: 243-248 (1886)

s6e (and Barton, G. H.) On the great dikes at Paradise, near Newport [R. I.]. Boston Soc N H, Pr 23:325-330 (1886)
Crosby, William Otis-Continued.

87 Tables for the determination of com. mon minerals ... 74 pp, Boston 1887. 21 ed, 84 pp, Boston 1888 3d ed, 106 pp. Boston 1895

S7a The elevated potholes near Shel. burne Falls, Mass. Tech Q 1:36-38 (1887)

88 Geology of the outer islands of Bos. ton harbor. Boston Soc N H, Pr 23:450457 (1888)

SSa Geology of the Black Hills of Dakota. Boston Soc N H, Pr 23:488-517; $24: 11$ (1888)

SSb Methods of instruction in mineral. ogy and structural geology in the Masss. chusetts Institute of Technology. Tech $Q$ 1: 187-194 (1888)

sse on the joint structure of rocks, Tech Q 1:245-250 (1888)

8Sd Quartzites and siliceous concretions. Tech Q 1:397-407 (1888) Sc Am Sup 2: 10466-10468 (1888)

SSe (and Greeley, J. T.) Vesurianite from Newbury, Mass. Teeh Q 1:407-408 (1888)

S8f (and Brown, C. L.) Gabnite of zinc spinel from Rowe, Mass. Tech Q 1: 408 (1888)

89 Physical history of the Boston Basid. Boston Soc N H. Teachers' School of Sc. ence, Lowell Free Courses 1889-90:22 pp. Boston 1889

89a Relations of the pinite of the Boston Basin to the felsite and conglomerate Tech Q 2:248-252 (1889)

90 Geological history of the Boston basin [Mass.]. Boston Soc N H, Pr 25:10-17 (1890)

90a The kaolin in Blandford, Mass Tech Q 3:228-237 (1890)

oob The Madison boulder [N. H.]. Appalachia $6: 61-70,105$ ( 1890$)$

91 On the contrast in color of the soils of high and low latitudes. Am G 8:72-82 (1891) Tech Q 4:36-45 (1891)

91 a Composition of the till or bouldet clay. Boston Soc N H, Pr 25:115-140 (1891)

92 Geological collections: dynamical geology and petrography. Guides to the museum of the Boston Society of Natural History. 302 pp, Boston 1892

92a Geology of ingham, Mass. (abst). Boston Soc N H, Pr 25: $99-512$ (1892)

93 Geology of the Boston Basin; Nantasket and Cohasset. Boston Soc $\mathrm{N} \mathrm{H}, 06$ P 4 v 1 pt $1: 1-177$, maps (1893)

93a The origin of parallel and intersecting joints. Am G $12: 368-375$ (1893)

94 Geology of the Boston Basin; Hing. ham. Boston Soc N H, Oc P 4 ₹ 1 pt $2: 179-288$, maps (1894)

94a (and Ballard, Hetty O.) Distri. bution an probable age of the fossil shells in the drumlins of the Boston Basin. AII J Sc (3) 48:486-496 (1894) 
Crosby, William Otis-Continued.

$94 \mathrm{~b} \mathrm{~A}$ classification of economic geologial deposits based on origin and original structure. Am G 13:249-268 (1894) Tech Q $7: 27-48$ (1894)

94e Origin of the coarsely crystalline rein granites or pegmatites (abst). Am G $13: 215-216$ (1894)

95 Sandstone dikes accompanying the great fault of Ute Pass, Colo. Essex Inst, B 27:113-147 (1895)

95a A classification of economical gedogical deposits. Eng M J 59:28-29 (1895)

96 Englacial drift. Am G 17:203-234 1896) Tech Q 9:116-144 (1896)

$96 \mathrm{a}$ Mr. [T. T.] Bouvé's work in geolagy and mineralogy. Boston Soc N H, Pr 27:236-239 (1896)

96b Glacial lakes of the Boston Basin (obst). Am G 17:128-130 (1896) Science in $\mathrm{s} 3: 212-213 \quad$ (1896)

97 Notes on chemical geology. $120 \mathrm{pp}$, Nass Inst Tech 1897

97a Contribution to the geology of Newport Neck and Conanicut Island. Am J Sc (4) $3: 230-236$, maps (1897)

$97 \mathrm{~b}$ (and Fuller, M. L.) Origin of pegmatite. Am G 19:147-180 (1897)

97e The great fault and accompanying sandstone dikes of Ute Pass, Colo. Science A 8 5:604-607 (1897)

98 History of the Blue Hills complex (obst). Am As, Pr 47:304-305 (1898) Am G $22: 263-264$ (1898)

98a Geology [of the Boston region]. See Grabau, 98

99 Geology of the Wachusett dam and Wachusett aqueduct tunnel of the Metropolitan Water Works in the vicinity of Clinton, Mass. Tech $Q$ 12:68-96 (1899)

99a Geological history of the Nashua Valley during the Tertiary and Quaternary perfods, Tech Q 12:288-324, map (1899) 99b Archean - Cambrian contact near Manitou, Colo. G Soc Am, B 10: 141-164, map (1899) Abst, Am G $23: 92$ (1899); Science n s 9:101 (1899); Ottawa Nat $12: 198$ (1899)

99e The glacial lake of the Nashua Valley (abst). Am G 23:102-103 (1899) Sclence n s 9:106 (1899)

00 Geology of the Boston Basin: the Blue Hills complex. Boston Soc N H, Oc P 4 ₹ 1 pt $3: 289-563$, map (1900)

00a Outline of the geology of Long lsland in its relations to the public water supply. Tech Q 13:100-119 (1900)

$00 \mathrm{~b}$ Notes on the geology of the sites of the proposed dams in the valleys of the Housatonic and Ten Mile rivers. Tech Q 13: $120-127$ (1900)

00e On the origin of phenocrysts and the development of the porphyritic texture in igneous rocks. Am G 25:299-310 (1900)
Crosby, William Otis-Continued.

01 The tripolite deposit of Fitzgerald Lake, near St. John, N. B. Tech Q 14: 124-127 (1901)

01a Geological history of the hematite iron ores of the Antwerp and Fowler belt in New York. Tech Q $14: 162-170$ (1901) Am G 29:233-242 (1902)

$01 \mathrm{~b}$ Are the amygdaloidal melaphyrs of the Boston Basin intrusive or contemporaneous? Am G 27:324-327 (1901)

02 Origin of eskers. Boston Soc N H, Pr $30: 375-411$ (1902) Am G $30: 1-38$ (1902)

02a Origin and relations of the auriferous veins of Algoma, western Ontario. Tech Q 15: 161-180 (1902)

02b A study of hard-packed sand and gravel. Tech Q 15:260-264 (1902)

03 A study of the geology of the Charles River estuary and the formation of Boston Harbor. Mass, Report of the Committee on Charles River dam, Boston, 1903; Appendix no $7: 345-369$, map (1903)

03a The hanging valleys of Georgetown, Colo, Am G $32: 42-48$ (1903) Tech Q $16: 41-50$ (1903) Abst, Science n s $17:$ 227 (1903): J G 11:117 (1903) ; Sc Am Sup $55: 22666$ (1903)

031 A study of the geology of the Charles River estuary and Boston Harbor ... [Mass.]. Tech Q 16:64-92 (1903)

o3e Structure and composition of the delta plains formed during the Clinton stage of the glacial lake of the Nashua Valley. Tech Q $16: 240-254$, map ; 17:37$75(1903-4)$

04 (and LaForge, L.) [Notes on water resources of] Massachusetts. U S G S, W-S P 102:94-117 (1904)

$04 a$ [Notes on water resources of] Rhode Island. U S G S, W-S P 102:119125 (1904)

04b Geology of the Weston aqueduct of the Metropolitan Waterworks in Southboro, Framingham, Wayland, and Weston, Mass. Tech Q 17:101-116 (1904)

o4e (and Loughlin, G. F.) A descriptive catalogue of the building stones of Boston and vicinity [Mass.]. Tech Q 17 : 165-185 (1904)

04d Memoir of Alpheus Hyatt. G Soc Am, B 14: 504-512, port (1904)

o5 [Underground waters of] Massachusetts and Rhode Island. U S G S, W-S P 114: 68-75 (1905)

o5n Water supply from the delta type of sand plain. U S G S, W-S P 145: 161178 (1905)

o5b The limestone granite contact deposits of Washington Camp, Ariz. Tech Q 18: 171-190 (1905) Am I M Eng, B1. Mo B 6:1217-1238 (1905); Tr $36: 626-$ 646 (1906) 
Crosby, William Otis-Continued.

o5e Genetic and structural relations of the igneous rocks of the lower Neponset Valley, Mass. Am G $36: 34-47,69-83$ (1905) Tech Q 18:386-409 (1905)

07 Ore deposits of the eastern gold belt of North Carolina, Tech Q 20:280-286 (1907) Am I Min Eng, B1-Mo 19:171178 (1908); Tr 38:849-856 (1908)

07 a Volcanic activity in Alaska. Science n s 26:78 (1907)

os Outline of the geology of Long Island, N. Y. N Y Ac Sc, An 18:425429 (1908) Abst, Science n 8 28:936 (1908)

12 Dynamic relations and terminology of stratigraphic conformity and unconformity. J G 20:289-299 (1912)

14 Physiographic relations of serpentine, with special reference to the serpentine stock of Staten Island, N. Y. J G $22: 582-593$ (1914) Abst, with discussion G Soc $A m$, B 25: 87-88 (1914)

14a Buried gorge of the Hudson River and geologic relations of Hudson syphon of the Catskill aqueduct (abst). G Soc $\Delta \mathrm{m}$, B 25:89-90 (1914)

See also Grabau, 98; Shaler, 90c

Cross, R. T.

87 Notes on aquamarines from Mount Antero, Colo. Colo Sc Soc, Pr 2: 138-140 (1887)

Cross, Charles Whitman.

82 (and Hillebrand, W. F.) On the minerals mainly zeolites occurring in the basalt of Table Mountain, near Golden, Colo. Am J Sc (3) $23: 452-458 ; 24$; 129-138 (1882)

S2a (and Hillebrand, W. F.) Notes on some interesting minerals occurring near Pike's Peak, Colo. Am J Sc (3) 24:281286 (1882)

s3 On hypersthene andesite and on triclinic pyroxene in augitic rocks. U S G S, B 1:19-42 (1883) Abst, $\Delta \mathrm{m}$ J Sc (3) 25:139-144 (1883); Science 1:177 (1883); Am Nat $17: 520-521$ (1883)

83a The useful minerals of the United States; division of the Rocky Mountains. U S G S, Min Res [1882] : 748-759 (1883)

83b (and Hillebrand, W. F.) On minerals of the cryolite group recently found in Colorado. Am J Sc (3) 26 : 271-294 (1883)

83e Explanatory note concerning "triclinic pyroxene." Am J Sc (3) 26:76 (1883)

84 (and others) The artesian wells of Denver; a report by a special committee of the Colorado Scientific Society, published by the society, $41 \mathrm{pp}$, Denver 1884

84a On sanidine and topaz, etc., in the nevadite of Chalk Mountain, Colo. Am J Sc (3) $27: 94-96$ (1884)

85 (and Hillebrand, W. F.) Contributions to the mineralogy of the Rocky Mountains. U S G S, B 20:113 pp (1885)
Cross, Charles Whitman-Continued.

S5a [Gold sand from Snake Rire Idaho.] Colo Sc Soc, $\operatorname{Pr} 1: 36-37$ (1885) 85b The artesian wells of Denver; $p$ logical relations. Colo Sc Soc, $\operatorname{Pr} 1: \pi i-t$ (1885)

85e A list of specially noteworthy til erals of Colorado. Colo Sc Soc, Pr 1:19t 144 (1885)

85d (with Iddings, J. P.) On ty widespread occurrence of allanite as ut accessory constituent of many rocks. An J Sc (3) 30:108-111 (1885)

86 Petrography [of the Leadville dif trict, Colo.]. U S G S, Mon 12:319-3. (1886)

$\mathbf{8 6 a}$ On the occurrence of topaz and gar net in lithophyses of rhyolite. $\mathrm{Am} \mathrm{J} \mathrm{\&}$ (3) $31: 432-438$ (1886) Colo Sc Soc, $\mathrm{P}$ $2: 61-70$ (1887)

86b (and Eakins, L. G.) On ptilott a new mineral [from Jefferson Co., Cola] Am J Sc (3) 32:117-121 (1886) Colos Soc, $\operatorname{Pr} 2: 71-76$ (1887)

86e [Landslide near Cimarron, Gunnisa Co., Colo.] Science 8:293 (1886)

87 The Cimarron landsilde, July, 18\% Colo Sc Soc, Pr 2 : 116-126 (1887)

88 Note on phonolite from Colond Colo Sc Soc, Pr 2: 167-170 (1888)

$\mathbf{8 8 a}$ Note on slipping planes and lawh lar twinning in galena. Colo $\mathrm{Sc} \mathrm{Soc}$. $2: 171-174$ (1888)

88b [Paramorphism of certain mine als.] Colo Sc Soc, Pr 2:182-183 (186 88e On some eruptive rocks from Cust Co., Colo. Colo Sc Soc, Pr $2: 228-5$ (1888)

89 The Denver Tertiary formatic Colo Sc Soc, Pr 3: 119-133 (1889)

S9a The Denver Tertiary formatiot Am J Sc (3) 37:261-282, map (1889)

90 ... secondary minerals of the amp? bole and pyroxene groups. $\Delta \mathrm{m} \mathrm{J} \mathrm{Sc}$ (t $39: 359-370 \quad(1890)$

91 On alunite and diaspore from th Rosita Hills, Colo. Am J Sc (3) 41:40 475 (1891)

91 a Constitution and origin of spher: lites in acid eruptive rocks. $\mathrm{Ph} \mathrm{Soc}$ Wes B $11: 411-443$ (1891)

91b Geology of the Rosita Hills, Cust Co., Colo. Colo Sc Soc, Pr $3: 269-2$ t (1891)

92 Post-Laramie deposits of Colontel Am J Sc (3) 44: 19-42 (1892)

92a (and Eakins, L. G.) A new of currence of ptilolite, Am J Sc (3) 4 t 96-101 (1892)

93 Igneous rocks from ... Coahulla as Nueva Leon, Mex., collected by R. T. Hit Am J Sc (3) 45: 119-120 (1893)

94 Description of the Plkes Peak sbef [Colo.]. U S G S, G Atlas Pikes Peak? (no 7) :5 pp, maps (1894) Abst, J G 251-253 (1896) 
Cross, Charles Whitman-Continued.

94a Description of the igneous formations. U S G S, G Atlas AnthraciteCrested Butte fol (no 9) : 4-6, maps (1894) 94b The laccolitic mountain groups of Colorado, Utah, and Arizona. U S G S, An Rp 1\% pt 2:157-241 (1894)

94c Intrusive sandstone dikes in granite. $G$ Soc Am, B $5: 2 \angle 5-230$ (1894) Abst, Am G $13: 215$ (1894) ; Am J Sc (3) 47: 142 (1894)

95 General geology of the Cripple Creek district, Colo. U S G S, An Rp 16 pt 2:13-109, map (1895)

95a The post-Laramie beds of Middle Park, Colo. (with discussion by R. C. Hills). Colo Sc Soc, Pr 4: 192-213 [1895] (separate ed, $27 \mathrm{pp}, 1892$ )

$95 \mathrm{~b}$ on a series of peculiar schists near Salida, Colo. Colo Sc Soc, Pr 4: 286-293 [1895] (separate ed, $10 \mathrm{pp}, 1893$ )

95e The geology of the Cripple Creek gold mining district Colo. (abst). Science a 8 1:559 (1895)

96 Geology of Silver Cliff and the Rosita Hills, Colo. U S G S, An Rp 17 pt 2: 263-403, maps (1896)

96a The diorite of Ophir Loop and its inclusions, with suggestions as to the origin of certain gneisses ETelluride quadrangle, Colo.] (abst). Am G 17:345 (1896) Science n s $3: 605-606$ (1896)

96b (and others) [Discussion on the Cretaceous-Eocene boundary.] Science $\mathbf{n} \mathbf{s}$ 3:641-642 (1896)

96e Landslides in the Telluride region of Colorado (abst). Science n $\mathrm{s}$ 4:962 (1896)

96d (with Emmons, S. F.) Geology of the Danver Basin in Colorado. U $\mathrm{S}$ G S, Mon $27: 556$ pp, maps (1896)

96e (with Gilbert, G. K.) A new laccolite locality in Colorado and its rocks (abst). Am G 17:407-408 (1896)

97 Igneous rocks of the Leucite Hills and Pilot Butte, Wyo. Am J Sc (4) 4: 115-141 (1897) Abst, Science n s 5:361 (1897)

$97 a$ An analcite basalt from Colorado. J G $5:$ : 684-693 (1897)

98 The geological versus the petrographical classification of igneous rocks. J G 6:79-91 (1898) Abst, Science n 8 7:83 (1898)

98a The geology of the Cripple Creek gold mining district, Colo. (with discussion by Franklin Guiterman, R. C. Hills, C. J. Moore, Philip Argall, P. H. Van Diest, and T. A. Rickard). Colo Se Soc, $\operatorname{Pr} 5$ : 24-49 [1898] (sęparate ed, $32 \mathrm{pp}, 1894$ )

98b The San Miguel formation [Colorado]. Colo Sc Soc, Pr 5: 235-241 [1898] (separate ed, $7 \mathrm{pp}, 1896$ )

98c Igneous rocks of the Telluride district, Colo. Colo Sc Soc, Pr $5: 225-234$

[1898] (separate ed: 9-18, (1896)

$$
28737^{\circ}-23-17
$$

Cross, Charles Whitman-Continued.

99 Description of the Telluride quadrangle [Colo.]. U S G S, G Atlas Telluride fol (no 57) : $18 \mathrm{pp}$, maps (1899)

$99 a$ (assisted by spencer, A. C.) Description of the La Plata quadrangle [Colo.]. U S G S, G Atlas La Plata fol (no 60) : $14 \mathrm{pp}$, maps (1899)

00 (and Spencer, A. C.) Geology of the Rico Mountains, Colo. U S G S, An Rp 21 pt 2:7-165, map (1900)

OOa Landslides of the Rico Mountains, Colo. (abst). G Soc Am, B 11: 583 (1900) Science n s 11:101 (1900)

01. Outline of geology [of Silverton quadrangle, Colo.]. U S G S, B 182:2939 (1901)

02 Geologic formations versus lithologic individuals. J G $10: 223-244$ (1902)

02a The development of systematic petrography in the nineteenth century. $J$ G $10: 332-376,451-499$ (1902)

$02 b$ (and others) A quantitative chemico-mineralogical classification and nomenclature of igneous rocks. J G 10:555-690 (1902)

03 (and others) Quantitative classification of igneous rocks, based on chemical and mineral characters, with a systematic nomenclature. $286 \mathrm{pp}$, Chicago $1903 \mathrm{Rv}$ by G. P. Merrill, Am G 32: 48-54 (1903)

03a Observations on Hawailan geology (abst). Science n s 17:740 (1903)

04 An occurrence of trachyte on the island of Hawail. $J$ G $12: 510-523$, map (1904)

04a A new Devonian formation in Colorado. Am J Sc (4) $18: 245-252$ (1904)

o5 (and Howe, Ernest.) Description of the Silverton quadrangle [Colo.]. U S G S, G Atlas Silverton fol (no 120): 34 pp, maps (1905)

05a (and Ransome, F. L.) Description of the Rico quadrangle [Colo.]. U S G S, G Atlas Rico fol (no 130): $20 \mathrm{pp}$, maps (1905)

05b (and Howe, E.) Description of the Needle Mountains quadrungle [Colo.]; topography and general geology. U S G S, G Atlas Needle Mountains fol (no 131): $13 \mathrm{pp}$, maps (1905)

o5e (and Howe, E.) Red beds of southwestern Colorado and their correlation. G Soc Am, B 16:447-498 (1905) Abst, Science n s $21: 349$ (1905)

06 Prowersose (syenitic lamprophyre) from Two Buttes, Colo. J G 14:165-172 (1906)

06a (and Iddings, J. P., Pirsson, L. V., and Washington, H. S.) The texture of igneous rocks. J. G. 14:692-707 (1906)

06b (with Howe, Ernest) Glacial phenomena of the San Juan Mountains, Colo. G Soc Am, B 17:251-274 (1906) 
Cross, Charles Whitman-Continued.

or stratlgraphic results of a reconnaissance in western Colorado and eastern Utah. J G 15: 634-679 (1907)

ora (and Howe, Ernest, and Irving, J. D.) Description of the Ouray quadrangle [Colo.]. U S G S, G Atlas, Ouray fol (no 153) : $20 \mathrm{pp}$, maps (1907)

07b Memoir of George H. Eldridge. G Soc Am, B $17: 681-687$ (1907)

o7e Methods of igneous intrusion (abst).

Sclence n s 25:621-622 (1907)

08 The Triassic portion of the Shinarump group, Powell. J G 16:97-123 (1908)

o8a Wind erosion in the platean country. G Soc Am, B 19:53-62 (1908)

08b Laramie formation ( $a b s t)$. Sclence n s $28: 128$ (1908)

09 The Laramie formation and the Shoshone group. Wash Ac Sc, Pr 11:27-45 (1909)

09a Fluidal gneiss and contemporary pegmatites (abst). Sclence n s 29:946 (1909)

09b The Slumgullion mud flow (abst). Science n s 30:126-127 (1909)

10 Description of the Engineer Mountain quadrangle, Colo. U S G S, G Atlas, Engineer Mountain fol (no 171): $14 \mathrm{pp}$, maps (1910)

10a The natural classification of igneous rocks. G Soc London, Q J 66:470506 (1910)

11 Geology [of the Lake City district, Colo.]. U S G S, B 478: 18-32, map (1911)

11 a The lavas of Hawail and their relations. Wash Ac Sc, J 1:61-64 (1911)

$11 b$ Personal reminiscences [of Samuel Franklin Emmons]. G Soc Wash, Memorlal of Samuel Franklin Emmons: 6-8 (1911)

12 Alunite deposits of Rosita Hills, Colo. U S G S, B 511: 38-43 (1912)

$12 a$ Use of symbols in expressing the quantitative classification of igneous rocks. J G 20:758-762 (1912)

12b (and Yddings, J. P., Pirsson, L. V., and Washington, H.S.) Modifleations of the quantitative system of classification of igneous rocks. J G 20:550-561 (1912)

12e Petrographic description [of rocks of Apishapa quadrangle, Colo.]. U S G S, G Atlas, Apishapa fol (no 186) : 9-10 (1912)

$12 d$ Certain criticisms of the quantitative classification of igneous rocks (with discussion). Int $\mathbf{G}$ Cong, XI, Stockholm, 1910, C R : 971-976 (1912)

12e (with Schultz, A. R.) Potashbearing rocks of the Leucite Hills, Sweetwater Co., Wyo. U S G S, B 512:39 pp (1912) Abst, Wash Ac Sc, J $2: 159$ (1912)

13 Lavas of Hawail and their relations (abst). G Soc Am, B 24:684 (1913)

14 Dike rocks of the Apishapa quadrangle, Colo. U S G S, P P 90:17-31 (1914) Abst, Wash Ac Sc, J 4:422 (1914)
Cross, Charles Whitman-Continued.

14a (and Larsen, E. S.) Contrion tions to the stratigraphy of southwesten Colo. U S G S, P P 90: 39-50 (1916 Abst, Wash Ac Sc, J $4: 237-238$ (1914)

14b Problems of petrographic classifa tion suggested by the "Kodurite series" of India. J G 22:791-806 (1914)

15 Lavas of Hawail and their relatios U S G S, P P $88: 97$ pp, map (1915) $A b s t$, by J. F. Hunter, Wash Ac Sc, J6 294-295 (1916)

15a On certain points in petrograptt classification. Am J Sc (4) $39: 657-6 \%$. (1915)

See also Davis (W. M.), 00; Emmoss (S. F.) 93; Powell, 93, 95 ; Vaughan, $0_{\text {: }}$ Willis, 01c

Crosskey, Henry W.

66 On the relation between the glacil deposits of Scotland and those of Canade G Soc Glasgow, Tr 2:132-138 (1866) Can Nat n s 3: 207-211 (1867)

71 (with Brady, G. S.) Notes on fost Ostracoda from the post-Tertiary deposits of Canada and New England. G Mag 8: $60-65$, 11 (1871)

Crossman, James H.

90 San Bernardino Co. Cal St M Bur An Rp 9:214-239 (1890)

Crow, Wade L.

o1 The Breckenridge [Summit Co., Cola] placer problem. Colo Sch Mines, B 1:194 220 (1901)

Crowell \& Murray.

11 The iron ores of Lake Superior. 1\% pp, maps, Cleveland $19112 \mathrm{~d}$ ed, $257 \mathrm{pr}$ maps, Cleveland $19143 \mathrm{~d}$ ed, $316 \mathrm{pp}$, maps Cleveland 1917

Crowther, Henry M.

o3 The copper deposits of the Beare River Range, Utah. Eng M J 75:985 (1903)

Crozier, A. A.

86 Evidences of glacial action on the shores of Lake Superior. Science $7: 15$ (1886)

Crüger, Hermann.

60 On some vegetable fossils occurrits in Trinidad. In Wall, G. P., and Sawkins J. G., Report on the geology of Trinldad (Great Britain, G S, Mem) : 166-178 (1860) Cruess, William V.

14 Comparison of the oysters of the lower and upper horizons of the Miocene o? the Muir syncline $(a b s t)$. G Soc Am, B $25: 154$ (1914)

Crump, Malcolm H.

98 The clays and building stones of Ket tucky. Eng M J 66: 190-191 (1898)

13 The oolitic limestones of Warren Ca [Ky.]. Ky G S (4) 1: 1037-1051 (1913) 13a Kentucky rock asphalt. Ky G S (4) 1: 1053-1065 (1913)

16 Oolltic building stone of the Borlins Gręen field. Ky. (abst). Science n s 43: 397 (1916) 
Cuatáparo, J. N.

75 (and Ramirez, Santlago) Descripcion de un mamifero fosil de especie desconocida perteneciente al género Glyptodon, encontrado entre las capas post-terciarias de Tequisquiac, en el distrito de Zumpango [México]. Soc Geog Mex, B (3) $2: 354$ 362 (1875)

Cubberley, Ellwood Patterson.

94 Indiana's structural features as rerealed by the drill. Ind, Dp $\mathbf{G} \mathbf{N}$ Res, $A n$ Rp 18:219-255, map (1894)

95 A key for determinative mineralogy, with blanks for laboratory analysis. 154 $\mathrm{pp}$, Vincennes, Ind., 1895

Cue, Wilson B.

97 The Michipicoton mining district in Ontario. Eng M J 64:758 (1897)

Culbert, M. T.

04 The iron belt west of Hutton. Ont Bur Mines, Rp 1904: 222-224 (1904)

Culbertson, Glenn,

9s Preliminary work for the approximate determination of the time since the retreat of the first great ice sheet. Ind Ac Sc, Pr 1897:242-243 (1898)

00 The weathering and erosion of north and south slopes. Ind Ac Sc, Pr 1899 : 167-170 (1900)

03 Ripple marks in "Hudson Limestone of Jefferson Co., Ind. Ind $\mathrm{Ac} \mathrm{Sc}, \mathrm{Pr} 1902$ : 202-205 (1903)

08 Some peculiarities in the valle erosion of Big Creek and tributaries, Ind Ac Sc, Pr 1907: 101-103 (1908)

11 The occurrence of conglomerate and sandstone of postglacial origin in Jefferson Co., Ind. Ind Ac Sc, Pr 1910 : 141143 (1911)

12 Observations having for their object the approximate determination of the time required for the erosion of Clifty and Butler ravines in Jefferson Co., Ind. Ind Ac Sc, Pr 1911: 169-170 (1912)

12a The occurrence of hand specimens of jointed structure in the New Albany shale, Ind Ac Sc, Pr $₫ 911: 171-172$ (1912)

16 The geology and natural resources of Jefferson Co. Ind $\mathrm{Dp} G \mathrm{~A}$ Res, An Rp $40: 223-239$ (1916)

Culbertson, Thaddeus A.

51 Journal of an expedition to the Mauvaises Terres and the upper Missouri in 1850. Smiths Inst, An Rp 5, 1850:84132 (1851)

Culin, Frank L., jr.

16 Magnesite. Ariz St Bur Mines, B $14: 10 \mathrm{pp}$ (1916)

16a Mica. Ariz St Bur Mines, B 16: $12 \mathrm{pp}$ (1916)

16b Gypsum. Ariz, Univ, Sur Mines, B $19: 8$ pp (1916)

16e Cement. Ariz, Univ, Bur Mines, B $25: 15$ pp (1916)
Culin, Frank L., jr.-Continned.

16d Celestite and strontianite, Ariz, Univ, Bur Mines, B $35: 4$ pp (1916)

16e Building stones. Ariz, Univ, Bur Mines, B 40:11 pp (1916)

17 Lime rocks. Ariz, Univ, Bur Mines, B $46: 8 \mathrm{pp} \mathrm{(1917)}$

17a Gems and precious stones of Arizona. Ariz, Univ Bur Mines, B 48:7 pp (1917)

Cullen, J. A.

16 (with Waggaman, W. H.) The recovery of potash from alunite. U S Dp Agr, B 415: 14 pp (1916)

Cullen, John.

17 Lime resources and industry in Oklahoma. Okla G S, B 26: 70 pp, map (1917) Culver, Garry E.

89 A possible elephant [Elephas bones, Vermillion, S. Dak.]. Science 14:103 (1889)

90 Report [of artesian water conditions of the Dakotas]. U S, 51st Cong 1st sess, S Ex Doc 222: 55-63 (1890)

92 Notes on a little known region in northwestern Montana. Wis Ac Sc, Tr $8: 187-205$ (1892)

92a (and Hobbs, W. H.) On a new occurrence of olivine diabase in Minnehaha Co., S. Dak. Wis Ac Sc, Tr $8: 206-210$ (1892)

93 Report [on underground water conditions in the Dakotas]. U S, 52d Cong 1st sess, S Ex Doc 41 pt 3:191-209, map (1893)

94 Notes on the geology of Itasca Co. Minn G S, An Rp 22:97-114 (1894)

94a Some New Jersey eskers. Science $23: 15-16$ (1894) Wis Ac Sc, Tr 10:19$23(1895)$

95 The erosive action of ice. Wis Ac Se, Tr 10:339-366 (1895) Abst, J G 3: $982-983$ (1895)

Cumenge, E.

82 Etude sur les gisements de charbon et de bitume de la Trinidad. An Mines (8) $2: 137-184$ (1882)

93 Sur une espèce minérale nouvelle découverte dans le gisement de cuivre de Boleo (Basse Californie, Mexique). Ac Sc Paris, C R 116: 898-900 (1893)

98 Sur le gite cuprifère d'Inguaran, Etat de Michoacan (Mexique). Soc Franç Minér, B 21:137-142 (1898) Soc Cient Ant Alz, Mem $12 \mathrm{Rv}: 84-86$ (1898)

99 Echantillon d'une espèce minérale nouvelle, la von diestite [from an Luis, Colo.; also a note on the occurrence of carnotite]. Soc Franc Minér, B 22 no 3-6: $25-26$ (1899)

99a (with Friedel, C.) Sur un nouveau minerai d'urane [carnotite, Montrose Co., Colo.]. Soc Franç Minér, B $22: 26-29$ (1899) Ac Sc Paris, C R 128:532-534 (1899) 
Oumings, Edgar Roscoe.

97 (with Prosser, C. S.) Sections and thickness of the Lower Silurian formations on West Canada Creek and in the Mohawk Valley. N Y St G, An Rp 15: 23-24, 615659 (1897) N Y St Mus, An Rp $49 v 2$ : 23-24, 615-659 (1898)

o0 Lower Silurian system of eastern Montgomery Co., N. Y. N Y St Mus, B 34 : 419-468, map (1900)

00a On the Waldron fauna at Tarr Hole,

Ind. Ind Ac Sc, Pr 1899:174-176 (1900)

00b The stream gradients of the lower Mohawk Valley [N. Y.]. Ind $\mathrm{Ac} \mathrm{Sc}, \mathrm{Pr}$ $\cdot 1899: 176-178$, map (1900)

01 The use of Bedford as a formational name. J G 9:232-233 (1901)

$\mathbf{0 1 a}$ Orthothetes minutus, n. sp., from the Salem limestone of Harrodsburg, Ind.

Am G $27: 147-149$, il (1901)

01b A section of the upper Ordovician at Vevay, Ind. Am G $28: 361-380$, il (1901)

01c Notes on the Ordovician rocks of southern Indiana. Ind $\mathrm{Ac} \mathrm{Sc}, \mathrm{Pr} 1900$ : 200-215 (1901)

01d Some developmental stages of $\mathrm{Or}$ thothetes minutus n. $\mathrm{sp}$. Ind $\mathrm{Ac} \mathrm{Sc}, \mathrm{Pr}$ 1900: 216-218 (1901)

02 (and Mauck, A. V.) A quantitative study of variation in the fossil brachiopod Platystrophia lynx. Am J Sc (4) 14:916. il (1902)

02a A revision of the bryozoan genera Dekayia. Dekayella, and Heterotrypa of the Cincinnati group. Am G 29:197-218, il (1902)

03 The morphogenesis of Platystrophia; a study of the evolution of a Paleozoic brachiopod. Am J Sc (4) $15: 1-48,121$ 136 (1903)

04 Development of some Paleozoic Bryozoa. Am J Sc (4) 17:49-78 (1904)

04a (with Prosser, C. S.) The Waverly formations of central Ohio. Am G 34: 335-361 (1904)

05 Development of Fenestella. Am J Sc (4) $20: 169-177$, il (1905) Abst, G Soc Am, B 16:562 (1906); Am G 35:50-51 (1905)

06 (and Beede, J. W.) Fauna of the Salem limestone of Indiana; Introduction. Ind Dp G, An Rp 30:1189-1201, il (1906)

06a Description of the Bryozoa of the Salem limestone of southern Indiana; Gastropoda, Cephalopoda, and Trilobita of the Salem limestone. Ind Dp G, An Rp 30 : 1274-1296, 1335-1375, il (1906)

06b The weathering of the Subcarboniferous limestones of southern Indiana. Ind Ac Sc, Pr 1905: 85-89 (1906)

os The stratigraphy and paleontology of the Cincinnati series of Indiana. Ind Dp G, An Rp 32: 605-1188, il, maps (1908)

10 Paleontology and the recapitulation theory. Ind Ac Sc, Pr 1909:305-340 (1910) Pop Sc Mo $77: 298-304$ (1910)
Cumings, Edgar Roscoe-Continued.

12 Development and systematic posith: of the monticuliporoids. G Soc Am, B 2: $357-370$, il (1912)

$12 a$ Geological conditions of munidici water supply in the driftless area of sont ern Indiana. Ind Ac Sc, Pr 1911: 111-14 (1912)

$12 b$ (and Galloway, J. J.) A note in the batostomas of the Richmond series Ind Ac Sc, $\operatorname{Pr} 1911$ : 147-167, il (1912)

13 (and Galloway, J. J.) The strati? raphy and paleontology of the Tanneri Creek section of the Cincinnati series of Indiana. Ind $\mathrm{Dp} G$, An Rp $37: 353-4 i 6$ 11, map (1913)

14 Some of the geological conditions of municipal water supply [in Indiana]. Is diana Sanitary \& Water Supply As, 7t An Convention, $\mathrm{Pr}$ : 157-162 [1914?]

15 (and Galloway, J. J.) Studies of the morphology and histology of the Trt postomata or monticuliporoids. G Soc An, B $26: 349-374$, il (1915)

17 Memorial of Charles Smith Prosst. G Soc Am, B 28:70-80, port (1917)

See also Hubbard (G D), 15 ; Roesler, 1 Cumings, Willard L.

11 (and Miller, B. L.) Characteristio and origin of the brown iron ores of Camb guey and Moa, Cubr. Am I M Eng, B 51 $147-268$ (1911) ; Tr 42:116-137 (1912)

See also Roesler, 16

Cumming, C. L.

15 The artesian wells of Montreal, Cas G S, Mem $72: 153$ pp, map (1915)

Cummings, Byron.

10 The great natural bridges of Utak Nat Geog Mag 21: 157-167 (1910)

Cammings, Uriah.

95 American cements. 299 pp, Bostot 1898

Cammings, Whlliam N.

o5 The Hostotipaquillo district, Jaliso Eng M J 79:942-943 (1905) Bol Minero 2 : 61-64 (1916)

Cnmmins, A.

92 Geology of the natural gas fields about Pittsburgh [Pa.]. Eng M J 54: 106-107 (1892)

Cummins, Duncan H.

92 Texas gypsum formation. Scienct $20: 333$ (1892)

Cummins, William Fletcher.

88 Mining districts in El Paso ca.

[Tex.]. G Sc B 1 no 2 (1888)

88a The Carboniferous formation is Texas. G Sc B 1 no 3 (1888)

s9 Report of geologist for northert Texas. Tex G S, Rp Prog 1 (1888) : 45-53 (1889)

90 The southern border of the centrsl coal field. Tex G S, An Rp 1:143-18? (1890)

90a The Permian of Texas and its ovet lying beds. Tex G S, An Rp 1:183-197 (1890) 
Cummins, William Fletcher-Continued. 90b (and Lerch, Otto) A geological survey of the Concho country, State of Texas. Am G 5: 321-335, map (1890)

91 Report on the seology \& northwest: ern Texas. Tex G S, An Rp $2: 357-552$, map, il (1891)

92 Report [on northwestern Texas]. Tex G S, An Rp $3: \mathbf{1 2 7}-223$, map (1892)

92a Report on the geography, topography, and geology of the Llano Estacato or Staked Plains with notes on the geology of the country west of the plains. Tex G S, An Rp 3:127-223, map (1892)

92b The Texas meteorites. Tex Ac Sc, Tr 1 no $1: 14-18$ (1892)

92e (with Damble, E. T.) The Double Mountain section [Tex.]. Am G 9:347851 (1892)

93 Notes on the geology of northwest Texas. Tex G S, An Rp 4 pt 1:177-238 (1893)

93a Tucumcari Mountain [N. Mex.]. Am G $11: 375-383$, map (1893)

93b Geology of Tucumcari, N. Mex. Science 21:282-283 (1893)

93e Review of R. T. Hill's Report on artesian water in Texas. $44 \mathrm{pp}[\mathrm{n} \mathrm{p}, \mathrm{n}$ d, 1893 ?] Notice, Am G 11: 420 (1893)

93d (with Dumble, E. T.) The Kent section and Gryphaa tucumearii Marcou. Am G 12:309-314 (1893)

95 A question of priority [name of formation in Texas]. Am G 15:395-396 (1895)

97 Texas Permian. Tex Ac Sc, Tr 2: 93-98 (1897)

08 The localities and horizons of Permian vertebrate fossils in Texas. J G 16 : $737-745$ (1908)

Cunningham, h. M.

86 New find of fossil diatoms. Science $7: 35$ (1886)

94 Diatomaceae. In Smith, E. A., and others, keport on ... Coastal Plain of Alabama : 61-65, Ala G S 1894

94a Notes on the microzoa of the Tertiary of south Alabama. In Smith, E. A., and others, Report on ... Coastal Plain of Alabama : 250-254, Ala G S, 1894

94b Notes on the micro-geology of Alabama; Cretaceous. In Smith, E. A., and others, Report on ... Coastal Plain of Alabama : 286-289, Ala G S, 1894

Cunningham-Craig. See Cralg.

Curran, Thomas F. V.

11 Carnotite in Paradox Valley, Colo. Fing M J 92: 1287-1288 (1911)

13 Carnotite. Eng M J 96:1165-1167, 1223-1225 (1913)

Currey, Richard $O$.

54 Geology of Tennessee. Southern J Md Phys Sc 2: 50-61, 77-86, map (1854) 54 a Geology of Benton Co., Ala. Southern J Med Phys Sc 2: 199-202 (1854)
Currey, Richard 0.-Continued.

55 (and Proctor, C. A.) Copper dlstrict of Tennessee, Georgia, North Carolina, and Virginia. Southern J Med Phys Sc 3 : $38-44$ (1855)

56 A sketch of the geology of Tennessee. Southern J Med Phys Sc 4:193-208, 257$272, \quad 321-336, \quad 385-400$; $5: 1-16, \quad 77-83$, $160-168,246-262,309-327$, map (1856-7) Reprinted, x, 128 pp, map, Knoxville, Tenn., 1857

57 A sketch of the geology of Tennessee ... 128 pp, map, Knoxville, Tenn., 1857

57a Copper region of Tennessee; a sketch of the geology of Tennessee; gold, silver, and coal. M Mag $8: 156-163,237-$ $243,450-460 ; 9: 34-44$ (1857)

59 A geological visit to the Virginia copper region. $64 \mathrm{pp}$, map, Knoxville, Tenn., 1859

so The copper and iron region of the Floyd-Carroll-Grayson plateau of the Blue Ridge in Virginia, etc. The Virginias 1 : $62-64,70-71,74-77,80-81,95$ (1880)

Currie, P. W.

01 On the ancient drainage at Niagara Falls. Can Inst, Tr 7:7-14 (1901)

Curtice, Cooper.

89 Oriskany drift near Washington, D. C. Am G 3:223-225 (1889)

See also Hill (R. T.), 91

Curtis, George Carroll.

98 A model of seacoast characteristics. $J$ Sch Geog 2: 215-227 (1898)

99 (and woodworth, J. B.) Nantucket, a morainal island. J G $7: 226$ 236, map (1899)

OO A description of the topographical model of metropolitan Boston. Published by the Board of Paris Exposition Managers of the Commonwealth of Massachusetts. $37 \mathrm{pp}$, map, Boston 1900

Ooa (with Smith, G. O.) Camasland, a valley remnant [Wash.]. G-Soc Am, B 11: $217-222$ (1900)

03 Secondary phenomena of the West Indian volcanic eruptions of 1902 . J G 11:199-215 (1903) Abst, Science n s 17 : 226 (1903) ; Sc Am Sup $55: 22647$ (1903)

03a Note on the West Indian eruptions of 1902. Am G 31:40-43 (1903)

03b Modern rational relief of the earth's surface. Am G 32: 178-182 (1903)

03e Scientific relief maps (abst). Science n s $17: 222$ (1903)

04 Evidence of recent differential movement along the New England coast (abst). Science n s 19:522-523 (1904)

10 Destruction of the drumlins in Boston Harbor (abst). Science n s $32 ; 127$ (1910)

$1 x$ Land reliefs that are true to nature. Am Geog Soc, B 43:418-427 (1911)

11 a Observations on changes of level on the Atlantic coast line from Cape Cod to Cape Race, Newfoundland (abst). Science n s $33: 468$ (1911) 
Curtis, George Carroll-Continued.

11b The contribution which the naturalistic model is bringing to earth science (abst). Science n s 33:468 (1911)

13 Work going on at Kilauea volcano. Science n s $38: 355-358$ (1913)

15 Kilauea, a drop fault crater (abst). G Soc Am, B 26:77 (1915)

15a Comprehensive coral island theory (abst). G Soc Am, B 26:78 (1915)

15b Age as the determinant of character in volcanoes (abst). G Soc Am, B 26:78 (1915)

15e Evidence of continental glaciation on Mount Katahdin [Me.] (abst). G Soc Am, B 26: 78-79 (1915)

15d Naturalistic land model, the "last word in geology " (abst). G Soc Am, B 26 : 79-81 (1915)

See also Sayles, 17

Curtis, Joseph Story (?-1918).

84 Silver-lead deposits of Eureka, Nev. U S G S, Mon 7 : xiii, 200 pp, map (1884)

84a Report on the mining geology of the Eureka district, Nev. U S G S, An Rp 4: 221-251, maps (1884)

S4b The Ruby Hill mines, Eureka, Nev. Science 4: 459-460 (1884)

85 The quantitative determination of silver by means of the microscope. U S G S, An Rp 6:323-352 (1885)

See also Powell, 85a

Cushing, Henry Platt (1860-1921).

88 Notes on the Berea grit in northeastern Ohio. Am As, Pr 36:213-215 (1888)

91 Notes on the Muir Glacier region, Alaska, and its geology. Am G 8:207230, map (1891)

92 Notes on the geology of the vicinity of Muir Glacier (Alaska). Nat Geog Mag $4: 56-62$, map (1892)

93 The movement of Muir Glacier. Am G $11: 276-278$ (1893)

94 Preliminary report on the geology of Clinton Co. [N. Y.]. N Y St G, An Rp $13: 473-489$, map (1894) N Y St Mus, An Rp $47: 667-683$, map (1894)

95 Faults of Chazy Township, Clinton Co., N. Y. G Soc Am, B 6:285-296, map (1895) Abst, Science n s 1:58-59 (1895)

96 Notes on the areal geology of Glacier Bay, Alaska. N Y Ac Sc, Tr 15:24-34 (1896) Abst, Science n s $3: 33-34$ (1896)

$96 \mathbf{a}$ On the existence of pre-Cambrian and post-Ordovician trap dikes in the Adirondacks. N $\mathrm{Y}$ Ac Sc, Tr 15:248-252 (1896) Abst, Science n s 3:677 (1896)

97 Report on the geology of Clinton Co. [N. Y.]. N Y St G, An Rp 15:21-22, 499-573, maps (1897) N Y St Mus, An Rp 49 v $2: 21-22,499-573$, maps (1898)

$97 \mathbf{a}$ Note on hypersthene andesite from Mt. Edgecumbe, Alaska, Am G 20:156159 (1897)
Cushing, Henry Platt-Continued.

98 Syenite porphyry dikes in the north. ern Adirondacks. G Soc Am, B $9: 239$ 256, map (1898) Abst, J G $6: 119-12$ (1898); Science n s 7:80-81 (1898); Ottawa Nat 11: 224 (1898)

99 Report on the boundary between the Potsdam and pre-Cambrian rocks north of the Adirondacks. N Y St G, An Rp 16: 1-27, map (1899) N Y St Mus, An Rp 50 v $2: 1-27$, map (1899)

99a Preliminary report on the geolog of Franklin Co., N. Y. N Y St G, An Bp 18:73-128, map (1899) N Y St Mus, An $\mathrm{Rp} 52$ v 2:73-128, map (1900)

99b Augite syenite gneiss near Locs Lake, N. Y. G Soc Am, B 10:177-19: (1899) Abst, Am G 23:106 (1899); Sdence n s 9:141 (1899)

O1 Geology of Rand Hill and vicinity, Clinton Co. [N. Y.]. N Y St Mus, An Pp $53:$ r37-82, map (1901)

O1a Origin and age of an Adirondact augite syenite $(a b s t)$. G Soc Am, B 12 464 (1901) Science n s 13:100 (1901)

02 Recent geologic work in Franklin abd St. Lawrence cos, [N. Y.]. N Y St Mos An Rp 54: r23-82, map (1902)

02a Pre-Cambrian outlier at Little Falls, Herkimer Co. [N. Y.], N Y St Mus, As Rp 54 : r83-95 (1902)

02b The derivation of the rock name " anorthosite." Am G 29: 190-191 (190\%)

o3 Petrography and age of the North umberland rock [Saratoga Co., N. Y.]. I Y St Mus, An Rp 55: r24-29 (1903)

04 Memoir of Peter Neff. G Soc Am, B 15:541-544, port (1904)

o5 Geology of the vicinity of Little Falls, Herkimer Co. [N. Y.] ; area comprised is the Little Falls quadrangle. N Y St $\mathrm{Mss}$ B $77: 95 \mathrm{pp}$, maps (1905)

05a Geology of the northern Adirondad region [N. Y.]. N Y St Mus, B 95:271453, maps (1905)

07 Geology of the Long Lake quadrangle N Y St Mus, B 115:451-531, map (1907) O7a Asymmetric differentiation in 1 bathylith of Adirondack syenite. G Soc Am, B 18:477-492, map (1907) Abot, Seience n s 25:774 (1907)

o7b How faults should be named ad classified. Ec G 2: 433-435 (1907)

07e Physical oscillations during the Cambro-Silurian in nortbeastern New Yort (abst). Science n s 26:403 (1907)

os Lower portion of the Paleozoic ser tion in northwestern New York. G Soc df B $19: 155-176$ (1908) Abst, Science D I $27: 407$ (1908)

10 Bleaching of granite at limestone cos tacts (abst). Science n s $32: 220$ (1910) G Soc Am, B 21: 786 (1910) 
Cushing, Henry Platt-Continued.

10a (and Fairchild, H. L., Ruedemann, R., and Smyth, C. H., jr.) Geology of the Thousand Islands region, Alexandria Bay, Cape Vincent, Clayton, Grindstone, and Theresa quadrangles, N. Y. N Y St Mus, B 145: 194 pp, maps (1910)

10b (with Ulrich, E. O.) Age and relations of the Little Falls dolomite (Calciferous) of the Mohawk Valley. N Y St Mus, B $140: 97-140$ (1910)

10e (with Ulrieh, E. O.) Age of the "Calciferous" formation of the Mohawk Valley, N. Y. (abst). Science n \& 32:192 (1910) G Soc Am, B 21:780-781 (1910)

11 Nomenclature of the lower Paleozoic rocks of New York. Am J Sc (4) 31:135145 (1911)

12 The age of the Cleveland shale of 0hio. Am J Sc (4) $33: 581-584$ (1912)

13 Northumberland volcanic plug. G Soc Am, B 24:335-350 (1913); discussion by L. V. Pirsson, J. V. Lewis, and I. C. White, 24:683-684 (1913)

14 (and Ruedemann, R.) Geology of Saratoga Springs and vicinity. N Y St Mus, B 169: 177 pp, maps (1914)

15 Diastrophic importance of the unconformity at the base of the Berea grit in Ohil. G Soc Am, B 26:96 (abst), 205216 (1915)

15a Age of the igneous rocks of the Adirondack region. Am J Sc (4) $39: 288$ 294 (1915)

16 Geology of the vicinity of Ogdensburg (Brier Hill, Ogdensburg, and Red Mills quadrangles), N X St Mus B 191: $64 \mathrm{pp}, \operatorname{map}$ (1916)

17 Structure of the anorthosite body in the Adirondacks. J G 25:501-509, 512514 (1917)

18 The Gouverneur quadrangle. N Y St Mus B 196:24-29 [1918]

See also Russell, $92 \mathrm{~b}$

Cushman, Joseph Augustine.

04 A new foot;rint from the Connecticut Valley. Am G 33: 154-156, il (1904)

04a Pleistocene Foraminifera from Panama. Am G 33:265-266 (1904)

04b Notes on the Pleistocene fauna of Sankaty Head, Nantucket, Mass. Am G 34:169-174 (1904)

04e Miocene barnacles from Gay Head, Mass., with notes on Balanus proteus, Conrad. Am G 34:293-296, il (1904)

05 Fossil crabs of the Gay Head Miocene, Am Nat 39:381-390, il (1905)

05a Notes on fossils obtained at Sankaty Head, Nantucket, in July, 1905. Am G 36:194-195 (1905)

06 The Pleistocene deposits of Sankaty Head, Nantucket, and their fossils. Nantucket Maria Mitchell As, Pub 1 no 1:1$21(1906)$
Cushman, Joseph Augustine-Continued.

or Types in the paleontological collections of the Boston Society of Natural History. Boston Soc N H, Pr 33:249-275 (1907)

17 Orbitoid Foraminifera of the genus Orthophragmina from Georgia and Florida. U S G S, P P 108: 115-118, il (1917)

18 Some Pliocene and Miocene Foraminifera of the Coastal Plain of the United States. U S G S, B 676:100 pp, il (1918)

18a Contributions to the geology and paleontology of the Canal Zone, Panama, and geologically related areas in Central America and the West Indies; The smaller fossil Foraminifera of the Panama Canal Zone. U S Nat Mus, B 103:45-87, il (1918)

18b The larger fossil Foraminifera of the Panama Canal Zone. U S Nat Mus, B $103: 89-102$, il (1918)

See also Eastman, 00

Custer, A. E.

17 Deep Creek, Clifton mining district, Utah. Eng M J 103: 915-920 (1917)

Cutbush, James.

14 On the, blue earth of New Jersey. Am Miner J 1:86-88 (1814)

Cutler, H. C.

11 Notes on Goldfield geology (discussion of paper by F. L. Ransome). Ee G 6:190-194 (1911)

12 Como, Nevado. M Se Press 104: $539-540$ (1912)

15 Goldfleld [Nev.]. Eng.M J 99 : 221224 (1915)

Cotting, Hiram Adolphus (1832-1892).

72 Mining in Vermont; an address before a meeting of the State Board of Agriculture, Manufactures and Mining at Burlington ...; [and] Report of the State geologist and curator of State cabinet. 27 pp, Montpelier 1872 The report is also in Vt St Bd Agr, Manuf, and M, 1st An Rp: 713-721, Montpelier 1872

75 Report of the geologist and curator [of the Vermont] State Cabinet for 1874 and 1875 [i. e. 1873-4] ... 24 pp, Montpelier 1875 Also in Vt St Bd Agr, Manuf, and M, 2d Bien Rp:759-782, Montpelier 1874

76 Report of the [Vermont State] geologist and curator State cabinet for 1875 and $1876 \ldots 26 \mathrm{pp}$, Rutland 1876 Also in Vt St Bd Agr, Manuf, and Y, 3d Bien Rp: $661-686$, Rutland 1876

78 Report of the [Vermont] State geologist [for 1877-8] ... In his Microscopic Revelations ...:29-32, Montpelier 1878 Also in Vt St Bd Agr, Manuf, and M, 5th Rp : 389-392, Montpelier 1878.

Cuvier, Georges.

04 Sur le Mégalonix ... dont les ossemens ont été découverts en Virgrinie en 1796. Mus d'Hist Nat, An 5:358-375, il (1804) 
Cuvier, Georges-Continued.

06 Sur le grand Mastodonte ... dont on trouve les os en divers droits des deux continens, et surtout press de bords de l'Ohio ... Mus d'Hist Nat, An 8:270-312, il (1806)

06a Sur différentes dents du genre des mastodontes ... Mus d'Hist Nat, An 8: 401-420 (1806)

D., H. H.

S4 Undulations in clay deposits. Science 3: 404 (1884)

D., $T$.

93 An account of a hill on the borders of North Carolina, supposed to have been a volcano. $\mathrm{Am} \mathrm{Ph} \mathrm{Soc}, \mathrm{Tr} 3: 231-233$ (1793)

Dabney, Charles w.

84 Phosphates in North Carolina.

Science 3: 31-32 (1884)

84a North Carolina phosphates. Elisha

Mitchell Se Soe, J 1:64-68 (1884)

84b Cassiterite from King's Mountain,

N. C. Science $3: 217$ (1884)

84e Note on cassiterite from King's Mountain, N. C. Elisha Mitchell Se Soc, J $1: 79-81$ (1884)

Dabney, T. G.

05 Geology of the Mississippi embayment. Memphis Eng Soc, J 4 no $3: 11-26$ (1905) [not seen]

Dachnowski, Alfred.

11 The problem of xeromorphy in the vegetation of the Carboniferous period. Am J Sc (4) $32: 33-39$ (1911)

12 Peat deposits of Ohio, their origin, formation, and uses. Ohio $G S$ (4) B 16 : $424 \mathrm{pp}$, map (1912)

Dacquê, E.

11 Die Stratigraphie des marinen Jura an den Rändern des Pazlfischen Ozeans. G Rundschau 2:464-498 (1911)

Daddow, Samuel Harries.

66 (and Bannan, B.) Coal, iron, and oil... 808 pp, map, Pottsville, Pa,, 1866

Daggett, Ellsworth.

83 Analyses and calorific values of some Utah coals. U S G S, Min Res [1882]: 76-81 (1883)

07 The extraordinary faulting at the Berlin Mine, Nev. Am I M Eng, B 14: 331-344 (1907) ; Tr 38:297-309 (1908)

Eng M J 83:617-621 (1907)

Dahiblom, Th.

14 The angle of shear. Int $G$ Cong, XII, 1913, C R : 773-774 (1914)

Dailey, I. M.

12 Report on the eruption of Katmal volcano. Am Geog Soc, B 44: 641-644 (1912)

Dake, Charles Laurence.

14. Stream piracy and natural bridges in the loess of southeast Missouri. J G 22 : 498-499 (1914)

15 The formation and distribution of residual iron ores. Am I M Eng, B 101: 937-946 (1915) ; Tr 53: 116-124 (1916)
Dake, Charles Laurence-Continued.

15a The formation and distribution of bog iron ore deposits (with discussion by A. C. Lawson and G. H. Cox). Am I y Eng, B $103: 1429-1436 ; 108: 2475-2476$ (1915); Tr 53:106-115 (1916)

16 (with Cox, G. H.) Geological cri. teria for determining the structural posi. tion of sedimentary beds. Mo Univ, Sci Mines, B 2 no $4: 59$ pp (1916)

18 The sand and gravel resources of Missouri. Mo Bur G (2) 15:274 pp (1918)

18a The Hart Mountain overthrust and associated structures in Park Co., Wyo. J G $26: 45-55$ (1918)

18b The Valley City graben, Utah. J $\theta$, $26: 569-573$ (1918)

Dale, Nelson Clark.

15 The Cambrian manganese deposits of Conception and Trinity bays, Newfound. land. $\mathrm{Am} \mathrm{Ph}$ Soc, $\mathrm{Pr} 54: 371-456$, map (1915) Abst, G Soc Am, B 25:73-74 (1914)

Dale, Thomas Nelson.

78 A contribution to the paleontology o! the vicinity of Poughkeepsie [N. Y.] Poughkeepsie Soc N Sc, Pr 1878:2 pp (1878)

79 On the age of the clay slates and grits of Poughkeepsie. $\Delta \mathrm{m} \mathrm{J} \mathrm{Sc} \mathrm{(3)} \mathrm{17:}$ $57-59$ (1879)

79a The fault at Rondout [N. Y.]. Am J Sc (3) 18: 293-295, 409 (1879)

79b A contribution to the paleontolos of the vicinity of Poughkeepsie [N. I.] Poughkeepsie Soc N Sc, Pr 1878-9:20-21 (1879)

79c [On fossillization.] Poughkeepsile Soc N Sc, Pr 1878-9: 24-25 (1879)

79d The Marlboro fossils [near Pough. keepsie, N. Y.]. Poughkeepsie Soc N Sc Pr 1878-9: 25 (1879)

83 A contribution to the geology of Rhode Island. Boston Soc N H, Pr 22: 179-201, map (1883) Am J Sc (3) 27: 217-228, 282-289, map (1884)

84 The geology of the tract known as "Paradise" near Newport [R. I.]. New. port $\mathrm{N}$ H Soc, Pr $2: 3-5$ (1884)

84a Remarks on some evidences of geological disturbance in the vicinity of New. port [R. I.]. Newport $\mathrm{N}$ H Soc, Pr 2: 5-8 (1884)

85 The geology of the mouth of Narrs. gansett Bay. Newport $\mathrm{N}$ H Soc, Pr 3 : 5-14, map (1885)

85a On metamorphism in the Rhode is land coal basin. Newport $\mathrm{N} \mathrm{H}$ Soc, $\mathrm{Pr} 3$ : 85-86 (1885) Can Inst, Pr (3) $3: 18-21$ (1885)

86 New England Upper Silurian. Can Inst, $\operatorname{Pr} 22$ or (3) 4: 69-70 (1886)

87 List of minerals and rocks occuring In the vicinity of Newport. Newport $\mathrm{N}$ H Soc, Pr 5:29-31 (1887)

87a The geology of Mount Greylocs (abst). Can Inst, Pr (3) $5: 145$ (1887) 
Dale, Thomas Nelson-Continued.

91 The Greylock synclinorium. Am G $8: 1-7$ (1891)

92 on the structure and age of the Stockbridge limestone in the Vermont Valley. G Soc Am, B 3:514-519, map (1892) 92a On plicated cleavage foliation. $\Delta \mathrm{m}$ J Sc (3) $43: 317-319$ (1892)

93 The Rensselaer grit plateau in New York. U S G S, An Rp 13 pt 2: 291-340, map (1893)

94 Mount Greylock, its areal and structural geology. U S G S, Mon 23:119-203 (1894)

$94 a$ on the structure of the ridge between the Taconic and Green Mountain ranges in Vermont. U S G S, An Rp 14 pt 2:525-549, maps (1894)

94b The structure of Monument Moun tain in Great Barrington, Mass. U S G S, An Rp 14 pt 2:551-565, map (1894) Abst, J G $3: 987$ (1895)

96 Structural details in the Green Mountain region and in eastern New York. U S G S, An Rp 16 pt $1: 543-570$ (1896)

99 The slate belt of eastern New York and western Vermont (with note on dike rocks by Florence Bascom). U S G S, An Rp 19 pt 3:153-300, maps (1899)

$00 \mathrm{~A}^{\mathrm{A}}$ study $\mathrm{y}^{\circ}$ of Bird Mountain, Vt. U S G S, An Rp 20 pt $2: 9-23$, map (1900)

02 structural details in the Green Mountain region and in eastern New York. U S G S, B $195: 22$ pp (1902)

03 The slate industry at Slatington, $\mathrm{Pa}$., and Martinsburg, W. Va. U S G S, B $213: 361-364$ (1903)

04 Note on Arkansas roofing slates. U S G S, B 225: 414-416 (1904)

04a Geology of the Hudson Valley between the Hoosic and the Kinderhook. U S G S, B 242:63 pp, map (1904)

04b Note on the geological relations of the Brandon lignite deposit. Vt, St G, Rp 4:163-165 (1904)

04e The geology of the north end of the Taconic Range. Am J Sc (4) $17: 185$ 190, map (1904)

05 Slate investigations during 1904. U S G S, B 260:486-488 (1905)

05a Taconic physiography. U S G S, B $272: 52 \mathrm{pp}$, map (1905)

05b Water resources of the Fort Ticonderoga quadrangle, Vt. and $\mathrm{N}$. $\mathrm{Y}$. U S G S, W-S P 110: 126-129 (1905)

06 The geological history of Mount Greylock [Mass.]. 17 pp, Pittsfield, Mass., 1906

06a Slate deposits and slate industry of the United States. U S G S, B 275:154 pp (1906)

$06 \mathrm{~b}$ Note on a new variety of Maine slate. U S G S, B 285: 449-450 (1906)

06e (and Ecke1, E. C.) Slate deposits of the United States. U S G S, B 275: $51-125$ (1906)
Dale, Thomas Nelson-Continued.

O7 The granites of Maine; with an introduction by George Otis Smith. U S G S, B $313: 202$ pp (1907)

07a Recent work on New England granites. U S G S, B $315: 356-359$ (1907)

os The granites of Vermont. Vt, St G, Rp 6:58-75 (1908)

osa The chief commercial granites of Massachusetts, New Hampshire, and Rhode Island. U S G S, B 354:228 pp (1908)

09 The granites of Vermont. U S G S, B $404: 138$ pp (1909) Vt, St G, Rp $7: 78-$ 197 (1910)

10 Supplementary notes on the granites of New Hampshire. U S G S, B 430:346372 (1910)

10a The Cambrian conglomerate of Ripton in Vermont. Àm J S (4) $30: 267-270$, map (1910)

11 Supplementary notes on the commercial granites of Massachusetts. U S G S, B 470: 240-288, map (1911)

11a (and Gregory, H. E.) The granites of Connecticut. U S G S, B 484:137 pp, map (1911) Abst, Wash Ac Sc, J 2 : $159-160$ (1912)

12 The commercial marbles of western Vermont. U S G S, B 521:170 pp, maps (1912) Abst, Wash Ac Sc, J $3: 152$ (1913)

12a The Ordovician outlier at Hyde Manor in Sudbury, Vt. Am J Sc (4) 33 : 97-102 (1912) ; 36:395-398 (1913)

13 Commercial qualities of slates of United States and their localities. U S G S, Min Res 1912 pt 2:693-707, map (1913)

14 The commercial marbles of western Vermont. Vt St G, Rp $9: 1-160$, maps (1914)

14 (and others) Slate in the United States. U S G S, B 586:220 pp, maps (1914) Abst, Wash Ac Sc, J 5: 25-26

(1915) [Revised ed. of B 275 (1906)]

14a The calcite marble and dolomite of eastern Vermont. Vt St G, Rp 9:224-276 (1914)

15 The calcite marble and dolomite of eastern Vermont. U S G S, B 589:67 pp, maps (1915) Abst, Wash Ac Sc, J 5 : 518 $519(1915)$

16 The Algonkian-Cambrian boundary east of the Green Mountain axis in Vermont. Am J Sc (4) 42:120-124 (1916)

See also Powell, 93, 95

Dall, William Healey.

68 Explorations in Russian America.

Am J Sc (2) 45:96-99 (1868)

68a Explorations in Aiuska. Boston Soc N H, Pr 12:143-145 (1868)

69 Observations on the geology of Alaska. U S Coast S, Coast Pilot of Alaska, pt 1:193-202, Washington 1869 Abst, Am Nat 3:668 (1870)

69 [Observations on Alaska.] Cal Ac Sc, Pr $4: 30-37$ (1869) 
Dall, William Healey-Continued.

$69 b$ Alluvial deposits of the Yukon River in Alaska. Boston Soc $\mathrm{N} \mathrm{H}, \operatorname{Pr} 13$ : 138 (1869)

70 A revision of the Terebratulidae and Lingulidae, with remarks on and descriptions of some recent forms. $\Delta \mathrm{m} \mathrm{J}$ Conch $6: 88-168$, il $(1870)$

71 Supplement to the "Revision of the Terebratulidae" with additions, corrections, and a revision of the Craniidae and Discinidae. Am $J$ Conch $7:: 9-85$, il (1871)

73 [Remarks on Kotzebue Sound region, Alaska.] Cal Ac Sc, Pr 4: 293-294 (1873)

$\boldsymbol{7 4}$ Notes on some Tertiary fossils from the California coast ... Cal Ac Sc, Pr 5 : 296-299 (1874)

77 Index to the names which have been applied to the subdivisions of the class Brachiopoda ... U S Nat Mus, B $8: 88$ pp (1877)

78 Report on Mount Saint Elias, Mount Fairweather, and some of the adjacent mountains [Alaska]. U $\mathrm{S}$ Coast $\mathrm{S}, \mathrm{Rp}$ 1875 (U S, 44th Cong 1st sess, H Ex Doc $81)$ : 157-165 (1878)

$78 a$ Neuere Forschungen auf den Aleuten. Deut Geog Blätter 2:38-43, 84-101 (1878)

79 Post-Pliocene fossils in the Coast Range of California. U S Nat Mus, Pr 1: 3 (1879)

79a Fossil mollusks from the later Tertiaries of California. U S Nat Mus, Pr 1: 10-16 (1879)

79b Distribution of Californian Tertiary fosstls. U S Nat Mus, Pr 1: 26-30 (1879) so On a "fossil glacier" of Yakutat Bay, Alaska. Am J Sc (3) 20:335 (1880) 81 Extract from a report ... [on Alaska]. Am J Sc (3) 21:104-111 (1881)

82 Note on Alaska Tertiary deposits. Am J Sc (3) 24:67-68 (1882)

82a List of papers, 1866-1882. 11 pp [Washington 1882]

84 Glaciation in Alaska. Ph Soc Wash, B $6: 33-36 \quad(1884)$

84a A new volcano island in Alaska. Sclence 3: 89-93 (1884)

85 List of marine Mollusca comprising the Quaternary fossils and recent forms from American localities between Cape Hatteras and Cape Roque including the Bermudas. U S G S, B $24: 336$ pp (1885)

85a Further notes on Bogosloff Island.

Science 5:32-33 (1885)

85b Miocene deposits in Florida. Science $6: 82$ (1885)

87 Notes on the geology of Florida. Am J Sc (3) 34:161-170 (1887)

90 Contributions to the Tertiary fauna of Florida, with especial reference to the Miocene Silex beds of Tampa and the Pliocene beds of the Caloosahatchie River. Wagner Free I Sc, Tr 3: $1654 \mathrm{pp}$, 1l, map (1890-1903)
Dall, Willam Healey-Contínued.

90 [Remarks upon the paleontology of the northwest coast of the United States.] Am Nat 24:1223-1224 (1890)

90b Types fossiles de l'éocène du Bassin de Paris, récemment đécouverts en Amérique. Soc Zool France, B 15: 97-98 (1890)

91 On the age of the Peace Creek beds Florida, Ac N Se Phila, Pr 1891:120

91 a Elevation of America in the Ceno. zoic periods. G Mag (3) $8: 287-288$ (1891) Am Nat 25: 735-736 (1891)

92 (and Harris, G. D.) Correlation pa pers; Neocene. U S G S, B 84:349 pp maps (1892)

92a Grand Gulf formation. Science 20: 164-165, 319-320 (1892)

92b On the species of Donax of enstem North America. Nautilus 5:125-127 (1892)

92e Note on Cytherea convexa Say. Nav. tilus $6: 52-53$ (1892)

93 Determination of the dates of publl. cation of Conrad's "Fossils of the Tertiary formation" and "Medial Tertiary." $\mathrm{Ph}$ Soc Wash, B 12 : 215-239 (1893)

$93 a$ Republication of Conrad's Fossils of the medial Tertiary of the United States, with an introduction. xvili, $136 \mathrm{pp}$, il, Phila 1893

94 (and Stanley-Brown, J.) Cenozolc geology along the Apalachicola River. $G$ Soc Am, B 5: 147-170, map (1894) Abst, Am G 13:137-138 (1894)

$94 a$ Notes on the Miocene and Pliocest of Gay Head, Marthas Vineyard, Mass., and on the "land phosphate" of the Ashlef River district, S. C. Am J Sc (3) 48: 296-301 (1894)

94b Notes on the Atlantic Miocent (abst). Am G 14: 202 (1894) Am As, Pt 43: 224-225 (1895)

95 Monograph of the genus Gnathodos Gray (Rangia, Desmoulins). U S Nat Mus, Pr 17:89-106, il (1895)

96 Report on coal and lignite of Alasks. U S G S, An Rp 17 pt 1:763-875, maps (1896)

$96 a$ Diagnoses of new Tertiary fossils from the southern United States. U S Nat Mus, $\operatorname{Pr} 18: 21-46$ (1896)

$96 b$ (with Guppy, R. J. L.) Descrip tions of Tertiary fossils from the Antll. lean region. U S Nat Mus, Pr 19:30\%331 , il (1896)

93 A table of the North American Tertiary formations, correlated with one another and with those of western Europe. with annotations. U S G S, An Rp $18 \mathrm{pt}$ 2 : 323-348 (1898)

98a Synopsis of the Recent and Ter tiary Psammobiidae of North Americk Ac N Sc Phila, Pr 1898: 57-62

$98 b$ Notes on the paleontological pub lications of Professor William Wagnet Wagner Free I Sc, Tr 5: 7-11, il (1898) 
Dall, William Healey - Continued.

98e A new subgenus of Coralliophaga [Oryctomya]. Nautilus 11:135 (1898)

$98 d$ On the present state of our knowledge of the North American Tertiary mollusk fauna (abst). Am As, $\operatorname{Pr} 47: 361$ (1898) Science n s 8:397 (1898)

99 Synopsis of the recent and Tertlary Leptonacea of North Amrerica and the West Indies. U S Nat Mus, Pr 21:873897, il (1899)

00 Notes on the Tertiary geology of 0ahu. G Soc Am, B 11:57-60 (1900)

01 The morphology of the hinge teeth of bivalves. Am Nat 35:175-182 (1901)

01a The structure of Diamond Head, 0abu. Am G $27: 386-387$ (1901)

01b A new Lyropecten [Eel River, Cal.]. Nautilus 14:117-118 (1901)

01e A gigantic fossil Lucina [Jamaica]. Nautilus $15: 40-42$ (1901)

01d (and Bartsch, Paul) A new Californian Bittium. Nautilus 15:58-59 (1901)

02 Alpheus Hyatt. Pop Sc Mo 60: 439441, port (1902)

02a On the true nature of Tamiosoma. Science n s $15: 5-7$ (1902)

02b The Grand Gulf formation. Science D 8 16:946-947 (1902)

03 The Grand Gulf formation. Science If $818: 83-85$ (1903)

04 Neozoic invertebrate fossils [of Alaska]. Harriman Alaska Exped 4:99122, il (1904)

04a An historical and systematic review of the frog-shells and tritons. Smiths Misc $\mathrm{Col} 47$ (Q Is 2) : 114-144 (1904)

04b (and Bartseh, Paul) Synopsis of the genera, subgenera, and sections of the family Pyramidellidae. Biol Soc Wash, Pr $17: 1-16$ (1904)

04e A singular Eocene Turbinella. Nautllus $18: 9-10$ (1904)

04d Charles Emerson Beecher. Science nf 8 19:453-455 (1904)

04e on the geology of the Hawailan Islands. Am J Sc (4) $17: 177$ (1904)

04f (with Clark, W. B., and Shattuck, G. B.) The Miocene deposits of Maryland. Md G S, Miocene : xxi-clv, map (1904)

05 Fossils of the Bahama Islands ... In The Bahama Islands, edited by G. B. Shattuck: 21-47, il, N Y 1905

05a John Wesley Powell. Ph Soc Wash, B 14: 300-308 (1905)

05b Nates on the fossils of the Bahamas (abst). Science n s 21:390-391 (1905)

05e (with Sehuehert, C., and others). Catalogue of the type specimens of fossil invertebrates in the department of geology, United States National Museum. U S Nat Mus, B 53 pt 1:704 pp (1905)

06 Biographical memoir of Charles Emerson Beecher, 1856-1904. Nat Ac Sc, Biog Mem 6:57-70, port (1906)
Da11, William Healey-Continued.

O7 A review of the American Volutidæ. Smiths Misc Col, 48 ( $Q$ Is 3 pt 3 ) : $341-373$ (1907)

07a Notes on some upper Cretaceous Volutidæ, with descriptions of new species and a revision of the groups to which they belong. Smiths Misc Col 50 (Q Is 4 pt 1) : 1-23, il (1907)

Ozb Note on the genus Psilocochlis Dall. Nautilus 20:128 (1907)

07e on climatic conditions at Nome, Alaska, during the Pliocene and on a new species of Pecten from the Nome gold-bearing gravels. Am J Sc (4) $23: 457-458$, il (1907)

os Another large Miocene Scala [Epitonium (Acrilla) atrooodi, Miocene, Alaska]. Nautilus 22:80-81 (1908)

09 Biographical memoir of William More Gabb, 1839-1878. Nat Ac Sc, Biog Mem $6: 345-361$, port (1909)

$09 a$ Conditions governing the evolution and distribution of Tertiary faunas. $J$ G 17:493-502 (1909)

$09 b$ Contributions to the Tertiary paleontology of the Pacific coast. I. The Miocene of Astoria and Coos Bay, Oregon. U S G S, P P 59:278 pp, il (1909)

09e Material toward a bibliography of publications on the post-Eocene marine mollusks of the northwest coast of America, 1865-1908. U S G S, P P 59:192216 (1909)

10 Notes on postglacial evidences of climatic changes in North America as indicated by marine fossils. Int $\mathrm{G}$ Cong, $\mathrm{XI}$, Stockholm; Die Veränderungen des Klimas seit dem Maximum der letzten Eiszeit: 365-366 (1910)

11 siographical sketch of Robert Edwards Carter Stearns, 1827-1909. Smiths Misc Col $56: 1-3$, port (1911)

11a Nature of Tertiary and modern marine faunal barriers and currents. G Soc Am, B 22:218-220 (1911)

$11 b$ Charles Abiathar White, 1826-1910. Nat Ac Sc, Biog Mem 7:223-243, port (1911)

12 The mollusk fauna of northwest America. Ac N Sc Phila, J (2) 15 : 241248 (1912)

12a New species of fossil shells from Panama and Costa Rica, collected by D. F. MacDonald. Smiths Misc Col, 59 no $2: 10$ pp (1912)

13 On a brackish-water Pliocene fauna of the southern Coastal Plain. U $\mathrm{S}$ Nat Mus, Pr 46:225-227, il (1913)

15 A monograph of the molluscan fauna of the Orthaulax pugnax zone of the Oligocene of Tampa, Fla. U S Nat Mus, B v0: $173 \mathrm{pp}$, il (1915)

$16 \mathrm{~A}$ contribution to the invertebrate fauna of the Oligocene beds of Flint River, Ga. U S Nat Mus, Pr $51: 487-524$, il (1916) 
Dall, William Healey-Continued.

16a On some anomalies in geographic distribution of Pacific coast Mollusca. Nat Ac Sc, Pr 2:700-703 (1916)

16b Note on the Oligocene of Tampa, Florida, the Panama Canal Zone, and the Antillean region. Malacol Soc L, Pr 12 : 88-39 (1916)

18 Reminiscences of Alaskan volcanoes. Sc Mo $7: 80-90$ (1918)

18a Pleistocene fossils of Magdalena Bay, Lower Californla, collected by Charles Russell Orcutt. Nautilus 32: 23-26 (1918)

See also Clark (W. B.), 04; Eastman, 00 ; Hill (R. T.), $98 \mathrm{c}$; Powell, $85 \mathrm{a}, 88,89$, $89 \mathrm{a}, 90,91,91 \mathrm{a}, 92,93,95$; Russell, 85d ; Smith (E. A.), 88a ; Stanton, 05d

Dalton, Leonard V.

09 On the origin of petroleum. Ec G 4: 603-631 (1909)

Daly, Marcel $R$.

16 The diastrophie theory; a contribution to the study of the mechanics of oil and gas accumulation in commercial deposits (with discussion by Engene Coste, F. G. Clapp, R. W. Pack, and the author). Am I M Eng, B 115:1137-1157 (1916); 125:871-891 (1917); Tr 56:733-781 (1917)

17 Geosynclines and petroliferous deposits; a contribution to the study of the relations between earth movements and hydrocarbon accumulations (with discussion by W. van der Gracht and F. G. Clapp). Am I M Eng, B 128: 1135-1146 (1917); $135: 695-700$ (1918); Tr 57:1054-1065 (1918)

18 Water surfaces in the oil fields. Am I M Eng, B 133: 151-157 (1918); Tr 59; 557-563 (1918)

Daly, Reginald Aldworth.

96 The quartz porphyry and assoclated rocks of Pequawket Mountain (the eastern "Kearsarge" of New Hampshire) (abst). Science n s 3:752 (1896)

97 Studies on the so-called porphyritic gneiss of New Hampshire. $J$ G 5:694$722,776-794$ (1897)

99 On the optical characters of the vertical zone of amphiboles and pyroxenes; and on a new method of determining the extinction angles of these minerals by means of cleavage pieces. Am Ac Arts, Pr 34: 309-323 (1899) Abst, Science n s 8 : 919-920 (1898)

$99 a$ on a new variety of hornblende. Am Ac Arts, Pr 34: 431-437 (1899)

99b The peneplain-a review. Am Nat 33 : 127-138 (1899)

00 The calcareous concretions of Kettle Point, Lambton Co., Ont. J G 8:135-150 (1900)

OOa The deepest fiord on the Labrador coast. Science n \& 12:688 (1900)
Daly, Reginald Aldworth-Continued.

01 The physiography of Acadia. Har. vard Coll, Mus C Z, B 38 (g s 5) : 73-103, map (1901)

o1a Marine currents and river defect tion. Science n s 13:951-954 (1901)

02 The geology of the region adjoining the western part of the international boundary. Can G S, Sum Rp 1901 (As Rp 14) : ^ 39-51 (1902)

02a The geology of the northeast coast of Labrador. Harvard Coll, Mus C Z, B 38 (g s 5) : 205-270 (1902)

O2b Report on geology [Brown-Harvard expedition to Nachvak, Labrador, in the year 1900]. Geog Soc Phila, B $3: 206-$ 212 (1902)

03 The geology of Ascutney Mountain, Vt. U S G S, B 209: 122 pp (1903)

03a The mechanics of igneous intr. sion. Am J Sc (4) $15: 269-298 ; 16: 107-$ 126 (1903) ; $26: 17-50$ (1908) Abst, J G, 11: 101-102 (1903)

$\mathbf{0 3 b}$ Geology of the western part of the international boundary (49th parallel). Can G S, Sum Rp 1902 (An Rp 15) : A 138149 (1903)

o3e Variolitic pillow lava from Ner. foundland. Am G 32: 65-78 (1903)

04 Geology of the international boundary [British Columbia]. Can G S, Sum Bp 1903 (An Rp 15) : A 91-100 (1904)

05 Geology of the western part of the international boundary ( 49 th parallel). Can G S, Sum Rp 1904 (An Rp 16) : $\Delta 91-100$ (1905)

05a The accordance of summit levels among alpine mountains; the fact and its significance. J G 13:105-125 (1905)

05b The classification of igneous introsive bodies. J G $13: 485-503$ (1905)

ose Machine-made line drawings for the illustration of scientific papers. Science n s 22: 91-93 (1905) Am J Sc (4) 19: 227-229 (1905)

05d The secondary origin of certain granites. $\Delta \mathrm{m} \mathrm{J} \mathrm{Sc} \mathrm{(4)} 20: 185-216$, maps (1905)

06 The differentiation of a secondary magma through gravitative adjustment [Moyie sill in the Purcell Mountain Range, Idaho-Montana]. Festschrift Harry Rosedbusch : 203-233; Stuttgart 1906

O6a The Okanagan batholith of the Cas. cade Mountain system. G Soc Am, B 17: 329-376 (1906)

06b Abyssal igneous Injection as : causal condition and as an effect of mountain building. Am J Sc (4) $22: 195-216$ (1906) Abst, Science n s 24:367-368 (1906); Am As, Pr 56-57: 267-268 (1907)

o6e The nomenclature of the North American Cordillera between the 47 th and 53 d parallels of latitude. Geog $\mathbf{J} 27: 586-$ 606 (1906) 
Daly, Reginald Aldworth-Continued. 06d Report on field operations in the geology of the mountains crossed by the international boundary (49th parallel). Can, Dp Interior, Rp Chief Astronomer (pt IX of An Dp Rp for 1905) : 278-283 (1906)

of The limeless ocean of pre-Cambrian time. Am J Sc (4) 23:93-115 (1907)

07a Report on fleld operations in the seology of the mountains crossed by the Iternational boundary (49th parallel). Can, Dp Interior, Rp Chief Astronomer (pt $V$ of An Dp Rp for 1906) : 133-135 (1907)

08 The origin of augite andesite and of related ultra-basic rocks. J G $16: 401-420$ (1908)

09 First calcareous fossils and the evolution of the limestones. G Soc Am, B 20: $153-170$ (1909)

09a The geology and scenery of the northeast coast [of Labrador]. In Labrador, the country and the people, by Wilfred T. Grenfell and others, pp $81-139$, N Y $19092 \mathrm{~d}$ ed, 1913

10 Average chemical compositions of iraeous-rock types. Am Ac Arts, Pr 45: 211-240 (1910)

10a Origin of the alkaline rocks. G Soc Am, B 21:87-118 (1910); discussion, 21 : 785 (1910) Abst, Science n s $32: 220$ (1910)

10b Pleistocene glaciation and the coral reef problem. Am J Sc (4) $30: 297-308$ (1910)

10e Hawallan volcanoes (abst). Science n s $32: 188$ (1910); G Soc Am, B 21: 767 (1910)

11 Origin of the coral reefs; a suggestion bearing on the question of the former Dobility of the earth's crust under the deep oceans. Sc Conspectus 1:120-123 (1811)

11a The nature of rolcanic action. Am Ac Arts, Pr 47:47-122 (1911)

11b Magmatic differentiation in Hawali. J G $19: 289-316$ (1911)

11e Relative erosive efficiency of ice caps and valley glaciers (abst). As Am Geog, An 1: 121 (1911)

12 Reconnaissance of the Shuswap lakes and vicinity (south central B. C.). Can G 8, Sum Rp $1911: 165-174$ (1912)

12a Pre-Cambrian formations in south central British Columbia $(a b s t)$. Science n $835: 311$ (1912) G Soc Am, B 23:721 (1912)

12b Some chemical conditions in the pre-Cambrian ocean. Int $G$ Cong, XI, Stockholm, 1910, C R : 503-509 (1912)

12e (and Miller, W. G., and Rice, Q. \$.) Report of the commission appointed to investigate Turtle Mountain, Frank, Alta. Can G S, Mem 27:34 pp,
Daly, Reglnald Aldworth-Continued.

13 Geology of the North Ameriean Cordillera at the forty-ninth parallel. Can, Dp Interior, Rp Chlef Astronomer, 1910, v 2 and $3: 1-799$, map (1913)

Also issued as Mem 38 of Canada G S. Ottawa 1912 [1915?]

13a Introduction to the geology of the Cordillera; annotated guide, Golden to Savona. Int G Cong, XII, Canada, Guide Book no 8 : 111-167, 202-234, maps (1913)

13b Sills and laccoliths illustrating petrogenesis. Int $\mathrm{G}$ Cong, XII, 1913, C R : 189-204 (1914) Advance copy 1913

14 Igneous rocks and their origin. xxil, $563 \mathrm{pp}$, New York $1914 \mathrm{Rv}$, by J. P. Iddings, Science n s 40:710-715 (1914); see also Waldemar Lindgren, Science $\mathbf{n}$ $41: 166$ (1915)

14a Geology of the Selkirk and Purcell Mountains at the Canadian Pacifie Railway (main line). Can G S, Sum Rp 1912 : 156-164 (1914)

15 A geological reconnaissance between Golden and Kamloops, B. C., along the Canadian Pacific Railway. Can G S, Mem $68: 260 \mathrm{pp}$, maps (1915)

15a The glacial-control theory of coral reefs. Am Ac Arts, Pr 51:157-251 (1915)

15b Ores, magmatic emanations, and modes of igneous intrusion; discussion of paper by B. S. Butler. Ec G 10:471-472 (1915)

16 Homocline and monocline (with discussion by G. W. Stose and W. H. Hobbs). G Soc Am, B 27:89-92 (1916)

$16 a$ Problems of the Pacific Islands. Am J Sc (4) 41:153-186 (1916)

16b A new test of the subsidence theory of coral reefs. Nat Ac Sc, Pr 2: 664-670 (1916) Abst, G Soc Am, B 28: 151 (1917)

17 Metamorphism and its phases. G Soc Am B 28:126-127 (abst), 375-418 (1917)

17 a Genetic classification of underground volatile agents. Ec G 12:487-504 (1917)

17b The geology of Pigeon Point, Minn. Am Jour Sc (4) $43: 423-448$ (1917)

17e Origin of the living coral reefs. Scientia $22: 188-199$, sup 60-74 (1917)

17d Low-temperature formation of alkaline feldspars in limestone. Nat Ac Sc, Pr 3: 659-665 (1917)

18 Genesis of the alkaline rocks. J G 26 : 97-134 (1918)

18a Field relations of litchfieldite and soda syenites of Litchfield, Maine. G Soc Am, B 29: 99 (abst), 463-470 (1918)

18b Thirteen-foot model of the world's most active volcano [Kilauea, Hawaii]. Sc Am 118: 132, 137-138 (1918)

See also Day (A. L.), 13 
Dalzell, T. J.

09 Report of the State Bureau of Mines [of] Colorado for the years 1907-8. 81 pp [Denver 1909]

11 Report of the State Bureau of Mines [of] Colorado for the years 1909-10. 110 pp, map [Denver 1911]

\section{Damour, A.}

71 Analyse d'un grenat du Mexique. Ac Sc Paris, C R 73: 1041-1042 (1871) Soc Cient Ant Alz, Mem 4:254-256 (1891)

Dana, Arnold Guyot.

85 On the gahnite of Rowe, Mass. Am J Sc (3) 29:455-456 (1885) Zs Kryst $10: 490-492$ (1885)

Dana, Edward Salisbury.

72 On the composition of the labradorite rocks of Waterville, N. H. Am J Sc (3) 3: 48-50 (1872) Yale Bicen Pub, Contr Miner : $387-390$ (1901)

$72 a$ on the datolite from Bergen Hill, N. J. Am J Sc (3) 4: 16-22 (1872)

72b On a crystal of andalusite from Delaware Co., Pa. Am J Sc (3) 4:473 (1872)

74 On the trap rocks of the Connecticut Valley. Am J Sc (3) $8: 390-392$ (1874) Am As, Pr 23 pt 2: 45-47 (1875)

75 [Progress in] mineralogy. In Annual record of science and industry for $1874:$ lxv-1xvil (1875) ... 1875: xcvi-xcix (1876) ... 1876: lxxxiv-1xxxviii (1877) 1877:151-164 (1878) $\ldots 1^{1878: 271-286}$ (1879)

$75 a$... chondrodite crystals from the Tilly Foster iron mine, Brewster, N. Y. Am J Sc (3) 9:63-64 (1875)

75b On the chondrodite from the Tilly Foster iron mine, Brewster, N. Y. Conn Ac, Tr 3:67-96 (1875) Am J Sc (3) 10 . 89-103 (1875)

76 (and Grinnell, G. B.) Geologieal report. In Ludlow, Wm., Report of reconnaissance ... to the Yellowstone National Park: 89-126, Washington 1876 Also in U S [War Dp] Chief Eng, An Rp 1876 (U S, 44th Cong 2d sess, H Ex Doc 1 pt 2 $\checkmark 2$ pt 3) App NN : 657-694 (1876)

76a On the optical character of the chondrodite of the Tilly Foster mine, Brewster, N. Y. Am J Sc (3) 11:139140 (1876)

76b On the samarskite, Mitchell Co., N. C $\Delta \mathrm{m}$ J Se (3) 11:201-204 (1876)

z6e On new twins of staurolite and pyrrhotite. Am J Sc (3) 11:384-387 (1876)

$76 d$ On the association of crystals of quartz and calcite in parallel position, as observed on a specimen from the Yellowstone Park. Am J Sc (3) 12:448-451 (1876) Zs Kryst 1: 39-42 (1877)

76e (with Grinnell, G. B.) On a new Tertiary lake basin. Am J Sc (3) 11: 126-128 (1876)

77 A textbook of mineralogy... $485 \mathrm{pp}$, N Y 1877 2d ed, 593 pp, N Y 1898
Dana, Edward Salisbury-Continued.

$77 \mathbf{a}$ On the occurrence of garnets with the trap of New Haven, Conn. Am J s (3) $14: 215-218 \quad(1877)$

78 (with Brush, G, J.) N Notice of three new phosphates from Fairfield $C_{0}$ Conn. Am J Sc (3) 15:398-399 (1878)

78a (with Brush, G. J.) Notice of s fourth new phosphate fram Fairfield $\mathrm{Ca}_{4}$ Conn. Am J Se (3) 15:481-482 (1878)

7Sb (with Brush, G. J.) on a new and remarkable mineral locality in Fair. field Co., Conn., with a description of sereral new species occurring there. $A \mathrm{~m} J$ \& (3) $16: 33-46,114-123$ (1878) Yale Bicen Pub, Contr Miner: 48-71 (1901)

79 (with Brush, G. J.) On the mineral locality in Fairfield Co., Conn., with the description of two additional ner species. Am J Se (3) 17:359-368 (1879) Yale Bicen Pub, Contr Miner : 72-80 (1901)

79a (with Brosh, G. J.) On the mineral locality in Fairfield Co., Conn. Am J Se (3) $18: 45-50$ (1879) Yale Bicen Pub, Contr Miner : 81-85 (1901)

80 (with Brush, G. J.) On crystallized danburite from Russell, St. Lawrenee Co. N. Y. Am J Sc (3) 20:111-118 (1880)

80a (with Brush, G. J.) On the mineral locality at Branchville, Conn.; spodu. mene and the results of its alteration. Am J Sc (3) 20:257-285 (1880) Yale Bicen Pub, Contr Miner : 86-104 (1901)

81 On the emerald green spodumene from Alexander Co., N. C. Am J Sc (3) 22: 179-182 (1881)

82 On crystals of monazite from Aler. ander Co., N. C. Am J Sc (3) 24:247250 (1882) Zs Kryst 7:362-365 (1882)

84 [Record of recent scientific progress in] mineralogy. Smiths Inst, An Rp 1882: 533-549 (1884)

84a A crystallographic study of the thinolite of Lake Lahontan. U S G S, B $12: 34$ pp (1884)

84b On the crystalline form of the sup posed herderite from Stoneham, Me. Am J Sc (3) $27: 229-232$ (1884)

84e Mineralogical notes. Am J Sc (3) $27: 479-481$ (1884)

85 [Record of scientific progress, 1883] mineralogy. Smiths Inst, An Rp 1883 661-679 (1885)

85a [Record of scientific progress, 1884] mineralogy. Smiths Inst, An Rp 1884 543-561 (1885)

851 (and Penfield, S. L.) Mineralog. cal notes. Am J Sc (3) 30:136-138 (1885)

86 [Record of scientific progress, 1885. mineralogy. Smiths Inst, An Rp 1885 687-712 (1886)

86a Catalogue of the collection of mete orites in the Peabody Musenm of Yale Col. lege. Am J Sc (3) 32 Sept. No. Appendix: 1-4 (1886) 
Dana, Edward Salisbury-Continued.

s6b On the crystallization of gold. Am J Sc (3) 32:132-138 (1886) Zs Kryst $12: 275-281$ (1886)

86e (and Penfield, S. L.) On two hitherto undescribed meteoric stones [Utah and Cape Girardeau, Mo.] Im J Sc (3) $32: 226-231$ (1886)

86d On the brookite from Magnet Cove, Ark. Am J Sc (3) $32: 314-317$ (1886)

86e Mineralogical notes. Am J Sc (3) $32: 386-390$ (1886)

$86 \mathrm{f}$ On the crystallization of native copper. Am J Sc (3) : : : 413-429 (1886) $86 \mathrm{~g}$ Ueber den Columbit. Zs Kryst 12 : 266-274 (1886) Abst, Am J Sc (3) 32: 386-387 (1886)

88 (and Penfield, S. L.) On the crystalline form of polianite. Am J Sc (3) $35: 243-247$ (1888) Zs Kryst 14:166172 (1888)

88a Preliminary notice of beryllonite, a new mineral. Am J Sc (3) $36: 290-291$ (1888)

89 [Record of scientific progress] mineralogy in 1886. Smiths Inst, An Rp 1887 pt $1: 449-476 \quad$ (1889)

89a (and Wells, H. ...) Description of the new mineral, beryllonite. Am J Sc (3) $37: 23-32 \quad(1:>9)$ Zs Kryst 15: 275-284 (1889)

$89 b$ Contributions to the petrography of the Sandwich Islands. Am J Sc (3) 37 : 441-467 (1889)

90 Mineralogy for 1887 and 1888 . 8miths Inst, An Rp 1888: 455-473 (1890) $90 \mathrm{a}$ On the barium sulphate from PerKins' Mill, Templeton, Province of Quebec. $\Delta \mathrm{m}$ J Sc (3) $39: 61-65$ (1890)

90b (and Wells, H. L.) On some selenium and tellurium minerals from Honduras. Am J Sc (3) 40:78-82 (1890) $90 \mathrm{c}$ (with Brush, G. J.) On the mineral locallty at Branchrille, Conn. Am J Sc (3) 39:201-216 (1890) Yale Bicen Pab, Contr Kiner : 105-120 (1901)

90d (with Hillebrand, W. F.) Additional notes on the tyrolite from Utah. Am J Sc (3) $39: 271-273$ (1890)

92 The system of mineralogy of James Dwight Dana, 1837-1868. lxiif, 1134 pp, 6th ed, N Y 1892 ; with appendixes, I, by R. S. Dana, $75 \mathrm{pp}, \mathrm{N}$ Y 1899 ; II by E. S. Dana and W. E. Ford, 114 pp, 1909 ; III, by W. E. Ford, $87 \mathrm{pp}, 1915$

95 Minerals and how to study them. $380 \mathrm{pp}, \mathrm{N}$ Y 1895

95a James Dwight Dana. Am J Sc (3) 49:329-356, port (1895)

12 George Jarvis Brush. Am J Sc (4) $33: 389-396$, port (1912)

16 A textbook of mineralogy, with an extended treatise on crystallography and physical mineralogy. New ed, 593 pp, N Y
Dana, Edward Salisbury-Continued.

18 (and others) A century of science in America, with special reference to the American Journal of Science, 1818-1918. $458 \mathrm{pp}$, portraits, New Haven, 1918

Reproduced with some additions from the Centennial Number, 1818-1918 (July, 1918) of the American Journal of Science.

Dana, James Dwight (1813-1895).

35 A new system of crystallographic symbols. Am J Sc 28:250-262 (1835)

36 On the formation of compound or twin crystals. Am J Sc $30: 275-300$ (1836)

37 (aided by G. J. Brush in 3d-5th ed) A system of mineralogy. xiv, $452,119 \mathrm{pp}$, New Haven 1837 ; 2d ed, 633 pp, N Y 1844; $3 d$ ed, 711 pp, N Y 1850 ; 4 th ed, 2 vols, 320,554 pp, N Y $1854 ; 5$ th ed, xlviii, 827 pp, N Y 1868, with appendixes, I 18681872 by G. J. Brush; II, 1872-1875 and III, 1875-1882, by E. S. Dana; for 6 th ed, see Dana (E S), 92

37a A new mineralogical nomenclature. Lyc N H N Y, An 4:9-34 (1837)

$\mathbf{3 7 b}$ On the identity of the torrelite of Thomson with columbite. Am J Sc 32: 149-153 (1837)

37e On the drawing of figures of crystals. Am J Sc $33: 30-50$ (1837)

37d Crystallographic examination of eremite. Am J Sc 33: 70-75 (1837)

38 Supposed new mineral at Bolton, Mass. Am J Sc 35: 178-179 (1838)

43 On the analogies between the modern igneous rocks and the so-called primary formations, and the metamorphic changes produced by heat in the associated sedimentary deposits. Am J Sc 45:104129, (abst with discussion) 138 (1843)

43a On the areas of subsidence in the Pacific as indicated by the distribution of coral islands. Am J Sc 45: 131-135 (1843) Edinb $\mathrm{N} \mathrm{Ph} \mathrm{J} 35: 341-345$ (1843)

$43 \mathrm{~b}$ On the distribution of corals (abst with discussion). Am J Sc 45:310-311 (1843)

44 On the composition of corals and the production of the phosphates, aluminates, silicates, and other minerals by the metamorphic action of hot water. Am J Sc $47: 135-136$ (1844) Edinb $\mathrm{N} \quad \mathrm{Ph} \quad \mathrm{J}$ $39: 293-295 \quad(1845)$

45 Observations on pseudomorphism. Am J Sc $48: 81-92, \quad 397-398 \quad$ (1845) Edin N Ph J $39: 251-264$ (1845)

$45 \Omega$ Origin of the constituent and adventitious minerals of trap and the allied rocks. Am J Sc 49:49-64 (1845) As Am G, Pr 6:26-28 (1845) Edinb $\mathrm{N} \mathbf{P h}$ J $41: 195-203,263-272$ (1846) Ph Mag 28 : 49-62 (1846)

46 Genera of fossil corals of the family Cyathophyllidae. Am J Sc (2) 1:178-186, il (1846) 
Dana, James Dwight-Continued.

$46 a$ On the occurrence of fluorspar, apatite and chondrodite in limestone. Am J Sc (2) $2: 88-89$ (1846)

46b On the volcanoes of the moon. Am $\mathrm{J} \mathrm{Sc} \mathrm{(2)} 2: 335-353$ (1846) Edinb $\mathrm{N} \mathrm{Ph}$ J $43: 10-33$ (1847)

47 On the origin of continents. Am J Sc (2) 3:94-100 (1847) Edinb N Ph J $43: 234-242$ (1847)

$47 \mathrm{a}$ Geological results of the earth's contraction. Am J Sc (2) 3:176-188; 4: 88-92 (1847)

$47 \mathrm{~b}$ Origin of the grand outline features of the earth. Am J Sc (2) 3:381-398 (1847)

47e Observations in reply to Mr. Lonsdale's "Remarks" [Tertiary corals]. Am J Sc (2) $4: 359-362$ (1847)

48 Manual of mineralogy ... 430 pp, New Haven 1848 2d ed, $455 \mathrm{pp}$, New Haven $18573 d$ ed, 474 pp, N Y 1878 4th ed, $517 \mathrm{pp}, \mathrm{N}$ Y 1887

49 Geology. United States exploring expedition, during the years $1838,1839,1840$, 1841,1842 , under the command of Charles Wilkes, U S N. Vol X, 756 pp, Phila 1849 Fossils from northwestern America (reprint: 722-730, U S G S, P $\quad$ P $59: 152$ 157 (1909)

49a Review of Chambers' Ancient sea margins, with observations on the study of terraces. Am J Sc (2) 7:1-14; (2) 8: 86-89 (1849)

49b Notes on upper California. Am J Sc (2) $7: 247-264$ (1849)

49e Observations on some points in the physical geography of Oregon and upper California. $\mathrm{Am}$ J Sc (2) $7: 376-394$ (1849)

50 On the isolation of volcanic action in Hawail, or volcanoes no safety valves. Am As, Pr 2: 95-100 (1850)

50a On the trend of islands and axis of subsidence in the Pacific. Am As, Pr 2: 321-325 (1850)

$50 b$ On denudation in the Pacific. Am J Sc (2) 9:48-62 (1850)

50e On isomorphism and atomic volume of some minerals. Am J Sc (2) $9: 220$ 245 (1850)

50d On danburite [from Danbury, Conn.] Am J Sc (2) 9:286-287 (1850)

50e On some minerals recently investigated by M. Hermann. Am J Sc (2) 9 ? 408-412 (1850)

50P Historical account of the eruptions on Hawaii. Am J Sc (2) $9: 347-364 ; 10$ : 235-244 (1850)

$50 \mathrm{~g}$ Observations on the mica family. Am J Sc (2) 10:114-119 (1850)

5oh Mineralogical notices. Am J Sc (2) $10: 245-255 \quad(1850) ; 11: 225-234 ; 12$ : $205-222, \quad 387-397 \quad(1851) ; 14: 264-280$ (1852) ; 15:430-449 (1853)
Dana, James Dwight-Continued.

51 On the physical and crystallographic characters of the phosphate of iron, manganese, and lithia of Norwich, Massacht. setts. Am J Sc (2) 11:100-101 (1851)

$51 a$ On coral reefs and islands. Am J Sc (2) $11: 357-372 ; 12: 25-51,165-186$, 329-338 (1851) ; 13:34-41, 185-195, 338$350 ; 14: 76-84$ (1852) Edinb N Ph J 52 33-62, 221-232 (1851-2)

$51 b$ On the crystallographic identity of eumanite and brookite. Am J Sc (2) 12: $397-398$ (1851)

51e On labradorite from the Island of Maui, Hawailan group. Am J Sc (2) 11: 121 (1851)

52 On the isomorphism of the chemical compounds comprised under the mineral species tourmaline. $\mathrm{Am}$ As, $\operatorname{Pr} 6: 235-$ 238 (1852)

52a On lettering flgures of crystals, Am J Sc (2) $13: 399-404$ (1852)

$52 b$ Note on the eruption of Mauna Loa. Am J Se (2) 14:254-257 (1852)

52e on some modern calcareous rock formations. Am J Sc (2) $14: 410-418$ (1852)

53 On coral reefs and islands. (From the author's exploring expedition report on geology, with additions.) 143 pp, map, N Y 1853

53a On changes of level in the Pacific Ocean. Am J Sc (2) 15:157-175 (1853) Edinb N Ph J 55: 240-262 (1853)

53b On the isomorphism of sphen and euclase. Am J Se (2) $16: 96-97$ (1853)

53e On the consolidation of coral fos. mations. Am J Sc (2) $16: 357-364$ (1853)

54 Mineralogical contributions. Am J Sc (2) $17: 78-88 ; 18: 249-254$ (1854)

$54 a$ Contributions to chemical mineral. ogy. Am J Sc (2) $17: 210-221,430-434$; 18:128-131 (1854)

54b Homoeomorphism of mineral species of the trimetric system. Lyc N HN An 6:37-64 (1854) Am J Sc (2) 18: 35-54 (1854)

55. Supplement to the mineralogy. Am J Sc (2) $19: 353-371$ (1855) ; 21:192$213 ; 22: 246-263 \quad(1856) ; 24: 107-132$ $(1857) ; 25: 396-416 ; 26: 345-364$ (1858); 28 : 128-144 (1859) $\checkmark$ [see also Brush, 60]

56 On volcanic action at Mauna Loa. Am J Sc (2) $21: 241-244$ (1856)

56a on American geological history. Am As, Pr $9: 1-36$ (1856) Am J Sc (2) $22: 305-334$ (1856) Can Nat $1: 395-430$ $(1856-57)$ Can J 3:357-361, 385-387 (1855)

56b On the plan of development in the geological history of North America. Am $\mathrm{J}$ Sc (2) $22: 335-349$ (1856) Am As, Pr 10 pt $2: 1-18$ (1857) Abst, Edinb N Pt $\mathrm{J}$, n s $5: 362-363$ (1857)

$\mathbf{5 7}$ Review of Illustrations of surface geology by E. Hitcheock. Am J Sc (2) $24: 430-433$ (1857) 
Dana, James Dwight-Continued.

59 Reply to Prof. Agassiz on Marcou's Geology of North America. Am J Sc (2) $27: 137-140$ (1859)

59a Eruption of Mauna Loa, Hawali. Im Sc (2) $27: 410-415$ (1859)

61 (and others) Correspondence of Joachim Barrande, Sir William Logan, and James Hall on the Taconic system and the gae of the fossils found in the rock of northern New England, and the Quebec group of rocks. Am J Sc (2) 31:210-226 (1861) Can Nat 6:106-120 (1861)

62 Fossil larve in the Connecticut River sandstone. Am J Sc (2) 33:451-452 (1862)

63 Manual of geology ... $798 \mathrm{pp}, \mathrm{ll}$, map, Phila 1863 ; rev ed, 800 pp, Phila 1864 2d ed, $828 \mathrm{pp}, \operatorname{map}, \mathrm{N}$ Y 1875 3d ed, $911 \mathrm{pp}$, il, map, N Y 1880 4th ed, 1087 pp, N Y 1895

$63 \mathrm{a}$ On the existence of a Mohawk Valley glacier in the glacial epoch. Am J Se (2) $35: 243-249 \quad(1863)$

63b Note on a fossil echinoderm from the Blue Limestone (Lower Silurian) of Cineinnati, Ohio. Am J Sc (2) $35: 295$ (1863)

63e On the Appalachians and Rocky Mountains as time boundaries in geological history. Am J Sc (2) 36:227-233 (1863)

63d On certain parallel relations between the classes of vertebrates, and on the bearing of these relations on the question of the distinctive features of the reptilian birds. Am J Sc (2) $36: 315-321$ (1863)

64 A textbook of geology. 354 pp, Phila 1864; 2d ed, 358 pp, N Y 1874 New textbook of geology, 4th ed, 411 pp, N Y 1883 Revised textbook of geology, rev, by W. N. Rice, 5 th ed, 482 pp, N Y 1897

64a On fossil insects from the Carboniferous formation in Illinois. Am J Sc (2) $37: 34-35$, il (1864)

$64 \mathrm{~b}$ on the crystallization of brushite. Cal Ac N Sc, Pr 3: 174-175 (1864) Am J Sc (2) $39: 45-46 \quad(1865)$

65 On the origin of prairies. Am J Sc (2) $40: 293-304$ (1865)

65a on the history of Eozoon canadense. Am J Sc (2) 40:344-362, il (1865)

66 Observations on the origin of some of the earth's features. Am J Sc (2) 42 : 205-211, 252-253 (1866)

67 Crystallogenic and crystallographic contributions. Am J Sc (2) 44:89-95, 252-263, 398-409 (1867) Ph Mag (4) 34: 178-185 (1867)

67 a On mineralogical nomenclature. Am J Sc (2) $44: 145-151,436$ (1867) Abst, Ph Mag (4) 34:407-408 (1867)

68 (and others) Recent eruption of Mauna Loa and Kilauea, Hawail. Am J Sc (2) $46: 105-123$ (1868)

$$
28737^{\circ}-23-18
$$

Dana, James Dwight-Continued.

69 (and Brnsh, G. J.) On the magnetite in the mica of Pennsbury, Pa. Am J Sc (2) $48: 360-362$ (1869)

ro Excursion to the hanging hills of Meriden. In Davis, C. H. S. History of Wallingford, Conn. : 53-66, Meriden, Conn., 1870.

71 On the geology of the New Haven region, with special reference to the origin of some of its topographical features. Conn Ac, Tr 2: 45-112, map (1871)

71a On the Quaternary, or post-Tertiary, of the New Haven region. Am J Sc (3) $1: 1-5,125-126$ (1871)

71b Historical notes of the earthquakes of New England, 1638-1869. Am J Sc (3) 1: 304-3 5 (1871)

71e On the supposed legs of the trilobite Asaphus platycephalus. Am J Sc (3) 1: $320-321,386$ (1871) An Mag N H (4) $7: 366-368$ (1871) Can Nat n s $6: 348$ $350(1872)$

71d Note on river terraces. Am $J$ Se (3) $2: 144-145$ (1871)

71e On the Connecticut River valley glacier and other examples of glacier movement along the valleys of New England. Am J Sc (3) 2:233-243 (1871)

T1f On the position and height of the elevated platean in which the glacier of New England in the glacial era had its origin. Am J Sc (3) 2:324-330 (1871)

71g Triassic sandstone of the Palisade Range. Am J Sc (3) 2:459-460 (1871)

72 Corals and coral islands. $\$ 98 \mathrm{pp}$, map, $\mathrm{N}+1872$, L $18853 \mathrm{~d}$ ed, $440 \mathrm{pp}$, N Y 1890

72a Notice of the address of Prof $T$. Sterry Hunt before the American Association at Indianapolis. Am J Sc (3) $3: 86-$ 93,$319 ; 4: 97-105$ (1872)

$72 b$ Greer. Mountain geology; on the quartzite. Am J Sc (3) $3: 179-186,250$ 256 (1872)

72e Supposed legs of trilobites. Am J Sc (3) $3: 221-222$ (1872)

72d On the oceanic coral island subsidence. Am J Sc (3) $4: 31-37$ (1872).

72e [Revlew of Hopkins' geological report on Louisiana for 1871]. Am J Sc (3) $4: 136-138(1872)$

72f [On the rock of the Palisades, N. J.] A m J Se (3) $4: 237$ (1872)

72s On the quartzite, limestone, and associated rocks of the vicinity of Great Barrington, Berkshire Co., Mass. Am J Sc (3) $4: 362-370,450-453$ (1872) ; $5: 47-53$, $84-91 ; 6: 257-278 \quad(1873)$

72h On the true Taconic. Am J Sc (3) $3: 468-471$ (1872)

72i What is true Taconlc? Am Nat 6 : 197-199 (1872) Can Nat n s 6:479-480 (1872) 
Dana, James Dwight-Continued.

73 On the crystalline limestone and the conformably associated Taconic and other schists of the Green Mountain region. [Collection of papers appearing in the $\mathrm{Am}$ J Sc] New Haven, Conn., 1873-1882

73a On staurolite crystals and Green Mountain gneisses of the Silurian age. Am Nat 7:658-660 (1873) Am As, Pr 22 pt 2:25-27 (1874) Abst, Can Nat n s $7: 163$ (1874)

73b The slates of the Taconic Mountains of the age of the Hudson River or Cincinnati group. Am Nat 7:708-710 (1873) Am As, Pr 22 pt 2:27-29 (1874)

73e on the glacial and Champlain eras in New England. Am J Sc (3) 5:198211, 217-218, 219 (1873) Abst, G Mag $10: 277$ (1873)

78d On the origin of mountains. Am J Se (3) 5:347-350 (1873)

73e On some results of the earth's contraction from cooling including a discussion of the origin of mountains and the nature of the earth's interior. Am J sc (3) $5: 423-443,474-475 ; 6: 6-14,104$ 115, 161-172, 304, 381-382 (1873) $\mathrm{Ph}$ Mag (4) $46: 41-54,131-140,210-219$, 276-289, 363-375 (1873)

73f Dr. Dawson on the post-Pliocene geology of Canada. Am J Sc (3) 6:226227 (1873)

$73 \mathrm{~g}$ Cretaceous of Long Island, N. Y. Am J Sc (3) 6:305 (1873)

$\boldsymbol{7 3 h}$ On rocks of the Helderberg era in the valley of the Connecticut... Am J Sc (3) $6: 339-352$ (1873)

74 Note on metamorphism and pseudomorphism... Boston Soc $\mathrm{N} H, \operatorname{Pr} 17$ : 167-170 (1874)

74a Glacial phenomena in Nicaragua. $\triangle \mathrm{m}$ J Sc (3) $7: 594-595$ (1874)

74b Reasons for some of the changes in the subdivisions of geological time in the new edition of Dana's Manual of Geology. Am J Sc (3) $8: 213-216$ (1874)

74e On serpentine pseudomorphs and other kinds from the Tilly Foster iron mine, Putnam Co., N. Y. Am J Sc (3) $8: 371-381,447-459$ (1874)

75 The geological story briefly told... xi, 263 pp, N Y 1875 [New ed] 302 pp, N Y 1895

75a An examination of the theories that have been proposed to account for the climate of the glacial period [review of paper by Thomas Belt]. Am J Sc (3) $9: 313-315$ (1875)

75b On the submergence during the glacial period. Am J Sc (3) $9: 315-316$ (1875)

75e Recent changes of level on the coast of Maine, with reference to their origin and relation to other similar changes. Am J Sc (3) 9:316-318 (1875)
Dana, James Dwight - Continued.

75d On Dr. Koch's evidence with ts gard to the contemporaneity of man asd the mastodon in Missouri. Am J Sc (3) $9: 335-346,398$ (1875) With title, Wr man a contemporary of the mammoth Pop Se Rv 14:278-290 (1875)

75e On southern New England during the melting of the great glacier. Am : Se (3) $10: 168-183,280-282, \quad 353-35 \%$, $409-438,497-508$, maps $(1875) ; 11: 151$ $12: 125-128$ (1876)

$75 \mathrm{f}$ Pseudomorphism and metamorphlsm: a correction. Am J Sc (3) 10:298-300 (1875)

76 Note on the "chloritic formation" on the western border of the New Harea region. $\mathrm{Am} \mathrm{J} \mathrm{Sc} \mathrm{(3)} 11: 119-122$ (1876)

76a on the damming of streams by drift ice during the melting of the grest glacier. Am J Sc (3) 11: 178-180 (1876)

76b [Plants as registers of geological age.] Am J Se (3) 11:407-409 (1876)

76e Age of angiospermous plants to ferred to the Cretrceous. Am J Sc (3 $11: 497-498$ (1876)

76d Glacial flood. Am J Sc (3) 12:6465 (1876)

76e Note on erosion. Am J Sc (3) 12 192-193 (1876)

77 Note on the glacial era. Am J \& (3) $13: 79-80$ (1877)

$\boldsymbol{7 7} \mathbf{a}$ An account of the discoveries in Vermont geology of the Rev. Augustos Wing. Am J Sc (3) $13: 332-347,40^{\circ}$ 419. map. 11 ; $14: 36-37$, map (1877)

$\mathbf{7 7 b}$ On the relations of the geology Vermont to that of Berkshire. Am J \& (3) $14: 37-48,132-140,202-207,257-264$ (1877)

$77 \mathrm{e}$ Note on the Helderberg formation of Bernardstown, Mass., and Vernon, Vt. All J Sc (3) $14: 379-387$ (1877)

78 On the driftless interior of North America. Am J Sc (3) 15:250-255 (1878)

$78 \mathrm{a}$ On "indurated bitumen" in cavities in the trap of the Connecticut Valley. All J Sc (3) 16:130-132 (1878)

$\mathbf{7 8 b}$ On some points in lithology. An J Sc (3) $16: 335-343, \quad 431-440$ (1878) Can Nat n s $9: 40-48,80-91$ (1879) Absh, G Mag (2) 6:222-225 (1879)

79 Note on mountain making by the contraction of the earth's crust. Am J SC (3) $17: 325-326$ (1879)

79a On the Hudson River age of the Taconic schists, and on the dependent rt lations of the Dutchess County and western Connecticut limestone belts. Am J Sc (3) $17: 375-388$, map ; $18: 61-64$ (1879)

79b On the composition of the capllary volcanic glass of Kilauea, Hawaii, called Pele's hair. Am J Sc (3) 18:134-135 (1879) 
Dana, James Dwight-Continued.

80 Gilbert's report on the geology of the Henry Mountains. Am J Sc (3) 19:1725 (1880)

80a List of papers on the Taconic system. Am J Sc (3) $19: 153-155$ (1880)

sob Note on the age of the Green Mountains. Am J Sc (3) $19: 191-200$ (1880)

soe Age of the Taconic rocks ... Am J Sc (3) $19: 236-237$ (1880)

sod 0 n the geological relations of the limestone belts of Westchester Co., N. Y. Am J Sc (3) $20: 21-32,194-220,359-375$, $450-456 \quad(1880) ; 21: 425-443$; 22 : 103$119,313-315,327-335$, maps (1881)

soe 0 a case in which various massive crystalline rocks including soda granite, quartz diorite, norite, hornblendite, pyroxenite, and different chrysolitic rocks, were made through metamorphic agencies in one metamorphic process. G Mag (2) 8:59-65, 110-119, 162-171 (1881) Am J Sc (3) 20: 194-220 (1880)

81 Dolerite (trap) of the TriassicJurassic area of eastern North America. Am J Sc (3) $22: 230-233$ (1881)

$81 \mathrm{a}$ on the relation of the so-called "kames" of the Connecticut River valley to the terrace formation. Am J Sc (3) $22: 451-468$ (1881)

82 The flood of the Connecticut River valley from the melting of the Quaternary glacier. Am J Sc (3) 23:87-97, 179-202, $360-373 ; 24: 98-104$ (1882)

s2a Note on the former southward discharge of Lake Winnipeg. Am J Sc (3) $24: 428-433$ (1882) Can Nat n s $10: 436-$ 442 (1883)

$82 \mathrm{~b}$ Geological age of the Taconic system. G Soc London, Q J 38: 397-408, map (1882) Abst, Am J Sc (3) 24:291-293 (1882); G Mag (2) $9: 281-282$ (1882)

83 Evidence from southern New England against the iceberg theory of the drift. Am As, Pr $32: 195-198$ (1884) Science 2: 390 392 (1883)

83a The origin of the Jura-Trias of eastern North America. Am J Sc (3) 25: 383386 (1883)

$83 b$ on the western discharge of the flooded Connecticut, or that through the Farmington Valley to New Haven Bay. Am J Se (3) $25: 440-448$ (1883)

83e Hemidiorite. Am J Sc (3) $25: 478$ (1883)

83d Elevated coral reefs of Cuba. Am J Sc (3) 26 : 148-149 (1883)

83e Phenomena of the glacial and Champlain periods about the mouth of the Connecticut Valley - that is, in the New Haven region. Am J Sc (3) 26:341-361, map (1883); $27: 113-130$, maps (1884)

83e The Tortugas and Florida reefs. Am J Sc (3) $26: 408-409$ (1883)
Dana, James Dwight-Continued.

84 On the southward ending of a great synclinal in the Taconic Range. Am J Se (3) $28: 268-275$, map (1884) Abst, Brit As, Rp 54:729-730 (1885) ; G Mag (3) 1: 473-474 (1884)

84a Professor James Hall on the "Hudson River" age of the Taconic slates. Am J Sc (3) 28:311-312 (1884)

84b Note on the Cortlandt and Stony Point hornblendic and augitic rock [N. Y.]. Am J Sc (3) $28: 384-386$ (1884)

84e Note on the origin of bedding in socalled metamorphic rocks. Am J Sc (3) $28: 393-396$ (1884)

84d Note on the making of limonite ore beds. Am J Sc (3) $28: 398-400$ (1884)

84e On the decay of quartzite and the formation of sand, kaolin, and crystallized quartz. Am J Sc (3) 28:448-452 (1884)

S4f Elevation of land during the glacial period. Ph Mag (5) 17:245 (1884)

85 On a system of rock notation for geological diagrams. Am J Sc (3) 29:7-10 (1885)

$85 a$ Decay of quartzite; pseudo-breccia. Am J Sc (3) $29: 57-58$ (1885)

85b On Taconic rocks and stratigraphy, with a geological map of the Taconic region. Am J Sc (3) $29: 205-222,437-443$, map (1885) ; 33:270-276, 392-419 (1887)

$85 \mathrm{e} . .$. on the origin and relations of continents and ocean basins. Am J Se (3) 29: $336-338$ (1885)

s5a Origin of coral reefs and islands. Am J Se (3) $30: 89-105,169-191$, map (1885)

85e The volcanic nature of a Pacific island not an argument for little or no subsidence. Am J Sc (3) $30: 158-159$ (1885)

s5e On displacement through intrusion. Am J Sc (3) $30: 374-376$ (1885)

$85 \mathrm{~g}$ Creation, or the Biblical cosmogony in the light of modern science. Bibliotheca Sacra 42:202-224 (1885)

85h Lower Silurian fossils at Canaan, N. Y. Science $6: 283$ (1885)

86 Berkshire geology [Massachusetts]. Berkshire Hist $\mathrm{Sc}$ Soc, Four Papers of: $1-25$ (1886)

86a On Lower Silurian fossils from a limestone of the original Taconic of Emmons. Am J Sc (3) $31: 241-248$ (1886) Abst, $A \mathrm{~m} \mathrm{As,} \mathrm{Pr.34:216-217} \mathrm{(1886)}$

86b Eruption at Kilauea, Hawaii, in March, 1886. Am J Sc (3) 31:397-398 (1886)

86e The history of Taconic investigation previous to the work of Professor Emmons. Am J Sc (3) 31:399-401 (1886)

s6d On some general terms applied to metamorphism, and to the porphyritic structure of rocks. Am, J Sc (3) 32 : 69-72 (1886) 
Dana, James Dwight-Continued.

86e The Taconic stratigraphy and fossils. Am J Se (3) $32: 236-239$ (1886)

s6f A dissected volcanic mountain; some of its revelations. Am J Sc (3) 32: 247-255 (1886)

$\mathbf{8 6 g}$ Geological age of the North Atlantic oceanic basin and origin of eastern American sediments. Am J Sc (3) 32 : 407-408 (1886)

86h Glaciers and glacialists. Science $8: 162-163$ (1886)

87 Volcanic action. Am J Sc (3) 33 102-115 (1887)

87a Kilauea. Am J Sc (3) 33:239240 (1887)

\$7b Eruption of Mauna Loa, Hawaii, in January. Am J Sc (3) 33: 310-312 (1887)

87e History of the changes in the Mt. Loa craters, on Hawaii. Am J Sc (3) 33 : 433-451, 34:81-97, 349-364 maps (1887); $35: 15-34, \quad 213-228, \quad 282-289$, maps ; $36: 14-32,81-112,167-175$, maps (1888)

87d Geology of Long Island: Am J Sc (3) $34: 153-155$ (1887)

87e A pothole of remarkable size in Archbald, Pa. Am J Sc (3) 34:489 (1887)

88 A brief history of Taconic ideas. Am J Sc (3) 36:410-427 (1888)

88a American report to the International Congress of Geologists at the meeting in London commencing September 17, 1888. Am J Sc (3) $36: 469-470$ (1888)

$\mathbf{8 8 b}$ On the cosmogony of Genesis. Andover Rv 9:197-200 (1888)

89 ...on Halemaumau and its debris cone. Am J Sc (3) $37: 48-50$ (1889)

89 Points in the geological history of the islands Maui and Oahu. Am $J$ Sc (3) $37: 81-103$, map (1889)

89b On the origin of the deep troughs of the oceanic depression; are any of volcanic origin? Am J Sc (3) $37: 192-$ 202, map (1889)

89e The name Silurian in geology. Pop Sc Mo $36: 276$ (1889)

90 Characteristics of volcanoes... xvi, 399 pp, N Y 1890

90a Areas of continental progress in North America... G Soc Am, B 1:36-48 (1890)

90b Sedgwick and Murchison; Cambrian and Silurian, Am J Se (3) 39:167-180, 235 (1890)

90e Subaerial decay of rocks and origin of the red color of certain formations. Am J Sc (3) $39: 317-319$ (1890)

ood Archean limestone and other rocks in Norfolk, Conn. Am J Sc (3) $39: 321$ (1890)

90e Archean axes of eastern North America. Am $J$ Sc (3) $39: 378-383$ (1890)
Dana, James Dwight-Continued.

901 Rocky Mountain protaxis and the post-Cretaceous mountain-making along ts course. Am J Sc (3) $40: 181-196$, ㅁas? (1890)

$90 \mathrm{~g}$ Fossils in the Taconic limeston belt at the west foot of the Taconic Range in Hillsdale, N. Y. Am J Sc (3) $40: 256$ 257 (1890)

90h Long Island Sound in the Quaternary era, with observations on the sub. marine Hudson River channel. Am J \& (3) $40: 425-437(1890)$

91 On the four rocks of the New Have region... $120 \mathrm{pp}$, maps, New Haven 1891

91a Note on the recent eruption of Kilauea, Hawail. Am J Sc (3) 41:448, 516 (1891)

$91 \mathrm{~b}$ [On the age of certain limestones]. Am J Sc (3) 42:70-72 (1891)

91e ... nonvolcanic igneous ejections, as illustrated in the four "Rocks" of the New Haven region, West Rock, Pine Rock, Mill Rock, and East Rock. Am J Sc (3) 42:79-110, maps (1891)

91d On Percival's map of the Jurs Trias trap belts of central Connectict with observations on the upturning of mountain-making disturbance of the form. tion. Am J Sc (3) $42: 439-447$, map (1891)

92 On subdivisions in Archean histor. Am J Sc (3) 43: 455-462 (1892)

92a Additional observations on the Jura-Trias trap of the New Haven region. Am J Sc (3) 44:165-169 (1892)

92b Further observations on the perms. nence of oceans and continents. Nat Sc 1 : $737-740 \quad$ (1892)

93 On New England and the upper Mis sissippi basin in the glacial period. $A m$ I Sc (3) $46: 327-330$ (1893)

94 Observations on the derivation and homologies of some articulates. $\mathrm{Am} \mathrm{J}$ S (3) $47: 325-329$ (1894) An Mag NH (6) $13: 502-506$ (1894)

95 Formation of dolomite. Am J Sc (3) $49: 426-427$ (1895)

See also Conrad, 46a ; Dewey, 57 ; Frazet, 88a ; Hitehcock (C. H.), 71a, 84; Hunt, 75 ; Johnson (S. W.), 51; Manross, 65; Marcou, 58; Whitfleld, 83a ; Winchell (N. H.), $88 \mathrm{~g}$

Dana, James Freeman (1793-1827)

18 (and Dana, S. L.) Outlines of the mineralogy and geology of Boston and its vicinity, with a geological map. $108 \mathrm{pP}$. map, Boston 1818. Also in Am Ac Arts. Mem 4:129-223, map (1818)

Dana, Samuel Luther (1795-1868)

18 (with Dana, J. F.) Outlines of the mineralogy and geology of Boston and its vicinity, with a geological map. $108 \mathrm{pP}$. map, Boston 1818. Also in Am Ac Arts. Mem 4:129-223, map (1818) 
Dana, Samuel Luther-Continued.

45 Analysis of coprolites from the New Red sandstone formation of New England, with remarks by Professor Hitchcock. Am J Sc 48:46-60 (1845)

Daneš, Jiri $V$.

06 Im Karstgebiete Jamaica's. Soc Hongroise Géog, Abrégé B, Suppl au Földrajzi Közlemények $35: 129-130$ (1906)

07 Das Erdbeben von San Jacinto am 25. Dezember, 1899 [southern California]. K-k Geog Ges Wien, Mitt 50:339-347 (1907)

09 Absence de traces glaciaires dans la Californie méridionale. La Géog 19:120122 (1909)

10 Geomorphologische Studien im Karstgeblete Jamaika's. Int Cong Geog, IX, C R 2:178-182 (1910)

14 Karststudien in Jamaica. K Böhm Ges Wiss, Mat-nat Cl, Szb 1914:72 pp, map [not seen]

Daniels, Edward.

54 First annual report on the geological survey of the State of Wisconsin. $84 \mathrm{pp}$, map, Madison 1854 Extract, with title, The lead veins of Wisconsin, M Mag 2:493$506(1854)$

54a [Some features of the lead district of Wisconsin.] Boston Soc N H, Pr 4: 387-389 (1854)

58 Annual report of the geological survey of the State of Wisconsin, for the year ending December 31, $1857.62 \mathrm{pp}$, Mad1son 1858

58a Report. In Report of the commissioners of the geological survey [of Wisconsin] : 9-12, Madison 1858

58b Iron ores of Wisconsin. M Mag $10: 13-27$ (1858)

58c [On Silurian rocks of Illinols and Wisconsin and fossils from the Potsdam of Wisconsin.] Boston Soc N H, Pr 6: 309-310 (1858)

Daniels, Joseph.

12 The Roslyn, Wash., coal field. Coal Age 1:1064-1066 (1912)

14 The coal fields of Pierce Co. [Wash.]. Washington G S, B 10:146 pp, maps (1914)

15 Structure of Pierce County coal field of Washington (abst). G Soc Am, B 26: 132-133 (1915)

Daniels, L. E.

05 Notes on the semi-fossil shells of Posey Co., Ind. Nautilus 19:62-63 (1905)

Dannenberg, A.

08 Beobachtungen an einigen Vulkanen Mexikos. Naturh Ver Preus Rheinl, Verh 64: 97-133 (1908)

Dappert, J. W.

06 Sedimentation, its relation to drainage. Ill Soc Eng, An Rp 21: 82-94 (1906)
Darton, Nelson Horatio.

82 The mineralogical localities in and around New York City and the minerals occurring therein. Sc Am Sup 14:5492$5493, \quad 5566-5568, \quad 5796-5797 ; \quad 16: 6629$ (1882-3)

S2a Notes on [the minerals of] the Weehawken tunnel [N. J.] N Y Ac Sc, Tr 1: 129-131 (1882)

S2b On a new locality for hayesine and its novel occurrence. Am J Sc (3) 23: 458-459 (1882)

s3 On the indurated shales between Bergen Hill and the Palisades, N. J. Sc Am Sup 16:6513-6514 (1883)

S3a on the disintegrated sandstone at New Durham, N. J. (abst) N Y Ac Sc, Tr 2:117-119 (1883)

85 Preliminary notice of fossils in the Hudson river slates of the southern part of Orange Co., N. Y., and elsewhere. Am $\mathrm{J}$ Sc (3) $30: 452-454$ (1885)

85a Ancient bone cave in Pennsylvania. Sc Am Sup 19: 7541-7542 (1885)

s5b On the Devonian age of the Green Pond Mountain rocks. Sc Am Sup 19: $7877-7878$ (1885)

86 On the area of Upper Silurian rocks near Cornwall Station, eastern-central Orange Co., N. Y. Am J Sc (3) $31: 209-$ 216 (1886)

86a The Taconic controversy in a nutshell. Science $7: 78-79$ (1886)

87 Bibliography of North American geology for 1886 . U S G S, B 44:35 pp (1887)

S9 North American geology for 1886. Smiths Inst, An Rp 1887 pt 1:189-229 (1889)

s9a On the great lava flows and intrusive trap sheets of the Newark system in New Jersey. Am J Sc (3) 38:134-139 (1889)

90 The relations of the traps of the Newark system in the New Jersey region. U S G S, B 67:82 pp, map (1890)

$90 a$ on the occurrence of basalt dikes in the upper Paleozoic series in central Appalachian Virginia; with notes on the petrography by J. S. Diller. Am J Sc (3) $39: 269-271 \quad(1890)$

91 Record of North American geology for 1887 to 1889 , inclusive. U $\mathbf{S} \mathbf{G} \mathbf{S}, \mathbf{B}$ $75: 173 \mathrm{pp} \mathrm{(1891)}$

91a Record of North American geology for 1890. U S G S, B 91: 88 pp (1891)

$91 b$ Mesozoic and Cenozoic formations of eastern Virginia and Maryland. G Soc Am, B 2: 431-450, map (1891)

91 e Record of a deep well at Lake Worth, southern Florida. Am J Sc (3) 41: 105-106 (1891)

$91 d$ Notes on the geology of the Florida phosphate deposits. Am J Se (3) 41:102105 (1891) 
Darton, Nelson Horatio-Continued.

91e On a fointed earth auger for geological explorations in soft deposits. Am G $7: 117-119$ (1891) Eng M J $51: 401$ (1891)

911 (with MeGee, W $J$ and others) The geology of Washington and vicinity. In Guide to Washington ... International Congress of Geologists, fifth session, Washington 1891: 38-64, map [1891]

92 Record of North American geology for 1891. U S G S, B $99: 73$ pp (1892)

92a The geology of Baltimore and its vicinity; physiography of the region and geology of the sedimentary rocks. In Guide to Baltimore (Am. Inst. Min. Eng., Baltimore meeting) : 125-139, map [Baltimore 1892]

92b On fossils in the Lafayette formation in Virginia. Am G 9:181-183 (1892)

92e Notes on the stratigraphy of a portion of central Appalachian Virginia. Am G $10: 10-18$ (1892)

92d Fossils in the "Archean" rocks of central. Piedmont Virginia. Am J Se (3) $44: 50-52$, il (1892)

93 On two overthrusts in eastern New York. G Soc Am, B 4:436-439 (1893)

93a The stratigraphic relations of the Oneonta and Chemung formations in eastern central New York. Am J Sc (3) 45 : 203-209 (1893)

93b The Magothy formation of northeastern Maryland. Am J Sc (3) 45:407419, map (1893)

93e On certain features in the distribution of the Columbia formation on the middle Atlantic slope (abst with discussion). Am G 11:244 (1893)

93d The Cenozoic history of eastern Virginia and Maryland (abst with discussion). Am G 12:171-172 (1893)

94 Report on the relations of the Helderberg limestones and associated formations in eastern New York. N Y St G, An Rp 13: $199-228$ (1894) N Y St Mus, An Rp 47: $393-422$ (1894)

94a Preliminary report on the geology of Albany Co. [N. Y.]. N Y St G, An Rp 13: 229-261 (1894) N Y St Mus, An Rp $47: 425-455$ (1894)

94b Preliminary report on the geology of Ulster Co. [N. Y.]. N Y St G, An Rp $13: 289-372$, map $(1894)$ N Y St Mus, An Rp 47:485-566, map (1894)

94c Geology of the Mohawk Valley in Herkimer, Fulton, Montgomery, and Saratoga cos. [N. Y.]. N Y St G, An Rp 13: 407-429 (1894) N Y St Mus, An Rp 47 : 601-623 (1894)

94d Description of the Fredericksburg sheet [Va,-Md.] U S G S, G Atlas Fredericksburg fol (no 13):6 pp, maps (1894)
Darton, Nelson Horatio-Continued,

94e Description of the Staunton sbet [Va.-W. Va.]. U S G S, G Atlas Staunto fol (no 14): 4 pp, maps (1894, Abt J G 3 ; 973-974 (1895)

94 Geologic relations from Green Pood N. J., to Skunnemunk Mountain, N. Y. Soc Am, B 5: 367-394, map (1894) (Abet) Am G 13: 211-212 (1894)

94g Outline of Cenozoic history of a por: tion of the middle Atlantic slope. J G 2: 568-587, maps (1894)

94h Shawangunk Mountain [Ulster Co, N. Y.]. Nat Geog Mag 6: 23-34 (1894)

941 Geologic relations in the belt from Green Pond, N. J., to Skunnemunk Mous tain, N. Y. (abst). Am G 13:211-21? (1894)

95 (and Kemp, J. F.) A newly dif covered dike at DeWitt, near Syracuse, $\mathrm{X}$. Y. Am J Sc (3) $49: 456-462$ (1895) Abst, G Soc Am, B 6:477-478 (1895); Science n s 1:65-66 (1895)

95a Artesian well prospects in easten Virginia, Maryland, and Delaware, dt I M Eng, Tr 24:372-397, map (1895)

96 Catalogue and index of contributios to North American geology, 1732-1891, 0 S G S, B 127: 1045 pp (1896)

$96 a$ Description of the Nomini shet [Md.-Va.]. U S G S, G Atlas Nominl fol (no 23 ) : 4 pp, maps (1896) 4 bst, J G 5: 413-414 (1897)

96b (and Tafr, J A.) Description of the Piedmont sheet [W. Va.-Md.]. O \& G S, G Atlas Piedmont fol (no 28): $6 \mathrm{~m}$ maps (1896) Abst, J G 5 : 411-412 (1897)

96a Description of the Franklin quat rangle [W. Va.-Va.]. U S G S, G Atlis Franklin fol (no 32):6 pp, maps (1896)

96d Artesian well prospects in th Atlantic Coastal Plain region. U S Q \& B $138: 232 \mathrm{pp}$, maps (1896)

96e Preliminary report on arteslas waters of a portion of the Dakotas. I 8 G S, An Rp 17 pt 2:603-694, maps (1896)

96f Notes on relations of lower members of the Coastal Plain series in South Car lina. $\mathrm{G}$ Soc Am, B 7:512-518 (1896) Abst, Am G 17:107-108 (1896); Sclence n s $3: 56$ (1896)

$96 \mathrm{~g}$ Examples of stream-robbing in the Catskill Mountains (abst). G Soc Am, B 7:505-507, map (1896) Am G 17:8f 99 (1896)

96h Résumé of general stratigraphic it lations in the Atlantic Coastal Plain frol New Jersey to South Carolina (abst). Al G $17: 108$ (1896) Science n 8 s:57 (1896)

961 Notes on the geology of the Blad Hills of Dakota (abst). Am G 17:264-265 (1896) Science n s 3:418 (1896)

96j Physiographic development of the District of Columbia region $(a b s t)$. Science n s $3: 606-607(1896) ; 5: 84$ (1897) 
Darton, Nelson Horatio-Continued.

97 A preliminary description of the faulted region of Herkimer, Fulton, Montgomery, and Saratoga cos. [N. Y.]. N Y St G, An Rp 14: 31-53, map (1895) [1897] N Y St Mus, An Rp 48 v 2:31-53, map (1895) [1897]

97a Preliminary geologic map of Albany Co., N. Y. Scale: 1 mile to the inch. N Y St G, An Rp $15 v$ 1: map (1897) N Y St Mus, An Rp 49 v $2:$ map (1898)

97b New developments in well boring and irrigation in eastern South Dakota, 1896. U S G S, An Rp 18 pt $4: 561-615$, maps (1897)

97e Dikes in Appalachian Virginia (abst.) J G $5: 324$ (1897) Science n s $5: 84$ (1897)

98 Underground waters of a portion of southeastern Nebraska. U S G S, W-S P $12: 56 \mathrm{pp}$, maps (1898)

98n Geothermal data from deep artesian wells in the Dakotas. Am J Sc (4) 5: 161-168 (1898) Abst, Science n 8 7:84 (1898)

98b On dikes of felsophyre and basalt in Paleozoic rocks in central Appalachian Virginia, with notes on the petrography by Arthur Keith. Am J Sc (4) $6: 305-$ 315, map (1898)

98e Geography of Washington, D. C. J Sch Geog 2: 201-205 (1898)

98d Discovery of marine Cretaceous in boring at Norfolk, Va. (abst). G Soc Am, B $9: 414-416$ (1898) Science $n$ \& $7: 52$ (1898)

98e On the Tertiary of South Dakota and Nebraska (abst). Science n s $7: 359$ (1898)

99 Description of Monterey quadrangle [Va.-W. Va.], U S G S, G Atlas Monterey fol (no. 61) : 7 pp, maps (1899)

99a ...geology and water resources of Nebraska west of the one hundred and third meridian. U S G S, An Rp 19 pt 4:719-785 (1899)

99b Jurassic formations of the Black Hills of South Dakota. G Soc Am, B 10 : 383-396, map (1899) Abst, Am G 23:94 (1899) ; Science n \& 9: 103 (1899)

99e The Bad Lands of South Dakota. Nat Geog Mag 10:339-343 (1899)

99d Discovery of fossil fish in the Jurassic of the Black Hills (abst). Am G 23:93 1899) Science n s 9:103 (1899) 99e Shore lines of Tertiary lakes on the slopes of the Black Hills (abst). Science n 8 9: 103 (1899) Am G 23:94 (1899) 99P Relations of Tertiary formations in western Nebraska region (abst). Am G 23 : 94 (1899)

99g (with Clarke, F. W.) On a hydromica from New Jersey. Am J Sc (4) $7: 365-366$ (1899)
Darton, Nelson Horatio-Continued.

00 Mesozoic stratigraphy of Black Hills of South Dakota (abst). Science n s 11: $143(1900)$

O0a Tertiary shore lines and deposits in the Black Hills, S. Dak. (abst). Science n $\&$ 11: 144 (1900)

00b Physiographic development of the Black Hills (abst). Science n s 11:825 (1900)

ooe (with Clarke, F. W.) On a hydromica from New Jersey. U S G S, B 167 : 154-155 (1900)

01 (and Keith, Arthur) Description of the Washington quadrangles [D. C.-Md.Va.] U S G S, G Atlas Washington fol (no 70) : $7 \mathrm{pp}$, maps (1901)

$01 a$... geology and water resources of the southern half of the Black Hills and adjoining regions in South Dakota and Wyoming. U S G S, An Rp 21 pt 4: 489-599, maps (1901)

013 Comparison of stratigraphy of the Black Hills with that of the front range of the Rocky Mountains (abst). G Soc Am, B 12:478 (1901) Science n 8 13:188 (1901)

02 Description of the Norfolk quadrangle [Va.-N. C ]. U S G S, G Atlas Norfolk fol (no 80 ) : 4 pp, maps (1902)

02a Description of the Oelrichs quadrangle [S, Dak.-Nebr.]. U S G S, G Atlas Oelrichs fol (no 85) : $6 \mathrm{pp}$, maps (1902)

02b Preliminary list of deep borings in the United States, Part I, Alabama-Montana. U S G S, W-S P 57:60 pp (1902)

02e Preliminary list of deep borings in the United States, Part II, Nebraska-Wyoming. U S G S, W-S P 61:67 pp (1902)

02d Catalog of photographs belonging to the Geological Society of America. G Soc Am, B 13: 377-474 (1902)

o2e Stratigraphy of the Bighorn Mountains (abst). Science n s 15:823 (1902)

03 Deseription of the Camp Clark quadrangle [Nebr.]. U S G S, G Atlas Camp Clark fol (no 87) : 4 pp, maps (1903)

03a Description of the Scotts Blur quadrangle [Nebr.]. U S G S, G Atlas Scotts Bluff fol (no 88) : 5 pp, maps (1903)

03b Preliminary report on the geology and water resources of Nebraska west of the one hundred and third meridian. U $\mathbf{S}$ G S, P P 17:69 pp (1903)

03e Some relations of Tertiary formations of the northern Great Plains (abst). Science n \& $17: 218$ (1903)

04 Description of the Newcastle quadrangle [Wyo.-S. Dak.]. U S G S, G Atlas Newcastle fol (no 107) : $9 \mathrm{pp}$, maps (1904)

O4a (and Smith, W. S. T.) Description of the Edgemont quadrangle [S. Dak. Nebr.]. U S G S, G Atlas Edgemont fol (no 108): $10 \mathrm{pp}$, maps (1904)

04b Gypsum deposits in South Dakota. U S G S, B 223: 76-78 (1904) 
Darton, Nelson Horatio-Continued.

04c Comparison of the stratigraphy of the Black Hills, Bighorn Mountains, and Rocky Mountain front range. G Soc Am, B $15: 379-448$ (1904) Abst, Science n s $17: 292$ (1903)

05 Preliminary report on the geology and underground water resources of the central Great Plains. U S G S, P P 32 : $433 \mathrm{pp}$, maps (1905)

05a Description of the Sundance quadrangle [Wyo.-S. Dak.]. U S G S, G Atlas Sundance fol (no 127) : 12 pp, maps (1905)

05b (and O'Harra, C. C.) Description of the Aladdin quadrangle [Wyo.-S. Dak.Mont.]. U S G S, G Atlas Aladdin fol (no 128) : 8 pp, maps (1905)

o5e The coal of the Black Hills, Wyo. U S G S, B 206: 429-433 (1905)

05a Zuni salt deposits, New Mexico.

U S G S, B 260: 565-566 (1905)

o5e [Underground waters of] Delaware.

U S G S, W-S P 114: 111-113 (1905)

osf (and Fuller, M. L.) [Underground waters of] Maryland; District of Columbia; Virginia. U S G S, W-S P 114: 114-135 (1905)

05g Preliminary list of deep borings in the United States (second edition, with additions). U S G S, W-S P 149:175 pp (1905)

05h The Zuñi salt lake. J G 13:185193, map (1905) Abst, Science n s 21: 219 (1905) ; G Soc Am, B 16:564 (1906) Sc Am Sup 59: 24326 (1905)

05i Age of the Monument Creek formation. Am J Sc (4) 20:178-180 (1905)

05j Discovery of the Comanche formation in southeastern Colorado. Science n $s$ 22:120 (1905)

o5k [The age of the Morrison formation of the Rocky Mountain region (abst).] Science n s 21:222 (1905) Sc Am Sup $59: 24327$ (1905)

051 Structure of the Great Plains and the mountains on their western margin (abst). Science n s 21:917 (1905)

06 Geology of the Owl Creek Mountains, with notes on resources of adjoining regions in the ceded portion of the Shoshone Indian Reservation, Wyo. U S, 59th Cong, 1st sess, Sen Doc no $219: 48$ pp, map (1906)

06a The hot springs at Thermopolis, Wyo. J G 14:194-200 (1906)

06b Fish remains in Ordovician rocks in Bighorn Mountains, wyo., with a résumé of Ordovician geology of the Northwest. G Soc Am, B 17:541-566, map (1906)

06e Description of the Bald Mountain and Dayton quadrangles, Wyo. U S G S, G Atlas, Bald Mountain-Dayton fol (no 141) : $15 \mathrm{pp}$, maps (1906)

o6d Description of Cloud Peak and Fort McKinney quadrangles, Wyo. U $\mathbf{S}$ G S, G Atlas Cloud Peak-Fort McKinney fol (no 142) : 16 pp, maps (1906)
Darton, Nelson Horatio-Continned. 06e Geology of the Bighorn Mountain U S G S, P P 51: 129 pp, map (1906) o6f Geology and underground waters of the Arkansas Valley in eastern Colorad U S G S, P P 52:90 pp, map (1906)

$\mathbf{0 6 g}$ Mineral resources of the Bighom Mountain region. U S G S, B 285:30s310 (1906)

06h The Great Plains of the central United States. Scottish Geog Mag 32:2 18 (1906)

or Discovery of Cambrian rocks th southeastern California. J G $15: 470-47$ i (1907)

ora Coals of Carbon Co., Mont. I \& G S, B 316:174-193 (1907)

Ozb (and O'Harra, C. C.) Descrip tion of the Devils Tower quadranglt [Wyo.]. U S G S, G Atlas Devils Towe: fol (no 150) : 9 pp, maps (1907)

o7e Bighorn Mountains. Nat Geog $\mathrm{Va}$ 18: 355-364 (1907)

ord Mexico, the treasure house of the world. Nat Geog Mag 18: 493-519 (1907)

ore Red beds in the Laramie mountain region (abst). G Soc Am, B 17:724-7: (1907)

08 Paleozoic and Mesozoic of central Wyoming. G Soc Am, B 19:403-470, map (1908)

O8a Marble of White Pine Co., Ner, near Gandy, Utah. U S G S, B $340: 37 \%-$ 380 (1908)

O8b (and Bayley, W. S., Sallsbur R. D., and Ktimmel, H. B.) Description of the Passaic quadrangle, N. J.-N. Y. S G S, G Atlas Passaic fol (no 157) 27 pp, maps (1908)

09 Geology and water resources of the northern portion of the Black Hills at. adjoining regions in South Dakota $\mathrm{at}$ ? Wyoming. U S G S, P P 65: 105 ph maps (1909)

09a Geology and underground waters of South Dakota. U S G S, W-S P 227: 158 pp, map (1909)

09b Structural materials in parts of Oregon and Washington. U S G S, B 387: $33 \mathrm{pp}$, map (1909)

09e Geologic basis for artesian predic tion. Am Water Works As, P 28th dt Conv, 1908: 280-291 (1909)

09 d Discovery of fish remains in 0 rdo vician of the Black Hills, S. Dak. (abst). G Soc Am, B 19:567-568 (1909)

09e (and O'Harra, C. C.) Descriptlon of the Belle Fourche quadrangle, S. Dak. S G S, G Atlas, Belle Fourche fol (Do 164) : $9 \mathrm{pp}, \operatorname{maps}(1909)$

o9f (and Siebenthal, C. E.) Geologt and mineral resources of the Laramie Basin, Wyo. U S G S, B 364: 81 pp, map (1909)

$09 \mathrm{~g}$ The stream robbery on which the Belle Fourche reclamation project is based (abst). Science n s 29:556-557 (1909) 
Darton, Nelson Horatio-Continued.

10 Cement materials in Republican Valley, Neb. U S G S, B $430: 381-387$ (1910) 10a A reconnaissance of parts of northwestern New Mexico and northern Arizona. V S G S, B $435: 88$ pp, map (1910)

$10 \mathrm{~b}$ Beconnaissance in Arizona and western New Mexico along the Santa Fé Rallroad (abst). G Soc, B 20:700 (1910) 10e (and Blackwelder, Eliot, and Siebenthal, C. E.) Description of the Laramie and Sherman quadrangles, Wyo. U S G S, G Atlas, Laramie-Sherman fol (no 173) :17 pp, maps (1910)

11 Economic geology of Ríchmond, Va, and vicinity. U S G S, B $483: 48$ pp, map (1911)

11a (and Burehard, E. F.) Fluorspar near Deming, N. Mex. U S G S, B 470 : 533-545, maps (1911)

11b List of underground temperatures in the United States (abst). G Soc Am, B 22: 716 (1911)

11e Geology of part of Luna Co., N. Sex. (abst). G Soc Am, B 22:718-719 (1911)

12 Notes on sand for mine flushing in the Scranton region [Pa.]. U S Bur Mines, B 25: 72-75 (1912)

12a Sandstone pinnacles [erosion forms in western Nebraska and Colorado.] Geologische Charakterbilder (H. Stille), Н 11, 6 pls and text, 1912

12b Sillca and lime deposition. Geologische Charakterbilder (H. Stille), H 12, 6 pls and text, 1912

12e Volcanic action in the Black Hills of South Dakota. Science n s 36:602-603 (1912)

12d Some features in the Grand Canyon of Colorado River (abst). Science n s 35 : 310 (1912) G Soc Am, B 23: 721 (1912)

13 Sand available for filling mine workings in the northern anthracite basin of Pennsylvania. U S Bur Mines, B 45:33 Pp, maps (1913)

13a Buried valley of Susquehanna River in Luzerne Co., Pa, J G 21:557-563 (1913) Abst, As Am Geog, An 2:111 [1913]

13b Construction of a structure map of the northern anthracite field (abst). Wash Ac Sc, J 3: 199-200 (1913)

13e Some structural features in the northern anthracite coal field $(a b s t)$. G 8 Am, B 24:676-677 (1913)

13d Geothermal data of the United States (abst). G Soc Am, B 24:677 (1913)

14 Some features of the Quaternary deposits in the Wyoming Valley region [Pa.]. Wyoming Hist $G$ Soc, $\operatorname{Pr} 13: 41$ 64, map (1914)

14a Lnderground $w$.. er of Luna Co., N. Mex. B S G S, W-S P 345: 25-37, map (1914)
Darton, Nelson Horatio-Continued.

$14 \mathrm{~b}$ Geology of the Helderberg escarpment [Albany Co., N. Y.]. Am Scenie and Historic Preservation Soc, An Rp 19: 353-356 (1914)

14e A peculiar fault in southwestern New Mexico. Wash Ac Sc, J 4:288-289 (1914)

14d Stratigraphy of red beds of New Mexico (abst). G Soc Am, B 25:81-82 (1914) Wash Ac Sc, J 4:295 (1914)

15 (and others) Guidebook of the western United States, Part C, The Santa Fe Route, with a side trip to the Grand Canyon of the Colorado. U S G S, B 613 : $194 \mathrm{pp}$, maps (1915) Abst, by E. S. Bastin, Wash Ac Sc, J 5 : 634 (1915)

15a Occurrence of explosive gases in coal mines. U S Bur Mines, B $72: 248$ pp (1915)

15b Memoir of W J McGee. As Am Geog, An $3: 103-110$ [1915]

15e A novel plan for stopping a landslide at Mount Vernon. Eng News 73 : $369-370$ (1915)

15a Extension of Morrison formation into New Mexico (abst). G Soc Am, B $26: 113$ (1915)

16 Geology and underground water of Luna Co., N. Mex. U S G S, B 618: 18s pp, map (1916) Abst, Wash Ac Sc, J 6 : $449-450$ (1916)

16 a Sedimentary rocks [north Laramie Mountains, Wyo.]. U S G S, B 626:53$56, \operatorname{map}(1916)$

16b Explosion eraters. Sc Mo,3:417430 (1916)

$16 \mathrm{e}$ Some geologic features of southeastern California (abst). Wash Ac Sc, J 6 : 23-24 (1916)

$16 d$ Sedimentary succession in southern New Mexico (abst). G Soc Am, B 27:86 (1916)

17 Description of the Deming quadrangle [N. Mex.]. U S G S, G Atlas Deming fol (no 207) : 15 pp, maps (1917)

17a A comparison of Paleozoic sections in southern New Mexico. U S G S, P P 108: 31-55 (1917) Abst, Wash Ac Sc, J 7 : 564 (1917)

17b Story of the Grand Canyon; a popular illustrated account of its rocks and origin. 81 pp, pub by Fred Harvey, Kansas City, Mo., 1917

17e Lower Paleozoic rocks of the southern New Mexico region (abst). G Soc Am, B 28: 172 (1917)

18 Artesian waters in the vicinity of the Black Hills, S. Dak. U S G S, W-S P 428: $64 \mathrm{pp}$, map (1918)

18a The structure of parts of the central Great Plains. U S G S, B 691: 1-26 (1918) Abst, Wash, Ac Sc J 8:503 (1918)

18b Structure of some mountains in New Mexico (abst). G Soc Am, B 29:72 (1918) 
Darton, Nelson Horatio-Continued.

See also Barrell, 13c; Bascom, 09a, b; Gregory (H E), 13; Merrill (F J H), 02 ; Powell, 95

Darwin, Charles.

89 The structure and distribution of coral reefs. $3 d$ ed, 344 pp, N Y 1889

Daubeny, Charles.

39 Sketch of the geology of North America ... xviii, $73 \mathrm{pp}$, map, Oxford 1839

39a ... thermal springs of North America ... Am J Sc $36: 88-93$ (1839)

39b On the geology and thermal springs of North America (abst). Brit As, Rp 8: sec 91-92 (1839)

Daubrée, Gabriel Auguste (1814-1896)

59 Synthetical studies and experiments on metamorphism and on the formation of crystalline rocks. An Mines (5) 16:155218 (1859) Smiths Inst, An Rp 1861: 228-304 (1862)

72 Examen des météorites d'Ovifak, Groenland, au point de vue du carbone et des sols solubles qu'ils renferment. Ac Sc Paris, C R 75:240-246 (1872) Abst, Chem Soc, J 25 : 993-995 (1872)

72a Examen des roches avec fer natif, découvertes en 1870, par M. Nordenskiold, au Grönland. Ac Sc Paris, C R 74: 1541-1549 (1872) Abst, Chem Soc, J 25 : 882-884 (1872); Can Nat n s 7:51-53 (1873)

86 The origin and structure of meteorites. Pop Sc Mo 29: 374-386 (1886)

88 Underground waters and mineral veins. Pop Sc Mo 33 : 633-642 (1888)

Davenport, R. W.

14 (with Ellsworth, C. E.) Preliminary report on a water-power reconnaissance in south-central Alaska. U S G S, B $592: 155-193$, maps (1914)

David, T. W. Edgeworth.

07 Conditions of climate at different geological epochs, with special reference to glacial epochs. Int $\mathrm{G}$ Cong, $\mathrm{X}$, Mexíco, C $R: 437-482$ (1907)

Davidson, A. D.

96 (with Weller, Stuart) Petalocrinus mirabilis (n. sp.) and a new American fauna. J G 4:166-173, il (1896)

Davidson, George (1824-1911).

73 The abrasions of the continental shores of northwestern America and the supposed anclent sea levels. Cal Ac Sc, Pr 5: 90-97 (1873)

73a on the auriferous gravel deposits of California. Cal Ac Sc, Pr 5: 145-146 (1873)

83 The Carson fossil footprints. $7 \mathrm{pp}$ [San Francisco 1883] Abst, M Sc Press 47:98 (1883)

84 Notes on the volcanic eruption of Mount St. Augustin, Alaska, October 6, 1883. Science $3: 186-189$ (1884) Nature $29: 441-442$ (1884)

84a The new Bogosloff volcano in Bering Sea. Sclence 3:282-286 (1884)
Davidson, George-Continued.

85 Recent voleanic activity in thUnited States; eruptions of Mount Base Science 6:262 (1885)

97 The submerged valleys of the of California, U. S. A., and of Lower Ca. fornia, Mex. Cal Ac Sc, Pr (3) G! 73-103 (1897)

04 The glaciers of Alaska that in shown on Russian charts or mentioned older narratives. Geog Soc Pacific, Tr (: $3: 1-98$, maps (1904)

06 The $\operatorname{San}$ Francisco earthquake April 18, 1906. Am Ph Soc, $\operatorname{Pr} 45: 16 t$ 165 (1906)

06a Points of Interest involved in th San Francisco earthquake. Am $\mathrm{Ph}$ sk Pr $45: 178-182$ (1906)

Davidson, Thomas (1817-1885).

63 On the Lower Carboniferous Bractit poda of Nova Seotia. G Soc London, Q! $19: 158-175$, il (1863)

74 (and King, William) On the $\mathrm{T}$ merellidae, a Paleozoic family of the Pal obranchs or Brachiopoda. G Soc Londe Q J 30:124-173, il (1874)

Davidson, Walter B. M.

91 Suggestions as to the origin at deposition of Florida phosphates. Engll J 51:628-629 (1891)

92 Florida phosphates; origin of th boulder phosphates of the Withlacoocle River district. Eng M J 53: 421 (18\%: [See Pratt, 92]

92a The present formation of pbir phatic concretions in deep-sea deposis Eng M J 53:499-500 (1892)

93 Notes on the geological origin d phosphate of lime in the United States at Canada. Am I M Eng, Tr 21:139-17 (1893)

Davis, C. Abbott.

o5 Check list of the minerals of $\mathrm{Rbot}$ Island, Roger Williams Park Mus, Pror dence, R. I., B 8:12 pp (1905) The d? teryx, 1: 59-71 (1905)

Davis, Charles Albert (1861-1916).

00 A contribution to the natural bi tory of marl. J G 8:485-497 (1900)

Ooa A remarkable marl lake. J G \& 498-503 (1900)

o1 A second contribution to the naturi history of marl. J G 9:491-506 (1901) 03 A contribution to the natural histort of marl. Mich G S 8 pt 3:65-96 (1900) 07 Peat, essays on its origin, uses, 2 : distribution in Michigan. Mich $\mathrm{G} \mathrm{S}$, Bf 1906: 93-395 (1907)

ora Israel Cook Russell. Mich Ac \& Rp 9:28-31 (1907)

отb Some interesting glacial phenomet in the Marquette region [Mich.]. Mid Ac Sc, Rp 9:132-135 (1907)

os Peat deposits as geological records Mich Ac Sc, Rp 10:107-112 (1908) 
Davis, Charles Albert-Continued.

08a Physiography and geology of Walnut Lake [Mich.]. Mich G S, Rp 1907: 164-173 (1908)

08b Preliminary report of peat deposits in North Carolina. N C G S, Ec P 15: $147-162$ (1908)

09 The possible use of peat fuel in Alaska. U S G S, B 379:63-66 (1909)

09 a Peat resources of the United States, exclusive of Alaska. U S G S, B 394: 6269 (1909) Nat Conservation Comm (60th Cong, 2d sess, Sen Doc no 676), Rp 3 : $476-482$ (1909)

09b Peat. U S G S, i.in Res 1908 pt $2: 795-804 ; 1909$ pt $2: 429-432 ; 1910$ pt $2: 459-468 ; 1911$ pt $2: 481-484 ; 1912$ pt $2: 497-501 ; 1913$ pt $2: 383-392 ; 1914$ pt $2: 375-385 \quad(1909-15)$

09e Report on the geology of Tuscola Co., Mich. Mich G S, Rp 1908: 121-353, maps (1909)

09d On the origin or peat (abst). Science n s $29: 947$ (1909)

09e (with Bastin, E. S.) Peat deposits of Maine. U S G S, B 376:127 pp (1909)

10 Some commercial aspects of peat as source of chemical products. Ec G 5 : $36-58$ (1910)

10a Salt-marsh formation near Boston and its geological significance. Ec $\mathrm{G} 5$ : 623-639 (1910) Abst, Science $\mathrm{n}$ s 32 : 192 (1910); G Soc Am, B 21: 766 (1910) $10 \mathrm{~b}$ The preparation and use of peat as fuel. U S G S, B 442:101-132 (1910)

10e Some evidences of recent subsidence on the New England coast (abst). Science is s $32: 63$ (1910)

11 The uses of peat for fuel and other purposes. U S Bur Mines, B 16:214 pp, map (1911)

11a Salt marshes, a study in correlation (abst). As Am Geog, An 1:139-143 (1911)

11b Peat deposits [of the Dismal Swamp] (abst). Science n s 33:910 (1911)

11e Study of 1ce-sheet erosion and deposition in the region of the Great Lakes (discussion) G Soc Am, B 22: 728 (1911) 12 Some coastal marshes south of Cape Cod $(a b s t)$. Science n s 35: 319 (1912); (with discussion by J. B. Woodworth and A W. Grabau), G Soc Am, B 23: 742-743 (1912)

13 Origin and formation of peat. U S Bur Mines, B 38:165-186 (1913

13a Peat deposit of geological interest near New Haven, Conn. (abst). G Soc Am, B 24: 700 (1913)

14 Some historical evidence of coastal subsidence in New England (abst, with discussion). G Soc Am, B 25:61-63 (1914)

15 Evidence of recent subsidence on the coast of Maine (abst). G Soc Am, B 26: 91-92 (1915)
Davis, Charles Albert-Continued.

15a On the fossil algae of the petroleumyielding shales of the Green River formation (abst). Science $\mathrm{n}$ is 41:570 (1915)

15b The occurrence of algae in carbonaceous deposits (abst). Science $\mathbf{n} \mathbf{s}$ $41: 839$ (1915)

15c The algal flora of some Eocene oil shales (abst). Science n s 41:879 (1915)

15d The algal flora of some Eocene shales (abst). Wash Ac Sc, J 5: 649-650 (1915)

16 On the fossil algae of the petroleumyielding shales of the Green River formation of Colorado and Utah. Nat Ac Sei, Pr 2:114-119 (1916) Abst, G Soc Am, B $27: 159-160(1916)$

$16 a$ Physiographic evidence of recent subsidence on the coast of Maine (abst). G Soc Am, B 27:108 (1916)

See also Johnson (D. W.), 12; Tarr (R. S.), $12 \mathrm{c}$

Davis, Charles $H$.

12 The Los Burros mining district [Cal.]. M Sc Press 104:696-698 (1912)

13 New species from the Santa Lueia Mountains, Cal., with a discussion of the Jurassic age of the slates at Slate Springs. J G 21: 453-45s (1913)

13a Discussion of the Jurassic age of the slates at Slate Springs, Monterey Co., Cal. (abst). G Soc Am, B 24: 131 (1913) Davis, Charles Henry (1807-1877).

49 Upon the geological action of the tidal and other currents of the ocean. Am Ac Arts, Mem n s 4:117-156 (1849)

$49 a$ The theory of the geological action of the tides. Am As, Pr 1:27-28 (1849)

51 On the law of the deposit of the flood tide. Am As, Pr 5: 2-3 (1851)

Davis, Charles Henry Stanley.

7o Physical history, geology, mineralogy, and mines [of Wallingford, Conn.] In his History of Wallingford, Conn. : 36-69, Meriden, Conn., 1870.

87 The Catopterus gracilis. Meriden Sc As, $\operatorname{Tr} 2: 19-22$, il (1887)

Davis, Darrell $\mathrm{H}$.

os A study of river meanders on the Middle Rouge [Mich.]. J G 16:755-764 (1908)

Davis, Elmer Fred.

13 The registration of earthquakes at the Berkeley station and at the Lick Observatory station from April 1 to September 30, 1912. Cal, Univ, Seism Sta, B 4:69-95 (1913) ... October 1, 1912 to March 31, 1913 ; B $5: 97-116$ (1914) ... April 1 to September 30,1913 ; B 6:117-133 (1914) ... October 1, 1913 to March 31,1914 ; B $7: 135-153$ (1914) ... April 1,1914 to September 30,$1914 ;$ B $8: 155-168$ (1914) ... October 1, 1914 to March 31,1915 ; B 9 : 169-188 (1915) ... April 1, 1915 to September 30,1915 ; B $10: 189-211$ (1916) ... October 1, 1915 to March 31,1916 ; B 11 : 213-242 (1916) ... April 1, 1916 to Septem- 
Davis, Elmer Fred-Continued.

ber 30,1916 ; B $12: 243-271$ (1917) ... October 1, 1916 to March 31,$1917 ;$ B 13 : 273-295 (1917) … April 1, 1917 to September 30,1917 ; B $14: 297-324$ (1918)

13a The Marvin strong-motion selsmograph. Seism Soc Am, B 3: 195-202 (1913)

14 Notes on the San Bruno earthquake of Jan. 23, 1914. Seism Soc Am, B 4:2528, map (1914)

15 Central California earthquake of November 8, 1914. Seism Soc Am, if 0 : 5-13 (1915)

15a The earthquakes of October 7,1915 , in central California. Seism Soc Am, B 5 : 230-235 (1915)

18 The Franciscan sandstone. Cal, Univ, Dp G, B 11:1-44 (1918)

1Sa The radiolarian cherts of the Franciscan group. Cal, Univ, Dp G, B 11: 235-432 (1918)

Davis, Emerson.

26 Notice of rocks and minerals in Westfield, Mass. Am J Se 10:213-215 (1826)

Davis, Floyd.

95 The coal supplies of Polk Co., Iowa. Eng M J 59: 149-150 (1895)

Davis, H. J.

99 Modification in the Jonathan Creek drainage basin [Ohio]. Denison Univ., Sc Lab, B 11:163-173, map (1899)

Davis, H. P.

10 The Davis handbook of the Cobalt silver district, with a manual of incorporated companies. $108 \mathrm{pp}$, published by The Canadian Mining Journal, 1910.

11 The Davis handbook of the Porcupine gold district [Ont.]. 131 pp, N Y 1911

Davis, Henry.

49 Notes on the Soufrière of St. Vincent. G Soc London, Q J 5:53-55 (1849)

Davis, Herbert $J$.

86 Pyrites. U S G S, Min Res 1885: 501-517 (1886)

\section{Davis, Horace.}

55 [On auriferous gravels near Sonora, Cal.] Cal Ac N Sc, Pr 1:61 (1855; 2d ed, $1873: 62$ )

Davis, Jacob P.

32 Geology of Wayne Co., Pa. (abst). Monthly Am J G $1: 520-523$ (1832)

Davis, John A.

12 The Little Powder River coal field, Campbell Co., Wyo. U S G S, B 471 : 423-440, maps (1912)

17 (with Kithil, K. L.) Mining and concentration of carnotite ores. U S Bur Mines, B 103: 89 pp (1917)

Davis, Melvin K.

10 (with Dryer, C. R.) A physio graphic survey of an area near Terre Haute, Ind. Ind Ac Sc, Pr 1909:263-267 (1910)

11 (with Dryer, C. R.) The work done by Normal Brook in thirteen years. Ind Ac Sc, Pr 1910:147-152 (1911)
Davis, N. B.

11 The character and possible origh of the green dolomites of New Ontario. Can M Inst, Q B 16:173-184 (1911): J 14: 678-689 (1912)

14 Tourmaline-bearing quartz veins, $B_{6}$ G $9: 689$ (1914)

15 The plasticity of clay and its rela. tion to mode of origin. Am I M Eng, B $98: 301-330$ (1915) ; $\operatorname{Tr} 51: 451-480$ (1916)

is Report on the clay resources of southern Saskatchewan. Can Mines Br: $93 \mathrm{pp}$, maps (1918)

Davis, R. O. E.

04 Analysis of kunzite. Am J Sc (4) $18: 29$ (1904)

15 Soil erosion in the Sonth, U S D p Agr, B 180:23 pp (1915)

Davis, Ralph E.

06 Mississippi Valley lead and zinc dis. trict. M World 24:548-549 (1906)

Davis, W. W.

17 Evidence bearing on a possible northeastward extension of Mississipplan seas in Illinois. J G 25:576-583 (1917) Davis, William J.

85 Kentucky fossil corals; a monograph of the fossil corals of the Sllurian and Devonian rocks of Kentucky (in two parts: pt 2 [pls.; pt 1 not issued]). Ky G \& (1885)

Davis, William Morris.

80 Banded amygdules of the Brighton amygduloid. Boston Soc N H, Pr 20: $426-428$ (1880)

81 Remarks on the geology of Mt. Desert, Me. Boston Soc N H, Pr 21:117-118 (1881)

$81 a$ (with Shaler, N. S.) Ilustrations of the earth's surface; glaclers. 195 pp, Boston 1881 Rv, by W J McGee, Science (ed Michels) 2:581-584, 624-630 (1881)

82 On the classification of lake basing. Boston Soc N H, Pr 21:315-381 (1882) Abst, $\Delta \mathrm{m}$ Nat 16:1028-1029 (1882)

82a Glacial erosion. Boston Soc N H, Pr 22: 19-58 (1882)

$82 b$... on the Triassic trap rocks of Massachusetts, Connecticut, and New Jer. sey. Am J Sc (3) $24: 345-349$ (1882)

82e The Little Mountains east of the Catskills [N. Y.]. Appalachia 3: 20-33 (1882)

83 On the relations of the Triassic traps and sandstones of the eastern United States, Harvard Coll, Mus C Z, B ? (g s 1): 249-309 (1883)

83a The folded Helderberg limestones east of the Catskills. Harvard Coll, Mus C Z, B 7 ( g s 1) : 311-329, map (1883)

83b The structural value of the trap ridges of the Connecticut Valley. Boston Soc N H, Pr 22: 116-124 (1883)

83e Becraft's Mountain [Columbia Co. N. Y.]. $\Delta \mathrm{m}$ J Sc (3) $26: 381-389$, map (1883) 
Daris, William Morris-Continued.

83d The nonconformity at Rondout, N. Y. $A m$ J Sc (3) $26: 389-395$, map (1883)

83e Lakes and valleys in northeastern Pennsylvania. Science 1:304-305 (1883) 83f The origin of cross valleys. Science $1: 325-327,356-357$ (1883)

83g Lake Bonneville. Science 1:570 (1883)

84 Gorges and waterfalls. Am J Se (3) 28:123-132 (1884)

84a The distribution and origin of drumlins. Am J Sc (3) $28: 407-416$ (1884)

84b Paleozoic high tides. Science 3 : 473-474 (1884)

84e Drumlins. Science 4:418-420 (1884)

85 Geographic classification, illustrated by a study of plains, plateaus, and their derivatives (abst). Am As, Pr 33:428432 (1885)

86 Brief notices of papers read before the geological section of the American Association. Am J Sc (3) $32: 319-324$ (1886)

86a The structure of the Triassic formathon of the Connecticut Valley. Am J Sc (3) $32: 342-352$ (1886)

86b Relation of the coal of Montana to the older rocks. U S 10th Census, 15: 697-712 (1886)

86e Earthquakes in New England. Appalachia 4:190-194 (1886)

86d Mechanical origin of the Triassic monoclinal in the Connecticut Valley (obst). $\triangle \mathrm{m}$ J Sc (3) $32: 321$ (1886) Am As, $\operatorname{Pr} 35: 224-227$ (1887) Boston Soc N H, Pr 23:339-341 (1887)

86e (with Shaler, N S., and Harris, T. W.) A series of twenty-five colored seological models and twenty-five photographs of important geological objects, each accompanied by letter-press description. 1886 [D. C. Heath \& Co.] [not seen]

87 Instruction in geological investigation. $A \mathrm{~m}$ Nat 21: $810-825$ (1887)

87 a The classification of lakes. Science 10:142-143 (1887)

88 The structure of the Triassic formation of the Connecticut Valley. U S G S, An Rp $7: 455-490$ (1888)

88 a Geographic methods in geologic inrestigation. Nat Geog Mag 1:11-26 (1888)

88b The topographic map of New Jersey. Science 12:206-207 (1888)

$88 \mathrm{c}$ Synclinal mountains and anticlinal ralleys. Science 12: 320 (1888)

89 Methods and models in geographic teaching. Am Nat $23: 566-583$ (1889) 4bst, Johns Hopkins Univ Circ 8:62 (1889)

89a The faults in the Triassic formation near Meriden, Conn. Harvard Coll, Yus C Z, B 16 (g \& 2): 61-87 (1889)
Bavis, Willam Morris-Continued.

89b (and whittle, C. L.) The intrusive and extrusive Triassic trap sheets of the Connecticut Valley. Harvard Coll, Mus C Z, B 16 (g s 2): 99-138 (1889)

89e The ash bed at Meriden and its structural relations. Meriden Sc As, Tr $3: 23-30$ (1889)

89d Topographic development of the Triassic formation of the Connecticut Valley. Am J Sc (3) 37:423-434 (1889)

89e The glacial origin of cliffs. Am G $3: 14-18$ (1889)

89P The rivers and valleys of Pennsylvania. Nat Geog Mag 1:183-253 (1889) $89 \mathrm{~g}$ A river pirate [Deer Run, Pa.]. Science 13: 108-109 (1889)

89h The contoured map of Massachusetts. Science 14:422-423 (1889)

90 Structure and origin of glacial sand plains. G Soc Am, B 1: 195-202 (1890)

90a The rivers of northern New Jersey, with notes on the classification of rivers in general. Nat Geog Mag 2:81110 (1890)

90b (and wood, J. W., jr.) The geographic development of northern New Jersey. Boston Soc N H., Pr 24:365-423 (1890)

90e The level of no strain. Am G 5: 190-191 (1890)

90d The Iroquois beach. Am G 6:400 (1890)

91 (and Leper, S. W.) Two belts of. fossiliferous black shale in the Triassic formation of Connecticut (with discussion by C. H. Hitcheock and B. K. Emrerson). G Soc Am, B 2:415-430 (1891)

$91 \mathrm{a}$ The geological dates of origin of certain topographic forms on the Atlantic slope of the United States. G Soc Am, B $2: 545-586$ (1891)

91b The lost volcanoes of Connecticut. Pop Sc Mo 40: 221-235 (1891)

91e Was Lake Iroquois an arm of the sea? Am G $7: 139-140$ (1891)

91d The physical geography of southern New England. Johns Hopkins Univ, Circ $10: 78-79$ (1891)

91e The Triassic sandstone of the Connecticut Valley. John Hopkins Univ, Circ 10:79 (1891)

92 The Catskill delta in the postglacial Hudson estuary. Boston Soc N H, Pr 25: 318-335 (1892) Abst, J G $1: 97-98$ (1893)

92a On the drainage of the Pennsylvania Appalachians. Boston Soc $\mathrm{N} \mathrm{H}, \mathrm{Pr}$ $25: 418-420$ (1892)

92b The subglacial origin of certain eskers. Boston Soc N H, Pr 25: 477-499 (1892) Abst, J G 1:95-96 (1893)

92e The Loup rivers in Nebraska. Science 19: 107-108, 220-221 (1892) 
Davis, William Morris-Continued.

93 Geographical illustrations; suggestions for teaching physical geography based on the physical features of southern New England. $46 \mathrm{pp}$, Harvard University, Cambridge, Mass. 1893

93a The Osage River and the Ozark uplift. Science $22: 276-279$ (1893)

93b Memorial of James Henry Chapin. G Soc Am, B 4:406-408 (1893)

94 (and Griswold, L. S.) Eastern boundary of the Connecticut Triassic. G Soc Am, B 5:515-530 (1894) Abst, Am G 13:145-146 (1894); Am J Sc (3) 47 : 136-137 (1894)

94a Physical geography in the university. J G 2:66-100 (1894)

94b Facetted pebbles on Cape Cod, Mass. Boston Soc N H, Pr 26:166-175 (1894) Abst, Am G 13:146-147 (1894)

94e The ancient ontlet of Lake Michigan. Pop Sc Mo 46:217-229 (1894)

94d Geographical work for state geological surveys. G Soc Am, B 5:604 608 (1894) Abst, Am G 13:146 (1894)

94e An outline of the geology of Mount Desert. In Flora of Mount Desert Island, Maine; A preliminary catalogue of the plants growing on Mount Desert and the adjacent islands, by Edward L. Rand and John H. Redfield : 43-71, Cambridge [Mass], 1894

95 The physical geography of southern New England: Nat Geog Soc, Nat Geog -Mon 1 no 9:269-304 (1895) Also in The physiography of the United States (Nat Geog Soc) : 269-304, N Y, American Book Co.. 1896

95a Bearing of physiography on uniformitarianism (abst) $\mathrm{G}$ Soc $\mathrm{Am}, \mathrm{B} 7$ : 8-11 (1895) Am G 16:243-244 (1895) Science n s 2:280 (1895)

$95 b$ Current notes on physiography. Science n \& 1: 174-181, 257-260, 292-295, 318-321, 487-488, 505-509, 568-571, 605$606,651-652,678-680$ (1895) ; $2: 10-11$, $39-41,97-99,228-229,266-267,373-375$, $514-515,617-619,657-658,687-688,727-$ $728,767-768,885-887$ (1895) ; 3:61-62, $127-128,195-197,275-277,396-397,472-$ $474,589-591,659-661,731-733,799-801$, $858-860,920-922(1896) ; 4: 42-44,107-$ $108,163-164,220-221,305-306,448-450$, $524-526,611-613,682-684,747-749,828-$ $829,910-912(1896) ; 5: 20-22,177-178$, 263-264, 336-337, 437-438, 507-508, 577$578,647-649,722-724,795-797,869-871$, 945-947 (1897) ; 6: 22-24, 93-94, 206-207, 285-287, $357-359,438-439,656-657,727-$ $728,834-835,872-873,985-987$ (1897); $7: 56-57,124-125,203-204,273-274,414$ ' $415,489-491,561-563,627-628,704-706$, $765-766,850-851$ (1898) ; 8: 40-42 (1898); 11 : 34-35, 154-156, 234-235, 314-315, 433$435,515-516,591-592,671-672,753-754$, $790-791, \quad 870-871, \quad 956-957, \quad 1032-1033$
Davis, William Morris Continued.

$(1900) ; 12: 73-74 \quad(1900) ; 13: 152-153$ $275-276,351-352,395-397,471-472,551-$ $552,628-629,751-753,791-793,871-872$ $950-951, \quad 1032-1033 \quad(1901) ; 14: 70-72$ $152-153,222-225,299-300,457-459,577-$ $538,617-618,698-699,778-779,856-859$, 975-977 (1901) ; $15: 74-75,154-156,234$ $235(1902) ; 16: 636-637,748-749,914$ $915,995-996 \quad(1902) ; 17: 115-117,193-$ $195,354-356, \quad 434-435, \quad 550-552,672-673$ (1903)

95e Notes on geological excursions $(a b s t)$. Science n s 2: 744 (1895)

96 Plains of marine and subaerial de nudation. G Soc Am, B $7: 378-398$ (1896) Abst, Am G 17:96-97 (1896); Science n s $3: 50-51$ (1896)

$96 \mathbf{a}$ The quarries in the lava beds at Meriden, Conn. Am J Se (4) 1:1-13, map (1896)

$96 \mathrm{~b}$ The outline of Cape Cod. Am Ac Arts, Pr $31:$ 303-332 (1896) Abst, Am G $17: 95-96$ (1896); Science n s $3: 49-50$ (1896)

96e [Physiographic features of the middle Susquehanna region, $\mathrm{Pa}$.$] Science 8$ 3: 786-787 (1896)

96d The State map of Connecticut as an aid to the study of geography in grammat and high schools. Conn Sch Doc no b, 1896 ; 14 pp (1896)

96e The State map of Rhede Island as an aid to the study of geography in gram. mar and high schools. Rhode Island, Edv cation Pub: $15 \mathrm{pp}$ (1896)

97 The State map of Massachusetts as an aid to the study of geography in gram. mar and high schools. Mass St Bd Bduc, 60th An Rp: 18 pp (1897)

97a Is the Denver formation lacustrine or fluviatile? Science n $s$ 6:619-621 (1897)

98 The Triassic formation of Connectcut. U S G S, An Rp 18 pt 2:1-192, map (1898)

9Sa The grading of mountain slopes (abst). Science n s $7: 81$ (1898)

$98 b$ (assisted by Snyder, W. H.) Pbysical geography. 428 pp, Boston 1898

99 The peneplain. Am G 23:207-239 (1899) An. Géog, Paris, B : 289-303, 385404 (1899)

99a The drainage of cuestas. $G$ As, London, $\operatorname{Pr} 16$ : 75-93 (1899)

oo Continental deposits of the Rockj Mountain region (discussion by S. F. Etrmons and W. Cross). G Soc Am, B 11: 596-604 (1900) Abst, Science n s 11:14t (1900)

o0a The fresh-water Tertiary forms. tions of the Rocky Mountain region. Am Ac Arts, Pr $35: 345-373$ (1900)

Q0b Notes on the Colorado Canyon dis trict. Am J Sc (4) 10:251-259 (1900) 
Davis, William Morris-Continued.

00e The conditions of formation of conglomerates, and criteria for distinguishing between lacustrine and fluviatile beds (abst with discussion). Science n s 11:429-430 (1900)

o0d The physical geography of the lands. Pop Sc Mo $57: 157-170$ (1900)

00e History of the Cincinnati anticline (discussion). G Soc Am, B 11:604-605 (1900)

00 Physiographic terminology with special reference to land forms (abst). Science n s $11: 99$ (1900)

$00 \mathrm{~g}$ The basin deposits of the Rocky Mountain region $(a b s t)$. Science n s 11: $144(1900)$

01 An excursion to the Grand Canyon of the Colorado. Harvard Coll, Mus C Z, B 38 (g s 5) : 107-201 (1901) Abst, G Soc Am, B $12: 483$ (1901); G Mag (4) $8: 324$ (1901) : Science n \& 13:138 (1901)

01a The geographical cycle. Int Geog Cong, VII, Verh pt 2:221-231 (1901)

01b Les enseignements du Grand Canyon du Colorado. La Géographie, Paris, 4 : 339 351 (1901)

01e Note on river terraces in New England (abst). G Soc Am, B 12:483-485 (1901)

02 River terraces in New Fngland. $\mathrm{Har}$ rard Coll, Mus C Z, B 38 (g \& 5) : 281346 (1902)

02a The terraces of the Westfield River, Mass. Am J Sc (4) 14: 77-94 (1902)

02b Base level, grade, and peneplain. J $G$ 10:77-111 (1902)

02e Field work in physical geography. J Geog 1: 17-24, 62-69 (1902)

02d Systematic geography. Am Ph Soc, Pr 41: 235-259 (1902)

02e Walls of the Colorado Canyon (abst). Science n s 15:87 (1902) G Soc Am, B $13: 528$ (1903)

$02 f$ Effect of shore line on waves $(a b s t)$. Science n s $15: 88$ (1902) G Soc Am, B $13: 528$ (1903)

03 An excursion to the plateau province of Utah and Arizona. Harvard Coll, Mus C Z, B $42(\mathrm{~g} \& 6): 1-50$ (1903)

$03 a$ The mountain ranges of the Great Basin. Harvard Coll, Mus C Z, B 42 (g s 6) : 129-177 (1903)

03b The stream contest along the Blue Ridge. Geog Soc Phila, B $3: 213-244$ (1903)

03e The development of river meanders.

G Mag (4) $10: 145-148$ (1903)

08d Practical exercises in physiography.

J Geog $2: 516-520$ (1903)

0Be The basin ranges of Utah and Nerada (abst). J G 11:120-121 (1903)

03e The Blue Ridge in southern Virginia and North Carolina (abst). J G 11 : $121(1903)$

03g The Blue Ridge of North Carolina (abst). Science n s 17:220 (1903)
Davis, William Morris-Continued.

03h The fresh-water Tertiaries at Green River, Wyo. (abst). Science n s 17:220221 (1903) G Soc Am, B 14:544 (1904) J G $11: 120$ (1903)

03i Block mountains of the basin-range province (abst). Science n $\mathrm{s}$ 17:301 (1903) G Soc Am, B 14:551 (1904) Eng M J 75:153 (1903)

04 The relations of the earth sciences in view of their progress in the nineteenth century. J G 12:669-687 (1904) Cong Arts and Sci (St Louis 1904) 4:488-503 (1906)

04a Glacial erosion in the Sawatch Range, Colo. Appalachia 10:392-404 (1904)

05 Glaciation of the Sawatch Range, Colo. Harvard Coll, Mus C Z, B 49 (g s 8): 1-11 (1905)

O5a The Wasatch, Canyon, and House ranges, Utah. Harvard Coll, Mus C Z, B 49 (g s 8):17-56 (1905)

$\mathbf{0 5 b}$ Complications of the geographical cycle. Int Geog Cong, VIII, Rp : 150-163 (1905)

05e The geographical cycle in an arid climate. J G 13: 381-407 (1905)

osa Leveling without base-leveling. Science n \& $21: 825-828$ (1905)

o5e The bearing of physiography upon Suess' theorles, Am J ' : (4) 19:265273 (1905) Abst, Int Geog Cong, VIII, Rp : 164 (1905)

osf [The Colorado Canyon (abst).] Science n s 21:860 (1905)

06 Incised meandering valleys. Geog Soc Phila, B 4 no 4:1-11 (182-192) (1906)

06a The g ographical cycle in an arid climate. Geog J 27 : 70-73 (1906)

06b The physiography of the Adirondacks [formation of scarps]. Scierce $\mathbf{n} s$ $23: 630-631$ (1906)

o6e The Colorado Canyon and its lessons. Liverpool G Soc Pr 10:98-102 (1906)

o6d The sculpture of mountains by glaciers. Scottish Geog Mag 22:76-89 (1096) Abst, Brit As, Rp 75:393-394 (1906)

06e Professor Nathaniel S. Shaler. Am J Sc (4) $21: 480-481$ (1906)

06f Professor Shaler and the Lawrence Scientific School. Harvard Eng J 5 : 129138 (1906)

07 (and Johnson, D. $N$., and Bowman, Isaiah) Current notes on land forms. Sclence n s 25:70-73, 229-232, 394-396, $508-510, \quad 833-836, \quad 946-949 ; \quad 26: 90-93$, $152-154,226-228,353-356,450-453,837-$ 839 (1907) ; $27: 31-33$ (1908)

$07 a$ The terraces of the Maryland coastal plain. Science n s 25:701-707 (1907)

07b The systematic study of mountains. Sclence n s 25:701-707 (1907) 
Davis, William Morris-Continued.

o7e Hanging valleys. Science n s 25 : 835-836 (1907)

07d The place of coastal plains in systematic physiography. J Geog 6: 8-15 (1907)

os Practical exercises in physical geography. $148 \mathrm{pp}$, Boston 1908

OSa Die Methoden der amerikanischen geographischen Forschung. Internationale Wochenschrift für Wissenschaft, Kunst, und Technik, Berlin, November 14, 1908.

09 Geographical essays. vi, $777 \mathrm{pp}$, Boston (1909)

09a Der grosse Cañon des ColoradoFlusses. Ges Erdk Berlin, Zs $3: 164-172$ (1909)

09b The Colorado Canyon: some of the lessons. Geog J, 33:535-540 (1909) Am Geog Soc, B 41:345-354 (1909) Abst, Brit As Rp 78: 948-949 (1909)

09e The systematic description of land forms. Geog J 34:300-318 (1909)

09d The physiographic subdivisions of the Appalachian Mountain system, and their effects upon settlement and history (abst). Brit As, Rp 78: 761-762 (1909)

10 Experiments in geographical description. Science n s 31:921-946 (1910) Am Geog Soc, B 42:401-435 (1910) Scottish Geog Mag 26: 561-586 (1910)

10 Notes on the description of land forms. Am Geog Soc, B 42:671-675, 840844 (1910) ; 43:46-51, 190-194, 598-604, $679-684, \quad 847-853 \quad(1911) ; \quad 44: 908-913$ (1912)

10b Antarctic geology and polar climates. $\mathrm{Am} \mathrm{Ph}$ Soc, P $49: 200-202$ (1910)

10e Practical exercises in physical geography (abst). Int Cong Geog, IX, C R 2 : 169-170 (1910)

10d Die Umgestaltung der Gebirgsformen durch die Gletscher (abst). Ver Erdk Leipzig, Mitt 1909:28-29 (1910)

10e The theory of isostasy (abst and discussion). G Soc Am, B 21: 777 (1910)

11 The Colorado Front Range, a study in physiographic presentation. As Am Geog, An 1:21-84 (1911) Abst, Science n s $33: 906$ (1911)

$11 \mathrm{a}$ Repeating patterns in the relief and in the structure of the land (discussion) (abst). G Soc Am, B 22:717 (1911)

11b Geographical descriptions in the folios of the geologic atlas of the United States (abst), G Soc Am, B 22:736 (1911)

12 Die erklärende Beschreibung der Landformen. xviii, 565 pp, Leipzig 1912

12a Relation of geography to geology (annual address of the president). G Soc Am, B 23: 93-124 (1912)

$12 \mathrm{~b}$ American studies on glacial erosion. Int G Cong, XI, Stockholm, 1910, C R : 419427 (1912)

12e Guidebook for the transcontinental excursion of 1912. American Geographical Society of New York. 144 pp, 1912.
Davis, William Morris-Continued.

13 Dana's confirmation of Darmin's theory of coral reefs. Am J Sc (4) 35: 173-188 (1913) Nature 90:632-834 (1913) Abst, Science n s 37:724 (1913)

13a Submerged valleys and barrier reefs Nature $91: 423-424$ (1913)

$13 \mathrm{~b}$ Nomenclature of surface forms on faulted structures. G Soc Am, B 24:187216 (1913)

13e The Grand Canyon of the Colorado. J Geog 11: 310-314 (1913)

13d Speculative nature of geology (abst). G Soc Am, B 24:686-687 (1913)

14 The home study of coral reefs. Am Geog Soc, B $46: 561-577,641-654,721-$ 739 (1914)

14a Meandering valleys and underft rivers. As Am Geog, An 3: 3-28 [1914?]

14b Sublacustrine glacial erosion in Montana (abst). G Soc Am, B 25:86 (1914)

15 A Shaler Memorial study of cotal reefs. Am J Sc (4) $40: 223-271$ (1915)

15a Preliminary report on a Shales Memorial study of coral reefs. Science : s $41: 455-458$ (1915)

15b The origin of coral reefs. Nat $A t$ Sc, $\operatorname{Pr} 1: 146-152$ (1915)

15e The Mission Range, Mont. Nat Ac Sc, Pr 1: 626-628 (1915)

15d Biographical memoir of John Wesles Powell, 1834-1902. Nat Ac Sc, Biog Mem $8: 11-83$, port (1915)

15e Biographical memoir of Peter Lesley, 1819-1903. Nat Ac Sc, Biog Mem 8: 155-240, port (1915)

15e Physiography of arid lands (discus sion). Brit As, Rp $84: 365-366$ (1915)

$15 \mathrm{~g}$ Problems associated with the origin of coral reefs suggested by a Shaler Met. orial study of the reefs... (abst). Scienct n s $41: 569$ (1915)

15h Sculpture of the Mission Ragge Mont. (abst). Science n s 42:685 (1915)

16 The principles of geographical de scription. As Am Geog, An 5:61-105 [1916?]

16a Problems associated with the study of coral reefs. Sci Mo 2: 313-333, 47 \% 501, 557-572 (1916)

16b The Mission Range, Montane Geog Rv 2:267-288 (1916) Abst, As All Geog, An 4:135-136 [1915?]

16e Extinguished and resurgent coral reefs. Nat Ac Sc, Pr 2:466-471 (1916)

16d Coral reef problem (abst). G $\mathrm{S} 0 \mathrm{c}$ Am, B $27: 46$ (1916)

16e Sinking islands versus a rising ocean in the coral-reef problem $(a b s t)$. Sclence n s $43: 721$ (1916)

17 Topographic maps of the United States. National Highways Association. Division of Physical Geography, Physio graphic B no 1:15 pp (1917)

17a The structure of high-standing atolls. Nat Ac Sc, Pr 3:473-479 (1917) 
Davis, William Morris-Continued.

$17 \mathrm{~b}$ The isostatic subsidence of volcanic islands. Nat Ac Sc, Pr $3: 649-654$ (1917) 17e Sublacustrine glacial erosion in Montana. Nat Ac Sc, Pr 4:696-702 (1917)

18 Coral reefs and submarine banks. J G 26 : 198-223, 289-309, 385-411 (1918)

18a Subsidence of reef-encircled islands. $G$ Soc Am, B 29:71-72 (abst), 489-574 (1918)

18b The Cedar Mountain trap ridge near Hartford. Am J Sc (4) $46: 476-477$ (1918)

18e Grove Karl Gilbert. Am J Sc (4) 46: 669-681 (1918)

18d Geological terms in geographical descriptions. Science n s 48:81-84 (1918)

See also Barrell, $13 \mathrm{c}$; Branner, 98 ; Campbell (H. D.), 91 ; Day (A. L.), 13 ; Diller, 90 ; Gilbert, 93b ; Grabau, 98 ; Hayes, 91 ; McGee, 90 ; Tarr (R. S.), 12c; Upham, 93f; Walcott, 90b; Williams (G. H.), $91 \mathrm{~b}$

Davison, Charles.

00 Methods of studying earthquakes. J G 8:301-308 (1900)

$05 \mathrm{~A}$ study of recent earthquakes. xii, $355 \mathrm{pp}, \mathrm{L} 1905$

06 The San Francisco earthquake of April 18. Nature 73:608-610 (1906) Sc Am Sup 61: 25416-25417 (1906)

07 The Kingston earthquake. Nature $75: 296$ (1907)

Davison, John M.

91 Analyses of kamacite, taenite, and plessite from the Welland meteoric iron. Am J Sc (3) 42:64-66 (1891)

96 Wardite, a new hydrous basic phosphate of alumina [Utah]. Am J Sc (4) 2:154-155 (1896)

99 Platinum and iridium in meteoric iron. Am J Sc (4) 7:4 (1899)

02 Internal structure of cliftonite. Am J Sc (4) $13: 467-468$ (1902)

06 Quartz nodule with radiate structure, Rochester Ac Sc, Pr 3:268-269 (1906)

06a (with Howard, K. S.) The Estacido aerolite. Am J Se (4) 22:55-60 (1906)

10 A contribution to the problem of Coon Butte. Science n s 32:724-726 (1910)

Dawkins, W. Boyd.

84 On some deposits of apatite near Ottawa, Can. Manchester G Soc, Tr 18: 47-60, 137-139 (1884)

Dawson, George Mercer (1849-1901).

74 Report on the Tertiary lignite formation in the vicinity of the forty-ninth paralle]. British North American Boundary Commission, G Rp Prog 1873:31 pp, Montreal 1874

$74 \mathbf{n}$ The lignite formations of the west. Can Nat n s $7: 241-242$ (1874)
Dawson, George Mercer-Continued.

$\mathbf{7 4 b}$ Note on the occurrence of Foraminifera, coccoliths, etc., in the Cretaceous rocks of Manitoba. Can Nat n \& 7:252257 , il (1874)

75 Report on the geology and resources of the region in the vicinity of the fortyninth parallel from the Lake of the Woods to the Rocky Mountains. British North American Boundary Cemmission : 379 pp, il, map, Montreal 1875

T5a On the superficial geology of the central region of North America. G Soc London, Q J 31:603-623, map (1875) Abst, G Mag (2) 2:515-516 (1875)

77 Note on the economic minerals, and mines of British Columbia. Can Pacific Railway, Rp on Surveys...to Jan. 1877 : 218-245, Ottawa 1877

$77 \mathbf{a}$ Geological map of a portion of the southern interior of British Columbia. Scale 1:506 880 Can G S 1877

77b Report on explorations in British Columbia, Can G S, Rp Prog 1875-6 : $233-265$ (1877)

77e Note on some of the more recent changes in level of the coast of British Columbia and adjacent regions. Can Nat n 8 8:241-248 (1877)

77d Mesozoic voleanic rocks of British Columbia and Chile; relation of volcanic and metamorphic rocks. G Mag (2) 4: 314-317 (1877)

7S Report on explorations in British Columbia, ehiefly in the basins of the Blackwater, Salmon, and Nechacco rivers, and on François Lake. Can G S, Rp Prog 1876-7:17-94, map (1878)

78a Report of a reconnaissance of Leech River and vicinity [B. C.]. Can G S, Rp Prog 1876-7: 95-102 (1878)

7Sb General note on the mines and minerals of economic value of British Columbia. Can G S, Rp Prog 1876-7: 103149 (1878)

78e Travelling notes on the surface geology of the Pacific slope. Can Nat $n$ s 8: 389-399 (1878)

78d On the superficial geology of British Columbia. G Soc London, Q J 34:89-123, map (1878)

7Se Erratics at high levels in northwestern America; barriers to a great ice sheet. G Mag (2) 5:209-212 (1878)

79 Preliminary report on the physical and geological features of the southern portion of the interior of British Columbia, 1877. Can G S, Rp Prog 1877-8: B 1-173 (1879)

79a Notes on the glaciation of British Columbia. Can Nat n s 9:32-39 (1879)

$79 b$ On a new species of Loftusia from British Columbia. G Soc London, Q J 35 : 69-75, il (1879) 
Dawson, George Mercer-Continued.

so Report on the Queen Charlotte Islands, 1878. Can G S, Rp Prog 18789 : B 1-101, maps (1880)

80 a Report...general geological features and minerals of economic impotance of part of the northern portion of British Columbia, and of the Peace River country. Can Paclfic Railway, Rp 1880:107-131, Ottawa 1880

80b Memorandum on the Queen Charlotte Islands, B. C. Can Pacific Rallway, Rp 1880:139-143, Ottawa 1880

81 On the lignite Tertiary formation, from the Souris River to the 108th meridian [Saskatchewan]. Can G S, Rp Prog 1879-80: A 12-49 (1881)

81 a Report on an exploration from Port Simpson on the Pacific coast to Edmonton on the Saskatchewan, embracing a portion of the northern part of British Columbia and the Peace River country, 1879. Can G S, Rp Prog $1879-80$; B 1-142, maps (1881)

81b Sketch of the geology of British Columbia. G Mag (2) 8:156-162, 214227, map (1881) Abst, Brit As, Rp 50 : $588-589$ (1880); Can Nat n s $9: 445-447$ (1880)

81e Additional observations on the superficial geology of British Columbia and adjacent regions. G Soc London, Q J 37 : 272-285 (1881)

s1d Note on the geology of the Peace River region. Am J Se (3) 21: 391-394 (1881) Can Nat n s 9:474-475 (abst) ; $10: 20-22$ (1881)

81e Geological character of the country drained by the Assiniboine and Red rivers. Can Nat n s 10:56-57 (1881)

81 Der Queen Charlotte-Archipel. Petermanns Mitt $27: 331-347$, map (1881)

83 Preliminary report on the geology of the Bow and Belly rivers region, Northwest Terr., with special reference to the coal deposits. Can G S, Rp Prog 1880-2: B $23 \mathrm{pp}$, map (1883)

83a Descriptive note on a general section from the Laurentian axis to the Rocky Mountains north of the 49 th parallel. R Soc Can, Pr Tr 1, iv : 39-44 (1883)

83b Nete on the Triassic of the Rocky Mountains and British Columbia. R Soc Can, $\operatorname{Pr} \operatorname{Tr} 1$, iv : 143-145 (1883)

83e Notes on the more important coal seams on the Bow and Belly River district. Can Nat n s 10:423-435 (1883)

83a Glacial deposits of the Bow and Belly River country. Science 1:477-479 (1883)

84 Notes on the coals and lignites of the Canadian Northwest... 21 pp, Montreal 1884

$84 a$ Recent geological observations in the Canadian Northwest Territory. Science $3: 647-648$ (1884)
Dawson, George Mercer-Continued.

84b On the occurrence of phosphates is nature. Ottawa Field Nat Club, Tr no 5: 91-98 (1884)

84e (with Selwyn, A. R. C.) Descrip tive sketch of the physical geography 8 d geology of the Dominion of Canada. [Can G S] : $55 \mathrm{pp}$, Montreal 1884 [To accos. pany] Map of the Dominion of Canads geologically colored... scale, 40 miles to 1 inch

85 (assisted by Mcconnell, R. G.) Report on the region in the vicinity of the Bow and Belly rivers, Northwest Terr. tory. Can G S, Rp Prog 1882-4: c 168 pp, maps (1885)

85a on the microscopic structure of ces. tain boulder clays and the organisms contained in them. Chicago Ac Sc, B 1: 59-69 (1885) Minn G $\mathrm{S}$, An Rp 13: 150-163 (1885)

85b The Saskatchewan country. Sciedoc 5: 340-342 (1885)

86 Preliminary report on the physical and geological features of that portion of the Rocky Mountains between latitudes $49^{\circ}$ and $51^{\circ} 30^{\prime}$. Can G S, An Rp 1: B 169 pp, map (1886)

87 Report on a geological examination of the northern part of Vancouver Island and adjacent coasts. Can $G S$, An $B p$ 2: B 1-107, map (1887)

$\mathbf{8 7 a}$ Notes to accompany a geological map of the northern portion of the Dominion of Canada, east of the Rocky Mountalns. Can G S, An Rp 2: в 62 p , map (1887)

87b On certain borings in Manitoba and the Northwest Territory. R Soc Can, Tt 4, iv : 85-99 (1887)

87e On the Canadian Rocky Mountains, with special reference to that part of the range between the forty-ninth parallel and the headwaters of the Red Deer Rivet. Can Rec Sc 2:285-300 (1887) Abst, Brit As, Rp 56:638-639 (1887); G Mag (3) $3: 505-506$ (1886)

88 Report on an exploration in the Yukon district, Northwest Territory, and adjacent portion of British Columbia. Cat G S, An Rp 3: B 1-183, maps (1888)

88a Note on the Cascade anthracite basin, Rocky Mountains. Am G 1:332333 (1888)

88b The geological observations of the Yukon expedition, 1887. Science 11:185186 (1888)

s8e Recent observations on the glacis. tion of British Columbia and adjacent regions. G Mag (3) $5: 347-350$ (1888) Am G 3:249-253 (1888)

89 The mineral wealth of British Colum. bia. Can G S, An Rp 3: r 163 pp (1889) 89a [Account of geological work in the southern interior of British Columbia.] Can G S, Sum Rp 1887-8 (An Rp 3): 60-66 (1889) 
Dawson, George Mercer-Continued. $89 \mathrm{~b}$ On the earlier Cretaceous rocks of the northwestern portion of the Dominion of Canda. Am J Sc (3) $38: 120-127$ (1889)

89e Notes on the ore deposit of the Treadwell mine, Alaska. Am G 4:84-88 (1889)

89d Glaciation of high points in the southern interior of British Columbia. G Mag (3) : $350-352$ (1889)

89e (with Dawson, J. W.) On Cretaceous plants from Port McNeill, Vancouver Island. R Soc Can, $\operatorname{Pr} \operatorname{Tr} 6$, iv : 71-72 (1889) Abst, Can Rec Sc 3:167 (1888)

90 Report on a portion of the West Kootanie district, B. C. Can G S, An Rp 4: B 66 pp, map (1890)

90a [Summary account of explorations in the southern part of British Columbia.] Can G S, Sum Rp 1888-9 (An Rp 4): 1 7-12 (1890)

90b [Notes on the Anderson River region, Northwest Terr.] Can Rec Sc 4: 28-29 (1890)

90e On the glaciation of the northern part of the Cordillera, with an attempt to correlate the events of the glacial period in the Cordillera and Great Plains. Am G 6:153-162 (1890)

90d Notes on the Cretaceoss of the British Columbia region; the Nanaimo group. Am J Sc (3) 39:180-183 (1890)

90e Chalk from the Niobrara Cretaceous of Kansas. Science 16:276 (1890)

91 [Summary report on field work in the southern part of British Columbia.] Can G S, Sum Rp 1890 (An Rp 5) : A $16-20$ (1891)

91a On the later physiographical geology of the Rocky Mountain region in Canada, with special reference to changes in elevation and to the history of the glacial period, $R$ Soc Can, Pr Tr 8, iv : 3-74 (1891)

91b Note on the geological structure of the Selkirk Range (with discussion by J. W. Spencer and G. K. Gilbert). G Soc Am, B 2:165-176 (1891) Extract in Wheeler, A. 0., The Selkirk Range, vol. 1, Ottawa, Government Printing Bureau, 1905, pp. $405-409$

92 Note on the distribution of the upturned Cretaceous beds of British America. Am J Sc (3) $43: 433-435$ (1892)

92a Exploration in northern British Columbia (abst). Ph Soc Wash, B 11: 502-503 (1892)

93 Notes on the geology of Middleton Island, Alaska. G Soc Am, B 4:427-431 (1893) Abst, with discussion, Am G 11: 244-245 (1893)

94 Geological notes on some of the coasts and Islands of Bering Sea and vicinity. G Soc Am, B 5: 117-146 (1894) Abst, Am G 13:137 (1894)
Dawson, George Mercer-Continued.

$94 a$ Notes on the occurrence of mammoth remains in the Yukon district of Canada and in Alaska. G Soc London, Q J $50: 1-8$ (1894) Abst, G Mag (3) $10: 574$ 575 (1893) ; Can Rec Sc $6: 59$ (1894)

94b Volcanic rocks of the Huronian. Science $23: 50$ (1894)

95 Report on the area of the Kamloops map sheet, B. C. Can G S, An Rp $7:$ B 427 pp, maps (1895)

95a Summary report on the operations of the Geological Survey for the year 1894. Can G S, An Rp n s 7:A 3-124 (1895) ... for the year 1895, An Rp n s 8: A 3-154 (1896) ... for the year 1896, An Rp n s 9: A $3-144$ (1897) ... for the year 1897, An Rp n s 10: A 3-156 (1898) ... for the year 1898, An Rp n s 11: A 3-208 (1899) ... for the year 1899, An Rp n s 12: A 3-224, maps (1900) ... for the year 1900, An Rp n s 13: A 3-203, map (1901) [also issued separately]

$\mathbf{9 5 b}$ [Summary report of investigations in southern British Columbia.] Can $G \mathbf{S}$, Sum Rp 1894 (An Rp 7) : A 14-29 (1895)

95e (and Meconnell, R. G.) Glacial deposits of southwestern Alberta in the vicinity of the Rocky Mountains. G Soc Am, B $7: 31-66$, map (1895) Abst, Am G $16: 235$ (1895); Ottawa Nat $9: 151$ (1895)

95d Note on the glacial deposits of southwestern Alberta. J G 3:507-511 (1895)

95e...amount of elevation...along the Rocky Mountain Range in British America since the close of the Creatceous period. Am J Sc (3) $49: 463-465$ (1895)

95f Interglacial climatic conditions. Am G $16: 65-66$ (1895)

96 [Report on] boring at Athabasca Landing [Alta.]. Can G S, Sum Rp 1895 (An Rp 8) A 8-16 (1896)

96a Notes on hydraulic mining in British Columbia. Gen M As Que, J 2:173176 [1896]

97 The physical geography and geology of Canada. $48 \mathrm{pp}$, Toronto 1897

$97 \mathbf{a}$ [The pre-Cambrian rocks of Canada.] Nature 56:396-401 (1897) Brit As, Rp 67: 628-640 (1898) Abst, Sc Am Sup 44: 18089-18090 (1897)

$97 \mathbf{b}$ Are the boulder clays of the Great Plains marine? J G 5:257-262 (1897)

97e [The Laurentide Glacier]. J G 5 : 78-81 (1897)

$9 S$ (assisted by MeEvoy, J.) British Columbia, Shuswap sheet [descriptions of formations on margin]. Scale 4 miles to 1 inch. Can G S 1898

99 Duplication of geologic formation names. Science n s 9:592-593 (1899)

99n (assisted by McEvoy, J.) British Columbia, Shuswap sheet; economic minerals and glacial striae. Scale 4 miles to 1 inch. Can G S 1899 
Dawson, George Mercer-Continued.

oo Experimental borings in northern Alberta. Can G S, Sum Rp 1899 (An Rp 12) : A 11-15 (1900)

OOa Economic minerals of Canada: Paris International Exhibition, 1900. 54 pp, map (1900)

OOb Remarkable landslip in Portneuf Co., Que. G Soc Am, B 10:484-490 (1900) Abst, Am G 23: 103 (1899); Science n s $9: 139$ (1899); Ottawa Nat 12:194-195 (1899)

01 Geological record of the Rocky Mountain region in Canada. G Soc Am, B 12: 57-92 (1901) Abst, Eng M J 71:51-52 (1901) In part, with title, Physical bistory of the Rocky Mountain region in Canada, Science n \& $13: 401-407$ (1901)

See also Becker, 91b; Upham, 91

Dawson, John William (1820-1899).

43 On the Lower Carboniferous rocks or gypsiferous formation of Nova Scotia. G Soc London, Pr 4:272-281 (1843) ; Q J 1: $26-35$ (1845)

45 On the newer coal formation of the eastern part of Nova Scotia. G Soc London, Pr 4:504-512, map (1845); Q J 1: $322-330$, map (1845)

46 Notices of some fossils found in the coal formation of Nova Scotia. G Soc London, Pr 2:132-136, il (1846)

47 The gypsum of Nova Scotia. Ac $\mathrm{N}$ Sc Phila, Pr $3: 270-274$ (1847)

48 On the mode of occurrence of gypsum in Nova Scotia, and on its probable origin. R Soc Edinb, Pr 2: 140-141 (1848)

48a On the boulder formation and su. perficial deposits of Nova Scotia. R Soc Edinb, Pr 2:141-142 (title on $p$ 140) (1848)

48b On the New Red Sandstone of Nova Scotia. G Soc London, Q J 4:50-59, map (1848)

49 On the coloring matter of red sand. stones and of greyish and white beds associated with them. G Soc London, Q J 5: 25-30 (1849)

$49 a$ Notice of the gypsum of Plaister Cove in the Strait of Canseau [Nova Scotia]. G Soc London, Q J $5: 335-339$ (1849)

50 On the metamorphic and metalliferous rocks of eastern Nova Scotia. G Soc London, Q J 6:347-364, máp (1850)

51 Notice of the occurrence of upright Calamites near Pictou, N. S. G Soc London, Q J 7:194-196 (1851)

52 Additional notes on the red sandstones of Nova Scotia. G Soc London, Q J 8:398-400 (1852)

53 On the Albert mine, Hilsborough, N. B. G Soc London, Q J 9:107-114 (1853)
Dawson, John William-Continued.

$53 a$ (with Lyell, C.) On the remains of a reptile (Dendrerpeton acadianum Hymn and Owen) and of a land shell discoverd in the interior of an erect fossil tree in th coal-measures of Nova Scotia. G Soc Los. don, Q J 9:58-63, il (1853)

54 On the coal measures of the Soth Joggins, N. S. G Soc London, Q J 10:142 , il (1854)

$54 a$ On the structure of the Albion col measures, Nova Scotia. G Soc London, 8 J $10: 42-47$ (1854)

54b On fossil coniferous wood frou Prince Edward Island. Ac N Sc Phila, Pr $7: 62-64$ (1854)

55 Acadian geology; an account of the geological structure and mineral resourcs of Nova Scotia and portions of the neighboring provinces of British America. 38 pp, 11, map, Edinburgh 1855; 2d ed, 694 pp, il, map, L 1868 ; $3 \mathrm{~d}$ ed, 694, $102 \mathrm{p}$. il, map, L 1878 ; 4 th ed, $694 \mathrm{pp}$, il, map L 1891 ; with supplement to $2 \mathrm{~d} \mathrm{ed,} 102 \mathrm{~F}$ L 1878; and supplementary note to th ed, $37 \mathrm{pp}, 1891 \mathrm{Rv}$ by E. J. Chapman, on J n \& 1:39-48 (1856)

$\mathbf{5 5 n}$ Notice of the discovery of a reptiian skull in the coal of Pictou [N. 8.] G Soc London, Q J 11:8-9 (1855)

55b On a modern submerged forest at Fort Lawrence, N. S. G Soc London, 0 J 11:119-122 (1855) Am J Sc (2) 21: 440-442 (1856)

57 On the geological structure and mineral deposits of the promontory Maimanse, Lake Superior. Can Nat 2:112 (1857)

$\mathbf{5 7 a}$ on the newer Plicene and post-Plit cene deposits of the vicinity of Montres! with notices of fossils recently discoverel in them. Can Nat 2:401-426, il (185i) Abst, Am J Sc (2) 25:275-277 (1857)

$\mathbf{5 7 b}$ On the parallelism of the rock formations of Nova Scotia with those of other parts of America. Am As, Pr 1 pt $2: 18-25$ (1857) Abst, Edinb N Ph J ns 5 ; 359-360 (1857)

57e Remarks on a specimen of fossi wood from the Devonian rocks (Gaspe sandstones) of Gaspe, Canada East. At As, Pr 10 pt 2:174-176, il (1857)

$57 \mathbf{1}$ On the varieties and mode of pres ervation of the fossils known as stert bergiæ. Can Nat $2: 299-305$, il (185i) Am As, Pr 11 pt $2: 67-74$, il (1858) Abst, Can I n s 2: 476-479 (1857)

57e On the newer Pliocene fossils of the St. Lawrence Valley. Can Nat? $279-280$ (1857) Am As, Pr 11 pt ? 74-75 (1858) Abst, Edinb N Ph J d $6: 351$ (1857)

58 Report of the Geological Survey of Canada, 1853 to 1856 . Can Nat $3: 32-39$ $81-97$ (1858) 
Dawson, John William-Continued.

58 a Coal in Canada; the Bowmanville discovery. Can Nat 3:212-223 (1858)

5sb A week in Gaspe. Can Nat 3: 321-331 (1858)

58e Newer Pliocene fossils of the St. Lawrence Valley (abst). Can $J \mathbf{n}$ s 3 : $86-87(1858)$ :

59 On the lower coal measures as dereloped in British America. G Soc London, Q J $15: 62-76$, il (1859) Abst, Can Nat $3: 190-192(1858) ; 4: 303-305$ (1859) 59a On fossil plants from the Devonian rocks of Canada. G Soc London, Q J 15 : $477-488$, il (1859) Can Nat $5: 1-14$, il (1860) Abst, Can Nat 4:303-305 (1859) ; Ph Mag (4) $17: 147-148$ (1859)

$59 b$ on the vegetable structures in coal. G Soc London, Q J 15:626-641, il (1859) dbst, Can J n s 5:305-307 (1860); Ph Mag (4) $17: 308-310$ (1859)

59e Additional notes on the post-Pliocene deposits of the St. Lawrence Valley. Can Nat 4:23-39, $11 \quad(1859)^{v}$ Abst, Am J Sc (2) $27: 434-436 \quad$ (1859)

$59 \mathrm{~d}$ On the microscopic structure of some Canadian limestones. Can Nat 4: 161-169 (1859)

60 Supplementary chapter to "Acadian geology "... $70 \mathrm{pp}$, Edinburgh 1860

60a on a terrestrial mollusk, a chilognathous myriapod, and some new species of reptiles from the coal formation of Nova Scotia. G Soc London, Q J 16:268277 , il (1860)

60b On the Silurian and Devonian rocks of Nova Scotia. Can Nat 5:132-143 (1860)

60e Notice of Tertiary fossuls from Labrador, Maine, etc., and remarks on the climate of Canada in the newer Pliocene or Pleistocene period. Can Nat 5:188200 , il (1860)

60d Notes on the earthquake of October, 1860. Can Nat $5: 363-372$ (1860)

60e on an undeseribed fossil fern from the lower coal measures of Nova Scotia. Can Nat 5:460-461 (1860) G Soc London, Q J $17: 5$ (1861)

60p New fossils from the coal measures of Nova Scotia (abst). Can J n s 5:205206 (1860)

$60 \mathrm{~g}$ Recent researches in the Devonian and Carboniferous flora of British America (abst). Am As, Pr 13:308-310 (1860) Can Nat 4:297-298 (1859)

610 an erect Sigillaria from the South Joggins, N. S. G Soc London, Q J 17: 522-524 (1861) Can Nat $7: 106-111$, il (1861)

61a Note on a carpolite from the coal formation of Cape Breton. G Soc London, Q J $17: 525-526$, il (1861) Can Nat 7 :

\section{1-113, il (1861)}

61b Notes on the geology of Murray Bay, lower St. Lawrence. Can Nat 6 : 138-150 (1861)
Dawson, John William-Continued.

61e On the pre-Carboniferous flora of New Brunswick, Maine, and eastern Canada. Can Nat $6: 161-180$, il (1861)

61d Drift deposits of western Canada. Can Nat 6:219-224 (1861)

61e The earthquake of July 12, 1861

[Canada]. Can Nat 6:329 (1861)

$61 \mathrm{O}$ On the recent discoveries of gold in Nova Scotia. Can Nat 6:417-430 (1861)

$61 \mathrm{~g}$ [Descriptions of new species of fossil plants from Perry, Me.]. Me $\mathrm{Bd} \mathrm{Agr,}$ 6th An Rp: 249-251, il (1861)

62 Notice of the discovery of additional remains of land animals in the coal meas ures of the South Joggins, N. S. G Soe London, Q J 18:5-7 (1862)

62a On the flora of the Devonian period in northeastern America. G Soc London, Q J 18: 296-330, il (1862) Am J Se (2) $35: 311-319 ; 36: 41-42$ (1863) Abst, Can Nat $7: 223-224(1862)$

$62 b$ Notes on the flora of the White Mountains in its geographical and geological relations. Can Nat $7: 81-102$ (1862)

62e On the footprints of Limulus as compared with the Protichnites of the Potsdam sandstone. Can Nat $7: 271-277$ (1862) Abst, Am J Se (2) 34:416-417 (1862)

62d Fossil plants discovered at Perry, Me.] Portland Soc N H, Pr 1: 99-100, il (1869) [1862] Me Bd Agr, 7th An Rp: 402-404 (1862)

63 Air breathers of the coal period; a descriptive account of the remains of land animals found in the coal formation of Nova Scotia... 81 pp, il, Montreal 1863 Can Nat $8: 1-12,81-92, \quad 159-160,161-$ $175,268-295$, il (1863)

63a On the coal measures of Cape Breton [N. S.] Am Ph Soc, Pr 9: 165-167, 208-209 (1863)

63b Further observations on the Devonian plants of Maine, Gaspé, and New York. G Soc London, Q J 19:458-469, il (1863)

63e Notice of a new species of Dendrerpeton and of the dermal coverings of certain Carboniferous reptiles. G Soc London, Q J 19:469-473 (1863)

63d On American Devonian. Am $\mathrm{J}$ Se (2) $35: 309-311$ (1863)

63e Note on the footprints of a reptile from the coal formation of Cape Breton. Can Nat $8: 430-431$, il (1863)

63f Synopsis of the flora of the Carboniferous period in Nova Scotia. Can Nat 8:431-457 (1863) Abst, Am J Sc, (2) $37: 419-426(1864)$

$63 \mathrm{~g}$ On two new coal plants from Nova Scotia (abst). Edinb N Ph J n s 18:298 (1863)

64 Address [on some points in Canadian geology]. Can Nat n s 1:218-229 (1864) Am J Sc (2) $38: 231-239$ (1864) 
Dawson, John William-Continued.

64a On the fossils of the genus Rusophycus. Can Nat n s $1: 363-367,458$, il (1864)

64b On two new coal plants from Nova Scotia (abst). Brit As, Rp 33: sec 67-68 (1864)

65 Notes on post-Pliocene deposits at Riviere-du-Loup and Tadoussac. Can Nat n s $2: 81-88$ (1865)

65a [Presidential address: progress of geology in Canada.] Can Nat n s $2: 300-$ 304 (1865)

65b On the structure of certain organic remains in the Laurentian limestones of Canada. G Soc London, Q J 21:51-59, il (1865) Can Nat n s 2:99-111, 127-128, il (1865)

65e Notes on the post-Pliocene deposits of Canada (abst). G Mag 2:561-563 (1865) Brit As, Rp 35 : sec 50 (1866)

65d The successive Paleozoic floras in eastern North America (abst). Brit As, Rp 35: sec 50-51 (1866) Can Nat n s 2: 452-454 (1865)

65e General view of the Paleozoic floras of North America (abst). G Mag 2:568569 (1865)

66 On the conditions of the deposition of coal, more especially as illustrated by the coal formation of Nova Scotia and New Brunswiek. G Soc London, Q J 22 : 95-169, il (1866) Abst, G Mag 3: 79 (1866)

66a Note on supposed burrows of worms in the Laurentian rocks of Canada. G Soc London, Q J 22:608-609, il (1866) Abst, Can Nat n s 3:321-322 (1868)

66b Comparisons of the icebergs of Belle Isle with the glaciers of Mont Blanc, with reference to the boulder clay of Canada, Can Nat n s 3 : 33-44 (1866)

66e The evidence of fossil plants as to the climate of the post-Pliocene period in Canada. Can Nat n s $3: 69-76$, il (1866) 4 bst, J Bot, London, 5 : 121-122 (1867)

67 On the discovery of a new pulmonate mollusk (Zonites (Conulus) priscus Cpr.) in the coal formation of Nova Scotia ; with a description of the species by P. P. Carpenter. G Soc London, Q J $23: 330-$ 333 , il (1867) Abst, Q J Sc 5:98 (1868)

67a Notes on fossils recently obtained from the Laurentian rocks of Canada, and on objections to the organic nature of Eozoon. G Soc London, Q J 23:257-265, il (1867) Am J Sc (2) $44: 367-376$ (1867) Can Nat n s $3: 312-321$, il (1868)

67b On some remains of Paleozoic inseats recently discovered in Nova Scotia and New Brunswick. G Mag 4:385-388, il (1867) Can Nat $n$ s $3: 202-206$, il (1867)

67e Coal discoveries and Primordial fossils in Nova Scotia. G Mag 4:73-74 (1867)
Dawson, John William-Continued, 67d Coal of Pietou, Nova Scotia. Mag 4: 74 (1867)

68 On new specimens of Eozoon cow dense... Am J Sc (2) 46:245-255, (1868)

68a Note [on Carboniferous beds Nova Scotia]. Can Nat n s 3:224 (18\%

$68 \mathrm{~b}$ Notices of some remarkable gever of plants of the coal formation. Can fir n $\mathrm{s} \quad 3: 362-374$, il (1868)

68e On recent geological discoveries the Acadian provinces of British Ameria (abst). Am As, Pr 16:117-119 (186 Can Nat n s 3:295-297 (1868)

69 On Calamites. An Mag N H $4: 272-273$ (1869)

69a The Wakefleld cave [Ontario], Can Nat n s 4:71-73 (1869)

69b Geological time. Can Nat in st 73-78 (1869)

69c Deep sea dredging in its relation t geology. Can Nat n s 4:78-81 (1869)

69d Calamites and Calamodendron, ou Nat n s 4: $81-85$ (1869)

69e On some new fossil plants, th from Gaspé $(a b s t)$. Can Nat n s 4:40t 465 (1869)

69P The primeval flora. Sc Am \& 34-35 (1869); Nat Se News 2:29(1896)

70 The primitive vegetation of ti earth. R Inst, Pr 6:165-172, il (18i Nature 2:85-88 (1870) Am Nat 4:47t 483 (1870)

70a Note on the genus Eophyton. Nat n 8 5: 20-22 (1870)

7ob The earthquake of October : 1870. Can Nat n s 5:282-289 (1870)

70e Notes on new points and correc tions in Acadian geology. N S Inst N \& Pr Tr 2 pt 3:166-169 (1870)

70d On the pre-Carboniferous floras of northeastern America, with especial refer ence to that of the Erian (Devonian) perio (abst). R Soc London, Pr 18:333-35 (1870) An Mag $\mathrm{N} H$ (4) $6: 103-16$ (1870)

70e On the graphite of the Laurentis of Canada. G Soc London, Q J 26:112117 (1870) ; abst, 25:406 (1869) (d) Nat n s 5:13-20 (1870)

7or Notes on the structure of Sigilloris (abst). G Soc London, Q J 26:165-10 (1870) Ph Mag (4) 40:74-75 (1870) Mag 7:87 (1870) Can Nat n s 5:94 (1870)

70g Note on some animal remains fros the Carboniferous and Devonian of Cansth (abst). G Soc London, Q J 26:16 (1870) G Mag $7: 87-88$ (1870) $\mathrm{Ph} \mathrm{Mt}$ (4) $40: 75(1870)$ Can Nat n s $5: 98-8$ (1870) 
Dawson, John William-Continued.

$70 \mathrm{~h}$ On the structure and affinities of sigillaria, Calamites, and Calamodendron. G Soc London, Q J 27:147-161 (1871); abst, 26:488-490 (1870) Abst, Ph Mag (4) $40: 384-386$ (1870); G Mag 7:293294 (1870)

70 i Handbook of zoology, with examples from Canadian species, recent and fossil. $264 \mathrm{pp}$, il, Montreal 1870 [1st and $2 \mathrm{~d}$ ed. not seen] 3d ed, $304 \mathrm{pp}$, il, Montreal 1886 71 (and Harrington, B. J.) Report on the geological structure and mineral resources of Prince Edward Island. 52 pp, il, Montreal 1871

71a The post-Pliocene geology of Canada. Can Nat n s 6:19-42, 166-187, 241259, 369-416, il, map (1871) Reprint, with title, Notes on the post-Pliocene geology of Canada... 112 pp, il, Montreal 1872

71b The fossil plants of the Devonian and Upper Silurian formations of Canada. Can G S [pt 1]: 1-92, 11 (1871); pt 2: $93-142$, il (1882)

71e On new tree ferns and other fossils from the Devonian. $G$ Soc London, Q J 27:269-274, il (1871) Abst, Ph Mag (4) 42:231-232 (1871); G Mag 8:231-232 (1871)

71d Note on Eozoon canadense. R Irish Ac, $\operatorname{Pr}$ (2) 1:117-123, 129-131 (1871)

71e On spore cases in coals. Am I Sc (3) $1: 256-263$, il $(1871)$

$71 f$ On the bearing of Devonlan botany on questions as to the origin and extinction of species. Am J Sc (3) 2: 410-416 (1871)

$71 \mathrm{~g}$ Some new facts in fossil botany. G Mag 8: 236-237 (1871)

72 On the Eozoon. Am J Sc (3) 4: 65-69 (1872)

72a Devonian and Lower Carboniferous plants, Am J Sc (3) 4:236-237 (1872)

$72 b$ Notes on the geology of Prince Edward Island in the Gulf of St. Lawrence. G Mag 9:203-209 (1872)

72e Note on footprints from the Carboniferous of Nova Scotia G Mag 9:251253 , il (1872)

72d On the physical geography of Prince Edward Island $(a b s t)$. Can Nat n s 6 : 342-343 (1872)

73 Report on the fossil plants of the Lower Carboniferous and Millstone Grit formations of Canada. 47 pp, 11, Can G S 1873

73a Note on the fossil plants from British Columbla ... Can $\mathrm{G} \mathrm{S}, \mathrm{Rp}$ Prog 1872-3 : 66-71, il (1873) Abst, Am J Sc (3) $7:$ 47-51 (1874)

73b Annual address of the president of the Natural History Society of Montreal. Can Nat n $8: 1-11$ (1873)

73e Remarks on Mr. Carruthers' view of Prototaxites. Mo Micro J 10:66-71 (1873) Can Nat n s $7: \mathbf{1 7 3 - 1 7 8 ~ ( 1 8 7 4 )}$
Dawson, John William-Continued.

73d Impressions and footprints of aquatic animals and imitative markings on Carboniferous rocks. Am J Sc (3) $5: 16-24$, il (1873) Can Nat n s $7: 65-74$, il (1873)

73e On the introduction of genera and species in geological time. Q J Sc 10 (n s 3): $363-366$ (1873)

73f Note in vindication of Leptophlœum rhombicum and Lepidodendron gaspianum. G Soc London, Q J 29:369371 (1873) Abst, G Mag 10:234-235 (1873)

73g American lake lasins and Artic currents. G Mag 10:137-138 (1873)

74 Annual address before the Natural Natural History Society of Montreal. Can Nat n s $7: 277-291$ (1874)

$\mathbf{7 4 a}$ On the upper coal formation of eastern Nova Scotia and Prince Edward Island in its relation to the Permian. G Soc London, Q J 30: 209-219 (1874) Abst, G Mag (2) 1:281-282 (1874): Can Nat n s : : 303-304 (1874)

$\mathbf{7 4 b}$ On the geological relations of the iron ores of Nova Scotia. Am As, Pr 22 pt $2: 138-146$ (1874) Can Nat n $s$ : 129-138 (1874)

74e Eozoon canadense. Nature 10:103, il (1874)

74d Note on a new Sigillari- showing scars of fructification (abst.) Am As, $\mathrm{Pr}$ 22 pt $2: 75-76$ (1874) Can Nat n s $7: 171$ (1874)

75 Life's dawn on earth: being the history of the oldest known fossil remains... 239 pp, il, L 1875

$75 a$ Address [of the vice president of the Association]. [Teaching of paleon tology on the origin and listory of life on the earth]. Am As, Pr 24 pt 2:3-26 (1876) (also separate, $26 \mathrm{pp}$, Montreal 1875 Am Nat 9:529-522 (1875)

75b Note on the plants collected by $\mathrm{Mr}$. G. M. Dawson, from the Lignite Tertiary deposits near the forty-ninth parallel. In Dawson, G. M., Report on the geology ... of the forty-ninth parallel, British $N$ Am Boundary Comm:327-331, Il, Montreal 1875

75e Carboniferous conifers. Am J Sc (3) $10: 301-302$ (1875)

75d Primitive man and revelation. Vic toria Inst, Tr 8: 59-63 (1875)

76 Note on the phosphates of the Lau. rentian and Cambrian rocks of Canada, G Soc London, Q J 32:285-291 (1876) Can Nat n \& $8: 162-170$ (1876)

76a On a recent discovery of Carbonlferous batrachians in Nova Scotia. Am J Sc (3) $12: 440-447$ (1876)

761 On some new specimens of fossil Protozoa from Canada. Am As, Pr 24 pt 2 : 100-105, il (1876)

76e Note on specimen of metadiabase from Connecticut Lake. Am J Sc (3) 12: 395 (1876) 
Dawson, John William-Continued.

76d On the occurrence of Eozoon canadense at Cote St. Pierre [Que.]. G Soc London, Q J $32: 66-74$, 11 (1876) Abst, G Mag (2) 2:334-335 (1875)

76e On Mr. Carter's objection to Eozoon. An Mag N H (4) 17: 118-119 (1876)

761 Eozoon canadense, according to Hahn. An Mag N H (4) $18: 29-38$ (1876)

76s Carboniferous pulmonates. Am J Sc (3) $12: 226-227$ (1876) Carboniferous land shells. Nature 14:317 (1876)

77 Annual address [of the president of the Natural History Society of Montreal]. Can Nat n s 8:293-303 (1877)

77a Note on a specimen of Diploxylon from the coal formation of Nova Scotía. G Soc London, Q J 33:836-842, il (1877) Abst, An Mag N H (4) 20:152-153 (1877); Can Nat n s 8:240-250 (1877)

77b New facts relating to Eozoon canadense. Am As, $\operatorname{Pr} 25: 231-234$ (1877) Can Nat n s 8: 282-285 (1877)

77e [On the geology of Belœil mountain, Quebec.] Can Nat n s 8:286-288 (1877)

77a Lower Carboniferous fishes of New Brunswick. Can Nat n s $8: 337-340$, il (1877)

77e Note on a fossil seal from the Leda clay of the Ottawa Valley. Can Nat n s $8: 340-341$ (1877)

77f The earthquake of November 4, 1877. Can Nat n s $8: 342-345$ (1877) Am J Sc (3) 15:321-324 (1877)

$\mathbf{7 7} \cong$ Notes on two Paleozoie crustaceans from Nova Scotia. G Mag (2) 4:56-58, il (1877)

77h Fossil floras and glacial periods. Nature 16:67-68 (1877)

77i The origin of the world according to revelation and science. Montreal 1877 th ed, 438, pp, L 1886 6th ed, 452 pp, L 1893 [other editions not seen]

78 Supplement to the second edition of Acadian geology... 102 pp, L 1878

7Sa Stromatopora as distinguished from Millepora. An Mag N H (5) 2:28-30 (1878)

78b Evolution and the apparition of animal forms. Princeton $\mathrm{Rv}$ yr 54 (n s) 1: 662-675 (1878)

78c Fossil agricultural implements. Victoria Inst, $\operatorname{Tr} 11: 29-32$ (1878)

79 On the microscopic structure of Stromatoporidae and on Paleozoic fossils mineralized with silicates in illustration of Eozoon. G Soc London, Q J 35:48-66, il (1879)

79a The genesis and migrations of plants. Princeton Rv $3: 277-294$ (1879) Nature 20:257-258 (18':9)

79b List of Tertiary plants from localities in the southern part of British Columbia, with the description of a new species of Equisetum. Can G S, Rp Prog 1877-8: в 186-187 (1879).
Dawson. John William-Continued.

79e Remarks on recent papers on the geology of Nova Scotia. Can Nat n 88 1-16 (1879)

79d A Canadian Pterygotus (Pterygots canadensis). Can Nat n s 9:103-105, il (1879)

79e Möbius on Eozoon canadense. Am J Sc (3) $17: 196-202$ (1879) Can Nat n $9:$ 105-112 (1879)

79f [Presidential address before the Natural History Society of Montreal.] Cas Nat n s 9:165-180 (1879)

$\mathbf{7 9 g}$ Notes on recent controversies te specting Eozoon canadense. Can Nat ns $9: 228-240 \quad(1879)$

79h Semi-metamorphic fossiliferous rocks containing serpentine. Am J Sc (3) 17 $327-328$ (1879)

so Fossil men and their modern repre. sentatives... $348 \mathrm{pp}$, Montreal 1880 24 ed, 354 pp, L 1883

80 a The chain of life in geological time. $272 \mathrm{pp}, \mathrm{L}$ [1880] ; $2 \mathrm{~d}$ ed, $1885 ; 3 \mathrm{~d}$ ed, 1888

sob Lecture notes on geology and outline of the geology of Canada... $100 \mathrm{PP}$. il, Montreal 1880 [not seen]

80c Note on the geological relations of the fossil insects from the Devonian of New Brunswick. Boston Soc N H, Annir Mem : 34-41 (of Scudder's paper) (1880)

sod New facts respecting the geological relations and fossil remains of the Silurian iron ores of Pictou, N. S. Can Nat n 5 $9: 313-314,332-344$ (1880)

soe Abstract of notes...on fossil plants collected...in the lignite Tertiary formation of Roches Percées, Souris River, Manitoba. Can Nat n s 9:447-448 (1880)

sor Revision of the land snails of the Paleozoic era, with descriptions of ner species. Am J Sc (3) 20:403-415, it (1880) Can Nat n s 9:449-463, il (1881)

Sog New Devonian plants and other Canadian fossils (abst). Can Nat n s 9 ; $472-473$ (1880)

soh On land snails of the Paleozoic period. (abst). Science (ed, Michels) 1: 136 (1880)

81 Note ... on fossil plants, collected .. in the lignite Tertiary formation of Roche Percée, Souris River [Saskatchewan]. Can G S, Rp Prog 1879-80: A $51-55$ (1881)

81a Note on Cretaceous fossil plants from the Peace River country. Can $G S$, Rp Prog 1879-80: B 120-122 (1881)

$81 b$ On the structure of a specimen of Uphantaenia ... Am Mus N H, B 1:12-13 (1881) Am J Sc (3) 22: 132-133 (1881)

81c Notes on new Erian (Devonlan) plants. G Soc London, Q J 37:299-308, il (1881) Abst, Can Nat D s $9: 475-476$ (1881)

81d The oldest known insects. Nature 24: $483-484$ (1881) 
Dawson, John William-Continued.

s1e Note on Spirorbis contained in an ironstone nodule from Mazon Creek [III.] with millipede. Boston Soc N H, $\operatorname{Pr} 21$ : $157-158$ (1881)

81f Paleontological notes; 1, A new species of Piloceras; 2, Saccammina ? (Calcisphara) eriana; 3 , New Devonian plants from the Bay de Chaleur. Can Nat b 8 10:1-11, il (1881)

s1g Note on a fern associated with Platephemera antiqua Scudder. Can Nat D s 10:102-104 (1881)

$\mathbf{8 1 h}$ The antiquity of man and the origin of species., Kansas City Rv Sc 4:530-536, 595-600 (1881)

81i Stromatopora and Caunopora. G Mag (2) $8: 141$ (1881)

82 On the results of recent explorations of erect trees containing animal remains in the coal formation of Nova Scotia. $\mathbf{R}$ Soc London, $\operatorname{Pr} 33: 254-256$ (abst); $\mathrm{Ph}$ Tr 173:621-659, il (1882) Abst, Nature $25: 354$ (1882) ; Can Nat n s 10:252-254 (1882)

82a Recent discoveries in the Erian (Devonian) flora of the United States. Am J Sc (3) $24: 338-345$ (1882)

$82 b$ [On the glaciation of North America.] Can Nat n s 10:183-184 (1882)

82e Note on specimens of Ptilophyton and associated fossils collected ... in the Chemung shales of Ithaca, N. Y. (abst). Am As, Pr $30: 204$ (1882)

82d The successive Paleozolc floras of Canada. Can Nat n s 10:372-378 (1882) 4bst, Am As, Pr 31: 415-416 (1883)

83 On some unsolved problems in geology. Am As, Pr 32:1-27 (1884) Science $2.190-201$ (1883) Pop Sc Mo 23:827$837 ; 24: 61-73$ (1883) Nature $28: 449$ 455 (1883)

83a On the Cretaceous and Tertiary floras of British Columbia and the Northwest Territory, $\mathrm{R}$ Soc Can, $\operatorname{Pr}$ Tr 1, iv : 15-34, il (1883)

$83 b$ On portions of the skeleton of a whale from gravel on the line of the Canada Pacific Railway, near Smith's Falls, Ont. Am J Sc (3) 25: 200-202 (1883) Can Nat n s 10:385-387 (1883) McGill Univ, Peter Redpath Mus, Rp 2: 7-9 (1883)

83e Preliminary notice of new fossils from the Lower Carboniferous limestones of Nova Scotia and Newfoundland. Can Nat n s 10:411-416 (1883) McGill Univ, Peter Redpath Mus, Rp 2 : 10-15 (1883)

83d Notice of graptolites of the Quebec group ... Can Nat n s 10:461-463 (1883) McGill Univ, Peter Redpath Mus, Rp $2: 15$ 17 (1883)

83e Canadian Pleistocene. G Mag (2) $10: 111-113$ (1883)

83f The Quebec group. In Harrington. B. J., Life of Sir William Logan, Appendix A : 403-418 (1883)
Dawson, John William-Continued.

83a Impressions on Potsdam sandstone [Rainbow Falls, Lake Champlain]. Science 1: 177 (1883)

83h On moraines. Science 2:321 (1883)

84 Observations on the geology of the line of the Canadian Pacific Railway. G Soc London, Q J $40: 376-388$ (1884) Abst, G Mag (3) 1:283-284 (1884)

$\mathbf{8 4 a}$ on the geological relations and mode of preservation of Eozoon canadense (abst). Brit As, Rp 53:494 (1884) Can Rec Se 1:58-59 (1884) Can Rec N H $1: 57-59$ (1884)

84b On the more ancient land floras of the old and new worlds (abst). Brit As, Rp 54:738-739 (1885) G Mag (3) 1: 469-470 (1884)

84e Spores and spore cases from the Erian formation (abst). Can Rec N H 1: 13 (1884)

S4d On rhizocarps in tle Paleozoic period $(a b s t)$. Am As, Pr $32: 260-264$, il (1884) Science $2: 326-327$ (1883) Can Rec N H 1:19-27, il (1884) Can Rec Sc $1: 19-27$, il $(1884)$

$\mathbf{8 5}$ On some relations of geological work in Canada and the Old World. R Soc Can, Pr Tr 2, iv : 1-5 (1885)

S5a Canadian and Scottish geology. Edinb G Soc, Tr 5:112-122 (1885)

85b Ancient insects and scorpions, Can Rec Sc 1: 207-208 (1885)

85e A modern type of plant in the Cretaceous [Brasenia antiqua, Belly River beds]. Science 5:514, il (1885)

S5d (with Bain, F.) Notes on the geology and fossil flora of Prince Edward Island. Can Rec Se 1: 154-161, 11 (1885)

86 Presidential address before the British Association for the Advancement of Seience, September 1886 [geologic history of the Atlantic ocean]. Can Rec Sc 2: $201-228,265-285 \quad(1886-7)$ Pop Sc Mo $30: 41-51, \quad 184-194$ (1886) Se Am Sup 22 : 9020-9023 (1886) Brit As, Rp 56 : $3-36$ (1887)

S6a On the Mesozoic floras of the Rocky Mountain region of Canada. $R$ Soc Can, $\operatorname{Pr} \operatorname{Tr} 3$, iv : 1-22, il (1886) Abst, Can Rec Sc 1:141-143 (1885); Science 5: 531-532 (1885); Am Nat 19:699-700 (1885) ; Nature $33: 32-34$ (1885)

86b Cretaceous floras of the Northwest. Can Rec Sc 2: 1-9 (1886)

s6e Note on boulder drift and sea margins at Little Metis, lower St. awrence. Can Rec Sc $2: 36-38$ (1886)

86d On rhizocarps in the Erian (Devonian) period in America. Chicago Ac Sc, B $1: 105-1:-$, il (1886)

s6e On the fossil flora of the Laramie series of western Canada (abst). Am J $\mathrm{Sc}$ (3) $32: 242-243$ (1886) Am Nat 20: $157-108$ (1886) 
Dawson, John William-Continued.

861 On the relations of the geology of the Arctic and Atlantic basins (abst). Brit As, Rp 56:638 (1887) G Mag (3) 3: 504-505 (1886)

$\mathbf{8 6 g}$ On Canadian examples of supposed fossil algae $(a b s t)$. Brit $\mathbf{A s}, \mathrm{Rp} 56: 651-$ 653 (1887, G Mag (3) 3:503-504 (1886)

s6h (with Grant, C. E.) Notes on Pleistocene fossils from Anticosti. Can Rec Sc 2: 44-48 (1886)

87 Presidential address; Some points in which American geological science is indebted to Canada. $\mathrm{R}$ Soc Can, $\operatorname{Pr} \operatorname{Tr} 4$, iv : 1-8 (1887)

$\mathbf{8 7 a}$ On the fossil plants of the Laramie formation of Canaca. I Soc Can, $\operatorname{Pr} \operatorname{Tr} 4$, iv : 19-34, il (1887) Abst, Am Nat 20: 635-637 (1886)

$\mathbf{8 7 b}$ Correlation of the geological structure of the maritime province of Canada with that of western Europe (abst). Can Rec Sc 2:404-406 (1887) Science 9:589590 (1887)

S8 The geological history of plants. The International Scientific Series vol 61: 290 pp, N Y 1888 Rv by L. F. Ward, Am Nat $22: 335-337$ (1888)

88 a Cretaceous Loras of the Northwest Territories of Canada. At. Nat 2:: 953 959 (1888)

88b Specimens o- Eozoon canadense and their geological and other relations. McGill Univ, Peter Redpath Mus, Notes on specimens-Sept. 1888:107 pp, il Extracts, Can Rec Sc $3: 201-226$, il (1888)

88c Notes on new facts relating to Eozoon canadense. G Mag (3) 5:49-54, il (1888) Abst, Br As, xp $57: 702$ (1888)

$\mathbf{8 s d}$ Note on fossil woods and other plant remains from the Cretaceous and Laramie formations of the western territories of Canada. R Soc Can, Pr Tr 5, iv:31-37 (1888) Abst, Can Rec Sc 2:499-502 (1887) ; Nature $36: 274-275$ (1887)

8se The earliest plants. Pop Sc Mo $32: 787-795,11$ (1888)

88f Preliminary note on new species of sponges from the Quebec group at Little Métis, Province of Quebec, Canada. Can Rec Sc 3:49-59 (1888) MeGill Univ, Peter Redpath Mus, Notes on specimensApril 1888:49-50 (1888)

88g On sporocarps discovered by Prof. E. Orton in the Erian shale of Columbus, Ohio. Can Rec Se 3: 137-140 (1888)

8sh on the Eozolc and Paleozoic rocks of the Atlantic coast of Canada in comparison with those of western Europe and of the interior of America. G Soc London, Q J 44:797-817 (1888) Abst, Can Rec Sc 3:182-183, 230-231 (1888)

89 Handbook of geology for the use of Canadian students. 250 pp, Montreal 1889 [not seen]
Dawson, John Willfam-Continued,

89 a On Nematophyton and allied form from the Devonfan (Erian) of Gaspé atd Baie des Chaleurs; Introductory notes. \& Soc Can, $\operatorname{Pr} \operatorname{Tr} 6$, iv : 27-36 (1889)

89b (and Dawson, G. M.) On Cre taceous plants from Port McNeill, Vancouver Island. R Soc Can, $\operatorname{Pr} \operatorname{Tr} 6$, ir: 71-72 (1889) Abst, Can Rec Sc $3: 167$ (1888)

89e Note on Balanus hameri in the Pleistocene at Riviere Beaudette, and on the occurrence of peculiar varieties of $1 / 50$ arenaria and $M$. truncata in the moden sea and in the Pleistocene. Can Rec Sc s: 287-292 (1889)

89d Saccamina eriana. Am J Sc (3) 37 : 318 (1889)

89e $\Delta$ new Erian (Devonian) plant alled to Cordaites. Am J Sc (3) $38: 1-$ 3, II (1889)

89f Supplementary note to a paper on the rocks of the Atlantic coast of Canade G Soc London, Q J 45: pt 180 (1889) $\mathrm{G}$ Mag (3) 6:236-237 (1889)

$\mathbf{8 9 g}$ Ueber einige devonische Pflanzes Deut G Ges, Zs 41:553-554 (1889)

$89 h$ On certain remarkable new tosd plants from the Erian and Carboniferous and affinities of the Paleozole gymnosperm (abst). Am Nat 23:809 (1889)

90 (and Penhallow, D. P.) On the Pleistocene flora of Canada. G Soc Am. B $1: 311-320$, il (1890) Abst, Am Nat 24: 293-294 (1890)

90a On new plants from the Erian and Carboniferous and on the characters and affinities of Paleozoic gymnosperms. McGlll Univ. Peter Redpath Mus, Notes on spect mens, $1890: 28$ pp, il Can Rec Se $4: 1-28$ il (1890)

90b On burrows and tracks of inverte brate animals in Paleozoic rocks, and othet markings. G Soc London, Q J 46:595-61t, il (1890) Abst, Can Rec Sc 4:234-235 (1890) ; G Mag (3) $7: 286-287$ (1890)

90e On new species of fossil sponges from the Siluro-Cambrian at Little Metis on the lower St. Lawrence; including notes on the specimens by Dr. G. J. Hinde. B Soc Can, $\operatorname{Pr} \operatorname{Tr} 7$, iv : $31-55$, il (is90) $A b s t$, Can Rec Sc 3:429-430 (1889)

90d On fossil plants collected ... on Mackenzie River and ... on Bow River. $B$ Soc Can, $\operatorname{Pr}$ Tr 7, iv : $69-74$ (1890) Absh Can Rec Sc 3:430 (1889)

90e Note on the geological relations of the fossil insects from the Devonian of New Brunswick. In Scudder, S. H.. The fossil insects of North America 1 : 186-193, il, N Y 1890

gor Note on a fossil fish and maride worm found in the Pleistocene nodules of Green's Creek on the Ottawa. Can Rec Si $4: 86-88$ (1890)

$90 \mathrm{~g}$ The Quebec group of Logan. Car Rec Sc $4: 133-143$ (1890) 
Dawson, John William-Continued.

$90 h$ On certain remarkable new fossil plants from the Erian and Carboniferous, and on the characters and affinities of Paleozoic gymnosperms (abst). Am As, Pr $38: 231$ (1890)

91 Carboniferous fossils from Newfoundland. G Soc Am, B $2: 529-540$, il (1891)

91a On new specimens of Dendrerpeton acadianum with remarks on other Carboniferous amphibians. G Mag (3) 8:145-156, il (1891)

91b Note on Hylonomus lyelli... G Mag (3) $8: 258-269$, il $(1891)$

91e (and Penhallow, D. P.) Note on specimens of fossil wood from the Erian (Deronian) of New York and Kentucky. Can Rec Sc $4: 242-247$, il (1891)

91d On fossil plants from the Similkameen Valley and other places in the southern interior of British Columbia. $\mathrm{R}$ Soc Can, $\operatorname{Pr} \operatorname{Tr} 8$, iv : 75-91, il (1891) Abst, Science $15: 373$ (1890)

92 Thomas Sterry Hunt. Can Rec Sc $5: 145-149$, port (1892)

92a Supplementary report on explorations of erect trees containing animal remains in the coal formation of Nova Scotia.

R Soc London, Pr 52:4-5 (1892)

92b (and Penhallow, D. P.) Parka decipiens; notes on specimens... $\mathrm{R}$ Soc Can, Pr Tr 9, iv : 3-16, il (1892)

92c On the mode of occurrence of remains of land animals in erect trees at the South Joggins, N. S. (abst). R S Can, Pr Tr 9 , iv : 127-128 (1892)

93 The Canadian ice age... 301 pp, Montreal 1893

93a On the correlation of early Cretaceous floras in Canada and the United States and on some new plants of this period. B Soc Can, Pr Tr 10, iv: 79-93, il (1893) 93b The late Dr. John Strong Newberry. Can Rec Sc 5: 340-343 (1893)

93e Geological notes. Can Rec Sc 5 : 386-393 (1893)

93d Note on fossil sponges from the Quebec group (lower Cambro-Silurian) at Little Metis, Can. (abst). G Soc Am, B 4:409-410 (1893)

93e The study of fossil plants. G Soc Am, B 5:2-5 (1893)

94 Some salient polnts in the science of the earth. $499 \mathrm{pp}, \mathrm{N}$ Y 1894

94a The meeting-place of geology and history. $223 \mathrm{pp}, \mathrm{L} 1894$ [also later editions]

94b Some recent discussions in geology. G Soc Am, B $5: 101-116$ (1894) Abst, Am G 13:135-137 (1894); Am J Sc (3) $47: 135-136$ (1894)

94e On new species of Cretaceous plants from Vancouver Island. R Soc Can, Pr Tr 11, iv: 53-73, il (1894)
Dawson, John William-Continued.

$94 d$ Note on the genus Naiadites as occurring in the coal formation of Nova Scotia; with an appendix by Wheelton Hind. G Soc London, Q J 50:435-442, il (1894) Abst, G Mag (4) $1: 189-190$ (1894)

94e Notes on the bivalve shells of the coal formation of Nova Scotia. Can Rec Sc 6:117-134, 167, il (1894) Revision of the bivalve mollusks of the coal formation of Nova Scotia. McGill Univ, Peter Redpath Mus, Notes on specimens-Nov. $1894: 18 \mathrm{pp}$, il (1894)

94f Preliminary note on recent discoveries of batrachians and other air breathers in the coal formation of Nova Scotia. Can Rec Sc 6:1-7 (1894)

$\mathbf{9 4 g}$ Our record of Canadian earthquakes [1879-1894]. Can Rec Sc 6:8-16 (1894)

94h The fossil plants of Canada as tests of climate and age. Nat Sc $4: 177-182$ (1894)

94i New discoveries of Carboniferous batrachians (abst). Am G 13:137 (1894) 95 The historical deluge... $56 \mathrm{pp}, \mathrm{N}$ Y [1895]

95a Synopsis of the air-breathing animals of the Paleozoic in Canada, up to 1894. $\mathrm{R}$ Soc $\mathrm{Can}, \operatorname{Pr} \operatorname{Tr} 12$, iv : 71-88 (1895)

95b On collections of Tertiary plants from the vicinity of the City of Vancouver, B C. R Soc Can, $\operatorname{Pr} \operatorname{Tr}(2) 1$, iv : 187-161, il (1895)

95e Note on a paper on "Eozoonal structure of the ejected blocks of Monte Somma." G Mag (4) 2:271-274 (1895)

95d Review of the evidence for the animal nature of Eozoon canadense. G Mag (4) $2: 443-449,502-506,545-550$ (1895) Can Rec Sc $6: 470-478 ; 7: 62-77$ (1896)

95e Note on a specimen of Beluga catodon from the Leda clay, Montreal. Can Rec Sc $6: 351-354$ (1895)

96 Additional notes on fossil sponges and other organic remains from the Quebec group at Little Metis on the lower St. Lawrence; with notes on rome of the specimens by Dr. G. J Hinde. R Soc Can, Pr Tr (2) 2, iv: 91-121, il (1896)

$96 a$ Pre-Cambrian fossils (abst). Brit As, Rp 66: 784-785 (1896) Can Rec Sc $7: 157-162$ (1896) G Mag (4) $3: 513-514$ (1896) Science n s 5: 253-254 (1897)

97 Relics of primeval life. 335 pp, Chicago $1897.336 \mathrm{pp}, \mathrm{L} 1897$.

$97 a$ On the genus Lepidophloios as illustrated by specimens from the coal formation of Nova Scotia and New Brunswick. $\mathrm{R}$ Soc Can, $\operatorname{Pr} \operatorname{Tr}$ (2) 3 , iv : 57-78, il (1897)

97b Note on Cryptozoon and other ancient fossils. Can Rec Se $7: 203-219$, il (1897) 
Dawson, John William-Continued.

97e Note on Carboniferous Entomostraca from Nova Scotia... Can Ree Se 7 : $316-323,396$, 11 (1897)

98 Note on Lepidophloios cliftonensis. G Soc Am, B 9:416 (1898) Science n s $7: 79$ (1898) Ottawa Nat 11:223 (1898) 98a Note on certain pre-Cambrian fossils supposed to be related to Eozoon (abst). Brit As, Rp $67: 656$ (1898)

99 Note on an echinoderm collected by Dr. Ami at Besserers, Ottawa River, in the Pleistocene (Leda clay). Ottawa Nat 13 : 201-202 (1899)

01 Fifty years of work in Canada; autobiographical notes. Edited by Rankine Dawson. $306 \mathrm{pp}$, port, L 1901

See also Frazer, $88 \mathrm{a}$; Hall, 90a ; Hartt, 67 ; Honeyman, 60 ; Kavanagh, 89 ; Matthew (G F), 63; Poole, 60; Richardson (J), 72a; Southall, 82

Dawson, Simon James.

59 Report on the exploration of the country between Lake Superior and the Red River Settlement and between the latter place and the Assiniboine and Saskatchewan. [Canada, Provincial secretary ] : $45 \mathrm{pp}$, map, Toronto 1859 Also in Canada, Legislative Assembly, J vol 17 app no 36, Toronto 1859 [A]so an edition in French]

Dawson, William L.

98 Glacial phenomena in Okanagan Co., Wash. Am G 22: 203-217, maps (1898)

Day, Arthur Louis.

04 The study of minerals in the Iaboratory $(a b s t)$. Science n s 19:733, 734-735 (1904)

95 (and Allen, E. T.) The isomorphism and thermal properties of the feldspars. Am J Sc (4) 19:93-142 (1905)

o5a (and Allen, E. T.) The isomorphism and thermal properties of the feldspars. Carnegie Inst Wash, Pub 31 : 13-75, Washington 1905

osb (and Shepherd, E. S.) The phase rule and conceptions of igneous magmas (discussion of paper by T. T. Read). Ec G $1: 286-289$ (1905)

05e (with Beeker, G. F.) The linear force of growing crystals. Wash Ac Sc, Pr 7: 283-288 (1905)

06 Mineral solution and fusion under high temperatures and pressures. Carnegie Inst of Wash, Y Bk 4:224-230 (1906)

06a (and Shepherd, E. S.) The lime silica series of minerals with optical study by F. E. Wright. Am Chem Soc, J 28: 1089-1114 (1906) Am J Sc (4) 22:265302 (1906) Tschermak's Miner Mitt N F $26: 169-232$ (1907)

07 Investigation of mineral solution and fusion under high temperatures and pressures. Carnegie Inst Wash, Y Bk 5:177185 (1907)

07 a Methods of igneous intrusion (abst). Science n s 25:622 (1907)
Day, Arthur Louis-Continued.

us Geology and radioactive substances Seience $n$ s $28: 526-527$ (1908)

09 Diopside and its related minerals (abst). Science n s 30:125-126 (1903)

10 Some mineral relations from the Iaboratory viewpoint. G Soc Am, B 21 . 141-178 (1910) Abst, Science n s 31: $599 ; 32: 218-219$ (1910)

$10 a$ [Report on the] Geophysical Laboratory. Carnegie Inst Wash, Y Bk 8: 97-107 (1910)

11 Geophysical research. Wash Ac Sc. J $1: 247-260$ (1911) Nature $88: 331-334$ (1912)

12 Are quantitative physico-chemial studies of rocks practicable? (with discus sion). Int $\mathrm{G}$ Cong, XI, Stockholm, C B: 965-967 (1912) Abst, Wash Ac Sc, J 3: 502 (1913)

13 (and Shepherd, E. S.) Water and volcanic activity. G Soc Am, B 24:573606, 707 (discussion by W. M. Davis, R. A. Daly, J. F. Kemp, and E-Howe) (1913) Smiths Inst, An Rp 1913:275-305 (1914)

13a Water and the magmatic gases. Wash Ac Sc, J 3:457-463 (1913) Ac \&c Paris, C R 157: 958-961 (1913)

14 (and Sosman, R. B., and Hostet. te:, J C.) The determination of mineral and rock densities at high temperatures Am J Sc (4) $37: 1-39$ (1914) N Jb, Bell Bd $40: 119-162$ (1915)

14 a Some observations of the voleano Kilavea in action $(a b s t)$. G Soc Am, B $25: 80-81$ (1914)

15 [Investigations in the] geophysical laboratory [of the Carnegie Institution of Washington]. Carnegie Inst Wash, Y Pt 13: 134-157 (1915)

15a Secondary sulphide enrichment of copper ores. M Sc Press 110:841-842 (1915)

15b The voleano Kilauea in action (abst). Wash Ac Sc, J 5:553 (1915)

16 Segregation in igneous rocks under the action of gravity; calcium carbonate; copper-sulphide ores. Carnegie Inst Wash, Y Bk 14 (1915) : 151-159 (1916)

16a Do volcanoes offer evidence in re gard to the interior of the earth? (ubst). Wash Ac Sc, J 6:634-635 (1916)

16b. Volcanic emanations (abst). III Ac Sc, Tr 8:31-32 [1916]

16e (with Becker, G. F.) Notes on the linear force of growing crystals. J G $24: 313-333$ (1916)

17 The iron oxides [investigation in Geo. physical Laboratory]. Carnegie Inst Wash, Y Bk no $15: 137-143$ (1917)

17 a Study of the recent activity of Mauna Loa (abst). G Soc Am, B 28: 127 (1917)

17b Cooling of a lava surface (abst). Wash Ac Sc, J $7: 194$ (1917)

See also Johnston (J), 13a 
Day, David Talbot.

83 Manganese. U S G S, Min Res [1882] : 424-427; $1883-4: 550-566 \quad(1883-5)$

83a Chromium. U S G S, Min Res [1882] : 428-430; 1883-4: 567-573; 1885 : $357-360(1883-6)$

83b Tungsten. U S G S, Min Res [1882] : $431-433 ; 1883-4: 574-575 ; 1885$ : 366 (1883-6)

85 Cobalt. U S G S, Min Res 1883-4 : $544-549 ; 1885: 361-365$ (1885-6)

85 a Zirconium; bromine; iodine; sul. phur. U S G S, Min Res 1883-4: 661, 851-858, 864-876 (1885)

85b Phosphate rock. U S G S, Min Res $1883-4: 783-808$; $1885: 445-458$ (1885-6) 86 Mineral resources of the United States, calendar year 1885 . U S G S : 576 pp (1886) $\quad \ldots \quad 1886: 813$ pp (1887) ... $1887: 832$ pp (1888) ... 1888:652 pp (1890) $\ldots 1889$ and $1890: 671$ pp (1892) ... 1891:630 pp (1893) ... 1892:850 pp (1893) ... 1893:810 pp (1894) ... 1894; C S G S, An Rp 16 pt $3: 646$ pp; pt 4 : $795 \mathrm{pp}$ (1895) ... 1895; An Rp 17 pt 3: $1058 \mathrm{pp}$ (1896) ... 1896; An Rp 18 pt 5: 1400 pp (1897) ... 1897; An Rp 19 pt 6 : 651, 706 pp (1898) … 1898; An Rp 20 pt 6:616, 804 pp (1899) ... 1899; An Rp 21 pt 6:656, 634 pp (1901)

97 A suggestion as to the origin of Pennsylrania petroleum. $\mathrm{Am} \mathrm{Ph}$ Soc, $\mathrm{Pr} 36$ : $112-115$ (1897)

99 Mineral resources of the Antilles, Hawail, and the Philippines. Eng Mag 17: 242-251 (1899)

00 The occurrence of fuller's earth in the Cnited States. Franklin Inst, J 150: 214-223 (1900)

01 Notes on the occurrence of platinum in North America. Am I M Eng, Tr 30: $702-708$ (1901) Alst, M Sc Press 81: 158 (1900)

01a Mineral resources of the Enited Statex, calendar year 1900 . U S G S : 927 Dp $(1901) \quad \ldots \quad 1901: 996$ pp $(1902)^{\circ} \ldots$ $1902: 1038$ pp (1904) _.. 1903:1204 pp (1904) $\ldots 1904: 1264$ pp (1905) ... 1905: 1403 pp (1906) ... 1906:1307 pp (1907) ... 1907; pt 1: 743 pp ; pt 2: 897 pp (1908) $02 \mathrm{La}$ variation des caractères des huiles brutes de Pennsylvanie et de l'Ohio. Cong intern pétrole, I, Paris 1900 , Notes ... : 5356, Paris 1902

03 Experiments on the diffusion of crude petroleum through fuller's earth (abst). Science n s $17: 1007-1008$ (1903)

04 Gypsum deposits in Florida. U S 6 8, B 223:48 (1904)

05 Black sands of the placer mines of the United States. U S, 59th Cong, 1st Ress, S Doc no $65: 8-15$ (1905)

05a Platinum, U S G S, Min Res 1904: $359-360 \cdot 1906: 551-562 ; 1907$ pt $1: 731-$ $732 ; 1908$ pt $1: 781-791(1905-9)$
Day, David Talbot-Continued.

06 (and Richards, R. H.) Investigation of the black sands from placer mines. U S G S, B 285: 150-164 (1906)

O6a (and Richards, R. H.) Black sands. U S G S, Min Res $1905:$ 1175-1258 (1906)

o7 The auriferous black sands of California. Mines and Minerals 27:564-565 (1907)

07a Black sands of the Pacific coast. Franklin Inst, J 164:141-153 (1907) M World 27:891, 974, 1013 (1907)

os Petroleum. U S G S, Min Res 1907 pt $2: 347-475 ; 1908$ pt $2: 345-440 ; 1909$ pt $2: 303-427 ; 1910$ pt $2: 327-458$; 1911 pt $2: 335-480 ; 1912$ pt $2: 361-495$ (1908-13)

09 The petroleum resources of the United States. U S G S, B 394:30-50 (1909) Nat Conservation Comm (60th Cong, 2d sess. S Doe no 676), Rp 3:446-464 (1909)

$09 a$ Natural-gas resources of the United States. U S G S, B 394:51-61 (1909) Nat Conservation Comm (60th Cong, 2d sess, S Doc no $676, \mathrm{Rp} 3: 465-475$ (1909)

093 [Map of United States showing] known productive oil and gas fieldis ce the United States in 1908. 2d ed. U S G S 1909 Scale, 110 miles to one inch.

09e The Mexican oil fields, their geology and the character of the oils. Petroleum Rv $20: 323$ (1909)

09d Analyses of crude petroleum from Oklahoma and Kansas. U S G S, B 381 : 494-503 (1910)

10. The distribution of platinum in the United States (abst). Science n s 31 : 518-519 (1910)

10a The conditions of accumulation of petroleum in the earth. Am I M Eng, B $42: 467-472 \quad(1910) ; \quad \operatorname{Tr} 41: 219-224$ (1911)

11 The distribution of petroleum. Int Geog Cong, IX, C R 3:66-71 (1911)

11 a Asphalt, related bitumens, and bituminou's rock. U S G S, Min Res 1909 pt $2: 721-733 ; 1910$ pt $2: 833-839 ; 1911$ pt $2: 1003-1021 ; 1912$ pt $2: 997-1006$ (1911-3)

12 (and Hill, Belle.) Natural gas. U S G S, Min Res 1911 pt 2: 279-333 (1912)

13 Platinum and allied metals. U S G S, Min Res 1912 pt $1: 1055-1059 ; 1913$ pt 1: $445-457(1913-4)$

14 Asphalt. U S G S, Min Res 1913 pt $2: 537-544$ (1914)

$14 a$ Petroleum and its derivatives. Franklin Inst, J 177:271-286 (1914)

$14 b$ (and others) [Map of the] oil and gas fields [of the United States] in 1913; seale, 1:2,500,000. U S G S (1914)

14e (with Woodrufr, E. G.) Oil shale of northwestern Colorado and northeastern Utah. U S G S, B 581: 1-21, map (1914) Abst, Wash Ac Sc, J $4: 170-171$ (1914) 
Day, David Talbot-Continued.

17 The petroleum industry of Mexico. Pan American Sc Cong, 2d, Pr, sec 3, vol 3: 238-245 (1917)

See also Adams (G I), 03b; Johnson (R H), 15; Ordonez, 14; Powell, 89, 89a, $90,91,91 \mathrm{a}, 92,95$; Washburne, 14b

Day, Fisk Holbrook.

78 On the fauna of the Nlagara and upper Silurian rocks as exhibited in Milwaukee Co., Wis., and in counties contiguous thereto. Wis Ac Sc, Tr $4: 113-125$ (1878)

Day, Jeremiah (1773-1867).

$10 \mathrm{~A}$ view of the theories which have been proposed to explain the origin of meteoric stones. Conn Ac, Mem 1:163$174(1810)$

Day, William Catheart.

88 Potassium salts. U S G s, Min Res, 1887 ; 628-650 (1888)

92 Stone. U S G S, Min Res 1889-90: $373-440$; 1891: 456-473; 1892: 704-711; $1893: 542-602$; An Rp 16 pt $3: 436-510$; 17 pt $3: 759-811 ; 18$ pt $5: 949-1068 ; 19$ pt 6 con : $205-309 ; 20$ pt 6 con : $269-464$ (1892-9)

95 Stone. U S G S, An Rp 16 pt 4:436$510(1895)$

96 The building stones of the United States. Franklin Inst, J 141:98-114 (1896)

Dean, Bashford.

93 Note on the mode of origin of the paired fins. - N Y Ac Sc, Tr 12:121-125 (1893)

93a On Trachosteus and Mylostoma; notes on their structural characters (abst.) N Y Ac Sc, Tr 12:70-71 (1893)

94 Contributions to the morphology of Cladoselache (Cladodus). J Morph 9:87114, il (1894)

94a A new cladodont from the Ohio Waverly, Cladoselache newberryi n. sp. N Y Ac Sc, Tr 13:115-119, il (1894)

95 Fishes, living and fossil. xiv, 300 pp, N Y 1895 Rv by Theodore Gill, Science n s $3: 909-917$ (1896)

96 Is Palaeospondylus a cyclostome? N Y Ac Sc, Tr 15:100-104 (1896)

96a On the vertebral column, fins, and ventral armoring of Dinichthys. N Y Ac Sc, Tr 15: 157-163, il (1896)

$96 \mathrm{~b}$ The fin-fold origin of the paired limbs in the light of the Ptychopterygia of Paleozoic sharks. Anat Anz 11: 673-679, 11 (1896)

96e Sharks as ancestral fishes. Nat Sc $8: 245-253$, il (1896)

97 Note on the ventral armoring of Dinichthys. N Y Ac Sc, Tr 16:57-61, 11 (1897)

$97 a$ On a new species of Edestus, $E$. lecontei, from Nevada. N Y Ac Sc, Tr 16: 61-69 (1897)
Dean, Bashford-Continued.

99 The Devonian lamprey Palaeospondy. lus gunni Traquair, with notes on the sys. tematic arrangement of the fishlike ver. tebrates. N Y Ac Sc, Mem 2:1-30, il (1899)

99a Devontan fishes for the American Museum. Science n s 10:978 (1899)

01 On two new arthrodires from the Cleveland shale of Ohio. N Y Ac Sc, Mem $2: 86-100$, il (1901)

01a On the characters of Mylostoma Newberry. N Y Ac Sc, Mem 2:101-109, 11 (1901)

01b Further notes on the relationships of the Arthrognathi. N Y Ac Sc, Mem 2: 110-123, il (1901)

02 The preservation of muscle fibres in sharks of the Cleveland shale. Am G 30 : 273-278, 11 (1902)

O2a Historical evidence as to the origin of the paired limbs of vertebrates. Am Nat $36: 767-776$, il (1902)

02b Biometric evidence in the problem of the paired limbs of the vertebrates. Am Nat $36: 837-846$ (1902)

04 In the matter of the Permian fish Menarpis. Am G 34:49-53, fl (1904)

06 Chimaeroid fishes and their development. $194 \mathrm{pp,} \mathrm{il,} \mathrm{Carnegie} \mathrm{Inst} \mathrm{Wasb,}$ Pub no 32, 1906

07 Dr. Eastman's recent papers on the kinship of the arthrodires. Science n s $26: 46-50$ (1907)

os Studies in fossil fishes during the year 1907. Science n \& $27: 201-205$ (1908)

09 Studies on fossil fishes (sharks, chimaroids, and arthrodires). Am Mus N H, Mem $9: 209-287$, il (1909)

09a The glant of ancient sharks. Am Mus J $9: 233-234$, il (1909)

11 The new "fossil aquarium" [restora. tions of Devonian fishes in their supposed natural habitat]. Am Mus J 11:161 (1911)

11 a Collecting fossil fishes in Ohio. Am Mus J 11:302-303 (1911)

$11 b$ Note on the Ohio placoderm Dixich. thys terrelli. Science n s 34:801 (1911)

12 Ten years' progress in vertebrate paleontology; Paleozolc fishes. G Soc Am B $23: 224-228$ (1912)

16 (and Eastman, C. R.) A bibliog. raphy of fishes. Vol 1, Authors' titles A-K : 718 pp. Vol 2, Authors' titles L-Z: 702 pp, Am Mus N H, N Y 1916, 1917

18 Charles Rochester Eastman (18681918). Am Mus J 18:506-507 (1918)

See also Hay (O P), 02 ; Newberry, 97

Dean, Reginald $\mathrm{S}$.

16 (with Cox, G. H., and Gottschalk, V. H.) Studies on the origin of Missour cherts and zinc ores. Mo Univ, Sch Mines, B tech s 3 no $2: 34$ pp (1916)

18 The formation of Missouri cherts. Am J Sc (4) 45:411-418 (1918) 
Deane, James (1801-1858).

43 Ornithichnites of the Connecticut River sandstones. Am J Sc 45:177-183 (1843)

44 On the fossil footmarks of Turner's Falls, Mass. Am J Sc 46:73-77, il (1844)

44a (and Hitcheock, Edward). On the discovery of fossil footmarks. Am J Sc 47: 381-401 (1844)

45 Illustrations of fossil footmarks, Boston J N H $5: 277-284$, il (1845)

45a Description of fossil footprints in the New Red sandstone of the Connecticut Valley. Am J Se 48: 158-167, il (1845)

45b Notice of a new species of batrachian footmarks. Am J Se 49:79-81 (1845) Abst, As Am G, Pr 6:25 (1845) 45e Fossil footmarks and raindrops. Am J Sc 49:213-215, il (1845)

47 Notice of new fossil footprints. Am J Sc (2) 3:74-79, il (1847)

47a Fossil footprints. Am J Sc (2) 4: 448-449 (1847)

48 Fossil footprints of a new species of quadruped. Am J Sc (2) $5: 40-41$, il (1848)

49 Illustrations of fossil footprints of the valley of the Connecticut. Am Ac Arts, Yem n s $4: 209-220$, il (1849)

50 Fossil footprints of Connecticut River. de N Se Phila, J (2) 2: 71-74, il (1850) 56 On the sandstone fossils of Connect1cat River. Ac N Sc Phila, J (2) 3:173178 , Il (1856)

61 Ichnographs from the sandstone of Connecticut River. 61 pp, 1l, Boston 1861 DeBar, J. H. Diss.

70 The West Virginia handbook... 193 pp, map, Parkersburg 1870

De Beque, G. R.

14 De Beque petroleum fleld in Colorado. Fing M J 98:652-653 (1914)

16 The bituminous shale industry in northwestern Colorado, Eng M J 102: 1011-1012 (1916)

De Bow, James Dunwoody Brownson (1820-1867).

51 The coal mines of Alabama compared with those of the other States. De Bow's Review 10:73-79 (1851)

52 Louisiana; minerals. In his the industrial resources of the Southern and Western States 1: 434-436 (1852)

Deby, Julien.

55 Canton copper mine, Cherokee Co., Ga. M Mag 5:395-397 (1855)

93 The fossil Aulisci of California. Torrey Bot Club, B 20:118-119 (1893)

De Cew, John.

61 Notes on the geology of the townships of Windham and Middleton, County of Norfolk, Canada West. Can J n s 6: 295-297 (1861)

62 Age of the Oriskany sandstone. Can J 4 \& $7: 190-193$ (1862)
Deck, Isalah.

55 Notes on the geological features of the Panama Rallroad. M Mag 4:240-245 (1855)

Decker, Charles Elijah.

12 A tufa deposit near Danville, Ill. Ill Ac Sc, Tr 5 : 109-111 (1912)

15 Preliminary paper on recent crustal movements in the Lake Erie region (abst). G Soc Am, B 26: 66-67 (1915)

15a Hemicones at the mouths of hanging valleys (abst). G Soc Am, B 26:76-77 (1915)

16 Recent crustal movements in the eastern part of the Great Lakes region. Ill Ac Sc, Tr 8: 97-100 [1916]

See also Kay (G F), 16d; Paige, 16a

Deckert, Emil.

96 Naturbrücken [natural bridges, Virginia and Arizona]. Himmel und Erde 8 : 160-170 (1896)

02 Martinique und sein Vulkanismus. Petermanns Mitt 48:133-136, map (1902)

02a Die Erdbebenherde und Schüttergebiete von Nord-Amerika in ihren Beziehungen zu den morphologischen Verhältnissen. Ges Erdk Berlin, Zs 1902:367-389, maps (1902)

03 Die Vulkanausbrüche von Martinique und St. Vincent. Frankfurter Ver Geog, Jber 66-67: 153-156 (1903)

de Cornely, V. R.

99 The gold resources of Mexico. Eng M J $67: 320-321,348$ (1899)

De Cou, Ralph E.

01 (with Downer, R. H.) A description of the working mines of Ouray Co., Colo. Colo Sch Mines, B 1 : 242-259 (1901) Deeks, William.

90 The Lower Helderberg formation of St. Helen's Island [Que.]. Can Rec Sc 4: 105-109, (1890)

Deeley, R. M.

13 North American and European drift deposits. G Mag (5) $10: 14-17$ (1913)

Deere, E. $O$.

os A fossil tusk found in the Equus beds in McPherson Co. [Kans]. Kans Ac Sc, Tr 21: 115-117, 11 (1908)

De Golyer, Everette Lee.

15 The effect of igneous intrusione on the accumulation of oil in the TampicoTuxpam region, Mex. Ec G 10:651-662 (1915)

15n The Furbero ofl field, Mexico. Am I M Eng, B 105:1899-1911 (1915); Tr 52 : 268-280 (1916)

15b [On Cretaceous and Tertiary formations of eastern Mexico]. Am I M Eng, B $108: 2434-2435$ (1905) ; Tr 52:265-267 (1916)

18 The geology of Cuban petroleum deposits. Am As Petroleum G, B 2:133167 (1918)

18a Possible oil and gas fields in the Cretaceous beds of Alabama (discussion). Am I M Eng, B 136:819-822 (1918) 
De Golyer, Everette Lee-Continued.

18b The theory of volcanic origin of salt domes. Am I M Eng, B 137 : 9871000 (1918) Discussion by J. A. Udden, B $139: 1147$ (1918)

18e Oil in southern Tamaulipas, Mexico (discussion). Am I M Eng, B 142:15601564 (1918)

18d The significance of certain Mexican oil field temperatures. Ec G $13: 275-$ 301 (1918)

1se Origin of the cap rock of the Gulf coast salt domes (discussion). Ec G 13: 616-620 (1918)

See also Hager, 18; Ord6ñez, 18

Dêgoutin, N.

12 Les grottes à cristaux de gypse de Naica (Mexique). Soc Cient Ant $\mathrm{Alz}$, Mem $32 \mathrm{rv}: 32-34,35-38$ (1912)

De Groot, Henry.

90 The San Francisco ocean placerthe auriferous beach sands. Cal St M Bur, An Rp 10:545-547 (1890)

See also Irelan, $90 a$

De Kalb, Courtenay.

94 The new gold fields of the Mosquito coast of Nicaragua. Eng M J 57 : 294-295 (1894)

96 Onyx marbles. Am I M Eng, Tr $25: 557-569$ (1896)

9s The onyx marbles. Stone $17: 397$ 405 (1898)

06 Secondary enrichment upward [in copper deposits north of Lake Huron]. M Sc Press 93:176 (1906)

O6a Do the geological relations of ore deposits justify the retention of the law of the apex? Ec G 1:801-809 (1906)

07 Geology of the Exposed Treasure lode, Mojave, California. Am I M Eng, B $13: 15-24$ (1907); Tr $38: 310-319$ (1908)

os Diffusion as a factor in ore deposition. M Se Press 96:226-227 (1908)

09 Copper mining at Ely, Nev. M Se Press 98:58-60 (1909)

09a The Utah copper mine [Bingham Canyon, Utah]. M Sc Press 98:516-521 (1909)

09b Boston Consolidated, Bingham, Utah [copper ores]. M Sc Press 98:553556 (1909)

10 Geologic bases of mining law. M Se Press $100: 642-647$ (1910)

10a Los Pilares mine, Nacozari [State of Sonora], Mexico. M Sc Press 100: $887-890 \quad(1910)$

16 Origin of nitrate. M Sc Press 112: 663-664 (1916)

16a Surficial indications of copper. M Sc Press 113: 115-116 (1916)

18 Ajo copper mines [Pima Co., Ariz.]. M Sc Press 116 : 115-119 (1918)

18a Sacramento Hill disseminated copper deposit [Bisbee, Ariz.]. M Sc Press 116: 549-554, 578-583 (1918)
Dekay, James Ellsworth (1792-1851).

23 Note on the organic remains termed Bilobites from the Cutskill Mountains, Lye N H N Y, An 1: 45-49 (1823)

24 Account of the discovery of a skele. ton of the Mastodon giganteum. Lyc N H N Y, An 1:143-147 (1824)

24a Observations on the structure of trilobites and description of an apparently new genus [1sotelus]. Lye $\mathrm{N} \mathrm{H} \mathrm{N} \mathrm{Y}$, An $1: 174-189$, il (1824)

25 Observations on a fossil crustaceous animal of the order Branchiopoda [Euryp. terus]. Lye N H N Y, An $1: 375-377$, il (1825)

27 Report on several multilocular shells from the State of Delaware; with observations of a second specimen of the new fos. sil genus Eurypterus. Lyc N H N Y, An $2: 273-279$, il (1827)

27 a Notes on a fossil skull ... of the genus Bos from the banks of the Missis. sippi ... Lyc N H N Y, An 2:280-291 (1827)

28 On the supposed transportation of rocks. Am J Sc 13: 348-350 (1828)

29 ... phenomena exhibited upon the surface of the primitive rocks in the vicinity of this city [New York] [glacis] striae] (abst). Am J Se 16:357 (1829)

30 On the remains of extinct reptiles of the genera Mosasaurus and Geosourus found in the secondary formation of New Jersey, and on the occurrence of ... coprolite ... in the same locality. Lyc N H N , An 3:134-141, il (1830)

$30 a$ On the discovery of coprolltes in North America [Cretaceous of New Jersey]. Ph Mag n s $7: 321-322$, il (1830)

36 Observations on a fossil jaw of a species of gavial from west [New] Jersey. Lyc N H N Y, An 3:156-165, il (1836)

42 [List of the fossil fishes of New York.] Zool N Y pt 4:385-387 (1842)

De Ia Beche, H. T.

27 Remarks on the geology of Jamaica. G Soc London, $\operatorname{Tr}$ (2) $2: 143-194$ (1827) Zs Miner (Leonhard) 1829, 1:81-108

\section{De la Condamine.}

os Les gisements pétrolifères du Wyoming. Soc Ind Min, C R men : 7-9 (1908)

\section{Delafield, James.}

22 ... sulphate of strontian of Lake Erie and Detroit River. Am J Sc 4:279-280 (1922) Transl in Struve, H. von, Beitrïge zur Mineralogie und Geologie des nörd. lichen Amerikas: 111-114, Hamburg 1822

22a Geological remarks on the Lake regions. Am J Sc $4: 282$ (1822) Transl. in Struve, $\mathrm{H}$ von, Beiträge zur Mineralogie und Geologie des nördlichen Amerikas: 117-118, Hamburg 1822

Delafield, John.

51 Geology of the County of Senecs. N Y St Agr Soc, Tr 10:434-480 (1851) 
Delafield, Joseph.

24 Notice of new localities of simple minerals along the north coast of Lake Superior... Lye N H N Y, An 1: 79-81 (1824)

Delafield, Richard.

29 Report of the survey of the passas of the Mississippi. U S, 21st Cong 1st sess, H Ex Doc $7: 7-11$ (1829)

Delafontaine, Marc.

76 Sur les limites des époques crétacée et tertiaire dans les Montagnes Rocheuses. Arch Sc Phys Nat $57: 206-214$ (1876)

77 Sur la faune crétacé des Montagnes Rocheuses. Arch Sc Phys Nat 59 : 209-232 (1877)

De Laski, John.

61 [Glaciation on Vinalhaven Island, Me.]. Me Bd Agr, 6th An Rp : 263-265 (1861)

62 Ancient glacial aetion in the southern part of Maine. Me Bd Agr, 7th $\mathrm{Au}$ Rp $: 382-388$ (1862) Abst, Am J Sc (2) 36 : $274-276$ (1863)

64 Glacial action about Penobscot Bay. An J Sc (2) $37: 335-344$ (1864)

66 Post-Tertiary of Maine. Am I Sc (2) $42: 426$ (1866)

69 On the motion of glaciers. Portland $\mathrm{Soc} N \mathrm{H}, \operatorname{Pr} 1$ : 168-178 (1869)

72 Glacial action on Mount Katahdin. Am J Sc (3) $3: 27-31$ (1872)

Delestry, Edmond Louis.

08 Formations [zinc bearing] west of Platte River, Wis. M World 28:758 (1908)

Dellenbaugh, Frederick S.

12 Cross cutting and retrograding of stream beds. Science $n$ \& $35: 656-658$ (1912)

18 Memorial to John Wesley Powell. Am Anthropologist 20:432-436 (1918)

Del Mar, Algernon.

08 Rawhide, Nev. [gold ores]. Eng M J $85: 853-854$ (1908)

De Loriol, P.

82 Description of a new species of Reurgueticrinus. Cin Soc N H, J 5: 118, il (1882)

Del Rio, André.

46 Découverte d'un manganate nouveau de cuivre et de zinc, qui a été trouvé par II. Herrera dans la halde de la mine de plomb d'Albarradon, près de Mazapil [Mexique]. Soc G France, B (2) $3: 24-25$ (1846)

49 Catalogue of the geological collection formed in the Isthmus of Tehuantepec... ర S, 30th Cong 2d sess, H Rp 145:160163 (1849)

De Lury, Justin Sarsfield.

06 Cobaltite occurring in northern Ontario, Can. Am J Sc (4) 21:275-276 (1906)

$28737^{\circ}-23-20$
De Lury, Justin Sarsfield.-Continued.

13 The outlying colbalt-silver areas [Ontario]; the area west of Bay Lake on the Montreal River. Ont Bur Mines, Rp 19 pt 2:152-154 (1913)

16 The Manigotagan gold district, Manit. Can M J 37:362-364 (1916)

$16 a$ The mineral belt north of The Pas, Manit. Can M J $37: 412-414$, map (1916)

16b (with wallace, R. C.) The mineral belt north of The Pas, northwestern Manit. and eastern Sask. Can M Inst, B 54:884-890 (1916)

17 Molybdenite at Falcon Lake, Manit Can M J 38:460-462, map (1917)

17a (with Wallace, R. C.) The mineral belt north of The Pas [Manit.]. In Northern Manitoba (issued by the Province of Manitoba) : 19-22 (1917)

18 Tungsten ore deposits near Falcon Lake, Manit. Can M J 39:186-188 (1918)

Demaret, Léon.

oo Les gisements des minerais de cuivre. Rv Univ Mines 50:234-275 (1900)

02 Les principaux gîsements de minerais de fer du monde ... An Trav Pub Belgique 1902: 243-301 Extrait, 61 pp, Bruxelles 1903

04 Les principaux gisements des minerais de mercure du monde. An M Belgique 9 : $80 \mathrm{pp}$ (1904)

04a Les principaux gisements de minerals de zinc des t́tats-Unis d'Amérique. Rv Univ Mines, (4) $6: 221-257$, maps (1904)

05 Les principaux gisements des minerais de manganèse du monde. An M Belgique 10 : 809-901 (1905) Extrait : 95 pp, Bruxelles 1905

Deming, J. L.

s8 (with C. L. Herrick and E. S. clarke) Some American norites and gabbros. Am G 1: 339-346 (1888)

Demming, Henry C.

13 The geology, petrography, and mineralogy of York County-past, present, and future. Eng Soc York, $\mathrm{Pa}, \mathrm{Pr} 2: 65-70$ (1913)

Denis, Théophile Constant.

OO [Gas fields in Ontario.] Can G S, An Rp 11: s 117-122, map (1900)

OOa [Oil fields of Ontario.] Can G S, An Rp 11: s 134-138, map (1900)

02 Occurrences of platinum in Canada. Can G S, An Rp 14: s 99-110 (1902)

0:3 Infusorial earth. Can G S, An Rp 15 ; s 19-28 (1903)

o:a The coal fields of Canada. Can G S. An Rp 15: s 53-93 (1903)

033. Manganese deposits of Canada. Can G S, An Rp 15: S 150-169 (1903)

03e The salt deposits of Canada. Can

G S, An Rp 15: s 214-239 (1903)

o5 (with Ingal1, E. D.) Geology of the country around Bruce mines. Algoma, Ont. Can G S, Sum Rp 1904 (An Rp 16) : A 179-190, map (1905) 
Denis, Théophlle Constant-Continued.

06 Western ofl, gas, and coal fields [Canada]. Can G S, Sum Rp 1906:164-169 (1906)

10 Report on the mining operations in the Province of Quebec for the year 1909. Que, Dp Col : 32 pp (1910)

11 Report on mining operations in the Province of Quebec during 1910. Que, Dp Col, Mines $\mathrm{Br}: 104 \mathrm{pp}$, (1911) ... 1911: $212 \mathrm{pp} \mathrm{(1912)} \mathrm{\ldots .1912:241} \mathrm{pp} \mathrm{(1913)} \mathrm{\ldots .}$ 1913: 166 pp (1914) ... 1914:151 pp (1915) ‥ 1915:146 pp (1916) _. 1916: 170 pp (1917) ... 1917:147 pp (1918)

12 The coal fields of Canada. Can Mines $\mathrm{Br}$, An Investigation of the Coals of Canada, vol 1 pt 2:21-126 (1912)

13 Extracts from reports on the District of Ungava recently added to the Province of Quebec under the name of the Territory of New Quebec: Que, Dp Col, Mines Br: $160 \mathrm{pp}$ (French ed $231 \mathrm{pp}$ ), map (1913) $2 d$ ed, 208 pp, map (1915)

Denison, F. Napier.

11 Earthquakes, strains, and stresses in relation to mine explosions. Can M I, B 14: 85-93 (1911); J 14: 84-92 (1912)

13 The horizontal pendulum in relation to certain phenomena. Seism. Soc Am, B 3: 103-112 (1913)

Dennis, Clifford G.

о7 Rare mercury ores [at Terlingua, Brewster Co, Tex]. M Sc Press 95:92 (1907)

Dennis, D. W.

99 An old shore line [Ordovician, near Richmond, Ind.]. Ind Ac Sc, Pr 1898: 288 (1899)

99a Two cases of variation of species with horizon. Ind Ac Sc, Pr 1898:288289 (1899)

Dennis, W. B.

02 A borax mine in southern Oregon.

Eng M J 73:581 (1902)

03 The quicksilver deposits of Oregon.

Eng M J 76:539-541 (1908)

Denniston, Goldsmith.

62 Survey of the County of Steuben. N Y St Agr Soc, Tr 21:548-570, map (1862)

63 Geology of the County of Orange. N Y St Agr Soc, Tr 22:153-166 (1863)

Denton, William (1815-1888).

66 On a mineral resembling albertite, from Colorado. Boston Soc N H, Pr 10: 305-306 (1866)

67 Geology and geological history. In Hollister, Ovando J., The mines of Colorado: 375-396, Springfield, Mass., 1867

68 Our planet, its past and future; or, Lectures on geology. 344 pp, Boston 1868

70 The irreconcilable records, or genesis and geology. $80 \mathrm{pp}$, Boston 1870

76 [An asphalt bed near Los Angeles, Cal. (Rancho La Brea)]. Boston Soc N H, Pr 18: 185-186 (1876)
Depéret, Charles.

08 The evolution of the Tertiary mam. mals and the importance of their mign tions. Am Nat 42: 109-114, 166-170, 303307 (1908)

13 The Oligocene of the Roanne Basin and its vertebrate fauna; with a post. scriptum by C. R. Eastman [correlation of American Tertiary horizons with those of France]. Am J Sc (4) $35: 350-352$ (1913)

Dequille, Dan.

95 The gold belts of Nevada. Eng y J $59: 532-533$ (1895)

95n Millions in gold beneath the lava flows. Eng M J 60:537-538 (1895)

96 The geological age of gold. Eng $\mathbb{M}$ J $62: 54$ (1896)

De Rance, Charles E.

75 Arctic geology. Nature 11: 447-449, $467-469,492-494,508-509$, map (1875)

76 Known facts and unknown problems of Arctic geology. G As London, $\operatorname{Pr} 4$ : $460-480$ (1876)

78 The geology of the Arctic regions: Manchester G Soc, Tr 20:441-447 (1878)

78a (with Feilden, H. W.) Geologr of the coasts of the Arctic lands visited by the late British expedition... G $\mathrm{Soc}$ London, Q J 34:556-567, map (1878) Notice, Amr J Sc (3) 16:139-140 (1878)

Derby, Alice Greenwood.

06 A subject index of the publications of the Geological Survey of Ohio, from its inception to and including Bulletin number eight, series four. Ohio G S (4) B $6: 15-233$ (1906)

Derby, Orville Adelbert (1851-1915).

87 The genesis of the diamond. Science $9: 57-58$ (1887)

89 On the occurrence of monazite as an accessory element in rocks. Am J Sc (3) 37 : 109-113 (1889)

91 On the occurrence of xenotime as an accessory element in rocks. Am J Sc (3) 41: 308-311 (1891)

$91 a$ On the separation and study of the heavy accessories of rocks. Rochester Ac Sc, Pr 1:198-206 (1891)

93 A study in consanguinity of eruptive rocks. J G 1:597-605 (1893)

95 Constituents of the Canyon Diablo meteorite. Am J Sc (3) 49:101-110 (1895)

98 On the origin of certain siliceous rocks; notes on Arkansas novaculite. J G 6: 366-368 (1898)

00 Notes on monazite. Am J Sc (4) 10:217-221 (1900) Sc Am Sup 50:20904 (1900)

11 Speculations regarding the genests of the diamond. $J$ G $19: 627-631$ (1911) ; $20: 451-456$ (1912) 
Derleth, Charles, fr.

07 The destructive extent of the California earthquake of $1906 \ldots$ In Jordan, D. S., editor, The California earthquake of 1906: 79-212, San Francisco 1907

Dern, George $\mathrm{H}$.

04 The geology of Mercur [Tooele Co., Dtah]. Mines and Minerals, 24:543-545 (1904)

Deroux, H.

61 Die Kupfergruben des Oberen See's (Lake Superior). Berg- u hütt Ztg 20 : 305-307, 329-331 (1861) From J Mines 7:- [not seen]

Derr, Homer Munro.

$03 \mathrm{~A}$ method of petrographic analysis based upon chromatic interference with thin sections of doubly-refracting crystals in parallel polarized light. Thesis, Univ. of Pa. 22 pp [Phila], The Randal Morgan Laboratory of Physics, 1903.

De Ryee, William.

88 Economic geology of Webb Co. [Tex.]. G Sc B 1 no 5 (1888)

De Schmid, Hugh Sweyn. Name changed to Spence, Hugh Swaine, in 1917.

11 On the mica deposits of Ontario and Quebec. Can Mines Br, Sum Rp 1910: 102-109 (1911)

12 Mica; its occurrence, exploitation, and uses (second edition). Can Mines $\mathrm{Br}$ : $411 \mathrm{pp}$, maps (1912)

12a on the phosphate and feldspar deposits of Ontario and Quebec. Can Mines Br, Sum Rp 1911: 117-122 (1912)

12b Mica mining in the Province of Quebec. Can M J 33: 423-426 (1912)

13 Continued examination of the phosphate and feldspar deposits of Ontario and Quebec. Can Mines Br, Sum Rp 1912: 86-88 (1913)

13a Mica mining in Canada. Can $M$ Inst, Q B 21:19-41 (1913); Tr 16:371393 (1913)

14 White mica occuriences in the Tête Jaune Cache and Big Bend districts of British Columbia. Can Mines Br, Sum Rp 1913: 42-49, map (1914)

16 Feldspar in Canada. Can Mines Br : $125 \mathrm{pp}$, maps (1916)

$16 \mathrm{a}$ Investigation of a reported discovery of phosphate in Alberta. Can, Wines $\mathrm{Br}, \mathrm{B} 12: 38 \mathrm{pp}$, map (1916)

$17 \mathrm{~A}$ reconnaissance for phosphate in the Rocky Mountains; and for graphite near Cranbrook, B. C. Can Mines Br, Sum ip 1916: 22-35 (1917)

Des Cloizeanx, Alfred.

75 Note sur la forme cristalline et sur les proprietés optiques de la durangite. An Chimle Phys (5) 4:401-406 (1875) La Naturaleza $4: 44-47$ (1877)

Dexhayes, Gerard Paul (1795-1875).

53 Note sur quelques fossiles rapportés par M. Morelet du Yucatan, Amérique centrale. Soc G France, B (2) 10:506-511 (1853)
Desor, Edouard (1811-1882).

47 [On striæ and other drift phenomena.] Am J Agr 6:214-218 (1847)

$47 \mathbf{a}$ On the phenomena of drift and glacial action in New England. Am J Agr 6: 213 [261]-214 [262] (1847)

47b [Fossils in drift at Brooklyn and at Westport, N. Y.] Boston Soc N H, Pr 2: 247 (1847)

47c [On parallel trains of boulders in Berkshire Co., Mass.] Boston Soc N H Pr 2:260-261 (1847)

48 [Sur le terrain erratique de l'Amérique du Nord.] Soc G France, B (2) 5:8998 (1848)

48a [Peculiarities in scratchings on puddingstone of Brookline, Mass.] Boston Soc N H, Pr 3: 28 (1848)

48b Drift fossils from Nantucket, Mass.] Boston Soc N H, Pr 3: 79-80 (1848)

49 (and Cabot, E. C.) On the Tertiary and more recent deposits in the Island of Nantucket [Mass.]. G Soc London, Q J $5: 340-344$ (1849)

$49 \mathrm{a}$ [ $O \mathrm{n}$ the ribbon structure of the fce in glaciers.] Boston Soc $\mathrm{N} \mathrm{H}, \operatorname{Pr} 3: 125$ 127 (1849)

49b Deposit of drift shells in the clifts of Sancati Island, of Nantucket. Am As, Pr 1: 100-101 (1849)

50 Des alluvions marines et lacustres, et du terrain erratique de l'Amérique du Nord. Soc G France, B (2) 7:623-630 (1850)

$50 \mathrm{a}$ [On the probable origin of so-called fossil rain drops.] Boston Soc $\mathrm{N} \mathrm{H}, \operatorname{Pr} 3$ : 200-202 (1850) ; 4:131 (1852)

50b [Potsdam sandstone from the St. Croix River, Wis.] Boston Soc $\mathrm{N} \mathrm{H}, \mathrm{Pr}$ $3: 202$ (1850)

50e [On mastodon remains at Galena, Mo.] Boston Soc N H, Pr 3: 207 (1850)

5od [On the sand dunes of Lake Superior.] Boston Soc N H, Pr 3: 207 (1850); 4: 41-42 (1851)

50e [On clay and drift deposits in the vicinity of Lake Superior.] Boston Soc $\mathrm{N}$ H, Pr $3: 235-236(1850)$

50p [On the relation of the allnvium to the drift of the Mississippi.] Boston Soc $\mathrm{N}$ H, Pr 3: 242-243 (1850)

$50 \mathrm{~g}$ [On a shark's tooth from Keokuk, Iowa.] Boston Soc N H, Pr 3:257-258 (1850)

50h [Notes on terraces of Lake Erie (with letters from Charles Whittlesey and J. A. Lapham on fossils in drift deposits).] Boston Soc N H, Pr 3: 291-292 (1850)

50i [On deposits of marine shells in Maine, on Lake Champlain, and the St. Lawrence and their probable origin (with discussion by H. D. Rogers).] Boston Soc $\mathrm{N} \mathrm{H}, \operatorname{Pr} 3: 357-358$ (1850)

50j [On the "ridge road" from Rochester to Lewiston, N. Y., and other terraces (with discussion by Charles Stodder).] Boston Soc N H, Pr 3: 358-359 (1850) 


\section{Desor, Fdouard-Continued.}

5ok [On swamps bordering the western rivers.] Boston Soc N H, Pr 3: 376 (1850)

501 on the parallelism of mountain chains in America. Boston Soc N H, Pr 3 : 380-382 (1850) Am J Sc (2) 12:118-120 (1851)

51 Sur l'unitê du phénomène erratique. Soc G France, B (2) 8:64-72 (1851)

$51 a$ Note sur lexistence de coquilles marines des mers actuelles dans le bassin du lac Ontario (Canada) jusqu'a l'altitude de 310 pieds. Soc G France, B (2) 8:420423 (1851)

$51 b$ [Origin of the coarse drift near Boston.] Boston Soc N H, Pr 4: 10 (1851)

51e [On the origin of some of the elements of the so-called Tertiary or drift of Lake Superior.] Boston Soc N H, Pr 4: 28-29 (1851)

$51 d$ [On the parallelism of the Quaternary deposits of Europe and America.] Boston Soc N H, Pr 4:49-51 (1851)

51e On the superficial deposits of this district. In Foster, J. W., and Whitney, J. D., Report on the geology of the Lake Superior land district, pt 2 (U S, 32 Cong spec sess, S Ex Doc 4):232-270 (1851) In part, $\mathrm{Am}$. J Sc (2) 13:93-109 (1852)

52 Post-Pliocene of the Southern States and its relation to the Laurentian of the North and the deposits of the Valley of the Mississippi. Am J Sc (2) 14:49-59 (1852)

52a Ueber den Parallelismus der Diluvialgebilde und erratischen Phänomene in der Schweiz, dem Norden von Europa und Nordamerika. Deut G Ges, Zs 4:669-679 (1852)

52b Sur les drifts de l'Amérique du Nord. Soc G France, B (2) 9:94-96 (1852)

52e Sur la carte géologique du lac Supérieur de MM. Foster et Whitney. Soc G France, B (2) $9: 280-281$ (1852)

52d Note sur le terrain quaternaire de 1'Amérique du Nord. Soc G France, B (2) $9: 281-285$ (1852) Annual Se Discovery (Wells) $1853: 269-272$. With title, Drift of the northern and western States, and note by Charles Whittlesey, An Se, Cleveland, 1: 47-48 (1852)

52e Sur le terrain de transition des Etats-Unis et leurs terrains diluviens. Soc G France, B (2) $9: 312-320$ (1852)

521 [On markings on a slab from the Clinton at Green Bay, Wis.] Boston Soc $\mathrm{N} H, \operatorname{Pr} 4: 166$ (1852)

52d [On the drift of eastern Massachusetts and elsewhere (with discussion by W. C. Redfield, H. D. Rogers, and C. T. Jackson).] Boston Soc N H, $\mathrm{Pr} 4: 180$ 181 (1852)

52h [On the origin of contorted strata of sand in diluvial deposits.] Am Ac Arts, Pr $2: 282-283$ (1852)
Desor, fodouard-Continued.

52i Drift of the northern and westen States (with note by Charles Whittlesey). An Sc, Cleveland, 1:47-48 (1852)

52j (with Rogers, H. D.) [0n th equivalence in geological age of the col formation of the United States and the anthraciferous strata of Mayenne and Sarthe, France.] Boston Soc N H, Pr 4: 189-191 (1852)

53 Sur le phénomène erratique du nord de l'Europe et de l'Amérique. Arch st Phys Nat 21: 180-183 (1852)

$53 a$ [Niagara Falls.] Deut G Ges, $z$ 5: 643-644 (1853)

54 Les cascades du Niagara et leur marche rêtrograde. Soc Sc Nat Neuchatel. B . 3: 157-171, map (1854) Transl, Pottville Sci As, B : 5-10, map (1855)

See also Perley, 50; Rogers (H D), 512; Warren, 49; Wyman, 50c

Deussen, Alexander.

11 Notes on some clays from Texas U S G S, B 470:302-351, maps [1911]

13 The survey of the artesian water te sources of southwest Texas. Irrigationist, San Antonio, Tex, 1 no $1: 9-11$ (1913)

14 Geology and underground waters of the southeastern part of the Texas Coastal Plain, U S G S, W-S P $335: 365$ pp, maps (1914)

16 (and Dole, R. B.) Ground water is Lasalle and McMullen cos., Tex. U S G \& W-S P $375:$ 141-177, maps (1916) Abst, Wash Ac Sc, J 6:224-225 (1916)

17 The Humble. Texas, ofl fleld (with discussion). Sothwestern As Petroleum G, B 1:60-84 (1917)

1s Review of developments in the Gulf coast country in 1917. Am As Petroleum G. B $2: 16-37$ (1918)

Devereux, Walter $B$.

81 The Deer Creek coal fields, Arizona. Eng M J 32:404-405 (1881)

82 The occurrence of gold in the Pots. dam formation, Black Hills, Dakota. Am I M Eng, $\operatorname{Tr} 10: 465-475$ (1882) Eng M J $34: 334-335,344-345$ (1882)

84 Notes on fron ore deposits in Pitkin Co., Colo. Am I M Eng, Tr $12: 638-641$ (1884)

Devine, $T$.

63 Description of a new trilobite from the Quebec group inirnus? logani]. Cal Nat $8: 95-98$, il (1863)

63 a Description of a new trilobite from the Quebec group [Menocenhalus salteri] Can Nat 8: 210-211, il (1863)

\section{Dewar, R.}

91 The occurrence of gold and silver in galena and iron pyrites. Can Inst, Tr 2 121-127 (1891)

Dewees, John H.

78 Report of progress in the Juniata dis. trict on the fossil iron ore beds of middle Pennsylvania. Pa G S, 2d, F : 1-139, maps (1878) 
Dewees. John H.-Continued.

85 Geological map of Perry Co. Pa G S, 2d. F2: in pocket (1885)

Dewey, Chester (1784-1867).

19 ... mineralogy and geology of the vicinity of Williams College, Williamstown, Mass. Am J Sc 1: $337-346$ (1819)

20 (and others) Localities of minerals. Am J Sc 2: 236-241 (1820)

20a Geological section from Taconick Range in Williamstown to the city of Troy on the Hudson. Am $\mathrm{J}$ Sc 2:246-248 (1820)

22 [Notes on Vermont minerals]. Am J Sc 4:274-277 (1822) Transl in Struve, H. von, Beiträge zur Mineralogie und Geologie des nördlichen Amerikas: 101-108, Hamburg 1822

22a Notice of crystallized steatite and ores of iron and manganese [Bennington, vt]. Am J Sc $5: 249-251$ (1822)

24... geology and mineralogy of the western part of Massachusetts and a small part of the adjoining states. Am J Sc 8: $1-60,240-244$, map (1824)

25 Notice of a singular conformation of limestone. Am J Sc 9:19-20 (1825)

25a Notice of the flexible or elastic marble of Berkshire Co. [Mass.]. Am J Se $9: 241-242$ (1825)

27 Porcelain clay? [Pownal, vt.]. Am J Sc 12: 298-299 (1827)

29 A history of the county of Berkshire, Mass. ; geology : 190-197, map. 197 pp, Pittsfleld, Mass., 1829

37 Remarks on the rocks of New York. Am J Se 33 : 121-123 (1837)

37 a Bones of the mammoth [New York]. Am J Sc 33: 201 (1837)

39 On the polished limestone of Rochester [N. Y.]. Am J Sc $37: 240-242$ (1839)

43 On the polished rocks of Rochester, N. Y. As Am G, Rp 264-266 (1843)

43a Striae and furrows of the polished rocks of western New York. Am J Sc $44: 146-150$ (1843)

45 On the gypsum beds of New York (abst). As Am G, Pr 6: 38-39 (1845)

57 Review of Geological report of the midland counties of North Carolina, by $\mathrm{E}$. Emmons. Am J Sc (2) 24:427-429 (1857)

Dewey, Frederic Perkins (1855-1921).

82 The Rich Hill iron ores [Va.] Am I II Eng, $\operatorname{Tr} 10: 77-80 \quad(.882)$

84 Some Canadian iron ores. Am I M Eng, Tr $12: 192-204$ (1884)

89 Note on the nickel ore of Russell Springs, Logan Co., Kans. Am I M Eng, Tr $17: 636-637$ (1889)

91 A preliminary descriptive catalogue of the systematic collections in economic geology and metallurgy in the United States National Museum, U S Nat Mus, B 42: 256 pp (1891)
Dewey, Frederic Perkins-Continued.

15 (with Van Orstrand, C. E.) Preliminary report on the diffusion of solids. U S G S, P P 95: 83-96 (1915)

Dewilde, E. J.

15 Geology applied to mining at Bisbee, Ariz. M World $42: 463-46 \pm$ (1:15)

15a Brief notes on copper deposits of Bisbee, Ariz. M World 42:583-585 (1915)

DeWolf, Frank Walbridge.

07 Coal investigations in the SalineGallatin field, Ill, and the adjoining area. U S G S, B 316:116-136 (1907) IH G S, B $8: 211-229$ (1908)

oza (with Purdy, R. C.) Preliminary investigations of Illinois fire clays. Ill G S, B 4:129-175 (1907)

os The coal resources of Illinois. Am I M Eng, B 24: 1103-1112 (1908)

osa Coal investigations in Saline and Williamson cos, Ill, Ill G S, B $8: 230$ 245 (1908)

Osb Recent work on the Illinois coal field (abst). Science n s $27: 958-959$ (1908)

ose (with Udden, J. A.) Notes on the Belleville-Breeze area. Ill G S, B 8 : 246-254 (1908)

09 The coal resources of Illinois. III G S, B 14:189-196 (1909)

09a The work of the [Illinois] State geological survey. Ill Ac Sc, Tr 2:74-76 (1909)

10 Administrative report for 1909. Ill G S. B $16: 10-23$ (1910)

10a (and others.) Studies of Illinois coal. Ill G S, B 16:177-301 (1910)

11 Geology of Franklin and Williamson $\cos$, Ill. Black Diamond 46 no $8: 12-13$ (1911)

12 Illinois mining and State geological survey. Ill Soc Eng An Rp 27:152-155 (1912)

13 Cooperative investigation of the Mississippian formations. Science n $\mathrm{s} 38$ : 706-707 (1913)

14 Wort of the state geological surveys. M Sc Press 108:35-37 (1914)

15 Administrative report from January 1,1910 to June 30,1911 . III G S, B 20: 7-18, map (1915) ...July 1, 1911 to June 30,1913 ; B $23: 11-23$, map (1917) ...July 1,1913 to June 30,1915 ; B 30 ; $11-22$, map (1917) ...July 1,1915 to June 30 , 1916 ; B 3, 3:11-25 map (1916)

15n (with Anderson, C. B.) Artesian waters in Chicago and surrounding territory. Ill Soc Eng, An Rp 30:69-72 (1915)

Dewolfe, Loran A.

06 The structure and succession at North Sydney and Sydney Mines, C. B. N S Inst Sc, Tr 11:289-323 (1906) 
Dewsnap, S. G.

91 The coal measures of Washington. Eng M J $52:$ 245-246 (1891)

Diaz, Severo.

o7 Efemérides del voleán de Colima según las observaciones practicadas en los observatorios de Zapotlán y Colima de 1893 a 1905. Int $G$ Cong, $X$, Mexico, $C R$ : 763-960 (1907)

Diaz Barriga, Manuel.

05 Geological formations in Mexico. South American J, London, $58: 269$ (1905)

Draz de León, Jesús.

94 Estudio sobre la constitución geologica de una parte del suelo en que descansa la ciudad de Aguascalientes... Soc Geog Mex, B (4) 3: 74-94 (1894)

Diaz Lozano, Enrique.

16 Descripción de unas plantas liásicas de Huayacocotla, Vera Cruz; algunas plantas de la flora liásica de Huauchinango, Puebla. Méx I G, B 34: 18 pp, il (1916)

17 Diatómeas fósiles mexicanas. Méx I G, An 1:27 pp, il (1917)

Dice, Lee Raymond.

17 Systematic position of several Amer1can Tertiary lagomorphs. Cal Univ, Dp G, B $10: 179-183$, il (1917) Abst, with discussion by J. C. Merriam, G Soe Am, B 27 : 169 (1916)

Diek, James E.

$\mathbf{S}$ The Whitepine section of the Tomichi district [Gunnison Co., Colo.]. Eng M J 106: 331-333 (1918)

Diek, William Joseph.

14 Conservation of coal in Canada with notes on the principal coal mines. Canada, Commission on Conservation : 212 pp, maps (1914)

15 (with Adams, F. D.) Discovery of phosphate of lime in the Rocky Mountains. Can, Comm Conservation: 36 pp, maps (1915)

16 (with Adams, F. D.) The extension of the Montana phosphate deposits northward into Canada. Nat Ac Sc, Pr 2: 62-64 (1916) Abst, G Soc Am, B 27:62 (1916)

17 (with Adams, F. D.) Discovery of thosphate of lime in the Rocky Mountains [Alberta]. Can M Inst, Tr 19:321-348, [1917]

Dickenson, George J.

49 [Report on Isle Royale.] U S, 31st Cong 1 st sess, $\mathrm{S}$ Ex Doc 1 pt 3 and $\mathrm{H} \mathrm{Ex}$ Doc 5 pt $3: 503-506$ (1849)

Diekerman, Q. E.

84 (and Wadsworth, M. E.) An ollvine-bearing diabase from St. George, Me. Boston Soc N H, Pr 23 : 28-29 (1884)

Diekerson, Roy Ernest.

08 Whitney Creek, its glaciation and present form. Cal Phys Geog Club, B 2 :
Dickerson, Roy Ernest-Continued.

11 The stratigraphic and faunal rela. tions of the Martinez formation to the Chico and Tejon north of Mount Diablo. Cal Univ, Dp G, B 6:171-177 (1911)

13 Fauna of the Eocene at Marysville Buttes, Cal. Cal Univ, Dp G, B $7: 257-$ 298, il, map (1913)

13a Minutes of the Pacific Coast section of the Paleontological Soclety [third an. nual meeting, April 6, 1912]. G Soc Am, B 24: 126-132 (1913)

13b Eocene of San Pedro Point, San Mateo Co, Cal. (abst, with discussion by A. C. Lawson and J. C. Merriam), G Soc Am, B 24: 126-127 (1913)

13e Stratigraphic and faunal relations of the Martinez and Tejon south of Mount Diablo, Cal. (abst, with discussion by G. D, Louderback and F. M. Anderson). G Soc Am, B 24:127 (1913)

14 Note on the faunal zones of the Tejon group. Cal Univ, Dp G, B 8: 17-25 (1914)

14a Fauna of the Martinez Eocene of California. Cal Univ, Dp G, B 8:61-180, il, maps (1914)

14b The Martinez and Tejon Eocene and associated formations of the Santa Ans Mountains [Cal.]. Cal Univ, Dp G, B 8: 257-270, map (1914)

14e The Martinez Eocene and associated formations at Rock Creek on the western border of the Mohave Desert area. Cal Univ, Dp G, B 8: 289-298 (1914)

14d New molluscan species from the Martinez Eocene of southern California. Cal Univ, Dp G, B 8: 299-304, il (1914)

14e Minutes of the fourth annual meet. ing of the Pacific coast section of the Paleontological Society. G Soc Am, B 25:150156 (1914)

14f Faunal zones of the Martinez Eocene of Callfornia (abst). G Soc Am, B 25: 154 (1914)

$14 \mathrm{~g}$ The Ione formation of the Sierra Nevada foothills, a local facies of the upper Tejon-Eocene. Sclence n s 40:67-70 (1914) Abst, G Soc Am, B 26: 168 (1915)

14h The fauna of the Siphonalia sutterensis zone in the Roseburg quadrangle, Oreg. Cal Ac Sc, $\operatorname{Pr}$ (4) 4:113-128, il (1914) Abst, G Soc Am, B 26:169-170 (1915)

15 Fauna of the type Tejon; its relation to the Cowlitz phase of the Tejon group of Washington. Cal Ac Sc, Pr (4) 5:33-98, il, maps (1915)

16 Stratigraphy and fauna of the Tejon Eocene of California. Cal Univ, Dp $G$, B $9: 363-524$, il, maps (1916)

$16 \mathbf{a}$ Fauna of the Tejon group in the Cantua district of the Coalinga quadrangle. Cal. (abst). G Soc Am, B 27:173 (1916)

16b Fauna of the Tejon in the San Diego Co. [Cal.] (abst). G Soc Am, B 27: 173 (1916) 
Diekerson, Roy Ernest-Continued.

17 (and Kew, W. S. W.) The fauna of a medial Tertiary formation and the sssoclated horizons of northeastern Mexico. Cal Ac Sc, Pr (4) $7: 125-156$, il (1917) 17 a Climate and its influence upon the oligocene faunas of the Pacific coast, with descriptions of somre new species from the yolopophorus lincolnensis zone. Cal Ac Sc, Pr (4) $7: 157-192$, il (1917)

$17 \mathrm{~b}$ Climatic zones of Martinez Eocene time. Cal Ac Sc, $\operatorname{Pr}$ (4) $7: 193-196$ (1917)

17c Ancient Panama canals. Cal AC Sc, $\operatorname{Pr}$ (4) $7: 197-205$ (1917) Abst, G Soc Am, B 28: 230-232 (1917)

$17 d$ (and Kew, W. S. W.) Tertiary mollusks and echinoderms from the vicinity of Tuxpan, Mex. (abst). G Soc Am, B 28:224-225 (1917)

17e Cretaceous and Tertiary horizons in the Marysville Buttes [Cal.] (abst). G Soc Am, B 28: 233-234 (1917)

18 Mollusca of the Carrizo Creek beds and their Caribbean affinities (abst). G Soc Am, B 29:148 (1918)

18a Proposed correlation of the Pacific and Atlantic Eocene (abst). G Soc Am, B $29: 148-149$ (1918)

18b Occurrence of the Siphonalia sutterensis zone, the uppermost Tejon horizon in the outer Coast Ranges of California (obst). G Soc Am, B 29: 163 (1918)

Dickeson, Montroville W.

45 On the geology of the Natchez bluffs. As Am G, Pr 6:77-79 (1845)

46 On fossil bones from the vicinity of Natchez, Miss. Ac N Sc Phila, Pr 3: $106-107$ (1846)

49 (with Brown, A. The sediment of the Mississippi River. Am As, Pr 1: 42-55 (1849)

57 Report of a geological survey and examination upon the lands owned by the Tennessee and Virginia Mining Company, including the mines known as the Cranberry, Wildeat, and Ann Phipps [Carroll Co., Va.]. M Mag 9:226-237 (1857)

Dickhaut, Henry E.

99 Collecting fossils in the Cincinnati shales. Am G 23: 335-336 (1899)

Dickinson, H. P.

08 Occurrence, character, and uses of some rare metals. M Science 57: 123-124 (1908)

Dickinson, Harold T.

03 Quarries of bluestone and other sandstones in the Upper Devonian of New York State. N Y St Mus, B 61:112 pp, map (1903)

Diekinson, John.

87 Remarks on the "petrified forest " of Arlzona (abst). Am As, Pr $35: 230$ (1887) Dickson, Charles William.

02 The concentration of barium in limestone. Sch Mines Q 23 : 366-370 (1902)
Dickson, Charles William-Continued.

O2a Note on the condition of nickel in nickeliferous pyrrhotite from Sudbury [Ont.]. Eng M J 73:660 (1902)

03 Note of the condition of platinum in the nickel-copper ores from Sudbury. Am J Sc (4) 15: 137-139 (1903)

o3a The mineralogy and geology of the Sudbury, Ont., copper-nickel deposits (abst). Science n s 17:793 (1903) N Y Ac Sc, An $15: 176$ (1904)

04 The ore deposits of Sudbury, Ont. Am I M Eng, Tr 34:3-67 (1904) Reprinted in Emmons, S. F., Ore deposits (pub. by Am I M Eng):455-516, N Y 1913

o5 The distribution of the platinum metals in other sources than placers (with discussion). Can M Inst, J $8: 192-214$ (1905)

06 Genetic relations of nickel-copper ores, with special reference to the deposits at St. Stephen, N. B., and Sohland, Germany. Can M Inst, J $9: 236-260$ (1906) ; Can M Rv 26:144-151 (1906)

Diekson, James.

34 An essay on the gold region of the United States. G Soc Pa, Tr 1:16-32 (1834) Abst, $\mathrm{Am} \mathrm{J}$ Sc $27: 348-351$ (1835) ; Edinb N Ph J $19: 185-188$ (1835)

35 On the science and practice of mining. $\mathrm{G}$ Soc $\mathrm{Pa}, \mathrm{Tr} 1: 360-408$ (1835)

Diekson, John (?-1847).

21 ... mineralogy and geology of parts of South and North Carolina. Am J Sc 3 : 1-4 (1821) Transl in Struve, H. von, Beiträge zur Mineralogie und Geologie des nördlichen Amerikas : 73-80, Hamburg 1822 Dienenbach, atto.

54 Beobachtungen ïber die Erz-Gänge und das Gang-Gebirge von Nord-Carolina und den angrenzenden Staaten. N Jb 1854 : 663-669

55 Bemerkungen über den Mineralreichtum der Vereinten Staaten von NordAmerika. N Jb $1855: 527-532 ; 1856: 385$ 394

55a Das Vorkommen von Chrom-Erzen und ihre Verarbeltung in den Vereinten Staten von Nord-Amerika. N Jb 1855 : 533-539

58 Bemerkungen über den Kupferbergbau in den Vereinigten Staaten von NordAmerika. Berg- u hütt Ztg 17 (N F 12) $47-48,66-68,75-76(1858)$

Dieh1, O. C.

o4 Gypsum [in Michigan and Utah]. Mich Miner 6 no $6: 21-24$ (1904)

Diener, C.

o7 Bericht über die Exkursionen des $\mathrm{X}$. Internationalen Geologen-Kongresses in Mexiko. K-k Geog Ges Wien, Mitt 50:211240 (1907)

Dietz, R.

24 Description of a testaceous formation at Anastasia Island [Fla.]. Ac N Sc Phila, J $4: 73-80$ (1824) 
Difenderfer, F. R.

73 Elephas americana in Mexico. Am J Sc (3) $6: 62(1873)$

Dignowity, C. L.

04 Gold fields of the East and their low grade ores. Am M Cong, Rp Pr 6:191 195 (1904) Abst, with title, Gold fields of the Atlantic coast, M Sc Press 87:183 (1903)

Diguet, Léon.

oo La Basse-Californie. An Géog, Paris, $9: 243-250 \quad(1900)$

Diller, Joseph Silas.

7 7 Westfield during the Champlain period. Am J Sc (3) 13:262-265, map (1877)

so The felsites and their associated rocks north of Boston [Mass.]. Boston Soc N H, Pr 20:355-368 (1880)

81 The felsites and their associated rocks north of Boston. Harvard Coll, Mus C Z, B 7 (g s 1): 165-180 (1881)

$81 a$ On the felsites of the vicinity of Boston [Mass.] Boston Soe N H, Pr 21: 168-169 (1881)

84 [Observations in the Cascade Range, Oreg.] Science $3: 52-53$ (1884) thon the

84a [Geologic work in northern California and in Oregon.] Science 3:366 (1884)

84b [Rocks of Lassen Peak and Mount Shasta.] Science 3:551-552 (1884)

s4e Voleanic sand which 'ell at Unalaska, Alaska, Oct. 20, 1883, and some considerations concerning its composition. Science 3: 651-654 (1884)

84d [On a fulgurite from Mount Thielson, Oreg.] Science 3:735-736 (1884)

84e Fulgurite from Mount Thielson, Oreg. Am J Sc (3) $28: 252-258$ (1884)

s4f [Rocks from Oregon.] Science 4: 71 (1884)

84g Report on atmospheric sand dust. from Unalaska. Nature 30:91-93 (1884)

85 The volcanic sand which fell at Unalaska October 20,-1883, and some considerations concerning its composition (with discussion). $\mathrm{Ph}$ Soc Wash, $\mathrm{B} \quad 7: 33-35$ (1885)

85a Coal in the Chico group of California. Science 5:43 (1885)

85b Dikes of peridotite cutting the Carboniferous rocks of Kentucky. Seience 5 : 65 (1885)

s5e Lava from the new voleano on Bogosloff Island. Science 5:66-67 (1885)

s5d (with Clarke, F. W.) Topaz from Stonebam, Me. Am J Sc (3) 29 : 378-384 (1885)

86 Note on the geology of northern California. U S G S, B 33: 23 pp (1886) Abst, $\mathrm{Ph}$ Soc Wash, B 9:4-5 (1887); Am J Sc (3) $33: 152-153$ (1887)

$86 a$ Notes on the peridotite of Elliott Co., Ky. Am J Sc (3) 32:121-125 (1886) Ky G S, Elliott Co (Crandall) : 20-25 [1887?]
Diller, Joseph Silas-Continued. $\mathbf{8 6 b}$ The genesis of the diamond Seience 8: 392 (1886) Ky G S, Elliott Co. (Crandall) : 25-28 [1887?]

86e (with Clarke, F. W.) Turquoise from New Mexico. Am J Sc (3) 32:211218 (1886)

87 Peridotite of Elliott Co., Ky. U \& G S, B 38: 31 pp (1887)

87a (and Kunz, G. F.) Is there a diamond field in Kentucky? Science 10: 140-142 (1887)

87b The latest volcanic eruption in northern California and its peculiar lare. Am J Sc (3) $33: 45-50$ (1887)

89 Geology of the Lassen Peak district [CaI.]. U S G S, An Rp 8: $395-432$, map (1889)

89a Mineralogical notes. Am J Sc (3) $37: 216-220$ (1889)

89b The history of porphyritic quart in eruptive rocks. Science 13:232 (1889)

90 Sandstone dikes (with discussion by W. M. Davis and B. K. Fmerson). G Soc Am, B 1: 411-442 (1890)

90 Note on the Cretaceous rocks of northern California. Am J Se (3) 40: 476-478 (1890)

91 A late volcanic eruption in norther California and its peculiar lava. U S G 8, B $79: 33$ pp (1891)

91 a First annual report of the committee on photographs [of the Geological Society of America]. G Soc Am, B 2: $615-630$ (1891)

92 Geology of the Taylorville region of California. G Soc Am, B $3: 369-394$ (1892) Abst, Am G 9:215 (1892)

92a Mica peridotite from Kentuck. Am J Sc (3) 44:286-289 (1892)

93 Cretaceous and early Tertiary of northern California and Oregon. G Soc Am, B 4:205-224, map (1893) Abst, Am G 11: 139 (1893)

93a Our youngest volcano [Lassen] Peak]. Nat Geog Mag 5:93-96 (1893)

93b... on the auriferous gravel of lacus. tral origin in the region of Taylorsville. Cal. Am J Sc (3) 46:398-399 (1893)

94 Tertiary revolution in the topos: raphy of the Pacific coast. U S G S, An Rp 14 pt 2:397-434, map (1894). I part, (with title, Revolution in the topography of the Pacific coast sin the auriferous gravel period) J G $2: 32-54$ (1894) Abst, Am J Sc (3) 46:74 (1893)

94a (and Stanton, T. W.) The Sbasts. Chico series. G Soc Am, B 5:435-464 (1894) Abst, Am G 13:208 (1894); All J Sc (3) $47: 141$ (1894)

94b (and Sehnehert, Charles) Dis. covery of Devonian rocks in Californis. Am J Sc (3) $47: 416-422$ (1894)

95 Description of the Lassen Peak sheet [Cal.]. U S G S, G Atlas Lassen Peak tol (no 15) : 4 pp, maps (1895; prel ed 1892 Abst, J G 3:974-976 (1895) 
Diller, Joseph Silas-Continued.

95a Mount Shasta; a typical volcano; Nat Geog Soc, Nat Geog Mon 1 no 8:237268 (1895) Also in The physiography of the United States (Nat Geog Soc) : 237268, N Y, American Book Co., 1896

96 A geological reconnaissance in northwestern Oregon. U S G S, An Rp 17. pt 1:441-520, map (1896)

96a The Klamath Mountains [Oreg.]. Jazama 1: 104-108, map (1896)

96b The structure and age of the Cascade Range (abst). Science n s $3: 823$ (1896) Am G 18:61 (1896)

96e Illustrations and description of Crater Lake [Klamath Co., Oreg.]. Text on back of Crater Lake Special Map, Oreg., ए S G S 1896

97 Crater Lake, Oreg. Am J Sc (4) 3: 165-172 (1897) Nat Geog Mag, 8:33-48 (1897) Mazama 1:161-170 (1897) J Sch Geog 1:266-269 (1897) Smiths Inst, An Rp 1897:368-379 (1898) Abst, J G $5: 219-220$ (1897); Sclence n s 5:81-82 (1897)

97a Hornblende basalt in northern California. Am G 19:253-255 (1897)

97b The origin of Camas swale [Oregon] (abst). Science n \& 6:923 (1897)

98 Description of the Roseburg quadrangle [Oreg.]. U S G S, G Atlas Roseburg fol (no 49): 4 pp, maps (1898)

98a The educational series of rock spectmens collected and distributed by the Dnited States Geological Survey. U S G S, B $150: 400$ pp (1898) ; reprint (1902)

99 The Coos Bay coal field, Oreg. U S G \&, An Rp 19 pt 3:309-370, map (1899) 99a Origin of Paleotrochis. Am J Sc (4) 7:337-342 (1899) Elisha Mitchell Sc Soc, J 16:59-67 (1900) Abst, Science n s 9:622 (1899)

99 btalactites of sand. Sclence n s 9 : 371-372 (1899)

99e Latest volcanic eruptions of the $\mathrm{Pa}$ cific coast. Science n \& 9:639-640 (1899) 00 The Bohemia mining region of westen Oregon. U S G S, An Rp 20 pt $3: 1$ 38 (1900)

01 Description of the Coos Bay quadrangle [Oreg.]. U S G S, G Atlas Coos Bay fol (no 73): 5 pp, maps (1901)

01 a Geomorphogeny of the Klamath Iountains (abst). G Soc Am, B 12:461 (1901) Science n s 13:97 (1901)

02 (and Patton, H. B.) The geology and petrography of Crater Lake National Park. U S G*S, P P 3:167 pp, maps (1902)

02a Topographic development of the Klamath Mountains. S G S, B $\quad$ : : 69 Dp, map (1902)

02b The wreck of Mt. Mazama. Science A 8 15:203-211 (1902)
Dillex, Joseph Silas-Continued.

02e (and Steiger, G.) Volcanic dust and sand from St. Vincent caught at sea and the Barbados. Science n 8 15:947950 (1902)

02d Volcanic rocks of Martinique and St. Vincent. Nat Geog Mag $13: 285-296$ (1902)

o2e Copper in northern California. M Sc Press, 85: 62, 72 (1902)

o2f The copper region of northern Callfornia $(a t s t)$. Science n s $15: 823$ (1902) Eng M $J$ 73: $857-858$ (1902)

02g Volcanic dust from Guatemala (abst). Science n s 16:1029 (1902)

03 Description of the Port Orford quadrangle [Oreg.]. U S G S, G Atlas Port Orford fol (no 89) : 6 pp, maps (1903)

o3a Copper deposits of the Redding region, Cal. U S G S, B 213:123-132 (1903)

03b Iron ores of the Redding quadrangle, Cal. U S G S, B 213:219-220 (1903)

o3e Limestone of the Redding district, Cal. U S G S, B $213: 365$ (1903)

03d Klamath Mountain section, Cal. Am J Sc (4) 15:342-362 (1903)

04 Mining and mineral resources in the Redding quadrangle, Cal,, in 1903. U S G S, B 225: 169-179 (1904)

04a The composition and structure of the Klamath Mountains (abst). Science n s 19:794 (1904)

o5 Mireral resources of the Indian Valley region, Cal. U 'S G S, I 260:45-49 (1905)

05a So-called "iron ore" near Portland, Oreg. U S G S, B 26g: $343-347$ (1905)

05b Coal in Washington, near Portland, Oreg. U S G S, ? 260:411-412 (1905)

05c The Bragdon formation. Am J Sc (4) $19: 379-387 \quad$ (1905)

06 Description of the Redding quadrangle [Cal.]. U S G S, G Atlas Redding fol (no 138): $14 \mathrm{pp}$, raps (1906)

06a Drainage of the Taylorsville region, Cal., during the auriferous gravel period (abst). Science n s 23:814 (1906)

o7 The Mesozoic sediments of southwestern Oregon. Am J Sc (4) $23: 401-$ 421 (1907)

07a Age of the pre-volcanic auriferous gravels in California. Wash Ac Sc $\mathrm{Pr}$ $8: 405-406$ (1907)

07b Asbestos. U S G S, Min Res 1906: 1123-1129; 1907 pt $2: 711-722 ; 1908$ pt $2: 697-706 ; 1909$ pt $2: 721-729 ; 1910$ pt $2: 823-831 ; 1911$ pt $2: 995-1001 ; 1912$ pt $2: 985-995 ; 1913$ pt $2: 339-354$, map ; 1914 pt $2: 93-102 ; 1915$ pt $2: 13-18 ; 1916$ pt $2: 19-24 ; 1917$ pt $2: 197-204(1907-18)$ 
Diller, Joseph Silas-Continued.

os Strata containing the Jurassic flora of Oregon. G Soc Am, B $19: 367-402$, map (1908) Abst, Science n s $27: 410-411$ (1908)

OSa Placer mines of the Riddles quadrangle, oreg. U S G S, B $340: 147-151$ (1908)

08b Geology of the Taylorsville region, Cal. U S G S, B 353 : 128 pp, map (1908) ose Local silification of the Knoxville (abst). Science n s 27:411 (1908)

09 The Rogue River valley coal field, Oreg. U S G S, B 341:401-405 (1909)

09a (and Kay, G. F.) Mineral resources of the Grants Pass quadrangle and bordering districts, Oreg. U S G S, B 380 : 48-79, map (1909)

09b Talc and soapstone. U S G S, Min Res 1908 pt $2: 869-878 ; 1909$ pt $2: 915-$ $923 ; 1910$ pt $2: 977-986 ; 1911$ pt $2: 1197-$ $1203 ; 1912$ pt $2: 1133-1160 ; 1913$ pt 2 : $153-163 ; 1914$ pt $2: 151-157 ; 1915$ pt 2 : $61-64 ; 1916$ pt $2: 25-28 ; 1917$ pt $2: 81-84$ (1909-18)

11 The types, modes of occurrence, and important deposits of asbestos in the United States. U S G S, B 470:505-524, maps (1911) Can M Inst, Q B13: 45-58 (1911) ; J 14:92-106 (1912)

11 a The auriferous gravels of the Trinity River basin, Cal. U S G S, B 470: 11-29, map (1911)

$11 b$ Major Clarence Edward Dutton. Seism Soc Am, B 1:137-142, port (1911)

11e (and Pishel, M. A.) Preliminary report on the Coos Bay coal field, Oreg. U S G S, B 431: 190-228, maps (1911)

11d Illustrations and description of Crater Lake [Text on back of topographic sheet] Crater Lake National Park, Klamath Co., Oreg., U S G S, 1911

12 Geological history of Crater Lake, Crater Lake National Park, Oreg. U S, Dp Interior: 31 pp (1912)

12a Mines and prospects of southwestern Oregon (abst). Wash Ac Sc, J 2:110 (1912)

13 Memoir of Clarence Edward Dutton. G Soc Am, B 24: 10-18, port (1913)

13a Chromic iron ore. U S G S, Min Res 1912 pt $1: 1047-1054 ; 1913$ pt $1: 29$ $39 ; 1914$ pt $1: 1-15 ; 1915$ pt $1: 1-6$ (1913-6)

14 Auriferous gravels in the Weaverville quadrangle, Cal. U S G S, B 540 : 11-21, map (1914)

$14 a$ Mineral resources of southwestern Oregon. U S G S, B $546: 147$ pp, maps (1914) Abst, Wash Ac Sc, J 4:329

14b The Lassen eruption. Science $\mathbf{n}$ s $40: 49-51$ (1914)

14c The eruptions of Lassen Peak, Cal. Seism Soc Am, B 4:103-107 (1914) Mazama 4:54-59 (1914)
Diller, Joseph Silas-Continued.

$14 d$ Mineral resources of the Southern States-distribution and production (abst). Science n \& $39: 399$ (1914)

15 (and others) Guidebook of the west. ern United States; Part D, The Shasta route and coast line. U S G S, B 614: $142 \mathrm{pp}$, maps (1915) Abst, by F. L. Ran some, Wash Ac Sc, J 5:582 (1915)

15a Mount Shasta, some of its geologi. cal aspects. Mazama 4:11-16 (1915) Abst, Wash Ac Sc, J 6: 147-148 (1916)

15b The relief of our Pacific coast. Science n \& 41:48-57, 513 (abst) (1915) Abst, G Soc Am, B 26:111 (1915)

15e The recent eruptions of Lassen Peak [Cal.] (abst). Wash Ac Sc, J 5: 31-32 (1915) G Soc Am, B 26:105 (1915) Science n $\mathrm{s} \quad 41: 510$ (1915)

15d (with Holway, R. S.) Characteristics of the Lassen Peak eruptions of May 20-22, 1915 (abst). G Soc Am, B $25: 397$ (1915)

16 The volcanic history of Lassen Peak. Science n s 43:727-733 (1916)

16a Lassen Peak, our most active vol. cano. Seism Soc Am, B 6:1-7 $(1916)$

$16 \mathrm{~b}$ Geologic history of : assen Peak (abst). Wash Ac Sc, J 6:404-406 (1916)

17 Arnold Hague. Am J Sc (4) 44: $73-75 \quad$ (1917)

17a Chromite. U S G S, Min Res 1916 pt $1: 21-38 ; 1917$ pt $1: 37-47(1917-8)$

17b Production of chromium. Am I M Eng, B 131: x-xii (1917)

17e Was the new lava from Lassen Peak viscous at the time of its eruption? (abst). Wash Ac Sc, J 7:82 (1917)

18 Asbestos, what it is and does for us. Tractor and Gas Engine Rv 11 no $4: 10-11$ (1918)

See also Becker, 91b; Darton, 90a: Powell, 89, 89a, 90, 91, 91a, 92, 93, 95; Russell, 87

Dilworth, J. B.

12 The Black Mountain coal district, Ky. Am I M Eng, B $62: 149-176$ (1912); Tr $43: 129-156$ (1913)

Dimmock, George.

79 The writings of Samuel Hubbard Scudder. Dimmock's Special Bibliography, no $3: 28$ pp, Cambridge Mass., 1879 [Prly pub]

Dinsmore, Charles A.

o8 The Moctezuma copper deposit In Mexico [Nacozari, Sonora]. M World 29: 475-478 (1908)

O8a The new gold camp of Sylvanite, N. Mex. M World 29:670=671 (1908)

09 The Patagonia district, Ariz. II World $31: 224$ (1909)

09a The Johnson and Dragoon districts, Ariz [copper ores]. M World $31: 833-834$ (1909)

091 Quicksilver deposits of Brewste: Co., Tex. M World $31: 877-878$ (1909) 
Dinsmore, Charles A.-Continued.

09e Development of a Texas tin mine [Mount Franklin, near El Paso]. M World $31: 1120$ (1909)

10 Courtland, Ariz., and its mining possibilities [copper ores]. M World $32: 747$ 749 (1910)

10a The Toyah oil field, Tex. M World $33: 176$ (1910)

10b Azure turquois mine, N. Mex. M World $33: 660$ (1910)

10e Tin quartz mining and smelting in Texas. M World $33: 1237-1238$ (1910)

D'Invilliers, Edward Vincent.

83 The geology of the South Mountain belt of Berks Co. Pa G S, 2d, D3, 2 : xxii, $441 \mathrm{pp}$, atlas (1883)

84 The geology of Center Co. Pa G S, 2d T4: xviil, $464 \mathrm{pp}$, maps (1884)

$84 a$ The brown hematite (limronite) ores of the Siluro-Cambrian limestone, No. II, of Center Co., Pa. Eng Club Phila, Pr 4: 209-222 (1884)

85 Nittany valley ores [Huntingdon Co.]. Pa G S, 2d, T3: 443-450 (1885)

86 Preliminary report of work done in 1885, on the resurvey of the Pittsburgh coal region. $\mathrm{Pa} G \mathrm{~S}$, An $\mathrm{Rp}$ 1885:125221, map (1886)

86a The Cornwall Iron ore mines, Lebanon $\mathrm{Co}, \mathrm{Pa}$. Am I M Eng, Tr 14:873904, map (1886)

86b (with Lesley, J. P.) Report on the Cornwall iron mines, Lebanon Co. $\mathrm{Pa}$ G S, An Rp 1885:491-570, map (1886)

87 Report on the Pittsburgh coal region. Pa G S, An Rp 1886, pt 1:1-372, maps (1887)

87a Report on the iron ore mines and llmestone quarries of the CumberlandLebanon Valley. Pa G S, An Rp 1886 pt 4:1409-1567, maps (1887)

87 b (with MeCreath, A. S.) The New River-Cripple Creek mineral region of Virginia. 171 pp, map, Harrisburg, Pa., 1887 87e (with MeCrenth, A. S.) Comparison of some southern cokes and iron ores. Am I M Eng, Tr 15: 734-753 (1887)

88 (with MeCreath, A. S.) Resources of the upper Cumberland Valley of southeastern Kentucky and southwestern Virginla ... $152 \mathrm{pp}$, map, Louisville 1888

91 Report on the geology of the four counties, Union, Snyder, Miflin, and Juniata.., Pa G S, 2d, F3: xxiv, 420 pp, maps and atlas (part by Charles E. Billin) (1891)

91a The phosphate deposits of the island of Navassa. G Soc Am, B 2:75-84 (1891)

92 (with MeCreath, A. S.) Geological and chemical report on a portion of the Virginla and Tennessee Coal and Iron Company's property... Wise Co., Va. 67 pp [n p, n d, 1892?]
D'Invilliers, Edward Vincent-Contd,

93 (with MeCreath, A. S.) The Clinch Valley coal fields [southwestern Va.]. U S G S, Min Res 1892: 521-528 (1893)

See also Cabrera, 98 ; Carll, 87 ; Lesley, 92

Disbrow, Levi.

27 Notice of some recent experiments in boring for fresh water. Am J Sc 12:136143 (1827)

Divers, Edward.

02 Suggested nature of the phenomena of the eruption of Mont Pelé on July 9, 1902. Nature $67: 126(1902)$

Dixon, J. D.

03 (with Nolan, A. W.) Geology of St. Helen's Island [Que.]. Can Rec Sc 9: $53-66$, map (1903)

Dixon, Roland $B$.

97 (and Drew, C. D.) Observations on the physiography of western Massachusetts. Seience n s $6: 847$ (1897)

Doane, Gustavus C.

71 Report upon the so-called Yellowstone expedition of 1870 . U S, 41 st Cong Sd sess, S Ex Doc 51:40 pp (1871)

Dobbs, W. Stewart.

06 [Report on a reconnaissance of] the region south of Cape Tatnam, Hudson Bay. Can G S, Sum Rp 1905: 69-73 (1906)

14 Geological sketch of the property of the Hayden gold mines, Ltd. [Porcupine distriet, Ont.] M Se Press 108: 534-535, map (1914)

Dobson, Peter.

26 Remarks on boulders [Connecticut]. Am J Sc 10:217-218 (1826)

44 Hints on the iceberg theory of drift. Am J Sc 46:169-172 (1844)

Dodds, Gideon S.

os Geology and physiography of the mesas near Boulder. Colo, Univ, Studies 6:11-19 (1908)

Dodge, Frank S.

87 On the survey of Kilauea in the last week of September and the first of October, 1886. $\mathrm{Am}$ J Sc (3) $33: 98-101$, maps (1887)

93 Kilauea in August, 1892. Am J Sc (3) $45: 241-246$ (1893)

Dodre, James A.

S2 Analyses [of rocks and minera] waters]. Minn G S, An Rp 10:201-210 (1882) ; 11:171-182 (1884); 13:98-103 (1885) ; 19:121-126 (1892)

88 Anthracite coal in the valley of the Bow River, Northwest Territory, Can. Am G $1: 172-173$ (1888)

90 (with winchell, $N$. H.) The Brenham, Kiowa Co., Kans., meteorites. Am G $5: 309-312 ; 6: 370-377(1890)$

Dodge, Richmond Elwood.

94 The geographical development of alluvial river terraces. Boston Soc $\mathrm{N} \mathrm{H}, \mathrm{Pr}$ 26 : $257-273$ (1894)

$94 a$ Continental phenomena illustrated by ripple marks. Science $23: 38-39$ (1894) 
Dodge, Richmond Elwood-Continued.

94b Additional species of Pleistocene fossils from Winthrop, Mass. Am J Sc (3) $47: 100-104$ (1894)

96 The Cretaceous and Tertiary peneplains of eastern Tennessee (abst). Science n s $3: 531$ (1896)

$02 \mathrm{An}$ interesting landslide in the Chaco Canyon, N. Mex. (abst). N Y Ac Sc, An 15:49-50 (1903) Science n s 15:746 (1902) Am G 29: 322 (1902)

02a Arroyo formation (abst). Am G $29: 322(1902) \quad N$ Y Ac Se, An 15:50 (1903)

10 The formation of arroyos in adobe. flled valleys in the southwestern United States (abst). Brit As, Rp 79:531-532 (1910)

See also Merrill (F J H), 02

Dodge, W. R.

15 Gold mining and milling in the southeastern States. M Sc Press 110:5962 (1915)

Dodge, W. W.

75 Notes on the geology of eastern Massachusetts. Boston Soc N H, Pr 17 : $388-419$ (1875)

75a On Triarthrus beckil, supposed to have been found in a bouker in the Connecticut Valley. Am J Sc (3) 10:300 (1875)

81 Lower Silurian fossils in northern Maine. Am J Sc (3) 22:434-436 (1881) 82 Notes on the geology of eastern Massachusetts. Boston Soc $\mathrm{N} \mathrm{H}, \operatorname{Pr} 21$ : 197-216 (1882)

83 On the relations of the Menevian argillites and associated rocks at' Braintree and vicinity, in Mass. Am $J$ Sc (3) 25:65-71, map (1883)

88 Som? localities of post-Tertiary and Tertiary fossils in Massachusetts. Am J Sc (3) $36: 56-57$ (1888)

90 Some Lower Silurian graptolites from northern Maine. Am J Sc (3) 40 : 153-155 (1890)

92 (and Beecher, C. E.) On the occurrence of Upper Silurian strata near Penobscot Bay, Me. Am J Sc (3) 43 : 412-418, map (1892)

Dolbear, C. E.

13 The Searles Lake potash deposit [Cal.]. Eng M J 95:259-261 (1913)

Dolbear, Samuel H.

10 Oceurrence of tungsten in Rand district, Cal. Eng M J 90:904-905 (1910)

14 The saline deposits of Cearles Lake, Cal. M World 41:797-800 (1914)

15 Infusorial earth. M Sc Press 110 : 580-583 (1915)

17 The origin and geochemistry of mag nesite. M Sc Press 114:237-238 (1917)

17 a The nature of chromic-iron deposits: M Sc Press 114:552-554 (1917)
Dole, Richard Bryant (1880-1917).

06 Use of fluorescein in the study underground waters. U S G S, W.S $160: 73-85$ (1906)

09 (and Stabler, H.) Denudation. S G S, W S P 234:78-93 (1909) Ne Conservation Comm (60th Cong, 2d sess, 8 Doc no 676), Rp 2: 126-140 (1909) Alst Science n s 29:313 (1909)

11 Rapid examination of water in gev logic surveys of water resources. Ee $G$ $6: 340-362$ (1911)

13 Exploration of salines in Silver Peak Marsh, Nev, U S G S, B $530: 330-345$, map (1913)

14 Mineral waters. U S G S, Min R6 1913 pt $2: 393-440 ; 1914$ pt $2: 175-219 ;$ 1915 pt $2: 307-344(1914-6)$

14a Some chemical characteristics of sea water at Tortugas and around Biscayse Bay, Fla. Carnegie Inst Wash, Pub 18? Papers from the Tortugas Lab 5:69-i8 (1914)

15 Chemical character of waters of the Coastal Plain of Georgia. U S G S, W-SP 341: 470-532 (1915)

16 (with Deussen, A.) Ground wate in La Salle and MeMullen cos., Tex. I G S, W-S P 375:141-177, maps (1916) Abst, Wash Ac Sc, J 6 : 224-225 (1916)

16a (with Mendenhall, W. C., and Stabler, H.) Ground water in San dot quin Valley, Cal. U S G S, W-S P 398: $310 \mathrm{pp}$, maps (1916)

18 Salinity of ocean-water at Fores Rocks, Fla. Carnegie Inst Wash, Pub 213, Papers from Dp Marine Blology 9:209315 (1918)

See also Van Winkle, 14

Dolley, Charles S.

87 On the helictites of Luray Cart [Va.]. Ac N Sc Phila, Pr 1886:351-35? (1887)

Dollfus, Auguste (1840-1869).

67 (and others) Observations géologiques faites dans le trajet de la Vera Cruz a Mexico. [France], Comm Sc Nes, Arch 2:124-127, Paris 1867

67a (and others) Récit d'une ascêt. sion au Popocatepetl (23 avril 1865); note explicative de la coupe géologique de Jes. ico au sommret du Popocatepetl. [France], Comm Sc Mex, Arch 2:187-208, Parls 1867 La Naturaleza 1: 180-195 (1870)

67b (and others) Mémoires et notes geologiques [Mexico]. [France], Comm St Mex, Arch 2:363-403, map Paris 1867

67e (and Montserrat, E. de) Nevado de Toluca; volcan de Colima. [France], Comm Sc Mex, Arch $3: 29-35,43-55$, Part 1867 La Naturaleza 6:27-31 (1882)

67d (and Montserrat, E. de) Etude sur le district de Sultepec [Mexico]. [France]. Comm Sc Mex, Arch $3: 471-496$. Paris 1867 
Dollfus, Auguste Continued

67e (with Montserrat, E. de) Observations géologiques faites aux Antilles. [France], Comm Sc Mex, Arch 2: 86-124, Paris 1867

68 (and Montserrat, E. de) Voyage gélogique dans les républiques de Guatemala et de Salvador. France, Mission Scientifique au Mexique et dans l'Amérique centrale, Géologie. ix, 539 pp, maps, Paris 1868

Dolmage, Victor.

16 A peculiar type of ore from the Tyee copper deposit of Vancouver Island. Ec G $11: 390-394$ (1916)

17 The geology of the Telkwa River district, B. C. Abstract of thesis, Massachusetts Inst Tech : 9 pp, 1917

18 The copper silver veins of the Telkwa distriet, B. C. Ec G $13: 349-380$ (1918)

Domeneeh, Manuel Victor.

99 Mineral resources of Porto Rico. Mines and Minerals $19: 529-532$ (1899)

Dominian, Leon.

04 The Goldfield district, Nev. Eng M J 78: 581-582 (1904)

04a (with Smith, E. P.) Notes on a trip to White Oaks, N. Mex. Eng M J $77: 799-800 \quad$ (1904)

Don, John R.

98 The genesis of certain auriferous lodes (with discussion by Joseph Le Conte, 8, F. Emmons, G. F. Becker, A. Winslow, and W. P. Blake). Am I M Eng, Tr 27; 564-668 (1898) ; 28: 799-803 (1899) Reprinted in part in Emmons, S. F., Ore deposits (pub, by Am I M Eng): 162-215, N Y 1913

Donald, James Thomas.

79 Notes on elephant remains from Washington Terr. Can Nat n s $9: 53-56$ (1879)

80 The Helderberg rocks of St. Helen's Island [Que]. Can Nat n s 9:302-304 (1880)

84 Samarskite from Berthier Co., Que. Can Rec N H 1: 52-54 (1884)

$84 a$ Notes on a deposit of clay at Côte St. Luc, Montreal, [Que.]. Can Rec N H 1:56-57 (1884)

90 Scolecite from a Canadian locality. Can Rec Sc 4: 99-100 (1890)

90 Notes on asbestos and some associated minerals. Can Rec Sc 4:100-104 (1890)

92 Note on magnesite from near Black Lake, Que. Can Rec Sc 5: 137 (1892)

93 The occurrence of platinum in Canada. Eng M J 55: 81-82 (1893)

96 Chromic iron; its properties, mode of accurrence, and uses. Gen M As Que, J 2 : 108-111 [1896]

99 A notable Canadian deposit of chromite. Can M Inst, I 2:25-27 (1899) Can M Rv 18: 40-41 (1899)
Donald, James Thomas-Continued.

O1 The composition of some Canadian limestones. Can M Inst, J 4:152-154 (1901) Can M Rv 20:67-68 (1901)

02 Notes on the limestone of the Philipsburg Railway and Coal Company [Philipsburg, Que.]. Can M Inst, J 5:47-48 (1902) Eng M J 73:657 (1902)

Donnelly, Ignatius.

83 Ragnarok, the age of fire and gravel. $452 \mathrm{pp}, \mathrm{N}$ Y 1883

Donnelly, Thomas F.

15 The copper deposits of San Cristobal, Santo Domingo (with discussion by F. L. Garrison). Am I M Eng, B 104: 17591768 ; $108: 2473-2474$ (1915) ; $\operatorname{Tr} 52: 645$ 656 (1916)

Doolittle, J. E.

o5 Gold dredging in California. Cal St M Bur, B 36: 7-108, maps (1905)

Doornik, J. E.

29 Observations concerning fossil organic remains. Am J Sc 15:90-109 (182ก)

Dopp, Mary.

13 Geological and geographical conditions affecting the development of Wisconsin. Am Geog Soc, B 45: 401-412 (1913)

Dornbach, L. M.

57 [Analysis of slate from Somerville, Mass.] Boston Soc N H, Pr 6:107-108 (1857)

Dorsey, George Edwin.

17 The habitat of Belemnitella americana and mucronata. Johns Hopkins Univ Circ n s 1917 no $3: 107-219$ [305-327]

Donglas, James (1837-1918).

64 The gold fields of Canada. Lit Hist Soc Quebec, Tr n s 2:51-66 (1864)

71 Notes on the copper deposits at Harvey Hill [Que.]. Lit Hist Soc Quebec, Tr n s 8:42-50 (1871)

74 The native copper mines of Lake Superior. Q J Sc 11:162-180 (1874) Can Nat n s 7:318-336 (1874)

81 The antimony deposits in Sonora [Mexico]. Eng M J 31:350 (1881)

87 (with Hunt, T. S.) The Sonora [Mex.] earthquake of May 3, 1887. Am Nat 21:1104-1106 (1887) Brit As, Rp $57: 712-713$ (1888)

92 The copper resources of the United States. Soc Arts, J 41:39-52 (1892) Se Am Sup 35:14183-14186 (1893)

93 Biographical notice of Thomas Sterry Hunt. Am I M Eng, Tr 21:400-410 (1893)

99 The Copper Queen mine, Ariz. M Sc Press 79:432-433, 460-461 (1899) Am I M Eng, Tr 29:511-546 (1900)

o1 Record of borings in the Sulphur Spring Valley, Ariz. ... $A m$ Ph Soc, $\mathrm{Pr}$ $40: 161-163$ (1901)

10 Early copper mining in the Province of Quebec. Can M Inst, Q B 11:63-81 (1910); J 13:254-272 (1911) Can M J $31: 452-456$ (1910) 
Douglas, James-Continued.

11 Earthquakes in mines. Can M Inst, Q B 14:77-83 (1911); discussion, 15: 129-130 (1911); J 14:75-83 (1912)

13 The copper-bearing traps of the Coppermine River [Can.]. Can M Inst, Tr 16:83-101, map (1913)

Douglas, Walter.

95 Lake of the Woods, Ont., gold district. Eng M J 59:152 (1895)

Donglass, Columbus C.

39 Report [on Ingham Co., and parts of Eaton and Jackson cos.]. Mich St G, An Rp 2: 66-77 (1839) Mich St Agr Soc, $\operatorname{Tr} 1854,6: 261-271$ (1855)

40 Report [on Jackson, Calhoun, Kalamazoo, Eaton, Ionia, Kent, Ottawa, Van Buren, and Allegan cos.]. Mich St G, An Rp 3:53-75 (1840) Mich St Agr Soc, Tr 1854, 6:271-290 (1855)

41 Report [on the northern portion of the Southern Peninsula]. Mich St G, An Rp 4:97-111 (1841) Mich St Agr Soc, Tr 1854, 6:290-303 (1855)

Douglass, Earl.

99 The Neocene lake beds of western Montana and descriptions of some new vertebrates from the Loup Fork. Thesis, Univ. Montana. $27 \mathrm{pp}$, il, Missoula, Mont., 1899

00 New species of Merycochoerus in Montana. Am J Sc (4) $10: 428-438$, il (1900) ; 11:73-83, if (1901)

02 Fossil Mammalia of the White River beds of Montana. Am Ph Soc, Tr n s 20: 237-279, il (1902)

02a A Cretaceous and lower Tertiary section in south central Montana. Am Ph Soc, Pr 41: 207-224, il (1902)

02b Dinosaurs in the Ft. Pierre shales and underlying beds in Montana. Science n s 15:31-32 (1902)

02e The discovery of Torrejon mammals in Montana. Science $n$ \& $15: 272-273$ (1902)

03 Astropecten? montanus, a new starfish from the Fort Benton, and some geological notes. Carnegie Mus, An 2:5-8, il (1903)

03a New vertebrates from the Montana Tertiary. Carnegie Mus, An 2: 145-199, il (1903)

05 The Tertiary of Montana. Carnegie Mus, Mem 2: 203-224, il (1905)

05a Some notes on the geology of southwestern Montana. Carnegie Mus, An 3 : $407-428$ (1905)

05b Source of the placer gold in Alder Gulch, Mont. Mines and Minerals 25: 353-355 (1905)

06 Generic names of merycoidodonts. Science n s $24: 565-567$ (1906)

07 Merycochoerus and a new genus of merycoidodonts, with some notes on other Agriochoeridae. Carnegie Mus, An 4:8498, 11 (1907)
Douglass, Earl-Continued.

oтa Some new merycoidodonts. Car. negie Mus, An 4:99-109, il (1907)

отb New merycoidodonts from the Mir. cene of Montana. Am Mus N H, B 23: $809-822$, il (1907)

os Vertebrate fossils from the Fort Union beds. Carnegie Mus, An 5:11-26 il (1908)

OSa Rhinoceroses from the Oligocest and Miocene deposits of North Dakota and Montana. Carnegie Mus, An 4:256-266, i (1908)

081 Fossil horses from North Dakota and Montana. Carnegie Mus, An 4:26\%277 , il (1908)

ose Some Oligocene lizards. Carnegit Mus, An $4: 278-285$, il (1908)

09 Description of a new species of Prcamelus from the upper Miocene of Mos tana, with notes upon Procamelus modi sonius Douglass. Carnegie Mus, $A n 5$ : 159-165, il (1909)

09a A geological reconnaissance th North Dakota, Montana, and Idaho; with notes on Mesozoic and Cenozoic geologr. Carnegie Mus, An 5:211-288, il (1909)

09b Dromomeryx, a new genus of Amet. ican ruminants. Carnegle Mus, An 5:457479, il (1909)

10 Preliminary descriptions of some net titanotheres from the Uinta deposits. Cas negie Mus, An 6: 304-313, il (1910)

14 Geology of the Uinta formation. $G$ Soe Am, B 25 : 417-420 (1914)

Douthitt, Herman.

17 Eryops; Eryopsoides, gen. nov., fro: the New Mexico Permian. Kans Unir Sc B $10: 237-242$ (1917)

17a The structure and relationships of Diplocaulus. [Chicago, Univ], Walker Mus, Contr 2 no $1: 3-41$, il (1917)

Donville, Henri.

91 Sur l'áge des couches traversées par le canal de Panama. Ac Sc Paris, C R 112: 497-499 (1891)

98 Sur les couches a rudistes du Texas Soc G France, B (3) $26: 387-388$ (1898)

98a Sur l'âge des couches traversées pat le canal de Panama. Soc G France, B (3) $26: 587-600$ (1898)

15 Les orbitoĩdes de l'île de la Trinite Ac Sc Paris, C R 161: 87-93 (1915)

15a Les orbitoĩdes de la presqu'ile de Californie. Ac Sc Paris, C R 161:409410 (1915)

15b Les couches a orbitoïdes de l'isthme de Panama. Soc $\mathbf{G}$ France, $\mathbf{C}$ R séances no $16: 129-131$ (1915)

17 Les orbitoïdes de l'ile de la Trinité. Ac Sc Paris, C R 164: 841-847, il (1917)

18 Les couches a orbitoïdes de l'Améri. que du Nord. Ac Sc Paris, C R 167:261267, il (1918)

Dowlen, Walton E.

o3 The Turtle Mountain rock side [Frank, Alta.]. Eng M J 76:10-12 (1903) 
Dowler, Bennett.

53 Tableaux... of New Orleans. $39 \mathrm{pp}$, New Orleans 1853

Dowling, Donaldson Bogart.

93 [Summary report of explorations in northern Saskatchewan.] Can G S, Sum Rp 1892 (An Rp 6) : A 22-25 (1893)

94 [Report on explorations in western ontario.] Can G S, Sum Rp 1893 (An Rp 6) : A 22-28, map (1894)

95 Notes on the stratigraphy of the Cambro-Silurian rocks of eastern Manitoba. Ottawa Nat $9: 65-74$ (1895) Abst, J G 3: 988 (1895)

96 Report on the country in the vicinity of Red Lake and part of the basin of Berens River, Keewatin. Can G S, An Rp $7: F 54 \mathrm{pp}$, map (1896)

96a (with Tyrrell, J. B.) Report on the country between Athabasca Lake and Churchill River. Can G S, Am Rp 8:D 120 pp, map (1896)

99 [Report on field work in the Lake Nipigon region, Ont.] Can G S, Sum Rp 1898 (An Rp 11) : $\triangle$ 94-99 (1899)

00 General index to the reports of progress, 1863-1884. Can G S: 475 pp (1900) 00a Report on the geology of the west shore and islands of Lak? Winnipeg. Can G S, An Rp 11: F 100 pp, map (1900)

00b Report on the east shore of Lake Winnipeg and adjacent parts of Manitoba and Keewatin. Can G S, An Rp 11: G 98 pp, map (1900)

00e [Report on explorations in the Saskatchewan district.] Can G S, Sum Rp 1899 (An Rp 12) : A 110-115 (1900)

00d A condensed summary of the field Work annually accomplished by the officers

of the Geological Survey of Canada from its commencement to 1865 . Ottawa Nat 4:107-118 (1900)

01 The physical geography of the Red River valley. Ottawa Nat 15:115-120 (1901)

02 Report on geological explorations in Athabasca, Saskatchewan, and Keewatin distrlets ... Can G S, An Rp 13: FF 44 pp, map (1902)

02a The west side of James Bay. Can G S, Sum Rp 1901 (An Rp 14) : A 109117 (1902)

03 Eastern Assiniboia and southern Manitoba. Can G S, Sum Rp 1902 (An Ap 15) : A 182-203, map (1903)

04 Report on an exploration of Ekwan River, Sutton Mill lakes, and part of the West coast of James Bay. Can G S, An Rp 14: v 1-37 (1904)

04a Report on the coal field of the Souris River, eastern Assiniboia. Can G S, An Rp 15: F 45 pp (1904)

04b On the coal basins in the Rocky Mountains, Sheep Creek and Cascade troughs, northward to the Panther River. Can G S, Sum Rp 1903 (An Rp 15) : A 83-91, map (1904)
Dowling, Donaldson Bogart-Continued.

05 The Cascade and Costigan coal basins and their continuation northward. Can G S, Sum Rp 1904 (An Rp 16): A 105-121, map (1905)

05a The stratigraphy of the Cascade coal basin [Alta.] (with discussion). Can M Inst, J 8:221-234 (1905) Can M Rv 24:105-111 (1905)

06 The northern extension of the Elk River coal basin. Can G S, Sum Rp 1905 : 59-62 (1906)

O6a Rocky Mountain coal areas between the Bow and Yellowhead passes. Can G $\mathrm{S}$, Sum Rp 1906:66-73 (1906)

06b Cretaceous section in the Moose Mountains district, southern Alta. G Soc Am, B $17:$ 295-302 (1906)

o7 Report on the Cascade coa! basin, Alta. Can G S : 37 pp, maps (1907)

07 a The coals and coal fields of Alberta, Saskatchewan, and Manitoba. Can M J 28 (n s 1 no. 3) : 81-83 (1907)

08 Explorations in the Rocky Mountains. Can G S, Sum Rp 1907:32-34 (1908)

osa Classification of coal. Can M Inst, J $11: 220-230$ (1908)

osb Classification of coals by the split volatile ratio. Can M J 29:143-146 (1908)

09 The coal fields of Manitoba, Saskatchewan, Alberta, and eastern British Columbia. Can G S, 111 pp, map (1909) ; revised edition, Mem 53:142 pp, map (1914)

09a Steam coals of the Cascade basin; lignite areas of Alberta and Saskatchewan; production of coal in Alberta and Saskatchewan. Can G S, Sum Rp 1908:7786 (1909)

09b The coal fields of Alberta. Ec G 4: 1-11, map (1909)

09e Report on Bighorn, Brazeau, and Saskatchewan coal lands [Alta]. Can M J $30: 77-78$ (1909)

09d Pressure in the formation and alteration of coal. Can M J 30: 102-104 (1909)

09e Report on Bighorn, Brazeau, and Saskatchewan coal lands [Alta]. The German Development Company, Ltd. [Rp] : $27-41$ [1909]

o9f The Kananaskis coal area [Alberta]. The German Development Company, Ltd. [Rp] : 42-47 [1909] Abst, Can M J 30: 141 (1909)

09g Chemical changes in the formation of coal. M World 31:507-510 (1909)

10 Coal fields south of the Grand Trunk Pacific railway, in the foothills of the Rocky Mountains, Alta. Can $\mathbf{S}$, Sum Rp 1909: 139-150, map (1910)

10a The Edmonton coal fleld, Alta. Can G S, Mem 8:59 pp, maps (1910)

10b Some possible chemical changes in the formation of coal. Can M Inst, J 12 : 254-270 (1910) 
Dowling, Donaldson Bogart-Continued.

10e The alteration of vegetable matter into coal. Can M Inst, Q B 10:141-150 (1910) ; J 13:180-189 (1911)

11 The formation of coal. R Soc Can, $\operatorname{Pr} \operatorname{Tr}$ (3) 4 iv : 23-35 (1911

$11 a$ Coal fields of Jasper Park, Alta. Can G S, Sum Rp 1910:150-168 (1911)

$11 \mathrm{~b}$ The undeveloped coal resources of Canada. Can M Inst, ": B 15:87-107 (1911); J 14:326-346 (1912)

11e Canadian coal resources. $M$ Soc $N$ S, J 16:147-155 (1911)

12 Geology of Roche lifiette map area, Jasper Park, Alta. Can G S, Sum Rp 1911 : 201-219 (1912)

12 a Notes on coal occurrences and the progress of development work in Alberta and Saskatchewan. Can G S, Sum Rp 1911: 219-224 (1912)

12b Canadian coal resources. Can Inst, Tr 9:99-106 (1912)

12e Notes on the progress of development work in coal areas of Alberta and Saskatchewan. Can M Inst, Tr 15:354363 (1912)

13 Winnipeg to Bankhead. Int $\mathrm{G}$ Cong, XII, Canada, Guide Book no 8:77-101, maps (1913)

$13 a$ Dunmore to Burmis; Calgary, Alta., to Winnipeg, Manit., via Grand Trunk Pacific Rallway. Int $G$ Cong, XII, Canada, Guide Book no $9: 15-18,131-149$, maps (1913)

13b The coal fields and coal resources of Canada. Int G Cong, XII, Canada, The Coal Resources of the World, 1: 1xii-lxill, $2: 439-523$, maps (1913)

14 The coal resources of the world-a summary. Can M Inst, Tr 17:374-405. maps (1914)

14a Geological notes to accompany map of Sheep River gas and oil field, Alta. Can G S, Mem 52: 26 pp, map (1914)

14b Coal areas in Flathead Valley, B. C. Can G S, Sum Rp 1913:139-141 (1914)

14e Geological notes on the Sheep River gas and oil field, Alta. Can G S, Sum Rp 1913 : 142-149 (1914)

14d North Saskatchewan River coal areas, Alta. Can G S, Sum Rp 1913:150152 (1914)

15 Coal fields and coal resources of Canada. Can G S, Mom 59:174 pp, maps (1915)

15a Coal fields of British Columbia. Can G S, Mem 69: 350 pp, map (1915)

15b Correlation and geological structure of the Alberta oll fields. Am I M Eng. B $102: 1305-1364$, map (1915); Tr 52: 353-362, map (1916) Abst, Can M J 36 : 335-336 (1915)

15e Structural geology of the Alberta ofl fields. Can M Inst, B 35 : 164-173 (1915); $\operatorname{Tr} 18: 182-191$ (1916)

15d Southern Alberta. Can G S, Sum Rp 1914: 43-51 (1915)
Dowlins, Donaldson Bogart-Contined. 15e The Cretaceous sea in Alberta. Soc Can, Tr (3) 9 iv : 27-42, maps (191: Abst, Science n s $42: 467-468$ (1915)

16 The formation of the great plains of northwestern Canada. Ottawa Nat 11-14 (1916) Science Conspectus 6:5i. 61 (1916)

16a Water supply, southeastern Albert. Can G S, Sum Rp 1915:102-110, nu (1916)

17 The southern plains of Alberta. Ca G S, Mem 93: 200 pp, map (1917)

$\mathbf{1 7 a}$ Investigations for coal, oil, gas, ad artesian water in western Canada. Can S, Sum Rp 1916: 76-85 (1917)

18 Water supply in southern Alberh, Can G S, Sum Rp 1917 pt C : 1-3 (1918)

18a Potash in saline waters in Sa katchewan. Can G S, Sum Rp 1917 pt C: 3-4 (1918)

18b Viking- $\Delta$ thabaska gas field. Ca G S, Sum Rp 1917 pt C: 5-6 (1918)

18c Preliminary study of the westen gas fields of Canada. R Soc Can, Tr (\$) 12 iv : 89-94 (1918)

See also Miller (W G), 12

Downer, R. H.

o1 Ore deposits of the American-Netti mine, Ouray, Colo. Colo Sch Mines, B 104-107 (1901)

O1a (and DeCen, R. E.) A descrip tion of the working mines of Ouray a Colo. Colo Sch Mines, B 1 : 242-259 (1901) Drake, Daniel.

25 Geological account of the Valley of the Ohio. Am Ph Soc, Tr n s $2: 124-19$ (1825)

Drake, Frank v.

o5 Mineral resources and mining in 0rgon. Am M Cong, 7th, Pr: 119-128 (1905) Drake, Noah Fields.

92 Stratigraphy of the Triassic form: tion of northwest Texas. Tex G S, An Bp $3: 225-247$ (1892)

93 Report on the Colorado coal fleld of Texas. Tex G S, An Rp 4 pt $1: 355-44$ maps (1893) Reprint, Tex, Univ, $B$ $1755: 75 \mathrm{pp}$, map (1917)

97 A geological reconnalssance of th? coal fields of the Indian Terr. Am Ph So: Pr $36: 326-419$, maps, il (1897) Lelas Stanford Univ, Contr Biol 14:226-410. maps, 11 (1898)

$\mathbf{9 7 a}$ The topography of California. J 6 $5: 563-578$ (1897)

04 (with Lindgren, W.) Description of the Nampa quadrangle [Idaho-Ore.] U S G S, G Atlas Nampa fol (no 103:5 pp, maps (1904)

O4a (with Lindgren, W.) Descriptlor of the Silver City quadrangle [Idaho] U S G S, G Atlas Silver City fol (D) 104) : 6 pp, maps (1904)

14 Economic geology of the Waynestor quadrangle [Tenn.]. Tenn St G S, Re Tenn 4:99-120 (1914) 
Drake, Noah Fields-Continued.

17 Report on the Colorado coal field of Texas. (Reprint from the Fourth annual report of the Geological survey of Texas.) Tex Univ, B 1755: 75 pp, map (1917)

Draper, Marshall D.

97 Hahns Peak mining region [Colo.]. Colliery Eng 17: 437-438 (1897)

04 The district of Goldfield, Nev. Eng M J $78: 383-384$ (1904)

Dresser, John Alexander.

96 Petrographical notes on some Archean rocks from Chelsea, Que. Ottawa Nat 10:129-133 (1896)

97 Geological report and map of the district about Montreal. Can Rec Sc 7 : 247-255 (1897)

99 [Preliminary report on Shefford Mountain, Que.] Can G S, Sum Rp 1898 (An Rp 11) : A 120-121 (1899) ; Sum Rp 1899 (An Rp 12) : A 138-139 (1900) ; Sum Rp 1900 (An Rp 13) : A 141-143 (1901)

00 Note on the glaciation of Mount Orford, P. Q. Can Rec Sc 8:223-225 (1900)

01 A hornblende lamprophyre dike at Richmond, P. Q. Can Rec Sc $8: 315-320$ (1901)

01a A preliminary note on an amygdaloidal trap rock in the eastern townships of the Province of Quebec. Ottawa Nat 14:180-182 (1901)

01b On the petrography of Mount Orford [Que.]. Am G 27:14-21 (1901)

01e on the petrography of Shefford Mountain [Que.]. Am G 28: 203-213, map (1901)

02 Report on the geology and petrography of Shefford Mountain, Quebee. Can G S, An Rp 13: L 35 pp (1902)

02a Petrography of Shefford and Brome Mountains [Que.]. Can G S, Sum Rp 1901 (An Rp 14) : A 185-189 (1902)

02b on the copper-bearing volcanic rocks in the eastern townships of the Province of Quebec. Can M Inst, J 5 : 81-86 (1902) Eng M J 73:412 (1902) Abst, Can M Rv 21: 165-166 (1902)

02e A petrographical contribution to the geology of the eastern townships of the Province of Quebec. Am J Sc (4) 14:4348, map (1902)

03 An investigation of the copper-bearIng rocks of the eastern townships, ProvInce of Quebec. Can G S, Sum Rp 1902 (An Rp 15) : A 304-318 (1903)

04 The copper-bearing rocks of the eastern townships, Quebec. Can G S, Sum Rp 1903: (An Rp 15) : a 146-149, map (1904)

04a A new area of copper-bearings rocks in the eastern townships of the Province of Quebec. Can M Inst, J 7:397-400 (1905) Can M Rv $23: 29$ (1904)

04b On the geology of Brome Mountain, one of the Monteregian Hills. Am J Sc (4) $17: 347-358$, maps (1904)

$$
28737^{\circ}-23-21
$$

Dresser, John Alexander-Continued.

05 The bedrock of the Gilbert River gold fields, Quebec (with discussion). Can M Inst, J 8 : 259-266 (1905) Can M Rv 24: 71 (1905)

o5a The copper-bearing rocks of the Sherbrooke district, P. Q. Can G S, Sum Rp 1904 (An Rp 16) : A 263-269 (1905)

O5b A note on varieties of serpentine in southeastern Quebec (with discussion) Can M Inst, J 8: 267-271 (1905)

06 A study in the metamorphic rocks of the St. Francis Valley, Que. Am J Sc (4) $21: 67-76$ (1906)

06a The Monteregian Hills; a series of volcanic buttes. J Geog 5:74-77 (1906)

o6b Copper deposits of the eastern townships of Quebec. Ec G 1:445-453 (1906) Can M Rv 26:186-188 (1906)

o6e Igneous rocks of the eastern townships of Quebec. G Soc Am, B 17:497522 (1906)

O6d Report on the geology of Brome Mountain, Que. Can G S, Ann Rp 16 G : 22 pp (1906)

o6e [Report on] St. Bruno Mountain. Can G S, Sum Rp 1905: 113-115 (1906)

o7 Report on the copper deposits of the eastern townships of Quebec with a review of the igneous rocks of the district. Can G S : $38 \mathrm{pp}$, map (1907)

os The serpentine belt of the eastern townships [Quebec]. Can G S, Sum Rp $1907: 72-73$ (1908)

0sa Report on a recent discovery of gold near Lake Megantic, Que. Can G S: 13 pp. maps (1908)

osb A recent discovery of gold near Lake Megantic, Que. Can M J 29:234235 (1908)

09 A geological reconnaissance along the National Transcontinental Railway from the St. Lawrence River to the interprovincial boundary between Quebec and New Brunswick. Can G S, Sum Rp 1908: 124-128 (1909)

o9n On a rare rock type from the Monteregian Hills, Canada. Am J Sc (4) $28: 71-73$ (1909)

09b On the asbestos deposits of the eastern townships of Quebec. Ec G 4: $130-140$ (1909) M World $30: 593-595$ (1909)

09e Mineral deposits of the serpentine belt of southern Quebec. Can M J 30 : $334-339,365-368$ (1909)

10 Climatic changes in southeastern Quebec since the glacial period. Int $G$ Cong, XI, Stockholm; Die Veränderungen des Klimas seit dem Maximuim der letzten Eiszeit : $380-382$ (1910)

10a Geology of St. Bruno Mountain, Province of Quebec. Can G S, Mem 7: 33 pp, maps (1910) 
Dresser, John Alexander-Continued.

10b Serpentine belt of southern Quebec. Can G S, Sum Rp 1909: 180-199 (1910); 1910: 208-219 (1911)

10e Mineral deposits of the serpentine belt of southern Quebec. Can, M Inst, J 12: 163-183, 646-649, map (1910)

10d On the distribution of asbestos de posits in the eastern townships of Quebec. Can M Inst, Q B 11 : 105-120, map (1910); J 13 : 414-437, map (1911) Can M J 31 : 465-470, map (1910)

11 On the slate industry in southern Quebec. Can M Inst, Q B 15:71-85 (1911) ; J 14:149-163 (1912) Can M J $32: 584-590$ (1911)

12 Reconnalssance along the National Transcontinental Railway in southern Que bec. Can G S, Mem 35: 42 pp, map (1912)

13 Preliminary report on the serpentine and associated rocks of southern Quebec. Can G S, Mem 22: 103 pp, maps (1913)

14 Asbestos in southern Quebec. Am I M Eng, B 93:2267-2274 (1914), Tr 50: 954-963 (1915) Can M J 35:600-604 (1914)

16 Part of the district of Lake St. John, Que. Can $\mathrm{G}$ S, Mem $92: 88 \mathrm{pp}$, map (1916)

16a The district southeast of and adJoining Lake St. John, Que, Can G S, Sum Rp 1915: 173-178 (1916)

$16 b$ Geological structure of the basin of Lake St. John, Que, R Soc Can, Tr (3) 10 iv : $125-130$, map (1916)

17 Gold-bearing district of southeastern Manitoba. Can G S, Sum Rp 1916:169175, map (1917)

17a Magmatic ore separation [occurrence of chromite in Quebec]. M Sc Press 115: 7 (1917)

See also Bowen (N. L.), 17a ; Taber, 16a Dresser, Myron A.

17 Some quantitative measurements of minerals of the nickel eruptive at Sudbury [Ont.]. Ec G 12: 563-580 (1917)

Dreverman, Fr.

o5 Bemerkungen úber John M. Clarke's Beschreibung der Naples-Fauna, II. Tell. Centralbl Miner $1905:$ 385-391

Drew, Charles D.

97 (with Dixon, R. B.) Observations on the physiography of western Massachusetts. Science n s 6:847 (1897)

Dreyer, C.

10 (and Goldsehmidt, v.) Ueber Albit von Grönland, nebst Zusatz von 0 . B. Böggild. N Jb Beil-Bd 29:537-592 (1910) Med Grönland 34:1-61 (1910)

Drinker, H. S.

73 ... mines and works of the Lehigh Zinc Company. Am I M Eng, Tr 1:67-75 (1873)

Dron, R. W.

oo Gold mining in the Sierra Nevada, Cal. (abst). G Soc Glasgow, Tr 11:265266 (1900)
Dron, R. W.-Continued.

02 The gold field of northwestern 0 . tario, Can. G Soc Glasgow, Tr 12:58-00 (1902)

\section{Drummond, A. T.}

$\mathbf{7 4}$ The distribution of some Canadias plants an argument for the marine origin of the Erie clays. Can Nat n s 7:221223 (1874)

s6 Our Northwest prairies, their origin and their forests. Can Rec Sc $2: 145-153$ (1886)

8s The prafries of Manitoba. Can Ret Sc $3: 39-43$ (1888)

89 The Great Lake basins of the St. Lawrence. Can Rec Sc 3:142-147 (abst) (1888) ; 247-287 (1889) Abst, Am G 3: 198-199 (1889); Science 13:32 (1889); Pop Sc Mo $35: 422-423$ (1889)

92 The physical features of the environs of Kingston, Ont., and their history. Cas Rec Sc 5 : 108-117 (1892)

95 The Rideau lakes [Ont.]. Can Rer Sc $6: 230-238$ (1895)

Drammond, R.

18 Minerals and mining, Nova Scotis. 368 pp, Stellarton, N S., 1918

Drushel, J Andrew.

os Glacial drift under the Saint Lonls [Mo.] loess. J G 16:493-498 (1908)

11 Studies in glacial geology in Saint Louis and vicinity. Ac Se St Louis, It 20:27-36 (1911)

Dryer, Charles Redway.

89 Report on the geology of Dekalb Co.: ... Allen Co. Ind, Dp G N H, An Rp 16: 98-130 (1889)

90 The glacial geology of the Ironde quoit region. Am G 5:202-207, map (1890)

92 Report upon the geology of Steuben Co. : ... Whitley Co. Ind, Dp G N Res, An Rp 17: 114-134, 160-170 (1892)

94 The geology of Noble Co.; ... La. grange Co. Ind, Dp G N Res, An Rp 18: 17-32, 72-82 (1894)

94a The drift of the Wabash-Erie ra gion; a summary of results. Ind, Dp G N Res, An Rp 18: 83-90, map (1894)

97 Studies in Indiana geography. First series. 113 pp, maps, Terre Haute, Ind. 1897

99 Jug Rock [near Shoals, Ind.]. Ind Ac Sc, Pr 1898: 268-269 (1899)

$99 a$ The meanders of the Muscatatuck at Vernon, Ind. Ind $\mathrm{Ac} \mathrm{Sc}, \operatorname{Pr} 1898$ : 270-273 (1899)

01 Lessons in physical geography. 430 pp, N Y 1901

O1a Certain peculiar eskers and esket lakes of northeastern Indlana. $J \quad G 9$ : 123-129, maps (1901) Abst, Ind Ac $B C$, Pr 1900:178 (1901)

o3 The use of the word geest in geology. Science n s $17: 234$ (1903) 
Dryer, Charles Redway-Continued.

04 Finger Lake region of western New York, G Soc Am, B 15:449-460, map (1904) Abst, Science n s 19:524 (1904) Sc Am Sup 57 : 23446-23447 (1904)

06 The geologic features of the Finger Lake region, N. Y. (abst). Science n $\mathbf{s}$ $24: 371-372$ (1906) ; Am As Pr 56-57:272 (1907)

07 Studies in Indiana geography. First series, rev ed. 114 pp, maps. Terre Haute, Ind. 1907

08 The Honeoye-Irondequoit kame moraine (abst). Science n s 27:731 (1908) 08a Glacial Lake Bloomfield [N. Y.] (abst). Seience n s $27: 731$ (1908)

10 Some features of delta formation. Ind Ac Sc, Pr 1909: 255-261 (1910)

10a (and Davis, M. K.) A physiographic survey of an area near Terre Haute, Ind. Ind $\mathrm{Ac} \mathrm{Sc}, \mathrm{Pr} 1909$ : 263267, map (1910)

11 A physiographic survey of the Terre Haute area. Ind $\mathrm{Ac} \mathrm{Sc}, \operatorname{Pr} 1910: 145-146$ (1911)

11a (and Davis, M. K.) The work done by Normat Brook in thirteen years. Ind $\mathrm{Ac} \mathrm{Sc}$, Pr 1910:147-152 (1911)

13 Wabash studies. Ind Ac Sc, Pr 1912 : 199-213, maps (1913)

18 The physiography of Indianapolis. Ind Ac Sc, $\mathrm{Pr} 1917: 55-57$, map (1918)

Drygalski, Erich von.

97 Grönlands Eis und sein Vorland. Grönland-Expedition der Gesellschaft für Erdkunde zu Berlin, 1891-1893, Bd 1:556 pp, maps, Berlin, 1897.

15 Tallibertiefung im Grand Canyon des Colorado. Am Geog Soc, Memorial Volume of Transcontinental Excursion of $1912: 343-348$ (1915)

Drysdale, Charles Wales (1885-1917).

12 Franklin mining camp, West Kootenay, B. C. Can G S, Sum Rp 1911: 133138, map (1912)

13 Western part of the belt of interior plateaus, Savona to Lytton [B. C.]. Int G Cong, XII, Canada, Guide Book no 8: 234-256, map (1913)

14 Geology of the Thompson River valley below Kamloops Lake, B. C. Can G S, Sum Rp 1912:115-150, map (1914)

14a Rossland mining camp, B. C. Can G S, Sum Rp 1913: 129 (1914)

15 Geology of Franklin mining camp, B. C. Can G S, Mem 56:246 pp, maps (1915)

15a Geology and ore deposits of Ross. land, B. C. Can G S, Mem 77:317 pp, maps (1915)

15b Ymir mining camp, West Kootenay district, B. C. Can G S, Sum Rp 1914: $37-38$ (1915)
Drysdale, Charles Wales-Continued.

15e Notes on the geology of the "Molly" molybdenite mine, Lost Creek, Nelson mining division, B. C. Can M Inst, Mo B $43: 872-880$ (1915) ; $\operatorname{Tr} 18: 247$ 255 (1916)

16 Bridge River map area, Lillooet mining division; Highland Valley copper camp, Ashcroft mining division; human skeleton from silt bed near Savona, B. C. Can G S, Sum Rp 1915: 75-92, maps (1916)

17 Ymir mining camp, B. C. Can $G \mathrm{~S}$, Mem 94:185 pp map (1917)

17a Investigations in British Columbia. Can G S, Sum Rp 1916: 44-63 map (1917)

18 (and Burling, L. D.) Rocky Mountains section in the vicinity of Whitemans Pass (abst). G Soc Am, B 29:145 (1918)

\section{Dublancd-Laborde.}

12 Sur l'existence de blocs ealcaires métamorphisés dans les tufs ponceux anciens de la Montagne Pelée. Ac Sc Paris, C R 154: 824-826 (1912)

Dubois, W. E.

71 Lake Superior silver mines. $\Delta \mathrm{m} \mathrm{Ph}$ Soc, Pr 11:527 (1871)

Ducatel, Julius Timoleon (1796-1849).

34 (and Alexander, J. H.) Report on the projected survey of the State of Maryland... 43 pp, map, Annapolis 1834 [also other editions] Also in Am J Sc 27:1-38. (1834)

35 Report of the geologist. In Report on the new map of Maryland, 1834:13-56, [another ed : 3-50], Annapolis 1835

36 Report of the geologist. In Report on the new map of Maryland, 1835:43-96, map [Annapolis 1836]

37 Report of the geologist. In Report on the nex map of Maryland, 1836:3-59 [Annapolis 1837]

37a Outline of the physical geography of Maryland, embracing its prominent geological features. Md Ac Sc, Tr 1:24-54, map (1837)

38 Annual report of the geologist of Maryland, 1837. $39 \mathrm{pp}$, maps [Annapolis 1838]

39 Annual report of the geologist of Maryland, 1838. 33 pp [Annapolis 1839]

40 Annual report of the geologist of Maryland, $1839.45 \mathrm{pp}$, maps [Annapolis 1840] Also other editions

41 Annual report of the geologist of Maryland, 1840. $59 \mathrm{pp}$ (another ed $46 \mathrm{pp}$ ), map [Annapolis 1841]

Duce, James Terry.

17 The Colorado State Bureau of Mines collection [of minerals]. Am Mineralogist, $2:$ 103-104 (1917)

17a Apparent cleavage in Cripple Creek telluride (calaverite). Am Mineralogist 2 : 125 (1917)

18 The effect of cattle on the erosion of canyon bottoms. Science n s $47: 450-452$ (1918) 
Duchassaing, Pierre.

47 Essai sur la constitution géologique de la partie basse de la Guadeloupe, dite la Grand-Terre. Soc G France, B (2) 4: 1093-1100 (1847)

55 Observations sur les formations modernes de l'ile de la Guadeloupe. Soc G France, B (2) 12:753-756 (1855)

Du Commun, Joseph.

29 Hypothesis on volcanos and earthquakes. Am J Sc 15:12-25 (1829)

Duden, Hans.

97 Some notes on the black slate or Genesee shale of New Albany, Ind. Ind, Dp G N Res, An Rp 21:108-119, il (1897) Dudley, William L.

S5 Iridium. U S G S, Min Res 18834: 581-591 (1885)

90 A curious occurrence of vivianite. Am J Se (3) 40:120-121 (1890)

Duerden, James Edwin.

02 Relationships of the Rugosa (Tetracoralla) to the living Zoantheae. Johns Hopkins Univ Circ 21:19-25 (1902) An Mag N H (7) 9:381-398 (1902)

02a The morphology of the Madreporaria; II, Increase of mesenteries in $M a$. drepora beyond the protocnemic stage. Johns Hopkins Univ Cire 21: 59-66 (1902) An Mag N H (7) $10: 96-115$ (1902)

02b The morphology of the Madreporaria, III ; the signifieance of budding and fission. An Mag N H (7) $10: 382-393$ (1902)

02e Boring algae as agents in the disintegration of corals. Am Mus N H, B 16 : 323-332 (1902)

02d The development of septa in Paleozoic corals $(a b s t)$. Seience n s $15: 350$ (1902)

03 The morphology of the Madreporaria, IV ; Fissiparous gemmation. An Mag N H (7) 11:141-155 (1903)

03a A method of studying the septal sequence in Paleozoic corals. Elisha Mitchell Sc Soc, J 19 : 32-33 (1903)

04 The morphology of the Madreporaria; septal sequence. Biol B $7: 79-104$, il (1904).

o4a Recent results on the morphology and development of coral polyps. Smiths Misc Col 47 (Q Is 2) : 93-111 (1904)

04b The antiquity of the zoanthid actinians. Mich Ac Sc, Rp 6:195-198 (1904)

o4e The development and relationship of the Rugosa (Tetracoralla) (abst). Science $n$ s $19: 217-218$, 525-526 (1904)

05 The morphology of the Madreporaria ; the fossula in rugose corals. Biol B 9 : $27-52$, il (1905)

05a Studies of the morphology, physiology, and the development of recent and fossil corals with bibliography. Mich Ac Sc, B 2 no $1: 3-4$ (1905)

06 The primary septa in rugose corals. Science n \& $24: 246-247$ (1906)
Dnerden, James Edwin-Continued.

06a The morphology of the Madrs poraria; VIII, The primary septa of the Rugosa. An Mag N H (7) 18:226-242, il (1906)

Du Faur, A. Faber.

87 The sulphur deposits of souther Utah. Eng M J 44:450 (1887)

Duflield, Morse S.

02 The Cumberland Plateau coal field Eng M J 74:442-443 (1902)

10 Western phosphate mines. Mins and Methods 2 no $1: 9-13$ (1910)

Dufonrq, Edward L.

10 Minas Pedrazzini operations neat Arizpe, Sonora, Mexico. Eng M J 90: 1105-1106 (1910)

Dufresne, A. O.

16 Report on mining operations in the Province of Quebec during the year 1915 . Que, Dp Col, Mines, and Fish, Mines Br: 146 pp, map, Quebec 1916

Duges, Alfredo (1827-1910).

82 Nota sobre un fosil de Arperos, Es tado de Guanajuato. Revista Cientfica Mexicana no $22: 9-11$, il [not seen1882?]

87 Platygonus alemanii nobis; fósil cus. ternario. La Naturaleza (2) $1: 16-18$, il (1887)

94 Felis fósil de San Juan de los Lago [México]. La Naturaleza (2) $2: 421-42$, il (1894)

97 Un megaterídeo de los E. U. Mexi canos. Ac Mex Cienc, An $2: 201-203$, (1897)

\section{Dulienx, Emile.}

09 Report on an exploration in the re gion of Lakes Chibougamau, Doré, Daríl, and Asinichibastat [Quebec]. Que, Dp Col, $\mathrm{Rp}$ on Mining Operations 1908:50-53 (1909)

10 The Chibougamau region, Province of Quebec. Can M Inst, J 12:184-192 (1910)

10a Le bassin houiller de l'Alberta et de la Saskatchewan, Canada. Soc Ind Min B (4) $12: 133-161$ (1910)

10b Les régions argentifères du nord de la Province d'Ontario, Canada. An Mines (10) 17:319-369 (1910)

12 Preliminary report on some iron de posits on the north shore of the River and Gulf of St. Lawrence. Que, Dp Col, Mines $\mathrm{Br}, \mathrm{Rp}$ on Mining Operations 1911: 71-134 (1912)

12a The magnetic sands of the north shore of the Gulf of St. Lawrence. Que, $\mathrm{Dp} \mathrm{Col}$, Mines $\mathrm{Br}, \mathrm{Rp}$ on Mining Operations 1911 : 135-159 (1912)

$12 b$ The titaniferous ores and the mas netic sands on the north shore of the St. Lawrence. Can M J 33:450-451 (1912)

13 Preliminary report on some fron-ore deposits in the Province of Quebec. Que, Dp Col, Mines Br, Rp on Mining Operations, 1912: 65-130 (1913) 
Dulieux, Fmile-Continued.

13a Le district aurifère de Porcupine, Province d'Ontario. Canada. Soc Ind Min, B (5) : 122-154 (1913) ; abst, C R 1913: 143-149

13b The iron resources of the Province of Quebec. Can M Inst, Tr 16:351-370 (1913)

16 Les gisements du fer de la Province de Québec et leur utilisation. Rv Trim Can 2: 173-183 (1916)

Dumais, P. H.

9s Quelques aperçus sur la géologie du Saguenay. Naturaliste Can 25:104-109, $137-140, \quad 172-175 \quad(1898) ; 26: 118-122$, $132-135,152-157,182-185$ (1899) ; $27: 11-$ $14,24-25,42-47,72-77,106-109,133-136$, $178-182(1900) ; \quad 29: 149-152, \quad 172-175$, 182-184 (1902) ; $30: 23-28,70-74,137-$ $142,147-149,172-176$ (1903) ; 31:15-19, $42-46,63-66,87-88$ (1904); $32: 15-16$. $30-33,51-54$ (1905)

Dnmble, Edwin Theodore.

88 The Nacogdoches oil field [Tex.]. G Sc B 1 no 3 (1888)

88n Origin of the shell mounds. G Sc B 1 no 3 (1888)

88b Notes on the iron ore deposits of eastern Texas, G Sc B 1 no 5 (1888)

89 Texas geological and mineralogical survey; first report of progress. $78 \mathrm{pp}$, Austin 1889

89a Texas asphaltum. G Sc B 1 no 11 (1889)

89b Petrified wood [Bastrop, Tex.]. Se B 1 no 12 (1889)

90 Report of the State geologist for 1889. Tex G S, An Rp 1: xvii-lxxv, map (1890)

90a Report on the existence of artesian waters west of ninety-seventh meridian, etc. [in Texas]. U S, 51st Cong 1st sess, S Ex Doc 222: 99-102 (1890)

90b (with Hill, R. T.) The igneous rocks of central Texas (abst). Am As, Pr $38: 242-243 \quad(1890)$

91 Preliminary report on the utilization of lignite. Tex G S: 8 pp, Austin 1891

91a Report of the State geologist for 1890. Tex G S, An Rp 2: v-lxxxviii (1891)

91b A general description of the iron ore district of east Texas. Tex G S, An Rp 2: 7-31, map (1891)

91e [The iron ore district of east Texas]; Anderson Co. : Houston Co. Tex G S, An Rp $2: 303-326$ (1891)

91d Important results of the Texas survey. Am G $7: 267-269$ (1891)

92 Second report of progress, 1891. Tex G S: 91 pp, Austin 1892

92a Report of the State geologist for 1891. Tex G S, An Rp 3: xv-xlix, map (1892)
Dumble, Edwin Theodore Continued.

92b Report on the brown coal and lfg. nite of Texas; character, formation, occurrence, and fuel uses. Tex G S: $243 \mathrm{pp}$, map, Austin 1892

92c Notes on the geology of the valley of the middle Rio Grande (with discussion, pp 483-4). G Soc Am, B 3:219230 (1892)

92d (and Cummins, W. F.) The Double Mountain section [Tex.]. Am G $9: 347-351 \quad$ (1892)

92e Sources of the Texas drift. Tex Ac Sc. Tr 1 no $1: 11-13$ (1892)

$92 \mathrm{f}$ Volcanic dust in Texas. Tex Ac Sc, Tr 1 no $1: 33-34$ (1892)

93 Report of State geologist. Tex G S, An Rp 4: xvil-xxxv (1893)

$93 \mathbf{a}$ Note on the occurrence of grahamite in Texas. Am I M Eng, Tr 21: 601-605 (1893)

93b (and Cummins, W. F.) The Kent section and Gryphaea tucumcarii Marcou. Am G 12:309-314 (1893)

93e (and Harris, G. D.) The Galveston deep well. Am J Sc (3) 46:38-42 (1893)

94 The Cenozoic deposits of Texas. J G 2:549-567 (1894)

95 Cretaceous of western Texas and Coahuila, Mex. G Soc Am, B 6:375-388 (1895)

95a Volcanic dust in Texas. Science n s 1:657-658 (1895)

95b Notes on the Texas Tertiaries. Tex Ac Sc, Tr 1 no 3:23-25 (1895)

95e The soils of Texas. Tex Ac Sc, Tr 1 no $4: 25-60$, map (1895) Abst, J G 4: 245 (1896)

97 Some Texas oil horizons. Tex Ac Sc, $\operatorname{Tr} 2: 87-92$ (1897) Abst, Science n s $6: 72(1897)$

98 Physical geography, geology, and resources of Texas. In Scarf, W. G., A comprehensive history of Texas, vol., 2:471516, Dallas, Tex., 1898

oo Triassic coal and coke of Sonora, Mex. G Soc Am, B 11: 10-14 (1900)

Oon Notes on the geolosy of Sonora, Mex. Am I M Eng, Tr 29:122-152 (1900)

0ob Natural coke of the Santa Clara coal field, Sonora, Mex. Am I M Eng, Tr $29: 546-549(1900)$

01 Cretaceous of Obispo Canyon, Sonora, Mex. Tex Ac Sc, Tr 4:81 (1901)

01 a Occurrence of oyster shells in volcanic deposits in Sonora, Tex. Tex Ac Sc, Tr 4:82 (1901)

01b The oil deposits of Texas. $4 \mathrm{pp}$ [reprinted from the] Houston Post, January 20,1901

o1e The iron ores of east Texas. $4 \mathrm{pp}$ [reprinted from the] Houston Post, June 16, 1901 Abst, Eng M J 72:104 (1901)

o1d Geology of the Beaumont oil field [Tex.]. $5 \mathrm{pp}$ [reprinted from the] Houston Post, June 28, 1901 
Damble, Edwin Theodore Continued.

02 Notes on the geology of southeastern Arizona. Am I M Eng, Tr 31:696-715 (1902)

02a The red sandstone of the Diabolo Mountains, Tex. Tex Ac Sc. Tr 4:103105 (1902)

02b Cretaceous and later rocks of Presidio and Brewater cos. [Tex.]. Tex Ac Sc, Tr 4:107-114 (1902)

02c A Carboniferous coal in Arizona. Am G 30:270 (1902)

02d The Tertiary of the Sabine River. Science n s 16:670-671 (1902)

o3 Geology of southwestern Texas. Am I M Eng, Tr 33:913-987, map (1903)

06 Age of petroleum deposits, Saratoga, Tex. [upper Miocene]. Science n s 23: 510-511 (1906)

os Tertiary deposits of northeastern Mexico. Science n s 27:273 (1908)

09 The Texas Tertiaries - a correction. Science n s 29:113-114 (1909)

11 The middle and upper Eocene of Texas. Tex Ac Se, Tr 11:50-51 (1911)

$11 \mathrm{n}$ The Carrizo sands. Tex Ac Sc, Tr 11: 52-53 (1911)

$11 b$ Tertiary deposits of northeastern Mexico. Science n s $33: 232-234$ (1911)

11e Rediscovery of some Conrad forms [Cretaceous fossils, western Texas]. Science n s 33: 970-971 (1911)

12 Notes on Tertiary deposits near Coalinga oil field [Cal.] and thelr stratigraphic relations with the upper Cretaceous. J G 20:28-37 (1912)

12a Tertiary deposits of eastern Mexico. Science n s 35:906-908 (1912)

$12 \mathrm{~b}$ The occurrence of gold in the Eocene deposits of Texas. Am I M Eng, B 70:1021-1024 (1912); Tr 44:588-591 (1913)

14 The age and manner of formation of petroleum deposits. Am I M Eng, B 87 : 501-512 (1914) ; Tr 48: 521-532 (1915)

15 Problem of the Texas Tertiary sands. G Soc Am, B $26: 398$ (abst), 447476, map (1915)

15a The occurrences of petroleum in eastern Mexico as contrasted with those in Texas and Louisiana. Am I M Eng, B 104:1623-1638 (1915); Tr 52:250-265 (1916)

15b Tertiary deposits of northeastern Mexico. Cal Ac Sc, Pr (4) 5 no $6: 163-$ 193,4 pls (1915)

15e Some events in the Eogene history of the present coastal area of the Gulf of Mexico in Texas and Mexico. J G 23: 481-498, map (1915)

16 Age of the Tuxpam beds [northeastern Mexico]. Science n s 43:712 (1916)

16a The geology of Texas: 1, Its part in the building of a continent; 2, Individuality; 3, Economic features. Rice Inst Pamphlet 3 no $2: 125-204$ (1916)
Dumble, Edwin Theodore-Continued.

18 Geology of the northern end of the Tampico embayment area. Cal Ac Sc, P: (4) $8: 113-156$, map (1918)

18a Funnel and antlclinal ring strus ture associated with igneous intrusions is Mexican oil fields (discussion). Am I M Eng, B 133: 92 (1918)

18b Origin of the Texas domes, Am I M Eng, B 142:1629-1636 (1918)

See also Hill (R T), 91; Lucas (A B), 02

Damble, J. H.

58 Ice phenomena, from observations on Rice Lake [Ontario]. Can J n s $3: 414$ 422 (1858)

Dunbar, Carl o.

14 (with Twenhore1, W. H.) Nodules with fishes from the coal measures of Kansas. Am J Sc (4) 38:157-163 (1914)

17 Rensselaerina, a new genus of Lowe? Devonian brachiopods. Am J Sc (4) 43: $466-470$, il (1917)

$\mathbf{1 7 a}$ Devonian and black shale sucees. sion of western Tennessee (abst). G Soc Am, B 28: 207 (1917)

18 Stratigraphy and correlation of the Devonian of western Tennessee. Am J \&c (4) $46: 732-756$, map (1918)

Dunbar, William. See Lewis (M), 06 Dunean, Gordon S.

12 Contribution to the study of the preCambrian rocks of the Harney Peak district of South Dakota. Am I M Eng, B $67: 751-762 \quad$ (1912); Tr $43: 207-218$ (1913)

\section{Dunean, Peter Martin (1824-1891)}

63 On the fossil corals of the West Indian islands. G Soc London, Q J 19:406458 , il $(1863) ; 20: 20-44$, Il, 358-4it $(1864) ; 24: 9-33$, il (1868)

64 On the correlation of the Mlocene beds of the West Indian islands... G Mag 1: 97-102 (1864)

65 (and Wall, G. P.) A notice of the geology of Jamaica, especially with ret. erence to the district of Clarendon; with descriptions of the Cretaceous, Eocene, and Miocene corals of the 1slands. G Soc London, Q J 21:1-15, 1l, map (1865)

73 On the older Tertiary formations of the West Indian islands. G Soc London, Q J $29: 548-565$, il (1873) Abst, with title, On fossil corals from the Eocene formation of the West Indies, $G$ Mag 10: 379-380 (1873)

79 On some spheroidal lithistid spongida from the Upper Silurian formation of New Brunswick. An Mag N H (5) 4:84 91, il (1879)

87 On a new genus of Madreporarla (Glyphastraea) with remarks on the mo: phology of Glyphastraea forbesi E. and $\mathrm{H}$. from the Tertiaries of Maryland. G Soc London, Q J $43: 24-32$, il (1887) 
Duncanson, H. B.

09 Observations on the shifting of the channel of the Missouri River since 1883. Science n s $29: 869-871$ (1909)

Danlop, John P.

11 (with Butler, B. S.) Silver, copper, lead, and zine in the Central States. U S G S, Min Res 1910 pt 1:611-674; 1911 pt $1: 793-872 ; 1912$ pt $1: 437-521$; 1913 pt $1: 81-171 ; 1914$ pt $1: 27-124$ (1911-5)

12 (and Butler, B. S.) Silver, copper, lead, and zinc in Central States. U S G S, Min Res 1911 pt 1: 793-972; 1915 pt 1: $45-137 ; 1917$ pt $1: 73-130$ (1912-8)

15 Gold, silver, copper, lead, and zinc In the Eastern States in 1914. U S G S, Min Res 1914 pt 1:139-163 (1915)

15a The production of metals and ores In 1913 and $1914 ; 1914$ and 1915. U S G S, Min Res 1914 pt $1: 415-425 ; 1915$ pt $1: 723-733$ (1915-6)

16 Secondary metals in 1915 . U S G S, Min Res 1915 pt $1: 21-28$ (1916) ; in 1916... 1916 pt $1: 39-52$ (1917)

17 (with MeCankey, H. D.) Gold and silver. $\mathrm{U}$ S G S, Min Res $1915 \mathrm{pt} 1$ : $767-803 ; 1916$ pt $1: 679-721$ (1917-8)

Dunn, Russe'l L.

94 Auriferous conglomerate in California. Cal St M Bur, Rp 12:459-471, map (1894)

94a The genesis of gold placers. M Sc Press 69: 229-230, 244-245 (1894)

97 The Alaska gold fields. M Se Press 75:121-122 (1897)

98 The country of the Klondike. M Sc Press $77: 400,425-426,449$ (1898)

See also Irelan, 93

Dunnington, F. P.

72 Analysis of genthite (nickel-gymnite) from North Carolina. Ch News 25:270 (1872)

78 The minerals of a deposit of antimony ores in Sevier Co., Ark. Am As, Pr 26:181-185 (1878)

88 On the formation of deposits of oxides of manganese. Am J Sc (3) $36: 175-$ 178 (1888)

91 Distribution of titanic oxide upon the surface of the earth. Am J Sc (3) 42 : 491-495 (1891)

Dupare, Louis.

00 Note sur la région cuprifère de l'extrémité nord-est de la péninsule de Keweenaw (Lac Supérieur). Arch Sc Phys Nat (4) 10:518-538 (1900)

Dupee, J. A.

56 [On copper deposits of Keweenaw Point, Lake Superior.] Boston Soc N H, Pr 5: 279-280 (1856)

Dnralde, Martin.

04 ... fossil bones, etc., of the country of Apelousas west of the Mississippi... Am $\mathrm{Ph} \mathrm{Soc}, \operatorname{Tr} 6: 55-58$ (1804)
Durand, C. $\mathrm{S}$.

10 The Yerington district, Lyon Co., Nev. Mines and Minerals $31: 24-25$ (1910) Durand, F. E.

73 Note on crystals of quartz of a red color by the interposition of cinnabar. Cal Ac Sc, Pr 4:211 (1873)

73a Description of a new mineral from the New Almaden mine. Cal Ac Sc, Pr 4: 218 (1873)

73b Notes on the crystallization of metacinnabarite. Cal Ac Sc, Pr. 4:219220 (1873)

73e Notes on the silver mines of Pioche [Nev.]. Cal Ac Sc, Pr 4:245-246 (1873)

Durand, W. F.

10 Proposed form of seismograph in. tended to give a direct indication of the forces in play (abst). G Soc Am, B 20: $708-710$ (1910)

\section{Durocher, J.}

60 Études sur l'orographie et la géologie de l'Amérique Centrale. Ac Sc Paris, C R $50: 1170-1175(1860)$

60a Recherches sur les systèmes de montagnes de l'Amérique Centrale. Ac Sc Paris, C R 51: 43-46 (1860)

Duror, Caroline A.

16 Report on the flora of the Swauk series; report on the fauna of the Maloney series. J G 24:570-582, il (1916)

See also Smith (W S), 16

Durst, David $M$.

16 Physiographic features of Cache Creek in Yolo Co. [Cal.]. Cal Univ Pub Geog 1 : 331-372, map (1916)

Darst, Fred M.

os Glacial cirques, Mt. Whitney region. Cal Phys Geog Club, B 2:8-14 (1908)

Duryee, Edward.

03 Cement investigations in Arizona. U S G S, B $213: 372-380$ (1903)

Dutton, Clarence Edward (1841-1912).

71 The causes of regional elevations and subsidences. Am $\mathrm{Ph}$ Soc, $\mathrm{Pr}$ 12:70-72 (1871)

74 A criticism upon the contractional hypothesis. Am J Sc (3) 8:113-123 (1874)

76 Critical observations on theories of the earth's physical evolution. Penn Monthly 7:364-378, 417-431 (1876) G Mag (2) $3: 322-328, \quad 370-376 \quad$ (1876) Abst, Am J Sc (3) 12:142-145 (1876)

77 Report on the lithologic characters of the Henry Mountain intrusives. In Gilbert, G. K., Report on the geology of the Henry Mountains (U S Geog G S Rocky Mtn Reg) : 61-65 (1877) 2d ed [with title, The intrusive rocks of the Henry Mountains ] : 147-151 (1880)

78 Irrigable lands of the valley of Sevier River. In Powell, J. W., Report on the lands of the arid region of the United States : 128-149 (1878) 
Dutton, Clarence Edward-Continued.

so Report on the geology of the high plateaus of Utah. U S Geog G S Rocky Mtn Reg (Powell) : xxxii, $307 \mathrm{pp}$, atlas (1880)

80a The causes of glacial climate (with discussion). $\mathrm{Ph}$ Soc Wash, B 2:43-48 (1880)

8ob On the Permian formation of North America. Ph Soc Wash, B 3:67-68 (1880)

81 The exeavation of the Grand Canyon of the Colorado River (abst). Am As, Pr $30: 128-130$ (1882) Science (ed, Michels) $2: 453-454$ (1881)

82 The physical geology of the Grand Canyon district. U S G S, An Rp 2:47166 (1882)

S2a Tertiary history of the Grand Can yon district. U S G S, Mon 2 : xiv, 264 pp, atlas (1882) Notice by J. D. Dana, Am J Sc (3) 24:81-89 (1882)

83 Petrographic notes on the volcanic rocks of the Yellowstone Park. U S G Geog S Terr (Hayden), An Rp 12 pt 2 : 57-62 (1883)

83a Recent exploration of the volcanic phenomena of the Hawaiian Islands. Am $\mathrm{J}$ Sc (3) $25: 219-226$ (1883)

84 Hawailan volcanoes. U S G S, An Rp 4: 75-219, maps (1884)

84a Geology of the Hawaiian Islands. Ph Soc Wash, B 6:13-14 (1884)

84b The volcanic problem stated. $\mathrm{Ph}$ Soc Wash, B 6:87-92 (1884)

84c The effect of a warmer climate upon glaciers. Am J Sc (3) $27: 1-18$ (1884)

84d The basalt fields of New Mexico. Nature 31:88-89 (1884) Abst, Am Nat $19: 390-391$ (1885)

85 Mount Taylor and the Zuñi Plateau [N. Mex.]. U S G S, An Rp 6:105-198, map (1885)

85a The volcanoes and lava flelds of New Mexico (abst, with discussion by $\mathrm{J}$. W. Powell). Ph Soc Wash, B 7:76-79 (1885)

S5b The latest volcanic eruption in the United States [Lassen Peak, 1883]. Science $6: 46-47$ (1885)

86 Crater Lake, Oregon, a proposed national reservation. Science $7: 179-182$ (1886)

87 The submerged trees of the Columbia River. Science 9:82-84 (1887)

87a (and Hayden, E.) Abstract of the results of the investigation of the Charleston earthquake. Science 9:489501 (1887)

87b The Charleston earthquake. Science $10: 10-11,35-36$ (1887)

88 On the depth of earthquake focl (abst). Ph Soc Wash, B 10:17-19 (1888)

s8a (with Newcomb, Simon) The speed of propagation of the Charleston earthquake. Am J Sc (3) 35:1-15 (1888)
Dutton, Clarence Edward-Continued.

89 The Charleston earthquake of Augut 31, 1886. U S G S, An Rp 9:203-528 (1889)

S9a On some of the greater problems of physical geology (with discussion by G. K. Gilbert and R. S. Woodward). $\mathrm{Ph} S 0 x$ Wash, B $11: 51-64,536-537$ [discussion] (1889)

91 The crystalline rocks of northern California and southern Oregon. Int $G$ Cong. IV, London 1888, C R:176-179 (1891)

91 a Volcanoes and earthquakes, Nica. ragua and Costa Rica. In The inter. oceanic canal of Nicaragua (published by the Nicaragua Canal Construction Com. pany) : 73-78, N Y 1891

04 Earthquakes in the light of the ner seismology. 314 pp, N Y 1904

06 Volcanoes and radioactivity. (Read before the National Academy of Sclences, April 17, 1906). 12 pp Englewood, N. J. 1906 Also in J G 14:259-268 (1906) Pop Sc Mo 68: 543-550 (1906)

See also Frazer, 88a; King (C), 80; Powell, 80a, 82, 84, 85, 85a, 88, 89, 89a; Russell, 85d.

Dutton, T. R.

47 Observation on the basaltic forms. tion on the northern shore of Lake Superior. Am J Sc (2) 4:118-119 (1847)

Dwight, A. S.

95 Notes on Montana sapphires. Colo Se Soc, Pr 4:174-175 [1885]

Dwight, Henry Edwin.

20 Account of the Kaatskill Mountains [N. Y.]. Am J Sc 2: 11-29 (1820)

Dwight, Sereno Edwards (1786-1850)

13 A dissertation on the origin of springs. Conn Ac, Mem 1: 311-328 (1813)

26 Description of the eruption of Long Lake and Mud Lake in Vermont... Am J Sc 11:39-54 (1826) Edinb $\mathrm{N}$ Ph J 2: 146-161 (1826) Zs Miner (Leonhard) 1828, I : 31-39, 257-261

Dwight, William Buck (1833-1906).

66 On a boulder and glacial scratches at Englewood, N. J. Am J Sc (2) $41: 10-$ 11 (1866)

$66 a$ On a subsidence of land at $\operatorname{Cos}$. sackie, N. Y. Am J Sc (2) $41: 12-15$ (1866)

79 On some recent explorations in the Wappinger Valley limestone of Dutchess Co., N. Y. Am J Sc (3) $17: 389-392$ (1879)

80 Recent explorations in the Wappinger Valley limestone of Dutchess Co., N. Y. Am J Sc (3) $19: 50-54,451-453$, il (1880)

$80 a$ The results of some recent paleon. tological investigations in the vicinity of Poughkeepsie [N. Y.]. Poughkeepsle Soc N Sc, Pr 1879-80:15-20 (1880)

81 Further discoveries of fossils in the Wappinger Valley or Barnegat limestope. Am J Sc (3) 21:78-79 (1881) 
Dwight, William Buck-Continued.

83 Recent investigations and paleontological discoveries in the Wappinger limestone of Dutchess and neighboring counthes, New York State (abst). Am As, $\mathrm{Pr}$ 31:384-387 (1883) Naturalists' Leisure Hour no $81: 4-9$ (1884)

84 Recent explorations in the Wappinger Valley limestone of Dutchess Co., N. Y. Am J Sc (3) $27: 249-259$, il (1884)

84a An interesting geological locality at Cornwall, Orange Co., N. Y. Vassar Bros Inst, $\operatorname{Tr} 2: 74-83$ (1884) Abst, Science $3: 51$ (1884)

84b Report of progress in geological inrestigation in the vicinity of Poughkeepsie [N. Y.]. Vassar Bros Inst, Tr 2:141-152 (1884)

85 The peculiar structure of Clark's clay beds near Newburgh, N. Y. Vassar Bros Inst, $\operatorname{Tr} 3: 86-97$ (1885) Abst, Am J Sc (3) $32: 241-242$ (1885)

86 Recent explorations in the Wappinger Valley limestone of Dutchess Co., N. Y. ; No. 5, Discovery of fossiliferous Potsdam strata at Poughkeepsie, N. Y. Am J Sc (3) 31:125-133, map (1886) Vassar Bros lnst, $\operatorname{Tr} 4: 130-141$, map (1887)

86a Discovery of fossiliferous Potsdam strata at Poughkeepsie, N. Y. (abst). Am As, $\operatorname{Pr} 34:$ 204-209 (1886)

86b (with Ford, S. W.) ... on fossils from metamorphic limestones of the Taconic series of Emmons at Canaan, N. Y. Am J Sc (3) $31: 248-255$, il (1886)

87 Recent explorations in the Wappinger Valley limestone of Dutchess Co., N. Y. ; No. 6, Discovery of additional fossiliferous Potsdam strata, and pre-Potsdam strata of the Olenellus group, near Poughkeepsie, N. Y. Am J Sc (3) $34: 27-32$ (1887) Vassar Bros Inst, Tr 4: 206-214 (1887)

87a Paleontological observations on the Taconic limestones of Canaan, Columbia $C_{0,}$ N. Y. (abst), Am Nat 21:270-271 (1887)

89 Recent explorations in the Wappinber Valley limestones and other formations of Dutchess Co., N. Y., No. 7. Am J Sc (3) $38: 139-153$, il (1889)

90 Some practical suggestions as to the preparation of thin sections of rocks and minerals. Vassar Bros Inst, Tr 5:64-73 (1890)

90a Discovery of a locality of Trenton limestone rich in ostracoid Entomostraca and other fossils, at Pleasant Valley, N. Y. Vassar Bros Inst, Tr 5:75-77 (1890)

$90 \mathrm{~b}$ The Cambrian system of strata. Vassar Bros Inst, Tr 5: 98-102 (1890)

90e Discovery of Possiliferous strata of the middle Cambrian, at Stissing, N. Y. Vassar Bros Inst, Tr 5: 102-109, il (1890) 90d Glacial phenomena (abst), Vassar Bros Inst, Tr $5: 116-118$ (1890)
Dwight, William Buck-Continued.

90e Fossils of the western Taconic limestone in the eastern part of Dutchess Co., N. Y. Am J Se (3) 39:71 (1890)

o1 Fort Cassin beds in the calciferous limestone of Dutchess County, N. Y. (abst). G Soc Am, B 12:490-491 (1901) Science n s 13:138 (1901)

See also Warring, 87

Dyar, W. W.

04 The colossal bridges of Utah. Century Mag 68:505-511 (1904)

Dyche, D. T. D.

92 [Roots of crinoids from the Cincinnati group]. Am G $10: 130$ (1892)

92a The crinoid Heteroerinus subcrassus [column and root]. Science 20:66 (1892)

$92 \mathbf{b}$ Remarks on the stems and roots of crinoids from near Lebanon; Ohio. Cin Soc N H, J 15: 101 (1892)

Dyer, Charles B. (1806-1883).

78 (with Miller, S. A.) Contributions to paleontology [descriptions of Cincinnatian and Niagaran fossils]. Cin Soc $\mathrm{N}$ H, J 1: 24-39, il (1878)

78a (with Miller, S. A.) Contributions to Paleontology, No $211 \mathrm{pp}$, Cincinnati, Ohio, 1878 [Priv pub]

Dynan, John L.

10 (with Agthe, F. T.) Paint-ore deposits near Lehigh Gap, Pa. U S G S, B 430:440-454 (1910)

16 The White Caps mine, Manhattan, Nev. M Sc Press 113: 884-885 (1916) F.

58 Mineral regions of Lake Superior. M Mag 11:248-252 (1858)

Eakin, Henry Miner.

10 'The influence of the earth's rotation upon the lateral erosion of streams. J G 18:435-447 (1910) Abst, Science $\mathrm{n}-31$ : 319-320 (1910)

10a (with Smith, P. S.) Mineral resources of the Nulato-Council region, Alaska. U S G S, B 442: 316-352 (1910)

11 (with Smith, P. S.) A geologic reconnaissance in southeastern Seward Peninsula and the Norton Bay-Nulata region, Alaska. U S G S, B 449: 146 pp (1911) (Abst), Wash Ac Sc, J 1:37-38 (1911)

11 a (with Smith, P. S.) The Shungnak region, Kobuk Valley [Alaska]. U S G S, B $480: 271-305$, maps (1911)

12 The Rampart and Hot Springs regions [Alaska] U S G S, B 520:271-286, map (1912)

13 A geologic reconnaissance of a part of the Rampart quadrangle, Alaska. U S G S, B 535: 38 pp, map (1913) Abst, Wash Ac Sc, J $3: 467-468$ (1913)

13a Gold placers of the Ruby district [Alaska]. U S G S, B 542:279-292, map (1913)

13b Gold placers of the Innoko-Iditarod region [Alaska]. U S G S, B 542:293303 (1913) 
Gakin, Henry Miner-Continued.

13e Quaternary problems of central Alaska (abst). Wash Ac Sc, J $8: 301-302$ (1913)

14 The Iditarod-Ruby region, Alaska. U S G S, B 578: 45 pp, maps (1914)

14a Placer mining in the Ruby district

[Alaska]. U S G S, B 592: 363-369 (1914)

14b Mineral resources of the YukonKoyukuk region, Alaska. U S G S, B 592 : 371-384, map (1914)

14e The conditions of "altiplanation" in sub-Arctic regions $(a b s t)$. Wash Ac Sc, J 4:171 (1914)

15. Tin mining in Alaska. U S G S, B 622: 81-94, maps (1915)

$15 a$ Mining in the Juneau region [Alaska]. U S G S, B 682: 95-102 (1915) 15b Mining in the Fairbanks district [Alaska]: U S G S, B 622: 229-238 (1915)

15e Mining in the Hot Springs district [Alaska]. U S G S, B 622:239-245 (1915)

15d Iron-ore deposits near Nome [Alaska]. U S G S, B 622:361-365 (1915)

15e Placer mining in Seward Peninsula [Alaska]. U S G S, B 622:366-373 (1915)

15P Effect of the earth's rotation as a deflecting force in stream erosion (abst). Wash Ac Sc, J 5 : 139-140 (1915)

16 The Yukon-Koyukuk region, Alaska. U S G S, B 631:88 pp, maps (1916) Abst, Wash Ac Sc, J 6:565-566 (1916)

16a Exploration in the Cosna-Nowitna region [Alaska]. U S G S, B 642:211221, map (1916)

17 Lode mining in the Juneau gold belt [Alaska]. U S G S, B 662:77-92, maps (1917)

17a Gold placer mining in the Porcupine district [Alaska]. U S G S, B 662 : 93-100, map (1917)

17b The Quaternary history of central Alaska (abst). Wash Ac Sc, J $7: 81$ (1917)

18 The Cosna-Nowitna region, Alaska. U S G S, B 667:54, maps (1918) Abst by R. W. Stone, Wash Ac Sc, J 8:502 (1918)

Eakins, L, G.

86 Meteoric Iron from New Mexico. Colo Sc Soc, Pr 2:15 (1886)

$86 a$ on allanite and gadolinite. Colo Sc Soc, Pr 2: 32-35 (1886)

s6b (with Cross, W.) On ptilolite, a new mineral [from Jeffenson Co., Colo.]. Am J Sc (3) 32:117-121 (1886) Colo Sc Soc, Pr 2: 71-76 (1887)

88 Two sulphantimonites from Colorado. Am J Sc (3) $36: 450-453$ (1898) Colo Sc Soc, $\operatorname{Pr} 3: 73-76$ (1889)

90 A new stone meteorite. Am J Sc (3) $39: 59-61$ (1890)
Fakins, L. G.-Continued.

90a Meteoric iron from North Carolin Am J Sc (3) 39:395-396 (1890)

91 New analyses of astrophyllite atd tschefrkinite. Am J Sc (3) $42: 34-28$ (1891)

92 (with Cross, W.) A new ocer. rence of ptilolite. $\Delta \mathrm{m}$ J Sc (3) $44: 96$ 101 (1892)

93 A new meteorite from Hamblen $\mathrm{C}_{0}$ Tenn, $A m$ J Sc (3) $46: 283-285$ (1893) Eakle, Arthur Starr.

93 On some dikes occurring near Lyo Mountain. Clinton Co., N. Y. Am G 12 31-36 (1893)

94 On allanite crystals from Franklin Furnace, N. J. N Y Ac Sc, Tr 13:102107 (1894) $\mathrm{Am} \mathrm{J}$ Sc (3) $47: 436-49$ (1894) Zs Kryst 23:209-211 (1894)

96 Beiträge zur krystallographisches Kenntniss der uberjodsauren und jodsauren Salze. Zs Kryst 26:558-588 (1896)

98 Topaz crystals in the mineral col lection of the U. S. National. Museum, U S Nat Mus, Pr 21: 361-369 (1898)

98 a Frionita, a new zeolite. Am J \& (4) $6: 66-68$ (1898) Zs Kryst $30: 176$ 178 (1898)

98b A biotite tinguaite dike from Mar chester-by-the-sea, Essex Co., Mass. Am I Sc (4) 6:489-492 (1898)

99 Miargyrit von Zacatecas, Mexico. 2s Kryst 31: 209-215 (1899)

o1 Mineralogical notes; with chemiel analyses by W. T. Schaller. Cal Univ, Bf G, B 2:315-325 (1901)

02 Colemanite from southern Callfornis Cal Univ, Dp G, B 3: 31-50 (1902) Abst

Science n s 15:417 (1902)

03 Palacheite. Cal Univ, Dp G, B 231-236 (1906)

O3a Note on the identity of palacheite and botryogen. $A m$ J Se (4) $16: 379-396$ (1903)

04 Mineral tables for the determination of minerals by their physical propertics $73 \mathrm{pp}, \mathrm{N}$ Y 1904

04a Phosphorescent sphalerite [Mart posa Co., Cal.]. Cal J Tech $3: 30-31$ (1904)

O4b (and Sharwood, W. J.) Luril nescent zinc blende [Mariposa Co., Cal.] Eng M J 77:1000 (1904)

o7 Notes on lawsonite, columbite, bergh barite, and calcite. Cal Univ, Dp G, B S 81-94 (1907)

O7a Weathered pyrite. M Sc Press 95: 492 (1907)

os Recent volcanic eruptions in Berist Sea. M Sc Press 96: 353 (1908)

08a Notes on some Callfornia minerals Cal Univ, Dp G, B 5 : 225-233 (1908)

11 Neocolemanite, a variety of colemas: ite, and howlite from Lang, Los Angeles Co., Cal. Cal Univ, Dp G, B 6:179-199 (1911) Abst, G S Am, B 23:70 (1912) 
Eakle, Arthur Starr-Contlnued.

12 The minerals of Tonopah, Nev. Cal Univ, Dp G, B $7: 1-20$ (1912) Abst, G Soc Am, B 23: 70 (1912)

14 Minerals of California. Cal St M Bur, B $67: 226$ pp (1914)

14a (and Rogers, A. F.) Wilkeite, a new mineral of the apatite group, and okenite, its alteration product, from southern California. Am J Sc (4) $37: 262-267$ (1914)

14b Some contact-metamorphic minerals in crystalline limestone at Crestmore, near Riverside, Cal. (abst). G Soc Am, B 25: 125 (1914)

16 Xanthophyllite in crystalline limestone. Wash Ac Sc, J 6:332-335 (1916)

17 Minerals associated with the crystalline limestone at Crestmore, Riverside Co., Cal. Cal Univ, Dp G, B 10:327-360 (1917)

17a Alpine County. In Mines and Mineral resources of Alpine County, Inyo County, Mono County (Chapters of State Mineralogist's Rp [15:5-27] (1915-16); 1-24, Cal St M Bur (1917)

$17 \mathrm{~b}$ (and MeLaughlin, R. P.) Mono County. In Mines and Mineral resources of Alpine County, Inyo County, Mono County (Chapters of State Mineralogist's Rp $[15: 135-175](1915-16) ; 131-171, \mathrm{Cal}$ St M Bur (1917)

See also Thompson (A P), 15

Eames, Henry H.

66 Report of the State geologist on the metalliferous region bordering on Lake Superior ... 21 pp, 2d ed, 23 pp, Saint Paul 1866

66 a Geological reconnaissance of the northern, middle, and other counties of Minnesota. $58 \mathrm{pp}$, Saint Paul 1866, a nother ed 1867

Eames, Richard, jr.

07 Copper in North Carolina. Eng M J 83:583 (1907)

Earle, Charles.

91 Palaeosyops and allied genera. Ac N Sc Phila, Pr 1891: 106-117, il

91a On a new species of Palaeosyops [P. megarhinus.] Am Nat 25:45-47, il (1891)

92 A memoir upon the genus Palaeosyops Leidy, and its allies. Ac $\mathrm{N}$ Se Phila, J (2) $9: 267-388$, il (1892)

92n Revision of the species of Coryphodon. Am Mus N H, B $4: 149-166$, Il (1892)

92b The variability of specific characters as exhibited by the extinct genus Coryphodon. Sclence $20: 7-9$, il (1892)

93 The evolution of the American tapir. $6 \mathrm{Mag}$ (3) $10: 391-396$ (1893)

93a on the systematic position of the genus Protogonodon. Am Nat 27:377-379 (1893)
Earle, Charles-Continued.

93b The structure and affinity of the Puerco ungulates. Science 22:49-51 (1893)

93e (with Wortman, J. L.) Ancestors of the tapir from the lower Miocene of Dakota. Am Mus N H, B 5:159-180, il (1893)

95 On a supposed case of parallelism in the genus Palaeosyops. Am Nat 29:622626 , il (1895)

95a (with osborn, H. F.) Fossil mammals of the Puerco beds [N. Mex.]. Am Mus N H, B $7: 1-70$, il (1895)

96 Notes on the fossil Mammalia of Europe; I, Comparison of the American and European forms of Hyracotherium. Am Nat $30: 131-135$ (1896)

96a Tapirs, past and present. Science n s $4: 934-935$ (1896)

97 Relations of Tarsius to the lemurs and apes. Science n s 5:258-260 (1897)

98 Relationship of the Chriacidae to the primates. Am Nat $32: 261-262$ (1898)

Earle, Raymond Bartlett (?-1918).

99 Mineral veins of the Mystic quarries, Somerville [Mass.] (abst). Science n s $9: 752$ (1899)

14 The genesis of certain Paleozoic interbedded iron ore deposits. N Y Ac Sc, An 24: 115-170 (abst, 23:277-278, 287) (1914) Abst, Science n s $38: 281-282$ (1913)

East, J. H., jr.

11 Sunlight mining district, Wyo. Eng M J 91:1155-1156 (1911)

Eastman, Charles Rochester (1868-1918). 95 Beitrïge zur Kenntniss der Gattung Oxyrhina mit besonderer Berïcksichtigung von Oxyrhina mantelli Agassiz. Palaeontographica $41: 149-191$, 11 (1895)

96 Preliminary note on the relations of certain body plates in the dinichthyids. Am J Sc (4) 2:46-50 (1896)

$96 \mathbf{a}$ Remarks on Petalodus alleghaniensis Leidy. J G 4:174-176 (1896)

$96 \mathbf{b}$ On the function and systematic importance of the aptychus in Ammonites (abst). Science n s 3:751-752 (1896)

96e Observations on the dorsal shlelds in the dinichthyids (abst). Am G 18: 222-223 (1896) Science n s 4:386 (1896)

97 On the relations of certain plates in the dinichthyids, with descriptions of new species. Harvard Coll, Mus C Z, B 31: $19-44$, il (1897)

97a On Ctenacanthus spines from , Keokuk limestone of Iowa. Am J Sc (4) $4: 10-12$, il (1897)

$97 \mathbf{b}$ Tamiobatis vetustus, a now form of fossil skate [Powell Co., Ky.] Am J Sc (4) : 85-90, fl (1897)

$97 \mathrm{c}$ On the occurrence of fossil fishes in the Devonian of Iowa. Iowa G S $7: 108$ 116, il (1897)

$97 \mathbf{A}$ On the characters of Macropetalich thys. Am Nat 31:493-499, il (1897) 
Eastman, Charles Rochester-Continued. 98 Dentition of Devonian Dtyctodontidae. Am Nat $32: 473-488,545-560$, il (1898)

98a Some new points in dinichthyid osteology. Am Nat $32: 747-768$, il (1898) $A b s t$, Am As, $\mathrm{Pr} 47: 371-372$ (1898); Science n s 8:400-401 (1898)

99 Upper Devonian fish fauna of Delaware Co., N. Y. N Y St G, An Rp 17: $317-327$, il (1899) N Y St Mus, An Rp $51 v 2: 317-327$, il (1899)

99a Jurassic fishes from Black Hills of South Dakota. G Soc Am, B 10:397408, il (1899)

99b Descriptions of new Diplodus teeth from the Devonian of northeastern Illinois. J G $7: 489-493$ (1899)

99c Some new American fossil fishes. Science n s 9:642-643 (1899)

oo Textbook of paleontology by Karl von Zittel. Vol. 1 [Invertebrata], $706 \mathrm{pp}$, il, N Y and L 1900 Rv by 5 . A. Bather, Science n s 11:980-984 (1900) Vol. 2 [Vertebrata], $283 \mathrm{pp}, \mathrm{ill}, \mathrm{N}$ Y and L 1902 2d ed, vol 1 [Invertebrata], $839 \mathrm{pp}, \mathrm{il}$, L and N Y 1913 Notice, by J. M. Clarke, Science n s 39:723-725 (1914) [The several parts revised by specialists.]

ooa Fossil lepidosteids from the Green River shales of Wyoming. Harvard Coll, Mus C Z, B 36:67-75, il (1900)

00b Dentition of some Deronian fishes. J G $8: 32-41$, il $(1900)$

o0e New fossil bird and fish remains from the middle Eocene of Wyoming. G $\mathrm{Mag}$ (4) $7: 54-58$, il (1900)

01 On Campoius, Edestus, Helicoprion, Acanthodes, and other Permo-Carboniferous sharks (abst). Science n s 14:795 (1901)

02 Some Carboniferous cestraciont and acanthodian sharks. Harvard Coll, Mus C Z, B 39: 55-99, il (1902)

02a The Carboniferous fish fauna of Mazon Creek, III. J G $10: 535-541$, il (1902)

02b Some hitherto unpublished observations of Orestes St. John on Paleozoic fishes, $\Delta \mathrm{m}$ Nat $36: 653-659$, il (1902)

02e Notice of interesting new forms of Carboniferous fish remains. Am Nat 36 : $849-854$, il (1902)

02d On Campyloprion, a new form of Edestus-like dentition. G Mag (4) 9:148152, il (1902)

02e On the genus Peripristis St. John. G Mag (4) $9: 388-391$, il (1902)

o2f (and Barbour, E. H.) Synopsis of the Missourian and Permo-Carboniferous fish fauna of Kansas and Nebraska (abst). Science n s 16:266-267 (1902)

02g Phylogeny of the cestraciont group of sharks (abst). Science n s 16:267 (1902)
Eastman, Charles Rochester-Continued. 03 On the nature of Edestus and $m$ lated forms. Mark Anniversary Volume [Harvard Univ.] : 279-289, il, N Y 1903

03a Carboniferous fishes from the ceetral Western States. Harvard Coll, Ins C Z, B $39: 163-226$, 11 (1903)

03b A peculiar modiflcation amongst Permian dipnoans. Am Nat $37: 493-495$, il (1903)

03e Devonian fish fauna of Iowa $(a b s t)$, G Soc Am, B 13:537 (1903)

04 On Upper Devonian fish remains from Colorado. Am J Sc (4) $18: 253-260$, t] (1904)

O4a On the dentition of Rhynchods and other fossil fishes. Am Nat $38: 295$ 299, il (1904)

04b Fossil plumage. Am Nat 38:669672, il (1904)

o4e Marginal and ridge scales in Cepho. laspis and Drepanaspis. Seience n s 19: 703-704 (1904)

04d A reeent paleontological induction. Sclence n s 20:465-466 (1904)

05 A brief general account of fosst fishes. N J G S, An Rp 1904:27-66, If (1905)

O5a The Triassic fishes of New Jerser. N J G S, An Rp 1904:67-130, il (1905) O5b The literature of Edestus. Am Mat $39: 405-409$ (1905)

ose Mont Pelée sive Mont Pelé. Sct. ence n s $21: 352-353$ (1905)

06 Dipnoan affinities of arthrodires. An J Sc (4) $21: 131-143$ (1906) Abst, Sct ence n 8 23:290 (1906); Am As, Pr 55: 379 (1906)

06a Structure and relations of Mylor toma. Harvard Coll, Mus C Z, B 50:1-20, il (1906)

o7 Mylostomid dentition. Harvard Coll, Mus C Z, B 50:211-228, il (1907)

O7a Types of fossil cetaceans in the $\mathrm{Mr}$. seum of Comparative Zoology. Harvard Coll. Mus C Z, B 51: 79-94, fl (1907)

07b Devonic fishes of the New York formations. N Y St Mus, Mem 10:235 pp, tl (1907) [Review, Hussakof, 08a]

os Notice of a new coelacanth fish from the Iowa KInderhook. J G 16:357-362, Il (1908) Abst, Sclence n \& 27:255 (1908)

osa Devonian fishes of Iowa. Iowa $\theta$

S $18: 29-386$, il (1908)

09 A new species of Helodus [Meadrille. Pa.]. Carnegie Mus, An 5 : 488-489 (1909)

09 Mylostomid dental plates. Sclence n s $29: 997-998$ (1909)

09b Mylostomid palatal dental plates Harvard Coll, Mus C Z, B $52: 261-269$, I (1909)

11 Triassic fishes of Connecticut. Cons G S, B 18: 77 pp il (1911)

11a Catalog of fossil fishes in the Catnegie Museum, Part I: Fishes from the upper Eocene of Monte Bolca. Carnegie Mus, Mem $4: 349-414$, il (1911) 
Eastman, Charles Rochester-Continued. 11b Jurassic saurian remains ingested within fish. Carnegie Mus, An 8:182-187, 11 (1911)

12 Ten years' progress in vertebrate paleontology; Mesozoic and Cenozoic fishes. G Soc Am, B 23: 228-232 (1912)

13 Brain structures of fossil fishes from the Caney shales (abst). G Soc Am, B 24: 119-120 (1913)

14 Notes on Triassic fishes belonging to the families Catopteridae and Semionotidae. Carnegie Mus, An $9: 139-148$, il (1914)

15 Dipterus remains from the upper Devonian of Colorado. Carnegie Mus, An $9: 279-283$, il (1915)

16 (and Gregory, W. K., and Matthew, W. D.) Recent progress in vertebrate paleontology. Science n s $43: 103-$ 110 (1916) ; 45:117-121 (1917)

16a Report of investigation of Paleozoic fishes (abst). N Y Ac Sc, An 26:439-440 (1916)

16b (with Dean, B.) A bibliography of fishes. Vol. 1, Author's titles A-K. 718 pp. Vol. 2, Author's titles L-Z, 702 Pp, Am Mus N H, N Y 1916, 1917

17 Fossil fishes in the collection of the United States National Museum. U s Nat Ifus, $\operatorname{Pr} 52: 235-304$, il (1917)

17a Dentition of Hydrocyon and its supposed fossil allies. Am Mus N H, B 37 : $757-760$, il (1917)

$17 \mathrm{~b}$ Campodus and Edestus remains (obst). G Soc Am, B 28:214 (1917)

See also Clark (W B), 01a, 04a.

Eastman, John Roble.

84 A new meteorite [Grand Rapids, Mlch.]. Am J Sc (3) 28:299-300 (1884) 4bst, $\mathrm{Ph}$-Soc Wash, B 7:32 (1885)

92 The Mexican meteorites. Ph Soc Wash, B $12: 39-51$ (1892)

Easton, H. D.

13 Report on the technology of Kentucky clays, including chemical and me. chanical analyses, and burning tests. Ky G \& (4) 1:713-888 (1913)

Easton, S. A.

02 Notes on Tonopah, Nev. Eng M J $73: 697$ (1902)

Eaton, Amos (1776-1842).

18 Index to the geology of the Northern States with a transverse section from Catskill Mountain to the Atlantic; prepared for the geological classes of Williams College ... 52 pp, Leicester $1818 \quad 2 \mathrm{~d}$ ed, xi, 286 pp, Troy, N Y 1820

18a Account of the strata perforated by, and of the minerals found in, the great adit to the Southampton lead mine. Am J Se 1: 136-139 (1818)

20 (and Beek, T. R.) A geological survey of the county of Albany... $56 \mathrm{pp}$, Albany 1820

22 A geological and agricultural survey of Rensselaer County in the State of New York.. $70 \mathrm{pp}$, Albany $\mathbf{1 8 2 2}$
Eaton, Amos-Continued.

22a on à singular deposit of gravel. Am J Sc 5:22-23 (1822)

221 ... the geology of the Highlands on the River Hudson. Am J Sc 5:231-235 (1822)

23 A geological and agricultural survey of Rensselaer Co. [N. Y.]. N Y Bd Agr, Mem 2:3-18 (1823)

23a Geological profile of the rocks from Onondago salt springs, N. $\mathbf{Y}$., to Williams College, Mass. N Y Bd Agr, Mem 2:4143 (1823)

23b On the probable origin of certain salt springs [New York]. Am J Sc 6 : 242-243 (1823)

24. A geological and agricultural survey of the district adjoining the Erie canal in the State of New York. 163 pp, Albany 1824

24a Progress of the geological survey on the grand canal [Erie Canal]. Am J Sc 8: 195-198 (1824)

24b Ought American geologists to adopt the changes in the science proposed by Phillips and Conybeare? Am J Se 8:261263 (1824)

27 ... diluvial deposits in the State of New York and elsewhere. Am J Sc 12:1720 (1827)

28 A geological nomenćlature for North America founded upon geological surveys taken under the direction of the Hon. Stephen Van Rensselaer. 31 pp. map, Albany 1828

28a Tabular view of North American rocks. Am J Sc 13:384-385 (1828)

28b Geological nomenclature, classes of rocks, etc. $\Delta \mathrm{m}$ J Sc 14:145-159, 359-368 (1828)

29 Argillite embracing anthracite coal. Am J Sc 16:299-301 (1829)

30 Geological prodromus. Am J Sc 17 : 63-69 (1830)

30a All primitive general strata, below granuiar quartz, are co-temporaneous and schistose. Am J Sc 17:334-335 (1830)

$30 b$ The gold of the Carolinas in talcose slate. Am J Sc 18: 50-52 (1830)

30e Direction and extent of primitive ranges. Am J Sc 18: 376 (1830)

30 ... coal formations in the state of New York; in connexion with the great coal beds of Pennsylvania. Albany Inst, Tr. 1: 126-130 (1830) Am J Sc 19:21-26 (1830)

30e Travelling term of Rensselaer for 1830 [notes on geology of New York]. Am J Sc 19:151-159 (1830)

31 Crotalus? reliquus, or Arundo? crotaloides. Am J Sc 20:122-123, il (1831)

31a The gold of Mexico in a rock equivalent to that which contains the gold of the Carolinas. Am J Sc 20:124 (1831)

31 beological equivalents. Am $\mathrm{J}$ Sc 21: 132-138 (1831) 
Eaton, Amos-Continued.

32 Geological textbook... 7, 63 pp, map, Albany 1830 2d ed, 134 pp, map, Albany 1832

32a Four cardinal points in stratigraphical geology established by organic remains. Am J Se 21: 199-200 (1832)

32b Trilobites. Am J Sc $22: 165-166$ (1832)

33 The coal beds of Pennsylvania equivalent to the great secondary coal measures of Europe. Am J Sc 23 : 399-400 (1833)

39 Cherty lime rock, or corniferous lime rock, proposed as the line of reference for state geologists of New York and Pennsyl vania. Am J Sc 36:61-71, 198 (1839)

40 References to North American locall. ties, to be applied in illustration of the equivalency of geological deposits on the eastern and western sides of the Atlantic. Am J Sc 39:149-156 (1840)

41 Eaton's geological note book for the Troy class of 1841 . $13 \mathrm{pp}$ [priv pub?, n p, 1841?]

Eaton, 1 . N.

91 The Winnebago meteorite. Am G 8: 385-387 (1891)

Eaton, George F.

98 The prehistoric fauna of Block Island, as indicated by its ancient shell heaps. Am J Sc (4) 6:137-159, maps (1898)

03 Notes on the collection of Triassic fishes at Yale. Am J Sc (4) 15:259-268, il (1903)

03a The characters of Pteranodon. Am J Sc (4) $16: 82-86$, il (1903) ; 17:318320 , il (1904)

04 John Bell Hatcher. Am J Sc (4) 18: 163-164 (1904)

o5 Occurrence of Mastodon humboldtii in northern Mexico. Am J Sc (4) 19:330 (1905)

os [The skull of Pteranodon (abst).] Sclence n s $27: 254$ (1908)

10 Osteology of Pteranodon. Conn AC Arts Sc, Mem 2:38 pp, il (1910)

Eaton, Harry Nelson.

os Micro-structure and probable origin of flint-like slate near Chapel Hill, N. C. Elisha Mitchell Sc Soc, J 24:1-8 (1908)

0Sa Micropegmatite at Chapel Hill [N. C. ]. Elisha Mitchell Sc Soc, J 24:104105 (1908)

09 Notes on the petrography of the granites of Chapel Hill, N. C. Elisha Mitchell Sc Soc, J 25: 85-91 (1909)

10 On the origin of flint-like slate near Chapel Hill, N. C. Science n s $32: 246$ (1910)

12 The geology of South Mountain at the Junction of Berks, Lebanon, and Lancaster cos., $\mathrm{Pa}$. J G 20:331-343, map (1912)

16 A giant pothole near Scranton, $\mathrm{Pa}$. (abst) Science n s 43:399 (1916)
Eaton, James Howard ( $3-1877)$.

72 Report on the geology of the region about Devil's Lake. Wis Ac Sc, Tr 1: 124-128 (1872)

73 On the relations of the sandstone conglomerates, and limestone of Sauk Co. Wis., to each other and to the Azole. Al J Se (3) 5:444-447, map (1873)

$\mathbf{7 4}$ On the relation of the sandstone, conglomerates, and limestone of the Bars. boo Valley to each other and to the Azoic quartzites. Wis Ac Sc, Tr $2: 123-12 i$ (1874)

Eaton, Samuel John Mills (1820-1889).

66 Petroleum, a history of the ofl re gion of Venango County, Pa. ... 299 pp, map, Phila 1866

Eberle, Frank.

05 The Willamette meteorite. M World $23: 279$ (1905)

09 The Arkansas diamond fields. If World $31: 285-286$ (1909)

Eberlin, Peter.

89 (with Kuntsen, H.) Om de geologiske Forhold i Dansk Östgrönland, Med Grönland $9: 235-2,0$ (1889)

Eby, J. H.

96 The occurrence of copper minerals in hematite ore, Montana mine, Soudan, Mino. L Sup M Inst, Pr 4:69-72 (1896) Minh, Univ, Engineers Year Book 5:108-110 (1897)

Eceles, James.

$\mathbf{8 1}$ On the mode of occurrence of some of the volcanic rocks of Montana, U. S. A. G Soc London, Q J 37:399-401 (1881)

Eeke1, Edwin Clarence.

99 Intrusives in the Inwood limestone of Manhattan Island. $\mathrm{Am}$ G $23: 122-124$ (1899)

01 ... cement industry in New York. N Y St Mus, B 44: 849-955 (1901)

01a A recently discovered extension of the Tennessee white phosphate fields. U S G S, Min Res 1900: 812-813 (1901)

01b The emery deposits of Westchester Co., N. Y. Mineral Industry 9:15-17 (1901).

o1e The formation as the basis for gea logic mapping. J G 9: 708-717 (1901)

02 The quarry industry in southeast ern New York. N Y St Mus, An Rp 54: r141-176, map (1902)

$02 a$ The classification of the crystalline cements. Am G 29:146-154 (1902)

02b The preparation of a geologic map. J G $10: 59-66$ (1902)

02c Summaries of the literature of structural materials. J G $10: 442-449$, 542-550 (1902); $11: 86-92, \quad 716-719$ (1903)

03 Gold and pyrite deposits of the Dab. lonega district, Ga. U S G S, B 213: 57-63 (1903)

03a Utilization of iron and steel slags U S G S, B $213: 221-231$ (1903) 
Eckel, Edwin Clarence-Continued.

$03 \mathrm{~b}$ Stoneware and brick clays of western Tennessee and northwetsern Mississippi. U S G S, B 213:382-391 (1903)

03e Salt and gypsum deposits of southwestern Virginia. U S G S, B 213:406416 (1903)

03d The white phosphates of Decatur Co., Tenn. U S G S, B 213: 424-425 (1903)

03e The cement resources of Alabama. U S, 58th Cong 1st sess, S Doc 19:1-11 (1903)

03f Molding sand; its uses, properties, and occurrence. N,Y St Mus, An Rp 55: r91-96 (1903)

03g The Dahlonega gold district of Georgia. Eng M J 75:219-220 (1903)

03h Dahlonega mining district, Ga. (abst). Science n s 17:793 (1903)

03i (with Hayes, C. W.) Iron ores of the Cartersville district, Ga. U S G S, B $213: 233-242$ (1903)

03j (with Hayes, C. W.) Occurrence and development of ocher deposits in the Cartersville district, Ga. U S G S, B 213 : 427-432 (1903)

04 Gypsum deposits in New York. U S G 8, B 223: 33-35 (1904)

04a Gypsum deposits in Virginia, U $\mathbf{S}$ G \&, B $223: 36-37$, map (1904)

04b The slate deposits of California and Utah. U S G S, B 225:417-422 (1904)

04e Cement-rock deposits of the Lehigh district of Pennsylvania and New Jersey. U \& G S, B 225:448-456 (1904)

04d The salt industry in Utah and Callfornia. U S G S, B 225:488-495 (1904) 04e The materials and manufacture of Portland cement. Ala G S, B $8: 1-59$ (1904)

04f On a California roofing slate of igneous origin. J G $12: 15-24$ (1904)

$04 \mathrm{~g}$ on the chemical composition of American shales and roofing slates. J G 12: 25-29 (1904)

04h The nonmetallic mineral products of the United States. M Mag 10:167-174, map (1904)

04i Brown hematite deposits of eastern New York and western New England. Eng If J $78: 432-434$ (1904)

04j (with Johnson, L. C.) [Notes on water resources of] Mississippi. U S G S, IV-S P $102: 332-357$ (1904)

$\begin{array}{llll}05 & \text { Cements, limes and plasters ... } & 712\end{array}$ pp. N Y 1905

05a (and others) Cement materials and Industry of the United States. U S G S, B $243: 395 \mathrm{pp}$, maps (1905)

05b Iron and manganese ores of the United States. U S G S, B 260:317-320 (1905)

05e Limonite deposits of eastern New York and western New England. U S G S, B 260: 335-342 (1905)
Ecke1, Edwin Clarence-Continued.

05d The iron ores of northenstern Texas.

U S G S, B 260: 348-354 (1905)

o5e The American cement industry. U

S G S, B 260: 496-505 (1905)

osf Portland-cement resources of New

York. U S G S, B 260:522-530 (1905)

O5g Pyrite deposits of the western Adirondacks, New York. U S G S, B 260: $587-588$ (1905)

o5h (and Crider, A. F.) Geology and cement resources of the Tombigbee River district, Miss.-Ala. U S, 58th Cong 3d sess, S Doc $165: 23$ pp. map (1905)

o5i (and Bain, H. F.) Cement and cement materials of Iowa. Iowa G S 15: 33-124 (1905)

05j The Clinton hematite. Eng M J 79:897-898 (1905)

o6 Cement materials of Mississippi. U S G S, B 283 : 71-84 (1906)

06a Contributions to economic geology, 1905 ; Investigation of iron ores and nonmetalliferous minerals. U S G S, B 285 : 20-24 (1906)

06b The Clinton or red ores of northern Alabama. U S G S, B 285:172-179 (1906) o6e The Oriskany and Clinton iron ores of Virginla. U S G S, B 285: 183-189 (1906)

o6d Cement resources of the Cumberland Gap district, Tenn.-Va. U S G S, B 285 : $374-376$ (1906)

06e Clays of Garland Co., Ark. U S G S, B 285 : 407-410 (1906)

O6f Gypsum and gypsum products. U S G S, Min Res 1905: 1105-1115 (1906)

06g (with Dale, T. N.) Slate deposits of the 'United States. U S G S, B 275 : 51-125 (1906)

O6h (with Emmons, S. F.) Contributions to economic geology, 1905. U S G S, B 285: 506 pp (1906) ...1906: Part I. Metals and nonmetals, except fuels; B $315: 505$ pp (1907)

07 Investigations of iron ores, structural materials, etc. U S G S, B 315:20-25 (1907)

07a The mineral-paint ores of Lehigh Gap, Pa. U S G S, B 315: 435-437 (1907) 07b Iron ores, pig iron, and steel. U S G S, Min Res 1906:67-102; 1907 pt 1: 51-85 (1907-8)

07e Manganese ores. U S G S, Min Res 1906: 103-109 (1907)

07d Mineral paints; geology and technology. U S G S, Min Res 1906: 11201122 (1907)

os Cement industry in the United States in $1907 ; 1908$. U S G S, Min Res 1907 pt $2: 477-493 ; 1908$ pt $2: 441-453$ (1908-9)

12 Bullding stones and clays: their origin, characters, and examination. xiv, 264 pp, N Y 1912

12a Iron-ore reserves. Eng Mag 43: $665-674,825-836 ; 44: 7-15$ (1912) 
Eekel, Edwin Clarence-Continued.

13 Portland cement materials and industry in the United States; with contributions by Ernest F. Burchard, A. F. Crider, G. B. Richardson, Engene A. Smith, J. A. Taff, E. O. Ulrich, and W. H. Weed. U S G S, B 522: 401 pp, maps (1913)

13a Brown iron ores as cavity fillings. Eng M J 96:1-2 (1913)

$13 \mathrm{~b}$ Engineering applications of geology Eng Record 67:667-668, 711-712 (1913)

14 Iron ores; their occurrence, valuation, and control. First ed, xvii, $430 \mathrm{pp}$, maps, New York 1914.

See also Dale ( $\mathrm{T}$ N) 14

Eeonomic Geology; a semi-quarterly journal devoted to geology as applied to mining and allied industries. Vol. 1, October-November 1905- Editor, John Irving

Edding fleld, F. $T$.

13 Manganese in superficial alteration. Ec G 8: 499-501 (1913)

Eddy, Lewis $H$.

13 The Mother Lode region, Cal. Eng M J 95:405-410, map (1913)

Ede, J. A.

92 The ores of Virginia. Ohio M J no $20: 25-33$ (1892)

94 Notes on the gold-bearing black sands of California. M Sc Press 69:294, 356,372 (1894)

98 The platinum metals of Plumas Co., Cal. M Sc Press 77:401 (1898)

oo Outlines of structural geology. M Sc Press 80:672, 701, 733-734 (1900)

02 Corundum in Montana. M Sc Press 84: 21 (1902)

o7 The auriferous black sands of Callfornia. Cal St M Bur, B 45: 5-10 (1907)

Edmonson, J. B.

12 Soll survey of Morgan and Owen cos. Ind, Dp G, An Rp 36:83-134, maps (1912)

Edmunds, E. S.

78 Geology of Lagrange Co., Ind. Kansas City Rv Sc 2:500-508 (1878) ; 3:2833 (1879)

Edson, George E.

06 Historical sketch of the Cambrian age as related to Vermont geology. Vt, St G Rp $5: 117-132$ (1906)

$06 \mathbf{a}$ The geology of St. Albans and vicinity. Vt, St G Rp 5:133-155, map (1906)

os Geology of the town of Swanton. Vt, St G Rp 6:210-220, map (1908)

Edson, Harry.

11 Notes on Ammonitella lunata Conrad [John Day region of Oregon]. Nautilus $24: 132$ (1911)

Edson, Obed.

84 The glacial perlod in the Chautauqua Lake region [N. Y.]. 13 pp [n p, n d (1884), priv pub]
Edwards, Arthur Mead.

59 On the diatomaceous forms contained in a peat marl from Milwaukee. Boston Soc N H, Pr 7: 79-80 (1859)

60 On some sub-peat deposits of Dis. tomaceae. Boston Soc N H, Pr 7:283287 (1860)

69 On guano deposits. Essex Inst, B 1: 11-13 (1869)

70 Note on itacolumite. Lyc N H N Pr 1: 33-36 (1870)

70a On some facts connected with the occurrence of deposits of fresh water Diatomaceae commonly known as infusorial earths. Lyc N H N Y, Pr 1:47-50 (1870)

70b Microscopical examination of two minerals. Lyc $\mathrm{N}$ H $\mathrm{N}$, $, \operatorname{Pr} 1: 96-98$ (1870)

7oe On the formation of deposits of freshwater Diatomaceae. Lyc N H X Y, Pr 1: 109-128, 242-243, 290-293, 296 (1870-71)

70d Results of a microscopical examins. tion of specimens of sand obtained from an artesian well [New Orleans, La.]. Lyc N H N Y, An 9: 329-333 (1870)

71 The origin of guano. Lyc N H N , Pr 1: 229-234 (1871)

71a Claystones from Hanover, N, H. Lyc N H N Y, Pr 1:258-259 (1871)

91 Report of the examination by means of the microscope of specimens of infusorial earths of the Pacific coast of the United States. Am J Sc (3) $42: 369-385$ (1891)

92 Hudson River "flord." Am J Sc (3) $43: 182-183$ (1892)

93 On a Champlain (?) deposit of Diatomaceae belonging to the littoral plain. Am J Sc (3) 45:385-388 (1893)

93a Discoliths in clay beds. Am J Sc (3) $45: 527$ (1893)

93b On marine fossil Diatomaceae from California and their geology. San Francisco Microse Soc, Tr 1:10-17 (1893)

93e The Diatomaceae of the Triassic (?) sandstone of New Jersey. Am Nat 27: 817-818 (1893)

95 The occurrence of Tertiary clay on Long Island. Am J Sc (3) 50:270 (1895)

95a Ornithichnites and jaw bone from the Newark sandstone of New Jersey. Am J Sc (3) $50: 346$ (1895)

96. On the occurrence of Neocene marine Diatomaceae near New York. Am Nat $30: 212-216$ (1896)

os The origin of petroleum in Call. fornia. La Nuova Norarisia, Modena, Italy, ser $19: 72-78$ (1908.

See also Newberry, $70 \mathrm{~J}$

Edwards, George E.

07 The lead and zine fields of south western Wisconsin. M World, 27:279280 (1907) 
Edwards, Henri Milne.

65 Rapport ... a des ossements fossils provenant de la vallée de Zacualco [Mexico]. [France], Comm Sc Mex, Arch 1: 401-407, Paris 1865

67 Rapport ... a la paléontologie et a la fauna actuelle du Mexique. [France], Comm Sc Mex, Arch 2:212-220, il, Paris 1867

Edwards, Henry W.

02 Notes on the geology of the Isthmus of Panama. Eng M J 73:862-863 (1902)

Edwards, J. Jep.

02 Paleontology of Bartholomew Co., Ind, mammalian fossils. Ind $\mathrm{Ac} \mathrm{Sc}, \mathrm{Pr}$ 1901: 247-248 (1902)

Edwards, Merwin Guy.

14 The occurrence of aluminum hydrates in clays. Ec G 9:112-121 (1914)

16 Introduction to optical mineralogy and petrography... $197 \mathrm{pp}$, Cleveland, Ohio, 1916

Edwards, Timothy.

93 A description of a horn or bone lately found in the River Chemung or Tioga .... [mammoth tusk?, Tioga Co., Pa.]. Am Ac Arts, Mem 2:164-165 (1793)

Edwards, W. F.

04 The new geology and vein formation (discussion). Colo Sc Soc, Pr 7:289-296 (1904)

04a Some notes on vanadium. Colo Sc Soc, Pr 7:297-312 (1904)

Edwards, W, H.

06 Notes on the produetion and uses of Canadian chrome. Can M Inst, J 9:35-38 (1906)

Edwards, William Seymour.

92 Coals and cokes in West Virginia... $162 \mathrm{pp}$, Cincinnati 1892

Edwords, Clarence E.

06 California's new coal fields. M World 24:245 (1906)

Egerton, P. de M. G.

53 Note on the fossil fish from Albert mine [Hillsborough, N. B.]. G Soe London, Q J 9:115 (1853)

Eggleston, Julius Wooster.

02 Some glacial remains near Woodstock, Conn. Am J Sc (4) 13:403-408, map (1902)

04 Physiography; an outline of its scope and application. Colo Sch Mines, B 2 no 3:96-110 (1904)

10 The complex of alkaline igneous rocks at Cuttingsville, Vt. $(a b s t)$. Science $\mathrm{n} s$ 32 (1910) G Soc Am, B 21:785-786 (1910)

18 Eruptive rocks at Cuttingsville, vt. Am J Sc (4) $45: 377-410$ (1918)

Egleston, Thomas (1832-1900).

63 Catalogue of minerals, with their formulas, etc. Smiths Misc Col 7 (156): $42 \mathrm{pp}$ (1863)

$$
28737^{\circ}-23-22
$$

Egleston, Thomas-Continued.

$63 a$ Report on the geological and mineralogical specimens collected by Mr. C. F. Hall in Frobisher Bay. Am J Sc (2) 35 : 294-295 (1863) Also in Hall, C. F., Arctic Researches ... : 594-595, N Y 1865

66 Diagrams to illustrate the lectures on crystallography... $\mathbf{x}$ pp, 38 pls, N Y $18663 d$ ed, xlvi pp, 40 pls, N Y 1874 4 th ed, xlviii pp, 44 pls, N Y 1889

66a Catalogue of minerals, with their formulae and crystalline systems... vii, 34 pp, School of Mines [N Y] $18662 d \mathrm{ed}, \mathrm{xv}$, 41 pp, N Y 1871

$66 \mathrm{~b}$ A check list of the silicates with their formulae and crystalline systems. 12 pp, N Y 1866

66e A geological and agricultural survey of 100 miles west of Omaha by the American Bureau of Mines. $44 \mathrm{pp}, \mathrm{N}$ Y 1866

67 Tables for the determination of minerals... N Y 1867 2d ed, 26 pp, N Y 1868 $3 \mathrm{~d}$ ed, $26 \mathrm{pp}, \mathrm{N}$ Y 1870 th ed, $27 \mathrm{pp}$, N Y 1886

71 Comparison of notations used to represent the faces of crystals. xvii pp, N $\mathrm{Y}$ 1871

72 Lectures on mineralogy... 189 pp, 34 pls, N Y 1871

74 Systems of notation of crystals. Lyc N H N Y, Pr (2) no 4: 135-136 (1874)

74a On the striations of crystals. Lyc N H N Y, Pr (2) no 4:146-148 (1874)

75 Analysis of rocks. Am I M Eng, Tr 3: 94-98 (1875) Eng M J 20:77-78 (1875)

79 Copper mining on Lake Superior. Am I M. Eng, Tr 6:275-312 (1879)

79a [The conglomerates of the Lake Superior copper region.] Am I M Eng, Tr 6: 606-611 (1879)

80 The iron ores and coals on the line of the Chesapeake \& Ohio Railway... The Virginias 1:24-25 (1880)

81 The formation of gold nuggets and placer deposits. Am I M Eng, Tr 9:633646 (1881)

87 Catalogue of minerals and synonyms. U S Nat Mus, B 33: 198 pp (1887)

91 Catalogue of minerals and synonyms. $378 \mathrm{pp}, \mathrm{N}$ Y 1891

See also American Bureau of Mines, 66

Eglorstein, Baron F. W. von.

64 Contributions to the geology and physical geography of Mexico... $40 \mathrm{pp}$, map, N Y 1864

Egozcue y Cia, Justo.

72 Descripción de algunas piezas fósiles correspondientes a grandes mamfferos de América. R Ac Cienc Habana, An 8:627634 (1872)

97 (with Cotteau, G.) Descripción de los equinoides fóslles de la Isla de Cuba, España, Com Mapa Geol, B $22=$ (2) $2: 1$ 99 , il (1897) 
Ehlers, George M.

18 An interesting illustration of a process of destruction of a glaciated surface. Mich Ac Sc, An Rp 20:59-63 (1918)

Ehnbom, L.

16 Geological sections in the vicinity of Golden [Colo.]. Colo Sch Mines Q 11 no $3: 11-15$ (1916)

Ehrenberg, Christian Gottfried (17951876).

39 Ueber zwel neue Lager fossiler KieselInfusorien in Frankreich und New York. K Preuss Ak Wiss Berlin, Ber 1839: 30-31 Abst, with title, Fossil Infusoria of West Point, N. Y., Am J Sc 39:191-192 (1840)

43 Verbreitung und Einfluss des mikroskopischen Lebens in Sud- und NordAmerika. K Preuss Ak Wiss Berlin, $\mathrm{Abh}$ Phys Kl 1841:291-445, il (1843); Ber 1841: 139-144 Notices [by J. W. Balley], Am J Sc $43:$ 393-395 (1842); The Geologist, London, $1843: 6-9$ Am J Sc $46: 297$ 313 (1844)

44 Ueber zwei neue Lager von Gebirgsmassen aus Infusorien als Meeres-Absatz in Nord-Amerika. K Preuss Ak Wiss Berlin, Ber 1844:57-97 Notice, by J. W. Bailey, Ehrenberg's Observations on the fossil Infusoria of Virginia and Maryland, and comparisons of the same with those found in the chalk formations of Europe and America. Am $\mathrm{J}$ Sc $48: 201-204$ (1845)

46 Halibiolitische aus mikroskopischen Polycystinen gebildete Gebirgsmasse von Barbados. K Preuss Ak Wiss Berlin, Ber $1846: 382-385 ; 1847: 40-60$, il

49 Neue Beobachtungen über das Lager von mikroskopischen reinen Süsswasserformen am Wasserfallflusse in Oregon. K Preuss Ak Wiss Berlin, Ber 1849:76-97. Abst, with title, On infusorial deposits on the River Chutes in Oregon, Am J Sc (2) $9: 140(1850)$

54 Mikrogeologie; das Erden und Felsen schaffende Wirken des unsichtbar kleinen selbstständigen Lebens auf der Erde. xxvili, 374,88 pp, 11, Leipzig 1854

55 Erläuterungen über den Grïnsand im Zeuglodon-Kalke Alabama's in NordAmerika, als besonders wohl erhaltene Polythalamien-Formen ... $\mathrm{K}$ Preuss Ak Wiss Berlin, Mber 1855: 86-90

55a Ueber die weitere Entwickelung der Kenntniss des Grünsandes als grïnen Polythalamien-Steinkerne, über braunrothe und corallrothe Steinkerne der PolythalamienKreide in Nordamerika ... K Preuss Ak Wiss Berlin, Mber $1855: 172-178$

66 Ueber einen Phytolitharien-Tuff als Gebirgsart im Toluca-Thale von Mexiko. K Preuss $A \mathrm{k}$ Wiss Berlin, Mber 1866: 158168 , il De la toba fitolitaria del Valle de Toluca, La Naturaleza $3: 118-132$, Il (1874)
Ehrenberg, Chrlstian Gottfried-Conte. 69 Ueber mächtige Gebirgs-Schichtes vorherrschend aus mieroskopischen Bacl. larien unter und bel der Stadt Mexiko. $\mathbb{k}$ Ak Wiss Berlin, Abh : 66 pp, il (1869)

70 Ueber die Bacillarien-Bänke im Hoch. lande Californien. K Preuss Ak Wiss Bes. lin, Mber $1870: 126-132$

70a Ueber die wachsende Kenntniss da unsichtbaren Lebens als felsbildende Bacll. larien in Californien. $\mathrm{K}$ Preuss Ak Wiss Berlin, Mber 1870: 259-264; Abh (phys): 1-74 (1870)

72 Ueber Prof. Whitney's neueste Ekläuterungen der Californischen Bacillarien. Gebirge. K Preuss Ak Wiss Berlin, Mber 1872 : 124-139

73 ... Polycystinen-Mergels von Barbs. dos... $\mathrm{K}$ Preuss $\Delta \mathrm{k}$ Wiss Berlin, Mher 1873: 213-263.

76 Forsetzung der mikrogeologischen Studien ... mit specieller Rücksicht auf den Polycystinen-Mergel von Barbados, K Ak Wiss Berlin, Abh 1875 , phys: $1-225$, il (1876)

\section{Ehrenfeld, Frederick.}

98 A study of the igneous rocks at Yotk Haven and Stony Brook, $\mathrm{Pa}$., and their accompanying formations. Thesis, Uni. versity of Pennsylvania. 24 pp, Phila 1898 [not seen]

13 (with Brown, A. P.) Minerals of Pennsylvania. $\mathrm{Pa}$ Top $\mathrm{G}$ S, Rp 9:160 pp, maps (1913)

16 Jointing as a fundamental factor in the degradation of the lithosphere. Am $\mathrm{Ph}$ Soc, Pr 55:363-399 (1916) Abst, Science n s 43: 721 (1916)

Eichwald, Eduard von.

71 Die Miocän- und Kreideformation ron Alaska und den aleutischen Inseln. In his Geognostisch-paleontologische Bemerkungen über die Halbinsel Mangischlak und die aleutischen Inseln : $88-200$, 11, St. Petersburg 1871

Eigenmann, C. H.

90 Description of a fossil species of Sebastodes [Tertiary, Port Harford, Cal.]. Zoe $1: 16$, il $(1890)$

Eights, James (1798-1882).

35 A synopsis of the rocks of the State of New York. Zodiac 1:27-28 (1835)

36 Notes of a pedestrian [geological notes on southeastern New York]. Zodisc $1: 111-112$, 113-116, 141-143, 146-147, $177-178$ (1836)

42 Description of Sphaeroma bumasti. formis. N Y G S, Geol N Y, second dist (Emmons) : 433-434, il (1842)

46 Outlines of the geological structure of Lake Superior mineral region belonging to the New York and Lake Superior Mining Company. 21 pp, Albany 1846 [appendix to] New York and Lake Superior Mining Company, First An Rp, Albany 1846 
Eights, James-Continued.

48 Notes of a geological examination and survey of Mitchell's cave, Town of Root, County of Montgomery, N. Y. Am J Agr 7:21-27 (1848)

52 Observations on the geological features of the post-Tertiary formation of the eity of Albany, and its vicinity. Albany Inst, $\operatorname{Tr} 2: 335-353$ (1852)

58 North Carolina; its geology, mining regions, scenery, etc. M Stat Mag 10: $183-188,268-273,369-373,423-427$ (1858) Eilers, A.

73 The metallurgical value of the lignites of the Far West. Am I M Eng, Tr 1: 216-223 (1873)

73a A new occurrence of the telluride of gold and silver. Am I M Eng, Tr 1: $316-320 \quad$ (1873)

Eisen, Gustav.

95 Explorations in the Cape region of Baja California in 1894. ... Cal Ac Sc, Pr (2) $5: 733-775$, maps (1895) Am Geog Soc, B 29:271-280, map (1897)

00 Explorations in the central part of Baja California. Am Geog Soc, B 32:397429, map (1900)

03 The earthquake and volcanic eruption in Guatemala in 1902. Am Geog Soc, B $35: 325-352$ (1903)

Ekblaw, W. Elmer.

12 Correlation of the Devonian system of the Rock Island region [III.]. III $\mathrm{Ac}$ \&c, Tr 5 : 96-109 (1912)

18 The importance of nivation as an erosive factor, and of soll flow as a transporting agency, in northern Greenland. Nat Ac Sc, $\operatorname{Pr} 4: 288-293$ (1918) Abst, G Soc Am, B 29:72-73 (1818)

18a Opportunities for geological work in the far Arctic (abst, with discussion by A. P. Coleman and E. O. Hovey). G Soc Am, B 29:85-86 (1918)

See also Fairchild, 18

Ekeley, John B.

09 The composition of some Colorado tungsten ores. Colo, Univ, Studies 6:9396 (1909) M World 30:280 (1909)

Elderhorst, William.

58 Chemical report of the ores, rocks, and mineral waters of Arkansas. In Owen, D. D., First report of a geological reconnaissance of the northern counties of Arkansas: 143-191, Little Rock, 1858

60 Chemical analyses made for the geological survey of Ark. In Owen, D. D., Second report of a geological reconnaissance of the midale and southern counties of Arkansas : 289-294, Phila, 1860

Eldridge, George Homans (1854-1905).

86 Montana coal fields. U S, 10th Census $15: 739-757$, map (1886)

88 on some stratigraphic and structural relations of the country about Denver. Colo, Mining Industry (Denver, Colo,) 3 no $3: 24-25$; no $4: 33-35 ;$ no $5: 44-45$ (1888) [not seen]
Eldridge, George Homans-Contlnued.

89 On some stratigraphical and structural features of the country about Denver, Colo. Colo Sc Soc, Pr 3: 86-118 (1889)

89a Some suggestions upon the methods of grouping the formations of the middle Cretaceous and the employment of an additional term in its nomenclature. Am J Sc (3) $38: 313-321$ (1889) Abst, Am Nat 24: 212 (1890)

90 On certain peculiar structural features in the foot hill region of the Rocky Mountains near Denver, Colo. Ph Soc Wash, B $11: 247-274$, map (1890)

92 The Florence oil field, Colo. Am I M Eng, $\operatorname{Tr} 20: 442-462$, map (1892) Abst, Eng M J $52: 422$ (1891)

93 A preliminary sketch of the phosphates of Florida. Am I M Eng, Tr 21: 196-231, map (1893)

93a Artesian wells of eastern Dakota. Int $\mathrm{G}$ Cong, V, Washington 1891, C R : 318 (1893)

94 Description of the sedimentary formations. U S G S, G Atlas AnthraciteCrested Butte fol (no 9):6-10, maps (1894)

94a A geological reconnaissance in northwest Wyoming. U S G S, B 119: 72 pp, map (1894)

95 A geological reconnaissance across Idaho. U S G S, An Rp 16 pt $2: 211-276$, maps (1895)

96 The uintaite (gilsonite) deposits of Utah. U S G S, An Rp 17 pt 1:909-949, maps (18996)

$96 n$ Occurrence of uintaite in Utah. Science n s 3:830-832 (1896)

96b (with Emmons, S. F.) Geology of the Denver Basin in Colorado. U S G $\mathrm{S}$, Mon $27: 556 \mathrm{pp}$, maps (1896)

99 (and others) Maps and descriptions of routes of explorations in Alaska in 1898. U S G S: 138 pp, maps (1899) Includes contributions by J. E. Spurr, W. C. Mendenhall, F. C. Schrader, A. H. Brooks, and others.

oo A reconnaissance in the Sushitna basin and adjacent territory, Alaska, in 1898. U S G S, An Rp 20 pt $7: 1-29$ (1900)

o1 The asphalt and bituminous rock deposits of the United States. U S G S, An Rp 22 pt 1:209-452, maps (1901)

01a The asphalt and bituminous rock deposits of the United States (abst). Science n s 13, 428 (1901)

03 Origin and distribution of asphalt and bituminous rock deposits in the United States. U S G S, B 213: 296-305 (1903)

o3n The petroleum fields of California. U S G S, B 213: 306-321 (1903)

06 The formation of asphalt veins. Ec G $1: 437-444$ (1906) 
Eldridge, George Homans-Continued.

07 (and Arnold, Ralph) The Santa Clara Valley, Puente Hills, and Los Angeles oil districts, southern Cal. U S G S, B $309: 266$ pp, map (1907)

See also Emmons (S F), 93 ; Powell, 91a, $92,93,95$

\section{Elftman, Arthur Hugo.}

93 The Pewabic quartzite (abst). Minn, Univ, Q B 1:115 (1893) Minn Ac N Sc, B $4: 28-29$ (1896)

94 Preliminary report of fieldwork during 1893 in northeastern Minnesota. Minn G S, An Rp 22:141-189, map (1894)

$94 a$ Notes on the anorthosites of northeastern Minnesota (abst). Minn, Univ, Q B $2: 23-24$ (1894)

$94 \mathrm{~b}$ The economic products of the preCambrian rocks of Minnesota (abst). Minn, Univ, Q B 2: 48-49 (1894)

94e Notes on the geology of Greenwood Lake area $(a b s t)$. Minn, Univ, Q B 2:5354 (1894)

95 Notes upon the bedded and banded structures of the gabbro and upon an area of troctolyte. Minn G S, An Rp 23:224230 (1895)

96 The Pewabic quartzite (abst). Minn Ac N Sc, B 4:28-29 (1896)

96a Ore deposits in Minnesota. Minn, Univ, Engineers Year Book [4]:115-117 (1896)

97 On the use of certain terms prominent in petrology $(a b s t)$. Science $\mathrm{n} s 5$ : 196 (1897)

98 The geology of the Keweenawan area in northeastern Minnesota. Am G 21: 90109, map, 175-188; 22:131-149, map (1898)

98a The St. Crolx River valley. Am G $22: 58-61$ (1898)

99 Preliminary report of field work during the summer of 1895 . Minn G S, An Rp 24: 148-149 (1899)

99a List of rock samples collected in northeastern Minnesota in 1895, 1896, and 1897. Minn G S, An Rp 24:150-170 (1899)

03 The Highland Range in [St. Louis Co.], Minn. Eng M J $75: 447-448$ (1903)

03a Postglacial time $(a b s t)$. J G 11: 109 (1903)

03b The relation betreen the Keewatin and Laurentide fce sheets (abst). J G 11: 109-110 (1903)

o3e Keewatin and Laurentide ice sheets in Minnesota (abst). G Soc Am, B 13 : 536-537 (1903)

Elie de Beaumont, Léonce (1798-1874).

50 [On the age of the Lake Superior sandstone.] Soc G France, B (2) 7:209 (1850)

Elkins, Marion G.

14 (and Wieland, G. R.) Cordaitean wood from the Indiana black shale. Am $\mathrm{J} \mathrm{Sc} \mathrm{(4)} 38: 65-78$, il (1914)
Ellery, J. G.

54 The property of the Catawba Mirty Company in McDowell Co., N. C. M $\mathrm{V}$ $3: 15-25$ (1854)

Elley, H. W.

15 Precipitants of gold and silver. G 10: $580-582$ (1915)

Elliott, Arthur $H$.

85 The colored marbles of Lake Chas plain (with discussion by J. S. Newbery. N Y Ac Sc, Tr 3:100-102 (1885)

Elliott, John B.

83 The age of the southern Appalachlas $\Delta \mathrm{m} \mathrm{J} \mathrm{Sc} \mathrm{(3)} \mathrm{25:282-298} \mathrm{(1883)}$

Elliott, R. S.

71 Report on the industrial resources of western Kansas and eastern Colorado. D? G S Wyo (Hayden), Prel Rp [4]:44. 458 (1871)

79 West of the Mississippi; geologic history. Lecture delivered in hall of Wast ington University, St Louis, April 2, 18\% $16 \mathrm{pp} \mathrm{[n} \mathrm{p,} \mathrm{n} \mathrm{d,} \mathrm{1879?]}$

Ellis, A. B.

92 The great earthquake of Port Ropl [Jamaica]. Pop Sc Mo 42: 774-784 (18\%) Ellis, Arthur Jackson (1885-1920)

15 (with Meinzer, O. E.) Gromil water in Paradise Valley, Ariz. U S G W-S P 375 : 51-75, map (1915)

16 Ground water in the Waterbury are Conn. U S G S, W-S P 397: 73 pp, 패 (1916)

$16 a$ (with Gregory, H. E.) Grout water in the Hartford, Stamford, Willimas tic, and Saybrook areas, Conn. U S G \& W-S P 374: 150 pp, maps (1916)

18 Mineral waters in 1916 . U S G \& Min Res 1916 pt 2:463-510 (1918)

Ellis, E. E.

o5 Zinc and lead mines near Dodgeville Wis. U S G S, B 260:311-315 (1905)

06 Occurrence of water in crystallint rocks. U S G S, W-S P 160: 19-2S (1906) 03 Ground water in the crystalline rock of Connecticut. U S G S, W-S P 232:54 103 (1909)

See also Gregory (H E), 09a.

E11is, Hubert I.

15 The Shushana mining distrit [Alaska]. Eng M J 99:731-733, ma? (1915)

Ellis, Mary.

03 Index to publications of the Ner York State Natural History Survey and Nem York State Museum, 1837-1902; also it cluding other New York publications on re lated subjects. N Y St Mus, B 66:653 pp (1903)

Ellis, W. H.

75 (with Nicholson, H. A.) On a te markable fragment of silicified wood from the Rocky Mountains. Can J n 8 14: 148-153 [in error for 348-353], il (1875) Abst, Br As, Rp $44: \sec 88-89$ (1875) 
Ellis, W. Hodgson.

97 Chemical composition of the anthraxolite. Ont Bur Mines, Rp 6:162-166 (1897)

97a (and Lawson, W.) Chemical notes on the so-called Sudbury coal. Can Inst, $\operatorname{Pr}$ n s 1: 67-68 (1897)

Ellis, William.

26 (with Goodrich, Joseph). ...voleanic character of the Island of Hawail. Am J Sc 11:2-36 (1826)

Ells, R. Hugh.

04 Prince Edward and Hastings cos., 0nt. Can G S, Sum Rp 1903 (An Rp 15) : A133-136 (1904)

Ells, Robert Wheelock.

73 Report of operations in boring for coal ... at Newcastle Bridge, Queens Co., N. B. Can G S, Rp Prog 1872-3: 231-237 (1873)

76 Second report on the boring operations ... at Newcastle Bridge, Queens Co., N. B. Can G S, Rp Prog 1874-5: 90-96 (1876)

76a Report on the iron ore deposits of Carleton Co., N. B. Can G S, Rp Prog 1874-5: 97-104, map (1876)

77 Report on the boring operations in the Northwest Territory, summer of 1875 . Can G S, Rp Prog 1875-6 : 281-291 (1877) 78 (with Builey, L. W.) Report on the Lower Carboniferous belt of Albert and Westmoreland cos., N. B. Can G S, Rp Prog 1876-7:351-401, map (1878)

79 Report on the pre-Silurian rocks of Albert, eastern Kings, and St. John cos., southern N. B., 1877-78, Can G S, Rp Prog 1877-8: D 13 pp (1879)

80 with Banley, L. W., and Matthew, G. F.) Report on the geology of southern New Brunswick ... Can G S, Rp Prog 1878-9: D 26 pp (1880)

81 Report on the geology of northern New Brunswick, embracing portions of the counties of Restigouche, Gloucester, and Nortbumberland, 1881. Can G S, Rp Prog 1879-80:D 47 pp (1881)

83 Report on the geology of northern and eastern New Brunswick and the north side of the Bay of Chaleurs 1881. Can G 8, Rp Prog 1880-2 : D 24 pp, maps (1883) 83a Report on the geological formations in the Gaspé Periinsula. Can G S, Rp Prog $1880-2$ : DD $32 \mathrm{pp} \mathrm{(1883)}$

85 Report on explorations and surveys in the interior of the Gaspé Peninsula [Que.], 1883. Can G S, Rp Prog 1882-4: \& 34 pp, maps (1885)

85a Report on the geological formations of eastern Albert and Westmoreland cos., $\mathrm{N}$. B, and portions of Cumberland and Colchester cos., N. S. Can G S, An Rp 1: 71 pp, map (1885)

87 A history of New Brunswick geology. $64 \mathrm{pp}$, Montreal 1887
Ells, Robert Wheelock-Continued.

$\mathbf{8 7 a}$ Report on the geology of a portion of the eastern townships of Quebec, relating more especially to the counties of Compton, Stanstead, Beauce, Richmond, and Wolfe. Can G S, An Rp 2:J $70 \mathrm{pp}$, map (1887)

88 Second report on the geology of a portion of the Province of Quebec. Can G S, An Rp 3: K 1-114, map (1888)

89 [Report on the Chaudiere gold districts and the asbestos deposits of the Thetford region.] Can $G \quad S$, Sum $R p$ 1887-8 (An Rp 3) : A 86-91 (1889)

$89 a$ Elementary lecture on geology. Ottawa Nat 2:117-134 (1889)

$\mathbf{8 9 b}$ Notes on the geological relations and mode of occurrence of some of the more important eeonomic minerals of eastern Quebec. Ottawa Nat 3:45-57 (1889)

89e (with Ami, Henry M.) Report of the geological branch [of the Ottawa Field Naturalists' Club]. Ottawa Nat 3:36-38 (1889)

90 Report on the mineral resources of the Province of Quebec. Can G S, An Rp 4: K 159 pp (1890)

$90 a$ [Report on work in the eastern townships of Quebec.] Can G S, Sum Rp 1888-9 (An Rp 4) : A 33-34 (1890)

$90 \mathbf{b}$ The stratigraphy of the "Quebec group". G Soc Am, B 1:453-467 (1890)

90e The mining Industries of eastern Quebec. Am I M Eng, Tr 18:316-333 (1890) In part, Can G S, An Rp 5: S 1926 (1891)

$90 d$ Geological progress in Canada. Ottawa Nat $3: 119-145$ (1890)

90e The geology of Quebec City. Science $16: 359(1890)$

91 [Summary report of work in the eastern townships of Quebec.] Can G S, Sum Rp 1890 (An Rp 5) : A 44-48 (1891)

91 a Asbestos, its history, mode of occurrence, and uses. Ottawa Nat 4:201225 (1891)

92 [Report on field work in southwestern Quebec.] Can G S, Sum Rp 1891 (An Rp 5) : A 35-39 (1892)

92a On the geology of part of the province of Quebec, south of the St. Lawrence. R Soc Can, Pr Tr 9, iv : 105-126 (1892)

92b The work of the geological survey of Canada. Ottawa Nat 5: 161-179 (1892)

93 [Report on field work in Ottawa and Argenteull cos., Que.] Can G S, Sum Rp 1892 (An Rp 6) : A 35-40 (1893)

93a The Laurentian of the Ottawa district. G Soc Am, B 4:349-360 (1893) Abst, Am G 11: 133-134 (1893)

94 [Summary report of field work in Ottawa and Pontlac cos., Que.] Can G S, Sum Rp 1893 (An Rp 6) : A 40-46 (1894)

$94 \mathbf{n}$ The geology of the proposed tunnel under the Northumberland Strait. $\mathrm{R}$ Soc Can, $\operatorname{Pr} \operatorname{Tr} 11$, iv : 75-84, map (1894) 
Ells, Robert Wheelock-Continued.

94b Recent deposits in the valley of the Ottawa River. Ottawa Nat 8:104-107 (1894)

94e Mica deposits in the Laurentian of the Ottawa district. G Soc Am, B 5:481488 (1894)

95 [Report on field work in Ottawa, Pontiac, and Carleton cos., Quebec and Ontario.] Can G S, Sum Rp 1894 (An Rp 7) : ^ 57-62 (1895)

95a The Potsdam and Calciferous formations of Quebec and eastern Ontario. R Soc Can, Pr Tr 12, iv : 21-30 (1895)

95b (and Barlow, A. E.) The physical features and geology of the route of the proposed Ottawa Canal between the St. Lawrence River and Lake Huron. R Soc Can, $\operatorname{Pr} \operatorname{Tr}(2)$ 1, iv : 163-190, map (1895)

95e Notes on recent sedimentary forma tions on the Bay of Fundy coast. N S Inst $\mathrm{Sc}, \operatorname{Tr} 8$ or (2) 1:416-419 (1895)

95d The apatite-bearing rocks of the Ottawa district. Can Rec Sc 6:213-222 (1895)

95e The Rensselaer grit plateau. Ottawa Nat 9:9-11 (1895)

95f. How rocks are formed. Ottawa Nat 9:157-166 (1895)

95g The Geological Survey of Canada and its operations. Can M Rv 14:15-16, $39-40 \quad$ (1895)

96 Report on a portion of the Province of Quebec comprised in the southwest sheet of the "Eastern townships" map (Montreal sheet). Can G S, An Rp $7: \mathrm{J}$ 1-92, map (1896)

$96 a$ [Report on field work in Renfrew Co., Ont., and Pontiac Co., Que.] Can G S, Sum Rp 1895 (An Rp 8) : A 64-68 (1896)

96b Paleozoic outliers in the Ottawa River basin. R Soc Can, $\operatorname{Pr} \operatorname{Tr}$ (2) 2, iv : 137-149 (1896)

96e The gold deposits of the eastern townships [Quebec]. [Fed] Can M Inst, J 1:109-126 (1896) Can M Rv 15:14 15 (1896)

$96 d$ (and others) Report of the geological branch [of the Ottawa Field Naturalists' Club]. Ottawa Nat 10:17-18 (1896)

96e The geology of the Ottawa and Parry Sound Railway. Ottawa Nat 10: 165-173 (1896)

96r The Geological Survey of Canada and its operations. Gen M As Que, J 2 : 160-172 [1896]

97 [Report of field work in eastern Ontario.] Can G S, Sum Rp 1896 (An Rp 9) : A 53-59 (1897)

$97 a$ Notes on the Archean of eastern Canada. R Soc Can, Pr Tr (2) 3, iv: 117124 (1897)

97b Memoir of N. J. Giroux. G Soc Am, B $8: 377$ (1897)
Ells, Robert Wheelock-Continued.

97e Note on "Origin and relations of the Grenville-Hastings seri ; of the Cand. dian Laurentian" [see Adams (F D), 97]. G Soc Am, B 8:401-402 (1897)

97d Recent conclusions in Quebec ology (abst). Brit As, Rp 67:640-64? (1898) Ottawa Nat 11:173-176 (1897)

9s [Report on field work on the Perth and Ottawa City sheets, eastern Ontario.] Can G S, Sum Rp 1897, (An Rp 10): 57-62 (1898)

98a Problems in Quebec geology. Cas Rec Sc $7: 480-502$ (1898)

98b Formations, faults, and folds of the Ottawa district. Ottawa Nat $11: 177-180$ (1898)

98e Sands and clays of the 0ttams basin. G Soc Am, B 9:211-222 (1898) Abst, J G $6: 117-118$ (1898); Science in s $7: 49$ (1898); Ottawa Nat 11:222 (1898)

98d Some characteristic genera of the Cambrian. G Mag (4) 5:83-85 (1898)

99 [Report on field work in southwest. ern Quebec and adjacent parts of Ontario. Can G S, Sum Rp 1898 (An Rp 11) : $\triangle 111$ 119 (1899)

99a Canadian geological nomenclature. R Soc Can, Pr Tr (2) 5, iv: $3-38$ (1899)

$99 \mathrm{~b}$ The mineral resources of the 0ttara district [Ont.]. Ottawa Nat 13:14-21, 25-46 (1899)

00 Report on the geology of the Three Rivers map sheet or northwestern sheet of the "Eastern townships" map, Quebec, Can G S, An Rp 11: J 1-62, map (1900)

OOa [Report on field work in the Ottawa region.] Can G S, Sum Rp 1899 (An Rp 12) : A 131-137 (1900)

Oob The physical features and geology of the Paleozoic basin between the lower Ottawa and St. Lawrence rivers. R Soc Can, Pr Tr (2) 6, iv : 99-120 (1900) Abst, Science n s 11: 1022-1023 (1900)

01 Report on the geology and natural resources of the area included in the map of the City of Ottawa and vicinity. Can $G$ \& An Rp 12: G 1-48 pp, map (1901)

01 a Report on the geology of Argenteuil, Ottawa, and part of Pontiac cos. Province of Quebec, and portions of Carle ton, Russell, and Prescott cos., Province of Ontario. Can G S, An Rp 12: J 1-138 pp. map (1901)

O1b [Report on field work in the Ottawa region, Quebec and Ontario.] Can G 8 , Sum Rp 1900 (An Rp 13): A 129-139 (1901)

o1e The Carboniferous basin in Ner Brunswick. R Soc Can, $\operatorname{Pr} \operatorname{Tr}$ (2) 7, iv: 45-56 (1901) Abst, Science n s 13:1017 (1901)

O1d The Devonian of the Acadian prov. inces. Can Rec Sc 8: 335-343 (1901)

ore Ancient channels of the ottawa River. Ottawa Nat $15: 17-30$, map (1901) 
Ells, Robert Wheelock-Continued.

02 The district around Kingston, Ont. Can G S, Sum Rp 1901 (An Rp 14) : A 172-185 (1902)

02a Marl deposits in Ontario, Quebec, New Brunswick, and Nova Socotia. Ottawa Nat 16:59-69 (1902)

03 Bulletin on asbestos. Can G S : 28 pp (1903)

03a The Albert shale deposits of Albert and Westmoreland cos., N. B. Can G S, Sum Rp 1902 (An Rp 15): A 363-369 (1903)

03b Report on the geology of Prince Edward Island with reference to proposed borings for coal. Can G S, Sum Rp 1902 (An Rp 15) : A 369-379, map (1903)

03e The oil fields of Gaspé [Que.]. Can G S, Sum Rp 1902 (An Rp 15) : A 340363, map (1903)

03d Notes on some interesting rock contacts in the Kingston district, Ont. R Soc Can, $\operatorname{Pr} \operatorname{Tr}$ (2) 9, iv : 97-108 (1903)

$03 \mathbf{e}$ The progress of geological investigation in Nova Scotia. N S Inst Sc, Pr Tr 10 or (2) $3: 433-446$ (1903)

04 Bulletin on apatite (phosphate of lime). Can G S: 32 pp (1904)

04a Bulletin on graphite. Can G S: 30 DP (1904)

04b Bulletin on mica. Can G S : 32 pp (1904)

04e Bulletin on the ores of copper in the provinces of Nova Scotia, New Brunswick and Quebec. Can G S: 58 pp (1904) 04d Report on the geology of a portion of eastern Ontario, Can G S, An Rp 14: J1-79, map (1904)

04e The recent landslides on the Lievre River, P. Q. Can G S, Sum Rp 1903 (An Ap 15) : A 136-139, map (1904)

64f Charlotte Co., N. B. Can G S, Sum Rp 1903 (An Rp 15) : A 150-160 (1904)

05 Nicola coal basin, B. C. Can G $\mathbf{S}$, Sum Rp 1904 (An Rp 16) : A 42-74, map (1905) In part, B C, Minister of Mines, An Rp 1905: 196-201 (1906)

$05 a$ Geology of Charlotte Co., N. B. Can G 8, Sum Rp 1904 (An Rp 16) : A 271-279 (1905)

06 [Report on] Graham Island (of the Queen Charlotte group, B. C.). Can G S, Sum Rp 1905:53-55 (1906) B C, Minister of Mines, An Rp 1906:74-93, map (1907)

06a Southern New Brunswick. Can G 8, Sum Rp 1906 : 131-139 (1906)

06b Report on Graham Island, B. C. Can G S, An Rp 16 B : 45 pp, maps (1906) 06e Some interesting problems in New Brunswick geology. R Soc Can, Pr Tr (2) 11, iv : 21-35 (1906)

66d Notes on the mineral fuel supply Canada. R Soc Can, $\operatorname{Pr} \mathrm{Tr}$ (2) 12 , iv : $267-$ 290 (1906) Abst, Science n s $23: 973$
E11s, Robert Wheelock-Continued.

07 Notes on the geology of the islands of Trinidad and Barbados, British West Indies. R Soc Can, $\operatorname{Pr} \operatorname{Tr}$ (3) 1, iv: 115130 (1907)

07a Notes on the geology and mineral resources of Trinidad and Barbados, B. W. Islands. Ottawa Nat 23:73-79 (1907)

отb Report on the geology and natural resources of the area included in the northwest quarter sheet, number 122 of the Ontario and Quebec series, comprising portions of the counties of Pontiac, Carleton, and Renfrew. Can G S : 71 pp, map (1907)

os Surveys in southern New Brunswick. Can G S, Sum Rp 1907: 74-76 (1908)

osn The geology and mineral resources of New Brunswick. Can G S : 135 pp, map (1908)

osb Report on the landslide at NotreDame de la Salette, Lièvre River, Que. Can G S: 10 pp (1908)

ose The carbonaceous and bituminous minerals of New Brunswick. Can M Inst, J $11: 204-219$ (1908)

osd The oil flelds of eastern Canada. N S Inst Se, Pr Tr 11 pt 4: 598-622 (1908) oSe Notes on mineral fuels of Canada. N S Inst Sc, Pr Tr 12 pt 1:61-71 (1908!

08f Notes on a proposed new base for the Cambrian rocks of southern New Brunswick. R Soc Can, $\operatorname{Pr} \operatorname{Tr}$ (3) 2 iv : 113120 (1908)

09 Bituminous shales of Nova Scotia and New Brunswick, with notes on the geology of the oil-shales of Scotland. Can G S, Sum Rp 1908: 132-142 (1909)

O9n Geological position and character of the oil-shale deposits of Canada. Can G $\mathrm{S}: 75 \mathrm{pp}$ (1909) Forms Part II of joint report on the bituminous, or ofl-shales, of New Brunswick and Nova Scotia, also, on the oil-shale industry of Scotland. Can, Dp Mines, 1909

10 Notes on the geology of the oil shales of Scotland, and their relations to somewhat simifar oil shales in eastern Canada. R Soc, Can, Pr Tr (3) 3 iv : $35-44$ (1910)

$10 a$ The oil shales of the maritime provinces [Canada]. M Soc N S, J 14: 1-12 (1910)

10b The commercial value of the oil shales of eastern Canada, based on their contents by analysis in crude oil and ammonium sulphate. M Soc N S, J 15:29-56 (1910)

10e Oll shales of eastern Canada. Can, G S, Sum Rp 1909: 200-216 (1910)

10 I Summary report of the work of the late Mr. Hugh Fletcher in northern Cumberland Co., N S ; compiled from his journal. Can G S, Sum Rp 1909: 225-227 (1910)

11. The oil fields and bitumens of Trintdad and Barbados. M Soc N S, J 16:129145 (1911) 
Ells, Robert Wheelock-Continued.

11a (and Ells, S. C.) Reconnaissance map of parts of Albert and Westmorland cos., N B [location of oil-shale deposits]. Can G S, Map 35A (1911) Scale 1:62500.

12 Notes on fossils found in certain metamorphic rocks of southern New Brunswick. $\mathrm{R}$ Soc Can, $\operatorname{Pr} \operatorname{Tr}$ (3) 5 iv : 17-24 (1912)

See also Adams (F D), $97 ; \mathrm{Ami}, 97$

Ells, Sydney C.

11 (with El1s, R. W.) Reconnaissance map of parts of Albert and Westmorland cos., N. B. Can G S, Map 35 A (1911)

12 Report on James Bay surveys; exploration, Cochrane to James Bay, June 9 th to Sept. 12th, 1911. Ontario, Temiskaming and Northern Ontario Railway Commission: $36 \mathrm{pp}$, maps, Toronto 1912

14 Preliminary report on the bituminous sands of northern Alberta. Can Mines $\mathrm{Br}$ : $92 \mathrm{pp}$, map (1914)

14a Summary report on bituminous sands of northern Alberta. Can Mines Br, Sum Rp 1913: 54-62, map (1914)

15 Notes on clay deposits near McMurray, Alta. Can Mines $\mathrm{Br}, \mathrm{B}$ 10:15 pp (1915)

16 Investigation of bituminous sands in northern Alberta. Can M J 37:73-74 (1916)

17 Investigation of bituminous sands of northern Alberta. Can Mines Br, Sum Rp 1916: 56-58 (1917)

17a Bituminous sands of northern Alberta. Can M Inst, Tr $20: 447-459$ (1917)

Ellsworth, C. E.

10 Placer mining in the Yukon-Tanana region, Alaska. U S G S, B 442: 230-245 (1910)

11 (and Parker, G. L.) Placer mining in the Yukon-Tanana region [Alaska]. U S G S, B 480: 153-192 (1911)

12 Placer mining in the Fairbanks and Circle districts [Alaska]. U S G S, B 520: 240-245 (1912)

14 (and Davenport, R. W.) Prelimtnary report on a water-power reconnaissance in south-central Alaska. U S G S, B $592: 155-193$, maps (1914)

Ellsworth, H. V.

13 The crystal habit of topaz from New Brunswick, Canada. Miner Mag $17: 39-44$ (1913)

16 A study of certain minerals from Cobalt, Ont. Ont Bur Mines, An Rp 25 pt $1: 200-243$ (1916)

Ellsworth, W. E.

14 The Calgary, Alberta, oil fields, Can. M World 40:1190-1194, 1234, maps (1914)

Elmendore, William $\mathrm{J}$.

os The White Horse copper belt in the Yukon. M World 28:55, 209-210, 253, 335 (1908)

\section{Elmore, Clarence J.}

96 Fossil Diatomaceæ from Nebraska and their relation to modern species. Torre Bot Club, B 23: 269-275 (1896)

98 A comparison of fossil diatoms tro Nebraska with similar deposits at st Joseph, Mo., and at Denver, Colo, Net? Ac Sc, Pub 6:238-242 (1898) Nebr st Hist Soc, Pr (2) $2: 238-242$ (1898)

14 Thomas County diatomite [Nebs.]. Nebr G S 7:51-52 (1914)

14a Progress in the study of the Nebraska diatoms. Nebr $G$ S $7: 53-56$ (1914)

Elrod, Morton John.

o3 The physiography of the Flathesd Lake region. Mont Univ, B 16 (Biol ser no 5) : 197-203, map (1903)

Elrod, Moses N.

76 (and MeIntire, E. S.) Orange $C_{\text {. }}$ Ind $\mathrm{G} S$, An Rp 7:203-239 (1876)

82 veology of Bartholomew Co. Ind, Dp G N H, An Rp 11:150-213, map (1882)

83 Geology of Decatur Co. Ind, Dp G N H, An Rp 12:100-152 (1883)

84 Geological and topographical surves of Fayette Co., Ind. Ind, Dp G N H, An Rp 14 pt 1: 41-60 (1884)

84a Geological and topographical surves of Union Co., Ind. Ind, Dp $\mathrm{G} \mathrm{N} \mathrm{H,} \mathrm{An}$ Rp 14 pt 1: 61-72 (1884)

84b Geology of Rush Co. Ind, Dp $\theta$ $\mathrm{N} \mathrm{H}$, An Rp 13 pt 1 : 86-115 (1884)

92 (and Benediet, A. C.) Geology of Wabash Co. Ind, Dp G N Res, An Rp 17: 192-259 (1892)

94 (and Benedict, A. C.) Geology of Cass Co. Ind, Dp G N Res, An Rp 19 17-39 (1894)

99 The geologic relations of some St. Louis group caves and sink holes. Ind $\mathrm{Ac}$ Sc, Pr 1898: 258-267 (1899)

02 Niagara group unconformities in In. diana. Ind Ac Sc, Pr 1901:205-215 (1902)

Elschner, Carl.

15 The Leeward Islands of the Hawailan group. $68 \mathrm{pp}$, Reprinted from the Sunday Advertiser, Honolulu 1915

Elsing, Morris $\mathrm{J}$.

13 Relation of outcrops to ore at Cananea [Mexico]. Eng M J 95: 357-362 (1913)

Elston, E. D.

17 Potholes, their variety, origin, and significance. Se Mo $5: 554-567 ; 6: 37-53$ (1917-8)

Elton, H. L.

07 (with Place, A. E.) Mines of the Taviche district, Oaxaca, Mex. Eng M J $84: 625-626$ (1907)

Elworthy, R. T.

17 (with Satterly, John.) Mineral springs of Canada; Part I, The radioactivity of some Canadian mineral springs. Can Mines Br, B 16:55 pp, map (1917) 
Elworthy, R. T.-Continued.

18 Mineral springs of Canada; Part II, The chemical character us some Canadian mineral springs. Can Mines $\mathrm{Br}: 173$ pp (1918)

\section{Ely, Fred B.}

16 On ore deposits [particularly, copper deposits of Arizona]. M Sc Press 113: 689-691 (1916)

Emerson, Benjamin Kendall.

79 On the geology of Frobisher Bay and Field Bay; a description of the geological collections made by C. F. Hall on his first royage, 1860-'62. In Hall, Charles F., Narrative of the second Arctic expedition (edited by J. E. Nourse) : 551-583, il, Washington 1879

82 On a great dike of foyaite or elaeolite syenite cutting the Hudson River shales in northwestern New Jersey. Am J Sc (3) $23: 302-308$ (1882)

$82 a$ On the dikes of micaceous diabase penetrating the bed of zinc ore at Franklin Furnace, Sussex Co., N. J. Am J Sc (3) 23:376-379 (1882)

s2b The Deerfield dike and its minerals [Mass.]. Am J Sc (3) 24:195-202, 270$278,349-359$ (1882)

86 The Holyoke range on the Connecticat (abst). Am J Sc (3) $32: 323-324$ (1886) Am As, Pr $35: 233-234$ (1887)

87 The Connecticut Lake of the Champlain period, north of Holyoke. $\Delta \mathrm{m}$ J Sc (3) $34: 404-405$ (1887)

$87 a$ The age and cause of the gorges cat through the trap ridges by the Connecticut and its tributaries (abst). Am As, Pr $35: 232$ (1887)

88 [Geology of Hampshire Co., Mass.] In Gay, W. B., Gazetteer of Hampshire Co., Kass, 1654-1887 : 10-22, Syracuse, N $\mathbf{X}$ (n d, 1888?]

$90 \mathrm{~A}$ description of the "Bernardston series" of metamorphic upper Devonian rocks. Am J Sc (3) $40: 263-275,362-$ 374, map (1890)

90a Porphyritic and gneissoid granites th Massachusetts (abst). G Soc Am, B 1: $559-561$ (1890)

91 On the Triassic of Massachusettts. G Soc Am, B 2:451-456 (1891)

92 Outlines on geology of the Green Mountain region in Massachusetts; Hawley sheet, descriptive text. U S G S, G Atlas. Hawley sheet ; 3 pp, maps (1892)

92a Proofs that the Holyoke and Deerfeld trap sheets are contemporaneous flows and not later intrusions. Am J Sc (3) 43: 146-148 (1892)

93 Notes upon two boulders of a very basic eruptive rock from the west shore of Canandaigua Lake; and their contact pheBomena upon the Trenton limestone. N Y 8t G, An Rp 12: 105-109 (1893) N Y St Jus, An Rp $46: 251-255$ (1893)
Emerson, Benjamin Kendall-Continued. 95 Mineralogical lexicon of Franklin, Hampshire, and Hampden counties, Mass. U S G S, B 126: 180 pp (1895)

95a Illustrations of peculiar mineral transformations. G Soc Am, B $6: 473-474$ (1895)

95b Geology of old Hampshire Co., Mass. (abst). G Soc Am, B 7:5-6 (1895) Am G 16:238 (1895) Science n $\quad$ s $\quad 2: 279$ (1895)

95e The Archean and Cambrian rocks of the Green Mountain Range in southern Massachusetts (abst). Am G 16:247 (1895) Science n s 2:400 (1895)

96 (and others) Honors to James Hall at Buffalo. Science n s $4: 697-717$, port (1896)

96a The true tuff beds of the Trias and the mud enclosures, the underrolling, and the basic pitchstone of the Triassic traps (abst). Am G 18:220 (1896) Science n s $4: 385-386$ (1896)

97 Diabase pitchstone and mud enclosures of the Triassic trap of New England. G Soc Am, B 8: 59-86 (1897)

98 Geology of old Hampshire Co., Mass., comprising Franklin, Hampshire, and Hampden counties. U S G S, Mon 29: 790 pp, maps (1898)

98a Outlines of the geology of western Massachusetts; Description of the Holyoke quadrangle. U S G S, G Atlas Holyoke fol (no 50 ) : $8 \mathrm{pp}$, maps (1898)

98b Geology of the Turner's Falls region [Mass.]. See Grabau, 98

99 The geology of eastern Berkshire Co., Mass. U S G S, B 159:139 pp, maps (1899)

00 The tetrahedral earth and zone of the intercontinental seas. G Soc Am, B 11 : $61-96$ (1900)

Ooa Difference in batholithic granites according to depth of erosion (abst). G Soc Am, B 10:499-500 (1900) Am G 23: 104-105 (1899) Science n s 9: 140 (1899)

00b A new bivalve from the Connecticut River Trias. Am J Sc (4) $10: 58$, il (1900)

O0e Some curious matters illustrative of geological phenomena. Am G 26:312-315 (1900)

02 Two cases of metamorphosis without crushing. Am G 30:73-76 (1902)

02a Note on corundum and a graphitic essonite from Barkhamsted, Conn. Am J Se (4) $14: 234-236$ (1902)

02b Holyokeite, a purely feldspathic dia. base from the Trias of Massachusetts. J G $10: 508-512$ (1902)

o3 Glacial cirques and rock terraces on Mount Toby, Mass. (abst). Science n s $17: 224$ (1903)

O3a A plumose diabase containing sideromelan and spherulites of calcite and blue quartz (abst). Science n s 17:296 (1903) 
Emerson, Benjamin Kendall-Continued. 03b (with Perry, J. H.) The geology of Worcester, Mass. Worcester N H Soc: 166 pp, il, map, Worcester, Mass., 1903

04 General geology; notes on the stratigraphy and igneous rocks [of Alaska]. Harriman Alaska Exped 4:11-56 (1904)

$04 a$ Note on a calcite prehnite cement rock in the tuff of the Holyoke Range. Am $\mathrm{J} \mathrm{Sc} \mathrm{(4)} 17: 277-278$ (1904)

04b (and Loomis, F. B.) On Stegomus longipes, a new reptile from the Triassic sandstones of the Connecticut Valley. Am J Sc (4) $17: 377-380$, il (1904)

05 Plumose diabase and palagonite from the Holyoke trap sheet (with discussion by A. R. Lane). G Soc Am, B 16:91-130, $\operatorname{map}(1905)$

05a Notes on some rocks and minerals from north Greenland and Frobisher Bay. Am G 35:94-104 (1905)

07 (and Perry, J. H.) The green schists and associated granites and porphyries of Rhode Island. U S. G S, B $311: 74 \mathrm{pp}$, map (1907)

O7a Quartz after prochlorite at Cranston and Worcester and coal plants at Worcester. Science n s 26:907 (1907)

os Distribution of diabase in Massachusetts. Science n s 28:318-319 (1908)

10 Geological suggestions derived from a new arrangement of the elements (abst). Science n s $32: 188$ (1910) G Soc Am, B $21: 766$ (1910)

11 Cirques and rock-cut terraces of Mount Toby [Mass.] G Soc Am, B 22 : 681-686 (1911)

11a Special problems and their study in economic geology (discussion). Ec G 6 : 73 (1911)

13 The question of the older and newer Appalachians. Science n s $37: 20-21$ (1913)

15 Northfieldite, pegmatite, and pegmatite schist. Am J Sc (4) $40: 212-217$ (1917)

16 Description of large cylinders of scoriaceous diabase in the normal Holyoke diabase [Mass.] Am J Sc (4) 41:321322 (1916)

16a Mineralogical notes. Am J Sc (4) 42: 233-234 (1916)

17 Geology of Massachusetts and Rhode Island. U S G S, B 597: $289 \mathrm{pp}$, map (1917) Abst, by R. W. Stone, Wash Ac Sc, J 8: 204 (1918)

17a Recurrent tetrahedral deformations and intercontinental torsions. An $\mathrm{Ph}$ Soc, Pr 56:445-472 (1917)

See also Campbell (H D), 91; Chadwick, 17a ; Davis, 91; Diller, 90 ; Powell, 93; Pumpelly, 91 ; Safford, 95a ; Salisbury, 93 ; Williams (G H), 90e; Williams (T), 96
Emerson, Edward H.

18 Geología de las minas [Cobre, ort ente, Cuba]. Bol Minas, Habana, 4:47-5! (1918)

Emerson, Frederick Valentine (18711919).

12 Some early physiographic inferences Science n \& $35: 374-375$ (1912)

16 Occurrence of intraformational cos. glomerate and breccia (abst). G Soc $\mathrm{Am}$, B $27: 93$ (1916)

18 Loess-depositing winds in Louisians. J G $26: 532-541$ (1918) Abst, G Soc Am, B $29: 79$ (1918)

See also Bucher, 18a; Shimek, 12c

Emerson, George H.

64 On magnetite and on unknown min. eral at Nahant [Mass.]. Essex Inst, Pr 4: 6-7 (1864)

Emerson, J. S.

87 Kilauea after the eruption of March, 1886. Am J Sc (3) 33:87-95 (1887)

02 Some characteristics of Kau. Am J Sc (4) 14:431-439 (1902)

Emerson, Philip.

oo Glacial erosion in the White Mous tain notches. Science n s $11: 911-919$ (1900)

04 Note on glacial topography in cen tral New Hampshire. Appalachía 10:299303 (1904)

Emerton, J. H.

87 The restoration of the skeleton of Dinoceras mirabile. Boston Soc N H, Pt $23: 342-343$ (1887)

Emery, J. B.

85 Description of Marble Cave, Mo. Kansas City Rv Sc 8: 614-622 (1885)

Emery, Rush.

- Studies on the North American lakes, and especially upon the drift formation in the Maumee Valley and upon the south. ern shores of Lakes Erie and Michigan; together with the connection of the festures presented in these localities with the geological history of the lakes. Diss. Georgía Augusta Univ., Göttingen. 35 ph $\mathrm{n}$, $\mathrm{n}$ d

Emery, Wilson B.

16 The igneous geology of Carrizo Monts tain, Ariz. $\Delta \mathrm{m} \mathrm{J} \mathrm{Sc} \mathrm{(4)} 42: 349-363$, map (1916)

18 Strueture and ofl and gas resoures of the Osage Reservation, Okla., T. $23 \mathrm{~N}$. R. 11 E. ; Tps. 22 and 23 N., R. 12 B. U S G S, B 686: 1-9, map (1918)

18a The Green River Desert section, Utab. Am J Sc (4) $46: 551-577$, map (1918)

Emig, W. H.

17 Travertine deposits of Oklahoms. Okla G S, B 29:76 pp (1917)

18 The travertine deposits of the At buckle Mountains, Okla. (abst). Sclence n s $47: 468$ (1918) 
Emley, Warren E.

14 (with Burchard, E. F.) The source, manufacture, and use of lime. U \& G S, Min Res 1913 pt $2: 1509-1593$ (1914)

Emmens, Newton W.

05 The Bingham mining camp [Utah]. yag $12: 457-464 \quad(1905)$

06 The Jones iron fields of New Mexco. M Mag 13:109-116 (1906)

10 Mineral resources of the "Lardeau,"

B. C. Can M Inst, J 12:453-476 (1910)

II World $31: 555-559$ (1909)

10a The True Fissure and Broadview wines, B. C. M World 32: 931-934 (1910) $10 \mathrm{~b}$ Gold ores of the Lardeau distriet, B. C. M World $32: 1261-1265$ (1910)

10e Geology and ore deposits of La France Creek [Nelson mining district, west Kootenay, B. C.]. M World 33:447-449 1910)

10d Recent mineral discoveries at Poplar, B. C. M World 33:571-572 (1910)

10e Portland Canal mining district, B. C. M World $33: 894-897,955-959$, 995-998 (1910)

11 Some notes on the Siwash Creek section, B. C. M World 34:937-939 (1911)

13 Mining in Lynn Creek district, B. C. World $38: 345-347$ (1913)

14 The mineral resources of the Lardeal and Trout Lake mining divisions [B. C.]. B C Bur Mines, B 2 (1914) : 65 PD, maps

14a on the Babine Lake section, Omineea district, B. C. M World 41:47-50, map (1914)

Emmens, Stephen $\mathbf{H}$.

92 Some new nickel minerals. Am Chem Soc, J 14:205-211 (1892) Ont Bur Mines, Rp 2:167-170 (1893) Abst, Fing M J 54:609 (1892)

92a The nickel deposits of North Carolina, Eng M J 53:476-477 (1892)

92b Faulting in veins. Eng M J 53: $492 ; 54: 27$ (1892)

Emmons, Arthur B. (1850-1922).

85 Notes on the Rhode Island and Mas. sachusetts coals. Am I M Eng, Tr 13: 510-517 (1885) Abst, Eng M J $38: 279$ 280 (1884)

86 Notes on Mount Pitt [Oreg.].

Ac Sc, B [1] no $4: 229-234$ (1886)

Emmons, Ebenezer (1799-1863).

24 ...granitic veins and beds in Chester, Jass, Am J Se $8: 250-252$ (1824)

26 Manual of mineralogy and geology... $230 \mathrm{pp}$, Albany $1826 ; 2 \mathrm{~d}$ ed, $299 \mathrm{pp}, \mathrm{Al}-$ bany 1832

36 Notice of a scientific expedition loost of Maine and Nova Scotia]. Am se $30: 330-354 \quad(1836)$

37 First annual report of the second feological district of the State of New Pork. N Y G S, An Rp 1: 97-153 (1837)
Emmons, Ebenezer-Continued.

38 Report of the second geological district of the State of New York. N $\mathbf{Y}$ G S, An Rp 2: 185-252 (1838)

39 Third annual report of the survey of the second geological district [of New York]. N $\mathrm{Y}$ G S, An Rp 3:201-239 (1839)

40 Fourth annual report of the survey of the second geological district [of New York]. N Y G S, An Rp $4: 259-353$ (1840)

41 Fifth annual report of the survey of the second geological district [of New York]. N Y G S, An Rp 5: 113-136 (1841)

41a Geology of the Montmorenci. Am Mag 1: 146-150 (1841) Am G 2:94-100 (1888)

42 Geology of New York. Part II, comprising the survey of the second geological district. $437 \mathrm{pp}$, il, maps, Albany 1842

42a Geological observations. Am Mag $2: 5-9 \quad(1842)$

42b Topography, geology, and mineral resources of the State of New York. In A gazetteer of the State of New York : 525, Albany, J. Disturnell, 1842 Extr, Am G 2: $352-355$ (1888)

43 (and Hall, James) Communication from Messrs. Emmons and Hall, State geologists [on the geological survey]. N Y Legislature, Documents of the Senate, 66th sess, vol. 2 no $60: 9$ pp (1843)

44 The Taconic System; based on observations in New York, Massachusetts, Maine, Vermont, and Rhode Island. $65,3 \mathrm{pp}, \mathrm{il}$, Albany $\mathbf{1 8 4 4}$

45 Agricultural geology. Am Q J Agr $2: 1-14,179-198$ (1845)

45a On the supposed Zeuglodon cetoides of Prof. Owen. Am Q J Agr 2:59-63, 366 , il (1845)

46 Agriculture of New York... Volume I [agricultural geology; Taconic system; New York system; soils] : 371 pp, map [not issued with vol], il, Albany 1846

46a Agricultural geology of Onondaga Co. [N. Y.]. Am Q J Agr $3: 161-193$ (1846)

46b Structure of granitic mountains. Am Q J Agr 3: 207-210 (1846)

46e Description of some of the bones of the Zeuglodon cetoides of Prof. Owen. Am Q J Agr 3 : 223-231, il (1846)

$46 d$ Some of the mineral resources of New York. Am Q J Agr 4:27-50 (1846)

46e The New York system. Am Q J Agr 4:199-202 (1846)

46f Remarks on the Taconic system. Am Q J Agr 4: 202-209 (1846)

46\% Conularia vernuelia $\mathrm{n}$. $\mathrm{s}$. [Carbon iferous limestone, Des Moines River, Iowa]. Am Q J Agr 4:330, il (1846)

47 The limestones and lime. Am J Agr $5: 65-82,113-126$ (1847) 
Emmons, Ebenezer-Continued.

47a No coal in the New York rocks. Am J Agr 6: 125-129 (1847)

47b Mining report, No. 1 [Winter ironore bed, Clintonville, $\mathrm{N}$. Y.]. Am J Agr $6: 192$ [240]-198 [246] (1847)

47e [On drift phenomena.] Am J Agr $6: 218$ (1847)

48 View of the head of the gorge at Summit [N. Y.]. Am J Agr 7:165-167 (1848)

49 On the identity of the Atops trilineatus and the Triarthrus beckii (Green), with remarks upon the Eliptocephalus asaphoides. Am As, Pr 1: 16-19 (1849)

49a [On gold in Montgomery Co., Md.] Am Ph Soc, Pr 5: 85-86 (1849)

52 Report of Professor Emmons on his geological survey of North Carolina [incl. report of S. MeLenahan: 168-173] (Executive doc no 13) $181 \mathrm{pp}$, Raleigh 1852

54 American geology, containing a state. ment of the principles of the science with full illustrations of the characteristic American fossils. Part I, 194 pp, Albany 1854 [review, Am J Sc (2) 19:397-406 (1855)] ; Vol. I, pt 1, 194 pp, pt 2, 251 pp, il, Albany 1855 ; pt VI [III], $152 \mathrm{pp}$, il Albany 1857. Another ed, 3 pts, Albany 1875

56 Geological report of the midland counties of North Carolina, 352 pp, il, maps, N Y and Raleigh 1856 Extract with title, Gold veins in the syenitic granite of the Salisbury and Greensborough belt, N. C. in M Mag (2) 2:25-36 (1860)

56a On new fossil corals from North Carolina. Am J Sc (2) 22:389-390 (1856) [See also $23: 278$ ]

57 Special report ... concerning the advantages of the valley of the Deep River as a site for the establishment of a national foundry. $14 \mathrm{pp}$, Raleigh 1857 Extr, M Stat Mag 10:281-288 (1858) De Bow's Rv 24: 403-409 (1858)

$\mathbf{5 7 a}$ Permian and Triassic systems of North Carolina (abst). Edinb N Ph J n s 5: 370 (1857)

58 Report of the North Carolina geological survey; agriculture of the eastern counties, together with descriptions of the fossils of the marl beds. xvi, $314 \mathrm{pp}$, il, Raleigh 1858

58a Fossils of the sandstones and slates of North Carolina. Am As, Pr 11 pt 2: 76-80 (1858)

58b [On the age of the Triassic of North Carolina and Virginia.] Ac Sc St L, $\operatorname{Tr} 1: 101-102$ (1858)

59 The chemical constitution of certain members of the Chatham series in the valley of Deep River, N. C. Am As, Pr 12: 230-232 (1859)

59a [On Clepsysaurus, Chatham Co., N. C.] Ac N Sc Phila, Pr 1859: 151

$59 b$ [On the debituminization of anthra. cite.] Ac N Sc Phila, Pr 1859:162
Emmons, Ebenezer-Continued.

60 Manual of geology ... $290 \mathrm{pp}$, Pril 18602 d ed, 297 pp, N Y 1863

See also Adams (C B), $47 \mathrm{c}$; Hale, w: Rogers (H D), 47

Emmons, Samuel Franklin (1841-1911

70 Geology of the Toyabe Range [Ner] Egan Canyon district [Nev.]. U \& Expl 40th Par (King), 3:320-348; 445. 450 , map [In atlas] (1870)

77 (with Hague, A.) Descriptive geol: ogy. U S G Expl 40th Par (King), 2:80 pp (1877)

79 The volcanoes of the Pacific coast d the United States. Am Geog Soc, J 9:4565 (1879)

82 Geology and mining industry of Leadville, Lake Co., Colo. U S G S, A Rp 2 : 210-290, map (1882)

82a The mining work of the United States Geological Survey. Am I M Eng, Th $10: 412-424$ (1882)

83 Introductory geological sketch Buffalo Peaks, Mosquito Range, Colo. os G S, B 1:11-17 (1883)

83a The Leadville [Colo.] porpbyr Science 1: 192 (1883)

84 Ore deposition by replacement. Soc Wash, B $6: 32-33$ (1884)

85 Geological sketch of the Rocky Mout tain division. U S, 10th Census 13:60104 (1885)

85a Address of the president [miner] wealth of Colorado]. Colo Sc Soc, Pt 1 3-12 (1885)

86 Geology and mining industry Leadville, Colo. U S G S, Mon 12: rrit $770 \mathrm{pp}$, atlas (1886)

87 The genesis of certain ore deposits. Am I M Eng, Tr 15:125-147 (1887) Bí printed in Emmons, S. F., Ore deposits $1-25$, N Y 1913

87 a Notes on the geology of Butte Mont. Am I M Eng, Tr 16:49-62 (1887)

87b Notes on some Colorado ore de posits. Colo Sc Soc, Pr 2: 85-105 (1887)

87c The submerged trees of the Colur bia River. Science 9:156-157 (1887)

88 Structural relations of ore deposits Am I M Eng, Tr 16:804-839 (1888) $\mathrm{Br}$ univ Mines (3) $10: 130-170$ (1890) Be printed in Emmons, S. F., Ore deposits $26-64$, N Y 1913

$88 \mathbf{a}$ On the origin of fissure veins. Cols Sc Soc, Pr 2: 189-208 (1888)

88b On glaciers in the Rocky Ifout tains. Colo Sc Soc, $\operatorname{Pr} 2$ : 211-227 (1885

88c Preliminary notes on Aspen, Coll Colo Sc Soc, Pr 2: 251-277 (1888)

90 Orographic movements in the Roct Mountains. G Soc Am, B $1: 245-28$ (1890) Abst, Am Nat 24:211-212 (1890

$90 a$ Notes on the gold deposits Montgomery Co., Md. Am I M Eng, I 18:391-411 (1890) 
Emmons, Samuel Franklin-Continued. $90 \mathrm{~b}$ [Geologic horizon of the beds from which the Nampa image was taken.] Boston Soc N H, Pr 24: 429-434 (1890)

92 Faulting in veins. Eng $M \quad J 53$ : 548-549 (1892)

93 Geological guide book of the Rocky Mountain excursion [with contributions by G. K. Gilbert, G. H. Williams, I. C. White, Bdward Orton, U. S. Grant, G. H. Eldridge, Arnold Hague, J. P. Iddings, W. H. Weed, A. C. Peale, Whitman Cross, C. D. Walcott, W J McGee, T. McK. Hughes, Fritz Frech, and H. M. Cadell]. Int G Cong, $\mathrm{V}$, Washington 1891, C R: 253-487, maps 1893)

93a (editor), Congrès géologique international; compte rendu de la $5^{\text {me }}$ session, Tashington, 1891. ix, 529 pp, Washington 1893

93b Progress of the precious metal industry in the United States since 1880. U S G S, Min Res 1892:46-94 (1893)

93e Fluorspar deposits of southern Ininois, Am I M Eng, Tr 21:31-53, map (1893)

94 Description of the Elk Mountains [Colo.]. U S G S, G Atlas AnthraciteCrested Butte fol (no 9) : 1-3, maps (1894) llost, J G 4: 253-256 (1896)

94a Geological distribution of the useful metals in the United States (with discusslon by John A. Church and Arthur Winslow; and W. H. Merritt 24:755-756). Am I I Eng, Tr 22:53-95, 732-738 (1894) Reprinted in Emmons, S. F., Ore deposits : $65-91$, N Y 1913

94b (and Merrill, G. P.) Geological sketch of Lower California. G Soc Am, B 5: 489-514, map (1894) Abst, Am G 13: 209-210 (1894)

96 (and Cross, W., and Eldridge, G. H.) Geology of the Denver Basin in Colorado. U S G S, Mon 27:556 pp, maps (1896)

96n The mines of Custer Co,, Colo. U \& G S, An Rp 17 pt 2: 405-472 (1896) $96 \mathrm{~b}$ Gold deposits of the Black Hills of South Dakota (abst). Science n s 4:801802 (1896)

97 (and Tower, G. W., Jr.) Economic Beology of the Butte special district [Mont.] U S G S, G Atlas Butte fol (no 38) : 3-8, map (1897)

97a The geology of government explorations (presidential address before Geological society of Washington). Science $n \mathrm{~s}$ $5: 1-15,42-51$ (1897) Also published by G Soc Washington, 39 pp, 1897

$97 \mathrm{~b}$ Some mines of Rosita and Silver Clif, Colo. Am I M Eng, Tr 26:773-823 (1897) Reprinted in part in Emmons, 8. F., Ore deposits : 139-161, N Y 1913

97e The origin of Green River. Science \& $6: 19-21$ (1897)
Emmons, Samuel Franklin-Continued. 98 Description of the Tenmile district quadrangle [Colo.]. U S G S, G Atlas Tenmile fol (no 48) : $6 \mathrm{pp}$, maps (1898)

98a Map of Alaska showing known goldbearing rocks, with descriptive text containing sketches of the geography, geology, and gold deposits and routes to the gold fields. U S G S : 44 pp, map (1898)

98b Alaska and its mineral resources. Nat Geog Mag 9:139-172, map (1898)

99 Plutonic plugs and subtuberant mountains (abst). Science n s 10:24-25 (1899)

00 Description of the Tintic special district; general conclusions. U S G S, G Atlas Tintic fol (no 65) : 7-8 (1900)

01 The secondary enrichment of ore deposits. Am I M Eng, Tr 30:177-217 (1901) ; 33:1058 (1903)

$01 a$ Notes on two desert mines in southern Nevada and Utah (abst). Science $\mathbf{n} \mathbf{s}$ $13: 426-427$ (1901)

02 The Delamar and Horn-Silver mines; two types of ore deposits in the deserts of Nevada and Utah. Am I M Eng, Tr 31: 65s-683 (1902)

02a The origin of ore deposits (discussion). Am I M Eng. Tr 31:953-959 (1902)

02b Clarence King. Am J Sc (4) 13 : 224-237 (1902)

02e The life and scientific work of Clarence King. Eng M J $73: 3-5$, port (1902)

03 (and Hayes, C. W.) Contributions to economic geology, 1902. U S G S, B 213: 449 pp (1903) ..1903; B 225:527 pp (1904) ...1904; B 260:620 pp (1905)

03a Investigation of metalliferous ores. U S G S, B 213:15-2S (1903)

03b Platinum in copper ores in Wyoming. U S G S, B 213: 94-97 (1903)

o3e (and others) Genetic classification ore deposits (abst, with discussion by J. F. Kemp, T. A. Rickard, F. L. Ransome, and C. R. Van Hise), Science n s 17 : 541-543 (1903)

03d (and others) The genetic classification of ore bodies; a proposal and a discussion. Eng M J $75: 256-258$ (1903)

03e (and others) A further discussion on ore deposits (by S. F. Emmons, J. F. Kemp, F. L. Ransome, T. A. Rickard, C. R. Van Hise, Waldemar Lindgren, W. H. Weed). Eng M J 75:476-479, 594-595 (1903)

o3f The Little Cottonwood granite body of the Wasatch Mountains. Am J Sc (4) 16: 139-147 (1903)

$\mathbf{0 3 g}$ The drainage of the Valley of Mexico (abst). Science n s $17: 309$ (1903)

04 Investigation of metalliferous ores. U S G S, B 225:18-24 (1904)

O4a Theories of ore deposition historically considered. G Soc Am, B 15:1-28 (1904) Smiths Inst, An Rp 1904:309336 (1905) Eng M J 77:117-119 (1904) 
Emmons, Samuel Franklin-Continued.

04b The Virginius mine [Colorado]. Eng M J $77: 311$ (1904) [See also Purington, 03]

04e [Origin of copper in Permian and Triassic beds (abst).] Science n 8 20: $760-761$ (1904)

04d (with Irving, J. D.) Economic resources of the northern Black Hills; Part II, Mining geology. U S G S, P P 26:43222, maps (1904)

o5 Investigation of metalliferous ores. U S G S, B 260: 19-27 (1905)

05a Copper in the "Red Beds" of the Colarado Plateau region. U S G S, B 260 : 221-232 (1905)

05b The Cactus copper mine, Utah. U S G S, B 260: 242-248, map (1905)

o5e Bingham mining district, Utah; Introduction-general geology. U S G S, P P 38: 17-25 (1905)

06 (and Ecke1, E. C.) Contributions to economic geology, 1995 U S G S, B 285:506 pp (1906) ...1906; Part I, Metals and nonmetals, except fuels : B 315 : 505 pp (1907)

06a What is a fissure vein? Ec G 1: 385-387 (1906)

06b A map and cross-sections of the Downtown district of Leadville [Colo.] (abst). Science n s 23:816-817 (1906)

06e Useful definitions. M Sc Press 93 : 355-356 (1906) Proper use of mining terms. M World 25: 715 (1906)

o6d Los Pilares mine, Nacozari, Mexico. Ec G 1:629-643 (1906) Abst, Eng M J $82: 1066-1067$ (1906)

06e Blographical notice of George H. Eldridge. Am I M Eng, B 8:247-257 (1906) ; Tr $37: 339-340$ (1907)

07 Uinta Mountains. G Soc Am, B 18: 287-302 (1907) Abst, Science n s 25:767768 (1907)

O7a (and Irving, J. D.) The Downtown district of Leadville, Colo. U S G S, B $320: 75 \mathrm{pp},(1907)$

07b Suggestions for field observations of ore deposits. M Sc Press 95: 18-20 (1907)

07e Biographical memoir of Clarence King, 1842-1901. Nat Ac Sc, Biog Mem $6: 25-55$, port (1907)

09 Development of modern theories of ore deposition. M Sc Press 99:400-403 (1909)

10 Economic geology in the United States. Can M Inst, J 12: 89-101 (1910) M World 30:1209-1211 (1909)

10a Cananea mining district of Sonora, Mexico. Ec G 5:312-356 (1910) Abst, Eng M J 90:402-404 (1910)

10b Theories of ore genesis of fifty years ago. M Sc Press 100:739-742 (1910)

10e Criteria of downward sulphide enrichment; discussion. Ec G 5:477-479 (1910)
Emmons, Samuel Franklin-Continued.

10d The Cobalt mining district of 0 . tario (abst). Science n s $31: 517$ (1910)

11 Cobalt district, Ontario. M Sc Press $102: 390-396$ (1911). Reprinted in Types of ore deposits (ed. by H. F. Bain), pp. 140-156 (1911)

13 Ore deposits; a sequel to the second edition of "The genesis of ore deposits," by Franz Pošepný and others; being a compilation of contributions to this science from the Transactions of the American Institute of Mining Engineers, with a critical introduction and synopsis. 854 pp, N Y 1913

See also Davis (W M), 00; Don, 98; Frazer, 88a ; Hague (J D), 04; Hovey, 00f: Jenney, 03; King (C), 71a, 80; Mal. colmson, 01 ; Pošepný, 94, 95; Powell, 82, $83,84,85,85 \mathrm{a}, 88,89,89 \mathrm{a}, 90,91,91 \mathrm{a}, 92$, 93; Rickard, 03; Russell, 85d; Spurr, 95; Weed, 03g

Emmons, William Harvey.

05 The Neglected mine and near-bs properties, Durango quadrangle, Colo. U \& G S, B 260:121-127 (1905)

O5a (with Irving, J. D.) Economic geology [of the Needle Mountains guad. rangle, Colo.]. U S G S, G Atlas Needle Mountains fol (no 131): 12-13 (1905)

06 Ore deposits of Bear Creek, near Silverton, Colo. U S G S, B $285: 25-27$ (1906)

06a The Cashin mine, Montrose $\mathrm{CO}_{\text {n }}$ Colo. U S G S, B 285:125-128 (1906)

o7 (and Garrey, G. H.) Notes on the Manhattan district [Nev.]. U S G S, B 308: 84-93 (1907)

$07 \mathbf{a}$ The Granite-Bimetallic and Cable mines, Philipsburg quadrangle, Mont. Us G S, B 315:31-55 (1907)

O7b Normal faulting in the Bullfrog district [Nev.]. Science n s 26:221-22? (1907)

os Geology of the Haystack stock, Cowles, Park Co., Mont. J G 16:193-229, map (1908)

08a A genetic classification of minerals. Ec G 3:611-627 (1908)

osb Gold deposits of the Little Rocky Mountains, Mont. U S G S, B $340: 96-116$ (1908)

08e Secondary enrichment in Granite Bimetallic mine, Philipsburg, Mont. (abst). Science n s 27:925 (1908)

09 Some regionally metamorphosed ore deposits and the so-called segregated veins. Ee G 4:755-781 (1909)

O9a Outcrop of ore bodies. M Sc Press $99: 751-754,782-787 \quad(1909) ; 100: 162-$ 163 (1910) Reprinted in Types of ore de posits (ed by H. F. Bain : 299-323 (1911)

10 A reconnaissance of some mining camps in Elko, Lander, and Eureka cos. Nev. U S G S, B 408: $130 \mathrm{pp}$, map (1910) 
Emmons, William Harvey-Continued. 10a Some ore deposits in Maine and the Milan mine, N. H. U S G S, B 432: 62 pp, map (1910)

10b The agency of manganese in the superficial alteration and secondary enrichment of gold deposits in the United States. Am I M Eng, B 46: 767-837 (1910) ; Tr 42:3-73 (1912) J G $19: 15-46$ (1911) Reprinted in Emmons, S. F., Ore deposits: 759-828 N Y 1913

10e Recent experiments relating to the transfer of gold by cold dilute mineral waters (abst). Science n s $32: 62$ (1910) 10d (with Ransome, F. L.) Geology and ore deposits of the Bullfrog district, Nev. U S G S, B 407: 130 pp (1910)

11 (and Laney, F. B.) Preliminary report on the mineral deposits of Ducktown, Tenn. U S G S, B 470:151-172 (1911)

11a Prospecting in the North (discussion). M Mag 4:116-117 (911)

11b The weathering and enrichment of pyritic gold ores $(a b s t)$. Science n s 33: 462 (1911)

12 The mineral composition of the primary ore as a factor determining the vertical extent of the secondary sulfide zone (abst). Wash Ac Sc, J $2: 359-360$ (1912)

13 The enrichment of sulphide ores. U S G S, B $529: 260 \mathrm{pp}$, (1913) Abst, by Sidney Paige, Wash Ac Sc, J 3:454-455 (1913)

13a The mineral composition of primary ore as a factor determining the vertical range of metals deposited by secondary processes. Int G Cong, XII, 1913, C R: 261-269 (1914) Advance copy 1913

13b (and Calkins, F. C.) Geology and ore deposits of the Philipsburg quadrangle, Mont. U S G S, P P $78: 271$ pp, maps (1913) Abst, Wash Ac Sc, J 4:163-164 (1914)

13e (and Harrington, G. L.) A comparison of waters of mines and of hot springs. Ec G 8:653-669 (1913)

13d (and Larsen, E. S.) A prellminary report on the geology and ore deposits of Creede, Colo. U S G S, B 530:42-65 (1913)

13e (and Larsen, E. S.) The hot prings and the mineral deposits of Wagon Wheel Gap, Colo. Ec G $8: 235-246$ (1913)

15 On temperatures that obtain in zones of chalcocitization. Ec G 10: 151-160 (1915)

15a (with Calkins, F. C.) Description of the Philipsburg quadrangle, Mont. U S G S, G Atlas Philipsburg fol (no 196) : 25 Pp, maps (1915)

16 [Report of the director of the Minnesota] Geological Survey [for 1914-15]. Xlinn, Univ, B 19: 145-148 (1916)

16a The iron ores of Minnesota.

Geog 14:177-182, map (1916)
Emmons, William Harvey-Continued.

17 The enrichment of ore deposits. U S G S, B 625 : 530 pp (1917) Abst, by A. K, Wash Ac Sc, J 7:512 (1917)

17a Exploration of metalliferous deposits. Am I M Eng, B 123: 355-366 (1917) ; Tr 58:232-243 (1918) M Sc Press 114: 436-440 (1917)

17b The conservation of copper. Pan American Sc Cong, 2d, Pr sec 3 vol 3: 246-253 (1917)

18 The principles of economic geology. 606 pp, N Y 1918 Review, by Joseph T. Singewald, Jr., Ec G $13: 325-332$ (1918)

18a Discussion of a paper headed " Genetic classification of underground volatile agents" [by R. A. Daly]. Ee G 13:144145 (1918)

See also Tarr (W A), $18 \mathrm{c}$

Emory, William Hemsley (1811-1887).

48 Notes of a military reconnaissance from Fort Leavenworth in Missouri to San Diego in California, including part of the Arkansas, Del Norte, and Gila Rivers. U S, 30th Cong 1st sess, S Ex Doc 7:5126 (1838) ; H Ex Doc 41: 5-126 (1848)

57 Report on the United States and Mexican boundary survey... U S, 34th Cong 1st sess, S Ex Doc 108 and $\mathrm{H} \mathrm{Ex}$ Doc 135: 258, 174 pp (v i), il, maps (1857)

$57 \mathbf{a}$ General deseription of the country adjacent to the boundary between the United States and Mexico. Am As, Pr 10 pt $2: 134-148$ (1857)

58 On a feature in the range of the western mountain system of North America. Am As, Pr 11 pt 2:56-57 (1858)

Emrich, Clarence $T$.

09 Mastodon bones [from Golden, Colo.]. Colo Sch Mines, B $5: 36-37$ (1909)

Endich, Frederic Miller (1851-1899).

74 Report [on the mining distriets of Colorado and on the geology of the San Luis district]. U S G Geog S Terr (Hayden), An Rp [7] : 275-301, 305-361, maps (1874)

74a On mineralogical systems. $\mathrm{Ph}$ Soc Wash, B $1: 77-83$ (1874)

75 Report on the mines and geology of the San Juan country. U S G Geog S Terr (Hayden), B [1] no 3 (2):151-164 map (1875)

76 Report [on the San Juan district, Colo.]. U S G Geog S Terr (Hayden), An Rp [8] : 181-240 (1876)

77 Report [on southern Colorado]. U S G Geog Sur Terr (Hayden), An Rp 9: 103235, maps (1877)

78 On the geology of the White River district. U S G Geog S Terr (Hayden), An Rp 10:61-131 (1878)

78a Catalogue of minerals found in Colorado. U S G Geog S Terr (Hayden), An Rp 10:133-159 (1878)

78b Report on the erupted rocks of Colorado. U S G Geog S Terr (Hayden), An Rp 10: 197-272 (1878) 
Endlich, Frederic Miller-Continued.

7Se On some striking products of erosion in Colorado, U S G Geog Sur Terr (Hayden), B 4:831-864 (1878)

79 Report on the geology of the Sweet water district. U S G Geog S Terr (Hayden), An Rp 11:3-158 (1879)

so The Island of Dominica [W. I.]. Am Nat 14: 761-772 (1880)

83 The mining regions of southern New Mexico. Am Nat 17:149-157 (1883)

83a [Geologic map of] part of central Wyoming. Surveyed in 1877 . Scale 4 miles to 1 inch. U S G Geog S Terr (Hayden). n d [1883?] [Also in 12th An Rp]

S3b (with Peale, A. C., and St. John. O.) Geological map of portions of Wy. oming, Idaho, and Utah. Scale 8 miles to 1 inch. U S G Geog S Terr (Hayden), n d [1883?] [Also in 12th An Rp]

89 The origin of the gold deposits near Ouray, Colo. Eng M J 48:335 (1889)

92 Manual of qualitative blowpipe analysis and determinative mineralogy. $456 \mathrm{pp}$, N Y 1892

96 Mining in the Mohave desert in Callfornia. Eng M J 62:197-168 (1896)

97 The Pearce mining district, Ariz.

Fng M .J 63:571 (1897)

Engelbach, H.

13 Les minerais de fer du lac Supérieur (Etats-Unis). Soc Ind Min, B (5) 4: 329-370 (1913)

Engelmann, George (1809-1884).

47 Remarks on the St. Louis limestone. Am J Sc (2) 3:119-120 (1847)

51 [Geological structure of the region between Little Rock and Hot Springs, Ark.] Am As, Pr 5:199-201 (1851)

Engelmann, Henry (1831-1899).

58 Report of a geological exploration from Fort Leavenworth to Bryan's Pass. [Kansas-Nebraska]. U S, 35th Cong 1st sess, H Ex Doc 2 (Rp Sec War 1857) : 489-517 (1858)

58a Preliminary report on the geology of the country between Fort Bridger and Camp Floyd, Utah Territory, and southwest of the latter place along Captain J. H. Simpson's routes, 1858. U S, 35th Cong $2 d$ sess, S Ex Doc 40:45-75 (1858)

60 (with Meek, F. B.) Notice of geological discoveries made by Capt. J. H. Simpson... in his recent explorations across the continent. Ac N Sc Phila, Pr 1860: 126-131

63 Topaz in Utah. Ac Sc St L, Tr 2: 114 (1863)

63a [On the Lower Carboniferous sys tem in southern Illinois.] Ac Sc St L, Tr $2: 188-190$ (1863)

66 Johnson Co.; Pulaski Co.; Pope Co. Ill G S 1: $376-495$ (1866); Ec G 1:320 $456(1882)$

66a (with Worthen, A. H.) Hardin Co. Ill G S 1:350-375, map (1866) ; Ec G $1: 291-319(1882)$
Engelmann, Henry-Continued.

68 Geology of Washington Co.; Clinton Co. ; Marion Co.; Jefrerson Co. Ill G s $3: 145-238$ (1868) ; Ee G $2: 72-179$ (1882

75 Important discovery of coal at Cen tralia, Ill. Ae Sc St L, Tr 3: eliv (1875)

76 Report on the geology of the country between Fort Leavenworth, K. T., and the - Sierra Nevada, near Carson Valley, Is Simpson, J. H. Report of explorations across the Great Basin of the Territory of Utah... in $1859: 243-336$, Washingtor 1876

76a The brown coals of Utah and ad joining territories. Am I M Eng, Tr 4 298-308 (1876) Eng M J 21:346-347 (1876)

\section{Engerrand, Jorge.}

10 (and Urbina, Fernando) Primera nota acerca de la fauna miocénica de Zulu. zum, Chiapas. Soc G Mex, B 6: xxvi, 119 140 , il (1910)

10a Informe acerca de una excursion geológica preliminar efectuada en el Estad de Yucatán. Méx I G, Par 3:371-424 (1910)

13 (and Paredes, T.) Informe rela tivo a la parte occidental de la region nort de la Baja California. Méx I G, Par 4 277-306 (1913)

Englehardt, Francis E.

83 Chemist's report [salt deposits, geo. ogy ; borings]. In $\mathrm{N} \mathrm{Y}$, Supt Onondaga Salt Springs, An Rp 1882:17-30 (1883 ...An Rp 1883: 13-39 (1884)

English, Walter Atheling.

14 The Fernando group near Newhall, Cal. Cal Univ, Dp G, B $8: 203-218$, il (1914).

14a The Agasoma-like gastropods of the California Tertiary. Cal Univ, Dp G, B $8: 243-256$, il (1914)

14b Fauna of lower Fernando serles (abst). G Soc Am, B 25: 151 (1914)

14e (with Pack, Robert W.) Geology and oil prospects in Waltham, Priest, Bitterwater, and Peachtree valleys, Cal. U S G B, B 581 : 119-160, map (1914)

16 Geology and oil prospects of Cuyams Valley, Cal. U S G S, B 621: 191-215, map (1916) Abst, Wash Ac Sc, ? 6:400401 (1916)

18 Geology and ofl prospects of the Sslinas Valley-Parkfield area, Cal. U S G S B $691: 219-250$ (1918) Abst, by R. W. Stone, Wash Ac Sc, J 8: 539 (1918)

Enriquez, E. W.

10 (with Kruger, H. A.) Geology of the Perry Park syncline, Colo. Colo Sch Mines, B 5:86-99 (1910)

Enzian, Charles.

16 (with MacDonald, D. F.) Pros pecting and mining of copper ore at Sants Rita, N. Mex. U S Bur Mines, B 107:122 pp, maps (1916) 
Epry, Ch.

14 Ripple marks. Smiths Inst, An Rp $1913: 307-318 \quad$ (1914)

Eriekson, M. B.

04 (with Willard, D. E.) A survey of the coteaus of the Missouri. N Dak, Agr Coll S, Bien Rp $2: 17-27$ (1904)

Ernest, T. R.

12 (with Parr, S. W.) A study of sand-lime brick. Ill G S, B 18:83 pp (1912)

Erni, C. P.

16 (with Bushnell, T. M.) Soil surrey of White Co. Ind, Dp $\mathbf{G} \mathbf{N}$ Res, 40th An Rp : 109-155, map (1916)

17 (and Beals, C. C.) Soil survey of Carroll Co. Ind, Dp $G$ Nat Res, An Rp 41: 45-66, map (1917)

Erni, Henry.

65 Coal oil and petroleum; their origin, bistory, geology, and chemistry... $196 \mathrm{pp}$, Pbila 1865

85 Mineralogy simplified... [For 1st ed, see Kobell, 67]. 2d ed, 395 pp, Phila $18853 d$ ed, xxviii, 383 pp Phila 1901 [pts 2 and 3, pp 184-362, revised by A. P. Brown, issued with title Chemical det: $r$ minative mineralogy...) 4th ed (revised by A. P. Brown), xxx, 414 pp Pbila 1908 Escobar, R.

06 Los pozos artesianos de Villa Ahumada, E. de Chihuahua, Soc Cient Ant Alz, Mem $24: 121-126$ (1906)

Estes, A. W.

09 Mineral resources of Arkansas. Am If Cong, 11th An Sess, Papers and $\mathrm{Pr}$ : 146-151 (1909)

Estes, Clarence.

18 (with whitaker, W. A., and Camphell, F. W.) The petroleum industry in Kansas. Eng M J 105: 817-821 (1918)

Etheridge, Robert (1819-1903):

60 On the occurrence of animal fossils, with a list of genera. In Wall, G. P., and Sawkins, J, G., Report on the geology of Trinidad (Great Britain, G S, Mem) :161$166(1860)$

69 Appendix $V$. to the geological survey of Jamaica and summary of the paleontology of the Caribbean area, In Sawkins, James G., Reports on the geology of Jamaica (Great Britain, G S, Mem) : 306339 (1869)

74 List of geological specimens collected by Captain A. H. Markham. In Markham, A. H., A whaling cruise to Baffin's Bay and the Gulf of Boothia... :297-298, L 1874

78 Paleontology of the coasts of the Arctic lands visited by the late British exDedition... G Soc London, Q J 34:568636, il (1878)

$28737^{\circ}-23$
Etheridge, Robert, jr. (1847-1920).

74 On the relationship existing between the Echinothuridae Wyville Thomson and the Perischoechinidae McCoy. G Soc London, Q J $30: 307-315$, il (1874)

77 (with Nicholson, H. A.) On As. codictyon, a new provisional and anoma. lous genus of Paleozoic fossils. An Mag N H (4) $19: 463-468$, il (1877)

77a (with Nicholson, H. A.) On the genus Tetradium, Dana, and a Britis species of the same. An Mag N $\mathrm{N}$ (4) 20 : 161-169, il (1877)

77b (with Nieholson, H. A.) Notes on the genus Alveolites Lamarck and on some allied forms of Paleozoic corals. Linn Soc J, Zool, 13:353-370, il (1877)

78 (with Nicholson, H. A.) On the genus Palaeacis... An Mag N H (5) $1: 206$ 227 (1878)

85 (with Nicholson, H. A.) On the synonymy, structure, and geological distribution of Solenopora compacta Billings. sp. G Mag (3) 2:529-535, il (1885)

Eustis, W. E. C.

78 The nickel ores of Orford, Quebec. Can. (with discussion by T. S. Hunt). Am I M Eng, $\operatorname{Tr} 6: 209-213$ (1879) Eng M J $25: 187$ (1878)

Evans, A. W.

o5 Jellico coal field [Kentucky and Tennessee]. Eng As South, Tr 15:43-52 (1905)

09 Lahausage mine, Ala. Mines and Minerals $30: 77-79$ (1909)

Evans, E. W.

64 On the action of oll wells. Am J Sc (2) $38: 159-166$ (1864)

66 On the oil-producing uplift of West Virginia. Am J Sc (2) $42: 334-343$ (1866) Evans, George Watkin.

10 Controller Bay coal field, Alaska. Mines and Minerals $30: 449-453,552-556$ (1910)

12 The coal fields of King County. Wash G S, B 3:247 pp, map (1912)

13 Some notes on the Groundhog anthracite coal field [B. C.] Can M Inst, Tr 16:434-441 (1913)

14 The Issaquah coal mine [Wash.]. Coll Eng 34:663-666 (1914)

Evans, Gurdon.

52 Geology of the County of Madison. N Y St Agr Soc, Tr 11:694-709 (1852)

Evans, Harry A.

89 The relation of the flora to the geological formations in Lincoln Co., Ky. Bot Gazette 14: $310-314$ (1889)

Evans, Herbert M.

04 A new cestraciont spine from the lower Triassic of Idaho. Cal Univ, Dp G, B $3: 397-401$, il (1904)

Evans, Horace F.

03 Canadian geology. M Sc Press 86 : 299-300 (1903) 
Evans, Horace F.-Continued.

03a The Adams Lake series, British Columbia. M Sc Press $86: 348-349$ (1903)

o5 The Nicola-Co]dwater coal beds [B. C.]. M World 23:200-201 (1905)

o5a The source of Fraser River gold [B. C. ]. M World 23 : 258-259 (1905)

05b The Cretaceous stratigraphy of Ashcroft, B. C. M World 23:285-286 (1905)

05e A further reconnaissance into Highland Valley, B. C. M World 23: 336 (1905) o5d Molybdenite in British Columbia. M World 23:443-444 (1905)

05e Kamloops [B. C.] and its geological conditions. M World 23:464 (1905)

o5f Interior plateau of British Columbia, M World 23:579 (1905)

$06 \mathrm{~A}$ reconnaissance into Tulameen, B. C. M World $24: 633,665,696,726$, $747 ; 25: 12$ (1906)

o6n International geology of Cascade region. M World 25:236-237 (1906)

06b Copper deposits of Eschelon Mountain, B. C. M World 25:266 (1906)

o6e The Similkameen and its beds [B. C.]. M World 25:399 (1906)

06d Marginal differentiation in biotites [Similkameen district, B. C.]. M World $25: 749$ (1906)

07 British Columbia placers; past and present. M World $26: 563,687,779$ (1907)

O7a Explorations in British Columbia. M World 26:333, 384, 472, 505-506 (1907)

07b Reconnaissance up West Fork of Kettle River. M World 27:65, 317 (1907)

o7e Certain features of the Rocky Mountains region. M World $27: 641,809$ (1907)

oza Nickle Plate mines on Striped Mountain [Similkameen Valley], B. C. M World $27: 1015,1057$ (1907) ; 28:63 (1908)

os Reconnaissance into Okanogan Mountains, Wash. M World 28:99-100, 254, $334, \quad 349,449,527,595,638,672, \quad 725$ (1908)

O8n The correlation of the international strata. M World 28: 795-796, 951-952; $29: 17,245,319-320$ (1908); 30:21-22, $55-56,129$ (1909)

Osb The copper deposits of Lake Osoyoos, Wash. M World 29:361-362 (1908)

10 The northern Caseades [Osoyors district, northern Wash.]. M Sc Press 100 : 448-449 (1910)

Evans, Isabel P.

14 Publications by Survey authors on metals and nonmetals except fuels. U S G S, B 580:413-455 (1914)

Evans, J. T.

84 Colemanite. Cal Ac Sc, B 1:57-59 (1884)

85 The chemical properties and relations of colemanite. Cal Ac Sc, B [1] no 2: $37-42$ (1885)
Evans, John (1812-1861).

54 [Notes on the geology of the reglon traversed by the northern Pacific railrosd survey.] U S, Pacific R R Expl (U S, 33 Cong 1st sess, H Ex Doc 46) : 20-23 (1854)

54a (and Shumard, B. F.) Descrlp tions of new fossil species from the Creta. ceous formation of Sage Creek, Nebrasks Terr. Ac $\mathrm{N}$ Se Phila, Pr $7: 163-164$ (1854)

54b (and Shumard, B. F.) Descrip. tions of new fossil species from the fresh. water Tertiary formation of Nebraska Terr, Ae N Sc Phila, Pr $7: 164-165$ (1854)

57 (and Shumara, B. F.) On som? new species of fossils from the Cretaceons formation of Nebraska Territory. Ac Sc St L, Tr 1:38-42 (1857)

61 Geological report [coals of the Chiriqui district, Panama]. U S, 36th Cong $2 d$ sess, H Ex Doc 41:45-55 (1861)

66 On a possible geological cause of changes in the position of the axis of the earth's crust. R Soc London, Pr 15: 46-54 (1866) Am J Sc (2) 43:230-239 (1867)

Evans, John William.

99 The gold-bearing sands of the Vet million River [Ont.]. Can M Inst, J 2: 105-107 (1899) Can M Rv 18:72-i4 (1899)

o7 How should faults be named and classified? Ec G 2: 803-806 (1907)

Evans, Nevil Norton.

98 Chemical composition of the granile from Pine Lake, Ont. (abst). Science ns $7: 82$ (1898)

o3 Native arsenic from Montreal [Que]. Am J Sc (4) 15:92-93 (1903)

o5 Chrysoberyl from Canada. Am J Sc (4) $19: 316-318$ (1905)

os (and Bancroft, J. A.) On the 00 currence of gedrite in Canada. Am J Se (4) $25: 509-512$ (1908)

See also Adams (F D), 98a

Eve, A. S.

O7 (and MeIntosh, D.) The amount of radium present in typical rocks in the immediate neighborhood of Montreal. Pli Mag (6) $14: 231-237$ (1907)

Everett, Oliver.

61 Geology of a section of the Rock River valley, from Oregon, in Ogle $\mathrm{Co.}$ to Sterling, in Whiteside Co. [III.]. III $\mathrm{X}$ H Soc, Tr 1:53-58 (1861)

90 (with U1rieh, E. O.) Descriptions of Lower Silurian sponges. Ill G S 8: 253-282, il (1890)

Everette, Willis Eugene.

o7 The geology of the Klondike. Sc Am Sup 64: 410-411 (1907); 65:14-16 (1908) os Genesis of the formation and depost tion of the Nevada desert gold, silver, and copper mines. Sc Am Sup 65:61 (1908)

OSa Formation of mineral veins. S Am Sup $65: 287-288, \quad 302-303,318-319$ (1908) 
Ewing, A, L.

84 Observations on the geologieal formations of Center Co. Pa G S, 2d, T 4:401434 (1884)

85 An attempt to determine the amount and rate of chemical erosion taking place in the limestone (Calciferous to Trenton) ralley of Center Co., Pa... Am J Sc (3) 29:29-31 (1885) Abst. Am As, Pr 33: 404-405 (1885)

Eyerly, T. L.

07 The geology of Hemphill Co. [Tex.] ; with a brief description of its topography, water supply, and soils. $16 \mathrm{pp}$, [priv pub? 1907]

Eyerman, John.

89 The mineralogy of Pennsylvania. Part I. To be used as a supplement in connection with Dr. F. A. Genth's Preliminary report on the mineralogy of Pennsylvania, 1875. $54 \mathrm{pp}$, Easton, $\mathrm{Pa}, 1889$ 89a on the mineralogy of the French Creek mines, $\mathrm{Pa}$. N Y Ac Sc, Tr $8: 56-59$ (1889)

89b Notes on geology and mineralogy. Ac N Se Phila, Pr $1889: 32-35$

90 Bibliography of North American vertebrate paleontology for the year 1889. Am G $5: 250-253$ (1890)

91 Bibliography of North American vertebrate paleontology for the year 1890 . Im G $7: 231-238$ (1891)

91a A catalogue of the paleontological publications of Joseph Leidy. Am G 8: 333-342 (1891)

92 Bibliography of North American vertebrate paleontology for the year 1891 . An G $9: 249-256$ (1892)

92a Preliminary notice of sothe minerals from the serpentine belt, near Easton, Pa. Ac N Sc Phila, Pr 1891:464465 (1892)

93 Bibliography of North American vertebrate paleontology for the year $1 \cdots 2$. dm G $11: 388-393$ (1893)

94 Preliminary notice of a new species of Temnocyon and a new genus from the John Day Miocene of Oregon. Am G 14: 320-321 (1894)

96 The genus Temnocyon and a new species thereof and the new genus Hypotemnodon, from the John Day Miocene of Oregon. Am G $17: 267-287$, il (1896)

04 Contributions to mineralogy. Am G 34: 43-48 (1904)

11 The mineralogy of Pennsylvania ; Part 2, Chemical analyses. $25 \mathrm{pp}$, Easton, Pa. 1911 [Priv pub, for part 1 see 89 above]

F., P.

80 Gunnison district, Colo. ; its geology. Ring M J $30: 56-57,87$ (1880)

Faber, Charles L.

86 Remarks on some fossils of the Cincinati group. Cin Soc N H, J $9: 14-20$, il (1886)
Faber, Charles L.-Continued.

92 (with Miller, S. A.) Description of some Carboniferous and Subcarboniferous Cephalopoda. Cin Soc N H, J 14:164-168, il (1892)

92a (with Miller, S. A.) Some new species and new structural parts of fossils. Cin Soc N H, J 15: 79-87, il (1892)

94 (with Miller, S. A.) New species of fossils from the Hudson River group and remarks upon others. Cin Soc $\mathrm{N} \mathrm{H}, \mathrm{J} 17$ : $22-33$, il (1894)

$94 a$ (with Miller, S. A.) Description of some Cincinnati fossils. Cin Sor $\mathrm{N} \mathrm{H}$, J $17: 137-158$, il $(1894)$

Faber, William L.

52 On carrollite, a new cobalt mineral [Carroll Co., Md.]. Am J Sc (2) 13:418419 (1852)

Failyer, G. H.

93 (and Bailey, E. H. S.) A revised list of Kansas minerals. Kans Ac Sc, $\mathrm{Tr}$ 13: $76-78$ (1893)

Fairbanks, Ernest E.

1s Method of indexing a mineral collection. Am Mineralogist 3:195 (1918)

Fairbanks, Harold Wellman.

90 Geology of the Mother Lode region. Cal St M Bur, An Rp 10:23-90, map (1890) Abst, Am G 7:209-222 (1890)

$90 a$ Notes on the character of the eruptive rocks of the Lake Huron region [Ont.]. Am G 6:162-172 (1890)

92 The pre-Cretaceous age of the metamorphic rocks of the California coast ranges. Am G $9: 153-166$ (1892)

93 Geology and mineralogy of Shasta Co. Cal St M Bur, Rp 11:24-53, map (1893)

$93 \mathbf{a}$ Notes on the geology and mineralogy of portions of Tehama, Colusa, Lake, and Napa cos. Cal St M Bur, Rp 11:54-75 (1893)

$93 \mathbf{b}$ Geology of San Diego; also of portions of Orange and San Bernandino cos. Cal St M Bur, Rp 11:76-120, map (1893)

93c Notes on a further study of the pre-Cretaceous rocks of the California cobast ranges. Am G 11:69-84, map (1893)

$93 d$ The validity of the so-called Wallala beds as a division of the California Cretaceous. Am J Sc (3) $45: 473-478$ (1893)

93e The relation between ore deposits and their enclosing walls. Eng M J 55: 200 (1893)

93f Notes on the occurrence of rubellite and lepidolite in southern California. Science $21: 35-36$ (1893)

94 Red Rock, Goler, and Summit mining districts in Kern Co. Cal St M Bur, Rp 12:456-458 (1894)

94a Preliminary report on the mineral deposits of Inyo, Mono, and Alpine cos. Cal St M Bur, Rp 12:472-478 (1894)

94b Geology of a section of Eldorado Co. Cal St M Bur, Rp 12:479-481 (1894) 
Fairbanks, Harold Wellman-Continued.

94e Geology of northern Ventura, Santa Barbara, San Luis Obispo, Monterey, and San Benito cos. Cal St M Bur, Rp 12: 493-526 (1894)

94d Review of our knowledge of the geology of the California coast ranges. G Soc Am, B 6:71-102 (1894) Abst, Am G $14: 198$ (1894)

94e ... localities of Mesozoic and Paleozoic in Shasta County, Cal. Am G 14 : $25-31$ (1894)

94f $A$ remarkable folded vein in the Ready Relief mine [Banner district, San Diego Co., Cal.]. Eng M J 57:321-322 (1894)

94m Some remarkable hot springs and associated mineral deposits in Colusa Co., Cal. Science 23:120-121 (1894)

95 On analcite diabase from San Luis Obispo Co., Cal. Cal Univ, Dp G, B 1 : 273-300 (1895)

95a The stratigraphy of the California coast ranges, J G 3:415-433 (1895)

95b Auriferous conglomerate in California. Eng M J 59:389-390 (1895)

96 Ore deposits with especial reference to the Mother Lode. Cal St M Bur, Rp 13: 665-672 (1896)

96a The geology of Point Sal [Santa Barbara Co., Cal.]. Cal Univ, Dp G, B 2 . 1-91, map (1896)

96b Notes on a breathing gas well [Santa Lucia range, San Luis Obispo Co. Cal.] M Sc Press 73:460-461 (1896) Science n s $3: 693-694$ (1896)

96e Notes on the geology of eastern Cali fornia. Am G 17: 63-74 (1896)

96d The mineral deposits of eastern Call fornia. Am G 17:144-158 (1896) M S، Press $73: 480-481,501$ (1896)

96e The age of the California coas ranges. $\mathrm{Am}$ G $18 \cdot 271-282$ (1896)

96f Straligraphy at Slate's Springs witl some further notes on the relation of the Golden Gate series to the Knoxville [Cal.] Am G 18: 350-356 (1896)

$96 \mathrm{~g}$ The possibilities of the petroleum in. dustry in California. Eng M J 61:588 (1896)

96h The coal beds of California. Eng M J $62: 10$ (1896)

96i The great Mother Lode of California. Eng M J 62:248-250 (1896)

97 Oscillations of the coast of California during the Pliocene and Pleistocene. $\mathrm{Am} \mathrm{G}$ 20:213-245 (1897)

97 a The geology of the san Francisco Peninsula. J G 5:63-67 (1897)

$\mathbf{9 7 b}$ An interesting case of contact metamorphism [El Paso Range, Cal.]. Am J Sc (4) $4: 36-38$ (1897)

$97 \mathrm{e}$ The tin deposits at Temescal, southern California. Am J Sc (4) 4:39-42 (1897) M Sc Press $75: 362$ (1897)
Fairbanks, Harold Wellman-Continued. $97 \mathbf{d}$ Outline of the geology of California with reference to its mineral deposits. I Sc Press 74:132, 152, 173, 193, 213, 232 (1897)

98 Geology of a portion of the southern coast ranges. J G 6:551-576 (1898)

98a The great Sierra Nevada fault scarp. Pop Sc Mo 52:609-621 (1898)

98b Bituminous rock deposits in the vicinity of San Luis Obispo, Cal. If Sc Press $76: 661$ (1898)

99 Some notes on the petroleum deposits of California. M Sc Press, 78: 533 (1899)

oo Geology of San Diego Co., Cal. West Am Sc 10:17-19 (1900)

01 The physiography of California, Am Bur Geog, B 2 : 232-252, 329-353 (1901)

01 a Pramid Lake, Nevada. Pop Se Mo 58:505-514 (1901)

01b Geology of the Three Sisters, Oreg. (abst.). G Soc Am, B $12: 498-499$ (1901) J G $9: 73$ (1901) Am G 27:131-132 (1901)

02. Lake Chelan, Wash. (abst.). Science n 8 15:412-413 (1902)

o3 The physiography of southern Arizona and New Mexico (abst.). J G 11:97-99 (1903) Eng M J 75:154 (1903)

04 Description of the San Luis guadrangle [Cal.]. U S G S, G Atlas San Luis fol (no 101) : 14 pp, maps (1904)

04a Gypsum deposits in California. Us G S, B 223: 119-123 (1904)

06 Practical physiography. 542 pp, Bos ton 1906

07 The great earthquake rift of Califor-

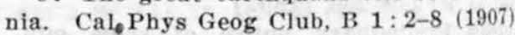
Reprinted in Jordan, D. S., editor, The California eartbquake of 1906:319-385, San Francisco 1907

o9 Physiography, an elementary science course in the High School. J Geog 7:217226 (1909)

10 Some topographical features of the western side of the Colorado Desert (abst). Science n s $32: 31$ (1910) G Soc Am, B 21: 793 (1910)

IOn (and Carey, E. P.) Glaciation in the San Bernardino Range, Cal. Science n 8 31:32-33 (1910)

Fairchild, Herman Le Roy.

$\boldsymbol{7} \boldsymbol{7}$ On the structure of Lepidodendron and sigillaria. N Y Ac Sc, An $1: 41-45$, $77-91,129-133$, il $(1877-8)$

81 On a recent determination of Lepido. dendron. Torrey Bot Club, B 8:62-64 (1881)

82 On a peculiar coal-like transforma. tion of peat recently discovered at Scran. ton, Pa. N Y Ac Sc, Tr 1: 71-76 (1882)

87 Elephants, ancient and modern, with reference also to the extinction of the mammoth... N Y Ac Sc, Tr 4:19-24 (1887) 
Fairchild, Herman Le Roy-Continued. 91 A section of the strata at Rochester, N. Y., as shown by a deep boring. Rochester Ac Se, Pr 1: 182-186 (1891)

92 Proceedings of the summer meeting beld at Washington, August 24 and 25, 1891. G Soc Am, B 3: 1-152 (1892)

92a Proceedings of the fourth annual meeting held at Columbus, Ohio, December 29. 30 , and 31,1891 . G Soc Am, B 3: 453-522 (1892)

92b Proceedings of the fourth summer meeting, held at Rochester, August 15 and 16, 1892. G Soc Am, B 4:1-12 (1892)

93 A memoir of Professor John Strong Newberry. N Y Ac Sc, Tr 12:152-168, port (1893)

93a Proceedings of the fifth annual meeting held at Ottawa, Canada, December 28,29 , and 30,1892 . G Soc Am, B 4: $371-440 \quad$ (1893)

93b Proceedings of the fifth summer meeting held at Madison, August 15 and 16, 1893. G Soc Am, B 5: 1-38 (1893)

94 Proceedings of the sixth annual meeting, held at Boston, December 27, 28, and 29, 1893. G Soc Am, B 5: 549-630 (1894)

94a Proceedings of the sixth summer meeting, held at Brooklyn, New York, August 14 and 15,1894 . $\mathrm{G}$ Soc $\mathrm{Am}, \mathrm{B}$ 6:1-28 (1894)

94b The evolution of the ungulate mammals (abst). Rochester Ac Sc, Pr 2:206209 (1894)

94e The geological history of Rochester, N. Y. Rochester Ac Sc, Pr 2:215-223 (1894)

94d The length of geologic time. Rochester Ac Sc, Pr 2: 263-266 (1894)

95 Proceedings of the seventh annual meeting held at Baltimore, December 27 , 28 , and 29,1894 . G Soc Am, B 6:423490 (1895)

95a Proceedings of the seventh summer meeting held at Springfield, Massachusetts, August 27 and 28,1895 . G Soc Am, B 7:1-16 (1895)

95b The kame-moraine at Rochester, N. I. Am G $16: 39-51$, map (1895) Abst, J G $3: 988-989$ (1895)

95e Glacial lakes of western New York. Q Soc Am, B 6:353-374, map (1895) Alst, Am G 15:202 (1895); Science n $\mathbf{s}$ 1:61 (1895)

95d Glacial lakes in western New York. Am Nat 29:160-161 (1895)

95 e Lake Newberry the probable successor of Lake Warren (abst with discussion). 6 Soc Am, B 6: 462-466 (1895) Science n $8 \quad 1: 61$ (1895) Am G 15:202-203 (1895)

95e The geology of Monroe County. In Landmarks of Monroe County, New York : 192-195, Boston, Mass., 1895
Fairchild, Herman Le Roy-Continued.

96 Proceedings of the eighth annual meeting held at Philadelphia, December 26, 27, and 28, 1895. G Soc Am, B 7 : 453-528 (1896)

96a Proceedings of the eighth summer meeting, held at Buffalo, New York, August 22, 1896. G Soc Am, B 8:1-16 (1896)

$96 \mathrm{~b}$ Kame areas in western New York south of Irondequoit and Sodus bays. J G 4:129-15y, maps (1896)

96e Glacial Genesee lakes. G Soc Am, B $7: 423-452, \operatorname{map}(1896)$ Abst, Am G $16: 237-238$ (1895) ; Science n s $2: 278$ 279 (1895) ; Am J Sc (3) $50: 345$ (1895)

96d Geology [of Monroe Co., N. Y., and vicinity]. Rochester Ac Sc, Pr 3:28-36, map (1896)

96e Four great kame areas of western New York (abst). Am G 17:104 (1896) Science n s $3: 55-56$ (1896)

97 Proceedings of the ninth annual meeting, held at Washington, December 29, 30, and 31,1896 . G Soc Am, B 8:359-418 (1897)

97a Proceedings of the ninth summer meeting, held at Detroit, 1 chigan, August 10, 1897. G Soc Am, B $9: 1-12$ (1897)

$\mathbf{9 7 \mathbf { b }}$ Lake Warren shore lines in western New lork and the Geneva Beach. G Soc Am, B 8:269-284, map (1897) Abst, J G 5:106-107 (1897); Science n s 5:88 (1897)

97 Glacial geology of western New York. G Mag (4) 4:529-537, map (1897) Abst, Brit As, Rp 67:664 (1898)

98 Proceedings of the tenth annual meeting, held at Montreal, Canada, December 28,29 , and 30,1897 . G Soc $A m, B$ $9: 391-432$ (1898)

98a Glacial geology in America. Am As, Pr $47: 257-290$ (1898) Am G 22: 154-189 (1898) Se Am Sup 46: 18972$18974, \quad 18989-18990,19001-19002$ (1898) Abst, Science n s $8: 462$ (1898)

98b Kettles in glacial lake deltas. J G 6 : 589-596 (1898)

9se Basins in glacial lake deltas (abst). Am G 22:254 (1898) Science n s $8: 467$ (1898) Am As, Pr 47: 291 (1898)

99 Proceedings of the tenth summer meeting, held at Boston, Mass., August 23, 1898. G Soc Am, B 10:1-20 (1899)

99 Glacial waters in the Finger Lakes region of New York. G Soc Am, B 10:2768, maps (1899) Abst, Am G 22:249 (1898) ; Science n s 8: 463 (1898)

99b Glacial lakes Newberry, Warren, and Dana, in central New York. Am J Sc (4) $7: 249-263$, maps (1899)

oo Proceedings of the eleventh annual meeting, held at New York City, December 28,29 , and 30,1898 . G Soc Am, B $10: 409-503$ (1900)

00a Proceedings of the eleventh summer meeting, held at Columbus, Ohio. August 22,1899 . G Soc Am, B 11:1-14 (1900) 
Fairchild, Herman Le Roy-Continued.

oob Proceedings of the twelfth annual meeting, held at Washington, D C., December $27,28,29$, and 30,1899 , including proceedings of first annual meeting of the Cordilleran section held at San Francisco, December 29 and 30, 1899. G Soc Am, B 11: $511-616$ (1900)

00e Proceedings of the twelfth summer meeting, held at New York City, June 26, 1900. G Soc Am, B 12:1-12 (1900)

Ood A channeled drumlin (abst). Science n s 11: 104 (1900)

ooe The geology of the Pinnacle Hills [Rochester, N Y.] (abst). Rochester Ac Sc, $\operatorname{Pr} 3: 176-178$ (1900)

oof Glacial lakes of western New York (abst). Rochester Ac Sc, Pr 3:180-181 (1900)

$\mathbf{O O g}$ The lacustrine history of the Genesee Valley (abst). Rochester Ac Sc, Pr 3: 188 (1900)

ooh Kame areas of western New York (abst). Rochester Ac Sc, Pr 3:190 (1900)

01 Proceedings of the thirteenth annual meeting, held at Albany, New York, December 27,28 , and 29,1900 , including proceedings of the second annual meeting of the Cordilleran section, held at San Francisco, December 28 and 29, 1900. G Soc Am, B $12: 445-502$ (1901)

01 a Proceedings of the thirteenth summer meeting, held at Denver, Colo, August 27,1901 . G Soc Am, B 13:1-16 (1901)

01b Beach structure in Medina sandstone. Am G 28:9-14 (1901) Abst, Science n s 11: 102 (1900)

02 Pleistocene geology of western New York, report of progress for 1900. N Y St Mus. An Rp $54:$ r103-139, maps (1902)

03 Proceedings of the fourteenth annual meeting held at Rochester, New York, December 31, 1901, and January 1 and 2, 1902, including proceedings of third annual meeting of the Cordilleran section held at San Francisco, Deeember 30 and 31, 1901. G Soc Am, B 13:475-546 (1903)

03a Proceedings of the fourteenth summer meeting held at Pittsburgh, Pa., July 1, 1902. G Soc Am, B 14:1-14 (1903)

03b Latest and lowest pre-Iroquois channels between Syracuse and Rome [N. Y.]. $\mathrm{N} Y$ St Mus, An Rp 55: r31-47, maps (1903)

04 Proceedings of the fifteenth annual meeting held at Washington, D. C., December 30 and 31,1902 , and January 1 and 2, 1903, including proceedings of the fourth annual meeting of the Cordilleran section held at San Francisco, December 30 and 31,1902 . G Soc Am, B 14: 495566 (1904)
Fairchild, Herman Le Roy-Continued,

$04 a$ Proceedings of the sixteenth annual meeting held at Saint Louis, Missouri, December 30 and 31,1903 , and January 1 , 1904, including proceedings of the fifth annual meeting of the Cordilleran section, held at San Francisco, January 1 and 2 1904. G Soc Am, B 15:523-636 (1904)

O4b Glacial waters from Oneida to Lit. tle Falls [N. Y.]. N Y St Mus, An Rp $56: \mathrm{r} 17-41$, maps (1904)

04e Geology under the planetesimal by. pothesis of earth origin (with discussion by E. H. Kraus, W. T. Lee, I. C. Rus. sell, and F. W. Sardeson. G Soc $A m$, B 15:243-266 (1904) Am G 33:94-116 (1904) Sc Am Sup 57:23446 (1904) Abst, Science n s $19 ; 531$ (1904)

04d Direction of preglacial stream flow in central New York. Am G 33:43-45 (1904)

04e Glacial drainage in central western New York (abst). G Soc Am, B 14:55? (1904)

o5 Ice erosion theory a fallacy. G Soc Am, B 16:13-74 (1905)

05a Pleistocene features in the Syracuse region, N. Y. Am G $36: 135-141$, тар) (1905)

osb The local glacia] features [of Syrz. cuse area, N. Y.]. Science n 8 22:333334 (1905)

o5e Some new problems in glaciolog? (abst). Science n s 22:335 (1905)

06 The geology of Irondequoit Bay [N. Y.] (abst). Rochester Ac Sc, Pr 3: 236-239 (1906)

$06 \mathbf{a}$ The predecessors of Niagara (abst). Rochester Ac Sc, Pr 3: 274-277 (1906)

O6b Proceedings of the seventeenth in nual meeting held at Philadelphia, Penn sylvania, December 29, 30, and 31, 1904 incluaing proceedings of the sixth annua meeting of the Cordilleran section held a Berkeley, California, December 30 and 31 1904. G Soc Am, B 16:531-594, 1906

o7 Glacial waters in the Lake Erie basin N Y St Mus, B 106: 86 pp, maps (1907)

ora Drumlins of central western New York. N Y St Mus, B 111: $391-443$ (1907)

oтb How should faults be named and classified? Ec G 2: 184-185 (1907)

07e Gilbert Gule (marine waters in 0ntario basin.) G Soc Am, B 17:712-718 (1907)

o7d Origin of Meteor Crater (Coon Butte), Ariz. G Soc Am, B 18:493-504 (1907)

07e A meteoric crater of Arizona. Int G Cong, X, Mexico, C R: 147-151, map (1907)

oze Drumlin structure and origin $(a b 81)$. G Soc Am, B 17:702-706 (1907)

$07 g$ Iroquois extinction $(a b s t)$. Science n 8 26:398-399 (1907) 
Fairchild, Herman Le Roy-Continued.

07h Proceedings of the eighteenth annual meeting held at Ottawa, Canada, December 27,28 , and 29 , including proceedings of the seventh annual meeting of the Cordilleran section, held at Berkeley, California, December 29 and 30,1905 . G Soc dm, B $17: 671-732$ (1907)

os Pleistocene history of the Genesee Valley in the Portage district. $\quad$ Y St Mus, B 118: 70-84 (1908)

08a Arched structure in Lockport limestone (abst). Science n s 27: 729 (1908)

09 Glacial waters in central New York. N Y St Mus, B 127:66 pp, map (1909)

09a Muitiple glaciation in New York (abst). Science n s 29:626 (1909) G Soc Am, B $20: 632$ (1910)

09b Correlation of the Hudsonian and the Ontarian glacier lobes (abst). Science n s 29:627 (1909) G Soc Am, B 20:634 (1910)

09e Glacial waters west and south of the Adirondacks (abst). Science n 8 29: 627 (1909) G Soc Am, B 20:633-634 (1910)

09d Drainage evolution in central New York (abst), Science n s 29:632-633 (1909) G Soc Am, B 20:668-670 (1910)

10 (with Cushing, H. P.) Geology of the Thousand Islands region, Alexandria Bay, Cape Vincent, Clayton, Grindstone, and Theresa quadrangles, N. Y. N Y St Yus, B 145: 194 pp (1910)

11 Preglacial course of the upper Hudson Biver (discussion). G Soc Am, B 22:724725 (1911)

11a Radiation of glacial flow as a factor in drumlin formation (discussion). G Soc Am, B 22: 734 (1911)

12 The glacial waters in the Black and Mohawk valleys $\mathrm{N}$ Y St Mus, B 160: $47 \mathrm{pp}$, maps (1912)

$12 \mathrm{n}$ The closing phase of glaciation in New York. N Y St Mus, B 158: 32-35 (1912) Abst, Science n s 35:316 (1912); (with discussion by J. W. Spencer), G Soc Am, B 23: $737-738$ (1912)

12b Postglacial erosion and oxidation (discussion). G Soc Am, B 23:295 (1912)

13 Pleistocene geology of New York State. G Soc Am, B 24:133-162 (1913) Science n s $37: 237-249,290-299$ (1913)

14 Review of the early history of the society. G Soc Am, B 25:17-24 (1914)

$14 a$ Pleistocene marine submergence of the Connecticut and Hudson valleys. G Soc Am, B 25: 63-65, 219-242 (1914)

15 Memoir of Joseph Le Conte. G Soc Am, B 26: 47-57, port (1915)

16 Postglacial marine waters in Vermont. Vt, St G, Rp 10:1-41 (1916)

16 a Pleistocene uplift of New York and adjacent territory. G Soc Am, B 27: $235-262,66-67$ (abst, with discussion by J. W. Spencer and R. D. Salisbury) (1916)
Fairchild, Herman Le Roy-Continued.

16b Pleistocene features in the Schenectady-Saratoga-Glens Falls section of the Hudson Valley (abst). G Soc Am, B 27 : 65-66 (1916)

17 Postglacial features of the upper Hudson Valley. N Y St Mus B 195:22 pp, map (1917)

17a Postglacial marine submergence of Long Island. G Soc Am, B 28: 142 (abst), 279-308, maps (1917)

17b Adventures of a watermol. Sc Mo $4: 5-15,174-186,226-237$ (1917)

13 Postglacial uplift of northeastern America. G Soc Am, B 29:187-238, 70-71 (abst with discussion by Frank Leverett and W. Elmer Ekblaw) (1918)

18a Glacial depression and postglacial uplift of nortbeastern America. Nat Ac Sc, Pr 4: 229-232 (1918)

18b Postglacial continental uplift. Science n s $47: 615-617$, map (1918)

18e Grove Karl Gilbert. Science n s 48:151-154 (1918)

See also Emerson, 96; Le Conte, 78; Miller (W J), 11; Spencer (J W), 12; Taylor (F B), 12a

Fairholme, George.

34 On the Falls of Niagara; with some observations on the distinct evidence which they bear to the geological character of the North American plains. Ph Mag (3) 5: 11-25 (1834)

Falconer, Hugh.

63 On the American fossil elephant of the regions bordering the Gulf of Mexico (E. columbi Falc.)... N H Rv 3:43-114 (1863)

Falconer, J. D.

02 The evolution of the Antilles, Scottish Geog Mag 18: 369-376 (1902)

02a Volcanic dust from the West Indies. Nature 66:132 (1902)

Falding, F, J.

86 Notes on Canadian fluor-apatite or fluor-phosphate of lime. Eng M J 42 : 383$384,402-404 \quad(1886)$

Fales, J. C. See Linney, 83

Falkenan, Louis.

02 Onyx on the Pacific coast. Tech Soc Pacific Coast, Tr 8: 199-202 (1892)

Fal1, Delos.

01 Marls and clays in Michigan. Mich Engineer 1901: 124-133 Mich Miner 3 no 11: 11-14 (1901)

o3 Marls and clays in Michigan. Mich G S 8 pt $3: 343-353$ (1903)

Fansett, George $R$.

18 Field tests for the common metals in minerals. Ariz, Univ, Bur Mines, B $93: 20$ pp (1918)

Faribanlt, Eugene Rodolphe.

87 Report on the Lower Cambrian rocks of Guysborough and Halifax cos., N. S. Can G S, An Rp 2: p 129-163, map (1887) 
Faribault, Eugene Rodolphe-Continued.

S9 [On the gold-bearing rocks of Halifax Co., N. S.] Can G S, Sum Rp 1887-8 (An Rp 3) : A 99-100 (1889)

90 [Summary report on the gold-bearing rocks of Colchester and Halifax cos., N. S.] Can G S, Sum Rp 1888-9 (An Rp 4) : A $45(1890)$

91 [Report on work on the gold-bearing roeks of Halifax Co., N. S.] Can G S, Sum Rp 1891 (An Rp 5) : $\triangle$ 61-62 (1891)

92 [Report on the gold-bearing rocks of the Atlantic coast of Nova Scotia.] Can G S, Sum Rp 1891 (An Rp 5) : A $55-59$ (1892)

93 [Report on gold-bearing rocks of the Atlantic coast of Nova Scotia.] Can G S, Sum Rp 1892 (An Rp 6) : A 54-59 (1893)

94 [Summary report of the examination of gold-bearing rocks of the Atlantic coast of Nova Scotia.] Can G S, Sum Rp 1893 (An Rp 6) : A 57-66 (1894)

95 [Report on field work on gold-bearing rocks of Atlantic coast of Nova Scotia.] Can G S, Sum Rp 1894 (An Rp 7) : A 9395 (1895)

96 [Report on field work in the goldbearing region of the Atlantic coast of Nova Scotia.] Can G S, Sum Rp 1895 (An Rp 8) : A 111-114 (1896)

97 [Report on fleld work on the goldbearing rocks of the Atlantic coast of Nova Scotia.] Can G S, Sum Rp 1896 (An Rp 9) : A 98-104 (1897)

9s [Report on field work on the goldbearing rocks of the Atlantic coast of Nova Scotia.] Can G S, Sum Rp 1897 (An Rp 10) : ^ 103-115 (1898)

99 [Report on field work in the goldbearing rocks of Nova Scotia.] Can G S, Sum Rp 1898 (An Rp 11): A 149-159 (1899)

$99 a$ On the gold measures of Nova Scotia and deep mining. Can M Inst, J $2: 119$ 129, map (1899) Can M Rv 18:78-82, map (1899)

00 [Report on the gold-bearing rocks of the Atlantic coast of Nova Scotia.] Can G S, Sum Rp 1899 (An Rp 12) : A 168-187 (1900)

00a The gold measures of Nova Scotia and deep mining. M Soc N S : 40 pp, map, Halifax, N. S. [1900?]

02 Nova Scotia gold fields. Can G S, Sum Rp 1901 (An $R p$ 14) : A 216-223 (1902)

03 Nova Scotia gold fields. Can G S, $\left.\begin{array}{lllllll}\text { Sum Rp } & 1902 \text { (An } R p & 15\end{array}\right)$ : A $\quad 401-429$ (1903)

o3a Nova Scotia; deep gold mining ... 16 pp, 1903 [with N S, Dp Mines, Rp 1903, Halifax, N. S., 1904]

04 Gold fields of Nova Scotia. Can G S, $\left.\begin{array}{lllllll}\text { Sum } & R p & 1903 & \text { (An } R p & 15\end{array}\right): \Delta \quad 174-186$ (1904)
Faribault, Eugene Rodolphe-Continuer os Gold fields of Nova Scotia. Can 68 Sum Rp 1904 (An Rp 16) : A $\quad 319-33$ ? (1905)

06 Gold fields of Nova Scotia. Can 68 Sum Rp 1905: 122-124 (1906) ; 1906:147152 (1906)

O6a Map of the Province of Nova Scotia... Seale 1:760320 or 12 miles to inch. Can G S 1906

os Lurenburg Co., N. S. Can G S, Sum Rp 1907:78-83 (1908)

09 Southern part of Kings and eastern part of Lunenburg cos., N. S. Can G \&, Sum Rp 1908: 150-158 (1909)

10 Tungsten deposit of Moose River, N. S. Can G S, Sum Rp 1909:228-234 (1910)

10a Southern part of Lunenburg Co., N. S. Can G S, Sum Rp 1909:235-239 (1910) Can M J 31:428 430 (1910)

10b Structure of the tungsten deposits of Moose River, N. S. M Soc N S, J 15: 59-64 (1910)

11 Gold-bearing series of Lahave basin, Lunenburg Co., N. S. Can G S, Sum Ip $1910: 248-253$ (1911)

11 a (with Burlow, A. E.) Preliminary report on the geology and mineral resources of the Chibougamau mining region. Que, Dp Col, Mines and Fish : 24 pp (1911)

11b (with Barlow, A. E.) Report on the geology and mineral resources of the Chibougamau region, Quebec. Que, Dept Col, Mines, and Fish, Mines Br: 224 P (1911)

12 Gold-bearing series of the basin of Medway River, N. S. Can G S, Sum Rp 1911 : 334-340 (1912)

13 Excursion in eastern Quebec and the maritime provinces; the gold-bearing series of Nova Scotia; Oldham gold district; annotated guide, Enfield, Oldham gold dis trict. Int $\mathrm{G}$ Cong, XII, Canada, Guide Book no 1, 158-205, map 1913

14 Greenfield and Liverpool town map areas, N. S. Can G S, Sum Rp 1912:372378 (1914)

14a Oldham gold district, N. S. Can G S, Sum Rp 1912: 379-382 (1914)

$14 b$ Clays in Lunenburg Co., N. S. Can G S, Sum Rp $1912: 383$ (1914)

14c Geology of the Port Mouton map area, Queens Co., N. S. Can G S, Sum Rp 1913: 251-258 (1914)

14d Geology of the gold district of Pleasant River Barrens, Lunenburg Co., N. S. Can G S, Sum Rp 1913: 259-263, map (1914)

15 Caledonia map area, Queens Co., N.S Can G S, Sum Rp 1914:103-106 (1915)

16 Gold-bearing series in northern por tions of Queens and Shelburne counties infusorial earth deposits at Loon Lake Island, Liverpool River, Queens Co., N. 8 . Can G S, Sum Rp 1915:186-192, map (1916) 
Faribault, Eugene Rodolphe-Continued. 17 Gold-bearing series in northern parts of Queens and Shelburne cos., N. S. Can G S, Sum Rp 1916: 284-286 (1917)

18 Investigations in western Nova Scotia. Can G S, Sum Rp 1917 pt F : 17-20 (1918)

Farish, John B.

91 A Boulder Co. mine. Colo Se Soc, Pr $3: 316-322$ (1891)

91a Interesting vein phenomena in Boulder Co., Colo. Am I M Eng, Tr 19:547$552(1891)$

92 On the ore deposits of Newman Hill near Rico, Colo. Colo Sc Soc, Pr 4:151164, map [1895] (separate ed, $16 \mathrm{pp}$, 1892). Abst, Eng M J 54:174-175 (1892) 07 The Dolores mine, Chlhuahua, Mexico. Eng M J $83: 849$ (1907)

Farnsworth, P. J.

83 The geology and topography of Iowa in a sanitary point of view. Iowa St Bd Health, Bien Rp 2: 385-396 (1883)

88 Pockets containing fireclay and carbonaceous materials in the Niagara limestone at Clinton, Iowa. Am G 2:331-334 (1888)

92 The Great Lake basins. Science 20: 74 (1892)

01 When was the Mississippi River Valley formed? Am G 28:393-396 (1901)

06 On the origin of the small mounds of the lower Mississippi Valley and Texas. Science n s 23:583-584 (1906)

Farr, Clifford H.

14 Notes on a fossil tree fern of Iowa. Іока Ac Sc, Pr $21: 59-65$, il (1914)

Farr, Marcus S.

96 Notes on the osteology of the White River horses, Am Ph Soc, Pr 35:147175 , il (1896)

Farrell, J. H.

12 Practical field geology; including a guide to the sight recognition of one hundred and twenty common or important minerals, by Alfred J. Moses. xi, 273 pp, N Y 1912

Farrington, A, C.

52 Metamorphic condition of a part of the large vein of franklinite in New Jersey. Am As, Pr 6: 241-242 (1852)

52a Fault in a metallic vein as seen at Sterling Mine, N. J. Am As, Pr 6:296 (1852)

Farrington, Oliver Cummings.

91 on crystallized azurite from Arizona. Am J Sc (3) 41:300-307 (1891)

92 The chemical composition of iolite. Am J Sc (3) 43:13-16 (1892) Yale Bicen Pub, Contr. Miner: 193-197 (1901) 95 Handbook and catalogue of the meteorite collection. Field Col Mus, Pub g \& 1:1-66 (1895)

95a James $D$. Dana as a teacher of geology. J G $3: 335-340$ (1895)

96 Phenomena of falling meteorites. Atm $\mathrm{G}$ 17:82-89 (1896)
Farrington, Oliver Cummings-Contd. 97 Observations on Popocatepetl and Ixtaccihuatl [Mex.]. Field Col Mus, Pub g s $1: 67-120$ (1897)

$\mathbf{9 7 a}$ The average specific gravity of meteorites. J G 5:126-130 (1897)

$\mathbf{9 7 \mathbf { b }}$ The eruptive rocks of Mexico. J $\mathbf{G}$ 5: 466-478 (1897)

98 Datolite from Guanajuato [Mex.]. Am J Sc (4) $5: 285-288$ (1898)

99 A fossil egg from South Dakota. Field Col Mus, Pub g s 1:191-200, il (1899)

00 New mineral occurrences. Field Col Mus, Pub g s 1: 221-231 (1900)

O0a Crystal forms of calcite from Joplin, Mo. Field Col Mus, Pub g s $1: 232-$ 241 (1900)

o1 The structure of meteorites. J G 9 : 51-66, 174-190 (1901)

01 a The constituents of meteorites. J G $9: 393-408$, 522-532 (1901)

01b The pre-terrestrial history of meteorites. J G 9:623-632 (1901)

o1e A century of the study of meteorites. Pop Sc Mo 58:429-433 (1901) Smiths Inst, An Rp 1901: 193-197 (1902)

o1d On the nature of the metallic veins of the Farmington [Kans.] meteorite. Am J Sc (4) 11:60-62 (1901)

o1e Observations on Indiana caves. Field Col Mus, Pub g s $1: 247-266$ (1901)

02 Meteorite studies. Field Col Mus, Pub g s $1: 283-315$ (1902) ; 3:111-129 (1907) ; $3: 165-193$ (1910)

02a A new meteorite from Kansas [Saline township, Sheridan Co.]. Science $\mathbf{n} \mathbf{s}$ 16: $67-68$ (1902)

$02 b$ Meteorites of northwestern Kansas (abst). Science n s $16: 260$ (1902) G Soc A m, B 14: 6 (1903)

02e (with Riggs, Elmer S.) The dinosaur beds of the Grand River valley of Colorado. Sc Am Sup 53: 22061-22062 (1902)

03 Gems and gem minerals. $229 \mathrm{pp}$, Chicago 1903

03n Catalogue of the collection of meteorites, May 1, 1903. Field Col Mus, Pub g 8 2: 79-124 (1903)

03b An occurrence of free phosphorus in the Saline Township meteorite. Am J Sc (4) $15: 71-72$ (1903)

04 Observations on the geology and geography of western Mexico, including an account of the Cerro Mercado. Field Col Mus, Pub g s 2:197-228 (1904) Abst Science n s 19:523-524 (1904); G Soc Am, B $15: 549-550$ (1904) ; Sc Am Sup 57: 23446 (1904)

04a The geographical distribution of meteorites. Pop Sc Mo 64: 351-354 (1904)

os The Rodeo meteorite. Field Col Mus, Pub g s $3: 1-6$ (1905)

06 The Shelburne and South Bend meteorites. Field Col Mus, Pub g \& $3: 7-23$ (1906) 
Farrington, Oliver Cummings-Contd. 06a Zoisite from Lower California. Field Col Mus, Pub g s 3:55-57 (1906)

06b Analysis of "iron shale" from Coon Mountain, Ariz. Am J Sc (4) $22: 303-$ 309 (1906)

06e Meteorite shower at Modoc, Kans. Science n s $23: 582-583$ (1906)

o6d Professor Henry A. Ward [died July 4, 1906]. Sclence n s 24:153-154 (1906)

07 Analyses of iron meteorites compiled and classified. Fíeld Col Mus, Pub g s 3 : 59-110 (1907)

os Correlation of copper and diamonds in the glacial drift of the Great Lakes region (abst). Science n s $27: 729$ (1908)

o8a (and Tillotson, E. W., jr.) Notes on various minerals in the museum collection. Field Col Mus, Pub g s 3:131-163 (1908)

10 Times of fall of meteorites. Am J Sc (4) $29: 211-215$ (1910)

10a A new Pennsylvania meteorite [Shrewsbury, York Co., Pa.]. Am J Sc (4) $29: 350-352$ (1910)

11 Analyses of stone meteorites. Field Mus, Pub g s $3: 195-214$ (1911)

11 a Quantitative elassification of meteorites $(a b s t)$. G Soc Am, B 22:736 (1911)

14 New meteorites. Field Mus, g s 5 : 1-14 (1914)

14a Meteorites vs, the earth. Am J Sc (4) $37: 200-201$ (1914)

15 Meteorites; their structure, composition, and terrestrial relations. $x, 233 \mathrm{pp}$, Chicago 1915 [author's pub] Rv by G. P. Merrill, Science n s 44:314-315 (1916)

15 a Catalogue of the meteorites of North America, to January 1, 1909. Nat Ac Sc, Mem 13: 513 pp, maps (1915)

16 Catalogue of the collection of meteorites. Field Mus, Pub g s 3:231312 (1916)

See also Merrill (G P), $16 e$

Farrovv, Edward $\mathrm{S}$.

11 Mineral resources of Bland County in southwestern Virginia. $\quad 37 \mathrm{pp}, \mathrm{N}$ Y 1911 [Priv pub]

Fath, Arthur Earl.

15 Copper deposits in the "red beds" - of southwestern Oklahoma. Ee G 10:140150 (1915)

16 An anticlinal fold near Billings, Noble Co., Okla. U S G S, B 641: 121-138, map (1916) Abst, Wash Ac Sc, J $7: 38-39$ (1917)

17 Structure of the northern part of the Bristow quadrangle, Creek Co., Okla., witu reference to petroleum and natural gas. U S G S, B 661 : 69-99, maps (1917) Abst, by R. W. Stone, Wash Ac Sc, J $8: 37-38$ (1918)
Faujas de Saint-Fond, Barthelemy.

03 Sur deux especes de bœufs dont on trouve les cranes fossiles en Allemagne, en France, en Angleterre, dans le nord de l'Amérique et dans d'autres contrées. Mos d'Hist Nat, Paris, An 2: 188-200, il (180?)

Fanlkner, H. W.

15 (with Allan, F. L.) The San $R_{a}$. fael vein at El Oro [Mex.]. M Mag 12: 281-285 (1915)

Fanx, Faber du.

87 The sulphur deposits of soutberu Utah. Am I M Eng, Tr 16:33-35 (1887) Fawns, Sydney.

05 Tin deposits of the world. $240 \mathrm{pp}$ L 1905

Fay, Albert Hill.

o7 Geology and mining of the tin de posits of Cape Prince of Wales, Alasks. Am I M Eng, B 17: 769-787 (1907); Tr $38: 664-682$ (1908)

09 The Vermont Copper Company [copper ores, Orange County, Vt.]. Eng I J 88: 364-365 (1909)

11 Shaft of the Detroit Salt Company. Eng M J 91:565-569 (1911)

Fay, Charles E.

11 The Canadian Rocky Mountains, Al pina Americana 2:19 pp, maps (1911)

Featherstonhaugh, George William (1780-1866),

31 Rhinoceroides alleghaniensis. Month. ly Am J G 1:10-12, il (1831)

$31 \mathrm{a}$ On the ancient drainage of North America and the origin of the cataract of Niagara. Monthly Am J G 1: 13-21 (1831) 32 Geology; No. 1, On the erust of the earth; No. 2, On the order of succession of the rocks composing the crust of the earth; No. 3 , On the constituent minerals, and the structure of the primary rocks. Monthly Am J G $1: 289-296,337-347$, 385-391 (1832)

32a General remarks on the constituents of primary rocks. Monthly Am J G 1: 308-312 (1832)

32b Natural bridge in Rockbridge $\mathrm{CO}_{0}$ Va. Monthly Am J G 1:414-416 (1832) 32e on mineral and metallic veins. Monthly Am J G 1:481-490 (1832)

35 Geological report of an examination made in 1834 of the elevated country between the Missouri and Red rivers. 97 pp, Washington 1835 (U S, 23d Cong 2d sess, H Ex Doc 151) Notice, Am J Sc 28: 379 (1835) Rv, Franklin Inst, J in s 17 : 109-117, 184-190 (1836)

35a A report of the mineralogical and geological investigations... [Ozark region]. U S, 23d Cong 2d sess, S Doc 153:43 pp [1835]

35b Account of the travertine deposited by the waters of the Sweet Springs, in Alleghany Co., Va... G Soc Pa, Tr 1:328334 (1835) 
Featherstonhaugh, George Wm.-Con. 36 Report of a geological reconnaissance made in 1835 from the seat of government by the way of Green Bay and the Wisconsin Territory to the Coteau de Prairie, an elevated ridge dividing the Missouri from the St. Peter's River. $168 \mathrm{pp}$, maps, Washington 1836 (U S, 24th Cong 2d sess, S Ex Doc 333)

44 Excursion through the slave States from Washington on the Potomac to the frontier of Mexico; with sketches of popular manners and geological notices. 168 pp, N Y 1844

45 On the excavation of the rocky channels of rivers by the recession of their cataracts. Brit As, Rp 14: sec 45-46 (1845)

47 A canoe voyage up the Minnay Sotor ; with an account of the lead and copper deposits in Wisconsin; of the gold region in the Cherokee country... 2 vols, 416, $351 \mathrm{pp}, \mathrm{L} 1847$

See also Long, 32

Featherstonhangh, J. D.

89 Memoir of Mr. G. W. Featherstonhaugh [1780-1866]. $\Delta \mathrm{m}$ G $3: 217-223$, port (1889)

Fechet, Eugene 0.

93 The mines of Sierra Mojada, Mexico. Eng M J 55:151-152 (1893)

77 The post-Tertiary beds of Grinnell Land and north Greenland. An Mag N H (4) $20: 483-489 \quad(1877)$

Feilden, Henry Wemyss.

78 (and De Rance, C. E.) Geology of the coasts of the Arctic lands visited by the late British expedition... G Soc London, Q J 34:556-567, map (1878) Notice, Am J Sc (3) 16:139-140 (1878)

78a Some remarks on interglacial epochs in reference to fauna and flora existing at the present day in the northern hemisphere between the parallels of $81^{\circ}$ and $83^{\circ}$ north. R Dublin Soc, Sc Pr n s 2:42-44 (1878) Can Nat n s $9: 126-128$ (1879)

Feistmantel, Ottokar.

89 Leber die jetzt aitesten dikotyledonen Pflanzen der Potomac-Formation in N. Amerika. K Böhm Ges Wiss, Mat-nat Cl, Szb 1: 257-268 (1889)

89 a Ueber die bis jetzt geologisch ăltesten Dikotyledonen. Deut G Ges, Zs 41 : $27-34(1889)$

Felix, Johannes.

88 Ueber ein Besuch des Jorullo in Hexico. Deut $G$ Ges, Zs 40:355-357 (1888)

90 (and Lenk, H.) Beiträge zur Geologie und Paläontologie der Republik Mexice. Th 1: 114 pp, Leipzig 1890; Th 2: 252, 1v pp, Leipzig, 1893-99 ; Th 3, Palaeontographica $37: 117-210(1-78)$, il, Stuttgart 1891
Felix, Johannes-Continued.

90a Beiträge zur Kenntniss der Gattung Protosphyraena Leidy. Deut $\mathrm{G}$ Ges, Zs $42: 278-302$, il $(1890)$

91 (and Lenk, H.) Uebersicht uber die geologischen Verbăltnisse des mexicanischen Staates Puebla. Palaeontographica 37 : 117-139, il (1891)

91 a Versteinerungen aus der mexicanischen Jura- und Kreide Formation. Palaeontographica $37: 140-194$, il (1891)

92 (and Lenk, H.) Ueber die tektonischen Verhältnisse der Republik Mexico. Deut G Ges, Zs $44: 303-323$, map (1892)

93 (and Nathorst, A.) Versteinerungen aus dem mexicanischen Staat Oaxaca. In Felix, J., and Lenk, H., Beiträge zur Geologie und Paläontologie der Republik Mexico, Th $2: 39-54$, il, Leipzig 1893

94 (and Lenk, H.) Ueber die mexicanische Vulcanspalte. Deut G Ges, Zs 46 : 678-681 (1894)

95 Geologische Reiseskizzen aus Nordamerika. Földtani Közlöny $25: 5-29 ; 24$ suppl : 69-94, map (1895)

$95 n$ (and Lenk, H.) Ueber das Vorkommen von Nummulitenschichten in Mexico, N Jb 1895, II : 208-209

96 Untersuchungen über fossile Hölzer; Hölzer aus dem Yellowstone Nationalpark. Deut G Ges, Zs 48:249-255, il (1896)

02 (and Lenk, Hans.) Bemerkungen zur Topographie und Geologie von Mexico. Deut G Ges, Zs 54:426-440 (1902)

Felix y Buelna, Ramon. See Buelna, Ramón Félix.

Fels, G.

03 Ein Anorthitauswïrfling von der Insel St. Christopher, Zs Kryst 37:450460 (1903)

Fenderson, W. C.

97 Turquoise mining in New Mexico. M Sc Press 74:192 (1897)

Fendler, A.

66 On prairies. Am J Sc (2) 41:154158 (1866)

Fenneman, Nevin Melancthon.

02 On the lakes of southeastern Wisconsin. Wis G S, B 8 (educ $s \quad 2$ ) : 178 pp, map, Madison, Wis., 1902 Rev ed : 188 pp, 1910

02a Development of the profile of equilibrium of the subaqueous shore terrace. J G 10:1-32 (1902)

02b The Arapahoe Glacier in 1902 . J G $10: 839-851$, map (1902)

o3 The Boulder, Colo, oil field. U S G S, B $213: 322-332$ (1903)

04 Structure of the Boulder oil field, Colo., with records for the year 1903. U S G S, B 225: 383-391 (1904)

o5 The Florence, Colo, oil field. U S G S, B 260:436-440 (1905) 
Fenneman, Nevin Melancthon-Contd.

05a Oil fields of the Texas-Louisiana Gulf coast. U S G S, B 260:459-467 (1905)

05b Geology of the Boulder district, Colo. U S G S, B 265:101 pp, maps (1905)

05e Effect of cliff erosion on form of contact surfaces. G Soc Am, B 16:205214 (1905) Abst, Sc Am Sup 59:24326 (1905)

osd Oil fields of the Texas-Louisiana Coastal Plain. M Mag 11:313-322 (1905)

o5e [On the control of the form of contact surfaces by marine denudation (abst).] Science n s 21:218 (1905)

06 Floodplains produced without floods. Am Geog Soc, B 38: 89-91 (1906)

o6a Oil fields of the Texas-Louisiana Gulf Coastal Plain. U S G S, B 282: 146 pp (1906)

06b (and Gale, H. S.) The Yampa coal field, Routt Co., Colo. U S G S, B $285: 226-239$, map (1906) ; B 297:7-81, map (1906)

07 Clay resources of the St. Louis district, Mo. U S G S, B 315:315-321 (1907)

07a Stratigraphic work in the vicinity of East St. Louis. Ill G S, B 4:213-217 (1907)

os Some features of erosion by uncencentrated wash. J G 16: 746-754 (1908)

09 Physiography of the St. Louis area. I11 G S, B 12:83 pp, map (1909)

09a Problems in the teaching of physical geography in secondary schools. J Geog $7: 145-157 \quad(1909)$

11 Geology and mineral resources of the St. Louis quadrangle, Mo.-Ill. U S G S, B 438: $73 \mathrm{pp}$, map (1911)

11a The State geological survey edueational bulletin (abst). As Am Geog, An 1: 123-127 (1911)

12 On the preglacial Miami and Kentucky rivers $(a b s t)$. G Soc Am, B 23: 736 (1912)

13 The Yellowstone National Park. J Geog 11:314-320 (1913)

14 Physiographic boundaries within the United States. As Am Geog, An 4:84 134, maps (1914)

$14 a$ Preglacial Miami and Kentucky rivers (abst, with discussion). G Soc Am, B 25:85 (1914)

16 Geology of Cincinnati and vicinity. Ohio G S (4), B 19:207 pp, maps (1916)

17 'hysiographic divisions of the United States. As Am Geog, An 6:19-98, map [1917]

17a Physiographic subdivisions of the United States. Nat Ac Sc, Pr 3:17-22 (1917)
Fenner, Clarence Norman.

92 Note on the geology of the Monte Cristo district, Snohomish Co., Wash. Sch Mines Q 14: 47-48 (1892)

93 The Old Telegraph mine, Bingham Canyon, Utah. Sch Mines Q 14:354-358 (1893)

os Features indicative of physlographlc conditions prevaling at the time of the trap extrusions in New Jersey. $J$ G 16: 299-327 (1908)

O8a Notes on the geology of the first Watchung trap sheet (abst). N Y Ac Sc, An 18:359-360 (1908)

10 The erystallization of a basaltic magma from the standpoint of physical chemistry. $\quad \Delta \mathrm{m} \quad \mathrm{J}$ S (4) $29: 217-234$ (1910)

10a A replacement of rhyolite porphyry by stephanite and chaleopyrite at Lead. ville, Colo. Sch Mines Q 31:235-240 (1910)

10b The Watchung basalt and the para. genesis of its zeolites and other secondary minerals. N $\mathbf{Y}$ Ac Sc, An 20:93-187 (1910)

10e Application of the law of mass action to phenomena of resorption in igneous rocks (abst). N Y Ac Sc, An 19: $325-326$ (1910)

12 The varlous forms of silica and their mutual relations. Wash Ac Sc, J 2:471480 (1912) Abst, G Soc Am, B 24:681 (1913)

12a (with Spurr, J. E.) Study of a contact-metamorphic ore deposit; the Dolores mine, at Matehuala, S. L. P., Mex. Ec G $7: 444-484$ (1912)

13 The stability relations of the silica minerals. Am J Sc (4) $36: 331-384$ (1913)

14 The mode of formation of certain gneisses in the Highlands of New Jerscy. J G 22: 594-612, 694-702 (1914) Abst, with discussion, G Soc Am, B 25:44-45 (1914) Abst, Wash Ac Sc, J $5: 180-181$ (1915)

14a Babingtonite from Passaic Co., N. J. Wash Ac Sc, J 4:552-558 (1914)

14b Additional notes on babingtonite from Passaic Co., N. J. Wash Ac Sc, J 4: 598-605 (1914)

15 A geological reconnaissance of Porto Rico $(a b s t)$. Wash Ac Sc, J 5: 488-490 (1915)

17 Relationship between the igneous and metamorphic rocks of the District of Columbia and vicinity $(a b s t)$. G Soc Am, B $28: 155-156$ (1917)

Fenton, Carroll Lane.

is A prominent mud-crack horizon of the Cedar Valley stage of the Iowa Devonian. Ottawa Nat $32: 113-115$ (1918)

Ferguson, Edw. G. W.

09 The mineral resources of Haitl, West Indies. M World 31:133-135 (1909) 
Ferguson, Edw. G. W.-Continued.

10 Peach Bottom slate deposits, Pa. II World $33: 183-184$ (1910)

Ferguson, Henry Gardiner.

08 (and Turgeon, F. N.) An oecurrence of Harney granite in the northern Black Hills. Harvard Col, Mus C Z, B 49 (g s 8) : 275-283, map (1908)

12 (and Bateman, A. M.) Geologic features of tin deposits. Ec G $7: 209-262$ (1912)

14 Gold lodes of the Weaverville quadrangle, Cal. U S G S, B 540:22-79, map (1914)

14a Lode deposits of the Alleghany district, Cal. U S G S, B $580: 153-182$ (1914)

15 Pocket deposits of the Klamath Mountains, Cal. Ec G $10: 241-261$, map (1915) 16 The Golden Arrow, Clifford, and Ellendale districts, Nye Co., Nev. U S G S, B $640: 113-123$ (1916)

17 Placer deposits of the Manhattan district, Nev, U S G S. B 640:163-193, taps (1917) Abst, Wash Ac Sc, J $7: 266$ (1917)

17a Graphite in 1916; 1917. U S G S, Jin Res 1916 pt $2: 43-59 ; 1917$ pt $2: 97-$ $119(1917-8)$

18 Tin deposits near Irish Creek, Va. Va G S, B XV-A:19 pp (1918) Abst, Science n s $47: 529$ (1918)

18a Tin deposits of Irish Creek. Eng 近 J $105: 5-7$ (1918)

Ferguson, J. B.

14 The occurrence of molybdenum in rocks with special reference to those of Hawaii. Am J Sc (4) $37: 399-402$ (1914) Abst, Wash Ac Sc, J 5:96 (1915)

18 (and Merwin, H. E.) The melting points of cristobalite and tridymite. Am J Sc (4) $46: 417-426$ (1918)

Fermor, L. Leigh.

14 On the formation in depth of oxidized ores and of secondary limestones. Int $\mathrm{G}$ Cong, X11, 1913, C R : 271-274 (1914)

16 Discussion of paper by Wysor, D C, Aluminium hydrates in the Arkansas bauxite deposits. Ec G $11: 886-690$ (1916)

See also Wysor, 16

Fernandez, Carlos.

83 Estudio sobre el origen de la palabra Chalchibuites $y$ composicion de la matriz $y$ de las vetas argentiferas del mineral de este nombre. La Naturaleza 6:303-309 (1883)

Fernandex, José G.

15 Geologia de la zona del canal, In Panama, Revista de Instrucción Pablica : 475 (1915) [not seen]

Fernandez de Cantro, José.

71 a Del petroleo y del chapapote considerados como combustibles, R Ac Cienc Habana, An $7: 519-527,575-591,615-624$; $8: 106-108, \quad 195-200, \quad 289-299$ (1871)
Fernández de Castro, Manuel (18251895).

62 Nota sobre la geologla de Santo Domingo. Revista Minera $13: 633-642$, 692$699, \quad 729-738 ; 14: 42-51,65-73 \quad$ (1862) [not seen]

64 De la existencia de grandes mamiferos fosiles en la isla de Cuba. R Ac Cienc Habana, An 1: 17-21, 54-60, 96-107 (1864) Revista Minera 16:161-178, $193-210$ (1865) [not seen]

64a Estudio sobre las minas de oro de la isla de Cuba [gold deposits]. R Ac Cienc Habana, An 1: 171-177, 205-217, 253-269, $301-311,356-366,396-413$ (1864-5) In part, Revista Minera 16:79-85 (1865) Reprint, $105 \mathrm{pp}$, Habana 1865

71 El Myomorphus cubensis, nuevo subgénero del Megalomyx. R Ac Cienc Habana, An $7: 463-476$ (1871) Revista Minera 22 : $165-178,190-205(1871)$ [not seen]

72 Nota sobre un diente de placoide fósil de la isla de Cuba, el Aetobatis poeyi. R Ac Cienc Habana, An 8:643-644 (1872)

73 Aetobatis poeyii, nueva especie fósil procedente de la isla de Cuba. Soc EspaĨola $\mathrm{H} \mathrm{N}$, An 2:193-212, il (1873) R Ac Cienc Habana, An $10: 368-374 ; 11: 61-70$, $93-109$, il (1874)

76 [Catálogo de los fósiles de la isla de Cuba.] R Ac Cienc Habana, An 13:320$326(1876)$

77 [Fósiles de la isla de Cuba, pertenecientes al género Asterostoma.] $\mathrm{R}$ Ac Cienc Habana, An 13:549-553 (1877)

77a Estudios geologicos sobre Cuba y Puerto Rico. Revista de Cuba, Habana, 1 : $506-513$ (1877)

S1 Iruebas paleontológicas de que la isla de Cuba ha estado unida al continente americano $y$ breve idea de su constitución geologica. España, Com Mapa Geol, B 8 : 357-372, map (1881) R Ac Cienc Habana, An 21:146-165 (1884)

82 ... estudio de los fenómenos geológicos que ofrece la isla de Cuba ... Int Cong Americanists, 4th, Madrid, 1881, Actas 1: $74-94,172-173(1882)$

is (and Salterain y Legarra, P.) Croquis geológico de Cuba ... See Hayes, 18

See also Hayes, 01

Fernandez Guardia, León.

10 The Cartago earthquake [Costa Rica] May 4th, 1910. 52 pp, San José, Costa Rica, 1910

Fernandez Peralta, Ricardo.

17 (with Tristan, J. Fidel) Informe presentado al Señor Ministro de Instruccion Páblica sobre la actividad del volcán Irazá. Colegio de Señoritas, Publicaciones, Serie A no. 1 (1917) [not seen] La Gaceta, Diario Oficial $39: 662-664$, San José, Costa Rica, December 4, 1917

Fernekes, Gustave.

o7 Precipitation of copper from chloride solutions by means of ferrous chloride. Ec G $2: 580-584$ (1907) 
Fernekes, Gustave-Continued.

07a The formation of Lake Superior copper. Science n s 25:589 (1907)

Ferrier, Walter F.

83 Notes on a fossil track from the Pots. dam sandstone of northern New York State (abst). Can Nat n s $10: 466-467$ (1883)

90 (with Nason, Frank L.) A notice of some zircon rocks in the Archean highlands of New Jersey. Am As, Pr 38: 244-245 (1890)

91 Short notes on some Canadian minerals. Can Rec Sc 4:472-476 (1891)

91a On harmotome from the vicinity of Port Arthur, Ont. Am J Se (3) 41:161 (1891)

92 Notes on the microseopical character of some rocks from the counties of Quebec and Montmorency... Can G S, An Rp 5: L $73-82$ (1892)

93 Catalogue of a stratigraphical collection of Canadian rocks prepared for the World's Columbian Exposition, Chicago, 1893. Can G S: 130 pp (1893)

95 Petrographical charaeter of some rocks from the area of the Kamloops map sheet B. C. Can G S, An Rp 7: B $349-400 \quad$ (1895)

95a Crystals. Ottawa Nat 9:117-131 (1895)

96 Notes on the microscopic structure of some rocks from the Labrador Peninsula. Can G S, An Rp 8: L 335-351 (1896)

96a Erythrite; stilpnomelane var. chalcodite: crystallized monazite; and pleochroic apatite from some Canadian localities. Ottawa Nat 9:193-195 (1896)

98 (with Barlow, A. E.) On the relations and structure of certain granites and associated arkoses of Lake Temiskaming, Canada (abst). Brit As, Rp 67: 659-660 (1898); G Mag (4) $5: 39-41$ (1898)

07 (with Weeks, F. B.) Phosphate deposits in western United States. U S G S, B 315:449-462 (1907)

17 Phosphate deposits of western United States and Canada. Can M J 38:209-210 (1917)

See also Adams (F D), 17b; Ami, 97 ; Ells, $96 \mathrm{~d}$

Fettke, Charles Reinhard.

12 Limonite deposits of Staten Island, N. Y. Sch Mines Q $33: 382-391$ (1912)

14 The Manhattan schist of southeastern New York State and its associated igneous rocks. N Y Ac Sc, An 23: 193-260 (1914)

17 Glass sands. Am Ceramic Soc, Tr $19: 160-194$ (1917)

18 (and Hubbard, Bela). The limonite deposits of Mayaguez Mesa, Porto Rico. Am I M Eng, B 135: 661-676 (1918)

18a The glass sands of Pennsylvania.

Science n s 48:98-100 (1918)

See also Roberts, 16
Feuchòre, Leon.

16 (with Bonillas, Y. S., and Tenney, J. B.) Geology of the Warren mining dis triet [Ariz.]. Am I M Eng, B 117:13971465, maps (1916) ; Tr $55: 284-355$, maps (1917)

Fenchtwanger, Lewis.

69 The meteorites from Poland and Mexico (abst). Am As, Pr 17:206-208 (1869)

Feust, Arthur.

12 The Chontales mining district, Nica ragua. M Se Press 105: 720-722 (1912)

Fewkes, J. Walter.

$\mathbf{8 8}$ On the origin of the present form of the Bermudas. Boston Soc N H, Pr 23: 518-522 (1888)

90 The origin of the present outlines of the Bermudas. Am G 5: 88-100 (1890)

90a On excavations made in rocks by sea urchins. Am Nat 24:1-21 (1890)

Field, Richard Montgomery.

15 On the validity of the genus Pletho peltis, Raymond. Ottawa Nat 29:37-4? (1915)

15a The use of the Roentgen ray in paleontology ; skiagraphy of fossils. Am J Sc (4) $39: 543-550$ (1915)

16 A preliminary paper on the origin and classification of intraformational conglom erates and breccias. Ottawa Nat $30: 29-36$, $47-52,58-66$ (1916)

17 Intraformational structure in the Ordovician limestone of central Pennsyl. vania (abst). 'G Soc Am, B 28:166-167 (1917)

Field, Roswell.

60 Ornithichnites or tracks resembling those of birds. Am J Sc (2) 29:361-363 (1860) Am As, Pr 13:337-340 (1860)

$60 a$ On the footmarks of the Connecticut River sandstones. Boston Soc N H, Pr 7: 316-317 (1860)

Field, V. W.

17 Clayton Peak, Utah; one of nature's storehouses of minerals. Am Mineralogist 2: 92-93 (1917)

Fieldner, Arno $C$.

14 (and others) Analyses of mine and car samples of coal collected in the fiscal years 1911 to 1913 . U S Bur Mines, B 85: $444 \mathrm{pp}$ (1914)

Filmer, Edwin A.

15 (with Rich, J. L.) The interglacial gorges of Six Mile Creek at Ithaca, N. Y. J G $23: 59-80$ (1915)

Finch, Elmer $\mathrm{H}$.

17 Muldoon district, Idaho. U S G S, P P 97: 106-110 (1917)

Fineh, Grant E.

97 Drift section at Oelwein, Iowa. Iowa Ac Sc, $\operatorname{Pr~4:54-58~(1897)~}$

01 A terrace formation in the Turkey River valley, in Fayette Co., Iowa. Iowa Ac Sc, Pr 8:204-206 (1901) 
Fineh, Grant E.-Contlnued.

04 Notes on the position of the indiriduals in a group of Nileus vigilans found at Elgin, Iowa. Iowa Ac Sc, Pr 11:179181, il (1904)

06 A study of a portion of the Iowan drift border in Fayette Co., Iowa. Iowa Ac Sc, Pr 13: 215-218 (1906)

Fineh, I.

33 Travels in the United States of America and Canada...and notices of the geology and mineralogy... 455 pp, L 1833 Fineh, John.

$23 \ldots$ on the Tertiary formations in smerica. Am J Sc $7: 31-43$ (1823)

24 ... geology of the country near Easton, Pa... Am J Sc $8: 236-240$, map (1824)

26 Memoir on the new or variegated sandstone of the United States. Am J Sc 10:209-212 (1826)

26a $0 n$ the Tertiary formations on the borders of the Hudson River. Am J Sc $10: 227-229$ (1826)

28 On the geology and mineralogy of the country near West Chester, Pa. Am J Sc 14:15-18 (1828)

31 ... mineralogy and geology of St. Lawrence Co., State of New York. Am J Sc 19:220-228 (1831)

Fineh, John Wellington.

04 The circulation of underground squeous solutions and the deposition of lode ores. Colo Sc Soc, Pr $7: 193-252$ (1904)

10 A geological journey in Guerrero [Mexico]. M Sc Press 101:496-500 (1910) Finch, Ruy Herbert.

16 The North Carolina earthquake of August 26, 1916. Mo Weather Rv 44:483 (1916)

16a The Alabama earthquake of October 18, 1916. Mo Weather Rv 44:690 (1916)

17 The Missouri earthquake of April 2, 1917. Seism Soc Am, B $7: 91-96$ (1917) Mo Weather Rv 45:187-188 (1917)

Fineh, W. W.

87 Infusorial earth at Santa Barbara, Cal, Santa Barbara Soc N H, B 1:8-11 (1887)

Finkelstein, Leo.

17 (with Quirke, Terence T.) Measurements of the radioactivity of meteorites. Am J Sc (4) 44:237-242 (1917)

Finlay, George Irving.

$00 \mathrm{~A}$ new occurrence of nepheline syenite and assoclated dikes in the State of Tamaulipas, Mexico, with a review of e distribution of these rocks in North America (abst). Science n \& 12:446-447 (1900) N Y Ac Sc, An 13:491-492 (1901)

01 The granite of Barre, vt. (abst). Sclence n \& 13:509 (1901) N Y Ac Sc, An 14:101-102 (1902)
Finlay, George Irving-Continued.

02 The granite area of Barre, vt. Vt, St G, Rp 3: 46-60 (1902)

02a Preliminary report of fleld work in the town of Minerva, Essex Co. [N. Y.]. N Y St Mus, An Rp 54: r96-102, map (1902)

02b Igneous rocks of the Algonkian series [of the Lewis and Livingston ranges, Mont.]. G Soc Am, B 13:349-352 (1902)

03 Geology of the San Pedro district, San Luis Potosi, Mexico. Sch Mines Q 25: 60-69 (1903)

O3a (and Kemp, J. F.) Nepheline syenite area of San José, Tamaulipas, Mexico (abst). Seience n s 17: 295 (1903) G Soc Am, B 14:534 (1904)

03b The geology of the nepheline syenite area at San José, Tamaulipas, Mexico (abst). Am G 32:63-64 (1903) Science n s 18:17-18 (1903) N Y Ac Sc, An 15: 188-189 (1904)

o3e Geological observations along the northern boundary of Montana (abst). N Y Ac Sc, An 15:68-69 (1903)

04 The geology of the San Jose district, Tamaulipas, Mexico. N Y Ac Sc, An 14: 247-295, map (1904)

06 Colorado Springs; a guide book describing the rock formations in the vicinity of Colorado Springs. $61 \mathrm{pp}$, map, Colorado Springs, Colo., [1906].

07 On an occurrence of corundum and dumortierite in pegmatite in Colorado. J G $15: 479-484$ (1907)

07a The Gleneyrie formation and its bearing on the age of the Fountain formation in the Manitou region, Colo. J G 15 : 586-589 (1907)

10 The calculation of the norm in igneous rocks. J G 18: 58-92 (1910)

10a An outline of mineralogy. Colo Coll Pub, gen s no 47 (Eng s 1 nos 8-10) : 165-175 (1910)

13 Introduction to the study of igneous rocks. vil, $228 \mathrm{pp}, \mathrm{N}$ Y 1913

16 Description of the Colorado Springs quadrangle, Colo. U S G S, G Atlas Colorado Springs fol (no, 203) :17 pp, maps (1916)

17 The geology of North Park, Colo. (abst). N Y Ac Sc, An $27: 272$ (1917)

Finlay, J. Ralph.

96 (with Smyth, H. L.) The geological structure of the western part of the Vermilion Range, Minn. Am I M Eng, Tr 25: $595-645$, map (1896)

o3 The mining industry of the Coeur d'Alenes, Idaho. Am I M Eng, $\mathrm{Tr} 33$ : 235-271, map (1903) Abst, Eng M J 75 : 87 (1903) ; Mines and Minerals 24:497498 (1904)

os Lead and zinc ores in Missouri. Eng M J 86:605-610 (1908)

18 The Southwest copper field [New Mexico-Arizona-Sonora], Eng M J 106: 199-205 (1918) 
Finlay, J. Ralph-Continued.

18a The Jerome district of Arizona. Eng M J 106:557-562, 605-610 (1918)

Finlayson, A. M.

10 Economics of secondary enrichment. M Sc Press 101: 71-75, 111-113 (1910)

Finney, Marian.

12 The limbs of Lysorophus. J Morph 23: 664-666 (1912)

Fiseher, Arthur Homer.

18 A summary of mining in the state of Washington. Wash, Univ, Eng Exp Sta Ser, B 4:124 pp, map (1918)

Fischer, Moritz.

87 Natural gas in Kentucky. Am Manufacturer, Nat Gas Suppl no $2: 22$, Dec 30 (1887)

90 The oil field of Barren Co., Ky. Eng M J $49: 197-198(1890)$

Fischer, $\mathrm{P}$.

72. Sur quelques fossiles de Y Alaska, rapportés par M. A. Pinart. Ac Se Paris, C R 75:1784-1786 (1872) A78o in Pinart, Alph. L., Voyages a la côte nord-ouest de l'Amérique : $33-36$, il, Paris 1875

Fish, Charles F.

81. The mineral springs of Saratoga [N. Y.] Pop Se Mo, 19:24-33 (1881)

Fishback, Martin.

10 The Black Range mining district, N. Mex. Eng M J 89: 911-912 (1910)

$10 a$ Mines of Zomelahuacan, Veracruz, Mexico. Eng M J 90:1017-1019 (1910)

Fishback, P. J.

02 Geological horizon of the petroleum in southeast Texas and southwest Louisiana. Eng M J 74:476 (1902)

Fisher, Cassius Asa.

00 Geology of Lincoln and environs. Nebr, Univ, Grad B 1:35-41 (1900) [not seen ]

01 Comparative value of bluff and valley wash deposits as brick material. Nebr St Bd Agr, An Rp 1900: 181-184 (1901)

O1a Directory of the limestone quarries of Nebraska. Nebr St Bd Agr, An Rp 1901 : 243-247 (1901)

01b (with Gould, C. N.) The Dakota and Carboniferous clays of Nebraska. Nebr St Bd Agr, An Rp 1900: 185-194, map (1901)

02 Discovery of the Laramie in Nebraska. Am G 30:315-316, map (1902)

02a (with Barbonr, E. H.) The geological bibliography of Nebraska. Nebr St Bd Agr, An Rp 1901: 248-266 (1902)

02b (with Barbonr, E. H.) A new form of calcite-sand crystal. Am J Sc (4) 14: 451-454 (1902)

04 Coal fields of the White Mountain region, N. Mex. U S G S, B $225: 293-294$ (1904)

O4a Coal of the Bighorn Basin, in northwest Wyoming. U S G S, B 225: 345-362 (1904)

05 The bentonite deposits of Wyoming. U S G S, B 260: 559-563 (1905)
Fisher, Cassius Asa-Continued.

06 Geology and water resources of the Bighorn basin, Wyo. U S G S, P P 53:7? pp, map (1906)

06a Description of the Nepesta quad. rangle [Colo.]. U S G S, G Atlas, Nepesta fol (no 135) : 5 pp, maps (1906)

o6b Preliminary report on the geology and underground waters of the Roswell artesian area, N. Mex. U S G S, W-S P 158:29 pp, map (1906)

06e Development of the Bear Creek coal fields, Mont. U S G S, B $285: 269-270$ (1906)

06d Mineral resources of the Big Hom Basin, U S G S, B 285:311-315 (1906)

07 The Great Falls coal field, Mont. U

S G S, B $316: 161-173$ (1907)

os Giant Springs at Great Falls, Mont. G Soc Am, B 19:339-346 (1908)

O8a Southern extension of the Kootenal and Montana coal-bearing formations in northern Montana. Ec G 3: 77-99 (1908)

08b Clays in the Kootenai formation neat Belt, Mont. U S G S, B $340: 417-423$ (1908)

09 Geology of the Great Falls coal field. Mont. U S G S, B 356: 85 pp, map (1909) 09 a Geology and water resources of the Great Falls region, Mont. U S G S, W s P 221: 89 pp, map (1909)

09b The Pocket coal district, $\mathrm{Va}$, in the Little Black Mountain coal field. U S G S, B 341 : 409-418 (1909)

10 Depth and minimum thickness of coal beds as limiting factors in valuation of coal lands. U S G S, B 424:48-75 (1910)

14 (and Calvert, W. R.) Geology of the Bering River field and its relations to coal mining conditions. U S $63 d$ Cong $2 d$ sess, H R Doc $876: 29-50$, maps (1914)

Fisher, Charles R.

94 Some evidences of a glacial epoch. $\mathrm{N} H$ Soc N B, B [3] no 12, App B:i-ri (1894)

Fisher, Davenport.

87 Description of an iron meteorite from St. Croix Co., Wis. Am J Sc (3) 34 : 381383 (1887)

Fisher, E. F.

06 Terraces of the West River, Brattle. boro, Vt. Boston Soc N H, Pr 33:9-42 (1906)

Fisher, G. J.

59 [Reindeer antler found at Sing sing, N. Y.] Ac N Se Phila, Pr 1859:194

Fisher, George $P$.

66 Life of Benjamin Silliman. 2 vols, 407,408 pp, port, N Y 1866

Fisher, $O$.

06 A suggested cause of changes of level in the earth's crust. Am J Sc (4) 21: 216-220 (1906)

Fisher, Samuel B.

36 Map of the first and second anthra. cite coal fields. Scale 200 perches to inch. Pottsville, $\mathrm{Pa}$., 1836 [not seen] 
Fisher, Walter L.

11 Alaskan coal problems. U S Bur Mines, B $36: 32$ pp, map (1911)

Fiteh, Asa.

50 Rocks and soils of Washington Co. [N. Y.] N Y St Agr Soc, $\operatorname{Tr}$ 9:816-909 (1850)

Fiteh, R. S.

16 (and Loughlin, G. F.) Wolframite and scheelite at Leadville, Colo. Ec G 11 ; 30-36 (1916) M World 44:1039-1040 (1916)

Fitton, William Henry.

36 Geological notice on the new country passed over by Captain Back during his late expedition. In Narrative of the Arctic land expedition to the mouth of the Great Fish River and along the shores of the Arctic Ocean in the years 1833, 1834, and 1835 by Captain George Back... : 543562 , L 1836 ... 399-411, Phila 1836

Fitzhagh, G. D.

05 The Portland cement materials of southwestern Arkansas. Eng As South, Tr 15:33-42, map (1905)

Fitzpatriek, T. J.

9s The drift section and the glacial stris in the vicinity of Lamoni, Iown, lowa $\mathrm{Ac} \mathrm{Se}, \operatorname{Pr} 5: 105-106$ (1898)

Flage, Arthur L.

13 The Elk City mining district, Idaho Co, Idaho, Am I M Eng, B 76:571-580, map (1913); $\operatorname{Tr} 45: 113-122$, map (1914)

13a Buffalo Hump mining distriet, Idaho. M World 38:813-81! (1913)

13b Preparation of rock sections. Eng M J 95: 1135-1136 (1913)

Fleck, Herman.

05 The alkali lakes of the San Luis Valley, Colo. Western Chemist and Metal. furgist $1: 2-4$ (1905)

07 (and Haldane, W. G.) A study of the uranium and vanadium belts of southern Colorado. Colo St Bur Mines, Rp 1905-6 : 47-115 (1907)

08 Welfare of Colorado's rare metal industry [pitchblende deposits of Gilpin Co. and ranadium deposits of Placerville, Colo.]. Colo Sch Mines, Bien Rp: 34-45 (1908); B 4:234-242 (1909) Mines and Minerals $30: 63-64$ (1909)

09 How to recognize pitchblende. Eng II J $88: 1026 \quad(1909)$

09a The uranium and vanadium deposits of Colorado. M World $30: 596-598$ (1909)

16 A series of treatises on the rare metals; tungsten, molybdenum, uranium. Colo Sc Soc, Pr 11: 103-176 (1916)

Fleck, W. I.

00 Pocket mining in southern Oregon. Eng M J 70:69 (1900)

Fleming, H. S.

87 General description of the ores used in the Chattanooga district. Am I M Eng, Tr $15: 757-761$ (1887)
Fleming, H. S.-Continued.

92 [Middlesboro, Ky.] Eng M J 53: 251-252 (1892)

Fleming, Mary A.

99 The potholes of Foster's Flats (now called Niagara Glen) on the Niagara River (abst). Am As, Pr 48:226-227 (1899) Science n \& $10: 489$ (1899)

Fleming, Sandford.

53 The valley of the Nottawasaga [Ontario]. Can J 1:223-226 (1853)

61 Notes on the Davenport gravel drift [Toronto, Ont.]. Can J n s 6:247-253 (1861)

63 Notes on the present condition of the oil wells of Enniskillen [Ont.]. Can J n s 8:246-249 (1863)

Fleming, W. L.

09 Notes on the Rainy River district, Ont. Eng M J 88:1064-1066 (1909)

11 Economic features of Porcupine ores [Ont.]. Eng M J 92:253-256 (1911)

Fleteher, Hugh (1848-1909).

77 Report of explorations and surveys in Cape Breton, N. S. Can G S, Rp Prog 1875-6:369-418, map (1877)

78 Report on the geology of part of the counties of Victoria, Cape Breton, and Richmond, N. S. Can G S, Rp Prog 1876-7:402-456, map (1878)

79 Report of explorations and surveys in Cape Breton, N. S. Can G S, Rp Prog $1877-8:$ F $32 \mathrm{pp}$, map (1879)

81 Report on part of the counties of Richmond, Inverness, Guysborough, and Antigonish, N. S., 1881. Can G S, Rp Prog 1879-80: F 125 pp (1881)

s5 Report on the geology of northern Cape Breton, Can G S, Rp Prog 1882-4: H $98 \mathrm{pp}$ (1885)

87 Report on geological surveys and explorations in the counties of Guysborough, Antigonish, and Pictou, N. S. Can G S, An Rp 2: P 5-128, maps (1887)

89 [Report on geologic work in Pictou and Colchester cos., N. S.] Can G S, Sum Rp 1887-8 (An Rp 3) : A 97-99 (1889)

90 Summary report on part of Pictou and Colchester cos., N. S.] Can G S, Sum Rp 1888-9 (An Rp 4) : A 43-45 (1890)

91 [Summary report of field work in Nova Scotia.] Can G S, Sum Rp 1890 (An Rp 5) : A 58-61 (1891)

92 Report on geological surveys and explorations in the counties of Pictou and Colchester, N S. Can G S, An Rp 5: p 193 pp (1892)

92a [Summary report of field work in Nova Scotia.] Can G S, Sum Rp 1891 (An Rp 5) : A 52-55 (1892)

93 [Summary report on field work in Cumberland and Hants cos., N. S.] Can G S, Sum Rp 1892 (An Rp 6) : ^ 59-65 (1893) 
Fleteher, Hugh-Continued.

94 The Sydney coal field [Cape Breton, N. S.]. Can M Rv 13:148-149, map (1894) M Soc N S, J $3: 112-124$, map (1895)

95 [Summary report on field work in Nova Scotia.] Can G S, Sum Rp 1894 (An Rp 7) : $\triangle$ 88-93 (1895)

96 [Report on field work in Nova Scotia.] Can G S, Sum Rp 1895 (An Rp 8) : A 105-111 (1896)

97 [Report on field work in the Sydney coal field, Cape Breton Island.] Can G S, Sum Rp 1896 (An Rp 9) : A 94-98 (1897)

98 [Report of field work in Nova Scotia.] Can G S, Sum Rp 1897 (An Rp 10) : A 98103 (1898)

99 [Report on field work in Cumberland Co., N. S.] Can G S, Sum Rp 1898 (An Rp 11) : A 139-148 (1899)

00 [Report of field work in northern Nova Scotia.] Can G S, Sum Rp 1899 (An Rp 12) : A 162-168 (1900)

OOa Descriptive note on the Sydney coal field, Cape Breton, Nova Scotia. To accompany a revised edition of the geological map of the coal fields. Can $G$ S: 16 pp, map (1900)

Oob Geological nomenclature in Nova Scotia. N S Inst Sc, Pr Tr 10 or (2) $3: 235-244$ (1900)

01 [Report on field work in Cumberland Co., N. S.] Can G S, Sum Rp 1900 (An Rp 13) : $\triangle 162-166$ (1901)

02 Kings and Hants cos., N. S. Can G S, Sum Rp 1901 (An Rp 14) : A 210-216, map (1902)

02a Geological nomenclature in Nova Scotia. N S Inst Sc, Pr Tr 10 or (2) 3: 323-329 (1902)

03 Surveys and explorations in Richmond, Cape Breton, Kings, Cumberland, and other counties of Nova Scotia. Can G S, Sum Rp 1902 (An Rp 15) : \$ 390-401, map (1903)

04 Northern part of Nova Scotia. Can G S, Sum Rp 1903 (An Rp 15) : ^ 160-174 (1904)

Osa Limits of the workable coals of the Cumberland coal fields in Nova Scotia. M Soc N S, J 8:123-126 (1904)

05 The counties of Cumberland, Hants, Kings, and Annapolis, N. S. Can G S, Sum Rp 1904 (An Rp 16): A 293-318, map (1905)

06 Geological work in the northwestern parts of Nova Scotia. Can G S, Sum Rp 1905: 118-122 (1906)

$06 a$ Surveys in western Nova Scotia. Can G S, Sum Rp 1906: 140-146 (1906)

os Summary report on explorations in Nova Scotia, 1907. Can G S, 15 pp (1'08)

OSa Section of rocks from Schulie to Spicer Cove, Cumberland Co., N. S., in descending order. N S Inst Sc, Pr Tr 11: 500-548, maps (1908)
Fleteher, Hugh-Continued.

09 Report on a portion of Cumberland Co., N. S. Can G S, Sum Rp 1908:143-148 (1909)

\section{Fleteher, L.}

87 On a meteoric iron (containing crystallized chromite) found about the year 1880 in Greenbrier Co., W. Va., U. S. A. Miner Mag 7:183-186 (1887)

90 The meteoric iron of Tucson [Ariz.]. Miner Mag $9: 16-36$ (1890)

$90 a$ On the Mexican meteorites, with especial regard to the supposed occurrence of wide-spread meteoritic showers. Minet Mag 9:91-178 (1890) La Naturaleza (2) $3: 57-120$ (1898) [Spanish]

Flett, John Smith.

02 Notes on a preliminary examination of the ash that fell on Barbados after the eruption at St. Vincent, W. I. G Soc Lon. don, Q J 58 : 368-369 (1902)

02a (with Anderson, T.) Prelim nary report on the recent eruption of the Soufrière in St. Vincent, and of a visit to Mont Pelé, in Martinique. R Soc London, Pr 70:423-445 (1902) Nature 68: 402-406 (1902) Smiths Inst, An Bp $1902: 309-330$ (1903)

03 (with Anderson, T.) Report on the eruptions of the Soufrière in St. Vith cent in 1902 and on a visit to Montagne Pelée in Martinique. $\mathrm{R}$ Soc London, $\mathrm{Ph}$ Tr ser A 200: 353-553 (1903)

os Petrographical notes on the products of the eruptions of May, 1902, at the Soufrière in St. Vincent. R Soc London, Ph Tr ser A 208: 305-332 (1908)

Fleury, Caron de.

69 Notas geologicas y estadisticas sobrt Sonora y la Baja California. Soc Geos Mex, B (2) 1: 44-52, 112-118 (1869) [not seen]

\section{Fleary, Luis.}

17 Geologia general de la República de El Salvador, en lo que se relaciona con ls mineria, mineralogia, metalurgí, y geología económica. Pan-American Sc Cong 2d, Washington, sec VII vol $8: 362-366$ 426-477, map (1917)

Flink, Gustaf.

98 Berättelse om en mineralogisk Rest 1 Syd-Grönland sommaren 1897. Nes Grönland 14: 221-262, 408-416 (1898)

o1 On the minerals from Narsarsuk of the Firth of Tunugdliarfik in southert Greenland. Med Grönland 24:7-180 (1901)

Flint, Earl.

90 ... the Nicaragua footprints. Science 15: 30-32 (1890)

Flint, George $M$.

os Gahnite from Charlemont, Mass $\Delta \mathrm{m} \mathrm{J} \mathrm{Sc} \mathrm{(4)} 26: 584$ (1908) 
Flores, Teodoro.

05 Los criaderos argentiferos de "Provi. dencia" y "San Juan de la Chica," San Pelipe. Estado de Guanajuato [México]. Soc G Mex, B $1: 169-173$, map (1905)

06 Le Xinantecatl ou volcan Nevado de Toluca, Int G Cong, X, Mexico, Guide Exc no $9: 16$ pp (1906)

06a Étude minière du district de Zacatecas [México]. Int $G$ Cong, $X$, Mexíco, Guide Ex no. $17: 25$ pp (1906)

06b (with Villarello, J. D.) Etude de la Sierra de Guanajuato [Mexico]. Int $G$ Cong, $X$, Guide Exc no $15: 33$ pp (1906)

$09 \mathrm{El}$ bundimiento del cerro de Sartenejas en los alrededores de Tetecala, Estado de Morelos. Méx I G, Par 2:363-384, map (1909)

09a Datos para la geologia del Estado de 0axaca. Soc G Mex, B 5:107-128 (1909)

09b Los yacimientos de tecali de los alrededores de Tequisistlan, municipalidad del mismo nombre, distrito de Tehuantepec, Estado de Oaxaca. Soc G Mex, B 6 : vilvill, $67-78$ (1909)

09e (with Villare11o, J. D.) Geologic study of the Sierra of Guanajuato. Eng M J 88:672-677 (1909)

10 La caverna de Cacahuamilpa, Guerrero. Soc G Mex, B 6 : xxvii, 93-112 (1910) 12 Algunos datos relativos á la mina de "La Delfina," Distrito de Bravos, Pstado de Guerrero. Soc G Mex, B 8: r-vi, 9-20 (1912)

13 (and Gonzalez, P., jr.) Exploradón de la parte central elevada de la porcion norte de la Península de la Baja California. Méx I G, Par 4:237-275 (1913)

16 Algunos datos sobre los criaderos de fosfato de calcjo en los alrededores de Monterrey, Nuevo León. Soc Cient Ant Alz, Hem $34: 351-362$ (1916)

16a Los criaderos de antimonio de México, Bol Minero 1:193-195 (1916)

16b Los criaderos de fosfato de calcio th los alrededores de Monterrey, N. L. [Méxíco]. Bol Minero $1: 132-135,164-165$ (1916)

18 El tequesquite del Lago de Texcoco. Méx I G, An no $5: 1-14$ (1918)

Florita Geologieal Survey.

13 Map of Florida showing topography, bard rock, and land pebble phosphate deposits, and areas of artesian flow, 1913. 8 cale 1 inch $=32$ miles (about).

Flower, W. H.

76 The extinct animals of North Amerlca. R Inst, Pr 8: 103-125, il (1876)

Fluek, Frank.

04 Lower Coal Measures of central Pennsylvania. Mines and Minerals 24: 574 (1904)
Fluker, W. H.

02 Gold mining in McDuffie Co., Ga. Eng M J 73:725-726 (1902) Am I M Eng, Tr 33:119-125 (1903)

Flynn, Benjamin $\mathrm{H}$.

04 (and Flynn, M. S.) The natural features and economic development of the Sandusky, Maumree, Muskingum, and Miami drainage areas in Ohio. U S G S, W S 91: 130 pp (1904)

Flynn, E. M.

11 An outline of the geology of the Porcupine area [Ont.]. In The Davis handbook of the Porcupine gold district: $35-41$ (1911)

Flynn, Frank H.

16 (with Peterson, Frank P.) The Walhalla district, S. C. Eng M J 101: 379-382 (1916)

F'1ynn, Margaret S.

04 (with FIynn, Benjamin H.) The natural features and economic development of the Sandusky, Maumee, Muskingum, and Miami drainage areas in Ohio. U $\mathrm{S} G \mathrm{~S}$, W-S P 91: 130 pp (1904)

Foerste, August Frederick.

$\mathbf{8 4}$ The power of motion in crinoid stems. Am Nat 18:57-58, il (1884)

85 The Clinton group of Ohio. Denison Univ, Sc Lab, B 1:63-120, il (1885); 2 : 89-110, 149-176, Il (1887) ; 3:3-12 (1888) 87 Flint Ridge Bryozoa [Ohio]. Denison Univ, Sc Lab, B 2: 71-88, il 71887)

87a Notes on Illaeni. Minn G $\mathrm{S}$, An $\mathrm{Rp}$ $15: 478-481$, il (1887)

$\mathbf{8 7 b}$ Recent methods in the study of Bryezoa. Sclence 10:225-226 (1887)

88 Notes on Paleozoic fossils. Denison Univ, Sc Lab, B 3: 117-136, il (1888)

88a Notes on a geological section at Todd's Fork, Ohio. Am G 2:412-419, 11 (1888)

88b Sections of fossils. Science 11:22 (1888)

88c (with Shaler, N. S.) Preliminary description of North Attleboro fossils [Cambrian, Mass.]. Harvard Coll, M C Z, B 16 (c s 2) : 27-41, il (1888)

89 The paleontological horizon of the limestone at Nahant, Mass. Boston Soc N H, Pr 24: 261-263 (1889)

89 Notes on Clinton group fossils, with special reference to collections from In diana, Tennessee, and Georgia. Boston Soc N H, Pr 24:263-355, il (1889)

89b Note-taking and the use of maps in geological fleld work. Am G 4: 229-237 (1889)

89e Fence wall geology. Am G 4:367371 (1889)

91 The age of the Cincinnati anticlinal. Am G 7:97-109 (1891)

91a On the Clinton oolitic iron ores. Am J Sc (3) 41:28-29 (1891) 
Foerste, August Frederick-Continued.

93 Fossils of the Clinton group in Ohio and Indiana. Ohio G S, Rp 7:516-601, il (1893)

93a Studies on the Chipola Miocene of Bainbridge, Ga., and of Alum Bluff, Fla., with an attempt at correlation of certain Grand Gulf beds with Miocene beds eastward. Am J Sc (3) $46: 244-254$ (1893)

93b New fossil localities in the early Paleozoics of Pennsylvania, New Jersey, and Vermont, with remarks on the close similarity of the lithologic features of these Paleozoics. Am J Sc (3) 46:435-444, maps (1893)

93e An examination of Glyptodendron Claypole, and of other so-called Silurian land plants from Ohio. Am G $12: 133-141$, il (1893)

93d On specific characters in Orthoceras. Am G 12:232-236, il (1893)

93e The reproduction of arms in crinoids. Am G $12: 270-271,340$, il (1893)

94 The upper Vicksburg Eocene and the Chattahoochee Miocene of southwest Georgia and adjacent Florida. Am J Se (3) 48: 41-54, map (1894)

95 On Clinton conglomerates and wave marks in Ohio and Kentucky. J G $3: 50$ $60,169-197$, map (1895)

96 An account of the middle Silurian rocks of Ohio and Indiana. Cin Soc $\mathrm{N} \mathrm{H}$, J 18: 161-199, map (1896)

97 A report on the geology of the middle and upper Silurian rocks of Clark, Jefferson, Ripley, Jennings, and southern Decatur cos. Ind, Dp G N Res, An Rp 21 : 213-288, maps (1897)

98 A report on the Niagara limestone quarries of Decatur, Franklin, and Fayette cos., with remarks on the geology of the middle and upper Silurian rocks of these and neighboring (Ripley, Jennings, Bartholomer, and Shelby) cos. Ind, Dp G N Res, An Rp 22 : 195-255, maps (1898)

99 Age and development of the Cincinnati anticline (abst). Science n s $10: 488$ (1899)

99a (with ShaIer, N. S.) Geology of the Narragansett Basin. U S G S, Mon $33: 402 \mathrm{pp}$, maps (1899)

oo A general discussion of the middle Silurian rocks of the Cincinnati anticlinal region, with their synonymy. Ind, Dp G $\mathrm{N}$ Res, An Rp 24: 41-80 (1900)

O0a ... history of the Cincinnati anticline (abst). Science n s 11:145 (1900)

01 Silurian and Devonian limestones of Tennessee and Kentucky. G Soc Am, B 12: 395-444 (1901) Abst, Science n s 13 : 134-135 (1901)

02 The Cincinnati anticline in southern Kentucky. Am G $30: 359-369$, map (1902)
Foerste, August Frederick-Continued. 02a Use of the terms Linden and $0^{2}$ ton limestones in Tennessee geology (bbrt Science n \& 15:90 (1902) G Soc Am, ? $13: 531$ (1903)

02b Bearing of Clinton and 0 sow formations on age of Cincinnati anticlis (abst). Science n s 15:90 (1902) Gs. Am, B 13:531-532 (1903)

03 The Richmond group along the wet ern side of the Cincinnati anticline in lo diana and Kentucky. Am G $31: 333-381$, maps (1903)

03a The Cincinnati group in westen Tennessee, between the Tennessee Rirer ad the central basin. J G $11: 29-45$, map (1906)

O3b Silurian and Devonian limestones di western Tennessee. J G 11:554-583, 67715, map (1903)

04 Description of the rocks formed ta the different geological periods in Indian: Ordovician and Silurian. Ind, Dp G N R An Rp 28: 21-39 (1904)

O4n Variation in thickness of the sst? divisions of the Ordovician of Indiat. Am G 34: 87-102, map (1904)

04b The Ordovician-Silurian contact b the Ripley Island area of southern Indiat with notes on the age of the Cincinat geanticline. $\mathrm{Am} \mathrm{J} \mathrm{Sc} \mathrm{(4)} \mathrm{18:321-3t:}$ maps (1904)

o5 Silurian elays, with notes on day of the Waverly and Irvine formations if Kentucky]. Ky G S, B 6:143-178 (1900

05a Notes on the distribution of Brad iopoda in the Arnheim and Waynesrili? beds [Cincinnati region]. Am G 36:24t 250 (1905)

05b The classification of the Ordoricat rocks of Obio and Indiana. Sclence is 22 : 149-152 (1905)

06 The Silurian, Devonian, and Irris formations of east-central Kentucky, with an account of their clays and limestoni Ky G S, B 7: 369 pp, maps (1906)

o9 Silurian fossils from the Kokom West Union, and Alger horizons of Iv diana, Ohio, and Kentucky. Cin Soc X B. J $21: 1-41$, il (1909)

O9a The Bedford fauna at Indian Field and Irvine, Ky. Ohio Nat $9: 515-523,1$ (1909)

O9b Fossils from the silurian formt tions of Tennessee, Indiana, and Kentucks Denison Univ, Sc Lab, B 14:61-116, (1909)

o9e Preliminary notes on Cincinnatis fossils. Denison Univ, Sc Lab, B 14:205 232, il (1909)

09d Preliminary notes on Cincinnatia and Lexington fossils. Denison Univ, \$ Lab, B 14:289-334, il (1909)

09e The Brachiopoda of the Richmon group (abst). Science n s 29:635 (1909) G Soc Am, B 20:699 (1910) 
Foerste, August Frederick-Continued. o9f (with Morse, W. C.) The Waverly formations of east central Kentucky. J G 17: 164-177 (1909)

10 Preliminary notes on Cincinnatian and Lexington fossils of Ohio, Indian?, Kentucky, and Tennessee. Denison Univ, Sc Lab, B 16:17-100, il (1910)

10a Oil, gas, and asphalt rock in Meade and Breckenridge cos. Ky G S, Rp Progress 1908-1909:69-85 (1910)

12 Report on the value of the Dix River as a source of water power. Ky G S, B 21:63 pp, with supplementary report of 3 pp (1912)

12a Strophomena and other fossils from Cincinnatian and Mohawkian horizons, chiefly in Ohio, Indiana, and Kentucky. Denison Univ, Sc Lab, B $17: 17-172$, il (1912)

12b The Arnheim formation within the areas traversed by the Cincinnati geanticline. Ohio Nat 12:429-456, il (1912)

12e The Ordovician section in the Manitoulin area of Lake Huron. Ohio Nat $13: 37-48$, map (1912)

12d (with Morse, W. C.) Preliminary report on the Waverlian formations of east central Kentucky and their economic ralues. Ky G S, B 16:76 pp (1912)

13 The geology of the Clay Cliffs, Cape Suyth, Manitoulin Island; The Mohawkian (Middle Ordovician) strata northeast of Kanitoulin Island. Int $\mathrm{G}$ Cong, XII, Canada, Guide Book no $5: 76-84,84-89$, map (1913)

13a Richmond formations of the provinces of Ontario and Quebec in Canada (abst). G Soc Am, B 24:110 (1913)

$13 \mathrm{~b}$ The identification of Trenton and lower geological horizons. Ky G S (4) 1:365-376 (1913)

13e A chemical study of the Trenton and Stones River rocks in central Kentucky. ky G S (4) $1: 377-386$ (1913)

13 The phosphate deposits in the upper Trenton limestones of central Kentucky. Ky $\& \mathrm{~S}$ (4) $1: 387-439$, map (1913)

14 The Rogers Gap fauna of central Kentucky. Cin Soc N H, J 21:109-156, il (1914)

14a Notes on the Lorraine faunas of ew York and the Province of Quebec. Denison Univ, Sc Lab, B $17: 247-339$, il (1914)

14b Notes on Agelacrinidae and Lepadocystinae, with descriptions of Thresher. discus and Brockocystis. Denison Univ, Se Lab, B $17: 399-474$, il (1914)

$15 \mathrm{An}$ introduction to the geology of Dayton [Ohio] and vicinity... $210 \mathrm{pp}, \mathrm{il}$, Map, Dayton, Ohio, 1915 [Priv pub]

16 Upper Ordovician formations in Ontarlo and Quebec, Can G S, Mem 83: 279 ID (1916)
Foerste, August Frederick-Continued.

$16 a$ Comarocystites and Caryocrinites. Ottawa Nat $30: 69-79,85-93,101-113$, il (1916)

$16 b$ Notes on Cincinnatian fossil types. Denison Univ, Sc Lab, B 18: 285-355, il (1916)

17 Intraformational pebbles in the Richmond group, at Winchester, Ohio. J G 25 : 289-306 (1917)

17 a Notes on Silurian fossils from Ohio and other central States. Ohio J Sc 17 : $187-204,233-267$, il $(1917)$

17b Notes on Richmond and related fossils. Cin Soc N H, J 22:42-55, il (1917)

17e The Richmond faunas of Little Bay de Noquette in northern Michigan. Ottawa Nat 31:97-103, il (1917)

See also Hull, 91

Fogh, Carl S.

94 Some geological features of the mines of Velardena, Mexico. Eng M J 57: 29-30 (1894)

Fohs, F. Julius.

o5 Clays in Crittenden and Livingston cos. Ky G S, B 6: 124-142 (1905)

06 Classification of faults and fractures into series and sets and its practical application. Eng M J 81:553-554 (1906)

07 Fluorspar deposits of Kentucky. Ky G S, B $9: 296$ pp (1907)

09 Kentueky fluorspar and its value to the iron and steel industries. Am I M Eng, B 28:411-423 (1909); T 40:261273 (1910) Abst, M World 30:12171220 (1909)

10 The fluorspar, lead, and zinc deposits of western Kentucky. Ec G 5:377386 (1910)

10a The barytes and associated deposits of central Kentucky. Ky G S, Rp Progress 1908-9: 94-99 (1910)

10b Resources of Lewis and Rowan cos. Ky G S, Rp Progress 1908-9:99-101 (1910)

12 Coals of the region drained by the Quicksand ereeks in Breathitt, Floyd, and Knott cos. Ky G S, B 18: 79 pp, maps (1912)

13 Barytes deposits of Kentucky. Ky G S (4) 1:441-588, maps (1913)

15 Oil and gas possibilities of Kentucky. Am I M Eng B 99:621-628 (1915); Tr $51: 649-656$ (1916)

Fontaine, Edward.

74 A lecture on the peculiarities of the physical geography of the Mississippi River and its delta. $26 \mathrm{pp}$, Washington, D. C., 1874

Fontaine, William Morris (1835-1913).

73 Notes on the West Virginia asphaltum deposit. Am J Sc (3) 6:409416 (1873)

74 The "Great Conglomerate" on New River, W. Va. Am J Sc (3) $7: 459-465$, $573-579 \quad(1874)$ 
Fontaine, William Morris-Continued.

75 On some points in the geology of the Blue Ridge in Virginia. Am J Sc (3) 9 : 14-22, 93-101 (1875)

75a On the Primordial strata of Virginia. Am J Sc (3) 9:361-369, 416-428 (1875)

76 The conglomerate series of West Virginia. $A m$ J Sc (3) 11:276-284, 374384 (1876) The Virginias 1:27-29 (1880)

76a (with Manxy, M. F.) Resources of West Virginia. $x, 430 \mathrm{pp}$, Wheeling 1876

77 Notes on the Vespertine strata of Virginia and West Virginia, Am J Sc (3) $13: 37-48, \quad 115-123$ (1877)

79 Notes on the Mesozoic strata of Virginia. $\mathrm{Am} J \mathrm{Sc}$ (3) $17: 25-39,151-157$, 229-239 (1879)

79a On some of the relations and teachings of geology. In his Introductory lecture...with a short account of the Lewis Brooks Museum of Natural History [Univ. Va.] : 21-48, Charlottesville, Va., 1879

so (and white, I. C.) The Permian or upper Carboniferous flora of West Virginia and southwestern Pennsylvania. $\mathrm{Pa}$ G S, 2d, PP : ix, 143 pp, il (1880)

81 The Mesozoic of Virginia. Am Ph Soc, Pr 19:349-352 (1881) Am Nat 16: 75-76 (1882)

81a [Fault of the Saltville Valley in southern Virginia.] Am Ph Soc, Pr 19: 350,352 (1881) Am Nat 16:76:(1882) The Virginias 2:93 (1881)

82 Notes on the coal of Little Sewell Mountain, Greenbrier Co., W. Va. The Virginias 3:7-8, map (1882)

82a The artesian well at Fort Monroe, Va. The Virginias 3: 18-19 (1882)

82b Notes on Virginia geology; the Brush Creek, Va., gold district. The Virginias 3 : 108-109 (1882)

82e Notes on the sulphuret deposits of Virginia. The Virginias $3: 154-155$ (1882)

83 Contributions to the knowledge of the older Mesozoic flora of Virginia. U S G S, Mon 6:144 pp, il (1883) Abst, The Virginias $6: 38-40$ (1885)

S3a Notes on the occurrence of certain minerals in Amelia Co., Va. Am J Sc (3) 25: $330-339$ (1883)

83b Notes on the mineral deposits at certain localities on the western part of the Blue Ridge. The Virginias 4:21-22, $42-47,55-59,73-76,92-93$ (1883)

83e Notes on the geology and mineral resources of the Floyd, Va., plateau. The Virginias $4: 167,178-180,185-192 ; 5: 8-$ $14,43(1883-4)$

88 The flora of the Potomac formation in Virginia $(a b s t)$. $\Delta \mathrm{m}$ As, Pr 36:275276 (1888)

89 The Potomac or younger Mesozoic flora. IT S G S, Mon $15: x i v, 377 \mathrm{pp}$, pls vol (1889)
Fontaine, William Morris-Continued. 90 (and Knowlton, F. H.) Notes in Triassic plants from New Mexico. U \& Nit Mus, Pr 13: 281-285, II (1890)

93 Description of some fossil plants fro the Great Falls coal field of Montana. S Nat Mus, Pr 15: 487-495, il (1893)

$93 n$ Notes on some fossil plants from the Trinity division of the Comanche series of Texas. U S Nat Mus, Pr $16: 261-282$, I (1893)

96 The Potomac formation in Virgini U S G S, B 145: 149 pp (1896)

$96 a$ Notes on some Mesozoic plants fro near Oroville, Cal. Am J Sc (4) 2:2i; 275 (1896)

98 Notes of the lectures on geology University of Virginia. Pt 1:173 pp: pt $2: 153$ pp; pt $3: 174$ pp (c 1898-9)

99 Note on Lower Cretaceous plants frou the Hay Creek coal field, Crook Co., Wro U S G S, An Rp 19 pt $2: 645-702$, il (1899)

oo Notes on fossil plants collected by Dr. Ebenezer Emmons from the older Mesonic rocks of North Carolina. U S G S, An P. 20 pt $2: 277-315$, il $(1900)$

00a Notes on Mesozoic plants from 0n ville, Cal. U S G S, An Rp 20 pt 2:34t 368 , il (1900)

oob (with Wanner, A.) Triassic fin of York Co., Pa. U S G S, An Rp 20 pt 2: 233-255, Il (1900)

See also Powell, 85a, 89a; Ward, 05

Foord, Arthur Humphreys.

83 Descriptions of species; I, On the Monticuliporidae of the Chazy, Black Biret. and Trenton formations, with descriptioss of ten new species; II, On some previousl unrecorded species of Ptilodictya, sticto pora, and Arthronema, from the Trento formation; III, On two species of Tetradiss from the Trenton and Hudson River forms tions. Can G S, Contr Micro-Pal [pt 1] 1-26, il (1883)

85 (with Nicholson, H. A.) On the genus Fistulipora M'Coy, with descriptioss of several species. An Mag N H (i) 16: $496-517$, il (1885)

87 On the genus Piloceras Salter as ellcidated by examples lately discovered in North America and Scotland. G Mag (3) $4: 541-546$, il (1887) Abst, Brit As, Bp $57: 717$ (1888)

88 Note on the genus Actinoceras... Mag (3) 5:487-48, il (1888)

Foot, Lyman.

21 Notices in geology and mineralog [Niagara to Plattsburgh, N. Y.] Am J $\mathrm{cc}$ 4:35-37 (1821)

Foote, Albert E. (1846-1895),

73 On zonochlorite, a new hydrous silt cate from Nipigon Bay, north shore of Lake Superior, B. A. $\Delta \mathrm{m}$ As, Pr 21:65-66. (1873) 
Foote, Albert E.-Continued.

80 On a probable pseudomorphism of gummite and uranotile after uraninite. Ac N Sc Phila, Pr 1880: 292; G Min Sec, Pr no $1: 56 \quad(1880)$

84 A large zircon [Renfrew Co., Ont.]. Ac N Sc Phila, Pr 1884: 214-215

86 The opal mines of Queretaro, Mex. Ac N Sc Phila, Pr 1886: 278-280 Eng M J $42: 170(1886)$

91 new locality for meteoric iron with a preliminary notice of the discovery of diamonds in the iron. Am J Sc (3) 42 : 413-417 (1891)

91a Geological features of the meteoric locality in Arizona. Ac N Sc Phila, Pr $1891: 407$

92 Catalogue of minerals and mineralogical books. 9th ed, 128 pp, Phila 1892

92a A new meteoric iron from Garrett Co., Md. Ac N Sc Phila, Pr 1891; 455 (1892) Am J Sc (3) 43:64 (1892)

92b A new locality for meteoric iron with a preliminary notice of the discovery of diamonds in the iron [Ariz.]. Am As, Pt 40:279-283 (1892) Abst, Am G 8: 192 (1891)

$93 \mathrm{~A}$ meteoric stone seen to fall at Bath, 8. Dak, Ac N Sc Phila, Pr 1892: 353-354 (1893)

93a Preliminary notice or a meteoric stobe seen to fall at Bath, S. Dak. Am J Se (3) $45: 64$ (1893)

Foote, Charles W.

77 Notes upon the geological history of Cayuga and Seneca lakes, together with a few general remarks upon the glacial period. Thesis, Cornell University. 14 pp Ithaca, S Y, 1877

Poote, Frederick W.

15 The Florence, Colo., oil field, Mex ม J $19: 48-49$ (1915)

Foote, Harry Ward.

96 On the occurrence of pollucite, mangano-columbite and microlite at Rumford, Me. Am J Sc (4) $1: 457-461$ (1896) Zs Kryat $27: 60-64$ (1896)

97 (with Penfleld, S. L.) On roeblingIte, a new silicate from Franklin Furnace, N. J., containing sulphur dioxide and lead. Am J Sc (4) 3:413-415 (1897)

97a (with Pratt, J. H.) On wellsite, a new mineral [Clay Co., N. C.]. Am J Sc (4) 3:443-448 (1897) Yale Bicen Pub, Contr Miner : 275-282 (1901)

$97 \mathrm{~b}$ (with Penfield, S. L.) On bixbyite, a new mineral, and notes on the assodated topaz. Am J Sc (4) 4:105-108 (1897) Yale Bicen Pub, Contr Miner : 283286 (1901)

97e (with Penfield, S. L.) Note concerning the composition of ilmenite. $\Delta \mathrm{m}$ J Sc (4) 4:108-110 (1897)

98 (with Penfield, S. L.) On clinohedrite, a new mineral from Franklin, N. J. Am J Sc (4) 5:289-293 (1898) Yale Bicen Pub, Contr Miner: 291-296 (1901)
Foote, Harry Ward-Continued.

99 (with Penfield, S. L.) On the chemical composition of tourmaline. Am J Sc (4) 7:97-125 (1899) Yale Bicen Pub, Contr Miner : 297-324 (1901)

10 Criteria of downw ard sulphide enrichment (discussion). Ec G $5: 485-488$ (1910)

11 (and Bradley, W. M.) On solid solution in minerals with special reference to nephelite. Am J Sc (4) $31: 25-32$ (1911)

12 (and Bradley, W. M.) On solid solution in minerals; II, The chemical composition of analcite. Am J Sc (4) 33 : 433-439-(1912)

12a (and Bradley, W. M.) The chemical composition of nephelite. Am J Sc (4) $33: 439-441$ (1912)

13 (and Bradley, W. M.) On solid solution in minerals; III, The constant composition of albite. Am J Sc (4) 36 : $47-50$ (1913)

$13 a$ (and Bradiey, W. M.) On solid solution in minerals; IV, The composition of amorphous minerals as illustrated by chrysocolla. $\Delta \mathrm{m} \quad \mathrm{J}$ Sc (4) $36: 180-184$ (1913)

14 (and Bradley, W. M.) On solid solution in minerals; $V$, The isomorphism between calcite and dolomite. Am J Sc (4) $37: 339-345 \quad$ (1914)

Foote, Warren Mathews.

95 Note on the occurrence of leadhillite pseudomorphs at Granby, Mo. Am J Sc (3) $50: 99-100$ (1895)

95a Preliminary note on a new alkall mineral. Ac N Sc Phila, Pr 1895:408-409 Am J Sc (3) 50:480-481 (1895)

97 Note on a new meteorite from the Sacramento Mountains, Eddy Co., N. Mex. Am J Sc (4) 3:65-66, il (1897)

98 Note on the occurrence of native lead with roeblingite, native copper, and other minerals at Franklin Furnace, N. J. Am J Sc (4) 6: 187-188 (1898)

99 Note on a new meteoric iron found near the Tombigbee River, in Choctaw and Sumter counties, Ala. Am J Se (4) 8: 153-156 (1899)

99 Note on a new meteoric iron found near Iredell, Bosque Co., Tex. Amr J Sc (4) $8: 415-416$ (1899)

04 Complete mineral catalogue... 215 pp, Phila [1904] 12th ed, 320 pp, Phila 1909

12 Preliminary note on the shower of meteoric stones near Holbrook, Navajo Co., Ariz., July 19, 1912... Am J Sc (4) 34: 437-456 (1912)

13 Factors in the exchange value of meteorites. Am Ph Soc, Pr 52:516-542 (1913)

15 Note on a new meteoric iron from Sams Valley, Jackson Co., Oreg. Am J Sc (4) $39: 80-86$ (1915) 


\section{Foote Mineral Company.}

12 Meteorites. Part I. Prices of Individual specimens. Part II. The Foote collection, with synopsis of the Rose-Tschermak-Brezina classification. 64 pp, Philadelphia 1912

17 Mineral Foote-notes, vol. 1, nos. 1-12 (1917)

Forbes, Edward.

45 On the fossil shells collected by $\mathrm{Mr}$. Lyell from the Cretaceous formations of New Jersey. G Soc London, Q J 1: 61-64, il (1845)

48 Description of some new fossil shells from Bissex Hill and Springfield in Barbados. An Mag N H (2) $1: 347-349$, 11 (1848)

Forbes, Edwin Horace.

96 On the epidote from Huntington, Mass., and the optical properties of epidote. Am J Sc (4) 1:26-30 (1896)

96a (with Penfield, S. L.) Fayalite from Rockport, Mass., and on the optical properties of the chrysolite-fayalite and of monticellite. Am J Sc (4) 1:129-135 (1896)

Forbes, Kate Marcia.

15 The volcano Kilauea. 31 pp [Honolulu 1915]

Ford, Frederick L.

03 The trap rock of the Connecticut Valley. Stone 26:130-133 (1903)

Ford, Henry Chapman.

90 Specimens of coniferous wood saturated with bitumen. Santa Barbara Soc N H, B 1:11 (1890)

$90 a$ Solfataras in the vicinity of Santa Barbara. Santa Barbara Soc N H, B 1: 53-56 (1890)

Ford, James.

06 Theory of the formation of coal fields. Eng M J 82:255-256 (1906)

Ford, Silas Watson.

71 Note on the discovery of the opercula of Hyolithes in New York. Am J Sc (3) $1: 472(1871)$

71a Notes on the Primordial rocks in the vicinity of Troy, N. Y. Am J Se (3) $2: 32-34$ (1871) Can Nat n s $6: 209-212$ (1871)

72 Descriptions of some new species of Primordial fossils. Am J Sc (3) 3:419422, il (1872)

73 On some new species of fossils from the Primordial or Potsdam group of Rensselaer Co., N. Y. (lower Potsdam). Am J Sc (3) $5: 211-215$, il (1873)

73a Remarks on the distribution of the fossils in the lower Potsdam rocks at Troy, N. Y., with descriptions of a few new species. Am J Sc (3) $6: 134-140$, il (1873)

75 Note on the discovery of a new locality of primordial fossils in Rensselaer Co., N. Y. Am J Sc (3) 9:204-206 (1875)
Ford, Sllas Watson-Continued.

76 On additional species of fossils tren the Primordial of Troy and Lansingburet Rensselaer Co., N. Y. Am J Sc (3) It: 369-371 (1876)

76a [On the stratigraphic position at the Troy beds, N. Y. (abst).] Am Nat 10: 316 (1876)

77 Note on Microdiscus speciosus. At J Sc (3) 13:141-142 (1877)

$77 \mathbf{a}$ On some embryonic forms of th lobites from the Primordial rocks at Tro N. Y. Am J Sc (3) $13: 265-273$, il (18:7)

78 Descriptions of two new species of Primordial fossils. Am J Sc (3) 15:12127, il (1878)

78n Note on ringulella caelata. Am J\& (3) $15: 127-129$ (1878)

7Sb Note on the development of Olent lus asaphoides. Am J Sc (3) 15:19. 130 (1878)

7Se On certain forms of Brachiopde occurring in the Swedish Primordial. In J Se (3) 15:364-366 (1878)

so Note on the trilobite, Atops tris neatus of Emmons. Am J Sc (3) 19:152. $153(1880)$

soa On the western limits of the $7 t$ conic system. Am J Sc (3) $19: 225-2 \%$ (1880)

81 Remarks on the genus Obolella. In J Sc (3) $21: 131-134$, il (1881)

81 a On additional embryonic forms trilobites from the Primordial rocks of Troy, N Y., with observations on the gebet Olenellus, Paradoxides, and Hydrocephala Am J Sc (3) $22: 250-259$, il (1881)

84 Note on the discovery of Primorilit fossils in the town of Stuyvesant, Columbit Co., N. Y. Am J Sc (3) 28:35-37 (1894)

$\mathbf{8 4 a}$ On the age of the glazed and cos torted slaty rocks in the vicinity of Scbr dock Landing, Rensselaer Co., N. Y. An J Sc (3) 28:206-208 (1884)

85 Observations upon the great fault it the vicinity of Schodack Landing, Rent selaer Co., N. Y. Am J Sc (3) $29: 16-19$ (1885)

85a Note on the age of the slaty at arenaceous rocks in the vicinity Schenectady, Schenectady Co., N. Y. At J Sc (3) 29:397-398 (1885)

86 (and Dwight, W. B.) ... on fosslis from metamorphic limestones of the Thconic series of Fmmons at Canaan, N. I. Am J Sc (3) 31:248-255, II (1886)

86a Notice of a new genus of Loré Silurian Brachiopoda. Am J Sc (3) 31 : $466-467$, il (1886)

86b Note on the recently proposed gents Billingsia [preoccupied; substitutes Blknia], Am J Sc (3) 32:325 (1886)

87 Notes on certain fossils discovered within the city limits of Quebec. N I Ac Sc, Tr $7: 2-5 \quad(1887)$

See also Winchell $(\mathrm{N} \mathrm{H}), 88 \mathrm{~g}$ 
Ford, William Ebenezer.

00 (with Penfield, S. L.) Siliceous calcites from the Bad Lands, Washington Co., S. Dak. Am J Se (4) \&: 352-354 (1900)

00a (with Penfield, S. L.) On some Interesting developments of calcite crystals. Am J Sc (4) 10:237-244 (1900) Yale Bicen Pub, Contr Miner : 357-364 (1901)

01 (with Penfield, S. L.) On calarerite Am J Sc (4) $12: 225-246$ (1901) 02 On the chemical composition of dumortierite. $\mathrm{Am} \mathrm{J} \mathrm{Sc}$ (4) 14:426-430 (1902) Zs Kryst $37: 417-421$ (1903)

03 Rickardite, a new mineral. Am J Sc (4) $15: 69-70$ (1903) Ch News 87: $56-57$ (1903) Zs Kryst 37:609-610 (1903)

03a on the chemical composition of axinite. Am J Sc (4) 15:195-201 (1903) Zs Kryst $38: 82-88$ (1903)

06 Some interesting beryl crystals and their associations. Am J Sc (4) $22: 217-$ 223 (1906) Zs Kryst $43: 12-17$ (1907) 06a (with Penfield, S. L.) On stibiotantalite. Am J Sc (4) $22: 61-77$ (1906) 08 Stephanite crystals from Arizpe, Sonora, Mexico. Am J Sc (4) 25:244-248 (1908) Zs Kryst 45:321-325 (1908)

08a (and Tillotson, E. W., jr.) On orthoclase twins of unusual habit. Am J Se (4) $26: 149-154$ (1908) Zs Kryst 46 : 129-134 (1909)

09 Neptunite crystals from San Benito Co., Cal. Am J Sc (4) $27: 235-240$ (1909) Zs Kryst $46: 321-325$ (1909)

09a (and Pogue, J. L.) Calcite crystals from Kelly's Island, Lake Frie. Am J Sc (4) 28:186-187 (1909)

09b (and Pogue, J. L.) Crystals of datolite from Bergen Hill, N. J. Am J Sc (4) $28: 187(1909)$

09e (and Ward, Freeman) Calamine crystals from the Urgan Mountains, Dona Ana Co., N. Mex. Am J Sc (4) 28:185186 (1909)

10 The effect of the presence of alkalies in beryl cpon its optical properties. Am J Sc (4) $30: 128-130(1910)$

10a (and Bradley, W. M.) Chemical and optical study of a labradorite. Am J Se (4) $30: 151-153$ (1910)

11 On some terderite crystals from Haine. Am J Sc (4) $32: 283-286$ (1911) Zs Kryst $50: 97-100$ (1912)

11 a Note on some analyses of stibiotantalite. Am J Sc (4) $32: 287-288$ (1911)

11b (and Crawford, R, D.) On a thodonite (fowlerite) crystal from Franklin, N. J. Am J Sc (4) $32: 289-290$ (1911)

12 Dana's Manual of mineralogy. 13th ed, $460 \mathrm{pp}, \mathrm{N}$ Y $19^{+2}$
Ford, William Ebenezer-Continued.

12a (and Bradley, W. M.) Pseudomorphs after stibnite from San Luis Potosi, Mex. Am J Sc (4) 34: 184-186 (1912)

$12 b$ George Jarvis Brush. Science n s $35: 409-411$ (1912)

13 (and Bradley, W. M.) Pyroxmangite, a new member of the pyroxene group and its alteration product, skemmatite. Am J Sc (4) 36:169-174 (1913) Zs Kryst 53 : 225-235 (1913)

$13 a$ On hetærolite from Leadville, Colo. Am J Sc (4) $35: 600-604$ (1913) Zs Kryst $53: 219-224$ (1913)

14 A contribution to the optical study of the amphiboles. Am J Sc (4) $37: 179$ 193 (1914). Zs Kryst 54: 1-16 (1914)

14a Mineral notes. Am J Sc (4) 38 : 502-504 (1914)

15 Dana's System of mineralogy. Third appendix to the sixth edition. $87 \mathrm{pp}, \mathrm{N} \mathbf{Y}$ 1915

15a (and Bradley, W. M.) On the identity of footeite with connellite together with the description of two new occurrences of the mineral. Am J Sc (4) 39 : 670-676 (1915)

15b A study of the relations existing between the chemical, optical, and other physical properties of the members of the garnet group. Am J Sc (4) $40: 33-49$ (1915)

16 (and Bradley, W. M.) On hydrozincite. Am J Sc (4) 42:59-62 (1916)

$16 a$ (and Bradiey, W. M.) Margarosanite, a new lead-calcium silicate from Franklin, N. J. Am J Sc (4) 42:159-162 (1916)

16b New mineral names. Am J Sc (4) $41: 566-570 ; 42: 504-505$ (1916); 43: $493-494 ; 44: 484-487$ (1917) ; $45: 477-$ 478 (1918)

17 Studies in the calcite group. Conn Ac, $\operatorname{Tr} 22: 211-248$ (1917)

17a A remarkable crystal of apatite from Mt. Apatite, Auburn, Me. Am J Sc (4) $44: 245-246$ (1917)

18 The growth of mineralogy from 1818 to 1918. Am J Sc (4) $46: 240-254$ (1918) Reprinted in A century of science in America : 268-288, New Haven, 1918.

See also Dana (E S), 92

Forman, Joshua.

30 ... salt formation of Salina, N. Y., and other places. Am J Sc 19:141-143 (1830)

Forrester, J. B.

15 [Geology of the Black Hawk coal mine, Emery Co., Utah.] Colliery Eng 36: 17-18 (1915)

18 A short comment on Bulletin 371 of the U. S. Geological Survey [Richardson, G. B., Reconnaissance of the Book Cliffs coal fields (1909)], Utah Ac Sc, Tr 1: 24-31 (1918) 
Forrester, J. B.-Continued.

18a A general survey of the Jurassic in southeastern Utah. Utah Ac Sc, Tr 1: 33-43 (1918)

Forrester, Robert.

93 Coal fields of Utah. U S G S, Min Res 1892: 511-520 (1893)

Forry, Samuel.

43 Meteorology... with some remarks upon the climates of the ancient world, as based on fossil geology. 48 pp, N Y 1843 Forsaith, Carl C.

16 A report on some allochthonous peat deposits of Florida. Bot Gaz 62:32-52 (1916) ; 63:190-208 (1907)

Forshey, Caleb Goldsmith.

52 Louisiana: geology and hydrography. In De Bow, J. D. B., The industrial resources, etc., of the Southern and Western States 1: 436 (1852)

74 On the alluvial basin of the Mississippi River styled the delta. Ph Soc Wash, B 1 App 2: $1-i x$ (1874) Also in Smiths Misc Coll 20 (1881)

75 Report of survey and borings made at the proposed site of Lake Borgne outlet [La]. U S [War Dp], Chief Eng, An Rp 1875 (U S, 44th Cong 1st sess, H Ex Doc 1 pt 2 ₹ 2 pt 1), App O:546-548, $622-629$ (1875)

78 Contributions to the physies of the Gulf of Mexico, and its chief affluent, the Mississippi River. Am As, $\mathrm{Pr} 26$ : 134-173 (1878)

Forstall, A. E.

92 The origin of coal and petroleum. Sc Am Sup 34: 13796-13797 (1892)

Forstner, William.

04 Genesis of ore deposits at the Royal mine, Hodson, Cal. M Sc Press $88: 314-315$ (1904)

04a The quicksilver deposits of Callfornia. Eng M J 78: 385-386, 426-428 (1904)

o7 Copper in Shasta Co., Cal. M Sc Press 94:625-626 (1907)

07 a Ore deposits in serpentine. M Sc Press 95: 121-122 (1907)

os Copper deposits in the western foothills of the Sierra Nevada. M Sc Press 96 : 743-748 (1908)

OSa The genesis of the copper ores in Shasta Co., west of the Sacramento River. M Sc Press 97: 261-262 (1908)

o9 Oil measures in the Coalinga district [Cal.]. M Sc Press 98: 386-387 (1909)

$09 a$ Historical geology of California. M Sc Press 98: 853-858, 891-892; 99 : 55-58, 91-92 (1909)

09b Geology of the Coalinga oil district. M Sc Press 99:566-567 (1909)

10 Occurrence of oil and gas [South Midway field, Kern Co., Cal.]. M Sc Press 101: 634-638 (1910)

11 The occurrence of oil and gas in the south Midway field, Kern Co., Cal. Ec G 6 : 138-155 (1911)
Forsyth, A.

99 (with O'Hnrra, C. C.) Notes on the geology and mineral deposits of a portion of the southern Black Hills. S Dak Sch Mines, B [2] : 41 pp, maps (1899)

Forvood, W. H.

82 Report. In Report of an exploration of parts of Wyoming, Idaho, and Montana... by Lieut. Gen. P. H. Sheridan... [U S, War Dp] : 36-56, Washington 1882

Forwood, W. Stump.

70 An historical and descriptive narra. tive of the Mammoth Cave of Kentucky. Phila 1870 4th ed, 241 pp, Phila 1875

Foshag, William.

18 Ulexite from Lang, Cal. Am Miner. alogist $3: 35$ (1918)

Foshay, P. Maxwell.

90 Preglacial drainage and recent geo. logical history of western Pennsylvania. Am J Sc (3) 40:397-403, map (1890)

90a (and Hice, R. R.) Newly discor. ered glacial phenomena in the Beaver $\mathrm{Val}$. ley. Am Nat 24:816-818 (1890)

91 (and Hice, R. R.) Glacial grooves at the southern margin of the drift [Pennsy]. vania]. G Soc Am, B 2: 457-464 (1891)

14 A moraine of Kansan or Nebraskan age at Jackson, N. H. Am J Sc (4) 38: 345-348, map (1914)

Foster, Ernest Le Neve.

85 Report of State geologist, Colorado, 1883-4. 59 pp, Denver Colo., 1885

$85 a$ Notes on a sulpho-bismuthite [State of Chihuahua, Mexico.]. Colo Sc Soc, Pr 1 $73-75$ (1885)

02 The Colorado Central lode, a parados of the mining law. Colo Se Soc, Pr 7:4153 (1902)

Foster, John Wells (1815-1873).

38 Report [on Muskingum Co., Obio]. Ohio G S, 2d An Rp: 9-10, 73-107 (1838)

39 Head of the Mastodon giganteum. Am J Sc 36: 189-191, il (1839)

41 [Sur la distribution du terrain silu. rien dans l'Amerique du Nord.] Soc 6 France, B $12: 86-87$ (1841)

49 [Report of field work in the Lake Superior land district.] U S, 30th Cong $2 d$ sess, S Ex Doc 2: 159-163 (1849)

49a (and Whitney, J. D.) Synopsis of the explorations ... in the Lake Superior land district in the northern peninsula of Michigan ... U S, 31st Cong 1st sess, S Ex Doc 1 pt 3 and $H$ Ex Doc 5 pt $3: 605-626$ maps (1849)

49b (and Hill, S. W.) Statisics of the mines of Keweenaw Point [Mich.]. U S 31 st Cong 1 st sess, S Ex Doc 1 pt 3 and H Ex Doc 5 pt $3: 759-765$ (1849)

49e [Field notes of work in Lake Superior region.] U S, 31st Cong 1st sess. $\mathrm{S}$ Ex Doc 1 pt 3 and $\mathrm{H}$ Ex Doc 5 pt 3 : 766-801 (1849)

$49 d$ [On the geological position of the Mastodon giganteus (with discussion).] Boston Soc N H, Pr 3:111-116 (1849) 
Foster, John Wells-Continued.

50 Introduction to the study of geology. Albany 1850 [not seen]

50a (and Whitney, J. D.) Report on the geology and topography of a portion of the Lake Superior land district in the State of Michigan; Part I, Copper lands. U S, $31 \mathrm{st}$ Cong 1st sess, H Ex Doc 69:-24 pp, teaps $(1850)$

50b (and Whitney, J. D.) Mineral reports [Lake Superior land district]. U 8. 31st Cong $2 d$ sess, H Ex Doc 9 (G Land office, Rp 1850) : 147-152 (1850)

51 (and Whitney, J. D.) Report on the geology of the Lake Superior land district: Part 2, The iron region, together with the general geology. U S, 32d Cong spec sess, S Ex Doc 4: xvi, 406 pp, il, maps (1851) Extracts, Am J Se (2) 17: 11-33 (1854)

51a (and Whitney, J. D.) On the eleration of mountain chains, In their Report on the geology of the Lake Superior land district. pt 2 (U S. 32d Cong spec sess, 8 Ex Doc 4) : 274-284 (1851)

51 b (and Whitney, J. D.) Geological map of the district between Keweenaw Bay and Chocolate River, Lake Superior, Michigan. Seale 3 miles to inch. n d [1851 ?] 51e (and Whitney, J. D.) Sur les terrains siluriens du district métallifère du lac Supérieur. Soc G France, B (2) 8: 89-100 (1851)

51d On fossil fish in the coal rocks of Ohio. Am J Sc (2) $12: 282-283$ (1851)

5le (and Whitney, J. D.) On the Azolc system, as developed in the Lake Superior land district (abst). Am As, Pr 5:4-7 (1851)

51f [On the age of the Connecticut Valley sandstone.] Am As, Pr 5:46 (1851) $51 \mathrm{~g}$ (and Whitney, J. D.) on the age of the sandstone of Lake Superior, with a description of the phenomena of the association of igneous rocks. Am As, Pr 5:22-38 (1851)

51 h (and Whitney, J. D.) On the different systems of elevation which have given configuration to North America, with an attempt to identify them with those of Europe. Am As, Pr 5:136-151 (1851) 511 On the alternations of marine and terrestrial organic remains in the Carboniferous series of Ohio. Am As, Pr 6: 301-304 (1851)

53 New species of fossil plants from 0bio. An Sc, Cleveland, 1:128-129, il (1853)

56 Report upon the mineral resources of the Illinois Central Railroad... $29 \mathrm{pp}$, IX 1856

57 On the geological position of the deDosits in which occur the remains of the fossil elephant of North America. Am ${ }^{48,} \operatorname{Pr} 10$ pt 2:148-169 (1857) Abst, Edinb $\mathrm{N}$ Ph J n s 5:361-362 (1857)
Foster, John Wells-Continued.

61 (and Whitney, J. D.) On the origin and stratigraphical relations of the trappean rocks of Lake Superior (ator). Annual of Scientific Discovery for 1861:285 (1861)

65 The geology and metallurgy of the iron ores of Lake Superior, being a report addressed to the Board of Directors of the Iron Cliffs Company. 16 pp, N Y 1865

65a (and Kimball, J. P.) Geology and metallurgy of the iron ores of Lake Superior. Iron Cliffs Company:98 pp, maps, N Y 1865

67 On the antiquity of man in North America. Chicago Acad Sc, Tr 1:227-257 (1867)

69 The Mississippi Valley; its physical geography... xvi, 443 pp, Chicago 1869

70 Recent advances in geology. Am Nat 4: 449-472 (1870)

71 Report on the iron smelting coals of southern Indiana adjacent to the Indiana Mineral Railway. 23 pp, Pittsburgh, Pa., 1871

72 The mountains of Colorado. Am Nat $6: 65-75$ (1872)

See also Warren, 49

Foster, William.

13 A remarkable carbonaceous deposit near Putnam, N. Mex. Ec G $8: 360-368$ (1913) Abst, Int Cong Applied Chem, VIII, 25: 667 [1913]

Foulke, William Parker.

58 [On vertebrate and other fossils from the marl of Camden Co., N. J.] Ac N Se Phila, Pr 1858 : 213-215, map

Fonllon, H. B. von.

92 Ueber einige Nickelerzvorkommen [Riddle in Oregon, Sudbury in Ontario]. K-k G Reichsanstalt, Jb $42: 223-310$ (1892)

Fowke, Gerard.

95 Preglacial and recent drainage channels in Ross Co., Ohio. Denison Univ, Sc Lab, B $9: 15-24$ (1895)

97 The formation of natural bridges. Stone 14:355-357 (1897)

98 Preglacial drainage in the vicinity of Cincinnati; its relation to the origin of the modern Ohio River, and its bearing upon the question of the southern limits of the ice sheet. Denison Univ, Sc Lab, B 11: 1-10, map (1898)

00 The preglacial drainage of Ohio; introduction. Ohio St Ac Sc, Sp P no 3 : 5-9 (1900)

o0n Preglacial drainage conditions in the vicinity of Cincinnati [Ohio]. Ohio St Ac Sc, Sp P no 3:68-75, map (1900)

01 Preglacial drainage in southwestern Ohio. Science n s 14:936-937 (1901)

06 Superficial deposits along the Mississippi. Ohio St Ac Sc, Pr 4 (14th An Rp) : 349-352 (1906)

07 Lansing man. Bur Am Ethnology, B $30: 759-760(1907)$ 
Fowke, Gerard-Continued.

os Surface deposits along the Mississippi between the Missouri and the Ohio Rivers. - Mo Hist Soc Col 3 no $1: 31-52$ (1908)

Fowler, Frank B.

00 The gold zone of Copalquin, Durango, Mex. Eng M J 69:225-226, 557-558 (1900)

Fowler, George L.

04 Coals and coal mining methods of the Pocahontas field [W. Va., and Va.]. Eng Mag 27: 217-232, map (1904)

Fowler, Henry W.

11 A description of the fossil fish remains of the Cretaceous, Eocene, and Miocene formations of New Jersey. N J G S, B 4:192 pp, il (1911)

Fowler, Samuel.

25 ... new and extraordinary minerals discovered in Warwick, Orange Co., N. Y. Am J Se $9: 242-245$ (1825)

32 An account of the sapphire and other minerals in Newton township. Sussex Co., N. J. Am J Sc 21:319-320 (1832)

Fowler, Samuel S.

99 Notes on the Ymir mine and its mill practice [Salmon River district, B. C.]. Can M Inst, J 3:3-10 (1900) Can M Rv 18: 249-251 (1899) M Sc Press $79: 517$ (1899)

Fox, Robert Were.

38 Origin of mineral veins. Franklin Inst, J n s 21 : 251-252 (1838)

Foye, James Clark (1841-1896).

75 Tables for the determination and classification of minerals... $38 \mathrm{pp}$, Chicago $18752 \mathrm{~d}$ ed, $85 \mathrm{pp}$, Chicago 1882

86 Hand-book of mineralogy ; determination, description and elassification of minerals found in the United States. $180 \mathrm{pp}$, N Y 1886 5th ed, 180 pp, N Y 1907

Foye, Wilbur G.

15 Nephelite syenites of Haliburton Co., Ont. Am J Sc (4) $40: 413-436$ (1915)

16 Are the "batholiths" of the Haliburton-Bancroft area, Ont., correctly named? J G 24:783-791 (1916)

$16 a$ The relation of the titaniferous magnetite ores of Glamorgan Township, Haliburton Co., Ont., to the associated scapolitic gabbros. Ec G 11:662-680 (1916)

18 Notes on a collection of rocks from Honduras, Central America. J G 26:524531 (1918)

Frans, Eberhard (1862-1915)

01 On the aqueous vs. eolian deposition of the White River Oligocene of South Dakota. Science n s 14: 211-212 (1901)

02 Geologische Streifzüge durch die Prärien und Felsengebirge Nordamerikas. Ver Vaterl Naturk Württemberg, Jahresh 58: 1xv-lxviii (1902)

04 Weitere Beiträge zur Fauna des Jura von Nordost-Groenland. Med Grönland 29 : $277-285$, il (1904)
Fraas, Eberhard-Continued.

06 In den Bad Lands von Süd-Dakota. Aus der Natur 2: 513-521, 552-559 (1906)

06a Vergleichung der amerikanischen und europilischen Juraformation. Int Amerikanisten-Kong, Stuttgart, 1904, Tag 14: 41-45 (1906)

Fraleek, Ernest Leigh (1875-1909).

o7 Iron pyrites in Ontario. Ont Bur Mines, An Rp 16 pt 1:149-201 (1907)

Frank, Fritz J.

06 Cobalt; Canada's wonderful silver camp; geological features of the region. Mines and Minerals 27:145-147 (1906)

Franke, Robert P.

O5 Geology of the Cochise mining dis. trict, Ariz. M Rep 51:503 (1905)

Franks, G. F.

98 (and Harrison, J. B.) The Glabigerina marls and basal reef rocks of Barbados; with an appendix on the Foraminifera, by F. Chapman. G Soc Lotdon, Q J 54:540-555, map (1898) Abst, G Mag (4) 5:333 (1898)

Frantrius, A. v.

61 Beiträge zur Kenntniss der Vulkane Costarica's. Petermann's Mitt $7: 329-338$, map (1861)

Fraprie, Frank Roy.

02 (with Palache, C.) Babingtonite from Somerville, Mass. ; babingtonite from Athol, Mass. Am Ac Arts, Pr $38: 383-393$ (1902)

06 On the chromates of cesium. Am J Sc (4) $21: 309-316$ (1906) Zs Kryst, 42: 113-119 (1906)

Fraser, A. W.

95 [Report on boring at Atbabsea Landing, Alta.l Can G S, Sum Rp 1894 (An Rp 7) : A 8-13 (1895)

99 Experimental borings in northern At berta. Can G S, Sum Rp 1898 (An Rp 11) : A 28-36 (1899)

Fraser, Lee.

о7 Coal mining in Michigan. Eng $x$ J 84:594-595, 1024-1027 (1907)

11 Costa Rica mineral resources. If $\mathrm{Sc}$ Press 102: 130-132 (1911)

Frazer, Persifor, jr. (1844-1909).

69 Mines and minerals of Colorado [and New Mexico]. U S G S Colo N Mes (Hayden), Prel Field Rp: 101-130 (1869); An Rp 3:201-228 (1873)

74 [On geologic features of Mine la. motte and Iron Mountain, Mo.] Ac N Sc Phila, $\operatorname{Pr} 1874 ; 85-86$

74a On the geology of certain lands is Ritchie and Tyler counties, W. Va. Ac N Sc Phila, Pr 1874:168-172

74b Hydrogeology (with discussion by E. $\mathrm{T} . \mathrm{Cox})$. $\mathrm{Am} \mathrm{I} \mathrm{M} \mathrm{Eng,} \mathrm{Tr} 3: 108-115$ (1875) Eng M J 18:161, 177-178 (1874) 
Frazer, Persifor, jr.-Continued.

75 Tables for the determination of minerals... 117 pp, Phila 1875 [Revised ed] $119, \mathrm{pp}$, Phila 1878 3d ed, $115 \mathrm{pp}$, Phila 1891 4th ed, 163 pp, Phila 1897 5th ed [not seen] 6 th ed, by Frazer, P., and Brown, Amos Peaslee, 125 pp, Phila, 1910

$75 a$ on some thin sections of the lower Paleozoic and Mesozoic rocks of Pennsylrania. Am I M Eng, $\mathrm{Tr}$ 3: $327-328$ (1875) Eng M J 19:227 (1875)

$75 \mathrm{~b}$ Weathering of rocks. Ac N Sc Phila, Pr 1874: 228 (1875)

$75 \mathrm{c}$ On thin sections of the traps of the Nesogoic basin. Ac N Sc Phila, Pr 1875: 72

75 Notes on the character of the lower Silurian slates at their outcrops [Pennsylrania]. Ac N Sc Phila, Pr 1875: 76

The On the Trias of York Co., Pa. Ac Se Phila, $\operatorname{Pr} 1875: 123$

$75 \mathrm{f}$ On the structure of the York County ralley limestone, and on microphotography if minerals. Ac N Sc Phila, Pr 1875: 128-129

$75 \mathrm{~g}$ On exfoliation of rock near Gettysbare. Am Ph Soc, Pr 14:295-297 (1875)

75h Origin of the Lower Silurian limonites of York and Adams cos. [Pa.]. Am Ph Soc, Pr $14: 364-370(1875)$

75 On the traps of the Mesozoic sandstote in York and Adams cos., Pa. Am Ph Soc, $\mathrm{Pr}$ 14: 402-414 (1875)

$75 j$ On microscopic sections of trap dokes...in Pennsylvania and Connecticut. An $\mathrm{Ph} \mathrm{Soc}, \operatorname{Pr} 14: 430-431$ (1875)

76 Report of progress in the district of York and Adams counties. Pa G S, 2d, C : Fill, $198 \mathrm{pp}$, maps (1876)

$76 \mathrm{a} \mathrm{A}$ study of the igneous rocks. Am IN Eng, $\operatorname{Tr} 5: 144-146$ (1877) Eng M $22: 300(1876)$

$76 \mathrm{~b}$ on the Mesozoic red sandstone of the dtlantic States. Ac N Sc Phila, Pr $1875: 440-442$ (1876)

760 On the age and origin of certain partz reins [York Co., Pa.]. Ac $\mathrm{N}$ Se Plila, Pr $1876: 36$

$76 d$ Notes on two traps; a case of alteration of earthy sediments. Ac N Sc Phila, $\operatorname{Pr} 1876: 60$

76e Notes on some Paleozoic limestones [Pa.]. Ac N Sc Phila, Pr 1876:60-63

$76 f$ On the glaciation of the South lountain [Pa.]. Am Ph Soc, Pr 14:647 1876)

$76 \mathrm{~g}$ Note on the "Lithologie du fond as mers" of M. Delesse. Am Ph Soc, Pr : $238-240 \quad(1876)$

7 Report of progress in the counties of lotk, Adams, Cumberland, and Franklin. G 8,2 d, C $2: 201-400$, map (1877)

77a The position of the American new it sandstone. Am I M Eng. Tr 494-501 1877) Eng M J $23: 29-298$ (1877)
Frazer, Persifor, jr.-Continued.

77b A study of the specular and magnetic iron ores of the new red sandstone in York Co., Pa. Am I M Eng, Tr $5: 132-143$ (1877) Eng M J 23:90-92 (1877)

77e Classification of coals. Am I M Eng, Tr 6:430-451 (1879) Pa G S, 2d, MM : 128-144 (1879) Eng M J 24: 224$225,241,260,277,294-295,311$ (1877)

77d On the Hudson River and Utica slates of Pennsylvania. Ac N Sc Phila, Pr $1877: 14-16$

77e Anthracite from " Third Hill Mountain," W. Va. Ac N Sc Phila, Pr 1877: $16-17$

77f On copper-bearing rocks of the Mesozoic formation. Ac N Sc Phila, $\mathrm{Pr} 1877$ : $17-19$

$7 \mathbf{7 g}$ Regarding some Mesozoic ores. Am Ph Soc, Pr 16:651-655, 664-665 (1877)

77h The copper ores of Pennsylxania. Polyt Rev 3:158-159, 168, 170 (1877)

78 Remarks on Professor Prime's paper [On the Paleozoic rocks of Lehigh and Northampton cos., Pa.l. Am $\mathrm{Ph} \mathrm{Soc,} \mathrm{Pr}$ $17: 255-258$ (1878)

78n Trap dike extending through Lan. caster Co., Pa. Am Ph Soc, Pr 17:270 (1878)

781 [Geological section along the Susquehanna River in Lancaster Co., Pa.] Am Ph Soc, $\operatorname{Pr} 17: 719-720$ (1878)

78e [Recent discovery of the "Martic" anticlinal crossing Lancaster Co., Pa.J Am Ph Soe, Pr 17: 725 (1878)

70 On the physical and chemical charaeteristics of a trap occurring at Williamson's Point [in Lancaster Co., Pa.]. Am Ph Soc, Pr 18: 96-103 (1879)

79a Copper veins near Liberty, Md, and Monterey, Pa.; and structure of Chicques rock near Columbia [Pa.]. Am Ph Soc, Pr 18: 220-221 (1879)

79b The Mesozoic sandstone of the Atlantic slope. Am Nat 13:284-292 (1879)

so The geology of Lancaster Co. Pa G S, 2d, CCC : x, $350 \mathrm{pp}$, atlas (1880)

soa Fossil (?) forms in the quartzose rocks of the lower Susquehanna [Cecil Co., Md.]. Am Ph Soc, Pr 18:277-279, il (1880)

Sob Determination of the Peach Bottom slates as of Hudson River age. $\mathrm{Am} \mathrm{Ph}$ Soc, Pr 18: 366-369 (1880)

81 Some copper deposits of Carroll Co., Md. Am I M Eng, Tr 9:33-40, map (1881)

s1a The Whopper lode, Gunnison Co., Colo. Am I M Eng, Tr 9:249-258 (1881)

81b Relations of the graphite deposits of Chester Co., Pa., to t:ie geology of the rocks containing them. Am I M Eng, Tr $9: 730-733(1881)$

82 Mémoire sur la géologie de la partio sud-est de la Pennsylvanie. Soc $\mathbf{G}$ Nord, Mém 1, II : $178 \mathrm{pp}$, maps (1882) 
Frazer, Persifor, jr.-Continued.

82a The horizon of the South Valley Hill rocks in Pennsylvania. Am Ph Soc, Pr 20:510-518 (1882)

83 Geological notes in the several townships of Chester Co. Pa G S, 2d, C4 : 215345, map (1883)

83a Review of Report C4, Second Geological Survey of Pennsylvania. Am Nat 17: 1020-1027 (1883)

S3b Mr. Theodore D. Rand's criticism of vol. C 4, geology of Chester Co., $\mathrm{Pa}$. Franklin Inst, J 116 (3) $86: 274-278$ (1883)

s3e Mr. Rand on the geological survey of Chester and Delaware cos., Pa. Am Nat $17: 1052-1053$ (1883)

83d [On crystalline rocks in eastern Pennsylvania]. Am Nat $17: 523-526$ (1883)

83e The iron ores of the middle James River [Va.]. Am I M Eng, Tr 11: 201216, map (1883)

83f A comparison of the Eozoic and lower Paleozoic in Sonth Wales with their Appalachian analogues. Am I M Eng, Tr 11 : 479-505 (1883)

83g The Eozoic and lower Paleozoic in south Wales and their comparison with their Appalachian analogues. Science 1: 108-109 (1883)

83h The geology and the copper deposits of Adams Co., Pa. Eng M J 35: 112 (1883) [See Bailey (J. T.), 83]

84 Reply to Mr. Theo. D. Rand's paper entitled "Notes on the geology of Chester Valley and vicinity," in the Proceedings Academy Natural Sciences, November, 1883 [with reply by T. D. Rand]. Franklin Inst, J 117 or (3) $87: 303-310$ (1884)

84a An hypothesis of the structure of the copper belt of the South Mountain [Pa.]. Am I M Eng, Tr 12:82-85 (1884)

$84 b$ The northern serpentine belt in Chester Co., Pa. Am I M Eng, Tr 12: 349-355 (1884)

84e The Peach Bottom slates of southeastern York and southern Lancaster counties [Pa.]. Am I M Eng, $\operatorname{Tr} 12: 355-$ 359 , il (1884)

84d Certain silver and iron mines in the States of Nuevo Leon and Coahuila, Mex. Am I M Eng, Tr 12:537-569, map (1884)

84e Trap dires in the Archean rocks of southeastern Pennsylvania. Am Ph Soc, Pr 21: 691-694 (1884)

84f A study of one point in the ArcheanPaleozoic contact line in southeastern Pennsylvania (abst). Am As, $\operatorname{Pr} 33: 394-396$, map (1885) Science 4:328 (1884)

$84 \mathrm{~g}$ Geological and mineral studies in Nuevo Leon and Coahuila. 36 pp, maps, Phila 1884 [not seen]

85 Report of the American committee delegates to the Berlin International Geological Congress, held Sept. 28 to Oct. 3, 1885. Am J Sc (3) $30: 454-475$ (1885)
Frazer, Persifor, jr.-Continued.

86 The "Centennial" and "Lotte" gold properties, Coahuila, Mex. Am I y Eng, Tr 14:196-205, maps (1886)

$86 n$ Sketch on the geology of York a Pa. Am Ph Soc, Pr 23:391-410, 마 (1886)

$86 \mathrm{~b}$ The work of the International gress of Geologists and of its committen [Berlin 1888]. Published by the Americas Committee... 109 pp, 1886

86e International geological congress at Berlin. Science 7: 141 (1886)

87 Geological questions. Science 10: (1887)

$\mathbf{8 7 a}$ International congress of geologists American Committee meeting at Alban Science 9:416-417 (1887) Am J Sc (3 33 : 510-512 (1887) Franklin Inst, J 12 or (3) $93: 423-424$ (1887)

$\mathbf{8 7 b}$ The relations of the Internatios geological congress to geological workex Science $9: 439-440$ (1887)

87e 'The geologists' congress [Archet question]. Science 10:119-120 (1887)

87d [Address of G. K. Gilbert, The wort of the International Congress of Geologists Am Nat 21: 841-847 (1887)

s8 (editor) International Congress Geologists; American Committee, Report of the subcommittees... Phila 1888 . in Am G 2:139-306 (1888) Int G Cone IV, London, 1888, C R App A: 219 W (1891)

8Sa (and others) Report of the subcos mittee on the Archean. In Internationil Congress of Geologists, American Con mittee, Reports... A 74 pp, Phila 1808 Am G 2:143-192 (1888) Int G Cong, IT, London 1888, C R App A : 13-86 (1891)

$\mathbf{8 8 b}$ A short history of the origin and acts of the international congress of 8 ologists, and of the American committe delegates to it, $A \mathrm{~m}$ G $1: 3-11,86-1 \mathrm{M}$ (1888)

88e International Geological Congres: Report of the subcommittee on the At chean. Am G 2:144-192 (1888)

s9 Reply to articles concerning the American committee of the internation congress of geologists... Am G $3: 65-i$. (1889)

90 The session of the International Get logical Congress in Philadelphia. $A \mathrm{~m} 6$ 5: 208-212 (1890)

90 a Archean characters of the rocks of the nucleal ranges of the Antilles. Is Nat 24:67-68 (1890) Abst, G Mag (3) $5: 518(1888)$; Brit As, Rp $58: 654-65$ (1889)

91 The Warrior coal field of norther: Alabama. Am G 7:305-320 (1891)

92 Joseph Leidy, M. D., LL. D. Am $9: 1-5$, port. (1892)

93 Thomas Sterry Hunt... Am G 11 1-13, port. (1893) 
Frazer, Persifor, jr-Continued.

94 The sixth session of the international congress of geologists. Am G $14: 259-271$ (1894)

96 Two supposed new trap dikes in Chester Co., Pa. Ac N Sc Phila, Pr 1896: 206-207

97 The seventh session of the International Geological Congress. Am Nat 31: $406-409(1897)$

97a [Obituary notice of Edward Drinker Cope.] Am Nat $31: 410-413$, port (1897) $97 \mathrm{~b}$ The International Congress returns to its proper mission. Am Nat $31: 524-$ 528 (1897)

98 Archean character of the nuclei of the Antilles, Am G 21:250-251 (1898)

98 a Notes on the northern Black Hills of South Dakota. Am I M Eng, Tr 27: 204-231, maps (1898)

99 Alphabetical cross reference catalogue of all the publications of Edward Drinker Cope from 1859 till his death in 1897. Soc Cient Ant Alz, Mem 14: 39-72, $233-256, \quad 439-466 ; \quad 15: 31-96 \quad$ (1899$1900)$

00 The life and letters of Edward Drinker Cope, Am G 26:67-128, port (1900)

01 Tables for the determination of $\mathrm{mfn}$ erals... $163 \mathrm{pp}$, Phila 1901

01a Memoir of Franklin Platt. G Soc Am, B $12: 454-455$ (1901)

01b Eighth session of the international congress of geologists, Paris, 1900. Am G $27: 335-342$ (1901)

02 Compte rendu, VIII congrès géologique international, Paris, 1900. Am G 29:110-116 (1902)

02a Catalogue chronologique des publications de Edward Drinker Cope, de 1859 a 1897, inclusivement. Soc G Belgique, An 29: BB 3-77 (1902)

03 J. Peter Lesley. Am G 32:133-136, port (1903)

03a History of the Caribbean Islands from a petrographic point of view (abst). Ac N Sc Phila, Pr 55:396-400 (1903) J 11: 126-130 (1903)

05 Geogenesis and some of its bearings on economic geology. Am I M Eng, Tr 35: 298-308 (1905)

06 Rocks of Mount Desert island, Maine. Soc Am, B 16:583-585 (1906)

06a The classification of coals (discusston of paper by M. R. Campbell). Am I Y Kng, B 8: 239-246 (1906); Tr 36:825833 (1906)

10 (and Brown, A. P.) Tables for the determination of minerals by physical Properties ascertainable with the aid of a few field instruments. 6 th ed, $125 \mathrm{pp}$, Palla 1910

See also Blandy, 79; Hitchcoek (C H), 840; Lewis, 83b, c; Lyman, 94a ; Pa G S, 2d, 76a; Prime, 75a ; Smock, 79
Frazier, Benjamin West (1841-1905).

82 On crystals of axinite from a locality near Bethlehem, Pa... Am J Sc (3) 24: 439-447 (1882)

Frear, William.

13 Pennsylvania limestone and lime supplies. Pa St Coll Agr Exp Sta, B 127 : 71-106 (1913)

Freeh, Fritz (1861-1917).

95 Das Profil des Grossen ColoradoCanyon. N Jb 1895 , II : 153-156

99 Die geographische Verbreitung und Entwickelung des Cambrium. Int G Cong, VII, St. Petersburg 1897, C R:127-151 (1899)

\section{Freeh, Fritz.}

07 Ueber die Klima-aenderungen der geologischen Vergangenheit. Int $\mathbf{G}$ Cong, X, Mexico, C R : 299-325 (1907)

07a Ueber Aviculiden von palaeozoischem Habitus aus der Trias von Zacatecas. Int $\mathrm{G}$ Cong, $\mathrm{X}$, Mexico, C R : 327-340, 11 (1907)

12 Über die paläozoische Geographie des arktischen Amerikas. Int $\mathrm{G}$ Cong, $\mathrm{XI}$, Stockholm, C R : 757-758 (1912)

12a Ueber den Gebirgsbau Nordamerikas. Himmel und Erde $25: 34-40$ (1912)

13 Fossilium catalogus; I, Animalia, Pars 1, Ammoneæ Devonicæ (Clymenildæ, Aphyllitidx, Gephyroceratida, Chelloceratidæ). $42 \mathrm{pp}$, Berlin 1913

See also Emmons (S F), 93 ; Gilbert, 93b Frechette, Howells.

11 Investigation of iron ore deposits at Torbrook, Annapolis Co., N. S. ; and magnesite deposits, township of Grenville, Argenteuil Co., Que. Can Mines Br, Sum Rp 1910: 87-92 (1911)

12 Western portion of Torbrook iron ore deposits, Annapolis Co., 2, S. Can Mines Br, B $7: 13 \mathrm{pp}, \operatorname{map}$ (1912)

14 Report on the nonmetallic minerals used in the Canadian manufacturing industries. Can Mines $\mathrm{Br}: 199 \mathrm{pp}$ (1914)

17 Canadian magnesite. Can $M$ Inst, Tr 19:139-147 [1917]

1s Limestones of Ontario. Can Mines Br, Sum Rp 1917: 23-48 (1918)

Frecheville, William.

09 (and Marriott, H. F.) A visit to the mineral districts of Canada. Inst $\mathbf{M}$ Met, Tr 18; 158-179, map (1909)

Free, E. E.

09 A possible error in the estimates of the rate of geologic denudation [eolian action in transporting material to the sea]. Science n s $29: 423-424$ (1909)

09a The phenomena of eolian sand drift (abst). Science n s 29: 751 (1909)

10 Solution and cementation in arid regions (abst). Science n s 32:61-62 (1910) 
Free, E. E.-Continued.

11 The movement of soil material by the wind, with a bibliography of eolian geology, by S. C. Stuntz and E. E. Free. U S, Dp Agr, Bur Solls, B $68: 1-173$ (1911) Abst, Wash Ac Sc, J 1: 129 (1911)

11 a Desert pavements and analogous phenomena (abst). Science n s, 33:35. (1911)

$11 b$ (with Stuntz, S. C.) Bibliography of eolian geology. U S Dp Agr, Bur Solls, B $68: 174-263$ (1911)

12 Nitrate prospects in the Amargosa Valley, near Tecopa, Cal. U S Dp Agr, Bur Soils, Circ 73:6 pp (1912)

12a Potash and the dry lake theory. $25 \mathrm{pp}, 1912$. [Published by the Rallroad Valley Company.]

13 Progress in potash prospecting in Railroad Valley, Nev. M Sc Press 107: 176-178 (1913)

13a The geology of the Cahuilla Basin [Cal.] (abst). Carnegie Inst Wash, $\mathbf{Y} \mathbf{B k}$ 12: 59-60 (1913)

14 The topographic features of the desert basins of the United States with reference to the possible occurrence of potash. U S Dp Agr, B 54:65 pp, map (1914)

14a Sketch of the geology and solis of the Cahuilla Basin. Carnegie Inst Wash, Pub 193 (MacDougal, The Salton Sea) : 2133 (1914)

See also MacDougal, 16

Freeland, Francis $T$.

86 The sulphide deposit of South Iron Hill, Leadville, Colo. Am I M Eng, Tr 14:181-189 (1886)

93 Fault rules. Am I M Eng, Tr 21: 491-502 (1893)

Freeman, Henry C.

68 Geology of La Salle Co. Ill G S 3: 257-287, map (1868); Ec G 2:202-236 (1882)

75 Geology of Livingston Co. Ill G S $6: 235-244$ (1875); Ec G $3: 586-596$ (1882)

85 The La Plata Mountains, Colo. Am I M Eng, Tr $13: 681-684$ (1885)

87 [Natural gas in Illinois.] Am I M Eng, Tr 15:539-541 (1887)

87a Earthquake phenomena [surface subsidences]. Eng M J 44:110-111 (1887)

95 The Ammon mines, Fergus Co., Mont.

Eng M J 59:416-417 (1895)

95a Boulder mining district, Mont. Eng M J $60: 583-534$ (1895)

Freeman, John R.

03 Report on subsidence of land and harbor bottom. Mass, Rp of the committee on Charles River dam, Appendix no 20: 529-572, Boston, $19 \mathrm{C3}$

Freeman, O. W.

15 The North Moccasin Mountains of Montana, M World 42:947-949, map (1915)
Freeman, O. W.-Continued.

15n The sapphire mines of Yogo, Mont M Se Press 110: 800-802 (1915)

16 Gypsum and lime industry in cers. tral Montana. M World 45:663-605 (1916)

16a Iceberg Lake [Glacier Nations Park, Mont.]. Mich Ac Se, Rp 17;19-21 (1916)

17 Mineral prospects in Fergus $C_{0}$ Mont. Eng M J 103:660-662 (1917)

French, Harold.

14 Genesis and revelations of the Fo semite Valley. Pop Sc Mo $85: 69-8$. (1914)

Frenzel, A. B.

98 A turquoise deposit in Mohave co. Ariz. Eng M J 66:697 (1898)

Frenzel, August.

98 Ueber das San Gregorio-Eisen [me teorite, Chihuahua, Mexico]. Tschermak Mitt N F 18:91-92, 367 (1898)

Freudenberg, Wilhelm.

09 Geologische Beobachtungen im Ge biete der Sierra Nevađa von Mexiko. Det G Ges, Monatsb 5:254-274 (1909)

10 Die Säugetierfauna des Pliocïns uted Postpliocäns von Mexiko; I, Carniroren. Pal Abh (Koken) N F $9: 195-231$, I (1910)

Friek, Childs.

18 Fauna of the Bautista Creek bat lands (abst). G Soc Am, B 29:163 (1918) Friedel, C.

99 (and Cumenge, E.) Sur un not veau minerai d'urane [carnotite, Montroe Co., Colo.]. Soc Franc Minér, B 22:26-29 (1899) Ac Se Paris, C R $128: 532-54+$ (1899)

Friedlaender, Benedict.

96 Der Vulkan Kilauea auf Hawall. Gesellschaft Urania zu Berlin, Sammlung, no $38: 38$ pp, Berlin 1896 Reprinted frow Himmel und Erde $\mathrm{Jg} 8 \mathrm{H} 1,3$

Friedlaender, Immanuel.

15 Gipfelausbruch des Mauna Loa 25 November 1914. Zs Vulkan 2:91-95 (1915)

18 Regelmässigkeit der Abstände rulkat ischer Eruptionszentren. Zs Vulkan 4:1532 (1918)

18a Ueber den vulkanischen Ausbruct in San Salvador in Juni 1917. Zs Vol. kan 4:193-200 (1918)

18b Vulkanische Nachrichten über ded Ausbruch in San Salvador. Zs Vulkan 4: 308 (1918)

Friedrich, James J.

86 Notes on local mineralogy [Nek $\mathrm{Yor}^{\mathrm{k}}$ Island]. N Y Ac Sc, Tr $5: 121$ (1886)

87 Notes on local mineralogy [New York City]. N Y Ac Sc, Tr $6: 130$ (1887)

$\mathbf{8 8}$ [Stalactitic melanterite and othe minerals from California.] N $\mathbf{Y}$ Ac $\$$ $\operatorname{Tr} 8: 22$ (1888) 
Friedrich, James J.-Continued.

89 [Silicified woods from California.] N Y Ac Sc, Tr $8: 29-30$ (1889)

s9a [On copper minerals from the Bisbee district, Ariz.]. N Y Ac Sc, Tr 8: $45-46$ (1888)

s9b Résumé of the lithology of Manhattan Island. N Y Ae Sc, Tr 8:53-55 (1889)

89e On some new species of Protozootites, Quaternary and Tertiary, from Callfornia, and on the importance of Protozoa a8 rock-building agents. N Y Ac Sc, Tr 9 : 32-36 (1889)

Frignet, Ernest.

65 Le Californie... 494 pp, Paris 1865 2d ed, $479 \mathrm{pp}$, Paris 1867

66 Coup d'oeil sur la constitution géologique et minière de la Californie et des territoires voisins. Soc G France, B (2) $23: 347-371$ (1866)

Frisbie, J. F,

80 Glacial moraines. $16 \mathrm{pp}$, Newton [Mass.], 1880

Fritel, P. H.

14 Sur l'attribution au genre Nuphar le quelques èspèces fossiles de la flore arctique. Soe G France, B (4) $13: 293-297$, II (1914)

14a Note sur les Aralias des flores crétadques de rAmérique du Nord et du Groenland. Soc G France, B (4) $14: 1-22$, il (1014)

Fritseh, Anton.

07 Miscellanea Palæontologica. I. Palæovoica. $23 \mathrm{pp}$, il Prag 1907.

Fritz-Gaertner, R.

78 The preparation of rocks and fossils for microscopical examination. Am Nat $12: 219-225$ (1878)

$78 a$ (with Hall, J. W.) On the structure of Astrcospongia meniscus. N Y St Ilus, An Rp 30: 111-116, il (1878)

79 Notes on phlogopite. N Y St Mus, An Rp 31: 72-78 (1879)

Prizell, Joseph P.

02 Tidal scour in harbours. As Eng Soe, J 28: 78-88 (1902)

Froebel, Charles.

70 Notes on some observations made in Dakota during two expedition under command of General Alfred Sully against the bostlle Sioux in the years 1864 and 1865 . Lje N H N Y, Pr 1: 64-73 (1870)

\section{Froehling \& Robertson.}

$04 \mathrm{~A}$ handbook on the minerals and tineral resources of Virginia. Prepared lor the Virginia Commission to the St. Lols Exposition. 159 pp, map, Richmond, Virginia [1904]

Pry, E, D.

10 The Lordsburg mining district, N.

Vex. Eng M J 90:820 (1910) $28737^{\circ}-23-25$
Fry, William H.

10 Topography of Fayetteville, N. C. Elisha Mitchell Sc Soc, J 26:123-126 (1910)

11 Some plutonic rocks of Chapel Hill [N. C.]. Elisha Mitchell Sc Soc, J 27 : 124-132 (1911)

11 M Minerals of the Chapel Hill region [N. C.]. Elisha Mitchell Se Soc, J 27: 133-135 (1911)

12 Mineral content of volcanic ashes from Kodiak. Science n s $36: 681-682$ (1912)

13 Sections of two Michigan salt wells. J G 21:320-322 (1913)

13a Log of well of Pennsylvania Salt Company, Detroit, Mich. J G 21:671 (1913)

15 Mineralogical constituents of clays. Ee G 10:292-295 (1915)

15a The weathering stability of minerals as illustrated in soils and soil-like materials (abst). Wash Ac Sc, J 5:491492 (1915)

15b (with Waggaman, W. H.) Phosphate rock and methods proposed for its utilization as a fertilizer. U S Dp Agr, B no $312: 37$ pp (1915)

Fuehs, Edmond,

85 Note sur les graviers aurifères de la Sierra Nevada de Californie. Soc G France, B (3) $13: 486-488$ (1885)

86 Note sur les gisements de cuivre du Boleo [Lower California]. As Franc, C R 14 pt $2: 410-426$, map (1886) Soc G -France, B (3) $14: 79-92$ (1886)

Fuehs, Th,

o5 U e ber Parapsonema cryptophysa Clarke und deren Stellung im System. Centralbl Miner 1905: 357-359

Fuller, Homer Taylor (1838-1908).

91 Preservation of glaciated rocks (abst). Am As, Pr 39:246 (1891)

92 Effects of drought and winds on alluvial deposits in New England. G Soc $\mathbf{A m}$, B $3: 148-149$ (1892)

04 Corundum and emery. Drury Coll, Bradley G Field Sta, B $1: 31-33$ (1904)

Fuller, John T.

os Report on property of the Arkansas Diamond Company. In Arkansas Diamond Company, Diamonds in Arkansas: 10-30, Little Rock 1908

09 Diamond mine in Pike Co., Ark. Eng M J 87:152-155 (1909)

See also Arkansas Diamond Company, 08

Fuller, Myron Leslie.

96 A new occurrence of Carboniferous fossils in the Narragansett Basin. Boston Soc N H, Pr. $27: 195-199$ (1896)

97 (with Crosby, W. O.) Orlgin of pegmatite. Am G 19:147-180 (1897)

98 Notes on a Carboniferous boulder train in eastern Massachusetts. Boston Soc N H, Pr. 28: 251-264, map (1898) 
Faller, Myron Leslie-Continued.

98a Champlain submergence in the Narragansett Bay region. Am G 21:310-321 (1898)

98b Crushed quartz and its origin, Stone 18:1-4 (1898)

99 Season and time elements in sandplain formation. J G $7: 452-462$, map (1899)

$99 a$ Rapidity of sand plain growth. Science n s 9:643-644 (1899)

$99 b$ Notes on an unusual orientation of phenocrysts in a dike. Tech Q 12:175179 (1899)

99e The occurrence and uses of mica. Stone 19:530-532 (1899)

00 An instance of subaqueous differential weathering. Am G 25: 355-359 (1900)

01 Probable representatives of pre-Wisconsin till in southeastern Massachusetts. J G 9:311-329, maps (1901)

O1a Possible pre-Wisconsin tills of Massachusetts (abst). Science n s $13: 664$ (1901)

02 (and Ashley, G. H.) Description of the Ditney quadrangle [Md.]. U S G S, G Atlas Ditney fol (no 84):8 pp, maps (1902)

02a The Gaines oil field of northern Pennsylvania. U S G S, An Rp 22 pt 3 : 573-627, maps (1902)

02b Etching of quartz in the interior of conglomerates. J G $10: 815-821$ (1902)

02c The Catskill rocks in northern Pennsylvania (abst). Science n s 15:664. 665 (1902)

03 (and Alden, W. C.) Description of the Gaines quadrangle [Pa.-N. Y.]. U S G S, G Atlas Gaines fol (no 92):9 pp, maps (1903)

O3a (and A1den, W. C.) Description of the Elkland and Tioga quadrangles [Pa.]. U S G S, G Atlas Elkland-Tioga fol (no 93) : 9 pp, maps (1903)

03b Natural gas [in the Brownsville quadrangle, $\mathrm{Pa}$.$] . U \mathbf{S}$ G $\mathrm{S}, \mathrm{G}$ Atlas Brownsville-Connellsville fol (no 94): 17-18 (1903)

O3e (and Ashley, G. H.) Recent work in the coal field of Indiana and Illinois. U S G S, B $213: 284-293$ (1903)

03d Asphalt, oil and gas in southwestern Indiana. U S G S, B 213:333-335 (1903)

o3e (and Clapp, F. G.) Marl-loess of the lower Wabash Valley. G Soc Am, B 14:153-176, map (1903) Abst, Am G $31: 158$ (1903) ; Science n s $17: 293$ (1903)

03r Probable pre-Kansan and Iowan deposits of Long Island, N. Y. Am G 32 : 308-312 (1903)

$03 \mathrm{~g}$ The Horseheads outlet of the glacial lakes of central New York (abst). Science n s $17: 26$ (1903)

o3h (and Veatch, A. C.) Results of the resurvey of Long Island, N. Y. Science n s $18: 729-731$ (1903)
Fuller, Myron Leslle-Continued.

04 (and Clapp, F. G.) Description the Patoka quadrangle [Ind.-III.]. G S, G Atlas Patoka fol (no 105): 12 ? maps (1904)

O4a Water supplies from wells in soot ern Louisiana. U S G S, W-S P 101: 74 (1904)

04b (and others) Contributions to to hydrology of eastern United States, 18 U S G S, W-S P 102: 522 pp (1904)

04e [Notes on water resources Florida. U S G S, W-S P $102: 238-2$ (1904)

04d Hyner gas pool, Clinton $\mathrm{C}_{0}, \mathrm{~A}$ U S G S, B 225 : 392-395 (1904)

04e Ice retreat in glacial Lake Nepose and in southeastern Massachusetts, ] 12:181-197, map (1904)

04f Evidence of caves of Put-indur Ohio, on question of land-tilting (abrif) Science n s 20:761 (1904)

o5 (and Lines, E. F., and Veated A. C.) Record of deep well drilling ti 1904. U S G S, B 264: 193 pp (1905)

o5a (and others) Contributions to th bydrology of eastern United States, $19 \mathrm{~m}$ U S G S, W-S P 110:211 pp (1905)

05b Triassic rocks of the Connectin Valley as a source of water supply. T G S, W-S P 110:95-112 (1905)

o5e Notes on the hydrology of chen U S G S, W-S P 110: 183-199 (1905)

o5d (and others) Underground water of eastern United States. U S G S, Ti: P 114: $285 \mathrm{pp} \mathrm{(1905)}$

o5e Occurrence of underground wates U S G S, W-S P 114: 18-40 (1905) osp [Underground waters of] New Haw shire. U S G S, W-S P 114: 57-59 (19:5)

o5g [Underground waters of] Penng]. vania. U E G S, W-S P 114:104-11! (1905)

O5h [Underground waters of] Nort Carolina. U S G S, W-S P 114:136-1) (1905)

05i [Underground waters of] Florida. S G S, W-S P 114: 159-163 (1905)

o5j [Underground waters of] West ginia. U S G S, W-S P $114: 271-2$ (1905)

o5le Bibliographic review and inder papers relating to underground waters por lished by the United States Geological vey, 1879-1904. U S G S, W-S P 120:12 pp (1905)

051 (and others) Contributions to the hydrology of eastern United States, 1006 U S G S, W-S P 145 : 220 pp (1905)

O5m Two unusual types of artesian for

U S G S, W-S P 145: 40-45 (1905)

o5n Construction of so-called founts: and geyser springs. U S G S, W-S P 16: 46-50 (1905)

o5o A ground-water problem in sot eastern Michigan. U S G S, W-S P 14: 129-147 (1905) 
Fuller, Myron Leslie-Continued.

$05 p$ Notes on certain large springs of the Ozark region, Mo. and Ark. U S G S, W-S P 145: 207-210 (1905)

05q Hydrolegic work of the U. S. Geological Survey in the eastern United States. Int Geog Cong, VIII, Rp: 509514 (1905)

$05 \mathrm{r}$ Geology of Fishers Island, N. Y. G Soc Am, B $16: 367-390$, map (1905)

05s Failure of wells along the lower Euron River, Mich., in 1904. Mich G S, Rp $1904: 1-29$ (1905)

05t Cause and periods of earthquakes in the New Madrid area, Mo., and Ark. (abst). Science n s $21: 349-350$ (1905)

05u Audubon's account of the New Madrid earthquake. Sclence n s 21:748749 (1905)

05v Pleistocene history of Fishers Island, N. Y. (abst). Am G 35:51 (1905) 05 w (with Darton, N. H.) [Underground waters of] Maryland; District of Columbia; Virginia. U S G S, W-S P 114: 114-135 (1905

06 (and others) Underground-water papers, 1906. U S G S, W-S P 160: 104 pp, (1906)

06a Significance of the term " artesian." U S G S, W-S P 160:9-15 (1906)

$06 \mathrm{~b}$ Representation of wells and springs on maps. U S G S, W-S P 160:16-18 (1906)

06e Total amount of free water in the earth's crust. U S G S, W-S P 160:59-72 (1906)

06a Peculiar mineral waters from crystalline rocks of Georgia. U S G S, W-S P $160: 86-91$ (1906)

06e (and Sanford, Samuel) Record of deep-well drilling for 1905 . U S G S, B 298: 299 pp (1906)

068 Underground water investigations in the United States. Ec G 1:554-569 (1906)

06g Clays of Cape Cod, Mass. U S G S, B 285: 432-441 (1906)

$06 \mathrm{~h}$ Glacial stages in southeastern New Bogland and vicinity. Science n s 24 : 467-469 (1906)

06i Our greatest earthquakes. Pop Sc $y_{0} 69: 76-86$ (1906)

06j Comparative intensities of the New Madrid, Charleston, and San Francisco farthquakes (abst). Science n s 23:917118 (1906)

06k Mineral waters. U S G S, Min Res 1905: 1285-1308 (1906)

07 Notes on the Jamaica earthquake. J $15: 696-721$ (1907)

07 a The elevated beaches of Labrador (obst). Science n s 25:32 (1907)

07b Phosphate rock. U S G S, Min Res 1906:1079-1084 (1907)
Fuller, Myron Leslie-Continued.

os Summary of the controlling factors of artesian flows. U S G S, B 319:44 pp (1908) Abst, G Soc Am, B 18:626634 (1908) ; Science n s $25: 767$ (1907)

09 Artesian waters of the Atlantic Coastal Plain. Am Water Works As, 28th An Conv, 1908, Pr : 294-322 (1909)

10 Underground waters for farm use. U S G S, W-S P 255:58 pp (1910)

11 (and others) Underground-water papers, 1910. U S G S, W-S P 258: 123 pp (1911)

$11 a$ (with Hall, C. W.) Geology and underground waters of southern Minnesota. U S G S, W-S P 256: 406 pp (1911)

12 The New Madrid earthquake. U S G S, B 494: $119 \mathrm{pp}$, map (1912) Abst (by A. H. Brooks), Wash Ac Sc, J 2:350351 (1912)

12a Domestic water supplies for the farm. $180 \mathrm{pp} N \mathrm{Y}^{*} 1912$

12b (and ciapp, F. G.) The underground waters of southwestern ohio. U S G S., W-S P $259: 228$ pp, maps (1912)

14 The geology of Long Island, N. Y. U S G S, P P 82: 231 pp, maps (1914) Abst, Wash Ac Sc, J 4:224-225 (1914)

16 Discussion on floods and flood prevention [geological factors in floods and flood control]. Am Soc Civil Eng, $\mathrm{Pr}$ $42: 810-819$ (1916)

17 Appalachian oil field. $G$ Soc $A m$, B $27: 617-654$ (1917)

Fullerton, Aubrey.

12 A coal mountain in the West [anthracite coal in Alberta]. Coal Age $2: 282$ (1912)

12a Natural gas belt in western Canada [A]berta]. M World $37: 670$ (1912)

Falmer, Elton.

93 On the occurrence of phosphates in Nebraska. J Analytical and Applied Chem 7: 95-98 (1893) Abst, Nebr Ac Sc, Pub $3: 10$ (1893)

Fuiton, A. R.

84 Copper in the drift of Iowa. Kansas City Rv Se $8: 151-152$ (1884)

Fulton, Charles H.

02 The cyanide process in the Black Hills of South Dakota. S Dak Sch Mines, B 5: $77 \mathrm{pp} \mathrm{(1902)}$

16 The ores of copper, lead, gold, and silver. U S Bur Mines, Tech P 143: 45 pp (1916)

Fuiton, Hamilton.

19 Report of sundry surveys... [North Carolina]. $70 \mathrm{pp}$, Raleigh 1819

Fulton, Henry.

91 (with Palmer, C. S.) The quartz porphyry of Flagstaff Hill, Boulder, Colo. Colo Sc Soc, Pr 3:351-358 (1891)

Fulton, John.

74 Note on the Somerset Co. coal beds in Pennsylvania. Am Ph Soc, Pr 14:157158 (1874) 
Fulton, John-Continued.

87 Mode of deposition of the iron ores of the Menominee range, Mich. Am I M Eng, Tr 16:525-536, map (1887)

See also Platt (F), $77 \mathrm{a}$

Fulton, R. L.

99 Nevada sulphur deposits. Eng M J $68: 64$ (1899)

Fulton, T. T.

06 The faults of Battery Point, Sydney, N. S. N S Inst Sc, Tr $11: 260-261$ (1906)

Fultz, Francis M.

94 Evidences of disturbance during the deposition of the Burlington limestones. Iowa Ac Sc, Pr 1 pt 4:56-58 (1894)

$94 a$ Interruption during the deposition of the Burlington limestones. $\Delta \mathrm{m}$ G 14 : 246-249 (1894)

95 Erosion during the deposition of the Burlington limestones. Am G 15:128-130 (1895)

95a How old is the Mississippi? (abst). Iowa Ac Sc, Pr 2: 39 (1895) J G 3:981 (1895)

$\mathbf{9 5 b}$ Formation of the flint beds of the Burlington limestones (abst). Iowa Ac Sc, Pr 2: 177 (1895)

95e Coincldence of present and preglacial drainage system in extreme southeastern Iowa (abst). Iowa $\mathrm{Ac} \mathrm{Sc}, \mathrm{Pr} 2$ : 208-209 (1895)

95d Extension of the Illinois lobe of the great ice sheet into Iowa. Iowa $\mathrm{Ac} \mathrm{Sc}, \mathrm{Pr}$ 2: 209-212 (1895)

95e Glacial markings in southeastern Iowa. Iowa Ac Sc, $\operatorname{Pr} 2: 213-217$ (1895) Abst, J G 3:981-982 (1895)

96 Recent discoveries of glacial scorings in southeastern Iowa. Iowa $\mathrm{Ac} \mathrm{Sc}, \operatorname{Pr} 3$ : 60-62 (1896)

$96 a$ Some facts brought to light by deep wells in Des Moines Co., Iowa. Iowa Ac Sc, Pr 3:62-63 (1896)

99 The Burlington artesian well [Iowa]. Iowa Ac Sc, Pr 6: 70-74 (1899)

Furlong, Eustace L.

04 An account of the preliminary excavations in a recently explored Quaternary cave in Shasta Co., Cal. Science n s $20: 53-55$ (1904)

O4a (with Sinclair, W. J.) Euceratherium, a new ungulate from the Quaternary caves of California. Cal Univ, Dp G, B $3: 411-418$, il (1904)

o5 Preptoceras, a new ungulate from Samwel Cave, Cal. Cal Univ, Dp G, B 4 : 163-169, il (1905)

06 The exploration of Samwel Cave [Cal.]. Am J Sc (4) $22: 235-247$ (1906)

07 Reconnaissance of a recently discov. ered Quaternary cave deposit near Auburn, Cal. Science n s 25:392-394 (1907).

10 An aplodont rodent from the Tertiary of Nevada. Cal Univ, Dp G, B 5 : $397-403(1910)$
Furman, H. Van F.

85 Notes on two ore deposits of south. western New Mexico. Scl. Mines Q 6: 138-142 (1885)

01 Gold mining In [southeastern] Alaska. Mines and Minerals 21:433-436 (1901)

Furman, John H.

81 The geology of the copper region of northern Texas and the Indian Territory (with discussion by J. S. Newberry). N Y Ac Sc, Tr 1: 15-20 (1881) Sclence (ed, Michels) $2: 558-560$ (1881)

89 The tin deposits of North Carolina. N Y Ac Sc, Tr 8:136-145 (1889)

G., R.

89 Notes on the geology of Grimes Co. [Tex.], G Se B 1 no 9 (1889)

Gabb, William More (1839-1878).

59 Catalogue of the invertebrate fos. sils of the Cretaceous formation of the United States, with references. $20 \mathrm{pp}$., Philadelphia, 1859. Also issued with Ac N Sc Phila, Pr 1859

50a Descriptions of two new species of Carboniferous fossils brought from Fort Belknap, Tex., by Dr. Moore. Ac N 8 Phila, Pr 1859: 297, il

60 Descriptions of some new species of Cretaceous fossils. Ac N Se Phila, J (2) $4: 299-305$ il $(1860)$

60a Descriptions of new species of fos sils, probably Triassic, from Virginia. As N Sc Phila, J (2) 4:307-308, il (1860)

601. Descriptions of new species of American Tertiary and Cretaceous fossils. Ac N Sc Phila, J (2) $4: 375-406$, il (1860)

60e Descriptions of new species of Cre taceous fossils from New Jersey. Ac N Sc Phila, Pr. 1860:93-95, II

60a On the identity of Ammonites tez anus, Roemer, and A. vespertinus, Morton. Ac $\mathrm{N}$ Sc Phila, Pr 1860: 202.

60e Description of a new species of cephalopod, from the Eocene of Texas. Ac N Se Phila, Pr $1860: 324$

Gor (and Horn, G. H.) Descriptions of new Cretaceous corals from New Jersey. Ac N Sc Phile, Pr $1860: 366-367$

60m Description of a new genus and species of amorphozoon, from the Cretaceous formation of New Jersey [Desmato. cium]. Ac N Sc Phila, Pr 1860:518

$60 h$ Description of a new species of Cassidulus, from the Cretaceous formation of Alabama. Ac N Sc Pbila, Pr 1860:519 60i [On the occurrence of Jurassic rock in the western states.] Ac N Sc Phila. Pr 1860: 548-549

60j Descriptions of some new species of Tertiary fossils from Chiriqui, Central America. Ac N Sc Phila, Pr 1860:567568

60k (with Conrad, T. A.) Illustrations of some fossils described in the Proceedings of the Academy of Natural Sciences. Ac N Se Phila, Pr $1860: 55$, il 
Gabb, William More-Continued.

61 Synopsis of the Mollusea of the Cretaceous formation, including the geographical and stratigraphical range and synonymy. Am Ph Soc, $\mathrm{Pr} \quad 8: 57-257$ (1861) Reprint, 201 pp, Phila 1861.

61a Synopsis of American Cretaceous Brachiopoda. Ac N Sc Phila, Pr 1861: 18-19

61b [Remarks on Gryphaea calceola and ostrea marshii.] Ac N Sc Phfla, Pr 1861: 21-22

61e [An outcrop of the Ripley group on Timber Creek, N. J.] Ac N Sc Phila, Pr $1861: 124$

61d Description of new species of Cretaceous fossils from New Jersey, Alabama, and Mississippi. Ac N Sc Phila, Pr 1861: $318-330$

61e Notes on Cretaceous fossils with descriptions of a few additional new species. Ac N Sc Phila, Pr 1861: 363-367

61f Descriptions of new species of American Tertiary fossils and a new Carboniferous cephalopod from Texas. Ac $\mathrm{N}$ Sc Phila, Pr $1861: 367-372$

$61 \mathrm{~g}$ A revision of the species Baculites, described in Dr. Morton's "Synopsis of the Cretaceous group of the United States." Ac N Sc Phila, Pr 1861: 394-396

62 (and Horn, G. H.) Monograph of the fossil Polyzoa of the Secondary and Tertiary formations of Nerth America. Ac X Se Phila, J (2) 5:111-179, il (1862)

64 Description of the Triassic fossils of Callfornia and the adjacent territories. Cal G S, Paleontology $1: 17-35$, il (1864)

64a Description of the Cretaceous fossils. Cal G S, Paleontology 1:55-236, il (1864)

64b On Cretaceous fossils from Sahoripa Valley, State of Sonora, Mexico.. Cal Ac N Sc, Pr 3: 153-154 ( 864)

64e Notes on some fossils from the goldbearing slates of Mariposa, with description of some new species. Cal Ac N Sc, Pr 8:172-173 (1864)

64d Communication on the San Luis Obispo quicksilver fossils. Cal Ac $\mathrm{N}$ Sc, Pr $3: 173-174$ (1864)

65 Check list of the Carboniferous, Triassic, Jurassic, and Cretaceous fossils of California and Nevada, prepared for the cabinet of the College of California. $8 \mathrm{pp}$, San Francisco 1865

66 Reply to Mr. Conrad's criticism on Mr. Gabb's "Report on the paleontology of California." Am J Conch 2:87-92 (1866)

67 On the subdivisions of the Cretaceous rocks of California. Cal Ac N Sc, Pr 3: 301-306 (1867) Am J Sc (2) 44:226229 (1867)

68 An attempt at a revision of the two families Strombidae and Aporrhaidae. Am $J$ Conch $4: 137-149$, il (1868)
Gabb, William More-Continued.

69 Cretaceous and Tertiary fossils. Cal G S, Paleontology $2: 299$ pp, il (1869)

$69 a$ Descriptions of some Secondary fossils from the Pacific States. Am J Conch 5: 5-18, il (1869)

69b Notes on the genera Alaria, Diarthema, Dicroloma, etc., being a supplement to " an attempt at a revision of the Strombidae and Aporrhaidae. Am J Conch 5: 19-23 (1869)

71 Notes on the geology of Santo Domingo. Am $J$ Sc (3) 1: 252-255 (1871)

71a Notes on the distribution of the vegetation of Santo Domingo. Am J Sc (3) $2: 127-129 \quad(1871)$

72 On the occurrence of petroleum in the island of Santo Domingo. Am J Sc (3) 1: 481 (1872)

72a Notes on the genus Polorthus Gabb. Ac N Sc Phila, Pr 1872:259-262, il

72b Notice of a collection of Cretaceous fossils from Chihuahua, Mex. Ac N Sc Phila, Pr $1872: 263-265$, il

73 On the topography and geology of Santo Domingo. Am Ph Soc, Tr $\mathrm{n}$ s 15 : 49-259, maps (1873)

73a Tables of Miocene fossils in Santo Domingo and list of fossils common to Panama and Santo Domingo. Am Ph Soc, Pr 12:571-573 (1873)

736 Notes on the island of Curaçao. Am J Sc (3) 5:382-383 (1873)

74 Note on the geology of Costa Rica. $\mathrm{Am} \mathrm{J}$ Sc (3) $7: 438-439 ; 8: 388-390$; $9: 198-204,320(1874-5)$

75 Note on the age of the Cretaceous of Vancouver Island and Oregon. Am J Sc (3) $10: 308$ (1875)

$75 a$ Notes on West Indian fossils. Mag (2) 2:544-545 (1875)

76 Note on the discovery of representatives of three orders of fossils new to the Cretaceous formation of North America. Ac N Sc Phila, Pr 1876:178-179

77 Notes on American Cretaceous fossils with descriptions of some new species. Ac N Sc Phila, Pr 1876:276-324 (1877)

81 Descriptions of Caribbean Miocene fossils. Ac N Sc Phila, J (2) $8: 337-348$, il (1881)

s1a Descriptions of new species of fossils from the Pliocene clay beds between Limon and Moen, Costa Rica, together with notes on previously known species... in the Caribbean area. Ac N Sc Phila, J (2) 8 : $349-380$, il (1881)

82 Notes on the geology of Lower California. Cal $\mathrm{G} \mathrm{S}$, Geology 2 App : 137-148 (1882)

95 Informe sobre la exploración de Talamanca [Costa Rica] verificada durante los años de 1873-74. Inst Ftsico-geog Nac Costa Rica, An 5:67-90 (1895) Reprint, 93 pp, San José de Costa Rica, A. C., 1894 
Gabb, William More-Continued.

10 Informes presentados al gobierno dominicano acerca del examen jeológico del territorio de la República Dominicana en los años $1869,1870,1871$. Revista de Agricultura año 6 [app]: $156 \mathrm{pp}$, Santo Domingo 1910

11 Esbozo general de la geología de Talamanca. Costa Rica, B Fomento $1: 132-136$ (1911)

Gage, James R.

73 On the occurrence of iron ores in Missouri. Ac Sc St $\mathbf{L}, \operatorname{Tr} 3: 181-192$ (1873)

74 Lead mines, southeast Missouri. Mo G S, Rp 1873-4:602-637 (1874)

$\boldsymbol{7 4 a}$ On the occurrence of the lead ores in Missouri. Eng M J 18:194, 209-210 (1874)

75 On the occurrence of the lead ores in Missouri. Am I M Eng, Tr $3: 116-125$ (1875)

77 The Ste. Genevieve Co. [Mo.] copper mines. Western Rv Sc 1: 603-605 (1877)

Gage, R. B.

or (with Kümmel, H. B.) The glasssand industry of New Jersey. N J G S, Rp 1906:77-96 (1907)

Gale, Hoyt Stoddard.

o5 Water resources of Cowee and Pisgah quadrangles, N. C. U S G S, W-S P 110: 174-176 (1905)

06 The Hahns Peak gold field, Colo. U S G S, B 285: 28-34, map (1906)

O6a (with Fenneman, N. M.) The Yampa coal field, Routt Co., Colo, U S G' S, B 285: 226-239 (1906)

o6b (with Fenneman, N. M.) The Yampa coal field, Routt Co., Colo. U S G S, B 297:81 pp (1906)

o7 Carnotite in Rio Blanco Co., Colo. U S G S, B 315: 110-117 (1907)

o7a Coal fields of the Danforth Hills and Grand Hogback in northwestern Colorado. U S G S, B 316: 264-301 (1907)

08 Gold placer deposits near Lay, Routt Co., Colo. U S G S, B 340:84-95 (1908)

Osa Carnotite and associated minerals in western Routt Co., Colo. U S G S, B 340: 256-262 (1908)

0sb Geology of the Rangely oil district, Rio Blanco Co., Colo., with a section on the water supply. U S G S, B 350:61 pp, maps (1908)

09 Coal fields of northwestern Colorado and northeastern Utah. U S G S, B 341 : 283-315, maps (1909)

10 Coal fields of northwestern Colorado and northeastern Utah. U S G S, B 415 : 265 pp, maps (1910)

10a Geology of the copper deposits near Montpelier, Bear Lake Co., Idaho. U S G S, B 430:112-121 (1910)
Gale, Hoyt Stoddard-Continued.

10b (and Riehards, R. W.) Prelim! nary report on the phosphate deposits is southeastern Idaho and adjacent parts Wyoming and Utah. U S G S, B 430: 457-535, map (1910)

10e Supposed deposits of graphite neer Brigham, Utah. U S G S, B 430:639-64 (1910)

10d (and Wegemann, C. H.) Th. Buffalo coal field, Wyoming. U S G S, B 381 : 137-169, maps (1910)

11 Rock phosphate near Melrose, Mort U S G S, B 470: 440-451 (1911)

12 Nitrate deposits. U S G S, B 523:3 pp (1912) Abst, Wash Ac Sc, J 4:10 (1914)

12a Field investigations for potash $h$ America. Am Fertilizer 37:38-40 (1912 M World $37: 491-492$ (1912)

12b Borax. U S G S, Min Res 1911 p 2:857-866, map (1912)

12c Magnesite. U S G S, Min Res 1911 pt 2:1113-1127 (1912)

12d (with Butler, B. S.) Alunite: newly discovered deposit near Marysvait Utah. U S G S, B 511: 64 pp (1912) (Abst), Wash Ac Sc, J 2: 193 (1912)

13 The origin of colemanite deposits. S G S, P P 85: 3-9 (1913) Abst, Wast Ac Sc, J 4:165-166 (1914)

13a The search for potash in the desert basin region. U S G S, B $530: 295-31$. map (1913)

13b Searles Lake, Cal. [potash]. ¿

G S. Min Res 1912 pt 2:884-890 (1913)

13e (with Yale, C. G.) Borax, V G S, Min Res 1912 pt $2: 839-846 ; 1913$ pt $2: 521-536$, map ; 1914 pt $2: 285-290$, map 1916 pt $2: 387-389$, map (1913-8)

13d (with Yale, C. G.) Magnesite. S G S, Min Res 1912 pt 2: 1071-1077 1913 pt $2: 441-454$, map : 1914 pt $2: 569$ 586, map; 1916 pt $2: 391-401$ (1913-8)

14 Notes on the Quaternary lakes of the Great Basin, with special reference to the deposition of potash and other salines. S G S, B 540: 399-406 (1914)

14a Prospecting for potash in Death Valley, Cal, U S G S, B $540: 407-415$ (1914)

14b Salt, borax, and potash in Salint Valley, Inyo Co., Cal. U S G S, B 540: 416-421 (1914)

14c Potash tests at Columbus Marsh, Nev. U S G S, B 540:422-427 (1914)

14d Sodium sulphate in the Carrivo Plain, San Luis Obispo Co., Cal. U S G \& B 540: 428-433 (1914)

14e Bcrate deposits in 'Ventura Co., Cal U S G S, B 540:434-456, map (1914)

14p Late developments of magnesite de posits in California and Nevada. U S G 8 , B 540: 483-520 (1914)

14g Salines in the Owens, Searles, and Panamint basins, southeastern Californis. U S G S, B 580: 251-323, map (1914) 
Gale, Hoyt Stoddard-Continued.

14h (and Hicks, W. B.) Octahedral crystals of sulphohalite. Am J Sc (4) 38 : 273-274 (1914)

15 Geologic history of Lake Lahontan. Science n s 41 : 209-211, map (1915)

16 Potash in Salduro salt deposit [ttah]. Eng M J $102: 780-782$ (1916)

17 Potash in 1916. U S G S, Min Res 1916 pt $2: 73-171$ (1917)

$17 \mathrm{a}$ Origin of nitrates in cliffs and ledges. M Sc Press 115:676-678 (1917)

See also Lee (W T), 15

Gale, L. D.

39 Report on the geology of New York Co. [N. Y.]. N Y G S, An Rp 3:177199 (1839)

43 Diary of a geological survey of the Island of New York. In Mather, W. W., Geology of New York, pt 1:581-604, Albany 1843

Gale, N. D.

47 On the Natchez Bluff formation (abst). Am J Agr 6:208 [256]-209 [257] (1847) Am J Sc (2) $5: 249-250$ (1848)

Galeotti, Henri Guillaume.

38 Notice sur un gite de mercure dans e sol tertiaire récent du Gigante au Mexique. Ac R Sc Bruxelles, B 5:196-202 1838)

3Sa Notice géologique sur les environs San José del Oro au Mexique. Ac R Sc Bruxelles, B 5: 737-751 (1838)

38b Notice géognostique sur les mines dalun de la barranca de Toliman au Mexique. Ac R Sc Bruxelles, B 5:751-755 1838)

39 Notice sur le calcaire crétacé des environs de Jalapa au Mexique. Soc G France, B $10: 32-39$ (1839)

40 (with Nyst, H.) Sur quelques fossiles du calcaire jurassique de Tehuacan au Yexique. Ac $\mathrm{R}$ Sc Bruxelles, B 7 pt 2: 212-221, il (1840)

41 Aperçu géognostique sur les environs de la Havane. Ac R Sc Bruxelles, B 8 pt :405-417, map (1841) $\mathrm{R}$ Ac Clenc Habana, An 27:119-126 (1890) Abst, Retista de la Habana 4:56 (1855)

Galindo, Juan.

35 Eruption of the volcano of Cosiguina [Nicaragua]. Am J Sc 28:332-336 (1835) Galindo y Villa, Jesús.

98 [Biografía del Don Antonio del Castillo.] La Naturaleza (2) 3: iii-viii (1898)

Gallaher, John A. (1842-1900).

98 Biennial report of the Bureau of feology and Mines, State of Missouri. 68 Pp, Jefferson City, Mo., 1898

00 Preliminary report on the structural and economic geology of Missouri. Mo B G Hines [Mo G S 13] : $258 \mathrm{pp}$, Jefferson City, $\mathrm{H}_{0,}, 1900$
Gallaher, John A.-Continued.

OOa New Year announcement of the Bureau of Geology and Mines of Missouri. 27 pp, Jefferson City, Mo., 1900

01 Geology of Missouri. In Encyclopedia of the History of Missouri, 3:31-41, N. Y. 1901

\section{Gallaher, Leo.}

01 Biennial report of the State geologist... 55 pp, Jefferson City, Mo., 1901

Galloway, C. F. J.

12 Bear River coal fleld, B. C. Can M J $33: 335-336,368-370$ (1912)

13 Report on the coal measures of the Peace River Canyon. B C Minister of Mines, An Rp 1912: 118-136, maps (1913)

\section{Galloway, Jesse James.}

12 (with Cumings, E. R.) A note on the batostomas of the Richmond series. Ind Ac Sc, Pr 1911: 147-167 (1912)

13 (with Cumings, E. R.) The stratigraphy and paleontology of the Tanner's Creek section of the Cincinnati series of Indiana. Ind $\mathrm{Dp} G$, An Rp $37: 353-478$, il, map (1913)

15 (with Cumings, E. R.) Studies of the morphology and histology of the Trepostomata or monticuliporoids. G Soc Am, B $26: 349-374$, il (1915)

Galloway, John D.

15 The mineral resources of a portion of the Omineca mining division [B. C.]. B C Bur Mines, B 4 (1915) 67 pp, map

Gallup, F. L,

06 (with Ries, H.) Report on the molding sands of Wisconsin. Wis $Q S$, B $15: 192-247$ (1906)

Galpin, S. L.

15 A preliminary report on the feldswar and mica deposits of Georgia. Ga $\mathbf{G} \mathbf{S}$, B $30: 190 \mathrm{pp}$, map (1915)

Galvez, Vicente.

16 Las aguas subterráneas en los municipios de Acatlán y Jaltepec, distrito de Tulancingo, Estado de Hidalgo. Méx I G, Par 5:429-475, map (1916)

18 Las aguas subterráneas al E. de Bahía Magdalena, Baja California. Méx I G, An 3:7-31, maps (1918)

1Sa Hidrología subterránea de los alrededores del pueblo de Tequesquipan y Hacienda de la Labor, Distrito de Temascaltepec, Estado de México. Méx I G, An $3: 53-58$, map (1918)

18b Estudio sobre la probabilidad de encontrar aguas subterráneas en el potrero de la Ciénega en el D. F. Méx I G, An $3: 53-58$ map (1918)

Gane, Henry Stewart.

95 A contribution to the Neocene corals of the United States. Johns Hopkins Univ Circ 15: 8-10 (1895)

00 Some Neocene corals of the United States. U S Nat Mus, Pr 22:179-198, 11 (1900) 
Gannaway, C. B.

84 [Geological report on] The county of Sebastian and city of Fort Smith [pp 1926]. In Mineral resources; the Valley of the Arkansas. 36 pp, Fort Smith 1884 [not seen]

Gannett, Henry (1846-1914).

82 The Unaweep Canyon [Colo.]. Pop Sc Mo $20: 781-786$ (1882)

83 Corundum and Emery. U S G S, Min Res [1882] : 467-481 (1883)

98 Physiographic types. U S G S, Top Atlas fol 1:4 pp, maps (1898)

98a Lake Chelan [Wash.]. Nat Geog Mag 9:417-428 (1898)

oo Physiographic types. U S G S, Top Atlas fol 2:2 pp, maps (1900)

01 The origin of Yosemite Valley, Nat Geog Mag $12: 86-87$ (1901)

o5 Lake Chelan [Wash.] and its glacier. Mazama 2: 185-189 (1905)

Ganong, William Francis.

96 Notes on the natural history and physiography of New Brunswick. N H Soc N B, B XIV : 40-52 (1896); XVI (4 pt 1) : 44-63 (1898) ; XVII (4 pt 2) : 122135 (1899); XVIII (4 pt 3 ) : 227-257 (1899); XIX (4 pt 4):313-340 (1901) ; XX (4 pt 5) : 427-471 (1902) ; XXI (5 pt 1) : 35-92 (1903): XXII (5 pt 2):179241 (1904); XXIII (5 pt 3$): 299-343$ (1905) ; XXIV (5 pt 4): 409-474 (1906) ; XXV (5 pt 5):519-546 (1907); XXVI (6 pt 1) : 17-39 (1908); XXVII (6 pt 2) : 85-109 (1909) ; XXVIII (6 pt 3 ):199218 (1910); XXIX (6 pt 4 ): $321-337$ (1911); XXX (6 pt 5) : 419-451 (1913)

97 Upon raised peat bogs in the Province of New Brunswick. $R$ Soc Can, Pr $\operatorname{Tr}$ (2) 3, iғ : 131-163 (1897)

Gans1, G. C.

10 (and Keep, G. A.) The Ophir mining district of Utah. Salt Lake M Rv 12 no $8: 17-20$ (1910)

Gareia Cubas, Antonio.

81 Ensayo estadistico de los Estados Unidos Mexicanos; Minerla. México, Ministerio de Fomento, An 5:291-629 (1881)

Gardiner, C. Roe.

11 Occurrences of native gems in North America. M World 34:593-595 (1911)

Gardiner, Frederick, $j$.

85 An Arizona natural bridge. Science $6: 67$ (1885)

Gardner, E. D.

14 New World mining district [Park Co., Mont.]. M Sc Press 108:880-884 (1914)

Gardner, James Henry.

o5 The kaolin deposits adjacent to the eastern rim of the western coal field, with notes on other clays in that region [ $K y$.$] .$ Ky G S, B $6: 7-63$ (1905)

O5a Clays of the Red River Valley [Ky.]. Ky G S, B 6:64-79 (1905)
Gardner, James Henry-Continued. o5b Clays and sands of the Jackson's Purchase region. Ky G S, B 6:80-128 (1905)

o5e Miscellaneous analyses of Kentuchs clays and marls. Ky G S, B 6:179-223 (1905)

07 (with Shaler, M. K.) Clay de posits of the western part of the Durang Gallup coal field of Colorado and $\mathrm{Ner}$ Mexico. U S G S, B 315: 296-302 (1900)

os The physical origin of certain c0s cretions. J G 16:452-458 (1908)

o9 The coal field between Gallina and Raton Spring, N. Mex., in the San Juan col region. U S G S, B $341: 3 \mathbf{s} 5-351$, map (1909)

09a The coal field between Durango, Colo., and Monero, N. Mex. U S G S, B $341: 352-363$, map (1909)

09b The coal field between Gallup and San Mateo, N. Mex. U S G S, B 341: 364-378, map (1909)

10 Isolated coal fields in Santa $\mathrm{Fe}$ and San Miguel cos., N. Mex. U S G S, B 381: 447-451 (1910)

10a The Carthage coal field, N. Mer. U S G S, B 381:452-460, map (1910)

10b The coal fleld between San Mates and Cuba, N. Mex. U S G S, B 381:461473, map (1910)

10e Oolitic limestone at Bowling Gren and other places in Kentucky. U S G \& B $430: 373-378$ (1910)

10a Carboniferous coal in New Mexio [coal beds on the Rio Pecos in San Miguel Co.]. Mines and Minerals $30: 570-571$ (1910)

10e The Puerco and Torrejon forms tions of the Nacimiento group. J G 18: 702-741, map (1910)

Iof Some notes on the Mammoth Care. Ky. (abst). Science n s $31: 718-719$ (1910)

11 The Mammoth Cave of Kentuds. Mines and Minerals 31:720-722 (1911)

12 Preliminary report on the econowic geology of the Hartford quadrangle. Ks G S, B 20:1-25, maps (1912)

12a Rock pbosphate in Kentucks. Mines and Minerals 33 : 207-209 (1912)

13 Field and office methods in the preparation of geologic reports; a special plate table for work on a large scale base map. Ec G $8: 495-499$ (1913)

13a The Broadtop coal field of Hunt ingdon, Bedford and Fulton cos. $\mathrm{Pa}$ Top G S, Rp 10:81 pp, maps (1913)

14 Geology of the Broadtop coal field [map] ; scale 1:24,000. Pa G S [1914]

15 A stratigraphic disturbance through the Ohio Valley, running from the Appala. chian Plateau in Pennsylvania, to the Ozark Mountains in Missouri. G gec 10 B $26: 66$ (abst), 477-483, map (1915) 
Gardner, James Henry-Contlnued.

15a The oil pools of southern Oklahoma and northern Texas. Ec G 10:422-434 (1915) Abst, G Soc Am, B 26: 102 (1915) 17 The Mid-Continent oil fields. G Soc Am, B 28: 685-720 (1917)

17a The vertical component in local folding (with discussion). Southwestern As Petroleum G, B 1:107-110 (1917)

17b Kentucky as an oil State. Science 8 46:279-280 (1917)

See also Clapp (F G), 14

Gardner, James T.

75 Report upon the southern coal and iron fields of Colorado Territory. $23 \mathrm{pp}$, Colorado Springs, Colo., 1875

Gardner, John Starkie.

79 Are the fossil floras of the Arctic regions Eocene or Miocene? Nature 19 : 124-127 (1879) Ausland 52:25-29 (1879) $800 \mathrm{n}$ the age of the Laramie formation as indicated by its vegetable remains. Am Nat $14: 565-569$ (1880)

84 On the relative ages of the American and the English Cretaceous and Eocene serieg. G Mag (3) 1:492-506 (1884) $\triangle$ bst, Brit As, Rp 54:739-741 (1885)

Gardner, Joseph,

74 Tripoli [Dubois Co]. Ind $\mathrm{G} \mathrm{S}, \mathrm{An}$ Rp $5: 423-425$ (1874)

Gardner, Julia Anna.

15 Relation of the late Tertiary faunas of the Yorktown and Duplin formations. In] I Sc (4) $39: 305-310$, map (1915)

16 (with Clark, W. B., and Berry, E. W.) Correlation of the Upper Cretaceous ormations, Md G S Upper Cret: $315-341$ 1916)

16a (with Clark, W. B., and Berry, 2.W.) The age of the middle Atlantic oast Upper Cretaceous deposits. Nat Ac Sc, Pr 2: 181-187 (1916)

17 The environment of the Tertiary maine faunas of the Atlantic Coastal Plain. lobns Hopkins Univ Circ, n s 1917 no 3: -44 [234-242] (1917)

See also Clark (W B), $6 \mathrm{~b}$

Girella, Napoleon.

49 Geological sketch on the formation of the soil of the Isthmus [of Panama]. 8, 30th Cong 2d sess, H Rp 145: 51924 (1849)

Garfias, Valentine Richard.

12 The effect of igneous intrusions on he accumulation of oil in northeastern Lexico. J G 20:666-672 (1912) Rv by Dranuel Friedlaender, Zs Vulkar. 5: 104(198 (19)

14 (with Arnold, Ralph) Geology and ectnology of the California ofl fields. Am If Eng, B 87:383-467, map (1914)

15 The oil region of northeastern Mex10. Ec G 10:195-224 (1915)

15 a General notes on Mexican oil fields. If Soc Am Univ, Y Bk 2:15-17 (1915)
Garfias, Valentine Richard-Continued.

17 (and Hawley, H. J..) Funnel and anticlinal ring structure associated with igneous intrusions in the Mexican oil fields. Am I M Eng, B 128:1147-1159 (1917); Tr 57:1071-1088 (1918)

18 Oil in southern Tamaulipas, Mexico (discussion). Am I M Eng, B 142:1560 (1918)

See also Ord6ñez, 18

Garland, Joseph.

s8 Copper mining at Tilt Cove, Newf. R G Soc Cornwall, Tr 11:99-105 (1888)

Garman, S.

83 [Remarks on the extinction of thr fossil horses of America.] Boston Sow $\mathrm{N} \mathrm{H}, \operatorname{Pr} 22: 252-253$ (1883)

Garnier, Jules.

91 Mines de nickel, cuivre, et platins du district de Sudbury, Canada. Soc Ing Civlls France, Mém (5) 44:239-25đ (1891)

Garrett, E. L.

85 Recession of Niagara Falls in 133 years. Nature 32:244-245 (1885)

Garrett, Robert E.

13 (with ohern, D. W.) The Ponca City oil and gas field. Okla 3 S, B 16 : 30 pp (1912)

Garrey, George $\mathrm{H}$.

os (with Spurr, J. E.) ... ore deposits in the Georgetown, Colo., mining district. U S G S, B 260:99-120 (1905)

06 (with Spurr, J. E.) The Idra Springs mining district, Colo. U S G s, B $285: 35-40$ (1906)

o7 (with Emmons, W. H.) Notes on the Manhattan district [Nev.] U S G S, B 308: 84-93 (1907)

08 (with Spurr, J. E.) Economic geology of the Georgetown quadrangle (together with the Empire district), Colo. U S G S, P P 63: 422 pp (1908)

10 (with Ransome, F. L.) Geology and ore deposits of the Bullfrog district, Nev. U S G S, B 407:130 pp (1910)

12 (with Spurr, J. E.) Study of a contact-metamorphic ore deposit; the Dolores mine, at Matahuala, S. L. P., Mex. Ec G $7: 444-484$ (1912)

Garrison, Frank Lynwood.

00 The Joplin zine district. Mines and Minerals 20: 462-463 (1900)

04 The genesis of limonite ores in the Appalachians. Eng $M \quad J$ 78:470-471 (1904)

O4a The iron ores of Shady Valley, Tenn. En M J 78: 590-592 (1904)

04b Tin in the United States. Eng M J $78: 830-832$ (1904)

o5 Gold in Santo Domingo. Eng M J $79: 1128-1130$ (1905)

o7 Gold mining in Santo Domingo: Eng M J $84: 490-492$ (1907)

o7a The Parral district, Mexico. M Sc Press 94: 373-374 (1907) 
Garrison, Frank Lynwood-Continued.

orb Metallic sulphides in the tuffs of Santo Domingo. M Sc Press 95:305-310 (1907)

ore Notes on minerals. Ac N Sc Phila, Pr 59: 445-446 (1907)

os Zinc and lead deposits of southwestern Missouri. M Sc Press 96:291-294, 325-328 (1908)

09 Ores formed by magmatic segregation. M Sc Press 98: 451-456 (1909)

09 a Nature of gold in alluvials. M Sc Press 98: 760-762 (1909)

11 Decrease of value in ore shoots with depth. Can M Inst, Q J 16:63-77 (1911); Tr 15:192-209 (1912) M Science 65: 152-154 (1912) $\mathbf{M}^{*}$ World $36: 346-347$ (1912) M Sc Press 104:558-561; 105 : 700-702 (1912)

12 Persistence of ore in depth. M Sc Press 105: 377-378 (1912)

15 The minerals of Santo Domingo. Eng M J $99: 641-644$ (1915)

See also Cabrera, 98 ; Donnelly, 15

Garrison, O. E.

81 The upper Mississippi region. Minn G S, An Rp 9:175-223 (1881)

Garside, G. W.

93 The mineral resources of southeast Alaska. Am I M Eng, Tr 21: 815-823, map (1893) Abst, Eng M J 55:175-176 (1893)

\section{Gasking, S.}

89 The Arctic current and floating ice as factors in Canadian geology. Liverpool G As, Tr 8:75-82 (1889)

Gass, J.

82 (and Pratt, W. H.) Bones of the mammoth in Washington Co., Iowa. Davenport Ac N Sc, Pr 3:177-178 (1882)

Gassaway, A. D.

99 The Magalia, Cal., drift mine. M Sc Press 78: 372-373, 400-401 (1899)

Gaudry, Albert.

72 Sur une dent d'Elephas primigenius, trouvée par M. Pinard dans l'Alaska. Ac Se Paris, C R 75:1281-1282 (1872) Also in Pinart, Alph. L. Voyages à la côte nordouest de l'Amérique : 29-31, Il, Paris 1875

ซ3 Sur une dent d'Elephas primigenius trouvée par M. Pinard dans l'Alaska. Soc G France, B (3) 1: 123-124 (1873)

85 Sur les Dinocératidés que M. Marsh a recuelllis dans 1 éocène du Wyoming. Ac Sc Paris, C R 101: 718-720 (1885)

92 Excursion dans les montagnes Rocheuses. Soc G France, B (3) 19:936-942 (1892)

92a Simflitudes dans le marche de l'évolution sur l'ancien et le nouveau continent. Soc G France, B (3) 19:1024-1035 (1892)

03 Observations paléontologiques dans l'Alaska. Ac Sc Paris, C R 137:553-554 (1903)
Gaussoin, Eugene.

66 Memoir on the Island of Navaser, West Indies. $32 \mathrm{pp}$ and atlas, Baltimos: 1866

Gauthier, $\mathrm{H}$.

17 Road materials in Two Mountals and the southeastern portion of Argented cos, Que. Can G S, Sum Rp 1916:198. 201 (1917)

Gautier, Armand.

o3 A propos de la composition des gat des fumerolles du Mont Pelé; remarọve sur l'origine des phénomènes volcanique Ac Sc Paris, C R 136:16-20 (1903)

06 The genesis of thermal waters at? their connection with volcanism. Trans by F. L. Ransome of "La genèse des eaur thermales et ses rapports avec le rola nisme" (An Mines (6) 9:316-370 (1906) Ec G 1 : 688-697 (1906)

Gawthrop, Robert $M$.

15 (with Hennen, R. จ.) Wromins and McDowell counties. W Va G $\mathrm{S}: 18$ pp, maps (1915)

Gaylord, Willis.

43 Geology as connected with agricul ture. In New York Tribune Extra, Usefu works for the people, No. 2:71-80 N 1843

Gazlay, Sayrs.

30 Origin of bituminous coal. Am J\& $17: 397-398$ (1830)

$30 \mathbf{a}$ Notice of the osseous remains at Big Bone Lick, Ky. Am J Sc 18:139-141 (1830)

33 Notices of fossil wood in Oblo. An $J$ Sc 25: 104-107 (1833)

Geballe, Pauline.

17 Phases of voleanism as shown in the Cascades [Wash.] (abst. Mazama 5: 166-169 (1917)

Gebhara, Jobn.

35 On the geology and mineralogy of Schoharie, N. Y. Am J Sc 28:172-177 map (1835)

Geddes, Charles Walter.

o9 Calabacillas gold mine [Chihuabus Mexico]. M Sc Press 98:689-690 (1909) Geddes, George.

60 [Geology of Onondaga Co., N. I.] N Y St Agr Soc, Tr 19:243-256 (1860)

Geddes, James.

26 ... geological features of the south side of the Ontario Valley [New York]. Am J Sc 11:213-218 (1826) Alban? Inst, $\operatorname{Tr} 1: 55-59$ (1830)

Geer, Gerard de.

92 Isobases of postglacial elevation. As G $9: 247-249$ (1892)

92 Or Pleistecene changes of level is: eastern North America. Boston Soc ? $\mathrm{H}, \operatorname{Pr} 25: 454-477$ (1892) Am G 11: 22-44 (1893)

Gehrmann, Charles A.

08 The gold camp of Rawbide. Fent ralda Co., Nev. M Science $57: 305-30 \%$ (1908) 
Geiger, H. R.

91 (and Keith, A.) The structure of the Blue Ridge near Harper's Ferry (with discussion by C. D. Walcott and C. H. Hitchoock). G Soc Am, B 2:155-164 (1891)

Geijer, Per.

14 Lake Superior-områdets prekambriska järnformationer. G Fören Stockbolm, Förh $35: 439-483$ (1914)

15 Some problems in iron-ore geology in Sweden and in America. Ec $\mathrm{G} 10$ : 299-329 (1915)

15a Den praktiska geologien i Nordamerika [economic geology in North America]. G Fören i Stockholm, Förh $37: 193$ 214 (1915)

Geijsbeek, Samuel.

11 The clay deposits of Washington. Am Ceramic Soc, Tr 13:751-764 (1911)

13 The clay deposits of Oregon. Am Ceramic Soc, Tr 15:644-658, map (1913) Geikie, Archibald.

79 Geology of the Far West [Rocky Mountains region; Yellowstone Park]. Nature 21:67-69 (1879) Abst, Pop Sc Mo $16: 568-569$ (1880)

so 0 n the Archean rocks of the Wasatch Mountains, Am J Sc (3) $19: 363-367$ (1880)

81 The ancient glaciers of the Rocky Mountains. Am Nat 15:1-7 (1881)

82 Geological sketches at home and abroad. 322 pp, N Y 1882

93 Geological change and time. Smiths Inst, An Rp 1892: 111-131 (1893)

97 The founders of geology. $297 \mathrm{pp}$, L 1897 The George Huntington Williams memorial lectures on the principles of geology, volume one. $297 \mathrm{pp}$, Baltimore 1901 2d ed, 486 pp, L 1905

Geikie, James.

85 The ice age in Europe and North America. Edinb G Soc, Tr 5:144-168 (1885)

91 Glacial geology. Smiths Inst, An Rp $1890: 221-230$ (1891)

Geinitz, Eugen,

02 Ueber die vulcanischen Ereignisse von Martinique und St. Vincent. Ver Freunde Naturg Mecklenburg, Arch 56: xxxvil-1ii (1902)

fieinitz, Hans Bruno.

66 Carbonformation und Dyas in Nebraska, K Leopoldino-Carolinische Deut Akad Naturf, Verb 33 Abh 4:91 pp, il (1866)

67 Carbonformation und Dyas in Nebraska. N Jb 1867:1-9

87 Ueber Nautilus alabamensis Morton, Neutilus siczac Sow., und Nautilus lingulatus v. Buch. N Jb 1887 , II : 53-56, il

Geldern, Otto von.

89 Falb's theory of earthquakes. Tech Soc Pacific Coast, Tr 6:1-35 (1889)
Gemmell, R. C.

97 The Camp Floyd mining district and the Mercur mines, Utah. Eng M J 63 : 403-404 (1897)

Genth, Frederick Augustus (1820-1893)

52 On some minerals which accompany gold in California. Ac $\mathrm{N}$ Sc Phila, $\operatorname{Pr} 6$ : 113-114 (1852)

52a On rhodophyllite, a new mineral. Ac N Sc Phila, Pr 6:121-124 (1852)

53 Contributions to mineralogy. Am J Sc (2) $16: 81-86,167-170$ (1853) ; 18 : $249-254, \quad 410-411 \quad(1854) ; \quad 19: 15-23$ (1855) ; $23: 415-427$ (1857) ; $28: 246-255$ (1859); $33: 190-206$ (1862); $45: 305-321$ (1868) ; (3) $38: 198-203$ (1889) ; 39:47-50; $40: 114-120, \quad 199-207 \quad(1890) ; 41: 394-$ $400,401-403$ (1891) ; 43:184-189; 44 : 381-389 (1892)

$53 a$ On a new variety of gray copper, perhaps a new mineral. Ac $\mathbf{N}$ Sc Phila, Pr 6: 296-297 (1853)

53b On owenite, a new mineral. Ac N Sc Phila, Pr 6 : 297-299 (1853)

54 On a new meteorite from New Mexico. Am J Sc (2) 17:239-240 (1854)

55 Herrerite identical with smithsonite. Ac N Sc Phila, Pr $7: 232-233$ (1855) Am J Sc (2) 20:118-119 (1855)

55a Analyses of the meteoric iron from Tuczon, Province of Sonora, Mexico. Ac N Sc Phila, Pr 7:317-318 (1855) Am J Sc (2) 20:119-120 (1855)

59 On the occurrence of gold. Am J Ac (2) $28: 253-255$ (1859) M Mag (2) 1: 147-150 (1859) Ph Mag (4) 18:318-820 (1859) In Cotta, B. von, und Müller, Hermann, Gangstudien oder Beiträge zur Kenntniss der Erzgänge 3:508-511, Freiberg 1860

60 Re-examination of the tetradymite (bornite Jackson) from Field's gold mine, Georgia; and on a new modification of wolfram. M Mag (2) 1:358-360 (1860)

$60 a$ On tetradymite; reply to Dr. C. T. Jackson. M Mag (2) 2:64-66 (1860)

68 [On cupriferous ores from Archer Co., Tex.] Ac N Sc Phila, Pr 1868: 227228

68n Catalogue of rocks. In Le Conte, John L., Notes on the geology of the survey for the extension of the Union Pacific Railway... : 69-76, Phila 1868

70 On native lead and iron from Montana Territory [and a meteorite from Rockingham Co., N. C.]. $\mathrm{Am} \mathrm{Ph}$ Soc, $\mathrm{Pr}$ 11: 443-444 (1870)

71 On the mineral resources of North Carolina. Franklin Inst, J 93 or (3) 63 : 48-61, 114-130 (1872) Separate, 31 pp, Phila 1871

73 Corundum, its alterations and associated minerals. Am $\mathrm{Ph}$ Soc, $\operatorname{Pr} 13: 361$ 406 (1873) Pa Univ, Lab, Contr no 1:46 pp, n d J Prak Chemie 9:49-112 (1874) Abst, Am J Sc (3) 6:461-462 (1873) 
Genth, Frederick Augustus-Continued.

74 Investigation of iron ores and limestones from ... iron ore banks on Spruce Creek, Half Moon Run, and Warrior's Mark Run, in Center, Blair, and Huntingdon cos., Pa. Am Ph Soc, Pr 14: 84-99 (1874)

74a [On corundum.] Am $\mathrm{Ph}$ Soc, $\mathrm{Pr}$ $14: 216-218$ (1874) Am J Sc (3) $8: 221-$ 223 (1874)

74b On American tellurium and bismuth minerals. $\mathrm{Am} \mathrm{Ph}$ Soc, $\mathrm{Pr}$ 14:223-231 (1874) Pa Univ, Lab, Contr no $3: 9$ pp [n d, 1874] J Prak Chemie 10:355-368 (1874)

75 Preliminary report on the mineralogy of Pennsylvania, with an appendix on the hydrocarbon compounds by Samuel P. Sadtler. Pa G S, 2d, B : 206 pp (1875)

75a [Minerals of North Carolina.] In Kerr, W. C., Report of the geological survey of North Carolina 1, App : 53-88, Raleigh 1875

76 Second preliminary report on the nimeralogy of Pennsylvania. Pa G S, 2d, B2 : 207-238 (1876)

$76 a$ on some American vanadium minerals. Am J Sc (3) $12: 32-36$ (1876)

78 On some tellurium and vanadium minerals. $\mathrm{Am} \mathrm{Ph}$ Soc, $\mathrm{Pr} 17: 113-123$ (1878) Zs Kryst 2:1-13 (1877) Abst, Am J Se (3) 14:423-424 (1877)

so On pyrophyllite from Schuylkill Co., Pa. Am Ph Soc, Pr 18: 279-280 (1880)

80a The so-called emery ore from Chelsea, Bethel Township, Delaware Co., Pa. Ac N Sc Phila, $\operatorname{Pr} 1880: 311$; Min G Sec, Pr no 1:75 (1880)

81 Analyses of minerals and rocks from Bucks, Montgomery, and Philadelphia cos., Pa. Pa G S, 2d, C6 : 94-136 (1881)

81a (and Kerr, W. C.) The minerals and mineral localities of North Carolina; being Chapter I of the second volume of the geology of North Carolina, 1881:1122, Raleigh 1881 [2d ed]:1-128, Raleigh 1885

82 Contributions to mineralogy. Am $\mathrm{Ph}$ Soc, $\mathrm{Pr} 20: 381-404$ (1882)

$82 a$ Note on a damourite from Berks Co., Pa. Ac N Sc Phila, Pr 1882:47-48; Min G Sec, Pr no 2:14-15 (1882)

84 On herderite. Am Ph Soc, Pr 21: 694-699 (1884)

85 (and Kerr, W. C.) The minerals and mineral localities of North Carolina. $128 \mathrm{pp}$, Raleigh 1885

S5a Additional analyses of minerals and rocks. $\mathrm{Pa} G \mathrm{~S}, 2 \mathrm{~d}, \mathrm{C5}: 111-120$ (1885)

85b (and Rath, G. vom) On the vanadates and iodyrite, from Lake. Valley, Sierra Co., N. Mex. Am Ph Soc, $\mathrm{Pr} 22$ : 363-375 (1885)

85e (and Rath, G. vom) Ueber Vanadate und Jodsilber von Lake Valley, Dona Ana Co., N. Mex. Zs Kryst 10:458-474 (1885)
Genth, Frederick Augustus-Continued. s6 Contributions to mineralogy. At Ph Soc, Pr 23:30-47 (1886)

87 Contributions to mineralogy. An Ph Soc, Pr 24:23-44 (1887)

$\mathbf{8 7 a}$ On an undescribed meteoric iron from east Tennessee. Ac N Sc Phila, P $1886: 366-368$ (1887)

s8 Lansfordit, ein neues Mineral [Lans ford, Schuylkill Co., Pa.]. Zs Kryst 14: 255-256 (1888)

89 On two minerals from Delaware $\mathrm{C}_{0}$, Pa. Ac N Sc Phila, Pr 1889:50-52

90 Jarosite from Utah. Am J Sc (3) $39: 73(1890)$

ooa (and Penfield, S. L.) On lans. fordite, nesquehonite, a new mineral, and pseudomorphs of nesquehonite after lans. fordite. Am J Sc (3) 39:121-137 (1890) Zs Kryst 17:561-577 (1890)

91 The minerals of North Carolins. U S G S, B 74:119 pp (1891)

91a Mineralogische Mittellungen, $z_{8}$ Kryst 18:585-594 (1891)

93 On the "anglesite" associated with boleite. Am J Sc (3) 45:32-33 (1893)

Geographical Society of Baltimore.

o5 The Bahama Islands, edited by George Burbank Shattuck. $680 \mathrm{pp}$, maps, N Y 1905

Geologieal and Mining Society of Ameriean Universities.

Year book. Vols. 1-2, 1914-5, Stanfori University

Geologieal Society of Ameriea.

Bulletin. Vol. 1, 1890- N Y

Editors, W J McGee, Joseph Stanley. Brown

Geological Society of Pennsylvania. Transactions. Vol. $1: 428,13 \mathrm{pp}$, Pbils 1835

Geologisches Zentralblatt, Berlin.

Includes many abstracts of articles on North American geology. The limits of the work made it impracticable to admit these.

George, Harold C.

06 The Nipissing mine, Cobalt, Ont. Eng M J 82: 967-968 (1906)

10 Empire-Enterprise zinc mines, Wis Eng M J $89: 1280-1282$ (1910)

15 The Wisconsin zinc district. Eng N J 100:295-300, 341-344, 385-388 (1915) 17 The Wisconsin zinc district. Am I M Eng, B 132: 2045-2074 (1917) ; Tr 59: 117-150 (1918)

George, Russel D.

or Polished pebbles. Science n s 25: 626-627 (1907)

09 The main tungsten area of Bouldet Co., Colo. Colo Sc Soc, P $9: 181-216$, maps (1909)

09a First report, 1908 , with accompsns. ing papers. Colo G S: 243 pp, maps (1909) 
George, Russel D.-Continued.

09b The main tungsten area of Boulder Co.. Colo., with notes on the intrusive rocks by R. D. Crawford. Colo G S, 1st Rp 1908: 7-103, map (1909)

09e (and Crawford, R. D.) The Hahns Peak region, Routt Co., Colo. Colo G S, 1st Rp 1908:189-229, map (1909) 10 A classification of igneous rocks. M Science $62: 390$ (1910)

11 A bibliography of uranium and vanadium. M Science 63:241 (1911)

13 Common minerals and rocks, their occurrence and uses. Colo St G S, B 6: $406 \mathrm{pp}$ (1913)

13a Geological relations in the Brush Creek region [Colo.]. M Science 67:148149, map (1913)

- 13b Geologic map of Colorado; scale 1:500,000. Colo G S (1913)

17 Common minersls and rocks, their occurrences and uses. Colo G S: 463 pp (1917)

Gerard, W. R.

79 The Hudson River grom at Poughkeepsie. Am Nat 13: 199 (1879)

Gerland, Georg.

99 Modern studies of earthquakes. Pop Sc Mo 54 . 362-371 (1899)

02 Der Ausbruch der Montagne Pelée auf Martinique. Deut Rundschau 112: 425-439 (1902)

Gerolt, Friedrich von.

26 Auszug aus einem Berichte uber eine bergminnische Expedition nach dem Bergwerks-Bezirk del Christo in Mexico. J Chem Phys 46 (=Jb 16) : 230-23 (1826) 26a Ueber einige Mexicanische GangGebilde. J Chem Phys $46(=$ Jb 16) : $237-$ 245 (1826)

27 Bericht über die bergmännische Expedition nach dem Bergwerks-Bezirk von Christo [Mexico]. Arch Bergbau 14:319 (1827)

27a Bericht uber die Silbergrube Areralo im Bergwerks-Revier Atotonilco el Chico [Mexico]. Arch Bergbau 14:2051 (1827) An Mines (2) 4:451-464 (1828)

27b Bericht iber die Silbergrube Santa Rosa im Bergwerks-Revier Chico [Mexico]. Areh Bergbau 14:52-57 (1827)

27e Bericht über die Gold- und SilberGruben Santissima, Flajonales, und Chalma im Bergdistrict del Oro. Arch Bergbau 14: 58-66 (1827)

27 d (and Berghes, C. de) Carta geogDóstica de los principales distritos minerales del Estado de México ... [Scale, 1: $25,000]$ Düsseldorf 1827 Reproduced, reduced, in Egloffstein, 64

6. Explanatory remarks upon the accompanying map and profiles. In Egloffstein, F. W. von, Contributions to the geology and physical geography of Mexico: $5-14$, N Y 1864
GeroIt, Friedrich von-Continued.

$64 a$ Observations made on two excursions from the City of Mexico to the Popocatepetl in 1833 and 1834. In Egloffstein, F. W. von, Contributions to the geology and physical geography of Mexico: 15-40, N Y 1864

Gerry, C. N.

09 Gold, silver, copper, lead, and zinc; Idaho. U S G S, Min Res 1908 pt 1:405435 (1909) ; 1909 pt $1: 333-357$ (1911)

11 Gold, silver, copper, lead, and zinc in Idaho and Washington. U S G S, Min Res 1910 pt $1: 446-469,597-605 ; 1911$ pt 1 : $570-602,778-788 ; 1912$ pt $1: 706-738,914-$ $923 ; 1913$ pt $1: 755-801 ; 1914$ pt $1: 597$ $654 ; 1915$ pt $1: 523-575 ; 1916$ pt $1: 565-$ $616(1911-8)$

Gesner, Abraham (1797-1864).

36 Remarks on the geology and mineralogy of Nova Scotia. xi, $272 \mathrm{pp}$, map, Halifax 1836

39 First report on the geological survey of the Province of New Brunswick. $87 \mathrm{pp}$, Saint John 1839

40 Second report on the geological survey of the Province of New Brunswick. xil, 76 pp, Saint John 1840

41 Third report on the geological survey of the Province of New Brunswick. xiv, 88 pp, Saint John 1841

42 Fourth report on the geological survey of the Province of New Brunswick. 101 pp, Saint John 1842

43 Report on the geological survey of the Province of New Brunswick ... 88 pp, Saint John 1843

43a A geological map of Nova Scotia, with an accompanying memoir (abst), G Soc London, Pr 4:186-190, map (1843) Ph Mag (3) 24:149-153 (1843)

49 The industrial resources of Nova Scotia ... $341,17,4 \mathrm{pp}$, map, Halifax, N.S. 1849

49 On the gypsum of Nova Scotia. G Soc Lonđon, Q J 5:129-130 (1849)

52 [anonymous] Review of "Reports on the geological relations, ehemical analysis, and microscopic examination of the coal of the Albert Coal Mining Company, situated in Hillsboro, Albert Co., N. B." as written and compiled by Charles T. Jackson, by a Fellow of the Geological Society of London. $40 \mathrm{pp}$, map, N Y 1852

61 A practical treatise on coal, petroleum, and other distilled oils. $134 \mathrm{pp}$, N Y, $18612 d$ ed, 181 pp, N Y 1865

61a On elevations and depressions of the earth in North America. G Soc London, Q J $17: 381-388$ (1861) Can J 3: 81-86 (1862)

62 On the petroleum springs in North America. G Soc London, Q J 18:3-4 (1862) 
Gesner, G. W.

96 Dr. Abraham Gesner; a biograph. lcal sketch. N H Soc N B, B [3] no $14: 3-$ 11, port (1896)

Gesner, William.

76 On the coal and iron resources of Alabama. Ac N Sc Phila, Pr 1876 ; 163165

Gester, G. C.

14 Geology of the southern end of the San Joaquin Valley (abst). G Soc Am, B $25: 123$ (1914)

17 Geology of a portion of the MeKittrick district, a typical example of the West Side San Joaquin Valley oil fields, and a correlation of the oil sands of the West Side fields. Cal Ac Sc, Pr (4) $7: 207-227$ (1917)

Gibb, George D.

60 On Canadian caverns. Geologist, London, 3 : 131-133, 161-179, 213-219, 341342 (1860) In part, Can Nat $6: 184-190$ (1861)

Gibbes, Lewis $R$.

57 On some points whlch have been over looked in the past and present condition of Niagara Falls. Elliott Soc N H Cuarleston, $\operatorname{Pr} 1: 91-100$ (1857)

57 a Remarks on Niagara Falls. Am As, Pr 10 pt 2:69-78 (1857)

59 Notice of the phenomena attending the shock of the earthquake of Dec. 19 1857 [Charleston, S. C.] Elliott Soc $\mathrm{N} \mathrm{H}$ Charleston, Pr 1:288-289 (1859)

Gibbes, Robert Wilson (1809-1866).

45 Description of the teeth of a new fossil animal found in the greensand of South Carolina. Ac N Sc Phila, Pr 2 : 254-256, il (1845)

46 On the fossil Squalidae of Columbia, S. C. Ac N Sc Phila, Pr $3: 41-43$ (1846)

47 On the fossil genus Basilosaurus, Harlan, (Zeuglodon, Owen) with a notice of specimens from the Eocene greensand of South Carolina. Ac N Sc Phila, J (2) 1:5-15, il (1847) Reprint, $13 \mathrm{pp,} \mathrm{il,}$ Phila 1847

47a Description of new species of squalides from the Tertiary beds of South Carolina. Ac N Sc Phila, Pr 3:266-268 (1847)

48 Monograph of the fossil Squalidae of the United States. Ac N Sc Phila, J (2) $1: 139-147$, il $(1848) ; 191-206$, if (1849)

48 a [On the validity of the name Dorudon.] Ac N Sc Phila, Pr 4:57 (1848)

49 The present earth the remains of a former world... $31 \mathrm{pp}$, Columbia, S. C., 1849

50 New species of Myliobates from the Eocene of South Carolina, with other genera not heretofore observed in the United States. Ac N Sc Phila, J (2) 1 : $299-300$, il $(1850)$

50a On Mosasaurus and other allied genera in the United States. $\mathbf{A m} \mathbf{A s}, \operatorname{Pr}$ $2: 77(1850)$
Gibbes, Robert Wilson-Continued.

50b [Notice of] new species of foss] Myliobates, from the Eocene of South Carolina, and new fossils from the Cretaceous, Eocene, and Pliocene of South Carolins, Alabama, and Mississippi. Am As, Pr 2: 193-194 (1850)

50e Remarks on the fossil Equus. An As, Pr 3:66-68 (1850)

50d Remarks on the northern Elephor of Prof. Agassiz. Am As, Pr 3:69 (1850)

50e Remarks on Mastodon angustiden $\Delta \mathrm{m} \mathrm{As,} \mathrm{Pr} \mathrm{3:69-70} \mathrm{(1850)}$

50P Fossils common to several forms. tions [Squalidae]. Am As, Pr 3:70-71 (1850)

51 A memoir on Mosasaurus and the three allied new genera, Holcodus, Cons. saurus, and Amphorosteus. Smiths Contr Knowl 2 art 5:13 pp, il (1851)

Gibbon, J. H.

45 Gold of North Carolina. Am J S 48: 398-399 (1845)

Gibbs, George (1776-1833).

14 Mineralogical notice respecting the West River Mountain, Connecticut Rivet Am Miner J 1:19-20 (1814)

14a Crystallized bodies discovered in meteoric stone. Am Miner J 1: 190 (181i)

$14 \mathbf{b}$ Observations on the mass of froz from Louisiana. Am Miner J 1:218-21 (1814)

19 On the tourmalines and other minerals found at Chesterfield and Goshen, Mass. Am J Sc 1:346-351 (1819)

Gibbs, George (1815-1873).

55 Report on a reconnaissance of the country lying upon Shoalwater Bay and Puget's Sound [Wash.]. U S, Pacific R R Expl (U S, 33d Cong 1st sess, I Er Doc 129 v 18 pt 1) 1:483-494 (1855)

55a Report upon the geology of the certral portion of Washington Terr. U \&, Pacific R R Expl (U S, 33d Cong 1st sess, H Ex Doc 129 v 18 pt 1) 1:494-51? (1855)

55b Note on geology of country east of Cascade Mountains, Oreg. Am J Sc (2) $20: 275 \quad(1855)$

71 Plasticity of rocks. Am Nat 4:695 (1871)

73 The "Glades" of Maryland. Al" Nat $7: 636$ (1873)

73a Physical geography of the north. western boundary of the United States Am Geog Soc, J 3:134-157; $4: 298-415$ (1873-4).

Gibbs, Walcott.

49 Field notes [in the Lake Superiot region in 1848]. U $\mathrm{S}, 31$ st Cong 1st sess $\mathrm{S}$ Ex Doc 1 pt 3 and $\mathrm{H}$ Ex Doc 5 pt 3 : $702-711$ (1849)

Gibson, Alexander Montgomery.

86 The Raccoon Mountain coal feld In McCalley, Henry, On the Warrior cot field : 544-555, Ala G S 1886 
Gibson, Alexander Montgomery-Contd.

91 Report on the coal measures of Blount Co. In MeCalley, Henry, Report on the coal measures of the plateau refion of Alabama: 114-122, 188-215, Ala G S, 1891

93 Report on the geological structure of Murphrees Valley and its minerals and other materials of economic value. Ala G. S: 132 pp, Montgomery, Ala., 1893

93a Report on the coal measures of Blount Mountain. Ala G S : 80 pp, map, Montgomery, Ala., 1893

95 Report upon the Coosa coal fleld with sections. Ala G S : 143 pp, Montgomery, Ala., 1895

Gibson, John.

73 Geological features of Huron Co., ont. Can Nat n s 7:34-40 (1873)

73a The salt deposits of western Ontario. Am J Sc (3) $5: 362-369$ (1873)

Gibson, John Bannister (1780-1853).

25 Observations on the trap rocks of the Connewago Hills near Midaleton, Dauphin $\mathrm{CO}_{0}$, and of the stony ridge near Carlisle, Cumberland Co., Pa. Am Ph Soc, Tr n s 2:156-166 (1825)

36 ...geology of the lakes and the valley of the Mississippi... Am J Se 29:201-213 (1836)

Gibson, Thomas W.

99 The corundum deposits of Onterio. Rng M J 67:500 (1899)

01 Report of the [Ontario] Bureau of Mines, 1901. $236 \mathrm{pp}$, Toronto, $1901 \quad \ldots$ 1902:309 pp, maps, Toronto $1902 \quad \ldots$ 1903: 354 pp, maps, Toronto, $1903 \quad \ldots$ 1904, pt 1:255 pp, maps; pt 2: 143 pp, Toronto $1904 \ldots 1905$, volume 14 pt $1: 374$ pp, map; pt 2:97 pp, maps (2d ed, 97 DP, 1906) ; pt $3: 188 \mathrm{pp}$, maps, Toronto 1905 ...1906, volume 15 pt $1: 218 \mathrm{pp}$, pt 2:127 pp, maps, Toronto 1906

07 Sixteenth annual report of the [Ontario] Bureau of Mines, 1907, vol 16 pt 1 : $248 \mathrm{pp}$, map, Toronto 1907 ; pt $2: 212 \mathrm{pp}$, maps (1908) Seventeenth...1908, vol 17: 356 pp, maps (1908) Eighteenth...1909, rol 18 pt $1: 311$ pp, maps; pt $2: 35$ pp, map (1909) Nineteenth...1910, vol $19 \mathrm{pt}$ 1:245 pp, maps (1910); pt 2: 279 pp, maps (1913) Twentieth...1911, vol 20 pt 1:301 DD, maps; pt 2:42 pp (1911) Twentyfrst...1912, vol 21 pt 1: 309 pp, maps; pt 2:216 pp, map (1912) Twenty-second... 1913, vol 22 pt 1: 284 pp, maps (1913); pt 2:151 pp, maps (1914) Twenty-third... 1914, vol 23 pt 1:300 pp, maps (1914) Twenty-fourth...1915, vol 24 pt $1: 275 \mathrm{pp}$, maps; pt 2:96 pp; pt 3:73 pp (1915) Twenty-fifth...1916, vol 25 pt $1: 311$ pp; Dt $2: 56 \mathrm{pp} ;$ pt $3: 71 \mathrm{pp}$, maps (1916) Twenty-sixth...1917, vol $26: 366 \mathrm{pp}$, maps (1917) Twenty-seventh...1918, vol $27 \mathrm{pt}$ 1:265 pp; pt 2:138 pp, maps (1918)
Gibson, Thomas W.-Continued.

11 The mineral resources of Ontario. Am Electrochem Soc, Tr 20:447-454 (1911)

Gidley, James Williams.

00 A new species of Pleistocene horse from the Staked Plains of Texas. Am Mus N H, B 13:111-116, il (1900)

01 Tooth characters and revision of the North American species of the genus Equus. Am Mus N H, B 14:91-142, il (1901)

02 A fossil armadillo from Texas. Am Mus J 2: 24-25, il (1902)

03 A new three-toed horse. Am Mus N H, B 19:465-476 (1903)

03a On two species of Platygonus from the Pliocene of Texas. Am Mus $\mathbf{N}$ H, B $19: 477-481$, il (1903)

03b The fresh-water Tertiary of northwestern Texas. Am Mus N H, B 19:617635, map (1903)

04 Proper generic names of Miocene horses. Am Mus N H, B 20:191-194 (1904)

04a (with Matthew, W. D.) New or little known mammals from the Miocene of South Dakota. Am Mus N H, B 20: 241-268, il (1904)

06 Evidence bearing on tooth-cusp development. Wash Ac Sc, Pr 8:91-106, Il (1906)

06a A new genus of horse from the Mascall beds, with notes on a small collection of equine teeth in the University of California. Am Mus N H, B 22:386-388, il (1906)

06b A fossil raccoon from a California Pleistocene cave deposit. U S Nat Mus, Pr 29:553-554, il (1906)

06e A new ruminant from the Pleistocene of New Mexico. U S Nat Mus, Pr. $30: 165-167$, il (1906)

o6d New or little known mammals from the Miocene of South Dakota. Am Mus N H, B $22: 135-153$, il (1906)

o7 A new horned rodent from the Miocene of Kansas. U $\mathrm{S}$ Nat Mus, $\operatorname{Pr} 32$ : 627-636, il (1907)

o7a Revision of the Miocene and Pllocene Equida of North America. Am Mus N H, B $23: 865-934$ (1907)

os Descriptions of two new species of Pleistocene ruminants of the genera Ovibos and Bootherium, with notes on the latter genus. U S Nat Mus, Pr 34:681-684, Il (1908)

osa Notes on a collection of fossil mammals from Virgin Valley, Nev. Cal Univ, Dp G, B $5: 235-242$, 11 (1908)

09 Notes on the fossil mammalian genus Ptilodus, with descriptions of new species. U S Nat Mus, Pr 36:611-636, il (1909)

10 Remarks on a restoration of Basilosaurus cetoides (abst). Science n s 31: 519 (1910) 
Gidley, James Williams-Continued.

12 Ten years' progress in vertebrate paleontology; Perissodactyla. G Soc $\mathbf{A m}$, B 23:179-181 (1912)

12a The lagomorphs an independent order. Science n s $36: 285-286$ (1912)

13 Notice of the occurrence of a Pleistocene camel north of the Arctic Circle. Smiths Misc Col 60 no $26: 2$ pp (1913)

13a An extinct American eland [Taurotragus americanus from Pleistocene cave deposits near Cumberland, Md.]. Smiths Misc Col 60 no $27: 3 \mathrm{pp}$, il (1913)

$13 \mathrm{~b}$ A recently mounted Zeuglodon skeleton in the United States National Museum. U S Nat Mus, Pr 44:649-654, il (1913)

13e Preliminary report on a recently discovered Pleistocene cave deposit near Cumberland, Md. U S Nat Mus, Pr 46: 93-102, il (1913)

14 Fauna of the Cumberland Pleistocene cave deposit (abst, with discussion). G Soc Am, B 25:142 (1914)

15 An extinct marsupial from the Fort Union with notes on the Myrmecobidae and other families of this group. U S Nat Mus, Pr 48:395-402, il (1915)

$15 a$ Notes on the possible origin of the bears (abst). Wash Ac Sc, J 5:333-334 (1915)

16 A talk on the extinct animal life of North America (abst). Wash Ac Sc, J $6: 228$ (1916)

17 Notice of a new Paleocene mammal, a possible relative of the titanotheres. U S Nat Mus, Pr 52:431-435, il (1917)

Giebel, C. G.

53 Beitrag zur Paläontologie des Texanischen Kreidegebirges. Naturw Ver [für Sachsen und Thüringen] in Halle, Jber 5 : $358-375$, il (1853)

53a Kreide-Versteinerungen aus Texas. N Jb $1853: 165$

Giesecke, Charles.

61 Catalogue of a geological and geographieal collection of minerals from the Arctic regions, from Cape Farewell to Baffin's Bay. R Dublin Soc, J 3:198-215 (1861)

Giesecke, Karl Ludwig.

10 Mineralogisches Reisejournal über Grönland. Med Grönland $35: 1-478$ (1910) Gilbert, Chester G.

13 (and Pogue, J. E.) The Mount Lyell copper district of Tasmania [includes notes on copper deposits of Shasta Co., Cal., and Ducktown, Tenn.]. U S Nat Mus, $\operatorname{Pr} 45: 609-625$ (1913)

17 The mineral industries of the United States; coal products-an object lesson in resource administration. U S Nat Mus, B 102 pt $1: 16 \mathrm{pp} \mathrm{(1917)}$

is (and Pogue, J. E.) The mineral Industries of the United States; coal, the resource and its full utilization. U S Nat Mus, B 102 pt 4:26 pp (1918)
Gilbert, Chester G.-Continued.

18 a (and Pogue, J. E.) Petroleum; resource interpretation. U $\mathbf{S}$ Nat $\mathrm{Yus}_{\text {, }}$ 102 pt $6: 74$ pp (1918)

Gilbert, Grove Karl (1843-1918).

71 Notes of investigations at Cohos [N. Y.] with reference to the circumstanco of the deposition of the skeleton of $y_{\text {a }}$ todon. N Y St Cab, An Rp 21:129-149 (1871)

T1a Report on the geology of Williams, Fulton, and Lueas cos. Ohio G S, R Prog 1870: 485-499 (1871)

71b Surface geology of the Maumee $\mathrm{Fa}$. ley. Lyc N H N Y, Pr 1: 175-178 (1871)

71e On the remains of a Mastodon from St. Johns, Auglaize Co., Ohio. Lye N N Y, Pr 1: 220-221 (1871)

71d On certain glacial and postglaclal phenomena of the Maumee Valley. Am Sc (3) 1:339-345 (1871)

72 Report. In Wheeler, G. M., Prelin inary report concerning explorations and surveys in Nevada and Arizona, 1871:9296, 'Washington 1872. A780, U S, 48 Cong 2d sess, S Ex Doc 65: 90-94 (18\%?

73 Reports on the surface geology the Maumee Valley, and on the geology of Williams, Fulton, and Lucas cos., and Test Sister Island. Ohio G S, Rp 1 pt 1 Geol ogy : 535-590, maps (1873)

74 Preliminary geological report, expe dition of 1872. U S Geog G S W 100th Mer (Wheeler), Progress Rp: 48-52, Wastington 1874

74a on certain recent geological and geographical researches in Arizona and Nevada. Ph Soc Wash, B 1: 54-56 (187i)

74b On sand sculpture in the West (abst). Ph Soc Wash, B 1:57 (1874)

74e On the Glacial epoch in Dtab and Nevada $(a b s t)$. Ph Soc Wash, B 1:84-\$ (1874)

74d On a cold geyser or intermittent artesian well in Ohio $(a b s t)$. Ph Sor Wash, B 1: 103 (1874)

74e On the age of the Tonto sandstones (abst). Ph Soc Wash, B 1: 109 (1874)

75 Report on the geology of portions o? Nevada, Utah, California, and Arizons U S Geog G S W 100th Mer (Wheeler), $3: 17-187$, maps [atlas sheets] (1875)

75a Report on the geology of portions of New Mexico and Arizona. U S Geog 6 S W 100th Mer (Wheeler), 3:503-56t (1875)

75b Wind-drift erosion. Am J Sc (3) $9: 151-152$ (1875)

75e Natural erosion by sand in the west ern territories (abst). Am As, Pr 23 pt $2:$ 26-29 (1875)

75d The recency of certain volcanoes of the western United States (abst). Am As, Pr 23 pt $2: 29-32$ (1875)

76 On the outlet of Great Salt Lake Am J Sc (3) $11: 228-229$ (1876) 
Gilbert, Grove Karl-Continued.

76 a The Colorado plateau province as a field for geological study. Am J Sc (3) 12:16-24, 85-103 (1876) Abst, Am As, Pr 23 pt $2: 32-35$ (1875)

77 Report on the geology of the Henry Mountains [Utah]. U S Geog G S Rocky Ith Reg (Powell) : 160 pp, maps (1877) 2d ed, $170 \mathrm{pp}$, maps (1880)

77a [On the Lake Bonneville basin (abst).] Am Nat 11:445 (1877) Ph Søc Wash, B 2:103 (1880)

$77 \mathrm{~b}$ Geological investigations in the Henry Mountains of Utah (abst). Am Nat $11: 447$ (1877)

78 Water supply [Great Salt Lake drainage basin, Utah]. In Powell, J. W., Report on the lands of the arid region of the Cnited States: 57-66, map (1878)

$78 \mathrm{a}$ The ancient ontlet of Great Salt Lake. Am J Sc (3) $15: 256-259$ (1878)

so The outlet of Lake Bonneville. Am J Sc (3) $19: 341-349$ (1880)

$80 a$ The drainage system of the Black Hills of Dakota. Ph Soc Wash, B 3:125$128(1880)$

s0b Ripple marks (abst). Ph Soc Wash, B 2:61-62 (1880)

80e The Wasatch a growing mountain (abst). Ph Soc Wash, B 2:195 (1880)

82 Contributions to the history of Lake Bonneville [Utah]. U S G S, An Rp 2: 167-200, map (1882)

82a A new method of measuring heights by means of the barometer. U S G S, An lip $2: 403-566$ (1882)

82b Postglacial joints. Am J Sc (3) 23: $25-27$ (1882)

82e On the origin of jointed structure. Am J Sc (3) $24: 50-53$ (1882)

83 Whitney's climatic changes. Science 1:141-142, 169-173, 192-195 (1883) [RV of Whitney, J. D., The climatic changes of later geological times.]

83a Pre-Bonneville climate. Science 2: 170 (1883)

83b [Faults and earthquakes in Great Basin region.] Science 2:580-581 (1883)

83e Drainage system and loess distribution of eastern Iowa. Scien 2:762 783 (1883)

84 On the origin of jointed structure. Am J Sc (3) $27: 47-49$ (1884)

$84 a$ A theory of the earthquakes of the Great Basin, with a practical application. Am J Sc (3) $27: 49-53$ (1883)

$84 \mathrm{~b}$ The sufficiency of terrestrial rotation for the deflection of streams. Am J $S_{C}$ (3) $27: 427-432(1884)$ Nat Ac Sc, Mem 3 pt 1: 7-10 (1885)

84e Ripple marks. Sclence $3: 375-376$ (1884)

84d Capitalization of names of forma-

tons. Science $3: 59-60(.384)$

$28737^{\circ}-23-26$
Gilbert, Grove Karl-Continued.

84e Plan for the subject bibliography of North American geology (abst). Brit As, Rp 54:732 (1885) G Mag (3) 1: 562 (1884)

85 The topographic features of lake shores. U S G S, An Rp 5: 69-123 (1885)

85a Introductory sketch of the Quaternary lakes of the Great Masin. U S G S, B 11: 9-12 (1885)

85b The diversion of water courses by the rotation of the earth (abst, with discussion). Ph Soc Wash, B $7: 21-24$ (1885)

85e Postglacial changes of level in the basin of Lake Ontario (abst). Science 6 : 222 (1885)

86 The inculcation of scientific method by example, with an illustraticn drawn from the Quaternary geology of Utah. Am J Sc (3) 31:284-299, map (1886)

86a The place of Niagara Falls in geologic history (abst). Am As, $\operatorname{Pr} 35: 222-$ 223 (1887) Am J Sc (3) $32: 322-323$ (1886) Science 8:205 (1886)

s6b Some new geologic wrinkles [postglacial anticlinals] (abst). $\Delta \mathrm{m}$ As, $\operatorname{Pr} 35$ : 227 (1887) Am J Sc (3) $32: 324$ (1886)

86e Geological survey of the United States. Appleton's Annual Cyclopedia, 1885 , n s 10:401-408 (1886)

87 The work of the International Congress of Geologists. $\mathbf{A m}$ As, $\operatorname{Pr} 36: 183-$ 206 (1888) Am J Sc (3) 34: 430-451 (1887) Nature $37: 19-22,40-43$ (1887) Abst, Science 10:87-88 (1887); Can Rec Sc 2:510-514 (1887) Résumé by E. de Margerie, Soc G France, B (3) $16: 2-7$ (1888)

87a On a prehistoric hearth under the Quaternary deposits in western New York (abst). Sc Am Sup 23: 9221-9222 (1887)

88 old shore lines in the Ontario basin (with discussion by J. T. B. Ives), Can Inst, $\operatorname{Pr}$ (3) 6:2-4 (1888)

88a Changes of level of the Great Lakes. The Forum 5:417-428 (1888)

90 Lake Bonneville. U S G S, Mon 1: xx, 438 pp, maps (1890)

90a The history of the Niagara River. N Y, Comm St Reservation at Niagara, An Rp 6:61-84 (1890) Smiths Inst, An Rp 1890:231-257 (1891)

$90 \mathrm{~b}$ The strength of the earth's crust (abst, with discussion by $\mathrm{A}$. Winchell and others). G Soc Am, B 1:23-27 (1890) Am Nat 24: 467-470 (1890)

91 Postglacial anticlinal ridges near Ripley, N Y., and near Caledonia, N. Y. (abst). Am G 8:230-231 (1891) Am As, Pr 40:249-250 (1892)

91a Classification of methods of correlation (abst, with discussion). Am G 8: 249-256 (1891)

92 The evolution of the moon (abst). Am Nat 26:1056-1057 (1892) 
Gilbert, Grove Karl-Continued.

93 The moon's face; a study of the origin of its features. Ph Soc Wash, B 12: 241-292 (1893)

93a Continental problems. G Soc Am, B $4: 179-190$ (1893) Smiths Inst, An Rp 1892: 163-173 (1893) Abst, Am G 11: 137 (1893)

$93 b$ (and others) Discussion sur la corrélation des roches clastiques. Int $G$ Cong, V, Washington 1893, C R:67-78, 151-175 (1893)

93e A theory of the formation of lunar craters (abst). N Y Ac Sc, Tr 12:93-95 (1893) Astronomy and Astrophysics 12 : 286 (1893)

94 The name "Newark" In American stratigraphy. J G 2:55-59 (1894)

94a The Niagara River as a geologic chronometer. Nature 50:53 (1894)

94b The chemical equivalence of crystalline and sedimentary rocks (abst). Am G $13: 213-214$ (1894)

95 Niagara Falls and their history. Nat Geog Soc, Nat Geog Mon 1 no $7: 203-236$ (1895) Also in The physiography of the United States (Nat Geog Soc) : 203-236, N Y, American Book Co., 1896

95a (and Gulliver, F. P.) Tepee buttes [Colorado]. G Soc Am, B $6: 333-342$, map (1895) Abst, Science n s $1: 59$ (1895); J G $3: 870-871+(1895)$

95b Lake basins created by wind erosion. J G 3:47-49 (1895) Sc Am Sup 39: 16157 (1895)

95e Sedimentary measurement of Cretaceous time. J G 3:121-127 (1895) Sc Am Sup 39:16180-16181 (1895) Abst, Science n s 1:64-65 (1895)

95d New light on isostasy. J G 3:331334 (1895)

95e A report on a geologic examination of some Coast and Geodetic Survey gravity stations. U S Coast S, Rp 1894 pt 2 App no $1: 51-55$ (1895)

95f A rock fissure [northern Arizona]. Science n s 2:117-119 (1895)

96 The origin of hypothesis, illustrated by the discussion of a topographic problem (presidential address before the Geological Society of Washington). Science n s 3:113 (1896) Also published by G Soc Washington, March 1896

$96 a$ The underground water of the Arkansas Valley in eastern Colorado. U S G S, An Rp 17 pt 2:551-601 (1896)

$96 \mathrm{~b}$ Laccolites in southeastern Colorado. J G 4:816-825, map (1896)

96e Age of the Potomac formation. Science $n$ s $4: 875-877$ (1896)

96d (and Cross, Whitman) A new laccolite locality in Colorado and its rocks (abst). Am G 17:407-408 (1896) Science n s 3:714 (1896)

96e The Algonquin River (abst). Am G $18: 231$ (1896) Science n s 4:384 (1896)
Gilbert, Grove Karl-Continued.

96P The Whirlpool-Saint David's ehanel (abst). Am G 18:232 (1896) Science ds 4:384 (1896)

96g Profile of the bed of the Niagara in its gorge (abst). Am G 18:232-233 (1896) Science n s 4:384 (1896)

97 Description of the Pueblo quadrangle [Colo.]. U S G S, G Atlas Pueblo fol (no 36) : 7 pp, maps (1897)

97 a Modification of the Great Lakes bf earth movement. Nat Geog Mag 8:233247 (1897) Smiths Inst, An Rp 1898: 349-361 (1899)

$\mathbf{9 7 \mathbf { b }}$ Old tracks of Erian drainage in western New York (abst). G Soc Am, B $8: 285-286$ (1897) J G $5: 109-110$ (1897) Science n \& 5:88 (1897)

97e Recent earth movements in the Great Lake region (abst), Science n 8 6: 689 (1897)

98 Recent earth movement in the Grat Lakes region. U S G S, An Rp 18 pt 2: 595-648 (1898)

98a Origin of the physical features of the United States. Nat Geog Mag 9:305317 (1898)

98b Boulder pavement at Wilson, N. Y. J G 6 : 771-775 (1898)

98e Joseph Francis James, 1857-1897. Am G 21: 1-11, port (1898)

9Sa A proposed addition to physiographic nomenclature. Science n 8 7:9495 (1898)

99 Submerged forest of the Columbit River (abst). Science n s 10:777 (1899) $99 a$ Glacial sculpture in western Ner York. G Soc Am, B 10:121-130 (1899) Abst, Am G 23: 103 (1899); Science in s $9: 143$ (1899)

99b Dislocation at Thirtymlle Point, N. Y. G Soc Am, B 10:131-134 (1899)

99e Ripple marks and cross bedding. $\theta$ Soc Am, B 10:135-140 (1899) Abst, Am G $23: 102$ (1899); Science n 8 9:139 (1899)

oo Rhythms and geologic time. Am As, Pr 49:1-19 (1900) Science n 8 11: 1001-1002 (1900) Pop Sc Mo $57: 339-$ $353(1900)$

OOa Edward Orton, geologist. Science n s 11:6-11 (1900)

0ob Memoir of Edward Orton. G Soc $\Delta \mathrm{m}$, B 11: 542-552, port (1900)

ooc [Hanging valleys]. G Soc $A m, B$ $11: 591$ (1900)

o0d Submerged forest of the Columbis River (abst). Science n s 11:99-100 (1900)

o1 Physical history of Niagara River Text on back of topographic map, Niagars River and vicinity. Scale $1: 62,500$. I 8 G S 1901. Abst, Am G 27:375-377 (1901)

02 (and Brigham, A. P.) An intro duction to physical geography. $380 \mathrm{PP}$. N Y 1902 [2d ed], 412 pp, N Y 1907 
Gilbert, Grove Karl-Continued.

02a Memoir of George Hammell Cook, 1818-1889. Nat Ac Sc, Biog Mem 4:135144 (1902)

02b John Wesley Powell. Science $\mathrm{n} / \mathrm{s}$ $16: 561-567$, port (1902) Smiths Inst, An Rp $1902: 633-640$, port (1903)

02e Joint veins (abst). Science n s 15 : 84-85 (1902) G Soc Am, B 13:521-522 (1903)

03 (editor) John Wesley Powell; a memorial to an American explorer and scholar. 75 pp, port, Chicago 1903. Reprinted from The Open Court 16: 705-716 (1902) ; $17: 14-25,86-94,162-174,228-239,281-$ $290,342-347,348-351$, port (1903)

03a Powell as a geologist. Wash Ac Sc, Pr 5: 113-118 (1903)

03b Proposed investigation of subterranean temperatures and gradients. Carnegie Inst Wash, $\mathrm{Y}$ Bk 1:285-286 (1903) 03e Physiographic belts in western New York (abst). Science n s 17:221 (1903) 03d A highly viscous eruption of rhyolite $(a b s t)$. Science $\mathrm{n}$ s $17: 221$ (1903)

03 e Origin of Basin ranges $(a b s t)$. Science n s 17:301 (1903) G Soc Am, B 14: 551 (1904)

03f Statics of a tidal glacier (abst). Sclence n s $17: 739-740$ (1903)

04 Glaciers and glaciation of Alaska. Harriman Alaska Exped $3: 231 \mathrm{pp}, \mathrm{N}$ Y 1904

04a Geology and paleontology of Alaska ; introduction. Harriman Alaska Exped 4: 1-8 (1904)

04b Variations of Sierra glaciers. Sierra Club B $5: 20-25$ (1904)

04e Systematic asymmetry of crest lines in the high Sierra of California. J G 12 : 579-588 (1904) Sierra Club B 5:279-286 (1905)

04d Domes and dome structure of the high Sierra. G Soc Am, B 15:29-36 (1904) Sierra Club B 5: 211-220 (1905) Abst, Science n s 19:528 (1904); Sc Am Sup $57: 23446$ (1904)

04e The mechanism of the Mont Pele spine. Science n s 19:927-928 (1904) Rng M J $78: 27$ (1904)

041 A case of plagiarism. Science $n \mathbf{s}$ 20: $115-116$ (1904)

$04 \mathrm{~g}$ Regulation of nomenclature in the work of the U. S. Geological Survey. Am G $33: 138-142$ (1904)

05 Plans for obtaining subterranean temperatures. Carnegie Inst Wash, Y Bk $3: 120$, 259-267 (1905)

05a Value and feasibility of a determination of subterranean temperature gradient by means of a deep joring. Carnegie Inst Wash, Y Bk 3:261-267 (1905) $05 \mathrm{~b}$ The scuipture of massive rocks (abst). Int Geog Cong, VII, Rp:191192 (1905)
Gilbert, Grove Karl-Continued.

o5e Undulations of certain layers of the Lockport limestone (abst). Science n s 21: 224 (1905)

o5d Terraces of the high Sierra, Cal. (abst). Science n s 21:822 (1905)

05e Fault phenomena near Glen Echo, Md. (abst). Science $n$ s 21:917-918 (1905)

06 Crescentic gouges on glaciated surfaces. G Soc Am, B $17: 303-316$ (1906) O6a Moulin work under glaciers. G Soc L . B, B $17: 317-320$ (1906)

$06 \mathrm{~b}$ Gravitational assemblage in granite. $G$ Soc Am, B 17:321-328 (1906)

o6e Israel Cook Russell, 1852-1906. J G $14: 663-667$, port (1906)

o6d The investigation of the California earthquake of 1906. Pop Sc Mo 69:97115 (1906) Reprinted in Jordan, D. S., editor, The California earthquake of 1506 : 213-256, San Francisco 1907

o6e The cause and nature of earthquakes. M Sc Press 92:272-273 (1906) Reprinted in After earthquake and fire: 32-34, San Franciseo 1906

o7 Rate of recession of Niagara Falls. U S G S, B 306:5-25 (1907) N Y, Comm St Res Niagara, An Rp 23:39-65 (1907)

07a The [San Francisco] earthquake as a natural phenomenon. U S G S, B 324 : 1-13 (1907)

os Lake ramparts [origin]. Sierra Club B $6: 225-234$ (1908)

osa The United States Geological Survey's hydraulic laboratory at Berkeley, Cal. (abst). Science n s 27:469 (1908)

osb Transportation of detritus by $\mathrm{Yuba}$ River $(a b s t)$. G Soc Am, B 18:657-659 (1908)

Ose Evolution of Niagara Falls. Science $n$ s $28: 148-151$ (1908)

09 The California earthquake of 1906. Am J Sc (4) $27: 48-52$ (1909)

$09 n$ Earthquake forecasts. Science $n \mathrm{~s}$ 29:121-138 (1909) M Sc Press 98:183186 (1909)

09b The convexity of hilltops. J G 17 : 344-350 (1909)

11 Edwin E. Howell [1845-1911]. Science $n$ s $33: 720-721$ (1911)

12 Memoir of Edwin E. Howell. G Soc Am, B 23: 30-32, port (1912)

13 Interpretation of anomalies of gravity. U S G S, P P $85: 29-37 \quad$ (1913) Abst, Wash Ac Sc, J 4: 192 (1914)

14 The transportation of debris by running water. U S G S, P P $86: 263$ pp (1914) Abst, Wash Ac Sc, J 4:154-158 (1914)

17 Hydraulic-mining debris in the Sierra Nevada. U S G S, P P 105: 154 pp (1917) Abst, by R. W. Stone, Wash Ac Sc, J 7 : 600-601 (1917) 
Gilbert, Grove Karl-Continued.

See also Dawson (G M), 91b; Dutton, 89a; Emmons (S F), 93; Frazer, 88a ; King (C), 80 ; Ohio State University, 99 ; Powell, 82, 83, 84, 85, 85a, 88, 89, 89a, 90, 91, 91a, 92, 93, 95; Pumpelly, 91 ; Russell, 87 ; Salisbury, 98b; Spencer (J W), 92, 92a; Tarr (R S), 12b; Walcott, 03a; White (C A), 80e; Wheeler, 72a, $74 \mathrm{a}$.

Gilbert, James.

57 The Arizona copper mine. Can J n s $2: 321-324$ (1857)

Gilbert, James Zacchaeus.

98 On the skull of Xerobates(?) undata Cope. Kans Univ Q $7: 143-148$, il (1898)

os Ancestors of our whales; Miocene [remains of a Miocene whale found at Los Angeles, Cal.]. S Cal Ac Sc, B 7:20-22, Il (1908)

10 The fossils of Rancho la Brea. S Cal Ac Sc, B $9: 11-51$, il (1910)

10 avesthes jordani, a primitive flounder from the Miocene of California. Cal Univ, Dp G, B 5:405-411, il (1910)

Gilder, Robert F.

or A primitive human type in America; the finding of the "Nebraska man." Putnam's Mo: $407-409$ (1907)

07a The Nebraska loess man. Records of the Past $6: 35-39$, il (1907)

Giles, Albert William.

18 The country about Camp Lee [near Petersburg], Va. Va G S, B 16:40 pp, maps (1918)

18a Eskers in the vicinity of Rochester, N. Y. Rochester Ac Sc, Pr 5:161-240 (1918)

Giles, W. B.

03 Bakerite (a new borosilicate of calcium) and howlite from California. Miner Mag 13: 353-355 (1903)

Gill, Adam Caper.

89 Note on some minerals from the chrome pits of Montgomery Co., Md. John Hopkins Univ Circ no $75: 100-102$ (1889)

95 Geological sketch of the Sierra Tlayacac in the State of Morelos, Mex. (abst). Am G 16:240-241 (1895) Science n s 2: 280 (1895)

96 [Notes on] mineralogy. Am Nat vols 30-31 (1896-7)

13 Conventional position of monocline crystals; a question in crystallographic usage. Science n s $37: 628-629$ (1913)

GiII, H. V.

06 On a possible connexion between the eruption of Vesuvius and the earthquake at San Francisco in April, 1906. R Dublin Soc, Sc Pr, n s 11: 107-110 (1906)

Gi11, Theodore Nicholas.

67 On the genus Fulgur and its allies. Am J Conch 3: 141-152, il (1867)

67a On the systematic position of Buccinum altile and $B$. escheri. Am J Conch $3: 153-154$, il (1867)
Gi11, Theodore Nicholas-Continued.

84 The relations of Didymodus, or DF. plodus. Science $3: 429-430$ (1884)

96 Note on the Devonian Palaeospondy. lus. Science n \& 4:10-11 (1896)

97 Edward Drinker Cope, naturalista chapter in the history of science. An Nat 31:831-863, port (1897) Science n s 6: 225-243 (1897)

05 An interesting Cretaceous chimaeroid egg case. Science n s 22:601-602 (1905)

osa Origin of fresh-water faunas (abst). Int Geog Cong. VIII, Rp: 617 (1905)

See also Dean, 95

Gillelen, F. M. L.

64 The oil regions of Pennsylvania. $67 \mathrm{pp}$, map, Pittsburgh, Pa. [c 1864]

Gillespie, $P$.

o5 Cement industry of Ontario. 0at Bur Mines, Rp 1905, 14 pt 1:118-183 (1905)

Gillette, Halbert Powers.

04 Osmosis as a factor in ore formation. Am I M Eng, Tr 34: 710-714 (1904) Be printed in Emmons, S. F.. Ore deposits (pub. by Am I M Eng) : 450-454, N Y 1913 Gillot, H.

o3 Sur la composition chimique des poussières volcaniques de la Martinique [W. I.]. Soc G Belgique, An $30: B$ 49-51 (1903)

Gilman, Daniel C.

99 The life of James Dwight Dana. 400 pp, port, N Y 1899

Gilmer, Francis William.

18 On the geological formation of the Natural Bridge of Virginia. Am $\mathrm{Ph} S o c$, Tr n s 1: 187-192 (1818)

Gilmor, Robert, jr.

14 A descriptive catalogue of minerals occurring in the vicinity of Baltimore. Am Miner J 1: 221-233 (1814)

Gilmore, Charles Whitney.

02 Discovery of teeth in Baptanodon, an ichthyosaurian from the Jurassic of Wyoming. Science n s $16: 913-914$ (1902)

02a (with Peterson, O. A.) Elosaurus parvus, a new genus and species of the Sauropoda. Carnegie Mus, An 1:490-499, il (1902)

03 Discovery of dental grooves and teeth in the type of Baptanodon (Sauranodon) (abst). Science n s 17:750 (1903)

o5 Osteology of Baptanodion Marsh. Carnegie Mus, Mem 2: 77-129, il (1905)

05a The mounted skeleton of Trioer tops prorsus. U S Nat Mus, Pr 29:43\%435, il (1905)

06 Notes on the osteology of Baptanodon, with a description of a new specles, Carnegie Mus, Mem 2:325-342, il (1906) $06 a$ Notes on some recent additions to the exhibition series of vertebrate fosslls. U S Nat Mus, Pr 30:607-611, il (1906)

06b Notes on a newly mounted skeleton of Merycoidodon, a fossil mammal. U \& Nat Mus, Pr 31:513-514, 11 (1906) 
Gilmore, Charles Whitney-Continued. 07 The type of the Jurassic reptile Jorosaurus agilis redescribed, with a note on Camptosaurus. U S Nat Mus, Pr 32 : 151-165, il (1907)

07a A new species of Baptanodon from the Jurassic * of Wyoming. Am J Sc (4) 23: 193-198 (1907)

08 Smithsonian exploration in Alaska in 1907 in search of Pleistocene fossil vertebrates. Smiths Mísc Col 51 [no 3] : 38 pp, il (1908)

09 Osteology of the Jurassic reptile Camptosaurus, with a revision of the spedes of the genus, and descriptions of two new species. U S Nat Mus, Pr 36:197332 , il (1909)

09a A new rhynchocephalian reptile from the Jurassic of Wyoming, with notes on the fauna of "Quarry 9." U S Fat Mus, $\operatorname{Pr} 37: 35-42$, il (1909)

10 Leidyosuchus sternbergii, a new species of crocodile from the Ceratops beds of Wyoming. U S Nat Mus, Pr 38:485-502, il (1910)

11 A new fossll alligator from the Hell Creek beds of Montana [Brachychampsa montana]. U S Nat Mus, Pr 41:297-302, il (1911)

12 A new mosasauroid reptile [GloVidens alabamaensis] from the Cretaceous of Alabama. U S Nat Mus, Pr 41:479484, il (1912)

12a The mounted skeletons of Campto. seurus in the United States National Museun. U \& Nat Mus, $\operatorname{Pr} 41: 687-696$, il (1912)

$12 b$ Remarks on the skeleton of the dinosaur Stegosaurus (abst). Science n s $35: 972$ (1912)

13 A new dinosaur from the Lance formation of Wyoming [Thescelosaurus reglectus]. Smiths Misc Col 61 no $5: 5$ pp, il (1913)

14 Osteology of the armored Dinosauria In the United States National Museum, With special reference to the genus Stegosqurus. U S Nat Mus, B $89: 136 \mathrm{pp}$, il (1014)

14a A new ceratopsian dinosaur from the Upper Cretaceous of Montana, with note on Hypacrosaurus. Smiths Misc Col 63 nо $3: 10 \mathrm{pp}$, il (1914)

14b A second occurrence of ichthyosaurian remains in the Benton Cretaceous. Sclence n s $39: 210$ (1914)

15 A new restoration of Stegosaurus. S Nat Mus, Pr 49:355-357, il (1915)

$15 a$ on the fore limb of Allosaurus fragilis. U S Nat Mus, Pr 49:501-513, il (1915)

$15 \mathrm{~b}$ Osteology of Thescelosaurus, an orthopodous dinosaur from the Lance formation of Wyoming. U S Nat Mus, Pr $49: 591-616$, il (1915)
Gilmore, Charles Whitney-Continued.

15c On the genus Trachodon. Science n $s$ 41:658-660 (1915)

15d Observations on new dinosaurian reptiles (abst). Wash Ac Sc, J $5: 411$ (1915) Science n s 41:878 (1915)

15e Some new dinosaurs (abst). Wash Ac Sc, J $5: 488$ (1915)

16 Contributions to the geology and paleontology of San Juan Co., N. Mex. ; 2, Vertebrate faunas of the Ojo Alamo, Kirtland, and Fruitland formations. U S G S, P P 98: 279-308, il (1916) Abst, by R. W. S., Wash Ac Sc, J 7:185 (1917)

$16 a$ The fossil turtles of the Uinta formation. Carnegie Mus, Mem 7:101161, il (1916)

16b Description of a new species of tortoise from the Jurassic of Utah [Glyptops utahensis]. Carnegie Mus, An 10:7-12, il (1916)

16e Description of two new species of fossil turtles from the Lance formation of Wyoming. U S Nat Mus, Pr 50:641-646, il (1916)

17 Brachyceratops, a ceratopsian dinosaur from the Two Medicine formation of Montana, with notes on associated fossil reptiles. U S G S, P P 103:45 pp, il (1917) Abst, by R. W. S., Wash Ac Sc, J $7: 267$ (1917)

18 A newly mounted skeleton of the armored dinosaur, Stegocaurus stenops, in the United States National Museum. U S Nat Mus, Pr 54:383-390, il (1918)

Gilpin, Edwin.

73 The grouping of the Pictou coal seams. N S Inst N Sc, $\operatorname{Pr} \operatorname{Tr} 3: 281-285$ (1873)

$73 a$ The Plctou coal field [N. S.]. N Engl Inst M Eng, Tr 22:139-149, map (1873)

74 Notes on the coal measures and lower Carbonfferous strata of western Newfoundland, N Engl Inst M Eng, Tr 23: 167-176, map (1874)

74a Sketch of the Carboniferous dis. trict of St. George's Bay, Newfoundland. N S Inst N Sc, Pr Tr $3: 357-364$ (1874)

75 The submarine coal of Cape Breton, N. S. N Engl Inst M Eng, Tr_24:173189, map (1875)

76 The southern synclinal of the Pictou coal field. N S Inst N Sc, Pr Tr 4:89-97 (1876)

77 Notes on specimens of iron ores, etc., collected in Pictou Co... N S Inst $\mathrm{N}$ Sc, Pr Tr 4:137-146 (1877)

77a The iron ores of Nova Scotia. N Engl Inst $M$ Eng, $\operatorname{Tr} 26: 71-88$, maps (1877)

77b Notes on some recent discoverles of copper ore in Nova Scotia. G Soc London, Q J 33:749-753 (1877) Abst, $\mathrm{Ph}$ Mag (5) $4: 310$ (1877) 
Gilpin, Edwin-Continued.

78 Canadian coals; their composition and uses. $N$ Engl Inst $M$ Mech Eng, $\mathrm{Tr}$ $27: 213-241$ (1878)

79 The limonite and limestones of Pictou Co., N. S. N S Inst N Sc, Pr Tr 5 : 31-38 (1879)

so The mines and mineral lands of Nova Scotia. [Nova Scotia, Dp Mines]: 129 pp, Halifax, N. S., 1880

81 The gypsum of Nova Scotia. N Engl Inst $M$ Eng, $\operatorname{Tr} 30: 53-68$, map (1881)

s1a on the occurrence of lievrite in Nova Scotia, N S Inst $N$ Sc, Pr Tr 5 : 253-255 (1881)

81b The trap minerals of Nova Scotia. N S Inst N Sc, Pr Tr 5: 283-296 (1881)

82 The minerals of Nova Scotia. Dominion Exhibition, 1882. 14 pp, Halifax, N. S., 1882

$82 n$ The northern outerop of the Cumberland coal field. N S Inst N Sc, Pr Tr 5 : 387-399 (1882)

82b The gold fields of Nova Scotia. N Engl Inst M Mech Eng, Tr 31:151-172 (1882) Abst, Eng M J $34: 5-6 \quad 17-18$ (1882)

S3 The folding of the Carboniferous strata in the maritime provinces of Canada. $\mathrm{R}$ Soc $\mathrm{Can}, \operatorname{Pr} \operatorname{Tr} 1$, iv: 137-142 (1883) Abst, Can Rec $\mathrm{N}$ H 1:13-14 (1884)

83a An analysis of a Pictou coal seam. N S Inst N Sc, $\operatorname{Pr} \operatorname{Tr} 6: 42-47$ (1883)

84 Results of past experience in gold mining in Nova Scotia (abst). Brit As, Rp 54:711-712 (1885) G Mag (3) 1: 564-565 (1884)

84a A comparison of the distinctive features of Nova Scotian coal fields (abst). Brit As, Rp 54:712-713 (1885) G Mag (3) $1: 467-468 \quad(1884)$

85 Notes on the manganese ores of Nova Scotia. R Soc Can, $\operatorname{Pr} \operatorname{Tr} 2$, iv: 7-13 (1885)

85a Notes on the DeBert coal field, Colchester Co., N S. N S Inst N Sc, Pr Tr $6: 93-97$ (1885)

$85 \mathrm{~b}$ Notes on the manganese ores of Loch Lomond, Cape Breton. N S Inst N Sc, $\operatorname{Pr} \operatorname{Tr} 6: 97-99$ (1885)

85c Feather-alum (halotrichite) from Glace Bay, Cape Breton. N S Inst N Sc, $\operatorname{Pr} \operatorname{Tr} 6: 175-179$ (1885)

86 Minerals of Nova Scotia. In $\mathrm{N} \mathbf{S}$, Dp Mines, Rp 1885:6-23, Halifax, N. S., 1886

86n The iron ores of Pictou Co., N. S. Am I M Eng, Tr 14: 54-63, map (1886)

$86 b$ The Nova Seotia gold mines. Am I M Eng, Tr 14:674-689, map (1886)

86e The geology of Cape Breton Island, N. S. G Soc London, Q J $42: 515-526$, map (1886)

86d The Carboniferous of Cape Breton. N S Inst N Sc, Pr Tr $6: 289-298 ; 7: 24-$ $35,100-117$ (1886-88)
G11pin, Edwin-Continued.

87 Notes on the limestones of East Rire Pictou, N. S. R Soc Can, Pr Tr 4, it. 159-166 (1887)

s8 The faults and foldings of the Picte coal field [N. S.]. R Soc Can, Pr Tr? iv : $25-30$ (1888)

89 Notes on the Nova Scotia gold vels R Soc Can, Pr Tr 6, iv: 63-70 (1859) Abst, Can Rec Sc 3: 162-163 (1888)

89a The geology of Cape Breton; th minerals of the Carboniferous. N S Inst N Sc, Pr Tr 7: 214-226 (1889)

90 The geological relations of the prit cipal Nova Scotia minerals. Am I M Ent Tr 18:198-205 (1890)

$90 a$ The geological writings of Rev. D. Honeyman... N S Inst $\mathrm{N}$ Sc, Pr Tr 7: $357-362$, port. (1890)

$90 \mathrm{~b}$ The Devonian of Cape Breton. N8 Inst $\mathrm{N}$ Sc, $\operatorname{Pr} \operatorname{Tr} 7: 381-387$, map (1890)

91 The evidence of a Nova Scotia Car boniferous conglomerate. R Soc Can, Pr it 8, iv: 117-121 (1891) Abst, Science 15: $373(1890)$

91 a Analyses of Nova Scotia coals and other minerals. N S Inst Sc, Pr Tr 8 o: (2) $1: 19-26$ (1891)

$91 \mathrm{~b}$ The iron ores of Nova Scotla. Car Soc Civil Eng, Tr 5: 97-119 (1891)

92 The geology of Cape Breton; the Lower Silurian. N S Inst Sc, Pr Tr 8 o: (2) $1: 167-174$ (1892)

93 Minerals of Nova Scotia. $15 \mathrm{pp}$ Halifax, N. S., 1893

$93 a$ Notes on Nova Scotia iron ores. If Soc N S, J 1 pt 2:8-14 (1893)

94 Note on an occurrence of manganess and zinc ore in Nova Scotia. M Soc $X 8$. J $2: 70-74$ (1894)

95 Note on the Sydney coal fleld. N \& Inst Sc, $\operatorname{Pr} \operatorname{Tr} 8$ or (2) $1: 435-438$ (1895)

96 Notes on the collection of Nort Scotia minerals... [Fed] Can M Inst, J 1: 193-196 (1896)

96a The iron ores of Nictaux, N. \& $\mathrm{N} S$ Inst $\mathrm{Sc}, \operatorname{Pr} \mathrm{Tr} 9$ or (2) $2: 10-20$ (1896)

96b The undeveloped coal fields of Nora Scotia. N S Inst Sc, $\operatorname{Pr} \operatorname{Tr} 9$ or (2) 2: 134-149 (1896)

97 Some analyses of Nova Scotia coals and other minerals. N S Inst Sc, Pr Tt 9 or (2) $2: 246-254$ (1897)

98 Ores of Nova Scotia ; gold, lead, and copper. [Nova Scotia, Dp Public Works and Mines ] : $46 \mathrm{pp}$, map, Halifax N. \$. 1898

98a The geological horizons of some Nova Scotia minerals (abst). Brit As, Rip 67: 663 (1898)

99 New mineral discoveries in Nors Scotia. N S Inst Sc, Pr Tr 10 or (2) 3: 79-90 (1899)

$99 a$ Nova Scotia gold fields. M J, Lon. don, 69:247-248 (1899) 
Gilpin, Edwin-Continued.

00 Minerals for the Paris Exhibition. N S Inst Sc, Pr Tr 10 or (2) $3: 248-272$ (1900)

00a Nova Scotia gold fields. In Farfbault, E. R., The gold measures of Nova Scotia; M Soc N S: 1-4, Halifax, N. S. [1900?]

01 The minerals of Nova Scotia. $78 \mathrm{pp}$, map, Halifax, N. S., 1901

02 The building stones of Nova Scotia. Stone 24:122-128 (1902)

03 Economic minerals of Nova Scotia; catalogue and description. Provincial exbibition $1903.39 \mathrm{pp}$, Halifax, N. S., 1903 [also with N S, Dp Mines, Rp 1903, Hallfax, N. S., 1904]

05 Sections and analyses of Nova Scotia coals. N S Inst Sc, Pr Tr 11: 8-17 (1905)

Gilpin, John Bernard (1810-1892).

74 Observations on some fossil bones found in New Brunswick, Dominion of Canada. N S Inst N Sc, Pr Tr 3:400404 (1874)

Gilpin, J. Elliott.

11 (and Bransky, O. E.) The diffusion of crude petroleum through fuller's earth, with notes on its geologic signiflcance. U S G S, B 475:50 pp (1911)

Gilpin, Thomas (1776-1853).

43 An essay on organic remains, as connected with an ancient tropical region of the earth. $39 \mathrm{pp}$, Phila 1843

43a Essay on the position of the organic remains, as connected with a former tropical region of the earth. $\mathrm{Am} \mathrm{Ph}$ Soc, Pr 4:27-29 (1843)

Gilpin, W.

57 The mountain formation of North America. M Mag 9:154-160 (1857)

Ginley, William. See Gurley, William F, E.

Girand, Jean.

02 Sur l'age des formations volcaniques anciennes de la Martinique. Ac Sc Paris, C R 135:1377-1379 (1902)

18 Esquisse géologique de la Martinique, avec carte géologique. $63 \mathrm{pp}$, map, Hanoi-Haiphong 1918

Girault, Edmundo.

10 San Rafael y Anexas Mining Company, Pachuca, Mexico. Inst Mex Minas y Met, Inf $1: 221-262$ (1910) Abst, Eng M J $90: 643-645$ (1910)

16 Reseña del minera de San Miguel Peras, distrito de Villa Álvarez, Estado de Oaxaca. Bol Minero 2:688-698 (1916)

Giroux, Joseph L.

06 The Giroux mines [Ely], Nev. Eng M J $82: 985-986$ (1906)

Gironx, N. J. (1859-1896).

90 Serpentines of Canada. Ottawa Nat 4: $95-116$ (1890)
Giroux, N. J.-Continued.

93 [Report on work in Berthier, Maskinongé and St. Maurice cos., Que.] Can G S, Sum Rp 1892 (An Rp 6) : A 40-45 (1893)

94 [Summary report of field work in the country west of St. Maurice River, Que.] Can G S, Sum Rp 1893 (An Rp 6) : $\triangle 46-52$ (1894)

96 [Report of field work in the St. Lawrence valley, Ontario and Quebec.] Can G S, Sum Rp 1895 (An Rp 8) : A 68-74 (1896)

97 [Report of field work in eastern Ontario.] Can G S, Sum Rp 1896 (An Rp 9) : А 59-64 (1897)

Girty, George Herbert.

95 Development of the corallum in Favosites forbesi var, ocoidentalis. Am G $15: 131-146$, il (1895)

$96 \mathrm{Mr}$. Sardeson and fossil tabulates. Am G 18: 332-333 (1896)

97 A revision of the sponges and coelenterates of the Lower Helderberg group of New York. N Y St G, An Rp 14:259. 322 , il (1895) [1897] N Y St Mus, An Rp 48 v $2: 259-322$, il (1895) [1897]

98 Description of a fauna found in the Devonian black shale of eastern Kentucky. Am J Sc (4) 6:384-394, Il (1898)

$98 a$ (with Spencer, A. C.) On the Devonian in southwestern Colorado (abst). Science n \& $7: 810$ (1898)

99 Preliminary report on Paleozoic invertebrate fossils from the region of the McAlester coal fleld, Indian T. U S G S, An Rp 19 pt 3: 539-600, il (1899)

99a Devonian and Carboniferous fossils [of Yellowstone National Park]. U S G S, Mon 32 pt $2: 479-599$, il (1899)

00 Devonian fossils from southwestern Colorado: The fauna of the Ouray lime stone. U S G S, An Rp 20 pt 2:25-81, il (1900)

o1 The Waverly group in northeastern Ohio (abst). Science n s 13:664 (1901)

02 The upper Permian in western Texas. Am J Sc (4) 14:363-368 (1902)

03 The Carboniferous formations and faunas of Colorado. U S G S, P P 16: $546 \mathrm{pp}, \mathrm{nl}$ (1903)

$03 \mathbf{a}$ Tabulated list of invertebrate fossils from the Carboniferous section of Kansas. U S G S, B 211: 73-83 (1903)

03b (with Adams, G. I.) Stratigraphy and paleontology of the upper Carboniferous rocks of the Kansas section. U S G S, B 211: 123 pp, maps (1903)

04 Note on the Carboniferous fossils [of the Bisbee quadrangle, Ariz.]. U S G S, P P 21: 46-54, 11 (1904)

04a Triticites, a new genus of Carboniferous foraminters. Am J Sc (4) 17 : 234-240, il (1904)

04b New molluscan genera from the Carboniferous. U S Nat Mus, Pr 27:721736,11 (1904) 
Girty, George Herbert-Continued.

04e The typical species and generic characters of Avioulipecten McCoy. $\Delta \mathrm{m}$ G 33: 291-296, il (1904)

04d The type of Aviculipecten. Am G 34: 332-333 (1904)

04e Upper Paleozoic rocks in Ohio and northwestern Pennsylvania (abst). Science n s 19:24-25 (1904)

05 Palentology [of Bingham mining district, Utah]. U S G S, P P $38: 387-393$ (1905)

O5a The relations of some Carboniferous faunas. Wash Ac Sc, Pr 7:1-26 (1905)

06 Report on fossil invertebrates [of the Cape Lisburne region, Alaska]. U S G S, B 278:22-26 (1906)

07 Report on marine Carbonlferous fossils from the coal fields of Arkansas. U S G S, B $326: 31-35$ (1907)

os The Guadalupian fauna. U S G S, P P 58:651 pp, il (1908) Rv by J. W. Beede, J G 17:672-679 (1909)

osa On some new and old species of Carboniferous fossils. U S Nat Mus, Pr $34: 281-303$, 11 (1908)

09 Upper Carboniferous. J G $17: 305-$ 819 (1909)

09a The Guadalupian fauna and new stratigraphic evidence. N Y Ac Sc, An 19 : 135-147 (1909)

$09 \mathrm{~b}$ The fauna of the Caney shale of Oklahoma. U S G S, B 377:106 pp, il (1909)

09c Palentology of the Manzano group of the Rio Grande valley, N. Mex. U S G S, B $389: 41-136$, il (1909)

10 The fauna of the phosphate beds of the Park City formation in Idaho. Wyoming, and Utah. U S G S, B 436:82 pp, il (1910) Abst, Wash Ac Sc, J 1:39 (1911)

10a New genera and species of Carboniferous fossils from the Fayetteville shale of Arkansas. N Y Ac Sc, An 20: 189-238 (1910)

10b New species of fossils from the Thaynes limestone of Utah. N Y Ac Sc, An 20: 239-242 (1910)

11 The fauna of the Moorefield shale of Arkansas. U S G S, B $439: 148$ pp, il (1911) Abst, Wash Ac Sc, J 1:38-39 (1911)

$11 a$ on the genus Syringopleura Schuchert. J G 19:548-554 (1911)

11b On some new genera and species of Pennsylvanian fossils from the Wewoka formation of Oklahoma. N Y Ac Sc, An 21:119-156 (1911)

12 On some invertebrate fossils from the Lykins formation of eastern Colorado. N Y Ac Sc, An 22:1-8, il (1912)

12a I, On some growth stages in Naticopsis altonensis McChesney; II, Notice of a Mississippian gastropod retaining coloration. Am J Sc (4) 34:338-340 (1912)
Girty, George: Herbert-Continued.

12b Geologic age of the Bedford shale of Ohio. N Y Ac Sc, An 22:295-319 (1912)

14 On the names of American fusulinas. J G $22: 237-242$ (1914)

15 Fauna of the Wewoka formation of Oklahoma. U S G S, B 544:353 pp, il (1915) Abst, Wash Ac Sc, J $5: 608$ (1915)

15a The fauna of the Batesville sand. stone of northern Arkansas. U S G S, B $593: 170 \mathrm{pp}$, il (1915) Abst, Wash Ac Sc, J $5: 603$ (1915)

15b Fauna of the so-called Boone chert near Batesville, Ark. U S G S, B 595:45 pp, il (1915) Abst, Wash Ac Sc, J 5: 604-605 (1915)

15e Faunas of the Boone limestone at St. Joe, Ark. U S G S, B $598: 50$ pp, il (1915) Abst, Wash Ac Sc, J $5: 605$ (1915)

15d Invertebrate paleontology [of the Pennsylvanian of Missouri]. Mo Bur $G$ (2) $13: 263-376$, Il (1915)

16 Some characters of the apical end of Pseudorthoceras knoxense McChesney. Am J Sc (4) $42: 387-388$, il (1916)

See also Collier, 07b; Gordon (C H), $11 \mathrm{a}$; Sardeson, $96 \mathrm{c}$

Gladson, W. N.

11 A preliminary report on White River and some of its tributaries. Ark G \&, Water Powers of Arkansas: 96 pp (1911) Gleason, Frank A.

14 Occurrence of coal in the northern anthracite field [Pa.] Penn St M Q 2: 3-24 (1914)

Glenn, Leonidas Chalmers.

95 Some notes on Darlingten, S. C., “bays." Science n s $2: 472-475$ (1895)

98 South Carolina. J Seh Geo $2: 9-15$, 85-92 (1898)

99 The Hatteras axis in Triassic and in Miocene time. Am G 23: 375-379 (1899) 03 Devonic and Carbonic formations of southwestern New York. N Y St Mus, B 69:967-989, map (1903) Abst, Science n $8 \quad 17: 292$ (1903); J G 11:112-113 (1903); G Soc Am, B 14:522-531 (1904)

04 [Notes on water resources of] Tennessee. U $\mathbf{S}$ G $\quad$ S, W-S P $102: 358-367$ (1904)

04a [Notes on water resources of] Kentucky. U S G S, W-S P $102: 369-373$ (1904)

O4b Notes on a new meteorite from Hendersonville, N. C., and on additional pleces of the Smithville, Tenn., fall. Am J Sc (4) $17: 215-216$ (1904)

04c The more common minerals of the region about Nashville [Tenn.]. Eng As South, Tr $14: 103-113$ (1904)

O4d Fossiliferous sandstone dikes in the Eocene of Tennessee and Kentucky (abst). Science n s 19:522 (1904)

05 [Underground waters of] South Caro. lina. U S G S, W-S P 114:140-152 (1905) 
Glenn, Leonidas Chalmers-Continued. 05a [Underground waters of] Tennessee and Kentucky. U S G S, W-S F 114:198208 (1905)

05b Gerard Troost. Am G $35: 72-94$, port (1905)

06 Underground waters of Tennessee and Kentucky west of Tennessee River and of an adjacent area in Illinois. U S G S, W-S P 164: 173 pp (1906)

06a The university training of engineers in economic geology. Ec G $1: 476-479$ (1906)

06b Erosion at Ducktown Tenn. (abst). Science n s 23:288 (1906) Am As, Pr $55: 377$ (1906)

06c The hydrology and geology of the Gulf embayment area of west Tennessee, mest Kentucky, and southern Illinois (abst). Science n s 23: 288 (1906) Am As, Pr 55: 377 (1906)

06d (with Ashrey, G. H.) Geology and mineral resources of part of the Cumberland Gap co2I field, Ky. U S G S, P P $49: 239$ pp (1906)

09 Coal resources of the South. Southern Commercial Cong., Official Proc, at the First Session...1908: 256-268 [1909]

10 Dr. Troost's monograph on crinoids. Vanderbilt Univ Q 10:275-279, port (1910)

11 Denudation and erosion in the southem Appalachian region and the Monongabela Basin. U S G S, P P 72:137 pp (1911)

12 A geological reconnaissance of the Tradewater River region, with special reference to the coal beds. Ky G S, B 17: 75 pp (1912)

12a The geology of Webster Co. Ky G S, Rp Progress 1910-11:25-35 (1912) 12b The growth of our knowledge of Tennessee geology. Tenn G S, Res Tenn 2: 167-219 (1912) [Bulletin 1-C]

12e The Arkansas diamond-bearing peridotite area $(a b s t)$. Science $n$ s $35: 312$ (1912); (with discussion by A. H. Purdue), G Soc Am, B 23: 726 (1912)

13 The general features of the Tennessee coal field north of the Tennessee Central Rallroad. Tenn G S, Res Tenn $3: 4-25$, map (1913) [Bulletin 2-B.]

14 A tripoli deposit near Butler, Tenn. Tenn G S, Res Tenn 4:29-35 (1914)

14a An unnoticed physiographic feature in Tennesse $(a b s t)$. Tenn Ac Sc, Tr 1: 73 (1914)

14b The tripoli deposits of Tennessee (obst). Science n \& $39: 403$ (1914)

15 Physiographic influences in the development of Tennessee. Tenn $G$ S, Res Tenn 5:44-64 (1915)

15a Recent oll developments near Oneida, Scott Co., Tenn. Tenn G B, Res Tenn 5:174-194, map (1915)
Glenn, Leonidas Chalmers-Continued.

15b Geology applied to dams and reservoirs. Eng As South, Pr 26:99-113 (1915)

16 The general features of the Tennessee coal field north of the Tennessee Central Railroad. Tenn G S, Res Tenn 6: 127-154, map (1916)

$16 a$ Pennsylvanian of Tennessee (abst). G Soc Am, B 27: 70 (1916)

17 Recent oil development at Glenmary, Tenn. Tenn G S, Res Tenn $7: 40-43$ (1917)

18 Dr. A. H. Purdue. Tenn G S, Res Tenn 8:3-6 (1918)

18a Discussion of the chemical analyses of the cave deposits of Tennessee. Tenn G S, Res Tenn 8: 139-142 (1918)

18b The Glenmary oil field. Tenn G S, Res Tenn 8:211-219 (1918)

See also Clark (W B), 04a

Glenn, Miltiades L.

16 A new occurrence of stevensite, a magnesium-bearing alteration product of pectolite. Am Mineralogist 1:44-46 (1916)

17 Pectolite pseudomorphous after quartz from west Paterson, N. J. Am Mineralogist $2: 43-45$ (1917)

17 a (with wherry, E. T.) Chalcedony mistaken for an iron sulphate mineral. Am Mineralogist 2:6-7 (1917)

GIenn, William.

96 Chromic iron, with reference to its occurrence in Canada. U S G S, An Rp 17 pt $3: 261-273$ (1896)

$96 a$ Chrome in the southern Appalachian region. Am I M Eng, Tr 25:481-499 (1896)

96b The form of fissure walls, as affected by subfissuring, and by the flow of rocks. Am I M Eng, Tr 25:499-513 (1896)

Goddard, Paul B.

41 On the Missourium kochii. Ac N Sc Phila, Pr 1: 115-116 (1841)

Goddard, Malcolm.

or Fish remains from the marine lower Triassic of Aspen Ridge, Idaho. Cal Univ, Dp G, B 5 : 145-148 (1907)

Godding, Miss D. W.

47 First lessons in geology. 142 pp, Hartford 1847

Goding, Francis.

66 On the petroleum or "green tar" and the "manjak" of Barbados (with discussion by R. J. L. Guppy). Sc As Trinidad, Pr 1 pt $1: 37-47$ (1866)

Godman, John D.

24 Description of the os hyoides of the Mastodon. Ac N Sc Phila, J 4:67-72, il (1824)

25 American natural history [contains notes on fossil vertebrates]. 3 vols, Phila 1825-8 2d ed, 1831

30 Description of a new genus and new species of extinct mammiferous quadruped. Am Ph Soc, Tr n s 3:478-485, il (1830) 
Godon, Sylvain.

09 Observations to serve for the mineralogical map of the State of Maryland. Am $\mathrm{Ph}$ Soc, Tr 6:319-323 (1809)

09a Mineralogical observations made in the environs of Boston in the years 1807 and 1808. Am Ac Arts, Mem 3:127-154 (1809) Mus d'Hist Nat, Paris, An 15: 455-472 (1810)

14 Mineralogical note respecting phosphated lime, and phosphated lead, from Pennsylvania. Am Miner J 1:30 (1814)

Göppert, Johann Heinrich Robert (18001884).

39 Ueber die fossilen Pflanzen-Abdrücke von Mauch Chunk [Pa.]. In Wied, Maximilian Prinz zu, Reise in das innere NordAmerica in den Jahren 1832 bis 1834 , Bd 1 : 636-642, Coblenz 1839

Goesse, John B.

11 (and Ruppe1, G. E.) Seismology in St. Louis University. St. Louis Univ, B 7 no $5: 53 \mathrm{pp},(1911)$

Goessman, Charles A.

66 Contribution to the chemistry of the mineral springs of Onondaga, N. Y. Am J Sc (2) $42: 211-218,368-375$ (1866)

See also American Bureau of Mines, 67

GoethaIs, George W.

16 Slides at Panama. Canal Record, Supplement to January 5, 1916 edition : 17 pp (1916)

Goetz, Alois.

12 The eastern Michipicoten iron range. Eng M J 93: 1090-1092 (1912)

Goldman, Marcus Isaac.

10 The Colorado Springs coal field, Colo. U S G S, B 381:317-340, map (1910)

15 Petrographic evidence on the origin of the Catahoula sandstone of Texas. Am $J$ Sc (4) $39: 261-287$ (1915) Abst, Wash Ac Sc, J 4:296-298 (1914)

16 The petrography and genesis of the sediments of the Upper Cretaceous of Maryland. Md G S, Upper Cret: 111-182 (1916)

17 Results of the microscopic examination of some rocks from the oil flelds of southeastern Ohio (abst). Wash Ac Sc, J $7: 310-311$ (1917)

17 a (with Stebinger, E.) Pleistocene, Sun River region, Mont. (abst). G Soc Am, B 28: 149 (1917)

Goldney, G. F. B.

07 (with Carden, A. D.) Notes on the Jamaica earthquake, 14th January, 1907. R Engineers J 6: 213-217 (1907)

Goldsberry, J. P.

14 (with Kraus, E. H.) The chemical composition of bornite and its relation to other sulpho-minerals. Am J Sc (4) 37: 539-553 (1914) N Jb 1914, 2:127-144 $A b s t$ with discussion, $\mathrm{G}$ Soc Am, B 25 : 90-91 (1914)
Goldsehmidt, Victor.

03 (and Nicol, W.) New forms of sperrylite. Am J Sc (4) 15:450-458 (1903)

04 From the borderland between crystal. lography and chemistry. Wis Univ, B 108, Sc \& 3:21-38 (1904)

os (and Mauritz, B.) Ueber Kalome! [crystallography of calomel from Terlingua, Tex.]. Z Kryst 44:393-406 (1908)

10 (and Parsons, A, L.) Notes on goethite [optical characters of goethite from Walton, N. S.]. Am J Sc (4) 29: 235-236 (1910) Z Kryst 47:238-241 (1910)

10a (with Palache, C.) Die Formen. reiben des Leadhillits. Zs Kryst 48:140147 (1910)

$10 b$ (with Dreyer, C.) Ueber Albit ron Grönland. N Jb, Beil Bd 29:537592 (1910) Medd Grönl 34:1-61 (1910)

11 The nature of crystals (abst). Science n s $33: 871$ (1911)

12 (with Pogue, J. E.) On quart from Alexander Co., N. C. Am J Sc (4) $34: 414-420$ (1912)

Goldsmith, E.

73 Trautwineite, a new mineral. Ac $\mathbb{X}$ Sc Phila, Pr $1873: 1-2,348-349$

74 Analysis of chromite from Monterey Co., Cal. Ac N Sc Phila, Pr 1873:365366 (1874)

74a Stibiaferrite, a nex mineral from Santa Clara Co., Cal. Ac N Sc Phila, Pt 1873 : 366-369 (1874)

74b The blue gravel of Callornia. Ac N Sc Phila, Pr 1874: 73-74

76 Halloysite from Indiana. Ac N BC Phila, Pr 1876: 140-142

76a On hexagonite, a new mineral. Ac N Sc Phila, Pr 1876:160-161

77 On boussingaultite and other minerals from Sonoma Co., Cal, Ac N Se Phila, Pr 1876: 264-266 (1877)

77a Pickeringite from Colorado. Ac N Sc Phila, Pr 1876:333-334 (1877)

$\mathbf{7 S}$ On the alkali of the plains in Bridget Valley, Wyo. Terr. Ac N Sc Phila, Pr $1878: 42-44$

78a Staffellite from Pike's Peak, Colo Ac N Sc Phila, Pr 1878:156-157

79 Asphaltum and amber from Vincent town, N. J. Ac N Sc Phila, Pr 1879: 40-42

79a On amber containing fossil insects. Ac N Sc Phila, Pr 1879: 207-208

89 Gadolinite from Llano Co., Tex. As N Sc Phila, Pr 1889: 164-165

90 Pealike phosphorite from Polk $\mathrm{CO}_{-}$ Fla, Ac N Sc Phila, Pr 1890:10

91 Basanite from Crawford Co., Ind. Ac N Sc Phila, Pr 1891: 99-104

93 Notes on some minerals and rocks. Ac N Sc Phila, Pr 1893: 174-180

93a A tempered stcel meteorite [God. haven, Disco Island]. Ac N Sc Phila, Pr 1893: $373-376$ 
Goldsmith, E.-Continued.

94 Volcanic products from the Hawalian Islands. Ac N Sc Phlla, Pr 1894: 105-109

98 Volcanic rocks of Mesozolc age in Pennsylvania. Ac N Sc Phila, Pr 1898: 90-97

98a The petrifaction of fossil bones. Ac N Sc Phila, Pr 1898: 98-100

$00 \mathrm{~A}$ collapsing crater [Pottstown, $\mathrm{Pa}$.] Ac N Sc Phila, Pr 1900: 424

07 The Jerseyite [meteoric stone, N. J.]. Franklin Inst, J 164: 369-373 (1907)

Goldthwait, James Walter.

03 (with Huntington, Ellsworth.) The Hurricane fault in southwestern Utah. J G $11: 46-63$, map (1903)

04 (with Huntington, Ellsworth.) The Hurricane fault in the Toquerville district, Utah. Harvard Coll, Mus C Z, B 42 (g s 6) : 199-259, map (1904)

05 The sand plains of glacial Lake Sudbury [eastern Mass.]. Harvard Coll, Mus C Z, B 42 (g s 6) : 263-301 (1905)

06 Correlation of the raised beaches on the west side of Lake Michigan. J G 14: 411-424 (1906)

07 The abandoned shore lines of eastern Wisconsin. Wis G S, B $17: 134$ pp (1907) 08 A reconstruction of water planes of the extinct glacial lakes in the Lake MichIgan basin. J G 16:459-476 (1908) Abst, Science n s $27: 724-725$ (1908)

08a The altitude of the Algonquin beach and its significance (abst). Sclence If 5 28: $382-383$ (1908)

08b Intercision, a peculiar kind of modification of drainage. School Science and Mathematics 8: 129-139 (1908)

08e (with Atwood, W. W.) Physical geography of the Evanston-Waukegan region. IIl $\mathrm{G}$ S, B $7: 102 \mathrm{pp} \mathrm{(1908)}$

09 Physical features of the Des Plaines Valley. Ill G S, B 11: 103 pp (1909)

09a Isobases of post-Algonquin elevation across Lakes Michigan and Huron (abst). Science n s 29:754 (1909)

09b (and Jacobson, R, C.) PrelimiDary report on measurements of altitude of the Algonquin and Nipissing shore lines in Ontario. Can G S, Sum Rp 1908: 112-114 (1909)

10 An instrumental survey of the shore lines of the extinct lakes Algonquin and Nipissing, in southwestern Ontario. Can Q 8 . Mem 10:57 pp, maps (1910)

$10 \mathrm{a}$ Isobases of the Algonquin and Iroquois beaches, and their significance. G Soc Am, B 21: 227-248, map (1910) Discussion, $21: 761-762$ (1910)

10b Glacio-lacustrine and postglacial features of the Connecticut Valley near Hanover, N. H. (abst). Science n s 32 : 126 (1910)

11 Raised beaches of southern Quebec. Can G S, Sum Rp $1910: 220-233$ (1911)
Goldthwait, James Walter-Continued.

11a The twenty-foot terrace and sea. cliff of the lower St. Lawrence. Am J Sc (4) $32: 291-317$ (1911) Abst, G Soc Am, B $22: 723-724$ (1911)

11b Accumulation of inherited features in shore lines of elevation (abst). As Am Geog, An 1: 111 (1911)

12 Records of postglacial changes of level in Quebec and New Brunswick. Can G S, Sum Rp 1911: 296-302 (1912)

13 Glacial cirques near Mount Washington. Am J Se (4) 35:1-19 (1913) Abstract with discussion by Frank Leverett, H. F. Reid, and J. B. Woodworth. G Soc Am, B 24:677-678 (1913)

13a Following the trail of ice sheet and valley glacier on the Presidential Range [White Mountains, N. H.]. Appalachia 13:1-23 (1913)

13b Excursion in eastern Quebec and the maritime provinces; physiography; Quebec and vicinity, physiographical notes; Rivière du Loup, the postglacial marine submergence; Bic, the postglacial marine submergence; Chaleur Bay, physiographic note. Int G Cong, XII, Canada, Guide Book no $1: 16-24,48-51,66-67,77-79$, 119-120 (1913)

13e The upper marine limit at Montreal; the upper marine limit at Covey Hill and vicinity. Int G Cong, XII, Canada, Guide Book no 3:119-126, map (1913)

14 Remnants of an old graded upland on the Presidential Range of the White Mountains. Am J Sc (4) $37: 451-463$, maps (1914)

14a Supposed evidences of subsidence of the coast of New Brunswick within modern time. Can G S, Mus B $2: 45-67$, map (1914)

14b Marine shore lines in southeastern Quebec. Can G S, Sum Rp 1912: 357-359 (1914)

14e Marine submergence at Montreal, Covey Hill, and Rigaud Mountain [Que.]. Can G S, Sum Rp 1913: 211 (1914)

14d Physiography and surficial geology of Nova Scotia. Can G S, Sum Rp 1913: 244-250 (1914)

14e Occurrence of glacial drift on the Magdalen Islands [Gulf of Saint Lawrence] (abst). G Soc Am, B 25: 84 (1914)

15 The occurrence of glacial drift on the Magdalen Islands [Gulf of St. Lawrence]. Can G S, Mus B 14:11 pp, map (1915)

15a Physiography and surface geology of Nova Scotia. Can G S, Sum Rp 1914: 102-103 (1915)

15b The origin of Lost River and its giant potholes [N. H.]. Science n s 42 : 834-836 (1915)

15e Remnants of a peneplain in the White Mountains of New Hampshire (abst). As Am Geog, An 3:112 [1915] 
Goldthwait, James Walter-Continued.

16 Glaciation in the White Mountains of New Hampshire. G Soc Am, B 27:67 (abst), 263-294 (1916)

$16 a$ Evidence for and against the former existence of local glaciers in Vermont. Vt St G, Rp 10:42-73, map (1916) Abst, with discussion by G. F. Wright, G. D. Hubbard, and J, L. Rich, G Soc Am, B 28 : 134-135 (1917)

17 Physiography of Cape Breton Island (abst). As Am Geog, An 6:125-126 [1917]

17a Snow arch in Tuckermans Ravine on Mount Washington (abst). G Soc Am, B 28: 144 (1917)

See also Johnson (D W), 17 ; Leverett, $13 \mathrm{c}$; Rich 17b

Gốmez, Julio.

$16 \mathrm{El}$ mineral de la Cañada, Tetela de Ocampo, Puebla. Bol Minero 2:126-127 (1916)

16a El mineral Aurora, distrito de Teziutlán, Puebla [México]. Bol Minero 2 : 446-455 (1916)

16b Informe acerca del mineral de San Miguel Tenango [Zacatlán, Estado de Puebla, México]. Bol Minero 2:575-576 (1916)

González, F.

11 (and Grothe, Albert, and Salazar S, Leopoldo) The mining industry of Mexico. No 1, State of Hidalgo. Part 1, $74 \mathrm{pp}$, Part 2, pp 77-108 Mexico 1911 [See also Grothe, 12]

Gonzflez, Pedro, Jr.

10 Estudio de las minas "El Cedro" y "Dos Estrellas" en Tlalpujahua, Michoacán, México. Soc G Mex, B 7: v-vi (1910)

González del Valle, Ambrosio.

72 Chapapote líquido [Cuba]. R Ac Cienc Habana, An 9:38-39 (1872)

Gonzales Viquez, Cleto.

10 Temblores, terremotos, inundaciones y erupciones volcánicas en Costa Rica, 1608-1910. 200 pp, San Jose de Costa Rica, 1910. Reviev, Seism Soc Am, B 1:23

Gooch, Frank Austin.

88 (and Whitfield, J. E.) Analyses of waters of the Yellowstone National Park. U S G S, B 47:84 pp (1888)

Gooch, Stapleton D.

18 (with Watson, T. L.) Vivianite from the land-pebble phosphate deposits of Florida. Wash Ac Sc, J 8: 82-88 (1918)

Goodale, Charles W.

89 The occurrence and treatment of the argentiferous manganese ores of Tombstone district, Ariz. Am I M Eng, Tr 17: $767-774$, map (1889) ; 18:910-912 (1890)

90 (and Akers, W. A.) ...notes on the geology of the Flint Creek mining district [Mont.]. Am I M Eng, $\operatorname{Tr} 18: 242-252$ (1890)

14 The Drumlummon mine, Marysville, Mont. Am I M Eng, B 92 : 2095-2120 (1914) ; Tr $49: 258-283$ (1915)
Goodale, Frank A.

11 Yerington-Buckskin copper distriet, Nev. Colo Sch Mines Mag 1 no $4: 3-8$ (1911)

Goodale, George L.

61 Mineral waters of Maine. Me Bd Agr, 6th An Rp: 443-456 (1861)

67 The geysers of California. Am Nat $1: 337-342$ (1867)

See also Hiteheock (C H), 62; Holmes (E), 62

Coodale, Stephen L.

10 The Bristol mines, Lincoln $\mathrm{Ca}_{0}$ Nev, Mines and Minerals $30: 507-50)$ (1910)

Goodchild, W. H.

16 The origin and occurrence of certain crystallographic intergrowths. Ec G 11 $397-402$ (1916)

Is Magmatic ore deposits of Sudbury, Ont. Ec G $13: 137-143$ (1918)

Goode, G. Brown.

96 The Lacoe collection in the Nationsl Museum. Science n s 4:8-10 (1896)

Goode, John Paul.

99 The piracy of the Yellowstone. JG $7: 261-271$ (1899) Am Bur Geog, B 2: 177-187 (1901)

Goode, Richard Urquhart.

98 Bitterroot Forest Reserve [IdahoMont.]. Nat Geog Mag 9:387-400 (1898) Goodfellow, G. E.

87 The Sonora earthquake. Sclence $9:$ $483-484,516 ; 10: 81-82$ (1887); $11: 162-$ 166 (1888)

Goodnow, Isaac T.

83 The Trinidad coal mines [Colo.]. Kansas City Rv Sc $7: 215-217$ (1883)

Goodrich, Harold Beach.

98 Recent warpings as shown by drainage peculiarities [Alaska]. U S G S, An Rp 18 pt $3: 276-289$ (1898)

Goodrieh, Joseph.

26 (and Ellis, William) ... volcanic character of the Island of Hawaii. Am J Sc 11:2-36 (1826)

29 [On the volcanic character of the Island of Hawaii]. Am J Sc $16: 345-347$ (1829)

33 ... volcanoes and volcanic phenomens of Hawaii (Owyhee) ... Am J Sc 25:199203 (1833)

Goodrich, Samuel Griswold (1793-1860). 44 The wonders of geology. $291 \mathrm{pp}$, Boston 1844 [Also N Y and Phila edi. tions]

Goodwillie, J. M.

93 A geological sketch, with notes on the geology of the Manitou Islands of Lake Nipissing, Ont. Science 22:101-104 (1893)

Goodwin, J. C.

02 Re-formed copper ores [Bisbee, Ariz.]. M Sc Press $85: 60,75,85$ (1902) 
Goodwin, W. L.

93 A highly nickeliferous pyrite [Sudbury, Ont.]. Can Rec Sc 5:346-347 (1893)

98 (and Miller, W. G.) Note on a mineral of the columbite group. Fed Can If Inst, J 3:151-152 (1898) Can M Rv $17: 109$ (1898)

Goodyear, Watson Andrews.

6s Salt Spring Valley and the adjacent region in Calaveras Co. Cal Ac $\mathrm{N}$ Sc, $\mathrm{Pr}$ $3: 387-399$ (1868)

73 Notes on the geology of the coast of Oregon. Cal Ac Sc, Pr 4:295-29s (1873)

73a Notes on the high Sierra south of Mount Whitney. Cal Ac Sc, Pr 5:180183 (1873)

77 The coal mines of the western coast of the United States. 153 pp, San Francisco 1877

79 The auriferous gravels of California.

If Sc Press 39: 182-183 (1879) Eng M J $28: 280,299-300 \quad(1879)$

80 Review of field notes of 1871 , and discussion of general topics connected with the [auriferous] gravel question [California]. Harvard Coll, Mus C Z, Mem 6 to $1: 488-526 \quad(1880)$

80a Earthquake and volcanic phenomena, December 1879 and January 1880 , in the republic of Salvador, Central America, $56 \mathrm{pp}$, Panama 1880

82 Detalled description of the .Fonte Diablo cosl field: additional notes on the Yonte Diablo coal mines. Cal G S, Geology 2 App : 3-32 (1882)

82a Notes descriptive of the condition of the Corral Hollow coal mines. Cal G S, Geology 2 App : $35-40 \quad(1882)$

82b Report on an examination of the quicksilver mines of California. Cal G S. Geology 2 App : 91-135 (1882)

88 Petroleum, asphaltum, and natural tas; coal. Cal St M Bur, An Rp 7:63178 (1888)

90 San Diego Co.; Santa Cruz Island. Cal St M Bur, An Rp 9: 139-155, 155-170, map (1890)

See also Irelan, $88 \mathrm{a}, 90 \mathrm{a}$

Gorby, S. S.

86 Geology of Tippecanoe Co. : ... Washthiton Co.; ... Benton Co.; the Wabash arch, Ind, Dp G N H, An Rp 15; 61-96, $117-153,198-220,228-241$ (1886)

$80 \mathrm{a}$ (and Lee, S. E.) Geology of Boone Co. Ind, Dp G N H, An Rp 15: $160-176$ (1886)

89 Geology of Miami Co. Ind, Dp G H, An Rp $16: 165-188$ (1889)

89 a Natural gas and petroleum; structural features of Indiana; sections of batural gas wells in Indiana. Ind, Dp GN H, An Rp 16:189-301, map (1889) 92 Seventeenth annual report, 1891. Ind, Dp G N Res : $705 \mathrm{pp}, \mathrm{n}$, Indianapolis
Gorby, S. S.-Continued.

93 Iimits of the natural gas supply. Eng Mag 5 : 419-426 (1893)

94 Eighteenth annual report, 1893. Ind, Dp G N Res : 356 pp, il, map, Indianapolis 1894

$94 a$ Nineteenth annual report, 1894. Ind, Dp G N Res : 296 pp, map, Indianapolis 1894

99 The onyx deposits of Barren Co., Ky. Eng M J 67: 707-708 (1899)

Gorton, Charles Henry.

89 Notes on the geology of southeastern Iowa. Am G 4:237-239 (1889)

90 Observations on the Keokuk species of Agaricocrinus. Am G 5:257-261, il (1890) Abst, Iowa Ac Sc, Pr 1887-9: 100-101 (1890)

$90 \mathbf{a}$ On the Keokuk beds at Keokuk, Iowa. Am J Sc (3) $40: 295-300$ (1890)

$90 \mathbf{b}$ On the brecciated character of the St. Louis limestone. Am Nat 24:305-313 (1890)

90c Notes on a fossil wood from the Keokuk limestone, Keokuk, Iowa (abst). Iowa Ac Sc. Pr 1887-9:97-98 (1890)

90d On the Keokuk beds and their contained fossils in the vicinity of Keokuk, Iowa (abst). Iowa $\mathrm{Ac} \mathrm{Sc}, \mathrm{Pr}$ 1887-89: 98-100 (1890)

91 Quaternary geology of Keokuk, Iowa. Northwestern Univ., Report of the Department of Natural History in the College of Liberal Arts:11-19, map, Evanston 1891

92 Quaternary geology of Keokuk, Iowa, with notes on the underlying rock structure. Am G 9:183-190 (1892)

92a On the Keokuk group. Am G 10 : 327-328 (1892)

93 A report on the Bevier sheet, including portions of Macon, Randolph, and Chariton $\cos$. Mo G S 9, Sheet Rp no 2: $75 \mathrm{pp}$, map [under separate cover, with abstract of report, by Arthur Winslow] (1893) [The Quaternary geology by .I. E. Todd: 37-47; Clays and shales, by H. A. Wheeler : 57-67]

95 Buried river channels in southeastern Iowa. Iowa G S 3:237-255 (1895)

95a Geology of Van Buren Co. Iowa G S 4:197-254, map (1895) Abst, J G $3: 979$ (1895)

95b Sycnite gneiss (leopard rock) from the apatite region of Ottawa Co., Can. G Soc Am, B 7:95-134 (1895) Abst, Am G $16: 241$ (1895); Ottawa Nat 9:152-153 (1895) : J G 4:377-379 (1896)

95e Stratigraphy of the Saint Louis and Warsaw formations in southeastern Iowa. J G $3: 289-311$, map (1895)

9s Notes on the Kalamazoo and other old glacial outlets in southern Michigan. J G $6: 477-482$, map (1898)

oo Geological report on Sanilac Co., Mich. Mich $G \mathrm{~S}, 7$ pt $3: 34$ pp, map (1900) 
Gordon, Charles Henry-Continued.

or On the origin and classification of gneisses. Nebr Ac Sc, Pub $7: 90-96$ (1901)

02 The Port Huron oil field. Mich G S, Rp 1901:269-281 (1902)

02a Wave cutting on west shore of Lake Huron, Sanilac Co., Mich. Mich G S, Rp 1901: 283-290 (1902) Mich Miner 4 no $12: 10-14 \quad(1902)$

04 On the pyroxenites of the Grenville series in Ottawa Co., Can. J G $12: 316-$ 325 (1904)

O4a On the paramorphic alteration of pyroxene to compact hornblende. Am G 34: $40-43$ (1904)

04b The work of rivers [erosion and sedimentation]. Northwest J Educ 15 no 7:3-6 (1904)

06 (and Graton, L. C.) Lower Paleozoic formations in New Mexico. Am J Sc (4) $21: 390-395 \quad$ (1906) Science $\mathbf{n} \mathbf{s}$ $23: 590-591$ (1906)

o7 Mississippian (Lower Carboniferous) formations in the Rio Grande Valley, N. Mex. Am J Sc (4) 24:58-64 (1907)

07a Notes on the Pennsylvanian formations in the Rio Grande Valley, N. Mex. J G $15: 805-816$ (1907)

07b New Mexico geology. Science n s $25: 109$ (1907)

07e Some features of the geology of Magdalena and Black Range region (abst). Science n s 25:824-825 (1907)

09 The chalk formations of northeast Texas. Am J Sc (4) $27: 369-373$ (1909) Abst, Science n s 29:629 (1909); G Soc Am, B 20:645-646 (1910)

$09 a$ The red beds of the Wichita-Brazos region of north Texas (abst). Science n s $29: 752$ (1909)

10 (with Lindgren, W.) The ore de. posits of New Mexico. U S G S, P P t8: 361 pp (1910)

11 Geology and underground waters of northeastern Texas. U S G S, W-S P 276: $78 \mathrm{pp}, \operatorname{map}$ (1911) Abst, Wash Ac Sc J 1: 183 (1911)

11a The Wichita formation of northern Texas, with discussions of the fauna and flora by George H. Girty and David White. J G 19:110-134, map (1911)

$11 \mathbf{b}$ The marbles of Tennessee. Tenn $\mathrm{G}$ S, B 2-D : 33 pp (1911)

11e Cement resources and possibilities [of Tennessee]. Tenn G S, Res Tenn 1: 58-69 (1911)

12 Cave marble (cave onyx) in Tennessee. Tenn G S, Res Tenn 2: 307-317 (1912) Abst, Science n s $35: 312-313$ (1912); G Soc $A m$, B 23: 729 (1912)

12a (and Jarvis, R. P.) Iron deposits in the Tuckahoe district, east Tenn. Tenn G S, Res Tenn 2: 458-478, map (1912)

13 Geology and underground waters of the Wichita region, north central Texas. U S G S, W-S P $317: 88$ pp, map (1913)
Gordon, Charles Henry - Continued.

13a Types of iron-ore deposits in Tes nessee. Tenn G S, Res Tenn 3:84-88 (1913)

13b Earthquakes in east Tennessee Seism Soc Am, B 3:191-194, map (1913) 14 Earthquakes in east Tennesse Tenn G S, Res Tenn 4:15-22, map (1914

14a Types of iron ore deposits in eas Tennessee $(a b s t)$. Tenn Ac Sc, Tr 1:60$70 \quad$ (1914)

14b The copper resources of the South ern States (abst). Science n s 39: 4 to (1914)

17 Nature and origin of the Holsto marble formation in east Tennessee (abst). Tenn Ac Sc, Tr 2:92 (1917)

18 Barite deposits of the Sweetwate district, east Tenn. Tenn G S, Res Tent $8: 48-82$, map (1918)

$18 \mathrm{n}$ on the nature and origin of th: stylolitic structure in Tennessee marbe J G 26:561-568 (1918) Abst, Science D: $47: 492$ (1918)

Gordon, Clarence E.

o5 Early stages of some Paleozit corals (abst). Science n s 21: 990 (1905)

06 Studies on early stages in Paleozl corals. Am J Sc (4) 21:109-127 (1906) Abst, N Y Ac Sc, An 17:596 (1907)

o7 The primary septa in rugose corals Science n $8 \quad 25: 345-347,733-734$ (abit) (1907)

o9 Some geological problems [metamo: phosed pre-Cambrian and Cambrian sed ments in New York and adjoining States: Science n \& 29 : 901-903 (1909)

10 [Prugress report on the Poughkeeps quadrangle, N. Y.] N Y St Mus, B 14l 16-20 (1910)

11 Geology of the Poughkeepsie quat rangle, N. Y. N Y St Mus, B 148:12 pp, map (1911)

14 Notes on the geology in the vicinit/ of Bennington, Vt. Vt St G, Rp $9: 33 i^{\circ}$ 370 , map (1914)

16 Some structural features in the Green Mountain belt of rocks (abst). Soc Am, B 27:101 (1916)

Gordon, J. M.

13 Classification of coals. Can $\mathrm{N}$ 34: 524-527 (1913)

Gordon, Reginald.

02 Bones of a mastodon found [Ner burgh, N. Y.]. Science n s 16:594 (190?

02a Tree trunks found with mastodo remains. Science n \& 16:1033 (1902)

Gordon, Samuel G.

15 (with Wherry, E. T.) An arrant ment of minerals according to their occul rence. Ac $\mathrm{N}$ Sc Phila, Pr 67:426-45 (1915)

16 An occurrence of lamellar calcte (argentine) in Pennsylvania. Am Minet alogist 1:55-56 (1916) 
Gordon, Samuel G.-Continued.

16 a A review of the genesis of the reolite deposits of First Watchung Mountain, N. J. Am Mineralogist 1:73-80 (1916)

18 Famous mineral localities; 3 , Amelia Court House, Va. Am Mineralogist 3:2729 (1918)

Gordon, Thomas $\mathrm{F}$.

36 Gazetteer of the State of New York ... [geology : 40-61]. 102, 801 pp, Phila 1836 Gordon, W. C.

05 The Black River section near Bessemer [Mich.]. Mich Ac Sc, Rp $7:$ 188-195 (1905) 07 (assisted by Lane, A. C.) A geological section from Bessemer down Black River. Mich G S, Rp 1906:397-507, map (1907)

Gordon, W. T.

09 Preliminary report on specimens of silicified wood [chiefly of Araucarioxylon] collected by John Muir, esq., at Adamana, near Holbrook, Ariz., U. S. A. R Bot Garden Edinb, Notes no 20:257-258 (1909)

Gorham, Frederic P.

05 The Cambrian deposits of North Attleboro, Mass. The Apterix, 1:53-58 (1905) Roger Williams Park Mus, Providence, R. I., B 9: 6 pp (1905)

German, Martin W.

00 Ice cliffs on White River, Yukon Tert. Nat Geog Mag 11:113-117 (1900) Gorrie, -

54 [On changes of level of the west coast of Florida.] Boston Soc N H, Pr 4: 391-392 (1854)

Gosling, A.

97 Izalco and other volcanoes in Central America. G Soc London, Q J 53: 221 (1897) Gosling, Edgar B.

94 A treatise on ozokerite. Sch Mines Q 16: 41-68 (1894)

Gossip, William.

64 The rocks in the vicinity [or Halltax, N. S.]. N S Inst N Sc, Pr Tr 1 pt 2:44-59 (1864)

65 [The Waverly gold mines, N. S.] N \& Inst $\mathrm{N}$ Sc, Pr $\operatorname{Tr} 1$ pt $3: 141-142$ (1865)

Gottsehalek, Carl.

10 The metamorphism of coal. Am G As, B $1: 3-7$ (1910)

Gottsehalk, A. L. M.

03 Gold fields of eastern Nicaragua. U \&, Dp Comm Labor, Dally Consular Reports no $1774: 2-9$ (1903)

GottsehaIl, V. H.

10 (with Bnehlex, H. A.) Oxidation of sulphides. Ec G 5:28-35 (1910)

12 (and Buehler, H. A.) Oxidation of sulphides (second paper). Ec G $7: 15$ 34 (1912)

16 (with Cox, G. H., and Dean, R. S.) Studies on the origin of Missouri cherts and zinc ores. Mo Univ, Sch Mines, B tech s 2 no $2: 34$ pp (1916)
Gould, Charles Newton.

96 A geologic section across the flint Hills along the Missouri Paclfic Railway, beginning near Cedarvale and extending to Winfield. Kans Univ G S 1: 31-34 (1896)

98 On a series of transition beds from the Comanche to the Dakota Cretaceous in southwest Kansas. Am J Sc (4) 5:169175 (1898)

99 On the finding of fossil insects in the Comanche Cretaceous of Kansas. Kans Ac Sc, Tr 16:284 (1899)

00 The Lower Cretaceous of Kansas. Am G 25:10-40 (1900)

O0a Nonconformities at the mouth of the Platte River. Am G 25:364-368 (1900)

Oob Some phases of the Dakota Cretaceous in Nebraska. Am J Sc (4) 9:429433 (1900)

o0e Stratigraphy of the McCann sandstone [Okla.] Kans Univ Q 9:175-177 (1900)

O0d Oklahoma building stone. Stone 21: 332-334 (1900)

o0e Oklahoma Geological Survey. Science n s 12: 559-560 (1900)

01 (and Fisher, C. A.) The Dakota and Carboniferous clays of Nebraska. Nebr St Bd Agr, An Rp 1900:185-194, map (1901)

01a Notes on the fossils from the Kansas-Oklahoma red beds. J G $9: 337-340$ (1901)

01b Notes on the geology of parts of the Seminole, Creek, Cherokee, and Osage nations [Oklahoma]. Am J Sc (4) 11: 185-190 (1901)

01e Tertiary springs of western Kansas and Oklahoma. Am J Sc (4) $11: 263-268$ (1901)

O1d Notes on the Kansas-OklahomaTexas gypsum hills. Am G 27:188-190 (1901)

01e The Dakota Cretaceous of Kansas and Nebraska. Kans Ac Sc, Tr 17:122178 (1901)

01 On the southern extension of the Marion and Wellington formation. Kans Ac Sc, Tr 17:179-181 (1901)

01g The Oklahoma salt plains. Kans Ac Sc, $\operatorname{Tr} 17: 181-184^{\circ}$ (1901)

01h Oklahoma limestone. Stone 23: 351-354 (1901)

02 General geology of Oklahoma. Okla, Dp G N H, Bien Rp 2: 17-74 (1904)

O2a Oklahoma gypsum. Okla, Dp G N H, Bien Rp 2: 75-137 (1902)

04 Gypsum deposits in Oklahoma. U $\mathbf{S}$ G S, B 223:60-67, map (1904)

04a Geology of the Wichita Mountains of Oklahoma. Okla, Dp G N H, Bien Rp 3 : 15-22 (1904)

04b Geology of Jacobs Cavern, MeDonald Co., Mo. Phillips Ac, Andover, Mass, Dp Archaeology, B 1:9-12 (1904) 
Gould, Charles Newton-Continued.

05 Geology and water resources of Oklahoma. U S G S, W-S P 148: 178 pp, maps (1905)

06 The geology and water resources of the eastern portion of the Panhandle of Texas, U S G S, W-S P 154:64 pp (1906)

of The geology and water resources of the western portion of the Panhandle of Texas. U S G S, W-S P 191:70 pp, map (1907)

Q7a The oil fields of Oklahoma. Eng M J $84: 259$ (1907)

$\mathbf{0 7 b}$ Extent and importance of Oklaboma gypsum deposits. M Science $56: 542$ 543, 583-584 (1907) ; 57: 73-74 (1908)

os The Oklahoma Geological Survey. Science n s 28: 438 (1908)

OSa Notes on the oil and gas industry of Oklahoma. M World 29:807-809 (1908)

osb The coal resources of Oklahoma. M World 29:880 (1908)

osc The tripoli deposits in Oklahoma. M World 29:922 (1908)

Osd (and Hutchison, L. L., and Nelson, Gaylord) Preliminary report on the mineral resources of Oklahoma. Okla $\mathrm{G} \mathbf{8}$, B 1:84 pp (1908)

ose Asphalt in Oklahoma. M Science $58: 427$ (1908)

09 Asphalt deposits of Oklahoma. M World $30: 84$ (1909)

09a The Oklaboma coal fields. Mines and Minerals $29: 275-276$ (1909)

10 Director's biennial report to the governor of Oklahoma. Okla G S, B 6:95 pp (1910)

10a The future of natural gas in Oklahoma. Nat Gas As Am, Pr 2:113-126 [1910]

$10 \mathrm{~b}$ A progress geological map of Oklahoma (abst). Science n s $32: 192$ (1910); G Soc Am, B 21: 777-778 (1910)

10e (and others) Brief chapters on Oklahoma's minerals. Okla G S, B 6:3395, map (1910)

1od (and ohern, D. W., and Hutchison, L. L.) Proposed groups of Pennsylvanian rocks of eastern Oklahoma. Okla St Univ, Research B 3:15 pp, map (1910)

11 Brief statement of the geological history of Oklahoma. Okla G S, Circ 2:13 pp, map (1911)

11 a Oklahoma metalliferous minerals. M Se Press 103: 10-12 (1911)

$11 b$ (and others) Preliminary report on the structural materials of Oklahoma. Okla G S, B 5: 182 pp, map (1911) [Includes chapters on granites iy Chas. H. Taylor; clays, by L. C. Snider; gypsum, by Chas. N. Gould and Frank A. Herald; Portland cement, by Gaylord Nelson.]

12 Petroleum and natural gas in Oklahoma. Ec G $7: 719-731$ (1912)

12a Geology of natural gas. Nat Gas As Am, Pr 4:192-201 (1912)
Gould, Charles Newton-Continued.

13 Petroleum in the red beds [0kll] Ee G 8:768-780 (1913)

13a The occurrence of petroleum al natural gas in the Mid-Continent fix Int $\mathrm{G}$ Cong, XII, 1913, C R : 861-86 (1914; advance copy 1913)

15 The occurrence and distribution petroleum and natural gas in the Carbe iferous rocks of Kansas and Oklabon Inst Petroleum Tech, J 1: 185-190 (1915)

17 Geological work in the Southwes Southwestern As Petroleum G, B 1:20-3 (1917)

Gould, Dayton $T$.

S7 The preglacial course of the Roti River, Ohlo. Western Reserve Hist So Tract (70) $2: 479-490$, map (1887)

Gov, James Ellis.

13 Preliminary note on the so-calle "loess" of southwestern Iowa. Iowa ! Se, Pr 20:221-230 (1913) Abst, Sciess n s $38: 241$ (1913)

Gow, Paul A.

$\mathbf{0 7}$ (and others). Report on the pros erty of the Daly-Judge Mining Compans Park City, Utah. Colo Sch Mines, B t 31-70 (1907) Mines and Minerals 25 $32-35,79-82$ (1907)

Gowing, F. A.

04 Notes on geology of Mineral Crail district, Pinal Co., Ariz. M Rep 49:501504 (1904)

Grabau, Amadeus William.

94 The preglacial channel of the Genest River. Boston Soc N H, Pr 26:359-3M (1894)

96 Glacial lakes of the Boston Bast (abst). Am G 17:128-130 (1896)

96a The succession of the fossil fauns in the Hamilton group at Eighteenmil Creek, N. Y. (abst). Am G 18:220-221 (1896) Science n s 4:386 (1896)

96b (with Crosby, W. O.) [Glacis lakes of the Boston Basin (abst). Sciend n s $3: 212-213$ (1896)

97 The sand plains of Truro, Wellfeet and Eastham [Mass.] (abst). Science if 5 : 334-335, 361-362 (1897)

98 (and others) Guide to localities illustrating the geology ... of the vicinity of Boston. A. A. A. S., 50th anniversart meeting, Boston, August, 1898. 100 ps [Includes contributions by W. M. Daris physiography ; J. E. Woodman, geology of north shore; W. O. Crosby, geology of south shore; B. K. Emerson, geology of Turner's Falls region; A. W. Grabal, paleontology; J. E. Wolfr, petrographite notes.]

98a Geology and paleontology of Eligti eenmile Creek and the lake-shore sections of Erie Co., N. Y. Buffalo Soc N Sc, B 6: 1-403, il (1898-9) 
Grabau, Amadeus William-Continued. 98b Paleontology of the Cambrian terranes of the Boston Basin (abst). Am As, Pr 47:305-306 (1898) Am G 22:264265 (1898) Science n s 8:505 (1898)

9se Siluro-Devonian contact in western New York (abst). Science $\mathrm{n}$ s 8:800 (1898)

99 The faunas of the Hamilton group of Eighteenmile Creek and vicinity in western New York. N Y St G, An Rp 16:227339 (1899) N Y St Mus, An Rp $50 v 2$ : 227-339 (1899)

99a Moniloporidae, a new family of Paleozoic corals. Boston Soc N H, Pr 28 : 409-424, il (1899)

99b [On the topography of lower Cape Cod, Mass. (abst).] Science n s 9:591 (1899)

99e some modern stratigraphic problems (abst). Science n s 10:85 (1899)

00 Lake Bouvé, an extinct glacial lake in the southern part of the Boston Basin [Mass.] Boston Soc $\mathrm{N} \mathrm{H}, \mathrm{Oc} \mathrm{P} 4 v 1 \mathrm{pt}$ 3:564-600, map (1900)

00a Paleontology of the Cambrian terranes of the Boston Basin [Mass.]. Boston $\mathrm{Soc} \mathrm{N} \mathrm{H}, \mathrm{Oc} \mathrm{P}_{4} v 1$ pt $3: 601-694$, il (1900)

00b Siluro-Devonic contact in Erie Co., N. Y. G Soc Am, B 11:347-376, il (1900) Abst, Sclence n s 11:105 (1900)

01 Guide to the geology and paleontology of Niagara Falls and vicinity. N Y St Mus, B 45:1-284, map, il (1901) Buffalo Soe N Sc, B $7: 1-284$, map il (1901) Also issued, in part, as appendix to $\mathrm{N} \mathrm{Y}$, Comm St Res Niagara, An Rp 18 (1902)

01a A preliminary geologic section in Alpena and Presque Isle cos., Mich. Am G 28:177-189 (1901)

01b Recent contributions to the problem of Niagara (abst). Science $n$ s 14:773 (1901) Am G 28:329-330 (1901) N Y Ac Sc, An 14: 139 (1902)

02 Stratigraphy of the Traverse group of Michigan. Mich G S, Rp 1901:163210, map (1902)

02a Traverse group of Michigan (abst). Science n s $15: 83$ (1902) G Soc Am, B $13: 519$ (1903)

02b Studies of Gastropoda. Am Nat $36: 917-945$, il (1902)

02e The Geological Society of America [Rochester, N. Y., December 31, 1901 to January 2, 1902]. Science n s 15: 81-91 (1902)

02d Geological excursions in the Pittsburgh coal region. Science n s 16:274276 (1902)

02e (with shimer, H. W.) Hamilton group of Thedford, Ont. G Soc Am, B 13:149-186 (1902) Abst, Science n s 15: $82-83$ (1902)
Grabau, Amadeus William-Continued.

O2f (with Johnson, C. W.) A new species of Clavilithes from the tiocene of Texas. Ac N Sc Phila, Pr 53:602-603, il (1902)

03 Stratigraphy of Becraft Mountain. Columbia Co., N. Y. N Y St Mus, E 69: 1030-1079, map (1903) Abst, G Soc Am, B 14:532 (1904); Science n s $17: 294$ (1903)

03a Paleozoic coral reefs. G Soc Am, B $14: 337-352$ (1903) Abst, Science n s 17 : 297 (1903)

03b Notes on the development of the biserial arm in certain crinoids. Am J Se (4) $16: 289-300$ (1903)

03e Studies of Gastropoda; II, Fulgur and Sycotypus. Am Nat $37: 515-539$, il (1903)

03d Geology of Becraft Mountain, N. Y. (abst). Science n s $17: 793$ (1903)

o3e ... new classification of rocks (abst). Science n s 18: 789 (1903)

o3f Limestone regions of Michigan (abst). N Y Ac Sc, An 15:81 (1903)

03g The phylogeny of the Fusidae (abst). N Y Ac Sc, An 15: $86-87$ (1903)

O3h (with Kemp, J. F.) The Washington meeting of the Geological Society of America, December $30,31,1902$, January 1 and 2,1903 , Science n s 17:290303 (1903)

04 Phylogeny of Fusus and its allies. Smiths Misc Col 44 (1417): $157 \mathrm{pp}$, il (1904)

04a On the classification of sedimentary rocks. Am G 33:228-247 (1904)

O4b The geology of Becraft Mountain, N. Y. N Y Ac Sc, An 15: 176 (1904)

04c Discussion of and suggestions regarding a new classification of rocks (abst). N Y Ac Sc, An 15: 201-202 (1904)

os Physical characters and history of some New York formations. Science $\mathrm{n}$ s 22 : 528-535 (1905)

O5a Relative ages of the Oneida and Shawangunk conglomerates (abst). G Soc Am, B 16:582 (1906); Science n s 21: 221-222 (1905)

05b Evolution of some Devonic spirifers (abst). Am G 35:195 (1905) Science n s $21: 426-427$ (1905)

o5e Types of sedimentary overlap (abst). Science n s 21 : 991-992 (1905)

06 Guide to the geology and paleontology of the Schoharie Valley in eastern New York. N Y St Mus, B 92:77-386, map (1906)

o6a (and Shimer, H. W.) North American index fossils. Sch Mines Q 27:138$248 ; \quad 28: 20-100, \quad 150-221, \quad 251-352$, il (1906-7)

o6b Notes on the character and origin of the Pottsville formation of the Appalachian region (abst). Science n s 24:691 (1906)

$$
28737^{\circ}-23-27
$$


Graban, Amadeus William-Continued.

o6e Discovery of the Schoharie fauna in Michigan (abst). Science n s 23:467 (1906) G Soc Am, B 17:718-719 (1907)

o7 Types of sedimentary overlap. G Soc Am, B 17:567-636 (1906) Abst, N $\mathrm{Y}$ Ac Sc, An 17:598-599 (1907)

07a Studies of Gastropoda; III, On orthogenetic variation in Gastropoda. Am Nat $41: 607-646$, il (1907)

отb Seventh international zoological congress, section of paleozoology. Science n 5 26:881-883 (1907)

07e Subaerial erosion cliffs and talus in the lower Devonic of Michigan (abst). Science n s 25:295-296 (1907)

07d Types of cross-bedding and their stratigraphic significance (abst). Science n s $25: 296$ (1907)

o7e Geology and scenery of the upper Genesee falls. Science n s 25: 538-539 (1907)

O7f Age and stratigraphic relations of the Chattanooga black shale (abst). Sclence n s 25:771 (1907)

$07 \mathrm{~g}$ The Medina sandstone problem $(a b s t)$. Science n s 25:771-772 (1907)

07h The Sylvania sandstone; a study in paleogeography $(a b s t)$. Science $\mathrm{n} s 26$ : 832 (1907) N Y Ae Se, An 18: 344 (1908)

07i Evolution of some Devonic Spirifers (abst). N Y Ac Sc, An 17: 574-575 (1907)

07j The geology of Letchwork Park [N. Y.]. Am Scenic and Historic Preservation Soe, An Rp 12:197-199 (1907)

os Discovery of the Schoharie fauna in Michigan (abst). N Y Ac Sc, An 18:267 (1908)

08a Notes on the character and origin of the Pottsville formation of the Appalachian region $(a b s t)$. N Y Ac Sc, An 18: 294 (1908)

0sb The scenery and geology of the gorges and falls [of central New York] (abst). N Y Ac Sc, An 18: 322-323 (1908)

ose A revised classification of the North American Siluric system (abst). Science n s $27: 622-623$ (1908)

osd (and Sherzer, W. H.) Devonic elements in the late Siluric fauna of southern Michigan (abst). Science n s $27: 726$ (1908)

ose Notes on the Traverse group of Michigan (abst). Science n s 27:726 (1908)

osf Preglacial drainage in central-western New York. Science n s 28: 527-534 (1908)

osp Continental formations of the North American Paleozoic $(a b s t)$. Science $\mathrm{n}$ s 28: 936 (1908)

osh (with sherzer, W. H.) Siluric fauna from Michigan (abst). Science n s 27:408 (1908)
Grabau, Amadeus William-Continued.

08i (with Lane, A. C.) The nomen. clature and subdivisions of the upper Siluric strata of Michigan, Ohio, and west ern New York (abst). Science n s 27 : 409 (1908)

09 A revised classification of the North American lower Paleozolc. Science n $29: 351-356$ (1909)

09a Physical and faunal evolution of North America during Ordovicic, Siluric, and early Devonic time. J G $17: 209-252$ (1909)

09b Tertiary drainage problems of east. ern North America (abst). Science is s $29: 632$ (1909)

o9e Some new or little-known geological terms and their application in stratigraphic writing $(a b s t)$. Science n s 29:750 (1909)

09d Early developmental stages in recent and fossil corals (abst). Science n s 29: 917 (1909) N Y Ac Sc, An 19: 299 (1910)

o9e The Medina and Shawangunk problems in Pennsylvania $(a b s t)$. Sclence $n \mathrm{~s}$ $30: 415$ (1909)

o9f (and Shimer, H. W.) North American index fossils; Invertebrates. Vol I, viii, 853 pp, Il, N Y 1909; Vol II, XV, $909 \mathrm{pp}$, il, N Y 1910

$09 \mathrm{~g}$ Report on an examination of the Portage Dam site, N. Y. Am Scenic and Historic Preservation Soc, An Rp 14:4551 (1909)

$09 h$ (with Sherzer, W. H.) New up per Siluric fauna from southern Michigan. G Soc Am, B 19:540-553 (1909)

10 (and Sherzer, W. H.) The Monroe formation of southern Michigan and adjoining regions. Mich $\mathrm{G} \mathrm{S}, \mathrm{g}$ \& 1 , Pub 2: $248 \mathrm{pp}$, il (1910)

10a Paleontology and ontogeny. Pop Sc Mo $77: 295-298$ (1910)

10b Tertiary drainage problems of eastern North America (abst). G Soc Am, B 20:668 (1910)

10e Intracolonial acceleration and re. tardation, and its bearing on species (abst). Science n s $32: 223$ (1910)

11 On the classification of sand grains. Science n s 33:1005-1007 (1911)

12 Studies of Gastropoda, IV ; Value of the protoconch and early conch stages in the classification of Gastropoda. Int Zool Cong, VII, Boston 1907, Pr: 753-766, il Cambridge 1912 [advance print 1910]

12a Syllabus of historical geology. 51 pp, N Y 1912

12b Stratigraphic and paleontol gic features of ancient delta deposits (abst). Science n s $35: 317$ (1912); (with discussion by J. M. Clarke, David White, G. W. Stose, Arthur Keith, E. T. Wherry, and H. B. Kümmel), G Soc Am, B 23:743-746 (1912) 
Graban, Amadeus William-Continued.

12e Structure of the Helderberg front (abst). Science n s 35:319 (1912); (with discussion by J. B. Woodworth, G Soc Am, B 23: $746-747$ (1912) N Y Ac Sc, An $21: 210$ (1912)

12d (and Reed, Margaret) Mutations of Spirifer mucronatus (abst). Int Zool Cong, VII, Boston 1907, Pr: 767-768, Cambridge 1912 [advance print 1910]

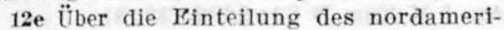
kanischen Silurs. Int $\mathrm{G}$ Cong, XI, Stockholm 1910, C R : 979-995 (1912)

$12 \mathrm{C}$ Continental formations in the North American Paleozoic. Int $\mathrm{G}$ Cong, XI, Stockholm 1910, C R : 997-1003 (1912)

13 Principles of stratigraphy. $1185 \mathrm{pp}$, I Y 1913

13a The origin of salt deposits with special reference to the Siluric salt deposits of North America (with discussion). If Met Soc Am, B 57 (vol 6 no 2) : 3344 (1913)

13b Early Paleozoic delta deposits of North America. G Soc Am, B 24: 399-528 (1913)

13e Preliminary report on the fauna of the Dundee limestone of southern Michigan. Mich G S, Pub 12 (g s 9 ) : $327-378$ (1913)

13d Was there a former Goat Island at Niagara Falls? (abst). N Y Ac Sc, An $22: 378$ (1913)

13e Irrational stratigraphy; the right and wrong way of reconstructing ancient continents and seas $(a b s t)$. Science $n \mathrm{~s}$ 38: 282 (1913)

13 A classification of marine deposits (alst, with discussion by J. Barrell). G Soc Am, B 24: 711-714 (1913)

$13 \mathrm{~g}$ Glacial erosion in the Genesee Valley system and its bearing on the Tertiary drainage problem of eastern North America (abst, with discussion by J. W. Spencer). 6 Soc Am, B $24: 718-719$ (1913)

13h Paleontological notes; 1 , polyphyletic genera ; 2 , an illustration of Waagen's theory of mutations (abst). G Soc Am, B 24:109 (1913)

14 Irrational stratigraphy; the right and the wrong way of reconstructing ancient continents and seas ( $a b 8 t$, wtih discussion). N Y Ac Sc, An 23:288 (1914) 15 North American continent in upper Deronic time $(a b s t)$. Science $n$ s 41 . 509-510 (1915) G Soc Am, B 26:88-90 (1915)

15a Olentangy shale of central Ohio and its stratigraphic significance (abst). G Soc Am, B 26:112, 156 (1915)

$15 \mathrm{~b}$ Hamilton group of western New York $(a b s t)$. G Soc Am, B 26:113, 158 (1915)

15e The black shale problem; a study In Paleozoic geography (abst). N Y Ac Sc, An $24: 378-379$ (1915)
Graban, Amadeus William-Continued.

16 Comparison of American and European lower Ordovician formations. G Soc Am, B 27:159 (abst), 555-622 (1916)

16a Distribution and inferred migration of American middle and upper Devonic corals (abst). G Soc Am, B $27: 147$ (1916)

16b Classification of the Tetraseptata [Tetracoralla], with some remarks on parallelism in development in this group; a study in orthogenesis (abst). G Soc Am, B $27: 148$ (1916)

17 Stratigraphic relationships of the Tully limestone and the Genesee shale in eastern North America. G Soc Am, B 28 : 945-958, 207-208 (abst) (1917)

17a (and o'Connell, Marjorie) Were the graptolite shales, as a rule, deep or shallow water deposits? G Soc Am, B 28: 959-964, 205-206 (abst) (1917)

17b Problems of the interpretation of sedimentary rocks. G Soc Am, B 28: 735744 (1917)

17e Age and stratigraphic relations of the Olentangy shale of central Ohio, with remarks on the Prout limestone and socalled Olentangy shales of northern Ohio. J G $25: 337-343$ (1917)

17d Comparison of the European and American Siluric (abst, with discussion by M. Y. Williams and W. H. Twenhofel). G Soc Am, B 28: 129-130 (1917)

17 Geology of the Island of Gotland in the Baltic Sea (abst). N Y Ac Sc, An 27 : 272-273 (1917)

17f Stratigraphic relations of the oilproducing to the oil-bearing sbales in the Paleozoic of North America; involving a new theory of oil distribution (abst). N Y Ac Sc, An 27:298 (1917)

18 Relation of the oil-bearing to the oilproducing formations in the Paleozoic of North America (abst), G Soc Am, B 29: 92-93 (1918)

18a Significance of the Sherburne bar in the upper Devonic stratigraphy (abst). G Soc Am, B 29:127-128 (1918)

18b Isolation as a factor in the development of Paleozoic faûnas (abst). G Soc Am, B 29:143 (1918)

1Se Conditions of deposition of marine salts and their bearing on the potash problem (abst), Science n $\mathrm{s} \quad 47: 493$ (1918)

$18 d$ The influence of the Ontario dome on the development of the Tertiary drainage of western New York, Ontario, and Michigan (abst). Science $\mathrm{n}$ s 47:493494 (1918)

See also Bucher, 17a; Davis (C A), 12 ; Earle, 13; Gregory (H E), 13

Grabill, L. R.

82 On the peculiar features of the Bassick mine [near Silver Clifr, Colo.] (with discussion). Am I M Eng. Tr 11:110117 (1882) Eng M J $34: 226-228$ (1882) 
Gracey, Arthur H.

98 Placer gold on Vermilion River. Ont Bur Mines, Rp 7:256-259, map (1898)

10 Sheep Creek district, B. C. Can M J $31: 100-101$ (1910)

Grad, $\mathrm{Ch}$.

71 Note sur les glaciers de l'ouest des Citats-Unis. Soc G France, B (2) 28 : 121-130 (1871)

Graham, Blakely.

o6 The Cooney district, N. Mex. Eng M J 82 : 731-732 (1906)

Graham, George

46 (and Anthony, J. G., and James, U. P.) Two species of fossil Asterias in the Blue Limestone of Cincinnati. Am J Se (2) $1: 441-442$, il (1846)

Graham, James C.

90 On a peculiar method of sand transportation by rivers. Am J Sc (3) $40: 476$ (1890)

Graham, Richard Percival Devereux.

06 Note on two interesting pseudomorphs in the McGill University mineral collection. Am J Sc (4) $22: 47-54$ (1906)

09 Dawsonite, a carbonate of soda and alumina. $\mathrm{R}$ Soc Can, $\operatorname{Pr} \operatorname{Tr}$ (3) 2, iv : $165-177$ (1909)

osa on a preliminary survey of the geology of the British Columbia coast from Kingcome Inlet to Dean Channel, including the adjacent islands. Can G S, Sum Rp 1908: 38-40 (1909) B C, Minister of Mines, An Rp 1908: 155-157 (1909)

$09 b$ On the optical properties of hastingsite from Dungannon, Hastings Co., Ont. Am J Sc (4) $28: 540-543$ (1909)

11 Native gold from Gold Harbour, Queen Charlotte Islands, B. C. Am J Sc (4) $31: 45-47 \quad$ (1911)

13 [Geological map of] coast and islands between Queen Charlotte Sound and Burke Channel, B. C. Scale $1: 253,440$. Can G S, Map 92A, 1913.

14 Note on the occurrence of scorodite, etc., at Cobalt, northern Ontario, Canada. R Soc Can, Pr Tr (3) 7, iv: 19-21 (1914)

$14 a$ (with Palacke, C.) Über die Krystallisation des Willemits. Zs Kryst 53:332-336 (1914)

14b. (with Tyrre11, J. B.) Yukonite, a new hydrous arsenate of iron and calcium, from Tagish Lake, Yukon Ter., Can.; with a note on the associated symplesite. R Soc Can, $\operatorname{Pr} \operatorname{Tr}$ (3) 7, iv : 13-18 (1914)

17 Origin of massive serpentine and chrysotile asbestos, Black Lake-Thetford area, Que. Ec G 12:154-202 (1917) Abst, Can M Inst, B 61:439-441 (1917)

18 (with Poitevin, E.) Contributions to the mineralogy of Black Lake area, Que. Can G S, Mus B $27: 82$ pp, map (1918)

See also Taber, $16 \mathrm{a}$
Graham, T. C.

os Mining camp of Topia, State of $\mathrm{D}_{2}$ rango, Mexico [silver-lead deposits]. I! World $29: 157-159$ (1908)

Graichen, W.

05 Das Kupfer-Gold-Lager von Globe, Ariz. Zs prak. G 13:39-40 (1905)

Grammer, F. L.

13 The laws of jointing (discussion), Am I M Eng, B $83: 2692$ (1913)

Grammer, John, jr.

18 ... coal mines in the vicinity of Rich. mond, Va. Am J Sc 1 : 125-130 (1918)

Granbery, J. H.

06 Magnetite deposits and mining at Mineville, N. Y. Fng M J 81:890-892 986-989, 1035-1038, 1082-1084, 11301132, 1178-1179 (1906) Reprinted (with revisions by the author) under the title, The Port Henry iron mines.

o7 The Schuyler mine, Kingsland, N. J. Franklin Inst, J 164:13-28, 217-22 (1907)

Grandin, M. V.

os Notes on the ore deposits of South Cheticamp, Cap Breton Island, N. S. N 8 Inst Sci, Pr Tr 11: 347-360 (1908)

Granger, Ebenezer.

21 ... vegetable impressions on the rocks connected with the coal formation of Zane ville, Ohio. Am J Sc 3:5-7, il (1821)

23 Notice of a curious fluted rock st Sandusky Bay, Ohio. Am J Sc 6:179-180 (1823)

\section{Granger, Walter.}

01 (with osborn, H. F.) Fore and hind limbs of Sauropoda from the Bone Cabin quarry [Wyo.]. Am Mus N H, B 14: 199-208, il (1901)

os A revision of the American Eocest horses. Am Mus N H, B 24:221-264, (1908) Abst, Science n \& 27:256 (1908)

09 Faunal horizons of the Washakie for mațion of southern Wyoming. Am Mis N H, B 26: 13-23 (1909)

10 Tertiary faunal horizons in the Wind River Basin, Wyo., with descriptions of new Eocene mammals. $\mathrm{Am}$ Mus $\mathrm{N} H, B$ $28: 235-251$, il (1910)

11 A new specimen of the four-tod horse; earliest known ancestor of the modern horse, the small four-toed Eohippus, discovered in the badlands of Wyoming Am Mus J 11: 85-88, il (1911)

$11 a$ (with Sinclair, W. J.) Eocepe and Oligocene of the Wind River and Bit. horn basins [Wyo.]. Am Mus N H, B 30: 83-117 (1911) Abst, G Soc Am, B 22: 722-723 (1911)

12 (with Sinclair, W. J.) Notes 01 the Tertiary deposits of the Bighorn Basid Am Mus N H, B 31:57-67 (1912)

14 On the names of lower Eocene faunal horizons of Wyoming and New Mexico. Am Mus N H, B $33: 201-207$ (1914) 
Granger, Walter-Continued.

14a Lower Eocene faunae of northwestern Wyoming (abst). N Y Ac Sc, An 23 : 263 (1914)

14b (with sinclair, W. J.) Paleocene deposits of the San Juan Basin, N. Mex. Am Mus N H, B 33: 297-316, maps (1914)

15 New evidence of the affinities of the Multituberculata (abst). G Soc Am, B 26 : 152 (1915)

15a (with Matthev, W. D.) A rerision of the lower Eocene Wasateh and Wind River faunas. Am Mus $\mathrm{N} H, \mathrm{~B} 34$ : $1-103,311-328,329-361,429-483$, il (1915)

17 Notes on Paleocene and lower Eocene mammal horizons of northern New Mexico and southern Colorado. Am Mus $\mathrm{N} \mathrm{H}$, B $37: 821-830$, il (1917)

17a (and Gregory, W. K.) A rerision of the Eocene primates of the genus Northarctus. Am Mus N H, B 37:841859. il (1917)

$17 \mathrm{~b}$ (with Matthew, W. D.) The skeleton of Diatryma, a gigantic bird from the lower Eocene of Wyoming. Am Mus .. H, B 37:307-326 (1917) Abst, G Soc Am, B 28: 212 (1917)

17e (with Matthew, W. D.) A giant Bocene bird [Diatryma Steini, Bighorn Basin, Wyo.]. Am Mus J 17:417-418, il (1917)

18 New tillodont skull from the Huerfano Basin, Colo. (abst). G Soc Am, B $29: 147-148$ (1918)

18a (with Matthew, W. D.) A revision of the lower Eocene Wasatch and Wind River faunas; Part V, Insectivora (continued), Glires, Edentata. Am Mus $\mathrm{NH}, \mathrm{B} 38: 565-657$, il (1918)

18b (with Matthew, W. D.) Fossil mammals of the Tiffany beds (abst). G Soc Am, B 29:152 (1918)

Grant, Charles Coote.

90 Notes on Beatricea (abst). Hamilton As, J Pr pt 6:122-126 (1890)

91 Notes on the Asteroidea, etc., living and fossil. Hamilton As, J Pr pt 7:128 131 (1891)

92 Notes on fossil Silurian plants, HamIlton, Ont. Hamilton As, J Pr 8:29-35, 147-148 (1892)

92a Notes on the Niagara Falls rocks. Hamilton As, J Pr 8: 135-139 (1892)

92b Geological notes on Marl Lake, Anticosti. Hamilton As, J Pr 8:140-146 (1892)

92e Fragments of Paleozoic sea floors from Hamilton, Ont., and Anticosti. Hamilton As, J Pr 8: 149-154 (1892)

93 Geological notes. Hamilton As, J Pr 9: 97-135 (1893)

94 Notes on local fossils in the glaciated chert Niagara beds. Hamilton As, J Pr $10: 79-89 \quad(1894)$

95 Opening address [notes on fossils, Hamilton, Ont.]. Hamilton As, J Pr 11: $60-64(1895)$
Grant, Charles Coote-Continued.

95a Brief notes on the Devonian rocks, Ontario. Hamilton As, $\mathrm{J} \operatorname{Pr} 11: 65-70$ (1895)

95b Geological notes in continuation. Hamilton As, J Pr 11:71-78 (1895)

96 Geological notes. Hamilton As, J Pr 12: 140-145 (1896)

96a Additional notes regarding our local graptolites. Hamilton As, J Pr 12 : 159-163 (1896)

97 Notes on some recent additions to Ontario paleontology. Hamilton $\mathrm{As}, \mathrm{J} \mathrm{Pr}$ $13: 20-26$ (1897)

$97 a$ Local paleontological notes in continuation. Hamilton As, J $\operatorname{Pr} 13: 27-33$, $34-37$ (1897)

97b The mineral of our local rocks. Hamilton As, J Pr 13: 38-43 (1897)

98 Geological notes. Hamilton As, J Pr $14: 89-100$ (1898)

99 Geological notes, Hamilton As, J Pr 15: 48-66 (1899)

oo Opening address [geological notes]. Hamilton Sc As, J Pr 16:75-82 (1900)

Oon Fossiliferous localities near Hamilton, Ont. Hamilton Se As, J Pr 16: $83-88$ (1900)

o1 Opening address, geological section. Hamilton Se As, J Pr 17:62-73, il (1901)

01 a Notes on a few fossils [Hamilton, Ont.]. Hamilton Se As, J Pr 17: 74-77, il (1901)

01b Niagara Falls as an index of time. Hamilton Sc As, J Pr 17: 78-83 (1901)

01e Geological notes, etc. Hamilton Sc As, J Pr 17: 84-96 (1901)

02 Opening address, geological section, for session 1901-1902. Hamilton Sc As, J Pr 18: 33-42 (1902)

02a Coral reefs, modern and ancient. Hamilton Sc As, J Pr 18:43-45 (1902)

02b Geological notes. Hamilton Sc As, J Pr 19:111-127, il (1903)

03 Geological notes. Hamilton Sc As, J Pr 18:48-52 (1902)

03a The origin of petroleum. Hamilton Se As, J Pr 19:142-145 (1903)

04 Notes on past collecting season. Hamilton Sc As, J Pr 20:29-46, il (1904)

o5 Notes on the late collecting season. Hamilton Sc As, J Pr 21:68-74, 80-86, il (1905)

06 Notes on the past collecting season [Silurian fossils, Hamilton, Ont.]. Hamilton Sc As, J Pr 22:107-120 (1906)

07 Notes on the late collecting season [Silurian fossils]. Hamilton Sc As, J $\mathrm{Pr}$ 23: 130-144 (1907)

os Notes on the late collecting season. Hamilton As, J Pr 24:20 pp [not numbered], il (1908)

10 A few hints on local fossil collecting here. Hamilton As, J Pr 25-26:99-106, i il (1910) 
Grant, C. E.

s6 (and Dawson, J. W.) Notes on Pleistocene fossils from Anticosti. Can Rec Sc $2: 44-48$ (1886)

Grant, E.

42 On the structure and history of the mastodontoid animals of North America (abst). G Soc London, Pr $3: 770-771$ (1842)

Grant, James A.

64 The geology of the Ottawa Valley. Can Nat n s $1: 419-426$ (1864)

so Cystidean life. Ottawa Field Nat Club, Tr no $1: 26-31$, il (1880)

81 Description of a new species of Porocrinus from the Trenton limestone. Ottawa Field Nat Club, Tr no $2: 42-44$, il (1881)

83 On the inferior maxilla of Phoca groenlandica from Green's Creek, Gloucester, Russell Co., Ont. (abst). R Soc Can, Pr Tr 1, iv : 286 (1883)

Grant, Ulysses Sherman.

89 Report of geological observations made in northeastern Minnesota during the summer of 1888. Minn G S, An Rp 17: 149-215 (1889)

90 Account of a deserted gorge of the Mississippi near Mínnehaha Falls. Am G $6: 1-6 \quad(1890)$

92 the stratigraphic position of the Ogishke conglomerate of northeastern Minnesota. Am G 10:4-10 (1892) Abst, Minn, Univ, Q B 1:60 (1892)

93 Field observations on certain granitic areas in northeastern Minnesota. Minn G $\mathrm{S}$, An Rp 20:35-110 (1893) Abst, Minn, Univ, Q B 1: 91-92 (1893)

93a The geology of Kekequabic Lake in northeastern Minnesota with special reference to an augite soda granite. Minn G $\mathrm{S}$, An $\mathrm{Rp} 21: 5-58$, map (1893) Abst, Minn, Univ, Q B 2:91 (1894)

93b Catalogue of rock specimens collected in northeastern Minnesota in 1892. Minn G S, An Rp 21:59-67 (1893)

93e Note on an augite-soda granite from Minnesota. Am G 11:383-388 (1893) Abst, Minn, Univ, Q B $2: 23$ (1894)

93d Note on quartz-bearing gabbro in Maryland. Johns Hopkins Univ Circ 12: 47-49 (1893) Abst, Minn, Univ, Q B 2: 22-23 (1894)

94 Preliminary report of field work during 1893 in northeastern Minnesota. Minn G S, An Rp 22: 67-86 (1894)

$94 a$ Note on the Keweenawan rocks of Grand Portage Island, north coast of Lake Superior. Am G 13:437-439 (1894) Abst, Minn, Univ, Q B 2: 92 (1894)

94b Volcanic rocks in the Keewatin of Minnesota. Science $23: 17$ (1894) Abst, Minn, Univ, Q B 2:55 (1894)

95 The name of the copper-bearing rocks of Lake Superior. Am G 15:192194 (1895)
Grant, Ulysses Sherman-Continued.

95a Reconnaissance map of the trit States [by W J McGee]. Am G 16:12 114 (1895)

95b List of rock samples collected 1894. Minn G $\mathrm{S}$, An Rp $23: 220-\mathrm{H}$ (1895)

95e (with Winchell, H. V.) Prelh nary report on the Rainy Lake gold regit Minn G S, An Rp $23:$ 36-105 (1895) Zs prak G 1897: 92-94

96 The stratigraphical position of t Ogishke Muncie conglomerate of northes ern Minnesota (abst). Minn Ac N sc, $4: 13$ (1896)

96a (with Winchell, N. H.) Ti canic ash from the north shore of th Superior. Am G 18:211-213 (1896)

97 Lakes with two outlets in nori eastern Minnesota. Am G 19:407-4 (1897)

98 Sketch of the geology of the easten end of the Mesabi iron range in Minnest Minn, Univ, Engineers' Year Book 6:th 62 , map (1898)

99 The geology of Itasca Co. ; ... Cor Co. ; ... Pokegama Lake plate; ... Gral Rapids plate; ... Swan Lake plate; ... Gil bro Lake plate; ... Snowbank Lake plati ... Fraser Lake plate; ... Akeley lat plate; ... Gunflint Lake plate; ... R Lake plate; ... Mountain Lake plate. Min G S, Final Rp $4: 166-192,313-357$, 36501, maps (1899)

99a Record of geological field wotk northeastern Minnesota 1892 to $18 \mathrm{c}$ Minn G S, An Rp 24: 85-144 (1899)

$99 \mathrm{~b}$ List of rock samples collected th northeastern Minnesota in 1898. Minn $\mathrm{S}$, An Rp 24:145-147 (1899)

99e A possibly driftless area in north eastern Minnesota. Am G $24: 377-384$ (1899)

99d [A driftless area in northeasten Minnesota (abst).] Science n s $9: 62 \%$ 624 (1899)

99e (with winchell, H. V.) Prellat nary report on the Rainy Lake gold te gion. Minn G S, Final Rp $4: 192-211$, map (1899)

Oo Preliminary report on the coppet bearing rocks of Douglas Co., Wis. $\mathrm{Wl}$ G S, B 6 (ec s 3) : 55 pp, maps, Madisot Wis., $1900.2 d$ ed, 83 pp, maps, Madisor, Wis., 1901

OOa Contact metamorphism of a basit igneous rock [Minn.]. G Soc Am, B 11 503-510 (1900)

oob (with Winchell, N. H.) The petrographic geology of the crystalliet rocks of Minnesota. Minn G S, Final ip 5: 75-936 (1900)

o1 Junction of Lake Superior sandstopi and Keweenawan traps in Wisconsil (abst). G Soc Am, B 13:6-9 (1901)

02 Lake Superior iron-ore deposits. At G $29: 47-51$ (1902) 
Grant, Ulysses Sherman-Continued,

03 Preliminary report on the lead and zinc deposits of southwestern Wisconsin. Wis G S, B 9 (ec s 5) : 103 pp, map, Madison, Wis., 1903

03a Geological excursion in the Pittsburgh region. G Soc Am, B $14: 3-4$ (1903)

04 Investigations on the Lake Superior iron-ore deposits. M Mag 10:175-183 (1904)

04a Field work in the Wisconsin lead and zinc district (abst). G Soc Am, B $15: 552-553$ (1904) Seience n s 19:526 (1904)

04b (and Bain, H. F.) A preglacial peneplain in the Driftless Area (abst) Science n s 19:528 (1904) Sc Am Sup $57: 23446 \quad$ (1904)

05 Zinc and lead deposits of southwestern Wisconsin. U S G S, B 260:304-310 (1905)

05a Water resources of the Mineral Point quadrangle, Wis. U S G S, W-S P $145: 67-73$ (1905)

05b Structural relations of the Wisconsin zine and lead deposits. Ec G 1:233242 (1905)

06 Report on the lead and zinc deposits of Wisconsin, with an atlas of detailed maps. Wis G $\mathrm{S}$, B $14: 100 \mathrm{pp}$, maps (1906)

06a Zinc and lead deposits in Wisconsin. M Mag 13:453-460 (1906)

06b Structural relations of the Wisconsin zinc and lead deposits. Ec G 1:233242 (1906)

06e Copper and other mineral resources of Prince William Sound. U S G S, B $284: 78-87 \quad(1906)$

06d The eastern limit of glacial Lake Agassiz (abst). Minn Ac Sc, B 4:208209 (1906)

07 (and Burchnrd, E. F.) Description of the Lancaster and Mineral Point quadrangles [Wisconsin-Iowa-Illinois]. U S G S, G Atlas Lancaster-Mineral Point fol (no 145) : $14 \mathrm{pp}$, maps (1907)

08 (and Perdue, M. J.) Millbrig sheet of the lead and zinc district of northern Illinols. III G $\mathrm{S}, \mathrm{B} \quad 8: 335-343$, map (1908)

09 Gold on Prince William Sound, Alaska. U S G S, B 379:97 (1909)

09a (and Higeins, D. F.) Copper mining and prospecting on Prince William Sound, Alaska, U S G S, B 379:87-96, map (1909)

09b (and Higmins, D. F.) Notes on the geology and mineral prospects in the vicinity of Seward, Kenai Peninsula, Alaska. U S G S, B 379:98-107 (1909) 10 Mining and pruspecting on Prince William Sound in 1909 . U S G S, B 442: 164-165 (1910)
Grant, Ulysses Sherman-Continued.

10a (and Higgins, D. F.) Preliminary report on the mineral resources of the southern part of Kenai Peninsula, Alaska. U S G S, B 442: 166-178, maps (1910)

$10 b$ (and Figgins, D. F.) Reconnaissance of the geology and mineral resources of Prince William Sound, Alaska. U S G S, B 443:89 pp, maps (1910) Abst, Wash Ac Sc, J 2:100 (1912)

10e Copper deposits of Prince William Sound, Alaska. M Sc Press 100:63-64 (1910)

10d (and Higgins, D. F.) Glaciers of Prince William Sound and the southern part of the Kenai Peninsula, Alaska; I, Glaciers of the northern part of Prince William Sound; II, Glaciers of Port Wells, Prince William Sound; III, Glaciers of the west coast of Prince William Sound; IV, Glaciers of the southern coast of the Kenai Peninsula. Am Geog Soc, B 42: 721-738 (1910); 43:321-338, 401-417, 721-737 (1911) Abst, G Soc Am, B 21:757-758 (1910)

13 (and Higgins, D. F.) Coastal glaciers of Prince William Sound and Kenai Peninsula, Alaska. U S G S, B

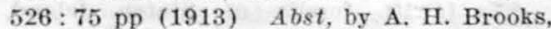
Wash Ac Sc, J 4:193 (1914)

14 (and Cady, G. H.) Preliminary report on the general and economic geology of the Baker district of eastern Oregon. Oreg Bur Mines, Min Res Oreg 1 no 6: 129-161 (1914)

15 (with Martin, G. C., and Johnson, B. L.) Geology and mineral resources of Kenai Peninsula, Alaska. U S G S, B 587 : 243 pp, maps (1915)

See also Emmons (S F), 93 ; McGee, $94 \mathrm{a}$ Grant, William $\mathrm{H}$.

51 Seven lenticular concretions from the black shale of the Hudson River group ... about four miles north of Stuyvesant Landing, Columbia Co. [N. Y.]. N Y St Cab, An Rp 4: 77-79 (1851)

Grasty, John Sharshall.

09 (with Mathews, E. B.) Report on the limestones of Maryland, with special reference to their use in the manufacture of lime and cement. Md G S $8: 225-477$ (1909)

O9a (with Mathews, E. B.) The character and structural relations of the limestones of the Piedmont in Maryland and Virginia (abst). Science n s 29:634-635 (1909)

10 (with Mathews, E. B.) Character and structural relations of the limestones of the Piedmont in Maryland and Virginia. Abst, G Soc Am, B 20:678 (1910)

12 An unusual occurrence of the mineral evansite. $\mathrm{Va}$, Univ, $\mathrm{Ph}$ Soc, $\mathrm{B}$ sc $\mathrm{s} 1$ : 223-230 (1912)

14 The limestones of Maryland, east of the Blue Ridge (abst). Science n s 39: 399 (1914) 
Grasty, John Sharshall-Continued.

14a (and Cline, J. H.) The slate deposits of the Southern States (abst). Science n s $39: 399-400$ (1914)

14b (with Watson, T. L.) The Piedmont limestones of the southeast Atlantic States (abst). Science n s 39: 399 (1914)

14e (with Watson, T. L.) The cement materials and industry of the Southern States (abst). Science n s 39:400 (1914)

15 (with Watson, T. L.) Barite of the Appalachian States. Am I M Eng, B 98: 345-390, maps (1915) ; Tr 51:514-559, maps (1916)

Gratacap, Louis Pope (1850-1917).

78 The Ice Age. Pop Sc Mo 12:319$327 ; 14: 90-102$ (1878)

81 The primeval American continent. Pop Sc Mo 19: 229-237 (1881)

84 Opinions upon clay stones and concretions. Am Nat 18:882-892 (1884)

s6 Fish remains and tracks in the Triassic rocks at Weehawken, N. J. Am Nat 20: 243-246 (1886)

87 The eozoonal rocks of Manhattan Island. Am J Sc (3) $33: 374-378$, il (1887)

S7a [Drift fossils of Staten Island, N. Y.] N Sc As Staten Island, $\operatorname{Pr} 1: 46$, 51-52 (1887)

87b [Serpentine rock of Staten Island, N. Y.] $N$ Sc As Staten Island, $\operatorname{Pr} 1: 55$ (1887)

89 [Fossils from a drift boulder, Staten Island, N. Y.] Nat $\mathrm{Sc}$ As Staten Island, Pr 2:7 (1889) Am Nat 23:549-550 (1889)

90 [On ripple-marked Potsdam sandstone from drift at Tottenville, Staten Island, N. Y.] Science 16:14 (1890)

91 [Trap rock from Lambert's Lane, Staten Island, N. Y.] N Sc As Staten Island, $\operatorname{Pr} 3: 5-6$ (1891)

91 a [Fossils in a drift boulder of Lower Helderberg limestone, Staten Island, N. Y.] N Sc As Staten Island, Pr 3:6 (1891)

92 [On fossils found in drift boulders on Staten Island, N. Y.] N Sc As Staten Island, $\operatorname{Pr} 3: 9-10$ (1892)

93 Additional determinations of Schoharie fossils from the drift [on Staten Island, N. Y.]. N Sc As Staten Island, Pr 4: 7 (1893)

94 [Fossils in drift boulders on Staten Island, N. X.] N Sc As Staten Island, $\mathrm{Pr}$ 4:11-12, 25 (1894)

$94 a$ Additions to the drift fossils of Staten Island [N. Y.]. N Sc As Staten Island, Pr 4:16-17 (1894)

95 The possible revival of Virginia City, Nev. Se Am Sup 40:16329-16330 (1895)

96 Fossils and fossilization. Am Nat $30: 902-912,993-1003$ (1896) ; 31:16-33, 191-199, 285-293 (1897)

98 Relation of James Hall to American geology. Am Nat $32: 891-902$, port (1898)
Gratacap, Louis Pope-Continued.

99 A plea for the popular exposition lithology for museum purposes. Am G? 281-287 (1899)

99a The Comstock lode [Nev.]. Sc th Sup 48: 19925-19926 (1899)

99b The significance of the accumulatim and distribution of boulders on the nori shore of the island [Staten Island, N. I. N Sc As Staten Island, Pr $7: 13-14$ (189)

99e Notes on the limonite beds on Ocen Terrace [Staten Island, N. Y.]. N Sc di Staten Island, Pr 7:28-29 (1899)

$\boldsymbol{0 0}$ Note on an interesting specimen calcite from Joplin, Mo. Am Mus $\mathrm{NH}$, 13: 95-97 (1900)

OOa The Hall geological collection. An Mus J $1: 57-60$, il (1900)

OOb Are the Kreischerville clays \& Cretaceous in age? [Staten Island, N. I.

N Sc As Staten Island Pr $7: 38-39$ (1900) 00c The asbestos mines at Thetfort Canada. Sc Am 82: 213-214 (1900)

01 Geology of the City of New York $82 \mathrm{pp}$ [N Y 1901] 2d ed, $119 \mathrm{pp}, \mathrm{ms} ;$ N Y 1904 3d ed, 232 pp, map, N Y 190

01a The Clove Valley Pleiostocene lak basin [Staten Island, N. Y.]. N Sc k Staten Island, $\operatorname{Pr} 8: 3-4$ (1901)

$01 b$ Paleontological speculations. G $27: 75-100 ; 28: 214-234$ (1901); 9 : 290-301 (1902)

o1e The Ward-Coonley collection of the teorites. Sc Am Sup 52:21382-2138 (1901)

02 The collection of minerals [Americat Museum of Natural History]. Am Mus l 2 no 2 sup (Guide Leaflet no 4):21 m (1902)

02a The great Jurassic dinosaur [Bros tosaurus]. Sc Am 86:5 (1902)

o3 Vade mecum guide. A popular guide to mineral collections; with a chapter of the development of mineralogy. $178 \mathrm{pp}$ N Y n d [1903?]

o5 Newfoundland, its geology and min eral resources. M World 23:525-5. (1905)

06 The largest American collection o meteorites. Pop Sc Mo 69 : 21-28 (1906)

os The state museum of minerals at $\mathrm{At}$ lanta, Ga. Mineral Collector 15:129-132 (1908)

09 Growth of the Bement collection of minerals. M World 30:673-675 (1909)

10 Robert Parr Whitfield. Science ins $31: 774-775$ (1910) Am J Sc (4) $29: 565-$ 566 (1910)

11 Biographical memoir of Robert Part Whitfield. N Y Ac Sc, An 20:385-398 port (1911)

12 A popular guide to minerals, with chapters on the Bement collection of minet als in the American Museum of Natural History, and the development of mineral. ogy : $330 \mathrm{pp}$, map, N Y 1912 
Gratacap, Louis Pope-Continued.

12a An unusual specimen of Mytilus middendorfii Grewingk, from Alaska. Am Mus N H, B $31: 69-70$, il (1912)

14 Tertiary fossils on Long Island. Nautilus $28: 85-86$ (1914)

17 Gem mining in the United States; tourmaline and turquoise. Am Mus J 17 : 65-69 (1917)

Graton, Louis Caryl.

03 Up and down the Mississaga.

Bur Mines, Rp 1903: 157-172 (1903)

03a On the petrographical relations of the Laurentian limestones and the granite in the township of Glamorgan, Haliburton Co., 0nt. Can Rec Sc $9: 1-38$ (1903) Rv by N. H. Winchell, Am G $32: 385-392$ (1903)

05 The Carolina tin belt. U S G S, B 260: 188-195, map (1905)

05a-(and Schaller, W. T.) Purpurite, a new mineral. Am J Sc (4) 20:146151 (1905) Zs Kryst 41:433-438 (1905)

05b Consanguinity in the eruptive rocks of Cripple Creek [Colo.] (abst). Science n s $21: 391$ (1905)

05e (with Hess, F. L.) The occurrence and distribution of tin. U S G S, B 260 : 161-187 (1905)

06 Description and petrology of the metamorphic and igneous rocks [Cripple Creek district]. U S G S, P P 54: 41-113 (1906) 06a Reconnaissance of some gold and tin deposits of the southern Appalachians. U S G S, B 293: 9-118 (1906)

$06 \mathrm{~b}$ (with Gordon, C. H.) Lower Paleoroic formations in New Mexico. Am J Sc (4) $21: 390-395$ (1906) Science n s 23 : 590-591 (1906)

06e (with Lindgren, W.) A reconnaissance of the mineral deposits of New Mexico. U S G S, B 285:74-86 (1906)

07 Copper. U S G S, Min Res 1906 : $373-438 ; 1907$ pt $1: 571-644$ (1907-8)

08 (and Siebenthal, C. E.) Silver, copper, lead, and zinc in Central States. U \& G S, Min Res 1907 pt $1: 483-549$ (1908)

10 The occurrence of copper in Shasta Co, Cal. U S G S, B 430:71-111 (1910)

10a (with Lindgren, W.) The ore deposits of New Mexico. U S G S, P P 68 : 361 pp (1910)

13 Investigation of copper enrichment. Fing M J $96: 885-887$ (1913)

13a Ore deposits at Butte, Mont. (dis(ussion). Am I M Eng, B $83: 2735-2736$ (1913)

13b (and Murdoch, Joseph) The sulphide ores of copper; some results of microscopic study (with discussion by $\mathrm{J}$. F. Kemp, H. V. Winchell, and L. C. Graton). Am I M Eng, B 77:741-811 (1913); Tr 45:26-93, 529-530 (1914)

13e Notes on rocks from the Coppermine River region, Can. Can M Inst, Tr 16:102-114 (1913)
Graton, Louis Caryl-Continued.

15 (and others) To what extent is chalcocite a primary and to what extent a secondary mineral in ore deposits (discussion). Am I M Eng, Tr 48:194-200 (1915)

17 (and Melaughlin, D. H.) Ore deposition and enrichment at Engels, Cal. Ec G 12:1-38 (1917)

18 (and MeLaughlin, D. H.) Further remarks on the ores of Engels, Cal. Ec G 13:81-99 (1918)

18a The relation of sphalerite to other sulphides in ores (discussion). Am I M Eng, B 136:844-845 (1918)

See also Billingsley, 15; Bonillas, 16 ; Lindgren, 15b ; Roberts (H M ), 18; Roesler, 16; Somers, 15; Teas, 17 ; Thompson (A P), 15 ; Tolman, 16a

Grave, Caswell.

01 The oyster reefs of North Carolina; a geological and economic study. Johns Hopkins Univ Circ 20:50-53 (1901)

Gray, A. B.

45 [Mineral lands of Lake Superior region.] U S, 28th Cong spec sess, S Ex Doc 175:14-22 (1845)

46 Report on mineral lands on Lake Superior. U S, 29th Cong 1st sess, H Doc 211: $23 \mathrm{pp}$, map (1846)

Gray, Alexander.

10 The alluvial gold fields of Quebec. M World $32: 801-802$ (1910)

10a Geology of the Porcupine gold fields defined [Ont.]. M World 33:266-270 (1910)

Gray, Alonzo.

53 (and Adams, C. B.) Elements of geology. $354 \mathrm{pp}$, N Y 1853

Gray, Asa.

34 (with Crawe, J. B.) ...mineralogy of a portion of Jefferson and St. Lawrence cos. (N. Y.). Am J Sc 25:346-350 (1834) Gray, Francis William.

09 The mining operations of the DominIon Coal Company [coal deposits of Cape Breton Island]. Can M J 30:10-16, 117182, 235-237 (1909)

13 The coal-fields and the coal-industry of eastern Canada. Inst $\mathbf{M}$ Eng, $\mathrm{Tr}$ $36: 23-60$ (1913)

17 The coal fields and coal industry of eastern Canada. Can, Mines Branch, B 14:67 pp, map (1917)

Grayson, Andrew $J$.

72 On the physical geography and natural history of the islands of the Tres Marias and of Socorro off the western coast of Mexico. Boston Soc N H, Pr 14:261-267 (1872)

Greaves-Walker, A. F.

07 The flint fire clay deposits of northeastern Kentucky. Am Ceramlc Soc, Tr $9: 461-472$ (1907) 
Greeley, James T.

88 (with Crosby, W. O.) Vesuvianite from Newbury, Mass. Tech Q 1:407-408 (1888)

Green, Henry A.

66 On a few of the fossiliferous locallties in Livingston and Genesee cos., N. Y. Am J Sc (2) 41:121-123; 42:426 (1866)

70 Geology of Henderson Co.; Warren Co.; Mercer Co.; Knox Co.; Stark Co. ; Woodford Co. Ill G S $4: 275-342$ (1870); Ec G 2:543-615 (1882)

Green, Jacob (1790-1841).

22 Notice of a mineralized tree, rocking stone, etc. [New York]. Am J Sc 5: 251-254 (1822)

30 Monograph of the cones [Conus] of North America including three new specles. Albany Inst., Tr 1: 121-125 (1830)

32 A monograph of the trilobites of North America... 93 pp, il, Phila 1832. A supplement to the monograph of the trilobites of North America... $24 \mathrm{pp}$, Phila 1835

33 Asaphus myrmecoides. Am J Sc 23: 397-398 (1833)

34 Descriptions of some new North American trilobites. Am J Sc 25:334337 (1834)

34 a Description of a new trilobite from Nova Scotia. $\mathrm{G}$ Soc $\mathrm{Pa}, \operatorname{Tr} 1: 37-39$, Il (1834)

37 Description of a new trilobite. An J Sc $32: 167-169$ (1837)

37a Description of several new trilobites. Am J Sc $32: 343-349$, il (1837)

37b Description of two new species of trilobites. Ac N Sc Phila, J $7: 217-226$, il (1837)

38 Some remarks on the genus Paradoxides of Brongniart and on the necessity of preserving the genus Triarthrus... Am J Sc $33: 341-344$ (1838)

38 Description of new trilobite [Calymene ronoii, N. Y.]. Am J Sc 33:406-407 (1838) An N H 1:79 (1838)

38b New trilobite, Asaphus polypleurus. Am J Sc $34: 380$ (1838)

39 Remarks on the trilobite. $\Delta \mathrm{m} \mathrm{J}$ Sc $37: 25-39$ (1839)

39a Description of a new trilobite [Asaphus diurus]. Am J Sc $37: 40$ (1839)

40 An additional fact illustrating the inferior surface of the Calymene bufo. Am J Sc $38: 410$ (1840)

Green, Raoul.

03 The Frank disaster [landslide, Frank, Alta.] Can M Rv 22: 103-110 (1903)

Green, W., jr.

64 Notes on the anthracite coal region in North America. N Engl Inst M Eng, Tr 13:25-40, maps (1864)

Green, William.

29 Notes on the country in the neighborhood of the Falls of Montmorency [Que.]. Lit Hist Soc Quebec, Tr 1: 181-188 (1829)
Green, William Lowthlan (1819-1890). 57 On the cause of the pyramidal form of the outline of the southern extremities of the great continents and peninsulas of the globe. Edinb $\mathrm{N} \mathrm{Ph} \mathrm{J}$ n $\mathrm{s} 6: 61-78$, map (1857)

59 Great eruption of the volcano Mauns Loa In the Island of Hawail. Edinb $\mathrm{N} \mathrm{Ph}$ J n s 10:94-97 (1859)

75 Vestiges of the molten globe... 59 pp, L 1875 ; pt 2, 337 pp, Honolulu 1887

77 The Hawailan islands on the reseau triangulaire. $7 \mathrm{pp}$, Boston 1877

84 The volcanic problem from the point of view of Hawaiian voleanoes. Honolulu, 1884 [not seen]

90 Notice of Prof. Jas. D. Dana's "Characteristies of volcanoes." $15 \mathrm{pp}$, Honolulu, H. I., 1890

Green, William Spotswood.

89 Explorations in the glacier regions of the Selkirk Range, B. C., in 1888. R Geog Soc, Pr 11:153-169, map (1889)

\section{Green, Wyman R.}

13 A description of the specimens of the teleostean genus Enchodus in the Uni versity of Kansas Museum. Kans Univ, Sc B 7:71-107, il (1913)

Greenan, James $O$.

14 Geology of Fairview, Nev. Eng If J $97: 791-793$ (1914)

Greenawalt, William E.

o7 The tungsten deposit of Boulder $\mathrm{C}_{0}$, Colo. Eng M J 83: 951-952 (1907)

12 The tungsten deposits of Boulder $\mathrm{Co}$., Colo. Cornell Civil Engineer 20:197-202 (1912)

\section{Greene, Francis V.}

53 Chemical investigation of remains of fossil Mammalia. Ac $\mathrm{N}$ Sc Phila, $\operatorname{Pr} 6$ : 292-296 (1853) Am J Sc (2) $16: 16-20$ (1853)

\section{Greene, Frank C.}

08 Fauna of the Florena shale of the Grand Summit section of Kansas, and remarks on the development of Dervya multistriata Meek and Hayden. Ind $\mathrm{Ac} \mathrm{Sc}, \mathrm{Pr}$ 1907: 114-127, il (1908)

08a The development of a Carboniferous brachiopod, Chonetes granulifer Owen. J G $16: 654-663$, Il (1908)

09 Caves and cave formations of the Mitchell limestone. Ind Ac Sc, $\operatorname{Pr} 1908$ : 175-184 (1909)

10 The Dakota-Permian contact in northern Kansas. Kans Univ, Sc B 5 : 1-8 (1910)

11 Fauna of the Brazil limestone. Ind Ac Sc, Pr 1910:169-171 (1911)

11 a The Huron group in restern Monroe and eastern Greene $\cos$, Ind. Ind $A c$ Sc, Pr 1910: 269-288 (1911)

14 The coal resources of a part of north. eastern Missouri. U S G S, B 541:223242, map (1914) 
Greene, Frank C.-Continued.

15 (with Hinds, H.) The stratigraphy of the Pennsylvanian series in Missouri. Ifo Bur G (2) $13: 407 \mathrm{pp}$, maps, il (1915)

17 (with Hinds, H.) Description of the Leavenworth and Smithville quadrangles [Mo.-Kans.]. U S G S, G Atlas, Leavenworth-Smithville fol (no 206), 13 pp, maps (1917)

is A contribution to the geology of eastern Osage Co. [Okla.]. Am As Petroleumm G, B 2: 118-123 (1918)

Greene, George K.

So Geology of Monroe Co. Ind, Dp Stat G, An Rp 2: 427-449, map (1880)

97 Notes on some Indiana fossils. Nat Sc J, New Bedford, Mass., 1: 29 (1897)

98 Contribution to Indiana paleontology, part I-XX (forming vol 1) : $204 \mathrm{pp}$, il, New Albany, Ind., 1898-1904; vol 2, pts $1-3 ; 38$ pp, il, New Albany, Ind., 1906 Greenland, Cyril Walter,

13 On the origin and structure of the carbonaceous schists of the lake of the Woods [Ont.]. Can M Inst, Tr 16:584597 (1913)

17 Gel minerals (colloid minerals). Am Mineralogist 2 : 113-115, 122-124, 134-138, 145-147 (1917)

18 The replacement of wood by calcite. Ec G $13: 116-119$ (1918)

Greeniee, W. B.

96 The amount of water in the earth's crust. Am G 18:33-35 (1896)

Greer, James. See Lyell, 71a

Greger, Darling $\mathrm{K}$.

04 The distribution and synonymy of Ptychospira sexplicata (White and Whitfield). Am G 33:15-17 (1904)

04a On the genus Rhynchopora King, with notice of a new species. Am G 33 ; $297-301$, il (1904)

0s A new Devonian brachiopod retaining the original color markings [Cranaena morsii]. Am J Sc (4) $25: 313-314$ (1908)

09 The Devonian of central Missouri. Am J Sc (4) $27: 374-378$ (1909)

10 Some rare and imperfectly known brachiopods from the Mississippian. Am J Sc (4) $29: 71-75$, il $(1910)$

14 On the retention of the original color ornamentation in fossil brachiopods. Nautilus 28:93-95 (1914)

15 Garland Carr Broadhead, with bibliography. Mo Hist Rv 9:57-74, port (1915)

15a (with Branson, E. B.) Devonian of central Missouri (abst). G Soc Am, B $26: 112$ (1915)

16 Pleistocene Mollusca from Callaway

Co., Mo. Nautilus $30: 64-66$ (1916)

17 A color-marked Euconospira from the Pennsylyanian of Missouri, and a list of references to coloration in fossil shells. Nautilus $30: 114-117$, il (1917)

18 Invertebrate fauna of the Grassy Creek shale of Missouri (abst). G Soc Am, B $29: 95$ (1918)
Greger, Darling K.-Continued.

18a (with Branson, E. B.) Amsden formation of the east slope of the Wind River Mountains of Wyoming and its fauna. G Soc Am, B 29:309-326 (1918) ; abst, $28: 170$ (1917)

\section{Gregs, A.}

89 Economic minerals of San Saba Co. Tex G S, Rp Prog 1 (1888) : 74-76 (1889)

Gregorio, Antoine de.

90 Monographie de la faune éocénique de l'Alabama. An G Paléont 7-8:346 pp, il (1890)

Gregory, Herbert Ernest.

99 Andesites of the Aroostook volcanic area of Maine. Am J Sc (4) 8:359-369 (1899) Yale Bicen Pub, Contr Miner: $467-480$ (1901)

oo Geology of the Aroostook volcanic area [Maine]. U S G S, B 165: 93-188, map (1900)

O0a Volcanic rocks from Temiscouata Lake, Que. Am J Sc (4) 10:14-18, map (1900)

04 [Notes on water resources of] Connecticut. U S G S, W-S P 102:127-168 (1904)

05 [Underground waters of] Connecticut. U S G S, W-S P 114: 76-81 (1905)

06 The geology of Connecticut in relation to its water supply. Conn $\mathrm{Bd} \mathrm{Ag}$, An Rp, $39: 283-297$ (1906)

06a The crystalline rocks [of Connecticut]. Conn G S, B 6:39-156, map (1906)

06b Glacial geology [of Connecticut]. Conn G S, B 6 : 225-159 (1906)

o6e (with Rice, W. N.) Manual of the geology of Connecticut. Conn G S, B 6: $273 \mathrm{pp}(1906)$

or Bibliography of the geology of Connecticut. Conn G S, B 8: 123 pp (1907)

ota (and Robinson, H. H.) Preliminary geological map of Connecticut. Conn G S, B $7: 39 \mathrm{pp}, \operatorname{map}$ (1907) Abst, G Soc Am, B 17:727 (1907)

09 Memoir of Angelo Hellprin. G Soc Am, B 19:527-536, port (1909)

09a Underground water resources of Connecticut; with a study of the occurrence of water in crystalline rocks, by E. E. Ellis. U S G S, W-S P 232: 200 pp (1909)

10 Some features of the geology of the Navajo Reservation [Ariz.-Utah] (abst). Science n s $32: 62$ (1910)

11 The San Juan oll field, San Juan Co., Utah. U S G S, B 431: 11-25, map (1911)

11a (with Campbell, M. R.) The Black Mesa coal field, Ariz. U S G S, B 431: 229-238 (1911)

$11 b$ (with Dale, T. N.) The granites of Connecticut. U S G S, B 484:137 pp (1911) 
Gregory, Herbert Ernest-Continued.

13 The Shinarump conglomerate. Am J Sc (4) 35:424-438 (1913) Abst (with discussion by $A$. W. Grabau and N. H. Darton), G Soc Am, B 24:679-680 (1913)

13a Preliminary geological map of the Navajo-Moki reservation (abst). G Soc Am, B 24:680 (1913)

14 A reconnaissance of a portion of the Little Colorado Valley, Ariz. Am J Se (4) 38: 491-501 (1914)

15 Note on the shape of pebbles. Am J Sc (4) 39:300-304 ( F915)

15a The formation and distribution of fluviatile and marine gravels. Am J Sc (4) $39: 487-508$ (1915)

15b The igneous origin of the "glacial deposits" on the Navajo Reservation, Arizona and Utah. Am J Sc (4) 40:97115 (1915)

15e The oasis of Tuba, Ariz. As Am Geog, An 5 : 107-119 (1915)

15d The Navajo country [Ariz.]. Am Geog Soc, B 47:561-577 (1915)

16 (and Ellis, A. J.) Ground water in the Hartford, Stamford, .Willimantic, and Saybrook areas, Conn. U S G S, W-S P $374: 150 \mathrm{pp}$, maps (1916)

16a The Navajo country; a geographic and hydrographic reconnaissance of parts of Arizona, New Mexico, and Utah. U S G S, W S P 380: 219 pp, maps (1916) Abst, Wash Ac Sc, J $7: 132$ (1917)

16b Garnet deposits on the Navajo Reservation, Arizona and Utah. Ec G 11: 223-230 (1916)

17 Geology of the Navajo country: a reconnaissance of parts of Arizona, New Mexico, and Utah. U S G S, P P 93: $161 \mathrm{pp}$, maps (1917) Abst, by R. W. Stone, Wash Ac Sc, J 8:64-65 (1918)

$17 a$ Seventh biennial report of the commissioners of the State Geological and Natural History Survey of Connecticut, 19151916. B $27: 17 \mathrm{pp} \mathrm{(1917)}$

18 (and others) Military geology and topography; a presentation of certain phases of geology, geography, and topography for military purposes. $281 \mathrm{pp}$, New Haven, 1918

18a A century of geology; Steps of progress in the interpretation of land forms. Am J Sc (4) 16:104-132 (1918) Reprinted in A century of science in America : 122-152, New Haven, 1918

Gregory, J. W.

90 Report [on artesian water in Nebraska, Kansas, and Oklahoma]. U S, 51st Cong 1st sess, S Ex Doc 222:145-172 (1890)

Gregory, James J. H.

62 On the geology of Marblehead [Mass.]. Essex Inst, Pr 2:306-311 (1862) ; 6:43-44 (1870)

64 [Geologic features of the Gloucester coast, Mass.] Essex Inst, Pr $3: 96$ (1864)
Gregory, James J. H.-Continued.

64 a [Geologic notes on the ..ynn reglon, Mass.]. Essex Inst, Pr 3:101-103 (1864

64b [Geologic notes on Middleton, Mass.]. Essex Inst, Pr 3: 109 (1864)

64c Topography, etc., of Powow Hill [near Amesbury, Essex Co., Mass.]. Es. sex Inst, Pr $3: 269-270$ (1864)

Gregory, John Walter.

89 Cystechinus crassus, a new species from the radiolarian marls of Barbados and the evidence it affords to the age and origin of those deposits (abst). G Mag (3) $6: 380-381$ (1889)

91 The Tudor specimen of Eozoon. G Soc London, Q J 47:348-355, il (1891)

92 Archaeopneustes abruptus, a new genus and species of echinoid from the Oceanic series in Barbados. G Soc London, Q J 48: 163-169, il (1892)

92a The microscopic structure of some Trinidad rocks. G Soc London, Q J 48 538-541 (1892)

92b The relations of American and European echinoid faunas. G Soc Am, B 3: 101-108 (1892)

95 Contributions to the paleontology and physical geology of the West Indies. 6 Soc London, Q J $51: 255-312$, il (1895) Abst, G Mag (4) 2:184-185 (1895)

97 Some problems of Arctic geology. Nature 56:301-303, 351-352, map (1897)

99 The plan of the earth and its causes. Geog J 13:225-251 (1899) Smiths Inst, An Rp 1898: 363-388 (1899) Am G 27: $100-119,134-147$ (1901)

99a New species of Cladophyllia, Prionastraea, and Stylina. An Mag N H (7) $4: 457-461$, il (1899)

o7 Climatic variations, their extent and causes. Int G Cong, Mexico 1906, C R: 407-426 (1907) Smiths Inst, An Rp 1908 339-354 (1909)

os Geology of the inner earth; igneous ores. Smiths Inst, An Rp 1907:311-330 (1908) Sc Am Sup 65:158-160 (1908)

Osa Niagara as a geological chronometer. Nature 79:11-12 (1908)

osb Origin of the Sudbury nickel ores. G Mag n s (5) 5:139-140 (1908)

o9 Catalogue of the fossil Bryozos in the Department of Geology, British Mnseum (Natural History). The Cretaceous Bryozoa, $v 2: 346 \mathrm{pp}$, il 1909

10 Criteria of downward sulphide en. richment (discussion). Ec G $5: 678-681$ (1910)

11 The fron ore supplies of the world. Science Progress 5 no $19: 371-382$ (1911) Sc Am Sup 72:306-308 (1911)

16 Henry Darwin Rogers; an address to the Glasgow University Geological Society, 20th January, 1916; with bibliography by Colin M. Leitch. $38 \mathrm{pp}$, port Glasgow 1916 
Gregory, Newman B.

10 Zinc mines of the Hualapai district, Ariz. M World 33: 1179-1180 (1910)

10a The Yellowpine mining district of Nevada. Eng M J 90:1308-1309 (1910) Gregory, William King.

01 Extracts from the reports of field parties sent by the department of vertebrate paleontology in search of fossil mammals and reptiles, 1900. Am Mus J 1: 140-145 (1901)

05 The weight of the Brontosaurus. Science n s $22: 572$ (1905)

06 (with Berry, E. W.) Prorosmarus alleni, a new genus and species of walrus. Am J Sc (4) $21: 444-450$ (1906)

07 The orders of teleostomous fishes; a preliminary review of the broader features of their evolution and taxonomy. N Y Ac Sc, An $17: 437-508$, il (1907)

10 The orders of mammals. Am Mus N H, B $27: 524 \mathrm{pp}$, il (1910)

10a Application of the quadrate-incus theory to the conditions in theridont reptiles and the genetic relations of the latter to the Mammalia (abst). Science n s 31 : 600 (1910)

$10 \mathrm{~b}$ Genetic relations of the Insectivora to other orders of mammals (abst). N Y de Se, An 19:297-299 (1910)

11 The limbs of Eryops and the origin of paired limbs from fins (abst). Seience n 8 33:508-509 (1911) N Y Ac Sc, An 21: $192-193$ (1912)

12 Ten years' progress in vertebrate paleontology ; marsupials, insectivores, and primates. G Soc Am, B 23:187-196 (1912)

12a Notes on the principles of quadrupedal locomotion and on the mechanism of the limbs in hoofed animals. N Y Ac Sc, An $22: 267-294$, il (1912)

12b Note on the upper Eocene titanotheroid Telmatherium? incisivum Douglass from the Uinta Basin. Science n $\mathrm{s} 35: 546$ (1912)

12e A new restoration of a titanothere. Am Mus J $12: 15-17$, il (1912)

12d Further notes on the evolution of paired fins (abst). N Y Ac Sc, An 21: 216 (1912)

12e Notes on the origin of paired limbs of terrestrial vertebrates (abst). N X Ac Sc, An 21:219-220 (1912)

13 Crossopterygian ancestry of the Amphibla. Science n s 37:806-808 (1913)

13a Homology of the "lacrimal" and of the alisphenoid" in recent and fossil reptiles. G Soc Am, B 24:118 (abst), 241-246, 1913)

13b Relationship of the Tupaider and of Eocene lemurs, especially Notharctus. G Soc Am, B 24:117 (abst), 247-252 (1913)

14 Skeleton of Notharctus, an Eocene lemuroid $(a b s t)$. G Soc Am, B 25:141
Gregory, William King-Continued.

14a (and others) Conference on convergent evolution, including a summary of the recent discussion before the British Association for the Advancement of Science (abst). $\quad \mathrm{N}$ Y Ac Sc, An 23:293-299 (1914)

15 Present status of the problem of the origin of the Tetrapoda, with special reference to the skull and paired limbs. N Y Ac Sc, An 26:317-383, il (1915)

$15 a$ (and Adams, L. A.) The temporal fossae of vertebrates in relation to the jaw muscles. Science n s 41:763-765 (1915)

15b I, On the relationship of the Eocene lemur Notharctus to the Adapidae and to other primates; II, On the classification and phylogeny of the Lemuroidea. G Soc Am, B 26: 419-446 (1915)

15e Observations on the phylogeny of the higher primates (abst). G Soc Am, B $26: 153$ (1915)

$15 d$ An American Eocene lemur (Notharctus Leidy) (abst). N Y Ac Sc, An 24: $383-384$ (1915)

16 The Cope-Osborn "theory of trituberculy" and the ancestral molar patterns of the primates. Am Mus $\mathrm{N} \mathrm{H}, \mathrm{B} 35$ : 239-257, il (1916)

16a Phylogeny of recent and extinct anthropoids, with special reference to the origin of man. Am Mus N H, B 35:258355 , il (1916)

$16 \mathrm{~b}$ Theories of the origin of birds. N Y Ac Sc, An 27:31-38 (1916)

16e Phylogenetic review of extinct and recent anthropoids, with special reference to the evolution of the human dentition (abst). G Soc Am, B 27: 149-150 (1916)

16d Preliminary report of the committee on the nomenclature of the skull elements in the Tetrapoda (abst). Geol Soc Am, B 27:152 (1916)

16e Present status of the problem of the origin of birds $(a b s t)$. N Y Ac Sc, An Rp 26:447-448 (1916)

16f (with others) Recent progress in vertebrate paleontology. Science n s 43 : 103-110 (1916) ; 45:117-121 (1917)

17 Second report of the committee on the nomenclature of the cranial elements in the Permian Tetrapoda; with appendices by R. Broom, D. M. S. Watson, and S. W. Williston. G Soc Am, B 28:210 (abst), 973-986 (1917)

17a Genetics versus paleontology. Am Nat 51:622-635 (1917)

17b (with Granger, W.) A revision of the Eocene primates of the genus Notharctus. Am Mus N H, B 37:841859 (1917)

See also Moodie, 16

Gregory, W. M.

02 Preliminary report on Arenac Co. and parts of Ogemaw, Iosco, and Alcona cos. Mich G S, Rp 1901:9-29 (1902) Extr, Mich Miner 4 no 3:11-15 (1902) 
Gregory, W. M.-Continued.

O4 The alabaster area. Mich G $\mathbf{S} 9$ pt 2: $60-77$ (1904)

05 Recent shore forms. Mich G S, Rp 1903: 301-305 (1905)

12 Geological report on Arenac Co. Mich G S, Pub 11 (g s 8):146.pp, map (1912)

Gregory, Winifred.

15 Bibliography of Minnesota mining and geology. Minn Sch Mines, Exp Sta, B 4:157 pp (1915)

Grenfell, Wilfred $T$.

09 The physiography of Labrador. In Labrador, the country and the people, by Wilfred T. Grenfell and others : 49-80, map, N Y 1909

Grenzig, J. A.

18 Developing crystallized mineral specimens. Am Mineralogist 3:152 (1918)

Gresley, W. S.

88 The formation of coal seams. Eng M J 45:142, 338 (1888)

90 North American geological notes. Manchester G Soc, Tr 21:68-74 (1890)

92 A hitherto undeseribed phenomenon in hematite. Am G 9:219-223 (1892)

92a Faulting in veins. Eng M J 53: 517, 660 (1892)

93 Note on anthracite "coal-apples" from Pennsylvania. Am I M Eng, Tr 21 : 824-832 (1893)

93a Notes on some Pennsylvanian calamites (abst). G Soc London, Q J 49: Pr 9 (1893) G Mag (3) 10:85 (1893)

93b Anthracite and bituminous coal beds (abst). G Soc London, Q J $49:$ Pr 11 (1893) G Mag (3) 10:136 (1893)

94 The "slate binders" of the "Pittsburg" coal bed. Am G 14:356-365 (1894)

$94 a$ Cone-in-cone; how it occurs in the Devonian series in Pennsylvania, U. S. A., with further details of its structure, varieties, etc. G Soc London, Q J 50:731-739 (1894)

96 Observations regarding the occurrence of anthracite, with a new theory of its origin. Am G 18:1-21 (1896)

$96 \mathbf{a}$ A granite boulder near Pittsburgh, Pa. Am G 18:331-332 (1896)

96b Organie markings in Lake Superior iron ores. Science n s $3: 622-623$ (1896)

97 Traces of organic remains from the Huronian (?) series, at Iron Mountain, Mich., ete. Am I M Eng, Tr 26:527-534, il (1897)

98 Clay veins vertically intersecting coal measures. G Soc Am, B 9:35-58 (1898)

99 Side light upon coal formation. Am G $23: 69-80$ (1899)

99a Possible new coal plants in coal. Am G 24:199-204, il (1899); 26:49-55, il $(1900) ; 27: 6-14,11(1901)$.

Gress, E. M.

18 Critical study of fossil leaves from the Dakota sandstone (abst). G Soc Am, B 29: 131 (1918)
Grewingk, Constantin (1819-1887).

48 Beitrag zur Kenniniss der geognos. tischen Beschaffenheit Californiens, Rus K Min Ges, St Petersburg, Verh 1847:142162 (1848)

50 Beitrag zur Kenntniss der orograph. ischen und geognostischen Beschaffenbet: der Nordwest Küste Amerikas mit dea anliegenden Inseln. Russ $\mathrm{K}$ Min Ges, st Petersburg, Verh 1848-9:76-342, maps (1850)

50a Die an der Westküste Nord-Ame. rika's und auf den Aleutischen Inseln bishet gefundenen fossilen Thier- und PflanzenReste. Russ K Min Ges, St Petersburg, Verh, 1848-9:343-366, il (1850)

Grider, Richard L.

o5 (with Bailey, E. W., and Rath, C. M.) A garnetiferous bed in Golden Gate Canyon, Jefferson Co., Colo. Colo Sch Mines, B 2 no $4: 80-86$ (1905)

Grier, Norman MeDowell.

14 A preliminary list of the fossil plants occurring in the roof of the Pittsburgh coal. Carnegie Mus, An $9: 125-128$ (1914) Grimng, C. S. S.

75 Origin of flint. Cin Q J Se 2:168174 (1875)

Grifnth, W. T.

11 Big Sandy coal flelds, Ky, Eng I J $92: 508-510$, map (1911)

Griffith, William.

01 An investigation of the burled valley of Wyoming [Pa.]. Wyoming Hist $\mathrm{G} \mathrm{Soc}$, Pr 6:27-36, map (1901) Abst, Am G 28: 324 (1901)

02 The anthracite of the Third Bill Mountain [Berkeley and Morgan cos.], W. Va. Franklin Inst, J 154: 431-439 (1902) 04 A Missouri coal field [Morgan Co.]. Eng M J 77:564-565 (1904)

06 Kinds and occurrence of anthracite coal. M Mag $13: 214-221$ (1906)

06a The Matanuska coal field, Alaska. Mines and Minerals 26:433-437 (1906) 12 (and Conner, E. T.) Mining con. ditions under the City of Scranton, $\mathrm{Pa}$. U S Bur Mines, B 25:89 pp (1912)

13 Approximate columnar sections show. ing the co-relation of anthracite coal beds of Pennsylvania. Colliery Eng 34 no 3 supplement (1913)

Griffiths, A. B.

63 The volcanic dust of Mont Pele. Cb News 88: 231 (1903)

Griggs, Jorge.

or Mines of Chihuahua, 1907; history, geology, statistics, mining companies directory. 349, xil pp [Chihuahua? 1907?]

Griggs, Robert Fiske.

04 The thickness of the Columbus limestone [Ohio]. Ohio Nat 4:67-68 (1904)

06 The Buffalo River [Minnesota]: an interesting meandering stream. Am Geog Soc, B 38:168-177 (1906)

09 Divided lakes in western Minnesota. Am J Sc (4) 27:388-392 (1909) 
Griggs, Robert Fiske-Continued.

18 The Valley of Ten Thousand Smokes [Katmai district, Alaska]. Nat Geog Mag 33:115-169 (1918)

$18 \mathbf{a}$ The eruption of Katmai. Nature 101: 497-499 (1918)

18b Are the Ten Thousand Smokes real rolcanoes? Ohio J Sc 19:97-116 (1918)

$18 \mathrm{e}$ The great hot mud flow of the Valley of Ten Thousand Smokes [Katmai, Alaska]. Ohio J Sc 19:117-142 (1918) Grimes, E. J.

15 (and Stevens, E. H.) Soll survey of Warren Co. [Ind.]. Ind Dp G, An Rp $39: 145-189$, maps (1915)

16 (and others) Soil survey of Starke Co., Ind. Ind $\mathrm{Dp} G$ Nat Res, An Rp 40 : 156-199, map (1916)

Grimes, J. A.

17 (with Billingsley, P.) Ore deposits of the Boulder batholith of Montana. Am I M Eng, B 124: 641-717 ; 130: 18691870 (1917); Tr 58: 284-361 (1918)

Grimes, J. Stanley.

58 Outlines of geonomy; a treatise on the physical laws of the earth and the creation of the continents. 168 pp, Boston 1858

66 Geonomy; creation of the continents by the ocean currents. $206 \mathrm{pp}$, Albion, Mich., 1866116 pp, Phila 1885

Grimsley, George Perry.

93 Microscopical study of Ohio limestones. Cin Soc N H, J 15:160-167 (1893)

94 The granites of Cecil Co., in northeastern Maryland. Cin Soc N H, J 17 : 59-67, 78-114 (1894)

96 The origin and age of the gypsum deposits in Kansas (abst). Am G 18:236237 (1896)

97 Gypsum in Kansas. Kans Univ Q 6:15-27 (1897)

97a Gysum deposits of Kansas. G Soc Am, B 8:227-240, map (1897) Abst, J G 5:94-95 (1897)

$97 \mathrm{~b}$ The study of natural palimpsests. Am G 19: 15-21 (1897) Kans Ac Bc, Tr $15: 127-130 \quad(1898)$

98 Gypsum in Kansas. Kans Ac Sc, Tr 15: 122-127 (1898)

99 (and Bailey, E. H. S.) Special report on gypsum and gypsum cement plasters. Kans̀ Univ G $\mathrm{S} 5: 183$ pp, maps, Topeka 1899

89a The buried treasures of Kansas, Kans St Bd Agr, Bien Rp 11:499-523 (1892)

99b The gold deposits of Nevada Co., Cal. Eng M J 68: 487 (1899)

01 Kansas mines and minerals. Kans Ac Sc, Tr $17: 200-207$ (1901)

02 Kansas mineral industries. Resources of the state... $10 \mathrm{pp}$, Topeka 1902

03 Oil, gas, and glass, chemical Industries, and minerals in Kansas. Kans, Bur Labor, Bien Rp 1:323-350, map (1903)
Grimsley, George Perry-Continued.

03a Economic geology of Iola and vicinity [Kans.]. Kans Ac Sc, Tr 18:78-82 (1903)

04 The gypsum of Michigan and the plaster industry. Mich G S 9 pt 2:246 pp, maps (1904)

04a Gypsum deposits in Michigan. U $\mathbf{S}$ G S, B 223: $45-47$ (1904)

04b Gypsum deposits in Kansas. U $\mathbf{S}$

G S, B 223:53-59 (1904)

04c A theory of origin for the Michigan gypsum deposits. Am G 34: 378-387 (1904)

o5 Origin of gypsum, with special reference to the origin of the Michigan deposits. Kans Ac Sc, Tr 19:110-117 (1905)

O5a Gypsum and gypsum products. U S G S, Min Res 1904:1037-1052 (1905)

o6 Clays, limestones, and cements. W Va G S 3: 565 pp [1906]

o7 Ohio, Brooke, and Hancock cos. W Va G S : 378 pp, maps [1907]

07a Portland cement resources of West

Virginia. Eng M J 83:998-999 (1907)

os Limestone in West Virginia. Eng M J 85:1144 (1908)

o9 Iron ores, salt, and sandstones. W Va G S 4:603 pp (1909)

10 Pleasants, Wood, and Ritchie cos. W Va G S : 352 pp, maps (1910)

16 Jefferson, Berkeley, and Morgan cos. W Va G S : $644 \mathrm{pp}$, maps (in atlas) (1916)

Grinnel1, Fordyce, jr.

08 Quaternary myriopods and insects of California. Cal Univ, Dp G, B 5:207215 , il (1908)

Grinnell, George Bird.

74 Preliminary report on paleontology [of the Black Hills exploration]. U S [War Dp], Chief Eng, An Rp 1874 (U S, 43d Cong 2d sess, H Ex Doc 1 pt 2 v 2 pt 2), Арp KK: 632-633 (1874)

75 Paleontological report. In Ludlow, William, Report of a reconnaissance of the Black Hills of Dakota...: 75-78, Washington 1875 Also in U S, Chief Eng, An Rp 1875 pt $2: 1177-1180$ (1875)

76 (and Dana, Edward S.) On a new Tertiary lake basin. Am J Sc (3) 11: 126-128 (1876)

$76 \boldsymbol{a}$ On a new crinoid from the Cretaceous formation of the West. Am J Sc (3) $12: 81-83$, il (1876)

76b (with Dana, E. S.) Geological report. In Ludlow, Wm., Report of a reconnaissance... to the Yellowstone National Park: 89-126, Washington 1876 Also in U S [War Dept], Chief Eng, An Rp 1876 (U S, 44th Cong 2d sess, H Ex Doc 1 pt $2 \vee 2$ pt 3) App NN : 657-694 (1876)

77 Notice of a new genus of annelids from the Lower Silurian. Am J Sc (3) $14: 229-230$, il (1877)

78 Sketch of Professor O. C. Marsh. Pop Sc Mo 13:612-617, port (1878) 
Grinnell, George Bird-Continued.

81 Monograph by Professor Marsh on the Odontornithes, or toothed birds of North America. Am J Sc (3) 21:255276, il (1881)

9s Northern Rocky Mountain glaciers. Science n s 8:711-712 (1898) Sc Am Sup $48: 19854$ (1899)

10 Othniel Charles Marsh, paleontologist, 1831-1899. In Leading Amerícan men of science, ed. by David Starr Jordan, pp 283-312, port, N Y 1910

Griswold, E.

84 [Report of the hydrography, topography, and geology of Mercer Co., Pa.]. Med Soc Pa, Tr 14:463-470 (1884)

Griswold, Leon S.

91 The novaculites of Arkansas (abst). Am As, Pr 39:248-250 (1891)

92 Whetstones and the novaculites of Arkansas. Ark G S, An Rp 1890, 3:443 pp, maps, Little Rock, Ark., 1892

92a The structure of the Ouachita uplift of Arkansas (abst). Am As, Pr 40: 261 (1892)

93 A basic dike in the Connecticut Triassic. Harvard Coll, Mus C Z, B 16 (g s 2) : 239-242 (1893)

94 (with Davis, W. M.) Eastern boundary of the Connecticut Triassic. G Soc Am, B 5:515-530 (1894) Abst, Am G $13: 145-146$ (1894)

95 The origin of the Arkansas novaculites. Boston Soc N H, Pr 26:414-421 (1895)

95a Origin of the lower Mississippi. Boston Soc N H, Pr 26:474-479, map (1895)

95b On the nomenclature of the finegrained siliceous rocks (abst). Science n $\mathrm{s}$ 1: 62 (1895)

95e Some features of the Arizona Plateau (abst). Science n s 2: 706-707 (1895)

96 Notes on the geology of southern Florida. Harvard Coll, Mus C Z, B 28 (g s 3) : 52-62 (1896)

98 The geology of Helena, Mont., and vicinity. As Eng Soc, J 20:51-68 (1898)

Griswold, William Tudor.

02 The Berea grit oil sand in the Cadiz quadrangle, Ohio. U S G S, B 198:43 pp, map (1902)

03 Structural work during 1901 and 1902 in the eastern Ohio ofl fields. U S G S, B 213: 336-344 (1903)

o5 Pittsburg coal in the Burgettstown quadrangle, $\mathrm{Pa}$. U S G S, B 260:402-410, map (1905)

06 Natural gas. U S G S, Min Res 1905: 799-812 (1906)

06a Petroleum. U S G S, Min Res $1905: 813-920 ; 1906: 827-896$ (1906-7)

o7 The coals of the Steubenville quadrangle in West Virginia. W Va G $\mathrm{S}$, Ohio, Brooke, and Hancock cos. : 224-237 [1907]
Grisvvold, William Tudor-Continued,

O7a (and Munn, M. J.) Geology of tha oil and gas fields in Steubenville, Burgettr town, and Claysville quadrangles, Obia W. Va., and Pa. U S G S, B 318: $196 \mathrm{pp}$. $\operatorname{map}$ (1917)

os Structure of the Berea oil sand is the Flushing quadrangle, Harrison, Bel. mont, and Guernsey cos., Ohio. U S G \& B 346: 28 pp, map (1908)

Grönwa11, Karl A.

17 The marine Carboniferous of nott. east Greenland and its brachiopod faura. Med Grönland 43:509-618, map (1917) Museum de Minéralogie et de Géologie de 1'Université de Copenhague, Communica. tions paléontologiques no 13 , Copenhagea (1917)

Grosspietsch, Oskar.

o8 Krystallform und optische Orientierung des Albit von Morro Velho und Gröt land. Tschermaks Mitt 27:353-376 (1908 Grote, Augustus Radeliffe.

75 (and Pitt, W. H.) Description of new crustacean from the Waterlime group at Buffalo [N. Y.]. Buffalo Soc N Sc, B $3: 1-2$, il (1875)

75a (and Pitt, W. H.) On new species of Eusareus and Pterygotus from theWater. lime group at Buffalo [N. Y.]. Buffalo $\mathrm{S} x$ N Sc, B $3: 17-20$, il (1875)

78 (and Pitt, W. H.) New specimen [of Pterygotus cummingsi] from the wate lime group at Buffalo, N. Y. Am As, Pr $26: 300-302$, il (1878)

Groth, P.

$\mathbf{8 3}$ Beiträge zur Kenntniss der natür lichen Fluorverbindungen. Zs Kryst 7 457-493 (1883)

10 The optical properties of crystals. Transl from 4th German ed. by B. H. Jack. son. $309 \mathrm{pp}, \mathrm{N}$ Y 1910

Grothe, Albert.

11 (with Gonzalez, F.) The mining industry of Mexico. No. 1, State of Hidal. go. Pt 1: $74 \mathrm{pp}$; Pt 2: 77-108 (1911)

12 (and Salazar s, Leopoldo) La in. dustria minera de México. Tomo 1, Estados de Hidalgo y México. 319 pp, México 1912 [See also González, 11]

12a (and Salazar S, L.) Ia industria minera de México, no 5 [tomo 2 pt 1]; Estado de Michoacán, primera parte, $p p$ 1-83, maps, Mexico 1912

Grout, A. J.

17 A fossil Camptothecium [woldenii, from Kansas drift, Wallingford, Iowa]. Bryologist, 20:9, il (1917)

Grout, Frank Fitch.

06 [Petroleum in] Randolph Co. Ill (i S, B 2: 74 (1906)

O7 The composition of coals. Ec G 2: $225-241$ (1907)

07a Cannel coal in northern Illinois. I11 G S, B 4: 197-198 (.907)

os The oxidation of pyrite. Ec G 3: 532-534 (1908) 
Grout, Frank Fitch-Continued.

0sa The classification of low-grade coais. Ec G $3: 647-649$ (1908)

09 The classification of geologic materials. Ec G 4:646-653 (1909)

09a The classification of coal. Ec G 4:653-658 (1909)

10 Keweenawan copper deposits. Ec G 5: 471-476 (1910)

10a Contribution to the petrography of the Keweenawan. J G $18: 633-657$, map (1910)

10b The composition of some Minnesota rocks and minerals. Science n s 32 :312$315(1910)$

11 The relation of texture to the composition of coal. Ec G $6: 449-464$ (1911) Abst, Science n s $33: 463$ (1911)

11a The American Association for the Advancement of Science, Section E. Science n s $33: 461-469$ (1911)

13 On the behavior of cold acid sulphate solutions of copper, silver, and gold with alkaline extracts of metallic sulphides. Ec G 8 : $407-433$ (1913)

13a (and Worcester, P. G., and Henderson, J.) Reconnaissance of the geology of the Rabbit Ears region, Routt, Grand, and Jackson cos. Colo G S, B 5 pt 1:1-57, map (1913)

14 (and Soper, E. K.) Preliminary report on the clàys and shales of Minnesota. Minn G S, B 11: 175 pp, map (1914)

16 The locallzation of values or occurrence of shoots in metalliferous deposits. Ec G 11: 395-397 (1916)

16a The clays of Minnesota. J Geog 14:185-187 (1916)

18 The pegmatites of the Duluth gabbro. Ec G $13: 185-197$ (1918)

18a The lopolith; an igneous form exemplified by the Duluth gabbro. Am J Sc (4) $46: 516-522$ (1918)

$18 \mathrm{~b}$ Internal structures of igneous rocks; their significance and origin; with special reference to the Duluth gabbro. J G 26 : 439-458 (1918) Abst, with discussion by W. J. Miller and M. E. Wilson; G Soc Am, B 29: 100-101 (1918)

18e Two-phase convection in igneous magmas. J G 26:481-499 (1918) Abst, G Soc Am, B 29:101-102 (1918)

18d A form of multiple rock diagrams. J G $26: 622-625$ (1918)

18e A type of igneous differentiation. J G 26: 626-658 (1918)

See also Miller (W J), 18a; Roberts (H M), 18

Guardiola, Ricardo.

12 Sobre el origen de los criaderos de Mayari [Cuba]. Revista Minera 63:2527 (1912)

Guentherodt, J. J.

96 'Twin Lakes region [of Colorado]. Colliery Eng 17:201-202 (1896)

$$
28737^{\circ}-23-28
$$

Guernsey, J. A.

31 Mastodon near Rochester, N. Y. Am J Sc $19: 358-359$ (1831)

Guerra, Manuel Fernández.

06 Solución á las cuestiones técnicogeológicas ... sobre si son denunciables los mantos de carbón de piedra y los depósitos de petróleo que existan en terrenos de propiedad particular. Soc G Mex, B 2: 87-110 (1906)

Guettard, Jean Etienne.

56 Mémoire dans lequel on compare le Canada à la Suisse par rapport a ses minéraux. Histoire de l'Académie Royale des Sciences, Paris, An 1752:189-220, map (1756)

Guild, F. N.

05 Petrography of the Tucson Mountains, Pima Co., Ariz. Am J Sc (4) 20: 313-318 (1905)

05a El Instituto Geológico de México. $\Delta \mathrm{m}$ G $36: 293-296$ (1905)

06 Notes on some eruptive rocks in Mexico. Am J Sc (4) 22:159-175 (1906) 07 The composition of molybdite from Arizona. Am J Sc (4) 23:455-456 (1907)

07a Coon Mountain crater. Science n s $26: 24-25$ (1907)

10 The mineralogy of Arizona. $103 \mathrm{pp}$, Easton, Pa. 1910

11 Mineralogische Notizen [Arizona, minerals]. Zs Kryst $49: 321-331$ (1911)

17 A microscopic study of the silver ores and their associated minerals. Ec $\mathrm{G} 12$ : 297-353 (1917) M Sc Press 115:857864 (1917)

Guillemin-Tarayre, Ed.

67 Mémoire sur les mines d'argent de la basse Californie. [France], Comm Sc Mex, Arch 2:403-415, Paris 1867

67a Lettre sur la Sonora. [France], Comm Sc Mex, Arch 2:422-431, Paris 1867

67b Note sur les mines de la province de Jalisco [Mexico]. [France], Comm Sc Mex, Arch 2: 477-488, Paris 1867

67c Rapport sur l'exploration minéralogique des régions mexicaines. [France], Comm Se Mex, Arch 3:173-340, Paris 1867

69 De la production des métaux précieux dans l'Amérique septentrionale. Soc Ind Min, B $15: 323-427$ (1869)

71 Description des anciennes possessions mexicaines du nord. France, Mis. sion Scientifique au Mexique et dans l'Amérique Centrale, Géologie pt 2:216 pp, maps, Paris 1871

Gniterman, Franklin (1856-1915).

91 Gold deposits in the quartzite formation of Battle Mountain, Colo. Colo Sc Soc, Pr 3: 264-268 (1891)

See also Cross, 98a; Van Diest, $95 a$

Guliek, Addison.

o4 The fossil land shells of Bermuda. Ac N Sc Phila, Pr 56:406-421, il (1904) 
Gulliver, Frederick Putnam (1865-1919). 93 The Newtonville sand plain [Mass]. J G 1:803-812 (1893) Abst, Am As, Pr 42: 178 (1894); (with discussion) Am G $12: 177$ (1893)

95 Tidal sand cusps $(a b s t)$. Science $\mathrm{n}$ s 2 : 705-706 (1895)

95a (with Gilbert, G. K.) Tepee buttes [Colorado]. G Soc Am, B 6:333342, map (1895) Abst, Science n s 1:59 (1895)

96 Cuspate forelands. G Soc Am, B 7 : 399-422 (1896) Abst, Am G 17:98 (1896) ; Science n s $3: 51$ (1896)

96a Types of lowland coasts. Science n s $3: 128$ (1896)

96b Tidal scour $(a b s t)$. Science n s 3 : $570-571$ (1896)

96e Post-Cretaceous grade plains in southern New England (abst). Am G 18 : 231 (1896)

98 Classification of coastal forms (abst). G Soc Am, B 10:18 (1899) Am G 22: 253 (1898) Science n s 8:466 (1898)

99 Shoreline topography. Am Ac Arts, Pr 34:149-258 (1899) Abst, with title, Classification of coastal forms, Am G 22: 253 (1898); Science n s 8:466 (1898); G Soc Am, B 10:19 (1899)

oo Thames River terraces in Connectlcut. G Soc Am, B 10:492-495 (1900) Abst, Am G 23:104 (1899); Science n s $9: 144$ (1899)

02 Joint meetings of the Geological Society of America, Section E, and the National Geographic Society [Pittsburgh, Pa., July 1-3, 1902]. Science n s $16: 258$ 268 (1902)

03 Cuttyhunk Island [Mass.] (abst). G Soc Am, B 13:538 (1903)

04 Nantucket shore lines. G Soc Am, B 14: 555-556; 15:507-522 (1904) Abst, Science n s 19:531 (1904); Sc Am Sup $57: 23446$ (1904)

o5 Island tying. Int Geog Cong, VIII, $\mathrm{Rp}$ : 146-149 (1905)

05a Sudbury Basin shore lines (abst). Science n s 22 : 334-335 (1905)

06 Brewsters Neck, Conn. (abst). Science n s 24:368-369 (1906) Am As, Pr 56-7:268-269 (1907)

07 The American Association for the Advancement of Science; Summer meeting, Section E-Geology and geography. Science n s $26: 397-404$ (1907)

07 a Ice present during the formation of glacial terraces $(a b s t)$. Science $n$ s 25 : 770-771 (1907) G Soc Am, B 18:640641 (1908)

os Graded surfaces (abst). G Soc Am, B $18: 609-610$ (1908)

09 Nantucket shore lines, IV (abst). Science n s 29:633 (1909) G Soc Am, B $20: 670(1910)$
Gulliver, Frederick Putnam-Continus

09a The American Association for Advancement of Science; Section $\mathrm{E}$, $\mathrm{G}$ ology and geography [Baltimore, Decembe 1908]. Science n s 29:747-757 (1909)

10 Geology and geography at the by ton-Cambridge meeting [meeting of Sectin $\mathrm{E}$ of the American Association for the $\mathrm{d}$. vancement of Science, December, 1900) Science n s 32:124-128 (1910)

$10 a$ Wauwinet-Coscata tombolo, Na tucket, Mass. (abst). Brit As, Rp \%: 536 (1910)

11 Delta form and structure of th Thames River terraces, Conn. (abst). it Am Geog, An 1: 116 (1911)

Gunning, W. D.

72 The past and future of Niagara. Pon Sc Mo 1: 564-573 (1872)

Gunter, Herman.

09 (with Sellards, E. H.) The fulleri earth deposits of Gadsden Co., Fla. Fu G S, An Rp 2: 253-291 (1909)

10 (with Sellards, E. H.) The artesis water supply of eastern Florida. Fla G \& An Rp 3: 77-195 (1910)

11 (with Sellards, E. H.) Roads ati road materials of Florida. Fla $G \mathrm{~S}, \mathrm{~B}$ : $31 \mathrm{pp}$ (1911)

12 (with Sellards, E. H.) The under ground water supply of west central and west Florida. Fla G S, - Rp 4:81-15 1912)

18 (with Sellards, E. H.) Geology be tween the Apalachicola and Ocklockite rivers in Florida. Fla G S, 10th and 11th An Rps: 9-56, map (1918)

$18 a$ (with Sellards, E. H.) Geolorg between the Choctawhatchee and Apalactcola rivers in Florida. Fla G S, 10 th and 11th An Rps: 77-102, map (1918)

Gunther, Charles Godfrey.

o5 The gold deposits of Plomo, San luis Park, Colo. Ec G 1 : 143-154, map (1905)

05a An interesting fault system [Ner York mine, Siskiyou Co., Cal.]. Eng II J $80: 1013$ (1905)

o7 (with Kemp, J. F.) The White Knob copper deposits, Mackay, Idaho. Am I M Eng, B 14: 301-328 (1907)

12 The examination of prospects; a mining geology. 222 pp, N Y 1912

Guppy, Robert John Lechmere (18361916).

63 On the Older Parian formation at Pointe a Pierre, Trinidad. G As, London, Pr 1:267-270 (1863) Geologist, London, 6: 204-207 (1863) B Am Pal no $35: 7-10$ (1921)

63a The Older Parian in Trinidad. Geologist, London, 6 : 363-364 (1863)

64 On the occurrence of Foraminifera in the Tertiary beds at San Fernando, Trint. dad. Sc As Trinidad, $\operatorname{Tr} 1: 11-12$ (1864?) [not seen] Geologist 7:159-160 (1864) B Am Pal no 35 : 11-12 (1921) 
Guppy, Robert John Lechmere-Continued. 65 On later Tertiary depo"'s at $\mathrm{Ma}$ tura on the east coast of Trinidad. Sc As Trinidad, $\operatorname{Tr} 1: 33-43$ (1865?) [not seen] G Mag $2: 256-261$ (1865) B Am Pal no $35: 13-23$ (1921)

66 On the Tertiary Mollusea of Jamaica. G Soc London, Q J $22: 281-295$, 11 (1866) Abst, G Mag 3:178-179 (1866); $\mathrm{Ph} \mathrm{Mag}$ (4) $31: 399-400 \quad(1866)$

66a On Tertiary Brachiopoda from Trinidad. G Soc London, Q J 22:295297, il (1866) Abst, G Mag 3:179-180 (1866) ; Ph Mag (4) 31:400 (1866)

66b On Tertiary echinoderms from the West Indies. G Soc London, Q J 22: 297301 , il (1866) Abst, G Mag 3:179 (1866) ; Ph Mag (4) $31: 400$ (1866)

$66 \mathrm{e}$ On the relations of the Tertiary formations of the West Indies. G Soc London, Q J $22: 570-590$, il (1866) Abst, G Mag $3: 373-374$ (1866)

67 On the Tertiary fossils of the West Indies, with especial reference to the classification of the Kainozoic rocks of Trinidad. Sc As Trinidad, Pr 1 pt 3:145-176 (1867) B Am Pal no $35: 24-55$ (1921)

$67 \mathbf{a}$ On the nature of Eozoon. G Mag 4:376-377 (1867)

$67 \mathrm{~b}$ Notes on West Indian geology ... and descriptions of some new fossils from the Caribbean Miocene. G Mag 4:496501 , il (1867)

69 Notes of a visit to Dominica. Sc As Trinidad, $\mathrm{Pr} 1$ pt $8: 377-392$ (1869) G Mag 9: $75-76 \quad(1872)$

70 On the discovery of organic remains a Caribbean series of Trinidad (abst). G Soc London, Q J 26:413-414 (1870) Abst, G Mag $7: 235 \quad(1870)$

72 On Foraminifera from the Tertiaries of San Fernando, Trinidad. Sc As Trinidad, Pr $2: 13-16$ (1872) G Mag 10:362 363 (1873)

73 On some new Tertiary fossils from Jamaica. Sc As Trinidad, Pr 2:72-88, il (1873) B Am Pal no 35: 56-72 (1921)

74 On the West Indian Tertiary fossils. G Mag (2) 1:404-411, 433-446, il (1874)

75 Supplement to the paper on West Indian Tertiary fossils. G Mag (2) $2: 41-42$ (1875)

76 On the Miocene fossils of Haiti. G Soc London, Q J 32: 516-532, il (1876)

77 On the physical geography and fossils of the older rocks of Trinidad. Sc As Trinidad, Pr 2 pt 11: 103-110 (1877) P Am Pal no $35: 76-88$ (1921)

77a On the discovery of Tertlary coal at Williamsville, Savanagrande ['Trinidadj. Sc As Trinidad, Pr 2 pt 11:110-114 (1877)

79 On the recent and Tertiary species of Leda and Nucula found in the West Indies; with notices of West Indian shells. Sc As Trinidad, $\operatorname{Pr} 2: 168-180$, il (1879?) [not seen] B Am Pal no 35:89-101, il (1921)
Guppy, Robert John Lechmere-Continued,

79a On a heterocercal fish found in the blue limestone series of the Laventille Hills. Sc As Trinidac, Pr $2: 180-181$, il (1879?) [not seen] B Am Pal no $35: 101$ 102 , II (1921)

79b On the fossil Ecuinodermata of the West Indies. Sc As Trinidad, $\operatorname{Pr} 2: 193$ 199 (1879?) [not seen] $\mathrm{B} \mathrm{Am} \mathrm{Pal} \mathrm{no} 35$ : 103-109 (1921)

90 Remarks on the geological position of the Polycystina beds of South Naparima [Trinidad], The Agricultural Record 3: 178-180 (1890) B Am Pal no $35: 110-112$ (1921)

92 The Tertiary microzoic formations of Trividad, W. I. G Soc London, Q J 48 : 519-538, map (1892) Abst, G Mag (3) 9 : $331-332 \quad(1892)$

93 The microzoa of the Tertiary and other rocks of Trinidad and the West Indies. Trinidad Field Naturalists' Club, J $1: 277-290$ (1893) B Am Pal no $35: 113$ 126 (1921)

95 On some Foraminifera from the microzoic deposits of Trinidad, W. I. Zool Soc London, Pr 1894: 647-653, il (1895)

96 (and Dall, W. H.) Descriptions of Tertiary fossils from the Antlllean region. U S Nat Mus, Pr 19: 303-331, il (1896)

98 Remarks on tome fossils from the Eocene of Naparima [Trinidad]. Vietoria Inst Trinidad, $\mathrm{Pr}$ [1] pt 3:169-170 (1898?) [not seen] B Am Pal no 35 : 127-128 (1921)

98a Notes on the passage between the Foraminifera beds and the radiolarian marls of Naparima. Victoria Inst Trinidad, Pr [1] pt 3:170-172 (1898?) [not seen] B Am Pal no 35: 128-130 (1921)

98b Notes on a specimen of Globigerina rock from Naparima. Victoria Inst Trinidad, Pr [1] pt 3:172 (1898?) [not seen] B Am Pal no $35: 130$ (1921)

00 On the Naparima rocks, Trinidad. G Mag (4) $\gamma: 322-325$ (1900).

02 On the occurrence of gold and coal in Trinidad, with a brief sketch of the geological history of the island. Victoria Inst, Trinidad, Pr 1:505-514 (1902) ; Industrial Trinidad : 520-531 (1903)

03 Tobagan fossils. Trinidad, Bot Dp, B no 38 (514): 541-543 (1903) B Am Pal no $35: 131-133$ (1921)

04 On some samples of rock from borings at Sangregrande, Trinidad. Victorla Inst, Trinidad, $\operatorname{Pr} 2: 1-7$ (1904) G Mag (5) 1:193-199 (1904)

O4a Observations on some of the Foraminifera of the oceanic rocks of Trinidad. Victoria Inst, Trinidad, $\operatorname{Pr} 2: 7-16$, il (1904) G Mag (5) 1:241-250, il (1904)

04b Preliminary geological notes on the Marbela manjak mine [Trinidad]. Victo. ria Inst, Trinidad, $\operatorname{Pr} 2: 16-17$ (1904) G Mag (5) 1:276-277 (1904) 
Guppy, Robert John Lechmere-Continued.

o4e Note on the Komuto shell bed [Trinidad]. Victoria Inst, Trinidad, $\mathrm{Pr}$ $2: 17$ (1904)

O4d Tobagan fossils; on some specimens of fossils from Tobago in the Vietoria Museum, Trinidad. Trinidad, Bot Dp, B no 514: 2 pp (1904)

05 The growth of Trinidad. Can Inst, Tr 8: 137-149 (1905) In part B Am Pal no $35: 193-195$ (1921)

os on some fossil shells from Comparo Road, Trinidad. Trinidad, Bot Dp, B Mise Information no 59:114-115 (1908) G Mag (5) 5:471-472 (1908) B Am Pal no 35: 140-141 (1921)

osa on the cement-producing materials of Naparima, Trinidad. Trinidad, Bot Dp. B Misc Information no $59: 115-116$ (1908) G Mag (5) $5: 472-473$ (1908)

09 The geological connections of the Caribbean region. Can Inst, Tr $8: 373-$ 391, map (1909)

09a Second note on the Marbela manjak mine [Trinidad]. (Trinidad, Dp Agr, B Agr Information 9 ( $\mathrm{n} s$ no 61 ):51-54 (1909) B Am Pal no $35: 134-139$ (1921)

09b Preliminary notice of a discovery of fossils in the Tamana district. Trinidad, Dp Agr, B Agr Information 9 (n s no 61) : 55-56, il (1909) B Am Pal no $35: 142-144$, il (1921)

10 On a collection of fossils from Springvale, near Couva, Trinidad. $\Lambda \mathrm{gr}$ Soc Trinidad and Tobago, $\operatorname{Pr} 10: 447-461$, il (1910) B Am Pal no $35: 144-157$, il (1921)

11 On the geology of Antigua and other West Indian Islands with reference to the physical history of the Caribbean region. G Soc London, Q J 67:681-700, map (1911) Agr Soc Trinidad and Tobago, Pr $12: 182-207$ (1912)

$11 a$ Fossils from Springvale, near Couva, Trinidad. Agr Soc Trinidad and Tobago, Pr 11:194-203, il (1911) B Am Pal no $35: 158-166$ (1921)

12 An account of some recent geological discoveries in the West Indies. Agr. Soc Trinidad and Tobago, $\operatorname{Pr} 12: 22-35$, il (1912) B Am Pal no $35: 166-181$ (1921)

12a Note on Dr. Watts's remarks on the geology of Antigua. Agr Soc Trinidad and Tobago, Pr 12:75-78 (1912) B Am Pal no $35: 181-184$ (1921)

12b Further note on the Caroni series at Savaneta. Agr Soc Trinidad and Tobago, Pr $12: 330-334$ (1912). B Am Pal no $35: 184-187$ (1921)

13 Observations on the geology of Martinique with notes on fossils from Trinidad and Venezuela. Agr Soc Trinidad and To. bago, Pr 13:159-163 (1913) B Am Pal no 35 : 188-192 (1921)

See also Goding, 66
Gurley, Revere R.

91 Some recent graptolitic literature. Am G $8: 35-43$ (1891)

92 The geological age of the graptolite shales of Arkansas. Ark G S, An Rp 1890, 3: 401-404 (1892)

92n New species of graptolites. Ark $G$ S, An Rp 1890, 3:416-418 (1892)

96 North American graptolites; new specles and vertical range. $J$ G $4: 63-102$, 291-311 (1896)

Gurley, William Frank Eugene.

78 [Ginley in error for Gurley] Notice of the discovery of the position of the crural processes in the genus Atrypa. Am Ph Soc, Pr 17:337-338, il (1878)

83 New Carboniferous fossils. Bulletin no $1: 9 \mathrm{pp}$, September 24, 1883 [Priv pub]

84 New Carboniferous fossils. Bulletin no $2: 12$ pp [Danville, Ill.], February 25, 1884 [Priv pub]

89 (with Miller, S. A.) Deseription of some new genera and species of Echino. dermata from the Coal Measures and Subcarboniferous rocks of Indiana, Missouri and Iowa. Ind, Dp G N H, An Rp 10: $327-373$, il (1889)

90 (with Miller, S. A.) Description of some new genera and species of Echino. dermata from the Coal Measures and Sub. carboniferous rocks of Indiana, Missouri, and Iowa. $59 \mathrm{pp}, 1890$ [priv pub]

90a (with Miller, S. A.) Description of some new genera and species of Echinodermata from the Coal Measures and Subcarboniferous rocks of Indiana, Missouri, and Iowa. Cin Soc $\mathrm{N}$ H, J $13: 2-25$, II (1890)

93 (with miler, S. A.) Description of some new species of invertebrates from the Paleozoic rocks of Illinois and adjacent states. Il St Mus N H, B 3:81 pp, Il (1893)

94 (with Miller, S. A.) Upper Devonian and Niagara crinoids. III St Mus N H, B 4: $37 \mathrm{pp}$, il (1894)

$94 a$ (with Miller, S. A.) New genera and species of Echinodermata. III St Mus $\mathrm{N} \mathrm{H}, \mathrm{B} 5: 53 \mathrm{pp}$, il (1894)

95 (with Miller, S. A.) Description of new species of Paleozoic Echinodermata. IIl St Mus N H, B 6:62 pp, il (1895)

$95 a$ (with Miller, S. A.) New and interesting species of Paleozoic fossils. III St Mus N H, B 7: 89 pp, il (1895).

96 (with Millex, S. A.) Description of new and remarkable fossils from the Paleozoic rocks of the Mississippi Valley. III St Mus N H, B 8:65 pp, il (1896)

$96 a$ (with Miller, S. A.) New species of crinoids from Illinois and other states. Ill St Mus N H, B 9:66 pp, il (1896)

96b (with Miller, S. A.) New species of Echinodermata and a new crustacean from the Paleozoic rocks. Ill St Mus N H, B 10:91 pp, il (1896) 
Gnrley, Willfam Frank Eugene-Contd.

96e (with Miller, S. A.) New species of Paleozoic invertebrates from Inlinois and other states. III St Mus N H, B 11: 50 pp, il (1896)

97 (with Miller, S. A.) New species of crinoids, cephalopods, and other Paleozoic fossils. Ill St Mus N H, $69 \mathrm{pp}$, il (1897) Gurlt, Adolf.

94 On a remarkable deposit of wolfram ore in the United States. Am I M Eng, Tr $22: 236-242$ (1894)

Guthrie, Ossian.

90 The Lake Michigan glacier and glacial channels across the Chicago divide. Read before the Chicago G Soc, Oct 30, 1890. $16 \mathrm{pp}$, maps

92 An experiment designed to show the upward movement of subglacial débris. Am G $9: 283-284$ (1892)

96 Relies turned up in the drainage canal [Chicago, III.]. W Soc Eng, J 1: 465-481 (1896)

\section{Gutiêrrez Lanza, R. P. Mariano.}

13 Conferencias de seismología Ac Cienc Yéd Habana, An $50: 164-230, \quad 271-338$ (1913) Reprint, xvi, 157 pp, Habana, 1914 Guyot, Arnold.

50 On the erratic phenomena of the White Mountains (abst, with discussion by H. D. Rogers, L. Agassiz, C. T. Jackson, James Hall, and W. C. Redfield). Am As, Pr 2:308-311 (1850)

61 On the Appalachian Mountain system. Am J Sc (2) $31: 157-187$, map (1861)

69 Artesian well at Terre Haute, Ind. Am J Se (2) 48:270-271 (1869)

80 On the physical structure and hypsometry of the Catskill Mountain region. Am J Se (3) $19: 429-451$ (1880)

Gwillim, J. C. (1868-1920).

96 Gold and silver ores of the Slocan, B, C. Can Rec Sc 6:494-498 (1896)

97 (and Johnson, W. S.) Some ores and rocks of southern Slocan division, West Kootenay, B. C. Can Rec Sc $7: 293-302$ (1897)

98 Some West Kootenay ore bodies [B. C.] Fed Can M Inst, J 3:19-26 (1898) Can M Rv 17: 17-19 (1898)

00 [Report on field work in the Atlin distriet, B. C.] Can G S, Sum Rp 1899 (An Rp 12): A 52-75 (1900); Sum Rp 1900 (An Rp 13) : A 52-62, map (1901)

$00 a$ Notes on the Atlin gold fieelds [B, C.]. Can M Inst, J 3:97-101 (1900) Can M Rv $19: 69-70(1900)$

01 Report on the Atlin mining district, B. C. Can G S, An Rp 12: B 48 pp, map (1901)

02 Characteristies of the Atlin gold field [B. C.]. Can M Inst, J $5: 21-32$ (1902) Can M Rv 21:13-16 (1902)

02a Glaciation in the Atlin district, $B$. C. J G 10:182-185 (1902)
Gwillim, J. C.-Continued.

o5 Notes on some western coals [Alberta and British Columbia]. Can M Inst, $\mathbf{J} \mathbf{7}$ : 422-424 (1905)

O5a Notes on the life history of coal seams (with discussion). Can M Inst, J 8: 235-243 (1905)

ot Western coal resources. Can M J 28 , no. 3 (n s 1 , no 1) : 16-18 (1907)

os A partial bibliography of publications referring to the geology and mineral industry of Alberta, British Columbia, and the Yukon. Can M Inst, J 11:433-444 (1908) Can M.J $29: 210-211,242-243$ (1908)

10 The North Thompson valley, B. C. Can M J 31:17 (1910)

11 (with Barlow, A. E.) Preliminary report on the geology and mineral resources of the Chibougamau mining region. Que, Dept Col, Mines, and Fish : 24 pp (1911)

11a (with Barlow, A. E.) Report on the geology and mineral resources of the Chibougamau region, Quebec. Que, Dp Col, Mines, and Fish, Mines $\mathrm{Br}: 224$ pp (1911) Haack, Wilbelm.

14 Ueber eine marine Permfauna aus Nordmexiko nebst Bemerkungen uber Devon daselbst. Deut $\mathrm{G}$ Ges, $\mathrm{Zs} 66: 482-504$, il (1914)

Hannel, Eugene.

os Summary report of the Mines Branch of the Department of Mines [of Canada] for the flscal year 1907-8. $100 \mathrm{pp}$, Ottawa 1908

10 The iron ores of Canada. Int Geol Cong, XI, Stockholm, 1910, The iron ore resources of the world $2: 721-743$, map (1910)

11 Summary report of the Mines Branch of the Department of Mines [of Canada] for the ealendar year ending December 31, 1910. $243 \mathrm{pp}$, Ottawa (1911) ...1911: 208 pp (1912) ...1912:174 pp (1913) ...1913: 214 pp (1914) ..1914:232 pp (1915) $\ldots 1915: 213 \mathrm{pp}$ (1916) $\ldots 1916: 183 \quad \mathrm{pp}$ (1917) $\quad \ldots 1917: 153 \mathrm{pp}$ (1918)

Harrmann, Erich.

11 Sobre una cueva en una corriente de lava en el Estado de Pueblo. Soc G Mex, B $7: 141-143$ (1911)

13 Geologische Streifzüge in Coahuila. Deut G Ges, Zs 65, Monatsb 1:18-47 (1913)

17 Zur tektonischen Geschichte Mexikos. Centralbl Miner 1917: 176-179

Hans, Hippolyt.

04 Der Vulkan... 340 pp, Berlin 1904

04a Zur Geologie von Canada. Petermanns Mitt 50:20-28, 47-55, map (1904)

Haas, William $\mathrm{H}$.

17 The influences of glaciation in Ohio. Geog Soc Phila, B 15: 19-42 (1917)

17n Erosion features of the Mesa Verde [Colo.]. Ill Ac Sc, Tr 9:211-219 [1917] 
Habersham, Joseph.

46 Memorandum of the most important fossil bones and shells, now in his possession, which were discovered in the year 1842 , on the Island of Skiddaway on the sea coast of Georgia. In Hodgson, W. B., Memoir on the Megatherium...:24-30, N Y 1846

Hackett, Edward F.

14 The coal field of Sebastian Co., Ark. Coal Age 6:630-631, map (1914)

Haddock, George.

73 Report of a geological reconnalssance of a part of the State of Arkansas, made during the years 1871-2. [Ark G S] : 63 pp, Little Rock 1873

Haddon, R. W.

06 Zinc mining in New Mexico [Magdalena Range]. Eng M J 81:845-846 (1906)

Hadley, Arthur Twining.

o7 James Dwight Dana. Pop Sc Mo 70 : 306-308 port (1907)

13 James Dwight Dana centenary; introductory remarks. G Soc Am, B 24: 55-56 (1913)

Haehl, Harry Lewis.

04 (and Arnold, Ralph) The Miocene diabase of the Santa Cruz Mountains in San Mateo Co., Cal. Am Ph Soc, Pr 43: 16-53, map (1904)

O7 (and others) Report of committee [of the San Francisco Association of members of the American Society of Civil Engineers] on the geology of the [San Franciscol earthquake. Am Soc Civil Eng, $\mathrm{Pr}$ $33: 307-313 \quad$ (1907); $\quad$ Tr $59: 216-222$ (1907)

Hapke, L.

S4 Ein neuer Fund von Meteoreisen aus Mexico und Bemerkungen uber mexicanischen Meteoriten. Naturw Ver Bremen, Abh 8:513-517 (1884)

Haertter, John H.

08 The southern anthracite coal field [Pennsylvania]. Eng M J 85:653-656 (1908)

Hafer, Claude.

10 The Real de Xichu mining district, Mexico. M World 32:1035-1036 (1910)

12 The mines of the Sonora Valley, Sonora, Mexico. M World 36:903-904 (1912)

13 Pyrophyllite in North Carolina. Eng M J 96:623-625 (1913)

14 Copper Creek district of Arizona. Eng M J 98:1145 (1914)

Hagemann, G.

66 On some minerals associated with the cryolite in Greenland. Am J Sc (2) 42: 93-94 (1866)

66a On erystallized eryolite. Am J Sc (2) $42: 268-269$ (1866)

69 On ivigtite. Am J Sc (2) 47:133134 (1869)
Hagen, Hermann August.

74 On amber in North America. Boster Soc N H, Pr 16:296-301 (1874)

81 The Devonian insects of New Brun. wick. Harvard Coll, Mus C Z, B $8: 27$. 282 (1881)

82 Fossil insects of the Dakota group Nature 25: 265-266 (1882)

Hager, Albert David (1817-1888).

58 The marbles of Vermont... $16 \mathrm{p}$, Burlington 1858

59 Geological map of the State of Ver. mont. Inset on map of the State of Vermont... H. F. Walling, N Y [1859] [not seen]

61 Economical geology of Vermont. Is Report on the geology of Vermont (Hitecock) $2: 733-870$ (1861)

61 a Physical geography and scenery. Is Report on the geology of Vermont (Hitchcock) 2:871-941 (1861)

71 Annual report of the State geologist for the State of Missouri. $23 \mathrm{pp}$, Jefferson City 1871 [Includes report by J. G. Norwood: 5-7]

Hager, Dorsey.

11 Value of geology in the petroleum in. dustry. M World $35: 435-437$ (1911); 36 : 412,680 (1912)

11 a Geological factors in oll production. M Sc Press 103: 738-741 (1911)

13 Anticlinal dome structure in Call fornia oil fields. Western Eng 3:196-199 (1913)

14 Anticlinal dome structure in Callfornia oil fields. West Eng 4 : 28-30 (1914)

14a Effects of faulting in ofl fields. West Eng 4: 442-445 (1914)

14b Unconformities and overlap and their effects on oil fields. West Eng 5: 168-169 (1914)

15 The new South Mountain oil field, Ventura Co., Cal. West Eng $5: 341-342$ (1915)

15a Geological features of the Oklahoma oil fields. West Eng 6:13-14 (1915)

15b Natural gas; its occurrence and properties. Eng M J 100:959-961 (1915)

16 Practical oil geology; the application of geology to oil field problems. $149 \mathrm{pp}$, N Y 1915 2d ed, 187 pp N Y 1916

16a The occurrence of the older beds in structural depressions. Ec G 11:276-278 (1916)

17 The evidence of the Oklahoma oil fields on the anticlinal theory (with dis. cussion by I. N. Knapp, C. Naramore, F. J. Hirschberg, R. H. Johnson, H. A. Wheeler, M. L. Requa, and the author). Am I If Eng, B $122: 195-198 ; 124: 626-635 ;$ Ir $56: 843-855$ (1917)

17a A few notes on the future work of the petroleum geologist in the Mid-Continent ofl fields. Am I M Eng, B 130:1793-1795 (1917) ; $\operatorname{Tr} 57: 891-893$ (1918) 
Hager, Dorsey-Continued.

1s Possible oil and gas fields in the Cretaceous beds of Alabama. Am I M Eng, Tr 59:424-431, map (discussion by E. De Golyer and I. N. Knapp : 431-434) (1918) ; $134: 469-476$; B $136: 819-822$ (discussion) (1918)

18 a Geology of the oil fields of north central Texas. Am I M Eng, B 138: 11091118, map (1918); diseussion by W. E. Pratt, B 140:1155-1156 (1918)

18b The search for new oil pools in the United States. Eng M J 105:11-12 (1918)

See also Conkling, 16

Hager, Lee.

04 The mounds of the southern ofl fields. Eng M J 78:137-139, 180-183, $\operatorname{map}(1904)$

See also Brokaw, 18

Hague, Arnold (1840-1917).

70 Geology of the White Pine district [Nev.]. U S G Expl 40th Par (King), $3: 409-421$, map [in atlas] (1870)

77 (and Emmons, S. F.) Descriptive geology. U S G Expl 40th Par (King), 2 : $890 \mathrm{pp}$ (1877)

$\mathbf{8 3}$ Geology of the Eureka district, Nev. U S G S, An Rp 3:237-290, map (1883)

83a (and Iddings, J. P.) Notes on the volcanoes of northern California, Oregon, and Washington Territory. Am J Sc (3) 26:222-235 (1883) Abst by M. E. Wadsworth, Am Nat 18:526-528 (1883)

84 (and Iddings, J. P.) Notes on twe rolcanic rocks of the Great Basin. Am J Se (3) $27: 453-463$ (1884)

84a Yellowstone National Park. Science 3: $135-136$ (1884)

85 (and Iddings, J. P.) On the development of crystallization in the igneous rocks of Washoe, Nev., with notes on the geology of the district. U S G S, B 17:44 Dp (1885)

85a Geological section of the Eureka district [Nev.]. U S, 10th Census 13:33 (1885)

86 (and Iddings, J. P.) Notes on the volcanic rocks of the republic of Salvador, Central America. Am J Sc (3) $32: 26-31$ (1886)

88 Geological history of the Yellowstone National Park. Am I M Eng, Tr 16: 783803, maps (1888) Smiths Inst, An Rp 1892:133-151 (1893) Abst, Pop Sc Mo $36: 282-283$ (1889)

89 ... leucite rock in the Absaroka Range, Wyo, Am J Sc (3) $38: 43-47$ (1889)

89a Soaping geysers. Am I M Eng, Tr 17:546-553 (1889) Smiths Inst, An Rp $1892: 153-161$ (1893)

92 Geology of the Eureka district, Nev. U S G S, Mon 20:xvii, 419 pp, atlas (1892)
Hague, Arnold-Continued.

96 Yellowstone National Park sheets; general description. U S G S, G Atlas Yellowstone National Park fol (no 30): 1-4, maps (1896) Abst, J G 5:405-407 (1897)

96a The age of the igneous rooks of the Yellowstone National Park. Am J Se (4) $1: 445-457$ (1896)

99 (and others) Geology of the Yellowstone National Park. U S G S, Mon 32 pt $2: 893$ pp, maps (1899)

99a Descriptive geology of Huckleberry Mountain and Big Game Ridge, Yellowstone National Park. U S G S, Mon 32 pt 2:165-202 (1899)

99b Description of the Absaroka quadrangle [Crandall and Ishawooa quadrangles, Wyo.]. U S G S, G Atlas Absaroka fol (no 52): 6 pp, maps (1899)

99e The early Textiary volcanoes of the Absaroka Range (presidential address before Geological Society of Washington). Science n s $9: 425-442$ (1899) Also published by $\mathrm{G}$ Soc Washington : $25 \mathrm{pp}$, April 1899

99d [Geological relief map of the Yellowstone Park (abst)]. Science n s 9:454 (1899)

o0 Othniel Charles Marsh. U S G S, An Rp 21 pt 1: 189-204 (1900)

01 Note sur les phénomènes voleaniques tertiaires de la chaine d'Absaroka [Wyo.]. Int $\mathrm{G}$ Cong, VIII, Paris 1900 , C R : 364365 (1901)

01a Report on the congress of geologists [eighth international geological congress]. In Report of the Commissioner-General for the United States to the International Universal Exposition, Paris, 1900, vol. 6: 198-204. U S, 56th Cong, 2d sess, S Doc no 232, Washington 1901

04 The Yellowstone National Park. Scribner's Mag 35: 513-528 (1904)

11 Origin of the thermal waters in the Yellowstone National Park. G Soc Am, B 22 : 103-122 (1911) Science $\mathrm{n}$ \& $33: 553-$ 568 (1911)

12 Geological history of the Yellowstone National Park. U S Dp Interior, 24 pp (1912)

12a Memoir of Samuel Franklin Emmons. G Soc Am, B 23:12-28, port (1912)

12b Biographical memoir of Samuel Franklin Emmons, 1841-1911. Nat Ac Sc, Biog Mem 7:307-334, port (1912)

See also Emmons (S F), 93; Frazer, $88 \mathrm{a}$; King (C), 71a, 80 ; Powell, 82, 83, $84,85,85 \mathrm{a}, 88,89,89 \mathrm{a}, 90,91,91 \mathrm{a}, 92$, 93,95

Hague, James Duncan.

70 Mining industry. U S G Expl 40 th Par (King), $3: x v, 647 \mathrm{pp}$, maps [in atlas] (1870) 
Hague, James Duncan-Continued.

87 Notes on the deposition of scorodite from arsenical waters in the Yellowstone National Park. Am J Sc (3) 34:171-175 (1887)

04 (and others) Clarence King memoirs. Published for the King Memorial Committee of the Century Association. 427 pp, port, N Y 1904

Hahn, Fritz Felix (1885-1914).

12 The form of salt deposits. Ec G 7 : 120-135 (1912)

$12 a$ On the Dictyonema fauna of Navy Island, N. B. N Y Ac Sc, An $22: 135-160$, il (1912)

$12 b$ E. O. Ulrich's "Revision der Paläozoischen Systeme" - ein Markstein der Stratigraphie als Wissenschaft? G Rundschau 3:544-556 (1912)

13 Untermeerische Gleitung bei Trenton Falls (Nordamerika) und ihr Verhältnis zu ähnlinchen Störungsbilders. N Jb, Bell Bd 36:1-41 (1913)

Hahn, Otto.

76 Giebt es ein Eozoon canadense? Eine mikrogeologische Untersuchung. Ver Vaterl Naturk Württemberg, Jahresh 32:132-155 $(1876) ; 34: 155-177$, il $(1878) ; 36: 71-74$ (1880) An Mag $\mathrm{N} H$ (4) $17: 265-282$ (1876)

Haines, Arthur L.

10 Some Devonian and Silurian fossils from northeastern Iowa. S Dak G S, B 4: 180-183 (1910)

Haines, Hiram.

72 Haines' report on the traffic resources of the South \& North Alabama Railroad. 40 pp, Montgomery, Ala., 1872 Haines, Mrs. Mary P.

79 List of fossils found in the Lower Silurian rocks in the vicinity of Richmond, Ind. Ind $G \mathrm{~S}$, An Rp 8-9-10:201-204 (1879)

Halberstadt, Baird.

03 Obituary, J. P. Lesley. Mines and Minerals $23: 556$, port (1903)

or Halberstadt's general map of the bituminous coal fields of Pennsylvania, 1907

10 The principal limestone deposits of Pennsylvania and their adaptability to the manufacture of Portland cement. Pa, Dp Ag, An Rp 15: 545-555 (1910)

14 The coals of the Pocono (No. $\mathbf{X}$ ) formation in Pennsylvania. Pa, Dp Agr, An Rp 19:404-408 (1914)

17 Memorial of Frank A. Hill. G Soc Am, B 28:67-70, port (1917)

Haldane, Wm. G.

ot (with Fleck, Herman) A study of the uranium and vanadium belts of southern Colorado. Colo $\mathbf{B}$ Mines, $\mathrm{Rp}$ 1905-6 : 47-115 (1907)
Haldeman, Samuel Stehman (1812$1880)$.

45 [On the Taconic system of Emmons (abst with discussion by H. D. Rogers and James Hall)]. As Am G, Pr 6:66-69 (1845)

47 [Description of Aeonia ebonina, Bedford Co., Pa.] Am J Agr 6:191-192 (1847)

47a Report on the supposed identity of Atops trilineatus Emmons with Triarthru beckii. Am J Agr 6:194-195 (1847) Am J Sc (2) 5:107-108 (1848)

Hale, C. S.

48 Geology of south Alabama. Am J \&C (2) $6: 354-363$ (1848)

51 Observations on the Gnathodon beds around the head of Mobile Bay. Am J Sc (2) $11: 164-174$ (1851)

Hale, David J.

03 Marl (bog lime)... Mich G S, 8 pt 3: $399 \mathrm{pp}$ (1903)

Hale, Fred A., Jr.

18 Ore deposits of the Yellow Pine min. Ing district, Clark Co., Nev, Am I M Eng, Tr 59:93-111 (1918); - B 134: 535-553 (1918); Eng M J 105:455-460 (1918)

18a Manganese deposits of Clark Co. Nev. Eng M J 105: 775-777 (1918)

Hale, John M.

65. Summary of the rocks in an old salt boring in Clearfield Co., $\mathrm{Pa} . \mathrm{Am} \mathrm{Ph} \mathrm{Soc,}$ Pr 9: 459-460 (1865)

Hale, Moses.

21 Geological notice of Troy [N. Y.]. Am J Sc 3:72-73 (1821)

Hale, P. M

83 In the coal and iron counties of North Carolina; a compilation from the geological reports of Drs. Emmons and Kerr... 425 pp, map, Raleigh 1883

Haley, D. F.

09 The auriferous antimony ore of West Gore, N. S. Eng M J 88:723-724 (1909)

18 Molybdenite operations at Climax, Colo. Am I M Eng, B 140:1183-1188 (1918)

Haliburton, R. G.

67 The coal trade of the new Dominion [map of the coal fields of Europe and America]. N S Inst $\mathrm{N}$ Sc, $\operatorname{Pr} \mathrm{Tr} 2 \mathrm{pt}$ 1 : 81-93, map (1867)

67a Explorations in the Pictou coal field. $\mathrm{N} S$ Inst $\mathrm{N}$ Sc, Pr Tr 2 pt 1:93-100, map (1867)

70 Explorations in the Pictou coal field in 1867 and 1868 . N S Inst N Sc, Pr Tr 2 pt $3: 155-164$ (1870)

Hall, Archibald A.

12 Analysis of a Florida clay. Durham Univ. Ph Soc, Pr $4: 228-229$ (1912) 
Hall, Benjamin M.

04 Water powers of Alabama, U S G S, W-S P $107: 253$ pp (1904)

Hall, Charles Edward.

76 Notes on glacial action visible along the Kittatinny or Blue Mountain, Carbon, Northampton, and Monroe cos., Pa. Am $\mathrm{Ph}$ Soc, Pr 14:620-621 (1876)

76a On glacial deposits at West Philadelphia. Am Ph Soc, Pr 14: 633-634, 647, map (1876)

76b On the...paleontological work of the Second Geological Survey of Pennsylvania, for the year 1875. Am Ph Soc, Pr 16: $55-60(1876)$

77 Contribution to paleontology from the Museum of the Second Geological Surrey of Pennsylvania. Am $\mathrm{Ph}$ Soc, $\operatorname{Pr} 16$ : 621-622 (1877)

78 Catalog of the geological museum, Part I; Collections of rock specimens. Pa G S, 2d, 0:217 pp (1878)

78 a Fossils colrected in Westmoreland Co., Pa. Am Ph Soc, Pr $17: 270$ (1878)

79 Laurentian magnetic 1ron ore deposits in northern New York. N Y St Mus, An Rp $32: 133-140$ (1879) [See also 85 a below ]

80 Catalog of the geological museum, Part II; Collections of rock specimens; paleontological specimens. Pa G S, 2d, $00: 272$ pp $(1880)$

$80 \mathrm{a}$ The relations of the crystalline rocks of eastern Pennsylvania to the Silurian limestones and the Hudson River age of the hydromica schists. $\mathrm{Am} \mathrm{Ph}$ Soc, $\mathrm{Pr}$ $18: 435-443$, map (1880)

81 The geology of Philadelphia Co., and of the southern parts of Montgomery and Bucks. Pa G S, 2d, C6: xx, $145 \mathrm{pp}$, map (1881)

83 Geology of the Chester Valley of Pennsylvania. Am Nat 17:646-648 (1883) 85 Field notes in Delaware Co. Pa G \$, 2d, C5 : xvi, 128 pp, map (1885)

$85 a$ Laurentian magnetic iron ore deposits of northern New York, accompanied by a geological map of Essex Co. N Y St G, An Rp 4:23-34, map (1885) [See also 79 above ]

86 (with Beecher, C. E.) Field notes on the geology of the Mohawk Valley. N I St G, An Rp 5:8-10, map (1886); 14: 54-56, map (1895)

86a (with Beecher, C. E., and Hall, J. W.) Note on the Oneonta sandstone in the ricinity of Oxford, Chenango Co, N. Y. N Y St G, An Rp 5: 11 (1886)

91 Notes on the manganese ore deposit of Crimora, Va, Eng M J 52:94 (1891) dm I M Eng, Tr 20:46-49 (1892)

03 Notes on a geological section from Iguala to San Miguel Totolapa, State of Guerrero, Mexico. Soc Clent Ant Alz, Mem $13: 327-335$ (1903)

See also Lesley, $83,83 a$
HaII, Charles Monroe (1870-1903).

03 (with Todd, J. E.) Description of the Alexandria quadrangle [S. Dak.]. U S G S, G Atlas Alexandria fol (no 100): 6 pp, maps (1903)

04 A brief history of glacial Lake Agassiz. N Dak, Agr Coll S, Bien Rp 2 : 27-30 (1904)

04a (with Todd, J. E.) Description of the De Smet quadrangle [S. Dak.]. U S G S, G Atlas De Smet fol (no 114): $6 \mathrm{pp}$, maps (1904)

04b (with Todd, J. E.) Geology and water resources of part of the lower James River valley, S. Dak. U S G S, W-S P 90 : 47 pp, maps (1904)

05 (and Willard, D. E.) Description of the Casselton and Fargo quadrangles [N. Dak.-Minn.]. U S G S, G Atlas Casselton-Fargo fol (no 117); $\boldsymbol{T}$ pp maps (1905)

Hall, Christopher Webber (1845-1911).

79 Field report. Minn G S, An Rp 7 : 26-29 (1879)

so Report [on the Lake Superior region]. Minn $G \mathrm{~S}$, An $\mathrm{Rp}$ 8:126-138 (1880)

SOa (with Peckham, S. F.) On lintonite and other forms of thomsonite, a preliminary notice of zeolites of the vicinity of Grand Marais, Cook Co., Minn. Am J Sc (3) $19: 122-130(1880)$

84 Physiographic conditions of Minnesota agriculture; a study in physical geography. A lecture delivered before the Minnesota State Horticultural Society... January $17,1884.15 \mathrm{pp}$ [1884]

89 A brief history of copper mining in Minnesota. Minn Ac N Sc, B 3:105-111 (1889) Abst, Minn, Univ, Q B 1:91 (1893)

89a The lithological characters of the Trenton limestone of Minneapolis and St. Paul, with a note on borings of the West Hotel artesian well. Minn Ac N Sc, B 3 : 111-124 (1889) Abst, Minn, Univ, Q B 1: 91 (1893)

89b The geological conditions which control artesian well boring in southeastern Minnesota. Minn Ac N Sc, B 3:128-143 (1889) Abst, Minn, Univ, Q B 1:90-91 (1893)

89e The distribution of the granites of the Northwestern States and their general lithologic characters (abst). Am $\mathbf{A s}, \mathrm{Pr}$ $37: 189-190 \quad(1889)$

91 [Notes on the Black Hills of South Dakota (abst)]. Minn Ac N Sc, B 3 : 185-186 (1891)

91 a The deep well at Minneopa, Minn. Minn Ac N Sc, B 3:248-250 (1891) Abst, Minn, Univ, Q B 1: 113 (1893)

91b Notes of a geological excursion into central Wisconsin. Minn Ac $\mathbf{N}$ Sc, B 3 : 251-268 (1891) Abst, Minn, Univ, Q B $1: 114$ (1893) 
Hall, Christopher Webber-Continued.

91e A notable dike in the Minnesota River valley (abst). Am As, Pr 39:263264 (1891)

91d Some of the conditions controlling successful artesian well boring in the Northwestern States (abst). Am As, Pr $39: 264-265$ (1891)

92 (and Sardeson, F. W.) Paleozoic formations of southeastern Minnesota (with discussion, pp 464-5), G Soc Am, B $3: 331-368$, map (1892) Abst, Am G 9:216 (1892); Minn, Univ, Q B 1:30 (1892)

93 The formation and deformation of Minnesota lakes. Science 21:314-315 (1893) Sc Am Sup 36:14625-14626 (1893) Abst, Minn, Univ, Q B 2:20-21 (1894)

95 (and Sardeson, F. W.) The mag. nesian series of the Northwestern States. G Soc Am, B 6:167-198, map (1895) Abst, Am J Sc (3) 46:303-304 (1893); Minn. Univ, Q B 2:19-20 (1894)

95a Mineral alterations in the granitic rocks of the Northwestern States (abst). Am As, Pr 43: 236 (1895)

97 Syllabus of general geology for students... $127 \mathrm{pp}$, Minneapolis 1897

98 Exploration for gold in the Central States. L Sup M Inst, Pr 49-60 (1898)

99 The gneisses, gabbro schists, and associated rocks of southwestern Minnesota. U S G S, B 157: 160 pp, maps (1899)

99a (and Sardeson, F. W.) Eolian deposits of eastern Minnesota. G Soc Am, B $10: 349-360$ (1899) Abst, Am G 23: 103 (1899) ; Science n s 9: 143 (1899)

99b Extent and distribution of the Archean in Minnesota (abst). Science $\mathrm{n} s$ 9: 412-413 (1899)

99e Distribution of the Keewatin in Minnesota. Science n s 10:107-110 (1899)

00 The Chengwatona series of the Keweenawan (abst). Am As, Pr 49:191 (1900) Science n s 12:994 (1900)

01 Keweenawan area of eastern Minnesota. G Soc Am, B 12:313-342, map (1901)

01a Keewatin area of eastern and central Minnesota. G Soc Am, B 12:343376, map (1901)

01b The geology of Minnesota. Int M Cong, 4th, Pr: 165-171 (1901)

O1e Sources of the constituents of Minnesota soils. Minn Ac N Sc, B 3:388406 (1901)

02 Minnesota-a sketch. J Geog 1: 241-249 (1902)

03 The geography and geology of Minnesota; Volume I, Geography of Minnesota. 299 pp, Minneapolis 1903

O3a The geology of Minnesota. Mines and Minerals $23: 532-534$ (1903)
Hall, Christopher Webber-Continued. 04 [Notes on water resources of] $\mathrm{x}$ nesota. U S G S, W-S P 102:441-bi (1904)

o5 [Underground waters of] Minnesc U S G S, W-S P 114: 226-232 (1905)

O5a The structure, lithology, and gos sis of the magnesian series of the Nort western States $(a b s t)$. Minn Ac N Sc, 4:119-123 (1905)

06 Some geological features of the $\mathrm{y}$. nesota Seaside Station [Vancouver Islasi] Postelsia, Yb Minn Seaside Station [? 305-347 St. Paul, Minn., 1906

os The red sandstone series of soth eastern Minnesota (abst). Science ns?: 722 (1908)

11 The material conditions of a munit pal water supply [underground waters th Minneapolis and St. Paul, Minn.] (ober Science n \& $33: 468-469$ (1911)

$11 a$ (and Meinzer, O. E., and Fuller M. L.) Geology and underground water of southern Minnesota. U S G S, W. 256: $406 \mathrm{pp}$, maps (1911)

See also Sardeson, 01a

Ha11, E. B.

16 (and Ambrose, A. W.) Descth tions of new species from the Cretaces and Tertiary of the Tesla, Pleasanton, Su Jose, and Mt. Hamilton quadrangles, C. Nautilus $30: 68-71,77-82$ (1916)

Ha11, Frank Henry.

93 Ancient gravels, Siskiyou Co. [Cal], M Sc Press 66:85 (1893)

Hall, Frederick (1780-1843).

21 Notice of iron mines and manular tures in Vermont and of some localities of earthy minerals. Am J Sc $4: 23-5$ (1821)

21 a Notice of ores of iron and mant nese, and of yellow ochre in Vermont. It J Sc 3:57-58 (1821)

23 ... curious water fall and of excar tions in the rocks [Vermont]. Am J Sc6 252-254 (1823)

24 Catalog of minerals found in the State of Vermont and in the adjacent States... 44 pp, Hartford 1824

36 A synopsis of a course of lecture on mineralogy; delivered at the Medical College, Washington, in the winter of 1835-6. 24 pp, Washington 1836

Ha11, James (1811-1898).

37 Ores of iron [of the second geologicl district of New York]. N Y G S, An Ri 1:127-149 (1837)

37a Descriptions of two species of trilo bites, belonging to the genus Paradoxide Am J Sc 33: 139-142, il (1837)

38 Second annual report of the fourth geological district of New York. N Y G 8 An Rp 2: 287-374 (1838)

39 Third annual report of the fouth geological district of the State of Ner York. N Y G S, An Rp 3: 287-339 (1839) 
Hall, James - Continued.

40 Fourth annual report of the survey of the fourth geological district [of New York]. N Y G S, An Rp 4:389-456 (1840)

41 Fifth annual report of the fourth geological district [of New York]. N Y G S, An Rp 5:149-179 (1841)

42 Niagara Falls; their physical changes and the geology and topography of the surrounding country. Boston J N H 4:106$134(1842)$

$42 a$... geology of the Western States. Am J Sc 42:51-62 (1842)

43 Geology of New York. Part IV, comprising the survey of the fourth geological district. 683 pp, il, map, Albany 1843

43n Communication from Mr. James Hall, one of the State geologists [on the condition of the geological survey]. N Y Legislature, Documents of the Senate, 66th sess, vol 2 no $59: 9 \mathrm{pp} \mathrm{(1843)}$

$43 b$ Geological map of the middle and western States [Hudson River to Mississippi River]. N Y [1843]

43e Notes explanatory of a section from Cleveland, Ohio, to the Mississippl River in a southwest direction; with remarks upon the identity of the western formations with those of New York. As Am G, Pp : $267-293$ (1843)

43d Remarks upon casts of mud furrows, wave lines, and other markings upon rocks of the New York system. As Am G, Rp : 422-432 (1843)

43e On wave lines and casts of mud furrows $(a b s t) . \quad \mathrm{Am} \quad \mathrm{J}$ Sc $45: 148-149$ (1843)

$43 f$ On the geographical distribution of fossils in the older rocks of the United States (with discussion). Am J Se 45: 157-160, 162-163 (1843)

$43 \mathrm{~g}$ [Section on the shore of Lake Erie (abst)]. Am J Sc 45:327-328 (1843)

43h Sections at Portage, New York (abst). Am J Sc 45:329-330 (1843)

43i [Galciated cherty limestone from bear Niagara, N. Y. (abst with discussion)]. Am J Se $45: 332$ (1843)

$43 \mathrm{j}$ (and others) [Discussion on drift phenomena.] Am J Se 45:332-333 (1843) 43k [Geology of the region of Niagara Falls (abst).] Boston Soc N H, Pr 1:52 (1843)

431 (with Emmons, E.) Communication from Messrs. Emmons and Hall, State geologists [on the geological survey]. N Y Legislature, Documents of the Senate, $66 \mathrm{th}$ sess, vol 2 no $60: 9$ pp (1843)

44 An address delivered before the Soclety of Natural History of the Auburn Theological Seminary...August 15, 1843. 20 pp, Auburn 1844

$44 \mathbf{n}$ The geological survey of New York. N Y St Agr Soc, Tr $3: 241-277$, il (1844)
Ha11, James-Continued.

44b Observations on Brachiopoda and Orthocerata (abst). Am J Sc 47:109 (1844)

44e On the geographical distribution of fossíls in the Paleozoic strata of the United States (abst). Am J Sc 47:117-118 (1844)

45 Nature of the geological formations occupying the portion of Oregon and North California included in a geographical survey under the direction of Captain Fre mont. In Fremront, J. C., A report of the exploring expedition to Oregon and North California in the years 1843-14; U S, 28th Cong 2d sess, S Ex Doc 174: 295-303 (1845) ; H Ex Doc 166:295-303 (1845)

45 a Descriptions of organic remains collected by Captain J. C. Frémont, in the geographical survey of Oregon and North Carolina. In Frémont, J. C. A report of the exploring expedition to Oregon and north Callfornia in the years 1843-44; U S, 28th Cong 2d sess, S Ex Doc 174: $304-310$, il $(1845)$; H Ex Doc 116:304310 , il (1845)

$45 \mathrm{~b}$ Nature of the strata and geographical distribution of the organic remains in the older formations of the United States. Boston J N H 5:1-20 (1845)

45e Description of some microscopic shells from the decomposing marl slate of Cincinnati. Am J Sc 48:292-295 (1845)

45d Fossil vegetables and shells from Oregon (abst). As Am G, Pr 6:66 (1845)

46 Notice of the geological position of the cranium of the Castoroides ohioensis. Boston J N H 5:385-391 (1846)

46a [On a deposit at Clyde, N. Y., containing a cranium of Castoroides ohioensis.] Boston Soc $\mathrm{N} \mathrm{H}$, Pr 2:167-168 (1846)

47 Descriptions of the organic remains of the lower division of the New York system. Pal N Y 1:338 pp, il (1847)

$47 a$...on certain fossils in the red sand-rock of Highgate [Vt.]. In Adams, C. B., Third annual report on the geology of the State of Vermont: 31 (1847)

48 Catalogue of specimens in the geological department of the geological survey [of New York]. N Y St Cab, An Rp 1: 39 pp (1848)

48a Catalogue of specimens in the paleontological department of the geological survey [of New York]. N Y St Cab, An Rp 1:15 pp (1848)

48b Upon some of the results of the paleontological investigations in the State of New York. Am J Sc (2) $5: 243-249$ (1848)

48e Remarks on the observations of S. S. Haldeman "on the supposed identity of Atops trilineatus with Triarthrus beckii." Am J Se (2) $5: 322-327$, il (1848) 
Hall, James-Continued.

49 List of minerals, geological specimens, and fossils, added to the collection during 1847 and 1848 . N Y St Cab, An Rp $2: 65-70$ (1849)

49a On the supposed impression in shale of the soft parts of Orthoceras. G Soc London, Q J 5:107-111, il (1849)

50 Description of new species of fossils, and observations upon some other species, previously not well known, from the Trenton limestone. N Y St Cab, An Rp 3: 173-183, il (1850)

$50 a$ on the trails and tracks in the sandstones of the Clinton group of New York ... Am As, Pr 2:256-260 (1850)

50b On the Brachiopoda of the Silurian period; particularly the Leptaenidae. Am As, $\operatorname{Pr} 2: 347-351$ (1850)

50e on graptolites, their duration in geological periods, and their value in the identification of strata. Am As, Pr 2: 351-352 (1850)

51 Catalogue of specimens of the rocks and fossils in the gray sandstone, Medina sandstone, Clinton group, Niagara group, Onondaga salt group, and a part of the Water-Lime group ... $\quad$ N $\quad$ Y St Cab, An Rp 4:117-146 (1851)

51 a Report [on the preparation of volumes illustrating the paleontology of New York]. N Y, Legislature, S Doc no 32:9 pp [Albany 1851]

51b Lower Silurian system; Upper Silurian and Devonian series. In Foster, J. W., and Whitney, J. D., Report on the geology of the Lake Superior land district, pt 2 (U S, 32 d Cong spec sess, S Ex Doc 4) : 140-166 (1851) Am J Se (2) 17 : 181-194 (1854)

51e Description of new or rare species of fossils from the Paleozoic series. In Foster, J. W., and Whitney, J. D., Report on the geology of the Lake Superior land district, pt 2 (U S, 32nd Cong spec sess, S Ex Doc 4) : 203-231, il (1851)

51d Parallelism of the Paleozoic deposits of the United States and Europe. In Foster, J. W., and Whitney, J. D., Report on the geology of the Lake Superior land district, pt 2 (U S, 32nd Cong spec sess, S Ex Doc 4) : 285-318 (1851)

51e New genera of fossil corals. Am J Sc (2) 11:398-401 (1851)

512 [Discussion of paper, On the Silurian rocks of the Lake Superior land district, by Prof. Jas. Hall.] Am As, $\operatorname{Pr} 5$ : 64-66 (1851)

52 Descriptions of the organic remains of the lower middle division of the New York system. Pal N Y 2:362 pp, il (1852)
Hall, James - Continued.

52a A chart giving an ideal section of the successive formations, with an actual geological section from the Atlantic to the Pacific ocean, the whole illustrated by the characteristic fossils of each formation. 58 x 71 inches, Albany, N. Y. [1852]

52b Key to a chart of the successive geological formations, with an actual section from the Atlantic to the Pacific ocean, illustrated by the characteristic fossils of each formation, $72 \mathrm{pp}$, Boston 1852 [see also Hall, 52a]

52e Geology and paleontology. In Stans. bury, Howard, Exploration and survey of the valley of the Great Salt Lake of Utah, including a reconnaissance of a new route through the Rocky Mountains (U S, 32nd Cong spec sess, S Ex Doc 3) : 399-414, il, Phila 1852 [another ed, with different title page, 1855]

52d Comparison of the geological fea. tures of Tennessee with those of the State of New York. Am As, Pr 6:256-259 (1852)

52e [Geological investigation on Drum. mond's Island and the north shore of Lakes Huron and Michigan.] Am Ac Arts, Pr 2: 253-254 (1852)

54 (with Lyell, Charles) Rappert sur la partie géologique de l'exposition de New York. An Mines (5) 6:1-83 (1854)

55 Notes on some fossils of the so-called Taconic system described by Doctor Emmons. Am J Sc (2) 19:434-435 (1855)

55a The Mauvaises Terres [Bad Lands, Nebr.]. Can J 3:357 (1855)

56 Descriptions and notices of the fos sils collected upon the route [Whipple's reconnaissance near the thirty-fifth par allel]. U S, Pacific R R Expl (U S, $33 d$ Cong $2 \mathrm{~d}$ sess, $\mathrm{S} \mathrm{Ex}$ Doc 78 and $\mathrm{H} \mathrm{Ex}$ Doc 91) 3 pt $4: 99-105$, il (1956)

56a (and Meek, F. B.) Descriptions of new species of fossils from the Creta. ceous formations of Nebraska, with observations upon Baculites ovatus and $B$. compressus, and the progressive development of the septa in Baculites, Ammonites, and Scaphites. Am Ac Arts, Mem n 8 $5: 379-411$, il (1856)

56b On the genus Tellinomya and allied genera. Can Nat 1:390-395, il (1856) N Y St Cab, An Rp 10:181-186, il (1857)

57 Descriptions of Paleozoic fossils... N Y St Cab, An Rp $10: 39-180$, il (1857)

57a Geology and paleontology of the boundary. In Emory, W. H., Report of the United States and Mexican boundary survey... (U S, 34th Cong 1st sess, S Es Doc 108 and $\mathrm{H}$ Ex Doc 135), v 1 pt 2 : 101-140, map (1857) Pp 126-138, 0bservations upon the Cretaceous strata of the United States..., reprinted in $\mathrm{Am} \mathrm{J} \mathrm{Sc}$ (2) $24: 72-86$ (1857) 
Hall, James-Continued.

57b (assisted by Lesley, J. P.) Map fllustrating the general geological features of the country west of the Mississippi Birer. [1857]

57e Direction of the currents of deposition and source of the materials of the older Paleozoic rocks (abst). Can Nat 2:284-286 (1857) Can J n $\mathrm{s} \quad 3: 88$ (1858) Edinb $\mathrm{N} \quad \mathrm{Ph} \quad \mathrm{J} \quad \mathrm{n} \quad \mathrm{s} \quad 6: 348-349$ (1857)

57d Observations upon the Carboniferous limestones of the Mississippi Valley (abst). Am J Sc (2) 23:187-203 (1857) Am As, Pr 10 pt 2:51-69 (1857) M Mag 9:529-542 (1857)

57e Remarks upon the genus Archimedes or Fenestella from the Carboniferous limestones of the Mississippi Valley. Am As, Pr 10 pt $2: 176-180$ (1857) Am J Sc (2) $23: 203-204$ (1857)

$57 f$ on some points in the geology of the upper Mississippi Valley $(a b s t)$. Edinb $\mathrm{N}$ Ph J n s $5: 362$ (1857)

57g [Comments on Prof. Gibbes' paper on Niagara Falls.] Am As, Pr 10 pt 2: 76-78 (1857)

$5 s$ (and Whitney, J. D.) Report on the geological survey of the State of Iowa, embracing the results of investigations made during... 1855, $56 \& 57$. Vol 1 pt 1 Geology: xv, 472, 4, 4 pp, map; pt 2 Paleontology : 473-724, 3, $30 \mathrm{pp}$, il [A]bany, $\mathrm{N}$ Y] 1858

58a Report. In Report of the commissioners of the geological survey [of Wisconsin] : 3-5. Madison 1858

58b Report [on Canadian graptolites]. Can G S, Rp Prog 1857: 109-145 (1858)

58e Note upon the genus Graptolithus, and description of some remarkable new forms from the shales of the Hudson River group... Can Nat $3: 139-150,161-177$, il (1858) Abst, Am J Sc (2) 26:117-119 (1858)

58d Crinoids of New York [in advance of Palenotology of New York, vol. 3]. Am J Se (2) $25: 276-279$ (1858)

59 Descriptions and figures of the organic remains of the Lower Helderberg group and the Oriskany sandstone. N Y G S, Pal 3:532 pp, il [p's vol] (1859)

59a Notice of the genera Ambanychia, Palaearca, and Megambonia. N Y St Cab, An Rp 12:8-14, il (1859)

$59 b$ Observations on the genera Capulus, Pileopsis, Acroculia, and Platyceras. N Y 8t Cab, An Rp 12:15-19, il (1859)

59e Observations on the genera Platyostoma and Strophostylus. N Y St Cab, An Rp $12: 20-21$, il (1859)

59d Observations on the genus Nucleoopira. N Y St Cab, An Rp 12:24-26, il (1859)
Hall, James-Continued.

59e [Observations on genera of Brachiopoda.] N Y St Cab, An Rp 12:27-44, ll (1859)

59f Notes upon the genus Graptolithus. N Y St Cab, An Rp 12:45-58, il (1859)

$59 \%$ Trilobites of the shales of the Hudson River group. N Y St Cab, An Rp 12 : 59-62, il (1859)

$59 \mathrm{~h}$ Catalogue of the species of fossils... of New York. N Y St Cab, An Rp 12: 63-96 (1859)

59i Supplementary note on the genus Ambonychia. N Y St Cab, An Rp 12: 110 , il (1859)

$59 j$ Contributions to the paleontology of Iowa; being descriptions of new species of Crinoidea and other fossils. Iowa G S 1 pt 2 Sup: 94 pp, il [Albany] 1859

59k New American trilobites [from Hudson River group of Vermont]. Can $\mathrm{J} n \mathrm{~s}$ $4: 491-493$ (1859)

60 Notices of new forms of the genus Graptolithus, and allied genera. $\mathrm{N}$ Y St Cab, An Rp 13: 55-64, il (1860)

60a [Observations on Brachiopoda.] N Y St Cab, An Rp 13:65-75, il (1860)

601 Descriptions of new species of fossils, from the Hamilton group of western New York, with notices of others from the same horizon in Iowa and Indiana. N Y St Cab, An Rp 13: 76-94, il (1860)

60c Notes and observations upon the fossils of the Goniatite limestone in the Marcellus shale of the Hamilton group in... New York and those of the Goniatite beds of Rockford, Ind.; with some analogous forms from the Hamilton group proper. N Y St Cab, An Rp 13:95-112, 125, il (1860)

60d Note upon the tribolites of the shales of the Hudson River group in the town of Georgia, Vt. N Y St Cab, An Rp 13:113119 , il (1860) Report on the geology of Vermont (Hitchcok) 1: 367-372 (1861)

60e New species of fossils from the Hudson River group of Ohio and other Western States. N Y St Cab, An Rp 13: 119-121, il (1860)

60f Observations upon a new genus of Crinoidea, Cheirocrinus. N Y St Cab, An Rp 13:121-124, il (1860)

$\mathbf{6 0 g}$ New species of fossils from the Niagara group of Wisconsin. Report of Progress for 1859 . $4 \mathrm{pp}$. Albany 1860 [not seen]

60h Report... in relation to the geological survey of the State of Iowa... $15 \mathrm{pp}$, Des Moines, Iowa, 1860 Also in Iowa, Legislative documents, 1859-60 [not seen]

60i Descriptions of new species of fossils from the Silurian rocks of Nova Scotia. Can Nat $5: 144-159$, il (1860) 
Hall, James - Continued.

60j On the formation of mountain ranges (abst). Can $\mathbf{J}$ n $\mathbf{s} 5: 542-544$ (1860)

61 ... fossils from the rocks of Hudson River group of Ohio and the Western States; with descriptions, N Y St Cab, An Rp 14: 89-92 (1861)

61 Note on the genera Bellerophon, Bucania, Carinaropsis, and Cyrtolites. N Y St Cab, An Rp 14:93-98 (1861)

$61 b$ Descriptions of new species of fossils from the Upper Helderberg. Hamilton, and Chemung groups. N Y St Cab, An Rp 14: 99-109 (1861)

61e Report of the superintendent of the Geological Survey, exhibiting the progress of the work, January 1, 1861 [including Descriptions of new species of fossils from the investigations of the Survey]. $52 \mathrm{pp}$, Madison 1861

61d Descriptions of new species of Crinoidea; from investigations of the Iowa Geological Survey. Preliminary notice. $19 \mathrm{pp}$, Albany 1861

61e Descriptions of new species of Crinoidea from the Carboniferous rocks of the Mississippi Valley. Boston J N H 7 : 261328 (1861)

61f [On the Primordial fauna and Point Levis, Quebec, fossils.] Am J Sc (2) 31 : 220-226 (1861) Can Nat 6:113-120 (1861) Can J n \& 6:284-292 (1861) Report on the geology of Vermont (Hitchcock) $1: 382-386$ (1861)

$61 \mathrm{~m}$ New species of Orthoceras [hageri]. In Report on the geology of Vermont (Hitchcock) 2:718, il (1861)

62 ... descriptions of new species of fossils from the Upper Helderberg, Hamil ton, and Chemung groups. N Y St Cab, An Rp 15:29-80 (1862) [Advance pub 1861]

62a. [On the position of the goniatite beds of Rockford, Ind.] N Y St Cab, An Rp 15: 81 (1862)

62b Preliminary notice of the trilobites and other Crustacea of the Upper Helderberg, Hamilton, and Chemung groups. N Y St Cab, An Rp 15:82-113 (1862) [Advance pub 1861]

62e Preliminary notice of some of the species of Crinoidea known in the Upper Helderberg and Hamilton groups of New York. N Y St Cab, An Rp 15:115-153, il (1862)

62d Observations upon a new genus of Brachiopoda. N Y St Cab, An Rp 15: 154-155, il (1862)

62e Observations on the genera Athyris (=Spirigera), Merista, Camarium, and Meristella. N Y St Cab, An Rp 15:176181 , il $(1862)$

62f Descriptions of new species of fossils, chiefly from the Hamilton group of western New York. N Y St Cab, An Rp $15: 181-191$, il (1862)
Hall, James - Continued.

$62 \mathrm{~g}$ Note on the genus Cypricardites N Y St Cab, An Rp 15: 192-193, il (1869)

62h [Illustrations of Conrad's speries Annual report 1841.] N Y St Cab, An Rp $15: 194$, il (1862)

62i Notes and corrections. N Y St Cab, An Rp 15: 195-197 (1862)

62j (and Whitney, J. D.) Report of the geological survey of the State of Wis. consin. Volume I. $455 \mathrm{pp}$, maps [Albany, N. Y.] 1862 [Whitney's part also issued separately. See Whitney, 62]

62k Paleontology of Wisconsin: remarks upon the condition of the fossils in the rocks of the several formations; cata. logue of fossils known in the Paleozole formations of Wisconsin, with observations upon some of the known species and de scriptions of several new forms. In Report of the geological survey of the State of Wisconsin, vol. I : 425-442 (1862)

621 [Sur la faune primordiale en Amér. que.] Soc G France, B (2) 19:725-734 (1862)

$62 \mathrm{~m}$ On the Catskill group of Ner York. Can Nat $7: 377-381$ (1861)

$62 n$ On a new crustacean from the Pots dam sandstone [Aglaspis, Wisconsin.] Can Nat $7: 443-445$, il (1862) Abst, Am J Sc (2) $35: 295 \quad(1863)$

620 On the Taconic system of Dr. Emmons. Am Ph Soc, Pr 9:5-7 (1862)

62p ... on the Potsdam sandstone and Hudson River rocks in Vermont. Am J Sc (2) $33: 106-108$ (1862)

62q ... rejoinder to eriticisms ... on his Contributions to paleontology. Am J Sc (2) $33: 127-132$ (1862)

63 Descriptions of new species of Brach iopoda from the Upper Helderberg, Hamilton, and Chemung groups. N Y St Cab, An Rp 16:19-37 (1863)

63n Observations upon some of the Brachiopoda, with reference to the characters of the genera Cryptonella, Centro. nella, Meristella, Trematospira, Runchospira, Retzia, Leptocoelia, and allied forms N Y St Cab, An Rp 16:38-59, il (1863)

631, Note on the genus Leptocoelia. N Y St Cab, An Rp 16:59-61, il (1863)

63e Observations upon the genus Strep. torhynchus, with remarks upon some spe cies heretofore referred to the geners Strophomena and Orthis. N Y St Cab, AD Rp 16:61-66, il (1863)

63d Note on the geological range of the genus Receptaculites in American Paleozoic strata. N Y St Cab, An Rp 16:6i-69 (1863)

63e Note on the occurrence of Astylo. spongia in the Lower Helderberg rocks. N Y St Cab, An Rp 16:69-70 (1863) 
Hall, James - Continued.

$63 f$ On the occurrence of crustacean remains of the genera Ceratiocaris and $D i$ thyrocaris, with a notice of some new spedes from the Hamilton group and Genesee slate. N Y St Cab, An Rp 16:71-75, il (1863)

63g Observations upon some spiralgrowing fucoidal remains of the Paleozoic rocks of New York. N Y St Cab, An Rp $16: 76-83$, il (1863)

63h Observations upon the genera Uphantaenia and Dictyophyton; with notiees of some species from the Chemung group of New York, and the Waverly sandstone of Ohio. N Y St Cab, An Rp 16: 84-91, il (1863)

63i The flora of the Devonian period. N Y St Cab, An Rp 16:92-118, il (1863)

63j ...fauna of the Potsdam sandstone... of the upper Mississippi Valley. N Y St Cab, An Rp 16:119-222, il (1863) Albany Inst, $\operatorname{Tr} 5: 93-195$, il (1867)

63k Notes and corrections. N Y St Cab, An Rp 16:223-226 (1863)

631 Observations upon some of the Brachiopoda, with reference to the genera Cryptonella, Centronella, Meristella, ani allied forms. Albany Inst, Tr 4: 125-148, il (1864) Am J Sc (2) $35: 396-406 ; 36$ : 11-15, il (1863)

64 Preliminary notice of some species of Crinoldea from the Waverly sandstone series of Summit Co., Obio, supposed to be of the age of the Chemung group of New York, N Y St Cab, An Rp 17:50-60 (1864)

64a [Remarks on the Catskill group.] Albany Inst, Tr 4: 307-308 (1864)

$64 \mathbf{b}$ Notice of some new species of fossils from a locality of the Niagara group, in Indiana; with a list of identified species from the same place. Albany Inst, Tr 4: 195-228 (1864)

64e Description of new species of fossils from the Carboniferous limestones of Indiana and Illinois. Albany Inst, $\operatorname{Tr} 4: 1$ 36 (1864)

64d (and Logan, W. E.) On the geology of eastern New York. Can Nat A 8 1:368-369 (1864) Am J Se (2) 39: $96-97$ (1864)

65 Figures and descriptions of Canadian organic remains; Decade II, Graptolites of the Quebec group. Can G S: 151 pp, il (1865)

65a. On the graptolites of the Quebec group. Can Nat n s 2: $42-53$ (1865)

$65 \mathrm{~b}$ On the occurrence of an internal convoluted plate within the body of certain specles of Crinoidea. Boston Soc N H, Pr 10:33-34 (1865) An Mag N H (3) $17: 398-399$ (1866)
Hall, James-Continued.

66 Descriptions of some new species of Crinoidea and other fossils from the Lower Silurian strata of the age of the Hudson River group and Trenton limestone. $17 \mathrm{pp}$. Printed in advance from the Report of the State Cabinet for 1866. Albany, $1866 \mathrm{~N}$ Y St Mus, An Rp 24: 205-224 (1872)

66a Observations on some species of Spirifera. Am Ph Soc, $\mathrm{Pr}$ 10:246-254 (1866) Pal N Y 4:251-257 (1867)

67 Descriptions and figures of the fossil Brachiopoda of the Upper Helderberg, Hamilton, Portage, and Chemung groups. N Y G S, Pal 4: 428 pp, il (1867)

$67 \mathbf{a}$ Notice of volume IV of the Paleontology of New York. N Y St Cab, An Rp 20:145-168, il (1867)

$\mathbf{6 7 b}$ Introduction to the study of the Graptolitidæ. N Y St Cab, An Rp 20: $169-240$, il (1867)

67e [Observations on genera of Brachiopoda.] N Y St Cab, An Rp 20:241-281, il (1867)

67d [Notes on Paleaster and other Echinodermata.] N Y St Cab, An Rp 20: $282-304$, il (1867)

67e Account of some new or little known species of fossils from rocks of the age of the Niagara group. N Y St Cab, An Rp 20:305-401, il (1867) [Rev ed, 1870]

67f On the geological structure of the southern part of Minnesota (abst). Can Nat n s 3:120-121 (1866) [1867]

$67 \mathrm{~g}$ On the geological relations of the mastodon and fossil elephant of North America (abst), Am Nat 1:500 (1867)

68 Report on building stones. 68 pp. Albany, N. Y., 1868

69 Geological history of the North American continent; a lecture delivered before the American Institute in New York. 24 pp, Albany 1869

69 Notes upon the geology of some portions of Minnesota, from St. Paul to the western part of the State. Am Ph Soc, Tr n s 13:329-340 (1869)

$69 b$ (with Logan, W. E.) Geological map of Canada ... [and of adjacent parts of the United States]. Scale 1:1,584,000. Can G S 1866 [1869] Notice, Am J Sc (2) $49: 394-398$ (1870)

70 On the relations of the Oneonta sandstone and Montrose sandstone of Vanuxem with the Hamilton and Chemung groups (abst). Am Nat 4:563-565, 639-640 (1870)

70a Recent progress in geology (abst). Albany Inst. Tr 6: 291-294 (1870)

71 Notes and observations on the Cohoes [N. Y.] mastodon. N Y St Cab, An Rp 21: 99-128 (1871) 
Hall, James-Continued.

$\boldsymbol{7 1 a}$ [Report on the] geological survey of the State of Wisconsin, 1859-1863. Paleontology, Part Third. Organic remains of the Niagara group and associated limestones. $94 \mathrm{pp}$, il, Albany 1871 [See also 67e]

71b On the fossil bivalve shells of the Upper Helderberg, Hamilton, Portage, and Chemung groups (abst). Albany Inst, $\mathrm{Pr}$ $1: 125-127$ (1871)

71e [On fossil trees from Gilboa, Schoharie Co., N. Y.] Albany Inst, $\operatorname{Pr} 1$ : 129-131, 132-134 (1871)

72 (and Whitfield, R. P.) Description of new species of fossils from the vicinity of Louisville, Ky., and the Falls of the Ohio. N Y St Mus, An Rp 24:181-200 (1872)

72n (and Whitfield, R. P.) Remarks on some peculiar impressions in sandstone of the Chemung group, N. Y. N Y St Mus, An Rp 24: 201-204, il (1872)

$\mathbf{7 2 b}$ Description of new species of fossils from the Hudson River group, in the vicinity of Cincinnati, Ohio. N Y St Mus, An Rp 24:225-232, il (1872) [Advance print 1871]

72e Reply to a "Note on a question of priority." Am J Sc (3) 4:105-109 (1872)

72d on the occurrence of trunks of Psaronius in an erect position, resting on their original bed, in rocks of the Devonian age in the State of New York ... (abst). Brit As, Rp 42: sec 103 (1872)

72e On the occurrence of trunks of Psaronius in an erect position resting on their original bed, in rocks of Devonian age in the State of New York ... G Mag $9: 463-465$ (1872)

72f On the relations of the middle and upper Silurian (Clinton, Niagara, and Lower Helderberg) rocks of the United States. G Mag 9:509-513 (1872) Abst, Brit As, Rp $42: \sec 103-104$ (1873)

73 (and Whitfield, R. P.) Descriptions of new species of fossils from the Devonian rocks of Iowa. N Y St Cab, An Rp 23: 223-239 (1873)

73a (and Whitfleld, R. P.) Notice of three new species of fossil shells from the Devonian of Ohio. N Y St Cab, An Rp $23: 240-241$ (1873)

73b (and whitfield, R. P.) Notice of two new species of fossil shells from the Potsdam sandstone of New York. N Y St Cab, An Rp 23 : 241-242 (1873)

73e [Note on Trematis.] $\mathrm{N}$ Y St Cab, An Rp 23: 243 (1873)

73d Notes on some new or imperfectly known forms among the Brachiopoda, etc. N Y St Cab, An Rp 23: 244-247 (1873)

74 Record of borings of Gardner oil well No. 3 at East Shamburg, Pa. N Y St Mus, An Rp 26: 31-33 (1874)

74a Descriptions of Bryozoa and corals of the Lower Helderberg group. N Y St Mus, An Rp 26:93-116 (1874)
Ha11, James - Continued.

$\mathbf{7 4 b}$ On the relations of the Niagara and Lower Helderberg formations, and theit geographical distribution in the United States and Canada. Am As, Pr 22 pt 2: 321-335 (1874) N Y St Mus, An Rp 27; 117-131 (1875) Abst, Can Nat n s 7: 157-159 (1874)

75 Descriptions of new species of Go niatitidae, with a list of previously de seribed species. N Y St Mus, An $\mathbb{B p}_{\mathrm{p}}$ $27: 132-136$ (1875)

75a (and Whitfield, R. P.) Descriptions of invertebrate fossils, mainly from the Silurian system. Ohio G S, Rp 2 pt ? Paleontology : 65-157, il (1875)

75b (and Whitfield, R. P.) Crinoids of the Genesee slate and Cheming group. Ohio G S, Rp 2 pt 2 Paleontology: 158161, il (1875)

75e ( $\operatorname{an}_{\mathrm{d}}$ Whitfield, R. P.) Crinoides of the Waverly group. Ohio G S, Rp ? pt 2 Paleontology: 162-179, il (1875)

z5d Report [on Hoosac tunnel]. Is Boston, Hoosac Tunnel, and Western Rail. road Company, Report of the Corporatos (Mass., H Doc no 9), Appendix: ili-rxir Boston 1875

76 The fauna of the Niagara group, in central Indiana. N Y St Mus, An Rp 28: 99-203, il [doc ed, without text, 1876] (1879)

76a Illustrations of Devonian fossils; corals of the Upper Helderberg and Ham ilton groups. N Y G S, Pal : 39 pls and expl (1876)

76b Note upon the geological position of the serpentine limestone of northen New York and an inquiry regarding the relations of this limestone to the Eoroon limestones of Canada $(a b s t)$. Am J Sc (3) $12: 298-300$ (1876)

76e On the geology of the souther counties of New York and adjacent parts of Pennsylvania, especially with reference to the age and structure of the Catskill Mountain Range (abst). Am As, Pr 24 pt $2: 80-84$ (1876) Am J Sc (3) 12 300-304 (1876)

77 (and Whitfield, R. P.) Paleottology. U S G Expl 40th Par (King), $4: 197-302$, il (1877)

78 Note on the genus Plumalina. N I St Mus, An Rp $30: 255-256$, il (1878)

78a Note upon the history and value of the term Hudson River group in Ameri. can geological nomenclature. $\mathrm{Am} \mathrm{As}, \mathrm{Pt}$ 26: 259-265 (1878)

78b [Geology of the Catskill regiot, N. Y.] Albany Inst, Pr $2: 126-130,213-$ 217 (1878)

78c [Observations on the geological structure of Marthas Vineyard and adjs. cent islands, Mass.] Albany Inst, Pr 2: 148-149 (1878)

78d On the geology of the Au Sable te gion. Albany Inst, $\operatorname{Pr} 2: 247-250$ (1878) 
Hall, James-Continued.

79 Descriptions of the Gastropoda, Pteropoda, and Cephalopoda of the Upper Helderberg, Hamilton, Portage, and Chemung groups. N Y G S, Pal 5 pt 2:xv, 492 pp, il [pls vol] (1879)

79a Notice of some remarkable crinoidal forms from the Lower Helderberg group. N Y St Mus, An Rp 28: 205-210, il (1879)

$79 \mathrm{~b}$ Corals and bryozoans of the Lower Helderberg group. N Y St Mus, An Rp 32:141-176 (1879)

79e The hydraulic beds and associated limestones at the Falls of the Ohio. Albany Inst, Tr $9: 169-180$ (1879)

so Sur la nomenclature des terrains paléozoïques aux Etats-Unis. Int $\mathrm{G}$ Cong, Paris 1878, C R: 60-67, (1880)

soa Note upon the relations of the Oneonta and Montrose sandstones of Vanuxem, and their relation to the sandstones of the Catskill Mountains. Science (ed, Miehels) $1: 290(1880)$

82 Memorial [in re Paleontology of New York] to the legislature of the State of New York. N Y, Senate Doc No 80, 5 pD (1882) [See also N Y Senate Doc No. 88, 17 pp (1882)

s2a Descriptions of the species of fossils found in the Niagara group at Waldron, Ind. Ind, Dp $\mathrm{G} N \mathrm{~N}, \mathrm{An} \mathrm{Rp} 11$ : $217-345$, il (1882)

83 [Second annual] report of the State geologist for the year 1882. N Y, Assembly Doc no $178: 17 \mathrm{pp}$, il (1883)

83a Discussion upon the manner of growth, variation of form and characters of the genus Fenestella, and its relations to Hemitrypa,. Polypora, Retepora, Oryptopora, etc. N Y St G, An Rp $2: 5-17$, il (1883)

83b Fossil corals and bryozoans of the Lower Helderberg group, and fossil bryozoans of the Upper Helderberg group [illustrations]. N Y St G, An Rp 2:17, il (1883)

83e List of Nlagara fossils from Waldron, Ind. N Y St Mus, An Rp 36:2125 (1883)

83d Bryozoa (Fenestellidae) of the Hamilton group, N Y St Mus, An Rp 36: 87-72 (1883)

83e On the structure of the shell in the genus Orthis. N Y St Mus, An Rp 36 : 73-75, il (1883)

83f Despriction of a new species of Stylonurus from the Catskill group [N. Y.] N Y St Mus, An Rp $36: 76-77$, il (1883)

$83 \mathrm{~g}$ [Description of Cryptozoön proliferum, n, g. and sp.] N Y St Mus, An Rp $36:$ pl 6 and explanation (1883)

83h Van Cleve's fossil corals. Ind, Dp G N H, An Rp 12:239-270, il (1883)

$$
28737^{\circ}-23-29
$$

Hall, James-Continued.

83i Descriptions of fossil corals from the Niagara and Upper Helderberg groups of Indiana. Ind, Dp G N H, An Rp 12:271318 , il (1883) In part, N Y St Mus, An Rp 35: 407-464 (1884)

83j [Spergen Hill fossils.] Ind, Dp G N H, An Rp 12:319-375, il (1883)

83k Descriptions of new species of fossils from the Niagara formation at Waldron, Ind. Albany Inst, $\operatorname{Tr} 10: 57-76$ (1883)

s31 Bryozoans of the Upper Helderberg and Hamilton groups. Albany Inst, Tr 10 : 145-197 (1883)

$\mathbf{8 3 m}$ Contributions to the geological history of the American continent. Am As, Pr 31: 29-69 (1883)

s3n Preliminary note on the microscopic shell structure of the Paleozoic Brachiopoda (abst). Am As, $\mathrm{Pr} 32: 266-268$ (1884) Science 2:325-326 (1883)

s3o The New York geological survey. Pop Sc Mo 22 : 815-825 (1883)

S4 Lamellibranchiata, I, Descriptions and figures of the Monomyaria of the Upper Helderberg, Hamilton, and Chemung groups. N Y G S, Pal 5 pt 1, I: xvili, 268 pp, il [pls and expl, 1883] (1884)

84a [First annual] report of the State geologist. N Y, Assembly [1882] Doc no $32: 15 \mathrm{pp}$, il (1884)

84b Classification of the Lamellibranchl. ata [and descriptions of genera and figures of species]. N Y St G, An Rp 1:8-15, il (1884)

84e [Third annual] report of the State geologist for the year 1883. N Y, Assembly Doc no 111:61 pp (1884)

84d Descriptions of the bryozoans of the Hamilton group (Fenestellidae excepted). N Y St G, An Rp 3:5-61 (1884)

84e Preliminary notice of the lamellibranchiate shells of the Upper Helderberg, Hamilton, and Chemung groups. N Y St Mus, An Rp 35: 215-406g (1884)

84f Descriptions of fossil corals from the Niagara and Upper Helderberg groups. N Y St Mus, An Rp 35:407-464, il (1884) [Published in advance: 59 pp, Albany 1882]

$84 \mathrm{~g}$ Descriptions of the species of fossil reticulate sponges, constituting the family Dictyospongidae. N Y St Mus, An Rp 35 : $465-481$, il (1884)

84h Note on the Eurypteridae of the Devonian and Carboniferous formations of Pennsylvania. Pa G S, 2d, PPP : 23-39, il (1884)

84i On the fossil reticulate sponges constituting the family Dictyospongidae (abst). Brit As, Rp 54:725-726 (1885) G Mag (3) 1:557-558 (1884) 
Hall, James-Continued.

$\mathbf{8 4 j}$ On the lamellibranchiate fauna of the Upper Helderberg, Hamilton, Portage, Chemung, and Catskill groups .... (abst). Brit. As, Rp 54: 726-727 (1885) G Mag (3) $1: 559-560(1884)$

85 Lamellibranchiata, II, Descriptions and figures of the Dimyaria of the Upper Helderberg, Hamilton, Portage, and Chemung groups. N Y G S, Pal 5 pt 1, II : lxii, 269-561, il (1885)

S5a [Fouth annual] report of the State geologist for the year 1884. N Y, Assembly Doc no $161: 47 \mathrm{pp}$, il (1885)

85b On the mode of growth and relations of the Fenestellidae. N Y St G, An Rp 4: 35-45, il (1885)

s5e On the relations of the genera Stictopora, Ptilodictya, Acrogenia, and allied forms in the Paleozoic rocks of New York. N Y St G, An Rp 4:46, il (1885)

s5d [On the characters of pectinoid shells.] N Y St G, An Rp $4: 47-48$, il (1885)

85e Report of the State geologist. N Y St Mus, An Rp 38:61-65 (1885)

85f Note on the intimate relations of the Chemung group and Waverly sandstone in northwestern Pennsylvania and southwestern New York (abst). Am As, Pr 33: 416-419 (1885)

85 $\mathrm{g}$ Note on the Eurypteridae of the Devonian and Carboniferous formations of Pennsylvania; with a supplementary note on Stylonurus excelsior. Am As, $\operatorname{Pr} 33$ : 420-422 (1885)

86 Fifth annual report of the State geologist for the year 1885. N Y, Assembly Doc no $105: 47$ pp, il, map (1886)

$\mathbf{8 6 a}$ [Illustrations with explanations of Upper Helderberg fossils.] N Y St G, An Rp 5: pls (1886)

86b Note on some obscure organisms in the roofing slates of Washington Co., N. Y. [Dactyloidites bulbosus]. N Y St Mus, An Rp $39: 160$, il (1886)

86e Report on building stones. N Y St Mus, An Rp $39: 186-225$ (1886)

86a Report of the State geologist. N Y St Mus, An Rp 39 : 226-229 (1886)

87 (and Simpson, G. B.) Corals and Bryozoa; descriptions and figures of species from the Lower Helderberg, Upper Helderberg, and Hamilton groups. N $\mathbf{Y}$ G S, Pal 6: xxvi, $298 \mathrm{pp}$, il (1887)

$\mathbf{8 7 a}$ Sixth annual report of the State geologist. $\mathrm{N} \mathrm{Y}$, Assembly Doc no $72: 70$ pp, ii (1887)

s7b Note on the occurrence of the Dictyospongidae in the State of New York. N Y St G, An Rp 6:36-38, map (1887)

87e Note on the discovery of a skeleton of an elk (Elaphus canadensis) in the town of Farmington, Ontario Co. [N. Y.]. N Y St G, An Rp 6:39 (1887)
Ha11, James-Continued.

87d Descriptions of Fenestellidae of th Hamilton group of New York. N Y St An Rp 6: 41-70, 11 (1887)

88 Supplement, contalning descriptios and illustrations of Pteropoda, Cephalop oda, and Annelida. N Y G S, Pal 5 pt? sup : 42 pp, 11 (1888)

88a (and Clarke, J. M.) Descriptios of the trilobites and other Crustacea of the Oriskany, Upper Helderberg, Hamilton, Portage, Chemung, and Catskill groups. \& Y G S, Pal 7 : lxiv, 286 pp, Il (1888)

88b Report of the State geologist for the year 1887. N Y St Mus, An Rp 41: 359-387 (1888) N Y St G, An Rp 9: 73-104 (1890)

88e Description of new species of Fenes. tellidae of the Lower Helderberg, with er. planation of plates illustrating species of the Hamilton group, described in the to port of the State geologist for 1886. N I St Mus, An Rp $41: 391-394$, 11 (1888)

89 Eighth annual report of the State geologist for the year 1888. N Y, Senate Doc no 66:150 pp (1889) N Y St Mus, An Rp $42: 349-496$ (1889)

89a Catalogue of the speclmens ar ranged by Prof. E. Emmons, as represents. tives of the Taconic system, in the State Cabinet of Natural History, at the close of the geological survey of New York in 1843. N Y St G, An Rp 8: 95-98 (1889) N I St Mus, An Rp 42:441-444 (1889)

89b [On tracks in Potsdam sandstone.] N Y St Mus, An Rp 42: 25-34, il (1889)

89e Description of Linnarssonia cf. pre tiosa Billings. R Soc Can, Pr Tr 7, iv:55 (1889)

90 Ninth annual report of the State geologist for the year 1889. N Y, Senate Doc no 60:104 pp $(1890)$ N Y St Mus, An Rp $43: 207-306$ (1890)

90a New forms of Dictyospongidae from the rocks of the Chemung group. N Y St G, An Rp 9: 56-60 (1890) N Y St Mus, An Rp $43: 258-262$ (1890) Abst (with discussion by Whlliam Dawson), G Soc Am, B 1:22-23 (1890)

90b Some suggestions regarding the subdivision and grouping of the species usu ally included under the generic term or this ... (abst). G Soc Am, B $1: 19-22$ (1890)

90e On the genus Spirifera, and its in. terrelations with the genera spiriferina, syringothyris, Eyrtia, and Cyrtina (abst). G Soc Am, B 1:567-568 (1890)

91 Tenth annual report of the State geologist for the year 1890. N Y, Senate Doc no $76: 155 \mathrm{pp}$, il (1891) N Y St Mus, An Rp $44: 35-114$, il (1892)

91a The genera of the Paleozoic Brach. iopoda. N Y St G, An Rp 10:15-17 (1891) N Y St Mus, An Rp 44: 45-48 (1892) 
Hall, James - Continued.

91b Continuation of descriptions of Bryozoa, not printed in volume VI, Paleontology of New York. N Y St G, An Rp $10: 35-57$ (1891) N Y St Mus, An Rp 44: $65-87 \quad(1892)$

91e Preliminary notice of Newberria, a new genus of brachiopods; with remarks on its relations to Rensselacria and $\mathrm{Am}$ phigenia. N Y St G, An Rp 10:91-98, il $(1891)$

91d On the family Orthidae of the Brachiopoda (abst). G Soc Am, B 2:636 (1891)

92 Eleventh annual report of the State geologist for the year 1891. N Y Senate Doc no $65: 223 \mathrm{pp}$, il (1892) i $\mathrm{Y}$ St Yus, An Rp 45: 321-369 (1892)

92a (and Clarke, J. M.) An introduction to the study of the Brachiopoda, intended as a hand book for the use of students. N Y St G, An Rp 11: 133-223, il (1892) N Y St Mus, An Rp 45:449616, il (1892)

92b The Oneonta sandstone and its relations to the Portage, Chemung, and Catskill groups (discussion). G Soc $\mathrm{Am}$, B 4:8-9 (1892) Abst, Am G 10:194 (1892)

93 (and Clarke, J. M.) An introduction to the study of the genera of Paleozoic Brachiopoda. N Y G S, Pal 8 pt $1: 367$ pp, il (1893); pt $2: 394 \mathrm{pp}$, il (1894)

93a Twelfth annual report of the State zeologist for the year 1892. N Y, Senate Doc no 40:142 pp (1893) N Y St Mus, An Rp $46: 153-187$ (1893)

93b A geological map of the State of New York. Am I M Eng, Tr $21: 566-572$ (1893)

94 Thirteenth annual report of the State geologist for the year 1893. N Y, Senate Doc no 88:597 pp, il (1894) N Y St Mus An Rp 47: 201-1137, il (1894)

94a The Livonia salt shaft, its history and geological relations, etc. N Y St G, An $\mathrm{Rp} 13: 9-22, \operatorname{map}(1894) \quad \mathrm{N} \quad \mathrm{Y}$ St Ius, An Rp 47: 203-216, map (r894)

94b (and Clarke, J. M.) Report of department of paleontology. N Y St G, An Rp 13:599-657 (1894) N Y St Mus, An $\mathrm{Rp} 47: 793-851$ (1894)

94e (and Clarke, J. M.) An introduction to the study of the Brachiopoda, intended as a handbook for the use of students, Part II. N Y St G, An Rp 13: 749-1015, il (1894) N Y St Mus, An Rp $47: 945-1137$, il (1894)

95 Report of the State geologist. N Y St Mus, An Rp 48: 41-44 (1895)

97 Fourteenth annual report of the State geologist for the year 1894. N Y, Senate Doc no 69:669 pp, il (1895) [1897] N Y St Mus, An Rp 48 v 2:669 pp il (1895) [1897]
Hall, James-Continued.

97a (and Clarke, J. M.) The new species of Brachiopoda described in Paleontology of New York, vol VIII, parts 1 and $2,1892-1894$. N Y St G, An Rp 14: 323-402, il (1895) [1897] N Y St Mus, An Rp 48 v 2:323-402, il (1895) [1897]

$\mathbf{9 7 b}$ Report of the State geologist and paleontologist 1895. N Y St Mus, An Rp 49 v $1: 11-15$ (1897)

97c Fifteenth annual report of the State geologist for the year 1895. N Y, Senate Doc no 66 [1896], 2 vols, 984 pp (1897) Also as vols 2 and 3 of $\mathrm{N}$ Y St Mus, An Rp 49 (1898)

$97 \mathbf{A}$ A discussion of Streptelasma and allied genera of rugose corals. N Y St G, An Rp 15: 24-25 (1897) N Y St Mus, An Rp 49 v $2: 24-25$ (1898)

97e The Paleozoic hexactinellid sponges constituting the family Dictyospongidae, Part I. N Y St G, An Rp 15:25-26 (1897) $\mathrm{N} \quad \mathrm{Y}$ St Mus, An Rp $49 \quad v \quad 2$ : 25-26 (1898)

98 (and Clarke, J. M.) A memoir on the Paleozolic reticulate sponges constituting the family Dictyospongidae. $N$ Y St G, An Rp 15 pt 2:741-984, il (1898); 16:341-448, il (1899) N Y St Mus, An Rp $49 v$ 3:741-984, il (1898); 50 v 2 : 341-448, il (1899) N Y St Mus, Mem 2: $350 \mathrm{pp}$, il (1898)

99 Sixteenth annual report of the State geologist for the year 1896. N Y Senate Doc no 51 (1897) : $444 \mathrm{pp}$, il (1899) Also as N Y St Mus, An Rp $50 v 2: 444 \mathrm{pp}$, il (1899)

99 Seventeenth annual report of the State geologist for the year $1897,564 \mathrm{pp}$ (1899) Also as $\mathrm{N}$ Y St Mus, An Rp 51 v 2:564 pp (1899)

See also Brainerd, 53a; Dana, 61; Frazer, 84c ; Gilbert, 93b; Guyot, 50 ; Haldeman, 45; Newberry, 53 ; Verneuil, 47a; Williams ( $\mathrm{G} \mathrm{H}), 90 \mathrm{~d}$; Winchell (N H), $88 \mathrm{~g}$

Hall, James W.

78 (and Fritr-Gaertner, R.) On the structure of Astraeospongia meniscus. N Y St Mus, An Rp $30: 111-116$, il (1878)

S6 (with Beecher, C. E., and Hall, C. E.) Note on the Oneonta sandstone in the vicinity of Oxford, Chenango Co. ,N Y. N Y St G, An Rp 5:11 (1886)

Hall, John G.

96 A geologic section from State line, opposite Boicourt, to Alma, principally along the Osage River. Kans Univ G S 1:99-106, (1896)

Ha11, Maxiwell.

07 Third report on earthquakes in Jamaica; the great earthquake of January $14 \mathrm{th}, 1907$, and the after shocks. No. 337. 22 pp, Jamaica, Government Printing Office, Kingston, 1907

07 a The Kingston earthquake, 1907 (abst). Nature 76:535 (1907) 
Ha11, Maxwell-Continued.

o9 Fourth report on earthquakes in Jamaica; on the periods of the shocks from the principal Jamaica earthquake centres and further notes on the great earthquake, 1907, Jan. 14. No. 365. 23 pp. Jamaica, Government Printing Office, Kingston, 1909

13 Notes on the geology of Jamaica, with a small geological map. No. 420 . 3 pp, map, Jamaica, Government Printing Office, Kingston 1913

Hall, R. Dawson Norris.

11 Geology of Indiana Co. [Pa.]. Coa] Trade B 25 no $9: 35-38$ (1911)

11 a Georges Creek coal field, Md. Coal Age 1:10-14 (1911)

Ha11, S. R.

45 (and Thompson, Z.) Report [northern Vermont]. In Adams, C. B., First annual report on the geology of the State of Vermont: 68-76 (1845)

46 Report [agcriultural geology]. In Adams, C. B., Second annual report on the geology of the State of Vermont: 174-214 (1846)

47 Report. In Adams, C. B., Third annual report on the geology of the State of Vermont : 27-31 (1847)

61 ... geology of northern Vermont. In Report on the geology of Vermont (Hitchcock) $2: 719-730(1861)$

6s Hall's alphabet of geology, or first lessons in geology and mineralogy ... 196 pp. Boston 1868

71 Geology and mineralogy of Orleans Co. [Vt.]. Archives of Seience (Orleans Co [Vt] Soc N Sc. Tr) 1:71-78 (1871)

Ha11, William Carvel (1869-1908).

07 Report of survey of erest line of Niagara Falls. U S G S, B 306:26-31 (1907) N Y, Comm St Res Niagara, An Rp 23:67-73 (1907)

HaIl, W. S.

93 The South Dakota artesian basin. Science 22:29-30 (1893)

Halla, Otto.

07 The beaches of Nome. M Se Press 94: 688 (1907)

Halland, Alfred S.

11 Cryolite and its industrial applications M World $34: 689-690$ (1911)

Hallett, P.

84 Notes on Niagara (abst). Brit As, Rp 54:744-745 (1885) G Mag (3) 1: $563-564$ (1884)

Hallock, Charles.

10. Physiography of the great Colorado Canyon. Am Antiquarian 32:213-216 (1910)

11 The interglacial period. Am Antiquarian $33: 197-198$ (1911)

Hallock, William.

91 Preliminary report of observations at the deep well at Wheeling, W. Va. (abst). Am G 8:192 (1891) Am As, Pr 40:257259 (1892) Am J Sc (3) $43: 234-236$ (1892)
Halloek, William-Continued.

92 The flow of solids [and application to geologic phenomena] (abst). $\mathrm{Ph}$ Soc Wash, B 11 : 509-511 (1892)

94 Note on further observations of tem. perature in the deep well at Wheeling. W. Va. (abst). Am As, Pr 42:173-175 (1894)

97 Subterranean temperatures at Wheel. ing, W. Va., and Pittsburgh, Pa. Sch Mines Q 18: 148-153 (1897)

01 Peculiar effects due to a lightning discharge on Lake Champlain in August 1900. J G 9:671-672 (1901)

03 An ascent of Mt. Whitney, Cal, with notes on the geology $(a b s t)$. Science $\mathrm{n}$ s $17: 505$ (1903)

Hallowell, Edward.

46 [On the fossil bones of a young mas. todon from near Plattsburg, N. J.] Ac N Se Pbila, Pr $3: 117,130$ (1846)

Hallowell, Henry B.

10 The silver mining camp of Cobalt, Ont. Western Chemist and Metallurgist 6: 89-96 (1910)

Hallowell, John K.

82 Geological monograph; Boulder County as it is. Published by the Colorado Mnseum of Applied Geology and Mineralogy. $19 \mathrm{pp}$, Denver, Colo., 1882

s2n Supposed Juratrias of the Front Range of Colorado. Kansas City Rv Sc 6: 492-496 (1882)

$\mathbf{8 2 b}$ On the occurrence of Iustrous coal with native silver [Ouray Co., Colo.]. Eng M J 33:90-91 (1882) [See Koenig, 81]

s3 Gunnison, Colorado's bonanza county. Colorado Museum of Applied Geeology and Mineralogy, Geological Monograph no 2: 168 pp, Denver, Colo., 1883.

$83 a$ Tertiary coal measures of Gunnison Co.. Colo. Kansas City Rv Sc 6:698-696 (1883)

Halse, Edward.

92 Notes on the occurrence of manganese ore near Mulegé, Baja California, Mex. N Engl Inst M Eng. Tr 41:302-307, map (1892) Eng M J 55:223-225 (1893)

94 Note on the antimony deposit of $\mathrm{El}$ Altar, Sonora, Mexico. Fed Inst M Eng, $\operatorname{Tr} 6: 290-294$ (1894)

$94 a$ Notes on some gold-bearing veins of Zacatecas, Mexico. Eng M J 58:78, 105107 (1894)

94b The Malacate silver and gold mines of Sultepec, Mexico. Eng M J 58:220-221 (1894)

94c Gold in Zacatecas, Mex. Eng M J 58: 605-606 (1894)

95. The quicksilver mines and reduction works at Huitzuco, Guerrero, Mex. N Engl Inst M Eng, Tr 45: 72-88, 158 (1895)

95a The silver district of Tehuilotepec, State of Guerrero, Mexico. Eng M J 60: 197-199 (1895) 
Halse, Edward-Continued.

00 Some silver-bearing veins of Mexico. Inst M Eng, $\operatorname{Tr} 18: 370-384$ (1900) ; 21 ; 198-213 (1901) ; 23:243-257 (1902); 24 : 41-60 (1903) ; $27: 169-189$ (1904) N Engl Inst M Mech Eng, Tr 50 : 202-217 (1902)

$00 \mathrm{a}$ The occurrence of tin ore at Sain Alto, Zacatecas, with reference to similar deposits in San Luis Potosi and Durango, Mex. Am I M Eng. Tr 29:502-511 (1900)

02 Notes on the structure of ore-bearing reins in Mexico. Am I M Eng, Tr 32: 285-302 (1902)

05 The occurrence of pebbles, concretions, and conglomerate in metalliferous veins, Am I M Eng, Bi-Mo B 4:719-742 (1905) ; Tr $36: 154-177$ (1906)

06 The geology of Chiapas and Tabasco, Mexico. M J, London, 79: 243-244 February 24 (1906)

See also Kunz, 02a

Haltenberger, Michael.

13 On a genetic system of sand dunes, including two new types. Am Geog Soc, B 45: 513-515 (1913)

Hambach, Gustav.

84 Notes about the structure and classification of the pentremites. Ac Sc St L, Tr 4:537-547, il (1884)

84a Description of new Paleozolc Echinodermata. Ac Se St L, Tr 4:548554 , il (1884) In part, Sedalia N H Soc, B $1: 29-30$ (1885)

90 A preliminary eatalogue of the fossils occurring in Missouri. Mo $\mathrm{G}$ S, B 1:6085 (1890)

03 Revision of the Blastoides, with a proposed new elassification and description of new species. Ac Sc St L, Tr 13:1-67, il (1903)

Hamilton, Fletcher.

15 Mineral production for 1914. Cal St M Bur, B 70:184 pp (1915)

16 Administrative statement. Cal St M Bur, Rp XIV of the State Mineralogist : xix-xxill (1916)

18 Magnesite, its occurrence and applieations. Mineral Foote-Notes 2 no $1: 2-5$ (1918)

Hamilton, P. S.

66 The auriferous deposits of Nova Scotia. N S Inst N Sc, Pr Tr 1 pt 4: 43-51 (1866)

69 On submerged forest trees in Cumberland basin. $\mathrm{N}$ S Inst $\mathrm{N}$ Sc, $\mathrm{Pr} T r 2$ pt 2:94-99 (1869)

\section{Hamilton, S. Harbert.}

99 (and Withrow, James R.) The progress of mineralogy in 1898. Am I M Eng, B 1:33 pp (1899)

99a The occurrence of mareasite in the Raritan formation. Ac N Sc Phila, Pr $1898: 485$ (1899)

99b Monazite in Delaware Co., Pa. Ac N Se Phila, Pr 1899: 377-378
Hamilton, S. Harbert-Continued.

00 (and Withrow, James R.) The progress of mineralogy in 1899. Am I M Eng, $B$ no $2: 96$ pp (1900)

01 Troost's survey of Philadelphia. Am G $27: 41-42$ (1901)

0: Minerals from Santiago province, Cuba, Ae N Se Phila, Pr 54:744-749 (1903)

04 The mineral industry; the cement industry. N J G S, An Rp 1903:95-121 (1904)

05 (with Hamilton, S. H.) A report upon some molding sands of New Jersey. N J G S, An Rp 1904: 187-246 (1905)

09 Notes on some ore deposits of Porto Rico. Eng M J 88:518-519 (1909)

Hamilton, W. R.

04 (with Kessler, H. H.) The orbicular gabbro of Dehesa, Cal. Am G 34: 133-140 (1904)

Hamilton, William $J$.

10 (with Kruger, H. A.) Geology of the Perry Park syncline, Colo. Colo Sch Mines, B 5:86-99 (1910)

Hnmin, Augustus Choate.

70 The gems of the United States, Am As, Pr 18: 210-216 (1870)

73 The tourmaline ... $107 \mathrm{pp}$, Boston 1873

74 Origin and properties of the diamond. Am As, Pr 22 pt 2:104-108 (1874)

95 The history of Mount Mica of Maine, U. S. A., and its wonderful deposits of matchless tourmalines, $72 \mathrm{pp}$, Bangor, Maine, 1895

Hamlin, Charles Edward.

81 Observations upon the physical geography and geology of Mount Ktaadn and the adjacent district [Maine]. Harvard Coll, Mus C Z, B 7 (g s 1) : 189-223, map (1881)

Hamiln, Homer (1864-1920).

17 Miscellaneous earthquakes in southern and eastern California. Seism Soc Am, B 7: 113-118 (1917)

18 Earthquakes in southern California. Seism Soc Am, B 8: 20-24 (1918)

18 a Aftershocks of the San Jacinto earthquake of April 21, 1918. Seism Soc Am, B $8: 131-134$ (1918)

Hamman, William David.

11 Practical geology and mineralogy. 224 pp. South Pasadena, Cal., 1911 Revised ed, $253 \mathrm{pp}, 1915$

12 Potash solutions in the Searles Lake region [Cal.]. M Science 65:372-373, 391-392 (1912)

12a The Searles Lake potash deposit. Eng M J 93:975-976 (1912)

See also Spencer (L J), 16

Hammond, Harry.

83 South Carolina ... [S C], St Bd Agr : $726 \mathrm{pp}$, map, Charleston 1883

84 Physico-geographical and agricultural features of the State of South Carolina. U S, 10th Census 6:461-503, map (1884) 
Hammond, John Hays.

90 The auriferous gravels of California; geology of their occurrence and methods of their exploitation. Cal St M Bur, An Rp $9: 105-138$ (1890)

90a Mining of gold ores in California. Cal St M Bur, An Rp 10:852-882 (1890)

Hammond, William A.

58 [On coniferous wood from the marl of New Jersey.] Ac N Se Phila, Pr 1858: 221-222

Hamor, William Allen.

16 (with Bacon, R. F.) The American petroleum industry. 2 vols, $963 \mathrm{pp}, \mathrm{N}$ Y 1916

Hanbury, David $T$.

03 Through the barren ground of northeastern Canada to the Arctic coast. Geog J $22: 178-191$, map (1903)

Hance, James Harold.

12 The Glendive lignite field, Dawson Co., Mont. U S G S, B 471: 271-283, map (1912)

13 The Coaldale coal field, Esmeralda Co., Nev. U S G S, B 531, 313-322, map (1913)

13a Notes on the occurrence of different varieties of clay. U S G S, Min Res 1912 pt 2:608-618 (1913)

14 Potash in western saline deposits. U S G S, B 540: 457-469 (1914)

15 Use of the slide rule in the computation of rock analyses. J G 23:560-568 (1915)

Hanchett, Aug. H.

65 Report of the State geologist, together with the physical geography, meteorology, and botany of the northeastern district of Minnesota, by Thomas Clark ... 82 pp, Saint Paul 1865

Hancock, Eugene Thomas.

10 Notes accompanying the lectures on geology applied to mining. $210 \mathrm{pp}$, Laneaster, Pa. 1910

15 The history of a portion of Yampa River, Colo., and its possible bearing on that of Green River. U S G S, P P 90: 183-189, map (1915) Abst, Wash Ac Sc, J 5 : 141-142 (1915)

18 Geology and oil and gas prospects of the Lake Basin field, Mont. U S G S, B 691 : 101-147, map (1918)

Hand, W. F.

05 (with Logan, W. N.) A preliminary report on some of the clays of Mississippi. Miss G S, B $3: 88$ pp (1905)

Handlirsch, Anton.

06 Die fossilen Insekten und die Phylogenie der rezenten Formen. Lief $1-4,640$ pp, il Leipzig 1906

06a A new blattoid from the Cretaceous of North America. U S Nat Mus, Pr 29 : $655-656$, il (1906)

06b Revision of American Paleozoic insects, U S Nat Mus, Pr $29: 661-820$, il (1906)
Handirseh, Anton-Continued.

07 Fossil insects and the development the class Insecta. Pop Sc Mo 70:55-4 (1907)

10 Canadian fossil inseets. Insects fra the Tertiary lake deposits of the southen interior of British Columbia, collected by Mr. Lawrence M. Lambe, in 1906. Can $\theta$ S, Mem 12, Cont Can Pal 2 : v-viii, 93-12 il (1910)

11 New Pareozoic insects from the vicis ity of Mazon Creek, IIl. Am J Sc (4) 31: $297-326,853-377$, il (1911)

See also Eastman, 00

Handy, F. M.

16 An investigation of the mineral do posits of northern Okanogan Co. Wash, st Coll, Dp G, B 100: 27 pp [1916?]

Haney, Marshall.

09 Copper deposits of Greene Co., $\mathrm{V}_{2}$. Eng M J 88:1286 (1909)

18 Copper deposits of the Blue Ridg? Mountains. Eng M J 106: 248 (1918)

18a Manganese development in Virginia. Eng M J 106:697 (1918)

Hanks, Henry Garber (1826-1907).

73 Notes on cuproscheelite. Cal Ac Sc, Pr 5: 133-134 (1873)

76 On the occurrence of durangite in the tin-bearing region of Durango, Mex. Am J Sc (3) $12: 274-276$ (1876)

81 Annual report of the [California] State mineralogist from June 1,1880 , to December 1, 1880. 43 pp [Sacramento 1881]

82 Second report of the [Callfornia] State mineralogist, from December 1, 1880, to October 1, 1882. $226 \mathrm{pp}$, Sacramento 1882

83 Third annual report of the State min. eralogist for the year ending June 1, 1883. Cal St M Bur:111 pp, map Sacramento 1883 [Includes Report on the borax deposits of California and Nevada]

84 Fourth annual report of the State mineralogist, for the year ending May 15, 1884. 410 pp, Sacramento 1884 [Includes Catalogue and description of the minerals of Callifornia.a.]

85 Fifth annual report of the State mineralogist, for the year ending May 15 , 1885. $235 \mathrm{pp}$, Sacramento 1885

86 Sixth annual report of the State mineralogist, Part I, for the year ending June 1, 1886. $145 \mathrm{pp}$ maps, Sacramento 1886 [Includes catalog of minerals.]

89 On the occurrence of hanksite in California. Am J Sc (3) $37: 63-66$ (1889)

90 On certain magnetic rocks of Arizona and California. A paper read before the San Francisco Microscopical Society, November $19,1890,4 \mathrm{pp}$ [1890]

92 Gaylussite [new variety, San Bernardino Co., Cal.]. M Sc Press 64:222 (1892) 
Hanks, Henry Garber-Continued.

93 Desquamation and decay of rocks and the formation of boulders. M Sc Press $67: 309,326,343$ (1893)

01 The deep-lying auriferous gravels and table mountains of California. $15 \mathrm{pp}$, San Francisco, Cal., 1901

05 Notes on " aragotite," a rare California mineral. R Micro Soc, J 1905:673676

Hanna, G. Dallas.

13 (and Johnston, E. C.) A Pleistocene molluscan fauna from Phillips Co., Kans. Kans Univ, Sc B $7: 111-121$, il (1913)

Hanna, George Byron.

82 Mines of the Appalachian Range [gold deposits, North Carolina, South Carolina, and Georgia]. Sch Mines Q 3:208214 (1882)

88 (with Kerr, W. C.) Ores of North Carolina; being chapter II of the second volume of the geology of North Carolina : 123-359, map, Raleigh 1888 [2d ed], Raleigh 1893

90 Geology of North Carolina. In Western North Carolina : 9-56, Charlotte, N. C., 1890 [not seen]

96 (with Nitze, H. B. C.) Gold deposits of North Carolina. N C G S, B 3 : 200 pp. maps, Winston 1896.

Hannibal, Harold.

09 A new Carinifex [sanctaclara n. sp.] from the Santa Clara lake beds (Pliocene), Cal, Nautilus 23: 40-41 (1909)

11 A Pllocene flora from the Coast Ranges of Callfornia. Torrey Bot Club, B $38: 329-342$, II (1911)

12 A synopsis of the recent and Tertiary freshwater Mollusea of the Californian province, based upon an ontogenetic classification. Malacological Soc, Pr 10:112166, 167-211 (1912)

14 (with Arnold, R.) Dickerson on Callfornia Eocene. Science n s 39:906908 (1914)

18 Jura-Cretaceous stonewart and limneas, supposedly from Arkansas. Science n 8 48: 578 (1918)

Hansell, N. V.

06 (with Newland, D. H.) Magnetite mines at Lyon Mountain, N. Y. Eng M J, $82: 863-865,916-918$ (1906)

Hantzseh, Bernhard.

09 Beiträge zur Kenntniss des norđöstlichsten Labradors. Ver Erdk Dresden, Mitt Heft $8: 168-229$ (1909)

Harboe, E. G.

07 Das Erdbeben von Charleston am 31. August 1886. Beitr Geoph $9: 105-110$ (1907)

Hard, Herbert A.

13 Road materials of North Dakota. N Dak, Agr Coll s, 6th Bien Rp:29-37 [1913]
Hard, Herbert A.-Continued.

13a A system of eskers and kames in eastern Barnes Co., N. Dak. N Dak, Agr Coll S, 6th Bien Rp: $39-43$ [1913]

Harden, E. B.

86 Report on fire clay [of Wellersburg coal basin, Somerset Co.]. Pa G S, An Rp 1885 : 239-249 (1886)

Harden, J. W.

73 The brown hematite ore deposits of South Mountain, between Carlisle, Waynesborough, and the southeastern edge of Cumberland Valley [Pa.]. Am I M Eng, $\operatorname{Tr} 1: 136-144$ (1873)

\section{Harder, Edmund Cecil.}

06 The joint system in the rocks of southwestern Wisconsin and its relation to the drainage network. Wis Univ, B, sc $\mathbf{s}$ $3: 207-246$ (1906)

os Manganese ores. U S G S, Min Res 1907 pt $1: 87-110 ; 1908$ pt $1: 135-156$ (1908-9)

o8a (with Leith, C. K.) The iron ores of the Iron Springs district, southern Utah. U S G S, B 338: 102 pp (1908)

09 The Taylor Peak and Whitepine ironore deposits, Colo. U S G S, B 380:188198, maps (1909)

09a The iron ores of the Appalachian region in Virginia. U S G S, B 380 : 215254 (1909)

09b Manganese deposits of the United States. U S G S, B 380:255-277 (1909)

09e Iron ores, pig iron, and steel. U S G S, Min Res 1908 pt 1:61-134 (1909)

o9d Chromic iron ore. U S G S, Min Res 1908 pt $1: 751-770$ (1909)

10 Manganese deposits of the United States, with sections on foreign deposits, chemistry, and uses. U S G S, B 427: 298 pp (1910)

10a Some chromite deposits in western and central California. U S G S, B 430 : $167-183$ (1910)

10b Some iron ores of western and central California. U S G S, B 430:219-227 (1910)

10e (and Rich, J. L.) The Iron Age Iron-ore deposit, near Dale, San Bernardino Co., Cal. U S G S, B 430: 228-239, map (1910)

10d Iron ores near Dayton, Nev. U S G S, B $430: 240-246$ (1910)

10e Deposits of brown iron ore near Dillsburg, York Co., Pa. U S G S, B 430 : $250-255(1910)$

Iof The gypsum deposits of the Palen Mountains, Riverside Co. Cal. U S G S, B $430: 407-416$ (1910)

$10 \mathrm{~g}$ Structure and origin of the magnetite deposits near Dillsburg. York Co., Pa. Ee G 5:599-622, map (1910)

11 (with Leith, C. K.) Hematite ores of Brazll and a comparison with hematite ores of Lake Superior. Ec G 6:670-686 (1911) 
Harder, Edmund Cecil-Continued.

12 Iron-ore deposits of the Eagle Mountains, Cal. U S G S, B 503: 81 pp, map (1912) Abst, Wash Ac Sc, J 4:162 (1914)

15 Iron bacteria. Science n 8 42:310 311 (1915)

17 (and Johnston, A. W.) Notes on the geology and iron ores of the Cuyuna district, Minn. U S G S, B $660: 1-26$, map (1917) Abst, by R. W. Stone, Wash Ac Sc, J 8:18-19 (1918)

17a Manganiferous iron ores of the $\mathrm{Cu}$ yuna district, Minn. Am I M Eng, B 129 : 1313-1344 (1917); Tr 58:453-486 (1918)

18 (and Johnston, A. W.) Preliminary report on the geology of east central Minnesota, including the Cuyuna iron-ore district. Minn G S, B 15:178 pp, maps (1918)

Hardie, W. D. L.

10 The Galt coal field, Alta. Can M Inst, Q B 10:151-156 (1910) ; J 13: 190195 (1911)

Harding, W. K.

14 Rice Lake gold mining district, Manitoba. M World 40:1154-1155 (1914)

16 Field for the prospector in Manitoba, Canada. M World 44: 993-996 (1916)

Hardinge, $H$. W.

or The Cobalt district, Ont. M World $26: 215$ (1907)

14 Kirkland Lake district, Ont. Eng M J 98:619 (1914)

Hardman, E. T.

76 On the origin of anthracite ... (abst).

R G Soc Ireland, J 14: 200-209 (1876)

Hardman, John E.

96 On the occurrence of galena at Smithfield, N. S. [Fed] Can M Inst, J 1:215-218 (1896) Can M Rv 14:225 (1895)

97 Notes on some mining districts in British Columbia. Fed Can M Inst, J 2 : 166-180 (1897) Can M Rv 16:109-112 (1897)

98 The gold fields of Canada. Can M Rv 17 : 156-163, 184-190 (1898)

o5 A new mineral area in Ontario [Cobalt, Ont.]. Can M Rv 24:95-98, 157-158 (1905)

O5a Quebec's new mineral region. Can M Rv 25:9-12, 43-47 (1905)

07 Cobalt, Canada, the new silver-mining district. Eng Mag $33: 21-34$ (1907)

08 A new iron-ore field in the Province of New Brunswick. Can M Inst, J 11: 156-164 (1908) Can M J 29:303-305, 336-337 (1908)

17 The Kingdon lead mine [Ont.]. Can M Inst, Tr 20:180-187 (1917)

Hardt, Anton.

98 The Blossburg [Pa.] coal region, Mines and Minerals $19: 126-128$ (1898)

Hare, Alfred.

81 Notes on the geology of Bedford, Sackville, and Hammond's Plains. N S Inst N Sc, Pr Tr 5 : 309-312 (1881)
Hare, R. F.

15 (with Meinzer, O. E.) Geologr and water resources of Tularosa Basin, N. Mex. U S G S, W-S P 343: 317 pp, maps (1915) Abst, Wash Ac Sc, J 6:452-453 (1916)

Hare, Sid. J.

91 Trilobites of the upper Coal Measure group at Kansas City, Mo. Kansas City Scientist $5: 33-36$, il (1891)

91a (with Rowley, R. R.) Descrip. tion of some new species of Echinodermata from the Subcarboniferous rocks of Pike Co., Mo. Kansas City Scientist 5:97-103, II (1891)

$91 b$ (with Rowley, R. R.) Description of some new species of crinoids and blas. toids from the Subearboniferous rocks of Pike and Marion cos., Mo., and Scott Co., Va. Kansas City Scientist 5:113-118, 11 (1891)

Hares, C. J.

15 Correlation of some of the Cretaceous and Eocene formations of central Wyoming (abst). Wash Ac Sc, J $5: 328-330$ (1915)

15a (with Lloyd, E. R.) The Cannonball marine member of the Lance formation of North and South Dakota and its bearing on the Lance-Laramie problem. J G 23: 523-547, map (1915)

16 Anticlines in central Wyoming. U $\mathrm{S}$ G S, B 641:233-279, map (1916) Abst, Wash Ac Sc, J $7: 265$ (1917)

$16 a$ Stratigraphic relations of some of the Cretaceous and Tertiary formations of the Hanna and Powder River basins with those of the Wind River Basin (abst). Wash Ac Sc, J $6: 255-256$ (1916)

$16 b$ (with Winchester, D. E., and others) The lignite field of northwestern South Dakota. U S G S, B 627: $169 \mathrm{pp}$, maps (1916) Abst, Wash Ac Sc, J 7 : 36-37 (1917)

17 Gastroliths in the Cloverly formation. Wash Ac Sc, J 7:429 (1917)

$\mathbf{1 7 a}$ The southern extension of the Eagle sandstone and its relation to the Niobrara shale in Wyoming (abst). Wash Ac Sc, J $7: 429-431$ (1917)

Harger, $O$.

74 Notice of a new fossil spider from the Coal Measures of Illinois. Am J Sc (3) $7: 219-223$, il (1874)

Hargreaves, James.

16 Notes on petrified trees found in the Rosedeer mine, Drumbeller, Alta. Can M Inst, Mo B 47: 299-305 (1916)

Harker, Alfred.

87 The Cortlandt rocks [Westchester Co., N. Y.] [See also Dana 81 and Callaway 87]. G Mag (3) 4:431-432 (1887)

02 Physical geology in the basin of the Colorado. Nat Sc 1: 205-210 (1892)

92a Thermometamorphism in igneous rocks. G Soc Am, B 3:16-22 (1892) 
Harker, Alfred-Continued.

93 On the migration of material during the metamorphism of rock masses. J G 1 : $574-578$ (1893)

00 Igneous rock series and mixed igneous rocks. J G 8: 389-399 (1900)

11 Some aspects of modern petrology. Science n s $34: 353-367$ (1911)

13 Fractional crystallization the prime factor in the differentiation of rock magmas. Int $\mathrm{G}$ Cong, XII, 1913, C R : 205-208 (1914) Advance copy 1913

16 Differentiation in intercrustal magma basins. J G 24:554-558 (1916)

Harkness, H. W.

74 A recent voleano in Plumas Co. Cal Ac Sc, Pr 5: 408-412 (1874)

Harlan, Richard (1796-1843).

23 Observations on fossil elephant teeth of North America. Ac N Sc Phila, J 3:6567 , il (1823)

24 on a new fossil genus, of the order Enallo Sauri (of Conybeare). Ac $\mathrm{N}$ Sc Phila, J $3: 331-337$, il (1824)

24a On an extinct species of crocodile not before described; and some observations on the geology of West Jersey. Ac N Sc Phila, J 4:15-24, il (1824)

25 Notice of the Plesiosaurus, and other fossil reliquiae, from the State of New Jersey. $\Delta c$ N Sc Phila, J $4: 232-236$, il (1825)

31 Description of the fossil bones of the Megalonyx, discovered in "White Cave," Ky. Ac N Sc Phila, J 6:269-288, il (1831)

31a Description of an extinct species of fossll vegetable of the family Fucoides. Ac N Sc Phifa, J 6:289-295, il (1831)

31b Tour to the caves in Virginia. Monthly Am J G 1:58-67 (1831)

31e Description of the jaws, teeth, and clavicle of the Megalonyx laqueatus. Monthly Am J G 1:74-76, il (1831)

32 On a new extinct fossil vegetable of the family Fucoides. Monthly Am J G 1: $307-308$ (1832)

34 Critical notices of various organic remains hitherto discovered in North America. G Soc $\mathrm{Pa}$, Tr 1:46-112, II (1834) Abst, Am J Sc 27:352-354 (1835) In part, Edinb N Ph J $17: 342-362 ; 18: 28$ $40(1834-5)$

34a Notice of fossil bones found in the Tertiary formation of the State of Louisiana, $\mathrm{Am} \mathrm{Ph}$ Soc, $\mathrm{Tr}$ n $\mathrm{s}$ 4:397-403 (1834)

34b Notice of the discovery of the remains of the Ichthyosaurus in Missouri. Am $\mathrm{Ph} \mathrm{Soc}, \mathrm{Tr} \mathrm{n}$ s 4:405-409, il (1834)

34e On the structure of the teeth in the Edentata, fossil and recent. G Soc $\mathrm{Pa}, \mathrm{Tr}$ 1: $40-45$ (1834)

34d [Découverte d'un nouveau saurien au Missouri.] Soc G France, B 4:124 (1834)
Harlan, Richard-Continued.

34e On some species of fossil saurians found in America (abst). Brit $\mathrm{As}, \mathrm{Rp} 3$ : 440 (1834)

35 Notice of fossil vegetable remains from the bituminous coal measures of Pennsylvania... G Soc $\mathrm{Pa}$, Tr $1: 256-259$, il (1835)

35a Description of a new fossil plant from Pennsylvania of the genus Equisetum. G Soc Pa, Tr 1:260-262, il (1835)

35b Notice of nondeseript trilobit 3 from the State of New York, with some observations on the genus Triarthrus, etc. G Soc $\mathrm{Pa}, \operatorname{Tr} 1: 263-266$, il (1835)

35e Notice of the os ilium of the Megalonyx laqueatus from Big Bone cave, White Co., Tenn. G Soc Pa, Tr 1:347, il (1835)

35d Description of the remains of the "Basilosaurus," a large fossil marine animal recently discovered in the horizontal limestone of Alabama. $\mathrm{G}$ Soc $\mathrm{Pa}, \mathrm{Tr}$ 1: $348-357$, il (1835)

35e Medical and physical researches; or original memoirs in medicine, surgery, physiology, geology, zoology, and comparative anatomy [includes memoirs on fossil vertebrates, plants, and invertebrates]. $653 \mathrm{pp}$, il, Phila 1835

39 On the discovery of the Basilosaurus and the Batrachiosaurus. G Soc London, Pr 3: 23-24 (1839) Abst, Ph Mag (3) 14: 302 (1839)

39a [Observations sur le Basilosaurus et le Batrachotherium.] Soc G France, B $10: 89-90 \quad(1839)$

41 On the discovery of the remains of the Basilosaurus or Zeuglodon. G Soc London, $\operatorname{Tr}$ (2) $6: 67-68$ (1841)

42 Description of the bones of a fossil animal of the order Edentata [Orycterotherium missouriense]. Am $\mathrm{Ph}$ Soc, $\mathrm{Pr}$ 2: 109-111 (1842)

42a Notice of two new fossil mamnals from Brunswick Canal, Ga.; with observations on some of the fossil quadrupeds of the United States. Am J Sc $43: 141-144$, il (1842)

42b Description of a new extinct species of dolphin from Maryland. Nat Inst, Washington, D. C., Pr 2:195-196, il (1842)

43 Description of the bones of a new fossil animal of the order Edentata. Am $\mathrm{J}$ Sc $44: 69-80$, il (1843)

43a Remarks on Mr. Owen's letter to the editors on Dr. Harlan's new fossil Mammalia. Am J Sc 45:208-211 (1843)

Harmon, A. K. P., jr.

15 Eel River valley, Humboldt Co., Cal. ; geology and oil possibilities. Cal St M Bur, B 69:455-459 (1915)

Harn, E. H.

96 Some crystallized micas of North Carolina. Minera] Collector 3:24-25 (1896) 
Harniy, H. J.

95 Volcanic dust [McPherson Co. Kans.]. Science n s 2:77-78 (1895)

98 "Cone-in-cone" (an impure calcite). Kans Ac Sc, Tr 15:22 (1898)

Harnsberger, T. $K$.

14 (with Watson, T. L.) Examples of intercision type of stream piracy in western Virginia. Va Univ, $\mathrm{Pub}, \mathrm{B} \mathrm{Ph}$ Soc, sc s 1: $437-442$ (1914)

Haro, José C.

82 Los criaderos de cobre de Michoacán. La Naturaleza 6:51-59 (1882)

11 Ligeros apuntes sobre accidentes geológicos en los Estados de Puebla y Morelos. Soc G Mex, B $7: 145-148$ (1911)

Harper, D. N.

86 (with Penfield, S. L.) On the chemical composition of herderite and beryl, with note on the precipltation of aluminum and separation of beryllium and aluminum. Am J Sc (3) 32:107-117 (1886) Yale Bicen Pub, Contr Miner : 138-142 (1901)

s6a (with Penfield, S. L.) On the chemical composition of ralstonite. Am J Sc (3) $32: 380-385$ (1886) Yale Bicen Pub, Contr Miner: 143-150 (1901)

Harper, George W.

96 (and Bassler, R. S.) Catalogue of the fossils of the Trenton and Cincinnati periods occurring in the vicinity of Cinclnnati, Ohio. $34 \mathrm{pp}$, Cincinnati 1896

Harper, Henry Winston.

02 A contribution to the chemistry of some of the asphalt rocks in Texas. Tex Univ Min S, B 3: 108-129 (1902)

Harper, Joseph H.

os The San Francisco earthquake of April 18, 1906. As Eng Soc, J 40:87-101 (1908)

Harper, Lewis.

56 Ceratites americanus. Ac N Sc Phila, $\operatorname{Pr} 8: 126-128$, il (1856)

57 Preliminary report on the geology and agriculture of the State of Mississippl. $350 \mathrm{pp}$, maps, Jackson, 1857

Harper, Roland $M$.

02 Taxodium distichum and related specles, with notes on some geological factors influencing their distribution. Torrey Bot Club, B 29:383-399 (1902)

02a Notes on the Lafayette and Columbia formations and some of their botanical features [Georgia]. Science n s 16: 68-70 (1902)

10 Preliminary report on the peat deposits of Florida. Fla G S, An Rp 3 : 197-375 (1910)

10a A botanical and geological trip on the Warrior and Tombigbee rivers in the coastal plain of Alabama. Torrey Bot Club, B $37: 106-126$ (1910)
Harrington, Bernard James (1848-1907)

71 (with Dawson, J. W.) Report the geological structure and mineral it sources of Prince Edward Island. $52 p$ il, Montreal 1871

73 Notes on samples of iron from the Acadia mines, N S. Can G S Rp Prog 1872-3: 28-31 (1873)

73a The coals of the West Coast [British Columbia]. Can G S, Rp Prog 1872-3: 76-83 (1873)

73b Notes on samples of brick clay from Fort Garry; analyses of serpentine from Abitibi and green mineral from Car. boniferous conglomerate, N. B. Can G \& Rp Prog 1872-3 : 296-300 (1873)

74 Notes on the iron ores of Canads and their development. Can $G \quad S, R_{p}$ Prog 1873-4; 192-259 (1874)

74a Saponite [Prince Edward Island]. Can Nat n s $7: 179-180$ (1874)

$\mathbf{7 4 b}$ Notes on dawsonite, a new carbon. ate. Can Nat n s 7:305-309 (1874)

76 Notes on a few Canadian minerals and rocks. Can G S, Rp Prog 1874-5:301312 (1876)

76n Sir William Edmond Logan. Can Nat n s $8: 31-46$, port (1876) Am J Sc (3) $11: 81-93$ (1876)

76b On the composition and mode of occurrence of the pyrrhotite from Elizs. bethtown, Ont. Am J Sc (3) 11:387-388 (1876)

$\boldsymbol{7 7}$ Notes on a few dikes cutting Laurentian rocks, more especially with reference to their microscopic structure. Can Nat a s $8: 315-324 \quad(1877)$

78 Notes on miscellaneous rocks and minerals. Can G S, Rp Prog 1876-7:465488 (1878)

78a Exposition universelle de 1878 \& Paris; Catalogue des minéraux, roches, et fossiles du Canada... [Can G S], 134 pp, Londres 1878 .

79 Report on the minerals of some of the apatite-bearing veins of Ottawa Co., Que., with notes on miscellaneous rocks and min. erals, 1878. Can G S, Rp Prog 1877-8: 6 52 pp (1879)

79a Notes on a few Canadian rocks and minerals. Can Nat n s 9:242-256 (1879)

so Notes on chrome garnet, pyrrhotite, and titantferous iron ore. Can Nat i 8 $9: 305-309$ (1880)

81 Note on the composition of darsonite. Can Nat n s 10:84-86 (1881)

83 Life of Sir William Logan. $432 \mathrm{pp}$ port, Montreal 1883

83a On some minerals new to Canada. R Soc Can, Pr Tr 1, iii : 79-81 (1883)

87 On some Canadian minerals. R Soc Can, $\operatorname{Pr}$ Tr 4, iil : $81-83$ (1887)

88 Note on specimen of lake fron ore from Lac la Tortue, P. Q. Can Rec Sc 3: 43-44 (1888) 
Harrington, Bernard James-Continued. 90 Notes on göthite, serpentine, garnet, and other Canadian minerals. Can Rec Sc 4:93-99 (1890)

90a On Canadian spessartite and mountain cork. Can Rec Sc 4:226-229 (1890)

91 Notes on specimens of nephrite from British Columbia. R Soc Can, $\operatorname{Pr} \operatorname{Tr} 8$, iii : 61-65 (1891)

91a On the so-called amber of Cedar Lake, North Saskatchewan, Can. Am J Sc (3) $42: 332-335$ (1891)

94 The composition of limestones and dolomites from a number of geological horizons in Canada. Can Rec Se 6:27-32 (1894)

94a on nepheline, sodalite, and orthoclase from the nepheline syenite of Dungannon, Hastings Co., Ont. Am J Sc (3) 48: $16-18$ (1894)

95 On some of the advances in mineralogical chemistry. R Soc Can, Pr Tr (2) 1, iil : 3-17 (1895)

96 The chemical composition of andradite from two localities in Ontario. Can Rec Sc 6:479-481 (1896)

96a (with Adams, F. D.) On a new alkali hornblende and a titaniferous andradite from the nepheline syenite of Dungannon, Hastings Co., Ont. Am J Sc (4) $1: 210-218$ (1896) Can Rec Sc $7: 77-88$ (1896)

01 George Mercer Dawson. Am G 28 : 67-76, port (1901) R Soc Can, Pr Tr (2) 9, iv : 183-192 (1902) Can Rec Sc $8: 413-425$, port (1902)

03 On the composition of some Canadian amphiboles. Am I Sc (4) $15: 392-394$ (1903)

03a On the formula of bornite. Am J Sc (4) $16: 151-154$ (1903)

05 On an interesting variety of fetid calcite and the cause of its odor. Am J Sc (4) $19: 345-348$ (1905)

06 On the composition of some Montreal minerals. R Soc Can, $\operatorname{Pr} \operatorname{Tr}$ (2) 11, iii : $25-28$ (1906)

07 Isomorphism as illustrated by certain varieties of magnetite. Miner Mag 14: 373-377 (1907)

See also Selwyn, 74

Harrington, Daniel.

01 Coal mining at Sunnyside, Utah. Colo Sch Mines, B 1:227-235 (1901)

Harrington, George Leavitt.

16 (with Mertie, J. B., jr.) Mineral resources of the Ruby-Kuskokwim region [Alaska] U S G S, B 642: 223-266, map (1916)

17 Gold placers of the Anvik-Andreafski region, Alaska. U S G S, B $662: 333-349$, map (1917) Abst, Wash Ac Sc, J $8: 248$ (1918)

18 The Anvik-Andreafski region, Alaska (including the Marshall district). U S G S, B 683: $70 \mathrm{pp}$, maps (1918)
Harrington, George Leavitt-Continued.

18 a Late Tertiary and Quaternary history of the lower Yukon River region (abst). Wash Ac Sc, J 8: 413 (1918)

Harrington, Mark Walrod.

76 Report on Olmsted Co.; Dodge Co.; Steele Co. Minn G S, An Rp 4: 75-114, maps (1876)

84 The geology of Olmsted Co. ; ...Dodge Co.; ... Steele Co. Minn G S, Final Rp 1: $325-346,367-375,394-403$, maps (1884)

85 Lost rivers. Science 6:265-266 (1885)

Harrington, W. Hague.

so Graphite of the Ottawa Valley. Ottawa Field Nat Club, $\operatorname{Tr}$ no 1:22-25 (1880)

Harris, Edward.

45 On the geology of the upper Missouri. Ac N Sc Phila, Pr 2: 235-240 (1845)

Harris, Gilbert Dennison.

90 The genus Terebellum in American Tertiaries. $\triangle \mathrm{m} \mathrm{G} 5: 315$ (1890)

91 The Fayetteville-Huntsville section. Ark G S, An Rp 1888, 4:149-154 (1891)

91 a Notes on the geology of southwestern New York. Am G 7:164-178 (1891)

$91 \mathrm{~b}$ On the confounding of Nassa trivittata Say and Nassa peralta (Con. sp.) Am G 8:174-176 (1891)

92 (with Dall, W. H.) Correlation papers; Neocene. U S G S, B $84: 349$ pp, maps (1892)

93 Preliminary report on the organic remains obtained from the deep well at Galveston, together with conclusions respecting the age of the various formations penetrated. Tex G S, An Rp 4 pt 1:115-119 (1893)

93a The Tertiary geology of Calvert Cliffs, Md. Am J Sc (3) $45: 21-31$, map (1893)

93b Correlation of Tejon deposits with Écene stages of the Gulf slope. Science $22: 97$ (1893)

93e Republication of Conrad's Fossil shells of the Tertiary formations of North America. $121 \mathrm{pp}$, il, Washington 1893

93d Remarks on Dall's collection of Conrad's works. Am G 11:279-281 (1893)

93e (with Dumble, E. T.) The Galveston deep well. Am J Sc (3) $46: 38-42$ (1893)

94 The Tertiary geology of southern Arkansas. Ark G S, An Rp 1892, 2: 207 $\mathrm{pp}$, il, map, Morrillton, 1894

94a On the geological position of the Eocene deposits of Maryland and Virginia. Am J Sc (3) $47: 301-304$, il (1894)

95 Claiborne fossils. B Am Pal no 1: 52 pp, il (1895)

95a Neocene Mollusca of Texas or fossils from the deep well at Galveston. B Am Pal no 3: $32 \mathrm{pp}$, il (1895)

95b New and otherwise interesting Ter tiary Mollusca from Texas. Ac N Sc Pbila, Pr 1895: 45-88, il 
Harris, Gilbert Dennison-Continued.

96 The Midway stage. B Am Pal no 4: $157 \mathrm{pp}$, il (1896)

96a New and interesting Eocene Mollusca from the Gulf States. Ac $\mathrm{N}$ Sc Phila, Pr 1896: 470-482, il

96b The Eocene stages of Georgia (abst). Am G 18:236 (1896)

97 The Lignitic stage, Part I, Stratigraphy and Pelecypoda. B Am Pal no 9 : 102 pp, il (1897)

99 The Lignitic stage, Part II, Scaphopoda, Gastropoda, Pteropoda, and Cephalopoda. B Am Pal no 11: 128 pp, il (1899)

99a (and Veateh, A. C.) A preliminary report on the geology of Louisiana. La St Exp Sta, G Agr La pt 5:354 pp, il, map [1899]

991. The Natchitoches area. La St Exp Sta, G Agr La pt 5:140-148, map [1899]

99e The Cretaceous and lower Eocene faunas of Louisiana. La St Exp Sta, G Agr La pt 5:289-310, il [1899]

ox Oil in Texas. Science $n$ \& $13: 666$ 667 (1901)

02 Eocene outcrops in central Georgia. B Am Pal no 16:7 pp (1902)

02a The geology of the Mississippi embayment with special reference to the State of Louisiana. La St Exp Sta, G Agr La pt 6:1-39, map (1902)

02b Subterranean waters of Louisiana. La St Exp Sta, G Agr La pt 6:195-252 (1902)

02c Oil in Louisiana. La St Exp Sta, G Agr La pt $6: 261-275$ (1902)

o4 Notes on elementary geologic mensuration. $61 \mathrm{pp}$, Ithaca 1904

04a Underground waters of southern Louisiana. U S G S, W-S P 101:98 pp, map (1904)

04b The Helderberg invasion of the Manlius. B Am Pal no 19:27 pp (1904)

05 Underground waters of southern Louisiana. La St Exp Sta, La G S, B 1: 1-77, maps (1905)

or Notes on the geology of the Winnfield sheet. La G S, B 5:36 pp, maps (1907)

07a Cartography of southwestern Louisiana with special reference to the Jennings sheet. La G S, B 6:24 pp, map (1907)

08 [The salt domes of Louisiana and Texas.] (abst). Sclence n s $27: 347-348$ (1908)

08a Note on the "Lafayette beds" of Louisiana. Science n \& 27:351 (1908)

08b Salt in Louisiana, with special reference to its geologic occurrence. La G S, B $7: 5-59$ (1908)

ose Domes; or, structural peculiarities of the salt-bearing localities of Louisiana and southeast Texas. La G S, B 7:59-83 (1908)
Harris, Gilbert Dennison-Continued.

osd (assisted by Marury, C. J., as: Reinecke, L.) Rock salt, its origin, $g$. logical occurrences, and economic impo: tance in the State of Louisiana, togette with brief notes and references to a. known salt deposits and industries of th world. La G S, B 7:259 pp (1908)

09 The geological occurrence of rock sat in Louisiana and east Texas. Ec G 4:1234, map (1909)

O9a Magnetic rocks [peridotite eru? tives about Murfreesboro, Ark.]. Scienc n \& $29: 384$ (1909)

09b (and Perrine, I., and Hopper, I. E.) Ofl and gas in northwestern Louisian with special reference to the Caddo fielt La G S, B 8:52 pp (1909)

10 Oil and gas in Louisiana with a brit summary of their occurrence in adjacert States. U S G S, B 429: 192 pp (1910)

10a The lower Tertiaries of Louisian Science n s 31:502 (1910)

12 Oil concentration about salt domes Science n s 35:546-547 (1912)

12a Dome theories as applied to Gill coast geology. Science n s $36: 173-174$ (1912)

13 Immense salt concretions. Pop \& Mo $82: 187-191$ (1913)

16 Horizon of the Shark River, N. 1. Eocene deposits. Science n s $43: 532-504$ (1916)

18 Age flow and ebb of the Eocene seas Science n s 48: 646-647 (1918)

See also Cooke (C W), 15 ; Norton, 15; Say, 96

Harris, Hunter L.

93 A new instance of stream capture [North Carolina]. Boston Soc N H, Pt $26: 27-29$ (1893)

94 History of the Atlantic shore line Elisha Mitchell Sc Soc, J 11:33-50, map (1894)

Harris, R. P.

65 On borax in California. Am $\mathrm{Ph}$ Soh Pr 9:450 (1865)

Harris, T. W.

92 Mount Bob, Mount Ida, or Snabe Hill [N. Y.]. Am J Sc (3) $43: 236-238$ (1892)

94 The kames of the Oriskany Valley [N Y.]. Am G $13: 384-390$ (1894)

Hnrrison, Alfred C.

O9 (and others) Persifor Frazer, 184t 1909. Franklin Inst, $J$ 168: 75-79, port (1909)

Harrison, Edwin.

68 Age of the porphyry hills of sout east Missouri. Ac Sc St L, Tr 2:50t (1868)

Harrison, H. H.

13 The barite deposits of the Island of Cape Breton, N. S. Min Soc N S, J 18 23-26 (1913) 
Harrison, John Burchmore.

89 (and Jukes-Browne, A. J.) Origin of the radiolarian earth of Barbados. Nature $39: 367$ (1889)

90 (and Jukes-Browne, A. J.) The geology of Barbados, being an explanation of the geological map of Barbados prepared by the same authors. $64 \mathrm{pp}$ [Salisbury] 1890

90a (and Jukes-Browne, A. J.) Geological map of Barbados. Scale 3960 feet to 1 inch [1890?]

91 (with Jukes-Browne, A. J.) The geology of Barbados. G Soc London, Q J 47:197-243 (1891) ; 48:170-226 (1892) Abst, G Mag (3) $8: 139$ (1891); (3) 9 : 88-89 (1892)

95 (and Jukes-Browne, A. J.) Notes on the chemical composition of some oceanic deposits. G Soc London, Q J 51: 313-328 (1895) Abst, G Mag (4) 2:186187 (1895)

96 The rocks and soils of Grenada and Carriacou... 60 pp, L 1896

98 (with Franks, G. F.) The Globigerina marls and basal reef rocks of Barbados; with an appendix on the Foraminfera, by F. Chapman. G Soc London, Q J 54:540-555, map (1898) Abst, G Mag (4) $5: 333$ (1898)

99 (and Jukes-Browne, A. J.) The oceanic deposits of Trinidad, British West Indies. G Soc London, Q J 55:177-189, map (1899)

02 (and Jukes-Browne, A. J.) The geology of Barbados. G Mag (4) 9:550554 (1902)

07 The coral rocks of Barbados. G Soc London, Q J 63:318-337, map (1907)

os Geological formation of Barbados. 16 pp, Barbados 1908

Harrison, Randolph.

85 Handbook of Virginia. 4th ed, 182 pp, maps, Richmond, Va. 1885 5th ed, 200 pp, Richmond, Va., iss6 [See also Pollard, Thomas.]

Harrison, Richard C.

07 Pockets in gold veins. M Sc Press 94:564 (1907)

Harrod, B. M.

88 Archean rocks in Texas. New orleans Ac Sc, Papers 1: 131-133 (1888)

Harshberger, John W.

11 Phytogeographic survey of North America. $790 \mathrm{pp}$, Leipzig 1911 [Forms vol. 13 of Engler, A., and Drude, O., Die Vegetation der Erde: Sammlung pflanzengeographischer Monographien.]

Hart, Charles A.

12 Note on "some early physiographic inferences," Science n s 35 : 693 (1912)

Hart, Edward.

03 Death Valley, Cal., and its borax industry. Am Ceramic Soc, Tr 5:64-73 (1903)
Hartley, Burton.

13 Field and office methods in the preparation of geologic reports; field methods in the "Tierra Caliente." Ec G 8:578-581 (1913)

17 The petroleum geology of the Isthmus of Tehuantepec. Ec G 12:581-588 (1917)

Hartley, Edward (1847-1870).

70 Report [on a part of the Pictou coal field, N. S.]. Can G S, Rp Prog 1866-9; 55-107 (1870)

70a Report on the coals and iron ores of Pictou Co., N. S. Can G S, Rp Prog 1866-9: 365-442, map (1870)

70b Notes on coal from the Springhill coal field, County Cumberland, N. S. Can G S, Rp Prog 1866-9:443-447 (1870)

Hartman, W. D.

57 Medical topography and geology [of Chester Co., Pa.]. Med Soc $\mathrm{Pa}$, Tr n s 2 : 109-118, map (1857)

Hartmann, Miner Lonis.

Is A bibliography of tungsten. S Dak Sch Mines, B 12:160-255 (1918)

$18 a$ (with Runner, J. J.) The occur rence, chemistry, metallurgy, and uses of tungsten, with special reference to the Black Hills of South Dakota. S Dak Sch Mines, B 12:4-159 (1918)

Hartnagel, Chris A.

o3 Preliminary observations on the Cobleskill ("Coralline") limestone of New York. N Y St Mus, B 69:1109-1175, map (1903)

o5 Notes on the Siluric or Ontario section of eastern New York. N Y St Mus, B $80: 342-358$ (1905) Abst, G Soc Am, B 16:582 (1906); Science n s 21:222 (1905) ; Sc Am Sup 59: 24327 (1905)

05a Structural relations and origin of the limonite beds at Cornwall, N. Y. (abst). Science n s 21:991 (1905)

o7 Stratigraphic relations of the Oneida conglomerate. N Y St Mus, B 107:29-38 (1907)

o7a Upper Siluric and lower Devonic formations of the Skunnemunk Mountain region. N $\mathbf{Y}$ St Mus, B 107:39-54, map (1907)

O7b Geologic map of the Rochester and Ontario Beach quadrangles. N Y St Mus, B 114: $35 \mathrm{pp}$, map (1907)

o7e Structural relations and origin of the limonite beds at Cornwall, N. Y. (abst). N Y Ac Sc, An 17:597-59s (1907)

os (with Newland, D. H.) Iron ores of the Clinton formation in New York State. N Y St Mus, B 123:76 pp (1908)

12 Classification of the geologic formations of the State of New York. N Y St Mus, Handbook 19 (of the State of New York Education Department) 2d ed, $99 \mathrm{pp}$. (1912) [For first ed, see Clarke (J M), $03 \mathrm{~g}]$ 
Hartt, Charles Frederic (1840-1878).

64 The gold of Nova Scotia of pre-Carboniferous age. Can Nat n s 1:459-461 (1864)

65 Preliminary notice of a fauna of the Primordial period in the vicinity of $\mathrm{St}$. John, N. B. In Balley, L. W., Observations on the geology of southern New Brunswick: 30-31 Frederickton 1865 Can Nat n s 2:318-320 (1865)

$65 a$ On the Devonian plant locality of the "Fern ledges," Lancaster, N. B., with a detailed section and notes on the fossils. In Bailey, L. W., Observations on the geology of southern New Brunswick: 131140, Frederickton 1865

65b List of New Brunswick fossils. In Bailey, L. W., Observations on the geology of southern New Brunswick:143-147, Frederickton 1865

67 On a subdivision of the Acadian Carboniferous limestones, with a description of a section across these rocks at Windsor, N. S. (with note by J. W. Dawson). Can Nat n s $3: 212-224$ (1867)

71 Discovery of mastodon remains at Mott's Corners near Ithaca, N. Y. Am Nat 5 : $314-315$ (1871)

Hartwell, E. Adams.

92 The Pearl Hill pothole [Mass.] Boston Soc N H, Pr 25:421-425 (1892)

Hartz, N.

96 Planteforsteninger fra Cap Stewart i Ost-Grönland, med en historisk Oversigt [Jurassic plants from Cape Stewart, eastern Greenland]. Med Grönland 19: $215-247,271-272$, 11 (1896)

Hartxe11, Joseph Culver.

96 The history and principles of geology and its aim. Am Nat $30: 177-183,271$ 279 (1896)

04 Das Oberdevon Europas und Nordamerikas. $73 \mathrm{pp}$, Inaug. Diss. München. 1904

06 Conditions of fossilization. J G 14 : 269-289 (1906)

13 The value of geochemistry to geology and geography (abst). Sclence n s $37: 458$ (1913)

Harvey, Arthur.

89 [Erosion in the valley of the Don, Ont.] Can Inst, Pr (3) $7: 28-29$ (1889)

$89 a$ Broad outlines of the geology of the northwest of Lake Superior. Can Inst, Pr (3) $7: 218-225$ (1889)

Harvey, LeRoy Harris.

86 The minerals and rocks of Arkansas. 32 pp, Phila 1886

86a On Anthracomartus trilobitus Scud. Ac N Sc Phila, Pr 1886 : 231-232

s8 A catalogue of the minerals and rocks in the museum. Me St Coll Lab $\mathrm{N}$ H, B 1 no $1: 27$ pp (1888)

Harvey, LeRoy Harris.

03 A study of the physiographic ecology of Mount Ktaadn, Maine. Maine, Univ, Studies no 5:50 pp (1903)

\section{Harvey, M.}

83 (with Hatton, Joseph.) Newfoundland ... [geology:150-157] $431 \mathrm{pp}$, map, Boston 1883

\section{Harvey, Philip.}

73 An essay on the glacial epoch. Read before the 'Teachers' Institute of Des Moines Co. [Iowa], August 21 1873. 24 pp, Burlington 1873

\section{Harvie, Robert, jr.}

10 On the origin and relations of the Paleozoic breccia of the vicinity of Montreal. R Soc Can, $\operatorname{Pr} \operatorname{Tr}$ (3) 3 iv: 249299 (1910)

11 Notes on the discovery of a telluride gold ore at Opasatica and its probable re. lations to the gold ores of the Porcupine and neighboring districts [Quebec]. Can M Inst, Q B 14:183-189, map (1911); J 14: 164-170, map (1912)

$11 a$ Geology of a portion of Fabre township, Pontiac Co., Que. Que, Dp Col, Mines $\mathrm{Br}: 33 \mathrm{pp}$ (French ed, $36 \mathrm{pp}$ ), map (1911)

11 b The Opasatica district, Que.; geological and mineralogical notes. Que, Dp $\mathrm{Col}$, Mines $\mathrm{Br}, \mathrm{Rp}$ on mining operations 1910 : 78-85 (1911)

12 Geology of Orford map area, Quebec, southern part of "serpentine belt," Bolton township. Can G S, Sum Rp 1911:286292 (1912)

13 Asbestos deposits of the Province of Quebec. Int G Cong, XII, Canada, Guide Book no $2: 99-117$, maps (1913)

14 Geology of Orford map area, and the southeast part of the "serpentine belt," Potton Township, Quebec. Can G S, Sum Rp 1913: 212-216 (1914)

15 Brome and Missisquol cos., Que. Can G S, Sum Rp 1914: 98-99 (1915)

16 Thetford-Black Lake map area, Que. Can G S, Sum Rp 1915: 172-173 (1916)

17 Thetford-Black Lake mining district, Que. Can G S, Sum Rp 1916:228-229 (1917)

Harvood, F. H.

03 The fluorspar and zinc mines of Kentucky and Illinois. M Sc Press $86: 87-88$, 101-102 (1903)

Haseltine, Robert M.

o1 Lignite deposits or fields of brown coal in North Dakota. Mines and Min. erals $21: 545-547$ (1901)

02 The bituminous coal field of Ohio. U S G S, An Rp 22 pt $3: 215-226$ (1902)

Haskell, Daniel C.

13 A partial bibliography of Niagara Falls. N Y Comm St Res Niagara, An Rp 29:49-98 (1913)

Haske11, Robert C.

59 On a visit to the recent eruption of Mauna Loa, Hawali. Am J Sc (2) 28: 66-71, 284 (1859) 
Haskins, Roswell Willson (1796-1870).

69 An examination of the hypothesis of central heat in the earth and of the assumed connection of volcanoes and earth. quakes therewith. 25 pp, Buffalo, N. Y., 1869

Hassan, A. A.

10 Preliminary notes on geology of the Poreupine district of Canada. Can M J 31: 561-562 (1910)

Hasse, Adelaide $\mathrm{R}$.

99 Reports of explorations printed in the documents of the United States Government (a contribution toward a bibliography). $90 \mathrm{pp}$, Office Superintendent of Documents, Government Printing Office, Washington 1899

Hastings, John B.

94 The Boise Basin in Idaho. Eng $M$ J 58:56 (1894) Sc Am Sup 38: 1554015541 (1894)

95 The Atlanta lode, Idaho. Eng M J $59: 128$ (1895)

95a Subclassification of zenogenous ore deposits. Eng M J 59 : 268-269 (1895)

06 Are the quartz veins of Silver Peak, Nev., the result of magmatic segregation? Am I M Eng, Tr $36: 647-654$ (1906) ; B 1 [7] :9-16 (1906) Reprinted in Emmons, 8. F., Ore deposits (pub. by Am I M Eng) : $621-628, N \mathrm{Y}, 1913$

06a (and Berkey, C. P.) The geology and petrography of the Goldfield mining district, Nev. Am I M Eng, B 8:295-314, map (1906) ; $\operatorname{Tr} 37: 140-159$, map (1907)

06b The geology of Goldfield, Nev. Eng M J $81: 843-844$ (1906)

08 Primary gold in a Colorado granite. Am I M Eng, B 21:311-317 (1908) ; Tr 39: 97-103 (1909)

08a Origin of pegmatite. Am I M Eng, B $21: 319-343$ (1908); Tr $39: 105-128$ (1909)

08b Volcanic waters. Am I M Eng, B 21: 345-354 (1908) ; Tr 39: 129-138 (1909) Abst, M Sc Press 97: 229-231 (1908)

08e Association of magnetite with sulphides in mineral deposits. M Sc Press 97 : $333-334,358-359$ (1908)

09 Meteor Crater [Ariz.]. M Sc Press 98: 523-525 (1909)

18 Ore deposits of the Boulder batholith of Montana (discussion). Am I M Eng, B $133: 72-75$ (1918) 17

See also Billingsley, 17; Spencer (A C),

Hateh, F. H

14 The relation of geology to mining. Ec G 9:205-235 (1914)

Hatch, Hamlin Brooks.

10 The Porcupine gold district, Ont. Can M J 31: 306-308 (1910)

Hateh, Laura.

17 Marine terraces in southeastern Connecticut. Am J Sc (4) 44:319-330 (1917)
Hatch, Laura-Continued.

17a The glaciers of $M t$. Jefferson

[Oreg.]. Mazama 5:136-139 (1917)

Hatcher, John Bell (1861-1904).

93 The Ceratops beds of Converse Co., Wyo. Am J Sc "(3) 45: 135-144 (1893)

93a The Titanotherium beds. Am Nat $27: 204-221$ (1893)

94 ... vertebrate fossils from the Loup Fork beds of northwestern Nebraska; with note on the geology of the region. Am Nat $28: 236-248$, il (1894)

94a A median horned rhinoceras from the Loup Forky beds of Nebraska. Am G 13: 149-150 (1894)

94b Discovery of Diceratherium, the twohorned rhinoceros, in the White River beds of South Dakota. Am G 13:360-361 (1894)

95 On a new species of Diplacodon, with a discussion of the relations of that genus to Telmatotherium. Am Nat 29:1084 1090 , il (1895)

95a Discovery, in the Oligocene of South Dakota, of Eusmilus, a genus of sabertoothed cats new to North America. Am Nat 29: 1091-1093 (1895)

95b The Princeton scientific expedition of 1895 [Uinta Basin, nortbeastern Utah]. Princeton Coll B 7:95-98 (1895)

96 Recent and fossil tapirs. Am J Se (4) $1: 161-180$, il (1896)

$96 a$ Some localities for Laramie mammals and horned dinosaurs. Am Nat 30 : 112-120 (1896)

97 Diceratherium proavitum. Am G 20: $313-316$, il (1897)

oo The Carnegie Museum paleontological expeditions of 1900 . Science n 8 12:718 $720(1900)$

00a Vertebral formula of Diplodocus Marsh. Science n \& 12:828-830 (1900)

01 Diplodocus Marsh; its osteology, taxonomy, and probate habits, with a restoration of the skeleton. Carnegie Mus, Mem $1: 1-63$, il (1901)

01a Some new and little known fossll vertebrates. Carnegie Mus, An 1:128144, il (1901)

01b On the cranial elements and the deciduous and permanent dentitions of Tita notherium. Carnegie Mus, An 1:256-262, il (1901)

o1e Sabal rigida; a new species of palm from the Laramie. Carnegie Mus, An 1: 263-264, il (1901)

o1d The Jurassic dinosaur deposits near Canyon City, Colo. Carnegie Mus, An 1 : $327-341$ (1901)

o1e On the structure of the manus in Brontosaurus. Science n s 14:1015-1017 (1901)

02 Ollgocene Canidae. Carnegie Mus, Mem 1:65-108, il (1902)

02a A mounted skeleton of Titanotherium dispar Marsh. Carnegie Mus, An 1: $347-355$, il (1902) 
Hateher, John Bell-Continued.

02b Structure of the forelimb and manus of Brontosaurus. Carnegie Mus, An 1:356-376, il (1902)

02e The genera and species of the Trachodontidae (Hadrosauridae, Claosauridae) Marsh. Carnegie Mus, An 1:377386 (1902)

02d Origin of the Oligocene and Miocene deposits of the Great Plains. Am Ph Soc, Pr 41: 113-131 (1902)

02e Discovery of a musk ox skull (Ovibos cavifrons Leidy) in West Virginia, near Steubenville, Ohio. Science n s 16:707709 (1902)

o2f A correction of Professor Osborn's note entitled "New vertebrates of the midCretaceous." Science n 8 16:\$31-832 (1902)

03 Osteology of Haplocanthosaurus with description of a new species, and remarks on the probable habits of the Sauropoda and the age and origin of the Atlantosaurus beds. Carnegie Mus, Mem 2:1-75, il (1903)

03a Discovery of remains of Astrodon (Pleurocoelus) in the Atlantosaurus beds of Wyoming. Carnegie Mus, An 2:9-14, il (1903)

03b Relative age of the Lance (Ceratops) beds of Converse Co., Wyoming, the Judith River beds of Montana, and the Belly River beds of Canada. Am G 31: 369-375 (1903)

03e The Judith River beds. Science n s $17: 471-472$ (1903)

03a (and Stanton, T. W.) The stratigraphic position of the Judith River beds and their correlation with the Belly River beds. Science n s 18:211-212 (1903)

03e Vertebrate paleontology at the Carnegie Museum. Science $n$ s 18:563-570 (1903)

03f A new sauropod dinosaur from the Jurassic of Colorado [Haplocanthus (renamed Haplocanthosaurus priscus]. Biol Soc Wash, Pr 16:1-2, 100 (1903)

04 An attempt to correlate the marine with the non-marine formations of the middle west (with note by T. W. Stanton). Am Ph Soc, Pr 54:341-365) (1904) Abst, Science n s 19:717 (1904)

05 Two new Ceratopsia from the Laramie of Converse Co., Wyo. Am J Sc (4) $20: 413-419$, il $(1905)$

O5n (with Stanton, T. W.) Geology and paleontology of the Judith River beds. U S G S, B 257: 128 pp, il (1905)

or (and Marsh, O. C., and Ln11, R. S.) The Ceratopsia. U S G S, Mon $49: 300$ pp, il (1907)

Hately, J. Geo.

07 Copper mining on the Colorado River. M World 26:809, map (1907)
Hatmaker, B. J.

16 St. Lawrence Co., N. Y., zinc feld, M World 44:689-690 (1916)

Hatschele, E.

12 (and Simon, A. L.) Gels, gelatin. ous quartz, and gold-ore deposition. I World $37: 280-282$ (1912)

Hatton, Joseph.

83 (and Harvey, M.) Newfoundland... [geology : 150-157] 431 pp, map, Boston 1883

Haner, Max.

85 Das Eozoon canadense; eine mikro. geologische Studie. $55 \mathrm{pp}$, il, Leiprig 1885

Haughton, Samuel.

57 [Geological notes and illustrations in M'Clintock's Reminiscences of Arctic ice travel.] R Dublin Soc, J 1:183-250, il, map (1857)

59 Geological account of the Arctic Archipelago ... In MeClintock, F. L., The voyage of the Fox in the Aretic seas; a narrative of the discovery of the fate of Sir John Franklin and his companions: 372-399, map, L 1859 G Soe Dublin, J $8: 196-213$ (1860) Nat Hist Rv 7 (no 26) : $139-156(1860)$

60 On the fossils brought from the Arctic regions in 1859 by Captain Sir F. L. M'Clintock. Nat Hist Rv 7 (no 27) : 359364 , il (1860) R Dublin Soc, J 3:53-58, il $(1860)$

HanItain, Herbert Edward Terrick.

oт Corundum at Craigmont [Ont.]. Can M J 28 no 12 (n s 1 no 10) :291-296 (1907)

13 The geologist. Can M J 34:182185 (1913) Can M Inst, Tr 16:545-564 (1913)

Haupt, Lewis M.

89 Discussion on the dynamic action of the ocean in building bars. Am Ph Soc, Pr 26: 146-171 (1889)

05 The menace to the entrance of New York Harbor $(a b s t)$. Science n s 21:136 (1905)

06 Changes along the New Jersey coast. N J G S, An Rp 1905:27-95 (1906)

Hanpt, Th.

43 Geognostische und bergmännische Bemerkungen über St. Domingo. Arch Miner $17: 536-663$ (1843)

Hausman, Leon Augustus.

16 (with Von Engeln, O. D.) An automatic, intermittent eruption, artificial geyser. School Science and Mathematics 16:116-122 (1916)

18 An example of the possible intricacy of glacial modification of drainage within a narrow area. Am J Sc (4) $45: 153-173$ (1918)

Hausmann, A.

91 Interesting occurrences of gold. Eng M J $51: 516$ (1891) 
Haüy, Rene Just.

11 Sur les cymophanes des Etats-Unis, Mus d'Hist Nat, Paris, An 18: 57-69 (1911) J Mines $30: 321-334$ (1811) Ueber den Chrysoberyl (Cymophane) aus Connect1cut... Annalen der Physik (Gilbert) 41: 53-61 (1812)

12 Sur des cristaux de pyroxène des environs de New Yorck. Mus d'Hist Nat, Paris, An 19:257-267 (1812) J Mines 33: 175-186 (1813)

Havenor, H. E.

11 The oil fields of Byron, Wyo. Salt Lake M Rv 12 no $19: 15-16$ (1911)

Hawailan Volcano Observatory.

14 Report of the Hawailan Volcano Observatory of the Massachusetts Institute of Technology and the Hawailian Volcano Research Association, T. A. Jaggar, Director, January-March, 1912. Published by the Society of Arts of the Massachusetts Institute of Technology, Boston. 74 pp [1914]

14a Weekly Bulletin, vol. 2 (1914)-6 (1918) T. A, Jaggar, director, principal contributor.

Hawes, George Wesson (1848-1882).

75 Catalogue of mineral localities in New Hampshire. 155 pp [priv pub, n p, n d, 1875?]

$75 \mathrm{a}$ The trap rocks of the Connecticut Valley. Am. J Sc (3) 9:185-192 (1875)

$75 \mathrm{~b}$ On diabantite, a chlorite occurring In the trap of the Connecticut Valley. Am I Sc (3) $9: 454-457$ (1875)

75e On zonochlorite and chlorastrolite. Am J Sc (3) $10: 24-26$ (1875)

76 The rocks of the "chloritic formation" on the western border of the New Haven region. Am J Se (3) 11:122-126 (1876)

76a On a lithia-bearing varlety of biotite. Am J Sc (3) 11: 431-432 (1876)

$76 \mathrm{~b}$ The greenstones of New Hampshire and their organic remains. Am J Sc (3) 12:129-137 (1876)

77 On grains of metallic iron in dolerites from New Hampshire. Am J Sc (3) 13: 33-35 (1877)

78 The mineralogy and lithology of New Hampshire. In Hitchcock, C. H., Geology of $\mathrm{NH}$, pt 4 [vol 3] : $262 \mathrm{pp} \mathrm{(1878)}$

79 On a group of dissimilar eruptive rocks in Campton, N. H. Am J Sc (3) 17 : 147-151 (1879) Yale Bicen Pub, Contr Miner : 394-399 (1901)

81 The Albany granite, N. H., and its contact phenomena, Am J Sc (3) 21:21-32 (1881) Yale Bicen Pub, Contr Miner: 400-414 (1901)

81a On liquid carbon dioxide in smoky quartz. Am J Sc (3) 21:203-209 (1881)

81b [Recent scientific progress in] geology. Smiths Inst, An Rp 1880:221-234 (1881)

$28737^{\circ}-23-30$
Hawes, George Wesson-Continued.

81e [Recent scientific progress in] mineralogy. Smiths Inst, An Rp 1880:299312 (1881)

82 On the mineralogical composition of the normal Mesozolic diabase upon the Atlantic border. U S Nat Mus, Pr 4:129134 (1882)

83 On a phosphatic sandstone from Hawthorne in Florida. U S Nat Mus, Pr 5: 46-48 (1883)

84 (and others) Report on the building stones of the United States and statistics of the quarry industry for 1880 . U S, 10th Census $10: 410 \mathrm{pp}$ (1884) Includes contributions by N. S. Shaler, J. E. Wolff, C. H. Hitchcock, H. W. Lindsley, G. H. Cook and J. C. Smock, J. H. Huntington, F. K. Singleton, C. E. Munroe, W. C. Kerr, W. H. Kerr, H. E. Colton, A. Gattinger, E. Orton, A. D. Conover, N. H. Winchell, W J McGee, G. C. Broadhead, and William Foster.

96 Notes on the microscopic characters of the Alabama crystalline or metamorphic rocks. Ala G S, B 5:131-132 (1896)

Hawkins, Alfred C.

10 Diverse effects of glaciation on the Cretaceous clays. Am J Sc (4) $30: 350-$ 353 (1910)

13 Somre interesting mineral occurrences at Princeton, N. J. Am J Sc (4) 35:446450 (1913)

14 Lockatong formation of the Triassic of New Jersey and Pennsylvania. N Y Ac Sc, An $23: 145-176$, map (1914)

15 Datolite from North Plainfield, Somerset Co., N. J. Am J Sc (4) $39: 473-474$ (1915)

15a (and Brown, C. W.) Basic rocks of Rhode Island; their correlation and relationships (abst). G Soc Am, B 26:92-93 (1915)

16 The occurrence of lamellar calcite in Rhode Island. Am Mineralogist 1:3-4 (1916)

17 Developing crystallized mineral specimens. Am Mineralogist 2: 101-102 (1917)

18 Notes on the geology of Rhode Island. Am J Sc (4) 46:437-472, map (1918)

18a Quartz crystals from Centerdale, R. I. Am Mineralogist 3:1-2 (1918)

$18 b$ (and wherry, E. T.) Famous mineral localities; 4 , The Joplin district. Am Mineralogist 3: 36-37 (1918)

18e Fibrous quartz from Rhode Island. Am Mineralogist 3:149-151 (1918)

18d Minerals of the saline domes of the Texas-Louisiana Coastal Plain. Am Mineralogist 3: 189-192 (1918)

Hawkins, B. Waterhouse.

74 On the pelvis of Hadrosaurus. Ac $\mathrm{N}$ Se Phila, Pr 1874: 90-91

75 Pelvis of Hadrosaurus. Ac $\mathrm{N}$ Sc Phila, Pr 1875: 329 
Hawkins, Edwin N.

89 (with Hawkins, J. D.) Plattnerite from Idaho. Am J Sc (3) 38: 165-166 (1889)

Hawkins, J. Dawson.

S9 (and Hawkins, E. N.) Plattnerite from Idaho. Am J Sc (3) 38: 165-166 (1889)

90 On minium from Leadville [Colo.]. Am J Sc (3) 39:42-43 (1890)

Hawley, H. J.

17 Stratigraphy and paleontology of the Salinas and Monterey quadrangles, Cal. (abst). G Soc Am, B 28: 225 (1917)

17a (with Garfias, V. R.) Funnel and anticlinal ring structure associated with igneous intrusions in the Mexican oil fields. Am I M Eng, B 128:1147-1159 (1917); Tr 57:1071-1088 (1918)

18 Cretaceous and Tertiary stratigraphy of the western end of the Santa Inez Mountains, Santa Barbara Co., Cal. (abst). G Soc Am, B $29: 164$ (1918)

Hawn, Frederick (1810-1898).

55 Report [on country between the Missouri and Mississippi rivers]. Mo G S, An Rp 1-2 pt 2:121-136 (1855) M Mag 5: 382-394 (1855)

58 The Trias of Kansas. Ac Sc St L, Tr 1: 171-172 (1858)

58 a (with Swallow, G. C.) The rocks of Kansas. Ac Se St L, Tr 1:173-197 (1858)

65 (with Swallow, G. C.) Report on the geological survey of Miami Co., Kans. 24 pp, map, Kansas City, Mo., 1865 Also in Prel $\mathrm{Rp}$ : 71-94 (1866)

66 Report [various counties in eastern Kansas]. Kans G S, Prel Rp (Swallow) : 95-122 (1866)

74 Geological observations [in the Ute country]. U S, $43 d$ Cong 1 st sess, H Ex Doc 193: 59-66, 69-88 (1874)

\section{Hawn, Laurens.}

74 Geological notes made on the Ute reconnaissance during examination of the Animas River. U S, 43 d Cong 1st sess, H Ex Doc 193: 66-69 (1874)

Haworth, Erasmus.

81 Chemical and dynamical geology. Kansas City Rv Sc 5: 75-83 (1881)

82 The chert rocks of Subcarboniferous

Kansas. Kansas City Rv Sc 5:669-676 (1882)

83 The coal fields of Cherokee Co.

[Kans.]. Kans Ac Sc, Tr 8:7-11 (1883)

83a Are there igneous rocks in Cherokee

Co.? Kans Ac Sc, Tr 8: 18-20 (1883)

83b Notes on Kansas minerals. Kans Ac Sc, Tr 8: 25-26 (1883)

84 A contribution to the geology of the lead and zinc mining district of Cherokee Co., Kans. Thesis, Kansas State University, 47 pp, Oskaloosa Iowa 1884.

85 Octahedral limonite [Dickinson Co., Kans.]. Kans Ac Sc, Tr 9: 25 (1885)
Haworth, Erasmus-Continued. 86 Millerite. Science $8: 369$ (1886)

88 A contribution to the Archean ogy of Missouri. Am G 1:280-297, : 382 (1888) Abst, Johns Hopkins Circ $7: 70-71$ (1888)

90 The crystalline rocks of Miss (abst). Iowa Ac Sc, Pr 1887-89: be(1890)

91 The age and origin of the crystall rocks of Missouri. Mo G S, B $5: 5$ (1891)

92 Notes on Missouri minerals, Ac Sc, Pr 1 pt $2: 33-35$ (1892)

92a Prismatic sandstone from Missor Science 19:34 (1892) Iowa Ac Sc, P pt $2: 36-37$ (1892)

94 Report on field work in geology season of $1893 \ldots$ University of Kans Kans Univ Q 2:99-101 (1894)

$94 a$ Relative value of limestone, $\operatorname{sal}$ stone, and shale for stratigraphic work Kansas. Kans Univ Q 2:102-104 (18\%-

94b (and Kirk, M. Z.) A geologic tion along the Neosho River from the $\mathrm{X}$ sissippian formation of the Indian Ter tory to White City, Kans., and along t Cottonwood River from Wyckoff to $P$ body. Kans Univ Q 2:104-115 (1894)

94e (and Piatt, W. H. H.) A geolot section along the Verdigris River from it State line to Madison. Kans Univ Q: 115-118 (1894)

94d A geologic section along the A. \& S. F. R. R. from Cherryvale to Lawren and from Ottawa to Holliday. Kans ti Q 2:118-126 (1894)

94e Resumé of the stratigraphy of ear ern Kansas. Kans Univ Q $2: 126-1$. (1894)

94f The topography of eastern Kanss Kans Univ Q 2:129-136 (1894)

$94 \mathrm{~g}$ The surface gravels of eastern $\mathrm{Ku}$ sas. Kans Univ Q 2:136-142 (1894)

94h (with Winslow, A., and Nasos F. L.) A report on the Iron Mountal sheet, including portions of Iron, St. Frit cois, and Madison cos. Mo G S 9, Shee $\mathrm{Rp}$ no 3:85 pp, map, Jefferson City 154

95 The crystalline rocks of Missourt [s cluding a section on General geology of th Missouri crystalline area, by C. R. Keyes. Mo G S 8: 81-222 (1895)

$95 a$ The stratigraphy of the Kanes Coal Measures. Kans Univ Q $3: 271-20$ (1895) Am J Sc (3) 50:452-466 (1805) Abst, J G $3: 983-984$ (1895)

95b Division of the Kansas Coal Mer ures. Kans Univ Q $3: 291-295$ (1895)

95e The coal fields of Kansas. Kas Univ Q 3:297-309 (1895)

95d Oil and gas in Kansas. Am $\mathbf{A s}, \mathrm{P}$ 43 : 229-236 (1895)

96 (and others) The University logical survey of Kansas. Vol I : xil, 35 pp, map, Topeka 1896 ; Vol II : xi, 318 ph map. Topeka 1897 
Haworth, Erasmus - Continued.

96a (and Bennett, John) A geologic section from Baxter Springs to the Nebraska State line. Kans Univ G S 1:3571 (1896)

96b A geologic section from Coffeyville to Lawrence; Résumé of the stratigraphy and correlations of the Carboniferous formations; Physiographic features of the Carboniferous; the coal fields of Kansas; Oil and gas in Kansas (preliminary) ; Surface gravels of the Carboniferous area; the Coal Measure solls. Kans Univ G S 1: 129-139, 145-269 (1896) Abst, J G 4: 645-646 (1896)

96e Local deformation of strata in Meade Co., Kans., and adjoining territory (preliminary). Am J Se (4) $2: 368-373$, map (1896)

97 Underground waters of southwestern Kansas. U S G S, W-S P 6:65 pp, map (1897)

97a Physiography of western Kansas; Physical properties of the Tertiary. Kans Univ G S 2:11-49, 247-284 (1897)

97b (and Beede, J. W.) The McPherson Equus beds. Kans Univ G S 2:285296 (1897)

97e The geology of underground water in western Kansas. Kans, Bd Irrig S, Rp 1895-6:49-114, maps (McPherson and vieinity, by C. S. Prosser and J. W. Beede), Topeka, 1897

98 Special report on coal. Kans Univ G S $3: 347$ pp, maps, Topeka 1898

98a Annual bulletin on mineral resources of Kansas for 1897. Kans Univ G S : 98 pp, Lawrence, Kans., 1898 ... for 1898 ; $127 \mathrm{pp}$, maps (1899) ... for 1899; $67 \mathrm{pp}, \operatorname{map}(1900) \quad \ldots$ for 1900 and $1901 ; \ldots 78$ pp $(1902) \quad \ldots$ for $1902 ; \ldots$ $135 \mathrm{pp}$, maps $(1903) \quad \ldots$ for $1903 ; \ldots 50$ pp (1904)

00 Relations between the Ozark uplift and ore deposits. G Soc Am, B 11: 231240 (1900)

00a (and Bennett, John.) Native copper near Enid, Okla. G Soc Am, B 12 : 2-4 (1900) Abst, Sc Am 83: 22 (1900)

00b The Galena-Joplin lead and zinc district. Mineral Industry 8:658-666 (1900) 01 Geology and mining interests of Kansas. Int $\mathrm{M}$ Cong, 4 th, $\operatorname{Pr}: 196-200$ (1901) 01a Petroleum and natural gas in Kansas. Eng M J $72: 397$ (1901)

02 The Chanute oil fields in Kansas. Eng M J $74: 477-478(1902)$

04 History, geography, geology, and metallurgy of Galena-Joplin lead and zinc. Kans Univ G S 8: 1-126 (1904)

04a (with Adams, G. I.) Economic geology of the Iola quadrangle, Kans. U S G S, B 238: 83 pp, maps (1904)

05 (and Sehrader, F. C.) Portlandcement resources of the Independence quadrangle, Kans. U S G S, B 260:506509 (1905)
Haworth, Erasmus-Continued.

O5a (and MeFarland, D. F.) The Dexter, Kans., nitrogen gas well. Science n s 21: 191-193 (1905) Abst, G Soc Am, B $16: 572$ (1906)

O5b (with Schrader, F. C.) Oil and gas of the Independence quadrangle, Kans. U S G S, B 260 : 146-458 (1905)

05c (with Sehrader, F. C.) Clay industries of the Independence quadrangle, Kans. U S G S, B 260:546-549 (1905)

06 (with Sehrader, F. C.) Economic geology of the Independence quadrangle, Kans. U S G S, B 296: 74 pp (1906)

os Prospecting for oil and gas. Am M Cong, 10th An Sess, Rp Pr : 247-255 (1908) Abst, M. World 28:25-26 (1908)

osa (and Bennett, John) The nomenclature of the Kansas Coal Measures employed by the Kansas State Geological Survey. Kans Ac Sc, Tr 21: 71-85 (1908)

08b (and others) Special report on oil and gas. Kans Univ G S 9:586 pp, maps (1908) [Rv, Bain, 07a]

ose (and Bennett, John) History of geological field work [in Kansas]. Kans Univ G S 9:42-56 (1908)

osd General stratigraphy [of Kansas]. Kans Univ G S 9: 57-121 (1908)

09 The life history of a river. Kans Ac Sc, Tr 22: 51-70 (1909)

09a Geology and its relation to gas. Nat Gas As Am, Pr 1: 364-369 (1909)

13 Special report on well waters in Kansas. Kans Univ G S, B 1:103 pp, maps (1913)

15 On crystalline rocks in Kansas. Kans Univ G S, B $2: 33$ pp, map (1915)

17 Historical outline of the oil and gas industry in Kansas. Kans G S, B 3: 19-24 (1917)

See also Adams (G I), 04a; Bain, 07a; Keyes, 95h ; Knight, 17a ; Logan, 97

Hay, A. M.

10 The new Porcupine gold fields, Ont. Can M J $32: 53-56$ (1910)

Hay, G. U.

99 The scientific work of Prof. Chas. Fred. Hartt. R Soc Can, Pr Tr (2) 5, iv : 155-165 (1899)

\section{Hay, Guillermo.}

91 Informe sobre el terreno carbonifero perteneciente a la Compañia Carbonffera de Piedras Negras en el Estado de Coahuila. Bol Agr Min 1:113-119 (1891)

Hay, Oliver Perry.

7S An examination of Prof. Leo Lesquereux's theory of the origin and formation of prairies. Am Nat 12:299-305 (1878)

87 On the manner of deposit of the glacial drift. Am J Sc (3) $34: 52-58$ (1887)

88 The northern limit of the Mesozoic rocks of Arkansas. Ark G S, An Rp 1888, 2 : 261-290 (1888) 
Hay, Oliver Perry-Continued.

95 Description of a new species of Petalodus ( $P$. securiger) from the Carboniferous of Illinois. J G $3: 561-564$, il (1895)

$\mathbf{9 5 a}$ On certain portions of the skeleton of Protostega gigas. Field Col Mus, Pub zool s $1: 55-62$, il (1895)

96 On the skeleton of Toxochelys latiremis. Field Col Mus, Pub zool s 1:99106, il (1896)

98 On Protostega, the systematic position of Dermochelys, and the morphogeny of the chelonian charapace and plastron. Am Nat $32: 929-948$, il (1898)

$98 \mathbf{a}$ Notes on species of Ichthyodectes, including the new species $I$. cruentus, and on the related and herein established genus Gillicus. Am J Sc (4) 6:225-232, Il (1898)

95b Observations on the genus of fossil fishes called by Prof. Cope Portheus, by Dr. Leidy Xiphactinus. Zool B 2:25-54, il (1898) Abst, Science n s $7: 646$ (1898)

9Se George Baur. Science n $s$ : 68 71 (1898)

99 Descriptions of two new specles of tortoises from the Tertiary of the United States. U S Nat Mus, Pr 22:21-24, 11 (1899)

99 an one little known and one hitherto unknown specices of Saurocephalus. Am J Sc (4) 7:299-304, il (1899) An Mag $\mathrm{NH}$ (7) $3: 480-487$, il (1899)

99b On some changes in the names, generic and specific, of certain fossil fishes. Am Nat $33: 783-792$ (1899)

99e On the nomenclature of certain American fossil vertebrates. Am G 24 : 345-349 (1899)

99d On the names of certain North American fossil vertebrates. Science n s $9: 593-594$ (1899)

99e Notes on the nomenclature of some North American fossil vertebrates. Science n s 10:253-254 (1899)

$99 f$ A census of the fossil Vertebrata of North America. Science n s 10:681684 (1899)

00 Descriptions of some vertebrates of the Carboniferous age. Am $\mathrm{Ph}$ Soc, $\mathrm{Pr}$ $39: 96-123$, il $(1900)$

ox Description of a new species of Baena ( $B$. hatcheri) from the Laranie beds of Wyoming. Carnegie Mus, An 1: $325-326$, il (1901)

01 a The chronological distribution of the elasmobranchs. Am Ph Soc, Tr n s $20: 63-75$ (1901)

02 Bibliography and catalogue of the fossil vertebrata of North America. U S G S, B 179:868 pp (1902) Rv by Bashford Dean, Science n s 16:701-703 (1902)

02a Descriptions of two species of extinct tortoises, one new. Ac $\mathrm{N}$ Sc Phila, $\operatorname{Pr} 54: 383-388$, il (1902)
Hay, Ollver Perry-Continued.

02b Description of a new species of Cladodus (C. formosus) from the Devonlas of Colorado. Am G $30: 373-374$, il (1902) 02e The composition of the shells of turtles (abst). N Y Ac Sc, An 14:111112 (1902)

02d Snoutfishes of Kansas (abst). An G 29:192-193 (1902) Science n 8 15:470 (1902) N Y Ac Sc, An 15:15 (1903)

03 On certain genera and species of North American Cretaceous actinopterons fishes. Am Mus N H, B 19:1-95, (1903)

03a Two new species of fossil turtles from Oregon. Cal Univ, Dp G, B 3:237241 , il (1903)

03b Description of a new genus and species of tortoise from the Jurassic of Colorado. Carnegie Mus, An 2:201-203,

il (1903)

03e On some recent literature bearing on the Laramie formation. Am G 32 : 115-120 (1903)

03d An important but not well known locality furnishing Cretaceous fishes (abst). Science n s 17:219 (1903) G Soc Am, B $14: 542$ (1904)

04 On some fossil turtles belonging to the Marsh collection in Yale University Museum. Am J Sc (4) 18:261-276, il (1904)

04a On two species of turtles from the Judith River beds of Montana. Carnegie Mus, An 3: 178-182, il (1904)

04b Society of the Vertebrate Paleon tologists of America [Philadelphia, Decem. ber 29, 1903]. Science n s $19: 253-25$ ? (1904)

04c On the finding of skulls of Trionychidae in the Bridger deposits of Wyoming (abst). Science n s 19:254 (1904)

04d A new gigantic tortoise from the Miocene of Colorado $(a b s t)$. Science in $s$ 19 : 503-504 (1904)

os On the group of fossil turtles known as the Amphichelydia; with remarks on the origin and relationships of the suborders, superfamilies, and families of testrdines. Am Mus N H, B 21:137-175, il (1905)

05a A revision of the species of the family of fossil turtles ealled Toxochelyidae, with descriptions of two new species of Toxochelys and a new species of Portiochelys. Am Mus N H, B 21:177-185, il (1905)

05b On the skull of a new trionychid, Conchochelys admirabilis, from the Puerco beds of New Mexico. Am Mus N H, B 21: $335-338$, il (1905)

o5c The progress of vertebrate paleon. tology at the American Museum of Natural History, New York. Am G $35: 31-34$ (1905) 
Hay, Oliver Perry-Continued.

05d Meeting of Section A of the Amerisal Paleontological Society. Am G 35 : 124-126 (1905)

05e The fossil turtles of the Bridger basin. Am G $35: 327-342$, il (1905)

05f The American Paleontological Sorety; Section A, Vertebrata [Philadelphia, December, 1904]. Science n s 21:294-300 (1905)

$05 \mathrm{~g}$ On the group of fossil turtles known as Amphichelydia (abst). Science Is $21: 297$ (1905)

05h A new gigantic tortoise from the Miocene of Colorado (abst). N Y Ac Sc, An $16: 312-313$ (1905)

06 Descriptions of two new genera (Echmatemys and Xenochelys) and two new species (Xenochelys formosa and Terrapene putrami) of fossil turtles. Am Mus N H, B 22:27-31, il (1906)

06a On two interesting genera of Eocene turtles, Ohisternon Leidy and Anosteira Leidy. Am Mus N H, B 22:155-160, il (1906)

06b Descriptions of new species of turtles of the genus Testudo, collected from the Miocene by the Carnegie Museum ; together with a description of the skull of stylemys nebrascensis. Carnegie Mus, An $4: 15-20$, il (1906)

06e Systematic paleontology of the Pleistocene deposits of Maryland; Reptilia. Ia G S, Pliocene and Pleistocene : 169-170, II (1906)

07 Descriptions of seven new species of turtles from the Tertiary of the United States. Am Mus N H, B 23:847-863, il (1807)

07a A new fossil stickleback fish from Nevada. U S Nat Mus, Pr 32:271-273 (1907)

$07 \mathrm{~b}$ A new genus and species of fossil shark related to Edestus Leidy. Science If 8 26: $22-24$, il $(1907)$

07e The turtles of the Bridger basin (abst). N Y Ac Sc, An 17:592 (1907)

08 Descriptions of five species of North American fossil turtles, four of which are new. U S Nat Mus, Pr 35:161-169, il (1908)

08a On certain genera and species of carnivorous dinosaurs, with special reference to Ceratosaurus nasicornis Marsh. U S Nat Mus, Pr 35: 351-366, il (1908)

08b Dr. W. J. Holland on the skull of Diplodocus. Science n s 28:517-519 (1908)

05e On the habits and pose of the sauropodous dinosaurs, especially of Diplodocus. Am Nat $42: 672-681$ (1908)

08a The fossil turtles of North America. Carnegie Inst Wash, Pub no $\mathbf{7 5 : 5 6 8 ~ p p , ~ i l ~}$ (1908)
Hay, Oliver Perry-Continued.

09 On the skull and the brain of Triceratops, with notes on the brain cases of Iguanodon and Megalosaurus. U S Nat Mus, $\operatorname{Pr} 36: 95-108$, il (1909) Abst, Science n s 29:713 (1909)

09a Description of two species of fossil turtles, Toxochelys stenopora and Chisternon? interpositum, the latter hitherto unknown. U S Nat Mus, Pr $36: 191-196$, il (1909)

09b Dr. Williston on "The fossil turtles of North America." Science n s 29 : 341-342 (1909)

o9e On the restoration of skeletons of fossil vertebrates. Science n s 30:93-95 (1909)

o9d The geological and geographical distribution of some Pleistocene mammals. Science n s 30:890-893 (1909)

09e On the nature of Edestus and related genera, with descriptions of one new genus and three new species. U $S$ Nat Mus, $\operatorname{Pr} 37: 43-61$, il (1909)

10 On the chranges of climate following the disappearance of the Wisconsin ice sheet. Int $\mathrm{G}$ Cong, XI, Stockholm, Die Veränderungen des Klimas seit dem Maximum der letzten Eiszeit: 371-374 (1910)

10a Where do the Lance Creek ("Coratops") beds belong, in the Cretaceous or the Tertiary? Ind Ac Sc, Pr 1909:277303 (1910)

$10 b$ On the manner of locomotion of the dinosaurs, especially Diplodocus, with remarks on the origin of the birds. Wash Ac Sc, Pr 12:1-25, il (1910)

10c Descriptions of eight new species of fossil turtles from west of the one hundredth meridian. U $\mathrm{S}$ Nat Mus, $\operatorname{Pr} 38$ : $307-326$, il (1910)

11 A fossil specimen of the alligator snapper (Macrochelys temminckii) from Texas. Am Ph Soc, $\operatorname{Pr} 50: 452-455$, il (1911)

11 Further observations on the pose of the sauropodous dinosaurs. Am Nat 45: 398-412 (1911)

12 The Pleistocene age and its verte. brata. Ind, Dp $G$, An Rp $36: 539-784$, maps (1912)

12a Ten years' progress in vertebrate paleontology; Chelonia. G Soc Am, B 23: 212-220 (1912)

12b The recognition of Pleistocene faunas. Smiths Misc Col 59 no $20: 16 \mathrm{pp}$, maps (1912)

12e On an important specimen of Edestus, with description of a new species, Edestus mirus. U S Nat Mus, Pr 42 : $31-38$, il (1912)

12d American Permian vertebrates. Am Nat $46: 561-565$ (1912)

13 Notes on some fossil horses, with descriptions of four new species. U S Nat Mus, Pr $44: 569-594$, il (1913) 
Hay, Oliver Perry-Continued.

13a Description of the skull of an extinct horse, found in central Alaska. Smiths Misc Col 61 no $2: 18$ pp, il (1913)

13b The extinct bisons of North America; with description of one new species, Bison regius. U S Nat Mus, Pr 46:161200 , il (1913)

13e Camels of the fossil genus Camelops. U S Nat Mus, Pr 46:267-277, il (1913)

14 The Pleistocene mammals of Iowa. Iowa G S $23: 662 \mathrm{pp}$, il (1914)

15 Contributions to the knowledge of the mammals of the Pleistocene of North America. U S Nat Mus, $\operatorname{Pr} 48: 515-575$, il (1915) Abst, Wash Ac Sc, J 5 : 582-583 (1915)

15a A contribution to the knowledge of the extinct sirenian Desmostylus hesperus Marsh. U S Nat Mus, Pr 49:381-397, il (1915)

16 Descriptions of two extinct mammals of the order Xenarthra from the Pleistocene of Texas. U S Nat Mus, Pr 51: 107-123, il (1916)

$16 a$ Descriptions of some fossil vertebrates found in Texas. Tex Univ, B 1916 no $71: 24 \mathrm{pp}$, il (1916)

$16 b$ Descriptions of some Floridian fossil vertebrates belonging mostly to the Pleistocene. Fla G S, An Rp $8: 39-76$, il (1916)

16e Investigation of the vertebrate paleontology of the Pleistocene epoch. Carnegie Inst Wash, Y Bk 14:386-387 (1916)

17 Description of a new species of Mastodon, Gomphotherium elegans, from the Pleistocene of Kansas. U S Nat Mus, Pr 53: 219-221, il (1917)

17a Description of a new species of extinct horse, Equus lambei, from the Pleistocene of Yukon Territory. U S Nat Mus, $\operatorname{Pr} 53: 435-443$, il (1917)

17b The Quaternary deposits at Vero, Fla., and the vertebrate remains contained therein. J G 25: 52-55 (1917)

17e Vertebrata mostly from stratum No. 3 at Vero, Fla., together with descriptions of new species. Fla G S, An Rp 9:43-68, il $(1917)$

17d on the finding of supposed Pleistocene human remains at Vero, Fla. Wash Ac Sc, J $7: 358-360$ (1917)

17e on a collection of fossil vertebrates made by Dr. F. W. Cragin from the Equus beds of Kansas. Kans Univ Sc B 10: $39-51$, il (1917)

$17 f$ Investigation of the vertebrate paleontology of the Pleistocene epoch. Carnegie. Inst Wash, $\mathrm{Y}$ Bk no 15:374-375 (1917)

18 Further considerations of the occurrence of human remains in the Pleistocene deposits at Vero, Fla. Am Anthropologist n s $20: 1-36$ (1918)
Hay, Oliver Perry-Continued.

18a A review of somre papers on fossi? man at Vero, Fla. Science n s $47: 370$. 371 (1918)

18b Doctor Ale§ Hrdliěka and the Vero [Fla.] man. Seience $n$ s $48: 459-46$ ? (1918)

18e [Report of work on Pleistocene Ver. tebrata]. Carnegie Inst Wash, Y Bk 16 1917 : 331-332 (1918)

See also Osborn, 051

Hay, Robert (1835-1895).

83 The igneous rocks of Kansas. Kans Ac Sc, Tr 8:14-18 (1883)

$83 a$ Fossil wood [Kansas]. Kans de Sc, Tr 8: 20-22 (1883)

85 Preliminary report on the geolog of Norton Co., Kans. Kans Ac Sc, Tr 9: 17-24, map (1885)

S5a Notes on the fossil jaw of Bison from the Pliocene of Norton Co. [Kans]. Kans Ac Sc, Tr 9:98 (1885)

85b In the Dakota [Kans.]. Kans de Sc, Tr 9:109-113 (1885)

87 A geological section in Wilson $\mathrm{CO}_{4}$ Kans. Kans Ac Sc, Tr 10:6-8 (1887)

87 a Report on geology. Kans $A c B c$ Tr 10:21-22 (1887)

s7b (and Thompson, A. H.) Histor ical sketch of geological work in the State of Kansas. Kans Ac Sc, Tr 10:45-5? (1887)

87c Natural gas in eastern Kansas. Kans Ac Sc, Tr 10:57-62 (1887) Kans St Bd Agr, Bien Rp 5 pt 2: 198-208 (1887)

87 d Note on a remarkable fossil. Kans Ac Sc, Tr 10:128-129, il (1887)

89 Horizon of the Dakota lignite. Kans Ac Sc, Tr 11:5-8 (1889)

$89 a$ The geology of Kansas. Kans Ac Sc, Tr 11: 35-37 (1889)

89b The Triassic rocks of Kansas (abst). Kans Ac Sc, Tr 11:38-39 (1889)

s9c Recent discoveries of rock salt in Kansas (abst). Am As, Pr 37:184-185 (1889)

89d Northwest Kansas; its topography. geology, climate, and resources. Kans $\mathrm{St}$. Bd Agr, Bien Rp 6 pt 2:92-116 (1889)

89e Salt; its discovery and manufacture in Kansas... Kans St Bd Agr, Bien Rp 6 pt 2:192-204 (1889)

90 A geological reconnaissance in south. western Kansas. U S G S, B 57:49 pp, map (1890)

90a Report [of investigations of artesian water conditions of the Great Plains]. U S, 51st Cong 1st sess, S Ex Doc 222: $37-47$ (1890)

901 Notes on some Kansas salt marshes. Kans Ac Sc, Tr 12: 97-100 (1890)

90e Notes on a Kansas salt mine. Am G $5: 65-67$ (1890) 
Hay, Robert-Continued.

90d Artesian wells in Kansas and the causes of their flow. Am G 5: 296-301 (1890)

92 Sandstone dikes in northwestern $\mathrm{Ne}$ braska. G Soc Am, B 3:50-55 (1892)

92a A contribution to the geology of the Great Plains. G Soc Am, B $3: 519-521$ (1892)

93 Artesian and underflow investigation between the ninety-seventh meridian and the foothills of the Rocky Mountains. U 8, 52d Cong 1st sess, S Ex Doc 41 pt 3: $7-39$, map (1893)

93a Geology and mineral resources of Kansas. Kans St Bd Agr, Bien Rp 8 pt 2 ; 99-162, map (1893)

93b President's address [the geology of the Great Plains]. Kans Ac Sc, Tr 13: 3-6 (1893)

93e Notice on some new species of fossil cephalopods. Kans Ac Sc, Tr 13:37-47, II (1893)

93d Additional note on the Brenham meteorite. Kans Ac Sc, Tr 13:75 (1893)

93e Note on the occurrence of granite in a deep boring in eastern Kansas. Kans Ae Sc, Tr $13: 75-76$ (1893)

$93 \mathrm{f}$ Some characteristics of the glaciated area of northeastern Kansas. Kans Ac Sc, Tr 13:104-106 (1893)

95 Water resources of a portion of the Great Plains. U S G S, An Rp 16 pt 2 : 535-588, maps (1895)

96 The geology of the Fort Riley Milltary Reservation and vicinity, Kans. U S G S, B 137:35 pp, map (1896)

96a On the eastern extension of the Cretaceous rocks in Kansas and the formation of certain sand hills. Kans Ac Sc, Tr 14:227-229 (1896)

$96 \mathrm{~b}$ The river counties of Kansas; some notes on their geology and mineral resources. Kans Ac Sc, Tr 14:230-260 (1896)

96e A bibliography of Kansas geology. Kans Ac Sc, Tr 14:261-278 (1896)

See also Gilbert (G K), $90 b$

Hayeock, Ernest (1868-1918).

00 Records of post-Triassic changes in Kings Co., N. S. N S Inst Sc, Pr Tr 10 or (2) $3: 287-302(1900)$

02 The geological history of the Gaspereau Valley, N. S. N $\mathbf{S}$ Inst Sc, Pr Tr 10 or (2) $3: 361-375$ (1902)

02a Fossils, possibly Triassic, in glaciated fragments in the boulder clay of Kings Co., N. S. N S Inst Sc, Pr Tr 10 or (2) $3: 376-378$ (1902)

03 Geology of the west coast of Vancouver Island. Can G S, Sum Rp 1902 (An Rp 15) : A 76-92 (1903)

05 Geology of part of the County of Ottawa [Que.]. Can G S, Sum Rp 1904 (An Rp 16) : A 232-239 (1905)
Haycoek, Ernest-Continued.

06 [Report on the] geology of parts of the counties of Labelle and Wright, Quebec. Can G S, Sum Rp 1905: 105-112 (1906)

Hayden, C. B.

43 On the rock salt and salines of the Holston [Va.]. Am J Sc 44:173-179 (1843)

Hayden, Everett.

86 The earthquake of August 31, 1886 [Charleston earthquake]. Science 8:224226 map (1886)

86a The Charleston earthquake; some further observations. Science 8:246-24s (1886)

S6b Earthquake sounds. Science 8: 369-370 (1886)

87 Professor Newberry on earthquakes. Science 9: 18 (1887)

87a (with Dutton, C. E.) Abstract of the results of the investigation of the Charleston earthquake. Science 9:489_ 501 (1887)

Hayden, Ferdinand Vandiveer (18291887).

56 Geological notes etc., on Nebraska. In Warren, G. K., Explorations in the Dacota country in the year 1855 ; U S, 34th Cong 1st sess, S Ex Doc 76: 66-79 (1856)

56a (with Meek, F. B.) Descriptions of new species of Gastropoda from the Cretaceous formations of Nebraska Terr. Ac N Sc Phila, Pr 8, 63-69 (1856)

56b (with Meek, F. B.) Descriptions of new species of Gastropoda and Cephalopoda from the Cretaceous formations of Nebraska Terr. Ac N Sc Phila, Pr 8:7072 (1856)

56e (with Meek, F. B.) Descriptions of twenty-eight new species of Acephala and one gastropod from the Cretaceous formations of Nebraska Terr. Ac N Sc Phila, Pr $8: 81-87$ (1856)

56d (with Meek, F. B.) Descriptions of new species of Acephala and Gastropoda, from the Tertiary formations of Nebraska Terr., with some general remarks on the geology of the country about the sources of the Missouri River. Ac N Sc Phila, Pr $8: 111-126$ (1856)

56e (with Meek, F. B.) Descriptions of new fossil species of Mollusca...; together with a complete catalogue of all the remains of Invertebrata hitherto described and identified from the Cretaceous and Tertiary formations [of Nebraska Terr.]. An N Sc Phila, Pr 8:265-286 (1856)

57 ...geological structure of the country bordering on the Missouri River, from the mouth of the Platte River to Fort Benton, in lat. $47^{\circ} 30^{\prime}$ N., long. $110^{\circ} 30^{\circ}$ W. Ac N Se Phila, Pr 1857: 109-116, map

$57 a$ Notes on the geology of the Mauvaises Terres of White River, Nebraska Terr. Ac N Sc Phila, Pr 1857:151-158 
Hayden, Ferdinand Vandiveer-Contd.

$\mathbf{5 7 b}$ (with Meek, F. B.) Descriptions of new species and genera of fossils, collected by Dr. F. V. Hayden in Nebraska Terr...; with some remarks on the Tertiary and Cretaceous formations of the Northwest... Ac N Sc Phila, $\operatorname{Pr} 1857$ : $117-148$

58 Explanations of a second edition of a geological map of Nebraska and Kansas, based upon information obtained in an expedition to the Black Hills... Ac $\mathbf{N}$ Sc Phila, Pr 1858:139-158 [In part] Am J Sc (2) $26: 404-408$ (1858)

58a (with Meek, F. B.) Fossils of Nebraska [Black Hills]. National Intelligencer March 16, 1858 [not seen]. Am $\mathrm{J}$ Sc (2) $25: 439-441$ (1858)

58b (with Meek, F. B.) Remarks on the lower Cretaceous beds of Kansas and Nebraska, together with descriptions of some new species of Carboniferous fossils from the valley of Kansas River. Ac $\mathrm{N}$ Sc Phila, Pr 10:256-266 (1858) Am J Sc (2) $27: 219-227$, il (1859)

58e (with Meek, F. B.) On the probable existence of Permian rocks in Kansas Terr. Ac N Sc Phila, Pr 1858:9-10

5SA (with Meek, F. B.) Descriptions of new organic remains collected in Nebraska Terr... together with some remarks on the geology of the Black Hills and portions of the surrounding country. Ac $\mathbf{N}$ Sc (2) $27: 219-227$, il (1859)

59 Catalogue of the collections in geology and natural history obtained by the expedition under command of Lleut. G. K. Warren. In Warren, G. K., Preliminary account of explorations in Nebraska and Dakota in the years 1855-56-57; U S, War Dp, An Rp 1858 (U S, 35th Cong 2d sess, H Ex Doc 2): 673-705 (1859); Reprint: 59-125, Washington 1875

$59 a$ Geological sketch of the estuary and fresh water deposit of the Badlands of the Judith, with some remarks upon the surrounding formations. $\mathrm{Am} \mathrm{Ph}$ Soc, Tr n s 11:123-138, map (1859)

59b (with Meek, F. B.) On the socalled Triassle rocks of Kansas and Nebraska. Am J Sc (2) $27: 31-35$ (1859)

59e (with Meek, F. B.) Geological explorations in Kansas Territory. Ac N Sc Phila, Pr 1859:8-30. (In part) Am J Sc (2) $27: 424-432$ (1859)

60 Notes on the geology of Nebraska and Utah Territory. Am J Sc (2) 29 : 433-434 (1860)

60a (with Meek, F. B.) On a new genus of patelliform shells from the Cretaceous rocks of Nebraska. Am J Se (2) 29 : 33-35 (1860)

60b (with Meek, F. B.) Descriptions of new organic remains from the Tertiary, Cretaceous, and Jurassic rocks of Nebraska. Ac N Sc Phila, Pr 1860:175-185
Hayden, Ferdinand Vandiveer-Contd. 60e (with Meek, F. B.) Systematit catalogue, with synonyma, etc., of Jurasis Cretaceous, and Tertiary fossils collected h Nebraska Terr... Ac N Sc Phila, Pr 18\% $417-432$

61 Sketch of the geology of the cyont about the headwaters of the Missouri an Yellow stone rivers. Am J Sc (2) 31:2\% 245 (1861) U S G Geog S Terr (Hayden). Prel Rp 1878: 21-29 (1878)

61a (with Meek, F. B.) Descriptios of new Lower Silurian (Primordial), Jun sic, Cretaceous, and Tertiary fossils, of lected in Nebraska Terr..., with some marks on the rocks from which they wer obtained. Ac $\mathrm{N}$ Sc Phila, Pr 1861: 415-447

62 On the geology and natural history of the upper Missouri. Am Ph Soc, $\mathrm{T}$ n s 12: 1-218, map (1863) Separate, 218 pp, map, Phila 1862

62a The Primordial sandstone of to Rocky Mountains in the northwestern teritories of the United States. Am J 8 (2) $33: 68-79$, il (1862) Extr, Can Jni $7: 149-151$ (1862)

62b Some remarks in regard to the pe riod of elevation of those ranges of the Rocky Mountains near the sources of the Missouri River and its tributaries. Am ? Sc (2) $33: 305-313$ (1862) U S G Geet S Terr (Hayden), Prel Rp 1878: $9-18$ (1878)

62e (with Meek, F. B.) Descriptions of new Cretaceous fossils from Nebrass Terr... Ac N Sc Phila, Pr 1862: 21-28

64 (with Meek, F. B.) Descriptions of new organic remains from northeastern Kansas, indicating the existence of Permian rocks in that territory. Albany Inst, $\operatorname{Tr} 4:$ 73-88 (1864)

65 (with Meek, F. B.) Paleontologr of the upper Missouri; invertebrates Smiths Contr Knowl 14 art 5 (172); 135 pp, il (1865)

66 [On a visit to Pipestone quarry, Minn.] Am Ph Soc, Pr 10:274-275 (1866)

66a Description of an extensive cbalk deposit on the Missouri River. Am Pb $\mathrm{Soc}$. Pr 10:277 (1866)

66b On the geology of the Missouri Val ley. Am Ph Soc, Pr 10: 292-296 (1866)

66e On the lignite beds on the upper tributaries of the Missouri [River]. At $\mathrm{Ph}$ Soc, $\mathrm{Pr} 10: 300-307$ (1866)

66d [On the Pipestone quarry of Da. kota.] Ac N Sc Pbila, Pr 1866: 291-29? 66e [On the extensive chalk deposit of the Missouri River.] Ac N Sc Phila, $P_{t}$ $1866: 314$

67 First annual report of the United States Geological Survey of the Territortes, embracing Nebraska. U S, Gen Land Of. Rp 1867: 100-107, $124-177$ (U $\mathrm{S}, 40 t \mathrm{t}$ Cong $2 d$ sess, H Ex Doc 1 v $3: 128-135$ 152-205) (1867) Reprint: 5-64 (1873) 
Hayden, Ferdinand Vandiveer-Contd. 67a Sketch of the geology of northeastern Dakota, with a notice of a short visit to the celebrated Pipestone quarry. Am J Sc (2) $43: 15-22$ (1867)

67b Remarks on the Cretaceous rocks of the West known as No. 1, or the Dakota group. Am J Sc (2) 43:171-179 (1867) 67e Notes on the geology of Kansas. Am J Sc (2) $44: 32-40$ (1867)

67d [On the Black Hills.] Am Ph Soc, Pr 10:322-326 (1867)

68 Second annual report of the United States Geological Survey of the Territories, embracing Wyoming. U S, Gen Land Off, Rp 1868: 111-120, 220-255 (U S, 40th Cong 3d sess, H Ex Doc 1 v 2 ) (1868) Reprint: $65-102$ (1873)

6Sa Rocky Mountain coal beds. Am J Se (2) 45:101-102 (1868)

68b Notes on the lignite deposits of the West. Am J Sc (2) 45: 198-208 (1868)

68e Remarks on the geological formations along the eastern margins of the Rocky Mountains. Am J Sc (2) $45: 322$ 326 (1868) U S G Geog S Terr (Hayden), Prel Rp 1878:13-16 (1878)

6sd Remarks on the possibility of a workable bed of coal in Nebraska. Am J Se (2) $45: 326-330$ (1868)

69 Preliminary field report [third anunal] of the United State Geological Surrey of Colorado and New Mexico. $155 \mathrm{pp}$, Washington 1869 Reprint: 103-251 (1873) 69 a Geological report of the exploration of the Yellowstone and Missouri rivers, under the direction of...W. F. Raynolds, 1859-60. 174 pp, map, Washington 1869 (U S, 40th Cong 2 d sess, S Ex Doc 77)

69b on the geology of the Tertiary formations of Dakota and Nebraska. Ac N Se Phila, J (2) 7:9-21, map (1869)

69e Notes on the geology of Wyoming and Colotado Territories. Am Ph Soc, Pr $10: 463-478 ; 11: 25-56$ (1869)

70 Sun pictures of Rocky Mountain scenery, with a description of the geographical and geological features and some account of the resources of the Great West. $150 \mathrm{pp}, \mathrm{N}$ Y 1870

70a Sections of strata belonging to the "Bear River group" near Bear River City, Wyo. Am. Ph Soc, Pr 11:420-425 (1870)

71 Preliminary report [fourth annual] of the United States Geological Survey of Wyoming and portions of contiguous Terri. tories (being a second annual report of progress). 511 pp, Washington 1871

72 Preliminary report of the United States Geological Survey of Montana and portions of adjacent Territories, being a filth annual report of progress. 538 pp, maps, Washington 1872
Hayden, Ferdinand Vandiveer-Contd.

72a (assisted by Peale, A. C.) [Geo$\operatorname{logic}$ map of] Montana and Wyoming Territories, embracing most of the country drained by the Madison, Gallatin, and upper Yellowstone rivers. Scale, 4 miles to 1 inch. U S G S Terr (Hayden) $\mathrm{n}$ d [1872]

72b Final report of the United States Geological Survey of Nebraska and portions of the adjacent Territories... U S, $42 \mathrm{~d}$ Cong 1st sess, H Ex Doc 19: 264 pp, map (1872)

72e The hot springs and geysers of the Yellowstone and Firehole rivers. Am $\mathrm{J}$ Sc (3) $3: 105-115,161-176(1872)$

72d The Yellowstone National Park. Am J Sc (3) 3:294-297 (1872)

72e Die neu entdeckten Geyser-Gebiete am oberen Yellowstone und Madison River. Petermanns Mitt 18:241-253, 321-326 (1872)

73 Sixth annual report of the United States Geological Survey of the Territories ... for the year 1872 . 844 pp, maps, Washington 1873

73a First, second, and third annual reports of the United States Geological Survey of the Territories for the years 1867 , 1868 , and 1869 [Reprints]. 261 pp, Washington 1873

74 [Seventh] annual report of the United States Geological and Geographical Survey of the Territories, embracing Colorado, being a report of progress of the exploration for the year 1873 . $718 \mathrm{pp}$, maps, Washington 1874

74a [On the age of the lignitic group.] U S G Geog S Terr (Hayden), B [1] no 2 : 1-2 (1874)

75 Note on some peculiar forms of erosion in eastern Colorado, with heliotype illustrations. U S G Geog S Terr (Hayden), B [1] no 3 (2): 210-211 (1875)

$75 a$ Notes on the surface features of the Colorado or Front Range of the Rocky Mountains. U S G Geog S Terr (Hayden), B [1] no 4 (2) : 215-220 (1875)

76 [Eighth] annual report of the Enited States Geological and Geographical Survey of the Territories, embracing Colorado and parts of adjacent territories, being a report of progress of the exploration for the year 1874. $515 \mathrm{pp}$, maps, Washington 1876

76a Notes on the lignitic group of eastern Colorado and portions of Wyoming. U S G Geog S Terr (Hayden), B [1] no 5 (2): 401-411 (1876)

76b Notes descriptive of some geological sectlons of the country about the headwaters of the Missouri and Yellowstone rivers. U S G Geog S Terr (Hayden), B $2: 197-209 \quad(1876)$ 
Hayden, Ferdinand Vandiveer-Contd. 76e The Yellowstone Park and the mountain regions of portions of Idaho, Nevada, Colorado, and Utah. 48 pp, maps, Boston 1876 [not seen]

76d On the ore-bearing rocks of Colorado. Am J Sc (3) $12: 71$ (1876)

76e Summary of the fleld work of the Hayden geological survey during the season of 1875. The Republic 6:149-160 (1876)

$\boldsymbol{7 7}$ Ninth annual report of the United States Geological and Geographical Survey of the Territories, embracing Colorado and parts of adjacent Territories, being a report of progress of the exploration for the year 1875. $827 \mathrm{pp}$, maps, Washington 1877

7za Preliminary report of the field work of the United States Geological and Geographical Survey of the Territories for the season of 1877 . U S, 45th Cong 2 d sess, $\mathrm{H}$ Ex Doc 1 pt 5 (Report of the Secretary of the Interior, $v 1$ ) : 755-787 (1877) Also separate, $35 \mathrm{pp}$, Washington 1877

$\boldsymbol{7 7 b}$ Notes on some artesian borings along the line of the Union Pacific Railroad in Wyoming Territory. U S G Geog S Terr (Hayden), B 3: 181-185 (1877)

77e (in charge) Geological and geographical atlas of Colorado and portions of adjacent territory. U S G Geog S Terr (Hayden). 1877, another ed 1881

77d Sketch of the origin and progress of the United States Geological and Geographical Survey of the Territories. $15 \mathrm{pp}$, Washington 1877

77e Explorations made under the direction of F. V. Hayden in 1876. Am J Sc (3) $13: 68-74$ (1877) The Republic 8 : $17-24$ (1877)

77f Progress of the U. S. geological survey ... The Republic 8: 217-226 (1877)

78 Tenth annual report of the United States Geological and Geographical Suryey of the Territories, embracing Colorado and parts of adjacent territories, being a report of progress of the exploration for the year 1876. $546 \mathrm{pp}$, maps, Washington 1878

$78 \mathbf{a}$ Preliminary report of the field work of the U. S. Geological and Geographical Survey of the Territories for the season of 1878. $29 \mathrm{pp}$, Washington 1878

78b Letter ... transmitting report of Professor Hayden upon geological and geographical surveys. U S, 45th Cong 2d sess, H Ex Doc 81: 22 pp, map (1878)

7Se Summary of the fleld work of the United States Geological and Geographical Survey of the Territories. Am J Sc (3) 15: 56-60 (1878)

78d The field work of the U. S. Geological and Geographical Survey of the Territories, for the season of 1877 . Am Nat $12: 96-114$ (1878)

78e Discovery of recent glaciers in Wyoming. Am Nat 12:830-831 (1878)

78f Wasatch group. Am Nat 12:831
Hayden, Ferdinand Vandiveer-Contd.

78g Glaciers in the Wind River Moun. tains [Wyo.]. Science News 1:20-21 (1878)

79 Eleventh annual report of the Jnited States Geological and Geographical Survey of the Territories, embracing Idaho and Wyoming, being a report of exploration for the year 1877 . $720 \mathrm{pp}$, maps, Washington 1879

80 The great West ... 87 pp, Phila 1880

80a Twin Lakes and Teocalli Mountain, central Colorado, with remarks on the gla. cial phenomena of that region. Am Nat 14: $858-862$ (1880)

83 Twelfth annual report of the United States Geological and Geographical Survey of the Territories; a report of progress of the exploration in Wyoming and Idaho for the year 1878. In two parts, $809,503 \mathrm{pp}$, maps, Washington 1883.

83a General geologic map of the area ex. plored and mapped by Dr. F. V. Hayden and the surveys under his charge 18691880. Scale 1:2600000. n d [1883?] [Also in $\mathrm{U}$ S $\mathbf{G}$ Geog $\mathrm{S}$ Terr (Hayden), 12th An Rp]

See also King (C), 80; Powell, 82, 85, $85 \mathrm{a}, 88$

Hayden, Horace Edwin.

01 Ralph Dupuy Lacoe. Wyoming Hist G Soc, $\operatorname{Pr} 6: 39-54$, port (1901) Am G '8: 335-344, port (1901)

Hayden, Horace Handel (1769-1844).

11 Geological sketch of Baltimore. Bal. timore Med Phil Lyc 1:255-271 (1811) (in pt) Am Miner J 1: 243-248 (1814)

20 Geological essays, or an inquiry into some of the geological phenomena to be found in various parts of America and elsewhere. $412 \mathrm{pp}$, Baltimore 1820 Rv by Silliman, B., Am J Sc, 3: 47-57 (1821)

22 Notice of a singular ore of cobalt and manganese [Maryland]. Am J Sc 4: 283-284 (1822) Transl. in Struve, H von, Beiträge zur Mineralogie und Geologie des nördlichen Amerikas: 119-121, Hamburg 1822

30 ... geology of the country near Bedford Springs in Pennsylvania, and the Bath or Berkeley Spring in Virginia. Am J Sc 19:97-104 (1830)

33 Description of the Bare Hills near Baltimore. Am J Sc 24:349-360 (1833) Hayes, Albert Orion.

14 Geology of the St. John map area, N. B. Cen G S, Sum Rp 1913: 228-243 (1914)

14a Geology of the Wabana iron ore of Newfoundland (abst). G. Soc Am, B $25: 74$ (1914)

15 Wabana iron ore of Newfoundland. Can G S, Mem 78: 163 pp, map (1915)

15 a St. John map area, N. B. Can G S, Sum Rp 1914: 100-101 (1915); 1915: 179 (1916) 
Hayes, Albert Orion-Continued.

16 Origin of the Wabana iron ore. Can II Inst, $\operatorname{Tr} 18: 225-246, \operatorname{map}$ [1916]

17 Investigations in New Brunswick and Nova Scotia. Can G S, Sum Rp 1916: 261-284, map (1917)

18 Investigations in Nova Scotia. Can G S, Sum Rp 1917 pt F : 20-32 (1918)

Hayes, Augustus Allen.

42 (with Teschemacher, J. E.) On the identity of pyrochlore with the microlite of Professor Shepard. Am J Sc $43: 33-35 \quad(1842)$

44 Re-examination of mierolite and pyrochlore. Am J Sc 46:158-166 (1844)

45 On the Alabama meteoric iron. Am J Se $48: 147-156$ (1845)

51 [On crystallized quartz containis] erystals of rutile from Waterbury, Vt.] Boston Soc N H, Pr 4:23-24 (1851)

55 [On the underground water at Boston, Mass.] Boston Soc N H, Pr 5 : 191$194(1855)$

$55 n$ [On the so-called verd-antique marble from Roxbury, Vt.] Boston Soc N H, Pr 5: 260-263, 339-341 (1855-6)

56 On serpentine rock. Am J Sc (2) $21: 382-385$ (1856)

56n [On coal at the Albert mine in New Brunswick.] Boston Soc N H, Pr 5: 306-307 (1856)

$56 \mathrm{~b}$ [On saline matter in rocks of eastern Massachusetts.] Boston Soe N H, Pr $6: 30$ (1856)

57 [On the origin of the concretions called claystones (wtih discussion by Charles Stodder).] Boston Soc N H, Pr 6:134-139 (1857)

$57 a$ [On the cementing materials of conglomerates (particularly the Roxbury conglomerate) and sandstones (with discussion by C. T. Jackson).] Boston Soc N H, Pr 6:167-169 (1857)

$57 \mathrm{~b}$ [On a peculiar form of guano.] Boston Soc N H, Pr 6:211-213 (1857)

61 On the occurrence of massive datolite in the mines of Lake Superior. Boston Soe N H, Pr 8: 62-64 (1861)

66 Description and analysis of a new kind of bitumen [Green River, Utah]. Boston Soc N H, Pr 10:306-307 (1866)

See also Marcou, 61b

Hayes, Charles Willard (1859-1916).

91 The overthrust faults of the soutbern Appalachians (with discussion by C. D. Walcott, W. M. Davis, and Bailey Willis). G Soc Am, B 2:141-154 (1891)

92 Report on the geology of northeastern Alabama and adjacent portions of Georgia and Tennessee. Ala G S, B 4:85 pp, map, Montgomery 1892. Abst, J G 1 : 98-99 (1893)

92a An expedition through the Yukon district. Nat Geog Mag 4:117-162, map (1892) Abst, G Soc. Am, B 3:495-496 (1892); Am G 9:216-217 (1892)
Hayes, Charles Willard-Continued.

93 (with Willis, Bailey) Conditions of Appalachian faulting. Am J Sc (3) 46 : 257-268 (1893) Abst, J G 1:861 (1893)

94 Ringgold atlas sheet [Ga.-Tenn.]. U S G S, G Atlas Ringgold fol (no 2):3 pp, maps (1894; prel ed 1892) Abst, J G 4:760-762 (1896)

94a Description of the Kingston sheet [Tenn.]. U S G S, G Atlas Kingston fol (no 4) : 4 pp, maps (1894; prel ed 1892) Abst, J G 4:762-764 (1896)

94b Chattanooga atlas sheet: description [Tenn.]. U S G S, G Atlas Chattanooga fol (no 6) : 3 pp, maps (1894; prel ed 1892) Abst, J G 764-766 (1896)

94c Description of the Sewanee sheet [Tenn.]. U S G S, G Atlas Sewanee fol (no 8) : 4 pp, maps (1894) Abst, J G 4: 766-768 (1894)

94d Bauxite. U S G S, Min Res 1893 : 159-167 (1894)

94e Geology of a portion of the Coosa Valley in Georgia and Alabama. G Soc Am, B 5:465-480, map (1894) Abst, Am G $13: 142$ (1894)

94r (and Campbell, M. R.) Geomorphology of the soutbern Appalachians. Nat Geog Mag 6:63-126, maps (1894)

$\mathbf{9 4} \boldsymbol{g}$ On the Devonian (Oriskany) in the southern Appalachians. Am J Sc (3) 47 : 237-238 (1894)

95 Description of the Stevenson sheet [Ala.-Ga.-Tenn.]. U S G S, G Atlas Stevenson fol (no. 19) : 4 pp, maps (1895)

95a Deseription of the Cleveland sheet [Tenn.]. U S G S, G Atlas Cleveland fol (no, 20): 4 pp, maps (1895)

95b Description of the Pikeville sheet ['Tenn.]. U S G S, G Atlas Pikeville fol (no. 21) : 4 pp, maps (1895)

95e Description of the McMinnville sheet [Tenn.]. U S G S, G Atlas MeMinnville fol (no 22): 3 pp, maps (1895)

95d Bauxite. U S G S, An Rp 16 pt 3 : 547-597, map (1895)

95e The Tennessee phosphates. U S G S, An Rp 16 pt 4:610-630, map (1895)

95p The southern Appalachians. Nat Geog Soc, Nat Geog Mon 1 no $10: 305-336$, map (1895) Also in The physiography of the United States (Nat Geog Soc) : 305336, map, N Y, American Book Co., 1896

$\mathbf{9 5} \mathrm{g}$ The geological relations of the southern Appalachian bauxite deposits. Am I M Eng, Tr 24:243-254, 861, map (1895)

95h Eastern Kentucky; its physiography and its people. Berea Q 1:1-8 (1895)

95i Notes on the geology of the Carters. ville sheet, Ga. (abst). Science n s 1: 668-669 (1895)

96 Description of the Gadsden quadrangle [Ala,]. U S G S, G Atlas Gadsden fol (no 35): 4 pp, maps (1896) 
Hayes, Charles Willard-Continued.

96n The Tennessee phosphates. U S G S, An Rp 17 pt 2: 513-550, maps (1896)

961 The white phosphates of Tennessee. Am I M Eng, Tr 25:19-28, map (1896)

96e The Devonian formation of the southern Appalachians (abst). Am G 17 : 107 (1896) Science n s 3:56 (1896)

97 Solution of silica under atmospheric conditions. G Soc Am, B 8:213-220 (1897) Abst, J G 5:319-321 (1897); Science n s $5: 82-\$ 3$ (1897)

97 a The Yukon district. J Sch Geog 1 : $236-241,269-274(1897)$

97b (and Brooks, A. H.) The crystalline and metamorphic rocks of northwest Georgia (abst). J G $5: 321-322$ (1897) Science n s 5:97 (1897)

$97 \mathrm{e}$ The geological relations of some southern iron ores (abst). Science n s 5 : 558 (1897)

98 The continental divide in Nicaragua (abst). Am G 22:253-254 (1898) Science n s $8: 466$ (1898)

99 Report on the geology and physiography of the Nicaragua Canal ronte. [U S], Nicaragua Canal Commission, Rp 1897-99: 87-192, Baltimore 1899

99a Physiography and geology of region adjacent to the Nicaragua canal route. G Soc Am, B 10:285-348, map (1899) Abst, Am G 23:94-96 (1899): Science n s $9: 105$ (1899)

99b Physiography of the Nicaragua Canal route. Nat Geog Mag 10:233-246, map (1899)

99e Lake region in Central America (abst). Science n s 9:153-154 (1899)

99d The Nicaragua Canal route. Science n s 10:97-104 (1899)

99e Physiography of the Chattanooga district, in Tennessee, Georgia, and Alabama. U S G S, An Rp 19 pt $2: 1-58$, maps (1899)

99f A brief reconnaissance of the Tennessee phosphate fields. U S G S, An Rp 20 pt 6 (con.) : $633-638$ (1899)

00 An assumed inconstancy in the level of Lake Nicaragua; a question of permanency of the Nicaragua Canal. Nat Geog Mag 11: 156-161 (1900)

O0a (and Brooks, A. H.) Ice cliffs on White River, Yukon Terr. Nat Geog Mag 11: 199-201 (1900)

0ob (and Camplell, M. R.) The relation of biology to physiography. Science n s 12 : 131-133 (1900)

ooc Solution sinks in a quartzite formation [Coldwater Mountain, Ala.] (abst). Science n \& 11:228-229 (1900)

ood The geological relations of the Tennessee brown phosphate $(a b s t)$. Science n s $12: 1005$ (1900)
Hayes, Charles Willard-Continued.

o1 (and Vaughan, T, W., and spen. eer, A. C.) Report on a geological recon. noissance of Cuba...: $123 \mathrm{pp}$, map [Ha vana?] 1901 Also in Civil report of Brig. Gen. Leonard Wood, Military governor of Cuba, for 1901 vol 1 Trans, with annota tions, by Pablo Ortega y Ros, Cuba, Dir Montes y Minas, Bol Minas, nos 2 and 3 132 pp, map (by Fernández de Castro and Salterain y Legarra) (1917)

$01 \mathbf{a}$ The Arkansas bauxite deposits. Us G S, An Rp 21 pt 3:435-472, maps (1901)

01 Tennessee white phosphate. U . G S, An Rp 21 pt 3:473-485 (1901)

01e Tennessee phosphates. Tenn, Comm Agr, Bien Rp 1899-1900: 291-304 (1901)

o1d Geological relations of the fron ores in the Cartersville district, Ga. Am I M Eng, Tr 30:403-419, map (1901)

02 Description of the Rome quadrangle [Ga.-Ala.]. U S G S, G Atlas Rome fol (no 78):6 pp, maps (1902)

02a The coal fields of the United States U S G S, An Rp 22 pt 3: 7-24, map (1902 02b The southern Appalachian coal field. U S G S, An Rp 22 pt $3: 227-26 ?$ maps (1902)

02e The asphalt deposits of Pike $\mathrm{C}_{0}$, Ark. Eng M J 74:782 (1902)

o2d Some facts and theories bearing on the accumulation of petroleum (abst). Science n s 16:1028 (1902)

o3 (and Ulrieh, E. O.) Description of the Columbia quadrangle [Tenn.]. U 8 G S, G Atlas Columbia fol (no 95):6 pp, maps (1903)

O3a (and Kennedy, W.) Oil fields of the Texas-Louisiana Gulf Coastal Plain. U S G S, B 212: 174 pp, maps (1903)

03b (with Emmons, S. F.) Contribu. tions to economic geology, 1902. U S G 8 . B 213:449 pp (1903) ...1903; B 225:527 pp (1904) ...1904; B 260:620 pp (1905)

o3c Contributions to economic geology. 1902 ; introduction. U S G S, B $213: 9-14$ (1903)

03d Investigation of nonmetalliferous economic minerals. U S G S, B 213:2930 (1903)

o3e Manganese ores of the Cartersville district, Ga. U S G S, B 213: 232 (1903i

o3f (and Ecke1, E. C.) Iron ores of the Cartersville district, Ga. U S G S, B $213: 233-242$ (1903)

o3g Coal fields of the United States. D S G S, B $213: 257-269$ (1903)

o3h Oil fields of the Texas-Louisiana Gulf Coastal Plain. U S G S, B $213: 345^{-}$ 352 (1903)

O3i Asphalt deposits of Pike Co., Ark. U S G S, B 213: 353-355 (1903)

03j Origin and extent of the rennessee. white phosphate. U S G S, B 213:418423 (1903) 
Hayes, Charles Willard-Continued.

03k (and Eekel, E. C.) Occurrence and derelopment of ocher deposits in the Cartersville district, Ga. U S G S, B 213: 427-432 (1903)

031 Tennessee phosphates. In Hradbook of Tennessee: $25-28$, Nashville 190. [not seen]

04 Contributions to economic geoiozy, 1903 ; introduction. U S G S, B 225: 1117 (1904)

04a Investigation of nonmetalliferous economic minerals. U $\mathrm{S}$ G S, B 225: $25-27$ (1904)

05 Contributions to economic geology, 1904. Introduction. U S G S, B 260: 11-18 (1905)

05 a Investigation of iron and nonmetalliferous economic minerals. U S G S, B $260: 28-31$ (1905)

06 The relation of the federal government to the mining industry. Am M Cong, 8th An Sess, Papers and addresses : 46-59 (1906)

07 The Gila River alum deposits. U S G S, B $315: 215-223$ (1907)

08 (and Lindgren, W.) Contributions to economic geology, 1907; Part I, Jetals and nonmetals, except fuels. U S

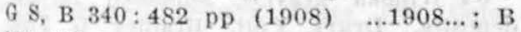
$380: 406$ pp $(1909) \quad \ldots 1909 \ldots ;$ B $430: 653$ pp (1910) ...1910...; B 470:558 pp (1911) 08a Investigations relating to noumetallic mineral resources. U S G S, B 340 : 12-17 (1908)

08b (and Phalen, W. C.) A commercial oecurrence of barite near Cartersville, Ga. U S G S, B $340: 458-462$ (1908) 08e (and Phalen, W, C.) Graphite deposits near Cartersville, Ga. U S G S, B $340: 463-465$ (1908)

09 Handbook for field geologists, $2 d$ ed. ix, 159 pp, N Y 1909 [The first edition bearing title, Handbook for field geologists in the United States Geological Survey, $159 \mathrm{pp}$, was issued by the Survey in 1908 for oflicial use.]

09a The iron-ore supply of the United States. Am I M Eng, B 28:373-379 (1909) M World $30: 875-876$ (1909)

09b Iron ores of the United States. U S G S, B 394: 70-113 (1909) Nat Conservation Comm, Rp (60th Cong 2d sess, 8 Doc 676). 3:483-520 (1909) Abst, M Sc Press 98 : 798-799 (1909)

09e Petroleum fields in Mexico. U $\mathrm{S}$, 61st Cong 1st sess, S Doc $79: 3$ (1909)

09d The mineral wealth of the South. southern Commercial Cong, Official Proc. at the First Session... 1908: 84-98 [1909]

10 Iron and manganese in the South. In The South in the building of the nation. vol 6:223-232, Richmond, Va., [c 1910]

10a slides in Culebra cut [Panama Canal Zone]. Canal Record 4:115 (1910)
Hayes, Charles Willard-Continned.

10b Discussion of a review by A. C. Lawson of A handbook for field geologists. Ec G 5: 61-63 (1910)

11 The State geological surveys of the United States [history, organization, etc.]. U S G S, B 465: 177 pp (1911)

11 The Mayari and Moa iron-ore deposits in Cuba. Am I M Eng, B 51:239245 (1911) ; Tr, 42:109-115 (1912)

$11 \mathrm{~b}$ Growth of concretions of different composition under a variety of conditions (abst). Seience n s 33:550-(1911)

11e Geological features bearing on the construction of the Panama canal (abst). Wash Ac Sc, J 1:46-48 (1911)

18 (and Vaughan, T. W., and Spencer. A. C.) Geology of Cuba ; a reprint of the chapters on physiography and general geology from the "Report on a geological reconnaissance of Cuba," partly revised by Pablo Ortega. Cuba, Dirección de Montes y Minas: 37 pp, map (by Manuel FernánCez de Castro and Pedro Salterain y Legarra), Habana 1918

See also Powell, 95 ; Safford, 95

Hayes, Ellen.

o3 Lunar calderas (abst). Science n s $17: 222-223$ (1903)

Hayes, George Edward.

37 ...geology of western New York. Am J Sc $31: 241-247$ (1837)

38 ...geology and topography of western New York. Am J Sc 35: 86-105 (1838)

38n Evidences of diluvial currents. Am J Sc 35: 191 (1838)

69 Geology of Buffalo... 42 pp, Buffalo 1869

Hayes, John Lord.

43 Probable influence of icebergs upon drift. Am J Se $45: 316-319$ (1843) Boston J N H 4:426-452 (1844)

44 Report on the geographical distribution and phenomena of volcanoes (abst). Am J Sc 47:127-128 (1844)

See also Nicollet, $43 \mathrm{~b}$

Hayes, Richard.

75 Catalogue of earthquakes for the years 1872-73. Ac Sc St L, Tr $3: 243-245$ (1875)

Hayes, Seth.

95 The Shaw mastodon [found near Cincinnati, Ohio, 1894]. Cin Soc N H, J 17:217-226 (1895) Abst, Ohio St Ac Sc, An Rp 3: 37-41 (1895)

Hayford. John Fillmore.

06 The geodetic evidence of isostasy, with a consideration of the depth and completeness of the isostatic compensation and of the bearing of the evidence upon some of the greater problems of geology. Wash Ac Sc, Pr $8: 25-40$ (1906)

o7. The earth a failing structure. $\mathrm{Ph}$ Soc Wash, B 15:57-74 (1907) Sc Am Sup 65: 121-123 (1908) Abst, Science n s 27:695-697 (1908) Rv by T. C. Chamberlin, J G 16:191-192 (1908) 
Hayford, John Fillmore-Continued.

oza (and Baldwin, A. L.) The earth movements in the California earthquake of 1906. U S Coast S, Rp Superintendent 1906-7, App 3:67-104 (1907)

09 The figure of the earth and isostasy from measurements in the United States. U S Coast S, 178 pp, Washington 1909

09a Results of a geodetic study of the San Francisco earthquake (abst). Science n $s$ 29: 199 (1909)

10 Supplementary investigation in 1909 of the figure of the earth and isostasy. $\mathrm{U}$ S Coast $\mathrm{S}, 80 \mathrm{pp}$, maps, Washington 1910

11 The relations of isostasy to geodesy, geophysics, and geology. Science n 8 33: 199-208 (1911)

12 Isostasy, a rejoinder to the article by Harmon Lewis. J G 20:562-578 (1912)

12a (and Bowie, William) The effect of topography and isostatic compensation upon the intensity of gravity. U S Coast S, Spec pub 10:132 pp (1912) Abst, Wash Ac Sc, J $2: 189-191$ (1912)

15 The earth from the geophysical standpoint. Am Ph Soc, Pr 54: 298-308 (1915) Smiths Inst, An Rp 1916:239248 (1917)

17 Gravity and isostasy. Science $n \mathbf{s}$ 45: $350-354$ (1917)

Haymonal, Rufus.

44 Notice of remains of Megatherium, Mastodon, and Silurian fossils. Am J Se $46: 294-296$ (1844)

69 Geology of Franklin Co. Ind $\mathbf{G ~ S}$, An Rp 1: 175-202 (1869)

Haynes, Henry W.

80 The fossil man. Pop Sc Mo 17: 350-358 (1880)

Haynes, Winthrop P.

13 Discovery of bivalve Crustacea in the coal measures near Pawtucket, R. I. Science $n$ \& $37: 191-192$ (1913)

15 New facts bearing on the Paleozoic stratigraphy of the region about Three Forks, Mont. (abst). G Soc Am, B 26: $157-158$ (1915)

16 The fauna of the upper Devonian in Montana; Part 2, The stratigraphy and the Brachiopoda. Carnegie Mus, An 10: 13-54, il (1916)

$16 a$ The Lombard overthrust and related geological features [Mont.]. J G 24:269-290, map (1916)

17 (with Moore, R. C.) Oil and gas resources of Kansas. Kans G S, B 3: 391 pp, maps (1917)

Hnys, Isaac.

30 Description of a fragment of the head of a new fossil animal, discovered in a marl pit, near Moorestown, $\mathrm{N}$. $\mathbf{J}$. $\mathrm{Am} \mathrm{Ph}$ Soc, Tr n s $3: 471-477$, il (1830)
Hays, Isaac-Continued.

34 Descriptions of the specimens of it ferior maxillary bones of mastodons. with remarks on the genus Tetracaulodon Godman, etc. Am Ph Soc, Tr n s 4:31339, il (1834) Reprint, 23 pp, ill, Phil 1833

41 On fossil bones, chiefly of the Ma. todon. Am Ph Soc, Pr 2:102-103, 105106 (1841)

42 Remarks on Prof. Owen's paper os Missouri fossils. Am $\mathrm{Ph}$ Soc, $\mathrm{Pr} 2: 188-$ 184 (1842)

43 On three papers relative to the mas todontoid animals in the collections of Mr. Koch. Am Ph Soc, Pr $2: 264-2 \%$ (1843)

43a On the family Proboscidea, theit general character and relations, their mode of dentition and geological distribution $\mathrm{Am} \mathrm{Ph} \mathrm{Soc,} \mathrm{Pr} \mathrm{3:44-48} \mathrm{(1843)}$

$43 b$ (with Horner, W. E.) Descrip tion of an entire head and various other bones of the Mastodon. Am Ph Soc, It n 8 s:37-48, il (1843)

52 [On a tooth of a fossil tapir fros North Carolina.] Ac N Sc Phila, Pr 6: 53 (1852)

Hays, Mabel.

o4 Winoka gravels, supposed Tertlary deposits. Drury Coll, Bradley G Fiell Sta, B 1:19-21 (1904)

Hayward, A. A.

os Salt: its history, occurrence, snt manufacture. M Soc N S, J 11:99-116 (1908)

10 Tungsten and Moose River scheelite veins [Nova Scotia]. M Soc N S, J 15: 65-78 (1910)

Haywara, M. W.

18 (with Brown, H. L.) Molybdenut mining at Climax, Colo. Eng M J 105: 905-907 (1918)

Hazard, D. L.

18 The relation between seismic and magnetic disturbances. Seism Soc Am, B $8: 117-124$ (1918)

Haxelhurst, G. F.

oo The Cripple Creek mining district, Colo. Eng M J 70:454-455, 545-540. $577-578, \quad 605, \quad 635-636, \quad 669-670, \quad \mathrm{~ms} ?$ (1900)

Head, Jeremiah.

97 The coal industry of the Southeastern States of North America. N Engl Inst $M$ Eng, $\operatorname{Tr} 46: 167-182$, map (1897) Head, William R.

95 Catalogue of recognized Paleozoic sponges of North America. 11 pp [Chicago 1895]

Headden, William Parker.

86 Note on columbite [from Turke? Creek, Jefferson Co. Colo.]. Colo Sc $\mathrm{SOC}_{1}$ Pr 2: 31 (1886)

88 [A deposit of infusorial earth is West Denver.] Colo Sc Soc, Pr 2:183 (1888) 
Headden, William Parker-Continued. 91 Columbite and tantalite from the Black Hills of South Dakota. Colo Sc Soc, Pr $3: 323-346$ (1891)

91a Columbite and tantalite from the Black Hills of South Dakota. Am J Sc (3) $41: 89-102$ (1891)

91b Notes upon the history of the discovery and occurrence of tin ore in the Black Hills, S. Dak. Colo Sc Soc, Pr 3 : $347-350$ (1891)

91e On black rutile from the Black Hills. Am J Sc (3) 41:249-250 (1891)

91d A new phosphate from the Black Hills of South Dakota. Am J Sc (3) 41: 415-417 (1891)

93 Stannite and some of its alteration products from the Black Hills, S. Dak. Am I Sc (3) $45: 105-110$ (1893)

93a Kehoeite, a new phosphate from Galena, Lawrence Co., S. Dak. Am J Sc (3) $46: 22-25$ (1893)

03 Significance of silicic acid in waters of mountain streams. Am J Sc (4) 16: $169-184$ (1903)

03a Mineralogical notes. Colo Sc Soc, Pr 7: 141-150 (1903)

05 The Doughty Springs, a group of radium-bearing springs, Delta Co., Colo. Am J Sc (4) 19:297-309 (1905) Colo Sc Soc, Pr 8: 1-30 (1905)

05a Mineralogical notes, No. II. Colo Se Soc, Pr 8: 55-70 (1905)

06 Mineralogical notes, no. III. Colo Se Soc, Pr 8: 167-182 (1906)

06a Some phosphorescent calcites from Fort Collins, Colo., and Joplin, Mo. Am J Sc (4) $21: 301-308$ (1906)

07 An examination of some coals from Routt Co., Colo. Colo Se Soc, Pr $8: 257$ 280 (1907)

07a A study of some Colorado coals-a comparison of some coals from Boulder, Routt, and Delta cos. Colo Sc Soc, $\operatorname{Pr} 8$ : 281-300 (1907)

07b Phosphorescent calcites. Mineral Collector 14: 21-22 (1907)

08 Meteoric iron from Currant Creek, Colo. Colo Sc Soc, Pr 9: 79-80 (1908)

09 The brown artesian waters of Costilla Co., Colo, their relations to certain deposits of natron or soda, and what they teach. Am J Sc (4) 27:305-315 (1909) 09a Notes on some mineral springs. Colo Sc Soc, Pr $9: 259-272$ (1909)

17 Mineralogical notes, No. IV. Colo Sc Soc, $\operatorname{Pr} 11: 177-183$ (1917)

17 a The waters of the Rio Grande; a contribution to the hydrology of the San Luls Valley, Colo. Colo Agr Coll, Exp Sta, B 230:62 pp (1917)

18 Alkalis in Colorado (including nitrates). Colo Agr Coll, Agr Exp Sta, B 289:58 pp (1918)
Heald, Kenneth Conrad.

15 (with Wegemann, C. H.) The Healdton iron fleld, Carter Co., Okla. U S G S, B 621: 13-30, map (1915)

16 The oil and gas geology of the Foraker quadrangle, Osage Co., Okla. U S G S, B 641: 17-47, map (1916) Abst, by R. W. S., Wash Ac Sc, J $7: 77$ (1917)

18 Structure and oil and gas resources of the Osage Reservation, Okla.; T. $25 \mathrm{~N}$., R. 9 E. U S G S, B $686: 27-41$, map (1918)

18a Structure and oil and gas resources of the Osage Reservation, Okla.; T. $27 \mathrm{~N}$, R. 7 E. U S G S, B $686: 129-135$, map (1918)

18b (and Mather, K. F.) Structure and oil and gas resources of the Osage Reservation, Okla; Tps. 24 and 25 N., R. 8 E. U S G S, B 686: 149-170, maps (1918)

18e Geologic structure of the northwestern part of the Pawhuska quadrangle, Okla. U S G S, B 691:57-100 (1918) Abst, by R. W. Stone, Wash Ac Sc, J 8: 249 (1918)

$18 d$ (with Winchester, D. E., and others) Structure and oil and gas resources of the Osage Reservation, Okla.: T. 25 N., R 10 E. U S G S, B $686: 59-73$, map (1918)

Healy, John R.

12 (with Berkey, C. P.) The geology of New York City and its relations to engineering problems (with discussion). Municipal Engineers of the City of New York, Pr 1911: 5-39 (1912)

Heap, R. R.

13 A geolegical drainage problem [Miami lead and zinc district in southwestern Missouri]. Eng M J 96:1205-1211 (1913)

Heatherington, $A$.

68 A practical guide... of the gold fields of Nova Scotia. $170 \mathrm{pp}$, Montreal 1868

74 The mining industries of Nova Scotia... 23 pp, L 1874

Hébert, E.

75 Documents sur la géologie du bassin du MacKenzie... Soc ( France, B (3) $3: 87-88$ (1875)

Hechinger, L. A.

14 (with Loughlin, G. F.) An unconformity in the Narragansett Basin of Rhode Island and Massachusetts. Am J Sc (4) $38: 45-64$, map (1914)

Hector, James.

59 [Geological observations.] [Great Britain, Colonial Office], Papers relutive to the exploration by Captain [John] Palliser of that portion of British North America which lies between the northern branch of the River Saskatchewan and the frontier of the United States, and between the Red River and Rocky Mountains, pp $42-45$, L 1859 
Hector, James-Continued.

61 On the geology of the country between Lake Superior and the Pacific Ocean between the 48 th and 54 th parallels of latitude. G Soc London, Q J 17:388-445, map (1861) Abst, Ph Mag (4) 21:537538 (1861)

$61 \mathrm{a}$ On the Pleistocene deposits of North America. Geologist, London, 4: $461-462$ (1861)

63 Geological report. [Great Britain, Colonial Office], The journals...relative to the exploration by Captain [John] Palliser of that portion of British North America...during the years 1857, 1858, 1859 , and 1860 , pp. 216-245, 314-325, maps [under separate cover 1865], L 1863

Hedburg, Edward.

09 The Calizona placers, Ariz. M World $31: 138$ (1909)

OOa The Greens Valley mining district, Ariz. M World 31:1245-1246 (1909)

Hedburg, Eric.

98 Lead and zinc ores; the manner of their occurrence and their geological relation to the coal area of ? issouri. Mines and Minerals 18:289-290 (1898)

02 The Missouri and Arkansas zine mines at the close of 1900 (with discussion by J. C. Branner and Henry W. Nichols). Am I M Eng, Tr 31:379-404, 1013-1023, map (1902)

06 The Wisconsin zinc fields. M World 24: 61-62 (1906)

Hedley, Edward.

65 On iron mines and iron manufacture of Nova Scotia. N Engl Inst M Eng, Tr 14:15-25, map (1865)

Heer, Oswald (1809-1883).

57 [On fossil plants of North Carolina.] Am J Sc (2) 24:428-429 (1857)

58 Descriptions of fossil plants from No, 1 of the Nebraska section [of Meek and Hayden]. Ac N Sc Phila, Pr 1858: $265-266$

59 On fossil plants collected by Dr. John Evans at Vancouver Island and at Bellingham Bay, Wash. Terr. Am J Sc (2) 28: 85-89 (1859)

$61 \ldots$ on the age of the Nebraska leaves. Am J Sc (2) 31:435-440 (1861)

62 Ueber die von Dr. Lyall in Grönland entdeckten fossilen Pflanzen. Naturf Ges Zürich, Vierteljahrsschr 7: 176-182 (1862)

65 Ueber einige fossile Pflanzen von Vancouver und Britisch-Columbien. Soc Helvétique Sc Nat, Nouv Mém 21: 10 pp, il (1865) Abst, Zs Ges Naturw 26:74-75 (1865)

66 Ueber den versteinerten Wald von Atanekerdluk in Furdgrönland. Naturf Ges Zürich, Vierteljahrssehr 11:259-280 (1866) Abst, Arch Sc Phys Nat n s 27: 242-250 (1866)
Heer, Oswald-Continued.

66a (with Capellini, J.) Les phyl. lites crétacées du Nebraska. Soc Helvêtique Sc Nat, Nouv Mém $22: 22$ pp, il (18f6)

67 On the Miocene flora of north Green. land. $\mathrm{R}$ Dublin Soc, J 5: 69-85 (1867) Abst, Brit As, Rp $36: \sec 53-55$ (1867); J Bot 4:310-314 (1866)

67a Ueber die Polarlïnder. $24 \mathrm{pp}, \mathrm{Zn}^{\mathrm{a}}$ rich 1867

67b Ueber die miocene Flora der Polar. länder. Schweiz Naturf Ges, Verh 1867: 139-152. Abst, Arch Sc Phys Nat 30:218231 (1867); An Mag N H (4) 1:61-69 (1868) ; G Mag 5 : 273-280 (1868)

68 Flora fossilis arctica. 7 vols., Zïrich 1868-73 [For digest of contents see Ma]loizel, Godefroy, Oswald Heer. Bibliog. raphie... : 46-51, Stockholm [1887]; also Knowlton, F, H., U S G S, B 152:15-10 (1898) ; B 696:24-25 (1919)]

68a ...fossila vexter från nordvestra Amerika... K Svenska Vet-Ak, Öfv 25:6368 (1868)

68b [Die Kreideflora des hohen Not dens.] N Jb 1868: 63-64

69 Fossile flora von Alaska. K Svenska Vet-Ak, Hdl 8, no 4: 41 pp, il (1869)

69a The Miocene flora of north Greet. land (abst). G Mag 6:322-324 (1869)

70 Contributions to the fossil flora of north Greenland... R Soc London, Ph Tr 159:445-488, fl (1870) ; Abst, $\operatorname{Pr} 17: 329-$ 332 (1869)

70a Prellminary report on the fosil plants collected by $\mathrm{Mr}$. Whymper in north Greenland in 1867. Brit As, Rp $39: 8-10$ (1870)

71 Förutskickade anmärkningar öfrer Nordgrönlands Kritflora... [Cretaceous flora of northern Greenland]. K Srenska Vet-Ak, Öfv 28:1175-1184 (1871) Vorläufige Bemerkungen über die Kreldeflora Nordgrönlands... Deut $G$ Ges, Zs 24: 155-164 (1872)

73 Om de miocena växter, som den svetska expeditionen 1870 hemfört från Grön. land. K Svenska Vet-Ak, Öfv 30 no 10 : 5-12 (1873)

74 Die Kreide-Flora der arctischen Zone. gegründet auf die von den schwedischen Expeditionen von 1870 und 1872 in Grön. land und Spitzenbergen gesammelten Pflan. zen. K Svenska Vet-Ak Hdl N F 12 no 6: $138 \mathrm{pp}$, il (1874)

74a Nachträge zur miocenen Flora Grönlands. K Svenska Vet-Ak Hdl N F 13 no $2: 29 \mathrm{pp}$, il $(1874)$

74b Beiträge zur Steinkohlen-flora de: arctischen Zone. K Svenska Vet-Ak Hdl N F 12 no $3: 11 \mathrm{pp}$, il (1874)

74e Pflanzenversteinerungen [eastern Greenland]. In Die zweite Deutsche Nordpolarfahrt... (Verein für die Deutsche Nordpolarfahrt in Bremen) $2: 512-517$, il Leipzig 1874 
Heer, Oswald-Continued.

78 Notes on fossil plants discovered in Grinnell Land... G Soc London, Q J 34: 66-72 (1878)

79 [On plants from Grinnell Land.] Schweiz Naturf Ges, Verh 61:316-317 (1879) Arch Sc Phys Nat (3) 2: 345-347 (1879)

79a Ueber das Alter der tertiären Ablagerungen der arktischen Zone. Das Ausland, Stuttgart, 52 : 141-145 (1879)

80 Nachträge zur fossilen Flora Grönlands. K Svenska Vet- $A \mathrm{k}$ Hdl N F 18 no $2: 17 \mathrm{pp}$, il (1880)

80a On the Miocene plants discovered on the Mackenzie River. $\mathbf{R}$ Soc London, Pr 30:560-562 (1880)

83 Ueber die fossile Flora von Grönland. Bot Jb (Engler) 4:367-385 (1883)

93 Oversigt over Grönlands fossile Flora. Med Grönland 5 : 79-202 (1893)

Heiderhofr, Frank.

88 Origin of the shell mounds. G Sc B 1 no 8 (1888)

Heikes, Victor Conrad.

05 Gold and silver; Arizona. U S G S, Jin Res $1904: 157-164 ; 1905: 134-185$; $1906: 147-177$ (1905-7)

05a Gold and silver; Idaho. U S G S, Min Res 1904:181-190; $1905: 214-242$; 1906: 240-267 (1905-7)

05b Gold and silver; Utah. U S G S, Min Res $1904: 212-217$; 1905 : 305-331; $1908: 334-362(1905-7)$

os Gold, silver, copper, lead, zinc; Arizona. U S G S, Min Res 1907 pt $1: 150$ $187 ; 1908$ pt $1: 286-313 ; 1909$ pt $1: 232$ $259 ; 1910$ pt $1: 320-347 ; 1911$ pt $1: 420$ $462 ; 1912$ pt $1: 536-568 ; 1913$ pt $1: 673-$ $707 ; 1914$ pt $1: 427-475 ; 1915$ pt $1: 485-$ $521 ; 1916$ pt $1: 283-319(1908-17)$

0sa Gold, silver, copper, lead, and zlnc; Idaho. U S G S, Min Res 1907: 279-312 (1908)

0sb Gold, silver, copper, lead, and zinc ; Utah. U S G S, Min Res 1907 pt 1:433$467 ; 1908$ pt $1: 542-573 ; 1909$ pt $1: 456-$ $485 ; 1910$ pt $1: 573-597 ; 1911$ pt $1: 740$ $777 ; 1912$ pt $1: 882-913 ; 1913$ pt $1: 365-$ $413 ; 1914$ pt $1: 717-756 ; 1915$ pt $1: 385-$ $419 ; 1916$ pt $1: 421-455(1908-18)$

09 Gold, silver, copper, lead, and zinc; Montana. U S G S, Min Res 1908 pt 1: $435-461 ; 1909$ pt $1: 357-386 ; 1910$ pt 1 : $469-498 ; 1911$ pt $1: 602-646 ; 1912$ pt 1 : $739-772 ; 1913$ pt $1: 583-620 ; 1914$ pt 1 : $757-797 ; 1915$ pt $1: 577-612 ; 1916$ pt 1 : $389-420$ (1909-17)

13 Precious and semiprecious metals: Nevada, U S G S, Min Res 1912 pt 1: $773-818$ (1913)

14 Gold, silver, copper, lead, and zinc ; Nevada. U S G S, Min Res 1913 pt 1: $803-844 ; 1914$ pt $1: 655-716 ; 1915$ pt 1 : $613-654 ; 1916$ pt $1: 457-500$ (1914-8)
Heikes, Victor Conrad-Continued.

16 (with Butler, B. S.) Notes on the Promontory district, Utah. U S G S, B 640: 1-10 (1916)

Heilprin, Angelo (1853-1907).

79 On some new Eocene fossils from the Claiborne marine formation of Alabama. A: N Sc Phila, Pr 1879: 211-216, il

80 A comparison of the Eocene Mollusea of the southeastern United States and western Europe... Ac N Sc Phila, Pr 1879 : $217-225 \quad(1880)$

Sor On the stratigraphical evidence afforded by the Tertiary fossils of the Peninsula of Maryland. Ac N Sc Phila, Pr 1880:20-33

81 On some new lower Locene Mollusca from Clarke Co., Ala., with some points as to the stratigraphical position of the beds containing them. Ac N Sc Phila, Pr $1880: 364-375$, il (1881)

81a Notes on the Tertiary geology of the southern United States. Ac N Sc Phila, Pr 1881:151-159

$81 b$ A revision of the cis-Mississippi Tertiary pectens of the United States. Ac N Sc Phila, Pr 1881: 416-422

81e Remarks on the molluscan genera Hippagus, Verticordia, and Pecchiolia. Ac N Sc Phila, Pr $1881 ; 423-428$

81 Note on the approximate position of the Eocene deposits of Maryland. Ac N Sc Phila, $\operatorname{Pr} 1881: 444-447$

82 A revision of the Tertiary species of Arca of the eastern and southern United States. Ac N Sc Phila, $\operatorname{Pr} 1881$ : 448-453 (1882)

82a On the occurrence of $2 \mathrm{mmonites}$ in deposits of Tertiary age. Ac N Sc Phila, Pr 1882: 94

$\mathbf{8 2 b}$ On the relative ages and classification of the post-Eocene Tertiary deposits of the Atlantic slope. Ac $N$ Sc Phila, Pr 1882: 150-186

s2e On the occurrence of nummulitic deposits in Florida, and the association of Nummulites with a fresh-water fauna. Ac N Sc Phila, Pr 1882: 189-193, il (1882)

82d On the age of the Tejon rocks of California, and the occurrence of ammonitic remains in Tertiary deposits. Ac N Sc Phila, Pr 1882: 196-214

83 The synchronism of geological formations. Ac N Se Phila, Pr 1883:197200

83a Synchronism of geological formations. Science 2:661-662, 794-795 (1883) : 3:60-61 (1884)

83b The ice of the glacial period; phenomena of glaciation. Ac $\mathrm{N}$ Sc Phila, Pr 1883:46-47, 49, 69-70

83e Note on a collection of fossils from the Hamilton (Devonian) group of Pike Co., Pa. Ac N Sc Phila, Pr 1883:213 
Heilprin, Angelo-Continued.

83d The Tertiary deposits of the Atlantic slope. Am Nat 17:308-309 (1883)

84 Contributions to the Tertiary geology and paleontology of the United States. 117 pp, map, Phila 1884

$84 a$ The Tertiary geolocy of the eastern and southern United States. Ac N Sc Phila, J (2) 9:115-154, map (1884) Reprinted in Contributions to the Tertiary geology and paleontology of the United States: 1-40, Phila 1884

84b North American Tertiary Ostreidae. U S G S, An Rp 4:309-316, il (1884)

84c On a Carboniferous ammonite from Texas. Ac N Sc Phila, Pr 1884:53-55, il 84d [New trilobite from alpack Ridge, Pa.] Science 4:154 (1884)

85 Town geology; the lesson of the Philadelphia rocks... 142 pp, il, map, Phila 1885

$85 a$ On a remarkable exposure of columnar trap near Orange, N. J. Ac N Sc Phila, Pr 1884: 318-320 (1885)

S5b Notes on some new Foraminifera from the nummulitic formation of Florida. Ac N Sc Phila, $\operatorname{Pr} 1884: 321-322$, il (1885)

85e The classification and paleontology of the U. S. Tertiary deposits. Science $5: 475-476 ; 6: 83-84$ (1885)

s5d On the direction of giaclal movement in Labrador. Science 6:388 (1885)

85e [On Conorbis princeps from the Oligocene of Manatee River, Fla. (abst.] Science 6: 499 (1885)

86 Description of the fossils contained in the [Wyoming Valley Carboniferous limestone] beds [Pa.] Wyoming Hist G Soc, Pr 2: 265-277, il (1886) Pa G S, An Rp 1885: 450-458, il (1886)

86a Notes on the Tertiary geology and paleontology of the southern United States. Ac N Sc Phila, Pr 1886:57-58

86b [Geological observations on Florida.] Science 7:353 (1886)

87 The geographical and geological distribution of animals. The International Scientific Series vol $57: 435 \mathrm{pp}$, N Y 1887

$87 \boldsymbol{a}$ Explorations on the rest coast of Florida... Wagner Free I Sc, Tr 1:134 pp, il (1887)

87b On Miocene fossils from southern New Jersey. Ac N Sc Phila, Pr 1886: 351 (1887)

87e The classification of the post-Cretaceous deposits. Ac N Sc Phila, Pr 1887: $314-322$

88 The geological evidences of evolution. $99 \mathrm{pp}$, il, Phila 1888

88 a Determination of the age of rock deposits. Ac N Sc Phila, $\mathrm{Pr}$ 1887:395 (1888)

88b The Miocene Mollusca of the State of New Jersey. Ac N Sc Phila, Pr 1887: 397-405 (1888)
Heilprin, Angelo-Continued.

88e [Remarks on Dr. Uhler's paper on the Albirupean of Maryland.] Am Ph Soc, Pr 25: 54 (1888)

89 The Bermuda Islands... 231 pp Phila 1889

90 The principles of geology. Vol. 7. of the Iconographic Encyclopaedia, $329 \mathrm{pp}$ Phila 1890

90a The corals and coral reefs of the western waters of the Gulf of Mexico. Ac N Sc Phila, Pr 1890:303-316

91 The Eocene Mollusca of the State of Texas, Ac N Se Phila, Pr 1890:393-406, il (1891)

91 a The geology and paleontology of the Cretaceous deposits of Mexico. Ac N Sc Phila, $\operatorname{Pr} 1890: 445-469$, Il (1891) Rr, Am G 10:121 (1892)

91b Geological researches in Yucatan. Ac N Sc Phila, Pr 1891: 136-158

94 The glaciers of Greenland. Pop Sc Mo 46:1-14 (1894)

95 The Port Kennedy deposit, Pa. Ac N Sc Phila, Pr 1895: 451

96 The earth and its story; a first book of geology. 267 pp, Boston 1896 Kansas ed [The geology of Kansas by S. W. Williston: 269-288], 288 pp, map, N Y 1899

96a The stone forest of Florissant. Pop Sc Mo $49: 479-484$ (1896)

99 Geology of the Klondike gold fields. Pop Sc Mo 55: 300-317 (1899) Extr from his Alaska and the Klondike... 315 PP, N Y 1899

O1 Fossils and their teachings. Sc Am Sup $52: 21472-21473$ (1901)

01a How to interpret the facts of geol. ogy. Se Am Sup 52: 21488-21489 (1901)

02 Mont Pelé in its might; a scientific study of the volcano's activity, from data gathered at the crater's mouth. McClure's Mag 19:359-368 (1902)

03 Mont Pelé and the tragedy of Martl. nique... $325 \mathrm{pp}$, Phila 1903

03a Mont Pele; the eruptions of August 24 and 30,1902 (abst). Science n s 17: 226 (1903) Sc Am Sup 55:22647 (1903)

03b The activity of Mount Pelé. Science n s $17: 546$ (1903)

o3e The ascending obelisk of the Montagne Pelée. Science n s 18:184-185 (1903) Pop Sc Mo 63:467-468 (1903)

04 The tower of Pelce; new studies of the great volcano of Martinique. $62 \mathrm{pp}$. Phila 1904

$04 a$ The nature of the Pele tower. Sctence n s 19:800-801 (1904)

o5 Uniformity in mountain elevations. Am Geog Soc, B 37: 726-729 (1905)

O5a Tower of Pelée $(a b s t)$. Int Geog Cong, VIII, Rp: 446 (1905)

06 The rock of the Pele obelisk and the condition of the volcano in February, 1906. Science n s 24:25-26 (1906)

06a The shattered obelisk of Mont Pelé. Nat Geog Mag 17:465-474 (1906) 
Heilprin, Angelo-Continued.

06b The concurrence and interrelation of volcanic and seismic phenomena. Science n s $24: 545-551$ (1906) Int G Cong, X, Mexico, 1906, C R : ${ }^{\uparrow 87-196 ~(1907) ~}$

07 The Catskill Mountains. Am Geog Soc, B 39:193-199 (1907)

os The eruption of Pelée a summary and discussion of the phenomena and their sequels. $72 \mathrm{pp}$, Phila 1908

See also Newberry, 89b; Smith (E A), $88 \mathrm{a}$

Heim, Arnold.

11 Ueber die Petrographie und Geologie der Umgebungen von Karsuarsuk, Nordseite der Halbinsel Nugsuak, W. Grönland. Med Grönland $47: 173-228$, map (1911)

11a Nordwest-Grönlands Gneisgebirge. Geologische Charakterbilder (H. Stille), H 6:6 pls and text, 1911

11b West-Grönlands Basalt- und Sedimentgebirge. Geologische Charakterbilder (H. Stille), H $7: 8$ pls and text, 1911

13 Lava-fields of the Kilauea, Hawaii. Geologische Charakterbilder (H. Stille), H $16: 8$ pls and text, 1913

15 Sur la géologie de la partie méridio. aale de la basse Californie. Ac Sc Paris, C R 161: 419-422 (1915)

16 Reisen im südlichen Teil der Halbinsiederkalifornien [Lower California]. Ges Erdk Berlin, Zs 1916:1-16

Heind1, Alexander J.

12 Graphic representation of oil-field structure. M Sc Press 105:824-827 (1912)

Heine, R, E.

02 (with Byers, H. G., and Ruddy, C. A.) The water resources of Washington. Wash G S 1 : 285-320 (1902)

Heiney, Wm. M.

01 River bends and bluffs. Ind $\mathrm{Ac} \mathrm{Sc}$ Pr 1900: 197-200 (1901)

Heinrich, M.

16 On the structure and classification of the Stromatoporoidea. J G 24:57-60 (1916)

Heinrieh, Oswald J. (1827-1886).

73 The Midlothian colliery Virginia. Am I M Eng, Tr 1:346-357, 360-364 (1873)

79 The Manbattan salt mine, at Goderich, Can. Am I M Eng, Tr 6:125-144 (1879)

79a The Mesozoic formation in Virginia. Am I M Eng. Tr 6: 227-274 (1879) The Virglnias $1: 120-126,142-145,155,176$ 177, 190-192 (1880)

83 The North Mountain coal field in Botetourt Co., Va. The Virginias 4:146147 (1883)

Helland, Amund.

79 Observations sur les glaciers du nord du Groenland et sur la formation des icebers, As Frans, C R 7:588-591 (1879)
Felland, Amund-Continued.

81 Geschwindigkeit der Bewegung der grönländischen Gletscher im Winter. Deut G Ges, Zs $33: 693-694$ (1881)

Helm, F.

91 On the affinities of Hesperornis. Nature $43: 368$ (1891)

Helmhacker, R.

96 Sepiolite. Eng M J 62:80-82 (1896)

Henahen, T. $R$.

13 Twelfth biennial report of the $\mathrm{Bu}$ reau of Mines of the State of Colorado for the years 1911 and 1912. 200 pp, Denver, Colo., 1913

14 Thirteenth biennial report of the Bureau of Mines of the State of Colorado for the years 1913 and 1914. 228 pp, Denver, Colo., 1914

Henderson, C. Hanford.

84 The copper deposits of the South Mountain [Pa.]. Am I M Eng, $\mathrm{Tr}$ 12: 85-90, map (1884)

93 Mica and mica mines. Eng M J 55: 4 (1893)

Henderson, Charles W.

09 Gold, silver, copper, lead, snd zinc ; Colorado. U S G S, Min Res 1908 pt 1 : $360-405 ; 1909$ pt $1: 290-333 ; 1910$ pt 1 : $384-445 ; 1911$ pt $1: 505-569 ; 1912$ pt 1 : $635-705 ; 1913$ pt $1: 227-278 ; 1914$ pt 1 : $255-313 ; 1915$ pt $1: 421-184 ; 1916$ pt 1 : 331-388 (1909-18)

O9a Gold, silver, copper, lead, and rinc : New Mexico; Texas. U S G S, Min Res 1908 pt $1: 506-509 ; 909$ pt $1: 430-441$, $454-455 ; 1910$ pt $1: 534-552$, 571-573; 1911 pt 1 : $702-721,739-740 ; 1912$ pt 1 : $819-846,876-881 ; 1913$ pt $1: 415-439$, $440-443 ; 1914$ pt $1: 211-238 ; 1915$ pt 1 : $357-383 ; 1916$ pt $1: 185-213$ (1909-17)

09b Gold, silver, copper, lead, and zinc ; South Dakota; Wyoming. U S r Min Res 1908 pt $1: 534-541,582-586 ; 1909$ pt $1: 450-454,491-494 ; 1910$ pt $1: 565-$ $570,606-610 ; 1911$ pt $1: 734-738,788$ $791 ; 1912$ pt $1: 867-875,924-930 ; 1913$ pt $1: 41-55 ; 1914$ pt $1: 239-254 ; 1915$ pt 1: $343-356 ; 1916$ pt $1: 269-282$ (1909-17)

12 (and winstanley, J. B.) Bibliography of the geology, paleontology, mineralogy, petrology, and mineral resources of Oregon, with subject index by Grabam J. Michael. Oreg, Univ, B n s 10 no 4: 49 pp (1912)

Henderson, J. T.

85 The commonwealth of Georgia. 379 pp, maps, Atlanta, Ga., 1885

Henderson, Junius.

03 The overturns in the Denver, basins. J G 11:584-586 (1903) Colo, Univ, Studies 1 : $345-347$ (1904)

04 Paleontology of the Boulder area. Colo, Univ, Studies 2: 95-106 (1904)

04a Arapahoe glacier in 1903 . J G 12 : 30-33 (1904) 
Henderson, Junius-Continued.

o5 Extinct glaciers of Colorado. Colo,

Univ, Studies 3: 39-44 (1905)

O5a Arapahoe Glacier in 1905. J G 13: 556 (1905)

06 The Tertiary lake basin of Florissant, Colo. Colo, Univ, Studies $3: 145-156$ (1906)

07 Topographic development of Chalk Bluffs and Pawnee Buttes. Colo Sc Soc, Pr 8: 247-256 (1907)

07a Scientific expedition to northeastern Colorado ; paleontology ; account of collections made. Colo, Univ, Studies 4:149152 (1907)

os The red beds of northern Colorado. J G 16:491-492 (1908)

08a The sandstone of Fossil Ridge in northern Colorado and its fauna. Colo, Univ, Studies 5: 179-192 (1908)

osb New species of Cretaceous invertebrates from northern Colorado. U S Nat Mus, Pr 34: 259-264, il (1908)

09 The foothills formations of north central Colorado. Colo G Survey, 1st Rept., 1908, pp. 145-188, map (1909)

Io Scientific expedition to northwestern Colorado in 1909; itinerary, topography, and geology. Colo, Univ, Studies 7:101112 (1910)

10a Fossil invertebrates from northwestern Colorado. Colo, Univ, Studies $7: 146-$ 149 (1910)

10b Extinet and existing glaciers of Colorado. Colo, Univ, Studies 8:33-76 (1910)

12 (with Coekerell, T. D. A.) ModIusca from the Tertiary strata of the West. Am Mus N H, B 31:229-234 (1912)

13 Geology and topography of the Rio Grande region in New Mexico. Bur Am Ethnology, B 54:23-39 (1913)

14 Recent progress in Colorado paleontology and stratigraphy. Colo Sc Soc, $\mathrm{Pr}$ $11: 5-22$ (1914)

18 The nomenclature and systematic position of some North American fossil and recent-mollusks. The Nautilus $32: 60-64$ (1918)

Hendrixson, W. S.

o7 Some features of the Iowa ground waters. Iowa Ac Sc, Pr 14:187-199 (1907) ; 16: 135-142 (1909)

Hendry, W. A.

65 On the discovery of a large bed of coal among the lean beds of the Joggins and Albert mine regions [Nova Scotia]. Am Ph Soc, Pr 9:459 (1865)

Heneage, E. F.

06 A consideration of the Archean period of the continents of North America and South Africa, with reference to mineral occurrences. Brit As, Rp 75:410-411 (1906)
Henegar, Herbert B.

12 Barite deposits in the Sweetwate: district. Tenn G S, Res Tenn $2: 424-429$ (1912)

Heneken, $\mathrm{T}$. $\mathrm{S}$.

53 On some Tertiary deposits in San Domingo. G Soc London, Q J 9: 115-129, map (1853)

Henke1, Isabel.

06 A study of tide pools on the west coast of Vancouver Island [B. C.]. Pac telsia, Yb Minn Seaside Station, St. Pad, Minn [2] : 275-304 (1906)

Hennen, Ray Vernon.

09 Marshall, Wetzel, and Tyler cos. Va G S : 654 pp, maps (1909)

10 Structural contours of map of Woot Ritchie, and Pleasants cos. showing oil and gas fields and structural contours. W $\mathrm{r}_{3}$ G S 1910 Seale 1:62500

11 Wirt, Roane, and Calhoun $\cos$. W $\mathrm{V}_{2}$ G S : 573 pp, maps (1911)

12 Doddridge and Harrison $\cos$. IV $\mathrm{Va}$ G S : 712 pp, maps (1912)

13 (and Reger, D. B.) Marion, No nongalia, and Taylor cos. W Va G S:84t pp, maps (1913)

14 (and Reger, D. B.) Preston $\mathrm{Co}$, W Va G S : 566 pp, maps (1914)

$14 a$ (and Reger, D. B.) Logan and Mingo cos. W $\mathrm{Va}$ G $\mathrm{S}: 776 \mathrm{pp}$, mags [1914],

14b General section, Kanawha series Kanawha Co. [W. Va.]. W Va G S, Ka. nawha Co: xxvi-xxvili (1914)

15 (and Gawthrop, R. M.) Wyoming and McDowell cos. W Va G S: 783 pp. maps (1915)

16 Figure showing bituminous coal bets in West Virginia : compiled and rerised to date, June 3,1916 . W Va G S [broadside 1916]

17 Braxton and Clay cos. W Va G S : 883 pp, maps (in case), (1917)

Henning, Karl L.

от Streifzüge in den Rocky Mountains. Globus $92: 25-29,46-49,101-107$ (1907)

o8 Der Carnotite. Globus $93: 155-15 i$ (1908)

OSa Streifzüge in den Rocky Mountains III, Der Mittelpark und der Gore Canyon. Globus $93: 312-318$ (1908)

o9 Streifzüge in den Rocky Mountains IV, Morrison und die Morrisonformation. Globus $96: 344-349$ (1909)

10 Streifzüge in den Rocky Mountafne V, Der Clear Creek Distrikt [Colo.]. Globus $98: 328-333,343-348,359-362$ (1910)

11 Die Erzlagerstätten der Vereinigten Staaten von Nordamerika, mit Einschlusi von Alaska, Cuba, Portorico, und den Philippinen nach Geschichte, Form, Inhalt, und Entstehung. 293 pp, Stuttgart, 1911

13 Die Red Beds; ein Beitrag zur Ge schichte der bunten Sandsteine. G Rund. schau $4:$ 228-244 (1913) 
Henrich, Carl.

79 The ore deposits of Leadville. Colo. Eng M J $27: 125-126,143,160-161,388-$ 390 (1879) ; $28: 34$ (1879) Abst, Sc Am Sup $7: 2658$ (1879)

85 The copper ore deposits and the copper production near Clifton, Ariz. Eng M J $39: 68-69$ (1885)

87 The San Pedro copper mine in New Mexico. Eng M J 43:183 (1887)

s7a The copper ore deposits near Morenci, Ariz. Eng M J $43: 202-203,219$ 220 (1887)

ss Some forms of ore deposits in limestone. Eng M J $46: 368-369$ (1888)

88 Metamorphism of rocks. Eng M J 46:461 (1888)

89 Notes on the geology and on some of the mines of Aspen Mountain, Pitkin Co., Colo. Am I M Eng, Tr 17:156-206, maps (1889)

89 The Slayback lode [Socorro Co., N. Mex.], a pecullar kind of fissure vein. Eng M J $48: 27$ (1889)

$89 b$ Is a faulted fissure always the oldest?-a study of faults. Eng M J 48: 159 (1889)

93 Zinc blende mines and mining near Webb City, Mo. Am I M Eng, Tr 21:325 (1893)

96 The Ducktown or deposits and the treatment of the Ducktown copper ores. Am I M Eng, Tr 25:173-245, maps (1896)

97 Faulting and accompanying features observed in glacial gravel and sand in southern Michigan. Am I M Eng, Tr 26: 460-464 (1897)

04 The Guanajuato mining district [Mex.]. M Mag 10:23-30, 101-108 (1904)

Henriksen, Kal L.

18 En Bemaerkning om Tertlaeret ved Kap Dalton 1 Oest-Groenland. Med Grönland $56: 203-206$, il (1918)

Henry, Carl D.

03 The white country granite of West Sugarloaf or Bald Mountain, Boulder Co., Colo, Colo Sc Soc $7: 112-116$ (1903)

Henry, J. T.

73 The early and later history of petroleum, with authentic facts in regard to its development in western Pennsylvania. 607 pp, Phila 1873

Henry, Joseph.

80 The glacial theory. $\mathrm{Ph} \mathrm{Soc}$ Wash, B 2:35-36 (1880)

Henry, T. $H$.

51 On the white blende of New Jersey, U. S. [cleiophane]. Ph Mag (4) 1:23 (1851)

\section{Henshaw, Fred F.}

09 Mining in the Fairhaven precinct, Alaska. U S G S, B 379:355-369 (1909)

10 Mining in Seward Peninsula, Alaska.

U S G S, B 442:353-371 (1910)
Hensoldt, $\mathrm{H}$.

89 Methods of modern petrography. Sch Mines Q $10: 212-218 ; 11: 29-36 ; 12$ : 132-136 (1889-91) [See also Luquer, 92]

S9a Meteorites and what they teach us. Am G 4:28-38, 73-84 (1889)

90 Crystallogenesis. Am G 5:301-309, 375-379 (1890)

Henton, John M.

o7 An interesting study in geology [land slip in Montana]. M World 27:975 (1907)

Henwood, William Jory.

42 A brief note to accompany a series of specimens from Lockport, near Nlagara, in the State of New York. G Soc London, Pr 3:453-454 (1842) Ph Mag (3) 20: $325-326$ (1842)

42a Notes to accompany a series of specimens from Chaleur Bay and the river Ristigouche in New Brunswick. $G$ Soc London, $\operatorname{Pr}$ 3:454-456 (1842). Ph Mag (3) $20: 326-328(1842)$

71 Notices of gold mines in Virginia. R G Soc Cornwall, Tr 8: 371-384 (1871)

71a On the native copper of Lake Superior. R G Soc Cornwall, Tr $8: 385$ 489 (1871)

71b On the metalliferous deposits of Gloucester in New Brunswick. R G Soc Cornwall, Tr 8:490-510 (1871)

71e Note on the copper-bearing granite of Saint Thomas in the Vale, Jamaica. R G Soc Cornwall, Tr 8:511-512 (1871)

Hepburn, Arthur E.

15 Gold dredgin $;$ in British Columbia. Mine, Quarry, and Derrick 1:187-189 (1915)

Herald, Frank A.

12 The Terry lignite field, Custer Co., Mont. U S G S, B 471:227-270, map (1912)

13 The Williston lignite field, Williams Co., N Dak. U S G S, B 531:91-157, map (1913)

See also Gould, 11b

Herbertson, Andrew J.

96 The history of the Great Lakes and Niagara. Se Am Sup 42:17398 (1896)

Herasman, W. H.

11 On the organic origin of the sedimentary ores of iron and of their metamorphosed forms, the phosphoric magnetites. Can M J 32:384-386 (1911)

Heriot, E. Mackay.

15 Potassium salts; an economlc geological study. Eng M J 100:669-672, $712-714$ (1915)

\section{Hermann, Adam.}

os Modern methods of excavating. preparing, and mounting fossil skeletons. Am Nat $42: 43-47$ (1908)

09 Modern laboratory methods in vertebrate paleontology. Am Mus N H, B $26: 283-331$, il (1909) 
Hernandez, James.

55 A philosophical, historical, and practical essay on the gold, silver, and quicksilver mines in Mexico and Peru. $86 \mathrm{pp}$ [L 1755 ?]

Herndon, J. H.

91 [The iron ore district of east Texas] ; Smith Co. Tex G S, An Rp 2:204-224 (1891)

Herold, Stanley C.

17 Tertiary Nassidae of the west coast of America (abst). G Soc Am, B 28:227 (1917)

Heroy, W. B.

13 Land classification : 1ts basis and methods. Ec G 8:337-359 (1913)

15 The relation of the Upper Cretaceous formations of southern Wyoming and northeastern Colorado (abst), Wash Ac Sc, J 5 : 330-331 (1915)

Herrera, A. L.

16 Estructuras organoideas en una variedad de opalo, la menilita, estudio acerca de las oolitas, México, Secretarfa de Fomento... Dirección de Estudios BIológicos, Bol 1:367-375 (1916)

Herrera y Gutiérrez, Mariano.

90 Análisis de la dolomía del distrito de Uruapan [México]. Soc Cient Ant Alz, Mem 3:93-96 (1890) La Naturaleza (2) $1: 397-399$ (1890)

Herrick, Clarence Luther (1858-1904)

77 The Trenton limestone at Minneapolis [Minn.]. Am Nat 11:247-248 (1877)

85 A compend of laboratory manipulation; and tables for the determination of the principal rock-forming minerals. Denison Univ, Sc Lab, B 1:121-136 (1885)

87 A sketch of the geological history of Licking Co. [Ohio]. Denison Univ, Sc Lab, B $2: 5-70,144-148$, il $(1887) ; 3: 13-110$, il $(1888) ; 4: 11-60,97-123$, il $(1890)$

S7a (with Tight, W. G.) Geology and lithology of Michipicoten Bay. Denison Univ, Sc Lab, B 2:19-143 (1887) Abst, Am Nat'21:654-655 (1887)

88 (and others) Some American norites and gabbros. $\mathrm{Am}$ G $1: 339-346$ (1888)

S9 Notes upon the Waverly group in Ohio. Am G 3:50-51, 94-99, il (1889)

90 Additions and corrections to Miller's North American Paleontology. Am G 5: 253-255 (1890)

90a The Philadelphia meeting of the international congress of geologists. Am G 5: 379-388 (1890)

91 The Cuyahoga shale and the problem of the Ohio Waverly. G Soc Am, B 2:3148 , il (1891)

93 Observations upon the so-called Waverly group of Ohio. Ohio G S, Rp 7 : 495-515 (1893)

96 The so-called Socorro tripoli. Am G 18: 135-140 (1896)
Herrick, Clarence Luther-Continued,

97 The geology of a typical mining cam in New Mexico [Magdalena Mountains] Am G 19: 256-262 (1897)

98 The geology of the environs of $\mathrm{A}$. buquerque, N. Mex. Am G $22: 26-43$ (1898) N Mex Univ, B 1:26-43 (1899)

98a The occurrence of copper and leat in the San Andreas and Caballo mour tains, N. Mex. Am G 22:285-291 (1898) N Mex Univ, B 1:285-291 (1899)

98b Papers on the geology of New Mes. ico. Denison Univ, Sc Lab, B 11:75-9? (1898) N Mex Univ, B 1:' 22 (1899)

98e The geology of the San Pedro cad the Albuquerque districts. Denison Unir, Sc Lab, B 11:93-116, map (1898) I Mex Univ, B 1:93-116, map (1899)

00 (and Bendrat, T, A.) Identifice. tion of an Ohio Coal Measures horizon in New Mexico. Am G 25:234-242 (1900) N Mex Univ, B 2:10 pp (1900)

o0a Report of a geological reconnais sance in western Socorro and Valencla cos. N. Mex. Am G 25:331-346, maps (1900) N Mex Univ, B 2:17 pp, maps (1900)

oob (and Johnson, D. W.) The geology of the Albuquerque sheet. Denison Univ, Sc Lab, B 11:175-239, il, ma? (1900) N Mex Univ, B 2:67 pp, 1l, map (1900)

ooe The geology of the white sands of New Mexico. J G $8: 112-128$, map, (1900) N Mex Univ, B 2:17 pp, map il (1900)

ood Miscellaneous economic papers. I Mex Univ, B 2:12 pp, map (1900)

01 Applications of geology to economk problems in New Mexico. Int $M$ Cong. 4th, Pr: 61-64 (1901)

03 Secondary enrichment of mineral veins in regions of small erosion. M SC Press 87:97 (1903)

04 A Coal Measure forest near Socorro, N. Mex. J G 12:237-251 (1904)

O4a Tue clinoplains of the Rio Grande. Am G $33: 376-381$ (1904)

04b Lake Otero, an ancient salt lake basin in southeastern New Mexico. Am G 34:174-189, map (1904)

04e Laws of formation of New Mexlco mountain ranges. Am G $\mathbf{3 3}: \mathbf{3 0 1 - 3 1 2 ,} 393$ (1904)

Herriek, E. C.

39 Fall of a meteorite In Missouri, Febrt. ary 13,1839 . Am J Sc $37: 385-386$ (1839)

Herriek, F. $H$.

83 Sand tracery. Science 1: 192 (1883) Ferrick, H. N.

04 Gypsum deposits in New Mesico. $\mathrm{U}$ \& $\mathrm{G}$ S, B 223: 89-99 (1904)

Herrick. R. L.

07 The Joplin zinc district. Mines and Minerals 28:145-157 (1907) 
Herrick, R, L.-Continued.

07a (with Scholl, G. P.) The Gold Prince mine and mill [at Animas Forks, Colo.]. Mines and Minerals. $27: 337-345$ (1907)

08 Mining and reduction of Ely ores. Mines and Minerals $29: 22-25, \quad 80-84$ (1908)

08a Routt Co., Colo., coals. Mines and Minerals $29: 230-234$ (1908)

09 The Alice mine, Colorado's largest ore body, situated in the Fall River district, Colorado. Mines and Minerals 29:294296 (1909)

09 a E1 Tigre mine, district of Montezuma, Sonora, Mexico. Mines and Minerals 29:483-487 (1909)

09b Ray consolidated mines, a low-grade copper property at Ray, Ariz. Mines and Minerals $29: 544-547$ (1909)

09e The Miami copper mines, [Globe,] Ariz. Mines and Minerals 30:80-84 (1909)

10 Mining at Miami, Ariz. Mines and Minerals $30: 751-756$, map (1910)

Hershey, Oscar H.

93 The Pleistocene rock gorges of northwestern Illinois. Am G 12:314-323 (1893)

93a The Utica shale in Stephenson Co., III. Sclence 22:202 [in error for 198] (1893)

94 The Elk Horn Creek area of St. Peter sandstone in northwestern Illinois. Am G 14: 169-179, map (1894)

95 The Columbia formations in northwestern Illinois. Am G 14:203-204 (1894) (abst); 15:7-24 (1895)

$95 a$ The Devonian series in southwestern Missouri. Am G 16:294-300 (1895)

$95 \mathrm{~b}$ River valleys of the Ozark Plateau. Am G $16: 338-357$ (1895)

95e On a Devonian limestone breccia in southwestern Missourl. Science n s 1: 676-678 (1895)

96 Ancient river deposits of the Spring River valley in Kansas. Am G 17:37-40 (1896)

96a Early Pleistocene deposits of northem Illinois. Am G 17:287-303 (1896)

96b Preglacial erosion cycles in northwestern Illinois. Am G 18:72-100 (1896) 96e The Silveria formation. Am J Sc (4) $2: 324-330 \quad(1896)$

96d Ozarkian epoch-a suggestion. Science $n$ s $3: 620-622$ (1896)

96 e An Ozark soil. Science n s $4: 261$ 263 (1896)

97 Eskers indicating stages of glacial recession in the Kansan epoch in northern Illinois. Am G 19:197-209, 237-253, map (1897)

97a The term Pecatonica limestone. Am G 20:66-67 (1897)

97b The physiographic development of the upper Mississippi Valley, Am G 20: 246-268 (1897)

97e The Florencia formation. Am J Sc (4) $4: 90-98$ (1897)
Hershey, Oscar H.-Continued.

$97 \mathbf{d}$ Mode of formation of till as illustrated by the Kansan drift of northern Illinois. J G 5:50-62 (1897)

97e The inferior boundary of the Quaternary era. Am Nat 31: 104-114 (1897)

$97 \mathrm{f} A$ "pocket" horizon In Trinity Co., Cal. M Sc Press $75: 549$ (1897)

$97 \mathrm{~g}$ The loess formation of the Mississippi region. Science n s 5:768-770 (1897)

98 Notes on the geology of Jamaica. Science n s 8: 154-155 (1898)

98 a Raised shore lines on Cape Maysi, Cuba. Science n s 8: 179-180 (1898)

99 Observations on dirt storms. Am G $23: 380-382$ (1899)

99 arigin and age of certain gold "pocket" deposits in northern California. Am G 24:38-43 (1899)

99b Age and origin of certain gold deposits on the Isthmus of Panama. Am G 24: $73-77$ (1899)

99c Correlation in the Ozark region; a correction. Am G 24:190-192 (1899)

99d The gold-bearing formation of Stephenson Co., Ill. Am G 24:240-244 (1899)

99e Archeological notes on central Minnesota. Am G 24:2S3-294 (1899)

99f The upper Coffee Creek mining district [Trinity and Siskiyou cos., Cal.] M Sc Press $79: 689$ (1899)

oo Gold-bearing lodes of the Sierra Costa Mountalns in California. Am G 25: 76-96 (1900)

OOa The upland loess of Missouri; its mode of formation. Am G $25: 369-374$ (1900)

$\mathbf{0 O b}$ Ancient alpine glaciers of the Sierra Costa Mountains in California. J G 8: 42-57 (1900)

00e Granites of the Sierra Costa Mountains in California. Science $n$ s 11:130 132 (1900)

O0d A curious phase of inter-stream erosion in southern Oregon. Science n s 11: 614-615 (1900)

01 Peneplains of the Ozark highland. Am G 27: 25-41 (1901)

01 Metamorphic formations of northwestern California. Am G 27:225-245 (1901)

01b Age of certain granites in the Klamath Mountains (abst). G Soc Am, B 12: 501 (1901) J G 9:76-77 (1901) Am G 27: 258-259 (1901)

01e The age of the Kansan drift sheet. Am G 28: 20-25 (1901)

o1d The geology of the central portion of the Isthmus of Panama. Cal Univ, Dp G, B 2: 231-267, map (1901)

o1e An unusual type of auriferous deposit. Science n \& 13:869-871 (1901)

02 The significance of the term Sierran, Am G 29:88-95 (1902) 
Hershey, Oscar H.-Continued.

02a Some crystalline rocks of southern California. Am G 29:273-290 (1902)

0.2b Some Tertiary formations of southern California. Am G 29:349-372 (1902) 02e Boston Mountain [Ark.] physiography. J G 10:160-165 (1902)

o2d Neocene deposits of the Klamath region, Cal. J G $10: 377-392$ (1902)

02e The significance of certain Cretaceous outliers in the Klamath region, Cal. Am J Sc (4) 14:33-37 (1902)

02f The Quaternary of southern Califormia. Cal Univ, Dp G, B 3:1-29, map (1902)

02g A supposed early Tertiary peneplain in the Klamath region, Cal. Science n s 15:951-954 (1902)

03 Some evidence of two glacial stages in the Klamath Mountains in California. Am G 31: 139-156 (1903)

$03 a$ Structure of the southern portion of the Klamath Mountains, Cal. Am G 31: 231-245 (1903)

03b The Sierran valleys of the Klamath region, Cal. J G 11:155-165 (1903)

03e The relation between certain river terraces and the glacial series in northwestern California. J G 11:431-458 (1903)

03d Certain river terraces of the Klamath region, Cal. Am J Sc (4) $16: 240-$ 250 (1903)

04 The Bragdon formation in northwestern California. Am G $33: 248-256$, $347-360$ (1904)

04a The river terraces of the Orleans Basin, Cal, Cal, Univ, Dp G, B 3:423475 (1904)

06 Some western Klamath stratigraphy. Am J Sc (4) 21:58-66 (1906)

08 Mining in Panama. M Sc Press 96 : 255-256 (1908)

osa Primary chalcocite in California. M Sc Press 96:429-430 (1908)

osb Foothill copper belt of the Sierra Nevada. M Sc Press 96:591-592; 97 322-323 (1908)

0se Amarilla iron and phosphate deposits [Eureka Co., Nev.]. M Sc Press $97: 535-536$ (1908)

09 The ancient Kobuk glacier of Alaska. J G $17: 83-91$ (1909)

09a Black Diamond [Del Norte Co., Cal.]. M Sc Press 98:147 (1909)

10 Origin of gold "pockets" in northern Californla. M Sc Press 101: 741-742 (1910)

11 Geology at Treadwell mines [Douglas Island, Alaska]. M Sc Press 102:296300, 334-335 (1911) Reprinted in Types of ore deposits (ed by H. F. Bain) : 157171 (1911)

11 a Del Norte Co. [Cal.], geology. M Sc Press 102: 468, map (1911)
Hershey, Oscar H.-Continued.

12 Some Tertiary and Quaternary geol. ogy of western Montana, northern Idaho, and eastern Washington. $\mathrm{G}$ Soc $A \mathrm{~m}, \mathrm{~B}$ $23: 75$ (abst), 517-536 (1912)

12a Geological reconnaissance in north. eastern Nicaragua. G Soc Am, B 23:493516, map (1912)

12b The Belt and Pelona series. Am J Se (4) 34:263-273 (1912)

12e Geology of the Pis Pis mining dis. trict in Nicaragua. M Sc Press 194:270272 (1912)

12d Genesis of lead-silver ores in Ward. ner district, Idaho. M Sc Press 104:750753, 786-790, 825-827, map (1912)

13 Origin of lead, zinc, and silver in the Cœur d'Alene [Idaho]. M Sc Press 107: 489-493, 529-533 (1913)

15 The geology of Iron Mountain [Shasta Co., Cal.]. M Sc Press 111:633638, map (1915)

16 Origin and distribution of ore in the Coeur d'Alene [Idaho]. 32 pp [Priv pub, about May, 1916. See M Sc Press 112: 734 (1916)]

17 Genesis of Success zinc-lead deposit [Coeur d'Alene district, Idaho] (discussion). Ec G 12:548-558 (1917)

18 Geology of the Success mine [Coent d'Alene district, Idaho]. M Sc Press 116: 470 (1918)

Herzer, Herman (1833-1912).

78 Geology of Brown Co. Ohio G S, Rp 3 pt 1:942-944 (1878)

93 A new tree from the Carboniferous rocks of Monroe Co., Ohio. Am G 11: $285-286$, il (1893)

93a A new fungus from the Coal Measures [Tuscarawas Co., Ohio]. Am G 11: $365-366$, il ; $12: 289-290$ (1893)

97 Psaronius. Ohio St Ac Sc, An Rp $5: 55-58(1897)$

ox Six new species, including two new genera, of fossil plants. Ohio St Ac Sc, An Rp $9: 22-29$, il (1901)

01a A new fossil sponge from the Coal Measures [Ohio]. Ohio St Ac Sc, An Rp $9: 30-31$, il (1901)

02 New fossil plants from the Carboniferous and Devonian. Ohio St Ac Sc, An Rp $10: 40-48$, il (1902)

02a New fossils from the Corniferous, Hamilton, and Medina series. Obio St Ac Sc, An Rp 10:49-66, il (1902)

Hess, Frank L.

05 (and Graton, L. C.) The occurrence and distribution of tin. U S G $S$, B 260:161-187 (1905)

05a (with Prindle, L. M.) Rampart placer region [Alaska]. U S G S, B 259: 104-119 (1905)

06 The York tin region [Alaska). U s G S, B 284:145-157 (1906) Eng Mag $32: 352-369$ (1906) 
Hess, Frank L.-Continued.

06a Some magnesite deposits of California. U S G S, B 285 : 385-392 (1906) Eng Mag 31:691-704 (1906)

06b What is a fissure vein? Ec G 1 . 700-702 (1906)

06e The Carolina tin deposito Eng Mag $32: 10-20$ (1906)

o6d (with Prindle, L. M.) The Ram. part gold placer region, Alaska. U S G S, B 280:54 pp (1906)

06e [Minor metals, etc.; antimony, arsenic, bismuth, cobalt, molybdenum, nickel, radium, selenium, tellurium, tin, titanium, tungsten, uranium, vanadium.] U S G S, Min Res 1905: 445-451; 1906 : 511-549, $1055-1058,1271 ; 1907$ pt $1: 627-630,707-$ $729 ; 1908$ pt $1: 599-601,709-749,771-$ $779 ; 1909$ pt $1: 573-590,629-630 ; 1910$ pt $1: 699-700,725-767: 1911$ pt $1: 855-$ $856,941-977 ; 1912$ pt $1: 833-837,963-$ $1045 ; 1913: 279-289,339-364 ; 1914$ pt 1 : $923-977 ; 1915$ pt $1: 743-766,805-850$ (1906-17)

08 The Baringer Hill (Texas) pegmatite dike (abst). Science n s 27:537 (1908)

08a Placers of the Rampart reglon [Alaska]. U S G S, B 337:64-98, map (1908)

08b Some molybdenum deposits of Maine, Utah, and Callfornia. U S G S, B 340 : 231-240 (1908)

08e The Arkansas antimony deposits. U S G S, B 340:241-252 (1908)

08d Note on a tungsten-bearing vein near Raymond, Calif. U S G S, B \$40: 271 (1908)

0se Minerals of the rare-earth metals at Baringer Hill, Llano Co., Tex. U S G S, B $340: 286-294$ (1908)

0se The magnesite deposits of California. U S G S, B 355: 67 pp (1908)

08g Graphite. U S G S, Min Res 1907 pt 2: 735-736 (1908)

08h (with Collier, A. J., and others). The gold placers of parts of Seward Peninsula, Alaska, Including the Nome, Council, Kougarok, Port Clarence, and Goodbope precincts. U S G S, B $328: 343$ pp (1908)

09 Tin, tungsten, and tantalum deposits of South Dakota. U S G S, B $380: 131$ 161 (1909)

09a Notes on a wolframite deposit in the Whetstone Mountains, Ariz. U S G S, B 380:164-165 (1909)

09b Texas celestite deposits. Eng M J $88: 117$ (1909)

09e Graphite mining near La Colorado, Sonora, Mexico. Eng Mag $38: 36-48$ (1909)

09d The Santa Maria graphite deposits, Mexico. M World 31:1078-1080 (1909) $4 b s t$, Science n s $30: 125$ (1909)

10 A reconnaissance of the gypsum deposits of California. U S G S, B 413:36 pp (1910)
Hess, Frank L.-Continued.

10a Gold mining in the Randsburg quadrangle, Cal. U S G S, B 430:23-47 (1910)

10b Gypsum deposits near Cane Springs, Kern Co., Cal. U S G S, B $430: 417-418$ (1910)

10e Mounds formed by mineral crystalllzation. M Sc Press 100:675 (1910) Abst, Science n s $31: 758$ (1910)

10d Lithium and its sources. M Sc Press 100: 822-824 (1910)

toe New rutile deposits near Richmond, Va. M World 33:305-307 (1910)

11 The arsenic deposits at Brinton, Va. U 5 G S, B 470: 205-211, map (1911)

11 a (and Wells. R. C.) An occurrence of strüverite [Black Hills of South Dakota]. Am J Sc (4) $31: 432-442,577$ (1911) Abst, Wash Ac Sc, J 1:88-89 (1911)

11b Lithium. U S G S, Min Res 1909 pt $2: 649-653$ (1911)

12 Tin resources of Alaska. U S G S, B 520:89-92 (1912)

12a Rare minerals of the South. Manufacturers Record 61 no 7 pt $2: 72-73$ (1912)

12b Prospecting for vanadium. M Sc Press $105: 366-367$ (1912)

12e (and Hess, Eva) Bibliography of the geology and mineralogy of tin. Smiths Misc Col 58 no $2 ; \nabla, 408$ pp (1912)

$12 d$ (with Watson, T. L.) Zirconiferous sandstone near Ashland, Va., with a summary of the properties, occurrence, and uses of zircon in general. Va Univ, $\mathrm{Ph}$ Soc, B (sc s) 1:267-292 (1912)

13 Vanadium in the Sierra de los Caba110 , N. Mex. U S G S, B 530:157-160 (1913)

13a Carnotite near Green River, Utah. U S G S, B 530: 161-164 (1913)

13b Notes on the vanadium deposits near Placerville, Colo. U S G S, B 530: 142-156 (1913)

13e A sulphur deposit in the San Rafael Canyon, Utah. U S G S, B 530:347-349 (1913)

$13 d$ (and Hunt, W. F.) Triplite from eastern Nevada. Am J Sc (4) $36: 51-54$ (1913) Wash Ac Sc, J 3:286 (1913)

14 (and Schaller, W. T.) Colorado ferberite and the wolframite series. U S G S, B 583:75 pp (1914)

14n A hypothesis for the origin of the carnotites of Colorado and Utah. Ec G 9:675-688 (1914) Abst, Wash Ac Sc, J $4: 236$ (1914)

$14 b$ (and Sehaller, W. T.) Pintadoite and uvanite, two new vanadium minerals from Utah. Wash Ac Sc, J 4:576-579 (1914)

16 Magnesium in 1915. U S G S, Min Res 1915 pt 1: 735-741 (1916) 
Hess, Frank L.-Continued.

17 Tungsten minerals and deposits. U S G S, B 652: $85 \mathrm{pp} \mathrm{(1917)} \mathrm{Abst,} \mathrm{by} \mathrm{R.} \mathrm{W.}$ Stone, Wash Ac Sc, J $7: 604$ (1917)

Hess, W. H.

00 The origin of nitrates in cavern earths. J G $8: 129-134$ (1900)

Hesse, Conrad E.

91 The paint-ore mines at Lehigh Gap [Pa.]. Am I M Eng, Tr 19:321-330, map (1891)

Henrteau, Ch. E.

03 Les charbons gras de la Pennsylvanie et de la Virginie occidentale. An Mines (10) $3: 379-475$ (1903)

$03 a$ L'industrie du pétrole en Californie. An Mines (10) 4:215-249 (1903)

Hewett, Donnel Foster.

12 A graphic method for dips on geologic sections. Ec G 7:190-191 (1912)

13 Sulphur deposits of Sunlight Basin, Wyo. U S G S, B 530:350-362, map (1913)

13a An occurrence of petroleum near Cody, Wyo. (abst). Wash Ac Sc, J 3:5152 (1913)

13b Manganese and manganlferous ores. U S G S, Min Res 1912 pt $1: 203-221$ (1913) ; 1913 pt $1: 57-74 ; 1914$ pt $1: 165-$ $181 ; 1915$ pt $1: 29-43 ; 1916$ pt $1: 731$ 756 (1913-8)

14 The ore deposits of Kirwin, Wyo. U S G S, B 540: 121-132 (1914)

14a Sulphur deposits in Park Co., Wyo.

U S G S, B 540: 477-480 (1914)

14b The Shoshone River section, Wyo, U S G S, B 541:82-113 (1914)

14c (with Pardee, J. T.) Geology and mineral resources of the Sumpter quadrangle, Oreg. Oreg Bur Mines, Min Res Oreg 1, no $6: 3-128$, map (1914)

15 Calculation of the thickness of strata represented in a series of outerops of varying dip $(a b s t)$. Wash Ac Sc, J 5:252 (1915)

16 Some manganese mines in Virginia and Maryland. U \& G S, B 640:37-71 (1916) Abst, Wash Ac Sc, J $7: 134-135$ (1917)

16a Manganese deposits in Virginia (abst). Wash Ac Sc, J 6:155-156 (1916) 17 (and Lupton, C, T.) Anticlines in the southern part of the Big Horn Basin, Wyo. U S G S, B 656:192 pp, maps (1917) Abst, by R. W. Stone, Wash Ac Sc, J 8: 204-205 (1918)

17 a The origin of bentonite and the geologic range of related materials in Big Horn Basin, Wyo. (abst). Wash Ac Sc, J 7 : 196-198 (1917)

17b [Manganese.] Am I M Eng, B 129: v-xili (1917)

18 (and others) Possibilities for manganese ore on certain undeveloped tracts in Shenandoah Valley, Va. U S G S, B 660: 271-296, maps (1918) Abst, by R. W. Stone, Wash Ac Sc, J 8:450 (1918)
Hewett, G. C.

89 The northwestern Colorado cos region. Am I M Eng, Tr 17:375-380 (1889)

02 Notes on southwestern Utah and its Iron ores. Colo Sc Soc, $\operatorname{Pr} 7: 55-66$, map (1902)

03 Section across the Sierra Madre 0 . cldental of Mexico (discussion). Am I If Eng, Tr 33 : 1059-1060 (1903)

03a The age af the Homestake lode, 8 , Dak. Eng M J 75:563-564 (1903)

Hewitt, W.

89 The evolution of the Grand Canyon of the Colorado. Liverpool G As, J 9:4955 [1889]

Heydon, A. Thurston.

97 Characteristics of the El Dorado gold belt [Cal,]. M Sc Press 74:233 (1897)

97a The marble belt [Amador and $\mathrm{E}$ ] Dorado cos., Cal.]. M Sc Press 74:305 (1897)

98 The geology of the White Pass. I Sc Press 77:133 (1898)

99 The headwaters of the Lewis Rivet [Yukon]. M Sc Press 78:65 (1899)

99a Glacial agency in lake formation M Sc Press 78:265 (1899)

Hibbard, H. V.

04 The water supply of the Tower quad rangle [N. Dak.]. N Dak $\Delta \mathrm{g}$ Coll $\mathrm{s}$ Bien Rp 2: 152-157 (1904)

06 (with Willard, D. E.) The Quater nary (drift) formations of the Tower quadrangle. N Dak, Agr Coll s, Blen Rp 3: 10-20 (1906)

06a (with willard, D. E.) Late glacial and postglacial deposits of the Cheyenne and Maple rivers. N Dak, Agr Coll S, Blen Rp 3:21-27 (1906)

o6b (with willard, D. E.) A peculiar type of hills. N Dak, Agr Coll \&, Blen Rp 3:55 (1906)

06e Description of the plateau region of North Dakota. N Dak, Agr Coll \&, Bien Rp $3: 133-142$ (1906)

Hice, Rlchard Roberts.

90 (with Foshay, P. 24.) Newly dis. covered glacial phenomena in the Beaver Valley. $\Delta \mathrm{m}$ Nat 24:816-818 (1890)

91 (with Fomhay, P. M.) Glacial grooves at the southern margin of the drift [Pennsylvania]. G Soc Am, B 2:457-464 (1891)

95 The inner gorge terraces of the upper Ohio and Beaver rivers. Am J Sc (3) $49: 112-120$ (1895)

03 Northward flow of ancient Beavet River. G Soc Am, B 14:297-304, map (1903) Abst, Sclence n s 17:300 (1903); J G 11: 103-104 (1903)

05 The clays of the upper Ohio and Beaver River region. Am Ceramic Soc, $\mathrm{Tr}$ $7: 251-262$ (1905)

09 The preglacial drainage of western Pennsylvania (abst). Sclence n B $29: 40$ (1909) 
Hice, Richard Roberts - Continued.

11 Unusual distortion of the lower K1tanning coal $(a b s t)$. G Soc Am, B 22: 716-717 (1911)

12 The geological origin of the freshwater fauna of Pennsylvania ; introductory note. $\mathrm{Pa}$ Top $\mathrm{G}$ S, Rp 1910-12:130-134 (1912)

12a The mineral production of Pennsylvania. $\mathrm{Pa}$ Top $\mathrm{G} \mathrm{S}, \mathrm{Rp}$ 1910-12:156-177 (1912)

15 The mineral production of Pennsylvania for the year 1913. Pa Top G S, Rp no $11: 108 \mathrm{pp}$ (1915)

See also Keele, 18a ; Roberts, 16

Hicks, Henry.

83 St. David's rocks and universal law. Science 2: 167-169 (1883)

85 The succession in the Archean rocks of America compared with that in the preCambrian rocks of Europe. G As, London, Pr 8: 255-277 (1885)

87 The Cambrian rocks of North Amerlca, G Mag (3) 4:155-158 (1887)

Hicks, Lewis Ezra.

73 Discovery of mastodon remains in 0hio. Am J Sc (3) 5:79 (1873)

78 Discovery of the Cleveland shale in Delaware Co., Ohio. Am J Sc (3) 16 : $70-71(1878)$

$78 a$ The Waverly group in central Ohio. Am J Sc (3) $16: 216-224$ (1878)

79 Boulders in coal. Am J Sc (3) 17 : 68-69 (1879)

85 The test well in the Carboniferous formation at Brownville, Nebr. Am J Sc (3) $29: 159-160 \quad(1885)$

$85 a$ The Dakota group south of the Platte River in Nebraska (abst). Am As, Pr 34:217-219 (1886) Science 6:221 (1885)

86 The Permian In Nebraska. Am Nat 20:881-883 (1886) Abst, Am As, Pr 35: 216-217 (1887)

87 Some typical well sections in $\mathrm{Ne}$ braska (abst). Am As, Pr 35:217-219 (1887)

87a The Lincoln salt basin (abst). Am As, $\operatorname{Pr} 35: 219$ (1887)

88 Geyserite in Nebraska. Am G 1: $277-280 ; 2: 64,437$ (1888)

$88 \mathrm{a}$ The reef bullders. Am G 1:297305 (1888)

88b [Quartzite between Niobrara and 0 Neill, Nebr., and its relations to the Valentine quartzite.] $\Delta \mathrm{m}$ G 2:351-352 (1888)

88e Diatomaceous earth in Nebraska. Am J Sc (3) $35: 86$ (1888)

89 Solls of Nebraska as related to geological formations. $\Delta \mathrm{m}$ G $3: 36-45$, map (1889)

90 Report on the stratigraphy and hydrology of Nebraska. U S, 51st Cong 1st sess, S Ex Doc 222: 71-86 (1890)
Hicks, Lewis Ezra-Continued.

$90 a$ Geology in its relations to agriculture. Nebr St Bd Agr, An Rp 1889: 364 376 , map (1890)

91 An old lake bottom [Custer Co., Nebr.]. G Soc Am, B 2:25-30 (1891)

91 a Silting, or basin irrigation. Nebr St Bd Agr, An Rp 1890:151-156 (1891)

92 The evolution of the Loup rivers in Nebraska. Sclence 19:59-60, 137 (1892)

$92 \mathbf{a}$ Readjustments of the Loup rivers; examples of abstraction due to unequal declivities. Science $19: 288-290$ (1892)

93 On the underflow and sheet waters, irrigable lands, and geological structure of Nebraska, with its effect upon the water supply U S, 52d Cong 1st sess, S Ex Doc 41 pt $3: 167-190$ (1893)

93a The geological structure and surface features of the region drained by the Loup rivers [Nebr.]. Nebr St Bd Agr, An Rp 1892: 337-359 (1893)

93b Some elements of land sculpture. G Soc Am, B 4:133-146 (1893)

Hicks, W. B.

14 (with Gale, H. S.) Octahedral crystals of sulphohalite. Am J Sc (4) 38 : 273-274 (1914)

$14 a$ (with Larsen, E. S.) Searlesite, a new mineral [San Bernardino Co., Cal.]. Am J Sc (4) 38:437-440 (1914) Abst, Wash Ac Sc, J 4: 397-398 (1914)

15 The composition of muds from Columbus Marsh, Nev. U S G S, P P 95 : 1-11. map (1915)

15n Evaporation of potash brines. U S G S, P P 95: 65-72 (1915)

16 Evaporation of brine from Searles Lake, Cal. U S G S, P P 9S: 1-8 (1916) $\Delta$ bst, Wash Ac Sc, J $6: 360$ (1916)

17 (and Balley, R. K.) Methods of analysis of greensand. U S G S, B 660 : 51-5s (1917)

Hidden, Willam Earl (1853-1918).

$80 \mathrm{An}$ account of the finding of a new meteorite in Cleberne Co., Ala. Am J Sc (3) $19: 370-371$ (1880)

80n A new meteoric iron from North Carolina. $\Delta \mathrm{m}$ J Sc (3) $20: 324-326$ (1880)

81 [On rare minerals of North Carolina.] In Genth, F. A., and Kerr, W. C., The minerals and mineral localities of North Carolina ... : 83-89 [2d ed: 89-93], Raleigh 1881

81a On the Whitfield Co., Ga., meteoric Iron. $\triangle \mathrm{m}$ J Sc (3) 21:286-287 (1881).

81b Notes on the mineral localities in North Carolina. Am J Sc (3) 22: 21-25 (1881)

82 Notes on some North Carolina minerals. $\Delta \mathrm{m}$ J Sc (3) $24: 372-374$ (1882)

82a The discovery of emeralds in North Carolina. N Y Ac Sc, Tr 1:101-105 (1882) 
Hidden, William Earl-Continued.

S2b A phenomenal find of fluid-bearing quartz crystals [Alexander Co., N. C.]. N Y Ac Sc, Tr 1: 131-136 (1882)

83 The discovery of emeralds in North Carolina. U S G S, Min Res [1882] : 500-502 (1883)

83a Hiddenite, the new emerald-green gem. U S G S, Min Res [1882] : 502-503 (1883)

84 (and Mackintosh, J. B.) On berderite( ?), a glucinum-calcium phosphate and fluoride, from Oxford Co., Me. Am J Sc (3) $27: 135-138$ (1884)

84a Tourmaline from Auburn, Me. Am J Sc (3) $27: 154-155$ (1884)

85 Mineralogical notes. Am J Sc (3) $29: 249-251$ (1885)

85a On hanksite, a new anhydrous sulphato-carbonate from San Bernardino Co., Cal. N Y Ac Sc, An 3:238-241 (1885) Am J Sc (3) 30:133-135 (1885)

86 On two masses of meteoric iron of unusual interest [Independence Co., Ark., and Laurens Co., S. C.] Am J Sc (3) 31 : 460-465 (1886)

86a Contributions to mineralogy. Am $\mathrm{J}$ Sc (3) 32:204-211 (1886)

86b A new meteorlc iron from Texas. Am J Sc (3) 32:304-306 (1886)

86e Recent discovery of emeralds and hiddenite in North Carolina. Am J Sc (3) $32: 483-484$ (1886)

86a Preliminary note on an iron meteorite from Maverick Co., Tex. N Y Ac Sc, $\operatorname{Tr} 5: 231$ (1886)

s6e A recently discovered meteoric iron from Independence Co., Ark. Sch Mines Q $7: 188-191$ (1886)

S6f On false pseudomorphs of quartz. Sch Mines Q 7 : 334-338 (1886)

$\mathbf{8 6 g}$ On a meteoric iron from [Lanrens Co.], S. C. Sch Mines Q 8: 31-34 (1886)

87 On the Mazapil meteoric iron, which fell November 27, 1885. Am J Sc (3) 33 : 221-226 (1887)

87a (and Washington, H. S.) Contributions to mineralogy. Am J Sc (3) 33: 501-507 (1887)

s7b on the iron meteorite which fell near Mazapil, Mexico ... N Y Ac Se, An 4: 45-65 (1887)

87e A notable discovery of precious stones in Alexander Co., N. C. N Y Ac Sc, $\operatorname{Tr} 6: 2-4 \quad(1887)$

8s On edisonite, a fourth form of titanic acid. Am J Sc (3) $36: 272-274$ (1888)

88a Mineralogical notes. Am J Sc (3) $36: 380-383$ (1888)

88b (and Mackintosh, J. B.) On a new thorium mineral, auerlite. Am J Sc (3) $36: 461-463$ (18£s) Zs Kryst 15: 295-297 (1889)
Hidden, William Earl-Continued.

s8e (and Mackintosh, J. B.) On: new sodium sulphatochloride, sulphobalite $\mathrm{Am}$ J Sc (3) $36: 463-464$ (1888) Zs Kryst $15: 294-295$ (1889)

S8d [New minerals, auerlite and sulphohalite.] N Y Ac Sc, Tr 8: 8-9 (1888)

89 (and Mackintosh, J. B.) A de. scription of several yttria and thoria minerals from Llano Co., Tex. Am J Sc (3) 38: 474-486 (1889)

s9a [Yttruim minerals from Llano $\mathrm{C}_{0}$, Tex.] N Y Ac Sc, Tr 8:185 (1889)

90 (and Mackintosh, J. B.) On the occurrence of polycrase, or of an allied species, in both North and South Carolina. Am J Se (3) 39:302-306 (1890)

9oa (and Penfield, S. L.) On hamlin. ite, a new rhombohedral mineral from the herderite locality at Stoneham, Me. Am J Sc (3) 39:511-513 (1890)

$90 \mathbf{b}$ Addendum to the minerals and min. eral localities of North Carolina. Elisha Mitchell Se Soc, J 6:45-78 (1890)

91 (and Mackintosh, J. B.) Supple. mentary notice on the polycrase of North and South Carolina. Am J Sc (3) 41: 423-425 (1891)

91a Prellminary notice of a new yttrium silicate. Am J Sc (3) $42: 430-431$ (1891)

93 On mackintoshite, a new thorium and uranium mineral. Am J Se (3) 46: 98-103 (1893)

93a (and Hillebrand, W. F.) D. scription of rowlandite. Am J Sc (3) 46: 208-212 (1893)

93b Mineralogical notes. Am J Sc (3) $46: 254-257$ (1893)

93e Two new localities for turquoise [ $\mathrm{X}$. Mex.]. Am J Sc (3) 46:400-402 (1893) 98 (and Pratt, J. H.) On rhodolite, new variety of garnet. Am J Sc (4) $5:$ 294-296 (1898)

98a (and Pratt, J. H.) Twinned erys. tals of zircon from North Carolina, Am J Sc (4) 6:323-326 (1898)

$98 \mathbf{b}$ Occurrence of sperrylite in North Carolina. Am J Sc (4) $6: 381-383$ (1898)

ose (and Pratt, J. H.) On the associated minerals of rhodolite. Am J Sc (4) $6: 463-468$ (1898)

99 (with Judd, J. W.) On a new mode of occurrence of ruby in North Carolina. Am J Sc (4) 8:370-381, map (1899)

00 The Hayden Creek, Idaho, meteoric iron. Am J Sc (4) 9:367-368 (1900)

05 Some results of late mineral re search in Llano Co., Tex. Am J Sc (4) $19: 425-433 \quad(1905)$

06 (and Warren, C. H.) On yttocrasite, a new yttrium-thorium-uranium titanate. Am J Sc (4) $22: 515-519$ (1906) Z Kryst 44:18-23 (1907) 
Hider, Arthur.

83 Report upon observations at Lake Providence, November 1879 to November 1880 [La.]. U S [War Dp], Chief Eng, An Rp 1883 (U S, 48th Cong 1st sess, H Ex Doc 1 pt 2 v 2 pt 3 ), App SS: 2191-2209 (1883)

Higgins, Daniel Franklin, jr.

09 (with Grant, U. S.) Copper mining and prospecting on Prince William Sound, Alaska. U S G S, B 379: 87-96 (1909)

09a (with Grant, U. S.) Notes on the geology and mineral prospects in the vicinity of Seward, Kenai Peninsula, Alaska. U S G S, B 379: 98-107 (1909)

10 (with Grant, U. S.) Preliminary report on the mineral resources of the southern part of Kenai Peninsula, Alaska. U S G S, B 442 : 166-178 (1910)

10a (with Grant, U. S.) Reconnaissance of the geology and mineral resources of Prince William Sound, Alaska. U S G S, B 443:89 pp (1910) Abst, Wash Ac Sc, J $2: 100$ (1912)

10b (with Grant, U. S.) Glaciers of Prince William Sound and the southern part of the Kenai Peninsula, Alaska; I, Glaciers of the northern part of Prince William Sound; II, Glaciers of Port Wells, Prince William Sound; III, Glaciers of the west coast of Prince William Sound; IV, Glaciers of the southern coast of the Kenal Peninsula. Am Geog Soc, B 42: 721-738 (1910) ; $43: 321-338, \quad 401-417, \quad 721-737$ (1911) Abst, G Soc Am, B 21:757-758 (1910)

12 The plane table in detailed geologic mapping (discussion). Ec G 7:502-506 (1912)

13 The plane table in geologic mapping with especial reference to graphic horizontal control by intersection methods. Ec G 8:729-751 (1913)

14 Secondary sillicate zones. Ec G 9: $73-77$ (1914)

Higgins, Edward, jr.

05 Zinc mining and smelting in southwestern Virginia. Eng M J 79:608-610 (1905)

Higrins, Edwin.

os Stripping Clinton iron ore in New York State. Eng M J $86: 1150-1152$ (1908)

09 Iron operations in the Chattanooga district. Eng M J $87: 1-5$ (1909)

09a Operations in the Cobalt district, Ont. Eng M J 87:1267-1272 (1909)

10 Copper deposits of the Globe-Kelvin districts [Ariz.] Eng M J 89:769-772, $813-816,870-874$, map (1910)

10a Copper deposits of northern Yuma Co., Ariz. M World $33: 855-857,903-904$, 949-951 (1910)
Hisrins, Edwin-Continued.

11 Copper Creek basin, Ariz. Eng M J 91 : $270-273$ (1911)

11a The Vekol copper deposits [Pinal Co., Ariz]. Eng M J 91:473-474 (1911) Higgins, James.

50 Report [of the State agriculturai chemist] to the House of Delegates of Maryland. $92 \mathrm{pp}$, Annapolis 1850 Second report ...: $126 \mathrm{pp}$, Annapolis 1852 Third report ...: :160 pp, Baltimore 1853 Fourth annual report ...: $92 \mathrm{pp}$, Baltimore 1854 Fifth agricultural report .. :93 pp, Annapolis 1856 Sixth ...:96, xxii pp, Annapolis 1858

Higrins, W. Mullinger.

36 The earth; its physical condition and most remarkable phenomena. $408 \mathrm{pp}, \mathrm{N} \mathrm{Y}$ 1836

Higgins, Will C.

09 The Sevier Consolidated mine of Gold Mountain, Piute Co., Utah. Salt Lake M R 11 no $3: 15-18$ (1909)

09 a Napoleon-Maghera mines in Sierra Madre Mountains, Box Elder Co., Utah. Salt Lake M Rv 11 no $14: 19-23$ (1909)

09b The Century and the Susannah mines, Golden, Utah. Salt Lake M Rv 11 no $16: 19-22$ (1909)

12 The Union Chief and Santaquin mines [Utah]. Salt Lake M Rv 14 no $10: 11-16$ (1912)

13 The American Ozokerite Company [ozokerite near Colton, Utah]. Utah, State Inspector of Mines, 8th Bien Rp, 1911-12: 130-141 (1913)

Higley, W. K.

86 A paper on Elephas primigenius Chicago Ac Sc, B $1: 123-127$, il (1886)

Hijar, Jerónimo.

o5 Ligeros datos sobre los criaderos de Peñoles, Oaxaca, y Tamazula, Jalísco. Soc G Mex, B 1: 207-212 (1905)

Hrjar y Haro, Luis.

os Apuntes sobre los yacimientos minerales de Campo Morado en el distrito de Aldama, Estado de Guerrero, México. Soc Cient Ant Alz, Mem 25:245-252 (1908)

Hildreth, Samuel Prescott (1783-1863).

25 Faets relating to certain parts of the State of Ohio. Am J Sc 10:1-8 (1825)

27 Notice of fossi] trees near Gallipolis, Ohio. Am J Sc 12: 205-206 (1827)

28 ... coal, diluvial and other strata of certain portions of the State of Ohio. Am J Sc 13:38-40 (1828)

29 ... rocks and minerals in the State of Ohio. Am J Sc 16:154-159 (1829)

33 ... the saliferous rock formation in the valley of the Ohio. Am J Sc 24:46-68 (1833)

34 Ten days in Ohio. Am J Sc 25:217257 (1834) 
Hildreth, Samuel Prescott-Continued.

35 Observations on the bituminous coal deposits of the valley of the Ohio, and the accompanying rock strata; with notices of the fossil organic remains and the relics of vegetable and animal bodies, illustrated by a geological map ... Am J Sc 29:1154, map, il (1835)

36 Report ... on the best method of obtaining a complete geological survey of the State of Ohio. $18 \mathrm{pp}$, Columbus 1836 [Ohio, Legislature], Rp No 1:65-80 [1837]

36a On the Lias of the West. Am J Sc $30: 395$ (1836)

36b Miscellaneous observations made during a tour in May, 1835, to the Falls of the Cuyahoga, near Lake Erie. Am J Sc 31: $1-84$, il (1836)

38 Report [on the Coal Measures]. Ohio G S, 1st An Rp : 25-63 (1838)

Hilgard, Eugene Woldemar (1833-1916).

58 Report on the geological and agricultural survey of the State of Mississippi. 22 pp, Jackson 1858

60 Report on the geology and agriculture of the State of Mississippi. xxiv, 391 pp, map, Jackson, 1860

66 On the Quaternary formations of the State of Mississippi. Am J Sc (2) 41: 311-325 (1866)

66a Remarks on the new division of the Eocene, or Shell Bluff group ... Am J Sc (2) $42: 68-70$ (1866)

66b Remarks on the drift of the western and southern states, and its relation to the glacier and iceberg theories. Am J Sc (2) $42: 343-347$ (1866)

67 On the Tertiary formations of Mississippi and Alabama. Am J Sc (2) 43 : 29-41 (1867)

$67 a$ Note on Dr. Andrew's paper on the glacial drift. Am J Sc (2) 43:241-242 (1867)

69 Prellminary report ... of a geological reconnaissance of Louisiana: De Bow's New Orleans Monthly Review 37-38:754769 (1869)

69 . On the geology of lower Louislana and the rock salt deposit of Petite Anse. Am J Sc (2) $47: 77-88$ (1869)

$69 \mathrm{~b}$ Summary of results of a late geological reconnaissance of Louisiana. Am J Sc (2) $48: 331-346$ (1869)

70 Report on the geological age of the Mississippi delta. $16 \mathrm{pp}$, Washington 1870

70a Report of examinations of speclmens from the New Orleans artesian well of 1856. U S [War Dp], Chief Eng An Rp 1870 (U S, 41st Cong 3d sess, से Ex Doc 1 pt 2 ₹ 2): 352-365 (1870) U S Army, Corps of Engineers, P P 13:636646 (1876)

70b The upper delta plain of the Mississipp1 (abst). Am Nat 4:638 (1870)
Milgard, Eugene Weldemar-Continued. 70e On the mud lumps of the passes of the Mississippl (abst). Am Nat 4:838689 (1870)

$\boldsymbol{r} 1$ On the geology of the delta and the mud lumps of the passes of the Mississippl. Am J Sc (3) 1: 288-246, 856-368, 425-435 (1871)

T1a On the geological history of the Gulf of Mexico. Am J Sc (3) 2: 391-404, map (1871) Am As, Pr 20:222-236, map (1872) La St Univ, An Rp Sup 1871: 207-222, map (1872) (Abst with discus. sion by Charles Whittlesey, C. A. White, A. Winchell, G. Little, J. B. Perry, E. C Andrews, Richard Owen), Am Nat 5:514518 (1871)

71b [On the origin of the alluvial lands of the lower Mississippi.] Am Nat 5:600 (1871)

72 On the geology of lower Louisian and the salt deposit on Petite Anse Island. Smiths Contr Knowl 23 art 3 (248) : 34 pp map (1872)

72a On some points in the geology of the Southwest. Am J Sc (3) 4:265-270 (1872)

73 Supplementary and final report of \& geological reconnaissance of Loulsiana.. $44 \mathrm{pp}$, New Orleans 1873

74 Note on lignite beds and their underclays. Am J Sc (3) $7: 208-210$ (1874)

74a On some points in Mallet's theory of vulcanicity. Am J Sc (3) 7:535-546 (1874)

78 (and Hopkins, F. V.) Report [on specimens obtained from borings between the Mississippi River and Lake Borgne, La.]. U S [War Dp], Chief Eng, An Rp 1878 (U S, 45th Cong $3 d$ sess, H Ex Doc 1 pt 2 ₹ 2 pt 2), App W $2: 855-890$, il (1878)

79 On the flocculation of particles... Am J Sc (3) $17: 205-214$ (1879)

79a The loess of the Mississippl Valley and the eolian hypothesis. Am J Sc (3) 18: 106-112 (1879)

79b Mississippi Valley loess. Sclence News 1:216-218 (1879)

81 The later Tertlary of the Gulf of Mexico. Am J Sc (3) 22:58-65, map (1881)

83 The salines of Louisiana. U S G S, Min Res [1882] : 554-565 (1883)

84 (and Hopkins, F. V.) Report upon the examination of specimens from borings on the Mississippi River between Memphis and Vicksburg. U S [War Dp], Chief Eng, An Rp 1884 (U S, 48th Cong 2d sess, H Ex Doc 1 pt 2 ₹ 2 pt 4), App TT : $2885-$ 2903 (1884)

$84 a$ Revlew of the general soil map of the cotton States. U S, 10th Census 5: 15-16, map (1884) 
Hilgard, Eugene Waldemar-Continued. 84b General features of the alluvial plain of the Mississippi River below the mouth of the Ohio. U S, 10th Census 5 : 85-88 (1884)

84e Physico-geographical and agricultural features of the State of Louisiana. U S, 10th Census 5:109-175, map (1884)

84d Physico-geographical and agricultural features of the State of Mississippi. U S, 10th Census 5: 209-345, map (1884)

84e Physico-geographical and agricultural features of the State of California. U S, 10th Census 6:663-783, map (1884)

84f The steep slopes of the western loess. Science 4:302 (1884)

85 The asphaltum deposits of California. U S G S, Min Res 1883-4:938-948 (1885)

85a The old Tertiary of the Southwest. Am J Sc (3) 30:266-269 (1885)

85b The classification and paleontology of U. S. Tertiary deposits. Science 6:44 (1885)

86 Dr. Otto Meyer and the southwestern Tertiary. Science 7:11 (1886)

87 The processes of soll formation from the northwestern basalts. Soc Promotion Agr Sc, Pr 8: 51-58 (1887) Abst, Am As, Pr 36:136-137 (1888)

87a The equivalence in time of American marine and intracontinental Tertiaries.

Science 9:535-536 (1887)

88 Agriculture and late Quaternary geology. Science 11:241-242 (1888)

90 Report on the asphaltum mine of the Ventura Asphalt Company. Cal St M Bur, An Rp 10:763-772 (1890)

91 Orange sand, Lagrange, and Appomattox. Am G 8:129-131 (1891)

92 The cienegas of southern California.

G Soc Am, B 3:124-127 (1892)

92a The age and origin of the Lafayette formation. Am J Sc (3) 43:389402 (1892)

93 Skizze der physikalischen und industriellen Geographle Californiens. Ges Erdk Berlin, Verh 20:116-130 (1893)

93a Die Bodenverbältnisse Callforniens. Deut G Ges, Zs 45:15-22 (1893)

96 The geologic efflcacy of alkall carbonate solution. Am J Sc (4) 2:100107 (1896)

$00 \mathrm{~A}$ historical outline of the geological and agricultural survey of the State of Mississippi. Miss Hist Soc, Pub $3: 207-$ 234 (1900) Am G 27:284-311 (1901)

01 Sketch of the pedological geology of California (abst). G Soc Am, B 12:490500 (1901) J G $9: 74-75$ (1901) Am G $27: 131$ (1901)

02 The debris fans of the arid region in their relation to the water supply (abst). Science n s 15:414 (1902)

03 The Grand Guif Pormation. Science n 8 18: 180-182 (1903)

03a The valley of southern California (abst).. J G 11:96 (1903)
Hilgard, Eugene Woldemar-Continued. 05 The prairie mounds of Louisiana. Science n s $21: 551-552$ (1905)

06 Soils; their formation, properties, composition, and relations to climate and plant growth in the humid and arid regions. 593 pp, N Y 1906

06 a Some peculiarities of rock weathering and soil formation in the arid and humid regions. Am $J$ Sc (4) 21:261269 (1906)

06b The exceptional nature and genesis of the Mississippi Delta. Science n s 24: 861-866 (1906) Abst, G Soc Am, B 17: 731 (1907)

06e Biographical memoir of Joseph Le Conte, 1823-1901. Nat Ac Sc, Biog Mem $6: 147-218$, port (1906)

or The causes of the glacial epoch. Int G Cong, X, Mexico, 1906, C R: 431-436 (1907) Science n s $25: 350-354$ (1907)

10 A new development at the mouth of the Mississippi (abst). Science n s 32:30 (1910) G Soc Am, B 21:791 (1910)

11 The Mississippl Delta (abst). As Am Geog, An 1:135 (1911)

12 A new development in the Missis. sippi Delta. Pop Sc Mo $80: 236-245$, map (1912)

See also Gilbert, 93b; McGee, 91g; Smith (E A), 88a

Hilgaxd, J. F.

81 The basin of the Gulf of Mexico. $\mathrm{Am} \mathrm{J} \mathrm{Sc} \mathrm{(3)} 21: 288-291$ (1881)

Hilgard, T. C.

69 The volcanic tide belt and the world's flood-gates. Am As, Pr $17: 252-267$ (1869) H111, Alexander.

00 The Ray copper mines, Arizona. Eng M J 69:587-588 (1900)

Hill, B. H.

94 Notes on Uintacrinus soclalis Grinnell. Kans Univ Q 3:20-21, 11 (1894)

Hi11, Belle.

07 Natural gas. U $\mathbf{S}$ G $\mathbf{S}$, Min Res $1906: 811-826 ; 1907$ pt $2: 323-346 ; 1908$ pt $2: 317-344 ; 1909$ pt $2: 269-302 ; 1910$ pt $2: 299-326 ; 1912$ pt $2: 301-359$ (190712)

H111, Benjamin Felix.

99 Notes on a set of rocks from Wyoming ... Sch Mines Q 20:357-364 (1899).

99a (with Kemp, J. F.) Preliminary report on the geology of Hamilton, Warren, and Washington cos. [N. Y.]. N Y St G, An Rp 18:137-162, maps (1899) N Y St Mus, An Rp 52 v 2: 137-162, maps (1900)

00 Contribution to the geology of part of Sonora, Mexico (abst). Science n s 12: 447 (1900) N X Ac Sc, An 13: 492 (1901)

01 (with Kemp, J. F.) Preliminary report on the pre-Cambrian formations in parts of Warren, Saratoga, Fulton, and Montgomery cos. [N. Y.]. N Y St Mus, An Rp $53:$ r $17-35$, maps (1901) 
Hill, Benjamin Felix Continued.

02 The Terlingua quicksilver deposits, Brewster Co., Tex. Tex, Univ, Miner S, B 4: $74 \mathrm{pp}$, map (1902)

03 The occurrence of the Texas mercury minerals. Am J Sc (4) 16:251-252 (1903) Zs Kryst 39: 1-2 (1904)

04 Gypsum deposits in Texas. U S G S, B $223: 68-73$ (1904)

04a (and Udden, J. A.) Geological map of a portion of -west Texas, showing parts of Brewster, Presidio, Jeff. Davis, and El Paso counties and south of the Southern Pacific R. R. Tex, Univ, Miner $\mathrm{S}$, Austin 1904 Scale $: 1$ inch $=5$ miles.

Hill, E.

85 On ice age theories. Brit As, Rp $54: 723-724$ (1885)

Hill, E. J.

94 An early observation bearing on the history of the Great Lakes. Am G 14:405 (1894)

Hill, Frank A. (1858-1915).

86 Description of the Wyoming buried valley between Pittston and Kingston [Pa.]. Pa G S, An Rp 1885:637-647 (1886)

S7 Report on the anthracite region. $\mathrm{Pa}$ G S, An Rp 1886 pt 3:919-1303, maps (1887)

87a Report on the metallic paint ores along the Lehigh River. $\mathrm{Pa} G \mathrm{~S}, \mathrm{An} \mathrm{Rp}$ 1886 pt $4: 1386-1408$ (1887)

87b Lehigh River section ... Pa $\mathrm{Pa}$ S, An Rp 1886 pt 4:1372-1385 (1887)

87e Geology and mining in the northern coal field of Pennsylvania. Am I M Eng, Tr 15:699-707 (1887)

94 Geological writings of Charles Albert Ashburner. G Soc Am, B 5:564-567 (1894)

Hi11, Franklin Chapman.

78 Report on the geology of Logan Co.; Champaign Co. Ohio G S, Rp 3 pt 1:482495, map (1878)

81 The fossil Dinocerata in the E. M. Museum at Princeton, N. J. (abst). Am As, Pr 29:524-527, il (1881)

86 On the mounting of fossils. Am Nat $20: 353-359 \quad(1886)$

Hill, Ira.

23 An abstract of a new theory of the formation of the earth. $211 \mathrm{pp}$, Baltimore 1823

Fill, James Madison.

09 Notes on the economic geology of southeastern Gunnison Co., Colo. U S G S, B $380: 21-40$, map (1909)

10 Notes on the placer deposits of Greaterville, Ariz. U S G S, B 430:11-22, map (1910)

10a Note on the occurrence of tungsten minerals near Calabasas, Ariz. U S G S, B $430: 164-166$ (1910)

10b (with Schrader, F. C.) Some occurences of molybdenite in the Santa Rita and Patagonia Mountains, Ariz. U S G S, B $430: 154-163$ (1910)
Hill, James Madison-Continued.

11 Notes on the economic geology of the Ramsey, Talapoosa, and White Horse min. ing districts, in Lyon and Washoe cos, Nev. U S G S B 470:99-108, map (1911)

I1a (with Bastin, E. S.) The Evergreen copper mine, Colo. Ee G 6:465-472 (1911)

12 The mining districts of the western United States, with a geologic introduc. tion by Waldemar Lindgren. U S G S, B 507 : 309 pp, maps (1912)

13 Notes on the northern La Sal Moun. tains, Grand Co., Utah. U S G S, B 530: 99-118 (1913)

13a The zinc-lead deposits of the Yellow Pine district, Nev. (abst). Wash Ac Sc, J $3: 238-239$ (1913)

13b Barytes and strontium; mineral paints. U S G S, Min Res 1912 pt 2: 955 $960,961-984 ; 1913$ pt $2: 49-70,163-174$, map ; 1914 pt 2 : 61-66, 103-122; 1915 pt 2 : 161-187, map ; 1916 pt 2 : $185-195,243$ $254 ; 1917$ pt $2: 5-6,285-291$ (1913-8)

14 Copper deposits of the White Mesa district, Ariz. U S G S, B 540:159-163 (1914)

14a The Yellow Pine mining district, Clark Co., Nev. U S G S, B 540:223274, map (1914)

14b The Grand Gulch mining region, Mohave Co., Ariz. U S G S, B $580: 39$ 58, map (1914)

15 Some mining districts in northeast ern California and northwestern Nevada. U S G S, B 594: $200 \mathrm{pp}$, maps (1915) $A b s t$, by E. S. Bastin, Wash Ac Sc, J 5 623-624 (1915)

15a Notes on the fine gold of Snake River, Idaho. U S G S, B 620: 271-294, maps (1915)

15b Platinum and allied metals. U S G S, Min Res 1914 pt $1: 333-352 ; 1915$ pt $1: 139-157 ; 1916$ pt $1: 1-20 ; 1917$ pt 1: 11-21 (1915-8)

15e (with Bastin, F. S.) Some features of the ore deposits of Gilpin Co. Colo. Wash Ac Sc, J 5 : 160-164, 185-186 (discussion) (1915)

16 Notes on some mining districts in eastern Nevada. U S G S B 648:214 $\mathrm{pp}$, maps (1916) Abst, Wàsh Ac Sc, J 6: 662 (1.916)

$16 a$ Gold, silver, copper, lead, and zinc in the Eastern States in 1915. U S G S, Min Res 1915 pt $1: 7-20 ; 1916$ pt 1: $321-329 ; 1917$ pt $1: 55-62 \quad(1916-8)$

$16 b$ (with Bastin, E. S.) Preliminary report on the economic geology of Gilpin Co., Colo. U S G S, B 620:295-323, maps (1916)

17 Bauxite and aluminum. U S G $\mathrm{S}$, Min Res 1916 pt $1: 159-170 ; 1917$ pt 1 : $1-9 \quad(1917-8)$ 
Hill, James Madison-Continued.

17 a (with Bastin, E. S.) Economic ${ }_{g} 00 \mathrm{logy}$ of Gilpin Co. and adjacent parts of Clear Creek and Boulder cos., Colo. U S G S, P P $94: 397$ pp, maps (1917) Abst by R. W. S., Wash Ac Sc, J $7: 266-$ 267 (1917)

See also Schrader, 15

Hill, N. P.

73 Pitchblende and tellurium gold ore in Colorado. Am J Sc (3) $5: 386-387$ (1873)

Hill, Robert Thomas.

85 Salient geologic features of Travis Co., Tex. Reprint: 1 p, from Austin (Texas) Stateman, Dec 15, 1885

87 The present condition of knowledge of the geology of Texas. U S G S, B $45: 95 \mathrm{pp}$ (1887)

87a The topography and geology of the Cross Timbers and surrounding regions in northern Texas. Am J Sc (3) 33:291303, map (1887)

87b The Texas section of the American Cretaceous. Am J Sc (3) 34:287-309 (1887)

88 Neozoic geology of southwestern Arkansas. Ark G S, An Rp 1888, 2:1260, il, maps, Little Rock, Ark., 1888

88a The Trinity formation of Arkansas, Indian Territory, and Texas. Science 11: 21 (1888)

8sb Notes on the geology of western Texas. G Sc B 1 no 6 (1888)

88c The geology of Texas. Texas School J n 8 6: $143-145$ (1888)

88d Notes upon the Texas section of the American Cretaceous (abst). Am As, Pr 36:216 (1888)

89 A preliminary annotated check list of the Cretaceous invertebrate fossils of Texas, accompanied by a short description of the lithology and stratigraphy of the system. Tex G S, B 4: xxxi, 57 pp (1889)

$89 \mathrm{a}$ Check list of the invertebrate fossils from the Cretaceous formations of Texas... 16, iv pp, Austin, Texas, 1889

89b Roads and material for their construction in the Black Prairie regions of Texas. $39 \mathrm{pp}$, Texas, Univ, December 1889

89e Paleontology of the Cretaceous formations of Texas, Part I. Tex, Univ, Sch G: [7 pp], il, Austin 1889

89d Events in North American Cretaceous history illustrated in the ArkansasTexas division of the southwestern region of the United States. Am J Sc (3) 37 : 282-290 (1889)

89e (and Penrose, R. A. F., jr.) Relation of the uppermost Cretaceous beds of the eastern and southern United States; and the Tertiary-Cretaceous parting of Arkansas and Texas. Am J Sc (3) 38: $468-473(1889)$

$$
28737^{\circ}-23-32
$$

Hi11, Robert Thomas-Continued.

sef A portion of the geologic story of the Colorado River of Texas. Am G 3 : 287-299 (1889)

$89 \mathrm{~g}$ The foraminiferal origin of certain Cretaceous limestones and the sequence of sediments in North American Cretaceous. Am G 4:174-177 (1889)

89h The Permian rocks of Texas. Sclence $13: 92$ (1889)

$89 i$ [Notes on the horizons of Texas fossils.] Am Nat 23: Feb 168, 169 (1889)

90 A brief description of the Cretaceous rocks of Texas and their economic value. Tex G S, An Rp 1: 103-141 (1890)

$90 a$ Occurrence of Goniolina in the Comanche series of the Texas Cretaceous. Am J Sc (3) 40:64-65 (1890)

$90 \mathrm{w}$ Classification and origin of the chief geographic features of the Texas region. Am G 5:9-29, 68-80, map (1890)

90e The fossils of the Trinity beds. Am G $5: 62(1890)$

90d Exploration of the Indian Territory and the medial third of Red River. Am G 6: 252-253 (1890)

90e The Texas Cretaceous. Am G 6: 253-254 (1890)

90r Pilot Knob, a marine Cretaceous volcano. Am G $6: 286-292$ (1890)

$90 \mathrm{~g}$ The Eagle Flats formation and the basins of the trans-Pecos or mountainous region of Texas (abst). Am As, $\operatorname{Pr} 38$ : 242 (1890)

9oh (and Dumble, E. T.) The igneous rocks of central Texas (abst). $\mathrm{Am} \mathrm{As}, \mathrm{Pr}$ 38: 242-243 (1890)

901 The geology of the Staked Plains of Texas, with a description of the Staked Plains formation (abst). Am As, $\operatorname{Pr} 38$ : 243 (1890)

90j The geology of the valley of the upper Canadian from Tascosa, Tex., to Tucumcari Mountain, N. Mex., with notes on the age of the same $(a b s t)$. Am As, Pr $38: 243$ (1890)

90k A classification of the topographic features of Texas with remarks upon the areal distribution of the geologic formations (abst). Am As, Pr 38: 243-244 (1890)

901 Roads and the materials for their construction in the Black Prairie region of Texas. Tex, Univ, B : 17-39, map, Austin [n d, 1890?] [not seen]

91 The Comanche series of the TexasArkansas region (with discussion by C. A. White and others). G Soc Am, B 2: 503528 (1891)

91 a Notes on a reconnaissance of the Ouachita mountain system in Indian Territory. Am J Sc (3) 42:111-124, map (1891)

91b Contributions to the geology of the Southwest. Am G 7:119-122 (1891) 
Hi11, Robert Thomas-Continued.

91e Notes on the geology of the Southwest. Am G 7: 254-255, 366-370 (1891)

91 d Preliminary notes on the topography and geology of northern Mexico and southwest Texas, and New Mexico. Am G $8: 133-141$ (1891)

91e Imbibition of rocks. U S, 51st Cong 2d sess, Sen Ex Doc 53:215-221 (1891)

91f The Tertiary formations of western Texas. Am Nat 25:49 (1891)

92 Notes on the Texas-New Mexican region. G Soc Am, B 3:85-100 (1892)

92a The geologic evolution of the nonmountainous topography of the Texas reglon; an introduction to the study of the Great Plains. Am G 10:105-115 (1892)

92b The third Texas report [notes on stratigraphy, etc.]. Am G 10:393-396 (1892)

92c The deep artesian boring at Galveston, Tex. Am J Sc (3) 44:406-409 (1892)

92d Underground waters of the arid regions. Eng Mag 3:653-660 (1892)

92e Zona minera de Santa Rosa [Coahuila]: informe geológlco y exploración. $\mathrm{Bol} \mathrm{Agr}$ Min é Ind 2 no $1: 107-155$ (1892)

92f The Neozoic formations in Arkansas (abst). Ph Soc Wash, B 11:501-502 (1892)

$\mathbf{9 3}$ On the occurrence of artesian and other underground waters in Texas, eastern New Mexico, and Indian Territory, west of the ninety-seventh meridian. U S, 52d Cong, 1st sess, S Ex Doc 41 pt $3: 41-166$, map (1893)

93a Paleontology of the Cretaceous formations of Texas; the invertebrate paleontology of the Trinity division. Biol Soc Wash, $\operatorname{Pr} 8: 9-40$, il (1893)

.93b The paleontology of the Cretaceous, formations of Texas; the invertebrate fossils of the Caprina limestone beds. Biol Soc Wash, Pr 8:97-108, il (1893)

93e The occurrence of hematite and martite iron ores in Mexico. $\mathrm{Am} \mathrm{J}$ Sc (3) 45 : 111-119 (1893)

93d The Cretaceous formations of Mexico and their relations to North American geographic development. Am J Sc (3) $45: 307-324$, map (1893)

93e Clay materials of the United States. U S G S, Min Res 1891:474-528; 1892 : $712-738 ; 1893: 603-617$ (1893-4)

o3f Mexico as an iron-producing country, Eng Mag 4:744-753, map (1893)

$93 \mathrm{~g}$ Artesian waters in the arld region. Pop Sc Mo $42: 599-611$ (1893)

93h Tucumcari [N. Mex.]. Sclence 22: 23-25 (1893)
Hi11, Robert Thomas-Continued.

94 Geology of parts of Texas, Indih Territory and Arkansas adjacent to $B$ River region. $G$ Soc $A m, B \quad 5: 297-200]$ map (1894) Abst, Am G 13:20s-4 (1894) ; Am J Sc (3) 47:141 (1894)

$94 a$ Notes on the Tertlary and late history of the Island of Cuba. Am J\& (3) $48: 196-212(1894)$

95 Discovery of a dicotyledonous fon In the Cheyenne sandstone. Am J Sc (8) $49: 473$ (1895)

$95 \mathbf{a}$ On outlying areas of the Comand series in Kansas, Oklahoma, and New Jer ico. Am J Sc (3) 50:205-234 (1895)

95b Notes on the geology of the Islat of Cuba. Harvard Coll, Mus C Z, B (g s 2) : 243-288 (1895)

$95 \mathbf{e}$ The radiolarian earths of Cute Science n 8 2:628-629 (1895)

96 A question of classification [Jum sic-Cretaceous boundary]. Science n 84 918-922 (1896) ; 5:921 (1897)

$96 \mathbf{a}$ Fundamental geographic relation of the three Americas. Nat Geog Mag 175-181 (1896)

$96 \mathrm{~b}$ On the Agassiz expedition Panama and Costa Rica $(a b s t)$. Sclens n s 3 : 140-141 (1896)

97 The Yellow limestone of Jamain Am J Sc (4) 3:251 (1897)

$97 \mathbf{n}$ The alleged Jurassic of Texas; reply to Professor Jules Marcou. Am Sc (4) 4:449-469 (1897)

$97 \mathbf{b}$ The easternmost volcanoes of the United States. Sclence n $\mathbf{s} 6: 594-50$ (1897)

97 c Memoir of Robert Hay. G Soc Al B $8: 370-374$ (1897)

98 (and Vaughan, T. W.) The Lowe Cretaceous Gryphaeas of the Texas regiot U S G S, B 151: 139 pp, il (1898)

$98 a$ (and Vaughan, T. W.) Descrly tion of the Nueces quadrangle [Tex.] U S G S, G Atlas Fueces fol (no 42): 4 p ? maps (1898)

98b (and Vaughan, T. W.) Geolos of the Edwards Plateau and Rio Grand? Plain adjacent to Austin and San Antonio Texas, with reference to the occurrence of underground waters U S G S, An Rp 18 : 2: 193-321, 11, maps (1898)

98c The geological history of the Isth. mus of Panama and portions of Costa Rle. with special determinations by W. H. Dall R. M. Bagg, T. W. Vaughan, J. E. Wolf H. W Turner, and Ake Sjögren. Harvar Coll, Mus C Z, B 28 (g s 3 ): 151-28: (1898)

98d Cuba and Porto Rico, with othet islands of the West Indies; their topogrs phy, climate, flora, products, industries cities, people, political conditions, etc. 429 pp, N Y $1898 \quad 2 d$ ed, 447 pp, N Y 1899

98e Cuba. Nat Geog Mag $9: 193-242$. 
Hill, Robert Thomas-Continued.

98f The stratigraphic succession in Jamaica (abst). Brit As, Rp $67: 642$ (1898) 99 The geology and physical geography of Jamaica; study of a type of Antillean development. Harvard Coll, Mus C Z, B 34 (g s 4) : $256 \mathrm{pp}$, maps (1899)

99a Mineral resources of Porto Rico. U S G S, An Rp 20 pt 6 (con.) : 771-778 (1899)

99b Porto Rico. Nat Geog Mag 10 : 93112 (1899)

00 Physical geography of the Texas region. U S G S, Top Atlas fol $3: 12$ pp, maps (1900)

00a The great Chisos rift along the canyons of the Rio Grande (abst). Am As, $\operatorname{Pr} 69: 189$ (1900) Science n 8 12: 992 (1900)

01 Geography and geology of the Black and Grand prairies, Tex. U S G S, An Rp 21 pt 7:666 pp., il, maps (1901)

01a The coast prairie of Texas. Sclence n s $14: 326-328$ (1901)

01b Geographic and geologic features of Mexico. Eng M J 72:561-564 (1901)

02 (and Vaughan, T. W.) Description of the Austin quadrangle [Tex.]. U S G S, G Atlas Austin fol (no 76):8 pp, maps (1902)

02a The geographic and geologic features, and their relation to the mineral products of Mexico. Am I M Eng, Tr 32 : 163-178, map (1902)

02b The Beaumont oil field, with notes on other oil fields of the Texas region. Franklin Inst, J 154:143-156, 225-238, 263-281 (1902) Am I M Eng, Tr 33: 363-405, map (1903)

02e Volcanic disturbances in West Indies. Nat Geog Mag 13:225-267 (1902)

02d The upland placers of La Clenega, Sotiora, Mexico. Fing M J 73:132-134 (1902)

02e The cinnabar déposits of the Big Bend province of Texas. Eng M J 74:305307, map (1902)

02f The volcano systems of the western bemisphere. Century Mag 64:473-483 (1902)

02g The wonders of the American desert. World's Work $3: 1818-1832$ (1902)

03 The Santa Eulalia district, Mexico. Eng M J 76:158-160 (1903)

03 a The ore deposits of Cananea [Mex.]. Eng M J 76:421 (1903)

03b Cananea revisited. Eng $M \quad J 6$ : 1000-1004 (1903)

03e The geologic and physiographic history of the lesser Antilles (abst). Science n \& $17: 225-226$ (1903) Sc Am Sup 55: 22647 (1903)

04 The Guanajuato mining district [Mexlco]. Eng $M$ J $77: 599-601,642-644$ (1904)
Hill, Robert Thomas-Continued.

05 Pele and the evolution of the Windward Archipelago. G Soc Am, B 16:243288, maps (1905)

O5a El Oro district, Mexico. Eng M J $79: 410-413$ (1905)

05b Enrichment in fissure veins. Eng M J $80: 645-646$ (1905)

05e Physical history of the Windward Islands as fllustrated in the larger story of Pelee-a study of volcanic and oceanic geography (abst). Int Geog Cong, VIII, Rp : 244-245 (1905)

o5d The physical geography of Mexico... (abst). Int Geog Cong, VIII, Rp : 765-766 (1905)

06 On the origin of the small mounds of the lower Mississippi Valley and Texas. Science n s $23:$ 704-706 (1906)

$06 a$ Geologic and geographic aspects of Mexico. M World 25:370-372, 459, 540541,596 (1906) ; $26: 69,187 ; 27: 589-591$, $633-634,805$ (1907)

07 Geology of the Sierra Almoloya, with notes on the tectonic history of the Mexican plateau. Science $n$ s 25:710-712 (1907) M World 26:530-532, 560 (1907)

07 a Pecullar formations of the Mexican arid regions. Eng M J $83: 662-666$ (1907)

orb Characteristies of some Mexican mining regions [Chibuabua, Sonora, and the western Sierra Madre]. Eng M J 84: 631-636 (1907)

07e Mexico; its geology and natural resources. M World 27:686-691 (1907)

ozd A preliminary geographic and geologic map of the State of Chibuahua, Mex. Am Mus N H, B 23: opp 442 (1907)

08 Growth and decay of the Mexican Plateau. Eng M J 85:681-688 (1908)

OSa The geology of the Sierra Almaloya, Mexico (abst). N Y Ac Sc, An 18:328 (1908)

08b The Goldfield [Nev.] type of ore occurrence. Eng M J 86:1096-1099 (1908)

0se A scientific search for a new gold field. Eng M J $86: 1157-1160$ (1908)

o8d Camp Alunite, a new Nevada gold district. Eng M J 86: 1203-1206 (1908)

09 The chalk formations of northeast Texas. Science n s 29:972-973 (1909)

12 Marble deposits of the Inyo Mountains [Cal.]. M Sc Press 105: 86-87 (1912)

13 The coal flelds of Mexico. Int $G$ Cong, XII, Canada, 1913, The Coal Resources of the World, 1:1xv-1xvii, 2:553559 (1913)

See also Powell, 95; Roemer, 88; Shu. mard ( $G \mathrm{G}), 86$

Hi11, Samuel W.

49 (with Foster, J. W.) Statistles of the mines of Keweenaw Point [Mich.]. U S, 31st Cong 1st sess, S Ex Doc 1 pt 3 and $H$ Ex Doc 5 pt $3: 759-765$ (1849) 
Hill, Samuel W.-Continued.

63 (with Stevens, W. H., and Williams, C. P.) Geological map of the trap range of Keweenaw Point, Lake Superior. Phila [1863] [not seen]

Hill, Walter Hovey.

95 The gold belt of Idaho. Eng M J $60: 172(1895)$

95a The Deadwood placer claims, Idaho. Eng M J $60: 225-226$ (1895)

96 The Little Giant mine at Warren, Idaho. Eng M J 62: 417 (1896)

Hill, William.

91 On the minute structure of some coral limestones from Barbados. G Soc London, Q J 47:243-248 (1891)

$91 \mathrm{a}$ On the structure of white limestone from Jamaica. G Soc London, Q J 47: 248-250 (1891)

Hille, F.

95 A recent trip to the Rainy River gold flelds [Ont.]. Can M Rv 14: $81-82$ (1895)

97 The western Ontario gold flelds and their genesis. Fed Can M Inst, J 2:7892 (1897) Can M Rv 16:153-158 (1897)

02 The iron ore deposits of western Ontario and their genesis. Can M Inst, J 5: 49-61 (1902)

04 Genesis of the Animikie iron range. Can M Inst, J 6: 245-287 (1904)

04a The Baraboo iron ore [Wis.]. Eng M J $77: 875$ (1904)

05 A correction in the classification of our gold formation [Ontario]. Can M Inst, J 8:183-191 (1905)

o6 The Atik-Okan nickeliferous pyrrhotite deposits and their origin. Can M Inst, J $9: 285-301$, map (1906)

07 Preliminary report on the iron ore deposits of western Ontario. Can, Dp Interior, Supt Mines, Rp 1907:13-18 (1907)

os Contribution to the discussion on the genesis of the graphite in Argenteuil and Labelle cos., in the Province of Quebec. Can M J 29:361-363 (1908)

osa Report on the examination of some iron ore deposits in the districts of Thunder Bay and Rainy River, Province of Ontario. Can Mines $\mathrm{Br}: 65$ pp 1908. The Iron Trade Rv 45: 497-501 (1909)

12 [Origin of petroleums]. Can M J $33: 145-147$ (1912)

Hillebrand, William Francis.

82 (with Cross, W.) On the minerals mainly zeolites occurring in the basalt of Table Mountain, near Golden, Colo. Am J Sc (3) $23: 452-458 ; 24: 129-138$ (1882)

82a (with Cross, W.) Notes on some interesting minerals occurring near Pike's Peak, Colo. Am J Sc (3) $24: 281-286$ (1882)

83 (with Cross, W.) On minerals of the cryolite group recently found in Colorado. Am J Sc (3) $26: 271-294$ (1883)
Fillebrand, William Francis-Continuet

84 On an interesting variety of löllingit and other minerals [Gunnison Co., Colo.] Am J Sc (3) 27:349-358 (1884) Coll Sc Soc, Pr 1:46-56 (1885)

85 (with Cross, W.) Contributions to the mineralogy of the Rocky Mountains U S G S, B 20:113 pp (1885)

$85 n$ On zunyite and guitermanite, two new minerals from the Colorado. Colo St Soc, Pr 1:124-131 (1885)

85b Mineralogical notes; I, On an as sociation of rare minerals from Utah; II, Miscellaneous. Colo Se Soc, Pr 1:112123 (1885)

s6 Emmonsite, a ferric tellurite [Tombstone, Ariz.]. Colo Sc Soc, $\operatorname{Pr} 2: 20-20$ (1886)

s8 (and Washington, H. S.) Notes on certain rare copper minerals from Utah. Am J Sc (3) 35:298-307 (1888) Colo Sc Soc, Pr 3:3-16 (1889)

89 Mineralogical notes. Colo Sc Soc, $\operatorname{Pr} \quad 3: 38-47$ (1889)

89a Analyses of three descloizites from new localities. Am J Sc (3) 37:434-349 (1889) Colo Sc Soc, Pr 3:193-199 (1890)

90 (and Dana, E. S.) Additional notes on the tyrolite from Utah. Am J Sc (3) $39: 271-273$ (1890)

91 New analyses of uraninite. Am d Sc (3) $42: 390-393$ (1891)

92 Zinc-bearing spring waters from Mls souri. Am J Sc (3) $43: 418-422$ (1892)

93 (with Hidden, W. E.) Description of rowlandite. Am J Sc (3) $46: 208-214$ (1893)

95 Chemical composition of calavertte from Cripple Creek, Colo. U S G S, An Rp 16 pt 2:133-135 (1895)

95a Calaverite from Cripple Creek, Colo. Am J Sc (3) $50: 128-131,42 \hbar$ (1895)

96 Remarkable phosphorescence in wol. lastonite. Am J Sc (4) 1:323 (1896) 97 (with Clarke, F. W.) Analyses of rocks, with a chapter on analytical metb ods, laboratory of the United States Gevlogical Survey, 1880 to 1890 . U S G \& B 148: 306 pp (1897)

98 Distribution and quantitative occur rence of vanadium and molybdenum in rocks of the United States. Am J Sc (4) 6: 209-216 (1898)

99 Praktische Anleitung zur Analys der Sillikatgesteine ... Trans. by B. Zschimmer, 86 pp, Leipzig 1899 (For 20 ed, see Hillebrand, 10)

99a Mineralogical notes; analyses of tysonite, bastnäsite, prosopite, jeffersonite covellite, etc. $\mathrm{Am} \mathrm{J} \mathrm{Sc} \mathrm{(4)} 7: 51-57$ (1899)

99b (and Turner, H. W.) On roscet lite. Am J Sc (4) $7: 451-454$ (1899) 
Hillebrand, William Francis-Continued. 99e Mineralogical notes; melonite?, coloradoite, petzite, hessite. Am J Sc (4) $8: 295-298$ (1899)

00 Distribution and quantitative occurrence of vanadium and molybdenum in rocks of the United States. U S G S, B 167: 49-55 (1900)

00n Mineralogical notes. U. S G S, B 167: 57-76 (1900)

$00 \mathrm{~b}$ Some principles and methods of rock analysis. U S G S, B 176:114 pp (1900)

00e (and Ransome, F. L.) On carnotite and assoclated vanadiferous minerals in western Colorado. Am J Sc (4) 10: 120-144 (1900)

02 (and Penfleld, S. L.) Some additions to the alunite-jarosite group of minerals. Am J Sc (4) 14:211-220 (1902) Zs Kryst $36: 545-554$ (1902) U S G S, B 262:32-41 (1905)

02a Chemical discussion of analyses of volcanic ejecta from Martinique and St. Vincent. Nat Geog Mag, 13:296-299 (1902)

04 Emmonsite(?) from a new locality. Am J Sc (4) $18: 433-434$ (1904)

04a (with Schaller, W. T.) Crystallographical and chemical notes on lawsonite. Am J Sc (4) 17:195-197 (1904)

04b (with Lindgren, W.) Minerals from the Clifton-Morenci district, Ariz. Am J Sc (4) 18:448-460 (1904) U S G S, B 262: 42-54 (1905)

05 (and Ransome, F. L.) On carnotite and associated vandiferous minerals in western Colorado. U S G S, B 262: 9-31 (1905)

05a Two tellurium minerals from Colorado, U S G S, B 262:55-57 (1905)

05b The composition of yttrialite, with a criticism of the formula assigned to thalenite. U S G S, B 262: 61-68 (1905)

05e Red beryl from Utah. Am J Sc (4) $19: 330-331$ (1905)

05d Preliminary announcement concerning a new mercury mineral from Terlingua, Tex. Sclence n s 22: 844 (1905)

05e (with Schaller, W. T.) Notes on lawsonite. U S G S, B 262:58-60 (1905) 07 The analysis of silicate and carbonate rocks, U S G S, B 305:200 pp (1907) Revision, B 422 : 239 pp (1910)

07a (and Sehaller, W. T, ) The mercury minerals from Terlingua, Tex.; kleinite, terlinguaite, eglestonite, montroydite, calomel, mercury. Am J Sc (4) 24:259274 (1907)

08 (with Canfield, F. A.) Mosesite, a new mercury mineral from Terlingua, Tex. Am J Sc (4) $30: 202-208$ (1908)

09 (and Sehaller, W. T.) The mercury minerals from Terlingua, Tex. U S G S, B 405: 174 pp (1909)
Hillebrand, William Francis-Continned. 10 Analyse der Silikat- und Karbonatgesteine. Trans by Ernst Wilke-Dörfurt, 258 pp, Leipzig 1910

10a (and Wright, F. E.) A new occurrence of plumbojarosite. Am J Sc (4) $30: 191-192$ (1910)

13 A danger to be guarded against in making mineral separations by means of heavy solutions. Am J Sc (4) 35:439440 (1913) Wash Ac Sc, J 3:137-138 (1913) Zs Kryst 53:1-3 (1913)

13a (and Merwin, H. E.) Two varieties of calciovolborthite (?) from eastern Utah. Am J Sc (4) 35:441-445 (1913) Wash Ac Sc, J $3: 138,503$ (abst) (1913) Zs Kryst 53: 4-9 (1913)

13b (and Wright, F. E., and Merwin, H. E.) Calcium vanadates from Peru, Colorado, and Utah. Wash Ac Sc, J 3: 157-158 (1913)

14 (and Merwin, H. E., and Wright, F. E.) Hewettite, metahewettite, and pascoite, hydrous calcium vanadates. $\mathrm{Am} \mathrm{Ph}$ Soc, Pr 53: 31-54 (1914) Abst, Wash Ac Sc, J $5: 179-180$ (1915)

See also Howell (E E), 94

Hills, B. W.

09 The molybdenite deposits of Tunk Pond, Maine. M World 31:323-324 (1909)

Hills, Richard Charles.

80 Note on the occurrence of fossils in the Triassic and Jurassic beds near San Miguel in Colorado. Am J Sc (3) 19 : $490(1880)$

82 Jura-Trias of southwestern Colorado. Am J Sc (3) $23: 243-244$ (1882)

84 Extinct glaciers of the San Juan Mountains, Colo. Am J Sc (3) 27:391396 (1884) Colo Sc Soc, Pr 1:39-46 (1885)

84a Kaolinite, from Red Mountain, Colo. Am J Sc (3) $27: 472$ (1884)

85 Ore deposits of Summit district, Rio Grande Co., Colo. Colo Sc Soc, Pr 1:2036, map (1885) Abst, Eng M J 35:332334 (1883)

S6 Remarks on the occurrence of coal in the Carboniferous formation at Aspen and Glenwood Springs, Colo. Colo Sc Soc, $\mathrm{Pr}$ $2: 25-26$ (1886)

86a Description of an asphalt-like mineral from Asphalt Wash, Utah. Colo Sc Soc, $\operatorname{Pr} 2: 27-28$ (1886)

87 Notes on the recent discovery of natural gas in Pitkin Co., Colo. Colo Sc Soc, Pr 2:106-107 (1887)

87a Circulation of water through the strata of the upper Cretaceous coal measure of Gunnison Co., Colo. Colo Sc Soc, Pr 2:127-133, map (1887)

89 Preliminary notes on the eruptions of the Spanish Peaks region. Colo Sc Soc, Pr 3:24-34 (1889) 
Hills, Richard Charles-Continued.

89a The recently discovered Tertiary beds of the Huerfano Ri er basin, Colo. Colo Sc Soc, Pr 3: 148-16t, map (1889)

89b Address of the retiring president [includes notes on Colorado stratigr phy]. Colo Sc Soc, Pr 3: 165-184 (1889)

90 Etched beryls from Mount Antero, Colo. Colo Sc Soc, Pr 3: 191-192 (1890)

$90 a$ Additional notes on the Huerfano beds. Colo Sc Soc, Pr 3:217-223 (1890) $\mathbf{9 0 b}$ Additional notes on the eruptions of the Spanish Peaks region. Colo Sc Soc, Pr 3:224-227 (1890)

91 [Crystals of vanadinite from Silver district, Ariz.] Colo Sc Soc, Pr 3:257 (1891)

$91 a$ [Pseudomorphous crystals of malachite after azurite from Bisbee, Ariz.] Colo Sc Soc, Pr 3:258 (1891)

91b Fulgurite from the Spanish Peaks, Colo Sc Soc, Pr 3:280-286 (1891)

91e Orographic and structural features of Rocky Mountain geology. Colo Sc Soc, Pr 3: 362-458, map (1891)

93 Coal fields of Colorado. U S G S, Min Res 1892: 319-365 (1893)

95 Remarks on the classification of the Huerfano Eocene. Colo Sc Soc, Pr 4: 7-9 [1895]

95a Types of past eruptions in the Rocky Mountains. Colo Sc Soc, $\operatorname{Pr} 4$ : 14-32 [1895]

95b Twin crystals of selenite. Colo Sc Soc, $\operatorname{Pr} 4: 32$ [1895]

98 Ore deposits of Camp Floyd district, Tooele Co., Utah. Colo Sc Soc, Pr 5: 5465 [1898] (separate ed, $12 \mathrm{pp}, 1894$ )

98a The Costilla meteorite [N. Mex.]. Colo Sc Soc, Pr 5:121-122 [1898] (separate ed, 2 pp, 1895)

99 Description of the Elmoro quadrangle [Colo.]. U S G S, G Atlas Elmoro fol (no 58): 5 pp, maps (1899)

00 Description of the Walsenburg quadrangle [Colo.]. U S G S, G Atlas Walsenburg fol (no 68): $6 \mathrm{pp}$, maps (1900)

01 Description of the Spanish Peaks quadrangle [Colo.]. U S G S, G Atlas Spanish Peaks fol (no 71): 7 pp, maps (1901)

02 The Oscuro Mountain meteorite [N. Mex.]. Colo Sc Soc, Pr 6:30-33 [1902] (separate ed, 4 pp, 1897)

o2a Eocene and earlier beds of the Huerfano Basin, Colo, and their relation to the Cretaceous (abst). Science n s 15: 417 (1902)

14 On a probable eighth fragment of the Glorieta meteorite. Colo Sc Soc, $\operatorname{Pr} 11$ : 1-4 (1914)

15 Coals and coal flelds of the Rocky Mountain region. Rocky Mountain Coal Mining Inst, 3d semiannual meeting : 25-40 [1915] M Science 72:22-26] (July), 2428 (August) (1915) Colliery Eng 36:137141 (1915)
Hilis, Richard Charles-Continued.

17 Notes on rare mineral occurrenco Colo Sc Soc, Pr 11: 203-208 (1917)

See also Cross, 95a, 98a ; Van Diest, of $95 \mathrm{a}$

Hills, Thomas M.

16 Reames Cave [Champaign Co., Obio] Ohio J Sc 16:209-215 (1916) Abst, 8d ence n s 43; 397 (1916)

Hills, Victor Gardiner.

09 Tungsten mining and milling. Coil Sc Soc, Pr 9:135-153 (1909) M Woth 30: 1021-1024 (1909)

12 Magmatic origin of ore-forming soli tions. M Sc Press 104:703 (1912)

$12 a$ Tungsten and the scheelite ming in Nova Scotia. M Soc N S, J 17:55-에 (1912)

12b The scheelite deposits of Nor Scotia. Can M Inst, $\operatorname{Tr} 15: 477-482$ (1912) Can M J 33:679-680 (1912)

12e Tungsten mining in Nova Scoti. Colo Sc Soc, Pr 10:203-210 (1912)

13 A tungsten mine in Nova Scotia. Sc Press 106: 448-450 (1913)

Hillside, A. M.

59 A familiar compend of geology to the school and family. $150 \mathrm{pp}$, Phila $18 \%$

\section{Hillyer, E.}

75 Structure of Stone Mountain, a grt nitic mass in Georgia. Am J Sc (3) 10: 234-235 (1875)

Hind, Henry Youle (1823-1908).

53 Notes on the geology of Toront [Ont]. Can J 1: 147-151 (1853)

57 On the minerals of Canada. Car Nat 2:52-63 (1857)

58 Geological sketch of the canoe routh from Fort William, Lake Superior, to the mouth of Red River, Lake Winnipeg, at of the valley of Red River, north of th forty-ninth parallel. In [Great Britsh Parliament... June 1859], Papers relatis to the exploration of the country betwet Lake Superior and the Red River Settle ment: 102-107, L 1859 [Canada, Provis cial Secretary], Report on the exploration of the country between Lake Superior and the Red River Settlement: 284-301, map Toronto 1858 [also an edition in Frencb]

59 Northwest Territory; Reports progress, together with a preliminary and general report on the Assiniboine and Sat katchewan exploring expedition [geologics] report:163-187] $201 \mathrm{pp}$, il, maps, To ronto 1859 [Also an edition in French] Also in Canada, Legislative Assembly, vol 19 app no 36 , Toronto 1859 Another edition, British North America; Reportsexpedition. [Great Britain, ParliamentAugust 1860] : 219 pp, il, maps L 1860

60 Narrative of the Canadian Red Riret exploring expedition of 1857 and of the th siniboine and Saskatchewan exploring es pedition of 1858 . 2 vols, 494,472 pp, msp 1860 
Hind, Henry Youle-Continued.

64 Observations on supposed glacial drift In the Labrador Peninsula, Western Canada, and on the south branch of the Saskatchewan. G Soc London, Q J 20:122130 (1864) Can Nat $n$ s $1: 300-304$ (1864) Can J n s 9:253-262 (1864)

65 A preliminary report on the geology of New Brunswick, together with a special report on the distribution of the "Quebec group" in the province. 293 pp., Frederickton $1865 R v$, Can Nat n s 2:232239 (1865)

69 Report on the Waverley gold district ... $62 \mathrm{pp}$, map, Halifax, N. S., 1869 69 a Gold deposits of Nora Scotla. Can Nat n s $4: 229-240$ (1869)

70 Report on the Sherbrooke gold district, together with a paper on the gneisses of Nova Scotia, and an abstract of a paper on gold mining in Nova Scotia. $79 \mathrm{pp}$, maps, Halifax, N. S., 1870

70a Preliminary report on a gneissoid series underlying the gold-bearing rocks of Nora Scotia and supposed to be the equivalent of the Laurentian system. $15 \mathrm{pp}$, Halifax, N. S., 1870

$70 \mathrm{~b}$ on gold mining and its prospects in Nova Scotia... Soc Arts, J 18:612-623 (1870)

$70 \mathrm{e}$ Notes on the structure of the Nova Scotia gold districts. N $\mathrm{S}$ Inst $\mathrm{N}$ Sc, Pr Tr 2 pt 3: 102-109 (1870)

70d on the Laurentian and Huronian serles in Nova Scotia and New Brunswick. Am J Se (2) $49: 347-355$ (1870)

70 e On two gneissoid series in Nova Scotic and New Brunswick supposed to be the equivalents of the Huronian (Cambrian) and Laurentian. G Soc London, Q J 26:468-479 (1870) Abst, G Mag 7 : $290-291$ (1870)

72 Report on the Mount Uniacke, Oldham, and Renfrew gold mining districts [N. S.]... 136 pp, maps, Halifax, N. S., 1872

73 Report on a topographical survey of part of the Cumberland coal field, with notices of the coal seams and their relation to the iron deposits of the Cobequids [N. 8.]. $68 \mathrm{pp}$, Halifax, N. S., 1873

77 Notes on some geological features of the northeastern coast of Labrador. Can Nat n s 8: 227-240, 262-278 (1877)

Hind, Wheelton.

04 The type of Aviculipecten. Am G $34: 200-201$ (1904)

Hinde, George Jennings (1839-1918).

74 (with Nicholson, H. A.) Notes on the fossils of the Clinton, Niagara, and Guelph formations of Ontario, with descriptions of new species. Can J n s 14: $137-152,137-144$ [bis ], il (1874)

75 Description of a new genus of tabulate coral [Sphaerolites nicholsoni, Dalbouste, N. B.] (abst). G Mag (2) 2:
Hinde, George Jennings-Continued.

77 The glacial and interglacial strata of Scarboro Heights and other localities near Toronto, Ont. Can J n s $15: 388$ 413 (1877)

78 Note on the occurrence near Toronto of boulders belonging to the Calciferous formation. Can J n s 15:644 (1878)

79 On conodonts from the Chazy and Cincinnati group of the Cambro-Silurian and from the Hamilton and Genesee shale divisions of the Devonian in Canada and the United States. G Soc London, Q J $35: 351-369$, il (1879) Abst, Can Nat n s $9: 189-190$ (1879) ; Nature 19:523 (1879)

$79 a$ On annelid jaws from the CambroSilurian, Silurien, and Devonian formations in Canada... G Soc London, Q J $35: 370-389$, il (1879) Abst, Can Nat n s $9: 190(1879)$; Nature $1 y: 523$ (1879)

$79 \mathrm{~b}$ On a new genus of favosite coral from the Niagara formation (U. Silurian), Manitoulin Island, Lake Huron. G Mag (2) $6: 244-246$, 11 (1879)

85 Description of a new species of crinoids with articulating spines [Hystricrinus carpenteri, Arkona, Ont.]. An Mag N H (5) $15: 157-173$, il (1885)

$\mathbf{s 7}$ On the genus Hindia and the name of its typical specles. An Mag N H (5) 19:67-79 (1887)

88 Notes on sponges from the Quebec group at Métis, and from the Utica slate. Can Rec Sc 3:59-68 (1888) McGill Univ, Peter Redpath Mus, Notes on specimensApril 1888: 59-68 (1888)

$88 \mathbf{n}$ On the history and characters of the genus Septastraea D'Orbigny (1849) and the identity of its type species with that of Glyptastraea Duncan (1887). G Soc London, Q J $44: 200-227$, il (1888)

8sb Note on the spicules described by Billings in connection with the structure of Archaeocyathus minganensis. G Mag (3) $5: 226-228$, il (1888)

89 On a new genus of siliceous sponges from the Trenton formation at Ottawa. Can Rec Sc 3: 395-398, il (1889)

89n On Archacocyathus Billings and on other genera allied to or associated with it from the Cambrian strata of North America, Spain, Sardinia, and Scotland. G Soc London, Q J 45:125-148, il (1889) Abst, Can Rec Sc 3:373-374 (1889)

91 Notes on a new fossil sponge from the Utica shale formation (Ordovician) at Ottawa, Canada. G Mag (3) $8: 22-24$, il (1891)

93 On Palaeosaccus davosoni Hinde, a new genus and species of hexactinellid sponge from the Quebec group (Ordovician) at Little Métis, Que. G Mag (3) 10:56-59, il (1893)

94 Note on the radiolarian chert from Angel Island ... Cal. Cal, Univ, Dp G, B $1: 235-240$, il (1894) 
Hinde, George Jennings-Continued.

97 Dr. G. M. Dawson. G Mag (4) 4: 193-195, port (1897)

See also Dawson ( $\mathrm{J}$ W), 90c, 96 ; East$\operatorname{man} 00$

Hindry, W. E.

09 The Esperanza mine, El Oro, Mexico. M Mag London, 1:131-138 (1909)

Hinds, Henry.

09 The coal deposits of Iowa. Iowa G S $19: 21-396$ (1909)

10 Coal fields of Iowa and Missouri. Mines and Minerals 31: 80-82 (1910)

11 The principal coal fields of northern Missouri. Mo Bur G Mines, Bien Rp : 2635 (1911)

12 The coal deposits of Missouri. Mo Bur G Mines (2) $11: 503$ pp, maps [1912?]

14 Oil and gas in Colchester and $\mathrm{Ma}$ comb quadrangles. III G S, Extr B 23: 8-13, map (1914)

15 (and Greene, F. C.) The stratigraphy of the Pennsylvanian series in Missouri. Mo Bur G (2) 13:407 pp, maps, il (1915)

16 The coal resources of the Clintwood and Bucu quadrangles, Va. Va G S, B 12 : $206 \mathrm{pp}$, maps (1916)

17 (and Greene, F. C.) Description of the Leavenworth and Smithville quadrangles [Mo-Kans.]. U S G S, G Atlas Leavenworth-Smithville fol (no 206): 13 pp, maps (1917)

17a Oil and gas in Colchester and $\mathrm{Ma}$ comb quadrangles. Ill $\mathrm{G} \mathrm{S}, \mathrm{B} 23: 45-50$, map (1917)

17b Geology and economic resources of Colchester and Macomb quadrangles. III G S, B 30:75-109, map (1917)

18 The geology and coal resources of Buchanan Co., Va. Va G S, B 18:1-250, maps (1918)

Hindshaw, Henry H.

o5 Peat. U S G S, Min Res 1904: 1229-1234 (1905)

Hines, C. M.

69 Geological notes. In Hayden, F. V., Geological report of the exploration of the Yellowstone and Missouri rivers (Raynolds) : 95-103 (1869)

Hinman, Russell.

88 The laws of corrasion. Sclence 12: 119-120 (1888)

Hinxichs, Gustavus.

67 Geology and mineralogy of Iowa. In Blanchard, Rufus, Handbook of Iowa... : 12-21, Chicago, 1867

68 Report of State chemist. Iowa G S, An Rp 1-2: 203-268 (1868)

71 The principles of pure crystallography. 44 pp, Davenport, Iowa, 1871

Hinriehs, G. D.

o5 Sur les metéorites d'Amana [Iowa]. Ac Sc Paris, C R $140: 545-547$ (1905)
Hinsdale, William Russell,

11 Report on Roaring Run fron or property, Botetourt and Allegheny cos., $V_{2}$ 51 pp, maps N Y 1911. [Priv pub]

Hinton, John Howard.

30 The history and topography of the United States of North America... [includes geology and mineralogy]. 2 vols, 476,48 pp, L 1830-2 2d ed, 2 vols, 520,580 pp, L $18343 \mathrm{~d}$ ed, L 1842 Am editions, 2 rols, 427, 507 pp, Boston 18342 d ed, 2 rols $444,520 \mathrm{pp}$, Boston $18453 \mathrm{~d}$ ed, 2 rols 427, 507 pp, Boston 1855

Hinton, Richard J.

90 A report on the preliminary inves. tigation to determine the proper location of artesian wells within the area of the ninety-seventh meridian and east of the foothills of the Rocky Mountains. U \&, 51st Cong 1st sess, S Ex Doc 222:5-30 (1890)

Hintze, Ferdinand Frlis, $j \mathrm{r}$.

13 A contribution to the geology of the Wasatch Mountains, Utah. N Y Ac Sc, An 23: 85-143 (1913)

15 The Basin and Greybull ofl and gas fields. Wyo, G Of, B 10:62 pp, msp (1915)

15a The Little Buffalo Basin ofl and gas field [Wyo.]. Wyo, G Off, B 11:6790, maps (1915)

15b The Grass Creek ofl and gas field [Wyo.]. Wyo, G Off, B $11: 91-120$, map (1915)

18 Age of the Martinsburg shale as interpreted from its structural and stratt. graphical relations in eastern Pennsyivania (abst). G Soc Am, B 29:94-95 (1918)

Hiortdahl, Th.

85 Colemanit, ein krystallisirtes Kalkborat aus Californien. Videnskabs-Selsk Christiania, Forh 1884 no $10: 8$ pp (1885) Zs Kryst 10: 25-31 (1885)

Hiteheoek, A. S.

04 Controlling sand dunes in the United States and Europe. Nat Geog Mag 15:4347 (1904)

Hitehcock, Charles Henry (1836-1919).

55 Impressions (chiefly tracks) on allu. vial clay, in Hadley, Mass. Am J Se (2) $19: 391-396$ (1855)

58 On a geological section from Green. field to Charlemont, Mass. Boston Soc N H, Pr $6: 330-332$ (1858)

$\mathbf{5 8 a}$ On fractured ledges of slate in Ver mont. Am As, Pr 11 pt. 2: 51-55 (1858)

59 Catalogue of rocks and minerals in the Massachusetts State collection. $65 \mathrm{pp}$, Board of Agriculture 1859 [not seen] [see also Hitchcock (E.), 59a]

59a Lithology of Vermont (abat). Nat $4: 296$ (1859)

60 On the so-called talcose schist of Vermont. Am As, Pr 13: 321-329 (1860) 
Hitchcock, Charles Henry-Continued.

$60 \mathrm{a}$ On the marks of ancient glaciers on the Green Mountain Range in Massachusetts and Vermont. Am As, Pr 13:329335 (1860)

60b Lake ramparts in Vermont. Am As, Pr 13: 335-337 (1860)

60e [On distorted pebbles in the conglomerate of Vermont.] Boston Soc N H, Pr $7: 208$ (1860) [In error attributed to E. Hitchcock, jr.]

60d [Observations on the geology of Vermont.] Boston Soc N H, Pr 7:236$237(1860)$

60e Road map of the island of Rhode Island or Aquidneck [colored geologically]. Scale 1 inch to the mile. N Y [1860] [not seen]

61 General report upon the geology of Maine. Me Bd Agr, 6th An Rp: 146-328 (1861)

61a Geology of the wild lands [Maine]. Me Bd Agr, 6th An Rp:377-419, map (1861)

61b Geology of the Island of Aquidneck [R. I.]. Am As, Pr 14:112-137 (1861)

61e Synchronism of coal beds in the New England and western United States coal basins. Am As, Pr 14:138-143 (1861)

61d [On the geology of Vermont, chiefly in connection with the Taconic system (with discussion by W. B. Rogers, and Jules Marcou).] Boston Soc N H, Pr 7 : 426-427 (1861)

61e ... fossils of the red sandstone formation of Vermont. Am J Sc (2) 32 : 454 (1861)

611 (with Holmes, Ezekiel.) Preliminary report upon the natural history and geology of the State of Maine, 1861. Me $\mathrm{Bd}$ Agr, 6th An Rp:91-458, Lugusta 1861

$61 \mathrm{~g}$ (with Hiteheock, E.) Geological map of the United States. Compiled for R. P. Smith's Wall map of the United States [1861?] [not seen]

62 Geology of Maine [includes contributions by G. L. Goodale, O. White, and E. Holmes]. Me Bd Agr, 7 th An Rp: 223-430, map (1862)

$62 n$ Notes on the geology of Maine. Portland Soc N H, Pr 1:72-85, map (1862)

62b Fossils of the Potsdam group in North America. Portland Soc N H, Pr 1: $87-90$ (1862)

62e A new species of Carpolithes [lescurii from Brandon, Vt.]. Portland Soc $\mathrm{N} \mathrm{H}, \operatorname{Pr} 1: 95-96$, il $(1862)$

62d (with Holmes, Ezekiel.) Second annual report upon the natural history and geology of the State of aine, 1862 . Me Bd Agr, 7th An Rp: 217-447, Augusta 1862

64 On the antimony mine of South Ham, C. E. [Quebec]. Am J Sc (2) $37: 405-$ 406 (1864)
Hitchcoek, Charles Henry-Continued.

65 The Albert coal, or albertite, of New Brunswick. Am J Se (2) 39:267-273 (1865)

66 Description of a new reptilian bird from the Trias of Massachusetts [Tarsodactylus expansus]. Lyc N H N Y, An 8: 301-302 (1866)

66a (with Hitehcoek, Edward.) Elementary geology. New ed, 430 pp, N Y 1866

67 The geological distribution of petroleum in North America. Brit As, Rp 36: sec 55-57 (1867) G Mag 4:34-37 (1867)

67a Relations of geology to theology. Bibliotheca Sacra 24:363-388, 429-481 (1867)

68 [On the geology of Andover, Mass.]. Essex Inst, $\operatorname{Pr} 5: 157-160$ (1868)

68a New American fossil fish from the Devonian. G Mag 5:184-185, il (1868)

68b New Carboniferous reptiles and fishes from Ohio, Kentucky, and Illinois. G Mag 5:186-187 (1868)

68e The Winooski marble of Colchester, Vt. (abst). Am As, Pr 16:119 (1868) Am Nat 1: 621 (1868)

68d The geology of Vermont (abst). Am As, Pr 16:120-122 (1868)

68e Explanation of a geological map of Maine. Am As, Pr 16:123 (1868)

68f The distortion and metamorphosis of pebbles in conglomerates (abst). Am As, Pr 16:124-127 (1868) Am Nat 1:621 (1868) Can Nat n s 3: 302 (1868)

69 First annual report upon the geology and mineralogy of the State of New Hampshire. $36 \mathrm{pp}$, map, Manchester 1869

69n Notes on the supposed fossil footmarks in Kansas. Am J Sc (2) $47: 132-$ 133 (1869)

70 Second annual report upon the geology and mineralogy of the State of New Hampshire. $37 \mathrm{pp}$, map, Manchester 1870

70n The geology of Vermont. $5 \mathrm{pp}$, fol, 1870 [not seen; author has stated that only 25 copies were circulated]

70b The lithology of New Hampshire; preliminary catalogue of 250 typical specimens, collected by the geological survey. $20 \mathrm{pp}$ [n p, n d, 1870?]

70e The geology and topography of the White Mountains (abst). Am Nat 4:567568 (1870)

70d Geological map [of New York]. In Asher \& Adams, New topographical atlas and gazetteer of New York:11-12, N Y [1870] [not seen]

70e The elevation of mountains. The Dartmouth, $4: 121-124$ (1870)

7of The Calaveras skull. Eng M J 9: 345-346 (1870)

71 Report of the geological survey of the State of New Hampshire showing Its progress during the year $1870.82 \mathrm{pp}$, Nashua 1871 
Hitehcoek, Charles Henry-Continued.

71a The distribution of maritime plants in North America; a proof of oceanic submergence in the Champlain period (abst). Am As, Pr 19:175-181 (1871) Notice by J. D. Dana, Am J Sc (3) 2:207-208 (1871)

71b Helderberg corals in New Hampshire. Am J Sc (3) 2:148-149 (1871)

71e Geological explorations in the Rocky Mountains, U S. A. G Mag 8:127-128 (1871)

71d Geological description [and geologic map] of Massachusetts. In Walling \& Gray, Official topographical atlas of Massachusetts : 17-22, map, 1871

72 Report of the geological survey of the State of New Hampshire showing its progress during the year 1̇̀71. $56 \mathrm{pp}$, map, Nashua 1872

72n Norian rocks in New Hampshire. Am J Sc (3) 3:43-47 (1872)

72b [On the fossils of Littleton, N. H.] Boston Soc N H, Pr 14:292 (1872)

72e Description of the geological map [of the United States]. U S Ninth Census 3: 754-756 (1872)

73 Report of the geological survey of the State of New Hampshire showing its progress during the year 1872. $15 \mathrm{pp}$, Nashua 1873

73a Relations of geology to agriculture. N H, Bd Agr, 3d An Rp:171-176, map (1873)

73b Classification of the rocks of New Hampshire [with discussion by C. T. Jackson and T. S. Hunt.] Boston Soc N H, Pr 15: 304-309 (1873)

73e Explanation of a new geological map of New Hampshire $(a b s t)$. $\mathrm{Am} \mathrm{As}$, Pr 21: 134-135 (1873)

73d Recent geological discoveries among the White Mountains, N. H. Am As, Pr 21: 135-151 (1873)

73e Footprints in the rocks. Pop Sc Mo $3: 428-441$, il (1873)

73f The coal areas of the United States of America. G Mag 10:99-101 (1873)

73g (and Blake, W. P.) [Description of] geological map of the United States compiled for the Ninth Census, 1872. G Mag 10: 371-373 (1873)

73h (and Blake, W. P.) Geological map of the United States. Accompanying the report of Rossiter W. Raymond, United States Commissioner of Mining Statistics. Scale 1 inch $=90$ miles. 1873.

74 (and Blake, W. P.) Geological map of the United States. In U S Ninth Census, Statistical Atlas pl 13-14 (1874) [Also issued with other publications] $\mathrm{R}$, Am J Sc (3) 6:64-66 (1873)

74a Map of the coal fields of the United States. In U S Ninth Census, Statistical Atlas pl 11-12 (1874)
Hiteheock, Charles Henry-Continued $74 \mathrm{~b}$ The coal measures of the United States. In U S Ninth Census, Statisticil Atlas : 12-14 (1874)

74e The geology of New Hampshire. Part I, Physical geography. 668 pp, Cos cord 1874

74d On Helderberg rocks in New Hamp shire. Am J Sc (3) $7: 468-476,557-571$ : $8: 68$, map (1874)

74e Geological history of Winnipiseoge Lake. Am As, Pr 22 pt 2: 120-131 (1874)

74f Note upon the Cretaceous strats of Long Island. Am As, Pr 22 pt 2:131-18. (1874)

74g The geology of Portland. Am ds Pr 22 pt 2:163-175 (1874)

74h (and Huntington, J. H.) Ged ogy of the northwest part of Maine. As As, $\operatorname{Pr} 22$ pt 2:205-214, map (1874)

741 The world before the introduction of life. Pop Sc Mo 4:513-528 (1874)

75 Physical history of New Hampshit (abst). Am As, Pr 23 pt 2:76-78 (1875

76 Existence of glacial action upon the summit of Mt. Washington, N. H. Am As Pr 24 pt 2: 92-96 (1876) Sc Mo, Toleda. O, $1: 581-587$ (1876)

76a Stratigraphical structure of the Cambrian and Cambro-Silurian rocks $\alpha$ western Vermont. Boston Soc $\mathrm{N}$ H, P? 18: 191-193 (1876)

76b The Atlantic system of mountains (abst). Appalachia 1: 11-14 (1876)

76e Ideal sections ... on line of fortieth parallel. Cal Ac Sc, Pr 6: pls opp 123 (1876)

76d Geological description [and geolog. cal map of the United States]. In The national atlas ... (O. W. Gray \& Sor) 181-184, map, Phila 1876 [Also appeass in numerous later editions]

77 The geology of New Hampshire Part II, Stratigraphical geology. $684 \mathrm{pP}$. map, Concord 1877

77a Physical history of New Hamp shire; a paper presented to the Board of Agriculture. $17 \mathrm{pp}$, Concord 1877

$\boldsymbol{7 7 b}$ Lenticular hills of glacial drift. Boston Sac N H, Pr 19: ( j-67 (1877)

77e [On the formation of mountain ranges.] Essex Inst, B 9:163-165 (1877)

77d Geology of the White Mountains [N. H.]. Appalachia 1:70-76 (1877)

77e Note upon the Connecticut Valles Helderberg. Am J Sc (3) 13:313-314 (1877)

77f The earlier forms of life. Pop $\mathrm{Sc}$ Mo $10: 257-272$ (1877)

$77 \mathrm{~g}$ Geology [and geological map of Ner Hampshire and Vermont] In Walling, H. F., Atlas of the State of New Hamp shire... : 9-17, 44-45 (map), N Y, Com stock \& Cline, 1877

78 (and others) The geology of Ner Hampshire... Parts III-V [vol 3]. 386. 262,103 pp, Concord 1878 
Hiteheoek, Charles Henry-Continued.

78a Glacial drift. Geology of N H, pt 3 [rol 3] : 177-338 (1878)

$\mathbf{7 8 b}$ The Atlantlc system of mountains. Geology of $\mathrm{N} \mathrm{H}$, pt 3 [vol 3]:366-371 (1878)

78e The geological map [of New Hampshire]. Geology of $\mathrm{N} \mathrm{H}$, pt 3 [vol 3] : 371372 (1878)

78d Economic geology [of New Hampshire]. Geology of N H, pt V [vol 3] : 103 pp, map (1878)

7Se Atlas accompanying the report on the geology of New Hampshire. N Y 1878

78f The geology of the Ammonoosuc mining district. (An extract from the Geology of New Hampshire.] $121 \mathrm{pp}$, maps, Concord 1878

78g Glacial markings among the White Mountains [N. H.]. Appalachia 1:243246 (1878)

79 Report on the Ammonoosuc gold fields, N. H. 11 pp [priv pub, n p, 1879]

$79 a$ The glacial period in eastern America. G Mag (2) 6:248-250 (1879)

79b The Loraine group. Science News 1:153-155 (1879)

81 North America in the ice period. Pop Se Mo $20: 229-242$ (1881)

81 a Geological map of the United States [explanatory text]. $29 \mathrm{pp}, \quad \mathrm{N} \quad \mathrm{Y} 1881$ Notice, Am J Sc (3) 21:505-506 (1881)

82 The crystalline rocks of Virginla compared with those of New England. Am I If Eng, $\operatorname{Tr} 10: 477-480$ (1882) The Virginlas 4 : 11-12 (1883)

s2a On Flat Top coal fleld [W, Va.]. The Virginias $3: 81$ (1882)

83 The early bistory of the North American Continent. Science 2: 293-297 (1883) Am As, Pr 32:181-193 (1884) Sc Am Sup 16:6468-6470 (1883)

$83 a$ The glacial flood of the Connecticut River valley $(a b s t)$. Am As, Pr 31 : 325329 (1883)

84 Description of geological sections crossing New Hampshire and Vermont. 33 pp, Concord, N H., 1884 Notice by J. D. Dana, Am J Sc (3) 29:66 (1885)

84a Geological sections across New Hampshire and Vermont. Am Mus N H, B 1:155-179 (1884) Also, with title, Description of geological sections crossing New Hampshire and Vermont, 33 pp, Concord, N. H., 1884

84b The geological position of the Philadelphia gneisses (with discussion by $P$. Frazer and T. D. Rand). Am I M Eng, Tr $12: 68-71$ (1884)

84e Identification of the Green Mountain gneisses in eastern New England (abst). Am As; Pr 33:396-397 (1885) Science $4: 327$ (1884)
Hitcheeck, Charles Henry-Continued. 85 The geology of northern New England (contains The geology of Vermont, $\mathbf{5}$ pp March 1st 1870; Geology [of Maine], 4 pp, map [1885]; [New Hampshire] topography [and] geology, $17 \mathrm{pp}$, map [of N. H. and Vt.] [1874]), folio (1885?)

S5a The crystalline rocks of Alabama. Am J Sc (3) 30:278-283 (1885)

85b The recent landslide in the White Mountains. Science 6:84-87 (1885)

85c The latest slides in the White Mountains. Science 6:306 (1885)

87 The geological map of the United States, Am I M Eng, Tr 15:465-488, map (1887)

S7a The late eruption from Kilauea. Science $9: 180-185$ (1887)

8s Date of publication of the report upon the geology of Vermont. Boston Soc $\mathrm{N} \mathrm{H}, \operatorname{Pr} 24: 33-37$ (1888)

SSa Report of the subcommittee on the Quaternary and Recent. In International Congress of Geologists, American Committee, Reports... H 12 pp, Phila 1888 Am G 2:300-306 (1888) Int $G$ Cong, IV, Lonđon 1888, C R App A : 211-219 (1891)

88b Genesis of the Hawailan Islands (abst). Am As, Pr 36:222-223 (1888)

89 Recent progress in ichnology. Boston Soc N H, Pr 24: 117-127 (1889)

89a Conglomerates in New England gueisses. Am G 3:253-256 (1889)

89b The discovery of fossil tracks in the Triassic of York Co., Pa. Am As, Pr 37 : 186 (1889)

90 The use of the terms Laurentian and Newark in geological treatises. Am G 5 : 197-202 (1890)

90a Significance of oval granitoid areas in the lower Laurentian (abst, with discussion by G. H. Williams). G Soc Am, B 1:557-558 (1890)

90b Wright's "Ice age in North America and its bearings on the antiquity of man." Bibliotheca Sacra 47:99-121 (1890)

90e Field studies of hornblende schist (abst). Am As, Pr 38:251 (1890)

91 The Redonda phosphate (with discussion by N. H. Winchell). G Soc Am, B 2 : 6-9 (1891)

92 Studies of the Connecticut valley glacler (with discussion). G Soc Am, B 4: 3-7 (1892) Abst, Am G 10:193-194, 217218 (1892)

92a Terminal moraines in New England (abst). Am G 10:219-220 (1892) Am As, Pr $41: 173-175$ (1892)

92b The Green Mountains' anticlinal. Science $20: 328$ (1892)

93 Glaciation of the White Mountains, N. H. G Soc Am, B 5: 35-37 (1893)

$93 a$ A single glacial epoch in New Eng. land. Am G 11: 194-195 (1893)

94 Ancient eruptive rocks in the White Mountains [N. H.] (abst). Am G 13:213 (1894) 
Hitcheoek, Charles Henry-Continued. 95 The Connecticut sandstone group. Science n s 1:74-77 (1895)

95a Divisions of the ice age in the United States and Canada. Am G 15:330335 (1895)

95b Edward Hitchcock. Am G 16:133149 , port. (1895)

95e High-level gravels in New England (abst with discussion by J. W. Spencer). G Soc Am, B 6:460-461 (1895) Am G 15: 199 (1895) Science n s 1:60 (1895)

95d Champlain glacial epoch (abst). G Soc Am, B 7:2-4 (1895) Am G 16:235236 (1895) Science $n$ s $2: 278$ (1895) Ottawa Nat 9:151 (1895)

95e Gotham's cave; or fractured rocks in northern Vermont (abst). Am G 16: 248 (1895) Am As, Pr 44: 133 (1896)

96 The geology of New Hampshire. J G 4: 44-62 (1896)

96a Paleozoic terranes in the Connect1cut Valley $(a b s t)$. G Soc Am, B 7:510512 (1896) Am G 17:105-107 (1896) Science n s $3: 56$ (1896)

97 Sketch of W. W. Mather. Am G 19: 1-15, port. (1897)

$97 \mathbf{a}$ The eastern lobe of the ice sheet. Am G 20:27-33 (1897)

$97 \mathbf{b}$ Note on the stratigraphy of certain homogeneous rocks (abst). G Soc Am, B $8: 389-390$ (1897) Science n $8 \quad 5: 86$ (1897)

98 Recent progress in ichnology. U S G S, Mon 29:400-406 (1898)

9Sa The Hudson River lobe of the Laurentide ice sheet $(a b s t)$. Am As, $\operatorname{Pr}$ 47:292 (1898) Am G 22:255 (1898)

Science n s 8: 467 (1898)

$98 \mathbf{b}$ The southern lobe of the Laurentian ice sheet (abst). Brit As, Rp 67:653-654 (1898)

00 William Lowthian Green and his theory of the evolution of the earth's features. Am G 25: 1-10, port (1900)

O0a Geology of Oahu. G Soc Am, B $11: 15-57$, map (1900)

Oob Evidences of interglacial deposits in the Connecticut Valley (abst). G Soc Am, B 12:9-10 (1900) Sc Am 83:22 (1900)

O0e Volcanic phenomena on Hawail. G Soc Am, B 12: 45-56 (1900)

01 The story of Niagara. Am Antiquarian $23: 1-24$ (1901) N Y, Comm St Res Niagara, An Rp 17: 75-107 (1901)

01a Tuff cone at Diamond Head $\mathrm{Ha}$ wailian Islands $(a b s t)$. G Soc Am, B 12 : 462 (1901) Science n s 13:98 (1901)

03 Notice of a species of Acidaspis from a boulder of Marcellus shale, found in drift, at West Bloomfield, N. J. Am Mus N H, B 19:97-98, il (1903)

03a Mohokea caldera on Hawail. G Soc Am, B 14:6-8 (1903) Abst, Science n s $16: 260$ (1902)
Hitehcoek, Charles Henry-Continod. 03b Protection of terraces in the uppe Connecticut River (abst). Science n 81 : 224 (1903) J G 11:121-123 (1903)

04 Glaciation of the Green Mounth Range. Vt, St G, Rp 4:67-85 (1904)

$04 a$ New studies in the Ammonoos district of New Hampshire. G Soc Am, ? 15:461-482, map (1904) Abst, Scienc n s $19: 524$ (1904); Sc Am Sup 57:234f (1904)

05 The geology of Littleton, N. H. (Rt printed from History of Littleton.) $32 \mathrm{~m}$ map, Cambridge, U. S. A., 1905

O5a Kilauea again active. Science $\mathbb{1}$ $21: 551$ (1905)

05b Fresh-water springs in the ocen Pop Se Mo 67:673-683 (1905)

06 Surfacial geology of the region abot Burlington [Vt.] Vt, St G, Rp 5:232-25 (1906)

06a The Champlain deposits of northen Vermont. Vt, St G, Rp 5: 236-253 (1906) o6b Geology of Diamond Head, 0abr G Soc Am, B 17:469-484 (1906)

o6e Mohokea caldera [Hawaii]. G So Am, B $17: 485-496$ (1906)

o7 Glacial Lake Memphremagog (abr) Science n s 25:773 (1907) G Soc Am, ? 18: $641-642$ (1908)

os Geology of the Hanover, N. H., quat rangle. Vt, St G, $\mathrm{Rp} 6: 139-186$ (1906) Abst, Science n s 28:381-384 (1908)

osa News from Kilauea. Seience \& 28: 19-20 (1908)

OSb (and Patten, W.) Studies of th tracks of Climatichnites (abst). Science! s 28:382 (1908)

09 Hawail and its volcanoes. 314 w Honolulu 1909 2d ed, with sup 1911

o9a The volcano Kilauea. Am Geog Soc

B $41: 684-691$ (1909)

10 Surfacial geology of the Champlas basin. Vt, St G, Rp 7: 199-212 (1910)

10a Supplementary note on the organlat tion of the Geological Society of Americh. G Soc Am, B $21: 741-746$ (1910)

11 The geology of Oahu in its relation to the artesian supply. Hawailan Foreste and Agriculturist 8: 27-29 (1911)

12 The Strafford quadrangle. Vt, st $\mathrm{G}_{\mathrm{H}}$ Rp 8: 100-145 (1912)

12a Tertiary deposits of Oahu (absth. G Soc Am, B 23:71 (1912)

12b The Hawailian earthquakes of 1868 Seism Soc Am, B 2:181-192, maps (1912)

15 Tertiary rocks of Oahu [Hawaliat Islands] (abst). G Soc Am, B 26:133134 (1915)

See also Brainerd (E), 90 ; Chamberlit 91c; Davis (W M), 91 ; Geiger, 91 ; Hawes 84 ; McGee, $91 \mathrm{~g}$; Salisbury, $93,93 \mathrm{a}$; Wis chell (N H), $88 \mathrm{~g}$

Hitehcoek, Edward (1793-1864).

15 Southampton lead mine [Mass.] basaltic columns [Mount Holyoke, Mass. N Am Rv 1: 334-338 (1815) 
Hitcheock, Edward-Continued.

18 ... geology and mineralogy of a section of Massachusetts on Connecticut River, with a part of New Hampshire and Vermont. Am J Sc 1: 105-116, 436-439, map (1818)

23 ... geology, mineralogy, and scenery of the regions contiguous to the River Connecticut, with a geological map and drawings of organic remains. Am $J$ Sc 6 : $1-86,201-236 ; 7: 1-30$ (1823)

24 ... geology of Marthas Vineyard and the Elizabeth Islands. Am J Sc $7: 240$ 248 (1824)

24a Notice of a singular conglomerate, and of an interesting locality of trap tuff or tufa. Am J Sc 8:244-247 (1824)

25 Notice of several localities of minerals in Massachusetts. Am J Sc 9:20-23 (1825)

26 Chlorophoeite [Turners Falls, Mass.]. Am J Sc 10:393-394 (1826)

28 Miscellaneous notices of mineral 10calities, with geological remarks. Am J Se $14: 215-230$ (1828)

29 Tin in Massachusetts. $\Delta \mathrm{m}$ J Sc 16 : 188-191 (1829)

32 Report on the geology of Massachusetts ... Am J Sc 22:1-70, map (1832)

32a A geological map of Massachusetts [to accompany Report on the geology of Mass., 1833] Boston [1832] [not seen] [also later editions]

33 Report on the geology, mineralogy, botany, and zoology of Massachusetts. 700 pp, map, il (in atlas), Amherst 1833 2d ed, $702 \mathrm{pp}$, Amherst 1835

35 On certain causes of geological change now in operation in Massachusetts. Boston J N H 1: 69-82 (1835)

35a The connection between geology and natural religion. Biblical Repository 5 : 113-138 (1835)

35b The connection between geology and the Mosaic history of the creation. Biblical Repository $5: 439-450 ; 6: 261-332$ (1835)

36 Description of the footmarks of birds (ornithichnites) on new red sandstone in Massachusetts. Am J Sc 29:307-340, il (1836)

36a Ornithichnites in Connecticut. Am J Sc 31:174-175 (1836)

36b Sketch of the geology of Portland [Me.] and its vicinity. Boston $J$ N H $1: 306-347$, map (1836)

36e Remarks on Professor Stuart's examination of Gen. 1, in reference to geology. Biblical Repository 7 : 448-487 (1836)

37 Fossil footsteps in sandstone and graywacke. Am J Sc 32:174-176 (1837)

37a Researches in theoretical geology, by $\mathrm{H}$. T. de la Beche, with preface and notes by Prof. Edward Hitchcock. 342 pp, N Y 1837
Hitehcoek, Edward-Continued.

38 Report on a re-examination of the economical geology of Massachusetts. 139 pp, Boston 1838

40. Elementary geology. Amherst 1840 Numerous later editions.

41 Final report on the geology of Massachusetts; Vol. I, containing economical geology, scenographical geology ; Vol. II, containing scientific geology, elementary geology. Vol I : xil, 1-299, map, Amberst 1841; vol II : 301-831, il, map, Northampton 1841

41a First anniversary address before the Association of American Geologists at their second annual meeting in Philadelphia, April 5, 1841. Am J Sc 41:232-275 (1841) Reprint, 48 pp. New Haven (1841)

$41 b$ [On joints in rocks] (abst). Am J Sc $41: 173$ (1841) As Am G, Rp : 25-26 (1843)

42 On the phenomena of drift in this country (abst with discussion). Am J Sc $43: 151-154$ (1842) As Am G, Rp : 45-49 (1843)

42a Remarks upon Mr. Murchison's anniversary address... [explanation of drift phenomena ]. Am J Sc $43: 396-398$ (1842)

43 The phenomena of drift, or glacioaqueous action in North America between the Tertiary and alluvial periods. As Am G, Rp : 164-221 (1843)

$43 a$ [On drift phenomena]. Am $\mathrm{J} \mathrm{Sc}$ $45: 324-325$ (1843)

43b Description of five new species of fossil footmarks, from the red sandstone of the valley of Connecticut River. As Am G, Rp : 254-264, il (1843)

43e Description of several species of fossil plants from the new red sandstone formation of Connecticut and Massachusetts. As Am G, Rp : 294-296, II (1843)

44 Explanation of the geological map attached to the topographical map of Massachusetts. 22 pp, Boston 1844

44a Geological map of Massachusetts. Scale, 5 miles to 1 inch or 1:316 800 . Inset on Topographical map of Massachusetts [Simeon Borden], Boston 1844

44b The trap tufa or voleanic grit of the valley of the Connecticut River (abst). Am J Sc 47: 103-104 (1844)

44c Dispersion of blocks of stone at the drift period in Berkshire County, Mass. (abst). Am J Sc 47:132-133 (1844)

44d Report on ichnolithology or fossil footmarks, with description of several new species and the coprolites of birds, and of a supposed footmark from the valley of Hudson River. Am J Sc $47: 292-322$, il ; (abst) 113-114 (1844)

44e Discovery of more native copper in the tom $n$ of Whately in Massachusetts, in the valley of the Connecticut River, with remarks upon its origin. $A m$ J Sc 47 : $322-323$ (1844) 
Hitchcock, Edward-Continued.

44P (with Deane, James.) On the discovery of fossil footmarks. Am J Sc 47 : 381-401 (1844)

45 ... on fossil footmarks, the lincolnite, etc. $\mathrm{Am} \mathrm{J} \mathrm{Sc} \mathrm{48:61-65} \mathrm{(1845)}$

45a Description of a singular case of the dispersion of blocks of stone connected with drift in Berkshire Co., Mass. Am J Sc $49: 258-265$ (1845)

45b An attempt to name, classify, and describe the animals that made the fossil footmarks of New England $(a b s t)$. As Am G, Pr 6: 23-25 (1845)

45e Remarkable facts respecting the magnetic polarity of trap rocks in New England (abst). As Am G, Pr 6:32 (1845)

46 [Notes on the geology of Vermont.] In Adams, C. B., Second annual report on the geology of the State of Vermont : 247252 (1846)

47 Description of two new species of fossil footmarks found in Massacbusetts and Connecticut. Am J Sc (2) 4:46-57, il (1847)

47a On the trap tuff, or volcanic grit, of the Connecticut Valley, with the bearings of its history upon the age of the trap rock and sandstone generally in that valley. Am J Sc (2) 4:199-207 (1847)

47b [On drift phenomena in New England.] Am J Agr 6: 216 (1847)

48 An attempt to discriminate and de scribe the animals that made the fossil footmarks of the United States and especially of New England. Am Ac Arts, Mem n s $3: 129-256$, il (1848)

50 On the river terraces of the Connecticut Valley, and on the erosions of the earth's surface. $\Delta \mathrm{m}$ As, $\operatorname{Pr} 2: 148$ 156 (1850)

$\mathbf{5 1}$ The religion of geology and its connected sciences. $408 \mathrm{pp}$, Glasgow [1851] 511 pp, Boston 1852 2d ed, 592 pp, Boston 1859

$51 a$. On the erosions of the earth's surface, especially by rivers. Brit As, Rp $20: \sec 85-87 \quad$ (1851)

51b On terraces and ancient seabeaches, especially those on the Connecticut River and its tributaries in New England. Brit As, Rp 20: sec 87-88 (1851)

52 Description of a slide on Mount Lafayette, at Franconia, N. H. Am J Sc (2) $14: 73-76$ (1852)

52a On the terraces and seabeaches that have been formed since the drift period, especially those along the Connecticut River. Am As, Pr 6: 264-269 (1852)

52b On the geological age of the clay slate of the Connecticut Valley in Massachusetts and Vermont. Am As, $\operatorname{Pr} 6$ : 299-300 (1852)

53 Outline of the geology of the globe, and of the United States in particular... $136 \mathrm{pp}$, il, maps, Boston $18532 \mathrm{~d}$ ed, Boston $18543 \mathrm{~d}$ ed, Boston 1856.
Hitehcock, Edward-Continued.

53a Report on certain points in the geology of Massachusetts. Massachusetts, Commonwealth, House ... no $39: 44 \mathrm{pp}, \mathbb{L}$ maps [Boston 1853]

53b Report on the coal field of Bristal Co. and of Rhode Island. In Mass, $\mathrm{H} \mathbb{B}$ no $45: 20$ pp [Boston? 1853]

53e Notes upon the specimens of rods and minerais collected. In Marcy, R. B, Exploration of the Red River of Louisian in the year 1852; U S, 32d Cong $2 \mathrm{~d}$ sess S Ex Doc 54:163-178 (1853); U S, 330 Cong 1st sess, H Ex Doc: 140-155 (18it)

53d Description of a brown coal deposit In Brandon, Vermont, with an attempt to determine the geological age of the priscipal hematite ore beds in the United States. Am J Sc (2) $15: 95-104$, il (1853)

53e The coal field of Bristol County and of Rhode Island. Am J. Sc (2) 16: $327-336$ (1853) M Mag 1:582-591 (1853)

54 [On fossi] footmarks of the Connec. ticut Valley.] Boston Soc N H, Pr 4:378379 (1854)

56 On a new fossil fish and new fossl footmarks. Am J Sc (2) $21: 96-100$ (1856)

56a Description of a large boulder in the drift of $\Delta$ mherst, with parallel strint upon four sides. Am J Sc (2) $22: 39$ i400 (1856)

$56 b$ Description of ... the sandstone and trap of Connecticut River valley in Mas sachusetts. Am As, Pr 9:225-227 (1856)

56e Additional facts respecting the tracks of the Otozoum moodii on the Lias. sic sandstone of the Connecticut Valley. Am As, Pr 9:228 (1856)

56d Account of the discovery of the for sil jaw of an extinct family of sharks, from the coal formation [Park Co., Ind.]. Am As, $\operatorname{Pr} 9: 229-230$, il (1856)

57 Illustrations of surface geologs. Smiths Contr Knowl 9 art $3: 155$ pp, maps (1857) $2 \mathrm{~d}$ ed, $155 \mathrm{pp}$, maps, Amberst 1860

$\mathbf{5 7 a}$ Report on the geological survey of the State of Vermont. 12 pp, Montpelier 1857

$\mathbf{5 7 b}$ [On impressions in the sandstone from Turner's Falls on Connecticut Rirer, Mass.] Boston Soc N H, Pr 6: 111 (1857) 57e [On fossil fruits from Brandon lif. nite deposits, vt.] Am Ac Arts, Pr $3: 3$ (1857)

57d On the age and dip of the Connecticut River sandstones, and the intercalation of the associated trap (abst). Edinb $N$ $\mathrm{Ph}$ J n s $6: 354$ (1857)

58 Ichnology of New England; a report on the sandstone of the Connecticut Val. ley, especially its footmarks... xil, $220 \mathrm{pp}$. 11, map, Boston 1858

58a Report on the geological surves of the State of Vermont. 13 pp, Burlington 1858 
Hiteheock, Edward-Continued. 59 Preliminary report on the geology of Vermont. $16 \mathrm{pp}$, Montpelier 1859

$59 a$ [Catalogue of the collection of rocks, minerals; and fossils in the State cabinet of Massachusetts.] Mass Bd Agr, An Rp 6: App iii-lxix (1859)

59b Devonian granites and Taconic rocks (abst with discussion). Can Nat 4: 298 (1859)

60 [On distorted pebbles in the conglomerate of Vermont (with discussion by C. T. Jackson).] Boston Soc N H, Pr $7: 353-$ $354(1860)$

61 (and others) Report on the geology of Vermont; descriptive, theoretical, economical, and scenographical. Vol. 1, 558 pp, vol, 2, 982 pp, maps, il, Claremont N H., $1861 \quad \mathrm{Rv}$ and summary by E. Billings, $A \mathrm{~m}$ J Sc (2) $33: 416-420$ (1862)

61a Remarks upon certain points in ichnology. Am As, Pr 14:144-156, il (1861) 61b On certain conglomerated and brecciated trachytic dikes in the lower Silurian rocks of Shelburne, in Vermont... Am As, Pr 14:156-158 (1861)

61e Additional facts respecting the Clathropteris of East Hampton, Mass. Am As, Pr 14:158-159 (1861)

61d on the conversion of certain conglomerates into talcose and micaceous schists and gneiss, by the elongation, flattening, and metamorphosis of the pebbles and the cement. $\Delta \mathrm{m} \mathrm{J} \mathrm{Sc} \mathrm{(2)} \mathrm{31:372-}$ 392 (1861)

61e (and Hitcheock, C. H.) Geological map of the United States. Compiled for R. P. Smith's Wall map of the United States [not seen]

63 Reminiscences of Amherst College... Northampton, Mass., 1863

63a New facts and conclusions respectIng the fossil footmarks of the Connecticut Valley, Am J Sc (2) $36: 46-57$, il (1863) 65 Supplement to the Ichnology of New England. A report to the government of Massachusetts in 1863. $96 \mathrm{pp}, \mathrm{il}$, Boston 1865

66 (and Hiteheock, C. H.) Elementary geology. New ed, $430 \mathrm{pp}$, N Y 1866 66a Supplement to the ichnology of New England. Am Ac Arts, Pr 6:85-92 (1866)

72 Discovery of a tooth of a mastodon In Massachusetts. Am J Sc (3) $3: 146$ (1872).

See also Dana (S L), 45 ; Jackson, 43c; Nicollet, $43 \mathrm{~b}$

Hiteheock, Edward, jr.

55 Description of a new species of Clathropteris discovered in the Connecticut Valley sandstone. Am J Sc (2) 20:2225, Il (1855)

56 A new fossil shell in the Connecticut Rlver sandstone, Am J Sc (2) $22: 239$ 240 (1856)
Hiteheock, Edward, Jr.-Continued.

59 A Vermont whale. Edinb $\mathrm{N} \mathbf{P h} \mathrm{J}$ n s $10: 299$ (1859)

Hiteheoek, Fanny R. M.

87 On the homologies of Edestus (abst). Am Nat 21: 847-848 (1887) Am As, Pr $36: 260-261$ (1888)

Hitchings, S. K.

85 Handbook of mineralogy. 60 pp, Biddeford, Me., 1885 [not seen]

Hixon, Hiram W.

o5 Geology of the Sudbury district [Ont.] Eng M J 79:334-335 (1905)

05a Volcanoes and earthquakes. Eng M J $79: 1245$ (1905)

06 The origin of earthquakes. Fng M J 81:864 (1906)

$06 \mathbf{a}$ The geological age of the earth as compared to the life of the sun. M Se Press 92: 297 (1906)

$\mathbf{0 6 b}$ The ore deposits and geology of the Sudbury district [Ont.] Can M Inst, J 9 : 223-235 (1906)

o6e The Sudbury nickel region. Eng M J $82: 313-314$ (1906)

o7 Genesis of ores of the Cobalt district. Eng M J 83:630 (1907)

07a Ore deposition. M Sc Press 94: 593-594 (1907)

оть Voleanic ash. M Sc Press 95: 809 (1907)

OS A theory of ore deposition. M Sc Press 96:800-801 (1908)

O8a Waters, meteoric and magmatic. M Sc Press $97: 82-83$ (1908)

08b The origin of coal. Eng M J 86: 238-239 (1908)

ose The relation of magmatic waters to volcanic action. Franklin Inst, J 166 : 297-307 (1908)

09 Earthquakes in the light of the new seismology. Franklin Inst, J 168:227234 (1909)

09a [Origin of the Sudbury, Ont., ores.] Inst M Met Tr 18: 196-198 (1909)

$09 \mathrm{~b}$ A theory of volcanic action and ore deposits, their nature and cause. Inst $\mathbf{M}$ Met, $\operatorname{Tr} 18$ : 202-219, 231-254 (1909)

10 Vulcanism and differential pressure in ore deposition. Ec G 5: 564-568 (1910)

11 Unsolved problems or geology [cause of faulting, earthquakes, volcanic action, metamorphism, thermal waters, mountain making, etc.]. Mines and Methods 2 no 5 : 101-107, no 7:151-152; [repeated in] 3 no $4: 361-367$ (1911)

Hixson, W. A.

14 Analyses of Iowa coals... Iowa G S, An Rp 24: 687-763, map (1914)

Hlawatseh, C.

o9 Bemerkungen uber den Benitoit. Zs Kryst $46: 602-603$ (1909)

09a Die Kristallform des Benitolt. Centralbl Miner 1909: 293-302, 410

o9b Bemerkungen über die Krystallklasse des Benitoit. Tschermaks Mitt N F $28: 178-181$ (1909) 
Hlarvatseh, C.-Continued.

o9e Bemerkungen zum Aragonit von Rohitsch, Natrolit, und Naptunit von S. Benito. Tschermaks Mitt N F 28:293-296 (1909)

10 Ueber Prehnit von Guanajuato, Mexiko. Tschermaks Mitt N F 29:249-255 (1910)

Hoadley, Charles W.

17 A mineralogical pilgrimage through Connecticut. Am Mineralogist 2:99-100 (1917)

18 An American occurrence of cronstedtite [Long Hill, Trumbull Township, Conn.]. Am Mineralogist 3:6 (1918)

Hobbs, Barnabas C.

72 Report of geological survey of Parke Co. Ind G S, An Rp 3-4: 341-384, map (1872)

Hobbs, Walter E.

99 Some new fossils from eastern Massachusetts. Am G 23:109-115, il (1899)

Hobbs, William Herbert.

$\mathbf{8 8}$ On the petrographical characters of a dike of diabase in the Boston Basin. Harvard Coll, Mus C $\mathrm{Z}$, B 16 (g s 2): 1-12 (1888)

88 . On the rocks occurring in the neighborhood of Ilehester, Howard Co., Md. Johns Hopkins Univ Circ 7:69-70 (1888)

$88 b$ On the use of the microscope in petrography. Am Mo Micro J 9:70-74 (1888)

89 On the paragenesis of allanite and epidote as rock-forming minerals. Am J Se (3) $38: 223-228$ (1889) Tschermak's Mitt 11:1-6 (1889)

92 Secondary banding in gneiss. G Soc Am, B 3:460-464 (1892)

$92 a$ Notes on some pseudomorphs from the Taconic region. Am G 10:44-48 (1892)

92b On some metamorphosed eruptives in the crystalline rocks of Maryland. Wis Ac Sc, $\operatorname{Tr} 8: 156-160$ (1892)

92e Note on cerusite from Illinols and Wisconsin. Wis Ac Sc, Tr 8:399-400 (1892)

92d On intergrowths of hornblende with augite in crystalline rocks. Science 20: 354 (1892)

92e (with Culver, G. E.) On a new occurrence of olivine diabase in Minnehaha Co., S. Dak. Wis Ac Sc Tr 8:206-210 (1892)

93 On the geological structure of the Mount Washington mass of the Taconic Range [Mass.]. J G 1:717-736, map (1893) Abst, Am Nat 28: 158-160 (1894)

93a The geological structure of the Housatonic Valley lying east of Mount Washington. J G 1:780-802 (1893) Abst, Am G 13: 142 (1894)

93b Phases in the metamorphism of the schists of southern Berkshire [Mass.]. G Soc Am, B 4: 167-178 (1893)
Hobbs, William Herbert-Continued.

93e On a rose-colored lime-and aluminabearing variety of talc. Am J Sc (3) 45 : 404-407 (1893)

93d New occurrence of parallel inter. growths of the minerals allanite and epldote. Am G 12: 218-219 (189B)

94 On a recent diamond find in Wiscon. sin and on the probable source of this and other Wisconsin diamonds. Am G 14:3135 (1894)

94a Differential faults. Am G $14: 35-$ 37 (1894)

94b Note on the English equivalent of Schuppenstruktur. J G 2: 206 (1894)

94e Volcanite, an anorthoclase augite rock chemically like the dacites (abst). G Soc Am, B 5:598-602 (1894) Am G $13: 214$ (1894)

$94 d$ [Notes on] mineralogy. Am Nat vols. $28-29(1894-5)$

95 Mineralogical notes. Am J Sc (3) 50: 121-128 (1895)

95a A contribution to the mineralogy of Wisconsin. Wis Univ, B, sc s 1:109-156 (1895)

95b Die krystallisirten Mineralien aus dem "Galena limestone" des südlichen Wisconsin und des nördlichen Illinois. Zs Kryst 25 : 257-275 (1895)

95e Pre-Cambrian volcanoes in soutber Wisconsin $(a b s t)$. Am G 16:240 (1895) Science n \& 2:279 (1895)

96 Chloritoid from Michigan-a correction. Am J Sc (4) $2: 87$ (1896)

$96 a$ Diamanten von Wisconsin. N Jb 1896 II : 249-251

97 Note on the geology of southwestern New England. J G 5:175-177 (1897)

99 Goldschmidtite, a new mineral. Am J Sc (4) $7: 357-364$ (1899) Zs Kryst 31; 417-425 (1899)

99a A spiral fulgurite from Wisconsin. Am J Sc (4) 8:17-20 (1899)

99b The diamond fleld of the Great Lakes. J G $7: 375-388$, map (1899)

99e Emigrant diamonds in America. Pop Sc Mo 56:73-83 (1899) Smiths Inst, An Rp 1901:359-366 (1902)

oo Suggestions regarding the classification of the igneous rocks. J G $8: 1-31$ (1900)

OOa A theory of origin of systems of nearly vertical faults $(a b s t)$. G Soc Am, B 12:10-11 (1900) Sc Am 83: $22(1900)$

oob Newark formation of the Pomeraug Valley, Conn. (abst). Science n s 11:141142 (1900) Eng M J 69:166 (1900)

01 The Newark system of the Pomperaug Valley, Conn. U S G S, An Rp 21 pt $3: 7-160$, maps (1901)

o1a The old tungsten mine at Trumbull, Conn. U S G S, An Rp 22 pt 2:7-22, maps (1901) 
Hobbs, William Herbert-Continued.

01b Still rivers of western Connecticut. G Soc Am, B 13:17-26 (1901) Abst, Am As, Pr 49:190 (1900) ; Science n s 12:993 (1900)

01e The river system of Connecticut. J G 9:469-485, maps (1901) Abst, Science n s 11:142 (1900)

01d Connecticut rivers. Science n s 14 : 1011-1012 (1901)

01e Diamondiferous deposits in the United States, Mineral Industry $9: 301$ 304 (1901)

01f The geologist awheel. Pop Sc Mo $58: 515-518$ (1901)

02 Former extent of the Newark system. G Soc Am, B 13: 139-148, map (1902)

02a The mapping of the crystalline schists. J G 10:780-792, 858-890 (1902)

02b An instance of the action of the ice sheet upon slender projecting rock masses. Am J Sc (4) $14: 399-403$, map (1902)

02e Edward Orton. Wis Ac Sc, Tr 13: 610-613, port (1902)

02d A meteoric iron [Algoma, Kewaunee Co., Wis.]. Science n s $15: 826$ (1902)

02e Geology of the river channels about Manhattan Island (abst). N Y Ac Sc, An $15: 74-76$ (1903) Sclence n s $16: 905-$ 906 (1902)

03 Meteorite from Algoma, Wis. G Soc Am, B 14:97-116 (1903) Abst, Science ns $16: 260$ (1902)

03a The geological structure of the southwestern New England region. Am J Sc (4) $15: 437-446$ (1903)

03b Tungsten mining at Trumbull, Conn. U S G S, B $213: 98$ (1903)

03e The frontier of physiography. Science n s $18: 538-540$ (1903)

03d Evidences of post-Newark normal faulting in the crystalline rocks of southwestern New England (abst). Science $\mathrm{n} \mathbf{8}$ $17: 223$ (1903) J G 11:118-119 (1903)

03e A record of post-Newark depression and subsequent elevation within the area of southwestern New England (abst). Science n \& $17: 223$ (1903) J G 11:119120 (1903)

038 Configuration of the rock floor of the vicinity of New York (abst). Science I s $17: 298$ (1903) Sc Am Sup 55:22647 (1903)

04 Lineaments of the Atlantic border region. G Soc Am, B 15:483-506, map (1904) Int Geog Cong, VIII, Rp : 193-203 (1905) Abst, Science n s 19:527 (1904); Sc Am Sup 57: 23446 (1904)

04a Tectonic geography of southwestern New England and southeastern New York (abst). G Soc Am, B 15:554-557 (1904) Science n s $19: 527$ (1904) Sc Am Sup 57: 23446 (1904)

05 The configuration of the rock floor of greater New York. U S G S, B 270:96 pp, maps (1905)
Hobbs, William Herbert-Continued.

05a Origin of the channels surrounding Manhattan Island, N. Y. G Soc Am, B 16: 151-182, map (1905)

05b The correlation of fracture systems and the evidences of planetary dislocations within the earth's crust. Wis Ac Sc, Tr 15: 15-29 (1905)

05e Examples of joint-controlled drainage from Wisconsin and New York. J G $13: 363-374$ (1905)

osd Contributions from the mineralogical laboratory of the Unlversity of Wisconsin. Am G 36:179-186 (1905)

06 On two new occurrences of the "Cortlandt series" of rocks within the State of Connecticut. Festschrift Harry Rosenbusch : 25-48, Stuttgart 1906

06a America and seismological research. Pop Sc Mo $69: 226-228$ (1906)

o6b Suggestions regarding a petrographic nomenclature based on the quantitative classification ( $\dot{a} b s t)$. Cong Arts and Sc (St. Louis 1904) 4:604 (1906)

07 Earthquakes, an introduction to seismic geology. 336 pp, N Y 1907

ora On some priciples of seismic geology. Beitr Geoph 7 : 219-292 (1907)

07b [Seismological research]. J G 15 : 182-184 (1907)

07e The recent advance in seismology. J G $15: 288-297,396-409$ (1907)

07d The iron ores of the Salisbury district of Conn., N. Y., and Mass. Ee Ge 2 : 153-181 (1907)

o7e Some topographic features formed at the time of earthquakes and the origin of mounds in the Gulf plain. Am $\mathrm{J}$ Se (4) $23: 245-256$ (1907)

ozf Origin of ocean basins in the light of the new seismology. G Soc Am B 18: 233-250 (1907) Abst, Science n s 25: 766 (1907)

07s Nathaniel Southgate Shaler. Wis Ac Sc, Tr 15: 924-927, port (1907)

orh The Charleston earthquake of August 31st, 1886, in a new light. G Mag (5) $4: 197-202$ (1907)

o7i (and Leith, C. K.) The pre-Cambrian voleanic and intrusive rocks of the Fox River valley, Wis. Wis Univ, B 158 sc s $3: 247-277$ (1907)

o7j Earthquakes viewed in a new light. Mich Ac Sc, Rp $9: 43-56$ (1907)

o7k Seismotectonic lines and lineaments-a rejoinder. Science n s 26:253255 (1907)

08 A study of the damage to bridges during earthquakes. $J$ G $16: 636-653$ (1908) Abst, Int Cong Geog, IX, C R 2: 214-219 (1910)

O8a Earth movements in the Laurentian basin since its occupation by the ice (abst). Science n s 27: 725 (1908) 
Hobbs, William Herbert-Continued.

08b Apparatus for instruction in geography and structural geology. Scottish Geog Mag 24:643-652 (1908) School Science and Mathematics $8: 566-570,662-$ 668 (1908) ; $9: 644-653$ (1909)

o8e (with Johnson, W. D.) The earthquake of 1872 in the Owens Valley, Cal. (abst). Science n s 27:723 (1908)

09 The evolution and the outlook of seismic geology. Am Ph Soc, Pr 48:259302 (1909) A3st, Science n 8 29:833 (1909)

09a Recent earth movements within the basin of the Laurentian lakes (abst). Brit As Rp 78: 707 (1909)

10 Soil stripes in cold humid regions, and a kindred phenomenon. Mich Ac Sc, Rp $12: 51-53$ (1910)

10a Characteristics of the inland-ice of the Arctic regions. $\mathrm{Am} \mathrm{Ph}$ Soc, $\mathrm{Pr} 49$ : 57-129 (1910)

10b The cycle of mountain glaciation. Geog J 35:146-163, 268-284 (1910) Abst, Brit As, Rp $79: 531$ (1910)

10e The modeling of physiographic forms in the laboratory: J Geog $8: 225-228$ (1910)

10d A national bureau of seismology. Science n s $31: 260$ (1910)

10e The international geological congress at Stockholm. Science $n$ s $32: 413-416$ (1910)

$10 P$ The earthquake of 1872 in the Owens Valley, California. Beitr Geoph 10:352385 (1910)

11 Characteristics of existing glaciers. $301 \mathrm{pp}, \mathrm{N}$ Y 1911

11 a Requisite conditions for the formation of ice ramparts. J G 19: 157-160 (1911)

11b Repeating patterns in the relief and in the structure of the land. G Soc Am, B 22:123-176, 718 (discussion) (1911)

11e The late glaciaf and postglacial uplift of the Michigan Basin. Mich $G \mathrm{~S}$, Pub 5 ( $\mathrm{g}$ s 3 ) : 11-68 (1911)

11d Earthquakes in Michigan. Mich G S, Pub 5 ( $\mathrm{g}$ s 3): 69-87 (1911)

11e The Pleistocene glaciation of North America viewed in the light of our knowledge of existing continental glaciers. $\Delta \mathrm{m}$ Geog Soc, B 43:641-659 (1911)

11e Allmentation of existing continental glaciers $(a b 8 t)$. Science n s 33:905 (1911)

12 Earth features and their meaning: an introduction to geology for the student and general reader. $\times x \times i x, 506 \mathrm{pp}, \mathrm{N} \mathbf{Y}$ 1912

12a Some considerations bearing upon the origin of lava $(a b s t)$. Sclence n 8 35: 790 (1912)

12b One phase of Washington science. Science n s $36: 477-479$ (1912)
Hobbs, William Herbert-Continued.

13 Some considerations concerning the place and origin of lava maculæ. Beitr Geoph $12: 329-361$ (1913) $\triangle$ bst, Mich Ac Sc, Rp 14:107 (1912)

13a Soil flow. Am Geog Soc, B 45 : 281284 (1913)

13b Variations in composition of pelitic sediments in relation to magmatic differen. tiation. Int G Cong, XII, 1913, C R : 241246 (1914; advance copy 1913)

14 Simple directions for the determina. tion of the common minerals and rocks; a laboratory course in general geology. 31 pp, N Y, 1914

$14 a$ Mechanies of formation of arcuate mountains. J G 22: 71-90, 166-188, 193208 (1914) Abst, G Soc Am, B 25:30-31 (1914)

14b Eduard Suess. J G 22:811-817, port (1914)

14e Buried lava tunnels as a factor in the drainage of craters of the Hawailan type. Zs Vulkan 1: 86-8S (1914)

15 The role of the glacial anticyclone in the air circulation of the globe. $A m \mathrm{~Pb}$ Soc, Pr 54: 185-225 (1915)

15a Range and rhythmic action of sandblast erosion from studies in the Libyan Desert (abst). G Soc Am, B 26:63 (1915)

$15 \mathrm{~b}$ New evidence of the existence of fixed anticyclones above continental glaciers (abst). G Soc Am B 26:73-74 (1915)

16 Assumptions involved in the doctrine of isostatic compensation, with a note on Hecker's determination of gravity at sea. J G 24: 690-717 (1916)

16a The extremes of mountain glacial erosion $(a b s t)$. Science n 8 43:398-899 (1916)

18 The eroslonal and degradational processes of deserts, with especial reference to the origin of desert depressions. As Am Geog, An $7: 25-60$ [1918]

$18 n$ The peculiar weathering processes of desert regions with illustrations from Egypt and the Soudan. Mich Ac Sc, An Rp 20:93-99 (1918)

See also Daly (R A), 16; Sayles, 16

Hobson, Bernard.

o7 An excursion to the volcanoes of Nevado de Toluca and Jorullo in Mexico. G Mag (5) 4:5-13 (1907)

07 a The volcanoes of Mexico. Scottish Geog Mag 23: 25-27 (1907)

07b (with Sol6rzano, M. M.) Plant remains in basalt, Mexico. G Mag (5) 4: 217-219 (1907)

13 The Twelfth International Geological Congress in Canada. G Mag n s (5) 10: 486-490 (1913)

Hobson. John B.

95 The auriferous gravels of British Columbia. Can M Rv 14:18-20 (1895) Gon M As Que, J $2: 177-189$ [1896]

See also Irelan, 90a, 93 
Hodge, E. T.

15 The composition of waters in mines of sulphide ores. Ec G 10:123-139 (1915) M Met Soc Am, B 84:98-112 (1915)

16 Field studies in the Coamo-Guyama region, Porto Rico (abst). N Y Ac Sc, An 26:434-436 (1916)

17 Geology of the Coamo-Guayama region, Porto Rico (abst). N Y Ac Sc, An 27: $277-278$ (1917)

See also Reeds, 16

Hodge, James Michael.

87 Preliminary report on the geology of parts of Letcher, Harlan, Leslie, Perry, and Breathitt cos. Ky G S, Preliminary reports on the southeastern Ky coal field: 31-52 (1887)

87a Preliminary report on the geology of the lower North Fork, Middle and South Forks, Kentucky River. Ky G S, Preliminary reports on the southeastern Kentucky coal field : 53-114, map (1887)

93 The Big Stone Gap coal field [Va.] (with discussion by M. R. Campbell). Am I M Eng, Tr 21:922-938, 1005-1006 (1893)

08 Summary of report on the region drained by the three forks of the Kentucky River. Ky G S, Rp Progress 1906-07: $36-45$ (1908)

10 Report on the coals of the three forks of the Kentucky River. Ky G S, B 11: $280 \mathrm{pp}$, maps (1910) [distributed 1912 or 1913].

12 Report on the upper Cumberland coal field; the region drained by Poor and Clover forks in Harlan and Letcher cos. Ky G S, B $13: 223$ pp, map (1912)

13 Report on the coals of the headwaters of Licking River, Magoffin Co. [Ky.]. Ky G S (4) 1: $889-921$ (1913)

13a Coals on the north side of the North Fork of Kentucky River in Perry and Knott cos. [Ky.]. Ky G S (4) 1:923-986 (1913)

$13 \mathrm{~b}$ The coals of the upper Carr Fork and Big Branch and Bull Creek region of North Fork of Kentucky Rvier. Ky G S (4) 1:987-1036 (1913)

14 Report on the coals of Macies and Leatherwood creeks, Perry Co. [Ky.]. Ky G S (4) 2 pt 2:7-67 (1914)

14a Report on the coals of Goose Creek and its tributaries in Clay and Knox cos., Ky. Ky G S (4) 2 pt 2: 69-146 (1914)

14b Report on the coals of the North Fork of Kentucky River from Hazard down to Krypton. Ky G S (4) 2 pt 2:147-198 (1914)

16 Supplementary report of the coals of Clover Fork and Poor Fork in Harlan Co. Ky G S: $64 \mathrm{pp}$, map (1916)

18 Coals of middle fork of Kentucky River in Leslie and Harlan cos. Ky G S: 166 pp (1918)
Hodge, James Michael-Continued.

$18 \mathbf{a}$ Coals of the north fork of Kentucky River in Perry and portions of Breathitt and Knott cos. Ky G S (4) 3 pt 3: 418 pp, maps (1918)

$18 b$ The coals of Goose Creek and its tributaries [Clay Co.]. Ky G S (4) 4 pt 3: 1-183 (1918)

Hodge, James Thacher (1816-1871).

38 On the Allagash section, from the Penobscot to the St. Lawrence River. In, Jackson, C. T., Second An Rp on the geology of the public lands belonging to the two states of Maine and Massachusetts : 49-73, Augusta, 1838

41 Observations on the secondary and tertiary formations of the southern Atlantic States. Am J Sc 41:332-344, abst 182-183 (1841) As Am G, Rp:94-111, abst $34-35$ (1843)

42 On the Wisconsin and Missouri lead region. Am J Sc 43: 35-72 (1842)

50 On the mineral region of Lake Superior. Am As, Pr 2:301-308 (1850)

53 Report on the mining properties...at Shelburne, N H. M Mag 1:27-34 (1853)

53a Report of the Lycoming Iron and Coal Company [Lycoming Valley, Pa.]. M Mag 1:455-468 (1853)

54 The Ulster lead mines. M Mag 2: 138-147 (1854)

69 Report of the coal properties of the Cumberland coal basin in Maryland... 69 pp, N Y 1869

71 On the Tertiary coals of the West. U S G S Wyo (Hayden), Prel Rp [4]: 318-329 (1871)

78 Report on the geology of Coshocton Co. Ohio G S, Rp 3 pt 1:562-565 (1878) Hodge, W. R.

12 West Shiningtree gold district [Ont.] : Eng M J $94: 343-345$ (1912)

Hodges, A. D.

85 Note on an occurrence of nickel and cobalt in Nevada. Am I M Eng, Tr 13: $657-658$ (1885)

Hodgson, William Brown.

46 Memoir on the Megatherium and other extinct gigantic quadrupeds of the coast of Georgia, with observations on its geologic features. $47 \mathrm{pp}$, map, N Y 1846

Hofer, Hans von.

77 Die Petroleum-Industrie Nordamerikas... Oesterreichische Commission fur die Weltaustellung in Philadelphia 1876, H 8 ; $166 \mathrm{pp}$, Wien 1877 Abst, Carinthia 68: 19-28 (1878)

78 Die Kohlen- und Eisenerz-Lagerstätten Nord-Amerikas... Oesterreichische Commission fuir die Weltaustellung in Philadelphia $1876: 260 \mathrm{pp}$, maps, Wien $187 \mathrm{~s}$ Abst, Carinthia 68:141-146 (1878)

10 Die Erdöllagerstätten in Alaska. Petroleum (Berlin) 5:741-746 (1910)

$10 a$ On the development of anticlinal theory [of oil and gas accumulation]; discussion. Ec G 5 : 492-493 (1910) 
Höfer, Hans von-Continued.

$10 \mathrm{~b}$ The origin of petroleum; discussion. Ec G 5: 564 (1910)

12 Temperature in oil regions. Ee G 7 : 536-541 (1912)

14 The origin of petroleum (translation). Am I M Eng, B 89:869-880 (1914) ; Tr 48: 481-503 (1915)

See also Coste, 14

Hogbom, A. G.

05 Zur Petrographie der kleinen Antillen. Upsala Univ, G Inst, B 6:214-233 (1905)

Hoeing, Joseph Bernard.

91 Map of Warren Co. by J. F. McAdoo ; geology by J. B. Hoeing. Scale 2 miles to 1 inch. Ky G S 1891

05 The oil and gas sands of Kentucky. Ky G S, B 1: 233 pp, maps (1905)

o7 Preliminary geological map of Kentucky. Ky G S 1907 Scale: 1 inch $=10$ miles

13 [First annual report]. Ky G S (4) $1: 1-78$ (1913)

$13 a$ The coals of the upper Big Sandy Valley and the headwaters of the North Fork of the Kentucky River. Ky G S (4) 1: 79-261 (1913)

14 Coal analyses in the western coal field [Ky.]. Ky G S (4) 2 pt $1: 219-414$ (1914)

Hoen, A. B.

03 Discussion of the requisite qualities of lithographic limestone, with report on tests of the lithographic stone of Mitchell Co., Iowa. Iowa G S $13: 339-352$ (1903)

Hoernes, Rudolf.

03 Die vulkanischen Ausbrüche auf den Klelnen Antillen [W. I.] Naturw Ver Steiermark, Mitt, 39 : 1xxxi-xcii (1903)

Hofman, C. F.

68 Notes on Hetch-Hetchy Valley. Cal Ac N Sc, Pr 3: 368-370 (1868)

Hofmann, F.

22 Noch Einiges von dem gediegnen Kupfer und dem Kupferschiefer in Connecticut. Annalen der Physik (Gilbert) $70: 431-436$ (1822)

Hofmann, George Christian (18371917).

76 Chemical contributions to the geology of Canada. Can G S, Rp Prog 1874-5: 313-319 (1876) ; Rp Prog 1875-6: 419-432 (1877) ; Rp Prog 1876-7 : 489-512 (1878) ; Rp Prog 1877-8: H 14 pp (1879) ; Rp Prog 1878-9: H 25 pp (1880); Rp Prog 1879-80: н 20 pp (1881); Rp Prog 1880-2 : H 16 pp (1883); Rp Prog 1882-4 : м M $19 \mathrm{pp} \mathrm{(1885);} \mathrm{An} \mathrm{Rp} \mathrm{1:} \mathrm{м} 29$ pp (1885); An Rp 2: T 42 pp 1887; An Rp 3: T 58 pp (1888); An Rp 4:R 68 pp (1890) ; An Rp 5: R 72 pp (1892) ; An Rp 6: R 93 pp (1895)

78 On Canadian graphite. Can G S, Rp Prog 1876-7 : 489-510 (1878)

79 Canadian apatite. Can G S, Rp Prog 1877-8: H 14 pp (1879)
Hofmann, George Christian-Continued. 85 Coals and lignites of the Northwest Territory [British Columbia and Alberta]. Can G S, Rp Prog 1882-4: M 44 pp (1885) S7 Magnetite crystals pseudomorph after pyrite. Am J Sc (3) 34: 408 (1887)

s8 On a specimen of Canadian native platinum from British Columbia. R Soc Can, Pr Tr 5, 1ii : 17-22 (1888)

90 Annotated list of the minerals occur. ring in Canada. Can G S, An Rp 4: $\mathrm{T} 67$ pp (1890)

90a Annotated list of the minerals occurring in Canada. $\mathrm{R}$ Soc Can, $\operatorname{Pr} \operatorname{Tr} 7$, iii: $65-105$ (1890)

91 On a pecullar form of metallic iron found in Huronian quartzite on the north shore of St. Joseph Island, Lake Huron, Ontario. $\mathrm{R}$ Soc Can, $\operatorname{Pr} \operatorname{Tr} 8$, ili : $39-42$ (1891) Am G 8:105-110 (1891)

91a Ilvaite, Am J Sc (3) $42: 432$ (1891)

93 Catalogue of section one of the museum of the Geological Survey embracing the systematic collection of minerals and collections of economic minerals and rocks and specimens illustrative of structural geology. Can G S ; 256 pp (1893)

95 A plumbiferous tetrahedrite. Am J Sc (3) $50: 273-274$ (1895)

96 Report of the section of chemistry and mineralogy. Can G S, An Rp $7: \mathbb{B}$ $68 \mathrm{pp}$ (1896); An Rp 8: r 59 pp (1897); An Rp 9: r 53 pp (1898); An Rp 11:R 55 pp $(1900)$; An Rp 12: R 64 pp (1901); An Rp 13: r 67 pp (1903)

98 On a remarkable occurrence of xenotime [Calvin, Ont.]. Am J Sc (4) 5:235 (1898)

98a Baddeckite, a new variety of musco. vite. Am J Sc (4) 6:274-275 (1898)

99 On the occurrence of polycrase in Canada. Am J Sc (4) $7: 243$ (1899)

ox On some new mineral occurrences in Canada. Am J Sc (4) $11: 149-153 ; 12$ : 447-448 (1901)

02 [Report on] chemistry and mineralogy. Can G S, An Rp 14 (Sum Rp 1901) : A 232-241 (1902); An Rp 15 (Sum Rp 1902) : A 429-441 (1903); An Rp 15 (Sum Rp 1903) : A 187-192 (1904); An Rp 16 (Sum Rp 1904) : A 337-349 (1905): Sum Rp 1905: 125-131 (1906); Sum Rp 1906: 153-157 (1906)

02a On the occurrence of chrompicotite in Canada [Lillooet district, B. C.]. Am J Sc (4) $13: 242-243$ (1902)

o5 Souesite, a native iron-nickel alloy occurring in the auriferous gravels of the Fraser, province of British Columbia, Catl. Am J Sc (4) $19: 319-320$ (1905)

See also Bell (R), 74 ; Robb, 74

Hofmann, W. J.

78 On the mineralogy of Nevada. U \& G Geog S Terr (Hayden), B 4:731-i45 (1878) 
Hofman, H. O.

10 Biographical notice of Franklin R. Carpenter. Am I M Eng, B 44:663-670 (1910) ; $\operatorname{Tr} 41: 869-876$ (1911)

11 Memoir of Franklin R. Carpenter, 1848-1910. G Soc Am, B 22: 48-52 (1911) Hogarty, Barry.

02 The andesite of Mount Sugar Loaf, Boulder Co., Colo. Colo Sc Soc, Pr 6: 173185 [1902] (separate ed, $12 \mathrm{pp}, 1899$ )

Hogg, James.

83 Southwestern Virginia. Sc Am Sup $15: 5832-5834$ (1883)

Holbrook, E. A.

17 The amorphous silica of southern Illinois. Eng M J 103: 1136-1139 (1917) Holbrook, Josiah.

51 Agricultural geology. 36 pp, Baltimore [1851]

Holden, Edward F.

18 Famous mineral localities; Beryl Mountain, Acworth, N. H. Am Mineralogist $3: 199-200$ (1918)

Holden, Edward Singleton.

87 List of recorded earthquakes in Califormia, Lower California, Oregon, and Washington Territory. $78 \mathrm{pp}$, Sacramento 1887

$\mathbf{8 8}$ Note on earthquake intensity in San Francisco. Am J Sc (3) 35:427-431 (1888)

89 Earthquakes in California (1888). Am J Sc (3) $37: 392-402$ (1889)

92 Earthquakes in California in 1890 and 1891. U S G S, B 95:31 pp (1892)

98 A catalogue of earthquakes on the Pacifie coast> 1769 to 1897 . Smiths Misc Col 37 (1087) : 253 pp (1898)

Holden, Fdwin C.

13 The mineral industry of Wisconsin. Wis Engineer $17: 158-173$ (1913)

Helden, Roy Jay.

06 The brown ores of the New RiverCripple Creek district, Va. U S G S, B 285: 190-193 (1906)

ot Mineral resources of Virginia, iron. In Watson, T. L. Mineral resources of Virginia : 402-491 (1907)

16 Oriskany iron ore (abst). G Soe $\mathrm{Am}$,

B $27: 64$ (1916)

See also Watson, 07e.

Holden, Ruth (1890-1917).

13 Cretaceous Pityoxyla from Cliffwood, N. J. Am Ac Arts, Pr 48:609-624, il (1913)

13a Some fossil plants from eastern Canada. Annals Bot $27: 243-255$, il (1913)

14 Cretaceous lignites from Cliffwood,

N. J. Bot Gaz 58:168-177. il (1914)

Holder, Charles Frederick.

93 Louis Agassiz; his life and work. $327 \mathrm{pp}$, port, N Y 1893

01 A remarkable salt deposit [Salton, CaI.]. Sc Am 84: 217 (1901)

01a Pyramids of Del Mar; erosion on the Pacific coast. Sc Am 85:8 (1901)
Holder, Charles Frederick-Continued.

04 Meteorites and their collectors. Se Am $90: 10$ (1904)

04a Natural monuments. Sc Am 90: 139 (1904)

Hole, Allen David.

02 (with Moore, Joseph) Concerning well-defined ripple marks in Hudson River limestone, Richmond, Ind. Ind $\mathrm{Ac} \mathrm{Sc}, \mathrm{Pr}$ 1901: 216-220 (1902)

10 Glacial geology of the Engineer Mountain quadrangle, Colo. U S G S, G Atlas, Engineer Mountain fol (no 171) : 8-9 (1910)

12 Terraces of the Whitewater River near Richmond, Ind. Ind Ac Sc, Pr 1911 : $71-81$ (1912)

12a Glaciation in the Telluride quadrangle, Colo. J G 20:502-529, 605-639, $710-737$, map (1912)

12b Soil survey of Hancock, Johnson, and Sbelby cos. Ind, Dp G $\mathrm{N}$ Res, An Rp $36: 31-82$, maps (1912)

15 Soil survey of Jay Co. [Ind.]. Ind Dp G, An Rp 39: 55-88, map (1915)

Holl, Harvey Buchanan (1820-1886).

$\boldsymbol{7 2}$ Notes of fossil sponges. G Mag 9 : $309-315,343-352$ (1872) Cin Q J Sc 1: $65-80 \quad(1874)$

Holland, L. F. S.

18 Recent developments in molybdenum [Climax, Summit Co., Colo.]. M Se Press 117: 529-531 (1918)

Folland, Thomas H.

14 The earth's crust. Science n s 40 : 533-541 (1914)

Holland, William Jacob.

oo The vertebral formula in Diplodocus Marsh. Science n s 11:816-818 (1900)

04 John Bell Hatcher. Carnegie Mus, An 2:597-604, port (1904) G Mag (5) $1: 568-573(1904)$

o5 A new crocodile from the Jurassic of Wyoming. Carnegie Mus, An 3:431-434, 1l (1905)

O5a The hyoid bone in Mastodon americanus. Carnegie Mus, An $3: 464-467$, il (1905)

06 The asteology of Diplodocus Marsh, with special reference to the restoration of the skeleton of Diplodocus carnegiei Hatcher... Carnegie Mus, Mem 2: 225-278, il (1906)

os An undetermined element in the osteology of the Mosasauridæ. Carnegie Mus, An $4: 162-167$, il (1908)

OSa A preliminary account of the Pleistocene fauna discovered in a cave opened at Frankstown, Pa., in April and May, 1907. Carnegie Mus, An 4:228-233, il (1908) Int Zool Cong, VII, Boston, 1907, Pr : 748-752 (1912)

osb Baptanodon not a "toothless" ichthyosaur. Science n s 27:191-192 (1908)

08e Dr. O. P. Hay on the skull of Diplodocus. Science n \& $28: 644-645$ (1908) 
Holland, William Jacob-Continued.

09 Deinosuchus hatcheri, a new genus and species of crocodile from the Judith River beds of Montana. Carnegie Mus, An 6: 281-294, il (1909)

10 A review of some recent criticisms of the restorations of sauropod dinosaurs existing in the museums of the United States, with special reference to that of Diplodocus carnegiei in the Carnegie Museum. Am Nat 44:259-283, il (1910)

12 Ten years' progress in vertebrate paleontology; Jurassic dinosaurs. G Soc Am. B 23: 204-207 (1912)

13 (and Peterson, O. A.) The osteology of the Chalicotheroidea. Carnegie Mus, Mem $3: 189-406$, il (1913)

15 A skull of Bison crassicornis. Carnegie Mus, An $9: 225$, il (1915)

$\mathbf{1 5 a}$ Heads and tails; a few notes relating to structure of the sauropod dinosaurs. Carnegie Mus, An 9:273-278, il (1915) Abst, G Soc Am, B 26:153 (1915)

16 A new species of Apatosaurus [near Jensen, Utah]. Carnegie Mus, An 10: 143-145 (1916)

16 a Skeletons of Diplodocus and $A p a-$ tosaurus in the Carnegie Museum (abst). G Soc Am, B 27:153 (1916)

Holley, A. L.

77 Notes on the iron ore and anthracte coal of Rhode Island and Massachusetts. Am I M Eng, Tr 6:224-227 (1879) Eng M J 24:399 (1877)

Holley, George W.

72 Niagara, its history and geology... $165 \mathrm{pp}$, Toronto 1872

$\mathbf{7 4}$ The proximate future of Niagara; in review of Prof. Tyndall's lecture thereon. Am As, Pr 22 pt 2:147-155, map (1874) Abst, Can Nat n s $7: 164-165$ (1874)

Holliek, Charles Arthur.

S4 [Fossil leaves at Tottenville, Staten Island, N. Y.] Science 3:24-25 (1884)

86 Fossil leaves, etc., from Kreischerville and New Jersey. N Sc As Staten Island, Pr 1: 31 (1886)

86a [Glaciation on Staten Island, N. Y.]. $N$ Sc As Staten Island, $\operatorname{Pr} 1: 45$ (1886)

86b [On vegetable remains in Cretaceous fireclay beds at Kreischerville, Staten Island, N. Y.]. Science $7: 221$ (1886)

89 [Leaf impressions in ferruginous sandstone, Arrochar station, Staten Island, N. Y.] N Sc As Staten Island, Pr $2: 3$ (1889) Am Nat 23:548 (1889)

89a [Triassic outcrop at Mariner's Harbor, Staten Island, N. Y.] N Sc As Staten Island, Pr 2:9-10 (1889) Am Nat 23: 1033-1034 (1889)

s9b [Cretaceous vegetable remains at Tottenville, Staten Island, N. Y.] N Sc As Staten Island, Pr 2:11 (1889) Am Nat 23: 1036. (1889)
Hollick, Charles Arthur-Continued.

90 [On clay beds on Staten Island, N. Y.] N Se As Staten Island, Pr 2:63 (1890) Am Nat 25: 403 (1891)

92 The paleontology of the Cretaceous formation on Staten Island [N. Y.]. X I Ac Sc, Tr 11: 96-104, il (1892)

92a Additions to the paleobotany of the Cretaceous formation on Staten Island, [N. Y.]. N Y Ac Se, Tr 12: 28-39, il (1892) 92b [On Cretaceous beds on Staten Island.] N Sc As Staten Island, $\operatorname{Pr} 3: 7-8$ (1892)

92e [On Cretaceous plant remains on Staten Island, N. Y.] N Sc As Staten Is. land, $\operatorname{Pr} 3: 12,13$ (1892)

92d Additions to the Cretaceous flora of Staten Island [N. Y.]. N Sc As Staten Island. $\operatorname{Pr} 3: 23-24$ (1892)

92e Notes on Staten Island clays... [N. Y.]. N Sc As Staten Island, Pr 3: 26-27 (1892)

$92 f$ Paleobotany of the Yellow gravel at Bridgeton, N. J. (abst). Torrey Bot Club, B 19: 330-333 (1892) Am As, Pr 41: 177178 (1892) Am G 10:221-222 (1892)

93 Plant distribution as a factor in the interpretation of geological phenomena, with special reference to Long Island and vicinity. $\quad \mathrm{N}$ Y Ac Sc, Tr 12:189-202 (1893)

93a Preliminary contribution to our knowledge of the (retaceous formation on Long Island and eastward. N Y Ac Sc, Tr $12: 222-237$, il (1893)

93b Observations on the geology and botany of Marthas Vineyard [Mass.] N I Ac Sc, Tr $13: 8-22$ (1893)

93e A new fossil palm from the Cretaceous formation at Glen Cove, Long Island [Serenopsis kempii]. Torrey Bot Club, B 20:168-169 (1893)

93a Some further notes upon Serenopis kempii. Torrey Bot Club, B 20:334-335, il (1893)

93e Notes on the geology of the new railroad cut at Arrochar [Staten Island, N. Y.]. N Sc As Staten Island, $\operatorname{Pr} 3: 45-$ 47 (1893)

93P [Triassic sandstone with fossils in drift material on Staten Island, N. Y.] N Sc As Staten Island, Pr 3:50 (1893)

$93 \mathrm{~g}$ A recent find of drift fossils at Prince's Bay [Staten Island, N. Y.]. N Sc As Staten Island, Pr $4: 2$ (1893)

93h Mineralogical notes [Staten Island, N. Y.]. N Sc As Staten Island, $\operatorname{Pr} 4: 6-7$ (1893)

94 Additions to the paleobotany of the Cretaceous formation on Long Island. Torrey Bot Club, B 21: 49-65, il (1894)

$94 a$ Fossil salvinlas, including description of a new species. Torrey Bot Club, B $21: 253-257$, il (1894)

94b A new fossil Nelumbo from the Laramie group at Florence, Colo. Torrey Bot Club, B 21: 307-310 (1894) 
Hollick, Charles Arthur-Continued.

94e Winglike appendages on the petioles of Liriophyllum populoides Lesq. and Liriodendron Newb., with description of the latter. Torrey Bot Club, B 21:467-471, 11 (1894)

94d [On the relationship of Spiraxis.] N Y Ac Sc, Tr 13:118-119 (1894)

94e Some further notes on the geology of the north shore of Long Island [N. Y.] N Y Ac Sc, Tr 13: 122-130 (1894)

94f Dislocations in certain portions of the Atlantic Coastal Plain strata and their probable causes. N Y Ac Sc, Tr 14: 8-20 (1894) Abst, with discussion by N. S. Shaler, G Soc Am, B 6:5-7 (1894); Am G $14: 197-198$ (1894)

$\mathbf{9 4} \mathbf{g}$ A recent discovery of fossil leaves at Arrochar [Staten Island, N. Y.]. N Sc As Staten Island, $\operatorname{Pr} 4: 11$ (1894)

94h Plant remains in limonite from the moraine at Clifton and their significance [Staten Island, N. Y.]. N Sc As Staten Island, $\operatorname{Pr} 4: 37-38$ (1894)

94i Recent investigations in the Cretaceous formation on Long Island, N. Y. (abst). Am As, Pr 42:175 (1894)

94j Notes on the northward extension of the Yellow gravel in New Jersey, Staten Island, Long Island, and eastward (abst). Am As, Pr 42:175-176 (1894)

94k A new fossil Liriodendron from the Laramle at Walsenberg, Colorado, and its significance (abst). Am G 14:203 (1894) Am As, Pr 43:225 (1895)

941 (with Kemp, J. F.) The granite at Mounts Adam and Eve, Warwick, Orange $C_{0 .}, N$. $Y$., and its contact phenomena. N Y Ac Sc, An $7: 638-650$ (1894)

95 Descriptions of new leaves from the Cretaceous (Dakota group) of Kansas. Torrey Bot Club, B 22:225-228, il (1895) 95a John Strong Newberry. U S G S, Mon 26: 15-20 (1895)

95b Further discovery of drift fossils at Princes Bay [Staten Island, N. Y.]. N Sc As Staten Island, Pr 5:3 (1895)

95e Identification of fossil leaves. Bot Gaz 20:332 (1895)

95d Marthas Vineyard Cretaceous plants (abst). G Soc Am, B 7: 12-14 (1895) Am G 16:239 (1895) Sclence n s $2: 281$ (1895)

95e Recent discovery of the occurrence of marine Cretaceous strata on Long Island (abst). Am As, Pr 44:133-135 (1896) Am G 16:248 (1895) Sclence n 8 2:400 (1895)

96 New species of leguminous pods from the Yellow gravel at Bridgeton, N. J. Torrey Bot Club, B 23: 46-49, il (1896)

96a The geology of Block Island. Science n s $4: 571-572$ (1896)

96b Geological notes, Long Island and Nantucket. $\mathrm{N} Y$ Ac Sc, Tr 15:3-10 (1896)
Hollick, Charles Arthur-Continued.

96e Geological notes, Long Island and Block Island. N $\mathrm{Y}$ Ac Sc, Tr 16:9-18 (1896) Abst, Science $n$ s $4: 695-696$ (1896)

$96 d$ Iron ore from the vicinity of New Springrille [Staten Island, N. Y.]. N Sc As Staten Island, Pr $5: 12$ (1896)

96 A recent examination of the serpentine area of Staten Island [N. Y.]. N Sc As Staten Island, Pr 5: 93-94 (1896)

96f Recent additions to the Cretaceous fossil flora of Staten Island [N. Y.]. N Se As Staten Island, $\operatorname{Pr} 6: 2$ (1896)

96g The Cretaceous clay marl exposure at Cliffwood, N. J. (abst). Am G 18:230 (1896) Sclence n s 4:386 (1896)

97 A new fossil grass from Staten Island. Torrey Bot Club, B 24: 122-124, il (1897)

97a A new fossil monocotyledon from the Yellow Gravel at Bridgeton, N. J. Torrey Bot Club, B 24: 329-331, il (1897)

$97 \mathbf{b}$ Affinities of Caulinites Ad. Brong. Torrey Bot Club, B $24: 582-584$, il (1897)

97e The Cretaceous clay marl exposure at Cliffwood, N. J. N Y Ac Sc, Tr 16: 124-136, il (1897)

97d A new Investigation of man's antiquity at Trenton, [N. J.]. Science n 8 6: 675-682 (1897)

97 Monocotyledonous plant remains in limonite [Staten Island, N. Y.]. N Sc As Staten Island, Pr 6:12-13 (1897)

97f The geological section at Cliffwood, N. J. (abst). Science n s 5: 239 (1897)

98 Notes on Block Island. N Y Ac Sc, An 11: 55-72 (1898)

98n Additions to the paleobotany of the Cretaceous formation on Staten Island (N. Y.), N Y Ac Sc, An 11:415-430, 11 (1898)

98b Exposure of Cretaceous material on Fingerboard road [Staten Island, N. Y.]. N Sc As Staten Island, Pr 6:55-56 (1898)

98e Notes on the glacial phenomena of Staten Island (abst). Science n s $8: 840$ (1898)

98d Further notes on Block Island [N. Y.] ; geology and botany (abst). Am G 21:200-201 (1898)

98e (and Britton, E. G.) A description of a new fossil moss from Seattle, Wash. (abst). Science n s 8: 83-84 (1898)

98f The age of the Amboy clay series as indicated by its flora $(a b s t)$. Am As, $\mathrm{Pr}$ 47: 292-293 (1898) Science n s 8:467-468 (1898) Am G 22:255-256 (1898)

$98 \mathrm{~g}$ Notes on the glacial phenomena of Staten Island [N. Y.] $(a b s t)$. N Y Ac Sc, An 11: 482 (1898)

99 Some features of the drift on Staten Island, N. Y. N Y Ac Sc, An 12:91-102, map (1899)

$99 a$ Some features of the Staten Island drift, N. Y. (abst). G Soc Am, B 10:2-4 (1899) Am G 22:249 (1898) Science n s $8: 463$ (1898) 
Holliek, Charles Arthur-Continued.

$99 \mathrm{~b}$ The relation between forestry and geology in New Jersey. Am Nat $33: 1-14$, 109-116, map (1899) N J G S, An Rp 1899, Rp on Forests: 173-201, map (1900)

99e A report on a collection of fossil plants from northwestern Louisiana. La St Exp Sta, G Agr La pt $5: 276-288$, il [1899]

99d Section E-Geology and geography of the American Association for the Advancement of Science [Columbus, Ohio, meeting, 1899] Science n s 10:487-491 (1899)

99e Note on deep wells, at Prince Bay and Huguenot [N. Y.]. N Sc As Staten Island, Pr $7: 19$ (1899)

99 Notes on the geology and botany of the Fox Hills golf links [Staten Island, N. Y.]. $\mathrm{N}$ Sc As Staten Island, $\mathrm{Pr} 7$ : 20-22 (1899)

99g A Quaternary lake deposit in the Moravian cemetery [Staten Island, N. Y.]. N Sc As Staten Island, Pr $7: 24-25$ (1899)

99h A reconnaissance of the Elizabeth Islands, Mass. (abst). Science n s $9: 818$ 819 (1899)

00 Geological notes [Staten Island, N. Y.]. N Sc As Staten Island, $\operatorname{Pr} 7: 30-$ 32 (1900)

OOa Drift and kame deposits on the line of the South Side boulevard [Staten Island, N. Y.]. $\mathrm{N}$ Sc As Staten Island, $\mathrm{Pr}$ 7: 37 (1900)

01 A reconnaissance of the Elizabeth Islands, Mass. N Y Ac Sc, An 13:387418 (1901) ; abst, 12:662-663 (1900)

01 a Discovery of a mastodon's tooth and the remains of a boreal vegetation in a swamp on Staten Island, N. Y. N Y Ac Sc, An 14:67-68 (1901)

02 Geological and botanical notes; Cape Cod and Chappaquidick Island, Mass. N Y Bot Garden, B 2:381-407, 11, map (1902)

02a Fossil ferns from the Laramie group of Colorado. Torreya 2:145-148, il (1902)

02b Notes on recent exposures in the soapstone rock [Staten Island, N. Y.]. $N$ Sc As Staten Island, Pr $8: 41-42$ (1902)

03 Field work during 1901 in the Cretaceous beds of Long Island. N Y St Mus An Rp 55 : r 48-51 (1903)

03a A fossil petal and a fossil fruit from the Cretaceous (Dakota group) of Kansas. Torrey Bot Club, B 30:102-105, il (1903)

03b Fossil plants from Kansas [Cretaceous]. N Y Bot Garden, J 4:66-68, il (1903)

03e Two additions to our list of drift fossils [Staten Island, N. Y.]. N Sc As Staten Island, $\operatorname{Pr} 8: 53$ (1903)
Hollek, Charles Arthur-Continued.

04 Additions to the paleobotany of the Cretaceous formation on Long Island, No. II. N Y Bot Garden, B 3:403-418, il (1904)

O4a Some recently discovered facts in regard to Silver Lake [Staten Island, N. Y.]. N Sc As Staten Island, Pr 9:1113 (1904)

04b Geological notes [Staten Island, N. Y.]. N Sc As Staten Island, Pr 9:25 (1904)

04e A recent discovery of amber and other fossil plant remains at Kreischer. ville [Staten Island, N. Y.]. N Sc As Staten Island, Pr $9: 31-32$ (1904)

04d A canoe trip down the Yukon River from Dawson to Anvik (abst). N Y dc Sc, An 16:333-335 (1905) Science n 8 19:859 (1904) Am G 33:399 (1904)

o5 The occurrence and origin of amber in the eastern United States. Am Nat $39: 137-145$, il $(1905)$

05a A recent discovery of amber on Staten Island. N Y Bot Garden, J 6:4548, il (1905)

05b The preservation of plants by geologic processes. N Y Bot Garden. J 6 115-118, il (1205)

05c Paleobotanical notes. N Y Bot Gar den, J 6 : 148-149 (1905)

osd Additional notes on the occurrene of amber at Kreiseherville [Staten Island, N. Y.]. N Sc As Staten Island, Pr $9: 35$ 36 (1905)

06 The Cretaceous flora of southern New York and New England. U S G S, Mon $50: 219 \mathrm{pp}$, il (1906)

o6a Origin of the amber found on Staten Island. N Y Bot Garden, J 7:11-12 (1906)

06b A newly discovered outerop of Trlassic rock on Staten Island [N. Y.] Staten Island $\mathrm{As}, \operatorname{Pr} 1: 16-17$ (1906)

06e A fossil forest fire [charred wood at Kreischerville, Staten Island, N. Y.] Staten Island As, Pr 1:21-23 (1906)

o6d Insect borings in Cretaceous lignite from Kreischerville. Staten Island $\mathrm{As}$, $\mathrm{Pr}$ 1: 23-24 (1906)

o6e A soapstone drift boulder containing magnetite. Staten Island As, Pr $1: 31-32$ (1906)

O6f The Pleistocene flora [of Maryland]: Systematic paleontology of the Pleistocene deposits of Maryland: Pteridophyta and Spermatophyta. Md G S, Pliocene and Pleistocene : 148-149, 217-237, il (1906)

06g (and Jefrrey, E. C.) Affinities of certain Cretaceous plant remains com. monly referred to the genera Dammara and Brachyphyllum. Am Nat $40: 189-216$, it (1906) 
Hollick, Charles Arthur-Continued.

08h (with Clark, W. B.) The Pliocene and Pleistocene deposits of Maryland; the interpretation of the paleontological criteria. Md G S, Pliocene and Pleistocene: 139-152 (1906)

07 Description of a new Tertiary fossil flower from Florissant, Colo. Torreya 7 : 182-184, il (1907)

07a Recent identifications of Cretaceous gymnosperms from Kreischerville, N. Y. (abst). Science n s 25: 292-293 (1907)

07b (with Britton, Elizabeth G.) American fossil mosses, with description of a new species from Florissant, Colo. Torrey Bot Club, B 34 : 139-142 (1907)

$0 s$ Drift boulders from the shore at Tottenville. Staten Island As, Pr 2:9 (1908)

08a Discovery of lignitic and bituminous coal at Kreischerville. Staten Island As, Pr 2:13 (1908)

08b Chemical analysis of Cretaceous amber from Kreischerville [Staten Island N. Y.]. Staten Island As, Pr 2:34 (1908) 08 e The museum collection of fossil plants, N Y Bot Garden, J $9: 214-226$, il (1908)

09 A new genus of fossil Fagacer from Colorado. Torreya $9: 1-3$, il (1909)

09a (and Jefrey, E. C.) Studies of Cretaceous coniferous remains from Kreischerville, N. Y. N Y Bot Garden, Mem $3: 188$ pp, il (1909)

10 Geological notes in connection with a recent lawsuit against the eity. Staten Island As, Pr 2:144-147 (1910)

10a A new fossil Polypore [Pseudopolyporus carbonicus, Carboniferous, W. Va.]. Mycologia 2: 93-94, 11 (1910)

10b A new fossil fucoid [Thamnocladus passifrons, Devonian (Catskill group), Franklin, Delaware Co., N. Y.]. Torrey Bot Club, B 37 : 305-307, il (1910)

10e Notes in connection with specimens recently obtained from serpentines of Staten Island (abst). N Y Ac Sc, An 19: 315-317 (1910)

11 The paleobotanical collections of the New York Botanical Garden. Am As Museums, Pr 4: 43-52 (1911) N Y Bot Garden, Contr 144 (1911)

11 a Notes on specimens recently collected in the serpentine area of Staten Island. Staten Island $\mathrm{As}, \mathrm{Pr}$ 3:31-33 (1911)

11 b Results of a preliminary study of the so-called Kenai flora of Alaska. Am J Sc (4) $31: 327-330$ (1911)

11e Discussion of the Cretaceous and Textiary floras of Alaska (abst). Wash Ac Sc, J 1: 142 (1911)

12 The relations of paleobotany to botany; ecology. Am Nat $46: 239-243$ (1912) Abst. Science n s $35: 148$ (1912)
Hollick, Charles Arthur-Continued.

$12 a$ Additions to the paleobotany of the Cretaceous formation on Long Island, No. III. N $\mathrm{Y}$ Bot Garden, B 8 no $28: 154$ 170 , il (1912)

13 Lester Frank Ward [1841-1913]. Science n s 38:75-77 (1913)

13a Preliminary correlation of the Cretaceous and Tertiary floras of Alaska (abst). G Soc Am, B 24:116 (1913)

14 A preliminary report upon the plants from the Pleistocene deposits [of East Kootenay, B. C.]. Can G S, Sum Rp 1913 : 133-135 (1914)

15 A new fossil species of Ficus and its climatic significance [Ficus interglacialis, Pleistocene, Kootenay Valley, B. C.]. N Y Bot Garden, J $16: 43-47$, il (1915) Abst, G Soc Am, B 26: 159 (1915)

15a A conspicuous Staten Island boulder trail. Staten Island As, Pr 5:8-9 (1915)

15b (with Britton, E. G.) A new American fossil moss [Plagiopodopsis scudderi from Florissant, Colo.]. Torrey Bot Club, B $42: 9-10$, il (1915)

16 A fossil fern monstrosity [Anomalofilicites monstrosus, Fort Union formation, Dawson Co., Mont.]. N Y Bot Garden, Mem 6:473-474, il (1916)

16a Some botanical and geological features of the Silver Lake basin [Staten Island, N. Y.]. Staten Island As, $\operatorname{Pr} 5$ : 60-65 (1916)

18 Some botanical problems that paleobotany has helped to solve. Brooklyn Bot Garden, Mem 1: 187-190 (1918)

See also Clark (W B), 01a, 04a ; Merrill (F J H), 02 ; Newberry, 98

Hollister, George Buell.

04 Physiographic features of the Susquehanna basin. U S G S, W-S P 108: 9-18 (1904)

05 Waters of a gravel-filled valley near Tully, N Y. U S G S, W-S P 145:179184 (1905)

O5a Hydrographic work of the U. S. Geological Survey. Int Geog Cong, VIII, Rp : 515-522 (1905)

Hollister, Ovando James (1834-1892).

83 Genesis of native copper. Kansas City Rv Sc 7: 457-460 (1883)

87 Gold and silver mining in Utah. Am I M Eng, Tr 16:3-18 (1887)

Holm, Theo.

95 On the valldity of some fossil species of Liriodendron. Bot Gaz 20:312-316, il (1895)

96 Remarks upon Paleohillia, a problematic fossil plant. Bot Gaz 21:207-209, il (1896)

Holman, F. C.

96 Notes on certain waterworn vein specimens. Am I M Eng, Tr 25:514-518 (1896) 
Holmes, Charles.

99 Coal and coal mining in Michigan. Eng M J 68:335-336 (1899)

Holmes, Ezekiel (1801-1865).

39 Report of an exploration and survey of the Territory on the Aroostook River during the spring and autumn of 1838 . [Maine, Board of Internal Improvements] : 78 pp, Augusta 1839

61 (and Hiteheock, C. H.) Preliminary report upon the natural history and geology of the State of Maine, 1861. Me Bd Agr, 6th An Rp: 91-458, Augusta 1861

61 a [Report on the physical geography of Maine.] Me Bd Agr, 6th An Rp : 100-112 (1861)

61b Notes and sketches of the wild lands explored. Me Bd Agr, 6th An Rp : 331-360 (1861)

62 (and Hitchcock, C. H.) Second annual report upon the natural history and geology of the State of Maine, 1862. Me Bd Agr, 7th An Rp:217-447, Augusta 1862

See also Hitcheock (C H), 62

Holmes, Francis Simmons (1815-1882).

49 Notes on the geology of Charleston,

S. C. Am J Sc (2) 7:187-201 (1849)

50 No fossil mammalian remrains except cetacean, in the Eocene marl of South Carolina. Am As, Pr 3: 68-69 (1850)

50a Observations on the geology of Ashley River, S. C. Am As, Pr 3:201-204 (1850)

56 Descriptions of new fossll Balani from the Eocene marl of Ashley River, S. C. Elliott Soc $\mathrm{N}$ H Charleston, Pr $1: 21$ (1856)

57 (with Tuomey, M.) Pleiocene fossils of South Carolina... 152 pp, 11, Charleston, S. C., 1857

58 Remains of domestic animals discovered among post-Pleiocene fossils in South Carolina. 2d ed, $16 \mathrm{pp}$, Charleston, S. C., 1858

59 [On post-Pleiocene fosslls of South Carolina.] Ac N Sc Phila, Pr 1859:177186

60 Post-Pleiocene Possils of South Carolina. $122 \mathrm{pp}$, il Charleston, S. C., 1860

70 Phosphate rocks of South Carolina and the "Great Carolina marl beds,"... 87 pp, Charleston, S. C., 1870

Holmes, John Simcox.

17 Some notes on the occurrence of landslides. Elisha Mitchell Sc Soc, J 33: 100-105 (1917)

Holmes, Joseph Austin (1859-1915).

85 Taxodium (cypress) in North Carolina Quaternary. Elisha Mitchell Sc Soc, J 2 : 92-93 (1885)

87 A sketch of Professor Washington Caruthêrs Kerr. Elís' Mitchell Sc Soc, J 4:1-24, port (1887)
Holmes, Joseph Austin-Continued.

89 Historical notes concerning the Norit Carolina geological surveys. Elisha Mitch ell Sc Soc, J 6: 5-18 (1889)

90 The conglomerate and pebble bels of the Triassic and Potomac formation in North Carolina (abst). Elisha Mitchell Sc Soc, J $6: 148$ (1890)

91 Mineralogical, geological, and agricol. tural surveys of South Carolina. Elish Mitchell Sc Soc, J 7:89-117 (1891)

92 Character and distribution of road materials. Elisha Mitchell Sc Soc, J 9: 66-81 (1892)

93 First biennial report of the State ge ologist, 1891-92. N C G S : 111 pp, maps Raleigh 1893

93a (and Cain, W.) Road materlals and road construction in North Carolina. N C G S, B 4:88 pp, Raleigh 1893

93b Geology of the sand-hill country of the Carolinas (abst). G Soc $\mathbf{A m}$, B $5: 33^{-}$ 34 (1893)

94 Biennial report of the State geologist, 1893-4. $15 \mathrm{pp}$, Raleigh $1894 \quad$... 1895-6: 17 pp, Raleigh $1896 \quad \ldots \quad 1897-8: 28$ pp, Raleigh 1898 ... 1899-1900:20 pp, Raleigh $1900 \quad \ldots$ 1901-2: 15 pp, Raleigh 1902 .. 1903-4:32 pp, Raleigh 1905

95 Notes on the kaolin and clay deposits of North Carolina. Am I M Eng, Tr 25: 929-936 (1896) Elisha Mitchell Sc Soc, J 12 : 1-10 (1895)

96 Corundum deposits of the southen Appalachian region. U S G S, An Rp 17 pt 3:935-943, map (1896)

$96 n$ Notes on the underground supplies of potable waters in the South Atlantic Piedmont Plateau. Am I M Eng, Tr 25: 936-943 (1896)

99 Geologic distribution of water power. N C G S, B 8: 68-88 (1899)

$99 a$ Mica deposits in the United States. U S G S, An Rp 20 pt 6 (con.) : 691-707 (1899)

99b Mica deposits of the United States (abst). G Soc Am, B 10:501-503 (1900) Am G 23:106-108 (1899) Science n s 9: 142 (1899) Eng M J $67: 174$ (1899)

99c Some geologic conditions favoring water power developments in the South Atlantic region (abst). Am As, $\operatorname{Pr} 48: 226$ (1899) Science n s 10:488 (1899)

00 The deep well at Wilmington, N. C. Science n s 11:128-130 (1900) Elisha Mitchell Sc Soc, J $16: 67-70$ (1900)

Ooa Geology and geography at the American Association [New York City, June, 1900] Science n s 12:989-996 (1900)

oob The Cretaceous and Tertiary section between Cape Fear and Fayetteville, N. C. (abst). Science n s 11: 143 (1900)

o1 The mica industry in 1900 . U S G S, Min Res 1900:852-856 (1901)

O4 Mica. U S G S, Min Res $1902: 985-$ 991 (1904) 
Holmes, Joseph Austin-Continued.

06 (and others) Preliminary report on the operations of the fuel-testing plant of the United States Geological Survey at St. Louis, Mo., 1905. U S G S, B 290:240 pp (1906)

06a (with Parker, E. W.) Report on the operations of the coal-testing plant of the U. S Geol. Survey at the Louisiana Purchase Exposition, St, Louis, Mo., 1904. Parts I-III. U S G S, P P 48: 1492 pp (1906)

11 Lignite deposits of the United States (abst). Science n s 33:944 (1911)

Holmes, Mary E.

87 The morphology of the carinae upon the septa of rugose corals. Diss, University of Michigan. $31 \mathrm{pp}$, il, Boston 1887

Holmes, Nathaniel.

60 on a meteoric iron found in $\mathrm{Ne}$ braska Ter. Ac Sc St L, Tr 1: 711-712 (1860)

68 [On the loess and drift of Illinois and Missouri.] Ac Sc St L, Tr 2:565659 (1868)

75 Delta of the Mississippi River (dis. cussion). Ac Sc St L, Tr $3:$ cxiv (1875)

76 Man and the elephant in Nebraska. Ac Se St L, Tr 3 : cexill-cexiv (1876)

Holmes, Thomas Vincent.

91 Further notes on the geological record. G As, London, $\operatorname{Pr} 12: 67-87$ (1891) Holmes, William Henry.

76 Report on the geology of the northwestern portion of the Elk Range. U S G Geog 8 Terr (Hayden), An Rp [8]: 5971, map (1876)

77 Report [on the San Juan district, Colo.]. U S G Geog S Terr (Hayden), An Rp 9:237-276, map (1877)

78 Report on the geology of the Sierra Abajo and west San Miguel Mountains. U S G Geog S Terr (Hayden), An Rp 10: 187-195 (1878)

79 Fossil forests of the volcanic Tertiary formations of the Yellowstone National Park, D S G Geog S Terr (Hayden), B 5 : 125-132 (1879)

79a Notes on an extensive deposit of obsidian in the Yellowstone National Park. Am Nat 13:247-250 (1879)

81 Glacial phenomena in the Yellowstone Park. Am Nat 15: 203-208 (1881)

83 Report on the geology of Yellowstone National Park. U S G Geog S Terr (Hayden), An Rp 12 pt 2: 1-57 maps (1883)

83a Preliminary geological map of the Yellowstone National Park. Surveyed in 1878. Scale 2 miles to 1 inch. U S G Geog 8 Terr (Hayden) $n$ d [1883?] [Also in 12th An $\mathrm{Rp}$ ]

93 Are there traces of glacial man in the Trenton gravels? J G 1: 15-37 (1893)

93a Traces of glacial man in Ohio. J G $1: 147-163$ (1893)

93b Vestiges of early man in Minnesota. Am G $11: 219-240$ (1893)
Holmes, William Henry-Continued.

97 Primitive man in the Delaware Valley. Science n s 6:824-829 (1897)

99 Review of the evidence relating to auriferous gravel man in California. Am Anthropologist n s $1: 107-121,614-645$ (1899) Smiths Inst, An Rp 1899: 419-472 (1901)

99a (with MeGee, W J). Geology and archeology of the California gold belt (abst). Am G 23: 96-99 (1899) Science n s $9: 104-105$ (1899)

02 Fossil human remains found near Lansing, Kansas. Am Anthropologist $\mathbf{n}$ s 4: 743-752 (1902) Smiths Inst, An Rp $1902: 455-462$ (1903)

18 On the antiquity of man in America. Science n s $47: 561-562$ (1918)

Holmquist, P. J.

09 Några jämförelsepunkter emellan nordamerikansk och fennskandisk prekambrisk geologi [compares the pre-Cambrian formations of North America with those of Scandinavia and Finland]. G Fören Stockholm, Förh $31: 25-51$ (1909)

Holst, Nils Olof.

86 Berättelse om en år 1880 i geologiskt syfte företagen resa till Grönland. Sveriges G Undersőkning, Ser C no 81:68 pp, map (1886)

Holt, William P.

13 The study of minerals and rocks in high school physical geography. J Geog 11 : $188-190$ (1913)

Holtedahl, Olaf.

12 On some Ordovician fossils from Boothia Felix and King William Land ... Videnskabs-Selsk Christiania, Skrift matnat Kl 1912 no $9: 11 \mathrm{pp}$, il (1912)

13 The Cambro-Ordovician beds of Bache Peninsula and the neighboring regions of Ellesmere Land. Second Norwegian Arctic Expedition in the Fram 1898-1902, Rp no 28: 14 pp, map, Videnskabs-Selskabet i Kristiania, 1913

14 On the fossil faunas from Per Schei's Series B in southwestern Ellesmere Land. Second Norwegian Arctic Expedition in the Fram 1898-1902, Rp no $32: 48$ pp, maps, Videnskabs-Selskabet i Kristiania, 1914

17 Summary of geological results. Second Norwegian Arctic Expedition in the Fram 1898-1902, Rp no $36: 27$ pp, map, Videnskabs-Selskabet 1 Kristiania, 1917

Holway, Ruliff $\mathrm{S}$.

04 Eclogites in California. $J$ G 12 : 344-358 (1904)

07 The history of the Blue Lakes [Lake Co., Cal.]. Cal Phys Geog Club, B 1 no 1 : 8-13: (1907)

07a Physiographic changes bearing on the faunal relationships of the Russian and Sacramento rivers, Cal. Seience n s 26 : 382-383 (1907) 
Holway, Ruliff S.-Continued.

09 (and Linsley, E. G.) A syllabus for the study of the physiographic provinces of California. Cal Phys Geog Club, B 2 no $2: 11-20$ (1909)

11 An extension of the known area of Pleistocene glaciation to the Coast Ranges of California [Snow Mountain]. Am Geog Soc, B 43:161-170 (1911)

13 The Russian River, a characteristic stream of the California Coast Ranges. Cal, Univ, Pub Geog 1 no 1 : 1-60 (1913)

14 Physiographically unfinished entrances to San Francisco Bay. Cal Univ, Pub Geog 1: 81-126, maps (1914)

14a Preliminary report on the recent voleanic activity of Lassen Peak. Cal Univ, Pub Geog 1:307-330 (1914) Am Geog Soc, B 46:740-755 (1914)

141. The effect of seven years' erosion on the California fault line of 1906. Am Geog Soc, B 46:420-426 (1914)

14e Apparent limits of former glaciation in the northern Coast Ranges of California (abst). G Soc Am, B 25:120-121 (1914)

15 The volcanic activity of Lassen Peak. Pop Sc Mo $86: 290-305$ (1915)

15a (and Diller, J. S.) Characteristics of the Lassen Peak eruptions of May 20-22, 1915 (abst and discussion). G Soc Am, B $26: 397$ (1915)

15b Physiographic geology. In Nature and science on the Pacific coast: 31-40, San Francisco 1915. (See Merriam, 15)

Holzinger, John.

85 Fossil elephant in Winona Co. Minn G S, An Rp 13: 147-149 (1885)

Honess, Arthur P.

17 On the etching figures of beryl. Am J Sc (4) $43: 223-236$ (1917)

17 a A study of the etching figures of the hexagonal-alternating type of crystals. Am Mineralogist 2: 57-62, 71-74 (1917)

17b The association of pyrite and stilbite in New Jersey. Im Mineralogist 2 : 117 (1917)

Is On the etching figures of the dihexagonal type. Am J Sc (4) 45:201-221 (1918)

Honeyman, David (1814-1889).

59 Abstract of a paper on the fossillferous rocks of Arisaig. N S Lit Sc Soc, Tr $1859: 19-29$

60 On new localities of fossiliferous Silurian rocks in eastern Nova Scotia [with note by J. W. Dawson]. Can Nat 5:293297 (1860)

62 On the geology of the gold fields of Nova Scotia. G Soc London, Q J 18: 342346, map (1862) Abst, Can Nat $7: 320$ (1862)

64 On the geology of Arisaig, Nova Scotia. G Soc London, Q J 20:333-345 (1864)
Honeyman, David-Continued.

65 Geological report. N S, Legislative Council, J Pr 1865 App no 17:6 pp (1865) 66 Geology of Antigonish Co., N. S. N Inst $\mathrm{N} S \mathrm{Sc}$ Pr Tr 1 pt 4:106-120, map (1866)

67 The geology of Gay's River gold feld. N S Inst N Sc, Pr Tr 2 pt 1: 76-81 (1867) $\mathbf{6 7} \mathbf{a}$ On the geological features of the Londonderry iron mines. $N \mathrm{~S}$ Inst $\mathrm{N} S \mathrm{Sc}$ Pr Tr 2 pt $1: 112-118$ (1867)

z0 Notes on iron deposits on East Riret in the County of Pictou, N S. N S Inst N Sc, $\operatorname{Pr} \operatorname{Tr} 2$ pt 4:67-73 (1870)

70a Laurentian rocks of Nova Scoti. Am J Sc (2) $50: 417-422$ (1870)

70b Notes on the geology of Arisaig, N, S. G Soc London, Q J 26:490-492 (1870) Abst, G Mag $7: 295$ (1870); Ph Mag (4) $40: 386$ (1870)

71 Note on limestone containing petroleum in Nova Scotia. Am J Se (3) 1: 386 (1871)

72 Record of observations on Nora Scotian geology. N S Inst $\mathrm{N}$ Se, Pr Tr $3: 6-18,31-40,62-73$ (1872)

72n Notes on the Montague gold mines. N S Inst N Sc Pr Tr 3: 93-94 (1872)

72b On pre-Carboniferous rocks of the Pictou coal field. N S Inst $\mathrm{N}$ Sc, Pr Tr 3 : 105-108, 141-143 (1872)

72c On the geology of the iron deposits of Pictou Co. N S Inst N Sc, Pr Tr 3: 171-173 (1872)

73 Notes on the geology of Nova Scotis and Cape Breton. N S Inst $\mathrm{N}$ Sc, Pr Tr $3: 193-202$ (1873)

$\boldsymbol{7 3 a}$ On the metamorphism of rocks in Nova Scotia and Cape Breton. N S Inst N Sc, Pr Tr 3:231-237 (1873)

73b The history of a boulder. N \& Inst $\mathrm{N}$ Sc, Pr Tr 3:321-326 (1873)

74 Nova Scotian geology. N S Inst N Sc, Pr Tr 3: 345-356, 385-393 (1874)

74a Skeleton of a whale in the Quater. nary of New Brunswick. Am J Sc (3) 7 : 597 (1874)

74b On the Quaternary containing the New Brunswick fossil cetacean; on Niagar coral reefs; and on Niagara fossils in trap. Am J Sc (3) 8:219-220 (1874)

76 A month among the geological forms. tions of New Brunswick, N S Inst N SC, Pr Tr 4:5-21 (1876)

$76 a$ Noval Scotian geology; Antigonish Co. N S Inst N Sc, Pr Tr 4: 47-79 (1876)

76b On the varieties of transported boulders from the Nova Scotia shore. Am $\mathrm{Ph}$ Soc, $\operatorname{Pr} 16: 237$ (1876)

77 Nova Scotian geology; superficial. N S Inst N Sc, Pr Tr 4: 109-122 (1877)

77a Nova Scotian geology at the Cen. tennial Exhibition-International Exhbltion of 1876. N S Inst N Sc, Pr Tr 4: 252-260 (1877) 
Honeyman, David-Continued.

78 Pre-Carboniferous formations of Annapolis and Kings cos. $\mathrm{N}$ S Inst $\mathbf{N}$ Sc, Pr Tr $4: 337-362$ (1878)

$78 a$ Nova Scotia geology; pre-Carboniferous; Lower Carboniferous, etc.; retrospect, to 1859. N S Inst $\mathrm{N}$ Sc, $\mathrm{Pr}$ Tr 4: $439-487$ (1878)

79 Nova Scotian geology [fossils from Cape Breton and from Annapolis Co.]. N S Inst N Sc, $\operatorname{Pr} \operatorname{Tr} 5: 16-21$ (1879)

79 a Nova Scotian geology; Kings Co. N S Inst N Sc, Pr Tr 5: 21-31 (1879)

79b Novia Scotian geology; notes to retrospect of 1878 . N S Inst N Sc. Pr Tr 5: 64-76 (1879)

80 Nova Scotian geology; Annapolis Co. continued. N S Inst N Sc, Pr Tr 5:119136 (1880)

80a Geological waifs from the Magdalen Islands. N S Inst N Sc, Pr Tr 5 : 136-138 (1880)

80b Nova Scotian geology; notes on a new geological progress map of Pictou Co. N S Inst N Sc, Pr Tr 5:192-216 (1850)

81 Nova Scotian geology; Digby and Yarmouth cos. N S Inst $\mathrm{N}$ Sc, $\mathrm{Pr}$ Tr 5: $227-247$ (1881)

81a Archean gneisses of the Cobequid Mountains. N S Inst N Sc, Pr Tr 5:271275 (1881)

82 Nova Scotia geology; superficial. N $\mathrm{S}$ Inst $\mathrm{N}$ Sc, $\operatorname{Pr} \operatorname{Tr} 5: 319-331$ (1882)

82a Geological notes; metalliferous sands. N S Inst $\mathrm{N}$ Se, Pr Tr $5: 334-337$ (1882)

83 Notes on a polariscopic examination of crystalline rocks of the Yarmouth goldbearing series. N S Inst N Sc, Pr Tr 6 : 7-8 (1883)

83a Glacial transportation in Nova Scotia and beyond. N S Inst N Sc, Pr Tr $6: 34-42$ (1883)

83b Nova Scotian geology; Halifax and Colchester cos. N S Inst N Sc, Pr Tr 6 : 52-67 (1883)

83e On some ferruginous concretions from the bed of Grand Lake, N S. (abst). R Soe Can, Pr Tr 1, iv : 285 (1883)

85 Glacial action at Rimouski, Canada ... N S Inst N Sc, Pr Tr 6:119-121 (1885)

85 a Notes of a polariscopic and microscopic examination of crystalline rocks of Nova Scotia and Cape Breton. N S Inst N Sc, $\operatorname{Pr} \operatorname{Tr} 6: 121-130$ (1885)

85b Geological notes of excursions with members of the British Association and others [notes on Nova Scotia]. N S Inst N Sc, $\operatorname{Pr} \operatorname{Tr} 6: 166-174$ (1885)

85e Louisburg, past and present; a historico-geological sketch. $\mathrm{N}$ S Inst $\mathrm{N}$ Sc, Pr $\operatorname{Tr} 6: 191-208$ (1885)

85d Our glacial problem (abst). N S Inst $\mathrm{N}$ Sc, $\operatorname{Pr} \operatorname{Tr} 6: 242-244$ (1885)
Honeyman, David-Continued.

85e Glacial distribution in Canada. G As, London, $\operatorname{Pr} 8: 377-381$ (1885) N S Inst $\mathrm{N}$ Sc, $\operatorname{Pr} \operatorname{Tr} 6$ pt 2 App : xili-xviil (1885)

85f On the geology of Halifax Harbor, Nova Scotia (abst). Brit As, Rp 54:714715 (1885)

86 Additional notes on glacial action in Halifax Harbor, northwest arm, and Bedford basin. $\mathrm{N}$ S Inst $\mathrm{N} \mathrm{Se}, \operatorname{Pr} \operatorname{Tr} 6: 251-$ 260 (1886)

86a Polariscopic examination of crystalline rocks of Antigonish Co. N S Inst N Sc, $\operatorname{Pr} \operatorname{Tr} 6: 299-301$ (1886)

$\mathbf{8 6 b}$ A revision of the geology of Antigonish Co. in N. S. N S Inst N Se, Pr Tr $6: 308-325$ (1886)

86e Geology of Cornwallis or MeNab's Island, Halifax Harbor. R Soc Can, $\mathrm{Pr} \mathrm{Tr}$ 3 , iv : 27 (1886)

86d Note on the identification of the Scotch and New Brunswick "albertites." Miner Mag $7: 77-78$ (1886)

87 Giants and pigmies (geological) ; earth's order of formation and life ... 99 pp, Halifax, N S., 1887

88 Geology of Aylesford, Kings Co., N. S. N S Inst N Sc, $\operatorname{Pr} \operatorname{Tr} 7: 7-12$ (1888)

S8a The Nautilus of the Brookfield limestone; Nautilus brookfieldi n. sp. N S Inst $\mathrm{N}$ Sc, $\operatorname{Pr} \operatorname{Tr} 7: 13$ (1888)

8sb Notes of examination by Prof. James Hall of the Silurian collections of the provincial museum. $\mathrm{N} S$ Inst $\mathrm{N}$ Sc, $\mathrm{Pr} \mathrm{Tr}$ 7: 14-17 (1888)

88e Geology of Halifax and Colchester cos. $\quad \mathrm{N} \quad \mathrm{S}$ Inst $\mathrm{N}$ Sc, $\mathrm{Pr}$ Tr $7: 36-47$ (1888)

s8d The giant trilobite of Moose River iron mine, N. S. N S Inst $\mathrm{N}$ Sc, Pr Tr $7: 63-65$ (1888)

88e Glacial geology of Nova Scotia. N S Inst $\mathrm{N}$ Sc, $\operatorname{Pr} \operatorname{Tr} 7: 73-85$ (1888)

s81 Carboniferous flora, with attached spirorbes. $\quad \mathrm{N}$ S Inst $\mathrm{N}$ Sc, $\operatorname{Pr} \operatorname{Tr} 7: 93-$ 94 (1888)

$\mathbf{8 8 g}$ Our museum meteorites, etc. N S Inst N Sc, Pr Tr 7:120-130 (1888)

8sh Noval Scotian superficial geology, with map, systematized and illustrated.

N S Inst N Sc, Pr Tr 7: 131-141 (1888)

89 A geological recreation in Massachusetts Centre, U. S. A. N S Inst N Sc, Pr Tr 7:197-201 (1889)

89a Glacial boulders of our fisheries and invertebrates, attached and detached. N S Inst N Sc, Pr Tr 7: 205-213 (1889)

90 Glacial geology of Cape Breton. N S Inst N Sc, Pr Tr $7: 337-344$ (1890)

$90 a$ Geological gleanings in Nova Scotia and Cape Breton. N S Inst N Sc, Pr Tr $7: 345-356$ (1890)

Honigmann, Ernesto.

16 El mineral de Tetela del Oro, Estado de Puebla [México]. Bol Minero 2:565575 (1916) 
Honigmann, Ernesto-Continued.

16a Informe sobre los principales distritos mineros productores de metales plomo-argentiferos del Estado de Puebla [México]. Bol Minero 2:632-643 (1916)

Hood, J. W.

83 Nickel ore from Piney Mountain, Douglas Co, Oreg. (abst). Miner Mag 5 : 193 (1883)

Hook, J. S.

14 The brown and blue phosphate deposits of south-central Tennessee. Tenn G S, Res Tenn 4:51-83, map (1914)

15 The white phosphates of Tennessee. Tenn G S, Res Tenn 5:23-33, map (1915) Hooker, W. A.

87 Notes on mining in Oaxaca [Mex.]. Am I M Eng, Tr 15:13-21 (1887)

Hooker, Worthington.

65 Science for the school and family; Part III, Mineralogy and geology. $360 \mathrm{pp}$, N Y [1865]

Hoover, Herbert Clark.

96 Some notes on "crossings" [North Star mine, Grass Valley, Cal.] M Sc Press 72: 166-167 (1896) ; 120:743-744 (1920).

97 Geology of the Fourmile placer mining district, Colo. Eng M J 63: 510 (1897) Hopkins, A. D.

00 Work of the prehistoric scolytid, Phloeosinus squalidens Scudd. Can G S, Contr Can Pal 2:91-92, il, (1900)

Hopkins, Cyril George (1866-1919).

10 Soil fertility and permanent agrieulture. $653 \mathrm{pp}$, Boston 1910

11 (and others) [County soil reports, nos. 1-18, incl. soil maps.] Ill, Univ, Agr Exp Sta (1911-18)

Bond Co., no 8:58 pp (1913)

Champaign Co., no $18: 61$ pp (1918)

Clay Co., no 1:32 pp (1911)

Du Page Co., no $16: 56$ pp (1917)

Edgar Co., no 15:56 pp (1917)

Hardin Co., no $3: 33$ pp (1912)

Kane Co., no $17: 60$ pp (1917)

Kankakee Co., no 13:72 pp (1916)

Knox Co., no $6: 43$ pp (1913)

Lake Co., no $9: 52$ pp (1915)

La Salle Co., no 5:45 pp (1913)

McDonough Co., no $7: 46$ pp (1913)

MeLean Co., no 10:52 pp (1915)

Moultrie Co., no 2:38 pp (1911)

Pike Co., no 11:48 pp (1915)

Sangamon Co. no 4: 40 pp (1912)

Tazewell Co., no $14: 68$ pp (1916)

Winnebago Co., no $12: 76$ pp (1916)

Hopkins, Evan.

48 Geology and topography of the Isthmus of Panama. Am J Sc (2) 6:123129 (1848) In part, Soc G France, B (2) $5: 48-49$ (1848)

Hopkins, Frederick Vincent.

7o First annual report of the Louisiana State geological survey. In La St Seminary of Learning [State Univ], An Rp 1869 : 77-109 (1870)
Hopkins, Frederick Vincent-Continued,

71 Second annual report of the geolog. ical survey of Louisiana... $1871.35 \mathrm{pp}$, map, New Orleans 1871 In La St Univ, An Rp 1870, New Orleans 1871

72 Third annual report of the geological survey of Louisiana, La St Univ, An Rp 1871: 163-206, map (1872)

78 (with Hilgard, E. W.) Report [on specimens obtained from boring be tween the Mississippi River and Lake Borgne, La.]. U S [War Dp], Chief Eng. An Rp 1878 (U S, 45th Cong 3d sess, $\mathrm{H}$ Ex Doc 1 pt 2 v 2 pt 2), App W 2: $855-890$, il (1878)

84 (with Hilgard, E. W.) Report upon the examination of specimens from borings on the Mississippi River between Memphis and Vicksburg. U S [War Dp] Chief Eng, An Rp 1884 (U S, 48th Cong 2d sess, H Ex Doc 1 pt 2 v 2 pt 4), App TT : 2885-2903 (1884)

Hopkins, L. L.

18 Sand; its occurrence, properties, and uses; a bibliography. Carnegie Library of Pittsburgh, 72 pp, Pittsburgh, 1918.

Hopkins, Oliver Baker.

14 A report on the asbestos, talc, and soapstone deposits of Georgia. Ga G S, B $29: 319 \mathrm{pp}$, map (1914)

$14 a$ Asbestos deposits of Georgia. Am I M Eng, B 93:2275-2284 (1914); Tr $50: 964-973$ (1915) Abst, Sclence n s 39 : 402 (1914)

16 Structure of the Vicksburg-Jackson area, Miss., with special reference to ofl and gas. U S G S, B 641; 93-120, map (1916) Abst, by R. W. S., Wash Ac Sc, J $7: 235$ (1917)

16 a Notes relating to the earthquake of October 18, 1916, in north central Als. bama. Mo Weather Rv $44: 690-693$ (1916)

17 The Palestine salt dome, Anderson Co., Tex. U S G S, B 661: 253-270, maps (1917) Abst, by R. W. Stone, Wash Ac Sc, J $8: 173$ (1918)

17a The Brenham salt dome, Washing. ton and Austin cos., Tex. U S G S, B 661:271-280, map (1917)

17b Oil and gas possibilities of the Hatchetigbee anticline, Ala. U S G S, B 661 : 281-313, map (1917) Abst, by R. W. Stone, Wash Ac Sc, J 8: 173-174 (1918)

17e (with Matson, G. C.) The De Soto-Red River oil and gas fleld, La. U S G S, B 661: 101-140, map (1917) Abst, by R. W. Stone, Wash Ac Sc, J $8: 35-36$ (1918)

17d (with Matson, G. C.) The Cor sicana oil and gas field, Tex. U S G S, B $661: 211-252$, maps (1917) Abst, by R. W. Stone, Wash Ac Sc, J $8: 36-37$ (1918)

18 Structure and ofl and gas resources of the Osage Reservation, Okla.; T. $25 \mathrm{~N}$. R. 11 and 12 E. U S G S, B 686:75-90, map (1918) 
Hopkins, Percy Engene.

12 Notes on McArthur township. Ont Bur Mines, An Rp 21 pt 1: 278-280 (1912)

14 (with Burrows, A. G.) The Kirkland Lake and Swastika gold areas and Maisonville, Grenfell, and Eby townships. 0nt Bur Mines, An Rp 23 pt $2: 1-39$, maps (1914)

15 Gold at Big Duck Lake [Ont.]. Ont Bur Mines, An Rp 24 pt 1:9-13, map (1915)

15a The Beatty-Munro gold area [Ont.]. Ont Bur Mines, An Rp 24 pt 1:171-184, map (1915)

15b The Kowkash gold area [Ont.]. Can M J $36: 583-584$ (1915)

15e (with Bnrrows, A. G.) The Kamiskotia Lake area [Ont.]. Ont Bur Mines, An Rp 24 pt 3:58-60, map (1915)

16 Iron pyrites deposits in southeastern Ont. Am I M Eng, B 116:1361-1369, map (1916) ; Tr 55:943-951, map (1917) Ont Bur Mines, An Rp 25 pt 1:192-199, map (1916)

16a Kowkash gold area. Ont Bur Mines, An Rp 25 pt 1:264-274 (1916)

16b (with Burrows, A. G.) Boston Creek gold area. Ont Bur Mines, An Rp 25 pt $1: 244-259$ (1916)

16e (with Burrovss, A. G.) Goodfish Lake gold area. Ont Bur Mines, An Rp 25 pt $1: 260-263$ (1916)

16d (with Burrows, A. G.) Boston Creek gold area and Goodfish Lake gold area. Ont Bur Mines, B 29:24 pp, maps (1916)

16e (with Burrows, A. G.) Boston Creek gold area [Ont.]. Can M J 37 : 399402 (1916)

17 The Kowkash gold area (second report). Ont Bur Mines, An Rp 26:190226, map (1917)

18 Ogahalla to Collins on the National Transcontinental Railway, Ont. Ont Bur Mines, An Rp 27 : 187-199, map (1918)

18a Notes on Lake Abitibi area. Ont Bur Mines, An Rp 27:200-214, maps (1918)

18b A recent discovery in northern Ontario [gold, Rickard Township]. Can M J $39: 56-58$ (1918)

Hopkins, Thomas Cramer.

91 Topographic features of Arkansas marble (abst). Am As, Pr $39: 247-248$ (1891)

92 The Eureka shale of northern Arkansas (abst). Am As, Pr 40:256-257 (1892)

93 Marbles and other limestones. Ark G S, An Rp 1890, 4:443 pp, atlas of maps, Little Rock 1893

94 Springs; the influence of stratigraphy on their emergence as illustrated In the Ozark uplift. Am G 14:365-368, map (1894)
Hopkins, Thomas Cramer-Continued.

94a (with Simonds, F. W.) The geology of Benton Co. Ark G S, An Rp 1891, $2: 1-75$, map (1894)

96 The Carbonfferous sandstones of western Indiana. Ind, Dp $\mathrm{G} N$ Res, An Rp 20:186-327, maps (1896) Stone 13: $229-238,335-342,456-466$ (1896)

$96 a$ The sandstones of western Indiana.

U S G S, An Rp 17 pt 3: 780-787 (1896)

96b Bullding stones. Min B 2:58-66 (1896)

96e Geology in the colleges and universities of the United States. U S Bur Educ, Rp 1893-4: 819-872 (1896)

96d Origin of conglomerates of western Indiana (abst). G Soc Am, B 8:14-15 (1896) Am G 18:230 (1896)

97 The building materials of Pennsylvania ; I, Brownstones. $\mathrm{Pa}$ St Coll, An Rp 1896, App : 122 pp (1897) Stone 15: $147-155,257-265,364-369$ (1897)

$97 a$ (and Siebenthal, C. E.) The Bedford oolitic limestone of Indiana. Ind, Dp G N Res, An Rp $21: 291-427$, maps (1897)

97b Brownstones of Pennsylvania. U S G S, An Rp 18 pt 5 : 1025-1043 (1897)

97e (and Siebenthal, C. E.) The Bedford oolitic limestone [of Indiana]. U S G S, An Rp 18 pt 5: 1050-1057 (1897)

97d Stylolites. Am J Sc (4) 4: 142-144 (1897) Stone 15:137-139 (1897)

$97 \mathrm{e}$ The geology of Pennsylvania. Min B $3: 39-48$ (1897)

97f A brief bibliography of economic geology. Min B 3 : 130-139 (1897)

98 The clays and clay industries of western Pennsylvania. Pa St Coll, An Rp 1897, App : 183 pp (1898)

98a Fire clays. Mines and Minerals 19 : 53-55 (1898)

98b Concentrlc weathering in sedimentary rocks. $G$ Soc $A m, B$ 9:427-428 (1898). Abst, Sclence n s $7: 84$ (1898)

98e Some feldspars in serpentine, southeastern Pennsylvania (abst). Am As, Pr 47:293-294 (1898) Science n 8 8:468 (1898) Am G 22: 256 (1898)

99 Feldspars and kaolins of southeastern Pennsylvania. Franklin Inst, J 148: 1-31 (1899)

99a Feldspar, its occurrence, mining, and uses. Mineral Industry $7: 262-268$ (1899)

00 The clays and clay industries of southeastern Pennsylvania. Pa St Coll, An Rp 1898-9, App : 76 pp (1900)

O0n The clays of the Great Valley and South Mountain areas in Pennsylvania. Pa St Coll, An Rp 1899-1900, App: 45 pp (1900)

oob Conshohocken plastic clays [Pennsylvania], G Soc Am, B 10:480-484, map (1900) Abst, Am G 23:102 (1899); Seiepce n s $9: 139$ (1899) 
Hopkins, Thomas Cramer-Continued. o0c Cambro-Silurian limonite ores of Pennsylvania, G Soc Am, B 11: 475-502 (1900)

ood The white clays of southeastern Pennsylvania. Eng M J 70:131 (1900)

o0e Limonite ores of Pennsylvania. Mines and Minerals 21:97-100 (1900)

01 A short discussion of the origin of the Coal Measures fire clays. Am G 28 : 47-51 (1901) With title, Fire clays of the Coal Measures, Mines and Minerals $22: 296$ (1902)

o1a Graphite and garnet [in southeastern Pennsylvania]. Mines and Minerals $21: 352$ (1901)

01b Recent theories as to the cause of the glacial period $(a b s t)$. Science $\mathrm{n}$ s 13 : 825-826 (1901)

02 (and Smallwood, W. M.) Some anticlinal folds $(a b s t)$. Science $n$ s 15: 89 (1902) G Soc Am, B $13: 530$ (1903)

03 Glacial climate. Onondaga $\mathrm{Ac} \mathrm{Se}, \mathrm{Pr}$ 1: 74-81 (1903)

03a Lower Carboniferous area in Indiana (abst). G Soc Am, B 13:519-521 (1903) Science n s 15:83 (1903)

O3b (with Smallwood, W. M.) A discussion of the origin of some anticlinal folds near Meadville, Pa. Syracuse Univ, B (4) $1: 18-24$ (1903)

04 Mineral resources of Onondaga Co., N. Y. N Y St Mus, An Rp 56: r109-114 (1904)

04a A short description of the topography of Indiana and of the rocks of the different geological periods; to accompany the geological map of the State. Ind, Dp G N Res, An Rp 28:15-77 (1904)

04b Contents of [and general index to] the published volumes of reports of the Indiana Geological Survey, the Department of Geology and Natural History, and the Department of Geology and Natural Resources. Ind, Dp G N Res, An Rp 28: 487-553 (1904)

04c The geological map of Indiana. Scale, 4 miles to 1 inch. Ind, Dp $\mathrm{G}$ N Res, An Rp 28 (1904)

05 Stratigraphic and economic geology of the Syracuse region [N. Y.] (abst). Science n s $22: 334$ (1905)

os General structural and economic features of the Indiana oolitic limestone. Ind Dp G, An Rp 32 : 310-335 (1908)

08a Elements of physical geography. $484 \mathrm{pp}$, Boston [1908]

09 (and Clark, B. W.) Laboratory manual in physical geography. 61 pp, Boston 1909

10 Glacial lakes and channels near Syracuse, New York (abst). G Soc Am, B $21: 761$ (1910)

10a Changes produced on springs by a sinking water table (abst). Science n s 32:190 (1910) G Soc Am, B 21:774 (1910)
Hopkins, Thomas Cramer-Continued.

10b Glacial erosion in the San Juan Mountains, Colo. Wyoming Hist G Soc Pr 11: 31-44 (1910)

14 The geology of the Syracuse quadrangle [N. Y.]. N Y St Mus, B 171:80 pp, map (1914)

14a High-level loop channel (abst). G Soc Am, B 25:68 (1914)

Hopkins, William.

55 ...general description of a remarkable fossil not known to be described, and by some supposed to be an ichthyodorulite. Am As, Pr 8:287-290, il (1855)

Hoppe, August.

99 Ueber einige Eruptivgesteine aus dem mexicanischen Staat Puebla. In Felix, J, and Lenk, H., Beiträge zur Geologie und Paläontologie der Republik Mexico, Th 2: 205-224, Iseipzig 1899

Hoppenstedt, A. V.

94 Informe sobre la visita al mineral de Palmarejo, Jalisco. Bol Agr, Min é Ind 3 no $12: 126-134$ (1894)

Hopper, Walter E.

11 The Caddo oil and gas field, La. Am I M Eng, B 52:283-309 (1911); Tr $42: 402-435$ (1912)

16 Michigan copper industry in 1915. Mich G S, Pub 21 (g s 17):11-56 (1916) Hopping, Roy.

99 Catalogue and price list of minerals for scientific and educational purposes. 66 pp, N Y [1899]

00 The practical study of common minerals, $67 \mathrm{pp}, \mathrm{N}$ Y 1900

Hoppoek, Albert E.

82 On the geology of "The Palisades." Sc Am Sup 13: 5045 (1882)

Hore, Reginald Edwin.

os Origin of cobalt-silver ores of northern Ontario. Ec G 3:599-610 (1908) Can M Inst, J 11:275-286 (1908) M si Press 97:874-876 (1908) Can M J 30: 118-120 (1909) ; abst, $29: 300-301$ (1908) 09 In the Michigan copper country. Can M J $30: 421-422$ (1909)

10 Diabase of the Cobalt district, Ont. J G 18:271-278 (1910)

10a on the glacial origin of Huronian rocks of Nipissing, Ont. J G 18:459-467 (1910) Mich Ac Sc Rp 12:43-46 (1910)

10b Silver deposits of Gowganda dis trict, Ont. M World $32: 1171-1173$ (1910)

10e The structure of silver deposits of Nipissing, Ont. M World 33:747-751 (1910)

10d Porcupine, the new gold region of the far north [Ontario]. M Sc Press 101: 705-706 (1910)

10e The Porcupine trail. Can M J 31: 617-622 (1910)

Iof Porcupine gold deposits, Ont. Can M J 31:649-656 (1910)

10g Porcupine and the Mother Lode. Can M J 31:746 (1910) 
Hore, Reginald Edwin-Continued.

10h The new gold fields of Porcupinc, Ont. Eng M J 90:1296-1298 (1910)

11 Differentiation products in quartz diabase masses of the silver fields of Nipis sing, Ont. Ec G 6:51-59 (1911)

$11 a$ On the nature of some Porcupine gold quartz deposits. Can M Inst, $Q$ B 15:57-70 (1911); J 14:171-184 (1912)

$11 b$ Gold quartz deposits of Porcupine, Ont. M Sc Press 102:588-591 (1911)

11e Geology of the Cobalt district, Ont. Am I M Eng, B 53:413-432 (1911) ; Tr 42: 480-499 (1912)

11d The silver fields of Nipissing, Ont. Can M Inst, Q B 17:81-105 (1911); J 14:612-636 (1912)

11e The discovery of silver deposits in Nipissing, Ont. M World 35: 1049-1053 (1911)

12 Decrease of values in ore shoots with deptb. Can M J 33: 260-263 (1912)

12a Mines and ores of Porcupine [Ont.]. Eng M J 93: 891-895 (1912)

$12 \mathrm{~b}$ The copper-mining industry of MichIgan. M World 36:601-603, 656-658, $707-710,763-767$ (1912)

12e Origin of the Sudbury nickel and copper deposits [Ont.]. M World $36: 1345$ 1349 (1912)

12d Silver mining at Cobalt, Ont. M Sc Press 105: 74-77 (1912)

12e The copper industry of Michigan. Mich G S, Pub 8 (g s 6) : 15-115 (1912)

12f On the origin of the Porcupine gold deposits. Can $M$ Inst, $T r$ 15: 218-230 (1912)

13 The outlying cobalt-silver areas [Ont.]; townships of Casey and Harris; area south of Lake Wendigo. Ont Bur Mines, An Rp 19 pt 2:145-148, 149-151, map (1913)

13a Gold-deposits of Porcupine district, Ont. Ec G $8: 482-488$ (1913)

13b Cobalt conglomerate [Ont.]. M Mag 8: 43 (1913)

13e Sflver deposits of the Cobalt district, Ontario, Canada. Mexican M J 16: 178-181 (1913)

13d The Coniagas mine, Cobalt, Ont. Eng M J 95 : 981-982 (1913)

13e Kirkland Lake gold deposits [Ont.]. Can M J 34:424-431, map (1913)

13e On the origin of the Porcupine gold deposits. Can M J 34: 548-551 (1913)

$13 \mathrm{~g}$ Magmatic origin of Sudbury nickelcopper deposits. Can M Inst, Q B 21:8596 (1913) ; Tr 16: 271-282 (1913)

13h Gold deposits of Porcupine district, Ont. Mich Ac Sc, Rp 15: 54-58 (1913)

131 Ripple-marked Huronian quartzite, at Nipissing mine, Cobalt, Ont. Mich Ac Sc, Rp 15:59 (1913)

14 The Michigan copper industry in 1913. Mich G S, Pub 16 (g \& 13:11-37 (1914)
Hore, Reginald Edwin-Continued.

15 Michigan copper deposits. Mich $\mathbf{G} \mathbf{S}$, Pub 19: 19-161 (1915)

Horn, George Henry (1840-1897).

60 (with Gabb, W. M.) Descriptions of new Cretaceous corals from New Jersey. Ac N Sc Phila, Pr $1860: 366-367$

62 (with Gabb, W. M.) Monograph of the fossil Polyzoa of the Secondary and Tertiary formations of North America. Ac N Sc Phila, J (2) $5: 111-179$, il (1862)

76 Notes on some coleopterous remains from the bone cave at Port Kennedy, Pa. Am Entom Soc, Tr 5 : 241-245 (1876)

Hornaday, W. D.

10 The cinnabar deposits of Terlingua, Tex. M World 33:1133-1134 (1910)

12 The ofl fields of Texas and their development. M World 36:1299-1300 (1912)

12a Importance of Mexico as a petroleum producer. M World 36:1307-1309 (1912)

12b The Santa Maria graphite mines, Mexico. M World 37:1041-1043 (1912)

13 The Juan Casiano oil field, State of Vera Cruz, Mexico. M World 38:100 (1913)

\section{Hornbeek, -}

41 Nogle bemaerkninger over St. Thomas's geognosie. Skandinaviske Naturforsker, Forh $2: 364-367$ (1841)

Horner, W. $\mathrm{E}$.

40 Note of the remains of the mastodon, and some other extinct animals, collected together in St. Louis, Mo. Am Ph Soc, Pr 1: 279-282 (1840) Am J Sc 40:56-59 (1841)

$40 n$ Remarks on the dental system of the mastodon, with an account of some lower jaws... where there is a solitary tusk on the right side. Am Ph Soc, Pr 1:307308 (1840) ; $2: 6-7$ (1841)

43 (and Hays, Isaac) Description of an entire head and various other bones of the mastodon. Am Ph Soc, Tr $\mathrm{n}$ s 8 : $37-47$, il (1843)

43a Remarks on the dental system of the mastodon, with an account of some lower jaws in Mr. Koch's collection, St. Lonis, Mo., where there is a solitary tusk on the right side. $\mathrm{Am} \mathrm{Ph}$ Soc, Tr n s 8: 53-59 (1943)

Horsford, Eben Norton (1818-1893).

40 On the geology of Cattaraugus Co. [N, Y.]. N Y G S, An Rp 4:457-472 (1840)

52 Solidification of the rocks of the Florlda Reefs and the sources of lime in the growth of corals. Am J Sc (2) 14: 245-253 (1852) Am As, Pr 6:207-215 (1852)

56 On the solidification of the coral reefs of Floriala, and the source of carbonate of lime in the growth of corals. Am As, Pr $7: 122-147$ (1856.) 
Horton, Frederick W.

06 Quicksilver. U S G S, Min Res 1905 : 393-404 (1906)

06a Platinum. U S G S, Min Res 1905: 423-434 (1906)

16 Molybdenum; its ores and their concentration. U S Bur Mines, B 111:132 pp (1916) Abst, M Se Press 114:276-278 (1917)

Horton, George F.

59 Geology [of Bradford Co., Pa.]. Med Soc $\mathrm{Pa}, \operatorname{Tr}$ n s $4: 48-54$, map (1859)

Horton, Robert E.

05 The drainage of ponds into drilled wells. U S G S, W-S P 145: 30-39 (1905)

15 Idiosyncrasies of underground water. Conn Soc Civil Eng, Pr 1915: 23-56

Horton, William.

39 Report on the geology of Orange Co. [N. Y.]. N Y G S, An Rp 3:135-175 (1839)

Hosea, R. M.

97 The Newcastle coal mines [Garfield Co., Colo.]. Colliery Eng $17: 377-382$, 425-429 (1897)

98 Anthracite in the Rockies. Mines and Minerals 18: 529-533; 19:7-9 (1898)

Hoskin, Arthur Joseph.

11 Topographical and geological mapping; methods and instruments employed by the parties making the survey in the field. Mines and Minerals $32: 312-314$ (1911)

12 (with Patton, H. B.) Geology and ore deposits of the Alma District, Park Co., Colo. Colo G S, B 3: 284 pp (1912)

18 The oil shale industry [northwestern Colorado]. M Sc Press 116:509-516 (1918)

Hoskins, Leander Miller.

96 Flow and fracture of rocks as re. lated to structure. U S G S, An Rp $16 \mathrm{pt}$ 1: $845-874$ (1896)

06 The rigidity of the earth. Science n s 24:403 (1906)

Hosler, Rush N.

10 The northern Appalachian coal field. Eng M J 89: 1122-1124 (1910)

Hostetter, J. C.

14 (with Day, A. L.) The determination of mineral and rock densities at high temperatures. Am J Se (4) 37:1-39 (1914)

16 (with Sosman, R. B.) Ferrous iron content and magnetic properties of the natural oxides of iron as an index to their origin and history $(a b s t)$. G Soc Am, B $27: 60-61$ (1916)

17 The linear force of growing crystals (abst). Wash Ac Sc, J 7: 195-196 (1917)

17a (with Sosman, R. B.) Zonal growth in hematite and its bearing on the origin of certain iron ores. Am I M Eng, B 126:933-943 (1917) ; $\mathrm{Tr} \quad 58: 434-444$ (1918) Abst, Wash Ac Sc, J 6:309 (1916) ; $8: 329$ (1918)
Hostetter, J. C.-Continued.

17b (with Wright, F. E.) The the modynamic reversibility of the equilibrim relations between a strained solld and it liquid. Wash Ac Sc, J 7:405-417 (191? Hotehkiss, Jedediah (1827-1899).

73 On the Virginias; their agricultun! mineral, and commercial resources. \& Arts [London], J 21: 238-251 (1873)

76 Virginia...its geology, soils, minerale $319 \mathrm{pp}$, maps, Richmond 1876

80 The Virginias, a mining, industrial, and scientific journal, devoted to the ds velopment of Virginia and West Virginis. 6 vols., 1880-1885, Staunton, Va.

son The coal fields of West Virginia abi Virginia in the Great Ohio or trans-dp. palachian coal basin. The Virginias $1: 18$. 21, map (1880)

80b The Shenandoah Valley Rallros and the mineral and other resources of the country tributary to it. The Virginias 1: $36-37,40$, 56-57, 60-61, map (1880)

soc The Smithers-Gauley tract of $\mathrm{col}$ lands [Fayette Co., W. Va.] The $\mathrm{F}$ : ginias $1: 47-49$, map (1880)

$80 d$ The resources of the Virginias on and near the proposed route of the Rict mond and Southwestern Railway. The Virginias 1: 90-93, 106-109 (1880)

soe Geological map of Virginia and West Virginia. The geology by Prof. Wil liam B. Rogers, chiefly from the Virginis state survey, 1835-41. Scale $1: 1,520,640$. In The Virginias 1 no 6 (1880)

81 Mineral deposits along the line of the Shenandoah Valley Railroad... $11 \mathrm{ph}$ map, Phila 1881 [not seen]

$81 a$ [Iron formations, Bratton Run rs]. ley, Rockbridge Co., Va.] The Virginiss $2: 53$ (1881)

81b Craig Creek basin [Craig Co., Va.]; its iron ores, etc. The Virginias 2:105109 (1881)

81e The Norfolk \& Western and Shenas. doah Valley railroads. The Virginias 2: 119-121 (1881)

82 The Van Buren Furnace estate; its geology, etc. [Shenandoah Co., Va.] The Virginias 3: 8-9, 12, map (1882)

82a The mineral resources of the region between the Valley of Virginia and the up. per Potomac coal basin. The Virginias 3: 66-67, map (1882)

82b. The Great Flat Top coal field [W. Va.]. The Virginias 3: 88-89, 92-93, map (1882)

82c Thickness of Coal Measures and beds in Great Kanawha coal field, W. V8. The Virginias 3:157 (1882)

82d The Virginia geological survey of 1835-41. The Virginias 3: 166-170 (1882)

83 The Dora, Va., "anthracite" coal mines. The Virginias 4:105-106 (1883)

83a The natural coke of Virginia; reply to $\mathrm{Dr}$. Raymond. The Virginias 4:104 (1883) 
Hotchkiss, Jedediah-Continued.

84 The Lower Helderberg or No. VI limestones of Virginia. The Virginias 5 : 113-114 (1884)

85 The geology of Highland Co., Va. The Virginias 6:121 (1885)

See also Williams ( $\mathrm{G} \mathrm{H}), 91 \mathrm{~b}$

Hotehkiss, William Otis.

05. An explanation of the phenomena seen in the Becke method of determining index of refraction. $A m$ G $36: 305-308$ (1905)

05a Cobalt mining district, Ont. M World $23: 634-636$ (1905)

07 Mining and mineral resources of Wisconsin. Am M Cong 9 th An Sess, Rp of $\mathrm{Pr}: 220-225$ (1907)

08 A table of index of refraction and birefringence of rock-making minerals. J G 16: 421-427 (1908)

10 A new model of the State of Wisconsin. Geog Soc Phila, B 8:65-68 (1910)

11 The general structure of the Forence fron district [Wis.] (abst), Science $\mathrm{n}$ s $33: 464$ (1911)

12 (and Thwaites, F. T.) Map of Wisconsin showing geology and roads 1911. Scale, 6 miles $=1$ inch. Wis G $\mathrm{S}$ [19̀12]

14 (and Steidtmann, E.) Limestone road materials of Wisconsin. Wis G S, B 34:137 pp, maps (1914)

15 (and others) Mineral land classification showing indications of iron formation...[Wisconsin]. Wis G S, B $44: 378$ pp, maps (1915)

17 A method of measuring postglacial time (with discussion by L. D. Burling and Frank Leverett). G Soc Am, B 28: 138-141 (1917)

17a Annual field trip of the American Association of State Geologists. Science n s $46: 556-557$ (1917)

Hough, Franklin B.

45 Burning well [Trumbull Co., Ohio]. Am J Se $49: 406-407$ (1845)

47 Observations on the geology of Lewis Co. [N. Y.]. Am J Agr 5:267-274, 314327 (1847)

51 On the cylindrical structure observed in Potsdam sandstone. Am As, Pr 4:352354 (1851)

51 a On the association of certain minerals in northern New York. Am As, Pr 5: 205-206 (1851)

$51 \mathrm{~b}$ List of mineralogical and geological specimens [from St. Lawrence Co., N. Y.] N Y St Cab, An Rp 4:82-90 (1851)

52 On the existence of diluvial agercies during the earlier geological periods. $\mathrm{Am}$ As, $\operatorname{Pr} 6: 262-264$ (1852)

Houghton, Douglass (1809-1845).

34 Report on the copper of Lake Superior. In Schoolcraft, H. R., Narrative of an expedition through the upper Mississippi to Itasca Lake...: 287-292, N Y 1834 Also in Schooleraft, H. R., Summary narrative... : 526-531, Phila 1855
Houghton, Douglass-Continued.

38 Report of the State geologist. Michigan, House of Representatives [Doc] no 14 ; Senate [Doc] no $16: 37 \mathrm{pp}$ (1838)

39 Second annual report of the State geologist of the State of Michigan. 39, $123 \mathrm{pp}$, Detroit 1839

39 Report of the State geolngist in relation to the improvement of State salt springs. Mich, House of Representatives [Doc] no $2: 8 \mathrm{pp}$ (1839)

40 [Third annual report of the State geologist of the State of Michigan.] MichIgan, House of Representatives [Doc] no $8: 124 \mathrm{pp}$, map (1840)

41 [Fourth] annual report of the State geologist. Michigan, House of Representatives [Doc] no $27: 184 \mathrm{pp}$ (1841) In part, with title General geology of the Upper Peninsula, U S, 29th Cong 2d sess, H Rp 591:6-38 map (1846)

41 a Metalliferous veins of the Northern Peninsula of Michigan. Am J Sc 41:183186 (1841) As Am G, Rp 35-38 (1843)

42 [Fifth] annual report of the State geologist. Mich, House of Representatives, Doc no 2, session 1842:436-441 (1842)

43 [Sixth] annual report of the State geologist. Michigan, Legislature, Doc no 8, session $1843: 398-402$ (1843)

44 [Seventh] annual report of the State geologist. Michigan, Legislature, 1844, Joint Doc no $11: 3$ pp (1844)

73 Lithology [of the Upper Peninsula]. Mich G S 2:239-246 (1873)

Houghton, Frederick.

14 The geology of Erie Co. [N. Y.]. Buffalo Soc N Sc, B $11: 3-84$, map (1914)

Houghton, George F.

56 Obituary of Professor Zadoc Thompson. Am J Sc (2) $22: 44-49$ (1856)

Houghton, Jacob, jr.

46 (and Bristol, T. W.) Reports of Wm. A. Burt, and Bela Hubbard on the geography, topography, and geology... of the south shore of Lake Superior... 109 pp, map, Detroit, 1846

79 The ancient copper mines of Lake Superior. Wis St Hist Soc, Coll, 8:140151 (1879)

Houghton, John C.

61 [Survey of Moosehead Lake reglon.] Me Bd Agr, 6th An Rp: 426-442 (1861)

Honser, Gilbert L.

93 Some lime-burning dolomites and dolomitic building stones from the Niagara of Iowa. Iowa G S 1, An Rp 1892:197207 (1893)

Hovey, Edmund Otis.

67 The crinoidal banks of Crawfordsville, Ind. Am Nat 1:554-555 (1867)

74 The largest fossil elephant tooth yet described (abst). Am As, Pr 22 pt 2: 112 (1874)

88 A cordierite gneiss from Connecticut. Am J Sc (3) $36: 57-58$ (1888) 
Hovey, Edmund Otis-Continued.

89 Observations on some of the trap ridges of the East Haven-Branford region. Am J Sc (3) 38:361-383, map (1889) Abst, Am As, Pr 38: 232-233 (1890)

90 The oil well at Southbury, Conn. Sc $\Delta \mathrm{m} 62: 275$ (1890)

93 An analcite copper boulder from the Keweenaw Range, Mich. Science 22:93 (1893)

94 Note on the petrography of certain basaltic boulders from Thetford, Vt. N Y Ac Sc, $\operatorname{Tr} 13: 161-164$ (1894)

94a A study of the cherts of Missouri. Am J Sc (3) 48:401-409 (1894) Mo G S 7: 727-739 (1894) AOst, Am G 14:196 (1894)

94b Microscopic structure of siliceous oolite. G Soe Am, B 5:627-629 (1894) Abst, Am G $13: 223-223$ (1894)

94e The annual meeting of the Geological Society of America [sixth annual, Boston, 1893]. Eng M J 57:3-4 (1894)

94d American "tripoli." Sc Am Sup $38: 15487$ (1894)

95 Section E-Geology and geography [American Association for the Advancement of Science]. Science n s $2: 399-402$ (1895)

95 a Notes on some specimens of minerals from Washington Heights, New York City. Am Mus N H, B $7: 341-342$ (1895)

96 Notes on the artesian well sunk at Key West, Fla., in 1895. Harvard Coll, Mus C Z, B 28 (g s 3):65-91 (1896) Abst, Am G 18:218-219 (1896); Science n s 4:385 (1896)

$96 a$ Catalogue of meteorites in the collection of the American Museum of Natural History to July 1, 1896. Am Mus N H, B 8 : 149-155 (1896)

96b Rare minerals from New York City (abst). Science n s 3:214 (1896)

97 A relatively acid dike in the Connecticut Triassic area. Am J Sc (4) 3 : 287-292, map (1897)

97a Pseudomorphs after halite from Jamaica, W. I. Am J Sc (4) 3:425 (1897)

98 American Association for the Advancement of Science-Section of geology and geography [Boston, August, 1898]. Eng M J 66:276-277 (1898)

98a (with Whitfield, R. P.) Catalogue of the type and figured specimens in the paleontological collection of the geological department, American Museum of Natural History. Am Mus N H, B 11: 500 pp (1898-1901)

99 Eleventh winter meeting of the Geological Society of America. Am G 23: 86109 (1899) Sc Am Sup 47:19288-19290 (1889)

99a Edward Orton. Eng M J 68:485, port (1899)

00 The annual meeting of the Geological Society of America [Washington, December, 1899]. Eng M J 69: 45 (1900)
Hovey, Edmund Otis-Continued.

OOa Geology and geography at the forty. ninth meeting of the American Association for the Advancement of Science. Sc Am $83: 22-23$ (1900)

O0b Note on a calcite group from Bisbec, Ariz. Am Mus N H, B 12:189-190 (1900) ooe Some of the collections in the get logical department of the [American] Mo. seum [of Natural History]. Am Mus J 1: $70-72(1900)$

ood Oliver Payson Hubbard. Am G 25: $360-363$, port. (1900)

00e The Wind Cave of South Dakota, Sc Am Sup 49:20458-20459 (1900)

oor Erosion forms in Harney Peak dis. trict, South Dakota (abst with discussion by S. F. Emmons). G Soc Am, B 11:5\$1582 (1900) Science n s 11:100 (1900)

OOg Scenery of the Harney Peak dis. trict in the Black Hills, S. Dak (abst). Science n s 11: 750-751 (1900)

Ooh Floating sand and stones. Science n s 11: 912-913 (1900)

00i The geological and paleontological collections in the American Museum of Natural History. Sclence n s 12:757-760 (1900)

o1 The thirteenth annual meeting of the Geological Society of America, Eng M J 71: 49-50 (1901) Sc Am 84:19 (1901) Sc Am Sup 51: 20948-20950 (1901)

01 a Geology of the fiftieth meeting of the American Association for the Adrance ment of Science. Eng M J $72: 297-298$ (1901)

01b Geology and geography at the Denver meeting of the American Association for the Advancement of Science. Se At Sup 52 : 21504-21505 (1901)

02 The fourteenth annual meeting of the Geological Society of America. Eng M J 73: 101-103 (1902)

02a The paleontological collections of the geological department of the American Museum of Natural History. J G 10: 252-255 (1902)

02b Ores of economic importance. $U$ s G S, Min Res 1901: 967-973 (1902)

02e A remarkable slab of fossil crinoids [Cintacrinus socialis]. Am Mus J 2:1114, il (1902)

02d A visit to Martinique and St. Vincent after the great eruptions of May and June, 1902. Am Mus J 2: 57-63 (1902)

02e Martinique and St. Vincent; a pret liminary report upon the eruptions of 1902 . Am Mus N H, B $16: 333-372$ (1902)

o2f Observations on the eruptions of 1902 of La Soufrière, St. Vincent, and Mt. Pelé, Martinique. Am J Sc (4) 14:319358 (1902)

02g The eruptions of La Soufrlère, St, Vincent, in May, 1902. Nat Geog Mag, $13: 444-459$ (1902) 
Hovey, Edmund Otis-Continued.

$02 h$ Notes on the Triassic and Jurassic strata of the Black Hills of South Dakota and Wyoming (abst). N Y Ac Sci, An $14: 152$ (1902) Science n s 15:27 (1902)

03 Annual meeting of the Geological Society of America and the American Association for the Advancement of Science, Section E [Washington, 1902-03]. Eng M J $75: 152-154$ (1903)

03a The annual meeting of the Geological Society of America and geology and geography at the convention of the American Association for the Advancement of Science. Sc Am Sup 55:22646-22648, 22665-22667 (1903)

03b Section E, Geology and geography [American Association for the Advancement of Science, Washington meeting]. Science n s $17: 217-229$ (1903)

03e The new cone of Mont Pelé and the gorge of the Rivière Blanche, Martinique. Am J Sc (4) $16: 269-281$ (1903)

03d Martinique and $S t$. Vincent revisited. Am Mus J 3: 41-55 (1903)

03e The rolcanoes of the Caribbean Islands; appearance of Mont Pele, Martinique, and La Soufrière, St. Vincent, one year after the great eruption. Sc Am Sup 56:23011-23014 (1903)

03f The marvelous obelisk of Mont Pelé. sc Am Sup 56:23354-23355 (1903) Abst, Sc Am 89: 407 (1903)

$03 \mathrm{~g}$ Some erosion phenomena on Mont Pelé and Soufrière (abst). Science $\mathrm{n} \mathbf{s}$ $17: 226$ (1903) Sc Am Sup 55:2264722648 (1903)

03h The inner cone of the Mont Pelé crater and its relation to the destruction of Morne Rouge (abst). Science n 8 17: 226 (1903) Sc Am Sup 55: 22647-22648 (1903)

03i "Mount Pelee." Science n s 17 : 1010 (1903)

03j Mont Pele from May to October, 1903. Science n s 18:633-634 (1903)

04 The Geological Society of America [sixteenth annual meeting, St, Louis, Mo.]. Eng M J 77:73-74 (1904)

04a The Grande Soufriere of Guadeloupe. Am Geog Soc, B 36:513-530, map (1904)

04b New cone and obelisk of Mont Pelé. G Soc Am, B 15:558-560 (1904)

04e Some erosion phenomena observed on the islands of Saint Vincent and Martinique in 1902 and 1903 . G Soc Am, B $15: 560-561$ (1904)

04d Grande Soufrière of Guadeloupe. G Soc Am, B $15: 561$ (1904)

04e Bibliography of literature of the West Indian eruptions published in the United States. G Soc Am, B 15: 562-566 (1904)
Hovey, Edmund Otis-Continued.

04f The Grande Soufrière of Guadeloupe, an analogue of Mont Pelé (abst). Science n s $19: 859-860$ (1904)

04g Mont Pelé from October 20, 1903, to May 20, 1904. Science n s 20:23-24 (1904)

04h The Soufrière of St. Vincent in July, 1904. Science n s 20:281-282 (1904)

o4i St. Vincent, British West Indies; the eruptions of 1902 and their immediate results (abst). Science n s 20:604-605 (1904)

04j The 1902-1903 eruptions of Mont Pele, Martinique and the Soufrière, St. Vincent. Int G Cong, IX, Vienna, 1903, C R : 707-738 (1904)

04k The Crystal Cave of South Dakota. Sc Am Sup 57: 23657-23658 (1904)

041 Phosphate rock. U S G S, Min Res 1903: 1047-1058; 1904: 1053-1064; $1905: 1117-1126$ (1904-6)

$04 m$ Salt. U S G S, Min Res 1903: 1059-1071 ; 1904 : 1065-1077 ; 1905 : 11271135 (1904-6)

94n Asphaltum and bituminous rock. U S G S, Min Res $1903: 745-754 ; 1904$ : $789-799 ; 1905: 1161-1169$ (1904-6).

05 Seventeenth annual meeting of the Geological Society of America. Sc Am Sup 59:24326-24327 (1905)

05a The Geological Society of America [Philadelphia, Pa. December 29-31, 1904]. Seience n s $21: 216-223$ (1905)

o5b Geological progress [seventeenth annual meeting of the Geological Society of America at Philadelphia, December, 1904]. Eng M J $79: 94-95$ (1905)

05e [American Association for the Advancement of Science] Section EGeology and geography [Philadelphia, December, 1904]. Science n s 21:135-138 (1905)

05d The American Association for the Advancement of Science; summer meeting of Section E-Geology and geography. Selence n s $22: 333-336$ (1905)

ose Geology and geography at the American Association for the Advancement of Science. Sc Am 92: 27 (1905)

o5f Volcanoes of Martinique, Guadaloupe, and Saba. Int Geog Cong, VIII, Rp : 447-451 (1905)

$\mathbf{O S g}$ Volcanoes of St. Vincent, St. Kitts, and Statia. Int Geog Cong, VIII, Rp: 452-454 (1905)

o5h The Cape York [Greenland] meteorites. Am Mus J $5: 3-7$ (1905)

05i The western Sierra Madre of the State of Chihuahua, Mex. Am Geog Soc, B $37: 531-543$ (1905) Abst, Science n s $22: 336$ (1905)

05j Antimony; arsenic; bismuth. U S G S, Min Res 1904: 363-376 (1905) 
Hovey, Edmund Otis-Continued.

06 The geology of the Guaynopita district, Chihuahua [Mexico]. Festschrift Harry Rosenbusch : 77-95, Stuttgart 1906

O6a [Report of the meeting of] Section E-Geology and geography, American Association for the Advancement of Science [New Orleans. December, 1905]. Science n $s \quad 23: 286-291$ (1906)

06b The American Association for the Advancement of Science; special meeting, Ithaca, New Jork, June 28-July 3, 1906; Section E-Geology and geography. Science n s $24: 365-372$ (1906)

06c The Willamette meteorite. Am Mus J $6: 105-116$ (1906)

o6d Notes on northern Mexico; its deserts, plateaus, and canyons. Geog Soc Phila, B 4:247-270 (1906)

06e The Tenth International Geological Congress [held in the City of Mexico, September, 1906]. Am Geog Soc, B 38: 730-741 (1906)

o6f The collections illustrating the rocks and minerals of Manhattan Island. Am Mus J 6:6-12 (1906)

06g Present condition of Mont Pelé (abst). G Soc Am, B 16:566-569 (1906) 06h Soufrière of Saint Lucia (abst). G Soc Am, B 16:569-570 (1906)

06i Boiling lake of Dominica (abst). G Soc Am, B 16: 570-571 (1906)

06j Geological notes on the western Sierra Madre of Chihuahua, Mexico (abst). Science n s 23:467 (1906)

o6k Notes on the geology of the Guaynopita, Chihuahua, Mexico, mining district (abst). Science n s 24:369 (1906) ; Am As, $\operatorname{Pr}$ 56-57: 270 (1907)

O61 Fluorspar and cryolite. U S G S, Min Res 1905: 1099-1103 (1906)

$06 \mathrm{~m}$ Lithium minerals. U S G S, Min Res 1905: 1271-1272 (1906)

O6n (with Whitfield, R. P.) Remarks on and descriptions of [invertebrate] Jurassic fossils of the Black Hills. Am Mus N H, B 22: 389-402 (1906)

o7 The American Association for, the Advancement of Science; meeting of Section E-Geology and geography. Science n s $25: 293-298$ (1907)

ora A geological reconnaissance in the western Sierra Madre of the State of Chihuahua, Mexico. Am Mus N H, B 23:401442, map (1907)

о7b La Sierra Madre occidentale de l'état de Chihuahua. Int $\mathrm{G}$ Cong, $\mathrm{X}, \mathrm{Mex}$ 1co, 1906, C R : 1259-1268 (1907)

o7c The Geological Society of America [New York meeting, December 27-29, 1906]. Science n s 25: 761-775 (1907)

ord The Selma meteorite. Am Mus $\mathrm{J} 7$ : 8-12 (1907)

ore The Isthmus of Tehuantepec and the Tehuantepec National Railway. Am Geog Soc, B 39: 78-91 (1907)
Hovey, Edmund Otis-Continued.

07e Volcanoes of Colima, Toluca, and Popocatepetl (abst). Science n s 25:764, 868 (1907) G Soc Am, B 18:635 (1908) N Y Ac Sc, An 18:314 (1908)

O7\% The foyer collection of meteorites Am Mus N H, Guide Leaflet no $26: 40$ pp (1907)

os Proceedings of the nineteenth annual meeting held at New York, N. Y., December 27,28 , and 29 , including proceedings of the eighth annual meeting of the Cordilleran section held at Stanford University, Callfornia, December 28 and 29, 1906. G Soc Am, B 18: 557-654 (1908)

OSa The Geological Society of America. Science n s 27:405-413 (1908) [Albuquerque N. Mex., meeting December 30 and 31,1907 ]

08b Ten days in camp on Mt. Pels, Martinique; the volcano six years after the great eruption. Am Geog Soc, B 40 662-679 (1908)

ose The Chester, N. Y., mastodon. N Y Ac Sc, An 18:147 (1908)

08d The petroleum and manjak industry of Barbados. M World 29:237-238 (1908)

ose Notes on the geology and geography of the western Sierra Madre [Mexico] (abst). N Y Ac Sc, An 18:266-267 (1908)

09 Striations and $U$-shaped valleys pro. duced by other than glacial action. G Soc Am, B 20:409-416 (1909) Abst, Science n s $29: 633$ (1909)

09a Earthquakes, their causes and effects. Am Ph Soc, Pr $48: 235-258$ (1909) Abst, Science n s 29:833 (1909)

09b Proceedings of the twentieth annual meeting of the Geological Society of America, held at Albuquerque, N. Mex., December 30 and 31 , including the proceed. ings of the ninth annual meeting of the Cordilleran section, held at the same place and time. G Soc Am, B 19:513-617 (1909)

09c The Geological Society of America [Baltimore meeting, December, 1908]. Science n s 29:623-639 (1909)

o9d Clearing out of the Wallibu and Rabaka gorges on Saint Vincent Island. G Soc Am, B 20:417-426 (1909)

o9e The Guffey, Colo., meteorite. Am Mus J 9: 237-243 (1909)

o9r Recent additions to the meteorites in the foyer [of the American Museum of Natural History]. Am Mus J 9:243-248 (1909)

o9g Camping on the Soufriere of St. vincent. Am Geog Soc, B 41:72-83 (1909)

O9h St. Pierre and Mt. Pelé in 1908. Am Mus J 9:33-40 (1909) 
Hovey, Edmund Otis-Continued.

091 Some of the latest results of explorations in the Hudson River at New York City $(a b s t)$. Science n $\mathbf{s}$ 29:280 (1909)

10 On the so-called Norwood "meteorite." Science n s 31: 298-299 (1910)

10a Proceedings of the twenty-first annual meeting, held at Baltimore, Md., December 29,30 , and 31,1908 . G Soc Am, B $20: 607-749$ (1910)

10b Memoir of Homer T. Fuller. G Soc Am, B 20:617-618, port (1910)

10e Proceedings of the twenty-second annual meeting of the Geological Society of America, held at Boston and Cambridge, Massachusetts, December 28, 29, 30, and 31, 1909. G Soc Am, B 21:1-86 (1910)

10d Twenty-second annual meeting of the Geological Society of America. Science 32 : 185-192, 218-224 (1910)

10e Robert Parr Whitfield. Am Mus J $10: 119-121$, port (1910)

10 Abstracts of papers presented at the twenty-second annual meeting of the soclety but not published in full in the preceding pages of this volume, together with discussions of papers as far as preserved. G Soc Am, B 21: 753-788 (1910)

11 Proceedings of the twenty-third annual meeting of the Geological Society of America, held at Pittsburgh, Pennsylvania, December 27,28 , and 29,1910 . G Soc $A m$, B $22: 1-84$ (1911)

11a Abstracts of papers presented at the twenty-third annual meeting of the society, but not published in full in the preceding pages of this volume, together with discussions of papers as far as preserved. G Soc Am, B 22:715-738 (1911)

11b Newly discovered cavern in the Copper Queen mine [at Bisbee, Ariz.]. Am Mus J 11: 304-307 (1911)

12 Proceedings of the twenty-fourth annual meeting of the Geological Society of America, held at Washington, D, C., December $27,28,29$, and 30,1911 , G Soc Am, B 23:1-68 (1912) Science n s 35: 310-320 (1912)

12n Abstracts of papers presented at the twenty-fourth annual meeting of the soclety, but not published in full in the preceding pages of this volume, together with discussions of papers so far as preserved. G Soc Am, B $23: 719-747$ (1912)

12b Cave material from a Mexican mine. Am Mus J $12: 218$ (1912)

12e New accessions of meteorites [in the American Museum of Natural History]. Am Mus J $12: 257-258$ (1912)

12d The seismograph at the American Museum [of Natural History, New York]. Am Mus J 12: 297-299 (1912)

12e The Kingston, New Mexico, siderite. N Y Ae Sc, An $22: 335-337$ (1912)
Hovey, Edmund Otis-Contlinued.

12p Geological sketch of the Hudson River region from Newburgh to the sea. In The geology, fauna, and flora of the lower Hudson Valley, prepared by the American Museum of Natural History and the New York Botanical Gardens ... [for] the Eighth International Congress of Applied Chemistry : 3-9, map, Concord, N. H. 1912

13 Proceedings of the twenty-fifth annual meeting of the Geological Society of America, held at New Haven, Connecticut, December 28, 29, 30, and 31, 1912. G Soc Am, B 24:1-90 (1913)

13a Abstracts of papers presented at the twenty-fifth annual meeting of the society, but not published in full in the preceding pages of this volume, together with discussions of papers as far as preserved. G Soe Am, B 24:669-719 (1913)

13b Dana, the teacher. G Soc Am, B 24: 60-64 (1913)

14 Proceedings of the twenty-sixth annual meeting of the Geological Society of America, held at Princeton, N. J., December 30 and 31,1913 , and January 1, 1914. G Soc Am, B 25: 1-118 (1914)

14a Note on landslides. Int $\mathrm{G}$ Cong, XII, 1913, C R : 793-795 (1914)

15 Proceedings of the twenty-seventh annual meeting of the Geological Society of America, held at Phlladelphia, Pennsylvania, December 29,30 , and 31,1914 . G Soc Am, B 26:1-128 (1915)

15n Proceedings of the twenty-seventh annual meeting of the Geological Society of America, held at Philadelphia, Pa., Dec. $29-31$, 1914. Science n s 41:507-514 (1915)

15b California meeting of the Geological Society of America. Science n 8 42:8687 (1915)

15e Volcanoes of the Lesser Antilles; observations on the present condition of the active volcanoes of Martinique, St. Vincent, and Gaudeloupe. Am Mus J 15 : 254-255 (1915)

18 Proceedings of the thirtieth annual meeting of the Geological Soclety of America, held at Saint Louis, Missouri, December 27,28 , and 29,1917 . G Soc $A m$, B $29: 1-118$ (1918)

$18 \mathrm{a}$ Notes on the geology of the region of Parker Snow Bay, Greenland (abst). G Soc Am, B 29:98 (1918)

See also Ekblaw, 18 a

Hovey, Horace Carter (1833-1914).

75 Brachiospongia [Franklin Co., Ky.]. Kans Ac Sc, Tr [3] 1874:10-11, 11 (1875) ; reprint $3: 111-113$, il $(1896)$ Kans St Bd Agr, An Rp 3:344-345, il (1875)

78 Discoveries in western caves. Am J Sc (3) 16:465-471 (1878)

82 Subterranean scenery (abst). N Y Ac Sc, Tr $2: 36-41$ (1882) 
Hovey, Horace Carter-Continued.

S2a A remarkable case of retention of heat by the earth (abst). Am As, Pr 30: $39-40$ (1882)

s3 Subterranean map making (abst). Am As, Pr $31: 345-348$, maps (1883)

86 Niagara River, gorge, and falls. Se Am Sup 22:8917 (1886)

90 The pits and domes of Mammoth Cave (abst). Am As, Pr 38:253-255 (1890)

91 Guide book to the Mammoth Cave of Kentucky... 75 pp, map, Cincinnati 1891

91a Mammoth Cave, Ky. Am Geog Soc, B $23: 47-79$ (1891)

91b The latest facts about Megalonyx. Sc Am 65: 161 (1891)

93 A remarkable instance of recent erosion [Crawfordsville, Ind.]. Sc Am 68:152 (1893)

95 The Isles of Shoals. Sc Am Sup 40 : 16547-16548 (1895)

95a Geological notes on the Isles of Shoals (abst). Am As, Pr 44:136-137 (1896) Am G 16:248-249 (1895) Science n s $2: 400-401$ (1895)

96 Celebrated American caverns...

228 pp, Cincinnati 1896

96a The making of Mammoth Cave. Sc Am 75:151 (1896) Abst, Am G 18:228 (1896) ; Science n s 4:385 (1896)

$96 \mathrm{~b}$ The Colossal Cavern of Kentucky. Sc Am $75: 183$ (1896) Abst, Am G 18:228 (1896)

97 (and Call, R. E.) Mammoth Cave of Kentucky... 112 pp, map, Louisville 1897

97a Mammoth Cave, its environs and contents. J Sch Geog 1: 133-139 (1897)

99 The life and work of James Hall, LL.D. Am G 23: 137-168, port. (1899)

00 Facts about the Megalonyx. Sc Am Sup $50: 20839$ (1900)

01 The lead and silver mines of Newbury [Mass.]. Sc Am Sup 51: 21284 (1901)

04 Colossal Cavern, Kentucky. Spelunca 5 no $37: 57-61(247-251)$ (1904)

08 Recent explorations in Mammoth Cave, with a revised map of the cave (abst). Science n s 28:381 (1908)

09 Hovey's Handbook of the Mammoth Cave of Kentucky ; a practical guide to the regulation routes, with maps and lllustrations. 64 pp. Louisville, Ky., 1909

12 Mammoth Cave of Kentucky (Hovey and Call); with an account of Colossal Cavern. Revised ed, 131 pp, Louisville 1912

$12 a$ Bibliography of the Mammoth Cave (a)st). G Soc Am, B 23:747 (1912)

14 (and Call, R. E.) Bibliographie chronologique è analytique de Mammoth Cave, Ky., Etats-Unis d'Amérique, 18151914 , traduite et ordonnée par E. A. Martel. Spelunca $9: 3-49$ (1914)
Hovey, S.

38 Geology of St. Crolx. Am J Sc:B474 (1838)

38a Geology of Antigua. Am J Se 35: 75-85 (1838)

How, Henry.

57 On the occurrence of natro-boro-cel. cite with Glauber salt in the gypsum of Nova Scotia. Edinb $\mathrm{N}$ Ph J n s 6:54-97 (1857) Am J Sc (2) 24:230-235 (1857) M Mag $9: 323-327$ (1857)

58 Chemical analysis of faroelite and some other zeolites oecurring in Non Scotia. Am J Sc (2) 26:30-34 (1858)

59 Description and analysis of thre new minerals, associates in the trap of the Bay of Fundy. N S Lit Sc Soc, Tr 1859: 30-41 Edinb $\mathrm{N}$ Ph $\mathrm{J}$ n $\mathrm{s} \quad 10: 84-94$ (1859)

60 On the ofl coal found near Pictou, N. S. ; and the comparative composition of the minerals often included in the tem coals. Am J Se (2) $30: 74-79$ (1860) Edinb N Ph J n s 12:80-87 (1860)

61 Natro-boro-calcite and another b. rate occurring in the gypsum of Nor Scotia. Am J Se (2) $32: 9-13^{-}$(1861) Edinb N Ph J n s 14:112-116 (1861)

$61 a$ On gyrolite occurring with calclts in apophyllite in the trap of the Bay of Fundy. Am J Sc (2) 32:13-14 (1861) Edinb $\mathrm{N} \mathrm{Ph}$ J n s 14:117-118 (1861)

62 [Examination of minerals from dif. ferent localities in Nova Scotia.] $N$ \& Legislative Council, J Pr 1862, App no 2: 60, Hallfax, N. S., 1862

63 On magnesia alum or pickeringite containing a little nickel and cobalt occur ring in slate in Hants Co. $N$ S Inst $N$ Sc, $\operatorname{Pr} \operatorname{Tr} 1$ pt $1: 85-87$ (1863)

$63 n$ Notice of the occurrence of a trilobite in the Lower Carboniferous limestobe of Hants Co. N S Inst $\mathbf{N}$ Sc, $\mathrm{Pr}$ Tr 1 : 87-88 (1863)

63b On some mineral waters of Nori Scotia. Can Nat 8:370-375 (1863)

63e On pickeringite occurring in slate in Nova Scotia... Ch Soc London, J $16: 200$ 206 (1863)

64 Notes on the economic mineralogy o? Nova Scotia. N S Inst $\mathrm{N}$ Sc, $\operatorname{Pr} \operatorname{Tr} 1$ pt $2: 78-86$ (1864) ; 1 pt $3: 128-138$ (1865); 1 pt $4: 58-66(1866) ; 2$ pt $1: 26-30$ (1869) ; 2 pt $3: 128-140$ (1870)

$64 a$ On mordenite, a new mineral from the trap of Nova Scotia. Ch Soc London, J $17:$ 100-104 (1864)

66 Contributions to the mineralogy of Nova Scotia. Ph Mag (4) $31: 165-170$ (1866) ; $33: 336-340$ (1867) ; $35: 32-41$, 218-219 (1868); 37:264-271 (1869); 39: $275-280(1870) ; 41: 270-274$ (1871); (5) $1: 128-138$ (1876)

67 Remarks on minerals prepared for the Paris Exhibition. N S Inst $\mathrm{N} \mathrm{Sc}$, Pt Tr 2 pt 1: 25-35 (1867) 
How, Henry - Continued.

69 The mineralogy of Nova Scotia; a report to the provincial government. 217 pp, Halifax, N. S., 1869

$760 \mathrm{n}$ the analysis of two Spring Hill coals. N S Inst $N$ Sc, $\operatorname{Pr} \operatorname{Tr} 4: 98-101$ (1876)

77 Notes on some North American pyrrhotites and other minerals containing nickel. Miner Mag 1: 124-127 (1877)

77a Contributions to the mineralogy of Nova Scotia. Miner Mag 1:257-260 (1877) ; 2:134-141 (1878)

Howard, John R.

55 Coal fields of Arkansas. De Bow's Review 18:257 (1855)

Howard, Kenneth S.

06 Preliminary notice of a new meteorite from Texas. Am J Sc (4) $21: 186$ (1906)

06a (and Davison, J. M.) The Estacado rerolite. Am J Sc (4) 22:55-60 (1906)

07 The Elm Creek aerolite. Am J Sc (4) $23: 379-381$ (1907)

Howard, L. $\mathrm{O}$.

14 The development of our radium-bearing ores. As Eng Soc, J 52:185-216, map (1914)

16 Geology of the Cottonwood districts [Utah]. M Sc Press 112: 557-562, map (1916)

Howarth, O. $\mathrm{H}$.

96 Popocatepetl and the volcanoes of the Valley of Mexico. Geog J 8:137-153 (1896)

Howe, A. B.

76 On gmelinite from Nova Scotia. Am J Sc (3) $12: 270-274$ (1876)

Howe, Ernest.

01 Experiments illustrating intrusion and erosion. U S G S, An Rp 21 pt 3: 291-303 (1901)

03 Recent tuffs of the Soufriere, St. Vincent [W. I.]. Am J Sc (4) 16:317322 (1903)

04 An occurrence of greenstone schists In the San Juan Mountains, Colo. J G $12 ; 501-509$ (1904)

05 Geology [of the Ouray district, Colo.]. U S G S, B 260:51-54 (1905)

05a (with Cross, W.) Red beds of southwestern Colorado and their correlation. G Soc Am, B 16:447-498 (1905) Abst, Science n s 21: 349 (1905)

05b (with Cross, W.) Description of the Silverton quadrangle, Colo. U S G S, G Atlas Silverton fol (no 120): $34 \mathrm{pp}$, maps (1905)

05e (with Cross, W.) Description of the Needle Mountains quadrangle, Colo. U S G S, G Atlas Needle Mountains fol (no 131) : 13 pp, maps (1905)

06 (and Cross, W.) Glacial phenomena of the San Juan Mountains, Colo. G Soc Am, B 17: 251-274 (1906) Abst, Science D s $23: 306-307$ (1906)
Howe, Ernest-Continued.

or Report on the geology of the [Panama] Canal Zone. Isthmian Canal Commission, An $R_{p} 1907$ (60th Cong, 1st sess., Sen Doc no 55) : 108-138 (1907)

Ora Istbmian geology and the Panama Canal. Ec G 2:639-658 (1907) Abst, Science n s 26:148 (1907)

07b (with Cross, W.) Description of the Ouray quadrangle [Colo.]. U S G S, G Atlas Ouray fol (no 153) : 20 pp, maps (1907)

os The geology of the Isthmus of Panama. Am J Sc (4) $26: 212-237$ (1908) Abst, Science n s $27: 959$ (1908)

09 Landslides in the San Juan Mountains, Colorado, including a consideration of their causes and their classification. U S G S, P P 67:58 pp (1909)

13 Landslides and the sinking of ground above mines. Int G Cong, XII, 1913, C R : 775-778 (1914; advance copy, 1913)

14 Petrographical notes on the Sudbury [Ont.] nickel deposits. Ec G $9: 505-522$ (1914)

15 Sulphide-bearing rocks from Litchfleld, Conn. Ec G $10: 330-347$ (1915)

15a Pyrrhotite, norite, and pyroxenite from Litchfield, Conn. (abst). G Soc Am, B $26: 83$ (1915)

See also Day (A L), 13

Howe, James Lewis.

86 Lithographic stone from Tennessee. Elisha Mitchell Sc Soc, J 3:144-145 (1886)

96 (and Campbell, H. D.) Examination of specimens from Chichen-Kanab, Yucatan. Am J Sc (4) 2:413-415 (1896)

03 (with Campbell, H. D.) A new(?) meteoric iron from Augusta Co., Va. Am J Sc (4) 15:469-471 (1903)

Howe, Joseph.

61 Tangier mines [gold, Nova Scotia]. N S, Legislative Council, J Pr 1861 App no $8: 1-3$ (1861)

Howe, Marshall A.

12 Reef-building and land-forming seaweeds (abst). Ac Nat Sc Phila, $\operatorname{Pr} 64$ : $137-138$ (1912)

$12 a$ The building of "coral" reefs. Science n \& $35: 837-842$ (1912)

15 Fossil calcareous algae from the Panama Canal zone, with reference to reef-building algae $(a b s t)$. Science $n$ s $42: 682$ (1915)

18 Contributions to the geology and paleontology of the Canal Zone, Panama, and geologically related areas in central America and the West Indies; on some fossil and recent Lithothamnieae of the Panama Canal Zone. U S Nat Mus, B 103:1-13, il $(1918)$

Howe, W. T. H.

94 (with Penfield, S. L.) On the chemical composition of chondrodite, humite, and clinohumite. Am J Sc (3) 47 : 188-206 (1894) Yale Bicen Pub, Contr Miner : 28-230 (1901) 
Howell, C. W.

70 Improvement of the mouth of the Mississippi River. U S [War Dp], Chief Eng, An Rp 1870 (U S, 41st Cong 3d sess, H Ex Doc 1 pt 2 v 2 ) : $326-347$ (1870)

74 Survey and improvement of Galveston harbor and entrance. U S [War Dp], Chiee Eng, An Rp 1874 (U S, 43d Cong 2 d sess, H Ex Doc 1 pt 2 ₹ 2 pt 1) : 722736 (1874)

Howell, Edwin Eugene (1845-1911).

75 Report on the geology of portions of Utah, Nevada, Arizona, and New Mexico. U S Geog G S W 100th Mer (Wheeler), 3: 227-301 (1875)

79 Chart of geological time. $33 \times 41$ inches, U S Geog G S Rocky Mtn Reg (Powell), n d [1879?]

87 Rockwood [Tenn.] meteorite. Science 10:107 (1887)

90 Notice of two new iron meteorites from Hamilton Co., Tex., and Puquios, Chili, S. A. Am J Sc (3) 40:223-226 (1890)

$90 a$ Description of new meteorites. Rochester Ac Sc, Pr 1: 86-95 (1890)

91 Notice of a new meteorite from Louisa Co., Va. Rochester Ac Sc, $\operatorname{Pr} 1$ : 173-174 (1891)

92 Description of the Mt. Joy meteorite [Adams Co., Pa.]. Am J Sc (3) 44:415416 (1892)

93 Catalogue of the department of mineralogy... $64 \mathrm{pp}$, Washington 1893

$93 a$ Cross Roads meteorite [Wilson Co. N. C.]. $A m$ J Sc (3) $46: 67$ (1893)

93b Beaver Creek meteorite [B. C.]. Science 22: 41 (1893)

94 Beaver Creek meteorite [B. C.] ; chemical discussion, by W. F. Hillebrand; microscopical discussion by G. P. Merrill. Am J Sc (3) $47: 430-435$ (1894)

95 On two new meteorites [Cherokee, Ga., and El Capitan, N. Mex.]. Am J Sc (3) $50: 252-254$ (1895)

08 Two new meteorites [Ainsworth, Nebr., and Williamstown, Ky.]. Science n s $27: 27-28$ (1908)

08a Description of the Williamstown meteorite. Am J Sc (4) 25:49-50 (1908)

08b The Ainsworth meteorite. Am J Sc

(4) $25: 105-107$ (1908)

See also Wheeler, $74 \mathrm{a}$

Howell, Jesse V.

16 The iron ore deposits near Waukon, Iowa. Iowa G S 25:33-101 (1916)

$16 a$ An outlier of the so-called Clinton formation in Dubuque Co., Iowa. ' Iowa Ac Sc, Pr 23:121-124 (1916) Abst, Science n s $44: 68$ (1916)

Howell, Ralph W.

15 (with Wegemann, C. H.) The Lawton oil and gas field, Okla. U S G S, B $621: 71-85$, map (1915)
Howell, Thomas $\mathrm{J}$.

83 The geological distribution of Noth American forests. Pop Sc Mo $23: 517-5 \%$ (1883)

Howley, James Patrick (1847-1918).

75 Report of geological exploration in Port-a-Port and St. George's bays. Ner. foundland G S, Rp Prog 1874 25(other ed : 27-74), map (1875) G S Nert: $372-409$ (1881)

77 [Report of geological exploration on the Gander and Gambo rivers.] $\mathrm{Ner}$. foundland G S, Rp Prog 1876:23-4) (1877) [not seen] G $S$ Newf: 436-40? (1881)

79 Report [on the north shore of $\mathrm{Con}$ ception Bay]. Newfoundland G S, Rp Prog 1878:- pp (1879) [not seen] G S Newt: 478-483 (1881)

$79 a$ Introduction to general report [Notre Dame Bay]. Newfoundland $G \&$ Rp Prog 1878: - pp (1879) [not seen] G S Newf : 483-511 (1881)

80 List of Newfoundland minerals Miner Mag 4: 36-41 (1880)

82 Report [on the Peninsula of Avalon, Newfoundland]. Newfoundiand $G$ S, Bp Prog 1881: 6-23, map (1882)

89 Report of progress, 1888. Newfound land $\mathrm{G}$ S : $18 \mathrm{pp}$ (another ed : $20 \mathrm{pp}$ ) 8t Johns 1889

$89 a$ The Taconic of eastern Newfound land. Am G 4: 121-125 (1889)

90 Report of progress, 1889. Newfound land $\mathrm{G}$ S: 23 pp, St. Johns 1890 Reprint, with title Report on the Carboniferous ara of Bay St. George, 1917

93 Report for 1891 and 1892 , on the Humber Valley and central Carboniferous area of the island. Newfoundland $G \mathrm{~S}$; 44 pp, St. Johns, Newfoundland, 1893

99 Report ... also of the mineral static tics of Newfoundland for the year 1898. [Newfoundland $G \quad S$ ] : 27 pp, St. Jolns, Newfoundland, 1899

00 Report of the mineral statistics fot 1899. Newfoundland G S: $18 \mathrm{pp}$, St. Johns 1900

01 Report on mineral statistics and mines of Newfoundland for the calendar year 1900. [Newfoundland G S] : 39 pP. St. Johns, N. F., 1901

02 Report on the mineral resources of the island for the calendar year 1901. Newfoundland G S: $32 \mathrm{pp}$, St. Johns, N. F. 1902

03 r.port on the mineral statistics of Newfoundland for the calendar year 1902 Newfoundland $G \quad S: 27$ pp [St. Johns] 1903

O3a Report of geological exploration in the district of White Bay, N. F., during the season of 1902. Newfoundland G S:28 pp [St. Johns] 1903 
Howley, James Patrick-Continued.

04 Report on the mineral resources of the island for the calendar year 1903. Newfoundland G S: 17 pp, St. Johns, Nfid., 1904

05 Report upon the mineral statistics of the island for the calendar year 1904; also report upon exploration and boring operations in the central Carboniferous basin near Grand Lake. Newfoundland G S: 47 pp, St. Johns, Nfld., 1905. Reprint, 1917

06 Report on the mineral statisties of Nelfoundland for the calendar year 1905 ; also report on the continuation of the coal boring operations in the central Carboniferous area near Goose Brook, Humber Valley. Newfoundland G S : 30 pp, St. Johns, N. F., 1906

07 Report upon the mineral statistics of the island for the calendar year 1906 ; also report on the coal boring operations near Goose Brook during the season of 1906. Newfoundland G $8: 28$ pp, St. Johns, N. F., 1907

07a Geological map of Newfoundland ... scale 1 inch $=7$ miles. 1907 .

09 The mineral resources of Newfoundland. $19 \mathrm{pp}$, [n p] 1909

09a Geology and mineral resources of Newfoundland, M World 31:701-704, map (1909)

09b Coal areas of Newfoundland. Can M J $30: 455-461, \operatorname{map}(1909)$

10 The iron ores of Newfoundland. Int $\mathrm{G}$ Cong, $\mathrm{X}$, Stockholm, 1910, The iron ore resources of the world $2: 747-752$ (1910)

10a The mineral resources of Newfoundland. Can M Inst, J 12:149-162, map (1910)

13 The coal deposits of Newfoundland. Int $\mathrm{G}$ Cong, XII, Canada, 1913, The coal resources of the world $1: 1 \times 1,2: 431-438$, map (1913)

17 Preliminary survey across the island from the Exploits Valley to the west coast ... New $\mathrm{G}$ S, Rp 1890:6-27, St. Johns, N. F., 1917

17 a Report on coal boring operations at the head of the Grand Lake. Newf G S, Rp 1893: 19 pp, St. Johns, N. F., 1917

$17 b$ Report for 1895 on coal exploration near Goose Brook; also report for 1896 on the geological structure and economic resources of the northwest coast; together with a historical sketch of the discovery and development of the coal areas of Newfoundland up to date. Newf $G$ S : $45 \mathrm{pp}$, St. Johns, N. F., 1917

17e Report on coal deposits in the Codroy River valley. Newf G S, Rp 1897 : 26 pp, St. Johns, N. F., 1917

17d A further examination of the coal trough of Bay St. George, together with a report of the mineral statistics for the year 1899 . Newf G S:25 pp, St. Johns, N. F., 1917
Howley, James Patrick-Continued.

17e Preliminary report on coal boring operations, together with report on coal boring operations, 1908. Newf G S:16 pp, St. Johns, N. F., 1917

18 Report on coal boring operations near MacGregor, Grand Lake, Carboniferous area. Newf G S, Rp 1907: 8 pp, St. Johns, N. F., 1918

18 a Report upon the coal boring operations near Goose Brook for the year 1909 ; also a report upon the mineral resources of Newfoundland for the year 1909 ; together with a report upon the petroliferous region situate on the northwest coast of Newfoundland; and a report upon the iron ores of Newfoundland; included with which is a report to the imperial government on the same subjects ... Newf G $\mathrm{S}$ : 87 pp, St. Johns, N. F., 1918

$18 b$ The coal deposits of Newfoundland. Newf G S : 39 pp, St. Johns, N. F., 1918

Howorth, Henry H.

73 Recent elevations of the earth's surface in the northern circumpolar regions. R Geog Soc, J 43 : 240-263 (1873)

91 The recent and rapid elevation of the American Cordillera. G Mag (3) 8:441450 (1891)

Hoy, Philo R.

71 Doctor Koch's Missourium. Am Nat 5: 147-148 (1871)

Hoyt, B. F.

14 The Judith Mountains, Fergus Co., Mont. M World 41:957-958 (1914)

Hoyt, John C.

10 A water-power reconnaissance in southeastern Alasks. U S G S, B 442 : 147-157 (1910)

Hoyt, S. L.

15 (with Nissen, A. E.) On the occurrence of silver in argentiferous galena ores. Ec G 10:172-179 (1915)

Hrdliěka, Aleš.

02 The crania of Trenton, N. J., and their bearing upon the antiquity of man in that region. Am Mus $\mathrm{N} H, \mathrm{~B} 16$ : 23-62 (1902)

03 The Lansing skeleton. Am Anthropologist n s $5: 323-330$ (1903)

or Skeletal remains suggesting or attributed to early man in North America. Bur Am Ethnology, B 33: 113 pp (1907)

17 Preliminary report on fiuds of supposedly ancient human remains at Vero, Fla. J G $25: 43-51$ (1917)

18 Recent discoveries attributed to early man in America [Vero, Fla., remains]. Bur Am Ethnology, B 66:67 pp, il (1918) Huard, v. A.

13 Abrêgé de géologie. $155 \mathrm{pp}$, Quebec 1913 Rv by Vernon L. Kellogg, under the title, A modern textbook of geology-and evolution, in Sclence n s $38: 64-67$ (1914)

Hubbard, Austin 0 .

25 ... lead veins of Massachusetts. Am J Sc $9: 166-167$ (1825) 
Hubbard, Bela (1814-1896).

39 Report [on Wayne and Monroe cos.] Mich St G, An Rp 2: 79-114 (1839) Mich St Agr Soc Tr 1855, $7: 355-386$ (1856)

40 Report [on Lenawee, Hillsdale, Branch, St. Joseph, Cass, Berrien, Washtenaw, Oakland, and Livingston cos.]. Mich St. G, An Rp 3:77-111 (1840) (With introductory letter) Mich St Agr Soc, Tr 1853, 5:279-312 (1854)

41 Report [on the geology of the organized counties of Michigan]. Mich St G, An Rp 4:113-146 (1841) Mich St Agr Soc, Tr 1853, 5:312-339 (1854)

46 General observations upon the geology and topography of the district south of Lake Superior ... U S, 29th Cong 1st sess, S Ex Doc 357: 20-29 (1846)

49 Geological report [of field work in Lake Euperior land district]. U S, 31st Cong 1 st sess, $\mathbf{S}$ Ex Doc 1 pt 3 and $\mathbf{H}$ Ex Doc 5 pt $3: 833-842,882-932$ (1849)

81 A Michigan geological expedition in 1837 [in Saginaw Valley, Mich.]. Michigan Pioneer Collections 3:189-201 (1881)

See also Houghton (J), 46

Hubbard, Bela.

18 (with Fettke, C. R.) The limonite deposits of Mayaguez Mesa, Porto Rico. Am I M Eng, B 135 : 661-676 (1918) Hubbard, Elisabeth.

11 (and Lane, A. C.) The intercollegiate geological excursion [Boston area]. Science n s $34: 611-614$ (1911)

Hubbard, George C.

92 The cystideans of Jefferson Co., Ind. Ind Ac Sc, $\operatorname{Pr} 1891: 67$ (1892)

92a Hudson River fossils of Jefferson Co., Ind. Ind Ac Sc, Pr 1891:68 (1892)

92b The upper limit of the Lower Silurian at Madison, Ind. Ind Ac Sc, $\mathrm{Pr}$ 1891: 68-70 (1892)

Hubbara, George David.

00 The Blue Mound quartzite [Wisconsin]. Am G 25: 163-168 (1900)

04 An interglacial valley in Illinois. J G $12: 152-160$ (1904)

04a A case of geographic influence upon human affairs [Illinois]. Am Geog Soc, B 36:145-157 (1904)

06 Drumlinoids of the Catatonk folio [N. Y.]. Am Geog Soc, B 38:355-365 (1906)

o7 Experimental physicgraphy. Am Geog Soc, B 39:658-666 (1907)

08 Some high-level terraces in southeastern Ohio. Am J Sc (4) 25:108-112 (1908)

08a Ancient finger lakes in Obio. Am J Se (4) $25: 239-243$ (1908)

08b Two notable landslides [near Waverly and in Monroe Co., Ohio.] Ohio Nat 8:287-289 (1908)

ose Stream diversion near Lakeville, Ohio. Ohio Nat 8:349-355 (1908)
Hubbard, George David-Continued.

Osd Rock terraces along the streams near Columbus, Ohio. Ohio Nat 9:397-403 (1908)

11 Large glacial boulders [drift deposits in Illinois]. J G $19: 377-380$ (1911)

11 (with Stanfer, C. R.) Geology of the Columbus quadrangle. Ohio G S, 4th ser, B 14: 133 pp (1911)

13 Gas and oil wells near Oberlin, Obio. Ec G $8: 681-690$ (1913) Abst, Science in s $37: 458-459$ (1913)

13a Evidence of very early glaciation in Ohio (abst). G Soc Am, B 24:696-697 (1913)

14 A Finger Lake bed in Ashland and Wayne cos, Ohio, with t'ted shore lines. Am J Sc (4) 37:444-450, map (1914)

$14 a$ Tilted shore lines of ancient Craig. ton Lake, Ohio. Science n s $39: 470-471$ (1914)

15 (and others) Description of the Co. lumbus quadrangle, Ohio. I S G S, G Atlas Columbus fol (no 197) : $15 \mathrm{pp}$, maps, il (1915)

15a Death Valley. J Geog $13: 277-280$ (1915)

16 Group relationship among physiographic features as an aid in field interpretation (abst). Science n s 43:397-395 (1916)

17 What has the future for geologists? Ohio J Se 17:83-96 (1917)

18 Possible local glaciation in southern Vermont (abst). As Am Geog, An $7: 77$ [1918]

See also Goldthwait, 17

Hubbard, J. D.

16 The quartz veins of Butte Co., Cal, Eng and M J 102: 352-353 (1916)

Hubbara, Lucius Lee.

93 Macroscopic minerals of Mlehigan. Mich G S, Rp 1891-2:174-176 (1893)

93a (with Koenig, G. A.) On pow. ellite from a new locality. Am J. Sc (3) $46: 356-358$ (1893)

94 Two new geological cross sections of Keweenaw Point [Mich.]. L Sup M Inst, Pr 2: 79-96 (1894)

95 The relation of the vein at the Cen tral mine, Keweenaw Point to the Kearsarge conglomerate. L Sup M Inst, Pr 3: 74-83 (1895)

95a The origin of salt, gypsum, and petroleum. Mich G S, 5 pt $2:$ ix-xxiv (1895) 98 Keweenaw Point, with particular reference to the felsites and their associated rocks. Mich G S 6 pt 2:155 pp, maps (1898)

99 Sixth annual report of the State geologist. Extracts from the annual reports of the State geologist of Michigan. $9 \mathrm{pp}$, Lansing 1899

01 Work of the Geological Survey in the Upper Peninsula. Mich Miner 3 no $3: 9$ (1901) 
Hubbard, Lucius Lee-Continued.

12 Geological notes on the Lake Superior copper formation. L Sup M Inst, Pr 17 : 9-11 (1912)

12a In the Lake Superior area what influence, if any, did the thickness and contour of foot wall beds have upon the subsequent deposition and distribution of copper in overlying beds? (with discussion). L Sup M Inst, $\operatorname{Pr} 17: 227-237$ (1912)

Hubbard, Oliver Payson (1809-1900).

37 Geological and mineralogical notices [New York]. Am J Sc 32:230-235 (1837)

38 Observations made during an excursion to the White Mountains in July, 1837. Am J Sc 34: 105-124 (1838)

50 The condition of trap dikes in New Hampshire an evidence and measure of erosion. Am J Se (2) 9:158-171 (1850)

$50 a$ on rutile and chlorite in quartz. Am J Sc (2) 10:350-352 (1850) Am As, Pr 4:25-28 (1851)

52 Beryls in Grafton, N. H. Am J Sc (2) $13: 264-265$ (1852)

53 Gold in Vermont. Am J Sc (2) 15 : 147 (1853)

85. Two varleties of the New Red sandstone used for bullding in New Haven, Conn. N Y Ae Sc, Tr 5:12-13 (1885)

87 [On a basaltic boulder in Woodbridge, Conn.] N Y Ac Sc, Tr 4:25 (1887)

89 [On a pothole near Catskill, N. Y., and a boring at New Haven, Conn.] N $\mathbf{Y}$ Ac Se, Tr 9:3 (1889)

Hudson, George Henry.

05 Contributions to the fauna of the Chazy limestone on Valcour Island, Lake Champlain [N. Y.] N Y St Mus, B 80 : 270-295, II (1905)

07 On some Pelmatozoa from the Chazy limestone of New York. N Y St Mus, B $107: 97-152$, il (1907)

07a On the structure, development, and relationship of Blastoidocrinus (Billings 1859) (abst.) Science n s 25:730 (1907)

07b Blastoidocrinus and its type (abst). Science n s 26:401 (1907)

09 Some items concerning a new and an old coast line of Lake Champlain. N Y St Mis, B 133: 159-163 (1909)

10 Joint caves of Valcour Island, their age and origin. N Y St Mus, B 140: 161196 (1910)

11 Studies of some early Siluric Pelmatozoa. N Y St Mus, B 149:195-272, il (1911)

12 Rill channels and their cause, a rocksurface character of glacial origin. vt, St G, Rp 8:232-246 (1912)

12a A fossil starfish with ambulacral covering plates [Protopalaeaster narrawayi, Ordoviclan, Ottawa, Ont.]. Ottawa Nat $26: 22-26,45-52$, il (1912)
Hudson, George Henry-Continued.

13 The use of the stereogram in paleobiology. N Y St Mus, B 164:103-130, il (1913)

$13 a$ Does the type of Protopalaeaster narrawyi present an oral or aboral aspect? Ottawa Nat $27: 77-84$, il (1913)

15 Some fundamental types of hydrospires with notes on Porocrinus smithi Grant. N Y St Mus, B $177 ; 163-166$, il (1915)

16 On the genus Urasterella, with description of a new species. N Y St Mus, B $187: 117-164$, il (1916)

16a Some notes on fossil collecting and on the Edrioasteroidea. Ottawa Nat 30 : 21-25, 40-46 (1916)

17 External structure of Steganoblastus as revealed through gum mountings and photomicrographic stereograms (abst). G Soc Am, B 28: 203 (1917)

$\mathbf{1 7 a}$ Some structural features of a fossil embryo crinoid (abst). G Soc Am, B 28 : 204 (1917)

18 The interesting geological features at the Champlain Assembly, Cliff Haven, N. Y. N Y St Mus, B 196:149-160 (1917) [1918]

18n Some structural features of a fossil embryo crinoid. N Y St Mus, B 196:161163, il (1917) [1918]

Hudson, Joseph G. S.

13 Sections of the Sydney coal fields, Cape Breton, N. S. Can Mines $\mathrm{Br}: 6 \mathrm{pp}$, map (1913)

Huels, Frederick William.

15 The peat resources of Wisconsin. Wis G S, B $45: 274$ pp, map (1915)

Huene, Friedrich von.

o6 Ueber die Dinosaurier der aussereuro. päischen Trias. G Pal Abh (Koken) N F 8 H $2: 1-60(97-156)$, il (1906)

os Die Dinosaurier der europäischen Triasformation mit Berücksichtigung der aussereuropäischen Vorkommnisse. G Pal Abh (Koken), Sup-B 1:xil, $419 \mathrm{pp,} \mathrm{il}$ $(1907-8)$ [Includes notes on the occurrence of American forms and comparisons with foreign forms. On p. 317 gives a table of the Newark red series by Schuchert.]

Osa (and Lull, R. S.) On the Triassic reptile Hallopus victor, Marsh. Am J Sc (4) $25: 113-118$, il (1908)

osb Neubeschreibung des Originals von Nanosaurus agilis Marsh. N Jb 1:134144, il (1908)

ose Zur Beurtellung der Sauropoden. Deut G Ges, Monatsb no 11:294-297 (1908)

09 Skizze zu einer Systematik und Stammesgeschichte der Dinosaurier. Centralbl Miner $1909: 12-22$

11 Kurze Mittellung iber Perm, Trias, und Jura in New Mexico [Rio Arriba Co.]. N Jb Beil B $32: 730-739$, il (1911) 
Huene, Friedrich von-Continued.

12 Beiträge zur Kenntnis des Schädels von Eryops. Anat Anz 41:98-104, il (1912)

12 Der Unterkiefer von Diplocaulus. Anat Anz 42: 472-475, il (1912)

13 A new phytosaur from the Palisades near New York. Am Mus N H, B 32 : 275282, il (1913)

13a The skull elements of the Permian Tetrapoda in the American Museum of Natural History, New York. Am Mus N H, B $32: 315-386$, il (1913)

13b Über Lysorephus aus de.a Perm von Texas. Anat Anz 43:389-396, il (1913)

14 Beiträge zur Geschichte der Archosaurier. G Pal Abh N F 13 H 1:1-53, il (1914)

14a Beiträge zur Kenntnis des Schädels einiger Pterosaurier. G Pal $\Delta b h$ N F 13 H 1 : 55-65, il (1914)

14b Nachträge zu meinen früheren Beschreibungen triassischer Saurischia. G Pal Abh N F 13 H 1:67-82, il (1914)

14e Über die Zweistæ̈mmigkeit der Dinosaurier, mit Beiträgen zur Kenntnis einiger Schädel. N Jb, Beil Bd 37:577-589, il (1914)

14d The dinosaurs not a natural order. Am J Sc (4) 38:145-146 (1914)

15 On reptiles of the New Mexican Trias in the Cope collection. Am Mus N H, B $34: 485-507$, il (1915)

Huggins, P. Foster.

$02 \mathrm{An}$ account of the eruptions of the Saint Vincent Soufrière. Kingston, St. Vincent, 1902 [not seen] Nat Geog Mag 14: 158-161 (1903)

Hughes, George.

85 On some West Indian phosphate deposits. G Soc London, Q J 41:80-81 (1885) Abst, G Mag (3) 2.90 (1885)

Hughes, N. C.

87 Genesis and geology; the harmony of the scriptural and geological records. 142 pp, Chocowinity, N. C., 1887 [not seen]

Hughes, Urban B.

16 A correlation of the peneplains of the Driftless Area. Iowa Ac Sc, Pr 23:125132 (1916)

Hughes, v. H.

11 Reconnaissance work. Mo Bur G Mines, Bien Rp : 36-54, map (1911)

Hughes, Wilson W.

15 Kaolin. M Sc Press 110:947-950 (1915)

Huguenin, Emilè.

17 Santa Barbara Co. : Ventura Co. In Mines and mineral resources of the counties of Monterey. San Benito, San Luis Obispo, Santa Barbara, Ventura (Chapters of State Mineralogist's Rp [15: 727769] 1915-16): 133-175, Cal St M Bur (1917)
Huguenin. Emile Continued.

$17 a$ (with Cloudman, H. C., and Mer. ri11, F. J. H.) San Bernardino County. In Mines and mineral resources of San Bernardino County, Tulare County (Chap. ters of State Mineralogist's Rp 1915-16): 1-125, Cal St M Bur (1917)

17b (with Waring, C. A.) Inyo Coun. ty. In Mines and mineral resources of Alplne County, Inyo County, Mono County (Chapters of State Mineralogist's Rp 191516) : 25-129, Cal St M Bur (1917)

See also Bradley (W W), 18

Hulbert, E. J.

55 (with Booth, J. C.) Geological and topographical map of the mineral dis. trict of Lake Superior, Mich. N Y 1855

HuIl, Edward.

84 On the geological age of the north Atlantic Ocean (abst). Brit As, 53:494495 (1884) Science 2:666 (1883)

86 The geological age of the north At. lantic Ocean. Nature 34: 496 (1886)

91 On the physical geology of Tennessee and adjoining districts ... [with notes and comments by Aug. F. Foerste in Am G reproduction]. G Soc London, Q J 47 69-77 (1891) Am G 7:345-351 (1891) Abst, G Mag (3) 8:45-46 (1891)

98 Professor J. W. Spencer on changes of level in Mexico. G Mag (4) 5:193-195 (1898)

12 Monograph on the suboceanic pbysiography of the north Atlantic Ocean; with a chapter on the suboceanic physical features off the coast of North America and the West Indian Islands, by Joseph William Winthrop Spencer. 41 pp, maps, London 1912

Hull, J. P. D.

18 (with Shearer, H. K.) A prelimi. nary report on a part of the pyrites deposits of Georgia. Ga G S, B $33: 229$ pp, map (1918)

Hulett, G. A.

17 (with Mack, E.) The water content of coal, with some ideas on the genesis and nature of coal. Am J Sc (4) 43: 89-110 (1917)

HuIst, Nelson P.

93 The gology of that portion of the Menominee Range east of the Menominee River. L Sup M Inst, Pr 1893: 19-29, map (1893) Abst, Eng M J $55: 366$ (1893)

05 Titanium and titaniferous iron ores.

L Sup M Inst, $\operatorname{Pr} 10: 31-47$ [1905]

Humboldt, Alexander von (1769-1859). 10 Essai politique sur le royaume de la Nouvelle Espagne. 2 vols, Paris 1810-11 2d ed, 4 vols, 1825-7 Jb Miner 1811: $240-248 ; 1813: 246-257$

23 Essal géognostique sur le gisement des roches dans les deux hémisphères. 379 pp. Paris 1823 Engl ed, 482 pp, L 1823 28 Geognostisch-metallurgischer Abríss von Amerika. Arch Bergbau $17: 255-385$ (1828) 
Humboldt, Alexander von-Continued. 54 Volcans des Cordillères de Quito et du Mexique. 16 pp, pls, Paris 1854

Hume, G. S.

17 Paleozoic rocks of Lake Timiskaming area [Ont]. Can G S, Sum Rp 1916: 188192, map (1917)

Humphreys, Andrew Atkinson (18101883).

57 Report upon the progress of the Pacific raflroad explorations and surveys. U S, Pacific R R Expl (U S, 33d Cong 2d sess, S Ex Doc 78 and $H$ Ex Doc 91) $7 \mathrm{pt}$ 3:11-18 (1857)

61 (and Abbot, H. L.) Report upon the physics and hydraulies of the Mississippi River... U S Army, Corps of Topographical Engineers Prof Papers no 4: 456, cxlvi pp, maps; Phila 1861 [Reprint, with additions], ... Prof Papers no 13:691 pp, maps, Washington $\mathbf{1 8 7 6}$

70 Letter to Sir Charles Lyell [on thickness of alluvium of the Mississippi River]. U \& [War Dp], Chief Eng, An Rp 1870 (U S, 41st Cong 3d sess, H Ex Doc 1 pt 2 v 2) : $365-377$ (1870) U S Army, Corps of Engineers, P P 13:646-650 (1876)

76 Geological age of the channel of the Mississippi River. U S Army, Corps of Engineers, P P 13 : 635-656 (1876)

78 Letter...giving information concerning the geographical and geological surveys of the War Department. U S [War Dp], Chiet Eng, An Rp 1878 (U S, 45th Cong $3 \mathrm{~d}$ sess, H Ex Doc 1 pt 2 v 2 pt 3 ), App NN2 : $1653-1660$ (1878)

78a Surveys by the War Department. U $\mathrm{S}, 45$ th Cong 2d sess, H Ex Doc $88: 8$ pp, map (1878)

Humphreys, Edwin W.

09 Recent fresh-water fossils from Bronx Borough, New York City. Nautilus 23:1011 (1909)

11 (and Julien, A. A.) Local decomposition of rock by the corrosive action of preglacial peat bogs. J G 19:47-56 (1911)

14 Some fossil leaves and their signifcance. Torreya 14: $39-42$, il (1914)

15 A new fossil fig and its significance. Guide to Nature $8: 82-84$, il (1915)

16 sphenozamites rogersiamus Fontaine; an addition to the Rhaetic flora of San Juancito, Honduras. N Y Bot Garden, J $17: 56-58$ (1916)

16n Triassic plants from Sonora, Mexico, Including a Neocalamites not previously reported from North America N Y Bot Garden, Mem 6: 75-78, 11 (1916)

Humphreys, W. J.

13 Volcanic dust and other factors in the production of climatic changes, and their possible relation to ice ages. U $\mathbf{S}$ Dp Agr, Mount Weather Observatory, B 6 pt 1 (W B no 511) : 34 pp (1913) Franklin Inst, J 176: 131-172 (1913) Wash Ac Sc J $3: 365-371$ (1913)
Humphreys, W. J.-Continued.

15 Changes of sea level due to changes of ocean volume (abst). Wash Ac Sc, J 5 : $445-446$ (1915)

16 The southern Appalachian earthquake of February 21, 1916. Monthly Weather Rv 44: 154 (1916)

16a Earthquakes felt in the United States during 1916. Mo Weather Rv 44 : 697-698 (1916)

17 The collection of earthquake data in the United States. Pan American Sc Cong, 2d, Washington, $\operatorname{Pr}$ sec 2 vol $2: 697-704$ (1917)

See also Vaughan, $15 \mathrm{c}$

Hungerford, Edward,

68 Evidences of glacial action on the Green Mountain summits. Am J Sc (2) 45:1-5 (1868)

68a Considerations relating to the climate of the glacial epoch in North America. Am As, Pr 16:108-111 (1868) Abst, Can Nat n s 3: 303-304 (1868)

$68 b$ Ripton sea beaches [Vt.] (abst). Am As, Pr 16:112-113 (1868) Can Nat n s $3: 305$ (1868)

Hunt, Alfred E.

93 Aluminum. U S G S, Min Res 1892 : $227-254$ (1893)

95 Bauxite (discussion). Am I M Eng, Tr 24:855-861 (1895)

Hunt, E. B.

63 On the origin, growth, substructure, and chronology of the Florida reef. Am J Sc (2) $35: 197-210$ (1863)

64 On the origin, growth, substructure, and chronology of the Florida reef. U S Cosst S, Rp 1862 (U S, 37th Cong 3d sess, H Ex Doc 22) : 241-248 (1864)

Hunt, J. G.

$\boldsymbol{7 4}$ On the contents of a mastodon's stomach. Boston Soc N H, Pr 17: 91-92 (1874)

Hunt, Joseph H.

90 A group of copper pseudomorphs after chalcocite, and silica and prehnite pseudomorphs after pectolite, from Paterson, N. J. N Y Ac Sc, Tr 9:140-144 (1890)

Hunt, Thomas Sterry (1826-1892).

46 Description and analysis of a new mineral species containlng titanium [enceladite]... Am J Sc (2) $2: 30-36$ (1846)

46a (with Silliman, B., jr.) On the meteoric iron of Texas and Lockport. Am $\mathrm{J}$ Sc (2) $2: 370-376$ (1846)

47 Report [analyses of minerals]. In Adams, C. B., Third annual report on the geology of the State of Vermont:23-27 (1847)

47n [Analyses of ores and mineral waters.] Can G S, Rp Prog 1845-6: 122125 (1847)

49 Report [on the examination of minerals, etc. with analyses]. Can G S, Rp Prog 1847-8: 125-165 (1849) 
Hunt, Thomas Sterry-Continued.

49a On the acid springs and gypsum de posits of the Onondaga salt group. Am J Sc (2) $7: 175-178$ (1849) Edinb $\mathrm{N} \mathrm{Ph} \mathrm{J}$ $47: 50-53 \quad(1849)$

$49 \mathrm{~b}$ Chemical examination of algerite, a new mineral species, including a deseription of the mineral by F. Alger. Boston J N H 6:118-123 (1849) Am J Sc (2) 8: 103-106 (1849)

50 Report [on examination of mineral waters and ores, with analyses]. Can G S, Rp Prog 1848-9: 47-65 (1850)

50a Report [on the examination of solls, mineral waters, and ores, with analyses]. Can G S, Rp Prog 1849-50:73-106 (1850)

501 On the geology of Canada. Am As, Pr 2:325-334 (1850) Am J Sc (2) 9: 12-19 (1850)

50e Chemical examinations of the waters of some mineral springs of Canada. Am J Sc (2) $9: 266-275$ (1850)

50d [On algerite from Franklin, N. J.] Boston Soc N H, Pr 3:150-151 (1850)

51 On the Taconic system. Am As, Pr 4: 202-204 (1851)

$\mathbf{5 1 a}$ On the mineral springs of Canada. Am J Sc (2) 11:174-181 (1851)

516 On the chemical constitution of the mineral warwickite. Am J Sc (2) 11 : 352-356 (1851)

51e Examinations of some Canadian minerals. Ph Mag (4) $1: 322-328$ (1851)

51d Description and analysis of loganite a new mineral species. $\mathrm{Ph} \mathrm{Mag} \mathrm{(4)}$ $2: 65-67$ (1851)

52 Report [on the examination of minerals and mineral waters]. Can G S, Rp Prog 1850-1: 35-54 (1852)

52a Report [of examination of minerals, soils, etc.]. Can G S, Rp Prog 1851-2 : 93-121 (1852)

52b Examination of some American minerals. Am J Sc (2) $14: 340-346$ (1852)

52e Remarks on the lithological and paleontological characters of the Potsdam sandstone. Am As, $\operatorname{Pr} 6: 271-273$ (1852)

52d Examinations of phosphatic matters, supposed bones, and coprolites occurring in the Lower Silurian rocks of Canada. G Soc London, Q J 8:209-210 (1852)

53 On the constitution and equivalent volume of some mineral species. Am J Sc (2) $16: 203-218$ (1853)

54 Report [on the examination of minerals, mineral waters, etc.]. Can G $\mathbf{S}, \mathrm{Rp}_{\mathrm{p}}$ Prog 1852-3: 153-179 (1854)

$54 a$ Remarks on the mineral species algerite. Am J Sc (2) $17: 351-352$ (1854)

54b on some of the crystalline limestones of North America. Can J 3:36-38 (1854) Am J Sc (2) $18: 193-200$ (1854)

54e On the composition and metamorphoses of some sedimentary rocks. Ph Mag (4) $7: 233-238$ (1854)
Yunt, Thomas Sterry-Continued.

54d (with Logan, W. E.) On the chemical composition of recent and fossil lingulae and some other shells. Am J Sc (2) $17: 235-239$ (1854) Can J 2:264265 (1854)

55 Examinations of some feldspathic rocks. Ph Mag (4) 9:354-363 (1855)

55a Observations sur les roches mag. nésiennes du groupe de la rivière Hudson.. Soc G France, B (2) 12:1029-1032 (1855)

$\mathbf{5 5 b}$ Note sur les sources acides et les gypses du Haut-Canada. Ac Sc Paris, C R $40: 1348-1351$ (1855)

55e Recherches sur les eaux minérales du Canada. Ac Sc Paris, C R 41:300-304 (1855)

55d On the so-called talcose slates of Green Mountains. Am J Sc (2) 19:417 (1855)

55e (with Logan, W. E.) Esquisse géologique du Canada...a l'exposition untverselle de Paris, 1855. [Can G S]:100 pp, map, Paris 1855 Map also in Soc 6 France, B (2) 12: opp 1316 (1855)

57 Report for the year 1853 [on mineral waters, etc.]. Can G S, Rp Prog 1853-6: 347-371 (1857)

57a Report for the year 1854 [on metamorphic rocks]. Can G S, Rp Prog 1853-6:373-390 (1857)

57b Report for the year 1855. Can $G$ S, Rp Prog 1853-6: 391-429 (1857)

57e Report for the year 1856 [on the mineralogy of metamorphic rocks]. Carl G S, Rp Prog 1853-6:431-494 (185i) Extract, with title, Contributions to the history of ophiolites. Am J Sc (2) 25 : $217-226$ (1857) ; 26:234-240 (1858)

57d On the serpentines of Canada and their associated rocks. R Soc London, Pr $8: 423-425$ (1857)

57e On the part which the silicates of the alkalis may play in the metamorphism of rocks. $R$ Sec London, $\operatorname{Pr} 8: 458-461$ (1857) $\mathrm{Ph} \mathrm{Mag}$ (4) $15: 68-70$ (1858) Am J Sc (2) $25: 287-289$ (1858)

57f On the chemical composition of the waters of the St. Lawrence and Ottawa rivers. Ph Mag (4) $13: 239-245$ (1857)

$57 \mathrm{~g}$ On the probable origin of some mag. nesian rocks. Am J Sc (2) 24:272-273 (1857) R Soc London, Pr 9:159-164 (1858)

$\mathbf{5 7 h}$ Note on the cherokine of C. U. Shepard. Am J Sc (2) 24:275 (1857)

57i On the origin and metamorphosis of some sedimentary rocks. Can $\mathrm{J}$ n s 2: 355-357 (1857) Abst, Can Nat $2: 261-262$ (1857)

57j On serpentine and some of its uses. Can Nat $2: 28-34$ (1857)

5 rke Origin of magnesian rocks (abst). Can Nat 2:258 (1857)

571 On some euphotides and other felspathic rocks $(a b s t)$. Edinb $\mathrm{N}$ Ph J $\mathrm{n}$ 5: 366-367 (1857) 
Hunt, Thomas Sterry-Continued.

$57 \mathrm{~m}$ on the serpentines of the Green Mountains and some of their assoeiates (abst). Edinb N Ph J n s 5: 367 (1857)

$57 \mathrm{n}$ General considerations on the metamorphism of the sedimentary recks (abst). Edinb N Ph J n s 6:350 (1857)

58 Report for the year 1857 [dolomites, limestones, etc.]. Can G S, Rp Prog 1857 : 193-229 (1858)

$58 a$ On the theory of igneous rocks and voleanoes. Can Nat 3:194-201 (1858) Can J n s 3: 201-208 (1858)

58b on the chemistry of the primeval earth. Am J Sc (2) 25: 102-103 (1859)

5se on the origin of the feldspars and on some points of chemical lithology. Am J Sc (2) $25: 435-437$ (1858)

$58 d$ on euphotide and saussurite. Am J Sc (2) $25: 437$ (1858)

59 Report for the year 1858 [intrusive rocks, magnesian limestones, etc.]. Can G S, Rp Prog 1858: 171-218 (1859) In part, Can J n s 5 : 426-442 (1860)

$59 a$ On some points in chemical geology. G Soc London, Q J 15:488-496 (1859) Can Nat 4:414-425 (1859) M Mag (2) 2:14-24 (1860) Abst, Brit As, $\mathrm{R}_{\mathrm{p}} 30$ : sec 83-84 (1861) ; Am J Sc (2) 30:133137 (1860); Ph Mag (4) 17:148-149 (1859)

$59 \mathrm{~b}$ Contributions to the history of euphotide and saussurite. Am J Sc (2) $27: 336-349$ (1859)

59e On some reactions of the salts of lime and magnesia and on the formation of gypsums and magnesian rocks. Am J Se (2) $28: 170-187,365-383$ (1859) v

$59 \mathrm{~d}$ On the formation of magnesian limestones. Can J n s 4:184-186 (1859)

59e Formation of silicious rocks (abst). Can Nat $4: 295-296$ (1859)

60 Contributions to the history of gypsums and magnesian rocks. $\mathrm{Am}$ As, $\operatorname{Pr} 13$ : 227-247 (1860). Abst, Can Nat 4:294295 (1859)

60a On some igneous rocks of Canada. Am J Sc (2) 29:282-284 (1860).

601 On the formation of gypsums and dolomites. $\mathrm{G}$ Soc London, Q J 16:152$154(1860)$

60e Analysis of Canadian wolfram [Lake Couchiching, Ont.]. Can J n s $5: 303$ (1860)

61 Notes on the history of petroleum or rock oil. Can Nat 6:241-255 (1861) Smiths Inst, An Rp $1861: 319-329$ (1862)

61 on some points in American geology. Am J Sc (2) $31: 392-414$ (1861) Can Nat 6: 81-105 (1861)

61b Note on chloritoid from Canada. Am J Sc (2) $31: 442-443$ (1861)

61e On the origin of some magnesian and aluminous rocks. Can Nat 6:180184 (1861) Am J Sc (2) 32:286-288 (1861)

$$
28737^{\circ}-23-35
$$

Hunt, Thomas Sterry-Continued.

61d Mr. Barrande on the Primordial zone in North America and on the Taconic system of Emmons. Can Nat $6: 374-383$ (1861) In part, Am J Sc (2) 32:427. 430 (1861)

62 [On the names of certain rocks.] Can Nat $7: 17-19$ (1862)

62a Note on the Taconic system of Emmons. Can Nat $7: 78-80$ (1862) Am J Sc (2) $33: 135-136 \quad(1862)$

62b Considérations sur la chimie du globe. Ac Sc Paris, C R 54: 1190-1194 (1862) Can Nat 7:201-205 (1862)

62e On the various theoretical views regarding the origin of the primitive formations; note. Can Nat $7: 262-263$ (1862)

62d Note on the occurrence of glauconite in the Lower Silurian rocks. Am J Sc (2) $33: 277-278$ (1862)

62e (with Logan, W. E.) Descriptive catalogue of a collection of the economic minerals of Canada [by W. E. Logan] and of its crystalline rocks [by T. S. Hunt]; London International Exhibition, 1862. Can G S : $88 \mathrm{pp}$, Montreal 1862

63 Contributions to the chemical and geological history of bitumens and of pyroschists or bituminous shales. $A \mathrm{~m} \mathrm{~J} \mathrm{Sc} \mathrm{(2)}$ $35: 157-171$ (1863)

63a On the gold mines of Canada and the manner of working them. Can Nat 8 : 13-19 (1863)

63b On the chemical and mineralogical relations of metamorphic rocks. G Soc Dublin, J 10:85-95 (1864) Dublin Q J Sc 3:220-230 (1863) Am J Sc (2) 36 : 214-226 (1863) Can Nat 8:195-208 (1863)

63e On the earth's climate in Pale ozoic times. Am J Se (2) : 396-398 (1863) Can Nat $8: 323-325$ (1863) Ph Mag (4) $27: 236-237$ (1864)

64 Contributions to lithology. $\Delta \mathrm{m} \mathrm{J} \mathrm{Sc}$ (2) $37: 248-266 ; \quad 38: 91-104, \quad 174-185$ (1864) Can Nat n s $1: 16-36,161-189$ (1864)

64a Laurentian rhizopods of Canada. Am J Se (2) $37: 431$ (1864)

64b Notes on the silicification of fossils. Can Nat n s 1:46-50 (1864)

64e On the geology of eastern New York. Can Nat n s 1:368-369 (1864) Am J Sc (2) $39: 96-97$ (1864)

64d On peat and its uses. Can Nat $\mathbf{n}$ s $1: 426-441$ (1864)

65 Canada; a geographical, agricultural, and mineralogical sketch. [Canada], Bureau of Agriculture: $33 \mathrm{pp}$, Quebec, 1865

65a Petroleum; its geological relations considered with especial reference to its occurrence in Gaspé. 19 pp, map, Quebec 1865. 
Hunt, Thomas Sterry-Continued.

65b Contributions to the chemistry of natural waters. Am J Sc (2) 39:176$193 ; 40: 43-60,193-213$ (1865) Can Nat n s $2: 1-21,161-183,276-299$ (1865)

65e On the mineralogy of Eozoon canadense. Can Nat n s 2:120-127 (1865)

65d A geographical sketch of Canada. Can Nat n s 2: 356-363 (1865)

65e On the mineralogy of certain organic remains from the Laurentian rocks of Canada. G Soc London, Q J 21:67-71 (1865)

66 Report [on the gold of Lower Canada]. Can G S, Rp Prog 1863-6:79-90 (1866)

66a Report [Laurentian limestones, minerals, petroleum, salt, porosity of rocks, peat, etc.]. Can G S, Rp Prog 1863-6: 181-291 (1866) Reprinted in part, with additions, under the title, on the mineralogy of the Laurentian limestones of North America, N Y St Cab, An Rp 21:47-98 (1871)

66b Further contributions to the history of lime and magnesia salts. Am J Sc (2) 42: 49-67 (1866)

66e On the primeval atmosphere. Am As, Pr 15:34-37 (1867) Can Nat n s $3: 117-120$ (1866)

66d On petroleum (abst). Am As, Pr $15: 29-30$ (1867) Can Nat n s $3: 121-123$ (1866)

67 Report on the gold region of Hastings. Can G S, Reports on the gold region of the County of Hastings : $3-6$ (1867)

$67 \mathbf{a}$ On the objects and method of mineralogy. Am J Sc (2) 43:203-206 (1867) Can Nat n s 3:110-114 (1866) [1867] Am Ac, Pr $7: 238-242$ (1868)

$67 \mathrm{~b}$ On the chemistry of the primeval earth. G Mag 4:357-369, 432, 477-478 (1867) Can Nat n s 3:225-234 (1867) Arch Sc Phys Nat n p 31:5-14 (1868) $\mathrm{R}$ Inst, $\operatorname{Pr} 5$ : 178-185 (1869)

67c Sur les pétroles de l'Amérique du Nord. Soc G France, B (2) 24:570-573 (1867)

67d Terrains anciens de l'Amérique du Nord (with discussions by J Marcou). Soc G France, B (2) 24:664-669 (1867)

67e Sur la théorie de l'origine des montagnes. Soc G France, B (2) 24:687689 (1867)

67f Sur la formation des gypses et des dolomies, Ac Sc Paris, C R 64:815-817 (1867)

679 Sur quelques réactions de sels magnésiens et sur les roches magnésifères. Ac Sc Paris, C R 64:846-849 (1867)

$67 h$ On the mineralogy of crystalline limestones (abst). G Mag 4:175-176 (1867)

67i On the Laurentian limestones and their mineralogy (abst). Am As, Pr 15: 54-57 (1867) Can Nat n s 3:123-125 (1866) [1867]
Hunt, Thomas Sterry-Continued.

68 Report on the gold region of Non Scotia. Can G S : 48 pp (1868)

68a On some points in the geology d Vermont. Am J Sc (2) 46:222-24 (1868)

$68 b$ Notes on the geology of south western Ontario. Am J Sc (2) $46: 35$ 362 (1868) Can Nat n s 4:11-20 (186\%) 68e A notice of the chemical geology Mr. D. Forbes. G Mag 5:49-59 (1868)

69 On the probable seat of volcanic as tion. G Mag 6:245-251 (1869) Can Nat n s 4:166-173 (1869) Am J Sc (2) 50: 21-28 (1869)

69a [Beloell Mountain, Quebec.] Can Nat n s $4: 220-222$ (1869)

69b The magnetic iron sands of Canads Can Nat n s 4:467-469 (1869)

69c [Description of the New England granite formation.] Essex Inst, B $1: 10$ 107 (1869)

$69 d$ On the geology of northeasten America (abst). Am Nat 3:442 (1869)

7o Report [on the Goderich salt region; on iron and iron ores]. Can G S, Rp Pros 1866-9:211-304 (1870) In part, Can Nat n 8 6:70-89 (1871)

70a On Laurentian rocks in eastern Mas sachusetts. Am J Sc (2) 49:75-78 (1870) Can Nat n s 5: 7-10 (1870)

70b On norite or labradorite rock. Am J Se (2) 49:180-186, 398 (1870) Can Nat $n$ s $5: 31-38$ (1870)

zoe On the geology of eastern New Eng. land. Am J Sc (2) 50: 83-90 (1870) Can Nat n s $5: 198-205 \quad(1870)$

70d On Laurentian rocks in Nova Scotia. Am J Sc (2) 50:132-134 (1870)

70e Contributions to the chemistry of copper. Am J Sc (2) 49: 153-157 (1870) Ac Sc Paris, C R 69:1357-1360 (1869) Oesterreichische Zs Berg- u Hüttenw 18: 157-159 (1870) Abst, Can Nat n s 4:324 (1869)

70p [On the black iron sand of sea beaches (abst).] Am Nat 4:569-570 (1870)

$\boldsymbol{7 0 g}$ The liquefaction of rocks. G Mag $7: 60-61$ (1870)

70h Volcanoes and earthquakes (abst). Am Geog Stat Soc, J 2 pt 2:89-98 (1870) Can Nat n s 4:387-397 (1869 [1870])

71 On the chemistry of the earth. Smiths Inst, An Rp 1869: 182-207 (1871)

T1a The geognosy of the Appalachians and the origin of crystalline rocks. Am Nat 5:450-509 (1871) Am As, Pr 20: 1-59 (1872) Abridged, Nature 5:15-17 (1871) Abst, G Mag 9:76-78 (1872)

71b Notes on granitic rocks. Am J Sc (3) $1: 82-89,182-191$ (1891); 3:115-125 (1872) Can Nat n s $5: 388-406$ (1870) [1871] Abst, Am As, Pr 19:159-161 
Hnnt, Thomas Sterry-Continued.

71c On a mineral silicate injecting Paleo roic crinoids. Can Nat n s 5:449-451 (1870) [1871] Am J Sc (3) 1:379-380 (1871)

71d Mineral silicates in fossils. Am J Sc (3) 2:57-58 (1871) Am Nat 5:445447 (1871)

71e On the oil-bearing limestone of Chicago. Am J Sc (3) 1:420-425 (1871) Can Nat n s 6:54-59 (1871) Am As, Pr 19: 157-159 (1871)

$71 \mathrm{f}$ On the oil wells of Terre Haute, Ind. Am Nat 5:576-577 (1871) Am J Sc (3) 2:369-371 (1871) Ind G S, An Rp 2:135-136 (1871)

$71 \mathrm{~g}$ On the geology of the vicinity of Boston. Boston Soc N H, Pr 14: 45-49 (1871)

71h Messrs. King and Rowney on Bozoon canadense. $\mathrm{R}$ Irish Ac, $\mathrm{Pr}$ (2) 1: 123-127 (1871)

711 [On the porphyries of the coast of Massachusetts.] Essex Inst, B 3:53-54 (1871)

$71 j$ On astronomy and geology (abst). Can Nat n s $5: 460-462$ (1870 [1871]

$71 \mathrm{k}$ The mountain of Montarville and its geological history (abst). Can Nat n s 6: 224-226 (1871)

711 On American iron sands (abst). Am As, Pr 19:131-132 (1871)

72 Report [on sllver ores from Eureka mine, near Port Hope, B. C., and on coal and lignites]. Can G S, Rp Prog 1871-2 : 66-67 (1872)

$72 a$ History of the names Cambrian and Silurian in geology. Can Nat $n \mathrm{~s} 6$ : 281-312, 417-448 (1872) G Mag 10: $385-395,453-461,504-510,561-566$ (1873)

72b Remarks on the late criticisms of Prof. Dana. Am J Sc (3) 4:41-52 (1872)

72e The origin of crystalline rocks: Am Chemist 2: 291-292 (1872)

73 The geognostical history of the metals. Am I M Eng, Tr 1:331-342 (1873)

73a [Iron ores of the ancient crystalline rocks of northern New York.] Am I M Eng, Tr 1:370-371 (1873)

73b Remarks on an occurrence of tin ore at Winslow, Maine. Am I M Eng, Tr 1:373-374 (1873)

73e The origin of metalliferous deposits. Am I M Eng, Tr 1:413-426 (1873) Van Nostrand's Fng Mag 11:326334 (1874) Ky G S, Rp Prog 2 n s : 301317 (1877) Also in Half-hour recreations in popular science (Dana Estes, ed) no 10 : 375-391, Boston [1873]

73d On some points in dynamical geology. Am J Sc (3) $5: 264-270$ (1873)

73e On the copper deposits of the Blue Riđge. Eng M J 16:25-26, 89-90, 106-107 (1873) In part, Am J Sc (3) 6:305-308 (1873)
Hunt, Thomas Sterry-Continued.

73f On the various theories to account for the phenomena of volcanism. Boston Soc N H, Pr 15:250-252 (1873)

$73 g$ [On concentric lamination in rocks.] Boston Soc N H, Pr 15: 261-262 (1872)

73h [Progress in] geology. In Annual record of science and industry for 1872 : xxxi1-xxxix (1873) ..1873: xliv-liv (1874) ...1874: lxvii-1xxvi (1875) ...1875: xcixcxiv (1876) ...1876: Ixxxix-civ (1877) $\begin{array}{lll}\ldots 1877: 165-182 & \text { (1878) } \quad \ldots 1878: 287-312\end{array}$ (1879)

74 The coal and iron of southern Ohio considered with relation to the Hocking Valley coal field and its iron ores... $78 \mathrm{pp}$, maps, Salem, Mass., 1874

74n The paleogeography of the North American continent. Am Geog Soc, J 4 : 416-431 (1874)

$74 \mathrm{~b}$ On the stratification of rock masses. Boston Soc N H, Pr 16:237-239 (1874)

74e [On the geologic occurrence of glauconite and fossil resins.] Boston Soc N H, Pr 16: 301-302 (1874)

74d The deposition of clays. Boston Soc N H, Pr 16:302-304 (1874)

74e. On Dr. Genth's researches on corundum and its associated minerals. Boston Soc N H, Pr 16:332-335 (1874)

74f Decomposition of crystalline rocks. Boston Soc N H, Pr 16:115-117 (1874) Abst, Am J Sc (3) $7: 60-61$ (1874)

$\mathbf{7 4 g}$ Supplementary note on the geology of the north shore of Lake Superior. Am I M Eng, Tr 2: 58-59 (1874)

74h The Ore Knob copper mine and some related deposits [Ashe Co., N. C.] (with discussion by $R$. W. Raymond). Am I M Eng, Tr 2:123-129 (1874)

74i The coals of the Hocking Valley, Ohio. Am I M Eng, Tr. 2:273-278 (1874) Eng M J $17: 182-183$ (1874)

74j Notes on the geology and economic mineralogy of the southeastern Appalachians (abst). Am As, Pr 22 pt $2: 113-$ 115 (1874)

741k The metamorphism of rocks (abst). Am As, Pr 22 pt 2:115-116 (1874) Can Nat n s $7: 162$ (1874)

741 Geology of southern New Brunswick (abst). Am As, Pr 22 pt $2: 116-117$ (1874)

74m Breaks in the American Paleozoic series (abst). Am As, Pr 22 pt 2:117-119 (1874) Can Nat n s $7: 160-161$ (1874)

74n Remarks on Prof. Newberry's paper on "Circles of deposition," etc. Am As, Pr 22 pt $2: 196-198$ (1874)

75 Chemical and geological essays. xxil, 489 pp, Boston 1875 Notice by J. D. Dana, Am J Sc (3) 9:102-109 (1875) 2d ed, xlv1, 489 pp, Salem 1878 3d ed, xlvi, 489 pp N Y 1891. 4th ed (with new preface), xlvi, $489 \mathrm{pp}$, N Y 1891 
Hunt, Thomas Sterry-Continued.

75a Report [on Hoosac tunnel]. In Boston, Hoosac Tunnel, and Western Railroad Company, Report of the corporators (Mass., H Doc no 9), Appendix ; xxv-xxiv, Boston 1875

75b The decayed gneiss of Hoosac Mountain [Mass.]. Boston Soc $\mathrm{N} \mathrm{H}, \operatorname{Pr} 18$ : 106-108 (1875)

75e On the decayed rocks of Hoosac Mountain [Mass.]. Am I M Eng, Tr $3: 187-188$ (1875)

75d On the Boston artesian well and its waters. Boston Snc N H, Pr $17: 486-$ 488 (1875)

75e Prof. J. D. Dana on the alteration of rocks. Boston Soc N H, Pr 18: 108-112 (1875)

$75 \mathrm{f}$ The disintegration of rocks and its geological significance $(a b s t)$. $\mathrm{Am} \mathrm{As,} \mathrm{Pr.}$ 23 pt $2: 39-41$ (1875) Am Nat 9:471$473(1875)$

$75 \%$ On the cement of some natural and artificial stones (abst). Am As, Pr 23 pt 1: 106-107 (1875)

76 The Cornwall iron mine and some related deposits in Pennsylvania. Am I M Eng, $\operatorname{Tr} 4: 319-325$ (1876)

76a A new ore of copper and its metallurgy. Am I M Eng, Tr 4:325-328 (1876)

77 The Goderich salt region [Ont.]. Am I M Eng, Tr 5:538-560 (1877) Eng M J 23:167-168, 185-186, 204, 215-217 (1877) Can G S, Rp Prog 1876-7 : 221243 (1878)

77a The Quebec group in geology. Boston Soc N H, Pr 19:2-4 (1877)

7 7b Geology of eastern Pennsylvania. Am As, Pr 25: 208-212 (1877)

77e On the history of the crystalline stratified rocks (abst). Am As, $\operatorname{Pr} 25$ : 205-208 (1877)

77d The geology of the older rocks of western America (abst). G Mag (2) 4: 574 (1877) Am As, Pr 26:265-266 (1878)

78 Special report on the trap dikes and azoic rocks of southeastern Pennsylvania. Pa G S, 2d, E : xxi, 253 pp (1878)

$78 \mathbf{a}$ On the geology of the Eozoic rocks of North America. Boston Soc $\mathrm{N} \mathrm{H}, \mathrm{Pr}$ $19: 275-279$ (1878)

78h The origin and succession of the crystalline rocks. G Mag (2) 5:466-473 (1878) Nature 18:443-445 (1878)

78e The geological relations of the atmosphere. Ac Sc Paris, C R 87:452-454 (1878) Abst, Nature 18:475 (1878); Brit As, Rp 48:544 (1879)

79 The history of some pre-Cambrian rocks in America and Europe. Am $\mathrm{J}$ Sc (3) $19: 268-283$ (1879) Can Nat n s 9: 257-275 (1880) Am As, Pr 28:279-296 (1880) Abet, Bostou Soc N H, Pr 20: 140-141 (1879)
Hunt, Thomas Sterry-Continued.

79a The coal and iron of the Hocking Valley, Ohio. Am I M Eng, Tr $7: 313-315$ (1879) Abst, Eng M J 27:200-201 (1879)

80 On the Iron-bearing and associated rocks of the Marquette region, and com. parisons with the Archean of Canada and of the eastern United States. [Wis G S], $\mathrm{G}$ Wis $3: 657-660 \quad(1880)$

80a The Taconic system in geology (abst). Am Nat 15:494-496 (1881) Can Nat n s 9: 429-431 (1880)

80b Sur les limites du terrain cambrien. Int $\mathrm{G}$ Cong, Paris 1878, C R:99-100 (1880)

s0c Des terrains précambriens dans l'Amérique du Nord. Int $\mathbf{G}$ Cong, Paris 1878, C R : 229-233 (1880)

sod The chemical and geological rela. tions of the atmosphere. Am J Sc (3) 19: $349-363$ (1880)

soe On the recent formation of quartz and on silicification in California. Am I Sc (3) 19:371-372 (1880) Can Nat n s 9: 435-437 (1880) Eng M J 29:369 (1880)

sor The genesis of certain iron ores (abst). Science (ed, Michels) 1:209 (1880) Can Nat n s 9:431-433 (1880)

$\mathbf{8 0 g}$ On the origin of anthracite. Science (ed, Michels) 1:303 (1880) Can Nat n 8 $9: 434-435$ (1880)

81 Coal and iron in southern Ohio; the mineral resources of Hocking Valley... 152 pp, map, Boston, Mass., 1881

81a Pre-Cambrian rocks. Can Nat n 8 $10: 126-127$ (1881)

82 Mineral physiology; an address delivered before Vassar Brothers' Institute, Poughkeepsie, N. Y., November 28, 1882. $21 \mathrm{pp}, \mathrm{n}$ p, n d [1882?] [priv pub?]

82a Sur les terrains éozoĩques ou pré. cambriens. Soc G France, B 3 (10);26-28 (1882)

82b [On the pre-Cambrian or Eozoic rocks of Europe as compared with those of North America (abst).] G Soc London, Q J : Pr 4-5 (1882) G Mag (2) 9:38-39 (1882)

83 The geological history of serpentines, including notes on pre-Cambrian rocks. R Soc Can, Pr Tr 1, iv : 165-215 (1883)

83a A historical account of the Taconic question in geology, with a discussion of the relations of the Taconian series to the older crystalline and to the Cambrian rocks. R Soc Can, Pr Tr 1 iv : 217-270 (1883) ; 2 iv : 125-157 (1885) Abst, Science $3: 675-676$ (1884)

83b Coal and iron in Alabama. Am I M Eng, $\operatorname{Tr} 11: 236-248$ (1883) Eng M J 35 : 113-115 (1883) . Abst, Seience 1:101102 (1883)

83e The decay of rocks geologically considered. Am J Sc (3) 26:190-213 (1883) Abst, Science 1:324-325 (1883); Am Nat $17: 645-646$ (1883) 
Hunt, Thomas Sterry-Continued.

83d The geology of Port Henry, N. Y. Can Nat n s 10:420-422 (1883)

83e The geology of Lake Superior. Science $1: 218-219$ (1883)

83f Notes on Prof. James Hall's address [Contributions to the geological history of the American continent]. Am As, Pr 31:69-71 (1883)

83g The serpentine of Staten Island, N. Y. (abst) Science 2:323 (1883) Am Nat 17: 1037-1039 (1883) Am As, Pr 32: 242-243 (1884)

84 The apatite deposits of Canada. Am I M Eng, Tr 12:459-468 (1884) Eng M J $37: 138-140$ (1884) Can Rec Se $1: 65$ 75 (1885)

84a The genesis of crystalline rocks. Am Nat 18: 605-607 (1884)

84b On Cambrian rocks of North America (abst). Am Nat 18:409-411 (1884) Can Rec Sc 1: 77-81 (1884)

84c The Eozoic rocks of North America (abst). Can Rec Sc 1:82-88 (1884) G Mag (3) $1: 506-510$ (1884) Brit As, Rp 54: 727-728 (1885)

84d [Record of recent scientific progress in] geology. Smiths Inst, An Rp 1882 : 325-345 (1884) Extr, The Virginlas 5: 141,161 (1884)

85 The origin of crystalline rocks. R Soc Can, $\operatorname{Pr} \operatorname{Tr} 2$, ifi: $1-67$ (1885) Alst, Can Rec Sc 1:75-77 (1884); Science 3: 674-675 (1884)

85a Les divisions du système éozoĩque de l'Amérique du Nord. Soc G Belgique, An 12: Mem 3-10 (1885)

85b The classification of natural silicates. Am Nat 19:795-798 (1885)

85e The geognosy of erystalline rocks (abst). Can Rec Sc 1: 147-148 (1885)

85d Biographical notice of Benjamin Silliman [jr.]. Am I M Eng, Tr 13:782785 (1885)

85e [Record of scientific progress, 1883] geology. Smiths Inst, An Rp 1883:443464 (1885)

86 Mineral physiology and physiography; a second series of chemical and geological essays... xvii, $710 \mathrm{pp}$, Boston 1886

86a A natural system of mineralogy, with a classification of native silicates. Reprinted from Mineral physiology and physiography, a second series of chemical and geological essays: 279-401. Boston [1886?]

86b On a natural system in mineralogy ; with a classification of native silicates. $R$ Soc Can, Pr Tr 3, ili : 25-93 (1886) Abst, Can Rec Sc 1: 129-135, 244-247 (1885) 2:116-119 (1886)

s6e Note on the apatite region of Canada. Am I M Eng, Tr 14: 495-496 (1886)

86d Apatite deposits in Laurentian rocks (abst). Am As, Pr 34:199 (1886)
Hunt, Thomas Sterry-Continued.

87 Supplement to 'A natural system in mineralogy, etc.' R Soc Can, Pr Tr 4, iii : $63-80$ (1887)

87a The genetic history of crystalline rocks. $\mathrm{R}$ Soc Can, $\mathrm{Pr}$ Tr 4 , iil: $7-37$ (1887)

s7b The Taconic question re-stated. Am Nat 21: 114-125, 238-250, 312-320 (1887)

87e Elements of primary geology. G Mag (3) 4:493-500 (18s7) Abst, Brit As, Rp 57: 704-705 (1888)

S7d (and Douglas, James) The Sonora [Mex.] earthquake of May 3, 1887. Am Nat 21: 1104-1106 (1887) Brit As, Rp 57:712-713 (1888) - Seism Soc Japan, Tr 12:29-31 (1888)

88 On crystalline schists. Int $\mathrm{G}$ Cong, IV, London 1888, C R: 65-79 (1891) Nature $38: 519-522$ (1888)

s8a On the study of mineralogy. Brit As, Rp 58:627-630 (1889) Can Rec Sc $3: 236-242$ (1888)

S8b Mineralogical evolution (abst). Brit As, Rp 58:682-684 (1889) Can Rec Sc $3: 242-245$ (1888)

89 The classification and nomenclature of metalline minerals. Am $\mathrm{Ph}$ Soc, $\mathrm{Pr} 25$ : 170-180 (1889) Abst, R Soc Can, Pr Tr 6, ili : $61-63$ (1889)

90 The iron ores of the United States. Am I M Eng. Tr 19:3-17 (1891) Eng M J $50: 601-602,622-624$ (1890) Iron Steel Inst, J 1890, II : 628-644 [1891]

90a The geological history of the Quebec group. Am G 5:212-225 (1890)

91 Systematic mineralogy based on a natural classification, $\quad 391 \mathrm{pp}$, N Y 1891

$91 \mathrm{n}$ [On the use of the term Ordoviclan.] Int $\mathrm{G}$ Cong, IV, London $1888, \mathrm{C}$ R : 225-226 (1891)

See also Blandy, 79; Eustis, 79; Frazer, 88a ; Hall, 64d; Hitcleoek (C H), 73b; Logan, 67; Niles, 75; Pechin, 75; Prime 75a; Smock, 74, 79; Winchell (N H), 88g Hunt, Walter Fred.

06 (with Kraus, E. H.) The occurrence of sulphur and celestite at Maybee, Mich. Am J Se (4) $21: 237-244$ (1906)

11 (and Van Horn, F. R.) Cerusite twins from the Begoña mine, Cerro de San Pedro, San Luis Potosi, Mexico. Am J Sc (4) $32: 45-47$ (1911) Zs Kryst $49: 357-$ 359 (1911)

11a (with Kraus, E. H.) Tables for the determination of minerals. 254 pp N Y (1911)

15 (with Clark, R. W.) Ungewöhnliche optische Eigenscbaften des Muscovits in dem Mar Villa Marmor von Cockeysville, Md. Centralbl Miner 1915:666-668

15a (with Kraus, E. H.) Manganhaltiger Albit von Kalifornien. Centralbl Miner $1915: 465-467$ 
Hunt, Walter Fred-Continued.

15b (with Van Horn, F. R.) Bournonite crystals of unusual size from Park City, Utah. Am J Sc (4) $40: 145-150$ (1915)

16 (and Kraus, 6. H.) Note on the variable composition of melanochalcite. Am J Sc (4) 41:211-214 (1916) Abst, G Soc Am, B 27:61 (1916)

Hunter, Andrew Frederick.

03 The Algonquin shore line in Simcoe Co., Ont. Can G S, Sum Rp 1902 (An Rp 15) : A 281-304 (1903)

o5 Raised shore lines along the Blue Mountain escarpment [south of Georgian Bay]. Can G S, Sum Rp 1904 (An Rp 16) : A 225-228 (1905)

os Shore lines between Georgian Bay and the Ottawa River. Can G S, Sum Rp $1907: 55$ (1908)

Hunter, C. L.

53 Notices of the rare minerals and new localities in western North Carolina. Am J Sc (2) 15:373-378 (1853)

Hunter, John Frederick (1888-1917).

14 The Aberdeen granite quarry near Gunnison, Colo. U S G S, B 540:359362 (1914)

14a Some cerusite deposits in Custer Co., Colo. U S G S, B 580:25-37 (1914)

14b Erosion and sedimentation in Chesapeake Bay around the mouth of Choptank River [Md.]. U S G S, P P 90: 715, map (1914) Abst, Wash Ac Sc, J 4 : 421-422 (1914)

14e (with Larsen, E. S.) Melilite and other minerals from Gunnison Co., Colo. Wash Ac Se, J 4:473-479 (1914)

16 (with Noble, L. F.) A reconnaissance of the Archean complex of the Granite Gorge, Grand Canyon, Ariz. U S G S, P P 98:95-113 (1916) Abst, Wash Ac Sc, J $7: 38$ (1917)

See also Cross, 15 ; Robinson (H H), 13

Hunter, William.

69 Observations on the bones commonly supposed to be elephants' bones which have been found near the Ohio River in America. R Soc London, Ph Tr 58:34-45, il (1769)

Huntington, Edward V.

14 (with Weeks, W. S.) The faultless faultinder. Eng M J 98:291-296 (1914)

Huntington, Ellsworth.

03 (and Goldthwait, J. W.) The Hurricane fault in southwestern Utah. J G 11:46-63, map (1903)

04 (and Goldthwait, J. W.) The Hurricane fault in the Toquerville district, Utah. Harvard Coll, Mus C Z, B 42 (g s 6) : 199-259, map (1904)

or Some characteristics of the glacial period in nonglaciated regions. G soc $\mathrm{Am}$, B 18:351-388 (1907)
Huntington, Ellsworth-Continued.

os Coincident activities of the earth and the sun. Pop Sc Mo 72:492-502 (1908) Abst, Sclence n s 28:575-576 (1908)

10 Post-Tertiary history of the lakes of Asia and Syria ( $a b s t$ and discussion). G Soc Am, B 21: 755-757 (1910)

12 William Morris Davis, geographer. G Soc Phila, B $10: 224-234$, port (1912)

12 a The Peninsula of Yueatan. Am Geog Soc, B 44: 801-822 (1912)

13 Bearing of recent climatic investiga. tions on geological theories (abst with dis. cussion by W. N. Rice, C. W. Brown, and A. L. Day). G Soc Am, B 24:687-688 (1913)

14 The climatic factor as illustrated in arid America. Carnegie Inst Wash, Pub 192 : 341 pp, maps (1914)

14a The solar hypothesis of climatic changes. G Soc Am, B 25:82-83 (abst), $477-590$ (1914)

16 Glaciation and stormy period of the fourteenth century $(a b s t)$. G Soc $A m, B$ $27: 67-68$ (1916)

18 Climate and the evolution of civilization. In The evolution of the earth and its inhabitants [edited by R. S. Lull]: 147-193, New Haven 1918

See also MacDougal, 16

Huntington, Joshua Henry (1833-1904).

74 Scenery of Coos Co. In Hitchook, C. H., Geology of $\mathrm{N}$ H, pt $1: 636-648$ (1874)

74a (with Hiteheock, C. H.) Geology of the northwest part of Maine. Am As, Pr 22 pt $2: 205-214$, map (1874)

$\boldsymbol{7} 7$ Geology of the Coos and Essex topographical district; geology of the Merri mack district, west part [N. H.]. In Hitchcock, C. H., Geology of $\mathrm{N} \mathrm{H}$, pt 2: 37-97, 466-517 (1877)

- 78 Notes on the surface geology of $\mathrm{Coos}$ Co. In Hitchcock, C. H., Geology of N H, pt 3 [vol 3] : 338-340 (1878)

$78 a$ Geology of the region about the headwaters of the Androscoggin River, Me. In Hitchcock, C. H., Geology of N E pt 3 [vol 3]: 358-366 (1878) Abst, Am As, $\operatorname{Pr} 26: 277-286$ (1878)

80 On the iron ore of Bartlett, N. H. Boston Soc N H, Pr $20: 288-292$ (1880)

83 Some observations in regard to the geology of Albert and Westmoreland cos., N. B. Appalachía 3: 175-176 (1883)

See also Hawes, 84 .

Huntington, Oliver Whipple.

86 On the crystalline structure of iron meteorites. Am Ac Arts, Pr 21:478-498 (1886) Am J Sc (3) 32:284-303 (1886) s7 On the Coahuila meteorites. Am J Sc (3) $33: 115-118$ (1887)

88 Catalogue of all recorded meteorites. Am Ac Arts, Pr 23:37-110 (1888)

89 The crystalline structure of the Coahuila irons. Am Ac Arts, $\operatorname{Pr} 24: 30-35$ (1889) 
Huntington, Oliver Whipple-Continued. $90 \mathrm{~A}$ new meteoric iron from Stutsman Co., N. Dak. Am $\Delta \mathrm{c}$ Arts, Pr 25:229232 (1890)

91 The Prehistoric and Kiowa Co., Kans., pallasites. Am Ac Arts, Pr 26: 1-12 (1891)

92 Diamonds in meteorites. Science 20: 15 (1892)

93 (with Kunz, G. F.) On the diamond in the Canyon Diablo meteoric iron... Am J Sc (3) $46: 470-473$ (1893)

94 Further observations upon the occurrence of diamonds in meteorites. $\mathrm{Am} \mathrm{Ac}$ Arts, Pr 29: 204-211 (1894)

94a The Smithville meteoric iron [De Kalb Co., Tenn.]. Am Ac Arts, Pr 29: 251-260 (1894)

Hnntley, D. B.

85 The mining industries of Utah. U S, 10th Census 13:405-489 (1885)

Huntley, Louis Grow.

15 The Mexican oil flelds. Am I M Eng, B $105: 2067-2075$, maps (1915) ; Tr 52 : 281-321, maps (1916)

15a Oil, gas, and water content of $\mathrm{Da}$ kota sand in Canada and United States (with discussion by E. W. Shaw). Am I M Eng, B 102:1333-1353; 108:2428-2430 (1915) ; $\operatorname{Tr} 52: 329-352$ (1916)

16 (with Johnson, R. H.) Principles of oil and gas production. $371 \mathrm{pp}, \mathrm{N} \mathrm{Y}$ 1916

Hurd, Rukard.

11 Hurd's iron-ore manual; a general reference, guide, handbook of the Lake Superior district. 162 pp, St. Paul, Minn. 1911

Hurlburt, E. B.

94 On alunite, from Red Mountain, Ouray Co., Colo. Am J Sc (3) $48: 130$ 131 (1894)

Hurlbat, W. D.

70 Geology of southern Minnesota... 37 pp, Rochester Minn., 1870.

Hurley, Thomas Jefferson.

00 Famous gold nuggets of the world. $64 \mathrm{pp}, 1900$ [Priv pub]

Hurst, L. A.

16 (and others.) Soil survey of Grant Co., Ind. Ind $\mathrm{Dp} G$ Nat Res, An Rp 40 : 72-108, map (1916)

Hus, Henri.

08 An ecological cross section of the Mississippi River in the region of St. Louis, Missouri. Mo Bot Garden, An Rp $19: 127-258$ (1908)

Hussak, Eugen.

86 The determination of rock-forming minerals. Transl from 1st German ed, by Erastus G. Smith. 233 pp, N Y 1886

Hnssakof, Louis,

05 Notes on the Devonian "placoderm," Dinichthys intermedius Newb. Am Mus N H, B 21: 27-36, il (1905)
Hussaliof, Louls Continued.

O5a On the structure of two imperfectly known dinichthyids. Am Mus $\mathrm{N} H, \mathrm{~B}$ $21: 409-414$, il (1905)

06 Studies on the Arthrodira. Am Mus N H, Mem $9: 105-154$, il $(1: \sim j)$

07 Zebrasoma deani, a fossil surgeon. fish from the West Indies. Am Mus $\mathrm{NH}$, B 23: 125-126, il (1907)

os Catalogue of the type and figured specimens of fossil vertebrates in the American Museum of Natural History ; Part I, Fishes. Am Mus N H, B 25:1-103, il (1908)

osa Review of Devonic fishes of the New York formations, by C. R. Eastman. Science n s 28:311-313 (1908)

09 The systematic relationships of certain American arthrodires. Am Mus N H, B $26: 263-272$, il (1909)

10 Vertebrate paleontology and the evidences for recapitulation. Pop Sc Mo 77 : 304-307 (1910)

11 Notes on some upper Devonian Arthrodira from Ohio, U. S. A., in the British Museum. G Mag (5) 8:123-128, il (1911)

11 a The Permian fishes of North America. In Revision of the Amphibia and Pisces of the Permian of North America by E. C. Case, (Carnegie Inst Wash, Pub no 146) : 153-175, il (1911)

12 Notes on Devonic fishes from Scaumenac Bay, Quebec. N Y St Mus, B 158: $127-139$, 11 (1912)

12a The Cretaceous chimmeroids of North America. Am Mus N H, B 31: 195-228, il (1912)

13 Descriptions of four new Paleozoic fishes from North America. Am Mus N H, B $32: 245-250$, il (1913)

15 (and Bryant, W. L.) The fauna of the conodont bed (basal Genesee) at Eighteenmile Creek, N. Y. (abst). G Soc Am, B 26:154 (1915)

16 The lungfish remains of the coal measures of Ohio, with special reference to the supposed amphibian Eurythorax of Cope. Am Mus N H, B $35: 127-133$, il (1916)

16 a Note on a palaeoniscid fish from a Permian formation in South Dakota. Am J Sc (4) $41: 347-350$, il (1916)

16b A new cyprinid fish, Leuciscus rosei, from the Mlocene of British Columbia. Am J Sc (4) $42: 18-20$, il (1916)

16e Discovery of the great lake trout, Cristivomer namaycush, in the Pleistocene of Wisconsin. J G 24:685-689, il (1916)

18 (and Bryant, W. L.) Catalog of the fossil fishes in the museum of the Buffalo Society of Natural Sciences. Buffalo Soc N Sc, B $12: 346 \mathrm{pp}$, il (1918)

Hussey, John.

78 Report on the geology of Clinton and Fayette cos. ; Shelby Co. ; Miami Co. Ohio G S, Rp 3 pt 1:429-481 (1878) 
Hussey, W. J.

11 List of earthquake shocks recorded at the observatory of the University of Michigan, Ann Arbor, during 1910. Seism Soc Am, B 1: $83-84$ (1911)

Huston, George.

10 Notes on geology of Snow Storm mine [Cour d'Alene region], Idaho. Eng M J $90: 1109-1110$ (1910)

11 Geology of the Cour d'Alene ores, Idaho. M Science $63: 360$ (1911)

12 Prichard formation rocks [Coeur d'Alene region, Idaho]. M World $36: 305$ (1912)

15 The copper beds of the Coeur d'Alene [Idaho]. M Sc Press 110:145-147, map (1915)

Huston, Samuel.

83 Peculiar faulting of a coal bed [Richmond, Ohio]. Science 1: 191-192 (1883)

Hutehins, John Power.

07 Gold-dredging practice at Ruby. Mont. Eng M J $83: 1223-1226 ; 84: 69-$ $72(1907)$

$07 a$ The essential data of placer investigations. Eng M J $84: 339-342$, 385386 (1907)

$07 \mathrm{~b}$ The nomenclature of modern placer mining. Eng M J 84:293-296 (1907)

o7e Dredging beach gravel deposits near Nome. Eng M J 84:955-961 (1907)

os Prospecting and mining gold placers in Alaska. U S G S, B 345: 54-77 (1908) Hutehins, Tho.

86 Description of a remarkable rock and cascade near the western side of the Youghiogeny River ... in Fayette Co., $\mathrm{Pa}$. Am Ph Soc, Tr 2:50-51 (1786)

Hutehinson, F. M.

10 Coals in the Central City, Madisonville, Calboun, and Newburg quadrangles of the western coal field. Ky G S, Rp Progress 1908-9:54-69 1910)

10a Preliminary report on oil and gas possibilities in the Newburg, Calhoun, Central City, and Madisonville quadrangles, including a discussion of the primary factors governing such accumulations. Ky G S, Rp Progress 1908-9: 85-92:(1910)

12 Report on the geology and coals of the Central City, Madisonville, Calhoun, and Newburg quadrangles, in Mublenberg, Hopkins, Ohio, McLean, Webster, Daviess, and Henderson cos. [Ky.]. Ky G S, B $19: 127 \mathrm{pp}$, maps (1912)

Hutchinson, Henry Neville.

91 The autobiography of the earth; a popular account of geological history. 290 pp, il, N Y 1891

92 Extinct monsters ... 254 pp, il, N I [1892]

94 Creatures of other days. $270 \mathrm{pp}$, il, N Y 1894

97 Prehistoric man and beast. $298 \mathrm{pp}$, N Y 1897
Hutchinson, Henry Neville-Continued.

17 Observations on the reconstructed skeleton of the dinosaurian reptile Diplo. docus carnegiei, as set up by Dr. W. J. Holland in the Natural History Museum in London, and an attempt to restore it by means of a model. G Mag (6) $4: 356$ 370,11 (1917)

Hutehinson, W. Spencer.

07 The Bonanza silver mines of Cobalt, Ont. Eng M J 83: 793-794 (1907)

O7a Barytes deposits at Five Islands, N. S. Eng M J $84: 825-826$ (1907)

Hutehison, L. L.

os (with Gould, C. N.) Preliminary report on the mineral resources of 0klahoma. Okla G S, B 1:84 Dp (1908)

10 (with Gonld, C. N.) Proposed groups of Pennsylvanian rocks of eastern Oklahoma. Okla Univ, Research B 3: $15 \mathrm{pp}$ (1910)

11 Preliminary report on the rock as. phalt, asphaltite, petroleum, and natural gas in Oklahoma. Okla G S, B 2: $256 \mathrm{pp}$., map (1911)

Huxley, Thomas Henry (1825-1895).

81 The rise and progress of paleontology. Pop Sc Mo 20: 165-175 (1881)

Hyatt, Alpheus (1838-1902).

65 Remarks on the Beatriceae, a new division of Mollusca. Am J Sc (2) 39: 261-266 (1865)

65a On Beatricea and Pasceoltus. Boston Soc N H, Pr 10:19 (1865)

65b On the structure of the shells of Cephalopoda. Boston Soc N H, Pr 10:24 (1865)

66 On the parallelism between the differ ent stages of life in the individual and those in the entire group of the molluscous order Tetrabranchiata. Boston Soc N H Mem 1: 193-209 (1866)

$\mathbf{6 6 a}[\mathrm{On}$ the agreement between the different periods in the life of the individual shell and the collective life of the tetrabranchiate cephalopods.] Boston Soc $\mathrm{N} \mathrm{H}, \mathrm{Pr} 10: 302-303$ (1866)

67 The fossil cephalopods of the Museum of Comparative Zoology. Harvard Coll., Mus C Z, B 1: 71-102 (1867)

67a [On Eozoon canadense.] Essex Inst, $\operatorname{Pr} 5: 110$ (1867)

68 The chasms of the Colorado. Am Nat 2: 359-365 (1868)

68 a $[O n$ the absence of distinct evidences of glaciation in the Yukon Valley, Alaska.] Boston Soc N H, Pr 12:149150 (1868)

68b [On Beatricea.] Essex Inst, $\operatorname{Pr} 5$ : 187 (1868)

68e [On the geology of the Adirondacks.] Essex Inst, $\operatorname{Pr} 6: 5-6$ (1868)

69 Rock ruins [Niagara Falls]. Am Nat $2: 77-85$ (1869)

69a [On the geology of Salem, Mass.]. Essex Iust, $\operatorname{Pr} 6: 51,52$ (1869) 
Hyatt, Alpheus-Continued.

70 [On a raised beach at Marblehead, Mass.]. Essex Inst, B 2:111 (1870)

71 On reversions amrong the ammonites. Beston Soc N H, Pr 14: 22-43 (1871)

71a [Some geologic features in the vieinity of Salem, Mass.]. Boston Soc N H, Pr 14:91-92 (1871)

71b On the geological survey of Essex Co. [Mass.]. Essex Inst, B $3: 49-53$ (1871)

72 Fossil cephalopods of the Museum of Comparative Zoology; embryology. Harvard Coll, Mus C Z, B 3:59-111, il

72a On the embryology and development of the shells of ammonoids and nautiloids. Boston Soc N H, Pr 14: 396-399 (1872)

$72 \mathrm{~b}$ The non-reversionary series of the Liperoceratidae, and remarks upon the series of the allied family, Dactyloidae. Boston Soc N H, Pr 15:4-21 (1872)

74 Evolution of the Arietidae. Boston Soc N H, Pr 16: 166-170 (1874)

74a Genetic relations of the Angulatidae. Boston Soc N H, Pr 17:15-23 (1874)

74b Appendix to commrunications on reversions among Ammonites. Boston Soc $\mathrm{N} \mathrm{H}, \operatorname{Pr} 17: 23-28$ (1874)

74e Appendix to communication on "the non-reversionary series of the Liparoceratidae. Boston Soc $N$ H, Pr 17:29-33 (1874)

75 Remarks on two new genera of Ammonites, Agassiceras and Oxynoticeras, Boston Soc N H, Pr 17:225-235 (1875) dbst, Am J Sc (3) 10:344-349 (1875)

75a. Abstract of a memoir on the "biological relations of the Jurassic Ammonites." Boston Soc N H, Pr $17: 236-241$ (1875)

76 [On the porphyries of Marblehead, Mass.] Boston Soc N H, Pr 18: 220-224 (1876)

$76 a$ Genetic relations of Stephanoceres. Boston Soe N H, Pr 18:360-400 (1876) 79 About pebbles. Boston Soc N H, Guides for science teaching. No 1:25 pp, Boston 1879; later ed, 26 pp, Boston 1892

83 Genera of fossil cephalopods. Boston Soc N F, Pr 22: 253-338 (1883)

84 The evolution of the Cephalopoda. Science 3: 122-127, 145-149 (1884)

84a The primitive conocoryphean. Science $4: 351$ (1884)

84b The protoconch of Cephalopoda. Am Nat 18:919-920 (1884)

84e Fossil Cephalopoda in the Museum of Comparative Zoology (abst). Am As, Pr $32: 323-361$ (1884)

85 Cruise of the Arethusa [to Newfoundland]. Science 6:384-386 (1885) Boston Soc N H 23: $316-319$ (1886)

$85 a$ [On Hyolithes from the St. John group.] N H Soc N B, B [1] no 4: 102 (1885) Con Rec Sc 1:141 (1885)
Hyatt, Alpheus-Continued.

85b Structure of the siphon in the Endoceratidae (abst). Am As, Pr 33: 490-491 (18S5)

85e Structure and affinities of Beatricea (abst). Am As, Pr 33: 492 (1885)

87 On primitive forms of cephalopods. Am Nat 21:64-66 (1887)

88 Values in classification of the stages of growth and decline with propositions for a new nomenclature. Boston Soc N H, Pr 23 : 396-408 (1888) Am Nat 22: 872-884 (1888)

SSa [The Taconic question.] Am G 2: 137 (1888)

89 Genesis of the Arietidae. Harvard Coll, Mus C Z, Mem 16 no 3 : xi, 238 pp, il (1889) Smiths Cont Knowl 26 [673]: xi, $238 \mathrm{pp}$, il (1889) Rv by J. M[arcou], Am G $6: 128-133(1890)$

89a Modes of evolution in fossil shells. N Y Ac Sc, Tr \& : 114-115 (1889)

91 Carboniferous cephalopods. Tex G S An Rp 2:327-356, il (1891)

92 Jura and Trias at Taylorville, Cal. G Soc Am, B 3: $395-412$ (1892)

92a Remarks on the Pinnidae. Boston Soc N H, Pr 25: 335-346 (1892)

93 Carboniferous cephalopods; second paper. Tex G S, An Rp 4 pt $2: 377-474$, il (1893)

93a The fauna of Tueumeari. Am G $11: 281$ (1893)

93b Phylogeny of an acquired characteristic. Am Nat $27: 865-877$, il (1893)

94 Phylogeny of an acquired characteris. tic. Am Ph Soc, Pr $32: 349-647$, il (1894)

94 a Trias and Jura in the Western States. G Soc Am, B $5: 395-434$ (1894) Abst, Am G 13:148 (1894); Am J Sc (3) 47:142-143 (1894)

95 Remarks on the genus Nanno, Clarke. Am G 16:1-12, il (1895)

95a Terminology proposed for description of the sbell in Pelecypoda (abst). Am G $16: 252-254$ (1895) Am As, Pr 44:145148 (1896)

96 Lost characteristics. Am Nat 30 : 9-17 (1896)

96 a Report on the Mesozoic fossils [from Alaska]. U S G S, An Rp 17 pt 1:907908 (1896)

97 Cycle in the life of the individual (ontogeny) and in the evolution of its own group (phylogeny). Am Ac, Pr 32:207224 (1897) Science n s 5: 161-171 (1897)

98 A new classification of fossil cephalopods (abst). Am As, Pr $47: 363-365$ (1898) Seience n 8 8:398 (1898)

03 Pseudoceratites of the Cretaceous, edited by $T$. W. Stanton. U S G S, Mon 44: $351 \mathrm{pp}$, il (1903)

05 (and Smith, J. P.) The Triasslc cephalopod genera of America. U $\mathbf{S} \mathbf{G} \mathbf{S}$, P P 40:394 pp, il (1905)

See also Bicknell, 69 ; Eastman, 00 ; Powell, 91, 91a, 92 ; Shaler, 71 
Hyde, Henry C.

93 The Santa Monica Diatomaceae. San Francisco Micro Soc, Tr 1: 18-24 (1893) Hyde, Jesse Elarl.

ot Changes in the drainage near Lancaster [Ohio]. Ohio Nat 4: 149-157, map (1904)

os Desiccation conglomerates in the coal measures limestone of Ohio. Am J Sci (4) 25: 400-408 (1908)

08a Camarophorella, a Mississipplan meristelloid brachiopod. Boston Soc N H, Pr 34:35-65, il (1908)

11 Notes on the absence of a soil bed at the base of the Pennsylvanian of southern Ohio. Am J Sci (4) 31:557-560 (1911)

$11 a$ The ripples of the Bedford and Berea formations of central and southern Ohio, with notes on the paleogeography of that epoch. J G $19: 257-269$ (1911)

$11 b$ (with Berkey, C. P.) Original ice structures preserved in unconsolidated sands. J G $19: 223-231$ (1911)

12 The geologieal history of Fairfield County, Ohio. Extract from History of Fairfield County and representative citizens, by Charles C. Miller: 203-223, Chieago, IIl., 1912

12a An occurrence of coal [near Somerset, Perry Co., Ohio] which bears evidence of unusual conditions accompanying its deposition. J G 20:316-330 (1912)

13 Excursion in eastern Quebec and the maritime provinces; character and fauna of the Riversdale and Union formations; annotated guide, Truro to Campbell's siding; the Carboniferous sections on Sydney Harbour. Int G Cong, XII, Canada, Guide Book no 1: 221, 222-225, 251-262 (1913)

14 The stratigraphic relations of the Riversdale-Union and Windsor formations of Nova Scotia. Can G S, Sum Rp 1912: 390-396 (1914)

14a The Windsor-Pennsylvanian section on the Strait of Canso, N. S. Can G S, Sum Rp 1913 : 264-269 (1914)

15 Windsor and Pennsylvanian formations in Nova Scotia. Can G S, Sum Rp 1914: 107-108 (1915)

15a Stratigrapby of the Waverly formations of central and southern Ohio. J G $23: 655-682,757-779$, map (1915)

Hyder, Frederick B.

15 Geology of Juneau district [Alaska]. Eng M J $99:$ 901-902 (1915)

Hynes, Dibrell P.

12 Notes on the geology of the Mina Mexico vein [Sahuaripa district of Sonora, Mexico]. Ec G $7: 280-286$ (1912)

Iekes, E. L.

10 Contribution to the geology of eastern Oregon (abst). G Soc Am, B 21 : 791 (1910)

Iadings, Joseph Paxson (1857-1920).

83 (with Hague, A.) Notes on the volcanoes of northern California, Oregon,
Iddings, Joseph Paxson-Continued. and Washington Territory. Am J Sc (3) $26: 222-235(1883)$

84 (with Hague, A.) Notes on the volcanic rocks of the Great Basin. An J Sc (3) $27: 453-463$ (1884)

85 On the occurrence of fayalite in the lithophyses of obsidian and rbyolite in the Yellowstone National Park. Am J Sc (3) $30: 58-60$ (1885)

s5a (and Cross, W.) On the wide spread occurrence of allanite, as an ac cessory constituent of many rocks. Am J Sc (3) $30: 108-111$ (1885)

85b (with Hague, A.) On the de- velopment of crystallization in the ingeous rocks of Washoe, Nev., with notes on the geology of the district. U S G S, B 17 $44 \mathrm{pp}$ (1885)

86 The columnar structure in the igneous rock on Orange Mountain, N. J Am J Sc (3) $31: 321-331$ (1886) Abst, Ph Soc Wash, B 8:19-24 (1885)

86a (with Hague, A.) Notes on the volcanic rocks of the republic of Salvador, Central America. Am J Sc (3) $32: 26$ 31 (1886)

$\mathbf{8 7}$ The nature and origin of lithophysae and the lamination of acid lavas. Am J Sc (3) $33: 36-45 \quad$ (1887)

8s Obsidian Cliff, Yellowstone National Park. U S G S, An Rp 7 : 249-295 (1888) S8a on the origin of primary quarts in basalt. $\mathrm{Am} J$ Sc (3) $36: 208-221$ (1888)

89 The crystallization of igneous rocks. Ph Soc Wash, B 11: 65-113 (1889)

90 On a group of volcanic rocks from the Tewan Mountains, N. Mex., and on the occurrence of primary quartz in certain basalts. U S G S, B 66:34 pp (1890)

90a The mineral composition and geological occurrence of certain igneous rocks in the Yellowstone National Park. Ph Soc Wash, B 11: 191-220 (1890)

91 The eruptive rocks of Electric Park and Sepulchre Mountain, Yellowstone Na. tional Park. U S G S, An Rp 12 pt 1: 569-664, map (1891)

O1a (and Penfield, S. L.) The minerals in hollow spherulites of rhyolite from Glade Creek, Wyo. Am J Sc (3) $42: 39$ 46 (1891)

91b Spherulitic crystallization. Ph Soc Wash, B 11:445-463 (1891)

92 Microscopical petrography of the erup. tive rocks of the Eureka district, Nev. U S G S, Mon 20:335-396 (1892)

92a The origin of igneous rocks. Ph Soc Wash, B 12:89-213 (1892)

93 The dissected volcano of Crandall Basin, Wyo. J G 1:606-611 (1893)

93a Genetic relationships among igneous rocks. J G $1: 833-844$ (1893) 
Iddings, Joseph Paxson-Continued.

94 (and Weed, W. H.) Livingston atlas sheet [Mont.]. U S G S, G Atlas Livingston fol (no 1) : $4 \mathrm{pp}$, maps (1894; prel ed 1892) Abst, J G 4:246-248 (1896)

94a George Huntington Williams. J G 2: 759-767. port (1894)

94b The dissected volcano of Crandall Basin, Wyo. Brit As, Rp 63: 753-754 (1894)

94c Petrological features of the dissected volcano of Crandall Basin, Wyo. (abst). Brit As, Rp 63: 763-765 (1894)

95 Absarokite-shoshonite-banakite series. J G $3: 935-959$ (1895)

96 Yellowstone National Park; igneous rocks. U S G S, G Atlas Yellowstone National Park fol (no 30):6 (1896)

96a Extrusive and intrusive igneous rocks as products of magmatic differentiation. G Soc London, Q J 52:606-617, map (1896) Abst, G Mag (4) $3: 383$ (1896)

96b Petrology as related to other branches of natural science (abst). Science n s $4: 928$ (1896)

98 On rock classification. J G 6:92111 (1898) Abst, Science n \& $7: 83-84$ (1898)

98 $\mathrm{n}$ Chemical and mineral relationships in igneous rocks. J G 6:219-237 (1898) 98b Bysmaliths. J G 6 : 704-710 (1898) 99 (and weed, W. H.) Descriptive geology of the Gallatin Mountains. U S G S, Mon 32 pt 2:1-59 (1899)

99a The intrusive rocks of the Gallatin Mountains. U S G S, Mon 32 pt 2:60-88 (1899)

99b The igneous rocks of Electric Peak and Sepulchre Mountain, Yellowstone National Park. U S G S, Mon 32 pt 2:89148, map (1899)

99c (and weed, W. H.) Descriptive geology of the northern end of the Teton Range, Yellowstone National Park. U S G S, Mon 32 pt 2:149-164, map (1899)

99d The dissected volcano of Crandall Basin, Wyo. U S G S, Mon 32 pt 2:215268, map (1899)

99e The igneous rocks of Absaroka Range ... [and other localities] Yellowstone National Park. U S G S, Mon 32 pt $2: 269-439$ (1899)

02 (with others) A quantitative chemicomineralogical classification and nomenclature of igneous rocks. J G 10:555-690 (1902)

03 Chemical composition of igneous rocks expresser by means of diagrams ... U S G S, P P 18:98 pp (1903)

03a Chemical composition of Igneous rocks expressed by means of diagrams (abst). Science n \& $17: 295$ (1903) G Soc Am, B 14:533 (1904) Eng M J 75: 153 (1903)

03b (with Cross, W., and others) Quantitative classification of igneous rocks. 286 pp, Chicago 1903
Iddings, Joseph Paxson-Continued.

04 A fracture valley system [Montana].

J G 12 : 94-105, map (1904)

04a Quartz-feldspar porphyry (graniphyro liparose-alaskose) from Llano, Tex. J G 12:225-231 (1904)

o5 The isomorphism and thermal properties of the feldspars; optical study. Carnegie Inst Wash, Pub 31:77-95, Washington 1905

06 Rock minerals, their chemical and physical characters and their determination in thin sections. 548 pp, N Y 1906 2 ed, 617 pp, N Y 1911

O6a (with Cross, W.) The texture of igneous rocks. J G 14:692-707 (1906)

os Memoir of Samuel Lewis Penfield. G Soc Am, B 18: 572-582, port (1908)

09 Igneous rocks, composition, texture and classification, description and occurrence. In two volumes; vol I, $464 \mathrm{pp}$, N Y 1909, vol II, xi, $685 \mathrm{pp}$, N Y 1913

09a The study of igneous rocks. Science $n$ \& $29: 201-217$ (1909) Australasian As, Rp 12:265-282 (1910)

11 Problems in petrology. Am Ph Soc, Pr 50:286-300 (1911)

12 (with Cross, W.) Modifications of the quantitative system of classification of igneous rocks. J G 20:550-561 (1912)

14 The problem of volcanism. xi, 273 pp, map, New Haven, 1914 Rv, by T. A. Jaggar, The Nation 101:155-157 (1915)

14a Some examples of magmatic differentiation and their bearing on the problem of petrographical provinces. Int $G$ Cong, XII, 1913, C R : 209-228 (1914)

is Memorial of Arnold Hague. G Soc Am B $29: 35-48$, port (1918)

See also Bowen, 16; Cross, 02b; Daly, 14; Emmons (S F), 93 ; Jaggar, 15; Walcott, 94 ; Williams (T), 96

Iglesias, Carlos A.

18 Ensayo para determinar la extensión total probable del área que se puede considerar como petrolifera en la República, asi como de las porciones ya exploradas [petroleum areas of Mexico]. Bol Petróleo 5: 333-335, map (1918)

Iglesias, Miguel.

77 (and Bareena, Mariano, and Matute, J. I.) Informe sobre los temblores de Jalisco y la erupción del volcán Ceboruco. México, Ministerio de Fomento, An 1: 115-204, map (1877)

Thering, Hermann v.

11 Die Umwandlungen des amerikanischen Kontinentes während der Tertiärzeit. N Jb, Beil B 32:134-176, paleogeographic map (1911)

Ihlseng, Magnus Colbjörn.

s6 Review of the mining interests of the San Juan region. Colo Sch Mines, An Rp Fieldwork... : 17-63, map (1886)

86a Report on oil fields of Fremont Co. [Colo.]. Colo Sch Mines, An Rp Fieldwork... : 65-80, map (1886) 
Ihlsens, Magnus Colbjörn-Continued.

88 Notes on Leadville [Colo. ]. Colo Sch Mines, An Rp 1887: 27-45 [1888]

96 A phosphate prospect in Pennsylvania. U S G S An Rp 17 pt $3: 955-957$ (1896)

oo The road-making materials of Pennsylvania. Pa, Dp Agr, B 69: 104 pp (1900)

Ihne, F. W.

09 Graphite in the United States. M Science $60: 297-298, \quad 316-318, \quad 343-346$ (1909)

Iles, Malvern W.

82 On the occurrence of smaltite in Colorado. Am J Sc (3) $23: 380$ (1882)

82a On the occurrence of vanadium in the Leadville ores. Am J Sc (3) 23:381 (1882)

IIlinois State Geologienl Survey.

12 Provisional geologic map of Illinois. Scale, 1:500,000. 1912

Imbeaux, Ed.

17 Les eaux souterraines des Citats-Unis. Särtryck ur Hyllningskrift tillägnad $J$. Gust. Richert: 221-258 (1917)

Ingall,

31 Remarks on the district traversed by the St. Maurice expedition, in the summer of 1829. Lit Hist Soc Quebec, Tr 2:7-23 (1831)

$\mathbf{3 1 a}$ Remarks on the country lying between the rivers St. Maurice and Saguenay, on the north shore of the St. Lawrence. Lit Hist Soc Quebec. Tr 2: 216-230 (1831) Ingall, Elfric Drew.

87 [Preliminary report on mining developments in the Thunder Bay district, Ont.] Can G S, An Rp 2: A 14-19 (1887)

ss Report on the mines and mining on Lake Superior [Ontario]. Can G S, An Rp 3 : H 1-114, 125-131, map (1888)

90 Division of mineral statistics and mines; annual report for 1889 . Can $\mathrm{G} S$, An Rp 4: s 124 pp (1890) ‥ 1890 : An Rp 5 : s 201 pp (1891) ... 1891: An Rp 5: ss 200 pp (1893) ... 1892; An Rp 6 : s 212 pp (1894) $\ldots$ for 1893 and 1894; An Rp 7: s 187 pp (1895) ... for 1895; An Rp 8:s $103 \mathrm{pp}(1896) \quad \ldots$ for $1896 ; \Delta \mathrm{n}$ Rp $9: \mathrm{s}$ 169 pp (1897) ... for 1897 ; An $\mathrm{Rp} 10: \mathrm{s}$ 230 pp (1898) $\ldots$ for 1898; $A n$ Rp 11: s $196 \mathrm{pp} \mathrm{(1900)} \mathrm{\ldots .} \mathrm{for} 1899$; An Rp $12: \mathrm{s}$

$144 \mathrm{pp} \mathrm{(1901)}$

91 Manganese. Can G S, An Rp 5:s 92-101 (1891)

92 On the cherts and dolomites of the Animikie rocks of Thunder Bay. Lake Superior. Can Rec Sc 5: 29-38 (1892)

94 Preliminary note on the limestones of the Laurentian system. Can Rec Sc 6:8891 (1894)

95 Silver mines of West Kootenay, B. C. M Soc N S, J $3:$ 141-148 (1895)

96 [Report on iron-ore deposits in eastern Ontario.J Can G S, Sum Rp 1895 (An Rp 8) : A 49-61 (1896)
Inga11, Enfric Drew-Continued.

97 Mercury [British Columbia], Can $G$ $\mathrm{S}$, An Rp $9: 8$ 83-85 (1897)

- 98 Iron ores of Nova Scotia. Can G 8 An Rp 10: s 97-113 (1898)

98a Lead. Can G S, An Rp 10:s 114 122 (1898)

00 The coal fields of Canada. Can G S An Rp 11: s 36-53 (1900)

01a Report on the iron-ore deposits 1900. Can G S, An Rp 13: s 160 pp (1901) ... 1901; An Rp 14: s 156 pp (1902)

1902 ; An Rp 15:s 276 pp (1903)

1903: An Rp 16:s 153 pp (1905)

O1a Report on the iron-ore deposits along the Kingston and Pembroke railway in eastern Ontario. Can G S An Rp 12: I $1-80$, maps (1901)

02 The progress of mining in Canada in 1901. Can G S, Sum Rp 1901 (An Rp 14): A 241-246 (1902)

03 Report of the mines section for 1902 . Can G S, Sum Rp 1902 (An Rp 15) :A 441-454 (1903)

03a Geology of the Bruce mines dis. triet, Algoma, Ont. Can G S, Sum Rp 1902 (An Rp 15): A 244-254 (1903): An Rp 15: s 101-111 (1903)

o3b Zinc. Can G S, An Rp $\quad .5:$ s $239-$ 249 (1903)

04 [Report of the] mines section. Can G S, Sum Rp 1903 (An Rp 15) : A 193195 (1904): Sum Rp 1904 (An Rp 16): A $372-373$ (1905) ; Sum Rp 1906:158164 (1906)

O4a Bruce mines district [Ont.] Can G S, Sum Rp 1903 (An Rp 15) : A 195196 (1904)

05 (and Denis, T.) Geology of the country around Bruce mines, Algoma, Ont. Can G S, Sum Rp 1904 (An Rp 16): $179-190$, map (1905)

osa Summary of the mineral produc. tion of Canada in 1904. Can G S, Sum Rp 1904 (An Rp 16) : A 374-383 (1905)

os Note on a system of conventional signs for mineral-oceurrence maps. Can M Inst, J 11:487-503 (1908)

09 [Report of the] water and borings branch. Can G S, Sum Rp 1908:159161 (1909); Sum Rp 1909:247 (1910): Sum Rp 1910:254-255 (1911)

12 Bore-hole records (water, oil, etc.). Can G S, Sum Rp 1911:343-345 (1912): $1912: 415-416 \quad(1914) ; 1913: 331-332$ (1914)

15 [Report of] water and borings division. Can G S, Sum Rp 1914: 138-143 (1915) ; $1915: 213-219$ (1916) ; 1916:309313 (1917)

Ingalls, A. O.

06 Earthquakes and their probable origin. Northwest M J 2 no $1: 2-12$ (1906)

09 The geology of Washington, with an attempt to classify the vein system. Northwest M J 7:51-53 (1909) 
Ingalls, Walter Renton.

96 The tin deposits of Durango, Mex. Am I M Eng, Tr 25: 146-163, map (1896)

98 Notes on the tin deposits of Mexico. Am I M Eng, Tr $27: 428-429$ (1898) 07 Mining the porphyry ore of Bingham [Utah]. Eng M J 84:431-440 (1907)

07a The copper mines of Ely, Nev. Eng M J $84: 675-682$ (1907)

$07 \mathrm{~b}$ The silver-lead mines of Eureka, Nev. Eng M J $84: 1051-1058$ (1907)

08 Lead and zinc in the United States... $368 \mathrm{pp}, \mathrm{N}$ Y 1908

Ingalsbe, F. R.

13 The Cour d'Alene mining district [Idaho]. Eng M J $96: 156-159$ (1913)

Ingersoll, Charles $\mathrm{A}$.

94 On hemimorphic wulfenite crystals from New Mexico. Am J Sc (3) 48: 19:195 (1894) Zs Kryst 23: 330-332 (1894)

Ingersoll, Ernest.

75 The sand dunes of the San Luis Valley [Colo.]. Am Nat 9:375-376 (1875)

Ingerroll, T. Dwight.

85 Glacial origin of Presque Isle, Lake Erle. Am Nat 19:865-867 (1885)

Ingham, William M.

95 A general index of the final summary report of the geology of Pennsylvania. $\mathrm{Pa} G \mathrm{~S}(2): 98, \mathbf{x x x} \mathrm{pp}$, Harrisburg 1895

Ingram, Henry B.

94 The great bluestone industry [New York]. Pop Sc Mo 45: 352-359 (1894)

08 Des voleans du Mexique. See Hongroise Géog, Abrégé B (Sup to Földrajzi Közlemények 36 livr 8-10) : 151-161 (1908)

Institute for Government Resenreh.

18 Service monographs of the United States Government, No. 1. The U. S. Geological Survey; its history, activities, and organization. $163 \mathrm{pp}$, maps, N Y 1918

International Geologienl Congress.

78 [First], Paris 1878, C R 313 pp, Paris 1880

Second, Bologne 1881, C R 663 pp, Bologne 1882

Third, Berlin 1885, C R 546 pp, Berlin 1888

Fourth, London 1888 , C $\quad$ R $482, \quad 219$, $178,10,40$ pp L 1891

Fifth, Washington 1891, C R 529 pp,

Washington 1893

Sixth, Zurich 1894 , C R 710 pp, Lausanne 1897

Seventh, St. Petersburg 1897, C R 464 Pp, St. Petersbourg 1899

Eighth, Paris 1900 , C R 2 vols : 1316 pp, Paris 1901

Ninth, Vienna 1903, C R 2 vols: 928 pp, Vienne 1904

Tenth, Mexico 1906, C R 2 vols: 1358 pp, Mexico 1907

Eleventh, Stockholm 1910, C R 2 vols : 1413 pp, Stockholm 1912
International Geolorical Congress -

Continued.

Twelfth, Canada 1913, C R 1934 pp, Ottawa 1914

03 Palaeontologia universalis [figure and descriptions of types of species published before 1850; includes American forms]. $1903-$ (?)

\section{lowa Geological Survey.}

14 Geologic map of Iowa, 1914. Scale $1: 1,000,000$. Iowa G S $24: \mathrm{pl} 64$ (1914)

14a Map of Iowa showing drift sheets, 1914. Seale $1: 1,000,000$. Iowa G S 24 : pl 65 (1914)

Irelan, William, Jr.

87 Sixth annual report of the State mineralogist, Part II, for the year ending June 1, 1s86. 222 pp, Sacramento 1887

s8 Seventh annual report of the State mineralogist for the year ending October 1, 1887. Cal St M Bur: 315 pp, Sacramento 1888

S8a Eighth annual report of the State mineralogist, for the year ending october 1 , 1888. Cal St M Bur : 946 pp, Sacramento 1888 [Includes Minera] resources of the State, with contributions by W. A. Good. year, H. A. Whiting, and Stephen Bowers]

90 Ninth annual report of the State mineralogist, for the year ending December 1, 1889. Cal St M Bur: 352 pp, Sacramento 1890

90n Tenth annual report of the State mineralogist, for the year ending December 1. 1890. Cal St M Bur: 983 pp, maps, Sacramento 1890. [Includes county reports by W. A. Goodyear, Henry De Groot, J. A. Brown, J. A. Miner, Alexander MeGregor, L. P. Goldstone, Myron Angel, E. B. Preston, W. L. Watts, J. B. Hobson, Stephen Bowers, and William P. Miller]

90b Rincon Hill well [San Francisco]. Cal St M Bur, An Rp 10:943-945 (1890) 93 Eleventh report of the State mineralogist (first biennial), two years ending September 15, 1892. 612 pp, maps, Sacramento 1893 [Includes county reports by W. L. Watts, E. B. Preston, W. H. Storms, J. B. Hobson and E. A. Wiltsee, Wm. G. Hobson, E. A. Wiltsee, and R. L. Dunn]

Irish, C. W.

85 Movement of the glaciers of the ice period in Iowa and its vicinity. Iowa Hist Rec 1:63-67, 115-123, 162-185 (1855)

Irvine, C. D.

os The beach placers of the south Pacific coast. M World 29: 321-322 (1908)

Osa Fine gold of Snake River, Idaho. M World 29:916 (1908)

Irving. John Duer (1874-1918).

96 The stratigraphical relations of the Erown's Park beds of Utah. N Y Ac Sc, $\operatorname{Tr} 15: 252-259$, map (1896) Abst, Science n s $3: 676$ (1896) 
Irving, John Duer-Continued.

98 Contact metamorphism of the Pallsades diabase (abst). Am G 21:398 (1898) Science n s $7: 683$ (1898) N Y Ac Sc, An 11: 472 (1898)

99 A contribution to the geology of the northern Black Hills. N Y Ac Sc, An 12 : 187-340, maps (1899)

99 Some contact phenomena of the Palisade diabase. Sch Mines Q 20:213223 (1899)

02 Some recently exploited deposits of wolframite in the Black Hills of South Dakota. Am I M Eng, Tr 31:683-695, map (1902)

03 Ore deposits of the northern Black Hills. Am M Cong, 6th, Pr: 38-51 (1904) U S G S, B 225:123-140 (1904) M Sc Press 87: 166-167, 187-188, 205, 221-222 (1903) Abst, M Rep 50:430-431 (1904) Hills. Am M Cong, 6th, Pr: 38-51 (1904)

04 (and Emmons, S. F.) Economic resources of the northern Black Hills; Part II, Mining geology. U S G S, P P $26: 43-222$, maps (1904)

O4n Mieroscopic structure and origin of certain stylolitic structures in limestone (alst). Am G 33:266-267 (1904) Science n s 19:580 (1904) N Y Ac Sc, An 16: $305-306$ (1905)

o5 (and Emmons, W. H.) Economic geology [of the Needle Mountains quadrangle, Colo.]. U S G S, G Atlas Needle Mountains fol (no. 131) : 12-13 (1905)

osa Ore deposits of the Ouray district, Colo. U S G S, B 260:50-77 (1905)

$\mathbf{0 5} \mathbf{b}$ Ore deposits in the vicinity of Lake City, Colo. U S G S, B 260:78-84 (1905)

05e University training of engineers in economic geology. Ee G 1:77-82 (1905)

o5a The ore deposits of the Ouray quadrangle, Colo. (abst). Sclence n s 21: 916-917 (1905)

06 Review of The geological map of Illinois, by Stuart Weller (III G S, B 1). Ec G 1: 816-818 (1906)

of (with Cross, W.) Description of the Ouray quadrangle [Colo.]. U S G S, G Atlas, fol 153:20 pp (1907)

o7a (with Emmons, S. F.) The Downtown district of Leadville, Colo. U S G S, B $320: 75$ pp (1907)

os the localization of values or occurrence of shoots in metalliferous deposits. Ec G $3: 143-154$ (1908)

10 Special problems and their study in economic geology. Ec G 5:670-677 (1910)

11 Replacement ore bodies; their characteristics and the criteria by means of which they may be recognized. Ec G 6 : 527-561 (1911) Can M Inst, Q B 17:3-79 (1911) ; J $14: 395-471$ Reprinted in Types of ore deposits, ed. by H. F. Bain : $220-298$ (1911)
Irving, John Duer-Continued.

11 a (and Baneroft, H.) Geology and ore deposits near Lake City, Colo. U \& G S, B 478: 128 pp, maps (1911) Abst, by A. H. Brooks, Wasb Ac Se, J 4:193-194 (1914)

12 Geological diagnosis. Ec G $7: 83-86$ (1912)

13 [Geologic field methods] (editorial). Ec G 8:64-65 (1913)

13 a The substructure of geological te ports. Ec G 8:66-96 (1913)

13b (and Smith, H. D., and Ferguson, H. G.) A selected list of the more important contributions to the investiga. tion of the origin of metalliferous ore de. posits. In Emmons, S. F., Ore deposits: $837-846$ N Y 1913

See also Graton, 15; Lindgren, $15 \mathrm{~b}$; Roesler, 16

Irving, Roland Duer (1847-1888).

72 On the age of the quartzites, schists, and conglomerates of Sauk Co., Wis. Am J Sc (3) 3:93-99, map (1872) Wis Ac Sc, $\operatorname{Tr} 1: 129-137$, map (1872)

73 Note on the age of the metamorphic rocks of Portland, Dodge Co., Wis. Am J Se (3) $5: 282-286$, map (1873)

74 On the age of the copper-bearing rocks of Lake Superior; and on the westward continuation of the Lake Superior synclinal. Am J Sc (3) 8:46-56, map (1874)

$\boldsymbol{7 4 a}$ On some points in the geology of northern Wisconsin. Wis Ac Sc, Tr 2: 107-119, map (1874)

74b on a band specimen showing the exact junction of the Primordial sandstones and Huronian schists. Wis Ac Sc, Tr 2: 139 (1874)

74e On the occurrence of gold and silver in minute quantities in quartz from Clark Co. Wis Ac Sc, Tr 2: 140-141 (1874)

75 Note on some new points in the ele mentary stratification of the Primordial and Canadian rocks of south central Wisconsin. Am J Sc (3) 9:440-443 (1875)

76 Note "on the youngest Huronlan rocks south of Lake Superior." $\Delta \mathrm{m}$ J Sc (3) $11: 493 \quad(1876)$

76a on kaolin in Wisconsin. Wis Ac Sc, $\operatorname{Tr} 3: 3-30$ (1876)

77 Geology of central Wisconsin. [W/s G S], G Wis $2: 407-636$, maps [part in atlas] (1877)

77a Report [on central and northern Wisconsin]. Wis G S, An Rp 1876:13-18 (1877)

$77 b$ Note on the age of the crystalline rocks of Wisconsin. $\Delta \mathrm{m} J$ Soc (3) 13: 307-309 (1877)

78 [Report on the Penokee iron range.] Wis G S, An Rp 1877:17-25 (1878)

$\mathbf{7 8 a}$ Origin of the driftless region of the Northwest. Am J Sc (3) 15:313-314, 406-407 (1878) 
Irving, Roland Duer-Continued.

79 Note on the stratigraphy of the $\mathrm{Hn}$ ronian series of northern Wisconsin; and on the equivalency of the Huronian of the Marquette and Penokee districts. Am J Sc (3) $17: 393-398$ (1879)

80 The geological structure of northern Wisconsin. [Wis G S], G Wis $3: 1-25$, map (1880)

soa Geology of the eastern Lake Superior district. [Wis G S], G Wis $3: 51-214$, maps (1880)

80b The mineral resources of Wisconsin. Am I M Eng, Tr 8:478-508, map (1880)

82 Microscopic examination of a suite of specimens from the Flambeau River country, Wis. [Wis G S], G Wis $4: 617-621$ (1882)

82a (and Van Hise, C. R.) Crystalline rocks of the Wisconsin Valley. [Wis G S] $G$ Wis $4: 623-714$, maps (1882)

83 Minerals of Wisconsin; lithology of Wisconsin. [Wis G S], G Wis $1: 309-361$ (1883)

83a Iron ores. [Wis $G$ S], $G$ Wis 1 : $613-636 \quad$ (1883)

83b The copper-bearing rocks of Lake Superior. U S G S, Mon 5: xvi, $464 \mathrm{pp}$, maps (1883)

83e The copper-bearing rocks of Lake Superior. U S G S, An Rp 3: 89-188, map (1883)

83d The copper-bearing rocks of Lake Superior. Science 1:140-141, 359-360, 422 (1883)

83e On the nature of the induration in the St. Peters and Potsdam sandstones and in certain Archean quartzites in Wisconsin. Am J Sc (3) 25:401-411 (1883)

83f on the paramorphic origin of the hornblende of the crystalline rocks of the northwestern states. Am J Sc (3) 26 : $27-32,321-322$ (1883) ; 27:130-134; 28 : 464 (1884)

83g The United States Geological Survey. Seh Mines Q 4:284-298 (1883)

84 (and Van Hise, C. R.) On secondary enlargements of mineral fragments in certain rocks. U S G S, B 8:56 pp (1884)

84a Note on the paramorphic origin of the hornblende of the crystalline rocks of the Northwest. Am J Sc (3) 28:464 (1884)

84b Metamorphism in the Huronian of the Northwest (abst). Science 4:327 (1884)

85 (and Chamblexlin, T. C.) Observations on the junction between the eastern sandstone and the Keweenaw series on Keweenaw Point, Lake Superior. U S G S, B $23: 124$ pp (1885) $R v$, Am G $1: 44-57$ (1888)

85a Investigation of the Archean formations of the northwestern states. U S G S An $\mathrm{Rp} 5: 175-242$, map (1885)
Irviug, Roland Duer-Continued.

85b Divisibility of the Archean in the Northwest. Am J Se (3) $29: 237-249$, map (1885)

85e The copper-bearing rocks of Lake Superior. Am J Sc (3) 29: 258-259 (1885)

86 Origin of the ferruginous sehists and iron ores of the Lake Superior region. Am J Sc (3) 32:255-272 (18.96) Eng M J $42: 347-349$ (1886)

87 Is there a Huronian group? Am J Sc (3) $34: 204-216, \quad 249-263, \quad 365-374$ (1887)

88 On the classification of the early Cambrian and pre-Cambrian formations; a brief discussion of principles, illustrated by examples drawn mainly from the Lake Superior region. U S G S, An Rep 7: 365-454, map (1888)

90 (and Van Hise, C. R.) The Penokee fron-bearing series of Michigan and Wisconsin. U S G S, An Rp 10, pt 1: 341-507, map (1890)

91 (and others) The crystalline schists of the Lake Superior district. Int G Cong, IV, London 1888, C R: 156-170 (1891)

92 (and Van Hise, C. R.) The Penokee iron-bearing series of Wisconsin and Michigan. U S G S, Mon 19: xix, 534 pp, maps (1892)

See also Frazer, 88a; Powell, 84, 85, 85a, 88,89 ; Williams (G H), 90

Irwin, D. D.

12 (with Pelton, E. F.) The planetable in geologic mapping (discussion). Ec G $7: 778-783$ (1912)

Isbister, A. K.

45 Some account of Peel River, North America. R Geog Soc, J 15:332-345, map (1845)

55 On the geology of the Hudson's Bay territories, and of portions of the Arctic and northwestern regions of America. G Soc London, Q J 11:497-520, map (1855) Am J Sc (2) $21: 313-338$ (1855)

Iseman, Percy R.

10 A brief description of the Gowganda silver district in Ontario, Canada. Sch Mines Q 31:172-176 (1910)

Ishikawa, $\mathrm{S}$.

04 Latest eruption of Colima Volcano, Mexico [in Japanese]. G Soc Tokyo, J 11: 98-103 (1904)

Issel, Arturo.

02 A proposito del recente disastro delle Antille, proposta e voti [eruption of Mont Pelé, Martinique]. Soc Ligustica Sc Nat e Geog, Atti 13: 77-90 (1902)

Ives, J. C.

58 Colorado exploring expedition; preliminary report. U S, 35 th Cong 2 d sess, $\mathrm{H} \quad \mathrm{Ex}$ Doc 2 (Rp Sec War) : 608-619 (1858)

Ives, James T. B.

87 Geology in the public schools. Can Inst, $\operatorname{Pr}(3) \quad 5: 125-128$ (1887) 
Ives, James T. B.-Continued.

$\mathbf{8 s}$ Iron and other ores of Ontario (with discussion). Can Inst, $\operatorname{Pr}(3) 5: 185-192$ (1888)

88a Method of constructing strata maps to represent stratification or bedding. Am I M Eng, $\operatorname{Tr} 16: 768-770$ (1888)

90 An occurrence of copper glance north of Lake Huron, with notes on the structure of the locality. Am I M Eng, Tr 18:7277 (1890)

See also Gilbert, 88

Ives, L. E.

15 Finding the Judson ore body [iron deposits near Crystal Falls, Mich.] Eng M J $99: 443-445$ (1915)

Jackson, Abraham Wendell.

82 On the general principles of the nomenclature of the massive crystalline rocks. Am J Sc (3) 24:113-129 (1882)

84 On colemanite, a new borate of lime. Am J Sc (3) 28:447-448 (1884)

85 On the morphology of colemanite. Cal Ac Sc, B [1], no 2:3-36 (1885)

86 Mineralogical contributions. Cal Ac Sc, B [1] no 4:358-374 (1886)

ss Fuilding stones. Cal St M Bur, An Rp 8: 885-894 (1888)

Jackson, Charles Thomas (1805-1880).

2S (and Alger, F.) ... mineralogy and geology of a part of Nova Scotia. Am J Sc $14: 305-330$ (1828) ; 15:132-160, 201217 (1829)

33 (and Alger, F.) Remarks on the mineralogy and geology of Nova Scotia. Am Ac Arts, Mem n s 1:217-330, map (1833) Reprint, $116 \mathrm{pp}$, map, Cambridge 1832

33a A description of a new mineral species from Nova Scotia [ledererite]. Am J Sc 25: 78-84 (1833)

34 An account of the chiastolite or macle of Lancaster [Mass.]. Boston J N H 1:55-62 (1834)

35 Chemical analysis of chrysocolla from the Holquin copper mines near Gibara, Cuba. Boston J N H 1:206-208 (1835)

35a [Sur les conglomérats de Roxbourg (Boston) et les dykes qu'ils contiennent.] Soc G France, B 7:27 (1835)

36 Chemical analysis of three varieties of bituminous coal and one of anthracite. Boston J N H 1: 357-360 (1836)

$\mathbf{3 6 a}$ On the collection of geological specimens and on geological surveys. Am J Sc 30:203-208 (1836)

37 First report on the geology of the State of Maine. viii, 128 pp, Augusta 1837 Accompanied by atlas of 24 pls

37a First report on the geology of the public lands in the State of Maine. [Mass, Legislature], Sen No $89: 47$ pp, Boston 1837

38 Second report on the geslogy of the State of Maine. 168 pp, Augusta 1838
Jackson, Charles Thomas-Continued.

38 . Second annual report on the geologn of the public lands belonging to the tro states of Massachusetts and Maine. [Mass, Legislature], House No $70: x i 1,93 \mathrm{pp}$, Boston 1838 Another ed, xi, 100, xxxril pp, Augusta [Maine], 1838

381 ... geology of Maine. Am J Sc 34: 69-73 (1838)

38 c Chemical analysis of meteoric lion from Claiborne, Clarke Co., Ala. Am J sc $34: 332-337$ (1838)

39 Third annual report on the geolog of the State of Maine. xiv, 276, lxiv $P p_{\text {, }}$ Augusta 1839

40 Report on the geological and agricultural survey of the State of Rhode Island. 312 pp, map, Providence 1840 Notice, by B. Silliman, jr., Am J Sc 40: 182-194 (1841)

41 First annual report on the geologr of New Hampshire. 164 pp, Concord 1841

$41 \mathbf{a}$ [On joints in rocks] (abst). Am J Sc 41: 172, 173 (1841) As Am G, Rp: 25,26 (1843)

41b [Infusorial deposit at Newfield, Maine] (abst). Am J Sc 41: 174 (1841) As Am G, Rp: 26 (1843)

41e $[\mathrm{On}$ the construction of geological maps] (abst). Am J Sc 41:186 (1841) As Am G, Rp : 38 (1843)

42 Report of the State geologist [1842]. In $\mathrm{N} \mathrm{H}, \mathrm{H} \mathrm{R}, \mathrm{J}$ session $1842: 239-244$ (1842)

43 Description of the tin veins of Jack son. N. H. As Am G, Rp : 316-321 (1843)

43a Remarks on zinc, lead, and copper ores of New Hampshire. As Am G, Rp 321-322 (1843)

43b [Metamorphic rocks of Pequawket Mountain, N. H. (abst)]. Am J Sc 45 145-146 (1843)

43e [On drift]; with discussion by .J. X Nicollet, E. Hitchcock, and W. C. Redfield. Am J Sc $45: 320-323$ (1843)

43d [Ores of New Hampshire.] Boston Soc N H, Pr 1: 90 (1843)

43e [On the cause of changes of the surface of the earth.] Boston Soc N H, Pr 1:123 (1843)

44 Final report on the geology and mineralogy of the State of New Hampshire... viii, 376 pp, map, Concord 1844

44a Analysis of pink scapolite and of cerium ochre from Bolton, Mass. Boston J N H 4:504-506 (1844)

44b [On yttrocerite from Worcester $\mathrm{C}_{0}$. Mass.] Boston Soc N H, Pr 1:165-161 (1844)

44e [Description and analysis of pink scapolite.] Boston Soc N H, Pr 1:167 (1844)

45. Views and map illustrative of the scenery and geology of the State of New Hampshire. 20 pp, map, Boston 1845 
Jackson, Charles Thomas-Continued.

45a [On minerals from Keweenaw Point, Lake Superior.] Boston Soc N H, Pr $1: 203$ (1845)

45b Remarks on the Alabama meteoric iron... Boston Soc $\mathrm{N}$ H, Pr 1:207-208 (1845) Am J Sc 48: 145-147 (1845)

45c [On copper ores of the Lake Superior region.] Boston Soc N H, Pr 2:5758 (1845)

45d [Trap dikes and associated minerals]. As Am G, Pr 6:28 (1845)

45e $[0 n$ minerals from Litchfield, Maine]. As Am G, Pr 6: 44-49 (1845)

45f On the copper and silver of Keweenaw Point, Lake Superior (with discussion by C. U. Shepard). Am J Sc 49:8193 (1845) As Am G, Pr 6:53-61 (1845) $45 \mathrm{~g}$ Sur le gisement de cuivre et d'argent natifs des bords du lac Superieur. Ac Sc Paris, C R 20:593-595 (1845) Soc G France, B (2) $2: 317-319$ (1845) Abst, N Jb $1845: 479-480$

46 Chemical and mineralogical fragments. Boston J N H 5: 405-412 (1846)

46a [On the copper and silver ores of the Lake Superior region.] Boston Soc $\mathrm{N}$ H, Pr $2: 110-114$ (1846)

46b [On the composition of lava from the erater of Kllauea in Hawail.] Boston Soc N H, Pr 2: 121 (1846)

46e [On copper and zine ores from Warren, N. H.] Boston Soc N H, Pr 2: 147 (1846)

46d [On the geology of the White Mountains, N. H. 7 Boston Soc N H, P'r $2: 147-148$ (1846)

46e Chemical analyses of the [copper] ores [or the Lake Superior region]. U S, 29th Cong 1st sess, H R, Rp no 591: 38-44 (1846)

47 [Report on the survey of the mineral lands in Michigan.] U S, Gen Land Ofi, Rp 1847 (U S, 30th Cong 1st Sess, S Ex Doc 2): 175-183 (1847)

47a [On three divisions in the diluvium of Maine.] Boston Soc N H, Pr 2:25f: (1847)

48 [On metamorphic rocks, particularly of Rhode Island.] Boston Soc $\mathrm{N} \mathrm{H}, \mathrm{Pr}$ $3: 19-20(1848)$

48a [Direction of drift scratches and cleavage planes of the Roxbury, Mass., greywacke.] Boston Soc $\mathrm{N}$ H, Pr $3: 28$ (1848)

48b [Notes on the Lake Superior region.] Boston Soc $\mathrm{N} H, \operatorname{Pr} 3: 76-77$, 228 (1848)

49 Report on the geological and mineralogical survey of the mineral lands of the United States in the State of Michigan ... U S, 31st Cong 1st sess, S Ex Doc 1 pt 3 and $\mathrm{H}$ Ex Doc 5 pt $3: 371-502$, maps (1849)

49a Copper of the Lake Superior region. Am J Sc (2) $7: 286-287$ (1849)
Jackson, Charles Thomas-Continued.

$49 \mathrm{~b}$ On the geological structure of Keweenaw Point [Mich.]. Am As, Pr 2: 288-301 (1850) Am J Sc (2) 10:65-77 (1849) An Mines (4) 17:103-115 (1850)

49c [On fissures in pudding stone of Roxbury, Mass. (with discussion by H. D. Rogers).] Boston Soc N H, Pr 3:127 (1849)

50 Remarks on the geology, mineralogy, and mines of Lake Superior. Am As, Pr 2: 283-287 (1850) Soc G France, B (2) $7: 667-673 \quad(1850)$

$50 \mathrm{a}$ Description of the vermiculite of Milbury, Mass. Am J Sc (2) 9:422-423 (1850) Boston Soc N H, Pr 3:243-24万 (1850)

50b [Jacksonite, identity with prehnite.] Boston Soc $\mathrm{N} H, \operatorname{Pr} 3: 247-248$ (1850)

50e [An analysis of the new mineral algerite.] Boston Soc $\mathrm{N} H, \operatorname{Pr} 3: 278$ $279(1850)$

50a [On asphaltum recently discovered in New Brunswick.] Boston Soc $\mathrm{N} \mathrm{H}$, Pr 3: 279-280 (1850)

50e [On tellurium ore from the gold mine of Whitehall, Va.] Boston Soc N H, Pr 3: 297-299 (1850)

50R [On Tertiary fossils from Marshfield, Mass.] Boston Soc N H, Pr 3: $323-324,329(1850)$

$\mathbf{5 0 g}$ IOn potholes at Orange, N. H., and elsehere.] Boston Soc N H, Pr $3: 324$ (1850)

50h [On the age of the sandstones of the United States.] Boston Soc N H, Pr $3: 335-339 \quad(1850)$

50i On the telluric bismuth of Virginia. Am J Sc (2) 10:78-80 (1850)

51 Analyses of pitchstone porphyry from Isle Royale and of a crystal of phosphate of lime from Hurdstown, N. J. Boston Soc N H, Pr 4:39-41 (1851) Am J Sc (2) $11: 401-403 \quad(1851)$

51a [On botryoidal fibrous phosphate of lime from Crown Point, N. Y.] Boston Soc N H, Pr 4:47-49 (1851)

51b [On asphaltic coal of New Brunswick.] Boston Soc N H, Pr 4:55-56, 64-65 (1851)

s1e [On Stigmaria and Sigillaria and other fossils from New Brunswick.] Boston Soc N H, Pr 4:73-74, 179-180 $(1851-2)$

51d On eupyrchroite of Crown Point, N. Y. Am J Sc (2) 12:73-74 (1851) Edinb N Ph J 51:328-331 (1851)

51e Discovery of fossil fish in the coal formation of New Brunswick. Am J Sc (2) $12: 281-282$ (1851)

$51 f$ On ancient potholes in rocks. Am As Pr 4:188-190 (1851)

$51 \mathrm{~g}$ Description and analysis of allanite from Franklin, N. J. Am As, Pi 4:323324 (1851) 
Jackson, Charles Thomas-Continued.

51 h Description of bismuthic tellurum or tetradymite from the gold mine of Whitehall, Va... Am As, Pr $4: 324-325$ (1851)

511 Analysis of red marl of Springfield, Mass. Am As, Pr 4:337-338 (1851)

52 [On fossil rain drops.] Boston Soc N H, Pr 4: 131-132 (1852)

52a [On fish and plants from the coal formation at Hillsboro', N. B.] Boston Soc N H, Pr 4:138-143 (1852)

$52 b$ [The syenite of Nahant, Mass., not a metamorphic rock.] Boston Soc N H, Pr 4:170 (1852)

52e [On the origin of the materials of some New Brunswick formations.] Boston Soc N H, Pr 4:179 (1852)

53 Geology, mineralogy, and topography of the lands around Lake Superior. U S, $32 \mathrm{~d}$ Cong 1 st sess, S Ex Doc 112 : 232-244 (1853)

53a Sur le terrain houiller d'Hillsboro, N. B. Soc $Q$ France, B (2) $10: 33-39$ (1853)

53b Sur les mines de cuivre et de hou ille de la Caroline du Nord. Soc G France, B (2) $10: 505-506$ (1853)

53e [On a deposit of eupyrchroite near Lake Champlain.] Boston Soc N H, Pr 4 : 259-260, 264-265 (1853)

53a Ueber den Metall-führenden Distrikt am Oberen See im Staate Michigan. Arch Miner 25: 656-667 (1853)

53e Report on the copper mine of the North Carolina Copper Company. M Mag 1: 44-47 (1853)

53P Shelburne [N. H.] lead mines. M Mag 1: 245-250 (1853)

539 Report on the Dolly Hide copper mine [Liberty, Md.] M Mag 1:476-480 (1853)

54 Observations sur quelques mines des Etats-Unis et sur le grès rouge du lac Supérieur. Ac Sc Paris, C R 39:803-807 (1854)

$\mathbf{5 4 a}$ [On the limestone holding the New Jersey franklinite and on limestone formations generally.] Boston Soc $\mathrm{N} \mathrm{H}, \operatorname{Pr} 4$ : 308-309 (1854)

54b [The Deep River coal region, N. C.] Boston Soc N H, Pr 4:397-399 (1854)

54e [On copper from Polk Co., Tenn., and from North Carolina and on the gold mines of Lumpkin Co., Ga.1 Boston Soc N H, Pr 4:399-401 (1854)

54d [On a new mine of gold, silver, lead, and copper, recently opened at Bridgewater, Vt.] Boston Soc N H, Pr 5:62 (1854)

54e Moore's gold mines, Dahlonega, Ga. M Mag 2: 24-27 (1854)

54f The coal lands of Egypt, Belmont, Evans, Palmer, and Wilcox plantations on Deep River, N. C. M Mag: 253-264 (1854)
Jackson, Charles Thomas-Continued.

55 Catalogue of rocks, minerals, and ores collected during the years 1847 and 1848 on the geological survey of the United States mineral lands in Michigan. Smiths Inst, An Rp 9, 1854:338-367 (1855)

55a [On geological discoveries by Mar cou among the Rocky Mountains.] Boston Soc N H, Pr 5: 191 (1855)

$55 \mathrm{~b}$ [On the association of minerals] Boston Soc N H, Pr 5 : 225-226 (1855)

55e Geology of parts of New Brunswick and Nova Scotia. Boston Soc N H, Pr 5: 242-250 (1855) M Mag 6: 117-123 (1856)

56 [On copper deposits, Lake Superior region.] Boston Soc N H, Pr 5:280-281 (1856)

$56 a$ Chemical analysis and comparison of serpentine marbles known under the name of verd antique. Boston Soc N H, Pr 5: 314-318, 341-343 (1856) Am J Sc (2) $2 \dot{3}: 123-126$ (1857) M Mag 6:410413 (1856)

561. [On the formation of stalactites.] Boston Soc N H, Pr 5: 335 (1856)

56e $[\mathrm{On}$ the bituminous-coal formation of Elk Co., Pa.] Boston Soe N H, Pr 6: 16-18 (1856)

56d [On the geology of Alger's beryl hill, Grafton, N. H.] Boston Soc N H, Pr $6: 23$ (1856)

56e [On the trap dikes and altered rocks of Cohasset, Mass., and on trap rocks in general.] Boston Soc $\mathrm{N} \mathrm{H}, \operatorname{Pr} 6: 23-24$ (1856)

561 Ridgway Farm \& Loan Co.'s property [Elk Co., Pa.] ; geological report. M Mag $7: 174-184$ (1856)

$56 \mathrm{~g}$ [On the coal formation of Deep River, N. C.] Boston Soc N H, Pr 6:3032 (1856) M Mag $7: 373-375$ (1856)

56h Chemical analysis of a variety of agalmatolite [Deep River, N. C.]. Boston Soc N H, Pr 6:32-33 (1856) M Mag 7: 375-376 (1856)

56i [On the Braintree, Mass., argillite and its trilobites.] Boston Soc N H, Pr 6: 42-44 (1856) M Mag $7: 454-456$ (1856)

56j Nouveau gisement de trilobites [Cambrian, Braintree, Mass.]. Ac Sc Paris, C R 43: 883-884 (1856)

57 Report on the coal fields on Deep River in North Carolina; the Fooshee and Street estates. M Mag 9:548-550 (1857) $57 \mathbf{a}$ [On a landslide near Portland, Me.] Boston Soc N H, Pr 6:133-134 (1857)

57b [On the cementing material of sandstones and conglomerates.] Boston Soc N H, Pr 6: 168-169 (1857)

57c [On the so-called copper mine at Elk Run, Fauquier Co., Va.] Boston Soc N $\mathrm{H}, \operatorname{Pr} 6: 183$ (1857)

$57 d$ [On the superposition of the Connecticut River sandstones on crystalline rocks at Northfield, Mass.]. Boston Soc $\mathrm{N} H, \operatorname{Pr} 6: 184$ (1857) 
Jackson, Charles Thomas-Continued.

57e Maryland marbles and iron ores. Boston Soc N H, Pr 6:243-245 (1857)

$57 \mathrm{f}$ [On the Deep River coal field, N. C.] Am Ac Arts, Pr 3:68-69 (1857)

58 Exploitation des mines [silver-lead, Davidson Co., N. C.]. Ac Se Paris, C R 46: 254-255 (1858)

$58 \mathbf{a}$ Sur quelques mines de la Caroline du Nord. Ac Sc Paris, C R 47:618-619 (1858)

59 Sur les gisements de l'or dans le Géorgie. Ac Sc Paris, C R 48:63o-640 (1859)

59a Sur la bornite de Dahlonega et sur les diamants de l'État de Géorgie. Ac Sc Paris, C R 48: 850-851 (1859)

59b Remarks on the metamorphism of rocks. M Mag (2) 1:27-32 (1859)

59e [On tetradymite and other minerals from Georgia.] Boston Soc N H, Pr 7 : 22-23, 24-25 (1859)

59d [On the theory of metamorphism, with particular reference to anthracite.] Boston Soc N H, Pr $7: 30-31$ (1859)

59e [On the genesis of the native copper and silver of Lake Superior.] Boston Soc N H, Pr 7:31 (1859)

598 [On the agency of thermal waters In the formation of minerals of trap rocks.] Boston Soc $\mathrm{N} H, \operatorname{Pr} 7: 45-47$ (1859)

$59 \mathrm{~g}$ [On Paradoxides from Newfoundland and Braintree, Mass.] Boston Soc $\mathrm{N} \mathrm{H}, \operatorname{Pr} 7: 75$ (1859)

59h (and Blake, John H.) [Report on the frozen well in Brandon, Vt.] Boston Soc N H, Pr $7: 81-84$ (1859)

591 Specular fron ore from Phillipsburg, N. J. Boston Soc N H, Pr 7:136 (1859) 59] [On the origin of marl in peat bogs.] Boston Soc N H, Pr 7: 151 (1859)

59k [Crystals of green feldspar, Mount Desert, Me.] Boston Soc N H, Pr $7: 160$ (1859)

591 [On a meteorite in Oregon.] Boston Soc N H, Pr $7: 174,175-6,191,279$ (1859-60)

$59 \mathrm{~m}$ On bornite from Dahlonega, Ga. Am J Sc (2) $27: 366-367$ (1859)

59n (with Blake, W. P.) The gold placers of the vicinity of Dahlonega, Ga. Report to the Yahoola River and Cane Creek Hydraulic Hose Mining Company. 64 pp, Boston 1859 Extract, M Mag (2) 1: $360-366 \quad$ (1860)

60 [On the origin of distorted pebbles.] Boston Soc N H, Pr 7: 209 (1860)

Boa on tetradymite and bornite; reply to Dr. F. A. Genth. M Mag (2) 1:466468 (1860)

61 [On the age of the red sandstones of Perry, Me., Nova Scotia, and Lake Superior.] Boston Soc N H, Pr $7: 396-398$ (1861)
Jackson, Charles Thomas-Continued. 61a $[O n$ a fossiliferous boulder from Saco River, Me.] Boston Soc N H, Pr 7 : 409 (1861)

61b [On coal from the Gulf of Chiriqui, Panama.] Boston Soc N H, Pr $7: 423,428$ (1861)

61e (and others) [Discussion on the Primordial fauna.] Boston Soc N H, Pr 8: 58 (1861)

62 On domeykite from the vicinity of Portage Lake, Lake Superior. Boston Soc $\mathrm{N} \mathrm{H}, \operatorname{Pr} 8: 258$ (1862)

62a [On gold in Nova Scotia (with discussion by Jules Marcou).] Boston Soc N H, Pr 9: 47 (1862)

$62 b$ [On metamorphic action in conglomerate.] Boston Soc N-H, Pr 9:57 (1862)

62e (and Blake, J. H., and Rogers, W. B.) $\ldots$ the frozen well of Brandon, Vt. Boston Soc N H, Pr 9:72-81 (1862)

63 [Sketch of the copper-bearing belt of Canada.] Boston Soc N H, Pr 9:202-203 (1863)

$63 a$ [On deposits of galena at Dubuque and Galena.] Boston Soc $\mathrm{N} \mathrm{H}, \operatorname{Pr} 9$ : 222-224 (1863)

63b Meteoric iron from Dakota Territory. Am J Sc (2) 36:259-261 (1863)

64 Observations sur les gites metalliferes de quelques parties de l'Amérique septentrionale et sur un nouvel aérolithe. Ac Sc Paris, C R 58: 240-242 (1864)

65 Notice of the death of Francis Alger of Boston. Boston Soc N H, Pr 10:2-6 (1865)

65a [Iron ore from Staten Island, N. Y.] Boston Soc N H, Pr 10:72 (1865) $65 \mathrm{~b}$ On the discovery of emery in Chester, Mass. Boston Soc N H, Pr 10:84-90 (1865) Am J Sc (2) 39:87-90 (1865)

65e Sur les mines d'or et d'argent de la Callfornie. Ac Se Paris, C R 61:947950 (1865)

65d Nouveaux détails sur les mines d'argent du Nevada. Ac Sc Paris, C R 61 : 998-999 (1865)

66 [On calcite from Martinsburg, N. X.] Boston Soc N H, Pr 10:97 (1866)

66a [Account of a journey through California and Nevada.] Boston Soc N H, Pr 10:224-229 (1866)

66b [Notes on glacial phenomena.] Boston Soc N H, Pr 10:245-246 (1866)

66e [Notes on the geology and mineral resources of California.] Boston Soc N H, Pr 10:262-263 (1866)

66d [On polishing of rocks of Smoky Valley, Nev., by wind-blown sand.] Boston Soc N H, Pr 10:303-304 (1566)

66e Chemical analyses of minerals associated with the emery of Chester, Mass. Boston Soc N H, Pr 10:320-322 (1866)

66f Analyses of some minerals from the emery mine of Chester, Mass. Am J Sc (2) $42: 107-108$ (1866) 
Jackson, Charles Thomas-Continued.

$66 \%$ On the discovery of corundum at the emery mine, Chester, Mass. Am J Sc (2) $42: 421$ (1866)

66h [On a meteorite from the Dakotah Indian country.] Am Ac, $\operatorname{Pr} 6: 166-167$ (1866)

67 [Analysis of a meteoric iron from Bear River, Colo.] Boston Soc N H, Pr 11: 71-72 (1867) Am J Sc (2) 43:280281 (1867)

67a [On the absence of meteorites in sedimentary strata.] Boston Soc N H, Pr 11: $82-83$ (1867)

67b [On the gold regions of Vermont.] Boston Soc N H, Pr 11:243-244 (1867)

68 [On fossil or submarine guano from Charleston, S. C.] Boston Soe $\mathrm{N} \mathrm{H}, \mathrm{Pr}$ 11: $392-393$ (1868)

68n [Beds of apatite in Canada West.] Boston Soc N H, Pr 12:88-90 (1868)

69 Tin ore in Winslow, Maine. Boston Soc N H, Pr 12: 267 (1869)

$69 a$ Sur les mines de cuivre du lac Supérieur et sur un nouveau gisement d'étain dans l'etat du Maine. Ac Sc Paris, C R 69: 1082-1083 (1869)

71 [On meteorites.] Boston Soc N H, Pr 13:412 (1871)

z1a Glacier theory of drift [with discussion by J. B. Perry and Charles Pickering 1 . Boston Soe $\mathrm{N} H, \operatorname{Pr}$ 14:65-75 (1871)

72 Report on Brandon frozen well [Vt.]. Boston Soc N H, Pr 14: 306-308 (1872)

72a Analysis of the meteoric iron of Los Angeles, Cal. Am J Sc (3) 4:495-496 (1872) Boston Soc N H, Pr 15:254-255 (1873)

87 Catalogue of rocks, minerals, and soils, collected during the geological survey of Rhode Island, summer of 1839 . Providence Franklin Society, Report on the geology of Rhode Island:58-68, Providence 1887

See also Agassiz (L), 72; Bouvé, 54; Desor, 52g; Guyot, 50; Hayes (A A), 57a; Hitcheock (C H), 73b; Hitcheock (E), 42, 60: Marcou, 61b; Mather, 61c; Nicollet, 43b; Niles, 71b, 72a ; Perrey, 55; Rogers (H D), 55a; Rogers (W B), 55, 60c ; Shaler, 69b, 71; Teschemacher, 43a

Jackson, J. B. S.

45.5 [On Mastodon giganteus from Sehooley's Mountain N. J.] Boston Soc N H, Pr 2:60-62 (1845)

Jackson, Robert Tracy.

90 Phylogeny of the Pelecypoda; the Aviculidae and their allies. Boston Soc N H, Mem 4:277-400, il (1890)

95 The development of Oligoporus (abst). Science n s 2:705 (1895)

96 (and Jagrar, T. A., jr.) Studies of Melonites multiporus, G Soc Am, B 7: 135-170, il (1896) Abst, Am G $16: 239$ $240(1895)$
Jackson, Robert Tracy-Continued. 96a Studies of Palaeechinoidea. G \& Am, B $7: 171-254,11$ (1896)

04 Charles Emerson Beecher. Am Nat $38: 407-426$, port (1904)

12 Phylogeny of the Echini, with a re vision of Paleozoic species. Boston $S_{0}$ N H, Mem 7:491 pp, il (1912)

13 Alpheus Hyatt and his principles of research. Am Nat 47:195-205, port (1913) Alst, G Soc Am, B 24: 105 (1913)

17 Fossil Echini of the Panama Cansl Zone and Costa Rica. U S Nat Mus, Pr $53: 489-501$, il (1917)

18 Contributions to the geology and paleontology of the Canal Zone, Panama and geologically related areas in Central America and the West Indies; Fossll Echini of the Panama Canal Zone and Costa Rica. U S Nat Mus, B 103:103116, il (1918)

See also Eastman. 00

Jackson, Thomas Franklin.

15 The paleobotany of the Bloomington, Ind.. quadrangle. Ind Ac Sc, Pr 1914: 395-398 (1915)

17 The description and stratigraphic relationships of fossil plants from the lower Pennsylvanian rocks of Indiana. Ind Ac Sc, Pr 1916:405-428, il (1917)

See also Beede, 15

Jacobs, E.

03 Ore quarrying in the Boundary dis. trict of British Columbia. Eng Mag 26: 236-249 (1903)

04 The coal fields of Crowsnest Pass. B. C. Eng Mag 27:36-57, map (1904)

10 St. Eugene mine and mill, East Kootenay, B. C. Eng M J $89: 420-423$ (1910)

10a Chitina Valley copper deposits [Alaska]. Mines and Minerals 31:315318 (1910)

11 Auriferous gravels of Cariboo, B. C. Eng M J $92: 598-602$ (1911)

12 The coal fields of western Canada. Coal Age 1:968-969 (1912)

17 Dr. C. W. Drysdale's work. Can M J $38: 346-347$ (1917)

Jacols, Elbridge Churchill.

14 Talc, and the talc deposits of Vermont. Vt St G, Rp $9: 382-429$, map (1914)

16 Copper mining in Vermont. Vt $\mathrm{st}$ G, Rp 10: 192-199 (1916)

$16 a$ The talc and verd antique deposits of Vermont. Vt St G, Rp 10:232-280, map (1916)

Jacobs, H. S.

77 Ancient river channels [California]. M Sc Press 34:264 (1877) Sc Am Sup 3: 1184 (1877)

\section{Jaeger, Fritz.}

15 Bemerkungen zur systematischen Beschreibung der Landformen. Am Geog Soc. Memorial Volume of Transcontinental Excursion of $1912: 77-84$ (1915) 
Jaekel, 0.

02 Bemerkungen über den Beinbau der Trilobiten, Deut G Ges, Zs 54:53-55 [Brief. Mitt.] (1902)

Jaggar, Thomas Augustus, jr.

94 Some conditions of ripple mark. Am G $13: 199-201$ (1894)

96 On the geological work of vortices and eddies (abst). Science n 8 s:375 (1896)

96a (with Jackson, R. T.) Studies of Melonites multiporus. G Soc Am, B $7: 135-170$, il (1896) Abst, Am G 16: 239-240 (1895)

98 An occurrence of acid pegmatite in diabase. Am \& 21:203-213 (1898)

98a Some conditions affecting geyser eruption. Am J Sc (4) $5: 323-333$ (1898)

98b Ein Mikrosklerometer zur Härtebestimmung. Zs Krys $29: 262-275$ (1898)

01 The laccoliths of the Black Hills. U S G S, An Rp 21 pt $3: 163-290$, maps (1901)

02 The next eruption of Pelé. Science n s $16: 871-872$ (1902)

02a Field notes of a geologist in Martinique and St. Vincent. Pop Sc Mo 61 : $352-368$ (1902)

02b The crater of the Soufrière volcano, 8t. Vincent. Harper's Weekly $46: 1281$ (1902)

03 Professor Heilprin on Mont Pe'é. Science n \& $17: 423-425$ (1903)

04 The eruption of Mont Pelé, 1851; translated from the French of LePrieur, Peyraud, and Rufz. Am Nat 38:51-73 (1904)

04a The initial stages of the spine on Pelé [Martinique, W. I.]. Am J Sc (4) $17: 34-40$ (1904)

04b The eruption of Pelé, July 9, 1902. Pop Sc Mo 64: 219-231 (1904)

04e Economic resources of the northern Black Hills; Part I, General geology. U S G S, P P 26:7-41, map (1904)

05 (and Palache, Charles) Description of Bradshaw Mountains quadrangle [Ariz.]. U S G S, G Atlas Bradshaw Mountains fol (no 126): 11 pp, maps (1905)

07 How should faults be named and classified? Ec G 2:58-62 (1907)

07 a Current methods of observing volcanic eruptions $(a b 8 t)$. Science $n$ \& 25 : 764-765 (1907)

08 Experiments illustrating erosion and sedimentation. Harvard Coll, Mus C $\mathrm{Z}$, B 49 (g s 8): 285-305 (1908) Abst, Science n s $25: 765$ (1907)

08a A theory of ore deposition. Discussion of a review by F. L. iansome, of paper by J. E. Spurr. Ec G $3: 529-532$ (1908)

08b Journal of the Technology expedition to the Aleutian Islands, 1907. Tech Rv $10: 1-37$ (1908)
Jagrar, Thomas Augustus, jr.-Contianed. OSe The evolution of Bogoslof Volcano. Am Geog Soc, B 40:385-400 (1908) Abst, Science n s 28:575 (1908)

10 Report of the committee on earthquake and volcano observations. G Soc Am, B $20: 659-660$ (1910) Abst, Science n s $29: 630-631$ (1909)

10a Special problems and their study in economic geology. Ec G 5:776-780 (1910)

$10 b$ Genetic classification of active volcanoes (abst). Science n s 32:188-189 (1910) G Soc Am, B 21:768 (1910)

11 The earthquake in Costa Rica. Sc Conspectus $1: 33-40$ (1911)

$11 \mathbf{a}$ The Costa Rica volcanoes and the earthquakes of April 13 and May 4, 1910. As Eng Soc, J 46:49-62, map (1911)

12 Structure of esker fans experimentally studied (abst). G Soc Am, B 23:746 (1912)

12a Succession in age of the volcanoes of Hawaii (abst). G Soc Am, B 23:747 (1912)

13 The Cross of Hawaii. Honolulu Chamber of Commerce, An Rp 1912, reprint 12 pp [1913?]

13a Scientific work on Hawailan volcanoes. Hawaiian Volcano Observatory, Special B: 15 pp (1913)

15 The outbreak of Mauna Loa, Hawail, 1914. Am J Se (4) $39: 167-172$ (1915)

15 a Activity of Mauna Loa, Hawaii, December-January, 1914-15. Am J Sc (4) $40: 621-639$ (1915)

15b Notes from a volcano laboratory [Hawaii]. Science Conspectus 5:85-103 (1915)

16 (and wood, H. O.) [Observations on Hawaiian volcanoes]. Hawailan Vol. cano Observatory, Weekly B 4, nos 1-12 (1916)

$16 a$ The proposed Hawaiian volcano museum. Hawaiian Volcano Observatory, Weekly B 3 no $4: 23-52$ (1915) [1916]

16b Mauna Loa outbreak. Hawaiian Volcano Observatory, Weekly B 4:39-46 (1916)

16e The great collapse at Halemaumau. Hawaiian Volcano Observatory, Weekly B 4: $47-51$ (1916)

17 Lava flow from Mauna Loa, 1916. Am J Sc (4) $43: 255-288$ (1917)

17 a Volcanologic investigations at $\mathrm{Ki}$ lauea. Am J Sc (4) 44:161-220 (1917)

17b Live a lava at Kilauea. Wash Ac Sc, J $7: 241-243$ (1917)

17e On the terms aphrolith and dermolith. Wash Ac Sc, J 7:277-281 (1917)

17d Thermal gradient of Kilauea lava lake. Wash Ac Sc, J $7: 397-405$ (1917)

18 The index of danger from volcanoes. Hawailan Volcano Observatory, Weekly B $6: 15-20$ (1918)

18 a Results of volcano study in Hawaii. Nature 101:54-57 (1918) 
Jagrar, Thomas A ugustus, jr.-Continued.

$18 b$ (and Romberg, Arnold) An experiment in teleseismic registration. Seism Soc Am, B 8: 88-89 (1918)

See also Hawailian Volcano Observatory, 14: Iddings, 14

James, C.

17 Tantalum. Mineral Foote-Notes 1 no $8: 1-7$ (1917)

17a Columbium. Mineral Foote-Notes 1 no $8: 7-8$ (1917)

James, Edwin (1797-1861).

22 Geological sketches of the Mississippi Valley. Ac N Sc Phila, J 2:326-329 (1822)

23 Account of an expedition from Pittsburgh to the Rocky Mountains performed in the years 1819 and '20... Major Stephen $H$. Long [descriptions of fossils by Thomas Say $1: 106 ; 2: 410-411]$. 2 vols, 503, 442, xcriii pp, Phila 1823 (also a London edition)

$23 a$ On the identity of the supposed pumice of the Missouri and a variety of amygdaloid found near the Rocky Mountains. Lyc N H N Y, An 1:21-23 (1823)

25 Remarks on the sandstone and floetz trap formations of the western part of the Valley of the Mississippi. Am Ph Soc, Tr n s 2 : 191-215 (1825)

27 Remarks on the limestones of the Mississippi lead mines. Ac N Sc Phila, J 5 : $376-380$ (1827)

James, F. Wilton.

05 Notes on the Minnewaska region, Ulster Co., N. Y. (abst). Am G 35:257258 (1905) Science $n$ s 21:510-511 (1905) N Y Ac Se, An 17:580-581 (1907) James, George D.

11 The San Juan oil field of Utah. Eng M J 92:1082-1084 (1911)

James, Joseph Francis (1857-1897).

84 The fucoids of the Cincinnati group. Cin Soc N H, J $7: 124-132,151-166$, il (1884-5)

84a Two species of Tertiary plants. Science $3: 433-434$, il (1884)

85 Evidences of beaches in the Cincinnati group. Science 5: 231-233 (1885)

85a Are there any fossil algae? Am Nat $19: 165-167$ (1885)

S5b Remarks on a supposed fossil fungus from the Coal Measures. Cin Soc N H, J $8: 157-159$ (1885)

s5e Remarks on some markings on the rocks of the Cincinnati group described under the names of Ormathichnus and Walcottia. Cin Soc N H, J 8: 160-163 (1885)

85d Remarks on the genera Lepidolites, Anomaloides, Ischadites, and Receptaculites from the Cincinnati group. Cin Soc N H, J $8: 163-166$ (1885)

86 Cephalopoda of the Cincinnati group. Cin Soc N H, J 8: 235-253, 11 (1886)
James, Joseph Francis-Continued.

86a Description of a new species of Gomphoceras from the Trenton of Wisco: sin. Cin Soc N H, J 8: 255, il (1886)

86b The geology of Cincinnatl [Ohio], Cin Soc N H, J 9:20 [84]-31 [95], 13\& 141 (1886)

86e Note on a recent synonym in ty? paleontology of the Cincinnati group. Cis Soc N H, J 9: 39 [103] (1886)

87 Protozoa of the Cincinnati grong Cin Soc N H, J 9:244-252 (1887)

87a Account of a well drilled for oil o: gas at Oxford, Ohio, May and June, 188:. Cin Soc N H, J 10:70-77 (1887)

s7b Well drilled for gas at Oxforl Ohio. Science 9:623 (1887)

87e Chalcedonized fossils. Science 10: 156 (1887)

87 d Sections of fossils. Science 10:180 (1887)

87e Microscopic sections of corals. Sd ence $10: 252$ (1887)

S7f (with James, U. P.) On the mow ticuliporoid corals of the Cincinnati group, with a critical revision of the species. Ch Soc N H, J 10:118-141, 158-184; 11: $15-48$, il (1887-8) Abst, Am As, Pr 3s: 223 (1888)

88 Sections of fossils. Science 11:50 (1888)

S8a An ancient channel of the Obi River at Cincinnati. Cin Soc N H, J11 96-101 (1888) Abst, Am As, Pr 37:19 (1889)

ssb The Ivorydale well in Mill Cret valley [Hamilton Co., Ohio]. Cin Soc ? H, J 11: 102-104 (1888)

8se Nomenclature of some Cincinnat group fossils. Am G 1: 333 (1888)

88d Monticulipora, a coral and not : polyzoon. Am G 1:386-392 (1888)

sse American fossil Cryptogamia. At Nat $22: 1107-1108$ (1888)

s8f Geological section of soutbwestern Ohio (abst). Am As, Pr 36:211 (1888)

89 Remarks upon sedimentation in the Cincinnati group. Cin Soc N H, J 12: 34-36 (1889)

89a Uriah Plerson James [1811-1889] Am G $3: 281-287$, port (1889)

89b Section of Makoqueta shales it Iowa. Am Nat 23:810 (1889)

$89 \mathrm{c}$ on variation; with special reference to certain Paleozoic genera. Am Nat 23:1071-1087 (1889)

90 On Laurentian as applied to a Qu. ternary terrane. Am G 5:29-35 (1890)

90a On the Maquoketa shales, and theit correlation with the Cincinnati group of southwestern Ohio. Am G 5: 335-356, 394 (1890)

90b Modiolopsis oblonga [name preoc cupied]. Am G 6:67 (1890)

90c On the name "Laurentian." All G $6: 133-134$ (1890) 
James, Joseph Francis-Continued.

90d A cave in the Clinton formation of ohio. Cln Soc N H, J 13:31-32 (1890) 90e Section of the Maquoketa shales in Iowa (abst). Am As, Pr 38:250-251 (1890)

90f Fucoids and other problematic organisms (abst). Am Nat 24:1222 (1890)

91 Manual of the pateontology of the Cincinnati group. Cin Soc N H, J 14: $45-72,149-163 ; 15: 88-100,144-159 ; 16$ : $178-208 ; 18: 67-88,115-140 ; 19: 99-118$, Il (1891-7)

91a The fauna of the Lower Cambrian or Olenellus zone (review of paper by C. D. Walcott). Am G 8: 82-86 (1891)

91b A brief history of the Ohio River. Pop Sc Mo $38: 739-748$ (1891)

91e Fish remains in the Lower Silurian. Sc Am 64: 129 (1891)

92 On the age of the Point Pleasant, Ohio, beds. Cin Soc N H, J 14:93-104 (1892) Abst, Am As, Pr $40: 283-284$ (1892); Science 18:157-158 (1891)

92a The preservation of plants as fossils. Cin Soc N H, J 15:75-78 (1892)

92b On problematic organisms and the preservation of algae as fossils. Am Nat 26:5-10 (1892) Abst, Am As, Pr 40: 284 (1892)

92e The genus Scolithus. Am Nat 26 ; 240-242 (1892)

92d Studies in problematic organisms; the genus Scolithus, G Soc Am, B 3:3244, il (1892)

93 Studies in problematic organisms; the genus Fucoides, Cin Soc N H, J 16: 62-81 (1893) Abst, Am As, Pr 42:173 (1894)

93a Remarks on the genus Arthrophycus Hall. Cin Soc N H, J 16:82-86 (1893) Abst Am As, Pr 42:172 (1894)

93b Fossil fungi. Cin Soc N H, J 16: 64-100 (1893)

93e The Cincinnati ice dam. Am G 11:199-202 (1893)

94 The St. Peter's sandstone. Cin Soc N H, J $17: 115-135$ (1894)

94a On the value of supposed Algae as geological guides. Am G 13:95-101 (1894) Abst, Am As, Pr 42:172-173 (1894)

95 Remarks on Daimonelix or "devil's corkscrew" and allied fossils. Am G 15 : $337-342$, il (1895)

95a Sponges; recent and fossil. Am Nat $29 ; 536-545$, il (1895)

95b The first fauna of the earth. Am Nat 29:879-887, 979-985 (1895)

96 An ally of Daimonelix. Am G 18: 193, il (1896)

96a [Corrections pertaining to Ordovician Brachiopoda]. Am G 18:392-393 (1896)
James, Joseph Francis-Continued.

97 Notes on the Potsdam and Lower Magnesian formations of Wisconsin and Minnesota (abst). J G 5:99 (1897)

See also Wolfi, $91 \mathrm{a}$

James, Uriah Pierson (1811-1889).

46 (with Graham, G., and Anthony, J. G.) Two species of fossil Asterias in the Blue Limestone of Cincinnati. Am J Sc (2) 1:441-442, il (1846)

71 Catalogue of Lower Silurian fossils, Cincinnati Group... 14 pp, Cin 1871 Additions $4 \mathrm{pp}, 1873$

72 On a new species of fossil from the Lower Silurian [Cyrtolites costatus]. Am J Sc (3) $3: 26$ (1872)

74 Descriptions of new species of Brachiopoda from the Lower Silurian RocksCincinnati group. Cin Q J Sc 1:19-22 (1874)

74a Descriptions of one new species of Leptaena, and two species of Cyclonema from the Lower Silurian rocks, Cincinnati group. Cin Q J Sc 1: 151-154 (1874)

74b Descriptions of new species of fossils from the Lower Silurian formation, Cincinnati group. Cin Q J Sc 1:239-242 (1874)

74c Descriptions of new species of Brachiopoda from the Lower Silurian formation, Cincinnati group. Cin Q J Se 1:333335 (1874)

75 Catalogue of Lower Slurian fossils of the Cincinnati group found at Cincinnati, Ohio, and vicinity ... with descriptions of some new species of corals and polyzoa. $8 \mathrm{pp}$, Cin 1875

78 [Descriptions of Cincinnatian and other Paleozoic fossils.] The Paleontologist, 7 nos, $44 \mathrm{pp}$, il (1878-1883)

83 Descriptions of fossils from the Cincinnati group. Cin Soc N H, J $6: 235-236$, il (1883)

84 Description of three species of fossils. Cin Soc N H, J $7: 20-24$, il (1884)

84a Descriptions of four new species of fossils from the Cincinnati group. Cin Soc N H, J $7: 137-140$, il (1884)

84b On conodonts and fossil annelid jaws. Cln Soc $\mathrm{N} H, J$ $7: 143-149$, il (1884)

S5 Glyptoorinus baeri Meek. Cin Soc N H, J 8: 71 (1885)

87 Agelacrinus holbrooli James. Cin Soc N H, J 10:25-26, il (1887)

87a (and James, J. F.) On the monticuliporoid corals of the Cineinnati group, with a critical revision of the species. Cin Soc N H, J 10 : 118-141, 158-184; 11 : 1548, il $(1887-8) \quad$ Abst, Am As, Pr $36: 223$ (1888)

\section{Jameson, E.}

89 Geology of the Leavenworth prospect well [Kans.]. Kans Ac Sc, $\operatorname{Tr} 11: 37-38$ (1889) 
Jameson, Robert.

26 Notes on the geology of the countries discovered during Captain Parry's second [and third] expedition, A. D. 1821-22-23. In Journal of a third voyage for the discovery of a northwest passage from the Atlantic to the Pacific...under Captain William E. Parry : 210-232, Phila 1826 : 132151 , L 1826

31 Arctic geology. In Leslie [John, and others]. Narrative of discovery and adventure in the Polar seas and regions... : 352373 , N Y 1831 3d ed: $464-488$, Edinburgh 1832

Jamieson, George $\mathrm{S}$.

05 On the natural iron-nickel alloy, awaruite. Am J Sc (4) $19: 413-415$ (1905)

05a (with Penfield, S. L.) On tychite, a new mineral from Borax Lake, Cal., and on its artificial production and its relations to northupite. Am J Se (4) 20 : 217-224 (1905) Zs Kryst 41:235-242 (1905)

\section{Jamison, C. E.}

11 Mineral resources of Wyoming. Wyo, St G, (B) B 1:1-40 (1911)

11a Geology and mineral resources of a portion of Fremont County, Wyo. Wyo [G S], (B) B 2:90 pp, map (1911)

12 The Douglas oil field, Converse Co., Wyo.; the Muddy Creek oil field, Carbon Co., Wyo. Wyo, St G (B) B $3: 50$ pp, maps (1912)

12a The Salt Creek oil field, Natrona Co., Wyo. Wyo, St G, (B) B 4:75 pp, map (1912)

12b Biennial report of the State geologist of Wyoming, September 30th, 1912. 13 pp, Cheyenne, 1912

Jandorf, Morton Lehmayer.

12 Preliminary report on the York Valley limestone belt in York Co. Pa Top G S, Rp 1910-1912: 50-129, maps (1912)

13 Copper in York Co., Pa. M Sc Press: 106:346-347 (1913)

Janin, Charles

18 Gold dredging in the United States. U S Bur Mines, B $127: 226$ pp (1918)

Janin, Louis, jr.

90 The Mulatos gold mines, State of Sonora, Mexico. Eng M J 49 : 131-132 (1890)

Jannctax, Ldouard.

75 Catalogue des échantillons et observations géognostiques [Alaska]. In $\mathrm{Pi}$ nart, Alph. L., Voyages a la cote nord-ouest de l'Amérique : 13-17. París 1875

86 Note sur la chrysocole de la Californie. Soc Minér France, B 9:211-213 (1886) Soc Cient Ant Alz, Mem 16: Rev 34-36 (1901)

Jarvis, May $M$.

o5 On the fossil genus Porocystis Cragin. Biol B $9: 388-390$, il (1905)
Jarvis, Royal P.

12 The valley and mountain iron ores enst Tennessee. Tenn G S, Res Tenn? 326-366 (1912) [Also published as $\mathrm{B}$ letin 2-C.]

12n (with Gordon, C. H.) Iron d. posits in the Tuckahoe district, east Ten Tenn G S, Res Tenn 2:458-478 (1912) Jefferis, W. W.

92 (with Rand, T. D.) Mineral locall ties of Philadelphia and vicinity. Ac S Sc Phila, Pr 1892:174-202

Jeferson, Mark Sylvester William.

97 The antecedent Colorado. Sciens n $s \quad 6: 293-295$ (1897)

98 The postglacial Connecticut at Tun ers Falls, Mass. J G 6:463-472, maps (1898)

98a Postglacial Connecticut. Science n s $8: 794$ (1898)

99 Beach cusps. J G $7: 237-246$ (1899)

02 Limiting width of meander belts Nat Geog Mag 13:373-384 (1902) Abst, Mich Ac Sc, Rp 4:174 (1904)

03 Somre shore features of Lake Huron (abst). Science n \& $17: 221$ (1903) J 6 11:123-124 (1903) Sc Am Sup 55:2264i (1903)

O3a Mount Pelee. Science n s 17:900 (1903)

04 The scaurs on the River Rouge [Mich.]. Science n s 19:150-151 (1904) 06 Material for geography of Micbigan 90 pp, Ypsilanti, Mich. 1906 Reprintel from Normal College News.

07 Lateral erosion on some Michigan rivers. G Soc Am, B 18: 333-350 (1907)

o7a Uplift increases rainfall, denudation diminishes it. Science $n$ s $25: 909-910$ (1907)

10 Beach cusps (abst). Science n 8 32: 192 (1910) G Soc Am, B 21: 765 (1910)

10a Meanders and scallops (abst). Sct. ence $n$ s $32: 192$ (1910) G Soc Am, B $21: 765$ (1910)

18 Some considerations on the geographical provinces of the United States. As Am Geog, An $7: 3-15$ [1918]

Jefrerson, Thomas.

99 A memoir on the discovery of certain bones of a quadruped of the clawed kind in the western parts of Virginia. Am Plu Soc, Tr 4:246-260 (1799)

Jefrey, Edward Charles.

04 A fossil Sequoia from the Sierta Nevada. Bot Gaz $38: 321-332$, il (1904) 06 (and Chrysler, M. A.) On Cretaceous pityoxyla. Bot Gaz $42: 1-15$, il (1906)

O6a (and Chrysler, M. A.) The lig. nites of Brandon [Vt.]. Vt St G, Rp 5: 195-201, il (1906)

O6b (with Hollick, A.) Affinities of certain Cretaceous plant remains commonly referred to the genera Dammara and Erachyphyllum. Am Nat 40:189-216 (1906) 
Jefirey, Edward Charles-Continued.

ot Araucariopitys, a new genus of araucarians. Bot Gaz $44: 435-444$, il (1907) os $0 n$ the structure of the leaf in Cretaceous pines. An Bot $22: 207-220$, il (1908)

09 (with Holliek, A.) Studies of Cretacesus coniferous remains from Kreischerville, N. Y. N Y Bot Garden, Mem 3:138 pp (1909)

$10 \mathrm{~A}$ new araucarian genus from the Triassic. Boston Soc N H, Pr 34:325332 , il (1910)

10a A new Prepinus from Martba's Vineyard. Boston Soc N H; Pr 34:333338 , il (1910)

10b Microscopic study of certain coals in relation to the sapropelic hypothesis (abst). Science n s $32: 220-221$ (1910) G Soc Am, B 21: 788 (1910)

11 The affinities of Geinitzia gracillima. Bot Gaz 51:21-27, il (1911)

11a David Pearce Penhallow. Bot Gaz 51:142-144, port (1911)

12 The history, comparative anatomy, and evolution of the Araucarioxylon type. Am Ac Arts, Pr 48:531-571, il (1912)

12a The relations of paleobotany to botany; morphology. Am Nat 46:225-238 (1912) Abst, Science n s 35:149 (1912)

13 Inadequacy of the sapropelic bypothesis of the origin of coal (abst). G Soc Am, B 24: 706 (1913)

13a Nature of the substance known as mother of coal and its relation to the process of coal formation (abst). G Soc Am, B $24: 715-716$ (1913)

14 On the composition and qualities of coal. Ec G $9: 730-742$ (1914)

14a Improvements in methods of investigating highly carbonized materials and their bearing on the mode of deposition of coal (abst). G Soc Am, B 25:58 (1914)

14b (with seott, D. H.) On fossil plants showing structure from the base of the Waverly shale of Kentucky. R Soc London, Ph Tr ser B $205: 315-373$ (1914)

15 The mode of origin of coal. J G 23 : 218-230 (1915)

16 Methods of studying coal. Science Conspectus $6: 71-76$ (1916)

17 Petrified coals and their bearing on the problem of the origin of coals. Nat Ac Sc, Pr 3: 206-211 (1917) Abst, G Soc Am, B 28 : 130-131 (1917)

Jefreys, John Gwyn (1809-1885).

77 The post-Tertiary fossils procured in the late Arctic expedition. An Mag N H (4) $20: 229-242, \quad 489-494$ (1877) Abst, Brit As, Rp $47: \mathrm{sec}, 72$ (1878)

Jefries, Wyman.

57 On some fossil bones collected in Texas [Brazos River]. Boston Soc H N, Pr $6: 51-55$ (1857)
Jellnm, S. P.

08 Central Idaho gold districts. Northwest $M$ News $3: 83-91,107-114,134-139$; $4: 2-6,31-37,66-73$ (1908-9) Reprinted, 84 pp, Spokane, Wash. 1909

Jenkins, Edward H.

11 William Henry Brewer. Am $J$ Sc (4) $31: 71-74$ (1911)

Jenkins, George E.

92 Notes on the active iron mines [of New Jersey]. N J G S, An Rp 1891: 235253 (1892)

97 Report on the iron mining industry; with notes on the active mines. N J G S, An Rp 1896: 319-336 (1897)

98 Supplemental notes on the mining industry of New Jersey. N J G S, An Rp 1897: $317-350$ (1898)

99 Fire brick and clay industry; the iron mining industry. N J G S, An Rp 1898: 195-237 (1899)

Oo Review of the mining industry. N J G S, An Rp 1899: 151-170 (1900)

Jenkins, John P.

21 Notice of some facts at Hudson [N. Y.] Am J Sec 4:33-35 (1821)

Jenkins, Olaf Pitt.

15 Geologic map of Tennessee. Tenn G S (1915) Scale 1:500,000. Rv, by R. D. Sqlisbury, J G 24:206-207 (1916)

16 Phosphates and dolomites of Johnson Co., Tenn. Tenn G S, Res Tenn 6:51106, map (1916) Abst, Tenn Ac Sc, Tr $2: 89$ (1917)

18 Two manganese deposits in northern Washington. Eng M J 105:1082 (1918)

18a Notes on the possible origin of the magnesite near Valley, Wash. Ec G 13 : 381-384 (1918)

18b Spotted lakes of epsomite in Washington and British Columbia. Am J Sc (4) $46: 638-644$ (1918)

Jenks, William.

os Copper in sandstone. M Science 58 : 150-151, 168-169 (1908)

Jenney, Walter Proctor (1849-1921).

74 Notes on the geology of western Texas near the thirty-second parallel. Am J Sc (3) $7: 25-29$ (1874)

$74 a$ [On the geology of western Texas.] Lyc N H N Y, Pr (2) no 3:68-69 (1874)

75 Report of geological survey of the Black Hills. U S, Comm Indian Affairs, An Rp 1875: 181-183 (1875)

76 The mineral wealth, climate and rainfall, and natural resources of the Black Hills of Dakota. U S G Geog S Black Hills (U S, 44th Cong 1st sess, S Ex Doc 51) : $71 \mathrm{pp}, \operatorname{map}(1876)$

so (with Newton, H.) Report on the geology and resources of the Black Hills of Dakota. U S Geog G S Rocky Mtn Reg (Powell) : $566 \mathrm{pp}$, atlas (1880)

s9 Graphitic anthracite in the Parker mine, Wood River, Idaho. Scb Mines Q $10: 313-315$ (1889) 
Jenney, Walter Proctor-Continued.

89a Notes on the dry lakes of southern Nevada and California with relation to the loess. Sch Mines Q 10:316-318 (1889)

94 The lead and zinc deposits of the Mississippi Valley (with discussion by W. P. Blake, Arthur Winslow, and F. L. Nason). Am I M Eng, $\operatorname{Tr} 22: 171-225$, 621646 (1894)

99 Field observations in the Hay Creek coal field [Wwo.]. U S G S, An Rp 19 pt $2: 568-593$ (1899)

03 The mineral crest, or the hrdrostatic level attained by the ore-depositing solutions in certain mining districts of the Great Salt Lake basin (with discussion by G. O. Smith and S. F. Emmons). Am I M Eng, Tr $33: 46-50,1060-1063$ (1903) M Sc Press $85: 297$ (1902) Eng M J 73 : 825-826 (1902)

03a The chemistry of ore deposition (with discussion by J. A. Church). Am I M Eng, Tr 33:445-498, 1065-1070 (1903) Abst, M Sc Press $86: 317-318$ (1903) Reprinted in Emmons, S. F., Ore deposits (pub. by Am I M Eng) : 305-363, N Y 1913

06 Structural features of the Ontario mineral belt, Park City, Utah. M Sc Press $92: 6-7$ (1906)

o6n The fissure system of the Ontario mineral belt [Utah]. M Sc Press $92: 24$ 25 (1906)

o6b Block-faulting and its relation to ore deposition. M Sc Press 92:54-55 (1906)

06e The ore deposits of the Ontario mineral belt [Utah]. M Sc Press 92:108109 (1906)

09 The Nevada meteorite. M Sc Press 98:93-94 (1909)

09a The great Nevada meteor of 1894 [Quinn Canyon meteorite]. Am J Sc (4) 28: 431-434 (1909)

09b Geology of the Manhattan district, Nev. Eng M J 88: 82-83 (1909)

09e Geological and physical conditions of Tonopah mines [Nev.]. M Sc Press 99 685-686 (1909) Eng M J 89: 29-30 (1910)

See also Powell, 91, 91a, 92

Jennings, E. P.

94 The Mesabi iron range. Science 23 : 73 (1894)

04 The copper deposits of the Kaibab Plateau, Ariz. (with discussion by H. F. Lunt). Am I M Eng, Tr $34: 839-841,989$ 990 (1904)

05 Origin of the magnetic iron ores of Iron Co., Utah. Am I M Eng, Tr 35: 338342 (1905)

O5a The Goldfield district, Nevada. Can M Inst, J 8:39-45 (1905)

06 The Lost Packer copper gold lode [Idaho]. Can M Inst, J 9:54-57 (1906) M Sc Press $92: 435-436$ (1906)
Jennings, E. P.-Continued.

or Genesis of the copper deposits of Yerington, Nev, Eng M J 83:1143-1144 (1907) Can M J 28 (n \& 1 no 12):365366 (1907)

os Secondary copper ores of the Ludwig mine, Yerington, Nev, Can M Inst, J 11: 463-466 (1908)

09 The copper deposits of Yerington, Nev. Am M Cong, 12th An Sess, Rp Pr: 423-427 (1909)

09a The localization of values in ore bodies and the occurrence of shoots in metalliferous deposits. Ec G $4: 255-257$ (1909)

12 A titaniferous Iron-ore deposits in Boulder Co., Colo. Am I M Eng, B 70: 1045-1056 (1912) ; Tr 44:14-25 (1913)

Jennings, Otto Emery.

o5 Notes on the vegetable tissues in Daemonelix. Carnegie Mus, Mem 2:190191 (1905)

13 Note on the geology of the Isle of Pines, Cuba. J G 21:367-369 (1913)

18 Report on a collection of Oligocene plant fossils from Montana (abst). G Soc Am, B 29:147 (1918)

Jennison, William Franklyn.

9s Manganese deposits of Nova Scotla. Fed Can M Inst, J 3:167-172 (1898) Can M Rv 17:113-114 (1898)

04 Notes on the history of manganese mining in part of Nova Scotia and on some of the geological conditions of the manganese belt running through Hants Co. M Soc N S, J 8:106-109 (1904)

11 Report on the gypsum deposits of the maritime provinces, Canada, Can Mines $\mathrm{Br}: 171$ pp, maps (1911)

Jensen, Adolf Severin.

09 On the fossil Quaternary molluse fauna of Greenland. Med Grönland 29: 289-305 (1909)

17 Quaternary fossils collected by the Danmark expedition. Med Grönland 43: 619-632 (1917)

Jensen, Joseph.

os (and others) Some salient features of the geology of Newhouse, Utah, and vi. cinity, 35 pp, maps, 1908 (Presented... for the degree of Bachelor of Science in Mining Engineering at the University of Utah.)

Jermy, Gustav.

S9 Report of geologists for southern Texas. Tex G S, Rp Prog 1 (1888) : 6164 (1889)

Jernegen, Joseph L., jr.

75 The Whale lode of Park Co., Colorado Terr. Am I M Eng, Tr 3: 352-356 (1875)

Jessen, A.

96 Geologiske Iagttagelser [geologic ob servations on Julianehaabs district, Greenland]. Med Grönland 16:123-169, map (1896) 
Jessup, Augustus E.

21 Geological and mineralogical notice of a portion of the northeastern part of the State of New York. Ac N Sc Phila, J 2:185-191 (1821) Transl. in Struve, H. von, Beiträge zur Mineralogie und Geologie des nördlichen Amerikas : 55-65, Hamburg 1822

Jessup, Douglas W.

13 Ore deposits of the Prince Consolidated mines [Ely mining district, Nev.]. M Sc Press 106: 773-775 (1913)

16 The Lakeview [zinc] mine [Boxelder Co.], Utah. Eng M J 102: 573-576 (1910) Jewell, Wilson.

56 Geological structure [of Philadelphia Co., Pa.] Med Soc Pa, Tr n s $1: 125$ 126, map (1856)

Jewet, Ezekiel.

62 [On the Catskill group in Delaware Co., N. Y.] N Y St Crb, An Rp 15:198 (1862) Can Nat 7:395-396 (1862)

64 On the probable identity of the Oneida conglmerate of central New York with the Medina formation. Am J Sc (2) 38: 121-122 (1864)

Jewett, J. J.

05 Notes on the topography and geology of New Mexico, Kans Ac Sc, Tr 19:141149 (1905)

Jillson, B. C.

66 [Geology of Alleghany Co., Pa.] Med Soc $\mathrm{Pa}, \operatorname{Tr}$ (4) 2:42-46, map (1866)

Jillson, Willard Rouse.

17 Preliminary note on the occurrence of vertebrate footprints in the Pennsylvanian of Oklahoma. Am J Sc (4) 44:5658 (1917)

17a New evidence of a recent volcanic eruption on Mt. St. Helens, Wash. Am J Se (4) 44:59-62 (1917)

17b The volcanic acticity of Mount St. Helens and Mount Hood in historical time Geog Rv 3 : 481-485 (1917)

Joerg, Wolfgang L. G.

10 The tectonic lines of the northern part of the North American Cordillera. Am Geog Soc, B 42:161-179, map (1910)

13 On the proper map for determining the location of earthquakes. As Am Geog, An 2:49-54 [1913]

14 The subdivision of North America into natural regions; a preliminary inquiry. As Am Geog, An 4:55-83 [1914]

\section{Johannsen, Albert.}

08 A key for the determination of rockforming minerals in thin sections. $542 \mathrm{pp}$, N Y 1908

08 Notes on the igneous rocks of western Arizona, U S G S, B $352: 81-92$ (1908)

10 Some simple improvements for a petrographical microscope. Am J Sc (4) $29: 435-438$ (1910)

11 Petrographic terms for field use. J (; $19: 317-322$ (1911)
Johannsen, Albert-Continued.

11 a A drawing board with revolving disk for stereographic projection. J G 19: $752-755$ (1911)

13 An accessory lens for observing interference figures of small mineral grains. J G 21: 96-98 (1913)

14 Manual of petrographic methods. 649 pp, N Y 1914

$14 a$ Petrographic analysis of the Bridger, Washakie, and other Eocene formations of the Rocky Mountains, with introductory note by W. D. Matthews. Am Mus N H, B $33: 209-222$ (1914)

14b Petrological abstracts and reviews. J G $22: 189-192,275-285,437-440,529-$ $533625-629,725-728$ (1914) ; 25:492497 ; $587-593,779-781$ (1917) ; 26:82-88, $186-189,272-282,377-381,471-477$ (1918)

17 Suggestions for a quantitative mineralogical classification of igpeous rocks. J G $25: 63-97$ (1917)

See also Weinschenk, 16

Johannsen, $O$. A.

12 A Tertiary fungus gnat [Mycomya cockerelli, Florissant, Colo.]. Anr J Sc (4) $34: 140$, il (1912)

Johns Hopkins University.

94 George Huntington Williams. The minutes of a commemorative meeting held in Johns Hopkins University, October 14. 1894 [includes address by William B. Clark ]. $19 \mathrm{pp}$, port, Baltimore 1894

Johnson, Alexander S.

52 Notice of some undescribed infusorial shells. Am J Sc (2) $13: 33$ (1852) Johnson, Alexander T.

o9 Mining in the Tonopah district. Am M Cong, 12th An Sess, Rp Pr: 412-417 (1909)

Johnson, Bertrand Leroy.

of Pleistocene terracing in the North Carolina Coastal Plain. Science n s 26: 640-642 (1907)

os Contributions to the geology of Rhode Island; notes on the history and geology of Iron Mine Hill, Cumberland. $\mathrm{Am} \mathrm{J}$ Sc (4) $25: 1-12$ (1908)

10 Occurrence of wolframite and cassiterite in the gold placers of Deadwood Creek, Birch Creek distriet, Alaska. U S G S, B $442: 246-250$ (1910)

12 Gold deposits of the Seward-Sunrise region, Kenal Peninsula [Alaska]. U S G S, B 520:131-173, map (1912)

12n (with Stephenson, L. W.) Water resources of the Coastal Plain of North Carolina. N C G S $3: 333-483$ (1912)

14 The Port Wells gold-lode district [Alaska]. U S G S, B 592: 195-236, maps (1914)

14a Mining on Prince William Sound [Alaska]. U S G S, B 592 : 237-243 (1914)

15 Mining on Prince William Sound [Alaska]. U S G S, B $622: 131-139$, map (1915) 
Johnson, Bertrand Leroy-Continued.

15a The gold and copper deposits of the Port Valdez district [Alaska]. U S G S, B 622:140-188, map (1915)

15b (with Capps, S. R.) The Ellamar district, Alaska. U S G S, B 605: 125 pp, maps (1915) Abst, Wash Ac Sc, J 6: 93-94 (1916)

15e (with Martin, G. C. and Grant, U. S.) Geology and mineral resourees of Kenai Peninsula, Alaska. U S G S B 587: $243 \mathrm{pp}$, maps (1915)

16 Retreat of Barry Glacier, Port Wells, Prince William Sound, Alaska, between 1910 and 1914. U S G S, P P 98:35-36 (1916)

16a Mining on Prince William Sound, Alaska. U S G S, B 642: 137-145 (1916)

17 Mining on Prince William Sound [Alaska]. U $\mathrm{S} \quad \mathrm{G} \quad \mathrm{S}, \quad \mathrm{B} \quad 662: 183-192$ (1917)

17n Copper deposits of Latouche and Knight Island distriets, Prince William Sound [Alaska]. U S G S, B 662:193220, map (1917)

17b Preliminary note on the occurrence of chalmersite, $\mathrm{CuFe}_{2} \mathrm{~S}_{3}$, in the ore deposits of Prince William Sound, Alaska. Ec G $12: 519-525$ (1917)

18 Chalmersite, $\mathrm{CuFe}_{2} \mathrm{~S}_{3}$, a new ore of copper (abst). Wash Ac Sc, J 8: 99 (1918)

18a The Valdez delta [Alaska] (abst). Wash Ac Sc, J 8:410-411 (1918)

Johnson, Charles Willison.

92 (with Pilsbry, H. A.) Catalogue of Fissurellidae of the United States. Nautilus 5:102-107 (1892)

98 New Cretaceous fossils from an artesian well boring at Mount Laurel, N. J. Ac N Sc Phila, Pr 1898:461-464, il

99 New and interesting species in the "Isaac Lea collection of Eocene Mollusca." Ac N Sc Phila, Pr 1899: 71-82, 11

99a A new Pliocene Polygyra from Florida. Nautilus $13: 67-68$, il (1899)

02 (and Grabau, A. W.) A new species of Clavilithes from the Eocene of Texas. Ac N Sc Phila, Pr 53:602-603, il (1902)

04 Description of two new Tertiary fossils. Nautilus $17: 143-144$, il (1904)

05 Annotated list of the types of invertebrate Cretaceous fossils in the collection of the Academy of Natural Sciences, Phila. Ac N Sc Phila, Pr 57:4-28 (1905)

17 (with Pilsbry, H, A.) New Mollusca of the Santo Domingan Oligocene. Ac N Sc Phila, Pr 69:150-202 (1917)

Johnson, Douglas Wilson.

00 (with Herrick, C. L.) The geology of the Albuquerque sheet. Denison Univ, Sc Lab, B 11:175-239, il, map (1900)

02 Notes of a geological reconnaissance in eastern Valencia Co., N. Mex. Am G $29: 80-87$, map (1902)
Johnson, Douglas Wilson-Continued. 02a On some Jurassic fossile from Dur ango, Mex. Am G $30: 370-372$ (1902)

02b Notes on the geology of the saline basins of central New Mexico (abst). \& Y Ac Sc, An 14:161-162 (1902) Science n s $15: 106-107$ (1902)

03 The geology of the Cerrilos Hills, X. Mex. Sch Mines Q 24:173-246, il, 30\%. $350,456-500 ; 25: 69-98$, map (1903) $A b s t$, Science n s $18: 17$ (1903); N Y Ac Sc, An 15:181-182 (1904)

03a Block Mountains in New Mexio, Am G 31: 135-139 (1903)

os The Tertiary history of the Tennes. see River. J G 13:194-231, map (1905)

O5a The distribution of freshwater faunas as an evidence of drainage modif. cations. Science n s 21:588-592 (1905)

05b Youth, maturity, and old age of topographic forms. Am Geog Soc, B 37: 648-653 (1905)

06 The scope of applied geology, and its place in the technical school. Ec G 1 243-256 (1906) Tech Q 19:25-36 (1906)

06a The New England intercollegiate geological excursion, 1905; geology of the Nantasket area. Science n 8 23:155-15t (1906)

06b Report on the geological excursion through New Mexico, Arizona, and Utsh. summer of 1906. Tech Q 19:408-415 (1906)

o7 Drainage modifications in the $\mathrm{T}$ s. lulah district. Boston Soc $\mathrm{N} \mathrm{H}, \operatorname{Pr} 23$ : 211-248 (1907)

$07 a$ Volcanic necks of the Mount Tay lor region, N. Mex. G Soe Am, B 18: 303-324 (1907) Abst, Science n 8 25: 769 (1907)

ozb A recent volcano in the San Fras. cisco Mountain region, Ariz. Geog $\mathrm{Soc}$ Phila, B 5:6-11 (1907)

ore River capture in the Tallulah dis. trict, Ga. Science n s $25: 428-432$ (1907)

ozd Current notes on land forms; rivet terraces in Vermont. Seience n s 25:7172 (1907)

o7e Current notes on land forms: a peneplain in the Grand Ganyon district. Science n s 26:837-838 (1907)

ozf (with Davis, W. M., and Bowman, I.) Current notes on land forms. Science n \& 25: 70-73, 229-232, 394-396, $508-510, \quad 833-836, \quad 946-949 ; \quad 26: 90-93$, $152-154,226-228,353-356,450-453,837-$ 839 (1907) ; $27: 31-33$ (1908)

o8 The origin of beach cusps (abst). Science n s 28:574 (1908)

o8a (and Matthes, F. F.) The rela. tion of geology to topography. In Prit ciples and practice of surveying, by Charles B. Breed and George L. Hosmer. Vol 2: 246-266, N Y 1908.

09 A geological excursion in the Grand Canyon district. Boston Soc N H, Pr 34: 135-161 (1909) 
Johnson, Douglas Wilson-Continued. 09a Hanging valleys. Am Geog Soc, B 41:665-683 (1909)

10 The origin of the Yosemite Valley [Cal.]. Appalachia 12:138-146 (1910)

$10 \mathrm{a}$ The southernmost glaciation in the United States. Science n s 31:218-220 (1910)

10b The supposed recent subsidence of the Massachusetts and New Jersey coasts. Science n s 32:721-723 (1910)

10e Beach cusps. G Soc Am, B 21 : 599-624 (1910)

10d (and Reed, W. G., jr.) The form of Nantasket Beach, Mass. J G 18:162189 (1910) Abst, Brit As, Rp 79:535 (1910)

11 Hanging valleys of the Yosemite. Am Geog Soc, B 43:826-837 890-903 (1911) Abst, As Am Geog, An i: 121-122 (1911)

11a Botanical evidence of coastal subsidence. Science n s 33:300-302 (1911)

11b Shore line changes in the ScituateMarshfield, Mass, region (abst). As Am Geog, An 1: 135-136 (1911)

11. Supposed recent subsidence of the Atlantic coast (abst). Science n s 33 : 906-907 (1911)

12 Fixité de la côte atlantique de l'Amérique đu Nord. An Géog 31:193212 (1912) The stability of the Atlantic coast (abst). Seience n s $35: 318$ (1912); (with discussion by C. A. Davis, J. W. Spencer, A. C. Lane, H. B. Kümmel), G Boc Am, B 23: 739-742 (1912)

12a The physical history of the Grand Canyon district (abst). Science n s 35 : 199 (1912)

13 Submarine Chamacyparis bog at Woods Hole, Massachusetts, and its relation to the problem of coastal subsidence (abst). G Soc Am, B 24:699-700 (1913)

13a Botanical phenomena and the problem of recent coastal subsidence. Rot Gaz $56: 449-468$ (1913)

13b The shore line of Cascumpeque Harbor, Prince Edward Island (abst). Science 4 \& $37: 958 \cdot(1913)$

14 (and Smith, Warren S.) Recent storm effects on the northern New Jersey shoreline, and their supposed relation to coastal subsidence. N J G S, B 12: 27-44 (1914)

14a Precise leveling and the problem of coastal subsidence (abst with discussiun). G Soc Am, B 25: 59-60 (1914)

14b Botanical phenomena and the problem of coastal subsidence (abst). Am Geog Soc, B 46: 432 (1914)

14e The shore line of Cascumpeque Harbor, Prince Edward Island (abst). N Y Ac Sc, An 23:261-262 (1914) As Am Geog, An 3:112 [1915]

15 The nature and origin of fiords. Sclence n s 41:537-543 (1915)
Johnson, Douglas Wilson-Continued.

15a (and Smith, W. S.) Wave work on the New Jersey coast. Pop Sc Mo 86 : $557-567$ (1915)

16 Contributions to the study of ripple marks. J G 24:809-819 (1916)

$16 a$ Plains, planes, and peneplanes. Geog Rv 1: 443-447 (1916)

16b Physiographic notes on the White Mountains (abst). G Soc Am, B 27:108 (1916)

17 Date of local glaciation in the White, Adirondack, and Catskill Mountains. G Soc Am, B 28:543-553 (1917) Abst, with discussion by J. W. Goldthwait, 28 : 136 (1917)

17n Is the Atlantic coast sinking? Geog Rv 3: 135-139 (1917)

18 Block faulting in the Klamath Lakes region [Oreg.]. J G 26:229-236 (1918)

See also Barrell, 13c; Spencer ( $\mathrm{J}$ ), $13 d$

Johnson, George H.

84 Human footprints on sandstone near Manaqua, in Nicaragua. Am J Sc (3) 27 : 239-240 (1884)

Johnson, Guy R.

97 The Embreville Estate [iron, northeastern] Tenn. Am I M Eng, Tr 26: 138144 (1897) Abst, Fing M J $61: 540$ (1896)

Johnson, H. A.

84 (and Thomas, B. W.) Microscoplc organisms in the boulder clays of Chicago and vicinity. Chicago Ac Sc, B 1:35-40 (1884) Am J Sc (3) 28:317-318 (1884) Abst, Science 3:237 (1884)

Johnson, Harry Roland.

08 (with Arnold, R.) The so-called volcano in the Santa Monica Mountains, near Los Angeles, Cal. Science n s 27: $553-554$ (1908)

09 Geology of the McKittrick-Sunset district, Cal (abst). Science n s $30: 63-64$ (1909)

O9a (with Arnold, R.) Sodium sulphate in Soda Lake, Carrizo Plain, San Luis Obispo Co., Cal. U S G S, B 380 : 369-371 (1909)

09b (with Arnold, R.) The earthquake rift in eastern San Luis Obispo Co., Cal. (abst). Science n s 29:558 (1909)

10 (with Arnold, R.) Preliminary report on the McKittrick-Sunset oil region, Kern and San Luis Obispo cos., Cal, U S G S, B 406: 225 pp (1910)

11 Water resources of the Antelope Valley, Cal. U S G S, W-S P 278:92 pp (1911)

13 Geologic notes on Santa Susanna district [Ventura Co., Cal.]. Western Eng 2 : 383-386 (1913)

Johnson, J. E., jr.

o3 Origin of the Oriskany limonites. Eng M J $76: 231-232$ (1903) 
Johnson, J. W.

43 [On lead ore and fossils near Sun bury, Pa.] Boston Soc N H, Pr 1:43-44 (1843)

Johnson, Jay Eliot.

12 (and Tibbey, B. F.) Field classificatipn of igneous rocks. Salt Lake M Rv 13 no $24: 17-19$ (1912)

Johnson, Jasper.

75. The Wilmington, Ill., coal field. Am I M Eng, Tr 3:188-202 (1875)

Johnson, John.

55 Notice of some spontaneous movements occasionally observed in the sandstone strata in one of the quarries at Portland, Conn. Am As, Pr 8:283-286 (1855) Johnson, Laurence.

82 The parallel drift hills of western New York. N Y Ac Sc, An 2: 249-266, map (1882) Abst, N Y Ac Sc, Tr 1: 77-80 (1882)

Johnson, Lawrence Clement.

84 [On the Ripley group in Alabama and Mississippi.] Science 3:80 (1884)

S5 Phosphatic rocks of Florida. Science $5: 396$ (1885)

87 (with Smith, E. A.) Tertiary and Cretaceous strata of the Tusealoosa, Tombigbee, and Alabama rivers. U S G S, B 43: $189 \mathrm{pp}$, map (1887)

s8 The iron regions of northern Louisiana and eastern Texas. U S, 50th Cong 1st sess, H Ex Doc 195: 54 pp. map (1888)

S\&a The structure of Florida, Am J Sc (3) 36:230-236 (1888) Abst, Am As, Pr 36:216-217 (1888)

89 The "Grand Gulf" formation of the Gulf States. Am J Sc (3) 38:213-216 (1889)

91 The Nita crevasse [Louisiana], G Soc Am B 2:20-25 (1891)

92 The Chattahoochee embayment [F]a.].

G Soc Am, B 3:128-133 (1892)

92n The Grand Gulf formation. Sclence $20: 151,247-248$ (1892)

92b The phosphate beds of Florida (abst). Am G 10:193 (1892)

93 Notes on the geology of Florida; two of the lesser, but typical phosphate fields. Am J Sc (3) 45: 497-503 (1893)

93a The Miocene group of Alabama. Seience $21: 90-91,107$ (1893)

94 The Orange sand (Lafayette) formation. In Smith, E. A., and others, Report on ... Coastal Plain of Alabama: 82-90, Ala G S, 1894

04 (and Eckel, E. C.) [Notes on water resources of] Mississippi. U S G S, W-S Paper 102:332-357 (1904)

05 [Underground waters of] Mississippi. U S G S, W-S P 114: 171-178, map (1905)

06 (with Crider, A. F.) Summary of the underground-water resources of Mississippi. U $\quad$ S $\quad$ G $\quad$ S, W-S $\quad$ P $\quad 159: 86$ pp (1906)

See also Powell, 84, 88, 89, 89a ; Smith (E A), 94
Johnsen, R. D. O.

05 Tennessee phosphate. Eng M J \& 204-207 (1905)

06 A unique lead deposit [Madison a. Mo.]. Eng M J 81:794 (1906)

Johnson, Roswell Hill.

10 Discussion of paper by M. J. Mom on Theories of oil and gas accumulation Ec G $5: 63-64$ (1910)

10n Marking oil maps. Ec G $5: 273$. 277 (1910)

11 Additional factors in the origin asi accumulation of oil (discussion). Ec 6 6: $808-811$ (1911)

12 The accumulation of ofl and gas in sandstone. Science n s $35: 458-459$ (1912)

$12 a$ The necessity for a theory of dif. ferential cementing in prospecting for of (discussion). Ec G $7: 708-709$ (1912)

15 The role and fate of the connate water in oil and gas sands (with discur sion by A. C. Lane, D. B. Reger, I. X Knapp, E. W. Shaw, and C. W. Wass burne). Am I M Eng, B 98:221-228: 101: 1157-1162 (1915); Tr 51:587-61 (1916)

$15 a$ The relation of the quality of oif to deformation. Ec G 10:676-678 (1915

15b A proposed classification of the at titude of geologic surfaces. Science n $42: 450-452$ (1915)

16 (and Huntley, L. G.) Principles of oil and gas production. $371 \mathrm{pp}, \mathrm{N}$ Y 1916

18 The distribution of underground salt water and its relation to the accumulation of oil and gas. Am As Petroleum G, B 2 : 172-176 (1918)

18 a Cause of the absence of water in dry sandstone beds (abst). G Soc $A m, B$ $29: 105$ (1918)

See also Hager, 17; Washburne, 140. $15 \mathrm{~b}$

Johnson, S. N.

69 On the geology of the coast of Maine (abst). Can Nat n s $4: 323-324$ (1869)

Johnson, S. W.

51 On the houghite of Professor Shep

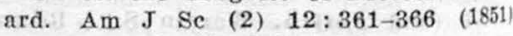
Am As, $\operatorname{Pr} 6: 243-246$ (1852)

Johnson, Walter Rogers (1794-1852).

39 Analysis of some of the minerals found at Karthaus and Three Runs, os the west branch of the Susquehanna River, Clearfield Co., $\mathrm{Pa}$. Franklin Inst, $\mathrm{J}$ D $23: 73-80$ (1839)

39 Examination of some of the antbrs. cites found in Sugar Loaf township Luzerne $\mathrm{Co}, \mathrm{Pa}$. Franklin Inst, J n \& 24 73-77 (1839)

39b Analysis of some of the anthracites and iron ores found on the headwaters of Beaver Creek, in the connties of Luzerne. Northampton, and Schuylkill, $\mathrm{Pa}$. Frank lin Inst, $J$ n s 24: 289-298 (1839) 
Johnson, Walter Rogers-Continued.

40 Report of a geological, mineralogical, and topographical examination of the coal field of Carbon Creek ... 47 pp, Phila 1840 Extract, Am J Sc 39:137-149 (1840)

41 Report of a survey and exploration of the coal and ore lands belonging to the Allegheny Coal Company in Somerset Co., Pa... 64 pp, map, Phila 1841

41a Report of an examination of the Bear Valley coal district in Dauphin Co., Pa. $36 \mathrm{pp}$, Phila 1841

41b Remarks on the Bear Valley coal district in Dauphin Co., $\mathrm{Pa}$. Franklin Inst, J (3) $2: 318-327$ (1841)

41e Some observations on the mechanical structure of coal, with evidences of the contemporaneous origin of its various kinds. Ac N Sc Phila, J 8:173-178 (1842) ; Pr 1:9-12 (1841)

41d [On the anthracite of Rhode Island.] Ac $\mathrm{N}$ Sc Phila, $\mathrm{Pr}$ 1:118-119 (1841)

44 On some specimens of rocks from the White Mountains. Ae $\mathrm{N}$ Sc Phila, Pr 2 $89-90$ (1844)

$48 \mathrm{~A}$ section of the coal seams and accompanying measures of the Harleton coal basin in Luzerne Co., Penn. (abst). Am J Sc (2) $5: 111-113$ (1848)

51 Some observations on the gold formations of Maryland, Virginia, and North Car olina. Am As, Pr 4: 20-21 (1851)

51a on the coal formation of central North Carolina, Am As, Pr 4:274-276 (1851)

53 The coal lands of the Deep River Company in North Carolina... M Mag 1: $352-365$ (1853)

Johnson, W. S.

97 (with Gwillim, J. C.) Some ores and rocks of southern Slocan division, West Kooteny, B. C. Can Rec Sc 7:293-302 (1897)

Johnson, Willard Drake (1859-1917)

96 An early date for glaciation in the Sierra Nevada (abst.) Am G 18:61-62 (1896) Science n s 3:823 (1896)

99 An unrecognized process in glacial erosion (abst). Am G 23:99-100 (1899) Science n s 9:106 (1899)

99a The work of glaciers in high mountains (abst). Science n s $9: 112-113$ (1899)

99b Subsidence basins of the high plains (abst). Science n s 9:152-153 (1899)

01 The High Plains and their utilization. U S G S An Rp 21 pt 4:601-741, maps $(1901) ; 22$ pt $4: 631-669$ (1902)

04 The profile of maturity in Alpine glacial erosion. J G 12:569-578 (1904) 05 The grade profile in alpine glacial eposion [Sierra Nevada, Cal.]. Sierra Club B 5:271-27s (1905)
Johnson, Willard Drake-Continued.

08 (and Hobbs, W. H.) The earthquake of 1872 in the Owens Valley, Cal. (abst). Science n s 27:723 (1908)

10 Recent faulting in Owens Valley, Cal. (abst). Science n s 32:31 (1910) G Soc Am, B 21: 792 (1910)

Johnson, William H.

01 The lead and zinc fields of the Ozark uplift. Am Bur Geog, B 2:59-73 (1901) Johnson, Woolsey McA.

07 The Kelly mine, N. Mex., and treatment of its [lead-zinc] ores. M World 27: 267-269 (1907)

Johnston, A. R.

45 Remarks on the geology of the vicinity of Fort Washita. As Am G, Pr $6: 75-77$ (1845)

Johnston, A. Walfred.

16 The physical geography of Minnesota.

J Geog 14: 161-165 (1916)

17 (with Harder, E. C.) Notes on the geology and iron ores of the Cuyuna district, Minn. U S G S, B 660:1-26, map (1917) Abst, by R. W. Stone, Wash Ac Sc, J 8: 18-19 (1918)

18 (with Harder, E. C.) Preliminary report on the geology of east central Minnesota, including the Cuyuna iron-ore district, Minn G S, B $15: 178$ pp, maps (1918)

Johnston, Christopher.

61 Upon a diatomaceous earth from Nottingham, Calvert Co., Md. Am As, Pr 14: 159-161 (1861)

74 About the rediscovery of the "Bermuda tripoli" near Nottingham on the Patuxent, Prince Georges Co., Md. Boston Soc N H, Pr $17: 127-129$ (1874)

Johnston, J. F, E.

02 Eastern part of the Abitibl region [Nipissing district, Ont.] Can G S, Sum Rp 1901 (An Rp 14): A 130-143, map (1902)

05 Geology of part of the County of Ottawa [Que.]. Can G S, Sum Rp 1904 (An Rp 16) : A 239-250 (1905)

Johnston, James Finlay Weir (17961855).

50 Report on the agricultural capacities of the Province of New Brunswick [geology: 11-22]. 262 pp, maps, Fredericton 18502 ed, $97 \mathrm{pp}$, map, Fredericton 1850 Johnston, John.

13 Note on the temperature in the deep. boring at Findlay, Ohio. Am J Sc (4) 36 : 131-134 (1913) Abst, Wash Ac Sc, J $3: 500$ (1913)

13n (and Adams, L. H.) Effect of high pressures on the physical and chemical behavior of solld substances (abst with discussion by H. F. Reid and A. L. Day). G Soc Am, B 24:674-675 (1913)

136 (and Niggli, Paul) The general principles underlying metamorphic processes. J G 21: 481-516, 588-624 (1913) 
Johnston, John-Continued.

14 (and Adams, L. H.) Oiservation: on the Daubrée experiment and capillarity in relation to certain geological speculations. J G 22:1-15 (1914) Abst, Wash Ac Sc. J 4:5-6 (1914)

15 Pressure as a factor in the formation of rocks and minerals. J G $23: 730-747$ (1915) N Jb 2:89-108 (1915)

15a Some effects of pressure on rocks and minerals (abst). G Soc $\Delta \mathrm{m}, \mathrm{B} 26$ : 83-84 (1915)

16 (and Williamson, E. D.) The rôle of inorganic agencies in the deposition of calcium carbonate. J G 24:729-750 (1916)

$16 \mathbf{a}$ (and others) The several forms of calcium carbonate. Am J Sc (4) 41:473512 (1916)

16b (and Adams, L. H.) On the measurement of temperature in bore holes. Ee G 11: 741-762 (1916)

16e Some factors which influence the deposition of calcium carbonate (abst). Wash Ac Sc, J 6:516-517 (1916) G Soc Am, B 27:49 (1916)

Johnston. Robert Angus Allister.

04 Bulletin on molybdenum and tungsten. Can G S: 16 pp (1904)

05. The copper claims of Aspen Grove and Aberdeen Camp, B. C. Can G S, Sum Rp 1904 (An Rp 16) ; A 74-80 (1905)

osa on the meteorite which fell near the village of Shelburne, township of Melancthon, Ont., in August, 1904. Can G S, Sum Rp 1904 (An Rp 16) : A $\quad 332-336$ (1905)

06 [Report on] work in Charlotte Co., N. B. Can G S, Sum Rp 1905: 117-118 (1906)

06a Surveys on parts of the proposed route of the Transcontinental Railway in New Brunswick. Can G S, Sum Rp 1906: $127-130$ (1906)

06b The Chambord meteorite [Quebec]. Ottawa Nat $20: 51$ (1906)

o6e Copper claims of Aspen Grove and Aberdeen Camp. B C, Minister of Mines, An Rp 1905: 201-205 (1906)

os [Report of the] section of mineralogy. Can G S, Sum Rp 1907:96-99 (1908); $1908: 162-170 \quad(1909) ; \quad 1909: 248-268$ (1910) : $1910: 256-268$ (1911)

12 [Report of the] mineralogical division. Can G S, Sum Rp 1911: 360-364 (1912)

13 Prehnite from Adams Sound, Admiralty Inlet, Baffin Island, Franklin. Can G S, Victoria Memorial Mus, B 1:95-98 (1913)

14 [Report on] Mineralogy. Can G S, Sum Rp 1912 : 411-414 (1914) ; 1913 : 327330 (1914) ; 1914:134-138 (1915) ; 1915 : 209-213 (1916) ; $1916: 302-309$ (1917)

15 A list of Canadian mineral occurrences. Can G S, Mem $74: 275$ pp (1915)
Tohnston, Robert Angus Allister-Contt

15a Gay Gulch and Skookum meteorito [Yukon]. Can G S, Mus B $15: 31$ p (1915)

\section{Johnston, William Alfred,}

06 [Report of the geological survey of the Peterborough sheet. Can G S, Sum B? 1905: 92-94 (1906)

o6a Peterborough, Prince Edward, and Simcoe sheets. Can G S, Sum Rp 1900: 124-126 (1906)

os Peterborough and Simcoe sheets. Can G S, Sum Rp 1907: 56-58 (1908)

09 Simcoe sheet, Ont. Can G S, Sur Rp 1908: 97-102 (1909)

10 Simcoe district, Ont. Can G S, Sun Rp 1909: 158-163 (1910)

11 Simcoe district, Ont. Can G S, Su Rp $1910: 188-192$ (1911)

12 Geology of Lake Simcoe area, 0 tario, Brechin and Kirkfield sheets. (an G S, Sum Rp 1911: 253-261 (1912)

13 Algonquin Beach, glacial phenomes: and Lowville (Ordovician) limestone tr Lake Simcoe district, Ont. Int $G$ Cone XII, Guide Book no 5 (issued by Can G 8): 23-35 (1913)

$13 a$ (with Keele, J.) The superfici deposits near Ottawa. Int $G$ Cong. XII. Guide Book no 3 (issued by Can G 8: 126-135 (1913)

14 Geology of Lake Simcoe area, Ont: Beaverton, Sutton and Barrie sheets. Ca G S, Sum Rp 1912: 294-300 (1914)

$14 \mathrm{a}$ The calcareous drift and lacustris deposits in Rainy River distriet, Ont. Can G S, Sum Rp 1913:170-177 (1914)

15 Rainy River district, Ont.; surficil geology and soils. Can G S, Mem 82:12 pp, map (1915)

15a Lake Simcoe and Rainy River dis tricts, Ont. Can G S, Sum Rp 1914:81 (1915)

16 Sutton, Barrie, and Ottawa areas Ont. Can G S, Sum Rp 1915: 137-138 (1916)

16 a The Trent Valley outlet of Lake At gonquin and the deformation of the Algon quin water plane in Lake Simcoe district, Ont. Can G S, Mus B 23: 27 pp, ms; (1916)

16b Late Pleistocene oscillations of set level in the Ottawa Valley. Can G S, Mos B 24:14 pp (1916)

16e The genesis of Lake Agassiz; a cont firmation. J G 24:625-638 (1916)

17 Pleistocene and recent deposits in the vicinity of Ottawa, with a description of the solls. Can G S, Mem 101: $69 \mathrm{pp}$, mat? (1917)

17a Superficial deposits and soils of Whitemouth River area, southeastern Mat itoba. Can G S, Sum Rp 1916: 179 (1917) 
Johnston, William Alfred-Continued.

17b Records of Lake Agassiz, in southeastern Manitoba, and adjacent parts of Ontario, Canada (with discussion by Frank Leverett, Warren Upham, and J. B. Tyrrell). G Soc Am, B 28: 145-148 (1917)

18 Reconnaissance soil survey of the area along the Hudson Bay Railway. Can G S, Sum Rp 1917 pt D : 25-36 (1918)

18a Semirefractory clay and pure quartz sand of Swan River valley [Manitoba]. Can G S, Sum Rp 1917 pt D : 37-39 (1918) Johnston, William Caley.

13 (with MacDonald, D. F.) Isthmian earthquakes. Canal Record 7:144-449, maps (1913)

Johnston-Lavis, H. J.

96 The Highwood Mountains of Montana and magmatic differentiation; a criticism (abst). Brit As, Rp 66:792-793 (1896) Sclence n s $5: 526$ (1897)

Johnstrup, F.

78 Gieseckes mineralogiske Rejse i Grönland [includes chapter on the mineralogical geology of Greenland]. $372 \mathrm{pp}$, maps, Kjöbenhavn 1878

Joly, Henri.

01 Notice sur le Dr. Professor Charles Otliniel Marsh (29 octobre 1831-18 mars 1899). Soc d'Etud Sc d'Angers, B n s $30: 114-117$ (1901)

Joly, John.

01 An estimate of the geological age of the earth. Smiths Inst, An Rp 1899: 247-288 (1901)

08 Uranium and geology. Nature 78 : 456-466 (1908) Science $\mathrm{n}$ s $28: 697-713$, 737-743 (1908) Sc Am Sup 66:318, 358359 (1908) Smiths Inst, An Rp 1908 : $355-384$ (1909)

09 Radioactivity and ceology; an account of the influence of radioactive energy on terrestrial history. $287 \mathrm{pp}, \mathrm{N}$ Y (1909)

Jonas, Anna I.

05 Serpentine in the neighborhood of Philadelphia. Am G $36: 296-304$ (1905)

14 (with Bliss, E. F.) Relation of the Wissahickon mica gneiss to the Shenandoah imestone and to the Octoraro mica schist, of the Doe Run-Avondale district, Coatesville quadrangle, $\mathrm{Pa}$. Dissertation ... Bryn Mawr College. 64 pp, maps (1914) [?Priv pub]

16 (with Bliss, E. F.) Relation of the Wissahickon mica gneiss to the Shenandoah limestone and Octoraro schist of the Doe Run and Avondale region, Chester Co., $\mathrm{Pa}$. U S G S, P P 98: 9-34, maps (1916),

17 Pre-Cambrian and Triassic diabase in eastern Pennsylvania. Am Mus N H, B 37:173-181, map (1917) Abst, N Y Ac Sc, An $27: 297-298$ (1917)

Jones, Alexander.

34 Bituminous coal [in Alabama]. Am $J$ Se $26: 190-191$ (1834)
Jones, Alfred W.

9s The Mentor beds [Kansas]. Kans Ac Se, Tr 15: 111-112 (1898)

99 New developments the Mentor beds [Kans.]. Kans $A c$ sc, $\operatorname{Tr} 16: 65-66$ (1899)

o3 Further studies in the Mentor beds [Kansas]. Kans Ac Sc, Tr 18:104-105 (1903)

05 The fauna of the Mentor [formation, Kansas]. Kans Ac Sc, Tr 19:122 (1905) Jones, Arthur J.

93 St. Louis limestone in Poweshiek Co., Iowa, Science 22:307 (1893)

94 Coal Measures of Poweshiek Co. [Iowa]. Iowa Ac Sc, $\operatorname{Pr} 1$ pt $4: 59-60$ (1894)

94a Cardiocarpus in Iowa, Iowa Ac Sc, $\operatorname{Pr} 1$ pt $4: 61$ (1894)

95 Record of the Grinnell deep boring [Iowa]. Iowa Ac Sc, Pr 2: 31-35 (1895)

95a Topaz crystals of Thomas Mountain, Utah. Iowa Ac Sc, Pr $2: 175-177$ (1895)

Jones, Charles Colcock.

o7 Phosphate rock in Utah, Idaho, and Wyoming. Eng M J 83 : 953-955 (1907)

09 An iron deposit in the California desert region. Eng M J $87: 785-788$ (1909)

09a Notes on Manhattan placers, Nye Co. Nev. Eng M J 88: 101-104 (1909)

io Iron ores of the Southwest. Am M Cong, 13th An Sess, Pr: 265-273 (1910)

13 The discovery and opening of a new phosphate field in the United States [northeastern Utah, southeastern Idaho, and western Wyoming]. Am I M Eng, B $82: 2411-2435 \quad$ (1913); Tr $47: 192-216$ (1914)

Jones, Clemens Catesby.

00 A geologic and economic survey of the clay deposits of the lower Hudson River valley. Am I M Eng, Tr 29:40-83, maps (1900)

Jones, Daniel.

85 An account of West River Mountain ... [Chester Co., N. H.]. Am Ac Arts, Mem 1:312-315 (1785)

Jones, Edward Leroy, jr.

14 (with Richardson, C. H.) The geology and mineralogy of Hardwick and Woodbury, Vt. Vt St G, Rp 9:294-336, maps (1914)

16 The physiography of Greensboro. Hardwick, and Woodbury, Vt. Vt St G, Rp $10: 74-100$ (1916)

Jones, Edward Leroy, jr.

14 (with Calkins, F. C.) Economic geology of the region around Mullan, Idaho, and Saltese, Mont. U S G S, B 540:167211, map (1914)

15 Gold deposits near Quartzsite, Ariz. U S G S, B 620:45-57, map (1915)

15a A reconnaissance in the Kofa Mts., Ariz. U S G S, B $620: 151-164$, map (1915)

$$
28737^{\circ}-23-37
$$


Jones, Edward Leroy, jr.-Continued.

16 Reconnaissance of the Conconully and Ruby mining districts, Wash. U S G S, B 640:11-36, map (1916) Abst, by R. W. S., Wash Ac Sc, J $7: 37-38$ (1917)

16a Lode mining in the Quartzburg and Grimes Pass belt, Boise Basin, Idaho. U S G S, B 640:83-111, map (1916) Abst, Wash Ac Se, J $7: 15$ (1917)

18 Manganese in the Colorado River desert region. M Sc Press 117:755-758 (1918)

Jones, F. O.

02 The formation and geology of the salt deposits. Sc Am 87:59 (1902)

o7 Glacial rock sliding [near Elmira, N. Y.]. J G 15:485-487 (1997)

Jones, Fayette Alexander.

04 New Mexico mines and minerals... 349 pp, Santa Fe, N. M., 1904

o5 Gold and silver; New Mexico. U S G S, Min Res 1904: 200-203 (1905)

06 Placers of Santa Fe Co., N. Mex. M World 25:425 (1906)

o7 The Lordsburg mining region, N. Mex. Fing M J 84:444-445 (1907)

os Epitome of the economic geology of New Mexico. $47 \mathrm{pp}$. Published by direction of the New Mexico Bureau of Immigration, 1908

O8a Sylvanite, N. Mex., the new gold camp. Eng M J 86:1101-1103 (1908)

OSb The new camp of Sylvanite, N. Mex. M Science 58:489-490 (1908)

o9 History and mining of turquoise in the Southwest. M World 31:1251-1252 (1909)

10 The Jones expedition to Tiburon Island, Mex. M World 32:269-270 (1910)

15 The mineral resources of New Mexico. N Mex Sch Mines, Min Res S, B 1:77 pp, $\operatorname{map}(1915)$

Jones, Grove B.

15 (and Hosler, R. S.) Soil survey of Elkhart Co., Ind. Ind $D p$ G, An $R p$ 39: 115-144, map (1915)

17 (and Brill, J. B.) Soil survey of Benton Co., Ind. Ind, Dp G Nat Res, An Rp 41.28-44, map (1917)

Jones, H. L.

87 (with 'right, W. G.) Geology and lithology of Michipicoten Bay. Denison Univ, Sc Lab, B 2:119-143 (1887) Abst, Am Nat 21:654-655 (1887)

Jones, Howard Grant.

81 Notes on the Cumberland or Potomac coal basin. Am Ph Soc, Pr 19:11-116 (1881)

Jones, J. Claude.

os Drainage about Springfield. Ill St G S, B $8: 68-71$ (1908)

12 The occurrence of stibnite at steamboat Springs, Nev. Science n s $35: 775-$ 776 (1912)

12a The origin of the anhydrite at the Ludwig mine, Lyon Co., Nev. (discussion). Ec G $7: 400-402$ (1912)
Jones, J. Claude-Continued.

13 The Barth iron ore deposit [Ner.] Ec G $8: 247-263$ (1913) Abst, G Soc Am. B 24: 96-97 (1913)

13a Geology of Rochester, Nev. M Sc Press 106: 737-738, map (1913)

13b Origin of travertine or tufa deposits of Salton Sink [Cal.] (abst). Carnegie Inst Wash, Y Bk 12: 60-61 (1913)

14 The tufa deposits of the Salton Sink. Carnegie Inst Wash, Pub 193 (MacDougal, The Salton Sea) : 79-83 (1914)

$14 \mathbf{a}$ The geologic history of Lake La. hontan [Nev.]. Science n s 40:827-830 (1914)

14b Occurrence of stibnite and metastib. nite at Steamboat Springs, Nev, (abst). G Soc Am, B 25: 126 (1914)

15 The Pleasant Valley, Nev., earthquake of October 2, 1915. Seism Soc Am, B 5: 190-205 (1915)

15a Origin of the tufas of Lake Labon. $\tan$ [Nev.] (abst). G Soc Am, B $26: 392$ (1915)

18 Note on the occurrence of a mamma lian jaw, presumably from the Trucke beds of western Nevada (abst). G Soc Am. B $29: 161$ (1918)

\section{Jones, John Matthew.}

66 On the geological features of the Ber. mudas. N S Inst N Sc, Pr Tr 1 pt 4:1826 (1866)

72 Recent observations in the Bermu das. Nature 6:262 (1872) Am J Sc (3) $4: 414-416$ (1872)

Jones, J. T.

93 (with winchell, H. V.) The Biwabik mine [Minn.]. Am I M Eng, Tr $21: 951-961$ (1893)

Jones, James $O$.

03 On the effect of the recent seismic disturbances in Guatemala, Costa Rica, and Nicaragua upon the level of the waters in Lakes Nicaragua and Managua, U S, 57 th Cong 2d sess, Sen Doc no 131:33 pp (1903) Jones, Joseph.

76 Notes on the resources of Louisiana. In Dennett, Daniel, Louisiana as it is... 190-200, New Orleans 1876

Jones, Lee $\mathrm{H}$.

98 The upper limit of the Knobstone in the region of Borden [Ind.]. Ind $\mathrm{Ac} \mathrm{Sc}$, Pr $1897: 257-258$, map (1898)

Jones, N. F.

S1 (and Lesley, J. P., and Ashburner, C. A,) Drillings for coal in Sergeant township, McKean Co. $\mathrm{Pa} G \mathrm{G}$ 2d, R Appendix A: $35 \mathrm{pp}$ (1881); RR $327-362$ (1885)

\section{Jones, Olive Mary.}

14 Bibliography of Colorado geology and mining, with subject index, from the earli. est explorations to 1912 . Colo G S, B 7: $493 \mathrm{pp}$ (1914) 
Jones, Paul M.

92 Geology of Nashville and vicinity. 58 pp, map, Nashville 1892 Thesis, Vanderbilt University

Jones, Robert W.

16 Albany slip clay [N. Y.]. Am Ceramic Soc, $\operatorname{Tr} 18: 242-262$ (1916)

$16 a$ Graphite industry in New York. Eng M J 102: 773-775 (1916)

is The manganese deposits of South Wallingford, vt. Eng M J 105:779 (1918)

Jones, S. C.

10 Abstract from preliminary report of the soil survey [of Kentucky]. Ky G S, Rp Progress 1908-09:22-35 (1910)

12 Soils of the Hartford quadrangle. Ky G S, B 20:26-33 (1912)

13 Soil surveys. Ky G S (4) 1:10671156 (1913)

Jones, S. Percy.

01 The geology of the Tallulah gorge, Ga. Am G 27:67-75. map (1901)

09 Second report on the gold deposits of Georgia. Ga G S, B $19: 283$ pp, maps (1909)

11 (with Kiimmel, H. B.) The mineral industry of New Jersey for 1910. N J G S, B 5:24 pp (1911)

Jones, Thomas Rupert (1819-1911).

58 On the Paleozoic bivalve Entomostraca of Canada. Can G S, Can Organic Remains, decade $3: 91-102$, il (1858)

58a Notes on the Beyrichiae and Leperditiae of Pennsylvania. G Pa [Rogers] $2: 834$, il (1858)

58b Notes on Paleozoic bivalved Entomostraca; No. 4, Some North American species. An Mag N H (3) 1:241-257, il (1858)

58e On some additional Paleozoic bivalved Entomostraca from Canada. An Mag N H (3) $1: 340-342$ (1858)

63 On fossil Estheriae and their distribution. G Soc London, Q J 19:140157 (1863)

64 The relationship of certain West Indian and Maltese strata, as shown by some Orbitoides and other Foraminifera. G Mag 1:102-106 (1864)

65 On the oldest known fossil, Eozoon canadense of the Laurentian rocks of Canada; its place, structure, and significance. Pop Sc Rv $4: 343-352$, il (1865)

66 Note on the Orbitoides and Nummulinae of the Tertiary asphaltic bed, Trinidad. G Soc London, Q J 22:592-593 (1866)

70 Note on some Entomostraca from Arisaig [N. S.]. G Soc London, Q J 26: 492 (1870)

75 Manual of the natural history, geology, and physics of Greenland and the neighboring regions... 783 pp, maps, L
Jones, Thomas Rupert-Continued.

76 (and Parker, W. K.) Notice sur les foraminifères vivants et fossiles de la Jamaique [W. I.]. Soc Malac Belgique, An 11:91-103, il (1876)

84 (and Kirkby, J. W.) On some Carboniferous Entomostraca from Nova Scotia. G Mag (3) $1: 356-362$, il (1884)

84a Some North American Leperditiae and allied forms. An Mag $\mathrm{N} H$ (5) 14 : 339-347 (1884)

86 On some fossil Ostracoda from Colorado. G Mag (3) $3: 145-148$, il (1886)

89 On some Paleozoic Ostracoda from Pennsylvania. Am G $4: 337-342$, il (1889)

S9a Notes on the Paleozoic bivalved Entomostraca; on some North American (Canadian) species. An Mag $\mathrm{N}$ H (6) $3: 373-387$, il (1889)

S9b (and Firkby, J. W.) On some Ostracoda from the Mabou coal field, Inverness Co., Cape Breton (Nova Scotia). G Mag (3) 6:269-271, il (1889)

90 On some Paleozoic Ostracoda from North America, Wales, and Ireland. G Soc London, Q J 46:1-31, il (1890) Abst, G Mag (3) 6:576 (1889)

$90 a$ On some Devonian and Silurian Ostracoda from North America, France, and the Bosphorus. G Soc London, Q J 46: $534-556$, il (1890)

- 91 On some Ostracoda from the CambroSilurian, Silurian and Devonian rocks. Can G S, Contr Can Micro-Pal pt 3:5999 , il (1891)

98 On some fossil Ostracoda from southwestern Wyoming and from Utah, D. S. A. G Mag (3) $10: 385-381$, 11 (1893)

95 On some fossil Ostracoda from Canada. G Mag (4) $2: 20-28$, il (1895)

98 On some Triassic (?) Estheriae from the red beds or Cimarron series of Kansas. G Mag (4) $5: 291-293$, il (1898)

99 (and Woodward, H.) Contributions to fossil Crustacea. G Mag (4) 6 : $388-395$, il (1899)

02 Notes on Dr. G. F. Matthew's Cambrian Ostracoda from northeastern America. G Mag (4) 9:401-403, il (1902)

03 On some Isochilinae from Canada and elsewhere in North America. G Mag (4) $10: 300-304$, il (1903)

04 Note on a Paleozoic Cypridina from Canada. G Mag (5) 1:438-439, il (1904)

o5 Some Paleozoic ostracods from Maryland. Johns Hopkins Univ Circ n s 1905 no $3: 30-33$ [222-225] il (1905)

See also Moore $(\mathrm{J} C), 63$

Jones, William A.

72 Report of a survey and exploration in the Uinta Mountains, Utah. U S [War Dp], Chief Eng, An Rp 1872 (U S, 42d Cong 3d sess, H Ex Doc 1 pt 2 v 2) : 1108-1118 (1872) 
Jones, William A.-Continued.

74 Report upon the reconnaissance of northwestern Wyoming made in the summer of 1873. U S, 43d Cong 1st sess, H Ex Doc $285: 210$ pp, maps (1874)

Jones, William F.

11 The geology of the Sargent oil field. Cal Univ, Dp G, B 6:55-78, map (1911)

14 Coal-bearing Eocene of western Washington; Pierce Co. (abst). G Soc Am, B $25: 121-122$ (1914)

18 A geological reconnaissance in Haiti ; a contribution to Antillean geology. J G 26: 728-752 (1918)

18a Discussion of paper by A. W. Lauer, "The petrology of reservoir rocks and its influence on the accumulation of petroleum." Ec G 13:147-149 (1918)

18b Intrusive origin of the Gulf coast salt domes; its bearing on the accumulation of oil (discussion). Ec G 13:621-622 (1918)

Joplins, James E.

98 The Marquette Range [Mich.]; its discovery, development, and resources. Am I M Eng, $\operatorname{Tr} 27: 541-555$ (1898)

Joralemon, Ira B.

72 Geology applied to mine examination. Eng M J 94: 247-249 (1912)

14 The Ajo copper mining district [Ariz.]. Am I M Eng, B $92: 2011-2028$, map (1914); $\operatorname{Tr} 49: 593-609, \operatorname{map}$ (1915) Eng M J 98 : 663-665, map (1914)

See also Bonillas, 16.

Jordan, David Starr.

97 Richard Owen. Pop Sc Mo 51:259265, port (1897)

06 The earthquake rift of 1906 [San Francisco earthquake] Pop Sc Mo 69: 289-309 (1906)

O6a (and Clark, G. A.) The Bogoslofs. Pop Se Mo $69: 481-489$ (1906)

o7 The fossil fishes of California; with supplementary notes on other species of extinct fishes. Cal Univ, Dp G, B 5:95144 (1907)

07a The California earthquake of 1906. 371 pp, San Francisco (1907)

os Note on a fossil stickleback fish from Nevada. Smiths Misc Col 52 (Q Is 5) : 117 (1908)

10 Description of a collection of fossil fishes from the bituminous shales at Riacho Doce, State of Alagôas, Brazil. [Includes Diplomystus dentatus Cope from the Eocene (Green River shales), at Fossil Station, Wyo.]. Carnegie Mus, An 7:23-34, il (1910)

13 (and Beal, C. H.) Supplementary notes on fossil sharks. Cal Univ, Dp G, B $7:$ 243-256 (1913)

Jordan, E. T. J.

92 The gas area [of Indiana]. Ind, Dp

G N Res, An Rp 17:328-364 (1892)

94 Report of the State supervisor of natural gas. Ind, Dp G N Res, An Rp 18: 196-218 (1894)
Joseph, M. H.

98 The Republic mine, Washington. Eng M J 66:545-546 (1898)

06 Tungsten ore in Washington. Eng M J $81: 409$ (1906)

Joseph, Phineas Eleasor.

15 Manganese. Ariz St Bur Mines, B 4: 11 pp (1915)

15a Molybdenum. Ariz St Bur Mines, B $5: 9 \mathrm{pp}$ (1915)

15b Asbestos. Ariz St Bur Mines, B 8: $8 \mathrm{pp}(1915)$

16 Mercury-quicksilver. Ariz St Bur Mines, B $12: 8$ pp (1916)

16a Vanadium. Ariz St Bur Mines, B $18: 10 \mathrm{pp} \mathrm{(1916)}$

16b Zinc. Ariz St Bur Mines, B 20:12 pp, (1916)

16e Antimony. Ariz, Univ, Bur Mines, B $22: 8 \mathrm{pp}$ (1916)

16a Copper. Ariz, Univ, Bur Mines, B $37: 14 \mathrm{pp} \mathrm{(1916)}$

16e Iron. Ariz, Univ, Bur Mines, B 43 : $13 \mathrm{pp}$ (1916)

16 Lead. Ariz, Univ, Bur Mines, B 45 $12 \mathrm{pp} \mathrm{(1916)}$

17 Miscellaneous minerals. Ariz, Univ, Bur Mines, B 49:6 pp (1917)

Joukowsky, E.

06 Sur quelques aflleurements nouveatr de roches tertiaires dans l'Isthme de Panama. Soc Phys Genève, Mém 35:155-178, il $(1906)$

Journal of Geology; a semiquarterly magazine of geology and related sciences. Vol. 1, 1893- Chicago, Ill. Editors, T. C. Chamberlin and others.

17 Symposium on the age and relations of the fossil human remains found at Vero, Fla.; Editorial note. J G 25: 1-3 (1917) Joy, Charles A.

65 Examination of a few American minerals, Lye $\mathrm{N} H \mathrm{H} \mathrm{Y}$, An $8: 120-125$ (1865)

Joyce, W. E.

o7 New supplies of anthracite coal [Pennsylvania]. Eng M J $84: 216-217$ (1907)

Juday, Chancey.

14 (with Birge, E. A.) The inland lakes of Wisconsin. Wis G S, B 27:137 pp, maps (1914)

Judd, Edward K.

o6 The Virgilina [Va.] copper belt. Eng M J $82: 1005-1008$ (1906)

o7 Soft iron ore in Tennessee. Eng II J $83: 567$ (1907)

o7a The bauxite industry in the South. Eng M J 83 : 574-575 (1907)

ozb The barytes industry in the Sonth. Eng M J, 83:751-752 (1907)

o7c New development in coal fields of New Mexico. Eng M J 84:8-11 (1907) os An arsenic mine in Putnam Co.n N. Y. Eng M J 85: 306 (1908) 
Judd, Emerson W.

05 New coal developments in northern New Mexico. Eng M J 80: 300-301 (1905) Jndd, J. W.

99 (and Hidden, W. E.) On a new mode of occurrence of ruby in North Carolina. $\mathrm{Am} \mathrm{J} \mathrm{Sc} \mathrm{(4)} 8: 370-381$ (1899) Miner Mag 12: 139-149 (1899)

Judson, John N.

09 The Vermont Copper Company. Fng M J $88: 524-525$ (1909)

Jukes, Joseph Beete (1811-1869).

39 Report on the geology of Newfoundland. $29 \mathrm{pp}$ [St. Johns 1839] In part, Edinb N Ph J 29: 103-111 (1840)

40 Report of the progress of the geological survey [of Newfoundland] during 1840. 3 pp [1840]

42 Excursions in and about Newfoundland during the years 1839 and 1840 . 2 vols, $322,354 \mathrm{pp}$, L 1842

43 General report of the geological survey of Newfoundland... during the years 1839 and $1840.160 \mathrm{pp}, \mathrm{map}$, London 1843. Reprinted in Jukes, J. B., Excursíns in and about Newfoundland during the years 1839 and $1840,2: 195-354$, L 1842

Jukes-Browne, A. J.

89 (with Harrison, J. B.) Origin of the radiolarian earth of Barbados. Nature $39: 367$ (1889)

90 The date of the high continental elevation of America. G Mag (3) 7:561-562 (1890)

90a (with Harrison, J. B.) The geology of Barbadoes, being an explanation of the geological map of Barbados prepared by the same authors. 64 pp [Salisbury] 1890

90a (with Harrison, J. B.) The geolcal map of Barbados. Scale 3960 feet to 1 inch [1890?]

91 (and Harrison, J. B.) The geology of Barbados. G Soc London, Q J 47 : $197-243$ (1891) ; 48:170-226, map (1892) Abst, G Mag (3) $8: 139$ (1891) ; (3) 9: 88-89 (1892)

91a Elevation and subsidence in Central America. G Mag (3) 8:143 (1891)

95 (with Harrison, 'J. B.) Notes on the chemical composition of some oceanic deposits. G Soe London, $\Psi$ J $51: 313-328$ (1895) Alst, G Mag (4) 2: 186-187 (1895)

99 (with Harrison, J. B.) The oceanic deposits of Trinidad, British West Indies. G Soc London, Q J 55:177-189, map (1899)

02 (with Harrison, I. B.) The geology of Barbados. G Mag (4) 9:550-554 (1902)

Julien, Alexis Anastay (1849-1920).

65 On metabrushite, zengite, ornithite. and other minerals of the Key of Sombrero, W. I. Am J Sc (2) $40: 367-379$ (1865)
Julien, Alexis Anastay-Continued.

66 On the geology of the Key of Sombrero, W. I. Lyc $\mathrm{N} H \mathrm{~N}$, An 8:251278 (1866)

73 Lithology. Mich G S, Upper Peninsula $2: 1-197$ (1873)

73a (with Brooks, T. B.) Lithology [of the Upper Peninsula]. Mich G S 2: $199-212(1873)$

79 On spodumrene and its alterations, from the granite veins of Hampshire Co., Mass. N $Y$ Ac Sc, An $1: 318-328$ (1879)

$79 a$ On the fissure inclusions in the fibrolitic gneiss of New Rochelle, N. Y. Am Q Micro J 1: 103-115 (1879)

79b On the composition of the cymatolite from Goshen, Mass. Am J Sc (3) 17 : 398-399 (1879)

so Microscopic examination of eleven rocks from Ashland $\mathrm{Co}$., Wis. [Wis G S], G Wis $3: 224-238$ (1880)

soa on the geological action of the humus acids. Am As, Pr 28: $311-410$ (1880)

81 The excavation of the bed of the Kaaterskill, N. Y. (abst, with discussion by E. C. H. Day and J. S. Newberry). N Y Ac Se, Tr 1:24-31 (1881) Science (ed, Michels) $2: 571-573$ (1881)

s1a The volcanic tuffs of Challis, Idaho, and other western localities (abst, with discussion by J. S. Newberry). N Y Ac Sc, $\mathrm{Tr}$ 1:49-56 (1882) Science (ed, Michels) $2: 606-609$ (1881)

82 The genesis of the erystalline iron ores (abst) [with discussion by J. S Newberry]. N Y Ac Sc, $\operatorname{Tr} 2: 6-8$ (1882) Eng M J 35:207-208 (1883)

82a The so-called Leadville porphyry. Am Nat 16:925 (1882)

83 The genesis of the crystalline iron ores. Ac N Sc Phila, Pr 1882:335-346 (1883) Eng M J 37:81-83 (1884)

$83 a$ The dunite beds of North Carolina. Boston Soc N H, Pr 22 ; 141-149 (1883)

s3b On a form of graphite found at Ticonderoga, N. Y. (abst) [with discussion by J. S. Newberry]. N Y Ac Sc, Tr 2: 148-149 (1S83)

83e (with Bolton, H. C.) The singing beach of Manchester, Mass. (abst). Science 2:325 (1883) Am As, Pr 32:251252 (1884)

s3a (with Bolton, H. C.) Musical sand. Selence 2:713 (1883)

84 The durability of building stones in New York City and vicinity. U S, 10th Census 10, Report on Building Stones: $364-393$ (1884)

84a A study of "Eozoon canadense" (abst). Am As, Pr $33: 415-416$ (1885) Science $4: 327-328$ (1884)

84b (with Bolton, H. C.) Musical sand, its wide distribution and properties (abst). Am As, Pr 33:408-413 (1885) Science $4: 329$ (1884) 
Julien, Alexis Anastay-Continued.

85 Notes on the glaciation of the Shawangunk Mountain, N. Y. N Y Ac Sc, Tr $3: 22-29$ (1885)

s5a (and Bolton, H. C.) Notice on the microscopical examination of a series of ocean, lake, river, and desert sands (abst). Am As, Pr 33: 413-415 (1885)

86 On the variation of decomposition in the iron pyrites, its cause and its relation to density. N Y Ac Sc, An 3:365-404 (1886) ; $4: 125-224$ (1888)

$\mathbf{8 6 a}$ The microscopical structure of the iron pyrites. N Y Micro Soc, J 2:85-96 (1886)

87 On the geology at Great Barrington, Mass. N Y Ac Sc, Tr 7:21-39 (1887)

88 (and Bolton, H, C.) The true cause of sonorousness in sand. N Y Ac Sc, Tr $8: 9-11$ (1888)

95 The elements of strength and weakness in building stones (abst). Am G 21: 397-398 (1898) Science n \& 7:683 (1898)

99 Note on a feldspar from the Calumet copper mine, Keweenaw Point, Mich. (abst). Science n s 9:719 (1899)

oo Notes on a feldspar from the Calumet copper mine, Keweenaw Point, Mich. (abst). N Y Ac Sc, An 12:650-654 (1900)

Oon Metamorphosed dikes in the mica schists of Morningside Heights (discussion). Science n s 11: 110-111 (1900)

oob The geology of central Cape Cod (abst). Science n s 12:924-925 (1900) Am G 27:44 (1901)

ooe The genesis of the pegmatite fn North Carolina (abst). Am As, $\operatorname{Pr} 49: 189$ (1900) Science n \& 12:992 (1900)

o0d Notes on the origin of the pegmatites from Manhattan Island (abst). Science n s 12:1006-1007 (1900)

ooe (with Stevenson, J. J.) Oliver Payson Hubbard. Science n $\mathrm{s}$ 11:742743 (1900)

01 A study of the structure of fulgurites. J G $9: 673-693$ (1901)

o1a The geology of central Cape Cod [Mass.] (abst). N Y Ac Sc, An 13:501 (1901)

015 Notes on the origin of the pegmatites from Manhattan Island and from North Carolina (abst). N Y Ac Sc, An 13: 507-508 (1901)

02 Erosion by flying sand on the beaches of Cape Cod [Mass.] (abst). N Y Ac Sc, An 14:152-153 (1902) Science n s $15: 27-28$ (1902)

02a On pyrite and marcaste. Sclence n 8 15:870-872 (1902)

03 Genesis of the amphibole schists and serpentines of Manhattan Island, N. Y. G Soc Am, B 14:421-494, map (1903)

04 The hornblende schist of Spuyten Duyvil Creek, Manhattan Island (abst). N Y Ac Sc, An 15:181 (1904)
Julien, Alexis Anastay-Continued.

04a The occlusion of igneous rock within metamorphic schists (abst). Am ( $33: 268$ (1904) Science n s 19:581 (1904) N Y Ac Sc, An 16:315 (1905.

05 Determination of brucite as a rock constituent (abst), Am G 35:258-259 (1905) Science n s 21:511 (1905)

o6 The occlusion of igneous rock within metamorphic schists, as illustrated on and near Manhattan Island, N. Y. N Y dc Sc, An $16: 387-446$ (1906)

O6a Determination of brucite as a rock constituent (abst). G Soc Am, B 16:586 (1906) N Y Ac Sc, An 17:581-582 (1907)

$\mathbf{0 6 b}$ Notes on glaciation of Manhattan Island (abst). Science n \& 23:388 (1906) G Soc Am, B 17:708-709 (1907) N Y Ac Se, An 17:609 (1907)

07 Present structural character and probable former extent of the Palisade trap (abst). Science n s 25: 184 (1907)

07a Relations of physiography to struc ture at Manhattan Island and vicinity (abst). Science n s 25:762-763 (1907)

$\mathbf{0 7 b}$ Evidence of the stability of the rock foundations of New York City (abst). Science n s 25: 868 (1907) N Y Ac Sc, An $18: 328-329$ (1908)

o7e on the pebbles at Harwick (Cape Cod), Mass,, and on rude arrowheads found among them (abst). Science n s 26:831-832 (1907) N Y Ac Sc, An 18 343-344 (1908)

os On determination of mineral constitution through recasting of analyses. N Y Ac Sc, An 18:129-146 (1908) Abst, Seience n s 28:351 (1908)

OSa A study of the mineral constitution of the chloritic group termed delessite (abst). Science n s 27:623-624 (1908)

10 The moulin potholes within New York City (abst). N Y Ac Sc, An 19:308 (1910)

10a Petrographic notes on certain rocks from Staten Island (abst). N Y Ac Sc, An $19: 317$ (1910)

11 (with Humphreys, E. W.) Local decomposition of rock by the corrosive action of preglacial peat bogs. J G 19:4756 (1911)

13 Alteration processes and products within the Grenville limestone (abst). G Soc Am, B 24: 717-718 (1913)

14 The genesis of antigorite and talc. $\mathrm{N}$ Y Ac Sc, An 24:23-38, 367 (abst) (1914)

See also Britton (N L), 82 ; Cleve, 81 ; Kemp, 01e; Newberry, 82c

Jumeau, L. P.

o5 Le phosphate de chaux (gisements connus) et les exploitations aux Etats-Unis en 1905.198 pp, map, Paris 1905

Justice, George M.

49 Gold from Montgomery Co., Ma. Am Ph Soc, Pr 5:84-85 (1849) 
Kaemmerer, Paul.

13 Versuch zu einer neuen Deutung der Struktur des Meteoreisens von Carthage (Tenn.). Centralbl Miner 1913: 17-25

13a Weitere Studien über die Struktur des Meteoreisens von Carthage (Tenn.). Centralbl Miner 1913 : 261-269

Kain, C. Henry.

92 (with Woolman, Lewis) Freshwater diatomaceous deposit from Staked Plains, Texas. Am Nat 26:505-506 (1892)

97 (with Schultze, E. A.) The Santa Monica [Cal.] diatomaceous deposit with list of references to figures of species. Torrey Bot Club, B 24 : 496-504 (1897)

Kain, John Henry (?-1849).

18 ... mineralogy and geology of the northwestern part of the State of Virginia and eastern part of the State of Tennessee. Am J Sc 1:60-67 (1818)

45 On the prairies of Alabama (abst). As Am G, Pr 6:68 (1845)

Kain, Samuel W,

95 Bibliography of scientific publications relating to the Province of New Brun3wick ... N H Soc N B, B [3] no 13:96-100 $(1895)$; no $14: 56-57$ (1896); no $15:$ \&3 (1897); no $16: 75-76$ (1898)

98 List of recorded earthquakes in New Brunswick. N H Soc N B, B no 16 (4 pt 1) : 16-22 (1898)

99a (with Matthew, G. F.) On urtesian and fissure wells in New Brunswick. N H Soc N B, B no 17 (4 pt 2):143-152 (1899)

04 Recent earthquakes in New Brunswick. N H Soc N B, B no 22 (5 pt 2) : 243-245 (1904)

Kalm, Peter.

53 En resa til Norra America. 3 vols, Stockholm 1753-1761 Also English, German, and French translations

70 Travels into North America [fossils at Fort St. Frederic or Crown Point 3: 21-24]. (TransI by John Reinhold Foster) Vol 1, Warrington 1770, vols 2, 3, map, L 1771

Kamm, R, M.

17 (with Clarke, F. W.) New analyses of echinoderms. Nat Ac Sc, Pr 3:401404 (1917)

Karpinskii, Aleksandr Petrovich.

09 [Trochiliscans from the State of Ohio.] Russ $K$ Min Ges St Petersburg, Verh (2) $47: 24-28$, il (1909) [in Russian ]

09n [On problematic organisms from the Carboniferous of Washington Co., Obio.] Russ K Min Ges St Petersburg, Verh (2) $47: 28-31$, il (1909) [in Russian]

Katz, Frank James.

09 (with Prindle, L. M.) The Fairbanks gold placer region, Alaska. U S G S, B 379:181-200 (1909)

10 Gold placers of the Mulchatna, Alaska. U S G S, B 442: 201-202 (1910)
Katz, Frank James-Continued.

10a (with Martin, G. C.) Outline of the geology and mineral resources of the Iliamna and Clark lakes region. U S G S, B 442:179-200 (1910)

11 A reconnaissance of the Willow Creek gold region [Alaska]. U S G S, B 480 : 139-152, map (1911)

12 (with Martin, G. C.) A geologic reconnaissance of the Iliamma region, Alaska. U S G S, B 485:138 pp (1912) Abst, Wash Ac Sc, J $2: 224-225$ (1912)

12a (with Martin, G. C.) Geology and coal fields of the lower Matanuska Valley, Alaska. U S G S, B 500:98 pp (1912) Abst, Wash Ac Sc, J 2:225-226 (1912)

13 Preliminary report on the geology of the Portland and Casco Bay quadrangle. Maine, St Water Storage Comm, An Rp 3: 170-184 (1913)

13a Clay in the Portland region, Maine. U S G S, B 530:202-206, map (1913)

13b Abrasive materials. U S G S, Min Res 1912 pt $2: 819-831 ; 1913$ pt $2: 253-$ $272 ; 1914$ pt $2: 549-568 ; 1915$ pt $2: 65-$ $80 ; 1916$ pt $2: 197-212 ; 1917$ pt $2: 213-$ $232(1913-8)$

13e Feldspar. U S G S, Min Res 1912 pt $2: 1007-1011 ; 1913$ pt $2: 145-151 ; 1914$ pt $2: 449-454 ; 1915$ pt $2: 43-53 ; 1916$ pt $2: 173-184 ; 1917$ pt $2: 139-144$ $(1913-8)$

$13 d$ Silica (quartz). U S G S, Min Res 1912 pt $2: 1012-1015 ; 1913$ pt $2: 175-$ $180: 1914$ pt $2: 443-448 ; 1915$ pt $2: 55-$ $60 ; 1916$ pt $2: 283-287 ; 1917$ pt $2: 207-$ $211(1913-8)$

14 (with Paige, S.) Recent literature on economic geology. Ec G $9: 494-502$, 690-701 (1914)

16 Note on a moraine in northwestern New England. Science, n s 44:102 (1916)

17 (and Keith, A.) The Newington moraine, Me., N. H., and Mass. U S G S, P P 108: 11-29, maps (1917) Abst, Wash Ac Sc, J $7: 515-516$ (1917)

17a Stratigraphy in southwestern Maine and southeastern New Hampshire. U S G S, P P 108:165-177, maps (1917) Abst, Wash Ac Sc, J 7:19\$-199 (1917)

18 Late Pleistocene shore line in Maine and New Hampshire $(a b s t)$. G Soc Am, B 29:74 (1918)

18a Pleistocene shore lines in Maine and New Hampshire (abst). Wash Ac Sc, J $8: 410$ (1918)

18b (with Hewett, D. F., and others) Possibilities for manganese ore on certain undeveloped tracts in Shenandoah Valley, Pa. U S G S, B $660: 271-296$, maps (1918) Abst, by R. W. Stone, Wash Ac Sc, J 8:450 (1918)

\section{Kavanagh, -}

89 On modern concretions from the St. Lawrence; with remarks [by J. W. Dawson 1 on cylinders found in the Potsdam sandstone. Can Rec Sc 3:292-294 (1889) 
Kay, Fred Hall.

12 The Carlinville oil and gas fleld. III G S, B 20:81-95, map (1915) ; extract: $39-50, \operatorname{map}(1912)$

15 Coal resources of District VII (Coal No, 6 west of Duquoin anticline) [Illinois]. IIl Coal M Investigations, B 11:233 pp, map (1915)

15a (and White, K. D.) Coal resources of District VIII (Danville) [I11.]. Ill Coal M Investigations, B 14:68 pp, maps (1915)

15b (with Morse, W. C.) The area south of the Colmar oil field [111.]. III G S, B 31:7-35 (1915)

15e (with Morse, W. C.) The Colmar oil field [H1l.]-a restudy. IIl $G$ S, B 31: 37-55, map (1915)

16 Petroleum in Illinois in 1914 and 1915. Ill G S, B $33: 71-90$ (1916)

$16 n$ Notes on Bremen anticline, Randolph Co. Ill G S, B 33:101-103 (1916)

17 Oil flelds of Illinois. G Soe Am, B $28: 655-666$ (1917)

17a Petroleum in Illinois in 1916. Ill G S, B $35: 11-18$ (1917)

Kay, George Frederick.

04 The Abitibi region. Ont Bur Mines, Rp 1904: 104-121 (1904)

о7 Nickel deposits of Nickel Mountain, Oreg. U S G S, B 315: 120-127 (1907)

os Gold-quartz mines of the Riddles quadrangle, Oreg. U S G S, B 340: 134147 (1908)

08a Notes on copper prospects of the Riddles quadrangle, Oreg. U S G S, B 340 : 152 (1908)

09 (with Diller, J. S.) Mineral resources of the Grants Pass quadrangle and bordering districts, Oreg. U S G S, B 380 : 48-79 (1909)

11 Some features of the Bering River coal field, Alaska. Iow a Ac Sc, P 18 : 85-92, map (1911)

$11 a$ The Bering River coal field, Alaska. Pop Sc Mo 79:417-430 (1911)

11 b Samuel Calvin [1840-1911]. Science $n \oplus 8$ 34: 106-107 (1911) G Mag (5) $8: 478-479$ (1911)

11e Problems on the border lines between geology and the other sciences (abst). Science n s 34:29 (1911)

12 Nineteenth and twentieth annual reports of the State geologist. Iowa G S 21 : ix-xvi, map (1912)

13 The American Association for the Advancement of Science; Section E-Geology and geography. Science n s $37: 456-460$ (1913)

14 A new gypsum deposit ín Iowa. U S G S, B 580:59-64 (1914) Abst, Science n E $39: 404$ (1914)

$14 a$ American Association for the Adrancement of Science; Section E, Geology and reography. Science n s 39:398-405 (1914)
Kay, George Frederick-Continued.

14b Twenty-first annual report of the State geologist. Iowa G S 23 : xvil-xlviil, map (1914)

14e Twenty-second annual report of the State geologist. Iowa G S, An Rp 24: vilxvi, maps (1914)

14d Mineral production in Iowa in 1911 and 1912. Iowa $G \quad S, A n R_{p} 24: 1-32$ (1914)

14e Some evidence of recent progress in geology (abst). Iowa Ac Sc, Pr 21:169172 (1914)

16 The American Association for the Advancement of Science, Section E. Geology and geography [Columbus, Ohio, December, 1915]. Science n s $43: 395-400$ (1916)

$16 a$ Twenty-third annual report of the State geologist. Iowa G S, 25: $\mathrm{x}$-xxiii (1916)

16b Mineral production in Iowa for 1913 and 1914. Iowa G S 25:1-32 (1916)

16e A note regarding the present status of the Iowan drift problem. Iowa $\mathrm{Ac} \mathrm{Sc}$. Pr 23: 75-76 (1916)

16d Some features of the Kansan drift in southern Iowa (abst, with discussion by W. C. Alden, Frank Leverett, and C. E. Decker). G Soc Am, B 27: 115-119 (1916)

16e Some evidence regarding the duration of the Yarmouth interglacial epoch (abst). Science n s 43:398 (1916)

16f Gumbotil, a new term in Pleistocene geology. Science n s 44:637-638 (1916)

17 Administrative report; twenty-fourth annual report of the State geologist Iowa G S, 26:1-8 (1917)

17a Mineral production in Iowa for 1915. Iowa G S 26:11-18 (1917)

17b Pleistocene deposits between Manilla in Crawford Co. and Coon Rapids in Carroll Co., Iowa. Iowa G S 26:213-231 (1917) Abst, Iowa Ac Se, Pr 24:99-100 (1917)

17e Ocheyedan mound, Osceola Co., Iowa. Iowa Ac Sc, Pr 24:101-102 (1917)

17d A note regarding a slight earth. quake at Iowa City, Iowa, on April 9. 1917. Iowa Ac Sc, Pr 24: 103 (1917)

18 Pleistocene deposits between Mantla, in Crawford Co, and Coon Rapids, in Carroll Co., Iowa (abst, with discussion by Frank Leverett, J. L. Rich, and J. E. Todd). G Soc Am, B 29:77-79 (1918)

Keating, William Hypolitus (1799-1840).

22 Syllabus of lectures on mineralogy and chemistry. Phila 1822 [not seen]

22a Account of the jeffersonite, a new mineral... Ac N Sc Pbila, J 2:194-204 (1882) Edinb Ph J 7:317-323 (1822)

22b (with Vanuxem, L.) On the geology and mineralogy of Franklin, in Sussex Co., N. J. Ac N Sc Phila, J 2:277-288 (1822) 
Keating, William Hypolitus-Continued.

24 Narrative of an expedition to the source of St. Peter's River, Lake Winnepeek, Lake of the Woods, etc., etc., performed in the year $1823 \ldots$ Stephen $H$. Long... 2 vols, 439,459 pp, map, Phila 18242 vols, 458, 248, $156 \mathrm{pp}$, map, L 1825

24a (with Vanuxem, L.) Observations upon some of the minerals discovered at Franklin, Sussex Co., N. J. Ac N Sc Phila, J 4: 3-11 (1824)

Keck. Rudolf.

83 The genesis of ore deposits. Eng M J $35: 3-4$ (1883)

Kedzie, G. E.

88 The bedded ore deposits of Red Mountain mining district, Ouray Co. Colo. Am I M Eng, Tr 16:570-581, map (1888) Eng M J 46: 104-106 (1888)

Kedzie, William K.

75 The Nebraska hot bluff. Kans Ac Sc, $\operatorname{Tr} 4: 10-13$ (1875) ; reprint (1906) Kans St Bd Agr, An Rp 4:694-697 (1875)

77 The elements of agricultural geology for the schools of Kansas, 96 pp, Cincinnati 1877

77a The Iola, Kans., mineral well. Western Rv Sc 1:257-260 (1877) Kans Ac Sc, Tr 6 :58-61 (1878) ; reprint (1906) Keele, Joseph (1863-1923).

05 The Duncan Creek mining district, Stewart River, Yukon Terr. Can G S, Sum Rp 1904 (An Rp 16) : A 18-42, map (1905)

06 A reconnaissance survey on the Stewart River. Can G S, Sum Rp 1905: 32-36 (1906)

06n Report on the upper Stewart River region. Yukon. Can G S, An Rp 16: C 23 pp (1906)

09 Explorations on the Pelly, Ross, and Gravel rivers, in the Yukon and Northwest territories. Can G S Sum Rp 1908: 33-37 (1909) Abst, M S̀c Press 99:66 (1909)

10 A reconnaissance across the Mackenzie Mountains on the Pelly, Ross, and Gravel Rivers, Yukon and Northwest Territorles. Can G S: 54 pp, map (1910)

10n Clays and shales in the maritime provinces. Can G S, Sum Rp 1909: 245246 (1910)

11 Clay resources of the western provinces. Can G S, Sum Rp 1910: 181-182 (1911)

11a (with Ries, H.) The clay and shale deposits of Nova Scotia and portions of New Brunswick. Can G S, Mem 16: 164 pp (1911)

12 Notes on tests of clay samples. Can G S, Sum Rp 1911 : 233-234 (1912)

12a Report on progress of investigation of clay resources. Can G S, Sum Rp 1911 : 234-239 (1912)

12b Placer gold in Meule Creek, Seignlory of Rigaud-Vaudreuil, Que. Can G S, Sum Rp 1911: 303-308 (1912)
Keele, Joseph-Continued.

12e Clay and clay industries of Canada. Applied Sc n s $7: 39-49$ (1912)

12d (with Ries, H.) Preliminary report on the clay and shale deposits of the western provinces. Can G S, Mem 24: 231 pp (1912)

13 (and Johnston, W. A.) The superficial deposits near Ottawa. Int $\mathrm{G}$ Cong, XII, Canada, Guide Book no 3:126-135 (1913)

$13 a$ (with Ries, H.) Report on the clay and shale deposits of the western provinces, Canada; Part II. Can G S, Mem 25: 105 pp (1913)

14 Clay and shaie deposits of New Brunswick. Can G S, Mem 44 : viii, 94 pp, $\operatorname{map}$ (1914)

$14 a$ Investigation of clay resources of Quebec. Can G S, Sum Rp 1912:351-356 (1914)

$14 b$ Report on progress of investigation of clay resources. Can G $\mathrm{S}$, Sum $\mathrm{R}_{\mathrm{p}} 1913$ : 288-292 (1914)

15 Preliminary report on the clay and shale deposits of the Province of Quebec. Can G S, Mem 64: 280 pp (1915)

15a Clay and shale deposits of the western provinces (part V). Can G S, Mem $66: 74 \mathrm{pp} \mathrm{(1915)}$

15b Investigation of the clay resources of Ontario. Can G S, Sum Rp 1914:87 (1915)

17 Northern portions of Pontiac and Ottawa cos., Que. Can G S, Sum Rp 1916:219-227 (1917)

18 Investigation of clay and shale resources. Can, Dp Mines, Mines Br, Sum Rp $1917: 97-111$ (1918)

18a Kaolin in Quebec (with discussion by $\mathrm{H}$ Ries and R. R. Hice). Am Ceramic Soc, J $1: 8-14$ (1918)

Keeler, James Edward.

90 Earthquakes in California in 1889. U S G S, B 68: 25 pp (1890)

Keeley, Frank J.

14 Notes on some igneous rocks at Ogunquit, Maine, and Pigeon Cove, Mass. Ac N Se Phila, Pr 66:3 8 (1914)

Keene, Joseph W.

72 (with Whitman, A. C.) Notes on mineralogy... 136 pp, Lewiston [Me.] 1872

Keeney, J. C.

29 Novaculite in Georgia. Am J Sc 16 : $185(1829)$

Keеp, G. A.

10 (with Gans1, G. C.) The Ophir mining district of Utah. Salt Lake Min Rv 12 no $8: 17-20$ (1910)

Keеp, Josiah.

93 Recent observations at Kilauea. Science 21: 76 (1893)

Kefrer, Frederic.

07 Methods of mining in the Boundary district, B. C. Eng Mag 33:441-454 (1907) 
Kener, Frederic-Continued.

07a Copper-smelting practice in the Boundary district, B. C. Eng Mag 33: $715-727$ (1907)

07b The Emma mine [Boundary district, B. C.]. Eng M J 84:490-491 (1907) Can M $J \quad 28$ (n 8 s 1 no 15 ) : 463-465 (1907)

os Mining in the Boundary district of British Columbia. Inst M Eng, Tr 35 : $580-588$ (1908)

15 Notes on the geology and exploration of Copper Mountain in the Similkameen district of British Columbia. Can M Inst, B 35:154-163 (1915); Tr 18:192-201 (1916)

Keilhack, Konrad.

07 Ueber das Onyxvorkommen von Etla, Oaxaca. Int Geol Cong, X, Mexico, 1906 , C $\mathrm{R}: 759-762$ (1907)

Keith, Arthur.

91 (with Geiger, H. R.) The struc ture of the Blue Ridge near Harper's Ferry. G Soc Am, B 2:155-164 (1891)

92 Geology of the Chilhowee Mountain in Tennessee. Ph Soc Wash, B 12:71-88. map (1892)

92a The geologic structure of the Blue Ridge in Maryland and Virginia. Am G $10: 362-368$ (1892)

94 Description of the Harpers Ferry sheet [Va.-Md.-W. V.]. U S G S, G Atlas Harpers Ferry fol (no 10): 5 pp, maps (1894) Abst, J G 4:758-760 (1896)

$94 a$ Geology of the Catoctin belt. U S G S, An Rp 14 pt $2: 285-395$ (1894)

95 Description of the Knoxville sheet [Tenn.-N. C.]. U S G S, G Atlas Knox ville fol (no 16): 6 pp, maps (1895)

$95 a$ New structural features in the Appalachians (abst). Science $n$ s $1: 58$ (1895)

96 Description of the Loudon sheet [Tenn.]. U S G S, G Atlas Loudon fol (no 25) : $6 \mathrm{pp}$, maps (1896) Abst, J G 5:416-417 (1897)

$96 a$ Description of the Morristown sheet [Tenn.]. U S G S, G Atlas Morristown fol (no 27):5 pp. maps (1896) Abst, J G $5: 417-419$ (1897)

96b Description of the Briceville quad rangle [Tenn.]. U S G S, G Atlas Briceville fol (no 33) : $4 \mathrm{pp}$, maps (1896)

96e Some stages of Appalachian erosion. G Soc Am, B 7:519-525, map (1896) Abst, Am G 17:109 (1896)

96 d Crystalline groups of the southern Appalachians (abst). Science n s 3:215216 (1896)

96e on the structure of the Cranberry district $(a b s t)$. Science n s 4:926-927 (1896)

97 Description of the Wartburg quadrangle [Tenn.]. U S G S, G Atlas Wartburg fol (no 40): 4 pp, maps (1897)
Keith, Arthur-Continued.

$97 \mathbf{a}$ Notes on the structure of the Cras. berry district in North Carolina (abst). Seience n s 5:86 (1897)

o1 Description of the Maynardville quadrangle [Tenn.]. U S G S, G Atlas Maynardville fol (no 75):6 pp, maps (1901)

O1a (with Darton, N. H.) Desctiption of the Washington quadrangles [D. C. Md.-Va.]. U S G S, G Atlas Washington fol (no 70): 7 pp, maps (1901)

02 Topography and geology of the south. ern Appalachians. U S, 57th Cong 1st sess, S Doc 84: 111-123 (1902)

02a Folded faults in the southern Ap. palachians (abst). Science n s 15:822823 (1902)

03 Description of the Cranberry quad. rangle [N. C.-Tenn.]. U S G S, G Atlas Cranberry fol (no 90) : 9 pp, maps (1903)

o3a Iron ore deposits of the Cranberry district, N. C.-Tenn. U S G S, B $213: 243-$ 246 (1903)

o3b Tennessee marbles. U S G S, B $213: 366-370$ (1903)

o3e Tale deposits of North Carolina. U S G S, B 213: 433-438 (1903)

04 Description of the Asheville quad rangle [N. C.-Tenn.]. U S G S, G Atlas Ashevilie fol (no 116) ; 10 pp, maps (1904)

O4a Recent zinc mining in east Ten nessee. U S G S, B 225: 208-213 (1904)

O4b Folded faults of the southern Appa lachians. Int G Cong, IX, Vienna, 1903, C R : 541-545 (1904)

o5 Description of the Greeneville quad. rangle [Tenn.-N. C.]. U S G S, G Atlas Greeneville fol (no 118) : 8 pp, maps (1905)

O5a Description of the Mount Mitchell quadrangle [N. C.-Tenn.]. U S G S, G Atlas Mount Mitchell fol (no 124): $10 \mathrm{pp}$, maps (1905)

o5b Bingham mining district, Utah; areal geology. ᄂ S G S, P P 38:27-70, $\operatorname{map}(1905)$

or Description of the Nantahala quad. rangle [N. C.-Tenn.]. U S G S, G Atlas Nantahala fol (no 143):11 pp, maps (1907)

o7a Description of the Pisgah quad. rangle [N. C.-S. C.]. U S G S, G Atlas Pisgah fol (no 147): $8 \mathrm{pp}$, maps (1907)

$07 \mathrm{~b}$ Description of the Roan Mountain quadrangle [Tenn.-N. C.]. U S G S, G Atlas Roan Mountain fol (no 151) : 11 pp, maps (1907)

oze The Appalachian mountains and valleys $(a b s t)$. Science n s $25: 865-867$ (1907)

09 The status of geologic names (abst). Science n s $30: 974-975$ (1909)

12 New evidence on the Taconic question (abst). Science $\mathrm{n}$ s 35:310 (1912) G Soc Am, B 23: 720-721 (1912) 
Keith, Arthur-Continued.

13 Further discoveries in the Taconic Mountains (abst). G Soc Am, B 24:680 (1913)

13a Production of apparent diorite by metamorphism (abst). G Soc Am, B 24: 684-685 (1913)

14 A pre-Cambrian unconformity in Vermont (abst). G Soc Am, B 25:39-40 (1914)

16 Topography [of Massachusetts]. U S G S, W-S P 415: 8-23 (1916)

16a A new form of metamorphism (abst). Sclence n s 43:541 (1916)

17 (and sterrett, D. B.) Tin resources of the Kings Mountain district, N. C. and S. C. U S G S, B 660:123-146, map (1917) Abst, by R. W. Stone, Wash Ae Sc, J $8: 129$ (1918)

17a Pleistocene deformation near Rutland, Vt. (abst). G Soc Am, B 28:165 (1917)

17 b (with Katx, F. J.) The Newington moraine, Me., N. H., and Mass. U S G S, P P 108: 11-29, maps (1917) Abst, Wash Ac Sc, J $7: 515-516$ (1917)

See also Barrell, 12a ; Branson, 12 ; Darton, 98b; Emmons (W H), 17 ; Grabau, 12b; Powell, 95 ; Umpleby, 17 ; Vaughan, $15 \mathrm{c}$

Keith, N. S.

06 The copper deposits of New Jersey. M Mag 13: 468-475 (1906)

Keller, Herman A.

82 Titaniferous garnet [Darby, Delaware Co., Pa.]. Ac N Se Phila, Pr 1882: 54-55; Min G Sec, Pr no $2:$ 21-22 (1882)

os The Copper River district, Alaska. Eng M J 85 : 1273-1278 (1908)

Keller, Harry F.

89 Ueber Kobellit von Ouray, Colo., und uber die chemische Zusammensetzung dieser Species, Zs Kryst 17:67-72 (1889)

91 (and Lane, A. C.) Chloritoid von Champion, Mich., U. S. A. Zs Kryst 19 : 383-385 (1891)

91a (with Lane, A. C.) Notes on Michigan minerals. Am J Sc (3) $42: 499-508$ (1891)

Kellerman, Karl F.

14 (and $\mathrm{Smith}, \mathrm{N}, \mathrm{R}$.) Bacterial precipitation of calcium carbonate. Wash Ac Sc, J $4: 400-402$ (1914)

15 Relation of bacteria to deposition of calcium carbonate (abst). Science n s 41 : $507-508$ (1915) G Soc Am, B 26:58 (1915)

Kelley, Edward G.

41 ...geological features of the Island of Owyhee or Hawaii... Am J Sc 40:117122 (1841)

Kelley, Walter S.

06 What is a fissure vein? Ec G 1:484 (1906)

Kellogg, D. $\mathbf{8}$.

92 Glacial phenomena in northeastern New York. Science 19:341 (1892)
Kelloge, L. O.

06 Sketch of the geology and ore deposits of the Cochise mining district, Cochise Co., Ariz. Ec G 1:651-659 (1906)

13 Notes on the Cuyuna range, I. Eng M J $96: 1199-1203$ (1913)

Kellogg, Louise.

10 Rodent fauna of the late Tertiary beds at Virgin Valley and Thousand Creek, Nev. Cal Univ, Dp G, B 5 : 421-437, il (1910)

11 A fossil beaver from the Kettleman Hills, Cal. Cal Univ, Dp G, B 6:401-402 (1911)

12 Pleistocene rodents of California. Cal Univ, Dp G, B 7:151-168, il (1912)

Kellogs, Orson.

49 A remarkable geological development in Elizabethtown, Essex Co., N. Y. Am As, Pr 1: 135-138 (1849)

Kellogr, Remington.

18 Pinnipeds from Miocene and Pleistocene deposits of California (abst). G Soc Am, B 29:161 (1918)

Kelly, Clyde.

13 (and Anspach, E. V.) A preliminary study of the waters of the Jemez Plateau, N Mex. N Mex Univ, B, Chem s 1 no $1: 1-73$ (1913)

Kelly, D. S.

87 Coal Measures of Lyou Co. [Kans.]. Kans Ac Sc, Tr 10:45 (1887)

Kelly, William.

09 Discussion of paper by J. J. Rutledge on the Clinton iron-ore deposits of Stone Valley, Huntington Co., Pa. Am I M Eng, B 25:107-108 (1909); $\operatorname{Tr} 40: 854-855$ (1910)

See also Roesler, 16

Kelvin, Lord (William Thomson).

98 The age of the earth as an abode fitted for life. Smiths Inst, An Rp 189\%: 337-357 (1898) Science n s 9:655-674, 704-711 (1899)

Ki emmerling, G. L. L.

15 Geologische problemen in Yosemite National Park. Nederlandsch Natuur- en Geneeskundig Congres, XV, Amsterdam, 1915, Handl : $530-534$ (1915)

Kemp, Alex. F.

57 Notes on the Bermudas and their natural history. Can Nat 2:145-156 (1857)

60 ...Acton copper mines [Quebec]. Can Nat 5:349-362 (1860)

Kemp, James Furman.

87 The geology of Manhattan Island [N. Y.] N Y Ac Sc, Tr 7: 49-64 (1887)

87a Notes on the ore deposits and ore dressing in southeastern Missouri. Sch Mines Q 9:74-81 (1887)

87b [On fossil plants from near Worcester, Mass.] N $\mathrm{Y}$ Ac Sc, $\operatorname{Tr} 4: 75-76$ (1887)

88 A brief review of the literature on ore deposits. Sch Mines Q 10:54-60, $116-123,326-336 ; 11 ; 359-370 ; 12: 218$ $235 \quad(1888-91)$ 
Kemp, James Furman-Continued.

S\&a A diorite dike at Forest of Dean, Orange Co., N. Y. Am J Sc (3) 35:331332 (1888)

8Sb On the Rosetown extension of the Cortlondt series. Am J Sc (3) $36: 247$ 253, map, (1888)

88e The dikes of the Hudson River Highlands. Am Nat 22:691-698 (1888)

89 (and Maristers, V. F.) On certain camptonlte dikes near Whitehall, Washington Co., N. Y. Am G 4: 97-102 (1889)

89a Barite from Aspen, Colo. Am J Sc (3) $37: 236-237$ (1889)

89b On certain porphyrite bosses in northwestern New Jersey. Am J Sc (3) $38: 130-134$ (1889)

90 On tbe dikes near Kennebunkport, Maine. Am G 5:129-140 (1890) Abst, G Soc Am, B 1: 31-32 (1890)

$90 a$ Notes on a nepheline basalt from Pilot Knob, Tex. Am G 6:292-294 (1890)

$90 \mathrm{~b}$ Notes on the minerals occurring near Port Henry, N. Y. Am J Se (3) 40 : 62-64 (1890)

91 The basic dikes occurring outside of the syenite areas of Arkansas. Ark G S, An Rp 1890, 2:392-406 (1891)

91n (and Williams, J. F.) Tabulation of the dikes of igneous rocks of Arkansas. Ark G S, An Rp 1890, 2: 407-427 (1891)

91b (and Marsters, V. F.) The trap dikes in the Lake Champlain valley and the neighboring Adirondacks. N Y Ac Sc, $\operatorname{Tr} 11: 13-23$ (1891)

91e The filling of mineral veins. Sch Mines Q 13:20-28 (1891)

91d Peridotite dikes in the Portage sandstones near Ithaca, N. Y. Am J Sc (3) $42: 410-412$ (1891)

91e Gestreifte Magnetitkrystalle aus Mineville, Lake Champlain-Gebiet, Staat New York. Zs Kryst 19:183-187 (1891)

02 John Francis Williams. Am G 9: 149-153, port. (1892)

92a Memorial of John Francis Williams. G Soc Am, B 3:455-458 (1892)

92b The classifieation of ore deposits. Sch Mines Q 14: 8-24 (1892)

92c The great shear zone near Avalanche Lake in the Adirondacks. Am J Sc (3) 44:109-114 (1892)

92d The elæolite syenite near Beemerville, Sussex Co. N. J. N Y Ac Sc, Tr 11; 60-71 (1892) Abst, G Soc Am, B 3:8384 (1892)

92e Petrographical notes. N Y Ac Sc, Tr $11: 126-131$ (1892)

92f A review of the work hitherto done on the greology of the Adirondacks. N Y Ac Sc, Tr 12:19-24 (1892)

93 The ore deposits of the United States. $302 \mathrm{pp}, \mathrm{N}$ Y 1893 2d ed, $343 \mathrm{pp}, \mathrm{N}, \mathrm{Y}$ 18953 d ed, 481 pp, N Y 1900 5th ed, $481 \mathrm{pp}, \mathrm{N}$ Y 1903
Kemp, James Furman-Continued.

O:a Memorial of John Strong Newberry. G Soc Am, B 4:393-406, port (1893)

93b In memoriam; Professor John Strong Newherry. Sch Mines Q 14:93$111,251-252$, port (1893)

93e Bibliography of Professor J. S. New. berry. N Y Ac Sc, Tr 12:173-186 (1898) 93d (and Marsters, V. F.) The trap dikes of the Lake Champlain region. Us G S, B 107: 62 pp, map (1893)

93e A basic dike near Hamburg, Sussex Co., N. J., which has been thought to con. tain leucite. Am J Sc (3) $45: 298-305$, map (1893)

93f Notes on the lower Coal Measures of western Clearfield Co., Pa. Sch Mines Q $14: 349-353$ (1893)

938 On an occurrence of gabbro (no rite) near Van Artsclalen's quarry, Bucks Co., Pa. N Y Ac Sc, Tr 12:71-77 (1893)

O3h Some recently discovered trilobites with appendages. Seience 21:344-345 (1893)

94 Preliminary report on the geology of Essex Co. [N. Y.]. N Y St G, An Rp 13: 431-472, maps (1894) N Y St Mas, An $\mathrm{Rp} 47: 625-666$, maps (1894)

$94 a$ Gabbros on the western shore of Lake Champlain. G Soc Am, B $5: 213-$ 224 (1894) Abst, Am G 13:214-215 (1894)

9.1b (and Hollick, A.) The granite at Mounts Adam and Eve, Warwick, Or ange Co., N. Y., and its contact phe nomena. N Y Ac Sc, An 7:638-650 (1894)

94c The ore deposits at Franklin Fur nace and Ogdensburg, N. J. N Y Ac Sc Tr $13: 76-96(1894)$

$94 d$ An orbicular granite from Quonochontogue Beach, R. I. N Y Ac Sc, Tt 13:140-144 (1894)

94e Additional note on leucite in Sns sex Co., N. J. Am J Sc (3) $47: 339-340$ (1894)

94f The zine mines at Franklin Furnace and Ogdensburg, N. J. (abst). Am G 14: 202 (1894) Am As, Pr 43: 237 (1895)

94. The nickel mine at Lancaster Gap. $\mathrm{Pa}$, and the pyrrhotite deposit at Anthony's Nose, on the Hudson (abst). Soc Am, B 6:3 (1894) Am G 14:195 (1894)

95 The geology of Moriah and Westport townships, Essex Co., N. Y. N I St Mus, B 14:325-355, map (1895)

95 a Lecture notes on rocks. Sch Mines Q $17: 38-56,128-159,267-295,401-434$ (1895)

95b Crystalline limestones, ophicalcites, and associated schists of the eastern Adirondacks. G Soc Am, B $6: 241-262$, map (1895) Abst, Science n $\mathbf{s} 1: 63$ (1895) J G $3: 983$ (1895) 
Kemp, James Furman-Continued.

95e The nickel mine at Lancaster Gap, $\mathrm{Pa}$., and the pyrrhotite deposits at $\mathrm{An}$ thony's Nose, on the Hudson. Am I M Eng, Tr 24:620-633, 888 (1895) Abst, G Soc Am, B 6:3 (1894); Am G 14:195 (1894)

95d The Baltimore meeting of the Geological Society of America. Science n s 1: $57-68$ (1895)

95e Seventh summer meeting of the Geological Society of America. Science n s 2 : 277-283 (1895)

958 The The geological section of the East River, at Seventieth Street, New York. N Y Ac Sc, Tr 14: 273-276 (1895,

95 $\mathrm{g}$ The iron-ore bodies at Mineville, Essex Co., N. Y. $(a b s t)$. Science n s 1: $669-670$ (1895)

95h Titaniferous iron ores of the AdIrondacks (abst). G Soc Am, B 7:15 (1895) Am G 16:241-242 (1895) Science $n \mathrm{~s} 2: 281$ (1895) Ottawa Nat 9:153 (1895)

95i (with Darton, N. H.) A newly discovered dike at De Witt, near Syracuse, N. Y. Am J Sc (3) $49: 456-462$ (1895)

95j (with Darton, N. H.) A new intrusive rock near Syracuse (abst). G Soc Am, B 6:477-478 (1895) Seience n s 1: $65-66$ (1895)

96 A handbook of rocks for use without the microscope. $176 \mathrm{pp}, \mathrm{N}$ Y 1896 2d ed, $185 \mathrm{pp}, \mathrm{N}$ Y 1900 3d ed, $238 \mathrm{pp}, \mathrm{N}$ Y 1904 4th ed, 248 pp, N Y 1908 5th ed, 272 pp, N Y 1911

$96 a$ An outline of the views held today on the origin of ores. Mineral Industry 4: 755-766 (1896)

96b The Geological Society of America leighth annual meeting, Philadelphia, December, 1895]. Science n $\mathrm{s}, 3: 46-57$ (1896)

96c Illustrations of the dynamic metamorphism of anorthosites and related rocks in the Adirondacks (abst). G Soc Am, B $7: 488-489$ (1896) Am G $17: 92$ (1896) Science n s $3: 48 \quad(.896)$

96d (and White, T. G.) [Dikes in the Adirondack region $(a b s t)$.] Science $n$ s $3: 214$ (1896)

96e The great quartz vein at Lantern Hill, Mystic, Conn., and its decomposition (abst). N Y Ac Sc, Tr 15:189 (1896) Science n s $3: 818$ (1896) Am C: $18: 63$ (1896)

968 The pre-Cambrian topography of the Adirondacks (abst). N Y Ac Sc, Tr 15: $189-190$ (1896) Science n $s \quad 3: 818-819$ (1896) Am G 18:63-64 (1896)

$96 \mathrm{~g}$ Glacial or postglacial diversion of the Bronx River (abst). Science n s 4: 696 (1896)
Kemp, James Furman-Continued.

97 Preliminary report on the geology of Essex Co. [N. Y.]. N Y St G, An Rp 15: 22-23, 575-614, maps (1897) N Y St Mus, An Rp $49 \quad v \quad 2: 22-23,575-614$, maps (1898)

97 a The leucite hills of Wyoming. G Soc Am, B 8:169-182, map (1897) Abst, J G 5:100-101 (1897); Science n s 5:82 (1897)

97b Physiography of the eastern Adirondacks in the Cambrian and Ordovician periods. G Soc Am, B 8:408-412, map (1897) Abst, J G 5:101-102 (1897); Science n s $5: 92$ (1897)

97e The glacial or postglacial diversion of the Bronx River from its old channel. N Y Ac Sc, Tr 16:18-24, map (1897)

97 d Geological Society of America; ninth annual meeting Washington, December 2931, 1896. Science n s 5: 81-99 (1897)

$97 \mathrm{e}$ Notes on the geology of the trail from Red Rock to and beyond Leesburg, Idaho (abst). Science n s 5:891 (1897)

98 Geology of the Lake Placid region. N Y St Mus, B 21:49-67, map (1898)

98a The geology of the magnetites near Port Henry, N. Y., and especially those of Mineville. Am I M Eng, Tr 27:146203 map (1898) Abst, Zs prak G 1897 : $318-321$

98b Geological occurrence and associates of the telluride gold ores. Mineral Industry $6: 295-320$ (1898)

98c The Montreal meeting of the Geological Society of America. Seience n s $7: 48-53,79-85 \quad$ (1898)

98d Some remarks on titaniferous magnetites (abst). Am G 22:62 (1898) Science n s $7: 812$ (1898)

9Se Minerals of the copper mines at Ducktown, Tenn. (abst). Science n s 8 : 839-840 (1898)

99 (and Newland, D. H.) Preliminary report on the geology of Washington, Warren, and parts of Essex and Hamilton cos. [N. Y.]. N Y St G, An Rp 17:499-533, maps (1899) N $\mathrm{Y}$ St Mus, An Rp $51 \quad v$ $2: 499-533$ maps (1899)

99a (and Newland, D. H., and Hill, B. F.) Preliminary report on the geology of Hamilton, Warren, : a Washington cos. [N. Y.]. N Y St G, An Rp 18: 137-162, maps (1899) N $\mathrm{Y}$ St Mus, An $\mathrm{Rp} 52 v$ $2: 137-162$, maps (1900)

991. The titaniferous iron ores of the Adirondacks. U S G S, An Rp 19 pt 3: $377-422$, maps (1899)

99c Granites of southern Rhode Island and Connecticut, with observations on Atlantic coast granites in general. G Soc Am, B $10: 361-382$, map (1899) Abst, Am G 23:105-106 (1899); Science n s 9: 140-141 (1899) 
Kemp, James Furman-Continued.

99d Eleventh annual meeting of the Geological Society of America, December 2sth, 29 th, and 30 th, New York. Science n s $9: 100-106,138-145$ (1899)

99e A brief review of the titaniferous magnetites. Sch Mines Q 20:323-356; 21:56-65 (1899)

99 Metamorphosed basic dikes in the Manhattan schists, New York City (abst). Science n s 9:140 (1899) Am G 23:105 (1899)

00 Pre-Cambrian sediments in the Adirondacks. Am As, Pr 49:157-184 (1900) Science n s 12:81-98 (1900) Abst, Eng M J 69: 769-770 (1900); Se Am Sup 49: 20489 (1901)

00a The twelfth annual meeting of the Geological Society of America [Washington, December, 1899]. Science n s 11:98-106, 140-146 (1900)

$00 b$ The re-calculation of the chemical analyses of rocks. Sch Mines Q 22:75-88 (1900)

ooc Metamorphosed dikes in the mica schists of Morningside Heights (abst). Science n \& 11:110 (1900)

ood Recent theories regarding the cause of glacial climate (abst, with discusseion). Science n s 11:110 (1900)

ooe Recent progress in investigation of the geology of the Adirondack region (abst). Science n s 12:1006 (1900) N Y Ac Sc, An 13: 506-507 (1901)

01 (and Hill, B. F.) Preliminary report on the pre-Cambrian formations in parts of Warren, Saratoga, Fulton, and Montgomery cos. [N. Y.]. N Y St Mus, An Rp $53: \mathrm{r} 17-35$, maps (1901)

01 a The Albany meeting of the Geological Society of America. Science n 813 : 95-100, 133-139 (1901)

011 Notes on the occurrence of asbestos in Lamoille and Orleans cos., Vt. U S G S, Min Res 1900 : 862-866 (1901)

o1e The Cambro-Ordovician outlier at Wellstown, Hamilton Co., N. Y. (abst, with discussion by A. A. Julien). Science n s 13:710 (1901)

o1d A new asbestos region in northern Vermont (abst). Science n s 14: 773-774 (1901) Am G 28:330 (1901) N Y Ac Sc, An 14:140-141 (1902)

o1e Notes on the physiography of Lake George $(a b s t)$. Science n s 14:774 (1901) Am G 28: 331-332 (1901) N Y Ac Se, An 14: 141-142 (1902)

0:2 The geological relations and distribution of platinum and associated metals. U S G S, B 193: 95 pp, maps (1902)

02a The rôle of the igneous rocks in the formation of veins. Am I M Eng, Tr 31: 169-198 (1902) Abst, Eng M J $71: 558$ (1902)

0.2b The deposits of copper ores at Ducktown, Tenn. Am I M Eng, Tr 31: 244 265, map (1902)
Kemp, James Furman-Continned.

02e Earthquakes and volcanoes: great natural cataclysms. The Century Mag 64: 593-609 (1902)

o2d Theodore G. White (obituary). N I Ac Sc, An 14: 148-149 (1902)

02e The Cambro-Ordovician outlier st Wellstown, Hamilton Co., N. Y. (abst) N Y Ac Sc, An 14: 113-115 (1902)

o2f Comments on the geology of Bins. ham Canyon, Utah (abst). N Y Ac se An 15:76-77 (1903) Science n s 16:906 (1902)

03 (and Knight, W. C.) Leucite hills of Wyoming. G Soc Am, B 14:305-338 map (1903) Abst, Science n s $17: 299,500^{\circ}$ (1903)

O3a Igneous rocks and circulating wates as factors in ore deposition. Am I M Eng Tr 33: 699-714 (1903) Reprinted in Et mons, S. F., Ore deposits (pub. by Am I y Eng) ; 235-250, N Y 1913

03b (and Grabau, A. W.) The Wast ington meeting of the Geological Soclets of America, December 30, 31, 1902, Januar? 1 and 2, 1903. Science n s $17: 290-30$. (1903)

03e The anthracite situation and prot lem. Engineering Company of America, no $1: 22$ pp N Y 1903

o3d Memoir of Theodore Greely White G Soc Am, B 13: 516-517 (1903)

03e A new speroidal granite. Sciene n s 18:503-504 (1903)

o3f On the differentiation of igneous magmas and the formation of ores. Ens M J $76: 804-805$ (1903)

03g The economic geology of the nonmetallic minerals based on American ex. amples. $191 \mathrm{pp} \mathrm{[N} \mathrm{Y} \mathrm{1903?]} \mathrm{[not} \mathrm{seen]}$

o3h (with Finlay, G. I.) Nepheline syenite area of San José, Tamaulipas Mexico (abst). Science n s 17: 295 (1905) G Soc Am, B 14:534 (1904)

O3i (with Knisht, W. C.) Geology of the Leucite Hills, Wyo. (abst). Science s $17: 299$ (1903)

04 Graphite in the eastern Adirondacks, N. Y. U S G S, B 225: 512-514 (1904)

04a Platinum in the Rambler mine, Wyo. U S G S, Min Res 1902: 244-250 (1904)

04b The formation of veins; a brief statement of general principles. M Mag 10: 89-93 (1904)

04c Ores from igneous magmas. Eng II J $77: 675$ (1904)

o5 The copper deposits at San Jose. Tamaulipas, Mex. Am I M Eng, Bi-Mo B 4: 885-910, maps (1905) ; Tr $36: 178-203$, maps (1906) Reprinted in Emmons, S. F, Ore deposits (pub. by Am I M Eng) : 557581 , N Y 1913 Abst, Sc Am Sup 59: 24326 (1905)

O5a Geological bookkeeping. G Soc Am, B $16: 411-418$ (1905)

05b Secondary enrichment in ore de posite of copper. Fic G 1:11-25 (1905) 
Kemp, James Furman-Continued.

05e The problem of the metalliferous veins. Ec G 1: 207-232 (1905)

05d What is a fissure vein? Ec G 1 : $167-169$ (1905)

05e Die Lagerstätten titanhaltigen Eisen erzes im Laramie Range, Wyoming, Ver Staaten. Zs prak G $13: 71-80$, map (1905) 05f The titaniferous magnetite in Wyo ming (abst). Am G 35:64 (1905) Science n s 21:67 (1905) N Y Ac Sc, An 16 $353(1905)$

05g The physiography of the Adiron dacks (abst). Science n s 21:998-989 (1905)

06 The problem of the metalliferous veins. Ec G $1: 207-232,699-700$ (1906) Science n \& 23:14-29 (1906) N Y Ac Sc, An 17:632-657 (1907) Smithsonian Inst, An Rp 1906: 187-206 (1907)

06a The physiography of the Adirondacks. Pop Sc Mo 68: 195-210 (1906)

06b On the formation of garnet zones at the contacts of eruptive rocks and limestones. M Sc Press $92: 220-221$ (1906)

07 Ore deposits at the contacts of intrusive rocks and limestones; and their significance as regards the general formation of veins. Int $\mathrm{G}$ Cong, $\mathrm{X}, \mathrm{Mexico}, 1906$, C R: 519-531 (1907) Ec G 2:1-13 (1907)

o7n (and Gunther, C. G.) The White Knob copper deposits, Mackay, Idaho. Am I If Eng, B 14:301-328 (1907); Tr 38: 269-296 (1908)

07b (and Ross, J. G.) A peridotite dike in the Coal Measures of southwestern Pennsylvania. N Y Ac Sc, An $17: 509-518$ (1907) Abst, G Soc Am, B 17:691 (1907) 07e Some new points in the geology of copper ores. M Sc Press 94:402-403 (1907) Eng M J 83:1192-1193 (1907) Can \& J 28 (n s 1 no 9): 274-275 (1907) 07d Physiography of the lower Hudson valley (abst). Science n s 25:762 (1907) 07e Physiography of the Adirondacks (abst). N Y Ac Sc, An 17:589-591 (1907)

$07 \mathrm{f}$ Recent interesting discovery of human implements in an abandoned river channel in southern Oregon (abst). N Y Ac Sc, An 17:606-608 (1907)

07g Dikes. M Sc Press 94:85-88 (1907)

08 Geology; a lecture delivered at Co. lumbia University, November 13, 1907. 35 pp, N Y 1908 Sch Mines Q 29:125-148 (1908) Abst, M Sc Press 96:497-500, 533-536 (1908); Sc Am Sup 65: 345-346 (1908)

08a The Mineville-Port Henry mine group. N Y St Mus, B 119:57-88 (1908) 08b Waters, meteoric and magmatic. $M$ Sc Press 96: 705-708 (1908)

08c Buried channels beneath the Hudson and its tributaries. Am J Sc (4) 26 $301-323$ (1908)
Kemp, James Furman-Continued.

osd Present trend of investigation on underground water (abst). Science $\mathbf{n} \mathbf{s}$ $28: 352$ (1908)

o8e The production of low-grade copper ore in the West (abst). Sclence n s 28: 936 (1908)

09 What is an ore? M Sc Press 98: 419-423 (1909) Can M J 30:692-693, 752-754 (1909) M World 30:1111-1114 (1909) Can M inst, J 12:356-370 (1910)

O9a Spheroidal weathering of dikes. M Sc Press 98: 443-444 (1909)

O9b Our knowledge of the filled channel of the Hudson in the Highlands and the submerged gorge on the continental shelf (abst). Science n s 29:279 (1909)

09c Review of The iron ores of the Iron Springs district in southern $\mathrm{Utah}$, by C. K. Leith and E. C. Harder (B 338, U S G S). J G 4: 782-791 (1909)

10 Iron ore reserves in the United States. (Int G Cong, XI, Stockholm, 1910), The iron ore resources of the world 2: 755-778, map (1910)

$10 a$ Iron ore reserves of Central America. (Int $\mathrm{G}$ Cong, XI, Stockholm, 1910), The fron ore resources of the world 2 : $789-790$ (1910)

10b Iron ore reserves in the West Indies. (Int G Cong, XI, Stockholm, 1910), The iron ore resources of the world 2 : 793-797 (1910)

10e (and Ruedemann, Rudolf) Ge ology of the Elizabethtown and Port Henry quadrangles, N. X. N Y St Mus, B 138: $173 \mathrm{pp}$, maps (1910)

10d Memoir of John Henry Caswell [1846-1909]. N Y Ac Sc, An 19:353-356 (1910)

10e The supply of iron. M Mag 3:363366 (1910)

10R The conservation of mineral resources. Ec G 5:765-771 (1910)

$10 \mathrm{~g}$ Further light on the gorge of the Hudson (abst). Science n $\mathrm{s} \quad 32: 186$ (1910); (with discussion), G Soc Am, B $21: 760-761$ (1910)

11 Geology and economics [supply of the principal metals and its probable duration.]. Sch Mines Q 32:126-148 (1911) Science n s 33:1-16 (1911) N Y Ac Sc, An 20: 365-384 (1911)

11 a Contact deposits. M Sc Press 103: 678-681 (1911) Reprinted in Types of ore deposits (ed by H. F. Bain) : 190-201 (1911)

11b Eleventh International Geological Congress. M Sc Press 102:28-29 (1911)

11e Comparative sketch of the precambric geology of Sweden and New York. N. $\mathrm{Y}$ St Mus, B 149:93-106 (1911) Abst, G Soc Am, B 22: 719 (1911)

11 d Geological problems presented by the Catskill aqueduct of the City of New York. Can M Inst, Q B 16:3-9 (1911); J 14; 472-478 (1912) 
Kemp, James Furman-Continned. 12 The mineral springs of Saratoga.

Y St Mus, B 159:79 pp (1912)

12a The Storm King crossing of the Hur son River by the new Catskill Aqueduct of New York City. Am J Sc (4) 34:1-11 (1912)

12b The future of the iron industry. especially in North America. Int G Cong. XI, Stockholm, 1910, C R: 321-328 (1912)

12e Pre-Cambrian formations in the State of New York. Int G Cong, XI, Stockholm 1910, C R: 699-719, map (1912)

12 Notes on garnet zones on the contact of intrusive rocks and limestones. Can M Inst, $\operatorname{Tr} 15: 171-186$ (1912)

13 Field and office methods in the preparation of geological reports (discussion); geological field methods. Ec G $8: 171-176$ (1913)

13a The ground-waters. Am I M Eng. B 76:603-624 (1913); $\mathrm{Tr} 45: 3-25$ (1914)

13b Artificial vein formation in the Tomboy mill, Telluride, Colo. Ec G $8: 543-$ 550 (1913)

13e Contact zones (discussion). Ec G $8: 597-610(1913)$

13a Water in veins. M Sc Press 107: 938-939 (1913)

13e The infuence of depth on the character of metalliferous deposits. Int G Cong, XII, 1913, C R: 253-260 (1914; advance copy 1913) Can M J 34:543-546 (1913) Abst, M World 39:591-593 (1913)

14 The newer theories of ore deposition. M Met Soc Am, B 79 (vol 7 no 12) : 188 197 (1914)

$14 a$ Secondary silicate zone (discussion). Ec G $9: 282$ (1914)

14b New point in the geology of the Adirondacks (abst with discussion). G Soc Am, B 25: 47 (1914)

15 The Mayari iron ore deposits, Cuba [includes description of Orbitoides kempi n. sp. by Majorie O'Connell]. Am I M Eng. B $98: 129-154 ; 103: 1461-1462$, il (1915) ; Tr $51: 3-30,11$ (1916)

15a The geology of the iron ore deposits in and near Daiquiri, Cuba. Am I M Eng, B 105:1801-1836 (1915) ; Tr $53: 3-39$ (1916)

15b Buried river channels of the northeastern States. Wyo Hist G Soc, $\operatorname{Pr} 14$ : 35-54 (1915)

16 The outlook for iron. Int Engineering Cong, 1915. Tr $5: 365-389$ (1916) Smiths Inst, An Rp 1916: 289-309 (1917)

18 John Duer Irving. Eng M J 106: 260-263, port 1918)

1Sa John Duer Irving. Science n s 48: 255-256 (1918)

18b (and Billingsley, P.) Notes on Gold Hill and vicinity, Tooele Co.. western Utah. Ee G $13: 247-274, \operatorname{map}$ (1918)

1Se Geology and mineral deposits. In Peele, Robert, Mining Engineers' Handbook : $73-116$, N Y 1918
Kemp, James Furman-Continued.

See also Billingsley. 15: Blake (W P), 93; Branner, 98; Browne (D H), 95; Day (A L) 13; Emmons (S F), 03c, e; Graton, 13b, 15; Hobbs, 11b; Miller (W .J). 11 Rickard, 03; Williams (G H), 90d; Wood man, 13a

Kempher, L. S.

18 Remarks on the geology of the north. central Texas oil and gas region. 22 pp. Fort Worth, Texas, 1918 [Priv pub, J. E. Head \& Co.]

Kempton, C. W.

79 Sketches of the new mining district at Sullivan, Maine. Am I M Eng, Tr 7: $349-356$ (1879)

96 [On tin deposits near Sain Alto, Zacatecas, Mex.] Am I M Eng. Tr 25:997998 (1896)

09 Some investigations of Santo Do. mingo minerals. M World $30: 637-639$ (1909)

O9n Mines and minerals in the New England States. M World $30: 837-838$ (1909)

Kendall, J, D.

99 The silver-lead deposits of the Slocan, B. C. Can M Rv 18:172-186, 199 (1899) Kendall, Percy F.

95 The ancient and modern glaciers of North America $(a b s t)$. Leeds G As, Tr $9: 37-41$ (1895)

Kennan, Chester T.

15 On carnotite deposits - and the Rand banket. M Sc Press 110:620-621 (1915)

15a Origin of "sandstone" ore deposits. M World 43: 213-215 (1915)

$15 b$ Some ore deposits in sandstone. M Science $71: 21-23$ (1915)

Kennedy, J. C.

98 The Wyoming copper region. Eng M J 66:640-641 (1898)

15 Occurrence of platinum at Boss mine, Nev. M World 42:939-940 (1915)

Kennedy, Stewart.

o7 Lignite of northeastern Wyoming. Mines and Minerals 27:294-297 (1907)

Kennedy, William.

84 Superficial geology of Dundas Valley and western Ancaster [Ont.]. Hamilton As, J Pr 1 pt $1: 103-142$ (1884)

89 The central basin of Tennessee; a study of erosion. Can Inst, $\mathrm{Pr}$ (3) $7: 28$, 64-108 (1889)

91 [Iron ore district of east Texas] : a description of counties. Tex G S, An Rp 2: 65-203 (1891)

92 Report [on eastern Texas]. Tex G S, Rp Prog 2 (1891) : 55-69 (1892)

92a Houston Co. Tex G S, An Rp 3 : 3-40, map (1892)

92b A section from Terrell, Kaufman Co., to Sabine Pass on the Gulf of Mexico. Tex G S, An Rp 3: 43-125 (1892)

93 Report on Grimes, Brazos, and Robertson cos. Tex G S, An Rp 4 pt $1: 1-84$, maps (1893) 
Kennedy, William-Continued.

93a Texas clays and their origin. Seience $22: 297-300$ (1893)

94 Geology of Jefferson Co., Tex. Am G $13: 268-275$ (1894)

$94 \boldsymbol{a}$ The age of the iron ores of east Texas. Science $23: 22-25$ (1894)

95 Iron ores of east Texas. Am I M Eng, Tr $24: 258-288,862-863$ (1895)

95a The Eocene Tertiary of Texas east of the Brazos River. Ac N Sc Phila, Pr $1895: 89-160$

03 (with Hayes, C. W.) Oil fields of the Texas-Louisiana Gulf Coastal Plain. U S G S, B $212: 174$ pp, maps (1903)

17 Coastal salt domes. Southwestern As Petroleum G, B $1: 34-59$ (1917)

18 Principles and problems of oil pros pecting in the Gulf coast country (discussion). Am I M Eng, B 139:1145-1146 (1918)

See also Matteson, 18

Kent, William.

77 The new iron district in southern Ohio. Eng M J $23: 377,396-397$ (1877)

Kenyon, Frederick C.

95 In the region of the new fossil, Dae monelix. Am Nat $29: 213-227$, il (1895) Kerr, D. G.

05 Corundum in Ontario. Inst $\mathrm{M}$ Eng, $\operatorname{Tr} 30: 143-157$ (1905)

Kerr, Frank M.

02 The sulphur deposits of Calcasleu Parish, La. As Eng Soc. J 28:90-97 (1902)

Kerr, H. L.

06 Exploration in Mattagami Valley. Ont Bur Mines, An Rp 15 pt 1: 116-135 (1906)

10 Nepheline syenites of Port Coldwell [Ont.]. Ont Bur Mines, An Rp 19 pt 1 : 194-232, map (1910)

Kerr, J. H

70 Observations on ice marks in Newfoundland, G Soc London, Q J 26:704 705 (1870) Abst; G Mag $7: 392$ (1870)

Kerr, Mark B.

96 Geologic surveys of the gold belt of California. M Sc Press 73:378 (1896)

Kerr, Washington Caruthers (1827-1885).

67 Report of the progress of the geological survey of North Carolina, 1866. 56 pp, Raleigh 1867

69 Report of the State geologist [18678]. [N C, Gen Assembly], Doc no 27 , Sess 1868-9. 57 pp [Raleigh 1869]

70 On some points in the stratigraphy and surface geology of North Carolina (abst). Am Nat 4:570 (1870)

70 Probable origin of the South Carolina phosphates (abst). Am Nat 4:571 (1870)

70b $\Lambda$ point in dynamical geology (abst). Am Nat 4: 639 (1870)
Kerr, Washington Caruthers-Continued.

73 Appendix to the report of the geological survey of North Carolina, 1873; being a brief abstract of that report and a general description of the State, geographical, geological, climatic, and agricultural. 24 pp, map, Raleigh, N. C., 1873 [Reprinted, with changes 1882 See Kerr, 82]

73a Topography as affected by the rotation of the earth [eastern North Carolina]. Am Ph Soc, Pr 13:190-192 (1873)

75 Report of the geological survey of North Carolina. Volume I, Physical geography, résumé, economical geology. xvili, $325,120 \mathrm{pp}$, il, map, Raleigh 1875

75a Observations on the Mesozoic of North Carolina. Am As, Pr 23 pt 2:47-49 (1875)

76 On frost drift in North Carolina. Ac N Sc Pbila, Pr 1876:157-158

so The mica veins of North Carolina. Am I M Eng. Tr 8: 457-462 (1880) The Virginias 1: 168-169 (1880) Eng M J 31: 211-212 (1881)

80a The gold gravels of North Carolinatheir structure and origin. Am I M Eng, $\operatorname{Tr} 8: 462-466$ (1880) The Virginias 1: $166,168(1880)$

81 Origin of some new points in the topography of North Carolina. $\Delta \mathrm{m} \mathrm{J}$ Sc (3) $21: 216-219$ (1881)

s1a On the action of frost in the arrangement of superficial earthy material. Am J Sc (3) $21: 345-358$ (1881)

S1b (with Genth, F. A.) The minerals and mineral localities of North Carolina; being chapter I of the second volume of the geology of North Carolina, 1881:1-122, Raleigh 1881 [2d ed] : 1-128, Raleigh 1885 82 Physiographical description of North Carolina, $32 \mathrm{pp}$, map, Raleigh, N. C., 1882

S2a Some peculiarities in the occurrence of gold in North Carolina. Am I M Eng, Tr 10:475-476 (1882)

s2b The "volcano" of Bald Mountain [N. C.] Eng M J 33:131 (1882)

83 Report on the geology and the soils of the tobacco region of North Carolina. U S, 10th Census 3: 715-719 (1883)

83a Geological relations of the topography of the south Appalachian plateau. Science 1: 105 (1883)

84 Physico-geographical and agricultural description of North Carolina. U S, 10th Census $6: 539-615$, map (1884)

84a Physico-geographical and agricultural description of the State of Virginia. U S, 10th Census 6: 627-638 (1884)

84b The geology of Hatteras and the neighboring coast. $\mathrm{Ph}$ Soc Wash, B 6 : 28-30 (1884)

85 Distribution and character of the Eocene deposits in eastern North Carolina. Elisha Mitchell Sc Soc, J 2:79-84 (1885) 
Kerr, Washington Caruthers-Continued.

$\mathbf{8 5 a}$ Notes on the geology of the region about Tampa, Fla. Elisha Mitchell Sc Soc, J $2: 86-90$ (1885)

85b The Eocene of North Carolina. Am Nat $19: 69$ (1885)

85e The mica mines of North Carolina. $\mathrm{Ph}$ Soc Wash, B 7:9 (1885)

85d (with Genth, F. A.) The minerals and mineral localities of North Carolina. $128 \mathrm{pp}$, Raleigh 1885.

s8 (and Manna, G. B.) Ores of North Carolina; being chapter II of the second volume of the geology of North Carolina 123-359, map, Raleigh 1888 [2d ed] Raleigh 1893

See also Hale, 83; Hawes, 84

Kessler, H. H.

04 (and Hamilton, W. R.) The orbicular gabbro of Dehesa, Cal. Am G 34: 133-140 (1904)

Kew, William Stephen Webster.

13 (and Stoner, R. C.) Monterey series on the south side of Mount Diablo, Cal. $(a b s t)$. G Soc Am, B 24:129 (1913)

14 Tertiary echinoids of the Carrizo Creek region in the Colorado Desert. Cal Univ, Dp G, B 8:39-60, il, map (1914)

14a Echinoderms of the San Pablo (abst). G Soc Am, B 25:152 (1914)

15 Tertiary echinoids from the San Pablo group of middle California. Cal Univ, Dp G, B $8: 365-376$, il (1915)

15a Geology of a portion of the Santa Ynez River district, Santa Barbara Co., Cal. (abst.). G Soc Am, B 26:401-402 (1915)

17 Recent additions to our knowledge of California Cenozoic echinoids (abst). G Soc Am, B 28: 226 (1917)

$17 a$ (with Dickerson, R. E.) The fauna of a medial Tertiary formation and the associated horizons of northeastern Mexico. Cal Ac Sc, Pr (4) $7: 125-156$. 11 (1917)

17b (with Dickerson, R. E.) Tertiary mollusks and echinoderms from the vicinity of Tuxpam, Mexico (abst). G Soc Am, B 28: 224-225 (1917)

18 Geologic range and evolution of the more important Pacific coast echinoids (abst). G Soc Am, B 29:164 (1918)

Kewitseh, Georg.

02 Die Vulkane Pele, Krakatau, Etna, Vesuv. $35 \mathrm{pp}$, Norden 1902

Keyes, Charles Rollin.

88 An annotated catalogue of the Mollusca of Iowa [includes list of Mollusea from loess]. Essex Inst, B 20:61-83 (1888)

88a On some fossils from the lower Coal Measures at Des Moines, Iowa. Am G 2 : 23-28 (1888)

88b The Coal Measures of central Iowa, and particularly in the vicinity of Des Moines. Am G 2:396-404 (1858)
Keyes, Charles Rollin-Continued.

SSe The sedentary habits of Platycera. Am J Sc (3) $36: 269-272$ (1888)

s8d On the fauna of the lower $\mathrm{Cos}$ Measures of central Iowa. Ac N Sc Phil Pr 1888: 222-246, il.

8Se Descriptions of two new fossils from the Devonian of Iowa. Ac N Sc Phila, P $1888: 247-248$, il

88f The attachment of Platycerata t fossil crinoids. Am Nat 22:924-92 (1888)

S8g Surface geology of Burlington, Iowa Am Nat 22:1049-1054, map (1888)

89 On the attachment of Platyceras t paleocrinolds and its effects in modifying the form of the shell. Am Ph Soc, $\operatorname{Pr} 25$ : 231-243, il (1889)

89a Soleniscus; its generic charactes and relations. Am Nat $23: 420-424$, Il (1889)

89b Variation exhibited by a Carbonic gasteropod. Am G 3:330-333, il (1889)

89e The subgeneric groups of Naticopsi. Am G 4:193-196, il (1889)

s9d Note on the distribution of certaln loess fossils. Am G 4:119-121 (1889)

89e The Carboniferous Echinodermata of the Mississippi Basin. Am J Sc (3) 38: 186-193 (1889)

89f Lower Carbonic Gastropoda frot Burlington, Iowa. Ac N Sc Phila, Pr 1859: 284-298

S9g The American species of Poly phemopsis. Ac N Sc Phila, Pr 1889:299302

89h Sphaerodoma; a genus of fossil gastropods. Ac N Se Phila, Pr 1889 : 303309

S9i Note on the distribution of Helicina occulta. Nautilus 3:18-19 (1889)

90 Certain forms of Straparollus from southeastern Iowa. Am G 5:193-197, il (1890)

$90 a$ Generic relations of Platyceras and Capulus. Am G 6:6-9 (1890)

90b Review of the progress of American invertebrate paleontology for the year 1889. Am Nat 24:131-138 (1890)

90e Genesis of the Actinocrinidae. Am Nat 24:243-254 (1890)

90d The naticoid genus strophostylus. Am Nat 24:1111-1117, il (1890)

90e Synopsis of American Carbonic Calyptraeidae. Ac N Sc Phila, Pr 1890: 150-181, il

90f Preservation of color in fossil shelis. Nautilus 4:30-31 (1890)

$90 g$ Discovery of fossils in the lime stones of Frederick Co., Md. Johns Hopkins Univ Circ 10:32 (1890)

91 Stratigraphy of the Carboniferous in central Iowa. G Soc Am, B 2:277-292 (1891) Abst, Iowa Ac Sc, Pr 1 pt 2:2728 (1892) 
Keyes, Charles Rollin-Continued.

91a A geological section across the Piedmont Plateau in Maryland. G Soc Am, B 2:319-322 (1891)

91b Remarks on the perisomic plates of the crinoids. Am J Sc (3) $41: 247-248$ (1891)

91e The Redrock sandstone of Marion Co., Iowa. Am J Sc (3) 41:273-276 (1891) Abst, Iowa Ac Sc, Pr 1 pt 2:2627 (1892)

91d Fossil faunas in central Iowa. Ac N Sc Phila, Pr 1891: 242-265

91e Review of the progress of American invertebrate paleontology for the year 1890. Am Nat 25:327-333 (1891)

91f Paleozoic fossils of Maryland. John Hopkins Univ Cire 11: 28-29 (1891)

92 The classification of the Lower Carboniferous rocks of the Mississippi Valley. Diss., Johns Hopkins Univ. 24 pp, Washington 1892

92a The principal Mississippian section. G Soc Am, B 3:283-300 (1892)

92b The Platyceras group of Paleozoic gastropods. Am G 10:273-277 (1892)

92e The present basal line of delimitation of the Carboniferous in northeastern Missouri. Am G 10:380-384 (1892)

92d A remarkable fauna at the base of the Burlington limestone in northeastern Missourf. Am J Sc (3) 44: 447-452 (1892)

92e "Nickel ore" from Iowa. Eng M J 54:634 (1892)

92f The occurrence of natural gas in Iowa and its probable future. U S Dp Agr, Weather Bur. Mo Rv Iowa Weather and Crop Service 3 no $12: 3-4$ (1892)

$92 \mathrm{~g}$ Age of certain sandstones near Iowa City [Iowa]. Iowa Ac Sc, Pr 1 pt 2: 26 (1892)

92h Eastern extension of the Cretaceous In Iowa. Iowa Ac Sc, Pr 1 pt 2:21 (1892)

92i Contribution to the fauna of the lower Coal Measures of central Iow a (abst). Iowa $A c$ Sc, $\operatorname{Pr} 1$ pt $2: 22-23$ (1892)

92j A new Conocardium from the Iowa Devonian. Iowa Ac Sc, Pr 1 pt $2: 23-24$ (1892)

921k Preliminary note on the sedentary habits of Platyceras. Iowa $\mathrm{Ac} \mathrm{Sc}, \mathrm{Pr} 1$ pt $2: 24$ (1892)

921 Evolution of Strophostylus. Iowa Ac Sc, Pr 1 pt $2: 25-26$ (1892)

$92 \mathrm{~m}$ (and Call, R. E.) On a Quaternary section eight miles southeast of Des Moines, Iowa. Iowa Ac Sc, Pr 1 pt 2:30 (1892)

93 Report [of assistant State geologist]. Iowa G S, An Rp 1892: 7-9 (1893) ... 3: 29-37 (1895) ... 4:27-28 (1895)

93a Geological formations of Iowa. lowa G S 1, An Rp 1892:11-144, map (1898)
Keyes, Charles Rollin-Continued.

93b Annotated catalogue of minerals.

Iowa G S 1, An Rp 1892: 181-196 (1893) 93e Bibliography of Iowa geology. Iowa

G S 1, An Rp 1892: 209-464 (1893)

93d Some Maryland granites and their origin. G Soc $\Delta \mathrm{m}, \mathrm{B} 4: 299-304$ (1893)

93e Epidote as a primary component of eruptive rocks. G Soc Am, B 4:305-312 (1893)

93f A new locality for millerite [Keokuk, Iowa]. Am G 11: 126 (1893)

93\% The unconformity of the Coal Measures and the St. Louis limestone in Iowa. Am G 12: 99-102 (1893)

$93 h$ An old volcanic eruption in Iowa. Science $21: 132$ (1893)

$93 i$ Sketch of the coal deposits of Iowa.

U S G S, Min Res $1892: 398-404$ (1893)

93j Natural gas and oil in Iowa. Iowa Ac Sc, Pr 1 pt 3:15-18 (1893)

93k Iowa mineralogical notes. Iowa Ac Sc, Pr 1 pt $3: 18-22$ (1893)

931 Surface disintegration of granitic masses. Iowa Ac Sc, Pr 1 pt $3: 22-24$ (1893)

$93 \mathbf{m}$ Some American eruptive granites. Iowa Ac Se, Pr 1 pt 3:24-26 (1893)

$93 n$ The Iowa coal beds. U S Dp Agr, Weather Bur, Mo Rv Iowa Weather and Crop Service 4 no $1: 3-5$ (1893)

930 An Iowa volcano. U S Dp Agr. Weather Bur, Mo Rv Iowa Weather and Crop Service 4 no $1: 5-6$ (1893)

93p Iowa's gypsum deposits. U S Dp Agr, Weather Bur, Mo Rv Iowa Weather and Crop Service 4 no $3: 2-4$ (1893)

94 Coal deposits of Iowa. Iowa G S $2: 536 \mathrm{pp}, \operatorname{map}$ (1894)

$94 a$ Geological map of Iowa. An Iowa (3) $1: 294-297, \operatorname{map}$ (1894)

94b A bibliography of North American paleontology, 1888-1892. U S G S, B 121: 251 pp (1894)

94e Paleontology of Missouri, part I. Mo G S 4: 271 pp, il, Jefferson City, 1894

$94 d$ Paleontology of Missouri, part II. Mo G S 5 : 266 pp, il, Jefferson City 1894

94e Crustal adjustment in the upper Mississippi Valley. G Soc Am, B 5: 231242 (1894) Abst, Am G 13:210-211 (1894)

94f The nature of coal horizons. J G 2 : 178-186 (1894)

94m Origin of anthracite. Am G 13: 411-415 (1894)

94h The Coal Measures of Iowa, Eng M J $57: 269-270,295-297,317-318$ (1894) Review, Am G 13:353-354 (1894)

94i Cretaceous formations of northwestern Iowa (abst). Iowa Ac Sc, $\mathrm{Pr} 1$ pt 4 : 24-25 (1894)

94j Derivation of the Unione fauna of the Northwest. Iowa $\mathrm{Ac} \mathrm{Sc}, \operatorname{Pr} 1$ pt 4: 25-29 (1894) 
Keyes, Charles Rollin-Continued.

$94 k$ Process of formation of certain quartzites (abst). Iоwa Ac Sc, Pr 1 pt 4 : 29-31 (1894)

941 A stratigraphic catalogue of Missouri fossils. Jefferson City 1894 [not seen] Reprinted in Mo G S, 4: $41-264$ (1894)

$94 m$ What the Iowa Geological Survey has been doing. U S Dp Agr, Weather Bur, Mo Rv Iowa Weather and Crop Service 5 no $1: 4-7$ (1894)

94n The geological mapping of Iowa. U S Dp Agr, Weather Bur, Mo Rv Iowa Weather and Crop Service 5 no $2: 4-6$ (1894)

95 Work and scope of the geological survey. Iowa G S $3: 45-98$, map (1895)

95a Glacial scorings in Iowa. Iowa G S 3:147-165 (1895)

95b Gypsum deposits of Iowa. Iowa G S $3: 257-304, \operatorname{map}$ (1895)

95e Geology of Lee Co. Iowa G S 3 : 305-407, map (1895)

95d Geology of Des Moines Co. Iowa G S 3:409-492, map (1895)

95e Biennial report of the State geologist... $60 \mathrm{pp}$, Jefferson City 1895 Biennial report... 63 pp, maps, Jefferson City 1897

95f Organization and results of a State geological survey. Mo $G$ S, 8:13-79 (1895)

95\% Characteristies of Ozark Mountains. Mo G S $8: 317-352$ (1895)

95h A report on Mine la Motte sheet, including portions of Madison, St. Francois, and Ste. Genevieve cos. Mo G S 9, Sheet $\mathrm{Rp}$ no $4: 132 \mathrm{pp}$, map [under separate cover] Jefferson City 1895 [Archean, by C. R. Keyes and E. Haworth : $24-44]$

95i Origin and relations of central Maryland granites. U S G S, An Rp 15:685-740, map (1895)

95j Stratigraphy of the Kansas Coal Measures. Am J Sc (3) $50: 239-243$ (1895)

95k The Cambro-Silurian question in Missouri and Arkansas. J G 3:519-526 (1895)

951 Acidic eruptives of northeastern Maryland. Am G 15:39-46 (1895)

$95 \mathbf{m}$ A hypsometric map of Missouri. Am G 15: 314-317, map (1895)

$95 n$ Superior Mississippian in western Missouri and Arkansas. Am G 16:86-91 (1895)

950 Granite rocks of Missouri. Eng M J $60: 516-517$ (1895)

95p Secular decay of granitic rocks. Iowa Ac Sc, $\operatorname{Pr} 2: 27-31$ (1895)

05q Synopsis of American Paleozoic echinoids. Iowa Ac Sc, $\mathrm{Pr} 2: 178-194$, il (1895)
Keyes, Charles Rollin-Continued.

95x Opinions concerning the age of th: Sioux quartzite $(a b s t)$. Iowa Ac Sc, P $2: 218-222$ (1895)

95s Methods of determining the natum resources of a region. $\mathrm{U} S \mathrm{~S}$ p Ag Weather Bur, Mo Rv Iowa Weather and Crop Service 6 no $3: 5-7$ (1895)

96 Areal geology of Missouri. Mo G \& $9: 11-16$ (1896)

96 a Bibliography of Missouri geolog. Mo G S 10:219-523 (1896)

96b The geological occurrence of clays Mo G S 11: 35-48, map (1896)

96c Geographic relations of the granite and porphyries in the eastern part of the Ozarks. G Soc Am, B $7: 363-376$, mat (1896) Abst, Am G 17:91-92 (1896); G $4: 375-377$ (1896)

96d Biographical sketch of Charles Wachsmuth. Am G $17: 131-136$, port (1896)

96e Thickness of the Paleozolc rocks th the Mississippi basin. Am G 17:169-17 (1896)

96f Serial nomenclature of the Carbon iferous. $\mathrm{Am} \mathrm{G} \mathrm{18:22-28} \mathrm{(1896)}$

96: Orotaxis, a method of geologic cot relation. Am G 18:289-302 (1896)

96h The Bethany limestone of the west ern interior coal fields. Am J Sc (4) 2 221-225 (1896)

96i Ueber das Carbon des Mississippl. thales. N Jb 1896 , I : 96-100

96j Missouri building and ornamental stones. Stone 12:432-436, 546-557; 13 30-32 (1896) Abst, Eng M J 62:199201 (1896)

96k Central Maryland granites. Stone $13: 421-428, \quad 527-531 ; \quad 14: 20-24, \quad 126-$ $129,226-228$ (1896-7)

961 A gigantic orthoceratite from the American Carboniferous. Science n s 3 : 94-95 (1896)

$96 \mathrm{~m}$ Iowa gypsum. Mineral Industry 4: $379-386$ (1896)

$96 \mathbf{n}$ Epoch in history of American sct. ence [biographical sketches of Charles Wachsmuth and Frank Springer]. An Iowa (3) $2: 345-364$, port, il (1896)

960 Note on the nature of cone-in-cone. Iowa Ac Sc, Pr $3: 75-76$ (1896)

96p Two remarkable cephalopods from the upper Paleozoic. Iowa Ac Sc, Pr 3: $76-78$, il (1896)

96q Structure of Uintacrinus. Am Nat $30: 819-821$, il $(1896)$

97 List of Carboniferous fossils from Des Moines. Iowa G S $7: 330-335$ (1897)

97a Dual character of the Kinderbook fauna. Am G 20:167-176 (1897)

97b Relations of the Devonian and Car. boniferous in the upper Mississippi Valley. Ac Sc St L, Tr 7: 357-369 (1897)

97 A new method of synchronizing strata. Sclence n s 6:655-C56 (1897) 
Keyes, Charles Rollin-Continued.

97d Memorial of Charles Wachsmuth, lowa Ac Sc, Pr 4:13-16, port. (1897)

97e Stages of the Des Moines, or chief coal-bearing series of Kansas and southwest Missouri and their equivalents in Iowa. Iowa Ac Sc, Pr 4:22-25 (1897)

97f (and Rowley, R. R.) Vertica! range of fossils at Louisiana [Mo.]. Iowa Ac Sc, Pr 4:26-40 (1897)

$97 \mathrm{~g}$ Distribution and character of Missouri clays. Mineral Industry 1896, 5 : $127-137$ (1897)

$\mathbf{9 7 h}$ The geological surveys of Iowa. An Iowa (3) $3: 111-123$ (1897)

97i The physical nature of the problem of general geological correlation (abst). J G 5:110-111 (1897)

98 The use of local names in geology. J G 6 : 161-170 (1898)

98a Probable stratigraphical equivalents of the Coal Measures of Arkansas. J G 6 : 356-365 (1898)

98b The genetic classification of geological phenomena. J G 6: 809-815 (1898)

9se Use of the term Augusta in geology. Am G 21: 229-235 (1898)

98d Elston Holmes Lonsdale [memorial]. Am G 21: 264-265 (1898)

98e Carboniferous formations of southwestern Iowa. Am G 21:346-350 (1898)

981 Remarks on the classification of the Mississippian series. Am G 22: 108-113 (1898)

$98 \mathrm{~g}$ The principal Missourian section (abst). Am G 22:251 (1898) Science n s $8: 464$ (1898)

98h Eolian origin of loess. Am J Sc (4) $6: 299-304$ (1898) Soc Belge G, B 12 :

Tr 14-21 (1901)

98i Modern stratigraphical nomenclature. Science n s $7: 571-572$ (1898)

98j The myth of the Ozark Isle. Science n s $7: 588-589$ (1898)

98k Structure of the coal deposits of the trans-Mississippian field. Eng M J 65 : 253-254, 280-281 (1898)

981 Geographic development of the Crimea. Iowa Ac Sc, Pr 5:52-54 (1898) $98 \mathbf{m}$ Carboniferous formations of the Ozark region. Iowa Ac Sc, $\operatorname{Pr} 5: 55-58$ (1898)

98n Some geological formations of the Cap-au-Gres uplift [III.]. Iowa $\mathrm{Ac} \mathrm{Sc}, \mathrm{Pr}$ 5: 58-63 (1898)

99 American homotaxial equivalents of the original Permian. J G $7: 321-341$ (1899)

99a The Missourian series of the Carboniferous. Am G 23: 298-316 (1899)

99b On stratification planes. Am G 24 : 294-300 (1899)

99e On the definition of geological terranes. Science n s 10:456-458 (1899)

99d Some physical aspects of general geological correlation. Iowa Ac Sc, $\mathrm{Pr} 6$ : 131-154 (1899)
Keyes, Charles Rollin-Continued.

oo Kinderhook stratigraphy. J G 8 : 315321 (1900)

00a The causes of ore deposits. Am G $25: 323-326$ (1900)

oob Correlative relations of certain subdivisions of the Coal Measures of Kansas. Am G 25: 347-353 (1900)

ooc Certain faunal aspects of the original Kinderhook. Am G $26: 315-321$ (1900)

ood Systematic arrangement of ore deposits on a geological basis. Science n s 11: 631-632 (1900)

00e Coal floras of the Mississippi Valley. Science n s 11 : $898-900$ (1900)

oof Initiation of new elements in fossil faunas. Science n s 12:146 (1900)

$00 \mathrm{~g}$ The geological position of transMississippian coals. Eng M J $69: 528-529$ (1900)

Ooh Formational synonymy of the Coal Measures of the western interior basin. Iowa Ac Sc, Pr $7: 82-105, \operatorname{map}(1900)$

001 Genesis of normal compound and normal horizontal faulting. Iowa Ac Sc, Pr 7: 112-113 (1900)

$00 j$ An Iowa scientist and his work [Frank Leverett]. Annals of Iowa (3) 4 : $383-392$, port $(1900)$

ook Bearing of ore genesis on classification of ore deposits. Mining and Metallurgical J 22:272-273 (1900) [not seen]

01 Note on the correlation of the Clarinda well section with the schematic section of the Carboniferous. Iowa G S 11: 461-463 (1901)

$01 a$ A depositional measure of unconformity [Carboniferous, Mississippi Valley]. G Soe Am, B 12:173-196 (1901) Abst, Sclence n s $13: 135-136$ (1901)

01b Composite genesis of the Arkansas Valley through the Ozark highlands. J G $9: 486-490$ (1901)

o1e Ore formation on the hypothesis of concentration through surface decomposition. Am G 27:355-362 (1901)

Ord Nomenclature of the Cambrian formations of the St. Francois Mountains [Mo.]. Am G 28:51-53 (1901)

ore A schematic standard for the American Carboniferous Am G 28:299-305 (1901)

oxf Time values of provincial Carboniferous terranes. Am J Sc (4) 12:305-309 (1901)

o1g Origin and classification of ore deposits. Am I M Eng. Tr $30: 323-356$ (1901) Summary, with title, Some modern aspects of a practical classification of ore deposits, Eng M J 69:771-772 (1900) Abst, Mining 5:176-179 (1900)

01h On a crinoidal horizon in the upper Carboniferous. Science n s 13:915-916 (1901)

011 Zone of maximum richness in ore bodies. Science n s 14:577-578 (1901) 
Keyes, Charles Rollin-Continued.

01j Derivation of the terrestrial spheroid from the rhombic dodecahedron. J G 9: 244-249 (1901)

01k Horizons of Arkansas and Indian Territory coals compared with those of other trans-Mississippian coals. Eng M J $71: 692-693$ (1901)

011 The stratigraphical location of named trans-Mississippian coals, Eng M J $72: 198$ (1901)

$01 \mathrm{~m}$ Contiguity of ore deposits of different generic relationships. Eng M J 72:597-598 (1901)

o1n Depositional equivalent of hiatus at base of our Coal Measures; and the Arkansan series, a new terrane of the Carboniferous in the western interior basin. Iowa Ac Se, Pr 8 : 119-128 (1901)

010 Names of coals west of the Mississippi River. Iowa Ac Sc, $\operatorname{Pr} 8: 128-137$ (1901)

011 Geology in the twentieth century. The Arena 26:21-33 (1901)

02 Devonian interval in Missouri. G Soe Am, B 13:267-292 (1902)

$02 a$ Cartographic representation of geological formations. $J$ G $10: 691-699$ (1902)

02b Determination of the Cambrian age of the magnesian limestones of Missouri. Am G 29:384-387 (1902)

02e Geological age of certain gypsum deposits. Am G 30:99-102 (1902)

02d Diverse origins and diverse times of formation of the lead and zinc deposits of the Mississippi Valley. Am I M Eng, Tr 31:603-611 (1902) M Metal 24:715-717 (1901) Abst, Mining 8:149-150 (1901)

02e The origin of ore deposits (discussion) Am I M Eng, Tr $31: 942-944,962-$ 966 (1902)

02f Character and stratigraphical peculiarities of the southwestern Iowa coal fields. Eng M J 73:661 (1902)

02g Magmatic differentiation of rocks. Science n s 15:32-33 (1902)

02h A Devonian biatus in the continental interior, its character and depositional equivalents. Iowa $\mathrm{Ac} \mathrm{Sc}, \operatorname{Pr} 9$ : 105-112 (1902)

03 Some recent aspects of the Permian question in America. Am G $32: 218-223$ (1903)

03a Geological structure of New Mexican bolson plains. Am J Sc (4) 15 : 207210 (1903)

o3b Ephemeral lakes in arid regions. Am J Sc (4) 16:377-378 (1903)

03e A remarkable silver pipe [central New Mexico]. Eng M J 76:805 (1903)

03d Geology of the Apache Canyon placers [south central New Mexico]. Eng M J 76:966-967 (1903)
Keyes, Charles Rollin-Continued.

o3e Significance of the occurrence of minute quantities of metalliferous mis. erals in rocks. Iowa $\mathrm{Ac} \mathrm{Sc}, \operatorname{Pr} 10: 99-10 \mathrm{~s}$ (1903)

o3f Genesis of certain cherts. Iowa t: Sc, Pr 10: 103-105 (1903)

03s Comparative values of different methods of geologic correlation in the Mis sissippi basin. Iowa Ae Se, Pr 10:105 107 (1903)

03h Geological formations of Ner Mexico. In Report of the Governor of Ner Mexico to the Secretary of the Interior, 1903: 337-341, Washington 1903

04 Notes on block mountains in Ner Mexico. Am G 33:19-23 (1904)

O4a Bolson plains and the conditions of their existence. Am G 34: 160-164 (1904)

04b Uncomformity of the Cretaceous on older rocks in central New Mexico. A J Sc (4) 18:360-362 (1904)

04c Iron deposits of the Chupaden Mesa [N. Mex.]. Eng M J 78:632 (1904) 04d The Hagan coal field [Sandoval Co. N. Mex.]. Eng M J 78:670-671 (1904)

04e Remarkable occurrence of aurichat. cite. Iowa Ac Sc, Pr 11: 253 (1904)

o4f Certain basin features of the high plateau region of southwestern United States (abst). Iowa Ac Sc, Pr 11:254257 (1904)

049 Note on the Carboniferous faunas of Mississippi Valley in the Rocky Mountain region. Iowa Ac Sc, Pr 11: 258-259 (1904)

o5 Geology and underground water conditions of the Jornada del Muerto, N. Mex. U S G S, W-S P 123: 42 pp, map (1905)

05a Structures of basin ranges. J G $13: 63-70$ (1905)

o5b The fundamental complex beyond the southern end of the Rocky Mountains. Am G 36:112-122 (1905)

o5e The Jurassic horizon around the southern end of the Rocky Mountains. Am G $36: 289-292$ (1905)

o5d Triassic system in New Mexico. Am J Sc (4) $20: 423-429$ (1905)

o5e Zinc carbonate ores of the Magdalen Mountains [N. Mex.]. M Mag 12:109-11t (1905)

O5f Ore deposits of the Sierra de 10 s Caballos [south central N. Mex.]. Eng M J $80: 149-151$ (1905)

O5g Bisection of mountain blocks in the Great Basin region $(a b s t)$. Iowa $\mathrm{Ac} S \mathrm{C}$. Pr $12: 165-167$ (1905)

osh Geological structure of the Jornada del Muerto and adjoining bolson plains [N. Mex.]. Iowa Ac Sc, Pr 12:167-169 (1905)

o5i Northward extension of the Lake Valley limestone [N. Mex.]. Iowa Ac Sc, Pr 12:169-171 (1905)

06 [Notes on the classification of American Carboniferous deposits]. J G 14:7176 (1906) 
Keyes, Charles Rollin-Continued.

06a Carboniferous formations of New Mexico. J G 14:147-154 (1906)

06b Orotaxial significance of certain unconformities. Am J Sc (4) 21:296-300 (1906)

06e The Dakotan series of northern New Mexico. Am J Sc (4) $22: 124-128$ (1906) 06d Geological section of New Mexico. Science n s 23: 921-922 (1906)

o6e Use of the term Permian in American geology. Science $n$ s 24:181-182 (1906)

06f Carboniferous coal measures in the Southwest. Eng M J 81: 1129 (1906)

06g Physiography of New Mexico. Geog 5:251-256 (1906)

06h Lime Creek fauna of Iowa in southwestern United States and northern Mexican region. Iowa Ac Sc, Pr 13: 197-198 (1906)

06i Alternation of fossil faunas. Iowa Ac Se, Pr 13: 199-201 (1906)

07 Volcanic craters in the Southwest. G Soc Am, B 17: 721-723 (1907)

07a Cerargyritic ores: their genesis and geology. Ec G 2: 774-780 (1907)

07b Aggraded terraces of the Rio Grande. Am J Sc (4) $24: 467-472$ (1907)

07e Physiographic significance of the Mesa de Maya [Colo.]. Iowa Ac Sc, Pr $14: 221-222$ (1907)

07d Tertiary terranes of New Mexico. Iowa Ac Sc, Pr 14:223-228 (1907) Abst, G Soc $A m$, B $17: 725$ (1907)

07e Volcanic phenomena about Citlaltepetl and Popocateptl (abst). Iowa. Ac Sc, Pr 14:229-230 (1907)

07f Mescal Canyon coal field, New Mexico. Eng M J 83: 957 (1907)

07g Preglacial river channels of central Iowa. An Iowa (3) $8: 13-17$ (1907)

08 Genesis of the Lake Valley, N. Mex., silver deposits. Am I M Eng, B 19:1-31, map (1908) ; $\operatorname{Tr} 39: 139-169$ (1909)

08a Rock-floor of intermont plains of the arid region. $\mathrm{G}$ Soc $\mathrm{Am}, \mathrm{B}$ 19:63-92 (1908)

08b Geotectonies of the Estancia Plains [N. Mex.]. J G 16:434-451 (1908)

08c Arid monadnocks. J Geog $7: 30-33$ (1908)

08d Geographic distribution of lead and zinc deposits of the Mississippi Valley. Eng M J 86: 1004-1005 (1908)

0se Eolian origin of certain lake basins of the Mexican tableland. Iowa Ac Sc, Pr $15: 137-141$ (1908)

08f Stratigraphic position of western red beds. Iowa Ac Sc, Pr 15: 143-144 (1908)

$08 \mathrm{~g}$ Some relations of the older and younger tectonics of the Great Basin region (abst). Iowa Ac Sc, Pr 15: 145-146 (1908)

09 Lineaments of the desert. Pop Sc Mo $74: 19-30 \quad(1909)$
Keyes, Charles Rollin-Continued.

09a Geologic processes and geographic products of the arid region (abst). G Soc Am, B 19: 570-575 (1909)

09b Erosional origin of the Great Basin ranges. J G $17: 31-37$ (1909)

o9e Ozark lead and zinc deposits, their genesis, localization, and migration. Am I M Eng, B 26:119-166 (1909) ; Tr 40: 184-231 (1910) M World 30:431-433, $481-485,543-546 \quad(1909)$

o9d Garnet contact deposits of copper and the depths at which they are formed. Ec G 4:365-372 (1909) M World 31: $465-466(1909)$

o9e Base-level of eolian erosion. J G 17:659-663 (1909)

o9f Borax deposits of the United States. Am I M Eng, B 34:867-903 (1909); Tr 40:674-710 (1910) Eng M J 88:826827 (1909)

o9o Locus of vadose ore deposition. Eng M J $87: 857-858$ (1909)

09h Migrations of the Joplin zinc belt. Eng M J 87:1049 (1909)

$09 i$ Differential effects of eolian erosion upon rock-belts of varying induration (abst). Science n s 29:752-753 (1909)

09j Locus of maximum lateral deflation in desert ranges $(a b s t)$. Science $\mathrm{n}$ s 29 : 753 (1909)

09k Significance of thrust planes in the Great Basin ranges. Iowa Ac Sc, Pr 16: 151-152 (1909) Abst, Science n s 29:982 (1909)

091 Orotaxial correlation of geologic terranes and diastrophism $(a b s t)$. Science $\mathbf{n}$ s $29: 982(1909)$

09m Carbonic column of Rio Grande re gion. Iowa Ac Sc, $\operatorname{Pr} 16: 159-163$ (1909) Abst, Science n s 29:982 (1909)

o9n Orotaxial geologic correlation and diastrophism, Iowa Ac Sc, $\operatorname{Pr} 16: 153-$ 157 (1909)

10 The ultimate source of ores. Am 1 M Eng, B 43:527-550 (1910); Tr 41: 139-162 (1911)

10a Ozark lead and zinc deposits; their genesis, locallzation, and migration. Am I M Eng, B 43:591-597 (1910); Tr 41: 879-885 (1911)

10b Criteria of downward sulphide enrichment (discussion). Ec G 5:558-564 (1910)

10e Controlling factors of ore localization in the Ozark region. Ec G 5:683688 (1910)

10d Porphyry coppers [occurrence and origin of disseminated copper deposits]. M Met Soc Am, B 25:316-320 (1910) M World $33: 229-230$ (1910)

10e Prospecting disseminated copper ore deposits. Eng M J 90:1055-1056 (1910)

$10 f$ Relations of present profiles and geologic structures in desert ranges. G Soc Am, B $21: 543-564$ (1910) 
Keyes, Charles Rollin-Continued.

10g Deflation and the relative efficiencies of erosional processes under conditions of aridity. G Soc Am, B 21:565-598 (1910)

10h Coon Butte and meteoritic falls of the desert (abst). G Soc Am, B 21:773774 (1910)

10i The Guadalupan series; and the relations of its discovery to the existence of a Permian section in Missouri. Ac Sc St. L, Tr 19: 123-129 (1910)

10j Abundance of meteorites on the Painted Desert [Arizona], and its bearing upon the planetesimal hypothesis of the origin of the earth. Ac Sc St. L, Tr 19: 131-150 (1910)

10k A quantitative measure of maximum arid deflation (abst). Science n s $32: 126-$ 127 (1910)

101 Theory of meteoric agglomeration and the ultimate source of the ores. Iowa Ac Sc, Pr $17: 169-176$ (1910)

$10 \mathrm{~m}$ Maxwell coulee and the diversion of the Rio Mora (abst). Iowa Ac Sc, Pr $17: 165-166(1910)$

10n Distribution of boranzas in the Pachuca silver district of Mexico (abst). Iowa Ac Sc, Pr. 17:167-168 (1910)

11 Origin of certain bonanza silver ores of the arid region. Am I M Eng, B 55: 541-558 (1911); $\operatorname{Tr} 42: 500-517$ (1912)

11a Mid-continental eolation. G Soc Am, B 22: 715-738 (1911)

11b The origin of the Great Plains. Science n s $34: 352$ (1911)

11e The laccolith in ore deposition. M Sc Press 103:382 (1911)

11 Sulphide ore bodies in oxidized zones. Eng M J 92:793-794 (1911)

$11 \mathrm{e}$ The agency of manganese in the su. perficial alteration and secondary enrichment of gold deposits in the United States (discussion). Am I M Eng, B 54:503-506 (1911) ; Tr. 42:917-920 (1912)

11 Fault scarps of the Basin ranges (abst). Science n s 33:466 (1911)

$11 \mathrm{~s}$ Graphics of ore origin. Iowa $\mathrm{Ac}$ Sc, $\operatorname{Pr} 18: 95-98$ (1911) Abst, Science n s 34: 29 (1911)

11 h Voleanic phenomena of Coon Butte region, Ariz. (abst). Iowa Ac Se, Pr 18: 99-100 (1911) Science n s 34:29 (1911)

11 Depositional phases of eolation under the stimulus of aridity $(a b s t)$. Iowa Ac Sc, Pr 18: 101-103 (1911) Science n s $34: 29$ (1911)

12 Relations of Missouri River loess mantle and Kansan drift sheet. Am J Sc (4) $33: 32-34$ (1912)

12a Deflative scheme of the geographic cycle in an arid climate. G Soc Am, B 23:537-562 (1912)

12b Toyalane and Lucero; their structure and genetic relations to other plateau plains of deserts. G. Soc Am, B 23:713718 (1912)
Keyes, Charles Rollin-Continued.

12e A chart of ore deposition. I Press 104: 763 (1912)

12d Trunk channels as ore localine Eng M J 94: 1067-1068 (1912)

12e Sundry provincial and local phes of the general geologic section of lor 2 (abst). Iowa Ac Sc, Pr 19:147-1/ (1912) Science n \& $36: 569$ (1912)

$12 f$ Nether delimitation of our carbot rocks. Iowa Ac Sc, Pr $19: 153-156$ (191. Abst, Science n s $36: 569$ (1912)

12\% Arid plateau plains as features eolic erosion. Iowa Ac Sc, Pr $19: 157-10$ (1912) Abst, Science n s $36: 569$ (1912

12h Wind-graved mesas and their w sage. Pop Sc Mo $81: 227-237$ (1912)

13 Critical criteria on basin-range str ture. Science n s $37: 226$ (1913)

$13 a$ Great erosial work of winds. P Se Mo $82: 468-477$ (1913)

13b Annotated bibliography of Iowa ology and mining. Iowa $G$ \& $22: 908$; (1913)

13e Original streams; and their role general desert leveling. $J$ G $21: 268$. (1913)

13d Antigravitational gradation. Scien n $8 \quad 38: 206$ (1913)

13e Marked unconformity between $\mathrm{C}$ boniferous and Devonian strata in upe Mississippi Valley. Am J Sc (4) 160-164 (1913)

13f W J MeGee, geologist, anthropols gist, hydrologist. An Iowa (3) $11: 1$ th 187 , port (1913)

13. Complexity of the glaclal perix and Iowa's role in its establishment. At Iowa (3) $11: 227-228$ (1913)

13h Anuglar amphitheaters of the Grat Canyon (abst). Science n s $37: 457-t^{\circ}$ (1913)

13i Geologic significance of enisled to lief $(a b s t)$. Science n s $37: 458$ (1913)

13j Iowan Cretacic sequence (abst Science n s 38: 241 (1913)

13k Terranal differentiation of Devoti succession in Iowa $(a b s t)$. Science n 3 241 (1913)

131 Possible occurrence of Tertiary de posits east of the Missouri River (abst Science n s 38:241 (1913)

13 magnitude of continental deposit (abst). G Soc Am, B 24:677 (1913)

13n Certain so-called meteoric irons Canyon Diablo (abst). G Soc Am, B 2 : 685-686 (1913)

130 Complete succession of Iowan Cre tacic terranes. Iowa Ac Sc, Pr 20:199201 (1913)

13p Recognition of beds of Tertiaric agt in our State. Iowa Ac Sc, $\operatorname{Pr} 20: 205$ (1913)

13q Late Devonic sequence of the Iort region (synopsis). Iowa $\mathrm{Ac} \mathrm{Sc}, \mathrm{Pr}$ 20: $205-206$ (1913) 
Keyes, Charles Rollin-Continued.

13r Certain features of eolic gradation. Int G Cong, XII, 1913, C R: 941-945 (1914; advance copy 1913)

14 Paleogeographical affinities of the Alexandrian series. Am J Sc (4) $37: 254$ 256 (1914)

14a Syllabus of a course of lectures on geologic processes and geographic products in arid regions. Revised reprint, $15 \mathrm{pp}$, Socorro 1914

14b Chart of the geologic terranes of Iowa. $3 \mathrm{pp}$, Des Moines, 1914

14e Scheme of the stratigraphic succession in Missouri. $4 \mathrm{pp}$, Des Moines 1914

14d Iowa's great period of mountain making. Iowa Ac Sc, $\operatorname{Pr} 21: 181-187$ (1914)

14e Serial subdivision of the early Carbonic succession in the continental interior. Iowa Ac Sc, Pr 21: 189-193, map (1914)

$14 f$ Our pre-Cambrian rocks. Iowa Ac sc, Pr 21: 195-202 (1914)

$14 \mathrm{~g}$ Foundation of modern geologic science in America. An Iowa (3) 11:401407 (1914)

14h Great ice ages in Iowa. An Iowa (3) $11: 465-469$ (1914)

14i Life and work of Charles Abiathar White. An Iowa (3) 11:497-504, port (1914)

14j Erosive potential of desert waters (abst). G Soc Am, B 25: 88 (1914)

14k Recent backward extension of the life record in geologic time $(a b s t)$. Science s $39: 405$ (1914)

141 Stratigraphic position of our oldest rocks [Iowa] (abst). Science n s $40: \mathbf{1 4 4}$ (1914)

$\mathbf{1 4 m}$ Siouan Mountains; an Iowan Triassic episode (abst). Science n s 40:144 (1914)

14n Serial unit in stratigraphic classification (abst). Science n s $40: 144$ (1914) 140 Rate of continental denudation. Science n s $40: 933-934$ (1914)

15 Syllabus of a course of lectures on the geology of New Mexico and its natural resources. Revised print, 24 pp., Socorro, School of Mines Press, 1915.

15a Conspectus of the geologic formations of New Mexico. $12 \mathrm{pp}$, Des Moines 1915

15b Sequence of rock formations in Kansas. 3 pp, Des Moines 1915.

15e Terranal differentiation of the Paleoroic succession. 2 pp, cbart, Des Moines 1915

15d Lake Superior highlands; their origin and age. $J$ G 23 : 569-574 (1915)

15e Complexity of the Alexandrian series. Science n s 41:863-864 (1915)

$15 \mathrm{f}$ Valley-fill of arid intermont plains. Science n s $42: 377-378$ (1915)

$15 \mathrm{~g}$ Exhumed seacoasts $(a / s t)$. Science n s $41: 950$ (1915)
Keyes, Charles Rollin-Continued.

15h Mountain structures in plains ( sst). Science n s 41:950 (1915)

$15 i$ Precise criteria of terranal correlation (abst). Science n s 41:950 (1915)

15j Miocene age of Dodge gypsum [Fort Dodge, Iowa]. Eng M J 100: 466 (1915)

15k Corrasive efficiency of natural sandblast (abst). G Soc Am, B 26:63-64 (1915)

151 False fault-scarps of desert ranges (abst). G Soc Am, B 26:65 (1915)

$15 \mathrm{~m}$ A measure of arid erosion (abst). G Soc Am, B 26:404 (1915)

15n Evolution of the general rock scheme in Iowa. An Iowa (3) 12:98-100 (1915)

15o Foundation of exact geologic correlation. Iowa Ac Sc, Pr 22:249-267 (1915)

15p Remarkable prairie synclinorium. Iowa Ac Sc, Pr 22: 268-271 (1915)

15 Contraposed shore lines on straits of Juan de Fuca (abst). Iowa Ac Sc, Pr $22: 272$ (1915)

16 Syllabus of course of lectures on the outlines of field geology with special reference to mining. Revised print, $30 \mathrm{pp}$, Socorro 1916

16a The girdled mountain; a direct consequence of general desert erosion (abst). Science n s $43: 399$ (1916)

$16 \mathrm{~b}$ Severe restrictions to normal geographic cycle. Science n s 44:238-239 (1916)

16e Desert regolith and its genetic relations to maximum epirotic deposition (abst). G Soc Am, B 27:57 (1916)

16d Controlling fault systems in Iowa. Iowa Ac Sc, Pr 23: 103-112 (1916) Abst, with title, Major discissive lines in prairie States, Science n s $44: 68$ (1916)

16e Terranal affinities of original Chouteau limestone. Iowa Ac Sc, Pr 23: 113118 (1916) Abst, with title, Wide areal extent of Chouteau limestone, Science $\mathbf{n} \mathbf{s}$ $44: 68-69$ (1916)

$16 f$ Coast range cirques of the Skeena basin [B. C.] (abst). Iowa Ac Sc. Pr 23 : 119 (1916) Abst, with title, Cirque phenomena in British Columbia, Science $\mathrm{n} s$ 44:69 (1916)

17 Orographic origin of ancient Lake Bonneville. G Soc Am, B 28: 351-374, 164 (abst) (1917)

17a Terracing of bajada belts. Nat Acad Sc, Pr 3: 33-38 (1917)

17b Lost mountains of the prairies. Sc Mo $4: 369-377$ (1917)

17e Competency of wind in land depletion. Mo Weather Rv 45:57-58 (1917)

17d Epicene profiles in desert lands. Science n s $45: 335-336$ (1917)

17 Climatic index of Bonneville Lake beds. Science n s 46:139-140 (1917)

17f Possible fan structure in Canadian Rockies (abst). Science n s $46: 45$ (1917) 
Keyes, Charles Rollin-Continued.

17g Parallelism of eastern and western interior coal fields. Coal Age 12:886-887 (1917)

17h High-level terraces of Okanogan Valley, Wash. Iowa Ac Sc, Pr 24:47-51 (1917)

17i Continental perspective of American pre-Cambrian stratigraphy. Iowa Ac Se, Pr 24:53-60 (1917)

17j Extent and age of Cap-au-Grès fault [Mississippi Valley]. Iowa Ac Sc, Pr 24: 61-66 (1917)

18 Lacustral record of past climates. Mo Weather Rv 46:277-280 (1918)

18a Rate of desert delta growth. Science n s $47: 193-194$ (1918)

18b Diverse ancestry of Great Basin lakes (abst). Science n s 47:469-470 (1918)

18e Formative setting of laccolithic mountains. Science n s 48: 138-139 (1918)

$18 d$ Geologic structure of Sierra del Oro in New Mexico. Eng M J 106:494-495 (1918)

18e Introduction of the new geology into Amerien. Johns Hopkins Alumni Mag $7: 15-22(1918)$

$18 \mathrm{f}$ Mechanics of laccolithic intrusion (abst). G Soc Am, B 29:75 (1918)

$18 \mathrm{~g}$ Faceted form of collapsing geoid (abst). G Soc Am, B 29: 76 (1918)

See also Buckley (E R), 09a; Haworth, 95: Salisbury, $98 \mathrm{~b}$

Keyes, John Arnold.

87 The falls of the Mississippi . Pop Sc Mo $31: 474-477$ (1887)

Keyes, W. S.

77 The Eureka lode, of Eureka, eastern Nevada. Am I M Eng, Tr 6:344-371 (1879) Eng M J 24:474-475; 25:24-25, $43-44(1877-8)$

Kiaer, Johan.

15 Upper Devonian fish remains from Ellesmere Land, with remarks on Drepanaspis. Second Norwegian Arctic Expedition in the Fram, 1898-1902, Rp no 33 : $58 \mathrm{pp}$, il, map (1915) (published by Videnskabs-Selskabet i Kristiania).

Kiess, E. E.

12 The after-shocks of the earthquakes of 1903,1906 , and 1911 as observed at Mount Hamilton, Cal. Seism Soc Am, B 2 : 92 (1912)

Kilham, John T.

o3 The oil wells of the United States. Onondaga Ac Sc, Pr 1: 136-148 (1903)

Killebrew, Joseph Buckner (1831-1906).

74 (and Safford, J. M.) Introduction to the resources of Tennessee [the geological formations of the State:26-46, map]. Tenn, Bur Agr, First and Second Reports: 1193 , xi pp, map, Nashville, Tenn., 1874
Killebrew, Joseph Buckner-Continued.

74a Tennessee; its agricultural resources and mineral wealth; being an abridgement of the first and second reports of the $\mathrm{Bu}$. reau of Agriculture, 168 pp, map, Nash. ville, Tenn., 1874

$74 \mathbf{b}$ Resources of Tennessee. xi, $88 \mathrm{pp}$ maps, Nashville 1874 [not seen]

76 Tennessee; its agricultural and min. eral wealth ... [Tenn, Bur Agr] : $196 \mathrm{pp}$ map, Nashville 1876

$76 \boldsymbol{n}$ Special report on the coal field of Little Sequatchee with a general description of the Cumberland tableland. [Tenn, Bur Agr] : 40 pp, map, Nashville 1876 Also in [Tenn], Bur Agr, Rp 1876:123164, map, Nashville, Tenn, 1877

76b Report on the Ocoee and Hiwassee mineral district. [Tenn, Bur Agr] : $67 \mathrm{pp}$, maps, Nashville 1876 Also in [Tenn], Bur Agr, Rp 1876:165-231, maps, Nasb. ville, Tenn., 1877

76e Mineral and agricultural resources of the portion of Tennessee along the Cincinnati Southern and Knoxville \& Ohio railroads, including the country between the two. [Tenn, Bur $\mathrm{Agr}$ ] : $145 \mathrm{pp}$, maps, Nashville 1876 Also in [Tenn], Bur Agr, Rp $1876: 233-377$, Nashville, Tenn., 1877

76d (with Safrord, J. M.) The elementary geology of Tennessee ... 255 pp. Nashville 1876

77 Oil region of Tennessee ... [Tent, Bur Agr] : 116 pp, map, Nashville, Tenn., 1877 Also in Tenn, Bur Agr, Rp 1877-8: 3-116, map, Nashville, Tenn., 1878

78 Geology and topography of the oil region of Tennessee, with some account of the oil springs and wells. Am As, Pr 26: 266-276 (1878)

81 Iron and coal of Tennessee. [Tenn, Bur Agr] : 220 pp; maps, Nashville 1881

83 Report on the culture and curing of tobacco in the United States [includes notes on geology]. U S, 10th Census $3: 583-950$ (1883)

88 The western iron belt of Tennessee. Eng M J 45: 18-19, map (1888)

89 Notes on the coal field of sonthwest Virginia. Eng M J 47:64-65 (1889)

91 The western iron belt of Tennessee. Eng M J 51 : 695-696 (1891)

96 The phosphate deposits in Maury Co., Tenn. Eng M J 62:462-463 (1896)

98 The phosphate deposits of Tennes. see-the sub-Devonian phosphates. Mant facturers' Record, 33: 389-391 (1898) Abst, Eng M J 66:68 (1898)

98a The phosphate deposits of Tennes. see-the Lower Silurian phosphates. Manufacturers' Record 34: 4-5 (1898)

O0 (with Snford, J. M.) The elements of geology of Tennessee. $264 \mathrm{pp}$, Nasnville. Tenn., 1900 
Kilpatrick, A. R.

52 The parish of Catahoula [La.] [geology : 268-271]. De Bow's Rv 12 (n s 2) : 256-275 (1852)

Kimball, James Putnam.

57 Flora from the Appalachian coal fleld. Diss., Göttingen. $38 \mathrm{pp}$, il, Göttigen 1857 Extract, with title, Ueber einige fossile Pflanzen aus der Kohlen-Formation von Pennsylvania und Ohio, N Jb 1858: $400-402$

60 On sodalite and elaeolite from Salem, Mass. Am J Sc (2) $29: 65-67$ (1860)

65 On the iron ores of Marquette, Mich. Am J Sc (2) 39:290-303 (1865)

65a (with Foster, J. W.) Geology and metallurgy of the iron ores of Lake Superior. Iron Cliffs Company: 98 pp, maps, N Y 1865

69 Notes on the geology of western Texas and of Chihuahua, Mexico. Am J Sc (2) $48: 378-388$ (1869)

70 On the Cretaceous age of silver deposits in Chihuahua, Mexico. Am As, $\mathrm{Pr}$ 18: $170-179(1870)$

70a on the silver mines of Santa Eulalla, State of Chihuahua, Mex. Am J Sc (2) $49: 161-175$ (1870)

76 On the occurrence of grahamite in the Huasteca, Mex, and notice of the geology of that region. Am J Sc (3) 12 : $277-286 \quad(1876)$

81 The Greenway iron ore belt of the James River, Va. The Virginias 2:2-5 (1881)

84 The Quemahoning coal field of Somerset Co., Pa. Am I M Eng, Tr 12:468496, maps (1884)

$84 \mathrm{a}$ The iron ore range of the Santiago district of Cuba. Am I M Eng, Tr 13: 613-634 (1885) Eng M J 38:423-427 (1884)

$\mathbf{8 4 b}$ Geological relations and genesis of the specular iron ores of Santiago de Cuba. Am J Sc (3) 28:416-429 (1884) Eng M J $38: 409-411$ (1884) Bol Minas, Habana, д0 $5: 83-95$ (1919)

84e Iron ores of the Juragua Hills near Santiago de Cuba. A geological report to the Juragua Iron Co., Ltd. 45 pp [n p, n d, 1884?]

90 Siderite basins of the Hudson River epoch [Columbia Co., N. Y.]. Am J Sc (3) $40: 155-160(1890)$

91 Genesis of iron ores by isomorphous and pseudomorphous replacement of limestone, etc. Am J Sc (3) $42: 231-241$ (1891); continued in Am G $8: 352-376$ (1891)

97 Physiographic geology of the Puget Sound basin. Am G 19:225-237, 304-322, map (1897)

97a Secondary occurrences of magnetite on islands of British Columbia by replacement of limestone and by weathering of eruptives, Am G 20:13-27 (1897)
Kimbal1, James Putnam-Continued.

$\mathbf{9 7 b}$ On the magnetite belt at Cranberry, N. C., and notes on the genesis of this iron ore in general in crystalline schists. Am G 20: 299-312 (1897)

9s Residual concentration by weathering as a mode of genesis of iron ore. Am G 21: 155-163 (1898)

99 The granites of Carbon Co., Mont.; a division and glacier field of the Snowy Range. Am Geog Soc, B 31:199-215 (1899)

02 Bohemia mining district of western Oregon. Eng M J 73:889-891 (1902)

Kimble, George W.

or Pockets in the upper portion of gold veins [Mt. Thompson, Eldorado Co. Cal.]. M Sc Press 94: 343-344 (1907)

07a The ancient river channels of California. M Sc Press 94:726-727 (1907)

Kinahan, George Henry.

82 Origin of jointed structure. Am J Se (3) 24:68-69 (1882)

83 Note on jointed strueture. Am J Se (3) $25: 476$ (1883)

84 On a possible genesis of the Canadian apatite. Manchester $G$ Soc, $\operatorname{Tr} 18: 123-$ 132 (1884)

85 On the use of the term esker or kam drift. Am J Sc (3) $29: 135-137$ (1885)

85a Canadian Archean or pre-Cambrian rocks and the Irish metamorphic rocks. G Mag (3) 2:159-169 (1885) R G Soc Ireland, J $17: 15-19$ (1886)

s6 Notes on the apatite of Buckingham, Ottawa Co. [Que.]. R G Soc Ireland, J $17: 1-2(1886)$

87 The terraces of the Great American Lakes and the roads of Glenroy. Edinb G Soc, Tr 5 : 221-223 (1887)

Kinahan, Gerrard A.

84 Note on the coal deposits of the northwest territories of Canada. R Dublin Soc, Se Pr n s 4:211-214 (1884) R G Soc Ireland, J 16: 275-278 (1886)

85. ... apatite deposits near Ottawa. Manchester G Soc, Tr 18:132-135 (1885) Kindle, Edward Martin.

94 (with Marsters, V. F.) Geological literature of Indiana (stratigraphic and economic). Ind Ac Sc, Pr 1893:156-191 (1894)

95 Dip of the Keokuk rocks at Bloomington, Ind. Ind Ac Sc, Pr 1894: 52-53 (1895)

96 The relation of the fauna of the Ithaca group to the faunas of the Portage and Chemung. B Am Pal no $6: 56 \mathrm{pp}$, il (1896)

96a The whetstone and grindstone rocks of Indiana. Ind, Dp G N Res, An Rp 20: 329-368, map (1896)

961) On some Paleozoic fossils from Baffinland. $\mathrm{Am} \mathrm{J} \mathrm{Sc} \mathrm{(4)} 2: 455-456$ (1896)

97 Pleistocene fossils from Baftinland and Greenland. Science $n$ s 6:91-93 (1897) 
Kindle, Edward Martin-Continued.

98 A catalog of the fossils of Indiana, accompanied by a bibliography of the literature relating to them. Ind, $\mathrm{Dp}$ G $\mathrm{N}$ Res, An Rp 22: 407-514 (1898)

99 The Devonian and Lower Carboniferous faunas of southern Indiana and central Kentucky. B Am Pal no 12:111 pp (1899)

or The Devonian fossils and stratigraphy of Indiana. Ind, Dp $\mathrm{G} N$ Res, An Rp 25: 529-758, 773-775, il (1901)

02 The Niagara limestones of Hamilton Co., Ind. Am J Sc (4) 14:221-224 (1902)

03 The Niagara domes of northern Indiana. Am J Sc (4) 15: 459-468 (1903)

04 The stratigraphy and paleontology of the Niagara of northern Indiana. Ind, Dp G N Res, An Rp 28: 397-486, il (1904)

04a (and Breger, C. L.) Paleontology of the Niagara of northern Indiana. Ind, Dp G N Res, An Rp 28:428-486, il (1904)

04b Note on some concretions in the Chemung of southern New York. Am G 33 : 360-363 (1904)

o4e A series of gentle folds on the border of the Appalachian system. J G 12 : 281-289, map (1904)

05 Salt and other resources of the Watkins Glen district, New York. U S G S, B 260: 567-572 (1905)

05n Water resources of the Catatonk area, N. Y. U S G S, W-S P 145:53-57 (1905)

05b (with Williams, H. S.) Contributions to Devonian paleontology, 1903. U S G S, B 244: 144 pp (1905)

06 Notes on the range and distribution of Reticularia lavis. J G 14:188-193 (1906)

OGa Faunas of the Devonian section near Altoona, Pa. J G 14:631-635 (1906)

06b The iron ores of Bath Co., Ky. U s G S, B 285 : 180-182 (1906)

07 Notes on the Paleozolc faunas and stratigraphy of southeastern Alaska. J G 15: 314-337 (1907)

O7a (with Brooks, A. H.) The Paleozoic section of the upper Yukon (abst). Science n s 25:181-182 (1907)

07b Note on a Tertiary basin in northern Alaska [Porcupine River]. Science n s 25:506-507 (1907)

os Occurrence of the Silurian fauna in western America. Am J Sc (4) 25:125129 (1908) Abst, Science n s $27: 348$ (1908)

08a Geologie reconnaissance of the Porcupine Valley, Alaska. G Soc Am, B 19 : 315-338, map (1908)

03b The fauna and stratigraphy of the Jefferson limestone in the northern Rocky Mountain region. B Am Pal 4 no 20:39 pp, il (1908)
Kindle, Edward Martin-Continued.

ose (with Brooks, A. H.) Paleozole and associated rocks of the upper Yukon, Alaska. $\checkmark$ Soc Am, B $19: 255-314$ (1908)

09 The Devonian fauna of the Ouray limestone. U S G S, B 391:60 pp, il (1909)

09a Notes on the Point Hope spit, Alaska. J G 17:178-189 (1909)

09b Diatomaceous dust on the Bering Sea ice floes. Am J Sc (4) $28: 175-179$ (1909)

09e The section at Cape Thompson, Alaska. Am J Sc (4) 28:520-528 (1909)

O9d (and Barnett, V. H.) The strati. graphic and faunal relations of the Wadron fauna in southern Indiana. Ind $D p$ G, An Rp 33 : $393-416$ (1909)

09e (with Williams, H. S.) Deserip. tion of the Watkins Glen-Catatonk distriet, N. Y. U S G S, 'G Atlas, fol $169: 33$ pp (1909)

11 The southerly extension of the Onondaga sea in the Allegheny region. J G $19: 97-103$ (1911)

$11 \mathbf{a}$ The recurrence of Tropidoleptus carinatus in the Chemung fauna of Virginia. J G $19: 346-357$ (1911)

11b The collapse of recent beds at Staunton, Va. Wash Ac Sc, Pr 13:35-49 (1911)

11e Cross-bedding and absence of fossils considered as criteria of continental de posits. Am J Sc (4) $32: 225-230$ (1911)

$11 d$ The faunal succession in the Port Clarence limestone, Alaska. Am J Sc (4) $32: 335-349$ (1911)

12 The Onondaga fauna of the Allegheny region. U S G S, B 508: 144 pp, il (1912) Abst, Wrsh Ac Sc, J 3:403-404 (1913)

12a The unconformity at the base of the Chattanooga shale in Kentucky. Am J Sc (4) $33: 120-136$ (1912)

12b The stratigraphic relations of the Devonian shales of northern Ohio, Am J Sc (4) $34: 187-213$ (1912)

12e Note on a ripple-marked limestone [Lake Winnipegosis, northern Manitoba]. Ottawa Nat 26:108-110 (1912)

13 Systematic palenotology of the Mid. dle Devonian deposits of Maryland; Vermes, Ostracoda. Md G S, Middle and Upper Devonian : $122,335-338$, il (1913)

$13 a$ Note on a process of fossilization in the Paleozoic lycopods. G Mag (5) 10: $337-340$, il (1913) Abst. G Soc Am, B 24: 115-116 (1913)

13b The unconformity at the base of the Onondaga limestone in New York and fts equivalent west of Buffalo. J G 21:301319 (1913)

13e (and Taylor, F. B.) Description of the Niagara quadrangle $[N \mathrm{Y}]$, U S G S, G Atlas Nlagara fol (no 190): $25 \mathrm{pp}$, maps (1913) 
Kindle, Edward Martin-Continued.

13d The age of the eurypterids of Kokomo, Ind. Am J Sc (4) $36: 282-288$ (1913)

14 Report of the invertebrate paleontologist. Can G S, Sum Rp 1912:404-406; $1913: 300-314 ; 1914: 122-130 ; 1915: 198$ $205 ; 1916: 295-300(1914-7)$

14a The Silurian and Devonian section of western Manitoba. Can G S, Sum Rp 1912: 247-261 (1914)

14b Notes on the Oriskany sandstone and the Ohio shale of the Ontario Peninsula. Can G S, Sum Rp 1912 : 286-290 (1914)

14e Columnar structure in limestone. Can G S, Mus B $2: 35-39$ (1914)

14d A comparison of the Cambrian and Ordovician ripple-marks found at Ottawa, Canada. J G $22: 703-713$ (1914)

14e An inquiry into the origin of $\mathrm{Ba}$ trachioides the antiquor of the Lockport dolomite of New York. G Mag (6) 1:158161 (1914)

14f What does the Medina sandstone of the Niagara section include? Science $\mathbf{n} \mathbf{s}$ $39: 915-918$ (1914)

15 (and Burling, L. D.) Structural relations of the pre-Cambrian and Paleozoic rocks north of the Ottawa and St. Lawrence valleys. Can $G \mathrm{~S}$, Mus B $18: 23 \mathrm{pp}$, maps (1915)

15a Notes on the geology and paleontology of the lower Saskatchewan River ralley. Can $\mathrm{G} S$, Mus $B \quad 21: 17 \mathrm{pp}$, il (1915)

15b Note on bottom currents in Lake Ontario. Am J Sc (4) $39: 192-196$ (1915)

15e Limestone solution on the bottom of Lake Ontario. Am J Sc (4) 39:651-656 (1915)

16 The Ordovician limestones of the Kingston area [Ont.]. Ont Bur Mines, An Rp 25 pt $3: 37-44$ (1916)

16a Bottom control of marine faunas as illustrated by dredging in the Bay of Fundy. $\Delta \mathrm{m} \mathrm{J} \mathrm{Sc} \mathrm{(4)} \mathrm{41:449-461} \mathrm{(1916)} \mathrm{Abst,}$ G Soc Am, B 27:160-161 (1916)

$16 b$ Notes on Devonian faunas of the Mackenzie River valley. Am J Sc (4) 42 : 246-248 (1916)

16e Small pit and mound structures developed during sedimentation. G Mag (6) 3:542-547 (1916)

16a Fossil collecting. Ottawa Nat 29 : 117-124 (1916)

17 Recent and fossil ripple mark. Can Q S, Mus B 25:56 pp (1917)

17a Some factors affecting the development of mud cracks. J G 25: 135-144 (1917)

17b Deformation of unconsolidated beds in Nova Scotia and southern Ontario. G Soc Am, B 28:323-334, 163 (abst) (1917)

17e Diagnostic characteristics of marine clastics, G Soc Am, B 28:905-916 (1917)
Kindle, Edward Martin-Continued.

18 Notes on sedimentation in the Mackenzie River basin. J G 26:341-360 (1918)

18a Separation of salt from saline water and mud. G Soc Am, B 29:80 (abst). 471-487 (1918)

18b An Ottawa beach of the Champlain sea. Ottawa Nat $32: 83-86$ (1918)

King, Alfred $T$.

44 Description of fossil foot marks, supposed to be referable to the classes birds, Reptilia, and Mammalia, found in the Carboniferous series in Westmoreland Co., $\mathrm{Pa}$. Ac N Sc Phila, Pr 2:175-180, il (1844)

45 Description of fossil footmarks found in the Carboniferous series in Westmoreland Co., $\mathrm{Pa}$. $\mathrm{Am} \mathrm{J}$ Sc $48: 343-352$, il (1845)

45a Footprints [Westmoreland Co., Pa.]. Am J Sc $49: 216-217$, il (1845)

45b Deseription of fossil footprints. Ac N Se Phila, Pr 2:299-300 (1845) Am J Sc (2) 1:268, il (1846)

54 On the ancient alluvium of the Ohio River and its tributaries. Ac N Se Phila, Pr 7:4-8 (1854)

54a Description of fossil trees in the coal rocks near Greensburg, Westmoreland Co., Pa. Ac N Sc Phila, Pr 7:64-65 (1854)

54b Description of fossil fruit found in the Carboniferous rocks of Beaver Co., Pa. Ac N Sc Phila, Pr 7:66 (1854)

King, Clarence (1842-1901).

7o The Comstock lode (Washoe mining district, Nev.]. U S G Expl 40th Par (King), 3:11-96, maps [in atlas] (1870)

70a The Green River coal basin [Utah]. U S G Expl 40th Par (King), 3:451-473 (1870)

71 Geological exploration of the fortieth parallel [report]. U S [War Dp], Chief Fing, An Rp 1871 (U S, 42d Cong 2d sess, H Ex Doc 1 pt 2 v 2) App $\mathrm{Z}: 1027-1030$ (1871)

71a On the discovery of actual glaciers on the mountains of the Pacific slope. Am J Sc (3) 1:157-167 (1871)

71b Active glaciers within the United States. Atlantic Monthly 27:371-377 (1871)

72 [Report on] geo'ogical exploration on the fortieth parallel from the Sierra Nevada to the eastern slope of the Rocky Mountains. U S [War Dp], Chief Eng, An Rp 1872 (U S, 42d Cong 3d sess, $H$ Ex Doc 1 pt 2 v 2): 101-102 (1872)

73 Annual report upon the geological exploration of the fortieth paranlel from the Sierra Nevada to the eastern slope of the Rocky Mountains. $10 \mathrm{pp}$, Washington 1873 A $7 s o$ in U S [War Dp], Chief Eng, An Rp 1873 (U S, 43d Cong 1st sess, H Ex Doc 1 pt 2 v 2), App DD: 1203-1210 (1873) 
King, Clarence-Continued.

74 Annual report upon the geological exploration of the fortieth parallel from the Sierra Nevada to the eastern slope of the Rocky Mountains. $6 \mathrm{pp}$, Washington 1874 Also in U S [War Dp], Chief Eng, An Rp 1874 (U S, 43d Cong 2d sess, H Ex Doc 1 pt 2 v 2 pt 2) App EE : $477-480$ (1874)

75 Annual report upon the geological exploration of the fortieth parallel from the Sierra Nevada to the eastern slope of the Rocky Mountains. 5 pp, Washington 1875 Also in U S [War Dp], Chief Eng, An Rp 1875 (U S, 44th Cong 1st sess, H Ex Doc 1 pt 2 v 2 pt 2) App KK: 919-920 (1875)

76 Annual report upon the geological exploration of the fortieth parallel from the Sierra Nevada to the eastern slope of the Rocky Mountains. $6 \mathrm{pp}$, Washington 1876 Also in U S [War Dp], Chief Eng. An Rp 1876 (U S, 44th Cong 2 d sess, H Ex Doc 1 pt 2 v 2 pt 3) App II : $217-218$ (1876)

76a Paleozoic subdivisions on the fortieth parallel. Am J Sc (3) 11:475-482 (1876)

76b Note on the Uinta and Wasatch ranges. Am J Sc (3) 11:494 (1876)

77 Annual report ... geological exploration of the fortieth parallel from the Sierra Nevada to the eastern slope of the Rocky Mountains. U S [War DD], Chief Eng. An Rp 1877 (U S, 45th Cong 2d sess, H Ex Doc 1 pt 2 v 2 pt 2) App MM: 1207 (1877)

77a Catastrophism and evolution. Am Nat 11:449-470 (1877) Separate, with cover title, Catastrophism and the evolution of environment : $37 \mathrm{pp}, 1877$

7s Annual report ... geological exploration of the fortieth parallel from the Sierra Nevada to the eastern slope of the Rocky Mountains. U S [War Dp], Chief Eng, An Rp 1878 (U S, 45th Cong 3d sess, H Ex Doc 1 pt 2 v 2 pt 3) App MM : 1419 (1878)

78a Systematic geology. U S G Expl 40th Par (King), 1:803 pp, maps (1878)

so First annual report of the United States Geological Survey. 79 pp (1880)

82 Production of the precious metals in the United States. U S G S, An Rp 2: $331-401$ (1882)

93 The age of the earth. Am J Sc (3) 45:1-20 (1893) Smiths Inst, An Rp $1893: 335-352$ (1894)

00 A great mining area [Cordilleran region]. M Se Press $80: 577-578$ (1900)

$00 a$ Testimony on Rossland veins and minerals [B. C.]. Mining 5: 99-105 (1900)

See also Powell, 82, 83

King, David.

51 The principles of geology explained, and viewed in their relations to revealed and natural religion. 220 pp, N Y 1851

King, Franklin Hiram.

82 Geology of the upper Flambeau Valley. [Wis G S], G Wis 4:583-615, maps (1882)
King, Franklin Hiram-Continued.

85 Lateral movements of the earth: crust. Science 5:514 (1885)

s6 Internal chemical and mechanimal erosion a factor in continent and mountait building. Am Nat 20:53-57 (1886)

99 Principles and conditions of the movements of ground water. U S G S, As Rp 19 pt $2: 59-294$ (1899)

11 Productivity of soils. Science in : $33: 614-619$ (1911)

King, Francis Plaisted.

90 (with Bayley, W. S.) Catalogue of the Maine geological collection, with \& brief outline history of the two surveys of the State. 32 pp, Waterville, Me., Ger logical Department Colby University, 1890

94 A preliminary report on the corun dum deposits of Georgia. Ga G S, B 2: $138 \mathrm{pp}$, map (1894)

96 (with Yeates, W. S., and MeCallie, S. W.) A preliminary report on a part of the gold deposits of Georgia. Ga G S, B 4-A : 542 pp (1896)

06 Basic magnesian rocks associated with the corundum deposits of Georgia. (Diss Johns Hopkins University) 32 pp, Baltimore, Md. 1906

King, Helen Dean.

99 Edward Drinker Cope. Am G 23:141, port. (1899)

King, Henry.

40 Report of a geological reconnaissance of that part of the State of Missouri adjacent to the Osage River. $19 \mathrm{pp}, 1840$ [not seen]

44 Geology of the Valley of the Missis sippi from the southern part of the State of Missouri to Wisconsin River in the Territory of Iowa (abst). Am J Sc 47:128130 (1844)

49 A geological survey of the State of Missouri. Western J (St. Louis) $3: 12$ 29, 76-83 (1849)

51 Some remarks on the geology of the State of Missouri, Am As, Pr 5:182-19? (1851)

52 Some remarks on the geology of the State of Missouri. Western $\mathbf{J}$ (St. Louis) $8: 228-242$ (1852)

King, Louis Vessot.

12 On the limiting strength of rocks under conditions of stress existing in the earth's interior. J G 20:119-138 (1912)

17 The mathematical theory of the internal friction and limiting strength of rocks under conditions of stress existing in the interior of the earth. J G 25:638658 (1917)

King, Shirley.

10 The Wilbur iron mine [Lanark Co., Ont.]. Can M Inst, J 12:582-591 (1910) King, William (1809-1886).

66 (and Rowney, T. H.) On the socalled "eozoonal rock." G Soc London, Q J 22: 185-218, il (1866) Abst, G Mag $3: 80$ (1866); Ph Mag (4) $31: 159$ (1866) 
King, William-Continued.

69 (and Rowney, T. H.) On the socalled "eozoonal rock." G Soc London, Q J 25:115-117 (1869) G Mag 6:84-87 (1869)

70 (and Rowney, T. H.) On Eozoon canadense. R Irish Ac, Pr 10:506-551, 11 (1870) Abst, Am J Sc (3) $1: 68,138-142$ (1871)

71 (and Rowney, T. H.) On the mineral origin of the so-called "Eozoon canadense." R Irish Ac, $\operatorname{Pr}$ (2) 1:140-153 (1871)

74 (and Rowney, T. H.) Remarks on the subject of "Eozoon." An Mag N H (4) $13: 390-396$ (1874)

74a (and Rowney, T. H.) "Eozoon" examined chiefly from a foraminiferal stąndpoint. An Mag N H (4) 14:274-289, il (1874)

74b (with Davidson, Thomas) On the Trimerellidae, a Paleozoic family of the Palliobranchs or Brachiopoda. G Soc London, Q J $30: 124-173$, il (1874)

76 (and Rowney, T. H.) Remarks on the "Dawn of life" by Dr. Dawson, to which is added a supplementary note [Eozoon]. An Mag N $\mathrm{H}$ (4) $17: 360-377$ (1876)

81 (and Rowney, T. H.) An old chapter of the geological record with a new interpretation ... with an introduction ... on the so-called "Eozoon canadense"... Ivii, 142 pp, L 1881

Kingsley, James L.

08 (with Silliman, Benjamin) Account of a remarkable fall of meteoric stones in Connecticut. Phila Med Phys J 3 pt 1:39-57 (1808)

09 (with Siliman, B.) Memoir on the origin and composition of the meteoric stones which fell ... in the County of Fairfield and State of Connecticut on the 14th of December, 1807 ... Am Ph Soc, Tr 6 : 323-343 (1809)

10 (with Silliman, B.) An account of the meteor which burst over Weston in Cunnecticut, in December, 1807, and of the falling of stones on that occasion. Conn Ac, Mem 1:141-161 (1810) Am J Sc (2) $47: 1-8 \quad(1869)$

Kingsley, John Sterling.

91 The Hat Creek [Nebr.] bad lands. Am Nat 25: 963-971 (1891)

94 The classification of the Arthropoda. Am Nat 28:118-135; 220-235 (1894)

97 The systematic position of the trilobites. Am G 20:33-38 (1897)

97a Edward Drinker Cope. Am Nat 31 : 414- 419 (1897)

See also Eastman, 00

Kinley, Isaac.

87 The North American lakes. Pop Sc Mo $31: 333-339$ (1887)
Kinney, Bryce $A$.

04 Annual report of the State natural gas supervisor. Ind, Dp $G$ N Res, An Rp $28: 357-375$ (1904) ; $29: 757-799$ (1905)

Kinney, H. D.

10 A new anthophyllite occurrence on Manhattan Island (abst). N Y Ac Sc, Au $19: 308(1910)$

Kinzie, Robert A.

04 The Treadwell group of mines, Douglas Island, Alaska. Am I M Eng, Tr 34 : 334-386 (1904) Abst, Eng M J 76 : 583587 (1903)

Kip, H, Z.

or A new method for the determination of the hardness of minerals. Am J Sc (4) $24: 23-32$ (1907)

Kirby, Edmund Burgis.

92 The ore deposits of Creede [Colo.] ... Eng M J $53: 325-326$ (1892)

98 The gold ore deposits of Mount Caribou, Idaho. Colo Se Soc, Pr 5:72-75 [1898]

98a [Genesis of ore chutes.] Colo Sc Soc, B 1897 no $10: 5-6$ [1898]

02 Methods of testing and sampling placer deposits. Colo Sc Soc, Pr 6:186199 [1902] (separate ed, $12 \mathrm{pp}, 1899$ )

04 The ore deposits of Rossland, B. C. (with discussion). Can M Inst, $J$ 7:4769 (1905) Can M Rv 23:60-64 (1904) M Sc Press 88:331, 347 (1904)

See also Austin, 02

Kirchhon, Charles.

83 Copper. U S G S, Min Res [1882] : $213-305 ; 1883-4$; $322-374 ; 1885$ : 208$243 ; 1886: 109-139 ; 1887: 66-97 ; 1888$ : $43-77 ; \quad 1889-90: 56-77 ; \quad 1891: 81-102$; $1892: 95-120 ; 1893: 62-88$; An Rp 16 pt $3: 332-358 ; 17$ pt $3: 81-129 ; 18$ pt 5 : $185-235 ; 19$ pt $6: 137-196 ; 20$ pt $6: 159-$ 220 ; 21 pt $6: 163-223$; Min Res 1900 : 141 $190 ; 1901: 157-198 ; 1902: 163-203 ; 1903$ : $201-239 ; \quad 1904: 221-257 ; \quad 1905: 343-362$ (1883-1906)

83a Lead. U S G S, Min Res [1882] : $306-323 ; 1883-4: 411-462 ; 1885$ : 244-271 : $1886: 140-153 ; 1887: 98-112 ; 1888: 78-$ $91 ; 1889-90: 78-87 ; 1891: 103-110 ; 1892$ : 121-129; 1893 : 89-102; An Rp 16 pt 3 : $359-377 ; 17$ pt $3: 131-162 ; 18$ pt $5 \quad 237$ $262 ; 19$ pt $6: 197-222 ; 20$ pt $6: 221-247$; 21 pt $6: 225-247$; Min Res $1900: 191-211$; $1901: 199-210 ; 1902: 205-216 ; 1903: 241-$ 252 ; $1904: 259-271$; 1905 : 363-370 (18831906)

83b Zinc. U S G $\mathrm{S}$, Min Res [1882] : $346-358 ; 1883-4$ : 474-491; 1885 : 272-283 ; 1886 : 154-159 ; $1887: 113-117$; 1888 : 92$96 ; 1889-90: 88-93 ; 1891: 111-116 ; 1892$ : 130-138; $1893: 103-110$; An Rp 16 pt 3 : $378-388 ; 17$ pt $3: 163-177 ; 18$ pt $5: 263-$ $280 ; 19$ pt $6: 223-239 ; 20$ pt $6: 249-266$; 21 pt $6: 249-266$; Min Res $1900: 213-227$; 1901 : $211-223$; $1902: 217-229$; 1903 : 253264 ; 1904 : $273-283$; 1905 : 371-377 (18831906) 
Kirchner, Walter C. G.

98 Contribution to the fossil flora of Florissant, Colo. Ac Sc St L, Tr 8:161188 , il (1898)

Kirchofer, William Gray.

05 The sources of water supply in Wisconsin. Wis Univ, B no 106, Eng s 3 : 163-249, map (1905)

Kirk, Charles Townsend.

04 A preliminary report on the contact of the Permian with the Pennsylvanian in Oklahoma. Okla, Dp G N H, Bien Rp 3: 5-14 (1904)

os Gold, silver, copper, lead, and zinc ; Montana. U S G S, Min Res 1907:312337 (1908)

12 Conditions of mineralization in the copper veins at Butte, Mont. Ec G $7: 35$ 82 (1912)

14 The geology of the Gallup Basin, N Mex. N Mex Univ, B 76 (g s 3, no 2) : 28-68, map (1914)

15 Certain structural features in the coal fields of New Mexico (abst). G Soc Am, B 26:405-406 (1915)

16 Tungsten district of Boulder Co., Colo. M Se Press 112: 791-795 (1916)

17 Significant features of western coal deposits. Southwestern As Petroleum G, B $1: 148-151$ (1917)

Kirk, Edwin.

11 The structure and relationships of certain eleutherozoic Pelmatozoa. U S Nat Mus, Pr 41: 1-137, il (1911)

14 Notes on the fossil crinoid genus Homocrinus Hall. U S Nat Mus, Pr 46 : 473-483, il (1914)

18 Stratigraphy of the Inyo Range [southern California]. U S G S, P P 110 : 19-48 (1918)

1Sa Paleozoic glaciation in southeastern Alaska. Am J Sc (4) 46:511-515 (1918) Abst, G Soc Am, B $29: 149-151$ (1918)

18b An Ordovician fauna from southeastern Alaska (abst). G Soc Am, B 29 : 143-144 (1918)

See also Walcott, 10, 14

Kirk, M. Z.

94 (with Haworth, Erasmus) A geologic section along the Neosho River from the Mississippian formation of the Indian Territory to White City, Kans., and along the Cottonwood River from Wyckoff to Peabody. Kans Univ Q 2:104-115 (1894)

96 A geologic section along the Neosho and Cottonwood rivers. Kans Univ G S 1 : 72-85 (1896)

$96 a$ The sands of the Kansas River valley. Kans Univ Q 4:125-128 (1896)

Firlk, Morris $P$.

04 (and Malcolmson, J. W.) A new quicksilver mining district [Brewster Co., Tex.]. Eng M J 77:685-686 (1904)

05 The Terlingua quicksilver district

[Tex.]. M Mag 11: 441-443 (1905)

09 The Presidio silver mines, Shafter, Tex. Eng M J 88:818-819 (1909)
Kirkaldy, G. W.

10 Three new Hemiptera-Heteropter from the Miocene of [Florissant], Cols. Entom News 21: 129-131 (1910)

Kirkby, J. W.

84 (with Jones, T. R.) On some Car. boniferous Entomostraca from Nova Scotil G Mag (3) 1:356-362, fl (1884)

89 (with Jones, T. R.) On some of tracoda from the Mabou coal field, inverness Co., Cape Breton (Nova Scotia). G Mag (3) 6:269-271, il (1889)

Kirklnnd, C.

89 The origin and formation of the ord of the Porcupine mine, Port Arthur, 0nt. Eng M J 47:347-348 (1889)

Kirkpatriek, F. A.

12 (and Nelson, W. A.) Tests on the clays of Henry Co. Tenn G S, Res Ten $2: 406-423$ (1912)

Kirkpatriek, J. W.

91 A boulder of copper and glacial striae in central Missouri, Science 18:344-345 (1891)

Kirkpatriek, R.

12 On the stromatoporoids and Eozoon. An Mag N H (8) 10:341-347 (1912)

12a On the structure of stromatoporoids and of Eozoon. An Mag N H (8) 10: $446-460$, il (1912)

12b On the structure of the stromatoporoid skeleton and on Eozoon. Nature $90: 37$ (1912)

Kirsopp, John, jr.

o3 The coal fields of Cook Inlet, Alasks, and the Pacific cosst. Inst $M$ Eng, Tr $21: 516-566$, maps (1903)

Kitchell, William (1827-1861).

55 First annual report of the geological survey of the State of New Jersey for the year 1854. $100 \mathrm{pp}$, New Brunswick 1855

55a ...physical geography and geologiel formation of Sussex Co. [N. J.]. N J G \&, An Rp 1: 28-55 (1855)

56 Second annual report on the geological survey of the State of New Jersy, for the year 1855 . $248 \mathrm{pp}$, maps, Trenton 1856

56a Report on the geological depart. ment; northern division of the State. N J G S, An Rp 2:111-248 (1856)

57 Report of the superintendent and State geologist for the year 1856. N J G $\mathrm{S}$, An Rp 3:5-38 (1857)

$\mathbf{5 7 a}$ Iron ores of New Jersey; geologieal occurrences, properties, metallurgy, etc. M Mag 8: 332-348, 434-438 (1857)

Isite, W. C.

17 An outline for a type report on ant oil field. Southwestern As P'etroleum G, B 1: 131-1:3 (1917)

Kithil, Karl L.

13 On the occurrence of a probable net mineral. Science n s 38:624-625 (1913)

15 Monazite, thorium, and mesothorium. U S Bur Mines, Tech P 110:29 pp (1915) 
Kithil, Karl L.-Continued.

17 (and Davis, J. L.) Mining and concentration of carnotite ores. U S Bur Mines, B 103: 89 pp (1917)

Kitson, H. W.

17 The mining districts of Joplin and southeast Missouri. Eng M J 104:1067$1073 ; 105: 359-364(1917-8)$. Reprinted in Mining practices (published by Eng $\mathbf{M}$ J) : 1-12, N Y 1919

Kittl, Ernst.

07 Die Triasfossilien vom Heureka Sund. Second Norwegian Arctic Expedition-in the Fram, 1898-1902, Rp (published by Videnskabs-Selskabet i Kristiania) no 7 : $44 \mathrm{pp}$, il (1907)

Kittredge, Geo. F.

76 The present condition of the earth's interior. $16 \mathrm{pp}$, Buffalo 1876

Klautzseh, A.

09 Das kalifornische Erdbeden vom 18. April 1906. Ges Erdk, Berlin, Zeitschr, $1909: 609-616$.

Klein, A. A.

12 (with Kraus, E. H.) Die optischen Eigenschaften einiger J eisilikate. Centralbl Min : 289-295 (1912)

Klein, Carl.

84 Analcim von Table Mountain bei Golden, Colo.; apophyllite von Table Mountain, Golden, Colo., von den Färoẻr Inseln and von Guanajuato, Mexico. N Jb 1884 , $1: 250-256$

02 Über die am 7. Mai 1902 vom Sonfrière auf St. Vincent ausgeworfene vulcanische Asche. K Preuss Ak Wiss Berlin, Szb $1902:$ : 993-994

04 Über das Meteoreisen von Persimmon Creek, bel Hot House, Cherokee Co., NordCarolina. K Preuss Ak Wiss Berlin, Szb $1904: 572$

Kleinsehmidt, J. L.

60 [Copper deposits of southern Appalachians.] In Cotta, B. von, und Müler, Hermann, Gangstudien oder Beiträge zur Kenntniss der Erzgänge $3: 256-259$, Fretberg 1860

69 Mitthellungen aus Montana Territorium. Berg- $\mathrm{u}$ hütt Ztg 28:97-98, 185 187, 211-212 (1869)

Kleinschmidt, $\mathrm{L}$.

84 Der Eisenberg Cerro Mereado bei Durango, Mexico. Berg- $\mathrm{u}$ hütt Ztg 43 : 533535 (1884)

Klem, Mary J.

00 The development of Agaricoorinus. Ac Sc St L, Tr 10:167-184, il (1900)

04 A revision of the Paleozoic Palae echinoidea, with a synopsis of all known species. Ac Sc St L. Tr 14: 1-98, il (1904)

Klippart, John Hancock (1823-1878)

71 Agricultural survey. Ohio G S, Rp Prog 1870:311-400 (1871)

74 [A new species of Spirifer, from Kelly's Island, Ohio]. Cleveland Ac, Pr 1: 120 (1874)
Klippart, John Hancock-Continued.

75 Discovery of Dicotyles (Platygonus) compressus, Le Conte [at Columbus, Ohio]. Am As, Pr 23 pt 2: 1-6 (1875) Cin Q J Sc 2: 1-6 (1875)

75a Mastodon remains in Ohio. Cin Q J Sc 2: 151-155 (1875)

\section{Klittke, $M$.}

96 Entwickelung. Organization, un d Leistungen der geologischen Landesaufnahmen in den Vereinigten Staaten von Nordamerika. Zs prak G 1896:209-213, $289-352$

97 Die geologische Aufnahme der Dominion of Canada. Zs prak G 1897:117144

Kloos, Johan Hermann (1842-1901).

71 Geologische Notizen aus Minnesota. Deut G Ges, Zs 23: 417-448, 648-652, map (1871) Minn G S, An $\mathrm{Rp} 10: 175-200$, map (1882)

72 A Cretaceous basin in the Sauk Valley, Minn. Am J Sc (3) 3:17-26 (1872)

77 Geognostische und geographische Beobachtungen im Staate Minnesota. Ges Erdk Berlin, Zs 12: 266-318 (1877) Transl, by N. H. Winchell, Minn G S, An Rp 19: 81-121 (1892) Also, Diss. Göttingen, 58 pp, Berlin 1877

77a (with Streng, A.) Ueber die Krystallinischen Gesteine von Minnesota in Nord-Amerika. N Jb $1877: 31-56,113-138$, 225-242 Minn G $S$, An Rp 11:30-85 (1884)

89 Untersuchungen iber Gesteine und Mineralien aus West-Indien. G ReichsMus Leiden, Samm (2) 1: 1-100, 169-206 (1889)

\section{Klopstoek, Paul.}

13 The Kennedy mining district, Nev. Am I M Eng. B 78:1041-1046 (1913) M World 39:63-65 (1913)

Klotz, Otto Julius.

95 Experimental application of the photo-topographical method of surveying to the Baird glacier, Alaska. J G $3: 512-518$ (1895)

99 Notes on glaciers of southeastern Alaska and adjoining territory. Geog J 14 523-534, maps (1899)

o7 Seismographic and magnetic work. Can, Dp Interior, Rp Chief Astronomer (pt $\mathrm{V}$ of An Dp Rp for 1906) : 7-37 (1907)

07a Recession of Alaska glaciers. Geog J $30: 419-421$ (1907)

O7b Earthquakes. Ottawa Lit Sc Soc, Tr 1907:130-144 (1907)

os Earthquakes and the interior of the earth. $\mathrm{R}$ Astron Soc Can, J 2:51-69 (1908)

10 Seismology, terrestrial magnetism, and gravity. Can, Dp Interior, Rp Chief Astronomer for 1908, App 1:7-60 (1910)

10a Microseisms, R Soc Can, $\operatorname{Pr} \operatorname{Tr}(3)$ 3 ili : 197-208 (1910) Science n s $32: 126$ (abst), 252-254 (1910) 
Klotz, Otto Julius-Continued.

$10 b$ Report of the permanent commlssion of the International Seismological Association. Science n s 32:199-200 (1910)

10c Seismology terrestrial magnetism, and gravity. Can, Dp Interior, Rp Chief Astronomer for 1909, App 1: 19-66 (1910)

11 Earthquake epicenters. Seism Soc Am, B $1: 143-148$ (1911)

13 Earthquake of April 28, 1913. Can, Dp Interior, Dominion Observatory, Ottawa, Pub 1 : 131-152 (1913)

13a The undagraph. Seism Soc Am, B $3: 20-23$ (1913)

15 Earthquake of February 18, 1911. Seism Soc Am, B 5: 205-213 (1915)

15a Earthquake of February 10, 1914. Can, Dp Interior. Dominion Observatory, Pub 3: 1-14 (1915)

16 Seismological tables. Can, Dp Interior, Dominion Observatory, Pub $3: 15$ 61 (1916)

17 The earthquake of January 30, 1917. Seism Soc Am, B $7: 34-36$ (1917)

$\mathbf{1 7}$ a Velocity of $L$ waves. Seism Soc Am, B $7: 67-71$ (1917)

17b Some memoranda from the chairman of the scientific committee. Seism Soc Am, B $7: 97-105$ (1917)

17e Locating submarine faults. Seism Soc Am, B $7: 127-129$ (1917)

18 Analysis of earthquake waves. Seism Soc Am, B 8:83-87 (1918)

18a The transmission of earthquake waves. $\mathrm{R}$ Soc Can, $\operatorname{Tr}$ (3) 12 iii : $37-41$ (1918)

Knapp, E. B.

s8 Glimpses of the geology of Onondaga Co., N. Y. 8 pp, Skaneateles, N. Y., n d [1888?]

Knapp, George N.

97 (with Salisbury, R. D.) Surface geology ; report of progress. N J G S, An Rp $1896: 1-23$, maps (1897)

04 Underground waters of New Jersey; wells drilled in 1903 . N J G S, An Rp 1903: 73-93, map (1904)

04a The Cliffwood clays and the Matawan. Am G 33:23-27 (1904)

04b (with Kitmmel, H. B.) The stratigraphy of the New Jersey clays. N J G S, Final Rp 6:117-209, maps (1904)

o5 [Underground waters of] New Jersey. U S G S, W-S P 114: 93-103 (1905)

07 [The Cretaceous formations of New Jersey.] N J G S, Pal 4:15-20 (1907)

17 (with Salisbury, R. D.) The Quaternary formations of southern New Jersey. N J Dp Cons, Div M G [N J G S]. Final report series of the State Geologist $8: 218 \mathrm{pp}$ (1917)

See also Bascom, 09a, b

Knapp, I, N.

12 Value of geology in the petroleum industry. M World 36:412 (1912)
Knapp, I. N.-Continued.

12a Natural gas, with incldental refer. ence to other bitumens. Franklin Inst, J $174: 477-498,639-662$ (1912)

14 Gas sands. Nat Gas As Am, $\operatorname{Pr} 6$ : 41-57 [1914].

See also Hager, 17, 18; Johnson (R H), 15 ; Matteson, 17

Knapp, J. G.

72 Ancient lakes of Wisconsin. Wis $\mathrm{Ac}$ Sc, Tr 1: 151-153 (1872)

\section{Knapp, M. A.}

97 The coal fields of Esmeralda Co., Nev. M Sc Press, 74:133 (1897)

06 The fault system of eastern Santa Eulalia [Mexico]. Eng M J 81: 993-994 (1906)

Knapp, S. A.

9s Occurrence and treatment of the car bonate of soda deposits of the Great Basin. M Sc Press 77:448 (1898)

99 Occurrence and recovery of sodium carbonate in the Great Basin. Mineral Industry $7: 626-634$ (1889)

o1 Tonopah [Nev.]. M S. Press 82: 231 (1901)

Kneeland, Samuel, Jr, (1821-1888).

56 [Sketch of the life of Zadock Thomp. son, 1796-1856.] Boston Soc N H, Pr 5 $312-313$ (1856)

72 On the glaciers of the Yosemite Val. ley. Boston Soc N H, Pr 15: 36-47 (1872)

73 On the volcanoes of the Sandwich Is. lands. Boston Soc N H, Pr 15:248-249 (1873)

74 On the geology, geography, and scenery of the Union Pacific Railroad. Boston Soc N H, Pr 16:375-376 (1874)

Knerr, E. B.

93 Note on a plnk barite from Atchison limestone [Kans.]. Kans $\mathrm{Ac}$ Se, $\mathrm{Tr} 13$ : 76 (1893)

96 A geologic section from Atchison to Barnes, along the central branch of the Missouri Pacific Railway. Kans Univ G S 1: 140-144 (1896)

$96 a$ Coal in Atchison Co., Kans, Kans Ac Sc, Tr $14: 216-217$ (1896)

Knight, C. Y.

07 A curious occurrence of copper [near Shingle Springs, Eldorado Co., Cal.]. M Sc Press 94: 242 (1907)

Knight, Cyril Workman.

o5 Analcite-trachyte tuffs and brecclas from southwest Alberta, Canada. Can Rec Sc $9: 265-278$ (1905)

05a Notes on some deposits in the eastern Ontario gold belt (with discussion). Can M Inst, J $7: 210-244$ (1905)

06 A new occurrence of pseudo-leucite [Yukon Terr.]. Am J Sc (4) 21:286293 (1906)

O6a (with Campbell, William.) The paragenesis of the cobalt-nickel arsenides and silver deposits of Timiskaming [Ont.]. Eng M J 81:1089-1091 (1906) 
Knight, Cyril Workman-Continued.

o6b (with Read, T. T.) The re-formation of soda-leucite. Am J Sc (4) 21 : 294-295 (1906)

o7 Oil and gas in Kent [Co,, Ont.]. Ont Bur Mines, An Rp 16 pt 1:92-104 (1907)

07a (with Miller, W. G.) GrenvilleHastings unconformity ... Ont B Mines Rp $16: 221-223$ (1907)

os The annual meeting of the Geological Society of America, at Albuquerque N. M. Can M J 29:675-679 (1908)

osa (with Miller, W. G.) GrenvilleHastings unconformity (abst). Science $\mathrm{n} \mathrm{s}$ $27: 407-408$ (1908)

09 The Winnipeg meeting of the British Association for the Advancement of Science. Can M J 30:644-648 (1909)

09a [On the Lower Huronian ice age.]

Can M J $30: 727-728$ (1909)

09b (with Miller, W. G.) GrenvilleHastings unconformity (abst). G Soc Am, B $19: 539-540$ (1909)

11 Mineral associations at Porcupine [Ont.]. M Sc Press 102:530 (1911)

$11 a$ Geology of the Cobalt district, Ont. (discussion). Am I M Eng, B 60:10351037 (1911) ; Tr 42:924-926 (1912)

$11 b$ (with Miller, W. G.) The Laurentian system. Ont B Mines, Rp 20:280284 (1911)

12 Recent underground development work at Cobalt. Can M Inst, Tr 15:231237 (1912)

13 The Qutlying cobalt-silver areas [Ont.]; Montreal River and Temagami forest reserve. Ont Bur Mines, An Rp 19 pt 2:155-164, map (1913)

13a The Madoc area [Ont.]. Int $G$ Cong, XII, Canada, Guide Book no $6: 55$ 62, maps (1913)

14 (with Miller, W. G.) The pre-Cambrian geology of southeastern Ontario, with an appendix on the correlation of the preCambrian rocks of Ontario, western Quebec, and southeastern Manitoba. Ont Bur Mines, Rp 22 pt $2: 151$ pp, maps (1914)

15 The north shore of Lake Huron [Ont.]. Ont Bur Mines, An Rp 24 pt 1: 216-241 (1915)

15a Records of wells drilled for oil and gas in Ontario. Ont Bur Mines, An Rp 24 pt 2:96 pp, map (1915)

15b (with Millex, w. G.) Metallogenetic epochs in the pre-Cambrian of Ontario. R Soc Can, Tr (3) 9 iv : 241-249, map (1915) : Ont Bur Mines, An Rp 24 pt 1: 243-248, map (1915)

15e (with Miller, W. G.) Review of pre-Cambrian classification in Ontario. $\mathrm{J}$ G 23:585-599, map (1915) Can M J 36: 265-266, map (1915) M Sc Press 111: 401-404, map (1915) Abst, G Soc Am, B $26: 87-88$ (1915); Science n s $41: 509$ (1915)
Knight, Cyril Workman-Continued.

17 (with Miller, W. G.) Euxenite, a radioactive mineral in South Sherbrooke township, Lanark Co. Ont Bur Mines, An Rp 26:314-317 (1917)

$17 a$ (with Miller, W. G.) Occurrence of euxenite in South Sherbrooke township, Ont. Am J Sc (4) $44: 243-244$ (1917)

Knight, F. C.

98 A suspected new mineral from Cripple Creek [Colo.] (with discussion by Richard Pearce). Colo Sc Soc, Pr 5: 66-71 [1898] (separate ed, $6 \mathrm{pp}, 1894$ )

Knight, Nicholas.

01 Some Iowa dolomites. Am J Sc (4) $11: 244-246$ (1901)

O1a Some recent analyses of Iowa building stones. Iowa Ac Sc, Pr 8:104-109 (1901)

02 Analysis of Mount Vernon loess. Am J Sc (4) $13: 325$ (1902) Am G 29:189 (1902)

03 Apatite crystals, Antwerp, N. Y. Am G $31: 62$ (1903)

04 The dolomites of eastern Iowa. Am G 34:64-66 (1904) G Mag (5) $1: 493-$ 495 (1904)

O4a Some features in the analysis of dolomite rock. Iowa $\mathrm{Ac}$ Sc, $\operatorname{Pr} 11: 127$ 131 (1904)

05 Estimation of the silica in the Bedford limestone [Indiana]. Am G 36:5760 (1905)

06 (and wheeler, W. H.) Dolomite and magnesite with reference to the separation of calcium and magnesium. Iowa Ac Sc, Pr 13: 167-171 (1906)

o7 The determination of silica. Iowa Ac Sc, Pr 14:201-211 (1907)

os The decomposition of dolomite. Iowa Ac Sc, Pr 15: 107-108 (1908)

14 Unusual dolomites. Iowa Ac Sc, $\mathrm{Pr}$ $21: 127-128$ (1914)

Knight, Ora Willis.

11 Research फork on certain Nova Scotia gold ores. M Soc N S, J 16:93-112 (1911) Can M J 32:622-626, 657-660 (1911)

Knight, S. H.

16 Lithogenesis and stratigraphy of the red beds of southeastern Wyoming (abst). G Soc Am, B 27:120-122 (1916)

17 Climatic conditions in southern Wyoming during deposition of the "red beds" (abst). N Y Ac Sc, An 27:255-256 (1917)

17a Age and origin of the red beds of southeastern Wyoming ( $a b s t$, with discussion by Erasmus Haworth and E. B. Branson). G Soc Am, B 28: 168-169 (1917)

Knight, Wilbur Clinton (1858-1903).

93 Geology of the Wyoming experiment farms and notes on the mineral resources of the State. Wyo, Univ, Wyo Exp Sta, B 14: 103-212 (1893)

95 Coals and coal measures of Wyoming. U S G S, An Rp 16 pt 4:208-215 (1895) 
Knight, Wilbur Clinton-Continued. 95ัa A new Jurassic plesiosaur from Wyoming. Sclence n s 2:449 (1895)

96 (and slosson, E. E.) The petroleum of Salt Creek, Wyo. Wyo, Univ, Sch Mines, Petroleum ser, B 1: 47 pp (1896)

86a The Salt Creek oil field, Wyo. Eng M J $61: 87-88$ (1896)

97 (and slosson, E. E.) The petroleum of the Shoshone anticlinal. Wyo, Univ, Sch Mines, Petroleum ser, B 2:34 pp (1897)

$97 \mathbf{a}$ The petroleum flelds of Wyoming. Mineral Industry 5:442-450 (1897)

97b "Mineral soap." Eng M J 63:600601 (1897)

9s Some new Jurassic vertebrates from Wyoming. Am J Sc (4) 5:186, 378-381, il (1898)

98n The natural soda deposits of Wyoming. Mineral Industry 6:612-616 (1898)

98b Bentonite [Wyoming]. Eng M J $66: 491$ (1898)

9se The building stones and clays of Wyoming. Eng M J 66:546-547 (1898)

99 (and Slosmon, E. E.) The oil fields of Creek and Uinta cos., Wyo. Wyo, Univ, Sch Mines, Petroleum ser, B 3:31 pp (1899)

99a The Nebraska Permian. J G 7 : 357-374, map (1899)

$99 \mathbf{b}$ Some new data for converting geological time into years. Science n s 10 : $607-608$ (1899)

99e (with Barbour, E. H.) The discovery of new invertebrates in the dinosaur beds of Wyoming (abst). Am As, Pr 48: 229-230 (1899) Science n s 10:490 (1899)

00 A preliminary report on the artesian basins of Wyoming. Wyo, Univ, Wyo Exp Sta, B 45: 107-251, il, map (1900)

OOa Jurassic rocks of southeastern Wyoming. G Soc Am, B $11: 377-388$, map (1900) Abst, Science n s 11:142-143 (1900)

oob Some new Jurassic vertebrates. Am J Sc (4) 10:115-119, il (1900)

ooe The Wyoming fossil fields expedition of July, 1899. Nat Geog Mag 11: 449-465 (1900)

01 The Sweetwater mining district, Fremont Co., Wyo. Wyo, Univ, Sch Mines, Univ G S, B [5] : 35 pp, map (1901)

01a (and Slosson, E. E.) The Dutton, Rattlesnake, Arago, Oil Mountain, and Powder River oll fields. Wyo, Univ, Sch Mines, Petroleum ser, B 4:57 pp, map (1901)

o1b (and slosson, E. E.) Alkali lakes and deposits. Wyo, Univ, Wyo Exp Sta, B $49: 71-123$, map (1901)

o1e The petroleum fields of Wyoming. Eng M J 72 : 358-359, 628-630 (1901)

o1d Potassium nitrate in Wyoming. Science n s 13:151-152 (1901)
Knight, Wilbur Clinton-Continued.

o1e Description of Bates Hole, II (abst). G Soc Am, B 12:495-496 (190 J G $9: 70-71$ (1901)

02 (and slosson, E. E.) The Ner castle oil field. Wyo, Univ, Sch Mines Petroleum ser, B 5:24 pp (1902)

02a Further notes on the occurrence rare metals in the Rambler mine, Wyomins Eng M J $73: 696$ (1902)

$\mathbf{0 2 b}$ The petroleum fields of Wyoming Eng M J $73: 720-723$ (1902)

02e The Laramie Plains red beds and their age. J G 10:412-422 (1902)

03 (and Slosson, E. E.) The Bonanza Cottonwood, and Douglas oil fields. Wya Univ, Sch Mines, Petroleum ser, B $6: 30 \mathrm{p}$. (1903)

O3a Some notes on the genus Baptanodon, with a description of a new species Am J Sc (4) 16:76-81, 11 (1903)

03b Epsom salt in Wyoming [Albany Co.]. Eng M J 75:259 (1903)

o3e (and Kemp, J. F.) Geology of the Leucite Hills, Wyo. (abst). Science n s $17: 299$ (1903)

03d Remains of elephants in Wyoming. Science n s $17: 828-829$ (1903)

ose Coal fields of southern Uinta $\mathrm{CO}_{0}$. Wyo. (abst). G Soc Am, B 13:542-544 (1903)

O3f (with Kemp, J. F.) Leucite hills of Wyoming. G Soc Am, B 14:305-336, map (1903) Abst, Science n s $17: 299$ (1903)

04 Gypsum deposits in Wyoming. U \& G S, B 223: 79-85 (1904)

12 The Green River, Utah, oil field. Salt Lake M Rv 13 no $22: 11-14$ (1912)

Kniker, Hedwig Thusnelda.

18 Comanchean and Cretaceous Pectinidae of Texas. Tex, Univ, B 1817:56 pp, il (1918)

Knirk, Carl F.

09 Natural gas in the glacial drift of Champaign Co. III G S, B 14:272-275 (1909)

Knope, Adolph.

o5 (and Thelen, P.) Sketch of the geology of Mineral King, Cal. Cal Univ, Dp G, B 4:227-262, map (1905)

08 Notes on the foothill copper belt of the Sierra Nevada. Cal Univ, Dp G, B 4: 411-423 (1906)

O6n An alteration of Coast Range serpentine. Cal Univ, Dp G, B 4:425-430 (1906)

o7 (with Paige, Sidney.) Stratigraphic succession in the region northeast of Cook Inlet, Alaska. G Soc Am, B 18: 325-332 (1907) Abst, Science n s 25: 182 (1907)

os The Seward Peninsula tin deposits. U S G S, B $345: 251-267$ (1908) 
Knope, Adolph-Continued.

OSa The mineral deposits of the Lost River and Brooks Mountain region, Seward Peninsula, Alaska. U S G S, B 345 : 268-271 (1908)

08b Geology of the Seward Peninsula tin deposits, Alaska. U S G S, B 358 : $71 \mathrm{pp}$, map, (1908)

08e Wolframite-topaz ore from Alaska (abst). Science n s 27:924 (1908)

osd (and Schaller, W. T.) Two new boron minerals of contact-metamorphic origin. Am J Sc (4) $25: 323-331$ (1908) Zs Kryst $48: 1-15$ (1910)

09 Some features of the Alaskan tin deposits [Seward Peninsula]. Ec G 4:214223 (1909) M World 30:969-971 (1909)

09a (with Moffit, F. H.) Mineral resources of the Nabesna-White River district, Alaska. U S G S, B $379: 161-180$ (1909)

10 The copper-bearing amygdaloids of the White River region, Alaska. Ec G 5 : 247-256 (1910) Abst, Science n s 29 : 949 (1909)

10a The probable Tertiary land connection between Asia and North America. Cal Univ, Dp G, B 5:413-420 (1910)

10b Mining in southeastern Alaska. U S G S, B 442: 133-143 (1910)

10e The occurrence of iron ore near Haines [southeastern Alaska]. U S G S, B $442: 144-146$ (1910)

10d (with Moffit, F. H.) Mineral resources of the Nabesna-White River district, Alaska. U S G S, B 417:64 pp (1910)

11 Geology of the Berners Bay region, Alaska, U S G S, B 446:58 pp, maps (1911) Abst, Wash Ae Sc, J 2:84-85

(1912)

11a Mining in southeastern Alaska. U S G S, B 480:94-102 (1911)

$11 b$ The Eagle River region, Alaska. U S G S, B 480; 103-111 (1911)

12 The Eagle River region, southeastern Alaska. U S G S, B 502:61 pp, maps (1912) Abst, Wash Ac Sc, J 3:258-259 (1913)

12a The Sitka mining district, Alaska. U S G S, B 504: 32 pp, map (1912). Abst, Wash Ac Sc, J 2:161 (1912)

13 Ore deposits of the Helena mining region, Mont. U S G S, B 527:143 pp, maps (1913)

13a The tourmalinic silver-lead type of ore deposit. Ec G 8:105-119 (1913)

13b A magmatic sulphide ore body at Elkhorn, Mont. Ec G 8; 323-336 (1913) Abst, Wash Ac Sc, J 2:358-359 (1912)

13e The fineness of gold in the Fairbanks district, Alaska (discussion). Ec G 8: 800-802 (1913)

14 Economic geology [review of literature]. Eng M J 97:112-114; $99: 102-$ $104 ; 101: 102-104 ; 103: 64-66$; $105: 105-$ $107(1914-8)$
Knopf, Adolph-Continued.

14a Mineral resources of the Inyo and White Mountains, Cal. U S G S, B 540: 81-120, map (1914)

14b The Darwin silver-lead mining district, Cal. U S G S, B 580:1-18 (1914)

14e Is the Boulder batholith a laccolith? (discussion). Ec G $9: 396-402$ (1914)

14d A platinum-gold lode deposit in southern Nevada (abst). M Sc Press 109: 990 (1914)

15 A gold-platinum-palladium lode in southern Nevada. U S G S, B 620:1-18, map (1915) Abst, M Sc Press 110:876879, map (1915); Wash Ac Sc, J $5: 370$ (1915)

15n Some cinnabar deposits in western Nevada. U S G S, B 620:59-68 (1915)

15b Plumbojarosite and other basic lead-ferric sulphates from the Yellow Pine district, Nev. Wash Ac Sc, J 5:497-503 (1915)

15e Platinum-gold lode deposit in southern Nevada (abst). G Soc Am, B 26:85 (1915)

16 Tin ore in northern Lander Co., Nev. U S G S, B 640:125-138 (1916) Abst, Wash Ac Sc, J $7: 15$ (1917)

16a Wood tin in the Tertiary rhyolites of northern Nevada. Ec G 11:652-661 (1916)

$16 \mathrm{~b}$ The composition of the average igneous rock. J G 24:620-622 (1916)

17 Tungsten deposits of northwestern Inyo Co., Cal. U S G S, B 640: 229-249 (1917) Abst, Wash Ac Sc, J $7: 357$ (1917)

17a $\mathrm{An}$ andalusite mass in the preCambrian of the Inyo Range, Cal. Wash Ac Sc, J $7: 549-552$ (1917)

18 A geologic reconnaissance of the Inyo Range and the eastern slope of the southern Sierra Nevada, Cal, ; with a section on the stratigraphy of the Inyo Range, by Edwin Kirk. U S G S, P P $110: 130 \mathrm{pp}$, maps (1918)

18a Geology and ore deposits of the Yerington district, Nev. U S G S, P P 114:68 pp, map (1918)

18b The antimonial silver-lead veins of the Arabia district, Nev. U S G S, B $660: 249-255$ (1918)

18e Strontianite deposits near Barstow, Cal. U S G S, B $660: 257-270$, map (1918) Abst, Wash Ac Sc, J $8: 94-95$ (1918)

18d Tin. U S G S, Min Res 1916 pt $1: 617-622 ; 1917$ pt $1: 63-72$ (1918)

18e Occurrence of the silver halides in the oxidized zone of ore deposits (discussion). Ec G 13:622-624 (1918)

Knott, W. T.

85 Report on the geology of Marion Co. Ky G S : 42 pp, map [1885?] 
Knowiton, Frank Hall.

S8 New species of fossil wood (Araucarioxylon arizonicum) from Arizona and New Mexico. U S Nat Mus, Pr 11:1-4, il (1888)

S8n Description of two new species of fossil coniferous wood from Iowa and Montana. U S Nat Mus, Pr 11:5-8, il (1888)

Ssb Description of two species of Palmoxylon, one new, from Louisiana. U S Nat Mus, Pr 11: 89-91, il (1888)

88e Description of a new fossil species of Chara [Wasatch group, Wales, Utah]. Bot Gazette 14:156-157, il (1888)

89 Fossil wood and lignite of the Potomac formation. U S G S, B $56: 72 \mathrm{pp}$, il (1889)

S9a The fossil wood and lignites of the Potomac fermation. Am G 3:99-106 (1889) Am As, Pr 37:206-208 (1889)

$\mathbf{8 9 b}$ Description of a problematic organism from the Devonian at the Falls of the Ohio. Am J Se (3) $37: 202-209$, il (1889)

90 A revision of the genus Araucarioxyion of Kraus, with compiled descriptions and partial synonymy of the specles. U S Nat Mus, Pr 12: 601-617 (1890)

90a (with Fontaine, Wm. M.) Notes on Triassic plants from New Mexico. U S Nat Mus, Pr $13: 281-285$, il (1890)

91 Description of fossil woods and lignites from Arkansas. Ark G S, An Rp $1889,2: 249-267$, il (1891)

91 a Report on fossil plants, by Lester F. Ward. Nat Geog Mag 3:199-200 (1891)

92 The fossil flora of the Bozeman coal field (abst). Biol Soc Wash, Pr 7:153154 (1892)

93 Notes on a few fossil plants from the Fort Union group of Montana, with a description of one new species. U S Nat Mus, $\operatorname{Pr} 16: 33-36$, il (1893)

93a Annotated list of the fossil plants of the Bozeman, Mont., coal field, with table of distribution and description of new species. U S G S, B 105:43-63, il (1893)

93b Report on fossil plants from near Ellensburg, Wash. U S G S, B 108: 103104 (1893)

93c Description of a new fossil species of Chara [C. stantoni, near Cookville, Wyo.]. Bot Gaz 18:141-142, il (1893)

93d Note on a new supposed endogenous tree from the Carboniferous. Science 21: 332-333 (1893)

94 A review of the fossil flora of Alaska, with descriptions of new species. U S Nat Mus, Pr $17: 207-240$, il (1894) Abst, Am J Sc (3) $47: 137$ (1894)

$94 a$ A new fossil hepatic from the lower Yellowstone in Montana [Preissites wardii]. Torrey Bot Club, B 21 : 458-460, il (1894)

94b Fossil plants as an aid to geology. J G $2: 365-382$ (1894)
Knowiton, Frank Hall-Continued.

94e Fossil flora of Alaska (abst). G Soc Am, B 5:573-590 (1894)

95 Report on a small collection of fossil plants from old Port Caddo Landing, on Little Cypress Bayou, Harrison Co, Tex. Am G 16: 308-309 (1895)

95a Description of a new problematical plant from the lower Cretaceous of Arkan. sas [Paleohillia arkansana]. Torrey Bot Club, B 22:387-390, il (1895)

95b Report upon a small collection of fossil plants from Black Hills, near Belvidere, Kans... Am J Se (3) $50: 212-214$ (1895)

95e Note on the examination of a col. lection of interglacial wood from Muir glacier, Alaska. J G 3:527-532 (1895)

96 The fossil plants of the Denver Basin, Colo. U S G S, Mon 27:466-473 (1896)

96a Report on fossil plants collected in Alaska... U S G S, An Rp 17 pt 1:876897 (1896)

96b The Tertiary floras of the Yellowstone National Park. Am J Sc (4) 2: $51-58$ (1896)

96e Report on a collection of fossll plants from Morgantown, W. Va. Am G 18: $370-372$ (1896)

96d Description of a supposed new species of fossil wood from Montana. Torrey Bot Club, B 23:250-252, il (1896)

96e American amber-producing tree. Science n s 3:582-584, il (1896)

97 [Description of Pityoxylon hollicki n. sp.] N $\mathbf{Y}$ Ac Sc, Tr $16: 134-136$, il (1897)

97a (with stanton, T. W.) Stratigraphy and paleontology of the Laramie and related formations in wyoming. G Soc Am, B 8:127-156 (1897) Abst, J G $5: 102-103$ (1897)

98 A catalogue of the Cretaceous and Tertiary plants of North America. U S G S, B $152: 244$ pp (1898)

98a Report on a collection of fossil plants from the Yukon River, Alaska. U S G S, An Rp 18 pt $3: 194-196$ (1898)

98b The fossil plants of the Payette formation. U S G S, An Rp 18 pt $3: 721-$ 744, il (1898)

98c The standing fossil forests of the Yellowstone National Park. Plant World 1: $53-55$ (1898)

98d In a coal swamp. Plant World 2: 21-23 (1898)

98e The Belly River horizon on the upper Missouri (abst). Science n s $7: 429$ (1898)

99 Fossil flora [of Yellowstone National Park]. U S G S, Mon 32 pt 2: 651-882, il (1899)

99a Report on some fossil wood from the Richmond Basin, Virginia. U S G S, An Rp 19 pt $2: 516-519$, il (1899)

00 Flora of the Montana formation. U S G S, B 163: 118 pp, il (1900) 
Knowlton, Frank Hall-Continued.

00a Description of a small collection of fossil wood from the Triassic area of North Carolina. U S G S, An Rp 20 pt 2:272-274. (1900)

oob Description of a new species of Araucarioxylon from the cycad bed of the Freezeout Hills, Carbon Co., Wyo. U S G S, An Rp 20 pt $2: 418-419$, il (1900)

ooe Description of a new genus ani species of fossil wood from the Jurassic of the Black Hills. U S G S, An Rp 20 pt $2: 420-422$, il $(1900)$

ood Fossil plants associated with the lavas of the Cascade Range [Oreg.]. U S G S, An Rp 20 pt $3: 37-64$, il (1900)

ooe Fossil plants of the Esmeralda formation. U S G S, An Rp 21 pt 2: 209220 , il (1900)

01 Report on fossil wood from the Newark formation of South Britain, Conn. U S G S, An Rp 21 pt 3:161-162 (1901)

01a A fossil nut pine from Idaho [Pinus lindgrenii]. Torreya $1: 113-115$, il (1901)

01b Fossil hickory nuts. Plant World 4: 51-52 (1901)

01e A fossil flower. Plant World 4:7374 (1901)

01d Fossil sequodas in North America. Plant World 4:111 (1901)

02 Fossil flora of the John Day Basin, Oreg. U S G S, B 204: 153 pp, il (1902)

02a Preliminary report on fossil plants from the State of Washington... Wash G S 1: 32-33 (1902)

$02 \mathrm{~b}$ Notes on the fossil fruits and lignites of Brandon, Vt. Torrey Bot Club, B $29: 635-641$, il (1902)

02e Report on a small collection of fossil plants from the vicinity of Porcupine Butte, Mont. Torrey Bot Club, B 29:705-709, il (1902)

02d Description of a new fossil species of Chara [Las Vegas, N. Mex.] Torreya $2: 71-72$, il (1902)

02e A fossil nut pine. Plant World 5 $33-34$, il (1902)

02f Fossil mosses. Plant World 5 : 243244 (1902)

02\% Six new species [criticism of Herzer, 01]. Science n s 16:273-274 (1902)

03 The publication of rejected names. Science n s 17:506-508 (1903)

04 Fossil plants from Kukak Bay [Alaska]. Harriman Alaska Exped 4:149162, il (1904)

04a Fossil floras of the Yukon (abst). Science n s 19:733-734 (1904)

05 Fossil plants of the Judith River beds. U S G S, B 257: 129-155, il (1905)

06 Report on Mesozoic fossil plants from northwestern Alaska. U S G S, B 278: 29-30 (1906)

06a Change of name [Querous huteheri]. Wash Biol Soc, Pr 19:95 (1906)
Knnowlton, Frank Hall-Continned.

07 Description of a collection of Kootanie plants from the Great Falls coal field of Montana. Smiths Mise Col 50 (Q Is 4) : 105-128, il (1907)

os Description of new fossil liverwort from the Fort Union beds of Montana. U S Nat Mus, Pr 35: 157-159, il (1908)

09 The stratigraphic relations and paleontology of the "Hell Creek beds," " Ceratops beds," and equivalents, and their reference to the Fort Union formation. Wash Ac Sc, Pr 11:179-238 (1909)

10 The climate of North America in later glacial and subsequent postglacial time. Int $\mathbf{G}$ Cong, XI, Stockholm, Die Verïnderungen des Klimas seit dem Maximum de letzten Eiszeit : 367-369 (1910)

10a Descriptions of fossil plants from the Mesozoic and Cenozoic of North America. I. 1. Two new fossil chain ferns (Woodwarlia) from Oregon and Wyoming. 2. A new name for Davallia tenuifolia Swartz, as identified by Dawson, and Asplenium tenerum Lesquereux. Smiths Misc Col 52 (Q Is 5) : 489-495, il (1910)

10b Succession and range of Mesozoic and Tertiary floras. $J$ G 18:105-116 (1910)

10e Biologic principles of paleogeog raphy. Pop Sc Mo 76:601-603 (1910)

10d The Jurassic age of the "Jurassic flora of Oregon." Am J Sc (4) 30:33-64 (1910)

10e (with White, D.) Evidences of paleobotany as to geological climate (abst). Science n s 31: 760 (1910)

11 Flora of the auriferous gravels of California. U S G S, P P 73: 57-64 (1911)

11a Further data on the stratigraphic position of the Lance formation ("Ceratops beds"). J G 19:358-376 (1911) Wash Ac Sc, J $1:$ 294-296 (1911)

$11 \mathrm{~b}$ Remarks on the fossil turtles accredited to the Judith River formation. Wash Ac Sc, Pr 13:51-65 (1911) Abst, Wash Ac Sc, J 1:64-65 (1911)

11e The study of fossil ferns. Am Fern J 1:105-110 (1911)

$11 d$ Description of two new fossil figs from Wyoming and Montana. Torrey Bot Club, B $38: 389-392$, il (1911)

11e Where are the Laramie dinosaurs? Science n s $34: 319-320$ (1911)

12 The relations of paleobotany to geology. Am Nat $46: 207-215 \quad$ (1912) Smiths Inst, An Rp 1912:353-358 (1913) Abst, Science n s 35: 148 (1912)

13 Results of a paleobotanical study of the coal-bearing rocks of the Raton Mesa region of Colorado and New Mexico. Am J Sc (4) 35:526-530 (1913) Abst, G Soc Am, E 24: 114 (1913) ; Wash Ac Sc, J 3 : $173-174$ (1913) 
Knowlton, Frank Hail-Continued.

$13 a$ Description of a new fossil fern of the genus Gleichenia from the upper Cretaceous of Wyoming, U S Nat Mus, Pr 45 : 555-558, il (1913)

13b The fossil forests of Arizona. Am Forestry 19:207-218 (1913)

13e Memoir of W J McGee. G Soc Am, B 24:18-29, port (1913)

14 The Jurassic flora of Cape Lisburne, Alaska, U S G S, P P 85: 89-55, il (1914) Abst, Wash Ac Sc, J 4:165 (1914)

14a Cre ceous-Tertiary boundary in the Rocky Mountain region. G Soc Am, B 25 : 325-340 (1914) Abst, Science n s 39 : 843 (1914)

14b Fossil forests of the Yellowstone National Park. U S Dp Interior, Off Secretary : $31 \mathrm{pp}$, map (1914)

14c A forest of stone [Gallatin Mts., Mont.]. Am Forestry 20: 709-718 (1914)

15 Description of a new fossil fern from the Judith River formation of Montana [Dryopteris lloydii]. Torreya 15:67-70 (1915)

$15 a$ Seed-bearing ferns. Am Fern J 5 : $83-87$ (1915)

16 The flora of the Fox Hill sandstone. U S G S, P P 98: 85-93, il (1916) Abst, Wash Ac Sc, J 6:564 (1916)

16a Contributions to the geology and paleontology of San Juan Co., N. Mex.; 4, Flora of the Fruitland and Kirtland formations. U S G S, P P 98:327-353, il (1916) Abst, by R. W. S., Wash Ac Sc, J $7: 186$ (1917)

166 A review of the fossil plants in the United States National Museum from the Florissant lake beds at Florissant, Colo., with descriptions of new species and list of type specimens. U S Nat Mus, Pr 51: 241-297, il (1916)

16e A lower Jurassic flora from the upper Matanuska Valley, Alaska. U S Nat Mus, $\operatorname{Pr} 51: 451-460$, il (1916)

16d Principles governing the use of fossil plants in geologic correlation. G Soc Am, B 27:525-530 (1916)

16 A new fossil Selaginella from the lower Tertiary of Montana. Torreya 16: 201-204, il (1916)

$16 f$ Notes on two conifers from the Pleistocene Rancho La Brea asphalt deposits, near Los Angeles, Cal. Wash Ac Sc J 6:85-86 (1916)

i6g Note on a recent discovery of fossil plants in the Morrison formation. Wash Ac Sc, J $6: 180-181$ (1916)

17 Fossil floras of the Vermejo and Raton formations of Colorado and New Mexico. U S G S, P P 101:223-435, il (1917)

17a A fossil flora from the Frontier formation of southwestern Wyoming. U S G S, P P 108: 73-107, il (1917) Abst, by R. W. Stone, Wash Ac Sc, J $7: 601-602$ (1917)
Knowlton, Frank Hall-Continued.

18 Relations between the Mesozoic floras of North and South America. G Soc Am, B 29:607-614 (1918)

See also Lesquereux, $87 \mathrm{a}, 88 \mathrm{a}, \mathrm{b}, 92$; Lindgren, 96c; Merriam, 01a ; Vaughan, $95 \mathrm{a}$

Knowiton, W. J.

67 On a new mineral from Rockport, Mass. Am J Sc (2) 44:224-226 (1867)

Knox, George.

14 Mining subsidence. Int $G$ Cong, XII, 1913, C R : 797-806 (1914)

Knox, H. H.

os Diffusion as a factor in ore deposi. tion. M Sc Press 97: 149-150, 421 (1908)

12 Criteria for replacement ore bodies (discussion). Ec G 7:295-297 (1912)

Knox, Jobn Knox.

17 Southwestern part of Thetford-Black Lake mining district (Coleraine sheet) [Que.]. Can G S, Sum Rp 1916:229245, map (1917)

18 Geology of the serpentine belt, $\mathrm{Col}$ eraine sheet, Thetford-Black Lake mining district, Quebec. Thesis, Univ. Chicago. 67 pp, map, Chicago 1918

Knox, M. V. B.

$\mathbf{7 4}$ Drift in Kansas. Am J Sc (3) 8 466-467 (1874)

75 Calamites [Kansas]. Kans Ac Sc, Tr 4:17-18 (1875); reprint (1906) Kans St Bd Agr, An Rp 4: 701-702 (1875)

Knox, Newton Booth.

o3 Dredging and valuing dredging. ground in Oroville, Cal. Can M Rv 22: 211-213 (1903)

Knutsen, $\mathrm{H}$.

S9 (and Eberlin, Peter) Om de geolo. giske Forhold I Dansk Östgrönland. Med Grönland 9:235-270 (1889)

Koch, Albrecht Karl.

39 Remains of the mastodon in Mis. souri. Am J Se 37: 191-192 (1839)

40 A short description of fossil remains found in the State of Missouri by the author. 8 pp, il, St. Louis 1840

47 Description of the Missourium, of Missouri leviathan ... $20 \mathrm{pp}$, Louisville, Ky., 1841 [also other editions]

42 On the Tetracaulodon. G Soc Lon. don, $\operatorname{Pr} 3: 714-716 \quad$ (1842) Geologist 1842: 175-177

43 Description of the Missourium theris. tocaulodon (Koch), or Missouri leviathan ... 5 th ed, $28 \mathrm{pp}$, Dublin 1843

45 Description of the Hydrargos sillimanii (Koch), a gigantic fossil reptile, of sea serpent lately discovered by the author in the State of Alabama ... $16 \mathrm{pp}, \mathrm{N} Y$ 1845

45a Description of the Hydrarchos har lani Koch (the name sillimanii is changed to harlani by the particular desire of Pro. fessor Silliman), a gigantic fossil reptile. lately discovered by the author in the State of Alabama... 2d ed, 24 pp, N Y 1845 
Koch, Albrecht Karl-Continued.

45b Die Riesenthiere der Urwelt, oder das neuentdeckte Missourium theristocaulodon (Sichelzahn aus Missouri) und die Mastodontoiden im allgemeinen und besondern ... viii, $99 \mathrm{pp}$, il, Berlin 1845 Rev, N Jb $1845: 760-766$

50 Ueber die Gattung Zeuglodon Owen (Basilosaurus Harlan, Hydrachus Koch, Dortidon Gibbes). Schles Ges, Jber 28: 59-60 (1850)

51 Das Skelet des Zeuglodon macrospondylus. Naturw Abh 4:53-64, il (1851)

5^a Entdeckung der Zeuglodontenreste. Freunde Naturw, Ber (Haidinger) 7:198199, 203-204 (1851)

57 [On the remains of Zeuglodon in Mississippi.] Ac Sc St L, Tr 1:17-19 (1857)

57a Mastodon remains in the State of Missouri ... Ac Sc St L, Tr 1:61-64 (1857)

Koch, Felix J.

11 The Calaveras skull [The skull is shown to be recent and placed where found for a hoax]. Am Antiquarian 33: 199-202 (1911)

Koch, Fred W.

07 California's inland sea [Salton sink region]. Cal Phys Geog Club, B 1:4-7 (1907)

Koeh, Friedrich Karl Ludwig (1799-1852).

51 Die Mineralgegenden der Vereinigten Staten Nord-Amerikas am Lake Superior... $72 \mathrm{pp}$, Göttingen 1851

51a [Kupfer- und Eisenerze am Lake Superior.] Deut G Ges, Zs 3:355-358 (1851)

52 Die Mineral-Regionen der obern Halbinsel Michigan's (N. A.) am Lake Superior und die Isle Royale. 248 pp, map, Göttingen 1852 Göttingischer Verein bergmånuischer Freunde (J. F. L. Hausmann), Studien 6:1-248, map (1854) Abst, M Mag 1: 261-268 (1853)

Koch, Johan Peter.

12 (and Wegener, A.) Die glaciologischen Beobachtungen der DanmarkExpedition. Med Grönland 46:1-77, maps (1912)

15 Forelobig Beretning om de vigtigste glaciologiske Iagttagelser paa den danske Forskninsrejse tvaers over Nordgrönland 1912-13 [observations on the ice of Greenland]. Dansk G Forening, Medd 4:311360 (1915) Vorläufiger Bericht uber die wichtigsten glazíologischen Beobachtungen auf der dänischen Forschungsreise quer durch Nordgrönland, 1912-13. Zs Gletscherk $10: 1-43$ (1917)

Koch, Louls $\mathrm{H}$.

17 Green calcite from Glens Falls, N Y. Am Mineralogist 2: 121 (1917)

17 a A new occurrence of ptilolite. Am Mineralogist 2: 143-144 (1917)
Koeberlin, F. R.

09 The Brewster fron-bearing district of New York. Ec G 4:713-754, map (1909)

Köhler, G.

87 Irregularities of lodes, veins, and beds [translated from German by Wm. B. Phillips]. Eng M J $43: 454-455 ; 44: 4-$ $5,21-22,60,79,96,113,130,131$ (1887)

Koehler, H.

35 On the anthracite deposit at Tamaqua, Schuylkill Co., Pa. G Soc $\mathrm{Pa}, \operatorname{Tr} 1$ : 326-327 (1835)

Köhler, H.

06 Die Vulcane von Collma. Prometheus $17: 214-219$ (1906)

Köhler, William.

66 [Anticlinal in Wythe Co., Va., lead mine.] Am Ph Soe, $\operatorname{Pr} 10: 270$ (1866)

Koenig, George Augustus.

76 Mineralogical notes. Ac N Sc Phila, Pr $1876: 36-37$

76a On tantalite from Yancey Co., N. C. Ac N Sc Phila, Pr 1876:39-40

76b on pachnolite and thomsenolite. Ac N Se Phila, Pr 1876:42-50

z6e On spessartite [from Yancey Co., N. C.]. Ac N Sc Phila, Pr 1876:53-54

76d Hydrotitanite, a new mineral. Ac N Se Phila, Pr $1876: 82-84$

76e Hexagonite, Goldmsith, a variety of tremolite. Ac N Sc Phila, Pr 1876:180181

77 On astrophyllite, arfvedsonite, and zircon, from El Paso Co., Colo. Am Ph Soc, Pr 16:509-518 (1877) Zs Kryst 1: 423-432 (1877)

77a On astrophyllite, arfvedsonite, and zircon. Ac N Sc Phila, Pr 1877:9-11

$\mathbf{7 7 b}$ On enstatite. Ac $\mathrm{N}$ Sc Phila, $\mathrm{Pr}$ 1877: 198-199

77e Protovermiculite, a new mineral species [Magnet Cove, Ark.]. Ac N Sc Phila, Pr 1877: 269-272

77d Mineralogical notes. Ac $\mathrm{N}$ Sc Phila, Pr 1877: 276

77e On strengite from Rockbridge Co., Va. Ac N Sc Phila, Pr 1877:277-278

78 Leidyit, ein neues Silicat der Zeolithgruppe und die vergesellschafteten Mineralien. Zs Kryst 2:300-303 (1878)

78a Mineralogical notes. Ac N Sc Phila, Pr 1877 : 290-291 (1878)

78b Mineralogical notes. Ac N Sc Phila, Pr 1877 : 292-293 (1878)

78e Mineralogical notes. Ac $\mathrm{N}$ Sc Phila, Pr 1877 : 294-295 (1878)

$\mathbf{7 8 d}$ On the association of grossularite, zoisite, heulandite, and leidyite, a new species. Ac N Sc Phila, Pr 1878:81-85

79 Mountain soap of California. Ac $\mathbf{N}$ Sc Phila, Pr 1878:405-406 (1879)

$79 a$ Mineralogical notes; randite. Ac N Sc Phila, Pr 1878:408-409 (1879)

so Notes on jarosite [Chaffee Co., Colo.]. Ac N Se Phila, Pr 1880:331-332 
Koenig, George Augustus-Continued,

81 On alaskaite, a new member from the series of bismuth sulphosalts. Am Ph Soc, Pr 19:472-477 (1882) Zs Kryst 6: $42-47$ (1881)

81a On the occurrence of lustrous coal with native silver in a vein in porphyry, in Ouray Co., Colo. Am I M Eng, Tr 9: 650-656 (1881) Abst, Eng M J 33:54 (1882) [see Hallowell, 82]

81b Jarosit von einer neuen Fundstätte [Chaffee Co., Colo.]. Zs Kryst 5:317321 (1881)

81c Beegerit, ein neues Mineral [Park Co., Colo.]. Zs Kryst 5:322-325 (1881)

82 Notes on monazite [Virginia]. Ac N Sc Phila, Pr 1882:15-16

82a Orthite from Amelia Court House, Va. Ac N Sc Phila, Pr 1882: 103-104

83 Note on zeolites from Delaware Co. [Pa.]. Ac N Sc Phila, Pr 1882:288289 (1883)

85 Note on cosalite, alaskaite, and beegerite. $\mathrm{Am} \mathrm{Ph}$ Soc, $\mathrm{Pr} 22$ : 211-213 (1885)

85a A new locality for beegerite [San Juan Co., Colo.]. Ac N Sc Phila, Pr 1885: 19

86 Mineralogical notes; composition of stromeyerite. Ac N Sc Phila, Pr 1886: 281-283

87 Manganese zinc serpentine from Franklin, N. J. Ac N Sc Phila, Pr 1886: 350-351 (1887)

$\mathbf{8 7 a}$ On schorlomite as a variety of melanite. Ac $\mathrm{N}$ Sc Phila, $\operatorname{Pr} 1886$ : 355-357 (1887)

s7b On zinc-manganese, asbestos [Franklin Furnace, N. J.]. Ac N Sc Phila, Pr 1887: 47-48

87e Preliminary note on a new mineral species from Franklin, N. J. Ac N Sc Phila, Pr 1887 : 310-311

88 Note on eleonorite from Sevier Co., Ark. Ac N Sc Phila, Pr 1888: 139-140

88 a Note on mazapilite, a new species [Zacatecas, Mex.]. Ac N Sc Phila, Pr 1888: 192

88b Ueber Alaskait. Zs Kryst 14:254255 (1888)

89 On anhydrite [Delaware Co., Pa.]. Ac N Sc Phila, Pr 1889:11-12

89a Mazapilite, a new mineral species. Ac N Sc Phila, Pr 1889:45-47

s9b Chloanthite, nicolite, desaulesite, annabergite, tephrowillemite, fluorite, and aquatite, from Franklin, N. J. Ac N Sc Phila, $\operatorname{Pr} 1889$ : 184-189

s9e Neue amerikanische Mineralvorkommen. Zs Kryst 17:85-92 (1889)

91 On paramelaconite, and the associated minerals. Ac N Sc Phila, Pr 1891: 284-291 Abst, Am J Se (3) $43: 158$ (1892)

$91 a$ Ueber Paramelaconit und Footeit. Zs Kryst $19: 597-603$ (1891)
Koenig, George Augustus-Continued. 93 (and Hubbard, L. L.) On port lite from a new locality [Houghton a Mich.] Am J Sc (3) $46: 356-358$ (1898 Zs Kryst 22 : 463-466 (1894)

01 The crystallization of mohawkit domeykite, and other similar arsenides, Sup M Inst, Pr 7:62-64 (1901)

O1a Ueber Mohawkit, Stlibiodomeykit Domeykit, Algodonit, und einige künstlicel Kupferarsenide. Zs Kryst 34: 67-77 (1901 02 On the new species melanochalcit? and keweenawite; with notes on some other known species. Am J Sc (4) 14:404-4l (1902)

04 Ueber die künstliche Darstellung roo Krystallen des Mohawkits, des Domeykits des Argento-Domeykits, des Stibiodomeykits des Keweenawits und anderer Arsenide: Krystallographische Untersuchung von F. B Wright. Zs Kryst 38:529-554 (1904)

12 New observations in chemistry and mineralogy. Ac N Sc Phila, J (2) $15: 400^{\circ}$ 426 (1912)

Koenigsberger, Joh.

11 (and Muhlberg, Max) Über Mer sungen der geothermischen Tiefenstufe. deren Technik und Verwertung zur gev logischen Prognose, und uber newe Messurgen in Mexiko, Borneo, und Mitteleurops N Jb, Beil B $31: 107-157$ (1911)

12 Transformations and chemical reac tions in their application to temperature measurements of geological occurrenes (translated by Joseph A. Ambler). Ec G 7 676-707 (1912)

Koep, C.

69 Ausbruch des Vulkans Izalco in Staate S. Salvador in Central-Amerika. Petermanns Mitt 15:434-435 (1869)

Kohl, J, G.

62 Die Mündungen des Mississippi. Zs Allg Erdk N F 13:161-209 (1862)

\section{Koken, E.}

88 Neue Untersuchungen an tertiäres Fisch-Otolithen [Alabama and Mississippi], Deut G Ges, Zs $40: 274-305$, il (1888)

Kolderup, Carl Fred.

o1 Guldforekomsterne 1 Alaska og til. grænsende strög. Naturen, Bergen, 25: 361-366, map (1901)

02 De vulkanske udbrud 1 Vestindien. Naturen, Bergen, $26: 353-363$ (1902)

03 The rock name anorthosyte Am G 31: 392-393 (1903)

Komoroviez, Maurice v.

12 Vulkanologische Studien auf einigen Inseln des Atlantischen Oceans. $191 \mathrm{pD}$, Stuttgart 1912

Konis, Charles.

24 Rock specimens. In A supplement to the Appendix of Captain Parry's voyage for the discovery of a northwest passage in the years 1819-20: ccxlvii-cclvil, I 1824 
Koons, B. F.

82 High terraces of the rivers of easten Connecticut. Am J Sc (3) $24: 425-42 S$ (1882)

83 On potholes on the edge of a blufr at Gurleyville, Conn. Am J Sc (3) 25:471 (1883)

84 Upon the kettle holes near Woods Hole, Mass Am J Sc (3) 27:260-264, map (1884)

85 Additional notes on the kettle holes of the Woods Hole region, Mass. Am J Sc (3) $29: 480-486$ (1885)

\section{Kornerup, A.}

79 Geologiske Iagtiagelser fra Vestkysten af Grönland [west coast of Greenland]. Med Grönland 1: 77-139 (1879)

81 Geologiske Iagttagelser fra Vestkysten af Grönland. Med Grönland 2:149194 (1881)

Kost, John (1819-?)

87 First report of the geological survey of Florida. Fla $\mathrm{G}$ S: $31 \mathrm{pp}$, Tallahassee, Fla., 1887 Abst, Seience 9:446-447 (1887)

87a Geology of Florida (abst). Am As, $\operatorname{Pr} 35: 231$ (1887)

Kraatz, K. von.

96 Note on the formation of gold ore. Am G 18: 100-108 (1896)

Kramm, H. E.

10 Serpentines of the central coast ranges of California. $\mathrm{Am} \mathrm{Ph}$ Soc, $\operatorname{Pr} 49$ : 315-349, map (1910) Abst, Science $\mathrm{n}$ s $32: 31$ (1910); G Soc Am, B 21:793 (1910)

12 Geology of Harrison Gulch, in Shasta Co., Cal. Am I M Eng, B 67:709-715, map (1912) ; $\operatorname{Tr} 43: 233-239$, map (1913)

12a Gypsum of New Brunswick. Can G S, Sum Rp 1911: $322-327$ (1912)

$12 \mathrm{~b}$ on the occurrence of manganese at New Ross in Nova Scotia. Can M Inst, Tr $15: 210-217$, map (1912)

13 Excursion in eastern Quebec and the maritime provinces; the Hillsborough gypsum deposit. Int G Cong, XII, Canada, Guide Book no 1 : 363-367 (1913)

Krantz, A.

55 [Metearites from Mexico.] Naturh Ver Preus Rheinl ... Verh 12 (Niederrhein Ges Bonn, Szb) : xlvii-xlvili (1855)

57 Ueber Meteoreisen vom Toluccathal in Mexico. An Pbysik 101: 152-153 (1857) Kraus, Edward Henry.

01 (and Reitinger, J.) Hussakite, a new mineral, and its relation to xenotime. Am G 30:46-55 (1902) Zs Kryst 34: 268-277 (1901)

01a (and Mez, G.) Ueber topische Axenverhaltnisse. Zs Kryst 34:389-396 (1901)

011. Ueber einige Salze der seltenen Erden. Zs Kryst 34:397-431 (1901)
Kraus, Edward Henry-Continued.

04 The occurrence of celestite near Syracuse, N. Y., and its relation to the vermicular limestones of the Salina epoch. Am J Sc (4) 18:30-39 (1904)

04a A new exposure of serpentine at Syracuse, N. Y. Am G $33: 330-332$ (1904)

04b Some interesting mineral occurrences in the Salina epoch (abst). Science n s 19:619-620 (1904)

05 Occurrence and distribution of celestite-bearing rocks. Am J Sc (4) 19 : 286-293 (1905) Abst, Am G 35:130 (1905); G Soc Am, B 16:574 (1906); Sc Am Sup $59: 24326$ (1905)

O5a On the origin of the cares of the island of Put-in-bay, Lake Erie. Am G 35: 167-171 (1905) Abst, Science n s 21: 219 (1905) ; G Soc Am, B 16:563 (1906) ; Sc Am Sup $59: 24326$ (1905)

05b Hydration caves. Science n 8 22: 502-503 (1905)

ose On the origin of the sulphur deposits at the Woolmith quarry, Monroe Co., Mich. Mich Ac Sc, Rp $7: 26-29$ (1905)

06 Essentials of crystallography. 162 pp, Ann Arbor, Mich, 1906

06a The teaching of crystallography. Science n s 24: 855-856 (1906)

06b (and Cook, C. W.) Datolite from Westfield, Mass. Am J Sc (4) $22: 21-28$ (1906) Zs Kryst 42:327-333 (1906)

o6e (and Hunt, W. F.) The occurrence of sulphur and celestite at Maybee, Mich. Am J Sc (4) 21:237-244 (1906) Zs Kryst $42: 1-12$ (1906)

o6d (and Scott, I. D.) Ueber interessante amerikanische Pyritkrystalle. Zs Kryst 44: 144-153 (1907)

os Interpretation of the chemical composition of the mineral benitoite. Science n s $27: 710-711$ (1908)

09 (and Cook, C. W.) Iodyrite from Tonopah, Nevada, and Broken Hill, New South Wales. Am J Sc (4) $27: 210-222$ (1909) Zs Kryst $46: 417-426$ (1909)

11 Descriptive mineralogy, with especial reference to the occurrences and uses of minerals. 334 pp, Ann Arbor, Mich. 1911

11n (and Hunt, W. F.) Tables for the determination of minerals by means of their physical properties, occurrences, and associates. $254 \mathrm{pp}, \mathrm{N}$ Y 1911

12 (and Youngs, L. J.) Ueber die Aenderungen des optischen Achsenwinkels in Gips mit der Temperatur [Variation of the optic angle of gypsum with temperature]. N Jb $1: 123-146$ (1912). $43 s t$, Science n s $35: 313$ (1912); G Soc Am, B $23: 726-727$ (1912)

12a (and Cooper, H, C., and Klein, A. A.) Die optischen Eigenschaften einiger Bleisilikate. Centralbl miner 1912: 289-295 
Kraus, Edward Henry-Continued.

$12 b$ (and Youngs, L. J.) Some Interesting changes in the optical properties of crystals with temperature (abst). Mich Ac Sc, Rp 14:108 (1912)

13 Die Aenderungen des optischen Axenwinkels im Glauberit mit der Temperatur. Zs Kryst 52:321-371 (1913)

$13 a$ (and Cook, C. W.) Die Kristallformen des Jodyrits von Tonopah, Nev. Centralbl Miner 1913:385-386

14 (and Goldsberry, J. P.) The chemical composition of bornite and its relation to other sulpho-minerals. Am J Sc (4) $37: 539-553$ (1914) N Jb 1914, 2: 127-144 Abst with discussion, G Soc Am, B 25: 90-91 (1914)

15 (and Funt, W. F.) Manganhaltiger Albit von Kalifornien. Centralbl Miner $1915: 465-467$

15a (with Cook, C. W.) Datolite from Great Notch, N. J. Am J Sc (4) $39: 642-$ 645 (1915)

16 (and Peck, A. B.) Ueber Anglesit von dem Tinticdistrikt, Utah. N Jb $2: 17$ 30 (1916)

$16 a$ (with Hunt, W. F.) Note on the variable composition of melanochalcite. Am J Sc (4) $41: 211-214$ (1916) Abst, G Soc Am, B $27: 61$ (1916)

17 (and Peck, A. B.) Some new thermo-optical observations on gypsum and glauberite. Mich Ac Sc, An Rp 19: 95-100 (1917)

See also Fatrchild, 04c

Krebs, Charles E.

11 Jackson, Mason, and Putnam counties. W Va G S: 387 pp, maps (1911)

63 and Teets, D. D., jr.) Cabell, Wayne, and Lincoln counties. W Va G S : 483 pp, maps (1913)

14 (and Teets, D. D., jr.) Kanawha County. W Va G S: 679 pp, maps (1914)

15 (and Teets, D. D., jr.) Boone County. W Va G S : 648 pp, maps (1915)

16 (and Teets, D. D., jr.) Raleigh County and the western portions of Mercer and Summers counties. W Va G S : $778 \mathrm{pp}$, maps (1916)

Krebs, Wilhelm.

03 Flutschwankungen und die vulkanischen Ereignisse in Mittelamerika [connection between high tides in the Pacific and volcanic activity in Central Amerika]. Globus $84: 72-74$ (1903)

Kreider, D. A.

94 (with Penfeld, S. L.) Mineralogical notes. Am J Sc (3) $48: 141-144$ (1894) Kreutz, Stefan.

07 Ueber Zwillingskrystalle des Calcites von Guanajuato, Mexico. Tschermaks Mitt N F $26: 140-141$ (1907)

Kroustschofr, $K$. de.

85 Note sur le granite variolitique de Craftsbury en Amérique. Soc Minér France, B $8: 132-141$ (1885) Abst, Am Nat 20: $275-276(1886)$
Kroustrchor, K, de-Continued.

85a Note sur une roche basaltique de la Sierra Verde (Mexique). Soc Minér France, B 8:385-396 (1885) Soc Clent Ant Alz, Mem 16: Rev 17-26 (1901)

Fruger, H. A.

10 (and Hamilton, W. J. and En. riquez, E. W.) Geology of the Perry Park syncline, Colo. Colo Sch Mines, B 5: 86-99 (1910)

Krukenberg, Carl Friedrich Wilhelm (1852-1889).

77 Mikrographie der Glasbasalte von Hawail ... 38 pp, Tubingen 1877 [not seen] Rv by Mohr, C. F., Nlederrhein Ges Bonn, Szb 34: 213-219 (1877)

Frusch, $P$.

99 Ueber eine Kupfererzlagerstäte in Nieder-Californien. Zs prak G 1899:83-86

13 Primäre und sekundäre erze unter besonderer Berüicksichtigung der "gel" und der "schwermetallreichen" Erze. Int G Cong, XII, 1913, C R : 275-286 (1914; advance copy 1913) M Sc Press 107 : 418423 (1913)

Kiimmel, Henry Barnard.

93 Some rivers of Connecticut. J G 1: 371-393, map (1893)

94 (with Salisbury, R. D.) Lake Passaic; an extinct glacial lake. N J G S, An Rp 1893:225-328, map (1894)

95 Some meandering rivers of Wisconsin. Sclence n s 1:714-716 (1895)

$95 a$ (with Salisbury, R. D.) Lake Passaic, an extinct glacial lake. J G 3: 533-560, map (1895)

96 Note on the glaciation of Pocono Knob and mounts Ararat and Sugar Loaf, Pa. Am J Sc (4) 1:113-114 (1896)

97 The Newark system; report of prog. ress. N . G G S, An Rp 1896: 25-88 (1897)

$\mathbf{9 7 a}$ The Newark system of New Jersey. J G 5: 541-562 (1897)

$\mathbf{9 7 b}$ Structure of the Newark formation of western New Jersey (abst). Science n s 5: 93-94 (1897)

98 The Newark system or red sandstone belt. N J G S, An Rp 1897:23-159, map (1898)

98 $\mathbf{a}$ The age of the artifact-bearing sand at Trenton [N. J.]. Science $\mathrm{n}$ s 7 : $115-117$ (1898)

99 The extension of the Newark system of rocks. N J G S, An Rp 1898: 43-57 (1899)

99a The Newark or new red sandstone rocks of Rockland Co., N. Y. N Y St G, An Rp 18:9-50 (1899) N Y St Mus, An $\mathrm{Rp} 52 v 2: 9-50 \quad(1900)$

$99 b$ The Newark rocks of New Jersey and New York. J G $7: 23-52$, map (1899) Abst, Am G 23:93 (1899); Science n s $9: 102-103$ (1899); Ottawa Nat $12: 198$ (1899)

Oo Notes on copper mines. N J G S, An Rp 1899:171-175 (1900) 
Kümmel, Henry Barnard-Continued.

00a [On the geology of the Palisades of the Hudson River $(a b s t)$.$] Science n$ s 11: 625-626 (1900)

01 Report on Portland cement industry. N J G S, An Rp 1900: 9-101, maps (1901)

01a The mining industry. N J G S, An Rp 1900:197-217 (1901) ... 1901 : 133-161 (1902) ... 1904:291-305 (1905) ... 1905: 315-325 (1906) ... 1906:173-181 (1907)

01b (and Weller, Stuart) Paleozoic limestones of Kittatinny Valley, N. J. G Soc Am, B 12:147-164, map (1901) Abst, Sclence n s $13: 134$ (1901)

01e The Palisades [N. J.] (abst). N Y Ac Sc, An 13:469-470 (1901)

02 Annual report of the State geologist for the year 1901. N J G S: $\mathbf{N} 8 \mathrm{pp}$, Trenton N J, $1902 \quad \ldots \quad 1902: 155$ pp (1903) .. $1903: 132 \mathrm{pp}(1904) \quad \ldots \quad 1904: 317 \mathrm{pp}$ (1905) $\ldots 1905: 338$ pp (1906) ... 1906: $192 \mathrm{pp}(1907) \quad \ldots \quad 1907: 192 \mathrm{pp}$ (1908) ... 1908: 159 pp (1909) ... 1909: 123 pp (1910)

02a (and weller. Stuart) The rocks of the Green Pond Mountain region. N J G S, An Rp 1901:1-51 (1902)

03 A summary of the work of geological survey of New Jersey with a subject index to its reports. N J G S: 27 pp (1903)

03a The iron and zinc mines. N J G S, An Rp 1902: 115-123 (1903)

04 (and Knapp, G. N.) The stratigraphy of the New Jersey clays. N J G S, Final Rp 6:117-209, maps (1904)

05 (and Hamilton, S. H.) A report upon some molding sands of New Jersey. N J G S, An Rp 19G4: 187-246 (1905)

05a Additional well records. N J G

S, An Rp 1904: 263-271 (1905)

06 The chemical composition of the white crystalline limestones of Sussex and Warren cos. N J G S, An Rp St G 1905 : 173-191 (1906)

07 The peat deposits of New Jersey. Ec G 2:24-33 (1907)

07a (and Gage, R. B.) The glass-sand industry of New Jersey. $N$ J G $\mathbf{S}$, An Rp St G 1906: 77-96 (1907)

08 Notes on the mineral industry, with mineral statistics. N J G S, An Rp 1907: 169-181 (1908) $\ldots$ 1908: 125-146 (1909) ... 1909:101-110 (1910)

08a Paleozoic sedimentary rocks of the Franklin Furnace quadrangle, N J. U S G S, G Atlas Franklin Furnace fol (no 161) : 10-12 (1908)

08b Iron ore in New Jersey. Eng M J $85: 1193$ (1908)

08e (with Darton, N. H, Description of the Passaic quadrangle, N. J.N. Y. U S G S, G Atlas, fol 157:27 pp (1908)
Kümmel, Henry Barnard-Continued.

osd (with Spencer, A. C.) Description of Franklin Furnace quadrangle, N. J. U S G S, G Atlas, fol 161:27 pp (1908)

09 Geological section of New Jersey. J G $17: 351-379$ (1909)

09a Copper mining in New Jersey. Eng M J 87:808 (1909)

09b Further notes on the changes at Manasquan Inlet. N J G S, An Rp St G 1908:17-21 (1909)

10 (and Poland, H. M.) Records of wells in New Jersey, 1905-1909. N J G S, An Rp 1909:69-100 (1910)

11 Annual administrative report of the State geologist for the year 1910 . N J G S, B 1:43 pp (1911) ... 1911; B 6: $82 \mathrm{pp}(1912) \quad \ldots 1912$; B $8: 35 \mathrm{pp}$ (1913) ... 1913; B $12: 25$ pp (1914) ... 1914; B $16: 43 \mathrm{pp}(915)$

$11 a$ (and Jones, S. P.) The mineral industry of New Jersey for 1910. N J G S, B 5:24 pp (1911)

$11 \mathrm{~b}$ The Cretaceous and Tertiary formations of New Jersey. N J G S, B 4: $7-21$ (1911)

12 The mineral industry of New Jersey for 1911. N J G S, B $7: 37 \mathrm{pp} \mathrm{(1912)}$

12a (with Lewis, J. V.) Geologic map of New Jersey, 1910-1912. Scale 1: 250000. N J G S (1912)

14 (with Bayley, W. S.) Dascription of the Raritan quadrangle, N. J. U S G S, G Atlas fol 191 (1914) Abst, Wash Ac Sc,

J 4:371 (1914)

$14 a$ (with Lewis, J. Volney) Geologic map of New Jersey. Scale 1: 250,000. N J G S [1914]

15 (with Lewis, J. V.) The geology of New Jersey ; a summary to accompany the geologic map (1910-1912) on the scale of $1: 250,000$. N J G S, B $14: 146$ pp, map (1915)

16 Report of the State geologist for 1915. N J, Dp Conservation..., An Rp $1915: 19-30 \quad(1916) \quad \ldots$ [for 1916] ; ... An Rp 1916:15-48 (1917) ... [for 1917] ; ... An Rp $1917: 23-50$ (1918)

See also Barrell, 12a; Bascom, 09a, b; Branson, 12; Grabau, 12b ; Johnson (D W), 12

Kuhre, K. D.

17 Tungstenite, a new mineral, in the Cottonwoods [Utah]. Salt Lake M Rv 19 no $18: 23-24$ (1917)

Kunhardt, Th.

69 Ausbruch des Vulkans von Colima in Mexiko. Petermanns Mitt 15:385 (1869)

Kunharit, $F$.

7o Der Vulkan Ceboruco in Mexiko. Petermanns Mitt $16: 426-427$ (1870)

Kuntze, Otto.

$99 \mathrm{On}$ the occurrence of quenstedtite near Montpelier, Iowa. Am G 23:119-121 (1899) 
Knnz, George Frederick.

83 Precious stones. U S G S, Min Res [1882] : 483-499; 1883-4: 723-782; 1885 : $437-444 ; 1886$; $595-605 ; 1887$ : 555-579 ; 1888 : $580-585 ; 1889-90: 445-448 ; 1891$ : $539-551 ; 1892: 756-781 ; 1893: 680-702$; An Rp 16 pt $3: 595-605 ; 17$ pt $3: 895$ $926 ; 18$ pt $5: 1183-1217 ; 19$ pt 6 con : $497-514 ; 20$ pt 6 con : $557-600 ; 21$ pt 6 con: 419-462; Min Res 1900:749-778; $1901: 729-771 ; 1902: 813-865 ; 1903: 911-$ $977 ; \quad 1904: 941-987 ; \quad 1905: 1323-1358$ (1883-1906)

83a On a large mass of Cretaceous amber from Gloucester Co., N J. N Y Ac Sc, Tr $2: 85-87$ (1883)

84 Topaz and associated minerals at Stoneham, Me. Am J Sc (3) 27:212-216 (1884) Abst, Am As, Pr 32:271-273 (1884)

$\mathbf{8 4 a}$ on the tourmaline and associated minerals of Auburn, Me. Am J Sc (3) $27: 303-305$ (1884) Abst, Am As, Pr 32 : $274-275$ (1884)

84b On andalusite from Gorham, Me. Am J Sc (3) $27: 305$ (1884) Abst, Am As, Pr 32: 270-271 (1884)

s4e On the white garnet from Wakefield, Can. Am J Sc (3) $27: 306$ (1884)

84 i On a white garnet from near Hull, Can. $(a b s t)$. Am As, Pr 32:269-270 (1884) Abst, Am As, Pr 32:271-273 (1884) .

84e A note on the finding of two fine American beryls (abst). Am As Pr 32: 275-276 (1884)

85 On the agatized woods, and the malachite, azurite, etc., from Arizona. N Y Ac Sc, $\operatorname{Tr} 5: 9-11$ (1885)

85a On remarkable copper minerals from Arizona. N Y Ac Sc, An 3:275-278 (1885)

85b On three masses of meteoric iron from Glorieta Mt., near Canoncito, Santa Fe Co., N. Mex. Am J Se (3) 30:235-238 (1885)

85e Native antimony and its associations at Prince William, York Co., N. B. Am J Sc (3) $30: 275-277$ (1885)

86 Meteoric iron from Jenny's Creek, Wayne Co., W. Va. Am J Sc (3) 31:145148 (1886) Am As, Pr $34: 246-249$ (1886)

86a Further notes on the meteoric iron from Glorieta Mt., N. Mex. Am J Sc (3) 32 : 311-313 (1886)

866 Agatized and jasperized wood of Arizona. Pop Sc Mo $28: 362-367$ (1886)

s6e The meteorite from Glorieta Mountain, Santa Fe Co. N. Mex. N Y Ac Sc, An $3: 329-334$ (1886)

86d Rare gems and interesting minerals, N Y Ac Sc, Tr 5:131-133 (1886)

86e Notes on some minerals from the West. N Y Ac Sc, Tr 5: 213-214 (1886)

$86 f$ Mineralogical notes. N Y Ac Sc, Tr 5 : 223-230 (1886)
Kunz, George Frederick-Continued.

$86 \mathbf{g}$ [An alamandine garnet crysta] found in New York City.] N Y Ac Sc, Tr 5: 265-266 (1886)

s6h A new meteoric iron from West Virginia. Science $7: 11-12$ (1886)

86i Native antimony and its associa. tions at Prince William, York Co., N. B, Am As, Pr 34: 237-240 (1886)

86j Mineralogical notes. Am As, Pr 34 : 240-242 (1886)

86k The tourmaline locality at Rum. ford, Oxford Co., Me. (abst). $\Delta \mathrm{mr} \mathrm{As}, \mathrm{Pt}$ 34: 242-243 (1886)

861 A pseudomorph of feldspar after leucite ( ?) from Magnet Cove, Ark. (abst). Am As, Pr 34:243-246 (1886)

87 The meteoric iron which fell in Johnson Co., Ark., 3.17 p. m., March 27, 1886. U S Nat Mus, Pr 10:598-605 (1887)

$\mathbf{8 7 a}$ A fifth mass of meteoric iron from Augusta Co., Va. Am J Sc (3) 33:58-58 (1887)

87b On two new meteorites from Car. roll Co., Ky., and Catorze, Mex. Am J Sc (3) $33: 228-235$ (1887)

87e on the meteoric iron which fell near Cabin Creek, Johnson Co., Ark., March 27, 1886. Am J Sc (3) $33: 494-499$ (1887)

87d On some American meteorites. Am J Sc (3) $34: 467-477$ (1887)

87e Mineralogical notes. Am J Sc (3) $34: 477-480$ (1887)

87f Meteoric iron from Carroll $\mathrm{Co}_{,}, \mathrm{Ky}$. N Y Ac Sc, Tr 6:71-76 (1887)

$\mathbf{8 7 g}$ a new meteor from Catorze, Mex. N Y Ac Sc, Tr 6:76-77 (1887)

87h Crystals of hollow quartz from Arizona. - N Y Ac Sc, Tr 6:122-124 (1887)

87i Description of the meteorite which fell near Cabin Creek, Johnson Co., Ark., March 27, 1886. N Y Ac Sc, Tr 6:141146 (1887)

87j A meteorite from Powder Hill Creek, Tenn. N Y Ac Sc, Tr 6:161-162 (1887)

87k Minerals from Fort George, New York City. N Y Ac Sc, Tr $7: 48-49$ (1887)

871 Meteorite from Glorieta Mountain, Santa Fe Co., N. Mex. Eng M J 44:22 (1887)

$\mathbf{8 7 m}$ A North Carolina diamond. Science 10:168 (1887)

$\mathbf{8 7 n}$ Remarkable occurrence of rock crys. tal in the United States (abst). Am As, $\operatorname{Pr} 35: 229-230$ (1887)

870 (with Diller, J. S.) Is there a diamond field in Kentucky? Science 10: 140-142 (1887)

88 Precious stones. Can G S, An Rp $3:$ s $65-80$ (1888)

88a Mineralogical notes. Am J Sc (3) $36: 222-224$ (1888)

$88 b$ On two new masses of meteoric iron [Linnville, N. C. ; Laramie Co., Wyo.]. Am J Sc (3) $36: 275-277$ (1888) 
Knnz, George Frederick-Continued.

88c [On the occurrence of bertrandite at Stoneham, Me., and Mount Antero, Colo.] N Y Ac Sc, Tr 8:11-13 (1888)

88d [On minerals in the trap of New Jersey.] N Y Ac Sc, Tr 8:16-17 (1888) sse Diamonds in meteorites. Science 11: 118-119 (1888)

89 Gem collection of the U.S. National Museum. Smiths Inst, An Rp 1886 pt 2 : 267-275 (1889)

89a Mineralogical notes on fluorite, opal, amber, and diamond. Am J Sc (3) 38: 72-74 (1889)

S9b A remarkable locality of American fluorite [Macomb, St. Lawrence Co., N. Y.]. N Y Ac Sc, Tr 8: 59-60 (1889)

89c [Notes on minerals.] N Y Ac Sc, Tr 8:158-163 (1889)

90 On five new American meteorites. Am J Sc (3) $40: 312-323$ (1890)

$90 \mathrm{a}$ On the group of meteorites recently discovered in Brenham township, Klowa Co., Kans. N Y Ac Sc, Tr 9:186-194 (1890)

90b Meteoric iron from Bridgewater, Burke Co., N. C. N Y Ac Sc, Tr 9:194197 (1890)

90e Meteoric fron from Colfax township, Rutherford Co., N. C. N Y Ac Sc, Tr 9: 197-198 (1890)

90d On the meteoric stone from Ferguson, Haywood Co., N. C. N Y Ac Sc, Tr $9: 198(1890)$

90e The aerolites which fell May 2d, 1890 , in Winnebago Co., Iowa. N Y AC Sc, Tr $9: 201-203$ (1890)

908 The Winnebago Co., Iowa, meteorites. Science 15:304 (1890)

$90 \mathrm{~g}$ On the group of meteorites recently discovered in Brenham township, Kiowa Co., Kans. Science 15:359-362 (1890)

$90 \mathrm{~h}$ On three new masses of meteoric iron [from North Carolina]. Elisha Mitchell Sc Soc, J 7:27-30 (1890)

91 On the occurrence of diamonds in Wisconsin. G Soc Am, B 2:63\$-639 (1891)

$91 \mathbf{a}$ on the occurrence of fire opal in a basalt in Washington State. G Soc Am, B 2:639 (1891)

91b Ueber neuere nordamerikanische Edelstein-Vorkommen. Zs Kryst 19:478482 (1891)

91e (and Weinschenk, E.) Meteoritenstudien [Washington, Kans.; Floyd Mountain, Va.] Tschermak's Mitt N F 12 : 177-185 (1891)

92 (and Weinsehenk, E.) Farmington, Washington Co., Kans., aerolite. Am J Sc (3) $43: 65-67$ (1892)

92a Mineralogical notes on brookite, octahedrite, quartz, and ruby. Am J Sc (3) $43: 329-330$ (1892)

92b (and Weinschenk, E.) On two meteoric irons [Virginia and Chile.] Am J Sc (3) $43: 424-426$ (1892)
Kunx, George Frederick-Continued.

93 (and Huntington, 0 . W.) On the liamond in the Canyon Diablo meteoric iron ... Am J Sc (3) $46: 470-473$ (1893)

$93 a$ Mineralogical notes on brookite, octahedrite, and quartz. Cal St M Bur, Rp $11: 207-209$ (1893)

94 Topaz from Texas. Am J Sc (3) 47 : 403-404 (1894)

$94 a$ A new locality of true emeralds [Bakersville, N. C.] Am J Sc (3) 48: $429-430 \quad$ (1894)

94b Mineralogical notes [diamonds from Wisconsin], N Y Ac Sc, Tr 13:144-145 (1894)

95 Precious stones. U S G S, An Rp 16 pt $4: 595-605$ (1895)

96 Memoir of Albert E. Foote. G Soc Am, B 7:481-485 (1896)

97 On the sapphires from Montana, with special reference to those from Yogo Gulch in Fergus Co. Am J Sc (4) $4: 417-420$ (1897)

$97 \mathbf{a}$ The genesis of the diamond. Science n s $6: 450-456$ (1897)

98 Meteoric stone that fell at Andover, Me. (abst). Science n s 8:840 (1898)

99 Native silver in North Carolina. Am J Se (4) $7: 242-243$ (1899)

01 Des progrès de la production des pierres précieuses aux Etats-Unis. Int G Cong, VIII, Paris 1900 , C R : 393-395 (1901)

02 Biographical notice of Thomas Egleston. Am I M Eng, Tr $31: 3-24$ (1902)

$02 a$ Gems and precious stones of Mexico (with discussion by Edward Halse). Am I M Eng, Tr 32:55-93 (1902) Abst, Eng M J $72: 713$ (1901)

$\mathbf{0 2 b}$ The composition of tourmaline. Eng M J $73: 482$ (1902)

03 On a new lilac-eolored spodumene [San Diego Co., Cal.]. Am J Sc (4) 16 : 264-267 (1903) Science n $s \quad 18: 280$ (1903)

03a Californite (vesuvianite); a new ornamental stone. Am J Sc (4) 16:397398 (1903)

03b Native bismuth and bismite from Pala, Cal. Am J Sc (4) $16: 398$ (1903)

o4 Gem minerals of southern California (abst). Science n s 19:107-108 (1904)

04a Clackamas meteoric iron (abst).

Science n s 19:108 (1904)

04b (with Baskerville, C.) Kunzite and its unique properties. $\mathrm{Am} \mathrm{J} \mathrm{Sc} \mathrm{(4)}$ $18: 25-28$ (1904)

o5 Gems, jewelers' materials, and ornamental stones of California. Cal St M Bur, B 37: 171 pp (1905)

O5a The exhibit of the U. S. Geological Survey radium collection shown at the St. Louis exposition [proposes name moissanite]. Science n s 21:665 (1905)

06 [Peridotite dike upon Manhattan Island] (abst). Science n s 23:388 (1906) 
Knnz, George Frederick-Continued.

O6a Description of the Modoc, Scott Co., Kans., meteorite $(a b s t)$. N Y Ac Sc, An 17:626-(1907) Science n s 23:388-389 (1906)

o7 History of the gems found in North Carolina. N C G S, B 12:60 pp (1907)

$07 \mathbf{a}$ Gems and precious stones of Mexico. Int $G$ Cong, $X$, Mexico, 1906: C R 1029-1080 (1907)

07b Occurrence of the diamond in North America $(a b s t)$. G Soc Am, B 17:692-694 (1907)

07c (and Washington, H. S.) Occurrence of diamonds in Arkansas. U S G S, Min Res 1906: 1247-1251 (1907)

o7d (and Washington, H. S.) Note on the forms of Arkansas diamonds. Am J Sc (4) $24: 275-276$ (1907)

08 [The cause of the San Francisco earthquake.] (abst). N Y Ac Sc, An 18: $289-290$ (1908)

OSa (and Washington, H. S.) Diamonds in Arkansas. Am I M Eng, B $20: 187-194$ (1908); Tr $39: 169-176$ (1909) Mines and Minerals 28:552-553 (1908) M World 28: 443 (1908)

12 On the occurrence of opal in northern Nevada and Idaho (abst). $\mathrm{N}$ X Ac Sc, An 21: 214-215 (1912)

13 The geology of the Hudson River and its relation to bridges and tunnels. Am Scenic and Historic Preservation Soc, An $R p$ 18:401-454 (1913)

14 John Boyd Thacher Park. Am Scenic and Historic Preservation Soc., An Rp 19 : $341-353$ (1914)

15 John Boyd Thacher Park; the Felderberg escarpment as a geological park (abst). G Soc Am, B 26:110-111 (1915) Science n \& 41:512-513 (1915)

16 Ivory and the elephant in art, in are beology, and in science. $527 \mathrm{pp}, \mathrm{N}$ Y 1916

17 Remarks on a pseudo-meteorite, fron pyrite crystals, and a black diamond (abst). N Y Ac Sc, An 27:271-272 (1917)

18 Genesis of the Sudbury nickel-copper ores (discussion [occurrence of palladium and platinum]). Am I M Eng, B 136: 848-849 (1918)

18a Biographical sketch of the late L. P. Gratacap. Am Mus J 18:302-304, port (p 298) (1918)

See also Earle, 13; Rath, 86i ; Roberts (H M), 18

Kurr, Johann Gottlob von.

69 Mineralogy illustrated. 22 pls and descriptive text, Boston 1869

Tachmann, $R$.

12 Ekzeme als geologische Chronometer [upgrowth of salt beds]. Deut G Ges, Zs, Monatsb 1912: 553-562
Lacoe, Ralph Dupuy (1824-1901).

82 [On fossil reptile tracks from the anthracite coal measures, near Pittston, Pa.]. Wyoming Hist G Soc, Pr Pub 3: 6-8 (1882)

83 List of Paleozoic fossil insects of the United States and Canada... Wyoming Hist G Soc, Pub no $5: 21$ pp (1883)

84 Catalogue of the Paleozoic fossil plants of North America. 15 pp, Pittston, Luzerne Co., Pa., 1884

Lacroix, Alfred.

s6 Propriétés optiques de quelques miné raux [variscite from Arkansas]. Soc Franç Minér, B $9: 5$ (1886)

90 Description des syénites néphéliniques de Pouzac, Hautes-Pyrénées et de Montréal, Canada, et de leurs phénomènes de_contact. Soc G France, B (3) 18:511-558 (1890)

95 Sur quelques minéraux des mines du Boléo, Basse-Californie. Mus d'Hist Nat, Paris. B 1:39-42 (1895) Soc Cient Ant Alz, Mem 15: Rev 33-35 (1900)

02 Les roches volcaniques de la Martinique. Ac Sc Paris, C R 134: 1246-1248 (1902)

02a Sur les cendres des éruptions de la Montagne Pelée de 1851 et de 1902 . Ac Sc Paris, C R 134: 1327-1329 (1902)

02b Mission de la Martinique. Ac Sc Paris, C R 135 : 147-150 (1902)

o2e (and others) Sur l'éruption de la Martinique. Ac Sc Paris, C R 135 : 377$391,419-431$ (1902)

o2d Sur les roches rejetées par l'éruption actuelle de la Montagne Pelée. Ac Sc Paris, C R 135: 451-454 (1902)

02e Les enclaves des andésites de l'éruption actuelle de la Montagne Pelée. Ac Sc Paris, C R 135: 470-472 (1902)

O2f Nouvelles observations sur les éruptions volcaniques de la Martinique. Ac Sc Paris, C R 135:672-674 (1902)

02a Sur l'état actual du volcan de la Montagne Pelée a la Martinique. Ac Sc Paris, C R 135: 771-773 (1902)

02h Etat actuel du volcan de la Martinique. Ac Sc Paris, C R 135:992-997 (1902)

021 Quelques observations minéralogiques faites sur les products de l'incendie de Saint-Pierre, Martinique. Ac Sc Paris, C R 135: 1068-1071 (1902)

02j Nouvelles observations sur les érup. tions volcaniques de la Martinique. Ac Sc Paris, C R 135: 1301-1307 (1902)

o2k Les roches volcaniques de la Martinique. Ac Sc Paris, C R 134: 1369-1371 (1902)

03 Les dernières éruptions de Saint-Vincent. An Géog, Paris, 12:261-268 (1903)

o3a Les éruptions des nuages denses de la Montagne Pelée. Ac Sc Paris, C R 136: 216-218 (1903)

03b L'éruption de la Montagne Pelée en janvier, 1903. Ac Sc Paris, C R 136:442443 (1903) 
Lacroix, Alfred-Continued.

03e Sur l'état actuel de la Soufrière de la Guadeloupe. Ac Sc París, C R 136: 656659 (1903)

03d Sur une éruption du volcan de Saint Vincent. Ac Sc Paris, C R 136: 803-807, (1903)

03e Principaux résultats de la mission de la Martinique. Ac Sc Paris, C R 136: 871-876 (1903)

03f La cordiérite dans les produits éruptifs de la Montagne Pelée et de la Soufrière de Saint Vincent. Ac Sc Paris, C R 137 : 145-147 (1903)

03g Les enclaves basiques des volcans de la Martinique et de Saint Vincent. Ac Sc Paris, C R 137 : 211-213 (1903)

03h Sur quelques productions bouenses accompagnant les éruptions de la Montagne Pelée. Rv Gén Sciences 14 : 115-116 (1903)

03i L'éruption de la Martinique. Soc Secours Amis Sciences, B : 49-93 (1903) [not seen] Rv Scient (4) 20:674-686 (1903)

03j Les dernières éruptions de SaintVincent. An Géog 12: 261-268 (1903)

03k Sur le gisement de la ealcédoine et des bois silicifiés de la Martinique. Soc Franç Miner, B 26: 150-152 (1903)

$04 \mathrm{La}$ Montagne Pelée et ses éruptions. xxii, 662 pp, Paris 1904

04a Sur la production de roches quartziferres au cours de l'éruption actuelle de la Montagne Pelée. Ac Sc Paris, C R 138: 792-797 (1904)

05 Le mode de formation d'un dôme volcanique et la cristallisation des roches éruptives quartzifères d'après les observations faites au cours de léruption de la Montagne Pelée. Rv Gén Sciences 16 ; 301315 (1905)

05a Sur un gisement de redondite a la Martinique. Soc Franc Miner, B 28:1316 (1905)

05b Observations faites a la Montagne Pelée sur les conditions présidant a la production de la tridymite dans les roches rolcaniques. Soc Franc Miner, B 28: 5660 (1905)

05e Le sulfate de soude des fumerolles secondaires a haute température de la Montagne Pelée. Soc Franc Miner, B 28:6068 (1905)

07 Contributions a l'étude des brèches et des conglomerats volcaniques (Antilles 1902-1903, Vésuve 1906). Soc G France, B (4) 6:635-685 (1907)

07a Sur la constitution minéralogique du dôme récent de la Montagne Pelée. Ac Sc Paris, C R 144: 169-173 (1907)

08 La Montagne Pelée après ses éruptions. $136 \mathrm{pp}$, Paris 1908

17 L'éruption du voican de Quetzaltepeque et le tremblement de terre destructeur de San Salvador (juin-juillet 1917). Ac Sc Paris, C R 165:1077-1082 (1917)

\section{Ladd, George Edgar.}

90 Building stones, clays, and sands of Iron, St. Francois, and Madison cos., Mo. Mo G S, B 1:22-44 (1890)

$90 a$ The clay, stone, lime, and sand industries of St. Louis City and County. Mo G S, B 3:5-84, map (1890)

91 Notes on the clays and building stones of certain western central counties tributary to Kansas City. Mo G S, B 5: 43-86 (1891)

96 Notes on certain undescribed clay occurrences in Missouri. Science n s 3:691693 (1896)

9s A preliminary report on a part of the clays of Georgia. Ga G S, B 6-A : 204 pp, map (1898)

9Sa Geological phenomena resulting from the surface tension of water. Am G $22: 267-285$ (1898)

99 Notes on the Cretaceous and associated clays of middle Georgia. Am G 23 : 240-249 (1899)

Ladshaw, George E.

92 Spartanburg, S. C., gold fields. Eng M J $54: 52$ (1892)

Laflamme, Joseph Clovis Kemner (18491910 ).

81 Eléments de minéralogie et de géologie. $288 \mathrm{pp}$, Quebec 1881

s3 Note sur la géologie du lac St. John. R Soc Can, Pr Tr 1, iv : 163-164 (1883)

85 Report of geological observations in the Saguenay region [Que.]. Can G S, Rp Prog 1882-4:D 18 pp (1885)

S5a Note sur certains dépôts aurifères de la Beauce [Que.]. R Soc Can, $\mathrm{Pr} \mathrm{Tr}$ 2 , iv : 227-230 (1885)

85b Note sur un gisement d'éméraude au Saguenay. R Soc Can, $\operatorname{Pr} \operatorname{Tr} 2$, iv : 231-232 (1885)

87 [On Ordovician rocks in Quebec north of the St. Lawrence.] Can G S, An Rp 2: A 36-38 (1887)

$\mathbf{8 7 a}$ Note sur le contact des formations paléozol̃ques et archéennes de la province de Québec. R Soc Can, Pr Tr 4, iv: 4347 (1887)

89 [Observations on the north side of the St. Lawrence above Quebec]. Can G $\mathrm{S}$, Sum Rp 1887-8 ( $\mathrm{An}$ Rp 3): A $31-32$ (1889)

S9a Le gaz naturel dans la province de Québec. R Soc Can, Pr Tr 6, iv: 15-25 (1889)

$9 x$ [Report on investigations in the county of Charlevoix, Que.] Can G S, Sum Rp 1890 (An Rp 5) : A 48-50 (1891) 92 [Report on the northwest shore of the St. Lawrence between Malbaie and Tadousac, Que.] Can G S, Sum Rp 1891 (An Rp 5) : A 44-45 (1892)

92a Le docteur Thomas Sterry Hunt. $16 \mathrm{pp}$ (extrait de l'Annuaire de l'Université Laval 1892-93), Quebec 1892

$$
28737^{\circ}-23-40
$$


Laflamme, Joseph Clovis Kemner-Con. 93 [Report on field work in Charlevoix and Montmoreney cos., Que.] Can G S, Sum Rp 1892 (An Rp 6) : A 45-46 (1893)

95 L'éboulis de St. Alban [landslide at St. Alban, Que.]. R Soc Can, Pr Tr 12, iv : $63-70$ (1895)

98 Influence d'un éboulement sur le régime d'une riviere [landslide, Ste. Anne, Quebec, 1894] (abst). Brit As, Rp 67: 658 (1898)

00 Modifications remarquables causées à l'embouchure de la rivière Ste. Anne par l'éboulement de St. Alban. R Soc Can, Pr $\operatorname{Tr}$ (2) 6, iv : 175-177 (1900)

ooa Eboulement a Salnt-Luc-de-Vincennes, Rivière Champlain, le 21 septembre, 1895. R Soc Can, $\operatorname{Pr} \operatorname{Tr}$ (2) 6, iv: 179$186(1900)$

02 Geological exploration of Anticosti. Can G S Sum Rp 1901 (An Rp 14) : A 190-196 (1902)

07 Les tremblements de terre de la region de Québec. R Soc Can, Pr Tr (3) 1 iv : $157-183$ (1907)

o9 Les montagnes Notre-Dame et les Shickshocks. Soc Géog Qué, B 3: 3-13 (1909)

09a Les Laurentides. Soc Géog Qué, B 3:67-70 (1909)

LaForge, Laurence.

04 (with Crosby, W. O.) [Notes on water resources of] Massachusetts. U S G S, W-S P 102: 94-117 (1904)

o5 Water resources of central and zouthwestern Highlands of New Jersey. U S G S, W-S P 110:141-155 (1905)

08 The structure of the marble belt of Fannin Co., Ga. (abst). Science n s 27 : 537 (1908)

09 Correlation of the rocks of the Boston region (abst). Science n s $29: 945-$ 946 (1909)

09a (with Palache, C.) Notes on the crystallography of leadhillite. Am Ac, $\mathrm{Pr}$ $44: 435-463$ (1909)

10 (with Sayles, R. W.) The glacial origin of the Roxbury conglomerate. Science $n$ s $32: 723-724$ (1910)

$10 a$ (with Palache, C.) Notizen über die Krystallographie des Leadhillits. I. Leadhillit von Utah. Zs Kryst 48:129-133 (1910)

12 Is there a Permian series? (abst). Wash Ac Sc, J 2:106-107 (1912)

13 (and Phalen, W. C.) Description of the Ellijay quadrangle [Ga.-N. C.-Tenn]. U S G S, G Atlas Ellijay fol (no 187) : 18 pp, maps (1913)

La Gorce, John Oliver.

15 The warfare on our eastern coast [coast erosion]. Nat Geog Mag 28:195230 (1915)

Laguerenne, Teodoro Luis.

75 Apuntes sobre el mineral de San Nicolás del Oro [Méx.]. La Naturaleza 3 : $167-171$ (1875)
Laguerenne, Teodoro Luis - Continued.

82 Informe... de exploración á los cria deros metalfferos de la Sierra del Estad de Guerrero. México, Ministerio de $\mathrm{F}$ mento, An 7:605-687 (1882)

os Estudio sobre la hidrografia subte. rránea del Estado de Morelos y la parte norte del Estado de Guerrero. La Naturleza (2) $3: 44-48$ (1898)

02 Estado de Tabasco [México]. Soc Cient Ant Alz, Mem 17:125-131 (1902)

09 Descripción de la zona minera en el mineral de Pregones, municipalidad de Teti. pac, Distrito de Alarcon, en el Estado de Guerrero. Soc G Mex, B 5:25-35 (1909)

Lahee, Frederick Henry.

os The filling of Emerald Lake [B. C.] by an alluvial fan. Science n \& $27: 752$ 753 (1908)

osa An alluvial fan, near Field, in B. C. Am Geog Soc, B 40:340-344 (1908)

osb A fault in an esker [near East Templeton, Mass.] Science n s 28:654655 (1908)

o9 Theory and hypothesis in geology. Science n s 30:562-563 (1909)

10 Dodecahedral jointing due to strain of cooling. Am J Sc (4) 29:169-170 (1910)

12 Crescentic fractures of glacial origin Am J Sc (4) - 33: 41-44 (1912)

$12 a$ Relations of the degree of meta. morphism to geological structure and to acid igneous intrusion in the Narragansett Basin, R. I. Am J Sc (4) $33: 249-262$, $354-372,447-469$ (1912)

12b A new fossiliferous horizon on Blueberry Mountain in Littleton, N. H. Science n s $36: 275-276$ (1912)

13 Geology of the new fossiliferous hori. zon and the underlying rocks, in Littleton, N. H. Am J Sc (4) $36: 231-250$, map (1913)

14 Late Paleozolc glaciation in the Bos. ton Basin, Mass. Am J Sc (4) $37: 316-$ 318 (1914)

14a Crystalloblastic order and mineral development in metamorphism. J G 22: 500-515 (1914)

14b Contemporaneous deformation; a criterion for aqueoglacial sedimentation. J G $22: 786-790$ (1914)

14e Misuse of the term "eruptive." Ec G $9: 72-73$ (1914)

16 Field geology. 508 pp, N Y 1916 1st ed, 2d impression, with appendix on geologic mapping, 528 pp, N Y 1916 [1917]

$16 a$ Origin of the Lyman schists of New Hampshire. J G 24:366-381 (1916)

See also Pirsson, 15

Laira, George A.

o5 The gold mines of the San Pedro dis. trict, Cerro de San Pedro, State of San Luis Potosi, Mex. Am I M Eng, Tr 35: 858-878, map (1905) 
Lake, John J.

75 Earthquakes and their causes. Pop Sc Mo $7: 732-738$ (1875)

Lakes, Arthur (1844-1917)

79 The dinosaurs of the Rocky Mountains. Kansas City Rv Sc 2:731-735 (1879)

86 The Trinidad coal region of southern Colorado. Colo Sch Mines, An Rp Fieldwork ...: :81-102 (1886)

86a The coal field of Crested Butte, Gunnison Co., Colo. Colo Sch Mines, An Rp Fleldwork ... : 103-12S, map (1886)

87 Geology of the Aspen mining region, Pitkin Co., Colo. Colo Sch Mines, Bien Rp $1886: 43-84$ (1887)

8s Geology of Colorado ore deposits. clix [2] pp, Denver, Colo., 1888 Also issued with Colo Sch Mines, An Rp 1887 [1888]

89 Geology of Colorado coal deposits. Colo Sch Mines, An Rp Field Work ...: 264 pp, maps (1889)

90 Extinct voleanoes in Colorado. Am G $5: 38-43$ (1890)

91 The fuel resources of Colorado. Am G 8:7-19 (1891)

93 Geology of Colorado and western ore deposits. 314 pp, maps, Denver, Colo., 1893

94 Colorado's new gold camps. Eng Mag 7:623-638 (1894)

94a The deep leads of California. Colliery Eng 14:170 (1894) M Sc Press 68: $136 \quad$ (1894)

95 Prospecting for gold and silver in North America. 207 pp, Scranton, Pa., 18952 2d ed, 287 pp, Scranton, Pa., 1896

95a Geology of Cripple Creek, Colo. 32 pp, Denver, 1895

95b Fossilized big trees, California. Sc Am Sup 39: 15862 (1895)

97 Sketch of a portion of the Gunnison gold belt, including the Vulcan and Mammoth Chimney mines [Colo.]. Am I II Eng, $\operatorname{Tr} 26: 440-448$ (1897) Abst, Zs prak G 1897: 100-101

97a The undeveloped economic resources of Colorado. Stone 14:358-369 (1897)

01 The geology of the oil fields of Colorado. Colo Sch Mines, B $1: 221-226$ (1901)

01a The geological occurrence of oil in Colorado (abst). oc Am Sup 52:21505 (1901)

02 Oil in Colorado. Mines and Minerais $22: 256-257$ (1902)

04 Gypsum deposits in Colorado. U S G S, B 223: 86-88 (1904)

04a The coal fields of Colorado. Colo Sch Mines, B 2 no $2: 1-23$ (1904)

04b Schists and slates as ore carriers. M Sc Press 88: 161-162 (1904)

04e Ore in anticlinals as at Bendigo, Australia, and Tombstone, Ariz. M Sc Press 88.193 (1904)
Lakes, Arthur-Continued.

04d The Lone Mountain district, near Tonopah, Nev. M Sc Press 88:246-247 (1904)

o4e Some of the ore deposits of Colorado. M Sc Press, $88: 377-378$ (1904)

$04 f$ Ore in rocks of all geological periods. M Rep 49:525-526 (1904)

o5 Geology of western ore deposits. New ed, 438 pp, map, Denver, Colo., 1905

05a Geology of the hot springs of Colorado and speculations as to their origin and heat. Colo Sc Soc Pr 8: 31-37 (1905)

05b San Juan region and some of its peculiar mines. M World 23: 34-35 (1905)

o5e Geology and economical geology [stratigraphy of the Denver Basin, Colo.] M World 23:312-314 (1905)

o5d Some of the veins of ore deposits of the Wood River district, Idaho. M World $23: 696-697$ (1905)

o5e Organic remains in ore deposits. Eng M J 79 : 1226-1227 (1905)

o5f Igneous rocks in ore deposition. Eng M J 80: 196 (1905)

05\% [Coal fields of Coloradó.] M Rep 51 (1905)

05h Geology of the hot springs of Colorado and speculations as to their origin and heat. M Rep 51:479-481 (1905)

o5i Fault phenomena. M Rep 52:6-7, $58-59,85-86,166-167$ (1905)

o5j Peat and its relation to coal. M Rep 52: 208-209 (1905)

06 The Dollarhide mine [Wood River region], Idaho. M World $24: 437$ (1906)

o6a The evolution of a mineral vein. M Sc Press 92:349 (1906)

06b The Gunnison gold belt of Celorado. M World 25:576 (1906)

or The spontaneous combustion of coal and its effect on the surrounding strata. Colo Sc Soc, Pr 8: 301-304 (1907)

os The coals and coal fields of Colorado.

M World 28:525-526, 565-566 (1908)

09 Ores in volcanic craters and fumarole orifices. M World $30: 425-427$ (1909)

o9a Modern ancient volcanoes and ore deposits. M World 30:583-584 (1909)

o9b The ore occurrence and origin of cave mines. M World 30:727-729 (1909) o9e Interesting little black dikes. M World 31: 218 (1909)

o9d The depth and continuity of fissure veins. M World $31: 363-364$ (1909)

11 The Wood River mining district of Idaho. M World 34:307-308 (1911)

13 The coal fields of western Canada. Colliery Eng 34:11-14, map (1913)

15 Mining in lake districts of British Columbia. M World $42: 411-414$ (1915)

16 The Electric-Point mine in Washington. M World 45:991-992 (1916) 
Lakes, Arthur-Continued.

Also numerous papers not listed here in the Colliery Engineer, vols. 13-18, and its successor Mines and Minerals, vols, 18-32; also in the Mining Reporter and in Mining Science.

Lamb, George Franklin.

o5 Field geology in Ohio State University. Am G 36:195-197 (1905)

10 Pennsylvanian limestones of northeastern Ohio below the lower Kittanning coal. Ohio Nat 10:89-135 (1910)

11 The Mississippian-Pennsylvanian unconformity and the Sharon conglomerate. J G 19:104-109 (1911)

14 Middle Mississippian unconformities and conglomerates in northern Ohio. Ohio Nat 14:344-346 (1914)

16 Outliers of the Maxville limestoue in Ohio north of the Licking River. Obio J Sc 16:151-154 (1916) Science n s 44: 867-868 (1916)

Lamb, H. Mortimer,

08 Canadian graphite. Eng M J 85 : 360-361 (1908)

13 General index together with summaries of papers contained in vols. I to $\mathrm{X}$, inclusive (1898-1907) of the Journal of the Canadian Min. Inst. $488 \mathrm{pp}$, Montreal 1913

13a Willet G. Miller. Can M J 34: 695 , port (1913)

Lambe, Lawrence Morris (1863-1919).

96 Description of a supposed new genus of Polyzoa from the Trenton limestone at Ottawa. Can Rec Sc $7: 1-3$, il (1896)

98 On the remains of mammoth in the museum of the Geological Survey department. Ottawa Nat 12:136-137 (1898)

99 A revision of the gencra; and species of Canadian Paleozoic corals; the Madreporaria Perforata and tie Alcyonaria. Can G S. Contr Can Pal 4:1-96, il (1899)

99 [Report on the collection of fossils in the Red Deer River district, Alta.1 Can G S, Sum Rp 1898 (An Rp 11) : A 182-190 (1899)

99b On some species of Canadian Paleozoic corals. Ottawa Nat $12: 217-226$, 237-258 (1899)

99e On reptilian remains from the Cretaceous of northwestern Canada. Ottawa Nat 13: 68-70 (1899)

99d Notes on a stromatoporoid from the Hudson River formation of Ontario. Ottawa Nat $13: 170-171$ (1899)

01 A revision of the genera and specles of Canadian Paleozoic corn's; the Madreporaria Aporosa and the Madreporaria Rugosa. Can G S, Contr Can Pal 4:97-197, il (1901)

01a Notes on a turtle from the Cre. taceous rocks of Alberta. Ottawa Nat 15 : 63-67, il (1901)
Lambe, Lawrence Morris-Continued. 02 New genera and species from the Belly River series (mid-Cretaceous). Cas G S, Contr Can Pal 3 pt $2: 23-81$, I] (1902)

02a Red Deer River, Alta. Can G \& Sum Rp 1901 (An Rp 14) : A 82-83 (1902

02b On Trionyx foveatus Leidy and Tri onyx vagans Cope from the Cret ceose rocks of Alberta. Can G S, Sum Rp 1901 (An Rp 14): A 83-87, il (1902)

03 [Report on] paleontological work. Can G S, Sum Rp 1902 (An Rp 15): 467-469 (1903) [Report on] vertebrate paleontology. Can G S, Sum Rp 190: (An Rp 15); A 205-207 (1904); Sum Rp 1904 (An Rp 16) : A 362-371 (1905); Sun Rp 1905: 135-138 (1906): Sum Rp 1906 1ร4-176 (1906); Sum Rp 1907:110-11? (1908): Sum Rp 908:176-178 (1909); Sum ..p 1909:269-273 (1910)

03a The lower jaw of Dryptosaurus in crassatus Cope. Ottawa Nat $17: 133-139$, il (1903)

03b Recent zoopaleontology: Stegoceras and Stereocephalus. Science n $\mathrm{s}$ 18:60 (1903)

04 On Dryptosaurus incrassatus Cope from the Edmonton series of the North. west Territory. Can G S, Contr Can Pal 3 pt 3:27 pp, 11 (1904)

O4a The grasping power of the manus of Ornithomimus altus Lambe. Ottawa Nat $18: 33-36$, il (1904) Abst, Science n s $19: 254$ (1904)

04b On the squamoso-parietal crest of two species of horned dinosaurs from the Cretaceous of Alberta. Ottawa Nat 18 : $81-84$, il (1904)

o5 [Report of field work in Cypress Hills, Saskatchewan, and list of vertebrates collected.] Can G S, Sum Rp 1904 (An Rp 16) : A 364-371 (1905)

o5a On the squamoso-parietal crest of the horned dinosaur Centrosaurus apertis and Monoclonius canadensis from the Cre taceous of Alberta. R Soc Can, Pr Tr (2) 10 , iv : $3-12$, il (1905)

05b The progress of vertebrate paleontology in Canada. R Soc Can, Pr Tr (2) 10 , iv : $13-56$ (1905)

ose On the tooth structure of Meso. hippus westoni (Cope). Am G $35: 243-$ 245, il (1905)

06 Notes on the fossil corals collected by Mr. A. P. Low at Beechey Island, South ampton Island, and Cape Chidley, in 1904 Cruise of the Neptune:322-328, il (1906) [See Low 06]

O6a Note on the age of the Horsefly, Similkameen, and Tranquille Tertiary beds of the southern interior of British Colum bia. Can G S, Sum Rp 1905: 137-138 (1906) 
Lambe, Lawrence Morris-Continued.

$06 \mathrm{~b}$ Descriptions of new species of Testudo and Baena with remarks on some Cretaceous forms. Ottawa Nat 19:187196, il (1906)

06e Boremys, a new Chelonian genus from the Cretaceous of Alberta. Ottawa Nat $19: 232-234$ (1906)

06d A new species of Hyracodon ( $H$. priscidens) from the Oligocene of the Cypress Hills, Assiniboia. R Soc Can, Pr Tr (2) 11 iv : $37-42$, il (1906)

06e Fossil horses of the Oligocene of the Cypress Hills, Assiniboia. R Soc Can, $\operatorname{Pr} \operatorname{Tr}$ (2) 11 iv : 43-52, il (1906)

06f On Amyzon brevipinne Cope, from the Amyzon beds of the southern interior of British Columbia. R Soc Can, Pr Tr (2) 12 iv: 151-156, il (1906) Abst, Science $\mathrm{n}$ s $23: 970-971$ (1906)

07 On a new crocodilian genus and specles from the Judith River formation of Alberta. R Soc Can, $\operatorname{Pr} \operatorname{Tr}$ (3) 1 iv : 219244, il (1907)

07a On a tooth of Oribos, from Pleistocene gravels near Midway, B. C. Ottawa Nat $21: 15-18$, il (1907)

08 The vertebrata of the Oligocene of the Cypress Hills, Saskatchewan. Can G S, Contr Pal 3 pt 4:65 pp, il (1908)

09 The fish fauna of the Albert shales of New Brunswick. Am J Sc (4) $28: 165-$ 174, il (1909)

10 The paleontological results of the Dominion government Arctic expedition of 1908-9 [notes on Silurian and Carboniferous fossils]. In Report on the Dominion of Canada government expedition to the Aretic islands and Hudson Strait on board the D. G. S, Arctic, by Captain J. E. Bernier [Can, Dp Marine and Fisheries], 479-489, Ottawa, 1910.

10a Palæoniseid fishes from the Albert shales of New Brunswick. Can G S, Mem 3, Contr Can Pal 3 pt $5: 68$ pp, il (1910)

$10 \mathrm{~b}$ Note on the parietal crest of Centrosaurus apertus and a proposed new generic name for stereocephalus tutus. Ottawa Nat 24:149-151 (1910)

11 On Aretotherium from the Pleistocene of Yukon. Ottawa Nat 25:21-26, il (1911)

11a [Report of] paleontological division. Can G S, Sum Rp 1910:269-273 (1911); 1911: 346-351 (1912)

12 Presidential address; The past vertebrate life of Canada. R Soc Can, Pr Tr (3) 5 iv : $3-15$ (1912)

13 The occurrence of helodont teeth at Roche Miette and vicinity, Alta. Can G S, Victoria Mem Mus, B 1:17-20, il (1913)

13a The manus in a specimen of Trachodon from the Edmonton formation of Alberta. Ottawa Nat $27: 21-25$, il (1913)
Lambe, Lawrence Morris-Continued.

$13 \mathrm{~b}$ Description of a hew species of Testudo, and of a remarkable specimen of Stylemys nebrascensis, from the Oligocene of Wyoming. Ottawa Nat $27: 57-63$, il (1913)

13e $A$ new genus and species of Ceratopsia from the Belly River formation of Alberta. Ottawa Nat 27:109-116, il (1913)

14 Leport of the vertebrate paleontologist. Can G S, Sum Rp 1912: 397-403, il ; $1913: 293-299 ; 1914: 116-121 ; 1915: 193-$ $198 ; 1916: 288-295 \quad(1914-7)$

$14 a$ On new species of Aspideretes from the Belly River formation of Alberta, with further information regarding the structure of the carapace of Boremys pulchra, R Soc Can, $\operatorname{Tr}$ (3) 8 iv : $11-16$, il (1914)

14b Description of a new species of Platysomus from the neighborhood of Banfr, Alta. R Soc Can $\mathrm{Tr}$ (3) 8 iv: $17-23$, il (1914)

14e On the fore limb of a carnivorous dinosaur from the Belly River formation of Alberta, and a new genus of Ceratopsia from the same horizon, with remarks on the integument of some Cretaceous herbivorous dinosaurs. Ottawa Nat 27:129-135, il (1914)

14d On Gryposaurus notabilis, a new genus and species of trachodont dinosaur from the Belly River formation of Alberta, with a description of the skull of Chasmosaurus belli. Ottawa Nat $27: 145-155$, il (1914)

14e On a new genus and species of carnivorous dinosaur from the Belly River formation of Alberta, with a description of Stephanosaurus marginatus from the same horizon. Ottawa Nat $28: 13-20$, il (1914)

$14 \mathrm{f}$ Contributions to Canadian paleontology. Can Rec Sc 9:383-386 (1914)

15 On Eoceratops canadensis gen. nov., with remarks on other genera of Cretaceous horned dinosaurs. Can G S, Mus B 12:49 pp, il (1915)

16 Ganoid fishes from near Banff, Alberta. R Soc Can, $\operatorname{Tr}$ (3) 10 iv: $35-44$, il (1916)

17 The Cretaceous theropodous dinosaur Gorgosaurus. Can G S, Mem 100:84 pp, il (1917)

17a On Cheneosaurus tolmanensis, a new genus and species of trachodont dinosaur from the Edmonton Cretaceous of Alberta. Ottawa Nat $30: 117-123$, il (1917)

17b A new genus and species of crestless hadrosaur [Edmontosaurus regalis] from the Edmonton formation of Alberta. Ottawa Nat $31: 65-73$, il (1917)

18 The Cretaceous genus Stegoceras, typifying a new family referred provisionally to the Stegosauria. B Soc Can, Tr (3) 12 iv : $23-36$, il (1918)

18a On the genus Trachodon of Leidy, Ottawa Nat $31: 135-139$ (1918) 
Lambe, Lawrence Morrls-Continued.

18b On the remains of a selachian from the Edmonton Cretaceous of Alberta. Ottawa Nat $32: 27-28$, il (1918)

Lambert, Avery E.

04 Description of Dalmanites lunatus. G Soc Am, B 15:480-481, il (1904)

05 A trilobite, Dalmanites lunatus, from Littleton, N. H., with notes on other fossils from the same locality. In Hitchcock, C. H., The geology of Littleton, N. H. (reprinted from History of Littleton) : 33-38, il, Cambridge, U. S. A., 1905

Lambert, J.

15 Echinides néogènes des Antilles anglaises. Soc Ac Agr... Département de l'Aube, Troyes, Mém 79 ((13) 52) : 17-33, il (1915)

Lambeth, W. A.

01 Notes on the geology of the Monticello area, Va. Thesis, University of Virginia. $22 \mathrm{pp}$, map, 1901

Lammers, Theo. L.

00 Ore deposits in the Cracker Creek district, Oreg. Eng M J 70:160 (1900)

O7 The Murray gold belt, Idaho. M Sc Press 94: 636-637 (1907)

Lamplngh, G. W.

85 On ice-grooved rock surfaces near Victoria, Vancouver Island; with notes on the glacial phenomena of the neighboring region, and on the Muir Glacier of Alaska. Yorkshire G Polyt Soc, Pr n s 9:57-70, map (1885)

86 On glacial shell beds in British $\mathrm{Co}$ lumbia. G Soc London, Q J 42:276-286 (1886) Abst, G Mag (3) 3:233-23t (1886)

Lancaster, Albert.

74 Note additionnelle au mémoir de $M$. W. T. Brigham, intitulé "Volcanic manifestations in New England, 1638-1870." Boston Soc N H, Mem 2:241-247 (1874)

Lancaster, Joseph.

10 Priest Lake district, Idaho. M World $32: 100(1910)$

Land, W. J. G.

11 (with Coulter, J. M.) An American Lepidostrobus. Bot $\mathrm{Gaz} 51: 449-453$ (1911)

Landero, Carlos F. de.

80 El molibdenite de San Sebastián, Jalisco. Soe Ing Jalisco, B 1: 58-60, 8087 (1880) [not seen]

84 Informe sobre las especies minerales del Estado de Jalisco. 41 pp, Guadalajara 1884

S8 Sinopsis mineralogica 6 catálogo descriptivo de los minerales. $528 \mathrm{pp}$, México 1888

91 Estudios mineralogicos y químicos; grosularita rosa de Xalostoc, Morelos. Soc cient Ant Alz, Mem 4:243-256 (1891)

91 a Grosularita rosa de Xalostoc, Morelos. Soc Cient Ant Alz, Mem 5: 243-256 (1891)
Landero, Carlos F. de-Continued.

$91 b$ on pink grossularite from (er/ Am J Sc (3) 41:321-323 (1891)

93 Informe sobre la región aurifera Santa Clara, Distrito Norte de la B (alifornia. Bol Agr Min 6 Ind 2 no $163-178$ (1893)

$93 a$ Informe sobre la negociacion mine de Analco. Bol Agr Min é Ind 3 no 131-171 (1893)

97 El aerolito de Atemajac de Tables [Jalisco]. Ac Mex Cienc, An 129-150 (1897)

Landes, Henry.

98 The Deu Pree lode, Washington Eng M J $65: 39-40$ (1898)

oo Index mining district, Wash. Mit ing $5: 1-4$ (1900)

02 Creation of a State Geological su vey. Wash G S 1:1-9 (1902)

02a An outline of the geology of Wast ington. Wash G S 1:11-35, map (190. 02b (and others) The metalliferous : sources of Washington, except iron. Wa G S 1:39-157 (1902)

o2e The nonmetalliferous resources Washington, except coal. Wash G $\mathrm{S}$ 161-213 (1902)

02d The coal deposits of Washingto Wash G S 1:257-281, map (1902)

03 (and Ruddy, C. A.) Coal depost of Washington. Wash G S 2 : 165-27 map (1903)

o5 The clay deposits of Washingtet U S G S, B 260:550-558 (1905)

05a Preliminary report on the unde: ground waters of Washington. U S G S W-S P 111: 85 pp, map (1905)

osb Field notes on Mt. Rainier [Wash, Mazama 2:220-223 (1905)

06 Cement resources of Washington.

S G S, B 285: 377-383 (1906)

o7 Round about Mount Baker. Mazam $3: 5-8 \quad(1907)$

11 The road materials of Washington Wash G S, B 2:204 pp (1911)

14 The mineral resources of Washingtor Wash G S, B 11:53 pp, map (1914)

16 The water resources of Washington. J Geog 14:323-331 (1916)

Landis, Edward K.

oo The Tilly Foster mine [magnetite Putnam Co., N. Y.]. Franklin Inst, 150:223-226 (1900)

Lane, Alfred Church.

89 The geology of Nahant. Boston Soc N H, Pr 24:91-95 (1889)

89a A pocket mapping instrument. Am G $4: 239-243$ (1889) Eng M J $49: 425-$ 426 (1890)

91 On the recognition of the angles of crystals in thin sections. $G$ Soc Am, B 2:365-382 (1891)

91a (and Keller, H. F., and Sharpless, F. F.) Notes on Michigan minerals Am J Sc (3) 42:499-508 (1891) 
Lane, Alfred Church-Continued.

91b Petrographical tables. Am G-7: 337-339 (1891)

91e (with Keller, H. F.) Chloritold von Champion, Mich., U. S. A. Zs Kryst $19: 383-385$ (1891)

93 Microscopic characters of rocks and minerals of Michigan. Mich G S, Rp 18912: 176-183 (1893)

94 Geologic activity of the earth's originally absorbed gases. G Soc Am, B 5: 259-280 (1894) Abst, Am G 13:138139 (1894)

94a What is Archean? Science 23:128 (1894)

94b A connection between the chemical and optical properties of amphiboles (abst). G Soc Am, B 6:3 (1894) Am G 14:195 (1894)

95 The geology of Lower Michigan with reference to deep borings (edited from notes of C. E. Wright). Mich G S 5 pt 2 : $100 \mathrm{pp}$ map (1895)

95a The bowels of the earth. Pop Sc Mo $47: 302-313$ (1895)

95b Crystallized slags from copper smelting (abst), G Soc Am, B 6:469-470 (1895)

$95 \mathrm{e}$ The relation of grain to distance from margin in certain rocks (abst). Science $n$ s $1: 61-62$ (1895)

97 Nature's concentrators. Eng M J $63: 542-543$ (1897)

97a The drainage of the Saginaw Valley. Science n s 5:553 (1897)

$97 \mathrm{~b}$ Grain of rocks $(a b s t)$. G Soc Am, B $8: 403-407$ (1897) J G $5: 222-223$ (1897) Science n s 5:97-98 (1897)

98 Geological report on Isle Royale, Mich. Mich $\mathrm{G}$ S 6 pt 1:281 pp, map (1898)

99 Water resources of the Lower Peninsula of Michigan. U S G S, W-S p $30: 97$ pp, maps (1899)

99a Lower Michigan mineral waters, a study into the connection between their chamical composition and mode of occurrence. U S G S, W-S P 31:97 pp, maps (1899)

$99 \mathbf{b}$ Note on a method of stream capture. G Soc Am, B 10:12-15 (1899) Abst, Am G 22: 252 (1898) ; Science n s 8: 465 (1898)

99e Magmatic differentiation in rocks of the copper-bearing series (abst). G Soc Am, B 10: 15-18 (1899) Am G 22: 251 (1898) Seience n s $8: 465$ (1898)

99d Coal in lower Michigan. Mich Miner 1 no. $3: 9-13$; no. $4: 9-16$; no. 5 : $9-12$; no. $6: 9-12$; no. $7: 9-12$; no. $8: 9-$ 12 ; no. $9: 9-12$; no. $10: 9-12$ (1899) Reprint, 36 pp, [Saginaw 1899]

99e Isle Royale; what has been accomplished in unearthing its mineral wealth. Mich Miner 1 no. $11: 18-21$; no. $12: 14$ 18 (1899)
Lane, Alfred Church-Continued.

00 Geological report on Huron Co., Mich. Mich G S 7 pt $2: 329$ pp, il, maps (1900)

Ooa (and Cooper, W. F.) Fossils of the Marshall and Coldwater. Mich G S 7 pt $2: 252-285$, il (1900)

oob The geothermal gradient in Michigan. Am J Sc (4) 9:434-438 (1900)

ooe The coal basin of Michigan. Eng M J 69:767-768; 70:12 (1900)

ood The geological survey; annual report of the State geologist for the year ending December 31, 1899. Mich Miner 2 no $3: 9-13$ (1900)

ooe Dr. L. L. Hubbard. Mich Miner 3 no $1: 14-15$, port $(1900)$

01 Michigan limestones and their uses. Eng M J 71 : 662-663, 693-694, 725 (1901)

01d The preglacial surface deposits of lower Michigan (abst). Science n s 14: 798-799 (1901)

01b Annual report of the State geologist [for 1900]. Mich Miner 3 no 2:1321 (1901)

o1e [Suggested changes in nomenclature of Michigan formations.] Mich Miner 3 no $10: 9$ (1901)

01d The economic geology of Michigan in its relation to the business world. Mich Miner 4 no $1: 9-15$ (1901)

02 Third annual report of the State geologist... for the year 1901. Mich G S, Rp 1901: 304 pp, maps (1902)

02a Subsurface geology [A]cona Co., Mich.]. Mich $\mathrm{G}$ S, Rp 1901:64-76, map (1902)

02b Economic geology [of Michigan]. Mich G S, Rp 1901: 121-137 (1902)

02e Limestones [of Michigan]. Mich G S, Rp 1901: 139-159 (1902)

02d Deep wells and prospects for oil and gas [in Mich]. Mich G S, Rp 1901: 211-237, maps (1902)

02e Salt. Mich G S, Rp $1901: 241-242$ (1902)

02f Geothermal gradient. Mich G S, Rp 1901: 244-251 (1902)

02g Coal in Michigan; its mode of occurrence and quality. Mich G S 8 pt 2: 233 pp, map (1902)

02h The northern interior coal field. U S G S, An Rp 22 pt 3:307-331, map (1902)

02i Report on certain lands leased for oil and gas near Cannel City, Morgan Co., Ky. 12 pp, Lansing 1902 [Priv pub]

02j Recent work of the Geological Survey. Mich Ac Sc, Rp 3: 38-39 (1902)

o2k Queneau on size of grain in igneous rocks (abst). Am J Sc (4) 14:393-396 (1902)

021 Asphalt in Delta Co., Mich. Eng M J 73:50 (1902)

$02 m$ Variation of geothermal gradient in Michigan (abst). Science n 8 15:88 (1902) G Soc Am, B 13:528-529 (1903) 
Lane, Alfred Church-Continued.

o3 Annual report Geological Survey of Michigan [for 1902]. Mich Miner 5 no 2: 16-26 (reprinted $26 \mathrm{pp}$, map) (1903)

03a Notes on the origin of Michigan boglimes. Mich G S 8 pt $3: 199-223$ (1903)

036 List of localities and mills [making Portland cement]. Mich G S 8 pt $3: 224$ 342 (1903)

03e Studies of the grain of igneous intrusives. G Soc Am, B $14: 369-384$ (1903) Abst, Science n s $17: 296$ (1903)

o3d Porphyritic appearance of rocks. G Soc Am, B 14:385-406 (1903) Abst, Science n s 17:296 (1903); J G 11: 107108 (1903) ; Eng M J 75: 153 (1903)

o3e Geological changes now going on [erosion of lake shore and changes in elevation]. Mich Engineer 1903:102-105 (1903)

03f The economic geology of Michigan (abst). Science n s 17:218 (1903) Eng M J 75:152 (1903) Sc Am Sup 55:22666 (1903)

04 The role of possible eutectles in rock magmas. J G 12: 83-93 (1904)

O4a Magnetic phenomena around deep borings. Mich Ac Sc, Rp 4:166-167 (1904)

04b Historical review of the geology of Michigan. Mich Ac Sc, Rp 5: 184-195 (1904)

04e The theory of copper deposition. Mich Miner 6 no $2: 9-11$, no $3: 9-11$ (1904) Am G 34:297-309 (1904) Mich G S, Rp $1903: 239-249$ (1905)

04d The science of raw materials, Mich Miner 6 no 4:9-11 (1904)

04e Building and road materials. Mich Miner 6 no $5: 9-12$; no $6: 9-11$ (1904)

04 Recent explorations for oil and gas. Mich Miner 6 no $8: 9-12$; no $9: 9-13$ (1904)

05 Fifth annual report of the State geologist ... for the year 1903 . Mich G S, Rp ... 1903: $342 \mathrm{pp}$, maps (1905) Sixth ... for 1904; Rp ... 1904:113-168 (1905) Seventh ... for 1905; Rp ... 1905: 535-571 (1906) Fighth ... for 1906; Rp ... 1906 : 573-594 (1907) Ninth ... for 1907; Rp ... $1907: 3-31$ (1908) Tenth ... for 1908; Rp ... 1908: 1-19, map (1909)

OSa Waters of the Upper Peninsula of Michigan. Mich G S, Rp 1903: 111-167 (1905)

o5b Limestone. Mich G S, Rp 1903: 169-174 (1905)

05e Transmission of heat into the earth. Mich G S, Rp 1903: 195-204 (1905) Mich Engineer 1904: 229-245

05d Grain of rock. Mich G S, Rp 1903 : 205-237 (1905)

o5e The Tamarack mine cross section and the Keweenawan lodes. Mich G S, Rp 1903 : 251-270 (1905)
Lane, Alfred Church-Continued. osp Deep borings for ofl and gas lin Michigan]. Mich G S, An Rp 1903:271294 (1905)

05g [Underground waters of] Michigan U S G S, W-S P 114: 242-247, map (1905) O5h The coarseness of igneous rocks and its meaning. Am G 35:65-72 (1905)

05i Comment on the "report of the special committee on the Lake Superior region ". J G 13:457-461 (1905)

06 The geology of Keweenaw Point, : brier description. L Sup M Inst, Pr 12: 81-104 (1907) Abst, Mines and Minerals 27: 204-206 (1906)

06a Die Korngrösse der Auvergnosen. $19 \mathrm{pp}$, Stuttgart 1906.

06b The influence of varying degrees of superfusion in magmatic differentiation. Can M Inst, J $9: 210-217$ (1906)

o6e The interior of the earth. Sclenes n s 24:404-405 (1906)

o6d The chemical evolution of the ocen (abst). J G 14:221-225 (1906) G Soc Am, B 17:691 (1907)

o6e The geologic day. J G 14:425-429 (1906)

06f Discussion of paper by Marius $\mathrm{B}$. Campbell. Hypothesis to account for the transformation of vegetable matter into the different grades of coal. Ec G 1:498499 (1906)

or (and Seaman, A. E.) Notes of the geological section of Michigan; Part I, The pre-Ordovician. J G $15: 680-695$ (1907)

ora Salt water, in the Lake mines. L Sup M Inst, Pr 12:154-163 (1907)

$07 \mathbf{b}$ The formation of Lake Superio: copper. Science n s 25:589 (1907)

07e The early surroundings of life. Science n \& $26: 129-143$ (1907)

ord Genetic connections of some gra. nitic dikes $(a b s t)$. Science n s 25:774 (1907)

o7e Different manifestations of the ophitic texture $(a b s t)$. Science n s 25: 774-775 (1907)

ozf (with Gordon, W. C.) A geological section from Bessemer down Black River. Mich G S, Rp 1906:397-507 (1907)

08 Van Hise on the division of the preCambrian. G Mag (5) 5:481-486 (1908)

o8a Summary of the surface geology of Michigan. Mich G S, Rp 1907:89-152, map (1908)

0Sb Genetic relations of some granitic dikes. G Soc Am, B 18: 644-648 (1908)

ose Ophitic texture (abst). G Soc Am, B 18:648-649 (1908)

osd Mine waters. L Sup Min Inst, Pr $13: 63-152$ (1908) 
Lane, Alfred Church-Continued.

0se Mine waters and their field assay. $G$ Soc Am, B 19:501-512 (1908) Abst, Science n s $27: 406$ (1908)

osf Schaeberle, Becker, and the cooling earth. Science n s 27:589-592 (1908)

08g Shepard on the underground water: of Missouri. Am J Sc (4) $25: 452-455$ (1908)

0Sh [Representation of culture features upon geological maps.] Ec G $3: 431-432$ (1908)

08i Discussion of paper by H. M. Howe, Piping and segregation in steel ingots [application to magmas]. Am I M Eng, Tr 38: 931-934 (1908)

09 (and Seaman, A. E.) Notes on the geological section of Michigan for geologists, teachers, and drillers. Part I. The pre-Ordovician. Mich G S, Rp 1908: 2142 (1909)

09a Notes on the geological section of Mlchigan; Part II, From the St. Peters up. Mich G S, Rp 1908:43-105 (1909) 09b Geology of the Porcupine Mountains, Mich. M World 30:1115-1117 (1909)

09e Michigan iron mines and their mine waters. M World 31:413-416 (1909)

09d (and others) Nomenclature and subdivision of the upper Siluric strata of Micligan, Ohio, and western New York. G Soc Am, B 19:553-556 (1909) Abst, Science n \& $27: 409$ (1908)

09e The decomposition of a boulder in the Calumet and Hecla conglomerate, and its bearing on the distribution of copper in the Lake Superior copper lodes as indicating the trend and characters of the waters forming the chute. Ec G $4: 158$ 173 (1909)

09 A gabbro-diorite aplite; an rgiritealbite dike rock from the Mesabi Range. Mich G. S, Rp 1908: 394-397 (1909)

09g (with Cooper, W. F.) Report on the geology of Tuscola County, Mich.; Paleozoic geology. Mich G S, Rp 1908: 175-196 (1909)

09h (with Wright, F. E.) Preliminary geological map of the Porcupine Mountains and vicinity. Mich G S, Rp 1909; pl 1, opp p 8 (1909)

10 Wet and dry differentiation of igneous rocks. Tafts Coll Studies 3 no $1: 39$ $53(1910)$

10a Michigan iron mines and their mine waters. Can M Inst, J 12: 114-129 (1910)

$10 \mathrm{~b}$ Notes on the geological section of Michigan; Part II, From the St. Peter sandstone up. J G 18: 393-429 (1910)

10e Winchell on ophitic texture. Science n s $32: 513$ (1910)

10 d Connate waters of the Atlantic coast (abst). Science n s 32:190 (1910) G Soc Am, B 21:774 (1910)
Lane, Alfred Church-Continued.

11 Native copper deposits. Can M Inst, Q B 13:81-87 (1911); J 14:316-322 (1912) Reprinted in Types of ore deposits (ed by H. F. Bain) : 133-139 (1911)

11a The Keweenaw series of Michigan. Mich G S, Pub 6 (g s 4) 2 rols : 983 pp, maps (1911)

11 b (with Hubbard, Elizabeth) The intercollegiate geological excursion. Science $n$ s $34: 611-614$ (1911)

12 Diamond drilling at Point Mamainse, Province of Ontario; with introduction by Alfred W. G. Wilson. Can Mines Br, B $6: 59 \mathrm{pp}$, map (1912)

12a Unexplored parts of the copper range of Keweenaw Point (with discussion). L Sup M Inst, Pr 17:127-143 (1912)

12b Aragonite coating gravel pebbles. Science n s $36: 81-82$ (1912)

12c Dark scale of hardness (abst). Science n s $35: 312$ (1912) G Soc Am, B $23: 725$ (1912)

12d Demonstration of relative refraction (abst). Science n s $35: 312$ (1912) G Soc Am. B 23:725 (1912)

12e The stratigraphic value of the "Laurentian." Int G Cong, XI, Stockholm, 1910, C R : 633-637 (1912)

$12 f$ The age of the Keweenawan series (abst). Mich Ac Sc, Rp 14:107-108 (1912)

13 Meteor dust as a measure of geologic time. Science $n$ s $37: 673-674$ (1913)

13a Origin of granites as well as mretacrystals by selective solution-a recantation (abst with discussion by G. P. Merrill). G Soc Am, B 24:704 (1913)

13b New light on the Keweenawan fault (abst). G Soc Am, B 24:718 (1913)

14 Mine water composition an index to the course of ore-bearing currents. Ee G $9: 239-263$ (1914) Tufts Coll Studies 4 no $1: 239-263$ (1914)

14a Effusive and intrusive in the quantitative classification (abst). G Soc Am, B $25: 43-44$ (1914)

15 Pre-Cambrian nomenclature. Science n s $42: 869-870$ (1915)

$15 a$ on certain resemblances between the earth and a butternut. Sc Mo 1:132139 (1915)

15b Can $U$-shaped valleys be produced by removal of talus? (abst). G Soc Am, B $26: 75$ (1915)

16 Keweenaw fault. G Soc Am, B 27: 93-100 (1916)

16a The scientific value of economic geology and double specialization. Ec G 11: 403-404 (1916)

16b Specific weight of drill cores $(a b s t)$. G Soc Am, B $27: 49$ (1916) 
Lane, Alfred Church-Continued.

16e (with Powers, S.) Magmatic differentiation in effusive rocks. Am I M Eng, B 110:535-548 (1916); (with discussion by $\mathrm{N}$. L. Bowen), $\operatorname{Tr} 54: 442-457$ (1917)

17 Lawson's correlation of the pre-Cambrian era. Am J Sc (4) $43: 42-48$ (1917) 17a Memorial of Charles A. Davis. G

Soc Am, B 28: 14-40, port (1917)

17b The origin of the mirabilite from the Isle Royale mine [Houghton, Mich.]. Am Mineralogist 2:63-84 (1917)

18 Israel Cook Russell (1852-1906).

Am Ac Arts, Pr 53: 855-858 (1918)

18a Prismatic cleavage in beryl. Am

Mineralogist 3: 47 (1918)

See also Emerson, 05; Johnson (D W), 12; Johnson (R H), 15; Lindgren, 15b; Stauffer, 16; Tolman, 16a ; Washburne, 14

Lane, Louis.

09 Santa Eulalia camp [Chihuahua, Mexico]. M Sc Press 99:16 (1909)

Laney, Francis Baker.

06 (with Watson, T. L.) The buildfng and ornamental stones of North Carolina. N C G S, B 2: 283 pp (1906)

os The Gold Hill copper district. N C G S, Ec P 15: 20-54 (1908)

osa (and Pogue, J. E., jr.) Outerop map of the Virgilina copper district of Person and Granville cos., N. C. N C G S [n d 1908?] Scale, 1:24000

09 (and Wood, K. H.) Bibliography of North Carolina geology, mineralogy, and geography, with a list of maps. N C G S, B 18: $428 \mathrm{pp} \mathrm{(1909)}$

10 The Gold Hill mining district of North Carolina. N C G S, B 21:137 pp (1910)

11 The relation of bornite and chalcacite in the copper ores of the Virgilina district of North Carolina and Virginia. Ec G 6:399-411 (1911) U S Nat Mus, Pr $40: 513-524$ (1911) N C G S, Ec P 23:19-28 (1911) Abst, Wash Ac Sc, J $1: 36$ (1911)

$11 a$ (with Emmons, W. H.) PrelimInary report on the mineral deposits of Ducktown, Tenn. U S G S, B 470:151172 (1911)

17 The geology and ore deposits of the Virgilina district of Virginia and North Carolina. Va G S, B 14 also N C G S, B $26: 176 \mathrm{pp}, \operatorname{map}(1917)$

18 (with Bastin, E. S.) The genesis of the ores at Tonopah, Nev. U S G S, P P 104: 50 pp (1918)

Lang, Herbert.

87 Silver in Oregon. Science 10:192 (1887)

88 Transcontinental rallways [Sierra and Cascade ranges]. Science 11:73-74 (1888)

99 Copper resources of California. Fng M J $67: 442,470,561-562,619-620 ; 68$ : 5, 247-248, 277 (1899)
Lang, Herbert-Continued.

07 The copper belt of California. M J $84: 909-913, \quad 963-966, \quad 1006-10:$ (1907) ; 85:420-421 (1908)

16 Black sand of the Pacific coast. Se Press 113: 811-813 (1916)

Lang, S. S.

06 The Burrow Mountain copper distrit [N Mex.]. Eng M J $82: 395-396$ (190 Langdon, Daniel W. (1864-1909).

86 Observations on the Tertiary of $\mathrm{V}$ sissippi and Alabama, with descriptions new species. Am J Sc (3) $31: 202-2$ (1886)

89 Some Florida Miocene. Am J (3) $38: 322-324$ (1889)

90 Geology of Mon Lonis Island, Moh Bay. Am J Sc (3) 40:237-238 (1890)

91 Geological section along the Chatt hoochee River from Columbus to Alm Bluff. Ga G S, 1st Rp Prog 1890-1: भ 97 (1891)

$91 a$ Variations in the Cretaceous an Tertiary strata of Alabama (with disces sion by C. A. White). G Soc Am, B : $587-605$ (1891)

93 Leaf impressions in the Eocene Te tiary of Alabama. Science 21:94(1893)

94 The Tertiary and Cretaceous form tions east of the Alabama River. Smith, E. A., and others, Report on Coastal Plain of Alabama : $368-445,1$ G S, 1894

96 The Loop Creek, W. Va., coal fiell Colliery Eng 16: 122 (1896)

See also Smith (E A), 94

Langdon, Frank Warren.

-83 The giant beaver, Castoroides ohit ensis Foster [Ohio]. Cin Soc $\mathrm{N} \mathrm{H}, \mathrm{J}$ 238-239 (1883)

Langley, Ralph W.

os The determination of small amouni of barium in rocks. Am J Sc (4) $26: 12 \%$ 124 (1908)

Iangley, Samuel Pierpont (1834-1906).

02 (and others) In memory of Jobr Wesley Powell. Science n s 16:782-7\% (1902)

o3 The greatest flying creature [Ornit] ostoma], Sc Am Sup 55: 22644-22645, (1903)

Langton, John.

55 The geological survey of Canada [t: port of legislative committee]. Can J 3 $234-237,250-256$ (1855)

Langworthy, A. E.

o1 The Atchison diamond-drill prosper hole [Kans.]. Kans Ac Sc, Tr 17:45-j. (1901)

Lankester, E. R.

zo On a new Cephalaspis [C. danosonil] discovered in America. G Mag $7: 397^{\circ}$ 398 , il $(1870)$ Can Nat n s $5: 222-22$ (1870) 
Lapham, Darius.

32 (and Lapham, Increase A.) ... primitive and other boulders of Ohio. Am J Sc $22: 300-303$ (1832)

Lapham, Increase Allen (1811-1875)

28 ... geology of the vicinity (of Louisville, Ky.]. Am J Sc 14: 65-69 (1828)

32 [with Lapham, Darius) ... primitive and other boulders of Ohio. Am J Sc $22: 300-303$ (1832)

37 Miscellaneous observations on the geology of Ohio. In Riddell, J. L., Report... geological survey of Ohio:31-34 [Columbus 1837 ]

44 A geological and topographical description of Wisconsin... 255 pp, Milwaukee, Wis,, $18442 \mathrm{~d}$ ed, with title: Wisconsin: its geography and topography... [geology and minerals: 52-70] $206 \mathrm{pp}$, map, Milwaukee 1846

47 On the existence of certain lacustrine deposits in the vicinity of the Great Lakes, usually confounded with the "drift." Am J Se (2) 3:90-94 (1847)

51 Geological formation of Wisconsin. Wis St Agr Soc, Tr 1: 122-128 (1851)

$51 \mathrm{n}$ on the geology of the southeastern portion of the State of Wisconsin... In Foster, J. W., and Whitney, J. D., Report on the geology of the Lake Superior land district, pt 2 (U S, 32d Cong spec sess, 8 Ex Doc 4) : 167-171 (1851)

55 On the number of teeth of the Mastodon giganteus. Boston Soc N H, Pr 5: 133-136 (1855)

55a A geological map of Wisconsin. Scale 1 inch $=28$ miles. N Y 1855

60 The Penokee iron range [Wis.]. Wis St Agr Soc, Tr 5: 391-400, map (1860)

60a [Discovery of Devonian rocks near Milwaukee, Wis.] Ac Sc St L, Tr 1:684 (1860) Am J Sc (2) $29: 145$ (1860)

69 A new geological map of Wisconsin... Scale 15 miles to 1 inch. Milwaukee 1869

76 Geology. In Walling, H. F., Atlas of the State of Wisconsin : 16-19, map, Boston 1876

77 Report of progress and results for the year 1873. [Wis G S], G Wis $2: 5-44$ (1877)

77a Report of progress and results for the year 1874. [Wis G S], G Wis $2: 45-66$ (1877)

See also Desor, $50 \mathrm{~h}$; Smith (J L), 69

Lapparent, A. de.

05 La Montagne Pelée et ses éruptions. An Géog $15: 97-110 \quad(1905)$

Lapworth, Charles.

87 Preliminary report on some graptolites from the lower Paleozoic rocks on the south side of the St. Lawrence from Cape Rosier to Tartigo River, from the north shore of the Island of Orleans, one mile above Cap Rouge, and from the Cove Fields, Que. R Soc Can, $\operatorname{Pr} \operatorname{Tr} 4$, iv : $167-184$ (1887)
Lapworth, Charies-Continued.

87a Fossils from Kicking Horse Pass [B. C.]. Science 9:320 (1887)

88 Note on graptolites from Dease Rlver, B. C. Can Rec Sc 3:141-142 (1888) G Mag (3) 6:30-31 (1889)

Larison, Cornelius W.

S1 Physical geography and geology of Hunterdon Co., N. J. In Snell, James P., History of Hunterdon and Somerset counties, N. J.: 159-181, Phila 1881

Larkin, Pierce.

10 The occurrence of a sauropod dinosaur in the Trinity Cretaceous of Oklahoma. J G 18: 93-98 (1910)

Larsen, Esper Signius.

Q9 (with Wright, F. E.) Quartz as a geologic thermometer. Am J Sc (4) $27: 421-447$ (1909)

11 The economic geology of Carson camp, Hinsdale Co., Colo. U S G S, B $470: 30-38$ (1911)

$11 a$ (and schaller, W. T.) Hinsdalite, a new mineral. Am J Sc (4) 32 : 251-255 (1911) Wash Ac Sc, J 1:25-26 (1911) Zs Kryst 50:101-105 (1912)

12 The mineral sulphides of iron; crystallographic study. Am J Sc (4) 33:218236 (1912)

13 Alunite in the San Cristobal quadrangle, Colo. U S G S, B 530:179-183 (1913)

$13 a$ (and Hunt, W. F.) Two vanadiferous wgirites from Libby, Mont. Am J Sc (4) $36: 289-296$ (1913) Zs Kryst $53: 209-218$ (1913)

13b (and Hunter, J. F.) Two sulphur deposits in Mineral Co., Colo. U S G S, B 530:363-369 (1913)

14 (and Hicks, W. B.) Searlesite, a new mineral [San Bernardino Co., Cal.]. Am J Sc (4) $38: 437-440$ (1914) Abst, Wash Ac Sc, J 4:397-398 (1914)

14a (and Hunter, J. F.) Melilite and other minerals from Gunnison Co., Colo. Wash Ac Sc, J 4:473-479 (1914)

14b (and Schaller, W. T.) Cebollite, a new mineral. Wash Ac Sc, J 4:480482 (1914)

14e (with Cross, W.) Contributions to the stratigraphy of southwestern Colo. U S G S, P P 90:39-50 (1914) Abst, Wash Ac Se J 4:237-238 (1914)

$14 d$ (with Umpleby, J. B.) Custerit, ein neues kontakt-metamorphes Mineral. Zs Kryst 53:321-331 (1914)

15 (with Mansfield, G. R.) Nepheline basalt in the Fort Hall Indian Reservation, Idaho. Wash Ac Sc, J 5:463-468 (1915)

16 (and Wells, R. C.) Some minerals from the fluorite-barite vein near Wagon Wheel Gap, Colo. Nat Ac Sc, Pr 2:360365 (1916)

16a (and Steiger, G.) Sulphatic canerinite from Colorado. Am J Sc (4) 42 : $332-334$ (1916) 
Larsen, Esper Signius-Continued.

16 (with Wells, R. C.) Lorettoite, a new mineral. Wash Ac Sc, J 6:669-672 (1916)

17 Eakleite, a new mineral from California. Am J Sc (4) 43:464-465 (1917)

$17 \mathbf{a}$ (and steiger, G.) Mineralogie notes. Wash Ac Sc, J $7: 6-12$ (1917)

17b (and Wherry, E. T.) Halloysite from Colorado. Wash Ac Sc, J 7:178180 (1917)

17e (and Wherry, E. T.) Leverrierite from Colorado. Wash Ac Sc, J 7:208217 (1917)

17d Proof that priceite is a distinct mineral species. Am Mineralogist 2:1-3 (1917)

17e Optical evidence that "hydrogiobertite" is a mixture. Am Mineralogist $2: 3$ (1917)

$17 \mathrm{f}$ Massicot and litharge, the two modifications of lead monoxide. Am Mineralogist $2: 18-19$ (1917)

17\% The optical properties of penfieldite. Am Mineralogist 2:20 (1917)

17h Is partschinite a distinct species? Am Mineralogist 2:20 (1917)

17i Durdenite from California. Am Mineralogist $2: 45-46$ (1917)

17j (and Brown, G. V.) Gilpinite, a new uranium mineral from Colorado. Am Mineralogist 2:75-79 (1917)

17k The probable identity of uranothallite and liebigite. Am Mineralogist $2 ; 87$ (1917)

18 The probable identity of mazapilite with arseniosiderite. Am Mineralogist 3 : 12-14 (1918)

See also Allen (E T), 09

Larsh, Paul A.

11 Caballo Mountain vanadium mines [N. Mex.]. Eng M J 92:118 (1911)

13 Lucky Bill lead-vanadium mine [Grant Co., N. Mex]. Eng M J 96:1103-1105 (1913)

Larsh, W. S.

09 Mining at Hamilton, Nev. ; geology of the White Pine district. Mines and Minerals $29: 521-523$, map (1909)

Larson, Andrew G.

15 The mineral and other resources of the north fork of the Kettle River in the Grand Forks mining division [B. C.]. B C Bur Mines, B 3 (1914): 22 pp, maps (1915)

Larsson, Per.

87 The Chapin iron mine, Lake Superior. Am I M Eng, Tr 16:119-128, map (1887) Eng M J 44:346, 347, 394, 395 (1887)

Lasswitz, Rudolf.

o4 Die Kreide-Ammoniten von Texas. G Pal Abh (Koken, E.) 10 (N F 6) H 4: $40 \mathrm{pp}$, il (1904)

Lathrop, J. H.

40 Applieations of the igneous theory of the earth. Am J Sc 39:90-95 (1840)
Lathrop, W. A.

84 Geological section at Pocahonts [Tazewell Co., Va.]. The Virginias 5:9; (1884)

Latimer, J. F.

12 Origin of petroleums. Can M J $3:$ 4-5 (1912)

Latimer, W. J.

15 Soll survey of Boone Co., W. V U S, Bur Solls and W Va G S : $26 \mathrm{pp}$, map (1915)

16 Soil survey of Raleigh Co., W. $T_{2}$. U S Dp Agr, Bur Soils : 34 pp, map (1918) Latrobe, B. Henry.

99 On the sand hills of Cape Henry h Virginia. $\mathrm{Am} \mathrm{Ph}$ Soc, $\mathrm{Tr}$ 4:439-44t (1799) Am Miner J 1:248-252 (1814) Am J Se (2) $40: 261-264$ (1865)

09 An account of the freestone quarries on the Potomac and Rappahannock rivers Am Ph Soc, Tr 6: 283-293 (1809)

Lanbe, Gustav C.

73 Geologische Beobachtungen gesammelt wäbrend der Reise auf der Hansa und gele gentlich des Aufenthaltes in Süd-Grönland. K Ak Wiss, Mat-nat Cl, Szb 68 Abt 1:17106, map (1873)

Lauer, A. W.

17 The petrology of reservolr rocks and its influence on the accumulation of petroleum. Ec G $12: 435-472$ (1917)

Lannay, L. de.

02 The origin of ore deposits (discus sion). Am I M Eng, Tr 31:947-951 (1902) Abst, Eng M J 71:558 (1901)

Lanr, Francis.

95 The bauxites; a study of a new mineralogical family. Am I M Eng, Tr 24: $234-242,855-861$ (1895)

Lanr, $P$.

61 Observations sur l'origine et la dis. tribution de l'or dans les divers terrains de la Californie. Ac Sc Paris, C R 53:10961099 (1861)

$63 \mathrm{Du}$ gisement et de l'exploitation de l'or en Californie. An Mines (6) $3: 34$ "435 (1863)

Lavagnino, $G$.

87 The old Telegraph mine [Bingham Canyon], Utah. Am I M Eng, Tr 16:2533 (1887) M Sc Press 78:589 (1899)

Law, E. Stanley.

06 Notes on a useful mineral [graphite]. Mineral Collector 12:169-173, 180-184 (1906)

07 On a rare occurrence in Delaware Co., Pa. Mineral Collector 14:33-35 (1907)

Lawes, George W.

11 Subaqueous phenomena at the mouth of the Mississippi River. As Eng Soc, J $46: 311-314$ (1911)

Lawrence, Benjamin Bowden (18581921).

02 The Pelican mine, Clear Creek Co.,

Colo. Colo Sc Soc, $\operatorname{Pr} 6: 41-45$ [1902] 
Lawrence, Benjamin Bowden-Continued. 06 Copper mining in Cuba, M Sc Press $93: 602$ (1906)

10 Two Cuban mines. Can M Inst, $Q$ B $11: 15-30 \quad(1910) ; \quad J \quad 13: 91-106 \quad$ (1911) Mines and Minerals $31: 235-240$ (1910)

See also Lindgren, $15 \mathrm{~b}$

Lawrence, Byrem.

43 A concise description of the geological formations and mineral localities of the Western states [Ohio Valley, mainly] ; designed as a key to the geological map of the same. $48 \mathrm{pp}$, Boston 1843

43a A geological map of the Western States [copied from David D. Owen's geological chart of the Ohio Valley]. Boston 1843 [not seen]

51 Coal in Arkansas. De Bow's Review $11: 320-321$ (1851)

52 Arkansas; geology of. In De Bow, J. D. B., The industrial resources, etc., of the Southern and Western States 1:8587 , New Orleans 1852

Lawson, Andrew Cowper.

85 Report on the geology of the Lake of the Woods region, with special reference to the Keewatin (Huronian?) belt of the Archean rocks. Can $\mathrm{G}$ S, An Rp 1: CC $151 \mathrm{pp}$, map (1885)

86 Some instances of gneissic foliation and schistose cleavage in dikes and their bearing upon the problem of the origin of the Archean rocks. Can Inst, Pr 22 or (3) 4:115-127 (1886)

87 [Preliminary report on the region east of the Lake of the Woods.] Can G S, An Rp 2: A 11-14 (1887)

$87 a$ Geology of the Rainy Lake region, with remarks on the classification of the crystalline rocks west of Lake Superior; preliminary note. Am J Sc (3) 33:473480 (1887)

87b Some recent developments in Archean geology (abst). Can Rec Sc 2:430431 (1887)

88 Report on the geology of the Rainy Lake region. Can G S, An Rp 3: F 182 pp, map (1888)

88 Notes on some diabase dikes of the Rainy Lake region [Ont.]. Can Inst, $\mathrm{Pr}$ (3) $5: 173-185$ (1888) Am G 1:199-211 (1888)

88b (with Adams, F. D.) On some Canadian rocks containing scapolite, with a few notes on some rocks associated with the apatite deposits. Can Rec Sc $3: 185-$ 201 (1888)

89 Foliation and sedimentation [in the Lake Superior region]. Am G 3: 169-178, $276-279$ (1889)

90 [Report on the country northwest of Lake Superior.] Can G S, Sum Rp 18889 (An Rp 4) : ^ 25-28 (1890)
Lawson, Andrew Cowper-Continued.

90a Note on the pre-Paleozoic surface of the Archean terranes of Canada (with discussion by J. W. Spencer). G Soc Am, B 1:163-173 (1890) Abst, Am G 5:119 (1890) ; Am Nat 24:208 (1890)

$90 \mathrm{~b}$ The internal relations and taxonomy of the Archean of central Canada. G Soc Am, B 1:175-193 (1890) Abst, Am Nat 24:290 (1890)

90e Note on the occurrence of native copper in the Animikie rocks of Thunder Bay [Ont.]. Am G 5: 174-178 (1890)

90d Note on the mapping of the Archean northwest of Lake Superior (abst). Am As, Pr 38:245-246 (1890)

91 (and Shntt, F. T.) Petrographical differentiation of certain dikes of the Rainy Lake region. Am G $7: 153-164$ (1891) Abst, Am As, Pr 38:246-247 (1890)

$91 a$ Lake Superior stratigraphy. Am G $7: 320-327,388$ (1891)

$91 b$ The Archean geology of the region northwest of Lake Superior. Int $\mathrm{G}$ Cong, IV, London 1888, C R:130-152 (1891)

93 The anorthosites of the Minnesota shore of Lake Superior. Minn G S, B 8: 1-23 (1893) Abst, Minn, Univ, Q B 1: $117-118$ (1893)

93a The laccolitic sills of the northwest coast of Lake Superior. Minn G S, B 8: 24-48 Abst, Mínn, Univ, Q B 1:116-117 (1893)

93b Sketch of the coastal topography of the north side of Lake Superior, with special reference to the abandoned strands of Lake Warren. Minc G S, An Rp 20: 181-289, map (1893)

93e The Cordilleran Mesozoic revolution. J G $1: 579-586$ (1893)

93d The geology of Carmelo Bay. Cal Univ, Dp G, B 1:1-59, map (1893)

93e The post-Pliocene diastrophism of the coast of southern California. Cal Univ, Dp G, B 1:115-160 (1893)

93f The Norian rocks of Canada. Science 21:281-282 (1893)

93g The abandoned strands of Lake Warren (abst). Am G 11: 177-178 (1893)

94 The geomorphogeny of the coast of northern California. Cal Univ, Dp G, B 1: 241-271 (1894)

$94 a$ A multiple diabase dike [Lake Superior]. Am G 13:293-297 (1894)

94b Note on the Chebalis sandstone [Washington]. Am G 13:436-437 (1894)

95 Sketch of the geology of the San Francisco Peninsula [Cal.]. U S G S, An Rp 15:399-476 (1895)

95a A contribution to the geology of the coast ranges. Am G 15:342-356 (1895) 
Lawson, Andrew Cowper-Continued.

96 On malignite, a family of basic plutonic orthoclase rocks, rich in alkalies and lime, intrusive in the Coutchiching schists of Poohbah Lake [Ont.]. Cal Univ, Dp G, B $1: 337-362$ (1896)

97 The geology of San Francisco Peninsula [Cal.]. J G 5:173-174 (1897)

oo Cordilleran section of the Geological Society of America [first annual meeting. San Francisco, Cal., December 29 and 30 , 1899]. Sclence n $\mathrm{s}$ 11:219-222 (1900)

OOa [Review of] The geology of Minnesota, vol. IV. Am J Sc (4) $9: 149-154$ (1900)

00b Recent progress in geology. International Monthly 2:403-417 (1900)

o1 Joseph Le Conte. Science n s 14: 273-277, port (1901)

O1a Drainage features of California (abst). G Soc Am, B 12:495 (1901) J G $9: 77-78$ (1901) Am G 27:132 (1901)

01b Feldspar corundum rock from Plumas Co., Cal. (abst). G Soc Am, B 12:501-502 (1901) J G $9: 78$ (1901) Am G 27:132 (1901)

02 (and Palache, C.) The Berkeley Hills, a detail of Coast Range geology, Cal Univ, Dp G, B 2 : 349-450, map (1902)

02a The Eparchean interval; a criticism of the use of the term Algonkian. Cal Univ, Dp G, B 3:51-62 (1902)

02b Third annual meeting of the Cordilleran section of the Geological Society of America. Science $\mathrm{n}$ s 15:410-417 (1902)

o3 Plumasite, an oligoclase corundum rock near Spanish Peak, Cal. Cal Univ, Dp G, B $3: 219-229$ (1903)

03a Geological section of the middle coast ranges of California (abst). G Soc Am, B 13:544-545 (1903) Science n s $15: 415(1902)$

04 The geomorphogeny of the upper Kern Basin. Cal Univ, Dp G, B 3:291376 (1904)

04a The orbicular gabbro at Dehesa, San Diego Co., Cal. Cal Univ, Dp G, B 3:383396 (1904) Abst, Science n $\mathrm{s} 15: 415$ (1902)

05 The relation of geology to the mining industry. M Sc Press 91:395 (1905)

06 The copper deposits of the Robinson mining district, Nev. Cal Univ, Dp G, B 4:287-357 (1906) [Rv. Lindgren, 07a]

$06 a$ The geomorphic features of the middle Kern [Cal.]. Cal Univ, Dp G, B 4: $397-409$ (1906)

o6b The geomorphogeny of the Tehachapi Valley system [Cal.]. CaI Univ, Dp G, B 4:431-462 (1906) Abst G Soc Am, B $17: 7 \div 0$ (1907)
Lawson, Andrew Cowper-Continued. o6e (and others) Preliminary report the [California] State Earthquake Ino gation Commission. $20 \mathrm{pp}$, [1906] : printed in M Sc Press $92: 399-401$ (19\% Science n $\&$ 23:961-967 (1906) Sc Sup 61:25482-25484 (1906) Nature it 285-286 (1906) Scottish Geog Mag : 423-430 (1906)

07 Methods of igneous intrusion (abt Science n s 25:622-623 (1907)

os (and others) The California eart quake of April 18, 1906. Report of th State Eartbquake Investigation Compis sion. Carnegie Inst Wash, Pub no 87 rol pt 1 : xviii, 254 pp; pt $2: 255-451$; atla 25 maps and seismograms (1908)

09 Slickensides. M Sc Press 98:2f (1909)

11 Seismology in the United Statio Seism Soc Am, B 1: 1-4 (1911)

11 a On some postglacial faults nex Banning, Ont. Seism Soc Am, B 1:15\% 166 (1911)

12 The geology of Steeprock Lake, 0nt Can G S, Mem 28: 7-15 (1912)

12 The Archean rocks of Rainy lak Can G S, Sum Rp 1911:240-243, = (1912)

12b The recent fault scarps at Gen Nev. Seism Soc Am, B 2:193-200 (191:

12e Fanglomerate, a detrital rock at $\mathrm{Bat}$ tle Mountain, Nev. $(a b s t)$. G Soc Am, : $23: 72(1912)$

12d Section of the Shinarump (abst G Soc Am, B 23:74-(1912)

12e Geology of the Nevada Hills (abst G Soc Am, B 23: 74 (1912)

$12 f$ Types of ore deposits - a review. Sc Press 104: 198-201 (1912)

12g Report on the geology and unde ground water supply of Livermore Valle [Cal.]. In The future water supply San Francisco; a report... by the Spring Valley Water Company : 223-230, San Fras cisco, Cal., 1912

13 The petrographic designation of allo vial-fan formations. Cal Univ, Dp G, B i 325-334 (1913)

13a The gold of the Shinarump at Paril [Utah]. Ec G 8:434-448 (1913)

13b Gold and coal mines of Nova Scoti. M Met Soc Am, B 65 (vol 6) : 281-28s (1913)

13c A standard scale for the pre-Cam brian rocks of North America. Int $\mathrm{G}$ Cone XII, 1913, C R:349-370 (1914, advane copy 1913)

13d The Archean geology of Rainy Lake re-studied. Can G S, Mem 40:115 map (1913)

14 Description of the San Francisco dis trict; Tamalpais, San Francisco, Concord, San Mateo, and Haywards quadrangles. U S G S, G Atlas San Francisco fol (Do 193) : 24 pp, maps (1914) 
Lawson, Andrew Cowper-Continued.

14a Is the Boulder "batholith" a laccolitb? - a problem in ore genesis. Cal Univ, Dp G, B 8: 1-15 (1914)

$14 \mathrm{~b}$ Ore deposition in and near intrusive rocks by meteoric waters. Cal Univ, Dp G, B 8:219-242 (1914) M Sc Press $109: 600-605$ (1914)

14e Diffusion or ore deposits. Min Sc Press 109: 20-21 (1914)

15 The epigene profiles of the desert. Cal Univ, Dp G, B $9: 23-48$ (1915) Abst, G Soc Am, B 26: 391 (1915)

16 The correlation of the pre-Cambrian rocks of the region of the Great Lakes. Cal Univ, Dp G, B 10:1-19 (1916)

See also Barlow, 90 ; Dake, 15a; Dickerson 13b; Eakle, 15; Martin (B), 13a ; Orton (E), 90a ; Powell, 95; Somers, 15 ; Taff, 13; Thompson (A P), 15

Lawson, George.

90 Obituary notice; David Honeyman [1814-1889]. G Soc Am, B 1:520-521 (1890)

Lawson, Publius Virgilius.

02 Preliminary notice of the forest beds of the lower Fox. Wis $\mathrm{N} H$ Soc, B $\mathrm{n} s$ $2: 170-173$ (1902)

06 Story of the rocks and minerals of Wisconsin. $202 \mathrm{pp}$, Appleton, Wis. [1906] Lawson, William.

97 (with Ellis, W. H.) Chemical notes on the so-called Sudbury coal. Can Inst, Pr n s 1:67-68 (1897)

Lawton, C. D.

88 sketch of the life and character of Charles E. Wright, late State geologist of Michigan. Am G 2: $307-311$, port. (1888) Lawton, E. M.

10 Genesis and classiflcation of Mexican onyx. M Sc Press 100:791-792 (1910)

Lawton, N. Oliver.

09 Makushin sulphur deposits, Unalaska. M Sc Press 98: 259-260 (1909)

Lay, H. C.

02 Recent geological phenomena in the "Telluride quadrangle" of the U. S. Geological Survey in Colorado. Am I M Eng, Tr 31:558-567 (1902)

Lay, William L.

83 On the deposits of earth wax (ozokerite) in Europe and Amrerica. N Y Ac Sc, Tr $2: 43-49$ (1883)

Lazo, Agustín M.

05 (and ordoñez, E.) Las canteras de San Lorenzo Totolinga y Echagaray [MéxIco]. Soc G Mex, B 1:25-34 (1905)

Lazo, José Esteban.

93 Naturaleza geológica. In Honduras, República, Primer anuario estadístico correspondiente al año de $1889: 5-6$, Tegucigalpa 1893

Lea, Henry deres

41 Description of some new species of fossil shells from the Eocene at Claiborne, Ala. Am J Se $40: 92-163$, il (1841)
Lea, Henry Cerey-Continued.

43 Description of some new fossil shells from the Tertiary of Virginia. $\mathrm{Am} \mathrm{Ph}$ Soc, $\operatorname{Pr} 3: 162-165$ (1843)

46 Description of some new fossil shells, from the Tertiary of Petersburg, Va. Am $\mathrm{Ph} \mathrm{Soc}, \mathrm{Tr}$ n s $9: 229-274$, il (1846)

48 Catalogue of the Tertiary Testacea of the United States. Ac N Sc Phila, Pr 4: $95-107$ (1848)

Lea, Isaac (1792-1886).

18 An account of the minerals at present known to exist in the vicinity of Philadelphia. Ac N Sc Phila, J 1 : 462-482 (1818)

25 On earthquakes, their causes and effects. Am J Sc 9:209-215 (1825)

33 Contributions to geology (Tertiary formation of Alabama; New Tertiary fossil shells from Maryland and New Jersey; New genus of fossil shell from New Jersey; Tufaceous lacustrine formation of Syracuse, Onondaga Co., N. Y.) 227 pp, il, Phila 1833

40 Notice of the Oolitic formation in America, with descriptions of some of its organic remains. Am $\mathrm{Ph}$ Soc, $\mathrm{Pr} 1: 225-$ 227 (1840)

43 On coprolites, Am Pb Soc, $\operatorname{Pr} 3$ : 143 (1843)

43a On specimens of anthracite coal from Pine Grove [Pa.]. Am $\mathrm{Ph}$ Soc, $\mathrm{Pr}$ 2: 229-230 (1843)

46 On a specimen of flexible quartz ... from Spartanburg district, $\mathbf{S}$. C. $\mathbf{A m ~} \mathrm{Ph}$ Soc, Pr $4: 244$ (1846)

49 On reptilian footmarks in the gorge of the Sharp Mountain near Pottsville, Pa. Am Ph Soc, Pr 5:91-94, il (1849) Am $\mathrm{J}$ Se (2) 9:124-126, il (1850)

49a [Fuss-Eindrücke eines Sauriers, Sauropus primaevus, Pennsylvanien.] Deut G Ges, Zs 1: 261-262 (1849)

50 On traces of a fossil reptile (Sauropus primaevus) found in the Old Red Sandstone. Brit $\Delta \mathrm{s}, \mathrm{Rp} 19: \mathrm{sec} 56$ (1850)

51 [On the bones of a reptilian quadruped from Lehigh Co., Pa.] Ac N Sc Phila, Pr 5: 171-172, 205 (1851)

$51 n$ [On the coal of Dauphin Co., Pa.] Franklin Inst, $J$ (3) 21:142-143 (1851)

52 Description of a new species of Eschara, from the Eocene of Alabama. Ac N Sc Phila, Pr 6:109-110, il (1852)

53 Description of a fossil saurian of the New Red Sandstone formation of Pennsylvania, with some account of that formation. Ac N Sc Phila, J (2) 2:185-202, il (1853) Reprint [with 53a] : 25-28, il, Phila 1852

53a On some new fossil mollusks in the Carboniferous slates of the anthracite seams of the Wilkesbarre coal formation. Ac N Sc Phila, J (2) 2:203-206, il (1853) Reprint: 1-23, il, Phila 1852 
Lea, Isaac-Continued.

53b On the fossil footmarks in the red sandstones of Pottsville, Schuylkill Co., Pa. Am $\mathrm{Ph}$ Soc, Tr n s 10:307-317, il (1853)

55 Description of a new mollusk from the red sandstone near Pottsville, Pa. Ac N Sc Phila, Pr $7: 340-341$, il (1855)

56 [On fossils from the New Red Sandstone formation of Pennsylvania.] Ac N Se Phila, $\operatorname{Pr} 8: 77-78$ (1856) Am J Sc (2) $22: 122-124,422-423$ (1856)

57 [On fossils from the red sandstone of Phoenixyille, Pa.] Ac N Sc Phila, Pr $1857: 149$

$\mathbf{5 7 a}$ [Observations on the geology of the red sandstone formation near Gwynned, Pa.] Ac N Sc Phila, Pr 1857:173

$\mathbf{5 7 b}[\mathrm{On}$ the geology of Braintree, Mass.] Ac N Sc Phila, Pr 1857: 205.

58 [On the age of the red sandstones of eastern United States.] Ac N Sc Phila, Pr 1858 : 90-92

$58 \mathbf{a}$ [On the Cretaceous of New Jersey and the United States in general.] Ac N Sc Phila, Pr 1858: 218-221

61 Descriptions of new fossil Mollusca, from the Cretaceous formation at Haddonfield, N J. Ac N Sc Phila, Pr 1861: 148150

66 Notes on some members of the feldspar family. Ac N Sc Phila, Pr 1866: 110-113

67 On two new minerals from Chester Co., Pa. Ac N Sc Phila, Pr 1867:44-45

68 Descriptions of Unionidae from the Lower Cretaceous formation of New Jersey. Ac N Sc Phila, Pr 1868:162-164

Lea, M. Carey.

40 (with Booth, James C.) Analysis of a chromic iron ore ... from Mahobal, near Gibara, Island of Cuba. Am J Sc 38 : 243-245 (1840)

41 On the first or southern coal field of Pennsylvania. Am J Sc $40: 370-374$ (1841)

Leach, J. C.

96 Report of the State natural gas supervisor. Ind, Dp G N Res, An Rp 20: $369-410$, map ; $21: 428-456 ; 22: 257-288$, map ; $23: 1673-1702 ; 24: 204-221$; 25: $394-417 ; 27: 477-493 ; 26: 426-444$ (18961903)

Leach, Norman L.

os The Moose Mountain Iron range, with special reference to the properties of Moose Mountain, Limited. Can M Inst, J 11: 147-150 (1908)

Leach, William Wilson.

02 Crows Nest coal fields [B. C.]. Can G S, Sum Rp 1901 (An Rp 14): A 69-81 (19u2)
Ieach, William Wilson-Continued.

03 The Blairmore-Frank coal fields [Alberta]. Can G S, Sum Rp 1902 (An Rp 15) : A 169-181, map (1903)

06 The Telkwa mining district, B C. Can G S, Sum Rp 1906:35-42 (1908) B C Minister of Mines, An Rp 1906:93100 (1907)

o7 The Telkwa River and vicinity, B.C. Can G S: 23,8 pp, map (1907)

07 a Some notes on the economic geologr of the Skeena River [B. C.]. Can M J 28 (n s 1 no 2) : 58-60 (1907)

os The Bulkiey Valley, B C. Can G \&, Sum Rp 1907:19-23 (1908) B C Mip. ister of Mines, An Rp 1907:77-81 (1908)

09 The Bulkley Valley and ricinity. Can G S, Sum Rp 1908: 41-45 (1909) Can M J 30:372-374 (1909) B C Minister of Mines An Rp 1908: 168-172 (1909)

10 The Skeena River district, B C. Can G S, Sum Rp 1909:61-63 (1910); 1910: 91-101 (1911)

10a Recent mining developments on the Skeena River, B. C. Can M Inst, Q B $10: 189-195$ (1910); J $13: 357-363$ (1911)

12 Geology of Blairmore map area, At berta. Can G S, Sum Rp 1911:192-200 (1912)

13 Burmis, Alta, to Elko, B. C. Int G Cong, XII Canada, Guide Book no 9: 22-46, maps (1913)

Leasure, D.

56 [Geological notes on Lawrence $\mathrm{CO}_{\text {. }}$ Pa.] Med Soc Pa, Tr n s 1: 96 (1856)

Leatherbee, Brigham.

10 Sierra County, N. Mex., vanadium de posits. M World 33: 799 (1910)

11 Vanadium in New Mexico. M Mag 5 : 282 (1911)

Lebling, Clemrens.

14 Tektonische Forschungen in den Appalachen. G Rundschau 5: 449-462, 511537 (1914-5)

Leckie, R. G. E.

93 Iron deposits of Torbrook. M Soc N S, J 1 pt $3: 53-57$ (1893)

96 Notes on the Grand Lake coal field of New Brunswick. [Fed] Can M Inst, J 1:67-71 (1896) Can M Rv 15:90-91 (1896)

\section{Leclercq, Jules.}

85 Les geysers de la terre des mervellles [Yellowstone National Park]. Soc Boy Belge Geog, B $9: 393-422$ (1885)

\section{Le Conte, John.}

55a Remarks on the Rev. Henry Moseley's paper "On the descent of glaciers." Am J Sc (2) 20:335-339 (1855)

s2 Origin of jointed structure in undis. turbed clay and marl deposits. Am J Sc (3) $23: 233-234$ (1882) 
LeConte, John Lawrence (1825-1883).

47 On coracite, a new ore of uranium. Am J Sc (2) $3: 173-175$ (1847)

48 On Platygonus compressus, a new fossil pachyderm. Am Ac Arts, Mem n s $3: 257-274$, il (1848)

$48 a$ Notice of five new species of fossil mammalia from Illinois. Am $J$ Sc (2) $5: 102-106$, il (1848)

51 [Observations on the geology of California and adjacent regions.] Ac N Sc Phila, Pr 5 : 264-265 (1851)

52 Notes on some fossil suilline pachyderms from Illinois, Ac $N$ Sc Phila, Pr 6:3-5, 56-57 (1852)

52a Notice of a fossil Dicotyles, from Missouri. Ac N Sc Phila, Pr 6:5-6 (1852)

52b [On Castoroides ohioensis from Shawneetown, Ill.] Ac N Sc Phila, $\operatorname{Pr} 6$ : 53 (1852)

55 Account of some volcanic springs in the Desert of the Colorado in southern California. Am J Sc (2) 19:1-6 (1855)

68 Notes on the geology of the survey for the extension of the Union Pacific Railway, E. D., from the Smoky Hill River, Kansas, to the Rio Grande. $76 \mathrm{pp}$, map, Phila 1868

68a Geologist's report. In Letter of John D. Perry, President of the Union Paciflc Railway ... : 23-28, Phila 1868

68b Cretaceous coal in New Mexico. Am J Sc (2) $45: 136$ (1868)

75 [On the geology of New Mexico.] Ac N Sc Phila, $\operatorname{Pr} 1875: 267-268$

Le Conte, Joseph (1823-1901).

57 On the agency of the Gulf Stream in the formation of the Peninsula of Florida. $\triangle \mathrm{m} \mathrm{As}, \operatorname{Pr} 10$ pt $2: 103-119$ (1857) Am J Sc (2) $23: 46-60$ (1857)

58 Lectures on coal. Smiths Inst, An Rp 1857:119-168 (1858)

59 Formation of oceans and continents (abst). Can Nat 4:293-294 (1859)

72 A theory of the formation of the great features of the earth's surface. Am $\mathrm{J} \mathrm{Sc}$ (3) $4: 345-355,460-472 \quad(1872) ; 5$ : $448-453$ (1873)

73 On some of the ancient glaciers of the Sierras. Cal Ac Sc, Pr $4: 259-262$ (1873) Am J Sc (3) $5: 325-342$, map (1873)

73a On the great lava flood of the Northwest; and on the structure and age of the Cascade Mountains. Cal Ac Sc, Pr $5: 214$ 220 (1873) Am J Sc (3) $7: 167-180,259$ 267 (1874)

74 Religion and science ... 324 pp N Y 1874 (later ed, 1880)

75 On some of the ancient glaciers of the Sierra Nevada, Am J Sc (3) 10:126-139 (1875) Cal Ac Sc, Pr 6: 38-48 (1876)

$$
28737^{\circ}-23-41
$$

Le Conte, Joseph-Continued.

76 On the evidences of horizontal crushing in the formation of the Coast Range of California. Am J Sc (3) 11:297-304 (1876)

$7 \boldsymbol{7}$ On critical periods in the history of the earth and their relation to evolution; and on the Quaternary as such a period. Am J Sc (3) 14:99-114 (1877) Am Nat 11:540-557 (1877) Western Rv Sc $1: 478-483,522-530$ (1877)

77a Hog wallows or prairie mounds [of California and Oregon]. Nature 15:530531 (1877)

78 Elements of geology. 588 pp, N Y 1878 ; [2d ed], $633 \mathrm{pp}, \mathrm{N}$ Y 1882 ; [3d ed], $640 \mathrm{pp}, \mathrm{N}$ Y 1891 ; 4 th ed, $670 \mathrm{pp}, \mathrm{N}$ Y $1896 ; 5$ th ed, rev. by H. L. Fairchild, 667 pp, N Y 1903

$78 n$ On the structure and origin of mountains, with special reference to recent objections to the "contractional theory." Am J Se (3) 16:95-112 (1878)

78b Geysers and how they are explained. Pop Sc Mo $12: 407-417$ (1878)

78e Geological climate and geological time. Nature 18:668 (1878)

79 On the extinct volcanoes about Laka Mono and their relation to the glacial drift. Am J Sc (3) $18: 35-44$ (1879)

79a Extinct western volcanoes. Science News 1:200-202 (1879)

80 The old river beds of California. Am J Sc (3) $19: 176-190$ (1880)

80 Coral reefs and islands. Nature $22: 558 \quad(1880)$

82 The recent discoveries of fossil footprints in Carson. From the Proceedings of the California Academy of Sciences, August 27th, 1882. $10 \mathrm{pp}$, il [San Franciseo 1882] Abst, Am Nat 16:921-923 (1882)

s2a (and Rising, W. B.) The phenomena of metalliferous vein formation now in progress at Sulphur Bank, Cal. Am J Sc (3) 24:23-33 (1882) Abst, Eng M J 34: 109-110 (1882)

83 On mineral vein formation now in progress at Steamboat Springs compared with the same at Sulphur Bank. Am J Se (3) $25: 424-428$ (1883)

$\mathbf{8 3 a}$ On the genesis of metalliferous veins. Am J Sc (3) 26:1-19 (1883)

83b The reefs, keys, and peninsula of Florida. Science 2: 764 (1883)

83e Carson footprínts. Nature 28:101102 (1883)

84 A compend of geology. 399 pp, N Y 1884 Revised ed, 426 pp, 1898

84 Flevation and subsidence. Nature $29: 212-213$ (1884)

84b The United States Geological Survey; Annual Reports, II, III. Science 4: 62-71 (1884) 
Le Conte, Joseph-Continued.

85 Earthquake shocks more violent on the surface than in mines. Science 6: 540 (1885)

86 A post-Tertiary elevation of the Sierra Nevada shown by the river beds. Am J Sc (3) $32: 167-181$ (1886)

s6a On the permanence of continent and ocean basins, with special reference to the formation and development of the North American continent. G Mag (3) 3:97101, 287-288 (1886)

87 The flora of the coast islands of Callfornia in relation to recent changes of physical geography. Cal Ac Sc, B 2 no 8: $515-520$ (1887) Am G 1:76-81 (1887) Am J Sc (3) 34:457-460 (1887)

$\mathbf{8 7 a}$ Determination of the depth of earthquakes. Science $10: 22-24$ (1887)

88 Mountain formation. Ph Mag (5) 25: 450-451 (1888)

88a Glacial motion. $\mathrm{Ph}$ Mag (5) 25 : 452 (1888)

89 The general interior condition of the earth. Am G 4: 38-44 (1889)

$89 a$ On the origin of normal faults and of the structure of the Basin region. Am J Sc (3) $38: 257-263$ (1889)

91 Tertiary and post-Tertiary changes of the Atlantic and Pacific coasts. G Soc Am, B $2: 323-328$ (1891)

$91 \mathbf{a}$ The mutual relations of land elevation and ice accumulation during the Quaternary period. G Soc Am, B 2:329-330 (1891)

93 Theories of the origin of mountain ranges. J G 1:543-573 (1893) Am As, Pr 42:1-27 (1894) Abst, Science 22:105 (1893)

93a Coral-reef formation. Science 22 : 318 (1893)

95 Critical periods in the history of the earth. Cal Univ, Dp G, B 1:313-336 (1895) Abst, J G 3:869-870 (1895)

96 Memoir of James Dwight Dana. G Soc Am, B 7:461-479, port (1896)

97 Earth-crust movements and their causes. G Soc Am, B 8:113-126 (1897) Science n s 5:321-330 (1897) Smiths Inst, An Rp 1896: 233-244 (1898)

98 Origin of transverse mountain valleys and some glacial phenomena in those of the Sierra. [Cal] Univ Chronicle 1:479-497 (1898)

99 The Ozarkian and its significance in theoretical geology. J G 7:525-544 (1899) Abst, Science n s 10:490 (1899) ; Am As, Pr 48:229 (1899)

00 A century of geology. Pop Sc Mo 56 : 431-443, 546-556 (1900) Smiths Inst,

An Rp 1900: 265-287 (1901)

O0a An early geological excursion (abst), Science n s 11: 221 (1900)

03 Autobiography, edited by W. D.

Armes. xvil, 337 pp, port, N X 1903

10 Genesis of ores. M Sc Press 100: 833-834 (1910)
Le Conte, Joseph-Continued.

See also Don, 98; Emerson, 96 ; Fraze: 88a; Pošepný, 94, 95;- Salisbury, 98b; Smith (E A), 88a

Le Conte, Joseph N.

O5 The evolution group of peaks. Siem Club B 5: 229-237 (1905)

06 The motion of the Nisqually Glacler, Mt. Rainier, U. S. A. Zs Gletscherk 1:192199 (1906) Sierra Club B 6:108-11 (1907)

o7 The High Sierra of California. Al. pina Americana no $1: 16 \mathrm{pp}$, map (pub by the American Alpine Club, Phila 1907)

Le Conppey de la Forest, Max.

03 Quelques grottes des Etats - Unis d'Amérique. Spelunca 5 no $35: 3-21$ (117135) (1903)

Ledonx, Albert Reid.

89 The Pipe Creek meteorite [Brandera Co., Tex.] N Y Ac Sc, Tr $8: 185-187$ (1889)

90 The newly discovered phosphate beds of Florida. N Y Ac Se, Tr 9:84-94 (1890) Eng M J 49:175-177 (1890) Bc Am Sup 30: 12104-12105 (1890)

91 Notes on the Sweet Grass Hills o! Montana and the Kootenai mines of British Columbia. N Y Ac Sc, Tr 10:57-66 (1891)

oo The Union Copper mines, Gold Hill, N. C. Eng M J 69:167-170 (1900)

01 Notes on the Oregon nickel prospects. Can M Inst J 4:184-189 (1901) Can M Rv 20:84-85 (1901)

02 The production of copper in the Boundary district, B. C. Can "M Inst, J 5:171-177 (1902) M Sc Press $84: 307$ (1902)

Ledoux, Auguste.

17 Aurichalcite from Big Cottonwood Canyon, Salt Lake Co., Utah. Wash Ac Sc, J $7: 361-365$ (1917)

Ledoux, Auguste Joseph Gaston (18881918).

16 Mineralogical exploration of east Templeton district, Que. Can G S, Sum Rp 1915 : 162-168 (1916)

18 Sand and gravel in Ontario. Ont Bur Mines, Rp 27 pt 2 : 138 pp, map (1918)

18a (and Walker, T. L.) Cerusite from Salmo, B. C. Ottawa Nat $32: 7-8$ (1918)

18b Tourmaline from Macdonald Island, Baffin Land. Ottawa Nat $32: 49-51$ (1918) Ledyara, T. D.

91 Some Ontario magnetites. Am I M Eng, Tr $19: 28-37$ (1891)

Lee, Charles A.

22 [Petros] On certain rocks supposed to move without any apparent cause [Sallsbury, Conn]. Am J Sc 5: 34-37 (1822)

24 Notice of the Ancram lead mine [Columbia Co., N. Y.]. Am J Sc 8:247250 (1824)

24a ... geology and mineralogy of Salis. bury, Conn. Am J Sc 8: 252-261 (1824) 
Lee, Charles A.-Continued.

25 ... the moving rocks of Salisbury

[Conn.]. Am J Se 9:239-241 (1825)

40 The elements of geology... 384 pp,

N Y 1840

43 On ancient climate as viewed in the light of fossil geology. In Forry, Samuel, Meteorology...: $45-48$, N Y 1843

Lee, Charles $\mathrm{H}$.

12 An intensive study of the water resources of a part of Owens Valley, Cal. U S G S, W-S P 294: 135 pp (1912)

13 Use and conservation of the underground reservoirs of California. Western Eng 3:189-194 (1913)

16 (and Clark, W. O.) Report of Soda Lakes investigation, Truckee-Carson project, near Fallon, Nev. Report of an investigation made by the U. S. Geological Survey: $657-706$, Washington 1916

Lee, Harry Allen.

98 Report of the State Bureau of Mines [of] Colorado for the year 1897. 167 pp, Denver, Colo., 1898.

99 The asphalt deposits of Middle Park, Colo. Eng M J 67:468 (1899)

00 Mineral resources of Colorado; Larimer Co. gypsum. Stone 21:35-37 (1900)

03 Report of the State Bureau of Mines [of] Colorado for the years 1901-2. 310 pp, Denver, Colo., 1903

Lee, Howard $\mathrm{S}$.

18 Pyrite deposits of Leadville, Colo. Am I M Eng, B 140:1223-1228 (1918) Abst, Eng M J $106: 384-385$ (1918)

Lee, Leslie Allen.

79 A peculiar cave in Utah. Am Nat 13: $460-462$ (1879)

05 The mineral resources of Maine. Am M Cong, 7 th, Pr : 227-232 (1905)

Lee, Montrose L.

12 A geological study of the Elisa mine, Sonora, Mexico. Ee G $7: 324-339$ (1912) Lee, $\mathrm{S}$. E.

86 A glossary [of geologic terms] ... Ind, Dp G N H, An Rp $15: 335-345$ (1886)

86a (with Gorby, S. S.) Geology of Boone Co. Ind, Dp $G N$ H, An Rp 15 : 160-176 (1886)

86b (with Thompson, W. H.) Maxinkuckee [Lake]. Ind, Dp $\mathrm{G} N \mathrm{~N}, \mathrm{An} \mathrm{Rp}$ 15:182-186 (1886)

Lee, Wallace.

11 Newburg district. Mo Bur G Mines, Bien Rp St G: 55-63, map (1911)

14 The geology of the Rolla quadrangle. Mo Bur G (2) $12: x i 1,111 \mathrm{pp}$, maps [1914]

15 Oil and gas in the Gillespie and Mt. Olive quadrangles, Ill. Ill G $\mathrm{S}, \mathrm{B}$ 31: 71-107, maps (1915)

16 Geology of the Kentucky part of the Shawneetown quadrangle. Ky G S : $73 \mathrm{pp}$, map (1916)

17 Coal in Gillespie and Mount Olive quadrangles. IIl G S, B 30:51-59 (1917)
Lee, Willis Thomas.

97 Fossil mosasaurid found near Flagler, Colo. Am Nat 31:614 (1897)

00 The origin of the debris-covered mesas of Boulder, Colo. J G 8:504-511, map (1900)

OOa The glacier of Mt. Arapahoe, Colo. J G 8:647-654 (1900)

01 The Morrison formation of south. eastern Colorado. J G $9: 343-352$, map (1901)

02 The Morrison shales of southern Colorado and northern New Mexico. J G $10: 36-58$, map (1902)

02a Note on the Carboniferous of the Sangre de Cristo Range, Colo. J G 10 : 393-396 (1902)

02b The areal geology of the Castle Rock region, Colo. Am G 29:96-110, map (1902)

02e Canyons of southeastern Colorado.

J Geog 1:357-370, map (1902)

03 The canyons of northeastern New Mexico. J Geog 2:63-82, maps (1903)

03a Age of the Atlantosaurus beds (abst). Science n s $17: 292-293$ (1903) J G 11:107 (1903) G Soc Am, B 14: 531-532 (1904)

04 The underground waters of Gila Valley, Ariz. U S G S, W-S P 104:71 pp, map (1904)

os Underground waters of Salt River valley, Ariz. U S G S, W-S P 136: 196 $\mathrm{pp}, \operatorname{map}(1905)$

05a Note on the glacier of Mount Lyell, Cal. J G $13: 358-362$ (1905)

06 Geology and water resources of Owens Valley, Cal. U S G S, W-S P 181: $28 \mathrm{pp} \mathrm{(1906)}$

06a Geology of the lower Colorado River. G Soc Am, B 17:275-284 (1906)

06b The Engle coal field, $N$ Mex. U S G S, B $285: 240$ (1906)

o6e Gypsum beds and water storage in the Pecos Valley of New Mexico (abst). Science n s 23:306 (1906)

o7 The Cove Creek sulphur beds, Utah. U S G S, B 315:485-489 (1907)

07a The Iron County coal field, Utah. U S G S, B 316:359-375 (1907)

отb Water resources of the Rio Grande Valley in New Mexico, and their development. U S G S, W-S P 188:50 pp, map (1907)

о7e Note on the red beds of the Rio Grande region in central New Mexico. J G $15: 52-58$ (1907)

07a Afton craters of southern New Mexico. G Soc Am, B 18: 211-220 (1907) Alst, Science n s 25:768-769 (1907)

oze The late history of the lower Colorado River (abst). Science n s 25:390391 (1907)

os Water resources of Beaver Valley, Utah. U S G S, W-S P 217:57 pp (1908) 
Lee, Willis Thomas-Continued.

osa Geologic reconnaissance of a part of western Arizona. U S G S, B 352:980 , map (1908)

osb Notes on the lower Paleozoic rocks of central New Mexico. Am J Sc (4) 26 : 180-186 (1908)

ose [Fossils from the red beds of New Mexico and their age] (abst). Science n s $27: 247$ (1908)

osd Local upturning sedimentary rocks at their outerop (abst). Science n s 27 : 891 (1908)

09 The Grand Mesa coal field, Colo. U S G S, B 341: 316-334, map (1909)

09a Unconformity in the so-called Laramie of the Raton coal field, N Mex. G Soc Am, B 20:357-368 (1909)

09b Stratigraphy of the Manzano group of the Rio Grande valley, N. Mex. U S G S, B 389: 5-40 (1909)

o9e On an occurrence of coal changed to coke and graphite in the Raton, $\mathrm{N}$ Mex., coal field (abst). Science n s 29:198-199 (1909)

09d The correlation of sections lithologically similar (abst). Seience n s 29 : 239 (1909)

o9e Unconformity separating the coalbearing rocks in the Raton field, $\mathrm{N}$ Mex. (abst). Science n s 29:624 (1909)

11 Criteria for an unconformity in the so-called Laramie of the Raton Mesa coal fields of New Mexico and Colorado (abst). Science n s $33: 355-356$ (1911) G Soc Am, B 22: 717 (1911)

12 The Tijeras coal field, Bernalillo Co., N Mex. U S G S, B 471:574-578, map (1912)

12a Coal fields of Grand Mesa and the West Elk Mountains, Colo. U S G S, B $510: 237$ pp, maps (1912)

12b Stratigraphy of the coal fields of northern central New Mexico. G Soc Am, B 23:571-686 (1912) Abst, Science n s 35 : 311 (1912)

12e Extinct volcanoes of northeast New Mexico. Am Forestry 18:357-365 (1912) 13 Graphite near Raton, N. Mex. U S G S, B $530: 371-374$ (1913)

13a The Cerrillos coal field, Santa Fe Co., N. Mex. U S G S, B 531: 285-312, maps (1913)

$13 \mathbf{b}$ Recent discovery of dinosaurs in the Tertiary. Am J Sc (4) 35:531-534 (1913) Abst, Wash Ac Sc, J $3: 173$ (1913)

13e Coal fields of Grand Mesa and the West Elk Mountains (abst). Wash Ac Sc, J 3 : 362-363 (1913)

14 Use of physiography in the study of Rocky Mountain stratigraphy (abst). Wash Ac Sc, J 4:8-9 (1914)
Lee, Willis Thomas-Continued.

15 (and others) Guidebook of the re? ern United States; Part B, The Overly Route, with a side trip to Yellowstone Par U S G S, B 612: 244 pp, maps (191: Abst, by F. L. Ransome, Wash Ac Sc, J: 580 (1915)

15a Relation of the Cretaceous form tions to the Rocky Mountains in Colo., a N. Mex. U S G S, P P 95:27-58, max (1915) Abst, Wash Ac Sc, J $5: 29$ (1915) ; G Soe Am, B 26: 114 (1915)

15b Reasons for regarding the Morrixn an introductory Cretaceous formation. Soc Am, B 26:303-314 (1915) Abit Wash Ac Sc, J 5:606-608 (1915)

16 The Axtec gold mine, Baldy, N. Mes U S G S, B 620:325-330 (1916)

17 Geology of the Raton Mesa and other regions in Colorado and New Mexico. T G S, P P 101: 9-221, map (1917) Abut by R. W. Stone, Wash Ac Sc, J 8:451-4: (1918)

17a The geologic story of the Rock Mountain National Park, Colo. U S Nat Park Service: 89 pp, maps (1917)

17b General stratigraphic break betwes Pennsylvanian and Permian in westen America $(a b s t)$. G Soc Am, B 28:162170 (1917)

17c Application of physiographic meth ods to the correlation of nonmarine formstions in the Rocky Mountains (abst). NI Ac Sc, An 27:266-267 (1917)

17d Relations of the Morrison and Surdance formations (abst). Wash Ac $8 c$, J $7: 431-432$ (1917)

18 Early Mesozoic physiography of the southern Rocky Mountains. Smiths Misc Col 69 no 4: 41 pp (1918)

See also Fairchild, $04 \mathrm{c}$

Leeds, Albert Ripley (1843-1902).

65 The geography and geology of petro. leum. Franklin Inst, $J$ (3) $49: 347-356$ (1865)

70 [Boulders in gneiss matrix near Philadelphia.] Ac N Sc Phila, Pr 1870: 134 135

71 Pennsylvania's foundation stones [general account of the geology]. Franklin Inst, J (3) $61: 337-345,412-417$ (1871)

71a Pennsylvania's ancient sea. Frank. lin Inst, J (3) $62: 55-61,133-139$ (1871)

72 Note upon aventurine orthoclase found at the Ogden mine, Sparta Township. Sussex Có., N. J. Am J Sc (3) 4:433-434 (1872)

73 Contributions to mineralogy. Am J Sc (3) $6: 22-26(1873)$

73a State geological surveys. Pop Si Mo $3: 226-229$ (1873)

74 [On a fulgurite near Fayetterille, N. C.] Ac N Sc Phila, Pr 1874:145 
Leeds, Albert Ripley-Continued.

75 On an asphaltic coal from the shale of the Huron River, Ohio, containing seams of sulphate of baryta. Lyc N H N Y, An 11: $105 \quad(1875)$

77 Notes upon the lithology of the Adirondacks. Am Chemist 7:328-339 (1877) N Y St Mus, An Rp 30:79-109 (1878)

Leeds, Stephen P.

54 Notes on the gold regions of North and South Carolina. M Mag 2:27-34, 357-369 (1854)

54a The Rudisel gold and copper mine of North Carolina [Charlotte, Mecklenburg Co.]. M Mag 2:516-518 (1854)

54b The coal lands of the Clinton County Coal Company of Pennsylvania. M Mag 3: 513-520 (1854)

58 What influence does water hold in mineral veins? M Mag 11:81-94, 159172 (1858)

58a On geological maps. M Mag 11: 106-112 (1858)

Lees, James Henry.

07 Report of the assistant State geolo. gist. Iowa G S $17: 7-10$ (1907) ; ... 18:69 (1908)

07a The skull of Paleorhinus, a Wyoming phytosaur. J G $15: 121-151$, il (1907)

09 General section of the Des Moines stage of Iowa. Iowa G S 19:598-604 (1909)

09n Bibliography of Iowa coals. Iowa G S $19: 659-687$ (1909)

09b Bibliography of Iowa peat. Iowa G S $19: 731-733$ (1909)

09e (and Hixson, A. W.) Analyses of Iowa coals. Iowa G S $19: 476-519$ (1909)

14 Earth movements and drainage lines in Iowa. Iowa $\mathrm{Ac} \mathrm{Sc}, \operatorname{Pr} 21: 173-180$ (1914) Abst, Science n s 40:144 (1914)

16 Physical features and geologic history of Des Moines Valley. Iowa G S 25: 423-615 (1916)

16a The Pleistocene of Capitol Hill [Des Moines, Iowa]. Iowa Ac Sc, Pr 23: 167-172 (1916) Abst Science n s $44: 68$ (1916)

17 Some geologic aspects of conservation. Iowa Ac Sc, Pr 24:133-154 (1917)

17a Some fundamental concepts of earth history. Iowa Ac Se, Pr 24:155-170 (1917)

18 A description of the region about Camp Dodge. Iowa G $\mathrm{S}: 60 \mathrm{pp}$, map (1918)

18a (and Alden, W. C.) The country around Camp Dodge. [Text on back of topographic map], Iowa, Camp Dodg. quadrangle, U S G S (1918)

See also Tomlinson, 18

Leflingwell, Ernest de Koven.

04 (with Capps, S. R.) Pleistocene geology of the Sawatch Range, near Leadville, Colo. J G 12:698-706 (1904)
Lefingwe11, Ernest de Koven-Contd.

os Flaxman Island [Alaska], a glacial remnant. J G $16: 56-63$ (1908)

13 A reconnaissance of the Arctic slope of Alaska (abst). Wash Ac Sc, J 3:343344 (1913)

15 Ground-ice wedges; the dominant form of ground ice on the north coast of Alaska. J G 23:635-654 (1915) Abst, Wash Ac Se, J $5: 186-187$ (1915)

Lefrmann, Henry.

S3 Contributions to the geological chemistry of Yellowstone National Park. Am J Sc (3) $25: 104-105,351$ (1883)

Legrett, Thomas $H$.

S9 Notes on the Rosario mine at San Juancito, Honduras, C. A. Am I M Eng, Tr 17:432-449, map (1889)

Leiberg, John B.

89 Some notes upon the more recent fossil flora of North Dakota and an inquiry into the causes that have led to the development of the treeless areas of the Northwest. Minn Ac N Sc, B 3:145-151 (1889)

Leicht, F, von.

99 Cinnabar in San Luis Obispo Co., Cal. M Sc Press 99: 482 (1899)

Leidy, Joseph (1823-1891).

45 Notes taken on a visit to White Pond, in Warren Co., N. J. Ac N Se Phila, Pr 2: 279-281 (1845)

47 On the fossil horse of America. Ac N Se Phila, Pr 3:262-266, 328, il (1847)

48 On a new fossil genus and species of ruminantoid Pachydermata; Merycoidodon culbertsonii. Ac N Sc Phila, Pr 4: $47-50$, il (1848)

48a on a new genus and species of fossil Ruminantia, Poëbrotherium wilsoni. Ac N Se Phila, Pr 3:322-326, il (1848) Am J Sc (2) $5: 276-279$ (1848) An Mag N H - (2) $1: 389-392$ (1848)

49 Tapirus americanus fossilis. Ac N Sc Phila, Pr 4: 180-182 (1849)

50 On Eucrotaphus jacksoni and Archaeotherium mortoni. Ac N Sc Phila, Pr 5: 90-93 (1850)

50a [On Rhinoceros occidentalis.] Ac N Sc Phila, Pr 5:119 (1850)

50b [Descriptions of mammalian remains from Missouri Terr.] Ac N Sc Phila, Pr 5: 121-122, 170-171 (1850)

51 [On fossil tortoises from Nebraska.] Ac N Sc Phila, Pr 5:172-173 (1851)

$\mathbf{5 1 a}$ [Descriptions of fossil ruminant ungulates from Nebraska Territory.] Ac N Se Phila, $\operatorname{Pr} 5: 237-239,276$ (1851)

$51 b$ [On Crocodilus antiquus from the Miocene of Westmoreland Co., Va.] Ac N Sc Phila, Pr 5:307 (1851)

51e [Descriptions of two species of Balaena from the Miocene of Virginia.] Ac N Sc Phila, Pr 5: 308-309 (1851)

51 d [Descriptions of fossil reptillan and mammalian remains.] Ac $\mathrm{N}$ Sc Phila, $\mathrm{Pr}$ $5: 325-328$ (1851) 
Leidy, Joseph-Continued.

51e [Descriptions of vertebrate fossils from the green sand of New Jersey.] Ac N Sc Phila, Pr 5:329-330 (1851)

52 Memoir on the extinct species of American ox. Smiths Contr Knowl 5 art $3: 20 \mathrm{pp}$, il (1852)

$52 a$ Description of the remains of extinct Mammalia and Chelonia from Nebraska Territory... In Owen, D. D., Report of a geological survey of Wisconsin, Iowa, and Minnesota...:535-572, il, Phila 1852

$\mathbf{5 2 b}$ Report upon some fossil Mammalia and Chelonia from Nebraska. Smiths Inst, An Rp 6, 1851: 90-92 (1852)

52c Description of a new species of crocodile from the Miocene of Virginia. Ac N Sc Phila. J (2) $2: 135-138$, il (1852)

52d [On Rhinoceros americanus from Nebraska Terr.] Ac $\mathrm{N}$ Se Phila, Pr $6: 2$ (1852)

52e [On Emys culbertsonii from Nebraska Terr.] Ac N Sc Phila, Pr 6:34 (1852)

52f [On Delphinus conradi from the Miocene of Virginia and Thoracosaurus grandis from the green sand formation of New Jersey.] Ac N Sc Phila, Pr 6:35 (1852)

$52 \mathrm{~g}$ [On Pontogeneus priscus from the Eocene of Louisiana.] Ac N Sc Phila, Pr 6:52 (1852)

52h [On fossil tortoises from Nebraska Terr.] Ac N Se Phila, Pr 6:59 (1852)

52i [On two crania of extinct species of ox.] Ac N Sc Phila, $\operatorname{Pr} 6: 71$ (1852)

52j [On Tapirus haysii.] Ac N Sc Phila, Pr 6:106, 148 (1852)

52k [Remarks on a fossil ox and on Edentata.] Ac $\mathrm{N}$ Sc Phila, $\operatorname{Pr} 6: 117$ (1852)

53 The ancient fauna of Nebraska, or a description of remains of extinct Mammalia and Chelonia from the Mauvaises Terres of Nebraska. Smiths Contr Knowl 6 art $7: 126 \mathrm{pp}$, il (1853)

53a Description of an extinct species of American lion, Felis atrox. Am $\mathrm{Ph}$ Soc, Tr n s 10:319-321, il (1853)

536 A memoir on the extinct Dicotylinae of America. Am Ph Soc, $\mathrm{Tr} n$ s $10: 323-$ 343 , il (1853)

53e [Remarks on several fossil teeth.] Ac N Sc Phila, Pr 6:241 (1853)

53d [On Ursus amplidens from Natchez, Miss.] Ac N Sc Phila, $\operatorname{Pr} 6: 303$ (1853)

53e [Observations on extinct Cetacea.] Ac N Sc Phila, Pr $6: 377-378$ (1853)

531 [Remarks on a collection of fossil Mammalia from Nebraska.] Ac N Sc Phila, Pr 6:392-394 (1853)

54 On Bathygnathus borealis, an extinct saurian of the New Red Sandstone of Prince Edward's Island. Ac N Sc Phila, J (2) $2: 327-330$, il $(1854)$ Am J Sc (2) 19: 444-446 (1854)
Leidy, Joseph-Continued.

$\mathbf{5 4 a}$ [On saurian vertebrae from Gres ville, Clark Co., Ark.] Ac $\mathrm{N}$ Sc Phila, $\mathrm{p}$ $7: 72$, il (1854)

54b [On Harlanus and other mammalian remains.] Ac $\mathbf{N}$ Sc Phila, $\operatorname{Pr} 7: 89-90$ (1854)

54e [On Dinictis felina from Nebraska.] Ac N Sc Phila, Pr 7:127 (1854)

54d Synopsis of extinct Mammalia, the remains of which have been discovered in the Eocene formations of Nebraska. Ac I Sc Phila, Pr $7: 156-157$ (1854)

54e Description of a fossil apparentis Indicating an extinct species of the camel tribe. Ac N Se Phila, Pr 7 : 172-173 (1854)

54f Notice of some fossil bones dis covered ... in the banks of the Ohio River, Indiana, Ac N Sc Phila, Pr 7:199-201 (1854)

$54 \mathrm{~g}$ Remarks on the question of the identity of Bootherium cavifrons with Oof bos moschatus or 0 . maximus. Ac $\mathrm{N} \mathrm{Sc}$ Phila, Pr $7:$ 209-210 (1854)

55 A memoir on the extinct sloth tribe of North America. Smiths Contr Knowl ? art $5: 68 \mathrm{pp}$, il (1855)

$55 a$ Indications of twelve species of $f 08$. sil fishes. Ac N Sc Phila, Pr $7: 395-397$ (1855)

55b Indications of five species, with two new genera, of extinct fishes. Ac N Sc Phila, Pr $7: 414$ (1855)

56 Descriptions of some remains of fishes from the Carboniferous and Devonian formations of the United States. Ac N Se Phila, J (2) $3: 159-165$, il (1856)

56 a Description of some remains of extinct Mammalia. Ac N Sc Phila, J (2) $3: 166-171$, il (1856)

56b Descriptions of two ichthyodorulites. Ac N Sc Phila, Pr 8:11-12 (1856) Am I Sc (2) $21: 421-422$ (1856)

56c Notices of some remains of extinet Mammalia, recently discovered by Dr. F. V. Hayden in the bedlands of Nebraska. Ac $N$ Sc Phila, Pr 8:59 (1856) Am J Sc (2) $21: 422-423$ (1856)

56d Notices of remains of extinct reptiles and fishes, discovered by Dr. F. V. Hayden in the badlands of the Judith Rivêr, Nebraska Terr. Ac N Se Phila, Pr $8: 72-73$ (1856) Am J Sc (2) 22:118120 (1856)

56e Notices of remains of extinct Mam. malia discovered by Dr. F. V. Hayden, in Nebraska Terr. Ac N Sc Phila, Pr 8:8890 (1856)

56P Notice of the remains of a species of seal, from the post-Pliocene deposit of the Ottawa River. Ac N Sc Phila, Pr 8:9091 , il (1856) Can Nat $1: 238$, il (1856)

$56 \mathrm{~g}$ Notices of several genera of extinct Mammalia, previously less perfectly characterized. Ac $\mathrm{N}$ Sc Phila, Pr 8:91-92 (1856) 
Leidy, Joseph-Continued.

$56 \mathrm{~h}$ [On extinct Dicotylinae of America.] Ac N Sc Phila, Pr 8:140 (1856)

56i Notice of some remains of extinct vertebrated animals. Ac $\mathbf{N}$ Sc Phila, $\mathrm{Pr}$ 8: 163-165 (1856)

56j Notices of remains of extinct vertebrated animals of New Jersey ... Ac N Sc Phila, $\operatorname{Pr} 8$ : 220-221 (1856)

56k Notices of remains of extinct vertebrated animals discovered by Prof. E. Emmons [in North Carolina]. Ac N Sc Phila, $\operatorname{Pr} 8: 255-256$ (1856) Am J Sc (2) $23: 271-272$ (1857)

561 Notice of some remains of fishes discovered by Dr. John E. Evans. Ac N Se Phila, Pr 8:256-257 (1856)

$56 \mathrm{~m}$ Notice of remains of two species of seals. Ac N Sc Phila, Pr 8: 265 (1856)

56n Remarks on certain extinct species of fishes. Ac N Sc Phila, Pr 8:301-302 (1856)

56o Notices of remains of extinct turtles of New Jersey ... Ac N Sc Phila, Pr $8 \cdot 303-304$ (1856)

56p Notices of extinct Vertebrata discovered by Dr. F. V. Hayden, during the expedition to the Sioux country... Ac $\mathrm{N}$ Sc Phila, Pr 8: 311-312 (1856)

57 List of extinct Vertebrata, the remains of which have been discovered in the region of the Missouri River; with remarks on their geological age. Ac $\mathrm{N}$ Sc Phila, Pr 1857: 89-91

57a [On fossils from Phoenixville, Pa.] Ac N Sc Phila, Pr 1857:149-150

$57 \mathbf{b}$ Notices of some remains of extinct fishes. Ac N Sc Phila, Pr 1857: 167-168

57e Rectiflcation of the references of certain of the extinct mammalian genera of Nebraska. Ac N Se Phila, Pr 1857: $175-176$

57d [On Mosasaurus.] Ac N Sc Phila, Pr 1857:176

57 e Notice of remains of the walrus discovered on the coast of the United States. Am Ph Soc, $\operatorname{Tr}$ n s $11: 83-86$, il (1857)

57f Descriptions of the remains of fishes from the Carboniferous limestone of Illinois and Missouri. $\mathrm{Am} \mathrm{Ph}$ Soc, Tr $\mathrm{n} s$ $11: 87-90$, il (1857)

$57 g$ Remarks on Saurocephalus and its allies. $\mathrm{Am} \mathrm{Ph} \mathrm{Soc}, \mathrm{Tr}$ n s 11:91-95, il (1857)

$\mathbf{5 7 h}$ Observations on the extinct peccary of North America ... Am Ph Soc, Tr n s $11: 97-105$, il (1857)

$57 \mathrm{i}$ Remarks on the structure of the feet of Megalonyx. Am $\mathrm{Ph}$ Soc, $\mathrm{Tr} \mathrm{n} s$ 11: $107-108$, il (1857)

58 [On remains of extinct animals from the Niobrara Valley]. Am J Sc (2) 25 : 441-442 (1858)

58a [Remarks on fossil Mammalia from Nebraska.] Ac N Sc Phila, Pr 1858: 7
Leidy, Joseph-Continued.

58b [On mastodon remains from Nebraska.] Ac N Sc Phila, $\operatorname{Pr}$ 1858:10

58c [On Mammalia from Niobrara Valley, Nebr.] Ac N Sc Phila, Pr 1858:11 5Sd [On Mastodon longirostris and Tapirus mastodontoides.] Ac N Sc Phila, Pr 1858:12

58e Notice of remains of extinct Vertebrata, from the valley of the Niobrara River, collected during the r ploring expedition of 1857, in Nebraska... Ac $\mathrm{N}$ Sc Phila, Pr 1858: 20-29

58f [On Procamelus from the Niobrara talley, Nebr.] Ac N Sc Phila, Pr 1858: 89

58s Hadrosaurus foulkii, a new saurlan from the Cretaceous of New Jersey ... Ac N Sc Phila, Pr 1858:215-218 Am J Sc (2) $37: 266-270$ (1858)

59 [On fish remains from the Carboniferous of Kansas.] Ac N Sc Phila, Pr $1859: 3$

59 a [Observations on Mastodon from Honduras and on Mosasaurus, with synonymy.] Ac N Sc Phila, Pr 1859:91-92

59b [On fossils from Phoenixville, Chester Co., Pa.] Ac N Sc Phila, Pr 1859: 110

59e $[$ On fish remains from Bethany, Va.] Ac N Sc Phila, Pr 1859: 110

59 d [On mammalian remains from Claiborne Co., Miss.] Ac $\mathrm{N}$ Sc Phila, Pr 1859: 111

59e $[O n$ vertebrate remains from Chatham Co,, N. C.] Ac N Sc Phila, Pr $1859: 162$

59f Extinct Vertebrata from the Judith River and great lignite formations of Nebraska. Am Ph Soc, Tr n s 11:139-154, il (1859)

$59 \mathrm{~g}$ [On the remains of reindeer found at Sing Sing, N. Y., and Vincentown, N. J.] Ac N Sc Phila, Pr 1859: 194

59h On the geology and the remains of some extinct Vertebrata in the Territory of Nebraska. Am Ph Soc, Pr 7: 10-11 (1859)

60 Description of vertebrate fossils. In Holmes, F. S., Post-Pliocene fossils of South Carolina : $99-122$, il, Charleston, S. C., 1860

60a [On the albertite of New Brunswick.] Ac N Sc Phila, Pr 1860:54

60b [On dicotyles from Gibson Co., Ind.] Ac N Sc Phila, Pr $1860: 416$

60e [On fossil teeth from Washington Co., Tex.] Ac N Sc Phila, Pr 1860: 416

c2 Observations upon the mammalian remains found in the crevices of the leadbearing rocks at Galena, Ill. In Hall, James, and Whitney, J. D., Report of a geological survey of the State of Wisconsin vol. I : 424 (1862)

65 Cretaceous reptiles of the United States. Smiths Contr Knowl 14 art 6 (192) $135 \mathrm{pp}$, il (1865) 
Leidy, Joseph-Continued.

65 arief review of a memoir on the Cretaceous reptiles of the United States... Smiths Inst, An Rp 1864: 66-73 (1865)

65b [On bones from a guano deposit on the Island of Orchilla, W. I.] Ac N Sc Phila, Pr 1865 : 181-182

65e [On the species of Rhinoceros.] Ac N Se Phila, Pr 1865: 176-177

65d [On bones and teeth of horses from California and Oregon.] Ac N Sc Phila, Pr $1865: 94$

66 [On a phalanx of an extinct reptile from Columbus, Miss.] Ac N Sc Phila, $\mathrm{Pr}$ 1866: 9

66a [On the remains of birds.] Ac $\mathrm{N}$ Sc Phila, Pr 1866: 237

66b [On fossil bones from Mauvaises Terres, White River, Nebr. (Drepanodon or Machairodus accidentalis).] Ac N Sc Phila, Pr 1866: 345

67 [On a skull of Bison antiquus from California.] Ac N Sc Phila, Pr 1867:85

67 a [Remarks on a fossil skull of Geomys bursarius from the loess of Nebraska.] Ac N Sc Phila, Pr 1867:97

$67 \mathrm{~b}$ [Remarks on a skull of Castoroides ohioensis from Charleston, III.] Ac N Sc Phila, Pr 1867 : 97-98

68 Notice of some vertebrate remains from Harden Co., Tex. Ac N Se Phila, $\mathrm{Pr}$ $1868: 174-176$

68a Indication of an Elotherium in California. Ac N Sc Phila, Pr 1868: 177

68b Notice of some reptilian remains from Nevada. Ac N Sc Phila, $\operatorname{Pr} 1868$ : $177-178$

6Se Notice of some vertebrate remains from the West Indian Islands (Cienfuegos, Cuba]. Ac N Sc Phila, $\operatorname{Pr} 1868$ : 178-180

$68 d$ Notice of some remains of horses. Ac N Sc Phila, Pr 1868: 195

68e Notice of some extinct cetaceans. Ac N Sc Phila, Pr 1868: 196-197

68f Remarks on a jaw fragment of $M e g a-$ losaurus. Ac N Sc Phila, Pr 1868: 197200

68 gemarks on Conosaurus of Gibbes. Ac N Sc Phila, Pr 1868: 200-202

68h Notice of American species of Ptychodus. Ac N Sc Phila, Pr 1868: 205-208

68i Notice of some remains of extinct pachyderms. Ac N Sc Phila, Pr 1868:230233

68j Notice of some remains of extinct Insectivora from Dakota. Ac N Sc Phila, Pr 1868: 315-316

69 On the extinct Mammalia of Dakota and Nebraska ... together with a synopsis of the mammalian remains of North America. Ac N Sc Phila, J (2) $7: 23-472$, il (1869)

$69 a$ Notice of some extinct vertebrates from Wyoming and Dakota. Ac $\mathrm{N}$ Sc Phila, Pr $1869: 63-67$

70 On the Elasmosaurus platyrus of Cope. Am J Sc (2) $49: 892$ (1870)
Leidy, Joseph-Continued.

70a [On Megacerops coloradensis from Colorado,] Ac N Sc Phila, Pr 1870: 1-?

70b [On reptilian remains from Colorado Pickens Co., Ala., and Wyoming.] Ae s Se Phila, Pr $1870: 3-5$

70e [Remarks on Mylodon remains fron Central America and on Dromatherim sylvestre.] Ac N Sc Phila, $\operatorname{Pr} 1870: 8-9$

70d [Remarks on Elasmosaurys platyuru and other vertebrate remains.] Ac N \& Phila, Pr 1870: 9-11

70e [Remarks on ichthyodorulites from Kansas and Tennessee and on mammalia remains from Illinois.] Ac $\mathrm{N}$ Sc Phila, $\mathrm{Pr}$ $1870: 12-13$

70f [On rhinoceros remains from the Badlands.] Ac N Sc Phila, Pr 1870:65-66

$70 \mathrm{~g}$ [On vertebrate remains from Idaho. Utah, and Oregon.] Ac N Sc Phila, P $1870: 66-67$

70h [Remarks on Hadrosaurus and its allies.] Ac N Sc Pbila, $\operatorname{Pr} 1870$ : 67-68

70i [On remains of Elephas and Bison from a well at Burlington, Kans.] Ac N Sc Phila, Pr 1870:69

70j [On new cyprinoid fishes from the Rocky Mountains region.] Ac N Se Phila, Pr $1870: 69-71$

7ok [On remains of Ovibos from Hat rison Co., Iowa.] Ac N Sc Phila, Pr 1870 73

701 [Notice of Nothosaurops occidus from Moreau River, S. Dak.] Ac N Sc Phila, Pr 1870: 74

70m Notes on the American mastodon and other fossils. Ac N Sc Phila, Pr 1870: 96-99 Am J Sc (3) 1:63-65 (1870)

70n [Description of Crocodilus elliotti from Wyoming.] Ac N Sc Phila, Pr 1870: 100

70o [On vertebrate fosslis from Wyoming.] Ac N Sc Phila, Pr 1870:109-110

70p [On vertebrate fossils from the John Day region, Oreg.] Ac $\mathrm{N}$ Sc Phila, Pr $1870: 111-113$

70q [On mammalian remains from Wyoming.] Ac N Sc Phila, Pr 1870:113-114

70r [On Graphiodon vinearius from Marthas Vineyard, Mass, and on Crooodilus elliotti.] Ac N Sc Phila, Pr 1870:122

70s [Descriptions of species of Emys and Saniwa from Wyoming.] Ac N Sc Phila, Pr 1870: 123-124

7ot [Remarks on vertebrate fossils from Table Mountain, Tuolumne Co., Cal.] Ac N Sc Phila, $\operatorname{Pr} 1870: 125-127$

70u [On Lophiotherium sylvaticum from Green River, Wyo., and on Protohippus.] Ac N Sc Phila, Pr 1870:126-127

70v On Discosaurus and its allies. Ac N Sc Phila, Pr 1870:18-22 Am J S? (2) $50: 139-140(1870)$

71 Report on the vertebrate fossils of the Tertiary formations of the West. U S G S Wyo (Hayden), Prel Rp [4]:340-370 (1871) 
Leidy, Joseph-Continued.

71a [On mammalian fossils from California.] Ac N Sc Phila, Pr 1871: 50

71b [On turtles from Wyoming.] Ac N Sc Phila, Pr 1871: 102-103

71e Remains of mastodon and horse in North Carolina. Ac N Sc Phila, Pr 1871: 113

71d Remains of extinct mammals from Wyoming. Ac N Sc Phila, Pr 1871: 113116

71e [On Palaeosyops from Fort Bridger, Wyo.] Ac N Sc Phila, Pr 1871: 118

71f Remarks on a fossil Testudo from Wyoming and supposed fossil turtle eggs. Ac N Sc Phila, Pr 1871: 154-155

71g Remarks on donations of fossils from Wyoming. Ac N Sc Phila, $\operatorname{Pr} 1871$ : 197

71h Remarks on mastodon, etc., of California, Ac N Sc Phila, $\operatorname{Pr} 1871$ : 198199

711 Note on Anchitherium. Ac N Sc Phila, Pr 1871: 199

71j Remarks on fossil vertebrates from Wyoming. Ac N Sc Phila, Pr 1871: 228229 (1871) Am J Sc (3) $2: 372-373$ (1871) Am Nat 5:664-666 (1871)

$71 \mathrm{k}$ Notice of some extinct rodents. Ac N Se Phila, Pr 1871 : 230-232

72 On the fossil vertebrates of the early Tertiary formation of Wyoming. U S G S Mont (Hayden), An Rp 5:353-372 (1872)

72a Remarks on the minerals of Mount Mica, Malne. Ac N Sc Phila, Pr 1871: 245-247 (1872)

72b Remarks on fossils from - Oregon. Ac N Sc Phila, Pr 1871: 247-248 (1872)

72e Notice of corundum. Ac N Sc Phila, Pr 1872: 19

72d Remarks on fossils from Wyoming. Ac N Sc Phila, Pr 1872:19-21

72e Remarks on some extinct mammals. Ac N Sc Phila, Pr 1872: $37-38$

72f Remarks on some extinct vertebrates. Ac N Sc Phila, Pr 1872:38-40

$72 \mathrm{~g}$ Remarks on mastodon from New Mexico. Ac N Sc Phila, Pr 1872: 142

$72 h$ on a new genus of extinct turtles. Ac N Sc Phila, Pr 1872:162

79i On some remains of Cretaceous fishes. Ac N Sc Phila, Pr 1872:162-163 72j Remarks on fossil shark teeth. Ac N Sc Phila, Pr 1872:166

72k On some new species of fossil Mammalia from Wyoming. Ac N Sc Phila, Pr 1872: 167-169 Am J Sc (3) $4: 239-240$ (1872)

721 Notice of a corundum mine [Unionville, Chester Co., Pa.]. Ac N Sc Phila, Pr 1872: 238-239

T2m Remarks on fossil mammals from Wyoming. Ac N Sc Phila, Pr 1872:240 242

72n Remarks on the action of wind and sand on rocks. Ac $\mathrm{N}$ Sc Phlla, $\operatorname{Pr} 1872$ : 243
Leidy, Joseph-Continued.

73 Contributions to the extinct vertebrate fauna of the Western Territories. U S G Geog S Terr (Hayden), Rp 1:358 pp, il (1873) Extract from introduction, Cin Q J Sc 1: 269-277 (1874)

73a [On fossils from Wyoming.] Ac $\mathrm{N}$ Sc Phila, $\operatorname{Pr} 1872: 267-268$ (1873)

73b Remarks on fossils from Wyoming. Ac N Sc Phila, Pr 1872:277 (1873)

73e Notice of fossil Vertebrata from the Miocene of Virginia. Ac N Sc Phila, Pr 1873:15 Am J Sc (3) 5:311-312 (1873)

73d Notice of remains of fishes in the Bridger Tertiary formation of Wyoming. Ac N Sc Phila, Pr 1873:97-99

73e Remarks on the occurrence of an extinct $\mathrm{hog}$ in America. Ac $\mathrm{N}$ Sc Phila, Pr 1873:207

73f Remarks on extinet mammals from California. Ac N Sc Phila, Pr 1873: 259260

74 Remarks on fossil elephant teeth. Ac N Sc Phila, Pr 1873: 416-417 (1874)

74a [Remarks on Thespesius and Ischyrotherium.] Ac N Sc Phila, $\mathrm{Pr}$ 1874: 74-75

74b Notice of remains of Titanotherium. Ac N Sc Phila, Pr 1874:165-166

75 Remarks on fossils presented. Ac N Sc Phila, Pr 1874: 223-224 (1875)

75a Remarks on a coal fossil, etc. [Pennsylvania]. Ac N Sc Phila, Pr 1875: 120

75b Remarks on elephant remains. Ac N Sc Phila, Pr 1875: 121

76 On Petalodus [apparently from green sand of New Jersey]. Ac $\mathrm{N}$ Sc Phlla, $\mathrm{Pr}$ $1876: 9$

76a Remrarks on fossils from the Ashley phosphate beds. Ac N Sc Phila, Pr 1876: $80-81,86-87,114-115$ Abst, Am J Sc (3) $12: 222-223$ (1876)

76b Fish remains of the Mesozoic red shales. Ac N Sc Phila, Pr 1876:81 Am J Sc (3) $12: 223 \quad(1876)$

76e Bituminous sediment of the Schuylkill River. Ac N Se Phila, Pr 1876:193

77 Description of vertebrate remains, chiefly from the phosphate beds of South Carolina. Ac N Sc Phila, J (2) 8:209261 , il (1877)

79 Fossil remains of a caribou. Ac N Sc Phila, Pr $1879: 32-33$

79a Fossil foot tracks of the anthracite coal measures. Ac N Sc Phila, Pr 1879: 164-165

80 Bone caves of Pennsylvania. Ac N Sc Phila, $\operatorname{Pr} 1880: 346-349$

81 Remarks on Bathygnathus borealis. Ac N Sc Phila, J (2) $8: 449-451$, 11 (1881)

82 Remarks on scme rock specimens [South Mountain, Berks Co., Pa., and Philadelphia gravels.] Ac N Sc Phila, Pr 1882: 10-12 
Leidy, Joseph-Continued.

S2a On tourmalines. Ae N Sc Phila, Pr $1882: 71-73$

$82 b$ Scolithus in gravel. Ac N Sc Phila, Pr 1882:93

83 On remains of horses. Ac N Sc Phila, Pr 1882: 290-291, il (1883)

83a On an extinct peccary. Ac $\mathrm{N}$ Sc Phila, Pr 1882 : 301-302 (1883)

83b A flint nodule from the greensand of New Jersey. Ac $\mathrm{N}$ Sc Phila, Pr $1883: 76$

84 Fossil bones from Loulsiana. Ac $\mathrm{N}$ Sc Phila, r 1884:22

S4a Foraminifera in the drift of Minnesota. Ac N Sc Phila, Pr 1884:22-23

84b Vertebrate fossils from Florida. Ac N Sc Phila, Pr 1884: 118-119.

s4e [On vertebrate remains from New Iberia, La.] Science 3:295 (1884)

85 Rhinoceros and Hippotherium from Florida. Ac N Sc Phila, Pr 1885:3233 , il

85a Remarks on $Z$ ir lodon. Ac N Sc Phila, Pr 1885 : 49-51, il

86 Mastodon and llama from Florida. Ac N Sc Phila, Pr 1886:11-12

86a An extinct boar from Florida. Ac N Sc Phila, Pr $1886: 37-38$, il

86b Caries in the mastodon. Ac $\mathrm{N}$ Sc Phila, Pr $1886: 38$

86e Toxodon and other remains from Nicaragua, C. A. Ac N Sc Phila, $\operatorname{Pr} 1886$ : 275-277, 11

87 Fossil bones from Florida. Ac N Se Phila, Pr $1887: 309-310$, il

s8 On a fossil of the Puma. Ac $\mathbf{N}$ Sc Phila, Pr 1888 : 9-10

89 Notice and description of fossils in caves and crevices of the limestone rocks of Pennsylvania. $\mathrm{Pa} \mathrm{G}$ S; An Rp 1887: $1-20$, il (1889)

89a The sabre-tooth tiger of Florida. Ac N Sc Phila, Pr 1889:29-31

89b Fossil vertebrates from Florida. Ac N Sc Phila, Pr 1889:96-97

89e Notice of some fossil human bones. Wagner Free I Sc, Tr 2:9-12, il (1889)

89d Description of mammalian remains from a rock crevice in Florida [Ocala, Marion Co.]. Wagner Free $I \mathrm{Sc}, \operatorname{Tr} 2$ : 13-17, il (1889)

89e Description of vertebrate remains from Peace Creek, Fla, Wagner Free I Sc, Tr 2:19-31, il (1889)

89R Notice of some mammalian remains from the salt mine of Petite Anse, Fla. Wagner Free I Sc, Tr $2: 33-40$, il (1889)

$\mathbf{8 9 g}$ On Platygonus, an extinct genus allied to the peccaries. Wagner Free I Sc, Tr 2: 41-50, il (1889)

90 Fossil vertebrates from Florida. Ac N Se Phila, Pr 1890:64-65
Leidy, Joseph-Continued.

90a Hippotherium and Rhinoceros from Florida. Ac N Sc Phila, Pr 1890:182. 183 , il

$90 \mathbf{b}$ Mastodon and Capybara of South Carolina. Ac N Sc Phila, Pr 1890: 184185

96 Fossil vertebrates from the Alachus clays of Florida, edited by Frederic $A$ Lucas. Waguer Free I Sc, $\operatorname{Tr} 4: 61 \mathrm{pp}, \mathrm{I}$ (1896)

\section{Leighton, Henry.}

o8 (and Bastin, E. S.) Road ma. terials of southern and eastern Maine. [ S Dp Agr, Off Public Roads, B 33:56 ph map (1908)

09 One hundred years of New York State geological maps, 1809-1909. N Y st Mus, B 133: 115-155 (1909)

10 The mining and quarry industry of New York State; report of operations and production during 1909 ; slate and stone. N Y St Nius, B 142: 70-88 (1910)

10a (with Newland, D. H.) Gypsum deposits of New York. N Y St Mus, B 143 $94 \mathrm{pp}$ (1910)

18 Pyrite in the coals of western Peno sylvania (abst) Science n 8 47:49 (1918)

See also Roberts, 16

Leighton, Morris Morgan.

13 An exposure showing post-Kansan glaciation near Iowa City, Iowa. J G 21 431-435 (1913)

13a Additional evidences of post-Kansat glaciation in Johnson Co., Iowa. Iowa dc Sc, Pr 20:251-256, map (1913)

15 Leaching of the Pleistocene drifts ot eastern Iowa (abst). Science n s 41:951 (1915)

16 The Pleistocene history of Iowa Rivet valley, north and west of Iowa City in Johnson Co. Towa G S 25:103-181 (1916)

$16 a$ Superimposition of Kansan drift on sub-Aftonian drift in eastern Iowa. Iowa Ac Sc, Pr 23: 133-139 (1916) Abst, Sclence $n$ s $44: 68$ (1916)

17 Post-Kansan erosion. Iowa $\mathrm{Ac} \mathrm{Sc}$, Pr 24:83-85 (1917)

17a The Buchanan gravels of Calvin and the Iowan valley trains. Iowa $\mathrm{Ac} \mathrm{Sc}$, Pr 24:86 (1917)

17b The Iowan glaciation and the $80^{\circ}$ called Iowan loess deposits. Iowa Ac Sc, Pr 24:87-92 (191')

17c (with Alden, W. C.) The Iowan drift; a review of the evidences of the Iowan stages of glaciation. Iowa G S, 26: 49-212, map (1917)

18 The country about Camp Lewis [Wash.]. Wash G S, B 18: 105 pp (1918) 
Ieith, Charles Kenneth.

93 Summaries of current North American pre-Cambrian literature. J G 6:527$541, \quad 739.753, \quad 840-854$ (1898); $7: 190$ $205,406-425,702-708,790-812$ (1899) ; $8: 433-443, \quad 512-525 \quad(1900) ; \quad 9: 79-87$, $441-458$ (1901) ; $10: 891-913$ (1902); 12 : $52-62, \quad 161-176 \quad(1904) ; \quad 13: 174-181$ (1905)

02 The Mesabi iron range (abst). Eng M J $73: 277$ (1902) Science n s 15:351 (1902)

03 The Mesabi iron-bearing district of Minnesota. U S G S, Mon 43:316 pp, maps (1903)

03a Geologic work in the Lake Superior iron district during 1902. U S G S, B 213: 247-250 (1903)

03b Moose Mountain iron range. Ont Bur Mines, Rp 1903: 318-321 (1903)

03e A comparison of the origin and development of the iron ores of the Mesabi and Gogebic iron ranges. L Sup M Inst, Pr 8:75-81 (1903)

04 The Lake Superior iron region during 1903. U S G S, B 225 ; 215-220 (1904)

04a Iron ores in southern Utah. U S G S, B 225: 229-237 (1904)

05 Rock cleavage. U S G S, B 239: 216 pp (1905)

05a A summary of Lake Superior geology with special reference to recent studles of the iron-bearing series. Am I M Eng, Bi-Mo B 3: 453-507, map (1905) ; Tr $36: 101-153$, map (1907) Reprinted in part in Emmons, S. F., Ore deposits : 633656 , map (1913)

$05 \mathrm{~b}$ Genesis of Lake Superior iron ores. Ec G 1:47-66 (1905)

06 Iron ores of the western United States and British Columbia. U S G S, B 285: 194-200 (1906)

06a The university training of engineers In economic geology. Ec G 1:479-481 (1906)

07 Iron ore reserves. Ec G 1:360-368 (1906) Smith Inst, An Rp 1906: 207-214 (1907)

07a The geology of the Cuyuna iron range, Minnesota. Ec G 2:145-152 (1907) 07b The metamorphic cycle. J G 15: 303-313 (1907)

07e (with Hobbs, W. H.) The preCambrian volcanic and intrusive rocks of the Fox River valley, Wis. Wis Univ, B 158 (Sc s 3 no 6) : 247-277 (1907)

08 The iron ores of Canada. Can M Inst, J $11: 91-105$ (1908) Ec G 3:276-291 (1908) Can M J 29:370-374 (1908)

$08 \mathrm{a}$ (and Harder, E. C.) The iron ores of the Iron Springs district, southern. Utah. U S G S, B 338: 102 pp, map (1908)

09 (with Van Hise, C. R.) Pre-Cambrian geology of North America. U S G S, B $360: 939$ pp (1909)
Leith, Charles Kenneth-Continued.

10 Discussion of review by J. F. Kemp of paper on Iron ores of Iron Springs, Utah. Ec G. $5: 188-192$ (1910)

10a An Algonkian basin in Hudson Fay; a comparison with the Lake Superior basin. Ec G 5: 227-246, map (1910)

11 Lake Superior type of iron-ore deposits. In Types of ore deposits (ed. by H. F. Bain) : 53-76 (1911)

$11 a$ (and Harder, E. C.) Hematite ores of Brazil and a comparison with hematite ores of Lake Superior. Ec G 6 : $670-686$ (1911)

$11 b$ (and Mead, W. J.) Origin of the iron ores of central and northeastern Cuba. Am I M Eng, B 51:217-229 (1911) ; Tr 42 : 90-102 (1912)

11e (with Van Hise, C. R.) The geology of the Lake Superior region. U S G S, Mon 52:641 pp (1911)

12 Use of geology in iron ore exploration. Ec G 7:662-675 (1912) Can M Inst, Tr $15: 552-566$ (1912)

12a (and Mead, W. J.) Metamorphic studies. J G 20:353-361 (1912)

12b Iron-ore reserves of Michigan. U $\mathbf{s}$ G S, Min Res 1911 pt $1: 175-190$ (1912)

13 Structural geology, 169 pp, N Y 1913, L. 1914

$13 a$ "Algonkian" vs. " pre-Cambrian". Ec G 8:507-508 (1913)

14 Relations of the plane of unconformity at the base of the Cambrian to terrestrial deposition in late pre-Cambrian time. Int G Cong, XII, 1913, C R : 335-337 (1914)

14a Pre-Cambrian correlation from a Lake Superior standpoint. Int $\mathrm{G}$ Cong, XII, 1913, C R : 409-421 (1914)

14b Notes on conservation of Lake Superior iron ores. Am I M Eng, B 86: $247-250$ (1914); $\operatorname{Tr} 50: 231-235$ (1915)

14e Recrystallization of limestone at igneous contacts. Ec G $9: 292-299$ (1914) Am I M Eng, B 90:1129-1134 (1914) ; Tr $48: 209-215$ (1915)

15 (and Mead, W. J.) Metamorphic geology; a textbook. 337 pp, N Y 1915

15a (and Mead, W. J.) Metamorphic studies; convergence to mineral type in dynamic metamorpbism. J G 23:600-607 (1915)

15b (and Allen, R. C.) Discussion of correlation [of pre-Cambrian formations of Lake Superior region]. J G 23: 703-729 (1915)

15e (and Mead, W. J.) Additional data on origin of lateritic iron ores of eastern Cuba. Am I M Eng, B 103:13771380 (1915) : Tr $53: 75-78$ (1916)

15d Influence of certain minerals on the development of schists and gneisses (abst). Sclence n s $42: 685$ (1915)

17 Iron ores of the Americas. Pan American Sc Cong, 2d, Washington, $\mathrm{Pr}$ sec 7 ₹ 8:954-959 (1917) 
Leith, Charles Kenneth-Continued.

18 International control of minerals. U

S G S, Min Res 1917 pt 1; 7a-16a (1918) 18a "War minerals" as a science. Eo

G $13: 497-499$ (1918))

See also Van Hise, 01

Lemos, Alix.

17 A new liquid damping contrivance for seismographs. Seism Soc Am, B 7 : 18-26 (1917)

Lenher, Victor.

07 (with Weidman, S.) Marignacite, a new variety of pyrochlore from Wausau, Wis. Am J Sc (4) $23: 287-292$ (1907)

09 Some observations on the tellurides. Ec G 4:544-564 (1909)

12 The transportation and deposition of gold in nature. Ee G $7: 744-750$ (1912)

14 On the deposition of gold in nature. Ec G 9:523-528 (1914)

16 The oxidation of manganese solutions in presence of the air. Ec G 11:115-117 (1916)

18 Further studies on the deposition of gold in nature. Ec G 13:161-184 (1918) Lenk, Hans.

90 (with Felix, J.) Beiträge zur Geologis und Paläontologie der Republik Mexim. Th 1: 114 pp, Leipzig 1890; Th 2: 252, iv pp. Leipzig 1893-99; Th 3 Palaeontographica $37: 117-210(1-78)$, fl, Stuttgart 1891

91 (with Felix, J.) Uebersicht ïber die geologischen Verhältnisse des mexicanischen Staates Puebla. Palaeontographica $37: 117-139$, il (1891)

92 (with Fellx, J.) Ueber die tektonischen Verhältnisse der Republik Mexico. Deut G Ges, Zs $44: 303-323$, map (1892)

94 (with Felix, J.) Ueber die mexicanische Vulcanspalte. Deut $\mathbf{G}$ Ges, Zs $46: 678-681$ (1894)

95 (with Felix, J.) Eeber das Vorkommen von Nummilitenschichten in Mexico. N Jb 1895 , II : 208-209

02 (with Felix, J.) Bemerkungen zur Topographie und Geologie von Mexico. Deut $\&$ Ges, Zs 54: 426-140 (1902)

Lennox, Arthur.

64 On the white limestone of Jamaica and its associated intrusive rocks (abst). Ph Mag (4) 28:159-160 (1864)

See also Sawkins, 69

Lennox, Thomas $H$.

86 The fossil sharks of the Devonian. Can Inst, $\operatorname{Pr}$ (3) $3: 120-121$ (1886)

Lenz, Oskar.

74 Specielle Darstellung der geologischen Verhältnisse Ostgrönlands. In Die zweite Deutsche Nordpolarfahrt in Bremen... Verein für die Deutsche Nordpolarfahrt in Bremen) 2:481-496, Leipzig 1874

Leonard, Arthur Gray.

94 Occurrence of zinc in northeastern Iowa. Iowa Ac Sc, Pr 1 pt $4: 48-52$ (1894)
Leonard, Arthur Gray-Continued.

94a Satin spar from Dubuque [Iowa], Iowa Ac Sc, Pr 1 pt 4:52-55 (1894)

95 Origin of the Iowa lead and zine de posits. Am G 16:288-294 (1895) Abst J G $4: 372$ (1896)

95a Lansing lead mines [Iowa]. Iowa Ac Sc, Pr $2: 36-38$ (1895)

96 Report [administrative]. Iowa G \& $5: 31$ (1896) ; 7:29-30 (1897)

$96 \mathbf{a}$ Recent developments in the $\mathrm{D}_{0}$ buque lead and zinc mines. Iowa $\mathrm{Ac} \mathrm{BC}$, Pr 3:64-66 (1896)

96b Lead and zinc deposits of Iowa. Eng M J 61:614 (1896)

96e A description of the [lead and zinc] mines of Iowa in the upper Mississippl region. Colliery Eng 17:121-122 (1896)

97 Lead and zinc deposits of Iowa. Iowa G S 6:9-66 (1897)

$97 \mathbf{n}$ Natural gas in the drift of Iowa. Iowa Ac $\mathrm{Se}$, Pr $4: 41-47$ (1897) Iowa Weather and Crop Service 8:7-9 (1897)

98 Geology of Dallas Co. Iowa G S 8: $51-118$, maps (1898)

osa (with Bain, H. F.) The middle coal measures of the western interior coal field. J G $6: 577-588$ (1898) Abst, G Soc Am, B 10:10-12 (1899); Am G 22:251 (1898): Science n 8 8:464 (1898)

01 Report of assistant State geologist Iowa G S $11: 31-32$ (1901) ; 12:28-32 (1902) ; 13:14-16 (1903)

01a The basic rocks of northeastern Maryland, and their relation to granite. Am G 28:135-176, map (1901)

02 Geology of Wapello Co. Iowa G 8 $12: 439-499$, map (1902)

04 State geological survey of North D: kota ; Third biennial report. $220 \mathrm{pp}$, maps Bismarck 1904

04a Topographic features and geological formations of North Dakota. N Dak G S Bien Rp 3:127-177 (1904)

06 Geology of Clayton Co. [Iowa]. Iowa G S 16:213-307, maps (1906)

06a The North Dakota-Montana lignite area. U S G S, B $285: 316-330$ (1906)

06b What should appear in the report of a State geologist? Ec G $1: 570-571$ (1906)

06e Administrative report. N Dak G S, Bien Rp 4:1-7 (1906)

o6d Stratigraphy of North Dakota clays. N Dak G S, Bien Rp 4:63-94, map (1906)

$\mathbf{0 7}$ The coal fields of parts of Dawson, Rosebud, and Custer cos., Mont. U S G S. B $316: 194-211$ (1907)

os (and others) Fifth biennial report State Geological Survey of North Dakota. 278 pp, Bismarck 1908

03a Geology of southwestern North Dakota, with special reference to the coal. N Dak G S, Bien Rp 5: 27-114 (1908) 
Leonard, Arthur Gray-Continued.

08b The geological history of North Dakota. N Dak G S, Bien Rp 5: 227-243 (1908)

09 (and Smith, C. D.) The Sentinel Butte lignite field, N. Dak. and Mont. U S G S, B $341: 15-35$, map (1909)

11 The Cretaceous and Tertiary formations of western North Dakota and eastern Montana. J G 19:507-547 (1911) Abst, G Soc Am, B $22: 722$ (1911)

11a Natural gas in North Dakota. U S G S, B 431: 7-10, map (1911)

11b The geologic map of North Dakota (abst). Science n s 33:464 (1911)

12 Description of the Bismarck quadrangle [N. Dak.]. U S G S, G Atlas B1smarck fol (no 181): 8 pp, maps (1912) Abst (by W. C. Alden), Wash Ac Sc, J 3: 466-467 (1913)

12a Administrative report. N Dak $G \mathrm{~S}$, Bien Rp 6:15-18 (1912)

12b The geology of south central North Daketa. N Dak G S, Bien Rp 6:21-99, map (1912)

13 The geological map of North Dakota. N Dak, Univ, Q J 4 no $1: 3-13$, map (1913)

16 Pleistocene drainage changes in western North Dakota. G Soc Am, B 27 : 295304,80 (abst) (1916)

16a The pre-Wisconsin drift of North Dakota. J G 24:521-532, map (1916)

16b The lignite deposits of North Dakota. N Dak, Univ, Q J 6:234-240 (1916)

17 The geological history of North Dakota. N Dak, Univ, Q J 7:228-235, map (1917)

Leonard, N. R.

75 Iowa County meteor and its meteorites. Am J Sc (3) 10:357-363 (1875)

Leonard, W. C.

18 Facts concerning the Kentucky ofl fields... $10 \mathrm{pp} \mathrm{[N} \mathbf{X}, 1918$ ]

Leonhard, Alexander $V$.

74 (with sehmidt, Adolph.) The lead and zinc regions of southwest Missouri. Mo G S, Rp 1873-4:381-502 (1874)

84 Notes on the mineralogy of Missouri. Ac Se St L, Tr 4: $440-452$ (1884)

84a on the occurrence of millerite in St. Louis. Ac Se St L, Tr $4: 493-495$ (1884)

Lereh, Otto.

90 (with Cammins, W. F.) A geological survey of the Concho country, State of Texas. Am G 5: 321-335, map (1890)

91 Remarks on the geology of the Concho country, State of Texas. Am G 7 : 73-77 (1891)

92 A preliminary report upon the hills of Louisiana north of the Vicksburg, Shreveport, and Pacifle R. R. La St Exp Sta, G Agr La pt 1:1-51 [1892]
[
Lereh, Otto-Continued.

98 A preliminary report upon the hills of Louisiana south of the Vicksburg, Shreveport and Pacific R. R. to Alexandria, La. La St Exp Sta, G Agr La pt $2: 53-158$ [1893]

LeRoy, Osmond Edgar (1873-1917).

01 Geology of Rigaud Mountain, Can. G Soc Am, B 12:377-394 (1901) Abst, Sclence n s 13:136-137 (1901); Can Rec Sc $8: 474$ (1902)

01 a [Report of field $x$ ork in the Montreal area, Que.] Can G S, Sum Rp 1900 (An Rp 13) : A 139-141 (1901)

04 (with Adams, F. D.) The artesian and other deep wells on the Island of Montreal [Que.]. Can G S, An Rp 14:0 74 pp, map (1904)

06 On surveys in New Westminster district and Texada Island, B. C. Can G S, Sum Rp 1906 : 31-34 (1906)

o7 The Marble Bay copper deposit [Texada Island, B. C.]. Can M J 28 (n s 1 no 7) : 200-202 (1907)

os Preliminary report on a portion of the main coast of British Columbia and adjacent islands included in New Westminster and Nanaimo districts. Can G S : $56 \mathrm{pp}$, map (1908)

09 Phoenix camp and Slocan district [B. C.]. Can G S, Sum Rp 1908:65-68 (1909)

10 Slocan distriet, B. C. Can G S, Sum Rp 1909:131-133 (1910); 1910:123-128 (1911)

12 The geology and ore deposits of Phoenix, Boundary district, B. C. Can G S, Mem $21: 110$ pp, maps (1912)

12a Geology of Nelson map area [West Kootenay district, B. C.]. Can G S, Snm Rp 1911: 139-157, map (1912)

13 West Kootenay and Boundary districts. Int $\mathrm{G}$ Cong, XII, Canada, Guide Book no 9:61-102, maps (1913)

13a Mother Lode and Sunset mines, Boundary district, B. C. Can G S, Mem $19: 56$ pp, maps (1913)

\section{Lesenllier,}

os Fragment sur la géologie de la Guadeloupe. J Phys 67:373-387 (1808)

Lesher, Carl F.

14 The Eden Ridge coal field, Coos Co., Oreg. U S G S, B 541: $399-418$, map (1914)

14n (with Rogers, G. S.) The use of thickness contours in the valuation of lenticular coal beds. Ec G 9:707-729 (1914)

15 Coal. U S G S, Min Res 1914 pt 2 : $587-746 ; 1915$ pt $2: 345-513 ; 1916$ pt 2 : 901-991 (1915-8)

17 (with Smith, G. O.) The cost of coal. Science n s 44:763-772 (1916) Am M Cong, 19th An Sess, Rp Pr: 452-464 (1917) Ec G $12: 42-55$ (1917) 
Lesley, J. Peter (1819-1903).

55 The Cumberland coal fields, Tenn. M Mag 5:45-52 (1855)

56 Manual of coal and its topography... 224 pp, Phila 1856

57 On the Broadtop coal basin in central Pennsylvania. Am As, Pr 10 pt $2: 78-81$ (1857) Abst, Edinb N Ph J n s 5:363364 (1857) ; Can J n s $2: 479-480$ (1857)

$\mathbf{5 7 a}$ (with Hall, James) Map illustrating the general geological features of the country west of the Mississippi River. [1857]

58 [On a curious reverse drainage near Ironton, Ohio.] Ac N Sc Phila, Pr 1858: 8-9

58a On three comparative sections of the Coal Measures in Kentucky, and in eastern and western Pennsylvania. Am As, $\operatorname{Pr} 11$ pt $2: 39-42$ (1858)

59 The iron manufacturer's guide to the furnaces, forges, and rolling mills of the United States... $\quad \mathbf{7 7 2}$ pp, N Y 1859

60 [Boulders in the highlands of Orange Co., N. Y.] Ac N Sc Phila, Pr 1860:97

$60 a$ [On the age of the White Mountains of New Hampshire.] Ac N Sc Phila, Pr 1860: 363-364

61 Note on Mr. Lesquereux's Table of comparative sections of Coal Measures. Am J Sc (2) 32:281-285 (1861)

62 [On the structure of a primary limestone bed on the Brandywine above Chad's ford, in illustration of the tongue structure of folded anticlinals.] Am $\mathrm{Ph}$ Soc, Pr 8: 281-283 (1862)

62a On the coal formation of southern Virginia. Am $\mathrm{Ph}$ Soc, $\operatorname{Pr} 9: 30-38$ (1862)

63 On the Coal Measures of Cape Breton, N. B. [in error for N. S.]. Am Ph Soc, Pr 9: 93-109, 167-170 (1863) (Revised) Am J Sc (2) 36:179-196 (1863)

$63 a$ [On a bitumen vein in Wood Co., W. Va.] Am Ph Soc, $\operatorname{Pr} 9: 183-197$ (1863)

65 On the recent discovery of lignite in Pennsylvania [and relations to the iron ore beds]. Am $\mathrm{Ph}$ Soc, $\operatorname{Pr} 9: 463-482$, map (1865)

65a on petroleum in the eastern coal field of Kentucky and records of borings in Pennsylvania. Am $\mathrm{Ph} \mathrm{Soc,} \operatorname{Pr} 10: 33-$ 68, 187-191, map (1865)

65b Note on the geological age of the New Jersey Highlands as held by Prof. H. D. Rogers. Am J Sc (2) 39:221-223 (1865)

66 [Borings in the petroleum region of Pennsylvania.] Am Ph Soc, $\mathrm{Pr} 10: 227-$ 241, map (1866)

69 Notes on a map intended to illustrate five types of earth surface in the United States, between Cincinnati and the Atlantic seaboard. Am Ph Soc, $\mathrm{Tr} \mathbf{n}$ $13: 305-312$, map (1869)
Lesley, J. Peter-Continued.

69 Section across the Alleghany Mos: tains, to illustrate the proportionate plia tion of the earth's surface to its radios Am Ph Soc, Pr 11: 115 (1869)

71 Recent exposure of a bed of soll brown hematite Iron ore in middle Pens sylvania. Am Ph Soc, Pr 12:16 (1871)

71a Note on an apparent violation d the law of regular progressive de-bitumit:zation of the American coal beds comis? east. Am Ph Soc, $\operatorname{Pr} 12: 125-138$, mas (1871)

71b Note on the titaniferous iron on belt, near Greensboro, N. C. Am Ph $\mathrm{S} \alpha$, Pr 12:139-158, map (1871)

72 Note on a fine upthrow fault at $\mathrm{Em}$ breeville Furnace in east Tennessee. An Ph Soc, Pr 12: 444-457, map (1872)

73 The geological structure of Tazewell, Russell, and Wise cos., in Virginia. An Ph Soc, Pr 12:489-513, map (1873)

$73 a$ A record of fourteen oil wells at Brady's Bend, Armstrong Co., Pa. Am Pl Soc, Pr 12: 562-570 (1873)

73b The iron ores of the South Moun tain, Cumberland Co., Pa. Am Ph Soc, Pt $13: 3-21$, map (1873)

73e ... Dunning's Creek fossil iron oft [Bedford Co., Pa.]. Am Ph Soc, Pr 13: 156-168, map (1873)

73d [Iron ores of middle Pennsylvanla.] $\mathrm{Am} \mathrm{Ph}$ Soc, Pr 13:264 (1873)

73e A study of the structure and erosion of Brush Mt., in Blalr Co., Pa. Am Pt Soc, Pr 13: 503-504, map (1873)

73e Topographical map of Pennsylvanis. colored for the principal geological forma tions. In Macfarlane, James, The coal re gions of America..., N Y 1873

$\mathbf{7 4}$ The brown hematite iron ore banks of that part of Nittany Valley...in Hunting. don and Centre cos., Pa... 99 pp, maps, Phila 1874

74a A collection of occasional surveys of iron, coal, and oil districts in the United States... Phila 1874

74b [On folding and faulting in middle Pennsylvania.] Am $\mathrm{Ph}$ Soc, Pr 14:2-4 (1874)

74c The brown hematite ore banks of Spruce Creek, Warrior's Mark Run, and Half Moon Run, in Huntingdon and Centre cos., Pa.. Am Ph Soc, Pr 14:19-83, 102107, map (1874)

75 [Report of progress for the year 1874 of the Second Geological Survey of Penn. sylvania.] xvil pp [1875]

75a Notes on the comparative geology of northeastern Ohio, northwestern Pennsylvania, and western New York. Pa G S. 2d, I : 57-108 (1875)

75b On a map and proflle of coal and oil measures along Slippery Rock Creek, in Lawrence Co., $\mathrm{Pa}$. $\mathrm{Pa} \mathrm{G} \mathrm{S}, 2 \mathrm{~d}, \mathrm{~J}: 90-$ 104, map (1875) 
Lesley, J. Peter-Continued.

75e Coal beds in the Subcarboniferous of Pennsylvania. Am J Sc (3) 10:153154 (1875)

75d On former mountain ranges in coutheastern Pennsylvania. $\mathrm{Am} \mathrm{Ph}$ Soc, Pr 14:436-437 (1875)

76 Historical sketch of geological explorations in Pennsylvania and other states; with an appendix containing the annual reports of the State geologist to the board of commissioners. $\mathrm{Pa} G \mathrm{~S}, 2 \mathrm{~d}, \mathrm{~A}: 200$, xxvi pp, Harrisburg 1876

76a The Boyd's Hill gas well at Pittsburgh [Pa.]. Pa G S, 2d, L : 217-237 (1876)

76b [On Ashburner's discovery of the age of the coal beds No. X in Huntingdon Co., Pa.] Am Ph Soc, Pr 14:638-639 (1876)

76e [On glacial blocks in West Philadelphia, Pa.] Am Ph Soc, Pr 14:644645 (1876)

76d On the "Fond des Mers" of $M$. Delesse. Am Ph Soc, Pr 16: 240 (1876)

77 Oil well records... of Pennsylvania. Am $\mathrm{Ph}$ Soc, $\operatorname{Pr} 16: 346-380$ (1877)

77a Memoir of Edward Hitchcock, 17931864. Nat Ac Sc, Biog Mem 1:113-134 (1877)

78 Preface [to report by J. H. Dewees on the fossil iron ore beds of the Juniata district]. Pa G S, 2d, F : vil-xlix (1878)

78a (and others) Report of progress in Bradford and Tioga cos. Pa G S, 2d, G: xil, $271 \mathrm{pp}$, maps (1878)

$78 b$ On a series of chemical analyses of Siluro-Cambrian limestone beds in Cumberland Co., Pa. Am Ph Soc, Pr $17: 260-266$ (1878)

78e On terrace levels in Pennsylvania. $\triangle \mathrm{m} \mathrm{J} \mathrm{Sc} \mathrm{(3)} \mathrm{16:68-69} \mathrm{(1878)}$

79 Note [on the classification of coals]. Pa G S, 2d, MM : 144-157 (1879)

$79 \mathrm{n}$ Notes on a series of analyses of the dolomitic limestone rocks of Cumberland Co., Pa. Pa G S, 2d, MM : 311-361 (1879) $79 b$ On the drift phenomena of the United States. Am Ph Soc, Pr 18: 85-86 (1879)

79e Notes on a series of analyses of the dolomitic limestone rocks of Cumberland Co., Pa, Am Ph Soc, Pr 18:114-120 (1879)

79d On the gas well at Murraysville, in Westmoreland Co., Pa. $\mathrm{Am} \mathrm{Ph}$ Soc, $\mathrm{Pr}$ 18:207-208 (1879)

79e Origin of pipe ore. G Mag (2) 6 : $459-460$ (1879)

80 (and others) The geology of Clinton Co. Pa G S, 2d, G4: xiv, 183 pp, maps (1880)

80a Sur les limites du terrain carbonifère et du terrain permien en Amérique d'après l'etude de leurs flores. Int G Cong, Paris 1878, C R : 130-135 (1880)
Lesley, J. Peter-Continued.

80b A Hudson River fossil plant in the roofing slate that is associated with chlorite slate and metamorphic limestone in Maryland, adjoining York and Lancaster counties, $\mathrm{Pa}$. Am J Sc (3) $19: 71-72$ (1880)

80e Ancient buried river channel crossing the Allegheny River. Am $\mathrm{Ph} \mathrm{Soc,} \mathrm{Pr}$ 18: 354 (1880)

sod Slab of roofing slate covered with casts of Buthotrephis flexuosa. Am Ph Soc, Pr 18:365-366 (1880)

81 [Remarks on the duplication of the Mountain limestone and the Mauch Chunk red shale formations.] Am Ph Soc, Pr 19: 110 (1881)

81 a [Remarks on Prof. Stevenson's conclusions respecting the date of the great Virginia faults.] Am $\mathrm{Ph}$ Soc, $\operatorname{Pr} 19: 155$ 156 (1881) The Virginias 2:92-93 (1881)

81b Notes on the models exhibited at the meeting Nov. 19, 1880 [Pa.] Am Ph Soc, Pr 19: 193-194 (1881)

81c Remarks on Prof. I. C. White's paper on the place of the Sharon conglomerate.] $\mathrm{Am} \mathrm{Ph}$ Soc, $\operatorname{Pr} 19: 202-203$ (1881)

s1d (with Jones, N. F.) Drillings for coal in Sergeant Township, McKean Co. Pa G S, 2d, R Appendix A : 35 pp (1881) ; RR : $327-362$ (1885)

S2 Glacial map of the Pocono Mountain Plateau and Delaware River Valley in Pike and Monroe cos. Pa G S, 2d, G6: xv-xix, map (1882)

82a [Discussion of the glacial theory.] Am Ph Soc, Pr 20:95-101 (1882)

82b On high-level drift. G Mag (2) 9 : 334-336 (1882)

83 (and others) The geology of Chester Co. Pa G S, 2d, C 4:394 pp, maps (1883) Rv by T. D. Rand, Franklin Inst, J 116 or (3) $86: 226-229$ (1883)

$83 a$ (and others) The geology of Lehigh and Northampton $\cos$. $\mathrm{Pa}$ G S, 2d, D3, 1: xxiv, $283 \mathrm{pp}$, atlas (1883)

83b Prefatory letter [to report of I. C. White on the Susquehanna River region]. Pa G S, 2d, G7 : v-xxvi (1883)

83e Note on the progress of the Second Geological Survey of Pennsylvania. Am Ph Soc, Pr 20:537-544 (1883)

s3d [On the exact equivalency of " Catskill" and "Ponent."] Am Ph Soc, Pr 20: $673-675$ (1883)

s3e Wright's ice dam at Cincinnati. Science $2: 436$ (1883)

84 [On quartz pebbles found in coal near Cannelton, Beaver Co., Pa.] Am Ph Soc, Pr 21:344 (1884)

84a [Remarks on the geology of southwestern Virginia.] $\mathrm{Am} \mathrm{Ph}$ Soc, $\mathrm{Pr} 21$ : 703-704 (1884)

85 A geological hand atlas of the sixtyseven counties of Pennsylvania. $\mathbf{P a} G \mathbf{S}$, 2d, X : 112 pp, maps (1885) 
Lesley, J. Peter Continued.

86 Annual report of the Geological Survey of Pennsylvania for 1885 : xxxix, 769 pp, maps, Harrisburg 1886; for 18s6, 4 pts : 1636 pp, maps (1887) ; for 1887: 105 pp (1889)

s6a The coal beds and fire clays of the Wellersburg basin in Somerset Co. Pa G S, An Rp $1885: 227-239$ (1886)

86b (and D'Invilliers, E. V.) Report on the Cornwall iron ore mines, Lebanon Co. Pa G S, An Rp 1885:491-570, man (1886)

s6e Some general considerations respecting the origin and distribution of the Delaware and Chester kaolin deposits. Pa G S, An Rp 1885: 571-591 (1886)

s6d ... pressure, quantity, composition, and fuel value of rock gas or the natural gas of the oil regions of Pennsylvania. Pa G S, An Rp 1885:657-680 (1886)

86e The geology of the Pittsburgh coal region. Am I M Eng, Tr 14:618-656, map (1886)

86f Dr. Orton's Ohio gas and oil report. Science 8:233-235 (1886)

87 Summary of the reports of the State geologist from 1874-1887. Pa G S (2) : $18 \mathrm{pp}$, Harrisburg 1887

89 (and others) Catalog of the geological museum, Part III [fossils, minerals, etc.]. Pa G S, 2d, OOO : 260 pp (1889)

s9n A dictionary of the fossils of Pennsylvania and neighboring States... Pa G S, 2d, P4: xiv, 1283, xili pp [in 3 vols], il (1889-90)

90 Obituary notice; Charles Albert Ashburner [1854-1889]. G Soc Am, B 1: 521-523 (1890)

90a Obituary notice of Charles Albert Ashburner. Am Ph Soc, $\operatorname{Pr}$ 28:53-59 (1890)

90b Biographical notice of Charles A. Ashburner. Am I M Eng, Tr 18:365-370 (1890)

90c Obituary notice of Leo Lesquereux. Am Ph Soc, Pr 28:65-70 (1890)

91 On the Grapeville gas wells [Westmoreland Co., Pa.] $\mathrm{Am} \mathrm{Ph}$ Soc, $\mathrm{Pr} 29$ : 11-16 (1891)

91 a on an important boring through 2000 feet of Trias in eastern Pennsylvania. Am Ph Soc, Pr 29:20-24 (1891)

$91 b$ Arteslan well in Lower Silurian limestone at Parkesburg, Pa. Am Ph Soc, Pr 29:45-47 (1891)

92 A summary description of the geology of Pennsylvania [in part by E. V. D'Invilliers and others]. $\mathrm{Pa} \mathbf{G} \mathrm{S}$, Final Rp, 3 vols, 2588 pp, il, atlas $(1892-5)$

95 Memoir of Leo Lesquereux, 18061889. Nat Ac Sc, Biog Mem 3:187-212 (1895)
Lesley, J. Peter-Continued.

See also Carll, 80, 83, 90 ; Chance, 78 , 80, 84; Claypole, 85; Dewees, 78; D' In. villiers, 91 ; Hall (C E), 81; Lesquereur. 86 ; Lewis (H C), 84 ; Platt (F), 77a: Platt (W G), 78, 80; Prime, 75; Sher. wood, 80a; Stevenson, 85; White (I C), $78,79,80,81,82,85$

Lesley, Joseph.

60 Survey of the Fourche Cove in $\mathrm{P}$. laski Co., Ark. In Owen, D. D, Second report of a geological reconnaissance of the middle and southern counties of As. kansas : 155-162, Phila 1860

61 Topographical and geological report of the country along the outcrop base line, following the western margin of the east. ern coal field of the State of Kentucky... Ky G S, Rp 4:439-494, map (1861)

62 Report [on the coal field around Cannelton, Perry Co.]. In Owen, Richard. Report of a geological reconnaissance of Indiana... : 343-345, Indianapolis 1862

73 The outcrop belt of the east Ken. tucky coal field. Am Ph Soc, Pr 13:270272, map (1873) Ky G s, Rp Prog 3 n s: 421-425, map (1877)

Leslie, E. H.

16 Tungsten in the Boulder district Colo. M Sc Press 113 : 353-355 (1916)

Lesquereux, Leo (1806-1889).

$\mathbf{5 2}$ On the coal bed of Zanesville [Ohio]. Boston Soc N H, Pr 4: 175-179 (1852)

52a Torfbildung im grossen Dismal Swamp. Deut G Ges, Zs 4 : 695-697 (1852)

54 New species of fossil plants from the anthracite and bituminous coal flelds of Pennsylvania, with introductory observa tions by H. D. Rogers. Boston $\mathrm{J} \mathrm{N} \mathrm{H} 6$ : 409-431 (1854)

57 Paleontological report of the fossil flora of the Coal Measures of the westem Kentucky coal field. Ky G S, Rp 3:499556 , il [pls. issued in brochure titled, Maps and illustrations referred to in vols. II t III of the report of the geological surves of Kentucky, 1857] (1857)

58 General remarks on the distribution of the coal plants in Pennsylvania, and on the formation of the coal. $\mathrm{G} \mathrm{Pa}$ [Rogers] 2: 837-847 (1858)

58a Description of the fossil plants found in the anthracite and bituminous coal measures of Pennsylvania. G Pa [Rogers] 2: 847-884, il (1858)

58b The fossil plants of the Coal Mess. ures of the United States with descriptions of the new species in the cabinet of the Pottsville Scientific Association. $24 \mathrm{pp}$, il, Pottsville 1858 Abst, Am J Sc (2) 26 112-113 (1858)

59 On some fossil plants of recent forma* tions. Am J Sc (2) $27: 359-366$ (1859) 
Lesquerenx, Leo-Continued.

59a On some questions concerning the coal formations of North America. Am J Sc (2) $28: 21-37(1859)^{5} ; 30: 63-74,367-$ ( $384(1860)$; 32:15-25, 193-205 (1861) ; $33: 206-216$ (1862) ; 35: 375-386 (1863)

60 Botanical and paleontological report on the geological state survey of Arkansas. In Owen, D. D., Second report of a geological reconnaissance of the middle and southern counties of Arkansas : 295-399, il, Phila, 1860

60a Note on Prof. Newberry's criticisms of Prof. Heer's determination of species of North American fossil plants. Am J Sc (2) $29: 434-436$ (1860)

$60 b$ On the formation of coal. M Mag (2) $1: 264-284 \quad(1560)$

61 On the fossil fruits found in connection with the lignites of Brandon, $v t$. Am J Sc (2) 32:355-363 (1861) Report on the geology of Vermont (Hitchcock) 2 : 712-718 (1861)

61a Report of the fossil flora and of the stratigraphical distribution of the coal in the Kentucky coal fields. Ky G $\mathbf{S}, \mathbf{R p}$ $4: 331-437$, il (1861)

62 Report on the distribution of the geological strata in the Coal Measures of Indiana. In Owen, Richard, Report of a geological reconnaissance of Indiarra... : 269-341, Indianspolis 1862

63 On the coal flora of America. Am $\mathrm{Ph}$ Soc, Pr 9:198-204 (1863)

65 On the origin and formation of prairies. Am J Sc (2) $39: 317-327 ; 40$ : 23-31 (1865) III G S $1: 238-254$ (1866) ; Ec G $1: 178-190$ (1882)

66 Report on the coal fields of Inlinois. IIl G S 1:208-237 (1866); Ec G 1:163177 (1882)

66a Report on the fossil plants of Illinois. III G S $2: 425-470$, il (1866)

68 [Notes on the fossil plants of the lignite beds of the West]. Am J Sc (2) $45: 205-208$ (1868)

68a On some Cretaceous fossil plants from Nebraska. Am J Se (2) 46:91-105 (1868)

68b [Observations on fossil plants of the coal formation of the Southwest.] Ac N Sc Phila, Pr 1868: 147-148

69 On Fucoides in the coal formations. Am Ph Soc, Tr n s 13:313-328, il (1869)

69a on species of fossil plants from the Tertiary of the State of Mississippl. Am $\mathrm{Ph}$ Soc, $\mathrm{Tr}$ n s $13: 411-433$, il (1869)

70 Report on the fossil plants of Illinois. Ill G S $4: 375-508$, il (1870)

71 On the fossil plants of the Cretaceous and Tertiary formations of Kansas and Nebraska. U S G S Wyo (Hayden), Prel Rp [4] : 370-385 (1871)

71n Mode of preservation of vegetable remains in our American coal measures. Am Nat $5: 340-353 \quad$ (1871)
Lesquereux, Leo-Continued.

72 An enumeration with descriptions of some Tertiary fossil plants from specimens procured in the explorations of Dr. F. V. Hayden in 1870. U S G S Terr (Hayden), An Rp 5 suppl : 22 pp, Washington 1872

72n Fossil flora. U S G S Mont (Hayden), An Rp 5: 283-318 (1872)

73 Lignitic formation and fossil flora. U S G S Terr (Hayden), An Rp 6:317427 (1873)

73a on the age of certain beds of Wyoming... Am J Sc (3) 5:308-309 (1873)

73b Age of the Rocky Mountain coal or lignitic formation. Am J Sc (3) 6: 441-450 (1873)

74 On the general characters and relation of the flora of the Dakota group. U S G Geog S Terr (Hayden), B [1] no 2: 52-62 (1874)

74a Contributions to the fossil flora of the Western territories; Part I, The Cretaceous flora. U S G Geog S Terr (Hayden), Rp 6:136 pp, il (1874)

$\mathbf{7 4 b}$ The lignitic formation and its fossil flora. U S G Geog S Terr (Hayden), An Rp [7] : $365-425$ (1874)

74e On the formation of the lignite beds of the Rocky Mountain region. Am J Sc (3) $7: 29-31 \quad(1874)$

74d On the remains of land plants in the Lower Silurian. $\mathrm{Am} \mathrm{J} \mathrm{Sc}$ (3) $7: 31-34$ (1874) Cin Q J Sc 1:43-45 (1874)

74e On the age of the lignitic formations of the Rocky Mountains. Am J Sc (3) $7: 546-557$ (1874)

75 Geological and geographical distribution of petroleum deposits and fucoidal remains. Pa G S, 2d, J: 104-107 (1875)

$75 \mathrm{a}$ A review of the fossil flora of North America. Penn Mo 6:591-603, 642-655 (1875)

76 A review of the fossil flora of North America. U S G Geog S Terr (Hayden), B [1] no 5 (2) : 233-248 (1876)

76a On some new species of fossil plants from the lignitic formations. U S G Geog S Terr (Hayden), B [1] no 5 (2) : 363389 (1876)

76b New species of fossil plants from the Cretaceous formation of the Dakota group. U S G Geog S Terr (Hayden), B [1] no 5 (2) : $391-400$ (1876)

76e On the Tertiary flora of the North American lignitic, considered as evidence of the age of the formation. U S G Geog $\mathrm{S}$ Terr (Hayden) An Rp [8]: 275-315 (1876)

76d A review of the Cretaceous flora of North America. U S G Geog S Terr (Hayden), An Rp [8] : 316-365, il (1876)

76e Species of fossil marine plants from the Carboniferous measures. Ind $\mathbf{G} \mathbf{S}, \mathbf{A n}$ Rp $7: 134-145$, 11 (1876) 
Lesquerenx, Leo-Continued.

76f Partial list of coal plants from the Alabama fields and discussion of the geological positions of several seams. Ala G S, Rp Prog 1875: 75-82 (1876)

77 On the progress of the North $A$ merican Carboniferous flora... $\mathrm{Am} \mathrm{Ph}$ Soc, $\mathrm{Pr}$ $16: 397-416(1877)$

78 Contributions to the fossil flora of the Western Territories: Part 2, The Terliary flora. U S G S Terr (Hayden), Rp $7: \mathrm{xv}, 366 \mathrm{pp}$, il (1878)

7Sa Illustrations of Cretaceous and Tertiary plants of the Western territories of the United States. U S G Geog S Terr (Hayden) : pls and expl (1S78)

781 Remarks on specimens of Cretaceous and Tertiary plants secured by the survey in 1877 ; with a list of the species hitherto described. U S G Geog S Terr (Hayden), An Rp 10:481-520 (1878)

78e Report on the fossil plants of the auriferous gravel deposits of the Sierra Nevada. Harvard Coll, Mus C Z, Mem 6 no $2: 62 \mathrm{pp}$, il (1878) Also in Contributions to American geology, vol. 2

7Sd Land plants, recently discovered in the Silurian rocks of the United States. Am Pli Soc, Pr $17: 163-173$, il (1878)

7se A species of fungus recently discovered in the shales of the Darlington coal bed (lower Productive Coal Measures, Allegheny series) at Cannelton in Beaver Co., Pa. Am Ph Soc, Pr $17: 173-175$, il (1878) Pa G S, 2d, Q : xlvii-li, il (1878)

$78 f$ on the Cordaites and their related generic divisions in the Carboniferous formations of the United States. Am. Ph Soc, Pr $17: 315-335$, il (1878)

79 On a branch of Cordaites, bearing fruit. $\mathrm{Am} \mathrm{Ph}$ Soc, $\mathrm{Pr} 18: 222-223$, il (1879)

so Description of the coal flora of the Carboniferous formation in Pennsylvania and throughout the United States. Pa G $\mathrm{S}$, $2 d, P: 977$, 1xili pp, il [3 vols, and atlas (1879) ] (1880-4)

81 Report on the recent additions of fossil plants. Harvard Coll, Mus C Z, B 7 (g s 1) : 225-230 (1881)

82 On some specimens of Permian fossil plants from Colorado. Harvard Coll, Mus C Z, B 7 (g \& 1 ) : 243-247 (1882)

82a Remarks on the Cretaceous and Tertiary flora of the Western territories. Am Nat 16:102-108 (1882)

82b On the Tertiary flora as related to the Tertiary animals of the West. Am Nat $16: 602$ (1882)

83 Contributions to the fossil flora of the Western territories; Part III, The Cretaceous and Tertiary floras. U S G S Terr (Hayden), Rp, 8:xii, 283 pp, il (1883)

S3a Contributions to the Miocene flora of Alaska. U S Nat Mus, Pr 5:443-449, il (1883)
Lesquereux, Leo-Continued.

84 Principles of Paleozoic botany the fauna of the Coal Measures. Ind G N H, An Rp 13 pt 2: 7-106, il (18s4)

84a Cretaceous leaves. Minn G \&, Rp 12:11-13 (1884)

84b The Carboniferous flora of $\mathrm{Rh}$ Island. Am Nat 18:921-923 (1884)

86 On the vegetable origin of coal [n] notes by J. P. Lesley]. Pa G S, An 1885: 95-124 (1886)

87 On the character and distributic of Paleozoic plants. Pa G S, An Rp lo pt 1:457-522 (1887)

87a List of recently identified for plants belonging to the United States $\mathrm{X}$ tional Museum, with descriptions of seres new species [compiled by F. H. Knowitor] U S Nat Mus, Pr $10: 21-46$, il (1887)

S7b Professor L. F. Ward's Synopsis the flora of the Laramie group. Am Sc (3) $34: 487-488$ (1887)

8S Fossil plants collected at Golde Colo. Harvard Coll, Mus C Z, B 16 s 2) : 43-59 (1888)

$88 a$ Recent determinations of fosi plants from Kentucky, Loulsiana, Oregi California, Alaska, Greeniand, etc., i: descriptions of new species [compiled F. H. Knowlton]. U S Nat Mus, Pr ll $11-38$, il $(1888)$

S8b List of fossil plants collected... Black Creek, near Gadsden, Ala., with s scriptions of several new species [cot piled by F. H. Knowlton ]. U S Nat It Pr 11:83-87, il (1888)

89 Fossil plants of the Coal Measurs of Rhode Island. Am J Sc (3) $37: 224$ 230 (1889)

90 Remarks on somre fossil remains w sidered as peculiar kinds of marine plats U S Nat Mus, Pr 13:5-12, il (1890)

92 The flora of the Dakota group, editk by F. H. Knowlton. U S G S, Mon 1t: $400 \mathrm{pp}$, il (1892)

93 The genus Winchellia. Am G 11: $209-213$, il (1893)

95 Cretaceous fossil plants from Mis nesota. Minn G S, Final Rp 3 pt 1:1-24 Il (1895) Abst, Minn, Univ, Q B 1:116 119 (1893)

Le Sueur, Charles Alexander (1778-1846)

18 Observations on a new genus of for sil shells [Machurea]. Ac N Sc Phila, 1: $310-313$, il (1818)

27 (with Troost, G.) Calamine in Mis souri; lead ores of Missouri. Am J Sc 12: 376-378, 379-380 (1827)

Lentrange, C. M.

10 Gem districts of San Diego Co., Cal M Science 61:469 (1910)

Letson, Elizabeth J.

01 Post-Pliocene fossils of the Niagarl River gravels. N Y St Mus, B 45:238252, il (1901) Buffalo Soc N Sc, B ? 238-252, il (1901) 
Lett, Stephen J.

12 Persistence of ore in depth. M Sc Press 105: 801-802 (1912)

13 The occurrence of gold in Ontario (discussion). Inst $\mathrm{M}$ Met, B 111:46-47 (1913)

Leuehs, Kurt.

os Ueber einige Invertebraten aus dem Perm von Texas. Centralbl Miner 1908: 684-690

\section{Lensehner, A. O.}

98 The earthquakes of March 30 and April 14 [1898]. [Cal] Univ Chronicle 1: 169-175 (1898)

06 The [San Francisco] earthquake. M Sc Press 92:274 (1906) Reprinted in After earthquake and fire:41-44, San Francisco 1906

Leverett, Frank.

89 Raised beaches of Lake Michigan. Wis Ac Sc, Tr 7: 177-192 (1889)

$\mathbf{8 9 a}$ Studies in the Indiana natural gas field. $\mathrm{Am} \mathrm{G} \mathrm{4:6-21} \mathrm{(1889)}$

89b on the occurrence of the "forest bed" beneath intramorainic drift (abst). Am As, Pr $37: 183-184$ (1889)

89e Glacial phenomena of northeastern Illinois and northern Indiana (abst). Am Nat 23: 808 (1889) $\Delta \mathrm{m}$ As, Pr 38: 248 (1890) Nature 40:557-558 (1889)

90 Changes of climate indicated by interglacial beds and attendant oxidation and leaching. Boston $\mathrm{Soc} \mathrm{N} \mathrm{H}, \mathrm{Pr} 24$ : 455-459 (1890)

90a Glacial studies bearing on the antiquity of man (abst). Boston Soc N H, Pr 24: 585-586 (1890)

91 Pleistocene fluvial planes of western Pennsylvasia. Am J Sc (3) 42:200-212, map (1891)

91a The Cincinnati ice dam (abst). Am G $8: 232-233$ (1891) Am As, Pr 40:250251 (1892)

92 On the correlation of moraines with raised beaches of Lake Erie. Am J Sc (3) 43:281-301, map (1892) Wis Ac Sc, Tr 8:233-240, map (1892) Abst, J G 1:99$100(1893)$

92a $O n$ the significance of the white clays of the Ohio region. Am G $10: 18-24$ (1892)

92b Relation of a Loveland, Ohio, implement-bearing terrace to the moraines of the ice sheet $(a b s t)$. Am As, Pr $40: 361$ 362 (1892)

92e Notes bearing upon changes in the preglacial drainage of western Illinois and eastern Iowa (abst). Am As, Pr 41: 176 (1892) Am G 10:220 (1892)

93 The glacial succession in Ohio. J G 1:129-146, map (1893)

93a Supposed glacial man in southwestern Obio. Am G 11: 186-189 (1893)

93b Relation of the attenuated drift border to the outer moraine in Ohio. Am G $11: 215-216$ (1893)
Leverett, Frank-Continued.

93e Changes of drainage in Rock River basin in Illinois (abst with discussion). Am G 12: 179-180 (1893) Am As, Pr 42: 179 (1894)

93 a Evidences of the diversity of the older drift in northwestern Illinois (abst). Am G 12:229 (1893)

94 (with Chamberlin, T. C.) Further studies of the drainage features of the upper Ohio basin. Am J Sc (3) $47: 247$ 283,483 (1894)

94a (with Chamberlin, T. C.) Certain features of the past drainage systems of the upper Ohio basin (abst, with discussion). Am G 13:217-219 (1894)

95 Soils of Illinois. In Illinois Board of World's Fair Commissioners at the World's Columbian Exposition [Chicago 1893], Report: 77-82, map, Springfield 1895

95a On the correlation of New York moraines with raised beaches of Lake Erie. Am J Sc (3) 50:1-20, map (1895)

956 The preglacial valleys of the Mississippi and its tributaries. J G $3: 740-763$ (1895)

96 The water resources of Illinois. U S G S, An Rp 17 pt 2:695-828, maps (1896)

$96 a$ The glacial deposits of Indiana. The Inland Educator 3:24-32, maps, Terre Haute, Ind., 1896

$96 \mathbf{b}$ The relation between ice lobes south from the Wisconsin Driftless Area (abst). Am G 17:102 (1896) Science n s 3:54 (1896) J G 4:757 (1896)

96e The loess of western Illinois and southeastern Iowa (abst). Am G 17:102103 (1896) Science n s 3:54-55 (1896) J G 4:244 (1896)

97 The water resources of Indiana and Ohio. U S G S, An Rp 18 pt 4:419-559, maps (1897)

$\mathbf{9 7 a}$ The glacial deposits of Indiana. In Dryer, C. R., Studies in Indiana geography ; first series: 29-41, map, Terre Haute, Ind., 1897

97b The Pleistocene features and deposits of the Chicago area. Chicago Ac Sc, G N H S, B 2: 86 pp, maps (1897)

$97 \mathrm{C}$ Changes in arainage in southern Ohio. Denison Univ, Sc Lab, B 9 pt 2:1821 (1897)

$97 \mathbf{1}$ On the changes of drainage in the Ohio River basin (abst). Science n s 5:85 (1897)

97e The relation of an abandoned river channel in eastern Iowa to the western edge of the Illinois ice lobe (abst). Science n 8 5:89 (1897)

98 The weathered zone (Sangamon) between the Iowan loess and Illinoian till sheet. I G 6:171-181 (1898) Iowa Ac Sc, $\operatorname{Pr} 5: 71-80$ (1898) Abst, Am G 21: 254-255 (1898) 
Leverett, Frank-Continued.

98a The weathered zone (Yarmouth) between the Illinoian and Kansan till sheets. Iowa Ac Sc, Pr 5: 81-86 (1898) J G $6: 238-243$ (1898) Abst, Am G 21: 254 (1898)

$98 b$ Correlation of moraines with beaches on the border of Lake Erie. Am G 21: 195-199 (1898)

98e The Peorian soil and weathered zone (Toronto formation?). J G $6: 244-$ 249 (1898)

99 The Illinois glacial lobe. U S G S, Mon $38: 817 \mathrm{pp}$, maps (1899)

99a Wells of northern Indiana. U $\mathbf{S}$ G S, W-S P 21: 82 pp, maps (1899)

$99 b$ Wells of southern Indiana. U S G S, W-S P 26:64 pp (1899)

99e The lower rapids of the Mississippi River. J G 7:1-22, map (1899) Iowa Ac Sc, $\operatorname{Pr} 6: 74-93$, map (1899)

99d Glacial phenomena of central Ohio (abst). Science n s 10:487-488 (1899) G Soc Am, B 11:2 (1900)

00 (with Campbell, M. R.) Description of the Danville quadrangle [III.-Ind.]. U S G S, G Atlas Danville fol (no 67) : $10 \mathrm{pp}$, maps (1900)

o1 Old channels of the Mississippi in southeastern Iowa. Annals of Iowa (3) $5: 38-51$, map (1901)

01a Glacial investigations in Michigan (abst). Science n s 13:616 (1901)

02 Glacial formations and drainage features of the Erie and Ohio basins. U S G S, Mon 41: 802 pp, maps (1902)

02a Report on the surface geology of Alcona Co., Mich. Mich G S, Rp 1901: 35-64, map (1902)

03 Summary of the literature of North American Pleistocene geology, 1901-1902. J G $11: 420-428,498-515,587-611$ (1903)

03a Glacial features of lower Michigan (abst). Science n s 17:224 (1903) J G 11: 117-118 (1903)

04 Glacial gravels [of the Kittanning quadrangle Pa.]. U S G S, G'Atlas Kittanning fol (no 115) : 9-10 (1904)

O4a Review of the glacial geology of the southern peninsula of Michigan. Mich Ac Sc, Rp 6: 100-110 (1904)

04b [Glacial geology of the Grand Rapids area.] Mich G S, 9 pt $2: 56-59$ (1904)

04e The loess and its distribution. Am G $33: 56-57$ (1904)

o5 [Underground waters of] Illinois ; Indianä; Ohio. U S G S, W-S P 114: 248270 , maps (1905)

O5a [Drumlins in the Grand Traverse region, Mich. (abst).] Science n s 21: 220 (1905) Sc Am Sup 59: 24326 (1905)

06 Drumlins in the Grand Traverse region of Michigan (abst). G Soc Am, B $16: 577$ (1906)
Leverett, Frank-Continued.

o6n Flowing-well districts in the east. ern part of the northern peninsula of Michigan. U S G S, W-S P 160:29-53 (1906)

O6b (and others) Flowing wells and municipal water supplies in the southern portion of the southern peninsula of Micht. gan. U S G S, W-S P 182: 292 pp, map (1906)

o6e Dr. I. C. Russell. Mich Ac Sc, B 3 no $1: 1-2$ (1906)

o6a Geological conditions of municipal and institutional water supplies in Michlgan. Mich Ac Sc, Rp 8: 99-105 (1906)

o7 (and others) Flowing wells and municipal water supplies in the middle and northern portions of the southern peninsula of Michigan. U S G S, W-S P 183: 393 pp (1907)

$07 \mathbf{a}$ The glacial deposits of Indiana. In Dryer, C. R., Studies in Indiana geog. raphy : 29-40, Terra Haute, Ind. 1907

os Geschichte der Eiszeit in Nord-amerika (abst). Naturw Wochensch 23:635637 (1908)

OSa (with Russe11, I. C.) Description of the Ann Arbor quadrangle, Mich. U \& G S, G Atlas Ann Arbor fol (no 155):15 pp, maps (1908)

09 Weathering and erosion as time measures, Am J Sc (4) $27: 349-368$ (1909)

10 Comparison of North American and European glacial deposits. Zs Gletscherk $4: 241-295,321-342$ (1910) [Rv, Chamberlin ( $\mathrm{T} C), 10$ ]

$10 a$ Outline of the history of the Great Lakes. Mich Ac Sc, Rp 12: 19-42 (1910)

10b Glacial investigations in the Lake Superior region in 1909 (abst). Q Soc Am, B 21: 762 (1910)

11 Surface geology of the northern peninsula of Michigan, with notes on agricultural conditions and water power. Mich G S, Pub 7 ( $\mathrm{g}$ s 5) : 91 pp, map (1911)

12 Surface geology and agricultural conditions of the southern peninsula of Michigan. Mich G S, Pub 9 (g s 7 ): 144 pp, maps (1912)

12a Postglacial erosion and oxidation (discussion). G Soc Am, B 23: 295 (1912)

12b Glacial investigations in Minnesota in 1911 (abst). Selence $n$ s $35: 315$ (1912); (with discussion by J. B. Tyrrell and Warren Upham), G Soe Am, B 23: 732-735 (1912)

12e Correlation of Lake Agassiz with glacial lakes in Great Lakes basins (abst). Mich Ac Sc, Rp 14:115 (1912)

13 Field and office methods in the preparation of geologic reports; field methods of glacial geology. Ec G 8:581-588 (1913)

$13 a$ Time relations of glacial lakes in the Great Lakes region (abst). Wash Ac Sc, J 3: 237-238 (1913)

13b Beginnings of Lake Agassiz (abst). G Soc Am, B 24: 697 (1913) 
Leverett, Frank-Continued.

13e Remarkable deformation of the Algonquin Beach (abst, with discussion by J. W. Goldthwait). G Soc Am, B 24:697 (1913)

13d Iowan drift (abst, with discussion by A. P. Coleman). G Soc Am, B 24:698699 (1913)

13e Early stages and outlets of Lake Agassiz. N Dak, Agr Coll S, Bien Rp 6: 17-28, map [1913]

14 The Pleistocene [of Minnesota with special reference to clay]. Minn G $\mathbf{S}, \mathbf{B}$ $11: 30-32$ (1914)

14a Map of the suriace formations of Minnesota. Sheet 1 [northwest quarter of State]. Scale 1:500,000. Minn G S, 1914

14b Observations on Craighton Lake [Ohio]. Am J Sc (4) 38:432-436, map (1914)

14e Notes concerning the features of St. Joseph Island, Lake Huron, Ont. Can G S, Sum Rp 1912: 271-274, map (1914)

14d Earth-movements in the Minnesota portion of the Lake Agassiz Basin during and since the lake occupancy (abst with discussion). G Soc Am, B 25: 34-35 (1914)

14e Problems of the glacial geologist (abst). Wash Ac Sc, J 4: 171-172 (1914)

15 (and Taylor, F. B.) The Pleistocene of Indiana and Michigan and the history of the Great Lakes. U S G S, Mon 53:529 pp, maps (1915) Abst, Wash Ac Sc, J 6 : $18-20 \quad(1916)$

15a Surface formations and agricultural conditions in northwestern Minnesota. Minn G S, B 12:78 pp, maps (1915)

16 (and Sardeson, F. W.) Map of the surface formations of Minnesota. Sheet 3 of A [southern part of State]. Scale 1: 500,000 . Minn G S 1916 .

16a Pleistocene deposits of Minnesota and adjacent districts (abst). G Soc Am, B 27:68-69 (1916)

17 Surface geology and agricultural conditions of Michigan. Mich G S, Pub 25 (g s 21) : 223 pp, map (1917)

17 a (and Sardeson, F. W.) Surface formations and agricultural conditions of northeastern Minnesota. Minn G S, B 13: 72 pp, maps (1917)

17b Glacial lakes and their correlative ice borders in the Superior basin (abst). Mich Ac Sc, An Rp 19:101-102 (1917)

17e Glacial formations in the western United States (abst, with discussion by G. F. Wright). G Soc Am, B $28: 143-144$ (1917)

18 The country around Camp Custer [Mich.]. [Text on back of topographic map], Michigan, Camp Custer quadrangle, U S G S (1918)

18a Features of the country around Camp Custer [near Battle Creek, Mich.] $(a b s t)$. Mich Ac Sc, An Rp 20:53-54 (1918)
Leverett, Frank-Continued.

18b Glacial lakes of Saginaw basin in relation to uplift $(a b s t)$. G Soc Am, B $29: 75$ (1918)

18c Drainage features and uplift of shore lines in Elsie and Perrinton quadrangles [Mich,] (abst). Mich Ac Sc, An Rp 20:55 (1918)

See also Carman, 12; Chamberlin, 10; Fairchlld, 18; Goldthwait, 13; Hotchkiss, 17 ; Johnston (W A), 17b; Kay (G F), 16d, 18; Shaw, 18a ; Shimek, 12c ; Tomlinson, 18; Upham, 94b.

Levette, Gilbert $M$.

74 Report of observations made in the counties of DeKalb, Steuben, Lagrange, Elkhart, Noble, St. Joseph and Laporte. Ind G S, An Rp 5:430-474 (1874)

76 Observations on the depth and temperature of some of the lakes of northern Indiana. Ind $\mathrm{G} S$, An Rp $7: 469-503$ (1876)

Levison, Wallace Goold.

03 Notes on fluorescent gems (abst). Science n s 18:789-790 (1903) Am G $33: 57-58$ (1904)

09 On the origin and sequences of the minerals of the Newark (Triassic) igneous rocks of New Jersey. N Y Ac Sc, An 19: 121-134 (1909) N Y Miner Cl, B 1:11-24 (1909)

13 Illustrations of mineral associations by means of color plate and other photographs of opaque specimens (abst). N Y Ac Sc, An 22:356-357 (1913)

16 Columnar manganocalcite from Franklin Furnace, N. J. Am Mineralogist 1:5 (1916)

18 Notes on gageite from Franklin Furnace, N J. Am Mineralogist 3: 153 (1918) Lếvy, Auguste Michel.

02 Sur la composition des cendres projetées le 3 mai 1902 par la Montagne Pelée. Ac Sc Faris, C R 134:1123-1124 (1902)

02a L'éruption de la Montagne Pelée et les volcans des petites Antilles. Rv Gén Sciences 13: 554-557 (1902)

Levy, Louis Edward.

o7 In memoriam; Angelo Heilprin. Franklin Inst, J $164: 313-326$, port (1907)

Lewington, Guy A. R.

09 White River copper properties [Alaska]. M Sc Press 99:755-756 (1909) Lewis, Elias, $j \mathrm{r}$.

66 Evidence of a probable modern change of level on the coast of Florida. $\mathrm{Am} \mathrm{J} \mathrm{Sc}$ (2) $41: 406$ (1866)

68 Evidences of coast depression along the shores of Long Island (abst). Am Nat 2: 334-336 (1868)

73 Boulder-like masses of clay in the Long Island drift. Pop Sc Mo 2:634 (1873)

76 The formation of sand dunes. Pop Sc Mo $8: 357-363$ (1876)

77 On watercourses upon Long Island

[N. Y.]. Am J Sc (3) 13:142-146 (1877) 
Lewis, Elias, jr.-Continued.

$\mathbf{7 7 a}$ Certain features of the valleys or watercourses of southern Long Island. Am $\mathrm{J} \mathrm{Sc} \mathrm{(3)} 13: 215-216,235-236$ (1877)

$\boldsymbol{7} \boldsymbol{7 b}$ Ups and downs of the Long Island coast. Pop Sc Mo 10:434-446 (1877)

89 Woodham artesian well, on Long Island, two miles east of East New York. Am J Sc (3) $37: 233$ (1889)

Lewis, Farmon.

11 The theory of isostasy, J G 19: 603-626 (1911)

Lewis, Henry Carvill (1853-1888).

76 On strontianite and associated minerals in Mifflin Co. [Pa.]. Ac N Sc Phila, Pr 1876: 11-12

so The optical characters of some micas. Ac N Se Phila, Pr 1880:244-251; Min G Sec, Pr no 1:8-15 (1880)

soa on an exfoliating talc. Ac $\mathrm{N}$ Se Phila, Pr 1880 : 252-253; Min G Sec, Pr no $1: 16-17$ (1880)

sob on siderophyllite, a new mineral [Pike's Peak, Colo.]. Ac N Sc Phila, Pr 1880:254-255; Min G Sec, Pr no 1: 18-19 (1880)

80e On sterlingite and damourite [Sterling, Mass.] Ac N Sc Phila, Pr 1880: 256: Min G Sec, Pr no 1: 20 (1880)

sod Vanadium in Philadelphia rocks. Ac N Sc Phila, Pr 1880:256-257; Min G Sec, $\operatorname{Pr}$ no $1: 20-21$ (1880)

soe The surface geology of Philadelphia and vicinity. Ac $\mathrm{N}$ Sc Phila, $\mathrm{Pr}$ 1880:258-272; Min G Sec, Pr no $1: 22$ $36(1880)$

sof On the Bryn Mawr gravel [southeastern Pa.]. Ac N Sc Phila, $\operatorname{Pr} 1880$ : 277-278; Min G Sec, Pr no $1: 41-42$ (1880)

$80 \mathrm{~m}$ on dendrites. Ac $\mathrm{N}$ Sc Phila, Pr 1880: 278-279; Min G Sec, Pr no $1: 42-43$ (1880)

Soh On a Jurassic sand [Maryland and New Jersey]. Ac N Sc Phila, Pr 1880: 279; Min G Sec, $\operatorname{Pr}$ no 1: 43 (1880)

801 The minerals of Surry Co., N. C. Ac N Sc Phila, Pr 1880:280; Min G Sec, Pr no 1: 44 (1880)

$\mathbf{8 0 j}$ A new locality for lignite [Montgomery Co., Pa.]. Ac N Sc Phila, Pr 1880: 281: Min G Sec, $\operatorname{Pr}$ no 1:45 (1880)

sok On serpentine in Bucks Co. [Pa.]. Ac N Sc Phila, Pr 1880:281; Min G Sec, Pr no 1:45 (1880)

801 The iron ores and lignite of the Montgomery Co. valley. Ac N Sc Phila, $\mathrm{Pr}$ 1880 : 282-291; Min G Sec, Pr no $1: 46-55$ (1880)

$80 \mathrm{~m}$ on a new fucoidal plant from the Trias. Ac N Sc Phila, Pr 1880:293294, il ; Min G Sec, $\operatorname{Pr}$ no $1: 57-58$, il (1880)

80n The Trenton gravel and its relation to the antiquity of man. Ac N Sc Phila, Pr 1880:296-309; Min G Sec, Pr no $1: 60-73(1880)$
Lewis, Henry Carvill-Continued.

soo On philadelphite [Philadelphis, Pa.]. Ac N Sc Phila, Pr 1880:310, 313328; Min G Sec, $\operatorname{Pr}$ no $1: 74,77-92$ (1880)

80p A Potsdam sandstone outcrop on the South Valley Hill of Chester Valler [Montgomery Co., Pa.] Ac N Sc Phila, Pr 1880: 329 ; Min G Sec, Pr no 1:93 (1880

soa The iron ores of the Brandon period (abst). Science (ed, Michels) 1:164 (1880) Am As, Pr 29:427-428 (1881)

80r The antiquity of man in eastern America, geologically considered. Science (ed, Michels) 1: 192-193 (1880)

81 The antiquity and origin of the Tren ton gravels. Fxtract from Primitive in dustry...by Chas. C. Abbott, 31 pp, Salem, Mass., 1881

81a The antiquity of man in easter America, geologically considered. Am As, Pr 29: 706-709 (1881)

81b [Notes on the Saltville district Va.] Am Ph Soc, Pr 19: 155 (1881) The Virginias $2: 92-93$ (1881)

82 [Mineralogical notes]. Am Nat 1618 (1882-1884)

82a Helvite from Amella Co., Va. An Nat $16: 337-338(1882)$

82b On a new substance resembling dop. plerite from a peat bog at Seranton, [Pa.]. $\mathrm{Am} \mathrm{Ph}$ Soc, $\mathrm{Pr} 20: 112-117$ (1882) Pa G S, An Rp 1885: 647-656 (1886)

82e Pseudomorphs of serpentine after dolomite. Ac N Sc Phila, Pr 1882: 36-38; Min $G$ Sec, $\operatorname{Pr}$ no $2: 3-5$ (1882)

82d On a new ore of antimony ISonora. Mex.]. Ac N Sc Pbila, Pr 1882:38-40; Min G Sec, Pr no 2:5-7 (1882)

82e On a fault in the Trias near Yard. leyville, Pa. Ac N Sc Phila, Pr 1882:4041: Min G Sec, Pr no 2: 7-8 (1882)

$82 f$ On two new localties of columbite. Ac N Sc Phila, Pr 1882: 51; Min G Sec, Pr no 2: 18 (1882)

S2g On the occurrence of fahlunite near Philadelphia, Ac N Se Phila, Pr 1882 51-52; Min G Sec, Pr no $2: 18-19$ (1882)

$82 h$ Note on aquacreptite. Ac $N$ Sc Phila, $\operatorname{Pr} 1882: 56-57$; Min G Sec, Pr no $2: 23-24$ (1882)

s2i On a mineral resembling dopplerite from a peat bed at Scranton, $\mathrm{Pa}$. Ac $\mathrm{N}$ Sc Phila, $\operatorname{Pr} 1882$ : 52-53; Min G Sec, $\mathrm{Pr}$ no $2: 19-20$ (1882)

82j On phytocollite, a new mineral. Ac N Sc Phila, Pr $1882: 68 ;$ Min G Sec, Pr no 2:35 (1882)

82k An American locality for helvite [Amelia Court House, Va.]. Ac $N$ Sc Phila, Pr 1882: 100-102.

s3 A summary of progress in mineralogy in 1882 [-1884]. Monthly notes in Am Nat 1882-84 [1883-5]

83a The great ice age in Pennsylvania. Franklin Inst, J 115 or (3) $85: 287-307$, map (1883) 
Lewis, Henry Carvill-Continued.

83b The geology of Philadelphia. Franklin Inst, 115 or (3) $85: 359-374$, 422-427 (1883) Rv by Persifor Frazer, Science 2: 269-270 (1883)

s3e Geology of Philadelphia [on p. 540 is a reply by Persifor Frazer]. Sclence $2: 492-403,652-653$ (1883)

siu [On the course of the great terminal moraine through Pennsylvania.] Am Ph Soc, Pr 20:662-664, map (1883)

s3e The great terminal moraine across Pennsylvania. Science 2:163-167, map (1883) Am As, Pr $31: 389-398$, map (1883)

83f [On the antiquity of $\mathrm{man}$ in America.] Ac N Sc Phila, Pr $1882: 292-293$ (1883)

83g Some enclosures in muscovite. Ac N Se Phila, Pr 1882:311-315 (1883)

83h On a supposed human implement from the gravel at Philadelphla. Ac N Sc Phila, Pr 1883: 40-43

83i [The thickness of the ice of the glacial period and the cause of its movement.] Ac N Sc Phila, Pr 1883:47-49

83j The ice of the glacial period; phenomena of glaciation. Ac N Sc Phila, Pr $1883: 47-49,70-71$

83k Crystallized serpentine from Delaware. Ac N Sc Phila, $\operatorname{Pr} 1883: 72-74$

831 Supposed glacial striae on Locust Mountain, Pa. Am J Sc (3) $26: 483-484$ (1883)

S4 Report on the terminal moraine in Pennsylvania and western New York. Pa G S, 2d, Z: 1vi, 299 pp, maps (1884)

84a On supposed glaciation in Pennsylvania south of the terminal moraine. Am J Sc (3) $28: 276-285$, map (1884)

84b An interesting mineral from Canada [cacoclasite, Wakefield, Ont.]. Am Nat 18: $416-417$ (1884)

84e Gold from North Carolina. Ac N Sc Phila, Pr 1883 : 301 (1884)

84d A phosphorescent variety of limestone. Ac N Sc Phila, Pr 1884:10-12

84e [Fossils in the Triassic shale of Phoenixville, Pa.] Science 3:295 (1884)

85 A great trap dike across southeastorn Pennsylvania. Am Ph Soc, Pr 22: 438-456 (1885) Abst, Science 4:328 (1884) ; Am As, Pr 33: 402-403 (1885)

85a Crythrite, genthite, and cuprite from near Philadelphia. Ac N Sc Phila, Pr $7885: 120-122$

85b Marginal kames. Ac N Sc Phila, Pr 1885:157-173, map (1885) Abst, G Mag (3) 1:565-566 (1884); Brit As, Rp $54: 720$ (1885)

86 Comparative studies upon the glaciation of North America, Great Britain, and Ireland. $\mathrm{Am}$ J Sc (3) $32: 433-438$ (1886) Am Nat 20:919-925 (1886) Brit As, Rp $56: 632-635$ (1887) G Mag (3) 4:28-32 (1887) Nature 35:89-91 (1886)

$86 a$ The genesis of the diamond. ence $8: 345-347$ (1886)
Lewis, Henry Carvill-Continued.

86b The direction of glaciation as ascertained by the form of the striae (abst). Brit As, Rp 55: 1019-1020 (1886)

86e Some examples of pressure fluxion in Pennsylvania (abst). Brit As, Rp 55: 1029-1030 (1886)

86d On a diamantiferous peridotite and the genesis of the diamond (abst). Brit As, Rp 56:667-668 (1887) G Mag (3) 4: 22-24 (1887) Science 8:345-347 (1886)

s7 On some important extra-morainic lakes in central England, North America, and elsewhere, during the period of maximum glaciation, and on the origin of extra-morainic boulder clay (abst). G Mag (3) 4:515-517 (1887) Brit As, Rp b7 : 692-693 (1888) Nature $36: 573$ (1887)

$87 a$ The matrix of the diamond (abst). Brit As, Rp 57:720-721 (1888) Nature $36: 571$ (1887)

s8 [Remarks on the new term "Alb1rupean formation."] Am Ph Soc, Pr 25: 53-54 (1888)

97 Papers and notes on the genesis and matrix of the diamond. xvi, $72 \mathrm{pp}, \mathrm{L} 1897$ Levis, J. L.

80 Fossil remains in southwest Missouri. Kansas City Rv Sc 4: 207 (1880)

Lewis, James A.

45 Kanawha gas. Am J Sc 49:209-211 (1845)

Lewis, James F.

98 The Chicago main drainage channel. Am I M Eng, Tr 27:288-332, maps (1898) Lewis, James 0 .

18 Petrology of reservoir rocks (discussion). Ec G 13:65-69 (191b)

Lewis, Joseph Volney.

93 Notes on building and ornamental stone. N C G S, Bien Rp 1: 57-103, map (1893)

95 Origin of the peridotites of the southern Appalachians. Elisha Mitehell Sc Soc, J $12: 24-37$, maps (1895)

96 Corundum and the basic magnesian rocks of western North Carolina. N C G S, B 11: $107 \mathrm{pp}$, map, Winston 1896

96 Corundum of the Appalachian crystalline belt. Am I M Eng, Tr 25:852-906 (1896)

05 (with Pratt, J. H.) Corundum and the peridotites of western North Carolina. N C G S 1: 464 pp, maps, Raleigh 1905

06 An Ontario lead deposit [Hastings Co.]. Ee G 1:682-687 (1906)

07 The double crest of Second Watchung Mountain. J G 15:39-45 (1907)

o7a Copper deposits of the New Jersey Triassic. Ec G 2:242-257 (1907)

ozb Structure and correlation of Newark trap rocks of New Jersey. G Soc Am, B $18: 195-210$ (1907) Abst, Science n s $26: 177-178$ (1907); N Y Ac Sc, An 18: 336 (1908)

07e The origin and relations of the Newark rocks. N J G S, An Rp St G 1906: 99-129, map (1907) 
Lewis, Joseph Volney-Continued.

o7d The Newark (Triassic) copper ores of New Jersey. N J G S, An Rp St G 1906: 131-164 (1907)

07e Properties of trap rocks for road construction. N J G S, An Rp St G 1906: 165-172 (1907)

ozf Glance as an original copper ore. Eng M J $84: 688$ (1907)

os The Palisade diabase of New Jersey. Am J Sc (4) 26:155-162 (1908)

OSa Petrography of the Newark igneous rocks of New Jersey. N J G S, An Rp St G 1907: 97-167, map (1908) Abst, Science n s $28: 574$ (1908)

09 Bullding stones of New Jersey. N J G S, An Rp St G 1908:53-124 (1909)

09a Prospecting for ores of the Goldfield type. Eng M J $87: 1121-1122$ (1909)

12 Notes on the paragenesis of the zeolites (abst). Science n s $35: 313$ (1912) ; (with discussion by A. C. Lane and F. R. Van Horn), G Soc Am, B 23 : 727 (1912)

12a (and Kümme1, H. B.) Geologic map of New Jersey, 1910-1912. Scale 1: 250,000. N J G S (1912) Another ed, 1914

13 Determinative mineralogy, with tables for the determination of minerals by means of their chemical and physical characters. $151 \mathrm{pp}, \mathrm{N}$ Y $19132 \mathrm{~d}$ ed, $155 \mathrm{pp}$, N Y 1915

14 Origin of pillow lavas. $\mathrm{G}$ Soc $\mathrm{Am}$, B 25:591-654 (abst with discussion 3233) (1914)

15 (and Kümmel, H. B.) The geology of New Jersey; a summary to accompany the geologic map $(1910-1912)$ on the scale of $1: 250,000$. N J G S, B 14:146 pp, map (1915)

15a Origin of the secondary minerals of the Triassic trap rocks. N J G S, B 16: 45-49 (1915)

15b The pillow lavas of the Watchung Mountains [N. J.]. N J G S, B 16:51-56 (1915)

16 Absence of pyrite from certain zeolite localities. Am Mineralogist 1:92 (1916)

16a (with Stose, G. W.) Triassic igneous rocks in the vicinity of Gettysburg, $\mathrm{Pa}$. G Soc Am, B 27:55-57 (abst), 623643, map (1916)

See also Cushing, 13; Morey, 16

Lewis, Julia F.

92 H. Carvill Lewis's work on the glaclal phenomena. Science 19:305-307 (1892)

Lewis, Meriwether.

04 (and Clark, W.) Original journals of the Lewis and Clark expedition, 18041806... See Thwaites, 04

06 (and others) Message from the President of the United States, communicating discoveries made in exploring the Missouri, Red River, and Washita, by Captains Lewis and Clark, Doctor Sibley and Mr. Dunbar;
Lewis, Meriwether-Continued.

with a statistical account of the countries adjacent. $\quad 171 \mathrm{pp}$, City of Washington 1800

14 (and Clark, W.) History of the expedition to the sources of the Missouri. See Allen (P), 14

Lewis, Robert S.

14 The Book Cliffs coal field, Utah. Am I M Eng, B 91:1729-1749 (1914); Tr $50: 658-678$ (1915)

Lewis, Samuel.

55 A few remarks on the green sand formation of New Jersey. Pottsville $8 c$ As, B : 11-13 (1855)

55a The cause of certain markings in coal. Pottsville Sc As, B : 14 (1855)

Lewis, Samuel J.

10 Mines of Ajuchitlan, Queretaro, Nexico. M Sc Press 100: 211-215 (1910)

10a Geology of Hostotipaquillo ore deposits [State of Jalisco, Mexico]. M sc Press 101: 335-337 (1910)

L'Hame, William E.

01 Thunder Mountain, Idaho. Mines and Minerals 21:558 (1901)

03 Thunder Mountain district, Idabo. Mines and Minerals 24:207-209 (1903)

Liddell, Charles A.

03 (with Parsons, H. F.) Coal and mineral resources of Routt Co. [Colo.]. Colo Sch Mines, B 1 no 4: 47-59 (1903)

Liddell, Donald M.

17 A Florida rare-mineral deposit. Eng M J 104:153-155 (1917)

Liebenam, W. A.

04 Der Cripple Creek Golddistrikt, seine Entdeckung, Entwicklung, Geologie, und Zukunft. Berg- u Hütt Ztg $63: 2-5,29-32$, $57-60,89-92,117-121,161-164$ (1904)

or Kupfervorkommen in Kalifornien und thre wirtschaftliche Bedeutung. Zs Berg Hiitten u Salinen-Wesen $55: 522-546$ (1907) Lieber, Oscar Montgomery (1830-1862). 54 A sketch of the geology of the State of Mississippi. M Mag 3:41-47, map (1854)

55 Some remarks on the metalliferous veins of the South. M Mag 5:306-312 (1855)

56 Report on the survey of South Carolina; being the first annual report... vil, 136 pp, maps, Columbia, S. C., 1856 2d ed., 1858 Extracts in M Mag 9:9-30, 105$121,355-358$ (1857)

56a The copper veins of the South. M Mag 7:367-371 (1856)

58 Report on the survey of South Carolina; being the second annual reprt... 145 pp, maps, Columbia, S. C., 1858 Extract, with title, Veins and vein mining, M Mag $10: 345-363$ (1858)

58a A fragmentary contribution to the vein geology of the Southern States. M Mag 10:108-112 (1858)

59 Report on the survey of South Caro. lina; being the third annual report... 28 , 223 pp, maps, Columbia 1859 
Lieber, Oscar Montgomery - Continued.

59a The itacolumite and its associates, comprising observations on their geological importance and their connection with the occurrences of gold... In his [3d annual] report on the survey of South Carolina: 75-220, Columbia, S. C., 1859 In German in Cotta, B. von, and Mïller, Herrm., Gangstudien ... 3:309-507, Freiberg 1860 59b Notes on certain ancient and present changes along the coast of South Carolina. Am J Sc (2) 28: 354-359 (1859)

59c A contribution to the geologic chronology of the southern Alleghanies. Am As, Pr 12:227-230 (1859)

59d South Carolina; her natural resources and agricultural products. Am Geog Stat Soc, J 1:252-256, map (1859)

59e Petrology and metamorphism. M Mag (2) 1:111-125 (1859)

60 Report on the survey of South Carolina; being the fourth annual report... 194 pp, maps, Columbia, S. C., 1860

60a Ueber das Goldvorkommen in NordCarolina. In Cotta, B. von, and Müller, Herrm., Gangstudien oder Beiträge zur Kenntniss der Erzgänge $3: 253-255$, Freiberg 1860

61 Notes on the geology of the coast of Labrador. U S Coast S, Rp 1860 (U S, 36th Cong 2d sess, H Ex Doc 14) : 402-408 (1861)

61a Die amerikanische astronomische Expedition nach Labrador im Jull 1860 . Petermanns Mitt $7: 213-219$, map (1861) Lighton, W. R.

88 The study of river geology. West Am Sc 4:24-26 (1888)

lilley, Albert Tell (1838-1922).

84 Detailed section of Chemung rocks exposed in the Gulf Brook gorge at Le Roy, Bradford Co., Pa. Am Ph Soc, Pr 21 : 304-305 (1884)

86 A revision of the section of Chemung rocks exposed in the Gulf Brook gorge at Le Roy, in Bradford Co., Pa. Am Ph Soc, Pr 23: 291-293 (1886)

Limber, John.

41 Fossil remains in Leneir Co., N. C. Am J Se 40:405 (1841)

Lincklaen, Ledyard.

45 The geology of Madison Co. [N. Y.]. Madison Co $\mathrm{Agr} \cdot \mathrm{Soc}$, Tr 1842-45:30-46, map, Hamilton N Y (1845)

61 Guide to the geology of New York, and to the State geological cabinet. N Y St Cab, An Rp 14:17-84, 1-41, il (1861)

Iincoln, Benjamin.

85 An account of several strata of earth and shells on the banks of York River in Virginia... Am Ac Arts, Mem 1:372-376 (1785)

Lincoln, D. F.

92 Glaciation in the Finger Lake region of New York. Am J Sc (3) 44:290-301, map (1892)
Lincoln, D. F.-Continued.

94 The amount of glacial erosion in the Finger Lake region of New York. Am .J Sc (3) $47: 105-113$ (1894) Abst, Am G $12: 177-178$ (1893) ; Am As, Pr $42: 177-$ 178 (1894)

97 Report on the structural and economic geology of Seneca Co. [N. Y.]. N Y St G, An Rp 14:57-125, map (1895) [1897] N Y St Mus, An Rp $48 v 2: 57-$ 125, map (1895) [1897]

Lincoln, Francis Church.

O7 Magmatic emanations. Ec G 2:258274 (1907)

O7a The association of alunite with gold in the Goldfield district, Nev. Ec G 2 : 801-803 (1907)

os The Promontorio silver mine, Durango, Mexico. Am I M Eng, B 19:83-99 (1908); Tr 38; 734-750 (1908) Eng M J $85: 756-759$ (1908) Abst, M World 28: 835-836 (1908)

09 The Big Bonanza copper mine, Latouche Island, Alaska. Ec G 4:201-213 (1909)

10 Some economic gold deposits of Alaska. Eng M J 90:551-554 (1910)

11 Certain natural associations of gold. Ec G 6:247-302 (1911); discussion, 7 : $87-88$ (1912)

$11 a$ Types of Canadian gold deposits. Eng M J $91: 470-472$ (1911)

$11 b$ Gold ores of Washington and Oregon. Eng M J 92:13-15 (1911)

11e Some gold deposits of the Northwest. Eng M J 92:408-410 (1911)

12 Gold deposits of Gibbonsville, Idaho. M Sc Press 105:47-49 (1912)

13 The quantitative mineralogical classification of gradational rocks. Ec G 8:551$564(1913)$

13a (and Rietz, H. L.) The determination of the relative volumes of the components of rocks by mensuration methods. Ec G 8:120-139 (1913)

17 The Massey copper mine, Ont. Eng M J 104:193-195 (1917)

Lindahl, Josua (1844-1912).

88 Dr. N. O. Holst's studies in glacial geology. Am Nat 22:589-598, 705-713 (1888)

90 Letter of transmittal. IIl G $\mathrm{S} 8$ : $\mathrm{v}-\mathrm{xi}(\mathbf{1 8 9 0})$

90a General index to volumes I-VIII. III G S 8: App 39-153 (1890)

92 Description of a skull of Megalonya leidyi n. sp. Am Ph Soc, Tr n s 17:1-10, il (1892)

95 Geological report. In Illinois Board of World's Fair Commissioners at the World's Columbian Exposition [Chicago, 1893], Report: 65-73, Springfield 1895

97 Description of a Devonian ichthyodorulite, Heteracanthus uddeni n. sp., from Buffalo, Iowa. Cin Soc N H, J 19:95-98, il (1897) 
Lindeman, Einar.

o7 Report on iron-ore deposits. Can, Dp Interior, Supt Mines, Rp 1907:32-37 (1907)

os Preliminary report on the iron-ore deposits of Vancouver and Texada Islands. Can Mines Br, Sum Rp 1907-8:35-43 (1908)

10 Iron-ore deposits of Vancouver and Texada Islands, British Columbia. Can Mines $\mathrm{Br}: 29 \mathrm{pp}$, maps (1910)

10a On the iron-ore deposits of the Bristol mine, Pontiac Co., Que. Can Mines Br, B 2:15 pp, map (1910)

11 Magnetite deposits of Texada and Vancouver Islands, Can M Inst, Q B 11: 203-216 (1910); J 13:107-120 (1911)

11 a The Austin Brook iron-bearing district, N. B. Can Mines Br, Sum Rp 1910: 76-86 (1911)

12 The iron-ore deposits along the Central Ontario railway. Can Mines $\mathrm{Br}$, Sum Rp 1911: 95-100 (1912)

12a Calabogie iron-bearing district [Renfrew Co., Ont.]. Can Mines Br, Sum Rp 1911 : 101-103 (1912)

12b Magnetometric survey of a nickellferous pyrrhotite deposit in the Sudbury district. Can Mines Br, Sum Rp 1911: 103-104, map (1912)

13 Austin Brook iron-bearing district, N. B. Can Mines $\mathrm{Br}: 15 \mathrm{pp}$, maps (1913)

13a Magnetite occurrences along the Central Ontario Railway. Can Mines Br: $23 \mathrm{pp}$, maps (1913)

13b Moose Mountain iron-bearing district, Ont. Can Mines Br, Sum Rp 1912 : 83-85 (1913)

14 Moose Mountain iron-bearing district, Ont. Can Mines $\mathrm{Br}: 14$ pp, maps (1914)

$14 a$ Magnetite occurrences near Calabogie, Renfrew Co., Ont. Can Mines Br: $16 \mathrm{pp}$, maps (1914)

14b Iron ore occurrences in Cape Breton. Can Mines Br, Sum Rp 1913: 31-36 (1914)

17 (and Bolton, L. L.) Iron ore occurrences in Canada. Vol 1, Descriptions of principal iron ore mines: 23-71, maps (in case) ; vol 2, Descriptions of iron ore occurrences : 222 pp, maps (in case) Can Mines Br, Ottawa 1917

Lindenmuth, A. C.

78 Report on the geology of Darke Co. Ohio G S, Rp 3 pt 1:496-518 (1878)

Lindenkohl, A.

83 Notes on the model of the Gulf of Maine... U S Fish Comm, B 3:449-454 (1883)

85 Geology of the sea bottom in the approaches to New York Bay. Am J Sc (3) $29: 475-480$ (1885)

91 Notes on the submarine channel of the Hudson River and other evidences of postglacial subsidence of the Middle Atlantic coast region. Am J Sc (3) 41:489499 , map (1891)
Lindgren, Waldemar.

86 Eruptive rocks of Montana. O \& 10th Census 15:719-737 (1886)

87 The silver mines of Calico, Cal. An I M Eng, Tr 15: 717-734, map (1887)

88 Contributions to the mineralogy of the Pacific coast. Cal Ac Sc, Pr (2) 1: 1-6 (1888)

89 Notes on the geology of Baja California, Mex. Cal Ac Sc, Pr (2) 1:173-198 (1889)

90 Petrographical notes from Baja Call. fornia, Mex. Cal Ac Sc, Pr (2) 2:1-1i (1890)

90a (with Melville, W. H.) Contr. butions to the mineralogy of the Pacife eoast. U S G S, B 61:40 pp (1890)

91 Notes on the geology and petrog. raphy of Baja California, Mex. Cal de Sc, Pr (2) 3:25-33 (1891)

91 a Eruptive rocks from Montana. Ac Sc, Pr (2) 3:39-57 (1891)

92 The gold deposit at Pine Hill, Cal. Am J Sc (3) 44:92-96 (1892)

92n The glacial period; a discussion of Mr. Manson's theory. M Sc Press 64:94 (1892)

93 Two Neocene rivers of California. Soc Am, B 4:257-298, map (1893)

93a A sodalite syenite and other rocs from Montana. Am J Sc (3) $45: 286-20^{\circ}$ (1893)

93b The auriferous veins of Meador Lake, Cal. Am J Sc (3) $46: 201-20 \%$ (1893) M Sc Press 68:118 (1894)

93e The relation between ore deposits and their enclosing walls. Eng M J 55 : $340-341$ (1893)

94 (and Turner, H. W.) Descriptlot of the gold belt [Cal.]; description of the Placerville sheet. o S G S, G Atlas Placerville fol (no 3) : $3 \mathrm{pp}$, maps (1894 reprint 1914) Abst, J G $4: 248-25$ ) (1896)

$94 a$ Description of the gold belt; de scription of the Sacramento sheet [Cal] U S G S, G Atlas Sacramento fol (no 5): $3 \mathrm{pp}$, maps (1894, reprinted 1914 ; prel el 1892) Abst, J G 4:250-251 (1896)

94b The gold-silver veins of Ophir, $\mathrm{Cal}$ U S G S, An Rp 14 pt $2: 243-284$, map (1894) Abst, M Sc Press 71:216, 23 (1895); J G $4: 373-374$ (1896)

94c An auriferous conglomerate of Jo rassic age from the Sierra Nevada. Am t Sc (3) $48: 275-280$ (1894)

95 (and Turner, H. W.) Description of the Marysville sheet [Cal.]. U S G \& G Atlas Marysville fol (no 17) : $2 \mathrm{pp}$, maps (1895) Abst, J G 3:976-977 (1895)

95a (and Turner, H. W.) Description of the gold belt; description of the Smarts ville sheet [Cal.]. U S G S, G Atiss Smartsville fol (no 18) : 6 pp, maps (1895) 
Lindgren, Waldemar-Continued. $95 \mathrm{~b}$ Characteristic features of California gold quartz veins. G Soc Am, B 6:221240, map (1895) M Sc Press 70:181182, 213-214, 244 (1895) Abst, Science n s $1: 68$ (1895)

96 Description of the [Nevada City, Cal.] special maps. U S G S, G Atlas Nevada City fol (no 29): 7 pp, maps (1896) Abst, J G 5:409-411 (1897)

96a Description of the gold belt; description of the Pyramid Peak quadrangle [Cal.]. U S G S, G Atlas Pyramid Peak fol (no 31): 8 pp, maps (1896)

$96 \mathrm{~b}$ The gold-quartz veins of Nevada City and Grass Valley districts, Cal. U S G S, An Rp 17 pt 2:1-262 (1896)

96e The age of the auriferous gravels of the Sierra Nevada; with a report on the flora of Independence Hill, by F. H. Knowlton. J G 4:881-906 (1896) Abst, Zs Prak G $1897: 226-227$

96d The gold quartz veins of California. Am G $17: 338-339$ (1896)

97 Description of the gold belt; descripthon of the Truckee quadrangle [Cal.]. U S G S, G Atlas Truckee fol (no. 39) : 8 pp, maps (1897)

97a The granitic rocks of the Pyramid Peak district, Sierra Nevada, Cal. Am J Sc (4) 3:301-314, map (1897)

97b Monazite from Idaho. Am J Sc (4) 4:63-64 (1897) M Sc Press 75:168 (1897)

$97 \mathrm{e}$ Filling and replacement in goldbearing fissure veins. Eng $M \quad J \quad 63: 573$ (1897)

97d The granitic rocks of the Sierra Nevada (abst). Science n s 5: 361 (1897)

98 Description of the Boise quadrangle [Idaho]. U S G S, G Atlas Boise folio (no 45) : 7 pp, maps (1898)

98a The mining district of the Idaho Basin and the Boise Ridge, Idaho. U S G S, An Rp 18 pt 3:617-719, maps (1898) 98b Orthoclase as gangue mineral in a fissure vein. Am J Sc (4) 5:418-420 (1898) M Sc Press $77: 32$ (1898)

9Se The primary gold deposits of the Slerra Nevada. M Se Press $76: 258-259$ (1898)

98d The canyons of the Salmon and Snake rivers, Idaho (abst). Science $\mathrm{n} s$ 7:71-72 (1898) Eng M J 65:158 (1898) 99 The copper deposits of the Seven Devils, Idaho. M Sc Press 78:125 (1899)

00 Description of the Colfax quadrangle [Cal.]. U S G S, G Atlas Colfax fol (no 66) : $10 \mathrm{pp}$, maps (1900)

$00 \mathrm{a}$ The gold and silver veins of Silver City, De Lamar, and other mining districts in Idaho. U S G S, An Rp 20 pt $3: 65-256$, maps (1900)

$00 b$ Granodiorite and other intermediate rocks. Am J Sc (4) 9:269-282 (1900)

00e Wood River mining distriet, Idaho (abst). Science n s $11: 348-349$ (1900)
Lindgren, Waldemar-Continued.

01 The gold belt of the Blue Mountains of Oregon. U S G S, An Rp 22 pt 2: 551-776, map (1901)

$01 a$ Metasomatic processes in flssure veins. Am I M Eng, Tr 30:578-692 (1901)

01b Rare minerals in gold quartz veins of eastern Oregon. M Sc Press 82:252 (1901)

o1e Trias in northeastern Oregon (abst). Science n s 13:270-271 (1901)

02 Tests for gold and silver in shales from western Kansas. U S G S, B 202: 21 pp (1902) Abst, Eng M J 74:111-112 (1902)

02a The character and genesis of certain contact deposits. Am I M Eng, Tr 31 : 226-244 (1902)

02b The gold production of North America, its geological derivation and probable future. M Sc Press 85:177, 193, 206 (1902)

02e A deposit of titanic iron ore from Wyoming (abst). Science n s 16:984-985 (1902)

03 The water resources of Molokaf, Hawalian Islands. U S G S, W-S P 77:62 pp (1903)

03a Neocene rivers of the Sierra Nevada. U S G S, B 213:64-65 (1903)

03b Mineral deposits of the Bitterroot Range and Clearwater Mountains, Mont. U S G S, B 213:66-70 (1903)

03e Copper deposits at Clifton, Ariz. U S G S, B 213: 133-140 (1903) Eng M J 75:705-707 (1903)

03d The geological features of the gold production of North America (with discussion by W. G. Miller, W. L. Austin, J. E. Spurr, and H. W. Turner). Am I M Eng, Tr 33:790-845, 1077-1083 (1903); 34: 921 (1904) Reprinted in Emmons, S. F., Ore deposits (pub, by Am I M Eng) : 424449, N Y 1913

03e The gold production of North America, its geological derivation and probable future. Int M Cong, 5th, Pr: 29-36 (1903)

o3f Notes on the geology of Molokai, Hawaiian Islands (abst). Science n s 17: 309 (1903)

03g Metallic sulphides from Steamboat Springs, Nev. (abst). Science n \& 17:792 (1903)

04 (and Drake, N. F.) Description of the Nampa quadrangle [Idaho-Oreg.]. U S G S, G Atlas Nampa fol (no 103): 5 pp, maps (1904)

O4a (and Drake, N. F.) Description of the Silver City quadrangle [Idaho]. U S G S, G Atlas Silver City fol (no 104): 6 pp, maps (1904)

04b A geological reconnalssance across the Bitterroot Range and Clearwater Mountains in Montana and Idaho. U S G S, P P $27: 123 \mathrm{pp}$, maps (1904) 
Lindgren, Waldemar-Continued,

04e Gypsum deposits in Oregon. U S G S, B 223: 111 (1904)

04d (and Ransome, F. L.) Report of progress in the geological resurvey of the Cripple Creek district, Colo. U S G S, B 254: 36 pp (1904)

O4e (and Hillebrand, W. F.) Minerals from the Clifton-Morenci district, Ariz. Am J Sc (4) $18: 448-460$ (1904) U S G S, B $262: 42-54$ (1905)

o5 Description of the Clifton quadrangle [Ariz.]. U S G S, G Atlas Clifton fol (no 129) : $13 \mathrm{pp}$, maps (1905)

o5a The copper deposits of the CliftonMorenci district, Ariz. U S G S, P P 43 : $375 \mathrm{pp}$, maps (1905)

05b The production of gold in the United States in 1904. U S G S, B 260:32-38 (1905)

o5e The production of silver in the United States in 1904. U S G S, B 260: 39-44 (1905)

o5d (and Ransome, F. L.) The geological resurvey of the Cripple Creek district, Colo. U S G S, B 260: 85-98 (1905)

o5e The genesis of the copper deposits of Clifton-Morenci, Ariz. Am I M Eng, Tr 35 : 511-550 (1905) Reprinted in Emmons, S. F., Ore deposits (pub. by Am I M Eng) : $517-556$, N Y 1913.

osp The occurrence of stibnite at Steamboat Springs, Nev. Am I M Eng, Bi-Mo B $2: 275-278$ (1905); Tr $36: 27-31$ (1906) Reprinted in Emmons, S. F., Ore deposits (pub. by Am I M Eng): 629-632, N Y 1913

O5g Ore deposition and deep mining. Ec G 1: $34-46$ (1905)

O5h Chemistry of copper deposits. Eng M J 79:189 (1905)

osi (and others) Gold and silver. U S G S, Min Res $1904: 141-220$; 1905:113$341 ; 1906: 111-371$ (1905-7)

05j The great fault of the Bitterroot Mountains (abst). Science n s 21:224 (1905)

o5k The subterranean gases of Cripple Creek [Colo.] (abst). Science n s 21: 662 (1905)

06 Metasomatic processes in the gold deposits of Western Australia. Ec G 1: 530-544 (1906)

O6a The Annie Laurie mine, Piute Co., Utah. U S G S, B 285: 87-90 (1906)

o6b (and Graton, L. C.) A reconnaissance of the mineral deposits of New Mexico. U S G S, B 285: 74-86 (1906)

o6e The gold deposits of Dahlonega, Ga. U S G S, B 293:119-128 (1906)

o6d (and Ransome, F. L.) Geology and gold deposits of the Cripple Creek district, Colo. U S G S, P P 54:516 pp, maps (1906)

o6e Ore deposition and deep mining. M Sc Press $92: 41$ (1906)
Lindgren, Waldemar-Continued.

o6r The Hamilton mine, N. Mex. (abst). Science n s 23:697-698 (1906)

06g Gold and pyrite. M Sc Press 93: 226 (1906)

06h Discussion of paper by John A. Reid, Sketch of the geology and ore de posits of the Cherry Creek district, Ari. Ec G 1: 698-699 (1906)

o61 Gold and silver; Colorado; Nen Mexico; South Dakota; Southern Apps. lachian States; Texas; Wyoming. U \& G S, Min Res 1905:185-214, 275-28t, 293-305, 337-341 (1906)

or The relation of ore deposition to physical conditions. Int $\mathrm{G}$ Cong, $\mathrm{X}$, Mer. ico, 1906, C R:701-724 (1907) Ec G 2: 105-127 (1907)

O7a Review of the copper deposits of the Robinson mining district, Nev., by A. C. Lawson (Cal Univ, Dp G, B 4:287357). Ec G 2:195-304 (1907)

отb Some gold and tungsten deposits of Boulder Co., Colo. Ec G 2:453-463 (1907)

ore Present tendencies in the study of ore deposits. Ec G 2: 743-762 (1907) M Sc Press 96:567-571 (1908) Abst, Science n s $27: 349-350$ (1908)

o7d The development of the metal mis. ing industries in the Western States. Am M Cong, 9th An Sess, Rp Pr: 156-165 (1907)

ore Methods of igneous intrusion (abst). Science n s 25:623 (1907)

os Will the production of gold in the world keep pace with the increasing de mands of commerce and trade? Am $\mathbb{I}$ Cong, 10th An Sess, Rp Pr:265-271 (1908)

o8a Investigations relating to deposits of metalliferous ores. U S G S, B 340: 18-22 (1908)

08b A geological analysis of the silvet production of the United States in 1906 . U S G S, B 340: 23-35 (1908)

ose Notes on copper deposits in Chaffer. Fremont, and Jefferson cos., Colo. U 8 G S, B 340: 157-174 (1908)

osd A recent vein at Ojo Caliente. N. Mex. (abst). Science n s $27: 348-349$ (1908)

OSe New occurrence of willemite [N. Mex.] and anhydrite [Newhouse, Utah] (abst). Science n s $^{*} 28: 933-934$ (1908)

osf (and MeCaskey, H. D.) Gold and silver. U S G S, Min Res 1907 pt 1: 111$135 ; 1908$ pt $1: 157-183$ (1908-9)

08g (with Hayes, C. W.) Contribu tions to economic geology, 1907; Part I, Metals and nonmetals, except fuels. U \&

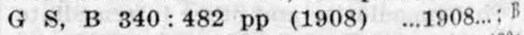
$380: 406$ pp (1909) ...1909...; B 430: $653 \mathrm{pp}(1910) \quad \ldots 1910 \ldots ;$ B $470: 558 \mathrm{pl}$ (1911) 


\section{Lindgren, Waldemar-Continued.}

09 The localization of values in ore bodies and the occurrence of shoots in metalliferous deposits. Fc $\mathrm{G}$ 4:56-61 (1909)

09a The Tres Hermanas mining district, N. Mex. U S G S, B 380:123-128 (1909)

09b Resurces of the United States in gold, silver, copper, lead, and zinc. U S G S, B 394:114-156 (1909) Nat Conservation Comm (60th Cong, 2d sess, Sen Doc no 676), Rp 3:521-557 (1909)

09e Metallogenetic epochs. Ec G 4: 409-420 (1909) Can M Inst, J 12:102113 (1910) Can M J 30:430-434 (1909) M World 31: 1111-1113 (1909)

09d [The discovery of a selenium mineral in the gold-quartz ores of the Republic district, Wash.] (abst). Science n s 30 : 972 (1909)

10 (and Graton, L. C., and Gordon, C. H.) The ore deposits of New Mexico. U S G S, P P 68: 361 pp, map (1910)

10a The hot springs at Ojo Callente and their deposits. Ec G 5: 22-27 (1910)

$10 b$ Anhydrite as a gangue mineral. Ec G 5:522-527 (1910)

10e Special problems and their study in economic geology. Ec G 5: 772-776 (1910)

11 The Tertiary gravels of the Sierra Nevada of California. U S G S, P P 73 : $226 \mathrm{pp}$, maps (1911) Abst, Wash Ac Sc, J 2:191-193 (1912)

11n Copper, silver, lead, vanadium, and uranium ores in sandstone and shale. Ec G $6: 568-581$ (1911)

11b Some modes of deposition of copper ores in basic rocks. Ec G 6:687-700 (1911)

11e Geology of the National mining district, Nev. M World 35:1175-1176, map (1911)

11d Platinum and allied metals. U S G S, Min Res 1909 pt $1: 595-601 ; 1910$ pt $1: 773-780 ; 1911$ pt $1: 987-1003$ (1911-2)

12 The nature of replacement. Ec $G$ $7: 521-535$ (1912)

12a The bonanza of National, Nev. (abst). Wash Ac Sc, J 2:107-108 (1912)

12b Successive phases of mineralization in veins of volcanic regions. Can $M$ Inst, Tr 15:187-191 (1912)

13 Mineral deposits. $\mathrm{xv}, 883 \mathrm{pp}, \mathrm{N} \mathrm{Y}$ 1913 2d ed, xviii, 957 pp, N Y 1919

13a 'Contributions to economic geology (short papers and preliminary reports), 1911 : Part I, Metals and nonmetals except fuels. U S G S, B 530:400 pp (1913)

14 (and Turner, H. W.) Reprints from Placerville, Sacramento, and Jackson folios [Cal.] (nos 3, 5, and 11):9 pp, maps, U S G S (1914)

14a (and Bancroft, H.) The Republic mining district, Wash. U S G S, B $550: 133-166$, map (1914)
Lindgren, Waldemar-Continued.

14b (and Whitehead, W. L.) A deposit of jamesonite near Zimapan, Mexico. Ec G $9: 435-462$ (1914)

14e The origin of the "garnet zones" and associated ore deposits. Ec G 9:283292 (1914) Am I M Eng, B $90: 949-956$ (1914) ; Tr 48:201-208 (1915)

15 Geology and mineral deposits of the National mining district, Nev, U S G S, B $601: 58 \mathrm{pp}$, map (1915) Abst, Wash Ac Sc, J $5: 580-581$ (1915)

15a The igneous geology of the Cordilleras and its problems. In Problems of American geology : 234-286, New Haven 1915

$15 b$ (and Ross, C. P.) The iron deposits of Daiquiri, Cuba (with discussion by Max Roesler, B. B. Lawrence, L. C. Graton, Harrison Souder, C. P. Berkey, A. C. Lane, and J. D. Irving), Am I M Eng, B $106: 2171-2190$ (1915) ; Tr 53:4066 (1916)

15e The origin of kaolin. Ec G $10: 89$ 93 (1915)

15d Processes of mineralization and enricnment in the Tintic mining district [Utah]. Ec G 10:225-240 (1915)

16 Gold and silver deposits in North and South America. Pan American Sc Cong, 2d, Washington, $\mathrm{Pr}$ see 7 vol $8: 560$ 577 (1917) Am I M Eng, B 112:721746, maps (1916) ; $\operatorname{Tr} 55: 883-909$, maps (1917) Smiths .Inst, An Rp 1917:147$173(1919)$

17 [On the deposition of the various forms of silica.] Am I M Eng, B 126: xvi (1917)

18 The occurrence of the halogen salts of silver. Ec G 13:225-226 (1918)

18a The Idaho peneplain (dicsussion). Ec G 13:486-488 (1918)

18b Volume changes in metamorphism. J G 26: 542-554 (1918)

18c Genesis of the Sudbury nickel-copper ores (discussion). Am I M Eng, B 136: 857 (1918)

18d John Duer Irving. Ec G 13:413418, port (1918)

18e John Duer Irving. Fng M J 106: 263-264 (1918)

See also Billingsley, 15 ; Daly, 14 ; Emmons (S F), 03d, e; Graton, 15; Hill (J M), 12; Powell, 95; Rickard, 03; Roberts (H M), 18 ; Weed, $03 \mathrm{~g}, \mathrm{k}$

Lindsey, G. G. S.

13 Mukoka Lakes [Ontario]. Int G Cong, XII, Canada, Guide Book no 6:4348, maps (1913)

Lindsley, James $G$.

79 A study of the rocks [faulting at Rondout, N. Y.]. Poughkeepsle Soc N Sc, Pr 1878-9:44-48 (1879)

Lindsley, Thayer.

11 The ore deposits at Porcupine [Ont.]. Eng M J 91: 1005-1006 (1911) 
Lindsley, Thayer-Continued.

14 Economic effect on certain ore deposits of changes in depth. Eng M J 97 : 1043-1046 (1914)

Lindström, Gustav.

76 On the affinities of the Anthozon Tabulata. An Mag $\mathrm{N} H$ (4) $18: 1-17$ (1876)

Lines, Edwin F.

05 (with Fullsr, M. L.) Record of deep well drilling for 1904. U S G S, B 264 : $193 \mathrm{pp}$ (1905)

07 Clays and shales of Clarion quadrangle, Clarion Co., Pa. U S G S, B 315 : 335-343, map (1907)

O7a Coals of the clarion quadrangle, Clarion Co., Pa. U \& G \&, B 316:13-19 (1907)

11 (with Shav, E. W.) Uescription of the Foxburg and Clarion quadrangles, $\mathrm{Pa}$. U S G S, G Atlas, fol 178 (1911)

12 The stratigraphy of Illinols witn reference to Portland-cement marerials. IIl G S, B $17: 59-76$ (1912)

17 Pennsylvanian fire clays ut slyinois. II1 G S, B 30:61-73 (1917)

Linforth, Frank A.

13 Applied geology in the Butte nanes. Am I M Eng, B 83:2611-2623 (19.3); Tr 46:110-122 (1914)

14 Dip chart (discussion). Am I k 1 Eng, B 96: 2823-2824 (1914)

Linn, Alonzo.

86 (and Linton, Laward) Notes on the Mountain Limestone in the Washington Co., gas wells. Pa G S, An Rp 1885: 222-225 (1886)

Linney, William M.

82 Notes on the rocks of central Kentucky, with list of fassils. Ky G S: $19 \mathrm{pp}$ [1882]

S3 Report on the geology of Garrard Co. Ky G S : 30 pp, map [18\&3 ?]

S3a Report on the geology of Lincoln Co. Ky G S : 36 pp, map [1883?]

83b Report on the geology of Mercer Co. Ky G S: 28 pp, map [Boyle and Mercer cos.; geology of Boyle Co. by J. C. Fales] [1883?]

83e Report on the geology of Washington Co. Ky G S : 23 pp, map [1883?]

84 Report on the geology of Spencer and Nelson cos. Ky G S: 58 pp, map [1884?]

85 Report on the geology of Clark and Montgomery cos. Ky G S: 75 pp, map [1885?]

86 Report on the geology of Bath and Fleming cos. Ky G S : 85 pp, map [1886?]

S6a Report of the geology of Mason Co. Ky G S : 31 pp, map [1886?]

87 Reports on the geology of Henry, Shelby, and Oldham cos. Ky G S: 18, 16, 34 pp, map [1887?]
Inton, Edward.

86 (with Linn, Alonzo) Notes on th Mountain Limestone in the Washint Co., gas wells. Pa G S, An Rp 1885:2\% 225 (1886)

98 On the formation of new ravins Am G 21:329-330 (1898)

Linton, Laura A.

96 (with Peekham, S. F.) On Trint dad pitch. Am $J$ Sc (4) $1: 193-2$ (1896)

Linton, Robert.

12 Geology of Ocampo district, Mexim Eng M J 94:653-655 (1912)

13 Texas iron ore deposits. Eng M : $96: 1153-1156$, map (1913)

\section{Lippineott, James $S$.}

81 An address to the fossil bones in ! private museum. Am Nat $15: 37-2$ (1881)

83 The history of anthracite coal ts nature and art. Am Nat 17:1-10 (1889)

Lister, George.

46 [On the fossil bones from Washin? ton Co., Ala., exhibited under the nam of Hydrarchos.] Boston Soc N H, Pr? 94-96 (1846)

Little, George.

75 Report of progress of the mineralc ical, geological, and physical survey of th State of Georgia... 1874. 36 pp [Atlants] 1675

76 Second report of progress of the mis eralogical, geological, and physical sures of the State of Georgia for 1875. $16 \mathrm{~m}$ [Atlanta] 1876

$\mathbf{7 6 a}$ Geological survey of the State of Georgia]. In Janes, Thomas P., Handbool of the State of Georgia: 17-109, ma? Atlants, Ga., 1876

78 Caialogue of ores, rocks, and wool selected irom the geological survey colle tion of tae State of Georgia, with a de scription of the geological formations. 10 pp, Atlanta, Ga, 1878

82 Report on the blue clay of the Mis sissippl River. U S Coast S, Rp 1850 (U S, 46th Cong $3 \mathrm{~d}$ sess, $\mathrm{S}$ Ex Doc 12) 145-171, map (1882)

83 A report on the blue clay of the Mississippi River. U S [War Dp], Chief Eng, An Rp 1883 (U S, 48th Cong 1st sess, H Ex Doc 1 pt 2 v 2 pt 3 ), Ap? SS : 2315-2339 (1883)

See also Hilgard, $71 \mathrm{a}$

Little, Homer Payson.

17 Development of knowledge concert ing the physical features of Anne Arundel County, with bibliography; the physios: raphy...; the geology...; the mineral it sources... : Md G S, Anne Arundel Counts: 23-132, maps (1917)

17a Pleistocene and post-Pleistocene get ology of Waterville, Me. G Soc Am, B 28:309-322, 167 (abst) (1917) 
Little, Homer Payson-Continued.

17b (with Millex, B. L., and others) Description of the Tolchester quadrangle, Md. U S G S, G Atlas Tolchester fol (no 204): $15 \mathrm{pp,} \mathrm{maps} \mathrm{(1917)}$

Little, James E.

17 Cuban iron mines and methods. Pan American Sc Cong, 2d, Washington, Pr sec 7 × $8: 270-281$ (1917)

Litton, Abram (1814-1901).

55 A preliminary report on some of the principal mines in Franklin, Jefferson, Washington, St. Francis, and Madison cos., Mo. Mo G S, An Rp 1-2 pt 2: 1-94 (1855) 57 Belcher \& Brother's artesian well [St. Louis, Mo.] Ac Sc St L, Tr 1: 80-86 (1857)

Livermore, Robert.

16 Mining districts of northern Ontario. M Sc Press 112: 89-92 (1916)

Livingston, Douglas Clermont.

12 Mining methods at Nacozari, Sonora, Mex. Am I M Eng, B 69:1009-1015 (1912) ; $\operatorname{Tr} 43: 662-669$ (1913)

14 (and Stewart, C. A.) The geology and ore deposits of the Dixie district, Idaho. Idaho Univ, B 9 no $2: 11 \mathrm{pp}$, map (1914)

18 The Idaho peneplain (discussion). Ec G $13: 488-492$, relief map (1918)

Liweh, Th.

85 Fahlerz vom Alaskagang im südwestlichen Colorado. Zs Kryst 10:488489 (1885)

Ljungstedt, 0 . A.

10 The erratic [a general account of the ice age in North America]. Nat Geog Mag $21: 525-531$ (1910)

Lloyd, E. Russell.

14 The Cannonball River lignite field, Merton, Adams, and Hettinger cos., N. Dak. U S G S, B 541: 243-291, maps (1914)

$14 \mathrm{n}$ The Cannonball marine member of the Lance formation ( $a b s t$ ). Wash Ac Sc, J 4:172-173 (1914)

14b (with Paige, S.) Recent literature on economic geology. Ec G 9:82-97 (1914)

15 (and Hares, C. J.) The Cannonball marine member of the Lance formation of North and South Dakota and its bearing on the Lance-Laramie problem. J G 23 : $523-547$, map (1915)

16 (with Winchester, D. E., and others) The lignite field of northwestern South Dakota. U S G S, B 627: $169 \mathrm{pp}$, maps (1916) Abst, Wash Ac Sc, J 7: 36-37 (1917)

17 (editor) The Bull Mountain coal field, Musselshell and Yellowstone cos., Mont. U S G S, B 647:218 pp, maps (1917) Abst, by R. W. Stone, Wash Ac Sc, J $7: 602-603$ (1917)

18 (and Mather, K. F.) Structure and oil and gas resources of the Osage Reservation, Okla.; T. 20 N., R. 11 E. U S G S, B 686:119-127, map (1918)
Lloyd, J. A.

49 Notes respecting the Isthmus of Panama. U S, 30th Cong, 2d sess, H Rp 145: 455-472 (1849)

Lloyd, John Uri.

04 When did the American mammoth and mastodon become extinct? Records of the Past $3: 43-46$ (1904)

Lloyd, T. C. B.

76 Geological notes from the State of New York [glacial, Jefferson Co.]. G Soc London, Q J 32:76-79 (1876) Abst, G Mag (2) $2: 520-521$ (1875)

Lobato, José G.

76 Geologia é hidrografía del Valle de México. Soc Geog Mex, B (3) 3:66-85 (1876) [not seen]

Lobeck, Armin Kohl.

15 Block diagrams of State physiography (abst). G Soc Am, B 26:77 (1915)

16 Position of the New England peneplain in the White Mountain region (abst). N Y Ac Sc, An 26:445-446 (1916)

17 The position of the New England peneplain in the White Mountain region. Geog Rv 3:53-60 (1917) Abst, G Soc Am, B $27: 108$ (1916)

18 The superb position of New York City as a center for physiographic study. N Y Ac Sc, An 28:1-50 (1918)

Lobley, J. Logan.

94 The origin of the gold of quartz veins. M Sc Press $69: 120$ (1894)

03 Volcanic action and the West Indian eruptions of 1902. Victoria Inst, Tr 35: 208-225 (1903)

Loeke, Augustus,

11 The geology of the Tonopah mining district [Nev.]. M Sc Press 103:523525 (1911). M World 35:1271-1272 (1911) Am I M Eng, B $62: 217-226$ (1912) : Tr 43:157-166 (1913)

12 The ore deposits of Goldfield [Nev.]. Eng M J 94: 797-802, 843-849 (1912)

12a The abnormal temperatures on the Comstock lode (discussion). Ec G 7:583587 (1912)

12b Tuolumne Table Mountain [near Jamestown, Cal.]. M Sc Press 165:85 (1912)

Locke, John (1792-1856).

38 Geological report. Ohio G S, 2d An Rp : 201-274 il, map (1838)

40 Report. In Owen, D. D., Report of a geological exploration of part of Iowa, Wisconsin, and Illinois... U S, 26th Cong 1 st sess, H Ex Doc $239: 116-159$ (1840) U S, 28th Cong 1st sess, S Ex Doc 407 : 147-189 (1844)

41 On a new species of trilobite found at Cincinnati, Ohio [Isotelus maximus] (abst). Am J Sc 41: 161 (1841); As Am G, Rp : 14 (1843)

41a On the geology of some parts of the United States west of the Alleghany Mountains (abst). Am J Sc 41:160-161 (1841) As Am G, Rp : 13-14 (1843) 
Locke, John-Continued.

42 On the fossil Cryptolithus tesselatus. Ac N Sc Phila, Pr 1: 196-197 (1842); 236, il (1843)

42a On a new species of trilobite of very large size [Isotelus megistos]. Am J Sc $42: 336-368$, il $(1842)$; As Am G, Rp : 221-224, il (1843)

$42 \mathrm{~b}$ On the rocks of the lead regions of the upper Mississippi. Am J Sc 43:147149 (1842) As $\Delta \mathrm{m}$ G, Rp: $43-45$ (1843) Abst, Geologist $1843: 32-34$

43 A new reflecting level and goniometer. As Am G, Rp: 238-239 (1843)

43a Notice of a prostrate forest under the diluvium of Ohio. As Am G, Rp : 240 241 (1843)

43b Notice of a new trilobite Ceraurus crosotus. Am J Sc 44: 346 (1843)

43e Supplementary notice of the Ceraurus crosotus. Am J Sc $45: 222-224$, il $(1843)$

46 Description of an Asterias from the Blue Limestone of Cincinnati. Ac $\mathrm{N}$ Sc Phila, $\operatorname{Pr} 3: 32-34$, il (1846)

46a Observations made...to determine the magnetical dip and the intensity of magnetical force, in several parts of the United States [includes notes on geology of stations]. Am Ph Soe, Tr n s 9:283-328 (1846)

47 [Geological observations in the Upper Peninsula of Michigan.] U S, Gen Land Off, Rp 1847 (U S, 30th Cong 1st sess, S Ex Doc 2) : 183-199 (1847)

49 Catalogue of specimens [and report of field work in Lake Superior region]. $U$ S, 31st Cong 1st sess, S Ex Doc 1 pt 3 and $\mathrm{H}$ Ex Doc 5 pt $3: 563-605$ (1849)

55 Catalogue of rocks, minerals, ores, and fossile collected by Dr. John Locke [Lake Superior region]. Smiths Inst, An Rp 9, 1854: 367-383 (1855)

See also Mather, $41 \mathrm{c}$

Locke, Joseph M.

$\mathbf{8 7}$ Gilsonite or uintahite, a new variety of asphaltum from the Uinta Mountains, Utah. Am I M Eng, Tr. 16:162-168 (1887)

Lockhart, Oliver C.

10 The oölitic limestone industry of Indiana. Ind Univ Studies no 9 (Ind Univ, B 8, no 8) : 71-110 (1910)

Lockington, W. N.

$\mathbf{8 5}$ On the causes of elevation and depression of the earth's surface. Science 6: $387-388$ (1885)

Loekwood, Samuel.

83 A Mastodon americanus in a beaver meadow [Freehold, N. J.] (abst). Am As, Pr 31:365-366 (1883)
Loel, W. F.

18 Vaqueros formation in Califomi (abst). G Soc Am, B 29:165 (1918)

Loew, Oscar.

73 (and Roessler, A. R.) Erforschung des Nordwesttheiles von Texas im Jakt 1872. Petermanns Mitt 19:453-467, mat (1873)

74 Lieutenant Wheeler's Expedition nad Neu-Mexiko und Arizona. Petermanns Yit $20: 401-416$, map (1874)

74a On wheelerite, a new fossil resin. Am J Sc (3) 7:571-572 (1874)

75 Geological and mineralogical report on portions of Colorado and New Mexico In Wheeler, G. M., Annual report... survess west of the 100th meridian...:97-116 (1875) Also in $\mathrm{U}$ S [War Dp], Chit Eng, An Rp 1875 (U) S, 44th Cong is sess, H Ex Doc 1 pt 2 v 2 pt 2) App LL: 1017-1036 (1875)

75a Report upon mineralogical, agricul. tural, and chemical conditions observed in portions of Colorado, New Mexico, and Arizona. U S Geog G S W 100th Ye (Wheeler), 3:569-661 (1875)

75b Lieutenant G. M. Wheeler's zweit Expedition nach Neu-Mexiko und Colorad 1874. Petermanns Mitt 21:441-45: (1875) ; $22: 209-217$, map (1876)

76 Report on the geological and minera: ogical character of southeastern Callfornil and adjacent regions. In Wheeler, G. M Annual report... surveys west of the 100 th meridian... : 173-199 (1876) Also in U \& [War Dp], Chief Eng, An Rp 1876 (U \& 44th Cong $2 d$ sess, H Ex Doc 1 pt 2 \%: pt 3) App JJ : 393-419 (1876)

76a Lieutenant Wheeler's Expedition durch das südliche Californien im Jabre 1875. Petermanns Mitt $22: 327-340,410$ 427, map (1876) ; 23: 134-140 (1877)

so Ein geologischer Spaziergang durch Neu-Mexico und Arizona. Geog Ge München, Jber 6:42-51 (1880)

Loewe, Stephan.

13 Die devonischen Korallen von Elles. mereland. Diss., Breslau, 23 pp, il, 1914. Also, Second Norwegian Arctic Expedition in the Fram 1898-1902, Report (published by Videnskabs-Selskabet 1 Kristiania) Do 30 (1913)

Loftus, J. P.

09 Round Mountain [Nevada], its mines and its history. Am M Cong, 12th At Sess. Rp Pr: 445-448 (1909)

Logan, C. A.

17 San Luis Obispo County. In Mines and mineral resources of the counties of Monterey, San Benito, San Luis Obispo, Santa Barbara, Ventura (Chapters of 8 t Mineralogist's Rp 1915-16): $80-132$, (al St M Bur (1917) 
Logan, C. A.-Continued.

17a (with Bradley, W. W.) San Benito County. In Mines and mineral resources of the counties of Monterey, San Benito, San Luis Obispo, Santa Barbara, Ventura (Chapters of St Mineralogist's Rp [15:674-726], 1915-16) : 22-79, Cal St M Bur (1917)

See also Bradley (W W), 18

Logan, William Edmond (1798-1875).

42 On the coal fields of Pennsylvania and Nova Scotia. G Soc London, $\operatorname{Pr} 3$ : 707-712 (1842) Geologist 1842:169-174

42a On the packing of ice in the river St. Lawrence. G Soc London, $\operatorname{Pr} 3: 766-$ 770 (1842) Can Nat $3: 115-122$ (1858)

45 Preliminary report [of progress, 1842]. Can G S, Rp Prog 1843: 159 pp (1845) [not seen]

45a [Remarks on the mode of making a geological survey of Canada.] Can G S, Rp Prog 1843:5-8 (1845) [not seen]

45b Report of progress for the year 1843 [general geologic features of eastern and western Canada]. Can G S, Rp Prog 1843: 23-50 (1845) [not seen]

45e Section of the Nova Scotia coal measures, as developed at the Joggins on the Bay of Fundy... Can G S, Rp Prog 1843: 92-159 (1845) [not seen] N S Inst Sc, Pr Tr 11: 419-499 (1908)

46 [On the geology of the Chat and Cascapedia rivers, Gaspé, and part of Chaleur Bay.] Can G S, Rp Prog 1844:5-66 (1846)

46a [Sections on Chaleur Bay and coast of Gaspé.] Can' G S, Rp Prog 1844: 78110 (1846)

$46 \mathrm{~b}$ On the packing of the ice in the River St. Lawrence; the occurrence of landslips in the modern deposits of its valley; and the existence of marine shells fn them and on the mountain of Montreal. G Soc London, Q J 2: 422-432 (1846)

47 [On the geology of the Ottawa River region.] Can G S, Rp Prog 1845-6: 5-98, 119-122 (1847)

47 a [On the geology and economic minerals of the north shore of Lake Superior.] Can G S, Rp Prog 1846-7: 5-46 (1847)

$47 \mathrm{~b}$ Remarks on the mining region of Lake Superior... 31 pp, Montreal 1847.

49 [On the geology of the country on the south side of the St. Lawrence from Montreal and Lake Champlain to the Chaudiere River, Quebec.] Can G S, Rp Prog 1847-8: 5-92 (1849)

49a Report on the north shore of Lake Huron. Can G S; 51 pp, map, Montreal 1849 [also doc. ed.]

50 [On the geology of the eastern townships of Quebec.] Can G S, Rp Prog 1849-50:5-72 (1850)

$$
28737^{\circ}-23-43
$$

Logan, William Edmond-Continued.

51 On the occurrence of a track and footprints of an animal in the Potsdam sandstone of Lower Canada. G Soc London, Q J $7: 247-250$ (1851)

52 [On the gold-bearing drift of the Chaudière River.] Can G S, Rp Prog 18501:5-11 (1852)

$\mathbf{5 2 a}$ [On the geology of the Beauharnois region, etc.] Can G S, Rp Prog 1851-2 : $5-56$ (1852)

52b On the footprints occurring in the Potsdam sandstone of Canada. $G$ Soc London, Q J 8:199-213, map (1852)

52e On the age of the copper-bearing rocks of Lake Superior and Huron, and various facts relating to the physical structure of Canada. Brit As, Rp 21: sec 5962 (1852) Am J Sc (2) 14:224-229 (1852)

53 On the rocks of Canada. Can J 1: 124-126 (1853)

54 [On the geology of the region north of the St. Lawrence between Montreal and Cape Tourmente, Quebec.] Can G S, Rp Prog 1852-3 : 5-74 (1854)

$54 a$ (and Hunt, T. S.) On the chemical composition of recent and fossil Lingulae and some other shells. Can J 2: 264-265 (1854) Am J Sc (2) $17: 235-239$ (1854)

54b On the physical structure of the western district of Upper Canada. Can J $3: 1-2$, map (1854)

54e Geology of western Canada [Ontario]. Can J 3:27-29 (1854)

54d Geological survey of Canada: report of progress for the year 1852-3 [extr]. Can J 3: 97-101 (1854)

55 (and Hunt, T. S.) Esquisse géologique du Canada...a l'exposition universelle de Paris, 1885. [Can G S] : 100 pp, map, Paris 1855 Map also in Soc G France, B (2) $12:$ opp 1316 (1855)

55a Sur la formation silurienne des environs de Quebec. Soc G France, B (2) $12: 504-508$ (1855)

57 [On the geology of Argenteuil and Two Mountains cos., Que.] Can G S, Rp Prog 1853-6: 5-57, map (1857)

$\mathbf{5 7 a}$ On the division of the Azoic rocks of Canada into Huronian and Laurentian. Can Nat 2:255-258 (1857) Can J n s 2: 439-442 (1857) Am As, Pr 11 pt 2:4447 (1858) Abst, Edinb N Ph J n s $6: 349$ (1857)

$57 b$ On the probable subdivision of the Laurentian series of rocks of Canada. Can Nat $2: 270-274$ (1857) Am As, Pr 11 pt $2: 47-51$ (1858) Can J n s 3:1-5 (1858) Abst, Edinb N Ph J n s $6: 350$ (1857)

58 Report for the year 1857. Can G S, Rp Prog 1857: 5-11 (1858) 
Loman, William Edmond-Continued.

$\mathbf{5 S a}$ Relative dates of various intrusive rocks cutting the Laurentian series in Canada. Can J n s 3:107-110 (1858)

59 [On the Laurentian limestones and drift of the Grenville region, Quebec.] Can G S, Rp Prog 1858:5-66, map (1859)

$59 a$ On the Laurentian limestones (abst). Can Nat 4:300-301 (1859)

60 On the track of an animal lately found in the Potsdam formation. Can Nat 5:279-285, il (1860) Am J Sc (2) 31: 17-23, il (1860)

$60 a$ Remarks on the fauna of the Quebec group of rocks, and the Primordial zone of Canada... Can Nat 5:472-477 (1860) Can J n s 6:40-46 (1861) Am J Sc (2) 31: 216-220 (1861) Report on the geology of Vermont (Hitchcock) 1:379-382 (1861)

$60 \mathrm{~b}$ Contribution to the history of the Laurentian limestones. $\mathrm{Am}$ As, $\operatorname{Pr} 13$ : 310-312 (1860)

61 Considerations relating to the Quebec group and the upper copper-bearing rocks of Lake Superior. Can Nat 6:199-207 (1861) Am J Se (2) $33: 320-327$ (1862)

61 The copper deposits of Acton and other localities in Canada. M Mag (2) 2: 1-14 (1861)

61b Remarques sur la faune des roches du groupe de Quebec et sur la zone primordiale du Canada... Soc G France, B (2) $18: 309-314$ (1861)

62 (and Hunt, T. S.) Descriptive catalogue of a collection of the economic minerals of Canada [by W. E. Logan] and of its crystalline rocks [by T. S. Hunt] ; London International Exhibition, 1862. Can G S : 88 pp, Montreal 1862

$62 a$...the age of the Quebec rocks. Am J Sc (2) $33: 105-106$ (1862)

63 (and others) Report on the geology of Canada. Can G S, Rp Prog to 1863: $983 \mathrm{pp}$, il, maps in atlas (1863)

$63 a$ On the rocks of the Quebec group at Point Lévis. Can Nat 8:183-194 (1863) Am J Sc (2) 36:366-377 (1863)

64 Notes on the gold of eastern Canada; being a reprint of portions of various reports of the Geological Survey of Canada from 1848 to 1863 . $40 \mathrm{pp}$, Montreal 1864.

$64 a$ On organic remains in the Laurentian rocks of Canada. Am J Sc (2) 37: 272-273 (1864) Can Nat n s 1:159-160 (1864)

64b (with Hall, James) On the geology of eastern New York. Can Nat n s $1: 368-369$ (1864) Am J Sc (2) 39: 96-97 (1864)

65 On the occurrence of organic remains in the Laurentian rocks of Canada. G Soc London, Q J 21:45-50 (1865) Can Nat in s 2:92-99 (1865)

66 [Summary] report [of the director]. Can G S, Rp Prog 1863-6:3-27 (1866)
Logan, Willlam Edmond-Continued, 67 (and others) Esquisse géologį̣ du Canada, suivie d'un catalogue descrip tif ... a l'exposition universelle de 185 . Can G S: 72 pp (1867)

67a On new specimens of Eozoon. Soc London, Q J $23: 253-257$ (1867) Cu Nat n s $3: 306-310$ (1868)

69 (and Ha11, Jamres) Geological ma of Canada... [and of adjacent parts of th United States]. Scale 1:1584000 miles to inch]. Can G S 1866 [180\% Notice, Am J Sc (2) 49:394-398 (18i) 70 Report on a part of the Pictou cul field, N. S, Can G S, Rp Prog 1866-8: 3-\$3, map (1870)

70a [Notes on the report of $R$. Bell a: the Nipigon region.] Can G S, Rp Pry, 1866-9:471-475 (1870)

See also Dana, 61; Hitchcock (E), 596; Murray, 66

Logan, William Newton.

97 The upper Cretaceous of Kansa; with an introduction by Erasmus Haworth Kans Univ G S 2: 195-234 (1897)

97 a Some new cirriped crustacari from the Niobrara Cretaceous of Kanss Kans Univ Q 6:187-189 (1897)

98 The invertebrates of the Benton, Nis brara, and Fort Pierre groups. Kans Utir G S $4: 431-518$, il (1898)

99 Contributions to the paleontology the upper Cretaceous series. Field of Mus, Pub g s 1:201-214, il (1899)

99a A discussion and correlation of cor tain subdivisions of the Colorado formt tion. J G $7: 83-91$ (1899)

$99 b$ Some additions to the Cretaceos invertebrates of Kansas. Kans Univ Q 8: $87-98$, il (1899)

00 A North Ameriean epicontinental ad of Jurassic age. J G $8: 241-273$, mans (1900)

O0a The stratigraphy and invertebrate faunas of the Jurassic formation in the Freeze-out Hills of Wyoming. Kans Unir Q $9: 109-134$, Il (1900)

04 Economic products of St. Lawrene Co., N. Y. N Y St Mus, An Rp 56: r118 124 (1904)

O4a The geology of Oktibbeha Co. (Geo logical and Industrial Survey of Missity sippi, Report I). Miss Agr Mech Coll, B1 no $2: 67$ pp, map (1904)

o5 (and Perkins, W. R.) The undes ground waters of Mississippi. Miss Agt Exp Sta, B 89: 112 pp (1905)

O5a (and Hand, W. F.) A preliminar report on some of the clays of Mississippt Miss G S, B 3 (Miss Agr Mech Coll, B ? no 3) : $88 \mathrm{pp}$, map (1905)

O5b Circular on the underground wates of Mississippi. Miss Agr Exp Sta: 16 p? (1905)

o7 Clays of Mississipp1; Part I, Brick clays and clay industry of northern Missis sippi. Miss G S, B 2:255 pp (1907) 
Logan, William Newton-Continued.

os Clays of Mississippi; Part II, Brick clays and clay industry of southern Mississippi. Miss G S, B 4: 72 pp, map (1908) 09 The pottery clays of Mississippi. Miss G S, B 6:228 pp (1909)

11 The structural materials of Mississippi. Miss G S, B 9:78 pp (1911)

13 The soils of Mississippi. Miss $\mathrm{Agr}$ Exp Sta, Tech B 4: 49 pp, map (1913)

16 Preliminary report on the marls and limestone of Mississippi. Miss G S, B 13 : 82 pp (1916)

18 The Mount Carmel fault. Ind Ac Sc, Pr $1917: 221-226$ (1918)

18a Certain indicia of dip in rocks. Ind Ac Sc, Pr 1917: 229-234 (1918)

Lombard, Robert $\mathrm{H}$.

17 (with Allen, E. T.) A method for the determination of dissociation pressures of sulphides, and its application to covellite (CuS) and pyrite $\left(\mathrm{FeS}_{2}\right)$. Am J Sc (4) $43: 175-195$ (1917)

Lombard, Warren R.

06 (and D'ooge, M. L.) Israel Cook Russell. Science n s 24:426-431 (1906)

Long, E. Tatum.

17 The formation of salt crystals from a hot saturated solution. Am J Sc (4) 43 : 289-292 (1917)

Long, Stephen Harriman (1784-1864).

23 Account of an expedition from Pittsburgh to the Rocky Mountains performed in the years 1819 and '20... See James (E), 23

24 Narrative of an expedition to the source of St. Peter's River, Lake Winnepeek, Lake of the Woods, etc., etc., performed in the year $1823 \ldots$ See Keating, 24

58 Inspection report on the passes of Mississippi River, May 31, 1858. U S, 35th Cong 1st sess, H Ex Doc 139: 72 pp, map (1858)

Long, Stephen S.

32 Description of a natural tunnel, in Scott Co., Va. (with remarks by G. W. Featherstonbaugh). Monthly Am J G 1: $347-355$ (1832)

Longyear, Robert Davis.

18 (with Roberts, H. M.) Genesls of the Sudbury nickel-copper ores as indicated by recent explorations. Am I M Eng, Tr 59:27-56 (1918); B 134:555584 (1918)

18a (with Roberts, H. M.) Exploration of nickel-copper properties in Falconbridge township, Sudbury district, Ont. Can M J 39:50-53 (1918)

$18 b$ (with Roberts, H. M.) Origin of Sudbury nickel-copper deposits. Can M J $39: 135-136$ (1918)

Lonsdale, Elston Holmes (1868-1898).

94 Southern extension of the Cretaceous In Iowa. Iowa Ac Sc, Pr 1 pt $4: 39-43$
Lonsdale, Elston Holmes-Contlnued.

94a Topography of the granite and porphyry region of Missouri. Iowa Ac Sc, Pr 1 pt $4: 43-48$ (1894)

95 Geology of Montgomery Co. Iowa G S $4: 381-451$, map (1895)

95 a Cement materials in Iowa (abst). Iowa Ac Sc, $\operatorname{Pr} 2: 172-174$ (1895) Eng M J $60: 153$ (1895)

95b Upper Carboniferous of southwestern Iowa. Iowa Ac Sc, Pr 2:197-200 (1895)

Lonsdale, William.

45 Account of six species of Polyparia obtained from Timber Creek, N. J. G Soc London, Q J 1:65-75, il (1845)

45a Account of ten species of Polyparia obtained from the Miocene Tertiary formations of North America. G Soc London, Q J $1: 495-509$, il (1845)

45b Account of twenty-six species of Polyparia obtained from the Eocene Tertiary formation of North America. G Soc Inondon, Q J 1:509-533, n (1845)

47 Remarks on the characters of several species of Tertiary corals from the United States. Am J Sc (2) $4: 357-359$ (1847)

53 Notes on the fossil corals of San Domingo. G Soc London, Q J 8:132-134 (1853)

Loomis, Frederic Brewster.

oo Die Anatomie und die Verwandtschaft der Ganoid- und Knochen-Fische aus der Krelde-Formation von Kansas, U. S. A. Palaeontographica $46: 213-283$, il (1900)

Ooa Siluric fungi from western New York. N Y St Mus, B 39:223-226, il (1900)

o1 On Jurassic stratigrapny in southeastern Wyoming. Am Mus $\mathrm{N} \mathrm{H}, \mathrm{B}$ 14: 189-197 (1901)

02 On Jurassic stratigraphy on the west side of the Black Hills; second paper on American Jurassic stratigraphy. Am Mus N H, B 16. 401-407, map (1902)

03 The dwarf fauna of the pyrite layer at the horizon of the Tully limestone in western New York. N Y St Mus, B 69 : $892-920$, il (1903)

04 Two new river reptiles from the titanothere beds. Am J Sc (4) 18:427432 , il (1904)

04a On some marine fossils in the titanothere beds (abst). Science n $\mathrm{s} 19$ : 254 (1904)

$04 b$ (with Emerson, B. K.) On Stegomus longipes, a new reptile from the Triassic sandstones of the Connecticut Valley. Am J Sc (4) $17: 377-380$, il (1904)

o5 Hyopsodidae of the Wasatch and Wind River basins. Am $J$ Sc (4) 19 : 416-424, il (1905)

05a The Amherst College expedition to the Wasatch and Wind River basins in 1904 (abst). Science n s 21: 296 (1905) 
Loomis, Frederic Brewster-Continued.

06 Wasatch and Wind River primates. Am J Sc (4) 21:277-285, il (1906)

06a A fossil bird from the Wasatch. Am

J Sc (4) $22: 481-482$, il (1906)

o7 Wasatch and Wind River rođents. Am J Sc (4) 23:123-130, il (1907)

ora Origin of the Wasatch deposits. Am J Sc (4) $23: 356-364$ (1907)

os The American Society of Vertebrate Paleontology [seventh annual meeting at Yale University]. Science n s 27:254256 (1908)

OSa Rhinocerotidæ of the lower Miocene. Am J Sc (4) 26:51-64 (1908)

08b A new horse from the lower Miocene [Parahippus tyleri, Sioux Co., Nebr.]. Am J Sc (4) $26: 163-165$, Il (1908)

ose [On a vertebrate fauna from the Niobrara beds of Wyoming (abst).] Science n s $27: 254$ (1908)

09 Turtles from the upper Harrison beds [Nebraska]. Am J Sc (4) 28:17-26 il (1909)

O9a Camets of the lower Miocene (abst). Science n s 29:196 (1909)

10 Osteology and affinities of the genus Stenomylus. Am J Sc (4) $29: 297-323$, il (1910)

10a A new genus of peccaries [Pediohyus ferus, Harrison beds, Converse Co., Wyo.]. Am J Sc (4) $30: 381-384$, il (1910)

10b Ontogeny, a study of the value of young features in determining phylogeny. Pop Sc Mo $77: 292-294$ (1910)

11 The camels of the Harrison beds, with three new species. Am J Sc (4) 31 : 65-70, il (1911)

11a A nex mink from the shell heaps of Maine. Am J Sc (4) $31: 227-229$, il (1911)

$11 \mathrm{~b}$ The adaptations of the primates. Am Nat 45: 479-492, il (1911)

14 Restoration of some Pyrotherium mammals (abst with discussion). G Soc Am, B 25: 139-140 (1914)

14a Analysis of the Pyrotherium fauna (abst with discussion). G Soc Am, B 25: 140 (1914)

15 A new mosasaur from the Fort Pierre [Platecarpus brachycephalus, Wyoming]. Am $J$ Se (4) $39: 555-566$, il (1915)

16 (with Blaney, D.) A Pleistocene locallty on Mt. Desert Island, Me. Am J Sc (4) $42: 399-401$ (1916)

17 South Carolina mastodon (abst). G Soc Am, B 28: 210-211 (1917)

18 An unusual mastodon. Am J Sc (4) 45: 438-444, il (1918)

Loomis, I. N.

46 An account of the geology of the Harpeth Ridge, Davidson Co., Tenn. Am J Sc (2) $1: 222-224$ (1846)
Loomis, Justin R.

52 The elements of geology... 198 pp, Boston 1852

Loper, S. Ward.

91 (with Davis, W. M.) Two belts ot fossiliferous black shale in the Triassic formation of Connecticut. $G$ Soc $A$ m, B $2: 415-430$ (1891)

López de Quintana, Dlego.

17 Informe sobre las minas del Cobm [copper deposits near Santiago, Cuba]. Cuba, Dir Montes, Bol Minas no 2:73-83 (1917)

Lopez Monroy, Pedro.

69 Observaciones sobre una presunts especie mineral nueva nativa de Méxion. La Naturaleza 1: 76-78 (1869)

$69 a$ Observaciones sobre algunos com. bustibles minerales de Méxíco. La Natt. raleza $1: 87-94$ (1869)

70 Hipotesis geológica; los estados de existencia de la tierra. La Naturaleza 1: 238-241 (1870)

Lord, David $N$.

55 Geognosy or the facts and principles of geology against theories. $192 \mathrm{pp}, \mathrm{N} I$ $18552 \mathrm{~d}$ ed, $193 \mathrm{pp}, \mathrm{N}$ Y 1857

Lord, Edwin Chesley Estes.

98 On the dikes in vicinity of Portland. Me. Am G 22:335-346, map (1898)

99 Petrographic report on rocks frotl the United States-Mexico boundary. I s Nat Mus, Pr 21: 773-782 (1899)

oO Report on igneous rocks from the + cinity of San Carlos and Chispa, Tex. U\& G S, B 164: 88-95 (1900)

OOa Notes on the geology and petrogra. phy of Monhegan Island, Me. Am G 20: 329-347, map (1900)

o7 Examination and classification of rocks for road building, including the phys ical properties of rocks with reference to their mineral composition and structure. U S Dp Agr, Off Public Roads, B 31:29 pp (1907) ; $37: 28$ pp (1911)

16 Relation of mineral composition and rock structure to the physical properties of road materials. U S Dp Agr, B 348:26 pp (1916)

\section{Lord, Eleazer.}

43 Geological cosmogony... 167 pp, N I 1843

Lord, Nathaniel Wright.

84 Report of chemical department. Ohlo G S, Rp 5: 1087-1113 (1884)

84a The Hanging Rock region [Ohio], Ohio M J 3: 3-10 (1884)

88 Natural and artificial cements. Obilo G S, Rp 6:671-695 (1888)

13 (and otbers) Analyses of coals is the United States with descriptions of mine and field samples collected between July 1, 1904, and June 30, 1910 . U \& Bur Mines, B 22: 1200 pp (1913) 


\section{Lord, P. B.}

11 (and Bonilias, $Y$. S.) Algunos criaderos argentiferos de cerca de Reyes, Durango. Soc G Mex, B 7:149-154, map (1911)

\section{Lorenzen, Johan.}

81 Undersögelse af nogle Mineraller i Sodalith-Syeniten fra Julianehaabs Distrikt. Med Grönland 2:43-77 (1881)

93 Kemisk Undersögelse af det metalliske Jern fra Grönland samt nogle af de dermed fölgende Bjergarter. Med Grönland $4: 133-172,275-282$ (1893)

93a Undersögelse af Mineralier fra Grönland. Med Grönland 7:1-31 (1893)

93b Fortsatte Undersögelser af Mineraller fra Kangerdluarsuk. Med Grönland 7 : 33-46 (1893)

Loriê, J.

89 Fossile Mollusken von Curaçao, Aruba, und der Küste von Venezuela. G Reichs-Mus Leiden, Samm (2) 1:111-149, il (1889)

Loring, Frank C.

07 Cobalt [Ont.]. M Sc Press 95:814815 (1907)

Loring, W. J.

11 The Porcupine gold field [Ont.]. M Mag 4:284-288 (1911)

Loriol, Perceval de.

$93 \mathrm{om}$ fossile Saltvandsdyr fra NordGrönland [marine fossils of north Greenland]. Med Grönland 5: 203-213 (1893)

Londerback, George Davis.

01 General geological features of Nevada, and their relationships to the prevalling economic deposits. Int $\mathbf{M}$ Cong, 4th, $\mathrm{Pr} \cdot 200-207$ (1901)

03 Some gypsum deposits of northwestern Nevada (abst). J G 11:99 (1903)

03a A structural section of a Basin range (abst). J G 11:102-103 (1903)

04 Gypsum deposits in Nevada. U S G S, B 223: 112-118 (1904)

04a Basin Range structure of the Hum. boldt region [Nev.]. G Soc Am, B 15: 289-346, maps (1904) Abst, Sc Am Sup $57: 23446$ (1904)

05 The Mesozoic of southwestern Oregon.

J G 13:514-555, map (1905)

06 The relation of radioactivity to volcanism. J G 14:747-757,1906)

06a Study of the Basin range structure and glaucophane and associated schists of California and Oregon. Carnegie Inst Wash, Y Bk 4:191 (1906)

07 Benitoite, a new alifornia gem $\mathrm{min}$ eral. Cal Univ, Dp G, B $5: 149-153$ (1907)

07a Where mammoths roved; recent discoveries in Carson, Nev., State prison. Sunset Mag 19:205-216, il (1907)

08 General geological features of the Truckee region east of the Sierra Nevada (abst). G Soc Am, B 18:662-669 (1908)
Londerback, George Davis-Continued.

osa The chief features of the stratigraphy and structure of Mount Diablo, Cal. (abst). Science n s 27: 16 (1908)

osb (and sharwood, W. J.) Crocidolite-bearing rocks of the California coast ranges (abst). G Soc Am, B 18: 659 (1908)

09 Benitoite, its paragenesis and mode of occurrence, with chemical analyses by Walter C. Blasdale. Cal Univ, Dp G, B 5: 331-380 (1909) Abst, Science n s 27:411 (1908)

09a Chief features of the stratigraphy and structure of Mount Diablo, Cal. (abst). G Soc Am, B $19: 537-538$ (1909)

10 The Geological Society of America; eleventh annual meeting of the Cordilleran section. Science n s $32: 30-31$ (1910)

10a Proceedings of the eleventh annual meeting of the Cordilleran section of the Geological Society of America, held at Berkeley, California, March 25 and 26, 1910. G Soc Am, B $21: 789-796$ (1910)

$10 \mathrm{~b}$ Secondary pseudostratification in Santa Barbara Co., Cal. (abst). Science n s 32:30-31 (1910) G Soc Am, B 21: 791 (1910)

10e (and Blasdale, W. C.) Ruby corundum from San Bernardino Co., Cal. (abst). Science n s $32:: 1$ (1910) G Soc Am, B 21: 793 (1910)

11 Lake Tahoe, California-Nevada. J Geog $9: 277-279$ (1911)

12 Pseudostratification in Santa Barbara Co., Cal. Cal Univ, Dp G, B $7: 21-38$ (1912)

12a Proceedings of the twelfth annual meeting of the Cordulleran section of the Geological Society of America, held at Berkeley, Cal., March 31 and April 1, 1911. G Soc Am, B 23:69-76 (1912)

12b Some general features of the Miocene of the southern coast range region of California (abst). G Soc Am, B 23: 72 (1912)

13 The Monterey series in California. Cal Univ, Dp G, B $7: 177-241$ (1913)

13a Proceedings of the thirteenth annual meeting of the Cordilleran section of the Geological Society of America, held at Stanford University, California, April 5, 1912. G Soc Am, B $24: 91-98$ (1913)

$13 \mathrm{~b}$ General features of the structure of the bedrock complex of the Sicrra Nevada (abst). G Soc Am, B 24:9S (1913)

14 Proceedings of the fourteenth annual meeting of the Cordilleran section of the Geological Society of America, held at Berkeley, Cal., April 11 and 12, 1913, G Soc Am, B 25: 119-126 (1914)

14a (with Sumner, F. B., and others) A report upon the physical conditions in San Francisco Bay... [sedimentation, etc.]. Cal Univ, Pub Zool 14 no 1:1-198 (1914) 
Louderback, George Davis-Continued.

15 Proceedings of the fifteenth annual meeting of the Cordilleran section of the Geological Society of America held at Seattle, Washington, May 21 and 22, 1914. G Soc Am, B 26: 129-140 (1915)

15a Basin Range faulting in the nortbwestern part of the Great Basin (abst). G Soc Am, B 26:138-139 (1915)

18 Californian manganese problem. M S Press 116: 451-452 (1918)

See also Butler, $15 \mathrm{a}$

Loughrin, Gerald Francis.

04 (with Crosby, W. O.) A descriptive catalogue of the building stones of Boston and vicinity [Mass.]. Tech Q 17 : 165-185 (1904)

o5 The clays and clay industries of Connecticut. Conn G S, B 4:121 pp, map (1905)

09 Ore deposition at Aspen, Colo. Ec G $4: 658-660$ (1909)

10 The Norwood meteorite (?]. Science n s $31: 418-419,580$ (1910) (See also Very, 10)

10a Intrusive granites and associated metamorphic sediments in southwestern Rbode Island. Am J Sc (4) 29:447-457, map (1910)

$10 b$ (and others) Recent literature on economic geology. Ec G $5: 81-89,283-$ 291, 575-585 (1910)

10c (with Barrell, J.) The lithology of Connecticut. Conn G S, B 13:207 pp (1910)

11 Contribution to the geology of the Boston and Norfolk basins, Massachusetts; I. The structural relations between the Quincy granite and the adjacent sedimentary formations. Am J Sc (4) 32:1732 , map (1911)

12 The gabbros and associated rocks at Preston, Conn. U S G S, B 492: 158 pp (1912). Abst (by C. E. Siebenthal), Wash Ac Sc, J 2:408-410 (1912)

13 Reconnaissance in the southern Wasatch Mountains, Utah. J G 21:436452 (1913) Abst, Wash Ac Sc, J 3:50-51 (1913)

14 A reconnaissance in the Canyon Range, west-central Utah. U S G S, P P 90:51-60, map (1914) Abst, Wash Ac Sc, J $5: 19$ (1915)

14a The oxidized zinc ores of the Tintic district, Utah. Ec G 9:1-19 (1914)

14b (and Hechinger, L. A.) An unconformity in the Narrangansett Basin of Rhode Island and Massachusetts. Am J Sc (4) 38:45-64, map (1914)

14e Stone industry. U S G S, Min Res 1913 pt $2: 1346-1366,1376-1387$; 1914 pt $2: 819-891 ; 1915$ pt $2: 761-842$; 1916 pt $2: 993-1078$ (1914-8)

15 Recent alunite developments near Marysville and Beaver, Utah. U S G S, B $620: 237-270$ (1915)
Loughlin, Gerald Francis-Continued.

15 a The gypsum industry in 1914. O8 G S, Min Res 1914 pt 2:261-270 (1915) 15b The production of sand and gravel in 1914. U S G S, Min Res 1914 pt 2 271-283 (1915)

15e The production of lime. U S G \&, Min Res 1914 pt $2: 363-373 ; 1915$ pt 2 : 245-264; 1916 pt $2: 433-462$ (1918)

15d Stratigraphy of the Tintic mining district, Utah (abst). Wash Ac Sc, J 5: 142 (1915)

15e (with Butler, B. S.) A recon. naissance of the Cottonwood-American Fork Mining region, Utah. U S G S, B $620: 165-226$, map (1915)

16 Slate. U S G S, Min Res $1915 \mathrm{pt}$ $2: 19-31 ; 1916$ pt $2: 61-72 ; 1917$ pt 2: 121-138 (1916-18)

$16 a$ Ores, magmatic emanations, and modes of igneous intrusion (discussion). Ec G 11:284-288 (1916)

16b Magnesia in limestone. National Lime Manufacturers' As, B no $4: 11 \emptyset$ (1916)

16e Faulting in the Tintic mining district, Utah (abst). Wash Ac Sc, J 6:190 (1916)

$16 d$ (with Fiteh, R. S.) Wolframite and scheelite at Leadville, Colo. Ec G 11: 30-36 (1916) M World 44:1039-1040 (1916)

17 Zinc carbonate and related copper carbonate ores at Ophir, Utah. U S G S, B $690: 1-14$ (1917) Abst, by R. W. Stope Wash Ac Sc, J 8:129-130 (1918)

17a (and Schaller, W. T.) Crandal. lite, a new mineral [Tintic mining dis trict, Utah]. Am J Sc (4) $43: 69-74$ (1917)

1s The oxidized zinc ores of Leadville Colo. U S G S, B 681: 91 pp (1918)

18a Two lamphrophyre dikes near $S a n-$ taquin and Mount Nebo, Utah. U S G 8, P P 120:101-109, map (1918)

Loughridge, Robert Hills (1843-1917), 84 Outline of the physical geography o! the State of Missouri. U S, 10th Census 5: 505-519 (1884)

84a Physico-geographical and agricultural features of the State of Arkansas. U S, 10th Census 5:543-630, map (1884) 84b Physico-geographical and agricul. tural features of the State of Texas. U $\$$, 10th Census 5:669-806, map (1884)

84c Physico-geographical and agricultural description of the Indian Territors. U S, 10th Census 5: 843-854 (1884)

84d Physico-geographical and agricul tural features of the State of Georgla U S, 10th Census 6:275-424, map (1884)

88 Report on the geological and ect nomic features of the Jackson's Purchase region, embracing the counties of Ballard. Calloway, Fulton, Graves, Hickman, IfCracken, and Marshall. Ky G S, F: 357 pp, maps (1888) 
Loughridge, Robert Hills-Continued.

90 Report on the geology of Clinton County, with map. Ky G S: 48 pp, map [1890?]

Louis, Henry.

78 Notes on Nova Scotian mineralogy. N S Inst N Sc, Pr Tr 4:423-428 (1878)

79 A new mineral (louisite) from Blomidon, N. S. N S Inst N Sc, Pr Tr 5: 15-16 (1879)

79a on the ankerite veins of Londonderry, N. S. N S Inst $\mathrm{N}$ Se, $\operatorname{Pr} \operatorname{Tr} 5: 47-$ 57 (1879)

97 [Copper deposits of New Annan, N. S.] Am I M Eng, Tr 26:1051-1052 (1897)

06 What is a fissure vein? Ec G 1: 481-484 (1906)

10 Criteria of downward sulphide enrichment. Ec G 5:390 (1910)

Love, A. E. H.

08 The origin of continents and oceans. Sc Am Sup 65: 268-270 (1908)

Lovejoy, Ellis.

88 The Pomeroy and Federal Creek coal field. Obio G S, Rp 6: 627-652, map (1888) Loveman, Michael Heilprin.

11 Geology of the Phillips pyrites mine near Peekskill, N. Y. Ec G $6: 231-246$ (1911)

12 Geology of the Miami copper mine [near Globe, Ariz.]. M Sc Press 105: 146148 (1912)

Lovervel1, J. T.

03 Gold in Kansas shales. Kans Ac Sc, Tr 18:129-133 (1903)

03a Gold in Kansas. Kans Ac Sc, Tr 18:134-137 (1903)

Low, Albert Peter.

85 Report on explorations and surveys in the interior of the Gaspé Peninsula, 1883. Can G S, Rp Prog 1882-4: F 21 pp (1885)

85a Report of the Mistassini expedition, 1884-5. Can G S, An Rp 1: D 1-33, map (1885)

87 Preliminary report on an exploration of country between Lake Winnipeg and Fudson Bay. Can G S, An Rp 2: F 1-19 (1887)

88 Report on explorations in James Bay and country east of Hudson Bay, drained by the Big, Great Whale, and Clearwater rivers. Can G S, An Rp 3: J 1-62 (1888)

90 The Mistassini region [Quebec]. Ottawa Nat $4: 11-28(1890)$

90a (with Ami, H. M.) Report of the geological branch [of the Ottawa Field Naturalists' Club]. Ottawa Nat $4: 70-73$ (1890)

91 [Summary report on work in the Lake St. John region, Que.] Can G S, Sum Rp 1890 (An Rp 5) : A 50-53 (1891)

92 [Report on field work in the southern parts of Champlain and Portneuf cos., Que.] Can G S, Sum Rp 1891 (An Rp 5) : A $45-48$ (1892)
Low, Albert Peter-Continued.

92a Report on the geology and economic minerals of the southern portion of Portneuf, Quebec, and Montmorency counties, Province of Quebec. Can G S, An Rp 5: L 1-71 (1892)

93 [Report on field work in Lake Mistassini region, Que.] Can G S, Sum Rp 1892 (An Rp 6) : A 46-48 (1893)

93a Notes on the glacial geology of western Labrador and northern Quebec. G Soc Am, B 4:419-421 (1893) Abst, Am G $11: 133-134$ (1893)

93b Notes on the glacial geology of the Northeast Territories (abst). Am G 11: 176 (1893)

95 [Report on explorations in northern Quebec.] Can G S, Sum Rp 1894 (An Rp 7) : ^ 62-80 (1895)

96 [Report of explorations in Labrador Peninsula.] Can G S, Sum Rp 1895 ( $\mathrm{An}$ Rp 8) : A 98-105 (1896)

$96 a$ Report on explorations in the Labrador Peninsula along East Main, Koksoak, Hamilton, Manicuagan and portions of other rivers in 1892-93-94-95. Can G S, An Rp 8: L 1-311 (1896)

97 [Report on field work in the northern part of Labrador Peninsula.] Can G S, Sum Rp 1896 (An Rp 9) : ^ 83-89 (1897)

97 a The Labrador area. Ottawa Nat $10: 208-216$ (1897)

98 Report on a traverse of the northern part of the Labrador Peninsula from Richmond Gulf to Ungava Bay. Can G S, An Rp 9: L 43 pp (1898)

98a [Report of exploration in the Hudson Strait region.] Can G S, Sum Rp 1897 (An Rp 10) : A 84-92 (1898)

99 [Report of explorations on the east coast of Hudson Bay.] Can G S, Sum Rp 1898 (An Rp 11) : A 124-133 (1899)

99a Report on an exploration of part of the south shore of Hudson Strait and Ungava Bay, Can G S, An Rp 11:L 47 pp, map (1899)

oo [Report on explorations of the east coast of Hudson Bay.] Can G S, Sum Rp 1899 (An Rp 12) : A 139-148 1900)

02 Report on an exploration of the east coast of Hudson Bay from Cape Wolstenholme to the south end of James Bay. Can G S, An Rp 13: D 84 pp, maps (1902)

o3 Report on the geology and physical character of the Nastapoka Islands, Hudson Bay. Can G S, An Rp 13 : DD 31 pp (1903)

o5 The government expedition to Hudson Bay and northward by the S. S. Neptune 1903-04. Can G S, Sum Rp 1904 (An Rp 16) : A 122-143 (1905)

o5a The field work of a physiography class on a glacial problem. $J$ Geog 4: 321-329 (1905)

o6 Report on the Dominion Government Expedition to Hudson Bay and the Arctic Islands on board the D. G. S. Neptune, 1903-1904. 355 pp, map Ottawa 1906 
Low, Albert Peter-Continued.

06a Report on the Chibougamau mining region in the northern part of the Province of Quebec. Can G S:61 pp, map (1906) Abst, Que Dp Col... Mining Operations 1905: 24-36 (1906)

06b Summary report of the Geological Survey department of Canada for the calendar year 1906. $206 \mathrm{pp}$, Ottawa 1906.

See also Miller (W G), 12

Lowe, Ephraim Noble.

10 Our waste lands, a preliminary study of erosion in Mississippi. Miss $\mathrm{G}$ S : $23 \mathrm{pp}$ [1910]

11 A preliminary study of solls in Mississippi. Miss G S, B 8:220 pp (1911)

12 Examination of iron ore deposits in Marshall and Benton cos. Miss G S : 23 pp (1912)

14 Fourth biennial report (1913-1914) of the director of the State Geological Survey to the Mississippi Legislature: $11 \mathrm{pp}$ [1914] Fifth biennial report, 19141915...: 12 pp [1916] Sixth biennial report, $1916-1917 \ldots$ : 12 pp [1918]

14a Preliminary report on iron ores of Mississippi. Miss G S, B 10:70 pp [1914]

15 Mississippi, its geology, geography, soils, and mineral resources. Miss $\mathrm{G} \mathrm{S}$, B $12: 335 \mathrm{pp}, \operatorname{map}$ (1915)

Lowe, Francis A.

82 The Silver Islet mine and its present development. Eng M J 34: 320-323 (1882) Lowell, F, L.

15 Mines and mineral resources of Del Norte, Humboldt, and Mendocino cos., Cal. Cal St M Bur, Chapters St Mineralogist's Rp 1913-14:59 pp (1915)

$15 a$ Mines and mineral resources of Mariposa, San Joaquin, and Stanislaus cos., Cal. Cal St M Bur, Chapters of St Mineralogist's Rp 1913-14, Fresno... counties: 143-208 (1915)

15b The counties of Del Norte, Humboldt, Mendocino. California St M Bur, Rp XIV of St Mineralogist : $371-425$ (1916) [issued as separate July, 1915]

See also Bradley (W W), 15

Lowrey, Thomas.

28 Water cement of Southington, Connecticut. Am J Sc $13: 382-383$ (1828)

Lowry, J. D.

01 Mining in Lower California. Eng M J $72: 457-458$ (1901)

Lueas, Anthony Francis (1855-1921).

96 The Avery Island salt mine and the Joseph Jefferson salt deposit, Louisiana. Eng M J 62 : 463-464 (1896)

00 Rock salt in Louisiana. Am I M Eng, $\operatorname{Tr} 29: 462-474$, map (1900) Abst, Eng M J 68: 577-579 (1899)

02 The great oil well near Beaumont, Tex. (with discussion by E. T. Dumble). Am I M Eng, Tr 31: 362-374 (1902)

12 Geology of the sulphur and sulphur oil deposits of the Coastal Plain. J Indus Eng Chem 4:140-143 (1912)
Lueas, Anthony Francis-Continued.

12a The dome theory of the Coastal Plain. Science n s 35:961-964 (1912)

17 A revlew of the exploration at Belle Isle, La. Am I M Eng, B 129:1435-1447 (1917) ; Tr 57:1034-1049 (with discus. sion) (1918)

18 Possible existence of deep-seated oil deposits on the Gulf coast. Am I M Eng, B 139:1119-1134 (1918); discussion by G. S. Rogers, B 142: 1558-1560 (1918)

See also Matteson, 18; Washburne, 14

Lneas, D. Jones.

75 On a map and profile of a line of levels through the Butler, Armstrong, and Clarion Co. oil flelds, with a geological section from well drillings. Pa G S, 2d, J: 79-89, map (1875)

Lueas, Frederic Augustus.

92 On Carcharodon mortoni Gibbes. Biol Soc Wash, Pr 7: 151-152 (1892)

95 Skeletons of Zeuglodon. Science n s 2: 42-43 (1895)

95a Notes on the osteology of Zeuglodon cetoides. Am Nat 29:745-746 (1895)

96 The exhibition of fossil vertebrates. Science n s 3:573-575 (1896)

97 Fossil bison of North America (abst). Science n s 6:814 (1897)

9s A new snake from the Eocene of Alabama [Pterosphenus schucherti]. O \& Nat Mus, Pr 21:637-638, il (1898)

98a Contributions to paleontology [croc odile, Utah; Dinictis, Nebraska]. Am J Se (4) $6: 399-400$ (1898)

98b The fossil bison of North Amerlea, with description of a new species (abst). Science n s 8:678 (1898)

99 The fossil bison of North America.

U S Nat Mus, Pr 21:755-771, il (1899)

99 a The characters of Bison occiden. talis, the fossil bison of Kansas and Alaska. Kans Univ Q 8:17-18, il (1899) oo Description of a new species of fossil fish from the Esmeralda formation. U \& G S, An Rp 21 pt $2: 223-226$, il (1900)

00a A new rhinoceros, Trigonias osborni, from the Miocene of South Dakota. U S Nat Mus, Pr 23: 221-224 (1900)

00b The pelvic girdle of Zeuglodon, Basilosaurus cetoides Owen, with notes on other portions of the skeleton. U S Nat Mus, Pr 23:327-331, il (1900)

00e A new fossil cyprinoid, Leuciscus turneri, from the Miocene of Nevada. U S Nat Mus, Pr 23:333-334, il (1900)

o0d Characters and relations of Galli nuloides, a fossil gallinaceous bird from the Green River shales of Wyoming. Har vard Coll, Mus C $\mathrm{Z}, \mathrm{B} 36: 79-84$, (1900)

ooe The truth about the mammoth. McClure's Mag 14: 349-355 (1900) Smiths Inst, An Rp 1899:353-359 (1901)

OOf The deposit of mastodon bones at Kimmswick, Mo. (abst). Science n s 12: 808 (1900) 
Lueas, Frederic Augustus-Continued.

00\% Paleontological notes. Science n s $12: 809-810$ (1900)

01 Animals of the past. $\mathbf{x x}, 258 \mathrm{pp}, \mathrm{N}$ Y 1901

01a The restoration of extinct animals. Smiths Inst, An Rp 1900:479-492, il (1901)

01b A new dinosaur, Stegosaurus marshi, from the Lower Cretaceous of South Dakota. U S Nat Mus, Pr 23:591-592, il (1901)

01e A flightless auk, Mancalla californiensis, from the Miocene of California U S Nat Mus, Pr $24: 133-134$, il (1901)

01d A fossil flightless auk [Los Angeles, Cal.] (abst). Science n s 13:428 (1901) 01e Some restorations of dinosaurs (abst). Science n s $13: 586$ (1901)

01 Vertebrates from the Trias of Arizona. Science n s 14:376 (1901)

$01 \mathrm{~g}$ The phylogeny of the toothed whales. Science n s 14:618-619 (1901)

02 The greatest flying creature, the great pterodactyl Ornithostoma. Smiths Inst, An Rp 1901:654-659, il (1902) Sc Am Sup $55: 22645-22646$, il (1903)

02a The dinosaurs or terrible lizards. Smiths Inst, An Rp 1901:641-646, il (1902)

02b Paleontological notes; North American elephantids. Science n s $15: 554-555$ (1902)

02e Paleontological notes [generic names Omosaurus and Stegosaurus]. Science n s $16: 435$ (1902)

02d Orange County [N. Y.] mastodons. Science n \& 16:669 (1902)

02e Constructing an extinct monster from fossil bones [Triceratops]. Sc $\Delta \mathrm{m}$ $86: 43$, il (1902)

03 Notes on the osteology and relationship of the fossil birds of the genera Hesperornis, Hargeria, Baptornis, and Diatryma. U S Nat Mus, Pr 26:545-556, il (1903)

04 A new batrachian and a new reptlle from the Trias of Arizona. U S Nat Mus, Pr 27: 193-195, il (1904)

04a A skeleton of Hesperornis. Smiths Misc Col 45 ( $Q$ Is 1) : 95, 11 (1904)

04b A new plesiosaur [Brachauchenias lucasi Williston]. Smiths Mise Col 45 (Q Is 1) : 96 , II (1904)

04e The dinosaur Trachodon annectens. Smiths Misc Col 45 (Q. Is 1):317-320, il (1904)

04d Eocene whales. Nature 71:102 (1904)

04e Paleontological notes: Pleurocoelus versus Astrodon; the armor of Zeuglodon. Sclence n s $19: 436-437$ (1904)

06 The elephants of the Pleistocene; Mammalia. Md G S, Pliocene and Pleistocene: $149-152,157-169$, il (1906)
Lueas, Frederlc Augustus-Continued.

06a (with Clark, W. B.) The Pliocene and Pleistocene deposits of Maryland; the interpretation of the paleontological criteria. Md G S, Pliocene and Pleistocene : 139-152 (1906)

08 Is Alabamornis a bird? Science $\mathrm{n} \mathbf{s}$ $27: 311$ (1908)

08a The size of the mammoth. Nature $78: 443$ (1908)

10 The armor of Stegosaurus. Nature $85: 73(1910)$

16 The beginnings of flight. Am Mus J $16: 5-11$, il (1916)

See also Leidy, 96

Lueke, P. K.

15 The relation of sulphides to water level in Mexico. Am I M Eng, B 138: 1105-1108 (1918)

Ludlof, K.

99 The discovery of gold-bearing conglomerate in British Columbia. M Sc Press $79: 692$ (1899)

Ludlow, Edwin.

02 The coal fields of Las Esperanzas, Coahuila, Mex. Am I M Eng, Tr $32: 140$ 156, map (1902)

06 Les gisements carboniferes de Coahuila [Mexico]. Int $\mathrm{G}$ Cong, $\mathrm{X}$, Mexico, Guide Exc 28:17 pp (1906)

09 The coal industry in Mexico. Eng M J 88: 661-664 (1909)

Ludlow, William.

75 Report of a reconnaissance of the Black Hills of Dakota made in the summer of 1874. $121 \mathrm{pp,} \mathrm{maps,} \mathrm{Washington}$ 1875 Also in U S, Chief Eng, An Rp 1875 pt 2 (U S, 44th Cong 1st sess, H Ex Doc pt 2 v 2):1113-1230, maps (1875)

76 Report of a reconnaissance from Carroll, Montana Territory, on the upper Missouri, to the Yellowstone National Park and return made in the summer of 1875 . $141 \mathrm{pp}$, maps, Washington 1876 Also in U S [War Dp], Chief Eng, An Rp 1876 (U S, 44th Cong 2d sess, H Ex Doc 1 pt 2 v 2 pt 3) App NN : 569-699 (1876)

Luedeking, $C$.

91 (and Wheeler, H. A.) Notes on a Missouri barite. $\triangle \mathrm{m} \mathrm{J} \mathrm{Sc} \mathrm{(3)} 42: 495-$ 498 (1891)

Lugeon, Maurice.

18 (and Sigg, Henri) Sur quelques roches éruptives de la Caroline du Nord. Soc Vaudoise Sc Nat, B 52:99-112 (1918)

Lukis, Ernest du B.

98 A new copper deposit in Mexico [Tezintian, State of Puebla]. Eng M J $65: 279-280$ (1898)

LuIl, Rlchard Swann.

03 Skull of Triceratops serratus. Am Mus N H, B 19:685-695, il (1903).

04 Fossil footprints of the Juratrias of North America. Boston Soc N H, Mem 5:461-557, il (1904) 
LuIl, Richard Swann-Continued.

O4a Note on the probable footprints of Stegomus longipes. Am J Se (4) 17:381382, il (1904)

04b Nature's hieroglyphics. Pop Se Mo 66: 139-149, il (1904)

o5 Megacerops tyleri, a new species of titanothere from the bad lands of South Dakota. J G 13:443-456, il (1905)

O5a Restoration of the titanothere Megacerops. Am Nat $39: 419-424$, il (1905)

osb Restoration of the horned dinosaur Diceratops. Am J Sc (4) $20: 420-422$, il (1905)

05e Footprint interpretation (abst). Science n s 21:299 (1905)

06 A new name for the dinosaurian genus Ceratops [Proceratops]. Am J Sc (4) $21: 144$ (1906)

06a Volant adaptation in vertebrates. Am Nat $40: 527-566$ (1906)

07 Phylogeny, taxonomy, distribution, habits, and environment of the Ceratopsia. U S G S, Mon 49: 159-198 (1907)

07a The evolution of the horse family as illustrated in the Yale collections. Am J Sc (4) $23: 161-182$ (1907) Reprint, Yale Univ, Peabody Mus N H, Guide no $1: 22$ pp, il (1907)

07b Fossils from the Connecticut Valley Triassic. Conn G S, B 8:47 (1907)

07e (with Hateher, J. B.) The Ceratopsia. U S G S, Mon $49: 300 \mathrm{pp}$, il (1907)

0 The evolution of the elephant. Am J Sc (4) 25:169-212, il (1908) Reprint, Yale Univ, Peabody Mus N H, Guide no 2: 44 pp, il (1908) Smiths Inst, An Rp 1908: $641-675$, il (1909)

08a The cranial musculature and the origin of the frill in the ceratopsian dinosaurs. Am J Sc (4) $25: 387-399$, il (1908) Abst, Science n s 27:255 (1908)

0sb (with Huene, F. R. von.) On the Triassic reptile Hallopus victor Marsh. Am J Sc (4) 25:113-118 (1908)

ose (with Huene, F. R. von.) Neubeschreibung des Originals von Nanosaurus agilis Marsh. N Jb $1: 134-144$ (1908)

o9 Dinosaur societies (abst). Science n s $29: 194$ (1909)

10 Relation of embryology and vertebrate paleontology. Pop Sc Mo 77:150153 (1910)

10a Dinosaurian distribution. Am J Sc (4) $29: 1-39$, il (1910)

10b Restoration of paleolithic man. Am J Se (4) $29: 171-172$, il (1910)

10c The armor of stegosaurus. Am J Sc (4) $29: 201-210$, il (1910)

10d Stegosaurus ungulatus Marsh, re cently mounted at the Peabody Museum of Yale University. Am J Sc (4) $30: 361-$ 377, il (1910)
Lull, Richard Swann-Continued.

11 (and Clark, W. B., and Berry, E. W.) Systematic paleontology of the Lower Cretaceous deposits of Maryland. Md G S, Lower Cretaceous : 179-596, (1911)

11 a The Reptilia of the Arundel forma. tion; Vertebrata. Md G S, Lower Cre taceous: 173-178, 183-211, il (1911)

12 The evolution of the Ceratopsia. Int Zool Cong, VII, Boston, 1907, Pr: 771-777 (1912; advance print 1910)

$12 \mathbf{a}$ 'Ten years' progress in vertebrate paleontology; Cretaceous dinosaurs. G Soc $\triangle \mathrm{m}$, B $23: 208-212$ (1912)

12b The life of the Connecticut Trias, Am J Sc (4) $33: 397-422$, il (1912)

12e Glacial man. Yale Rv 1:376-389 (1912)

13 The Yale collection of fossil horses. Yale Univ Col no 1:12 pp, il (1913)

13a The Yale expedition of 1912 (abst). G Soc Am, B 24:117 (1913)

14 Fossil dolphin from California. Am J Sc (4) $37: 209-220$, il (1914)

$14 a$ Elephants and their progenitors: the story of the evolution of the elephants or Proboscidea from their earllest recorded ancestor, the Moeric beast. Ec Conspectus $4: 61-70$, il (1915)

14b Rulers of the Mesozoic. Yale Rr. n 8 3:352-363 (1914)

14e New mastodon find in Connecticat (abst). C Soc Am, B 25:143 (1914)

15 Triassic life of the Connecticut Var. ley. Conn G S, B 24:285 pp, il, maps (1915)

15a Sauropoda and Stegosauria of the Morrison of North America co upared with those of Europe and eastern _.frica. G $\mathrm{Soc}$ Am, B 26: 323-334 (1915)

15b A Pleistocene ground sloth, Mylodon harlani, from Rock Creek, Tex. Am J Sc (4) $39: 327-385$, il, map 1915)

15e The mammals and horned dinosaurs of the Lance formation of Niobrara $\mathrm{Co}$, Wyo. Am J Sc (4) $40: 319-\cdots$ (1915)

15d Ant-hill fossils [fossil fields of Ne braska and Wyoming]. Pop Se Mo 87: 236-243 (1915)

17 Organic evolution; a textbook. 729 pp, il, N Y 1917

17a The Triassic fauna and flora of the Connecticut Valley. U S G S, B 597: 105127 , il (1917)

17b On the functions of the "sacral brain" in dinosaurs. A. J Sc (4) 44: 471-477 (1917)

17e Horned artiodactyl from the Tertiary of Nebraska (abst). G Soc Am, B $28: 211$ (1917)

17d Brontotherium; a new mount in the Yale Museum (abst). G Soc Am, B 28: 214 (1917)

17e Barosaurus; a gigantic sauropod dinosaur (abst). G Soc $\therefore \mathrm{m}$, B 28:214215 (1917) 
LnIl, Richard Swann-Continued.

18 (editor) The evolution of the earth and its inhabitants. $208 \mathrm{pp}$, il, New Haven 1918

18a The pulse of life. In The evolution of the earth and its inhabitants : 109-146, il, New Haven 1918

18b Fossll footprints from the Grand Canyon of the Colorado. Am J Sc (4) 45 : $337-346$, il (1918)

18e on the development of vertebrate paleontology. Am J Sc (4) $46: 193-221$ (1916) Reprinted in A century of science in America : 217-247, New Haven 1918

See also Schuchert, 14c; Sinclair, 17a

Lundgren, Bernhard.

96 Anmärkningar om några Jurafossil från Kap Stewart i Ost-Grönland [Jurassic fossils from Cape Stewart in eastern Greenland]. Med Grönland 19: 189-214, 268271, il (1896)

Lungwitz, E. E.

00 The lixiviation of gold deposits by vegetation. Eng M J 69:500-502 (1900)

Lunt, Horace Fletcher.

15 A fluorspar mine in Colorado [Mineral Co.]. M Sc Press 111: 925-926 (1915)

See also Jennings, 04

Lupton, Charles T.

10 (with Stone, R. W.) The Powder River coal field, Wyo., adjacent to the Burlington Railroad. U S G S, B 381 : 115-136 (1910)

11 The eastern part of the Bull Mountain coal field, Mont. U S G S, B 431: 163-189, maps (1911)

12 The Deep Creek district of the Vernal coal field, Uinta Co., Utah. U S G S, B 471:579-594, maps (1912)

12n The Blacktail (Tabby) Mountain coal field, Wasatch Co., Utah. U S G S, B 471:595-628, map (1912)

$12 b$ Notes on the geology of the San Rafael Swell, Utah. Wash Ac Sc, J 2: 185-188 (1912)

13 Gypsum along the west flank of the San Rafael Swell, Utah. U S G S, B 530 : 221-231, map (1913)

14 Oll and gas near Green River, Grand Co., Utah. U S G S, B 541: 115-133, map (1914)

14a Oil and gas in the western part of the Olympic Peninsula, Wash, U S G S, B 581:23-81, maps (1914)

15 The Orofino coal field, Clearwater, Lewis, and Idaho cos., Idaho. U S G S, B 621: 99-108, map (1915)

16 Oil and gas near Basin, Big Horn Co., Wyo. U S G S, B 621: 157-190, maps (1916)

16a Geology and coal resources of Castle Valley in Carbon, Emery, and Sevier cos., Utah. U S.G S, B 628: 88 pp, map (1916) Abst, Wash Ae Se, J $6: 504-505$ (1916)
Lupton, Charles T.-Continued.

$16 b$ (and Condit, D. D.) Gypsum in the southern part of the Big Horn Mountains, Wyo. U S G S, B 640:139-157, map (1916) Abst, by R. W. S., Wash Ac Sc, J $7: 78$ (1917)

16e Notes on the stratigraphic and structural relations in southern and eastern Big Horn Basin, Wyo. (abst). Wash Ac Sc, J $6: 310-311$ (1916)

17 (with Hewett, D. F.) Anticlines in the southern part of the Big Horn Basin, Wyo. U S G S, B 656: 192 pp, maps (1917) Abst, by R. W. Stone, Wash Ac Sc, J 8:204-205 (1918)

17 a (with Woolsey, L. H., and Riehards, $R$. W.) The Bull Mountain coal field, Musselshell and Yellowstone cos., Mont. U S G S, B 647: 218 pp, maps (1917) Abst, by R. W. Stone, Wash Ac Sc, J $7: 602-603$ (1917)

Lupton, N. T.

85 Meteoric iron from Coabuila, Mex. Am J Sc (3) 29:232-233 (1885)

Luquer, Lea McIlvaine.

92 Methods of modern petrography. Sch Mines Q 13: 357-364 (1892) [See also Hensoldt, 89]

92a (with Moses, A. J.) Alabandite from Tombstone, Ariz.; wavellite from Florida. Sch Mines Q 13:236-239 (1892)

93 Mineralogical notes [muscovite, talc, microcline, yttrialite, orthoclase inclosing pyroxene]. Sch Mines Q 14:327-329 (1893)

94 The optical recognition and economic importance of the common minerals found in building stones. Sch Mines Q 15:285336 (1894)

94a (with Moses, A. J.) Index to mineralogical literature. Sch Mines Q 15 : 163-179 (1894)

95 (and Volckening, G. J.) On three new analyses of sodalite, from three new localities. Am J Se (3) $49: 465-466$ (1895)

96 (and Ries, H.) The "augen"gneiss area, pegmatite veins, and diorite dikes at Bedford, N. Y. Am G 18:239261 (1896)

96a The minerals of the pegmatite veins at Bedford N. Y. Am G 18:259261 (1896)

96b Optical mineralogy. Sch Mines Q $17: 435-469$ (1896)

97 Optical scheme. Sch Mines Q 19: 93-96 (1897)

98 Minerals in rock sections... 117 pp, N Y $18982 d$ ed, 147 pp, N Y 1905

02 On the determination of relative refractive indices of minerals in rock sections by the Becke method. Sch Mines Q $23: 127-133$ (1902) Abst, Science n s 15 : 867 (1902)

04 Ramosite not a mineral. Am $\mathbf{J}$ Sc (4) $17: 93-94$ (1904) Soc Cient Ant Alz, Mem 21: Rev 48 (1904) 
Luquer, Lea McIlvaine-Continued. O4a Bedford cyrtolite. Am G 33:17-19 (1904)

os Fusion table of minerals in the oxygas blowpipe flame. Sch Mines Q 29: 179-182 (1908)

See also Merrill (F J H), 94a,

Lusk, Graham.

86 The Luray caverns [Page Co., Va.]. Sch Mines Q 7: 148-152 (1886)

Luther, D. Dana.

94 Report on the geology of the Livonia salt shaft. N Y St G, An Rp 13:21-130 (1894) N Y St Mus, An Rp $47: 217-324$ (1894)

97 The stratigraphic position of the Portage sandstones in the Naples Valley and the adjoining region. N Y St G, An Rp 15:13-14, 223-236, map (1897) N Y St Mus, An Rp $49 v 2: 13-14,223-236$, map (1898)

97a The economic geology of Onondaga Co., N. Y. N Y St G, An Rp $15: 14-16$, 237-303, map (1897) N Y St Mus, An Rp 49 v $2: 14-16,237-303$, map (1898)

99 The brine springs and salt wells of the State of New York and the geology of the salt district. N Y St G, An Rp 16: 171-226, map (1899) N Y St Mus, An Rp $50 v 2: 171-226$, map (1899)

02 Stratigraphic value of the Portage sandstones [with note by J. M. Clarke]. N Y St Mus, B 52:616-631 (1902)

02a (with Clarke, J. M.) Contact lines of upper Siluric formations on the Brockport and Medina quadrangles [N. Y.]. N Y St Mus, B $52: 517-523$ (1902)

03 Stratigraphy of Portage formation between the Genesee Valley and Lake Erie. N Y St Mus, B 69:1000-1029, map (1903)

04 (with Clarke, J. M.) Stratigraphic and paleontologic map of Canandaigua and Naples quadrangles [N. Y.] N Y St Mus, B 63: $76 \mathrm{pp}$, map (1904)

05 (with Clarke, J. M.) Geology of the Watkins and Elmira quadrangles [N. Y.]. N Y St Mus, B 81:3-29, map (1905)

o5a (with Clarke, J. M.) Geologic map of the Tully quadrangle [N. Y.]. N Y St Mus, B 82: 35-52 (1905)

06 Geologic map of the Buffalo quadrangle [N. Y.]. N Y St Mus, B 99: 29 pp, map (1906)

06a Geology of the Penn Yan-Hammondsport quadrangles. N Y St Mus, B $101: 37-58$, map (1906)

os (with Clarke, J. M.) Geologic map and descriptions of the Portage and Nunda quadrangles. N Y St Mus, B 118:43-69 (1908)

09 Geology of the Geneva-Ovid quadrangles, N. Y. N Y St Mus, B 128: 41 pp, map (1909)

10 Geology of the Auburn-Genoa quadrangles. N Y St Mus, B 137: $36 \mathrm{pp}$, map (1910)
Luther, D. Dana-Continued.

11 Geology of the Honeoye-Wayle quadrangles. N Y St Mus, B 152:29 B map (1911)

14 Geology of the Attica-Depew quel rangles. N Y St Mus, B 172: 34 pp, me (1914)

Lutre11, Estelle.

15 Bibllography of Arizona mining metallurgy, and geology. Ariz Univ, Ba Mines, B 23: 49 pp (1915)

Lyell, Charles (1797-1875).

37 Principles of geology... 1st $A$ z from 5th London ed, vol 1, $546 \mathrm{pp}$, vol: 553 pp, Phila 1837 ; new...ed, 824 pp, N ! $1854 ; 11$ th...ed, vol. $1,671 \mathrm{pp}$, vol $2,6 \%$ pp, N Y 1877

39 Elements of geology. 1st Am. from 1st L ed, 316 pp, Phila 1839

41 Remarks on some fossil and recest shells collected ... in Canada. G Soc Los don, $\operatorname{Pr} 3: 119-120$ (1839) ; $\operatorname{Tr}$ (2) 6 135-141, il (1841)

42 Eight lectures on geology... 56 ph N Y $184252 \mathrm{pp}$, N Y 1843

42a On some of the phenomena cos nected with the Coal Measures and olde strata of Pennsylvania. Geologist 1842: 25-27 G Soc London, Pr 3:554-55 (1842) Ph Mag (3) 21:306-309 (1842)

42b A memoir on the recession of the Falls of Niagara. G Soc London, Pr 3: 595-602 (1842) Geologist 1842:122-12]

42e on the Tertiary formations ast their connexion with the chalk in Vi: ginia and other parts of the United States G Soc London, Pr 3:735-742 (1842) Geologist $1842: 213-218$

42d On the fossil footprints of bird and impressions of raindrops in the valler of the Connecticut. G Soc London, $\operatorname{Pr} 3$ : 793-796 (1842) Am J Se 45:394-39i (1843)

43 On the ridges, elevated beaches, it land cliffs, and boulder formations of the Canadian lakes and valley of St. Lawrence G Soc London, Pr 4:19-22 (1843) Am J Sc 46:314-317 (1844) Ph Mag (3) 23: 183-186 (1843) Geologist 1843:130-134

43a On the Tertiary strata of the Island of Marthas Vineyard in Massachusetts. 6 Soc London, Pr 4: 31-33 (1843) Am J Sc $46: 318-320$ (1844) Ph Mag (3) $23: 187$ 189 (1843) Geologist 1843:160-163

43b On the geological position of the Mastodon giganteum and associated fossil remains at Bigbone Lick, $\mathrm{Ky}$., and othe: localities in the United States and Canada. G Soc London Pr 4:36-39 (1843) AD Mag N H 12:125-128 (1843) Am J Sc $46: 320-323$ (1844) Ph Mag (3) $23: 190$ 193 (1843) Geologist 1843:169-174

43e on the upright fossil trees found at different levels in the coal strata of Cum. berland, N. S. G Soc London, Pr $4: 176-$ 178 (1843) Am J Sc $45: 353-356$ (1843) 
Lyell, Charles-Continued.

43a On the coal formation of Nova Scotia and on the age and relative position of the gypsum and accompanying marine limestones. G Soc London, Pr 4:184-186 (1843) Am J Sc 45:356-359 (1843)

44 Notes on the Cretaceous strata of New Jersey and parts of the United States bordering the Atlantic. Am J Sc 47:213214 (1844) G Soc London, Q J 1:55-60 (1845)

$44 a$ On the probable age and origin of a bed of plumbago and anthracite occurring in mica schist near Worcester, Mass. Am J Sc 47:214-215 (1844) G Soc London, Q J 1:199-202 (1845)

45 Travels in North America in the years 1841-42, with geological observations on the United States, Canada, and Nova Scotia. 2 vols, 251, 221 pp, N Y 1845 2 vols, 316,272 pp, map, L 1845 German ed, 395 pp, Halle 1846 [Also later editions]

45a On the Miocene Tertiary strata of Maryland, Virginia, and of North and South Carolina. G Soc London, Q J 1:413-429, il $(1845)$

45b Observations on the White Limestone and other Eocene or older Tertiary formations of Virginia, South Carolina, and Georgia. G Soc London, Q J $1: 429-442$, il (1845)

46 [On the Eocene of Alabama and Georgia]. $\quad$ m J Sc (2) $1: 313-315$ (1846) 46a Coal field of Tuscaloosa, Ala. Am J Sc (2) $1: 371-376$ (1846)

$46 b$ On the evidence of fossil footprints of a quadruped allied to the Cheirotherium in the coal strata of Pennsylvania. Am J Sc (2) $2: 25-29$ (1846)

46e Observations on the fossil plants of the coal field of Tuscaloosa, Ala. Am J Sc (2) $2: 228-230$ (1846)

$46 d$ Notice on the coal fields of Alabama. G Soc London, Q J 2: 278-282 (1846)

46e On the newer deposits of the Southern States of North America. G Soc London, Q J 2 : 405-410 (1846)

46f On footmarks discovered in the Coal Measures of Pennsylvania. G Soc London, Q J 2: $417-420$ (1846)

47 On the structure and probable age of the coal field of the James River, near Richmond, Va, G Soc London, Q J 3:261280, II (1847)

47a On the delta and alluvial deposits of the Mississippi, and other points in the geology of North America, observed in the years 1845,1846 . Brit As, Rp 16 : sec 117119 (1847) Am J Sc (2) $3: 34-39$ (1847)

$47 \mathrm{~b}$ On the alleged coexistence of man and the Megatherium [Natchez, Miss.]. Am J Sc (2) $3: 267-269$ (1847)

$47 \mathrm{e}$ on the relative age and position of the so-called nummulite limestone of Alabama. Am J Sc (2) 4:186-191 (1847) G Soc London, Q J 4:10-16 (1848)
Lyell, Charles-Continued.

48 On the fossil footmarks of a reptile in the coal formation of the Alleghany Mountains. Athenaeum 1848: 166167

49 A second visit to the United States of North America. 2 vols, 273, $287 \mathrm{pp}$, N Y 1849 ; L 1849 2d ed, 2 vols, L 1855. $3 \mathrm{~d}$ ed, L 1855

$49 a$ Notes on some recent footprints on red mud in Nova Scotia. G Soc London, Q J 5:344 (1849)

51 Lower Silurian reptile in Canada. Am J Sc (2) 12:120-121 (1851)

$\mathbf{5 1 a}$ On impressions of raindrops in ancient and modern strata. $\mathrm{R}$ Inst, $\mathrm{Pr}$ $1: 50-53$ (1851)

51b On fossil rain marks of the recent, Triassic, and Carboniferous periods. G Soc London, Q J 7:238-247 (1851)

53 A manual of elementary geology ... [From the 4th L ed], $512 \mathrm{pp}, \mathrm{N}$ Y 1853 [From the 5th L ed], 647 pp, N Y 1855

$53 a$ On the discovery of some fossil reptilian remains, and a land shell in the interior of an erect fossil tree in the Coal Measures of Nova Scotia, with remarks on the origin of coal fields and the time required for their formation. $\mathbf{R}$ Inst, $\mathbf{P r}$ 1: 281-288 (1853) Am J Sc (2) 16:3341 (1853)

53b (and Dawson, J. W.) On the remains of a reptile (Dendrerpeton acadianum Wyman and Owen) and of a land shell discovered in the interior of an erect fossil tree in the Coal Measures of Nova Scotia. G Soc London, Q J 9:5863 , il (1853)

54 Special report on the geological, topographical, and hydrographical departments of the [New York Industrial] Exhibition. Return ... House of Commons ... Feb. 6, 1854:50 pp, L 1854

$54 a$ (and Hall, J.) Rapport sur la partie géologique de l'exposition de New York. An Mines (5) 6:1-83 (1854) [Transl of 54]

55 Extrait d'un rapport sur la partle géologique de l'exposition de New York en 1853. Soc G France, B (2) 12:400-428 (1855)

$55 a$ On certain trains of erratic blocks on the western borders of Massachusetts, United States. R Inst, $\operatorname{Pr} 2$ : 86-97 (1855)

63 The geological evidences of the antiquity of man ... 518 pp, Phila 1863

69 [Rate of formation of delta of the Mississippi.] G Soc London, Q J 25:11 (1869)

71 The student's elements of geology. 624 pp, L 1871640 pp, N Y 1886

71a Oolite coal field of Virginia [copied by James Greer, from a MS, by Charles Lyell]. $3 \mathrm{pp}$ [priv pub, Dayton 1871?]

96 The student's Lyell; a manual of elementary geology; edited by John W. Judd. $635 \mathrm{pp}, \mathrm{N}$ Y 1896 
Lykins, William H. R.

84 List of fossils in Kansas City [Mo.] and vicinity. Kansas City Rv Sc 8: 72-77 (1884)

Lyle, D. A.

78 The springs of southern Nevada. Am Nat 12:18-27 (1878)

Lyman, Benjamin Smith (1835-1920).

66 [On slickensided slabs from Plymouth, Luzerne Co., Pa.] Ac N Sc Phila, Pr 1866: 107-108

67 On the great Carboniferous conglomerate in Sullivan Co., Pa, Ac N Sc Phila, Pr 1867: 125-127

67a Against the supposed former plasticity of the puddingstone pebbles of Purgatory, R. I. Am As, Pr 15: 83 (1867)

6s on the Lower Silurian brown hematite beds of America [southwest Virginia]. Am As, Pr 16.114-117 (1868) The Virginias 2:190 (1881) Abst, Am Nat 1: 620-621 (1868); Can Nat n s 3:302 (1868)

73 On the importance of surveying in geology. Am I M Eng, Tr 1:183-192 (1873) Van Nostrand's Eng Mag 11: 334-339 (1874)

73a The Staley's Creek and Nick's Creek iron region near Marion, Smyth Co., Va. Am Ph Soc, Tr n s $15: 33-47$, map (1873)

85 Contour lines on geological maps. Mag (3) 2:132, 134, 335 (1885)

86 Geology of the Lowmoor, Va., iron ores. Am I M Eng, Tr 14:801-809, map (1886)

89 Report on the New Boston and Morea coal lands, in Schuylkill Co., Pa. Pa G S, An Rp 1887: 37-91, map (1889)

91 [On the Triassic of Bucks Co., Pa.] Am Ph Soc, Pr 29:24-25 (1891)

93 The great Mesozoic fault in New Jersey. Am Ph Soc, Pr 31:314-317, map (1893)

93a An occurrence of coarse conglomerate above the Mammoth anthracite bed. Am I M Eng, Tr 21: 713-719, map (1893)

94 Age of the Newark brownstone [N. J.] $\mathrm{Am} \mathrm{Ph}$ Soc, $\mathrm{Pr} 33: 5-10$ (1894)

$94 a$ Some New Red horizons [with remarks by Persifor Frazer]. Am Ph Soc, Pr 33:192-215, maps (1894)

94b The name "Newark" in American stratigraphy. J G 2: 59-61 (1894)

95 Report on the New Red of Bucks and Montgomery cos. Pa G S, Final Rp 3 pt $2: 2589-2638$, maps, il (1895)

95a Some Coal Measure sections near Peytona, W. Va. Am Ph Soc, Pr 33: 282-309, map (1895)

95b The Yardley fault [Bucks Co., Pa.]. Am Ph Soc, Pr 34:381-384 (1895) Abst, J G $4: 245$ (1896)

95e The Chalfont fault rock, so-called [Bucks Co., Pa.]. Am Ph Soc, Pr 34: 384-388 (1895) Ab8t, J G $4: 245$ (1896)
Lyman, Benjamin Smith-Continued.

96 Folds and faults in Pennsylvanis anthracite beds. Am I M Eng, Tr 25:327369, 1010-1011 (1896)

96a Note on the trap rock of the Pall. sades. Am J Sc (4) 1:149 (1896)

98 Some illustrations of the influence of geological structure on topography. Frank. lin Inst, J 145 : 355-360 (1898)

98a Copper traces in Bucks and Montgomery cos. [Pa.]. Franklin Inst, J 146: 416-423, map (1898)

oo Movements of ground water. Frank. line Inst, J $150: 285-299$ (1900)

02 Lodel Creek and Skippack Creek [Pa.]. Ac N Sc Phila, Pr 53:604-607 (1902)

02a Accounting for the depth of the Wyoming buried valley [Pa.]. Ac N $\mathrm{Sc}$ Phila, Pr 54: 507-509 (1902)

03 The original southern limit of the Pennsylvania anthracite beds. Am I If Eng, Tr 33: 561-567, map (1903)

O3a Biographical notice of J. Peter Les. ley $(a b s t)$. Am I M Eng, Tr 34:726-739 $(1904)$; in full as advance separate 35 p (1903)

09 Need of instrumental surveying in practical geology. Am I M Eng, B 32: 667-674 (1909); Tr $40: 636-643$ (1910)

See also Branner, 98

Lyman, C. S.

49 Observations on the "old crater" adjoining Kilauea (Hawaii) on the east. Am J Sc (2) $7: 287$ (1849)

49a Notes on the California gold reglon. Am J Sc (2) 8:415-419 (1849) Ph Mag (3) $35: 470-474$ (1849)

51 On the recent condition of Kilauea [Hawaii]. Am J Sc (2) 12:75-82 (1851)

59 A record of earthquakes, kept at Hilo, Hawail. Am J Sc (2) $27: 264-266$ (1859) Lyman, Henry M.

59 On the recent eruption of the volcano Mauna Loa in the Sandwich Islands. Boston Soc N H, Pr 7: 38-39 (1859)

$59 a$ On the recent volcanic eruption in the Sandwich Islands. Boston Soe N H, Pr $7: 134-135$ (1859)

Lyman, Kate.

05 (with Park, Emma J.) The Spring. field [Mo.] water supply; descriptions of springs and the geology of the district. Drury Coll, Bradley G Field Sta, B $1: 45^{-}$ 49 (1905)

osa (with Park, Emma J.) The Hannibal formation in Greene Co. [Mo.]. Drury Coll, Bradley G Field Sta, B 1:7990 (1905)

Lyman, R. H.

06 Coal mining at Holden, W. Va. Eng M J $82: 1120-1122,1170-1172$ (1906)

Lyman, W. D.

96 The glaciers of Mount Adams [Wash.]. Mazama 1:98-101 (1896) 
Lynch, C. N.

53 Artesian well at Charleston, S. C. An Sc, Cleveland, 1:108 (1853)

Lyneh, P. R.

53 The artesian well, Charleston, S. C. An Sc, Cleveland, $1: 276-278$ (1853)

Lyon, D. A.

01 Serpentine marbles of Washington. Mines and Minerals $21: 349$ (1901)

See also Landes, 02b

Lyon, Edward West.

09 The progress of gold mining in North Carolina. Eng M J 87 : 293-297 (1909)

Lyon, Sidney Smith (?-1872).

56 Topographical geological report of that portion of Kentucky including Union and part of Crittenden $\cos$... Ky G S, Rp [1] : 381-400, map (1856)

57 Topographical geological report of the progress of the survey of Kentucky through Hopkins, Crittenden, Caldwell, Greenup, and Carter $\cos .$. Ky G S, Rp 2:303-376 (1857)

57 a ... topographical geological report of the progress of the survey of Kentucky in the counties of Greenup, Carter, Lawrence, and Hancock for the year 1857. Ky G S, Rp 3: 423-463 (1857)

57b Paleontological report [descriptions of Carboniferous Echinodermata]. Ky G $\mathrm{S}, \mathrm{Rp} 3: 465-498$, il [pls. issued in brochure titled, Maps and illustrations referred to in vols. II \& III of the report of the geological survey of Kentucky, 1857] (1857)

59 (and Casseday, S. A.) Description of nine new species of Crinoidea from the Subcarboniferous rocks of Indiana and Kentucky. Am J Sc (2) 28:233-246 (1859)

60 (and Crsseday, S. A.) Description of nine new species of Crinoidea from the Subcarboniferous rocks of Indiana and Kentucky. Am J Sc (2) 29:68-79 (1860)

60a (and Casseday, S. A.) A synonymic list of the Echinodermata of the Paleozoic rocks of North America. Am Ac Arts, Pr 4:282-304 (1860)

$60 b$ Remarks on the stratigraphical arrangement of the rocks of Kentucky ... Ac Se St L, Tr 1: 612-621 (1860)

60c Descriptions of four new species of Blastoldea from the Subcarboniferous rocks of Kentucky. Ac Sc St L, Tr 1: 628-634, il (1860)

61 Topographical geological report of the progress of the geological survey of Kentucky for the years 1858 and 1859. Ky G S, Rp 4: 495-599 (1861)

61 a Descriptions of new Paleozoic fossils from Kentucky and Indiana. Ac N Sc Phila, Pr 1861 : 409-414

62 (and Casseday, S. A.) Description of two new genera and eight new species of fossil Crinoidea from the rocks of Indiana and Kentucky. Am Ac Arts, Pr 5:16-31 (1862)
Iyon, Sidney Smith-Continued.

69 Remarks on thirteen new species of Crinoidea from the Paleozoic rocks of Ind., $\mathrm{Ky}$., and Ohio, and a description of certain peculiarities in the structure of the columns of Dolatocrinus, and their attachment to the body of the animal. $\mathrm{Am} \mathrm{Ph}$ Soc, $\operatorname{Tr} \mathrm{n}$ s $13: 443-466$, il (1869)

Ly.on, Victor Wathen.

79 Descriptions of three new species of Calceolidx from the Upper Silurian rocks of Kentucky. Ac N Se Phila, Pr 1879: 43-46

Lyons, A. B.

96 Chemical composition of Hawailan soils and of the rocks from which they have been derived. Am J Sc (4) 2:421429 (1896)

\section{M., J.}

90 Dr. David Honeyman [1817-1889]. Am G 5:185-186 (1890)

Marek, G. A.

$\boldsymbol{7} 2$ On the geology of the Isthmus of Choco, of Darien, and of Panama. Boston Soc N H, Pr 15:191-192 (1872)

Mabery, Charles Frederic.

97 On the composition of American petroleum. Am Ph Soc, Pr 36:126-136 (1897)

01 Composition of Texas petroleum. $\mathrm{Am}$ Ch Soc, J 23:264-267 (1901)

02 La composition du pétrole américain. Cong intern pétrol, I, Paris 1900, Notes ... : 59-73, Paris 1902

03 A résumé of the composition and occurrence of petroleum. Am Ph Soc, $\mathrm{Pr}$ $42: 36-54$ (1903)

16 The relations of the chemical composition of petroleum to its genesis and geologic occurrence. Ec G 11:511-527 (1916)

See also Rogers (G S), $\mathbf{1 7} \mathrm{c}$

Mabry, T. O.

98 The brown or yellow loam of north Mississippi and its relation to the northern drift. J G 6:273-302 (1898)

MeAdams, William.

83 The glacial period in Inlinois. Kansas City Rv Sc 7:219-221 (1883)

83n Animal remains from the loess and glacial clays (abst). Am As, Pr $32: 268$ 269 (1884) Science 2:327 (1883)

83b A new vertebrate from the St. Louis limestone (abst). Am As, Pr 32: 269 (1884) Science 2:327 (1883)

84 Fossils from the drift of the valleys of the Illinois and Mississippi rivers. AC Sc St L, Tr 4: 1xxix-1xxxi (1884)

McAdie, Alexander George.

07 Catalogue of earthquakes on the Pacific coast, 1897-1906. Smsths Misc Col 49 art $5: 64$ pp (1907)

11 Seismological observations of the future. Seism Soc Am, B 1: 8-9 (1911)

$11 a$ Surface mcasurement of earthquake displacement, Seism Soc Am, B 1:33-34 (1911) 
MeAdie, Alexander George-Continued.

15 President's address, meeting of the Seismological Society of America, Stanford University, Cal., August 4, 1915 (with discussion). Seism Soc Am, B 5:121-219, 177-189 (discussion) (1915)

MeAdoo, William Gibbs (1820-1894).

81 (and White, H. C.) Elementary geology of Tennessee. 118 pp, N Y 1881

Macallum, A. B.

04 The paleochemistry of the ocean in relation to animal and vegetable protoplasm. Can Inst, Tr $7: 535-562$ (1904)

Macaulay, D. A.

15 The Drumheller coal field, Alta. Can M Inst, B 41 : 718-730 (1915) ; $\operatorname{Tr} 18$ : 322334 (1916)

MeBeth, Reid Sayers.

18 Pioneering the Gulf coast; a story of the life and accomplishments of Capt. Anthony F. Lucas. $80 \mathrm{pp}$, port [N Y 1918]

MeBeth, William A.

00 The physical geography of the region of the great bend of the Wabash. Ind Ac Sc, Pr 1899: 157-161. map (1900)

$00 a$ An interesting boulder [New Richmond, Montgomery Co., Ind.]. Ind Ac Sc, Pr 1899: 162 (1900)

o1 The development of the Wabash drainage system and the recession of the ice sheet in Indiana. Ind Ac Sc, $\operatorname{Pr} 1900$ : 184-192, map (1901)

$01 a$ A theory to explain the western Indiana boulder belts. Ind $\mathrm{Ac} \mathrm{Sc}, \mathrm{Pr}$ 1900: 192-194 (1901)

02 Wabash River terraces in Tippecanoe Co., Ind. Ind An Sc, Pr 1901:237-243 (1902)

02a History of the Wea Creek in Tippecanoe Co., Ind. Ind Ac Sc, Pr 1901 : 244247 (1902)

05 An esker in Tippecanoe Co., Ind. Ind Ac Sc, $\operatorname{Pr} 1904: 45-46$ (1905)

05 Notes on the delta of the Mississippi River. Ind Ac Sc, Pr 1904: 47-49 (1905)

10 The Tippecanoe an infantile drainage system. Ind Ac Sc, Pr 1909:341-343 (1910)

15 Shawnee mound, Tippecanoe Co., as a glacial alluvial cone. Ind $\mathrm{Ac} \mathrm{Sc}, \mathrm{Pr}$ 1914: 385-388 (1915)

16 Loess and sand dune deposits in Vigo Co., Ind. Ind Ac Sc, $\operatorname{Pr} 1915: 185-188$ (1916)

16a Volume of the ancient Wabash River. Ind Ac Sc, Pr 1915: 189-190 (1916) MaeBride, Thomas Huston.

83 The Little Missouri badlands. Pop Sc Mo $23: 468-475,634-642$ (1883)

93 A new cycad [Bennettites dacotensis]. Iowa Univ, Lab N H, B 2 : 391-393, il (1893) Am G 12:248-250, il (1893)

94 North American cycads. Iowa Ac Sc, Pr 1 pt 4:62-65 (1894)
MacBride, Thomas Huston-Continued.

96 Notes on certain fossil plants from the Carboniferous of Iowa (abst). Am $\theta$ 18:226-227 (1896) Science n s $4: 386$ 387 (1896)

97 A pre-Kansan peat bed [in Iowa]. Iowa Ac Sc, $\operatorname{Pr} 4: 63-66$ (1897)

99 Geology of Humboldt Co. Iowa G \& $9: 109-154$, map (1899)

00 Geology of Osceola and Dickinson cos. Iowa G S 10:185-239, maps (1900) 01 Geology of Clay and O'Brien cos Iowa G S 11:461-497, maps (1901)

02 Geology of Cherokee and Buena Vista cos., with notes on the limits of the Wis. consin drift as seen in northwestern Iowa. Iowa G S 12 : 303-353, maps (1902)

03 Geology of Kossuth, Hancock, and Winnebago cos. Iowa G S $13: 81-122$, maps (1903)

05 The geology of Emmet, Palo Alto, and Pocahontas cos. Iowa G S 15:227259, maps (1905)

06 Geology of Sac and Ida cos. Iowa G S 16:509-562, maps (1906)

07 On certain fossil plant remains in the Iowa herbarium. Davenport $\mathrm{Ac} \mathrm{Sc}$. Pr $10: 153-162,11$ (1907)

10 Geology of Hamilton and Wright cos Iowa G S 20:97-149, maps (1910)

MeCanery, Richard S.

03 (with Yung, M. B.) The ore de posits of the San Pedro district, N. Mer Am I M Eng, Tr $33: 350-362$, maps (1903) Eng M J 75: 297-299 (1903)

MeCalley, Henry (1852-1904).

S1 Report on the geology of that part of north Alabama lying north of the Ten nessee River. Ala G S, Rp Prog 1879-80: 65-158 (1881)

s6 On the Warrior coal field. Ala G S: xv, 571 pp, Montgomery, Ala., 1886.

86a North Alabama, or the mountaln, manufacturing, and mineral region of Als. bama. In Dubose, John W. (ed.), The mineral wealth of Alabama and Birming. ham illustrated:17-41, Birmingham, Ala, 1886

91 Report on the coal measures of the plateau region of Alabama. Ala G S:238 pp, map, Montgomery, Ala., 1891

$91 \mathbf{a}$ Natural gas and petroleum in north Alabama. Ala Ind Sc Soc, Pr $1: 35-48$ (1891)

92 Alabama bauxite. Ala Ind $\mathrm{Sc} S \mathrm{~S}$, Pr 2:20-32 (1892) Abst, Science 20: 303-304 (1892) ; Eng M J 54:584 (1892)

94 Bauxite mining. Science $23: 29-30$ (1894)

95 Alabama barite, or heavy-spar. Al Ind Sc Soc, Pr 5: 25-29 (1895)

96 Report on the valley regions of Als. bama (Paleozoic strata). Part I, on the Tennessee Valley region. Ala G S: 436 pp, map, Montgomery, Ala., 1896 
MeCalley, Henry-Continued.

96a The limonites of Alabama geologically considered. Eng M J 62:583-584 (1896)

97 Report on the valley regions of Alabama (Paleozoic strata). Part II, On the Coosa Valley region. Ala G S: $862 \mathrm{pp}$, Montgomery, Ala., 1897

97a The hematites of Alabama geologically considered. Eng M J 63:43-44 (1897)

$97 \mathrm{~b}$ The fluxing rocks of Alabama geologically considered. Eng M J 63:115116 (1897)

98 Map of the Warrior coal basin with columnar sections of formations so far as it carries workable coals. Ala G S, 1898 [For report, see 00 below]

00 Report on the Warrior coal basin. 327 pp, map, Jacksonville, Fla., 1900

01 The Alabama coal fields. Mines and Minerals 21:446-449 (1901)

04 (with Smith, E. A.) Index to the mineral resources of Alabama. Ala G S : 79 pp, map, Montgomery, Ala., 1904

MeCallie, Samuel Washington.

92 Remains of the mastodon recently found in Tennessee. Science 20:333 (1892)

94 A preliminary report on the marbles of Georgia. Ga G S, B 1:92 pp, maps (1894) 2d ed, 126 pp (1907)

96 A preliminary report on a part of the phosphates and marls of Georgia. Ga G S, B 5-A: 101 pp (1896)

96a (with Yeates, W. S., and King, F. P.) A preliminary report on a part of the gold deposits of Georgia. Ga G S, B 4-A : 542 pp (1896)

97 Gold deposits of Georgia. $17 \mathrm{pp}$, map, Atlanta, Ga., 1897

98 A preliminary report on the artesianwell system of Georgia. Ga G S, B 7 : $214 \mathrm{pp}$, maps (1898)

$00 \mathrm{~A}$ preliminary report on a part of the iron ores of Georgia; Polk, Bartow, and Floyd cos. Ga G S, B 10-A: 190 pp, map (1900)

00a Some notes on the brown iron ores of Georgia. Eng M J 69:255-256 (1900) $00 \mathrm{~b}$ Notes on the fossil iron ores of Georgia. Eng M J 70:757-758 (1900)

01 A preliminary report on the roads and road-building materials of Georgia. Ga G S, B 8:264 pp, map (1901)

o1a Mineral resources of Georgia. Int M Cong, 4th, Pr: $33-42$ (1901) Also, 20 pp, map, Atlanta, Ga., 1901

01b Some notes on the trap dikes of Georgia. Am G 27:133-134, map (1901)

02 The Ducktown copper mining district [Tenn.]. Eng M J 74:439-441 (1902)

03 An erratic boulder from the Coal Measures of Tennessee. Am G 31:46-47 (1903)

$$
28737^{\circ}-23-44
$$

MeCallie, Samuel Washington-Continued. O3a Sandstone dikes near Columbus, Ga. Am G 32:199-202 (1903)

03b The Barboursville oil field, Ky. Eng M J $76: 12-13$ (1903)

04 A preliminary report on the coal deposits of Georgia. Ga G S, B 12:121 pp, map (1904)

O4a [Notes on water resources of] Georgia. U S G S, W-S P 102: 207-237 (1904)

o5 Experiment relating to problems of well contamination at Quitman, Ga. U S G S, W-S P 110: 45-54 (1905)

O5a [Underground waters of] Georgia. U S G S, W-S P 114: 153-158 (1905)

06 Stretched pebbles from Ocoee conglomerate [of Georgia]. J G 14:55-59 (1906)

06a An intermittent flowing well [A]bany, Ga.]. Science n s 24:694 (1906)

o7 Some notes on schist-conglomerate occurring in Georgia. J G 15:474-478 (1907)

o7a A preliminary report on the marbles of Georgia ( $2 \mathrm{~d}$ ed). Ga G S, B 1:126 pp, maps (1907)

os A preliminary report on the underground waters of Georgia. Ga G S, B 15 : $370 \mathrm{pp}$, map (1908)

OSa Report on the fossil iron ores of Georgia. Ga G S, B 17:199 pp, maps (1908)

09 In memoriam, William Smith Yeates, 1856-1908. Ga G S, B 19:7-8 (1909)

09a The Pickens Co. meteorite. Science n s $30: 772-773$ (1909)

10 A preliminary report on the mineral resources of Georgia. Ga G S, B 23:208 pp, maps (1910)

10a A second report on the public roads of Georgia. Ga G S, B 24:37 pp (1910)

$10 \mathrm{~b}$ Georgia ocher mining and treatment. M World $33: 1225-1226$ (1910)

11 Handbook of mineral resources of Georgia. Ga G S:37 pp (1911) Revised ed : 48 pp (1918)

11a Bauxite deposits of southern Georgla. Eng M J 91:1050, map (1911)

12 The ocher deposits of Georgia. Colliery Engineer $33: 46-47$ (1912)

13 A preliminary report on the mineral springs of Georgia. Ga G S, B 20:190 pp, map (1913)

13a Outlook for the gold-mining industry of Georgia. M World 38:22-23 (1913)

17 High potash-bearing slates in Georgia. Eng M J 104: 643 (1917)

MeCallum, A. L.

os A review of some recent schemes for the classification of coals. M Soc N S, J 12: 113-116 (1908)

osa An interesting occurrence of scheelite in Nova Scotia. Can M J 29:456-457 (1908)

12 Scheelite in Nova Scotia. N S Inst Scl, $\operatorname{Pr}$ Tr $12: 250-252$ (1912) 
MacCal1um, A. P.

13 Origin of chalcocite. Eng M J 96 : 893-894 (1913)

MeCarn, H. L.

94 Notes on the geology of the gold field of Cripple Creek, Colo. Seience 23:31-35 (1894)

96 Pine Creek district [Gilpin Co.], Colo. M Sc Press $73: 173$ (1896)

04 The Planet copper mines [Bill Williams Fork, Ariz.]. Eng M J 78:26-27 (1904)

MeCarty, Edward P.

15 Manganiferous iron ores of the Cuyuna Range [Minn.]. Eng M J 100:400402 (1915)

MeCarthy, Gerald.

07 Ground and deep waters of North Carolina. N C Bd Health, B 22 no $1: 1$ 14 (1907)

MeCaskey, Hiram Dryer.

o7 Gold and silver; southern Appalachian States; Texas; Vermont. U S G S, Min Res 1906: 323-334, 362 (1907)

os Notes on some gold deposits of Alabama. U S G S, B 340:36-52 (1908)

osa Gold, silver, copper, lead, and zinc in Eastern States. U S G S, Min Res 1907 : 551-570 ; 1908 : 645-681 ; 1909 : 533$547 ; 1910: 675-691 ; 1911$ pt $1: 873-888$; 1912 pt $1: 417-436 ; 1913$ pt $1: 173-196$ (1908-14)

osb Gold, silver, copper, lead, and zinc ; Texas. U S G S, Min Res 1907:432-433 (1908)

ose Quicksilver. U S G S, Min Res 1907 pt $1: 677-692 ; 1908$ pt $1: 683-695$; 1909 pt $1: 549-559 ; 1910$ pt $1: 693-710$; 1911 pt $1: 889-921$; 1912 pt $1: 931-948$; 1913 pt $1: 197-212 ; 1914$ pt $1: 315-332$; 1915 pt $1: 259-277^{\circ}(1908-16)$

osd (with Linderen, W.) Gold and silver. U S G S, Min Res 1907 pt 1:111$135 ; 1908$ pt $1: 157-183$ (1908-9)

11 Gold and silver. U S G S, Min Res 1900 pt $1: 121-149 ; 1910$ pt $1: 119-153$; 1911 pt $1: 211-254 ; 1912$ pt $1: 225-273$; 1913 pt $1: 845-885 ; 1914$ pt $1: 829-965$ (1911-6)

14 (with Butler, B. S.) Copper ores of the New London mine [Frederick Co., Md.] Am I M Eng, B 91:1681-1688 (1914) ; $\operatorname{Tr} 49: 284-291$ (1915)

17 (and Dunlop, J. P.) Gold and silver. U S G S, Min Res 1915 pt 1 : 767$803 ; 1916$ pt $1: 679-721$ (1917-8)

MeCaslin, David S.

83 Geology of Jay Co. Ind, Dp G N H, An Rp $12: 153-176$ (1883)

84 Geology of Johnson Co. Ind, Dp G N H, An Rp 13, pt 1: 116-137 (1884)

01 The geology of the artesian basin in South Dakota. Minn Ac N Sc, B 3:380388 (1901)

MacCaughey, Vaughan.

18 A survey of the Hawailian coral reefs. Am Nat 52:409-438 (1918)
MeCaughey, William J.

13 (and Fry, W. H.) The microscopic determination of soil-forming minerals. D S Dp Agr, Bur Soils, B 91: 100 pp (1913)

18 Copiapite in coal. Am Mineralogist 3: 162-163 (1918)

Mecauley, C. A. H.

78 Report on the San Juan reconnais. sance of 1877. U S [War Dp], Chief Eng, An Rp 1878 (U S, 45th Cong 3d sess, H Ex Doc 1 pt 2 v 2 pt 3), App SS: 1750-1867 (1878)

Mecharles, $A$.

87 The footsteps of time in the Red River valley, with special reference to the salt springs and flowing wells to be found in it. Hist Sc Soc Manit, $\operatorname{Tr} 27: 18 \mathrm{pp}$ (1887)

$\mathbf{8 7 a}$ Notes on the geology of the Winnt. peg district, Manitoba (abst). Edinb $G$ Soc, $\operatorname{Tr} 5: 331-333$ (1887)

Mechesney, J. H.

59 Descriptions of new species of fossils from the Paleozoic rocks of the Western States; Ext. Trans. Chicago Academy of Sciences, vol. 1. $76 \mathrm{pp}$, il, Chicago 1859 Notice, Am J Sc (2) 40:116-119 (1865)

61 Descriptions of new fossils from the Paleozoic rocks of the Western States; from the transactions of the Chicago Academy of Sciences, October 11th, 1859; Extract no. 2. Pp 77-95, il [Chicago 1861] Notice, $A \mathrm{~m}$ J Sc (2) $32: 122-123$ (1861)

67 Descriptions of fossils from the Paleozoic rocks of the Western States, with illustrations. Chicago $\mathrm{Ac} \mathrm{Se}, \mathrm{Tr} 1: 1-57$, il (1867) [First published as an extract in 1859]

Meclintock, F. L.

57 (and Haughton, S.) Reminis cences of Arctic ice travel in search of Sir John Franklin and his companions. R Dublin Soc, J 1: 183-238 (1857)

MeClung, C. E.

98 Microscopic organisms of upper Cretaceous. Kans Univ G S 4:413-427, 1l (1898)

05 The fossil bison of Kansas. Kans Ac Sc, Tr 19:157-159, il (1905)

06 The University of Kansas expedition into the John Day region of Oregon. Kans Ac Sc, Tr 20:67-70 (1906)

os Ichthyological notes of the Kansas Cretaceous. Kans Univ Sc B 4: 233-243, il (1908)

OSa Restoration of the skeleton of Bisol occidentalis. Kans Univ Sc B 4:247-252, il (1908)

MeClure, Frank G.

15 Gold placers of Arizona. Ariz St Bur Mines, B no 10:15 pp, map (1915) MeClure, W. Frank.

04 A great mammoth's tooth [molar of Elephas primigenius near Amboy, Ohio]. Sc Am $90: 60$, il (1904) 
Maceo, Albrecht.

04 Die Eisenerzlagerstätten am Lake Superior. Zs Prak G 12:48-53, 377-399, map (1904)

MeCollum, Elmer V.

05 (with Bartow, E.) Kansas petroleum. Kans Ac Sc, Tr 19:56-59 (1905)

MeConnell, Richard George.

85 Report on the Cypress Hills, Wood Mountain, and adjacent country. Can G S, An Rp 1: c 1-78, maps (1885)

S5a (with Dawson, G. M.) Report on the region in the vicinity of the Bow and Belly rivers, Northwest Territory. Can G $\mathrm{S}, \mathrm{Rp}$ Prog 1882-4 : c 168 pp, maps (1885)

87 Report on the geological structure of a portion of the Rocky Mountains ... Can G S, An Rp 2: D 41 pp (1887)

89 Note on the geology of Mt. Stephen, B. C. Am G 3:22-25 (1889)

90 [Report of an exploration north of Lesser Slave Lake, Alberta.] Can G S, Sum Rp 1888-9 (An Rp 4) : A 12-15 (1890)

90a Glacial features of parts of the Yukon and Mackenzie basins. G Soc Am, B 1:540-544 (1890) Abst, Am G 5:119 (1890): $\Lambda \mathrm{m}$ Nat 24:208 (1890)

91 Report on an exploration in the Yukon and Mackenzie basins, Northwest Terr. Can G S, An Rp 4: D 163 pp, map (1891)

91a [Summary report on the Athabasca region, Alberta.] Can G S, Sum Rp 1890 (An Rp 5) : A 21-26 (1891)

91b [Tar sands on the Athabasca River.] Can G S, An $\mathrm{Rp}$ 5: s 144-147 (1891)

92 [Report on the Bow River valley, Alta.] Can G S, Sum Rp 1891 (An Rp 5): A 18-19 (1892)

93 Report on a portion of the district of Athabasca, comprising the country between Peace River and Athabasea River north of Lesser Slave Lake. Can G S, An Rp 5: D 67 pp, maps (1893)

93a [Report on explorations in the Rocky Mountains.] Can G S, Sum Rp 1892 (An Rp 6) : A 10-12 (1893)

94 [Report on a geological exploration of the Finlay and Omenica rivers, northern British Columbia.] Can G S, Sum Rp 1893 (An Rp 6) : A 16-22 (1894)

95 [Report on fleld work in West Kootanie district B C.] Can G S, Sum Rp 1894 (An Rp 7) : ^ $30-38$ (1895)

95a (with Dawson, G. M.) Glacial deposits of southwestern Alberta in the vicinity of the Rocky Mountains. G Soc Am, B 7:31-66, map (1895) Abst, Am G $16: 235$ (1895)

96 Report on an exploration of the Finlay and Omenica rivers [northern British Columbia]. Can G S, An Rp 7:c 40 pp (1896)
McConnell, Richard George-Continued.

96a [Report on the West Kootanie district, B. C.] Can G S, Sum Rp 1895 (An Rp 8) : A 22-37 (1896)

97 [Report of field work in West Kootanie district, B. C.] Can G S, Sum Rp 1896 (An Rp 9) : A 18-30 (1897)

9S [Report on field work in West Kootenay district B. C.] Can G S, Sum Rp 1897 (An Rp 10) : A 27-33 (1898)

99 [Report on field work in Yukon.] Can G S, Sum Rp 1898 (An Rp 11) : A 4655 (1899)

99a (and Tyrrell, J. B.) Preliminary note on the gold deposits and gold mining in the Klondike region, Yukon district. Can G S, Sum Rp 1898 (An Rp 11) : A 5562 (1899)

oo Preliminary report on the Klondike gold fields, Yukon district, Canada. Can G S : 44 pp, map (1900)

O0a The Klondike region, Yukon. Can G S, Sum Rp 1899 (An Rp 12) : A 16-52, map (1900)

Oob The old valley gravels of the Klondike. Can M Inst, J 3:124-127 (1900) Can M Rv $19: 52-53$ (1900)

01 [Report of field work in Yukon.] Can G S, Sum Rp 1900 (An Rp 13) : ^ 3752 (1901)

o1a (and Broek, R. W.) British Columbia, West Kootenay sheet, geologically coloured. Scale, 4 miles $=1$ inch. Can G $\mathrm{S}$, An Rp 14 [n. d., about 1901]

02 The Yukon distriet. Can G S, Sum Rp 1901 (An Rp 14) : A 25-39, maps (1902)

$02 a$ Note on the so-called basal granite of the Yukon Valley. Am G 30:55-62 (1902)

o3 The Macmillan River, Yukon district. Can G S, Sum Rp 1902 (An Rp 15) : A 2238, map (1903)

o4 Klondike district, Yukon Territory. Can G S, Sum Rp 1903 (An Rp 15) : A 34-42 (1904)

O4a (and Broek, R. W.) Report on the great landslide at Frank, Alta. Canada, Dp Interior, An Rp 1902-3 pt 8 App: 17 pp (1904)

o5 Report on the Klondike gold fields. Can G S, An Rp 14: B 71 pp, maps (1905)

o5a The Kluane mining district, southwestern portion of Yukon district. Can G S, Sum Rp 1904 (An Rp 16): A 1-18, map (1905)

05b Recent mineral discoveries on Windy Arm, Tagish Lake, Yukon. Can G S : 12 pp, map (1905)

06 [Report on the] headwaters of White River. Can G S, Sum Rp 1905:19-26 (1906)

o6n [Report on the] Windy Arm district, northwestern B C. Can G S, Sum Rp 1905: 26-32 (1906)

o6b Klondike district. Can G S, Sum Rp 1906: 20-21 (1906) 
MeConne11, Richard George-Continued.

ofe Recent mineral discoveries on Windy Arm of Tagish Lake [B. C.]. B C, Minister of Mines, An Rp 1905:64-68 (1906) Mines and Minerals 27:15-16 (1906)

06d Note on Windy Arm silver-bearing veins. Can M Inst, J 9:49-53 (1906)

o7 Report on gold values in the Klondike high level gravels. Can G $\mathrm{S}: 34 \mathrm{pp}$, map (1907) [French ed, 38 pp]

09 The Whitehorse copper belt, Yukon Terr. Can G S: 63 pp, maps (1909) Abst, Can M J 30:709-714, 747-752 (1909)

$09 a$ Northwestern portion of Texada Island. Can G S, Sum Rp 1908:46-50 (1909) B C, Minister of Mines, An Rp 1908: 150-154, map (1909)

10 Changes in postglacial temperatures in the Yukon. Int $\mathrm{G}$ Cong, XI, Stockholm, Die Veränderungen des Klimas seit dem Maximum der letzten Eiszeit: 395 (1910)

10a Texada Island and Moresby Island, B. C. Can G S, Sum Rp 1909:69-83 (1910)

11 Portland Canal district [B. C.]. Can G S, Sum Rp $1910: 59-89$, map (1911)

12 Observatory Inlet, B. C. Can G S, Sum Rp 1911: 41-50, maps (1912)

12a Salmon River district [B. C.]. Can

G S, Sum Rp 1911:50-56, map (1912)

12b Portland Canal district [B. C.].

Can G S, Sum Rp 1911: 56-71, map (1912)

13 Prince Rupert and Skeena River;

Granby Bay, Observatory Inlet. Int Geol Cong, XII, Canada, Guide Book no 10:535, 162-168, maps (1913)

$13 a$ Portions of Portland Canal and Skeena mining divisions, Skeena district, B. C. Can G S, Mem 32:101 pp, maps (1913)

14 Texada Island, B. C. Can G S, Mem 58: $112 \mathrm{pp}$, maps (1914)

$14 a$ Geological section along the Grand Trunk Pacific railway from Prince Rupert to Aldermere, B. C. Can G S, Sum Rp 1912: 55-62 (1914)

14b Princess Royal Island, B. C. Can

G S, Sum Rp 1912:63-67 (1914)

14c Texada Island, B. C. Can G S, Sum Rp 1912:68 (1914)

14d Rainy Hollow mineral area, B. C. Can G S, Sum Rp 1913: 29-33, map (1914)

14e Recent development at the Hidden Creek mine. Observatory Inlet, B. C. Can G S, Sum Rp 1913: 55-57 (1914)

14 Pritannia mine, Howe Sound, B. C. Can G S, Sum Rp $1913: 76-79$ (1914)

15 Summary report of the Geological Survey [of Canada] for the calendar year 1914. $201 \mathrm{pp}$, maps (1915) ...1915:307 pp, maps (1916)

MeCormick, Calvin.

86 The inclusions in the granite of Craftsbury, Vt. Ac N Sc Phila, Pr 1886: 19-24
MeCormiek, Clinton P.

09 Mining on Prince William Sound, Alaska. M World 31:1199-1202 (1909)

Mecormiek, E.

00 The ore deposits of Yreka mining dis trict, Idaho. Eng M J 69:404 (1900)

00 The copper deposits of southwestern Nevada. M Sc Press 81:401 (1900)

01 The Santa Fe mining district, Ner. Mines and Minerals 21:407 (1901)

o7 Diente, Mexico. M Sc Press $95: 648$ (1907)

MeCornack, Ellen Condon.

06 A student's geological map of Ore gon; with notes. Oreg, Univ, B n s 3 no 5:25 pp, map, Eugene [1906]

14 A study of Oregon Pleistocene; the Oregon Desmostylus skull. Oreg Univ B n s 12 no $2: 16 \mathrm{pp}$, il (1914)

MeCourt, Walter Edward.

06 Fire tests of some New York build. ing stones. N Y St Mus, B 100:38 pp (1906)

O6a (with Parmelee, C. W.) A re port on the peat deposits of northern Ner Jersey. N J G S, Rp 1905:223-313 (1906)

o7 The fire-resisting qualities of some New Jersey building stones. N J G \&, An Rp St G 1906: 19-76 (1907)

10 Diamonds in Arkansas. Ac Sc St. Louis, Tr $18: 11 x-1 \times$ (1910) Abst, Sclence a s $30: 127$ (1909)

17 (assisted by Albertson, M., and Bennett, J. W.) The geology of Jackson Co. Mo Bur G Mines (2) $14: 158 \mathrm{ph}$ maps (1917)

MeCoy, Alexander Watts.

13 Artesian water in Missourl. Mo Univ B, Eng Exp Sta, Ser 4 no $3: 73 \mathrm{pp}$ (1913)

16 Some effects of capillarity on oil accumulation. J G 24:798-805 (1916) Southwestern As Petroleum G, B 1:140147 (1917)

18 on the migration of petroleur through sedimentary rocks. Am As Pe troleum G, B 2:168-171 (1918)

MeCracken, Stephen B.

76 The State of Michigan, embracing sketches of its history, position, resources, and industries [incl. mineral resources: 48-73]. 136 pp, Lansing, Mich., 1876

MeCrady, John.

59 On the zoological affinities of graptolites. Elliott Soc N H Charleston, $\mathrm{Pr}$ 1: 229-236 (1859)

$59 a$ Remarks on the Eocene formation in the neighborhood of Alligator, Florids. Elliott Soc N H Charleston, Pr 1:282283 (1859)

MeCreath, Andrew Smith.

75 Report of progress in the laborator! of the survey at Harrisburg. $\mathrm{Pa} G$ \&, $2 \mathrm{~d}, \mathrm{M}: \mathbf{1 0 5}$ pp (1875) 
MeCreath, Andrew Smith-Continued.

79 Second report of progress in the laboratory of the survey at Harrisburg. Pa G S, 2d, MM : 438 pp (1879)

$\mathbf{8 1}$ Third report of progress in the laboratory of the survey at Harrisburg. Pa G S, 2d, M3 : 126 pp (1881)

81a An analysis of a pure dolomite exposure, in mass, in Franklin Co. [Pa.]. $\triangle \mathrm{m}$ Ph Soc, Pr 19:197 (1881)

83 The mineral wealth of Virginia... $105 \mathrm{pp}$, Harrisburg 1883 [2d ed], 157 pp, map Harrisburg 1884

S3a The iron ores of the Valley of Virginia. Am I M Eng, Tr 12:17-26 (1883) Eng M J $35: 334-335$ (1883) The Virginias $4: 94-96$ (1883)

87 (and d'Invilliers, E. V.) The New River-Cripple Creek mineral region of Virginia. $171 \mathrm{pp}$, map, Harrisburg, Pa., 1887

87a (and d'Invilliers, E. V.) Comparison of some southern cokes and iron ores. Am I M Eng, Tr 15: 734-753 (1887)

88 (and d'Invilliers, E. V.) Resources of the upper Cumberland Valley of southeastern Kentucky and southwestern Virginia ... $152 \mathrm{pp}$, map, Louisville $188 \mathrm{~s}$

92 (and d'Invilliers, E. V.) Geological and chemical report on a portion of the Virginia and Tennessee Coal and Iron Company's property ... Wise Co., Va. $67 \mathrm{pp}$ [n p, n d, 1892 ?]

93 (and d'Invilliers, E. v.) The Clinch Valley coal fields [southwestern Va.]. U S G S, Min Res 1892:521-528 (1893)

MeCreery, J M.

90 Note on some of the causes of extinction of species. Am G 5:100-104 (1890)

MCulloch, (Dr.)

19 Geological memoranda. In Ross, John, A voyage of discovery ... for the purpose of exploring Baffin's Bay ..., Appendix no. III : $1 \times x y-1 \times x \times i i$, L 1819

MeCnlloeh, Thomas.

92 List of localities for trap minerals in Nova Scotia. N S Inst Sc, Pr Tr 8 or (2) 1: 160-166 (1892)

MacCurdy, George Grant.

17 Archaeological evidences of man's antiquity at Vero, Fla. J G $25: 56-62$ (1917)

$17 \mathbf{a}$ The problem of man's antiquity at Vero, Fla. Am Anthropologist $n$ s 19 : 252-261 (1917)

MeCutehen, August R.

84 [Physico-geographical and agricultural features of] northwest Georgia. U S, 10th Census 6: 285-295, map (1884)

85 [Topography, climate, geology, and economic minerals of Georgia.] In Henderson, J. T., The commonwealth of Georgia : 3-157, maps, Atlanta, Ga., 1885

MeDaniel, Benjamin $\mathbf{F}$.

84 Geology and mineralogy in Essex Co., Mass, Essex Inst, B 16:133-140 (1884)
MeDaniel, Benjamin F.-Continued.

84a Geology and mineralogy of New bury [Mass.]. Essex Inst, B 16:163-169 (1884)

MeDermott, Walter.

77 The Silver Islet vein, Lake Superior. Eng M J 23:54-55, 70-71 (1877) Inst M Met, Tr 18:220-231 (1909) Can M J $30: 135-138$ (1909)

MacDonald, Bernard.

o3 The ore deposits of Rossland, B. C. Eng M J $76: 198-199$ (1903)

09 Discussion of paper by C. R. Keyes, Genesis of the Lake Valley, New Mexico, silver deposits. Am I M Eng, B 26:211216 (1909)

18 Remarks on the Sonora earthquake; its behavior at Tepic, Sonora, etc. Seism Soc Am, B 8:74-78 (1918)

MacDonald, Donald Francis.

06 Economic features of northern Idaho and northwestern Montana. U S G S, B 285: 41-52 (1906)

09 Notes on the Bohemia mining district, Oreg. U S G S, B $380: 80-84$ (1909)

09a Notes on the economic geology of northern Idaho and northwestern Montana. U S G S, B 384: 92-108 (1909)

10 The Weaverville-Trinity Center gold gravels, Trinity Co., Cal. U S G S, B $430: 48-58$ (1910)

12 Heated areas in Culebra cut [Panama Canal]. Canal Record 5:225-226 (1912)

12a Heating of local areas of ground in Culebra cut, Canal Zone. Science n s 35 : 701-702 (1912)

$12 b$ Coal deposits on the Canal Zone. Canal Record 5:255 (1912)

12e Geology of Culebra cut [Panama Canal]. M Sc Press 105: 726 (1912)

12d Geology of Culebra cut; nature and conduct of slides. Canal Record 6:88 (1912)

12e Slides in the Culebra cut at Panama. Eng Record 66:228-233 (1912)

13 Notes on the gold lodes of the Carrville district, Trinity Co., Cal. U S G S, B $530: 9-41$, map (1913)

13a Geology of the Isthmus [of Panama]. Canal Record 6:213-215 (1913)

13b Geology of western Panama; Chiriqui Volcano. Canal Record 6: 424 (1913)

13e Earthquakes and the Panamra Canal; a study of the geological conditions on the Isthmus and what it reveals. Sc Am 109: 303-305 (1913)

13a Excavation deformations. Int $\mathrm{G}$ Cong, XII, 1913, C R: 779-792 (1914) Advance copy 1913

13e (and Johnston, W. C.) Isthmian earthquakes. Canal Record 7:144-149, maps (1913)

13f Geologic section of the Panama Canal Zone (abst). G Soc Am, B 24: $707-711$ (1913) 
MacDonald, Donald Francis-Continued.

14 Report of the physiography and general geology of the lower flood plain of the Sixaola River and the hills at and near Punta Mona. Costa Rica-Panama Arbitration, Appendix No. 2 to the counter case of Costa Rica, pp 73-111, maps, Washington, Press of Gibson Bros, inc., 1914

15 Some engineering problems of the Panama Canal in their relation to geology and topography. U S Bur Mines, B 86 : $88 \mathrm{pp}$, map (1915)

15a Some earthquake phenomena noted in Panama. Science $\mathrm{n} \&$ 41:783-784 (1915)

16 Report of geologist [on the slides of the Panama Canal]. Panama Canal, Governor, An Rp 1916: 599-603 (1916)

16a Outline of Canal Zone geology. In Goethals, George W., The Panama Canal; an engineering treatise: 67-83, N Y 1916

$16 b$ (and Enxian, Charles.) Prospecting and mining of copper ore at Santa Rita, N. Mex. U S Bur Mines, B 107 : 122 pp, maps (1916)

Macdonald, J. A.

06 The occurrence and development of the cobalt-ore deposits [of northern Ontario]. Eng Mag 31:406-416 (1906)

MeDenald, $M$.

$\boldsymbol{7 9}$ Semiannual report of the superintendent of the Virginia Military Institute, enclosing the report of a geological and mineral examination of a portion of the James River iron belt. 23 pp, map, Richmond 1879 Reprinted in the Virginias 1: 10-13 (1880)

MeDonald, P. B.

11 The Porcupine gold district, Ont. M Science 63: 231-233 (1911)

12 History of the Cascade iron range of Michigan. M World 37:902-905 (1912)

13 Mining in northern New York. Eng M J 95: 689-692, map (1913)

13a Applied geology, Michigan iron ranges. Eng M J 96 : 208-210 (1913)

14 Kaolin mining operations in the South. M Eng World 40:281-282 (1914)

15 Newfoundland's iron mines. Can M J $36: 554-555$ (1915)

16 Scheelite mining and grading [southern California]. M Sc Press 112:40-41 (1916)

MaeDona1d, Simon D.

82 Geological notes [Sable Island]. N

S Inst N Sc, Pr Tr 5:337-339 (1882)

83 Notes on Sable Island. N S Inst N Sc, Pr Tr 6:12-33, 110-119, 265-280 (1883-86)

MaeDonald, W. T.

12 The San Juan oil field, Utah. Western Eng 1: 37-46 (1912)

Macdougal, Daniel Trembly.

06 The delta of the Rio Colorado. Am Geog Soc, B 38:1-16 (1906)
Macdongal, Daniel Trembly-Continud o7 The desert basins of the Colond delta. Am Geog Soc, B 39: 705-729 (1907) os Changes in the delta of the Colorad River (abst). Science n s 27:266-25 (1908)

09 Origination of self-generating matte and the influence of aridity upon its ev lutionary development. J G 17:603-0\% (1909)

14 (and others) The Salton Sea; study of the geography, the geology, th floristics, and the ecology of a desert basit Carnegie Inst Wash, Pub 193:182 (1914)

15 The Salton Sea [Cal.]. Am J \& (4) $39: 231-250$ (1915)

$15 \mathbf{a}$ (and Sykes, G.) The travertip record of Blake Sea [Cal.] Science n. $42: 133-134$ (1915)

16 (and others) The Salton and $\mathrm{N}$ have Desert regions. Carnegie Inst Wast Y Bk 14 (1915) : 90-97 (1916)

17 A decade of the Salton Sea. Gev Rv 3: 457-473 (1917)

MeDowell, J. C.

17 Geology in its relation to the of Industry. Am M Cong, 19th An Sess, B Pr : 284-302 (1917)

Mace, Clement $\mathrm{H}$.

11 Genesis of Leona Heights ore deposti Cal. M World 35:1320 (1911)

MeEven, Thomas.

30 (with Vaux, R.) Notice of the $\mathrm{fl}$ of a meteoric stone at Deal in New Jerse? Ac N Sc Phila, J 6: 181-182 (1830)

MeEvoy, James.

93 [Report on field work in the Sbr swap region, B. C.] Can G S, Sum $\mathbb{f}$ 1892 (An Rp 6) : A 7-10 (1893); Sum fif 1894 (An Rp 7) : A 20-22 (1895); Sut Rp 1895 (An Rp 8) : A 37-39 (1896)

94 [Summary report on explorations t: west central British Columbia.] Can $G$ s Sum Rp 1893 (An Rp 6) : A 13-16 (1894

98 (with Dawson, G. M.) Brifts Columbia, Shuswap sheet [descriptions formations on margin]. Scale 4 miles t 1 inch. Can G S 1898

99 [Report of fleld work from Edmot ton to the Fraser River via Yellow Heal Pass.] Can G S, Sum Rp 1898 (An B? 11) : $\triangle$ 71-86 (1899)

$99 a$ (with Dawson, G. M.) Brittst Columbia, Shuswap sheet; economic mit erals and glacial striae. Scale 4 miles t 1 inch. Can G S 1899

oo Report on the geology and natur resources of the country traversed by th Yellow Head Pass route from Edmonto to Tête Jaune Cache, comprising portios of Alberta and British Columbia. Can S, An Rp 11: D 44 pp, map (1900)

o1 Geological and topographical map East Kootenay district, B. C. Can G \& An Rp 12: map (1901) 
McEvoy, James - Continued.

01a [Report on field work in the Crowsnest Pass coal field, B. C.] Can G S, Sum Rp 1900 (An Rp 13) : A 84-95 (1901)

04 Notes on the special features of coal mining in the Crowsnest, B. C. Can M Inst, J $7: 500-504$ (1905) Can M Rv 23 : 51-52 (1904) Abst, Eng M J 77:601602 (1904)

09 Report on the Kananaskis coal lands [Alta.]. The German Development Company, Ltd. [Rp] : 48-62 [1909] Abst, Can M J 30:141-143 (1909)

09a Report on Bighorn and Brazeau coal lands [Alta.]. The German Development Company, Ltd. [Rp] : 65-82 [1909] Abst, Can M J $30: 143$ (1909)

MeEwan, Eula D.

17 Some morphological variations in Platystrophia (abst). G Soc Am, B 28: 201-202 (1917)

MeFarland, David Ford.

05 Composition of gas from a well at Dexter, Kans, Kans Ac Sc, Tr 19:60-62 (1905)

05a (with Haworth, E.) The Dexter, Kans., nitrogen gas well. Science n s 21: 191-193 (1905) Abst, G Soc Am, B 16: 572 (1906)

\section{MacFarland, Ira.}

09 Development of petroleum in Nevada. Am M Cong, 12th An Sess, Rp Pr: 418422 (1909)

MeFarland, R. W.

93 The close of the ice age in North America. Science 22:45-46 (1893)

Maefarlane, Graham.

90 Notes on Ameriean cannel coal, Am I M Eng, Tr 18:436-438 (1890)

96 The eastern coal regions of Kentucky. Am I M Eng, Tr 25:518-532 (1896)

13 Clinton iron-ore deposits in Kentucky and Tennessee (discussion). Am I M Eng, Tr 44:889 (1913)

Macfarlane, James (1819-1885).

73 The coal regions of America... 679 pp, maps, N Y 1873 3d ed, 697 pp, N Y 1877

74 Die Steinkohlen der Vereinigten Staaten von Nordamerika. Ges Erdk Berlin, Zs 9: 241-265, 351-364 (1874)

78 Discovery of rock salt at Wyoming in western New York. Am J Sc (3) 16: 144 (1878)

79 An American geological railway guide, giving the geological formation at every rallway station... 219 pp, N Y $1879 \quad 2 d$ ed (rev. by James R. Macfarlane), 426 pp., N Y 1890

83 The "earthquake" at New Madrid, Mo., in 1811, probably not an earthquake (abst). Am As, Pr 32:247-248 (1884) Science 2: 324 (1883)

84 The formation of canyons and precipices. Science 4:99-101 (1884)
MacFarlane, James.

09 The Ohio Copper Company, Bingham, Utah. M World 30:345-348 (1909)

Macfarlane, Thomas (1834-1907).

62 On the primitive formations in Norway and in Canada and their mineral wealth. Can Nat $7: 1-20,113-127,161$ 171 (1862)

62a Contributions to the history of the Acton copper mine. Can Nat $7: 447-471$ (1862)

63 On the origin of eruptive and primary rocks. Can Nat $8: 295-323,329-$ $358,457-478$ (1863)

65 Geological sketch of the neighborhood of Rossie [St. Lawrence Co., N. Y.] Can Nat n s 2:267-275 (1865)

66 Report [on the mineral deposits and rocks of part of Hastings Co., Ont.]. Can G S, Rp Prog 1863-6; 91-113 (1866)

66a Report [on the east shore of Lake Superior, Ontario]. Can G S, Rp Prog 1863-6:115-164 (1866)

66b On the rocks and cupriferous beds of Portage Lake, Mich. Can G S, Rp Prog 1863-6: 149-164 (1866) Can Nat n s 3: 1-18 (1866)

67 On the geological formations of Lake Superior. Can Nat n s 3:177-201, 241$256(1867-8)$

69 On the geology and silver ore of Woods Location, Thunder Cape, Lake Superíor. Can Nat n s $4: 37-48,459-463$, map (1869)

70 On the origin and classification of original or crystalline rocks. Can Nat $\mathbf{n} \mathbf{s}$ $5: 47-54,159-165,304-312$ (1870); 6 : 259-280 (1872)

71 Observations on Canadian geology. $24 \mathrm{pp}$, Montreal 1871

79 Remarks on Canadian stratigraphy. Can Nat n s 9:91-102 (1879)

so on the classification of original rocks. Am I M Eng, Tr 8:63-71 (1880)

80a Silver Islet [Ont.]. Amr I M Eng, $\operatorname{Tr} 8: 226-253$, map (1880)

MacFarren, H. W.

09 The story of Bingham Canyon [Utah]. M Sc Press 99: 129-130 (1909)

09a Ozokerite in Utah. M Sc Press 99 : 789-790 (1909)

\section{MeGee, Emma R.}

15 Life of W J McGee... 240 pp, port, privately printed, Farley, Iowa, 1915

MeGee, W J [1. e. William John] (18531912).

78 On the relative position of the forest bed and associated drift formations in northeastern Iowa. Am J Sc (3) 15:339341 (1878)

79 On the superposition of glacial drift upon residuary clays. Am J Sc (3) 18: 301-303 (1879)

79a On the complete series of superflcial formations in northeastern Iowa. Am As, Pr $27: 198-231$ (1879) 
MeGee, W J-Continued.

79b Notes on the surface geology of a part of the Mississippi Valley. G Mag (2) $6: 353-361,412-420,528$ (1879)

so The "laterite" of the Indian Peninsula [includes notes on the ferriferous deposits of the upper Mississippi basin]. G Mag (2) $7: 310-313$ (1880)

soa On some Iowa kames and aasar (abst). Iowa Ac Sc, Pr $1875-80: 19,25$ (1880)

81 On some elements in orographic displacement. Am J Sc (3) 21:276-278 (1881)

$\mathbf{8 1 a}$ On the thickness of the ice sheet at any latitude. Am J Sc (3) 22:264-267 (1881)

81b On local subsidence produced by an ice sheet. Am J Sc (3) 22:368-369 (1881)

s1e A contribution to Croll's theory of secular climatal changes. Am J Sc (3) $22: 437-443$ (1881)

s1d On maximum synchronous glaciation. Am As, Pr 29:447-509 (1881) Science (ed, Michels) 2:566-567 (1881)

81e The geology of Iown soils. Iowa St Hort Soc, Tr 15: 101-105 (1881)

82 (and Call, R. E.) On the loess and associated deposits of Des Molnes, Iowa. Am J Sc (3) 24:202-223, map (1882)

82a Modifications proposées dans la nomenclature géologique. Int $\mathrm{G}$ Cong, II, Bologna 1881, C R: 620-622 (1882)

82b The relations of geology and agr1culture. Iowa St Hort Soc, Tr 16:227240 (1882) Revised, $18 \mathrm{pp}$, Washington 1884

S3 Note on jointed structure. Am J Se (3) $25: 152-153$ (1883)

$83 a$ On the present status of the eccentricity theory of glacial climate. Am J Sc (3) 26:113-120 (1883)

83b On the origin and hade of normal faults. Am J Sc (3) 26:294-298 (1883)

s3e Report on geology and soils. Iоша St Hort Soc, Tr 17:270-280 (1883)

83d The geological distribution of forests. Pop Sc Mo 24: 115 (1883)

83e [Buried driftwood in District of Columbla.] Science 2:724 (1883)

83f On glacial canyons (abst). Am As, Pr 32:238 (1884) Science 2:315-316 (1883)

84 The drainage system and the distribution of the loess of eastern Iowa. $\mathrm{Ph}$ Soc Wash, B 6:93-97 (1884) Iowa St Hort Soc, Tr 18: 328-339 (1.884)

85 On the meridional deflection of ice streams. Am J Sc (3) $29: 386-392$ (1885)

85a Map of the United States... areal distribution of geologic groups. U S G S, An Rp 5:35-38 and pl 2 (1885) Annuaire géologique universel (Dagincourt) 2:App 26-27, map (pl. 1) (1886)
MeGee, W J-Continued.

s6 Geologic formations [of Washingti D. C., and vicinity]. D C, Health 0ffe Rp 1885: 19-20, 23-25 (1886) Abst, b J Sc (3) $31: 473-474$ (1886)

S6a Some features of the recent ear quake [Charleston]. Science $8: 271-$. (1886)

86b Quaternary phenomena about to head of Chesapeake Bay (abst). Am J? (3) $32: 323$ (1886)

87 Ovibos cavifrons from the loess Iowa. $\quad \mathrm{m}$ J Sc (3) $34: 217-220$ (185: 88 The geology of the head of Ches peake Bay. U S G S, An Rp $7: 537-6 !$ maps (1888)

SSa Three formations of the Middle lantic slope [Potomac, Appomattox, C Inmbia]. Am J Sc (3) $35: 120-143,32$ $330,367-388,448-466$ (1888)

88b Notes on the geology of Macon a Mo. Ac Sc St L, Tr $5: 305-336$ (1888)

88e Paleolithic man in America; antiquity and environment. Pop Sc $y$ $34: 20-36$ (1888)

88d The classification of geograpt forms by genesis. Nat Geog Mag 1:27 36 (1888)

8se Some definitions in dynamical ogy. G Mag (3) 5:489-495 (1888)

8sf The Columbia formation. Am 4 Pr 36:221-222 (1888)

89 The geologic antecedents of man the Potomac Valley. Am Anthropologit $2: 227-234$ (1889)

89a An American geologic society. ence $13: 8-9$ (1889)

89b Topographic types of northeaste Iowa (abst). Am Nat 23:808 (1889)

90 The southern extension of the di pomattox formation. Am J Sc (3) 4 15-41 (1890) Abst, Am G 5:120 (1890) (with discussion by W. M. Davis at C. D. Walcott), G Soc Am, B 1:546-5t (1890); Am Nat 24:209 (1890)

90a Encroachments of the sea. I Forum 9:437-449 (1890)

$90 b$ Geology for 1887 and 1888. Smitt Inst, An Rp 1888: 217-260 (1890)

90e Topographic types of northeaster Iowa (abst). $\mathrm{Am} \mathrm{As,} \mathrm{Pr} 38: 248-24$ (1890)

91 The Pleistocene history of noth eastern Iowa. U S G S, An Rp 11 pt I 189-577, maps (1891)

91 a Rock gas and related bitumess U S G S, An Rp 11 pt 1:589-616 (189!

911 The Lafayette formation. U S G An Rp 12 pt 1: $347-521$, maps (1891)

91e (and others) The geology of $\mathrm{W}:$ ington and vicinity. In Guide to Was ington and its scientific institutions, prit pared by the local committee for the if ternational Congress of Geologists, fil session, Washington 1891:38-64, [1891] Also in Int G Cong, V, Washist ton 1891, C R : 219-251 (1893) 
MeGee, W $\mathbf{J}$-Continued.

91d The field of geology and its promise for the future. Minn Ac N Sc, B 3 ; 191-206 (1891)

91e The flood plains of rivers. The Forum $11: 221-234$ (1891)

91f The Columbia formation in the Mississippi embayment (abst). Am As, Pr $39: 244-245$ (1891)

91g Neocene and Pleistocene continent movements (abst, with discussion by E. W. Hilgard, C. H. Hitchcock, and W. Upham). Am G 8: 234-235 (1891) Am As, Pr 40: 253-254 (1892)

91h Classification of Pleistocene forma. tions and land forms (abst). Am G 8: 248 (1891)

91i The Appomattox formation in the Mississippi embayment $(a b s t)$. G Soc Am, B $2: 2-6$ (1891)

92 The Gulf of Mexico as a measure of isostasy. Am J Sc (3) 44: 177-192 (1892) Abst, G Soc Am, B 3:501-504 (1892) [with discussion]; Am G 9:217 (1892)

92a The areal work of the United States Geological Survey. Am G $10: 37$-379 (1892)

92b Man and the glacial period. Science $20: 317$ (1892)

92e The southern old flelds (abst). Am As, $\operatorname{Pr} 40: 417$ (1892)

92d Pleistocene geography (abst). Am G $10: 223(1892)$

92e Distribution of the Lafayette formation (abst with discussion). Am G 10 : 223-224 (1892)

93 Areal work of the United States Geological Survey. Am I M Eng, Tr 21: 608-617 (1893)

93a Man and the glacial period. Am Anthropologist 6 : 85-95 (1893)

93b [Correlation of clastic rocks.] Int G Cong, V, Washington 1891, C R:160166 (1893)

93e [Genetic classification of Pleistocene deposits.] Int $\mathrm{G}$ Cong, V, Washington 1891, C R : $65-66,198-207$ (1893)

93d Note on the "age of the earth." Science 21:309-310 (1893)

93e The Pleistocene history of northeastern Iowa ( $a b 8 t$ with discussion). Am G 11:178-179 (1893)

93f The antiquity of man in America (abst with discussion). Am G 12:174 176 (1893)

93g Graphic comparison of post-Columbia and post-Lafayette erosion (abst). Am G $12: 180$ (1893) Am As, Pr $42: 179$ (1894)

93h A fossil earthquake (abst). G Soc Am, B $4: 411-414$ (1893)

93i Cenozoic history of eastern Virginia and Maryland (discussion). G Soc Am, B $5: 24$ (1893)

94 The potable waters of eastern United States. U S G S, An Rp 14 pt 2:1-47 (1894)
MeGee, W J-Continued.

94a Reconnaissance map of the United States showing the distribution of the geologic system [s] so far as known, 1893. U S G S, An Rp 14 pl 2 (1894) Notice, by U. S. Grant, Am G 16:113-114 (1895)

94b Preliminary geologic map of New York. N Y G S (printed by U S G S), 1894. Six sheets, scale $1: 316,800$.

94c Glacial canyons. J G $2: 350-364$ (1894)

$94 d$ [Columbia and Lafayette formations]. G Soc Am, B 5:100 (1894)

94e The extension of uniformitarianism to deformation. G Soc Am, B 6:55-70 (1894) Abst, Am G 14: 199-200 (1894)

95 Remarks on the geology of Arizona and Sonora (abst). Science n $\mathrm{s}$ 1:59 (1895)

95a The topographic development of Soora (abst). Science n s 1: 558-559 (1895)

95b A miniature extinct volcano (abst). Am As, Pr 43: 225-226 (1895)

96 Expedition to Seriland [Sonora, Mex.]. Science n s 3:493-505 (1896)

96a Two erosion epochs-another suggestion. Science n s 3: 796-799 (1896)

96b Geographic history of the Piedmont Plateau. Nat Geog Mag $7: 261-265$ (1896)

$96 \mathrm{e}$ (and others) Honors to James Hall at Buffalo. Science n s $4: 697-717$, port (1896)

96d The geologic map of the State of New York (abst). Science n s 3:418 (1896)

96e The formation of arkose (abst). Sctence n s 4: 962-963 (1896)

97 Sheetflood erosion. G Soc Am, B 8: 87-112 (1897) Alst, Am G 18:228-229 (1896) ; Science n s 4:385 (1896)

98 Geographic development of the District of Columbia. Nat Geog Mag 9:317323 (1898)

9Sa The geospheres. Nat Geog Mag 9 : 435-447 (1898)

99 (and Holmes, W. H.) Geology and archeology of the California gold belt (abst). Am G 23:96-99 (1899) Science n s 9:104-105 (1899)

99a The pre-Lafayette (Tennessean) base level (abst). Am As, Pr 48:227 (1899) Science n s 10:489 (1899)

oe The lessons of Galveston [Tex.]. Nat Geog Mag 11:377-383 (1900)

O0n The Gulf of California as an evidence of marine erosion (abst). Scienc n s $11: 429$ (1900)

0ob Occurrence of the Pensauken(?) formation (abst). Am As, Pr 49:187 (1900) Science n s 12:989-990 (1900)

02 The Antillean volcanoes. Pop Sc Mo $61: 272-281$ (1902)

02n The New Madrid earthquake. Am G 30:200-201 (1902)

02b Geest. Am G 30:381-384 (1902).

U S G S, An Rp 11 pt 1:277-280 (1891) 
MeGee, W I-Continued.

06 Glaciation in the Sonoran province [Mex.] [volcanic origin of deposits aseribed to glacial action by Merrill, F. J. H, 06a]. Science n s $24: 177-178$ (1906)

07 River sediment as a factor in applied geology (abst). Sclence n s 25: 765 (1907)

os Outlines of hydrology. G Soc Am, B 19: 193-200 (1908)

OSa Lafayette deposits in Louisiana. Science n s 27:472 (1908)

11 Soil erosion. U S Dp Agr, Bur Solls, B $71: 60$ pp (1911) Abst, Wash Ac Sc, J $1: 161$ (1911)

13 Wells and subsoil water. U S Dp Agr, Bur Soils, B 92:185 pp (1913)

See also Chamberlin, 90 ; Emerson, 96 ; Emmons (S F), 93; Hawes, 84; Orton (E), 90a ; Powell, 85, 85a, 88, 89, 89a, 90, 91, 91a, 92, 93; Russell, 85d; Salisbury, 93a ; Shaler, 81 ; Spencer (J W), 93a ; Tyrrell, $90 \mathrm{a}$; Walcott, $03 \mathrm{a}$

MeGehee, M.

83 Handbook of the State of North Carolina, exhibiting its resources and industries. [North Carolina], Board of Agriculture: vi, 154 pp, Raleigh 1883

YeGil1, John T.

17 James M. Safford. Tenn Ac Sc, Tr 2: 48-54 (1917)

MeGrath, J. W.

16 The iron mines of Wabana, Newfoundland. Can M J 37:315-317 (1916)

16a Newfoundland coal deposits. Can M J $37: 439-441$ (1916)

MeGregor, J. G.

94 Geological writings of David Honeyman. G Soc Am, B 5:567-569 (1894)

MeGregor, James Howard.

02 Characters and relationships of the belodont reptiles (abst). N Y Ac Sc, An 14: 90-91 (1902)

02a The ancestry of the Ichthyosauria (abst). Science n s 16:27 (1902) N Y Ac Sc, An 15: 55 (1903)

04 The relationships of the Phytosauria (abst). Science n s 19:254-255 (1904)

o6 The Phytosauria, with special reference to Mystriosuchus and Rhytidodon. Am Mus N H, Mem 9:29-101, il (1906)

- See also Osborn, 051

MeGuier, Henry.

69 [On the antiquity of man as shown by excavations in Saratoga Springs, N. Y.] Boston Soc N H, Pr $12: 398-400$ (1869)

MeGuire, W. W.

34 On the prairies of Alabama. Am J Sc 26: 93-98 (1834)

Machatschek, Fritz.

13 Jungrulkanische Erscheinungen in den westlichen Gebirgen der amerikanischen Union. Deut Rundschau für Geog, J 35 : 289-300 (1913)
Machatschek, Fritz-Continued.

15 Ein Profil durch die Sierra Nevada mit einem Vergleich mit der Schollenstruk. tur in Zentralasien. Am Geog Soc, Me. morial Volume of Transcontinental Excur. sion of $1912: 313-327$ (1915)

MeInnes, William.

87 (with Bailey, L. W.) Report on explorations in portions of the counties of Victoria, Northumberland, and Restigouche, N. B. Can G S, An Rp $2: N 19$ pp, map (1887)

8S (with Bailey, L. W.) Report on explorations and surveys in portions of northern New Brunswick, and adjacent areas in Quebec, and in Maine. Can G \&, An Rp 3: M 52 pp, map (1888)

89 (with Bailey, L. W.) Observations in northern New Brunswick. Can $G \&$, Sum Rp 1887-8 (An Rp 3) : A 91-93 (1889)

91 [Summary report of work in the Rainy Lake region, Ont.] Can G S, Sum Rp 1890 (An Rp 5) : A 37-40 (1891)

92 [Summary report of field work in western Ontario.] Can G S, Sum Rp 1891 (An Rp 5) : A 25-28 (1892)

93 [Report of field work in western 0 . tario.] Can G S, Sum Rp 1892 (An Rp 6) : ^ 25-26 (1893)

93a (with Bailey, L. W.) Report on portions of the Province of Quebec and adjoining areas in New Brunswick and Maine, relating more especially to the counties of Temisconata and Rimouski, P. Q. Can G S, An Rp n s 5: м 28 pp, ma? (1893)

95 [Report on field work in Lake Npigon region, Ontario.] Can G S, Sum Bf 1894 (An Rp 7) : A 49-51 (1895)

96 [Report on the region east of Rains Lake, Ont.] Can G S, Sum Rp 1895 (As Rp 8) : A 45-49 (1896)

97 [Report on work in the Rainy Lake country, western Ontario.] Can G S, Sum Rp 1896 (An Rp 9) : A 34-43 (1897)

98 [Report on field work in the Rainy River region, western Ontario.] Can G S, Sum Rp 1897 (An Rp 10) : A 38-43 (1898)

99 Report on the geology of the area covered by the Seine River and Lake She bandowan map sheets, comprising portions of Rainy River and Thunder Bay districts, Ontario. Can G S, An Rp 10: H 65 pp, maps (1899)

$99 a$ [Report on fleld work in western Ontario.] Can G S, Sum Rp 1898 (An Rp 11) : A 87-94 (1899)

o0 [Report on field work in the English River region, western Ontario.] Can $G$ \&, Sum Rp 1899 (An Rp 12) : A 115-12? (1900)

o1 [Report of field work in the Port Arthur region, western Ontario.] Can G S, Sifm Rp 1900 (An Rp 13): A 104-121 (1901) 
MeInnes, William-Continued.

02 Region southeast of Lac Seul [western Ont.]. Can G S, Sum Rp 1901 (An Rp 14) : A 89-95 (1902)

03 Region on the northwest side of Lake Nipigon [Ont.]. Can G S, Sum Rp 1902 (An Rp 15) : A 208-213 (1903)

04 The Winisk River, Keewatin district. Can G S, Sum Rp 1903 (An Rp 15) : A 100-108, map (1904)

05 The upper parts of the Winisk and Attawapiskat rivers [Ont.]. Can G S, Sum Rp 1904 (An Rp 16): A 153-160 (1905)

06 [Report on] the headwaters of the Winisk and Attawapiskat Rivers. Can G S, Sum Rp 1905: 76-80 (1906)

06a Explorations along the proposed line of the Hudson Bay Railway. Can G S, Sum Rp 1906:87-98 (1906)

08 Pasquia Hills and lower Carrot River region. Can G S, Sum Rp 1907:41-47 (1908)

09 Explorations on the Churchill River and South Indian Lake. Can G S, Sum Rp 1908: 87-92 (1909)

09a Report on a part of the Northwest Territories of Canada, drained by the Winisk and upper Attawapiskat rivers. Can G $\mathrm{S}: 58$ pp, map (1909)

10 Lac LaRonge district, Saskatchewan. Can G S, Sum Rp 1909: 151-157 (1910)

11 Saskatchewan River district [Saskatchewan]. Can G S, Sum Rp 1910: 169-173 (1911)

13 (and Dowling, D. B., and Leach, W. W.) The coal resources of the world, ... XII International Geological Congress, Canada, 1913. 3 rols 1266 pp, maps and atlas, Toronto, 1913

13a The basing of Nelson and Churchill rivers. Can G S, Mem 30:146 pp, map (1913)

17 Summary report of the [Canada] Geological Survey, Department of Mines, for the calendar year 1916. $419 \mathrm{pp}$, maps, Ottawa, 1917

See also Miller (W G), 12

MeIntire, E. $\mathrm{S}$.

76 (with Elrod, M. N.) Orange Co. Ind $\mathrm{G} \mathrm{S}$, An Rp $7: 203-239$ (1876)

MeIntosh, D. S.

13 Note on recent earthquake in Cape Breton. N S Inst Sc, Pr Tr 12:311-312 (1913)

15 Notes on granite contact zone, near Halifax, N. S. N S Inst Sc, Pr Tr 15: 244-249 (1915)

16 A study of the Cow Bay beaches [N. S.]. N S Inst Sc, Pr Tr 14 pt 2: 109-119 (1916)

MeIntosh, Kenneth.

06 The question of subsidence at Loulsbourg, Cape Breton. N S Inst Sc, Tr 11: 264-270 (1906)
MeIntyre, Albert W.

o7 Copper deposits of Washington. Am M Cong, 9th An Sess, Rp Pr: 238-250, 1907.

MeIntyre, James

49 [Report on Isle Royale]. U S, 31st Cong 1st sess $\mathrm{S}$ Ex Doc 1 pt $3 \mathrm{H} \mathrm{Ex} \mathrm{Doc}$ 5 pt 3:506-509 (1849)

Mack, Edward.

17 (and Hulett, G. A.) The water content of coal, with some ideas on the genesis and nature of coal. Am J Sc (4) 43: 89-110 (1917)

MeKay, A. W.

66 The red sandstone of Nova Scotia. Brit As, Rp $35: \sec 66-67$ (1866)

Mackay, Alexander Howard.

84 A preliminary examination of the siliceous organic remains in the lacustrine deposits of the Province of Nova Scotia, Canada (abst). Brit As, Rp 54: 742 (1885) G Mag (3) 1:561-562 (1884)

85 Organic siliceous remains in the lake deposits of Nova Scotia. Can Rec Sc 1: 236-244 (1885)

91 Pictou Island. $\mathrm{N}$ S Inst $\mathrm{Sc}, \mathrm{Pr} \mathrm{Tr}$ 8 or (2) 1:76-83, map (1891)

96 [Notes on the geology of the Nictaux region, N. S.] $\mathrm{N} S$ Inst $\mathrm{Sc}, \operatorname{Pr} \operatorname{Tr} 9$ or (2) $2: x v-x v i(1896)$

00 [Discussion of paper by H. M. Ami, On the subdivisions of the Carboniferous system in eastern Canada.] N S Inst Sc, Pr Tr 10 or (2) 3:xlvii-xlviii (1900)

MeKee, G. W.

04 Prismatic crystals of hematite. Am J Sc (4) 17:241-242 (1904) Soc Cient Ant Alz, Mem 21: Rev 15-17 (1904)

MeKee, Ralph $\mathrm{H}$.

06 The primeval atmosphere. Science n s $23: 271-274$ (1906)

MeKellar, Peter.

88 The correlation of the Animikie and Huronian rocks of Lake Superior. R Soc Can, Pr Tr 5, iv : 63-73 (1888)

90 On potholes north of Lake Superior unconnected with existing streams. G Soc Am, B 1: 568-570 (1890) Abst, Am Nat 24: 292-293 (1890)

95 The silver mines of Thunder Bay [Ont.]. Can M Rv 14:41-42 (1895) Abst, Eng M J 59:391 (1895)

96 Observations on mining in Thunder Bay district [Ont.]. [Fed] Can M Inst, J 1:13-16 (1896) Can M Rv 15:58 (1896)

99 The gold-bearing veins of Bag Bay near Lake of the Woods [Ont.]. Can M Rv 18: 144-147 (1899) Am I M Eng, Tr 29:104-115 (1900) Abst, G Soc Am, B $10: 495-497$ (1900); Am G 23: 104 (1899); Science n s 9:144 (1899); Ottawa Nat $12: 196$ (1899)

MeKellar, S. B.

74 Mining on the north shore of Lake Superior. $26 \mathrm{pp}$, Toronto 1874 [not seen] 
Mackensen, Bernard.

o5 Report on the excavation of mastodon remains [Hondo, Medina Co., Tex.]. Sc Soc San Antonio, B 1:3-10, il (1905)

Mackenzie, G. S.

s5 On an occurrence of rare copper minerals from Utah. Miner Mag 6:181-182 (1885)

Mackenzie, George Cleghorn.

os The iron and steel industry of Ontario. Ont Bur Mines, An Rp 17: 190-342 (1908)

12 The magnetic Iron sands of Natashkwan, County of Saguenay, Province of Quebec. Can Mines Br : 49 pp, maps (1912)

Mackenzie, George L.

03 A quick way of preparing sections of rocks. Eng M J 76:348-349 (1903)

MacKenzie, John David (1888-1922).

14 South Fork coal area, Oldman River, Alta. Can G S, Sum Rp 1912: 235-246, maps (1914)

$14 a$ South central Graham Island, B. C. Can G S, Sum Rp 1913:34-54 (1914)

14b The Crowsnest volcanics. Can G S, Mus B 4:33 pp, map (1914)

15 Graham Island, B. C. Can G S, Sum Rp 1914: 33-37 (1915)

15a Flathead special map area, B. C. Can G S, Sum Rp 1914: 41-42 (1915)

$\mathbf{1 5 b}$ The primary analcite of the Crowsnest volcanics. Am J Se (4) 39:571-574 (1915)

16 Telkwa Valley and vicinity, B. C. Can G S, Sum Rp 1915: 62-69, maps (1916)

$16 a$ Geology of a portion of the Flathead coal area, B. C. Can G S, Mem 87: $53 \mathrm{pp}$, maps (1916)

$16 b$ Geology of Graham Island, B. C. Can G S, Mem 88: 221 pp, maps (1916)

16e The geology of Graham Island, B. C. Abstract of thesis, Massachusetts Institute of Technology. $10 \mathrm{pp}, 1916$

Mackenzie, Kenneth Gerard.

10 (with Richardson, Clifford) A natural naphtha from the Province of Santa Clara, Cuba. Am J Sc (4) 29:439446 (1910)

Mackenzie, S. S.

64 The local geology of Topsfield [Mass.]. Essex Inst, $\operatorname{Pr} 3: 49-55$ (1864) Mackie, S. J.

58 [The geology of Canada.] Geologist, London, $1: 286-289$ (1858)

MeKinstry, Hugh E.

16 The minerals of Brinton's quarry, Chester Co., Pa. Am Mineralogist 1:5762 (1916)

Mackintosh, James B.

84 (with Hidden, W. E.) On herderite ( $?$ ), a glucinum calcium phosphate and fluoride, from Oxford Co., Me. Am J Sc (3) $27: 135-138$ (1884)

88 (with Hidden, W. E.) On a new tharium mineral, auerlite. $\Delta \mathrm{m} J$ Sc (3) s6: 461-463 (1888)
Mackintosh, James B.-Continued.

8Sa (with Fidden, W. E.) On a ner sodium sulphato-chloride, sulphohalite Am J Sc (3) 36:463-464 (1888)

89 (with Hidden, W. E.) A descrip. tion of several yttria and thoria minerals from Llano Co., Tex. Am J Sc (3) 38: 474-486 (1889)

89a (with Hidden, W. E.) Sulfohalit, eln neues Natrium-Sulfatochlorid. Zs Kryst 15:294-295 (1889)

89b (with Hidden, W. E.) Auerlith, ein neues Thorium-mineral. Zs Kryst 15: 295-297 (1889)

90 (with Hidden, W. E.) On the 0 . currence of polycrase, or of an allied spe. cies, in both North and South Carolina. Am J Sc (3) 39:302-306 (1890)

91 (with Hidden, W. E.) Supple. mentary notice on the polycrase of North and South Carolina. Am J Sc (3) 41 423-425 (1891)

Maclaren, Charles.

42 The glacial theory of Professo: Agassiz. $\quad \Delta \mathrm{m}$ J Sc 42:346-365 (1842)

Maclaren, James Malcolm.

02 Ores which are deposited by underground waters. M Sc Press $85: 281$ (1902)

08 Gold, Its geological occurrence and geographical distribution. $687 \mathrm{pp}$, London 1908

12 Persistence of ore in depth. If $\$ c$ Press 105: 534-535 (1912)

13 The persistence of ore in depth. Int G Cong, XII, 1913, C R : 295-304 (1914) Advance copy 1913 M Sc Press 108: 566567 (1914)

MeLaughlin, D. H.

17 (with Graton, L. C.) Ore deposi. tion and enrichment at Engels, Cal. Ec 6 12: 1-38 (1917)

18 (with Graton, L. C.) Further te marks on the ores of Engels, Cal. Ec 6 13: 81-99 (1918)

MeLaughlin, J. E.

o3 Barela Mesa coal fleld [Colo.] Mines and Minerals 24:139 (1903)

MeLaughlin, R. P.

07 Geology of the Bodie district, Cal. M Sc Press 94: 795-796 (1907)

15 (and Waring, C. A.) Petroleum industry of California. Cal St M Bur, B 69: $519 \mathrm{pp}$, map folio, il (1915)

15a (and Bradley, W. W.) Mines and mineral resources of Madera Co., Cal. Cal St M Bur, Chapters of St Mineralogist's Rp 1913-14, Fresno... counties : 105-14? (1915)

15b Masonic mining district, Mono $\mathrm{CO}_{\mathrm{H}}$ Cal. M Sc Press 110:27-29 (1915)

17 (with Eakle, Arthur S.) Mono County. In Mines and mineral resources of Alpine County, Inyo County, Mono County (Chapters of State Mineralogist's Rp 1915-16): 131-171 Cal St M Bur (1917)

See also Bradley (W W), 15 
MacLean, A.

13 Ordovician and Silurian of Stony Mountain and Stonewall, Manitoba; Calgary to Winnipeg via Canadian Northern Railway. Int G Cong, XII, Canada, Guide Book no $8: 69-77,349-370$, maps, 1913

14 (and Wallace, R. C.) Gypsum and salt in Manitoba. Can G S, Sum Rp 1913 : 165-169 (1914)

15 Pembina Mountain, Manit. Can G S, Sum Rp 1914: 69-71 (1915)

16 Pembina Mountain, southern Manitoba. Can G S, Sum Rp 1915: 131-133 (1916)

17 Southeastern Saskatchewan. Can G S, Sum Rp 1916: 156-159 (1917)

18 Lignite area of southern Saskatchewan. Can G S, Sum Rp 1917 pt C : $35-41$ (1918)

MacLean, John Patterson.

78 Mastodon, mammoth, and man. pp, il, Cincinnati 1878 2d ed, 1880

MacLean, Thomas Archibald.

12 Notes on the Porcupine gold region, Ont. M Soc N S, J 19:82-93 (1912)

13 Lode mining in Yukon; an investigation of quartz deposits in the Klondike division. Can Mines Br, Sum Rp 1912: 121-139, maps (1913)

14 Lode mining in Yukon; an investigation of quartz deposits in the Klondike division. Can Mines Br : 205 pp, maps (1914) MeLearn, Frank Harris.

15 The Cretaceous sections on the Crowsnest River, west of the Blairmore sheet, Alta. Can G S Sum Rp 1914: 62-63 (1915)

15a Notes on the cores of Winnipeg wells, Manit. Can G S, Sum Rp 1914: 72 (1915)

15b The lower Ordovician (Tetragraptus zone) at St. John, N. B., and the new genus Protistograptus. Am J Sc (4) 40 : 49-59 (1915)

16 Jurassic and Cretaceous, Crowsnest Pass, Alta. Can G S, Sum Rp 1915:110 112 (1916)

17 Athabasca River section, Alta. Can G S, Sum Rp 1916: 145-151 (1917)

18 Peace River section, Alberta. Can G S, Sum Rp 1917 pt C: 14-21 (1918)

18a The Silurian Arisaig series of Arisalg, N. S. Am J Sc (4) 45:126-140 (1918)

18b Revision of some phacopid genera. Ottawa Nat $32: 31-36$ (1918)

MeLeish, John.

09 Annual report on the mineral production of Canada during the calendar year 1906. Can, Dp Mines, Mines Br: 182 pp (1909) ... 1907 and $1908: 286$ pp (1910) ... $1909: 291 \mathrm{pp}(1911) \quad \ldots$ 1910:328 pp (1912) $\ldots 1911: 316$ pp (1913) .. 1912:339 pp (1914) $\ldots 1913: 363$ pp (1914) ... 1914: 362 pp (1915) $\ldots 1915: 364$ pp (1916) $\quad \ldots$ $1916: 343$ pp (1918)
MeLellan, J.

10 The mineral resources of the Queen Charlotte Islands, B. C. Can M Inst, Q B $10: 167-175$ (1910); J $13: 288-296$ (1911)

MeLennan, John F.

15 Quartz veins in lamprophyre intrusions. Eng M J 99:11-13 (1915)

16 Gold-quartz replacements in intrusive rocks [geology and ores of the Feather River region, northern Cal.] $M$ World 44: 389-392 (1916)

17 Effects of faults on richness of ore. M Sc Press 114:185 (1917)

MeLeod, Alexander.

14 Practical instructions in the search for, and the determination of, the useful minerals, including the rare ores... ix, $114 \mathrm{pp}, \mathrm{N}$ Y 1914 2d ed, xxivil, $254 \mathrm{pp}$, N Y 1917

MeLeod, C. $\mathrm{H}$.

97 (and Callendar, H. L.). Our record of Canadian earthquakes [1894-1897]. Can Rec Sc $7: 323-326,375-376$ (1897) MeLeod, John W.

10 Notes on the Copper Lake mine, Antigonish, N. S. Can M Inst, J 12:630639 (1910)

MeLonth, C. D.

02 Some general remarks on the topography, soils, water resources, flora, etc., of Muskegon Co. Mich G S, Rp 1901 : 104107 (1902)

Maclure, Wllliam (1763-1840).

o9 Observations on the geology of the United States, explanatory of a geological map. $\mathrm{Am}$ Ph Soc, $\mathrm{Tr} 6: 411-428$, map (1809) J Phys 69:204-213 (1809)

09a Sur la géologie des Etats-Unis. J Phys 69: 201-203 (1809)

11 Suite des observations sur la géologie des Ctats-Unis, servant a l'explication de la carte ci-jointe. J Phys 72:137-165, map (1811)

17 Observations on the geology of the United States of America ... 127 pp, map, Phila 1817 kv by Rafinesque, C. S., Am Mo Mag $3: 41-44$ (1818)

17 a Observations on the geology of the West India Islands, from Barbados to Santa Cruz, inclusive. Ac N Sc Phila, J 1: 134-149 (1817)

18 Observations on the geology of the United States of North America ... Am Phil Soc, Tr n s 1:1-91 map (1818) Zs Miner (Leonhard) 1826, I : 124-138

18a Essay on the formation of rocks... Ac $N$ Sc Phila, J 1:261-276, 285-310, 327-345 (1818) Reprint, 60 pp, Phila 1818

19 ... outlines of geological arrangement, with particular reference to the system of Werner. Am J Sc 1:209-213 (1819)

22 Comparative features of American and European geology. Am J Sc 5:197198 (1822) 
Maclure, William-Continued.

23 Some speculative conjectures on the probable changes that may have taken place in the geology of the continent of North America east of the Stoney Mountains. Am J Sc 6: 98-102 (1823)

24 Remarks on the rocks accompanying anthracite at Wilkesbarre and elesewhere. Am J Sc $7: 260-261$ (1824)

$\mathbf{2 4 a}$... the systematic arrangement of rocks, and on their probable origin, especially of the secondary. Am J Sc 7:261264 (1824)

25 European systems of geology not always applicable to American geology. Am J Sc $9: 158-160$ (1825)

25a Geological systems; geological maps; chatoyant feldspar. Am J Sc 9:253-256 (1825)

29 Remarks on the theory of a central heat in the earth and on other geological theories. Am J Sc 15:384-386 (1829)

29a [Geologieal notes on Mexico and the United States]. Am J Sc 16:159-163 (1829)

29b Remarks on the igneous theory of the earth. Am J Sc 16:351-352 (1829)

31 Geological remarks relating to Mexico. Am J Sc 20:406-408 (1831)

32 Essay on the formation of rocks, or an inquiry into the probable origin of their present form and structure. $53 \mathrm{pp}$, New Harmony, Ind., 1832

$32 a$ Observations on the geology of the West India islands from Barbados to Santa Cruz, inclusive. $17 \mathrm{pp}$, New Harmony, Ind., 1832

MeMastex, John Bach.

81 Stratigraphical report upen the Bridger beds in the Washakie Basin, Wyo. E. M. Mus $G$ (Coll $\mathrm{N} J$ ) Contr 1 no 1: 45-54 (1881)

81 a The "Badlands" of Wyoming and their fossil remains. Am Geog Soc, J 12 : 109-130 (1881)

MacMechen, Thomas $R$.

92 The ore deposits of Creede, Colo. Eng M J 53:301-303 (1892)

MacMillan, Conway.

93 The probable physiognomy of the Cretaceous plant population. Am Nat 27 : 336-345 (1893)

$93 a$ Note on the probable character of the general Cretaceous flora. Minn, Univ, Q B 1:96 (1893)

MeMillan, James G.

05 Explorations in Abitibi. Ont Bur Mines, Rp 1905, 14 pt 1: 184-212 (1905)

10 Geological report of Arctic expedition, 1908-9. In Report on the Diminion of Canada government expedition to the Arctic islands and Hudson Strait on board the D. G. S. Arctic, by Captain J. E. Bernier [Can, Dp Marine and Fisheries]: 382-469 Ottawa 1910
MeMillan, James G.-Continued.

12 Report on the geology of the sta along the T. \& N. O. Railway trial bs between Gowganda and Porcupine. $24 \mathrm{~m}$ map, Toronto 1912

MacMillan, W. D.

17 On the hypothesis of isostasy. J $25: 105-111$ (1917)

MeNair, F. W.

11 Note on a method in teaching optici mineralogy. Am J Sc (4) $31: 292-24$ (1911) Abst, Science n s $33: 465$ (191! MeNair, S. S.

12 What is a stratifled rock? Eng 1 J 94: 147 (1912)

MeNairn, William Harvey.

o1 On a large phlogopite crystal.

J Sc (4) 12:398 (1901)

10 On the origin of Canadian apatit Can Inst, Tr 8: 495-514 (1910)

Macomb, Montgomery Meigs.

81 Annual report upon the geographice and topographical surveys of the territor of the United States west of the 100t meridian... U S [War Dp], Chief kny An Rp 1881 (U S, 47th Cong 1st sess, Ex Doc 1 pt 2 ₹ 2 pt 3), App UU: $280^{\circ}$ 2809, map (1881)

82 Annual report upon the geographit and topographical surveys of the territory of the United States west of the 100t meridian... U S [War Dp], Chief Eng, is Rp 1882 (U S, 47th Cong 2d sess, H E Doc 1 pt 2 v 2 pt 3), App TT : 2821-284 map (1882)

83 Annual report upon the geograpbic and topographical surveys of the territor of the United States west of the 100t meridian... U S [War Dp), Chief Eng, A Rp 1883 (U S, 48th Cong 1st sess, H $\mathrm{E}$ Doc 1 pt 2 v 2 pt 3), App UU : $2379-238$ (1883)

Meouat, Walter.

72 Report on exploration of country th tween Lake St. John and Lake Mistassit [Que.]. Can G S, Rp Prog 1871-2: 115119 (1872)

73 Report of an examination of th country between lakes Timiskaming an Abitibi [Que.]. Can G S, Rp Prog 187\% $3: 112-135$ (1873)

74 Report on a portion of the coal fiel of Cumberland Co., N S. Can G S, B Prog 1873-4: 161-170 (1874)

Macoun, John,

74 Geology and minerals-from North Saskatchewan via Peace River British Columbia. Can Pacific Railway Rp Prog to Jan. 1874: 74-79, Ottawa 18:

77 Geological and topographical note on the lower Peace and Athabasca rivers Can G S, Rp Prog 1875-6:87-95 (187i) McQuesten, C. A.

16 Minas de manganeso en Punta $\cos ^{2}$ cepcion, municipalidad de Mulege, Bsy California, México. Bol Minero 1:232 235 (1916) 
MeRae, John C.

89 The geological formation at Port Colborne [Ont.], as shown by drilling for natural gas. Can Inst, $\operatorname{Pr}$ (3) $6: 338-341$ (1889)

MacVicar, John.

17 Foothill coal areas north of the Grand Trunk Pacific railway, Alberta Can G S, Sum Rp 1916: 85-93, map (1917)

Mewhirter, A. J.

85 Revised handbook of Tennessee [geology and mineral resources: 12-52]. [Tenn, Bur Agr] : 200 pp, map, Nashville 1885

MeWhorter, Tyler.

82 Beds of Carboniferous drift in the bluffs of East Davenport [Iowa]. Daven. port Ac Sc, Pr 3: 129-130 (1882)

Maddren, Alfred $G$.

05 Smithsonian exploration in Alaska in 1904 in seareh of mammoth and other fossil remains. Smiths Misc Col 49 (1584) : $117 \mathrm{pp}$, map (1905)

05a Notes on the occurrence of mammoth remains in Alaska (abst). Science n 8 21: $746(1905)$

08 (with Moffit, F. H.) The mineral resources of the Kotsina and Chitina valleys, Copper River region, Alaska, U S G S. B $345: 127-175$ (1908)

09 Gold placers of the Ruby Creek district, Alaska. U S G S, B $379: 229-233$, map (1909)

09a Placers of the Gold Hill district. Alaska. U S G S, B $379: 234-237$ (1909) $09 \mathrm{~b}$ Gold placers of the Innoko district, Alaska. U S G S, B $379: 238-266$ (1909) 09e (with Moffit, F. H.) Mineral resources of the Kotsina-Chitina region, Aiaska. U S G S, B 374:103 pp (1909) 10 The Innoko gold-placer district, Alaska, with accounts of the central Kus. kokwim Valley and the Ruby Creek and Gold Hill placers. U S G S, B 410:87 pp, map (1910)

10a The Koyukuk-Chandalar gold region, Alaska. U S G S, B $442: 284-315$, map (1910)

11 Gold placer mining developments in the Innoko-Iditarod region [Alaska]. U S G S, B 480: 236-270, map (1911)

12 The Ruby placer district [Alaska].

U S G S, B 520: 287-296, map (1912)

12 a Geologic investigations along the Canada-Alaska boundary. U S G S, B 520 . 297-314 (1912)

13 The Koyukuk - Chandalar region, Alaska. U S G S, B 532:119 pp, map (1913)

14 Mineral deposits of the Yakataga district, Alaska. U S G S, B 592: 119-153, rapap (1914)

14a Quaternary history of the Mount St. Elias region, Alaska $(a b s t)$. Wash Ac Sc, J $4: 10-11$ (1914)
Maddren, Alfred G.-Continued.

15 Gold placers of the lower Kuskokwim, with a note on copper in the Russian Mountains [Alaska]. U S G S, B 622 : 292-360 (1915)

15a (with Smith, P. S.) Quicksilver deposits of the Kuskokwim region [Alaska]. U S G S, B 622: 272-291 (1915)

17 Gold placers near the Nenana coal field [Alaska]. U S G S, B 662: 363-402 (1917)

\section{Madison, Bishop.}

06 [On the remains of a mammoth in Wythe Co., Va.] Med Phys J 15:486 (1806)

\section{Madsen, Victor.}

03 On Jurassic fossils from East Greenland. Copenhagen Univ, Min G Mus, Comm Pal, no 6 (1903) Med Grönland 29:157210, il, map (1904)

Magie, William Francis.

10 Physical notes on Meteor Crater, Ariz. $\mathrm{Am} \mathrm{Ph}$ Soc, $\operatorname{Pr} 49: 41-48$ (1910) Abst, Science n s 31: $872-873$ (1910)

Magnus, Harry C.

05 Abrasives of New York State. N Y St Mus, An Rp 57:158-179 (1905)

O5a (with Merrill, F. J. H.) Distribution of Hudson schist and Harrison diorite in the Westchester County area of the Oyster Bay quadrangle [N. Y.]. N Y St Mus, An Rp 57:193-194, map (1905)

Maguire, Don.

98 Gold mines of Mercur [Utah]. Mines and Minerals 19:81-83, 130-131 (1898)

99 Central Idaho gold field. Mines and Minerals $19: 289-291$ (1899)

99a Snake River gold fields of Idaho. Mines and Minerals 20:56-58 (1899)

00 Precious stones and gem materials of the Pacific coast states and territories of the United States. Mines and Minerals $20: 255-256$ (1900)

OOa Silver-bearing sandstones of southern Utah. Mines and Minerals 20: u23-324 (1900)

00b The hydrocarbons of eastern Utah, with special reference to the deposits of ozokerite, gilsonite, and elaterite. Mines and Minerals $20: 398-400$ (1900).

Mailhiot, Adhémar.

11 Geological reconnaissance in the Gaspe district, Que. Que Dp Col..., Mines Br, Rp on mining operations $1910: 86-94$ (French ed : 91-99), maps (1911)

14 Granites of the eastern townships of Quebec. Can G S, Sum Rp 1913: 217-218 (1914)

15 Granites of the eastern townships, Que. Can G S, Sum Rp 1914: 100 (1915)

16 Les bassins houillers du Canada. Rv Trim Can 1: 364-372 (1916) 
Mailhiot, Adhémar-Continued.

18 Geology of a portion of the projected township of Lemieux, County of Gaspe, P. Q. ; comprising a description of the zinc and lead deposits at the head of Berry Mountain Creek, a tributary of the Great Cascapedia River. Que., Dp Colonization, ..., $\mathrm{Rp}$ on mining operations, $1917: 117-145$, map (1918)

Main, John F.

90 The plasticity of glacier ice. Colo Se Soc, Pr 3 : 205-210 (1890)

\section{Maine State Survey Commission.}

07 Fourth biennial report, 1905-1906. 8 pp, Augusta 1907 Fifth... 1907-1908: 11 pp, Waterville 1909 Sixth... 1909-1910: 16 pp, Augusta 1911

Malcolm, Wyatt.

12 Gold fields of Nova Scotia. Can G S, Mem 20:331 pp, maps (1912)

13 Oil and gas prospects of the northwest provinces of Canada. Can G S, Mem $29: 99$ pp, map (1913)

14 Notes on radium-bearing minerals. Can G S, Prospector's Hbk 1: 26 pp (1914)

15 The oil and gas fields of Ontario and Quebec. Can G S, Mem 81: 248 pp (1915)

16 Bibliography of Canadian geology for 1914. R Soc Can, $\operatorname{Tr}$ (3) 9 iv: 279-305 (1916) ... for $1915 \ldots$ (3) 10 iv : 131-168 (1917)

18 Hints on prospecting for a few Canadian minerals. Can $M$ Inst, B 76:692704 (1918)

Maleolmson, James W.

01 The Sierra Mojada, Coahưila, Mex., and its ore deposits (with discussion by S. F. Emmons). Am I M Eng, Tr 32: 100-139, 566-567 (1902) Eng M J 72: 705-710 (1901)

04 (with Kirk, M. P.) A new quicksilver mining district [Brewster Co., Tex.]. Eng M J 77:685-686 (1904)

Mallery, Willard.

04 Native gold in igneous rocks. Eng M J 77:596 (1904)

16 A discovery of celestite [Lavic station, San Bernardino Co., Cal.]. M Sc Press 113: 952 (1916)

Mallet, John William.

57 On the rose-colored mica of Goshen, Mass. Am J Sc (2) 23: 180 (1857)

57 a Results of some analyses made for the Geological Survey of the State of Alabama [marble, limestone, greensand, clay, iron ore]. Am J Sc (2) 23:181-185 (1857)

58 Report of chemical department of the geological survey for the year 1855 . In Tuomey, M., Second biennial report on the geology of Alabama: 169-222, Montgomery 1858 .

5Sa On schrötterite from Cherokee Co., Ala. Am J Sc (2) $26: 79-81$ (1858)
Mallet, John William-Continued.

58b (with Tnomey, M.) Lists of ta sils from the Cretaceous and Tertiary fo: matiops in Alabama and Mississippi. A Tuomey, M., Second biennial report on th geology of Alabama : 253-275, Montgomery 1858

71 On three masses of meteoric in: from Augusta Co., Va. Am J Se (3) ?: 10-15 (1871) The Virginias 6:94(1885)

75 On limonite with the color sil translucency of göthite. Am J Sc (3) ?: 460-461 (1875)

$7 \boldsymbol{7}$ On sipylite, a new niobate from $\mathrm{Al}$ herst Co., Va. Am J Sc (3) $14: 397-40$ (1877)

77a Sobre la composición qufmica de ha “guanajuatita" 6 seleniuro de bismuto $d$. Guanajuato. La Naturaleza 4 : 73-76 (15ii).

78 On the chemical composition of gunajuatite, or selenide of bismuth, fron Guanajuato, Mex. Am J Se (3) $15: 294$ 296 (1878)

78 a On a fourth mass of meteoric in from Augusta Co., Va. Am J Se (3) 15: 337-338 (1878) The Virginias 6:96-1i (1885)

$78 b$ on barcenite, a new antimonsh from Huitzuco, Mex. Am J Sc (3) 16 306-309 (1878)

79 " Barcenita " ; descripeion de un nut antimoniato. La Naturaleza $4: 198$-2 (1879) Soc Geog Mex, B (3) 4:271- t (1879)

79a Estudio acerca de la misma esped mineral [livingstonita]. La Naturaleza 271-273 (1879) ; 5:84-88 (1880)

$\mathbf{8 1}$ On the crystalline form of sipylit Am J Sc (3) $22: 52$ (1881)

84 On a mass of meteoric fron fro Wichita Co., Tex. Am J Sc (3) $28: 28:$ 288 (1884)

06 A stony meteorite from Coon Butt Ariz. Am J Sc (4) 21:347-355 (1906)

Mallet, Robert (1810-1881).

73 Note on the history of certain recerf views in dynamical geology. Am J Sc (? $5: 302-303$ (1873)

$75 \ldots$ on the origin, and mechanism o production, of the prismatic or columna structure of basalt. Am J Sc (3) 9:200211 (1875)

Mallett, E. J.

75 On Middle Park mineral coal [Colo.] Am J Sc (3) 9:146-147 (1875)

Malloch, George Stewart (1879-1914). os The Cascades, Palliser, and Costigi? coal basins. Can G S, Sum Rp 1907:35-th (1908)

09 The Bighorn coal basin [A1ta]. (2) G S, Sum Rp 1908: 70-76 (1909)

10 A reconnaissance on the upper Fras River between Fort George and Tête Jat? Cache. Can G S, Sum Rp 1909: 123-s (1910) 
Malloch, George Stewart-Continued.

11 Bighorn coal basin, Alta. Can G S, Mem $9: 66 \mathrm{pp}$, maps (1911)

12 Notes on the Groundhog coal basin, Skeena district, B. C. Can M Inst, Tr 15: 278-281 (1912) ; 15 pt 1: P 22-25 (1912)

12a Reconnaissance on the upper Skeena River, between Hazelton and the Groundhog coal field, B. C. Can G S, Sum Rp $1911: 72-90$, map (1912)

14 The Groundhog coal field, B. C. Can G S, Sum Rp 1912: 69-101, map (1914)

14a Metalliferous deposits in the vicinity of Hazelton, B. C. Can G S, Sum Rp 1912 : 102-107 (1914)

Malott, Clyde A.

15 The Flatwoods region of Owen and Monroe cos., Ind. Ind Ac Sc, Pr 1914: 399-428, map (1915)

16 Valley trenching and gradation plains in southern Indiana and associated regions (abst). Science n s $43: 398$ (1916)

See also Beede, 15

Manchester, James G.

10 Asteriated rose quartz in New York. M World $32: 1185-1186$ (1910)

14 The minerals of Broadway, New York City. N Y Miner Club, B 3:52 pp, map (1914)

17 (and Stanton, G. S.) A discovery of gem garnet in New York City. Am Mineralogist $2: 85-86$ (1917)

18 (and Bather, W. T.) Famous mineral localities; Mt. Mica, Mt. Apatite, and other localities in Maine. Am Mineralogist $3: 169-174$ (1918)

Mann, Charles.

76 Increase Allen Lapham; a memorial. Read before the Wis. Natural History Society. 21 pp [n p, n d, 1876?]

Mann, Horace.

66 [Notes on the volcano Kilauea, Hawaii.] Boston Soc N H, Pr 10:229230 (1866)

66a [On denudation observed in the rocks of the Hawaiian Islands.] Boston Soc N H, Pr 10: 232-234 (1866)

67 [On the crater of Haleakala, East Maui, Hawailan Islands.] Boston Soc N H, Pr $11: 112-113$ (1867)

Mann, R. L.

11 Secondary enrichment in gold veins. M Sc Press 102:691 (1911) M Science 70 December : 22-23 (1914)

16 Gwl Head manganese deposit, San Bernardino Co., Cal. M World 44:743744 (1916)

Manning, $P . C$.

01 Glacial potholes in Maine. Portland Soc N H, Pr 2: 185-200 (1901)

Manross, N. $\mathbf{S}$.

55 Notice of the pitch lake of Trinidad. Am J Sc (2) 20:153-160 (1855) $28737^{\circ}-23-45$
Manross, N. S.-Continued.

65 Notes on coal and iron ore in the State of Guerrero, Mex. [with Note on the Azoic age and metamorphic origin of the iron ore, by J. D. Dana]. Am J Sc (2) $39: 309-312,358$ (1865)

Mansfield, George Rogers.

06 Post-Pleistocene drainage modiflcations in the Black Hills and Big Horn Mountains. Harvard Coll, Mus C Z, B 49 (g s 8) : 59-87, maps (1906)

O6a The origin and strueture of the Roxbury conglomerate. Harvard Coll, Mus C Z, B 49 (g s 8) : 91-271, map (1906)

o7 The characteristics of various types of conglomerates. J G $15: 550-555$ (1907)

os The Baraboo region of Wisconsin. J Geog 6:286-292 (1908)

osa Glacial and normal erosion in Montana and Wisconsin. J Geog $6: 306-312$ (1908)

09 Glaciation in the Crazy Mountains of Montana. G Soc Am, B 19:558-567 (1909) Abst, Science n $8 \quad 27: 409-410$ (1908)

11 The origin of Clin Lake, Mont. Geog Soc Phila, B 9 no $2: 10-19$ (1911) Abst, Science n s 32:191 (1910); (with discussion) G Soc Am, B 21: 764 (1910)

11a An unusual type of lateral hanging valley. Geog Soc Phila, B 9 no $4: 40-47$ (1911)

11b (with Richards, R. W.) Preliminary report on a portion of the Idaho phosphate reserve. U S G S, B 470:371439 (1911)

12 (with Richards, R. W.) The Bannock overthrust, a major fault in southeastern Idaho and northeastern Utah. J G 20:681-709 (1912)

14 (with Riehards, R. W.) Geology of the phosphate deposits northeast of Georgetown, Idaho. U S G S, B 577:76 pp, map (1914)

15 Nitrate deposits in southern Idaho and eastern Oregon. U S G S, B 620:1944, map (1915)

15a (and Larsen, E. S.) Nepheline basalt in the Fort Hall Indian Reservation, Idaho. Wash Ac Sc, J 5:463-468 (1915)

15b Geology of the Fort Hall Indian Reservation, Idaho (abst). Wash Ac Sc, J $5: 492-493$ (1915)

16 (and Roundy, P. V.) Revision of Beckwith and Bear River formations of southeastern Idaho. U S G S, P P 98: 75-84 (1£16) Abst, Wash Ac Sc, J $6: 565$ (1916)

$16 a$ A reconnaissance for phosphate in the Salt River Range, Wyo. U S G S, B $620: 331-349$, map (1916) 
Mansfield, George Rogers-Continued.

16b Subdivisions of the Thaynes limestone and Nugget sandstone, Mesozoic, in the Fort Hall Indian Res rration, Idaho. Wash Ac Sc, J 6:31-42 (1916) Abst,

G Soc Am, B 27:70 (1916)

16e (and Roundy, P. V.) Some Jurassic and Cretaceous formations of southeastern Idaho (abst). Wash Ac Sc, J $6: 157$ (1916)

16d Geologic map of the Fort Hall Indian Reservation (abst). G Soc Am, B $27: 64$ (1916)

16e Preliminary geologic map of the Wayan quadrangle, Idaho-Wyo. (abst). G Soc Am, B 27:65 (1916)

16P (and Roundy, P. V.) Stratigraphy of some formations hitherto called Beckwith and Bear River in southeastern Idaho (abst). G Soc Am, B 27:70-71 (1916)

17 The phosphate resources of the United States. Pan American Sc Cong, 2d, Washington, $\mathrm{Pr}$, sec 7 v $8: 729-766$, maps (1917)

18 Origin of the western phosphates of the United States. Am J Sc (4) $46: 591-$ 598 (1918)

18a Sulphur in Jemez Canyon, N. Mex. Eng M J 106: 449 (1918) [In error attributed to Philip S. Smith]

Mansfield, Ira $\mathrm{F}$.

05 Fireclay, coals, and titles of the cannel coal tract at Cannelton, Beaver County, Pa. 40 pp, 13 pls. (incl. maps), Beaver Falls, Penna., Tribune Printing Co., Printers, 1905 [Priv pub]

Mansfield, J. F.

81 Eurypterus from Darlington shales, Pennsylvania. Am $\mathrm{Ph}$ Soc, Pr 19:351, 352 , il (1881)

Mansfield, Wendell C.

16 Mollusks from the type locality of the Choctawhatchee marl. U S Nat Mus, Pr 51:599-607, il (1916)

18 Molluscan fauna from the calcareous marls in the vicinity of Deland, Volusia Co., Fla. Fla G S, 10th and 11th An Rp : 111-123, il (1918)

Manson, Marsden.

91 The cause of the Glacial Period and an explanation of geological climates. Tech Soc Pacific Coast, $\operatorname{Tr} 8: 147-168$ (1891)

92 Cause of geological climates. M Sc Press 64: 154 (1892)

94 A reply to "Causes and conditions of glaciation." Am G $14: 192-194$ (1894)

99 The laws of climatic evolution. Am G $23: 44-57$ (1898)

99 a The evolution of climates. Am G 24: 93-120, 157-180, 205-209, map (1899)

03 Evolution of climates. Revised, enlarged, and reprinted from Am $\mathbf{G}$ [24] $1899: 86$ pp, 1903

03a [Duration of postglacial time]. Am G $32: 128-130$ (1903)
Manson, Marsden-Continued.

04 The evolution of climate (abst). So ence n s 20:801-802 (1904)

o7 Climats des temps géologiques, lẹ développement et leurs causes. Int $\mathrm{G}$ Cong X, Mexico, 1906, C R : 349-405 (1907)

12 The significance of early and Pleistocene glaciations. Int $\mathrm{G}$ Cong. $\mathrm{XI}$ Stockholm, 1910, C R : 1089-1106 (1912)

13 The evidences of interglacial period on the Slerra Nevada Mountains, Califomis Int G Cong, XII, Canada: 3 pp (1919) (advance copy)

17 The bearing of the facts revealed in Antarctic research upon the problems d the ice age. Science n $s$ 46:639-64 (1917)

18 Progressive deglaciation and the amelioration of climate. Science $n$ s ti: 487-488 (1918)

Mante11, Gideon Algernon.

46 Description of footmarks and otte imprints on a slab of New Red sandsto: from Turner's Falls, Mass. G Soc Losda Q J 2:38 (1846)

Manzano, Jesús P.

02 The mineral zone of Santa Maria $d$, Rio, San Luis Potosi, Mex. Am I M Ey $\operatorname{Tr} 32: 478-483$ (1902)

17 Región minera de Santa Maria d. Rio, Estado de San Luis Potosi [Mériou) Bol Minero 3:2-7 (1917)

Maqueo Castellanos, Esteban.

09 Breves apuntes sobre geología $y$ dh matología del Istmo de Tehuantepec. \& Mex Geog Estadística, B (5) $3: 165^{-1}$ i (1909)

Mar, F. W.

90 On the so-called perofskite, fro Magnet Cove, Ark. Am J Sc (3) $40: 4$ to 405 (1890)

Marais, C. L. P.

02 (with Truman, B. C.) Le pétrì en Californie. Cong intern pétrole, Paris 1900, Notes... : 57-59, Paris 1902

Marbut, Curtis Fletcher.

95 The geographic development of Cror ley's Ridge [Mo.-Ark.]. Boston Soc N B Pr 26: 479-488 (1895)

96 Physical features of Missouri. G S 10:11-109, map (1896)

$96 a$ (with Shaler, N. S.) The glact brick clays of Rhode Island and sout eastern Massachusetts. U S G S, An H 17 pt 1: 951-1004 (1896)

96b (with Woodworth, J. B.) Queen's River moraine in Rhode Islat J G 4:691-703 (1896)

98 Reports on areal geology; geologich description of the Clinton sheet; ... houn sheet; ... Lexlngton sheet; geolof of the Richmond quadrangle, includit portions of Ray and Carroll cos.; geolos of the Huntersville quadrangle, includist portions of Randolph, Howard, and Cbst ton cos. Me G S 12 pt 2, Sheet $\mathrm{rps}$ 6-10: 15-371, maps (1898) 
Marbut, Curtis Fletcher-Continued.

98a Cote Sans Dessein [Mo.], and Grand Tower [III.]. Am G 21: 86-90, maps (1898)

02 The evolution of the northern part of the lowlands of southeastern Missouri. Mo Univ, Studies 1 no 3 : viil, 63 pp, maps (1902)

02a Development of the southeastern Missouri lowlands (abst). Science $\mathrm{n}$ s $16: 262$ (1902) G Soc Am, B 14:10 (1903)

03 Sandstones of the Ozark region in Missouri - $(a b s t)$. Science n s 17:291 (1903)

04 Geology and physiography [of Missouri]. In The State of Missouri... [Louisiana Purchase Exposition, Paris ] : 63-70, map, Columbia, Mo., 1904

04a ... physiography of the Ozark region in Missouri (abst). Science n s 19: 527 (1904)

05 Physiography in the university. J Geog 4:23-30 (1905) Int Geog Cong, VIII, Rp : 997-1004 (1905)

os The geology of Morgan Co. Mo Bur G Mines (2) $7: 97 \mathrm{pp}, \operatorname{map}$ [1908]

10 A preliminary report on the general character of the soils and the agriculture of the Missouri Ozarks. Mo, Univ, Coll Agr, Agr Exp Sta, Research B 3:151-273, map (1910)

13 Geology. Mo, Univ, B se s $1: 125$ 146 (1913)

13a (and others) Solls of the United States (edition, 1913). U S Dp Agr, Bur Soils, B 96: 791 pp (1913)

16 Characteristics of the soil and its relation to geology (abst). G Soc Am, B 27:114-115 (1916)

Mareh, W. J.

57 A sketch of the mines and copper region of southwestern Virginia. M Mag $9: 217-220$ (1857)

Mareou, John Belknap (?-1912).

83 The International Geological Congress [Second, Bologna]. Science 1:512513 (1883)

83a The affinities of Richthofenia. Science $2: 103$ (1883)

84 A review of the progress of North American invertebrate paleontology for 1883. Am Nat 18: $385-392$ (1884)

$84 a$ (with Marcou, J.) Mapoteca geologica americana; a catalogue of geological maps of America (North and South) 17521881 , in geographic and chronological order. U S G S, B 7:184 pp (1884)

85 A list of the Mesozoic and Cenozoic types in the collections of the U. S. National Museum. U S Nat Mus, Pr $8: 290-$ 344 (1885)

85a Progress of North American invertebrate paleontology for 1884. Am Nat 19: 353-360 (1885)
Marcou, John Belknap-Continued.

85b A review of the progress of North American invertebrate paleontology for 1884. Smiths Inst, An Rp 1884: 563-582 (1885)

85e Blbliography of publications relating to the collection of fossil invertebrates in the United States National Museum; including complete lists of the pritings of Fielding B. Meek, Charles A. White, and Charles D. Walcott. U S Nat Mus, B 30 : $333 \mathrm{pp}$ (1885)

86 Supplement to the list of Mesozoic and Cenozoic invertebrate types in the collections of the National Museum. U S Nat Mus, Pr 9:250-254 (1886)

S6a Record of North American invertebrate paleontology. Smiths Inst, An Rp 1885 : 713-759 (1886)

s6b Review of the progress of North American invertebrate paleontology for 18s5. Am Nat 20:505-514 (1886)

87 Review of the progress of North American paleontology for the year 1886 . Am Nat 21: 532-544 (1887)

88 Review of the progress of North American paleontology for the year 1887 . Am Nat 22:679-691 (1888)

89 North American paleontology for 1886. Smiths Inst, An Rp 1887 pt 1: 231287 (1889)

Marcou, Jules (1824-1898).

49 Note sur la houille du Comté de Chesterfleld, près de Richmond (Êtat de Virginia). Soc G France, B (2) 6:572575 (1849)

51 Réponse a la lettre de MM. Foster et Whitney sur le lac Supérieur. Soc G France, B (2) 8:101-105 (1851)

53 A geological map of the United States, and the British provinces of North America; with an explanatory text, geological sections and plates of fossils which characterize the formations. Map, and text $92 \mathrm{pp}$, il, Boston $1853 \mathrm{Rv}, \mathrm{Am} \mathrm{J}$ Sc (2) 17:199-206 (1854)

53a [Sur la decouverte de poissons fossiles dans le terrain houiller du NouveauBrunswick.] Soc G France, B (2) 10 : 39 (1853)

54 Esquisse d'une classification des chaines de montagnes d'une partie de l'Amérique du Nord. Ac Sc Paris, C R 39:1192-1197 (1854) An Mines (5) 7 : 329-350 (1855) M Mag $7: 321-333$ (1856)

54a Sur la géologie des montagnes Rocheuses, entre le fort Smith (Arkansas) et Albuquerque (Nouveau-Mexique). Soc G France, B (2) 11:156-160 (1854)

54b Résumé d'une section géologique des montagnes Rocheuses a San Pedro, sur la cote de l'océan Pacifique. Soc G France, B (2) $11: 474-478$ (1854) 
Marcou, Jules-Continued.

55 Résumé of a geological reconnaissance extending from Napoleon at the junction of the Arkansas with the Mississippi to the Pueblo de los Angeles in California. In Whipple, A. W., Report of explorations... near the thirty-fifth parallel... U S, Pacific R R Expl (U S, 33d Cong 1st sess, H Ex Doc 129 v 18 pt 2) : 40-48 (1855); also (U S, 33d Cong $2 d$ sess, S Ex Doc 78 and H Ex Doc 91) 3 pt $4: 165-171$ (1856)

55a Geological notes of a survey of the country comprised between Preston, Red River, and El Paso, Rio Grande del Norte. In Pope, John, Report of exploration ... near the thirty-second parallel..., U S, Pacific R R Expl (U S, 33d Cong 1st sess, H Ex Doc 129 v 18 pt 2) : 125-128 (1855)

55b Notes géologiques sur le pays compris entre Preston sur la rivière Rouge et El Paso sur la Río Grande del Norte. Soc G France, B (2) 12 : 808-813 (1855)

55e Résumé explicatif d'une carte ge̊ologique des Etats-Unis et des provinces anglaises de l'Amérique du Nord, avec un profil géologique allant de la vallée du Mississippi aux côtes du Pacifique, et un planche de fossiles. Soc G France, B (2) 12: 813-936, map, il (1855) An Mines (5) 7:pl ix (1855) Rv by W. P. Blake, Am J Sc (2) $22: 383-388$ (1856)

55d Esquisse d'une classification des chaines de montagnes d'une partie de l'Amérique du Nord. An Mines (5) 7:329350 (1855) Also in his Geology of North America : 70-80, Zurich 1858

55e Sur un mémoire relatif a la classification des chaînes d'une partie de l'Amérique du Nord. Ac Sc Paris, C R 40:734741 (1855)

55e Sur le gisement de l'or en Californie. Areh Sc Phys Nat 28: 124-135 (1855) Also in his Geology of North America: 81-84, Zurich 1858

$55 \mathrm{~g}$ Le terrain carbonifère dans l'Amérique du Nord. Arch Sc Phys Nat 29:95117 (1855)

55h Ueber die Geologie der Vereinigten Staten und der Englischen Provinzen von Nord-Amerika. Petermanns Mitt 1:149159, map (1855)

56 Résumé and field notes, with a trans. lation by Wm. P. Blake [Whipple's reconnaissance near the thirty-fifth parallel]. U S, Pacific R R Expl (U S, 33d Cong 2d sess, S Ex Doc 78 and $\mathrm{H} \mathrm{Ex} \mathrm{Doc} \mathrm{91)} 3 \mathrm{pt}$ $4: 121-164$, map (1856)

57 Lettres sur les roches du Jura et leur distribution géographique dans les deux hémisphères. $\mathrm{xxiv,} 364 \mathrm{pp}$, map, Paris 1857-1860

58 Geology of North America; with two reports on the prairies of Arkansas and Texas, the Rocky Mountains of New Mexico, and the Sierra Nevada of Callfornia ... 144 pp, il, map, Zurich 1858 Rv by J. D. Dana, Am J Sc (2) $26 ; 323-333$ (1858)
Marcon, Jules-Continued.

58a Amerlcan geology; letter on soma points of the geology of Texas, New Mes ico, Kansas, and Nebraska, addressed to Messrs. F. B. Meek and F. V. Hayden. 16 pp, Zurich 1858 [priv pub]

58b Geology of the Rocky Mountains M Mag 11:98-106 (1858)

58e [Réclamation au sujet de la géologit des montagnes Rocheuses.] Soc G France B (2) $15: 533-537$ (1858)

58d ... description géologique des mon tagnes Rocheuses. Arch Sc Phys Nat 2:102-121 (1858) Abst, Soc G France, : (2) $16: 133$ (1859)

59 Dyas et Trias ou le nouveau grib rouge en Europe, dans l'Amérique du Nori et dans l'Inde [Triassic red beds]. Arch Sc Phys Nat n s 5:5-37, 116-146 (1859) Critical notice by R. I. Murchison in Al J Sc (2) 28:256-259 (1859)

59 a Reply to the criticisms of James D. Dana. $40 \mathrm{pp}$, Zurich 1859

596 [On the age of varions formations in northern and western United States] Ac Se St L, Tr 1: 325 (1859)

60 [On the Braintree, Mass., slate atd formations of like age elsewhere.] Bosto Soc N H, Pr 7:357-358 (1860)

$60 a$ On the primordial fauna and the Taconic system. Boston Soc N H, Pr 7 $369-371,375,376-382$ (1860)

$60 \mathrm{~b}$ Notes on the geology of Kansas and Nebraska. Ac Sc St L, Tr 1:610-611 (1860)

60c [On the occurrence of Jurassts rocks in the Western States.] Ac N Sc Phila, Pr 1860: 548

61 Notes on the Cretaceous and Car bonlferous rocks of Texas. Boston $80 x$ N H, Pr 8: 86-97 (1861)

61a [On the Primordial of Canada] Boston Soc N H, Pr 8: 97-98 (1861)

$61 \mathrm{~b}$ On the occurrence of silver asd gold in the Rocky Mountains and Califor nia (with discussion by C. T. Jacksot, W. B. Rogers, and A. A. Hayes.) Bostot Soc N H, Pr 8:172 (1861)

61e The Taconic and Lower Silurias rocks of Vermont and Canada. Boston Sot N H, Pr 8: 239-253 (1861)

62 Observations on the terms "Pénéen," "Permian," and "Dyas." Boston Soc $\$$ H, $\operatorname{Pr} 9: 33-36$ (1862)

62a List additionnelle des fossiles du tet rain taconique de l'Amérique du Nord Soc G France, B (2) $19: 746-752$ (1862)

62b Letter to M. Joachim Barrande of the Taconic rocks of Vermont and Canada $15 \mathrm{pp}$, Cambridge 1862 [priv pub]

64 Une reconnaissance géologique 80 Nebraska. Soc G France, B (2) 21: 132146 (1864)

$64 a$ Notice sur les gisements des let tilles trilobitifères taconiques de la Point Lévis, au Canada. Soc G France (2) 21 236-250 (1864) 
Marcon, Jules-Continued.

64b Die Dyas-Formation in Nebraska. N Jb 1864: 51-52

65 Le Niagara quinze ans après. Soc G France, B (2) $22: 290-300,529-530$ (1865) 66 ... la géologie californienne. Soc G France, B (2) $23: 552-559$ (1866)

67 Le terrain crétacé des environs de Sioux-City de la Mission des Omahas et de Tekama, sur les bords du Missouri. Soc G France, B (2) 24:56-71, map (1867)

67a Le Dyas au Nébraska. Soc G France, B (2) 24:280-299, map (1867)

67b Notes géologiques sur les frontières entre le Mexique et les Etats-Unis. [France], Comm Sc Mex, Arch 2:74-80, Paris 1867

67e Distribution géographique de l'or et de l'argent aux Etats-Unis et dans les Canadas. Soc Géog, Paris, B 14:523-534 (1867)

68 On the Dyas in Nebraska. Ac Sc St L, Tr 2: 562-564 (1868)

73 On a second edition of the geological map of the world. Am Nat $7: 345-352$ (1873)

75 Explication d'une seconde édition de la carte géologique de la terre. 222 pp, map, Zurich 1875

75a On the Terebratula mormonii. Ac Sc St L, Tr $3: 252-255$ (1875)

$75 b$ Bericht uber eine Erforschungs-Ex-

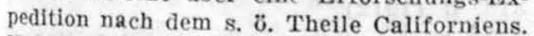
N Jb $1875: 960-961$

75e Untersuchungen in Californien. $\mathrm{K}-\mathrm{k}$ $G$ Reichsanstalt, Verh 1875: 215-216

76 Report on the geology of a portion of southern California. In Wheeler, G. M., Annual report... surveys west of the 100 th meridian... : 158-172 (1876) Also in U S [War Dp], Chief Eng, An Rp 1876 (U S, 44th Cong $2 d$ sess, $H$ Ex Doc 1 pt 2 v 2 pt 3) App JJ : 378-392 (1876)

81 Sur les colonies dans les roches taconiques des bords du lac Champlain. Soc G France, B (3) $9: 18-46$, map (1881) Criticism by J. D. Dana, Am J Sc (3) 22 : 321-322 (1881)

83 Note sur la géologie de la Californie. Soc G France, B (3) 11:407-435, map (1883) Abst, $\Delta \mathrm{m}$ Nat 17:1271-1273 (1883)

83u Mitthellungen uber die Geologie Callforniens. N Jb 1883 , II : 52-58

84 (and Mareou, J. B.) Mapoteca geologica americana; a catalogue of geological maps of America (North and South) 1752-1881, in geographic and chronologic order. U S G S, B 7:184 pp (1884) 85 The "Taconic system" and its place in stratigraphic geology. Am Ac Arts, Pr $20: 174-256$ (1885).

85a Ebenezer Emmons. Science $5: 456$ 458, port (1885)

\section{Marcou, Jules-Continued.}

85b Relative ages of Ameriean and English Neozoic series. G Mag (3) 2:4647 (1885)

86 On two plates of stratigraphical sections of the Taconic ranges by Prof. Zames Hall. Science $7: 393-394$ (1886)

86a Glaciers and glacialists. Science $8: 76-80$ (1886)

s7 On the use of the name Taconic. Boston Soc N H, Pr 23:343-355 (1887)

S7a Tabular view of American classification and nomenclature. Broadside sheet, July 1887 [priv pub]

ss American geological classification and nomenclature. $75 \mathrm{pp}$, Cambridge 1888 [priv pub]

88n The Taconic of Georgia [Vt.] and the report on the geology of Vermont. Boston Soc N H, Mem 4:105-131 (1888)

s8b Paleontologic and stratigraphic "principles" of the adversaries of the Taconic. Am G 2:10-23, 67-88 (1888)

88e Geology of the vicinity of Quebec City. Am G $2: 355-356$ (1888)

89 Canadian geological classification for the Proyince of Quebec. Boston Soc N H, $\operatorname{Pr} 24: 54-83$ (1889)

89a On some dates of the "Report on the geology of Vermont." Boston Soc N H, Pr 24:83-89 (1889)

89b Some remarks on Professor Henry S. Williams' report of the subcommittee on the upper Paleozolc (Devouic) ... Am G 3 : 60-61 (1889)

s9e Barrande and the Taconic system. A m G 3: 118-137 (1889)

89d The original locality of the Gryphaea pitcheri Morton. Am G 3: 188-193 (1889)

s9e [The classification of the Cambrian]. Am G 4:62 (1889)

89R The Mesozoic series of New Mexico. Am G 4 : 155-165, 216-229 (1889)

\$9g Jura, Neocomian, and chalk of Arkansas. Am G 4:357-367 (1889)

90 Reply to the questions of Mr. Selwyn on "Canadian geological classification for Quebec." Boston Soc N H, Pr 24: 357-364 (1890)

90a The Triassic flora of Richmond, Va. Am G 5 : 160-174 (1890)

90b The American Neocomian and the Gryphaea pitcheri. Am G 5:315-317(1890)

90e The lower and middle Taconic of Europe and North America. Am G $5: 357-$ $375 ; 6: 78-102,221-233$ (1890)

90d Use of the terms Laurentian and Champlain in geology. $\mathrm{Am}$ G $6: 64-66$ (1890)

91 Geology of the environs of Quebec, with map and sections. Boston Soc $\mathrm{N} \mathrm{H}$, Pr 25: 202-227, map (1891)

91 a Biographical notice of Ebenezer Emmons [1800-1863]. Am G 7:1-23 (1891) 
Marcon, Jules-Continued.

92 ... on "The scope of paleontology and its value to geologists ",... Am G 10:257260 (1892)

92a On the classification of the Dyas, Trias, and Jura in northwest Texas. Am G $10: 369-377$ (1892)

92b The geological map of the United States and the United States Geological Survey. $56 \mathrm{pp}$, Cambridge, Mass., 1892

92e A little more light on the United States Geological Survey. 11 pp, Cambridge, Mass., 1892 [priv pub]

93 Second supplement to "Mapoteca geologica americana," 1752-1881. Am G 11: 95-99 (1893)

$93 a$ Remarks on a part of the review of the third Texas report [geology of Tucumcari region]. Am G 11:212-214 (1893)

93b Cerro Tucumcari. Am G 12:103107, map (1893)

93e The Tucumcar1 fossils [N. Mex.]. Sclence 21:358-360 (1893)

94 Growth of knowledge concerning the Texas Cretaceous. Am G 14:98-105 (1894)

$94 a$ Note on the geological map of the State of New York. Am G 14:257-259 (1894)

96 Life, letters, and works of Louis Agassiz. 2 vols, 302,318 pp, port, N Y 1896

96a The Jura of Texas. Boston Soc N H, Pr 27:149-158 (1896)

96b The Jura in the United States. Science n s 4:945-947 (1896)

97 Rules and misrules in stratigraphic classification. Am G 19:35-49, 111-131 (1897)

$97 \mathbf{a}$ Jura and Neocomian of Arkansas, Kansas, Oklahoma, New Mexico, and Texas. Am J Sc (4) 4:197-212 (1897)

$97 \mathbf{b}$ Note on "the easternmost volcanoes of the United States." Science n s 6:667668 (1897)

See also Hitchcock (C H), 61d; Hunt, $67 \mathrm{~d}$; Jackson, 61c, 62a

Marey, Oliver (1820-1899).

66 (with Winchell, Alexander.) Enumeration of fossils collected in the Niagara limestone at Chicago, Ill.; with descriptions of several new species. Boston Soc $\mathrm{N} H$, Mem 1:81-114, il (1866)

Marey, R. B.

50 [Report on expedition from Fort Smith to Santa Fe, N. Mex.] U S, 31st Cong, 1st sess, S Ex Doc 64:169-227 (1850)

Marett, Elias.

72 On the copper and nickel mines at Tilt Cove, Newfoundland. $N$ Inst $N$ Sc, Pr Tr 3: 27-31 (1872)

Margerie, Emmanuel de.

84 Les plateaux du Colorado; paysage et structure géologique d'après les travaux des géologues américains. Club Alpin Franç, An 10:417-449 (1884)
Margerie, Emmanuel de - Continued.

87 Presentation d'un relief en platre de la Pennsylvanie et observations sur las plissements des terrains paléozolques, So G France, B (3) $15: 356-357$ (1887)

92 Bibliography undertaken by the It. ternational Congress of Geologists. Am J Sc (3) $43: 71-73$ (1892) Am G $9: 64$ 67 (1892)

02a Sur la découverte de phénomènes de recouvrement dans les Appalaches. $\operatorname{Soc} \theta$ France, B (3) 19:426-429 (1892)

os La carte géologique internationale d: l'Amérique du Nord. An Geog 17:56-i (1908)

13 Deux accidents cratériformes; Crater Lake (Oreg.) et Meteor Crater (Ariz.), An Géog 22: 172-184 (1913)

14 The geological map of the world Int $\mathrm{G}$ Cong, XII, 1913, C R:173-18: (1914)

Marinelli, Olinto.

15 Confronto fra 1 " Badlands" italiani e quelle americani. Am Geog Soc, Memo rial Volume of Transcontinental Excursion of $1912: 223-230$ (1915)

Mark, Clara Gould.

11 The Mercer limestone and its associated rocks in the Newark-Zanesville to gion. Denison Unir, Sc Lab, B 16:26\%314, il (1911)

12 The fossils of the Conemaugh fot mation in Ohio. Ohio G S (4) B 17:261318 , il (1912)

16 The stratigrapby of Flint Range Ohio (abst). Science n s $43: 396-39^{\circ}$ 1916)

Marsh, Dexter.

48 Fossil footprints. Am J Sc (2) 6: $272-275$, il (1848)

Marsh, Othniel Charles (1831-1899).

61 The gold of Nova Scotia. Am J \& (2) $32: 395-400$ (1861) Abst, Can Nat $6: 427-430$ (1861)

62 On the saurian vertebrae from Nors Scotia. Am J Se (2) $33: 278$ (1862)

62a Description of the remains of a net enaliosaurian (Eosaurus acadianus) frot the coal formation of Nova Scotia. Am Sc (2) 34:1-16 (1862) Abst, Can Nat $7: 205-213$ (1862) ; G Soc London, Q J 19: $52-56$ (1863)

63 Catalogue of mineral localities in Ner Brunswick, Nova Scotia, and Newfoundland. Am J Sc (2) $35: 210-218$ (1863)

67 Discovery of additional mastodon $"$ mains at Cohoes, N Y. Am J Sc (2) 43. 115-116 (1867)

67 a A catalogue of official reports upos geological surveys of the United States and British provinces. Am J Sc (2) $43: 116$ 121, 399-404 (1867)

$\mathbf{6 7 b}$ Notice of a new genus of fosti sponges from the Lower Silurian [Franklit Co., Ky.]. Am J Sc (2) 44:88 (1867) 
Irarsh, Othniel Charles-Continued.

67e Contributions to the mineralogy of Nova Scotia; ledererite identical with gmelinite. Am J Sc (2) $44: 362-367$ (1867)

68 On the Palaeotrochis of Emmons from North Carolina. Am J Sc (2) 45 : 217-219, il (1868)

6 Sa Notice of a new and diminutive species of fossil horse (Equus parvulus) from the Tertiary of Nebraska. Am J Se (2) $46: 374-375$ (1868)

68b On the origin of the so-called lignilites or epsomites $(a b s t)$. Am As, $\operatorname{Pr~16:~}$ 135-143 (1868) Can Nat $n$ s $3: 293$ (1868)

68e On certain effects produced upon fossils by weathering (abst). Can Nat n s $3: 305$ (1868)

69 Description of a new species of Protichnites, from the Potsdam sandstone of New York. Am As, Pr $17: 322-324$ (1869) $\triangle \mathrm{m}$ J Sc (2) $48: 46-49$ (1869)

$69 \mathrm{a}$ On the preservation of color in fossils from Paleozoic formations. Am As, Pr 17: 325-326 (1869)

69b Notice on some new mosasauroid reptiles from the Greensand of New Jersey. Am J Sc (2) 48:392-397 (1869) Abst, Can Nat n s 4:331 (1869); G Mag 7: 376-377 (1870) ; Am Nat 3:446 (1869)

69e Description of a new and gigantic fossil serpent (Dinophis grandis) from the Tertiary of New Jersey. Am J Sc (2) 48 : $397-400$ (1869) Abst, Am Nat 4:254 (1870)

69d Remarkable locality of vertebrate remains in the Tertiary of Nebraska (abst). Am Nat $3: 445$ (1869) Can Nat n s 4: 322-323 (1869)

70 Notice of some fossil birds from the Cretaceous and Tertiary formations of the United States. Am J Sc (2) 49:205-217, 272 (1870) Abst, Ac N Sc Phila, Pr 1870:5-6; G Mag $7: 377-378$ (1870)

70a Notice of a new species of gavial from the Eocene of New Jersey, Am J Sc (2) $50: 97-99$ (1870) G Mag $7: 427$ (1870)

$70 b$ Discovery of the Mauvaises Terres formation in Colorado. Am J Sc (2) 50 : 292 (1870) Can Nat n s $5: 240$ (1870)

$70 \mathrm{c}$ [Remarks on reptilian remains from New Jersey, etc.] Ac $N$ Sc Phila, Pr $1870: 2-3$

70d [Notice of Dicotyles antiquus from Shark River Miocene of New Jersey.] Ac N Sc Phila, Pr 1870:11

70e Notice of some new Tertiary and Cretrceous fishes (abst). Am As, Pr 18: $227-230$ (1870)

71 On the geology of the eastern Uinta Mountains, Am J Sc (3) 1:191-198 (1871)

71 a Notice of a fossil forest in the Tertiary of California. Am J Sc (3) $1: 266$ 268 (1871)
Marsh, Othniel Charles-Continued.

71b Description of some new fossil serpents from the Tertiary deposits of Wyoming. Am J Sc (3) 1:322-329 (1871) Italia, R Comitato G, B $3: 273-278$ (1872)

71e Notice of some new fossil reptiles from the Cretaceous and Tertiary formations. Am J Sc (3) $1: 447-459$ (1871) Italia, R Comitato G, B $3: 278-283,338-$ 342 (1872)

71d Note on a new and gigantic species of pterodactyl. Am J Sc (3) $1: 472$ (1871)

71e Notice of some new fossil mammals and birds from the Tertiary formation of the West. Am J Sc (3) $2: 120-127$ (1871) Italia, R Comitato G. B $3: 350-353$ (1872)

$71 f$ Notice of some new fossil mammals from the Tertiary formation. Am J Sc (3) $2: 35-44$ (1871) Italia, R Comitato G, B $3: 343-350$ (1872)

715 [On new reptiles and fishes from the Cretaceous and Tertiary, chiefly from the Rocky Mountain region.] Ac $\mathrm{N}$ Sc Phila, Pr 1871: 103-105

71h [On a tooth of Lophiodon from the Miocene marl of Cumberland Co., N. J.] Ac N Sc Phila, Pr 1871: 9-10

72 Discovery of a remarkable fossil bird. Am J Se (3) 3:56-57 (1872)

72a Discovery of additional remains of Pterosauria with descriptions of two new species. Am J Sc (3) 3:241-248 (1872)

72b Discovery of the dermal scutes of mosasauroid reptiles. Am J Sc (3) 3 : 290-292 (1872)

72c Notice of a new species of Hadrosaurus. Am J Sc (3) 3:301 (1872)

72d Preliminary description of Hesperornis regalis, with notice of four other new species of Cretaceous birds. Am $\mathrm{J}$ Se (3) 3:360-365 (1872) An Mag N H (4) 10 : 212-217 (1872) Italia, R Comitato G, B $3: 211-217$ (1872)

72e on two new ornithosaurians from Kansas. Am J Sc (3) 3:374-375 (1872)

72f On the structure of the skull and limbs in mosasauroid reptiles, with descriptions of new genera and species. Am J Sc (3) $3: 448-464$, il $(1872)$

725 Preliminary description of new Tertiary mammals. Am J Sc (3) $4: 122-128$, 202-224 (1872)

72h Note on Rhinosaurus. Am J Sc (3) $4: 147(1872)$

72i Notice of some new Tertiary and post-Tertiary birds. Am J Sc (3) 4:256262 (1872) Abst, Ac N Sc Phila, Pr $1870: 11$

72j Preliminary description of new Tertiary reptiles, Am J Sc (3) $4: 298-309$ (1872)

72k Note on Tinoceras anceps. Am J Sc (3) $4: 322$ (1872)

721 Notice of a new species of Tinoccras. Am J Sc (3) $4: 323$ (1872)

$72 \mathrm{~m}$ Notice of some remarkable fossil mammals. Am J Sc (3) $4: 343-344$ (1872) 
Marsh, Othniel Charles-Continued.

72n Notice of a new and remarkable fossil bird. Am J Sc (3) $4: 344$ (1872) Am Nat $7: 50$ (1872) An Mag N H (4) $11: 80$ (1873)

72o Discovery of fossil Quadrumana in the Eocene of Wyoming. Am J Sc (3) 4: $405-406$ (1872) G Mag 10:33 (1873) Am Nat $7: 179-180$ (1873)

72p Note on a new genus of carnivores from the Tertiary of Wyoming. Am J Sc (3) $4: 406$ (1872) G Mag 10:33-34 (1873)

$\mathbf{7 2 \alpha}$ Notice of a new reptile from the Cretaceous [Kans.] Am J Sc (3) 4:406 (1872) G Mag 10:24 (1873)

72r Synopsis of the fossil forms [of North American birds]. In Coues, Elliott, Key to North American birds, pp 347-350, Salem 1872 Abst, Am J Sc (3) 5:229230 (1873)

72s Boulders in coal. Am Nat 6:439 (1872)

73 Notice of a new species of Iehthyornis. Am J Sc (3) 5:74 (1873)

$\mathbf{7 3 a}$ On the gigantic fossil mammals of the order Dinocerata. Am J Sc (3) 5: 117-122, il, 293-296, 310-311 (1873) J Zool, Paris, 2: 160-168, il (1873) An Sc Nat, Zool (5) 17 art 9:1-8, il (1873)

73b On a new subclass of fossil birds (Odontornithes). Am J Sc (3) 5: 161-162 (1873) An Nat $7: 115-117$ (1873) An Mag N H (4) $11: 233-234$ (1873) G Mag 10:115-116 (1873) An Sc Nat, Zool (5) 17 art $9: 8-10$ (1873)

73e Notice of new Tertiary mammals. Am J Se (3) $5: 407-410,485-488$ (1873)

73d New observations on the Dinocerata. Am J Sc (3) 6:300-301 (1873)

73e On some of Professor Cope's recent investigations. Am Nat $7: 51-52$ (1873)

73f The fossil mammals of the order Dinocerata. Am Nat $7: 146-153$, il (1873)

$\mathbf{7 3 g}$ On the genus Tinoceras and its allies. Am Nat $7: 217-218$ (1873)

73h Tinoceras and its allies. Am Nat $7: 306-308$ (1873)

73i Note on the dates of some of Professor Cope's recent papers. Am Nat 7 : 173 (1873) Am J Sc (3) 5: 235-236 (1873)

73j On the dates of Professor Cope's recent publications. Am Nat $7: 303-306$ (1873)

731k Reply to Professor Cope's explanation. Am Nat $7:$ Appendix to June no: ix pp (1873)

731 Communication on the discovery of new Rocky Mountain fossils. Am Ph Soc, Pr 12:578-579 (1873) Ann Sc Géol, 3 art $6: 99-100$ (1873)

$73 m$ On the gigantic mammals of the American Eocene. $\mathrm{Am} \mathrm{Ph}$ Soc, $\operatorname{Pr} 13$ : 255256 (1873)
Marsh, Othniel Charles-Continued.

74 On the structure and affinities of th Brontotheridae. Am J Sc (3) $7: 81-86$, (1874) Am Nat 8:79-85, il (1874)

$74 \Omega$ Notice of new equine mammals from the Tertiary formation. Am J Sc (3) 247-258, il (1874) (in part) An Mag N B (4) $13: 397-400$, il (1874) (in part) Cis Q J Sc 1: 157-160 (1874)

74b Notice of new Tertiary mammals III. Am J Sc (3) 7:531-534 (1874)

74c Small size of the brain in Tertisy mammals. Am J Sc (3) 8:66-67 (1874) Am Nat 8:503-504 (1874) An Mag \ H (4) 14: 167 (1874) J Zool, Parls, 3: 326-327 (1874)

74d Fossil horses in America. Am Nat $8: 288-294$, il $(1874)$

75 Ancient lake basins of the Rocky Mountain region. Am J Sc (3) 9:49-5? (1875) Abst, Am Nat $9: 119(1875) ; G$ Mag (2) 2: 232-233 (1875)

$75 \boldsymbol{a}$ New order of Eocene mammals Am J Sc (3) 9:221 (1875) Am Nat 9: 182-183 (1875) An Mag $\mathrm{N} \mathrm{H}$ (4) 15: 307 (1875) Nature 11:368 (1875) ? Zool, Paris, 4 : 70-71 (1875)

75b Notice of new Tertfary mammals IV. $\mathrm{Am} \mathrm{J} \mathrm{Sc} \mathrm{(3)} 9: 239-250$ (1875)

75e On the Odontornithes, or birds with teeth. Am J Sc (3) $10: 403-408$, il (1875) Am Nat $9: 625-631$, il (1875) G Mas (2) $3: 49-53$, il (1876) J Zool, Paris 4: 494-502 (1875)

76 Principal characters of the Dito cerata. $\mathrm{Am}$ J $\mathrm{Sc}$ (3) 11:163-168, (1876) J Zool, Paris, 5:136-145, (1876)

76a Principal characters of the Tillo dontia. Am J Sc (3) 11:249-251, (1876) J Zool, Paris, 5: 244-248, (1876)

76b Principal characters of the $\mathrm{Bror}$ totheridae. Am J Sc (3) 11:335-340, 1 (1876) J Zool, Paris, $5: 248-255$, (1876)

76e On some characters of the genos Coryphodon Owen. Am J Sc (3) 11 425-428, 11 (1876)

76d Notice of a new suborder of ptert sauria. Am J Sc (3) 11:507-509 (1876)

76e Notice of new Odontornithes. At J Sc (3) 11:509-511 (1876) J Zool Paris, 5: 304-306 (1876)

76f Recent discoveries of extinct ant mals. Am J Sc (3) 12:59-61 (1876) Am Nat 10:436-439 (1876)

76m Notice of new Tertiary mammak V. Am J Sc (3) 12:401-404 (1876)

76h Principal characters of Americat pterodactyls. Am J Sc (3) 12:479-480 (1876)

77 Principal characters of the Coryphodontidae. Am J Sc (3) 14:81-85 (1877 J Zool, Paris, 6:380-385 (1877) Abst, Am Nat 11:500 (1877) 
Marsh, Othniel Charles-Continued.

77a Characters of the Odontornithes, with notice of a new allied genus. Am J Se (3) 14:85-87 (1877) J Zool 6:385389 (1877) Abst, Ann Se Géol 8 no $3: 2$ pp (1877); Am Nat $11: 500$, il (1877)

$\mathbf{7 7 b}$ Notice of a new and gigantic dinosaur [Titanosaurus]. Am J Sc (3) 14 : 87-88 (1877) J Zool, Paris, 6:248-250 (1877)

77e Notice of some new vertebrate fossils. Am J Sc (3) $14: 249-256$, il (1877)

77d Introduction and succession of vertebrate life in Amrerica. Am J Sc (3) 14 : $337-378$ (1877) Am As, Pr 26:211-258 (1878) Nature $16: 448-450,470-472,489-$ 491 (1877) Pop Sc Mo $12: 513-527,672-$ 697 (1878) Rv Scient (2) 14 [an 7]: 1039-1046, 1064-1074 (1878)

77e A new order of extinct Reptilia (Stegosauria) from the Jurassic of the Rocky Mountains. Am J Sc (3) 14:513514 (1877)

77f Notice of new dinosaurian reptiles from the Jurassic formation. $A m$ J Se (3) $14: 514-516 \quad(1877)$

$\mathbf{7 7 g}$ Brain of Coryphodon. Am Nat 11 : 375 (1877)

7s New species of Ceratodus from the Jurassic [of Colorado]. Am J Sc (3) 15 : 76 , il (1878) An Mag N H (5) 1:184 (1878)

78a Notice of new dinosaurian reptiles. Am J Sc (3) $15: 241-244$, il (1878)

78b Notice of new fossil reptiles. Am J Sc (3) 15:409-411 (1878)

78e Fossil mammal from the Jurassic of the Rocky Mountains. Am J Sc (3) 16 : 459 (1878) An Mag N H (5) 2:108 (1878)

78d New pterodactyl from the Jurassic of the Rocky Mountains. Am J Sc (3) 16: 233-234 (1878)

78e Principal characters of American Jurassic dinosaurs. Am J Sc (3) 16:411416 , il $(1878) ; 17: 86-92$, il (1879)

78p Brain of a fossil mammal [Ooryphodon]. Nature 17:340 (1878)

79 A new order of extinct reptiles (Sauranodonta) from the Jurassic formation of the Rocky Mountains. Am J Sc (3) $17: 85-86 \quad(1879)$

79 a Principal characters of American Jurassic dinosaurs. Am J Sc (3) 17:8692, il (1879)

79b Additional characters of the Sauropoda. Am J Sc (3) 17:181-182 (1879) 79e The vertebrae of recent birds. Am J Se (3) $17: 266-269$, il (1879)

79d Polydactyl horses, recent and extinct. Am J Sc (3) $17: 499-505$, il (1879)

79e Notice of a new Jurassic mammal. Am J Sc (3) 18:60-61 (1879) An Mag NH (5) 4:167-168 (1879) G Mag (2) 6: 371-372 (1879)
Marsh, Othniel Charles-Continued.

79R Additional remains of Jurassic mammals. Am J Sc (3) $18: 215-216$, il (1879)

79m History and methods of paleontological discovery. Am As, $\operatorname{Pr} 28: 1-42$ (1880) Am J Sc (3) 18:323-359 (1879) Pop Sc Mo 16:219-236, 363-380 (1879$80)$ Nature 20:494-499, 515-521 (1879) Kosmos, Leipzig, Jg 3 Bd $6: 339-352,425-$ 445 (1880)

79h Notice of new Jurassic mammals. Am J Sc (3) 18: 396-398 (1879)

$79 i$ Notice of new Jurassic reptiles. Am J Sc (3) 18:501-505, il (1879)

so Odontornithes; a monograph on the extinct toothed birds of North America. U S G Expl 40th Par (King), $7: 201 \mathrm{pp}$, il (1880) Yale Coll, Peabody Mus, Mem 1: $201 \mathrm{pp}$, il (1880)

80a New characters of mosasauroid reptiles. Am J Sc (3) 19:83-87, il (1880)

sob the limbs of Sauranodon, with notice of a new species. Am J Sc (3) 19 : $169-171$, il, 491 (1880)

soe Principal characters of American Jurassie dinosaurs, Pt. III. Am J Sc (3) 19: 253-259 (1880)

sod The sternum in dinosaurian reptiles. Am J Sc (3) $19: 395-396$, il (1880)

soe Notice of Jurassic mammals representing two new orders. Am J Sc (3) 20 : 235-239, il (1880)

Sor List of genera established by Professor 0 . C. Marsh, 1862-1879. 12 pp, $\mathrm{n}$ p, n d [New Haven 1880?] [priv pub]

s1 Principal characters of American Jurassic dinosaurs, IV. Am J Sc (3) 21 : 167-170 (1881)

s1a A new order of extinct Jurassic reptiles (Coeluria). Am J Sc (3) 21:339340 , il (1881)

s1b Discovery of a fossil bird in the Jurassic of Wyoming. Am J Sc (3) 21 : 341-342 (1881) An Mag N H (5) 7 : 488-489 (1881)

81e Note on American pterodactyls. Am J Sc (3) $21: 342-343$ (1881)

81d Principal characters of American Jurassic dinosaurs, Pt. V. Am J Se (3) $21: 417-423$, il (1881)

s1e Notice of new Jurassic mammals. Am J Sc (3) 21:511-513 (1881)

81f Restoration of Dinoceras mirabile. $\mathrm{Am} \mathrm{J} \mathrm{Sc} \mathrm{(3)} 22: 31-32$, il (1881)

81g Jurassic birds and their allies. Am J Sc (3) $22: 337-340$ (1881) An Mag $\mathrm{N}$ H (5) $8: 452-455$ (1881) G Mag (2) 8: 485-487 (1881) Science (ed, Michels) $2: 512-513$ (1881) Pop Sc Mo 20:312315 (1882) Kosmos, Stuttgart, Jg 5 Bd $10: 231-234$ (1881) Abst, Nature 24: 501 (1881) 
Marsh, Othniel Charles-Continued.

$81 h$ Classification of the Dinosauria. Am J Sc (3) 23:81-86 (1881) An Mag $\mathrm{N}$ H (2) $9: 79-84$ (1882) Nature 25: 244-246 (1882) G Mag (2) 9:80-85 (1882) Kosmos, Stuttgart, Jg 5 Bd 10 : $382-387$ (1881)

82 The wings of pterodactyls. Am J Sc (3) 23:251-256, il (1882) G Mag (2) $9: 205-210$, il (1882) Nature $25: 531$ 533 , il (1882) Kosmos, Stuttgart, Jg 6 Bd $11: 103-108$, il (1882)

83 Birds with teeth. U S G S, An Rp $3: 45-88$, il (1883)

S3a Principal characters of American Jurassic dinosaurs; Part VI, Restoration of Brontosaurus. Am J Sc (3) 26:81-85, il (1883) G Mag (2) 10:385-388, il (1883)

83b On the supposed human footprints recently found in Nevada. Am J Sc (3) $26: 139-140$, il (1883)

S4 Principal characters of American Jurassic dinosaurs; Part VII, On the Diplodocidae, a new family of the Sauropoda. Am J Sc (3) $27: 161-167$, il (1884) G Mag (3) 1:99-107, il (1884) Notice by Achille Six, Soc G Nord, An 11:237-240 (1884)

84a A new order of extinct reptiles (Macelognatha). Am J Sc (3) $27: 341$, 11 (1884)

84b Principal characters of American Jurassic dinosaurs; Part VIII, The order Theropoda. Am J Sc (3) $27: 329-340$, Il (1884) G Mag (3) 1:252-262, il (1884) Kosmos, Stuttgart, 15 (1884, 2) : 357-365 (1884) Abst, Science 3: 542-544, il (1884)

84e Principal characters of American Cretaceous pterodactyls; Part I. The skull of Pteranodon. Am J Sc (3) $27: 423-426$, Il (1884) G Mag (3) $1: 345-348$, il (1884)

84d $O n$ the united metatarsal bones of Ceratosaurus. Am J Sc (3) 28:161-162, il (1884)

84e On the classification and affinities of dinosaurian reptiles (abst), Brit As, Rp 54: 763-766 (1885) Nature 3:68-69 (1884) Science $4: 261$ (1884)

85 The gigantic mammals of the order Dinocerata. U.S G S, An Rp 5:243-302, 1) (1885)

85a Names of extinct reptiles. Am J Sc (3) $29: 169$ (1885)

85b On the size of the brain in extinct animals (abst). Brit As, Rp 55:1065 (1886) Nature 32:562 (1885) Science 6: 360 (1885)

86 Dinocerata, a monograph of an extinct order of gigantic mammals. U S G S, Mon 10: xvili, 243 pp, il (1886) Rv, Am J Sc (3) $29: 173-204$ (1885)

87 American Jurassic mammals. Am J Sc (3) $33: 327-348$, il (1887) G Mag (3) 4: 241-247, 289-299, 11 (1887) Abst, Brit As, Rp $54: 734-736$ (1885)
Marsh, Otbniel Charles-Continued.

87 a Notice of new fossil mammals. th J Śc (3) $34: 323-331$, ॥l (1887)

$\mathbf{8 7 b}$ Principal characters of Amerion Jurassic dinosaurs; Part IX, The skull ad dermal armor of Stegosaurus. Am J \& (3) $34: 413-417$, 11 (1887) G Mag (3) : 11-15, il (1888)

88 Notice of a new genus of Sauropods and other new dinosaurs from the Potoms formation. Am J Sc (3) $35: 89-94$, (1888)

8sa Notice of new fossil sirenian, fron California. Am J Sc (3) 35:94-96, n (1888)

88b A new family of horned Dinosauri from the Cretaceous. Am J Sc (3) 36: $477-478$, il (1888)

89 Restoration of Brontops robuste from the Miocene of America (abst). Brit As, Rp 58: 706-707 (1889) Am J Sc (3) $37: 163-165$, Il (1889) G Mag (3) 6:89101, il (1889)

89a Comparison of the principal fors of the Dinosauria of Europe and Ametla G Mag (3) 6:204-210 (1889) Am J \& (3) $37: 323-331$ (1889)

89b Notice of new American Dinosaurit Am J Sc (3) $37: 331-336$, il (1889)

89e Discovery of Cretaceous Mammally $\Delta \mathrm{m} \mathrm{J} \mathrm{Sc} \mathrm{(3)} \mathrm{38:81-92,} \mathrm{177-180,} \mathrm{il} \mathrm{(1800}$

s9d Notice of gigantic horned Dinosauth from the Cretaceous. Am J Sc (3) 3 173-176, il (1889)

89e The skull of the gigantic Cerato sidae. Am J Sc (3) $38: 501-506$, il (1880) G Mag (3) $7: 1-5,11(1890)$

90 Description of new dinosaurian $m_{f}$ tiles. Am J Sc (3) 39:81-86, il (1890)

$90 a$ Distinctive characters of the ord Hallopoda. Am J Sc (3) $39: 415-417$, (1890)

$90 \mathrm{~b}$ Additional characters of the Cet topsidae, with notice of new Cretaceos dinosaurs. Am J Sc (3) $39: 418-426$, (1890)

90e Notice of new Tertiary mammat Am J Sc (3) 39:523-525 (1890)

90d Notice of some extinct Testudingti Am J Sc (3) 40:177-179, il (1890)

90e Additional genera established Professor O. C. Marsh, 1880-1889. if th New Haven 1890 [not seen]

91 A horned artiodactyle (Protocer) celer) from the Miocene. Am $J$ Sc $(5$ 41 : 81-82 (1891)

91 a The gigantic Ceratopsidae, or hord dinosaurs, of North America. Am J (3) $41: 167-178$, il (1891) G Mag (3) 193-199, 241-248, il (1891) Abst, Bat As, Rp 60 : 793-795 (1891)

91b Restoration of Triceratops. ADI Sc (3) $41: 339-342$, il (1891) $Q \mathrm{Mag}$ (8) $8: 248-250$, il (1891)

91e Restoration of Stegosaurus. AD Sc (3) $42: 179-181$, il (1891) G Mag $8: 385-387$, il (1891) 
Marsh, Othniel Charles-Continued.

91d Notice of new vertebrate fossils. Am J Sc (3) $42: 265-269$ (1891)

91e Geological horizons as determined by vertebrate fossils. Am J Sc (3) 42 ; 336-338 (1891) Int $G$ Cong, V, Washington 1891, C R : 156-159 (1893)

91f Notes on Mesozoic Mammalia. Ac N Sc Phila, Pr 1891: 237-241 (1891) Am Nat $25: 611-616$ (1891)

91g On the Cretaceous mammals of North America (abst). Brit As, Rp 60 : 853-854 (1891)

92 The skull of Torosaurus. Am J Sc (3) $43: 81-84$, il (1892)

92a Discovery of Cretaceous Mammalia, Pt. 3. Am J Se (3) $43: 249-262$, il (1892) 92b Recent polydactyle horses. Am J Sc (3) $43: 339-355$, il (1892)

92e A new order of extinct Eocene mammals (Mesodactyla). Am J Sc (3) 43 : $445-449$, il (1892)

92d Notice of new reptiles from the Laramie formation. Am J Sc (3) $43: 449$ 453, Il (1892)

92e Notes on Triassic Dinosauria. Am

J Sc (3) $43: 543-546$, il (1892)

92f Notes on Mesozoic vertebrate fossils. Am J Sc (3) 44:171-176, il (1892)

922 Restorations of Claosaurus and Ceratosaurus. Am J Sc (3) 44:343-349, il (1892) G Mag (3) $10: 150-157$, il (1893) Se Am Sup 34:14068-14069, il (1892)

92h Restoration of Mastodon americanus Cuvier. Am J Sc (3) $44: 350$, il (1892) G Mag (3) $10: 164$, il (1893) Sc Am Sup $34: 14085$, il (1892)

$93 \mathrm{~A}$ new Cretaceous bird allied to Hesperornis. Am J Sc (3) $45: 81-82,11$ (1893)

$93 a$ The skull and brain of Claosaurus.

Am J Sc (3) $45: 83-86$, 11 (1893)

93b Restoration of Anchisaurus. Am J Sc (3) $45: 169-170$, il (1893) G Mag (3) $10: 151-152$, il (1893)

93e Restoration of Coryphodon. Am J Sc (3) $46: 321-326$, il (1893) G Mag (3) $10: 481-487$, il (1893)

93d Description of Miocene Mammalia. Am J Sc (3) 46:407-412, il (1893)

93e Some recent restorations of dinosaurs. Nature 48:437-438 (1893)

94 Restoration of Camptosaurus. Am J Sc (3) $47: 245-246$, il (1894) G Mag (4) $1: 193-195$, il (1894) Se Am Sup 37 : 15209-15210, il (1894)

94a Restoration of Elotherium. Am J Sc (3) $47: 407-408$, il (1894) G Mag (4) 1:294-295, 11 (1894)

94b A new Miocene mammal. Am J Sc (3) $47: 409$, il (1894)

94e Footprints of vertebrates in the Coal Measures of Kansas. Am J Sc (3) $48: 81-84$, il (1894) G Mag (4) $1: 337-$ 339 , il (1894) Sc Am Sup 38:1549115492 , il (1894)
Marsh, Othniel Charles-Continued.

94d The typical Ornithopoda of the American Jurassic. Am J Sc (3) 48: 8590 , il (1894)

94e Eastern division of the Miohippus beds, with notes on some of the characteristic fossils. $\mathrm{Am} \mathrm{J} \mathrm{Sc} \mathrm{(3)} 48: 91-94$, il (1894)

94 Miocene artiodactyls from the eastern Miohippus beds. Am J Sc (3) 48: $175-178$, il (1894)

$94 \mathrm{~g}$ Description of Tertiary artiodactyls. Am J Sc (3) $48: 259-274$, il (1894) Rv, by E. D. Cope, Am Nat 28: $867-869$ (1894)

94h A gigantic bird from the Eocene of New Jersey. Am J Sc (3) $48: 344$, il (1894)

94i A new Miocene tapir. Am J Sc (3) $48: 348$ (1894)

95 The Reptilia of the Baptanodon beds. Am J Sc (3) 50:405-406, il (1895)

$95 n$ On the affinities and classification of the dinosaurian reptiles. Am J Sc (3) $50: 483-498$, il (1895) Int Zool Cong, 3d, C R: 196-211, il (1896) G Mag (4) 3: $388-400$ (1896)

951) Restorations of extinct animals, Plate I. [New Haven 1895] [not seen]

95c Restorations of dinosaurian reptiles,

Plate II. [New Haven 1895] [not seen] 96 The dinosaurs of North America. U S G S, An Rp 16 pt $1: 133-414$, il (1896) Extract, Sc Am Sup $43: 17828$ 17829 , il (1897)

96a Vertebrate fossils [of the Denver Basin, Colo.]. U S G S, Mon $27: 473-550$, il (1896)

96b a new belodont reptile (Stegomus) from the Connecticut River sandstone. Am $\mathrm{J}$ Sc (4) $2: 59-62$, il (1896)

96e The geology of Block Island [R. I.]. Am J Sc (4) 2:295-298, 375-377 (1896)

96d Amphibian footprints from the Devonian. Am J Sc (4) 2:374-375, il (1896)

96e The Jurassic formation on the Atlantic coast. Am $J$ Sc (4) $2: 433-477$ (1896) Science n s 4:805-816 (1896)

97 The Stylinodontia, a suborder of Eocene edentates. Am J Sc (4) 3:137-146, il (1897)

97a The affinities of Hesperornis. Am J Sc (4) $3: 347-348$ (1897) G Mag (4) $5: 38-39$ (1898)

97b Principal characters of the Protoceratidae. Am J Sc (4) $4: 165-176$, il (1897)

97e The skull of Protoceras. G Mag (4) $4: 433-439$, il (1897)

98 New species of Ceratopsia. Am J Sc (4) $6: 92$ (1898)

98a The Jurassic formation on the Atlantic coast. Am J Sc (4) 6:105-115 (1898) Science $\mathrm{n}$ s $8: 145-154$ (1898)

98b Cycad horizons in the Rocky Mountain region. Am J Sc (4) 6:197 (1898) Science n s $8: 153-154$ (1898) 
Marsh, Othniel Charles-Continued.

9Se The value of type specimens and importance of their preservation. Am J Sc (4) 6:401-405 (1898) G Mag (4) $5: 548-552$ (1898)

98d The origin of mammals. Am J Sc (4) $6: 406-409$ (1898) Science $n$ s 8 : $953-955$ (1898)

98e The comparative value of different kinds of fossils in determining geological age. G Mag (4) 5:565-568 (1898) Am J Sc (4) $6: 483-487$ (1898)

98f On the families of sauropodous Dinosauria (abst). Am J Sc (4) 6:487488 (1898) Brit As, Rp 68:909-910 (189e) G Mag (4) 6:157-158 (1899)

985 List of scientific publications of Othniel Charles Marsh... 1861-1897. 53 pp, n p (1882-98)

98h The vertebrate paleontology of the U. S. Geological Survey and National Museum. 12 pp [New Haven] 1898 [not seen ]

981 Vertebrate fossils collected for the U. S. Geological Survey, 1882-1892. 4 pp

[New Haven 1898] [not seen]

99 Footprints of Jurassic dinosaurs. Am J Sc (4) 7:227-232, il (1899)

$99 a$ Note on a Bridger Eocene carnivore. Am J Sc (4) $7: 397$ (1899)

99b The comparative value of different kinds of fossils in determining geological age. Brit As, Rp 68:869-872 (1899)

99e The origin of mammals. Int Cong Zool, 4th, Pr: 71-74 (185y) G Mag (4) 6:13-16 (1899)

99d The value of type specimens and importance of their preservation. Int Cong Zool, 4th, Pr: 158-162 (1899)

07 (with Hatcher, J. B.) The Ceratopsia. U S G S, Mon $49: 300 \mathrm{pp}$, il (1907)

See also Powell, 84, 85, 85a, 88, 89, 89a, 90, 91, 91a, 92, 93, 95

Marsha11, D. T.

92 Pyrite incrustations of the Cretaceous formations of Middlesex Co., N J. Science 19:151 (1892)

Marshall, J. R.

18 Gold-bearlng district of southeastern Manitoba. Can G S, Sum Rp 1917 pt D : 17-21 (1918)

18a Star Lake area, Manitoba, Can G S, Sum Rp 1917 pt D : 21-22 (1918)

Marshall, William B.

92 Report on a deposit of marl and peat in the town of New Baltimore [Greene Co., N. Y.]. N Y St Mus, An Rp 45:46-52 (1892)

Marsters, Vernon Freeman.

89 (with Kemp, J. F.) On certain camptonite dikes near Whitehall, Washington Co., N. Y. Am G 4:97-102 (1889) 90 Triassic traps of Nova Scotia... Am G $5: 140-145$ (1890)
Marsters, Vernon Freeman-Continued.

91 (with Kemp, J. F.) The trap dika in the Lake Champlain valley and th neighboring Adirondacks, N Y Ac Sc, Tr 11: 13-23 (1891)

93 (with Kemp, J. F.) The trap dike of the Lake Champlain region. $U$ S G \& B $107: 62 \mathrm{pp}$, map (1893)

94 (and Kindle, E. M.) Geologie literature of Indlana (stratigraphic and economic). Ind Ac Sc, Pr 1893:156-191 (1894)

95 Camptonite dikes near Danbs borough, Vt. Am G $15: 368-371$ (1895)

95a Camptonites and other intrusives of Lake Memphremagog [Canada]. Am G 16: 25-39 (1895)

02 Topography and geology of Bean Blossom Valley, Monroe Co., Ind. Ind $\mathrm{A}$ Sc, Pr 1901: 222-237 (1902)

04 A preliminary report on a portion of the serpentine belt of Lamoille and Orleans cos. Vt, St G, Rp 4:86-10. (1904)

05 Petrography of the amphibolite serpentine, and associated asbestos deposit of Belvidere Mountain, Vt. G Soc Am, 16: 419-446, maps (1905)

o5a The serpentine and associated asbestos minerals of Belvidere Mountain vt. (abst). Science n s 21:426 (1900 Am G 35:194-195 (1905) N Y Ac Sc, ts $17: 573-574$ (1907)

06 A preliminary report on a portion of the serpentine belt of Lamoille and Orleat: cos. Vt, St G, Rp $5: 35-61$ (1906)

Martel, E. A.

o5 Scientific exploration of caves. It Geog Cong, VIII, Rp : 165-172 (1905)

14 Explications sur Mammoth Cart 1912. Spelunca $9: 241-302$ (1914)

Martin, Al. H.

os A new copper district in Californits [Tehama Co.]. M World 28: 24 (1508)

osa Mining and smelting on Shasta per belt [Cal]. M World 29:309-311 (1908)

o9 San Francisco district, Ariz. World $31: 368$ (1909)

O9a The Alleghany mining district, $(a)$ M World 31:589-592 (1909)

$09 b$ Gold mining at Grass Valley, $\mathrm{Cl}$ M World 31:823-825 (1909)

10 The east side of the Shasta coppe belt [Cal.]. M World 32:99-100 (1910)

10a The Copper Creek mining distril Ariz. M World 32:515-516 (1910)

10b The Bannock mining district, Ner M World 32:835 (191.)

10c Nevada City gold mining distric Cal. M World 33:567-568 (1910) Science 63: 160-163 (1911)

10d Gem mining in California a prof able industry. M World $33: 1227-122$ (1910) 
Martin, Al. H.-Continued.

10e The Lander mining district, Nev. M Science $61: 508-511$ (1910)

Martin, Bruce.

12 Fauna from the type locality of the Monterey series in California. Cal Univ, Dp G, B $7: 143-150$ (1912)

13 Geological section of a portion of the coast ranges in the eastern part of San Luis Obispo Co., Cal. (abst). G Soc Am, B 24:93 (1913)

13a Faunal relations of the upper Neocene in the Sargent oil fields, Cal. (abst, फith discussion by A. C. Lawson, B. L. Clark, F. M. Anderson, and J. C. Merriam). G Soc Am, B 24: 129 (1913)

14 Descriptions of new species of fossil Mollusca from the later marine Neocene of California. Cal Univ, Dp G, B $8: 181-202$, il ( $(1914)$

14a (with Anderson, F. M.) Neocene record in the Temblor Basin, Cal., and Neocene deposits of the San Juan district, San Luis Obispo Co., Cal. Cal Ac Sc, Pr (4) 4:15-112, il, maps (1914)

16 The Pliocene of middle and northern California. Cal Univ, Dp G, B $9: 215-259$ (1916)

Martin, Daniel Strobel.

64 Minerals and the methods of studying them; a treatise for beginners prepared for the benefit of the Metropolitan Fair [descriptive catalogue, by R. W. Raymond: 12-19]. $19 \mathrm{pp}, \mathrm{N}$ Y 1864

71 On mica schist filled with minute crystals of kyanite and on crystalline limestone from New York City. Lyc N H N Y, Pr 1:222-223 (1871)

71 a The coal of Orange Co., N. Y. Lyc N H N Y, Pr 1: 259-260 (1871)

$71 b$ A clay containing recent shells from Lewes, Del. Lyc N H N Y, Pr 1: 289-290 (1871)

73 Primordial fossils from Troy, N. Y. Lyc N H N Y, Pr (2) [no 1] : 10-11 (1873)

$\mathbf{7 4}$ [Remarks on serpentines of the eastern United States.] Lyc N H N Y, Pr (2) no $3: 66-67$ (1874)

$\mathbf{7 4 a}$ [On the distribution of Mesozolc rocks in the middle Atlantic States and the Cretaceous of Long Island, N. Y.] Lyc N H N Y, Pr (2) no 4:126-127 (1874)

$74 \mathrm{~b}$ on the rhombic crystallization of graphite (abst). Lyc N H N Y, Pr (2) no 4:138, 145-146 (1874)

74e [On bones from the Miocene marl of Mathews Court House, Va.] Lyc N H $\mathrm{N} Y, \operatorname{Pr}(2)$ no $4: 139-140$ (1874)

75 Note upon the earthquake of December, 1874 [New York]. Am J Sc (3) 10: 191-194 (1875)

76 On the rocks of New York Island and their relation to the geology of the middle [Atlantic] States (abst). Liverpool G Soc, Pr 3: 118-120 (1876)
Martin, Daniel Strobel-Continued.

76a An account of the occurrence of Siiurian fossils in the drift of Long Island (abst). Am Nat 10:191 (1876)

82 A new eurypterid (Stylonurus excelsior) from the Catskill group. N Y Ac Sc, $\operatorname{Tr} 2: 8$ (1882)

85 The Trenton, N. J., gravels and their contained implements, as bearing on the antiquity of man (abst). N Y Ac Sc, Tr $3: 7-12$ (1885)

s5a [On the characters of the tide-water gneiss.] N Y Ac Sc, Tr 5:19-20 (1885)

87 The "field of rocks" [near Philadelphia, Pa.] N Y Ac Se, Tr $7: 16-18$ (1887)

88 Geological map of New York City and vicinity. Scale 1 mile to three fourths inch. N Y 1888

89 The origin of diagonal trends in the earth's crust, with application to the production of normal and reversed faults and the folding of strata. N Y Ac Sc, Tr 9: 15-20 (1889)

$89 a$ A note on the colored clays recently exposed in railroad cuttings near Morrisania, N. Y. N Y Ac Sc, Tr 9:46 (1889)

91 The international geological congress. Science 18:290-291 (1891)

98 Geological map of New York City and vicinity. $14 \mathrm{pp}$ [ $\mathrm{N}$ Y] 1898

99 Glacial geology in America. Pop Sc Mo $54: 356-361$ (1899)

$99 a$ Sketch of Thomas Egleston. Pop Sc Mo $55: 256-265$, port (1899)

00 Notes on the geology of central South Carolina (abst). Am As, Pr 49:189 (1900) Science n s 12:992 (1900)

ox Minerals found at Haddam, Me. (abst). N Y Ac Sc, An 13:501 (1901)

02 Geological notes on the neigbborhood of Buffalo [N. Y.] $(a b s t)$. N Y Ac Sc, An 14:162-163 (1902) Science n s 15: 107 (1902) Am G 29:125 (1902)

06 The mineralogical and geological cabinets of South Carolina College. S C Coll, B $4: 11-22$ (1906)

os A beryl from Haddam Neck, Conn. (abst). N Y Ac Sc, An 18:294-295 (1908)

12 [On schernikite and winchellite, two new varieties of minerals] (abst). N Y Ac Sc, An 21: 189-190 (1912)

15 A pecullar form of radiated tourmaline from Virginia (abst). N Y Ac Sc, An 24: 367-368 (1915)

See also Britton (N L), 82; Merrill (F J H), 90a

Martin, George Curtis.

$98 \mathrm{An}$ occurrence of dunite in western Massachusetts. Am J Sc (4) 6:244-248, map (1898)

o1 (with Clark, W. B.) The Eocene deposits of Maryland. Md G S, Eocene : 21-92, map (1901)

02 The geology of Garrett County; the mineral resources of Garrett County. Md G S, Garrett Co : 55-182, 183-231 (1902) 
Martin, George Curtis-Continued,

02a (with Clark, W. B.) Correlation of the Coal Measures of Maryland. G Soc Am, B 13:215-232, map (1902) Abst, Science n $\mathrm{s}$ 15: 84 (1902)

02b (with Clark, W. B.) The correlation of the Coal Measures in Maryland (abst). Science n 8 15:905-906 (1902)

04 Petroleum fields of Alaska and the Bering River ceal fields. U S G S, B 225 : 365-382. (1904)

04a [The oil fields of Alaska (abst).] Science n s 19:733 (1904)

05 Geology of the Maryland coal district. Md G S 5: 241-290 (1905)

05a The petroleum fields of the Pacific coast of Alaska, with an account of the Bering River coal deposits. U S G S, B $250: 64 \mathrm{pp}$, maps (1905)

o5b The Cape Yaktag placers [Alaska]. U S G S, B 259: 88-89 (1905)

o5e Gold deposits of the Shumagin Islands [Alaska]. U S G S, B 259:100101 (1905)

o5d Notes on the petroleum fields of Alaska. U S G S, B 259:128-139 (1905)

o5. Bering River coal field. U S G S, B $259: 140-150$ (1905)

o5f Water resources of the Accident and Grantsville quadrangles, Md. U S G S, W-S P 110: 168-170 (1905)

osg Water resources of the Frostburg and Flintstone quadrangles, $\mathrm{Md}$. and W. Va. U S G S, W-S P 110: 171-173 (1905)

osh (with Clark, W. B.) Correlation of the formations and members [of the Coal Measures of Maryland]. Md G S 5: 291-315, map (1905)

05i (with Clark, W. B., and Rutledge, J. J.) Distribution and character of Maryland coal beds. Md G S 5:317-512, maps (1905)

05j (with Stanton, T. W.) Mesozoic section on Cook Inlet and Alaska Peninsula. G Soc Am, B 16:391-410, map (1905)

osk (with Stose, G. W.) Water resources of the Pawpaw and Hancock quadrangles, W. Va., Md., and $\mathrm{Pa}$. U S G S, W-S P 145: 58-63 (1905)

06 Distribution and character of the Bering River coal. U S G S, B 284: 65-77 (1906)

O6a Preliminary statement of the Matanuska coal field. U S G S, B 284: 88-100 (1906)

06b A reconnaissance of the Matanuska coal field, Alaska, in 1905 U S G S, B $289: 36$ pp, map (1906)

o7 The Alaska coal fields. U S G S, B 314 : 40-46 (1907)

o7a Petroleum at Controller Bay [Alaska]. U S G S, B 314: 89-103 (1907)

os Geology and mineral resources of the Controller Bay region, Alaska. U S G S, B $335: 141$ pp, map (1908)
Martin, George Curtis-Continued.

08a Description of the Accident ad Grantsville quadrangles, Md.-Pa.-W. $T_{2}$ U S G S, G Atlas, Accident-Grantsville fol (no 160) : 14 pp, maps (1908)

09 The Niobrara limestone of northen Colorado as a possible source of Portlad cement material. U S G S, B 380:314 326 (1909)

10 Coal of the Denver Basin, Col. Os G S, B 381: 297-306 (1910)

10a (and Katz, F. J.) Outline of the geology and mineral resources of the $I l$. amna and Clark lakes region. U S G \& B 442:179-200, map (1910)

11 Preliminary report on a detailed sut vey of part of the Matanuska coal fields U S G S, B 480: 128-138, maps (1911)

12 Mesozoic stratigraphy of Alash (abst). G Soc Am, B 23: 724-725 (1912)

12a (and Katz, F. J.) A geologit reconnaissance of the Iliamna region, Alaska. U S G S, B 485: 138 pp, mas (1912) Abst, Wash Ac Sc, J 2:224-225 (1912)

12b (and Katz, F. J.) Geology and coal fields of the lower Matanuska Valler. Alaska. U S G S, B 500:98 pp, maps (1912) Abst, Wash Ac Sc, J $2: 225-228$ (1912)

13 Mineral deposits of Kodiak and the neighboring islands [Alaska]. U S G 8 B 542:125-136, map (1913)

13a The recent eruption of Katmal Fol cano in Alaska; an account of one of th: most tremendous volcanic explosions knom in history. Nat Geog Mag 24:131-181, map (1913)

14 (and Mertie, J. B., jr.) Minerl resources of the upper Matanuska as Nelchina valleys [Alaska]. U S G S, $592: 273-299$, map (1914)

15 (and Johnson, B. L., and Grant U. S.) Geology and mineral resources of Kenai Peninsula, Alaska. U S G S, B $587: 243$ pp, maps (1915)

16 Triassic rocks of Alaska. G Soc As B $27: 119$ (abst), 685-718, il (1916)

18 Gold, silver, copper, and lead it Alaska in 1917 ; mines report. U S G \& Min Res 1917 pt $1: 131-145$ (1918)

See also Clark (W B), 01a, 04a, 050i Taylor (F B), 16

Martin, H. T.

o7 Some new features in Uintacrine Kans Univ Sc B $4: 193-196$, fl (1907)

13 On a comparison of three skults: Castoroides ohioensis, Castoroides kansenth and Vastor. Kans Univ Sc B 6:389-39\% 11 (1912) [1913]

$13 \mathbf{a}$ Notice of a new fish from the Per mian of Kansas, with description. Kat Univ Sc B $7: 185-186$ (1913)

Martin, J. $O$.

o1 The Ontario coast between Fairhare and Sodus bays, N. Y. Am G 27:331-33t, map (1901) 
Martin, James C.

16 The pre-Cambrian rocks of the Canton quadrangle [N. Y.]. N Y St Mus, B $185: 112$ pp, maps (1916)

\section{Martin, $\mathrm{K}$.}

88 Geologische Studien über Niederländisch West-Indien... $237 \mathrm{pp}$, il, maps, Leiden 1888 Also issued as Zweiter Theil of Bericht über eine Reise nach niederländisch West Indien... Leiden 1888

\section{Martin, Lawrence.}

05 (with Tarr, R. S.) Recent change of level in Alaska. Science n s 22:879880 (1905)

06 Observations along the front of the Rocky Mountains in Montana (abst). Amr Geog Soc, B 38: 98-99 (1906)

06a (with Tarr, R. S.) Recent changes of level in the Yakutat Bay region, Alaska. G Soc Am, B 17:29-64 (1906)

07 Possible oblique minor faulting in Alaska. Ec G 2:576-579 (1907)

07a (with Phalen, W. C.) Clays and shales of southwestern Cambria Co., Pa. U S \& S, B 315:344-354 (1907)

09 The relation of geology to topography. Am Geog Soc, B 41:138-142 (1909)

09a The Malaspina glacier region of Alaska. J G 17:664-666 (1909)

09b (with Mead, W. J.) Apparatus for topographic field work on models in the laboratory. J Geog 7:209-211 (1909)

10 The study of glaciers in Alaska in 1909. Zs Gletscherk 4:142-146 (1910)

10n The Hubbard Glacier, Alaska. Pop Sc Mo 76:293-305 (1910)

10b Alaskan earthquakes of 1899. G Soc Am, B 21: 339-406 (1910) Abst, Science n s $32: 189$ (1910)

10e (with Tarr, R. S.) Oscillations of Alaskan glaciers (abst). Science n s 32: 185-186 (1910) G Soc Am, B 21:758759 (1910)

10d (with Tarr, R. S.) The National Geographic Society's Alaskan expedition of 1909. Nat Geog Mag 21:1-54 (1910)

11 Physical geography of the Lake Superior region. U S G S, Mon 52: 85-117 (1911)

11 a The Pleistocene [geology of the Lake Superior region]. U S G S, Mon 52 : $427-459$ (1911)

$11 b$ The National Geographic Society researches in Alaska. Nat Geog Mag 22: 537-561 (1911)

11e Two glaciers in Alaska (abst). G Soc Am, B 22:731 (1911)

$11 d$ (with Phalen, w. C.) Mineral resources of Johnstown, Pa., and vicinity. U S G S, B $447: 142$ pp (1911)

12 Gletscheruntersuchungen längs der Küste von Alaska. Petermanns Mitt 58, II : 78-81, map (1912)
Martin, Lawrence-Continued.

$12 a$ (with Tarr, R. S.) Glaclal deposits of the continental type in Alaska (abst). Science n s $35: 313$ (1912) G Soc Am, B 23: 729-730 (1912)

12b (with Tarr, R. S.) She earthquakes at Yakutat Bay, Alaska, in September, 1899. U S G S, P P 69: $135 \mathrm{pp}$ (1912) (Abst), Wash Ac Sc, J $2: 421-$ 422 (1912)

13 Juneau-Yakutat section. Int G Cong, XII, Canada, Guide Book no 10:121-162, maps (1913)

13a Memoir of Christopher Webber Hall [1845-1911]. As Am Geog, An 2 : 101-104 [1913]

13b Mount Mazama and Crater Lake. J Geog 11: 322-324 (1913)

13e Glacier National Park. J Geog 11: 324-326 (1913)

13d Un chemin de fer sur glacier dans l'Alaska. La Nature, Paris, 41:404-407 (1913)

13e Some feaures ce glaciers and glaciation in the College Fiord, Prince Wflliam Sound, Alaska. Zs Gletscherk $7: 289-333$, maps (1913)

$13 f$ Alaskan glaciers in relation to life. Am Geog Soc, B 45: 801-818, map (1913)

$13 \mathrm{~g}$ Canyon and delta of the Copper River in Alaska (abst). G Soc Am, B 24 : 699 (1913)

13h (and Williams, F. E., and Bean, E. F.) A manual of physical geography excursions. $207 \mathrm{pp}$ (some blank), Madison, Wis., 1913

$13 i$ Glaciers and international boundaries. Se Am Sup $76: 129,136-138$ (1913)

14 The physical geography of Wisconsin. J Geog 12 226-232 (1914)

14a Submarine topography in Glacier Bay, Alaska (abst). G Soc Am, B 25:8889 (1914)

14b (with Tarr, R. S.) College physiography. $837 \mathrm{pp}$, New York 1914

14e (with Tarr, R. S.) Alaskan glacier studies of the National Geographic Society in the Yakutat Bay, Prince William Sound and lower Copper River regions. xi, $498 \mathrm{pp}$, maps, Washington, The $\mathrm{Na}$ tional Geographic Society, 1916

15 The filling of fiords in Alaska (abst). As Am Geog, An 3:112-113 [1915]

15a Ralph Stockman Tarr. Zs Gletscherk 9:139-144 (1915)

15b Glaciers of southeastern Alaska. Zs Gletscherk 9:157 (1915)

15e The age of Niagara Falls. Zs Gletscherk $9: 157-158$ (1915)

16 The physical geography of Wisconsin. Wis G S, B $36: 549 \mathrm{pp}$, maps (1916)

16a The gorge of the upper Mississippi as a rival of the Rhine gorge. Geog Soc Phila, B 14:127-147 (1916)

17 Rock terraces in the Driftless Area of Wisconsin (abst). G Soc Am, B 28: 148-149 (1917) 
Martin, Lawrence-Continued.

18 Gravel terraces of the Mississippi River in Wisconsin (abst). As Am Geog, An $7: 79$ [1918]

Martinez Baca, Eduardo.

87 Informe sobre los placeres auriferos de Calamaht, Baja California. México, Ministerio de Fomento, An $8: 286-327$ (1887)

91 Informe sobre los criaderos de carbón de Piedras Negras, Estado de Coahuila. Bol Agr Min é Ind 1 no $4: 93-112$ (1891)

92 Informe sobre los criaderos metalrferos...en el distrito de Villa Aldama, Estado de Nuevo Léon. Bol Agr, Min é Ind 1 no $7: 117-130$ (1892)

Martins, Ch.

47 Du transport de certains blocs erratiques de la Scandinavie et de l'Amérique septentrionale par des glaces flottantes, consideré comme conséquence de l'ancienne extension des glaclers et des changements de niveau de ces contrées... Soc G France, B (2) $4: 1113-1123$ (1847)

Martonne, Emmanuel de.

13 Le pare national du Yellowstone; étude morphologique. An Géog 22:134148 (1913)

15 Le parc national du Yellowstone; esquisse morphologique. Am Geog Soc, Memorial Volume of Transcontinental Excursion of $1912: 231-250$ (1915)

Martyn, William.

85 Pyrites. U S G S, Min Res 1883-4: 877-905 (1885)

Marvin, Charles Frederick.

05 Earthquakes recently recorded at the Weather Bureau. U S Dp Agr, Mo Weather Rv 33: 308-309 (1905)

06 The record of the great [San Francisco] earthquake written in Washington by the seismograph of the U. S. Weather Bureau. Nat Geog Mag $17: 296-298$ (1906)

06a Improvements in seismographs with mechanical registration. U S Dp Agr, Mo Weather Rv 34: 212-217 (1906)

07 The Kingston earthquake. Mo Weather Rv 35: 5-6 (1907)

$07 \mathbf{a}$ The Mexican earthquake of April 15, 1907 , with notes on the nature of movements induced by earthquakes. Mo Weather Rv $35: 157-159$ (1907)

os A design for a universal seismograph with duplex recorders for horizontal motion (abst). Science n s 27:723-724 (1908)

Marvine, Archibald Robertson (18481876).

71 Notes on reported mineral deposits lying between Santo Domingo City and Azua, etc. [Santo Domingo]. U S, 42d Cong 1st sess, S Ex Doc 9:105-111 (1871)

73 Correlation of the rocks of Houghton and Keweenaw cos. Mich G S, 1 pt 2: 47-61 (1873)
Marvine, Archibald Robertson-Continued

73a General structure and lithology of the Eagle River section; descriptive cross section of the Eagle River district, Mich G S, 1 pt 2: $95-140$ (1873)

74 Report [on Middle Park region, Colo.]. U S G Geog S Terr (Hayden), An Rp [7]: 83-192, maps (1874)

74a Gold HIll mining region, its postion and general geology. U S G Geog S Tert (Hayden), An Rp [7] : 685-687 (1874) An J Sc (3) $8: 29-33$ (1874)

75 Report on the geology of route from St. George, Utah, to Gila River, Ariz. U 8 Geog G S W 100th Mer (Wheeler), 3:189225 (1875)

Marx, Carl Michael.

26 Untersuchung eines einaxigen Glimmers aus Nord Amerika. Zs Miner (Leon. hard) 1826 , II : $405-410$

Marx, $R$.

68 Beitrag zur Kènntniss centralamerf. canischer Laven. Diss, Göttingen. $27 \mathrm{pP}$, Berlin 1868

\section{Maryland, Censervation Commis.}

sion.

o9 Mineral resources [of Maryland]. Md, Conservation Comm, Rp 1908-09:2572 (1909)

\section{Maryland Geological Survey.}

o7 [Geological] map of Maryland, pre pared by Maryland Geological Survey, Wm. Bullock Clark, State Geologist, 1907 Scale $1: 187,500$.

11 Report of the State Geological and Economic Survey Commission for 1910 and 1911. $16 \mathrm{pp}$, Baltimore 1911

12 Guide to the State mineral exhibit illustrating the mineral resources and is. dustries, geology, and modern methods of road construction installed by the Marf. land Geological Survey in the 0ld Fall of Delegates at Annapolis, Md. $61 \mathrm{pp}$, Baltimore 1912

\section{Mason, F. H.}

O1 Potters clay at Middle Musquodobolt [N. S.] Can M Rv 20:175-176 (1901) M Soc N S, J 6:88-93 (1902)

\section{Mason, $O$.}

25 Notice of a rocking stone [Rhode Island]. Am J Sc 10:9-10 (1825)

Mason, S. C.

83 A prellminary list of fossils found in Riley Co. [Kans.]. Kans Ac Sc, Tr 8: 12-13 (1883)

Mason, William D. H.

78 On the batrachian foot tracks frot the Ellengowan shaft, in Schuylkill $\mathrm{Co}$ $\mathrm{Pa} . \quad \mathrm{Am} \mathrm{Ph}$ Soc, $\mathrm{Pr} 17: 716-719,723$ (1878)

\section{Massachusetts, House of Repre-} sentatives.

37 Report, etc., relating to the geolog. cal survey of the State. House [doc] Do $26: 16 \mathrm{pp}$ [Boston] 1837 
Massachusetts, State Board of Gdueation.

74 Report on the proposed survey of the Commonwealth. 19 pp, Boston 1874

75 Report of the special committee on the proposed scientific survey of the Commonwealth. $63 \mathrm{pp}$, Boston 1875

\section{Matamoros, Luis.}

os Discussion of paper by J. H. Harper, The San Francisco earthquake of April 18, 1906. As Eng Soc, J $40: 318-319$ (1908) Mather, Kirtley Fletcher.

09 The age of the Licking Narrows at Black Hand, Ohio. Denison Univ, Sc Lab, B 14:175-187 (1909)

12 (with Atwood, W. W.) The evidence of three distinct glacial epochs in the Pleistocene history of the San Juan Mountains, Colo. J G 20:385-409 (1912)

15 The fauna of the Morrow group of Arkansas and Oklahoma. Denison Univ, Sc Lab, B 18: 59-284, il (1915)

15a (with Atwood, W. W.) The grand canyon of the Gunnison River (abst). As Am Geog, An 5:138-139 (1915)

16 Notes on Canadian stratigraphy and paleontology. Science n s 43:607-611; 44:645-649 (1916)

16a (with Wilson, A. E.) Synopsis of the common fossils of the Kingston area [Ont.]. Ont Bur Mines, An Rp 25 pt $3: 45-62$ (1916)

16b (with Atrvood, W. W.) Geographic history of the San Juan Mountains since the close of the Mesozoic era (abst). G Soc Am, B $27: 38-39$ (1916)

17 Pottsville formations and faunas of Arkansas and Oklahoma. Am J Sc (4) 43: 133-139 (1917)

17a The Champlain sea in the Lake Ontario basin. J G $25: 542-554$ (1917)

$17 \mathbf{b}$ The Trenton fauna of Wolfe Island, Ont. Ottawa Nat $31: 33-40$ (1917)

17e Notes on Canadian stratigraphy and paleontology. Science n 8 46:66-70 (1917)

18 Superficial dip of marine limestone strata; a factor in petroleum geology. Ec G $13: 198-206$ (1918) Abst, Science n s $47: 470$ (1918)

18a Diminution of the Antartic ice cap and the amelioration of climate. Science n s $47: 218-219$ (1918)

18b Parables from påleontology. Atlantic Mo 122: 35-43 (1918)

18e (with Heald, K. C.) Structure and oil and gas resources of the Osage Reservation, Oklahoma; Tps. 24 and $25 \mathrm{~N}$., R. 8 E. U S G S, B 686:149-170, maps (1918)

$18 d$ (with Lloyd, E. R.) Structure and ofl and gas resources of the Osage Reservation, Okla.; T. 20 N., R. 11 E. U S G S, B 686:119-127, map (1918)
Mather, William Williams (1804-1859).

30 On xanthite and its crystalline form, with a notice of mineral localities. Am J Sc 18: 359-361 (1830)

31 Geological notices; section in Connecticut: Highlands of New York. Am J Sc 21: 94-99 (1831)

33 Elements of geology... 139 pp, Nortich, [Conn.] 1833 4th ed, 286 pp, N Y 1841

$33 a$ Geological map [of New London and Windham counties, Conn.]. Am J Sc $23: 404$ (1833)

33b ...notice of some of the principal silver mines of Mexico and South America. Am J Sc $24: 213-237$ (1833)

34 Sketch of the geology and mineralogy of New London and Windham counties in Connecticut. $36 \mathrm{pp}$, map, Norwich 1834

$34 a$ [Discovery of fossil fishes in the Connecticut Valley.] N Jb 1834:531-532

37 First annual report of the first geological district of New York. N Y G S, An Rp 1:61-95 (1837)

$37 a$ (and Conrad, T. A.) Queries proposed by the geologists of the new survey of the State of New York. Am J Sc $33: 124-133$ (1837)

38 (and others) First annual report on the geological survey of the State of Ohio. $134 \mathrm{pp}$, Columbia 1838

38a (and others) Second annual report on the geological survey of the State of Ohio. $286 \mathrm{pp}$, map. Columbus 1838

38b Geological queries. Ohio G S, 1st An Rp: 111-121 (1838) Reprinted with title, A series of geological queries contained in the first annual report on the geological survey of Ohio. $38 \mathrm{pp}$, Columbus 1838

38c Report of the first geological district of the State of New York. N Y G S, An Rp 2:121-184 (1838)

$38 d$ [On bones and teeth of Elephas jacksoni found in Ohio and on the term Waverly]. Am J Sc $34: 362-364$, il (1838)

39 Report on the geological reconnaissance of Kentucky made in $1838.40 \mathrm{pp}$ [Frankfort 1839] Ky, House of Representatives, J 1838-9, App : 239-278 [1839]

39a Third annual report of the first geological district of the State of New York. N Y G S, An Rp 3:67-134 (1839)

40 Fourth annual report of the first geological district of the State of New York. N Y G S, An Rp 4: 209-258 (1840)

41 Letter ... relative to the geological survey of the State [of New York]. N Y G S, An Rp $5: 59-61$ (1841)

41a Fifth annual report on the geological survey of the first geological district of New York. N Y G S, An Rp 5: 63-112 (1841)

41b [On joints in rocks] (abst). Am J Sc $41: 172$ (1841) As Am G, Rp : 24-25 (1843) 
Mather, William Williams-Continued.

41e (and others) [On boulders and diluvial scratches]. Am J Se 41:174-176 (1841) As Am G, Rp: 26-29 (1843)

42 Catalogue of the geological specimens collected on the late survey of the State of Ohio. $7 \mathrm{pp}, 11$ tables [Columbus ? 1842]

43 Geology of New York. Part I, comprising the geology of the first geological district. $653 \mathrm{pp}, \mathrm{il}$, map, Albany, 1843. In part (extracts relating to Putnam Co.) in Blake, William J., The history of Putnam County, N. Y...: 23-77, N Y 1849

44 On the origin of the sedimentary rocks of the United States and on the causes that have led to their elevation above the level of the sea (abst). Am J Sc $47: 95-98$ (1844)

45 On the physical geology of the United States east of the Rocky Mountains and on somre of the causes affecting the sedimentary formations of the earth, Am J Sc $49: 1-20,284-301$ (1845)

53 On the alleged great coal bed of Perry Co. [Ohje]. Am J Sc (2) $15: 450$ (1853)

59 Report on the Statehouse artesian well at Columbus, Ohio. $41 \mathrm{pp}$, Columbus 1859

Mathews, Alfred E.

74 Geological chart of the world with special reference to North America. $30 \times 48$ Inches, 1874

Mathews, Edward Bennett.

95 The granites of Pikes Peak, Colo. G Soc Am, B 6:471-473 (1895)

95a Notes on some flattened garnets from North Carolina. Johns Hopkins Univ Circ 15:8 (1895)

97 Bibliography and cartography of Maryland, including publications relating to the physiography, geology, and mineral resources. Md G S 1:229-401 (1897)

98 An account of the character and distribution of Maryland building stones... Md G S 2: 125-241, maps (1898)

98a The maps and map-makers of Maryland. Md G S 2:337-488, maps (1898)

98b The first geological excursion along the Chesapeake in 1608. Johns Hopkins Univ Cire 18:14-15 (1898)

00 The granitic rocks of the Pike's Peak quadrangle [Colo.]. J G $8: 214-240$ (1900)

O0a A simple modeling machine (abst). Am As, Pr 49:191-192 (1900) Science n s 12:994-995 (1900)

02 The mineral resources of Cecil Co. Md G S, Cecil Co : 195-226 (1902)

$02 a$ Recent work in the Piedmont area of northern Maryland (abst). Science $\mathrm{n} \mathrm{s}$ $15: 906$ (1902)

o3 Quantitative classification of igneous rocks (abst). Am G 31:399-40? (1903)
Mathews, Edward Bennett-Continued.

03a The practical working of the quantitative classification $(a b s t)$. Sclence n 8 $17: 668-669$ (1903)

04 The structure of the Piedmont $\mathrm{Pla}$ teau as shown in Maryland. Am J Sc (4) $17: 141-159,249$, map (1904)

o5 Correlation of Maryland and Pent. sylvania Piedmont formations. G Soc Am, B $16: 329-346$, map (1905)

O5a (and Miller, W. J.) Cockeysville marble [Maryland], G Soc Am, B 16: $347-366$, map (1905)

06 (with Clark, W. B.) Report on the physical features of Maryland. Md G 8 , Spec Pub 6, pts 1, 2: 284 pp (1906)

or Anticlinal domes in the Piedmont of Maryland. Johns Hopkins Univ Cire n s $1907: 615-622$, map

09 (and Grasty, J. S.) Report on the limestones of Maryland, with special refer. ence to their use in the manufacture of lime and cement. Md G S 8:225-477 (1909)

O9a (and Grasty, J. S.) The character and structural relations of the limestones of the Piedmont in Maryland and Virginia (abst). Science n s 29:634-635 (1909) G Soe Am, B 20:678 (1910)

O9b (with Clark, W. B.) Maryland mineral industries, 1896-1907. Md G S 8: 97-223 (1909)

11 Relation of scientific to practical work in State surveys. Ec G $6: 181-187$ (1911)

13 (and Reed, G. E.) Bibliography of the department of geology of the Johns Hopkins University, 1883-1913. Johns Hopkins Univ Circ 1913 no $10: 143$ pp

17 Submerged "deeps" in the Susquehanna River. G Soc Am, B 28:335-346, 151 (abst) (1917)

17a The use of average analyses in defining igneous rocks. Johns Hopkins Unir Circ n s 1917 no $3: 12-17$ [210-215] (1917)

17b (with Miller, B. L., and others) Description of the Tolchester quadrangle, Md. U S G S, G Atlas Tolchester fol (no 204) : 15 pp, maps (1917)

18 Wm. Bullock Clark, Ph. D., LL. D., State geologist, 1896-1917. Md G S 10: $31-37$, port (1918)

18n (with Clark, W. B., and Berry, E. W.) The surface and underground water resources of Maryland, including Delaware and the District of Columbia. Md G S $10: 169-542$ (1918)

Mathey, C. C.

os Platte River geology [Wisconsin]. M World 28:875 (1908)

Mathez, Auguste.

03 Geology of the Cananeas [State of Sonora, Mex.]. M Sc Press $86: 352-353$ (1903)

09 Rye Valley gold mines, Oreg. M Sc Press $99: 687$ (1909) 
Matson, George Charlton.

04 A contribution to the study of the interglacial gorge problem [New York]. J G 12 : 133-151, map (1904)

05 Peridotite dikes near Ithaca, N. Y. J G 13:264-275 (1905)

09 Water resources of the Blue Grass region, Kentucky; with a chapter on the quality of the waters, by Chase Palmer. U S G S, W-S P 233 : 223 pp, map (1909)

09 a Notes on the clays of Florida. U S

G S, B $380: 346-357$ (1909)

09b (and Clapp, F. G.) A preliminary report on the geology of Florida with special reference to the stratigraphy. Fla G S, An Rp 2: 25-173, map (1909)

10 Report on examination of material from the sea bottom between Miami and Key West, Florida. Carnegie Inst Wash, Pub no 133, Papers from the Tortugas Laboratory 4:120-125 (1910)

11 Pollution of underground waters in limestone. U S G S, W-S P 258:48-56 (1911)

11a Mineral waters. U S G S, Min Res 1910 pt 2: 921-958 ; 1911 pt $2: 1137$ $1174 ; 1912$ pt $2: 1093-1131$ (1911-3)

13 Notes on the clays of Delaware. U S G S, B 530: 185-201 (1913)

13a (and Sanford, Samuel) Geology and ground waters of Forida. U S G S, W-S P 319:445 pp, map (1913) Abst, Wash Ac Sc, J 4:458-459 (1914)

15 The phosphate deposits of Florida. U S G S, B 604: 101 pp, maps (1915) Abst, by W. C. Phalen, Wash Ac Sc, J 5 : 648 (1915)

16 The Pliocene Citronelle formation of the Gulf Coastal Plain. U S G S, P P 98: 167-192 (1916) Abst, Wash Ac Sc, J 6 : 668 (1916)

16a The Catahoula sandstone. U S G S, P P 98: 209-226, map (1916) Abst, Wash Ac Sc, J 6:664 (1916)

16b The Caddo oil and gas field, La. and Tex. U S G S, B 619:62 pp, map (1916)

16e Gas prospects south and southeast of Dallas [Tex.]. U S G S, B 629:77119 , map (1916)

17 Louisiana clays; including results of tests made in the laboratory of the Bureau of Standards at Pittsburgh. U S G S, B $660: 147-158$, map (1917) Abst, by R. W. Stone, Wash Ac Sc, J 8:205 (1918)

17a (and Hopkins, O. B.) The De Soto-Red River oil and gas field, La. U S G S, B 661: 101-140, map (1917) Abst, by $\mathrm{R}$, W. Stone, Wash Ac Sc, J $8: 35-36$ (1918)

17b (and Hopkins, O. B.) The Corsicana oil and gas field, Texas. U $\$$ G S, B 661 : 211-252, maps (1917) Abst, by R. W. Stone, Wash Ac Sc, J 8: 36-37 (1918)

Mattair, L. H.

07 New silver district in the Temagami reserve [Ort.] Eng M J 83:1144 (1907)
Mattei, A. C.

17 Two Santa Barbara Channel earthquakes. Seism Soc Am, B 7:61-66 (1917)

Matteson, W. G.

11 Common features of silver districts; with special reference to the geological features of the silver-producing areas of Colorado. Mines and Minerals $32: 296-298$ (1911)

12 Geologic structure of silver districts. Mines and Minerals $32: 358-360$ (1912)

12a Minerals common to silver deposits. Mines and Minerals $32: 438-440$ (1912)

12b Genesis of silver deposits. Mines and Minerals 32:504-506 (1912)

17 The need and advantages of a national bureau of well-log statistics. Am I M Eng, B 122: $287-290$; $124: 635-640$; $125: 833-834 ; 126: 986-987$ (1917) ; $\mathrm{Tr}$ $56: 881-891$ (1917)

17a The practical value of oil and gas bureaus (with discussion). Am I M Eng, B 126:979-981; $130: 1857-1862$ (1917); $\operatorname{Tr} 57: 1010-1012$ (1918)

18 Principles and problems of oil prospecting in the Gulf coast country. Am I M Eng, Tr 59:435-469 (with discussion by A. F. Lucas, G. S. Rogers, E. W. Shaw, Eugene Coste, Kirby Thomas, William Kennedy, C. W. Washburne, and the author): $469-491,704-705)$ (1918) ; B 134:429468, and discussion $136: 823-835 ; 139$ : $1145-1146 ; 140$ : 1163-1164 (1918)

18n Age of the oil in soutbern Oklahoma flelds (discussion). Am I M Eng, B $136: 842$ (1918)

See also Powers, $17 \mathrm{~b}$

Matthes, François fomile.

oo Glacial sculpture of the Big Horn Mountains, Wyo. U S G S, An Rp 21 pt $2: 167-190$, map (1900)

O0a Glacial sculpture in the Big Horn Mountains (abst). Science n $\mathrm{s}$ 11:507 (1900)

02 Glacial erosion in the northern Rockies (abst). Science n s 15:507 (1902)

04 The Alps of Montana. Appalachia $10: 255-276$, map (1904)

O4a The significance of $U$-shaped glaeier and stream channels (abst). Science n s 19:856-857 (1904)

05 The Lewis Range of northern Montana and its glaciers $(a b s t)$. Int Geog Cong, VIII, Rp : 478-479 (1905)

07 The new map of the Yosemite Valley (abst). Science n s 26:146-148 (1907)

os The mapping of land forms (abst). Science n s 27:893-894 (1908)

O8a (with Johnson, D. W.) The relation of geology to topography. In Principles and practice of surveying, by Charles B. Breed and George L. Hosmer, $v$ 2:246266 , N Y 1908

09 The glacial character of Yosemite Valley $(a b s t)$. Science n s 29:240, 754 (1909) 
Matthes, François Emile-Continued.

09a Débris tracks on the domes of the Yosemite region (abst). Science n s 30 : 61-62 (1909)

10 The half dome of the Yosemite Valley (abst). Science n s 31:519 (1910)

10a The cliff sculpture of the Yosemite Valley $(a b s t)$. Science n s $32: 186$ (1910) (with discussion) G Soc Am, B 21:759760 (1910)

10b Little studies in the Yosumite Valley; 1, The extinct Eagle Peak Falls; 2, The striped rock floor of the Little Yosemite Valley ; 3, The winds of the Yosemite Valley ; 4, El Capitan moraine and ancient Lake Yosemite. Sierra Club B $7: 222-224$ (1910); $8: 3-9,89-95$ (1911); $9: 7-15$ (1913)

11 Lessons of the Little Yosemite Valley (abst). G Soc Am, B 22:730-731 (1911)

12 Sketch of Yosemite National Park and an account of the origin of the $\mathrm{Yo}_{\mathrm{O}}$ semite and Hetch Hetchy valleys. $47 \mathrm{pp}$, U S Dp Interior, Office of the Secretary, Washington 1912

12a Undescribed glaciers of Mt. Rainier (abst). Wash Ac Sc, J 2: 297-298 (1912)

13 Level of maximum precipitation as a factor in the glaciation of Mount Rainier (abst). G Soc Am, B 24:701-702 (1913)

13a The glaciers of Mount Rainier. Appalachia $13: 24-27$ (1913)

14 Mount Rainier and its glaciers, Mount Rainier National Park. U S Dp Interior, $48 \mathrm{pp}$ (1914)

14a Studying the Yosemite problem. Sierra Club B 9:136-147 (1914)

14b The glaciers of Mount Rainier [Wash.]. Am Forestry 20:646-667 (1914)

14e Concave exfoliation (abst). Wash Ac Sc, J $4: 295$ (1914)

14d Moraine Dome and the moraines of the Little Yosemite Valley (abst). Wash Ac Sc, J $4: 295-296$ (1914)

15 Is the delineation of land forms capable of being rationalized? (abst). As Am Geog, An 3:115 [1915]

15a The conference on the delineation of physiographic provinces in the United States. As Am Geog, An 4:127-129 [1915]

15b Studies on glacial cirques in the Sierra Nevada (abst and discussion). Wash Ac Sc, J 5 : 254-256 (1915)

16 Tertiary-Quaternary orogenic history of the Sierra Nevada in the light of recent studies in the Yosemite region (abst). G Soc Am, B $27: 46-47$ (1916)

$16 a$ The Mount Rainier National Park. [Text on back of topographic map], WashIngton, Mt. Rainier National Park, U S G S, 1916

17 The post-Pleistocene moraines of the Sierra Nevada (abst). As Am Geog, An 6 : 128-129 [1917]
Matthes, François Émile-Continued.

18 The country around Camp McClellan. [Text on back of topographic map], Ala bama, Anniston quadrangle, Camp $\mathrm{M}_{6}$ Clellan, U \& G S, 1918

18a The country around Camp Gordos [near Atlanta, Ga.]. [Text on back o? topographic map], Georgia, Camp Gordon and vicinity, U S G S, 1918

Mntthew, George Frederick.

63 Observations on the geology of st. John Co., N. B. (with note by J. W. Daw. son). Can Nat 8:241-259, map (1863)

65 Cupriferous rocks of southeastern New Brunswick. In Bailey, L. W., 0bservations on the geology of southern New Brunswick : $149-151$, Frederickton 1865

65a Notes on the geology of Chariotte County. In Balley, L. W., Observations on the geology of southern New Brunswick: 153-157, Frederickton 1865

65b Dunsinane coal. In Bailey, L. $\mathbb{W}_{4}$ Observations on the geology of southern New Brunswick: 157-158, Frederickton 1865

65e On the Azoic and Paleozoic rocks o? southern New Brunswick. G Soc London, Q J 21:422-434, map (1865) Abst, Can Nat n s $3: 387-391$ (1868)

70 (and Bailey, L. W.) Remarks on the age and relations of the metamorphic rocks of New Brunswick and Maine. Am As, Pr 18: 179-195 (1870) Abst, Am Nat $3: 442-444$ (1869); Can Nat n s $4: 326$ 328 (1869)

72 On the surface geology of Nerf Brunswick. Can Nat n s 6:89-107 (1872) ; $7: 433-454$ (1875)

72a (with Bailey, L. W.) Preliminary report on the geology of southern New Brunswick. Can G S, Rp Prog 1870-1:13240 (1872)

73 Impressions of Cuba. Can Nat n 8 $7: 19-34,75-85$ (1873)

73a (with Bailey, L. W.) Report of observations on the Carboniferous system of New Brunswick, in the counties of Queens, Sunbury, and a portion of York. Can G S, Rp Prog 1872-3: 180-230 (1873)

74 Note sur les mollusques de la forms. tion post-Pliocène de l'Acadie (traduction du manuscript anglais par Armand Thie. lens). Soc Malac Belgique, An 9:33-50 (1874) Can Nat n s 8:104-117 (1876)

76 (with Bailey, L. W.) Summary report of geological observations in New Brunswick. Can G S, Rp Prog 1874-5: 84-89 (1876)

77 (with Bailey, L. W.) Report of geological observations in southern New Brunswick. Can G S, Rp Prog 1875-6: 348-368 (1877)

78 Report on the slate formations of the northern part of Charlotte Co., N. B., with 4 summary of geological observations in the southeastern part of the same counts. Can G S, Rp Prog 1876-7 : 321-350 (1878) 
Matthew, George Frederick-Continued.

79 Report on the Upper Silurian and Kingston (Huronian) of southern New Brunswick, 1877. Can G S, Rp Prog 18778: E 6 pp (1879)

79a Report on the superficial geology of southern New Brunswick, 1878. Can G S, Rp Prog 1877-8: EE 36 pp (1879)

80 Tidal erosion in the Bay of Fundy. Can Nat n s $9: 368-373$ (1880)

80a (with Bailey, L. W., and Ells, R. W.) Report on the geology of southern New Brunswick... Can $\mathbf{G}$ S, Rp Prog 1878-9: D 26 pp (1880)

82 (and Bailey, L. W.) ... sur les roches cambriennes du Nouveau-Brunswick, Canada. Int $\mathrm{G}$ Cong, II, Bologna 1881, C R: 646-648 (1882)

83 Illustrations of the fauna of the St. John group. R Soc Can, $\operatorname{Pr} \operatorname{Tr} 1$, iv : 87$108,271-279$, il (1883) $4 b 8 t$, Science 3 : 676 (1884)

s3a On a method of distinguishing lacustrine from marine deposits. R Soc Can, Pr Tr 1, iv : 147-149 (1883)

83b Lacustrine formation of Torryburn Valley. N H Soc N B, B [1] no 2:3-9 (1883)

S4 The geological age of the Acadian fauna (abst). Brit As, Rp 54:742-743 (1885) G Mag (3) 1:470-471 (1884)

84a The primitive conocoryphean (abst). Brit As, Rp 54:743-744 (1885) G Mag (3) $1: 471-472$ (1884)

S5 Illustrations of the fauna of the St. John group continued; on the Conocoryphea with further remarks on Paradoxides. R Soc Can, $\operatorname{Pr} \operatorname{Tr} 2$, iv : 99-124, il (1885)

85a An outline of recent discoveries in the St. John group. N H Soc N B, B [1] no 4:97-102 (1885) Can Rec Sc $1: 136-141$ (1885)

85b A new genus of Cambrian pteropods. Can Rec Sc $1: 149-152$, il (1885)

85e On the probable occurrence of the great Welsh Paradoxides, $P$. davidis, in America. Am J Sc (3) $30: 72-73$ (1885)

85d Notice of a new genus of pteropods from the St. John group (Cambrian). Am J Sc (3) $30: 293-294$, il (1885)

85e Note on the genus Stenotheca. G Mag (3) 2:425-426 (1885)

86 Illustrations of the fauna of the St. John group continued; No. III, Descriptlons of new genera and species, including a description of a new species of Solenopleura by J. F. Whiteaves. R Soc Can, Pr Tr 3, iv : 29-84, il (1886)

86n The structural features of Discina acadica Hartt of the St. John group. Can Rec Sc 2: 9-11, il (1886)

86b Discovery of a pteraspidian fish in the Silurian rocks of New Brunswick. Can Rec Sc 2: 251-252, il (1886)
Matthew, George Frederick-Continued.

s6e Synopsis of the fauna in Division I of the St. John group, with preliminary notes on the higher faunas of the same group. N H Soc N B, B [1] no 5:25-51 (1886)

S6d Pteropod of the St. John group. Am J Sc (3) 31:72 (1886)

86e Note on the occurrence of Olenellus? kjerulf in America. Am J Sc (3) $31: 472-473$ (1886)

s7 On the Cambrian faunas of Cape Breton and Newfoundland. $R$ Soc Can, Pr $\operatorname{Tr} 4$, iv: 147-157, il (1887) Abst, Can Rec Sc 2:255-258 (1886)

S7a Additional note on the pteraspidian fish found in New Brunswick. Can Rec Sc $2: 323-326$, il (1887)

87b Illustrations of the fauna of the St. John group: No. 4, On the smaller eyed trilobites of Division I, with a few remarks on the species of the higher divisions of the group. Can Rec Sc 2:357363,432 (1887)

$\mathbf{8 7}$ e Illustrations of the fauna of the St. John group; No. 5 , On the great Acadian trilobite, Paradoxides regina (abst). Can Rec Sc 2: 434 (1887)

87d A preliminary notice of a new genus of Silurian fishes [Diplaspis]. N H Soc N B, B [2] no $5: 69-73$, il (1887)

87e The great Acadian Paradoxides. Am J Sc (3) $33: 388-390$ (1887)

s7f On the kin of Paradoxides (Olenellusf) kjerulfi. Am J Sc (3) $33: 390-392$ (1887)

88 Illustrations of the fauna of the St. John group; No. IV, Description of a new species of Paradoxides (Paradoxides regina); The smaller trilobites with eyes (Ptychoparidae and Ellipsocephalidae). R Soc Can, $\operatorname{Pr} \operatorname{Tr} 5$, iv: 115-166, il (1888)

S8a On a basal series of Cambrian rocks in Acadia. Can Ree Sc 3:21-29 (1888)

s8b On the classification of the Cambrian rocks in Acadia. Can Rec Sc $3: 71-81$, $303-315,371-372$, il $(1888-9)$

8se On Psammichnites and the early trilobites of the Cambrian rocks in eastern Canada. Am G 2:1-9 (1888)

S9 How is the Cambrian divided? A plea for the classification of Salter and Hicks. Am G 4:139-148 (1889) Can Rec Sc 3: 475-485 (1889)

89a On the occurrence of Leptoplastus in the Acadian Cambrian rocks. Can Res Sc $3: 485-489$, il (1889)

s9b On some remarkable organisms of the Silurian and Devonian rocks in southern New Brunswick. R Soc Can, $\operatorname{Pr} \operatorname{Tr} 6$, iv: 49-62, il (1889) Abst, Can Rec Sc 3:161162 (1888)

89e Second note on Stenotheca. G Mag (3) $6: 210-211$ (1889)

s9d Sur le développement des premiers trilobites. Soc R Malac Belgique, An 23: $351-362$, il (1889) 
Matthew, George Frederick-Continued. 90 On Cambrian organisms in Acadia. R Soc Can, Pr Tr 7, iv: 135-162, il (1890) Abst, Can Rec Sc 3: $383-3871889$

90a Charles Frederick Hartt. Can Rec Sc $4: 111-130$, port (1890) N H Soc N B, B [2] no $9: 1-24$, port (1890)

9ob Eozoon and other low organisms in Laurentian rocks at St. John. N H Soc N B, B [2] no $9: 36-41$, il (1890)

90e On the occurrence of sponges in Laurentian rocks at St. John, N. B. N H Soc N B, B [2] no $9: 42-45$, il (1890)

$90 \mathrm{~d}$ Tracks of organic origin in rocks of the Animikie group. Am J Se (3) 39 : 145-147 (1890)

91 Illustrations of the fauna of the St. John group, No. V. R Soc Can, Pr Tr 8, iv : 123-166, il (1891)

$91 a$ On some causes which may have influenced the spread of the Cambrian faunas. Can Rec Sc $4: 255-269$ (1891)

$91 \mathbf{b}$ On a new horizon in the St. John group. Can Rec Sc 4 : 339-343 (1891)

91e Note on Leptoplastus. Can Rec Sc $4: 461-462$, il (1891)

$91 d$ [On the horizon of Diplaspis acadica.] Am G 8:61-62 (1891)

91e Notes on Cambrian faunas. Am G $8: 287-291$ (1891)

92 Illustrations of the fauna of the St. John group, No. VI. R Soc Can, I'r Tr 9, iv : 33-65, il (1892)

92a List of the fossils found in the Cambrian rocks in and near St. John. N H Soc N B, B [2] no 10 : xi-xxiil (1892)

92b Protolenus, a new genus of Cambrian trilobites. N H Soc N B, B [2] no $10: 34-37$, il (1892)

92e Are the eozoonal limestones at St. John, N. B., pre-Cambrian? Am G 9 : 212-214 (1892)

93 On the diffusion and sequence of the Cambrian faunas. R Soc Can, $\operatorname{Pr} \operatorname{Tr} 10$, iv : $3-16 \quad$ (1893)

$93 a$ Illustrations of the fauna of the St. John group, No. VII. R Soc Can, Pr Tr 10, iv : $95-109$, il (1893)

93b Notes on Cambrian faunas; development of the fauna of band $b$ in the Acadian division (Div. 1) of the St. John group. Can Rec Sc 5:247-258, il (1893)

93e Trematobolus. Can Rec Sc 5:276279 , il (1893)

93d Is the fauna called "Primordial" the most ancient fauna? Can Rec Sc 5: 347-350 (1893)

93e The climate of Acadia in the earliest times. N H Soc N B, B [3] no 11:3-18 (1893)

93e The St. John group. Am G 12 : 340-341 (1893)

94 Illustrations of the fauna of the St. John group, No. VIII. R Soc Can, Pr Tr 11, iv : $85-129$, il (1894)

94a Ancient myriapods. Can Rec Sc 6 : 93-99 (1894)
Matthew, George Frederick-Continued. $94 b$ Postglacial faults at St. Jobn, N. B, Am J Sc (3) 48:501-503 (1894)

94e Movements of the earth's crust at St. John, N. B., in postglacial times. $\mathrm{N}$ B Soc N B, B [3] no $12: 34-42$ (1894)

94d The outlets of the St. John River. $\mathrm{N}$ H Soc N B, B [3] no 12: 43-62 (1894)

94e Organic remains of the Little River group (abst). Am G 14:67 (1894)

95 On the organic remains of the Little River group, No. II. R Soc Can, $\mathrm{Pr} T$ ? 12, iv : $89-100$, il (1895)

95a On the organic remains of the Little River group, No. III. R Soc Can, Pr Tr 12, iv : 101-111, il (1895)

95b Traces of the Ordovician system on the Atlantic coast. R Soc Can, $\mathrm{Pr} \operatorname{Tr}(2)$ 1 , iv : 253-271, il (1895)

95e Organic remains of the Little River group, No. IV. R Soc Can, Pr Tr (2) 1 , iv : $273-279$, il (1895)

95d Report on the summer eamp at French Lake [N. B.]. N H Soc N B, B [3] no 13: 84-88 (1895)

95e Report on the summer camp at Lepreau Basin [N. B.]. N H Soc N B, B [3] no 13: 88-93 (1895)

95f [Cambrian Brachiopoda, St. John]. $\mathrm{N} H$ Soc N B, B [3] no 13:94-95, 1l (1895)

95m Early Protozoa. Am G $15: 146-153$ (1895)

95h The Protolenus fauna. N Y Ac Sc, $\operatorname{Tr} 14: 101-153$, il (1895) Abst, Sclence n s $1: 452-453$ (1895)

951 Two new Cambrian graptolites with notes on other species of Graptolitidae of that age. N Y Ac Sc, Tr 14:262-273, il (1895)

96 On the occurrence of cirripedes in the Cambrian rocks of North America. N I Ac Sc, Tr 15:144-146, il (1896)

96a Faunas of the Paradoxides beds in eastern North America. N Y Ac Sc, Tr $15: 192-247$, il (1896)

96b Notes on Cambrian faunas; the genus Microriscus. Am G $18: 28-31$ (1896)

96e Some features of the early Cambrian faunas (abst). Brit As, Rp 66:785-78: (1896)

97 Studies of Cambrian faunas. R SoC Can, Pr Tr (2) 3, iv: $165-203$, il (1897) 97a Abraham Gesner; a review of his scientific work. N H Soc N B, B [3] no $15: 3-48$, map (1897)

97b Description of an extinct Paleozoic insect [Geracus tubifer], and a review of the fauna with which it occurs. $\mathrm{NH}$ Soc N B, B [3] no 15:49-60, Il (1897)

$97 \mathrm{c}$ What is the Olenellus fanna? Am G $19: 396-407$ (1897)

97 d The oldest Siphonotreta. G Mag (4) $4: 68-71$, il (1897) 
Matthew, George Frederick-Continued.

97e Some features of the early Cambrian faunas (abst). Science n s 5:254256 (1897)

98 Studies on Cambrian faunas, No. 2 ; The Cambrian system in the Kenvebecasis Valley [N. B.]. R Soc Can, Pr Tr (2) 4 , iv: $123-153$, 11 , map (1898)

98a Recent discoveries in the St. Jobn group, No. 2. N H Soc N B, B no 16 (4 pt 1):32-43, il, map (1898)

98b The oldest Paleozoic fauna (abst). Am As, Pr 47:301-302 (1898) Am G $22: 262$ (1898) Science n s 8:503-504 (1898)

98c Some characteristic genera of the Cambrian (abst). Brit As, Rp 67:657658 (1898) G Mag (4) 5:82-83 (1898)

99 Studies on Cambrian faunas, No, 3 : Upper Cambrian faunas of Mount Stephen, B. C.-the trilobites and worms. R Soc Can, $\operatorname{Pr} \operatorname{Tr}$ (2) 5, iv : 39-66, il (1899)

99a Studies on Cambrian faunas, No. 4 : Fragments of the Cambrian faunas of Newfoundland. R Soc Can, Pr Tr (2) 5, iv : $67-95$, il (1899)

99b The Etcheminian fauna of Smith Sound, Newfoundland. R Soc Can, Pr Tr (2) 5, iv: 97-119, il (1899)

99e A new Cambrian trilobite [Metadoxides magnificus]. N H Soc N B, B no 17 (4 pt 2):137-142, il (1899)

99d (and Kain, S. W.) On artesian and fissure wells in New Brunswick. N H Soc N B, B no 17 (4 pt 2) : 143-152 (1899)

99e Preliminary notice of the Etcheminlan fauna of Newfoundland. N H Soc N B, B no 18 (4 pt 3 ): 189-196, il (1899)

992 Preliminary notice of the Etcheminian fauna of Cape Breton. N H Soc N B, B no 18 (4 pt 3 ) : 198-208, il (1899)

99g A Paleozoic terrane beneath the Cambrian. N $\mathrm{Y}$ Ac Sc, An 12:41-56 (1899)

00 [Report on the Cambrian rocks of Cape Breton Island.] Can G S, Sum Rp 1899 (An Rp 12: A 187-189 (1900)

00a A forest fire at St. John [N. B.] about 2000 years ago, Can Rec Sc 8: 213-218 (1900)

$00 \mathrm{~b}$ Oldhamia. Can Rec Se 8: 228-232, fl (1900)

00e Mr. Walcott's view of the Etcheminian. Am G 25:255-258 (1900)

01 Acrothyra and Hyolithes-a comparison. R Soc Can, Pr Tr (2) 7, iv : 93-107, Il (1901)

01a Hyolithes gracilis and related forms from the lower Cambrian of the St. John group. R Soc ${ }^{\circ}$ Can, Pr Tr (2) 7, iv : 109111, il (1901)

01b A backward step in paleobotany. $R$ Soc Can, Pr Tr (2) 7, iv : 113-122 (1901) Abst, Science n s 13:1019 (1901)
Matthew, George Frederick-Continued.

01e New species of Cambrian fossils from Cape Breton. N H Soc N B, B no 19 (4 pt 4) : 269-286, il (1901) Abst, Am J Sc (4) $11: 396$ (1901)

o1d Acrothyra, a new genus of Etcheminian brachiopods. N H Soc N B, B no 19 (4 pt 4) 303-304, il (1901)

01e [The Devonian of the Acadian provinces.] Can Rec Sc 8:344-345 (1901)

011 Les plus anciennes faunes paléozoîques. Int $\mathrm{G}$ Cong, VIII, Paris 1900. C R : 313-316 (1901)

01g Are the St. John plant beds Carboniferous? Am G 27:383-386 (1901)

$01 \mathbf{h}$ Monocraterion and Oldhamia. Irish Naturalist 10:135-136 (1901)

02 [On Cambrian and Silurian rocks in York Co., N. B.] Can G S, Sum Rp 1901 (An Rp 14) : A 197-201 (1902)

02a Cambrian rocks and fossils of Cape Breton. Can G S, Sum Rp 1901 (An Rp 14) : A 223-232 (1902)

$02 b$ Notes on Cambrian faunas. R Soc Can, $\operatorname{Pr} \operatorname{Tr}$ (2) 8, iv : 93-112, il (1902)

02e Ostracoda of the basal Cambrian rocks in Cape Breton. Can Rec Sc 8:437468 , il (1902)

02d Additional notes on the Cambrian of Cape Breton, with descriptions of new species. N H Soc N B, B no 20 (4 pt 5) : $377-426$, il (1902)

o2e Stratigraphy vs. paleontology in Nova Scotia. Science n s 16:513-514 (1902)

03 Report on the Cambrian rocks of Cape Breton. Can G S: 246 pp, il (1903) 03a An attempt to classify Paleozoic batrachian footprints. R Soc Can, $\operatorname{Pr} \mathrm{Tr}$ (2) 9 , iv : 109-121, il (1903)

03b New genera of batrachian footprints of the Carboniferous system in eastern Canada. Can Rec Sc 9:99-111, il (1903)

03e Note in reference to batrachian footprints. N H Soc N B, B no 21 (5 pt 1) : 102 (1903)

o3d On batrachian and other footprints from the Coal Measures of Joggins, N. S. N H Soc N B, B no 21 (5 pt 1):103-108, il (1903)

03e "How long ago was Aurerica peopled?" Am G 32:195-196 (1903)

04 Note on Oliver's Cave [near st. John, N. B.]. N H Soc N B, B no 22 (5 pt 2):171-174 (1904)

04a Notes on Cambrian faunas; No 9 [Protolenus]. N H Soc N B, B no 22 (5 pt 2) : 246 (1904)

O4b Note on the genus Hylopus of Dawson. N H Soc N B, B no 22 (5 pt 2): 247-252, il (1904)

04c Physical aspect of the Cambrian rocks in eastern Canada, with a catalogue of the organic remains found in them. $\mathrm{N}$ H Soc N B, B no 22 (5 pt 2): 253-278 (1904) 
Mutthew, George Frederick-Continued.

o5 New species and a new genus of batrachian footprints of the Carboniferous system in eastern Canada. $\mathrm{R}$ Soc Can, $\operatorname{Pr} \operatorname{Tr}$ (2) 10, iv: $77-121$, il (1905)

06 A review of the flora of the Little River group. R Soc Can, $\operatorname{Pr} \operatorname{Tr}$ (2) 12, iv : $99-149$, il (1906) Abst, Science $\mathbf{n} \mathbf{s}$ 23 : $972-973$ (1906)

06a New species and a new genus of Devonian plants. N H Soc N B, B 24 (5 pt 4) : 393-398, il (1906)

o6b Notes on Cambrian faunas; No. 9, Ostracoda; 10, Trilobita. N H Soc N B, B 24 (5 pt 4) : 406, 475-480 (1906)

oz A new genus and a new species of Silurian fish. R Soc Can, $\operatorname{Pr} \operatorname{Tr}$ (3) 1, iv : 7-11. il (1907)

07a On some new species of Silurian and Devonian plants. $\mathrm{R}$ Soc Can, Pr Tr (3) 1 , iv $185-197$, il (1907)

07b Note on Archøozoon. N H Soc N B, B 25 (5 pt 5) : 547-552, il (1907)

os The physical evolution of Acadia; Part I, The insular stage, or pre-Devonian development. N H Soc N B, B 26 (6 pt 1) : 3-16, maps (1908)

osa Geological cycles in the maritime provinces of Canada. $\mathrm{R}$ Soc Can, Pr Tr (3) 2. iv : 121-143 (1908)

09 Phosphate deposits of South Carolina and New Brunswick. N H Soc N B, B 27 (6 pt 2) : 121-126 (1909)

10 Changes of climate in the maritime provinces after the maximum of the latest glaciation. Int $\mathrm{G}$ Cong, XI, Stockholm, Die Veränderungen des Klimas seit dem Maximum der letzten Eiszeit : $377-380$ (1910)

10a The geological age of the Little River group. $\mathrm{R}$ Soc $\mathrm{Can}, \operatorname{Pr} \operatorname{Tr}$ (3) 3, iv : $67-75, \operatorname{map}(1910)$

10b Revision of the flora of the Little River group, No. II. R Soc Can, Pr Tr (3) 3 , iv : 77-113, fl (1910)

10c Remarkable forms of the Little River group. $\mathrm{R}$ Soc Can, $\operatorname{Pr} \operatorname{Tr}$ (3) 3 , iv : 115-133, il (1910)

10d The oldest Silurian flora [Beaver Harbor, N. B.]. N H Soc N B, B 28 (6 pt 3) : 241-250 (1910) [See also White (D), 11a ]

11 Review of the flora of the Little River group; No. III. R Soc Can, $\mathrm{Pr}$ Tr (3) 4 ; iv : 3-21, il (1911)

12 Were there climatic zones in Devonian time? R Soc Can, $\operatorname{Pr} \operatorname{Tr}$ (3) 5, iv: 125-153 (1912)

12a A new flora in the older Paleozolc, rocks of southern New Brunswick. $R$ Soc Can, $\operatorname{Pr} \operatorname{Tr}$ (3) 6, iv : 83-99, il (1912)

12b The sudden appearance of the Cambrian fauna. Int G Cong, XI, Stockholm, 1910 , C R : 547-559 (1912)
Matthew, George Frederick-Conthum,

14 The physics of the Cambrian forma tion in eastern Canada, and the peculiar. ties of its faunas. R Soc Car, Tr (3) \& iv : $69-85$ (1914)

16 Notes on Cambrian faunas, No. 12 $\mathrm{R}$ Soc Can, $\operatorname{Tr}$ (3) 10, iv : 45-54 (1916) See also Ruedemann, 03

Matthew, William Diller.

$\mathbf{9 3}$ On the phosphate nodules from the Cambrian of southern New Brunswick. I Y Ae Se, Tr 12:108-120 (1893)

$93 a$ On antennae and other appendages of Triarthrus beckii. N Y Ac Se, Tr 12: 237-241, il (1893) Am J Sc (3) 46:121125 , il (1893)

94 The intrusive rocks near St. Jobn, N. B. N Y Ac Sc, Tr 13: 185-203 (1894)

94a The crystalline rocks near St. John, N. B. N H Soc N B, B [3] no $12: 16-33$, map (1894)

95 The volcanic rocks of the maritime provinces of Canada. N H Soc N B, B [3] no $13: 76-83$ (1895)

95a The effusive and dike rocks near $\mathrm{St}$. John, N. B. N Y Ac Sc, Tr $14: 187-218$ (1895)

95b Monazite and orthoclase from South Lyme, Conn. Sch Mines Q 16:231-233 (1895)

96 Metamorphism of Triassic coals at Egypt, N. C. $(a b 8 t)$. Science n s $3: 214$ (1896)

97 Notes on intrusive rocks near St. John, N. B. N H Soc N B, B [3] no 15: 61-64 (1897)

97a A revision of the Puerco fauna. Am Mus N H, B 9:259-323, il (1897)

97b Development of the foot in the Pa. laeosyopinae. Am Nat 31:57-58 (1897)

$97 \mathbf{c}$ On the status of the Puerco fauns (abst). Anat Anz 14:231--32 (1897) Scievce n s 6:852 (1897)

98 un some new characters of Claenodon and oxyuena (abst). Science n 8 8:880 (1898)

99 Is the White River Tertiary an eolian formation? Am Nat 33:403-408 (1899)

OO A provisional classification of the fresh-water Tertiary of the West. Am Mus N H, B 12: 19-75 (1900)

Ooa Notes on the geology of the Laramie Plains and Rattlesnake Mountains in Wyoming (abst). Science n s 11:111 (1900)

oob (with wortman, $\quad$ L.) The ancestry of certain members of the Canidae, the Viverridae, and Procyonidae. Am Mus N H, B $12: 109-138$, il (1900)

01 Fossil mammals of the Tertiary of northeastern Colorado. Am Mus it H, Mem $1: 355-447$, il (1901)

01a Additional observations on the Creodonta. Am Mus N H, B 14:1-38, il (1901) 
Matthew, William Diller-Continued.

02 The hall of fossil vertebrates [American Museum of Natural History]. Am Mus J 2 no 1 sup (Guide Leeaflet no 3 ) : 19 $\mathrm{pp}$, il (1902)

02a A skull of Dinocyon from the Miocene of Texas. Am Mus N H, B 16:129136 , il (1902)

02b On the skull of Bunaelurus, a musteline from the White River Oligocene. Am Mus N H, B $16: 137-140$, il (1902)

02e New Canidae from the Miocene of Colorado. Am Mus N H, B $16: 281-290$, il (1902)

02d A horned rodent from the Colorado Miocene, with a revisio": of the Mylagaull, beavers and hares of the American Tertiary. Am Mus N H, B 16:291-310, il (1902)

02e The skull of Hypisodus, the smallest of the Artiodactyla, with a revision of the Hypertragulidae. Am Mus $\mathrm{N}$ H, B 16: $311-316$, il (1902)

02f List of the Pleistocene fauna from Hay Springs, Nebr. Am Mus N H, B 16: 317-322 (1902)

03 Illustrations of evolution among fossil mammals; A, The horse. Am Mus J 3 no 1 sup (Guide Leaflet no 9 ) ; 30 pp. il (1903)

03a The collection of fossil vertebrates... in the American Museum of Natural History. Am Mus J 3 no 5 sup (Guide Leaflet no 12) : $32 \mathrm{pp}$, il (1903)

03b The fauna of the Titanotherium beds at Pipestone Springs, Mont. Am Mus $\mathrm{N} \mathrm{H}, \mathrm{B} 19: 197-226$, il (1903)

03e A fossil hedgehog from the American Oligecene. Am Mus N H, B 19:227229, il (1903)

03d Recent zoo-paleontology ; concerning the ancestry of the dogs. Science $\mathrm{n} \mathrm{s}$ $17: 912-913$ (1903)

04 A complete skeleton of Merycodus. Am Mus N H, B 20:101-129, 11 (1904)

04a Notice of two new Oligocene camels. Am Mus N H, B 20:211-215 (1904)

04b (and Gidley, J. W.) New or littleknown mammals from the Miocene of South Dakota. Am Mus N H, B 20:241-268, il (1904)

04c The arboreal ancestry of the Mammalia. Am Nat 38: 811-818 (1904)

04d Outlines of the continents in Tertiary times (abst). Am G 33:268-269 (1904) Science n s 19:581-582 (1904)

04e ... evolution of the camel... (abst). Sclence n s $19: 892$ (1904)

05 Notice of two new genera of mammals from the Oligocene of South Dakota. Am Mus N H, B 21:21-26, il (1905)

05a Fossil carnivores, marsupials and small mammals in the American Museum of Natural History. Am Mus J 5:23-59, il $(1905)$
Matthew, William Diller-Continued.

05b The mounted skeleton of Brontosaurus. Am Mus J 5:63-70, il (1905)

o5e Notes on the osteology of Sinopa, a primitive member of the Hyaenodontidae. Am Ph Soc, Pr 44: 69-72 (1905)

o5d Outlines of the continents in Tertiary times (abst). N Y Ac Sc, An 16: $315-316$ (1905)

ose On Eocene insectivora and on Pantolestes in particular (abst). Science n s $21: 298-299$ (1905)

06 The osteology of Sinopa, a creodont mammal of the middle Eocene. U S Nat Mus, Pr 30:203-233, il (1906)

06a Hypothetical outlines of the continents in Tertiary times. Am Mus N H, B $22: 353-383$, paleogeographic maps (1906) 06b Fossil Chrysochloridae in North America. Science n s $24: 786-788$ (1906)

06e (and Gidley, J. W.) New or littleknown mammals from the Miocene of South Dakota. Am Mus N H, B 22: 135-153, il (1906)

07 A lower Miocene fauna from South Dakota. Am Mus N H, B $23: 169-219$, il (1907)

os Allosaurus, a carnivorous dinosaur, and its prey. Am Mus J $8: 3-5$, il (1908)

osa The new Ichthyosaurus. Am Mus J $8: 7-8$, il (1908)

osb Mammalian migrations between Europe and North America. Am J Sc (4) $25: 68-70$ (1908)

ose A four-horned pelycosaurian from the Permian of Texas. Am Mus $\mathrm{N} H, \mathrm{~B}$ $24: 183-185$, il (1908)

98d Osteology of Blastomeryx and phylogeny of the American Cervidæ. Am Mus N H, B 24:535-562, il (1908)

09 The Carnivora and Insectivora of the Bridger Basin, middle Eocene. Am Mus N H, Mem 9:289-567, il (1909)

09a Observations upon the genus $A n$ codon. Am Mus N H, B 26:1-7 (1909)

09b Faunal lists of the Tertiary Mammalia of the West. U S G S, B 361: 91120 (1909)

09e The oldest land reptiles of North America. Am Mus J 9:91-95, il (1909)

09d Seventh annual meeting of the American Society of Vertebrate Paleontologists. Science n s $29: 194-198$ (1909)

o9e (and Cook, H. J.) A Pliocene fauna from western Nebraska [Sioux Co.]. Am Mus N H, B 26:361-414, il (1909) Abst, Science n s 29:196-197 (1909)

o9f (with osborn, H. F.) Geological correlation through vertebrate paleontology by international cooperation. N Y Ac Sc, An $19: 41-44$ (1909)

10 On the skull of Apternodus and the skeleton of a new artiodacty] [Eotylopus reedi] Am Mus N H, B 28:33-42, il (1910) Abst, Science n s 29:196 (1909) 
Matthew, William Diller-Continued.

10a On the osteology and relationships of Paramys, and the affinities of the Ischyromyidæ. Am Mus N $\mathrm{H}, \mathrm{B} 28: 43-72$, il (1910)

10b The phylogeny of the Felidæ. Am Mus N H, B 28:289-316, il (1910)

10e The palentologic correlation through the Bache fund. Science n s 31:407-408 (1910)

10d The pose of sauropodous dinosaurs. Am Nat 44:547-560 (1910)

10e The continuity of development. Pop Sc Mo $77: 473-478$ (1910)

10? The new plesiosaur [Cryptoclidus]. Am Mus J 10:246-250, il (1910)

11 Fort Lee dinosaur [in Triassic shales along the Hudson River]. Am Mus J 11: 28-29 (1911)

11a The ground sloth group. Am Mus J 11:113-119, il (1911)

$11 \mathrm{~b}$ A tree-climbing ruminant (Agriocharus]. Am Mus J $11: 162-163$, il (1911)

11e The amphibians of the great coal swamps. Am Mus J 11:197-200, il (1911)

$11 d$ Fossil vertebrates, what they teach, Am Mus J 11 : 246-247 (1911)

11e Climate and evolution (abst). Science n s $33: 508$ (1911) N Y Ac Sc, An $21: 190-191$ (1912)

12 Ten years' progress in vertebrate paleontology : Carnivora and Rodentia. G Soc Am, B 23: 181-187 (1912)

12a The new four-toed horse skeleton. Am Mus J 12:186, il (1912)

12b New dinosaurs for the American Museum. Am Mus J $12: 219$ (1912)

12c The ancestry of the edentates as illustrated by the skeleton of Hapalops, a Tertiary ancestor of the ground sloths. Am Mus J 12:300-303, il (1912) Reprint, $8 \mathrm{pp}$, il (1913)

13 Certain theoretical considerations affecting phylogeny and correlation. G Soc Am, B 24: 283-292, 118 (abst), (1913)

$13 a$ The laws of nomenclature in paleontology. Science n s $37: 788-792$ (1913)

13b A zalambdodont insectivore from the basal Eocene. Am Mus N H, B 32 : $307-314$, il (1913)

13e Nomenclature in paleontology. Science n s $38: 87-88$ (1913)

13d American Museum expeditions for fossil vertebrates. Am Mus J $13: 286-287$ (1913)

13e The asphalt group of fossil skeletons [from Rancho La Brea, Cal.]. Am Mus J $13: 291-297$, il (1913)

$13 f$ Cuban fossil mammals; preliminary note $(a b s t)$. G Soc Am, B 24:118-119 (1913)

13g Evolution of the horse in nature. Am Mus N H, Guide Leaflet 36:1-35, 61-63, il (1913)
Matthew, William Diller-Continued.

14 Evidence of the Paleocene vertebrate fauna on the Cretaceous-Tertiary problem. G Soc Am, B 25: 381-402 (1914)

14a Time ratios in the evolution of mammalian pbyla; a contribution to the problem of the age of the earth. Science n s $40: 232-235$ (1914)

14b Report of progress in the revision of the lower Eocene faunas (abst). G Soc Am, B 25:144-145 (1914)

14c Notes on Cuban fossil mammals (abst). N Y Ac Sc, An 23: 263 (1914)

14d A zalambdodont insectivore from the basal Eocene of New Mexico (abst). N Y Ac Sc, An 23:263-264 (1914)

14e New discoveries in the American Eocene (abst). Brit As, Rp 83, 1913:491 (1914)

15 The Tertiary sedimentary record and its problems. In Problems of American geology : 377-478, il, New Haven 1915

15a (and Granger, W.) A revision of the lower Eocene Wasatch and Wind River faunas. Am Mus N H, B 34:1-103, $311-328,329-361,429-483$, Il (1915)

15b Climate and erolution. N Y Ac Sc, An 24:171-318 (1915) Rv by Charles Schuchert [including observations on paleogeography and physiography] An J So (4) $40: 83-85$ (1915)

15e Dinosaurs, with special reference to the Amrerican Museum collections. Am Mus N H, Handbook series no $5: 162$ pp, il (1915)

15d Mammoths and mastodons; a guide to the collections of fossil proboscideans in the American Museum of Natural Hls tory. Am Mus N H, Guide Leaflet series no $43: 26 \mathrm{pp}$, il (1915)

15e (and Brown, B.) Corythosaurus, the new duck-billed dinosaur. Am Mus J $15: 427-428$ (1915)

15f New discoveries in the Lower EOcene mammals (abst). N Y Ac Sc, An $24: 383$ (1915)

$15 \mathrm{~g}$ Affinities of Hyopsodus (abst). G Soc Am, B 26: 152 (1915)

15h Reconstruction of the skeleton of Brachiosaurus (abst). G Soc Am, B 26: 153 (1915)

15i (and others) General consideration of paleontologic criteria used in deter. mining time relations (discussion). G Soc Am, B $26: 411$ (1915)

15j (with Cope, E. D.) Hitherto unpublished plates of Tertiary Mammalia and Permian Vertebrata. Am Mus N H, Mon s $2:$ pls and expl (1915)

15k (with Torre, C.) Megalocnus and other Cuban ground sloths (abst). G Soc Am, B $26: 152$ (1915)

16 A marsupial from the Belly Bivet Cretaceous; with critical observations upon the affinities of the Cretaceous mammals Am Mus N H, B 35:477-500, il (1916) 
Matthew, William Diller-Continuer.

16a The grim wolf of the tar pits; th great extinct wolf Canis dirus from th asphalt deposits at Rancho La Brea nea Los Angeles [Cal.]. Am Mus J 16:45-47. il (1916)

16b A reptllian aeronaut; a new skele ton of Pteranodon, the giant flying reptile of the Cretaceous period. Am Mus J 16 : 251-252, il (1916)

16e Scourge of the Santa Monica Moun tains [sabre-toothed tiger of Rancho La Brea deposits]. Am Mus J 16:469-472, il (1916)

$16 d$ Kunz on fvory and the elephant Am Mus J 16:485-496, il (1916)

16e Methods of correlation by fossil vertebrates. G Soc Am, B 27:515-524 (1916)

$16 f$ New sirenian from the Tertiary of Porto Rico, W. I. N Y Ac Sc, An $27: 23$ 29 , il ; $26: 439$ (abst) (1916)

$\mathbf{1 6 g}$ The horse and his progenitors. Science Conspectus 6:1-15, il (1916)

16h (with others) Recent progress in vertebrate paleontology. Science n s 43 : 103-110 (1916) ; 45:117-121 (1917)

16i (with Eastman, C. R., and Gregory, W. K.) Recent progress in vertebrate paleontology. Science n s 43:103-110 (1916) ; $45: 117-121$ (1917)

17 (and Granger, W.) The skeleton of Diatryma, a gigantic bird from the lower Eocene of Wyoming. Am Mus N H, B $37: 307-326$, il (1917) Abst, G Soc Am, B 28: 212 (1917)

17a A Paleocene bat. Am Mus $\mathrm{N} \mathrm{H}, \mathrm{B}$ $37: 569-571$, il (1917)

17b Absence of the pollex in Perissodactyla. $\Delta \mathrm{m}$ Mus $\mathrm{N} \mathrm{H}, \mathrm{B} \quad 37: 573-577$ (1917)

17e The dentition of Nothodectes. Am Mus N H, B 37: 831-839, il 1917)

17d A fossil deer from Argentina; with a discussion of the distribution of various types of deer in North and South America. Am Mus J $17: 207-211$, il (1917)

17 e (and Granger, W.) A giant Eocene bird [Diatryma steini, Big Horn Basin Wyo.]. Am Mus J $17: 41:-418$, il (1917)

17e Gigantic Megatherium from Florida (abst). G Soc Am, B 28: 212 (1917)

$17 \mathrm{~g}$ Diatryma, a gigantic Eocene bird (abst). Science n s 46:246 (1917)

18 Contributions to the Snake Creek fauna; with notes upon the Pleistocene of western Nebraska. Am Mus N H, B 38 : 183-229, il (1918)

18a (and Granger, Walter) A revislon of the lower Eocene Wasatch and Wind River faunas; Part V, Insectivora (continued), Glires, Edentata. Am Mus N H, B $38: 565-657$, Il (1918)

18b Affinities and origin of the Antil. lean mammals. G Soc Am, B 29:657-666 (1918)
Matthew, William Diller-Continued.

18e The mounted skeleton of Moropus in the American Museum. Am Mus J 18: 121-123, il (1918)

18d Skeletons of the Cuban ground sloth in the Havana and American museums. Am Mus J $18: 313$, il (1918)

18e A Tertiary alligator. Am Mus J $18: 505-506$, 11 (1918)

$18 \mathrm{f}$ Generic nomenclature of the Proboscidea (abst). G Soc Am, B 29: 141 (1918)

1Sg Affinities and phylogeny of the extinct Camelidae (abst). G Soc Am, B 29 : 144 (1918)

18h (and Granger, Walter) Fossil mammals of the Tiffany beds (asbt). G Soc Am, B 29: 152 (1918)

$18 i$ Notes on American Pliocene rhinoceroses (abst). G Soc Am, B 29:153 (1918)

See also Barbour (T), 16; Johannsen, $14 \mathrm{a}$

Mattice, Asa Edson.

99 How Michigan was made. Mich Miner 2 no $1: 15-17$; no. $2: 9-14 ;$ no 3 : $13-17$; no $4: 20-22$; no $5: 9$ (1899-1900) Matute, Juan Ignacio.

75 Informe y colección de artículos relativos á los fenómenos geologicos verificados en Jalisco en el presente año $y$ en épocas anteriores. [México], edición official, $t$, 167 , vi, 2 pp, Guadalajara 1875

7 7 (with Irlesias, M., and Barcena, M.) Informe sobre los temblores de Jalisco y la erupción del volcán Ceboruco. México, Ministerio de Fomento, An $1: 115-$ 204. map (1877)

87 Informe... de la "Divina Providencia " y minas anexas en los placeres de Ostula [Michoacán]. México, Ministerio de Fomento, An 8: 477-496, map (1887)

Manek, A. V.

02 (with Cumings, E. R.) A quantitative study of variation in the fossil brachioped Platystrophia lynx. Am J Sc (4) 14:9-16, il (1902)

\section{Maughas, M. M.}

53 Geological researches in Missourl. Western J (St Louis) 9:382-396 (1853)

Maury, Carlotta Joaquina.

02 a comparison of the Oligocene of western Europe and the southern United States. B Am Pal no $15: 94$ pp, 1l, map (1902)

os An interglacial fauna found in $\mathrm{Ca}$ yuga Valley and its relation to the Pleistocene of Toronto. J G $16: 565-567$ (1908)

OSa (with Harris, G. D.) Rock salt. La G S, B $7: 259$ pp (1908)

09 A new connecting link in the genesis of Fulgur [Levifusus fulguriparens, Eocene, Montgomery, La.]. Am J Sc (4) 27 : 335, il (1909)

10 New Oligocene shells from Florida. B Am Pal no 21: 119-164, il (1910) 
Maury, Carlotta Joaquina-Continued.

12 A contribution to the paleontology of Trinidad, Ac N Sc Phila, J (2) 15:23112, il (1912) Abst, Ac N Sc Phila, $\mathrm{Pr}$ 64: 132-134 (1912)

17 Santo Domingo type sections and fossils, Part I. B Am Paleont 5 no 29 (1st and $2 \mathrm{~d}$ sections) : $240 \mathrm{pp}$, il (1917) Part II, Stratigraphy, 5 no $30: 43 \mathrm{pp}$, 11 (1917) 18 Santo Domingan paleontological explorations. J G 26:224-228 (1918)

Maury, Matthew Fontaine (1806-1873).

37 Notice of the gold veins of the United States' mine near Fredericksburg, Va. Am J Sc $32: 325-330$ (1837)

52 On the geological agency of the winds. Am As, $\operatorname{Pr} 6: 277-296$ (1852)

Maury, M. F., jr.

73 The resources of the coal field of the upper Kanawha with a sketch of the iron belt of Virginia... 44 pp, Baltimore 1873

76 (and Fontaine, W. M.) Resources of West Virginia. x, $430 \mathrm{pp}$, Wheeling 1876

Maury, Mytton.

90 A contribution to the theory of earthquakes. N S Inst $N$ Sc, $\operatorname{Pr} \operatorname{Tr} 7$ : 475-478 (1890)

Maw, George.

78 Geological history of the North Ameriean lake region. Gardeners' Chronicle n s 10:169-170 (1878) G Mag (2) 5:455-456 (1878) Abst, Am J Sc (3) 16 : 394-395 (1878)

Mawby, W.

94 Notes on the Triassic rocks of New Jersey, U. S. A. Liverpool G Soc, Pr 7 : 206-212 (1894)

Maxon, E. T.

15 (and others) Soil survey of Oneida Co., N. Y. Cornell Univ, Agr Exp Sta, B $362: 59$ pp, maps (1915)

Maxwell, Henry V.

04 Tennessee iron ores. Eng M J 78: 742 (1904)

Maxwe11, J. B.

45 On the discovery of mastodon bones... near Hackettstown, N. J. $A m \mathrm{Ph}$ Soc, Pr 4:118-121, 127 (1845) Ph Mag (3) $26: 453-456$ (1845)

Maxwell, Volney L.

58 Mineral coal; two lectures. Wyo Hist G Soc, Pub no 1:53 pp (1858)

Maxwell, Walter.

98 Lavas and solls of the Hawailian Islands. Investigations of the Hawailan Experiment Station and Laboratories. The Hawalian Sugar Planters' Association, 186 pp, map, Honolulu 1898 Reprint 1905.

Maycoek, J. D.

21 Geological description of Barbados... Q J Sc 11: 10-20, map (1821)

Mayer, Alfred Goldsborough.

11 Alpheus Hyatt, 1838-1902. Pop Sc Mo $78: 128-146$, port (1911)
Mayer, Alfred Goldsborough-Continued.

16 Submarine solution of limestone in relation to the Murray-Agassiz theory of coral atolls. Nat Ac Sc, Pr 2 : 28-30 (1916) Mayer, W. P.

17 Popular oil geology. $15 \mathrm{pp}$, Chicago, 1917 [Priv pub]

Maynard, George W.

91 The ore deposits of Pioche, Nev. Eng M J 51:171-172 (1891)

98 The chromite deposits on Port av Port Bay, Newfoundland. Am I M Eng, Tr 27:283-288 (1898)

os The mines of northwestern Altar, Sonora, Mexico. Eng M J 86: 71-72 (1908) Maynard, Thomas Poole.

10 The upper Cayugan of Maryland (abst). Science n s 32:218 (1910) G Soc Am, B 21: 781 (1910)

11 Portland cement and cement resources of the Southern States. Am M Cong, 14th An Sess, Rp Pr : 208-213 (1911)

12 A report on the limestones and cement materials of north Georgia, Ga G S, B 27 : 293 pp, map (1912)

13 Pigeon slates of Tennessee. Stone 34: 82-83 (1913)

13a The green slates of Georgia. Stone 34:198-200 (1913) Sc Record 1:76-85 (1913) [not seen]

13b White rock phosphates of Decatur Co., Tenn. Tenn G S, Res Tenn $3: 161-169$ (1913)

14 The Tennessee phosphates (abst). Science n s 39:401 (1914)

14a The green slates of Georgia (abst). Tenn Ac Sc, Tr 1:68 (1914)

15 The Mineral Hill mining district, Nev. M World 42:1117-1119 (1915)

16 Pottery possibilities in the vicinity of Macon, Ga. ; report of the investigation in the Macon district of the raw materials used in the manufacture of pottery products. Pub. by Macon Chamber of Commerce and Central of Georgia Railway, 51 pp, maps [1916]

See also Swartz, 13a

Maxyck, Wm. G.

78 (and Vogdes, A. W.) Description of a new fossil from the Cretaceous beds of Charleston, S. C. Ac N Sc Phila, Pr $1878: 272$, il

Mead, Charles Searing.

o3 Field geology in Ohio State University. Am G 32 : 261-263 (1903)

06 Adaptive modifications of occipital condyles in Mammalia. Am Nat $40: 475$ 483 , il (1906)

Mead, Daniel Webster.

93 Notes on the hydrogeology of Illinols in relation to its water supplies. Ill $\mathrm{Soc}$ Eng, Rp 8: 48-68, maps (1893)

94 The hydro-geology of the upper Mis. sissippi Valley and of some of the adjoin. ing territory. As Eng Soc, J $13: 329-396$, maps (1894) 
Mead, Daniel Webster-Continued.

94a The geology of Wisconsin water supplies. $19 \mathrm{pp}$, map, Rockford, IIl, 1894 [priv pub]

94b Geological map and table of economic resources of Illinois. $n \quad p, \quad n \quad d$ [Rockford, Ill, 1894?] [priv pub]

Mead, H. L.

06 Minerals of Washington. Wash, Untv, B (2) $25: 40-48$ (1906)

Mead, J. R.

90 Notes on the occurrence of gold in Montana. Kans Ac Sc, Tr 12:5-6 (1890) 9s The drill hole at Wichita [Kans.]. Kans Ac Sc, Tr 15: 20-22 (1898)

01 The Flint Hills of Kansas. Kans Ac Sc, Tr $17: 207-208$ (1901)

Mead, Warren Judson.

07 Redistribution of elements in the formation of sedimentary rocks. J G 15 : 238-256 (1907)

os The relation of density, porosity, and moisture to the specific volume of ores. Ec G 3:319-325 (1908) M Sc 58:89-91 11908)

09 (and Martin, Lawrence) Apparatus for topographic field work on models in the laboratory. J Geog 7:209-211 (1909)

11 (with Leith, C. K.) Origin of the iron ores of central and northeastern Cuba. Am I M Eng, B 51: 217-229 (1911)

12 Some geological short-cuts. Ec G 7 : 136-144 (1912)

12a (with Leith, C. K.) Metamorphic studies. J G 20:353-361 (1912)

14 The average igneous rocks. J G $22: 772-781$ (1914)

15 Occurrence and origin of the bauxite deposits of Arkansas. Ec G 10:28-54 (1915)

15a (with Leith, C. K.) Metamorphic geology; a textbook. $337 \mathrm{pp}, \mathrm{N}$ X 1915

$15 b$ (with Leith, C. K.) Metamorphic studies; convergence to mineral type in dynamic metamorphism. J G 23:600-607 (1915)

15e (with Leith, C. K.) Additional data on origin of lateritic iron ores of eastern Cuba. Am I M Eng, B 103:13771380 (1915); $\operatorname{Tr} 53: 75-78$ (1916)

Meade, Frank.

00 Coal mines of Pictou [Colo.]. Mines and Minerals 21: $1-3 \quad(1900)$

Meade, Richard $\mathrm{K}$.

18 Strontium; its occurrence, industrial application, and the manufacture of 1 ts salts. Mineral Foote-Notes 2 no $2: 2-12$ (1918)

Meade, William.

14 Description and analysis of an ore of lead from Louisiana [Ste. Genevieve, Mo.]. Am Miner J 1:7-10 (1814)

14 Mineralogical notice respecting elastic marble from Massachusetts. Am Miner J 1:93-95 (1814)
Meade, William-Continued.

14b A description of several combinations of lead, lately discovered at Northampton [Mass.]. Am Miner J 1: 149-151 (1814)

27 Remarks on the anthacites of Europe and America. Am J Sc 12:75-83 (1827)

28 Chemical analysis and description of the coal lately discovered near Tioga River in the State of Pennsylvania. Am J Sc 13 : 32-35 (1828)

2Sa ...new mineral spring at Albany [N. Y.]. Am J Sc 13: 145-158 (1828)

30 ...new locality of zircon [Orange $\mathrm{Co}$., N. Y.]. Am J Sc 17:196-197 (1830)

Meader, J. B.

72 On the mineral resources of Utah. Boston Soc N H, Pr 14:341-345 (1872)

Meadows, Thomas C.

95 (and Brown, Lytle) The phosphates of Tennessee. Am I M Eng, Tr 24: 582-594, map (1895) Abst, Eng M J 58: $365-366$, map (1894)

Meads, Alfred.

oo The copper district on Lake Superior. Eng M J 70:694 (1900)

Means, A. H.

14 Tourmaline-bearing gold quartz veins of the Michipicoten district, Ont. Ec G 9 : 122-135 (1914)

15 Geology and ore deposits of Red Clifi, Colo. Ec G 10:1-27 (1915)

16 Some new mineral occurrences from the Tintic district, Utah. Am J Sc (4) 41: 125-130 (1916)

Meany, Edmond S.

06 Professor Thomas Condon. Pacific Monthly $16: 565-569$, port (1906)

Mease, James (1771-1846).

o7 A geological account of the United States... 496, xiv pp, Phila 1807

Medley, Eduardo.

18 (witi Brödermann, J.) Reconocimiento petrolffero en la Provincia de Santa Clara [Cuba]. Fomento, Habana, $1: 255-$ 258 (1918)

Meeds, A. D.

91 The Stillwater deep well [Minn.]. Minn Ac N Sc, B $3: 274-277$ (1891) Abst, Am G $3: 342-343$ (1889); Science $13: 401$ (1889)

96 A new locality for cobalt in Minnesota (abst). Minn Ac N Sc, B 4:18 (1896)

Meehan, Thomas.

83 Some evidences of great modern geological changes in Alaska. Ac N Sc Phila, Pr 1833: 187-189

84 Notes on glaciers in Alaska. Ac N Sc Phila, Pr 1883 : 249-255 (1884)

Meek, Fielding Bradford (1817-1876).

55 Report on Moniteau Co. Mo G S, An Rp 1-2 pt 2: 96-119, map (1885) 
Meek, Fielding Bradford-Continued.

56 (and Hayden, F. V.) Descriptions of new species of Gastropoda from the Cretaceous formations of Nebraska Terr. Ac N Sc Phila, Pr 8:63-69 (1856)

56a (and Hayden, F. V.) Descrip. tions of new species of Gastropoda and Cephalopoda from the Cretaceous formations of Nebraska Terr. Ac N Se Phila, Pr 8: 70-72 (1856)

56b (and Hayden, F. V.) Descriptions of twenty-eight new species of Acephala and one gasteropod, from the Cretaceous formations of Nebraska Terr. Ac N Sc Phila, Pr 8: 81-87 (1856)

56e (and Hayden, F. V.) Descriptions of new species of Acephala and Gastropoda from the Tertiary formations of Nebraska Terr., with some general remarks on the geology of the country about the sources of the Missouri River. Ac N Sc Phila, Pr 8: 111-126 (1856)

56d (and Hayden, F. V.) Deseriptions of new fossil species of Mollusca...; together with a complete catalogue of all the remains of Invertebrata hitherto described and identified from the Cretaceous and Tertiary formations [of Nebraska Terr.]. Ac N Sc Phila, Pr $8: 265-286$ (1856)

56e (with Hall, James) Descriptions of new species of fossils from the Cretaceous formations of Nebraska, with observations upon Baculites ovatus and B. compressus, and the progressive development of the septa in Baculites, Ammonites, and Scaphites. Am Ac Arts, Mem n s 5:379411 , il (1856)

57 (and Hayden, F. V.) Descriptions of new species and genera of fosslls, collected by Dr. F. V. Hayden in Nebraska Terr...; with some remarks on the Tertiary and Cretaceous formations of the Northwest... Ac N Sc Phila, Pr 1857: 117-148

58 (and Hayden, F. V.) Fossils of Nebraska [Black Hills]. National Intelligencer March 16, 1858 [not seen]. Am J Sc (2) 25:439-441 (1858) M Stat Mag $10: 292-295$ (1858)

$58 a$ (and Hayden, F. V.) On the probable existence of Permian rocks in Kansas Terr. An N Sc Phila, Pr 1858 : 9-10

58b (and Hayden, F. V.) Descriptions of new organic remains collected in Nebraska Terr...together with some remarks on the geology of the Black Hills and portions of the surrounding country. Ac N Sc Phila, Pr 1858:41-59, map

58c (and Hayden, F. V.) Remarks on the lower Cretaceous beds of Kansas and Nebraska, together with descriptions of some new species of Carboniferous fossils from the valley of Kansas River. Ac N Sc Phila, Pr 1858: 256-266 Am J Sc (2) 27 : 219-227, 11 (1859)
Meek, Fielding Bradford-Continued.

59 Remarks on the Cretaceous fossils collected by Pvofessor Henry Y. Hind on the Assiniboine and Saskatchewan explor. ing expedition, with descriptions of some new species. In Hind, H. Y., Northwest Territory ; Reports... Assiniboine and Saskatchewan exploring expedition : $182-185$, il Toronto 1859

$59 a$ (and Hayden, F. V.) On the socalled Triassic rocks of Kansas and Nebraska. Am J Sc (2) $27: 31-35$ (1859)

59b (and Hayden, F. V.) Geological explorations in Kansas Territory. Ac N Sc Phila, Pr 1859: 8-30 (In part) Am J Sc (2) $27: 424-432$ (1859) -

60 (and Hayden, F. V.) On a new genus of patelliform shells from the Cre. taceous rocks of Nebraska. Am J Sc (2) $29: 33-35$ (1860)

60a (and Engrelmann, H.) Notice of geological discoveries, made by Capt. J. H. Simpson...in his recent explorations across the continent. Ac N Sc Phila, Pr 1860: 126-131

60b (and Hayden, F. V.) Descriptions of new organic remains from the Tertiary, Cretaceous, and Jurassic rocks of Nebraska. Ac N Sc Phila, Pr 1860:175-185

60e Descriptions of new fossil remains collected in Nebraska and Utah, by the es. ploring expeditions under the command of Capt. J. H. Simpson... Ac N Sc Phila, Pr $1860: 308-315$

6od (and worthen, A. H.) Descriptions of new species of Crinoidea and Echinoidea from the Carboniferous rocks of Illinois, and other Western States. Ac N Sc Phila, Pr 1860: 379-397

60e (and Hayden, F. V.) Systematic catalogue, with synonyma, etc., of Jurassic, Cretaceous, and Tertiary fossils collected in Nebraska Terr... Ac N Sc Phila, Pr 1860: 417-432

6or (and Worthen, A. H.) Descriptions of new Carboniferous fossils from Illinois and other Western States. AC N Sc Phila, Pr 1860:447-472

61 (and worthen, A. H.) ... age of the Goniatite limestone at Rockford, Indiana, and its relation to the "black slate" of the Western States, and to some of the succeeding rocks above the latter. Am J Sc (2) $32: 167-177,288$ (1861)

61 a Reply to Mr. Marcou's strictures on Mr. F. B. Meek in his Notes on the Cretaceous and Carboniferous rocks of Texas. Am J Sc (2) 32:278-280 (1861)

61b (and Worthen, A. H.) Descriptions of new Paleozoic fossils from Illinols and Iowa. Ac N Sc Phila, Pr 1861: 128148

61e Descriptions of new Cretaceous fossils collected by the Northwestern Boun. dary Commission, on Vancouver and Sucta islands. Ac N Sc Phila, Pr 1861:314-315 
Meek, Fielding Bradford-Continued.

61d (and Hayden, F. V.) Descriptions of new Lower Silurian (Primordial), Jurassic, Cretaceous, and Tertiary fossils, collected in Nebraska Terr..., with some remarks on the rocks from which they were obtained. Ac N Se Phila, Pr 1861:415447

62 (and Hayden, F. V.) Descriptions of new Cretaceous fossils from Nebraska - Terr... Ac N Se Phíla, Pr 1862: 21-28

63 Remarks on the family Actaeonidae with descriptions of some new genera and subgenera. Am J Sc (2) 35: 84-94 (1863)

64 Description of the Carboniferous fossils. Cal G S, Paleontology $1: 1-16$, il (1864)

64a Description of the Jurassic fossils. Cal G S, Paleontology $1: 37-53$, il (1864)

64b Remarks on the family Pteriidae (=Aviculidae) with descriptions of some new fossil genera. Am J Sc (2) $37: 212$ 220 (1864)

64e Check list of the invertebrate fossils of North America; Cretaceous and Jurassic. Smiths Misc Col 7 (177): 40 pp (1864)

64d Check list of the invertebrate fossils of North America; Miocene. Smiths Mise Col 7 (183) : 32 pp (1864)

64e Descriptions of new organic remains from the Cretaceous rocks of Vancouver's Island. Albany Inst, Tr 4:37-49 (1864)

64f (and Hayden, F. V.) Descriptions of new organic remains from northeastern Kansas, indicating the existence of Permian rocks in that territory. Albany Inst, $\operatorname{Tr} 4: 73-88$ (1864)

65 Description of fossils from the auriferous slates of Callfornia. Cal G $\mathrm{S}$, Geology 1:477-482, il (1865)

65a (and Hayden, F. V.) Paleontology of the upper Missouri; invertebrates. Smiths Contr Knowl 14 art 5 (172): 135 pp, il (1865)

65b Remarks on the Carboniferous and Cretaceous rocks of eastern Kansas and Nebraska... Am J Sc (2) $39: 157-174$ (1865)

65e (and worthen, A. H.) Note in relation to a genus of crinoids [Erisocrinus] from the Coal Measures of Illinois and Nebraska, Am J Sc (2) $39: 350$ (1865)

65d Preliminary notice of a small collection of fossils found by Dr. Hays on the west shore of Kennedy Channel at the highest northern localities ever explored. Am J Sc (2) $40: 31-34$ (1865) Also in Hayes, I. I., The open polar sea...: 341 , L 1867

65e (and worthen, A. H.) Notice of some new types of organic remains, from the Coal Measures of Illinois. Ac N Sc Phlla, Pr 1865: 41-53
Meek, Fielding Bradford-Continued.

65f '(and worthen, A. H.) Remarks on the genus Taxocrinus (Phillips) MeCoy, 1844 ; and its relations to Forbesiocrinus, Koninck and Le Hon, 1854, with descriptions of new species. Ac $\mathrm{N}$ Sc Phila, Pr 1865 : 138-143

65g (and Worthen, A. H.) Descriptions of new species of Crinoidea, etc., from the Paleozolc rocks of Illinois and some of the adjoining States. Ac N Sc Phila, Pr 1865: 143-155

65h (and Worthen, A. H.) Descriptions of new Crinoidea, etc., from the Carboniferous rocks of Illinois and some of the adjoining States. Ac N Sc Phila, Pr 1865: 155-166

$65 i$ Note on the genus Gilbertsocrinus Phillips. Ac N Sc Phila, Pr 1865: 166-167

65j (and Worthen, A. H.) Contributions to the paleontology of Illinols and other Western States. Ac N Sc Phila, Pr $1865: 245-273$

65k Observations on the microseopic shell structure of Spirifer cuspidatus Sowerby, and some similar American forms. Ac N Sc Phila, Pr 1865:275-277

66 (and Worthen, A. H.) Introduction (to volume II, Paleontology) [includes discussion of nomenclature of Illinois formations]. IIl G S 2:ili-xix (1866)

66a (and Worthen, A. H.) Descriptions of invertebrates from the Carboniferous system. Ill G S $2: 143-411$, il (1866)

66b Note on the affinities of the Bellerophontidae. Chicago Ac Sc, $\operatorname{Pr} 1: 9-11$ (1866)

66e (and worthen, A. H.) Descriptions of Paleozoic fossils from the Silurian, Devonian, and Carboniferous rocks of Illinois, and other Western States. Chicago Ac Sc, Pr 1:11-23 (1866)

66d (and Worthen, A. H.) Contributions to the paleontology of Illinois and other Western States. Ac N Sc Phila, Pr $1866: 251-275$

67 Remarks on the geology of the Mackenzle River, with figures and descriptions of fossils from that region... Chicago Ac Sc, Tr 1: 61-114, il (1867)

67 a Note on the use of the name Hudson River group. Am J Se (2) $43: 256-257$ (1867)

67b Note on Bellinurus danae from the Illinois Coal Measures. Am J Sc (2) 43 : $257-258$ (1867)

67e Note on a new genus of fossil Crustacea [Euproops]. Am J Sc (2) 43 : 394-395 (1867)

67d On the punctate shell structure of Syringothyris. Am J Sc (2) $43: 407-408$ (1867)

67e Remarks on Prof. Geinitz's views respecting the upper Paleozoic rocks and fossils of southeastern Nebraska. Am J Sc (2) $44: 170-187,282-283,327-339$ (1867) 
Meek, Fielding Bradford-Continued.

67f Note on the genus Palaeacis Haime, 1860 (=Sphenopoterium M. and W., 1S66). Am J Sc (2) 44:419-420 (1867)

68 Paleontology : Lower Silurian species; Upper Silurian species; Devonian species; Carboniferous species. Ill G S 3:291-565, il (1868)

68a (and Worthen, A. H.) Preliminary notice of a scorpion, a Eurypterus?, and other fossils from the Coal Measures of Illinois. Am J Sc (2) $45: 19-28$ (1868)

$68 b$... a remarkable new genus of corals, probably typical of a new family. Am J Sc (2) $45: 62-64$ (1868)

68c Note on the shell structure and family affinities of the genus Aviculopecten. Am J Sc (2) 45:64-65 (1868)

68d Note on Ethmophyllum and Archeocyathus. Am J Sc (2) 46:144 (1868)

6Se (and Worthen, A. H.) Remarks on some types of Carboniferous Crinoidea with descriptions of new genera and species of the same, and of one echinoid. Ac N Sc Phila, Pr 1868: 335-359

69 (and worthen, A, H.) Notes on some points in the structure and habits of Paleozoic Crinoidea. Ac N Sc Phila, Pr 1868: 323-334 (1869) Am J Sc (2) 48 : 23-40 (1869) Can Nat n s 4:434-452 (1869)

$69 a$ (and worthen, A. H.) Descriptions of new Crinoidea and Echinoidea, from the Carboniferous rocks of the Western States, with a note on the genus onychaster. Ac N Sc Phila, Pr 1869:67-83

69b (and Worthen, A. H.) Remarks on the Blastoidea, with descriptions of new species. Ac N Sc Phila, Pr 1869:83-91

69e (and Worthen, A. H.) Descriptions of new Carboniferous fossils from the Western States. Ac N Sc Phila, Pr 1869: $137-172$

69d F. B. Meek's reply to Prof. Swallow. $9 \mathrm{pp}, \mathrm{n}$ p, $\mathrm{n}$ d [Washington 1869(?)] [priv pub]

70 List of fossils from Utah, with some notes. U S G Expl 40th Par (King), 3: 459-466 (1870)

70a (and worthen, A. H.) Note on the relations of Synocladia King 1849, to the proposed genus Septopora Prout 1858. Ac N Sc Phila, Pr $1870: 15-18$

rob (and worthen, A. H.) Descriptions of new species and genera of fossils from the Paleozoic rocks of the Western States. Ac N Sc Phila, Pr 1870:22-56

70c Descriptions of fossils collected by the U. S. Geological Survey... [Rocky Mountains region] Ac $\mathrm{N}$ Sc Phila, $\mathrm{Pr}$ $1870: 56-64$

70d A preliminary list of fossils collected by Dr. Hayden in Colorado, New Mexico, and California, with brief descriptions of a few of the new species. Am Ph Soc, Pr 11: 425-431 (1870)
Meek, Fielding Bradford-Continued.

70e Geology of the line of the grest Pacific rallway. G Mag 7:163-164 (1870)

71 Preliminary paleontological repor, consisting of lists of fossils, with descrip tions of some new types, ete. U S G s Wyo (Hayden), Prel Rp [4]:287-318 (1871)

71a Preliminary notice of a new specis of Trimerella from Ohio. Am J Sc (3) 1 : $305-306$ (1871)

71b On some new Silurian [Ordovician] crinoids and shells. Am J Se (3) $2: 290^{\circ}$ 299 (1871)

71e Remarks on the genus Lichenocr. nus. Am J Sc (3) 2:299-302 (1871) An Mag N H (4) $8: 341-345$ (1871)

71d Descriptions of somre new types of Paleozoic shells. Am J Conch $7: 4-10$, i] (1871)

71e Descriptions of new species of in. vertebrate fossils from the Carboniferous and Devonian rocks of Ohio. Ac N SC Phila, Pr 1871: 57-93

71f Descriptions of new species of fos. slls from Ohio and other Western States and Territories, Ac N Sc Phila, Pr 1871: 159-184

$71 \mathrm{~g}$ Notice of a new brachiopod from the lead-bearing rocks at Mine Lamotte, Mo. Ac N Sc Phila, Pr 1871: 185-187,

71h Lists of Carboniferous fossils from West Virginia; descriptions of new species W Va Univ, Rp Bd Reg 3:68-73 (1871)

72 Report on the paleontology of east. ern Nebraska with some remarks on the Carboniferous rocks of that district. In Hayden, F. V., Final report of the United States Geological Survey of Nebraska.. (U S, 42d Cong 1st sess, H Ex Doc 19): $83-239$, il (1872)

72a Preliminary list of the fossils col lected... in Utah and Wyoming Territories, with descriptions of a few new species. U S G S Mont (Hayden), An Rp 5:373377 (1872)

72b Supplementary note on the genus Lichencrinus. Am J Sc (3) $3: 15-17$ (1872) An Mag $\mathrm{N} H$ (4) $9: 247-248$ (1872)

72e Descriptions of two new starfishes and a crinoid from the Cincinnati group of Ohio and Indiana. Am J Sc (3) 3: 257-262 (1872)

72d Descriptions of new species of fos. sils from the Cincinnati group of Ohlo. Am J Sc (3) 3:423-428 (1872)

72e Descriptions of a few new species and one new genus of [Ordovician and] Silurian fossils from Ohio. Am J Sc (3) 4: 274-281 (1872)

72R Descriptions of new western Pale0. zoic fossils, mainly from the Cincinnat group of the Lower Silurian series of Obio. Ac N Sc Phila, Pr 1871: 308-336 (1872) 
Meek, Fielding Bradford-Continued.

73 Preliminary paleontological report, consisting of lists and descriptions of fossils, with remarks on the ages of the rocks in which they were found, etc. U S G S Terr (Hayden), An Rp 6:429-518 (1873)

73a (and worthen, A. H.) Descriptions of invertebrates from Carboniferous system. Ill G S 5:321-619, il (1873)

73b Deseriptions of invertebrate fossils of the Silurian and Devonian systems. Ohio G S, 1 pt 2 Paleontology : 1-243, il (1873)

73e Miller, Morgan, and Saline cos. In Reports on the geological survey of the State of Missouri, 1855-1871: 111-188, maps, Jefferson City 1873

73d Spergen Hill fossils identified among specimens from Idaho. Am J Sc (3) 5 : 383-384 (1873)

74 Pleurotomaria taggarti [Colo.]. U S G Geog S Terr (Hayden), An Rp [7] : 231 (1874)

74a Notes on some of the fossils figured in the recently-issued fifth volume of the Illinois State geological report. Am J Sc (3) $7: 189-193,369-376,484-490,580-584$ (1874)

74b New genus Euchondria Meek. Am J Sc (3) $7: 445$ (1874)

74e On the age of the lignitic formation of the Rocky Mountain region. Am J Sc (3) $8: 459-463 \quad(1874)$

75 Note on some fossils from near the eastern base of the Rocky Mountains, west of Greeley and Evans, Colo, and others from about two hundred miles farther eastward, with descriptions of a few new species. U S G Geog S Terr (Hayden), B [1] (2) $1: 39-47$ (1875)

$75 a$ [Description of Olenus (Olenellus) gilberti Meek.] In Gllbert, G. K., Report on the geology of portions of Nevada, Utah, California, and Arizona (U S Geog G S W 100th Mer), 3:182-183 (1875)

75b (and Worthen, A. H.) Descriptions of invertebrates. III G S $6: 489-532$, II (1875)

75e A report on some of the invertebrate fossils of the Waverly group and Coal Measures of Ohio. Ohio G S, Rp 2 pt 2 Paleontology : 269-347, il (1875)

76 A report on the invertebrate Cretaceous and Tertiary fossils of the upper Missouri country. U S $\mathrm{G}$ S Terr (Hayden), Rp 9: lxiv, 629 pp, il (1876)

$76 a$ Notice of a very large goniatite from eastern Kansas. U S G Geog S Terr (Hayden), B [1] no 6 (2): 445 (1876)

76b Descriptions and illustrations of fossils from Vancouver's and Sucia islands and other nurtbwestern localities. U S G Geog S Terr (Hayden), B $2: 351-374$, il (1876)

$$
28737^{\circ}-23-47
$$

Ireek, Fielding Bradford-Continued.

76e Note on the new genus Uintacrinus Grinnell. U S G Geog S Terr (Hayden), B $2: 375-378$, il (1876)

76d Descriptions of the Cretaceous fos sils collected... In Macomb, J. N., Report of the exploring expedition from Santa Fe... in 1859 ; U S Army, Eng Dp : 119-133, il, Wash 1876

76e Report on the paleontological collections of the expedition. In Simpson, J. H., Report of explorations across the Great Basin of the Territory of Utah... in $1859: 337-373$, il, Washington 1876

77 Paleontology. U S G Expl 40th Par (King), 4:1-197, il (1877)

80 Descriptions of new species of fossil plants from Alleghany Co., Va.; with some remarks on the rock seen along the Chesapeake and Ohio Railroad, near the White Sulphur Springs of Greenbrier Co., W. Va. $\mathrm{Ph}$ Soc Wash, B 2 App VIII: $1-x i x$, il (1880)

See also Cope, $75 \mathrm{c}$

Meeks, Reginald.

o7 The iron-ore mines of the Mesabi range. Eng M J 84: 193-195 (1907)

07a The Montreal River silver district [Ont.]. Eng M J 84: 544-548 (1907)

Meem, John $G$.

86 Limonite pseudomorphs after pyrite. Am J Sc (3) 32:274-276 (1886)

Megraw, H. A.

10 Old mining eamp of Pozos, Guanajuato, Mex. Eng M J 89: 961-963 (1910)

Mehl, Maurice Goldsmith.

12 Pantylus cordatus Cope [Baylor County, Tex.]. J G 20:21-27, il (1912)

12a Muronosaurus? reedii sp. nov. and Tricleidus? laramiensis Knight, American Jurassic plesiosaurs. J G 20:344-352, il (1912)

13 Angistorhinus, a new genus of Phytosauria from the Trias of Wyoming. J G $21: 186-191$, il (1913)

14 (with Weller, S.) Western extension of some Paleozoic faunas in southeastern Missouri (abst). G Soc Ami, B 25 : 135-136 (1914)

15 The Phytosauria of the Trias. J G $23: 129-165$, il (1915)

15a Poposaurus gracilis, a new reptlle from the Triassic of Wyoming. J G 23 : $516-522$, il (1915)

15b New reptiles from the Trias of Arizona and New Mexico. Science n s 41: 735 (1915)

16 Caimanoidea visheri, a new crocodilian from the Oligocene of South Dakota. J G 24:47-56, il (1916)

Meigs, Charles D.

51 A memoir of Samuel George Morton... $48 \mathrm{pp}$, port, Phila 1851. Extracts, Am J Se (2) $13: 153-178$ (1852) 
Meiss, Montgomery C.

80 On the movements caused in large ice fields by expansion and contraction, as illustrative of the formation of anticlinal and synclinal axes in geological formations. Ph Soc Wash, B 2 App vii : $i-i v$ (1880)

86 The Charleston earthquake. Science $8: 390-391$ (1886)

Meinecke, Franz.

09 Der Meteorkrater von Canyon Diablo in Arizona und seine Bedeutung für die Entstehung der Mondkrater. Naturw Wochensch 24: $801-810$ (1909)

Meinhold, Felix.

o4 Die Kïste der mittleren atlantischen Staaten Nordamerikas. Diss, Leipzig. 89 pp, Crimmitschau 1904.

Meinzer, Oscar Edward.

10 Preliminary report on the ground waters of Estancia Valley, N. Mex. U S G S, W-S P $260: 33$ pp (1910)

11 Geology and water resources of Estancia Valley, N Mex., with notes on ground-water conditions in adjacent parts of central New Mexico. U S G S, W-S P $275: 89 \mathrm{pp}$ (1911) Abst, Wash Ac Sc, J 2: 226-227 (1912)

11a Ground water in Juab, Millard, and Iron cos., Utah. U S G S, W-S P 277 : $162 \mathrm{pp}$ (1911) A \&st, Wash Ae Sc, J 2 : 226 (1912)

$11 b$ (with HaI1, C. W.) Geology and underground waters of southern Minnesota. U S G S, W-S P 256: 406 pp (1911)

12 The development of a typical bolson in the Southwest $(a b s t)$. Wash Ac Sc, I 2 : $357-358$ (1912)

12a (with Norton, W. H., and others) Underground water resources of Iowa. U S G S, W.S P 293: 994 pp, maps (1912) Iowa G S 21: 29-1186, maps (1912)

13 (and frelton, F. C.) Geology and water resources of Sulphur Spring Valley, Ariz. U S G S, W-S P 320:9-213, map (1913)

14 Preliminary report on groundwater for irrigation in the vicinity of Wichita, Kans. U S G S, W-S P 345 : 1-9 (1914)

$14 a$ Ground water for irrigation on the Great Plains. U S G S, W-S P 345: 21-23 (1914)

141. The water resources of Butte, Mont. U S G S, W-S P 345: 79-125, map (1914)

15 (and Hare, R. F.) Geology and water resources of Tularosa Basin, N. Mex. U S G S, W-S P $343: 317$ pp, maps (1915) Alst, Wash Ac Sc, J 6:452-453 (1916)

15a (and Ellis, A. J.) Ground water in Paradise Valley, Ariz. U S G S, W-S P 375:51-75, map (1915)

15b Ground water in Big Smoky Valley, Nev. U S G S, W-S P 375: 85-116, map (1915)

16 Arteslan water for irrigation in Little Pitterroot Valley, Mont. U S G S, W-S P 400: 9-37, maps (1916)
Meinzer, Oscar Edward-Continued.

16a Physical features of Guantanam Bay and adjacent areas in Cuba (abst). Wash Ac Sc, J 6:189 (1916)

17 Geology and water resources of the Big Smoky, Clayton, and Alkali Spring val leys, Nev. U S G S, W-S P 423:16i po maps (1917) Abst, Wash Ac Sc, J 8:9596 (1918)

17a Ground water for irrigation in Lodgepole Valley, Wyo. and Neb. U S G S W-S P 425:37-69, maps (1917) Alut, Wash Ac Sc, J 8:65 (1918)

18 Bibliography and index of the publt cations of the United States Geological Survey relating to ground water. U S G \& W-S P 427: 169 pp, map (1918)

18a The geologist in war times; rela tion to military supplies (discussion). E G $13: 314-315$ (1918)

18b The glacial history of Columbi River in the Big Bend region (abst). Wash Ac Sc, J 8:411-412 (1918)

1Sc (with Schwennesen, A. T. Ground water in Quincy Valley, Wash. U S G S, W-S P 425: 131-161 (1918)

See also Schwennesen, 17 ; Waring (C A) 13

Meissner, C. A.

94 Analysis of limestones and dolomite of the Birmingham, Ala., district. Alt Ind $\mathrm{Sc}$ Soc, $\operatorname{Pr} 4: 12-23$ (1894)

02 Some of the pyrites deposits at Por au Port, Newfoundland. Eng M J t? 626-627 (1902) M Soc N S, J $7: 55-6$ (1903)

Melander, A. L.

o3 Some additions to the Carboniferou terrestrial arthropod fauna of Illinols. J 6 11: 178-198, il (1903)

Meleher, J. C.

88 Notes on the economic minerals of Fayette Co. [Tex.]. G Sc B 1 no 8: (1888)

Melero, Marcos de Jestís.

75 Noticia acerca de un diente fosll is Squalus antediluviano [Cuba]. R Ac Clesc Habana, An 11: 484-489, 539 (1875)

Melgareio, A.

10 The greatest volcanoes of Mexiou. Nat Geog Mag 21: 741-760 (1910)

Mell, Patrick Hues.

80 The Claiborne group and its $\mathrm{ft}$ markable fossils. Am I M Eng, Tr 8: 304-313 (1880)

S1 Auriferous sate deposits of the southern mining region. Am I M Eng, Ti $9: 399-402$ (1881) Eng M J $31: 398-399$ (1881)

82 The southern soapstones, kaolin, and fire clays, and their uses. Am I M Ens Tr 10:318-322 (1882)

Melsted, V. J.

os (with Barry, J. G.) The geology of northeastern North Dakota with spects reference to cement materials. $N$ Dak $G$ A Bien Rp 5: 115-211 (1908) 
Melville, William Harlow.

90 (and Lindgren, W.) Contributions to the mineralogy of the Pacific coast. U S G S, B 61: 40 pp (1890)

$90 a$ Metacinnabarite from New Almaden, Cal. Am J Sc (3) 40:291-295 (1890)

91 The chemistry of the Mount Diablo rocks. G Soc Am, B 2: 402-414 (1891)

91a Powellite-calcium molybdate; a new mineral species. Am J Sc (3) 41:138-141 (1891)

91b Diaspore crystals. Am J Sc (3) 41 : 475-477 (1891)

92 Josephinite, a new nickel-iron. Am J Se (3) $43: 509-515$ (1892)

Melzer, Emil.

10 The North Pole mine, Baker Co., Oreg. Eng M J 89:868-869 (1910)

Memminger, C. J.

94 Florida kaolin deposits. Eng M . $57: 436$ (1894)

Menaul, P. L.

16 (with Clark, J. D.) The rôle of colloidal migration in ore deposits. Ec $\mathbf{G}$ $11: 37-41$ (1916)

Mendenhall, Thomas Corwin.

86 Report on the Charleston earthquake. Mo Weather Rv $14: 233-235$ (1886) Nature $35: 31-33(1886)$

87 The Charleston earthquake. Science $9: 584-587$ (1887)

88 Selsmoscopes and seismological investigations. Am J Sc (3) 35:97-114 (1888)

89 On the intensity of earthquakes, with approximate calculations of the energy involved. Am As, Pr 37:190-195 (1889)

97 Life and letters of William Barton Rogers. Science n \& 6:1-9, port (1897)

Mendenhall, Walter Curran.

96 (with Campbell, M. R.) Geologic section along the New and Kanawha rivers in West Virginia. U S G S, An $\mathrm{Rp} 17 \mathrm{pt}$ $2: 473-511$ (1896)

99 [Reconnaissance from Resurrection Bay to the Tanana River, Alaska (ałst).] Science n s 9:551 (1899)

00 A reconnaissance from Resurrection Bay to the Tanana River, Alaska, in 1898 . U S G S, An Rp 20 pt $7: 265-340$, maps (1900)

OOa (with Smith, G. O.) Tertiary granite in the northern Cascades. G Soc Am, B 11:223-230 (1900) Abst, Science n s $11: 144$ (1900)

01 A reconnaissance in the Norton Bay region, Alaska, in 1900. In Brooks, A. H., and others, Reconnaissances in the Cape Nome and Norton Bay regions, Alaska, in $1900: 187-218$, U S G S 1901

02 Reconnaissance from Fort Hamlin to Kotzebue Sound, Alaska. U S G S, P P 10:68 pp, maps (1902)

02a Notes on the geology of the Klondike (abst). Science n s 15: 389 (1902)
Mendenhall, Walter Curran-Continued. 03 (and Sehrader, F. C.) The mineral resources of the Mount Wrangell district, Alaska. U S G S, P P 15:71 pp, maps (1903)

O3a The Chistochina gold fleld, Alaska. U S G S, B 213: 71-75 (1903)

o3b (and Schrader, F. C.) Copper deposits of the Mount Wrangell region, Alaska. U S G S, B 213: 141-148 (1903) 03c The Wrangell Mountains, Alaska. Nat Geog Mag 14: 395-407 (1903)

03d A Carboniferous section in the upper Copper River valley, Alaska (abst). Science n s 17:25-26 (1903)

03e Chitina copper deposits, Alaska (abst). Science n s 17:387 (1903)

05 Geology of the central Copper River region, Alaska. U S G S, P P 41: $133 \mathrm{pp}$, $\operatorname{map} 3$ (1905)

05a Development of underground waters in the eastern coastal plain region of southern California. U S G S, W-S P 137:140 pp, maps (1905)

$\mathbf{0 5} \mathbf{b}$ Development of underground waters in the central coastal plain region of southern California. U S G S, W-S P 138: 162 pp, maps (1905)

o5e Develpment of underground waters in the western coastal plain region of southern California. U S G S, W-S P 139 : $105 \mathrm{pp}$, maps (1905)

05d The hydrology of the San Bernardino Valley, Cal. U S G S, W-S P 142 : 124 pp, maps (1905)

os Two mountain ranges of southern California [San Bernardino and San Gabriel ranges] (abst). G Soc Am, B 18:660661 (1908)

osa Ground waters and irrigation enterprises in the foothill belt, southern Callfornia. U S G S, W-S P 219:180 pp (1908)

osb Preliminary report on the ground waters of San Joaquin Valley, Cal. U S G S, W-S P 222: 52 pp (1208)

09 A phase of ground иater problems in the West. Ec G 4:35-45, map (1909)

09 Some desert watering places in southeastern California and southwestern Nevada. U S G S, W-S P 224:98 pp (1909)

09b Ground waters of the Indio region, Cal., with a sketch of the Colorado Desert. U S G S, W-S P $225: 56$ pp (1909)

o9e Underground waters. U S G S, W-S P 234:68-77 (1909) Nat Conservation Comm Rp (60th Cong 2d sess, Sen Doc no 676) 2:86-94 (1909)

09d The Colorado Desert. Nat Geog Mag 20:681-701 (1909)

09e A coal prospect on Willow Creek, Morrow Co., Oreg. U s G S, B 341: 406408 (1909)

10 Notes on the geology of Carrizo Moun. tain and vicinity, San Diego Co., Cal. J G 18: $336-355$ (1910) 
Mendenha11, Walter Curran-Continued. 16 (and others) Ground water in San Joaquin Valley, Cal. U S G S, W-S P 398 : $310 \mathrm{pp}$, maps (1916) Abst, Wash Ac Sc, J $6: 502-503$ (1916)

See also Eldridge, 99

Menne11, J. L.

10 Oil in Mexico. M Mag 2:448-450 (1910)

Mercalli, Giuseppe.

02 Le antiche eruzioni della Montagna Pelée. Soc Italiana Sc Nat Milano, Atti 41 : 313-322 (1902)

Mereanton, P. L.

13 Les variations périodiques des glaciers, XVIII me rapport, 1912; terres polaires, Grönland. Zs Gletscherk 8:60-62 (1913)

Mercer, Henry Chapman.

94 Reexploration of Hartman's Cave, near Strondsburg. Pa., in 1893. Ac N Sc Phila, Pr 1894: 96-104

95 ... re-exploration in 1894 and 1895 of the "Bone Hole," now known as Irwin's Cave, at Port Kennedy, Montgomery Co., Pa. Ac N Sc Phila, Pr 1895: 443-446

97 The finding of the remains of the fossil sloth at Big Bone cave, Tennessee, in 1896. Am Ph Soc, $\mathrm{Pr} 36: 36-70$, il (1897)

99 The bone cave at Port Kennedy, Pa., and its partial excavation in 1894,1895 , and 1896. Ac N Sc Phila, J (2) 11:269285 (1899)

Mereiai, G.

15 Escursione mineralogica nel Canada. Soc G Italiana, B 34:181-201 (1915)

Meredith, Thomas.

27 ... Belmont anthraeite mines in Pennsylvania. Am J Sc $12: 301-302$ (1827)

Merivale, Walter.

98 Occurrence and mining of manjak in Barbados, W. I. N Engl Inst M Eng, Tr 47:119-127 (1898); 48:33-36 (1899)

Merriam, Clinton Hart.

02 Bogeslof, our newest volcano [Alaska]. Harriman Alaska Exped 2:291336 (1902)

O2a Bogoslof volcanoes. Smiths Inst, An Rp 1901: 367-375 (1902)

13 The remarkable extinct fauna of southern California revealed in the asphalt deposits near Los Angeles $(a b s t)$. Science n s $38: 314$ (1913)

Merriam, John Campbell.

94 Ueber die Pythonomorphen der Kansas-Kreide. Palaeontographica 41:139 , il (1894)

95 On some reptilian remains from the Triassic of northern California. Am J Sc (3) $50: 55-57$, il (1895)

96 Sigmogomphius lecontei, a new castoroid rodent from the Pliocene near Berkeley, Cal. Cal Univ, Dp G, B 1 : 363370 , il (1896)
Yerriam, John Campbell-Continued.

96a Note on two Tertiary faunas fro the rocks of the southern coast of $\mathrm{V}:$ couver Island. Cal Univ, Dp G, B 2:10\%108 (1896)

$\mathbf{9 7}$ The geologic relations of the Marting group of Californis at the typical locality J G 5:767-775 (1897)

97 a New species of Tertiary Mollom from Vancouver Island. Nautilus 11: 6t. 65 (1897)

98 The distribution of the Neocene urchins of middle California and its ber ing on the classification of the Neocest formations. Cal Univ, Dp G, B $2: 109-11$, (1898)

99 The Tertiary sea urchins of midth California. Cal Ac Se, Pr (3) G 1:161174, il (1899)

$99 \mathbf{a}$ The fauna of the Sooke beds Vancouver Island. Cal Ac Sc, Pr (3) G1: $175-180$, il (1899)

99b Report on the expedition to th Jobn Day fossil fields [Oregon]. [Ca]] Univ Chronicle 2:217-224, map (1893)

oo Ground sloths in the California Qn ternary. G Soc Am, B 11:612-614, (1900) Abst, Science n s 11:219 (1900)

OOa Classification of the John Day bet (abst). Science n s 11:219-220 (1900)

01 Geological section through John Dar Basin (abst). G Soc Am, B 12:496-49: (1901) J G $9: 71-72$ (1901) Am G 2n! 132 (1901)

01 a A contribution to the geology of te John Day Basin [Oreg.]. Cal Univ, Dp G B $2: 269-314$ (1901)

01b The John Day fossil beds [Oreg], Harper's Mag 102: 581-590 (1901)

02 Triassic Ichthyopterygia from Calt fornia and Nevada. Cal Univ, Dp G, B 3 : 63-108, il (1902) Abst, Science n s $15:$ 411-412 (1902)

03 New Ichthyosauria from the upper Triassic of California. Cal Univ, Dp G, B $3: 249-263$, il (1903)

03a The Pliocene and Quaternary Cant dae of the Great Valley of California. (a) Univ, Dp G, B 3:277-290, il (1903)

03b (and sinclair, W. J.) The cort lation of the John Day and the Mascall (abst). J G 11:95-96 (1903)

o3e Primitive characters of the Triasth ichthyosaurs (abst). Science n s 17:297 (1903) G Soc Am, B 14:536 (1904)

o3d Recent literature on Triassic Id thyosauria. Science n s 18:311-31? (1903)

04 A note on the fauna of the lowe Miocene in California. Cal Univ, Dp G, $3: 377-381$ (1904)

04a A new marine reptile from the Trt assic of California [Thalattosaurus alesot drae]. Cal Univ, Dp G, B 3:419-421, (1904) 
Merriam, John Campbell-Continued.

05 A primitive ichthyosaurian limb from the middle Triassic of Nevada. Cal Univ, Dp G, B 4:33-38, il (1905)

05a A new sabre-tooth from California. Cal Univ, Dp G, B 4: 111-175 (1905)

05b The Thalattosauria, a group of marine reptiles from the Triassic of California. Cal Ac Sc, Mem 5:1-52, il (1905) Abst, Science n s $19: 218$ (1904)

05e The types of limb structure in the Triassic Ichthyosauria. Am J Sc (4) 19: 23-30 (1905) Abst, Science n s 19:218 (1904)

05d The occurrence of ichthyosaur-like remains in the Upper Cretaceous of Wyoming. Science n s 22:640-641 (1905)

05e A new group of marine reptiles from the Triassic of California [Thalattosaurus]. Int Cong Zool, 6th, C R: 247-248 (1905)

06 On the occurrence of Desmostylus Marsh. Science n s 24: 151-152 (1906)

06a Recent discoveries of Quaternary mammals in southern California. Science n 8 24:248-250 (1906)

06b Carnivora from the Tertiary formations of the John Day region. Cal Univ, Dp G, B 5:1-64, il (19v6)

o6e Preliminary note on a new marine reptile [Omphalosaurus nevadanus] from the middle Triassic of Nevada. Cal Univ, Dp G, B 5:71-79, 11 (1906)

06d Recent cave exploration in California. Am Anthropologist n s 8:221-228 (1906)

07 Tertiary faunas of the John Day region. Cal Univ, Dp G, B 5:171-205 (1907)

07a The occurrence of middle Tertiary mammal-bearing beds in northwestern Nevada. Science n s $26: 380-382$ (1907)

08 Triassic Ichthyosauria, with special reference to the American forms. Cal Univ, Mem 1:1-196, il (1908)

08a Notes on the osteology of the thalattosaurian genus Nectosaurus. Cal Univ, Dp G, B $5: 217-223$, il (1908)

08b Primitive characters of American Triassic ichthyosaurs (abst). G Soc Am, B 18:659 (1908)

0se Death trap of the ages [asphalt beds at Rancho La Brea, Cal.]. Sunset Mag $21: 465-475$, il $(1908)$

09 The skull and dentition of an extinct cat closely related to Felis atrox Leidy. Cal Univ, Dp G, B $5: 291-304$, il (1909)

09a The occurrence of strepsicerine antelopes in the Tertiary of northwestern Nevada. Cal Univ, Dp G, B $5: 319-330$ (1909)

09b Note on the occurrence of human remains in Californian caves. Science n s 30:531-532 (1909)
Merriam, John Campbell-Continued.

09e $A$ death trap which antedates Adam and Eve; the discovery of a Californian tar swamp that holds the bones of extinct monsters. Harpers Weekly 53, Dec. 18, $1909: 11-12$, il

10 The skull and dentition of a primitive ichthyosaurian from the middle Triassic [Phalarodon fraasi, West Humboldt Range, Nev. 1. Cal Univ, Dp G, B $5: 381-390$, il (1910)

10a New Mammalia from Rancho La Brea. Cal Univ, Dp G, B 5 : 391-395 (1910)

10b Tertiary mammal beds of Virgin Valley and Thousand Creek, in northwestern Nevada; Part I, Geologie history. Cal Univ, Dp G, B 6:21-53, il (1910)

10e The relation of paieontology to the history of man, with particular reference to the American problem. Pop Se Mo $77: 597-601$ (1910)

10d The true story of the Calaveras skull. Sunset Mag 24:153-15s (1910)

10e Synopsis of lectures in paleontology. Cal Univ, Series Syllabuses, Synopsis no 20, 1910 [not seen]

11 The fauna of Rancho La Brea; Part, I, Occurrence. Cal Univ, Mem 1: 197-213, il (1911)

11 Note on a gigantic bear [Arctotherium californicum] from the Pleistocene of Rancho La Brea, Cal. Cal Univ, Dp G, B $6: 163-166$, il (1911)

11 b A collection of mammalian remains from Tertiary beds on the Mohave Desert. Cal Univ, Dp G, B $6: 167-169$, il (1911)

11e Tertiary mammal beds of Virgin Valley and Thousand Creek in northwestern Nevada; Part II, Vertebrate faunas. Cal Univ, Dp G, B 6:199-304, il (1911)

11d (and Bryant, H. C.) Notes on the dentition of Omphalosaurus. Cal Univ, Dp G, B $6: 329-332$, il (1911)

11e Notes on the genus Desmostylus of Marsh. Cal Univ, Dp G, B 6:403-412, il (1911)

12 The fauna of Rancho La Brea; Part II, Canidse. Cal Univ, Mem $1: 215-272$, il (1912)

12a Recent discoveries of, Carnivora in the Pleistocene of Rancho La Brea. Cal Univ, Dp G, B $7: 39-46$, il (1912)

12b Ten years' progress in vertebrate paleontology; marine reptiles. G Soe $\mathrm{Am}$, B $23: 221-223$ (1912)

13 Tapir remains from late Cenozoic beds of the Pacific coast region. Cal Univ, Dp G, B $7: 169-175$, il (1913)

$13 a$ The skull and dentition of a camel from the Pleistocene of Rancho La Brea. Cal Univ, Dp G, B $7: 305-323$, il (1913)

13b. A peculiar horn or antler from the Mohave Miocene of California. Cal Univ, Dp G, B $7: 335-339$, il (1913) 
Merriam, John Campbell-Continued.

13e Notes on the canid genus Tephrocyon. Cal Univ, Dp G, B $7: 359-372$, il (1913)

13d Vertebrate fauna of the Orindan and Slestan beds in middle California. Cal Univ, Pp G, B $7: 373-385$, il (1913)

13e Preliminary report on the horses of Rancho La Brea. Cal Univ, Dp G, B 7 : $397-418$, il (1913)

13f New anchitherine horses from the Tertiary of the Great Basin area. Cal Univ, Dp G, B $7: 419-434$, il (1913)

$\mathbf{1 3} \boldsymbol{s}$ New protohippine horses from Tertiary beds on the western border of the Mohave desert. Cal Univ, Dp G, B 7:435441, il (1913)

13h (and Pack, R. W.) Suggested paleontologic correlation between continental Miocene deposits of the Mohave region and rarine Tertiary beds of San Joaquin Valley, Cal. (abst). G Soc Am, B 24:128 (1913)

14 The occurrence of Tertiary mammalian remains in northeastern Nevada. Cal Univ, Dp G, B 8: 275-281, il (1914)

14a Preliminary report on the discovery of human remains in an asphalt deposit at Rancho La Brea [Cal.]. Science n s 40 : 198-203 (1914) Abst, S Cal Ac Sc, B 13: 27-29 (1914)

145 Correlation between the Tertiary of the Great Basin and that of the marginal marine province in California. Science $n$ s $40: 643-645$ (1914)

14e Vertebrate fauna of the Orindan and Siestan formations (abst). G Soc Am, B 25:156 (1914)

i's (and others) Nature and science on the Pacific coast; a gundebook for sc1entific travelers in the West. Edited under the auspices of the Pacific coast committee of the American Association for the Advancement of Science. 302 pp, San Francisco 1915

15a Significant features in the history of life on the Pacific coast. In Nature and science on the Pacific coast: 88-103, San Francisco 1915 (See Merriam, 15)

15b Tertiary vertebrate faunas of the North Coalinga region of California. Am Ph Soc, Tr n s 22: 191-234, il (1915)

15e New species of the Hipparion group from the Pacific coast and Great Basin provinces of North America. Cal Univ, Dp G, B $9: 1-8$, il (1915)

15d New horses from the Miocene and Pliocene of California. Cal Univ, Dp G, B $9: 49-58$, il (1915)

15e Remains of land mammals from marine Tertiary beds in the Tejon Hills, Cal. Cal Univ, Dp G, B $8: 283-288$, il (1915)
Merriam, John Campbell-Continued.

$15 f$ An occurrence of mammalian : mains in a Pleistocene lake deposit at ty tor Pass, near Pyramid Lake, Nev. a Univ, Dp G, B $8: 377-384$, il (1915)

$15 \mathrm{~g}$ Extinct faunas of the Mohave Des ert, their signifleance in a study of th origin and evolution of life in Ameria Pop Sc Mo $86: 245-264$, il (1915)

$\mathbf{1 5 h}$ Relation of the Tertiary geolozic scale of the Great Basin to that of th Pacific coast marginal province (abst). Soc Am, B $26: 136-137$ (1915)

151 Antiquity of man in California fro the point of view of the paleontologit (abst). Science n s $42: 543-544$ (1915)

16 Tertlary vertebrate fauna from th Cedar Mountain region of western Nerad Cal Univ, Dp G, B 9:161-198, il, 방 (1916)

16a Relationship of Equts to Pliohipis suggested by characters of a new speds from the Pliocene of Callfornia. Cal Chit Dp G, B $9: 525-534$, il (1916)

16b (and Stock, C., and Moody, C. L. An American Pliocene bear [Rattlesat beds, John Day region, Oreg.]. Cal Chi Dp G, B 10:87-109, il (1916)

16e Mammalian remains from the or nac formation of the Tejon Hills, a Cal Univ, Dp G, B 10:111-127, il (191) 16d Mammalian remains from a $b$ Tertiary formation at Ironside, Oreg. A Univ, Dp G, B 10:129-135 (1916)

16e (and Stoek, C., and Moody, C. L Fauna of the Rodeo Pleistocene (abst). Soc Am, B 27:169-170 (1916)

16f Hipparion-like horses of the Pacil coast and Great Basin provinces (abit G Soc Am, B 27:171 (1916)

16is (and Camp, Charles L) Reces' studies on skull structure of Thalati saurus (abst). G Soc Am, B 27:17 (1916)

17 (and Buwalda, J. P.) Age strata referred to the Ellensburg form tion in the White Bluff's of the Columl River. Cal Univ, Dp G, B $10: 255-$ (1917)

17a Relationship of Pliocene mammals faunas from the Pacific coast and Gro Basin provinces of North America.

Univ, Dp G, B $10: 421-443$ (1917)

17b Pliocene mammalian faunas North America $(a b s t)$. G Soc Am, B 5 196 (1917)

17e Felidae of Rancho La Brea (abst G Soc Am B 28:211 (1917)

17d (and Stock, C.) Fauna of t) Pinole tuff (abst). G Soc Am, B 28:2 (1917)

18 Evidence of mammalian paleontoles relating to the age of Lake Lahontan. Univ, Dp G, B 10:517-521 (1918) 
Merriam, John Campbell-Continued.

1Sa New Mammalia from the Idaho formation. Cal Univ, Dp G, B 10:523530, il (1918)

18b Note on the systematic position of the wolves of the Canis dirus group. Cal Univ, Dp G, B 10:531-533 (1918)

18e New puma-like cat from Rancho La Brea, Cal Univ, Dp G, B $10: 535-537$, il (1918)

18d Fauna of the Idaho formation (abst). G Soc Am, B 29: 162 (1918)

See also Buwalda, 16 ; Dice, 17 ; Dickerson, 13b; Martin (B), 13a ; Nomland, 16a Merriam, L. B.

03 The development of a new coal field in Colorado. Western Soc Eng, J 8:617637 (1903)

Merrill, Frederick James Hamilton (18611916).

85 Observations on the recent formations of the Atlantic coast of New Jersey. N J G S, An Rp 1885: 61-95 (1885)

86 On the geology of Long Island. N Y Ac Sc, An 3:341-364, map (1886)

s6a On some dynamic effects of the ice sheets (abst). Am J Sc (3) $32: 324$ (1886) Am As, Pr 35:228-229 (1887)

87 Paleozolc rocks [of Green Pond Mountain region, N. J.]. N J G S, Rp 1886: 112-122 (1887)

87a Yellow gravel [of New Jersey]. N

J G S, Rp 1886: 129-134 (1887)

87b Note on the Green Pond Mountain group of New Jersey. N Y Ac Sc, Tr 6: 59 (1887)

87e Index of current literature relating to North American geology. Seh Mines Q $8: 172-173, \quad 285, \quad 375 ; 9: 85-87, \quad 188$ (1887-8)

89 A note on the colored clays recently exposed in railroad cuttings near Morrisania, N. Y. N Y Ac Sc, Tr $9: 45-46$ (1889)

90 On the metamorphic strata of southeastern New York. Am J Sc (3) 39:383392 (1890)

90a Some anclent shore lines and their history [with discussion]. N Y Ac Sc, $\operatorname{Tr} 9: 78-82(1890)$

90b Barrier beaches of the Atlantic coast. Pop Sc Mo $37: 736-745$ (1890)

90 e [On the stratigraphy of the Gay Head section at Marthas Vineyard.] G Soc Am, B 1:556 (1890) Am Nat 24:563-564 (1890)

91 Quaternary geology of the Hudson River valley. N Y St. G, An Rp 10:103109 (1891)

91a on the postglacial history of the Hudson River valley. Am J Sc (3) 41 : 460-466 (1891)

93 Salt and gypsum industries of New York. N Y St Mus, B 11:89 pp, map (1893)

94 The geology of natural scenery. Pop Sei $\mathrm{M}_{0} \quad 46: 240-244 \quad$ (1894)
Merrill, Frederick James Hamilton-Con.

$94 a$ Report on... mines and mining. [New York, World's Fair Managers], Rp of the Board of General Managers of the exhibit of the State of New York at the World's Columbian Exposition [Chicago, 1893] : 313-360, Albany, 1894 (Minerals by L. M. Luquer : $319-328$; clays by. H. Ries : $342-356)$

95 Mineral resources of New York State. N Y St Mus, B 15:365-595, map (1895)

96 Post-Pliocene deposits of Sankaty Head [Nantucket, Mass]. N Y Ac Sc, Tr $15: 10-16$ (1896)

96a Notes on the geology of Block Island. N Y Ac Sc, Tr 15: 16-19 (1896) 97 Road materials and road building in New York. N Y St Mus, B $17: 89-134$, map (1897)

$97 \mathbf{a}$ Geology of the vicinity of greater New York $(a b s t)$. Science n s $6: 815-816$ (1897) Am G 21: 72-73 (1898)

98 The geology of the crystalline rocks of southeastern New York. N Y St Mus, An Rp $50 v 1: 21-31$ (1898)

9Sa The origin of the serpentines in the vicinity of New York. N Y St Mus, An Rp 50 v 1:32-44 (1898)

98b Preliminary list of public geological and mineralogical collections in the United States and Canada. N Y St Mus, An Rp 50 v $1: 45-74$ (1898)

9se A guide to the study of the geological collections of the New York State Museum. N Y St Mus, B 19:105-262, map (1898)

98d The geology of greater New York (abst). N Y Ac Sc, Tr 16:370-371 (1898)

99 Origin of the white and variegated clays of the north shore of Long Island. N Y Ac Sc, An 12:113-116 (1899)

00 Origin of the highland gorge of the Hudson River (abst). G Soc Am, B 10: 498-499 (1900)

01 Nineteenth report of the State geologist, 1899. N Y St Mus, An Rp 53: r5 -158 (1901). Also issued as separate.

02 (and others) Description of the New York City district [N. Y.-N. J.]. U S G S, G Atlas New York City fol (no 83) : $19 \mathrm{pp}$, maps (1902)

02a Twentieth report of the State geologist, $1900: 189$ pp (1902) Reprinted from N Y St Mus, An Rp 54: r5-183 (1902)

O2b Description of the State geologic map of 1901 . N Y St Mus, B $56: 3-37$ (1902)

03 Twenty-first report of the State geologist, 1901:99 pp (1903) Reprinted from N Y St Mus, An Rp 55: r5-101 (1903)

o4 Twenty-second report of the State geologist, 1902:140 pp (1904) Reprinted from N Y St Mus, An Rp 56:r5-126 (1904) 
Merrill, Frederick James Hamilton-Con. 04a Twenty-third report of the State geologist, $1903: 203$ pp (1904) Reprinted from $N$ Y St Mus, An Rp 57:5-197 (1905)

O5 (and Magnus, H. C.) Distribution of Hudson schist and Harrison diorite in the Westchester County area of the Oyster Bay quadrangle [N. Y.]. N Y St Mus, An Rp 57:193-194, map (1905)

o5a The northeast extremity of the pre-Cambrian highlands [of Putnam and Dutchess cos., N. Y.]. N Y St Mus, An Rp 57:195-197, map (1905)

05b Bromine. U S G S, Min Res 1904: 1029-1030 ; 1905: 1097-1098 (1905-6)

05e Geology of Sonora, Mex. Eng M J $80: 976$ (1905)

06 The mercury deposits of Mexico. M World 24: 244 (1906)

06a Evidences of glaciation [morainal material] in southern Arizona and northern Sonora. Science n s 24:116-118 (1906)

06b The Copete district, central Sonora

[Mexico]. Eng M J 82:628-629 (1906)

06e The mining camps of Sinaloa, Mex-

ico. Eng M J 82:635-636 (1906)

06d Paleozoic strata in Sonora [Mex-

ico]. Eng M J 82:897 (1906)

o6e The mines of Planchas de Plata; the interesting geology of an historic mining district of Sonora [Mexico]. Eng M J $82: 1111-1112$ (1906)

07 Shear zones in Sonora [Mexico]. Eng M J $83: 583$ (1907)

07a Heretical vein types in Sonora

[Mexico]. Eng M J 83:657 (1907)

o7b The mineralization of Mexico. Eng

M J $83: 667$ (1907)

oze Santa Cruz, a new copper camp in

Sonora [Mexico]. Eng M J 83:1043 (1907)

07a Copper in the Sonora quartz veins. Eng M J 84: 498 (1907)

o7e Erosion and oxidation in Sonora

[Mexico]. M Sc Press 95:268 (1907)

os Memoir of William Buck Dwight. G

Soc Am, B 18: 571-572 (1908)

Osa The mineral resources of Sonora

[Mexico]. M Sc Press 96:33-40 (1908)

Reprint, 23 pp, 1911

osb Surface enrichment in Sonora. M Sc Press 96:802-803 (1908)

ose Metamorphic ranges in Sonora, Mexico. M Sc Press 97: 296 (1908)

OSd Dry placers of northern Sonora

[Mexico]. M Sc Press 97:360-361 (1908)

ose Ore bodies without walls. M Sc

Press 97: 455 (1908)

o9 Santa Eulalia mines, Chihuahua. M

Sc Press 98:37-39; 99:119 (1909)

$09 a$ Official definitions of mining terms.

M Sc Press $99:$ 16-18 (1909)

12 The Spring Valley oil field in southwestern Wyoming. M Se Press 104: 163165 (1912)
Merrill, Frederick James Hamilton-Ch.

14 Geology and mineral resources of $s$ Diego and Imperial cos. [Cal.]. Cal \& M Bur: 113 pp (1914)

16 The counties of San Diego, Imperial Cal St M Bur, Rept XIV of the Stat Mineralogist : $635-743$ (1916) [issued a separate December 1914]

17 Mines and mineral resources of ls Angeles County, Orange County, Rire: side County. Cal St Min Bur (Chapters of State Mineralogist's $\mathrm{Rp}$ [15:461-589]) $136 \mathrm{pp} \mathrm{(1917)}$

17a (with Clondman, H. C., and Huguenin, E.) San Bernardino Connts. In Mines and minerals of San Bernardina County, Tulare County (Chapters of Stat? Mineralogist's Rp 1915-16): 1-125, Cal \& M Bur (1917)

See also Chamberlin, 90 ; Rosenbusch. 88; White (D), 90

Merrill, George Perkins.

S2 Microscopic examination and \& termination of the building stones of Maise Me, St Coll Agr, An Rp 1882:89-10 Augusta 1882

83 Note on a Potsdam sandstone, conglomerate, from Berks Co., Pa. U Nat Mus, Pr 5: 660-661 (1883)

$\mathbf{8 3 a}$ On the black nodules or so-calle inclusions in the Maine granites. U S Nir Mus, $\operatorname{Pr} 6: 137-141$ (1883)

83b Preliminary note on the erystallis schists of the District of Columbia. I Nat Mus, Pr 6: 159-161 (1883)

83e On the collection of Maine buildity stones in the United States Natloos Museum. U S Nat Mus, Pr 6:165-18 (1883)

83a Fluidal cavities in quartz-grains sandstones. Seience 1:221 (1883)

84 On prochlorite from the District Columbia. U S Nat Mus, Pr 7:67 (1884)

84a Microscopic structure [of stots used for building]. U S, 10th Census 1 Report on Building Stones: 15-29 (184

84b Notes on the character of the rod formations in the vicinity of Auburn, Me, St Coll Agr, An Rp 1884: App 11-1 Augusta 1884

84e Hornblende andesite from the wh Bogosloff volcano. Science 4:524 (184t s5 On hornblende andesites from new valcano on Bogosloff Island in Berits Sea. U S Nat Mus, Pr 8: 31-33 (1885)

$85 a$ On deposits of volcanic dust at: sand in southwestern Nebraska. U S N Mus, Pr 8: 99-100 (1885)

$85 \mathrm{~b}$ Notes on the mineralogy and lit? ology of the District of Columbia. I Nat Mus, Pr 8: 351-353 (1885)

85e Supposed crude jade from Alasi Science 5:209 (1885)

$85 d$ Volcanic dust from southwest Nebraska. Science 5:335 (1885) 
Merr1II, George Perkins-Continued.

85e Building and ornamental stones of the United States. Pop Sc Mo 27:520532 (1885)

86 On fulgurites. U S Nat Mus, Pr 9: 83-91 (1886)

86a Notes on the composition of certain "Pliocene sandstones" from Montana and Idaho. Am J Sc (3) 32: 199-204 (1886)

87 Fulgurites or lightning holes. Pop Sc Mo $30: 529-539$ (1887)

$\mathbf{8 7 a}$ Common salt : its geology and manufacture. Chautauquan 8:82-85 (1887)

88 on the serpentine of Montville, N. J. U S Nat Mus, Pr 11: 105-111 (1888)

$\mathbf{8 8 a}$...secondary enlargement of augites in a peridotite from Little Deer Isle, Me. Am J Sc (3) 35: 488-490 (1888)

88b On a new meteorite from the San Emigdio Range, San Bernardino Co., Cal. Am J Sc (3) $35: 490-491$ (1888)

s8e The literature of geyserite. Am G $2: 436-437$ (1888)

ssd [Serpentine, Montville, Morris Co., N. J.] Science 11:282, 302 (1888)

sse (with Clarke, F. W.) A nephrite and jadeite. U S Nat sus, $\operatorname{Pr} 11: 115$ 130 (1888)

s8f (with Whitfeld, J. E.) The Fayette Co., Tex., mèteorite. Am J Sc (3) 36 : 113-119 (1888)

89 The collection of building and ornamental stones in the U. S. National Museum; a handbook and catalogue. Smiths Inst, An Rp 1886 pt 2: 277-648 (1889)

89a on the San Emigdio [San Bernardino Co., Cal.] meteorite. U S Nat Mus, Pr 11:161-167 (1889)

89b On a peridotite from Little Deer Isle, in Penobseot Bay, Maine. U S Nat Mus, Pr 11: 191-195 (1889)

89e On the ophiolite of Thurman, Warren Co., N. Y., with remarks on the Eozoon canadense. Am J Se (3) 37:189191 (1889)

89d Among the Pennsylvania slate quarries. Sc Am Sup 27:10874-10875 (1889)

90 Notes on the serpentinous rocks of Essex Co., N. Y. ; from aqueduct shaft 26. New York City ; and from near Easton, $\mathrm{Pa}$. U S Nat Mus, Pr 12:595-600 (1890)

90a Petrography for 1887 and 1888 . Smiths Inst, An Rp 1888: 327-354 (1890)

91 Stones for building and decoration. 453 pp, N Y 18912 2d ed, 506 pp, N Y $18973 \mathrm{~d}$ ed, 551 pp, N Y 1903

91 a Handbook for the department of geology in the U. S. National Museum; Part 1, Geognosy, the materials of the earth's crust. Smiths Inst, An Rp 1890, Rp U S Nat Mus : 503-591 (1891)

92 On some basic eruptive rocks in the vicinity of Lewiston and Auburn, Androscoggin Co., Maine. Am G 10:49-55
Merrill, George Perkins-Continued.

92a (and Packard, R. L.) On an azure-blue pyroxenic rock from the middle Gila, N. Mex. Am J Sc (3) $43: 279-280$, maps (1892)

92b The wind as a factor in geology. Eng Mag 2: 596-607 (1892)

98 Notes on the petrography of the $\mathrm{Pa}$ leozoic section in the vicinity of Three Forks, Mont. U S G S, B 110; 47-54 (1893)

93a The newer eruptive rocks [of Nantasket area, Mass.]. Boston Soc N H, Oc P 4 v $1: 31-44$ (1893)

94 On the formation of stalactites and gypsum incrustations in caves. U S Nat Mus, Pr 17: 77-81 (1894)

$94 a$ The formation of sandstone concretions. U S Nat Mus, $\operatorname{Pr} 17: 87-88$ (1894)

$94 b$ (with Emmons, S. F.) Geological sketch of Lower California. G Soc Am, B 5:489-514, map (1894) Abst, Am G $13: 209-210$ (1894)

95 The onyx marbles; their origin, composition, and uses, both ancient and modern. Smiths Inst, An Rp 1893, Rp U S Nat Mus: $539-585$ (1895) Stone 11:495$502 ; 12: 1-8,116-121,228-236,326-330$, $425-429, \quad 559-564 ; \quad 13: 9-12, \quad 116-120$ (1895-6)

95a Directions for collecting rocks and for the preparation of thin sections. U S Nat Mus, B 39 pt I: 15 pp (1895)

95b Notes on some eruptive rocks from Gallatin, Jefferson, and Madison cos., Mont. U S Nat Mus, Pr 17:637-673 (1895)

95e Disintegration of the granitic rocks of the District of Columbia. G Soc Am, B $6: 321-332$ (1895)

95d Asbestos and asbestiform minerals (abst). Am G 16:240 (1895) Ottawa Nat $9: 152$ (1895)

96 Notes on asbestos and asbestiform minerals. U S Nat Mus, Pr 18:281-299 (1896)

96a The principles of rock weathering. J G 4:704-724, 850-871 (1896)

96b Disintegration and decomposition of diabase at Medford, Mass. G Soc Am, B 7 : 349-362 (1896) Abst, Am G 17:91 (1896) ; Science n s $3: 374-375$ (1896)

96e An occurrence of free gold in granite. Am J Sc (4) 1: 309-311 (1896)

96d On the composition and structure of the Hamblen Co., Tenn., meteorite. Am J Sc (4) $2: 149-153$ (1896)

97 A treatise on rocks, rock weathering, and solls. $x x, 411$ pp, N Y 1897 New ed, xxi, 400 pp, N x 1906

$97 \mathbf{a}$ Notes on the geology and natural history of the Peninsula of Lower Californla. Smiths Inst, An Rp 1895, Rp U S Nat Mus : 971-994 (1897)

97b Weathering of micaceous gneiss in Albemarle Co., Va. G Soc Am, B 8: 157168 (1897) Abst, J G 5:98-99 (1897) ; Science n s $5: 95-96$ (1897) 
Merrill, George Perkins-Continued.

98 The physical, chemical, and economic properties of building stones. Md G S 2: 47-123 (1898)

99 A discussion on the use of the terms rock-weathering, serpentinization, and hydrometamorphism. G Mag (4) 6:354-35s (1899) Am G 24:244-250 (1899)

$99 a$ Preliminary note on new meteorites from Allegan, Mich,, and Mart, Tex. Science n s 10:770-771 (1899)

99 b A consideration of some little known American ornamental stones. Stone 19 : 225-230 (1899)

oo (and stokes, H. N.) A new stony meteorite from Allegan, Mich., and a new iron meteorite from Mart, Tex. Wash Ac Se, $\operatorname{Pr} 2: 41-68$ (1900)

Ooa The Marsh collection of vertebrate fossils. Am G 25: 171-173 (1900)

oob Nepheline melilite basalt from Oabu, Hawaiian Islands. Am G $25: 312-313$ (1900)

ooe Troost's map of the environs of Philadelphia. Am G 26:391-392 (1900)

ood Sandstone disintegration through the formation of interstitial gypsum. Science n s $11: 850-851$ (1900)

o1 Guide to the study of the collections in the section of applied geology. Smiths Inst, An Rp 1899, Rp U S Nat Mus: 156483 (1901)

01. On a stony meteorite which fell near Felix, Perry Co., Ala., May 15, 1900. U S Nat Mus, Pr 24:193-198 (1901)

01b The department of geology in the National Museum. Am G 28:107-123 (1901)

02 A newly found meteorite from Admire, Lyon Co., Kans. U S Nat Mus, Pr 24: $907-913$ (1902)

02a What constitutes a clay. Am G $30: 318-322$ (1902)

02b Rutile mining in Virginia (abst). Science n s 15:389 (1902) Eng M J 73: 351 (1902)

02e Notes on a (hitherto undescribed) meteorite from Admire, Kans. (abst). Science n s 15:546-547 (1902)

03 A newly-found meteorite from Mount Vernon, Christian Co., Ky. Am G 31 : 156-158 (1903)

03a John Wesley Powell. Am G 31 : $327-333$, port (1903)

04 The nonmetallic minerals; their occurrence and uses. 414 pp, N Y 1904

$04 a$ On the glacial pothole in the National Museum. Smiths Mise Col 45 (Q Is 1) : 100-103 (1904)

05 The division of applied geology, U. S. National Museum. Am I M Eng, Bi-Mo B 4 : 929-937 (1905)

o5a On the origin of veins in asbestiform serpentine. $\mathrm{G}$ Soc Am, B 16:131136 (1905) Abst, Sc Am Sup 59:24326 (1905)
Merrill, Georre Perkins-Continued.

o5b Gold and its associations. Eng J $79: 992-993$ (1905)

06 A new meteorite from Scott $\mathrm{C}$. Kans. Science n s $23: 391-392$ (1906)

O6n The development of the glacial br. pothesis in America. Pop Sc Mo 68:300322 (1906)

06b On a new stony meteorite fru Modoc, Scott Co., Kans. Am J Sc (4) $21: 356-360$ (1906)

o6e Contributions to the history American geology. U S Nat Mus, An Bi 1904: 189-733 (1906)

o6d University training of engineers economic geology. Ec G 1:387-391 (1906)

o7 On a newly found meteorite fro Selma, Dallas Co., Ala. U S Nat Mos Pr 32: 59-61 (1907)

o7a Notes on the composition ati structure of the Hendersonville, N. C. w: teorite. U S Nat Mus, Pr $32: 79-5$ (1907)

orb On the meteorite from Rich Mom tain, Jackson Co., N. C. U S Nat Mus, P? $32: 241-244$ (1907)

o7e On a peculiar form of metames phism in siliceous sandstone. U S NE Mus, Pr 32:547-550 (1907) Abst, sd ence n s 25: 965 (1907)

ozd (and Tassin, Wirt) Contributios to the study of Canyon Diablo meteorits Smiths Misc Col 50 (Q Is 4) : 203-21 (1907)

o7e Catalogue of the type and figur: specimens of fossils, minerals, rocks, as ores in the Department of Geology, Unite States National Museum; Part II, Fos vertebrates; fossil plants; minerals, roc: and ores. U S Nat Mus, B 53 pt $2: 3$ pp (1907)

os The Meteor Crater of Canyon Diabli Ariz. ; its history, origin, and associate meteoric irons. Smiths Misc Col $50(\mathrm{Q}$ 4) : 461-498 (1908)

oSa Cari Ludwig Rominger. Smits Misc Col 52 (Q Is 5) : $79-82$, port (1906 08b Edward Travers Cox. Smiths Mis Col 52 (Q Is 5) : 83-84, port (1908)

09 A beretofore undeseribed stony mett orite from Thomson, McDuffie $\mathrm{Co}_{\text {., }}$, Smiths Mise Col 52 (Q Is 5 ) : $473-4$ i (1909)

09a Coon Butte or Meteor Crater (abst. Seience n s $29: 239-240$ (1909)

096 The composition of stony meteorite compared with that of terrestrial igneos rocks, and considered with reference to thet efficacy in world-making. Am J Sc (4) 27 469-474 (1909) Abst, Science n s 29,9t (1909)

10 Memoir of W[illiam] $\mathrm{S}$ [mith] Feate [1856-1908]. G Soc Am, B 20:618-61? port $(1910)$

IOa The Meteor Crater of Arizost Australasian As, Rp 12:320-323 (1910) 
Merrill, George Perkins-Continued.

11 On the supposed origin of the moldavites and like sporadic glasses from various sources. U $\mathrm{S}$ Nat Mus, Pr 40:481486 (1911) Abst, G Soc Am, B 22: 736 (1911)

$11 \mathrm{a}$ The fossil forests of Arizona. $23 \mathrm{pp}$, [Washington 1911] (Copyrighted and compiled for Supt. Stevenson by George P. Merrill, 1911.)

12 A second meteoric find from Scott Co., Kans. U S Nat Mus, Pr 42: 295-296 (1912)

12a A recent meteorite fall near Holbrook, Navajo Co., Ariz. Smiths Misc Col 60 no $9: 4$ pp (1912)

12b A newly-found meteoric iron from Perryville, Perry Co., Mo. U S Nat Mus, Pr $43: 595-597$ (1912)

13 Dana, the geologist. G Soc Am, B $24: 64-68$ (1913)

13a A newly found meteorite from near Cullison, Pratt Co., Kans. U S Nat Mus, Pr 44:325-330 (1913)

$13 \mathrm{~b}$ On the minor constituents of meteorites. $\mathrm{Am} \mathrm{J} \mathrm{Sc} \mathrm{(4)} \mathrm{35:509-525} \mathrm{(1913)}$

13e The "fossil forest" of Arizona. Am Mus J $13: 311-316$ (1913)

15 The Fisher, Polk Co., Minn., meteorite. U S Nat Mus, Pr 48:503-506 (1915)

15a Report on some carbonic acid tests on the weathering of marbles and limestones. U S Nat Mus, Pr $49: 347-349$ (1915)

15b On the monticellite-like mineral in meteorites, and on oldhamite as a meteoric constituent. Nat Ac Sc, Pr 1:302-308 (1915) Abst, Science n s $41: 946$ (1915)

15e Researches on the chemical and mineralogical composition of meteorites. Nat Ac Sc, Pr 1:429-431 (1915)

16 Report on researches on the chemical and mineralogical composition of meteorites, with especial reference to their minor constituents. Nat Ac Sc, Mem 14 mem 1:29 pp (1916)

16a Handbook and descriptive catalogue of the meteorite collections in the United States National Museum. U S Nat Mus, B 94:207 pp (1916)

16b A recently found iron meteorite from Cookeville, Putnam Co., Tenn. U S Nat Mus, Pr 51: $325-326$ (1916)

16e Notes on the Whitfield Co., Ga., meteoric irons, with new analyses. U S Nat Mus, $\operatorname{Pr} 51: 447-449$ (1916)

16d A newly found meteoric stone from Lake Okechobee, Fla, U S Nat Mus, Pr 51: $525-526$ (1916)

16e Chemical and mineralogical composition of meteorites (abst, with discussion by 0. C. Farrington). G Soc Am, B 27:50 (1916)

17 A new find of meteoric stones near Plainview, Hale Co., Tex. U S Nat Mus, Pr 52: 419-422 (1917)
Merrill, George Perkins-Continued.

17a On the calcium phosphate in meteoric stones. Am J Sc (4) $43: 322-324$ (1917)

18 Further notes on the Plainview, Tex., meteorite. U S Nat Mus, Pr 54:503-505 (1918)

$18 \mathbf{a}$ On the Fayette Co., Tex., meteorite finds of 1878 and 1890 and the probability of their representing two distinct falls. U S Nat Mus, Pr 54:557-561 (1918)

18b Tests for fluorine and $t$ in in meteorites with notes on maskelynite and the effect of dry heat on meteoric stones. Nat Ac Sci, Pr $4: 176-180$ (1918)

18e $A^{\prime}$ second meteorite find in Florida [Eustis, Lake Co.]. Am J Sc (4) 45: 64-65 (1918)

18d A peculiar fibrous form of opal. Am Mineralogist 3 : 11-12 (1918)

18e Lazulite in an unusual form. Am Mineralogist $3: 192$ (1918)

See also Cross, 03; Farrington, 15; Howell, 94 ; Lane, 13a ; Faber, 16a ; Troost, 26 ; Watson, 06

Merrill, Georgia Drew.

91 History of Androscoggin Co., Me. [geology : 22-32]. 879 pp, Boston, Mass., 1891

Merrill, J. A.

95 Fcssil sponges of the flint nodules in the lower Cretaceous of Texas. Harvard Coll, Mus C Z, B 28 (g 's 3 ): $1-26$, il (1895)

Merrill, N. F.

82 Concerning the lithological collection of the exploration of the fortieth parallel. Boston Soc N H, Pr 21:234-243, 452470 (1882)

\section{Merriman, Mansfield.}

98 The slate regions of Pennsylvania. Stone 17:77-90, map (1898)

Merritt, John Wesley.

13 Structural geology of the Hanover district, N. H. (abst). G Soc Am, B 24: 672-674 (1913)

14 Sedimentary character of garnetiferous hornblende schist, Hanover, N. H. (abst). G Sos Am, B 25:75 (1914)

Merritt, W. C.

89 On an ascent of Mount Loa [Hawaii]. Am J Sc (3) 37:51-52 (1889)

Merritt, William Hamilton (1855-1918).

82 The magnetic iron ores of Victoria Co. [Ont.]. Can Inst, Pr n s 1:261-267 (1882)

83 Occurrence of magnetic ore deposits in Victoria Co., Ont. (abst). Am As, Pr 31: 413-415 (1883)

84 On the occurrence, localities, and output of the economic minerals of Canada (abst). Brit As, Rp 54:719 (1885) G Mag (3) 1:521 (1884)

86 The Cascade anthracite coal field of the Rocky Mountains, Canada. G Soc London, Q J $42: 560-564$ (1886) 
Merritt, William Hamilton-Continued.

88 (and others) Report on the mining industries of Canada. Can Inst, Pr (3) $5: 240-254$ (1888)

8Sa Map of the Province of Ontario... Seale 45 miles to 1 inch, $n$ d [188s?]

89 The minerals of Ontario and their development. Am I M Eng, Tr 17:293300 (1889)

90 Notes on some coals in western Canada. Am I M Eng, Tr 18:313-316 (1890)

92 Notes on the possibilities of iron and steel production in Ontario. Can Inst, Tr 2 : 299-314 (1892)

93 The coal flelds of Canada. Colliery Eng $13: 232,250-251,278 ; 14: 7-8,40$, $64-65,90-92,121-122,146-147,173-175$, $201-202,229-230,309-311$ (1893-4)

95 A few notes on merchantable mica in the Laurentian. Can M Rev 14:44-45 (1895)

97 The occurrence of gold ores in the Rainy River district, Ontario, Can. Am I M Eng, Tr 26: $853-863$ (1897)

98 Gold-bearing reefs and placers of northern British Columbia. Fed Can M Inst, J 3: 103-112 (1898) Can M Rv 17: 74-78 (1898)

99 An occurrence of free-milling gold veins in British Columbia. Can M Inst, J 2:143-148 (1899) Can M Rv 18:112-114 (1899)

See also Emmons (S F); $94 \mathrm{a}$

Merrivak, Walter.

98 Barbados manjak. Eng M J $66: 790$ 691 (1898)

Mertie, John Beaver, jr.

12 (with Prindle, L. M.) Gold placers between Woodchopper and Fourth of July creeks, upper Yukon River. U S G S, B 520: 201-210 (1912)

13 Igneous rocks fof the Circle quadrangle, Alaska]. U S G S, B 538: 36-48 (1913)

13a Igneous rocks of the Raton Mesa region [N. Mex.] (abst). Wash Ac Sc, J 3 : 302 (1913)

14 (with Martin, G. C.) Mineral resources of the upper Matanuska and Nelchina valleys [Alaska]. U S G S, B 592 : 273-299, map (1914)

15 Copper and gold deposits of the Kotsina-Kuskulana district, Alaska (abst). Wash Ac Sc, J $5: 485-486$ (1915)

16 (and Harrington, G. L.) Mineral resources of the Ruby-Kuskokwim region [Alaska]. ' U S G S, B 642: 223-266, map (1916)

17 The gold placers of the Tolovana district, Alaska. D S G S, B 662:221-277, maps (1917) Abst, by R. W. Stone, Wash Ac Sc, J $8: 454-455$ (1918)

17a Lode mining in the Fairbanks district, Alaska. U S G S, B 662: 403-424, maps (1917)
Mertie, John Beaver, jr,-Continued.

17b Lode mining and prospecting Seward Peninsula [Alaska]. U S G \&, B 662 : 425-449 (1917)

17e Placer mining on Seward Peninsulh [Alaska]. U S G S, B $662: 451-458$ (1917) Merwin, Herbert E.

os Some late Wisconsin and post-Wig consin shore lines of northwestern Ver mont. Vt St G, Rp 6:113-138 (1908) Harvard Coll, Mus C Z, B 49 (g \& 8) : 309330 (1908)

09 (with Palache, C.) Alamosite, new lead silicate from Mexico. Am J \& (4) $27: 399-401 \quad$ (1909)

11 Quartz and fluorite as standards of density and refractive index. Am J Sc (4) $32: 429-432$ (1911) Wash Ac Se, J 1:58 (1911)

11n The temperature stability ranges density, chemical composition and optical and crystallographic properties of the at kali feldspars. Wash Ac Sc, J 1:59-6) (1911)

11b A method of determining the detsity of minerals by means of Rohrbachs solution having a standard refractive indes Am J Se (4) 32:425-428 (1911)

11e The topographic development of the Catskill Mountains (abst). Science in s $33 ; 550-551$ (1911)

13 The simultaneous crystallization of ealcite and certain sulphides of iron, cop per, and zinc (abst). Wash $\mathrm{Ae} \mathrm{Sc}$, J 3 : 504 (1913)

$13 a$ Media of high refraction and some standard media of lower refraction for the determination of refractive indices with the microscope (abst). G Soc Am, B 24:60 (1913)

14 The simultaneous crystallization of ealcite and certain sulphides of iron, $\operatorname{cop}$ per, and zinc: a crystallographic study. Am J Sc (4) $38: 355-359$ (1914)

$14 a$ The optical properties of azurite and alamosite. Wash Ac Sc, J 4:253-254 (1914)

$14 b$ (witb Hillebrand, W. F.) Hewettite, metahewettite, and pascoite, hydrous calcium vanadates. Am Ph Soc, Pr 53:3154 (1914)

15 (with Posnjak, E., and Allen, $B$ T.) The sulphides of copper. Ec G 10 491-535 (1915)

16 The forms of calcium carbonate and their occurrence (abst). Wash Ac Sc, J $6: 517$ (1916)

16a (and Posnjak, E.) Definition and determination of the mineral bydroxides of iron (abst). G Soc Am, B 27:61 (1916)

16b (with Johnston, J., and Williamson, E. D.) The several forms of ealcium carbonate. Am J Sc (4) $41: 473$ 512 (1916) 
Merwin, Herbert E.-Continued.

16e (with Zies, E. G., and Allen, E. T.) Some reactions involved in secondary copper sulphide enrichment. Ee G 11: 407-503 (1916)

18 (with Ferguson, J. B.) The melting points of cristobalite and tridymite. Am J Sc (4) 46: 417-426 (1918)

18a (with Rankin, G. A.) The ternary system $\mathrm{MgO}-\mathrm{Al}_{2} \mathrm{O}_{3}-\mathrm{SiO}_{2}$. Am J Sc (4) $45: 301-325$ (1918)

See also Allen (E T), 12; Tolman, 16a Merz, Alfred.

o7 Beiträge zur Klimatologie und Hydrographle Mittelamerikas [San Juan Valley in Nicaragua and Costa Rica]. 96 pp, Leipzig [1907]

\section{Mesler, R. D.}

08 (with Siebenthal, C. E.) Tripoli deposits near Seneca, Mo. U S G S, B $340: 429-437$ (1908)

Messler, Abram.

81 The physical features of Somerset Co. [N. J.]. In Snell, James P., History of Hunterdon and Somerset cos., N. J. : 551-559, Phila 1881

Meuche, A. H.

11 The development of the copper mines of Lake Superior and their geological relations. Mich $G$ S, Pub 6 ( 8 \& 4) vol 2 : 887-931 (1911)

Meunier, Stanislas.

88 Détermination lithologique de la météorite de Fayette Co., Tex. Ac Sc Paris, C R 107 : 1016-1018 (1888)

14 Origin and mode of formation of magmatic gases. Wash Ac Sc, J 4:213218 (1914)

15 Observations sur la théorie générale des phénomènes glaciaires et sur les galets striés. Ae N Se Phila, Pr 67:2-24 (1915)

15a Théorie du gneiss et des terrains cristallophylliens en général [origin of gneiss and crystalline schist]. Ac $\mathrm{N}$ Sc Phila, $\operatorname{Pr} 67: 351-362$ (1915)

16 Observations nouvelles sur la structure des fers météoriques de Canyon Diablo, Ariz.; conséquences quant aux circonstances de la chute de ces fers. Ac Sc, Paris, C R 162: 171-173 (1916)

$16 a$ A theory of terrestrlal volcanoes and the geography of the moon. Wash $\Lambda \mathrm{c}$ Sc, J 6:635-649 (1916)

\section{Mêxieo. Instituto Geológico.}

09 Catálogo de los temblores (macro y microsefsmos) sentidos en la Republica Mexicana durante el primer semestre de 1909. Méx I G, Par 3: 173-199 (1909)

11 Catálogo de los temblores (macroselsmos) sentidos en la Republica Mexicana y microseísmos registrados en la Estación Selsmologica Central, durante el año de 1910. Microsefsmos registrados en las estaclones seismologicas de Mazatian y Oaxaca, de agosto á diciembre de 1910 . Méx I G, Par 3:527-587 (1911)
Méxieo, Instituto Geolósico-Contd.

12 Estación seismológica central; catálogo de los mícroseísmos registrados durante el año de 1911. Méx I G, Par 4 : 3385 (1912)

13 Memoria de la Comisión del Instituto Geológico de México que exploró la región norte de la Baja California. Méx I G, Par 4: 87-534, maps (1913)

13a Catálogos de los movimientos registrados durante el año de $1911 \ldots . \quad$ Méx I G, Par 5: 5-79 (1913)

13b Analisis hechos en la Laboratorio de Química del Instituto Geológico de México. Mex I G, Par 5: 83-189 (1913)

14 Catálogos de los sé́smos registrados durante el año de 1912 ... Méx I G, Par 5 : 229-349 (1914)

$14 a$ Rocas mexicanas, clasificadas al microscopio en el Instituto Geológico de México. Méx I G, Par 5:352-426 (1914)

17 Canteras de las municipalidades de Naucalpan y Huisquiluean, Estado de Mé xíco [building stones]. Bol Minero 3:1315 (1917)

Meyer, Abraham.

82 Note on the drift of Lycoming Co., Pa. Ac N Sc Phila, Pr 1882:50; Min G Sec, Pr no $2: 17$ (1882)

82a On the fossil ores of Lyeoming Co. [Pa.]. Ac N Se Phila, Pr 1882: 52; Min G Sec, Pr no 2: 19 (1882)

90 Notes on the presence of Umbral or Mountain limestone in Lycoming Co., Pa. Ac N Sc Phíla, Pr 1889:310-311 (1890)

93 Notes on the occurrence of quartz and other minerals in the Chemung measures, near the line of Lycoming and Tioga counties, Pa, Ac N Sc Phila, Pr 1893: $194-196$

93a Pyrophyllite slates in nerthern Pennsylvania, Ac N Se Phila, Pr 1893: $197-200$

Meyer, F. C.

91 The probable origin of the ore deposits in the mines of Missouri. Kansas City Scientist 5:82-85 (1891)

Meyer, Oskar Erich.

11 Die Entwickelung der arktischen Meere in paläozoischer Zeit. N Jb, Bell Bd $31: 184-219$ (1911)

13 Die Devonischen Brachiopoden von Ellesmereland. Second Norwegian Arctic Expedition in the Fram 1898-1902, Rp (published by Videnskabs-Selskabet i Kristiania) no $29: 43 \mathrm{pp}$, il (1913)

Meyer, Otto.

84 Notes on Tertiary shells. Ac N Se Phila, Pr 1884: 102-112, II

85 The genealogy and the age of the species in the southern old Tertiary. Am J Se (3) $29: 457-468 ; 30: 60-72,421-435$, il (1885)

85n The classification and paleontology of the U. S. Tertiary deposits. Science 6: 143-144 (1885) 
Meyer, Otto-Continued.

s6 Contributions to the Eocene paleon tology of Alabama and Mississippi. Ala G S, B $1: 61-85$, il (1886)

86a Observations on the Tertiary and Grand Gulf of Mississippi. Am J Sc (3) $32: 20-25$ (1886)

86b Notes on the variation of certain Tertiary fossils in overlying beds [Vicksburg beds]. Am Nat 20:637-638, il (1886)

s6e (and Aldrich, T. H.) The Tertiary fauna of Newton and Wautubbee, Miss. Cin Soc N H, J 9:40 [104]-50 [114], 11 (1886)

87 On invertebrates from the Eocene of Mississippi and Alabama. Ac N Se Phila, Pr 1887:51-56, il

87a Beftrag zur Kenntnis der Fauna des Alttertiärs von Mississippi and Alabama. Senckenbergische Nat Ges Frankfurt, Ber 1887, Vor: $3-22$, il (1887)

88 On Miocene invertebrates from Virginia. Am Ph Soc, $\operatorname{Pr} 25 ; 135-144$, il (1888)

88a Upper Tertiary invertebrates from west side of Chesapeake Bay. Ac N Sc Phila, Pr 1888: 170-171, 11

88b ... North American eastern Tertiary. Am G 2: 88-94 (1888)

89 Fish oteliths of the southern OldTertiary. Am Nat 23:42-43 (1889)

90 (and Penfield, S. L.) Results obtained by etching a sphere and crystals of quartz with hydrofluoric acid. Conn Ac, Tr 8:158-165 (1890) Yale Bicen Pub, Contr Miner : 160-167 (1901)

Meyer, Ralph A.

11 The Porcupine gold area [Ont.] M Sc Press 102: 756-757 (1911)

\section{Mezger, A.}

91 Some geological observations in the vicinity of Charlotte, N. C. Eng M J $52: 725$ (1891)

91 a (with Thies, A.) The geology of the Haile mine [Lancaster Co., S. C.]. Am I M Eng, Tr 19:595-601, map (1891)

Mexger, C. A.

96 The monazite districts of North and South Carolina (with discussion by $\mathrm{R}$. W. Raymond). Am I M Eng, Tr 25:822-826, 1036-1040 (1896)

Michaud, Gustavo.

11 Resinas fosiles en Costa Rica. Costa Rica, B Fomento $1: 131-132$ (1911)

12 Nota sobre el epicentro del terremoto del 30 de diciembre de 1888. Costa Rica, Centro de Estudios Sismológicos, An 1911: 9-15 (1912)

Miche1, A.

66 Report on the gold region of Lower Canada. Can G S, Rp Prog 1863-6:49-77 (1866)

67 Report on the gold region of HastIngs. Can G S, Reports on the Gold Region of the County of Hastings: 7-11 (1867)
Michel, Hermann.

14 Ueber Meerschaum von Grant $C_{0}$. Neu-Mexiko. Kolloid Zs 14 : 146-149 (1914) Michelin, Hardouin.

55 Sur les oursins vivants et fossiles da Antilles et du golfe du Mexique. Soe $\theta$ France (2) $12: 756-759$ (1855)

56 [Sur deux oursins tertiaires de h? Jamaique.] Soc G France, B (2) 13:224 (1856)

Miehel-Lévy. See Lévy.

Michelson, A. A.

14 Preliminary results of measurements of the rigidity of the earth. J G 22:97130 (1914)

Michigan, Geological Survey.

93 Report of the State Board of Ger logical Survey for the years 1891 and $1892 \ldots 192$ pp, Lansing 1893

\section{Michigan, Legislature.}

65 Report of the committee on salines, relative to the saline resources of the State of Michigan. Mich, Legislature 1865, Howe Doc no $37: 20$ pp (1865)

Miekle, George R.

91 Notes on nickel. Can Inst, Tr 2: $77-92$ (1891)

s7 Mineralogical notes on Sudbury at thracite. Can Inst, Pr n 8 1:64-66 (1897)

02 The iron-bearing rocks of the Nasta. pokan Islands. Can M Inst, J 5:256-2et (1902)

10 The Kent gas field [Ont.]. Ont wit Mines, An Rp 19 pt 1: 149-153, map (1910)

11 The probable number of productire veins in the Cobalt district, Ont. Can $\mathbb{I}$ Inst, J $13: 325-335$ (1911)

14 The chemical composition of naturl gas found in Ontario. Ont Bur Mines An Rp 23 pt 1:237-273 (1914)

See also Coste, 04

Mickleborough, John.

78 (and wetherby, A. G.) A clast fled list of Lower Silurian fossils, Cineis: nati group. Cin Soc $\mathrm{N} H, \mathrm{~J} 1: 61-86$ (1878)

S3 Locomotory appendages of trilobites Cin Soc N H, J $6: 200-206$, il (1883) All Nat $17: 1275-1277$, il (1883) G Mag (3) $1: 80-84,162-165$, il (1884)

middleton, George.

06 Notes on Georgia's geology. Mineral Collector $13: 101-104, \quad 115-118, \quad 137-141$ (1906)

Middleton, Jefferson.

11 Fuller's earth. U S G S, Min Res 1910 pt $2: 841-846 ; 1911$ pt $2: 1031$ $1035 ; 1912$ pt $2: 1017-1022 ; 1913$ pt 2: $109-115 ; 1914$ pt $2: 35-40 ; 1915$ pt 2 : $9-12 ; 1916$ pt $2: 239-241 ; 1917$ pt 2 : 25.-255 (1911-18)

12 Feldspar and quartz. U S G \& Min Res 1911 pt 2: 1023-1030 (1912) Middleton, W. G.

oo (and Moore, J.) Skull of fostl bison. Ind Ac Sc, Pr 1899: 178-181, il (1900) 
Miers, Henry A.

93 Quartz from the Emerald and Hiddenite mine, N. C. Am J Se (3) 46 : 420-424 (1893)

01 Yukon; a visit to the Yukon gold fields. $32 \mathrm{pp}, 1901$ [Priv pub]

03 Gold mining in Klondike [Yukon dist., Can.]. R Inst, $\operatorname{Pr} 17: 72-81$ (1903)

07 Obituary; Samuel Lewis Penfield. Miner Mag 14:264-268, port (1907)

Mighels, Jesse W.

42 (and Adams, C. B.) Description of fossil shells (Nucula and Bulla) occurring at Westbrook, Me. Boston J N H 4:5354 (1842)

Mileh, L.

08 Ueber den Kaolinit von der National Belle mine bei Silverton, Colo. Centralbl Miner 1908: 1-3

Millar, Austin Q.

09 The Arkansas diamrond fields. M Sc Press 99:534 (1909)

11 Summary of diamonds and diamond mines. M World $34: 1125-1127, \mathbf{1 1 8 8 - 1 1 9 0}$ (1911)

Millar, C. C. Hoyer.

91 The phosphate fields of Florida. 48 pp, L 1891

92 Florida, South Carolina, and Canadian phosphates. 223 pp, L 1892

Miler, Arthur McQuiston.

95 High level gravel and loam deposits of Kentucky rivers. Am G 16:281-287, map (1895)

96 The assoclation of the gastropod genus Cyclora with phosphate of lime deposits. Am G $17: 74-76$ (1896)

98 The hypothesis of a Cincinnati Silurian island. $A m$ G 22: $78-85$ (1898)

98a Natural arches of Kentucky. Science n s $7: 845-846$ (1898)

00 Hydrostatic vs. Iithopiestic theory of gas well pressure. Science n \& 11:192193 (1900)

01 Preglacial drainage in southwestern Ohio. Science n s 14:534-535 (1901)

03 A brilliant meteor [Bath Co., Ky.]. Science n s $17: 114-115$ (1903)

03a Additional facts concerning the Bath Furnace meteoric fall of November 15, 1902. Science n \& 18:243-244 (1903)

03b A new meteorite ("Bath Furnace") from Kentucky (abst). Science n s 17:228 (1903) Eng M J 75:154 (1903) Sc Am Sup 55: 22666 (1903)

05 The lead and zinc bearing rocks of central Kentucky, with notes on the min. eral veins. Ky G S, B 2:35 pp (1905)

06 Classification and mapping of the lower Ordovician of Kentucky (abst). Ohio Nat $6: 447-448$ (1906)

os Abstract of report on the lower (or "conglomerate") measures along the western border of the eastern coal fleid. Ky G S, Rp Prog 1906-1907 : 27-35 (1908)
Miller, Arthur McQuíston-Continued.

09 Evidence that the Appalachian and central coal fields were once connected across central Kentucky (abst). Science n s 29:624 (1909) G Soc Am, B 20: 621-624 (1910)

10 Coals of the lower measures along the western border of the eastern coal field. Ky G S, B 12: 83 pp, maps (1910) [distributed 1912 or 1913]

13 Ice caves. Science n s $37: 980-981$ (1913)

13a Geology of the Georgetown quadrangle [Ky.]. Ky G S (4) 1:317-351 (1913)

14 Geology of Franklin Co. [Ky.]. Ky G $S$ (4) 2 pt $3: 7-87$, maps (1914)

14 avolution by selection of mutations. Science n s $40: 636-637$ (1914)

15 The Ordovician Cynthiana formation. Am J Sc (4) 40:651-657 (1915)

15a Wind gaps. Science n s $42: 571$ 573 (1915)

16 Faulting in north central Kentucky (with discussion by F. R. Van Horn). G Soc Am, B 27:101-104 (1916)

16a Some historic fish remains [from Vanceburg, Ky.] (abst). Science n s 44: 71-72 (1916)

17 Table of geological formations for Kentucky. 7 pp, Lexington, Ky., March, 1917

17a Map of Georgetown quadrangle. Ky G S, 1917

Miller, Benjamin LeRoy.

01 Geology of Marion Co. Iowa G S $11: 127-197$, map (1901)

05 (with Shattuek, G. B.) Physiography and geology of the Bahama Islands. In The Bahama Islands, edited by G. B. Shattuck : $3-20$, N Y 1905

06 Description of the Dover quadrangle [Del.-Md.-N. J.]. U S G S. G Atlas Dover fol (no 137) : $10 \mathrm{pp}$, maps (1906)

O6a (with Clark, W. B.) A brief summary of the geology of the Virginia Coastal Plain. Va G S, B (g s) 2:11-24 (1906)

07 The economic resources of Calvert $\mathrm{Co}$. Md G S, Calvert Co. : 123-134 (1907)

$07 \mathbf{n}$ The economic resources of St. Mary's Co. Md G S, St Mary's Co. :113-124 (1907)

07b (with Shattuek, G. B.) Description of the Patuxent quadrangle [Md.D. C.]. U S G S, G Atlas fol $152: 12$ pp (1907)

10 Erosion intervals in the Tertiary of North Carolina and Virginia. G Soc Am, B $20: 673-678$ (1910) Abst, Science n s $29: 634$ (1909)

11 Prince Georges County ; physiography, geology, and mineral resources. $\mathrm{Md} G \mathrm{~S}$, Prince Georges Co. : 24-150, map (1911)

11a Paint shales of Pennsylvania, U S G S, B $470: 485-496$ (1911) 
Miller, Benjamin LeRoy-Continued.

$11 b$ The mineral pigments of Pennsylvania. $\mathrm{Pa}$ Top $\mathrm{G} S, \mathrm{Rp} 4: 101 \mathrm{pp}$ (1911)

11e (with Cumings, W. L.) Characteristics and origin of the brown iron ores of Camaguey and Moa, Cuba. Am I M Eng, B $51: 247-268$ (1911)

12 Description of the Choptank quadrangle [Md.]. U S G S, G Atlas Choptank fol (no 182) : 8 pp, maps (1912)

$12 a$ The geology of the graphite deposits of Pennsylvania. Ec G $7: 762-777$ (1912)

$12 b$ (with Clark, W. B., and Stephenson, L. W.) The stratigraphy of the Coastal Plain of North Carolina. N C G S 3: 33-44 (1912)

12c (and Stephenson, L. W.) The Coastal Plain of North Carolina; bibliography. N C G S 3: 44-73 (1912)

12d The Coastal Plain of North Carolina; the Tertiary formations: N C G S 3: 171-258 (1912)

12e Graphite deposits of Pennsylvania. Pa Top G S, Rp 6:147 pp (1912)

$12 f$ (with Clark, W. B.) The physiog raphy and geology of the Coastal Plain province of Virginia. Va G S, B $4: 13-222$ (1912)

12g (with Clark, W. B., and Stephenson, L. W.) The stratigraphy of the Coastal Plain; the geological history of the Coastal Plain of North Carolina. N C G S $3: 34-44,291-303$ (1912)

13 The graphite industry of Pennsylvania. M World $38: 625-628$ (1913)

13 Tertiary coal fields of the Rio Grande. Coal Age 4:230-263 (1913)

14 Geology lof Lehigh Co., Pa.]. In Anniversary history of Lehigh County, Pennsylvania 1: 1-14, Allentown, Pa., 1914

14a Analysis of the report of the geologist appointed by the Commission of Engineers of the Costa Rica-Panama Boundary Arbitration. Costa Rica-Panama Arbitration, Appendix No. 2 to the counter case of Costa Rica, pp 3-70, Washington, Press of Gibson Bros. inc., 1914. [See MacDonald (D F), 14]

16 (with Singrewald, J. T.) The genesis and relations of the Daiquiri and Firmeza iron-ore deposits, Cuba. Am I M Eng, B 111:671-678 (1916) ; Tr 53:6774 (1916)

16a (with Singewald, J. T.) Mining in Oriente Province, Cuba. Eng M J 101: $587-592$ (1916)

17 (and others) Description of the Tolchester quadrangle, Md. U S G S, G Atlas Tolchester fol (no 204):15 pp, maps (1917)

17a The slides of the Panama Canal. Science n s $45: 164-166$ (1917)

See also Bascom, 09a, b ; Roesler, 16 Miller, Edward.

35 Geological description of a portion of the Alleghany Mountains. G Soc Pa, Tr 1 : 251-255 (1835)
Miller, Elmer I.

or A week in the Mount Lassen am Cinder Cone region of northern Californit Am Bur Geog, B 2:150-156 (1901)

Miller, Eric Rexford.

18 (with Winchell, A. N.) The dus falls of March 1918. Mo Weather Rv 48: $502-506$ (1918)

18a (with winchell, A. N.) The dos fall of March 9, 1918. Am J Sc (4) 46: 599-609 (1918)

Miller, George Washington.

ox Field book of practical mineralog $190 \mathrm{pp}$, Denver 1901

03 Inustrated field book; the mine eraminer's companion... 217 pp, Denrer Colo., 1903 [also later editions]

O3a The mine examiner and prospector's companion. $3 \mathrm{~d}$ ed, 387 pp, Denver 1900 4 th ed, 1907

03b The Verde mining district, Yavapai Co., Ariz. M Sc Press 86: 70-71 (1903)

04 Geology of the Butte mining district Mont. Ores and Metals 13 (10): 15-16 (11) : 19-20 (1904)

06 Elements of mining geology and met allurgy... $2 \mathrm{~d}$ ed, $489 \mathrm{pp}$, Denver, Colo 1906

o7 The mine examiner and prospector companion. A practical treatise on mit ing geology ... 387 pp, Denver, Colit [1907]

o8 The various mining districts of Col orado. M Science $57: 462-464,507-510$ $532-534,549-551 ; 58: 128-130,207-20$ $228-229,246-247$ (1908)

O8n The De Lamar mines, Lincoln Co. Nev. M Science 58:347-348 (1908)

11 Ore deposits and underground water circulation. M World $31: 483-484$, 631$633,733-735, \quad 777-780$ (1911)

11 a Ore deposits and receptacle-making processes. M World 34:971-972, 1029$1030,1081-1082,1171-1173$ (1911)

12 The original source of metalliferous ores. M World $36: 515-516$ (1912)

12a Two phases in the genecis of ote deposits. M World 36:1095-1097, 11511152 (1912)

Miller, Gerrit Smith, jr.

99 A new fossil bear from Ohio [Crsi] procerus]. Biol Soc Wash, $\operatorname{Pr} 13: 53-56$, il (1899)

miller, H. H.

97 The Segovia gold region 2 : Nicaragus Eng M J 64:335-336 (1897)

Miller, Loye Holmes.

o9 Pavo californicus, a fossil peacoct from the Quaternary asphalt beds of Rancho La Brea. Cal Univ, Dp G, B 5: 285-289, il (1909)

o9n Teratornis, a new avian genus from Rancho La Brea. Cal Univ, Op G S: $305-317$, il (1909)

10 Wading birds from the Quaternat? asphalt beds of Rancho La Brea. Cal Univ, Dp G, B 5:439-448, il (1910) 
Miller, Loye Holmes Continued.

10a The condor-like vultures of ancho La Brea. Cal Univ, Dp G, B 6:1-19, il (1910)

11 Additions to the avifauna of the Pleistocene deposits at Fossil Lake, Oreg. Cal Univ, Dp G, B $6: 79-87$, il (1911)

11a A series of eagle tarsi from the Pleistocene of Rancho La Brea, Cal. Cal Univ, Dp G, B 6:305-316, il (1911)

11b Avifauna of the Pleistocene cave deposits of California. Cal Univ, Dp G, B $6: 385-400$, il (1911)

11e A synopsis of wur knowledge concerning the fossil birds of the Pacific coast of North America. Condor (Hollywood, CaI) $13: 117-118$ (1911)

12 Contributions to avian paleontology from the Pacific coast of North America. Cal Univ, Dp G, B 7:61-115 (1912) Abst, G Soc Am, B 24: 132 (1913)

14 Bird remains from the Pleistocene of San Pedro, Cal. Cal Univ, Dp G, B 8:31-38 (1914)

16 A review of the species Pavo californicus [Rancho La Brea, Cal.]. Cal Univ, Dp G, B 9:89-96, il (1916) Abst, G Soc Am, B 27:171 (1916)

16a The owl remains from Rancho La Brea [Cal.]. Cal Univ, Dp G, B $9: 97-$ 104 (1916)

16b Two vulturid raptors from the Pleistocene of Rancho La Brea [Cal.]. Cal Univ, Dp G, B 9:105-109, il (1916) Miller, Morris.

- A treatise on the science of geology [abandoned beaches], $11 \mathrm{pp}$, Salem, O., n d [priv pub]

Miller, Samuel Almond (1837-1897).

74 [Notes and deseriptions of Cincinnati group fossils.] Cin Q J Sc $1: 2-18,147$ $150,232-236,282, \quad 343-351, \quad 368-375$, il (1874) ; $2: 86-87,274-284,378-379$, il (1875)

74a The position of the Cincinnati group in the geological column of fossiliferous rocks of North America. Cin Q J Sc 1: $97-115$ (1874)

74b Monograph of the Crustacea of the Cincinnati group. Cin Q J Sc 1: 115-147, Il (1874)

74e Monograph of the Lamellibranchiata of the Cinclnnati group. Cin Q J Sc 1: 211-231, il (1874)

74d Monograph of the Gastropoda of the Cincinnati group. Cin Q J Sc 1:302321 , il (1874)

74e Remarks upon the genus Anomalodonta and the $n$ ords Megaptera and Opisthoptera, and the species gigantea and alata. Cin Q J Sc 1:326-333 (1874)

75 Monograph of the class Brachiopoda of the Cincinnati group. Cin Q J Sc 2: $6-62$, il (1875)

$$
28737^{\circ}-23-48
$$

Miller, Samuel Almond-Continued.

75a Class Cephalopoda (Cuvier) as represented in the Cincinnati group. Cin Q J Sc 2:121-134, il (1875)

75b Notice of the Chemical and geological essays of T. Sterry Hunt, and of the words Cambrian and Silurian. Cin Q J Sc 2:155-161 (1875)

75e Review of the glacial theory. Cin Q J Sc 2:259-267 (1875)

$75 d$ Some new species of fossils from the Cincinnati group and remarks upon some described forms. Cin Q J Sc 2: 349-355, il (1875)

77 The American Paleozoic fossils; a catalogue of the genera and species ... 253 pp, Cincinnati, Ohio, 1877. 2d ed, 334 pp, Cnicinnati, Ohio, 1883

78 (and Dyer, C. B.) Contributions to paleontology [descriptions of Cincinnatian and Niagaran fossils]. Cin Soc $\mathrm{N} \mathrm{H,} \mathrm{J} 1$ : 24-39, il (1878)

78a (and Dyer, C. B.) Contributions to Paleontology, No. 2. 11 pp, Cincinnati, Ohio, 1878 [Priv pub]

$\mathbf{7 8 b}$ Description of a new genus [Angellum] and eleven new species of fossils, with remarks upon others well known, from the Cincinnati group. Cin Soc N H, J $1: 100-108$, il (1878)

78e Description of eight new species of Holocystites from the Niagara group [of Indiana]. Cin Soc N H, J 1:129-136, ll (1878)

79 Catalogue of fossils found in the Hudson River, Utica slate, and Trenton groups as exposed in the southeast part of Indiana, southwest part of Ohio, and northern part of Kentucky. Ind G S, An Rp 8-9-10:22-56 (1879)

79a (and others) Report of committee on geological nomenclature [of strata in the vicinity of Cincinnati]. Cin Soc $\mathrm{N} \mathrm{H}$, J $1: 193-194$ (1879) Am J Sc (3) 17: 484-485 (1879) Ind G S, An Rp 8-9-10 : 23-25 (1879)

79b Remarks upon the Kaskaskia group, and descriptions of new species of fossils from Pulaski Co., Ky. Cin Soc N H, J 2 : $31-42$ (1879)

79e Description of twelve new fossil species [Niagaran and Cincinnatian] and remarks upon others. Cin Soc $\mathrm{N} \mathrm{H,} \mathrm{J} \mathrm{2} \mathrm{:}$ 104-118, il (1879)

80 Silurian [Ordovician] ichnolites, with definitions of new genera and species. CIn Soc N H, J 2:217-222, il (1880)

Soa Description of two new species from the Niagara group and five from the Keokuk group. Cin Soc N H, J 2:254259, il (1880)

80b Note upon the habits or some fossil annelids. Cin Soc N H, J 2:260 (1880)

soe [On the Trenton rocks of Kentucky.] Cin Soc N H, J 3: 73 (1880) 
viller, Samuel Almond-Continued.

sod Description of four new species of Silurian [and Ordovician] fossils. CIn Soc N H, J 3 : 140-144, il (1880)

soe Description of four new species and a new variety of Silurian fossils, and remarks upon others [mainly Ordovician]. Cin Soc N H, J 3: 232-236, il (1880)

sof On the growth of paleontology as a science. Davenport Ac Sc, Pr 2: 206 (1880)

$80 \mathrm{~g}$ On the synonymy of two species of spirifera. Davenport Ac Sc, Pr $2: 220-221$ (1880)

st North American Mesozoic and Cenozoic geology and paleontology. $338 \mathrm{pp}$, Cincinnati 1881. Reprinted from Cincinnati Soc $\mathrm{N}$ H, J $2: 140-161,223-244$ (1879) ; $3: 9-32,79-118, \quad 165-202, \quad 245-$ $288(1880) ; \quad 4: 3-46, \quad 93-144, \quad 183-234$ (1881)

81 a Description of five new species of Silurian fossils, and remarks upon an undetermined form [all but one, Ordovician]. Cin Soc $\mathrm{N}$ H, J $3: 314-317$, il (1881)

81b Description of some new and remarkable crinoids and other fossils of the Hudson River group and notice of Strotoerinus bloomfieldensis. Cin Soc N H, J 4: 69-77, il (1881)

s1e New species of fossils and remarks upon others from the Niagara group of Illinois. Cin Soc N H, J $4: 166-176$, il (1881)

$81 d$ Description of new species of fossils. Cin Soc N H, J $4: 259-262$, il (1881)

s1e Observations on the unification of geological nomenclature with special reference to the Silurian formation of North America. Cin Soc N H, J 4:267-293 (1881)

81f Subcarboniferous fossils from the Lake Valley mining district of New Mexico, with descriptions of new species. Cin Soc N H, J $4: 306-315$, il (1881)

81g Description of new species of fossils from the Hudson River group, with remarks upon others. Cin Soc N H, J 4:316-319, il (1881)

82 Notice of a work by Prof. Nicholson on the genus Monticulipora. Cin Soc N H, J $5: 25-33$ (1882)

82a Description of two new general and eight new species of fossils from the Hudson River group, with remarks upon others. Cin Soc N H, J 5:34-44, 11 (1882)

82b Description of ten new species of fossils. Cin Soc $\mathrm{N} \mathrm{H,} \mathrm{J} \mathrm{5:79-88,} \mathrm{il}$ (1882)

82e Brief mention of some of the men who aided in developing the science of geology in America, but who are known no longer except by their works. Cin Soc N H, J 5: 101-115 (1882)

82d Description of three new species and remarks upon others. Cin Soc N H, J $5: 116-117$, il (1882)
Miller, Samuel Almond-Continued.

82e Description of three new orders four new families in the class Echinodes ata and eight new species from the Silor and Devonian formations. Cin Soc $\mathrm{NH}$ $5: 221-231$, il (1882)

$\mathbf{8 3}$ Glyptocrinus redefined and restrict Gaurocrinus, Pyenocrinus, and Comp. crimus established and two new species scribed. Cin Soc N H, J 6:217-234, (1883)

83a Response to the remarks of Mesr Wachsmuth and Springer on the geve Glyptocrinus and Reteocrinus. Am J: (3) $26: 105-113$ (1883)

83b (with Worthen, A. H.) Desch tions of new Carboniferous echinoder III G S $7: 327-338$, il (1883)

84 Description of a beautiful start and other fossils. Cin Soc N H, J $7: 16$ 20, il (1884)

88 The Taconic system as established Emmons and the laws of nomenclature : plicable to the subject. Am G 1:235-? (1888)

88n A new genus of crinoids from t: Niagara group. Am G 1:263-264 (186.

89 North American geology and palen tology... $664 \mathrm{pp}, \mathrm{il}$, Cincinnati 1889 Fir appendix, $1892: 665-718$; Second appendt October, 1897: 719-793

89a The structure, classification, arrangement of American Paleozoic crinolls into families. Ind, Dp G N H, An Rp 16 302-326 (1889)

89b (and Gurley, W. F. E.) Deschil tion of some new genera and species Echinodermata from the Coal Measures as: Subcarbonlferous rocks of Indiana, M souri, and Iowa. Ind, Dp G N H, An B $16: 327-373$, il (1889)

90 (and Gurley, W. F. E.) Descriptic of some new genera and species of Echis dermata from the Coal Measures and Str carboniferous rocks of Indiana, Missout: and Iowa. $59 \mathrm{pp}, 1890$ [priv pub]

90a The structure, classification, ani arrangement of American Paleozoic crinoid into families. Am G $6: 275-286,340-3 t^{\circ}$ (1890)

9ob (and Gurley, W. F. E.) Descrip tion of some new genera and species Echinodermata from the Coal Measure and Subcarboniferous rocks of Indiats Missouri, and Iowa. Cin Soc N H, J 13: $3-25$, il (1890)

91 A descriptin of some Lower Carboo iferous crinoids from Missouri. Mo $\mathrm{G} \&$ B 4:40 pp, il (1891)

92 Paleontology. Ind, Dp $\mathrm{G} N$ Res, At Rp 17:611-705, il (1892)

92a (and Faber, C. L.) Description some Carboniferous and Subcarboniferous Cephalopoda. Cin Soc N H, J 14 : 164-164 il (1892) 
Miller, Samuel Almond-Continued.

92b (and Faber, C. L.) Some new species and new structural parts of fossils. Cin Soc N H, J 15: 79-87, il (1892)

93 (and Gurley, W. F. E.) Descriptions of some new spccies of invertebrates from the Paleozoic rocks of Illinois and adjacent states. IIl St Mus N H, B 3: $81 \mathrm{pp}$, il (1893)

94 (and Gurley, W. F. E.) Upper Devonian and Niagara crinoids. Ill St Mus N H, B 4:37 pp, il (1894)

94a (and Gurley, W. F. E.) New genera and species of Echinodermata. III St Mus N H, B 5:53 pp, il (1894)

94b Paleontology. Ind, Dp G $\mathrm{N}$ Res, $\mathrm{An}$ Rp $18: 257-356$, il (1894)

94e (and Faber, C. L.) New species of fossils from the Hudson River group and remarks upon otiers. Cin Soc $\mathrm{N} \mathrm{H}$, J $17: 22-33$, il (1894)

94d The petrified forest of Arizona. Cin Soc N H, J 17:56-58 (1894)

94e (and Faber, C. L.) Description of some Cincinnati fossils. Cin Soc N H, J $17: 137-158$, il (1894)

95 (and Gurley, W. F. E.) Description of new species of Paleozoic Echinodermata. Ill St Mus N H, B 6:62 i.p, fl $(1895)$

95a (and Gurley, W. F. F.) New and interesting species of Paleozoic fossils. IIl St Mus N H, B 7:89 pp, il (1895)

96 (and Gurley, W. F. E.) Description of new and remarkable fossils from the Paleozoic rocks of the Mississippi Valley. Ill S: Mus N H, B 8:65 pp, il (1896)

96n (and Gurley, W. F, E.) New species of crinolds from Illinois and other States. IIl St Mus N H, B 9:66 pp, Il (1896)

96b (and Gurley, W. F. E.) New species of Echinodermata and a new crustacean from the Paleozoic rocks. Ill st Mus N H, B 10:91 pp, il (1896)

96e (and Gurley, W. F. E.) New species of Paleozoic invertebrates from Illinols and other States. III St Mus $\mathrm{N} \mathrm{H}$, B 11:50 pp, il (1896)

97 (and Gurley, W. F. F.) New species of crinolds, cephalopods, and other Paleozoic fossils. Ill St Mus N H, B 12: $69 \mathrm{pp}$, Il (1897)

97a Strophomena and the type of the genus. Nat Se J, New Bedford, Mass., 1 : 29-35 (1897)

Miller, Sylvanus.

36 ... mastodon bones in Oran . Co., N. Y. Am J Sc 31:171-1/2 (1836)

Miller, Thomas D.

98 The recently developed oil field of Texas [Corsicana]. Eng M $T$ 65: 734-735 (1898)

Miller, $W$.

56 Notice of the recent eruption of Mauna Loa in Hawail (abst). G Soc London, Q J 12:171 (1856)
Miller, W.-Continued.

56a Further notice of the recent eruption from the volcano of Mauna Loa in Hawaii (Owhyhee) (abst). G Soc London, Q J 12:386-387 (1856)

Miller, Willet Green.

95 The Glendower iron deposit [Frontenac Co., Ont.]. Can M Rv $14: 40-41$ (1895)

96 (and Brock, R. W.) Some dikes cutting the Laurentian system in the counties of Frontenac, Leeds, and Lanark, Ont. Can Rec Sc 6:481-488 (1896)

97 Note on some basic dike and volcanic rocks of eastern Ontario and Quebec. Can Inst, $\operatorname{Pr}$ n s 1:85-86 (1897)

98 on some nickeliferous magnetites (abst). Brit As, Rp 67: 660-661 (189s)

9Sa (with Goodwin, W. L.) Note on a mineral of the columbite group. Fed Can M inst, J 3:151-152 (1898) Can M Rv $17: 109(1898)$

99 Corundum and other minerals. Ont Bur Mines, Rp 8: 205-240 (1899)

99 Notes on the corundum-bearing rocks of eastern Ontario, Can. Am G 24: 276-282, map (1899)

99b Notes on prospecting for corundum. Can Inst, $\operatorname{Pr}$ n s 2: 23-26 (1899)

00 Minerals of Ontario, with notes. Ont Bur Mines, Rp 1900: 192-212 (1900)

o1 Iron ores of Nipissing district. Ont Bur Mines, Rp 1901: 160-180 (1901)

o1a On some newly discovered areas of nepheline syenite in central Canada. Am G $27: 21-25$ (1901)

01b The iron ore fields of Ontario. Can M Inst, J 4:265-283 (1901) Can M Rv $20: 151-158$ (1901)

02 The eastern Ontarlo gold belt. Ont Bur Mines, Rp 1902: 186-207, map (1902) Abst, Eng M J 74:850 (1902)

02a Lake Timiskaming to the Height of Land. Ont Bur Mines, Rp 1902: 214-230 (1902)

02b Eastern Ontario; a region of varied mining industries. Can M Inst, J 5 : 233255 (1902) Can M Rv 21: 116-122 (1902) 03 Iron ranges of northern Ontario. Ont Bur Mines, Rp 1903: 304-317 (1903)

o3a Nepheline syenite in western Onta. rio. Am G 32: 182-185 (1903)

03b Cobalt-nickel arsenides and silver in Ontario. Eng M J 76:888-890 (1903) Can M Rv 22: 244-249 (1903)

04 Cobalt-nickel arsenides and silver. Ont Bur Mines, Rp 1904: 96-103 (1904)

04a Undeveloped mineral resources of Ontario (with discussion). Can M Inst, J 7:377-396 (1905) Can M Rv 23:110114 (1904)

05 The limestones of Ontario. Ont B Mines, Rp 1904 pt 2: 143 pp (1905)

05a Boston Township iron range. Ont Bur Mines, Rp 190514 pt $1: 261-268$ (1905) 
Miller, Willet Green-Continued.

05b The cobalt-nickel arsenides and silver deposits of Timiskaming. Ont Bur Mines, Rp 1905, 14 pt 2:66 pp, maps (1905) ; 2d ed: 97 pp, waps (1906) ; $3 \mathrm{~d}$ ed, Rp 1907 , vol 16 pt $2: 212$ pp, maps (1908) ; 4th ed, Rp 19 pt $2: 279$ pp, maps (1913)

o5e Pre-Cambrian rocks in the vieinity of Lake Temiskaming, Ont. (abst). G Soc Am, B 16:581-582 (1906) Sclence n s $21: 221$ (1905) Sc $\Delta m$ Sup $59: 24327$ (1905)

06 Minerals and how they oceur. 252 pp, Toronto [1906]

07 Lake Abitibi gold deposits. Ont Bur Mines An Rp 16 pt 1:219-220 (1907)

O7a (and Knight, C. W.) Grenville Hastings unconformity and the probable identity in age of the Grenville limestone with the Keewatin iron formation of the Lake Superior region. Ont Bur Mines, An Rp 16 pt 1:221-223 (1907)

07b Mines and mining of Cobalt [Ont.] Can M J 28 (n s 1 no 1): 7-11 (1907)

os (and Knight, C. W.) GrenvilleHastings unconformity (abst). Science $n$ s $27: 407-408$ (1908) G Soe Am, B 19: $539-540$ (1909)

09 The pre-Cambrian rocks of Canada (abst). Can M J $30: 647$ (1909) Brit As, Rp $79: 474-475$ (1910)

10 Porcupine district of Ontario. M Sc Press 101: 232 (1910)

10a Gold and silver ores of Canada (abst). Brit As, Rp 79:479 (1910)

$10 b$ Iron deposits of Canada (abst). Brit As, Rp 79:480 (1910)

11 Topaz, tin, and granites in Ontario. ran M J 32:582-583 (1911)

$11 \mathrm{n}$ Notes on the Cobalt area [Ont.]. Eng M J 92:645-649 (1911)

11b A geological trip in Scotland: PreCambrian of northwest Highlands compared with that of Ontario. Ont Bur Mines, An Rp 20 pt 1:259-269 (1911)

11e (and Knight, C. W., The Laurentian system. Ont Bur Mines, Ar Rp 20 pt $1: 280-284$ (1911)

11 d Pre-Cambrian of Sweden, with comments on American taxonomic parallels, (discussion) (abst), G Soc Am, B 22: 719 (1911)

12 (and others) Reports on the District of Patricia recently added to the Province of Ontario. Ont Bur Mines, An Rp 21 pt 2: 216 pp, maps (1912) [A general account of the District of Patricia. including geologic features. Harlier reports on various parts of the area by Robert Bell, D. B. Dowling, Alfred W. G. Wilson, Charles Camsell, A. P. Low, William McInnes, W. J. Wilson, and Owen O'Sullivan are reproduced.]
Miller, Willet Green-Continued.

12a The prineiples of classification of the pre-Cambrian rocks, and the extent to which it is possible to establish a ebropologieal classification. Int $\mathrm{G}$ Cong, $\mathrm{XI}$ Stockholm, 1910, C R: $73-682$, map (1912)

12b (with Daly, R. A.) heport of the commission appointed to investigate Turtle Mountain, Frank, Alta, Can G S, Men $27: 34$ pp (1912)

13 The Sudbury-Cobalt-Poreupine to gion; preface. Int $\mathrm{G}$ Cong, XII, Canada Guide Book no $7: 5-7,51-108,139-148$, maps (1913)

13a The cobalt-nickel arsenides and silver deposits of Temiskaming (Cobalt and adjacent areas). Ont Bur Mines, dn Rp 19 pt $2: 279$ pp. maps (1913)

$13 b$ Cobalt and adjacent areas [0nt.] Can M J 34: 87-90 (1913)

13e (and Knight, C. W.) Sudbury. Cobalt, and Porcupine geology [0nt.]. Eng M J 95:1129-1133, map (1913)

14 (and Knight, C. W.) The pre Cambrian geology of southeastern Ontario, with an appendix on the correlation of the pre-Cambrian rocks of Ontario, western Quebec, and southeastern Manitoba. Ont Bur Mines, Rp 22 pt 2:151 pp, mape (1914)

14a The pre-t ambrian rocks north of Lake Huron (prefatory note). Ont Bur Mines, An Rp 23 pt $1: 202-203$ (1914)

15 (and Knight, C. W.) Metalloge netic epochs in the pre-Cambrian of Onta rio. $\mathrm{R}$ Soc Can, Tr (3) 9 iv: 241-249. map (1915) Ont Bur Mines, Ar Rp 24 p 1: 243-248, map (1915)

15a (and Knight, C. W.) Revision of pre-Cambrian classification in Ontario J G 23:585-599, map (1915) Can of J 36: 265-266, map (1915) M Sc Press 111 401-404, map (1915) Abst, G Soc Am, B $26: 87-88$ (1915); Science n $841: 509$ (1915)

17 (and Knight, C. W.) Euxenite, radioactive mineral in South Sherbrookt township, Lanark Co. Ont Bur Mines, ds Rp 26:314-317 (1917)

17 a Lateritic ore deposits; with com ments on the nature of laterites in general. Ont Bur Mines, An Rp 26:318-334 (1917)

17b (and Knight, C. W.) Occurretice of euxenite in South Sherbrooke Township Ont. Am J Sc (4) 44:243-244 (1917)

17e Petroleum in Canada. G Soc Am B 28: 721-726 (1917)

See also Lindgren, 03d ; Roberts (H M). 18

Miller, William John.

O5 (with Mathews, E. B.) Cockey ville marble [Maryland]. G Soc $A m, B$ $16: 347-366$, map (1905)

o7 (with Carey, E. P.) The crystabline rocks of the Oak Hill area, near San Jose Cai. J G 15: 152-169 (1907) 
Miller, William John-Continued.

os Highly folded between nonfolded strata at Trenton Falls, N. Y. J G 16 428-433 (1908)

09 Geology of the Remsen quadrangle, including Trenton Falls and vicinity in Oneida and Herkimer cos. N Y St Mus, B $126: 51 \mathrm{pp}, \operatorname{map}(1909)$

$09 a$ Ice movement and erósion along the southwestern Adirondacks. Am J Sc (4) 27 : 289-298 (1909)

09b Pleistocene geology of the south western slope of the Adirondacks (abst). Science n s 29:627 (1909) G Soc Am, B $20: 635-637$ (1910)

10 Geology of the Port Leyden quad rangle, Lewis Co., N. Y. N Y St Mus, B $135: 61$ pp, map (1910)

10a Origin of color in the Vernon shale. N Y St Mus, B 140:150-156 (1910)

10b Trough faulting in the southern Adirondacks. Science n s 32:95-96 (1910)

11 Preglacial course of the upper Hud son River. G Soc Am, B 22:177-186 (1911)

11a Exfoliation domes in Warren Co. N. Y, N Y St Mus, B $149: 187-194$ (1911)

11b Geology of the Broadalbin quadrangle, Fulton-Saratoga cos., N. Y. N Y St Mus, B 153:65 pp, map (1911)

12 The garnet deposits of Warren Co. N. Y. Ec G $7: 493-501$ (1912)

12 a Contact action of gabbro on granite in Warren Co., N. Y. Seience n s $36: 490-$ 492 (1912)

$12 b$ (with Norton, W. H., and others) Underground water resources of Iowa. U S G S, W-S P 293: 994 pp, map (1912) Iowa G S 21:29-1186, maps (1912)

13 Early Paleozoic physiography of the southern Adirondacks. N Y St Mus, B 164: 80-94 (1913) Abst, G Soc Am, B 24: 701 (1913)

13a The garnet deposits of Warren Co., N. Y. N Y St Mus, B 164:95-102 (1913)

13b Variations of certain Adirondack basic intrusives. J G $21: 160-180$, map (1913)

14 The geological history of New York State. N Y St Mus, B 168: 130 pp (1914)

14a Geology of the North Creek quadrangle, Warren Co., N. Y. N Y St Mus, B $170: 90 \mathrm{pp}, \operatorname{map}$ (1914)

14b Magmatic differentiation and assimilation in the Adirondack regions. G Soc Am, B 25: 243-264 (abst with discussion : 45-46) (1914)

15 Notes on the intraformational contorted strata at Trenton Falls [N. Y.] N Y St Mus, B 177:,135-143 (1915)

15a The great rift on Chimney Moun tain [Adirondack Mts., N. Y.]. N Y St Mus, B 177 : 143-146 (1915)

16 An introduction to historical geology, with special reference to North Amrerica. 399 pp, N Y 1916
Miller, William John-Continued.

$16 a$ Geology of the Lake Pleasant quadrangle, Hamilton Co., N. Y. N Y St Mus, B 182:75 pp, map (1916)

16b Origin of foliation in the preCambrian rocks of northern New York. J G 24:587-619, map (1916) Abst, G Soc Am, B $27: 57-58$ (1916)

17 Geology of the Blue Mountain, N. Y., quadrangle. $\mathrm{N}$ Y St Mus, B 192:68 pp, map (1917)

17a The Adirondack Mountains. N Y St Mus, B 193: 97 pp, maps (1917)

17b A classification of metamorphic rocks. G Soc Am, B 28:451-462, 155 (abst) (1917)

18 Lake Placid quadrangle, Schroon Lake quadrangle. N Y St Mus, B 196: 29-31 (1918)

18a Adirondack anorthosite. G Soc Am, B 29:99-100 (abst with discussion by W. S. Bayley and F. F. Grout), 399-462, map (1918)

18b Banded structures of the Adirondack syenite-granite series. Science n s $48: 560-563$ (1918)

See also Chadwick, 16, 17a ; Grout, 18b; Norton, 12 ; Wilson (M E), 18a

Millern, Alexander von.

64 All about petroleum and the great oil districts of Pennsylvania, West Virginia, Ohfo, etc. $89 \mathrm{pp}, \mathrm{N}$ Y 1864

Millis, John.

11 What caused the drumlins? Science n s $34: 60-62$ (1911)

14 What was the cause of the eskers? Science n s 39:208-209 (1914)

Millington, John.

34 (with Rio, Andres Del.) ...Rappahannock gold mines in Virginia. G Soc Pa, Tr 1: 147-166 (1834)

Mills, Frank $\mathrm{S}$.

03 The delta plain at Andover, Mass. Am G 32:162-170 (1903)

O3a River terraces and reversed drainage [Catatonk Valley, N. Y.]. J G 11: $670-678$ (1903)

08 The economic geology of northern New York. Eng M J 85: 306-308 (1908) Mills, James Cooke.

os The graphite mines of Santa Maria [Sonora, Mexico]. Mines and Minerals 29 : 98-100 (1908)

Mills, James Ellison (1834-1901).

57 [On slate from Somerville, Mass.] Boston Soc N H, Pr 6:107-108 (1857)

71 Manganese deposits in Virginia. Am Chemist 2:49-51 (1871)

92 Stratigraphy and succession of the rocks of the Sierra Nevada of California. G Soc Am, B 3:413-444, map (1892) Abst, Am G 9:215 (1892)

See also Tyrrell, 90a

rills, Robert.

26 Statistics of South Carolina... [geelogy : 17-60]. 782, 48 pp, Charleston,

S. C., 1826 
Mins, Ronald Van Auken.

17 (and Wells, R. C.) The evaporation of water at depth by natural gases (abst). Wash Ac Sc, J $7: 309-310$ (1917) Mills, S. Dillon.

04 Some recent rock movements in the Laurentian and Huronian areas [Ontario]. Can M Inst, J $7: 177-184$ (1905) Can M Rv $23: 174-177$ (1904)

o5 Occurrence of hematite north of Little Current, Georgian Bay [Ont.]. Can M Rv 25: 119-122 (1905)

Mills, W. Magoon.

04 A physiographic and ecological study of the Eagle Lake (Winona Lake) region, Ind. Ind, Dp $\mathrm{G} N$ Res, An Rp 28:377394 (1904)

Millspaush, C. F.

92 Fossil flora; supplement to the flora of West Virginia [List of fossil plants identified from West Virginia, with formation and locality]. W Va Agr Exp Sta, B no 24 (vol. 2 , no. 12) : 519-537 (1892)

Millward, William.

09 Fossils from the glacial drift and from the Devonian and Mississippian near Meadville, Pa. Carnegie Mus, An 5:480487 (1909)

Milne, John.

76 Ice and ice work in Newfoundland. G Mag (2) $3: 303-308,345-350,403-410$ (1876)

$\mathbf{7 7}$ On the rocks of Newfoundland. G Mag (2) 4:251-262 (1877)

86 Earthquakes and other earth movements. International Scientific series, No. 55. $363 \mathrm{pp}, \mathrm{N}$ Y 1886

02 The recent volcanic eruptions in the West Indies. Nature 66:56-58, 107-111, 370-373 (1902)

02a West Indian volcanic eruptions. Nature 67:91-92 (1902)

03 World-shaking earthquakes in relation to volcanic eruptions in the West Indies. Brit $A s$, Rp $72: 682-83$ (1903)

10 After-shocks of the earthquake at Jamaica, January 14, 1907. Brit As, Rp $79: 51-55$ (1910)

Milne-Edwards. See Edwards, H. M. Milner, W. C.

12 History of albertite. M Soc N S, J 17:62-69 (1912)

Milton, Maxwell C.

13 The Oro Blanco district of Arizona. Eng M J 96:1005-1007 (1913)

Mineral Collector ...

Vols. 1, March 1894-15, February 1909. N Y Editors, Albert C. Bates and Arthur Chamberlain

\section{Mineral Industry.}

93 The mineral industry, its statisties, technology, and trade, in the United States and other countries, from the earliest times to the end of 1892 . Edited by Richard P. Rothwell. Vol 1 (1892) -. N Y 1893 -
Minor, J. C., Jr.

94 (with Penfield, S. L.) On the chemical composition and related physical properties of topaz. Am J Sc (3) 4: 387-396 (1894) Yale Bicen Pub, Cont Miner : 231-241 (1901)

Minor, Jessie.

04 (with Babcock, E. N.) The Giry. don sandstone and its mineral waters: Drury Coll, Bradley G Field Sta, B 1:2231 (1904)

Minor, Philip.

99 A theory of the genesis of ore df posits. M Sc Press $79: 747$ (1899)

Minot, Charles Sedgwick.

98 A memento of Professor Edward D. Cope [diagram showing phylogeny of Mar malia]. Science n s 8: 118-114 (1898)

13 A tribute to Joseph Leidy, Sciend n s $37: 809-814$ (1913)

Minsha11, F. W.

88 The history and development of the Macksburg oil field. Ohio G S, Rp b: 443-475 (1888)

Minthorn, Daniel.

87 [Geology of Jefferson Co., N. I.] Jefferson Co Hist Soc, Tr 1886-7:132144 (1887)

Miranda y Marrón, Manuel.

09 Los terremotos del año de 1908. Sox Cient Ant A1z, Mem 28: 93-153 (1909)

12 El temblor del 7 de junio de 1911 Soc Cient Ant Alz, Mem 32:27-66 (1912) Miser, Hugh Dinsmore.

13 Developed deposits of fuller's earth in Arkansas. U S G S, B 530:207-220 map (1913)

14 New areas of diamond-bearing pert dotite in Arkansas. U S G S, B 540:534 546 (1914)

16 (with Purdue, A. H.) Descriptiot of the Eureka Springs and Harrison quad rangles, Ark.-Mo. U S G S, G Atlar Eureka Springs-Harrison fol (no 202):22 pp, map (1916)

17 Manganese deposits of the Caddo Gar and De Queen quadrangles, Ark. U S G 8 B 660:59-122, map (1917) Abst, Wash Ac Sc, J $7: 587$ (1917)

17 a Structure of the Waynesboro quad rangle with special reference to oil and gas. Tenn G S, Res Tenn $7:$ 199-219, ms? (1917)

18 (and Purdue, A. H.) Gravel de posits of the Gaddo Gap and De Queet quadrangles, Ark. U S G S, B $690: 15-22$. map (1918) Abst, Wash Ac Sc, J 8: 535 (1918)

18a (and Purdue, A. H.) Asphalt deposits and oil conditions in southwestern Arkansas. U S G S, B 691: 271-292, mat? (1918) 
Miser, Hugh Dinsmore-Continued.

18b (with Hewett, D. F., and others) Possibilities for manganese ore on certain undeveloped tracts in Shenandoah Valley, Va. U S G S, B $660: 271-296$, maps (1918) Abst, by R. W. Stone, Wash Ac Sc, J $8: 450$ (1918)

18e (with Stephenson, L. W.) Camp Pike and the adjacent country [Arkansas]. [Text on back of topographic map]. Arkansas, Little Rock quadrangle, Camp Pike, U S G S, 1918

\section{Mississippi Geologieal Survey.}

os First biennial report of the Mississippi Geological Survey Commission. $7 \mathrm{pp}$, Nashville, Tenn., 1908 [Second and] third blennial report ...: 14 pp [1911]

\section{Missonri Bureau of Geology and}

\section{Mines.}

12 Geological map of Missouri, 1912. Scale 11 miles to 1 inch

Mitchell, Elisha (1793-1857).

27 Report on the geology of North Carolina, Part III. [N C] Bd Agr: 1-27, Raleigh, 1827

28 On the character and origin of the low country of North Carolina. Am J Sc $13: 336-347$ (1828)

29 On the geology of the gold region of North Carolina. Am J Sc 16:1-19, map (1829); $17: 400$ (1830)

42 Elements of geology, with an outline of the geology of North Carolina ... 141 pp, map, 1892

05 Diary of a geological tour by Dr. Elisha Mitchell in 1827 and 1828 , with introduction and notes by Dr. Kemp P. Battle. N C Univ, James Sprunt Hist Mon no 6: 73 pp, Chapel Hill 1905

Mitehell, Evelyn Groesbeeck.

0s An apparently new protoblattid famfly from the Lower Cretaceous [of Montana]. Smith Mise Col 52 (Q I 5) : 8586 , II (1908)

Mitchell, Graham John.

15 Minerals of Oregon. Oregon Univ, B n s 13 no $3: 61$ pp (1915)

16 (with Butler, G. M.) Preliminary survey of the geology and mineral resources of Curry Co., Oreg. Oreg Bur Mines, Min Res Oreg 2 no 2:134 pp, map (1916)

18 Evidence of recent changes of level in Porto Rico, as shown by studies in the Ponce district (abst). G Soc Am, B 29 : 138-141 (1918)

Mitehell, Guy Elliott.

10 Landslides and rock avalanches. Nat Geog Mag $21: 277-287$ (1910)

10a Our coal lands. Nat Geog Mag 21: 446-451 (1910)

101) A new source of power; billions of tons of lignite, previously thought too poor coal for commercial use, are made easily available. Nat Geog Mag 21:935944 (1910)
Mitehell, Guy Elliott-Continued.

12 Potash deposits in America. Cassier's Mag 41: 291-301 (1912)

18 Billions of barrels of oll locked up in rocks. Nat Geog Mag 33: 195-205 (1918) Mitehe11, Henry.

so Notes concerning alleged changes in the relative elevations of land and sea. U S Coast S, Rp 1877 (U S, 45th Cong 2d sess, S Ex Doc 12) : 98-103 (1880)

Mitehell, James A.

95 The discovery of fossil tracks in the Newark system (Juratrias) of Frederick Co., Md. Johns Hopkins Univ Cire 15: 1516, il (1895)

Mitchell, R. H.

92 (with Baskerville, Charles) An example of river adjustment [Jackson River, Va.]. Elisha Mitehell Sc Soc, J $9: 64-66$ (1892)

Mitehill, Samuel Latham (1764-1831).

98 A sketeh of the mineralogical history of the State of New York. Medical Repository, N Y, 1:293-314, 445-452 (1798)

14 Descriptive catalogue accompanying a suite of mineral specimens [from New York]. Am Miner J 1:1-5 (1814)

14a The physical geography of the first range of mountains extending across New Jersey, from the Hudson to the Delaware ... Am Miner, J 1: 70-79 (1814)

14b Account of the remains of marine animals in a fossil state, in New Jersey. Am Miner J 1: 95-96 (1814)

14e An amendment proposed to the geological chart of the United States, as respects the character of the north side of Long Island ... Am Miner J 1:129-133 (1814)

14d A sketch of the scenery in the region around Harpers Ferry ... Am Miner J 1: 211-218 (1814)

14e Geology of Long Island. Am Miner J $1:$ :261-268 (1814)

15 A detalled narrative of the earth. quakes ... [North America, 1811-1813]. Lit Ph Soc N Y, Tr 1:281-307 (1815)

18 Observations on the geology of North America; illustrated by the description of various organic remains found in that part of the world. In Cuvier, Georges, Essay on the theory of the earth: $319-431$, il, N Y 1818

18a An account of the impression of a fish in the rocks of Oneida Co., N. Y. [Eurypterus remipes De Kay]. Am Mo Mag 3: 291 (1818).

23 Observations on the teeth of the Megatherium recently discovered in the United States [Georgia]. Lyc N H N Y, An 1: 58-61 (1823)

26 Catalogue of the organic remains and other geological and mineralogical articles contained in the collection presented to the New York Lyceum of Natural History. $40 \mathrm{pp}, \mathrm{N}$ Y 1826 
Mitehill, Samuel Latham-Continued.

27 (and others) Discovery of a fossil walrus in [Accomac Co.], Va. Lye N H N Y, An 2:271-272 (1827)

2S A lecture on some parts of the natural history of New Jersey ... 34 pp, N Y 1828

See also Phillips (W), 18

Mitivier, M. M.

92 New footprints from the Connecticut Valley (abst). Am As, Pr $40: 286$ (1892)

Mixer, Fred K.

S6 (and Williams, H. U.) Fish remains from the Corniferous near Buffalo [N. Y.]. Buffalo Soc N Sc, B 5: 84 (1886)

96 The discovery of a new fish fauna

from the Devonian rocks of southwestern New York (abst). Am G 18:223 (1896) Science n s 4:386 (1896)

Mixter, William G.

68 On willemite and tephroite. Am J Sc (2) $46: 230-232$ (1868)

Moberg, Johan Christian.

99 Bidrag till kännedomen om Steenstrupin. Med Grönland 20:245-263 (1899)

Mobius, Karl,

78 Der Bau des Eozoon canadense. Paleontographica 25:175-192, il (1878)

79 Principal J. W. Dawson's criticism of my memoir on the structure of Eozoon canadense compared with that of Foraminifera. Am J Sc (3) 18:177-185 (1879)

Moeller, W. H.

94 The Mercur gold deposits in the Camp Floyd district, Utah. Eng M J 57 : 51 (1894)

Moflit, Fred Howard.

o3 The copper mines of Cobre, Santiago de Cuba (abst). Am G 32:64 (1903) Science n s 18:18 (1903) N Y Ac Sc, An 15:189 (1904)

04 The Kotzebue placer gold field of Seward Peninsula, Alaska. U S G S, B 225: 74-80 (1904)

05 The Fairhaven gold placers, Seward Peninsula, Alaska. U S G S, B 247:85 pp, maps (1905)

05a The gold placers of Turnagain Arm [Alaska]. U S G S, B 259: 90-99 (1905) 06 Gold flelds of the Turnagain Arm region [Alaska]. U S G S, B 277:7-52 (1906)

O6a Gold mining on Seward Peninsula [Alaska]. U S G S, B 284:132-144 (1906)

o7 The Nome region [Alaska]. U S G S, B 314:126-145 (1907)

08 Notes on copper prospects of Prince William Sound, Alaska. U S G S, B 345 : $176-178$ (1908)

osa (and Maddren, A. G.) The mineral resources of tue Kotsina and Chitina valleys, Copper River region, Alaska. U S G S, B 345: 127-175, map (1908)
Moflit, Fred Howard-Continued.

o9 Mining in the Kotsina-Chitina, Cht tochina, and Valdez Creek regions, Alask U S G S, B 379:153-160 (1909)

O9a (and Knopf, Adolph) Minerals sources of the Nabesna-White River dis trict, Alaska. U S G S, B $379: 161-19$ (1909)

09b (and Maddren, A. G.) Minerl resources of the Kotsina- 'hitina region Alaska. U S G S, B 374:103 pp (190\% 10 Mining in the Chitina distrit Alaska. U S G S, B 442: 158-163 (1910)

10a (and Knope, Adolph) Mineral it sources of the Nabesna-White River de trict, Alaska; with a section on the Quternary by S. R. Capps. U S G S, B 417: 64 pp (1910)

11 The upper Susitna and Chistichin districts, Alaska. U S G S, B 480: 11?127, map (1911)

11 a (and Capps, S. R.) Geology ari mineral resources of the Nizina distrit Alaska. U S G S, B 448:111 pp, ma (1911) Abst, Wash Ac Sc, J 1: 130 (1911

11b Valdez Creek [Alaska]. U S G A P P 70:167-169 (1911)

12 Headwater reglons of Gulkana as Susitna rivers, Alaska, with accounts the Valdez Creek and Chistochina place districts. U S G S, B 498: $82 \mathrm{pp}$, mil (1912) Abst, Wash Ac Sc, J $2: 349-35$ (1912)

12a The Taral and Bremner River dit tricts. U S G S, B 520:95-104, 뼈 (1912)

12b The Chitina copper distriet [Alaska]. U S G S, B 520:105-10 (1912)

13 Geology of the Nome and Grand ces tral quadrangles, Alaska. U S G B, B $533: 140 \mathrm{pp}$, map (1913) Abst, Wash At Sc, J 4 : 164-165 (1914)

13a Mining in Chitina Valley [Alaska). U S G S, B 542: 81-85 (1913)

14 Geology of the Hanagita-Bremnet region, Alaska. U $\mathrm{S}$ G $\mathrm{S}, \mathrm{B} 576: 56 \mathrm{ph}$ maps (1914)

14a Preliminary report on the Brost Pass region. U S G S, B 592:301-305, map (1914)

14b Mining in the Valdez Creek plact district. U S G S, B 592: 307-308 (1914)

15 (and Pogue, J. E.) The Broad Pas region, Alaska, U S G S, B 608:80 pp. maps (1915) Abst, Wash Ac Sc, J 6:96 (1916)

15n Mineral deposits of the Kotsint Kuskulana district, with notes on mining in Chitina Valley [Alaska]. U S G S, B 622: 103-117, maps (1915)

16 Mineral resources of the npper Chi tina Valley [Alaska]. U S G S, B 64 ? 129-136, map (1916)

17 Mining in the lower Copper Rive basin [Alaska]. U S G S, B 662:15\% 182, maps (1917) 
Moffit, Fred Howard Continued.

is The upper Chitina Valley, Alaska. U S G S, B $675: 82$ pp, maps (1918)

\section{Moissan, Henri.}

02 Sur la présence de l'argon, de l'oxyde de carbone, et des carbures d'hydrogène dans les gaz des fumerolles du Mont Pelé A la Martinique. Ac Sc Paris, C R 135 : 1085-1088 (1902)

04 Sur la présence de l'argon dans les gaz des fumerolles de la Guadeloupe. Ac Sc Paris, C R 138: 936-938 (1904)

04a Nouvelles recherches sur la météorite de Cañon Diablo. Ac Sc Paris, C R 139:773-780 (1904) Abst, Am J Sc (4) $19: 191$ (1905)

Molengraafr, Gustaaf Adolf Frederick.

86 De geologie van het eiland $\mathrm{st}$, Eustatius ... Diss, Utrecht. 61 pp, Leiden 1886 [In Dutch]

8s Het geologisch Verband tusschen de West-Indische Eilanden. Natuur-en Geneeskundig Cong, I, Amsterdam 1887, Hand I : 287-296, map [St. Martin Island] (1888)

Mollman, W.

02 Asbestos and its production in Canada. Can M Inst J 5:343-356 (1902) Can M Rv 21: 152-154 (1902)

Monckton, Geofrey F.

91 The auriferous series of Nova Scotia. G As, London, $\operatorname{Pr} 11: 454-464$ (1891)

97 Notes on the gold-bearing lodes of Cayoosh Creek, B C. Fed Can M Inst, J $2: 1-4$ (1897) Can M Rv 16:67-70 (1897) 98 Notes on mining on the coast of British Columbia and the adjacent islands. Fed Can M Inst, J 3:98-99 (1898) Can M Rv $17: 70-72$ (1898)

99 Mining districts near Kamloops Lake, British Columbia. Inst $M$ Eng, Tr 18: 293-310 (1899)

04 Cinnabar-bearing rocks of British Columbia. Inst $M$ Eng, Tr 27:463-469, map (1904)

13 Geological notes on a human skeleton found in silt at Savona, B. C. G Mag (5) (10) : 364-370 (1913)

\section{Monro, Alex.}

86 On the physical features and geology of Chignecto Isthmus. N H Soc N B, B [1] no 5:20-24 (1886)

Monroe, Charles E.

99 (and Teller, Edgar E.) The fauna of the Devonian formation at Milwaukee, Wis. J G $7: 272-283$ (1899)

00 A notice of a new area of Devonian rocks in Wisconsin. J G $8: 313-314$ (1900)

02 Notes on a collection of Hamilton fossils from the town of Bethany, Genesee Co., N. Y. Wis N H Soc, B n s 2:57-67 (1902)

\section{Monroy, Pedro López.}

69 Observaciones sobre una presunta especie mineral nueva nativa de México. La Naturaleza 1:76-78 (1869)
Mon roy, Pedro López-Continued.

69 abservaciones sobre algunos combustibles minerales de México. La Naturaleza 1:87-94 (1869)

88 Las minas de Guanajuato. Mexico, Ministerio de Fomento, An 10:69-709 (1888)

Montessus de Ballore, Fernand de.

84 T'emblores y erupciones volcánicas en Centro-América. 246 pp, San Salvador 1884

ss Tremblements de terre et eruptions volcaniques au Centre-Amérique depuis la conquête espagnole jusqu'à nos jours. Soc Sc Nat Saone-et-Loire : 293 pp, map. Dijon 1888

90 Estudio de la distribución horaria diurna $y$ nocturna de los movimientos seísmicos y su relación con les culminaciones de la luna. Soc Cient Ant $\mathrm{Alz}$, Mem 3: 105-121 (1890)

91 Etude critique des lois de répartition saisonnière des seismes. Soc Cient Ant Alz, Mem 5 : 277-292 (1891)

92 México seismico. Soc Cient Ant Alz, Mem 6:49-60, map (1892)

98 L'Amérique Centrale et l'Amérique du Sud sismiques. Soc Cient Ant $\mathrm{Alz}$, Mem 11: 263-277, map (1898)

98a Les Etats-Unis sismiques. Areh Sc Phys Nat (4) 5:201-216 (1898)

00 Le Mexique sismique. Arch Sc Phys Nat (4) 9:253-268 (1900)

02 Les manifestations volcaniques et sismiques dans les Antilles. Rv Gén Sciences $13: 669-674$ (1902)

04 Les relations sismico-géologíques de la Mediterranée antillienne. Soc Cient Ant Alz, Mem 19:351-373 (1904)

$09 \mathrm{La}$ topographie sismique des Coast Ranges de Californie et le mouvement tectonique du 18 avril 1906. An Géog 18: 341-355 (1909)

16 Earthquake intensity scales. Seism Soc Am, B 6:227-231 (1916)

17 The Mexican earthquake of November 12, 1912. Seism Soc Am, B 7:31-33 (1917)

\section{Montgomery, Henry.}

81 A blastoid found in the Devonian rocks of Ontario. Can Nat n s 10:80-84, il (1881)

95 Volcanic dust in Utah and Colorado. Science n \& 1:656-657 (1895)

oo A large crystal of spodumene. Science n s 12:410 (1900)

Montgomery, Hugh $\mathrm{T}$.

99 The Kankakee Valley. Ind Ac Sc, Pr 1898:277-282, map (1899)

99n The glacial phenomena as exhibited in northern Indiana and southern Michlgan and the resulting waterways. Northern Ind Hist Soc, Pub no $2: 20 \mathrm{pp}$, South Bend, Ind, 1899 
Montgomery, Thomas $H$.

01 Missing links. Sc Am Sup 52 : 21732-21734,(1901)

04 A list of the types of fossil verte. brates in the museum of the University of Texas. Biol B 8:56-58 (1904)

Monthly American Journal of Geology and Natural Science...

Conducted by G. W. Featherstonhaugh. 1 vol:524 pp, Phila 1831

Montonlien. Eduardo I.

18 The mining industry in the Republic of Cuba. The Cuba Review 16 no 12 : 12-26 (1918)

Montserrat, F. de.

67 (and Dollfus, A.) Observations géologiques faites aux Antilles. [France]. Comm Sc Mex, Arch 2:86-124, Paris 1867

67a (with Dollfus, A., and Pavie, P.) Observations géologiques faites dans le trajet de la Vera Cruz a Mexico. [France], Comm Sc Mex, Arch 2:124-127, Paris 1867

67b (with Dollfus, A., and Pavie, P.) Récit d'une ascension au Popocatepetl (23 avril 1865); note explicative de la coupe géologique de Mexico au sommet du Popocatepetl. [France], Comm Sc Mex, Arch $2: 187-208$, Paris 1867

67e (with Dollfas, A., and Pavie, P.) Mémoires et notes géologiques [Mexico]. [France], Comm Se Mex, Arch 2:363-403, map, Paris 1867

67d (with Dollfus, A.) Nevado de Toluca; volcan de Colima. [France], Comm Sc Mex, Arch 3:29-35, 43-55, Paris 1867

67e (with Dollfus, A.) Etude sur le district de Sultepec [Mexico]. [France], Comm Sc Mex, Arch 3:471-496, Paris 1867

68 (with Dollfus, A.) Voyage géologique dans les républiques de Guatemala et de Salvador. France, Mission Scientifique au Mexique et dans l'Amérique Gentrale, Géologie ix, 539 pp, maps, Paris 1868

82 (with Donfus, A.) Nevado de Toluca [México]. La Naturaleza 6:27-31 (1882)

Moodie, Roy Lee.

08 The relationship of the turtles and plesiosaurs. Kans Univ Sc B 4:317-327, i) (1908)

OSa The ancestry of the caudate Amphibia. Am Nat $42: 361-373$, il (1908)

08b The dawn of quadrupeds in North America. Pop Sc Mo 72:558-566, il (1908)

08c Dissorophus, a correction [D. ar. ticulatus a synonym for D. multicinctus]. science n s $27: 30-31$ (1908)

USd The clasping organs of extinct and recent Amphibia. Biol B 14:249-259, il (1908)
Moodie, Roy Lee-Continued.

ose The lateral line system in extinct Amphibia. J Morphology $19: 511-540$, (1908)

09 Vertebrate paleontology: the Lren rophidæ; Stegocephala ; the Cotylosauria; the oldest known reptile; the age of the Gaskoble ; Bison occidentalis ; Nectocaura: Callibrachion. Am Nat $43: 116-124$ (1909)

09a The Carboniferous quadrupeds; those of Kansas, Ohfo, Illinois, and Pens. sylvania in their relation to the classifes. tion of the so-called Amphibia and Stego cephala. Kans Ac Sc, Tr $22: 239-247$, (1909)

09b A contribution to a monograph of the extinct Amphibia of North America: New forms from the Carboniferous. J $G$ $17: 38-82$, il (1909)

09e The Microsauria, ancestors of the Reptilia. G Mag (5) 6:216-220, il (1909)

09d New or little-known forms of $\mathrm{Ca}$. boniferous Amphibia in the American M seum of Natural History. Am Mus N B B $26: 347-357$, il (1909)

10 The alimentary canal of a Carbonit. erous salamander. Am Nat $44: 367-375$ il $(1910)$

10a The Amphibia of the Mazon Crees shales, Illinois. Seience n s $31: 233-254$ (1910)

10b A new labyrinthodont from Kansas Science n s $32: 721$ (1910)

11 Recent contributions to a knowleds of the extinct Amphibia. Am Nat $45: 375-$ 384 (1911)

11 a new labyrinthodont from the Kan sas Coal Measures [Erpetosuchus kanses. sis]. U S Nat Mus, Pr $39: 489-495$, (1911)

11b Two amphibians, one of them new from the Carboniferous of Illinois. I \& Nat Mus, $\operatorname{Pr} 40: 429-433$, il (1911)

11c An embryonic plesiosaurian pro podial. Kans Ac Sc, Tr 23-24:95-101, i (1911)

12 The skull structure of Diplocantw magnicornis Cope and the amphibian ordet Diplocaulia. J Morphology 23:31-3: (1912)

12a The "stomach stones" of reptiles Science n s $35: 377-378$ (1912)

$12 b$ The Mazon Creek, IIl., shales an their amphibian fauna. Am J Sc (4) 34 277-285, il (1912)

12e An American Jurassic frog. Am J Sc (4) $34: 286-288$ (1912)

13 Vertebrate footprints in the lower Permian of Kansas. Am J Sc (4) $35: 31$ 33 , il (1913)

13a The Pennsylvanic Ampbibia of the Mazon Creek, Ill., shales. Kans Unir so B $6: 323-359$, il (1913)

13b. Some recent advances in vertebrate paleontology. Am Nat $47: 183-192,248-$ 256 (1913) 
Moodie, Roy Lee-Continued.

$14 \mathrm{~A}$ list of the described species of fossil Amphibia. Kans Univ Sc B 9:11-28 (1914)

14a The fossil frogs of North Amrerica. Am J Sc (4) 38:531-536, il (1914)

15 Some methods of studying fossil Amphibia embedded in coal. Kans Univ Sc B $9: 185-193$, il (1915)

15a Some recent studies on fossil Amphibia, Am Nat $49: 369-376$ (1915)

15b The Coal Measures Amphibia and the Crossopterygia. Am Nat $49: 637-644$ (1915)

15e A Coal Measures amphibian with an osseous tarsus. Am J Sc (4) 39:509-512, il (1915)

15d The migrations and geographic distribution of the fossil Amphibia. Am J Se (4) $40: 186-190, \operatorname{map}$ (1915)

15e A remarkable microsaur from the Coal Measures of Ohfo. Science n 8 41: 34-35 (1915)

$15 \mathrm{f}$ A sphenoidal sinus in the dinosaurs. Science n s 41:288-289 (1915)

15g The scaled amphibia of the coal Measures. Science n s $41: 463-464$ (1915)

16 The Coal Measures Amphibia of North America. Carnegie Inst Wash (Pub no 238$)$ : 222 pp, il (1916) Rv by W. K. Gregory, Am Nat 51:311-320 (1917)

16a Two caudal vertebrae of a sauropodous dinosaur exhibiting a pathological lesion. Am J Sc (4) 41:530-531 (1916)

16b The growth of bone in Cretaceous times. Science n s 43:35-36 (1916)

16e Mesozoic pathology and bacteriology. Science n s $43: 425-426$ (1916)

16d Bacteriologic and pathologic evidences in past geologic ages. Chicago Pathological Soc, Tr 10:84-88 (1916)

17 (with Williston, S. W.) Ogmodirus martinii, a new plesiosaur from the Cretaceous of Kansas. Kans Univ Se B $10: 61-73$, il (1917)

17a The influence of disease in the extinction of races. Sclence $n$ \& $45: 63-64$ (1917)

17b Studies in paleopathology; General consideration of the evidences of pathological conditions found among fossil animals. Annals of Medical History $1: 374-393$ N Y 1917

18 Paleontological evidences of the antiquity of disease. Sc Mo $7: 265-281$ (1918)

18a Synthesis of paleontology and medical history. Science n 8 48:619-620 (1918)

181. Diseases of the mosasaurs (abst). G Soc Am, B 29: 147 (1918)

18e On the parasitism of Carboniferous crinoids. J Parasitology 4:174-175 (1918) $A b s t$, Am Soc Zoologists, Pr: 34, December 17, 1917 (not seen); Anatomical Record, Phila, 14: 102-103 (1918)
Moodie, Roy Lee-Continued.

18d Studies in paleopathology; opisthotonos and allied phenomena among fossil vertebrates. Am Nat 52:384-394 (1918)

$18 e^{\circ}$ Studies in paleopathology; pathological evidences of disease among ancient races of man and extinct animals. Surgery, Gynecology, and Obstetries, Chicago, $27: 498-510$ (1918)

$18 f$ Pathologic lesions among extinct animals; a study of the evidences of disease millions of years ago. Surgical Clinics of Chicago 2:318-331 (1918)

Moody, A. E.

07 Aggradation and degradation of valleys. Ohio Nat 8:191-197 (1907)

Moody, Clarence Lemuel.

16 Fauna of the Fernando of Los Angeles [Cal.]. Cal Univ, Dp G, B $10: 39-62$, il (1916)

$16 a$ (with Merriam, J. C., and stoek, C.) An American Pliocene bear [Rattlesnake beds, John Day region, Oreg.]. Cal Univ, Dp G, B 10:87-109, il (1916)

$16 b$ (with Merriam, J. C. and Stock, C.) Fauna of the Rodeo Pleistocene $(a b s t)$. G Soc Am, B $27: 169-170$ (1916)

17 The breccias of the Mariposa formation in the vicinity of Colfax, Cal. Cal Univ, Dp G, B 10:383-420 (1917)

17a Fauna of the Fernando formation of Los Angeles, Cal. (abst) G Soc Am, B 28: 234 (1917)

18 (and Taliaferro, N. L.) Anticlines near Sunshine, Park Co., Wyo. Cal Univ, Dp G, B 10:445-459, il (1918)

Mooexs, C. A.

15 The soils of Tennessee. Tenn G S, Res Tenn 5: 155-173 (1915)

Mook, Charles Craig.

14 The dorsal vertebrae of Camarasaurus Cope. Am Mus N H, B $33: 223-227$, il (1914)

14a Notes on Camarasaurus Cope. N Y Ac Sc, An 24:19-22, il (1914) Abst, G Soc Am, B 25: 143 (1914)

15 Origin and distribution of the Morrison formation. G Soc Am, B $26: 315-322$ (1915)

15a A statistical study of variation in Spirifer mucronatus (abst). N Y Ac Sc, An 24:398 (1915)

16 A study of the Morrison formation. N Y Ac Se, An 27:39-191, map (1916)

17 Criteria for the determination of species in the Sauropoda, with description of a new species of Apatosaurus. Am Mus N H, B $37: 355-360$, ll (1917)

17a The fore and hind limbs of Diplodocus. Am Mus N H, B 37:815-819, il (1917)

17b (with osborn, H, F.) Skeleton and restoration of Camarasaurus (abst). G S Am, B $28: 215$ (1917)

1s The habitat of the sauropod dinosaurs. J G $26: 459-470$ (1918) 
Mook, Ruth Raeder.

15 A new cephalopod from the Silurian of Pennsylvania [Trochoceras grovaniense]. Am J Sc (4) 40:617-620 (1915)

Moon, F. W.

13 Field and office methods in the preparation of geologic reports (discussion). Ec G $8: 795-797$ (1913)

Moore, Charles.

so Proofs of the organic nature of Eazoon canadense. Brit As, Rp 50:582583 (1880)

Moore, Charles J.

O1 The formation of the Cripple Creek mining district, Teller Co., Colo. Int M Cong, 4th, Pr : 87-91 (1901)

01a The formation of the Leadville mining district, Lake Co., Colo. Int $\mathbf{M}$ Cong, 4th, $\mathrm{Pr}: 175-179$ (1901)

04 Geology applied to mining, or the practical use of geology in mining. Colo Sch Mines, B 2 no. 3:68-77 (1904)

12 Recent developments at Leadville, Colo. (discussion). Ec G $7: 590-592$ (1912)

13 The London mine, Mosquito mining district, Park Co., Colo. Am I M Eng, B $75: 415-427 \quad(1913) ; \quad \operatorname{Tr} 45: 239-250$ (1914). M World 38:817-818 (1913)

Moore, David $\mathrm{R}$.

85 Two hours among the fossils of Franklin Co., Ind. Brookville Soc $\mathrm{N} \mathrm{H}, \mathrm{B} 1$ : 44-45 (1885)

86 Fossil corals of Franklin Co., Ind. Brookville Soc N H, B 2:50-51 (1886)

Moore, Elwood $\mathrm{S}$.

06 Additional notes on the iron ranges of eastern Michipicoten. Ont Bur Mines, An Rp 15 pt 1: 200-206 (1906)

07 Iron ranges east of Lake Nipigon; the ranges around Lake Windegokan. Ont Bur Mines, An Rp 16 pt 1: 136-148 (1907)

os Iron ranges east of Lake Nipigon; the Onaman iron ranges. Ont Bur Mines, An Rp $17: 170-189$ (1908)

OSa (with Coleman, A. P.) Iron ranges east of Lake Nipigon. Ont B Mines, Rp $17: 136-169$ (1908)

09 Iron range north of Round Lake [Ont.] Ont Bur Mines, An Rp 18 pt 1: 154-162 (1909)

O9a Bog iron on English River [Ont.]. Ont Bur Mines, An Rp 18 pt $1: 180-195$ (1909)

09b Geology of Onaman iron range area. Ont Bur Mines, An Rp 18 pt $1: 196-253$ (1909)

o9e The geology of the Lake Wendigokan region [Ont.]. Can Inst, Tr 8 pt $3: 341$ 361, map (1909)

10 Lake Savant Iron Range area [Ont.]. Ont Bur Mines, An Rp 19 pt $1: 173-193$, map (1910)

10a The occurrence and origin of some bog iron deposits in the district of Thunder Bay, Ont. Ec G 5:528-537 (1910)
Moore, Elwood S.-Continued.

11 Differentiation of Keweenawan dis bases in the vicinity of Lake Niplen [Ont.]. J G 19:429-438 (1911)

11 a The Sturgeon Lake gold field, on Ont Bur Mines, An Rp 20 pt 1:133-15, map (1911)

11 bermilion Lake pyrite deposits, 0ut Ont Bur Mines, An Rp 20 pt $1: 199-20$ map (1911)

11e Report on the Tip Top copper mles Ont. Ont Bur Mines, An Rp 20 pt 1 209-213 (1911)

12 Sillceous oolites and other cones tionary structures in the vicinity of Stat College, Pa, J G 20:259-269 (1912 Abst, Brit As, Rp $81: 390$ (1912)

12a Hydrothermal alteration of granis and the source of vein-quartz at the $\&$ Anthony mine. Ec G 7:751-761 (1912.

$12 \mathrm{~b}$ The pre-Cambrian beds of northen Ontario (abst). Brit As, Rp 81:390-3it (1912)

14 Region east of the south end of Lat: Winnipeg [Manit.]. Can G S, Sum Bi $1912: 262-270, \operatorname{map}(1914)$

14a Oolitic and pisolitic barite from th Saratoga oil field, Tex. G Soc Am, B 2 $77-79$ (1914)

14b Mud cracks open under water. As J Se (4) 38:101-102 (1914)

14e Hydrothermal alteration of granite Ec G $9: 392-395$ (1914)

14d The excursions of the Internationt Geological Congress. Penn St M Q 1:6\% 81 (1914)

15 Volcanoes in Hawail. Penn St II $2: 47-62$ (1915)

16 "Pele's tears" and their bearing the origin of the australites. G Soc $A$ in B $27: 51-55$ (1916)

17 An additional note on the oolitic and pisolitic barite from the Saratoga oll fell Texas. Science n s $46: 342$ (1917)

18 The iron formation on Belcher br lands, Hudson Bay, with special referese to its origin and its associated algal liwt stones. J G 26: $412-438$ (1918) Abst, 6 Soe Am, B 29: 90 (1918)

18a Algal limestone on the Belcher to lands, Hudson Bay (abst). G Soc Am, $29: 128$ (1918)

Moore, F. Cushing.

10 Eleventh annual report of the mith ing industry of Idaho for the year 1909 139 pp [1910]; Twelfth ... 1910:24 [1911] [See also Bell ( $\mathrm{R} \mathrm{N}), 06$ ]

Moore, Francis, jr.

40 Map and deseription of Texas ... 14 pp, Phila $1840 ; 2 d$ ed, 143 pp, N Y 1844

59 Geological sketch of Texas. In Tt Texas Almanac for 1860 (Richardson Co.) 3:91-99, Galveston 1859

Moore, Frederick.

02 Gold in North Carolina. Sc Am Sup $53: 21918$ (1902) 
Moore, Gideon E.

64 On brushite, a new mineral occurring in phosphatic guano. Cal Ac N Sc, Pr 3: 167-168 (1864)

77 Preliminary notice of the discovery of a new mineral species [hetaerolite]. Am J Sc (3) $14: 423$ (1877)

85 (and Zepharovieh, V. von) Kallait pseudomorph nach Apatit aus Californien. Zs Kryst $10: 240-251$ (1885)

\section{Moore, Harry A.}

10 East Cœur d'Alene mining district, Mont. M World 33:271-276 (1910)

10a Windfall Creek placers, western Montana. M World 33:312-313 (1910)

Moore, Jacob B.

23 On a rocking stone in Durham, N. H. Am J Sc 6:243-244 (1823)

Moore, John Carrick.

50 On some Tertiary beds in the Island of San Domingo. G Soc London, Q J 6 : 39-44 (1850)

53 Notes on the fossil Mollusca and fish from San Domingo. G Soc London, Q J 9 : 129-132 (1853)

63 On some Tertiary shells from Jamaica; with a note on the corals by P. M. Duncan, and a note on some Nummulinae and Orbitoides by T. R. Jones. G Soc London. Q J 19:510-515 (1863)

Moore, Joseph.

90 Description of a new species of gigantic beaver-like rodent [identified by Cope as Hippopotamus amphibius]. Cin Soc N H, J $13: 26-30,103$, il (1890) Am Nat $24: 772(1890)$

$90 a$ Concerning a skeleton of the great fossil beaver, Castoroides ohioensis. Cin Soc N H, J 13: 138-169, il (1890)

$90 \mathrm{~b}$ A recent find of Castoroides. Am Nat 24:767-768 (1890)

91 Concerning some portions of Castoroides ohioensis not heretofore known (abst). Am As, $\operatorname{Pr} 39: 265-267$ (1891)

93 The recently found Castoroides in Randolph Co., Ind. Am G $12: 67-74$, il (1893)

93a An inquiry as to the cause of variety in rock deposits as seen in Hudson River beds at Richmond, Ind. Ind Ac Sc, Pr 1892: 26-27 (1893)

$93 \mathrm{~b}$ Glacial and preglacial erosion in vicinity of Richmond, Ind. Ind Ac Sc, Pr 1892: 27-29 (1893)

C7 Account of a morainal stone quarry of Upper Silurian limestone near Richmond [Ind.]. Ind Ac Sc, Pr 1896:75-76 (1897)

97a The Randolph mastodon. Ind Ac Sc, Pr $1896: 277-278$, il (1897)

00 A cranium of Castoroides found at Greenfield, Ind. Ind Ac Sc, Pr 1899: 171173 , il (1900)

00a (with Midaleton, W. G.) Skull of fossil bison. Ind Ac Sc, $\operatorname{Pr} 1899: 178$ 181 , il $(1900)$
Moore, Joseph-Continued.

02 (and Hole, A. D.) Concerning welldefined ripple marks in Hudson River limestone, Richmond, Ind. Ind $\mathrm{Lc} \mathrm{Sc}, \mathrm{Pr}$ 1901 : 216-220 (1902)

Moore, Neil Preston.

16 (with Young, S. W.) Laboratory studies on secondary sulphide ore enrichment. Ec G $11: 349-365,574-581$ (1916)

Moore, Phil. H.

09 Leipsigate gold mining district, N. S. M World 30:309-312 (1909)

Moore, Philip North.

74 The iron ores of southeastern Missouri. Mo G S, Rp 1873-4:638-671 (1874)

76 Report on the iron ores of Greenup, Boyd, and Carter cos., the Kentucky div1sion of the Hanging Rock iron region. Ky G S, Rp Prog 1 n s: 59-136 (1876) ; Eastern Coal Field 乞: 79-156 (1884)

77 Report on the geology of the Nolin River district, embracing portions of Grayson, Edmonson, Hart, and Butler cos. Ky G S, Rp Prog 2 n s: 79-134, map (1877) ; Western Coal Field D:1-56 (1884)

77a Report upon the Airdrie furnace and property, Muhlenberg Co., Ky. Ky G S, Rp Prog 2 n s: 161-188 (1877) ; Western Coal Field D:69-96 (1884)

78 Report on the iron ores and the iron manufacture of the Kentucky Red River iron region. Ky G S, Rp Prog 4 n s : 183216 (1878) ; Eastern Coal Field C:211244 (1884)

78a Report on a geological reconnaissance of the region adjacent to the Kentucky and Virginia State line from Cumberland Gap to the Chatterawha or Big Sandy River. Ky G S, Rp Prog 4 n s: $217-240$ (1878)

78b Report on the iron ores in the vicinity of Cumberland Gap. Ky G S, Rp Prog 4 n s : 241-254 (1878) ; Eastern Coal Field C: $245-258$ (1884) The Virginias $1: 78-80(1880)$

78c Report on the geology of a section from near Campton, Wolfe Co., to the mouth of Troublesome Creek, Breathitt Co. Ky G S, Rp Prog 4 n s: 255-284 (1878); Eastern Coal Field C: 259-288 (1884)

78d on the geology of Hancock Co. Ky G S, Rp Prog 4 n s: $389-421$ (1878); Western Coal Field D : 97-129 (1884)

$78 \mathrm{e}$ On the geology of the region adjacent to the eastern border of the western coal field, from the Louisville, Paducah, and Southwestern Rallway to the Ohio River. Ky G S, Rp Prog 4 n s: 423-444 (1878)

78f (with Crandall, A. R.) On the geology of portions of the upper Cumberland River valley in Bell and Harlan cos. Ky G S, Rp Prog 4 n s : 445-453 (1878) 
Moore, Raymond Cecil.

17 (and Haynes, W. P.) Oil and ga resources of Kansas. Kans G S, B 3:391 pp, maps (1917)

17a The stratigraphy of the Kinderhook group in western lllinois and Missouri $(a b s t)$. Ill Ac Se, Tr 9:211 [1917]

18 The environment of Camp Funston : with a chapter on the western theatre of war by D. W. Johnson. Kans G S, B 4 $81 \mathrm{pp}$, maps (1918)

18n Geologic history of crystalline rocks of Kansas. Am As Petroleum G, B 2:98113 (1918)

Moore, Richard B.

13 (and Kithil, K. L.) A preliminary report on uranium, radium, and vanadium. U S Bur Mines, B 70:101 pp (1913)

18 Radium ore deposits. Eng M J 106: 392-393 (1918)

Moore, S. R.

18 Geology of the Success mine [Coeur d'Alene district, Idaho]. M Sc Press 116 : 8 (1918)

Moore, W. D.

73 On footprints in the Carboniferous rocks of western Pennsylvania. Am J Sc (3) $5: 292-293$ (1873)

Morean de Jonnes, Alexandre.

17 Précis topographique et géologique sur l'ile de la Martinique. 27 pp [Paris 1817] Abst, $J$ de Pharmacie, Paris, $3: 478-480$ (1817)

20 Exploration géologique et minéralogique du volcan éteint de la Montagne Pelée dans l'sle de Martinique. Soc Philom Paris, B $1820: 8$ [not seen]

22 Histoire physique des Antilles françaises; savoir, la Martinique et les iles de la Guadeloupe; contenant la géologie de l'archipel des Antilles, le tableau du climat de ces iles, la minéralogie des Antilles françaises... T. 1: 560 pp, Paris 1822

46 Note sur un tremblement de terre qui a été ressenti à la Guadeloupe dans le nuit du 16 au 17 décembre 1845. Ac Sc Paris, C R 22:307 (1846)

59 Note sur le tremblement de terre de 1a Martinique. Ac Sc Paris, C R 8:329$331 ; 9: 415$ (1859)

Morehead, J. M.

91 Occurrence of gold in Montgomery Co., N. C. Elisha Mitehell Sc Soc, J 7 : 87-88 (1891)

Morey, George W.

16 Importance of water as a magmatic constituent (abst, with discussion by J. V. Lewis). G Soc Am, B $27: 50-51$ (1916)

Morgan, Alfred.

79 A review of Dr. F. V. Hayden's geological and topographical atlas of Colorado, with a sketch of the geology of northwest. ern America. Liverpool $G$ Soc, Pr 4:1844 (1879)
Morgan, William Conger.

04 (and Tallmon, M. C.) A fossilen from Arizona, Cal Univ, Dp G, B 3:40 410, il (1904)

o4a (and Tallmon, M. C.) A pecolle? occurrence of bitumen and evidence as is its origin. Am J Sc (4) $18: 363-7$. (1904)

04b The origin of bitumen. Cal J Tes $4: 49-50$ (1904) Am G 35:46-50 (194: Morganroth, L. C.

01 The caves of Huntingdon $\mathrm{Co}_{0}, \mathrm{~A}$ Eng M J 71:664 (1901)

14 The occurrence, preparation and 0 use of magnesite, Am I M Eng, B is: 2345-2352 (1914) ; Tr 50:890-900 (1918

16 Pennsylvania fire clay. Am I M m B $110: 475-481$ (1916); (with discussit by D. B. Reger), Tr 54:477-484 (1917) Morningstar, Helen.

16 The origin of the Newark series it the Philadelphia district (abst). Sciess n \& $43: 395-396$ (1916)

Morris, Charles.

85 The primary conditions of fossilit tion. Ae N Sc Phila, Pr 1885: 97-101

85a Attack and defense as agents in 8 imal evolution. Ac N Sc Phila, Pr 185 385-392

89 Theories of the formation of on islands. Ac N Sc Phila, $\operatorname{Pr} 1888$ : 419-19 (1889)

96 Life before fossils. Am Nat 바 188-194, 279-285 (1896)

Morris, H. C.

12 Prospecting for tungsten. M Press 104:885 (1912)

Morris, Henry G.

03 Hydrothermal activity in the ver at Wedekind, Nev. Eng M J $76: 275-27$ (1903)

Morris, Marshall.

97 Kentucky bituminous rock. Fng I J $63: 46$ (1897)

Morris, Russell L.

99 A map of West Virginia... [econoti data ]. Scale, 10 miles to inch. $\mathrm{W} \mathrm{Va} G$ ? $18992 \mathrm{~d}$ ed, revised, 1901 Notice, b G 28: 328-329 (1901)

Morris, S. Fisher.

so The New River coal field of W6 Virginia. Am I M Eng, Tr $8: 261-85$ (1880) The Virginias 1: 102-104 (1800) Horrison, Alfred J. See Schöpf, 88 Morrison, T. M.

14 (with Crabb, G. A.) Soil surves d Orange Co., N. Y. Cornell Univ, Agr Br Sta, B 351: 745-800, map (1914)

Morsack, Cajetan.

09 Feldspar mining in Ontario. M J $87: 759-760$ (1909)

Morse, Arthur J.

94 The Harney Peak tin mines [Blad Hills, \$. Dak.]. Eng M J 58:463 (184t 
Morse, Edward Sylvester.

69 On the landslides in the vicinity of Portland, Me. Boston Soc N H, Pr 12: 235-244, map (1869)

84 Man in the Tertiaries. Am Nat 18 : 1001-1012 (1884) Am As, Pr 33:579591 (1885) Abst, Science 4:244-246 (1884)

14 An avalanche of rocks [Mount Desert Island, Me.]. Science n s 40:241 (1914)

Morse, Eldridge.

85 Tide lands of Washington Territory. In Nesbit, D. M., Tide marshes of the United States, U S, Dp Agr, Misc, Spec Rp no 7:62-111 (1885)

Morse, Fred W.

94 Redonda and its phosphates. Pop Sc Mo $46: 78-87$ (1894)

Morse, Fremont.

08 The recession of the glaciers of Glacier Bay, Alaska. Nat Geog Mag 19: $76-78$ (1908)

Morse, James 0 .

30 Observations on the great greywacke region of the State of New York. Albany Inst, Tr 1:84-85 (1830)

Morse, William Clifford.

07 The Columbus esker. Ohio Nat 7 : 63-72 (1907)

09 (and Foerste, A. F.) Tro Waverly formations of east central Kentucky. J G $17: 164-177$ (1909)

10 The Maxville limestone. Ohio G S

(4) B $13: 128 \mathrm{pp}(1910)$

10a (with Prosser, C. S.) Outlines of field trips in geology for central Ohio. $74 \mathrm{pp}$, Columbus, Obio (1910)

11 The fauna of the Maxville limestone. Ohio St Ac Sc, Pr 5 (Sp P no 17) : 355 420 , il (1911)

12 (and Foerste, A. F,) Preliminary report on the Waverlian formations of east central Kentucky and their economic values. Ky G S, B 16:76 pp (1912)

15 (and Kay, F, H.) The area south of the Colmar ofl field IIl.]. Ill $\mathrm{G} \mathrm{S}$,

B 31: 7-35 (1915)

15a (and Kay, F. H.) The Colmar ofl field [III.] a restudy. III G S, B $31: 37$ 55. map (1915)

16 The origin of the coarse breccia in the St. Louis limestone (abst). Science n 8 43:399-400 (1916)

16 a Combination of structures in the Colmar oil field in western Illinois $(a b s t)$. Science n \& 43:400 (1916)

16b A power chisel for paleontologic laboratories. Science n s 44:142-143 (1916)

Morton, J. H.

77 The coal mines of central Utah. Eng M J $23: 76-77$ (1877)

Morton, John.

66 Remarks on the pitch lake of Trinidad, N S Inst N Se, Pr Tr 1 pt $4: 66-71$ (1866)
Morton, Samuel George (1799-1851).

29 Analysis of tabular spar from Bucks Co., Pa... Ac N Sc Phila, J 6:46-49 (1829)

29a Description of a new species of Ostrea; with some remarks on the 0 . convexa of Say. Ac N Se Phila, J 6:50-51, il (1829)

$29 b$ Geological observations on the secondary, tertiary, and alluvial formations of the Atlantic coast of the United States. Arranged from the notes of Lardner Vanuxen. Ac N Sc Phila, J 6:59-71 (1829)

29c Description of the fossil shells which characterize the Atlantic Secondary formation of New Jersey and Delaware; including four new species. Ac N S: Phila, J $6: 72-100$, il (1829)

29d Description of two new species of fossil shells of the genera Scaphites and Crepidula; with some observations on the ferruginous sand, plastic clay, and upper marine formations of the United States. Ac N Sc Phila, J 6:107-119, il (1829)

29e Notice of some fossils recently discovered in New Jersey. Ac N Sc Phila, J $6: 120-129$, il (1829)

30 Synopsis of the organic remains of the ferruginous sand formation of the United States, with geological remarks. Am J Sc 17:274-295 (1830) ; 18:243250 , il $(1830) ; 23: 288-294$, il (1833) ; $24: 128-132$, il (1833)

30a Additional observations on the geology and organic remains of New Jersey and Delaware. Ac N Se Phila, J 6:189204. il (1830)

32 On the analogy which exists between the marls of New Jersey, etc., and the chalk formation of Europe. Am J Se 22: $90-95$ (1832)

34 Synopsis of the organic remains of the Cretaceous group of the United States. $88 \mathrm{pp}$, Il, Phila 1834 Appendix, Catalogue of the fossil shells of the Tertiary formations of the United States: 8 pp Additional observations, June, 1835: [4 pp]

35 Notice of the fossil teeth of fishes of the United States, the discovery of the Galt in Alabama, and a proposed division of the American Cretaceous group. Am J Sc $28: 276-278$ (1835)

36 Notice and description of organic remains ... [valley of the Ohio]. Am J Sc $29: 149-154$, il (1836)

41 A memoir of William Maclure ... 37 pp, port, Phila 1841 2d ed, $33 \mathrm{pp}$, port, Phila 1844

41 a Description of several new species of fossil shells from the Cretaceous deposits of the United States. Ac N Sc Phila, Pr 1:106-110 (1841)

41b On two new species of fossils from the lower Cretaceous strata of New Jersey. Ac N Sc Phila, Pr 1:132-133 (1841) 
Morton, Samuel George-Continued.

42 Description of some new species of organic remains of the Cretaceous group of the United States; with a tabular view of the fossils hitherto discovered in this formation. Ac N Sc Phila, J 8:207-227, il (1842)

44 A memoir of William Maclure ... Am J Se $47: 1-17$, port (1844)

44 a Description of the head of a fossil crocodile from the Cretaceous strata of New Jersey. Ac N Sc Phila, Pr 2:82-85, il (1844) Am J Se 48:265-267 (1845)

44b On some fossil bones of Mosasaurus from New Jersey. Ac N Sc Phila, Pr 2: 132-133 (1844)

45 [On remains of Mosasaurus occidentalis from New Jersey.] Ac N Sc Phila, Pr 2:132-138 (1845)

46 [On Cretaceous fossils from Burling ton, N. J.] Ac N Sc Phila, Pr $3: 32,39$ (1846)

46a Description of two new species of fossil Echinodermata from the Eocene of the United States. Ac N Sc Phila, Pr 3:51 (1846) Am J Sc (2) $2: 273$ (1846) An $\mathrm{Mg}$ N H 18: 357 (1846)

Mortson, O. C.

76 Geological notes on northern and central Montana. Hist Soc Mont. Cont 1 : $285-300$ (1876)

92 Report on the geological character of certain sections of the State of Montana. showing the possibility of imbibition of water which would be avallable for artesian purposes. U S, 52d Cong 1 st sess, S Ex Doc 41 pt 2:78-83, map (1892)

Mosely, E. L.

02 Submerged valleys in Sandusky Bay [Ohio]. Nat Geog Mag 13:398-403 (1902) Abst, Science n s 16:264 (1902)

05 Formation of Sandusky Bay and Cedar Point [Ohio]. Ohio St Ac Sc, $\operatorname{Pr} 4$ : 179-238 (1905)

05a Change of level at the west end of Lake Erie (abst). Mich $\Delta c$ Sc, J, 7 ; 38-39 (1905)

Moseley, E. T.

98 Notes on the recent discovery of coal near Cochrane's Lake, Cape Breton, N. S. Can M Rv 17:137-138 (1898) M Soc N S, J $4:$ 26-31 (1899)

Moser, Carlos.

11 Boquillas zinc deposits [Coahuila, Mexico]. Mines and Minerals $31: 479$ (1911)

Moses, Alfred Joseph (1859-1920).

85 Tables for the determination of min erals. Sch Mines Q 6:339-346 (1885)

92 (and Luquer, L. McI.) Alabandite from Tombstone, Ariz.; wavellite from Florida. Seh Mines Q 13:236-239 (1892)

92a Graphite pressure pseudomorphs. Sch Mines Q 14:51-52 (1892)

92b Magnetite pseudomorphous after hematite [Antwerp, N. Y.]. Sch Mines Q 14: 52 (1892)
Moses, Alfred Joseph-Continued.

92c (with Waller, E.) A probaly new nickel arsenide [Grant Co., N. Mer] Sch Mines Q 14:49-51 (1892)

93 Mineralogical notes: the gangue Arizona ettringite; gypsum crystals fro Utah; heulandite and stilbite from Ups Montclair, N. J. Sch Mines Q 14:32 326 (1893)

$93 a$ One of the gypsum crystals fron the cave at South Wash, Wayne Co., Util Science 21: 230-231 (1893)

93b Mineralogical notes. Am J Sc (f $45: 488-492$ (1893)

93e Ettringit und Alabandin von Tont stone, Ariz. Zs Kryst 23:16-19 (1893)

94 (and Luquer, L. McI.) Inder t mineralogical literature. Sch Mines Q15: 163-179 (1894)

95 [Mineralogical notes.] Sch Mines $16: 226-231$ (1895)

96 (and Weinsehenk, E.) Ueber eft: einfache Vorrichtung zur Messung de Brechungsexponenten kleiner Krystalle mit telst Totalreflexion. Zs Kryst 26:150-10 (1896)

97 (and Parsons, C. L.) Elements mineralogy, crystallography, and blowpip analysis. $342 \mathrm{pp}, \mathrm{N}$ Y $18972 \mathrm{~d}$ ed, 4 t pp, N Y 1900 3d ed, 444 pp, N Y 190 4 th ed [not seen] 5th ed, $631 \mathrm{pp}, \mathrm{N}$. 1916

97.2 An introduction to the study as experimental determination of the chars ters of crystals. Sch Mines Q 18:208. $288, \quad 385-422 ; \quad 19: 14-35, \quad 113-149,20$ $282,374-391 ; 20: 107-142$ (1897-9)

97b Some new appliances and method for the study of crystals. N Y Ac Sc, Tt $16: 45-56 \quad(1897)$

99 The characters of crystals; an intr duction to physical crystallography. 21 pp, N Y 1899

oo simple tables for the determinatia of the common or economically importat minerals. Sch Mines Q 21: 192-193 (1900 00a Professor Thomas Egleston. S Mines Q 21:197-218, port (1900)

$00 b$ Professor Thomas Egleston. Sclede n s $11: 361-364$ (1900)

01 Mineralogical notes. Am J Sc it 12: 98-106 (1901) Zs Kryst $35: 417-4$. (1902)

02 (and Rogers, A. F.) Formulae s: graphic methods for determining crystal in terms of coordinate angles and Miller indices. Sch Mines Q 24:1-36 (1902) Zs Kryst 38: 209-226 (1903)

o: Eglestonite, terlinguaite, and mot troydite, new mercury minerals from to lingua, Tex. Am J Sc (4) 16:253-3 (1903) Zs Kryst 39:3-13 (1904)

04 The crystallization of molybdeniti Am J Sc (4) $17: 359-364$ (1904)

o5 The crystallization of luzonite, ${ }^{\text {s }}$. other crystallographic studies. Am J 8 (4) $20: 277-284$ (1905) 
Moses, Alfred Joseph-Continued.

06 The determination of the geometrical constants of a crystal from its interfacial angles. Sch Mines Q 27:432-461 (1906)

10 Guide to the "sight recognition" of seventy important minerals. Sch Mines Q $31: 355-380$ (1910)

10a Some tests upon the synthetic sapphires of Verneuil. Am J Sc (4) $50: 271-$ 274 (1910)

13 A scheme for utilizing the polarizing microscope in the determination of minerals of nonmetallic luster. Sch Mines Q $34: 305-334$ (1913)

15 Tables for the determination of gems and precious or ornamental stones without injury to the specimen. Sch Mines Q 36 : 199-232 (1915)

18 Mineralogy. In Peele, Robert, Mining Engineers' Handbook: 1-72, N Y 1918 See also Farrell, 12

Moses, Otto A.

83 The phosphate deposits of South Carelina. U S G S, Min Res [1882] : 504 521 (1883)

Mosier, Henry.

13 Field and office methods in the preparation of geologic reports; tables showing apparent dip of structure planes, in any vertical section. Ee G 8:492-495 (1913) Mosler, Chr.

77 Der Kupferbergbau am Obern See in Nord-Amerika [copper, Lake Superior district]. Zs Berg Hütten- u Salinen-Wesen $25: 203-221$, map $(1877) ; \quad 27: 77-97$ (1879) ; $28: 210-236$ (1880)

Mosnat, H. R.

99 Artesian wells of the Belle Plaine area. Iowa G S $9: 521-562$, map (1899)

Moss, Theodore F.

50 Description of a new carpolite from Arkansas. Ae N Sc Phila, $\operatorname{Pr} 5: 59$, il (1850)

Moubray, J. M

11 Prospecting in the North (discus. sion), M Mag 4:117-118 (1911)

Moudy, R. B.

00 (with Slosson, E. E.) The Laramie cement plaster. Published as part of the 10th An $\mathrm{Rp}$ of the Wyo Coll Agr and Me chanies, 18 pp, Laramie 1900. Abst, Eng M J $70: 518(1900)$

Moulton, F. R

00 (with Chamberlin, T. C.) Certain recent attempts to test the nebular hypothesis. Science n s 12:201-208 (1900) Mountmorres, Viscount.

07 Notes on the Jamaica earthquake. Liverpool Univ, Inst Commercial Research, Q J 2:71-82 (1907)

Moxham, Edgar C.

93 The "great gossan lead" of Virginia. Am I M Eng. Tr 21:133-138 (1893)

Moxon, Charles.

43 On the geology of the United States. Geologist London, 1843: 56-64, map (1543)

$$
28737^{\circ}-23-49
$$

Moziño Suárez de Figueroa, Joseph Mariano.

74 Descripción del volcán de Tuxtla [Méx.]. La Naturaleza 3:106-114 (1874) Mudge, Benjamin Franklin (1817-1879). 62 [Geologieal observations in the vicinity of Manchester, Mass.] Essex Inst, Pr $2: 39(1862)$

62a The salt marsh formations of Lynn [Mass.]. Essex Inst, Pr 2: 117-119 (1862)

62b [Notes on the geology and mineralogy of Lynnfield, Mass.] Essex Inst, Pr 2 : 291-292 (1862)

62e [On boulders near Groveland, Mass.]

Essex Inst, Pr 2: 406-408 (1862)

66 First annual report on the geology of Kansas. $56 \mathrm{pp}$, Lawrence 1866

66a Discovery of fossil footmarks in the Liassic (?) formation in Kansas. Am J Sc (2) 41:174-176 (1866)

73 Red sandstone of central Kansas. Kans St Bd Agr, Tr 1872: 394-396 (1873) Kans Ac Sc, Tr 1 (reprint) : 37-39 (1895)

73n Geology of the Arkansas. Kans St $\mathrm{Bd}$ Agr, $\operatorname{Tr} 1872: 408-410$ (1873) Kans Ac Sc, Tr 1 (reprint) : 50-53 (1895)

74 [On the mineral resources of Kansas.] Kans St Bd Agr, An Rp 3: 102-107 (1874)

74a Recent discoveries of fossil footprints in Kansas. Kans Ac Sc, $\mathrm{Tr}$ [2] $1873: 7-9$ (1874): reprint $2: 71-74$ (1896)

75 Pliocene Tertiary of western Kansas. Kans Ac Sc, Tr [3] 1874:17-19 (1875) ; reprint $3: 113-117$ (1896) Kans $\mathrm{St} B d$ Agr, An Rp 3: 351-353 (1875)

75a Rare forms of fish in Kansas. Kans Ac Sc, $\operatorname{Tr}$ [3] 1874:22 (1875); reprint 3:121-122 (1896) Kans St Bd Agr, An Rp 3: 356 (1875)

75b Geology of Kansas. Kans St Bd Agr. An Rp 4:107-127, map (1875)

76 Notes on the Tertiary and Cretaceous periods of Kansas. U S G Geog S Terr (Hayden), B 2: 211-221 (1876)

$7 \boldsymbol{7}$ Notes on the Tertiary and Cretaceous periods of Kansas. U S G Geog S Terr (Hayden), An Rp 9:277-294 (1877)

$77 \mathbf{a}$ Annual report of the committee on geology [of Kansas] for the year ending November 1, 1876. Kans Ac Sc, Tr 5: 4-5 (1877) ; reprint (1906)

77b Bison latifrens in Kansas. Kans Ac Sc, $\operatorname{Tr} 5: 9-10 \quad(1877)$; reprint : 10 (1906)

78 Geology of Kansas. Kans St Bd Agr, Bien Rp 1:46-88, map (1878)

78 a Cretaceous forests and their migration. Kans Ac Sc, Tr 6:46-48 (1878); reprint (1906)

78b Internal heat of the earth. Kans Ac Sc, Tr 6:49-51 (1878); reprint: 4851 (1906)

79 The new sink hole in Meade Co. Kans. Kansas City Rv Sc 3:152-153 (1879) 
Mudge, Benjamin Franklin-Continued.

79a Another view of the antiquity of man. Kansas City Rv Sc $3: 222-224$ (1879)

79b Are birds derived from dinosaurs? Kansas City Rv Sc 3: 224-226 (1879)

79e Botany and evolution. Kansas City Rv Sc $3: 257-263,321-328$ (1879)

80 Geology and evolution. Kansas City Rv Sc 4: 90-95, 162-165, 195-199, 289293 (1880)

81 Metamorphic deposit found in Woodson Co. [Kans.]. Kans Ac Sc, Tr 7:1213 (1881) ; reprint : 11-13 (1906)

81a List of minerals found in Kansas. Kans Ac Sc, Tr $7: 27-29$ (1881); reprint (1906)

Mudge, E. H.

93 Observations along the valley of Grand River, Mich. Am G 12:284-288 (1893)

94 Drainage systems of the Carboniferous area of Michigan. Am G 14:301-308 (1894)

95 Central Michigan and the postglacial submergence. Am J Sc (3) 50:442-445 (1895)

97 Some features of preglacial drainage in Michigan. Am J Sc (4) 4:383-386, map (1897)

99 The mouth of Grand River [Mich.] Am J Sc (4) 8:31-34 (1899)

oo Further notes on preglacial drainage in Michigan. Am J Sc (4) 10:158-160 (1900)

Mïgge, 0 .

97 Kalkspath von Guanajuato. N Jb $1897,2: 76-78$

99 Ueber die Structur des Grönländischen Inlandeises und ihre Bedeutung für die Theorie der Gletscherbewegung. N Jb 1899, II : 123-136

oo Weitere Versuche über die Translationsfähigkeit des Eises, nebst Bemerkungen ïber die Bedeutung der Structur des grönlandischen Inlandeises. N Jb 1900 , II : $80-98$

Müller, Albrecht.

57 Ueber die Kupferminen am Obern See im Staate Michigan, Nordamerika. Naturf Gs Basel, Verh 1:411-438 (1857) Abst, N Jb $1857: 79-81,589-590$

Müler, Johannes.

47 Basilosaurus. Am J Sc (2) 4:421422 (1847)

47a Ueber die von Herrn Koch in Alabama gesammelten fossilen Knochenreste seines Hydrarchus. Arch Anat Phys Wiss Med $1847: 363-377,378-396$ (1847)

47 b Ueber die Wirbelsäule des Zeuglodon cetoides. K Preuss Ak Wiss Berlin, Ber $1847: 185-200$

47c Untersuchungen liber den Hydrachos. K Preuss Ak Wiss Berlin, Ber 1847: 103-114 N Jb 1847:623-631
Miller, Johannes-Continued.

49 Ueber die fossllen Reste der Zeug to donten von Nordamerica ... 39 pp, il, Ber lin 1849

51 Zur Kenntniss der Zeuglodonten. Preuss Ak Wiss Berlin, Ber 1851;236-2:

Muilenburg, Garrett A.

14 On the occurrence of precious stone in the drift [of Iowa]. Iowa $\mathrm{Ac} \mathrm{Sc}, \mathrm{Pr} 21$ 203-204 (1914)

Muir, A. H.

11 The geology of the artesian wate supply of the San Antonio area. $42 \mathrm{pm}$ maps, St. Louis, Mo., 1911

Muir, John (1838-1914).

72 On the effects of the earthquake of March 26, 1872, in the Yosemite Valley. Boston Soc N H, Pr 15: 185-186 (1872)

72a Living glaciers of California Overland Monthly 9:547-549 (1872) An J Sc (3) 5:69-71 (1873)

74 Studies in the Sierra; No. 1, Mous tain sculpture. Overland Monthly 12: 393-403 (1874) Sierra Club B 9:225-23 (1915) Abst, Am J Sc (3) $7: 515-516$ (1874)

$74 a$ Studies in the Sierra; No. 2, Mom tain sculpture, origin of Yosemite vallers Overland Monthly 12:489-500 (1874) Sierra Club B 10:62-77 (1916)

$\mathbf{7 4 b}$ Studies in the Sierra; No, $3, \mathrm{As}$ cient glaciers and their pathways. Ores land Monthly 13:67-79 (1874) Siem Club B 10:184-201 (1917)

74e Studies in the Sierra; No. 4, Gle cial denudation. Overland Monthly 13: 174-184 (1874) Sierra Club B 10:304318 (1918)

74d Studies in the Sierra; No. 5, Post glacial denudation. Overland Monthly 13: 393-402 (1874) Sierra Club B 10:414428 (1919)

74e Studies in the Sierra; No. 6, Forms. tion of soils. Overland Monthly $13: 530$ 540 (1874)

75 Studies in the Sierra; No. 7, Mout tain building. Overland Monthly 14:6473 (1875)

75a Studies in the formation of mout tains in the Sierra Nevada, Cal. (abst). Am As, Pr 23 pt 2:49-64 (1875)

77 On the postglacial history of Sequio gigantea. Am As, Pr 25:242-253 (1877)

84 On the glaciation of the Arctic and subarctic regions visited by the United States steamer Corvin In the year 1881. In Hooper, C. L., Report of the cruise o! the U. S. Revenue steamer Thomas Corith in the Arctic ocean, 1881 (U S, 48th Con? 1st sess, S Ex Doc 204) : 135-147, Wastington 1884

02 Notes on the Pacific coast glacierHarriman Alaska Exped 1: 119-135 (1902) 
Mnir, John-Continued.

17 The glaciation of the Arctic and subarctic regions visited during the cruise. In his The cruise of the Corwin; journal of the Arctic expedition of 1881 in search of De Long and the Jeannette, edited by William Frederic Bade, pp 235-258, Boston, Houghton Mifflin Company, 1917.

Mulholland, William.

18 Earthquakes in their relation to the Los Angeles aqueduct. Seism Soc Am, B 8 : 13-19 (1918)

Munn, Malcolm John.

07 (with Griswold, W. T.) Geology of the oil and gas fields in Steubenville, Burgettstown, and Claysville quadrangles, Ohio, W. Va, and Pa. U S G S, B 318: 196 pp (1907)

os Petroleum and gas [in western Pennsylvania ]. Pa Top G S, Rp 1906-08:266306 (1908)

08a (with Ashley, G. H.) Report of progress on geologic work under the Topographic and Geologic Survey Commission of Pennsylvania. $\quad \mathrm{Pa}$ G S, Rp 1906-8: 81-340 (1908)

09 Studies in the application of the anticlinal theory of oil and gas accumulation [Sewickley quadrangle, Pa.]. Ec G 4:141$157(1909)$

09a The anticlinal and hydraulic theories of ofl and gas accumulation. Ec G 4:509$529(1909)$

10 Geology of the oil and gas fields of the Sewickley quadrangle, Pa. Pa Top G S, Rp 1:170 pp, map (1910)

10a Geology of the oil and gas fields of the Clarion quadrangle, $\mathrm{Pa}$. Pa Top G S, Rp 3:111 pp, map (1910)

$10 b$ Oil and gas fields of eastern and south central Kentucky. Ky G S, Rp Prog. 1908-09:92-94 (1910)

-11 Deseription of the Sewickley quadrangle, Pa. U S G S, G Atlas Sewickley fol (no 176): $16 \mathrm{pp}$, maps (1911)

11a Oil and gas fields of the Carnegle quadrangle, Pa. U S G S, B 456:99 pp. maps (1911)

11b Preliminary report upon the oil and gas developments in Tennessee. Tenn G S, B 2-E : 46 pp (1911)

11e Reconnaissance report on the Fayette gas field, Ala. Ala G S, B 10:66 pp, maps (1911)

11d (with Shaw, E. W.) Coal, oil and gas of the Foxburg quadrangle, Pa. U S G S, B $454: 85$ pp (1911)

11 e (with Shaw, E. W.) Description of the Burgettstown and Carnegie quadrangles, $\mathrm{Pa}$. U S G S, G Atlas, fol 177 (1911)

11f (with Shav, F. W.) Description of the Foxburg and Clarion quadrangles, Pa. U S G S, G Atlas, fol 178 (1911)

12 Description of the Claysville quadrangle $[\mathrm{Pa}$,$] . U S G S, G Atlas Claysville$ fol (no 180): 14 pp, maps (1912)
Munn, Malcolm John-Continued,

12a The Campton oil pool, Ky. U S G S, B 471:9-17, map (1912)

12b Oil and gas development in Knox Co., Ky. U S G S, B 471:18-29, map (1912)

12e The Fayette gas field, Ala. U S G S, B 471: 30-55, map (1912)

12d Explorations for natural gas and oil at Memphis. Tenn G S, Res Tenn 2:48-68, map (1912)

12e The Spring Creek oil field, Tenn. Tenn G S, Res Tenn 2:273-285, map (1912)

$12 f$ Problems of oil and gas accumula. tions in the Appalachian region (abst). Wash Ac Sc, J 2: 428-429 (1912)

13 The Menifee gas field and the Ragland oil field, Ky. U S G S, B 531:926, maps (1913)

14 Reconnaissance of the Grandfield district, Okla. U S G S, B $547: 83$ pp, maps (1914) Abst (by C. H. Wegemann), Wash Ac Sc, J $4: 419-421$ (1914)

14a Reconnaissance of oil and gas fields in Wayne and McCreary cos., Ky. U S G S, B 579:105 pp (1914) Wash Ac Sc, J 5: 20-21 (1915)

\section{Mã̃oz Lumbier, Manuel.}

18 La seismología en México hasta 1917. Méx I G, B 36: 102 pp (1918)

Murchison, Roderick Impey.

43 Address delivered at the anniversary meeting of the Geological Society of London ... [North America, pp 73-94]. 118 pp, L 1843

55 On the occurrence of numerous frag ments of fir wood in the islands of the Arc tic Archipelago; with remarks on the rock specimens brought from th ' region. $G$ Soc London, Q J 11:536-541 (1855) Am J Sc (2) $21: 377-382$ (1856)

57 [Remarks on rock specimens from the Aretic Archipelago.] In MeClure, R., edited by Sherard Osborn, The discovery of the Northwest Passage, 2d ed:401-408, L 1857

Mn rdock, Joseph.

16 Microscopical determination 0 : the opaque minerals: an aid to the study of ores. $165 \mathrm{pp}, \mathrm{N}$ Y 1916

Murgoei, G. M.

05 On the genesis of riebeckite and riebeckite rocks. Am J Sc (4) 20:133-145 (1905)

06 Suggestion as to the origin of riebeckite rocks. G Soc $\mathrm{Am}, \mathrm{B} 16: 575-576$ (1906)

06 a I. Contribution to the classification of the amphiboles; II. On some glaucophane schists, syenites, etc. Cal Univ, Dp G, B 4:359-396 (1906)

Murie, J.

78 (with Nicholson, H. A.) On the minute structure of Stromatopora and its allies. Linn Soc, J, Zool, 14:187-246, il (1878) 
Mnrphy, John $R$.

72 The mineral resources of the Terri tory of Utah ... iv, 104 pp, map, L 1872

Murphy, M.

85 Some physical features of Nova Scotia, with notes on glacial action. N S Inst N Sc, Pr Tr 6:130-145 (1885)

Mnrphy, T. D.

07 The mines of El Doctor [Mexico] M Sc Press 95: 241-245 (1907)

Murray, Alexander (1810-1884).

45 Report [on the geology of the district between Georgian Bay and the lower extremity of Lake Erie]. Can G S, Rp Prog 1843:51-91 (1845) [not seen]

46 Report [on the geology of the Bonaventure River, Quebec]. Can G S, Rp Prog 1844:67-77 (1846)

47 Report [on the geology of the Matane, Ste. Anne, and St. John rivers, Gaspé]. Can G S, Rp Prog 1845-6:99118 (1847)

47a Report fon the geology of the Kaministikwia and Michipicoten rivers, On tario]. Can G S, Rp Prog 1846-7; 47-57 (1847)

49 Report [on the geology of the Lake Huron region, Ontario]. Can G S, Rp Prog 1847-8: 93-124 (1849)

50 Report Ion the geology of the Lake Huron region, Ontario]. Can G S, Rp Prog $1848-9: 7-46(1850)$

52 Report [on the geology of the peninsula between lakes Huron and Erie]. Can G S, Rp Prog 1850-1 : 13-33 (1852)

52a Report [on the geology of the re gion between the Ottawa, St. Iawrence, and Rideau rivers]. Can G S, Rp Prog 1851-2:57-91 (1852)

54 Report [on the geology of the region between Kingston and Lake Simcoe, Ont.] Can G S, Rp Prog 1852-3 : 75-152 (1854)

54a Geology of western Canada; western and Huron districts [Ontario]. Can J $3: 49-52,73-76(1854)$

57 Report for the year 1853 [region be tween Georgian Bay and the Ottawa River, Ontario]. Can G S, Rp Prog 1853-6:5999, map (1857)

57 a Report for the year 1854 [Maganatawan River and Lake Nipissing, Ontario]. Can G S, Rp Prog 1853-6: 101-125 (1857)

$\mathbf{5 7 b}$ Report for the year 1855 [south western Ontario, Lake Nipissing, and French River]. Can G S, Rp Prog 1853$6: 127-143$ (1857)

57e Report for the year 1856 [region north of Lake Huron]. Can G S, Rp Prog 1853-6: 145-190, maps (1857)

58 Report for the year 1857 [French River, Georgian Bay, and Echo Lake region, Ont.]. Can G S, Rp Prog 1857: 1327, map (1858)

59 Report for the year 1858 [copper bearing rocks north of Lake Huron]. Can G S, Rp Prog 1858: 64-104 map (1859)
Murray. Alexander-Continued.

66 Report on the geology of Newfon land for 1865 [1864]; with a prefate report and an appendix by W. E. Log $46 \mathrm{pp}$, map, Montreal $1866 \mathrm{G} \mathrm{S}$ Ner $1-50$ (1881)

67 [Report of the geological surves Newfoundland for 1866.] St. John's N. 1867 [not seen] G S Newf: 73-101 (18

67a Mineral resources of Newfoundlas Soc Arts London, J 15: 705-712 (180 G S Newf : 102-109 (1881)

6s Report upon the geological surver Newfoundland for the year 1867. 34 \% St. Johns, N. F., 1868 G S Newfoundlasl 111-136 (1881)

68a Report upon the geological sure of Newfoundland for 1868. $68 \mathrm{pp}, 8$ Johns 1868 [not seen] G S Newf:13 $186(1881)$

69 The economic value of a geologia survey ... $20 \mathrm{pp}$, Montreal 1869

7o Report upon the geological surves Newfoundland for the year 1869. $35 \mathrm{n}$ St. Johns 1870 [not seen] G S Newf:18 209 (1881)

70a Report upon the geological surr of Newfoundland for the year 1870 . pp, St. Johns, N. F., 1870 G S Nert 210-249 (1881)

72 Report upon the geological surver Newfoundland for the year 1871. 49 : St. Johns, N. F., 1872 G S Newf: 25 . 278 (1881)

73 Report upon the geological surnt [of Newfoundland] for the year 1872 . pp, St. Johns, N. F., 1873 G S Nert 279-297 (1881)

$73 n$ Report of progress for the yex 1873. Newfoundland G $\mathrm{S}: 47 \quad \mathrm{pp}$, mat Montreal 1873 Other editions, $96 \mathrm{pp}$, \$ Johns $1873 ; 78 \mathrm{pp}$, map, St. Johns $18 \mathrm{i}$ G S Newf : 298-350 (1881)

75 Report upon the geological survey of Newfoundland for the year 1874. Ner foundland G S, Rp Prog 1874:3-24, \& John's, Newfoundland, 1875 G S Nerf 351-409 (1881)

76 Report of progress for the year $18{ }^{\circ}$. Newfoundland G S:17 pp (another ed $22 \mathrm{pp})$, St. Johns, N. F., 1876 G S Newf 410-422 (1881)

77 Report of progress for the year 187 Newfoundland G S : 63 ps, St. Johns 187 [not seen] G S Newf: 423-462 (1881)

78 Report of progress for the year $18 \%$ Newfoundland G S: 13 pp. St Johns $187 \%$ [not seen] G S Newf: $463-469$ (1881)

79 Report of progress for the yest 1878. Newfoundland G S:- pp [? Johns 1879] [not seen] G S Newf: 470511 (1881)

79 aistribution of the serpentine ast associated rocks with their metallic of in Newfoundland $(a b s t)$. Ph Mag (5) $t$ 216 (1879) 
Murray, Alexander-Continued.

80 Report of progress for the year 1879. Newf G S : - pp [? St. Johns 1880] [not seen] G S Newf:512-531 (1881)

81 Geological survey of Newfoundiand [revised reprints of reports, 1864-1880]. 536 pp. L 1881

s1a Special report upon the discovery of gold near Brigus, Conception Bay ... G S Newf: $532-536$ (1881)

81b The gold region near Brigus, Newfoundland. Eng M J 31:232 (1881)

s1e Mining in Newfoundland. Eng M J $31: 430(1881)$

82 Report of progress for the year 1881.

Newfoundland G S: $16 \mathrm{pp}$, map, St. Johns, Newfoundland, 1882

83 Glaciation of Newfonndland. R Soc Can, Pr Tr 1, iv : 55-76 (1883)

Murray, David.

64 Petroleum, its history and properties. Albany Inst, $\operatorname{Tr} 4: 149-166$ (1864)

83 A catalogue of the published works of James Hall, 1836-1882 [with supplement to 1883]. N Y St Mus, An Rp 36: $79-94$ (1883) ; $42: 75-97$ (1889)

Murray, E. P.

10 (with Cox, G. H.) Some relations between the composition of a mineral and its physical properties. Mo Univ, Sch Mines, B 1:3-39 (1910)

Murray, Herbert.

99 The Cape Nome district, Alaska. Eng M J 68: 641-642 (1899)

Murray, J, C.

07 Prospecting in Ungava. Can M J 28 (n s 1) : 109-112, 148-149, 173-174 (1907)

Murray, John.

85 Reports of dredging ... in the Gulf of Mexico (1877-78), in the Caribbean (1878$79)$, and along the Atlantic coast ...; report on the specimens of bottom deposits. Harvard Coll, Mus C Z, B $12: 37-61$ (1885)

11 Alexander Agassiz, his life and scientific work. Science n s 33: 873-887 (1911)

Murrish, John (1820-1886).

71 Report on the geological survey of the lead regions. Wisconsin [Commissioner of the survey of the lead district] : 65 pp [1871?] Also in Wis St Agr Soc. $\mathrm{Tr} 10: 393-477$ (1872)

72 On the results of recent investigations in the lead regions of Wisconsin. Wis Ac Sc, Tr 1: 193 (1872)

73 Report on the geological survey of the mineral regions. Wis St Agr Soc, Tr 11: 469-494 (1873)

\section{Musbach, F, L.}

14 (and others) Reconnaissance soll survey of north part of north-western Wisconsin. Wis G S, B $32 ; 92$ pp, map (1914)

\section{Muscoviei, Armand.}

06 Notes on a deposit of nickeliferous pyrrhotite at Malachite Point [Que.]. Can M Inst, J $9: 221-222$ (1906)

\section{Musgrave, Robert.}

04 Copper deposits of Mount Sicker, Vancouver [Island, B. C.]. Eng M J 78:673674 (1904)

Mattkewski, Richard A.

10 Additional notes on Trichocnemis aliena Scudder. Wis $\mathrm{N}$ H Soc, B $8: 106-$ 109 (1910)

Myers, Geo. H.

15 (with Tront, L. E.) Bibliography of Oklahoma geology, with subject index. Okla G S, B 25: 105 pp (1915)

Myers, P. C.

99 Report on a fossil diatomaceous deposit in Muscatine Co., Iowa. Iowa Ac Se, Pr 6: 52-53 (1899)

N.

25 On boulders and rolled stones. Am J Se $9: 28-39$ (1825)

Nagant, $H$.

of Rare earths in the Province of Quebec. Que, Dp Col ... Mining operations 1905 : 39-43 (1906) Rv Univ Mines (4) $15: 223-226$ (1906)

Nansen, Fridtjof.

01 (editor) The Norwegian North Polar expedition 1893-1896. 6 vols, L 1901-05

04 The bathymetrical features of the North Polar seas, with a discussion of continental shelves and previous oscillations of the shore line, Norwegian North Polar Expedition, 1893-1896, Seientific Results 4, XIII : 231 pp, maps, L 1904

Napolski, Alexander von.

04 Beitrag zur Kenntniss der Gesteine der Republik Honduras. Diss, Tübingen. 46 pp, Leipzig 1904 [not seen]

Napper, Charles W.

14 Flood erosion along Paint Creek, Fayette Co., Ohio. Ohio Nat $14: 252-255$ (1914)

16 Occurrence of carbonaceous material in the Greenfield member of the Monroe formation. Ohio J Se 16:155-158 (1916)

17 Concretionary forms in the Greenfield limestone. Ohio J Sc 18: 7-13 (1917)

Naramore, Chester.

07 Gold and silver; Colorado; New Mexico; South Dakota; Wyoming. U S G S, Min Res 1906: 199-240, 300-312, 319 $323,368-371$ (1907)

os Gold, silver, copper, lead, and zinc ; Colorado; New Mexico; South Dakota; Wyoming. U S G S, Min Res 1907:235$279,398-414,428-432,477-482$ (1908)

09 (and Yale, C. G.) Gold, silver, copper, lead, and zinc; Nevada. U S G S, Min Res 1908 pt 1: 462-506 (1909)

11 Gold, silver, copper, lead, and zine; Nevada, U S G S, Min Res 1909 pt 1: $386-430 ; 1910$ pt $1: 498-534 ; 1911$ pt 1 : 646-702 (1911-2)

See also Hager, 17

Narraway, J. E.

96 (and Rnymond, P. E.) A new American Oybele. Carnegie Mus, An 3 : $599-604$, il (1906) 
Naraway, J. E.-Continued,

os (with Raymond, P. E.) Notes on Ordovician trilobites; Illaenidae from the Black River limestone near Ottawa, Can ada. Carnegie Mus, An 4:242-255 (1908)

10 (with Raymond, P. E.) Notes on Ordovician trilobites; III, Asaphidae from the Lowville and Black River. Carnegie Mus, An 7:46-59 (1910)

12 List of trilobites found at Ottawa and immediate vicinity. Ottawa Nat 26 : 98-100 (1912)

Nash, Alanson.

27 ... lead mines and veins of Hampshire Co., Mass., and of the geology and mineralogy of that region. Am J Sc 12: 238-270 (1827)

Nash, James P.

15 Road materials of Texas. Tex Univ, B 1915 no $62: 70$ pp (1915)

17 Texas granites. Tex Univ, B 1725: 8 pp (1917)

18 (with Roberts, J. R.) The geology of Val Verde Co. Tex Univ, B 1803:51 pp, map (1918)

Nason, Frank Lewis.

$\mathbf{8 7}$ On the location of some vertebrate fossil beds in Honduras, C. A. Am J Sc (3) $34: 485-487 \quad(1887)$

88 Some New York minerals and their localities. N Y St Mus, B 4:20 pp (1888)

89 The Triassic rocks, or the red sandstones of New Jersey. N J G S, Rp 1888: 16-44. map (1889)

89a Geological studies of the Archean rocks. $\mathrm{N} J \mathrm{G} \mathrm{S}$, An Rp 1889:12-65 (1889)

$\mathbf{8 9 b}$ Geological studies of the Triassic or red sandstone and trap rocks. N J G S, An Rp 1889:66-72 (1889)

s9e A new locality of the camptonite of Hawes and Rosenbusch. Am J Se (3) $38: 229-230$ (1889)

90 (and Ferrier, W. F.) A notice of some zircon rocks in the Archean highlands of New Jersey. Am As, Pr 38:244245 (1890)

90a Scapolite rock. Am J Sc (3) 39 : $407(1890)$

90b The Goler gold diggings [Cal.]. Eng M J 59:223 (1890)

90e On the intrusive origin of the Watchung traps of New Jersey (abst). G Soc Am, B 1:562-563 (1890) Am Nat 24: $212(1890)$

91 The post-Archean age of the white limestones of Sussex Co., N. J. N J G $\mathrm{S}$, An Rp 1890:25-50, map (1891)

91 a Notes on the active iron mines [of New Jersey]. N J G S, An Rp 1890:51127, map (1891)

91b The post-Archean age of the white limestones of Sussex Co., N. J. Am G 7 : $241-253 ; 8: 166-171$ (1891)

91 Eruptive iron ores. Eng M J 51: 693 (1891)
Nason, Frank Lewis-Continued.

92 A report on the iron ores of 1 souri ... Mo G S 2:366 pp, map, Jeffers City 1892

93 The magnesian series of the 0uri uplift. Am G 11:91-94 (1893)

$\mathbf{9 3 a}$... iron-bearing rocks of the Adiro dack Mountains. Am G 12:25-3: (184) $93 \mathrm{~b}$ "The correct succession of th Ozark series" ; a review reviewed. Am $12: 141-147$ (1893)

94 The economic geology of Albany $a$ [N. Y.]. N Y St G, An Rp 13:263-28: (1894) N Y St Mus, An Rp 47:459-44 (1894)

94a Economic geology of Ulster $\mathrm{C}_{0}$. $\mathbb{A}$ Y.] N Y St G, An Rp 13: 373-406 (189t) N Y St Mus, An Rp 47:567-600 (1894)

94b The chemical composition of sod of the $\mathbf{x}$ hite limestones of Sussex C0., N.J. Am G 13: 154-164 (1894)

94e Summary of facts proving the Car brian age of the white limestones of St sex Co., N. J. Am G 14:161-169 (1894)

94d The franklinite deposits of Mit Hill, Sussex Co., N. J. Am I M Eng. Tt 24:121-130 (1895) Eng M J 57:19:198 (1894)

94 [On the minerals of Franklin F: nace, N. J.] N Y Ac Sc, $\operatorname{Tr} 13: 97-\mathrm{S}$ (1894)

941 Origin of the Iron pyrites depodts in Louisa Co., Va. Eng M J 57:41t416 (1894)

$94 \mathrm{~g}$ (with Winsiow, A., and Haworth. E.) A report on the Iron Mountain sheet including portions of Iron, St. Francols and Madison cos. Mo $\mathrm{G} S 9$, Sheet Rp D 3:85 pp, map, Jefferson City 1894

95 The geological structure of the Risg wood iron mines, N. J. Am I M Eng, It 24:505-521, map (1895)

96 The auriferous gravels of the uppt Columbia River [B. C.]. Eng M J 61: $279-280$ (1896)

97 British Columbia-the Big Bend dis trict, West Kootenay. Eng M J 63:453454 (1897)

o0 The geology and vein systems of the Mount Wilson mining district, Colo. Ens M J $69: 681-682$ (1900)

01 On the presence of a limestone con glomerate in the lead region of $\mathrm{St}$. Frands Co., Mo. Am J Sc (4) 11:396 (1901)

01 a The geological relations and the agt of the St. Joseph and Potosi limestones of St. Francois Co., Mo. Am J Se (4) 12 358-361 (1901) Eng M J 73:861 (1902)

$01 b$ The origin of vein cavities. Bus M J 71: 177-179, 209-210 (1901)

02 The disseminated lead ores of south east Missouri. Eng M J 73:478-480 (1902)

06 Limestones associated with pyrite? and pyrrhotite of the Appalachian system. Eng M J 82:170-172 (1906) 
Nason, Frank Lewis-Continued.

09 Some phenomena of the folding of rock strata. Ec G 4:421-437 (1909)

12 The bearing of the theories of the origin of magnetic iron ores on their possible extent. Am I M Eng, B 67:695708 (1912) ; Tr $43: 291-304$ (1913)

14 The disseminated lead district of southeast Missouri (discussion). Eng M J 97: 1158-1159 (1914)

15 Zinc deposits of eastern Tennessee. Eng M J 99: 734-736 (1915)

15a Geological anatomy of a Tennessee zinc mine [New Prospect mine, Lead Mine Bend, Union Co., Tenn.]. Eng M J 100: 259-262 (1915)

17 Characteristics of zinc deposits in North America. Am I M Eng, I 125: 799-824 (1917) ; Tr $57: 830-862$ (with discussion by H. A. Buehler and J. T. Boyd) (1918)

17a Principles governing zinc ore deposits. M Sc Press 115: 647-651 (1917)

See also Campbell (H D), 91 ; Jenney, 94 Nathorst, Alfred Gabriel (1850-1921).

93 (with Felix, J.) Versteinerungen aus dem mexicanischen Staat Oaxaca. In Felix, J., and Lenk, H., Beiträge zur Geologie und Paläontologle der Republik Mexico, Th 2:39-54, il, Leipzig 1893

01 Bidrag till nordöstra Grönlands geologi. G Fören Stockholm, Förh 23:275305 , map (1901)

04 Die oberdevonische Flora des Ellesmere-Landes. Report of the Second Norwegian Arctic Expedition in the Fram 1898-1902. No. 1, 22 pp, 1l, VidenskabsSelskabet i Kristiania 1904

11 Contributions to the Carboniferous flora of northeastern Greenland. Med Grönland 43:337-346, il; Mus Minêr G Univ Copenhague, Comm paléont no 9 (1911) : Danmark-Eksped til Grönlands Nordöstkyst, $1906-1908$, Bd $3: 339-346$, il (1911)

12 On the value of the fossil floras of the Arctic regions as evidence of geological climates. Smiths Inst, An Rp 1911: 335344 (1912) Int G Cong, XI, Stockholm, 1910, C ג: 743-756, maps (1912)

15 Tertiăre Pflanzenreste aus EllesmereLand. Second Norwegian Arctic Expedition in the Fram, 1898-1902, Rp $35: 16$ pp, 11 (1915)

Nathurst, E. 0 .

88 Formation of coal seams. Eng M J 45: 194-195 (1888)

\section{National Geographic Society.}

96 The physlography of the United States; ten monographs by J. W. Powell, N. S. Shaler, I. C. Russell, Bailey Willis, C. Willard Hayes, J. S. Diller, W. M. Davis, G. K. Gilbert. 345 pp, N Y, American Book Co., 1896
Nattress, Thomas.

02 The Corniferous exposure in Anderdon. Ont Bur Mines, Rp 1902:123-127 (1902)

07 The geological continuity of Essex and Kent cos., Ont., and Monroe and Wayne cos., Mich. Mich Ac Sc, Rp 9:177-184, map, (1907)

10 The contour of the Sylvania sandrock and related strata in the Detroit River area. Mich Ac Sc, Rp 12:47-50 (1910)

11 The extent of the Anderdon beds of Essex Co., Ont., and their place in the geologic column. Mich Ac Sc, Rp 13: 8796 (1911)

12 Geology of the Detroit River area. Ont Bur Mines, An Rp 21 pt 1:281-287, map (1912)

12a Additional notes on the geology of the Detroit River area. Mich Ac Sc, Rp $14: 109-113$ (1912)

17 On the prospect of oil being found under the Ontario-Ohio-Micbigan section of Lake Erie. Mich Ac Sc, An Rp 19:87-94 (1917)

18 On the manner of occurrence of potassium nitrate in Oregon. Mich Ac Sc, An Rp 20:57-58 (1918)

Naumann, Edmund.

98 Ueber Reisebeobachtungen in Mexico. Deut G Ges, Zs 50:106-109 (1898)

Navarro, D. V.

o7 Le cobalt dans l'etat de Jalisco. Soc Cient Ant Alz, Mem 25:51-57 (1907)

Navia, Severo.

74 Nota sobre la plata sulfúrea pseudomorfosis de rosicler oscuro. La Naturaleza $3: 154-156$ (1874)

77 Arseniuro de cobalto (smaltine). La Naturaleza $4: 41-42$ (1877)

77a Galena selenifera [México]. La Naturaleza $4: 42-44$ (1877)

Neal, W. 1 .

96 Some of the crystalline rocks of Salt Lake and Davis cos., Utah. Utah Univ $Q$ 2: 90-96 (1896)

Needham, $B$.

57 Report on the Tunungwant coal fleld of McKean Co., Pa. M Mag 9:306-316 (1857)

Nefr, Peter.

90 The Sylvania sand in Cuyahoga Co., obio. G Soc Am, B 1:32-34 (1890)

Neill, A. T.

90 The half-yearly report of the geological section of the Familton Association, ending April 30, 1890. Hamilton As, J Pr pt $6: 121-127$ (1890)

Neill, James W.

96 Camp Floyd district, Utah. Eng M J $61: 85-86$ (1896)

Neilson, James.

91 (and others) Addresses commemoratlve of George Hammell Cook... 53 pp, port, Newark, N J 1891 
Neiswender, C. B.

13 Frost erystals formed underground.

Eng M J $96: 492-493$ (1913)

Nelson, Aven.

03 Wilbur Clinton Knight. Science n s 18: 406-409 (1903)

Nelson, C. Nelson.

06 The Sahuaripa district, Sonora, Mexico. Eng M J $82: 629-631$ (1906)

10 San Javier, an old silver district of Sonora, Mexico. Eng M J 90:660-661 (1910)

Nelson, Edward $T$.

79 On the oricin of stylolites. Am J Sc (3) $17: 68(1879)$

Neison, Gaylord.

os (with Gould, C. N.) Preliminary report on the mineral resources of Oklahoma. Okla G S, B 1:84 pp (1908)

09 Tripoli deposits at Seneca, Mo. M

World 31: 552 (1909)

See also Gould, $11 \mathrm{~b}$

Neison, N. C.

17 Kentucky and her cave men. Am Mus J 17:221-233, il (1917)

18 Additional studies in the Pleistocene at Vero, Fla. Science n s 47:394-395 (1918)

Neison, N. P.

93 The formation of a terrace. Am G $12: 125-126(1893)$

Nelson, Richard J.

37 On the geology of the Bermudas. G Soc London, $\operatorname{Tr}$ (2) $5: 103-123$ (1837) Abst, Soc G France, B $9: 290-291$ (1838)

53 On the geology of the Babamas and on coral formations generally. G Soe London, Q J 9:200-215 (1853)

velson, Wilbur Armistead.

11 Clay deposits of west Tennessee. Tenn G S, B 5:118 pp, map (1911)

11 a The Fernvale iron ore of Davidson Co. Tenn G S, Res Tenn 1:44-57 (1911)

11b A new manganese deposit in Tennessee. Tenn G S, Res Tenn 1:220-228 (1911)

12 Notes on lead in Tennessee. Tenn G S, Res Tenn 2: 100-117 (1912)

$12 a$ Lignite and lignitic clay in west Tennessee. Tenn G S, Res Tenn 2:157160 (1912)

12b The Monteagle wonder cave [Grundy Co., Tenn.]. Tenn G S, Res Tenn 2: 294306 (1912)

12e (with Kirkpatrick, F. A.) Tests on the clays of Henry Co. Tenn G S, Res Tenn 2:406-423 (1912)

13 The Tennessee coal field south of the Tennessee Central Railroad. Tenn G S. Res Tenn 3:26-49 (1913) [A1so published as Bulletin 2-B]

13a Mineral products along the Tennessee Central Railroad. Tenn G S, Res Tenn $3: 137-160$ (1913)

15 Two natural bridges of the Cumberland Mts. [Tenn.]. Tenn G S, Res Tenn 5:76-80 (1915)
Nelson, Wilbur Armistead-Continued.

16 The Tennessee coal fleld south of the Tennessee Central Railroad. Tenn $G$ \& Res Tenn $6: 155-183$ (1916)

Nelson, William.

92 The geologieal history of the Passik Falls, Paterson, N. J. 40 pp, Paterson, N. J., 1892

Nesbit, D. M.

85 Tide marshes of the United States U S, Dp Agr, Misc, Spec Rp no $7: 259$ pp (1885)

Netlleroth, Henry (1835-1887).

89 Kentucky fossil shells; a monograph of the fossil shells of the Silurian and De vonian rocks of Kentucky. Ky G S:245, iy $\mathrm{pp}$, il (1889)

Nettleton, Edwin $\mathrm{S}$.

7z On the first systematic collection and discussion of the Venango Co. oil wells of western Pennsylvania. Am $\mathrm{Ph}$ Soc, $\mathrm{Pr}$ $16: 429-495$ (1877)

Neues Jahrbuch für Mineralogie, Gè logie und Paläontologie. Stuttgart.

Includes many abstracts of articles on North American geology. The limits of the work made it impracticable to admit these. Nenman, L. M.

14 (with Tarr, W. A.) A study of the effects of heat on Missouri granites. Mo Univ, B 15 no $27: 64$ pp (1914)

Neumayer, L.

04 Die Koprolithen des Perms ron Texas. Palaeontographica 51:121-128, il (1904)

\section{Neumayr, $M$.}

S4 Die Intertrappean beds im Dekan und die Laramie gruppe im westlichen Nordamerika. N Jb 1884, I : 74-76

Nevius, J. Nelson.

97 Kaolin in Vermont. Eng M J 6t: 189 (1897)

98 Dr. James Hall. Eng M J 66:184, port (1898)

99 The talc industry of St. Lawrence Co. [N. Y.]. N Y St Mus, An Rp 51: r119-127 (1899)

$99 a$ The history of Cayuga Lake valley. N Y St Mus, An Rp 51: r129-153, map (1899)

99b Fibrous tale in St. Lawrence Co. N. Y. Eng M J $67: 234-235$ (1899)

oo A fossil plant from Orange Co. [N. Y.] N $\mathrm{Y}$ St Mus, An Rp $52:$ r $79-81$, il (1900)

Oon [Gold in the sands of New York.] N Y St Mus, An Rp $52:$ r $82-87$ (1900)

01 Roofing slate quarries of Washington Co. [N. Y.]. N Y St Mus, An Rp 53: r135-150 (1901)

o1n Emery mines of Westchester $\mathrm{Co}$. [N. Y.]. N Y St Mus, An Rp 53:r151154 (1901)

03 The Sain Alto tin deposits [State of Zacatecas, Mexico]. Eng M J 75:929 (1903) 
Nevius, J. Nelson-Continued.

12 The Castle Dome lead district, Ariz. M Sc Press 104: 854-855 (1912)

15 Reconnaissance of Goodsprings dis trict, Nev. M World 42:897-899 (1915)

16 Notes on the Randsburg tungsten district, Cal. M World 45: 7-8 (1916)

Newberry, John Strong $(1822-1892)$.

53 Fossil fishes of the Cliff limestone [Ohio]. An Sc, Cleveland, 1:12-13, il (1853)

53a Fossil plants from the Ohio coal basin. An Sc, Cleveland, $1: 95-97,106-$ 108 (1853)

53b New fossil plants from Ohio. An Sc, Cleveland, $1: 116-117,152-153,164$ 165 (1853) ; $2: 2-3$, il (1854)

53e The structure and affinities of certain fossil plants of the Carboniferous eru. An Sc, Cleveland, $1: 268-270$, il (1853)

53 ( On the characteristics of the Carboniferous flora of Ohio, with descriptions of fifty new species of fossil plants (abst). An Sc, Cleveland, $1: 280-281$ (1853)

53e On the fossil fishes of the Cliff lime stone of Ohio (abst with discussion by James Hall), An Sc, Cleveland, 1:282283 (1853)

54 Note on the vegetation of the drift. An Sc, Cleveland, $2: 76-77$ (1854)

56 Report upon the geology of the route [Williamson's survey in California and Oregon]. U S, Pacific R R Expl (U S, $33 d$ Cong $2 d$ sess, S Ex Doc 78 and $H$ Ex Doc 91) 6 pt $2: 5-68$ (1856)

$56 a$ on the structure and affinities of certain fossil plants of the Carboniferous era. Am As, Pr 7:157-162, il (1856)

$56 \mathrm{~b}$ On the Carboniferous Cora of Ohio, with descriptions of fifty new species of fossil plants. Am As, Pr $7: 163-166$ (1856)

56e On the fossil fishes of the Clif limestone of Ohio. Am As, Pr 7:166-167 (1856)

56d Description of several new genera and species of fossil fishes from the Car boniferous strata of Ohio. Ac N Sc Phila, Pr 8:96-100 (1856)

57 Report on the economical geology of the Ashtabula and New Lisbon Rail Road. Made November 1, 1856. 47 pp, map. Cleveland, Ohio, 1857 Also in Ashtabula \& New Lisbon Railroad Co., An Rp: $13-56$, Cleveland 1857

$57 \mathbf{a}$ On the mode of formation of cannel coal. Am J Sc (2) $23: 212-215$ (1857) M Mag $9: 352-355$ (1857)

57b New fossil fishes from the Devonian rocks of Ohio. Am J Sc (2) 2 $2^{\star}: 147-149$ (1857) Nat Inst, Washington, D. C., $\mathrm{Pr}$ n s 1: 119-126, il (1857)

57e [Eurylepis proposed for Mekolepis. preoccupied.] Ac $\mathrm{N}$ Se Phila, Pr 1857:
Newberry, John Strong-Continued.

57d On the deposits of the fossil fishes and reptiles of Linton, Ohio (abst). Edinb N Ph J n s 5:364-365 (1857)

59 The rock oils of Ohio (from the Ohio agricultural report for 1859). 14 pp [n p, 1859]

59a Explorations in New Mexico. Am J Sc (2) 28:298-299 (1859)

60 Notes on the ancient vegetation of North America. Am J Sc (2) 29:208$218 ; 30: 273-275$ (1860) In part, Can Nat $6: 73-77$ (1861)

61 Geological report. In Ives, J. C., Report upon the Colorado River of the West ( $U^{\circ}$, 36th Cong 1st sess, S Ex Docand $\mathrm{H}$ Ex Doc 90), pt $3: 154 \mathrm{pp}$, il, maps (1861)

61a Report on the State house well [Columbus, Ohio]. From report of Superintendent of State House for 1860:11 pp [Columbus 1861?] Abst, M Mag (2) 2: 84-90 (1861)

62 Notes on American fossil fishes. Am J Sc (2) 34: 73-7S, il (1862)

62a Notes on the surface geology of the basin of the Great Lakes. Boston Soc N H, Pr 9:42-46 (1862)

63 Descriptions of fossil plants... [Vancouver Island and Washington]. Boston J N H $7: 506-525$ (1863)

66 (and Worthen, A. H.) Descriptions of new species of vertebrates, mainly from the Subcarboniferous limestone and Coal Measures of Illinois. III G S 2:9134, il (1866)

6s Note on the later extinct floras of North America, with descriptions of some new species of fossil plants from the Cretaceous and Tertiary strata. Lyc N H N Y, An 9:1-76 (1868) Abst, Am J Sc (2) $46: 401-407 \quad$ (1868)

6sa on some fossil reptiles and fishes, from the Carboniferous strata of Ohio, Kentucky, and Illinois. Am As, $\mathrm{Pr} 16$ : 144-146 (1868) Can Nat n s 3:299-301 (1868)

6sb On some remarkable fossil fishes, discovered ... in the black shale (Devonian) at Delaware, Ohio. Am As, Pr 16:146147, il (1868) Can Nat n s $3: 297-299$, il (1868)

68e Geology [of Ohio]. In Atlas of the State of Ohio ... H. F. Walling, published for Henry S. Stebbins by H. H. Lloyd \& Co. : 11-13, map, N Y 1868

69 Report on the Cretaceous and Tertiary plants. In Hayden, F. V., Geological report of the cxploration of the Yellowstone and Missouri rivers (Raynolds): 145-174 (1869)

69a On the surface geology of the basin of the Great Lakes and the Valley of the Mississippi. Lye N H N Y, An $9: 213-234$ (1869) Am Nat 4:193-218 (1870) Abst, Am J Sc (2) 49:111-114 (1870); Am Nat $2: 444-445$ (1868) 
Newberry, John Strong-Continued

696 On the flora and fauna of the Mio cene Tertiary beds of Oregon and Idaho. Am Nat 3:446-447 (1869)

70 The geological survey of Ohio, its progress in 1869 ; report of an address delivered to the legislature of Ohio, February 7, 1870. $60 \mathrm{pp} \mathrm{[N} \mathrm{Y} \mathrm{1870]}$

70a Preliminary geologieal map of Ohio. 13x11. [Ohio G S] 1870

7ob (and Worthen, A. H.) Description of fossil vertebrates. Ill G S 4:343374 , il $(1870)$

zoc On the earliest traces of man found in North America. Lyc N H N T, Pr 1: 2-5 (1870) Nature 2:366-367 (1870)

7oa the ancient lakes of western America, their deposits and drainage. Lyc N H $\mathrm{N}$ Y, Pr 1:25-32 (1870) Nature 2:385387 (1870)

7oe [Paucity of organic remains in redcolored rocks.] Lye N H N Y, Pr 1: 36-37 (1870)

rof Marble beds of Vermont. Lyc N H N $Y, \operatorname{Pr} 1: 62-63 \quad(1870)$

$70 \mathrm{~g}$ [On the cranium of a walrus obtained at Long Braneh]. Lyc N H N Y, Pr 1:75 (1870)

zoh The geological position of the remains of elephant and mastodon in North America. Lye $\mathrm{N}$ H $\mathrm{N}$ Y, Pr 1:77-83 (1870) Abst, Am Nat 5: 729-731 (1871); Nature 4: 340 (1871)

70i On recent deep-sea dredgings. Lyc N H N Y, Pr 1: 106-108 (1870)

roj The genesis of sandstones (with discussion by A. M. Edwards, B N. Martin, and C. A. Seely). Lyc N H N Y, Pr 1: 131-134 (1870)

70k Remarkable gas wells in [Knox Co.] Ohio. Am Chemist 1: 201-202 (1870)

71 Report on the progress of the geological survey of Ohio in 1869. Ohio G S, [Rp Prog 1869], pt 1:3-53, map, Columbus 1871

71a Report of progress of the geological survey in 1870. Ohio G S, Rp Prog 1870: 5-14 (1871)

71b Sketch of the structure of the lower Coal Measures in northeastern Ohio. Ohio G S, Rp Prog 1870:14-53 (1871)

71e [Explanation of the geological map of Ohio]. In Ohio, Secretary of State, An Rp 1870:186-194, map, Columbus 1871

71d The ancient lakes of western America; their deposits and drainage. Am Nat 4:641-660 (1871) Can Nat n $8: 112$ 118 (1871) U S G S Wyo (Hayden), Prel Rp [4]:329-339 (1871) Also in Hayden, F. V., Sun pictures of Rocky Mountain scenery ...: 135-150, N Y 1870 (?)

71e Fossil leaves from the Cretaceous sandstone of Fort Harker and fossil piants from the Miocene Tertiary of Oregon. Lyc N H N Y, Pr 1: 148 (1871)
Newberry, John Strong-Continued,

71f On a plece of red sandstone cons ing impressions of leaves from Willin burgh. Lye N H N Y, Pr 1:149-1 (1871)

$71 \mathrm{~g}$ Fossil fishes from the Devo rocks of Ohio. Lye N H N Y, Pr 1: $153 .(1871)$

71h On titaniferous iron ores. Lyes N Y, Pr 1: 223-224 (1871)

71i Fossils from the prosphate beds South Carolina. Lyc N H N Y, Pr 1:2 241 (1871)

71j [Anthracites of the Western Stato Lyc N H N Y, Pr 1: 252 (1871)

$71 k$ On the gas wells of Ohio and $\mathrm{Pet}$ sylvania. Lyc $N$ H N Y, Pr $1: 266-$ ? (1871)

72 (and Andrews, E. B.) Report progress of the geological survey of ot for the year 1871. Two different editio 12 pp [Columbus 1872]

72a Notes on American asphaltum. 1 Chemist 2: 427-428 (1872)

73 The general geological relations 2 structure of Ohio. Ohio G S, Rp 1 pt: Geology : 1-167 (1873)

73a Report on the geology of Cuyatoo Co. ; ... Summit Co. Ohic G S, Rp 1 pt Geology : 171-222, maps (1873)

73b Descriptions of fossil fishes. 0 G S, Rp 1 pt 2 Paleontology : 245-205, (1873)

73e Descriptions of fossil plants. G S, Rp 1 pt 2 Paleontology : 357-385. (1873)

73d On Ohio and other gas wells. J Sc (3) 5:225-228 (1873)

73e [On quartz pebbles and bouldos from Keyport, N. J.] Lyc N H N Y, f (2) [no 1] : 9-10 (1873)

73f The Salina group [Ohio]. Lyc H N Y, Pr (2) [no 1] : 11-12 (1873)

74 Geology of Ohio: surface geoloz Ohio G S, Rp 2 pt 1 Geology : 1-80, map (1874)

;4a The Carboniferous system. Ohlo S, Rp 2 pt 1 Geology : 81-180 (1874)

74b Report on the geology of Erie and the islands ; ... of Lorain Co. Ohio $\mathrm{S}, \mathrm{Rp} 2$ pt 1 Geology : 183-224, map (18it

74c Circles of deposition in America sedimentary rocks. Am As, $\operatorname{Pr} 22 \mathrm{pt}$ ? 185-196 (1874) Abst, Can Nat n s ? 163-164 (1874); Lyc N H N Y, $\operatorname{Pr}$ (2 no $4: 122-124(1874)$

74d On the parallelism of coal seams. $\mathrm{Am} \mathrm{J} \mathrm{Sc} \mathrm{(3)} 7: 367-369 \quad(1874)$ Cin l $J$ Sc 1:267-269 (1874)

74e on the lignites and plant beds of western America, Am J Sc (3) $7: 399$ 404 (1874)

74f On the so-called land plants frot the Lower Silurian of Ohio. Am J Sc (3) 8:110-113, il (1874) Cin Q J Sc $1: 335^{-}$ 338 (1874) 
Newberry, John Strong-Continued.

$\mathbf{7 4 g}$. The iron resources of the United States. Int Rv 1: 754-780 (1874)

74h Notes on the genus Conchiopsis, Cope. Ac N Se Phila, Pr 1873: 425-426 (1874)

74i Coals and lignites of the Western States and Territories. Lyc N H N Y, Pr (2) [no 2] : 9-10 (1874)

$\mathbf{7 4 j}$ [On the horizon of the mammalian remains of the Ohio drift.] Lyc $\mathrm{N} \mathrm{H} \mathrm{N} \mathrm{Y,}$ $\operatorname{Pr}$ (2) [no 2] : 12 (1874)

$\mathbf{7 4 k}$ [On the distribution of copper deposits.] Lyc N H N Y, Pr (2) [no 2] : 16-17 (1874)

741 [The history of the class of fishes in the older rocks of North America.] Lyc N H N Y, Pr (2) [no 2] : 25-28 (1874)

$74 \mathrm{~m}$ On Coelacanthus from the Coal Measures of Linton, Ohio. Lyc N H N Y, $\operatorname{Pr}(2)$ [no 2] : 30-32; no $3: 76-77$ (1874)

$74 \mathbf{n}$ (On the occurrence of chromic iron and serpentine in California). Lyc $\mathrm{N} \quad \mathrm{H}$ N Y, $\operatorname{Pr}(2)$ no $3: 66$ (1874)

74o [Remarks on the geology of western Texas.] Lye N H N Y, Pr (2) no 3 : 69-70 (1874)

74p [On Dicotyles compressus from Columbus, Ohio.] Lyc N H N Y, Pr (2) no $3: 77-78$ (1874)

74q [On the age of lignite flora of the West.] Lyc N H N Y, Pr (2) no 3:7879 (1874)

$74 \mathbf{r}$ [On Castoroides ohioensis from Nashport, Ohio.] Lyc N H N Y, Pr (2) no 4:92-93 (1874)

$74 \mathrm{~s}$ [On the Lower Cretaceous of Long Island, N. Y.] Lye N H N Y, Pr (2) no 4: 127 (1874)

74t [The Linton coal bed of Ohio and its fauna.] Lye N H N Y, Pr (2) no 4: 134-135 (1874)

$74 \mathbf{n}$ On the structure and origin of the Great Lakes. Lyc N H N Y, Pr (2) no 4: 136-138 (1874)

74v [On Dinichthys terrelli from the Huron shale of Lorain Co., Ohio.] Lyc N H N Y, Pr (2) no 4:149-151 (1874)

$74 w$ Fossil plants from the Ohio coal basin. Cleveland Ac, Pr 1:26-53, il (1874)

74x Note on the vegetation of the drift. Cleveland Ac, Pr 1: 76-80 (1874)

$\mathbf{7 4 y}$ Analysis of Ohio coals. Cleveland Ac, $\operatorname{Pr} 1: 80-82$ (1874)

75 Descriptions of fossil fisbes. Ohio G S, Rp 2 pt 2 Paleontology: 1-64, il (1875)

$75 a$ On an asphaltic coal from the shale of the Huron River, Ohio, containing seams of sulphate of baryta. Lyc N H N $\mathrm{Y}$, An 11:105-106 (1875)
Newberry, John Strong-Continued.

76 Geological report. In Macomb, J. N., Report of the exploring expedition from Santa Fe, New Mexico, to the junction of the Grand and Green rivers of the Great Colorado of the West in 1859 ; U S Army, Eng Dp : 9-118, map, Wash 1876

76a Descriptions of the Carboniferous and Triassic fossils collected... In Macomb. J. N., Report of the exploring expedition from Santa Fe ... in 1859; U S Army, Eng Dp : $135-148$, il 1876

76b The causes of the cold of the Ice Period. Pop Sc Mo $9: 280-290$ (1876)

76e Fossil fishes and footprints from the Trias of New Jersey (abst). Am Nat $10: 191$ (1876)

76d [On the origin of petroleum (abst).] Am Nat $10: 316-317$ (1876)

77 [Description of] Rhynchodus excavatus Newberry. [Wis G S], G Wis $2: 397$ (1877)

7S Review of the geological structure of Ohio. Ohio G S, Rp 3 pt 1:1-51 (1878)

78a Report on the geology of Tuscarawas Co. : Columbiana Co. ; Portage Co. ; Stark Co. Ohio G S, Rp 3 pt $1: 52-176$, maps (1878)

78b Report on the geology of Jefferson Co.; Mahoning Co. Ohio G S, Rp 3 pt 1 : $716-814$ (1878)

78e Deseriptions of new fossil fishes from the Trias. N Y Ac Sc, An 1:127128 (1878)

78d Descriptions of new Paleozoic fishes. N Y Ac Sc, An 1:188-192 (1878)

78e The geological history of New York Island and harbor. Pop Sc Mo 13:641$660(1878)$

78f New fossil fishes. Science News 1 : 36-37 (1878)

78m Mooted points in American geology. Science News 1: 38-40 (1878)

79 (and others) Geological atlas of the State of Ohio. Scale 1 mile to inch. Ohio G $\quad$ S 1879

79a [Carboniferous fish remains from Harrison Co.] Ind $G$ S, An Rp 8-9-10: 341-349 (1879)

79b On the discovery of mineral wax, ozocerite, in Utah. Am J Sc (3) $17: 340-$ 341 (1879)

79e The geological survey of the fortieth parallel. Pop Sc Mo $15: 302-317$ (1879)

79d Silver deposits. Science News 1: 211-212 (1879)

80 The geological history of the North American flora. Torrey Bot Club, B 7 : 74-80 (1880) Sc Am Sup 10:3909-3910 (1880)

Son The origin and classification of ore deposits. Sch Mines Q 1:87-104 (1880) Kansas City Rv Sc $4: 165-170,200-205$ (1880) Eng M J $29: 421-422,437-438$ (1880) 
Newberry, John Strong-Continued.

sob The genesis of our iron ores. Sch Mines Q 2:1-17 (1s80) Eng M J 31: $286-287,298-300 \quad(1881)$

soe Report on the properties of the Stormont Silver Mining Company, at Silver Reef, Utah. Eng M J 30:269 (1880)

S1 The genesis and distribution of gold. Sch Mines Q 3:4-15 (1881) Eng M J $32: 416-417,433-434$ (1881) Kansas City Rv Sc 5 : 617-619 (1882)

S1a Geological facts recently observed in Moutana, Idaho, Utah, and Colorado. $\mathrm{N}$ Y Ac Sc, Tr 1:4-8 (1881) Science (ed, Michels) 2:523-524 (1881)

sib The iron ores of southern Utah. Am Nat 15: 410-412 (1881)

81e The Silver Reef sandstones. Eng M J $31: 4-5$ (1881)

s1a American Cretaceous flora. Nature $24: 191-192(1881)$

82 The origin and relations of the carbon minerals. N Y Ac Sc, An 2: 267-286 (1882) Abst, Tr 1:109-111 (1882)

s2a On the geology of the region ad. jacent to the Mammoth Cave, Ky. N Y Ac Se, Tr 1:65-66 (1882)

82b Hypothetical high tides as agents of geological change. N Y Ac Sc, Tr 1: 80 $85(1882)$

s2e on the origin of crystalline iron ores $(a b s t)$ [with discussion by A. A. Julien]. N Y Ac Sc, Tr 2:13-17 (1882) Eng M J $35: 208$ (1883)

82d On supposed Tertiary ammonites. Ac N Sc Phila, Pr 1882: 194-195

s2e On the origin and drainage of the basins of the Great Lakes. Am Ph Soc, Pr 20: 91-95 (1882)

s3 On the physical conditions under which coal was formed. Sch Mines Q 4: 169-173 (1883) Science 1:89-91 (1883) Ohio M J $1: 168-172$ (1883)

83 The origin of the carbonaceous matter in bituminous shales. N Y Ac Se, An $2: 357-367$ (1883)

83b $[O n$ the coal beds of Massillon, Ohio.] N Y Ac Sc, Tr 2:87-88 (1883)

s3e The bontany and geology of the country bordering the Rio Grande, in Texas and Chibuahua (abst). N Y Ac Sc, Tr 2; 90-95 (1883)

83d Some interesting remains of fossil fishes, recently discovered [Mylostoma]. N Y Ac Sc, Tr 2: 144-147 (1883)

83e The evidences of ancient glaciation in North America, and their bearing on the theory of an ice period (abst). N Y Ac Sc, $\mathrm{T}_{1} 2: 155-159$ (1883)

s3f Brief descriptions of fossil plants, chiefly Tertiary, from western North Ameriea. U S Nat Mus, $\operatorname{Pr} 5: 502-514$ (1883)

83g The ancient glaciation of North America, its extent, character, and teachings (abst). Am As, Pr 32٪198-199 (1884) Science 2:316 (1883)
Newberry, John Strong-Continued,

83h The eroding power of ice (abst) Am As, Pr 32:200-201 (1884) Science $2: 320$ (1883)

84 The deposition of ores. Sch Mines ? $5: 329-344$ (1884)

$84 a$ The drift deposits of Indiana. Ind Dp G N H, An Rp 14 pt 1:85-97 (1884)

84b Description of Ctenacanthus worighti, n. sp. N Y St Mus, An Rp $35: 206$, il (1884)

84e High tides in geological histor Science $3: 402$ (1884)

S4d [Remarks on the glacial history of North America (abst).] Science 4:258259 (1884)

84e Phases in the evolution of the North American continent $(a b s t)$. Brit As, Bp $54: 719-720$ (1885) G Mag (3) $1: 52$ 523 (1884)

S4f On the recent discovery of new and remarkable fossil fishes in the Carbonife: ous and Devonian rocks of Ohio and Ind. ana (abst). Brit As, Rp 54:724-75 (1885) G Mag (3) 1:523-524 (1884)

85 The eroding power of ice. Sch Mina Q 6:142-153 (1885)

85a Notes on the surface geology of the country bordering the Northern Pacife Railroad. Am J Sc (3) $30: 337-346$ (1885)

85b Saporta's problematical organisms of the ancient seas. Science $5: 507-505$ (1885)

85e Descriptions of some peculiat screwlike fossils from the Chemung rocks [Spiraxis]. N Y Ac Sc, An $3: 217-220$, il (1885)

85d Notes on the geology and botany of the country bordering the Northern Paclfe Rallroad. $N$ Y Ac Sc, An 3:242-270 (1885)

she [On copper in Triassic rocks.] NI Ac Sc, Tr 3: 18-19 (1885)

85f The relations of Dinichthys as shor: by complete crania recently discovered by Mr. Jay Terrell in the Huron shale of Ohio $(a b s t)$. N Y Ac Sc, Tr $3: 20$ (1885)

85g Some peculiar screwlike casts frow the sandstones of the Chemung group of New York and Pennsylvania [Spiraxis]. N Y Ac Sc, Tr 3:33-34 (1885)

85h The erosive power of glacier lae and its influence on the topography of North America (abst). N Y Ac Sc, Tr 3: 51-52 (1855)

85i On the American Trias. N I dc Sc, Tr $5: 18-19$ (1885)

85j Description of some gigantic placo derm fishes recently discovered in the Devonian of Ohio. N Y Ac Sc, Tr $5: 25-28$ (1885)

85k Cone-in-cone. G Mag (3) 2:55\% 560 (1885)

851 The salt deposits of New York Eng M J $39: 247$ (1885)

86 Earthquakes. Sch Mines Q $8: 1-19$ (1886) N Y Ac Sc, Tr 6:18-35 (1887) 
Newberry, John Strong-Continued.

s6a The flora of the Amboy clays [New Jersey]. Torrey Bot Club, B 13:33-37 (1886)

86b Description of a species of Bauhinia from the Cretaceous clays of New Jersey. Torrey Bot Club, B 13:77-78, il (1886)

s6e $[$ On the Permian in North Amer. ica]. Am J Sc (3) 31:154 (1886)

86d North America in the Ice Period. Pop Sc Mo $30: 1-10$, map (1886)

s6e [On Edward Hull's memoir on the geological age of the north Atlantic Ocean.] N Y Ac Sc, Tr 5: 77-79 (1886)

86P The Cretaceous flora of North Amer. ica, N Y Ac Sc, Tr 5: 133-137 (1886)

86g Discusiones acerca del hombre del Peñón. La Naturaleza 7 : 284-285 (1886)

87 Geological notes; the Great Falls coal field, Mont.; kersantite; grahamite in Colorado; the origin of graphite. Sch Mines Q 8:327-335 (1887)

87a The ancestors of the tulip tree.

Torrey Bot Club, B 14:1-7, il (1887)

$\mathbf{S 7 b}$ Some recent discoveries of rock salt in western New York. N Y Ac Sc, Tr 4: $55-57$ (1887)

87e The fauna and flora of the Trias of New Jersey and the Connecticut Valley. N Y Ac Sc, Tr 6:124-128 (1887)

87a Coelosteus, a new genus of fishes from the Lower Carboniferous limestone of Illinols (abst). N Y Ac Sc, Tr 6:137138 (1887)

87e A new meteorite from Tennessee. N Y Ac Sc, Tr 6: 160-161 (1.887)

87f Description of a new species of Titanichthys (abst). N Y Ac Sc, Tr 6 : 164-165 (1887)

87g Professor Newberry on earthquakes. Science 9:91-92 (1887)

88 Fossil fishes and fossil plants of the Triassic rocks of New Jersey and the Connecticut Valley. U S G S, Mon 14: xiv, $152 \mathrm{pp}$, il (1888)

88a Rhaetic plants from Honduras. Am J Se (3) $36: 342-351$, il (1888)

$\mathbf{8 8 b}$ Sur les restes de grands poissons fossils récemment découverts dans les roches dévoniennes de l'Amérique du Nord [Dinichthys, Titanichthys]. Int $\mathrm{G}$ Cong, III, Berlin 1885, C R : 11-14 (1888)

88c The future of gold and silver. Sch Mines Q 9:97-109 (1888)

88d The coals of Colorado. Sch Mines Q 9: $327-341$ (1888)

88e Geological notes: the origin of the loess: marble deposits of the western

United States. Sch Mines Q 10:66-72 (1888)

$88 \mathrm{P}$ Th Colorado oil fields [Florence oil field]. Eng M J 46: 498-499 (1888) Sc Am Sup 27: 10948-10949 (1889)

$\mathbf{8 8 g}$ on the structure and relations of Edestus, with description of a gigantic new species. N Y Ac Sc, An 4:113-122, II (1888)
Newberry, John Strong-Continued.

88h Triassic plants from Honduras. N $\mathrm{Y}$ Ac Sc, Tr 7: 113-115 (1888)

8si [On the origin of rock-salt deposits.] N Y Ac Sc, Tr $7: 127-128$ (1888)

SSj Note on a new species of Rhizodus from the St. Louis limestone at Alton, Ill. N Y Ac Sc, Tr 7:165 (1888)

881 on the fossil fishes of the Erie shale of Ohio $(a b s t)$. N Y Ac Sc, Tr 7 : 178-180 (1888)

881 The new oil field of Colorado and its bearing on the question of the genesis of petroleum [Florence field]. N Y Ac Sc, Tr $8: 25-28$ (1888)

$\mathbf{s 5 m}$ The oil fields of Colorado (abst). Am As, Pr 37:186-187 (1889) Pop Sc Mo $34: 142$ (1888)

s9 The Paleozoic fishes of North America. U S G S, Mon 16:340 pp, il (1889) $89 a$ The [Florence] oil field of Colorado. Sch Mines Q 10:97-102 (1889)

89b The Laramie group, its geological relations, its economic importance, and its fauna and flora. N Y Ac Sc, Tr $9: 27-32$ (1889) Abst, Am G $5: 118$ (1890); (with discussion by E. D. Cope, Angelo Heilprin, J. B. Tyrrell, and L. F. Ward) G Soe Am, B 1:524-532 (1890)

s9e The rock-salt deposits of the Saline group in western New York. N Y Ac Sc, Tr $9: 39-45$ (1889)

89a Devonian plants from Ohio, Cin Soc N H, J 12:48-56, il (1889)

89e The history of the Great American Lakes (abst). Eng M J 48:201-202 (1889) Sc Am Sup 28:11505-11506 (1889)

90 Notes on the geology of the Aspen mining district [Colo.]. Am I M Eng, Tr 18: $273-278$ (1890)

90a on the genus oracanthus Agassiz. N Y Ac Sc, Tr 9:131-133 (1890)

9ob On Dendrophycus triassicus Newb. Am Nat 24: 1068-1069 (1890)

90e The first oil well; the birth of a great industry. Harper's Mag 81:723729 (1890)

91 The flora of the Great Falls coal field, Mont. Am J Sc (3) $41: 191-201$, il (1891)

91a The genus Sphenophyllum. Cin Soc N H, J $13: 212-217$, il (1891)

02 American Devonian fishes found in Belgium. Am Nat 26:1025 (1S92)

95 The flora of the Amboy clays, edited by Arthur Hollick. U S G S, Mon 26: 260 pp, il (1895)

97 New species and a new genus of American Paleozolc fishes... N Y Ac Sc, Tr $16: 282-304$, il (1897)

9s The later extinct floras of North Amerien, edited by Arthur Hollick. U. S. G S, Mon $35: 295 \mathrm{pp}$, il (1898) 
Newberry, John Strong-Continued.

See also Brainerd, 53a; Britton (N L), 82 ; Cleve, 81 ; Elliott (A H), 85 ; Furman, 81 ; Julien, 81, 82, 83 ; Powell, $89 a$; Smith (E A), 88a; Warring, 85; White (D), 90 ; Williams (G H), 90e; Winchell (N H), $88 \mathrm{~g}$

Newberry, Spencer Baird.

84 On some specimens of nickel ore from Nevada. Am J Sc (3) 28:122 (1884)

93 Cement. U S G S, Min Res 1891: 529-538; $1892: 739-747 ; 1893: 618-623$; An Rp 16 pt $3: 580-585 ; 17$ pt $3: 881-$ $893 ; 18$ pt $5: 1169-1177 ; 19$ pt 6 con: $4^{\circ}-494 ; 20$ pt 6 con: $539-550 ; 21$ pt 6 cun: $393-406$; Min Res 1900:737-744 (1893-1901)

Neweomb, C. S.

17 Chrome mining and concentration. Am I M Eng, B 131: vi-x (1917)

Newcomb, Simon.

S8 (and Dutton, C. E.) The speed of propagation of the Charleston earthquake. Am J Sc (3) 35:1-15 (1888)

Newcombe, C. F.

14 Pleistocene raised beaches at Victoria, B. C. Ottawa Nat 28:107-110, map (1914)

Newe11, Frederick Haynes.

8s Niagara cephalopods from northern Indiana. Boston Soc N H, Pr 23:466486, il (1888)

s9 Richmond coal field, Va. G Mag (3) 6: 138-139 (1889)

98 Mesa Verde [Colo.]. Nat Geog Mag $9: 431-434$ (1898)

New Jersey Geologieal Survey.

81 Geological map of New Jersey, 1881. Scale 6 miles to 1 inch

87 Atlas of New Jersey. 20 sheets, incl. geol. map [1887-9]

Newland, David Hale.

99 (with Kemp, J. F.) Preliminary report on the geology of Washington, Warren, and parts of Essex and Hamilton cos. [N. Y.]. N Y St G, An Rp 17:499-533, maps (1899) N Y St Mus, An Rp $51 v 2$ : 499-533, maps (1899)

99a (with Smyth, C. H., jr.) Report on progress made during 1898 , in mapping the crystalline rocks of the western Adirondack region. $N$ Y St $G, A n$, $R p$ : 129-135 (1899) N Y St Mus, An Rp 52 v 2:129-135 (1900)

99b (with Kemp, J. F.) Preliminary report on the geology of Hamilton, Warren, and Washington cos. [N. Y.]. N Y St G, An Rp 18:137-162, maps (1899) $\mathrm{N}$ Y St Mus, An Rp $52 v 2: 137-162$, maps (1900)

01 The serpentines of Manhattan Island and vicinity and their accompanying minerals. Sch Mines Q 22:307-317, 399-410 (1901)
Newland, David Hale-Continued.

o5 The mining and quarry industry of New York State; report of operations ad production during 1904. N Y St Mus, B $93: 909-970$ (1905) $\quad \ldots$ 1905; B $102: 198$ pp (1906) ‥ 1906; B 112: 80 pp (1907) 1907; B 120:82 pp (1908) … 1908; B 132 : 99 pp (1909) ‥ 1909; B $142: 96$ pp (1910) ... 1910; B 151:82 pp (1911) ... 1911; B 161 : 114 pp (1912) ... 1912; B $166: 114$ pp (1913) ... 1913; B 174: 111 pp (1914) ... 1914; B $178: 88$ pp (1915) $\quad \ldots \quad 1915 ;$ B $190: 92$ pp (1916) .. 1916; B 196:247-304 (1917) [1918]

06 (and Hansell, N V.) Magnetite mines at Lyon Mountain, N. Y. Eng M J $82: 863-865,916-918$ (1906)

O6a Recent earthquakes recorded at Albany, N Y. Science n s 23:851 (1906) O6b Zinc ore in northern New York. Eng M J 81 : 1094-1095 (1906)

07 On the associations and origin of the nontitaniferous magnetites in the Adiros. dack region. Ee G $2: 763-773$ (1907)

07 a The iron ores of the Adirondack re gion (abst). Science n \& 26:401-403 (1907)

08 Geology of the Adirondack magnetic iron ores. N Y St Mus, B 119:5-182, map (1908)

Osa (and Hartnagel, C. A.) Iron ores of the Clinton formation in New York State. N Y St Mus, B 123:76 pp, map (1908)

09 The Clinton ores of New York State. Am I M Eng, B 27:265-283 (1909); Tt $40: 165-183$ (1910)

O9a A pecullar landslip in the Hudson River clays, N Y St Mus, B 133:156-158 (1909)

10 (and Leighton, Henry) Gypsum deposits of New York. N Y St Mus, B 143: 94 pp (1910)

13 The microstructure of titaniferous magnetites (discussion). Ec G 8:610-613 (1913)

15 Albany molding sand. Am Inst Metals, $\operatorname{Tr} 9: 404-408$ (1916; preprint 1915)

15a Albany molding sand. Am Foundry. men's As, Tr 24:161-176 (1916; preprint 1915)

16 The quarry materials of New York; granite, gneiss, trap, and marble. N Y st Mus, B 181 : 212 pp (1916)

16a Landslides "in unconsolidated sedtments; with a description of some occur rences in the Hudson Valley. N Y St Mus, B 187:79-105 (1916) Abst, G Soc Am, B $27: 58-59$ (1916)

16b Albany molding sand. N Y St Mus, B 187: 107-115 (1916)

16e The new zine mining district neat Edwards, N. Y. Ee G $11: 623-644$ (1916) 17 Illustrations of the deformation of limestone under regional compression (abst). G Soc Am, B 28:163 (1917) 
Newland, David Hale Continued.

17 a The zinc-pyrite deposits of the Et wards district, N. Y. N Y State Defensw Council, B no 2:72 pp (1917)

17b Pyrite in northern New York. Eng M J $104: 947-948$ (1917)

18 Plastic deformation of Grenville limestone. N Y St Mus, B 196:145-147 (1918) Newman, Bruno.

07 The mining district of Asientos, Mexico, Eng M J 83: 1044-1046 (1907)

Newnam, William E.

17 Lead mining and smelting at Galetta, Ont. Am I M Eng, J: 124: 425-429 (1917)

Newsom, John Flesher.

95 (with Branner, J. C.) Syllabus of lectures on economic geology. $70 \mathrm{pp}$ (one half blank), Palo Alto, Cal., 1895 2d ed, 368 pp (one half blank), Stanford University 1900

97 The Red River and Clinton monoclines, Ark.; with introduction by John C. Branner. Am G 20:1-13, map (1897)

98 A geological section across southern Indiana from Hanover to Vincennes. J G 6: 250-256 (1898)

98a A geological section across southern Indiana from Hanover to Vincennes. Ind Ac Sc, Pr 1897: 250-253 (1898)

98b The Knobstone group in the region of New Albany. Ind Ac Sc, Pr 1897:253256, map (1898)

99 The effect of sea barriers upon uitimate drainage. J G $7: 445-451$ (1899)

99a (and Price, J. A.) Notes $\rightarrow$ the distribution of the Knobstone group in Indiana. Ind Ac Sc, Pr 1898: 289-291, map (1899)

02 Drainage of southern Indiana. J G $10: 166-181$, map (†902)

02a A natural gas explosion near Waldron, Ind. J G 10:803-814, map (1902)

02h (with Brnnner, J. C.) The phosphate rocks of Arkansas. Ark Agr Exp Sta, B 74:61-128 (1902)

03 A geologic and topographic section across southern Indiana from the Ohio River at Hanover 'o the Wabash River at Vincennes, with a discussion of the general distribution and charactc of the Knobstone group in the State of India a. Ind, Dp G N Res, An Rp 26:227-302, maps (1903)

03n Clastic dikes. G Soc Am, B 14: 227-268 (1903)

08 Notes on the structure of the Santa Cruz Range, Cal. (abst). Gerl Soc Am, B $18: 657(1908)$

09 (with Branner, J. C., and Arnold, Ralph). Description of e Santa Cruz quadrangle, Cal. U S G S, G Atlas Santa Cruz fol (no 163) : 11 pp, maps (1909)
Yewton, Edmund.

13 (with Appleby, ... R.) Preliminary oncentration tests on Mesabi ores [Itasca Co., Minn.]. Minn Sch Mines, Exp Sta, B 2 : 126 pp (1913)

15 (with Appleby, W. R.) Preliminary concentration tests on Cuyuna ores [Minn.]. Minn Sch Mines, Exp Sta, B 3:66 pp (1915)

18 Manganiferous iron ores of the Cuyuna district, Minn. Minn, Univ, Sch Mines, Exp Sta, B 5:126 pp, map (1918)

Newton, H. A.

86 Relations of the earth's rocks to meteorites. Can Rec Sc 2: 228-241 (1886)

93 Lines of structure in the Winnebago Co., meteorites and in other meteorites. Am J Sc (3) $45: 152-153$ (1893)

Newton, Henry (1845-1877).

75 The ores of iron; their geographical distribution... Am I M Jng, Tr $3: 360$ 391 (1875)

76 [Rocks and Cretaceous and Jurassic fossils collected by the U. S. Black Hills expedition (abst).] Am Nat 10:191-192 (1876)

so (and Jenney, W. P.) Report on the geology and resources of the Black Hills of Dakota. U S Geog G S Rocky Mtn Reg (Powell) : 566 pp, atlas (1880)

Newton, R. Bullen.

92 On the American Paleozoic gastropod, Tremanotus Hall emend. P. Fischer... G Mag (3) 9:337-341, il (1892)

02 List of Thomas Say's types of Maryland (U. S.) Tertiary Mollusca in the British Museum. G Mag (4) 9:303-305 (1902)

New York (State), Geological Survey.

42 Geological map of the State of New York [and sections]. N Y 1842 [2d ed] Agricultural and geological map of the State of New York. N Y 1844

New York Mineralogieal CIub.

o7 Bulletin, vol. 1, 3 nos. issued: $52 \mathrm{pp}$, N Y $1907,1909,1914$

New York State Musenm.

04 Economic geology of New York. N Y St Mus, Hdbk 17:40 pp (1904)

Nicholas, F.

99 The economic geology of Jamaica. Institute of Jamaica, Kingston, J 2:502509 (1899)

Nicholas, Francis Child.

o7 The Union copper mines of North Carolina. M World 27:883-884 (1907)

o7a The Gold Hill copper mine, and its development. M World 27:1001-1002 (1907)

О7b Recent developments at Furnace Creek copper mines. M World 27:10871088 (1907)

os The Douglas copper properties in [Fundicion, State of Sonora] Mexico. M World $28: 245-246$ (1908) 
Niebolas, Francis Child-Continued.

osa Properties of the New York \& Hon duras Rosario Mining Co. [at San Juancito, in Honduras, Central America]. M World $28: 367-369$ (1908)

0sb South Fxtension Homestake min eral formations [northern Black Hills, S. Dak.]. M World 29:121-124 (1908)

ose Mineral deposits of Jamaica in West Indies. M World 29:883-884 (1908)

09 A method of demonstrating ore formations. M World 30:349-350 (1909)

10 The volcanic formations of Costa Rica. M World 32:1081-1082 (1910)

11 The Copete ore deposits of Sonora, Mexico. M World 34:293-295 (1911)

$11 \mathrm{a} A$ theory of ore deposits in the Black Hills. M World $35: 333-335$ (1911)

Nieholls, H. A. Alford.

02 Notes on the recent eruptions of Mt. Pelé. Nature 66:638-639 (1902)

Nichols, Andrew.

56 On the peculiar syenitic formation in South Danvers [Mass.]. Essex Inst, Pr 1: 19-20 (1856)

Nichols, Edward.

82 Some drift hematite deposits in east Tennessee. Am I M Eng. Tr 10:480-482 (1882)

s8 An aluminum ore [Floyd Co., Ga.]. Am I M Eng. Tr 16:905-906 (1888)

Niehols, Henry Windsor.

97 On the genesis of clay stone. Am G $19: 324-329$ (1897)

01 Nitrates in cave earths. J G $9: 236$ 243 (1901)

06 New forms of concretions. Field Col Mus, Pub g s 3:25-54 (1906)

07 Absence of lead and copper from certain deep sea deposits. Ec G $2: 309-311$ (1907)

See also Hedburg, 02

Nichols, John A.

65 Notice of potholes near Ponltney, Vt. Am J Sc (2) 40:264-265 (1865)

Nichols, R. H.

10 An open valley near Harrisburg, Ohio. Ohio Nat 11:210-213 (1910)

Nichols, Ralph.

13 Lead-silver mines of Gilmore, Lemhi Co., Idaho. Am I M Eng, B 83: 26252627 (1913) ; Tr 46:937-939 (1914)

Niehols, W.

95 How gold occurs in nature. Can $M$ Rv $14: 171$ (1895)

Nicholson, Frank.

82 A review of the Ste. Genevieve cop per deposit [Mo.]. Am I M Eng, $\operatorname{Tr} 10$ : 444-456 (1882)

03 The Wisconsin zinc fields. Eng M J $76: 847-849$ (1903)

Nicholson, H. H.

13 Gold deposits and their associated minerals. M Science 68:96-99 (1913)

14 Oil and gas fields of north Texas. M Science $69: 34-37$ (1914)
Viebolson, Henry Alleyne (1844-1899),

71 On the "colonies" of M. Barrand Can Nat n s 6: 188-203 (1871)

72 Textbook of geology for schools ax colleges. $266 \mathrm{pp}, \mathrm{N}$ Y 1872

72n On the genera Cornulites and Tes taculites and on a new genus Conchio lites. Am J Sc (3) $3: 202-206$, il (187?

$\mathbf{7 2 b}$ Contemporaneity of strata and t doctrine of geological continuity. Can J 1 s $13: 269-281$ (1872)

72e The imperfection of the paleonto logical record. Can J n s $13: 379-991$ (1872)

72d On Ortonia, a new genus of tubicolst annelids, with notes on the genus Tento culites. G Mag $9: 446-449$, il (187?) Abst, Brit As, Rp 42: sec 118-119 (1873)

73 On some fossils from the Quebee group of Point Lévis, Que. An Mag N (4) $11: 133-143$, il $(1873)$

$73 \mathbf{a}$ On some new species of strom topora. An Mag N H (4) $12: 89-95$, I (1873)

73b On the geology of the Thunder Bay and Shabendowan mining districts on the north shore of Lake Superior. G Sx London, Q J 29:16-24, map (1873) Abk G Mag 10:42-43 (1873) ; Brit As, Rp 42: sec 118 (1873)

73e Descriptions of two new species of fossil tubicolar annelids. G Mag 10:5457 , il (1s73)

73d On the species of Favosites from the Devonian rocks of western Ontario, cas J n s 14:38-50 (1873) G Mag 10:56\%$570(1873)$

73e Nature of a silicified forest in the Rocky Mountains with an account of 1 supposed fossil chip. Brit As, Rp 42: 8 192 (1873)

74 Report upon the paleontology of the Province of Ontario. $133 \mathrm{pp}, \mathrm{il}$, Toronto 1874

74a Summary of recent researches on the paleontology of the province of Ontario Can J n s 14:125-136 (1874)

74b (and Hinde, G. J.) Notes on the fossils of the Clinton, Niagara, and Guelp? formations of Ontario, with descriptions of new specices. Can J n s $14: 137-152,137-$ 144 [bis], il (1874)

74c Descriptions of new fossils frow the Devonian rocks of western Ontario Can Nat n s $7:$ 138-147 (1874)

74d On the affinities of the gens? Stro.iatopora, with descriptions of two ner species. An Mag N H (4) 13:4-13, (1874)

74e Descriptions of two new geners and species of Polyzoa from the Devoniat rocks. An $\mathrm{Mag} \mathrm{N} \mathrm{H}$ (4) $13: 77-85$, (1874)

74f On Duncanella, a new genus of Paleozoic corals. An Mag N H (4) 13: 333-335, il (1874) 
Nicholson, Henry Alleyne-Continued.

$\mathbf{7 4} \mathbf{g}$ Descriptions of species of Chaetetes from the Lower Silurian rocks of North America. G Soc London, Q J 30:499-515, il (1874) Abst, G Mag (2) $1: 426-427$ (1874)

74h Descriptions of new fossils from the Devonian formations of Canada West. G Mag (2) $1: 10-16,54-60,117-126,159-$ 16:3, 197-201, il (1874)

74i On Columnopora, a new genus of tabulate corals. G Mag (2) $1: 253-254$, il (1874)

$\mathbf{7 4 j}$ On the genera Conchicolites and $\mathrm{Or}$ tonin. Cin Q J Sc 1: 236-239 (1874)

75 Report upon the paleontology of the Province of Ontario. $96 \mathrm{pp}$, il, Toronto 1875

75a Description of the corals of the Silurian and Devonian systems. Ohio G S, Rp 2 pt 2 Paleontology : 181-242, il (1875)

75b Deseriptions of Amorphozoa from the Silurian and Devonian formations. Ohio G S, Rp 2 pt 2 Paleontology : 243-255, il $(1875)$

75e Descriptions of Polyzoa from the Silurian formation. Ohio G S, Rp 2 pt 2 Paleontology : 257-268, il (1875)

75d (and Ellis, W. H.) On a remarkable fragment of silicified wood from the Rocky Mountains. Can J n s 14: 148-153 [in error for $348-353$ ], il (1875) Abst, Brit As, Rp 44: sec 88-89 (1875)

75e Notes on the Gastropoda of the Guelph formation of Canada. G Soc London, Q J $31: 543-551$, il (1875) Abst, G Mag (2) $2: 514$ (1875)

75f Descriptions of new species of Cystiphyllum from the Devonian rocks of North America. G Mag (2) $2: 30-33$, il (1875) Abst, Brit As, Rp 44: sec 91 (1875)

75g Descriptions of new species and of a new genus of Polyzoa from the Paleozoic rocks of North Ameriea. G Mag (2) 2 : $33-38$, il (1875)

75h On some of the massive forms of Chatetes from the Lower Silurian. G Mag (2) $2: 175-177$ (1875)

751 On the Guelph limestones of North Amrerica and their organic remains. G Mag (2) $2: 343-348$ (1875)

$75 \mathrm{j}$ Descriptions of species of Hippothoa and Alecto from the Lower Silurian rocks of Ohio, with a description of Aulopora arachnoidea Hall. An Mag N H (4) 15 : 123-127, il (1875) Abst, Brit As, Rp 44 : 90 (1875)

75k Descriptions of new species of Polyzoa from the Lower and Upper Silurian rocks of North America. An Mag N H

(4) $15: 177-184$, il (1875) Abst, Brit As, Rp 44:90-91 (1875) vicholson, Henry Alleyne-Continued.

751 On the bearing of certain paleontological facts upon the Darwinian theory of the origin of species and on the general doctrine of evolution. Victoria Inst, $\mathrm{Tr}$ $9: 207-231$ (1875)

$75 \mathrm{~m}$ On the mining districts on the north shore of Lake Superior. N Engl Inst M Eng, Tr 24:237-249, maps (1875)

75n on the mode of growth and increase amongst the corals of the Paleozoic period. R Soc Edinb, Tr $27: 237-249$, il (1875)

75o On Favistella stellata and Favistella calicina, with notes on the affinities of Favistella and allied genera (abst). Brit As, Rp 44: sec 89-90 (1875) G Mag (2) 2: $279(1875)$

76 Notes on the Paleozoic corals of the State of Ohio. An Mag N H (4) 18: $85-94$, il (1876)

77 (and Etheridge, R., jr.) Notes on the genus Alveolites Lamarck and on some allied forms of Paleozoic corals. Linn Soc, J, Zool, $13: 353-370$, il (1877)

$\mathbf{7 a}$ (and Etheridge, R., jr.) On Ascodictyon, a new provisional and anomalous genus of Paleozoic fossils. An Mag N H (4) $19: 463-468$, il $(1877)$

77b (and Etheridge, R., jr.) On the genus Tetradium Dana and a British species of the same. An Mag:- H (4) 20 : $161-169$, il (1877)

77e (and Thomson, James) Descriptions of some new or imperfectly understood forms of Paleozoic corals (abst). R Soc Edinb, Pr 9:149-150 (1877)

7S The ancient life history of the earth... 407 pp, N Y 1878

78n (and Murie, J.) On the minute structure of stromatopora and its allies. Linn Soc, J, Zool, 14: 187-246, il (1878)

$\mathbf{7 8 b}$ On the minute structure of the corals of the genera Heliophyllum and Crepidophyllum. An Mag N H (5) 1:44-54 (1878)

7Sc (and Etheridge, R., jr.) On the genus Palaeacis... An Mag N H (5) 1: $206-2 \div 7$ (1878)

78d (with White, C. A.) Bibliggraphy of North American invertebrate paleontol$\operatorname{ogy}_{\ldots}$ U S G S Terr (Hayden) Misc Pub no $10: 132$ pp $(1878)$

79 On the structure and affinities of the "tabulate corals" of the Paleozoic period... 342 pp, il, Edinburgh 1879

79a (with White, C. A.) Supplement to the bibliography of North Lmerican Invertebrate paleontology. U S G Geog S Terr (Hayden), B 5:143-152 (1879)

so On the minute structure of the recent Heteropora neozelanica Busk and on the relations of the genus Heteropora to Monticulipora. An Mag N H (5) 6:329$339,414-423$, il $(1880)$

$$
28737^{\circ}-23-50
$$


Nicholson, Henry Alleyne-Continued.

81 On the structure and affinities of the genus Monticulipora and its subgenera... 240 pp, il, Edinburgh 1881

85 (and Foord, A. H.) On the genus Fistulipora McCoy, with descriptions of sev. eral species. An Mag N H (5) 16:496517 , il (1885)

85a (and Etheridge, Robert, jr.) On the synonymy, structure, and geological distribution of Solenopora compacte Billings, sp. G Mag (3) $2: 529-535$, il (1885)

s7 On some new or imperfectly known species of stromatoporoids. An Mag N H (5) $19: 1-17$, il (1887)

88 On certain anomalous organisms which are concerned in the formation of some of the Paleozoic limestones. G Mag (3) $5: 15-24$, il $(1888)$

89 On the relations between the genera Syringolites Hinde and Roemeria Edwards and Haime and on the genus Caliapora Schlüter. G Mag (3) 6:433-438, il (1889)

Nickles, John M.

90 Studies on Monticulipora. Am G 6 : 396-399 (1890)

91 A local deposit of Chester sandstone. Am G $7: 47-48$ (1891)

95 Geological section-St. Louis to Shawneetown. In Illinois Board of World's Fair Commissioners at the World's Columbian Exposition [Chicago 1893], Rp : 155-176, Springfield 1895

95 a Geological section in southern Illinois through Waterloo, Sparta, Murphy. boro, and Olmstead. In Illinois Board of World's Fair Commissioners at the World's Columbian Exposition [Chicago 1893], Rp : 177-223, Springfield 1895

00 (and Bassler. R. S.) A synopsis of American fossil Bryozoa including bibliog. raphy and synonymy. U S G S, B 173: 663 pp (1900)

02 The geology of Cincinnati [Obio]. Cin Soc N H, J 20:49-100 (1902)

$02 a$ Description of a new bryozoan, Homotrypa bassleri, n. sp., from the Warren beds of the Lorraine group. Cin Soc N H, J $20: 103-105$, il (1902)

03 The Richmond group in Ohio and Indiana, and its subdivisions, with a note on the genus strophomena and its type. Am G 32: 202-218 (1903)

05 The upper Ordovician rocks of Kentucky and their Bryczoa. Ky G S, B 5: $64 \mathrm{pp}$, il (1905)

O5a Land sculpturing displayed about Cincinnati [Ohio]. Cincinnati, Univ, Teachers' B (3) 1 no $2: 5-18, \operatorname{map}(1905)$

09 Bibliography of North American geology for 1906 and 1907, with subject index. U S G S, B $372: 317$ pp (1909) ...1908; B 409: 148 pp (1909) ...1909; B $444: 174 \mathrm{pp}(1910) \quad \ldots 1910 ;$ B $495: 179$ pp $1911 \ldots 1911$; B $524: 162$ pp (1912) ...1912; B $545: 192$ pp (1913) ...1913; B 584: 183 pp (1914) ...1914; B 617:167
Nickles, John M.-Continued.

pp (1915) ..1915; B 645: 144 pp (191 ...1916; B $665: 172$ pp (1917) ...1917: $684: 154$ pp (1918) ...1918; B 698:1 pp (1919)

Nicol, John M.

07 Black sand. M Sc Press 94:82(1907)

09 Placers of Waldo, south Or.o. M Press 99:122-124 (1909)

Nicol, William.

96 Anhydrite in Ontario. Can Rec ? $7: 61$ (1896)

98 Crystallised pyrrhotite from Front nac Co., Ont. Can Rec Sc $7: 477-4$ (1898)

03 (with Goldsehmidt, V.) Ner forms of sperrylite. Am J Sc (4) $15: 46$ 458 (1903)

04 Spinel twins of pyrite. Am J Sc ( $17: 93$ (1904)

Nicolas, F. J.

o8 General index to reports, 1885-1908 Can G S, 1014 pp (1908)

o9 General index of the reports of th Bureau of Mines of Ontario, Volumes I t XVI (1891-1907), $466 \mathrm{pp}$, Toronto 1908

Nicolau, Th.

01 Untersuchungen an den eisenfuihre den Gesteinen der Insel Disko. Med Grit land $24: 215-248$ (1901)

Nicollet, Joseph Nicolas (1786-1843).

41 On the geology of the region on th upper Mississippi and the Cretaces formation of the upper Missouri. Am : Sc 41:180-182 (1841) As Am G, Bp $32-34$ (1843)

43 Report intended to illustrate a mal of the hydrographical basin of the uppe Mississippi River (List of fossils belons ing to the several formations alluded to th the report. arranged according to localltis pp. 167-170). U S, 26th Cong 2d sess, ? Doc 237 (H Doc 52) : 170 pp, map (1840

43a On the Cretaceous formation of the Missouri River (with discussion). Am Se 45:153-155 (1843)

$43 b$ (and others) [Discussion on th explanation of the drift.] Am J Sc 45: 319-327 (1843)

43e On the mineral region of the State of Missouri (abst). Am J Sc $45: 340-341$ (1843)

See also Jackson, 43c

Nicolls, J. H. H.

18 (with Stansfield, E.) Analysis of Canadian fuels; in five parts. Part $I, T$ th maritime provinces, B 22: $\mathbf{2 8}$ pp; Part 11 Quebec and Ontario, B 23: 25 pp ; Part III Manitoba and Saskatchewan, B 24:15 pp Part IV, Alberta and the Northwest tert tories, B 25: 68 pp ; Part V, British Colut bia and Yukon Territory, B 26:24 pp, Cat Mines $\mathrm{Br} 1918$ 
Nicolls, William Jasper.

97 The story of American coals. 405 pp, Phila 1897

Nicolson, John Thomas.

97 (with Adams, F. D.) Preliminary notice of some experiments on the flow of rocks (abst). G Mag (4) 4:513-514 (1897) Brit As, Rp 67:642-643 (1898) Science n s $7: 82-83$ (1898)

98 (with Adams, F. D.) Experiments on the flow of rock... (abst). Science $\mathrm{n} \mathbf{s}$ $7: 82-83$ (1898)

01 (with Adams, F. D.) An experimental investigation into the flow of marble. R Soc London, Ph Tr ser A 195 : 363-401 (1901) Alst, G Mag (4) 8:322323 (1901)

02 (with Adams, F. D.) An experimental investigation into the flow of marble. Can Rec Sc 8:426-436 (1902)

Niermeyer, Jan Frederik.

13 Kraters in sedimentair Gesteente in Arizona en Nieuw-Mexico. Nederlandsch Natuur- en Geneeskundig Congres, XIV, Delft, 1913, Hand 14:430-436 (1913)

Nikitin, S.

90 Einiges ïber den Jura in Mexico und Centralasien. N Jb $1890,2: 273-274$

Niles, John H.

66 Geology of the fire lands [Ohio]. Fire Lands Pioneer, Sandusky, Ohio, $7: 42-$ $49(1866)$

Niles, William Harmon.

65 [On the systematic position of Pasceolus.] Boston Soe N H, Pr 10:19-20 (1865)

65a [Remarks on the relations between the vegetation and geology in the hills of western Massachusetts.] Boston Soc N H, Pr 10:49-50 (1865)

66 (and Wuchsmuth, Charles.) Evidence of two distinct geological formations in the Burlington limestone. Am J Sc (2) $42: 95-99$ (1866)

66a [On the subdivision of the Burlington limestone of Iowa.] Boston Soc N H, Pr 11:6-7 (1866)

69 [On the occurrence of shells of existing species in a boring at Fort Warren, Boston Harbor.] Boston Soc N H, Pr 12: 244, 364 (1869)

71 On the physical features of Massachusetts. Boston Soc N H, Pr 13:414415 (1871)

71 a some interesting phenomena observed in quarrying. Boston Soc $\mathrm{N} \mathrm{H}, \mathrm{Pr}$ $14: 80-87$ (1871) ; $16: 41-43$ (1873)

71b [On the conglomerates of Montague and Brighton, Mass. (with discussion on conglomerates by Charles Pickering. W. T. Brigham, and C. T. Jackson.] Boston Soc $\mathrm{N}$ H, Pr 14:128-129 (1871)

72 Peculiar phenomena observed in auarrying. Am J Sc (3) $3: 222-223$ (1872) viles, William Harmon-Continued.

72a [Metamorphism of pebbles in conglomerate rocks at Chestnut Hill Reservoir, Boston, Mass. with discussion by N. S. Shaler and C. T. Jackson.] Boston Soc $\mathrm{N} \mathrm{H}, \operatorname{Pr} 15: 1-2$ (1872)

73 Some remarks upon the agency of glaciers in the excavation of valleys and lake basins. Boston Soe N H, Pr 15 : 378381 (1873)

74 On some expansions, movements, and fractures of rocks, observed at Monson, Mass. Am As, Pr 22 pt 2: 156-163 (1874)

75 The physical features of the State of Massachusetts (with discussion by T. S. Hunt). Boston Soc N H, Pr 17:507-508 (1875)

76 The geological agency of lateral pres. sure exhibited by certain movements of rocks. Boston Soe N H, Pr 18:272-284 (1876)

78 Upon the occurrence of zones of different physical features upon the slopes of mountains. Boston Soc N H, Pr 19:324330 (1878)

78 Upon the relative agency of glaciers and subglacial streams in the erosion of valleys. Boston Soc N H. Pr 19:330-336 (1878) Am J Sc (3) $16: 366-370$ (1878)

84 On the causes of turns in lava streams. Boston Soc N H, Pr 22:490 (1884)

94 A geological study of Lake Mohonk and Lake Minnewaska, N. Y. (abst). Am G $13: 211$ (1894)

See also Shaler, $70 \mathrm{~b}, 71$

Nishihara, George Hironao.

14 Importance of carbonates in the role o: secondary enrichment. Ec G $9: 483-485$ (1914)

14a Manganese as an impurity in some of the sulphides. Ec G $9: 485$ (1914)

14b The rate of reduction of acidity of descending waters by certain ore and gangue minerals and its bearing upon secondary sulphide enrichment. Ec G 9 : 743-757 (1914)

Nissen, Arvid E.

15 (and Hoyt, S. L.) On the occurrence of silver in argentiferous galena ores. Ee G 10:172-179 (1915)

Nitze, Henry Benjamin Charles (18671900).

91 Notes on the Dan River coal basin in North Carolina. Eng M J 51: 448 (1891)

92 Notes on some of the magnetites of southwestern Virginia and the contiguous territory of North Carolina (with discussion by E. C. Pechin). Am I M Eng, Tr $20: 174-188$ (1892)

92a The magnetic iron ores of Ashe Co., N. C. Elisha Mitchell Sc Soc, J 8:78-95. map (1892) Am I M Eng, Tr 21:260-280 (1893)

92b Magnetic iron ore in Granville Co., N. C. Eng M J $53: 447$ (1892) 
Nitze, Henry Benjamin Charles-Contd.

93 Iron ores of North Carolina. N C G

$\mathrm{S}$, Bien Rp 1: 25-56, maps (1893)

93a Iron ores of North Carolina. N C

G S, B 1:239 pp, map, Raleigh 1893

95 Monazite and monazite deposits in North Carolina. N C G S, B 9:47 pp, map, Winston 1895

95a Monazite. U S G S, An Rp 16 pt 4: 667-693 (1895)

95b Monazite. Elisha Mitchell Sc Soc, J $12: 38-48$, map (1895)

96 (and Hanna, G. B.) Gold deposits of North Carolina. N C G S, B 3:200 pp, maps, Winston 1896

96a North Carolina monazite. Am I M Eng, $\operatorname{Tr} 25: 40-43$ (1896)

96b (and Wilkens, H. A. J.) The present condition of gold mining in the southern Appalachian States (with discussion by A. Thies and R. W. Raymond,. Am I M Eng, Tr 25:661-796, 1016-1027 (1896)

97 (and Wilkens, H. A. J.) Gold mining in North Carolina and adjacent south Appalachian regions. N C G S, B $10: 164 \mathrm{pp}$, Raleigh 1897

97a Monazite. Franklin Inst, J 144: 127-133 (1897)

$97 \mathbf{b}$ Some late views of the so-called Taconic and Huronian rocks in central North Carolina. Elisha Mitchell Sc Soc, I 13: 53-72 (1897)

97e The limonite ores of Cherokee Co., N. C. En: M J $63: 330-331$ (1897)

97 d The genesis of the gold ores in the central slate belt of the Carolinas. Eng M J $63: 628-629$ (1897)

99 Investigations of some of the mineral resourees of Porto Rico. U S G S, An Rp 20 pt 6 con : $779-787$ (1899)

Niven, William.

95 On a new locality for xenotime, monazite, etc., on Manhattan Island. Am J Sc (3) $50: 75 \quad(1895)$

10 Mineral resources of the State of Guerrero, Mexico. Eng M J 90:672-674 (1910)

Nixen, Harmon A.

13 (and Tight, D. J.) Drainage changes in the Moot's Run area, Licking Co., Ohio, Denison Univ, Sc Lab, B 17 : 219-230 (1913)

Noble, John D.

02 Lindustrie du pétrole au Canada. Cong intern pétrole, I, Paris 1900, Notes... : 73-79, Paris 1902

Noble, Levi F.

10 Contributions to the geology of the Grand Canyon, Ariz.; the geology of the Shinumo area. Am J Sc (4) $29: 369-386$, 497-528, map (1910)

11 The Grand Canyon of the Colorado. science n s $34: 378+380$ (1911)
Noble, Levi F.-Continued.

14 The Shinumo quadrangle, Grand yon district, Ariz. U S C S, B 549: pp, map (1914) Abst, Wash Ac Sc, ] 181-182 (1915)

16 (and Hunter, J. F.) A recon sance of the Archean complex of Granite Gorge, Grand Canyon, Ariz. G S, P P 98: 95-113 (1916) Abst, $\pi$ Ac Sc, J $7: 38$ (1917)

18 Geologic history of the Bright is quadrangle, Ariz. Text on back of th graphic sheet, Bright Angel quadrat: Ariz. (Coconino Co.). U S G S, 1918

Nörgerath, Johann Jacob.

26 Ueber Meteoreisen aus Mexico [J] pileo, Toluca]. J Chem u Physik (Schr: ger) $47: 74-76 \quad$ (1826)

48 Gediegen Kupfer und Silber von L Superior. N Jb 1848:555

Nolan, A. W.

O3 (and Dixon, J. D.) Geology of Helen's Island [Quebec]. Can Rec Sc 53-66, map (1903)

Nomland, Jorgen $O$.

16 Corals from the Cretaceous and tiary of California and Oregon. Cal ti Dp G, B 9:59-76, il (1916) Abst, Gs Am, B $27: 174$ (1916)

16a Relation of the invertebrate to vertebrate faunal zones of the Jacall and Etchegoin formations in the nor Coalinga region, Cal. Cal. Univ, Dp B $9: 77-78$, il (1916) Abst, with dist sion by J. C. Merriam, G Soc Am, B : 172 (1916)

16b Fauna from the lower Pliocene Jacalitos Creek and Waltham Canjw Fresno Co,, Cal. Cal Univ, Dp G, B $199-214$, il (1916)

17 New fossil corals from the Pacl coast. Cal Univ, Dp G, B 10:185-190, (1917)

17a The Etchegoin Pliocene of mid California, Cal Univ, Dp G, B 10:19: 254 , i] $(1917)$

17b Fauna of the Santa Margarita be in the North Coalinga region of Califort: Cal Univ, Dp G, B $10: 293-326$, il (191:

17e Fauna of the Etchegoin Pliocenes middle California (abst). G Soc Am, 28: 229-230 (1917)

Nopesa, Francis.

o5 Remarks on the supposed clavicle the sauropodous dinosaur Diplodocus. Io Soc London, Pr 1905 vol $2: 289-294$, (1905)

Nordenskjø1d, A. E.

71 Redogörelse för en expedition til Grönland år 1870. K Svenska Vet-di Förh, Öfv 27:973-1082 map (1871) dt count of an expedition to Greenland in tor year 1870 . G Mag $9: 289-306,355-36^{\circ}$ $409-427,449-463,516-524$, map (1872)

72 Remarks on the Greenland meteorites G Soc London, Q J 28:44-46 (1872) Mag 9: 88-89 (1872) 
Nordenskjöd, A. E.-Continued.

83 On the inland ice of Greenland. Science $2: 732-738$ (1883)

s6 Arksutit från Ivigtut i Grönland. G Fören Stockholm, Förh 8:172-175 (1886)

Nordenskjöld, Otto.

99 Die geologische Verbältnisse der Goldlagerstiitten des Klondikegebietes. Zs Prak Geol 1899: 71-83, map

99a ... surface geology of the Yukon Territory. Am G 23:288-298 (1899)

04 Notes on some specimens of rocks collected by $C$. Kruuse on the east coast of Greenland between lat. $65^{\circ} 35^{\circ}$ and $67^{\circ} 22^{\prime} \mathrm{N}$. Med Grönland 28: 1-16 (1904)

09 On the geology and physical geography of east Greenland. Med Grönland 28:151-284, map (1909)

North, Edward.

90 The Pico Canyon oil field. Cal St M Bur, An Rp 10:283-298 (1890)

North, Frederick J.

13 On the genus Syringothyris Winchell. G Mag (5) 10:393-401, il (1913)

North, H. B.

13 Pseudomorphs of limonite after marcasite. Am J Sc (4) $35: 270-272$ (1913)

Northrop, John D.

16 Asphalt, related bitumens, and bituminous rock. U S G S, Min Res 1914 pt $2: 347-362 ; 1915$ pt $2: 135-150$; 1916 pt $2: 263-281 ; 1917$ pt $2: 233-251$ (1916-8)

16a Natural gas. U S G S, Min Res 1914 pt $2: 747-818: 1915$ pt $2: 927-1015$; 1916 pt $2: 585-678(1916-8)$

16b Petroleum. U S G S, Min Res 1914 pt $2: 893-1098 ; 1915$ pt $2: 559-760 ; 1916$ pt $2: 679-886 \quad(1916-8)$

Northrop, John Isaiah (1861-1891).

90 Notes on the geology of the Bahamas.

N Y Ac Sc, Tr 10:4-22 (1890)

Norton, Edward G.

15 The origin of the Louisiana and east Texas salines (with discussion by G. D. Harris). Am I M Eng, B 97:93-102; 101:1120-1122, map (1915) ; Tr 51:502513 , map (1916)

Norton, Henry $B$.

13 The drifts and other problems. 163 pp, Minneapolis 1913

Norton, R. Henry.

91 Notes on coal mining in Oregon. Am I M Eng, $\operatorname{Tr} 19: 23-28$ (1891)

Norton, S.

10 The iron ores of New York State. Iron Age 85: 382-387 (1910)

Norton, William Harmon.

94 Notes on the lower strata of the Devonian series in Iowa. Iowa Ac Sc, Pr 1 pt $4: 22-24$ (1894)

95 Certain Devonian and Carboniferous outliers in eastern Iowa. Iowa $\mathbf{G} \mathbf{S} \mathbf{3}$ : 115-133 (1895)
Norton. William Harmon-Continued.

95a Thickness of the Paleozoic strata of northeastern Iowa. Iowa G S 3:167210 (1895)

95b Geology of Linn Co. Iowa G S 4: 121-195, map (1895) Abst, J G 3:979 (1895)

95e Occurrence of Megalomus canadensis Hall in the Leclaire beds at Port Byron, Ill. Iowa Ac Sc, Pr 2:42-43 (1895)

$95 d$ Geological section of the Y. M. C. A. artesian well at Cedar Rapids, Iowa. Iowa Ac Sc, Pr 2: 194-196 (1895)

96 Report [administrative]. Iowa $\mathbf{G} \mathbf{S}$ $5: 29-30 \quad(1896) ; \ldots \quad 7: 31 \quad(1897) ; \ldots .10:$ 31-35 (1900) ;... 11:33-34 (1901) ;... 12 : 33-34 (1902) ;... 13:17-19 (1903)

96a Variation in the position of the nodes on the axial segments of pygidium of a species of Encrinurus. Iowa $\mathrm{Ac} \mathrm{Sc}, \mathrm{Pr} 3$ : $79-81$ (1896)

97 Artesian wells of Iowa. Iowa G S 6 : $113-428$ (1897)

98 The artesian wells of Iowa. Iowa Eng Soc, Pr 10:98-101 (1898)

99 Geology of Scott Co. Iowa G S 9 : 389-519, maps (1899)

01 Geology of Cedar Co. Iowa G S 11 : 279-396, maps (1901)

O1a The relation of physical geography to other science subjects. Science $\mathrm{n}$ s 14: $205-210(1901)$

05 The elements of geology. 461 pp, Boston 1905

o5a [Underground waters of] Iowa. U S G S, W-S P 114: 220-225 (1905)

05b Water supplies at Waterloo, Iowa. U S G S, W-S P 145: 148-155 (1905)

o6 Geology of Bremer Co. lowa G S 16 : $319-405$, maps (1906)

11 Glaciated rock surfaces near Linn and near Quarry, Iowa, with a table of bearings of glacial striae in lowa. Iowa Ac Sc, Pr 18: 79-83 (1911)

12 (and others) Underground water resources of Iowa. U S G S, W-S P 293: $994 \mathrm{pp}$, maps (1912) Iowa G S $21: 29$ 1186, maps (1912)

17 A classification of breccias. J G 25 : 160-194 (1917)

Norwoed. Charles Joseph.

73 List of fossils from the Coal Measures of Missouri, collected in 1872. Mo G S, Prel Rp Iron Ores and Coal Fields, 1872 pt $2: 416-420$ (1873)

74 Coal Measures [of Jasper Co.]. Mo G S, Rp 1873-4: 92-96 (1874)

74a Report [on Vernon Co.]. Mo G $\mathbf{S}$, Rp 1873-4:139-154 (1874)

74b Coal Measures [of Howard Co.]. Mo G S, Rp 1873-4: 201-221 (1874)

74e Putnam Co.; Schuyler Co. Mo G S, Rp 1873-4: 272-302 (1874) 
Norwood, Charles Joseph-Continued.

76 Report on the geology of the region adjacent to the Louisville, Paducab, and Southwestern Railroad. Ky G S, Rp Prog 1 n s: $355-448$ (1876)

76a Report of a reconnaissance in the lead region of Livingston, Crittenden, and Caldwell cos. Ky G S, Rp Prog 1 n s : 449-493, map (1876)

77 Report of a reconnaissance on the proposed line of railway from Livingston station to Cumberland Gap. Ky G S, Rp Prog 2 n s : 201-243 (1877)

$7 \mathbf{7 a} A$ reconnaissance report on the lead region of Henry Co., with some notes on Owen and Franklin cos. Ky G S, Rp Prog 2 n s: 245-276 (1877)

7s A report of examinations made along the paths of the north and south running railways in western Kentucky. Ky G S, Rp Prog 4 n s : 285-337 (1878)

78a A report of a reconnaissance of a part of the Breckenridge cannel coal district. Ky G S, Rp Prog 4 n s: $339-364$ (1878); Western Coal Field D: 193-218 (1884)

so A general account of the geology of a part of Ohio Co. Ky G S, Rp Prog 5 n $s: 77-123 \quad(1880)$; Western Coal Field D : 131-177 (1884)

05 Clays in several parts of Kentucky, with seme account of sands, marls, and limestones. Ky G S, B 6:223 pp (1905)

05a Repert on the progress of the survey for the years 1904 and 1905 . Ky G $\mathrm{S}: 56 \mathrm{pp}(1905) \quad \ldots 1906$ and $1907 ; \ldots 88 \mathrm{pp}$ (1908) ...1908 and $1909 ; \ldots 127$ pp (1910) ...1910 and 1911 ; ...38 pp, map (1912)

Norwood, Joseph Granville (1807-1895).

46 (and owen, D. D.) [On a fossil fish, Macropetalichthys rapheidolabris, from southern Indiana.] Boston Soc N H, Pr $2: 102,116$ (1846)

46a (and owen, D. D.) Deseription of a new fossil fish from the Paleozoic rocks of Indiana. Am J Sc (2) $1: 367-371$, Il (1846)

46b (and Owen, D. D.) Description of a remarkable fossil echinoderm, from the limestone formation of St. Louis, Mo. Am J Sc (2) 2:225-228, il (1846)

47 (with Owen, D. D.) Researches among the Protozoic and Carboniferous rocks of central Kentucky made during the summer of 1846.12 pp. il, St Louis 1847 Abst, Am J Sc (2) $5: 268-269$ (1848)

48 Report. In Owen, D. D., ...report of a geological reconnaissance of the Chippewa land district of Wisconsin and the northern part of Iowa (U S, 30th Cong 1st sess, S Ex Doc 57) : 73-129 (1848)

52 Geological report of a survey of portions of Wisconsin and Minnesota... In Owen, D. D., Report of a geological survey of Wisconsin, Iowa, and Minnesota... : 209418, Phila 1852
Norwood, Joseph Granville-Continuat 53 Report of progress of the State logical survey... 13 pp, Springfield 1853

55 (and Pratten, Henry) Notice Producti found in the Western States Territories, with descriptions of twelve species. Ac N Sc Phila, J (2) 3:5-22, (1855)

$55 a$ (and Pratten, Henry) Notice the genus Chonetes, as found in the Wes: ern States and Territories, with descrip tions of eleven new species. Ac $N$ \& Phila, J (2) $3: 23-31$, il (1855)

55b (and Pratten, Henry) Notice of fossils from the Carboniferous series of the Western States, belonging to the genen Spirifer, Bellerophon, Pleurotomaria, Ma rocheilus, Natica, and Loxonema, with it scriptions of eight new characteristic sp cies. Ac N Sc Phila, J (2) 3:71-77, i (1855)

57 Abstract of a report on Illinois coale I11 G S: \&3, v pp, map. Chicago 1857

58 Permian in Illinois [La Salle Co.] Ac Sc St L, Tr 1: 115-116 (1858) Am t Sc (2) 26:129-131 (1858)

66 Report on the Rosiclare lead mins [Hardin Co., 111.]. III G $\mathbf{S} 1: 366-37$ ? (1866) ; Ec G $1: 309-316$ (1882)

74 Abstract of notes on Madison Co, Mo G S, Rp 1873-4 : 371-379 (1874)

See also Hager, 71

Notestein, Frank B.

18 Some chemical experiment: bearint on the origin of certain uranium-vanadiut ores. Ec G 13:50-64 (1918)

Notman, Arthur,

13 Geology of the Bisbee ore deposits [Ariz.]. Inst $\mathrm{M}$ Met, Tr 22:550-56. (1913) M World 38:567-570 (1913) Ens M J 95:557-559 (1913)

Novarese, Vittorio.

Oo Rocks and minerals of South Alasks In Filippi, Filippo de, The ascent of Mount St. Elias, App E : 232-239, Westminstet 1900 .

Noyes, William Albert.

97 Composition of Indiana coals. Ind, Dp G N Res, An Rp 21:97-107 (1897)

Nugent, E.

84 Synchronism of geological formations. Science $3: 33-34$ (1884)

Nugent, Nicholas.

11 Account of the pitch lake of the Island of Trinidad. G Soc London, Tt 1 : 63-76 (1811)

18 Notices of geology in the West In dies. Am J Sc 1: 140-142 (1818)

21 A sketch of the geology of the Island of Antigua. G Soc London, Tr $5: 459-475$ (1821)

Nutt, Rush.

32 On the origin, extension, and con. tinuance of prairies. Am J Sc $23: 40-45$ (1832) 
Nutt, Rush-Continued.

32a Miscellaneous geological topics relating to the lower part of the vale of the Mississippi... Am J Sc 23:49-65 (1832)

Nuttall, Thomas (1786-1859).

21 A journal of travels into the Arkansas Territory during the year $1919 \ldots$ xii, 296 pp, Phila 1821

21a ...geological structure of the Valley of the Mississippi. Ac $N$ Sc Phila, J $2: 14-52$ (1821)

21b Observations on the serpentine rocks of Hoboken in New Jersey and on the minerals which they contain. Am J Sc 4: 16-23 (1821)

22 ...minerals of Patterson and the valley of Sparta in New Jersey. Am J Sc 5: 239-248 (1822) N Y Med Phys J 1 : 194-204 (1822)

Nutter, Edward Hoit.

01 Sketch of the geology of the Salinas Valley, Cal. J G 9:330-336, map (1901)

02 (and Barber, W. B.) On some glaucophane and associated schists in the coast ranges of California. J G 10:738744 (1902)

Nutting, P, G.

11 Isostasy, oceanic precipitation, and the formation of mountain systems. Science $n$ s $34: 453-454$ (1911)

Nye, Harold $B$.

84 Remains of a prehistoric tree [Oswego, Oreg.]. Science $3: 347$ (1884)

Nye, Robert.

00 The Boise, Idaho, Basin mining district. M Sc Press 81:400 (1900)

Nylander, Olof $O$.

01 Shells of the marl deposits of Aroostook Co., Me., as compared with the living forms in the same locality. Nautilus 14: 101-104 (1901)

09 Fossil and living shells found in Little Mud Lake, Westmanland, Aroostook Co. Me. Nautilus 22:105-106 (1909)

Nyst, H.

40 (and Galeotti, H.) Sur quelques fossiles du calcaire jurassique de Tehuacan au Mexique. Ac R Sc Bruxelles, B 7 pt 2 : 212-221, il (1840)

Nystrom, Erik.

08 Peat and lignite, their manufacture and uses in Europe. Can Mines Br: 247 pp (1908)

09 (and Anxep, S. A.) Investigation of the peat bogs and peat industry of Canada during the season 1908-9. Can Mines Br, B 1: 25 pp (1909)

Obalski, Joseph (1852-1915).

90 Mines and minerals of the Province of Quebec. $177 \mathrm{pp}$ [Quebec?] 1889-1890 Also French ed, $175 \mathrm{pp}$

94 Notes on the white mica deposits and mines of the Saguenay region [Que.], Can M Rv 13:7 (1894) Gen M As Que, J $2: 25-28$ [1896]

96 Chromic iron in Quebec. Gen M As Que, J 2:111-115 [1896]
Obalski, Joseph-Continued.

98 Chromic iron in the Province of Quebec, Canada. [Que], Dp Col Mines : $30 \mathrm{pp}$, map [Quebec] 1898

99 Report on the mines of the Province of Quebec for the year 1898. [Que], Dp Col Mines : 57 pp (1899) ... 1899;... 51 pp (1900)

99a Mining in Quebec Province in 1898.

Can M Inst, J $2: 62-65$ (1899)

01 Mining operations in the Province of Quebec during the year 1900. [Que], Dp Col Mines : 37 pp [1901]

01a Notes on the magnetic iron sand of the north shore of the St. Lawrence. Can M Inst, J 4:91-98 (1901) Can M Rv $20: 34-37$ (1901)

02 Mining operations in the Province of Quebec for the year 1901 [Que], Dp Lands, Mines, and Fisheries : $47 \mathrm{pp}$ [1902] $\ldots 1902 ; \ldots: 48$ pp [1903] ... $1903 ; \ldots: 86$ pp [1904] ... 1904;..: $47 \mathrm{pp}, \operatorname{map}(1905)$ ... 1905; [Que], Dp Col, Mines and Fisheries : 43 pp [1906] ... 1906; 59 pp, map (1907) $\quad \ldots \quad 1907 ; \ldots: 61 \mathrm{pp}$, map (1908) .. $1908 ; \ldots: 85$ pp [1909]

04 On a mineral containing "radium" in the Province of Quebec (with discussion). Can M Inst, J 7:245-256 (1905) Can M Rev 23:114-116 (1904) Eng M J $77: 441$ (1904)

05 A new mining district in Quebec. Eng M J $79: 513$ (1905)

06 Chibogomo mining district. Que Dp Col...Mining Operations 1905: 23-36 (1906)

06a Rare earths in pegmatite veins. Can M Inst, J 9:72-73 (1906)

07 New discoveries in northern Quebec. Eng M J 83:559 (1907) Can M J 28 no 4 (n s 1 no 2$): 46$ (1907)

os Gold in the eastern townships of the Province of Quebec. Can M Inst, J 11: 251-255 (1908)

o'Brien, Charles J.

03 Geology of the district west of Red. ding, Cal. M Sc Press 86:349 (1903)

O3a Igneous rocks; how to identify them. M Sc Press 87:50 (1903)

Ochsenias, Carl.

\$2 Geologisches und montanistisches aus Utah. Deut G Ges, Zs $34: 288-372$ (1882)

$\mathbf{8 8}$ On the formation of rock-salt beds and mother liquor salts. Ac N Sc Phila, Pr 1888: 181-187

99 Ueber junge Hebungen in der Hudsonbai. Deut G Ges, Zs 51:571-573 (1899)

oo Natürlicher Koks in den Santa ClaraKohlenfeldern, Sonora, Mexiko. Zs Prak G $8: 21$ (1900)

02 Natronsalpeter in Californien. Zs Prak G $10: 337-339$ (1902)

o'Connell, Marjorie.

13 Distribution and occurrence of the eurypterids. G Soc Am, B 24:499-515 (1913)

14 Revision of the genus Zaphrentis. $\mathrm{N} \mathrm{Y}$ Ac Sc, An 23:177-192 (1914) 
O'Conne11, Marjorie-Continued.

14a Description of some new Siluric gastropods. Buffalo Soc N Sc, B 11:93-101, il (1914)

15 A classification of aqueous habitats (abst). G Soc Am, B 26:159 (1915)

16 The habitat of the Eurypterida. Buffaio Soc Nat Sc, B 11:277 pp, il (1916)

17 Notes on the geology of Oesel in the Gulf of Riga (abst). N Y $\Delta \mathrm{c}$ Sc, An 27 : 273 (1917)

17a (with Grabau, A. W.) Were the graptolits shales, as a rule, deep or shallow water deposits? G Soc Am, B 28:959964, 205-206 (abst) (1917)

18 George Jennings Hinde. Science n s $48: 588-590$ (1918)

See also Chadwick, $17 \mathrm{~b}$; Kemp, 15

Odendall, Leonhard.

09 Die Kupfererzlagerstäten in Nordamerika. Inaug Diss, Univ sonn. $63 \mathrm{pp}$, Köln 1909

Odiura, E.

84 The sand plains and changes of water level of the Upper Ottawa. Ottawa Field Nat Club, $\mathrm{Tr}$ no 5:38-51 (1884) Abst, Science 3:107-108 (1884)

o'Denne11, Gretehen.

13 Bibliograpby of Washington geology and geography. Wash G S, B $12: 63$ pp (1913)

\section{oebbeke, K.}

85 Ueber das Gestein vom Tacoma-Berg. Washington Territory. N Jb 1885, I : 222226

oehlert, D. P.

- Paleontologia universalis. See International Geological Congress, 03

Oestreich, Karl.

15 Die Grande Coulée [Washington]. Am Geog Soc, Memorial Volume of Transcontinental Excursion of 1912:259-273 (1915)

15a Geomorphologische Lcschouwingen van het gebied der Yereenigde Staaten van Noord-Amerika, naar aaleiding van het op de Transcontinentale Excursie van 1912 geziene. Nederlandsch Natuur- en Geneeskundig Congres, XV, Amsterdam 1915, Handl : 499-510 (1915)

ofret, A.

97 El $\mathrm{X}$ congreso geológico internacional en México. Méx, Sec Fomento, B (2) 7, VI : $1-48$ (1907)

Ogilvie, Alan G.

14 I es variations périodiques des glaciers, 1913; Glaciers of the Canadian Rockies and Selkirk Mountains. Zs Gletscherk 9:60-61, (1914)

Ogilvie, Ida Helen.

02 Glacial phenomena in the Adirondacks and Champlain Valley. J G 10 :397412. map (1902)

oza An analcite-bearing camptonite from New Mexico. J G 10:500-507 (1902,
Osilvie, Ida Helen-Continued

04 Geological notes on the vicinity Banfi, Alta, J G 12:408-414, map (1)

04a The effect of superglacial débris the advance and retrea of some Cans glaciers, J G 12: 722-743 (1904,

05 Geology of the Paradox Lake drangle, N. Y. N Y St Mus, B 96: 508, map (1905)

o5n The high-altitude conoplain topographic form illustrated in the Mountains. Am G $36: 27-34$ (190:i)

07 A contribution to the geolog soutbern Maine. N Y Ac Sc, An 17:5 558, map (1907)

os Some igneous rocks from the of Mountains, $\mathrm{N}$ Mex. J G $16: 230$. (1908)

16 Field observations on the lom problem (abst). N Y Ac Sc, An 26:4 433 (1916)

Ogilvie, W. M.

97 Gold mining in the Yukon distr Can M Rv 16:168-170 (1897)

o'Harra, B. M.

16 Black Hills gold-bearing iron-quar tremolite belt. Eng M J 101:770(1916)

o'Harra, Cleophas Cisney.

99 (and Forsyth, A.) Notes on geology and mineral deposits of a pott of the southern Black Hills. S Dak Mines, B [2] : 41 pp. map. (1899)

o0 The geology of Allegany Co. Md 6 Allegany Co: 57-163 (1900)

oon A history of the early explorati and of the progress of geological investle tion in the Black Hills region. S Dals Mines, B 4:7-44, maps (1900)

00b A bibliography of contributions the geology and geography of the Ba Hills region. S Dak Sch Mines, Dp $6, B$ 4:45-88, Rapid City, S. Dak., 1900

o1 Black Hills ore deposits. Int Cong, 4th, Pr : 97-100 (1901)

02 The mineral wealth of the Blad Hills. S Dak G S, B 3: 1-80 (1902) Dak Sch Mines, B 6 (Dp (i) : 88 (1902)

of The geology and mineralogy of t Black Hills region. Am M Cong, 6th, Pt 87-93 (1904) Also in Black Hills, Sobt Dakota: Papers read before the Blad Hills Mining Men's Association... : 119-1? Omaba 1904

05 (with Darton, N. H.) Descriptiol of the Aladdin quadrangle [, fyo.-S. Dak Mont.]. U S G S, G Atlas Aladdin to (no 128): 8 pp, maps (1905)

ө7 (with Darton, N. H.) Description of the Devils-Tower quadrangle [W] U S G S, G Atlas Devils Tower fol (t) 150) : 9 pp (1907)

os The geology of Black Hills cemet material. S Dak Sch Mines, B $8: 9:$ (1963) 
o'Harra, Cleophas Cisney-Continued.

09 (with Darton, N. H.) Description of the Brlle Fourche quadrangle, S. Dak. U S G S, G Atlas Belle Fourche fol (no 164) : $9 \mathrm{pp} \mathrm{(1909)}$

10 The badland formations of the Black Hills region [S. Dak.]. S Dak Sch Mines, Dp G, B 9:152 pp, map (1910)

17 A bibliography of the geology and mining interests of the Black Hills region. S Dak Sch Mines, B $11: 216,7$ pp, map (1917)

18 The geology of petroleum deposits. Pahasapa Q 7 no 2:17-37 (1918)

See also Clark (W B), 00a

ohern, Daniel Webster.

07 Contributions to the paleontology of the Paleodevonian of Maryland. Johns Hopkins Univ Circ, n \& 1907 : 91-93 [679681]

10 The stratigraphy of the older Pennsylvanian rocks of northeastern Oklahoma. 0kla St Univ, Research B 4:40 pp, map (1910) Abst, G Soc Am, B 22:720-721 (1911)

10a (with Geuld, C. N.) Proposed groups of Pennsylvanian rocks of eastern Oklahoma. Okla Univ, Research B 3:15 pp (1910)

12 Director's biennial report to the governor of Oklahoma, 1912 ; mineral production of Oklahoma from 1901 to 1911. Okla G S, B 15: 47 pp (1912)

12a (and Garrett, R. E.) The Ponca City oil and gas field. Okla G S, B 16 : $30 \mathrm{pp}$, maps (1912)

13 Field and office methods in the preparation of geological reports; some suggestions as to field methods. Ec G $8: 376-381$ (1913)

13a Systematic paleontology of the Lower Devonian deposits of Maryland; Crinoidea, Vermes, Md G S, Lower Devonian : 249-259, il (1913)

$13 b$ (and Maynard, T. P.) Systematic paleontology of the Lower Devonian deposits of Maryland; Pelecypoda, Gastropoda, Cephalopoda, Trilobita. Md G S, Lower Devonian : 450-512, il (1913)

18 A contribution to the stratigraphy of the red beds. Am As Petroleum G, B 2 ; 114-117, map (1918)

See also Conkling, 16

\section{Ohio Geologieal Survey.}

09 A geological map of Ohio. J. A. Bownocker, State geologist. Based on preceding maps by Newberry and orton. Richmond-Lorraine boundary by Foerste and Morse; glacial boundary and shove of glacial Lake Erie (Lake Maumee) after Leverett. Scale 8 miles to 1 inch, 1909

\section{Ohio state University.}

99 In memoriam, Edward Orton... pp, port, Columbus [1899?]
Oh1y, Julius.

oo Ozokerite. M Sc Press $81: 8-9$ (1900)

OOa Uranium and its ores. M Se Press $81: 221(1900)$

02 The origin of petroleum. Mines and Minerals $22: 532-533$ (1902)

\section{Olklahoma Geological Survey.}

os The Oklahoma Geological Survey, its origin, scope, and purpose. Circular no. 1. $190812 \mathrm{pp}$, Norman, Okla.

14 Geologic map of eastern Oklahoma. Scale 1 inch $=6$ miles 1914

$14 a$ Structural map of the Cushing oil field. [1914]

olcott, Eben E.

75 The Ore Knob copper mine and reduction works, Ashe Co., N. C. Am I M Eng, $\mathrm{Tr}$ 3 : 391-397 (1875)

87 Battle Mountain mining district, Eagle Co., Colo. Eng M J 43:418, 436-437 (1887)

oleott, Theodore F.

09 A new species of Teleoceras from the Miocene of Nebraska. Am J Sc (4) 28 : $403-404(1909)$

old, R. O.

69 Colorado...its history, geography, and mining... 64 pp, L 1869

72 Colorado...its mineral and other resources. $96 \mathrm{pp}, \mathrm{L} 1872$

Oldham, Riehard Dixon.

os Note on the duration of the first preliminary tremor in the San Francisco and Colombian earthquakes. Brit As, Rp $77: 93$ (1908)

09 The geological interpretation of the earth movements associated with the Californian earthquake of April 18th, 1906. G Soc Lendon, Q J 65:1-16 (1909)

OIdroyd, Ida $\mathrm{S}$.

18 Relationships of recent and fossil invertebrate faunas on the west side of the Isthmus of Panama to those on the east side (abst). G Soc Am, B 29:16? (1918) oldroyd, T. S.

14 A remarkably rich pocket of fossil drift from the Pleistocene; Cal. Nautilus 28: $80-82$ (1914)

16 Mollusean faunas from Deadmans Island (abst), G Soc Am, B $27: 173$ (1916)

\section{Oliphant,' Fideleo Hughes.}

97 Petroleum. U S G S, An Rp 18 pt $5: 747-893 ; 19$ pt 6 con : $1-166 ; 20$ pt 6 con : $1-202 ; 21$ pt 6 con : $1-292$; Min Res 1900 : $537-627 ; 1901: 525-611 ; 1902$ : $535-$ $630 ; 1903$ : $635-718 ; 1904$ : 675-759 (18971905)

97 a Natural gas. U S C S, An Rp 18 pt 5: $895-918 ; 19$ pt 6 con : $167-204 ; 20$ pt 6 con : $203-224 ; 21$ pt 6 con : 293-318; Min Res $1900 ; 629-651 ; 1901 ; 613-632 ; 1902$; $631-655 ; 1903: 719-743 ; 1904 ; 761-788$ (1897-1905)

Olmsted, Denison (1791-1859).

20 Red sandstone formation of North Carolina. Am J Sc 2:175-17 ${ }^{\wedge}$ (1820) 
Olmsted, Denison-Continued.

22 Descriptive catalogue of rocks and minerals collected in North Carolina. Am J Sc $-257-264$ (1822)

24 Report on the geology of North Carolina, conducted under the direction of the Board of Agriculture, Part I. 44 pp, 1824 Abst, Am J Sc 14:230-251 (1828); (2) 19:430-433 (1855)

25 On the gold mines of North Carolina. Am J Se 9: 5-15 (1825)

27 Report on the geology of North Carolina, Part II. [N C] Bd Agr, no $2: 85-$ 142, Raleigh 1827 Notice, Am J Sc 14 : 230-251 (1828)

57 Biographical memoir of William C. Redfield. Can Nat 2:426-446, port (1857)

olshausen, Theodor.

53 Das Miss'ssippi-T" a! und die einzelnen Staaten des Mississippi-Thals geographisch und statistisch beschrieben. 2 vols, 426, $201 \mathrm{pp}$, Kiel 1853

olsson, Axel.

12 Description of a new genus and species of Palrechinoldea [Lepidechinoides ithacensis, Devonian, Ithaca, N. Y.]. Am J Sc (4) $33: 442-446$, il (1912)

12a New and interesting fossils from the Devonian of New York. B Am Pal 5 no 23: $7 \mathrm{pp}$, il (1912)

14 New and interesting Neocene fossils from the Atlantic Coastal Plain. B Am Pal no $24: 24 \mathrm{pp}$, il (1914)

$14 a$ Notes on Miocene correlation. Nautilus $27: 101-103$ (1914)

16 New Miocene fossils [North Carolina and Virginia]. B Am Pal no $27: 32 \mathrm{pp}$, il (1916)

17 The Murfreesboro stage of our east coast Miocene. B Am Pal no 28:11 pp (vol 5: 155-163) (1917)

olsson-Seffer, Pehr.

03 Examination of organic remains in postglacial deposits. Am Nat $37: 785-797$ (1903)

os Relation of wind to topography of coastal drift sands. J G 16:549-564 (1908)

10 Genesis and development of sand formations on marine coasts. Augustana Libr Pub $7: 5-41$ (1910)

Omori, Fusakichi.

06 Note on the San Francisco earthquake of April 18, 1906. [Japan] Earthquake Investigation Com, Publications in Foreign Languages no 21, App 2:3 pp (1906)

O6n On the great earthquake of April 18th, 1906. of San Francisco. J Geog (pub by Tokyo Geog Soc) 18:764-777 (1906) [In Japanese]

06b Observations of distant earthquakes. Astron Soc Pacific, Pub 18: 193-203 (1906) M Sc Press 92:397-398 (1906) Reprinted in After earthquake and fire: 138-147. San Francisco 1906
Omori, Fusakichi-Continued.

o6e On seismic motion and some of tions of earthquakes to other phenome Astron Soc Pacific, Pub 18:235-: (1906)

or On the estimation of the time of currence at the origin of a distant ear quake from the duration of the first liminary tremor observed at any ple Imp Earthquake Investigation Com, B 1-4 (1907)

07a Preliminary note on the cause the San Francisco earthquake of April 1906. Imp Earthquake Investigation Ca B 1:7-25 (1907) Reprinted in Jorde D. S., editor, The California earthquaker 1906: 281-318, San Francisco 1907

o7b Preliminary note on the seist graphic observations of the San Francis earthquake of April 18, 1906. Imp Eath quake Investigation Com, B $1: 26-5$ (1907)

07e Note on the transit velocities of t: Guatemala earthquake of April 19, 196 Imp Earthquake Investigation Com, B 44-46 (1907)

o7d Comparison of the faults in three earthquakes of Mino-Owari, Formo and San Francisco. Imp Eerthquake vestigation Com, B 1:70-72 (1907)

o'Neal. Frank E.

14 The Smoky River coal field [Alti] Coll Eng 34:346-347 (1914)

14a Coal flelds of Tasper Park, Ail Coll Eng $34: 399-402$ (1914)

O'Nenl, John S.

98 Phosphate rock in the South. As South, Tr 9:51-61 (1898)

O'Neill, John Johnston.

12 Beloeil and Rougemont mountats Que. Can G S, Sum Rp 1911:293-3 (1912)

14 St. Hilaire (Beloeil) and Rougettr mountains, Que. Can G S, Mem 13:1 pp, map (1914)

15 Canadian Arctic expedition, 19!! geological reconnaissance of the Art coast between Demarcation Point, and Mackenzie River; with a section inland the Firth River, Mackenzie district. G S, Sum Rp 1914: 112-115 (1915)

16 Geological reports, Canadian Are expedition, 1915. Can G S, Sum Rp 1919 $236-241$ (1916) ; 1916:331-334 (1917)

17 Notes on the occurrence of nat copper in Arctic Canada. Can M is B $59: 180-186$ (1917)

18 Economic geology of the Haxelti district, B. C. Can G S, Sum Rp 18 pt B : 9-12 (1918)

\section{Ontario, Royal Commission.}

90 Report of the Royal Commission the mineral resources of Ontario... pp, map, Torunto 1890 
Orahood, C. H.

16 Fountain County soil report. Ind, Dp G Nat Res, An Rp 40:200-209, map (1916)

Orbigny, Alcide d'.

39 Foraminifères. xlviii, $224 \mathrm{pp}$, il, Paris 1839. In Sagra, Ramón de la, Histoire physique, politique et naturelle de l'ile de Cuba.

49 Prodrome de paleontologie... 3 vols, Paris 1849-1852

55 [Fossils of Cuba; pls. without text.] In Sagra, Ramón de la, Histoire physique, politique et naturelle de l'ile de Cuba $t 8$ (Atlas de zoología) Paris 1855

Oreutt, Charles Russell.

87 Minerals and mines of San Diego [Co., Cal.]. West Am Sc 3:69-72 (1887) 89 The gold fields of Lower California. West Am Se 6 (no 42) : 4-5 (1889)

89a Some notes on Tertiary fossils of Californla. West Am Sc 6:70-71 (1889)

s9b Some notes on Tertiary fossils of California. West Am Sc 6:84-87 (1889)

90 The Colorado Desert. Cal St M Bur, An Rp 10:899-919 (1890)

98 Note on the occurrence of tourmalines in California (abst). Am As, $\operatorname{Pr~} 47$ : 306 (1898) Am G 22:265 (1898) Science n s $8: 505$ (1898)

0rdoñex, Ezequiel.

90 Los hierros meteóricos de México. Soc Cient Ant Alz, Mem 3: 305-309 (1890) Ciel et Terre 11:473-477 (1890)

91 El Pedregal de San Ángel; apuntes para la petrografía del México. Soc Cient Ant Alz, Mem 4:113-116 (1891) La Naturaleza (2) $1: 502-504$ (1891)

91a Apuntas para el estudio de las formaciones sedimentarias del valle de México ; las tobas calizas. Soc Cient Ant Alz, Mem 4: 239-242 (1891)

92 Una ascensión al Pico de Teira. Soc Cient Ant Alz, Mem 5:105-112 (1892)

92a Algunas obsidianas de México. Soc Cient Ant Alz, Mem 6:33-45 (1892)

93 La roca de calendario azteca. Soc Clent Ant Alz, Mem 6:327-332 (1893) La Naturaleza (2) 2:301-303 (1893)

93a (with Aguilera, J. G.) Datos para la geología de México. $87 \mathrm{pp}$, Tacubaya, D. F., Mexico, 1893. Reprint of Méx I G, B 4-6: 192-270 (1897)

94 Notas acerca de los ventisqueros del Ixtaccihuatl. Soc Cient Ant Alz, Mem 8: 31-42 (1894)

94a Un fragmento de roca granítica encontrado en el volcán Ceboruco [Méx.]. La Naturaleza (2) 2:418-421 (1894)

94b Reseña sobre la geologfa del Mezquital del Oro, Distrito de Juehipila, Estado de Zacatecas. Bol Agr Min é Ind 3 no $10: 189-206$ (1894)

94e Informe del mineral del Zopilote [Territorio de Tepic]. Bol Agr Min é Ind 3 no $11: 166-182$ (1894)
Ord6ñez, Ezequiel-Continued.

94d (with Aguilera, José G.) Breve explicación del bosquejo geologico de la República Mexicana. La Naturaleza (2) 2 : $385-389$, map (1894)

95 Las rocas eruptivas del suroeste de la Cuenca de México. Méx I G, B 2: 46 pp (1895)

95a Observaciones relativas a los volcanes de México. Soc Cient Ant $\mathrm{Alz}$, Mem 8: 183-196 (1895)

95b Notas acerca de la investigación de las aguas subterráneas. Asoc Ing y Arq, An 4:309-334 (1895) [not seen]

95e (with Aguilera, J. G.) Expedición científica al Popocatepetl. Comisión geológica mexicana: $48 \mathrm{pp}$, map, Mexico 1895

96 Memoir of Antonio del Castillo. Soc Am, B $7: 486-488$ (1896)

97 Itinerarios geológicos. Méx I G, B $4-6: 30-77$ (1897)

97a Rocas eruptivas. Méx I G, B 4-6: 251-270 (1897)

97b Descripción de las rocas [del mineral de Pachuca]. Méx I G, B 7-9:99-124 (1897)

97e Las rocas del mineral de San José de Gracia, distrito de Sinaloa, Sinaloa. Soc Cient Ant Alz, Mem 10: 89-93 (1897)

97d (with Aguilera, J. G.) Las fumarolas de Popecatepetl. Soc Cient Ant Alz, Mem 10:185-188 (1897)

9s Note sur les gisements d'or du Mexique. Soc Cient Ant Alz, Mem 11:217240 (1898)

9Sa Les volcans Colima et Ceboruco. Soc Cient Ant Alz, Mem 11: 325-333 (1898)

98b Breve reseña de las excursiones verlficadas durante el $7^{*}$ Congreso geológico internacional. Soc Cient Ant Alz, Mem 11: $81-87$ (1898)

98c Les filons argentifères de Pachuca, Mexique. Soc G France, B (3) 26:244258 (1898)

99 (and Rangel, M.) El Real del Monte [Hidalgo]. Mex I G, B 12:105 pp (1899)

99a Rocas eruptivas [de Orizaba]. Méx I $G$, B $13: 51-52(1899)$

996 (and Bäse, E.) Apuntes para la geología del valle de Chilpancingo [Guerrero, Mexico]. Soc Cient Ant Alz, Mem $14: 5-12$ (1899)

00 Un voyage a la "Sierra Madre del Sur." Soc Clent Ant Alz, Mem 14:162$173(1900)$

oon Las rhyolitas de México. Méx I G, B $14: 75$ pp, map (1900); 15:76 pp (1901)

oob Les volcans du valle de Santiago. Soc Cient Ant Alz, Mem 14: 299-326 (1900) La Naturaleza (2) $3: 388-403$ (1900)

01 The mining district of Pachuca, Mexico. Eng M J 72:719-721 (1901) Am I M Eng, Tr $32: 224-241$ (1902) 
Ord6п̃ez, Ezequiel-Continued.

01 a The onyx marble deposits of Jimul. co, Coahuila. Soc Cient Ant Alz, Mem 15 : $381-385$ (1901)

01b La industria minera en México. Asoe Ing Arq, An 9:227-238 (1901) [not seen]

02 Le Xinantecatl ou volean Nevado de Toluca [México]. Soc Cient Ant Alz, Mem 18: 83-112 (1902)

02a El sahcab de Yucatán. Soc Cient Ant Alz, Mem 18: 217-223 (1902)

02b Los voleanes de Zacacu, Michoacán [México]. Soc Cient Ant Alz, Mem 18: $257-265$ (1902)

0:2e Les cendres d'un volcan près du Santa Maria, Guatemala. Soc Cient Ant Alz, Mem 18: Rev 33-36 (1902)

03 Les demières éruptions du volcan de Colima [México]. Soc Cient Ant Alz, Mem 20:99-104 (1903)

04 El mineral de Angangueo, Michoacán. Méx I G, Par 1: 59-74, map (1904)

04a Las aguas subterráneas de Amozoc [Puebla]. Méx I G, Par 1: 117-120 (1904)

04b Las cenizas del voleán de Santa María. Mex I G, Par 1: 229-234 (1904)

05 Deseripcion de las rocas [de los Estados de Chiapas y Tabasco]. Méx I G, B 20:101-113 (1905)

05a Los crateres de Xico [México]. Soc G Mex, B $1: 19-24$ (1905)

05b Las barrancas de las Minas y de Tatatila, E. de Veracruz [México]. Soc G Mex, B 1: 119-133 (1905)

O5e El Nauhcampatepet1 6 Cofre de Perote [México]. Soc G Mex, B 1: 151-168 (1905)

05d Los Xalapazcos del Estado de Puebla. Mex I G, Par 1:293-344, map (1905) ; 349-393, map (1906)

o5e Sobre algunos ejemplos probables de tubos de ernpción. Soc Cient Ant Alz, Mem 22 : 141-150 (1905)

o5f Las rocas arcaicas de México. Soc Cient Ant Alz, Mem $22: 315-331$ (1905-6)

05g El mineral de Angangueo [Michoacán]. [Méx], Sec Fom (2) 4 (II) : 550564 (1905) Soc Michoacan Geog, B 1 : $136,143-144,146-148$ (1905) [not seen]

o5h Los criaderos de mármol-ónix de la hacienda de Jimulco [Coahulla]. [Méx], Sec Fom, B (2) 5 (II) : 164-174 (1905)

osi (with Lazo, A. M.) Las canteras de San Lorenzo Totolinga y Echagary [México]. Soe G Mex, B 1:25-34 (1905)

05j Geología de México. In Southworth, J. R., Las minas de México..., vol. 9: 15-26, Mexico (printed in Liverpool), 1905

06 (with Roel, F.) Análisis químico de la chiluca y de la cantera. Soc G Mex, B 2: 47-50 (1906)

Ofá Excursion de México a Jalapa [México]. Int G Cong, X, Mexico, Guide Exc no I: 11 pp (1906)
Ordбnеz, Ezequiel-Continued.

06b Excursion de Esperanza a Jift Int $\mathrm{G}$ Cong, $\mathbf{X}$, Mexico, Guide Exc no: 2 pp (1906)

o6e L'archaĭque du Cañon de Tom Int $\mathrm{G}$ Cong, $\mathrm{X}$, Mexico, Guide Exc $\mathrm{w}^{\mathrm{C}}$ 30 pp (1906)

06a Excursion de México à Patzcuan Uruapam. Int $G$ Cong, $X$, Mexico, $G$ Exc no VIII : 18 pp (1906)

o6e Le Jorullo. Int G Cong, $\mathrm{X}$, Mer Guide Exc no XI : 55 pp (1906)

06f Les eratères d'explosion de Valle Santiago [México]. Int G Cong, X, Jeri Guide Exc no XIV : 8 pp (1906)

o7 Oil in the State of Vera Cruz. I Press 95: 247-248 (1907)

os El Valle de Cerritos, Estado des Luis Potosi. Mex I G, Par 2:263(1908)

osa Coal in Cóahuila [Mexico]. y Press 96: 363-364 (1908)

osb Hostotipaquillo and the Lerma $B^{-}$ [State of Jalisco, Mexico]. M Sc Press? $705-708$ (1908) Can M J $29: 662 a-6$ (1908)

ose A brief review of the mining lot try of Mexico. Ec G 3:677-687 (1908) 09 Physical and geological feature Mexico mining. M World 31:15 (190)

O9a Le Metlacueyatl, Mexique. An 6 18: 356-361 (1909)

10 Les gisements de fer du Merin Int $\mathbf{G}$ Cong, XI, Stockholm, 1910, iron-ore resources of the world $2: 781$ (1910)

$10 n$ Occurrence and prospects of ol Mexico. Eng M J 89:1020 (1910)

10b Iron resources of the Republic Mexico. Eng M J 90:665-667 (1910)

10e El pico de Tancitaro, Michorh Soc Cient Ant Alz, Mem 30:11-17 (I5)

12 The recent Guadalajara earthgus Seism Soc Am, B 2:134-137 (1912)

$12 a$ Los temblores recientes de $G 08$ lajara. Soc Cient Ant Alz, Mem 32: 272 (1912)

13 The Magistral district, Jalisco, ico. Eng M J 96: 491-492 (1913)

14 The oil fields of Mexico (with cussion by D. T. Day, P. W. Henry, I. C. White), Am I M Eng, B 94: 25 2535 (1914) ; 100:817-818 (1915) $50: 859-869$ (1915) M World $41: 9$ 1000 (1914)

16 Las aguas subterráneas en las mils de Pachuca $y$ Real del Monte [Mério Soc Cient Ant Alz, Mem 34: 65-73 (1

16a A short note on the oil flelds Mexico. Soc Cient Ant Alz, Mem 34:18 127 (1916)

16b El distrito minero de Hostotipagl $y$ - el Río de Lerma 6 de Santiago fJatis México]. Bol Minero 2: 497-501 (1916) 
Ord6ñez, Ezequiel Continued.

1s Oil in southern Tamaulipas, Mexico, Am I M Eng, B 137: 1001-1008 (1918); discussion by V. R. Garfias and E. De Golyer, $142: 1560-1564$ (1918)

See also Aguilera, 97

Ordway, Albert.

61 On the supposed identity of the Paradoxides harlani Green with the Paradoxides spinosus Boeck. Boston Soc N H, Pr $8: 1-5$, il (1861)

61a On the occurrence of other fossil forms at Braintree, Mass. Boston Soc N H, Pr 8:5-6 (1861)

oregon, Bureau of Mines and Geology.

15 [First biennial] report of the commission. $23 \mathrm{pp}$ [1915]

15a Minerals and mineral industries of Oregon. Panama-Pacific ed: 40 pp, maps (1915)

Oregon, University of.

07 In memory of Thomas Condon, Professor of Geology, 1876-1906. Oreg Univ, B n s 4 no 8:64 pp, port (1907)

o'Reilly, J. P.

86 The late American earthquake [Charleston] and its limits. Nature 34: $570-571$ (1886)

Ormiston, James,

93 Notes of a visit to Vancouver Island and its coal fields. M Inst Scotland. $\mathrm{Tr}$ 14: $150-160$, map (1893) Abst, Eng M J $55: 293$ (1893)

Orr, Ellison.

88 Brown hematite in Allamakee Co., Iowa. Am G 1:129-130 (1888)

07 Exposures of Iowan and Kansan (?) drift, east of the usually accepted west boundary line of the Driftless Area. Iowa Ac Sc, Pr $14: 231-236$ (1907)

Orr, William.

01 An outline of eight excursions for the study of the physical geograpby and geology of Springfield, [Mass.] and vicinity. Published for the Springfield Geological Club by the City Library Association. $16 \mathrm{pp}$, Springfield, Mass, 1901

Ortegay, Ros Pablo.

18 El petróleo en Cuba. Soc Cubana Ing, Rv 10:700-715 (1918) Petroleum in Cuba. Cuba Review 16 no $11: 17-23$ (1918)

See also Hayes, 01

Ortmann, Arnold E.

96 An examination of the arguments given by Neumayr for the existence of climatic zones in Jurassic times. Am J Sc (4) $1: 257-270 \quad(1896)$

$96 \mathbf{a}$ On separation and its bearing on geology and zoogeography. Am J Sc (4) 2:63-69 (1896)

97 The systematic position of Crangopsis vermiformis (Meek) from the sub-Carbonil'erous rocks of Kentucky. Am J Sc (4) 4: 283-289 (1897)
Ortmann, Arnold E.-Continued.

$97 a$ On a new species of the palinurid genus Linuparus found in the Upper Cretaceous of Dakota. Am J Sc (4) 4:290296 (1897)

01 Ueber die Decapoden-Gattungen Linuparus und Podocrates. Centralbl Miner $1901: 713-714$

o2 The geographical distribution of freshwater decapods and its bearing upon ancient geography. Am Ph Soc, $\mathrm{Pr}$ 41:267-400 (1902)

12 The geological origin of the freshwater fauna of Pennsylvania. Pa Top G S, Rp 1910-12: 135-149 (1912)

See also Roberts, 16

Orton, Edward (1829-1899).

70 On the occurrence of a peat bed beneath deposits of drift in southwestern Ohio. Am J Sc (2) 50:54-57, 293 (1870) Ohio G S, Rp Prog 1869:165-167 (1871)

71 Report on geology of Montgomery Co. Ohio G S [Rp Prog 1869], pt 3: 143-171, map (1871)

71 a The geology of Highland Co. Ohio G S, Rp Prog 1870:253-310, map (1871)

71b Geological structure of Ohio. In Ohio, Secretary of State, An Rp 1870: 194-200, Columbus 1871

73 Report on the third geological district; geology of the Cincinnati group; Hamilton, Clermont, Clarke cos. Ohio G S, Rp 1 pt 1 Geology: $365-480$, maps (1873)

$\boldsymbol{7 3 a}$ The water supply of southwestern Ohio as connected with its geological structure. In Ohio, Secretary of State, An Rp 1872, 2d ed : 204-213, Columbus 1873

74 Report on third district; geology of Pike Co. ; Ross Co. ; Greene Co. Ohio G S, Rp 2 pt 1 Geology : 611-696, maps (1874)

7s Report on the geology of Warren Co.; Butler Co.; Preble Co.: Madison Co. Ohio G S, Rp 3 pt $1: 381-428$, maps (1878)

7Sa Report on the geology of Franklin Co. Ohio G S, Rp 3 pt 1:596-646, map (1878)

78b Supplemental report on the geology of the Hanging Rock district. Ohio G S, Rp 3 pt 1:883-941 (1878)

79 The Berea sandstone of Ohio. Ohio, Secretary of State, An Rp 1878:591-599 (1879)

79a Note on the Waverly strata of Ohio. Am J Sc (3) 18:138-139 (1879)

so Review of stratigraphical geology of eastern Ohio. Ohio, Secretary of State, An Rp 1879:589-623, map (reprint $33 \mathrm{pp,}$ map) (1880)

82 Source of bituminous matter in the Devonian and Subcarboniferous black shales of Ohio. Am J Sc (3) 24:171-174 (1882)

S2a The Berea grit of Ohio. Am As, Pr $30: 167-174$ (1882) 
Orton, Edward-Continued.

82b The Great Kanawha coal fields. The Virginias $3: 6$ (1882) [From Ohio State Journal]

82e The growth and order of the lower Coal Measures. Ohio M J 1 no $1: 16-25$ (1882) [not seen]

s3 A source of the bituminous matter of the black shales of Ohio. Am As, Pr $31: 373-384$ (1883)

83a The lower Coal Measures of Ohio. Ohio M J 1: 97-108 (1883) [not seen]

83b The Ohio coal field. Ohio M J 2: 43-46 (1883)

84 The stratigraphical order of the lower Coal Measures of Ohio. Ohio G S, Rp 5:1-128 (1884)

84a The coal seams of the lower Coal Measures of Ohio. Ohio G S, Rp $5: 129$ $300,773-815,843-1058$ (1884)

$\mathbf{8 4 b}$ The iron ores of Ohio considered with reference to their geological order and geographical distribution. Obio $G \mathrm{~S}$, Rp $5: 371-435$ (1884)

84e Building stones of Ohio. Ohio G S, Rp 5:577-642 (1884) U S, 10th Census 10, Report on Building Stones:188-215 (1884)

84d The clays of Ohio ... Ohio G S, Rp 5: 643-721 (1884)

84e The Bedford cannel coal [Ohio]. Ohio M J $2: 80-86$ (1884) Eng M J 37 : 175-176 (1884)

84f The iron ores of Ohio. Ohio M J 2 : 105-113 (1884)

84g The gas wells of Ohio. Ohio M J 2:185-193 (1884)

84 The constitution of Ohio coals. Ohio M J 2: 200-206 (1884)

84i The Massillon coal field. Ohio M J $3: 32-38$ (1884)

84j The horizons of petroleum and inflammable gas in Ohio (abst). Am As, Pr 33: $397-398$ (1885) Science 4:325-326 (1884)

84k The correlation of the lower Coal Measures of Ohio and eastern Kentucky (abst). Am As, Pr 33:398-399 (1885) Science 4:325 (1884)

S5 The natural gas wells of northwestern Ohio. Science 5: 474 (1885)

85a Problems in the study of coal, with a sketch of recent progress in geology. Am As, $\operatorname{Pr} 34: 173-197$ (1886). Abst, Science B : $217-219$ (1885)

86 Preliminary report upon petroleum and inflammable gas. Ohio $\mathrm{G}$ S: $76 \mathrm{pp}$, map, Columbus, O., 1886. Reprinted for the author, with a supplement: $200 \mathrm{pp}$, map, Columbus, O., 1887

86a Characteristics of Ohio coals. U S, 10th Census 15:619-622 (1886)

86b Petroleum and natural gas as found in Ohio. Science $7: 560-564$, map (1886)
Orton, Edward-Continued.

86e The recently discovered soures natural gas and petroleum in northwest Ohio (abst). Am As, Pr 34:202. (1886) Science $6: 220 \cdot(1885)$

$\mathbf{8 6 d}$ The record of the deep well of: Cleveland Rolling Mill Company, Cleveln Ohio (abst). Am As, Pr $34: 220-4$ (1886)

87 The Trenton rock and gas sup Ohio M J 5 : 85-89 (1887)

$\mathbf{8 7 a}$ Natural gas in Ohio in 1887 . Manufacturer, Nat Gas Suppl no $2: 21$, $t$ 30 (1887)

88 The geology of Ohio considered in: relations to petroleum and natural of Ohio G S, Rp 6:1-59 (1888)

88a The origin and accumulation petroleum and natural gas. Ohio G \& : 6 : $60-100$ (1888)

88b The Trenton limestone as a $50 \mathrm{~m}$ of oil and gas in Ohio. Ohio G S, Rp 101-310 (1888)

88e The Berea grit as a source of and gas in Ohio. Ohio G S, Rp $6: 311$ map (1888)

88d The Ohio shale as a source of and gas in Ohio. Ohio G S, Rp 6:4l 442 (1888)

88e Gypsum or land plaster in $\mathrm{OH}^{\mathrm{H}}$ Ohio G S, Rp 6: 696-702 (1888)

88f The production of lime in 0 th Ohio G S, Rp 6: 703-771 (1888)

SSg The drift deposits of Ohio. G S, Rp 6: 772-782 (1888)

8Sh Supplemental report on the gas fields and oil fields of Ohio. Ohio $\theta$ ? 6 : 783-792 (1888)

$88 i$ Geological map of Ohio. Scale, miles to 1 inch. Accompanies Ohio 6 i Rp 6 (1888)

8Sj Map of the oil and gas fields Allen, Auglaize, and Mercer $\cos$, 180 Scale, 2 miles to 1 inch. Accompani Ohio G S, Rp 6 (1888) Also in First 1 Rp (1890)

88k Map of the ofl and gas fields Hancock and Wood cos. Scale, 2 miles 1 inch. Accompanies Ohio G S, Rp (1888) Also in First An Rp (1890)

881 Gypsum or land plaster in 0 bi U S G S, Min Res 1887:596-600 (1800 $88 \mathrm{~m}$ The condition of oil and gas pt duction in northern Ohio and Indias Ohio M J $6: 29-32$ (1888)

8Sn The Trenton limestone as an formation. Am G 1:133 (1888)

89 The Trenton limestone as a source petroleum and inflammable gas in Ohlo 2 Indiana. U S G S, An Rp 8:475-662, 마 (1889)

89a Review of the westward extenst of the Hocking Valley coal field. Ot M J no 18:7-20 (1889)

89b Natural gas. Ohio $\mathbf{M}$ J no $18: 2$ 30 (1889) [not seen] 
orton, Edward-Continued.

89e The discovery of sporocarps in the Ohio shale (abst). Am As, $\operatorname{Pr} 37: 179$ 181 (1889)

s9d The new horizons of oil and gas in the Mississippi Valley (abst). Am As, Pr $37: 181-182$ (1889)

90 First aunual report of the Geological Survey of Ohio (Third organization). x, 323 pp, maps, Columbus, O., 1890

90a Origin of the rock pressure of natural gas in the Trenton limestone of Obio and Indiana (with discussion by White, I. C., and others). G Soc Am, B 1: 87-97 (1890) Smiths Inst, An Rp 1891: 155-162 (1893) Abst, Science 15:10 (1890) ; Am G $5: 119$ (1890)

90b Leo Lesquereux [1806-1889]. Am G 5:284-296, port. (1890)

$90 \mathrm{e}$ On the origin of the rock pressure of the natural gas of the Trenton limestene of Ohio and Indiana. Am J Sc (3) 39 : 225-229 (1890)

$90 d$ On the origin of the rock pressure of natural gas in the Trenton limestone of Ohio and Indiana. Ohio M J no $19: 32-40$ (1890)

90e The geography and geology of Ohlo [preceded by a biography of the author]. In Howe, Henry, Historical collections of Ohio 1: $59-89$, Columbus 1890

91 Report on the occurrence of petroleum, natural gas, and asphalt rock in western Kentucky... Ky G S : 233 pp, maps [1891]

91a On the occurrence of Megalonyx jeffersoni in central Ohio (abst). G Soc Am, B $2: 635$ (1891)

92 On the occurrence of a quartz boulder in the Sharon coal of northeastern Ohio. Am J Sc (3) 44:62-63 (1892)

93 Preface [historical, administrative, etc.]. Ohio G S, Rp $7: v-x v i$ (1893)

93a Geological scale and geological structure of Ohio. Ohío G S, Rp $7: 3-44$, map (1893)

931 The clays of Ohio, their origin, composition, and varieties. Ohio G S, Rp 7 : 45-68 (1893)

93e The coal fields of Ohio, Ohio $\mathrm{G} \mathrm{S}$, Rp 7: 255-290 (1893)

93a Coal fields of Ohio. Maps showing outcrop boundaries of principal coal seams, Seale, maps 1-9, 2 miles to 1 inch; map 10, 10 miles to 1 inch. Accompany Ohio G S, Rp 7 (1893)

94 Geological surveys of Ohio. J G 2: 502-516 (1894)

94a The stored power of the world. Ohio M J no 21: 102-121 (1894)

96 [Blographical sketch of Prof. J. S Newberry.] Ohio M J no 22:12-18, port (1896)

96a An approximate determination of the coal resources [of Ohio] based on the recent maps of the geological survey. Ohio M J no 23: 96-118 (1896)
Orton, Edward-Continued.

98 Geological probabilities as to petroleum. G Soc Am, B 9:85-100 (1898)

98a What geology owes to the miner of eoal. Ohio M J no 25:82-90 (1898)

99 The rock waters of Ohio. U S G S, An Rp 19 pt 4:633-717 (1899)

99a Petroleum and natural gas in New York. N Y St Mus, B $30: 395-526$, map (1899)

99b Geological structure of the Iola gas field [Allen Co., Kans.]. G Soc Am, B 10:99-106 (1899) Abst, Am G 23:101102 (1899); Science n s 9:138-139 (1899); Ottawa Nat $12: 197$ (1899)

See also Emmons (S F), 93; Hawes, 84 Orton, Edward, jr.

93 The clay-working industries of Ohio. Ohio G S, Rp $7: 69-254$ (1893)

01 The classification and nomenclature of the silicates. Am Ceramic Soc, $\operatorname{Tr} 3$ : $65-81$ (1901)

03 The organization and work of the Geological Survey of Ohio. Ohio G S (4) B 1: $\mathrm{i}-\mathrm{xxi}$ (1903)

04 (and Peppel, S. V.) The lime resources of Ohio available for Portland cement manufacture. Ohio G S (4) B 3: 88-101 (1904)

06 (and Peppel, S. V.) The limestone resources and the lime industry in ohio. Ohio G S (4) B 4:365 pp (1906)

07 The kaolin deposits of Bollinger Co., Mo. Am Ceramic Soc, Tr 9:62-94 (1907)

09 The Mills moraine, with some general remarks, on the glaciation of the Longs Peak region of Colorado (abst). Science n 8 29:751-752 (1909)

osann, Carl Alfred.

92 Ueber ein Mineral der Nosean-HauynGruppe im Eläolithsyenit von Montreal. N Jb 1892 , I : 222-224

93 Report on the rocks of trans-Pecos Texas. Tex G S, An Rp 4 pt 1:121-138 (1893)

93a Melilite-nepheline basalt and nepheline-basanite from southern Texas. J G 1 : 341-346 (1893)

$93 b$ (with Andrene, A.) Tiefencontacte an den intrusiven Diabasen von New Jersey. Naturh-med Ver Heidelberg, Verh (N F) $5: 16-27$ (1893) $R v$, N Jb 1893, I : 505

96 Beiträge zur Geologie und Petrographie der Apache (Davis) Mts., west Texas. Tschermak's Mitt N F 15:394456 (1896)

02 Notes on certain Archean rocks of the Ottawa Valley. Can G S, An Rp 12: o 84 pp (1902)

osbon, Clarence $\mathrm{C}$.

18 Peat in 1917. U S G S, Min Res 1917 pt $2: 257-283$, map (1918)

osborn, A.

58 Field notes of geology. $82 \mathrm{pp}, \mathrm{N} \mathbf{Y}$ 1858 
Osborn, Henry Fairfield.

78 (and others) Paleontological report of the Princeton scientific expedition of 1877 [Eocene, Bridger Basin, Wyo.]. Princeton Coll, [E. M.] Mus G, Contr [B] 1: $146 \mathrm{pp}$, il (1878)

79 The lower jaw of Loxolophodon. Am J Sc (3) $17: 304-309$, il (1879)

81 A memoir upon Lexolophodon and Uintatherium... E. M. Mus C (Coll N J) Contr 1: 1-44 (1881)

82 (with Seott, W. B.) Orthocynodon, an animal related to the rhinoceros, from the Bridger Eocene. Am J Sc (3) 24: 223-225 (1882) An Mag $\mathrm{N} H$ (5) 10 : $332-334$ (1882)

83 Achaenodon. an Eocene bunodont. Princeton Coll, E. M. Mus G, Contr, B no $3: 23-35$, il (1883)

S3a (with scott, W. B.) On the skull of the Eocene rhinoceros, Orthocynodon, and the relation of this genus to other members of the group. Princeton Coll, E. M. Mus G, Contr, B no $3: 1-22$, il (1883)

84 (with scott, W. B.) On the origin and development of the rhinoceros group (abst). Brit As, Rp $53: 528$ (1884)

86 A new mammal from the American Triassic. [Microconodon tenuirostris]. Science 8:540, il (1886)

s7 Observations upon the upper Triassic mammals, Dromatherium and Microconodon. Ac N Sc Phila, Pr 1886: 359-363, il (1887)

87a On the structure and classification of the Mesozoic Mammalia (abst). Ac N Sc Phila, Pr 1887: 282-292, il

87b The Triassic mammals, Dromatherium and Microconodon. $\mathrm{Am} \mathrm{Ph}$ Soe, Pr 24:109-111, il (1887)

s7e Note upon the genus Athrodon. Am Nat 21: 1020 (1887)

s7d A pineal eye in the Mesozoic Mammalia. Science 9:92 (1887)

87e The pineal eye in Tritylodon. Science $9: 114$, il $(1887)$

87f No parietal foramen in Trityl don. Science 9:538 (1887)

$\mathbf{8 7 a}$ The origin of the tritubercular type of mammalian dentition. Science 10:300 (1887)

87h (with Scott, W. B.) Preliminary account of the fossil mammals from the White River formation ... Harvard Coll, M C Z, B $13: 157-171$, il (1887)

s8 on the structure and classification of the Mesozoic Mammalia. Ac N Sc Phila, J (2) $9: 186-265$, il (1888)

8Sa Additional observations upon the structure and classification of the Mesozoic Mammalia. Ac N Sc Phila, Pr 1888: 292301 , il

88b The mylohyold groove in the Mesozoic and Recent Mammalia. Am Nat 22 : 75-76 (1888)
Osborn, Henry Fairfield-Continued.

88e The nomenclature of the mambi molar cusps. Am Nat 22:926-928 (18) 8sd The evolution of mammalian of to and from the tritubercular type. Nat 22:1067-1079, il (1888) Abst, As, Rp 58:660 (1889)

s8e (with scott, W. B.) Prelimin report on the vertebrate fossils of Uinta formation, collected by the Pris ton expedition of 1886. Am $\mathrm{Ph} \mathrm{Soc}$ ? $24: 255-264$, il (1888)

89 The paleontological evidence for transmission of acquired characters. Nat 23:561-566 (1889) Am As, Pr 273-276 (1890) Science 15:110-1 (1890) Nature 41:227-228 (1890) D As, Rp 59:621-623 (1890)

90 (with scott, W. B.) Prelimin account of the fossil mammals from: White River and Loup Fork formatil part II, the Carnivora and Artiodact [and] the Perissodactyla. Harvard Mus C Z, B 20:65-100, il (1890)

90a (with Seott, W. B.) The fat malia of the Uinta formation. An Soc, $\operatorname{Tr}$ n \& 16:461-572, il (1890)

91 A review of the Cretaceous Mas= lia. Ac N Se Phila, Pr 1891: 124-1: Am Nat $25: 44-45,298$ (abst), 595-ti il (1891)

91 a A reply to Professor Marsh's "Y on Mesozoic Mammalia." Am Nat 775-783 (1891) Abst, Am As, P (1892)

91b Meniscotheridae and Chalicother dea. Am Nat 25: 911-912 (1891)

92 (and Wortman, J. L.) Fossil unt mals of the Wasatch and Wind River th Am Mus N H, B 4:81-147, il (1892)

92a (and Wortman, . . L.) Charad of Protoceras (Marsh), the new artiodr from the lower Miocene. Am Mus \& B 4:351-371, il (1892)

92b The ancestry of Chalicotheris Science $19: 276$ (1892)

92e Sur la découverte du Palaeonictie Amérique. Soc G France, B (3) 20:4 436 , il (1892)

$92 d$ Nomenclature of mammalian ta cusps. Am Nat 26:436-437 (1892)

92e Is Meniscotherium a member of Chalicotherioidea? Am Nat 26:506il (1892)

92f What is Lophiodon? Am Nat? 763-765 (1892)

929 Palaeonictis in the $\Delta$ merican lor Eocene. Nature $46: 30$ (1892)

93 The rise of the Mammalia in N America. Am J Sc (3) $46: 379-392$, th 466 , il (1893) Am As, Pr $42: 188-22 i$, (1894)

$93 a$ Artionyx, a new genus of th lopoda. Am Mus $\mathrm{N}$ H, B $5: 1-18$, (1893) 
osborn, Henry Fairfield-Continued.

98b Aceratherium tridactylum from the lower Miocene of Dakota. Am Mus N il. B $5: 85-86$ (1893)

93e Fossil mammals of the upper Cretaceous beds. Am Mus N H, B $5: 311-330$, il (1893)

93d The Ancylopoda, Chalicotherium, and Artionyx. Am Nat 27:118-133, 1l (1893)

93e Recent researches upon the succession of the teeth in mammals. Am Nat 27 : 493-508 (1893)

$93 \mathrm{f}$ The collection of fossil mammals in the American Museum of Natural History, N. Y. Science 21: 261 (1893)

93g Artionyx, a clawed artiodactyl. Nature $47: 610-611$, il (1893)

93h Protoceras, the new artiodactyl. Nature $47: 321-322$, il (1893)

93i The evolution of teeth in Mammalia in its bearing upon the problem of phylogeny (abst). N Y Ac Sc, Tr 12:187 (1893)

94 (and Wortman, J. L.) Fossil mammals of the lower Miocene White River beds. Am Mus N H, B $6: 199-228$, il (1894)

94a A division of the eutherian mam mals into Mesoplacentalia and Cenoplacentalia. N Y Ac Sc, Tr 13:234-237 (1894)

95 (and Earle, Charles) Fossil mam mals of the Puerco beds [N. Mex.]. Am Mus N H, B $7: 1-70$, il (1895)

95a Fossil mammals of the Uinta beds [Utah]. Am Mus N H, B $7: 71-106$, il (1895)

95b (and Wortman, J. L.) Perissodactyls of the lower Miocene White River beds. Am Mus N H, B $7: 343-375$, il (1895)

95e Vertebrate paleontology in the American Museum. Science n s 2:178$179(1895)$

36 The cranial evolution of Titano. therium. Am Mus N H, B 8:157-197, il (1896)

96a Prehistoric quadrupeds of the Rockies. Century Mag 52:705-715, : (1896)

96b Titanotheres of the American Museum of Natural History (abst). Am Nat $30: 162-163$ (1896) Sclence n $8 \quad 3: 33$ (1896) Anat Anz 11:512 (1896) Zool Anz $19: 48$ (1896)

97 The Huerfano lake basin, southern Colorado, and its Wind River and Bridger fauna. Am Mus N H, B 9:247-258 (1897)

97 a Lambdotherium not related to Palaeosyops or the titanotheres. Am Nat 31 . 55-57 (1897)

$97 \mathbf{b}$ Wind River and Bridger beds in the Huerfano Lake basin. Am Nat 31:966968 (1897)

$$
28737^{\circ}-23-51
$$

Osborn, Henry Fairfield-Continued.

97e Trituberculy; a review dedicated to the late Professor Cope. Am Nat 31:9931016 , il (1897)

97d The origin of the teeth of the Mammalia. Science n s 5:576-577 (1897)

97 e The Ganodonta or primitive edentates with enamelled teeth. Science n s 5: 611-612 (1897)

97f Edward D. Cope. Science n s 5: 705-717, port (1897)

$\mathbf{9 7 g}$ A great naturalist, Edward Drinker Cope. Century Mag 55:10-15, port, il (1897)

97h On the phylogeny of the early Eocene titanotheres $(a b s t)$. Science n 8 : 107 (1897)

97i Wasatch and Bridger beds in the Huerfano lake basin (abst). Am As, $\mathrm{Pr}$ 46: 205-206 (1898) Am G 20:198 (1897) Science n s 6:688 (1897)

97j Reconstruction of Phenacodus primaevus, the most primitive ungulate (abst). Am Nat $31: 980$ (1897) Am As, Pr $46: 238$ (1898)

98 (and others) Fossil vertebrates in the American Museum of Natural Histor-. Articles collected from the American $\mathrm{Mu}$ seum Bulletins. Vols. I-VI, N Y 18981918

98a The extinct rhinoceroses. Am Mus N H, Mem 1: 75-164, il (1898)

98b A complete skeleton of Teleaceras fossiger; notes upon the growth and sexual characters of this species. Am Mus N H, B 10:51-59, il (1898) Science n s $7: 554-557$, il (1898)

98e A complete skeleton of Coryphadon radians; notes upon the locomotion of this animal. Am Mus $\mathrm{N}$ H, B $10: 81-91$, il (1898)

9Sd Remounted skeleton of Phenacodus primaevus; comparison with Euprotogonia. Am Mus N H, B $10: 159-164$, il (1898)

9Se Evolution of the Amblypoda; Part I, Taligrada and Pantodonta. Am Mus N H, B $10: 169-218$, il (1898)

98f Additional characters of the great herbivorous dinosaur Camarasaurus. Am Mus N H, B 10:219-233, il (1898)

98 The origin of the Mammalia. Am Nat $32: 309-334$, il (1898)

98h Paleontological problems. Science n \& $7: 145-147$ (1898)

9si Paleontological notes. Science $n \mathbf{s}$ $7: 164-165$ (1898)

$\mathbf{9 8 j}$ Origin of the Mammalia. Science n s $7: 176-178$ (1898)

98k The characters and phylogeny of the Amblypoda (abst). Science n s $7: 226$ (1898)

981 A complete skeleton of Coryphodon radians; notes upon the locomotion of this animal. Science n \& $7: 585-588$, il (1898) 
osborn, Henry Fairfield-Continued.

$98 \mathrm{~m}$ Models of extinct vertebrates.

Sclence n s $7: 841-845$, il (1898)

98n On the presence of a frontal horn in Aceratherium incisivum Kaup. (abst). Science n s 8: 850 (1898)

9So Reconstruction and model of Phenacodus primaevus Cope (abst). Brit As, Rp $67: 684$ (1898)

9Sp On skeletons and restorations of Tertiary Mammalia (abst). Brit As, Rp $67: 684$ (1898)

9S9 The origin of the Mammalia (abst). Brit As, Rp 67 : 686-687 (1898)

99 A complete mosasaur skeleton, osseous and cartilaginous. Am Mus $\mathrm{N} \mathrm{H}$, Mem 1:167-188, il (1899) Extract, Seience n s 10:919-925, il (1899)

99a A skeleton of Diplodocus. Am Mus N H. Mem 1: 191-214, il (1899)

$99 \mathrm{~b}$ The origin of mammals. Int Cong Zool, 4th, Pr: 70-71, 413-419 (1899) Am J Sc (4) 7:92-96 (1899) Abst, Science n s $8: 358$ (1898)

99e Restoration of extinct vertebrates from the American Museum of Natural History. Int Cong Zool, 4th, Pr: 174 (1899)

99d Frontal horn on Aceratherium incisivum. Science n s 9:161-162 (1899)

99e Additional characters of Diplodocus (abst). Science n s 9:315-316 (1899)

$99 \mathrm{f}$ Upon the structure of Tylosaurts dyspelor, including the cartilaginous sternum $(a b s t)$. Science n s $9: 913$ (1899)

$99 m$ A skeleton of Diplodocus recently mounted in the American Museum. Science n s $10: 870-874$, il (1899)

oo Fore and hind limbs of carnivorous and Lerbivorous dinosaurs from the Jurassic of Wyoming. Am Mus N H, B 12: 161172 , il (1900)

O0a Phylogeny of the rhinoceroses of Europe. Am Mus N H, B 13:229-267, il (1900)

00b Oxycna and Patriofelis restudied as terrestrial creodonts. Am Mus N H, B $13: 269-279$, il (1900)

ooe Intercentra and hypapophyses in the cervical region of mosasaurs, lizards, and Sphenodon. Am Nat $34: 1-7$, il (1900)

ood A glacial pothole in the Hudson River shales near Catskill, N. Y. Am Nat $34: 33-36 \quad(1900)$

Ooe The angulation of the limbs of Proboseidia, Dinocerata, and other quadrupeds in adaptation to weight. Am Nat 34 : $89-94$, il (1900)

oof Reconsideration of the evidence for a common dinosaur-avian stem in the Permian. Am Nat $34: 777-799$, il (1900)

$00 \mathrm{~g}$ Origin of the Mammalia; III, Occipital condyles of reptilian tripartite type. Am Nat $34: 943-947$, il (1900)

ooh Parallels between Tertiary horizons. N Y Ac Sc, An 13:3-44 (1900)
Osborn, Henry Fairfield-Continued

ooi Faunal relations of Europe America during the Tertiary period : theory of the successive invasions of African fauna into Europe. Science : 11: 561-574 (1900) N Y Ac Sc, An 45-64 (1900)

OOj Scientific publications of Hex Fairfield Osborn. N Y Ac Sc, An 13:60 (1900)

ook Recent zoo-paleontology. Sciz n $8 \quad 11: 115-116 \quad(1900) ; 12: 76 ;-6$ (1900) ; 14:330-331, 498-499, 578-20 $699-700$ (1901) ; $15: 355-357,514$ (190. $16: 673-676, \quad 713-715, \quad 749-752 \quad$ (196) $17: 157-158, \quad 312-314, \quad 356-357,673-6$ (1903) ; $18: 655-668, \quad 699-702, \quad 835-5$ (1903); 19:35-36, 271-272 (1904); t 315-316 (1905)

01 (and Granger, W.) Fore and the limbs of Sauropoda from the Bone call quarry [Wyo.]. Am Mus N H, B 14:16 208, il (1901)

01a Restorations and models of the tinct North American mammals. Am $\mathrm{V}_{\mathrm{H}}$ J 1: 85-87, 11 (1901)

01b Summer work of the departmet vertebrate paleontology [Americas y seum of Natural History]. Am Mus J: $159-160$ (1901)

o1e Des méthodes précises mises actobment en oeuvre dans l'étude des vertent fossiles des Etats-Unis d'Amérique. Int Cong. VIII, Paris 1900 , C R: $353-356$, (1901)

o1d Corrélation des horizons de mut miferes tertiaires en Europe et en Amérint Int G Cong, VIII, Paris $1900, \mathrm{C}$ R: $35^{\circ}$ 363 (1901)

01e The recent progress of vertebr paleontology in America. Science in 8 1! 45-49 (1901)

o1f Systematic revision of the Ameriat Eocene primates and of the rodent fally Mixodectidae (abst). Science n $\mathrm{s} 13: 62 \mathrm{r}$ 624 (1901) N Y Ac Sc. An 14:111 (1906

O1g Recent progress in paleontolos Science n s 13: 872-873 (1901)

O1h Professor Fraas on the aqueous is eolian deposition of the White River Olig cene of South Dakota. Science n 8 14: 210-212 (1901)

02 Dolichocephaly and brachycephaly ti the lower mammals. Am Mus N H, B 16: $77-89$, il (1902)

02a The four phyla of Oligocene titsi otheres. Am Mus N H, B 16:91-109, (1902) Abst, Science n s 15:626 (1906?

02b American Eocene primates, and th supposed rodent family Mixodectidae. Af Mus N H, B 16:169-214, il (1902)

o2e Distinctive characters of the mid Cretaceous fauna. Can G S, Contr Pal 3 pt 2:5-21 (1902)

02d Homoplasy as a law of latent? potential homology. Am Nat $36: 259-2 i$ il $(1902)$ 
osborn, Henry Fairfield-Continued.

02e The law of adaptive radiation. Am Nat $36: 353-363$ (1902)

02f The fossil tree bridge in the Arizona petrified forest. Science $\mathrm{n}$ s 16:991 (1902)

03 The reptilian subclasses Diapsida and Synapsida and the early history of the Diaptosauria. Am Mus N H, Mem 1:451507 , il (1903)

03a Ornitholestes hermanni, a new compsognathoid dinosaur from the upper Jurassic. Am Mus N H, B 19:459-464, il (1903)

03b Glyptotherium texanum, a new glyptodont, from the lower Pleistocene of Texas. Am Mus N H, B $19: 491-494$, il (1903)

03e The skull of Creosaumis. Am Mus N H, B 19:697-701, il (1903)

03d On the age of the Belly River series or formation in Canada. Ottawa Nat 16: 227-228 (1903)

03e Evolution of the Proboscidea in North America (abst). Science n s $17: 249$ (1903)

03f On the primary division of the Reptilia into two subclasses, Synapsida and Diapsida. Science n s 17:275-276 (1903) 04 An armadillo from the middle Eocene (Bridger) of North America. Am Mus N H, B $20: 163-165$ (1904)

04a New Oligocene horses. Am Mus $N$ H, B 20:167-179, il (1904)

04b Manus, sacrum, and caudals of Sauropoda. Am Mus N H, B 20:181190 , il (1904)

04e Teleorhinus brovoni, a teleosaur in the Fort Benton. Am Mus N H, B 20: 239-240 (1904)

04d New Mfocene rhinoceroses with revision of known species. $\mathrm{Am}$ Mus $\mathrm{N} \mathrm{H}$, B $20: 307-326,11$ (1904)

04e The great Cretaceous fish Portheus molossus Cope. Am Mus N H, B 20:377381 , il (1904)

04P Revised list of casts, models, photographs, and restorations of fossil vertebrates. Am Mus N H, B 20 Sup : 52 pp, il (1904)

04g Reclassification of the Reptilia. Am Nat $38: 93-115$, il $(1904)$

04h Paleontological evidence for the original tritubercular theory. Am $\mathbf{J} \mathbf{S c}$ (4) $17: 321-323$, il (1904)

04i Recent advances in our knowledge of the evolution of the horse. $\mathrm{Am} \mathrm{Ph}$ Soc, $\operatorname{Pr} 43: 156-157$ (1904)

04j The dinosaurs of the Bone Cabin quarry. Century Mag 68:680-694, il (1904)

04k On the position of the bones of the forearm in the Opisthocalla or Sauropoda (abst). Science n \& 19:255-256 (1904)

041 On the use of the sand blast in cleaning fossils $(a b s t)$. Science $n$ \& 19:256 (1904)
Osborn, Henry Fairfield-Continued.

$04 \mathrm{~m}$ Conclusive paleontological evidence for the tritubercular theory (abst). Science n s $19: 256$ (1904)

04n A reclassification of the Reptilia (abst). Science n s $19: 256-257$ (1904)

040 On the primary components of vertebrae and their relations to ribs (abst). Seience n s 19:257 (1904)

04p The classification of the Reptilia (abst). Science n s 19:307-308 (1904)

04q Recent advances in our knowledge of the evolution of the horse $(a b s t)$. Science n s 19:717 (1904)

o5 Tyrannosaurus snd other Cretaceous carnivorous dinosaurs. Am Mus N H, B 21: 259-265, il (1905)

05a The evolution of the horse in America. Century Mag 69:3-17, il (1905)

05b Ichthyosaurs [evolution]. Century Mag 69: 414-422 (1905)

o5e The present problems of paleontology. Cong Arts and Sc (St. Louis 1904) 4:566-585 (1906) Pop Sc Mo 66:226242 (1905)

o5d Western explorations for fossil vertebrates. Pop Sc Mo 67:561-568 (1905)

ose Ten years' progress in the mammalian paleontology of North America. Int Cong Zool, 6th, C R: 86-113, il (1905) Am G 36:199-229 (1905)

05f Evolution of the horse; recent discoveries and studies. Int Corg Zool, 6th, C R : 282 (1905)

O5g [The phylogeny and classification of the reptiles (abst)]. Am G 35:124-125 (1905)

05h Recent discoveries of extinct animals in the Rocky Mountain region and their bearings on the present problems of evolution (abst). Science $n$ s $21: 28$ (1905)

05i Ten years' progress in mammalian paleontology (abst, with discussion by $\mathrm{S}$. W. Williston, J. H. MeGregor, O. P. Hay). Science n s $21: 294-296$ (1905)

$\mathbf{0 5} \mathbf{j}$ Recent vertebrate paleontology; fossil mammals of Mexico. Science n s 21: 931-932 (1905)

05k Recent vertebrate paleontology. Science n s 22: 188-189 (1905)

o51 Skull and skeleton of the sauropodous dinosaurs, Morosaurus and Brontosaurus. Science n s $22: 374-376$ (1905)

$05 \mathrm{~m}$ The classification of the Reptilia (abst). N $\mathrm{Y}$ Ac Sc, An 16:302-303 (1905)

O5n Recent discoveries of extinct animals in the Rocky Mountains and their bearings on present problems of evolution (abst). $\mathrm{N}$ Y Ac Sc, An 16:357-359 (1905)

05o The evolution of the horse (abst). Brit As, Rp 74: 607-608 (1905)

06 Tyrannosaurus, upper Cretaceous carnivorous dinosaur (second communication). Am Mus N H, B 22: 281-296, il (1906) 
Osborn. Henry Fairfield-Continued.

06a The skeleton of Brontosaurus and skull of Morosaurus. Nature $73: 282-284$, il (1906)

06b The causes of extinction of Mammalia. Am Nat $40: 767-795, \quad 829-859$ (1906)

o7 Tertiary mammal horizons of North America. Am Mus N H, B 23:237-253, il (1907)

07a A mounted skeleton of the Columbian mammoth. Elephas columbi. Am Mus N H, B 23: 255-257, il (1907)

07b A mounted skeleton of Naosaurus, a pelycosaur from the Permian of Texas. Am Mus N H, B $23: 265-270$, il (1907)

oze Evolution as it appears to the paleontologist. Science $n$ s $26: 744-749$ (1907)

07d A paleontological trip to northwestern Nebraska (abst). Science n 826 : 871-872 (1907)

07 The reclassification of the Mammalia (abst). N Y Ac Sc, An 17:611-613 (1907)

o7f Discovery of a supposed primitive race of men in Nebraska. Century Mag $73: 371-375$ (1907)

07g Edward Drinker Cope. Pop Sc Mo $70: 314-316$, port (1907)

07h Evolution of mammalian molar teeth to and from the triangular type. vi, $250 \mathrm{pp}, \mathrm{il}, \mathrm{N}$ Y 1907

07i Explorations of John Bell Hatcher for the paleontological monographs of the United States Geological Survey, together with a statement of his contributions to American geology and paleontology. U S G S, Mon 49: xvii-xxvi (1907)

os The four inseparable factors of evolution ; theory of their distinct and combined action in the transformation of the titanotheres, an extinct family of hoofed animals in the order Perissodactyla. Science $n$ s $27: 148-150$ (1908)

osa Coincident evolution through rectigradations and fluctuations (third paper). Science n s $27: 749-752$, il (1908)

0sb New or little known titanotheres from the Eocene and Oligocene. Am Mus N H, B 24: 599-617, il (1908)

ose A paleontological trip to northwestern Nebraska (abst). N Y Ac Sc, An 18: 351-352 (1908)

osa Dolichocephaly and brachycephaly in titanotheres (abst). Science n s 27:255 (1908)

09 Cenozoic mammal horizons of western North America, with faunal lists of the Tertiary Mammalia of the West. U S G S, B 361: $138 \mathrm{pp}$, map (1909)

09a The epidermis of an iguanodont dinosaur [Trachodon annectens, Converse Co., Wyo.J. Science n s 29:793-795 (1909)

$09 b$ On a skeleton of Trachodon (abst). Science n s $29: 197-198$ (1909)
Osborn, Henry Fairfield-Continued.

09e Upon a skull of Bison latifrou (abst). Science n s 29:198 (1909)

o9a The upper Cretaceous iguanodo: dinosaurs. Nature 81: 160-162, il (190) o9e (and Matthew, W. D.) Geolos cal correlation through vertebrate palew tology by international cooperation; Com lation Bulletin, no. 1; Plan and scope. Kr Ac Sc, An 19:41-44 (1909)

10 The age of mammals in Europe, Asi. and North America. xvii, $635 \mathrm{pp}$, il NI 1910

10a Correlation of the Cenozoic throut its mammalian life, J G 18:201-21: (1910)

10b Paleontologic evidences of adantit radiation. Pop Sc Mo $77: 77-81$ (1910)

10e The paleontologic correlation throun the Bache fund. Science n s $31: 407-40$ (1910)

11 A dinosaur mummy. Am Mus J 11: 7-11, Il (1911)

11a Biological conelusions drawn frot the study of the titanotheres (abst). \&

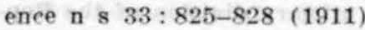

12 Evolution as it appears to the palen tologist. Int Zool Cong, VII, Boston, 194\%, Pr: $733-739$ (1912) [Advance print: 7 m 1910]

12a A means of estimating the age of the mastodon and other Proboscidea (abst. Int Zool Cong, VII, Boston, 1907, Pr: 78784, il (1912) [Adrance print: $3 \mathrm{pp}$, I] 1910]

12b The continuous origin of certain wh characters as observed by a paleontologit Reprinted from the Harvey lectures, seris 1911-12:153-204, il, Phila [1912?] 시 Nat $46: 185-206,249-278$, il (1912)

12e Crania of Tyrannosaurus and Ath saurus (Tyrannosatrus contributions no. 3). Am Mus N H, Mem n s $1: 3-30$, il (1912

12d Integument of the iguanodont dint saur Trachodon. Am Mus N H, Mem Ds 1: 31-54, il (1912)

12e Craniometry of the Equidae. in Mus N H, Mem n s 1:55-100, il (1912)

$12 f$ Tetraplasy, the law of the four in separable factors of evolution. Ac N \& Phila, J (2) 15 : 273-309 (1912) ; abst, Pt 64: 144-146 (1912)

12g Ten years progress in vertebrate paleontology; Correlation and paleogeo raphy. G Soc Am, B $23: 232-256$ (191?

12h Phylogeny and ontogeny of the horns of mammals. Science $n$ s $35: 595-$ 596 (1912) Abst, N Y Ac Sc An 22:34 (1913)

13 Tyrannosaurus, restoration and model of the skeleton. Am Mus N H, B 32:9192 , il (1913)

13a Eomoropus, an American Eocene chalicothere. Am Mus N H, B 32:261274 , il (1913) 
osborn, Henry Fairfield-Continued.

13b Lower Eocene titanotheres, genera Lambdotherium, Eotitanops. Am Mus N H. B $32: 407-415$, il (1913)

13e The skull of Bathyopsis, Wind River uintathere. Am Mus N H, B $32: 417-420$, il (1913)

13d Skull measurements in man and the hoofed mammals (abst). N Y Ac Sc, An $22: 341-342$ (1913)

13e Joseph Leidy, 1823-1891. Nat Ac Sc, Blog Mem $7: 335-396$, port (1913)

14 close of the Cretaceous and opening of Eocene time in North :merica. G Soc Am, B 25: 321-323 (1914)

14 a Recent results in the phylogeny of the titanotheres. G Soc Am, B 25:403405 (1914)

14b New methods of restoring Eotitanops and Brontotherium. G Soc Am, B 25 : 406, il (1914)

14e Restoration of the world series of elephants and mastodons, G Soc Am, B $25: 407-410$, il (1914)

14d Rectigradations and allometrons in relation to the conceptions of the "mutations of Waagen " of species, genera, and phyla. G Soe Am, B 25:411-416 (1914)

14e Final results in the phylogeny of the titanotheres (abst with diseussion). G Soc Am, B 25: 139 (1914)

15 Men of the old stone age, their environment, life, and art, $545 \mathrm{pp}$, il N Y $19152 d \mathrm{ed}, 1916$ 3d ed, $559 \mathrm{pp}, 11, \mathbf{N} \mathbf{Y}$ 1918

15a Origin of single characters as observed in fossil and living animals and plants. Am Nat 49:193-239, il (1915)

15b Review of the Pleistocene of Europe, Asia, and northern Africa. N Y Ac Sc, An 26:215-315 (1915)

15e Close of Jurassic and opening of Cretaceous time in North America. G Soc Am, B 26: 295-302 (1915)

16 Two new Oligocene titanotheres. Am Mus N H, B $35: 721-723$, il (1916)

16a Skeletal adaptations of Ornitholestes, Struthiomimus, Tyrannosaurus. Am Mus N H, B $35: 733-771$, il (1916)

16b The origin and evolution of life upon the earth. Sc Mo $3: 5-22,170-190$, $289-305, \quad 313-334, \quad 502-513, \quad 601-614$, il (1916)

16e Additional characters of Tyrannosaurus and Ornithomimus (abst). G Soc Am, B 27:150-151 (1916)

16d Pelvis and sacrum of Camarasaurus (abst). G Soc Am, B 27:151 (1916)

17 The origin and evolution of life, on the theory of action, reaction, and interaction of energy. xxxi, $322 \mathrm{pp}, \mathrm{il}, \mathrm{N} \mathbf{Y}$

17a The "ostrich" dinosaur and the "tyrant" dinosaur. Am Mus J 17:5-13,
Oshorn, Henry Fairfield-Continued.

17b (and Mook, C. C.) Skeleton and restoration of Camarasaurus (abst). G Soc Am, B 28: 215 (1917)

17e Ostrich dinosaur, Struthiomimus, and a restudy of Ornitholestes (abst). G Soc Am, B 28: 215 (1917)

18 Equidae of the Oligocene, Miocene, and Pliocene of North America, iconographic type revision. Am Mus N H, Mem n 8 pt $1: 1-330$, il (1918)

18a Samuel Wendell Williston, 18521918. J G 26:673-689 (1918)

18b Observations on the skeletons of Moropus cooki in the American Museum (abst). G Soc Am, B 29:131-133 (1918)

1Se A long-jawed mastodon skeleton from South Dakota and phylogeny of the Proboscidea (abst). G Soc Am, B 29: 133-137 (1918)

See also Cope, 98

Oshorn, Henry Stafford (1823-1894).

92 Prospector's field book and guide... 175 pp, Phila 1892 8th ed, 377 pp, Phila 1910

\section{Osborn, Herbert.}

92 On some Carboniferous fossils from Jackson Co., Iowa. Iowa Ae Sc, Pr 1 pt $2: 115$ (1892)

Osburn, Raymond $\mathrm{C}$.

06 Adaptive modifications of the limb skeleton in aquatic reptiles and mammals. $N$ Y Ac Se, An 16:447-482, il (1906)

o7 The origin of vertebrate limbs; recent evidence upon this problem from studies on primitive sharks. N Y Ac Sc, An $17: 715-436$ (1907)

Osgood, Samuel W.

99 The east Tennessee zinc-mining district. Eng M J 87:401-404 (1909)

10 Zinc mining in Tennessee. Tenn $G$ S. B 2-G : 18 pp (1910)

osgood, Wilfred $\mathrm{H}$.

05 Mastodon remains in the Yukon Valley. Biol Soc Wash, Pr 18:254-255 (1905)

05a Scaphoceros tyrrelli, an extinct ruminant from the Klondike gravels. Smiths Mise Col 48 (Q Is 3 ): 173-185, il (1905)

o'Shuughnessy, M. M.

99 The copper resources of California. In California Mines and minerals (pub. by California Miners' Association) : 205-218. San Francisco, Cal., 1899

Osmont, Vance $C$.

o5 A geological section of the Coast Ranges north of the Bay of San Francisco. Cal Univ, Dp G, B 4:39-87 (1905)

o5a Arcas of the Callforvia Neocene. Cal Univ, Dp G, B 4: $89-100$, il (1905)

o'sullivan, Owen.

os Survey of the south and west coast of James Bay. Can G S, Sum Rp 1904 (An Rp 16) : A 173-179, map (1905) 
o'sullivan, Owen-Continued.

06 [Report on] a survey of the coast of Hudson Bay from York Factory to Severn River. Can G S, Sum Rp 1905: $73-76$ (1906)

06a On explorations along the proposed route of the Canadian Northern Rallway, between Split Lake and Fort Churchill. Can G S, Sum Rp 1906: 99-102 (1906)

os Explorations along the National Transcontinental Railway location from La Tuque westward [Que.]. Can G S, Sum Rp 1907: 67-68 (1908)

09 Survey of the south coast of Hudson Bay from the Severn River to Cape Henrietta Maria. Can G S, Sum Rp 1908: 93-94 (1909)

See also Miller (W G), 12

Otsuka, S.

03 A short sketch on the petroleum industry of Europe and America [in Japanese]. Japan G S, B 16 no $1: 82 \mathrm{pp}$, maps (1903)

Outerbridge, Alexander E., jr.

09 The copper mines of Jamaica, British West Indies. Eng Mag 37:793-805 (1909)

$09 \mathrm{a}$ The mineral wealth of the islands of Newfoundland and Jamaica. Franklin Inst, J 168: 457-469 (1909)

Overbeck, Robert Milton.

16 A metallographic study of the copper ores of Maryland. Ec G 11:151-178, 504506 (discussion by C. F. Tolman, jr.) (1916)

17 Lode deposits near the Nenana coal field, Alaska. U S G S, B 662:351-362, map (1917)

18 Igneous rocks [of the upper Chitina Valley, Alaska]. U S G S, B 675:52-66 (1918)

Owen, David Dale (1807-1860).

38 Report of a geological reconnaissance of the State of Indiana made in the year $1837 \ldots 34$ pp. Indianapolis 1838 Reissued with Second report in 1839.

39 Second report of a geological survey of the State of Indiana made in the year $1838 \ldots 46$ pp, Indianapolis 1839 2d ed (with First report), $54 \mathrm{pp}$, Indianapolis 1839

40 Report of a geological exploration of part of Iowa, Wisconsin, and Illinois... in 1839. U S, 28th Cong 1st sess, S Ex Doe $407: 191$ pp, il, maps (1844) Mineral lands of the United States, U S, 26th Cong 1st sess, H Ex Doc 239:161 pp (1840)

40a Catalogue of mineralogical and geological specimens at New Harmony, Ind., collected... by William Maclure... $16 \mathrm{pp}$, New Harmony, Ind., 1840

42 Regarding human footprints in solid limestone. Am J Sc $43: 14-32,11$ (1842)

43 On the geology of the Western States. Am J Sc $45: 151-152,163-165$ (1843)
Owen, David Dale - Continued.

$43 a$ Fossil palm trees found in Poen Co., Ind. Am J Sc 45:336-337 (1843)

43b On some fossil trees from New Hir. mony, Ind. Ac N Sc Phila, Pr 1:270-27] (1843)

43e On the geology of the Western Stats of North America. G Soc London, B $4: 1-4$ (1843) Ph Mag (3) 23:180-18 (1843)

44. Review of the New York geologial reports. Am J Sc $46: 143-157$ (1844): $47: 354-380$ (1844); $48: 296-316$ (1845): (2) $1: 43-70 \quad(1846) ;(2) 3: 57-74,164$ 171 , il (1847)

46 On the geology of the Western Stats of North America [eastern Mississippi $\mathrm{V}$ : ley]. G Soc London, Q J $2: 433-447$, د4 (1846) ; Abst, Pr $4: 1-4$ (1843)

$46 a$ (with Norwood, J. G.) Descrip. tion of a new fossil fish from the Paleorit. rocks of Indiana. Am J Se (2) $1: 36$ 371, il (1846)

46b (with Norwood, J. G.) Descrip tion of a remarkable fossil echinedera, from the limestone formation of St. Louls Mo. Am J Sc (2) $2 ; 225-228$, il (1846)

46e (with Norwood, J. G.) [0n s fossil fish, Macropetalichthys rapheidolo. bris, from southern Indiana.] Boston $5 \propto$ $\mathrm{N} \mathrm{H}, \operatorname{Pr} 2: 102,116$ (1846)

47 Preliminary report... of the geolog. cal survey of Wisconsin and Iowa. U \& Gen Land Ofr, Rp 1847 (U S, 30th Cong 1st sess, S Ex Doc 2) : 160-173 (1847)

47a (and Norwood, J. G.) Researchis among the Protozolc and Carboniferos rocks of central Kentucky made duritis the summer of $1846.12 \mathrm{pp}$, il, St Louts 1847 Abst, Am J Sc (2) 5:268-269 (1848)

47b Termination of the Paleozoic periol and commencement of the Mesozoic. Am I Sc (2) $3: 365-368$ (1847)

48 ... report of a geological reconnais. sance of the Chippewa land district of Wis. consin and the northern part of Iows. U S, 30th Cong 1st sess, S Ex Doc 57: $134 \mathrm{pp}$, il, map, Washington 1848

48a [Exploration du Wisconsin.] Soe G France, B (2) 5:294-296 (1848)

50 (and Shumard, B. F.) Descriptions of fifteen new species of Crinoidea from the Subcarboniferous limestone of Iows... Ac N Sc Phila, J (2) $2: 57-70$, il (1850)

50a Notice of fossil remains from the "Mauvais Terres" or badlands of White River [S. Dak.]. Ac N Sc Phila, Pr 5: 66-67, 328 (1850)

51 ... geological surveys made in Wis. consin, Iowa, and Minnesota, in the years 1847-'48-'49 and '50... (abst). Am As, Pr 5: 119-131 (1851)

$51 a$ On the paleontology of the lowest sandstones of the Northwest. $\mathrm{Am} \mathrm{As}, \mathrm{Pt}$ $5: 169-172$ (1851) 
Owen, David Dale-Continued.

51b (and Shumard, B. F.) On the number and distribution of fossil species in the Paleozoic rocks of Iowa, Wisconsin, and Minnesota. Am As, Pr 5:235-239 (1851)

52 Report of a geological survey of Wisconsin, Iowa, and Minnesota and incidentally of a portion of Nebraska Terr. xxrviii, 638 pp, il, map, Phila 1852

52a Description of new and imperfectly known genera and species of organic remains... In his Report of a geological survey of Wisconsin, Iowa, and Minnesota... : 573-587, il, Phila 1852

52b (and Shumard, B. F.) Descriptions of cne new genus and twenty-two new species of Crinoidea from the Subcarboniferous limestone of Iowa. In Owen, D. D., Report of a geological survey of Wisconsin, Iowa, and Minnesota... : 587-598, il, Phila 1852

52e (and Shumard, B. F.) Descriptions of seven new species of Crinoidea from the Subcarboniferous limestone of Iowa and Illinois. Ac N Se Phila, J (2) 2:89-94, il (1852)

52d Notice of a new mineral from Callfornia, Ac N Se Phila, Pr 6:108-109 (1852)

52e [On the occurrence of Fusilina cylindrica.] Ac N Sc Phila, Pr 6:118 (1852)

$52 f$ [Remarks on the geology of Wisconsin, Iowa, and Minnesota.] Ac $\mathrm{N}$ Sc Phila, Pr 6:189-191 (1852)

53 Description of two new minerals and a new earth [thalia]. Ac $\mathrm{N}$ Se Phila, J (2) $2: 179-183$ (1853)

53a [On thalia and saponite.] Ac N Sc Phila, Pr 6:379-380 (1853)

55 Catalogue of geological speclmens... Smiths Inst, An Rp 9, 1854: 393-396 (1855)

56 Report of the geological survey in Kentucky, made during the years 1854 and 1855. 416 pp, maps, Frankfort, Ky., 1856

57 Second report of the geological survey in Kentucky, made during the years 1856 and 1857. 391 pp, Frankfort, Ky., 1857

57 a Third report of the geological surrey in Kentucky, made curing the years 1856 and 1857. 589 pp, Frankfort, Ky., 1857

$57 \mathrm{~b}$ Geological reort in relation to the goils of Kentucky. M Mag 8:424-434 (1857)

57e Geological report on the Tunungwant coal field of MeKean Co., Pa. M Mag $9: 244-258$ (1857)

58 First report of a geological reconnaissance of the northern counties of Arkansas during the years 1857 and 1858 . $256 \mathrm{pp}$, Little Rock, 1858

58a The minerals and sjrings of Arkansas. De Bow's Review 25 : 199-205 (1858)
Owen, David Dale-Continued.

59 Report of a geological reconnaissance of the State of Indiana made in the year 1837 ... Part first, $63 \mathrm{pp}$, Indianapolis 1859. Issued with this, Continuation of report of a geological reconnaissance of the State of Indiana made in the year $1838 \ldots$ Part second, $69 \mathrm{pp}$, Indianapolis 1859

60 Second report of a geological reconnaissance of the middle and southern counties of Arkansas, made during the years 1859 and 1860. $433 \mathrm{pp}$, il, map, Phila 1860

61 Fourth report of the geological survey in Kentucky, made during the years 1858 and 1859 . 617 pp, Frankfort, Ky., 1861

61a Condensed report of the geological and agricultural survey of the State of Indiana for 1859 and $1860.29 \mathrm{pp}$, Indianapolis 1861

owen, J.

88 Notes on the geology of the Rio Grande Valley. G Sc B 1 no 2 (1888)

s9 Report of geologists for southern Texas. Tex G S, Rp Prog 1 (1888) : 69-74 (1889)

owen, J. S.

31 Fossil remains found in Anne Arundel Co., Md. Monthly Am J G 1:114-118 (1831)

Owen, Luella Agnes.

98 Cave regions of the Ozarks and Black Hills. 228 pp, Cincinnati 1898

01 The bluffs of the Missouri River. Int Geog Cong, VII, Verh pt $2: 686-690$ (1901)

o3 More concerning the Lansing skeleton. Bibliotheca Sacra, $73: 572-578$ (1903)

04 The loess at St. Joseph. Am G 33 : 223-228, map (1904) Abst, Science n s $19: 533$ (1904)

o5 Evidence on the deposition of loess. Am G 35: 291-300 (1905)

13 The relation of geologieal activity to conservation of soil and the waters of flowing streams (abst). Science n s $37: 459$ (1913)

owen. Richard [English] (1804-1892).

39 Observations on the teeth of the Zeuglodon, Basilosaurus of Dr. Harlan, G Soc London, $\operatorname{Pr} 3: 24-28$ (1839) $\mathrm{Ph} \mathrm{Mag} \mathrm{(3)}$ $14: 302-307$ (1839)

41 Observations on the Basilosaurus of Dr. Harlan (Zeuglodon cetoides Owen). G Soc London, Tr (2) 6: 69-79 (1841)

43 On Dr. Harlan's notice of new fossil Mammalia. Am J Sc 44:341-345 (1843)

46 [Observations on certain fossils from near Darien, Ga.] Ac N Sc Phila, Pr 3: 93-96 (1846)

47 General geological distribution and probable food and climate of the mammoth. Am J Sc (2) 4:13-19 (1847) 
Owen, Richard [English]-Continued.

47a Observations on certain fossil bones from the collection of the Academy of Natural Sciences of Philadelphia. Ac $\mathrm{N}$ Sc Phila, J (2) 1: 18-20, Il (1847)

49 Notes on remains of fossil reptiles... in greensand formations of New Jersey. G Soc London. Q J 5:380-383, il (1849)

51 On the Megatherium ( $M$. americanum Cuvier and Blumenbach.) $\mathrm{R}$ Soc London, $\mathrm{Ph} \operatorname{Tr} 1851: 719-764$, il ; $145: 359-388$, il $(1855) ; 146: 571-589$, il $(1856) ; 148$ : $261-278$, il $(1859) ; 149: 809-829$, il (1860)

51 a Description of the impressions on the Potsdam sandstone...in Lower Canada. G Soc London, Q J $7: 250-252$ (1851)

52 [On footprints from Clinton rocks in the vicinity of Niagara Falls.] G Soc London, Q J 8:213 (1852)

52a Description of the impressions and footprints of the Protichnites from the Potsdam sandstone of Canada. G Soc London, Q J 8: 214-225, il (1852)

53 (with Wyman, J.) Notes on tie reptilian remains [from the Coal Measures of Nova Scotia]. G Soc London, Q J 9: 64-67, il (1853)

54 On a fossil imbedded in a mass of Pictou coal from Nova Scotia [Baphetes planiceps]. G Soc London, Q J 10:207208, il (1854)

55 Note on some remains of Ichthyosaurus discovered ... at Exmouth Island, in Lat. $77^{\circ} 16^{\prime} \mathrm{N}$, and Long. $96^{\circ} \mathrm{W}$. In Belcher, Edward. The last of the Arctic voyages, vol $2: 389-391$, il, London 1855

55a Additional remarks on the skull of the Baphetes planiceps Ow. G Soc London, Q J 11:9-10 (1855)

55b On the fossil skull of a mammal (Prorastomus sirenoides Owen) from the Island of Jamaica. G Soe London, Q J 11: $541-543$, il (1855)

60 Memoir on the Megatherium or giant ground sloth of America (Megatherium americanum Cuvier). 84 pp, il, L 1860

62 Descriptions of specimens of fossil reptilia discovered in the Coal Measures of the South Joggins, N. S. G Soc London, Q J 18:238-244, il (1862)

69 On the fossil teeth of equines from Central and South America ... R Soc London, $\operatorname{Pr} 17: 267-268$ (1869)

70 On fossil remains of equines from Central and South America referable to Equus conversidens Ow., Equus tau Ow., and Equus arcidens Ow. $\mathrm{R}$ Soc London, $\mathrm{Ph} \operatorname{Tr} 159: 559-573$, il (1870)

70a on remains of a large extinct llama (Palauchenia magna Ow.) from Quaternary deposits in the Valley of Mexico. $\mathrm{R}$ Soc London, $\mathrm{Ph}$ Tr 160:65-77 (1870)
Owen, Richard [English]-Continued, 76 On the existence or not of horns : the Dinocerata. Am J Sc (3) 11:401-4? (1876)

78 On the occurrence in North Ameris of rare extinct vertebrates found fre. mentarily in England. An Mag N H (5) $2: 201-223$, il (1878); (5) 4:53-61, (1879) ; (5) $5: 177-181$, il (1880)

Owen, Richard [Americąn] (1810-1890)

52 Report [on Pigeon Point region, Minn.] In Owen, D. D., Report of a st logical survey of Wisconsin, Iowa, and Mir nesota ... : 396-400, Phila 1852

57 Key to the geology of the globe. 256 pp, Phila 1857

62 Report of a geological reconnaissatict of Indiana made during the years 1859 and $1860 \ldots x v i, 368 \mathrm{pp}, \mathrm{il}$, Indianapolis $186 \%$

65 (and Cox, E. T.) Report on the mines of New Mexico. 59 pp, Washingtor 1865

66 On the deposit of rock salt at Ner Iberia [La.]. Ac Sc St L, Tr $2: 250-25$ ? (1866) Am J Sc (2) 42:120-123 (1866)

72 Contributions to physiographic aod dynamical geology, involving the discussion of terrestrial magnetism. Am As, Pr 20 . 208-216 (1872)

72a Terrestrial magnetism [and recent volcanoes and earthquakes]. Frankil Inst, J 94 : 126-132 (1872)

80 Law according to which the metals and their ores came to or near to the sur face of the earth. Science (ed, Michels) 1: 226-228 (1880)

81 The law of land-forming on our globe Am As, Pr 29, 437-446 (1881)

$\mathbf{8 1 a}$ On the unification of geological nomenclature. Science (ed, Michels) 2: 438-440 (1881)

82 Résumé d'un rapport sur l'unification de la nomenclature géologique. Int 6 Cong, II, Bologna 1881, C R: 623-6:8 (1882)

83 Contribution to seismology (abst). Am As, Pr $31: 329-336$ (1883)

83a Law of fracture, or fissuring, spplied to inorganic and organic matter (abst). Am As, Pr 31: 337-344 (1883)

84 The earth's orographic framework its seismology and geology (abst). Am As. Pr 32:253-256 (1884) Sclence 2:321322 (1883)

84a The continental type, or normal orography and geology of continents (abst). Am As, Pr 32: 256-260 (1884) Science $2: 321-322$ (1883)

85 American earthquakes. Pacific Sc No 1:1-4 (1885) [not seen]

87 The relation of the pole of the land. hemisphere to continents, to the magnetic system, and to seismic force. Am Neteorogical J 4:275-280 (1887)

$87 \mathbf{a}$ The relation between geographical forms and geological formations. Am Meteorological J 4:309-313 (1887) 
owen, Richard [American]-Continued.

88 Probable derivation of the terrestrial spheroid from the rhombic dodecahedron. Am Meteorological J 5 : 289-293 (1888)

s9 Additional facts respecting the law governing the distribution in space of seismism. Am Meteorological J 5:419-421 (1889)

See also Hilgard, 71a

owens, Wm. G.

92 A mateorite from central Pennsylvania. Am J Sc (3) 43:423-424 (1892)

Pack, Frederick James.

06 Geology of Pioehe, Nev., and vicinity. Sch Mines Q 27:285-312, 365-386, map (1906)

06a Cambrian fossils from the Pioche Mountains, Nev. J G 14, 290-302, il (1906) Pack, Robert Wallace.

09 Notes on echinoids from the Tertiary of California. Cal Univ, Dp G, B 5:275283, il (1909)

13 Notes on Scutella norrisi and Scutaster andersoni. Cal Univ, Dp G, B 7:299304, 11 (1913)

14 Ornamental marble near Barstow, Cal. U S G S, B 540: $363-368$ (1914)

14a Reconnaissance of the BarstowKramer region, Cal. U S G S, B 541: 141-154, map (1914)

14b (and English, W. A.) Geology and oil prospects in Waltham, Priest, Bitterwater, and Peachtree valleys, Cal. U S G S, B $581: 119-160$, map (1914)

15 (with Anderson, R.) Geology and ofl resources of the west border of the San Joaquin Valley north of Coalinga, Cal. U S G S, B 603: 220 pp, map (1915) Abst, Wash Ac Sc, J $5: 647-648$ (1915)

16 Structural features of the San Joaquin Valley oil flelds, Cal. (abst). Wash Ac Se, J $6: 309-310$ (1916)

17 The estimation of petroleum reserves (with discussion by C. W. Washburn). Am I M Eng, B 128:1121-1134: $130: 1866-$ 1868 (1917); Tr 57:968-983 (1918)

17a Oil fields of the Pacific coast. G Soc Am, B 28:677-684 (1917)

15 The estimation of petroleum reserves. Am I M Eng, Tr 57:968-981 (discussion by C. W. Washburne), 981-983 (1918)

See also Daly (M R), 16

Packard, Alpheus Spring, jr. (18311905).

61 Fish River lakes [Me.]. Me Bd Agr, 6th An Rp: 420-425 (1861)

66 Results of observations on the drift phenomena of Labrador and the Atlantic coast southward. Am J Sc (2) 41:30-32 (1866) Can Nat n \& 2:441-444 (1865) [1866]

67 Ice marks and ancient glaciers in the White Mountains. Am Nat 1:260-269 (1867)

67 a Evidences of the existence of anclent local glaciers in the White Mountain valleys. Am J Sc (2) $43: 42-43$ (1867)
Packard, Alpheus Spring, fr.-Continued. $67 \mathbf{b}$ Observations on the glacial phenom. ena of Labrador and Maine. Boston Soc N H, Mem 1:210-262 (1867)

68 The hairy mammoth. Am Nat 2: 23-35, il (1868)

69 [Essex Co., Mass.] Am Nat 3:335336 (1869)

71 Geology of the phosphate beds of South Carolina. Essex Inst, B 3:55-58 (1871) Am Nat 6:55-58 (1872)

71a (and others) The Mammoth Cave and its inhabitants. Am Nat 5:739-761 (1871)

73 Comparison of the glacial phenomena of New England with those of Europe. Am Nat $7: 210-213$ (1873) Essex Inst, B 5 : 1-2 (1873)

76 The Great Salt Lake in former times. Am Nat 10:675-681 (1876)

76a On the supposed ancient outlet of Great Salt Lake. U S G Geog S Terr (Hayden), B [1] no 5 (2) : 413-414 (1876)

76b Ice marks in Newfoundland. Am Nat $10: 694-695$ (1876)

77 Pan-ice work and glacial marks in Labrador. Am Nat 11:568-569 (1877)

77a Glacial marks on the Pacific and Atlantic coasts compared. Am Nat 11:674680 (1877)

So Fossil crawfish from the Tertiaries of Wyoming. Am Nat 14:222-223 (1880)

81 On a crayfish from the lower Tertiary beds of western Wyoming. U S G Geog S Terr (Hayden), B 6:391-397, il (1881)

81a A fossil phyllopod crustacean from the Quaternary clays of Canada. Am Nat 15: $496-497$ (1881) Can Nat n s $10: 122$ 123 (1881)

81b A fossil Tertiary crayfish. Am Nat $15: 832-834$, il (1881)

82 Glacial marks in Labrador. Am Nat 16: $30-33$ (1882)

s2a The Paleozoic allies of Nebalia. Am Nat $16: 945-853$, il (1882)

83 Geological succession of Phyllopoda. U S G Geog S Terr (Hayden), An Rp 12 pt $1: 359-362$ (1883)

83a The systematic position of the Archipolypoda, a group of fossil myriopods. Am Nat $17: 326-329$ (1883)

s5 Types of Carboniferous Xiphosura new to North America. Am Nat 19:291294 (1885)

85a The Syncarida, a group of Carboniferous Crustacea. Am Nat 19:700-703 (1885)

86 On the Syncarida, a hitherto undescribed group of extinct malacostracous Crustacea. Nat Ac Sc, Mem 3 pt 2:123128, il (1886)

86a On the Gampsonychidae, an undescribed family of fossil sc..izopod Crustacea. Nat Ac Sc, Mem 3 pt 2:129-133, il (1886) In part, Am Nat 19:790-793 (1885) 
Packard, Alpheus Spring, jr.-Continued. s6b On the Anthracaridae, a family of Carboniferous macrurous decapod Crustacea. Nat Ac Sc, Mem 3 pt $2: 135-139$, il (1886) In part, Am Nat 19:880-881 (1885)

86e Geological extinction and some of its apparent causes. Am Nat $20: 29-40$ (1886)

S6d Ascent of the volcano of Popoca tepetl. Am Nat 20:109-123 (1886)

86e Discovery of lamellate thoracic feet in the Phyllocarida. Am Nat 20:155-156 (1886)

s6r On the class Podostomata, a group embracing the Merostomata and trilobites. Am Nat 20:1060-1061 (1886) An Mag N H (5) 19:164-165 (1887)

$\mathbf{8 6} \mathrm{g}$ Discovery of the thoracic feet in a Carboniferous phyllocaridan. Am Ph Soc, Pr 22:380-383, il (1886)

87 On the Carboniferous xiphosurous fauna of North America. Nat Ac Sc, Mem 3 pt $2: 143-157$, il (1887)

$\mathbf{8 7 a}$ Notes on the physical geography of Labrador. Am Geog Soc, B 19:403-422, $\operatorname{map}(1887)$

S8 A summer's cruise to northern Labrador. Am Geog Soc, B 20:337-363, 445463, map (1888)

89 Paleontological notes; 1 , On Carboniferous arthropods from Illinois; 2 , Recent discovery of annelids and the supposed track of a gastropod mollusk, in the Carboniferous shales of Rhode Islend. Boston Soc N H, Pr 24: 209-215 (1889)

$89 a$ Recent discoveries in the Carboniferous flora and fauna of Rhode Island. Am J Sc (3) $37: 411$ (1889)

90 An attempt to explain glacial lunoid furrows. Am G 5:104-106 (1890)

91 The Labrador coast... 513 pp, N Y 1891

98 A half century of evolution, with special reference to the effects of geological changes on animal life. Am As, $\mathrm{Pr} 47$ : 311-356 (1898) Am Nat 32:623-674 (1898) Science n s 8:243-257, 285-294, 316-323 (1898)

98a on the Carboniferous fauna of Rhode Island and Massachusetts ( $a b s t)$. Am As, Pr $47: 360-361$ (1898) Science n s $8: 397$ (1898)

98b On the systematic position of the trilobites (abst). Am As, $\mathrm{Pr} 47: 365$ (1898) Science n s 8:398 (1898)

00 View of the Carboniferous fauna of the Narragansett Basin. Am Ac Arts, Pr $35: 399-405$, il $(1900)$

O9a A new fossil crab from the Miocene greensand bed of Gay Head, Marthas Vineyard. with remarks on the phylogeny of the genus Cancer. Am Ac Arts, $\operatorname{Pr} 36$ : 1-9, il (1900)
Packard, Alpheus Spring, jr.-Continuel oob On supposed merostomatous an! other Paleozoic arthropod trails, with note on those of Limulus. Am Ac Arts, Pr 30: $61-71$ (1900)

Packard, Earl Leroy.

14 Some west coast Mactridae (abst). G Soc Am, B 25: 151-152 (1914)

15 Evolution of the Pacific coast Mas tridae (abst). G Soc Am, B 26:170 (191:)

16 Faunal studies in the Cretaceous of the Santa Ana Mountains of soutben California. Cal Univ, Dp G, B 9:137-15. map (1916) Abst, G Soc $\Delta \mathrm{m}$, B 27:17t (1916)

16a Mesozoic and Cenozoic Mactrinse of the Pacific coast of North Americ Cal Univ, Dp G, B 9:261-360, il (1916)

16b Minutes of the sixth annual meet ing of the Pacific coast section of the Paleontological Society. G Soc Am, B 2i: 168-174 (1916)

Packard, George A.

o7 Round Mountain camp, Nev. Eng M J 83:150-151 (1907)

07a Gold measures of Tangier, N. \&. M Sc Press 95: 430-431 (1907)

o9 Jefferson Canyon, Nev. M Sc Pres $99: 26$ (1909)

O9a Copper mines and smelteries of Shasta Co., Cal. Eng M J 88:393-399 (1909)

16 The Gold Lake district, Manit. Eng M J 101: 339-340 (1916)

Packard, Robert Lawrence.

92 (with Merrill, G. P.) On an azure blue pyroxenic rock from the middle Gilk. N. Mex. Am J Se (3) $43: 279-280$, maps (1892)

94 Note on a blue mineral, supposed to be ultramarine, from Silver City, N. Mes. U S Nat Mus, Pr 17:19-20 (1894)

$94 a$ Variscite from Utah. Am J Se (3) $47: 297-298$ (1894)

$94 \mathbf{b}$ Genesis of nickel ores. U S G \&, Min Res 1893: 170-177 (1894)

94e Natural sodium salts. U $S$ G 8 , Min Res 1893: 728-738 (1894)

95 On an occurrence of copper in west ern Idaho. Am J Sc (3) $50: 298-300$ (1895)

97 Aluminum. U S G S, An Rp $18 \mathrm{pt}$ $5: 281-285$ (1897)

Padon, Alfred.

51 Arkansas minerals. De Bow's Review 11:406-407 (1851)

Page, David.

46 Rudiments of geology. $288 \mathrm{pp}$, Phils 1846

49 Elements of geology. $332 \mathrm{pp}, \mathrm{N} \mathrm{Y}$ 1849 3d Am ed, 288 pp, N Y 1849

Page, W. T.

82 Analysis of allanite of unusual chem. ical composition from Bedford Co., Va. Cb News $46: 195$ (1882) 
Page, W. T.-Continued.

82a on metallic iron accompanying native gold in Montgomery Co., Va. Ch News $46: 205$ (1882)

Page, William N.

so Hawk's Nest-Gauley Mountain geological section. The Virginias 1:22 (1880)

89 The Glenmore iron estate, Greenbrier Co., W. Va. Am I M Eng, Tr 17 : 115-124, map (1889)

93 The Carboniferous age and the origin of coal. Eng M J 56:347-349, 613-614 (1893)

Pagliueci, Frank D.

05 The quicksilver deposits of Huitzuco [Guerrero, Mexico]. Eng M J 79:417418 (1905)

Paige, Sidney.

06 The Herendeen Bay coal field. U S G S, B 284:101-108 (1906)

07 (and Knope, Adolph) Stratigraphic succession in the region northeast of Cook Inlet, Alaska. G Soc Am, B 18: $325-332$ (1907) Abst, Science n s 25:182 (1907) 07 a Rceonnaissance in the Matanuska and Talkeetna basins, with notes on the placers of the adjacent region. U S G S, B 314:104-125 (1907)

07b Geologic reconnaissance in the Matanuska and Talkeetna basins, Alaska. U S G S, B $327: 71$ pp. (1907)

0s (with Wright, C. W.) Copper deposits on Kasaan Peninsula, Prince of Wales Island. U S G S, B 345:98-115 (1908)

09 The Hanover iron-ore deposits, N. Mex. U S G S, B $380: 199-214$ map (1909)

09a Marble prospects in the Chiricahua Mountains, Ariz. U S G S, B 380 : 299311 (1909)

09b The "rock wall" of Rockwall, Tex. Science n \& 30:690-691 (1909)

10 Preliminary report on pre-Cambrian geology and iron ores of Llano Co., Tex. C S G S, B 430, 256-268 (1910)

11 Mineral resources of the Llano-Burnet region, Texas, with an account of the pre-Cambrian geology. U S G S, B 450: $103 \mathrm{pp}, \operatorname{map}$ (1911)

11a The ore deposits near Pinos Altos, N. Mex. U S G S, B 470:109-125, map (1911)

11b Metalliferous ore deposits near the Burro Mountains, Grant Co., N. Mex. U S G S, B $470: 131-150$, map (1911)

12 Description of the Llano and Burnet quadrangles [Tex.]. U S G S, G Atlas Llano-Burnet fol (no 183):16 pp, maps (1912)

12a Gravel as a resistant rock [physiographic history of a portion of the Silver City quadrangle, N. Mex.]. J G 20:49-52 (1912)

12b Rock-cut surfaces in the desert ranges. J G 20:442-450 (1912)
Paige, Sidney-Continued.

12e The origin of turquoise in the Burro Mountains, N. Mex. Ec G $7: 382-392$ (1912)

12d The geologic and structural relations at Santa Rita (Chino), N. Mex. Ee G $7: 547-559$, map (1912)

12e The Llano-Burnet region, Tex. (discussion). Ec G 7:593-594 (1912)

13 Pre-Cambrian structure of the northern Black Hills, South Dakota, and its bearing on the origin of the Homestake ore body. G Soc Am, B $24: 293-300$ (1913); (discussion by J. D. Irving) 24:704-705 (1913) Abst, Wash Ac Se, J $3: 173$ (1913)

13a Critical criteria on Basin Range structure. Science n s 37:710-711 (1913)

13b The bearing of progressive increase of viscosity during intrusion on the form of laccoliths. J G 21:541-549 (1913)

13e (and Lloyd, E. R.) Recent literature on economic geology. Ec G 8:300$307,807-816$ (1913)

$14 \mathbf{a}$ (and Lloyd, E. R.) kecent literature on economic geology. Ec G $9: 82-97$ (1914)

$14 b$ (and Katz, F. J.) Recent literature on economic geology. Ec G 9:494$502,690-701$ (1914)

14e The mechanics of granite intrusion in the Black Hills, S. Dak. (abst). Wash Ac Sc, J 4: 173 (1914)

15 A model lllustrating character of faulting at the Homestake ore body. Wash Ac Sc, J $5: 487$ (1915)

15a Recent literature on economic geology. Ec G 10:484-488 (1915); 11 : 293-297 (1916)

16 Description of the Silver City quadrangle, N. Mex. U S G S, G Atlas Silver City fol (no 199) : 19 pp, maps (1916)

$16 a$ The mechanics of intrusion of the Black Hills (S. D.) pre-Cambrian granite. Nat Ac Sc, Pr 2:113-114 (1916) Abst, with discussion by Joseph Barrell, C. E. Decker, and the author, G Soc Am, B 27 : 104-106 (1916)

16b Pre-Cambrian structure of the Black Hills, S. D. $(a b s t)$. G Soc Am, B 27:106 (1916)

17 Memorandum on the Missouri earthquake of April 9, 1917. Mo Weather Rv $45: 318$ (1917)

18 (and Steiger, George) Fluorine in sericitization. Wash Ac Se, J 8: 234-239 (1918)

See also Vaughan, 15c

Paisley, C. H.

73 Notes on the marine clays occurring at the railway cutting on the left bank of the Tattagouche River [Gloucester, Co., N. B.]. Can Nat n s $7: 41-43$ (1873)

74 On the post-Pliocene formation near Bathurst, N B. Can Nat n s $7: 268-270$ (1874) 
Palache, Charles.

93 The soda rhyolite north of Berkeley. Cal Univ, Dp G, B 1: 61-72 (1893)

94 The lherzolite serpentine and associated rocks of the Petrero, San Francisco. Cal Univ, Dp G, B 1: 161-179 (1894)

$94 a$ On a rock from the vicinity of Berkeley containing a new soda amphibole. Cal Univ, Dp G, B 1: 181-192 (1894)

96 (with Ransome, F. L.) Ueber Lawsonit, ein neues gesteinsbildendes Mineral aus Californien. Zs Kryst 25:531-537 (1896)

98 The crystallization of the calcite from the copper mines of Lake Superior. Mich G S 6 pt $2:$ 161-184 (1898)

99 Powellite crystals from Miehigan. Am J Sc (4) 7:367-369 (1899) Zs Kryst $31: 529-531$ (1899)

$99 n$ Note on epidote and garnet from Idaho. Am J Se (4) : : 299-302 (1899)

00 Notes on tellurides from Colorado. Am J Sc (4) 10:419-427 (1900) Zs Kryst 34: 539-548 (1901)

02 A description of epidote crystals from Alaska. Am Ac Arts, $\mathrm{Pr}$ 37:531-535 (1902) Zs Kryst 36:433-437 (1902)

o2a (and Fraprie, F. R.) Babingtonite from Somerville, Mass, ; babingtonite from Athol, Mass. Am Ac Arts, Pr 38:383393 (1902) Zs Kryst 37:422-432 (1903)

02b (with Lawson, A. C.) The Berkeley Hills, a detail of Coast Range geology. Cal Univ, Dp G, B $2: 349-450$, map (1902)

o2e (with Woln, J. E.) Apatite from Minot, Maine. Am Ac Arts, Pr 37:517 528 (1902) Zs Kryst $36: 438-448$ (1902)

04 (and Wood, H. O.) A crystallographic study of millerite. Am J Sc (4) 18: $343-359$ (1904)

04a The Alaska-Treadwell mine; notes on the geology of the mine and vicinity. Harriman Alaska Exped 4 : 59-66 (1904)

04b Geology about Chictagof Cove, Stepovak Bay; with notes on Popof and Unga islands [Alaska]. Harriman Alaska Exped 4: $69-88$ (1904)

04c Minerals [collected by the expedition]. Harriman Alaska Exped 4:91-96 (1904)

05 (with Jagrar, T. A., Jr.) Description of Bradshaw Mountains quadrangle [Ariz.]. U S G S, G Atlas Bradshaw Mountains fol (no 126): 11 pp, maps (1905)

06 On octahedrite, brookite, and titanite from Somerville, Mass., U. S. A. Festschrift Harry Roscnbusch : 311-321, Stuttgart 1906

07 Mineralogical notes. Am J Sc (4) 24:249-258 (1907) Zs Kryst 44:14-22 (1907)

$07 a$ Occurrence of olivine in the serpentine of Chester and Middrefeld, Mass. Am J Sc (4) 24:491-4:5 (1907)
Palache, Charles-Continued.

os Mineralogy of the Franklin Furnsy quadrangle, N J. U S G S, G Atlas Frat lin Furnace fol (no 161) : 8-10 (1908)

08a (with Spencer, A. C.) Desch, tion of Franklin Furnace quadrangle, Nir Jersey. U S G S, G Atlas, fol $161: 27$. (1908)

09. Note on a crystal form of benitote Am J Sc (4) $27: 393$ (1909)

O9a (and LaForge, L.) Notes on ty erystallography of leadhillite. Am des! Arts, Pr 44: 435-463 (1909) Zs Kryst 48: 129-139 (1910)

09b (and Merwin, H. E.) Alamosit a new lead silicate from Mexico. Am J\& (4) $27: 399-401(1909)$ Zs ..ryst $46: 51$ 515 (1909)

o9e On connellite and chalcophylitit from Bisbee, Arizona. Am S Sc (4) 2 : $537-540$ (1909)

o9d (and wood, H, O.) Crystals graphic notes on minerals from Cheste, Mass. Am Ac Arts, Pr 44:641-652 (1900)

10 Contributions to the - ineralogy of Franklin Furnace, N J. Am J Sc (4) 29: 177-187 (1910) Zs Kryst 47:576-5s (1910)

10a (and Goldschmidt, V.) Die For menreihen des Leadhillits. Zs Kryst 4s: 140-147 (1910)

10b Fayalite in the granite of Rod port, Mass. (abst). Science n $\$ 32: 22$ (1910) G Soc Am, B 21: 787 (1910)

10e (with Warren, C. H.) Pegmatit in the granite of Quincy, Mass. (absfi. Science n s $32: 220$ (1910) G Soc Am, B $21: 784$ (1910)

11 (and Warren, C. H.) The chemidel composition and crystallization $e^{-}$paristi and a new occurrence of it in the granite pegmatites at Quincy, Mass., L. . A with notes on microcline, riebeckite, xgir ite, ilmenite, octahedrite, fluorite, and will fenite from the same locality. Am J $\mathrm{d}$ (4) $31: 533-557$ (1911) Zs Kryst 49 332-356 (1911)

11 a (with warren, C. H.) The pes matites of the riebeckite-ægirite granite of Quincy, Mass. Am Ac, Pr 47:125-168 (1911)

12 The identity of parisite and synchi site. Am J Sc (4) 34: 490 (1912)

13 (and Schaller, W. T.) Hodgkit sonite, a new mineral from Franklin futnace, N. J. Wash Ac Sc, J $3: 474-478$ (1913)

13a (and Graham, R. P. D.) on the crystallization of willemite. $\mathrm{Am} \mathrm{J}$ Sc (4) 36:639-644 (1913)

14 Supplementary note on the crystal form of hodgkinsonite. Wash $\mathrm{Ac} \mathrm{Sc}_{\text {, }}$ 4: 153-154 (1914)

14a (and Graham, R. P. D.) Über die Krystallisation des Willemits. Zs Kryst $53: 332-336$ (1914) 
Palache, Charles-Continued.

14b (and Sehaller, W. T.) Hodgkinsonit, ein neues Mineral von Franklin, N. J. Zs Kryst $53: 529-532,675-676$ (1914)

17 Tungsten and its ores.

Mineral Foote-notes 1 no $6: 1-10$ (1917)

Palacios, Enrique Juan.

18 Indicaciones petroliferas en la costa del Pactfico. Soc Cient Ant Alz, Mem 37: 61-64 (1918)

Pafueontologia universalis. See International Geological Congress, 03

Palmer, Andrew $\mathrm{H}$.

15 The inauguration of seismological work in the United States Weather Bureau. Seism Soc Am, B 5:63-70 (1915)

16 California earthquakes during 1915. Seism Soc Am, B 6:8-25 (1916)

16a An eruption of Lassen Peak. Mo Weather Rv 44:571-573 (1916)

17 California earthquakes during 1916. Seism Soc.Am, B 7:1-17 (1917)

18 California earthquakes during 1917. Seism Soc Am, B 8:1-12 (1918)

Palmer, Charles M.

03 Chrysocolla; a remarkable case of hydration. Am J Sc (4) 16:45-48 (1903) Palmer, Charles Skeele.

90 A preliminary paper on the eruptive rocks of Boulder Co., and adjoining cos., Colo. Colo Sc Soc, Pr $3: 230-236$ (1890)

91 (and Fulton, Henry) The quartz porphyry of Flagstaff Hill, Boulder, Colo. Colo Se Soc, Pr 3: 351-358 (1891)

98 (and Stodalard, W. B.) The dike on the Columbia vein in Ward district, Boukder Co., Colo. Colo Sc Soc, Pr. 5 ; 159-164 [1898] (Separate ed, 6 pp 1895) Palmer, Chase.

09 Arizonite, ferric metatitanate [from a pegmatite dike near Hackberry, Ariz.]. Am J Sc (4) $28: 353-356$ (1909)

11 The geochemical interpretation of water analyses. U S G S, B 479:31 pp (1911) Abst, by Herman Stabler, Wash Ac Sc, J 2: 155-157 (1912)

13 (and Bastin, E. S.) The rôle of certain metallic minerals in precipitating silver and gold. Am I M Eng, B 77:843857 (1913); Tr 45:224-238 (1914)

13a Metallic minerals as precipitants of silver and gold. Ec G 8:140-170 (1913, 14 Mineralogy of waters from artesian wells at Charleston, S. C. U S G S, P P 90: $90-94$ (1914)

14a Studies in silver enrichment, tetranickel-triarsenide, its cpacity as silver precipitant. Ee G 9:664-674 (1914)

$14 \mathrm{~b}$ Genesis of glauconite (abst).

Soc Am, B 25: 91 (1914)

15 Bornite as silver precipitant. Wash Ac Sc, J $5: 351-354$ (1915)

15 a The silver-precipitating capacity of certain arsenides as an index of their constitution (abst). Wash Ac Sc, J $5: 486$ (1915)
Palmer, Chase-Continued.

17 Diarsenides as silver precipitants. Ec G 12: 207-218 (1917)

Palmer, George Thomas.

09 The medicinal springs of Illinois. Ill G S, B 10:62-75 (1909)

Palmer, Harold Schjoth.

16 Nomographic solutions of certain stratigraphic measurements. Ec G 11:1429 (1916)

18 New graphic method for determining the depth and thickness of strata and the projection of dip. U S G S, P P 120:123128 (1918)

Palmer, Howard.

10 Some tramps across the glaciers and snow fields of British Columbia. Nat Geog Mag 21: 457-487 (1910)

12 Observations on the Sir Sandford Glacier, 1911 [B. C.]. G०og J 39:446453 (1912)

Palmer, Irving A.

18 Manganese. Colo Sch Mines Mag 8 no $4: 55-57$ (1918)

\section{Palmer, Leroy A.}

11 Mining copper ore with steam shovels [Bingham, Utah]. M Mag 4:293-296 (1911)

$11 a$ Development of the Castle Valley coal field, Utah. M World $35: 15-18$ (1911)

13 Tungsten in Boulder Co., Colo. Eng M J 96:99-105 (1913)

14 Ore occurrence at the Cloverdale mine [Sonoma Co., Cal.]. M Sc Press 108 : 812 (1914)

14a Western Montana coal fields. Coll Eng 34: 721-724 (1914)

14b Eastern Montana coal fields. Coll Eng $35: 19-22$ (1914)

16 The Oatman district, Ariz. Eng M J 101: $895-900$ (1916)

16a The Oatman district, Ariz. M Sc Press 113: 193-196 (1916)

16b The Yellow Pine district, Nev. Eng M J 102:123-125 (1916)

16e A sedimentary magnesite deposit [Bissell, Cal.]. Eng M J 102: 965-967 (1916)

18 The Calico district, Cal. M Sc Press $116: 755-758$ (1918)

Palmer, T. S.

o4 Index generum mammalium; a list of the genera and families of mammals. U S, Dp Agr. Div Biol Surv, North American fauna no $23: 984 \mathrm{pp}$, Washington 1904 Palmer, William (1856-1920).

09 Description of a new species of leatherback turtle from the Miocene of Maryland [Psephophorus calvertensis]. U S Nat Mus, Pr $36: 369-373$, il (1909)

15 Certain Miocene fossils [Chesapeake Beach, Md.] Wash Ac Sc, J $5: 261-262$ (1915)

17 The fossil sea cow of Maryland (abst). Science n 8 45:344 (1917) 
Panton, J. Hoyes.

83 Gleanings from the geology of the Red River valley [Manit.] Hist Sc Soc Manit, Tr 3: 10 pp (1883)

S3a Silurian strata near Winnipeg [Manit.] Science 2:169-170 (1883)

84 Fragmentary leaves from the geological records of the great northwest. Hist Sc Soc Manit, $\operatorname{Tr} 4(1883-4): 9$ pp (1884)

84a Gleanings from outcrops of Silurian strata in the Red River valley [Manit.]. Hist Sc Soc Manit, $\operatorname{Tr} 15: 13 \mathrm{pp}$ (1884) Abst, Brit As, Rp $54 \quad 715-716 \quad$ (1885); G Mag (3) 1: 474-475 (1884)

s6 Notes on the geology of some islands in Lake Winnipeg [Manit.]. Hist Sc Soc Manit, Tr 20:10 pp (1886)

SS Places of geological interest near Medicine Hat [Alta.]. Can Inst, $\operatorname{Pr}$ (3) 5: 150-162 (1888)

88a Places of geological interest on the banks of the Saskatchewan $(a b s t)$. Brit As, Rp $57: 714-715$ (1888)

89 The caves and potholes at Rockwood, Ont. Can Inst, $\operatorname{Pr}$ (3) $6: 244-253$ (1889)

91 The mastodon and mammoth in Ontario, Canada. G Mag (3) 8:504-505 (1891) Brit As, Rp 61:654-655 (1892)

Panyity, L. S.

17 The southern extremity of the "Clinton" gas pools in Ohio. Am I M Eng, B 126:963-967 (1917); $\quad$ Tr $57: 984-988$ (1918) Abst, Eng M J 104: 207-208 (1917)

18 Lithology of the Berea sand in southeastern Ohio, and its effect on production. Am I M Eng, B 140:1317-1320 (1918)

Papke, Herman.

os A visit to the mineral localities at Paterson and Great Notch, New Jersey. Mineral Collector 15:113-118 (1908)

Pardee, Joseph Thomas.

09 Faulting and vein structure in the Cracker Creek gold district, Baker Co., Oreg. U S G S, B 380:85-93, map (1909)

10 Placer gravels of the Sumpter and Granite districts, eastern Oregon. U S G S, B 430:59-65 (1910)

10a The glacial Lake Missoula, J G 18 : 376-386 (1910)

11 Geology and mineralization of the upper St. Joe River basin, Idaho. U S G S, B $470: 39-61, \operatorname{map}$ (1911)

13 Some further discoveries of rock phosphate in Montana. U S G S, B 530: 285-291, map (1913)

13a Coal in the Tertiary lake beds of southwestern Montana. U S G S, B 531: 229-244, map (1913)

14 (and Fewett, D. F.) Geology and mineral resources of the Sumpter quadrangle, Oreg. Oreg Bur Mines, Min Res Oreg 1, no 6:3-128, map (1914)

17 The Garrison and Philipsburg phosphate fields, Mont. U S G S, B 640: 195228, maps (1917)
Pardee, Joseph Thomas-Continued.

$17 \mathbf{n}$ The Dunkleberg mining distric Granite Co., Mont. U S G S, B 660:24: 247, maps (1917) Abst, Wash Ac $\$ c$, $8: 249$ (1918)

18 Ore deposits of the northwestern pur of the Garnet Range, Mont. U S G S ? 660:159-239, map (1918) Abst, Wash s Sc, J 8: 290 (1918)

18a Geology and mineral deposits of th Colville Indian Reservation, Wash, Us G S, B $677: 186$ pp, map (1918)

18b Manganese at Butte, Mont. I? G S, B 690:111-130 (1918) Abst, b R. W. Stone, Wash Ac Sc, J $8: 450-45$ (1918)

18c Some manganese deposits in Mat: son Co., Mont. U S G S, B 660:131-13 (1918)

18d (and Parks, H. M.) Manganes deposits near Lake Creek, Oreg. Eng II $106: 872-873$ (1918)

Paré, A. A.

os Mining and mining methods of th Yukon. Can M Inst. J 11:545-565 (1908) Paredes, Trinidad.

os Apuntes para la geologla de la regio lagunera del Tlahualilo. Soc G Mex, B 4 $37-42$ (1908)

09 Apuntes sobre un criadero de colns en Cerro Seco, E. de Guerrero. Soc G Xes, B $5: 103-106$ (1909)

O9a Estudio hidrológico de la regín de Rioverde y Arroyo Seco en los Estados d: San Luis Potosi y Querétaro. Méx I G, Par 2: 291-337, map (1909)

09b Estudio hidrologico del Valle de Ixmiquilpán, Estado de Hidalgo. Més G, Par 3:141-172 (1909)

12 Apuntes sobre algunos minerales de Estado de Chihuahua. Soc G Mex, B 8: vii, 21-40 (1912)

13 Informe sobre el pozo de Yurecuaro, Michoacán [Méx.] Méx I G, Par 5: 219224 (1913)

16 Los recursos de aguas del Valle do Tecalitian, Cantón de Ciudad Guzmini, Estado de Jaliseo [México]. Méx I G, Pat 5:477-501 (1916)

17 El Instituto Geologico nacional. Bol Minero 4:471-486 (1917)

18 Exploración geológica de una parte del Estado de Guerrero [México]. Bol Minero 6:481-498 (1918)

Park, Emma J.

o4 Winoka gravels, supposed Tertiary deposits. Drury Coll, Bradley G Field Sta. B $1: 14-19$ (1904)

os (and Lyman, Kate) The Spring field [Mo.] water supply; descriptions of springs and the geology of the district. Drury Coll, Bradley $G$ Field Sta, B 1:4549 (1905)

O5a (and Lyman, Kate) The Hannibal formation in Greene Co. [Mo.]. Drars Coll, Bradley G Field Sta, B $1: 79-90$ (1905) 
Park, James.

05 On the cause of border segregation in some igneous magmas. M Rep 51:481482 (1905)

06 Contact metamorphism in its relation to ore deposits. M Se Press 93:544-545 (1906)

Parke, John G,

55 Report of explorations for that portion of a railroad route near the thirtysecond parallel of north latitude lying between Dona Ana, on the Rio Grande, and Pinas villages, on the Gila. U S, Pacific R R Expl (U S, 33d Cong 1st sess, H Ex Doc 129) : 53 pp (1855); also (U S, 33d Cong $2 d$ sess, $\mathrm{S}$ Ex Doc 78 and $\mathrm{H}$ Ex Doc 91) $2: 22$ pp (1856)

Parker, Charles A.

04 Evidences of rheumatold arthritis in the Lansing man. Am G $33: 39-42$ (1904) Parker, Edward Wheeler.

92 Coal [and numerous other sections]. U S G S, Min Res 1889-90 (1892) and succeeding volumes to 1912 pt 2 (1913)

00 Arkansas bauxite deposits. Mines and Minerals 20:327-328 (1900)

05 The known coal fields of the United States. M World 22:469-471 (1905)

06 (and Holmes, J. A., Campbell, M. R.) Report on the operations of the coal-testing plant of the United States Geological Survey at the Louisiana Purchase Exposition, St. Louis, Mo., 1904. U S G S,PP P 48: 1492 pp (1906)

os How long will our coal supplies meet the increasing demands of commerce? Am M Cong, 10th An Sess, Rp Pr:239246 (1908)

09 (with Cample11, M. R.) Coal flelds of the United States, U S G S, B 394: 7-26 (1909)

Parker, H. W.

$84[\mathrm{On}$ remains of the mammoth in Iowa.] Science 4:46 (1884)

85 Footprints in the rocks of Colorado. Science 5:312-313 (1885)

Parker, Horatio Newton.

11 Quality of the water supplies of Kansas. U S G S, W-S P 273:375 pp, map (1911)

Parker, John D.

81 The Burlington gravel beds [Kans.]. Kansas City Rv Sc 5: 325-331, 492 (1881)

81a Memorial of Prof. Benjamin F. Mudge. Kans Ac Sc, Tr $7: 7-11$ (1881); reprint (1906)

84 The Russell artesian well [Kans.]. Kansas City Rv Sc 8:65-69 (1884)

8ta The Burlington gravel beds [Kans.] Kansas City Rv Sc 8: 386-387 (1884)

Parker, Nathan H.

56 Parker's sectional and geological map of Iowa ... Scale 8 miles to 1 inch. N Y 1856
Parker, Nathan H.-Continued.

65 Parker's geological map of the State of Missouri showing the location of the principal deposits of iron, lead, zine ... Scale 18 miles to 1 inch. St Louis, Mo., 1865

Parker, Richard A.

s8 The new Michigan gold fields [Ishpeming distriet]. Eng M J 46:238-239 (1888)

93 The iron ore region of Lake Superior. Eng Mag 6: 152-175, 285-303 (1893)

Parker, Samuel.

38 Journal of an exploring tour beyond the Rocky Mountains ... [geology : 208-227] 371 pp, map, Ithaca, N Y 1883; 2d ed [geology : 316-330], $400 \mathrm{pp}, 1840 ; 3 \mathrm{~d}$ ed, 408 pp, 1842 ; 4 th ed, 416 pp, 1844; 5th ed, $422 \mathrm{pp}, 1846$

Parker, William B.

56 Notes taken during the expedition commanded by Capt. R. B. Marcy ... through unexplored Texas... 242 pp, Phila 1856

Parkins, Almon Ernest.

10 A waste filled valley (abst). Mich Ac Sc, Rp 12:53 (1910)

11 Valley filling by intermittent streams. J G 19:217-222 (1911)

Parkinson, John.

01 Some lake basins in Alberta and British Columbia. G Mag (4) $8: 97-101$ (1901)

O1a The hollow spherulites of the Yellowstone... G Soc London, Q J 57:211225 (1901) Abst, G Mag (4) 8:235-236 (1901)

Parks, Emerson M.

16 (with winchester, D. E., and others) The lignite field of nort'iwestern South Dakota. U S G S, B 627: 169 pp, maps (1916) Abst, Wash Ac Sc, J 7: 36-37 (1917)

Parks, George A.

15 Kachemak Bay lignite deposits of Alaska. Colo Sch Mines Mag 5:44-49 (1915)

Parks, Henry Martin.

12 Road materials in the Willamette Valley. Oreg Bur Mines, : 1:63 pp, map (1911, 2d ed 1912)

12a The economic geological resources of Oregon. Oreg Bur Mines (Oreg Agr Coll, Coll B, Extension Series 5 no 2): $120 \mathrm{pp}$ (1912)

14 Preliminary ret $\mathrm{rt}$ on buili.ng stone in Oregon. Oreg Bur Mines, Min Res Oreg 1 no $2: 10-46$, maps (1914)

16 [Biennial report of the Oregon $\mathrm{Bu}$ reat of Mines and Geology, 1915-1916], 1:) pp (1916)

16a (and swartley, A. M.) Handbook of the mining industry of Oregon. Oreg Bur Mines, Min Res Oreg 2 no 4: 306 pp, map (1916)

is (with Pardee, J. T.) Manganese deposits near Lake Creek, Oreg. Eng M J $106: 8: 2-873$ (1918) 
Parks, William Arthur.

98 Geology of base and r eridian lines in Rainy River district. Ont Bur Mines, Rp 7 : 161-183, map (1898)

99 The Nipissing-Algoma boundary [Ontario]. Ont Bur Mines, Rp 8:175-196, map (1899)

oo The Huronian of the Moose River basin [Ont.]. Toronto, Univ, Studies, $g$ s no $1: 35 \mathrm{pp}$, map (1900)

01 [Report on field work in the Muskoka district of Ontario.] Can G S, Sum Rp 1900 (An Rp 13) : A 121-129 (1901)

02 The country east of Nipigon Lake and River [Ont.]. Can G S, Sum Rp 1901 (An Rp 14) : A 105-109 (1902)

o3 Region lying northeast of Lake Nipigon [Ont.]. Can G S, Sum Rp 1902 (An Rp 15) : A 213-222 (1903)

03a Fossiliferous roeks of southwest Ontario. Ont Bur Mines, Rp 1903: 141156 (1903)

04 Devonian fauna of Kwataboahegan River. Ont Bur Mines, Rp 1904: 180-191, il (1904)

04a A remarkable parasite from the Devonian rocks of the Hudson Bay slope. Am J Sc (4) $18: 135-140$ (1904)

o5 The geology of a district from Lake Timiskaming northward. Can G S. Sum Rp 1904 (An Rp 16) : A 198-225 (1905)

05a The study of stratigraphy (with discussion). Can M Inst, $J$ 7:168-176 (1905)

05b Formation of coal beds and life of the coal-forming age $(a b s t)$. Hamilton Sc As, J Pr 21:67 (1905)

06 [Report on] the valley of the Tobique River, N. B. Can G S, Sum Rp 1905: 115-117 (1906)

o7 The stromatoporoids of the Guelph formation in Ontario. Toronto, Univ, Studies g s 4: 40 pp, 11 (1907)

ота The Cobalt [Ont.] mining district. past and present. Hamilton Sc As, $J$ s'r 23 : $42-45$ (1907)

08 Niagara stromatoporoids. Toronto, Univ, Studies g s $5: 68$ pp, 11 (1908)

o8a Notes on the ophiurian genus Protaster, with description of a new speeles. Can Inst, $\operatorname{Tr} 8: 363-372$, il (1908) osb On an occurrence of Hybocystis in Ontario. Ottawa Nat $21: 232-236$, il (1908)

08e Notes on Silurian stromatoporolds from Hudson's Bay. Ottawa Nat 22:2529 (1908)

09 Notes on the ophiurian genus, Pro. taster, with description of a new species. Can Inst, $\operatorname{Tr} 8: 363-372$, Il (1909)

09 a Note on the ornamentation of Periglyptocrinus priscus. Ottawa Nat 23:153155 , il (1909)

09b Silurian stromatoporoids of America (exclusive of Niagara and Guelph). Toronto, Univ, Studies g \& $6: 52 \mathrm{pp}$, il (1909)
Parks, William Arthur-Continued,

10 Ordovician stromatoporoids of Ames: ica. Toronto, Univ, Studies g \& $7: 52$ p il (1910)

10a A new cystid from the Clinton for. mation of Ontario, Lepadocystis elintones. sis. Am J Sc (4) $29: 404-406$, il (1910) Abst, Science n s $32: 224$ (1910)

10b Preliminary report on the building and ornamental stones of Ontario, south the Ottawa and French rivers. Can Mines Br, Sum Rp 1910: 110-114 (1910)

12 The building and ornamental stones of the maritime provinces. Can Mines Be. Sum Rp 1911: 84-86 (1912)

12a Report on the building and orn. mental stones of Canada, vol 1. Can Mines $\mathrm{Br}: 376 \mathrm{pp}$ (1912)

13 [Ordovician fossils from Shamattam: River (Manit.) and Silurian fossils from Fawn and Severn rivers (Patricia district. Ont.) ]. Ont Bur Mines, An Rp 22 pt 1 : 190-196 (1913)

13a The buflding and ornamental stones of the Province of Quebec. Can Mines Bt, Sum Rp 1912: 76-79 (1913)

13b The paleontology of the Guelph Onondaga, and Hamilton formations in western Ontario. Int G Cong, X11, Canade, Guide Book no 4:77-123, maps, il (1913)

13e The Paleozoic section at Hamiltos, Ont. Int G Cong, XII. Canada, Guide Book no $4: 125-140$, map (1913)

13d Silurian section at the forks of Credit River: Ordovician section on Credit River near Streetsville, Ont.; Geology of selected areas on Lakes Erie and Hum in the Province of Ontario. Int $\mathrm{G}$ Cons XII, Canada, Guide Book no 5 : 5-13, 15-21 37-107, maps (1913)

14 Report on the building and ornames tal stones of Canada; vol. 2, Maritim provinces. Can Mines $\mathrm{Br}$ : 264 pp (1914)

$14 a$ Report on the building and orns mental stones of Canada; vol. 3 , Provinct of Quebec. Can Mines Br: 304 pp (1914)

15 Paleozoic fossils from a region soutbwest of Hudson Bay. R Can Inst, Tr 11 : $3-95$, il (1915)

16 Report on the building and oms. mental stones of Canada; vol. 4. Provines of Manitoba, Saskatchewan, and Alberta. Can Dp Mines, Mines Br : 333 pp (1916)

17 Report on the building and orns: mental stones of Canada; vol. 5 , Provisce of British Columbia. Can Dp Mines, Mines Br : 236 pp, maps (1917)

17a Building and ornamental stones of British Columbia. Can Dp Mines, Mines Br, Sum Rp 1916: 59-60 (1917)

Parmelee, C. W.

06 (and MeCourt, W. E.) A report on the peat deposits of northern New Jersey. N J G S, An Rp St G 1905; 2 \& 313 (1906! 


\section{Parmenter, C. S.}

99 Fossil turtle cast from the Dakota epoch. Kans Ac Sc, Tr 16:67, il (1899)

Parr, S. W.

06 Composition and character of Illinois coals. Ill G S, B $3: 27-78$ (1906)

06a The coals of Illinois. Eng M J 81 : 86 (1906)

07 Chemical analyses of certain coals. III G S, B $4: 188-197$ (1907)

10 The chemical composition of Illinois coal. Ill G S, B $16: 203-243$ (1910)

12 (and Ernest, T. R.) A study of sand-lime brick. Illinois $G \mathrm{~S}, \mathrm{~B} \quad 18: 83$ pp (1912)

Parra, Antonio.

87 Descripcion de diferentos piezas de historia natural las más del ramo marítimo... $195 \mathrm{pp}$, il, Havana 1787 [not seen]

Parrish, S. F.

01 The B. C. mine, Summit Camp, Boundary district [B. C.]. Eng M J 72: 92 (1901)

Parry, Charles Christopher (1823-1890). 57 General geological features of the country. In Emory. W. H., Report on the United States and Mexican goundary survey ... (U S, 34th Cong 1st 8 \&s, S Ex Dor 108 and $\mathrm{H}$ Ex Doc 135), v pt $2: 1-2:$ (1857)

57a Geological features of the Rio Grand valley from EI Paso to the mouth of the Pecos River. In Emory, W. A., Report on the United States and Mexican boundary survey ... (U $\mathrm{S}, 34 \mathrm{th}$ Cong 1st sess, S Ex Doc 108 and $\mathrm{H}$ Ex Doc 135), F 1 pt $2: 49-61$ (1857)

57b Physical and geological description of the country fror: the initial point on the Pacific to the junction of the Gila and Colorado. In Emory, W. H., Report on the United States nd Mexican boundary survey ... (U S, 34th Cong 1st sess, S Ex Doc 108 and $\mathrm{H}$ Ex Doc 135), v 1 pt 2 : 78-99 (Inel. extract from report of Arthur Schott : 92-98) (1857)

57e Reconnaissance to the month of the Gila River from San Diego, Cal... In Emory, W. H., Report on the United States and Mexican boundary survey ... (U S, 34th Cong 1st sess, S Ex Doc 108 and $\mathrm{H} \mathrm{Ex}$ Doc 135) v 1: 125-130 (1857)

69 Preliminary report. In Palmer, Wm. J., Report of surveys across the continent in 1867-68 ...: 196-228, Phila 1869

Parsons, Arthur Leonard.

02 Greensand marl. U S G S, Min Res 1901: 823-827 (1902)

02a Recent developments in the gypsum industry in New York State. N Y St Mus, An $\mathrm{Rp} 54: \mathrm{r} 177-183$ (1902)

04 The gypsum deposits of New York State $(a b s t)$. Science n \& 19:855-856 (1904)

$$
28737^{\circ}-23-52
$$

Parsons, Arthur Leonard-Continued.

o5 Peat; its formation, uses, and occurrence in New York. N Y St Mus, An Rp 57:15-88 (1905)

05a Notes on the gypsum industry in New York. N Y St Mus, An Rp 57:89157 (1905)

os Geology of Thunder Bay-Algoma boundary. Ont Bur Mines, An Rp 17 : 95-135 (1908)

10 (with Goldschmidt, V.) Notes on goethite. Am J Sc (4) $29: 235-236$ (1910)

11 Gold fields of Lake of the Woods, Manitou, and Dryden, Ontario. Ont Bur Mines, An Rp 20 pt 1: 158-198 (1911); 21 pt 1:169-204, map (1912)

13 The Lake of the Woods and other areas. Ont Bur Mines, An Rp 22 pt 1: 210-232, maps (1913)

$13 a$ Carrier to Coldwell; Coldwell to Port Arthur; Winnipeg to Port Arthur. Int G Cong, XII, Canada, Guide Book no 8 : 14-16, 24-36, 370-386, maps (1913)

15 The productive area of the Michipicoten iron ranges [Ont.] Ont Bur Mines, An Rp 24 pt 1:185-213, maps (1915)

16 Iron deposits of Hunter Island with notes on the Gunflint Lake area. Ont Bur Mines, An Rp 25 pt 1:163-191, maps (1916)

17 Molybdenite deposits of Ontario, Ont Bur Mines, An Rp 26:275-313, maps (1917)

18 Slate Islands, Lake Superior. Ont Bur Mines, An Rp 27: 155-167, map (1918)

18a Mineral developments in northwestern Ontario. Ont Bur Mines, An Rp $27: 168-186$, map (1918)

Parsons, Charles Lathrop.

97 [with Moses, A. J.) Elements of mineralogy, crystallography, and blowpipe analysis, $342 \mathrm{pp}, \mathrm{N}$ Y $1897.2 \mathrm{~d}$ ed, 414 pp, N Y 1900 3d ed, 444 pp, N Y 1906 4 th ed [not seen] 5th ed, $631 \mathrm{pp}, \mathrm{N} \mathbf{Y}$ 1916

13 Fuller's earth. U S Bur Mines, B 71: 88 pp (1913)

14 Our radium resources. Am M Cong, Rp 16th An Sess 1913: 223-234 (1914)

17 The occurrence and preparation of radium and associated metals. Pan American Sc Cong. 2d, Washington, Pr sec 7 vol $8: 310-322$ (1917)

18 Iceland spar in Montana. Science u \& $47: 508-509$ (1918) Abst, M Sc Press $116: 824$ (1918)

Parsons, Floyd W.

06 Coal mining by open stripping in Pennsylvania [Hazelton district]. Eng M Jour 81: 1239-1240 (1906)

o6a Mining in the George's Creek coal field [Md.]. Eng M J 82:687-691 (1906)

06b Coal mining in the Fairmont field, W. Va. Eng M J $82: 1018-1020$, 10701074 (1906) 
Parsons, Floyd W.-Continued.

of Coal mining in southern West Virginia. Eng M J $84: 881-885$ (1907)

07a The coal-mining situation in northern Wyoming. Eng M Jour 84:930-935 (1907)

отb Montana's great coal fields and its collieries. Eng M J 84:978-981 (1907)

os The coal mines of soutbern Wyoming. Eng M J 85: 118-120 (1908)

12 Mining coal on the Virginian Railroad [southern West Virginia]. Coal Age 1: 1039-1043 (1912)

Parsens, H. F.

03 (and Liddell, C. A.) Coal and mineral resources of Routt Co. [Colo.]. Colo Sch Mines, B 1 no 4: 47-59 (1903)

Parsons, H. G.

00 The oil flelds of Kern Co., Cal. M Se Press 81: 492-493, 520-521, 531 (1900)

O0a Oil fields of Fresno Co., Cal. M Se Press 81:545 (1900)

Parsons, T. S.

o7 Some unknown American natural bridges. Mineral Collector 14:103-104 (1907)

Parsons, W. F. C.

06 Prospecting for iron ore in the Torbrook iron district, Annapolis Co., N. S. Can M Inst, J 9:31-34 (1906)

Partz, August.

54 Examinations and explorations on the gold-bearing belts of the Atlantic States. M Mag 2: 378-388; $3: 161-168$ (1854)

Pastor y Giraud, Antonio.

12 (with wittich, Ernst) Riesengipskristalle aus Chihuahua, Nord-Mexiko. Centr Min : 731-733 (1912)

Pate, William F.

oS (and Bassler, R. S.) The late Niagaran strata of west Tennessee. U S Nat Mus, $\operatorname{Pr} 34: 407-432$ (1908)

Patoni, Carlos.

17 Región minera de Potrillos [Estado de Durango, México]. Bol Minero 3:6873, map (1917)

Patriek, G. E.

75 Kansas chalk. Kans Ac Sc, Tr 4: 13-15 (1875); reprint (1906) Kans St Bd Agr, An Rp 4: 697-699 (1875)

$\mathbf{7 7}$ The Waconda meteorite [Kans.]. Kans Ac Sc, Tr 5:12-13 (1877); reprint: 13-14 (1906)

$\mathbf{7 7 a}$ The Iola gas well [Kansas]. Kans Ac Sc, Tr 5 : 13-15 (1877) ; reprint : 14-16 (1906)

83 Protozoan remains in Kansas chalk.

Kans Ac Sc, Tr 8: 26-27 (1883)

Patten, William.

02 On the structure and classification of the Tremataspidae. Am Nat 36:379-393, il (1902)

03 On the structure of the Pteraspidae and Cephalaspidae. Am Nat $37: 827-859$, 11 (1903)

04 New facts concerning Bothriolepis. Biol B $7: 113-124$, il (1904)
Patten. William-Continued.

05 studies relating to the origin of verte brates. Carnegie Inst Wash, Y Bk $3: 1+$ t (1905)

os (with Hiteheoek, C. H.) Studies of the tracks of Climatichnites (abst). Science n s 28: 382 (1908)

Patterson, Lawson B.

62 Twelve years in the mines of Call. fornia ... and notes on the origin of gold deposits. 108 pp, Cambridge [Mass.], 1862

Patterson, R. M.

50 Ueber die Beschaffenheit und das Vorkommen des Goldes, Platins und der Diamanten in den Vereinigten Staaten. Deut G Ges, Zs 2:60-64 (1850)

Patton. Horace Bushnell.

93 Microscopic study of some Michigan rocks. Mich G S, Rp 1891-2:184-186 (1893)

96 Lecture notes on crystallography. 34 pp, Golden, Colo., 1896 Rev ed, 47 pp, N Y $19053 \mathrm{~d}$ ed, $54 \mathrm{pp}$, Golden, Colo., 1911

98 Spherulites containing chalcedony and opal in Colorado. Colo Sc Soc, $\mathrm{Pr} 5: 165-$ 170 [1898] (separate ed, $6 \mathrm{pp}, 1896$ )

98a Peculiar geological formations at the headwaters of the Rio Grande, Colo. Colo Sc Soc, Pr 5: 171-172 [1898] (sepa. rate ed: $7-8,1896$ )

99 Tourmaline and tourmaline schists from Belcher Hill, Colorado. G Soc Am, B 10:21-26 (1899) Abst, Am G 22:251 (1898); Science n s $8: 464-465$ (1898)

oo Thomsonite, mesolite, and chabazite from Golden, Colo. G Soc Am, B 11: 461$474 \quad(1900)$

01 Section E, Geology and geography [American Association for the Advancement of Science]. Science n 8 14:794800 (1901)

02 Crater Lake, Oregon. Colo Sc Soc $\operatorname{Pr} 6: 27-29$ [1902]

02a (with Diller, J. S.) The geology and petrography of Crater Lake National Park. U S G S, P P $3: 167$ pp, maps (1902)

03 Synopsis of paper on the develop ment of pseudomorphs. Colo Sc Soc, Pr $7: 103-107 \quad$ (1903)

04 Fault planes in the Dakota fire clay beds at Golden, Colo (abst). G Soc Am B 15:583 (1904)

o5 Faults in the Dakota formation at Golden, Colo. Colo Sch Mines, B $3: 26-32$ (1905)

os Topaz-bearing rhyolite of the Thomas Range, Utah. G Soc Am, B $19: 177-192$ (1908) Abst, Science n s 27:410 (1908)

09 The Montezuma mining district of Summit Co., Colo. Colo G S, 1st Rp 1908 105-144, map (1909)

10 Rock streams of Veta Peak, Colo. G Soc Am, B 21:663-676; (discussion) 21 764-765 (1910) Abst, Science n s 32:191 (1910) 
Patton, Horace Bushnell-Continued.

10a (and others) Geology of the Grayback mining district, Costilla Co., Colo. Colo G S, B 2:111 pp, maps (1910)

12 (and Hoskin, A. J., and Butler, G. M.) Geology and ore deposits of the Alma district, Park Co., Colo. Colo G S, B $3: 284 \mathrm{pp}$, map (1912)

15 (and Wolf, H. J.) Preliminary report on the Cresson gold strike at Cripple Creek, Colo. Colo Sch Mines, Q 9 no 4: 1-15 (1915)

15a Primary chalcocite in the fluorspar veins of Jefferson Co., Colo., $(a b s t)$. G Soc Am, B $26: 84$ (1915)

15b Recent remarkable gold "strike" at the Cresson mine, Cripple Creek, Colo. (abst). G Soc Am, B 26:84-85 (1915)

15e Occurrence of flow breccias in Colorado (abst). G Soc Am, B 26:399-401 (1915)

16 Geology and ore deposits of the Bonanza district, Saguache Co., Colo. Colo G S, B $9: 136$ pp, maps (1916)

17 The Cresson bonanzas at Cripple Creek [Colo.]. M Sc Press 115:381-385 (1917)

18 Geology and ore deposits of the Platoro-Summitville mining district, Colo. Colo G S, B 13: 122 pp, maps (1917) [1918]

Patton, Jacob Harris.

88 Natural resources of the United States. $x v, 523$ pp, N Y 1888

Patton, William.

55 [Geology of a portion of Calaveras Co.] Cal, Surveyor General, An Rp 1854 : 86-88 [1855]

Pan1, Fred P.

12 Ueber Azurit, Vanadinit, Mimetesit, Calamin. Zs Kryst 50:600-604 (1912)

Pauleke, W.

14 Über tektonische Experimente. Int G Cong, XII, 1913, C R : 835-841 (1914) Pavie, Paul.

67 (with Dollfus, A., and Tontserrat, E. de) Observations géolo ziques faites dans le trajet de la Vera Cruz a Mexico. [France], Comm Sc Mex, Arch 2:124-127, Paris 1867

67a (with Dollexs, A., and Montserrat, E. de) Récit d'une ascension au Popocatepetl ( 23 avril 1865); note explicative de la coupe géologique de Mexico an sommet du Popocatepetl. [France], Comm Sc Mex, Arch 2:187-208, Paris 1867

67b (with Dolleus, A., and Montserrat, E. de) Mémoires et notes géologiques [Mexico], [France], Comm Sc Mex, Arch 2:363-403, map, Paris 1867

\section{Pavlow, Alexis.}

92 On the marine beds losing the Jurasslc and opening the Cretaceous, with the history of their fauna. G Soc Am, B 3 : 61-64 (1892)
Pavlow, Marie.

87 Etudes sur l'histoire paléontologique des ongulés en Amérique et en Europe. Soc Imp Nat Moscou, B n s 1: $343-373$, 11 (1887) ; 2:135-182, il (1889)

Payen, M.

63 [Sur fossiles trouvés aux environs de la Basse-Terre, Guadeloupe.] Soc G France, B (2) 20:475-476 (1863)

Payne, C. A.

04 The zinc ores of Virginia. Eng M J $78: 544$ (1904)

Payne, Henry M.

05 The Tug River coal field [Mingo Co.. W. Va.]. Mines and Minerals 25:391393 (1905)

14 Coal mining in Yukon Terr. Coll Eng 35: 133-135 (1914)

Peach, B. N.

12 The relation between the Cambrian faunas of Scotland and North America. Nature $90: 49-56$ (1912)

Peale, Albert Charles (1849-1914).

72 Report on minerals, rocks, thermal springs, etc. U S G S Mont (Hayden), An Rp 5:165-204 (1872)

72a (with Hayden, F. V.) [Geologic map of] Montana and Wyoming Territories, embracing most of the country drained by the Madison, Gallatin, and upper Yellowstone rivers. Scale, 4 miles to 1 inch. U S G S Terr (Hayden) n d [1872]

73 Report [on explorations in Colorado, Utah, Montana and Yellowstone Park]. U S G S Terr (Hayden), An Rp 6:97-187 (1873)

74 Report [on the South Park region, Colo.1. U S G Geog S Terr (Hayden), An Rp [7]: 193-273 (1874)

74a Mines noted by the South Park division ... 1873. U S G Geog S Terr (Hayden) An Rp [7]:301-305 (1874)

76 Report [on valleys of Eagle, Grand, and Gunnison rivers, Colo.]. U S G Geog $\mathrm{S}$ Terr (Hayden), An Rp [8]: 73-180. maps (1876)

77 Report [on the Grand River district, Colo.]. U S G Geog S Terr (Hayden), An Rp 9:31-101, maps (1877)

$77 \boldsymbol{a}$ On a peculiar type of eruptive mountains in Colorado. U S G Geog S Terr (Hayden), B 3:551-564 (1877)

77b Notes on the age of the Rocky Mountains in Colorado. Am J Sc (3) 13 : $172-181$ (1877)

77e Note on the eriticism of Prof. Stevenson. Am J Sc (3) 13:388-389 (1877)

77d Thermal springs and geysers Penn Mo 8:507-528 (1877)

78 Geological report on the Grand River district [Colo.]. U S G Geog S Terr (Hayden), An Rp 10:161-185. maps (1878)

78 a The ancient outlet of Great Salt Lake. Am J Se (3) $15: 439-444$ (1878) 
Peale, Albert Charles-Continued.

79 Report on the geology of the Green River district [Wyo.]. U S G Geog S Terr (Hayden), An Rp 11:509-646, maps (1879)

79a Jura-Trias section of southeastern Idaho and western Wyoming. U S G Geog S Terr (Hayden) B 5:119-123 (1879)

$\mathbf{7 9 b}$ The Laramie group of western Wyoming and adjacent regions. U S G Geog S Terr (Hayden), B 5: 195-200 (1879)

83 The thermal springs of Yellowstone National Park. U S G Geog S Terr (Hayden), An Rp 12 pt 2:63-454 (1883)

83a [Geologic map of] parts of western Wyoming, southeastern Idaho, and northeastern Utah. Surveyed in 1877. Scale 4 miles to 1 inch. U S G Geog $\mathbf{S}$ Terr (Hayden), $n$ d [1883?] [Also in 12th An Rp]

83b (and others) Geological map of portions of Wyoming, Idaho, and Utah. Scale 8 miles to 1 inch. U S G Geog $\mathrm{S}$ Terr (Hayden), $n$ d [1883?] [Also in 12th An Rp]

s3e Some geyser comparisons. Science 2: 101-102 (1883)

S4 The world's geyser regions. Pop Sc Mo $25: 494-508$ (1884)

85 Mineral waters. U S G S, Min Res $1883-4: 978-987 ; 1885: 536-543 ; 1886$ : $715-721 ; 1887: 680-687 ; 1888: 623-630$; 1889-90: 521-535: 1891 : 601-610 ; 1892 : $823-834: 1893: 772-794$ : An Rp 16 pt 3 : $707-721: 17$ pt $3: 1025-1044 ; 18$ pt 5 : $1369-1389 ; 19$ pt 6 con : $659-680 ; 20$ pt 6 con : $747-769 ; 21$ pt 6 con : $597-622$; Min Res 1900: 899-905 (1885-1901)

85a Devonian strata in Montana. Science $5: 249$ (1885)

86 Lists and analyses of the mineral springs of the United States. U S G S, B $32: 235$ pp (1886)

86a Lacustrine deposits of Montana. Science $8: 163-165$ (1886)

87 The classification of American mineral waters. Am Climatological As, Tr 4 : 156-166 (1887)

90 Ferdinand Vandiveer Hayden. $\mathrm{Ph}$ Soc Wash, B $11: 476-478$ (1890)

93 The Paleozote section in the vicinity of Three Forks, Mont. U S G S, B 110: 56 pp, map (1893)

94 Natural mineral waters of the United States. U S G S, An Rp 14 pt 2:51-88 (1894)

96 Description of the Three Forks sheet [Mont.]. U S G S, G Atlas Three Forks fol (no 24) : 5 pp. maps (1896) Abst, J G $5: 407-409$ (1897)

09 On the application of the term Laramie. Am J Sc (4) 28:45-58 (1909)

12 On the stratigraphic position and age of the Judith River formation. J G 20 : $530-549,640-652,738-757$ (1912)

13 The laws of nomenclature in paleontology. Science n \& 37:979-980 (1913)

See also Emmons (S F), 93 ; Powell, 89, $89 \mathrm{a}, 90,91,91 \mathrm{a}, 92$
Peale, Rembrandt.

02 Account of the skeleton of the mam moth, a nondescript carnivorous animal of immense size, found in America. $46 \mathrm{pp}$. L 1802

o3 An historical disquisition on the mammoth or great American incognitum .. 91 pp, L 1803

Pearee, Richard.

86 Address of the retiring president [includes notes on minerals of Colorado]. Colo Sc Soc, Pr 2:1-6 (1886)

$86 a$ Notes on the occurrence of goslarite in the "Gagnon" mine, Butte City [Mont.]. Colo Se Soc, Pr 2:12-13 (1886)

S7 Note on what appears to be a new mineral from the Gagnon mine, Butte, Mont. Colo Sc Soc, Pr 2: 70 (1887)

87 a Notes on a new occurrence of copper arsenates and associated minerals in Utah. Colo Sc Soc, Pr 2:134-137 (1887)

$\mathbf{8 7 b}$ Additional notes on copper arse nates and associated minerals from Utab. Colo Sc Soc, Pr 2: 150-153 (1887)

87 e The association of minerals in the Gagnon vein, Butte City, Mont. Am I M Eng, $\operatorname{Tr} 16: 62-64$ (1887)

88 Notes on pharmacosiderite [Mam. moth mine, Utah]. Colo Sc Soc, $\mathrm{Pr} 2$ : 180-181 (1888)

88a Supposed mixture of bornite and stromeyerite [Idaho Springs, Colo.]. Colo Sc Soc, $\operatorname{Pr} 2: 188$ (1888)

89 The genesis of ore deposits. Colo S Soc, $\operatorname{Pr} 3: 71-72$ (1889)

90 Notes on the occurrence of sesquisulphate of iron in New Mexico. Colo $\mathrm{Sc} B o c$ Pr 3:228 (1890)

$90 a$ Address of the retiring president [paragenesis of gold-bearing ores]. Colo Sc Soc, Pr 3: 237-244 (1890)

$90 \mathrm{~b}$ The association of gold with other metals in the West. Am I M Eng, Tr 18: 447-457 (1890)

91 [Tellurium and bismuth in sulphide ores of Leadville, Colo.]. Colo Sc Soc, Pr $3: 257$ (1891)

95 The eruptive dikes near Manchester, Mass. Colo Sc Soc, Pr 4:365-366 [1895] 97 The occurrence of tellurium in Montana. Eng M J 63:117 (1897)

98 The mode of occurrence of gold in the ores of the Cripple Creek district. Colo Sc Soc, Pr 5:5-10 [1898] (separate ed, 8 pp, 1894) Abst, Eng M J $57: 271$ (1894)

98 Further notes on Cripple Creek ores. Colo Sc Soc Pr 5:11-16 (1898] (separate ed, $7 \mathrm{pp}, 1894$ )

98b Occurrence of tellurium in oxidized form associated with gold. Colo Sc soc, $\operatorname{Pr} 5:$ 144-147 [1898] (separate ed, 4 pp, 1895) 
Pearee, Richard-Continued.

9Sc some notes on the occurrence of uraninite in Colorado. Colo Sc Soc, Pr 5: 156-158 [1898] (separate ed, 3 pp, 1896) M Sc Press 113:44 (1916)

$9 S d$ Notes on the occurrence of a rich silver and gold mineral containing tellurium, in the Griffith lode near Georgetown, Clear Creek Co., Colo. Colo Sc Soc, Pr 5: 242-243 [1898] (separate ed, 2 pp, 1897) Abst, Eng M J 63: 139 (1897)

98 e Notes on the occurrence of tellurium in an oxidized form in Montana. Colo Sc Soc, Pr 5:244-245 [1898] (separate ed, $2 \mathrm{pp}, 1897$ )

989 Note on the occurrence of rhodocrosite in the Original mine, Butte, Mont. Colo Sc Soc, B 1898 no $1: 8$ [1898]

$98 \mathrm{~g}$ Notes on the occurrence of selenium with pyrite rich in gold and silver [Mexico]. Colo Sc Soc, B 1898 no 5 : 1-2 [1898]

9\$h Remarks on a gold nugget from [Bear Gulch], Mont. Colo Sc Soc, B 1898 no $5: 2-3 \quad[1898]$

98i [Telluride ore from Sierra Blanca, Colo.]. Colo Se Soc, B 1898 no $6: 4-6$ [1898]

02 The occurrence of rhodocrosite in the Original mine, Butte, Mont. Colo Sc Soc, Pr 6:103 [1902]

02a Notes on the occurrence of selenium with pyrite rich in gold and silver, and remarks on a gold nugget from Montana, Colo Sc Soc, Pr 6: 157-159 [1902]

04 A trachytic boulder [from Colorado]. R G Soc Cornwall, Tr 12:760 (1904)

16 Uraninite in Colorado. M Sc Press $113: 43-44$ (1916)

Sce also Knight (F C), 98; Van Diest, 95 a

Pearee, S. L.

10 Piedras Verdes disseminated-copper zone [Alamos district, Sonora, Mexico]. Eng M J $89: 920(1910)$

Pearce, Stanley $\mathrm{H}$.

92 (with Penfleld, S. L.) On polybasite and tennantite from the Mollie Gibson mine in Aspen, Colo. Am J Sc (3) 44v: 15-18 (1892)

Pearse, John Barnard.

64 On some minerals of the chlorite group. Am J Sc (2) 37:221-225 (1864)

Pearson, Herbert William.

01 Oscillations in the sea level. G Mag (4) $8: 167-174,223-231,253-265$ (1901)

02 A nebulo-meteoric hypothesis of creation. Edited by W. F. Phelps. 38 pp, Duluth, Minn., 1902

04 The place of the great raised beaches in geology. As Eng Soc, $\mathbf{J} 32: 78-90$ (1904)

08 The place of the great raised beaches in geology (abst). Science $n$ s 27:189180 (1908)

08n The basis for a new geology; rafsed beaches and their cause. Sc Am Sup 65: $186-188,202-204,218-220,234-236$ (1908)
Pearson, J. R.

12 (and Hofr, L. R.) Asbestos and its uses. Can Soc Civil Eng, Tr 26: 141-155 (1912)

Pearson, Karl.

03 The fossil man of Lansing, Kansas. Nature 68:7 (1903)

Peary, Robert Edward.

94 The Cape York ironstone [Greenland]. Am Geog Soc, B 26:447-488 (1894)

98 Northward over the great ice... 2 vols, 521, $625 \mathrm{pp}, \mathrm{N}$ Y 1898

Pease, William H.

48 Observations on the geology and natural history of Mexico. Ac N Sc Phila, Pr 4 : 91-94 (1848)

Peattie, Roderick.

14 Topography of the bedrock under Chicago; with discussion. W Soc Eng, J $19: 590-611$, map (1914)

17 (with Atwood, W. W.) Saving the silts of the Mississippi River (abst). G Soc Am, B 28: 149-151 (1917)

Pechin, Edmund C.

75 The minerals of southwestern Pennsylvania. Am I M Eng, Tr 3:399-408 (1875) Eng M J $19: 146-147,226$ (1875)

s9 The iron ores at Buena Vista, Rockbridge Co., Va. Eng M J 48:92-93 (1889)

91 The iron development and ore resources of Virginia. Iron Steel Inst, J 1890, II : 318-339 [1891] Am I M Eng, $\operatorname{Tr} 19: 1016-1035$ (1891)

92 Virginia Oriskany iron ores. Eng M J $54: 150$ (1892)

96 The Oriskany iron ores at Rich Patch mines, Va. Eng M J $61: 113,134,159-$ 160 (1896)

See aiso Nitze, 92

Peck. Albert B.

17 Mirabilite from the Isle Royale copper mine, Houghton, Mich, Am Mineralogist 2:62-63 (1917)

17 a (with Krans, E. H.) Some new thermo-optical observations on gypsum and glauberite. Mich Ac Sc, 19th An Rp: 95100 (1917)

Peck, Claudian.

51 Minerals of Louisiana. De Bow's Review 11:220 (1851)

Peek, Frederick Burritt.

oo On serpentines and tales in the ri: cinity of Easton, $\mathrm{Pa} .(a b s t)$. Science n s 11: 229 (1900)

01 Preliminary notes on the occurrence of serpentine and talc at Easton, Pa. N Y Ac Sc, An 13:419-430, map (1901)

o4 Basal conglomerate in Lehigh and Northampton counties, Pa. G Soc Am. B 14:518-521 (1904) Abst, Science $n$ s $17: 291$ (1903) ; J G 11:108-109 (1903) ; Eng M J $75: 154$ (1903)

04a The atlantosaur and Titanotherium beds of Wyoming. Wyoming Hist G Soc, Pr $8: 25-41$, il (1904) 
Peek, Frederick Burritt-Continued.

04b The cement belt in Lehigh and Northampton counties of Pennsylvania. Mines and Minerals 25:53-57 (1904)

o5 The talc deposits of Phillipsburg, N. J., and Easton, Pa. N J G S, An Rp 1904: 161-185 (1905)

06 (and Ashley, G. H.) he Punxsutawney and Glen Campbell coal fields of Indiana and Jefferson cos., Pa. U S G S, B 285:276-279 (1906)

os Geology of the cement belt, in Lehigh and Northampton counties, $\mathrm{Pa}$... Ec G $3: 37-76$ (1908)

11 Preliminary repost on the talc and serpentine of Northampton County and the Portland cement materials of the Lehigh district. Pa Top G S, Rp 5:65 pp, map (1911)

Peek, Jacob.

32 Geological and mineralogical account of the mining districts in the state of Georgia, western part of North Carolina and of east Tennessee. Am J Sc 23:1-10, map (1832)

Peck, W. R.

13 (and Sampson, R. J.) The Harlan coal field in Kentucky. Coal Age 3:796800, map (1913)

15 The Harlan, Ky., coal field. Colliery Eng 35:649-655 (1915)

Peckham, Herbert E.

01 On the bituminous deposits situated at the south and east of Cardenas, Cuba. Am J Sc (4) $12: 33-41$ (1901)

Peckham, Stephen Farnham (1838-1918).

69 Notes on the origin of bitumens ... Am Ph Soc, Pr 10:445-462 (1869)

69a On the probable origin of albertite and allied minerals. Am J Sc (2) 48 : 362-370 (1869)

se (and Hall, C. W.) On lintonite and other forms of thomsonite, a preliminary notice of zeolites of the vicinity of Grand Marais, Cook Co., Minn. Am J Sc (3) 19: 122-130 (1880) Minn G S, An Rp 8 : 166-172 (1880)

82 Examination of the bituminous substances occurring in southern California. Cal G S, Geology 2 App : 49-90 (1882)

84 Report on the production, technology, and uses of petroleum and its products. U S, 10th Census 10:319 pp, maps (1884)

84a The origin of bitumens. Am J Sc (3) $28: 105-117$ (1884)

87 List of books, papers, and references on rock oil and gas. $\mathrm{Pa}$ G S, An Rp 1886 pt 2:828-895 (1887)

94 On the origin of bitumens. Am J Sc (3) $48: 389-395$ (1894)

$94 a$ Petroleum in southern California. Science 23: 74-75 (1894)

95 Petroleum in southern California. U S G S, An Rp 16 pt 3:370-374 (1895)
Peekhrm, Stephen Farnham-Continod 95a What is bitumen? Franklin Inst, 150:370-383 (1895) Sc Am Sup 41 17071-17072, 17083-17084 (1896)

$95 \mathbf{b}$ On the pitch lake of Trinidad. An J Sc (3) $50: 33-51$, maps (1895) G $\mathrm{M}$ (4) $2: 416-425,452-458$ (1895)

96 (and Linton, Laura A.) On Trin dad pitch. Am J Sc (4) 1:193-207 (1898) 97 On the nature and origin of petr leum. Am Ph Soc, $\operatorname{Pr} 36: 103-112$ (1897

98 The genesis of bitumens, as related to chemical geology. Am $\mathrm{Ph} \mathrm{Soc}, \mathrm{Pr} 37$; 108-139 (1898)

Peele, Robert.

13 Definition of "ore." M Met Soc Am B 64 (vol 6 no 9) : 256-263 (1913)

Peet, C. A.

o9 Green River oil fields in Wayne Ca Utah. Salt Lake M Rv 11 no 18:19-21 (1909)

Peet, Charles Emerson.

94 (with Salisbury, R. D.) Drift pht nomena of the Palisade ridge. N J G \& An Rp 1893: 157-224 (1894)

04 Glacial and postglacial history of the Hudson and Champlain valleys. J G 12 $415-469,617-660$, maps (1904)

Peet, Stephen D.

91 Natural and artificial terraces. At G 7:113-117 (1891)

91a The flood piain and the mound builders. Am G 8:44-51 (1891)

Peile, A. J.

13 Notes on the geology of the Bermodr Islands. G Mag (5) 10:413-414 (1918) Peirce, Benjamin.

58 on the formation of continents (abst). Can J n s 3:69-70 (1858)

Pellitero, Valentín.

95 Apuntes geológicos referentes al it. nerario de Sagua de Tánamo a Santa Cats. lina de Guantánamo en la Isla de Cuba Espan̂a, Com̀ Mapa Geol, B 20:89-98, ma (1895)

Pelton, E. F.

12 (and Irwin, D. D.) The plane table in geologic mapping (discussion). Ec $G$ i: 778-783 (1912)

Pemberton, J. R.

IS A résumé of the past year's develop. ment in Kentucky [oil flelds] from a gos. logic standpoint. Am As Petroleum G, B $2: 38-52$ (1918)

Peña, Marcelo.

16 El mineral de Santa Rosa, Muzquit Coahuila [México]. Bol Minero $2: 305-$ 312 (1916)

Penek, Albrecht.

98 Der Illecillewaetgletscher im Selkir gebirge. Deut u Österr Alpenverein, Zs 29: 55-60 (1898) Transl, by D. R. Keys, Cas Inst, $\operatorname{Pr} n$ s $2: 57-60$ (1899)

99 Observations made on a tour in Canada. Can Inst, Pr n s 2: 61-73 (1899)

05 Climatle features in the land surface Am J Sc (4) $19: 165-174$ (1905) 
Penek, Albrecht-Contlnued.

06 The relations of physiography to the other sciences. Cong Arts and Sc (St. Louis 1904) 4:607-625 (1906)

09 North America and Europe; a geographical comparison. Science $\mathrm{n}$ s, 29 321-329 (1909) J Geog 8:73-83 (1909, Scottish Geog Mag 25: 337-346 (1909)

09a The antiquity of $\operatorname{man}(a b s t)$ Science $n$ s $29: 359-360$ (1909)

Penek, Walther.

12 Studien am Kilauea, Hawail. Ges Erdk Berlin, Zs 1912:180-203

Penfield, Samuel Lewis (1856-1906).

77 On the chemical composition of triphylite from Grafton, N. H. Am J Sc (3) 13: 425-427 (1877)

79 On the chemical composition of triphylite. Am J Sc (3) 17:226-229 (1879)

$79 a$ on the chemical composition of amblygonite. Am J Se (3) 18:295-301 (1879) Yale Bicen Pub, Contr Miner : 121-123 (1901)

so On the chemical composition of childrenite. Am J Sc (3) $19: 315-316$ (1880) Yale Bicen Pub, Contr Miner: 124-125 (1901)

80u Analyses of some apatites contain. Ing manganese. Am J Sc (3) 19:367-369 (1880)

81 Analysis of farosite from the Vulture mine, Ariz. Am J Sc (3) 21:160 (1881)

82 On the occurrence and composition of some American varieties of monazite. $\triangle \mathrm{m}$ J Sc (3) 24:250-254 (1882) Zs Kryst $7: 366-370 \quad(1882)$

83 Analyses of two varieties of lithio. philite (manganese triphilite). Am J Sc (3) $26: 176 \quad(1883)$

$83 n$ On a variety of descloizite from Mexico. Am J Sc (3) 26:361-365 (1883)

83b (with Brnsh, G. J.) On scovillite, a new phosphate of didymium, yttrium, and other rare earths, from Salisbury, Conn. Am I Sc (3) $25: 459-463$ (18s3)

84 On the occurrence of alkalis in beryl. Am J Sc (3) $28: 25-32$ (1884)

$84 a$ (with Brush, G. J.) On the identity of scovillite with rhabdophane. Am J Sc (3) $27: 200-201$ (1884)

85 Crystallized tiemannite and metacinnabarite. Am J Sc (3) $29: 449-454$ (1885) Yale Bicen Pub, Contr Miner: 130-133 (1901)

85 a Crystals of analcite from the Phoenix mine, Lake Superior copper region. Am J Se (3) 30:112-113 (1885)

S5b (with Dana, E. S.) Mineralogical notes. Am J Sc (3) 30:136-139 (1885)

85e (with Wells, H. L.) Gerhardtite and artificial basic cupric nitrates. $\mathrm{Am} J$ Sc (3) $30: 50-57$ (1885) Yale Bicen Pub, Contr Miner : 134-137 (1901)

86 Brookite from Magnet Cove, Ark. Am J Sc (3) $31: 387-389$ (1886)
Penfield, Samuel Lewis-Continued.

86a (and Harper, D. N.) On the chemical composition of herderite and beryl, with note on the precipitation of aluminum and separation of beryllium and aluminum. Am J Sc (3) 32:107-117 (1886) Yale Bicen Pub, Contr Miner: 138-142 (1901)

s6b (and Sperry, F. L.) On pseudomorphs of garnet from Lake Superior and Salida, Colo. Am J Se (3) 32:307-311 (1886)

s6e (and Harper, D. N.) on the chemical composition of ralstonite. Am J Sc (3) $32: 380-385$ (1886) Yale Bicen Pub, Contr Miner: 143-150 (1901)

86a Crystallized vanadinite from Arizona and New Mexico. Am J Se (3) 32 : 441-443 (1886)

86e (with Dana, E. S.) On two hitherto undeseribed meteoric stones [Utah and Cape Girardeau, Mo.]. Am J Se (3) $32: 226-231$ (1886)

87 Phenacite from Colorado. Am J Sc (3) $33: 130-134$ (1887) Colo Sc Soc, Pr 2 : 141-146 (1887)

S7a (and sperry, E. S.) On the chemical composition of howlite ... Am J Sc (3) $34: 220-223$ (1887)

s7b (and Sperry, F. L.) Triclinic feldspars with twinning striations on the brachypinacoid. Am J Sc (3) 34:390-393 (1887)

88 Bertrandite from Mt. Antero, Colo. Am J Se (3) 36:52-55 (1888)

$88 a$ (and sperry, E. S.) Mineralogical notes. Am J Sc (3) $36: 317-331$ (1888)

S8b (with Dana, E. S.) On the erystalline form of polianite. Am J Sc (3) 35: 243-247 (1888) Zs Kryst 14: 166-172 (1888)

89 On the crystalline form of sperry1ite. Am J Sc (3) $37: 71-73$ (1889) Zs Kryst 15:290-292 (1889) Yal Bicen Pub, Contr Miner: 157-159 (1901)

s9a On some curiously developed pyrite crystals from French Creek, Delaware Co., Pa. Am J Sc (3) 37: 209-212 (1889)

s9b Crystallized bertrandite from Stoneham, Me., and Mt. Antero, Colo. Am J Se (3) $37: 213-216$ (1889)

90 On spangolite, a new copper mineral. $\begin{array}{lllllll}A \mathrm{~m} & \mathrm{~J} & \mathrm{Sc} & \text { (3) } & 39: 370-378 & (1890) & \mathrm{Zs}\end{array}$ Kryst 18:499-506 (1890) Yale Bicen Pub, Contr Miner : 168-175 (1901)

90a Crystallographic notes. Am J Sc (3) $40: 199-207$ (1890)

90b Chalcopyrite crystals from the French Creek iron mines, St. Peter, Chester Co., Pa. Am J Sc (2) 40:207-211 (1890) Zs Kryst 18: 512-516 (1890)

90e Anthophyllite from Franklin, Macon Co., N. C. Am J Sc (3) $40: 394-397$ (1890) 
Penfield, Samuel Lewis-Continued.

90d Some observations on the beryllium minerals from the Mt. Antero, Colo. Am J Sc (3) $40: 488-491$ (1890)

90e (with Genth, F. A.) On lansfordite, nesquehonite, a new mineral, and pseudomorphs of nesquehonite after lansfordite. Am J Sc (3) 39:121-137 (1890)

$90 r$ (with Hidden, W. E.) On hamlinite, a new rhombohedral mineral from the herderite locality at Stoneham, Me. Am J Sc (3) 39:511-513 (1890)

$90 \mathrm{~g}$ (with Meyer, Otto) Results obtained by etching a sphere and erystals of quartz with hydrofluoric acid. Conn Ac, Tr 8:158-165 (1890) Yale Bicen Pub, Contr Miner: 160-167 (1901)

91 On the chemical composition of aurichalcite. Am J Se (3) 41:106-109 (1891)

91a (with Iddings, J. P.) The minerals in hollow spherulites of rhyolite from Glade Creek, Wyo. Am J Sc (3) $42: 39-46$ (1891)

92 Crystallographic notes. Am J Sc (3) 43 : 184-189; 44 : 381-389 (1892)

92a (and Pearce, S. H.) On polybasite and tennantite from the Mollie Gibson mine in Aspen, Colo. Am J Se (3) 44:15-18 (1892)

$92 b$ (with Wells, H. L.) On herderite from Hebron, Me. Am J Sc (3) 44:114116 (1892)

93 On cookeite from Paris and Hebron, Me. Am J Sc (3) 45:393-396 (1893)

93a Mineralogical notes. Am J Sc (3) 45 : 396-399 (1893).

93b On pentlandite from Sudbury, Ont., Can., with remarks upon three supposed new species from the same region. Am J Se (3) $45: 493-497$ (1893)

94 (and Pratt, J. H.) On the chemical composition of staurolite and the regular arrangement of its carbonaceous inclusions. Am J Sc (3) 47:81-89 (1894) Zs Kryst $23: 64-72$ (1894)

94a (and Howe, W. T. H.) On the chemical composition of chondrodite, humite, and clinohumite. Am J Se (3) 47 : 188-206 (1894) Zs Kryst 23:78-98 (1894) Yale Bicen Pub, Contr Miner : 218-230 (1901)

94b Contributions to the crystallization of willemite. Am J Sc (3) 47:305-309 (1894) Zs Kryst 23: 73-77 (1894)

94e On the crystallization of herderite. Am J Sc (3) 47:329-339 (1894) Zs Kryst 23: 118-130 (1894)

94d (and Minor, J. C., jr.) On the chemical composition and related physical properties of topaz. Am J Sc (3) 47 : 387-396 (1894) Zs Kryst 23:321-329 (1894) Yale Bicen Pub, Contr Miner : 231241 (1894)
Penfeld, Samuel Lewis-Continued.

94e (and Kreider, D. A.) Mineralo, ical notes. Am J Se (3) 48:141-14 (1894)

94f Mineralogical notes. Am J Sc (B) 48:114-118 (1894) In part, Zs Krges $23: 262-264 \quad$ (1894)

$94 \mathrm{~m}$ Anatas von Magnet Cove, Ark. ? Kryst $23: 261$ (1894)

95 (and Pratt, ?. H.) Effect of th mutual replacement of manganese and in on the optical properties of lithlophillt and triphylite. Am J Sc (3) $50 ; 387-3 \%$ (1895) Zs Kryst 26:130-133 (1896)

$\mathbf{9 5} \mathbf{a}$ On some devices for the separation of minerals of high specific gravity. An J Sc (3) $50: 446-448$ (1895) Zs Krgst $26: 134-137$ (1896)

96 (and Forbes, E. H.) Fayalite fru Rockport, Mass., and on the optical pros erties of the chrysolite-fayalite group ast of monticellite. Am J Sc (4) $1: 129-15$ (1896) Zs Kryst 26:143-149 (1896)

$96 a$ (and Pratt, J. H.) On the occe. rence of thaumasite at West Paterson, N. Am J Sc (4) 1:229-233 (1896) Zs Krst $26: 262-266$ (1896) Yale Bicen Pók Contr Miner : 246-251 (1901)

$96 \mathrm{~b}$ On pearceite, a sulpharsenite of st ver and on the crystallization of polybasite Am .J Se (4) 2:17-29 (1896) Zs Kry $27: 65-77$ (1896)

97 (and Foote, H. W.) On roeblingite a new silicate from Franklin Furnas, N. J., containing sulphur dioxide and leat Am J Sc (4) 3:413-415 (1897) Zs Krys $28: 578-580$ (1897)

97a (and Foote, H. W.) On bixbyite a new mineral, and notes on the associatel topaz. Am J Sc (4) 4:105-108 (189i) Zs Kryst 28:592-595 (1897) Yale Bict Iub, Contr Miner : 283-286 (1901)

$97 \mathbf{b}$ (and Foote, H. W.) Note cos cerning the composition of llmenite. An ? Sc (4) 4:108-110 (1897) Zs Kryst 28: 596-597 (1897)

97e On the chemical composition hamlinite and its occurrence with bertran ite at Oxford Co., Me. Am J Sc (4) 4: 313-316 (1897) Zs Kryst 27:588-591 (1897) Yale Bicen Pub, Contr Minet 287-290 (1901)

98 (and Foote, H. W.) On clipe hedrite, a new mineral from Franklin, N.J. Am J Sc (4) 5:289-293 (1898) Zs Kryt 30:587-591 (1899) Yale Bicen Puk Contr Miner : 291-296 (1901)

98 a on pearceite, a sulpharsenite of silver, and on the crystallization of polsbasite. Colo Sc Soc, Pr 5 : 210-224 [1898] (separate ed, $15 \mathrm{pp}, 1896$ )

99 (and Foote, H. W.) On the chem eal composition of tourmaline. Am J \& (4) 7:97-125 (1899) Zs Kryst 31:321$352(1890)$ Yale Bicen Pub, Contr Minet 297-324 (1901) 
Penfield, Samuel Lewis-Continued.

99a (and warren, C. H.) On the chemical composition of parisite and a new occurrence of it in Ravalli Co., Mont. Am J Sc (4) 8:21-24 (1899) Zs Kryst 32 : 4-8 (1899)

99b (and Warren, C. H.) Some new minerals from the zinc mines at Franklin, N. J., and note concerning the chemical composition of ganomalite. Am J Sc (4) $8: 339-353$ (1899) Zs Kryst $32: 227-242$ (1900) Yale Bicen Pub, Contr Miner : 325342 (1901)

00 On graftonite, a new mineral from Grafton, N. H., and its intergrowth with triphylite. Am J Sc (4) $9: 20-32$ (1900) Zs Kryst $32: 433-445$ (1900)

00. (and Ford, W. E.) Siliceous calcites from the badlands, Washington $\mathrm{Co}$., S. Dak. Am J Sc (4) 9:352-354 (1900) Zs Kryst $33: 513-515$ (1900)

00b on the chemical composition of sulphohalite. Am J Sc (4) 9:425-428 (1900) Zs Kryst $33: 523-526(1900)$ Yale Bicen Pub, Contr Miner : 343-347 (1901)

00e On the interpretation of mineral analyses; a criticism of recent articles on the constitution of tourmaline. Am J Sc (4) $10: 19-32(1900)$ Zs Kryst $33: 527-$ 541 (1900) Yale Bicen Pub, Contr Miner: 348-356 (1901)

ood (and Ferd, W. E.) On some interesting developments of calcite crystals. Am J Sc (4) $10: 237-244 \quad(1900)$ Zs Kryst $33: 513-522(1900)$ Yale Bicen Pub, Contr Miner: $357-364$ (1901)

00e On the chemical composition of turquoise. Am J Sc (4) 10:346-350 (1900) Zs Kryst 33:542-547 (1900) Yale Bicen Pub, Contr Miner : $365-370$ (1901)

oof Contact goniometers and protractor of simple construction. Mineral Collector 7:97-103 (1900) Zs Kryst 33:548-554 $(1900)$

01 The stereographic projection and its possibilities from a graphical standpoint. Am J Sc (4) 11:1-24, 115-144 (1901) Zs Kryst $35: 1-24$ (1901)

01a (and Ford, W. E.) On calaverite. $A \mathrm{~m}$ J Sc (4) $12: 225-246 \quad$ (1901) Zs Kryst $35: 430-451$ (1902)

01b (and Pirsson, L. V.) Contributions to mineralogy and petrogrephy... Yale Bicen Pub: 482 pp, N Y 1901

02 On the solution of problems in crystallograph; by means of graphical methods based upon spherical and plane trigonometry. Am J Se (4) $14: 249-284$ (1902)

02a (with Hillebrand, W. F.) Some additions to the alunite-jarosite group of minerals. Am J Sc (4) 14:211-220 (1902) Zs Kryst $36: 545-554$ (1902) U S G S, B 262:32-41 (1905)

02b (with wells, H. L.) On a new occurrence of sperrylite [Wyoming]. Am J Sc (4) 13:95-96 (1902)
Penfield, Samuel Lewis-Continued.

03 Tables of minerals ... $77 \mathrm{pp}$, New Haven, Conn., 1903 2d ed, 88 pp, N Y 1907

05 On crystal drawing. Am J Sc (4) $19: 39-75$ (1905)

O5a (and Jamieson, G. S.) On tychite, a new mineral from Borax Lake, Cal., and on its artificial production and its relations to northupite. $A m J$ Sc (4) $20: 217-224$ (1905) Zs Kryst $41: 235$ 242 (1905)

06 On the drawing of crystals from stereographic and gnomonic projections. Am J Sc (4) 21:206-215 (1906) Zs Kryst 43:1-11 (1907)

o6a (and Ford, W. E.) On stiblotantalite. Am J Se (4) $22: 61-77$ (1906) Zs Kryst $42: 334-350$ (1906)

o7 (and Stanley, F. C.) On the chemical composition of amphibole. Am J Sc (4) $23: 23-51$ (1907) Zs Kryst $43: 233-$ 260 (1907)

See also Brush, 74

Penhallow, David Pearce (1854-1910).

89 On Nematophyton and allied forms from the Devonian (Erian) of Gaspé and Baie des Chaleurs. $\mathrm{R}$ Soc Can, $\operatorname{Pr} \operatorname{Tr} 6$, iv : $27-47$, il (1889) Abst, Can Rec Sc $3: 166-167$ (1888)

90 Notes on Devoniau plants. R Soc Can, $\operatorname{Pr} \operatorname{Tr} 7$, iv: $19-30$, il (1890) Abst, Can Rec Sc 3: 430-432 (1889)

90a (with Dawson, J. W.) On the Pleistocene flora of Canada. G Soc $A \mathrm{~m}$, B $1: 311-320$ (1890)

91 (with Dawson, J. W.) Note on specimens of fossil wood from the Erian (Devonian) of New York and Kentucky. Can Rec Sc 4:242-247, fl (1891)

92 Two species of trees from the postglacial of Illinois. R Soc Can, $\operatorname{Pr} \operatorname{Tr} 9$, iv : $29-32$, il (1892)

92a A new species of Larix from the interglacial of Manitoba. Am G 9:368371 (1892)

92b A preliminary examination of socalled cannel coal from the Kootanie of British Columbia. Am G $10: 331-339$, il (1892)

92e (with Dawson, J. W.) Parka decipiens; notes on specimens ... $\quad$ R Soc Can, $\operatorname{Pr} \operatorname{Tr} 9$, iv : 3-16, il (1892)

93 Notes on Erian (Devonian) plants from New York and Pennsylvania. U S Nat Mus, Pr 16:105-114, il (1893)

93 a Notes on Nematophyton crassum. U S Nat Mus, Pr 16:115-118, il (1893)

94 Note on interglacial plants from the Don Valley, Toronto. Am G 13:93-95 (1894)

96 Contributions to the Pleistocene flora of Canada. R Soc Can, Pr Tr (2) 2, iv: 59-77 (1896)

96a Nematophyton crassum. Can Rec Sc $7: 151-156$, il (1896) 
Penhallow, David Pearce-Continued.

96b Nematophyton ortoni n. sp. [from upper Erian of Ohio]. An Bot 10:41, il (1896)

97 Myelopteris topekensis $\mathrm{n}$. sp., a new Carboniferous plant [from Topeka, Kans.] Bot Gaz $23: 15-31$, il (1897)

99 Pleistocene flora of the Don Valley [Toronto, Ont.]. Brit As, Rp 68:525529 (1899)

00 Notes on the North American species of Dadorylon ... R Roc Can, $\mathrm{Pr} \mathrm{Tr}$ (2) 6 , iv : 51-97, il $(1900)$ Abst, Science n s 11: $1022-1023(1900)$

ooa The Pleistocene flora of the Don Valley [Toronto, Ont.]. Brit As, Rp 70 : 334-339 (1900)

01 A decade of North American paleo. botany, 1890-1900. Science n \& $13: 161-$ $176(1001)$

0.2 Osmundites skidegatensis n. sp. [Cretaceous, Queen Charlotte Islands, B. C.]. R Soc Can, Pr Tr (2) 8, iv: 3-29, il (1902)

02a Notes on Cretaceous and Tertiary plants of Canada. R Soc Can, Pr Tr (2) 8 , iv : $31-91$, il (1902)

03 Notes on Tertiary plants. R Soc Can, $\operatorname{Pr} \operatorname{Tr}$ (2) 9, iv : 33-95, il (1903)

o5 Observations upon some noteworthy leaf variations, and their bearing upon paleontological evidence. Can Rec Sc 9 : 279-305, il (1905)

05a Notes on Tertiary plants from Canada and the United States. R Soc Can, $\operatorname{Pr} \operatorname{Tr}$ (2) 10, iv : 57-76 (1905)

05b (and Ami, H. M.) Determinations of fossil plants from various localities in British Columbia and the Northwest Territories ... with notes on the geological horizons indicated... Can G S, Sum Rp 1904 (An Rp 16) : A 389-392 (1905)

o5e A blazing beach [Kittery Point, Me.] Science n s 22:794-796 (1905) Pop Sc Mo $70: 557-564$ (1907)

06 Notes on Tertiary and Cretaceous plants (abst). Science n s 23:972 (1906)

07 A manual of the North America gymnosperms, exclusive of the Cycadales, but together with certain exotic species. 274 pp, il, Boston 1907

07a Contributions to the Pleistocene flora of Canada. Am Nat $41: 443-452$, il (1907)

O7b A contribution to our knowledge of the origin and development of certain marsh lands on the coast of New England. R Soc Can, $\operatorname{Pr} \operatorname{Tr}$ (3) 1 , iv: 13-55 (1907)

ore Notes on fossil woods from Texas. R Soc Can, $\operatorname{Pr} \operatorname{Tr}$ (3) 1, iv : 93-113, il, 1907

07d A report on fossil plants from the international boundary survey for 1903-5, collected by Dr. R. A. Daly. R Soc Can, Pr Tr (3) 1, iv: $287-351$, il 1907 Can, Dp Interior, Rp Chief Astronomer 1910, 3: $800-840$, il (1913)
Penhallow, David Pearce-Continned.

os Some fossil piants from the midlle Devonian of Milwaukee, Wis. Wis $\mathrm{N} \mathrm{H}$ Soc, B $6: 8-12$, il $(1908)$

O8a Report on a collection of fossi] woods from the Cretaceous of Alberta Ottawa Nat 22: $82-85,11$ (1908)

08b Report on Tertiary plants of British Columbia collected by Lawrence M. Lambe in 1906, together with a discussion of previously recorded Tertiary floras. Can G S : 167 pp, 11 (1908)

10 The relation of paleobotany to phylogeny. Pop Sc Mo 77:333-338 (1910) Pennsylvania, General Assembly.

34 Report of the committee of the Sen. ate upon the subject of the coal trade. $\mathrm{Pa}_{\text {, }}$ Senate, J 2 : 449-572, Harrisburg 1834

Pennsylvania GeologienI Survey, Sec ond.

76 Report of the Board of Commis sioners for $1875: 11$ pp $[1876] ; \ldots$ for $1876: 10 \mathrm{pp}$, map [1877] ; ... for $1880: 5$ $\mathrm{pp}$, map [1881]; ... [for 1881-2]:7 pp, $\operatorname{map}[1883] ; \ldots$ [for $1883-4): 4,11 \mathrm{pp}$, maps $[1885] ; \ldots$ for $1885-6: 6 \mathrm{pp}$, maps [1887] ; ... for $1887-8: 6$ pp [1889] ; ... for $1891-2: 8$ pp [1893] ; ... for $1893-4: 4 \mathrm{pp}$ [1895]

76a Atlas; maps of Adams, Franklin, and Cumberland cos., and South Mountain. D6 and D7, 1876-1885

$\mathbf{8 8}$ Atlas to report on Bucks and Montgomery cos. C7: 12 sheets, 1888

90 General map of the anthracite coal fields of Pennsylvania and adjoining cos. Scale $1: 126,720$. Revised by A. Dr. Smith 1890

91 Geological maps of Schuylkill, Catbon, Berks, and Dauphin counties. Scale. 2 miles to 1 inch. 1891

Pennsylvania. Topographic and Ge ologie Survey Commission.

02 Topographic and geologic surves of Pennsylvania made in cooperation with the United States Geological Survey, during the years 1899 and 1900 . $135 \mathrm{pp}$, map 1902

o6 Topographic and geologic survey of Pennsylvania made in cooperation with the United States Geological Survey, 18991906. 308 pp, map, Harrisburg, Pa., 1906

os Topographic and geological surves of Pennsylvania, 1906-1908. 375 pp, map Harrisburg, Pa,, 1908

11 [Report], 1908-1910. 103 pp, maps Harrisburg 1911

12 Topographic and geological survey of Pennsylvania, $1910-1912$. 182 pp, maps Harrisburg 1912

14 Biennial report of the topograptic and geologic survey of Pennsylvania for the two years ending June 1, 1914. 23? pp, maps, Harrisburg 1914

$14 a$ Geologic map of southwestern Penth sylvania. Pa Top G S, Rp $2: 29 \mathrm{pp}$, maps (1914) 
Pennsylvania, Topographie and Geologie Survey Commission-Con.

15 The mineral production of Pennsylvania, 1911. Pa Top G S, Rp $8: 138$, 52, 84 pp [n d, 1915?]

16 Oil and gas map of southwes'rn Pennsylvania. Text 22 pp (1916) and map, scale $1: 250,000$

Penrose, Richard Alexander Fullerton, jr.

88 Nature and origin of deposits of phosphate of lime, with an introduction by N. S. Shaler. U S G S, B $46: 143$ pp (1888)

89 Report of geologist for eastern Texas. Tex G S, Rp Prog 1 (1888 : 54-60 (1889)

89a Notes on certain building stones of east Texas. G Sc B 1 no 11 (1889) Science $13: 295$ (1889)

89b (with Hill, R. T.) Relation of the uppermost Cretaceous beds of the eastern and southern United States; and the Tertlary-Cretaceous parting of Irkansas and Texas. Am J Sc (3) $38: 468 \quad 473$ (1889)

90 A preliminary report on the geology of the Gulf Tertiary of Texas from Red River to the Rio Grande. Tex G S, An Rp 1:3-101 (1890)

91 Manganese, its uses, ores and deposits. Ark G S, An Rp 1890, 1 : xxvii, 642 pp, maps, Little Rock 1891

91a The distribution of manganese in North America. Eng M J 52:126 (1891)

$91 \mathrm{~b}$ The origin of the manganese ores of northern Arkansas, and its effect on the associated strata $(a b s t) . \Delta \mathrm{m} \mathrm{As}, \mathrm{Pr}$ $39: 250-252$ (1891)

92 The iron deposits of Arkansas. Ark G S, An Rp 1892, 1: 153 pp, map, Little Roek 1892

92a The Tertiary iron ores of Arkansas and Texas. G Soc Am, B 3:44-50, map (1892)

93 A Pleistocene manganese deposit near Golconda, Nev. J G 1:275-282 (1893)

$93 a$ The chemical relation of iron and manganese in sedimentary rocks. J G 1 : $356-370$ (1893)

94 The superficial alteration of ore deposits. J G 2:28s-317 (1894) Abst, Eng M J 59:341-342 (1895) Reprinted in Emmons, S. F., Ore deposits (pub. by Am I M Eng) : 110-138, N Y 1913 [See also Raymond ( $\mathrm{R}$ ), 95]

95 Mining geology of the Cripple Creek district, Colo. U S G S, An Rp 16 pt 2 : 111-209 (1895)

98 The ore deposits of Cripple Creek, Colo. Colo Sc Soc, Pr 5: 50-53 [1898] (separate ed: 33-37, 1894)

03 Present condition of gold mining in Aretic America. Eng M J 76:807-809, $852-853$ (1903)
Pencose, Richard Alexander Fullerton, jr.-Continued.

10 Some causes of ore shoots. Ec G 5 : $97-133$ (1910) Reprinted in Types of ore deposits (ed by H, F. Bain) : 324-354 (1911)

10a Memoir of Persifor Frazer [18441909]. G Soc Am, B 21:5-12, port (1910)

13 The Twelfth International Geological Congress. Franklin Inst, J 176:583-586 (1913)

14 Certain phases of superficial diffusion in ore deposits. Ec G $9: 20-24$ (1914)

17 What a geologist can do in war. 28 pp, Phila 1917

18 Memorial of Amos P. Brown. G Soc Am, B 29:13-17, port (1918)

See also Branner, 98

Peola, Paolo.

os Impronte vegetali del Carbonifero dell Illinois (Stati Uniti d'America) [Mazon Creek, Morris Co., IIl.]. Soc G Italiana, B 26:323-332, fl (1908)

Peppei, Samuel Vernon.

os Gypsum deposits in Ohio. U S G S, B $223: 38-44$, map (1904)

94a (with Oxton, E., jr.) The lime resources of Ohio avallable for Portland cement manufacture. Ohio G S (4) B 3: 88-101 (1904)

05 The manufacture of artificial sand stone or sand-lime brick. Ohio G S (4) B $5: 79 \mathrm{pp}, 1905$

06 (with Orton, E., jr.) The limestone resources and the lime industry in Ohio. Ohio G S (4), B 4:365 pp (1906)

Pepperberg, Leon J.

os Cement material near Havre. Mont. U S G S, B 380: $327-336$ (1909)

09a The Milk River coal field. Mont. U S G S. B $381: 82-107$, map (1909)

10 Notes on the mineral deposits of the Bearpaw Mountains, Mont. U S G S, B 430:135-146 (1910)

11 Variscite near Lucin, Utah. M Sc Pres 103: 233-234 (1911)

12 The southern extension of the Milk River coal field, Chouteau Co., Mont. U S G S, B 471: 359-383, map (1912)

15 [Structural features in Palo Pinto Co.. Tex.]. West Eng $6: 252-254$ (1915)

15a The accumulation of petroleum near the outcrop of oil sands. West Eng 5: $463-465$ (1915)

Pepperberg, Roy V.

10 Coal in Nebraska [near Peru]. Nebr G S 3:275-307, map (1910)

10 Preliminary notes on the Carboniferous flora of Nebraska. Nebr G S 3:311330 , il $(1910)$

Peragallo, Oreste.

o9 San Ygnacio mill and mine, Chihuahua, Mexico. Eng M J 88:1263-1265 (1909) 
Peralta, Ricardo Fernández.

14 Ascensión al volcán de Miravalles [Costa Rica]. Costa Rica, Ministerio de Fomento, B 4: 160-171 (1914)

Pereival, James Gates (1795-1856).

22 ... the locality of sulphate of barytes ... and of various other minerals in Berlin, Conn. Am J Sc 5:42-45 (1822)

42 Report on the geology of the State of Connecticut. 495 pp, map, New Haven 1842

54 The Hazelgreen [lead] mine, Wis.; its geological aspect. M Mag 2:631-632 (1854)

55 Annual report on the geological survey of the State of Wisconsin. $101 \mathrm{pp}$, map, Madison 1855

55a Geology of Wisconsin. M Mag 4: 345-361; 5:113-128, 217-229 (1855)

56 [Second] annual report of the geological survey of the State of Wisconsin. $111 \mathrm{pp}$, Madison 1856 German ed, $103 \mathrm{pp}$, Milwaukee 1856

Perdue, M. J.

OS (with Grant, U. S.) Milbrig sheet of the lead and zine district of northern Ininois. IH G S, B $8: 335-343$ (1908)

Perisho, Ellwood Chappell.

o6 The State survey of South Dakota. Ac Sc Sioux City, Iowa, 2:79-84 (1906)

07 What should appear in the report of a State geologist. Ec G $2: 435-438$ (1907)

10 Preliminary report on the geology of the Rosebud Reservation, including Gregory and Tripp cos. S Dak G S, B 4 (Rp St G 1908): $82-122$ (1910)

10a The State survey of South Dakota. S Dak G S, B 4:184-192 (191C)

11 The geology of Harding Co., S Dak. (abst). Science n s $33: 463-464$ (1911)

12 (and Visher, $\mathrm{S}$. S.) preliminary report upon the geography, geology, and biology of Mellette, Washabaugh. Bennett, and Todd cos., S. Dak. S Jak G S, B 5: $152 \mathrm{pp}$, maps (1912)

14 Report of the State geologist for 1913-1914. S Dak G S, B 6:107-115 (1914)

Perkins, Edwin T.

07 Mining and smelting at Granby, Mo. Eng M J 84:388-390 (1907)

Perkins, George Henry.

70 Notice of a recent landslide on Mount Passaconaway [N. H.]. Am J Sc (2) 49 : 158-161 (1870)

71 Notes on the geodes of Illinois. Am Nat 5:698-705 (1871)

83 The Winooski marble of Vermont (abst). Am As, Pr 31: 388 (1883)

85 The Winooski or Wakefield marble of Vermont. Am Nat 19:128-136 (1E85)

98 Report on the marble, slate, and granite industries of Vermont. $68 \mathrm{pp}$, Rutland 1898
Perkins, George Henry-Continued.

oo Report of the State geoiogist on th mineral industries of Vermont, 1899-1900. 83 pp, Burlington 1900

02 Report of the State geologist on the mineral industries and geology of certain areas of Vermont. Third of this serig 1901-02:191 pp, Albany, N. Y., 190. Fourth, 1903-04:236 pp, Montpelier, 7t. 1904 Fifth, 1905-06:351 pp, Montpelier, Vt., 1906 Sixth, 1907-08:302 pp, Coocord, N. H., 1908 Seventh, 1909-10:38l pp, Bellows Falls, Vt., 1910 Eighth, 19.112 : 269 pp, Montpelier, Vt., 1912 Ninth. 1913-14:448 pp, Burlington, Vt., 1914 Tenth, 1915-16:333 pp, Burlington, vt. 1916

02a Sketch of the life of Zadock Thomp son. Am G 29:65-70, port (1902) Vt. St G, Rp $3: 7-13$, port (1902)

02b List of reports on the geology of Vermont : $\mathbf{1 8 4 5}-\mathbf{1 9 0 0}$; list of publication on the geology of Vermont. Vt, st $G_{\text {, }}$ Rp 3:14-21 (1902)

02e Report on mineral industries. Vt. St G, Rp $3: 31-45$ (1902)

02:I The geology of Grand Isle. $\mathrm{Vt}, \mathrm{8t}$ G, Rp 3: 102-173, map, il (1902)

O4 List of works on the geology of Ter mont. Vt, St G, Rp 4:16-21 (1904)

O4a Mineral resources of the State. fit St G, Rp 4:22-26 (1904) ... 5:1-6 (1906) $\quad \ldots 6: 1-57(1908) \quad \ldots 7: 331-372$ map (1910) ... 8:247-269, map (1912) $\ldots 9: 430-439, \operatorname{map}(1914) \quad \ldots 10: 293-294$ $\operatorname{map}(1916)$

04b Geology of Grand Isle Co. Vt, 8 G, Rp 4: 103-143. maps (1904)

04e On the lignite or brown coal of Brandon and its fossils. Vt, St $G, B_{p} 4$ 153-162 (1904)

04d Description of species found in the Tertiary lignite of Brandon, Vt, Vt, St G, Rp 4: 174-212, il (1904)

04e Hydrology; a summary of invest: gations upon the drinking waters of Ver mont. Vt, St G, Rp 4:213-223 (1904)

O4f [Notes on water resources of] Ver mont. U S G S, W-S P 102: 73-93 (1904

05 [Underground waters of] Vermot? U S G S, W-S P 114: 60-67 (1905)

O5a Tertiary lignite of Brandon, Vt., and its fossils. G Soc Am, B 16:499-516, f (1905)

o5b Mineral resources of Vermont. As M Cong, 7 th, Pr: 161-165 (1905)

06 The lignite or brown coal of Brandmen Vt, St G Rp 5: 188-194 (1906)

O6a Fossils of the [Brandon] lignite Vt. St G Rp 5 : 202-230, il (1906)

06b The drinking waters of Vermont. $\mathrm{Vt}$, St G, Rp 5 : 254-344 (1906)

os Fossil Cetacea of the Pleistocene the United States and Canada, with specil reference to Delphinapterus vermontans Thompson. Vt, St G, Rp 6: 76-112, (1908) 
Perkins, George Henry-Continued.

08a Preliminary report on the geology of Franklin Co. Vt, St G, Rp 6:189-209 (1908)

08b Preliminary report on the geology of Chittenden Co. Vt, St G, Rp 6:221-264, map (1908)

08e Tale and soapstone in Vermont. Eng M J 86:753 (1908)

08d The Cambrian rocks of Vermont (abst). Science n s 28:573 (1908)

10 On a skeleton of a whale in the Prorincial Museum, Halifax, N. S. ; with notes on the fossil Cetacea of North America. $\mathrm{N}$ S Inst Sc, $\operatorname{Pr} \operatorname{Tr} 12: 139-163$, il (1910, author's separates 1908)

10a History and condition of the State cabinet [of Vermont]. Vt, St G, Rp 7 : $1-75(1910)$

$10 \mathrm{~b}$ Geology of the Burlington quad rangle, Vt. Vt, St G, Rp $7: 249-256$, map (1910)

11 The geological history of Vermont (abst). Appalachia $12: 325-326$ (1911)

12 A general account of the geology of the Green Mountain region. Vt, St G, Rp $8: 17-100$ (1912)

14 History of the Vermont marble industry. Vt, St G, Rp $9: 161-223$ (1914)

16 The geology of western Vermont. Vt, St G, Rp 10:200-231, maps (1916)

18 Memorial of Henry Martyn Seely. G Soc Am, B 29:65-69, port (1918)

Perkins, Henry Coit (?-1873).

42 Notice of fossil bones from Oregon Territory. Am J Sc $42: 136-140$, il (1842)

42a ... fossil bones from Oregon. Boston J N H $4: 134-136$ (1842)

Perkins, W. R.

05 (with Logan, W. N.) The underground waters of Mississippi. Miss Agr Exp Sta, B 89:112 pp (1905)

Perley, Henry F.

65 Gold mines and gold mining in Nova Scotia. Can Nat n \& 2:198-218 (1865)

Perley, Moses H.

50 [On subsidence of the shore of Newfoundland (with discussion by E. Desor, J. E. Cabot, Jeffries Wyman, and J. H. Abbot).] Boston Soc N H, Pr 3:374-375 (1850)

62 Observations on the geology and physical characteristics of Newfoundland. Can Nat $7: 321-334$ (1862)

Perrenoud, G. F.

86 Tale [New York]. U S G S, Min Res 1885:534-535 (1886)

Perret, Frank A.

08 Some conditions affecting volcanic eruptions. Science n \& 28:277-287 (1908)

13 The lava fountains of Kilauea. Am J Sc (4) $35: 139-148$ (1913)

13a The floating islands of Halemaumau. Am J Sc (4) 35:273-282 (1913)

13b The circulatory system in the Halemaumau lava lake during the summer of 1911. Am J Sc (4) $35: 337-349$ (1913)
Perret, Frank A.-Continued.

13e Subsidence phenomena at Kilauea in the summer of 1911. Am J Sc (4) 35 : $469-476$ (1913)

13d Some Kilauean ejectamenta. Am J Sc (4) $35: 611-618$ (1913)

13e Some Kilauean formations. Am J Sc (4) 36:151-159 (1912)

$13 f$ A method of increasing and controlling the period in vertical motion seismographs. Am $J$ Sc (4) $36: 297-300$ (1913)

13g Volcanic research at Kilauea in the summer of 1911; with a report by $\mathrm{Dr}$. Albert Brun on the material taken directly from "Old Faithful." Am J Sc (4) 36: 475-488 (1913)

13h The ascent of lava. Am J Sc (4) $36: 605-608$ (1913)

14 The diagrammatic representation of volcanic phenomena. Am J Sc (4) 37 : 48-56 (1914)

See also Hawailan Volcano Observatory 14

Perrey, Alexis.

47 Documents sur les tremblements de terre du Mexique et dans l'Amérique Centrale. Soc d'Émulation des Vosges, An 6 : 536-573 (1847) [not seen]

50 Mémoire sur les tremblements de terre aux Etats-Unis et dans le Canada. Soc d'Emulation des Vosges, An 7:341$402(1850)$

55 [On the frequency of earthquakes and their cause (with discussion by Charles Stodder, C. T. Jackson, Charles Pickering, W. B. Rogers).] Boston Soc N H, Pr $5: 137-142$ (1855)

66 Documents sur les tremblements de terre et les phénomènes volcaniques des fles aleutiennes, de la péninsule d'Alaska et de la côte No. d'Amérique. Ac Sc Dijon, Mém (2) $13 \mathrm{sec} s c: 121-251$ (1866)

Perrine, Charles Dillon.

93 Earthquakes in California in $\mathbf{1 8 9 2}$. U S G S, B 112:57 pp (1893)

93a Earthquakes in California in 1893.

U S G S, B 114: 23 pp (1893)

95 Earthquakes in California in 1894.

U S G S, B 129:25 pp (1895)

96 Earthquakes in California in 1895.

U S G S, B 147:23 pp (1896)

98 Earthquakes in California in 18961897. U S G S, B 155:47 pp (1898)

99 Earthquakes in California in 1898. U S G S, B 161:31 pp (1899)

Perrine, Irving.

18 Geological conditions in central Kansas. Am As Petroleum G, B 2:70-97 (1918)

Perry, E. R.

10 (and Hutchison, L. L.) History, geology, and statistics of Oklahoma oil and gas fields. $14 \mathrm{pp} \mathrm{[1910]}$ 
Perry, E. S.

17 Tripoll deposits of Oklahoma. Okla G S, B 28: 32 pp (1917)

17a Geologic handbook of the Miami mining district; containing a summary of the geologic conditions at Miami, and a brief outline of the formation of the ore bodies. $30 \mathrm{pp}$, map, 1917 [published by the author]

Perry, E. W.

90 Snake Hill, N. J., as a locality for minerals. Science $16: 360-361$ (1890)

Perry, George W.

89 Biennial report of the State geologist... Vt [Legislature] H R, J 1888: $552-556$ (1889)

90 [Report of the State geologist.] Vt [Legislature] H R, J 1890:431-435 (1890)

91 The relation of the strength of marble to its structure. Eng M J 52:453 (1891)

94 Biennial report of the State geologist... for 1893-94. $8 \mathrm{pp}, \mathrm{Vt}$, State Officers' Reports for 1893-94, Rutland 1894

Perry, John Bulkley (1825-1872).

68 Queries on the red sandstone of Vermont and its relations. Boston Soc N H, Pr 11: 341-353 (1868)

$68 \mathbf{a}$ The red sandstone of Vermont and its relations. Am As, Pr 16:128-134, 158 (1868)

69 A point in the geology of western Vermont. Am J Sc (2) $47: 341-349$ (1869)

69a Sketch of the life of Dr. Ebenezer Emmons. Boston Soe N H, Pr 12:214216 (1869)

70 A discussion of sundry objections to geology. $32 \mathrm{pp}$, Cambridge, Mass., 1870

70a The supposed elevation and depression of the continent during the glacial period $(a b s t)$. Am Nat 4:508-510 (1870)

71. On the glacial period in New England. Boston Soc N H, Pr 14:62-63 (1871)

71a [On the so-called scolithi of the Potsdam.] Boston Soc N H, Pr 14:139 (1871)

71b Boulder trains in Berkshire Co., Mass. Am As, Pr 19:167-169 (1871) Abst, Am Nat 4:565-566 (1870)

71e The supposed elevation and depression of the continent during the glacial period. Am As, Pr $19: 169-172$ (1871)

71d On the "Eozoön" limestone of eastern Massachusetts. Am Nat $5: 538-539$, 539-541 (1871) Am As, Pr 20:270-276 (1872)

71e The natural history of the counties Chittenden, Lamoille, Franklin, and GrandIsle. Vt Historical Gazetteer 2 no 12 : 21-88, Burlington, Vt., 1871

72 On eozoonal limestones of eastern Massachusetts. Boston Soc N H, Pr 14: 199-204 (1872)
Perry, John Bulkley-Continued.

72a Hints towards the post-Tertiary bic tory of New England... Boston $\mathrm{Soc} N \mathrm{~B}$, Pr 15: 48-148 (1872)

See also Hilgard, 71a ; Jackson, 71a: Shaler, 71

Perry, Joseph Hartshorn.

85 Note on a fossil coal plant found of the graphite deposit in mica schist, at Worcester, Mass, Am J Sc (3) 29:157158 (1885)

98 The physical geography of Worcester, Mass. Worcester N H Soc: $40 \mathrm{pp}$, Wo: cester, Mass., 1898

03 (and Emerson, B. K.) The of ology of Worcester, Mass. Worcester Natrral History Society : $166 \mathrm{pp}$, il, map, Tos. cester, Mass., 1903

O3a Notes on the geology of Mount Kearsarge, X. H. J G 11:403-412 (1909) 04 Geology of Monadnock Mountain N. H. J G $12: 1-14$, map (1904)

o7 (with Emerson, B. K.) The gren schists and associated granites and por phyries of Rhode Island. U S G S, B 311 : 74 pp (1907)

Perry, Nelson W.

82 (with Clarke, F. W.) A new mis eral from Colorado [gunnisonite]. An Chem J $4:$ 140-142 (1882)

84 A new mineral [ramosite, San Lats Potosi]. Am I M Eng, Tr 12:628-60 (1884) Eng M J 37:140 (1884)

89 The Cincinnati rocks; what has been their physical history? Am G 4:326-3\% (1889)

Perry, Stuart H.

93 A classification of topographic forms Am G 12: 153-159 (1893)

Peter, Alfred $M$.

85 (with Peter, R.) Fourth, fifth, and sixth chemical reports... Ky G S, Chemial Analyses A 2:328, 20 pp (1885)

s8 (with Peter, R.) Chemical report of the coals, soils, clays, petroleum, mit: eral waters, etc., of Kentucky. Ky G \& [Chemical Analyses] A 3:171 pp [1888] Peter, Robert (1805-1894).

56 Chemical report of the minerals rocks, and soils. Ky G S. Rp [1]:251379 (1856)

57 Second chemical report of the ofs rocks, solls, coals, mineral waters, etc. of Kentucky. Ky G S. Rp 2:117-300 (185i)

$\mathbf{5 7 a}$ Third chemical report of the soils marls, ores, rocks, coals, mineral waters etc., of Kentucky. Ky G S, Rp $3: 17$ 420 (1857)

60 Chemical analysis of the soils, sut soils, under-clays, clays, and nitre-earths of Ark. In Owen, D. D., Second report of 1 geological reconnaissance of the middle and southern counties of Arkansas: 163-28\% Phila 1860 
Peter, Robert-Contlnued.

61 Fourth chemical report of the soils, marls, ores, rocks, coals, iron furnace products, mineral waters, etc., of Kentucky. Ky G S, Rp 4 : 39-321 (1861)

61a Obituary notice of the late principal geologist of Kentucky, David Dale Owen, M. D. Ky G S, Rp $4: 323-330$ (1861)

62 A report of the chemical analysis of thirty-three soils of Indiana ... In Owen, Richard, Report of a geological reconnaissance of Indiana ... : 241-26。, Indianapolis 1862

76 (and Talbutt, J. H.) Chemical report of the solls, marls, clays, ores, coals, iron furnace products, mineral waters, etc., etc., of Kentucky. Ky G S, Rp Prog 1 n s : $137-316$ (1876) Reprinted in Ky G $\mathrm{S}$, Chemical Analyses A [1]: 1-180 (1884)

78 (and Talbutt, J. H.) Chemical report of the solls, coals, ores, iron furnace products, clays, marls, mineral waters, rocks, ete., of Kentucky. Ky G S, Rp Prog 4 n s: 1-166 (1878) Reprinted in Ky G S, Chemical Anaiyses A [1] : 181-345 (1884)

$\mathbf{8 0}$ Chemical report of the soils, coals, ores, clays, marls, mineral waters, rocks, ete, of Kentucky. Ky G S, Rp Prog 5 n s : 159-250, 395-487 (1880) Reprinted in $\mathrm{Ky}$ G S, Chemical Analyses A [1]:347-463 (1884) ; A 2: 1-93 (1885)

84 First, second, and third chemrical reports... Ky G S, Chemical Analyses A [1]: $477 \mathrm{pp}$ (1884)

85 (and Peter, A. M.) Fourth, fifth, and sixth chemical reports... Ky G s. Chemical Analyses A 2:328, 20 pp (1885)

85a Comparative views of the composition of the solls, limestones, elays, marls, etc., of the several geological formations of Kentucky.. Ky G S, Chemical Analyses A 2:95-156 (1885)

88 (and Peter, A. M.) Chemical report of the coals, solls, clays, petroleum, mineral waters, etc., of Kentucky. Ky G 8, [Chemical Analyses] A 3:171 pp [1888]

05 Chemical report of the coals, clays, mineral waters, etc,, of Kentucky. Ky G S, B 3: $77 \mathrm{pp}$ (1905)

Petereit, A. H.

07 Crystallized native copper from Bisbee, Ariz. Am J Se (4) $23: 232$ (1907)

Peters, Edward Dyer (1849-1917).

82 Notes on the Oscura copper fields, and other mines in New Nexico. Kng M J 34 : 270-272 (1882)

85 The mines and reduction works of Butte City, Mont. U S G S, Min Res 18834:374-396 (1885)

85a The copper mines of Butte, Mont. Eng M J 39 : 208-209 (1885)

85b The silver veins of Butte, Mont. Eng M J $39: 261-262$ (1885)

50 The Sudbury ore deposits [Ont.]. Am I M Eag. Tr 18:278-289 (1890)
Petersen. Theodor.

72 Guadalcazarit, ein neues Mineral [Mexico]. Miner Mitt (Tschermak) ( $\mathrm{K}-\mathrm{k}$ G Reichsanstalt, Jb 22) 1872:69-70

Peterson, Frank P.

16 (and Flynn, F. H.) The Walhalla district. S. C. Eng M J 101:379-382 (1916)

Peterson, Olof August.

02 (and Gilmore, C. W.) Elosaurus parvus, a new genus and species of the Sauropoda. Carnegie Mus, An 1:490-499, il (1902)

04 Osteology of Oxydactylus, a new genus of camels from the Loup Fork of Nebraska. Carnegie Mus, An 2:434-476, il (1904)

O4a Recent observations upon Daimonelix. Science n \& 20:344-345 (1904)

05 Description of new rodents and discussion of the origin of Datmonelix. Carnegie Mus, Mem 2: 139-202, il (1905)

05a Suggestions regarding the probable origin of Daimonelix (abst). Science $\mathbf{n} \mathbf{s}$ $21: 296$ (1905)

05b Preliminary note on a gigantic mammal from the Loup Fork beds of Nebraska [Dinochoerus hollandi]. Science n s 22: 211-212 (1905)

o5e A correction of the generic name (Dinochoerus) given to certain fossil remains from the Loup Fork Miocene of Nebraska. Science n s 22:719 (1905)

06 New suilline remains from the Miocene of Nebraska. Carnegie Mus, Mem 2 : $305-324$, il (1906)

O6a Preliminary description of two new species of th2 genus I ceratherium Narsh. from the Agate Spring fossil quarry. Sc1ence $n$ s $24: 281-283$ (1906)

o6b The Agate Srring ossil quarry [Nebraska]. Carnegie Mus, A : 487494 , ๆ (1906)

o6e The Miocene beds of western Nebraska and eastern Wyoming and their vertebrate faunæ. Carnegie Mus, An 4: 21-72, il (1906)

os Description of the type specimen of Stenomylus gracilis Peterson. Carnegle Mus, An 4:286-300, il (1908)

09 A revision of the Wntelodontida. Carnegie Mus, Mem 4:41-156, il (1909)

09a A new genus of carnivores from the Miocene of western Nebraska [Daphanodon]. Science n \& 29:620-621 (1909)

10 Description of new ca-nivores from the Miocene of western Nebraska. Carnegie Mus, Mem 4:205-278, il (1910)

11 A new camel from the Miocene of Nebraska [Oxydactylus longirostris]. Carnegie Mus, An $7:\llcorner 60266$, il (1911)

11a A mounted skeleton of Stcnomylus hitchcocki, the Stenomylus quarry, and remarks upon the aftinities of the genus. Carnegie Mus, An $7: 267-273$, il (1911)

11b A mounted skeleton of Diceratherium cooki Petersen. Carnegie Mus, An 7 : 274-279, il (1911) 
Peterson, Olof August-Continued.

12 Ten years' progress in vertebrate paleontology; Artiodactyla. G Soc Am, B $23: 162-178 \quad(1912$,

12a A group of stencmylins recently prepared and exhibited in the Carnegie Museum. Carnegie Mus, An $8: 366-369$, il (1912)

12b Recently proposed species of the genus Diceratherium. Science n s $36: 801$ (1912)

13 (with Holland, W. J.) The osteology of the Chalicotheroidea. Carnegie Mus, Mem 3:189-406, il (1913)

14 A new titanothere from the Uinta Eocene. Carnegie Mus, An $9: 29-52$, il (1914)

14a A small titanothere from the lower Uinta beds. Carnegie Mus, An 9:53-57, il (1914)

14b A mounted skeleton of Platigonus leptorhinus in the Carnegie Museum. Carnegie Mus, An 9:114-117, il (1914)

14e Some undescribed remains of the Uinta titanothere Dolichorhinus. Carnegie Mus, An 9:129-138, il (1914)

14d The osteology of Promerycochoerus. Carnegie Mus, An 9:149-219, il (1914)

$14 \mathrm{e}$ Correction of a generic name. Carnegie Mus, An 9:220 (1914)

17 Report upon the fossil material collected in 1913 by the Messrs. Link in a cave in the Isle of Pines. Carnegle Mus, An 11:359-361 (1917)

17a A fossil-bearing alluvial deposit in Saltville Valley, Va. Carnegie Mus, An 11 : $469-474$, il (1917)

18 New artiodactyls from the upper Eocene of the Uinta Basin, Utah (abst). G Soc Am, B 29:153 (1918)

Peterson. William.

14 Phosphate deposits in the Mississippian rocks of northern Utah. Science n s $40: 755-756$ (1914)

Petitot, Émile.

75 Notes géologiques sur le bassin du Mackenzie. Soc G France, B (3) 3:8893, 611-612 (1875)

83 On the Athabasca district of the Canadian Northwest Territory. R Geog Soc. Pr 5:633-655 (1883) Can Rec Se 1:2783 (1884) Can Rec N H 1:27-52 (1884) Petre, Reginald W.

98 Mines of the La Plata Mountains, Colo. Eng M J .66:667-668 (1898)

03 Mines of the Pinites and Azul mountains, Sonora, Mexico. Eng M J 76:466 (1903)

Petros. See Lee (C A), 22

Petrunkeviteh, Alexander.

13 A monograph of the terrestrial Paleozoic Arachnida of North America. Conn Ac, $\operatorname{Tr} 18: 1-137$, il (1913)

$13 a$ Paleozoic Arachnida-scorpions and spiders (abst). G Soc Am, B 24:106 (1913)

See also Eastman, 00.
Pettee, J. T.

91 James G. Percival. Meriden Sc As Tr $4: 22-38$, port (1891)

Pettee, William Henry (1838-1904).

80 Report of an examination of portions of the gravel mining region of Californis; in Placer, Nevada, Yuba, Sierra, Plumas, and Butte cos.; made in 1879. Harvard Coll, Mus C Z, Mem 6 no $1: 379-487$, map (1880)

Pettit, William.

47 Remarks respecting the copper dis. triet of Lake Superior. Franklin Inst, J (3) $13: 338-345$, map (1847)

Phalen, William Clifton.

04 Notes on the rocks of Nugsuaks Peninsula and its environs, Greenland Smiths Misc Col 45 (Q Is 1): 183-21? (1904)

O4a A new occurrence of unakite [t ray, Va.]. Smiths Mise Col 45 (Q Is 1 ) 306-316 (1904)

06 Origin and occurrence of certain iroo ores of northeastern Kentucky. EC G 1: 660-673 (1906)

06a Copper deposits near Luray, $V_{2}$ U S G S, B 285: 140-143 (1906)

06b Coal resources of the Kenova quadrangle. U S G S, B 285: 259-268 (1906)

06e Clay resources of northeastern Kentucky. U S G S, B 385: 411-416 (1906)

o7 Coal resources of Johnstown, Pa., abl vicinity. U S G S, B 316: 20-41 (1907)

o7a (and Martin, Lawrence) Clay and shales of southwestern Cambria Ca Pa. U S G S, B 315: 344-354 (1907)

os Iron ores near Ellijay, Ga. U S G B $340: 330-334$ (1908)

o8a Economic geology of the Kenors quadrangle, Kentucky, Ohio, and West Vit ginia. U S G S, B 349:158 pp (1908)

OSb Bauxite and aluminum. U S G \& Min Res 1907 pt 1:693-705; 1908 pt 1 $697-708 ; 1909$ pt $1: 561-572 ; 1910$ pt 1 $711-723 ; 1911$ pt $1: 923-939 ; 1912$ pt $t$ 949-962; 1913 pt $1: 1-27 ; 1914$ pt 1 $183-209 ; 1915$ pt 1 : $159-174$ (1908-16)

o8e Abrasive materials. U S G S, Min Res 1907 pt $2: 607-626 ; 1908$ pt $2: 581$ $598 ; 1909$ pt $2: 609-627 ; 1910$ pt $2: 683^{-}$ $697 ; 1911$ pt 2 : $835-854(1908-12)$

osd Salt, bromine, and calcium chlorlde U. S G S, Min Res 1907 pt 2:659-67? 1908 pt $2: 643-657 ; 1909$ pt $2: 661-683$ 1910 pt $2: 769-781 ; 1911$ pt $2: 919-986$ 1912 pt $2: 909-929 ; 1913$ pt $2: 291-307$ 1914 pt $2: 291-306 ; 1915$ pt $2: 265-27$ (1908-16)

08e Sulphur and pyrite. U S G S, Mis Res 1907 pt $2: 673-683 ; 1908$ pt $2: 659-$ $668 ; 1909$ pt $2: 685-700 ; 1910 \mathrm{pt}$ : $783-798 ; 1911$ pt $2: 937-957 ; 1912$ pt 2 931-953; 1913 pt $2: 23-47 ; 1914$ pt ? 131-149; 1915 pt $2: 291-306$ (1908-16)

osf (with Hayes, C. W.) A commet cial occurrence of barite near Cartersille Ga. U S G S, B 340: 458-462 (1908) 
Phalen, William Clifton-Continued.

10 Description of the Johnstown quadrangle, $\mathrm{Pa}$. U S G S, G Atlas Johnstown fol (no 174) : $15 \mathrm{pp}$, maps (1910) Abst, Wash Ac Sc; J $2: 135$ (1912)

$10 \mathrm{a}$ on a peculiar cleavage structure resembling stretched pebbles, near Ellijay, Ga. J G 18: 554-564 (1910)

11 Preliminary report of the coal resources of the Pikeville special quadrangle of eastern Tennessee. Tenn G S, B 9: 23-68 (1911); Res Tenn 1: 117-162, map (1911)

11a (and Martin, Lawrence) Mineral resources of Johnstown, $\mathrm{Pa}$, and vicinity. U \& G S, B 447: 142 pp, map (1911) Abst, Wash Ac Sc, J 2: 135 (1912)

11b Potash salts. U S G S, Min Res 1910 pt $2: 747-767 ; 1911$ pt $2: 889-917$; 1912 pt $2: 877-908 ; 1913$ pt $2: 85-107$; 1914 pt $2: 9-33 ; 1915$ pt $2: 95-133$ (1911-6)

12 Description of the Kenova quadrangle [Ky.W. Va.-Ohio]. U S G S, G Atlas Kenova fol (no 184): 16, maps (1912) Abst, Wash Ac Sc, J $3: 455$ (1913)

12a Prospecting for bauxite-aluminum ore. M Sc Press 105:305-307 (1912)

12b Prospecting for chromium ore. M Sc Press 105: 400-401 (1912)

12e Chromic iron ore. U S G S, Min Res 1911 pt 1:979-986 (1912)

12d Barytes; mineral paints, U S G S, Min Res 1911 pt 2:965-970, 971-993 (1912)

13 The occurrence of potash salts in the bitterns of the eastern United States. U S G S, B $530: 313-329$ (1913)

13a Phosphate rock. U S G S, Min Res 1912 pt $2: 855-876 ; 1913$ pt $2: 273-307$; 1914 pt $2: 41-56 ; 1915$ pt $2: 227-244$ (1913-6)

14 Celestite deposits in California and Arizona. U S G S, B 540:521-533 (1914)

14a The bauxite industry in the Southern States (abst). Science n s 39:400-401 (1914)

14b The outlook for the aluminum industry in the South (abst). Science $n \mathbf{s}$ $39: 401$ (1914)

14e The salt industry of the Southern States (abst). Science n s 39:401-402 (1914)

15 The search for potash salts in the United States. Commercial Fertilizer, 1915 Year Book : 37-40 (1915)

16 The conservation of phosphate rock in the United States. Am I M Eng, B 119: 1901-1934 (1916); Tr 57:99-132 (1918)

$16 a$ The conservation of phosphate rock in Tennessee. Tenn G S, Res Tenn 6: 193-216 (1916)

16b The production of phosphate rock in 1914. Am Fertilizer Hand Book 9: c 2-13 (1916)

$$
28737^{\circ}-23-53
$$

Phalen, William Clifton-Continued.

17 The central Kentucky phosphate field. Ky G S, Report on the phosphate rocks of central Kentucky : 80 pp, maps (1915) [1917].

17a Technology of salt making in the United States. U S Bur Mines, B 146: 149 pp (1917)

17b Potash salts, 1915. Am Fertilizer Hāndbook 10:73-90 (1917)

See also Matson, 15 ; Stutzer, 12

Phelps, Frank B.

92 The copper region of Michigan. Eng Mag 4:47-63 (1892)

Philippi, E.

o7 Ueber junge Intrusionen in Mexiko und ihre Beziehungen zur Tektonik der durchbrochenen Schichtgesteine, nach den Forschungen von E. Böse und C. Burckhardt. Centralbl Miner 1907: 449-460

Phillips, Alexander Hamilton.

94 A recent analysis of Pele's hair and a stalagmite from the lava caves of Kilauea. Am J Sc (3) $47: 473-474$ (1894)

99 The mineralogical structure and chemical composition of the trap of Rocky Hill, N. J. Am J Se (4) 8:267-285 (1899)

04 Radium in an American ore. $\mathrm{Am} \mathrm{Ph}$ Soc, Pr 43: 157-160 (1904)

10 Gageite, a new mineral from Franklin, N. J. Am J Sc (4) $30: 283-284$ (1910)

11 Notes on recent find of zincite crystals (Franklin Furnace, N. J.]. Am J Sc (4) $31: 464-465$ (1911)

12 Mineralogy, an introduction to the theoretical and practical study of minerals. 699 pp, N Y 1912

13 A simple model for illustrating the symmetry of crystals. Am J Sc (4) 36 : 30-32 (1913)

16 New zine phosphates from Salmo, B. C. $A \mathrm{~m} \mathrm{~J} \mathrm{Sc} \mathrm{(4)} 42: 275-278$ (1916)

$16 a$ Some new forms of natrolite. Am $\mathrm{J}$ Se (4) $42: 472-474$ (1916)

17 A rare habit and new form of franklinite. Am Mineralogist 2:5 (1917)

is A possible source of vanadium in sedimentary rocks. Am J Sc (4) 46 : 473-475 (1918)

\section{Phillips, Drury McN.}

12 (with vdden, J.) A reconnaissance report on the geology of the oil and gas fields of Wichita and Clay cos., Tex. Tex Univ, B 246 (sc s 23) : 308 pp (1912)

Phillips, Francis Clifford.

97 On the genesis of natural gas and petroleum. $A \mathrm{~m} \mathrm{Ph}$ Soc, $\mathrm{Pr} 36: 116-121$ (1897)

$97 a$ on the occurrence of petroleum in the cavities of fossils. $\mathrm{Am} \mathrm{Ph}$ Soc, $\mathrm{Pr}$ $36: 121-126$ (1897) 
Phillips, John (1800-18').

42 Notices of a great cavern, of the remains of elephants, and of a well sunk in pumice, etc., in Mexico. Geo'ngist 1842 : 168-169 G Soc London, Pr 3: 705-706 (1842)

Phillips, John Arthur (1822-1887).

68 Notes on the chemical geology of the gold fields of California. Ph Mag (4) $36: 321-336,422-433$ (1868) Abst, $\mathrm{R}$ Soc London, $\operatorname{Pr} 16: 294-299$ (1868) ; Am J Sc (2) $47: 134-139$ (1869)

73 Note on the silicified woods of California. G Mag 10:98-99 (1873)

77 The alkaline and boracic lakes of California. Pop Sc Rv 16 (n s 1) : 153163 (1877) Western Rv Sc 1:225-235 (1877)

79 A contribution to the history of mineral veins [based on American ore deposits]. G Sec Lenden, Q J 35:390-395 (1879)

Phillips, John Van Cleve.

54 The geology of the Upper Mississippi lead region. M Mag 2:129-138 (1854)

59 Report on the geology "the mineral districts contiguous to the Iron Mountain Railroad. 14 pp, map, St Louis 1859

7 7 Geology of the West [boring at St. Louis, Mo.]. Western Rv Sc 1:488-491 (1877) Sc Am Sup 4:1432 (1877)

Phillips, William (1775-1828).

16 An outline of mineralogy and geology... 192 pp, N Y 1816

18 An elementary introduction to the knowledge of mineralogy...with notes and additions on American articles by Samuel $\mathrm{L}$. Mitchill. xlii, $255 \mathrm{pp}, \mathrm{N}$ Y 1818

33 ... Georgia gold mines. Am J Sc 24: 1-18 (1833)

44 An elementary treatise on mineralogy...with numerous additions to the introduction by Francis Alger. 5th ed from 4 th $\mathrm{L}$ ed, cl, $662 \mathrm{pp}$, Boston 1844

Phillips, William Battle (1857-1917).

83 North Carolina phosphates; in part a report to the Navassa Guano Company. 19 pp, Wilmington, N C., 1883

84 North Carolina phosphates. Elisha Mitchell Sc Soc, J 1: 60-63 (1884)

85 Analysis of erystals of dogtooth spar from Gander Hall, New Hanover Co., N. C... Elisha Mitchell Sc Soc, J 2:62-63 (1885)

88 Mica mining in North Carolina. U S G S, Min Res 1887: 661-671 (1888)

88 a Mica mining in North Carolina. Eng M J 45 : 286, 306-307, 322, 324, 382$383,398,418,436$ (1888) Elisha Mitchell Sc Soc, J 5: 73-97 (1888) Sc Am Sup $26: 10449, \quad 10462-10463, \quad 10474-10475$ (1888)

02 A preliminary report on a part of the lower gold belt of Alabama in the counties of Chilton, Coosa, and Tallapoosa. Ala G S, B 3:97 pp, map, Montgomery 1892
Phillps, William Battle-Continued.

93 A list of minerals containing at lees one per cent of phosphoric acid. Am Iy Eng, Tr 21: 188-196 (1893)

93a Murfree's Valley and its mineni [Ala.]. Eng M 56:448-449 (1893)

94 On the phosphate rock of Tenness Ala Ind Sc Soe, Pr 4:44-48 (1894)

94a The phosphate rocks of Tenness Eng M J 57: 417 (1894)

95 Coal in western North Caroling Eng M J 60:612-613 (1895)

96 Iron making in Alabama. Ala 68 164 pp, Montgomery, Ala., 18962 . 380 pp, Montgomery, Ala., 1898 3d ed. 2 pp, University, Ala., 1912

97 The gold regions of Alabama, C. S. $\mathrm{N}$ Engl Inst $\mathrm{M}$ Eng, $\mathrm{Tr} \cdot \mathbf{4 7}: 19-23$, aㅏ (1897)

$\mathbf{9 7 a}$ Mining low-grade gold ores in thr bama. Eng M J 64:185-186 (1897)

$\mathbf{9 7 b}$ The southwestern extremity of th Appalachian gold fields. Eng M J 64 398 (1897)

98 The brown-ore deposits near Lees Ala. Eng M J 65:489-490 (1898)

99 Copper deposits of North Carolite Eng M J 67: 382 (1899)

01 Texas petroleum. Tex Univ Min 8 : 1: $102 \mathrm{pp}$, map (1901)

01a The Beaumont ofl field, Texas. Em M J $71: 175-176$ (1901)

01b The zinc-lead deposits of southre Arkansas. Eng M J 71:431-432 (1901)

01e The bat-guano caves of Tems Mines and Minerals 21:440-442 (1901)

02 Sulphur, oil, and quicksilver in trast Pecos Texas. Tex Univ Min S B 2:43 H map (1902)

02a Coal, lignite, and asphalt rodi Tex Univ Min S B 3:137 pp, maps (190.

04 Report of progress of the Universitit of Texas Mineral Survey for the year et ing December 31, 1903. Tex Univ Min S $7: 14 \mathrm{pp}$, map (1904)

O4a The coal, lignite, and asphalt rodi of Texas. W Soc Eng, J 9:571-592, mif (1904)

04b A new quicksilver field in Brewsiel Co., Tex. Eng M J $77: 160-161$ (1904)

o4e Lead ore in Burnet Co., Tex. Bt M J $77: 364$ (1904)

O4d Extension of the quicksilver distrid in Brewster Co., Tex. Eng M J 78:21: (1904)

O4e Condition of the quicksilver indor try in Brewster Co., Tex. Eng M J is: 553-554 (1904)

O5 The quicksilver deposits of Brewstit Co., Tex. Ec G 1: 155-162 (1905)

05a A coking coal in Chihuahua. M J 79:661-662, map (1905)

o5b Terlingua quicksilver district [Texsi)] M World 23: 259-260 (1905)

06 Quicksilver deposits of Terlingua di trict, Brewster Co., Tex. Am M Cong, 8th An Sess, Pr: 184-193 (1906) 
Phillips, William Battle Continued.

0s Geology of quicksilver deposits. M World 29: 131 (1908)

09 The South Lorraine silver district, Ont. Eng M J $87: 214-215$ (1909)

09a Condition of the quicksilver industry in Texas. Eng M J 88:1022-1024 (1909)

09b Iron ores of Llano Co., Tex. Manufacturers' Record 56 no $1: 49$ (1909)

10 The mineral resources of Texas. Tex Dp Agr, B 14: 45 pp (1910)

10a The Guaynopa district of Chihuahua, Mexico. M Sclence 62:297-298 (1910)

10b Shafter silver district, Presidio Co., Tex. Eng M J 90:1303-1305 (1910)

11 The Permian copper ores in Texas. Eng M J 92: 1181-1182 (1911)

11a (and worrell, S. H.) The composition of Texas coals and lignites. Tex, Univ, B 189 (sc s 19) : 5-57 (1911)

12 Iron making in Alabama. $3 \mathrm{~d}$ ed, 254 pp, Ala G S (1912)

12a Sulphur deposits in Culberson (formerly a part of El Paso) Co., Tex. Am Fertilizer 36 no $12: 44 \mathrm{~g}-46$ (1912)

13 (and worrell, S. H.) The fuels used in Texas. Tex Univ, B 307 (sc s 35) : 287 pp (1913)

14 The mineral resources of Texas. Tex Univ, B 365 (sc s 29) : 362 pp (1914)

14a Fuel oil in the Southwest; with a bibliography of fuel oll generally. Am I M Eng, B 90:1023-1070 (1911); $\operatorname{Tr} 48$; $565-612$ (1915)

15 Investigation of sources of potash in Texas. Am I M Eng, B 98:115-127 (1915); r 51:438-450 (1916

17 The sulphur deposits in Culberson Co., Tex, Am I M Eng, B 129:14491466 ; B 104: 644-645 (1917) ; Tr $58: 265-$ 283 (1918) Abst, Eng M J 104:644-645 (1917)

17a Quicksilver industry of Texas. M Sc Press 115: 93 (1917)

See also Köhler, 87

Phinney, Arthur John.

82 Geology of Delaware Co. Ind, Dp G $\mathrm{N} H$, An Rp 11: 126-149, map (1882)

83 Geology of Randolph Co. Ind Dp G N H, An Rp 12: 177-195 (1883)

84 Geology of Grant Co. Ind, Dp G N H, An Rp 13 pt 1: 138-153 (1884)

86 ['Geology of] Henry Co. and portions of Randolph, Wayne, and Delaware. Ind, Dp $G$ Nat Res, An Rp 15:97-116 (1886) 87 The Indiana gas field. Am Manufacturer, Nat Gas Suppl no $2: 11$, map, Dec. 30 (1887)

91 The natural gas field $\&$ Indiana. U \& G S, An Rp 11 pt $1: 579-742$, map
Piatt, W. H. H.

94 (with Haworth, E.) A geologic section along the Verdigris River from the State line to Madison. Kans Univ Q 2: 115-118 (1894)

Picher, 2. H.

17 Road materials in Soulanges and Vaudreuil cos., Que. Can G S, Sum Rp 1916: 201-206 (1917)

18 Road materials in a portion of Vaudreuil Co., Que., and along the St. Lawrence River from the Quebec boundary to Cardinal, Ont. Can G S, Mem 106:12 pp (1918)

\section{Pickard, Byron 0 .}

12 The Oro Grande mine in Grant Co., N Mex. M Science 65: 166-168 (1912)

12a The Apache mines of the Owl Head district, Ariz. M Science 65:473-475 (1912)

Pickering, Charlès.

54 [Distribution of boulders between Salem and Danvers, Mass.] Boston Soc N H, Pr $5: 24$ (1854)

71 [On the drift in the vicinity of Salem.] Boston Soc N H, Pr 14:91-92 (1871)

71a [On volcanic phenomena of $\mathrm{Ha}$ waii] (with discussion by W. T. Brigham). Boston Soc N H, Pr 14: 128 (1871)

See also Jackson, 71a ; Niles, 71b; Perrey, 55

Pickering, William H.

os Lunar and Hawaiian physical features compared. Am Ac Arts, Mem 13:151-179 (1906)

07 The place of origin of the moon - the voleanie problem. J G $15: 23-38$ (1907)

09 The origin of meteorites. Pop Astron $17: 273-282$ (1909)

09a The chance of collision with a comet, iron meteorites, and Coon Butte [Ariz.]. Pop Astron $17: 329-339$ (1909)

Pierce, $B$.

57 On the origin of the great lines of land and water on the surface of our globe (abst). Can Nat 2:283-284 (1857)

Pierce, James.

1S Discovery of native crystallized carbonate of magnesia on Staten Island, with a notice of the geology and mineralogy of that island. Am J Sc 1:142-146 (1818)

20 ... geology, mineralogy, scenery, etc., of the secondary region of New York and New Jersey, and the adjacent regions. Am J Sc 2:181-199 (1820)

22 Geology, mineralogy, scenery, etc, of the Highlands of New York and New Jersey. Am J Sc 5: 26-33 (1822)

23 A memoir on the Catskill Mountains ... Am J Sc 6: 86-97 (1823)

23a Notice of the alluvial district of New Jersey ... Am J Sc 6: 237-242 (1823)

25 Notices of the agriculture, scenery, geology, and animal. vegetable, and mineral productions of the Floridas ... Am J Sc 9: 119-136 (1825) 
Pierce, James-Continued.

26 ... on the shell-marl region of the eastern parts of Virginia and Maryland, and upon the bituminous-coal formation in Virginia and contiguous region. Am J Sc $11: 54-59$ (1826)

27 ... mountain districts of Pennsylvania and the mineral resources of that State ... Am J Sc 12: 54-74 (1827)

Pieree, R. A.

12 The lignite fields of Colorado. Coal Age 1:534-538 (1912)

Pierce, S. J.

97 The preglacial Cuyahoga Valley. Am G 20:176-181,(1897)

01 The Cleveland water-supply tunnel. Am G 28: 380-385 (1901)

Piers, Harry.

07 Economic minerals of Nova Scotia ; Catalogue and description of a collection at the Provincial Exhibition, Hallfax. Revised ed, 60 pp. In $\mathrm{N} S \mathrm{Dp}$ Mines $\mathrm{Rp}$, 1906. Halifax 1907

es Discovery of tin in Nova Scotia. M Soc N S, J 12: 159-161 (1908)

12 On the occurrence of tin in Nova Scotia. N S Inst Sc, Pr Tr 12:239-249 (1912)

12a Mastodon remains in Nova Scotia. N S Inst Sc, Pr Tr 13:163-174 (1912)

13 The occurrence of opal in grante near New Ross, Lunenburg Co., N. S. N S Inst Sc, $\operatorname{Pr} \operatorname{Tr} 12: 446-449$ (1913)

Pieschel, Carl.

55 Die Vulkane von Mexico. Zs Allg Erdk $4: 379-400 ; 5: 124-147,190-199 ; 6$ : 81-91, 489-532 (1855-6)

56 Die Vulkane der Republik Mexico. 1 p, 18 pls, Berlin 1856 [not seen]

Piggot, Aaron Snowden (1822-1869).

58 The chemistry and mineralogy of copper. $388 \mathrm{pp}$, Phila 1858

$\mathbf{5 8 a}$ History of the copper region of Lake Superior. M Mag 10:124-142 (1858) From his The chemistry and metallurgy of copper ... : 216-254, Phila 1558

Pike, J. W.

So Preservation of fossil insects and plants on Mazon Creek [IIl.]. Science (ed, Michels) $1: 163(1880)$

81 Preservation of fossil insects and plants on Mazon Creek [III.] Am As, Pr $29: 520-524$ (1881)

85 The genesis and conservation of volcanic energy ( $a b s t)$. Am As, Pr 33:432438 (1885)

Pillsbury, J. E.

11 The influence of marine currents on deposition in continental seas (abst). Science $n$ s $33: 314-315$ (1911)

Pilsbry, Henry Augustus.

92 (and Johnson, C. W.) Catalogue of Fissurellidae of the United States. Nantilus 5: 102-107 (1892)

96 Pleurotomaria crotaloide. Morton in the New Jersey Cretaceous. Ac it Sc Phila, Pr 1896:10-11
Pilsbry, Henry Augustus-Continued. $96 a[O n$ a deposit containing foet Unionidae at Fish House, N. J. (abrit Science n s 3:851-852 (1896)

97 Geology of the mussel-bearing din of Fish House, N. J. Ac N Se Phila, $h$ $1896: 567-570$ (1897)

$97 \mathbf{a}$ The affinities of Floridian Mioce land snails. Ac is Sc Phila, Pr 1897:

$97 \mathrm{~b}$ Scalpellum and Balcnus from Ters Ac N Sc Phila, Pr 97:332-03? i

98 Note on the "i rencia formation: Am J Sc (4) 5:232-233 (1898)

98a (and Sharp, ienj.) Scaphopod of the San Domingo Tertiary. Ac X\& Phila, $\operatorname{Pr} 1897: 465-576$, il (1898)

01 Crustacea of the Cretaceouz form tion of New Jersey. Ac N Sc Phila, A 53:111-118 (1901)

05 Planorbis alabamensis and dilatate in the Floridian Pliccene. Nautilus 18: 34 (1905)

10 A new Haitian Oligocene horim Ac N Sc Phila, Pr $62: 487-489$, il (1910

11 Scaphopoda of the Jamaican 0lip cene and Costa Rican Plir sene. Ac N \& Phila, $\operatorname{Pr} 63: 165-169$, il (1911)

11a A new Eephora of the Chesapealt Miocene, Ac N Sc Phila, Pr 63:438-49 if (1911)

$11 b$ (with Brown, A. P.) Tanns it the Gatun formation. Isthmus of Panat Ac N Sc Phila, Pr 63:336-373 (1911)

12 Notes on some Pleurotomida of th Cretaceous of New Jersey. Ac N Sc Ptil $\operatorname{Pr} 63: 534-535$ (1912)

12a (with Brown, A. 2') Note on collection of fossils from Wilmington, C. An N Sc Phila, Pr 64: 152-153 (191: 14 (with Brown, A. P.) Fresh-wate mollusks of the Oligocene of Antigua. N Sc Phila, Pr 66: -09-213, il (1914

17 (and Johnson, C. W.) New lusca of the Santo Domingan Oligocene. N Sc Phila, Pr 69: 150-202 (1917)

18 Cirripedia from the Panama cast Zone. U S Nat Mus, B 103:185-188, (1918)

See also Clark (W B), 16b; Eastman, Pinart, Alph. L.

75 Voyages a la cote nord-ouest l'Amérique exécutés durant les années 18: 72. 51 pp, il, Paris 1875 [Minéralogle et géologie par MM. Jannettaz et De Cesst 13-27; Paléontologie par MM. A. Gaudr et P. Fischer : 29-36]

Pingel, C.

35 [On the gradual sinking of part the west coast of Greenland.] G Soc lot don, Pr 2: 208-209 (1835) Soc G Frave B $7: 96-97$ (1836)

$41 \mathrm{Om}$ Saenkningen af Grönlands kyst. Skandinaviske Naturforsker, Foth : 353-363 (1841) 
Pingel, C.-Continued.

$43 \mathrm{Om}$ den af porphyrgange gjennembrudte röde Sandsteen $\mathrm{i}$ det sydlige Grönland. K Danske Vidensk Selsk, Afh (4) $10: 299-318$ (1843) ; abst, Overs Forh $1835-6: 28-30$ (1836)

47 Nogle bemaerkninger om iisdriften under Grönlands vestkyst. Skandinaviske Naturforsker, Forh 5:600-605 (1847)

Piper, Charles Vancouver.

05 The basalt mounds of the Columbia lava. Science n s 21:824-825 (1905)

Pirsson, Louis Valentine (1860-1919).

90 On mordenite. Am J Sc (3) 40 : 232-237 (1890) Yale Bicen Pub, Contr Miner : 178-182 (1901)

90a On the fowlerite variety of rhodonite from Franklin and Stirling, N. J. Am J Sc (3) $40: 484-488$ (1890)

91 On some remarkably developed caleite crystals. Am J Sc (3) 41: 61-64 (1891)

91a Gmelinite from Nova Scotia. Am J Sc (3) $42: 57-63$ (1891)

91b ?ineralogical notes. Am J Sc (3) $42: 405-409$ (1891)

91e (with Weed, W. H.) Oecurrence of sulphur, orpiment, and realgar in the Yellowstone National Park. Am J Sc (3) $42: 401-405$ (1891)

93 Datolite from Loughboro, Ont. Am J Sc (3) $45: 100-102$ (1893)

93a on the geology and petrography of Conanicut Island, R. I. Am J Sc (3) 46 : 363-378, maps (1893)

94 On the crystallization of enargite. Am J Sc (3) $47: 212-215 \quad$ (1894) Zs Kryst 23:114-117 (1894)

94a on some phonolitic rocks from the Black Hills [S. Dak.]. Am J Sc (3) 47 : 341-346 (1894)

94b (and Wells, H. L.) On the oceurrence of leadhillite in Missouri and its chemical composition. Am J Sc (3) 48: 219-226 (1894)

95 Complementary rocks and radia dikes. Am J Sc (3) 50:116-121 (1895)

95a On some phonolitic rocks from Montana. Am J Sc (3) 50:394-399 (1895)

95b (with weed, W. H.) Highwood Mountains of Montana. G Soc Am, B 6: $389-422$, map (1895)

95e (with Weed, W. H.) On the igneous rocks of the Sweet Grass Hills, Mont. Am J Sc (3) $50: 309-313$ (1895)

95d (with weed, W. H.) Igneous rocks of Yogo Peak, Mont. Am J Sc (3) $50: 467-479$ (1895)

96 On the monchlquites or analcite group of igneous rocks. J G $4: 679-690$ (1896)

96a A needed term in petrography (abst). G Soc Am, B 7:492-493 (1896) Am G $17: 94$ (1896) Science n s $3: 49$ (1896) J G $4: 128$ (1896)
Pirsson, Louis Valentine-Continued.

96b (with Weed, W. H.) Geology of the Castle Mountain mining district, Mont. U S G S, B 139: 164 pp, maps (1896)

96c (with Weed, W. H.) The Bearpaw Mountains, Mont. Am J Sc (4) 1:283$301,351-362$; $2: 136-148$, 188-189, map (1896)

$96 d$ (with Weed, W. H.) Missourite, a new leucite rock from the Highwood Mountains of Montana. Am J Sc (4) 2: 315-323 (1896) Yale Bicen Pub, Contr Miner : $457-466$ (1901)

96e (with weed, W. H.) The geology of the Little Rocky Mountains [Mont.]. J G : 399-428 (1896)

97 On the corundum-bearing rock from Yogo Guleh, Mont. Am J Se (4) 4: 421423 (1897)

98 (with Weed, W. H.) Geology and mineral resources of the Judith Mountains of Montana. U S G S, An Rp 18 pt 3: 437-616, maps (1898)

99 On the phenocrysts of intrusive igneous rocks. Am J Sc (4) , : 271-280 (1899) Abst, Sclence n s 9:142 (1899); Am G 23: 106 (1899)

on Petrography of the igreous rocks of the Little Belt Mountains, Mont. U S G S, An Rp 20 pt 3:463-581 (1900) (in part) Yale Bicen Pub, Contr Miner: 436456 (1901)

OOa (and Robirson, H. H.) On the determination of minerals in thin rock sections by their maximum birefringence. Am J Se (4) 10:260-265 (1900)

01 (with Penfield, S. L.) Contributions to mineralogy and petrography ... Yale Bicen Pub, 482 pp, N Y, 1901

01 a (with Weed, W. H.) Geology of the Shonkin Sag and Palisade Butte laccoliths in the Highwood Mountains of Montana. Am J Sc (4) $12: 1-17$ (1901)

02 (with others) A quantitative chemico-mineralogical classification and nomenclature of igneous rocks. J G 10 :555690 (1902)

03 (with Cross, W., and others) Quantitative classification of igneous rocks. 286 pp, Chicago 1903

o5 Petrography and geology of the igneous rocks of the Highwood Mountains, Mont. U S G S, B $237: 208$ pp, maps (1905)

05a The petrographic province of central Montana. Am J Sc (4) 20:35-49, map (1905)

osb (and Washington, H. S.) Contributions to the geology of New Hampshire; I, Geology of the Belknap Moun tains. Am J Sc (4) $20: 344-352$, map (1905)

06 Samuel Lewis Penfield [obituary]. Am J Se (4) $22: 353-367$, port (1906)

OGa [Obituary notice of] Israel Cook Russell. Am J Sc (4) $21: 481$ (1906) 
Pirsson, Louis Valentine-Continued.

o6b (and Washington, H. S.) Contributions to the geology of New Hampshire; No. II, Petrography of the Belknap Mountains. Am J Sc (4) 22:439-457, 493-514 (1906)

o6e (with Cross, W.) The texture of igneous rocks. J G 14:692-707 (1906)

o7 (and Washington, H. S.) Contributions to the geology of New Hampshire; No. III, On Red Hill, Moultonboro. Am J Sc (4) $23: 257-276,433-447$ (1907)

07a Angelo Heilprin. Am J Sc (4) 24 : 284 (1907)

os Rocks and rock minerals, a manual of the elements of petrology without the use of the microscope. 414 pp, N Y 1908

10 Note on the occurrence of astrophyllite in the granite of Quincy, Mass. Am J Sc (4) $29: 215-216$ (1910)

10a Crustal warping in the TemagamiTemiskaming district, Ont. Am J Se (4) $30: 25-32$, map (1910)

$10 b$ On an artificial lava-flow and its spherulitic crystallization. Am J Se (4) $30: 97-114,425-426$ (1910)

11 (and Rice, W. N.) Contributions to the geology of New Hampshire; IV, Geology of Tripyramid Mountain. Am J Se (4) $31: 269-291$, map (1911)

11 a Contributions to the geology of New Hampshire; V, Petrography of Tripyramia Mountain. Am J Se (4) $31: 405-431$ (1911)

11b Obituary notice of Samuel Franklin Emmons. Am J Sc (4) $31: 467-468$ (1911) 12 (with Cross, W.) Modifications of the quantitative system of classification of igneous rocks. J G 20:550-561 (1912)

13 (and Vaughan, T. W.) A deep boring in Bermuda Island. Am J Sc (4) 36 : 70-71 (1913)

14 (and Schuchert, C.) Note on the occurrence of the Oriskany formation on Parlin Stream, Maine. Am J Sc (4) 37 : 221-224 (1914)

14n Geology of Bermuda Island; the igneous platform. Am J Sc (4) 38:189206 (1914)

14b Geology of Bermuda Island; petrology of the lavas. Am J Sc (4) 38:331344 (1914)

14c (and Vaughan, T. W.) Contributions to the geology of Bermuda (abst). Science n s $39: 568$ (1914)

15 (and Sehnehert, C.) A textbook of geology. $1051 \mathrm{pp}$, il, maps, N Y 1915 [Another ed in 2 vols, pt $1: 1-444$; pt 2 : 405-1026] Rv by Shimer, H. W., and Labee, F. H., Science n s 43:497-501 (1916) Rv by J. W. Gregory, Nature 98 : 206-207 (1916)

15a The microscopical characters of volcanic tuffs-a study for students. Am J Se (4) $40: 191-211$ (1915)

15b Origin of certain ore deposits [in sedimentary formations]. 186 (1915)
Pirsson, Louis Valentine-Continued.

18 The rise of petrology as a science Am J Sc (4) $46: 222-239$ (1918) B printed in A century of science in Amerles: 248-267, New Hayen 1918

See also Cross, 02b ; Cushing, 13

Pisani, F.

64 Sur la carphosidérite du Groenlaxy Ac Sc Paris, C R 58:242-244 (1864)

73 Analyse d'une jeffersonite de Fran lin, N. J. Ac Sc Paris, C R $76: 23 \pi-2 \%$ (1873)

89 Sur la cuprodescloizite du Mexique divers autres vanadates, Soc Franç Mithe B $12: 38-43$ (1889)

Pishel, Max A.

11 (with Diller, J. S.) Preliminar report on the Coos Bay coal field, Ots U S G S, B 431: 190-228 (1911)

12 Lignite in the Fort Berthold Indian Reservation, N. Dak, north of Missomi River. U S G S, B 471:170-186, 叫 (1912)

14 (with Calvert, W. R., and othes Geology of the Standing Rock and Cheyen: River Indian reservations, N. and S. Dak U S G S, B $575: 49$ pp, maps (1914 Abst, Wash Ac Sc, J 4:425 (1914)

Pitt, William H.

75 (with Grote, A. R.) Description of a new crustacean from the Waterlime grow at Buifalo [N. Y.]. Buffalo Soc N Sc, t $3: 1-2$, il (1875)

$75 a$ (with Grote, A. R.) On Der species of Eusarcus and Pterygotus fro the Waterlime group at Buffalo [N, I] Buffalo Soc N Se, B $3: 17-20$, il (1875)

78 (with Grote, A. R.) New specimen from the Waterlime group at Buffalo, N.I Am As, Pr 26:300-302, il (1878)

Pittier, Henri Francois.

10 Costa Rica-Vulcan's smithy. N Geog Mag 21:494-525 (1910)

12 Kostarika; Beiträge zur Orographi und Hydrographie. Petermanns Mitt, Ers $175: 48 \mathrm{pp}$, map (1912)

Pjetursson, Helgi.

98 Geologiske Optegnelser [geologit notes on Egedesminde district, Greenland? Med Grönland 14:288-347 (1898)

Place, A. E.

o7 (and Elton, H. L.) Mines of $y$ Taviche district, Oaxaca, Mexico. Eng M $84: 625-626$ (1907)

Plate, H. R.

o7 The old camp at Ward, Nev. M \& Press 94: 281 (1907)

Platen, Paul.

os Untersuchungen fossiler Hölzer as dem Westen der Vereinigten Staten wo Nordamerika. Nature Ges Leipzig, \$zb 34 1-164, il (1908) Also, Inaug. Diss. Whip zig

09 Die fossilen Wälder am Ametbst: Mount im Yellowstone-Nationalpark $15:$ die mikroskopische Untersuchung thrk Hölzer. Prometheus $20: 241-246$, il (1909) 
Platt, Franklin (1844-1900).

75 Report of progress in the Clearfield and Jefferson district of the bituminous coal fields of western Pennsylvania. Pa G S, 2 d, H : viii, 296 pp, maps (1875)

76 Special report on the coke manufacture of the Youghlogheny River valley in Fayette and Westmoreland cos., with geological notes of the coal and iron ore beds. Pa G S, 2d, L: 252 pp (1876)

76a Durability of the natural gas supply. $\mathrm{Pa}$ f S, 2d, L : 161-172 (1876)

77 (and Platt, W. G.) Report of progress in the Cambria and Somerset district of the bituminous coal fields of western Pennsylvania: Part I, Cambria. Pa G S, 2d, HH : xxx, $194 \mathrm{pp}$, maps and atlas (1877)

77a (and Platt, W. G.) Report of progress in the Cambria and Somerset district of the bituminous coal fields of western Pennsylvania; Part II, Somerset. Pa G S, 2d. HHH : $x \times x i v, 348 \mathrm{pp}$, maps and atlas (1877)

78 Coal basins of Bradford and Tioga cos., and at the forks of Pine Creek in Potter Co. Pa G S, 2d, G : 97-234 (1878)

78a (and Sanders, R. H.) Section of the Paleozoic rocks in Blair Co. [Pa.]. Am $\mathrm{Ph}$ Soc, Pr $17: 349-352,714$ (1878) Pa G S, 2d, F : 261-264 (1878)

79 Character of some Sullivan Co. [Pa.] coals, $\mathrm{Am} \mathrm{Ph}$ Soc, $\operatorname{Pr} 18: 186-191$ (1879)

80 Report on the coal fields [of Potter Co.]. Pa G S, 2d, GGG : $67-95$ (1880)

80a The Queen's Run coal basin in Clinton Co., north of the Susquehanna River. Pa G S, 2d, G4: 153-164 (1880)

80 b The Tangascootac coal basin in Centre and Clinton cos., soutu of the Susquehanna. $\mathrm{Pa}$ G S, 2d, G4: 165-174 (1880)

80e (with Sherwood, A.) The geology of Lycoming and Sulliran cos. Pa G S, 2d, GG : ix, 268 pp, maps (1880)

81 ... upon the causes, kinds, and amount of waste in mining anthracite. $\mathrm{Pa} G \mathrm{~S}$, 2d, A2:134 pp (1881)

81a The geology of Blair Co. Pa G S, 2d, T: 311 pp, atlas (1881)

Platt, James M.

09 The Turquoise mining district, Ariz.

Eng M J $87: 213$ (1909)

09a The Zacualpan district, Mexico.

Eng M J 88:670-671 (1909)

Platt, William Green ugh.

77 (with Platt, F.) Reyort of progress in the Cambria and Somerset district of the bituminous coal fields of western Pennsylvania ; Part I, Cambria. $\mathrm{Pa} \& \mathrm{~S}$, 2d, HH : xxx, 194 pp, maps and atlas (1877)

77a (with Platt, F.) Report of progress in the Cambria and Somerset district of the bituminous coal fields of western Pennsylvania ; Part II, Somerset. Pa G S, $2 \mathrm{~d}$, HHH : xxxiv, $348 \mathrm{pp}$ maps and atlas (1877)
Platt, William Greenough-Continued.

78 Report of progress in Indiana Co. $\mathrm{Pa}$ G S, 2d, НННН : $\mathbf{x v i , ~} 16 \mathrm{pr}$ map (1878)

So Report of progress in Armstrong Co. Pa G S, 2d, H5 : 1xvii, 338 pp, map (1880)

81 Report of progress in Jefferson Co. $\mathrm{Pa}$ G S, 2d, H6: xxxiv, 218 pp, map (1881)

Plotts, William.

o5 Origin of petreleum, coal, etc ... 29 pp, Whittier, Cal., 1005 [Priv pub]

11 Isogeotherm hypothesis of mineral occurrence and origin. Origin of coal and other carbonaceous products. $68 \mathrm{pp}$, Whit. tier, Cal, 1911 [Priv pub]

16 Brotheriy relationship of minerals [isogeotherm hypothesis of mineral occurrence and origin]. Out West Mag 43: 165-167 (1916)

Plumb, Carlton H.

o5 The Tercio coal mining district, Colo. Drury Coll, Bradley G Field Sta, B 1: 94-100, map (1905)

14 The tripoli industry. Eng M J 96 : 1285-1287 (1914)

Plummer, Fred G.

93 A diagonal moraine [Washington]. Am G $12: 231-232$ (1893)

PInmmer, J. K.

15 Petrography of some North Carolina solls and its relation to their fertllizer requirements. J Agr Research 5:569-582 (1915)

Plummer, John $T$.

4. Suburban geology, or rocks, soil, and water about Richmond, Wayne Co., Ind. Am J Sc $44: 281-313$, 11 (1843)

Pockman, L. T.

10 Arteaga district, Chihuahua, Mexico. Inst Mex Minas Met, Inf 1: 202-203 (1910) Eng M J 90:656-657 (1910)

Poey, Andrés.

55 Table chronologique des tremblements de terre ressentis a l'tle de Cuba de 1851-

55. 26 pp, Paris 1855 (Extrait de Nouvelles annales des voyages, 1855) [not seen ]

58 Catalogue chronologique des tremblements de terre ressentis dans les Indes occidentales de 1530 a 1858 ... Soc Météorologique France, An 5: 75-127, 227-252 (1858)

59 Ensayo de una seismolog1a del Valle de Méjico.... 13 pp, Habana 1859 [not seen]

74 Rapports entre les taches solaires, les tremblements de terre aux Antilles et au Mexique et les éruptions volcaniques sur tout le globe. Ac Sc Paris, C R 78:51-55 (1874)

Poey, Felipe.

72 Curso elemental de mineralogia, 183 pp, Habana 1872 . 
Pogue, J. L.

09 (with Ford, W. E.) Calcite crystals from Kelly's Island, Lake Erie. Am $\mathrm{J}$ Sc (4) 28:186-187 (1909)

09a (with Ford, W. E.) Crystals of datolite from Bergen Hill, N. J. Am J Sc (4) $28: 187$ (1909)

Pogue, Joseph Ezekiel.

os (with Laney, F. B.) Outcrop map of the Virgilina copper district of Person and Granville cos., N. C. N C G S [1908?]

09 Crystallographic notes on calcite. Smith Misc Col 52 (Q Is 5) : $465-468$ (1909)

09a On a remarkable cube of pyrite, carrying crystallized gold and galena of unusual habit. Smiths Misc Col 52 (Q Is 5) : $477-483$ (1909)

09b Geology and structure of the ancient volcanic rocks of Davidson Co., N. C. Am J Sc (4) $28: 218-238$, map (1909)

10 Cid mining district of Davidson Co., N. C. N C G S, B 22: 144 pp, map (1910)

10a On olivine diabase from Davidson Co., N. C. U S Nat Mus, Pr $37: 475-484$, map (1910)

11 On calamine crystals from Mexico, rutile-mica intergrowth from Canada, and pseudomorphs of marcasite after pyrrhotite from Prussia. U S Nat Mus, Pr 39:571579 (1911) Zs Kryst 49:455-458 (1911)

11 a A possible limiting effect of ground water upon eolian erosion. J G 19:270271 (1911)

11b Gold- und Bleiglanzkrystalle in Verwachsung mit einem Würfel von Pyrit. Zs Kryst $49: 225-226$ (1911)

11e The great Rainbow Natural Bridge of southern Utah. Nat Geog Mag 22: 1048-1056 (1911) Abst, Science n s 33: 355 (1911)

12 (and Goldselimidt, V.) On quartz from Alexander Co., N. C. Am J Sc (4) $34: 414-420$ (1912)

13 On a cerusite twin from the Mammoth mine, Pinal Co., Ariz. Am J Sc (4) 35: 90-92 (1913)

15 The turquoise; a study of its history, mineralogy, geology ... Nat Ac Sc, Mem 12 pt 2 mem $3: 206$ pp (1915)

15a The Cantwell formation; a continental deposit of Tertiary age in the Alaska Range. J G 23: 118-128 (1915)

15b (with Moffit, F. H.) The Broad Pass region, Alaska. U S G S, B 608: 80 pp, maps (1915) Abst, Wash Ac Sc, J 6:95 (1916)

17 Military geology. Science n s $46: 8$ 10 (1917)

17a Mineral resources in war and their bearing on preparedness. Sc Mo $5: 120$ 134 (1917)

17b The mineral industries of the United States; fertilizers, an interpretation of the situation in the United States. U S Nat Mus, B 102 pt $2: 22$ pp (1917)
Pogne, Joseph Ezekiel-Continued.

17e The mineral industries of the United States; sulphur, an example of is. dustrial independence. U $\mathbf{S}$ Nat Mus, 103 pt $3: 10$ pp (1917)

18 Optical fluorite in southern milinols IIl G S, Extract from B 38: 8 pp (1918)

18a A laboratory method of teachin elementary crystallography. An Minerals gist $3: 179-182,193-194$ (1918)

$18 b$ (with Gilbert, C. G.) The mtr eral industries of the United States; cosi the resource and its full utilization. of Nat Mus, B 102 pt 4:26 pp (1918)

1Se (with Gilbert, C. G.) Petroleun; a resource interpretation. U S Nat Mos B 102 pt 6:74 pp (1918)

Pohlig, Hans.

85 Ammoniten aus Mexiko und Persien Niederrhein Ges Bonn, Szb 42:92-01 (1885)

s7 Ueber Molaren amerikanischer $\mathrm{Bl}$ phanten (abst). Naturh Ver Preus Rheirl Verh 44 (Niederrh Ges Bonn) Szb:111118 (1887)

88 [Geologic observations in Mexico. Naturh Ver Preus Rheinl ..., Verh (Nieder rhein Ges Bonn, Szb) (5) 5:64-66 (1868

94 Le premier crâne complet du Rhinoeros (Caenopus) occidentalis Leidy. Soc Belge G, B 7: M 41-44, II (1894)

12 Sur une vieille mandibule de "Tetr. caulodon ohioticum" Blum., avec défesse in situ. Soc Belge G, B 26;187-193, l (1912)

\section{Pohlman, Julius.}

81 On certain fossils of the Waterlime group near Buffalo [N. Y.]. Buffalo $S * x$ N Sc, B $4: 17-22$, il (1881)

82 Additional notes on the fauna of the Waterlime group near Buffalo [N. I.] Buffalo Soc N Sc, B $4: 41-45$, il (185:)

83 The life history of the Niagan River (abst). Science 2:315 (1883) dt As, $\operatorname{Pr} 32: 202$ (1884)

84 Geology of Erie Co. [N. Y.]. Smith, H. Perry, History of the City of Buffalo and Erie County, vol. 1:350-350, Syracuse, N. Y., 1884.

85 (and whitfield, R. P.) An Ameth can Silurian scorpion. Science 6:183184, il (1885)

86 Fossils from the Waterlime group near Buffalo, N. Y. Buffalo Soc N Sc, B $5: 23-32$, il (1886)

86a The thickness of the Onondaga salt group at Buffalo, N. Y. Buffalo Soc N Sa B $5: 97-98$ (1886)

$\mathbf{8 6 b}$ The Niagara Gorge (abst). Am ds, Pr 35:221-222 (1887) Science 8:205 (1886)

89 Cement rock and gypsum deposits in Buffalo [N. Y.]. Am I M Eng, Tr 10 250-253 (1889)

89a The life history of Niagara. At I M Eng, Tr $17: 322-338$, maps (1889) 
Poltevin, Eugene.

18 (and Graham, R. P. I Contributions to the mineralogy of Black Laive area, Que. Can G S, Mus B $27: 82 \mathrm{pp}$. map (1918)

18a Notes on the origin of colerainite. $\mathrm{R}$ Soc Can, Tr (3) 12 iv : $37-39$ (1918) Poland, Howard $M$.

10 (with Kümmel, H. B.) Liecords of wells in New Jersey, 1905-1909. Iv J G S, Rp 1909: 69-100 (1910)

Pollard, C. L.

94 [Fossil leaves of Cretaceous age from Eaton's Neck, Long Island, . Y.] N Y Ac Sc, Tr 13:180-181 (1894)

Pollard, Thomas.

79 A handbook of Virginia. 2d ed, 182 pp, map, Richmond, a., 1879 [Accompanies $\mathrm{Va}$, Commissioner of Agr, 2d An Rp] 3d ed, 1881

Pomel, A.

68 Sur le Myomorp:us cubensis, sousgenre nouveau du Megalonyx. Ac Sc Paris, C R $67: 665-668,850$ (1868)

Pomeroy, Richard A.

88 The Petite Anse salt mine [La.]. Am I M Eng, Tr 17:107-113 (1889) Eng M J 46:280-281 (1888) Sc Am Sup 26: 10719-10720 (1888)

Pomeroy, Samuel Wyllys.

32 Remarks on the coal re,ion between Cumberland and Pittsburgh. Am J Sc 21 342-347 (1832)

Pompeckj, Josef Felix.

00 Jura-Fossilien aus Alaska. Russ K Min Ges St Petersburg, Verh (2) 38:239 282 , il (1900)

Pond, Edward J.

87 A Cretaceous river bed [Hays Co., Tex.] Science 9:536-537 (1887)

Poole, Henry Skeffington.

54 Journals of exploratory works at the Albion mines, Pictou, N. S. G Soc London, Q J 10:47-51 (1854)

60 Notes on the coal field of Pictou [with introductory note by J. W. Dawson]. Can Nat $5: 285-293$ (1860)

62 [Report of examination of western part of Nova Scotia.] N S, Iegislative Council, J Pr 1862, App no 2:36-59, Halifax, N. S., 1862

63 On the characteristic fossils of different coa' seams in Nova Scotia. N S Inst $\mathrm{N} \mathrm{Sc}, \operatorname{Pr} \operatorname{Tr} 1$ pt $1: 3 \mathrm{C}-45 \quad(1863)$

73 The Great American Desert. N S Inst $\mathrm{N} \mathrm{Sc}, \operatorname{Pr} \operatorname{Tr} 3: 208-220$ (1873)

80 The gold leads of Nova Scotia. G Soc London, Q J $36: 307-313$ (1880) Abst, Can Nat n s 9:189 (1879); Nature 19: 523 (1879)

86 The Pictou coal field [N. S.] Am I M Eng, Tr 14: 403-408 (1886)

89 Ice in the Carboniferous period. N S Inst N Sc, Pr Tr $7: 202-204$ (1889)

90 surface geology of the Pictou coal field. $\mathrm{N}$ S Inst $\mathrm{N}$ Sc, $\operatorname{Pr}$ Tr $7: 388-393$ (1890)
Poole, Henry Skeffington-Continued.

93 The Pictou coal field; a geological revision. N S Inst Se, $\operatorname{Pr} \operatorname{Tr} 8$ or (2) 1 : 228-343, map (1893)

96 A mineralized zone in Nova Scotia. [Fed] Can M Inst, J 1:221-231 (1896) Can M Rv 14:226-227 (1895)

98 The mineralogy of the Carboniferous. Fed Can M Inst, J 3:77-81 (1898) Can M Rv 17:50-51 (1898)

00 Notes on a Cape Breton mineral containing tungsten ... N S Inst Sc, $\operatorname{Pr} \operatorname{Tr} 10$ or (2) $3: 245-247$ (1900)

02 The coal problem in New Brunswick. Can G S, Sum Rp 1901 (An Rp 14) : A 206208 (1902)

02a Stigmaria structure. N S Inst Sc, Pr $\operatorname{Tr} 10$ or (2) $3: 345-347$, il (1902)

02b The coal fields of New Brunswick, Canada. Inst M Eng, $\operatorname{Tr} 23: 40-47$, map (1902)

o3 Report on the coal prospects of New Brunswick. Can G S, An Rp 13: м 26 pp (1903)

O3a Notes on the geology of Anthracite, Alberta. Can G S, Sum Rp 1902 (An Rp 15) : ^ 149-151 (1903)

03b The Carboniferous rocks of Chignecto Bay. Can G S, Sum Rp 1902 (An Rp 15): A 379-384 (1903)

o3e A submerged tributary to the great preglacial river of the Gulf of St. Lawrence. R Soc Can, $\operatorname{Pr} \operatorname{Tr}$ (2) 9, iv : 143147 (1903)

o3d Notes on Dr. Ami's paper r i ictyonema slates of Angus rook, Ner Canaan, and Kentrille, N. S. N S Inst Sc, Pr Tr 10 or (2) $3: 451-454$ (1903)

04 Report on the Pictou coal field, N. S. Can G S, An Rp 14: $\mathrm{m} 38 \mathrm{pp}$, map (1904)

04a A trip to West Virginia [coal fields]. M Soc N S, J 8:127-131 (1904)

o5 Is there coal under Prince Edward Island? $\mathrm{N} S$ Inst Sc, $\mathrm{J}, \mathrm{Tr}$ 11:1-7 (1905)

06 [Report on] the Nanaimo-Comox coal field. Can G S, Sum Rp 1905: 55-59 (1906) B C, Minister of Mines, An Rp 1906: 204-206 (1907)

$06 a$ On the age of this conglomerate cap. ping the Cambrian rocks of Nova Scotia. N S Inst Se, Pr Tr 11:236-244 (1906)

06b Subsidence of the Atlantic coast of Nova Scotia. N S Inst Sc, Pr Tr 11:262263 (1906)

o6e Features of the continental shelf off Nova Scotia. R Soc Can, $\operatorname{Pr} \operatorname{Tr}$ (2) 12, iv : 67-82, map (1906) Abst, Seience $\mathrm{n}$ s $23: 972$ (1906)

06d The sunken land of Bus (lat. 35 west, long. 53 north). N S Inst Sc, Pr Tr 11:193-198 (1906) 
Poole, Henry Skeffington-Continued.

07 The barytes deposits of Lake Ainslle and North Cheticamp, N. S., with notes on the production, manufacture, and use of barytes in Canada. Can G S: 43 pp, Ottawa 1907

os Pre-Cambrian volcanic bombs from near Lake Ainslle, Inverness Co., N. S. N S Inst Sc, Pr Tr 11:339-346 (1908)

osa A section of Carboniferous rocks in Cumberland County, Nova Scotia ; (1) Detailed section of rocks from West Ragged Reef to the Joggins mines and Minudie, by Sir William E. Logan (republished); and (2) From Schulie to Spicer Cove, by Hugh Fletcher. $\mathrm{N} S$ Inst Sc, $\operatorname{Pr} \operatorname{Tr} 11$ : 417-550, maps (1908)

Poole. Herman.

92 Michipicoten Island and its copper mines. Eng M J 54:125 (1892)

Pope, Frederick J.

00 Investigation of. agnetic iron ores from eastern Ontario. $\Delta \mathrm{m}$ I M Eng, Tr $29: 372-105$ (1900)

11 Magmatic differentiation a factor in the occurrence of ore shoots [Pachuca district, Hidalgo, Mexico]. Ec G 6:503-511 (1911)

Pope, George S.

16 Analyses of coals purchased by the government during the fiscal years 19081915. U S Bur Mines, B 119:118 pp (1916)

Pope, John (1822-1892).

50 Report of an exploration of the Territory of Minnesota. U S, 31st Cong 1st sess, S Ex Doc 42: 48 pp, map (1850)

55 Report of exploration of a route for the Pacific railroad near the thirty-second parallel of latitude from the Red River to the Rio Grande. U S, Pacific R R Expl (U S, 33d Cong 1st sess, H Ex Doc 129 v 18 pt 2) : 324 pp (1855); also (U S, $33 \mathrm{~d}$ Cong $2 \mathrm{~d}$ sess, $\mathrm{S} \mathrm{Ex}$ Doc 78 and $\mathrm{H}$ Ex Doc 91) $2: 185 \mathrm{pp} \mathrm{(1856)}$

Porch, E. L., jr.

17 The Rustler Springs sulphur deposits. Tex, Univ, B no 1722: 71 pp (1917)

Porter, E. A.

12 Placer mining in the Fortymile, Eagle, and Seventymile River districts [Alaska]. U S G S, B 520: 211-218 (1912)

Porter, E. P.

05 Gold and silver; South Dakota; Wyoming. U S G S, Min Res 1904: 206211, 219-220 (1905)

Porter, J.

23 ... the Roxbury rocking stone [Mass.]. Am J Sc $7: 59-61$ (1823)

25 Notice of a rocking stone in Savoy, Mass. Am J Sc 9:27-28 (1825)

Porter, J.

13 Geological features of the Coast Range [British Columbia]. In The Northern Cordilleran (pub by the British Colum. bia Mountaineering Club) : 46-50 (1913)

\section{Porter, J. A.}

97 The Smuggler-Union mines, Tellurid Colo. Am I M Eng, $\operatorname{Tr} 26: 449-459$ (189i) $A b s t$, M Sc Press $73: 461$ (1896); Zs prat G 1897: 99-100

Porter, John B.

87 The iron ores and coals of Alabame Georgia, and Tennessee. Am I M Eng, T $15: 170-218$ (1887)

Porter, John T.

o7 Properties and tests of fuller's earth U S G S, B 315: 268-290 (1907)

Porter, T. C.

02 Volcanic dust from the West Indies Nature 66:131-132 (1902)

Porter. William s.

28 ... geology, etc., of Alabama. Am । Sc $13: 77-79$ (1828)

Pošepný, Franz (1836-1895).

77 Geologisches aus dem Hochlande in western Nordamerika's. K-k G Reichsa. stalt, Verh 1877:61-66

94 The genesis of ore deposits. Am IV Eng, Tr 23: 197-369 (with discussion: 587$608 ; 24: 942-1006)$ (1894)

95 The genesis of ore deposits; a tres. tise (with discussion by W. P. Blake, Atthur Winslow, T. A. Rickard, H. V. Wit chell, J. A. Church, S. F. Emmons, G. I. Becker, F. M. F. Cazin, R. W. Raymond, Joseph Le Conte). [Reprinted from A I M Eng, Tr 23 and 24.] 265 pp, N I $18952 d$ ed, xxi, 806 pp, N Y 1902

Posnjak, Eugen.

15 (and others) The sulphides of cor per. Ec G 10:491-535 (1915)

16 (with Merwin, H. E.) Definition and determination of the mineral hydros ides of iron $(a b s t)$. G Soc Am, B 27:61 (1916)

See also Tolman, 16a

Posselt, C.

56 Die Küpfer-Distrikte des Obersee's Lake Superior. N Jb $1856: 1-10$

Posselt, Ludwig.

50 Gebirge und Bergbau von Zacateas Mexico. N Jb 1850:317-319

Postma, G. E.

13 Trachytic perlite from Lone Hill near San Jose, Cal (abst). G Soc Am, B $24: 94$ (1913)

Potter, C. E.

33 Notice of a rocking stone [Hanovet, N. H.]. Am J Sc 24:185-186 (1833)

Potter, William Bleecker.

73 Geology of Lincoln Co. Mo G \& Prel Rp Iron Ores and Coal Fields, 18\%? pt $2: 217-289$ (1873)

75 [Deposit of semi-anthracite colt Johnson Co., Ark.] Am I M Eng, Tr 3: $33-34$ (1875)

77 The character and composition of the lignite coals of Colorado. Am I M Eab $\operatorname{Tr} 5: 365-375$ (1877) 
Pourtales, Louis François de (18241880).

70 [Examination of materials from the bottom and shores of the Mississippi River.] U S [War Dp], Chief Eng, An Rp 1870 (U S, 41st Cong $3 d$ sess, $\mathrm{H}$ Ex Doc 1 pt 2 v 2):370-375 (1870) U S Army, Corps of Engineers, P P 13:651-654 (1876)

71 Constitution of the bottom of the ocean off Cape Hatteras. Boston Soc N H, Pr 14:58-59 (1871)

Powell, George.

5s List of localities at which beds of coal appear ... In Tuomey, M., Second biennial report on the geology of Alabama: 277-286, Montgomery 1858.

Powell, John Wesley (1834-1902).

72 Survey of the Colorado River of the West. U S, $42 \mathrm{~d}$ Cong $2 \mathrm{~d}$ sess, H Misc Doc $173: 12$ pp (1872)

73 Report of the survey of the Colorado of the West. U S, $42 \mathrm{~d}$ Cong $3 \mathrm{~d}$ sess, H Misc Doc $76: 16 \mathrm{pp} \mathrm{(1873)}$

$73 a$... geological structure of a district of country lying to the north of the Grand Canyon of the Colorado. Am J Sc (3) 5 : 456-465 (1873)

74 Report of explorations in 1873 of the Colorado of the West and its tributaries. $36 \mathrm{pp}$, Washington 1874 Also in U S, 43d Cong 1st sess, H Misc Doc 265: 29 pp (1874)

74a Remarks on the structural geology of the valley of the Colorado of the West. $\mathrm{Ph}$ Soc Wash, B 1:48-51 (1874)

75 Exploration of the Colorado River of the West and its tributaries. xi, $291 \mathrm{pp}$, map, Washington 1875

75a Physical features of the Colorado valley. Pop Se Mo $7: 385-399,531-542$, $670-680$ (1875)

76 Report on the geology of the eastern portion of the Uinta Mountains and a region of country adjacent thereto. U S G Geog S Terr (Powell) : vil, 218 pp, maps [in atlas], Washington 1876

76a Types of orographic structure. Am J Sc (3) $12: 414-428$ (1876)

77 Report on the geographical and geological survey of the Rocky Mountain region. $19 \mathrm{pp}$, map, Washington 1877 . Also in $\mathrm{U} \mathrm{S}, 45$ th Cong $2 \mathrm{~d}$ sess, $\mathrm{H}$ Ex Doc 1 th 5: 789-805 (1877)

78 Report on the lands of the arid region of the United States, with a more detailed account of the lands of Utah. U S, 45 th Cong 2d sess, H Ex Doc 73:195 pp, maps (1878) 2d ed, 1879

78 a Letter...transmitting a report of Professor Powell in regard to surveys... U S, 45th Cong 2d sess, H Ex Doc 80:19 pp, map (1878)

80 Prefatory note. In Dutton, C. E., Report on the geology of the high plateaus of Utah (U S Geog G S Rocky Mtn Reg) : vil-xíi $(1880)$
Powe11, John Wesley-Continued.

$80 a$ Monoclinal ridges (abst, with discussion by C. E. Dutton and W. B. Taylor). Ph Soc Wash, B 2:74-79 (1880)

82 Second annual report of the United States Geological Survey, 1880-81. 588 pp (1882)

82a Sur la nomenclature générale, sur le coloriage et les signes conventionnels des cartes géologiques. Int $\mathrm{G}$ Cong, II, Bologna 1881, C R: 627-641 (1882)

8: Third annual report of the United States Geological Survey, 1881-82. 564 pp (1883)

83a [On terraces.] Science 2:321 (1883)

84 Fourth annual report of the United States Geological Survey, 1882-83. 473 pp (1884)

$84 \mathrm{a}$ of the state of the interior of the earth. Science $3: 480-482$ (1884)

84b On the fundamental theory of dynamic geology. Science 3:511-513 (1884)

85 Fifth annual report of the United States Geological Survey, 1883-84. 469 pp (1885)

S5a Sixth annual report of the United State Geological Survey, 1884-85. 570 pp (1885)

S5b On the organization of scientific work of the general government. Extracts from the testimony taken by the joint commission of the Senate and House of Representatives to " consider the present organizations of the Signal Service, Geological Survey, Coast and Geodetic Survey, and the Hydrographic Office of the Navy Department, with the view to secure greater cficiency and economy of administration." $1-49, \quad 162-209,378-451$ pp, Washington 1885

85e The organization and plan of the United States Geological Survey. Am J Sc (3) $29: 93-102$, map (1885)

s6 (and others) Testimony before the joint commission to consider the present organization of the Signal Service, Geological Survey, Coast and Geodetic Survey, and the Hydrographic Office of the Navy Department, etc. U S, 49th Cong 1st sess, S Misc Doc 82 (1886)

$86 a$ The cause of earthquakes. The Forum 2:370-391 (1886)

88 Seventh annual report of the United States Geological Survey, 1885-86. $656 \mathrm{pp}$ (1888)

$88 \mathbf{n}$ The U. $\mathbf{S}$. Geological Survey. In Report of the select committee of the United States Senate... to enquire into and examine the methods of bisiness and work in the executive departments... U S, 50th Cong 1st sess, S Rp 507 pt $2: 377-490$ (1888)

88b Operations of he national survey during the year ending June 30, 1888 . Science $12: 148-150$ (1888) 
Powe11, John Wesley-Continued.

s8e Methods of geologi cartography in use by the United States Geological Survey. Int $\mathrm{G}$ Cong, III, Berlin 1885, C R : 221-240 (1888)

s8d Communication on the American report of the International Congress of Geologists. Am J Sc (3) 36:476a-476e (1888)

s8e The laws of hydraulic degradation. Science $12: 229-233$ (1888)

s8f Physical features of the Atlantic coast (abst). Johns Hopkins Univ Circ $7: 73$ (1888)

89 Eighth annual report of the United States Geological Survey, 1886-87. 2 pts, 1063 pp (1889)

S9a Ninth annual report of the United States Geological Survey, 18£7-88. 717 pp (1889)

89b Ferdinand Vandiveer Iayden. U S G S, An Rp 9:31-38 (1889)

s9e Roland Duer Irving. U S G S, An Rp 9:38-42 (1889)

90 Tenth annual report of the United States Geological Survey, 1888-89. Part 1, $774 \mathrm{pp}$, maps (1890)

91 Eleventh annual report of the United States Geological Survey, 1889-90. Pt 1, 757 pp. maps (1891)

$91 a$ Twelfth annual report of the United States Geological Survey, 1890-91. $675 \mathrm{pp}$, maps (1891)

$91 \mathrm{~b}$ On the crystalline schists of the United States and their relations; introduction. Int $\mathrm{G}$ Cong, IV, London 1888, C R : 153-155 (1891)

91e The new lake in the desert [Coahuila basin, Cal.]. Scribner's Mag 10: 463-468 (1891)

91d Doctor [G. H.] Cook as a geologist. See Neilson, 91

9te Map coloring and cartography (abst, with discussion). Am G 8:256257 (1891)

92 Thirteenth annual report of the United States Geological Survey, 1891-92, pt 1, 240 pp (1892)

93 Fourteenth annual report of the United States Geological Survey, 1892-93, pt 1:321 pp (1893)

93a The work of the U. S. Geological Survey. Science 21:15-17 (1893)

93b The geologic map of the United States. Am I M Eng, Tr 21:877-887 (1893)

93e Discussion sur le coloriage des cartes géologiques. Int $\mathbf{G}$ Cong, V, Washington 1891, C R : 79-80, 208-211 (1893)

95 Fifteenth annual report of the United States Geological Survey, 1893-94, 755 pp. (1895)

95a Canyons of the Colorado. 400 pp, Meadville, Pa., 1895
Powell, John Wesley-Continued.

95b Physiographic processes: Nat Geog Soc, Nat Geog Mon 1 no 1: 1-32 (1895) Also in The Physiography of the United States (Nat Geog Soc) : 1-32, N Y, Amer. can Book Co., 1896

95e Physiographic features: Nat Gen Soc, Nat Geog Mon 1 no 2:33-64 (1895) Also in The physiography of the United States (Nat Geog Soc) : 33-64, N Y, Amen ican Book Co., 1896

95d Physiographic regions of the United States: Nat Geog Soc, Nat Geog Mon 1 vo 3:65-100, map (1895) Also in The phrsi. ography of the United States (Nat Geo? Soc) : 65-100, map, N Y, American Book Co., 1896

96 James Dwight Dana, Science n \& 3: 181-185 (1896)

98 An hypothesis to account for the movement in the crust of the earth. J $G$ $6: 1-9$ (1898)

See also Dutton, 80a, 85; Frazer, 88: Gilbert, 93b; White (C A), 80e; Willis, 01e Powell, Samuel Lawrence.

93 Notes on minerals recently obtained from the quarries of Jones Falls [Baltimore, Md.]. Johns Hopkins Univ Circ $12: 49-50$ (1893)

10 (with Watmon, T. L.) Discovery of fossils in the Quantico slate belt ... (abst). G Soc Am, B 21: 782 (1910)

11 (with Watson, T. L.) Fossil etr. dence of the age of the Virginia Piedmont slates. Am J Sc (4) $30: 33-44$ (1911)

14 A comparison of the Ordovician tion of southwest Virginia, with that New York (abst). Science n s 39:404-405 (1914)

15 Discovery of the Normanskill grapto lite fauna in the Athens shale of southwestern Virginia. J G 23: 272-281 (1915) Powell, W. Byrd.

42 A geological report upon the Fourch Cove and its immediate vicinity [Ark.]$22 \mathrm{pp}$, map, Little Rock 1842

Powers, H. C.

04 The smoking bluffs of the Missourl River region. Ac Sc Sioux City, Pr 1:5760 (1904)

Powers, Sidney.

14 (and Shimer, H. W.) Notes on the geology of the Sun River district, Mont. J G 22 : 556-559 (1914)

$14 a$ (with warren, Charles H.) Gt ology of the Diamond Hill-Cumberland diz trict in Rhode Island-Massachusetts. $\theta$ Soc Am, B 25: 75, 435-476, map (1914)

15 The origin of the inclusions in dikes J G 23 : 1-10, 166-182 (1915)

15a The geology of a portion of shet burne Co., southwestern Nova Scotia. N 8 Inst Sc, Pr Tr 13: 289-307 (1915)

$\mathbf{1 5 b}$ The recent activity of Kilauea ad Mauna Loa, Hawati. Science n $82: 14$ * 154 (1915) 
Powers, Sidney-Continued.

15e Hawail's great volcanoes and the study of them. Am Geog Soc, B 47:577583 (1915)

15d Acadian Triassic (abst). G Soc Am, B 26: 93-94 (1915)

15e Geological history of the Bay of Fundy (abst). G Soc $A \mathrm{~m}, \mathrm{~B}$ 26:94-95 (1915)

16 The Acadian Triassic. J G $24: 1-26$, $105-122,254-268$, map (1916)

16a (and Lane, A. C.) Magmatic differentiation in effusive rocks. Am I M Eng, B 110:535-548 (1916); (with discussion by N. L. Bowen), Tr 54:442-457 (1917)

$16 \mathrm{~b}$ Explosive ejectamenta of Kilauea. Am J Sc (4) 41:227-244 (1916)

16e Voleanic domes in the Pacific. Am J Sc (4) $42: 261-274$ (1916)

16d Recent changes in Bogoslof Volcano. Geog Rv 2: 218-221 (1916)

16e Intrusive bodies at Kilauea. Zs Vulkanologle $3: 28-35$ (1916)

161 Tectonic lines in the Hawaiian Islands (abst). G Soc Am, B $27: 109-110$ (1916)

17 Tectonic lines in the Hawailan Islands. G Soc Am, B 28:501-514 (1917) Rv by Immanuel Friedlaender, Zs Vulkan 5: 98-104 (1919)

17a Granite in Kansas. Am J Sc (4) $44: 146-150$ (1917)

$17 \mathrm{~b}$ Age of the ofl in southern Oklahoma fields (with discussion by W. E. Pratt and W. G. Matteson). Am I M Eng, B 131: 1971-1982 (1917); Tr $59: 564-577$ (1918)

17e The Healdton ofl fleld, Okla. Ec G 12: 594-606 (1917)

17d Ordovician strata beneath the Healdton ofl field, Okla. (abst). G Soc Am, B 28: 159 (1917)

18 Notes on the geology of eastern Guatemala and northwestern Spanish Honduras. J G 26:507-523 (1918)

18n Letter concerning San Salvador eruptíon. Zs Vulkanologie 4:201 (1918)

Prather, John K.

01 On the fossils of the Texas Cretaceous, especially those colleced at Austin and Waco. Tex Ac Sc, Tr 4:85-87 (1901)

02 A preliminary report on the Austin chalk underlying Waco, Tex., and the adfoining territory. Tex Ac Sc, Tr 4:115122 (1902)

05 The Atlantic Highlands section of the New Jersey Cretacic. Am G 36:162178 (1905)

05a
$(1905)$ Glauconite. $\quad$ G $13: 509-513$

Pratt, Joseph Hyde.

94 Mineralogical notes on cerusite, calamine, and zircon. Am J Se (3) 48:212215 (1894)
Pratt, Joseph Hyde-Continued.

94a (with Penfiela, S. L.) On the chemical composition of staurolite and the regular arrangement of its rbonaceous inclusions. Am J Sc (3) $47: 81-89$ (1894) Zs Kryst 23: 64-72 (1894)

95 (with Penfield, S. L.) Effect of the mutual replacement of manganese and iron on the optical properties of lithiophilite and triphylite. Am J Sc (3) 50:387-390 (1895) Zs Kryst 26:130-133 (1896)

96 On northupite; pirssonite, a new mineral; gaylussite and hanksite from Borax Lake, San Bernardino Co., C 1 . Am J Se (4) $2: 123-135$ (1896) Zs Kryst $27: 416$ 429 (1896) Yale Bicen Pub, Contr Miner : 261-274 (1901)

96a (with Penfield, S. L.) On the occurrence of thaumasite at West Paterson, N. J. Am J Sc (4) 1:229-233 (1896) Yale Bicen Pub, Contr Miner : 246-251 (1901)

97 (and Foote, H. W.) On wellsite, a new mineral [Clay Co., N. C.]. Am J Sc (4) $3: 443-448$ (1897) Zs Kryst 28:581587 (1897) Yale Bicen Pub, Contr Miner : 275-282 (1901)

97 a On the crystallography of the Montana sapphires. Am J Sc (4) 4:424-428 (1897)

97b Notes on North Carolina minerals. Elisha Mitchell Sc Soc, J 14: 61-83 (1897)

98 Mineralogieal notes on cyanite, zircon, and anorthite from North Carolina. Am J Sc (4) 5:126-128 (1898)

98a Mineralogical notes on anthophyllite, enstatite, and beryl (emerald) from North Carolina. Am J Sc (4) 5:429-432 (1898)

98b On the origin of the corundum, associated with the peridotites in North Carolina. Am J Sc (4) 6:49-65, maps (1898)

98c Occurrence, origin, and chemical composition of chromite (abst). N Y Ac Sc, An 11:489-490 (1898) Eng M J 66: 696 (1898)

98d (with Hidden, W. E.) On rhocolite, a new variety of garnet. Am J Sc (4) $5: 294-296$ (1898)

9Se (with Hidden, w. E.) Twinned crystals of zircon from North Carolina. Am J Sc (4) 6:323-326 (1898)

9se (with Hidden, W. E.) On the associated minerals of rhodolite. Am J Sc (4) $6: 463-468$ (1898)

99 On the occurrence, origin, and chemical composition of chromite. Am J Sc (4) $7: 281-286$ (1899) Am I M Eng, Tr 29: 17-39 (1900)

$99 a$ On the separation of alumina from molten magmas, and the formation of corundum. Am J Sc (4) $8: 227-231$ (1899)

99b On the erystallography of the rubies from Macon County, North Carolina. Miner Mag 12:150-151 (1899) 
Pratt, Joseph Hyde-Continued.

oo Talc and pyrophyllite deposits in North Carolina. N C G S, Ec P 3:29 pp (1900)

O0a On two new occurrences of corundum in North Carolina. Am J Sc (4) 10 : 295-298 (1900)

Oob The chromite deposits of North Carolina. Eng M J 70:190 (1900).

01 The occurrence and distribution of corundum in the United States. U S G S, B $180: 98 \mathrm{pp} \mathrm{(1901)}$

01a The mining industry in North Carolina during 1900. N C G S, Ee P 4:36 pp (1901) ...1901; ...Ec P 6:102 pp (1902) ...1902; ...Ec P $7: 27$ pp (1904) ..1903; ...Ec P 8: 74 pp (1904) ...1904; ... Ec P $9: 95$ pp (1905) ...1905; Ec P $11: 96$ pp (1907) ...1906; Ec P $14: 144$ pp (1907) ...1907; Ec P 15:176 pp (1908)

01b A peculiar iron of supposed me teoric origin, from Davidson Co., N. C. Elisha Mitchell Sc Soc, J $17: 21-26$ (1901)

01e The South Mountain gold region of North Carolina. M Metal 24:108, 134135 (1901)

o1d Tungsten, molybdenum, uranium, and vanadium. U S G S, An Rp 21 pt 6 : 299-318; Min Res $1900: 257-265 ; 1901$ : 261-270; $1902: 285-288$ (1901-4)

oxe Aluminum and bauxite. U S G S, Min Res 1900:229-231 (1901)

011 Antimony. U S G S, Min Res $1900: 251-255$ (1901)

01g Talc and soapstone. U S G S, Min Res $1900: 779-786 ; 1901: 773-780 ; 1902$ : $867-872$; 1903: 979-987 ; 1904: 989-994 ; 1905: 1361-1368 (1901-6)

01h Abrasive materials. U S G S, Min Res 1900 : 787-801; 1901 : 781-809; 1902 : $873-890$; 1903 : 989-1015 ; 1904 : 995-1015 ; 1905 : 1069-1085 (1901-6)

01i Asbestos. U S G S, Min Res $1900: 861-868 ; 1901: 887-895 ; 1902$ : 963966 ; $1903: 1111-1116$; 1904: 1125-1142 ; (1901-5)

01j Graphite. U S G S, Min Res 1900: $875-877 ; 1903: 1121-1129$; 1904:11571167 (1901-5)

01k Mica. U. S G S, Min Res 1901: $873-878 ; 1904: 1175-1184$ (1901-5)

011 A new meteoric iron from Davidson Co. N. C. (abst). Science n s 13:900901 (1901)

02 Nickel and cobalt. U S G S, Min Res 1901: 241-250 ; 1902: 263-270 (1902-4)

02a Lithium. U S G S, Min Res 1901: $239-240$; $1902: 259-261$; $1903: 313-315$; 1904: 361-362 (1902-5)

02b Fluorspar and cryolite. U S G S, Min Res 1901: $879-885$; 1902: 899 $902 ; 1903: 1029-1032 ; 1904: 1031-1036$ (1902-5)

02e Barytes. U S G S, Min Res 1901: 915-919; 1902 : 945-948 ; 1903 :1089-1094 ; $1904: 1095-1102 \quad(1902-5)$
Pratt, Joseph Hyde-Continued.

02d Chromite or chromic iron ore. if G S, Min Res 1901: 941-948; 1902:967$969(1902-4)$

02e Monazite and zircon. U S G S, Mio Res 1901: $949-954 ; 1902: 1003-100 \%$; $1903: 1163-1170 ; 1904: 1209-1227$; 1905 : 1313-1317 (1902-6)

O2f Strontium ores. U S G S, Min Ba 1901 : 955-958 (1902)

02g Gold deposits of Arizona. Eng y I 73: 795-796 (1902)

O2h Gold mining in the soutbern ip palachians. Eng M J 74:241-242 (1909. 021 Marble and tale of North Carolin Stone $24: 145-149$ (1902)

04 (and Sterrett, D. B.) The tin de posits of the Carolinas. N C G S, B 19: 64 pp, Raleigh 1904

04a Sulphur and pyrite. U S G S, Min Res 1903: 1073-1087; 1904:1079-109t (1904-5)

O4b (with struthers, J.) Tin, Os G S, Min Res 1903: 335-349 (1904)

- O5 (and Lewis, J. V.) Corundum abl the peridotites of western North Carolis N C G S 1: 464 pp, maps, Raleigh 1905

O5a Arizona asbestos deposits. M Worli $23: 17$ (1905)

o5b The graphite industry. M World 23: $64-66$ (1905)

o5e Tin. U S G S, Min Res 1904:377380 (1905)

o6 Corundum and its occurrence and distribution in the United States. U 80 S, B 269:175 pp (1906)

O6a The cement gold ores of Deadwoot Black Hills, S. Dak. Elisha Mitchell \& Soc, J 22 $23-27$ (1906)

o6b The building and ornamental stona of North Carolina; a review. Ellsis Mitchell Sc Soc, J $22: 63-79$ (1906)

o7 Biennial report of the State geologis [of North Carolina], 1905-6. 58 pp, X c G S (1907) $\quad \ldots \quad 1907-08: 60 \quad$ pp (1908) [1909] ... 1909-10:152 pp (1911) 1911-12: 118 pp (1913) ... 1913-14:176 pp (1915) ... 1915-16:202 pp (1917)

os (and sterrett, D. B.) Monazite and monazite mining in the Carolinas. Elist Mitchell Sc Soc, J 24: 61-86 (1908)

o9 New occurrence of monazite in North Carolina. Elisha Mitchell Sc Soc, J 25: 74-77 (1909)

O9a (and Sterrett, D. B.) Monazite and monazite mining in the Carolinas Am I M Eng, B 30:483-511 (1909); Tt $40: 313-340$ (1910)

10 The conservation and utilization of our natural resources. Elisha Mitchell \& Soc, J 26 : 1-25 (1910)

11. (and Berry, H. M.) The mining tis dustry in North Carolina during 1908 1909, and 1910 . N C G S, Ec P 23:134 P? (1911) 
Pratt, Joseph Hyde-Continued.

13 New occurrences of monazite in North Carolina. Elisha Mitchell Sc Soc, J 28:153-156 (1913) Abst, G Soc Am, B $24: 686$ (1913)

13a Geological history of western North Carolina. Elisha Mitchell Sc Soc, J 29 : $35-44$ (1913)

14 The mining industry in North Carolina during 1911 and 1912. N C G S, Ec P 34:342 pp (1914)

14a The occurrence and utilization of certain mineral resources of the Southern States. Elisha Mitchell Sc Soc, J $30: 1-25$, 90-115 (1914)

15 The Coggins (Appalachian) gold mine [Montgomery Co., N. C.]. Elisha Mitchell Sc Soc, J 30: 165-178 (1915)

15a Certain magnetic iron ores of Ashe Co. [N. C.]. Elisha Mitchell Se Soc, 30 : 179-187 (1915)

16 Zircon, monazite, and other minerals used in ... lighting apparatus. $\mathrm{N}$ C G S, B 25:120 pp, map (1916)

16a Memorial sketch of Dr. Joseph Austin Holmes. Elisha Mitchell Sc Soc, J $32: 1-15$, port (1916)

16b Memorial of Joseph Austin Holmes. G Soc Am, B 27:22-35, port (1916)

17 Monazite in the United States. Mineral Foote-Notes 1 no $10: 3-15$ (1917)

Pratt, Nathaniel Alpheus.

57 On two sulphurets of copper from the Canton, Ga., mine. Am J Se (2) 23:409414 (1857)

68 Ashley River phosphates: History of the marls of South Carolina and of the discovery and development of the native bone phosphates of the Charleston basin ... 42 pp, Pbila 1868

92 Florida phosphates; the origin of the boulder phosphates of the Withlacoochee River district. Eng M J $53: 380$ (1892) [See Davidson, 92]

Pratt, W. H.

76 Report on a geological examination of the section of the bluffs [at Davenport, Iowa]. Davenport Ac Sc, Pr 1:96-99 (1876)

82 Geological section of the blu ${ }^{m}$ i.t East Davenport [Iowa]. Davenport Ac Sc, Pr 3:106-107 (1882)

82a Section of the bluff at Sixth street, Davenport [lowa]. Davenport Ac Sc, Pr $3: 127-129$ (1882)

82b An artesian well at Moline, III. Davenport Ac Sc, Pr 3:181-182 (1882)

82e (with Gass, J.) Bones of the mammoth in Washington Co., Ic wa. Davenport Ac N Sc, Pr $3: 177-178$ (1882)

Pratt, Wallace E.

18 Age of the ofl in the southern Oklahoma fields (discussion). Am I .A Eng, B $135: 708-709 \quad(1918)$

\section{Pratten, Henry.}

55 (with Norwood, J. G.) Notice of Producti found in the Western States and Territories, with descriptions of twelve new species. Ac N Sc Phila, J (2) $3: 5-22$, il (1855)

55a (with Norwood, J. G.) Notice of the genus Chonetes, as found in the Western States and Territories, with descriptions of eleven new species.' Ac N Sc Phila, J (2) $3: 23-31$, il (1855)

$\mathbf{5 5 b}$ (with Norwood, J. G.) Notice of fossils from the Carboniferous series of the Western States, belonging to the genera Spirifer, Bellerophon, Pleurotomaria, Macrocheilus Natica, and Loxonema, with descriptions of eight new characteristic species. Ac N Sc Phila, J (2) 3:71-77, il (1855)

Preiswerk, H.

o5 Diopsid aus dem Eozoon-Kalk von Côte St. Pierre, Canada. Zs Kryst 40 : 498-500 (1905)

Prescott, Basil.

os Ilvaite from Shasta Co., Cal. Am J Sc (4) 26:14-16 (1908)

o8a The occurrence and genesis of the magnetite ores of Shasta Co., Cal. Ec G $3: 465-480$, map (1908)

15 The main mineral zone of the Santa Eulalia district, Chihuahua [Mexico]. Am I M Eng, B 98: 155-198 (1915); Tr 51: 57-99 (1916)

15a Some observations on contact metamorphic ore deposits. Ec G 10:55-69 (1915)

\section{Prescott, William.}

39 A sketch of the geology and mineral. ogy of the southern part of Essex Co., in Mass, Essex $\mathrm{Co} \mathrm{N}$ H Soc, J 1:78-91 (1839)

\section{Pressey, Henry Albert.}

02 Hydrography of the southern Appalachian Mountain region. U S G S, W-S P 62 and $63: 190$ pp, maps (1902)

02 Water powers of the State of Maine. U S G S, W-S P 69: 124 pp (1902)

Prest, Walter Henry.

92 Evidence of the postglacial extension of the southern coast of Nova Scotia. N S Inst $\mathrm{Sc}, \operatorname{Pr} \operatorname{Tr} 8$ or (2) $1: 143-147$ (1892)

95 Deep mining in Nova Scotia [geology of the auriferous formation]. N S Inst Sc Pr Tr 8 or (2) 1:420-434 (1895)

96 Glactal succession in central Lunenburg. N S Inst Sc, Pr Tr 9 or (2) 2:158170 (1896)

02 On drift ice as an eroding and transporting agent. N S Inst Sc, Pr Tr 10 or (2) 3: 333-344 (1902)

o3 Supplementary notes on drift ice as a transporting agent. N S Inst Sc, Pr Tr 10 or (2) $3: 455-457$ (1903)

12 Report on cave examination in Hants Co., N. S. N S Inst Sc, Pr Tr 13:87-94 (1912) 
Preston, C. H.

01 Prof. W. H. Barris. Am G 28:358. 361 , port (1901)

Preston, E. B.

90 Los Angeles Co.; Lassen Co. Cal St M Bur, An Rp 9: 189-213 (1890)

See also Irelan, $90 \mathrm{a}, 93$

Preston, H. L.

92 Prelimihary note of a new meteorite from Kenton Co., Ky. Am J Sc (3) 44: $163-164(1892)$

92a Notes on the Farmington, Washington Co., Kans., meteorite. Am J Sc (3) 44: 400-401 (1892)

93 Preliminary note of a new meteorite from Kenton Co., Ky. Rochester Ac Sc, Pr $2: 151-153$ (1893)

98 On iron meteorites, as nodular structures in stony meteorites. Am J Sc (4) 5: 62-64 (1898)

98 a San Angelo meteorite [Tom Green Co., Tex.]. Am J Sc (4) $5: 269-272$ (1898)

00 Illinois Gulch meteorite [Deer Lodge Co., Mont.]. Am J Sc (4) 9:201-202 (1900)

00a Two new American meteorites [Luis Lopez, N. Mex., and central Missouri]. $A \mathrm{nx}$ J Sc (4) $9: 283-286$ (1900)

$00 \mathrm{~b}$ On a new meteorite from Oakley, Logan Co., Kans. Am J Sc (4) 9:410$412(1900)$

02 Niagara meteorite [Forks Co., N. Dak.]. J G 10:518-519 (1902)

02a The Franceville, El Paso Co., Colo., meteorite. J G 10:852-857 (1902) Rochester Ac Sc, Pr 4:75-78 (1902)

03 Reed City meteorlte [Michigan]. J G 11:230-233 (1903) Rochester Ac Sc, Pr $4: 89-91$ (1903)

06 A new method of etching iron meteorites, with special adaptation for photographic or plate purposes. Rochester Ac Sc, Pr $3: 264-267$ (1906)

\section{Prenssner, Ludwig.}

88 Ueber ein merkwürdiges Schwefelvokommen in Louisiana [suplhur, Calcasieu]. Deut G Ges, Zs 40:194-197 (1888)

Price, Eli Kirk (1797-1884).

76 The glacial epochs. Am $\mathrm{Ph} \mathrm{Soc,} \mathrm{Pr}$ 16:241-276 (1876)

Price, George McCready.

06 Illogical geology, the weakest point In the evolution theory. 93 pp, Los Angeles, Cal., 1906

11 God's two books, or plain facts about evolution, geology, and the Bible. $193 \mathrm{pp}$, Washington, D. C., 1911.

13 The fundamentals of geology and their bearings on the doctrine of a literal creation. 267 pp, map, Mountain View, Cal., 1913.
Price, James A.

98 Notes on Indiana geology. Ind te Sc, Pr $1897: 262-266$, map (1898)

99 (with Newsom, J. F.) Notes on the distribution of the Knobstone group is Indiana. Ind Ac Sc, Pr 1898: 289-291, map (1899)

00 A report upon the Waldron shale ant its horizon in Decatur, Bartholomer, Shelby and Rush cos., Ind ... Ind, Dp G I Res, An Rp 24:81-143, map (1900)

01 (and Shaaf, A.) Spy Run aod Poinsett Lake bottoms [near Fort Warpe Ind.]. Ind Ac Sc, Pr 1900:179-181 (1901)

o1a (and Shaap, A.) Abandond meanders of Spy Run Creek [Allen Co. Ind.] Ind Ac Sc, $\operatorname{Pr} 1900: 181-184$, ma? (1901)

Price, John M., jr.

96 Rock exposures about Atchlson [Kans.]. Kans Ac Sc, Tr 14:218-219 (1896)

Price, William Armstrong.

14 Notes on the paleontology of Kanawha Co. [W. Va.]. W Va G S, Kanawbs County : 639-655 (1914)

14a Notes on the paleontology of Pres ton Co. [W. Va.] W Va G S, Preston County : 472-553 (1914)

15 Notes on the paleontology of Loga and Mingo cos. [W. Va.]. W Va G \& Logan and Mingo counties : 750-755, mas (1915)

15a Notes on the paleontology of Boose Co., with descriptions of fossils from Boone Logan, and Mingo cos. [W. Va.]. If it G S, Boone County : 591-619, il (1915)

16 Notes on the paleontology of Lewis and Gilmer cos. W Va G S, Lewis and Gilmer counties : 616-629 (1916)

16 a Notes on the paleontology of Raleigh, Wyoming, McDowell, and adjacent cos. W Va G S, Raleigh County : 663-734, il (1916)

17 Notes on the paleontology of Braxtos and Clay cos. In Braxton and Clay coun ties : 803-806, W Va G S 1917

17a The Uffington shale of northern West Virginia-absence of marine fauns. In Braxton and Clay counties: 807-816, W Va G S 1917

17b The Uffington shale of West Virginis and its supposed marine fauna. Sclence n s $46: 540-542$ (1917)

18 Notes on the paleontology of Batbour, Upshur, anu western portion of Ran. dolph cos.; invertebrate fossils from the Conemaugh and Pottsville series. W Va 0 S, Barbour and Upshur counties : 777-804, il (1918)

18a The Kanawha black flint and othet cherts of West Virginia $(a b s t)$. Science s $47: 468-469$ (1918) 
Prichard, William A.

04 Observations on Mother Lode gold deposits, Cal. (with diseussion by $H$. W. Turner). Am I M Eng, Tr 34:454-466, 973-974 (1904) Abst, Eng M J 76:125127 (1903)

Prime, A. J.

45 Great American mastodon. Am Q J Agr 2: 203-212 (1845)

Prime, Frederick, jr.

75 Report of progress on the brown hematite ore ranges of Lehigh Co. $\mathrm{Pa}$ G S, 2d, D: 73 pp, map (1875)

$75 a$ On the occurrence of the brown hematite deposits of the Great Valley (with discussion by T. S. Hunt and P. Frazer). Am I M Eng, Tr 3:410-417 (1875) Am J Sc (3) 9:433-440 (1875) Eng M J $20: 285-287$ (1875)

78 The brown hematite deposits of the Siluro-Cambrian limestones of Lehigh Co... Pa G S, 2d, DD : xi, 99 pp, maps (1878)

$78 a$ on the Paleozoic rocks of Lehigh and Northampton cos., $\mathrm{Pa}$. $\mathrm{Am} \mathrm{Ph}$ Soc, Pr 17:248-254 (1878) [With title, On the discovery of Lower Silurian fossils in limestone associated with hydromica slates and on other points in the geology of Lehigh and Northampton cos., eastern Pa.] Am J Sc (3) 15 : 261-269 (1878)

79 A catalogue of officlal reports upon geological surveys of the United States and Territories, and of British North America. Am I M Eng, Tr 7:455-525 (1879); 8 : 466-478 (1880) ; 9:621-632 (1881)

79 M Moraines and surface drift deposits of Northampton Co., Pa. $\mathrm{Am} \mathrm{Ph} \mathrm{Soc,}$ $\operatorname{Pr} 18: 84-85$ (1879)

80 The mineral resources of the Page Valley [Pa.]. The Virginias $1: 34-36,38$ (1880)

86 The coals of the United States. U S, 10th Census 15:605-617 (1886)

See also Cotta, 70 ; Lesley, $83 a$

Prime, Temple.

65 Monograph of American Corbiculadae (recent and fossil). Smiths Mise Col 7 [145] : $80 \mathrm{pp}$, il (1865)

Prince, Thomss.

55 Earthquakes the work of God ... Boston 1755 [Facsimile of title page in Harvard Coll, Mus C Z, B 55, no $5: \mathrm{pl}$ (1917) ]

Prindle, Louis Marcus.

94 Note on an apatite crystal from Alexander Co., N. C. Johns Hopkins Univ Cire $13: 83$ (1894)

04 Gold placers of the Fairbanks district, Alaska. U S G S, B 225:64-73 (1904)

05 The gold placers of the Fortymile, Birch Creek, and Fairbanks regions, Alaska. U \& G S, B 251 : 89 pp, maps (1905)

05a (and Hess, F. L.) Rampart placer region [Alaska]. U S G S, B 259: 104-119 (1905)
Prindle, Louis Marcus-Continued.

06 Yukon placer fields [Alaska]. U S G S, B 284: 109-127 (1906)

06a The Yukon-Tanana region, Alaska ; Description of Circle quadrangle. U S G S, B 295: 7-27, map (1906)

o6b (and Hess, F. L.) The Rampart gold placer region, Alaska. U S G S, B 280:54 pp, map (1906)

07 The Bonnifield and Kantishna regions

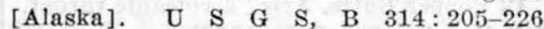
(1907)

os The Fairbanks and Rampart quadrangles, Yukon-Tanana region, Alaska. U S G S, B 337 : 9-63, map (1908)

osa Occurrence of gold in the YukonTanana region, Alaska. U S G S, B 345 : 179-186, map (1908)

osb The Fortymile gold-placer district, Alaska. U S G S, B 345:187-197 (1908)

09 The Fortymile quadrangle, YukonTanana region, Alaska. U S G S, B 375 : 52 pp, map (1909)

O9a (and Katz, F. J.) The Fairbanks gold placer region, Alaska. U S G S, B $379: 181-200$, map (1909)

10 Sketch of the geology of the northeastern part of the Fairbanks quadrangle, Alaska. U S G S, B 442: 203-209, map (1910)

10a Auriferous quartz veins in the Fair banks district, Alaska. U S G S, B 442 : 210-229 (1910)

11 The Mount McKinley region, Alaska; descriptions of the igneous rocks and of the Bonnifield and Kantishna districts. U S G S, P P $70: 136-154,169-180$ (1911)

12 (and Mertie, J. B., jr.) Gold placers between Woodchopper and Fourth of July creeks, upper Yukon River. U S G S, B 520: 201-210, map (1912)

13 A geologic reconnaissance of the Fairbanks quadrangle, Alaska. U S G S, B $525: 220 \mathrm{pp}$, maps (1913)

13a (and Katz, F. J.) Detailed description of the Fairbanks district. U S G S, B 525: 59-152, maps (1913)

13b A geologic reconnaissance of the Circle quadrangle, Alaska. U S G S, B 538: 82 pp, maps (1913)

See also Brooke, 11

Prior, G. T.

90 On polybasite from Santa Lucia mine, Guanaxuato, Mexico. Miner Mag 9:13-15 (1890)

18 On the chemical composition of the meteorites Amana (=Homestead) and Eagle Station [Iowa and Ky.]. Miner Mag 18:173-179 (1918)

Pritehett, Annie $\mathrm{H}$.

o5 Fossil Cephalopoda, described by Hyatt and Cragin, in the museum of the University of Texas. Biol B $8: 365-366$ (1905) 
Privat-Deschanel, Paul.

02 L'êtat de Californie. Soc Géog Lyon, B $17: 843-860(1902)$

Probert, Frank $\mathrm{H}$.

03 Secondary enrichment. Eng M J 76 : 958-959 (1903)

10 Deep mining in the Guanajuato district, Mexico. Eng M J 90:1310-1312 (1910)

12 Copper Butte, Ariz., a volcanic throat. Eng M J 94:499-500 (1912)

14 The Three $\mathrm{R}$ mine, Patagonia district, Ariz. M Sc Press 109:174-176 (1914)

16 Oatman, Ariz. [geology and minerallzation]. M Sc Press 112:17-20 (1916)

16a Surficial indications of coppar. M Sc Press 112:665-671, 815-821, 893-899; 113 : 81-87, 267-275 (1916)

Problems of American geology. See Yale University, Silliman Foundation

Procter, John Robert (1844-1903).

80 Resources of the North Cumberland Valley comprising parts of Whitley, Knox, Bell, Harlan and Letcher cos. Ky G S [Rp Prog] 6 n s: 291-314 [1880]

82 Report on the progress of the survey from May 1, 1880, to January 1, 1882. Ky G $\mathbf{S}: 19$ pp (1882) ... January 1882, to January 1884; Ky G \$ 42 pp (1884) ... January 1884 to January 1886 : Ky G S : 20 pp (1884) ... 1886 and 1887 ; Ky G S : 28 pp (1887) ... from January 1888 to January 1890; Ky G S: 13 pp (1890) ... from January 1890 to January 1892 ; Ky G S : 26 pp, map (1892)

S7 The mineral resources of Kentucky.

Eng M J 44:372-376, map (1887)

88 The mineral resources of Tennessee.

Eng M J 45: 21-22 (1888)

92 On the resources of the Middlesbo rough district [Ky.]. Iron and Steel Inst. in America in 1890, special vol. of $\mathrm{Pr}: 485-$ 492 [1892]

See also Chamberlin, 90

Proctor, Charles A.

55 (with Currey, R. O.) Copper district of Tennessee, Georgia, North Carolina, and Virginia: Southern J Med Phys Sc 3:38-44 (1855)

Prosser, Charles Smith (1860-1916).

88 Explorations for gas in central New York. Am I M Eng, Tr 16:940-951. (1888)

$\mathbf{8 8 a}$ Section of the lower Devonian and upper Silurian strata in central New York, as shown by a deep well at Morrisville (abst). Am As, Pr 36: 208-209 (1888)

$\mathbf{8 8 b}$ The upper Hamilton of Chenango and Otsego counties, N. Y. (abst). Am As, Pr 36: 210 (1888)

90 The thickness of the Devonian and Silurian rocks of western central New York. Am G 6 : 199-211 (1890)

91 The geological position of the Cats. kill group. Am G $7: 351-366$ (1891)
Prosser, Charles Smith-Continued.

92 The geological age of the rocks of the novaculite area. Ark $G \mathrm{~S}$, An $\mathrm{R}$ ? 1890, 3:418-423 (1892)

92n Notes on the Lower Carboniferovs plants from the Ouachita uplift. Ark $\theta$ $\mathrm{S}$, An Rp 1890, 3:423-424 (1892)

92b The Devonian system of eastern Pennsylvania. Am J Se (3) 44:210-221 (1892)

92e Notes on the geology of Skunne munk Mountain, Orange Co., N. Y. N Y Ac $\mathrm{Sc}, \operatorname{Tr} 11: 132-149$ (1892)

92d The thickness of the Devonian and Sllurian rocks of western New York; ap proximately along the line of the Genesee River. Rochester Ac Sc, Pr 2:49-104 (1892)

93 The Devonian section of central Ner York along the Unadilla River. N Y St G, An Rp 12:110-142 (1893) N Y St Mus, An Rp 46: 256-288 (1893)

93a The thickness of the Devonian and Silurian rocks of central New York. G Soc Am, B 4:91-118 (1893)

93b The upper Hamilton and Portage stages of central and eastern New York Am J Sc (3) $46: 212-230$ (1893)

93e Clay deposits of Kansas, U S G S Min Res 1892 : 731-733 (1893)

94 Kansas River section of the Permo Carboniferous and Permian rocks of KaD sas. G Soc Am, B 6:29-54 (1894)

95 The Devonian system of eastern Pent sylvania and New York. U S G S, B 120 $81 \mathrm{pp}$, map, il (1895)

95a The classification of the upper Pale ozoic rocks of central Kansas. J G 3:682$705,764=800 \quad$ (1895)

97 The classification and distribution of the Hamilton and Chemung series of central and eastern New York. N Y St G, As Rp 15:12-13, 83-222, map (1897) N Y st Mus, An Rp $49 v 2: 12-13,83-222$, map (1898)

97a (and Cumings, E. R.) Sections and thickness of the Lower Silurian forms. tions on West Canada Creek and in the Mohawk Valley. N Y St G, An Rp 15:2224, 615-659 (1897) N Y St Mus, An Bp $49 v$ 2: 23-24, 615-659 (1898)

97b The upper Permian and the lowet Cretaceous. Kans Univ G S 2:51-194 (1897)

97e Comparison of the Carboniferous and Permian formations of Nebraska and Kat sas. J G 5 : 1-16, 148-172 (1897)

97d The Permian and upper Carbonifer ous of southern Kansas. Kans Univ Q 6 149-175 (1897)

99 Classification and distribution of the Hamilton and Chemung series of central and eastern New York, Part 2. N Y St G, An Rp 17:65-315, maps (1899) N Y 8t Mus, An Rp 51 v $2: 65-315$, maps (1899) 
Prosser, Charles Smith-Continued.

99a (and Rowe, R. B.) Stratigraphic geology of the eastern Helderbergs. N Y Bt G, An Rp 17:329-354 (1899) N Y St Mus, An Rp 51 v $2: 329-354$ (1899)

99b Correlation of the Carboniferous rocks of Nebraska with those of Kansas. J G $7: 342-356$, map (1899)

99e Note on the distribution of the Cheyenne sandstone. Kans Univ Q 8:135136 (1899)

00 Sections of the formations along the northern end of the Helderberg Plateau. N Y St G, An Rp 18: 51-72 (1899) N Y St Mus, An Rp 52 v 2: 51-72 (1900)

00a Notes on the stratigraphy of the Mohawk Valley and Saratoga Co. N Y St Mus, B $34: 469-482$ (1900)

00b The Shenandoah limestone and Martinsburg shale. J G 8:655-663 (1900)

00c Gas well sections in the upper Mohawk Valley and central New York. Am G 25: 131-162 (1900)

ood Section of the Alloway, N. Y., well. Am G $25: 353-355$ (1900)

01 The classification of the Waverly series of central Ohio. J G $9: 205-231$ (1901)

01a The term Bedford limestone. J G 9:270-272 (1901)

01b The Palcozolc formations of Allegany Co., Md. J G 9:409-429 (1901)

01e Names for the formations of the Ohio Coal Measures. Am J Sc (4) 11 : 191199 (1901)

02 The Sunbury shale of Ohio. J G 10: 262-312, 328 (1902)

02a Revised classification of the upper Paleozoic formations of Kansas. J G 10 : 703-737 (1902)

$02 \mathrm{~b}$ The specimen of Nematophyton in the New York State Museum. Am G 29: $372-377$ (1902)

02e Richard Burton Rowe. Am i 30 : 128-129 (1902)

03 The nomenclature of the Ohio geological formations. J G $\mathbf{1 1}: \mathbf{5 1 9}-546$ (1903)

03a Notes on the geology of eastern New York. Am G 32: 381-384 (1903)

04 (and Beede, J. W.) Description of the Cottonwood Falls quadrangle [Kans.]. U S G S, G Atlas Cottonwood Falls fol (no 109): 6 pp, maps (1904)

04n Description and correlation of the Romney formation of Maryland. J G 12: 361-372 (1904)

04b (and Cumings, E. R.) The Waverly formations of central Ohio. Am G 34 : 335-361 (1904)

05 Revised nomenclature of the Ohio geological formations. Ohio G S (4) B 7 : 36 pp, Columbus 1905

05a The Delaware limestone. J G 13: 413-442 (1905)

05b Notes on the Permian formations of Kansas. Am G 36:142-161 (1905)
Prosser, Charles Smith-Continued.

06 Stratigraphic geology. Ohio St Ac Sc, Pr $4: 340-348$ (1906)

$06 \mathbf{a}$ Note on the use of Buena Vista as the name of a geological terrain. Am J Sc (4) $21: 181-182$ (1906)

o7 Section of the Manlius limestone at the northern end of Helderberg Plateau [N. Y.]. J G $15: 46-51$ (1907)

os (with Lane, A. C.) The nomenclature and subdivisions of the upper Silurie strata of Michigan, Ohio, and western New York (abst). Science n s 27:409 (1908)

10 The anthracolithic or upper Paleozoic rocks of Kansas and related regions. J G 18 : 125-161 (1910)

10a (and Morse, W. C.) Outlines of field trips in geology for central ohio. 74 pp, Columbus, Ohio, 1910. 2d ed, 112 pp, Columbus, Ohio, 1915.

12 The disconformity between the Bedford and Berea formations in central Ohio. J G 20:585-604 (1912)

12a The Devonian and Mississippian formations of northeastern Ohio. Ohio G S (4), B $15: 574 \mathrm{pp}$ (1912) Abst, Wash Ac Sc, J $2: 352-353$ (1912)

13 The Huron and Cleveland shales of northern Ohio. J G 21:323-362 (1913)

$13 a$ Lower Devonian; introduction, historical review and bibliography. Md G S, Lower Devonian : 42-66 (1913)

13b Systematic paleontology of the Middle Devonian deposits of Maryland; Cœlenterata. Md G S, Middle and Upper Deronian: 119-122, il (1913)

13e (and Kindle, E. M., and Swartz, C. K.) The Middle Devonian deposits of Maryland. Md G S, Middle and Upper Devonian : 23-114 (1913)

13d (and Kindle, E. M.) Systematic paleontology of the Middle Devonian deposits of Maryland; Brachipoda, Pelecypoda, Gastropoda, Cephalopoda, Trilobita. Md G S, Middle and Upper Devonian : 124335 , il (1913)

13e (and Swartz, C. K.) The Upper Devonian deposits of Maryland. Md G S, Middle and Upper Devonian : 339-409 (1913)

15 The middle and upper Devonian of the Romney, W. Va., region. J G 23:1126 (1915)

16 The classification of the Niagaran formations of western Ohio. J G 24:334365 (1916) Abst, Science n s $43: 394-395$ (1916)

16a Ripple marks in Ohio limestones. J G 24:456-475 (1916)

16b The stratigraphic position of the Hillsboro sandstone [Ohio]. Am J Sc (4) 41: 435-448 (1916) Abst, Science n s 43: 395 (1916)

See also Haworth, 97 97c; Hubbard (G D), 15 ; Williams (G H), 91b 
Prosser, Mary Wilson.

06 A bibliography of the publications relating to the geology of Ohio other than those of the State Geological Survey. Ohio G S (4) B 6:235-332 (1906)

Prosser, W. T.

11 Katalla, Alaska, oil fields. M World $35: 746$ (1911)

Prosser, Warren C.

10 Tungsten in San Juan Co., Colo. Eng M J 90:320 (1910)

11 Gold deposits of San Juan, Colo. Mines and Minerals $31: 335-337$ (1911)

11 a The Bear Creek sylvanite camp [near Silverton], Colo. Eng M J 91:712 (1911)

14 Silver Lake basin, Colo. Eng M J $97: 1229-1231$ (1914)

Prout, Henry G.

74 Report of reconnaissance in the Ute country. U S, 43d Cong 1st sess, H Ex Doc 193:6-51 (1874)

Prout, Hiram A. (?-1862).

46 Gigantic Palaeotherium. Am J Sc (2) $2: 288-289$, il (1846)

47 Description of a fossil maxillary bone of a Palaeotherium. Am J Se (2) 3:248250 , il (1847)

48 On the geology of the valley of the Mississippi. Western $\mathrm{J}$ (St. Louis) 1 : 243-252 (1848)

48a On the economical geology of the State of Missouri. Western J (St. Louis) 1:429-439 (1848)

51 The advantages of a geological survey of the State of Missouri. $29 \mathrm{pp}$, St. Louis 1851

51a Description of a new grapolite found in the Lower Silurian rocks near the Falls of the St. Croix River, Am J Sc (2) 11: 187-191, il (1851)

57 Description of a new species of Productus from the Carboniferous limestone of St. Louis [Mo.]. Ac Se St L, Tr 1: $43-45$, il (1857)

58 Description of new species of Bryozoa from Texas and New Mexico... Ac Sc St L, Tr 1: 228-235 (1858)

$\mathbf{5 8 a}$ First of a series of descriptions of Carboniferous Bryozoa. Ac Sc St L, Tr 1: 235-237 (1858)

58b Second series of descriptions of Bryozoa from the Paleozoic rocks of the Western States and Territories. Ac Sc St L, Tr $1: 266-273$ (1858)

59 Third series of descriptions of Bryozoa from the Paleozoic rocks of the Western States and Territories. Ac Sc St L, Tr 1:443-452, il (1859)

60 Fourth series of descriptions of Bryozoa from the Paleozoic rocks of the Western States and Territories. Ac Sc St L, Tr $1: 571-581$ (1860)

60a On a fossil tooth found at King's salt works, near Abingdon, Va. Ac Sc St L, Tr 1:699-700 (1860)
Prout, Hiram A.-Continued.

66 Descriptions of new species of Bro zoa. Ac Sc St L, Tr 2: 410-413 (1866)

$66 a$ Descriptions of Polyzoa from ty Paleozoic rocks. III G S 2:412-423, (1866)

Pronty, William Frederlck.

os The meso-Silurian deposits of Mar. land. Am J Sc (4) $26: 563-574$ (1908)

09 The Coosa coal field of Alabam Eng M J 88: 921-923 (1909)

11 Roads and road materials of dia bama. Ala G S, B 11: 148 pp (1911)

12 Map of the Coosa coal fleld, with sections. $30 \times 39$ inches. Scale, 1 inch 1.5 miles. Ala G S, 1912

12a Waterworn coal pebbles in ca: boniferous sandstone. J G 20:769-m (1912)

15 Crystalline marbles of Alabam (abst). G Soc Am, B 26:104 (1915)

16 Preliminary report on the crystallit: and other marbles of Alabama. Ala G \& B $18: 212 \mathrm{pp}$, map (1916)

$16 a$ Crystalline marbles of Alabama. Soc Am, B 27:63-64 (abst), 437-450, ma) (1916)

16b (with Swartz, C. K.) Siluria system of Maryland (abst). G Soc Am, B $27: 89 \cdot(1916)$

Providence Frankin soclety.

87 Report on the geology of Rhod Island. Providence Franklin Soc: 130 p 11, Providence 1887

Provot, F. A.

16 A geological reconnaissance of th Jerome district [Ariz.]. 33 pp, mat Jerome, A riz, 1916

16a Jerome [Arizona] mining distrik geology. Eng M J 102:1028-1031 (1916) Prudhomme, F.

82 Rapport sur les archives de la $\mathrm{Cos}$ mission Scientifique du Mexique [notes a Mexico and the West Indies]. Soc $G$ Now mandie, B $7: 33-46$ (1882)

Prutzman, Paul W.

04 Production and use of petroleus to California. Cal St M Bur, B $32 ; 230 \mathrm{ph}$, maps, Sacramento 1904

10 Coalinga oil field [Cal.]. M Sciente 61: 464-466 (1910)

10a The origin of petroleum. Cal Des rick 2 nos 11, 12 ; 3 nos 1-6 (1910)

12 History and geology of Californta of fields. M World 36:1191-1192 (1912)

13 Petroleum in southern Californis Cal St M Bur, B 63: 430 pp, maps (1913)

15 Notes on the Santa Maria ofl fields [Cal.]. West Eng 6:256-257 (1915)

Pruvost, Pierre.

13 Les bassins houillers du Canads Soc G Nord, Lille, An $42: 258-293$, maps (1913)

Pryor, Jose T.

o8 A theory of ore deposition. M \& Press $97: 323$ (1908) 
Puga, Guillermo B.

87 Les tremblements de terre du Mexfque, 3 et 29 mai 1887 . La Nature 15, 2 : 182-183 (1887)

88 Reseña de una exploración geológica en el Estado de Veracruz. La Naturaleza (2) $1: 49-53$ (1888)

88a Reseña de la topografía y geología de la Sierra de Guadalupe, Valle de México. Soc Cient Ant Alz, Mem 2:25-85 (1888) La Naturaleza (2) 1:197-205 (1889)

$90 \mathrm{La}$ altima erupción del volcán de Colima. Soc Cient Ant Alz, Mem 3: 97-102 (1890)

91 (and Aguilar y Santillan, R.) El temblor del 2 de diciembre de 1890 . Soc Cient Ant Alz, Mem 4:131-154 (1891)

91a El cerro de la Estrella 6 de Ixtapalapa [México]. La Naturaleza (2) 1 : 488-492 (1891)

91b (with Aguilar y Santillán, R.) Geodinámico; catálogo de los temblores de tierra $y$ fenómenos volćñicos verificados en la República Mexicana durante el año de 1889 y 1890 . Soc Cient Ant Alz, Mem 4:179-191, 323-329 (1891)

92 Apuntes para la geología del Valle de México; el Peñón de los Baños. La Naturaleza (2) 2:86-96, map (1892)

Pugh, Griffith Thompson.

05 Pleistocene deposits of South Carolina, with an especial attempt at ascertaining what must have been the environmental conditions under which the Pleistocene Mollusca of the State lived. Thesis, Vanderbilt University. $\mathbf{7 4} \mathrm{pp}$, Nashville, Tenn, 1905

Pulsifer, H. B.

13 Development of the Wisconsin zinc field. M World $38: 1231-1233$ (1913)

14 New Hampshire mica deposits near Grafton. M World 41: 141-143 (1914)

Pultz, John Leggett.

04 The Big Stone Gap coal field of Virginia and Kentucky. Eng Mag 28:71-85, map (1904)

07 Mining in the Cumberland Gap coal field. Eng. M J 83: 808-810 (1907)

Pumpelly, Raphael (1837-1923).

63 Mineralogical sketch of the silver mines of Arizona. Cal Ac $\mathrm{N}$ Sc, $\operatorname{Pr} 2$ : 127-139 (1863)

71 The paragenesis and derivation of copper and its associates on Lake Superior. Am J Sc (3) 2: 188-198, 243-258, 347-355 (1871)

72 (with Brooks, T. B.) On the age of the copper-bearing rocks of Lake Superior. Am J Sc (3) 3:428-432 (1872)

73 Preliminary report on the iron ores fad coal flelds from the field work of 1872 . xvi, 214. 441 pp, N Y 1873

73a Notes on the geology of Pilot Knob and its vicinity. Mo G S, Prel Rp Iron Ores and Coal Fields, 1872 pt $1: 3-28$, maps (in atlas) (1873)
Pumpelly, Raphael-Continued.

73b Copper district [Upper Peninsula]. Mich G S, 1 pt $2: 143$ pp (1873)

75 On pseudomorphs of chlorite after garnet at the Spurr Mountain iron mine, Lake Superior. Am J Sc (3) 10:17-21 (1875)

76 The iron district of Michigan. $5 \mathrm{pp}$, published by Centennial Committee, American Institute of Mining Engineers, Phila. 1876

76a The iron ores of Missouri. Eng M J $22: 1$ (1876)

$7 \boldsymbol{7}$ On the influence of marine life and currents in the formation of metalliferous deposits. Ky G S, Rp Prog 2 n s:318330 (1877)

78 Metasomatic development of the copper-bearing rocks of Lake Superior. Am Ac Arts, Pr 13: 253-309 (1878)

79 The relation of secular rock disintegration to loess, glacial drift, and rock basins. Am J Sc (3) $17: 133-144$ (1879)

79a United States Geological Survey of the Fortieth Parallel, vol. I (review). Am J Sc (3) $17: 296-302$ (1879)

so Lithology of the Keweenawan system. [Wis G S], G Wis $3: 27-49$ (1880)

s6 Geographical and geological distribution of the iron ores of the United States. U S, 10th Census 15:3-36, maps (1886)

S6a Bituminous coals and lignites of the Northwest. U S, 10th Census 15: 691-695 (1886)

s8 On the fossils of Littleton, N. H. Am $\mathrm{J} \mathrm{Sc} \mathrm{(3)} 35: 79-80$ (1888)

91 The relation of secular ruck-disintegration to certain transitional crystalline schists (with discussion by G. H. Williams, B. K. Emerson, and G. K. Gilbert). G Soc Am, B $2:$ 209-223 (1891)

92 (and Van Hise, C. R.) ... structural relations of the Upper Huronian, Lower Huronian, and basement complex on the north shore of Lake Huron. Am J Sc (3) 43 : 224-232 (1892)

93 An apparent time break between the Eocene and Chattahoochee Miocene in southwestern Georgia. Am J Sc (3) 46: 445-447 (1893)

$93 a$ [Correlation of clastic rocks; preCambrian.] Int $\mathrm{G}$ Cong, V, Washington 1891, C. R : 173-174 (1893)

93b Memorial of Thomas Sterry Hunt. G Soc Am, B $4: 379-393$ (1893)

94 Geology of the Green Mountains in Massachusetts. U S G S, Mon 23:5-34, maps (1894)

$18 \mathrm{My}$ reminiscences. 2 vols, $844 \mathrm{pp}$, maps, N Y 1918

See also Frazer, $88 \mathrm{a}$; Gilbert, $93 \mathrm{~b}$; King, (C), 80; Powell, 82, 85a, 88, 89, 89a, 90, $91,91 \mathrm{a}, 92$

Purdue, Albert Homer (1861-1918).

95 Observations on the glacial drift of Jasper Co. Ind Ac Sc, Pr 1894:43-46 (1895) 
Purdue, Albert Homer-Continued.

96 The Charleston (Mo.) eartiquake. Ind Ac Sc, Pr 1895: 51-53 (1896)

01 Valleys of solution in northern Arkansas. J G 9:47-50 (1901)

01 Illustrated note $\sim n$ a miniature overthrust fault and anticline. $J$ G 9 : 341-342 (1901)

01b Physiography of the Boston Mountains, Ark. J G 9:694-701, map (1901) Abst, Sc Am Sup 52:21505 (1901)

03 The saddleback topography of the Boone chert region, Ark. (abst). Science n s $17: 222$ (1903) Sc Am Sup 55:22666 (1903)

04 [Notes on water resources of] Arkansas. U S G S, W-S P 102: 374-388 (1904)

$04 a$ A topographic result of the alluvial cone. Ind Ac Sc, Pr 1903: 109-111 (1904)

05 [Underground waters of] northern A r kansas. U S G S, W-S P 114: 188-197, map (1905)

O5a Water resources of the Winslow quadrangle, Ark. U S G S, W-S P 145 : 84-87 (1905)

05b Water resources of the contact region between the Paleozolc and Mississippi embayment deposits in northern $\Delta$ rkansas. U S G S, W-S P 145: 88-119, map (1905)

o5e Concerning the natural mounds. Science n s 21: 823-824 (1905)

06 Structural relations of the Wisconsin zinc and lead deposits. Ec G 1:391-392 (1906)

07 Cave-sandstone deposits of the sonthern Ozarks. G Soc $\Delta \mathrm{m}, \mathrm{B}$ 18:251-256 (1907) Abst, Science n s 25:764 (1907)

07a Developed phosphate deposits of northern Arkansas. U S G S, B 315 : 463473 (1907)

07b Description of the Winslow quadrangle [Ark.-Ind.-Terr.]. U S G S, G Atlas Winslow fol (no 154): 6 pp, maps (1907)

ore On the origin of limestone sink holes. Science n s $26: 120-122$ (1907)

07d The phosphates of northern Arkan. sas. Eng M J 83:1038 (1907)

os A new discovery of peridotite in Arkansas. Ec G $3: 525-528$ (1908)

09 The slates of Arkansas. Ark G S : 1-95, map (1909)

$09 a$ Structure and stratigraphy of the Ouachita Ordovician area, Ark. $(a b s t)$. G Soc Am, B $19: 556-557$ (1909)

10 The slates of Arkansas. U S G S, B $430: 317-334$ (1910)

10a The collecting area of the waters of the hot springs, Hot Springs, Ark. J G 18 : 278-285 (1910) Ind Ac Sc, Pr 1909: 269275 (1910)

11 Recently discovered hot springs in Ar. kansas [Caddo Gap, Montgomery Co., Ark.]. J G $19: 272-275$ (1911)

12 Compendium of the mineral resources of Arkansas. [Little Rock] Board of Trade Bulletín, 30 pp, 1912
Purdue, Albert Homer-Continued.

12a Administrative report of the State geological survey, 1912. Tenn G S, B 15: $17 \mathrm{pp} \mathrm{(1912)}$

12b The zinc deposits of northeastern Tennessee. Tenn G S, B 14:69 pp, map (1912)

12c The zinc deposits of northern Tennessee. M Science $66: 249-251$ ( 1912$)$

12d Some neglected principles of phys. ography. Ind Ac Sc, Pr, 1911:83-87 (1912)

12e The iron industry of Lawrence and Wayne cos. Tenn G S, Res Tenn 2:370388 (1912)

13 Water supply for citles and towns Tenn G S, Res Tenn 3: 80-83 (1913)

$13 a$ Geology and engineering. Tenn S, Res Tenn 3: 105-109 (1913)

13b The gullied lands of west Tennes. see. Tenn G S, Res Tenn 3:119-136 (1913)

13e The minerals of Tennessee, their nature, uses, occurrence, and literature (lierature by Elizabeth Cockrill). Tenn G \&, Res Tenn 3: 183-230 (1913)

13d Field and office methods in the prep. aration of geologic reports; note taking. Ec G 8:712 (1913)

14 Administrative report of the State geologist, 1914. Tenn G S, B 18:17 pp (1914)

14a A double waste from billside wash. Tenn G S, Res Tenn 4:36-37 (1914)

14b Bauxite in Tennessee. Tenn G \& Res Tenn 4:87-92 (1914)

14e Road materials of Tennessee. Tem G S, Res Tenn 4: 132-135 (1914)

14d Zinc mining in Tennessee. Eng $M$ J 98 : 419-421, map (1914)

14e Some neglected principles of physi. ography (abst). Tenn Ac Sc, Tr 1:92-9t (1914)

16 (and Miser, H. D.) Description of the Eureka Springs and Harrison quadran. gles, Ark.-Mo. U S G S, G Atlas Eureka Springs-Harrison fol (no 202) : 22 pp, maps (1916)

16a Oil and gas conditions in the cen. tral basin of Tennessee. Tenn G S, Res Tenn 6:3-16 (1916)

16b Oil and gas conditions in the Reel. foot Lake district of Tennessee. Tenn $G$ \&. Res Tenn $6: 17-36$ (1916)

16e Notes on manganese in east Tent nessee. Tenn G S, Res Tenn 6:111-123 (1916)

17 Administrative report of the State geologist, 1916. Tenn St G S, Res Tenn $7: 5-25$ (1917)

17a The Glenmary oil field. Tenn \& \&, Res Tenn 7:105-108 (1917)

17 b General oil and gas conditions of the Highland Rim area in Tennessee. Tenn G S, Res Tenn $7: 220-228$ (1917) 
Pardue, Albert Homer-Continued.

17e The State geologist and conservation. Science n s 45:249-252 (1917) Am M Cong, 19th An Sess, Rp Pr: 193-197 (1917)

18 Manganese deposits of Bradley Co. Tenn G S, Res Tenn 8:46-47 (1918)

18a (with Miser, H. D.) Gravel deposits of the Caddo Gap and De Queen quadrangles, Ark. U S G S, B 690:15-29, map (1918) Abst, Wash Ac Sc, J $8: 538$ (1918)

18b (with Miser, H. D.) Asphalt deposits and oil conditions in southwestern Arkansas. U S G S, B 691: 271-292, map (1918)

See also Adams (G I), 04

Purdy, Ross C.

07 (and DeWolf, F. W.) Preliminary investigations of Illinois fire clays. IIl G S, B 4: 129-175, map (1907)

Purington, Chester Wells (1871-1923).

94 Geological and topographical features of the region about Atlanta, Ga. Am G 14:105-108, map (1894)

97 The Telluride mining district, San Juan Mountains, Colo. (abst). Science $\mathbf{n} \mathbf{s}$ $5: 890$ (1897)

98 Preliminary report on the mining industries of the Telluride quadrangle. Colorado. U S G S, An $R p 18$ pt $3: 745-848$, map (1898)

99 Economic geology [of the Telluride quadrangle, Colo.]. U S G S, G Atlas Telluride fol (no 57) : 15-18 (1899)

99a Economic geology [of the La Plata quadrangle, Colo.]. U S G S. G Atlas La Plata fol (no 60) : 12-14 (1899)

03 The Contact, Nevada, quaquaversal (with discussion by Philip Argall). Colo Sc Soc, Pr $7: 127-138$ (1903)

03a The Camp Bird mine, Ouray, Colo., and the mining and milling of the ore. Am I M Eng, Tr 33:499-528, map (1903) Abst, Eng M J 75:820-822 (1903)

03b Secondary enrichment. Eng M J $75: 472-473$ (1903)

03e Observations on gold deposits. Eng M J 75:854-855, 893-894, 929-931 (1903)

Reprinted in Ore deposits : 68-90, N Y 1903

03d Geology of the Virginius mine [San Juan Mountains, Colo.]. Eng M $-76: 458$ (1903)

05 Methods and costs of gravel and placer mining in Alaska. U $\mathbf{S} \mathbf{G} \mathbf{S}, \mathbf{B}$ $259: 32-46$ (1905)

05a Ore horizons in the veins of the San Juan Mountains, Colo. Ec G 1:129133 (1905)

05b The Camp Bird and Smuggler-Union flssures [San Juan Mountains, Colo.] Eng M J $79: 1243-1244$ (1905)

06 Vein mining in Alaska. M Sc Press $92: 310$ (1906)

07 The Vulture mine [Mariposa Co.], Ariz. M Sc Press 94:308-310 (1907)
Purington, Chester Wells-Continued.

07a Copper in serpentine. M Sc Press $94: 719-720 \quad(1907)$

os Treasure Mountain, Colo. M Sc Press 97 : 23-25 (1908)

See also Rickard, 03

Pnrves, J. C.

73 Esquisse stratigraphique et especes fossiles de l'ile d'Antigoa [W. I.] Soc Malac Belgique, An 8: xxv-xxvili (1873)

85 Esquisse géologique de l'île d'Antigoa. Mus R d'Hist Nat Belgique, B $3: 273-318$. map (1885)

Putnam, Bayard $T$.

85 The evidences of glaciation on Mount Kearsarge, N. H. Newport N H Soc, Pr 3: 74-84 (1885)

86 Notes on the samples of iron ore collected in Connecticut and Massachusetts ; ... New York; ... New Jersey ; Michigan and northern Wisconsin; ... west of the one-hundredth meridian. U S, 10th Census $15: 83-87,89-144,145-177,179-221$, $421-455,469-505$, maps (1886)

Putnam, F. W.

84 Man and the mastodon. Science 4: 112 (1884)

$85 \mathrm{Man}$ and the mastodon. Science 6 : 375-376 (1885)

Putnam, George Rockwell.

12 Condition of the earth's crust. Science n s $36: 869-871$ (1912)

Pynehon, W. H. C.

95 The great falls of the Mohawk at Cohoes, N. Y. (abst). Am As, Pr 44:138 (1896) Am G $16: 254$ (1895) Science n s 2:401 (1895)

96 The ancient lavas of Connecticut. Conn Q 2:309-319 (1896)

98 Some common evidences of glacial action in Connecticut. Conn Q 4:294-303 (1898)

99 Iron mining in Connecticut; I, Ores and ore beds. Conn Mag $5: 20-26$ (1899)

05 Drilled wells of the Triassic area of the Connecticut Valley. U S G S, W-S P $110: 65-94$ (1905)

Quackenbush, L. S.

09 Notes on Alaskan mammoth exped1tions of 1907 and 1908. Am Mus N H, B $26: 87-130$, il (1909)

\section{Qnebec, Commissioner of Crown}

Lands.

76 [Annual] report of tue Commissioner of Crown Lands of the Province of Quebec for the twelve months ended 30th June 1876 [-1898]. Quebec 1876-98. [Includes notes on the occurrence and geologic relations of mineral deposits]

\section{Quenean, Augustin L.}

02 Size of grain in igneous rocks in relation to the distance from the cooling wall. Sch Mines Q 23:181-195 (1902) Abst, Sclence n s 15:107 (1902); Am G 29: 125-126 (1902); N Y Ac Sc. An 14: 163 (1902) 
Queneau, Augustin L.-Continued. 02a The gold sands of Cape Nome [Alaska]. Eng Mag 23:497-510 (1902) Quereau, Edmund Chase.

98 Topography and history of Jamesville Lake, N. Y. G Soc Am, B 9:173-182, map (1898) Abst, Science n s 7:50-51 (1898)

Quickel, R. D.

10 Analyses and heat values of coals. Ky G S, Rp Prog 1908-09: 102-126 (1910) Quin, John T.

07 The building of an island, being a sketch of the geological structure of the Danish West Indian island of St. Croix, or Santa Cruz. 106 pp, Christiansted, St. Croix 1907

Quirke, Terence Thomas.

17 Espanola distriet, Ont. Can G S, Mem 102:75 pp, map (1917)

$\mathbf{1 7 a}$ Classification of ore deposits based upon origin, deformation, and enrichment. Ec G $12: 607-609$ (1917)

17b (and Finkelstein, Leo.) Measurements of the radio-activity of meteorites. Am J Sc (4) $44: 237-242$ (1917)

1s The geology of the Killdeer Mountains, N. Dak. J G $26: 255-271$ (1918)

Rabot, Charles.

09 Revue de glaciologie, no 3 (avril 1903-1er janvier 1907) [Includes glaciers of the Cascade Mountains Sierra Nevada, Rocky Mountains, and Alaska] Soc Fribourgeoise Sc Nat, Mém 5 : 1-343 (1909) Rachel, George W.

78 Die Hot Bluffs im nördlichen Nebraska. Gaea 14:224-229 (1878)

Rafinesque, Constantine Schmaltz (17831840).

21 Description of a fossil medusa forming a new genus, Trianisites cliffordi. Am $J$ Sc 3: 285-287, il (1821)

32 Atlantic journal and friend of knowleage [vol. 1] in eight numbers... [numerous notes on geology and fossils]. 212 pp, il, Phila 1832-3

$32 a$ Visit to Big Bone lick [Ky.] in 1821. Monthly Am J \& 1: 355-358 (1832)

39 [Description of Trianisites and related forms.] Soc G France, B 10:378381 (1839)

39a Notice sur les fossiles de la vallée Sherman des monts Alleghany. Soc G France, B 10:381-382 (1839)

64 The complete writings... on recent and fossil conchology. Ed. by W. G. Binney and G. W. Tryon, jr, $96,7 \mathrm{pp}$, il, N Y 1864 See also Maclure, 17

Rapter, George W.

o5 Hydrology of the State of New York. N Y St Mus, B $85: 902$ pp, maps (1905)

Ragsdale, G. H.

88 Evidence of drift at Gainesville, Tex. G Se B 1 no 7 (1888)
Ralph, Edward W.

o7 Mining conditions at Ely, Nev, II \& Press 94:120-121 (1907)

Ramirez, Santiago.

72 Apuntes geognosticos, estadistien mineralógicos, $\boldsymbol{y}$ geográficos sobre el Miners del Oro. Soc Geog Mex, B (2) 4:208-224 (1872)

73 (and Reyes, V.) Informe sobre los temblores y volcanes de Aguafría y Jaripeo. Soc Geog Mex, B (3) 1: 67-88 (1873)

75 (and Báreena, M.) Informe sobre el fenomeno geológico de Xochitepec. $80 c$ Geog Mex, B (3) 2:48-60 (1875)

75a Observaciones á la presunta especle mineral la medinita. Soe Geog Mex, B (3) $2: 114-118$ (1875)

75b Apuntes sobre la formación mine ralógica y geológica del distrito minero de San Nicolás del Oro [México]. Soc Geog Mex, B (3) 2:406-436 (1875)

75e (with Cuataparo, J. N.) Descrip. cion de un mamíero fósil de especie des. conocida perteneciente al género Glypto. don, encontrado entre las capas post-Tes. ciarias de Tequisquac, en el distrito de Zumpango [México]. Soc Geog Mex, B (3) $2: 354-362$ (1875)

$\boldsymbol{7 7}$ Informe... sobre el reconocimiento practicado en el mineral de Cuitlanapa en el Estado de Guerrero. México, Ministerio de Fomento, An 3:331-337 (1877)

77a Informe sobre el mineral de Guadal cázar en el Estado de San Luis Potost. México, Ministerio de Fomento, An 3:339404 (1877)

77b Informe... de exploracion en k Sierra Mojada. México, Ministerio de Fo. mento, An 3:627-687 (1877)

79 Dictamen sobre la prioridad en el descubrimiento de la nueva especie minerl la barcenita... Soc Geog Mex, B (3) 4: 275-283 (1879)

79a Informe sobre el mineral de Guadalcázar, en el Estado de San Luis Potosí.. 90 pp, México 1879

so Informe que como resultado de su exploración en la Sierra Mojada [Co3. huila ]... 63 pp. map, il, México 1880

81 Informe sobre los criaderos de carbon mineral que se encuentran en el Estado de Tlaxcala. $17 \mathrm{pp}$, México 1881

82 Informe... exploración a los distritos de Matamoros Iznicar, Chiautla, y Acatlán en el Estado de Puebla [México] y del estudio de sus criaderos de carbón mineral. México, Ministerio de Fomento, An 7:796. map (1882)

82a Informe sobre los criaderos de car. bón mineral... en el Estado de Tlaxeala [México]. México, Ministerio de Fomento, An $7: 99-107$ (1882) 
Ramirez, Santiago-Continued.

s2b Estudio de unos ejemplares de carbón mineral procedentes del distrito de Tlaxiaco en el Estado de Oaxaca. México, Ministerio de Fomento, An $7: 108-113$ (1882)

s2e Informe... sobre exploracion en la municipalidad de Tlaquiltenango perteneciente al distrito de Tetecala del Estado de Morelos para el reconocimiento de unos supuestos criaderos de carbón. México, Ministerio de Fomento, An 7:114-128 (1882)

82d Informe sobre la exploración hecha en los yacimientos carboníferos del distrito de Huetamo en el Estado de Michoacín. México, Ministerio de Fomento, An $7: 178$ 191 (1882)

s2e Informe sobre la exploracion hecha en el cantón de Jalapa con el objeto de examinar sus terrenos carbonfferos. Mé. xico, Ministerio de Fomento, An $7: 306-332$ (1882)

82f Informe sobre la exploracion hecha en. los terrenos de Tulitic en la jurisdicción del distrito de Alatriste perteneciente al Estado de Puebla, con el objeto de estudiar sus yacimientos de carbón. México, Ministerio de Fomento, An $7: 524-537$ (1882)

82g Informe... de exploración en los minerales de La Campechana en el Estado de Guanajuato y Comanja y El Roble en el de Jalisco. México, Ministerio de Fomento, An 7:548-581 (1882)

$\mathbf{8 2 h}$ Informe relativo al reconocimiento de la negociación minera llamada " Minas de la Canal y anexas" en el mineral de Zacualpán. México, Ministerio de Fomento, An 7:582-604 (1882)

821 Informe sobre los depósitos carbontferos del cerro de El Tambor en el distrito de Huauchinango. México, Ministerio de Fomento, An 7:688-699 (1882) La Naturaleza $6: 284-293$ (1883)

82j Los criaderos de carbón en el Estado de Coahuila... 16 pp, México 1882 [not seen]

84 Noticia hístórica de la riqueza minera de México... 768 pp, México 1884

86 Litología; introducción al estudio de las rocas, xiv, $685 \mathrm{pp}$, México 1886 [not seen]

92 Estudios sobre el carbón mineral. 179 pp, México 1892

Ramirez, Simeón.

16 Minerales que acompañan al oro en los yacimientos auríferos de México. Bol Minero 1: 129-132 (1916)

Rammelsberg, Karl Friedrich (18131899).

53 Gesteine der Antillen. Deut G Ges, Zs 5:694-697 (1853)

66 Ueber das Buntkupfererz von Ramos In Mexiko und die Constitution dieses Mineral iberhaupt, Deut G Ges Zs 18: 19-22 (1866) La Naturaleza $3: 251-253$ (1875)
Rammelsberg, Karl Friedrich-Contd.

66a Ueber den Castellit, ein neues Mineral aus Mexiko. Deut G Ges, Zs 18:23-24 (1866) La Naturaleza 3:249-251 (1875)

66b Ueber den Xon litit, ein neues wasserhaltiges Kalksilikat, und den Bustamit aus Mexíko. Deut $\mathrm{G}$ Ges, Zs 18:17, 33-34 (1866) La Naturaleza $3: 288-290$ (1875)

66e Ueber den Enargit aus Mexiko und einen neuen Fundort des Bethierits, Deut G Ges, Zs 18:241-244 (1866) La Naturaleza $3: 336-340$ (1875)

69 Ueber Tellurwismuthsilber aus Me. xico. Deut G Ges, Zs 21:81-82 (1869)

69a Ueber zwei Meteoreisen aus Mexico [Misteca alta and Yanhuitlan]. Deut G Ces, Zs 21: 83 (1869)

83 Ueber den Cuprodescloizit, ein neues Vanadinerz aus Mexico. K Preus Ak Wiss Berlin, Szb 1883:1215-1216 Abst, Am J Sc (3) $27: 412-413$ (1884)

Ramos, Joaquín M.

S7 Informe relativo á... exploradora de la Baja California. México, Ministerio de Fomento, An $8: 117-284$ (1887)

Ramsay, Andrew C.

58 On the geological causes that have influenced the scenery of Canada and the northeastern provinces of the United States (abst). $\mathrm{R}$ Inst, Pr 2:522-524 (1858) Can Nat $3: 263-265$ (1858)

59 On some of the glacial phenomena of Canada and the northeastern provinces of the inited States during the drift period. G Soc London, Q J 15:200-215 (1859) Can Nat 4 : 325-342 (1859)

65 On the Eozoon and the Laurentian rocks of Canada. R Inst, Pr $4: 374-377$ (1865)

\section{Ramsay, George S.}

96 The northeastern bituminous coal measures of the Appalachian system. $\Delta \mathrm{m}$ I M Eng, Tr 25: 76-83 (1896)

Ramsay, J, D.

09 The Maple Mountain mining district [Montreal River mining division] of Ontario. Can M J 30:526-527 (1909)

Rand, J. C.

06 Some minerals occurring at Worcester, Mass. Mineral Collector 12:165-166 (1906)

os Notes on some minerals occurring near Boston, Mass. Mineral Collector 15: $57-58(1908)$

Rand, Theodore Dehon (1836-1903).

68 On a new mineral in cryolite. Ac N Sc Phila, Pr 1868: 142-143. Am J Sc (2) $46: 400-401$ (1868)

70 [On a recent disturbance in Potsdam sandstone near Philadelphia, Pa.] Ac N Sc Phila, Pr 1870:134

72 Notes on feldspar and some other minerals of Philadelphia and vicinity. Ac N Sc Phila, Pr 1871: 299-304 (1872)

77 On the rocks near Philadelphia. Ac N Sc Phila, Pr 1877:251-254 
Rand, Theodore Dehon-Continued.

79 On a belt of serpentine and steatite in Radnor Township, Delaware Co., Pa. Ac N Sc Phila, Pr 1878: 402-404 (1879)

so Serpentine belts of Radnor Township, Delaware Co., Pa. Ac N Se Phila, Pr $1880: 225-226$

soa Change of serpentine into quartz. Ac N Se Phila, Pr 1880:241-242; Min G Sec, Pr no 1:5-6 (1880)

sob On randite [Philadelphia, Pa.]. Ac N Sc Phila, Pr 1880:274-275; Min G Sec, Pr no 1:38-39 (1880)

soc Some microscopic enclosures in mica. Ac N Sc Phila, Pr 1880:276-277; Min G Sec, Pr no 1:40-41 (1880)

sod Potsdam sandstone near King of Prussia [Montgomery Co., Pa.]. Ac N Sc Phila, Pr 1880:279; Min G Sec, Pr no 1: 43 (1880)

soe On a peculiar stratification in gneiss. Ac N Sc Phila, Pr 1880 : 280-281; Min G Sec, Pr no $1: 44-45$ (1880)

80 f The northern belt of serpentine in Radnor township [Delaware Co., Pa.]. Ac N Sc Phila, Pr 1880:295; Min G Sec, Pr no 1:59 (1880)

$\mathbf{8 2}$ Notes on the geology of Radnor and vicinity [Delaware Co., Pa.]. Ac N Sc Phila, Pr 1882:42-47; Min G Sec, Pr no $2: 9-15$ (1882)

82a Notes on the geology of lower Merion and vicinity [Montgomery Co., $\mathrm{Pa}$.$] .$ Ac N Se Phila, Pr 1882:61-67, map; Min G Sec, Pr no $2: 28-34$, map (1882)

83 Geology of lower Merion and vicinity [Pa.]. $A m$ Nat 17:965-967 (1883)

84 Notes on the geology of Chester Valley [P2.] and vicinity. Ac $\mathrm{N}$ Se Phila, Pr 1883:241-247 (1884)

86 Notes on the Lafayette serpentine belt. Ac N Se Phila, Pr 1885 : 407 (1886)

87 Notes on the geology of Radnor township in Delaware Co., Pa. [and vicinity]. $\mathrm{Pa}$ G S, An Rp 1886 pt 4: 1569-1618, map (1887)

89 A discussion on the rocks of Pennsylvania and New York. N Y Ac Sc, Tr 8: $47-53$ (1889)

90 Notes on the drift on Block Island. Ac N Sc Phila, Pr 1889:408-409 (1890)

$90 \mathbf{a}$ Notes on the genesis and horizons of the serpentines of southeastern Pennsylvania. Ac N Se Phila, Pr 1890: 76-123

91 Geology of the South (Chester) Valley Hill [Pa.]. Ac N Sc Phila, Pr 1890: 435-436 (1891)

91a The sandstones of Chester Valley, Pa. Ac N Sc Phila, Pr 1891: 119-120

92 (and Jeneris, W. W., and Cardeza, J. T. M.) Mineral localities of Philadelphia and vicinity. Ac $\mathrm{N}$ Sc Phila, $\mathrm{Pr} 1892$ : 174-202

92a Geology of the Isles of Shoals [N. H.]. Ac N Sc Phila, Pr $1892 ; 324-325$
Rand, Theodore Dehon-Continued.

93 The supposed South Chester Valles Hill fault. Ac N Sc Phlla, Pr 1892:445447 (1893)

95 The Sadsbury steatite [Chester $C_{0}$ Pa.]. Ae N Se Phlla, Pr 1894:455-460 (1895)

96 Trap dikes in Chester Co., Pa. Ac N Sc Phila, Pr 1895 : 540-541 (1896)

96a The serpentines of eastern Pennsy. vania. Ac N Sc Phila, $\operatorname{Pr} 1896: 219$

98 The Birdsboro trap quarries [Chester Co., Pa.]. Ac N Sc Phila, Pr 1898: 10

00 Notes on the geology of southeastern Pennsylvania. Ac N Sc Phila, $\mathrm{Pr} 1900$ $160-338$

See also Frazer, 84; Hitcheock (C H), $84 \mathrm{~b}$; Lesley, 83

Randall, F. A.

75 Observations of the geology around Warren, Pa. Pa G S, 2d, I : 50-54 (1875)

94 Preliminary report of the geology of Cattaraugus and Chautauqua $\cos$. [N. Y.]. N Y St G, An Rp 13:517-527 (1894) N Y St Mus, An Rp 47:711-719 (1894)

Randa11, J. S.

86 Minerals of Colorado. $49 \mathrm{pp}$, Georgetown, Colo., 1886 [not seen]

Randa11, S. S.

46 Incentives to the cultivation of the science of geology... 189 pp, N Y 1846

Randolph, E. Oscar.

16 Physiography of the Isle of Palms. S. C. Elisha Mitchell Sc Soc, J 32:50-51 (1916) Abst, Science n s $44: 362$ (1916)

Rangel, Manuel F.

99 (with ord6ñez, E.) El Real del Monte [Hidaigo]. Mex I G, B 12:105 pp (1899)

02 Criadero de fierro del Cerro de Metcado de Durango. Mex I G, B 16:3-14 (1902)

11 Apuntes sobre la distribucion de mine. rales en el Estado de Durango. Soc G Mex, B $7: 105-123$ (1911)

See also Aguilera, 97

Rankin, George Atwater.

14 (with Wright, F. E.) Physical. chemical system, lime-alumina-silica and its geological significance (abst). G Soc Am, B 25: 92 (1914)

15 The ternary system $\mathrm{CaO}-\mathrm{Al}_{2} \mathrm{O}_{3}-\mathrm{SiO}_{2}$ with optical study by F. E. Wright. Am J Sc (4) $39: 1-79$ (1915)

18 (and Merwin, H. E.) The ternary system $\mathrm{MgO}-\mathrm{Al}_{2} \mathrm{O}_{3}-\mathrm{SiO}_{2}$. Am J Sc (4) 45 : 301-325 (1918)

Rankin, Robert J.

55 A report on the economic value of the semi-bituminous coal of the Cumberland coal basin. M Mag 4:47-60 (1855)

Ransome, Frederick Leslie.

93 The eruptive rocks of Point Bonita [Marin Co., Cal.]. Cal Univ, Dp G, B 1: 71-114, map (1893)

94 The geology of Angel Island [Cal.]. Cal Cniv, Dp G, B 1: 193-234, map (1894) 
Ransome, Frederlek Leslie-Continued.

95 On lawsonite, a new rock-forming mineral from the Tiburon Peninsula, Marin Co., Cal. Cal Univ, Dp G, B $1: 301-312$ (1895)

96 (and Palache, C.) Ueber Lawsonit, ein neues gesteinsbildendes Mineral aus Californien. Zs Kryst 25:531-537 (1896)

96a The Great Valley of California; a criticism of the theory of isestasy. Cal Univ, Dp G, B 1 : 371-428 (1896)

97 The age of the California coast ranges. Am G 19:66-67 (1897)

97a (with Turner, H. W.) Description of the Sonora quadrangle [Cal.]. U S G S, G Atlas Sonora fol (no 41): 5 pp, maps (1897)

98 Some lava flows of the western slope of the Sierra Nevada, California. U S G S, B $89: 7$. pp (1898) Abst, Am J Sc (4) 5: $355-375$ (1898)

98a (with Turner, H. W.) Description of the gold belt; Description of the Big Trees quadrangle [Cal.]. U i G S, G Atlas Big Trees fol (no 51) : 8 pp, maps (1898)

99 On a new occurrence of nepheline syenite in New Jersey. Am J Sc (4) 8: 417-426, map (1899)

99a Microscopic petrography of the rocks from the Nicaragua Canal region. [U S], Nicaragua Canal Commission, Rp 1897-99: 184-192, Baltimore 1899

00 Deseription of the Mother Lode district [Cal.]. U S G S, G tlas Mother Lode fel (no, 63) : 11 pp, maps (1900)

08a A peculiar clastic dike and its associated ore deposits [Ouray, Colo.] (abst). Science n s $11: 348$ (1900)

$00 \mathrm{~b}$ The fissure systems of the Silverton quadrangle, Colo. (abst). Science $\mathrm{n}$ s 12 : $926(1990)$

00c (with Hillebrand, W. F.) On carnotite and associated vanadiferous minerals in western Colorade. Am J Sc (4) 10: 120-144 (1900)

01 The ore deposits of the Rico Mountains, Colo. U S G S, An Rp 22 pt 2 : 229-397, map (1901)

01 a ... economic geology of the Silverton quadrangle, Colo. U S G S, B 182:265 pp, maps (1901) ; reprint (1903).

01b A peculiar clastic dike near Ouray, Colo., and its associated deposit of silver ore. Am I M Eng. Tr 30:227-236 (1901)

02 Recent progress in petrology. Science n s $15: 673-674$ (1902)

02a Faulting and mountain structure in central Arizona $(a b s t)$. Science ns 15: 711 (1902)

03 Geology of the Globe copper district, Ariz. U S G S, P P 12:168 pp, map (1903)

03a Copper deposits of Bisbee, Ariz. U S G S, B 213: 149-157 (1903)

03b The copper deposits of Bisbee, Ariz. Eng M J 75:444-445 (1903)
Ransome, Frederick Leslie-Continued. 04 The geology and ore deposits of the Bisbee quadrangle, Ariz, U S G S, P P 21: 168 pp, maps (1904)

04a Description of the Globe quadrangle [Ariz.]. U S G S, G Atlas Globe fol (no 111) : $17 \mathrm{pp}$, maps (1904)

04b Description of the Bisbee quadrangle [Ariz.]. U S G S, G Atlas Bisbee fol (no 112) : $17 \mathrm{pp}$, maps (1904; reprint: $19 \mathrm{pp}$, 1914)

04e The geology and copper deposits of Bisbee, Ariz. Am I M Eng, Tr 34:618642, map (1904)

04d The geographic distribution of metalliferous ores within the United States. M Mag 10:7-14 (1904)

o4e (with Lindgren, W.) Report of progress in the geological resurvey of the Cripple Creek district, Colo. U S G S, B 254:36 pp (1904)

05 Economic geology of the quadrangle [Silverton, Colo.]. U S G S, G Atlas Silverton fol (no 120) : 26-34 (1905)

o5a Ore deposits of the Coeur d'Alene district, Idaho. U S G S, B 260: 274-303, maps (1905)

O5b The present standing of applied $i$ :ology. Ee G 1:1-10 (1905)

05e The Coeur d'Alene district [Idaho]. M Mag 12:26-32 (1905)

osd (with Hillebrand, W. F.) On carnotite and associated minerals in western Colerado. U S G S, B 262:9-31 (1905)

o5e (with Lindgren, W.) The geological resurvey of the Cripple Creek district, Colo. U S G S, B 260: 85-98 (1905)

06 The probable cause of the San Francisco earthquake. Nat Geog Mag $17: 280$ 296 (1906) M Sc Press 92:396-397 (1906) Reprinted in After earthquake and fire: 130-137, San Francisco 1906

06a The directions of movement and the nomenclature of faults. Ec G 1:777-787 (1906)

06b Geelogy of the Bisbee district, Ariz. Eng M J 81:1103 (1906)

06e (with Lindgren, W.) Geology and gold deposits of the Cripple Creek district, Colo, U S G S, P P 54:516 pp (1906)

07 Preliminary account of Goldfield, Bullfrog, and other mining districts in southern Nevada. U S G S, B 303: 7-83, map (1907)

$07 \mathbf{a}$ The association of alunite with gold in the Goldfield district, Nev. Ec G 2 : 667-692 (1907) Abst, Science n s 27: 189 (1908)

os (and Calkins, F. C.) The geology and ore deposits of the Cour d'Alene district, Idaho. U S G S, P P 62:203 pp, maps (1908)

OSa A comparison of some Paleozoic and pre-Cambrian sections in Arizona (abst). Science n s 27:68-69 (1908) 
Ransome, Frederick Leslie-Continued. 0sb Pre-Cambrian sediments and faults in the Grand Canyon of the Colorado. Science n s $27: 667-669$ (1908)

ose The relation between certain orebearing veins and gouge-filled fissures. Ec G $3: 331-337$ (1908)

osa A theory of ore deposition. Ec G $3: 420-425$ (1908)

ose An apatitic minette from northeastern Washington. Am J Sc (4) 26 : 337-341 (1908)

09 The geology and ore deposits of Goldfield, Nev. U S G S, P P 66:258 $\mathrm{pp}$, map (1909)

o9n The Hornsilver district, Nev. U S G S, B 380: 41-43 (1909)

09 b Round Mountain, Nev. U S G S, B $380: 44-47$ (1909)

09e The Yerington copper district, Nev. U S G S, B 380 : 99-119 (1909)

$09 d$ Notes on some mining districts in Humboldt Co., Nev. U S G S, B 414: 75 pp, map (1909)

09e Characteristics of some ore deposits of southern Humboldt Co., Nev. (abst). Science n s $30: 972-973$ (1909)

10 Criteria of downward sulphide enrichment. Ec G 5:205-220 (1910) Can M Inst, Q B 10:85-99 (1910) ; J 13:393407 (1911)

10 aeology and ore deposits of the Goldfield district, Nev. Ec G 5:301-311, 438-470 (1910)

10b Geology at Globe, Ariz. M Sc Press $100: 256-257$ (1910)

10e (and Emmons, W. H., and Garrey, G. H.) Geology and ore deposits of the Bullfrog district, Nev. U S G S, B $407: 130 \mathrm{pp}$, map (1910)

I0d (with Sehaller, W. T.) Bismite. Am J Sc (4) $29: 173-176$ (1910)

11 Geology and ore deposits of the Breckenridge district. Colo. U S G S, P P $75: 187 \mathrm{pp}, \operatorname{map}(1911)$ Abst, Wash Ac Sc, J 1: 89-90 (1911)

11a Samuel Franklin Emmons. Science n $s$ 33:601-604 (1911) Reprinted by Geol Soc Washington in Memorial of Samuel Franklin Emmons: 1-6, port, 1911

$11 b$ Surface indications of ore shoots. M Sc Press 102:697-699 (1911)

11e Geology of the Globe district, Ariz. M Sc Press 102: 747-748 (1911)

$11 d$ Note on some albitite dikes in Nevada. Wash Ac Sc, J 1:114-118 (1911)

11e The literature of ore deposits in 1910. Ec G 6:325-339 (1911)

12 Genesis of the lead-silver ores of Wardner district, Idaho. M Sc Press 105 : 143-144 (1912)

12a The plane table in detalled geologic mapping. Ec G $7: 113-119$ (1912)

13 Notes on the Bisbee district, the Globe and Miami districts, Ray, and Jerome, Ariz, U S G S, B 529:17 -187 , 192-193 (1913)
Fansome, Frederick Leslie-Continued, $13 a$ The Turquoise copper-mining trict, Ariz. U S G S, B 530: 125-134, (1913)

13b [Protore, term for unenriched of ritic material]. Ec G 8: 721 (1913)

14 Copper deposits near Superior, Arit U S G S, B 540: 139-158 (1914)

14a Wurtzite at Goldfleld, Nev. Wab Ac Se, J 4:482-485 (1914)

15 The Tertiary orogeny of the Nort American Cordillera and its problems. In Problems of American geology : 287-378, maps, New Haven 1915

15a Quicksilver deposits of the Mazaizal Range, Ariz. U S G S, B 620:111-18 (1915)

15b The Paleozolc section of the Ray quadrangle, Ariz. Wash Ac Sc, J 5:38\% 388 (1915)

16 Some Paleozoic sections in Arizon and their correlation. U S G S, P P 95: 133-166, maps (1916) Abst, Wash Ac \& J $6: 681-682$ (1916)

See also Bonillas, 16; Campbell (M R) 15 ; Diller, 15 ; Emmons (S F), 03c, d, e Gautier, 06; Graton, 15 ; Lee (W T), 15 Riekard, 03; Weed, 03g

Rath, Charles M.

05 (with Bailey, E. W., and Grider. R. L.) A garnetiferous bed in Golden Gate Canyon, Jefferson Co., Colo. Colo Sch Mines, B 2 no $4: 80-86$ (1905)

Rath, Gerhard vom (1830-1888).

53 Nuttalit von Bolton in Massacho setts; Wernerit von Gouverneur [in Nem York [. An Physik (3) 30 [90]:93-100 (1853)

53a Gelber Skapolith von Bolton in Mas. sachusetts. An Physik (3) 30 [90]:297300 (1853)

60 Augit-Krystalle von Warwick, Orange Co.. im St. New York. An Pbysik (4) 21 [111] : 263-266 (1860)

68 Ueber eine neue Krystanform der Kleselsäure [tridymite, Pachuca, Mexico]. An Physik (5) [133]:507-508 (1868)

68 Ueber eine neue krystallisirte Modlflcation der Kieselsäure [tridymite from Pachuca Mexico]. K Preus Ak Wiss Berlin, Mber 1868:201-206 An Physik (5) 15 [135] : 437-454 (1868)

71 Über die chemische Zusammensetzung des Feldspaths von Bolton, Mass. Nieder rhein Ges Bonn, Szb 28:16 (1871)

72 Feldspath von Bolton in Massachr. setts. An Physik (5) 24 [144]:376-377 (1872)

74 Ueber die Krystallisation und $\mathrm{Z}_{\text {wil- }}$ lingsbildungen des Tridymits. K Preus Ak Wiss Berlin, Mber 1874:165-178 do Physik 152:1-17 (1874)

747. Ein ausgezeichneter Kalkspathkrystall vom Oberen See in Nordamerika. An Physik 152: 17-21 (1874) 
Rath, Gerhard vom-Continued.

75 Beiträge zur Petrographie: Der Andesit von Toluca in Mexico ; Der Obsidianäbnliche Andesit von Conejos am Rlo Grande del Norte, Colorado. Deut G Ges, Zs $27 ; 325-328$ (1875)

75a Die Meteoriten des naturhistorischen Museums der Universität Bonn. Naturh Ver Preus Rheinl, Verh $32: 353-376$ (1875)

76 Arkansit umgewandelt in Rutil aus Arkansas. An Physik (6) 8 [158]: 407412 (1876)

76a Brookit-(Arkansit-)Krystalle von Magnet Cove, Ark. Niederrhein Ges Bonn, Szb 33: 38 (1876)

76b Krystalle des Amazonsteins entdekt im Jahre 1875 unfern des Pike's Peak in Colorado. Niederrhein Ges Bonn, Szb 33 : 102-103 (1876)

77 Mineralogische Beiträge: Paramorphosen von Rutil nach Brookit (Arkansit); Ueber Achtlingskrystalle des Rutils von Magnet Cove, Ark. Naturh Ver Preus Rheinl, Verh 34:178-186 (1877)

7a Kalkspath-Krystalle von Bergenhill, N. J. Neiderrhein Ges Bonn, Szb 34:219226 (1877)

77b Rutil in Formen des Eisenglanzes aus dem Binnenthal und über Achtlinge des Rutils aus Arkansas. Zs Kryst 1:1317 (1877)

77e Der Kalspath von Bergen Hill, N. J. Zs Kryst 1: 604-614 (1877)

78 Einige krystallographische Beobachtungen am Kupfer rom Obern See. Zs Kryst 2 : 169-173 (1878)

so [Rutile from Graves Mountain. Ga., and meteorite from Estherville, Emmet Co., Iowa.] Niederrhein Ges Bonn, Szb 37 : 239-241 (1880)

81 [Kyanite from Lincoln Co., Ga.] Zs Krystal 5: 23 (1881)

84 Elnige Wahrnehmungen längs der Nord-Pacific-Bahn zwischen Helena, der Hauptstadt Montanas, und den Dalles (Oregon) am Ostabhange des KaskadenGebirges. Deut G Ges, Zs $36: 629-641$ (1884)

84a Geologisches aus Utah. N Jb 1884, I : $259-268$

84b Mineralogische Notizen (Quarze aus Alexander Co., N. C.; Stephanit aus Mexico; Colemanit aus Californien). Naturh Ver Preus Rheinl, Verh 41: 290-342 (1884)

84c Ueber die Fahrten und Fussstapfen Im Hofe des Staatsgefängnisses von Nevada. Niederrhein Ges Bonn, Szb 41:2230 (1884)

84d [Observations in Nevada.] Niederrhein Ges Bonn, Szb 41 : 61-79 (1884)

84 e [Observations in Mexico.] Niederrhein Ges Bonn, Szb 41 : 100-126 (1884)

84f lObservations on Iron Mountain, Mo.] Niederrhein Ges Bonn, Szb 41:126134 (1884)
Rath, Gerhard vom-Continued.

$\mathbf{8 4 m}$ Ueber das Kaskaden-Gebirge und den Durchbruch des Columbia. Niederrhein Ges Bonn, Szb 41: 206-224 (1884) ; 42:34-56. 321 (1885)

85 Arizona: Studien und Wahrnehmungen. Sammlg $\nabla$ Vorträgen XIV : 239-350, Heidelberg 1885. Separate : 112 pp ; $2 d$ ed, Heidelberg 1888

s5a Ueber Colemanit [Dry Lake, southern Cal.]. N Jb 1885, I : 77-78

85b Ueber das Gangrevier von Butte, Mont. N Jb 1885, I : 158-168

s5e Geographisch-geologische Blicke auf die pacifischen Länder Nordamerica's. Ges Erdk Berlin, Verh 12: 402-418 (1885)

85d Quarze aus Nord-Carolina. Zs Kryst $10: 156-173(1885)$

S5e Quarze aus Burke County, NordCarolina. Zs Kryst 10:475-487 (1885)

85f Mineralien aus den Vereinigten Staaten [mica from Conn., quartz from N. C., aragonite from Colo.] Niederrhein Ges Bonn, Szb 42 : 56-62 (1885)

85g Quarz-krystalle aus Nord-Carolina. Niederrhein Ges Bonn, Szb 42:235-246 (1885)

85h Ueber einige vulkanische Punkte in den Counties Napa und Lake, Cal. Niederrhein Ges Bonn, Szb 42 : 246-258 (1885)

s5i Ueber einen Quarzkrystall von Nord-Carolina. Niederrhein Ges Bonn, Szb 42 ; $301-302$ (1885)

85j Ueber die Umgebungen von San Francisco, Santa Cruz, und New Almaden [Cal.]. Niederrhein Ges Bonn, Szb 42 : 303-321 (1885)

s5k Wahrnehmungen auf einer Reise durch das sildliche Californien. Niederrhein Ges Bonn, Szb 42:344-370 (1885)

851 Wahrnehmungen in der Umgebung von Silver Cliff, Salida, Leadville, und Gunnison, Colo. Naturh Ver Preus Rheinl, Verh 42: Cbl 92-134 (1885)

$85 m$ (with Bodewig, C.) Colemanit aus Californien. Zs Kryst 10:179-186 (1885)

85n (with Genth, F. A.) On the vanadates and iodyrite from Lake Valley, Sierra Co., N. Mex. Am Ph Soc, Pr $22: 363-375$ (1885)

S5o (with Genth, F. A.) Ueber Vanadate und Jodsilber von Lake Valley, Donna Anna Co., N. Mex. Zs Kryst 10:458-474 (1885)

s6 Geologische Wahrnehmungen in Californien längs der Central Pacific Rallroad und in dem Goldgebiet von Dutch Flat, Placer Co. Niederrhein Ges Bonn, Szb 43: 21-34 (1886)

86a [Mineralien aus den Vereinigten Staaten.] Niederrhein Ges Bonn, Szb 43 : 34-36 (1886)

86b [Beryl from Alexander Co., N. C.] Niederrbein Ges Bonn, Szb 43:66-68, 254 (1886) 
Rath, Gerhard vom-Continued.

86e Mineralien aus Alexander Co., N. C. Niederrhein Ges Bonn, Szb 43:149-160 (1886)

86 Mineralien und Gesteine vom National Park, Wyo. Niederrhein Ges Bonn, Szb $43: 193-211$ (1886)

s6e Mineralien aus den Counties Jefferson und St. Lawrence, N. Y. Niederrhein Ges Bonn, Szb 43: 222-225 (1886)

s6f Erze und Bergbau in Chihuahua und Zacatecas [Mexico]. Niederrhein Ges Bonn, Szb 43: 225-253 (1886)

S6œ Ueber Wahrnehmungen auf der Reise von Zacatecas nach Mexico. Naturh Ver Preus Rheinl, Verh 43 : Cbl 89-130 (1886)

86h Mineralogische* Notizen [quartz from North Carolina]. Ver Naturk Cassel, Festschrift : 98-105 (1886)

s6i Extracts from the notes on the Bement collection of minerals by Prof. Gerhard vom Rath, transl. from the Naturh Ver Preus Rheinl, Verh 41: 295-304 (1884) by Geo. F. Kunz. Reprinted from the Jeweler's Circular, vol. 16, no. 12, Jan. 1886. $11 \mathrm{pp}, \mathrm{N}$ Y 1886

87 Einige neue und seltene Flächen an Quarzen... [North Carolina]. Zs Kryst $12: 453-459$ (1887)

87a Ueber Cristobalit vom Cerro $\mathbf{S}$. Cristóbal bei Pachuca, Mexico. N Jb 1887, I : $198-199$

87b Ueber das Territorium Utah. Niederrhein Ges Bonn, Szb 44:168-213 (1887)

s7e Hanksit aus S. Bernardino Co., Cal. Niederrhein Ges Bonn, Szb 44:233 (1887)

88 Pennsylvanien... $155 \mathrm{pp}$, Heidelberg 1888

88 a Einige Gesteine von Lake View und von Virginia City [Nev.]. Niederrhein Ges Bonn. Szb 45: 14-19 (1888)

Rathbun, J. C.

06 Marble in the Northwest. M World 24: 441 (1906)

Rathbun, Mary J.

os Descriptions of fossil crabs from California. U S Nat Mus, Pr $35: 341-349$ (1908)

16 Description of a new genus and species of fossil crab from Port Townsend, Wash. Am J Sc (4) 41:344-346, il (1916)

17 New species of South Dakota Cretaceous crabs. U S Nat Mus, Pr 52:385391 , il (1917)

17a Description of a new species of crab from the California Pliocene. I S Nat Mus, Pr 53:451-452, il (1917)

18 Decapod crustaceans from the Panama region. U S Nat Mus, B 103: 123-184, 11 (1918)

Rau, Albert G.

97 Glacial striae [Northampton Co., Pa.]. Science n s $6: 668$ (1897)
Itnuf, Hermann.

93 Palaeospongiologie. Palaeontograph. ica $40: 1-346$, il (1893); 41:223-272, I] (1895)

95 Ueber Porooystis pruniformis Cragin $(=$ ? Araucarites wardi Hill) aus dea unteren Kreide in Texas. $\mathrm{N}$ Jb 1895, I: $1-15$, il

Ravene1, Edmund.

41 Description of two species of fossil Scutella from South Carolina. Ac N Sc Phila, Pr 1:81-82 (1841)

42 Description of two new species of fossil Scutella from South Carolina. Ac N Se Phila, J $8: 333-336$, il (1842)

44 Description of some new species of fossil organic remains, from the Eocene of South Carolina. Ac N Sc Phila, Pr 2:9698 (1844)

50 ... catalogue of the recent and fossil echinoderms of Carolina. Am As, Pr 3: 159-161 (1850)

59 Description of three new species of univalves, recent and fossil. Elilott Soc S H. Charleston, Pr 1 : 280-282 (1859)

Raviez, Louis G.

15 Experiments in the enrichment of silver ores. Ec G 10:368-389 (1915)

Ravn, J. P. J.

03 The Tertiary fauna at Kap Dalton in East Greenland. Copenhagen Univ, Min G Mus, Comm Pal, no 4 (1903) Med Grö̀. land $29: 93-140$, il (1904)

11 Beretning om en geologisk Undersögelsesrejse til Disko og Nugssuak-Halvö ! Vest Grönland. Med Grönland 47:147-172 (1911)

$11 a$ On Jurassic and Cretaceous fossils from northeast Greenland. Med Grönland 45:433-500, 11. map (1912) Copenhagen, Univ, Min G Mus, Comm Pal no 10 (1911)

18 De marine Kridtaflejeringer i Vest. Groenland og deres Fauna [Cretaceous, western Greenland]. Med Grönland 56: $309-366$, il (1918)

\section{Ray, Frank A.}

14 The Ohio coal supply and its exhans. tion. Ohio St Univ, B 18 no $32: 46$ pp, maps (1914)

Ray, James C.

14 Paragenesis of the ore minerals in the Butte district, Mont. Ec G 9:463481 (1914)

14a The reflecting microscope in mining geology and metallurgy. M Sc Press 108: 922-926 (1914)

15 The copper beds of the Coeut d'Alene [Idaho]. M Sc Press 110:299301, map (1915)

15a Examples of successive replacement of earlier sulphide minerals by later sulphides at Butte, Mont. (abst). G. 800 Am, B 26:402-403 (1915) 
Ray, James C.-Continued.

16 The origin and occurrence of certain crystallographic intergrowths (discussion of paper by Julius Segall). Ec G 11 : 179-185 (1916)

See also Thompson (A P), 15

Raymond, Percy Edward.

02 The Crown Point section [Essex Co., N. Y.]. B Am Pal no 14:44 pp, il (1902)

03 The faunas of the Trenton at the type section and at Newport, N. Y. B Am Pal no $17: 18$ pp (1903)

04 The Tropidoleptus fauna at Canadaigua Lake, N. Y., with the ontogeny of twenty species. Carnegie Mus, An 3 : $79-177$, il (1904)

04a The developmental changes in some common Devonian brachlopods. Am J Sc (4) $17: 279-300$, il (1904)

05 The trilobites of the Chazy limestone. Carnegie Mus, An $3: 328-386$, 11 (1905)

05a Note on the names Amphion, Harpina, and Platymetopus. Am J Sc (4) $19: 377-378$ (1905)

05b The fauna of the Chazy limestone (abst). Am J Sc (4) 20:353-382 (1905)

06 The Chazy formation and its fauna. Carnegie Mus, An 3:498-598, il (1906)

06a An Ordovician gastropod retaining color markings. Nautilus 19:101-102 (1906)

06b (with Narraway, J. E.) A new American Cybele. Carnegie Mus, An 3 : 599-604 (1906)

07 on the occurrence, in the Rocky Mountalns, of an upper Devonic fauna with Clymenia [near Three Forks, Mont.]. Am J Sc (4) $23: 116-122$ (1907)

07 a on the discovery of reptilian remains in the Pennsylvanian near Pittsburgh, Pa. Science n s 26:835-836 (1907)

08 The Gastropoda of the Chazy formation. Carnegie Mus, An 4:168-225, il (1908)

08a On the discovery of vertebrate fossils in the Pennsylvanian, near Pittsburg, Pa. $(a b s t)$. Science n s 27:727 (1908)

08b (and Narravay, J. E.) Notes on Ordovician trilobites: Illænidæ from the Black River limestone near Ottawa, Canada. Carnegie Mus, An 4:242-255, il (1908)

09 The fauna of the upper Devonian in Montana; Part I, The fossils of the red shales. Carnegie Mus, An 5:141-158, il (1909)

09a Some sections of the Conemaugh series between Pittsburgh and Latrobe, Pa. Carnegie Mus, An 5: 166-177 (1909)

09b Notice of two new horizons for marine fossils in western Pennsylvania. Science n s 29:940-941 (1909)

10 Notes on Ordovician trilobites; II, Asaphidæ from the Beekmantown. Carnegie Mus, An $7: 35-45$, il $(1910)$
Raymond, Percy Edward-Continued.

10a (and Narraway, J. E.) Notes on Ordovician trilobites; III, Asaphidæ from the Lowville and Black River. Carnegie Mus, An $7: 46-59$, il (1910)

$10 b$ Notes on Ordovician trilobites; IV. New and old species from the Chazy. Carnegie Mus, An $7: 60-80$, il (1910)

10e A preliminary list of the fauna of the Allegheny and Conemaugh series in western Pennsylvania. Carnegie Mus, An $7: 144-158$, il (1910)

$10 d$ Note on the age of the Tribes Hill formation. Am J Sc (4) $30: 344-346$ (1910)

10e On two new trilobites [Bathyurus superbus and Isotelus arenicola $]$ from the Chazy near Ottawa, Ont. Ottawa Nat 24: 129-134, il (1910)

10P Trilobites of the Chazy formation in Vermont. Vt, St G, Rp $7: 213-248$, il (1910)

11 The Brachiopoda and Ostracoda of the Chazy. Carnegie Mus, An 7:215-259, il (1911)

11 a Preliminary notes on the "Chazy" formation in the vicinity of Ottawa, Ont. Ottawa Nat 24:189-197 (1911)

116 A preliminary list of the fauna of the Allegheny and Conemaugh series in western Pennsylvania. $\mathrm{Pa}$ Top $\mathrm{G}$ S Comm, Rp 1908-10:81-98, il (1911)

11e [Report on] invertebrate paleontology. Can G S, Sum Rp 1910:274 (1911)

11 Chazy formation in the Ottawa valley (abst). G Soc Am, B 22:719-720 (1911)

11e Sketch of the local geology, City of Pittsburgh [Pa.] (abst). G Soc Am, B 22: 721 (1911)

12 The Clymenia fauna in the American Devonian. Int Zool Cong, VII, Boston, 1907, Pr: 741-744 (1912)

12n Notes on parallelism among the Asaphidæ: R Soc Can, Pr Tr (3) 5 iv: 111120 , il (1912)

$12 b$ On two new Paleozoic starfish (one of them found near Ottawa), and a new crinoid [Palaaster? wilsoni, Ordovician near Ottawa, Ont., Mariacrinus? insuetus, Devonian, Three Forks shale, Logan, Mont., and Schanaster montanus, Madison limestone at Spring Canon, near Alder, Mont.]. Ottawa Nat $26: 77-81$, il (1912)

12e on the nature of the so-called " covering plates" in Protopalœaster narrawayi. Ottawa Nat 26:105-108, il (1912)

12d [Report of the] Paleontological division; invertebrate. Can $\mathrm{G} S$, Sum Rp 1911: 351-35T (1912)

13 Some changes in the names of genera of trilobites. Ottawa Nat 26:137-142 (1913)

13a A further note on Cryptolithus versus Trinucleus. Ottawa Nat $27: 26-30$ (1913) 
Raymond, Percy Edward-Continued.

13b Excursion in eastern Quebec and the maritime provinces; Quebec and vicinity. Int G Cong, XII, Canada, Guide Book no 1 : 25-48, map (1913)

13e Ordovician of Montreal and Ottawa. Int $G$ Cong, XII, Canada, Guide Book no $3: 137-160$ (1913)

$13 \AA$ Notes on Cyclocystoides. Can G S, Vietoria Mem Mus, B 1:23-32, Il (1913)

13e Notes on some new and old trilo. bites in the Victoria Memorial Museum: Canada Geol. Survey, Victoria Mem Mus, B $1: 33-39$, il (1913)

13P Description of some new Asaphidæ. Can G S, Victoria Mem Mus, B 1:41-48, Il (1913)

13\% Two new species of Tetradium. Canada G S, Victoria Mem Mus, B 1:4950. il (1913)

13h A revision of the species which have been referred to the genus Bathyurus. Can G S, Victoria Mem Mus, B 1: 51-69, il (1913)

$13 i$ (and Barton, D. C.) A revision of the American species of Ceraurus. Harvard Coll, Mus C Z, B 54:525-543, il (1913)

13j Correlation of the middle Ordovician formations of Ontario and Quebec (abst). G Soc Am, B 24: 111 (1913)

13k Report on invertebrate paleontology. Harvard Coll, Mus C Z, An Rp $1912-3: 38-40 \quad$ (1913) ...1913-4:40-41 (1914) ...1914-5:35-36 (1915) ...1915-6 : 30-31 (1916) ‥1916-7:29-30 (1917) ...1917-8: $25-26$ (1918)

14 Notes on the ontogeny of Paradoxides, with the description of a new species from Braintree, Mass. Harvard Coll, Mus C Z, B $58: 225-244$, il (1914)

$14 a$ Notes on the ontogeny of Isotelus gigas Dekay. Harvard Coll, Mus C Z, B $58: 247-263$, 11 (1914)

14b A Beatricea-like organism from the middle Ordovician. Can G S, Mus B 5: $10 \mathrm{pp}$, il (1914)

14e The Trenton group in Ontario and Quebec. Can G S, Sum Rp 1912: 342-350 (1914)

14d The succession of faunas at Levis, Quebec. Can G S, Sum Rp 1913: 219-222 (1914)

14e The succession of faunas at Lévis, P. Q. Am J Sc (4) 38:523-530 (1914)

15 Revision of the Canadian species of "Agelacrinites," Ottawa Nat 29:53-62, 11. (1915)

16 Expedition to the Baltic provinces of Russia and Scandinavia; Part I, The correlation of the Ordovician strata of the Baltic basin with those of eastern North America. Harvard Coll, Mus C Z, B 56 (g s 10) : 179-286 (1916)
Raymond, Percy Edward-Continuel $16 a$ New and old Silurian trilobites tra southeastern Wisconsin, with notes on th genera of Illaenidae. Harvard Coll, th C Z, B $60: 3-41$, il (1916)

16b The Pelecypoda of the Chazy fur tion. Carnegie Mus, An 10:325-343 (18t)

16e A new Ceraurus from the Chaz.

Y St Mus, B 189:121-126, il (1916)

$\mathbf{1 6 d}$ The genera of the Odontopleuribe Ottawa Nat 29:135-139 (1916)

17 Beecher's classification of trilotith after twenty years. Am J Sc (4) 43:1\% 210, il (1917)

See also Eastman, 00

Raymond, Rossiter Worthington (1841918).

69 Mineral resources of the States at Territories west of the Rocky Mountiss [U S, Treas Dp] : $256 \mathrm{pp}$, Washington 19/

70 Statistics of mines and mining in the States and Territories west of the Rodj Mountains [2d report]. [U S, Treas Dp]: $805 \mathrm{pp}$, Washington $1870 \quad \ldots\left[3 \mathrm{~d}^{\mathrm{d}}\right.$ report]: 566 pp (1872) ...4th An Rp:566 \% (1873) ...5th An Rp: 550 pp (1873) .6t An Rp: 585 pp (1874) ...7th An Rp:5th pp (1875) ...8th An Rp : 519 pp (1877)

70a Mineral deposits. In his Statistis of mines and mining in the States and Trritories west of the Rocky Mountains [2] report]. [U S, Treas Dep] : 445-468, Was ington 1870

73 The geographical distribution of mit ing districts in the United States. Am I Eng, Tr 1: 33-39 (1873)

73a General geological map of the United States [by Hitchcock, C. H., and Blake, W. P.]. In his Statistics of mines and mit ing... 5th An Rp: 480-484, Washingtos 1873

74 Remarks on the occurrence of anthra cite in New Mexico, Am I M Eng, Tr 2: 140-142 (1874)

76 The spathic iron ores of the Hudson River. Am I M Eng, Tr 4: 339-343 (1876)

79 The Eureka-Richmond case [genesis o! Ruby Hill deposit, Eureka district, Ner.]. Am I M Eng, Tr 6: 371-393 (1879)

79a The Jenks corundum mine, Macot Co., N. C. $A m$ I M Eng, $\operatorname{Tr} 7: 83-90$ (1879)

79b Note on the zinc deposits of south. ern Missouri. Am I M Eng, Tr $8: 165-167$ (1880) Eng M J 28:240-241 (1879)

s2 Hoefer's method of determining faults in mineral veins. Am I M Eng, Tr 10:456-465 (1882) Eng M J 34:56-58 (1882)

83 The natural coke of Chesterfield $\mathrm{CO}$, Va. Am I M Eng, Tr 11: 446-448 (1883) The Virginias 4:145-146 (1883)

83a The divining rod. U S G S, Min Res [1882] : 610-626 (1883)

85 The classiflcation of ore deposits. Eng M J 39:437-438 (1885) 
Raymond, Rossiter Worthington-Contd. s5a The geology of the Comstock lode. Eng If J 40:397-398 (1885)

ss The origin of the Leadville deposits. Eng M J $45: 249-250,339$ (1888)

s9 Note on a specimen of gilsonite from Uintah Co., Utah. Am I M Eng, Tr 17: 113-115 (1889)

94 A new classification of economic geological deposits, Eng M J 58:412-413 (1894)

95 The superficial alteration of ore deposits, Eng M J $59: 338$ (1895) [See Penrose, 94]

01 Recent contributions to the science of ore deposits, Mineral Industry 9 : 753-762 (1901)

03 Biographical notice of Clarence King. Am I M Eng, Tr 33:619-650 (1903)

05 What is a fissure vein? Ec G 1: 169-172 (1905)

07 Geology of Jamaica as related to its bistory. M Sc Press 95:145-146 (1907) 08 Dip and piteh. Am I M Eng, B 20:195-196 22:609-614 (1908); Tr 39 : 326-327, 898-916 (1909) M World 28 : 373 (1908)

09 Biographical notice of James Duncan Hague. Am I M Eng, B 26:109-117, port (1909)

09a (and others) Dip and pitch [with reference to ore bodies]. Am I M Eng, B $26: 197-209$ (1909)

10 Biographical notice of William Phipps Blake. Am I M Eng, B 45: 749-762, port (1910) : $\operatorname{Tr} 41: 851-864$, port (1911)

11 Memoir of William Phipps Blake, 1826-1910. G Soc Am, B $22: 36-47$, port (1911)

See also Becker, $95 \mathrm{a}$; Hunt, $74 \mathrm{~h}$; Mezger, 96; Nitze, 96b; Pošepný, 94, 95.

Raymond, William James.

02 Dr. James G. Cooper. Nautilus 16 : 73-75, port (1902)

03 Writings of James G. Cooper, M, D., on conchology and paleontology, Nautllus $17: 6-12$ (1903)

04 A new species of Pleurotoma from the Pliocene of California. Nautilus 18: 14-16 (1904)

Read, Matthew Canfleld (1825-?).

71 Sketches of the geology of Geauga and Holmes cos. Ohio G S, Rp Prog 1870 : 463-484 (1871)

73 Reports on the geology of Ashtabula, Trumbull, Lake, and Geauga cos. Ohio G $\mathrm{S}, \mathrm{Rp} 1$ pt 1 Geology : 481-533, map (1873)

78 Report on the geology of Huron Co. : Richland Co.; Knox Co. ; Licking Co. Ohio G S, Rp 3 pt 1: 289-361, map (1878)

78 a Report on the geology of Ashland Co.; Wayne Co.; Holmes Co. Ohío G S, Rp 3 pt 1:519-561, map (1878)
Read, Matthew Canfield-Continued.

7sb Report on the geology of the Hocking Valley coal field. Ohio $\mathrm{G} S \mathrm{~S}, \mathrm{kp} 3 \mathrm{pt}$ 1: $647-715$ (1878)

83 Berea grit. U S G S, Min Res [1882] : 478-479 (1883)

Read, Thomas Thornton.

o3 Nodular-bearing schists near Pearl, Colo. J G 11: 493-497 (1903)

03a Preliminary note upon the rare metals in the ore from the Rambler mine, Wyo. Am J Se (4) $16: 268$ (1903)

04 The alkali deposits of Wyoming. Am G 34: 164-169 (1904)

04a Copper mining in the Encampment, Wyo., and Pearl, Colo., districts. M Rep $50: 462-463$ (1904)

o5 The phase rule and conceptions of igneous magmas-their bearing on ore deposition. Ee G 1: 101-108 (1905)

06 The secondary enrichment of copperiron sulphides. Am I M Eng, B 8: 261-267 (1906), B $13: 145$ (1907); Tr $37: 297-$ 303 (1907)

06a (and Knight, C. W.) The reformation of soda-leucite. Am J Sc (4) $21: 294-295$ (1909)

o6b Gold mining in the southern Appalachians (abst). Science $n$ s $23: 389$ (1906) N Y Ac Sc, An 17:625 (1907)

o7 Oxidation of pyrite. Ec G 2:505 (1907)

os The San Juan region, Colo. M Sc Press 97:632-635, 668-672 (1908)

12 The Nevada-Douglas mines [Lyon Co., Nev.]. M Sc Press 105:206-207 (1912)

13 The sulphide ores of copper; some results of microscopic study (discussion). Am I M Eng, B $82: 2609-2610$ (1913)

15 Copper mining in Michigan. Min Mag $12: 220-224$ (1915)

See also Day (A L), 06b; Graton, 15

Reade Thomas Mellard (1832-1909).

85 Denudation of the two Americas. Liverpool G Soc, Pr 5:8-41 (1885) Am J Sc (3) 29:290-300 (1885) Reprinted in his The evolution of earth structure: 255-282, L 1903

86 The North Atlantic as a geological basin. Liverpool G Soc, Pr 5:114-130 (1886) Reprinted in his The evolution of earth structure: 283-295, L 1903

89 Physical theories of the earth in relation to mountain formation. Am G 3 : 106-111 (1889)

90 Origin of normal faults. Am J Se (3) $39: 51-52(1890)$

91 ... origin of mountain ranges... Am G $8: 275-287$ (1891)

$91 n$ The cause of active compressive stress in rocks and recent rock flexures. Am J Sc (3) 41:409-414 (1891) 
Reade, Thomas Mellard Continued.

92 Physics of mountain building; some fundamental conceptions. Am G 9:238243 (1892)

94 Continental growth and geological periods. Nat Sc $4: 290-298, \quad 337-343$ (1894)

03 The evolution of earth structure... xv, 342 pp, L 1903

Reagan, Albert B.

03 Geology of the Jemez-Albuquerque region, N. Mex. Am G 31:67-111, map (1903) Abst, Ind $\mathrm{Ac} \mathrm{Sc}, \operatorname{Pr} 1902: 187-$ 197, map (1903)

03a Age of the lavas of the plateau region. Am G $32: 170-177$ (1903)

03b Geology of the Fort Apache region in Arizona. Am G $32: 265-308$, map (1903)

o3e The Jemez coal fields [N. Mex.]. Ind Ac Sc, Pr 1902: 197-198 (1903)

04 Geology of Monroe Co., Ind., north of the latitude of Bloomington. Ind $\mathrm{AC}$ Sc, Pr 1903: 205-233, map (1904)

04 . What is the age of the Aubrey limestone of the Rocky Mountains? Ind Ac Sc, Pr 1903: 235 (1904)

04b Some fossils from the lower Aubrey and upper Red Wall limestones in the vicinity of Fort Apache, Ariz. Ind Ac Sc, Pr 1903: 237-246, il (1904)

04e The fossils of the Red Wall compared with those of the Kansas Coal Meas. ures. Ind Ac Sc, Pr 1903: 249-251 (1904) Centralbl Miner 1907:609-611

o5 Some geological observations in the central part of the Rosebud Indian Reservation, S. Dak. Am G 36:229-243, map (1905)

o7 Some geological studies of northwestern Washington and adjacent British territory. Kans Ac Sc, Tr 20 pt 2: 95121. maps (1907)

os A probable origin of the small mounds of the lower Mississippi and Texas coast. Ind Ac Sc, Pr 1907: 99-100 (1908)

08a Summary of glacial literature relating to glacial deposits. Kans Ac Sc, Tr 21: 86-110 (1908)

08b The blowing of soils. Science $n$ s 28: 653-654 (1908)

09 Some notes on the Olympic Peninsula, Wash. Kans Ac Sc, Tr 22:131-238, map (1909)

09 a A probable origin of the numerous depressions in the mesa south of the arroyo formed by the outlet of Tijeras Canyon in the Sandias near Albuquerque, N. Mex. Ind Ac Sc, Pr 1908:165 (1909)

10 Die Fossilien der Clallamformation mit denjenigen der Tertiärformationen in Vancouver-Insel und mit denjenigen der Astoria-Miocănformation in Oregon verglichen. Centralbl Miner 1910:646-651

11 Effect of ice in lake upon the shore line. Ind Ac Sc. Pr 1910: 119 (1911)
Reagrn, Albert B.-Continued.

11n Geology of the Olympic Penho Wash (abst). Science n s 33:464 118

$11 b$ Correlation notes [occurrence fossils described by Girty from the Ifor field shales of Arkansas in the loper : Wall of Arizona]. Science n 8 34:18 128 (1911)

11e Coal near Pinedale, Navajo 0 Ariz. Science n s 34:271-272 (1911)

11d Mineral resources of the 0 lyz Peninsula, Wash. M World $35: 4:-4$ (1911)

11e Mineral resources of Ft. Apache gion, Ariz. M World $35: 1274$ (1911)

12 Mineral resources of Jemez.l. querque region [N. Mex.]. M World, X 23 (1912)

14 The glacial epoch. Kans Ac Sc: $26: 70-83$ (1914)

15 The marine Tertiary stratigraph the north Pacific coast of North Ameri (review of an article by Ralph Arnold u Harold Hannibal). Kans Ac Sc, Tr? 47-49 (1915)

16 The Olympic coal fields of Wasbin ton. Ind $\mathrm{Ac} \mathrm{Sc}, \operatorname{Pr} 1915: 415-418$ (19:1

16a Some notes on the Olympic Peti: sula, Wash. Science n s 44:171-1i (1916)

16b The glacial period. The Sunspot no $11: 13-30$ (1916)

17 Geology of the Deep Creek regit Utah. Salt Lake M Rv 19 no $6: 25-$ (1917)

17a The Deep Creek Reservation and Indians [Utah]. The Red Man 9:21 236 (1917)

Reasoner, John P.

84 University Cave, Greencastle, $\mathrm{PU}$ nam Co. Ind, Dp G N H, An Rp 14 pt li: $73-75(1884)$

Reber, Louis E., jr.

16 The mineralization at Clifton-Horew [Ariz.]. Ec G 11:528-573 (1916)

Redfeld, John Howard (1815-1895)

37 Fossil fishes of Connecticut and Yor sachusetts, with a notice of an undescribs genus. Lyc N H N Y, An 4:35-40 (185i

Redfeld, William C. (1789-1857).

38 Some account of two visits to the mountains in Essex Co., N. Y., in the yeat 1836 and 1837 ; with a sketch of the north ern sources of the Hudson. Am J Sc 30 301-323 (1838)

41 Short notices of American fosil fishes. Am J Sc 41:24-28 (1841)

43 Notice of newly discovered fish bels and a fossil footmark in the red sandstont formation of New Jersey. Am J Sc 4 t 134-136 (1843)

43a ... new fishes and other fossil memo. rials from the new red sandstone of Ner Jersey (abst with discussion). Am J sc $45: 314-315$ (1843)

44 IOn drift phenomena in Portage $\mathrm{C}^{\mathrm{O}}$. Ohio (abst)]. Am J Sc 47:120-121 (184t) 
Redfield, William C.-Continued.

47 On the remains of marine shells of existing species found interspersed in deep portions of the hills of drift and boulders in the heights of Brooklyn, on Long Island, near New York City. Am J Agr C:213214 (1847) Am J Sc (2) 5:110-111 (1848)

49 [Geological action of the tides.] Am As, $\operatorname{Pr} 1: 28-30$ (1849)

50 On some fossil remains [Vulpes] from Broome Co., N. Y. Am As, Pr 2: 255-256 (1850)

51 On the post-Permian date of the red sandstone rocks of New Jersey and the Connecticut Valley, as shown by their fossil remains. Am As, $\operatorname{Pr} 5: 45-46$ (1851)

$51 \mathrm{a}$ On the fossil rain marks found in the red sandstone rocks of New Jersey and the Connecticut Valley, and their authentic character. Am As, Pr 5:72-75 (1851)

53 On the geological age and affinities of the fossil fishes which belong to the sandstone formations of Connecticut, New Jersey, and the coal field near Richmond in Virginia. An Sc, Cleveland, 1:270-271 (1853)

56 On the relations of the fossil fishes of the sandstone of Connecticut and other Atlantic States to the Liassic and Oolitic periods. Am J Sc (2) 22:357-363 (1856)

57 On the relations of the fossil fishes of the sandstone of Connecticut and other Atlantic States, to the Liassic and Jurassic periods, Am As, Pr 10 pt $2: 180-188$ (1857) Abst, Fdinb N Ph J n s 5:369370 (1857)

See also Desor, 52g: Guyot, 50 ; Hall, 43i, j; Eitcheock (E), 42; Jackson, 43c ;

Nicollet, $43 \mathrm{a}, \mathrm{b}$

Redway, Jacques Wardlaw.

94 ... the production of crystalline schists by dynamometamorphism. Science $23: 79$ (1894)

01 A great lava flood. Am Bur Geog, B 2:157-163 (1901)

07 Some notes on the San Francisco earthquake. Geog J 29:436-440 (1907)

07a The vagaries of the Colorado River. Scottish Geog Mag 23: 360-363 (1907)

Reed, E. A.

05 The semi-precious stones of the United States. M Sc Press $90: 355-356$ (1905)

Reed, F. R. Cowper.

99 A new trilobite from Mount Stephen, Field, B. C. [Oryctocephalus reynoldsi]. G Mag (4) $6: 358-361$, il (1899)

Reed, H. W.

11 Secondary enrichment of gold deposits [San Juan region, Colo.]. M Sc Press 102: 825 (1911)

Reed, Howard S.

00 A meteorological hypothesis of the cause of the glacial epoch. An G 25:109113 (1900)
Reed, Margaret.

10 (with Graban, A. W.) Mutations of Spirifer mucronatus (abst). Int Zool Cong, VII, Boston 1907, Pr: 767-768 (1912) [Advance print, 1910]

Reed, Stephen,

73 On trains of boulders and on the transport of boulders to a level above that of their source. Am J Sc (3) $5: 218-219$ (1873)

Reed, W. J.

09 (with Tafr, J. A.) The Madill ofl pool, Okla. U S G S, B 381:32-41 (1909)

Reed, W. T. L.

85 On surface geology of Fredericton (abst). N H Soc N B, B [1] no $4: 85-86$ (1885)

Reed. William Gardner, $j r$.

08 The form of Nantasket Beach (abst). Science n s 28:574-575 (1908)

10 (with Johnson, D. W.) The form of Nantasket Beach, Mass. J G 18:162189 (1910)

Reeds, Chester Albert.

07 (with Bowman, I.) Water resources of the East St. Lous district. Ill G S, B 5: 128 pp (1907)

08 (with Bowman, I.) Water resources of the East St. Louis district (abst). III G S, B 8: 30-40 (1908)

$10 \mathrm{~A}$ report on the geological and mineral resources of the Arbuckle Mountains, Oklahoma. Okla G S, B 3:69 pp, map (1910)

11 The Hunton formation of Oklahoma. Am .J Sc (4) $32: 256-268$ (1911)

14 Oolites of the Chimneyhill formation, Okla. (abst with discussion). G Soc Am, B $25: 75-76$ (1914)

14a Mounting of rock and fossil specimens with sulphur (abst). G Soc Am, B $25: 136$ (1914)

15 Graphic projection of Pleistocene climatic oscillations (abst). G Soc Am, B 26: 106-109 (1915) Science n s 41:510-512 (1915)

15a Geologic deposits in relation to Pleistocene man (abst). G Soc Am, B 26:109 (1915) Science n s 41:512 (1915)

16 Stages in the geologic bistory of Porto Rico (abst with discussion by E. T. Hodge), G Soc Am, B 27:83-84 (1916)

16a Porto Rican localities yielding vertebrate fossils (abst). N Y Ac Sc, An 26: $436-438$ (1916)

17 Collections of meteorites in the Amer ican Museum. Am Mus J $17: 28-31$ (1917)

17a Fossil faunas of Porto Rico (abst). N Y Ac Sc, An 27:280-281 (1917)

Reese, Charles L.

92 On the influence of swamp waters in the formation of the phosphate nodules of South Carolina. Am J Sc (3) $43: 402-406$ (1892)

98 Petroleum inclusion in quartz erys. tals. Am Ch Soc, J $20: 795-797$ (1898) 
Reeside, John Bernard, jr.

17 The Helderberg limestone of central Pennsylvania. U S G S, P P 108: 185-225 (1917)

\section{Reeves, Frank.}

17 The absence of water in certain sandstones of the Appalachian oil fields. Ec G $12: 354-378$ (1917)

17a Origin of the natural brines of oil fields. Johns Hopkins Univ Circ n s 1917 no $3: 57-68 \quad[255-266]$ (1917)

Reger, David Bright.

14 (with Hennen, R. V.) Logan and Mingo counties. IV Va G $\mathrm{S}: 776 \mathrm{pp}$, maps [1914]

14a (with Hennen, R、V.) Preston co. W Va G S, Co Rp : 566 pp, maps (1914)

16 Lewis and Gilmer counties. W Va G $\mathrm{S}: 660 \mathrm{pp}, \mathrm{maps}$ (1916)

16a The possibility of deep sand ofl and gas in the Appalachian geosyncline of West Virginia (with discussion). Am I M Eng, B $117: 1709-1724$ (1916) ; $\operatorname{Tr} 56: 856-875$ (1917)

18 (assisted by Teets, D. D. jr.) Barbour and Upshur counties and western portion of Randolph County. W V G S [Co, Reports], ciii, 867 pp, maps (1918)

See also Johnson (R. H), 15 ; Morganroth, 16

Reichenbach, Karl F. von.

57 Ueber die Meteoriten aus dem Tolucathale in Mexico. An Physik 102:621625 (1857)

Reid, Clement.

92 Great Lakes. Nat Sc 1:117-123 (1892)

Reid, George D.

02 The Burro Mountain copper district, N. Mex. Eng M J 74:778-779 (1902)

07 The Seven Devils and Snake River district [Idaho-Oregon]. Eng M 84:401402 (1907)

Reid, Harry Fielding.

92 Report of an expedition to the Muir Glacier, Alaska... U S Coast S, Rp 1891 pt 2 (U S, $52 d$ Cong 1 st sess, H Ex Doc 43 pt 2) : 487-501, map (1892)

92a Studies of Muir Glacier. Alaska. Nat Geog Mag 4:19-55, map (1892)

93 Glacier Bay, Alaska (abst). Am J Sc (3) 46:305-306 (1893)

95 The variations of glaciers. J G 3 : 278-288 (1895) Science n s $3: 867$ (1896) ... II, J G $5: 378-383$ (1897) ... III, J G 6: $473-476(1898) \quad \ldots$ IV, J G $7: 217-225$ (1899) $\quad \ldots$ V, J G $8: 154-159 \quad$ (1900) ... VI, J G $9: 250-254$ (1901) ... VII, J G 10 : 313-317 (1902); Arch Sc Phys Nat (4) 14: 301-302 (1902) ... VIII, J G 11:285288 (1903) ; Arch Sc Phys Nat (4) 16 : 92-94 (1903) ... IX, J G 12:252-263 (1904); Arch Sc Phys Nat (4) 18:191-193 (1904) … X, J G 13:313-318 (1905) ; Arch Sc Phys Nat (4) 20:185-187 (1905) ... XI, J G 14:402-410 (1906); Zs Gletscherk 1: 178-180 (1906) ... XII, J G 16:
Reid, Harry Fielding-Continued. 46-55 (1908); Zs Gletscherk 2:181-18 (1908) ... XIII, J G 16: 664-668 (1908); Zs Gletscherk 3:180-182 (1909) ... XII J G 17:667-671 (1909); Zs Gletscherk 4 $174-175$ (1910) ‥ XV, J G $19: 83-8$ (1911); Zs Gletscherk 5:197-202 (1911) ... XVI, J G 19:454-461 (1911); Zs Gkt scherk 6:100-103 (1911) ... XVII, J $21: 422-426$ (1913) ; Zs Gletscherk $7: 201$ 202 (1913) ... XVIII, J G 21:748(1913); Zs Gletscherk 8:57-60 (1918) ... XIX, J G $23: 548-553 \quad(1915) ; z_{s}$ Gletscherk $9: 56-59$ (1914) $\quad \ldots \quad$ XX, J 6 $24: 511-514$ (1916)

96 Glacier Bay and its glaciers [Alask]. U S G S, An Rp 16 pt 1:415-461, maps (1896)

96a The mechanics of glaciers. J G 912-928 (1896)

96b Notes on glaciers (abst). G so Am, B 7:508 (1896) Am G 17:10: (1896) Seience n s $3: 53-54$ (1896)

96e The flow of glaciers (abst). Johts Hopkins Univ Circ 15:90-91 (1896)

97 Mechanics of glaciers; moraines and stratification (abst). Science n s $5: 91-2$. (1897)

$97 \mathbf{a}$ The stratification of glaciers and the origin of some moraines (abst). Science n s $5: 318$ (1897)

99 Qualities of good road metals and the methods of testing them. Md $G 8$ $3: 315-330$ (1899)

99a Stratification of glaciers $(a b s t)$. G Soc Am, B 10:4-5 (1899) Am G 22:249 (1898) Science n s $8: 463$ (1898)

00 Movement of glaciers (abst). Science n s 11: 103 (1900)

OOa Stratification and banded structure of glaciers (abst). Science n s 11:103104 (1900)

01 De la progression des glaciers, leut stratification, et leurs veins bleues. Int G Cong, VIII, Paris 1900, C R : 749-705 (1901)

O1a Observations of earthquakes. Jobns Hopkins Univ Circ 20:75-76 (1901)

02 Notes on Mounts Hood and Adams and their glaciers $(a b s t)$. G Soc Am, B $13: 536$ (1903) Science n $\mathrm{s}$ 15:906 (1902)

03 Glaciers. Mazama 2 : 119-122 (1903)

04 The relation of the blue veins of glaciers to the stratification, with a note on the variations of glaciers. Int $\mathrm{G}$ Cong: IX, Vienna 1903, C R: 703-706 (1904)

o5 The reservoir lag in glacier varia. tions. Int Geog Cong, VIII, Rp: 487-491 (1905)

O5a Records of seismographs in North America and the Hawaiian Islands. Tert Magn $10: 81-96,177-189$ (1905)

o5b The flow of glaciers and their stratification. Appalachia 11:1-6 (1905) 
Reid, Harry Fielding-Continued.

05e The glaciers of Mt. Hood [Oreg.] and Mt. Adams [Wash.]. Mazama $2: 195$ 200 (1905)

06 Studies of the glaciers of Mount Hood and Mount Adams. Zs Gletscherk 1 : 113-132 (1906)

06a Records of seismographs in North America and the Hawaiian Islands. Terr Magn $11: 185-197$ (1906)

07 A proof of Kurowski's rule for determining the height of the nevé line on glaciers. Johns Hopkins Univ Cire n s 1907 no $7: 21-23$ [609-611] Zs Gletscherk $3: 142-144$ (1908)

07a on the internal and basal melting of the ice of glaciers. Johns Hopkins Univ Cire n s 1907 no $7: 24-26$ [612-614] Zs Gletscherk $3: 68-70$ (1908)

07b Rapport de la Commission internationale des glaciers. Int $\mathrm{G}$ Cong, $\mathrm{X}$, Mexico, 1906, C R : 164-170 (1907)

os Report of seismological committee of the International Seismological Association (abst). Seience n s 27:724 (1908)

0sa Mechanies of the Californian earthquake, 1906 (abst). Science n s 27:991992 (1908)

$09 \mathrm{Mr}$. Manson's theory of geological climates. Sclence n \& 29:27-29 (1909)

09a Geometry of faults. G Soc Am, B 20:171-196 (1909)

09b Seismological notes. $\mathrm{Am} \mathrm{Ph}$ Soc, Pr 48:303-312 (1909) Abst, Science n s $29: 833$ (1909)

09e Observations on glaciers. Can Alpine J $2: 92-96$ (1909)

10 The California earthquake of April 18, 1906. The mechanics of the earthquake. Vol. II of the Report of the [Callfornia] State Earthquake Investigation Commission (Carnegie Inst Wash, Pub no 87, vol 2) : 192 pp (1910)

10a On mass movements in tectonic earthquakes and the depth of the focus. Beitr Geoph $10: 318-351$ (1910)

$10 \mathrm{~b}$ Additional note on the geometry of faults. G Soc Am, B 21: $737-740$ (1910)

10e The mechanics of faults (abst). Science n s 32:191 (1910) G Soc Am, B 21:766 (1910)

11 The elastic-rebound theory of earthquakes. Cal Univ, Dp G, B 6:413-444 (1911)

11a Isostasy and mountain ranges. Am Ph Soc, Pr 50:444-451 (1911) Am Geog Soc, B 4.: 354-360 (1912) Abst, Science n \& $33: 907$ (1911)

11b Remarkable earthquakes in central New Mexico in 1906 and 1907 . Seism Soc Am, B 1:10-16 (1911)

11e The earthquake of southeastern Maine, March 21, 1904. Seism Soc Am, B $1: 44-47$ (1911)
Reid, Harry Fielding-Continued.

12 List of strong shocks in the United States and dependencies. Brit As, Rp 81: 41-45 (1912)

12a On the choice of a seismograph. Seism Soc Am, B 2:8-30 (1912)

$12 b$ On the nomenclature of faults (abst). Science n s 35:319 (1912) G Soc Am, B $23: 74$ (1912)

12e The formation of mountain ranges (abst). Coal Age 1: 703 (1912)

12d Note on mountain-producing forces (abst). G Soc Am, B 23: 71 (1912)

12e The transmission curve. Int As Seism, Manchester, 1911, C R : 265-267 (1912)

12f The energy of earthquakes. Int As Seism, Manchester, 1911, C R: 268-272 (1912)

$12 \mathrm{~g}$ Earth movements and earthquakes during the elevation of mountain ranges. Int As Seism, Manchester, 1911, C R : 273274 (1912)

13 Determination of the constants of a seismograph. Seism Soc Am, B $3: 24-33$ (1913)

13a (and others). Report of the committee [of the Geological Society of America] on the nomenclature of faults. G Soc Am, B 24:163-186 (1913) [Preliminary edition with the title Proposed nomenclature of faults, subject to revision, was printed May 1, 1912.]

14 The influence of earthquake disturbances on suspended magnets. Seism Soc Am, B 4:204-214 (1914)

$14 \mathrm{n}$ Earthquake sea waves (abst with discussion). G Soc Am, B 25:33-34 (1914)

15 Constitution of the interior of the earth as indicated by seismological investigations. $\mathrm{Am}$ Ph Soc, $\mathrm{Pr}$ 54:290-297 (1915) Smiths Inst, An Rp 1916:234239 (1917)

17 Note on the earthquakes at Almirante, Republic of Panama, in April, 1916. Seism Soc Am, B $7: 27-30$ (1917)

17a Geometric plans of the earth, with special reference to the planetesimal hypothesis (abst). G Soc Am, B 28:124 (1917)

18 Note on the velocity of long waves and the average depth of the ocean. Seism Soc Am, B 8:34-37 (1918)

18a The starting point of earthquake vibrations. Seism Soc Am, B 8:79-82 (1918)

See also Goldthwait, 13: Johnston (J), 13a; Russell, 92b; Tarr, 05e; Upham, 94b Reid, Harvey.

11 Geological strata in Jackson Co., Iowa. Iowa Nat $3: 13-19$ (1911)

Reid, Hiram A.

81 Geological chart. Kansas City RV Se 5:138 1881) 
Reid, John A.

02 The igneous rocks near Pajaro. Cal Univ, Dp G, B 3: 173-190 (1902)

04 Preliminary report on the building stones of Nevada, including a brief chapter on road metal. Nev Univ, Dp G M, B 1 no $1: 58$ pp (1904)

05 The structure and genesis of the Comstock Lode. Cal Univ, Dp G, B 4: 177-199 (1905)

06 A detail of the great fault zone of the Sierara Nevada (abst). G Soc Am, B $16: 593$ (1906)

$06 \mathbf{a}$ Sketch of the geology and ore deposits of the Cherry Creek district, Ariz. Ee G 1: 417-436 (1906)

07 How should faults be named and classified? Ec G 2:298-308 (1907)

07a The ore deposits of Copperopolis, Calaveras Co., Cal. Ec G $2: 380-417$ (1907)

O7b The training of economic geologists and the teaching of economic geology. Ec G $2: 418-427$ (1907)

o7e Secondary changes at Cherry Creek, Ariz. M Sc Press 94:31-33 (1907)

ord The country east of the Mother Lode [in Placer Co., Cal.]. M Sc Press 94: 279-280 (1907)

07e The meaning of striations. M Sc Press $94: 783$ (1907)

orf Some ore deposits in the Inyo Range, Cal. M Sc Press 95: 80-82 (1907)

os A note on the geology of the Coso Range, Inyo Co., Cal. J G $16: 64-72$ (1908)

oSa The ore deposits of Copperopolis, Cal. Ec G 3:340-342 (1908)

08b The copper belt of California. Eng M J $85: 420$ (1908)

ose Foothill copper belt of the Sierra Nevada. M Sc Press $96: 388-393 ; 97: 48-$ 49 (1908)

osd A Tertiary river channel near Carson City, Nev. M Sc Press $96: 522-525$ (1908)

11 The geomorphogeny of the Sierra Nevada northeast of Lake Tahoe [Nev.]. Cal Univ, Dp G, B 6:89-161, map (1911)

18 silver deposition and enrichment at Cobalt, Ont. (discussion). Ec G 13:385892 (1918)

Reid, John T.

17 Earthquake crevices in Nevada. Eng M J, 104:465 (1917)

Reid, S.

45 A chain of erratic serpentine rocks passing through the centre of Berkshire Co., Mass. (abst). As Am G, Pr 6:12 (1845)

Reinecke, Leopold.

os (with Harris, G. D.) Rock salt. La G S, B 7:259 pp (1908)

10 Beaverdell district, west fork of Kettle River, B. C. Can G S, Sum Rp 1909: $118-122$ (1910) ; 1910:120-122 (1911)
Reinecke, Leopold - Continued.

10 a Silver and gold deposits on of West Fork of Kettle River, B, C. Can Inst, Q B 12:135-139 (1910); J 14:3: 211 (1912)

12 Beaverdell map area, Yale distit B. C. Can G S, Sum Rp, 1911:130-18 (1912)

12a Bibliography of Canadian geolon for the years 1908 to 1911 (inclusive) $R$ Soc Can, $\operatorname{Pr} \operatorname{Tr}$ (3) 6 iv: 139-89 (1912)

15 Ore deposits of the Beaverdell man area, B. C. Can G S, Mem $79: 178$ w map (1915)

15a Physiography of the Beaverdell my area and the southern part of the interic plateaus of British Columbia. Can $A$ \& Mus B 11: 49 pp, map (1915)

15b Road materials in Ontario. (n G S, Sum Rp 1914: 88-91 (1915)

16 Road material surveys in 1914. Can G S, Mem 85: 244 pp, maps (1916)

$16 a$ Road material surveys in Ontari and Quebec. Can G S, Sum Rp 1915:14:155 (1916)

16b Average regional slope, a criterio for the subdivision of old erosion surface J G $24: 27-46$ (1916)

17 Road material surveys in 1915 . Ca G S, Mem 99:190 pp, maps (1917)

17a Road material surveys in Ontarb and Quebec. Can G S, Sum Rp 1916:192194 (1917)

18 Nonbituminous road materials. Ec G $13: 557-597$ (1918)

Reinhold, Eli $\mathrm{S}$.

82 Pyrophyllite and alunogen in coll mines. Ac $\mathrm{N}$ Sc Phila, $\operatorname{Pr} 1882 ; 55-50$; Min G Sec, Pr no 2: 22-23 (1882)

82a On diorite [Placer Co., Cal.]. Ac D Sc Phila, Pr 1882: 59 ; Min G Sec, Pr no 2: 26 (1882)

Reinholt, Oscar $\mathrm{H}$.

11 Rejuvenation of a gold section of California [San Diego Co.]. M World 35: 233-235 (1911)

Reitinger, $J$.

02 (with Kraus, E. H.) Hussakite, a new mineral, and its relation to renotime. Am G 30:46-55 (1902)

Remmers, Otto.

91 Untersuchungen der Fjorde an det Kiiste von Maine ... Inaug. Diss. Leiprig. $64 \mathrm{pp}$, Leipzig 1891

Rémond, Auguste (?-1867).

63 Description of two new species of bivalve shells from the Tertiaries of Contra Costa Co. Cal Ac N Sc, Pr 3:13 (1863)

63a Description of two species of Sct tella. Cal Ac N Sc, Pr 3:13-14 (1863)

63b Description of four new species of Echinodermata from the Tertiaries of Contra Costa Co. Cal Ac N Sc, Pr 3:52-54 (1863) 
Rómond, Auguste Continued.

66 Notice of geological explorations in northern Mexico. Cal Ac N Sc, Pr 3:244257 (1866) Abst, Am J Sc (2) 42:261264 (1867)

Renault, Bernard.

99 Sur quelques microorganismes des combustibles fossiles. Soc Ind Min, B (3) $13: 865-1161$, il $(1899) ; 14: 5-159$, il (1900)

Renwiek, James ( ?-1863).

23 Examination of a mineral frem Andover Furnace, Sussex Co., N. J. Lyc N H N J, An $1: 37-42$ (1823)

24 Notes on the geology of Trenton Falls (N. Y.). Lyc N H N Y, An 1:185-189 (1824)

38 Outlines of geolegy ... 96 pp, N Y 1838

Requa, Mark Lawrence.

10 The oil resources of California. An address delivered before the Mining Association, University of California, Berkeley. 24 pp, map. [Priv pub 1910?]

11 Oil resources of California. M Mag 4: 47-52 (1911)

12 Present conditions in the California oil fields. Am I M Eng, Tr 42:837-846 (1912)

16 Petroleum resources of the United States. U S, 64th Cong 1st Sess, S Doc $363: 18$ pp (1916)

Reuss, A. E.

61 Die Foraminiferen des senoniscben Grünsandes von New Jersey. K Ak Wiss, Mat-nat Cl, Szb 44, 1:334-342, 11 (1861) Reyer, E.

92 On the causes of the deformation of the earth's crust. Sc Am Sup 34:1387413875 (1892)

Reyer, F.

86 Zwei Profile durch die Sierra Nevada. $\mathrm{N}$ Jb, Beil Bd 4:291-326, map (1886)

Reyes, Vincente.

73 (with Ramirex, S) Informe sobre los temblores $y$ volcanes de Aguafría $y$ Jaripeo. Soc Geog Mex, B (3) 1:67-88 (1873)

Reynolds, Wm G.

19 Outline of a theory of meteors. Am J Se 1:266-276 (1819)

Reynoso, José J.

09 El mineral de Naica, Fstado de Chihuahua. Soc G Mex, B 5:8-9 (1909)

Rhoads, Samuel N.

95 Distribution of the American bison in Pennsylvania, with remarks on a new fossil species. Ac N Sc Phila, Pr 1895: 244-248

98 Notes on living and extinct species of the North American Bovidae. Ac N Sc Phila, Pr 1897: 483-502 (1898)

98a Notes. on the fossil walrus of eastern North America. Ac N Sc Phila, Pr $1898: 196-201$

\section{Rhode Island.}

76 Report of the Commission to prepare a plan for a thorough geological and scientific survey of the State. $13 \mathrm{pp}$, Providence 1876

Riced, $\mathbf{A}$.

06 Terremoto di San Francisco al 18 Aprile 1906. Ac Gioenia Sc Nat Catania, B n s $90: 2-6$ (1906)

Rice, Claude $\mathbf{T}$.

o6 Tonopah, Nev. Eng M J 82:106108. (1906)

O6a Mining at Tonopah [Nev.]. Eng M J $82: 199$ (1906)

06b The Bullfrog mining district, Nev. Eng M J 82:534-536 (1906)

o6e The Manhattan mining district, Nev. Eng M J $82: 581-584$ (1906)

06d Gold and silver at Fairview, Nev. Eng M J $82: 729-730$ (1906)

08 The ore deposits of Santa Eulalia, Mexico. Fng M J 85: 1229-1233 (1908)

08r Ores and mines of Santa Eulalia, Mexico. Eng M J 85: 1283-1286 (1908)

08b El Rayo gold mine, near Santa Barbara, Mexico. Eng M J 86:78-80 (1908)

ose The silver-lead mines of Santa Barbara, Mexico. Eng M J 86:207-211 (1908)

08d The silicious silver mines of Parral, Mexico. Eng M J 86:276-280 (1908)

ose Zacatecas, a fameus silver camp of Mexico. Eng M J 86:401-407, map (1908) ose Pachuca and Real del Monte silver district [Hidalgo, Mexico]. Eng M J 86: $519-525$ (1908)

OSg Guanajuato, the great silyer camp of Mexico. Eng M J 86:669-672 (1908)

10 Value of geolegical work in limestone regions. Eng M J 90:1161-1163 (1910)

11 Development of the Goldfield mines. Eng M J 91 : 119-122 (1911)

11a Tonopah [Nev.] and its geology. Eng M J 91:966-970, map (1911)

11b Present conditions at Tonopah mines [Nev.]. Eng M J 92:17-21 (1911) 12 Copper mining at Lake Superior. Eng M J $94: 119-124$ (1912)

Rice, E. R.

10 Classification of igneous rocks. M Se Press 100:901 (1910)

13 Graphics applied to fault problems. Eng M J 95:609-612 (1913)

Rice, Franklin P.

85 An account of the discovery of a mastodon's remains in Northborough, Worcester County, Mass. 8 pp, Il [Worcester, Mass.] 1885 [not seen]

Rice, George $\mathbf{S}$.

12 (with Daly, R. A.) Report of the commission appointed to investigate Turtle Mountain, Frank, Alta. Can G S, Mem $27: 34$ pp (1912) 
Rice, Marion.

18 Petrographic notes on the ore deposits of Jerome, Ariz. Am I M Eng, B $141: 1497-1502$ (1918)

Rice, William North.

s3 Connecticut minerals. Science 1:601 (1883)

84 The geology of Bermuda. U S Nat Mus, B 25:1-32 (1884)

s6 On the trap and sandstone in the gorge of the Farmington River at Tariffville, Conn. Am J Sc (3) $32: 430-433$ (1886)

86a The eccentricity theory of the glacial period. Science $8: 188-189$, 347 (1886)

96 Anticlinorium and synclinorium. Am J Sc (4) $2: 168-169$ (1896)

96a American Association for the Adrancement of Science; Section E-Geology and geography. Science $n$ s $4: 382-388$ (1896)

97 A suggestion in regard to the theory of volcanoes $(a b s t)$. Am As, $\mathrm{Pr} 46: 199$ 200 (1898) Am G 20:198 (1897) Science n s $6: 690$ (1897)

04 The physical geography and geology of Connecticut. Conn Bd Agr, An Rp $37: 94-113$ (1904)

$04 \mathrm{n}$ The proper scope of geological teaching in the high school and academy. Nat Educ As, Pr 1903: 853-856 (1904)

o5 The classification of mountains. Int Geog Cong, VIII, Rp : $185-190$ (1905)

06 (and Gregory, H. E.) Manual of the geology of Connecticut. Conn G S, B $6: 273 \mathrm{pp}$, map (1906)

06a The Triassic [of Connecticut]. Conn G S, B 6: 157-222 (1906)

06b On the use of the words synclinorium and anticlinorium (abst). Science n s $23: 286-287$ (1906) Am As, Pr 55: $375-376 \quad(1906)$

o7 The contributions of America to geology. Science n \& 25:161-175 (1907) Am As Pr 56-57: 461-484 (1907)

10 James Dwight Dana, geologist, 18131895. In Leading American men of science, ed by David Starr Jordan : 233-268, port, N $\ 1910$

11 (with Pirsson, L. V.) Contributions to the geology of New Hampshire, IV ; Geology of Tripyramid Mountain. Am J Sc (4) 31: 269-291 (1911)

13 Dana, the man. G Soc Am, B 24: $56-60$ (1913)

15 The geology of James Dwight Dana. In Problems of American Geology: 1-42, port, New Haven 1915

See also Dana, 64

Rich, John Lyon.

06 Local glaciation in the Catskill Mountains. J G 14:113-121 (1906)

os Marginal glacial drainage features in the Finger Lake region [N. Y.]. J G 16: 527-548 (1908)
Rich, John Lyon-Continued.

10 The physiography of the Bishop at glomerate, southwestern Wyo, J G j. 601-632 (1910)

10a (with Harder, E. C.) The th Age iron-ore deposit, near Dale, San Be nardino Co., Cal. U S G S, B $430: 228-2$ : (1910)

11 Gravel as a resistant rock. J G B: 492-506 (1911)

11 a Recent stream trenching in th semiarid portion of southwestern $\mathrm{Ner}$ Mexico, a result of removal of vegetatin cover. Am J Sc (4) 32:237-245 (1911) Abst, As Am Geographers, An 1:1: (1911)

12 (with Tarr, R. S.) The propertis of ice; experimental studies. Zs Gletschei $6: 225-249$ (1912)

14 Divergent ice flow on the platen northeast of the Catskill Mountains as ot vealed by ice-molded topography. $G \mathrm{~s}$ Am, B 25: $68-70$ (1914)

$14 a$ Certain types of stream valleys at their meaning. J G $22: 469-497$ (1914)

14b The occurrence of unusually lart boulders in gravel deposits [N. Mex.]. It J Sc (4) $38: 441-445$ (1914)

15 The Allendale oil field [IIl.]. III S, B $31: 57-68$, map (1915)

15a (and Filmer, E. A.) The inte: glacial gorges of Six Mile Creek at Ithach, N. Y. J G 23: 59-80 (1915)

15b Notes on the physiography and git cial geology of the northern Catskill Mour tains. Am J Sc (4) $39: 137-166$, mas (1915)

15e Some peculiarities of glacial et sion near the margin of the continental glacier in central Illinois (abst). G $8 \%$ Am, B 26: 70-73, map (1915)

16 Oil and gas in the Birds quadrangle III G S, B 33: 105-145, maps (1916)

16a Oil and gas in the Vincennes guad rangle. Ill $G$ S, B $33: 147-175$, mass (1916)

16b Petrography [of the pre-Cambrial rocks of Luna Co., N. Mex.]. U S G S, B 618: 21-23 (1916)

17 A graphical method of determining the average inclination of a land surface from a contour map. . III Ac Sc, Tr $9: 19^{\circ}$ 199 [1917]

17n [Petrographic descriptions of is neous rocks of the Deming quadrangle, I Mex.], U S G S, G Atlas Deming fol (no 207) : 7-8 (1917)

17b Local glaciation in the catsill Mountains (abst, with discussion by F. B. Taylor and J. W. Goldthwait). G Soc dis B 28:133-134 (1917)

18 The glacial phenomena of the Catskill Mountains. N Y St Mus, B $196: 32-39$ (1917) [1918]

18a Geologic dates in physiograpbic de scriptions. Science n s $47: 43-44$ (1918) 
Rich, John Lyon-Continued.

18b An old erosion surface in Idaho; is it Eocene? Ec G 13:120-136 (1918)

18e Dating of peneplains; an old erosion surface in Idaho, Montana, and Washington-is it Eocene? (abst with discus sion by Bruce L. Clark and Eliot Blackwelder). G Soc Am, B 29:89-90 (1918)

See also Chadwick, 16 ; Goldthwait, 17 ; Kay (G F), 18; Sayles, 16; Tomlinson, 18 Richard, Louis $M$.

11 Garnet deposits of Georgia. M World $34: 1135$ (1911)

15 Copper deposits in the "Red Beds" of Texas. Ec G 10:634-650 (1915)

Riehards, Mrs. Ellen Henrietta (Swallow) (1842-1811).

82 First lessons in minerals. $32 \mathrm{pp}$, Boston 1882

84 First lessons on minerals. Boston Soc N H, Guides for science teaching, No. XIII : 48 pp, Boston 1884; another ed, 1893

Riehards, Gary F.

88 Lithological notes on contact phenomena in South Carolina. Denison Univ, Sc Lab, I $4: 5-10$ (1888)

Richards, Joseph W.

01 "Mohawkite" [ledouxite]. Am J Sc (4) $11: 457-458$ (1901)

Riehards, R. H.

06 (with Day, D. T.) Investigation of the black sands from placer mines. U S G S, B 285: 150-164 (1906)

Richaras, Ralph Webster.

04 A new habit for chalcopyrite. Am J Se (4) $17: 425-426(1904)$ Tufts Coll Studies 1:383-385 (1904)

07 Synopsis of mineral characters, alphabetically arranged for laboratory and field use. $99 \mathrm{pp}, \mathrm{N}$ Y 1907

08 The Dragoon, Ariz, tungsten deposits.

M Science 57:93-94 (1908)

09 The central part of the Bull Mountain coal field, Mont. U.S G S, B 381: 60-81, map (1909)

10 (with Gale, H. S.) Preliminary report on the phosphate deposits in southeastern Idaho and adjacent parts of Wyoming and Utah. U S G S, B 430:457-535 (1910)

11 Notes on lead and copper deposits in the Bear River Range, Idaho and Utah. U S G S, B 470:177-187 (1911)

11a (and Bridges, J. H.) Sulphur deposits near Soda Springs, Idaho. U S G S, B $470: 499-503$, map (1911)

$11 b$ (and Mansfield, G. R.) Prelimi nary report on a portion of the Idaho phosphate reserve. U S G S, B 470:371439, maps (1911)

12 (and Mansfield, G. R.) The Bannock overthrust, a major fault in southeastern Idaho and northeastern Utah. J G 20: 681-709 (1912)
Richards, Ralph Webster-Continued.

13 Methods of field work in the phosphate districts of Idaho, Montana, Wyoming, and Utah (discussion). Ec G 8: 181-188 (1913)

$13 a$ Niter near Melrose, Mont. (abst). Wash Ac Sc, J 3: :J1 (1913)

13b (and Mansfield, G. R.) Structural features of a portion of southeast Idaho (abst). G Soc Am, B 24:675 (1913)

13e (and Mansfield, G. R.) Bannock thrust-a major fault in southeast Idaho (abst and discussion by Eliot Blackwelder). G Soc Am, B 24:675-676 (1913)

14 Niter near Melrose, Mont. U S G S, B $540: 470-473$ (1914)

14a (and Mansfield, G. R.) Geology of the phosphate deposits northeast of Georgetown, Idaho. U S G S, B 577:76 pp, map (1914) Abst, Wash Ac Sc, J 5 : 24 (1915)

17 (with Woolsey, L. H., and Lupton, C. T.) The Bull Mountain coal field, Musselshell and Yellowstone cos., Mont. U S G S, B $647: 218$ pp, maps (1917) Abst, by R. W. Stone, Wash Ac Sc, J $7: 602-603$ (1917)

Riehards, Robert $H$.

75 On a newly-discovered lead vein in Newburyport, Mass, Boston Soe N H, Pr $17: 200-204$ (1875)

Richards, W, B.

13 Geology of the Panther Creek Valley, Pa. Coal Age 3: 722-727, maps (1913)

Richardson, Charles Henry.

97 Source of the famous Thetford limburgite. Science n s 6:632-633 (1897)

98 The Washington limestone in Vermont (abst). Am As, Pr $47: 295-296$ (1898) Sclence $\mathrm{n}$ s $8: 469-470 \quad$ (1898) Am G $22: 257-258$ (1898)

02 The terranes of Orange Co., Vt. Vt St G, 3d Rp : 61-101, map (1902)

06 The areal and economic geology of northeastern Vermont. Vt St G, 5th Rp: 63-115 (1906)

os The geology of Newport, Troy, and Coventry. Vt St G, 6th Rp: 265-291, map (1908)

10 Asbestos in Vermont. $\nabla \mathrm{t}$ St $\mathrm{G}, 7$ th Rp : $315-330$ (1910)

11 The asbestos deposits of the New England States. Can M Inst, Q B 13: 59-69, 131-150 (discussion) (1911); J 14 : $107-117 ; 117-137$ (discussion) (1912)

12 The terranes of Craftsbury, Vt. Vt St G, 8th Rp : 162-183, map (1912)

12a (and Collister, M. C.) The terranes of Albany, $V t$. Vt $S t G, 8$ th $R p$ : 184-195, map (1912)

12b (and Convay, E. F.) The terranes of Irasburg, $V t$. $V t$ St $G, 8$ th $R p$ : 146-161, map (1912)

13 Eeonomic geology. 320 pp, N Y 1913 
Richardson, Charles Henry-Continued 14 (and Turner, H. G.) The terranes of Greensboro, Vt. Vt St $\epsilon$, 8th Rp: 277293, map (1914)

14a (and Brainerd, A. E., and Jones, D. J.) The geology and mineralogy of Hardwick and Woodbury, Vt. Vt St G, 9th Rp: 294-336, maps (1914)

16 The geology of Calais, East Mont pelier, and Berlin, Vt. Vt St G, 10th Rp: 111-149, maps (1916)

17 Building stones and elays. $437 \mathrm{pp}$, Syracuse, N. Y., 1917

18 The Ordovician terranes of central Vermont (abst). Science n $8 \quad 47: 493$ (1918)

Richardson, Charles Samuel.

53 Views on American mines and minerals [Northampton distriet, Mass.]. M Mag 1: 489-496 (1853)

54 Northampton distriet; the Loudville mines. M Mag 2:13-20 (1854)

54a The cobalt and nickel mines in Chatham, Conn. M Mag 2:124-128 (1854)

54b The slate quarries of Vermont. M Mag 2: 271-282 (1854)

54e Northampton district; the Williston lead and copper mine. M Mag 2:395-396 (1854)

54d The Hartford County Mining Company's property at Bristol, Conn. M Mag 2: 490-493 (1854)

54e Northampton mining district, Mass.; the Northhampton mine. M Mag 2:634636 (1854)

54f The old Bristol copper mine, Conn. M Mag 3: 251-255 (1854)

$\mathbf{5 4 g}$ The great silver lead mine, Shelburne, N. H. M Mag 3:481-489 (1854)

55 The Kingston coal mines, Peoria Co., IIl. M Mag 4:379-386; $5: 1-24$ (1855)

Richardson, Clifford.

01 (and Wallace, E. C.) Petroleum from the Beaumont, Texas, field. Soc Chem Ind, J 20:690-693 (1901)

06 The petroleums of North America. A comparison of the character of those of the older and newer fields. Franklin Inst, J $162: 57-70,81-128$ (1906)

10 Grahamite, a solid native bitumen. Am Chem Soc, J 32 : 1032-1049 (1910)

10a (and Mackenzie, K. G.) A natural naphtha from the Province of Santa Clara, Cuba. Am J Sc (4) 29:439-446 (1910)

15 A unique geophysical phenomenon, Trinidad asphalt, interesting from the point of view of dispersoid chemistry. J Phys Chem 19:241-249 (1915)

16 The origin of petroleum and asphalt. J Industrial Eng Chem 8:4 (1916)

$16 \mathbf{a}$ Gilsonite and grahamite; the result of the metamorphism of petroleum under a particular environment. $J$ Industrial Eng Chem 8: 493-494 (1916)
Richardson, Clifford-Continued.

17 The nature and origin of petrolen and asphalt. Metallurgical Chem Eng 16: 25-27 (1917)

See also Rogers (G S), $17 \mathrm{c}$

Riehardson, George Burr.

01 (with Brooks, A. H., and Collitr, A. J.) A reconnaissance in the Cax Nome and adjacent gold fields of Sewr Peninsula, Alaska, in 1900 . U 8 G \& Reconnaissances in the Cape Nome sil Norton Bay regions, Alaska, in 1900:1-18 maps (1901)

02 The misnamed Indiana anticlis [Pa.]. J G 10:700-702, map (1902)

o3 The upper red beds of the blat Hills. J G 11: 365-393, map (1903)

04 Report of a reconnaissance in tras Pecos Texas, north of the Texas and Pacily Railway. Tex Univ Min S B 9:119 \% map (1904)

04a Description of the Indiana quat rangle [Pa.]. U $\mathrm{S}$ G $\mathrm{S}, \mathrm{G}$ Atlas Indisu fol (no 102) : 7 pp, maps (1904)

04b The stratigraphic sequence in tras Pecos Texas north of the Texas and Pact Railway (abst). Science n s 19:794-ik (1904)

o5 Natural gas near Salt Lake City Utah. U S G S, B 260:480-483 (1905)

05a Salt, gypsum, and petroleum trans-Pecos Texas. U S G S, B $260: 5 \mathrm{H}$ 585, map (1905)

O5b Native sulphur in El Paso Co., Ter C S G S, B 260: 589-592 (1905)

06 Underground water in the valless Utah Lake and Jordan River, Utah. Ui G S, W-S P 157:81 pp (1906)

06a Tin in the Franklin Mountains, Ter U S G S, B 285: 146-149, map (1906)

06b Coal in Sanpete Co., Utah. I G S, B $285: 280-284$, map (1906)

06e The Franklin Mountains, Ter, (abt) Science n s $23: 266-267$ (1906); 25:76 (1907)

o7 Underground waters in Sanpete $a \mathrm{~d}$ central Sevier valleys, Utah. U S G S, $\mathbb{E}$ ? P 199:63 pp (1907) Abst, Science n s 28: 817 (1906)

ora The Book Cliffs coal fleld, betret Grand River, Colorado, and Sunnyside, Utah. U S G S, B 316: 302-320 (1907)

os Paleozoic formations in trans. Pear Texas. Am J Sc (4) $25: 474-484$ (1908)

osa Antimony in southern Utah. US 6 S, B $340: 253-256$ (1908)

08b Petroleum in southern Utah [Vlrgit City ]. U S G S, B 340:343-347 (1908)

o8e Portland cement materials near Paso, Tex. U S G S, B 411-414 (1908)

09 Description of the El Paso quad rangle, 'Tex. U S G S, G Atlas El Pal fol (no 166) : $11 \mathrm{pp}$, maps (1909) 
Richardson, George Burr-Continued.

09a The Harmony, Colob, and Kanab coal felds, southern Utah. U S G S, B 341: 379-400, map (1909) Utah, State Mine Inspector, 8th Bien Rp 1911-12:141-170, map (1913)

09b Reconnaissance of the Book Cliffs coal field between Grand River, Colo,, and Sunnyside, Utah. U S G S, B 371:54 pp, map (1909)

10 The Trinidad coal fietd, Colo. U S G

8. B $381: 379-446$, map (1910)

10a Stratigraphy of the upper Carboniferous in west Texas and southeast New Mexico. Am J Sc (4) 29:325-337 (191C) Abst, Science n s $32: 224$ (1910)

11 Clay near Calhan, El Paso Co., Colo. U S G S, B 470: 293-296 (1911)

12 The Monument Creek group. G Soc Am, B 23: 267-276, map (1912) Abst, Science n s $35: 311-312$ (1912)

$12 a$ Structure of the foothills of the Front Range, central Colorado (abst). Wash Ac Sc, J 2:429-430 (1912)

13 The Paleozoic section in northern Utah. Am J Sc (4) 36:406-416 (1913)

14 Deseription of the Van Horn quadrangle, Tex. U S G S, G Atlas Van Horn fol (no 194) : 9 pp, maps (1914)

14a Petroleum near Dayton, N. Mex. U S G \&, B 541: 135-140, map (1914)

15 Description of the Castle Rock quadrangle, Colo. U S G S, G Atlas Castle Rock fol (no 198) : 13 pp, maps (1915)

17 Note on the age of the Scranton coal, Denver Basin, Colo. Am J Sc (4) 43 : 243244 (1917)

17a Note on Appalachian oil-fleld brines. Ec G 12:39-41 (1917)

$17 b$ Note on the diffusion of sodium chloride in Appalachian oll-field waters. Wash Ac Sc, J $7: 73-75$ (1917)

See also Eckel, 13 ; Edden, $15 \mathrm{~b}$

Richardson, James.

57 Report for the year 1856 fon the Island of Anticosti and the Mingan Islands]. Can G S, Rp Prog 1853-6: 191245, map (1857) Reprinted in Roche, A. R., Island of Anticosti...: 45-92, N Y 1865

58 Report for the year 1857 [Gaspe Peninsula]. Can G S, Rp Prog 1857:2993, maps (1858)

59 Report [on a portion of the Gaspe Peninsula, Que.J. Can G S, Rp Prog 1858: 105-169, map (1859)

66 Report lon the Quebec group in the eastern townships of Quebec]. Can G S, Rp Prog 1863-6: 29-45 (1866)

70 Report [on the region south of the St. Lawrence between the Chaudiere River and the Temiscouata road, Quebec]. Can G S, Rp Prog 1866-9:119-141, map
Richardson, James - Continued.

70a Report [on a geological exploration on the north shore of the lower St. Lawrence]. Can G S, Rp Prog 1866-9:305311 (1870)

72 Report on the country north of Lake St. John [Que.]. Can G S, Rp Prog 1870-1: 283-308 (1872)

$72 a$ Report on the coal fields of the east coast of Vancouver Island [with note on fossil plants by J. W. Dawson]. Can G S, Rp Prog 1871-2: 73-97, map (1872)

73 Report on the coal fields of Vancouver and Queen Charlotte Islands. Can G S, Rp Prog 1872-3: 32-65, 84-86 map (1873)

74 Report on geological explorations in British Columbia. Can G S, Rp Prog 1873-4: 94-102 (1874)

76 Report on explorations in British Columbia. Can G S, Rp Prog 1874-5: 7183 (1876)

78 Report on the coal fields of Nanaimo, Comox, Cowichen, Burrard Inlet, and Sooke, B. C. Can G S, Rp Prog 1876-7 : 160-192 (1878)

81 Report of a geological exploration of the Magdalen Islands. Can G S, Rp Prog 1879-80: G 1-11 (1881)

Richardson, James.

73 Wonders of the Yellowstone. $256 \mathrm{pp}$, N Y 1873 2d ed, N Y 1882

Richardson, James.

86 Lagging subsidence vs. elevation in physiographical geology. Sc Am Sup 21 : $8547-8548$ (1886)

Fichardson, John (1787-1865).

23 Geognostical observations, In Franklin, John, Narrative of a journey to the shores of the Polar Sea in the years 1819 , 20,21 , and $22: 497-538$, L 1823 In part in Douglas, George M., Lands forlorn : 275276, N Y 1914

28 Topographical and geological notices. In Franklin, John, Narrative of a second expedition to the shores of the Polar Sea in the years 1825,1826 , and 1827 , appendix no I: i-lviii, L 1828 ; Appendix : 263318 , Phila 1828

51 Physical geography [and geologica] observations on British North Imerica]. In his Arctic searching expedition ; a journal of a boat voyage through Rupert's Land and the Arctic sea..., vol. 2 : 161-211, map, L 1851

$51 \mathrm{a}$ On some points of the physical geograpby of North America in connection with its geological structure. G Soc London, Q J $7: 212-215$ (1851)

54 The zoology of the voyage of H. M. S. Herald... Vertebrals, including fossil mam. mals. $172 \mathrm{pp}, \mathrm{il}$, London $\mathbf{1 8 5 4}$

$54 a$ [On some points in the ostoology of the Mastodon and fossil elephant.] Bos. ton Soc N H, Pr $5: 82-84$ (1854) 
Richardson, Joshua W.

59 [On coal deposits of Big Coal River, Boone Co., W. Va.] Boston Soc. N H, Pr $7: 32$ (1859)

Richardson, Ralph.

84 On points of dissimilarity and resemblance between Acadian and Scottish glacial beds (abst). Brit As, Rp 54:722 (1885) G Mag (3) 1:517-518 (1884)

87 On Canadian and Scottish glacial geology, Edinb G Soc, Tr 5:205-212 (1887)

\section{Richter, C. M}

o7 (and MeAdie, A. G.) Phenomena connected with the San Francisco earthquake. Monthly Weather Review 35:505$506(1907)$

Richthofen. Ferdinand von (1833-1905). 64 Reisebericht aus Californien. Deut $G$ Ges, Zs $16: 331-340$ (1864)

64a Ueber Californien. Deut G Ges, Zs $16: 606-610$ (1864)

6. The natural system of voleanic rocks. Cal Ac Sc, Mem 1 pt 2:98 pp (1868)

6Sa Mittheilungen von der Westkïste Nordamerikas. Deut G Ges, Zs 20:663$726: 21: 1-80,599-619(1868-9)$

69 Ueber das Alter der goldführenden Gïnge und der von ihnen durchsetzten Gesteine. Deut G Ges, Zs 21:723-740 (1869) Zs Ges Naturw $35: 223-226$ (1870)

Riekard, Edgar.

o3 Tin deposits of the York region, Alaska. Eng M J 75:30-31 (1903)

Rickard, Forbes.

99 Notes on the vein formation and mining of Gilpin Co., Colo. Am I M Eng, Tr 28: 108-126 (1899)

o1 Notes on Nome and the outlook for vein mining in that district. Eng $M \quad J$ $71: 275-276$ (1901)

o4 Copper deposits in Sinaloa and southern Sonora. Eng M J 78:97-98 (1904)

$04 a$ Notes on tungsten deposits in Arizona, Eng M J 78:263-265 (1904)

o7 The Boundary district, B. C. M Sc Press 94: 511-513 (1907)

o9 Gold ore near Newcastle, Colo. M Sc Press 99: 503 (1909)

13 Pitchblende from Quartz Hill, Gilpin Co., Colo. M Sc Press 106: 851-856 (1913)

Riekard, Thomas Arthur.

93 The persistence of ores in lodes in depth. Eng M J 55:51-52 (1893)

95 Certain dissimilar occurrences of gold-bearing quartz (with discussion by Philip Argall). Colo Sc Soc, Pr 4:323339 [1895] (separate ed, 23 pp, 1893)

95a Porphyry. Eng M J 59:578 (1895)

96 The Cripple Creek gold field [Colo.]. M Sc Press 72:284-285 (1896)

96a Vein walls. Am I M Eng, Tr 26: 193-241 (1897) Eng M J 63:282-284, 307-309 (1897) M. Sc Press 73:152, 172,
Riekard, Thomas Arthur-Continued 194, 216-217 (1896) Can M Rv 16:21 217, 229-235 (1897) Colliery Eng 11 $527-531 ; 18: 7-10$ (1897)

97 The Enterprise mine, Rico, Colo, I M Eng, Tr 26:906-980 (1897)

$97 \boldsymbol{\Omega}$ The Lake of the Woods gold 6e [Ontario]. Eng M J 64:5-8 (1897)

9s The minerals which accompany gal and their bearing upon the richness ore deposits. Inst $\mathrm{M}$ Met, $\operatorname{Tr} 6: 194-21$ (1898) Abst, Eng M J $65: 494-45$ (1898); M Sc Press 77:81-82, 105-14 (1898)

9sa Vein structure in the Enterptia mine [Rico, Colo.]. Colo Sc Soc, Pr ; 123-130 [1898] (separate ed, 8 pp, 180:

99 The Cripple Creek [Colo.] gold fith M Sc Press 79:688-689, 716-717, $(1899) ; 80: 4-5(1900)$ Inst M Met, tै $8: 49-96$ (1900)

oo The Cripple Creek district, Colo. The Official Manual of the Cripple Cro district, Colorado, U. S. A., published t Fred Hills, Colorado Springs, Colo, 15-28 (1900)

o1 The Cripple Creek volcano [Colal Am I M Eng, Tr $30: 367-403$, map (190! Abst, M Sc Press 81:36, 68, 93 (1900)

01 a The telluride ores of Cripple Crath [Colo.] and Kalgoorlie [West Australi: Am I M Eng, Tr 30:708-718 (1901)

O1b The formation of bonanzas in th upper portions of gold veins. Am I M Bs Tr 31: 198-220 (1902) M Sc Press \&: $6-7,15,25,36$ (1901)

02 An example of the localization rich ore [Independence mine, Cripple Creb district, Colo.]. Eng M J 74:84i-8it (1902)

o3 (and others) Ore deposits; a dis cussion [by S. F. Emmons, W. H. Weet J. E. Spurr, W. Lindgren, J. F. Kems F. L. Ransome, T. A. Rickard, C. R. Ia Hise, C. W. Purington] republished frot the Engineering and Mining Journal [ii: $256-258,476-479,594-595]$. 90 pp, NI 1903 [See also Fmmons (S F), 03, and Weed, 03]

O3a Across the San Juan Mountains 115 pp, N Y 1903 (appeared serially in the Eng M J 76, 1903)

03b The veins of Boulder [Colo.] axt Kalgoorlie [W. Australia]. Am I M Eaf Tr 33:567-577 (1903)

o3e The lodes of Cripple Creek [Colo. $]$. Am I M Eng, Tr 33:578-618 (1903) Abst, Eng M J 75:179-181 (1903)

03d Water in veins-a theory. But M J $75: 402-403$ (1903)

o3e The syncline as a structural type. Eng M J 75:746 (1903)

05 The copper mines of Lake Superiot. $164 \mathrm{pp}, \mathrm{N}$ Y 1905 (appeared serially is Eng M J 78, 1904) 
Rickara. Thomas Arthur-Continued.

06 (and others) After earthquake and fire. A reprint of the articles and editorial comment appearing in the Mining and Scientific Press immediately after the disaster at San Francísco, April 18, 1906. 194 pp, San Francisco 1906

06a Geology of the mines at El Oro, Mexico. M Sc Press 93: 350-354 (1906)

06b The geological distribution of gold. M Sc Press 93:477-480 (1906) Am M Cong, 9th An Sess, Rp Pr 226-233 (1907) Mines and Minerals 27:256-257 (1907)

07 Journeys of observation [notes on geology and ores of Mexico]. $255 \mathrm{pp}$, San Francisco 1907

07a Cobalt, Ont. M Sc Press 94:23-25 (1907)

$07 \mathrm{~b}$ The geology of the Veta Madre [Mexico]. M Sc Press 94:534-537 (1907) 07e Lodes in the Tertiary eruptives of Colorado. M Sc Press 95: 180-182 (1907) 08 The historical development of Colorado viewed from a geological standpoint. M Sc Press $96: 295-296$ (1908)

08a Goldfield, Nev.; geological notes. M Sc Press $96: 738-742$ (1908)

08b Waters, meteoric and magmatic. M Sc Press $96: 872-875$ (1908)

0se Copper deposits of White Horse [Yukon Terr.]. M Sc Press 97:778-779 (1908)

09 Alaska and the Yukon. M Sc Press 98: 15-22 (1909)

10 Geological distribution of the precious metals in Colorado. M Sc Press 100:89$96, \quad 150-155, \quad 316-320 \quad(1910)$

11 Ore shoots. M Sc Press 102:498499 (1911)

12 The domes of Nova Scotia. Inst M Met, $\operatorname{Tr} 21: 506-566, \operatorname{map}(1912)$ Can M J $33: 224-230, \quad 273-276, \quad 310-313, \quad 345-348$ (1913) M Sc Press 104:492-494 (1912) Can M Inst, $\operatorname{Tr} 15: 396-476, \operatorname{map}(1912)$

12a Persistence of ore in depth. M Sc Press 105: 232-234, 264-266 (1912)

13 Water in veins. M Sc Press 107: 693-694 (1913)

14 Persistence of ore in depth (with discussion). Inst $\mathrm{M}$ Met, B $122: 1-44$; 123:3-9 (1914); $130: 1-8 \quad$ (1915); Tr $24: 3-190$ (1915)

15 Goldfield revisited. M Sc Press 110: 907-909 (1915)

15a Igneous intrusions. M Sc Press $111: 556-558$ (1915)

16 Theoretical considerations governing the persistence of ore. M Sc Press 112: 83-88 (1916)

17 The Nickel Plate mine and mill [Hedley, B. C.]. M Sc Press 114:80-86 (1917)

17a Grand Forks and Phoenix, B. C. II Sc Press 114:262-267 (1917)

18 The story of the U. V. X. Bonanza [Jerome district, Ariz.]. M Sc Press 116: 47-52 (1918)
Riekard, Thomas Arthur-Continued.

See also Cross, 98a; Emmons (S F), 03e; Pošepny, 94, 95; Van Diest, 95a

Rickert, Julius.

02 Coal in Alberta, Canada. Eng M J $73: 766-767$ (1902)

Ricketts, Louis D.

s3 The ores of Leadville and their modes of occurrence... $68 \mathrm{pp}$, Princeton 1883

88 Annual report of the Territorial geologist to the governor of Wyoming, January 1888. $87 \mathrm{pp}$, Cheyenne, Wyo., 1888

90 Annual report of the Territorial geologist to the governor of Wyoming, January 1890. $80 \mathrm{pp}$, Cheyenne, Wyo., 1890

92 Faulting in veins. Eng M $\mathrm{J} \mathbf{5 3}$. 565-566 (1892)

Ricketts, P. De P.

s3 Certain ores from North Carolina (abst). N Y Ac Sc, Tr 2: 149-150 (1883) Riddell, John Leonard (1807-1867).

36 Remarks on the geological features of Ohio... Western Mo Mag, Cincinnati, $5: 160-172$ (1836)

37 Report... on the method of obtaining a complete geological survey of this State [Ohio]. $\quad 30 \mathrm{pp}$ [Columbus 1837]

39 ... geology of the Trinity country, Tex. Am J Sc $37: 211-217$ (1839)

Rider, Ezra B.

10 Notes on King Bros,' asbestos mine, Thetford, Que. Can M Inst, J 12:618-629 (1910)

Ridgway, John L.

13 Field and office methods in the preparation of geological reports (discussion); illustrations. Ec G $8: 279-289$ (1913)

Ridgway, Thomas S.

58 Physical features of the siliceous conglomerate rock and Carboniferous limestone along the eastern outcrop of the coal formation of the United States. M Mag 11: 253-254 (1858)

63 Report on the oil district of Oil Creek in the State of Pennsylvania. Franklin Inst J (3) $45: 269-273$ (1863)

70 Memorial in relation to the coal field of Rhode Island. Rhode Island, General Assembly : $12 \mathrm{pp}$, Providence 1870

72 Geological report upon the iron ore, coal, and other mineral deposits found along the line of the Chesapeake and Ohio Railroad. 24 pp, map, N Y 1872

Ries, Heinrich.

91 The Quaternary deposits of the Hudson River valley between Croton and Albany. N $\mathrm{Y}$ St G, An Rp 10:110-155 (1891)

$91 \mathrm{n}$ Note on rock exposure at $143 \mathrm{~d}$ and 144 th streets and Seventh Avenue [New York City]. N Y Ac Sc, Tr 10:113-114 (1891)

91b The clays of the Hudson River valley. N Y Ac Sc, Tr 11:33-39 (1891) 
Ries, Heinrich-Continued.

93 Notes on the clays of New York State and their economic value. $\mathrm{N} Y \mathrm{Ac} \mathrm{Sc}, \mathrm{Tr}$ $12: 40-47$ (1893)

94 On the occurrence of Cretaceous clays at Northport, Long Island [N. Y.]. Sch Mines, Q, $15: 354-355$ (1894)

$94 \mathbf{a}$ List and bibliography of the minerals occurring in Warwick township [Orange Co., N. Y.]. N Y Ac Se, An 7 : 651-654 (1894)

94b A Pleistocene lake bed at Elizabethtown, Essex Co., N. Y. N Y Ac Sc, Tr 13 : 107-109 (1894)

94e on some new forms of wollastonite from New York State. N Y Ac Sc, Tr 13: 146-147, 207-208 (1894)

94d Microseopic organisms in the clays of New York State. N Y Ac Sc, Tr 13: 165-169 (1894)

95 Clay industries of New York. N Y St Mus, B $12: 93-262$ (1895)

$95 \mathbf{a}$ On a granite diorite near Harrison, Westchester Co., N. Y. N Y Ac Sc, Tr 14: 80-86 (1895)

96 The limestone quarries of eastern New York, western Vermont, Massachusetts, and Connecticut. U S G S, An Rp 17 pt 3: 795-811 (1896)

96a The monoclinic pyroxenes of New York State. N Y Ac Sc, An 9:124-180 (1896) Abst, J G 4:651-652 (1896)

$96 \mathrm{~b}$ A visit to the bauxite mines of Georgia and Alabama (abst). Science $\mathbf{n} \mathbf{s}$ 3: 530-531 (1896)

96e (with Luquer, L. M.) The "augen"-gneiss area, pegmatite veins, and diorite dikes at Bedford, N. Y. $\Delta \mathrm{m} G 18$ : 239-261 (1896)

97 Deposits of useful clay. U S G S, An Rp 18 pt 5 (con) : 1127-1168 (1897)

97a Quartz and feldspar. U S G S, An Rp 18 pt $5: 1365-1368$ (1897)

97b Geology of Orange Co. [N. Y.]. N Y St G, An Rp 15:18-19, 393-475, maps (1897) $\mathrm{N} \mathrm{X}$ St Mus, An Rp $49 v 2: 18-$ 19. 393-475, maps (1898)

$97 c$ Physical tests of the Devonian shales of New York State to determine their value for the manufacture of clay products. N Y St G, An Rp 15:673-698 (1897) N Y St Mus, An Rp $49 v 2: 673-698$ (1898)

97d Clay deposits and clay industry in North Carolina. N C G S, B 13:157 pp, Raleigh 1897

97e Allanite crystals from Mineville, Essex Co., N. Y. N Y Ac Se, Tr $16: 327-329$ (1897)

$97 \mathbf{f}$ Note on a beryl crystal from New York City. N Y Ac Sc, Tr 16:329-330 (1897:

98 Physical tests of New York shales. Sch Mines Q 19:192-194 (1898)

98a The fuller's earth of South Dakota. A m I M Eng, Tr $27: 333-335$ (1898)
Ries, Heinrich-Continued.

98b The clays and clay-making industry of Colorado. Am I M Bng, Tr 27:338340 (1898)

99 Limestones of New York and thel: economic value. N $\mathbf{Y}$ St G, An Rp 1t: 355-467 (1899) N Y St Mus, An Rp 51, $2: 355-467$ (1899)

99a TLe origin, properties, and use of shale. Mich G S, An Rp 1899 [reprinted from Mich Miner 1 no. $12: 11-13 ; 2$ no. 1 : 31-32 ; no. $3: 21-23$ (1899-1900)]

$99 \mathrm{~b}$ A report on Louisiana clay samples La St Exp Sta, G Agr La pt 5:263-27 [1899]

99e The ultimate and the rational analy sis of clays and their relative advantage Am I M Eng, Tr 28: 160-166 (1899)

00 Preliminary report on the clays of Alabama. Ala G S, B 6:220 pp (1900)

00 a Clays and shales of Michigan; thel properties and uses. Mich G S 8 pt $1: 6^{\circ}$ pp (1900)

001 Clays of New York, their propertie and uses. N Y St Mus, B $35: 493-94$. map (1900)

oOc Notes on a trip from Port Jervis to Rondout [N. Y.]. N Y St Mus, An Rp 5? r88-91 (1900)

00d The origin of kaolin. Am Ceramk Soc, Tr 2: 93-99 (1900)

ooe Note on the occurrence of allanite in the Yosemite Valley, Cal. $(a b s t)$. Sclence n \& $11: 229-230(1900)$ N Y $A-S c$, As $13: 438-439$ (1901)

oOP The origin, properties, and uses of shale. Stone $20: 338-\vdots 42,449-452,543-$ 545 (1900)

$00 \mathrm{~g}$ The shales of Michigan. Stone 21: 20-24 (1900)

o1 Feldspar and quartz. U S G S, ti Rp 21, pt 6 con : $593-596$ (1901)

01 a Lime and cement industries of $\mathrm{Ner}$ York, N Y St Mus, B 44:639-848, twa? (1901)

01b Theodore Greely White. Am G 28 269-270, port. (1901)

02 Flint and feldspar. U S G S, Mit Res $1901: 935-939 ; 1902: 971-973 ; 1903$ $1117-1119 ; 1904: 1143-1145 ; 1905: 1359$ $1360(1902-6)$

02a Report on the clays of Marylad Md G S 4:203-505, maps (1902)

03 The clays of the United States east of the Mississippi River. U S G S, P P $11: 298 \mathrm{pp}$, maps (1903)

o3a Uses of peat and Its occurrence in New York. N Y St Mus, An Rp 55: $55^{2}$ 90 (1903)

o3b Magnetite deposits at Minerille. N. Y. Mines and Minerals $24: 49-5 !$ (1903)

o3e The coal mines at Las Esperants Mexico. Mich Miner 5 no $2: 13-15$ (1909) 04 The clays and clay industry of Neff Jersey. N J G S, Final Rp $6: 1-115,211$ 523 (1904) 
Ries, Heinrich-Continued.

04a Notes on mineral developments in the region around Ithaca [N. Y.]. N Y St Mus, An Rp 56: r107-108 (1904)

04b Notes on recent mineral developments at Mineville [Essex Co., N. Y.]. N Y St Mus, An Rp 56 : r125-126 (1904) 05 Economic geology of the United States. $435 \mathrm{pp}, \mathrm{N}$ Y 1905 2d ed, $451 \mathrm{pp}$, N Y 1907

05a The coal fields of Texas. Mines and Minerals 26 : 104-105 (1905)

06 Clays; their occurrence, properties, and uses. $490 \mathrm{pp}$, N Y 1906

06a The clays of Texas. Am I M Eng, B 11:767-805 (1906); Tr $37: 520-558$ (1907)

06b The clays of Wisconsin and their uses. Wis G S, B $15: 1-191$ (1906)

06e (and Gallnp, F. L.) Report on the molding sands of Wisconsin. Wis $\mathbf{G}$ 8, B $15: 192-247$ (1906)

96d The clays of the Virginia coastal plain. Va G S g s B 2:25-176 (1906)

07 What should be embraced in a geological study and report on clays? Am Ceramic Soc, Tr 9:480-482 (1907)

07a Notes on the rational composition of clays. Am Ceramic Soc, Tr 9: 772-776 (1907)

$07 \mathrm{~b}$ Clays of Virginia. In Watson, $\mathrm{T}$. L., Mineral resources of Virginia : 167-187 (1907) [Extracted from B 2, Va G S. See 06d]

08 The clays of Texas. Tex Univ, B 102 (sc s 2 no 12) : 316 pp (1908)

08a (and Rosen, J. A.) Report on foundry sands. Mich G S, Rp 1907:3385 (1908)

09 The geological investigation of clays. II World $30: 1118(1909)$ Can M Inst, J $12: 350-355$ (1910)

10 The clay and shale deposits of Nova Scotia, and portions of New Brunswick and Prince Edward Island. Can i S, Sum Rp 1909: 240-244 (1910) Can M J 31: $470-471,499-500 \quad(1910)$ Can M I, Q B $11: 83-103(1910) ; \quad J \quad 13: 336-356$ (1911) M Soc N S, J 15: 9-26 (1910)

10a Economic geology, with special reference to the United States. New ed, 589 Pp, N Y 1910

11 Clay and shale deposits of western Canada. Can G S, Sum Rp 1910:174180 (1911)

11a The clay and shale deposits of the western provinces of Canada. Can M Inst, Q B 16:11-54 (1911); J 14:351-394 (1912)

11b A review of the theories of the origin of white residual kaolins. Am Ceramic Soc, $\operatorname{Tr} 13: 51-74$ (1911)

11e (and Keele, J.) The clay and shale deposits of Nova Scotia and portions of New Brunswick. Can G S, Mem 16: 164 pp (1911)
Ries, Heinrich-Continued.

12 Building stones and clay products. xv, 415 pp, N Y 1912

12a Report on progress of investigation of clay resources. Can $G \mathbf{S}$, Sum $\mathrm{Rp}$ 1911 : 225-229 (1912)

12b Whiteware materials in Ontario and Quebec, kaolin near Huberdeau, Que. Can G S, Sum Rp 1911:229-232 (1912)

12e (and Keele, J.) Preliminary report on the clay and shale deposits of the western provinces. Can G S, Mem 24: 231 pp, maps (1912)

13 Fire-clay deposits of Canada. Am I M Eng, B 75:429-442, map (1913) ; Tr $45: 123-136$, map (1914)

$13 a$ Recent changes in the Asulkan Glacier [B. C.] (abst). G Soe . m, B 24: 696 (1913)

$13 b$ (and Keele, J.) Report on the clay and shale deposits of the western provinces, Canada; Part II. Can G S, Mem 25: 105 pp (1913)

13e Clay and shale deposits of the western provinces of Canada. Can M Inst, Tr 16:528-537 (1913)

14 (and Watson, T. L.) Engineering geology. xxvi, $672 \mathrm{pp}, \mathrm{N}$ Y 1914 2d ed, xxvii, $722 \mathrm{pp}, \mathrm{N}$ Y 1915

$14 a$ Economic geology. $3 d$ ed, 589 pp, N Y 1914 th ed, $856 \mathrm{pp}$, N Y 1916

$14 b$ Clay and shale deposits of the west. ern provinces, Canada; Part III, Can G S., Mem $47: 73$ pp (1914)

14e Clay investigations in western Canada. Can G S, Sum Rp 1912:229-233 (1914)

14d Clays of British Columbia and Alberta. Can G S, Sum Rp 1913:284-287 (1914)

14e The occurrence of aluminum hy drate in clays. Ec G 9:402-404 (1914)

15 Clay and shale deposits of the western provinces (part IV). Can G S, Mem $65: 83 \mathrm{pp}$ (1915)

16 Memorial of Theodore Bryant Comstock. G Soc Am, B 27:12-15, port (1916)

17 (and Somers, R. E.) The clays of the Piedmont province, Va. Va G S, B 13: $86 \mathrm{pp}$, map (1917)

17 a A peculiar type of clay. Am J Sc (4) $44: 316-318$ (1917)

17b Chromium; its ores and uses. Mineral Foote-Notes 1 no $11: 4-11$ (1917)

18 The occurrence of high-grade American clays and the possibility of their further development. Am Ceramic Soc, J 1: 446-467 (1918)

See also Clark (W B), 00a ; Keele, 18a ; Merrill (F J H), 94a ; Teas, 17; Watson, $07 \mathrm{e}$

Rigre, Joseph.

SS The Wyoming oil fields. Sc Am Sup $25: 10404-10405$ (1888) 
Riggs, Elmer Samuel.

96 A new species of Dinictis from the White River Miocene of Wyoming. Kans Univ Q 4:237-241, il (1896)

$96 \mathbf{a}$ Hoplophoneus occidentalis. Kans Univ Q 5:37-52, il (1896)

98 On the skull of Amphictis. Am J Sc (4) 5:257-259, il (1898)

99 The Mylagaulidae, an extinct family of sciuromorph rodents. Field Col Mus, Pub g s 1 : 179-187, il (1899)

oo Fossil hunting in Wyoming. Science n s $11: 233-234$ (1900)

01 The dinosaur beds of the Grand River valley of Colorado. Field Col Mus, Pub g s $1: 267-274$ (1901)

01a The fore leg and pectoral girdle of Morosaurus. Field Col Mus, Pub g $\mathrm{s} 1$ : 275-281, il (1901)

o1b The largest known dinosaur. Science $n$ s $13: 549-550$ (1901)

02 (and Farrington, 0 . C.) The dinosaur beds of the Grand River valley of Colorado Sc Am Sup 53:22061-22062 (1902)

03 Structure and relationships of opisthocoelian dinosaurs, part I, Apatosaurus Marsh. Field Col Mus, Pub g s 2 : 165-196, il (1903)

03a Brachiosaurus altithorax, the largest known dinosaur. Am J Sc (4) 15:299306. il (1903)

03b The vertebral column of Brontosaums. Science n s $17: 393-394$ (1903)

03c The use of pneumatic tools in the preparation of fossils. Science $n$ s 17 : $747-749$ (1903)

04 structure and relationships of opisthocoelian dinosaurs, part II, The Brachiosauridae. Field Col Mus, Pub g s 2 : 229247, il (1904)

04a Dinosaur footprints from Arizona. Am J Sc (4) 17:423-424, il (1904)

06 The carapace and plastron of Basilemys sinuosus, a new fossil tortoise from the Laramie beds of Montana. Field Col Mus, Pub g s 2: 249-256, il (1906)

o9 Loup Fork beds of eastern Wyoming (abst). Science n s 29:196 (1909)

12 New or little known titanotheres from the lower Uinta formations, with notes on the stratigraphy and distribution of fossils. Field Mus N H, Pub g s 4: 17-41, il (1912)

Riggs, Robert Baird.

85 The Grand Rapids meteorite, Am J Sc (3) $30: 312(1885)$

87 A new meteoric iron and an iron of doubtful nature. Am J Sc (3) 34:59-60 (1887)

$\mathbf{8 7 a}$ On two new meteoric irons [Grand Rapids and Abert] and an iron of doubtful nature. U S G S, B 42:94-97 (1887)

88 The analysis and composition of tourmaline. $\mathrm{Am} \mathrm{J}$ Sc (3) 35:35-51 (1888)
Ringueberg, Eugene N. S.

82 The evolution of forms from the Clinton to the Niagara group. Am Nat $16: 711-715$, il (1882)

82a Description of two new species of crinoids from the shales of the Niagan group at Lockport, N. Y. Cin Soc N H, J 5:119-121, il (1882)

84 New fossils from the four groups of the Niagara period of western New York Ac N Sc Phila, Pr 1884: 144-150, il

84a A new Dinichthys from the Portage group of western New York. Am J \& (3) $27: 476-478$, il (1884)

86 New genera and species of fossils from the Niagara shales. Buffalo Soc I Sc, B $5: 1-22$, il (1886)

87 A trilobite track illustrating on mode of progression of the trilobite (abst). Am As, Pr 35:228 (1887)

s8 The Niagara shales of western Ner York... Am G 1:264-272 (1888)

s8a Some new species of fossils from the Niagara shales of western New York Ac N Sc Phila, Pr 1888: 131-137, il

89 The.Calceocrinidae; a revision of the family with descriptions of some ner species. N $\mathrm{Y}$ Ac Sc, An $4: 388-408$, I (1889)

90 The Crinoidea of the lower Niagarl limrestone at Lockport, N. Y., with Der species. N Y Ac Sc, An 5:301-306, \# (1890)

Rink, $\mathrm{H}$.

67 Udsigt over Nordgrönlands geos nosi... K Danske Vid Selsk Skrift (5) 8: 73-98, map (1867)

87 Results of the recent Danish ex plorations in Greenland, with regard to the inland ice. Edinb G Soc, Tr $5: 286-200$ (1887)

Rio, Andrés Manuel del (1765-1849).

95 Elementos de orictognosía... 2 rols 171, 208 pp. Mexico 1795, 1805. 2d th $683 \mathrm{pp}$, Phila 1832

34 Observations on the treatise of mit eralogy of Mr. C. U. Shepard ... G S Pa, Tr 1: 113-136 (1834)

34a (and Millington, J.) ... Rapps hannock gold mines in Virginia. G $\mathrm{Sox}$ $\mathrm{Pa}$, Tr 1: 147-166 (1834)

41 Manual de geología $70 \mathrm{pp}$, il Mesio 1841

Rio de la Loza, Leopoldo (1807-1876).

65 El fierro meteorico de Yanhuitls. Soc Geog Mex, B 10:667-672 (1865)

65a Descripción del aerolito de Fat huitlán. $8 \mathrm{pp}$, México, Imprenta de di drade y Escalante, 1865

Riordan, Owen.

82 The upper Potomac coal field. Tt Virginias 3:94 (1882)

Riotte, Eugene N.

67 [On a new mineral, stetefeldtite from Nevada.] Boston Soc N H, Pr 11 216-218 (1867) 
Ripley, H. Ernestine.

11 Bibliography of the published writings of Henry Fairfield Osborn for the years 1877-1910. 30 pp, Lancaster, $\mathrm{Pa}$. 1911

16 Bibliography of the published writings of Henry Fairfield Osborn for the years 1877-1915. $2 \mathrm{~d}$ ed, $74 \mathrm{pp}$ [priv pub 1916]

Ris, F.

10 The identity of two Odonata fossils. Wis N H Soc, B 8:102-105 (1910)

Rising, W. B.

82 (with Le Conte, J.) The phenomena of metalliferous vein formation now in progress at Sulphur Bank, Cal. Am J Sc (3) $24: 23-33 \quad$ (1882)

Riter, George W.

13 Asphalt and rare hydrocarbons. Dtah, State Mine Inspector, 8 th Bien $\mathrm{Rp}$ 1911-12:126-129 (1913)

Ritter, Etienne A.

95 Sur quelques zéolites de la BasseCalifornie. Soc Franç Minér, B 18:106107 (1895)

95a Êtude de quelques roches éruptives de la Basse-Californie. Arch Se Phys Nat (3) $33: 330-343$ (1895) Mus d'Hist Nat, Paris, B 1:43 (1895) Soc Cient Ant Alz, Mem 15: Rev 89-90 (1901)

05 Le district aurifère de Cripple Creek, Colo. An Mines (10) $7: 465-487$ (1905)

06 The genesis of mineral waters : a dis. cussion of their relations to volcanic action and the formation of ore deposits. Eng M J 82:869-870 (1906)

06a Le tremblement de terre de San Francisco du 18 avril 1906. Soc G France, B (4) $6: 287-293 \quad(1906)$

06b Les bassins lignitiferes et houillers des Montagnes Rocheuses. An Mines (10) $10: 5-84$ (1906)

07 The origin of ore deposits. $84 \mathrm{pp}$, [Denver, Colo, 1907]

07a Le gisement de cuivre d'Evergreen. Ac Sc Paris, C R 145: 1187-1188 (1907)

es The Evergreen copper deposit, [Apex, Gilpin Co.] Colo. Am I M Eng, B 19: 33-47 (1908) ; Tr 38: T51-765 (1908) M World $28: 485-486$ (1908)

08a The Montezuma mining district, [Summit Co.] Colo. Fng M J 85: 241244 (1908) Mines and Minerals 28:501504 (1908)

09 Ore formation in the Wonder district, Nev. Eng M J 87:289-292 (1909)

13 The Rico mining district, Colo. M World $38: 895-898$ (1913)

16 Oatman and the Tom Reed-Gold Road mining district, Ariz. M World 44 : 645-648 (1916)
Ritter, Wm. E.

o1 Some observations bearing on the probable subsidence during recent geological times of the island of Santa Catalina off the coast of southern California. Science n s $14: 575-577$ (1901)

Rivers, J. J.

02 Pandora (Kennerlia) grandis Dall. S Cal Ac Sc, B 1:69, il (1902)

04 Descriptions of some undescribed fossil shells of Pleistocene and Pliocene formations of the Santa Monica Range [Cal.]. S Cal Ac Sc, B 3:69-72 (1904)

13 A new species of Bathytoma from the upper Pleistocene of San Pedro, Cal. S Cal Ac Sc, B 12:29 (1913)

Rivière, A.

37 Note sur un énorme fossile trouvé dans la Louisiane. $8 \mathrm{pp}$, Paris, 1837

Rivot, L. E.

55 Voyage au lac Supérieur. An Mines (5) $7: 173-328$ (1855) M Mag $6: 28-37$, 99-106, 207-213, 414-418; $7: 249-255$, $359-367 ; 9: 60-65(1856-7)$

55a Sur le gisement du cuivre natif au lac Supérieur, Etats-Unis d'Amérique. Ac Sc Paris, C R 40:1306-1309 (1855)

56 Ueber die Kupfererz-Lagerstätten am Obern See in den Nordamerikanischen Freistaaten. Berg- u hiitt Ztg 15:261-263, $269-271,277-279,293-295,314-315,317-$ $318, \quad 325-328,333-334,341-343,349-351$, $357-359, \quad 365-367,381-382 \quad$ (1856) [not seen ]

56a Notice sur le lac Supérieur. An Mines (5) $10: 365-474$ (1856)

Roark, Louis.

18 Brief notes on field methods used in geological work of Mid-Continent oil fields. Ind $\mathrm{Ac}$ Sc, $\mathrm{Pr} 1917: 235-239$ (1918)

Robb, Charles.

60 Observations on the physical geology of the western districts of Canada [Niagara region]. Can J n s 5:497-512 (1860)

61 On the petroleum springs of western Canada [Ontario]. Can J n s $6: 313-323$ (1861)

62 Some observations relating to the physical condition of the superficial deposits in Canada. Can Nat $7: 382-389$ (1862)

62a on the petroleum springs of western Canada. Pharmaceutical J (2) $4: 67-72$ (1862)

70 Report [on the geology of western New Brunswick]. Can G S, Rp Prog 1866 $9: 173-209$, map (1870)

72 Supplementary report on the geology of northwestern New Brunswick. Can G S, Rp Prog 1870-1: 241-251 (1872)

72a Records of mines and mineral statistics [Canada]. Can G S, Rp Prog 1871$2: 146-154$ (1872) 
Robb, Charles-Continued.

73 Report on the coal mines of the eastern or Sydney coal field of Cape Breton, N. S. Can G S, Rp Prog $1872-3: 238-295$ (1873)

74 Report on explorations and surveys in Cape Breton, N. S. [with appendix by C. Hoffman]. Can G S, Rp Prog 1873-4: 171-188 (1874)

76 Report on explorations and surveys in Cape Breton, N. S. Can G $\mathbf{S}$, Rp Prog 1874-5 : 166-266, maps (1876)

82 The geology of St. Ignace Island, Lake Superior. Can Nat n \& $10: 172-180$ (1882)

Robb. James (1815-1861).

41 Remarks upon certain geological features of the River St. John in New Brunswick ... Brit As, Rp $10: \sec 115-118$ (1841) Abst, Am J Sc 41:55-56 (1841)

50 [Report on coal in New Brunswick.] In Johnston, J. F. W., Report on the agricultural capabilities of the Province of New Brunswick : $38-47$, Fredericton 1850

51 Notice of observations on drift striae in New Brunswick. Am As, Pr 4:349-351 (1851)

Robbins, F.

03 Ore occurrence at Leadville, Colo. M Sc Press 86:168 (1903)

Robert, Eugène.

41 Observations géologiques faites au Grönland en 1836 .... Soc G France, B 12 : 365-369 (1841)

Roberts, David E.

96 Notes on the Cretaceous formations of the Eastern Shore of Maryland. Johns Hopkins Univ Circ 15:16-17 (1896)

Roberts, Hugh M.

18 (and Longyear, R. D.) Genesis of the Sudbury nickel-copper ores as indicated by recent explorations. Am I M Eng, Tr 59:27-56 (discussion by G. F. Kunz, F. F. Grout, W. G. Miller, A. M. Bateman, C. P. Berkey, Waldemar Lindgren, and L. C. Graton : 57-67) (1918) ; B 134:555-584; discussion, B 136:848858 (1918) Can M Inst, $\operatorname{Tr} 21: 80-117$ [1919]

$18 a$ (and Longyear, R. D.) Exploration of nickel-copper properties in Falconbridge township, Sudbury district, Ont. Can M J 39:50-53 (1918)

18b (and Longyear, R. D.) Origin of Sudbury nickel-copper deposits. Can M J 39 : 135-136 (1918)

Roberts, John R.

18 (and Nash, J. P.) The geology of Val Verde Co. Tex, Univ, B 1803:51 pp, map (1918)
Roberts, Milnor.

03 Note on the action of frost on soll J G $11: 314-317$ (1903)

06 (and others) The School of Mines series of rock specimens from the State of Washington, collected and described by the School of Mines of the University of Wash. ington. Washington, Univ, B (2) $25: 40$ pp (1906)

09 A wonderland of glaciers and snows [Mount Rainier National Park, Wash.]. Nat Geog Mag 20:530-538 (1909)

10 The Nicola Valley coal field, B. C. Am I M Eng, B $37: 27-32(1910) ; \operatorname{Tr} 40$ : 798-803 (1910)

17 (and others). The College of Mines series of ores, coals, and useful rocks of Washington ... Wash, Univ, B, Gen ser no 110: 97 pp (1917)

See also Landes, 02b; Weaver, 15

Roberts, R. D.

93 'The earth's history; an introduction to modern geology. $270 \mathrm{pp}, \mathrm{N}$ Y 1893

Roberts, Thomas P.

16 The glacial epoch (with discussion by R. R. Hice, A. E. Ortmann, Henry Leighton, Charles R. Fettke, and Harry J. Lewis). Engineers' Soc Western $\mathrm{Pa}, \mathrm{Pr}$ $32: 565-611$ (1916)

Roberts, William $\mathrm{F}$.

S8 Geological reconnaissance of the Cossatot mineral zones crossing the counties of Sevier, Howard, and Polk in the southwestern limits of the State of Arkansas bordering on the Choctaw nations of Indians. The Age of Steel 63 no $15: 8$; no $20: 15 ;$ no $21: 10$; no $22: 12$; no 24 15 ; no $26: 10-11 ; 64$ no $1: 5 ;$ no $2: 10$ 11 ; no $3: 14-15$; no $4: 11$; no $13: 10$ (1888)

Roberts-Austen, W. C.

98 Canada's metals ... 46 pp, map, L 1898

Robertson, Felix.

o5 Additional observations on the Falls of Niagara and particularly on their (sup. posed) original position. Phila Med Phys J 1 pt 2: 61-68 (1805)

Robertson, James D.

90 On a new variety of zinc sulphide from Cherokee Co., Kans. Am J Sc (3) .40:160-161 (1890)

93 Notes on the formation of the fron ores. Science 21:131 (1893)

95 The Missouri lead and zinc deposits. Am G 15: 235-248 (1895)

Robertson, John B.

67 Memorial and explorations in rela. tion to the agricultural, mineral, and mas. ufacturing resources of the State [Louisiana] ...: $30 \mathrm{pp}$, New Orleans 1867 
Robertson, William Fleet.

9) Reports. In Annual report of the minister of mines for the year ending 31 st December, 1898, being an account of mining operations for gold, coal, etc., in the Province of British Columbia:957-1230, maps, Victoria, B. C., 1899 ; ... 1899 ... 545-890, map (1900) ...: 705-1027, maps (1901) ; ... $1901 \ldots$ : 917-1232 D, xxviii, map (1902) ; ... $1902 \quad \ldots$ : H $5-320 \quad(1903) ; \ldots$ 1903 ...: H5-275, maps (1904)

05 Report of Bureau of Mines. In Annual report of the minister of mines for the year ending 31st December 1904, being an account of mining operations for gold, coal, etc., in the Province of British Columbia: G 5-317, map, Victoria, B. C., 1905; 1905 ... J5-273, map (1906) ; ... $1906 \ldots$. H 5-276, map $(1907) ; \ldots 1907 \ldots$ L $5-$ 235, map (1908) ; ... $1908 \quad \ldots$ : J $5-269$, maps (1909) ; ... $1909 \quad \ldots$ : K $5-298$, map (1910) ; ... 1910 ... K 5-269, maps (1911) ; ... $1911 \ldots$ : K 5-313, maps (1912; ... 1912 ...: K 5-349, maps $(1913)$; ... 1913: K 5459, maps (1914) ; ... $1914 \quad \ldots:$ K $\quad 5-544$, maps (1915) ; ... 1915 ... : К 5-473, (1916) ; ... $1916 \ldots$. K 5-547, maps (1917) ; ... 1917 ... : F 5-552, maps (1918)

06 Do the geologieal relations of ore deposits justify the retention of the law of the apex? Ec G 1: 809-810 (1906)

06a The northern interior plateau lying between the Fraser and Skeena rivers. B C, Minister of Mines, An Rp 1905: 89137 (1906)

06b Windy Arm mineral locations [B. C.]. Eng M J 81: 701-704 (1906)

10 Geology of the Portland Canal district, B. C. M Science 62:621-623 (1910)

14 Preliminary review and estimate of mineral production, 1913. B C Bur Mines, B 1 (1914) : 35 pp ... 1914,... B 1 (1915) : $42 \mathrm{pp} \ldots 1915, \ldots$ B 1 (1916): 50 pp

16 Memorial of William John Sutton. G Soc Am, B 27:35-37, port (1916)

Robertson, Wyndham.

82 Some notes on the Holston, Va,, salt and gypsum. The Virginias $3: 20-21,42$ (1882)

Robiuson, A. H. A.

17 Investigation of iron ores. Can Dp Mines, Mines $\mathrm{Br}$, Sum Rp 1916:15-20 ; $1917: 11-22$, map (1917-8)

17 a Iron ore occurrences in Canada; introductory, 1:1-22. Can Dp Mines, Mines Br, Ottawa, 1917.

Robinson, C. W.

15 An investigation of radioactive minerals in eastern Canada. Can G S, Sum Rp 1914: 109-112 (1915)

Robinson, F. C.

84 On allanite from Topsham, Me. Am $\mathrm{J} \mathrm{Se} \mathrm{(3)} 27: 412$ (1884)
Robinson, Henry Hollister.

00 (with Pirsson, L. V.) On the determination of minerals in thin rock sections by their maximum birefringence. Am J Sc (4) 10:260-265 (1900)

01 On octahedrite and brookite, from Brindletown, N. C. Am J Sc (4) 12 : 180-184 (1901) Zs Kryst $35: 425429$ (1902)

or The Tertiary peneplain of the plateau district, and adjacent country, in Arizona and New Mexico. Am J Sc (4) 24:109129 (1907)

o7a (with Gregory, H. E.) Preliminary geological map of Connecticut. Conn G S, B $7: 39$ pp (1907)

os Ancient water planes and crustal deformation. J G 16:347-356 (1908)

10 A new erosion cycle in the Grand Canyon district, Ariz. J G $18 ; 742-763$ (1910)

11 The single cycle development of the Grand Canyon of the Colorado. Science n s 34: 89-91 (1911)

13 The San Franciscan volcanic field, Ariz. U. S. G S, P P $76: 213$ pp, map (1913) Abst by J. F. Hunter, Wash Ac Sc, J 4 : 195-196 (1914)

16 The summation of chemical analyses of igneous rocks. Am J Sc (4) 41:257275 (1916)

Robinson, Heath $\mathrm{M}$.

16 Ozokerite in central Utah. U S G S, B 641: 1-16, map (1916) Abst, by R. W. S., Wash Ac Sc, J $7: 76-77$ (1917)

\section{Robinson. Neil.}

04 The Kanawha and New River coal fields of West Virginia, U. S. A. 23 pp, Charleston W Va 1904 [Priv pub]

Robinson, Samuel.

25 A catalogue of American minerals with their localities ... $316 \mathrm{pp}$, Boston 1825

Robinson, Thomas.

85 The strata exposed in the east shaft of the waterworks extension [Washington, D. C.] (abst). Ph Soc Wash, B 7:69-71 (1885)

Robinson, W. I.

15 Two new fresh-water gastropods from the Mesozoic of Arizona. Am J Se (4) $40: 649-651$ (1915)

$15 a$ (with Cane, E. C.) The geology of Limestone Mountain and Sherman Hill in Houghton Co., Mich. Mich G S, Pub 18 (g \& 15) : 165-181 (1915) J G 23: 256-260 (1915)

16 On the Paleozoic alcyonarian, Tumularia. Am J Sc (4) $42: 162-164$ (1916)

17 The relationship of the Tetracoralla to the Hexacoralla. Conn Ac Arts, Tr $21: 145-200$, il (1917)

Robles, Manuel.

49 Geology of the Isthmus of Tehuantepec. U S, 30th Cong $2 \mathrm{~d}$ sess, H Rp 145 : $111-117$ (1849) 
Robles, $R$.

06 Etude minière de la "Veta Colorado" de Minas Nuevas a Hidalgo del Parral (Etat de Chihuahua). Int $\mathbf{G}$ Cong $X$. Mexico, Guide Exe no XXI : 15 pp (1906)

OGa (with Villarello, J. D.) Étude de la Sierra de Guanajuato [Mexico]. Int G Cong, X, Guide Exc no 15:33 pp (1906)

09 (with Villarello, J. D.) Geologic study of the Sierra of Guanajuato. Eng M J $88: 672-677$ (1909)

Roekstroh. Edwin.

03 Recent earthquakes in Guatemala. Nature 67:271-272 (1903)

Rockwe11, Alfred P.

72 Discovery of the tusk of an elephant in Colorado. Am J Sc (3) 3:373374 (1872)

Rockve11, Cleveland.

02 The Coos Bay coal fields [Oreg.]. Eng M J $73: 238-240,270-271$ (1902)

Rockwood, Charles Greene.

72 Notices of recent earthquakes. Am $J \mathrm{Sc}$ (3) $4: 1-4: 5: 260-263 ; 6: 40-44$; $7: 384-387 ; 9: 331-334 ; 12: 25-30 ; 15$ : $21-27 ; 17: 158-162 ; 19: 295-299 ; 21$ : $198-202 ; 23: 257-261 ; 25: 353-360 ; 27$ : $358-364 ; \quad 29: 425-437 ; \quad 32: 7-19$ (1872$86)$

72a On the Owen's Valley earthquake. Am J Sc (3) 4:316-318 (1872)

83 Notes on Canadian earthquakes. Can Nat n s $10: 455-458$ (1883)

85 [Record of scientific progress, 1884] vulcanology and seismology. Smiths Inst, An Rp 1884: 215-235 (1885)

85a Earthquake of January 2, 1885 [eastern U. S.]. Selence 5: 129-130 (1885)

86 [Record of scientific progress, 1884] vuleanology and seismology. Smiths Inst, An Rp 1885: 471-493 (1886)

87 The Charleston earthquake. Am J Sc (3) $33: 71-73$ (1887)

89 [Record of scientific progress] vulcanology and seismology for 1886. Smiths Inst, An Rp 1887 pt 1:289-312 (1889)

Roddy, H. Justin.

09 The lower Cambrian of Lancaster Co., Pa. (abst). Science n s 30:415 (1909)

15 Concretions in streams formed by the agency of blue green algae and related plants. Am Ph Soc, Pr 54:246-258 (1915)

Rodgers, M. K.

11 Surface indications of ore shoots in depth. M Sc Press $102: 824-825$ (1911)

Rodman, C. S.

67 (with Brush, G. J.) Observations on the native hydrates of iron. $\mathrm{Am} \mathrm{J} \mathrm{Sc}$ (2) $44: 219-222$ (1867)

Rodriguez, $B$.

78 L'asphalte de Banes (Ille de Cuba). Rv Univ Mines (2) 4:756-759 (1878)
Rodriguez Ferrer, Miguel.

82 La isla de Cuba estuvo unida un dia al continente americano. Int Cong Ameri. eanists, 4th, Madrid, 1881, Aetas 1:95-113 (1882)

Roe, A. D.

06 A mineral resembling meerschaum from the serpentine range of Hampden $\mathrm{C}_{0}$. Mass., with deseriptions of interesting in. cluded erystals. Minn de N Sc, B 4:268276 (1906)

Roel, F.

06 (and ordỗnez, E.) Análisis quf. mico de la chíluca $y$ de la cantera. Soc $G$ Mex, B 2:47-50 (1906)

Roemer, Ferdinand (1818-1891).

46 A sketch of the geology of Texas. Am J Sc (2) 2:358-365 (1846) An Mag N H 19:426-431 (1847)

48 Contributions to the geology of Texas. Am J Sc (2) 6:21-28 (1848)

48a Geologen-Versammiung zu Boston. N Jb 1848: 44-47

4sb Ueber gegliederte, aus Kalk-Stück. chen zusammengesetzte Tentakeln oder Pinnulae auf den sogenannten Ambulacral. Feldern der Pentremiten. N Jb 1848 : 292296, II

48e Ueber eine neue Art der Gattung Blumenbachium (König) und mehre un. zweifelhafte Spongien in obersilurischen Kalkschichten der Graftschaft Deeatur im Staate Tennessee in Nord-Amerika. N Jb 1848: $680-686$, il

48d Ueber ein bisher nicht beschriebenes Exemplar von Eurypterus aus devonischen Schichten des Staates New York in Nord-Amerika. Palaeontographica 1:190193 (1848)

48e [Sur une pentremite des êtatsUnis.] Soc G France, B (2) 5: 296 (1848) 49 Texas... xiv, 464 pp, map, Bonn 1849

50 Ueber Stephanocrinus, eine fosslle Crinoiden-Gattung aus der Familie der Cystideen. Arch Naturg 16, $1: 365-375$, il (1850)

51 Monographie der fossilen Crinoidenfamilie der Blastoideen und der Gattung Pentatrematites im Besonderen. Arch Naturg 17, 1:323-397, il (1851) Reprint, 77 pp, il, Berlin 1852

52 Die Kreidebildungen von Texas und Ihre organischen Einschlüsse. 100 pp, Il, Bonn 1852

53 Dorycrinus, ein neues Crinoidengeschlecht aus dem Kohlenkalke Nordamerika's. Arch Naturg 19, 1:207-222, il (1853)

53a Geologische Arbeiten über Texas. N J $1853: 39-44$

53b [Observations on Homalonotus and Dipleura.] N Jb $1853: 579-581$

55 Ueber den Bau von Melonites multi. pora, ein Echinid des amerikanischen Kohlenkalks. Arch Naturg 21, 1 : 312-330, il $(1855)$ 
Roemer, Ferdinand-Continued.

60 Die silurische Fauna des westlichen Tennessee. $100 \mathrm{pp}$, il, Breslau 1860 Transl (in part), Cin Q J Sc 1:29-35, 190-192, 247-253 (1874)

60a Silur-Fauna von Tennessee. N Jb $1860: 327$

78 [On Eurypterus lacustris from Buffalo, N. Y.] Schles Ges, J-Ber 55:58 (1878)

so Notiz über Belemnites ambiguus Morton aus der Kreide von New Jersey. N Jb 1880 , II : $\mathbf{1 1 5}-\mathbf{1 1 7}$

83 Notiz über die Gattung Dictyophyton. Deut G Ges, Zs 35: 704-708 (1883)

84 [On the genus Dictyophyton Hall.] Schles Ges, J Ber 61 : 152-153 (1884)

8 Ueber H. v. Meyer's Mastodon humboldti Cuv.? aus Mexico. N Jb 1887, I : 114-115

87a Graptocarcinus texanus, ein Brachjure aus der oberen Kreide von Texas. N Jb 1887, I : 173-176, il

88 Ueber eine durch die Häufigkeit Hippuritenartiger Chamiden ausgezeichnete Fauna der oberturonen Kreide von Texas. Palaeont Abh (Dames u. Kayser) 4:281296, il (1888) Notice, by R. T. Hill, Am J Sc (3) $37: 318-319$ (1889)

$88 a$ Ueber die Gattungen Pasceolus und Cyclocrinus. N Jb 1888, I : 74-75

$\mathbf{8 8 b}$ Macraster, eine nene SpatangoidenGattung aus der Kreide von Texas, N Jb 1888, I : $191-195$, il

Roepper, William T. (1810-1880).

70 Notice of some minerals from New Jersey. Am J Sc (2) 50:35-38 (1870)

78 On a pseudomorph after anorthite from Franklin, N. J. Am J Sc (3) 16: 364-365 (1878)

Rördam, K.

89 Undersögelse af Olivinsten fra-Siorarsuit ved Kangamiut i Grönland [olivine rock from Siorarsuit, Greenland]. Med Grönland 8:123-130 (1889)

93 Zirkonsyre, fremstillet af Eudialyt [zirconia produced from eudialite]. Med Grönland $7: 47-53$ (1893)

Roesler, F. E.

90 Report [on the underground water supply of Texas]. U S, 51st Cong 1st sess, S Ex Doc 222 : 243-319 (1890)

Roesler, Max.

16 Geology of the iron-ore deposits of the Firmeza district, Oriente Province, Cuba (with discussion by W. L. Cummings, William Kelly, J. T. Singewald, jr., J. D. Irving, L. C. Graton, C. P. Berkey, and the author). Am I M Eng, B 118: 17891839 (1916) ; (discussion) 123-125:375$376, \quad 439-448, \quad 856-859$ (1917) ; Tr 56 : $77-141$ (1917)

See also Lindgren, $\mathbf{1 5 b}$
Rössler, A. R.

68 Geologische Untersuchungen in Texas. K-k G Reichsanstalt, Verh 1868: 188-190 Abst, G Soc London, Q J 25 pt $2: 5-6$ (1869)

69 Kupfererze u. s. w. in Texas. K-k G Reichsanstalt, Verh 1869:2.

69a Allgemeine Bemerkungen über die Geologie der Gegenden jenseits des Mississippi-Flusses. K-k G Reichsanstalt, Verh $1869: 361-363$.

73 (with Loew, O.) Erforschung des Nordwesttheiles von Texas im Jahre 1872. Petermanns Mitt 19:453-467, map (1873)

75 Reply to the charges made by S. B. Buckley, State geologist of Texas, in his official report of 1874 against Dr. B. F. Shumard and A. R. Roessler. 12 pp [N Y 1875] [priv pub]

76 Map of Archer Co., State of Texas... Scale 4000 varas ( 2 miles) to inch. N Y 1876 [Shows geology, mineral localities, etc. Similar maps also of Brown, Comanche, Fayette, Galveston, Gillespie, Hamilton, Haskell, Jack, Llano, McCulloch, Marion, Montague, Rains, Red River, San Saba, and Young cos.]

76a Some account of the mineral wealth of Texas. In Albert Hanford's Texas State Register for 1876: 87-90, Galveston 1876

$76 b$ Geological sketch of the Sour Lake region, Hardin Co., Tex. In Albert Hanford's Texas State Register for 1876: 93-95, Galveston 1876

76e Beschaffenheit und geologische Verhältnisse des Sauersee's in Hardin Co., Tex. K-k G Reichsanstalt, Verh 1876 : $227-229$

Roethe, A. J.

96 The lead and zinc fields of Wisconsin. Eng M J $61: 88-89$ (1896)

Rogers, A. N.

83 The mines and mills of Gilpin Co., Colo. Am I M Eng, Tr 11:29-51 (1883)

Rogers, A. P.

09 The new oil field in Utah. Eng M Jour $87: 989$ (1909)

13 The Byron oil field of Wyoming. Eng M J 96: 869 (1913)

Rogers, Austin Flint.

99 Cupro-goslarite, a new variety of zinc sulphate. Kans Unir Q 8:105-106 (1899)

99n Normal ankerite from Phelps Co., Mo. Kans Univ Q 8:183 (1899)

99b (with Beede, J. W.) New and little known pelecypods from the Coal Measures. Kans Univ Q $8: 131-134$, il (1899)

oo Sphalerite crystals of a peculiar habit and with one new form, from Galena, Kans. Am J Sc (4) 9:134-136 (1900)

OOn Mineralogical notes. Am J Sc (4) $9: 364-366$ (1900) 
Rogers, Austin Flint-Continued.

OOb New bryozoans from the Coal Meas. ures of Kansas and Missouri. Kans Univ Q 9:1-12, il (1900)

ooe Annotated list of the minerals oe curring in the Joplin lead and zinc district. Kans Univ Q 9:161-165 (1900)

Ood Occurrence of the bryozoan genus Rhabdomeson in America. Kans Univ Q $9 \vdots 173-17 t$, il (1900)

o0e The Pottawatomie and Douglas formations along the Kansas River. Kans Univ Q 9:234-254 (1900)

oof (with Beede, J. W.) Coal Meas ures faunal studies. Kans Univ Q 9 233-254 (1900) ; Kans Univ Sc B 1:163181 (1902); $2: 459-473$ (1904); $3: 377-$ 388 (1906)

O1 Mineralogical notes, No. 2. Am J Sc (4) $12: 42-48$ (1901)

01 a A list of the crystal forms of calcite with their interfacial angles. Seh Mines Q 22:429-448 (1901)

o1b A list of minerals arranged according to the thirty-two crystal classes. Sch Mines Q 23:79-98 (1901)

02 Some new American species of Cyclus from the Coal Measures. Kans Univ, Sc B 1: 269-275, il (1902)

02a Mineralogical notes, No. 3 . Sch Mines Q 23:133-139 (1902)

02b The crystallography of the calcites of the New Jersey trap region. Sch Mines Q 23:336-347 (1902)

02e New graphical methods in crystal. lography. Sch Mines Q 23:67-72 (1902)

o2d The minerals of the Joplin, Mo., lead and zinc region (abst). Science $\mathrm{n} s$ 15: $867-868(1902) \quad N$ Y Ac Sc, An 15: 60-61 (1903)

02e (with Moses, A. J.) Formulae and graphic methods for determining crystals in terms of coordinate angles and Miller indices. Sch Mines Q 24:1-36 (1902)

o3 Ein neuer Transporteur zur Bestimmung der Indices der Krystallflächen. Zs Kryst $38: 491-494$ (1903)

03a (with Moses, A. J.) Formeln und graphische Methoden zur Bestimmung von Krystallen auf Grund von Coordinatenwinkeln und Miller'schen Indices. Zs Kryst 38: 209-226 (1903)

04 A method for the exact expression of crystal habit. Sch Mines Q 25: 199-203 (1904)

O4a Minerals of the Galena-Joplin lead and zinc district. Kans Univ G S 8: 445-509 (1904)

06 The determination of minerals in crushed fragments by means of the polarizing microscope. Sch Mines Q 27:340359 (1906)

o6a Some points in teaching crystallography. Science n s 24:620-621 (1gु06)
Rogers, Austin Flint-Continued.

o6b (with Beede, J. W.) Coal Meas. ures faunal studies, IV. Upper Coal Meas. ures, Neosho River section. Kans Univ, Sc B $3: 375-388$ (1906)

o7 Stöber's method of making crystal drawings. Sch Mines Q 38:222-225 (1907)

07a The gnomonic projection from a graphical standpoint. Sch Mines Q 29: 24-33 (1907)

O7b Aegirite and riebeckite rocks from Oklahoma, J G $15: 283-287$ (1907)

o8 A simple reflection goniometer. Science n s $27: 929-930$ (1908)

08n Note on the crystal form of benitoite. Science n s, 28:616 (1908)

O8b (with Beede, J. W.) Coal Meas. ures faunal studies: Faunal divisions of the Kansas Coal Measures. Kans Univ G S $9: 318-385$ (1908)

09 Pyrite crystals from Bingham, Utah. Am J Sc (4) 27:467-468 (1909)

10 Notes on some pseudomorphs, petri. factions, and alterations. $\mathrm{Am} \mathrm{Ph}$ Soc, $\mathrm{Pr}$ $49: 17-23$ (1910)

10a Anhydrite and associated minerals from the salt mines of central Kansas, Am J Sc (4) 29:258-261 (1910)

$10 \mathrm{~b}$ Minerals from the pegmatite veins of Rincon, San Diego Co., Cal. Sch Mines Q 31: 208-218 (1910)

10c The study of rocks without the use of the microscope. Science n s 31:739 $740(1910)$

10d The paragenesis of minerals (abst). Science n 8 32:31 (1910) G Soc Am, B $21: 792$ (1910)

11 A new synthesis and new occurrences of covellite. Sch Mines Q 32:298-304 (1911)

11a Eglestonite from San Mateo Co, Cal. Am J Sc (4) $3<: 48-50$ (1911)

$11 b$ On corundum syenite (uralose) from Montana. J G $19: 748-751$ (1911)

11e Orthoclase-bearing veins from Raw. hide, Nev., and Weehawken, N. J. Ec $G$ 6: $790-798$ (1911)

12 Introduction to the study of minerals: a combined textbook and pocket manual. 522 pp, N Y 1912

12a Baddeleyite from Montana. Am J Se (4) $33: 54-56$ (1912)

121. Lorandite from the Rambler mine, Wyo. Am J Sc (4) 33: 105-106 (1912)

12e The occurrence and origin of gypsum and anhydrite at the Ludwig mine, Lyon Co., Nev. Ec G 7: 185-189 (1912)

12d Dahllite (podolite) from Tonopah, Nev.; vœlckerite, a new basic calcium phos. phate; remarks on the chemical composition of apatite and phosphate rock. Am J Sc (4) $33: 475-482$ (1912) Zs Kryst $52: 209-217$ (1913)

12e The paragenesis of minerals. Ec G $7: 638-646$ (1912) 
Rogers, Austin Flint-Continued.

$12 \mathrm{f}$ Notes on rare minerals from California. Sch Mines Q 33:373-381 (1912) M World $37: 105-106$ (1912)

12g Orthoclase as a vein mineral (abst). G S Am, B 23: 72 (1912)

13 Delafossite, a cuprous metaferrite from Bisbee, Ariz. Am J Sc (4) $35: 290$ 294 (1913)

13a Observations on the feldspars. J G $21: 202-207$ (1913)

13b The nomenclature of minerals. Am Ph Soc, Pr 52 : 606-615 (1913)

13e Upward secondary sulphide enrichment and chalcocite formation at Butte, Mont. Ec G 8:781-794 (1913)

13d Validity of the law of rational indices of crystal faces (abst). G S Am, B $24: 93$ (1913)

13e Gypsum and anbydrite from the Ludwig mine, Lyon Co., Nev. (abst). G Soc Am, B $24: 94$ (1913)

14 Secondary sulphide enrichment of copper ores with special reference to micro. scopic study. M Se Press 109:680-686 (1914)

$14 a$ Nomenclature of minerals (abst). G Soc Am, B 25:124-125 (1914)

$14 b$ (with Eakle, A. S.) Wilkeite, a new mineral of the apatite group, and okenite, its alteration product, from southern California. Am J Sc (4) 37:262-267 (1914)

14e (with Turner, H. W.) A geologic and microscopic study of a magmatic copper sulphide deposit in Plumas Co., Cal., and its modification by ascending secondary enrichment. Ec G 9:359-391 (1914)

14d A new locality for voelckerite [Santa Clara Co., Cal.] and the validity of voelckerite as a mineral species. Miner Mag $17: 155-162$ (1914)

15 Lawsonite from the central Coast Ranges of California. Am J Sc (4) 39 : 105-112 (1915)

15a Notes on the occurrence of anhydrite in the United States. Sch Mines $Q$ $36: 123-142$ (1915)

15b The study of ores at Stanford. G M Soc Am Univ, Yr Bk 2: 20-24 (1915)

16 Sericite a low temperature hydrothermal mineral. Ec G $11: 188-150,506-$ 507 (discussion by C. F. Tolman, jr.) (1916) Abst, G Soc Am, B 26:395 (1915)

16 a Origin of copper ores of the "red beds" type. Ec G 11:366-380 (1916)

16b The so-called graphic intergrowth of bornite and chalcoeite. Ec G 11:582-593 (1916)

16e (with Tolman, C. F., jr.) A study of the magmatic sulfid ores. Leland Stanford Junior Univ Pub, Univ Ser: 76 pp (1916)

17 A review of the amorphous minerals. J G $25: 515-541$ (1917)
Rogers, Austin Flint-Continued.

17a (with Tolman, C. F., jr.) The origin of the Sudbury nickel ores. Eng M J 103:226-229 (1917)

17b (with Tolman, C. F., jr.) The magmatic sulfids (abst). G Soc Am, B 28: 132-133 (1917)

18 The occurrence of cristobalite in California. Am J Sc (4) $45: 222-226$ (1918)

18 An American occurrence of periclase and its bearing on the origin and history of calctte-brucite rocks. Am J Sc (4) 46 : $581-586$ (1918)

See also Thompson (A P), 15

Rogers, Brownell.

93 The Genesee River. Science 21:121 (1893)

Rogers, G. 0 .

93 Drift mounds near Olympia, Wash. Am G 11 : 393-399 (1893)

Rosers, Gaillard Sherburne (1889-1919).

10 The character of the Hudson Gorge at New York City. Sch Mines Q 32:2642 (1910)

11 Original gneissoid structure in the Cortlandt series. Am J Sc (4) $31: 125$ 130 (1911)

11 a Geology of the Cortlandt series and its emery deposits. N Y Ac Sc, An 21 : 11-86, map (1911)

13 The Little Sheep Mountain coal field. Dawson, Custer, and Rosebud cos., Mont. U S G S, B 531: 159-227, maps (1913)

13a A study in the petrology of sedimentary rocks. J G 21:714-727 (1913)

13b Overthrust fault in nearly flat strata. J G $21: 534-536$ (1913)

14 Geology and coal resources of the area southwest of Custer, Yellowstone and Big Horn cos., Mont. U S G S, B 541: 316-328, map (1914)

$14 \mathbf{n}$ The phosphate deposits of South Carolina. U S G S, B 580:183-220, maps (1914)

14b The occurrence and genesis of a persistent parting in a coal bed of the Lance formation. Am J Sc (4) 37:299304 (1914)

14c (and Lesher, C. E.) The use of thickness contours in the valuation of lenticular coal beds. Ec G 9:707-729 (1914)

16 Oll field waters and their chemical relations to oil; particularly the conversion of sulphates into carbonates by hydrocarbons (abst). Wash Ac Sc, J 6:189190 (1916)

17 Baked shale and slag formed by the burning of coal beds. U S G S, P P 108: 1-10 (1917) Abst, Wash Ac Sc, J $7: 563-$ 564 (1917)

17 a Chemical relations of the ofl-field waters in San Joaquin Valley, Cal. U S G S, B 653:119 pp (1917) Abst, Wash Ac Sc, J $7: 586$ (1917) 
Rogers, Gaillard Sherburne-Continued.

17b The Cleveland gas field, Cuyahoga Co., Ohio; with a study of rock pressure. U S G S, B 661:1-68, maps (1917) Abst, Wash Ac Sc, J 7:308 (1917)

17 e Relation of sulphur to variation in the gravity of California petroleum (with discussion by C. W. Washburn, Clifford Richardson, and Charles F. Mabery). Am I M Eng, B 127:1023-1039; 130:18621866 (1917); Tr 57:989-1009 (1918)

17d The interpretation of water analy. ses by the geologist. Ec G $12: 56-88$ (1917)

18 The petrology of reservoir rocks and its influence on the accumulation of petroleum (discussion). Ec G 13:316-324 (1918)

18a Intrusive origin of the Gulf coast salt domes. Ec G $13: 447-485$ (1918)

See also Lucas (A F), 18; Matteson, 18 Rogers, Henry Darwin (1808-1866).

35 Report on the geology of North Amer ica. Brit As, Rp 4:1-66 (1835)

35a A guide to a course of lectures on geology... 43 pp, Phila 1835

35b On the Falls of Niagara ... Am J Sc $27: 326-335$ (1835) Edinb N Ph J $19: 281-292$ (1835)

36 Report on the geological survey of the State of New Jersey. 157 pp, Freehold, N. J. 1836 Another ed, 174 pp, Phila, 18362 d ed, 188 pp, Phila, 1836

$\mathbf{3 6 a}$ First annual report of the State geologist. $22 \mathrm{pp}$, Harrisburg, 1836

37 (and Rogers, W. B.) Contributions to the geology of the Tertiary formations of Virginia. Am $\mathrm{Ph}$ Soc, $\mathrm{Tr} \mathrm{n} \mathrm{s} 5: 319$ 341 (1837) ; $6: 347-379$, il (1839) A reprint ... on the geology of the Virginias: $661-672$, 11, N Y 1884 Abst, Am J Sc 38: 182-184 (1840)

38 Second annual report on the geolog ical exploration of the State of Pennsylvania. $93 \mathrm{pp}\left(91 \mathrm{pp}^{*}\right)$ Harrisburg 1838 ; 39 Third ... 119 pp (118 pp*) (1839); 40 Fourth ... 215 pp $\left(252 p^{*}\right)(1840) ; 41$ Fifth ... 156 pp $\left(179 \mathrm{pp}^{*}\right) \quad(1841) ; 42$ Sixth ... 28 pp (1842)

* Another edition. Issued also in legisla. tive documents with different pagination.

38a Some facts on the geology of the central and America. G Soc London, Pr 2:103-106 (1838)

39a (and Rogers, W. B.) Contribufions to the geology of the Tertiary formations of Virginia; second series. Am Ph Soc, Pr 1: 88-90 (1839)

40a Description of the geology of the State of New Jersey, being a final report. 301 pp, map, Phila 1840 Reprint, 227 pp, Trenton 1865
Rogers, Henry Darwin-Continued.

41 a Observations upon the geological structure of Berkshire, Mass, and the neighboring parts of New York. Am Pl Soc, Pr 2:3-4 (1841)

$41 \mathrm{~b}$ (and others). Report on the Ornt thichnites or footmarks of extinct birds in the new red sandstone of Massachusetts and Connecticut ... Am J Sc 41:165-16s (1841) As Am G, Rp: 18-21 (1843) At Mag N H $8: 235-238$ (1842)

41e [Origin of overturned folds in Pennsylvania] (abst). Am J Sc 41:177 (1841) As Am G, Rp : 29-30 (1843)

42a [On striated surfaces in northeast. ern Pennsylvania and on the origin of c0n glomerate] (abst). Am J Sc 43:180-181 (1842) As Am G, Rp: 72-73 (1843) Geologist 1843: 40

42b On ground and polished surfaces at the contact of ancient secondary strats (abst). Am J Sc 43:181 (1842) As At G, Rp: 73 (1843)

42e (with Rogers, W. B.) Observ. tions on the geology of the western penit. sula of Upper Canada, and the wester part of Ohio. Am $\mathrm{Ph}$ Soc, Tr $\mathrm{n}$ s $8: 273-$ 284 (1843); Pr 2:120-125 (1842)

43 On the earthquake of January 4 . 1843. Am Ph Soc, Pr $2: 258-259$ (1843)

43a (and Rogers, W. B.) On the phenomena of the great earthquakes which occurred during the past winter...and on a general theory of earthquake motion, by which they propose to elucidate several points in geological dynamics. $\mathrm{Am} \mathrm{Ph} \mathrm{S}_{0}$, Pr 3:64-67 (1843)

43b An inquiry into the origin of the Appalachian coal strata, bituminous and anthracitic. As $\mathrm{Am}$ G, Rp: 71 (abst) $433-474$ (1843). Abst, Am J Sc 43:17s179 (1842) ; Geologist 1843: 39-40

43e (and Rogers, W. B.) On the physical structure of the Appalachias chain, as exemplifying the laws which bave regulated the elevation of great mountain chains generally (abst). Geologist 1842 235-240 Brit As, Rp $12: \sec 40-42$ (1843) Am J Sc $44: 359-362$ (1843)

$43 d$ On hydrated minerals and antediluvian temperatures $(a b s t)$. Am J $s c$ $45: 147$ (1843)

43e [Cause of crescent-formed dikes of trap in New Jersey and Connecticut]. Am J Se $45: 334$ (1843)

43f (and Rogers, W. B.) Theory of earthquake action. Am J Sc $45: 341-347$ (1843)

43g (with Rogers, W. B.) On the physical structure of the Appalachian chain, as exemplifying the laws which regulated the elevation of great mountain chains generally. As Am G, Rp: 70-71 (abst), 47t531 (1843) A reprint ... on the geology of the Virginias: 601-642, N Y 1884 Abst, Am J Se $43: 177-178$ (1842) 
Rogers, Henry Darwin-Continued.

44 Address [on the recent progress of geological research in the United States] delivered at the meeting of the Association of American Geologists and Naturalists held in Washington, May, 1844. Am J Sc 47: 137-160, 247-278 (1844) Reprint, $58 \mathrm{pp}$ (1844) Abst, Edinb N Ph J $37: 392-395$ (1844)

44a On the probable constitution of the atmosphere at the period of the formation of coal (abst). Am J Sc 47:105 (1844)

44b (and Rogers, W. B.) A system of classification and nomenclature of the Paleozoic rocks of the United States with an account of their distribution more particularly in the Appalachian mountain chain (abst). Am J Sc 47:111-112 (1844)

45 [On the bones of Zeuglodon, recently exhibited under the name of Hydrarchos.] Boston Soc N H, Pr 2: 79 (1845)

45a (and Rogers, W. B.) [On boulder trains in Berkshire Co., Mass.] Boston Soc N H, Pr 2: 79-80 (1845)

45b [The cause of drift phenomena] (abst). As Am G, Pr 6: 12-14 (1845)

45e On the direction of the slaty cleavages in strata of the southeastern belts of the Appalachian chain, and the parallelism of the cleavage dip with the planes of maximum temperature (abst). As Am G, Pr 6: $49-50(1845)$

46 (and Rogers, W. B.) On the geological age of the White Mountains. Am J Sc (2) 1:411-421 (1846)

46a (and Rogers, W. B.) An account of two remarkable trains of angular erratic blocks in Berkshire, Mass., with an attempt at an explanation of the phenomena. Boston J N H $5: 310-330$ (1846)

46b [On the geology and mineralogy of the southern shore of Lake Superior.] Boston Soc N H, Pr 2:124-125 (1846)

47 On the drift of New England and the River St. Lawrence ( $a b s t$ with discussion by L. Agassiz and E. Emmons). Am J Agr 6:214 [262] (1847)

47a [On drift phenomena.] Am J Agr $6: 217-218$ (1847)

48 Fossils in the White Mountains. Am J Sc (2) $5: 116(1848)$

48a [On the cause of metamorphism in rocks.] Boston Soc N H, Pr 3: 20 (1848)

48b [Altered shales and sandstone from New Hope, Pa.]. Boston Soc N H, Pr $3: 30$ (1848)

49 On the geology of Pennsylvania. Brit As, Rp 18: $\sec 74-75$ (1849)

50 [On the origin of the green sand of New Jersey.] Boston Soc N H, Pr 3 : 248249 (1850)

50a [On the origin of New York and Pennsylvania beds of limestone.] Boston Soc N H, Pr 3 : 258-259 (1850)

$50 b$ [On the origin of salt lakes.] Boston Soc N H, Pr 3:259-260 (1850)
Rogers, Henry Darwin-Continued.

50c On the structural features of the Appalachlans ... Am As, Pr 2:113-115, 118 (1850)

50d On the analogy of the ribbon structure of glaciers to the slaty cleavage of rocks. Am As, Pr 2:181-182 (1850)

5oe $O n$ the origin of the drift, and of the lake and river terraces of the United States and Europe ... Am As, Pr 2:239 $255(1850)$

51 [On the cause of the want of symmetry in the curves of the earth's strata, as seen in the great mountain chains of America and Europe (with discussion by E. Desor).] Boston Soc N H, Pr 4:32-33 (1851)

51 a On the coal formation of the United States, and especially as developed in Pennsylvania. Am As, $\operatorname{Pr} 4: 65-70$ (1851)

$51 \mathbf{b}$ On the connection of the deposits of common salt with climate. Am As, Pr $4: 126$ (1851)

51e On the position and character of the reptilian footprints in the Carboniferous red shale formation of eastern Pennsylvania. Am As, Pr 4:250-251 (1851)

52 [On the coal at Hillsboro, N. B. (with discussion by C. T. Jackson).] Boston Soc N H, Pr 4: 169-179 (1852)

52n (and Desor, E.) On the equivalence in geolegical age of the coal formation of the United States and the anthraciferous strata of Mayenne and Sarthe, France. Boston Soc N H, Pr 4:189-191 (1852)

53 Report on the Wheatley and Brookdale mines, Chester Co., Pa. M Mag 1: 375-387 (1853)

53a Sur les recherehes géologiques en Pennsylvanie. Soc $G$ France, B (2) 10 : 326-328 (1853)

53b [Observations on earthquakes.] Boston Soc N H, Pr 4:301 (1853)

54 The Lackawanna coal basin; its geology and mining resources around Seranton, Pa. M Mag 2:388-395, 475-490, $609-620$ (1854)

54a [On flexures in coal basins.] Boston Soc N H, Pr 4:328 (1854)

546 [On the inclination and thickness of the sandstone of the Connecticut VaIley.] Boston Soc $\mathrm{N} H$, Pr $4: 379-380$ (1854)

54e [On the epoch of the mammoth or Elephas primigenius.] Boston Soc N H, Pr 5: 22-23 (1854)

$54 d$ [On the formation of coal.] Boston Soc N H, Pr 5: 43 (1854)

55 Salt and gypsum of the Preston Val ley of the Holston River, Va. M Mag 4: 28-36 (1855)

55a [Footprints and other impressions on Carboniferous red shale of Pennsylvania (with discussion by J. C. Warren, W. B. Rogers, and C. T. Jackson).] Boston Soc N H, Pr 5: 182-186 (1855) 
Rogers, Henry Darwin-Continued.

$55 \mathrm{~b}$ [On the geology of the eastern base of the Roeky Mountains.] Boston Soc N H, Pr 5: 190-191 (1855)

56 On the geology and physical geography of North America. R Inst, $\operatorname{Pr} 2$ : 167-187 (1856) Franklin Inst, J (3) 33 : 224-230, 363-368 (1857) M Mag 8:417$424 ; 9: 45-51,514-522$ (1857)

$56 a$ Geolegical map of the United States and British North America. In Johnston, A. K., Physical atlas of natural phenomena, pl 8, Edinburgh 1856 [not seen]

57 Classification of the metamorphic strata of the Atlantic slope of the Middle and Southern States. Boston Soc N H, Pr 6 : 140-145 (1857)

$57 a$ [On the nomenclature of superposed strata.] Boston Soc N H, Pr 6 : 183-184 (1857)

57b On the correlation of North Amer lcan and British Paleozoic strata. Brit As, Rp 26: sec 175-186 (1857)

58 The geology of Pennsylvania, a government survey. 2 vols, $4^{\circ}$; vol 1 : xxvii, $586 \mathrm{pp}$; vol 2 : xxiv, $1046 \mathrm{pp}$, il, maps, Philadelphia 1858

$\mathbf{5 8 a}$ Sketch of the geology of the United States. G $\mathrm{P}_{2}$ 2:741-775 (1858)

581 Conditions of the physical geography attending the production of the Paleozoic strata of the United States. G Pa 2 : 776-815 (1858)

5Se Organic remains of the Paleozoic strata of Pennsylvania. G Pa $2: 815-836$, il (1858)

58d On the laws of structure of the more disturbed zones of the earth's crust. G Pa 2:885-916 (1858)

58e Classification of the several types of orographic structure visible in the Appalachians and other undulated mountain chains. G Pa 2:917-941 (1858)

58 Coal fields of the United States and British provinces. G $\mathrm{Pa} 2: 942-1019$, map (1858)

58g Geological map of the State of Pennsylvania ... Scale 5 miles to 1 inch. [Pa G S 1858]

5Sh Geological and topographical map of the anthracite fields of Pennsylvania ... [Pa G S] 1858

60 On the distribution and probable origin of the petroleum or rock oil of western Pennsylvania, New York, and Ohio. Ph Soc Glasgow, Pr 4: 355-359 (1860)

65 On a peculiar fossil found in the Mesozoic sandstone of the Connecticut Valley. Brit As, Rp $34: \sec 66$ (1865)

66 On petroleum. $\mathrm{Ph}$ Soc Glasgow, $\mathrm{Pr}$ 6: $48-60$ (1866)

See also Bouvé, 54; Desor, 50, 52g; Guyot, 50 ; Haldeman, 45; Hall, 43f, 1, J ; Hitcheock (E), 42 ; Jackson, 49c ; Lesquereux, 54; Mather, 41c; Nicollet, 43a; Warren, 49 ; Wyman, 50c

\section{Rogers, R. V.}

09 The geolegical survey of northeastem Chihuahua, Mexica. Mex M J 9 no $5: 24$ (1909)

\section{Rogers, Reese F.}

15 The iron ore deposits of Lewis $\mathrm{CO}_{4}$ Tenn. Tenn G S, Res'Tenn 5:91-146, map (1915)

Rosers, Robert E.

49 (with Rogers, W. B.) On the de composition of rocks by meteoric water. Am As, Pr 1: 60-62 (1849)

59 A few facts regarding the geological survey of Pennsylvania ... 22 pp, Phila 1859

Rogers, William Barton (1804-1882).

36 Report of the geological reconnais. sance of the State of Virginia. 143 pp Phila 1836; another ed, Doc No 24, 52 pp [Richmond 1836] Reprint: 21-122 (1884) Extr, The Virginias $3: 135, \quad 138-130$ (1882) ; $4: 110-111$ (1883)

37 Report of the progress of the geolog ical survey of the State of Virginia for the year 1836. (Doc no 34): 14 pp [Richmond 1837] Reprint:123-145 (1884) Another ed [with second report] $30 \mathrm{pp}$. Phila 1838 Extr, The Virginias 4:111112 (1883)

37a (with Rogers, H. D.) Contribu. tions to the geology of the Tertiary for. mations of Virginia. Am Ph Soc, $\operatorname{Tr}$ is 5: 319-341 (1837) ; $6: 347-379$, il (1839) A reprint ... on the geology of the Vir ginias: 661-672, il, N Y, 1884 Abst, Am J Sc $38: 182-184$ (1840)

38 Report of the progress of the geo logical survey of the State of Virginia for the year 1837 (Doc No 45) : 24 pp [Richmond 1838] Reprint:147-188 (1884) Another ed [with first report] pp 31-87, Phila 1838 Extr, The Virginias 4:112113 (1883)

39 Report of the progress of the geological survey of the State of Virginia for the year 1838. (Doc No 56) : 32 pp (Richmond 1839] Reprint: 189-243 (1884) Extr, The Virginias $3: 158-159, \quad 164$ (1882) ; 4:113-115 (1883)

39a (with Rogers, H. D.) Contribt tions to the geology of the Tertiary formations of Virginia; second series. Am Ph Soc, Pr 1: 88-90 (1839)

40 Report of the progress of the geolog. ical survey of the State of Virginia for the year 1839 . $161 \mathrm{pp}$, Richmond 1840 Beprint : 245-410 (1884) Extr, The Virginias $3: 71-73,77,158-159,164$ (1882): 4: 115-116 (1883)

41 Report of the progress of the geological survey of the State of Virginia for the year 1840 . $132 \mathrm{pp}$, Richmond 1841 Reprint : 411-535 (1884) Extr, The Virginias $2: 58-59$ (1881) 
Rogers, William Barton-Contiuned,

42 Report of the progress of the geological survey of the State of Virginia for the year 1841. $12 \mathrm{pp}$, Richmond 1842 Reprint : $537-546$ (1884)

42a (and Rogers, H. D.) Observations on the geology of the western peninsula of Upper Canada, and the western part of Ohio. Am Ph Soc, Tr n s 8:273284 (1843) ; Pr 2:120-125 (1842)

$42 \mathrm{~b}$ on the porous anthracite or natural coke of eastern Virginia: Am J Sc 43:175-176 (1842) As Am G, Rp: 68 (1843) Abst, Geologist 1843: 39

42e Observations on subterranean temperature made in the mines of eastern Virginia (abst). Am J Sc $43: 176$ (1842) As Am G, Rp: 69 (1843)

42d [On erosion of strata underlying the Oriskany sandstone] (abst). Am J Sc 43:181-182 (1842) As Am G, Rp:7374 (1843)

42e [On the age of the coal formation of Richmond, Va., and of the Frederickshurg sandstone.] Ac N Sc, Phila, $\mathrm{Pr}$ 1: $142,250(1842)$

$42 f$ (with Rogers, H. D.) On the structure of the Appalachian chain as exemplifying the laws which have regulated the elevation of great mountain chains generally (abst). Am J Sc 43:177-178 (1842) As Am G, Rp : 70-71 (1843)

43 (and Rogers, H. D.) On the physical structure of the Aappalachian chain, as exemplifying the laws which have regulated the elevation of great mountain chaings generally. As Am G, Rp: 70-71 (abst), 474-531 (1843) A reprint ... on the geology of the Virginias: 601-642, N Y 1884 Abst, Am J Se $43: 177-178$ (1842)

$43 a$ On the age of the coal rocks of eastern Virginia. As Am G, Rp: 68 (abst), 298-316, il (1843) A reprint ... on the geology of the Virginias: $645-658$, il, N Y 1884 Abst, Am J Sc 43:175 (1842); Geologist $1843: 38-39$

43b On the connection of thermal springs in Virginia with anticlinal axes and faults. As Am G, Rp : 323-347 (1843) A reprint ... on the geology of the Virginlas: 577-597, N Y 1884 Abst, Am J Sc $43: 176$ (1842); As Am G, Rp: 69 (1843) ; Geologist 1843: 39

43e Observations of subterranean temperature in the coal mines of eastern Virginia. As Am G, Rp: 532-538 (1843) A reprint ... on the geology of the Virginias: $569-574$, N Y (1884)

43d On the limits of the infusorial stratum in Virginia. Am $J$ Se $45: 313$ 314 (1843)

43e (with Rogers, H. D.) Theory of earthquake action. Am J Sc $45: 341-347$ (1843)
Rogers, William Barton-Continued.

431 (with Rogers, H. D.) On the phenomena of the great earthquakes which occurred during the past winter ... and on a general theory of earthquake motion, by which they propose to elucidate several points in geologieal dynamics. $\mathrm{Am} \mathrm{Ph}$ Soc, $\operatorname{Pr} 3: 64-67$ (1843)

43g (with Rogers, H. D.) On the physical structure of the Appalachian chain, as exemplifying the laws which have regulated the elevation of great mountain chains generally (abst). Geologist 1842: 235-240 Brit As, Rp 12 : sec $40-42$ (1843) Am J Sc $44: 359-362$ (1843)

44 (with Rogers, H. D.) A system of classification and nomenclature of the Paleozoic rocks of the United States with an account of their distribution more particularly in the Appalachian mountain chain (abst). Am J Sc 47:111-112 (1844)

45 (with Rogers, H. D.) [On boulder trains in Berkshire Co., Mass.] Boston Soe $\mathrm{N} \mathrm{H}, \operatorname{Pr} 2: 79-80$ (1845)

46 (with Rogers, H. D.) On the geological age of the White Mountains. Am J Se (2) 1:411-421 (1846)

$46 \mathrm{n}$ (with Rogers, H. D.) An account of two remarkable trains of angular erratic blocks in Berkshire, Mass., with an attempt at an explanation of the phenomena. Boston J N H 5:310-330 (1846)

48 On the transporting power of currents (abst). Am J Sc (2) $5: 115-116$ (1848)

49 (and Rogers, R. E.) On the decomposition of rocks by meteoric water. Am As, Pr 1:60-62 (1849).

49n Observations on the southern shore of Lake Superfor. Am As, Pr 1:79-80 (1849)

54 [Geological relations of the New Red Sandstone of the Middle States and Connecticut Valley to the coal-bearing rocks of eastern Virginia and North Carolina.] Boston Soc N H, Pr 5:14-18 (1854) A reprint...on the geology of the Virginias: $765-768$ N $\quad$ Y $1884 \quad$ M Mag $5: 128-132$ (1885)

54a On the natural coke in the vicinity of Richmond, Va. Boston Soc N H, Pr 5 : 53-56 (1854) Am Ac Arts, Pr 3:106-107 (1857) The Virginias 4:158-159 (1883) A reprint...on the geology of the Virginias : $677-678$, N Y 1884

54b The property of the Pridevale Iron Company [Preston Co., W. Va.]. M Mag 3: 355-370, 489-499 (1854) A reprint...on the geology of the Virginias : $679-705, \mathrm{~N} \mathrm{Y}$ 1884

55 [Note on the coal-bearing rocks near Richmond, Va., and the New Red Sandstone of North Carolina (with discussion by C. T. Jackson.] Boston Soc N H, Pr 5: 186 (1855) 
Rogers, William Barton-Continued.

$\mathbf{5 5 a}$ [On lignite from Lancaster Co., Pa., and eastern Virginia.] Boston Soc N H, Pr 5:189-190 (1855)

55b [On Mesozoic rocks in Virginia.] Boston Soc N H, Pr 5: 201-202 (1855)

55e [On the metamorphic influence of trap rocks on adjacent sedimentary strata in Prince William Co., Va.] Boston Soc N H, Pr 5: 202-204 (1855)

56 On the origin and accumulation of the protocarbonate of iron in coal measures [and on the color of rocks]. Boston Soc N H, Pr $5:$ 283-288 (1856) Am J Sc (2) $21: 339-343$ (1856) M Mag $6: 201-207$ (1856)

56a [Nitrates in cave earths.] Boston Soc N H, Pr 5:334-335 (1856) A reprint ...on the geology of the Virginias : 763-764, N Y 1884

56b [On the growth of stalactites.] Boston Soc N H, Pr $5: 336-337$ (1856) A reprint ... on the geology of the Virginias: $764-765$, N Y 1884

56e [On trilobites from Braintree, Mass., and on the geologic relations of the district.] Boston Soc $\mathrm{N} \mathrm{H}, \operatorname{Pr} 6: 27-29$, $40-41$ (1856) M Mag $7: 371-373,454$ (1856)

56d Discovery of Paleozoic fossils in eastern Massachusetts. Am J Sc (2) 22 : 296-298 (1856)

56e On the discovery of Paradoxides in the altered rocks of eastern Massachusetts. Edinb N Ph J n s 4:301-304 (1856) ; abst, n s $6: 314-315$ (1857)

57 [On the age of the Deep River coal field, N. C.] Am Ac Arts, Pr 3:69 (1857)

57 a Proofs of the Protozolc age of some of the altered rocks of eastern Massachusetts from fossils recently discovered. Am Ac Arts, Pr $3: 315-318$ (1857)

$\mathbf{5 7 b}$ [Sketch of the life of Michael Tuomey.] Boston Soc N H, Pr 6:185186 (1857)

57e [On the scientific work of William C. Redfield.] Boston Soc N H, Pr 6:186191 (1857)

57 d [On the faults and joints of the slate rocks of Governor's Island in Boston Harbor.] Boston Soc N H, Pr 6 : 217-218 (1857)

58 [On anticlinal flexures.] Boston Soc N H, Pr 6: 332-333 (1858)

58 a $[O n$ the Clinton iron ores of the Appalachian belt.] Boston Soc $\mathrm{N} \mathrm{H}, \mathrm{Pr}$ 6: $340-341$ (1858)

59 [On the thickness of the earth's crust.] Boston Soc $\mathrm{N} H, \operatorname{Pr} 7: 47-48$ (1859)

$59 a$ [On the infusorial earth from the Tertiary of Virginia and Maryland and the geological relations of the strata.] Boston Soc N H, Pr 7:59-64 (1859)
Rogers, William Barton-Continued. $59 b$ [On the age of the rocks of Perm Me. (with discussion by C. T. Jackson), Boston Soc N H, Pr 7:86 (1859)

59e [On the rate of aceumulation of deposits in the South Joggins in Nor Scotia.] Boston Soc N H, Pr 7:168-170 (1859)

59d [On the parallelism of the Lowe Carboniferous of Pennsylvania and Virginit and of Nova Scotia and New Brunswick. Boston Soc N H, Pr $7: 170-173$ (1859)

60 [On the geology of the Eastport if gion, Me.] Boston Soc N H, Pr $7: 227-228$ (1860)

60a [On the geology of western Ver: mont.] Boston Soc N H, Pr $7: 237-239$ (1860) Can Nat 6:326-328 (1860)

b) [On the stratigraphical relations deposits formed in an ocean under the conditions of stationary, subsiding, and rising position of the sea bottom (with discussion by L. Agassiz).] Boston Soc X $\mathrm{H}, \operatorname{Pr} 7: 246-249,273-275$ (1860)

60e $[\mathrm{On}$ the coal vein at the Albert mine, New Brunswick (with discussion by C. T. Jackson), ] Boston Soc N H, Pr $7: 294-295$ (1860)

60d [On passage beds.] Boston Socy $\mathrm{H}, \operatorname{Pr} 7: 319-322$ (1860)

60e [On the albertite of New Brust wick.] Ac N Sc Phila, Pr 1860:98

61 [On fossiliferous Potsdam pebbles in Carboniferous conglomerate in eastert Massachusetts.] Boston Soc N H, Pr i 389-391 (1861)

61 a [On elongated form and paralle arrangement of pebbles.] Boston Soc Y H, Pr $7: 391-394$ (1861)

$61 \mathrm{~b}$ On the group of rocks constitution the base of the Paleozoic series in the United States. Boston Soe $\mathrm{N} H$, Pr 7 : 394-395 (1861)

61e [On the age of sandstones of $8 t$ Croix, N. B., and Perry, Me.] Boston Six N H, Pr $7: 398-399$ (1861)

61d [Boulder with Devonian fossils from Saco River, Me.] Boston Soc $\mathrm{N} \mathrm{H}, \mathrm{Pt}$ 7: 409 (1861)

61e [On the Paleozoic rocks of Denti River in Maine.] Boston Soe $\mathrm{N} \mathrm{H}$, Pt $7: 419$ (1861)

61: [On the primordial fauna and the Taconic system.] Boston Soc N H, Pr $7: 419-422,427$ (1861)

61o Notes on the geological structure of western Vermont (abst). In Report on the geology of Vermont (Hitcheock) 1:32t327 (1861)

62 (with Jackson, C. T., and Blaké, J. H.) $\ldots$ the frozen well of Brandon, it Boston Soc N H, Pr 9: 72-81 (1862)

75 On the Newport conglomerate [Mass]. Boston Soc N H, Pr 18: 97-101 (1875) 
Rogers, William Barton-Continued.

$75 a$ On the gravel and cobblestone deposits of Virginia and the Middle [Atlantic] States. Boston Soc N H, Pr 18:101-106 (1875) The Virginias 3:58-59 (1882) A reprint... on the geology of the Virginias: $709-713$, N Y 1884

75b Hotchkiss' geological map of Virgin $^{\circ}$ and West Virginia, the geology by Prof. W. B. Rogers... Scale 24 miles to 1 inch. Richmond $1875 \quad 2 d$ ed, 1885

so Table of the geological formations found in Virginia and West Virginia. The Virginias $1: 14-15(1880) ; 3: 61$ (1882)

80a The iron ores of Virginia and West Virginia. The Virginias $1: 128-130,138$ $140,152-153,160-161,170-171,174-175$, $182-183,186-188$ (1880)

81 Infusorial stratum and associated Tertiary beds in the vicinity of Richmond, Va. The Virginias 2:58-59 (1881)

82 The infusorial deposit of Virginia in the Fort Monroe artesian well. The Virginias $3: 151-152$ (1882) A reprint...on the geology of the Virginias : 733-736, N Y 1884

82a The fossils of formation No. III in Virginia. The Virginias $3: 175$ (1882)

$\mathbf{8 2 b}$ Notes on the geology of the Virginias. The Virginias $3: 190(1882) ; 4$ : $12-13,38-39,59-61,71-72,88-90$ (1883)

$84 \mathrm{~A}$ reprint of annual reports and other papers on the geology of the Virginias. $832 \mathrm{pp}$, il, with map and sections, N Y 1884

84a Some observations on the Tertiary marl of lower Virginia, 1834 . A reprint... on the geology of the Virginias: 1-20, N Y 1884

84b Analyses of waters of the principal mineral springs of Virginia. A reprint... on the geology of the Virginias: 547-564, N Y 1884

84c Notes from Macfarlane's geological railway guide, 1879. Virginia and West Virginia. In A reprint ... on the geology of the Virginias : $715-729$, N Y 1884

84d History of the survey [of the State of Virginia]. In A reprint ... on the geology of the Virginias : 749-763, N Y 1884. 85 Geological sections on Coal River, W. Va, The Virginias $6: 153-154$ (1885) 96 Life and letters of William Bcrto. Rogers, edited by his wife. 2 vols., 427 , $451 \mathrm{pp}$, port, Boston 1896

See also Agassiz (L). 60; Hitcheock (C H), 61d; Hotchkiss, 80e; Marcou, 61b ; Perrey, 55 ; Rogers (H D), 55a

Rogers, William Luttrell.

88 The philosophy of glacier motion. Am Geog Soc, B 20:481-501 (1888)

RohIfing, D. P.

17 The great Horn Silver vein in Beaver Co. [Utah]. Salt Lake M Rv 1. no 12: 23-24 (1917)
Rohn, Oscar.

Oo A reconnaissance of the Chitina River and the Skolai Mountains, Alaska. U S G S, An Rp 21 pt $2: 393-440$, maps (1900)

03 The Baraboo iron range [Sauk Co., Wis.]. Eng M J 76:615-617 (1903)

Rohwer, S. A.

os A fossil larrid wasp [Pison cocker. elle, Florissant, Colo.] Am Mus N H, B 24:519-520 (1908)

osa on the Tenthredinoidea of the Florissant shales. Am Mus N H, B 24: $521-530 \quad(1908)$

08b The Tertiary Tenthredinoidea of the expedition of 1908 to Florissant, Colo. Am Mus N H, B 24:591-595, il (1908)

08e A fossil mellinid wasp [Mellinus handlirschi, Florissant, Colo.]. Am Mus N H, B 24;597 (1908)

09 The fossil Ceropalide of Florissant, Colo. Psyche 16:23-28 (1909)

09a Trree new fossil insects from Florissant, Colo. Am J Sc (4) 28: 5 53 536 (1909)

o9b New Hymenoptera from western United States. Am Entom Soc, Tr 35:99136 (1909)

Roldán, L. Villar.

11 Estudio geológico y minero de la Sierra de EI Oro, Durango. Soc G Mex, B $7: 125-134$, map (1911)

Rolfe, Charles Wesley.

89 Characters and distributio of the genera of Brachiopoda. Am Nat 23:983998 (1889)

90 Artesian water from the drift [111.]. Am G 6:32-35 (1890)

03 The geology of Illinois as related to its water supply. Ill Univ, Chem S Waters III, Rp 1897-1902:41-56, maps (1903)

os Geology of clays. Ill G S, B $9: 1-35$ (1908

O8a Geological distribution of r aring brick material in Illinois. Ill G $\mathrm{S}, \mathrm{B}$ : : 36-46 (1908)

Rolfe, Deette.

15 Geologic influences in the economic derelopment of the Pennsylvania Piedmont Plateau. Geog Soc Phil:, B 13:133-1.4 (1915)

Rolfe, Frank.

18 (and Strong, A. M.) The earthquake of April 21, 1918, in the San iacinto Mcuntains. [Cal.]. Seism Soc $\angle \mathrm{m}$, B 8 : 63-67 (1918)

Rolker, Charles !.

79 The late operations o the Mariposa estate [gold veins, Mariposa Co., Cal.]. Am I M Eng, Tr 6: 45-164 (1879)

81 The silver sandstone district of Utan (with discussion by G. W. Maynard). Am I M Eng, Tr 9:21-33 (1881)

84 Popular fallacies on precious metal ore deposits. Eng M J 38:2U 295 (1884) 
Rolker, Charles M.-Continued.

S6 Note on an exhibition of banded structure in a gold rein. Am I M Eng, $\operatorname{Tr} 14: 265-266$ (1886) Eng M J 40:367 (1०86)

86a Notes on certaiv iron ore deposits in Colorado. Am I M Eng. Tr 14: 266-273 (1886)

86b Notes on the Leadville ore deposits [Colo.]. Am I M Eng, Tr 14:273-292 (1886) Eng M J 41:36-40 (1886)

95 The production of tin in various parts of the world. U S G S, An Rp 16 pt $3: 458-538$ (1895)

Rolland, $G$.

78 Notice sur les tellurides dor et d'argent du comté de Boulder, Colorado, fitats-Unis. An Mines (7) $13: 159-176$ (1878)

$78 \boldsymbol{a}$ Les gisements de mercure de Californie. Soc Minér France, B 1:98-104 (1878)

78b Les gisements de mercure de Californie. An Mines (7) 14:384-432 (1878) Romanes, James.

12 Geology of a part of Costa Rica. G Soc London, Q J 69: 103-139 (1912)

12n Geological notes on the Peninsula of Nicoya, Costa Rica. G Mag (5) 9: 258-265, 46 (abst), map (1912)

Fomanet du Caillad, F.

08 Les roches kaolinifères du bassin du lac Népigon, Canada. Ac Se Paris, C R $147: 361-364$ (1908)

Romberg, Arnold.

18 (with Jaggar, T. A., jr.) An ex. periment in teleseismic registration. Seism Soc Am, B 8: 88-89 (1918)

Romeyn, Henry.

00 Salt mines of Avery's Island, La. Mines and Minerals 20:438-439 (1900)

Rominger, Carl Ludwig (1820-1907).

62 True position of the so-called Waukesha limestone of Wisconsin. Am J Sc (2) $34: 136$ (1862)

62 Description of Calamoporae found in the gravel deposits near Ann Arbor, Michigan, with some introductory remarks. Am J Se (2) 34:389-400 (1862)

63 Exposition of the true nature of Pleurodictyum problematicum. Am J Sc (2) $35: 82-84$ (1863) An Mag N H (3) 11: 390-391 (1863)

63a [Note on the structure of the loop in Leptocoelia concava Hall.] Am J Sc (2) $35: 84$ (1863)

66 Observations on Chaetetes and some related genera, in regard to their system. atic position; with an appended description of some new species. Ac N Sc Phila, Pr $1866: 113-123$

73 Paleozoie rocks [Upper Península]. Mich G S 1 pt 3:105 pp (1873)

76 Geology of Lower Peninsula. Mich G S, 3 pt 1:225 pp, map (1876)
Rominger, Carl Ludwig-Continued.

76n Observations on the Ontonagon sil. ver mining district and the slate quarries of Huron Bay. Mich G S 3 pt $1: 151-166$ (1876)

76b Paleontology: fossil corals. Mich G S 3 pt 2:161 pp, il (1876)

81 Upper Peninsula; Marquette iron region. Mich G S 4:1-154, map (1881)

81 a Menominee iron region. Mich G 8 , $4: 155-241$ (1881)

86 On the minute structure of Stromato. pora and its allies. Ac N Sc Phila, Pt 1886 : $39-56$

87 Description of a new form of Bry. ozoa. Ac N Se Phila, $\operatorname{Pr} 1887$ : 11, il

87a Description of Primordial fossils from Mount Stephen, N. W. Territory of Canada. Ac N Sc Phila, Pr 1887:1219, il

88 [Fossils from Mount Stephen, Can ada]. Am G 2:356-359 (1 1888 )

90 Studies on Monticulipora. Am G 6: 102-121 (1890)

92 On the occurrence of typical tha tetes in the Devonian strata at the Falls of the Ohio... Am G $10: 56-63$, il (1892)

93 Report of the State Geologist fot 1881-1882. Mich G S, Rp 1891-2:25-28; ... for 1882-1883: 29-31 (1893)

95 Geological report on the Upper Peninsula of Michigan ...; iron and copper re gions. Mich G S 5 pt 1: 179 pp (1895)

Roorbach, Geotge B.

10 Shore line changes in the Winthrop area, Massachusetts. Geog Soc Phila, B 8: 46-64 (1910) Abst, As Am Geog, An 1: 136 (1911)

13 The fault-block topography of the Mohawk Valley. Geog Soc Phila, B 11: 51 66, map (1913) Abst, As Am Geog, do $3: 114$ [1915]

Root, Edward W.

68 On wilsonite from $\mathrm{St}$. Lawrence $\mathrm{CO}_{4}$ N. Y. $A m$ J Sc (2) $45: 47-48$ (1868)

6Sa On enargite from the Morning Stat mine, Cal. Am J Sc (2) 46:201-205 (1868)

Root, W. A.

09 The Lida mining district of Nerade M World 31: 123-125 (1909)

Ropes, Leverett $\mathrm{S}$.

o1 Montana corundum. Eng M J 72: 787 (1901)

16 Observations on Marysville district, Mont. M World 44:395-396 (1916)

16a Activities in the Marysville minish district, Mont. M World 44: 819-821 (1916)

Rose, Bruce.

14. Savona map area. B. C. Can 6 \& Sum Rp 1912 : 151-155 (1914)

14a Willowbunch coal area, Sask. Cal G S, Sum Rp 1913: 153-164, map (1914) 
Rose, Bruce-Continued.

15 Reconnaissance along the Red Deer, James, Clearwater, and North Saskatchewan rivers, Alta. Can G S, Sum Rp 1914: 52-53 (1915)

15a Wood Mountain coal area, Sask. Can G S, Sum Rp 1914:64-67, map (1915)

16 Wood Mountain-Willowbunch coal area, Sask. Can G S, Mem 89:103 pp, map (1916)

16a Blairmore map area, Alta. Can G S, Sum Rp 1915: 110 (1916)

17 Reconnaissance of upper Elk Valley coal basin, B. C. Can G S, Sum Rp 1916: 63-66 (1917)

17a Crowsnest coal field, Alta. Can G S, Sum Rp 1916:107-114 (1917)

18 Crowsnest and Flathead coal areas, B. C. Can G S, Sum Rp 1917 pt C : 28-35 (1918)

Rose, C. M.

15 (with Coryell, H. N.) Soil survey of Howard Co. [Ind.]. Ind Dp G, An Rp $39: 20-54$, map (1915)

Rose, L.

11 Vorkommen und Gewinnung der an Durchbruchgesteine gebundenen Kupfererze in den Wüstengebieten des südwestlichen Nordamerika8. Glückauf 47:1-14, 69-81, $101-110,141-155,181-194$ (1911)

11a Der Bergbau und seine Aussichten in Britisch-Kolumbien. Glückanf $47: 853-$ 861, 897-905, 937-948, 973-981 (1911)

13 Zur Frage der Entstehung der Erzlagerstätten von Leadville (Kolorado), Glückauf 49 : 885-888 (1913)

Rose, Robert Seldon.

04 The geology of some of the lands in the Upper Peninsula [Mich.]. L Sup M Inst, $\operatorname{Pr} 10: 88-102$ [1905] M World 21: 205-207 (1904) Abst, Eng M J 78:343344 (1904)

Rosenbusch, H.

88 Microscopic physiography of the massive rocks; translated by F. J. H. Merrill. Sch Mines Q $9: 362-373 ; 10: 43-53$ (1888)

06 Remarques sur la roca verde et les intercalations argileuses dans celle-ci. Int G Congr, X, Mexico, Guide Exc no XVI: $17-20$ (1906) (See Burckhardt, 06)

06a Remarques sur quelques roches éruptives de la région de la Sierra de Concepción del Oro [México]. Int $\mathrm{G}$ Congr, $\mathrm{X}$, Mexico, Guide Exc no XXIV: 13-15 (1906)

06b Remarques sur les roches éruptives de la région de la Sierra de Mazapil et Santa Rosa [México]. Int $G$ Congr, $X$, Mexico, Guide Exc no XXVI : 25-28 (1906)

Ross, A. C.

99 The rare metal tungsten. Can $\mathrm{M}$ Ry 18:107-108 (1899) M Soc N S, J 5: $31-35$ (1900)
Ross, Angus.

72 Zones of lines of elevation in the earth's crust. N S Inst N Sc, Pr Tr 3: 126-141 (1872)

Ross, Clarence S.

16 The "chloritic" material in the ores of southeastern Missouri. Ec G 11 : 289290, 594 (1916)

16a (with Sarage, T. E.) The age of the iron ore in Wisconsin. $\Delta \mathrm{m} J \mathrm{Jc}$ (4) $41: 187-193$ (1916)

17 The chloritic material of the ores of southeastern Missouri (abst). Ill Ac Sc, Tr $9: 209$ [1917]

18 Structure and oil and gas resources of the Osage Reservation, Okla.; Tps. 20 and 21 N, R. 12 E. U S G S, B 686: 171-178, map (1918)

Ross, Clyde Polbemus.

15 (with Lindgren, W.) The Iron deposits of Daiquiri, Cuba. Am I M Eng, B 106:2171-2190 (1915); Tr 53:40-66 (1916)

Ress, J. G.

o7 (with Kemp, J. F.) A peridotite dike in the Coal Measures of southwestern Pennsylvania. N Y Ac Sc, An 17:509 518 (1907)

Ross, John.

35 Narrative of a second voyage in search of a northwest passage ... Geology, Appendix : cl-cvi, L 1835

Ross, O. C. D.

92 The origin of petroleum (abst). Brit As, Rp 61:639-641 (1892)

Rothe, Karl Eduard.

27 Geognostische und mineralogische Bemerkungen über den Nord-Amerikanischen Freistaat Nord-Karolina. Zs Miner (Leonhard) 21 , II : 349-362 (1827)

28 ... gold mines of North Carolina. Am I Sc 13:201-217 (1828) Reprinted in [N C] Bd Agr, Papers on agricultural subjects ...: : 29-43, Raleigh 1828 [?]

Rothermel, John G.

94 Fossil man. Pop Sc Mo 44:616-637 (1894)

Rothpletz, August (1853-1918).

92 On the formation of oolite. Am G $10: 279-282$ (1892)

10 Über die Ursachen des Kalifornischen Erdbedens von 1906. K Bayer Ak Wiss, Mat-phys K1, Szb, 1910 Abh 8: 32 pp

15 Ueber die systematische Deutung und die stratigraphische Stellung der ältesten Versteinerungen Europas und Nordamerikas mit besonderer Berücksichtigung der Cryptozoen und Oolithe; I. Teil, Die Fauna der Beltformation bei Helena in Montana; II. Teil, Ueber Cryptozoon, Eozoon, und Atikokania. K Bayer Ak Wiss. Mat-phys Kl, Abh 28; Teil I, Abh 1:46 pp, 11 (1915); Teil II, Abh 4:92 pp, il (1916) 
Rothrock, J. T.

89 The sand dunes of Lewes, Del. Ac N Sc Phila, Pr 1889: 134-135

Rothwell, Richard Pennefather (18361901).

69 [Sections in the anthracite fields, Pa.] Am Ph Soc, Pr 11:113 (1869)

73 ... difficulties in the identification of coal beds. Am I M Eng, Tr 1:62-63 (1873)

74 Alabama coal and iron. Am I M Eng, Tr 2: 144-157, 158 (1874) Eng M J $17: 49-52(1874)$

so The Silver Reef district, southern

Utah. Eng M J 29:25-26 (1880)

81 The gold-bearing mispickel veins of Marmora, Ontario, Can. Am I M Eng, Tr $9: 409-420$ (1881)

82 The gold fields of the southern portion of the Island of San Domingo. Am I M Eng, Tr 10:345-354 (1882) Eng M J $34: 31-32$ (1882)

87 Pyrites. U S G S, Min Res 1886: $650-675$ (1887)

Rottermund, E. S. de.

56 Report on the exploration of Lakes Superior and Huron. (Return to an address of the Legislative assembly) $24 \mathrm{pp}$ [Toronto 1856]

57 Second rapport sur lexploration des laes Supérieur et Huron. [Canada, Dp Crown Lands] : 50 pp, Toronto, 1857

57a [Sur une collection de roches du Canada.] Soc G France, B (2) 14:419427 (1857)

Rouaix, Pastor.

10 Memoria sobre el aspecto general de la Sierra Madre Durangueña, México. Soc G Mex, B 7: vii-viii (1910)

Rouillard, Eugène.

17 Les calcaires de la province de Québec. Soc Géog Qué, B 11:140-142 (1917)

Roundy, P. V.

14 Original color markings of two species of Carboniferous gastropods. Am J Sc (4) $38: 446-450$ (1914)

16 (with Mansfield, G. R.) Revision of the Beckwith and Bear River formations of southeastern Idaho. U S G S, P P 98: 75-84 (1916) Abst, Wash $\Delta c$ Sc, J 15 : 565 (1916)

16a (with Mansfield, G. R.) Stratigraphy of some formations hitherto called Beckwith and Bear River in southeastern Idaho (abst). G Soe Am, B 27:70-71 (1916)

$16 b$ (with Mansfield, G. R.) Some Jurassic and Cretaceous formations of southeastern Idaho (abst). Wash Ac Sc, J $6: 157$ (1916)

Routledge, Wm.

75 Notes on the Sydney coal field in the Island of Cape Breton, British North Amer1ea. N Engl Inst M Eng, Tr 24:191-216, map (1875)
Routledge, Wm.-Continued.

86 The Sydney coal field, Cape Breton, N. S. Am I M Eng, Tr 14:542-5t) (1886)

Rovirosa, José N.

93 Viaje á Teapa y á las sierras qu concurren á la formación de su valle [México]. La Naturaleza (2) 2:269-28s (1893)

Rowe, Jesse Perry.

os Some volcanic ash beds of Montan Mont, Univ, B 17 (g s no 1) : 32 pp (190i) 03a Some Montana coal fields. Am 6 $32: 369-380$, map (1903)

04 Nodular barite and selenite crystas of Montana. Am G 33: 198-199 (1904)

04a Pseudomorphs and crystal cavitic Am J Sc (4) 18: 80 (1904)

os Montana gypsum deposits. Am $\mathrm{G}$ 35: 104-113, map (1905)

05a The Montana coal fields. M $\mathrm{Kat}$ 11: 241-250 (1905)

o6 Montana coal and lignite deposits Mont, Univ, B 37 ( $\mathrm{g}$ s no 2) : 82 pp (1906) o7 Montana coal and lignite deposits M World 26:62-65 (1907)

07a Montana coal mines. Mines at Minerals $27: 481-484$ (1907)

отb Montana gypsum deposits. Minc and Minerals 28:59-60 (1907)

os Some economic geology of Montani Mont, Univ, B 50 (g s no 3) : 70 pp (1906 osa Mining in the Coeur d'Alene distrik Idaho. Mines and Minerals 28:549-55it (1908)

08b Barytes deposits in Montana. World 28:637 (1908)

ose The coal and lignite deposits of Mo tana. M World 28: 673-676, 717-718 (1906) osd Graphite deposits in Montana.

World 28: 839 (1908)

ose The coal industry of Montana.

M J 85:1055-1058 (1908)

O8f Gypsum deposits of Montana. E M J $85: 1243$ (1908)

o8g The Cour d'Alene mining distric Idaho. M World 29:739-740, 777-7it $843-845 \quad(1908) ; 30: 11-14,89-92,111^{-}$ $120,318-320,357-358,428-430$ (1909)

09 Development of Montana's sapphir mines. M World 31 : 921-923 (1909)

09a The Roundup coal mines of Nor tana. M World 31: 1057-1061 (1909)

10 Red Lodge and Bear Creek coal minks Mont. M World 32 : $59-62, \quad 320-3$ t (1910)

10a Determination of common ores minerals. M World $32: 697-699,853-8$ i $889-891, \quad 929-930, \quad 989-992, \quad 1031-10$ th $1125-1128 ; 33: 7-9,51-53,225-226$ (1910)

$\mathbf{1 0 b}$ Gold dredging operations in Mct tana. M World 33: 347-352 (1910)

10e Iron Mountain Tunnel Compars? Montana [Iron Mountain district, Missovl Co., Mont.]. M World 33:518-519 (1910) 
Rowe, Jesse Perry - Continued.

10d History and geology of the Garnet district, Mont. M World 33: 703-708 (1910)

10e Geology and ore deposits of Clinton district [Missoula Co., Mont.]. M World 33: 1099-1101 (1910)

11 Practical mineralogy simplified... 162 pp, N Y 1911

11a Occurrences and theories of ore deposits. M World $35: 9-10,59-61$ (1911) 11b Geology and ores of the Carter district, Mont. M World 35:579-581 (1911)

11e Mines of Missouka Co., Mont. Mines and Minerals 31: 581-584 (1911)

11d Placer-mining operations in western Montana (Flathead Co.]. M World $34: 877-878$ (1911)

15 Probable oil and gas in Montana. Eng M J 99 : 647-649 (1915)

15a (and Wilson, R. A.) Bull Mountain coal field, Mont. Colliery Eng 36 no $1: 7-11$; no $2: 74-79$, map (1915)

16 (and Wilson, R. A.) Geology and economic deposits of a portion of eastern Montana. Mont Univ Studies, Ser no 1: $58 \mathrm{pp}$, map (1916)

Rowe, Ríchard Burton (1872-1902).

99 (with Prosser, C. S.) Stratigraphic geology of the eastern Helderbergs. N Y St G, An Rp 17:329-354 (1899) N Y St Mus, An Rp $51 \quad v \quad 2: 329-354$ (1899)

See also Clark (W B), 00a ; Swartz, 13a Rowley, Robert Roswell.

89 The Chouteau group of eastern Missouri. Am G 3:111-116 (1889)

89a Observations on three Kinderhook fossils. Am G 3: 275-276 (1889)

90 Batocrinus calvini, a new species of Burlington crinoid. Am G $5: 146-147$, il (1890)

90a Some observations on natural casts of crinoids and blastoids from the Burlington limestone. Am G 6:66-67 (1890) 91 The Keokuk limestone and Coal Measures of Pike Co., Mo. Kansas City Scientist 5: 26-27 (1891)

91a The Trenton linrestones and Hudson River shales [Pike Co., Mo.]. Kansas City Scientist 5 : 57-59 (1891)

$91 \mathrm{~b}$ Fossil collecting in the Burlington limestone [Pike Co., Mo.]. Kansas City Scientist 5:71-72 (1891)

91e (and Hare, S. J.) Description of some new specles of Echinodermata from the Subcarboniferous rocks of Pike Co., Mo. Kansas City Scientist 5: 97-103, il (1891)

91d (and Hare, S. J.) Description of some new species of crinoids and blastoids from the Subcarboniferous rocks of Pike and Marion cos., Mo., and Seott Co., Va. Kansas City Seientist $5: 113-118$, il (1891)
Rowley, Robert Roswell-Continued.

93 Range of Chouteau fossils [Mo.]. Am G 12:49-50 (1893)

93a The Hamilton beds of Callaway Co., Mo. Am G 12: 203-205 (1893)

93b Description of some new species of crinoids, blastoids, and brachiopods from the Devonian and sub-Carboniferous rocks of Missouri. Am G $12: 303-309$, il (1893)

94 New species of crinoids and brachiopods from the Missouri Hamilton. Am G $13: 151-154$, il (1894)

95 Description of a new genus and five new species of fossils from the Devonian and sub-Carboniferous rocks of Missouri. Am G 16:217-223, il (1895)

97 (with Keyes, C. R.) Vertical range of fossils at Louisiana [Mo.]. Iowa Ac Sc, Pr 4:26-40 (1897)

00 New species of crinoids, blastoids, and cystoids from Missouri. $\mathrm{Am}$ G 25 : $65-75$, il (1900)

O0a Description of new species of fossils from the Devonian and Subcarboniferous rocks of Missouri. Am G $25: 261-273$, il (1900)

Oob Notes on the fauna of the Burlington limestone at Louisiana, Mo. Am G 26 : 245-251 (1900)

01 Two new genera and some new species of fossils from the upper Paleozoic rocks of Missouri. Am G 27:343-355, il (1901)

02 New species of fossils from the Subcarboniferous rocks of northeastern Missouri. Am G 29:303-310, il (1902)

04 The Echinodermata of the Missouri Silurian and a new brachiopod. Am G 34: 269-282, il (1904)

o5 Missouri paleontology [descriptions of Echinodermata and other fossils]. Am G $35: 301-311$, il (1905)

06 [Descriptions of fossils.] In Greene, G. K., Contribution to Indiana paleontology, vol. 2 , pts. 1 and 2 (1906)

os The geology of Pike Co. Mo Bur G Mines (2) 8:122 pp, map [1908]

16 The Edgewood limestone of Pike Co., Mo. Am J Sc (4) 41:317-320 (1916)

Rowney, Thomas Henry (1817-1894).

66 (with King, W.) On the so-called "eozoonal rock." G Soc London, Q J 22 : 185-218, il (1866) Abst, G Mag $3: 80$ (1866): Ph Mag (4) $31: 159$ (1866)

69 (with King, W.) On the so-called “eozoonal rock," G Soc London, Q J 25: 115-117 (1869) G Mag 6:84-87 (1869)

7o (with King, W.) On Eozoon canadense. $\mathrm{R}$ Irish Ac, Pr 10:506-551, il (1870) Abst, Am J Sc (3) $1: 68,138-$ 142 (1871)

71 (with King, W.) On the mineral origin of the so-called "Eozoon eanalense." $\mathrm{R}$ Irish $\mathrm{Ac}, \operatorname{Pr}$ (2) $1: 140-153$ (1871)

$$
28737^{\circ}-23-57
$$


Rowney, Thomas Henry-Continued.

74 (with king, W.) Remarks on the subject of "Eozoon." An Mag N H (4) $13: 390-396$ (1874)

74a (with King, W.) "Eozoon" examined chiefly from a foraminiferal standpoint. An Mag N H (4) $14: 274-289$, il (1874)

76 (with King, W.) Remarks on the "Dawn of life" by Dr. Dawson, to which is added a supplementary note [Eozoon]. An Mag N H (4) $17: 360-377$ (1876)

S1 (with King, W.) An old chapter of the geological record with a new inter. pretation ... with an introduction ... on the soecalled "Eozoon canadense"... Ivii, 142 pp, L 1881

Roy, Andrew.

75 Origin of coal. Eng M J 20:31, 54-55 (1875)

76 The coal mines ... 367 pp, Cleveland, Ohio, 1876.

76a The Mahoning Valley coal region [Ohio]. Am I M Eng, Tr 4:188-190 (1876)

76b The Allegheny coal field. Fing M J 21:442 (1876)

83 The coal fields of West Virginia. The Virginias $4: 159-160$ (1883)

83a Origin of coal and early mining. Ohio M J 1 : 147-168 (1883)

84 The Ohio coal field. Ohio M J 2: 121-129 (1884)

84a The Jackson shaft coal, and the Wellston coal of Jackson Co. Ohio M J 2: 162-175 (1884)

84b Sketch of the Glasgow-Port Washington works of Tuscarawas Co. [iron ore]. Ohio M. J 3 : 10-15 (1884)

84e Review of Prof. Orton's discussion of the lower Coal Measures of Ohio. Ohio M J 3:39-49 (1884)

85 The practical miner's companion; or, Papers on geology and mining in the Ohio coal field. $288 \mathrm{pp}$, Columbus 1885

87 Peculiarities of coal seams. Ohio M J 5 : 89-92 (1887)

s8 Waving of the coal measures. Ohio M J $6: 33-38$ (1888)

90 The mines and mining resources of Ohio. In Howe, Henry, Historical collections of Ohio 1:110-118, Columbus 1890

92 The eoals of the Twelve Pole region of West Virginia. Ohio M J no $20: 47-51$ (1892)

94 The coal seams of Jackson Co. Ohio M J no 21:12-16 (1894)

99 The Guyandot, W. Va,, coal field. Ohio M J no $26: 43-45$ (1899)

$99 a$ Geology of the Jackson coal shaft [Jackson Co., Ohio]. Ohio M J no 27: 120-124 (1899) Abst, Fing M J 65:164 (1898)

\section{Roy, Thomas,}

37 On the ancient state of the Nori American continent $(a b s t)$. G Soc lat don, $\operatorname{Pr} 2: 537-538$ (1837)

Royal Ontario Nickel Commission.

17 Report of the Royal Ontario Niat Commission, with appendix. 584, 219, 6 . pp, maps, Toronto 1917

Rubel, A. C.

16 Tungsten. Ariz St Bur Mines, B 11 11 pp (1916)

16a Coal in Arizona. Ariz St Be Mines, B 17:12 pp (1916)

Rubio, Pascual Ortiz.

06 El Axalapazco de Tacámbaro. \& G Mex, B 2:65-69 (1906)

Ruekman, John $\mathrm{H}$.

13 Evidence indicating an unconformity at the base of the Tamiosoma zone in th Coalinga oil field, Cal. (abst, with discus sion by J. A. Taff). G Soc Am, B 24:18 (1913)

Ruddy, C. A.

02 (with Byers, H. G., and Heine R. E.) The water resources of Washing ton. Wash G S 1: 285-320 (1902)

03 (with Landes, Henry.) Coal of posits of Washington. Wash G \$ 2:165277, map (1903)

Ruedemann, Rudolf.

95 Synopsis of the mode of growth asi development of the graptolitic genus Diph graptus. Am J Sc (3) 49:453-455, (1895)

96 Note on the discovery of a sessit Conularia. Am G 17:158-165; 18:65.71, il (1896)

97 Development and mode of growth of Diplograptus MeCoy. N Y St G, An Bf $14: 217-249$, il (1895) [1897] N Y \& Mus, An $\mathrm{Rp} 48 \quad v \quad 2: 217-249$, il (1895) [1897]

97a Evidence of current action in th Ordovician of New York. Am G $19: 36^{\circ-}$ 391 (1897)

98 The discovery of a sessile Comulari. N Y St G, An Rp $15: 24,699-728$, il (189i) N Y St Mus, An Rp $49 v 2: 24,699-728$, 1 (1898)

98a Additional note on the oceanic en rent in the Utica epoch. Am G 21:75-8t (1898)

98b on the development of Tetradius cellusosum Hall sp. Am G $22: 16-25$, I (1898)

98c Synopsis of recent progress in the study of graptolites. Am Nat 32:1-16 (1898)

o1 Hudson River beds near Albany sal their taxonomic equivalents. N Y St Mos, B $42: 489-587$, il (1901) Abst, G Soc At B $12: 11$ (1900)

O1 a Trenton conglomerate of Rysedorpl Hill, Rensselaer Co., N. Y., and its fause N Y St Mus, B 49:3-114, 11 (1901) 
Ruedemann, Rudolf-Continued.

02 The graptolite (Levis) facies of the Beekmantown formation in Rensselaer Co., N. Y. N Y St Mus, B 52:546-575 (1902) 02a Mode of growth and development of Goniograptus thureaui MeCoy. N Y St Ius, B $52: 576-592$, il (1902)

02b (with Clarke, J. M.) Contact lines of upper Siluric formations on the Brockport and Medina quadrangles [N. Y.]. X Y St Mus, B 52: 517-523 (1902)

03 The Cambric Dictyonema fauna in the slate belt of eastern New York. N Y St Mus, B $69: 934-958$ (1903) Rv by G. F. Matthew, Can Rec Sc 9:196-197 (1905)

03a (with Clarke, J. M.) Guelph fauna in the State of New York. N Y St Mus, Mem 5: $195 \mathrm{pp}$, il (1903)

03b (with Clarke, J. M.) Catalogue of type specimens of Paleozoic fossils in New York State Museum. N Y St Mus, B $65: 847 \mathrm{pp}$ (1903)

04 Graptolites of New York, Part I; Graptolites of the lower beds. N Y St Mus, Mem $7: 455-803$, il (1904)

05 The structure of some primitive cephalopods. N Y St Mus, B $80: 296-341$, il (1905)

06 Cephalopoda of the Beekmantown and Chazy formations of the Champlain basin. N Y St Mus, B 90:389-611, il (1906)

07 The Lower Siluric paleogeography of the Champlain basin (abst). Science $\mathrm{n} \varepsilon$ $26: 399-400$ (1907)

08 Graptolites of New York: Part 2, Graptolites of the higher beds. N Y St Mus, Mem 11:583 pp, il (1908)

08a Note on Dictyonema websteri $(=D$. retiforme). N S Inst Se, Pr Tr 11: xlvii (1908)

09 Types of inliers observed in New York. N Y St Mus, B 133:164-193 (1909)

09n Some marine alge from the Trenton limestone of New York. N Y St Mus, B $133: 194-216$, il (1909)

10 On the symmetric arrangement in the elements of the Paleozoic platform of North America. N Y St Mus, B 140:141-149, maps (1910) Am J Sc (4) 30:403-411, maps (1910)

10a Anatomy and physiology in invertebrate extinct organisms. Pop Sc Mo 77 : 142-145 (1910)

10b (with Clarke, J. M.) Mode of life of the Eurypterida $(a b s t)$. Science $\mathrm{n} s$ $32: 224$ (1910)

10c (with Cushing, H. P.) Geology of the Thousand Islands region, Alexandria Bay, Cape Vincent, Clayton, Grindstone. and Theresa quadrangles, N. Y. N Y St Mus, B $145: 194$ pp (1910)

10d (with Kemp, J. F.) Geology of the Elizabethtown and Port Henry quadrangles, N, Y. N Y St Mus, B 138:173 Dp (1910)
Ruedemann, Rudolf-Continued.

11 Stratigraphic significance of the wide distribution of graptolites. $G$ Soc Am, B $22: 231-237$ (1911)

11a Frankfort and Utica shales of the Mohawk Valley (abst). G Soc Am, B 22: 720 (1911)

12 Note on a specimen of Plectoceras jason (Billings). N Y St Mus, B 158: 141-142, il (1912)

12a (with Clarke, J. 21.) The Eurypterida of New York. N Y St Mus, Mem 14, 2 vols (1912)

14 An alternative explanation of the origin of the Saratoga mineral waters (abst with discussion). G Soc Am, B 25: 38 (1914)

14a (with Cushing, H. P.) Geology of Saratoga Springs and vicinity. N Y St Mus, B 169:177 pp, maps (1914)

16 Account of some new or little-known species of fossils, mostly from the Paleozoic rocks of New York. N Y St Mus, B $189: 7-112$, il (1916)

$16 a$ Note on the habitat of the eurypterids. N Y St Mus, B 189:113-115 (1916)

16b The presence of a median eye in trilobites. N Y St Mus, B 189:127-143, il (1916) Abst, G Soe Am, B 27:146147 (1916)

16e The cephalic suture lines of Cryptolithus (Trinucleus auct.). N Y St Mus, B $189: 144-148$, il (1916)

16d On the presence of a median eye in trilobites. Nat Ac Sc, Pr 2:234-237 (1916)

17 Graptolite zones of the Utica shale (abst). G Soc Am, B 28: 206 (1917)

18 The paleontology of arrested evolution. N Y St Mus, B 196: 107-134 [1918]

1Sa The phylogeny of the acorn bar. nacles. Nat Ac Sc, Pr 4:382-384 (1918)

See also Eastman, 00

Rihl, Alfred.

o7 Überblick über die geographischen und geologischen Verhältnisse Alaskas. Petermanns Mitt 53:1-16 (1907)

Rüst, D.

92 Radiolaria from the Pierre formation of northwestern Manitoba. Can G S, Contr Can Micro-Pal pt 4:101-110, il (1892)

Rufin, Edmund (1794-1865).

43 Report of the commencement and progress of the agricultural survey of South Carolina for $1843.120,56$ pp, Columbia 1843

44 Secondary and Miocene marls on and near Lynch's Creek... In Tuomey, M., Report on the geological and agricultural survey of the State of South Carolina, 1844: 59-63 (1844)

50 Description of a nut found in Eocene marl [Virginia]. Am J Sc (2) 9:127129 , il $(1850)$ 
Ruftin, Edmund-Continued.

61 Agricultural, geological, and descriptive sketches of lower North Carolina and the similar adjacent lands, $296 \mathrm{pp}$, Raleigh 1861

Rufrner, E. H.

77 Geological notes [on the Staked Plains of Texas]. U S [War Dp], Chief Fing, An Rp 1877 (U S, 45th Cong 2d sess, H Ex Doc 1 pt 2 v 2 pt 2) App RR : 14311438 (1877)

Rufner, William Henry (1824-?).

so Something about the minerals of southwest Virginia. The Virginias 1:97 (1880)

83 (with Campbe11, J. L.) A physical survey extending from Atlanta, Ga., acros3 Ala. and Miss. to the Mississippi River along the line of the Georgia Pacific Railway... 147 pp, map, N Y 1883

89 A report on Washington Territory. 242 pp, maps, N Y 1889

89a Report on the landed property of the Buena Vista Company [Rockbridge Co. Va.] 104 pp, maps, Phila 1889

92 Some recent mineral discoveries in the State of Washington. Science 19:5859 (1892)

Rugrles, Daniel.

36 Geological and miscellaneous notice of the region around Fort Winnebago, Mich. Am J Sc 30:1-8 (1836)

45 Considerations respecting the copper mines of Lake Superior. Am J Sc 49:6472 (1845)

Ruhl, Otto.

o4 The King-Ritter fault [Springfield area, Mo.]. Drury Coll, Bradley G Field Sta, B 1:33-36 (1904)

O4a Observations at Pegmatite Hill [Camden Co., Mo.]. Drury Coll, Bradley G Field Sta, B 1:36-40 (1904)

os The calamine deposits of southwest Missouri. M World 28:787-788 (1908)

O8a Unconformity and deposits [lead and zinc deposits in Mo.-Kans, district]. M Sc Press 96:778-780 (1908)

08b Miami lead and zinc district in Oklahoma. Eng M J 86:910-912 (1908)

09 History of southeast Missouri lead district. M World 30:721-724 (1909)

Ruhm, H. D.

03 The present and the future of the Mount Pleasant [Tenn.] phosphate field. Eng As South, Tr 13:42-64 (1903)

o7 Phosphate mining in Tennessee. Eng M J $83: 522-526$ (1907)

Runda11, W. H.

95 Quicksilver ores at Guadalcazar, Mexico. Sc Am Sup 40:16289-16290 (1895)

Runner, J. J.

16 The geology of tungsten deposits. Pahasapa Q 5 no 2:13-22 (1916) Abst, M Sc Press 112:405-406 (1916)
Runner, J. J.-Continued.

I6a Geological occurrence of mang? nese: Pahasapa $Q 6$ no $1: 9-17$ (1916) Abst, M Sc Press 114:128-129 (1917)

18 (and Hartmann, M. L.) The $\alpha$ currence, chemistry, metallurgy, and use of tungsten, with special reference to the Black Hills of South Dakota. S Dak Sch Mines, B 12:4-159 (1918)

Ruschenberger, W. S. W.

52 Elements of geology. Book VIII, 210 pp, in his Elements of Natural History, ? vols, Phila 1850-2

92 A sketch of the life of Joseph Leidy. Am $\mathrm{Ph}$ Soc, $\mathrm{Pr} 30: 135-184$ (1892)

Ruschhaupt, $F$.

69 On the salt mines of St. Dominge. G Soc London, Q J 25: 256-257 (1869)

Rush, William W.

09 Bear River district [B. C.]. M \& Press 99: 152 (1909)

10 Notes on Portland Canal mining diz trict, B. C. Can M J $31: 228-230$ (1910) Russe11, B. E.

os Nacozari mining district, Sonon Mexico. Eng M J 86:657-662 (1908)

osn Las Chispas mines, Sonora, Mexion. Eng M J 86: 1006-1007 (1908)

Russell, Byron P.

s8 Report on the salt well [Lincoln, Nebr.]. Nebr, Commissioner of Public Lands and Buildings, 6 th Bien Rp:57-84, Lincoln, Nebr., 1888

Russell, Francis W.

88 A crystalline rock near the surfact in Pawnee Co., Nebr. Am G 1:130-13! (1888)

88a The salt well at Lincoln, Nebr. As G 1: 131 (1888)

91 Preliminary notes on the geology of central Nebraska. Am G $7: 38-44$ (1891)

92 Notes upon Nebraska Tertiary. An G 9:178-181 (1892)

Russe11, Israel Cook (1852-1906).

76 On the formation of lakes. Pop \& Mo $9: 539-546$ (1876)

77 Concerning footprints. Am Nat 11: $406-417$, il (1877)

78 On the intrusive nature of the Tr. assic trap sheets of New Jersey. Am J \& (3) $15: 277-280$ (1878)

78a On the occurrence of a solid hydo carbon in the eruptive rocks of New Jerse. Am J Sc (3) 16:112-114 (1878)

78b On the physical history of the Trt assic formation in New Jersey and the Con necticut Valley. N Y Ac Sc, An 1:220254 (1878) Critical review by J. D. Dant. Am J Sc (3) $17: 328-330$ (1879)

78e A new form of compass clinometet. N $Y$ Ac Sc, An 1: 263-264 (1878)

79 The geological museum of the School of Mines, Columbia College [N. Y.]. Att Nat 13:502-513 (1879)

so On the former extent of the Triassic formation of the Atlantic States. Am Nat 14 : 703-712 (1880) 
Rnssell, Israel Cook-Continued.

soa On the geology of Hudson Co., N. J. $\mathrm{N} Y$ Ac Sc, An 2:27-80 (1880) Abst, Science (ed, Michels) $2: 63-65$ (1881)

82 Sulphur deposits in Utah and Montana. N Y Ac Se, Tr 1:168-175 (1882)

Eng M J $35: 31-32$ (1883)

83 Sketch of the geological history of Lake Lahontan, a Quaternary lake of northwestern Nevada. U S G S, An Rp $3: 189-235$, map (1883)

83a Playas and playa lakes. Pop Sc Мo $22: 380-383$ (1883)

84 A geological reconnaissance in southern Oregon. U S G S, An Rp 4:431-464, maps (1884)

84a Glaciers of the high Sierra in California. Science 3:208 (1884)

84b Lakes of the Great Basin. Science $3: 322-323$ (1884)

85 Geological history of Lake Lahontan, a Quaternary lake of northwestern Nevada. U S G S, Mon 11:288 pp, maps (1885)

85a Existing glaciers of the United States. U S G S, An Rp 5 : 303-355, maps (1885)

85b The existing glaciers of the high Sierra of California (with discussion). Ph Soc Wash, B $7: 5-8$ (1885)

85e Deposits of volcanic dust in the Great Basin. Ph Soc Wash, B 7:18-20 (1885)

85d (and others) What is a glacier? Ph Soe Wash, B 7:37-39 (1885)

87 Notes on the faults of the Great Basin and of the eastern base of the Sierra Nevada (abst, with discussion by G. K. Gilbert, Balley Willis, and J. S. Diller). Ph Soc Wash, B 9:5-8 (1887)

88 The Great Basin. Overland Monthly (2) $11: 420-426$ (1888)

89 Quaternary history of Mono Valley, Cal. U S G S, An Rp 8: 261-394, maps (1889)

89a Subaerial decay of rocks and origin of the red color of certain formations. U S G S, B 52:63 pp (1889)

$89 b$ Subaerial deposits of the arid region of North America. G Mag (3) 6 : 289-295, 342-350 (1889)

89e The Newark system. Am G 3:178182 (1889)

90 Notes on the surface geology of Alaska (with discussion by N. S. Shaler and T. C. Chamberlin). G Soc Amr, B 1: 99-162 (1890) Abst, Am G 5:118-119 (1890)

90a Ice cliffs on Kowak River, Alaska ... Am G $6: 49-52$ (1890)

90b Roland Duer Irving. Ph Soc Wash, B 11: $478-480(1890)$

91 Are there glacial records in the Newark system? Am J Sc (3) 41:499-505 (1891)

91a Explorations in Alaska. Am G 7 : $33-38$ (1891)
Russe11, Israel Cook-Continued.

91 b Has “ Newark" priority as a group name. Am G 7:238-241 (1891)

91e An expedition to Mount St. Elias, Alaska. Nat Geog Mag 3:53-191, map (1891)

91d The expedition of the National Geographic Society and the United States Geological Survey (1890) [Mount St. Elias region, Alaska]. Century Mag 41:872884 (1891)

92 Correlation papers; The Newark system. U S G S, B $85: 344$ pp, maps (1892)

92a Mount St. Elias and its glaciers. $A m$ J Se (3) 43:169-182, map (1892) Abst, Am G 9:216 (1892)

92b Origin of the gravel deposits beneath Muir Glacier, Alaska (with discussion by G. F. Wright, H. F. Reid, and H. P. Cushing). Am G 9:190-197 (1892)

92e Climatic changes indicated by the glaciers of North America. Am G $9: 322$ 336 (1892)

93 Second expedition to Mount Saint Elias, in 1891. U S G S, An Rp 13 pt 2 : 1-91, map (1893)

93n A geological reconnaissance in central Washington. U S G S, B 108: 108 pp, map (1893)

93b Malaspina Glacier [Alaska]. J G $1: 219-245$, map (1893)

93e Geological history of the Laurentian basin. J G 1: 394-408 (1893)

94 Alaska; its physical geography. Scottish Geog Mag 10:393-413, map (1894)

95 Lakes of North America... 125 pp, Boston 1895

95a Present and extinct lakes of $\mathrm{Ne}$ vada: Nat Geog Soc, Nat Geog Mon 1 no 4:101-136 (1895) Also in The physiography of the United States (Nat Geog Soc) : 101-136, N Y, Am Book Co., 1896

95b The Newark system. Science n s 1: 266-268 (1895)

95e The influence of débris on the flow of glaciers. J G $3: 823-832$ (1895)

96 Igneous intrusions in the neighborhood of the Black Hills of Dakota. J G 4: 23-43 (1896)

$96 a$ On the nature of igneous intrusions. J G 4: 177-194 (1896)

96b Igneous intrusions and voleanoes. Pop Se Mo $50: 240-250$ (1896)

97 Glaciers of North America... 210 pp, Boston 1897

97 a Volcanoes of North America... 346 pp, N Y 1897

$\mathbf{9 7 b}$ A reconnaissance in southeastern Washington. U S G S, W-S P 4:96 pp, map (1897)

97 A note on the "plasticity" of glacial ice. Am J Sc (4) $3: 344-346$ (1897) Abst, J G 5:104-105 (1897) 
Russe11, Israel Cook-Continued.

97 d Principal features of the geology of southeastern Washington (abst). Am J Sc (4) $3: 246-248$ (1897) Science $n$ s 5 : 94 (1897) J G 5:107-109 (1897) Mining $3: 163-165$ (1897)

98 Rivers of North America... xix, 327 pp, N Y 1898

98a Glaciers of Mount Rainier. U S G S, An Rp 18 pt $2: 349-415$, maps (1898)

9sb The great terrace of the Columbia and other topographic features in the neighborhood of Lake Chelan, Washington. Am G 22:362-369 (1898)

98e The glaciers of North America. Geog J 12 : 553-564 (1898)

98d Geography of the Laurentian basin. Am Geog Soc, B 30:226-254, map (1898)

9Se Topographic features due to landslides. Pop Sc Mo 53:480-489 (1898)

99 [Plutonic plugs]. $J$ if $7: 96-97$ (1899)

99a General geology of the Cascade Mountains in northern Washington ( $a b s t)$. Am G 23: 96 (1899) Science n s 9:103104 (1899)

00 ...geology of the Cascade Mountains in northern Washington. I $\mathrm{S} G \mathrm{G}, \mathrm{An}$ Rp 20 pt $2: 83-210$, maps (1900)

00a Topographic $a^{\prime}$ as of the United States. Science n s 12:1003-1004 (1900)

oob Deposits of calcareous marl in Michigan (abst). Science n s 11:102 (1900)

01 Geology and water resources of Kez Perce Co., Idaho. U S G S, W-S P 53 and 54: 141 pp, map (1901)

02 The Portland cement industry in Michigan. U S G S, An Rp 22 pt $3: 629$ 685, maps (1902)

02a Geology and water resources of the Snake River plains of Idaho. U S G S, B $199: 192 \mathrm{pp}$, map (1902)

02b The recent volcanic eruptions in the West Indies. Nat Geog Mag 13:267-285 (1902)

02e Volcanic eruptions on Martinique and St. Vincent. Nat Geog Mag $13: 415$ 436 (1902) Smiths Inst, An Rp 1902: 331-349 (1903)

02d Geology of Snake River plains, Idaho (abst). Science $n$ s $15: 85-86$ (1902) G Soc Am, B 13:527 (1903)

03 Notes on the geology of southwestern Idaho and southeastern Oregon. U S G S, B $217: 83 \mathrm{pp}$, map (1903) Abst, with title, Recent volcanic craters in Idaho and Oregon, G Soc Am, B 14:549 (1904)

03a Preliminary report on artesian basins in southwestern Idaho and southeastern Oregon. U S G S, W-S P 78:53 pp, map (1903)

03b Glacier cornices. J G 11: 783-785 (1903)
Russel1, Israel Cook-Continued.

03e The Pelé obelisk. Science n 818 : $792-795$ (1903)

04 North Amerien, 435 pp, N Y 194

O4a Criteria relating to massive soli volcanic eruptions. Am J Sc (4) 17:25t 268 (1904)

04b Physiographic problems of to-dst J G 12:524-550 (1904) Cong Arts st Sci (St Louls 1904) 4:627-649 (1906)

04e Douglass Houghton. Mich Ac \& Rp 4:160-162, port (1904)

04d Bela Hubbard. Mich Ac Sc, Rp 4 163-165, port (1904)

05 Preliminary report on the geolog and water resources of central Orego U S G S, B 252: 138 pp, map (1905)

05a A geological reconnaissance alor the north shore of lakes Huron and Mich igan. Mich G S, Rp 1904:33-112 ma; (1905)

05b Hanging valleys. G Soc $\mathrm{Am}, \mathrm{B}$ 16: 75-90 (1905) Abst, Sclence n \& 21 218 (1905) ; Se Am Sup $59: 24326$ (1900

05e The influence of caverns on topos raphy. Science n s $21: 30-32$ (1905)

o5d The Pelé obelisk once more. Sct ence n \& 21:924-931 (1905)

05e Drumlin areas in northern Michiga Mich Ac Sc, Rp $7: 36-37$ (1905) Abit G Soc Am, B 16:577-578 (1906); Am $35: 177-179(1905)$; Science n s $21: 220$ 221 (1905) ; Sc Am Sup $59: 24326$ (1905

06 Memoir of William Henry Pettee. Soc Am, B $16: 558-560$ (1906)

07 The surface geology of portions at Menominee, Dickinson, and Iron cos, Mich. Mich G S, Rp 1906:7-91, map (1907)

07 a Concentration as a geological prib ciple. G Soc Am, B 18: 1-28 (1907)

07b Drumlins of Michigan (abst), Soc Am, B 17: 707 (1907)

os (and Leverett, Frank) Description of the Ann Arbor quadrangle, Mich. Us G S, G Atlas Ann Arbor fol (no 155):13 pp, maps (1908)

See also Fairchild, 04c

Russell, Philip G.

18 The coals of Sexton Creek ... [Clas Co., Ky.]. Ky G S (4) 4 pt $3: 185-20$ ) (1918)

Rutherford, J. R.

10 Coal mining in Pictou Co., N. S. Cat M Inst, J 12:598-617 (1910)

Rutherford, John.

70 The coal fields of Nova Scotia. Eng1 Inst $M$ Eng, $\operatorname{Tr} 19: 113-167$, maps (1870) Also, 58 pp, maps, Newcastle-upos: Tyne 1871

70a On a peculiarity in the Block-house seam, Cow Bay, Cape Breton. N S Inst $\mathrm{N}$ Se, $\operatorname{Pr}$ Tr 2 pt 3:18-22 (1870)

98 Notes on the albertite of New Brun? wick. Fed Can M Inst, J $3: 40-46$ (1898) Can M Rv 17:19-22 (1898) 
Rutland, Joshua.

01 Mammals and reptiles; or, what was the ice age? Sc Am Sup 51:21032-21033 (1901)

Rutledge, John Joseph.

05 (with Clark, W. B., and Martin, G. C.) Distribution and character of the Maryland coal beds. Md G S 5:317-512, maps (1905)

06 Davis pyrites mine, Mass., a unique deposit ... Eng M J $82: 673-676,724-728$, $772-775$ (1906)

08 The Clinton iron-ore deposits of Stone Valley, Huntingdon Co., Pa. Am I M Eng, B 24:1057-1087 (1908); $\operatorname{Tr} 40: 134-164$ (1910)

See also Clark (W. B.), 05b

Rutley, Frank (1842-1904).

79 The study of rocks, an elementary textbook on petrology. N Y $18792 d$ ed, 321 pp, N Y 1881

81 The microscopic characters of the ritreous rocks of Montana, U. S. A. G Soc London, Q J 37:391-399 (1881) Abst, May (2) $8: 235-236$ (1881)

90 On composite spherulites in obsidian from Hot Springs, near Little Lake, Cal. G Soc London, Q J 46:423-428 (1890) Abst, G Mag (3) $7: 233-234$ (1890)

94 On the origin of certain novaculites and quartzites. G Soc London, Q J 50: 377-392 (1894) Abst, G Mag (4) 1:232233 (1894)

Ruttman, Ferdinand S.

87 Notes on the geology of the Tilly Foster ore body, Putnam Co., N. Y. Am I M Eng, Tr 15: 79-90 (1887)

Ruxton, George F.

$50 \mathrm{On}$ the voleanic rocks of northern Mexico, G Soc London, Q J 6:251 (1850) Ryan, George $H$.

17 Geology and ore deposits of Miller Hill, American Fork mining district, Utah. Salt Lake M Rv 19 no 9:21-25 (1917)

Sabatini, V.

08 Il vulcano " Colima." Italia, R Comitato G, B 39 (4) $9: 279-292$ (1908)

Sachs, A.

05 Der Kleinit, ein hexagonales Queck silberoxychlorid von Terlingua in Texas. K Preuss Ak Wiss Berlin, Szb 1905 : 10911094

06 Notiz zu der chemischen Zusammensetzung des Kleinits. Centralbl Min 1906 : 200-202

07 Zinnoberkristalle aus Sonoma County in Kalifornien; Gips- und Kalkspatkristalle von Terlingua in Texas. Centralbl Miner 1907: 17-19

\section{Sadtler, Benjamin.}

97 The occurrence and treatment of certain gold ores of Park Co., Colo. Am I M Eng, Tr $26: 848-853$ (1897)

06 Gold and tin in northwestern Black Hills. M World 24:520-522 (1906)
Sadtler, Samuel $P$.

95 Asphalts and bitumens. Franklin Inst, J $140: 198-212$ (1895)

97 The genesis and chemical relations of petroleum and natural gas. $\mathrm{Am} \mathrm{Ph}$ Soc, Pr 36: 93-102 (1897)

See also Genth, 75

\section{Saemann, L.}

50 Remarks on boltonite. Am As, Pr 2: 105-109 (1850)

Safely, Robert.

66 Discovery of mastodon remains at Cohoes, N. Y. Am J Sc (2) $42: 426$ (1866)

Safford, James Merrill (1822-1907).

51 The Silurian Basin of middle Tennessee, with notices of the strata surrounding it. Am J Sc (2) 12:352-361 (1851)

53 On the parallelism of the Lower Silurian groups of middle Tennessee with those of New York. An Sc, Cleveland, 1 : 249-251 (1853) Am As, Pr 7:153-156 (1856) Can J 2:138-139 (1854)

53a Tooth of Getalodus [error for Petalodus] ohioensis [Ohio]. Am J Sc (2) $16: 142$ (1853)

56 A geological reconnaissance of the State of Tennessee; being the author's first biennial report. 164 pp (legislative ed, 120 pp), map, Nashville, Tenn., 1856

56a Geological map of the State of Tennessee... Scale 12 miles to 1 inch. Nashville [1856?]

56b Remarks on the genus Tetradium, with notices of the species found in middle Tennessee. Am J Sc (2) $22: 236-238$ (1856)

57 Second biennial report [on the geology of Tennessee]... 11 pp, Nashville, Tenn., 1857

58 On Tennessee geological history. Am J Sc (2) 26:128-129 (1858)

59 On some points in American geological history. Am J Sc (2) 27:140-141 (1859)

60 [Third biennial] report of the State geologist ... 1859. Tenn, Reports to the General Assembly 185n-60:295 - 302 (1860)

$60 a$ On the species of Calceola found in Tennessee. Am J Sc (2) 29:248-249 (1860)

61 The Upper Silurian beds of western Tennessee. Am J Sc (2) 31:205-209 (1861)

64 On the Cretaceous and superior formations of west Tennessee. Am J Se (2) $37: 360-372$ (1864)

66 Note on the geological position of petroleum reservoirs in southern Kentroky and in Tennessee. Am J Sc (2) 42:104107 (1866)

69 Geology of Tennessee. $550 \mathrm{pp}, \quad$ il, map, Nashville 1869 [Part I. Physical geography : 124 pp, first published in Nashville in 1861] 
Safrord, James Merrill-Continued.

74 Agricultural and geological map of Tennessee ... to accompany the reports of the Bureau of Agriculture. Scale 12 miles to 1 inch. N Y [1874] 2d ed [revised] Nashville [1875]

74a (with Killebrew, J. B.) Intro. duction to the resources of Tennessee [the geological formations of the State: $26-46$, map]. Tenn, Bur Agr, First and Second Reports : 1193, xi pp, map, Nashville, Tenn., 1874

76 (and Killebrew, J. B.) The elementary geology of Tennessee ... 255 pp, Nashville 1876

77 The topography and geology of Nashville [Tenn.], with remarks on their sanitary bearing. Nashville, Bd Health, :p 2 : 145-151, Nashville, Tenn,, 1877

80 Geological and topographical features of Tennessee in relation to disease ... Tenn St Bd Health, Rp 1: 237-290, map (1880) ; $2: 365-379$ (1885)

84 Physico-geographical and agricultural features of the State of Tennessee. U S, 10th Census $5: 381-464$, map (1884)

85 The agricultural geology of the State of Tennessee ... [Tenn, Legislature] Appendix to the Senate Journal of the fortyfourth General Assembly, 1st sess, 1885 : $39-119$, Nashville 1885

85a Mineral springs [of Tennessee]. Tenn St Bd Health, B 1 Suppl Oct: 15-16 (1885)

87 The economic and agricultural geology of the State of Tennessee. In Tennessee, Comm Agr, Bien Rp [1885-6] : 55-167, Nashville 1887

S7a The upland geological formations of Obion, Dyer, Lauderdale, Tipton, and Shelby cos. ... Tenn St Bd Health, B 2 : $151-153 ; 3: 3-4,18-19$ (1887)

$\mathbf{8 7 b}$ The topography and geology of middle Tennessee as to natural gas. Am Manufacturer, Nat Gas Suppl no $2: 21-22$, Dec 30 (1887)

88 Agricultural and geological map of Tennessee; issued by B. M. Hord, Commissioner of Agriculture... Scale 12 miles to 1 inch. Chicago [1888]

89 Report of State geologist. Tenn, Gen Assembly, 46th, Sen J : 715-739 (1889)

$89 a$ Regions in west Tennessee of sulphur waters and chalybeate waters, respectively; the line of division between the two regions; the origin of iron ore. Tenn St Bd Health, B 4:210-212 (1889)

89b (and Vogdes, A. W.) Description of new species of fossil Crustacea from the Lower Silurian of Tennessee ... Ac N Sc Phila, Pr $1889: 166-168$, il

90 The water supply of Memphis, Tenn. Tenn St Bd Health, B 5:98-106 (1890) Abst, Am As, Pr $39: 244$ (1891)

91 Certain bones of Megalonyx not before known (abst). Am G 8:232 (1891)
Safrord, James Merrill-Continued.

92 The pelvis of a Megalonyx and other bones from Big Bone cave, Tennessec. Soc Am, B 3:121-123 (1892) Abst, de As, Pr $40: 289$ (1892); Am G $8: 193,2$ ? (1891)

92a Note on the Middleton formath of Tennessee, Mississippi, and Alabas G Soc Am, B 3:511-512 (1892)

92b The Middleton formation of Tes nessee, Mississippi and Alabama; with a note on the formations at LaGiang, Tenn. Am G 9:63-64 (1892)

92e The topography, geology, and wata supply of Sewanee [Franklin Co., Tenn.] Tenn St Bd Health, B 8:89-98 (1892)

93 The Tennessee coal measures, o G S, Min Res 1892: 497-506 (1893)

94 Phosphate-bearing rocks in midd Tennessee. Am G 13:107-109 (1894

94a The phosphate beds of Tennesse Eng M J $57: 366$ (1894)

95 Tennessee phosphate rocks (with : note by $C$. W. Hayes on The white phos phates of Tennessee). Tenn Bur Agt, Bien Rp 1893-4 : 211-224 (1895)

96 A new and important source of phor phate rock in Tennessee. Am G 18:281264 (1896)

96a Agricultural and geological map at Tennessee; issued by T. F. P. Allison, Cos missioner of Agriculture... Scale 12 mild to 1 inch. 1896

98 [Report of] Department of geolog, minerals, mines, and mining. In Officil history of the Tennessee Centennial Ir. position : 366-385, Nashville, Tenn., 1896

99 (and Sehuehert, C.) The Camdes chert of Tennessee and its lower Oriskst fauna. Am J Sc (4) $7: 429-432$ (1899)

00 (and Killebrew, J. B.) The tr ments of the geology of Tennessee. $264 \mathrm{ph}$ Nashville, Tenn., 1900

01 Classification of the geological form. tions of Tennessee. G Soc Am, B 13:1014 (1901)

O1a Horizons of phosphate rock in Tet. nessee. G Soc Am, B 13:14-15 (1901)

Sagra, Ramón de la.

42 Histoire physique, politique et natt. relle de l'ile de Cuba [géologie et minéralo. gie $1: 107-136,230-232$ ], Paris 1842 His toria fisica, polftica y natural de la isla de Cuba [geologia y mineralogía 1:60-76], Paris 1842

Sahlin, Axel.

93 The tale industry of the Gouvernetit district, St. Lawrence Co., N. Y. Am IX Eng. Tr 21: 583-588 (1893)

St. Clair, Stuart.

14 Origin of the Sudbury ore deposits. M Sc Press 109:243-246 (1914)

$14 a$ Titaniferous iron-ore deposits. Pens St M Q 1:112-118 (1914) 
st. Clair, Stuart-Continued.

17 Oil investigations in 11linois in 1916; parts of Williamson, Union, and Jackson cos, III G S, B 35:40-55, map (1917)

17a Oil possibilities of Ava area. III G S, B $35: 57-65$, map (1917)

17b Oil possibilities of Centralia area. III G S, B $35: 67-73$, map (1917)

17e Clay deposits near Mountain Glen, Union Co., Ill. Ill G S, Extract from B 36 : $15 \mathrm{pp}(1917)$

St. John, Orestes Hawley (1841-1921).

67 (with White, C. A.) Descriptions of new Subcarboniferous and Coal Measures fossils collected upon the geological survey of Iowa; together with a notice of new generic characters observed in two species of brachiopods. Chicago Ac Sc, Tr 1:115127 , il (1867)

67a (with White, C. A.) Preliminary notice of new genera and species of fossils. lowa State Geological Survey. [3 pp, Iowa City 1867]

68 Report [of field work]. Iowa G S, An Rp 1-2:84-87 (1868).

68a Letters [geology of the Raccoon River region; surface geology of the middle region of western Iowa]. Iowa $G$ S, An Rp 1-2: 171-201 (1868)

70 Geology of the middle region of western Iowa and other counties. Iowa $\mathrm{G} S$, 2:1-200 (1870)

$70 a$ Carboniferous system [of Iowa]. Iowa G S $1: 264-284$ (1870)

$70 b$ Descriptions of fossil fishes, from the upper Coal Measures of Nebraska. Am Ph Soc, Pr 11:431-437 (1870)

72 Descriptions of fossil fishes from the upper Coal Measures of Nebraska. In Hayden, F. V., Final report of the United States Geological Survey of Nebraska... (U S, 42d Cong 1st sess, H Ex Doc 19) : 239-245 (1872)

75 (and Worthen, A, H.) Descriptions of fossil fishes. III G S $6: 245-488$, il (1875)

76 Notes on the geology of northeastern New Mexico. U S G Geog S Terr (Hay den), B 2:279-3e8 (1876)

79 Report of the geological field work of the Teton division. U S G Geog S Terr (Hayden), An Rp $11: 321-508$, map (1879)

83 (and Worthen, A. H.) Descriptions of fossil fishes. III G S $7: 55-264$, il (1883)

83a Report on the geology of the Wind River district. U S G Geog S Terr (Hayden), An Rp 12 pt 1: 173-269 (1883)

$83 b$ [Geologic map of] parts of western Wyoming and southeastern Idaho. Scale 4 miles to 1 inch. U S G Geog S Terr (Hayden), $n$ d [1883?] [Also in 12th An Rp]

83e Sketch of the geology of Kansas. Kans St Bd Agr, Bien Rp 3:571-599, map
St. John, Orestes Hawley-Continued.

s3d (with Peale, A. C. and Endlich, F. M.) Geological map of portions of Wyoming, Idaho, and Utah. Scale 8 miles to 1 inch. U S G Geog $\mathbf{S}$ Terr (Hayden), $n$ d [1883?] [also in 12th An Rp]

85 Artesian wells. Kans St Bd Agr, 4th Bien Rp, 1883-4: 591-603 (1885)

87 Notes on the geology of southwestern Kansas. Kans St Bd Agr, Bien Rp '5 pt $2: 132-152$ (1887)

See also Eastman, $02 b$

St John, Samuel.

51 Elements of geology... 334 pp, Hudson, Ohio, 1851 Another ed, N Y 1851

Sainte-Claire Deville, Charles Joseph, $1814-1876$.

40 Lettre sur l'état géologique de quelques fles de l'Amérique septentrionale [Trinidad and other West Indian islands] : Ac Sc Paris, C R 11:983-986 (1840)

60 Observations sur le tremblement de terre éprouvé à la Guadeloupe le 8 février 1843. In Recherches sur les principaux phénomènes de météorologie et de physique terrestre aux Antilles, t 1:7-76, Paris, 1860

67 Rapport sur divers mémoires de qéologie envoyés par MM. Dollfus, de Montserrat, et Pavie. [France], Comm Sc Mex, Arch 2:339-346, Paris 1867

67 a Note sur l'analyse des gaz recueillis aux Antilles... [France], Comm Sc Mex, Arch 2:436-441, Faris 1867

Saladin, Êdouard.

92 Note sur les mines de cuivre du Boleo, Basse Californie. Soc Ind Min, B (3) $6: 5-46 \quad(1892)$

Salazar Salinas, Leopoldo.

01 Apuntos relativos al mineral de Taxco de Alarcón, Estado de Guerrero. Soc Cient Ant Alz, Mem 16:167-177 (1901)

11 (with Gonzalez, F.) The mining industry of Mexico. No 1, State of Hidalgo. Pt 1:74 pp; Pt $2: 77-108$ (1911)

12 (with Grothe, A.) La industria minera de México. T. 1, Estados de Hidalgo $y$ México. $319 \mathrm{pp}$ México (1912)

12a (with Grothe, A.) La industria minera de México, no. 5 [tomo 2 pt 1]: Estado de Michoacán, primera parte, pp 1-83, maps, Mexico 1912

13 La industria minera de México, no 6 [tomo 2 pt 2]; Estado de Michoacán. segunda parte, pp 85-112, maps, Mexico 1913

\section{Sales, Reno H.}

08 The localization of values in ore bodies and the occurrence of shoots in metalliferous deposits; ore shoots at Butte, Mont. Ee G $3: 326-331$ (1908) Eng M J $86: 226-227$ (1908) Abst, M Sc Press 97: 190-191 (1908)

10 Superficial alteration of the Butte veins. Ee G 5:15-21 (1910) 
Sales, Reno H.-Continued.

$10 a$ Criteria of downward sulphide enrichment (discussion). Ec G $5: 681-682$ (1910)

12 Review of Butte geological report. Eng M J 94:729-731 (1912)

13 Ore deposits at Butte, Mont. Am I M Eng, B 80:1523-1626 (1913); Tr 46:3-109 (1914) Eng M J 96:439-440, $587-589$ (1913) M Sc Press 107:453459 (1913)

Salisbury, Charles $M$.

81 Geology of the valley of the Narragansett. Sc Advocate, Atco, N. J., 2 : 18-20 (1881)

Salisbury, Rollin D. (1858-1922).

83 Chemical analyses. [Wis G S], G Wis $1: 303-308$ (1883)

85 Columnar structure in subaqueous elay. Science 5:287 (1885)

85a (with Chamberlin, T. C.) On the Driftless Area of the upper Mississippi Valley. U S G S, An Rp 6:199-322, maps (1885)

86 Notes on the dispersion of drift copper. Wis Ac Sc, $\operatorname{Tr} 6: 42-50$ (1886)

91 A further note on the age of the Orange sands. Am J Sc (3) $42: 252-253$ (1891)

$91 \mathrm{a}$ On the relationship of the Pleistecene to the pre-Pleistocene formations of Crowley's Ridge and adjacent areas south of the limit of glaciation. Ark G $\mathrm{S}$, An Rp $1889,2: 224-248$ (1891) Am $\mathrm{J}$ Se (3) $41: 359-377$ (1891)

$91 \mathrm{~b}$ On the probable existence of a second driftless area in the basin of the Mississippi (abst). Am G 8:232 (1891) Am As, Pr 40:251-253 (1892)

91e On the northward and eastward extension of pre-Pleistocene gravels in the basin of the Mississippi (abst). Am G 8: 238 (1891)

91d On certain extramorainic drift phenomena of New Jersey (abst). Am G 8 : 238-239 (1891)

91e (with Chamberlin, T. C.) On the relationship of the Pleistocene to the pre-Pleistocene formations of the Mississippi Basin, south of the limit of glaciation. Am J Sc (3) $41: 359-377 \cdot(1891)$

92 A preliminary paper on drift or Pleistocene formations of New Jersey. N J G S, An RP 1891: 35-108, maps (1892)

92a Certain extramorainic drift phenomena of New Jersey. G Soc Am, B 3 : 173-182 (1892) Abst, Am G 8:238-239 (1891)

92b on the northward and eastward extension of the pre-Pleistocene gravels of the Mississippi basin (abst). G Soc Am, B $3: 183-186$ (1892) Am G 8: 238 (1891)

93 Surface geology-report of progress, 1892. N J G S, An Rp 1892: 37-166, map (1893)
Salisbury, Rollin D.-Continued.

93a Distinct glacial epochs and the of teria for their recognition. J G 1:61: (1893) Abst, with diseussion by $\pi$ : MeGee, C. H. Hitcheock, Warren Uphr Robert Bell, and B. K. Emerson, An 6 $11: 171-175$ (1893)

93b The older drift in the Delaware $T_{t}$. ley. Am G 11: $360-362$ (1893)

93e Cenozoic history of eastern Virzith and Maryland (discussion). G Soc in B $5: 24$ (1893)

94 (and others) Surface geology; to port of progress. N J G S, An Rp 18:5: 33-328, maps (1894) Abst, J G $3: 984$. 985 (1895)

94a [Isostasy and the glacial epot]. J G 2 : 222-224 (1894)

94b Superglacial drift. J G $2: 613$-t: (1894)

94e The drift, its characteristics as relationships. $J$ G $2: 708-724,837-8$. (1894)

94d [Lafayette and Columbia form tions]. G Soc Am, B 5:100 (1894)

94e An illustration of the effect of stut nant ice in Sussex Co., N. J. $(a b s t)$. At As, $\operatorname{Pr} 42: 180$ (1894)

94f A phase of superglacial drift (abet! Am As, Pr 42: 180 (1894)

95 Surface geology; report of progres N J G S, An Rp 1894: 1-149, map (1846

95a Agencies which transport materis on the earth's surface. J G $3: 70-5$ (1895)

95b (and Kümme1, H. B.) Lake Pu saic, an extinct giacial lake. J G 3:55560 , map (1895)

95e Preglacial gravels on the quartit range near Baraboo, Wis, J G $3: 655-5$ (1895)

95d The Greenland expedition of 186 J G 3:875-902 (1895)

95e Surface formations of southern Nef Jersey. G Soc Am, B 6:483-488 (1885 Abst, Am G 15:203-204 (1895); Sclens n s 1:67 (1895)

96 Surface geology; report of progtes N J G S, An Rp 1895: 1-16, map (1896)

$96 a$ Salient points concerning the th cial geology of north Greenland. J G t $769-810$ (1896)

96b Loess in the Wisconsin drift forth tion. J G 4:929-937 (1896)

96e Stratified drift. J G 4:948-4t (1896)

96d The Philadelphia brick clays, et it Science n s 3:480-481 (1896)

96 e Volcanic ash in soutbwestern $X$ braska. Science n s 4:816-817 (1896) 97 (and Knapp, G. N.) Surface of ology ; report of progress. N J G \&, Bt Rp 1896:1-23, maps (1897)

97a (and Atwood, W. W.) Drift ptr nomena in the vicinity of Devil's Lake 2il Baraboo, Wis. J G $5: 131-147$, as? (1897) 
Salisbury, Rollin D.-Continued.

$97 \mathrm{~b}$ On the origin and age of the relicbearing sand at Trenton, N. J. Science n $s$ $6: 977-981$ (1897)

98 Surface geology ; report of progress, 1897. N J G S, An Rp 1897:1-22, map (1898)

9Sa The physical geography of New Jersey. N J G S, Final Rp 4:1-170, maps (1898)

98b (and others) A symposium on the classification and nomenclature of geologic time divisions. J G 6:333-355 (1898)

99 The soils of New Jersey and their relation to the geological formations which underlie them. N J G S, An Rp 1898 : 1-41, map (1899)

99a (and Alden, W. C.) The geography of Chicago and its environs. Geog Soc Chieago, B 1:64 pp, maps [1899]

00 (and Atwood, W. W.) The geography of the region about Devil's Lake and the Dalles of the Wisconsin. Wis G S, B 5 (ed \& 1); 151 pp, Madison, Wis, 1900

00a The local origin of glacial drift. J G 8: 426-432 (1900)

00b Certain late Pleistocene loams in New Jersey and adjacent States $(a b s t)$. Am As, Pr 49:192-193 (1900) Science n \& $12: 995(1900)$

01 The surface formations in southern New Jersey, N J G S, An Rp 1900: xxxili-x] (1901)

01a Glacial work in the western mountains in 1901. J G 9:718-731 (1901)

02 (and others) The glacial geology of New Jersey. N J G S, Final Rp 5: xxvii, $802 \mathrm{pp}$, maps (1902)

02a Recent progress in glaciology. Science n s 15:353-355 (1902)

02b The geology of the Grand Canyon region. In The Grand Canyon of Arizona, published by the Passenger Department of the Santa Fe [Atchison, Topeka, and Santa Fe Ry system] : 68-82 [Chicago] 1902

08 (and Blackwelder, E.) Glaciation In the Bighorn Mountains [Wyo.]. J G $11: 216-223$ (1903)

04 Three new physiographic terms. J G $12: 707-715(1904)$

04a (with Chamberlin, T. C.) Geology. 3 vols, N Y 1904-06 Vol. 1, Geologic processes and their results, xix, 654 pp, 1904; 2d ed, xix, 684 pp, 1905 Vol 2. Earth bistory; genesis-Paleozoic, xxv1, 692 pp, il, map, 1906 Vol. 3, Earth history; Mesozoic, Cenozoic, xi, $624 \mathrm{pp}$, il 1906

05 The mineral matter of the sea, with some speculations as to the changes which have been involved in its production. $J G$ $13: 469-484$ (1905)
Salisbury, Rollin D.-Continued.

06 Glacial geology of the Bald Mountain and Dayton quadrangles, Wyo. U S G S, G Atlas Bald Mountain-Dayton fol (no 141) : 9-12 (1906)

06a Glacial geology of the Cloud Peak and Fort McKinney quadrangles, Wyo. U S G S, G Atlas Cloud Peak-Fort McKinley fol (no 142) : 9-12 (1906)

06b Glacial geology of the Bighorn Mountains. U $S$ G S, P P $51: 71-96$ (1906)

o6e The Illinois geological survey. J G 14:65-67 (1906)

07 Physiography. $770 \mathrm{pp}, \mathrm{N}$ Y 1907

os Quaternary system of the Franklin Furnace quadrangle, N. J. U S G S, G Atlas Franklin Furnace fol (no 161): 13-18 (1908)

osa (and Atwood, W. W.) The inter. pretation of topographic maps. U S G S, P P 60:84 pp, maps (1908)

osb (with Darton, N. H.) Description of the Passaic quadrangle, N. J.-N. Y. U S G S, G Atlas, fol $157: 27$ pp (1908)

ose (with Spencer, A. C.) Description of Franklin Furnace quadrangle, N. J. U S G S, G Atlas fol 161:27 pp (1908)

09 Physical geography of the Pleistocene with special reference to Pleistocene conditions. I G 17:589-599 (1909)

10 (with Willis, Bailey) Outlines of geologic history with especial reference to North America. $306 \mathrm{pp}$, Chicago 1910

11 Study of ice-sheet erosion and deposition in the region of the Great Lakes (discussion). G Soc Am, B 22: 728 (1911)

$11 \mathrm{n}$ System of Quaternary lakes in the Mississippi basin (discussion). G Soc Am, B $22: 732$ (1911)

13 (and Trowbridge, A. C.) The interpretation of topographic maps; a laboratory manual for use in connection with the topographic maps of the United States Geological Survey, to accompany beginning courses in physiography. v, 64 pp, New York, 1913

13n (and Trowbridge, A. C.) Laboratory exercises in structural and historieal geology; a laboratory manual based on folios of the United States Geological Survey, for use with classes in structural and historical geology. v, $76 \mathrm{pp}$, New York 1913

13b (and Trowbridse, A. C.) Studies in geology; a laboratory manual based on topographic maps and folios of the United States Geological Survey, for use with classes in physiographic and structural geology. v, 68 pp, New York 1913

14 (with Bayley, W. S.) Description of the Raritan quadrangle, N. J. U S G S, G Atlas fol 191 (1914) Abst, Wash Ac Sc, J 4:371 (1914)

14a (with Chamberlin, T. C.) Introductory geology. $708 \mathrm{pp}$, New York, 1914 
Salisbury, Rollin D.-Continued.

17 (and Knapp, G. N.) The Quaternary formations of southern New Jersey. N J Dp Cons, Div M G [N J G S], Final report series of the State Geologist $8: 218$ pp (1917)

18 (and Barrows, H. H.) The environment of Camp Grant. III G S, B 39 : 75 pp (1918)

18a The American Association for the Advancement of Science; Section E, Geology and Geography [proceedings sixtyninth meeting in Pittsburgh, December 28 and 29,1917$]$. Science $n$ s $47: 467-470$, 492-494 (1918)

18b Geology in education. Science $\mathbf{n} 8$ $47: 325-335$ (1918)

See also Chamberlin, 02 ; Fairchild, 16a; Jenkins, 15 ; Merrill ( $\mathrm{F} \mathrm{J} \mathrm{H}$ ), 02 ; Wright (G F), 92

Salter, John William (1820-1869).

52 Geology [and paleontology]. In Sutherland, Peter C., Journal of a voyage in Baffin's Bay and Barrow Straits ... vol. 2, appendix : cexvii-cexxxiti, il, L 1852.

52a Note on the fossils ... from the Ottawa River. Brit As, Rp 21: sec 63-65 (1852) Am J Sc (2) 14:229-233 (1852)

53 On Arctic Silurian fossils. G Soc London, Q J 9:312-317 (1853)

55 Arctic Carboniferous fossils. In Belcher, Edward, Account of the last of the Arctic voyages, vol $2: 377-389$, il, L 1855

58 (and Billings, E.) On Cyclocystoides, a new genus of Echinodermata from the Lower and middle Silurian rocks. Can G S, Can Organic Remains, decade 3:8690 , il (1858)

59 Figures and descriptions of Canadian organic remains [Ordovician]; Decade I. Can G S: 47 pp. il (1859)

59a On fossils of the Lingula flags or "zone primordiale." G Soc London, Q J $15: 551-555$, 11 (1859)

63 On some fossil crustacea from the Coal Measures and Devonian rocks of British North America. G Soc London, Q J $19: 75-80$, il (1863) Abst, G Soc London, Q J 18:346 (1862); Can Nat $7: 320$ (1862)

85 List of fossils from the Carboniferous outlier in the Flathead Valley [B. C.]. Can G S, Rp Prog 1882-4: B 41-42 (1885) Salterain y Legarra, Pedro de (18351893).

80 Apuntes para una descripción físicogeológica de las jurisdicciones de la $\mathrm{Ha}$ bana y Guanabacoa, Isla de Cuba. España, Com Mapa Geol, B $7: 161-225$, map (1880) Also, 72 pp, map, Madrid 1880

83 Ligera reseña de los temblores de tierra occurridos en la Isla de Cuba. España, Com Mapa Geol, B 10:371-383 (1883) R Ac Cienc Habana, An 21 : 203218 (1884)
Salterain y Legarra, Pedro de-Con. 18 (with Fernandez de Castro, If.) Croquis geologico de Cuba ... See Hayes, 18

Sumple, Clarence C.

os Amber in Santo Domingo. Eng y J $80: 250-251$ (1905)

Sampson, Francis Asbury (1842-1918).

82 Natural history [of Pettis Co., Mo.], including its geological formations; its paleontology ... In The history of Pettis County, Missouri ... :221-239, n p, 1882

88 Notes on the Subcarboniferous series at Sedalia, Mo. N Y Ac Sc, Tr $7: 246-$ 247 (1888)

90 A bibliography of the geology of Missourf. Mo G S, B $2: 158$, xviii pp (1890)

93 Missouri official geological reports Science $21: 311-312$ (1893)

13 The New Madrid and other eartb. quakes of Missouri. Seism Soc Am, B 3: $57-71$ (1913)

14 Post-Pliocene shells of Providence and Lupus, Mo. Nautilus 28:15-17 (1914)

Sampson, R. J.

15 Harlan coal field in southeastem Kentucky. Colliery Eng 35:371-37t (1915)

Sanborn, J. F.

o8 Some geological features affecting the Catskill water supply. Harvard Eng d $7: 88-94$ (1908)

Sandberg, August.

13 Report of a reconnaissance alonz lower Coppermine River, Can. Can H Inst, $\operatorname{Tr} 16: 86-99$, map (1913) $4 l s 0$ in Lands forlorn, by George M. Douglas, pp 277-285, map, New York 1914

Sandberger, F.

75 Ueber merkwïrdige Quecksilbererı aus Mexico. K Bayer Ak Wiss München, Mat-phys C1, Szb 5: 202-205 (1875)

Sanders, George N.

45 [Mineral region of Lake Superior.] U S, 28th Cong 2d sess, S Ex Doc 117:39 (1845); 28th Cong spec sess, S Ex Doc $175: 8-14$ (1845)

Sanders, Richard $H$.

78 (with Platt, F.) Section of the Paleozoic rocks in Blair Co. [Pa.]. Am $\mathrm{Ph}$ Soc, Pr 17:349-352, 714 (1878) Pa G S, Rep F : 261-264 (1878)

83 Bluestone Flat Top Coal Company's lands [W. Va.]. The Virginias 4:175176 (1883)

Sanford, Edward.

30 An account of depositions of calcareous tufa at Chittenango, Madison Co. N. Y. Anr J Sc 18:354-356 (1830)

Sanford, Samuel.

06 Record of deep-well drilling for 1905 ; well records. U S G S, B 298: 15296 (1906) 
Sanford, Samuel-Continued.

06a (with Fuller, M. L.) Record of deep-well drilling for 1905. U S G S, B 298: 299 pp (1906)

07 Mineral waters. U S G S, Min Res 1906: 1165-1194; 1907 pt $2: 751-784$; 1908 pt $2: 755-790 ; 1909$ pt $2: 857-895$ (1907-11)

09 The topography and geology of southern Florida. Fla G S, 2 d An Rp : 175-231 (1909)

11 Saline artesian waters of the Atlantic Coastal Plain. U S G S, W-S P 258: 75-86 (1911)

13 The underground-water resources of the Coastal Plain province of Virginia. Va G S, B $5: 361 \mathrm{pp}, \operatorname{map}$ (1913)

14 (and Stone, Ralph W.) Useful minerals of the United States. U S G S, B $585: 250$ pp (1914)

16 The rise of sea level shown by coastal dunes. Science n s $43: 348-349$ (1916)

17 (with Sehrader, F. C., and stone, R. W.) Useful minerals of the United States (a revision of Bulletin 585). U S G S, B 624: 412 pp (1917)

Santos, J. R.

77 Analysis of native antimony ocher from Sevier Co., Ark. Ch News 36:167 (1877)

77 a Examination of an unusual form of stibnite from Oregon. Ch News $36: 167$ (1877)

$77 \mathrm{~b}$ Analysis of aluminous chrysocolla from Utah. Ch News $36: 167-168$ (1877) Saporta, Gaston de.

68 Sur la flore fossile des régions arctiques. Soc Bot France, B $15: 64-71$ (1868)

Sapper, Karl Theodor.

93 Bemerkungen ilber die rüumliche Verthellung und morphologischen Eigenthümlichkeiten der Vulcane Guatemalas. Deut G Ges, Zs 45:54-62 (1893)

93a Ueber die räumliche Anordnung der mexikanischen Vulkane. Deut G Ges, Zs 45: 574-577 (1893)

94 Ein Beitrag zur Geologie von Oaxaca. Deut G Ges, Zs 46:675-678 (1894)

94a Kratertypen in Mexiko und Guatemala. Petermanns Mitt 40:82-85 (1894)

94b Grundzüge der physikalischen Geographie von Guatemala. Petermanns Mitt Erg 24 no 113: 59 pp, maps, 1894

94e Informe sobre la geografía física y la geología de los Estados de Chiapas y Tabasco. Bol Agr Min é Ind 3 no $9: 187-$ 211 (1894)

96 Sobre la geografía física y la geología de la Península de Yucatán. Méx I G, B $3: 57$ pp, maps (1896) Transl in part, J G $4: 938-947$ (1896)

96a Geology of Chiapas, Tabasco, and the Peninsula of Yucatan, J G 4:938-947 (1896)
Sapper, Karl Theodor-Continued.

96b Dampfquellen und Schlammvulkane in San Salvador. Weut G Ges, Zs 48:1426 (1896)

97 Ueber Erderschütterungen in der Republik Guatemala in den Jahren 1895 und 1896. Deut G Ges, Zs 49: 201-202 (1897)

$\mathbf{9 7 a}$ Ueber die räumliche Anordnung der mittelamerikanischen Vulcane. Deut G Ges, Zs $49: 672-682$, map (1897)

99 Ueber Gebirgsbau und Boden des nördlichen Mittelamerika, Petermanns Mitt, Erg 27 no 127 : 119 pp, maps (1899)

$99 a$ Der Vulkan Las Pilas in Nicaragua. Deut G Ges, Zs 51: 578-587 (1899)

oo Bemerkungen über einige Vulkane von Guatemala und Salvador. Petermanns Mitt 46:149-161 (1900)

01 Die südlichsten Vulkane MittelAmerikas. Deut G Ges, Zs $53: 24-51$ (1901)

O1a Die Alta Verapaz (Guatemala). Geog Ges Hamburg, Mitt $17: 78-214$, maps (1901)

02 Das Erdbeben in Guatemala vom 18. April 1902. Petermanns Mitt 48: 193-195, map (1902)

03 Der Ausbruch des Vulkans Santa Maria in Guatemala (Oktober 1902). Centralbl Miner 1903: 33-44, 71-72

03a Die jüngsten Ereignisse am Vulkan Izalco (Salvador). Centralbl Miner 1903: 103-111

03b Ein Besuch der Insel Grenada. Centralbl Miner 1903: 182-186

03e Bericht über einen Besuch von st. vincent. Centralbl Miner 1903 : 248-258

o3d Zur Kenntniss der Insel $\mathrm{S}$. Lucia in Westindien. Centralbl Miner 1903: 273-278 ose Ein Besuch der Insel Montserrat (Westindien). Centralbl Miner 1903: 279283

03f Ein Besuch der Inseln Nevis und S. Kitts (S. Christopher). Centralbl Miner $1903: 284-287$

03g Ein Besuch von Dominica. Centralbl Miner 1903: 305-314

03h Ein Besuch von S. Eustatius und Saba. Centralbl Miner 1903:314-318

031 Ein Besuch von Guadeloupe. Centralbl Miner 1903:319-323

03j Ein Besuch von Martinique. Centralbl Miner $1903: 337-358$

osk Der Krater der Soufrière von st. Vincent. Centralbl Miner $1903: 369-373$

osi St. Vincent. Globus $84: 297-303$, $377-383$ (1903)

04 Die vulcanischen Ereignisse in Mittelamerika im Jahre 1902 . N Jb 1904, I : 39-90

O4a Die vulcanischen Kleinen Antillen und die Ausbriche der Jahre 1902 und 1903 N Jb 1904, II : 1-70, map

04b Neue Beiträge zur Kenntnis von Guatemala und Westsalvador. Petermanns Mitt $50: 203-210$, maps (1904) 
Sapper, Karl Theodor-Continued.

O4c Neuere vulcanische Ereignisse in Mittelamerika. Centralbl Miner 1904: $449-450$

05 In den Vuleangebieten Mittelamerikas und Westindiens... 334 pp, maps, Stuttgart 1905

O5a Ueber Gebirgsbau und Boden des sudlichen Mittelamerika. Petermanus Mitt Erg 32 no 151: 82 pp, maps (1905)

o5b Ein neuer Vulkanausbruch in Mittelamerika, Centralbl Miner 1905:172. 175

o5e Grundzüge des Gebirgbaus von Mittelamerika. Int Geog Cong, VIII, Rp : 231-238, map (1905)

06 Erdbebenserie von Masaya (Nicaragua) 1. bis 5. Januar, 1906. Centralbl Miner 1906 : 257-259

11 Die jüngsten vulkanischen Vorgänge in Mittelamerika. Centralbl Miner 1911: 531-534

12 Das Erdbeben von Sarchí (Kostarika) am 6. Juni 1912. Petermanns Mitt $58: 340-341$ (1912)

13 Die mittelamerikanischen Vulkane. Petermanns Mitt, Erg 38 no $178: 173$ pp, maps (1913)

14 Die Hölle von Masaya [Nlearagua]. N Jb, Beil Bd 39 (Festband Bauer) : 415445 (1914)

16 Alte und neue Bilder des Masaya und Momotombo [velcanoes, Nicaragua]. Zs Vulkan 2:226-231 (1916)

18 Geschwistervulkane in Guatemala. Zs Vulkanologie 4:1-14, map (1918)

18 a Tätigkeit des Lassen Peak in den Jahren 1914 und 1915 bis Anfang 1916. Zs Vulkanologie 4:51-52 (1918)

Sardeson, Frederick William.

92 The lower Silurian formations of Wisconsin and Minnesota compared (abst). Minn, Univ, Q B 1:29 (1892)

92a The range and distribution of the Lower Silurian fauna of Minnesota with descriptions of some new species $(a b s t)$. Minn, Univ, Q B 1:29 (1892)

92b (with Hall, C. W.) Paleozoic formations of southeastern Minnesota (with discussion, pp. 464-465). G Soc Am, B $3: 331-368$, map (1892) Abst, Am G $9: 216$ (1892)

94 Note on “Nanno." Am G 14:402403 (1894)

95 (with Hall, C. W.) The magnesian series of the Northwestern States. G Soc Am, B 6:167-198, map (1895)

96 The Galena and Maquoketa series. Am G $18: 356-368$ (1896) ; $19: 21-35,91$ $111,180-190$, il (1897)

96a The Saint Peter sandstone. Minn Ac $N$ Sc, B $4: 64-88$, il (1896) Abst, Minn, Univ, Q B 1:29-30 (1892)

96b The fauna of the Magnesian series. Minn Ac N Sc, B 4:92-105, il (1896)
Sardeson, Frederick William-Contind 96e Ueber die Beziehungen der fossis Tabulaten zu den Alcyonarien. $\mathrm{N} J \mathrm{Jb}$ Bd 10:249-362, il (1896) Rv by G. I G[irty], Am G 18:37-42 (1896) [see al: p. 131]

97 Nomenclature of the Galena Maquoketa series. Am G $19: 330-2 \%$ (1897)

$\mathbf{9 7 a}$ On Streptelasma profundum (0wea S. corniculum Hall. Am G 20:277-4\%. il (1897)

$97 \mathbf{b}$ On glacial deposits in the Driftin Area. Am G 20:392-403 (1897)

98 Intraformational conglomerates the Galena series. Am G $22: 315-32$ (1898)

9Sa The so-called Cretaceous deposits in southeastern Minuesota. J G 6:679-69 (1898)

98b Remarks on the loess. Iowa Sc, $\operatorname{Pr} 5: 11-12$ (1898)

99 A new cystocrinoidean species fru the Ordovician. Am G 24:263-276, (1899)

99a What is the loess? Am J Sc (i) $7: 58-60$ (1899)

99b Lichenaria typa W. \& S. AP Sc (4) $8: 101-105$, il (1899)

99e [On the primitive structure of the crinoid stem (abst).] Science n s 9:62 (1899)

99d (with Ha11, C. W.) Eolian dt posits of eastern Minnesota. G Soc Am, B $10: 349-360$ (1899) Abst, Am G 23:104 (1899); Science n 8 9: 143 (1899)

00 Meteorology of the Ordovician. As G $26: 388-391$ (1900)

01 Problem of the Monticuliporoida J G $9: 1-27,149-173$, il (1901)

01 a Paleozoic fossils in the drift. Mins Ac N Sc, B 3:317-318, 309-310 (abit with discussion by C. W. Hall) (1901)

$01 \mathrm{~b}$ Fossils in the St. Peter sandstone Minn Ac N Sc, B 3: 318-319 (1901)

01e The Lower Silurian formations of Wisconsin and Minnesota compared. Mint Ac N Sc, B 3:319-326 (1901)

01d The range and distribution of the Lower Silurian fauna of Minnesota with descriptions of some new species. Minn $A c$ N Sc, B 3:326-343, 11 (1901)

O1e Note on the western Tertiary. Sct ence $n$ \& $13: 868-869$ (1901)

02 On the deceptive fossillization of et tain pelecypod species and on the gens Eurymya. Am G $30: 39-45$, il (1902)

02a The Carboniferous formations of Humboldt, Iowa. Am G $30: 300-312$, il (1902)

03 The phylogenic stage of the Cam brian Gastropoda. J G 11:469-492. 11 (1903)

O3a Observations on the genus Romit geria. Am G 32: 260-261 (1903) 
Sardeson, Frederick William-Continued. 05 A peculiar case of glacial erosion. J G $13: 351-357$ (1905)

06 The folding of subjacent strata by glacial action. J G 14:226-232 (1906)

07 Galena series. G Soc Am, B 18: 179 194 (1907) Abst, Sclence n s 25:771 (1907)

08 Beginning and recession of Saint $\mathrm{An}$ thony Falls. G Soc Am, B $19: 29-52$ (1908) Abst, Science n s 27: 729 (1908)

08a Geological history of the Redstone quartzite [Minnesota]. G Soc Am, B 19 : 221-242, map (1908)

08b Discoid crinoidal roots and Camarocrinus. J G 16:239-254, il (1908)

11 Characteristics of the glacial drift sheets in Minnesota $(a b s t)$. Science $n$ s $33: 467$ (1911)

14 Characteristics of a corrosion conglomerate. G Soc Am, B 25:39 (abst), 263-276 (1914)

16 Description of the Minneapolis and St. Paul district, Minn. U S G S, G Atlas Minneapolis-St. Paul fol (no 201) : 14 pp, maps (1916)

16a (with Leverett, F.) Map of the surface formations of Minnesota. Sheet 3 of A [southern part of State]. Scale 1:500,000. Minn G S 1916

17 (with Leverett, F.) Surface formations and agricultural conditions of northeastern Minnesota. Minn G S, B 13 : $72 \mathrm{pp}$, maps (1917)

See also Fairchild, 04c

Sargent, R. H.

09 The monarchs of Alaska [physio graphic features]. Nat Geog Mag 20:611$623(1909)$

Sarle, Clifton $\mathrm{J}$.

01 Reef structures in Clinton and Niagara strata of western New York. Am G 28: 282-299 (1901)

03 A new eurypterid fauna from the base of the Salina of western New York. N Y St Mus, B 69:1080-1108, il (1903)

04 Economle geology of Monroe Co. [N.

Y.] and contiguous territory. N Y St Mus, An Rp 56: r75-106, map (1904)

05 The burrow origin of Arthrophyous and Daedalus (Vexillum) (abst). Science n $822: 335$ (1905)

06 Arthrophyous and Dadalus of burrow origin. Rochester Ac Sc, Pr 4:203-210, il (1906)

06n Preliminary note on the nature of Tronurus. Rochester Ac Sc, Pr 4: 211-214 (1906)

Sartorius, Charles.

67 The earthquake in eastern Mexice of the second of January, 1866. Smiths Inst, An Rp 1866: 432-434 (1867)

71 Eruption of the volcano of Colima In June, 1869. Smiths Inst, An Rp 1869 : 422-423 (1871) Am J Sc (3) 2:381-383 (1871)
Satterfield, George.

77 [Record of well boring in Warren Co., Tenn.] Tenn, Bur Agr, Rp 1877-8:114 116 (1877)

Satterly, John.

17 (and Elworthy, R. T.) Mineral springs of Canada; Part I, The radioactivity of some Canadian mineral springs. Can Mines Br, B 16: 55 pp, map (1917)

Sauer, Carl Ortwin.

16 Geography of the upper Illinois Valley and history of development. III G S, B $27: 208 \mathrm{pp}, \operatorname{map}$ (1916)

Saunders, Edwin $J$.

14 The coal fields of Kittitas Co. [Wash.]. Wash G S, B 9: 204 pp, maps (1914)

16 The physical geography of Washington. J G 14: 309-322, map (1916)

\section{Sannders, William $H$.}

73 Coals of Kansas. Kans St Bd Agr, Tr 1872: 387-389 (1873) Kans Ac Sc, $\operatorname{Tr} 1$ (reprint) : 30-32 (1895)

Saussure, Henri de.

58 Description d'un volean éteint du Mexique resté inconnu jusqu'à ce jour. Soc G France, B (2) 15: 76-87 (1858)

58a Ascension du Pic d'Orizaba au Mexique. Schweiz Namre Ges, Verh 43 : 79-83 (1859) Arch Sc Phys Nat n p 3: 118-122 (1858)

59 Note sur la formation du volcan de Jorullo (Mexique). Soc Vaudoise Sc Nat, B $6: 195-197$ (1859)

82 De la géologie de l'ile de Cuba. Int Cong Americanists, 4th, Madrid, 1881, Actas 1: 169-172 (1882)

Sanvage, E.

75 Notice sur les minerais de fer du Lac Supérieur. An Mines (7) 8:1-35 (1875)

Savage, Joseph (1823-1891)

78 On mastodon remains in Douglas Co. [Kans.]. Kans Ac Sc, Tr 6:10-11 (1878); reprint (1906)

81 Sink holes found in Wabaunsee Co. [Kans.]. Kans Ac Sc, Tr $7: 26-27$ (1881) ; reprint (1906)

85 Notes on the geology of the Spanish Peaks [Colo.]. Kans Ac Sc, Tr 9:113114 [1885]

Savage, Thomas Edmund.

01 Drift exposure in Tama Co. [Iowa]. lowa Ac Sc, $\operatorname{Pr} 8: 275-278$ (1901)

02 Geology of Henry Co. Iowa G S 12 : 237-302, map (1902)

03 Geology of Tama Co. Iowa G S 13 : 185-253, map (1903)

03a The Toledo lobe of Iowan drift. Iowa Ac Sc, Pr 10:123-129 (1903)

04 A buried peat bed in Dodge town. ship, Union Co., Iowa. Iowa Ac Sc, Pr 11: 103-109 (1904)

o5 Report of assistant State geologist. Iowa G S $15: 12-14 \quad$ (1905) ;..16:13-15 (1906) 
Savage, Thomas Edmund-Continued.

o5a Geology of Benton Co. Iowa G S $15: 125-225$, map (1905)

05b Geology of Fayette Co. Iowa G S $15: 433-546$, maps (1905)

05e A preliminary report on the peat resources of Iowa. Iowa G S, B 2:5-21 (1905)

o5d Report on tests of Iowa coals made at the Government coal-testing plant at the Louisiana Purchase Exposition, St. Louis, Mo., 1904. Iowa G S, B 2:22-38 (1905)

06 Report of the assistant State geologist. Iowa G S 16:13-15 (1906)

06a Geology of Jackson Co. Iowa G S 16: 563-648, maps (1906)

06b Geological map of Iowa. Scale 8 miles to 1 inch. Geological base map only ; copyright 1907 by the Iowa Publishing Company, Davenport, Iowa. Compiled ... as a part of the report for the year 1905 . Iowa G S 1906

o6e Pike County gas field. III G S, B 2 : $77-87$ (1906)

o7 Water resources of the Springfield quadrangle. Inl G S, B 4: 235-244 (1907)

os On the lower Paleozoic stratigraphy of southwestern Illinois. Am J Sc (4) 25: 431-443 (1908) मll G S, B 8: 103-116 (1908)

09 The Ordovician and Silurian formations in Alexander Co., III. Am J Sc (4) 28:509-519 (1909)

09a Clay seams or so-called horsebacks near Springfield, IIl. Ec G 5:178-187 (1910) Ill Ac Sc, Tr 2:38-44 (1909)

10 The geology and coal resources of the Herrin, Ill., quadrangle. Ill G S, B 16: 266-285, map (1910)

$10 n$ The faunal succession and the correlation of the pre-Devonian formations of southern Illinois. III G S, B 16:302-341, il (1910)

10b The fauna of the Girardeau limestone and of the Edgewood formation (abst). Science n s 32:224 (1910)

10e The Grand Tower (Onondaga) formation of Illinois, and its relation to the Jeffersonville beds of Indiana. Ill Ac Sc, Tr $3: 116-132$ (1910)

11 Geology of Herrin quadrangle [IIIinois]. Mines and Minerals 31:527-531 (1911)

11a Coal geology of the Herrin quadrangle in Illinois. Black Diamond 46 no 10:14-16 (1911)

12 The Channahon and Essex limestones in Illinois. Ill Ac Sc Tr 4: 97-103 (1912)

12a (with Shaw, E. W.) Description of the Murphysboro and Herrin quadrangles [I11.]. E S G S, G Atlas, fol 185 (1912)

13 Alexandrian series in Missouri and Illinois. G Soc Am, B 24:351-376; 111112 (abst) (1913)
Savage, Thomas Edmund-Continued.

13a Stratigraphy and paleontology the Alexandrian series in Illinois and $\mathrm{Nis}$ souri. IIl G S, B 23:67-160, il 1917 [E tract : $124 \mathrm{pp}$, il (1913)]

1:3b Some interesting new species of 8 thropods from Devonian strata of Illinols Am J Sc (4) 35: 149-152 (1913)

13e The study of deep well drillings Illinois. III Water Supply As, Pr 5:59-4. (1913)

14 On the conditions under which th vegetable matter of the Illinois coal bet accumulated. J G $22: 754-765$ (1914) II Ac Sc, $\operatorname{Tr} 7: 100-110$ [1915?]

14a The relations of the Alexandrin series in Illinois and Missouri to the 8 Iurian section of Iowa. Am J Sc (4) 38 : 28-37 (1914)

15 The geology and mineral resources the Springfield quadrangle. Ill G S, B 20: $97-130$, map (1915)

15a Alexandrian rocks of northeaster Illinois and eastern Wisconsin (abst). Soc Am, B 26:95 (1915)

16 Geologic structure of Canton and Avon quadrangles. Ill G S, B $33: 91-\%$ maps (1916)

16a Alexandrian rocks of northeasten Illinois and eastern Wisconsin. G Soc An B $27: 305-324$ (1916)

$16 \mathrm{~b}$ (and Ross, C. S.) The age of the iron ore in eastern Wisconsin. Am J \& (4) $41: 187-193$ (1916)

16e The loess in Illinois; its origin and age. III Ac Sc, Tr 8: 100-117 [1916]

16d (and Van Tuyl, F. M.) The University of Illinois Hudson Bay expetltion. Science n \& 44:632 (1916)

17 Relations of loess and drift in Cantos quadrangle. III G S, B 30:109-114, ma? (1917)

17a (and Van Tuy1, F. M.) Geologr of the area of Paleozoic rocks in the vicinitf of Hudson and James bays, Canada (abst). G Soc Am, B 28:171 (1917)

18 (and Crooks, H. F.) Early Sllurias rocks of the Northern Peninsula of Michi. gan. Am J Sc (4) 45:59-64 (1918)

18a Correlation of the early Silurian rocks in the Hudson Bay region. J $G 26$ : 334-340 (1918)

18b The Thebes sandstone and Orcbard Creek shale and their faunas in Illinols III Ac Sc, Tr $10: 261-275$, il [1918]

18e Tentative correlation of the Pennsst. vanian strata. in the eastern interiot. western interior, and Appalachian regios by their marine faunas (abst). G Soc AD, B $29: 97$ (1918)

See also Blatchley (W S), 06

Savieki, Wm. V.

01 Geological survey of Michigan ; report of field work for 1900 . Mich Miner 3 bo $3: 9-11$ (1901) 
Saville, M. H.

90 The Sanborn boulder [Rockport, Mass.]. Boston Soc N H, Pr 24:586-588 (1890)

Sawkins, James Gay (1806-1878).

57 (with Wall, G. P.) ...survey of the economic geology of Trinidad. Smiths Inst, An Rp 1856:281-288 (1857)

60 (with Wall, G. P.) Report on the geology of Trinidad; or, Part I, of the West Indian Survey. [Great Britain], G S, Mem. $211 \mathrm{pp}$, map, L 1860

63 On the association of granite with the Tertiary strata near Kingston, Jamaica. G Soc London, Q J 19:35 (1863)

69 (and others) Reports on the geology of Jamaica; or Part II of the West Indian Survey; with contributions from G. P. Wall, Lucas Barrett, Arthur Lennox, and C. B. Brown. [Great Britain], G S, Mem. $339 \mathrm{pp}$, map, L 1869

Sawyer, A. H.

14 Russellville brown iron ore district [Ala.]. Eng M J 98:49-50 (1914)

Sawyer, Amos.

75 On the origin of ravines in the prairie. Ac Sc St L, Tr 3: cxlix (1875)

Say, Benjamin.

33 (and others) Report of a committee of the House of Representatives recommending an appropriation by the Legislature to make a geological survey of the State, under the direction of the Geological Society of Pennsylvania. $10 \mathrm{pp}$, Harris burg 1833

Say, Thomas (1787-1834).

19 ... species of zoophytes, shells, etc., principally fossil. Am J Sc 1:3\&1-387 (1819) ; $2: 34-45$ (1820)

24 Fossil shells found in a shell mass from Anastasia Island [Fla.]. Ac $\mathrm{N}$ Sc Phila, J $4: 78-80$ (1824)

24a An account of some of the fossil shells of Maryland. Ac N Sc Phila, J 4: $124-155$, il (1824)

25 On two genera and several species of Crinoidea. Ac N Sc Phila, J 4:289-296 (1825)

96 A reprint of the paleontological writings of Thomas Say; with an introduction by G. D. Harris. B Am Pal no 5:115 pp, il $(1896)$

See also James (E), 23

Sayler, Nelson.

65 Geological map of Ohio with the adfoining portions of Pennsylvania and West Virginia. Scale 15 miles to 1 inch. Cincinnati 1865

65a Geological map of Indiana. Scale 1 in $=16$ miles. Cincinnati 1865

65b Geological map of Kentucky... Scale 1 in $=16$ miles. Cincinnati 1865

66 An outline geological map of Tennessee, including portions of Mississippi, Alabama, and Georgia. Scale 18 miles to 1 incb. Cincinnati 1866

$$
28737^{\circ}-23-58
$$

Sayles, Ira.

65 Oil region of Pennsylvania. $\Delta \mathrm{m} J$ Sc (2) 39:100-101 (1865)

88 An inquiry into the state of earth's interior. Am Nat 22:17-21 (1888)

Sayles, Robert W.

09 Glacial clays of the Maine coast. Science n s 30:968 (1909)

10 (and LaForge, L.) The glacial origin of the Roxbury conglomerate. Science n s $32: 723-724$ (1910)

11 Report on the geological collection. Harvard Coll, Mus C Z, An Rp 1910-1: 36 (1911); 1911-2:40 (1912); 1912-3 : $41-42$ (1913) ; 1913-4: 42 (1914); 1914-5 : $37-38$ (1915) ; 1915-6: 32 (1916) ; 1916-7 : 30 (1917) ; 1917-8:27 (1918)

13 The history of Lost River [N. H.]. Science n s $37: 611-613$ (1913)

13a Earthquakes and rainfall. Seism Soc Am, B 3:51-56 (1913)

14 The Squantum tillite [Mass.]. Harvard Coll, Mus C Z, B 66 (g s 10) : 141175 (1914)

15 Tillite in New Hampshire. Science n s 41:220-221 (1915)

16 Banded glacial slates of Permo-Carboniferous age, showing possible seasonal variations in deposition. Nat $\mathrm{Ac} \mathrm{Sc}, \mathrm{Pr}$ 2:167-170 (1916) Abst, with discussion by W. W. Atwood, W. H. Hobbs, Joseph Barrell, F. B. Taylor, J. L. Rich, and J. B. Woodworth, G Soc Am, B 27:110114 (1916)

17 A new contribution to American geology [relief model of Kilauea by G. C. Curtis]. Science n s $46: 162-163$ (1917)

17 a Microscopic structural features of the banded glacial slate of Permo-Carboniferous age at Squantum, Mass. (abst). G Soc Am, B 28:152 (1917)

18 A naturalistic model of Kilauea. Volcano, Hawail. Geog Rv $5: 38-43$ (1918) Scalia, Salvador.

05 (with Burekhardt, C.) La fauna marine du Trias supérieur de Zacatecas. Méx I G, B $21: 44 \mathrm{pp}$, il (1905)

06 (with Burckhardt, C.) Géologie des environs de Zacatecas. Int $G$ Cong, $X$, Guide Exc. no. 10:25 pp (1906)

17 Geología de los alrededores de $\mathrm{Hi}$ dalgo del Parral, Chih[uahua, México]. Bol Minero 4:230-233 (1917)

\section{Schanf-Regelman, E.}

o7 Rare metals and minerals and their uses. Eng Mag $33: 91-98$ (1907)

07 a Asbestos; its mining, preparation, markets, and uses. Eng Mag 34:68-S0 (1907)

Schaeberle, John Martin.

06 An ignored theory of the ice age. Science n s 24:439-440, 695 (1906)

os The earth as a heat-radiating planet. Science n \& $27: 392-393$ (1908)

osa Geological climates. Science n s $27: 894(1908)$ 
Schaeberle, John Martin-Continued.

08b On the origin and age of the sedi. mentary rocks. Science n s 28:562-565 (1908)

\section{Schaeffer, Charles A.}

83 On the occurrence of gold in Williamson Co., Tex. Am I M Eng, Tr 11:318321 (1883) Eng M J 36:34 (1883)

84 A new tantalite locality [Black Hills, S. Dak.]. Am J Sc (3) 28:430 (1884)

85 Note on tantalite and other minerals, accompanying the tin ore in the Black Hills. Am I M Eng, Tr 13:231-233 (1885) Eng M J 38:285 (1884)

Schaeffer, F. C.

18 On the peat of Dutchess Co., N. Y. Am J Sc 1:139-140 (1818)

19 Localities of minerals. Am J Sc 1: 236-237 (1819)

Schaefer, George C. (1815-1873).

51 Fossil coniferous wood from the lower Devonian strata, Lebanon, Marion Co., Ky. Am As, Pr 4:193-194 (1851)

57 Description of the structure of the fossil wood from the Colorado desert [Williamson's reconnaissance in California]. U S, Pacific R R Expl (U S, 33d Cong $2 d$ sess, S Ex Doc 78 and $\mathrm{H}$ Ex Doc 91) 5 pt $2: 338-339$ il (1857) [See also Blake (W P), 57]

Schaller, Waldemar Theodore.

03 Minerals from Leona Heights, Ala meda Co., Cal. Cal Univ, Dp G, B 3:191217 (1903)

03a Spodumene from San Diego Co., Cal. Cal Univ, Dp G, B 3: 265-275 (1903)

04 Notes on some California minerals. Am J Sc (4) $17: 191-194$ (1904)

O4a (and Hillebrand, W. F.) Crys. tallographical and chemical notes on law sonite. Am J Sc (4) 17:195-197 (1904)

04b The tourmaline localities of southern California. Science n s $19: 266-268$ (1904)

05 (and Hillebrand, W. F.) Notes ou lawsonite. U S G S, B 262:58-60 (1905)

05a Dumortierite. Am J Sc (4) 19 : 211-224 (1905) U S G S, B 262:91-120 (1905)

05b. Mineralogical notes. U S G S, B 262:121-144 (1905)

o5e Crystallography of lepidolite. Am J Sc (4) $19: 225-226$ (1905) [See also 05b]

o5d (with Graton, L. C.) Purpurite, a new mineral. Am J Sc (4) 20:146-151 (1905) Zs Kryst 41:433-438 (1905)

06 Siderite and barite from Maryland. $\mathrm{Am} J \mathrm{Sc}$ (4) $21: 364-370 \quad$ (1906) Zs Kryst 42:321-326 (1906)

o7 The chemical composition of molybdic opher. Am J Sc (4) 23:297-303 (1907) Zs Kryst $43: 331-337$ (1907) [See also 11]

07a Mineralogical notes. - Am J Sc (4) 24:152-15s (1907) Zs Kryat 44:1-8 (1907) [See also 11]
Sehaller, Waldemar Theodore-Continuel.

o7b (with Hillebrand, W. F.) Th: mercury minerals from Terlingua, Ter. Am J Sc (4) 24:259-274 (1907)

08 Notes on powellite and molsbdits Am J Sc (4) $25: 71-75$ (1908) Zs Krrst $44: 9-13$ (1907) [See also 11]

o8a Some calcite erystals with Der forms. Wash Ac Sc, Pr 11:1-16 (1909) Zs Kryst 44:321-331 (1908) [See also 11]

Osb (with Knope, A.) Two new boton minerals of contact-metamorphic origin Am J Sc (4) $25: 323-331$ (1908)

o9 (with Hillebrand, W. F.) The mercury minerals from Terlingua, Tex. D S G S, B 405: 174 pp (1909) Zs Krrgs $47: 433-575(1910)$

10 Chemical composition of hulsite and paigeite. Am J Sc (4) 29:543-549 (1910) [See also 11]

10a Ludwigite from Montana. Am J Sc (4) $30: 146-150$ (1910) Zs Kryst 48: 545-549 (1911) [See also 11]

$10 \mathrm{~b}$ The probable identity of podolite with dahllite. Am J Sc (4) $30: 309-310$ (1910) Zs Kryst 48:559-561 (1911) [Set also 12]

10e The identity of stelznerite with antlerite. Am J Sc (4) 30:311-31? (1910) Zs Kryst 49:9-10 (1911) [See also 12]

10d Barbierite, a monoclinic soda feldspar. Am J Sc (4) 30:358-359 (1910) Soc Franç Minér, B $33: 320-321$ (1910) Wash Ac Sc J 1:114 (1911) Zs Kryst 50: $347-348$ (1912) [See also 12]

10e Axinit von Californien. Zs Kryst 48:148-157 (1910) [See also 11]

10f Some pegmatites from southern Call. fornia $(a b s t)$. Science n \& $31: 516-517$ (1910)

$10 \mathrm{~g}$ (and Ransome, F. L.) Bismite [from the Goldfield district, Nev.]. Am J Sc (4) $29: 173-176$ (1910) Zs Kryst $48: 16-19(1910)$ [See also 11]

10h (with Canfeld, F. A.) Mosesite, a new mercury mineral from Terlingus, Tex. Am J Sc (4) 30:202-208 (1910) Zs Kryst $49: 1-8$ (1911) [See also 12]

11 Mineralogical notes, series 1 . U 86 S, B 490: 109 pp (1911) [See also 07, $07 \mathrm{a}, 08,08 \mathrm{a}, 10,10 \mathrm{a}, \mathrm{e}, \mathrm{g}]$

11a Natramblygonite, a new mineral. Am J Sc (4) $31: 48-50$ (1911) Zs Krrst $49: 233-235$ (1911) Abst, Wash Ac Sc, J $1: 37$ (1911) [See also 12]

$11 b$ Bismuth ochers from San Diego $\mathrm{CO}_{4}$ Cal. Am Chem Soc, J 33: 162-166 (1911) Zs Kryst $49: 229-232$ (1911) Abst, Wash Ac Sc, J $1: 37$ (1911)

11e Ferritungstite, a new mineral [from Washington]. Am J Sc (4) $32: 161-162$ (1911) Zs Kryst 50:112-113 (1912) Abst, Wash Ac Sc 1:24-25 (1911) [See also 12] 
Schaller, Waldemar Theodore Continued. 11d Krystallographische Notizen über Albit, Phenakit, und Neptunit. Zs Kryst $48: 550-558$ (1911) Abst, Wash Ac Sc, J $1: 37$ (1911) [See also 11]

11e Die chemische Zusammensetzung von Jamesonit und Warrenit. Zs Kryst 48: 562-565 (1911) Abst, Wash Ac Sc, J 1: 88 (1911) [See also 11]

$11 f$ The chemical composition of nephelite. Wash Ac Sc, J 1: 109-112 (1911) Zs Kryst $50: 343-346$ (1912) [See also 16a]

11g The relations of purpurite and heterosite. Wash Ac Sc, J 1: 113 (1911)

$11 \mathrm{~h}$ Cuprodescloizite from California. Wash Ac Sc, J 1: 149-150 (1911) [See also 12]

111 Chemical composition of the French phosphorite minerals. Wash Ac Sc, J 1 : 151 (1911)

11j A study of the rutile group. Wash Ac Sc, J 1:177 (1911) [See also 12]

$11 \mathbf{k}$ The alunite-beudantite group. Am J Sc (4) $32: 359-364$ (1911). Zs Kryst 50:106-111 (1912) Wash Ac Sc, J 1: 112-113 (1911) [See also 12]

111 (with Butler, B. S.) Thaumasite from Beaver County, Utah. Am J Sc (4) 31:131-134 (1911) Zs Kryst 49:236-238 [See also 12]

$11 \mathrm{~m}$ (with Butler, B. S.) Some minerals from Beaver County, Utah. Am J Sc (4) $31: 418-424$ (1911) Zs Kryst $50: 114-119(1912) \quad$ [See also 12]

$11 \mathrm{n}$ (with Butler, B. S.) Beaverite, a new mineral. Wash Ac Sc, J $1: 26-27$ (1911)

110 (with Larsen, E. S., jr.) Hinsdalite, a new mineral. A J Sc (4) 32 : 251-255 (1911) Wash Ac Sc, J 1:25-26 (1911) Zs Kryst 50:101-105 (1912) [See also 12]

12 Mineralogical notes, series 2. U S G S, B 509:115 pp (1912) Abst, Wash Ac Sc, J 2:349 (1:12) [See also 10h, c, d, h, 11a, c, d, e, h, j, k, l, m, o, 12a, d]

12a Crystallized turquoise from Virginia. Am J Sc (4) 33:35-40 (1912) Zs Kryst 50:120-125 (1912) Abst, Wash Ac Sc, J 1: 58-59 (1911) [See also 12]

12b New manganese phosphates from the gem tourmaline field of southern Cali fornia. Wash Ac Sc, J $2: 143-145$ (1912)

12e The erystallography of variscite. Wash Ac Sc, J 2:143 (1912)

12d Crystallized variscite from Utah. U S Nat Mus, Pr 41:413-430 (1912) Zs Kryst $50: 321-342$ (1912) Abst, Wash Ac Sc, J 1: 150-151 (1911) [See also 12]

12e Beitrag zur Kenntnis der Turmalingruppe. Zs Kryst 51:320-343 (1912) Abst, Wash Ac Sc, J $3: 151$ (1913)

13 Immense bloedite crystals. Wash Ac $\mathrm{Se}, \mathrm{J} 3: 75-76$ (1913) [See also 16a]
Schaller, Waldemar Theodore-Continued.

13a The calculation of mineral formulas. Wash Ac Sc, J $8: 97-98$ (1913) [See also 16a]

13b The refractive indices of strengite. Wash Ac Sc. J 3:249-250 (1913) [See also 16a]

13e Die Krystallform des Natronambly. gonits. Zs Kryst $51: 246-247$ (1912) 4 bst, with titie, The crystallography of natramblygonite, Wash Ac Sc, J 3:152 (1913) [See also 16a]

13d Über "feste Lösungen " in Turmalin. Zs Kryst 53: 181 (1913)

13e (with Umpleby, J. B., and Larsen, E. S.) Custerite, a new contact metamorphic mineral. Am J Sc (4) $36: 385-394$ (1913) Zs Kryst 53: 321-331 (1914) [See also $16 \mathrm{a}]$

13f (with Palache, C.) Hodgkinsonite, a new mineral from Franklin Furnace, N. J. Wash Ac Sc, J 3:474-478 (1913) Zs Kryst 53:529-532, 675-676 (1914) [See also 16a]

14 Mineralogical notes, series 3 . Wash Ac Sc, J 4:354-356 (1914)

$14 a$ The identity of empressite with muthmannite. Wash Ac Sc, J 4:497-499 (1914)

14b (with Hens, F. L.) Colorado ferberite and the wolframite series. U S G S, B 583:75 pp (1914)

14e (with Hess, F. L.) Pintadoite and uvanite, two new vanadium minerals from Utah. Wash Ac Sc, J 4:576-579 (1914)

14d (with Larsen, E. S.) Cebollite, 1 new mineral. Wash Ac Sc, J 4:480-482 (1914) [See also 16a]

14 (with Palnche, C.) Hodgkinsonit, ein neues Mineral von Franklin, N. J. Zs Kryst $53: 529-532,675-676$ (1914)

$14 f$ (with Umpleby, J. B.) Custerit, ein neues kontaktmetamorphes Mineral. 7s Kryst 53:321-331 (1914)

15 The supposed vanadic acid from Lake Superior is copper oxide. Am J Se (4) 39: 404-406 (1915)

15n Four new minerals. Wash Ac Se, J $5: 7$ (1915)

16 Cassiterite in San Diego Co., Cal. U S G S, B 620:351-354 (1916)

$16 a$ Mineralogic notes, series 3 . U S G S, B 610:164 pp (1916) Abst, Wash Ac Sc, J $6: 453-454$ (1916) [See also $11 \mathrm{~g}$. $13,13 a, b, c, d, e, f, 14 d]$

16b (and Bniley, R. K.) Intumescent kaolinite. Wash Ac Sc, J 6:67-68 (1916)

16e Mica. U S G S, Min Res 1915 pt 2: $277-290 ; 1916$ pt $2: 291-308 ; 1917$ pt 2 : $183-195 \quad(1916-8)$

16d Gems and precious stones. U S G S, Min Res 1915 pt $2: 843-858 ; 1916$ pt $2: 887-899 ; 1917$ pt $2: 145-168$ (1916-8) 
Sehaller, Waldemar Theodore-Continued. 17 On the identity of hamlinite with goyazite. Am J Sc (4) $43: 163-164$ (1917)

17a Ilsemannite, hydrous sulphate of molybdenum. Wash Ac Sc, J 7:417-420 (1917)

17b Minasragrite, a hydrous sulphate of vanadium. Wash Ac Sc, J 7:501-503 (1917)

17e Lithium minerals; thorium minerals; zirconium and rare-earth minerals. U S G S, Min Res 1916 pt 2: 7-17, 223237, 377-386 (1917)

17d (with Butler, B. S.) Magnesioludwigite, a new mineral. Wash Ac Sc, J $7: 29-31$ (1917)

17e (with Loughlin, G. F.) Crandallite, a new mineral [Tintic mining district, Utah]. Am J Sc (4) $43: 69-74$ (1917)

18 Zirconium and rare-earth minerals. Mineral Foote-Notes 2 no $3: 2-14$ (1918)

See also Eakle, 01

Seharf, John Thomas.

86 Topography, boundaries, and geology. In his History of Westchester County, New York... vol I : 1-9, map, Phila 1886

Seharf, Robert Francis.

09 On the evidences of a former landbridge between northern Europe and North America. $\mathrm{R}$ Irish Ac, Pr 28 B:1-28 (1909)

09a On an early Tertiary land connection between North and South America. Am Nat 43:513-531 (1909)

11 Distribution and origin of life in America. $497 \mathrm{pp}$, maps, some paleogeographic, London 1911

Seheffel, Earl R.

o7 The origin of Spring Valley gorge. Denison Univ, Sc Lab, B 13:154-166 (1907)

08 An esker group south of Dayton, Ohio. Ohio Nat $8: 231-242$ (1908) Denison Univ, Se Lab, B 14: 19-33 (1908)

o9 Significance of drainage changes near Granville, Ohio. Denison Univ, Sc Lab, B 14: 157-174 (1909)

Schei, Per (1875-1905).

os Summary of geological results [Second Norwegian North Polar Expedition in the Fram, 1898-1902]. Geog J 22:56-65, map (1903)

04 Preliminary account of the geological investigations made during the Second Norweglan polar expedition in the Fram. In Sverdrup, Otto, New land; four years in the Arctic regions $2: 455-466$, map, L 1904

Scherer, George H.

o5 Geology of the Hahatonka district, Camden Co. [Mo.]. Drury Coll, Bradley G Field Station, B 1:58-67 (1905)
Seherer, J.

11 Earthquakes in Haiti, April 12-0eto. ber 10, 1911. Seism Soc Am, B 1:11] (1911)

12 Great earthquakes in the island d Haiti. Seism Soc Am, B $2: 161-180$, 때가 (1912)

12a Notes on remarkable earthqual sounds in Haiti. Seism Soc Am, B : 230-232 (1912)

Sehiel, James.

55 Geological report of the country et plored under the 38 th and 41 st parallels of north latitude in 1853-54. In Beckwith, E. G., Report... forty-first parallel. U \& Pacific R R Expl (U S, 33d Cong 1st sess H Ex Doc 129 v 18 pt 2) : 120-133 (1855); also (U S, 33d Cong 2d sess, S Ex Du 78 and $\mathrm{H}$ Ex Doc 91) $2: 96-107$ (1855)

$\mathbf{5 5 a}$ List and description of organic it mains collected during the exploration the central Pacific railroad line 1853-5 In Beckwith, E. G., Report... forty-fis parallel. U S, Pacinc R R Expl (U \& 33d Cong 1st sess, H Ex Doc 129 $\mathrm{H}$ pt 2) : 134-135 (1855); also (U S, 35) Cong $2 d$ sess, S Ex Doc 78 and $H$ tit Doc 91) 2: 108-109, il (1855)

61 On the presence of phosphoric ad in igneous rocks. Am J Sc (2) $31: 35$ (1861)

Schimper, Wilhelm Philipp (1808-1880)

79 The age of the Laramie. Am Nit $13: 197-198$ (1879)

Schioetz, O. E.

01 Results of the pendulum observatios and some remarks of the constitution of the earth's crust. Norwegian North Polit Expedition 1893-1896, Scientific Resuls 2. VIII : 90 pp, Christiania 1901

Schleiden, Emil.

34 [Observations in Mexico.] N 5 $1834: 33-34$

39 Lagerstätte von Gold- und Silber Erzen zu Guadeloupe y Calvo in Meriko und deren geognostische Umgebung. N. 1839: 301-304

Schlesinger, Frank.

15 Variations of latitude; their bearias upon our knowledge of the interior of the earth. Am Ph Soc, Pr 54: 351-358 (1915) Smiths Inst, An Rp 1916:248-254 (1917) Schlüter, Cl.

$\mathbf{s 7}$ Ueber die regulären Echiniden det Kreide Nordamerika's. Niederrbein Ges Bonn. Szb $44:$ 38-42 (1887)

87a Einige Inoceramen und Cephalo poden der Texanischen Kreide. Nieder rhein Ges Bonn, Szb 44:42-45 (1887)

Schlumberger, C.

82 Remarks upon a species of Cristel laria [from Livingston, Ala.] Cin $\mathrm{Soc} N$ H, J $5: 119$, il (1882) 
Schlnndt, Herman.

09 (and Moore, R. B.) Radloactivity of the thermal waters of Yellowstone National Park. U S G S, B $395: 35$ pp (1909)

Schmeckebier, Laurence Frederick.

04 Catalogue and index of the publications of the Hayden, King, Powell, and Wheeler surveys. U S G S, B 222: 208 pp (1904)

Schmid, H, S. de. See De Schmid, H. S. sehmidhnber, -

43 [Ueber das Vorkommen des Goldes in Georgien und Süd-Carolina.] Arch Miner $17: 663-672$ (1843)

Sehmidt, Adolf.

73 The iron ores of Missouri. Mo G S, Prel Rp Iron Ores and Coal Fields, 1872 pt $1: 45-214 \quad(1873)$

74 (and Leonhard, A.) The l-ad and zinc regions of soutbwest Mi souri. Mo G S, Rp 1873-4:381-502 (1874)

$\mathbf{7 4 a}$ The lead region of central Mis souri. Mo G S, Rp 1873-4:503-577 (1874)

74b Practical rules for judging of and for developing deposits of iron ore in Missouri. Mo G S, Rp 1873-4:578-586 (1874)

75 On the forms and origin of the lead and zinc deposits of southwest Missouri. Ac Se St L, Tr $3: 246-252$ (1875)

Schmidt, C.

03 Ueber vulkanische Asche gefallen in San Cristobal L. C. (Sïd-Mexiko) am 25 Oktober 1902. Centralbl Miner 1903: 131 Schmidt, Friedrich.

92 The Eurypterus beds of Oesel as compared with those of North America (abst). G Soc Am, B 3:59-60 (1892)

Sehmidt, Jullus.

55 Geognostische Reise in San Salvador, Zentral Amerika; Trachyt, Braunkohle. N Jb $1855: 170-171$

Schmidt, Oscar.

86 The Mammalia in their relation to primeval times. The International Scientific series, vol $53: 308 \mathrm{pp}, \mathrm{N}$ Y 1886

Schmitt, Joseph.

04 Monographie de rile d'Anticosti (golfe Saint-Laurent). vi, 370 pp, map, Paris 1904 Sehmitz, E. J.

84 Contributions to the geology of Alabama. Am I M Eng, Tr 12:144-172 (1884)

85 Geology and mineral resources of the Rio Grande region in Texas and Coahuila [Mex.]. Am I M Eng, Tr 13:388-405, map (1885)

95 The structure of the Richmond coal basin [Va.], Am I M Eng, Tr 24:397408 (1895)

96 A section of Rich Patch Mountain at Iron Gate, Va. Am I M Eng, Tr 25: $477-481$ (1896)
Schmitz, E. J.-Continued.

96a The oil boom of [northeastern] Tennessee. Eng M J 61:228-229 (1896)

97 Copper ores in the Permian of Texas. Am I M Eng, Tr 26:97-108 (1897)

99 Notes of a reconnaissance from Springfield, Mo, into Arkansas. Am I M Eng, Tr 28:264-270 (1899)

Schnabel, Anton.

13 Das Salinenwesen der Vereinigten Staaten von Nord-Amerika, Berg u Hütt Jb $61: 84-163$ (1913)

Schnatterbeck, C. C.

06 Antimony; bismuth. U S G S, Min Res 1905: 435-439, 441-443 (1906)

Sehneider, E. A.

90 (with Clarke, F. W.) Experiments upon the constitution of the natural silieates. Am J Sc (3) 40:303-312, 405$415,452-457$ (1890)

91 (with Clarke, F. W.) On the constitution of certain micas, vermiculites, and chlorites. $\mathrm{Am} \mathrm{J} \mathrm{Sc} \mathrm{(3)} 42: 242-251$ (1891)

Schneider, Hyrum.

13 Physiography of Golden [Colorado] and vicinity and its relation to the geologic structure. Colo Sch Mines, Q 8 no 3:1-12, $\operatorname{map}(1913)$

15 Geologic age of the Coal Creek batholith and its bearing on some other features of the geology of the Colorado front range (abst). G Soc Am, B 26: 398-399 (1915)

Sehneider, Philip F.

94 Notes on the geology of Onondaga Co., N. Y. 47 pp, Syracuse 1894

97 A geologic fault at Jamesville, near Syracuse, N. Y. Am J Sc (4) 3:458-460 (1897)

97a Limestones of central New York. Onondaga Hist As, Sc ser no 1:16 pp (1897) Stone 18:26-29 (1898)

99. The Marcellus fault [Onondaga Co., N. Y.l. Onondaga Hist As, Sc ser no 2: 7 pp (1899)

02 New exposures of eruptive dikes in Syracuse, N Y. Am J Sc (4) $14: 24-26$ ( 1902$)$

03 The whetstone industry (Abst). Onondaga Ac Sc, Pr $1: 20-31$ (1903)

03a The paleobotany of Onondaga [notes on fucoids of Medina, Clinton, and Niagara formations] (abst). Onondaga Ac Sc, Pr 1: 31-32 (1903)

o3b The geology of the serpentines of central New York. Onondaga Ac Sc, Pr 1 : 110-117 (1903)

o3e Notes on some eruptive dikes near Ithaca [N. Y.]. Onondaga Ac Sc, Pr 1: $130-136$ (1903)

04 South Onondaga geology [N. Y.]. In Newman, W. W., The septuagenary of the South Onondaga Methodist Episcopal Society : 80-84, Syracuse, N. Y., 1904 
Schneider, Philip F.-Continued.

o5 Preliminary note on some overthrust faults in central New York. Am J Sc (4) $20: 308-312(1905)$

05a The correlation of some alnoite dikes in East Canada Creek (abst). Science $\mathrm{n}$ s $22: 673$ (1905)

o7 A preliminary report on the Arkansas diamond field. Ark Bur of Mines...: $16 \mathrm{pp}$ (1907)

os The formation of the diamond (abst). Science n 8 27:822 (1908)

Osa A unique collection of peridotite. Science n s 28:92-93 (1908)

08b Geology and mining in Arkansas diamond field (abst). M World 28:255257 (1908)

Schoch, E. P.

16 Ozokerite from the Thrall oil field. Tex, Univ, B 1916 no $66: 79-81$ (1916)

Schönderf, Friedrich.

o9 Organisation und Aufbau der Armwirbel von Onychaster [structural features of Onychaster flexilis Meek and Wortben]. Nassauischer Ver Naturk, Jb 62:49-63, il (1909)

Sehöp?, Johann Darid (1752-1800).

87 Beiträge zur mineralogischen Kenntniss des östlichen Theils von Nordamerika und seiner Gebürge. 194 pp, Erlangen 1787 .

88 Reise durch einige der mittlern und südlichen vereinigten nordamerikanischen Staaten... 1783 und 1784, Erlangen 1788 Transl, with title, Travels in the Confederation (1783-1784), by Alfred J. Morrison, 2 vols, 426,344 pp, Phila 1911

Schoneld, Stuart James.

10 Recomaissance in East Kootenay, B. C. Can G S, Sum Rp 1909:135-138 (1910)

11 Reconnaissance in East Kootenay, Cranbrook sheet [B. C.]. Can G S, Sum Rp (1910) : 130-134 (1911)

12 Reconnaissance in East Kootenay [B. C.]. Can G S, Sum Rp 1911:158164, map (1912)

12a The origin of the silver-lead depesits of East Kootenay, B. C. FC G 7 : 351-363 (1912)

12b The geology of East Kootenay, B. C., with special reference to the origin of granite in sills. Abstract of thesis, Massachusetts Institute of Technology. 8 pp, 1912.

13 The Cordillera; Elko to Kootenay Lake, British Columbia. Int $\mathrm{G}$ Cong, XII, Canada, Guide Book no 9:18-21, 46-61, maps (1913)

14 Reconnaissance in East Kootenay. B. C. Can G S, Sum Rp 1912: 221-228, map (1914) ; 1913:130-138 (1914)

$14 a$ The origin of granite (micropegmatite) in the Purcell sills. Can G S, Mus B 2:1-32 (1914)
Sehofeld, Stuart James-Continued.

14b The pre-Cambrian (Beltian) rock of southeastern British Columbia and theit correlation. Can G S, Mus B 2:79-91, map (1914)

14e The origin of the Rocky Mountains: story of the creation of this great moun. tain system as deciphered from the dock. mentary evidence of the strata themselres. Sc Conspectus 4:122-131 (1914)

15 Geology of Cranbrook map area, B. C. Can G S, Mem $76: 245$ pp, maps (1915)

15 A Answorth mining camp, B. C. Can G S, Sum Rp 1914:38-41 (1915)

16 Kootenay district, B C. Can G \& Sum Rp 1915: 93-94 (1916)

16a Ainsworth mining camp [Kootenay district, B. C.]. Can M Inst, $\operatorname{Tr} 18: 202-$ 212 (1916)

18 The late Captain Osmond Edgar Le Roy. Can M Inst, B 70:1<9-155 (1918)

Seholl, George P.

of (and Herriek, R. L.) The Gold Prince mine and mill [at Animas Forks, Colo.]. Mines and Minerals $27 \cdot 337-345$ (1907)

Seholz, Carl.

05 The coal fields of Arkansas and in. dian Territory. M Mag 11:520-524 (1905)

Sehomburgk, Robert $\mathrm{H}$.

47 The microscopical siliceous Polycys tina of Barbados... An Mag N H 20:115127 , il (1847)

48 he history of Barbados... and an $8 c$ count of its geology and natural produc tions. $722 \mathrm{pp}, \mathrm{il},-1848$

Schooleraft, Henry Rowe (1793-1864).

19 A view of the lead mines of Missouri. $299 \mathrm{pp}, \mathrm{N}$ Y 1819

21. Narrative journal of travels throng the northwestern regions of the United States... 419 pp, map, Albany 1821

21a Account of the native copper on the southern shore of Lake Superior. Am . Sc 3:201-216 (1821) Transl in Struve $\mathrm{H}$. von, Beiträge zur Mineralogie und $\mathrm{Ge}$ ologie des nördlichen Amerikas : 23-49, Hamburg 1822

21b Geological character of the lime stone of the Missouri lead mine region. Am J Sc 3 : 248-249 (1821)

22 On the number, value, and position of the copper mines on the southern shote of Lake Superior. U S, 17th Cong $2 \mathrm{~d}$ sess, S Doc 5:33 pp (1822)

22a Remarkable fossil tree ... on the River Des Plaines, Ill. Am J Sc 4:285291 (1822)

22b A memoir on the geological post. tion of a fossil tree discovered in the secondary rocks of the river Desplaines. $18 \mathrm{pp}$, Albany 1822

22e Bericht iber das gediegene Kupfer das sich an der Südküste des Ober-Sees in Nord-Amerika in grossen Massen findet. An Physik (Gilbert) 70:337-348 (1822) 
Schoolcraft, Henry Rowe-Continued.

23 Notice of a recently discovered copper mine on Lake Superior, with several other localities of minerals. Am J Sc 7 : 43-49 (1823)

25 Remarks on native sllver from Michigan. Lyc N H N Y, An 1:247-248 (1825)

34 Narrative of an expedition through the upper Mississippi to Itasca Lake... 307 pp, map, N Y 1834

42 On the action of the North American lakes. Geologist $1842: 287-288$

43 On the production of sand storms and lacustrine beds by causes associated with the North American lakes. Brit As, Rp $12: \sec 42-44$ (1843)

53 Scenes and adventures in the semiAlpine region of the Ozark Mountains of Missouri and Arkansas... (Appendix, Observations on the mineralogy, geology...). $256 \mathrm{pp}$, Phila 1853

55 Summary narrative of an exploratory expedition to the source of the Mississippi River in $1820 \ldots 596 \mathrm{pp}$, Phila 1855

55 a Discovery of a coal basin on the western borders of the Lake of the Woods. $\triangle \mathrm{m}$ J Sc (2) 19:232-234 (1855)

59 Geology of Albany Co., [N. Y.] In Munsell, Joel, Annals of Albany, 10:162166, Albany, N Y 1859

Sehott, Arthur.

55 The Cretaceous basin of the Rio Bravo del Norte. Am As, Pr 8: 272-283 (1855)

57 ...geology of the lower Rio Bravo del Norte [Rio Grande]. In Emory, W. H., Report on the United States and Mexican boundary survey...(U S, 34th Cong 1 st sess, 8 Ex Doc 108 and $H$ Ex Doc 135), $v$ I pt $2: 28-48$ (1857)

57 a Geological observations on the country along the boundary line lying between the 111th degree of longitude and the initial point on the Rio Colorado. In Emory, W. $\mathrm{H}$, Report on the United States and Mexican boundary survey...(U S, 34 th Cong 1 st sess, $\mathrm{S}$ Ex Doc 108 and $\mathrm{H}$ Ex Doc 135), v 1 pt $2: 62-77$ (1857)

$57 \mathbf{b}$ Geological observations on the pluto-volcanic slope of the Sierra Madre along the azimuth boundary line through northwest Sonora. Am As, Pr 10 pt 2: 25-50 (1857)

66 Die Küstenbildung des nördlichen Yukatan. Petermanns Mitt 12:127-130 (1866)

See also Parry, 57b

Schottler, W.

03 Bemerkung über die in San Cristobal (S.-Mexico) am 25. Okt. 1902 gefallene Asche. Centralbl Miner 1903: 288-289 Schrader, Frank Charles.

96 The geology of the Woonsocket basin (abst). Science n s 3: 142-143 (1896)

99 [Reconnaissance in the Copper River district, Alaska (abst).] Science n $\mathbf{n} 9$; $551-552(1899)$
Schrader, Frank Charles-Continued.

oo (and Brooks, A. H.) Preliminary report on the Cape Nome gold region, Alaska. U S G S: 56 pp, maps (1900) Abst, Mines and Minerals 20:534-537 (1900)

OOa A reconnaissance of a part of Prince William Sound and the Copper. River district, Alaska, in 1898. U S G S, An Rp 20 pt $7: 341-423$, maps (1900)

oob Preliminary report on a reconnaissance along the Chandlar and Koyukuk rivers, Alaska, in 1899. U S G S, An Rp 21 pt 2:441-486, map (1900)

ooc The Cape Nome gold district [Alaska]. Nat Geog Mag 11:15-23 (1900)

01 (and spencer, A. C.) The geology and mineral resources of a portion of the Copper River district, Alaska. U S G S : $94 \mathrm{pp}$, maps (1901)

01a (and Brooks, A. H.) Some notes on the Nome gold region of Alaska. Am I M Eng, $\operatorname{Tr} 30: 236-247$, map (1901)

02 Geological section of the Rocky Mountains in northern Alaska. G Soc Am, B $13: 233-252$ (1902) Abst, Seience n s 15 : $665-666$ (1902)

03 (with Mendenhall, W. C.) The mineral resources of the Mount Wrangell district, Alaska. U S G S, P P 15: $71 \mathrm{pp}$, maps (1903)

o3n (with Mendenhall, W. C.) Cop per deposits of the Mount Wrangell region, Alaska. U S G S, B 213:141-148 (1903)

$04 \mathrm{~A}$ reconnaissance in northern Alaska,... - U S G S, P P 20:139 pp, maps (1904)

o5 (and Haworth, E.) Oil and gas of the Independence quadrangle, Kans. U S G S, B 260:446-458 (1905)

o5a (and Haworth, E.) Clay industries of the Independence quadrangle, Kans. U S G S, B 260: 546-549 (1905)

05b (with Hawerth, E.) Portlandcement resources of the Independence quadrangle, Kans. U S G S, B 260:506-509 (1905)

06 The Durango-Gallup coal field of Colorado and New Mexico. U S G S, B 285: 241-258 (1906)

o6a (and Haworth, E.) Economic geology of the Independence quadrangle, Kans, U S G S, B 296: 74 pp, map (1906)

o6b Copper deposits of the Zuñi Mountains, N. Mex. (abst). Science n s $23: 916$ (1906)

os Description of the Independence quadrangle, Kans. U S G S, G Atlas Independence fol (no 159): 7 pp, maps (1908)

08a The mineral deposits of the Cerbat Range, Black Mountains, and Grand Wash Cliffs, Mohave Co., Ariz. U S G S. B 340:53-83 (1908) Abst, Science n s 27 : $957-958(1908)$ 
Schrader, Frank Charles-Continued.

o9 Mineral depesits of the Cerbat Range, Black Mountains, and Grand Wash Cliffs, Mohave Co., Ariz. U S G S, B $397: 226$ pp, map (1909)

10 An occurrence of monazite in northern Idaho. U S G S, B 430: 184-190 (1910)

10a (and Hill, J. M.) Some occurrences of molybdenite in the Santa Rita and Patagonia Mountains, Ariz. U S G S, B $430: 154-163(1910)$

11 Gold-bearing ground moraine in northwestern Montana. U S G S, B 470: 62-74 (1911)

12 A reconnaissance of the Jarbidge, Contact, and Elk Mountain mining districts, Elko Co., Nev, U S G S, B 497: $162 \mathrm{pp}$, map (1912) Abst, Wash Ac Sc, J $2: 439-440$ (1912)

13 Notes on the Antelope district, Nev. U S G S, B 530: 87-98, map (1913)

$13 a$ Alunite in Patagonia, Arizona, and Bovard, Nev. Ee G 8:752-767 (1913)

14 Alunite in granite porphyry near Patagonia, Ariz. U S G S, B 540:347-350 (1914)

14a Alunite at Bovard, Nev. U S G S, B 540:351-356 (1914)

14b Gold placers on Wind and Bighorn rivers, Wyo. U S G S, B 580:127-145, map (1914)

14e The Rochester mining district, Nev. U S G S, B $580: 325-372$, map (1914)

15 Mineral deposits of the Santa Rita and Patagonia mountains, Ariz., with contributions by James M Hill. U S G S, B $582: 373 \mathrm{pp}$, maps (1915) Abst, Wash Ac Se, J $5: 519-521$ (1915)

15a Some features of the ore deposits in the Santa Rita and Patagonia mountains, Ariz. $(a b 8 t)$. Wash Ac Sc, J 5 : 252-253 (1915)

15b A sulphide-bearing monzonite from Arizona (abst). Wash Ac Sc, J 5:485 (1915)

16 Geology and ore deposits of Mohave Co., Ariz. (with discussion by J. Dana Sperr, John B. Platts, and John Carter Anderson). Am I M Eng, B 119:19351967, maps (1916) ; (discussion) 123:379$384 ; 124: 456-460$ (1917) ; Tr $56: 195-$ 236, maps (1917)

16a The ore deposits of Mohave Co., Ariz. M Sc Press 113:733-737 (1916)

16b Ore deposits of the Rochester district, Nev. (abst). Wash Ac Sc, J 6: 518-519 (1916)

17 (and Stone, R. W., and Sanford, S.) Useful minerals of the United States (a revision of Bulletin 585). U S G S, B $624: 412$ pp (1917)

17a The geologic distribution and genesis of the metals in the Santa Rita-Patagonia mountains, Ariz. Ec G $12: 237-269$ (1917)
Schrader, Frank Charles-Continued.

IS Quicksilver deposits of the Phoent Mountains, Ariz. U S G S, B $690: 95-1$ (1) (1918) Abst, by R. W. Stone, Wash Ac \& J $8: 538$ (1918)

18a (with Stose, G. W.) Manganey deposits of east Tennessee. Tenn G S, RA Tenn 8: 153-207, 228-324 (1918)

See also Eldridge, 99

Sehramm, Eck Frank.

04 A preliminary report on the bullding stone of Oklahoma. Okla, Dp G N H, Biet Rp 3: 37-49 (1904)

Sehroyer, C. R.

15 Buried stream channels at the bas of the Pennsylvania system in southeasten Ohio. Ohio Nat 15:519-523 (1915)

Sehubert, E. A.

09 The mineral resources of Virginis Am M Cong, 11th An Sess, Papers and st dresses : 121-245 (1909)

Sehuehert, Charles.

89 A list of the fossils occurring in th Oriskany sandstone of Maryland, New Yoth. and Ontario. N Y St G, An Rp $8: 50-86$ (1889) N Y St Mus, An Rp $42 ; 396-4$ ). (1889)

90 On Syringothyris Winchell and its American species. N Y St G, An Rp 9:2538 (1890) N Y St Mus, An Rp 43:23t239 (1890)

90 List of species of the America Paleozoic Orthis, spirifera, Spiriferina and Syringothyris. N Y St G, An Rp? 38-55 (1890) N Y St Mus, An Rp 43: $240-257$ (1890)

92 (with winche11, N. H.) Prelimnary descriptions of new Brachiopoda from the Trenton and Hudson River groups of Minnesota. Am G 9: 284-294 (1892)

93 A classification of the Brachiopods. Am G 11:141-167 (1893)

93a On the development of the shell of Zygospira recurvirostra. Biol Soc. Wasb, Pr 8:79-82, il (1893)

93b (with Beecher, C. E.) Develop ment of the brachial supports in Dielastio and Zygospira. Biol Soc Wash, $\operatorname{Pr} 8: 71$ 78 , il $(1893)^{\circ}$ Abst, Am Nat 28:260 (1894)

94 A revised classification of the spirc bearing Brachiopoda. Am G 13:102-10 (1894)

$94 a$ Spire-bearing genera of the Paleo zoic Brachiopoda. Am G 13:128-13? (1894)

94b (with Diller, J. S.) Discovery of Devonian rocks in California. Am J (3) $47: 416-422$ (1894)

95 Directions for collecting and prepat ing fossils. U $\mathbf{S}$ Nat Mus, B 39 pt $\mathrm{K}: 31$ pp (1895)

95a Dry dredging in the Mississippial sea. Science n \& 2:679-681 (1895)

95b American fossil Brachiopoda. Sc ence n s $2: 722-724$ (1895) 
Schnehert, Charles-Continued.

95e (with Winchell, N. H.) Sponges, graptolites, and corals from the Lower Silurian of Minnesota. Minn G S, Final Rp 3 pt $1: 55-95$, il (1895)

95d (with winchell, N. H.) The Lower Silurian Brachiopoda of Minnesota. Minn $\mathrm{G} S$, Final Rp 3 yt $1: 333-474$, il (1895)

96 Report on Paleozoic fossils from Alaska. U S G S, An Rp 17 pt $1: 898-906$ (1896)

$96 \mathbf{a}$ On the arrangement of great paleontological collections. Science n s 3:576579 (1896)

97 A synopsis of American fossil Brachiopoda including bibliography and synonymy. U S G S, B $87: 464$ pp (1897) 97a On the fossil phyllopod genera, Dipeltis and Protocaris, of the family Apodidae. U S Nat Mus, Pr 19:671-676, il (1897)

$97 \mathrm{~b}$ What is a type in natural history? Science n $85: 636-640$ (1897)

98 (with White, D.) Cretaceous series of the west coast of Greenland. G Soc Am, B 9:343-368, map (1898) Abst, Science n 8 $7: 52-53 \quad$ (1898)

99 The fossil field's expedition to Wyoming. Science n \& 10:725-728 (1899)

99a (with Clarke, J. M.) The nomenclature of the New York series of geological formations. Science n s 10:874-878 (1899) Am G 25: 114-119 (1900)

99b (with Safford, J. M.) The Camden chert of Tennessee and its lower Oriskany fauna. Am J Sc (4) 7:429-432 (1899)

00 On the Lower Silurian (Trenton) fauna of Baffin Land. U S Nat Mus, Pr $22: 143-178$, il $(1900)$

00a Lower Devonic aspect of the Lower Helderberg and Oriskany formations. G Soc Am, B 11: 241-332 (1900) Abst, Science $n$ \& $11: 104 \quad(1900)$

01 On the Helderbergian fossils near Montreal, Can. Am G 27:245-253, il (1901)

02 (with U1rich, E. O.) Paleozoic seas and barriers in eastern North America. N Y St Mus, B 52:633-663, map (1902)

03 On the lower Devonic and Ontaric formations of Maryland, U S Nat Mus, Pr $26: 413-424$ (1903)

03a The I. H. Harris collection of invertebrate fossils in the United States National Museum. Am G 31:131-135, port. (1903)

03b On the Manlius formation of New York. Am G 31:160-178, il (1903)

03e On the faunal provinces of the middle Devonic of America and the Devonic coral sub-provinces of Russia, ith two paleogeographic maps. Am G 32: 137 162, maps (1903)

03a On new Siluric Cystoidea, and a new Camarocrinus, Am G $32: 230-240$ 11903)
Schuchert, Charles-Continued

04 A noteworthy crinoid [Uintacrinus socialis from Logan Co., Kans.]. Smiths Misc Col 45 (Q Is 1) : 450, il (1904)

04a On Siluric and Devonic Cystidea and Camarocrinus. Smiths Misc Col 47 (Q Is 2) : 201-272, il (1904)

04b Charles Emerson Beecher. Am J Sc (4) $17: 411-422$, port (1904)

04e The stratigraphy and paleontology of the Niagara of northern Indiana. Am J Sc (4) 18:465-469 (1904)

O4d Dall's contributions to the Tertiary fauna of Florida. Am G 33:143-154 (1904)

05 (assisted by Dall, W. H., Stanton, T. W., and Bassler, R. S.) Catalogue of the type specimens of fossil invertebrates in the department of geology, United States National Museum. U S Nat Mus, B 53 pt. 1: $704 \mathrm{pp} \mathrm{(1905)}$

O5a Contributions to Devonian paleontology. Am J Sc (4) $19: 460-463$ (1905)

O5b The mounted skeleton of Triceratops prorsus in the U. S. National Museum. Am J Sc (4) 20:458-459, il 1905

05e John Bell Hatcher. Am G 35 : 131141, port. (1905)

o5d (and Buckman, S. S.) The nomenclature of types in natural history. Science n \& 21: 899-901 (1905)

06 Memoir of Charles Emerson Beecher. G Soc Am, B 16:541-548, port (1906)

06a A new American pentremite. U S Nat Mus, Pr $30: 759-760$, il (1906)

06b The Russian Carboniferous and Permian compared with those of India and America ; a review and discussion. Am J Sc (4) $22: 29-46,143-158$ (1906)

o6e The Tenth International Geological Congress at Mexico City. Am J Sc (4) $22: 463-465$ (1906)

os Newark red series of Connecticut. G Pal Abh (Koken), Sup Bd 1:317 (1908) 09 Paleogeography of North America (abst). Science n s 29:629-630 (1909)

09a Obituary, Joseph Frederick Whiteaves. Am J Sc (4) 28:508 (1909)

o9b Obituary, Hugh Fletcher. Am J Sc (4) $28: 508$ (1909)

10 Paleogeography of North America. G Soc Am, B 20:427-606 (1910) Rv, Am J Sc (4) 29:552-557 (1910); Science n s 31:909-912 (1910)

$10 a$ Age of the Gaspé sandstone (discussion). G Soc Am, B 20:695-696 (1910)

10b Biologic principles of paleogeography. Pop Sc Mo $76: 591-600$ (1910)

10e on the brachiopod genus syringothyris in the Devonian of Missouri. Am J Sc (4) $30: 223-224$ (1910)

10d (and Twenhofel, W. H.) Ordovicic-Siluric section of the Mingan and Anticosti islands, Gulf of St. Lawrence. G Soc Am, B 21:677-716 (1910) Abst, Science n s $32: 223$ (1910) 
Schuchert, Charles-Continued.

11 Paleogeographic and geologic significance of recent Brachiopoda. G Soc Am, B $22: 258-275$ (1911)

12 Jackson on the phylogeny of the Echini. Am J Sc (4) 34:251-263 (1912)

13 Lower Devonian; introduction, paleogeography of the Devonian. Md G S, Lower Devonian : 33-41 (1913)

$13 a$ (and others) The Lower Devonian deposits of Maryland. Md G S, Lower Devonian : 67-96 (1913)

$13 b$ Systematic paleontology of the Lower Devonian deposits of Maryland; Cystoidea. Md G S, Lower Devonian : 227248, il (1913)

13e (and Maynard, T. P.) Systematic paleontology of the Lower Devonian deposits of Maryland; Brachiopoda. Md G S, Lower Devonian: 290-449, il (1913)

$13 d$ The delimitation of the geologic periods illustrated by the paleogeography of North America. Int G Cong, XII, 1913, C R : 555-591 (1914; advance print 1913)

13e Field and office methods in the preparation of geologic reports; fossils for stratigraphic purposes. Ec G 8:588-597 (1913)

$13 f$ The Cataract; a new formation at the base of the Siluric in Ontario and New York (abst). G Soc Am, B 24:107 (1913)

139 Climates of the past. Yale Rv n s $2: 719-728$ (1913)

14 Fossilium catalogus: I, Animalia (F. Frech, ed), Pars 3, Stelleroidea palaeozoica. 53 pp, Berlin 1914

14a Medina and Cataract formations of the Siluric of New York and Ontario. G Soc Am, B 25: 277-320, map (1914)

14b Climates of geologic time. Carnegie Inst Wash, Pub 192:265-298, paleogeographic maps (1914) Smiths Inst, An Rp 1914: 277-311 (1915)

14e Mammut americanum in Connecticut; with a note on the Farmington specimen, by Richard S. Lull. Am J Sc (4) 37 : $321-330$, il (1914)

14d Obituary-Professor Newton Horace Winchell. Am J Sc (4) $37: 566$ (1914)

14e (and Barre11, J.) A revised geologic time-table for North America. Am J Sc (4) $38: 1-27$ (1914)

$14 f$ Notes on Arctic Paleozoic fossils. Am J Sc (4) 38:467-477 (1914)

14g (with Pirsson, L. V.) Note on the occurrence of the Oriskany formation on Parlin Stream, Maine. Am J Sc (4) 37 : 221-224 (1914)

15 Revision of Paleozoic Stelleroidea with special reference to North American Asteroidea. U S Nat Mus, B 88:301 pp, il (1915)

15a Preface to Problems of American Geology : vii-viii. New Haven 1915
Schuchert, Charles-Continued.

15b The conditions of black shale of position as illustrated by the Kupferschief and Lias of Germany. Am Ph Soc, Pr 54 259-269 (1915)

15e [Observations on pre-Cambrian df posits and fossils.] Am J Sc (4) 39:22: (1915)

15d The basal Silurian formations of eastern North America. Nat Ac Sc, Pr 1: 359-360 (1915)

15e (with Pirsson, L. V.) A textbool of geology. $1051 \mathrm{pp}, \mathrm{il}, \mathrm{map} 3$, N Y 1915 [A nother ed in 2 vols, pt 1:1-444; pt? 405-1026] Rv, by Shimer, H. W., ad Lahee, F. H., Science n s 43:497-501 (1916)

16 Correlation and chronology in geolog on the basis of paleogeography. G Soc An B 27: 491-514 (1916)

16a Silurian formations of southeasten New York, New Jersey, and Pennsylvanit G Soc Am, B 27:531-554 (1916)

16b The problem of continental fras turing and diastrophism in Oceanica. An $J$ Se (4) 42:91-105 (1916) Nat $\Delta c$ \& Pr 2: 407-413 (1916)

16e On pre-Cambrian nomenclature. An J Sc (4) $42: 475-485$ (1916)

16d The earliest fresh-water arthropos. Nat Ac Sc, Pr 2: 726-733 (1916)

17 Atlantis, the "lost" continent. Gers Rv 3:64-66 (1917)

17a Atlantis and the permanency d the North Atlantic ocean bottom. Nat $\mathrm{A}$ Sc, Pr 3:65-72 (1917)

18 The earth's changing surface and climate during geologic time. In The ent lution of the earth and its inbabitants [edited by R. S. Lull] : 45-81, New Harel 1918

18a Age of the American Morrison 8nd East African Tendaguru formations. $G \mathrm{Bx}$ Am, B $29: 245-280$ (1918); abst, $28: 20$ (1917)

18b On the Carboniferous of the Grand Canyon of Arizona. Am J Sc (4) $45: 347^{-}$ 361 (1918)

18e The Cambrian of the Grand Cansw of Arizona. Am J Sc (4) $45: 362-30$ (1918)

18d A century of geology; the progres of historical geology in North Ameria Am J Sc (4) 46:45-103 (1918) Bt printed in A century of science in Americ: 60-121, New Haven 1918

18e Henry Shaler Williams; an appt ciation of his work in stratigraphy. Am / Sc (4) $46: 682-687$ (1918)

See also Berry, 16; Eastman, 00; Mar thew (W D), 15b; Swartz, 13a; Twes hofen, 09

Sehiitz, Andreas Gotthelf (1771-1807).

91 Beschreibung einiger Nordamerikat ischen fossilen. 16 pp, Leipzig 1791 [pot seen] 
Sehultz, Alfred Reginald.

05 [Underground waters of] Wisconsin district. U S G S, W-S P 114: 233-241 (1905)

07 Some observations on the movements of underground water in confined basins. J G $15: 170-181$ (1907)

07a Gold development in central Uinta Co., Wyo., and at other points on Snake River. U S G S, B 315: 71-88 (1907)

07b Coal fields in a portion of central Uinta Co., Wyo. U S G S, B $316: 212$ 241 (1907)

08 The Labarge oil field, central Uinta Co., Wyo. U S G S, B $340: 364-373$, map (1908)

09 The northern part of the Rock Springs coal field, Sweetwater Co., Wyo. U S G S, B 341: 256-282, maps (1909)

10 The southern part of the Rock Springs coal field, Sweetwater Co., Wyo. U S G S, B 381:214-281, maps (1910)

$10 \mathrm{n}$ Weathering of coal in the arid region of the Green River Basin, Sweetwater Co., Wyo. U S G S, B 381: 282296 (1910) Abst, Science n s 31:759$760(1910)$

10b Deposits of sodium salts in Wyoming. U S G S, B 430:570-589 (1910)

12 (and Cross, W.) Potash-bearing rocks of the Leucite Hills, Sweetwater Co., Wyo. U $\quad$ S G S, B $512: 39$ pp (1912) Abst, Wash Ac Sc, J 2: 159 (1912)

13 (and Richaras, R. W.) A geologic reconnaissance in southeastern Idaho. U S G S, B 530:267-284, map (1913)

14 Geology and geography of a portion of Lincoln Co., Wyo. U S G S, B 543 : $141 \mathrm{pp}$, map (1914) Abst, Wash Ac Sc J 4:370 (1914)

15 (with weidman, S.) The underground and surface-water supplies of Wisconsin. Wis G S, B $35: 664$ pp, map (1915)

18 A geologic reconnaissance for phosphate and coal in southeastern Idaho and western Wyoming. U S G S, B 680:84 pp, maps (1918)

18a A geologic reconnaissance of the Uinta Mountains, northern Utah, with spe cial reference to phosphate. U S G S, B $690: 31-94$, maps (1918) Abst, by R. W. Stone, Wash Ac Sc, J 8:453-454 (1918)

Schultze, E. A.

97 (and Kain, C. H.) The Santa Monla [Cal.] diatomaceous deposit with list of references to figures of species. Torrey Bot Club, B 24: 496-504 (1897)

Sehultze, Max.

74 Eozoon canadense. An Mag $\mathrm{N} \mathrm{H} \mathrm{(4)}$ 13: $324-325$ (1874)

Schuster, A.

11 Some problems of seismology. Seism Soc Ath, B 1:97-100 (1911)
Sehuster, Julius.

os Ueber ein pliocänes Eichenholz aus Idaho [Quercinium plioconicum from Pliocene near Lincoln City]. N Jb 1908 II : $49-54$, il

Schuster, M.

87 Mikroskopische Beobachtungen an californischen Gesteinen. N Jb, Beil Bd $5: 451-578$ (1887) Abst, Am Nat $22: 452$ (1888)

Sehwarz, Ernst H. L.

o6 The thickness of the ice cap in the various glacial periods. G Mag (5) $3: 120$ 124 (1906)

09 The probability of large meteorites having fallen upon the earth. J G 17 : 124-135 (1909)

12 The Atlantic and Pacific types of coast. Geog J 40:294-299 (1912)

Schwarz, Julius.

34 Geognostische Bemerkungen am Tepetonco in Mexico. N Jb 1834:205

Sehwarz, Manuel.

os Coal mines of Mexico. Mines and Minerals $29: 33-34$ (1908)

12 Le charbon au Mexique. Soc Cient Ant Alz, Mem 32 Rv : 1-23 map (1912)

Sehwarz, T. E.

89 Notes on the ore occurrence of the Red Mountain district [Ouray Co., Colo.]. Colo Se Soc, Pr 3: 77-85 (1889)

$\mathbf{9 0}$ The ore deposits of Red Mountain, Ouray Co., Colo. Am I M Eng, Tr 18: 139-145 (1890)

95 [The ore occurrence at the Independence mine, Battle Mountain, Cripple Creek, Colo.] Colo Sc Soc, $\operatorname{Pr} 4: 4: 2$ [1895]

97 Vein walls (discussion). Am I M Eng. Tr 26:1056-1060 (1897)

03 Notes on an occurrence of mica in Boulder Co. [Celo.]. Colo Sc Soc, $\operatorname{Pr} 7$ : 139-140 (1903)

o5 Features of the occurrence of ore at Red Mountain, Ouray Co., Colo. Am I M Eng, Bi-Mo B $2: 267-274$ (1905) ; Tr 36 : 31-39 (1906)

Sehweinitz, E. A. de,

96 A meteorite from Forsyth Co., N. C. Am J Sc (4) 1:208-209 (1896)

Sehweitzer, Paul.

71 Analyses of sandstones from New Jersey, Lye N H N Y, Pr 1: 196 (1871)

71 a Notes on felsites of the Palisade Range. Lyc N H N Y, Pr 1:244-252 (1871)

92 A report on the mineral waters of Missouri. Mo G S 3:256 fp, map, Jefferson City 1892

Schwennesen, Alvin Theodore.

14. Ground water for irrigation in the vicinity of Enid, Okla. U S G S, W-S P 345:11-20, map (1914) 
Sehwennesen, Alvin Theodore-Con.

14a Ground water for irrigation in the valley of North Fork of Canadian River near Oklahoma City, Okla. U S G S, W-S P 345: 41-51, map (1914)

17 Ground water in San Simon Valley, Ariz, and N. Mex. U S G S, W-S P 425: 1-35, maps (1917) Abst, by O. E. Meinzer, Wash Ac Sc, J 8:128 (1918)

18 Ground water in the Animas, Playas, Hachita, and San Luis basins, N. Mex. U \$ G S, W-S P 422: 152 pp, maps (1918)

18a (and Meinzer, O. E.) Ground water in Quincy Valley, Wash. U S G S, W-S P 425: 131-161 (1918)

seoble, T. C.

97 The natural resources of the country between Winnipeg and Hudson Bay; our northern outlet. Can Inst, $\operatorname{Pr}$ n s 1:1718 (1897)

Seofield, W. H.

97 (with U1rich, E. O.) The Lower Silurian Gastropoda of Minnesota. Minn G S, Final Rp 3 pt $2: 813-1081$, il (1897) Seotland, Horace.

90 On the geology of Jamaica. Institute of Jamaica, Popular Lectures, Fifth series: 3-49 (1890)

scott, A. C.

02 A brief summary of glacier work. Am G $30: 215-261(1902)$

Scott, Andrew.

57 Notes on the Bermuda Islands. Am J Sc (2) $24: 274$ (1857)

Seott, Dukinfield Henry.

os The present position of Paleozoic botany. Smiths Inst, An Rp 1907:371405 , il (1908)

11 The evolution of plants. $256 \mathrm{pp}, \mathrm{N}$ Y 1911

14 (and Jefrey, E. C.) On fossil plants showing structure from the base of the Waverly shale of Kentucky. R Soc London, Ph Tr ser B 205:315-373 (1914)

Seott, George $\mathrm{S}$.

1S Iridescent quartz from New York City. Am Mineralogist $3: 183$ (1918)

Seott, Irving Day.

o7 (with Kraus, E. H.) Ueber interessante amerikanische Pyritkrystalle. Zs Kryst 44:144-153 (1907)

14 The spacing of fracture systems and Its influence on the relief of the land. Beitr Geoph 13:163-181, 241-260 (1914)

Seott, J. G.

09 Coal in Alberta. Soc Géog Qué, B 3 : 41-44 (1909)

Scott, O. N.

02 The ore deposits of Copper Mountain, Similkameen district, B. C. Can M Inst, J 5:493-502 (1902) Can M Rv 21:173176 (1902)

Seott, Robert H.

72 Heer's Flora fossilis arctica. G Mag 9: 69-72 (1872)
Scott, Samuel.

97 Map of the Black Hills of Sonth Dakota and Wyoming, with full descriptions of mineral resources, etc. $40 \mathrm{pp}$, mas. Custer City, S. Dak., 1897

Seott, W. A.

09 Mining on Prince of Wales Islad Alaska. M Sc Press 98: 885-886 (1909)

09a Haines district, Alaska. M Sc Pras 99: 198-199 (1909)

seott, Will.

16 Report on the lakes of the Tippecan basin, Ind. Ind Univ, Studies 3 Study n 31 : $39 \mathrm{pp}$, maps (1916)

$16 a$ A report on the lakes of the Thp pecanoe basin. Ind Ac Sc, $\operatorname{Pr} 1915: 37 \%$ 378 (1916)

Scott, William.

00 Notes on the mineral deposits of Ner foundland. Eng M J 70:155-156 (1900) Scott, William Berryman.

82 (and osborn, H. F.) Orthocynodos. an animal related to the rhinoceros, frou the Bridger Eocene. Am J Sc (3) 24:222225 (1882) An Mag N H (5) 10:332-344 (1882)

s3 (and osborn, H. F.) On the stril of the Eocene rhinoceros, Orthocynodin and the relation of this genus to otbrt members of the group. Princeton coll E. M. Mus G, Contr, B no $3: 1-22$, (1883)

83a Two new Eocene lophiodonts Princeton Coll, E. M. Mus G, Contr, B st $3: 46-53$, il (1883)

84 A new marsupial from the Mioces of Colorado. Am J Sc (3) $27: 442-443$, (1884)

84a (and osborn, H. F.) On th origin and development of the rhinocers group (abst). Brit As, Rp 53:528 (158t)

85 Cervalces americanus, a fossil moos? or elk, from the Quaternary of New Jerse? Ac N Sc Phila, Pr 1885: 181-202, il

s5a [Elk, Cervalces americants, trot Warren Co., N. J.]. Princeton Univ, E. II Mus G, An Rp 4:4-6, il (1885)

85b A fossil elk or mose from th Quaternary of New Jersey. Science : $420-422$, il (1885)

s5e The osteology of Oreodon (abst) Am As, Pr 33: 492-493 (1885)

86 On some new forms of the Dinoce rata. Am J Sc (3) $31: 303-307$, il (1886)

86a Some points in the evolution of th horses. Science $7: 13,11(1886)$

86b [On Tinoceras stenops.] Am Nit $20: 316$ (1886)

87 (and osborn, H. F.) Preliminar? account of the fossil mammals from the White River formation... Harvard Coll M C Z, B $13: 151-171$, il (1887)

87a American elephant myths. Scril ner's Mag 1: 469-478, il (1887) 
Scott, William Berryman-Continued.

88 (and osborn, H. F.) Preliminary report on the vertebrate fossils of the Uinta formation, collected by the Princeton expedition of 1886. Am $\mathrm{Ph}$ Soc, $\mathrm{Pr}$ 24: 255-264, il (1888)

$8 s a$ On some new and little known creodonts. Ac N Sc Phila, J (2) 9:155-185, il (1888)

$\mathbf{8 8 b}$ The upper Eocene lacustrine formations of the United States (abst). Am As, $\operatorname{Pr} 36: 217$ (1888)

88e Origin of American Carnivora (abst). Am As, Pr 36: 258 (1888)

89 A comparison of the American and European Tertiary Mammalia. Princeton Coll B $1: 20-21$ (1889)

89a The Oreodontidae. Princeton Coll B 1:75-77 (1889)

89b Notes on the osteology and systematic position of Dinictis felina Leidy. Ac N Sc Phila, Pr 1889: 211-244, il

90 (and Osborn, H. F.) The Mammalia of the Uinta formation. Am Ph Soc, Tr n s 16:461-572, il (1890)

90a (and Osborn, H. F.) Preliminary account of the fossil mammals from the White River and Loup Fork formations; part II, the Carnivora and Artiodactyla [and] the Perissodactyla. Harvard Coll, Mus C Z, B 20:65-100, il (1890)

90b Beitritge sur Kenntnis der Oreodontidae. Morph Jb $16: 319-395$, il (1890)

90c The dogs of the American Miocene. Princeton Coll B 2:37-39 (1890)

$910 n$ the mode of evolution in the Mammalia. Princeton Coll B 3:62-68 (1891)

91a The Princeton scientific expedition of 1891 [Deep River, Mont.]. Princeton Coll B 3:88-91 (1891)

$91 \mathrm{~b}$ On the osteology of Poebrotherium; a contribution to the phylogeny of the Tylopoda. J Morph 5:1-78, il (1891)

91e On the osteology of Mesohippus and Leptomeryx with observations on the modes and factors of evolution in the Mammalia. J Morph $5: 301-404$, il (1891)

92 On some of the factors in the evolutiot of the Mammalia. Princeton Coll B 4: 11-17 (1892)

92a The genera of American Creodonta. Princeton Coll B 4:76-81 (1892)

92b A revision of the North American Creodonta with notes on some genera which have been referred to that group. Ac N Sc Phila, Pr 1892: 291-323

93 The Princeton scientific expendition of 1893. Princeton Coll B 5 : 80-84 (1893)

93a The evolution of the premolar teeth in the mammals. Ac N Sc Phila, Pr 1892: $405-444$, il (1893)

93b on a new musteline from the John Day Miocene. Am Nat 27:658-659 (1893) 93e The mammals of the Deep River beds (Mont.) A Nat 27:659-662 (1893)
Scott, William Berryman-Continued.

94 Notes on the osteology of Agriochoerus Leidy (Artionyx 0. \& W.). Am $\mathrm{Ph}$ Soc, $\operatorname{Pr} 33: 243-251$, il (1894) Princeton Coll B 6:98-100 (1894)

94a The manus of Hyopotamus. Am Nat 28:164-165 (1894)

94b Notes on the osteology of Ancodus (Hyopotamus). G Mag (4) 1:492-493 (1894)

94e The later Tertiary lacustrine formations of the West $(a b s t)$. G Soc Am, B 5 : 594-595 (1894) Am J Sc (3) $47: 139-140$ (.r94) Am G 13:141-142 (1894)

95 The structure and relationsbips of Ancodus. Ac N Sc Phila, J (2) 9:461497,536 , il $(1895)$

95a The osteology of Hyaenodon. Ac N Sc Phila, J (2) 9:499-535, il (1895)

5b The Mammalia of the Deep River beds [Mont.]. Am Ph Soc, Tr n s 18:55185, il (1895) Abst, Princeton Coll B 6: 76-78 (1894) Rv by E. D. Cope, Am Nat 28 : 790-791 (1894)

95e A new insectivore from the White River beds [Protosorex, South Dakota]. Ac N Sc Phila, Pr 1894:446-448 (1895)

95d Protoptychus hatcheri, a new rodent from the Uinta Eocene. Ac N Sc Phila, Pr 1895 : 269-286

95e The osteology and relations of Protoceras. J Morph $11: 303-374$, il (1895)

95f A restoration of Hyaenodon. G Mag (4) $2: 441-443$, il (1895)

95g On the Creodonta (abst). Brit As, Rp 65: 719-720 (1895)

$\mathbf{9 5 h}$ On the Tertiary lacustrine formations of North America (abst). Brit As, Rp 65: 681-682 (1895)

96 Die Osteologie von Hyracodon Leidy. Festschrift zum siebigsten Geburtstage von Carl Gegenbaur 2:351-384, il (1896)

96a On the osteology of Elotherium Pomel. Int Zool Cong, 3d, C R : 317-319 (1896)

96b Paleontology as a morphological discipline. Science n s 4:177-188 (1896)

96c $\mathbf{A}$ question of priority [nomenclature of a Texas formation]. Am G 17:58 (1896)

97 An introduction to geology. xxvil, $573 \mathrm{pp}, \mathrm{il}, \mathrm{N}$ Y 1897 2d ed, xxvii, $816 \mathrm{pp}$, il, N Y 1907

97a Preliminary notes on the White River Canidae. Princeton Univ B 9:1-3 (1897)

97b The osteology of Hyracodon. Princeton Univ B 9:11-13 (1897)

97e Lakes. Se Am Sup $43: 17756-17758$ (1897)

97d Glaciers. Sc Am Sup 44:1800518006 (1897)

98 The osteclogy of Elotherium. Am Ph Soc, Tr n s $19: 273-324$, il (1898) 
Scott, William Berryman-Continued.

9Sa Notes on the Canidae of the White River Oligocene. Am Ph Soc, Tr n 8 19: $325-415$, il (1898)

98b Preliminary note on the selenodont artiodactyls of the Uinta formation. Am $\mathrm{Ph}$ Soc, $\operatorname{Pr} 37: 73-81$ (1898)

98c Memoir of Edward D. Cope. G Soc Am, B 9:401-408 (1898)

99 The selenodont artiodactyls of the Uinta Eocene. Wagner Free I Sc, $\operatorname{Tr} 6$ : xiii, $121 \mathrm{pp}$, il (1899)

o1 Historical geology. Sc Am Sup 52: 21352-21353 (1901)

01a Earth carving. Sc Am Sup 52: 21456 (1901)

04 John Bell Hatcher. Science n s 20: 139-142 (1904)

o6 Memoir of John B. Hatcher. G Soc Am, B 16:548-555, port (1906)

13 A history of land mammals in the western hemisphere. xfv, 693 pp, N Y 1913

13a Restoration of Tertiary mammals (abst). G Soc Am, B 24:105-106 (1913)

16 The Isthmus of Panama in its relation to the animal life of North and South America. Science n s 43:113-124 (1916)

17 The theory of evolution, with special reference to the evidence upon which it is founded. $183 \mathrm{pp}, \mathrm{N}$ Y 1917

See also Osborn, 78

scott, W. K.

64 On a supposed change of level in a part of the Green Mountains. Am J Sc (2) $38: 243-248$ (1864)

Scovell, Josiah Thomas (1841-1915).

89 Another old channel of the Niagara River. Am G 3:195-196 (1889)

91 An old channel of the Niagara River (abst). Am As, Pr 39:245-246 (1891)

93 Mount Orizaba or Citlaltepet] [Mex ico]. Scienee $21: 253-257$ (1893)

96 Some minor eroding agencies. Ind Ac Sc, Pr 1895: 54-55 (1896)

96a Kettle holes near Lake Maxinkuc kee [Ind.]. Ind Ac Sc, Pr 1895:55-56 (1896)

97 Geology of Vigo Co., Ind. Ind, Dp G N Res, An Rp 21:507-576, map (1897)

99 Terraces of the lower Wabash. Ind Ac Sc, Pr 1898: 274-277, map (1899)

Scoville, $S$. 8 .

78 A large boulder in southern Ohio. Cin Soc N H, J 1: 56 (1878)

Scrope, G. Poulett.

28 Have the elevating effects of rolcanic power been perceived on the eastern side of the American continent? [with remarks by B. Silliman]. Am J Sc 13 : 190-192 (1828)

Sendder, Samuel Hubbard (1837-1911) 65 The Devonian insects of $\mathrm{St}$. Johns, N. B. Can Nat n s 2:234-236 (1865)
Scudder, Samuel Hubbard-Continued. $65 a$ On Devonian insects from $\mathrm{Xa}$ Brunswick. Am J Sc (2) $39: 357-25$ (1865) Entom Soc London, $\operatorname{Tr}$ (3) $2 \mathrm{Pr}$ 117-118 (1865) Can Nat n \& 2:234-2\% (1865) In Bailey, L. W., Observations on the geology of southern New Brunswict: 140-141, Frederickton 1865

65b On fossil insects from Illinois. in J Sc (2) $10: 268-271$ (1865)

65e [Notes on the geology of Cuba and the Isle of Pines.] Boston Soc N H, A $10: 47-49$ (1865)

$65 \mathrm{~d}$ [On the structure of the wings of Carboniferous insects from Illinois.] Boe ton Soc N H, Pr 10:95-90 (1865)

66 An inquiry into the zoological reli tions of the first discovered traces of fose neuropterous insects in North America Boston Soc N H, Mem 1:173-192, i (1866)

67 On some remains of Paleozoic is sects recently discovered in Nova Scotis and New Brunswick. G Mag 4:385-as il (1867) Can Nat n 8 3:202-206, (1867)

$67 \mathbf{a}$ [On Insecta from the Deronin rocks of New Brunswick.] Boston \& N H, Pr 11:150-151 (1867)

67b [On fossil larva from the Connet cut River sandstone.] Boston Soc N B Pr 11: 140 (1867)

67e [On insects from the Tertiary bot Green River, Colo.] Boston Soc N H, P 11 : 117-118 (1867)

68 Supplement to descriptions of artic lates. III G S 3:566-572, il (1868)

68a The fossil insects of North Americ G Mag $5: 172-177,216-222$ (1868)

$\mathbf{6 8 b}$ The insects of ancient America. An Nat $1: 625-631$, il (1868)

68e [On two new insects from the $\operatorname{col}$ Measures at Morris, III., and Tallmad, Ohio.] Boston Soe N H, Pr 11:401-4l (1868) Am J Sc (2) 46:419-421 (1866

68d [Marks left by glaciers.] Bostu Soc N H, Pr 12: 151 (1868)

69 On the fossil myriapods of the ext formations of Nova Scotia and Englasl (abst). G Soc London, Q J 25:441 (1869)

72 Fossil insects from the Rocky Mout tains. Am Nat 6:665-668 (1872)

$\boldsymbol{7 3}$ On the Carboniferous myriapods pr served in the sigillarian stumps of Nori Scotia [and supplementary note]. Bosts Soc N H, Mem 2: 231-239 (1873), 561562 , il (1878)

74 Two new fossil cockroaches from th Carboniferous of Cape Breton. Can Mit n s $7: 271-272$, il (1874)

75 Fossil butterflies. Am As, Mem 1 $99 \mathrm{pp}$, il (1875)

75a The Tertiary Physopoda of Colorad U S G Geog S Terr (Hayden), B [1] no ? (2) : 221-223 (1875) 
Sendder, Samuel Hubbard Continued. 75b Note on the post-Pliocene strata of Sankoty Head [Nantucket Island, Mass.]. Am J Sc (3) $10: 365-366$ (1875)

75e On insects occurring in Carboniferous shale at Cape Breton. Boston Soc N H, Pr 18: 113-114 (1875)

76 Fossil Orthoptera from the Rocky Mountain Tertiaries. U S G Geog $\mathrm{S}$ Terr (Hayden), B [1] no 6 (2):447-449 (1876)

76a Fossil Coleoptera from the Rocky Monntain Tertiaries. U S G Geog S Terr (Hayden), B 2:77-87 (1876)

76b Brief synopsis of North American earwigs, with an appendix on the fossil species. U S G Geog S Terr (Hayden), B 2: 249-260 (1876)

76e New and interesting insects from the Carboniferous of Cape Breton. Can Nat n s $8: 88-90$, il (1876) Am As, Pr 24 pt $2: 110-111$, il (1876)

76d Post-Pliocene fossils from the bluff at Sankoty Head. Nantucket. Boston Soc N H, Pr 18: 182-185 (1876)

$76 \mathrm{e}[\mathrm{On}$ the close affiliation of the insects of Furope and America in the Carboniferous epoch.] Boston Soc N H, Pr 18: $358-359$ (1876)

76f Fossil Paleozoic insects [Amerícan Carboniferous]. G Mag (2) 3:519-520 (1876)

77 The first discovered traces of fossil insects in the American Tertiaries. U S G Geog S Terr (Hayden), B 3: 741-762 (1877)

77a Description of two species of Carabidae found in the interglacial deposits of Searboro Heights, near Toronto, Canada. U S G Geog S Terr (Hayden), B 3:763764 (1877)

77b The insects of the Tertiary beds at Quesnel [B. C.]. Can G S, Rp Prog $1875-6 ; 266-280$ (1877)

77e On the wing of a cockroach from the Carboniferous formation of Pittstown, $\mathrm{Pa}$. [Blattina fascigera]. Boston Soc N H, Pr 19: 238-239 (1877)

77d On fossil ants from South Park, Colo. Am Nat $11: 191$ (1877)

78 An account of some insects of unusual interest from the Tertiary rocks of Colorado and Wyoming. U S G Geog S Terr (Hayden), B 4:519-543 (1878)

$78 \mathrm{a}$ The fossil insects of the Green River shales. U S G Geog S Terr (Hayden), B $4: 747-776$ (1878)

78b Additions to the insect fauna of the Tertiary beds at Quesnel, B. C. Can G S, Rp Prog 1876-7:457-464 (1878)

78e The annual address of the president [surveys of the West]. Appalachia 1: 207-243 (1878)

78d An insect wing of extreme simplicity from the coal formation. Boston Soc $N$ H, $\operatorname{Pr} 19: 248-249$ (1878)
Scudder. Samuel Hubbard-Continued.

7Se Rhachura, a new genus of fossil Crustacea. Boston Soc N H, Pr 19:296300 (1878)

7Sf A Carboniferous Termes from Illinois. Boston Soc N H, Pr $19: 300-301$ (1878)

79 The early types of insects, or the origin and sequence of insect life in Paleozoic times. Boston Soc N H, Mem 3: 13-21 (1879) Abst, Am J Sc (3) 17: 72-74 (1879)

79a Paleozolc cockroaches; a complete revision of the species of both worlds, with an essay toward their classificatic Boston Soc N H, Mem 3: 23-134, il (1879)

79b The fossil insects collected... in the interior of British Columbia. Can G S, Rp Prog 1877-8: B 176-185 (1879)

so The Devonian insects of New Brunswick. Boston Soc N H, Anniv Mem: 41 pp, il (1880) Abst, Am J Se (3) 21 : 111-117 (1881); An Mag N H (5) 7 : 255-261 (1881); Am Nat 14:905-907 (1880) : Science 1:292-293 (1880) ; Kosmos 5: 217-223 (1881)

80a A bibliography of fossil insects. Harvard Univ, B $2: 48-51,87-88,157-$ $161,202-208,252-257,296-299,333-337$, 407-414 (1880-82) Reprint, Harvard Univ, Bib Contr no $13: 47$ pp, Cambridge, Mass., 1882

sob Concerning the probable age of Haulover Beach at the head of Nantucket Harbor [Mass.]. Boston Soc N H, Pr. 20: 329-330 (1880)

s1 The Tertiary lake basin at Florissant, Colo., between South and Hayden parks. U S G Geog S Terr (Hayden), B 6: 279-300, map (1881); An Rp 12 pt 1 : 271-293, map (1883)

s1a Relation of Devonian insects to later and existing types. Am J Se (3) 21:111-117 (1881)

s1b The structure and affinities of Euphoberia Meek and Worthen, a genus of Carboniferous Myriapoda. Am J Sc (3) $21: 182-186$ (1881)

s1e White ants in the American Tertiaries. Harvard Univ B 2:219 (1881) [not seen]

82 Nomenclator zoologicus; an alphabetical list of all generic names that have been employed by naturalists for recent and fossil animals from the earliest times to the close of the year 1879. Part I, Supplemental list. U S Nat Mus, B 19 : $376 \mathrm{pp}$ (1882) Part II, Universal index : 340 pp (1884)

82a Archipolypoda, a subordinal type of spined myriapods from the Carboniferous formation. Boston Soc N H, Mem 3: $143-182$, il (1882)

82b The affinities of Palaeocampa Meek and Worthen as evidence of the wide diversity of type in the earliest known myriapods. Am J Sc (3) 24:161-170 (1882) An Mag N H (5) $10: 286-295$ (1882) 
Seudder, Samuel Hubbard-Continued. 82e On additional remains of articulates obtained by Dr. Dawson from sigillarian stumps in the coal field of Nova Scotia, R Soc London, $\mathrm{Ph} \operatorname{Tr} 173: 649$ 650 (1882)

82d Fossil spiders. Tarvard Univ, B 2 : 302-303 (1882) Field Naturalist, Manchester, Engl., 1 no. 3:61-63 (1882)

s2e A new and unusually perfect Carboniferous cockroach from Mazon Creek, III. Boston Soc $\mathrm{N}$ H, Pr 21:391-396 (1882)

s2r Notes on some of the Tertiary Neuroptera of Florissant, Colo., and Green River, Wyo. Boston Soc N H, Pr 21:407409 (1882)

82g Older fossil insects west of the Mississippi. Boston Soc N H, Pr 22:5860 (1882)

84 Two new and diverse types of Carboniferous myriapods, Boston Soc N H, Mem 3: 283-297, il (1884)

84a The species of Mylacris, a Carboniferous genus of cockroaches. Boston Soc N H, Mem $3:$ 299-309, il (1884)

84b The fossil white ants of Colorado. Am Ac Arts, Pr 19:133-145 (1884)

84e Triassic insects from the Rocky Mountains. Am J Sc (3) 28:199-203 (1884)

85 Systematische Uebersicht der fossilen Myriopoden, Arachnoideen, und Insekten. Sonderabzug aus Zittel, Handbuch der Paleontologie, I. Abtheilung, Paleozoologie, Bd. II : 721-831, München 1885

85a Palaeodictyoptera, or the affinities and classification of Paleozoic Hexapoda. Boston Soc N H, Mem 3:319-351, il (1885)

85b Winged insects from a paleontological point of view, or the geological history of insects. Boston Soc N H, Mem 3:353358 (1885)

85e A contribution to our knowledge of Paleozoic Arachnida. Am Ac Arts, Pr 20 : 13-22 (1885)

s5d Dictyoneura and the allied insects of the Carboniferous epoch. Am Ac Arts, Pr 20:167-173 (1885)

s5e Description of an articulate of doubtful relationship from the Tertiary beds of Florissant, Colo. Nat Ac Sc, Mem 3 pt 1: 85-90, il (1885)

85P The relations of the Paleozoic insects. Am Nat 19:876-878 (1885)

85g New genera and species of fossil cockroaches from the older American rocks. Ac N Sc Phila, Pr 1885:34-39 An Mag N H (5) $15: 408-414$ (1885)

85h Notes on Mesozoic cockroaches. Ac N Se Phila, Pr 1885:105-115 An Mag $\mathrm{N} H$ (5) $16: 54-64$ (1885)

851 The geological history of myriapods and arachnids. Psyche 4:245-250 (1885) Abst, Am Nat 19: 1210-1211 (1885)
Seudder, Samuel Hubbard-Continuel.

86 Systematic review of our presert knowledge of fossil insects includity myriapods and arachnids. U S G S, B 31: 128 pp (1886)

86a The oldest known insect lari, Mormolucoides articulatus, from the $\mathrm{Co}$ necticut River rocks. Boston Soc N B. Mem 3: 431-438, il (1886)

86b Note on the supposed myriapoda genus Trichiulus. Boston Soc N H, Mer $3: 438$ (1886)

s6e A review of Mesozoic cockroaches Boston Soc N H, Mem $3: 439-486$, il (188)

86d The operations of a prehlstork beetle. Can Entomologist 18:194-19 (1886)

86e The cockroach of the past. Is Miall, L. C., and Denny, Alfred, The stroc ture and life history of the cockroach 205-220, il, L 1886

88 An interesting Paleozoic cockrosd fauna at Richmond, Ohio. Boston Soe NH, Pr 24: 45-53 (1888-9)

s9 Fossil butterfles. In $h$ is The bitterflies of the eastern United States as Canada with special reference to New Eos land, vol $1: 756-760$, Cambridge 1889

$89 a$ The fossil butterflies of Florisant [Colo.]. U S G S, An Rp 8:433-474, (1889)

90 The fossil insects of North AmerictVol 1, The pre-Tertiary insects, $455 \mathrm{pp}$, 11 vol 2, The Tertiary insects, $663 \mathrm{pp}$, il NI 1890

90a The Tertiary insects of North Amet ica. U S G S Terr (Hayden), Rp 18: $734 \mathrm{pp}$, il (1890)

90b A classed and annotated biblio: raphy of fossil insects. U S G S, B 69 : $101 \mathrm{pp} \mathrm{(1890)}$

90e New types of cockroaches from th Carboniferous deposits of the United States Boston Soc N H, Mem 4:401-415, (1890)

90d New Carbonlferous Myriapoda frod Illinois. Boston Soc N H, Mem 4:417-4t? il $(1890)$

90e The insects of the Triassic beds at Fairplay, Colo. Boston Soc N H, Mem 4. $457-472$, il (1890)

90p Illustrations of the Carboniferovs Arachnida of North America, of the order Anthracomarti and Pedipalpi. Boston $S \alpha$ N H, Mem 4:443-456, II (1890)

90 semains of Coleoptera in the intet glacial clays of Scarboro, Ont. Boston So N H, Pr 24: 467-468 (1890)

$\mathbf{9 0 h}$ Physiognomy of the American Tet tiary Hemiptera. Boston Soc N H, Pr 24 562-579 (1890)

901 The work of a decade upon fossil it sects, 1880-1889. Psyche 5:287-29? (1890)

90j The fossil insect localities in th Rocky Mountains region. Psyche 5:36 (1890) 
Scudder, Samuel Hubbard-Continued.

91 Index to the known fossil insects of the world including myriapods and arachnids. U S G S, B 71: 744 pp (1891)

91a [On the occurrence of fossil insects in the West.] Psyche 6:101-102 (1891) 92 Some insects of special interest from Florissant, Colo., and other points in the Tertiaries of Colorado and Utah. U S G S, B $93: 35 \mathrm{pp}$, il (1892)

92a The Tertiary Rhynchophora of Noth America. Boston Soc N H, Pr 25 : 370-386 (1892)

93 Tertiary rhynchophorous Coleoptera of the United States. U S G S, Mon 21 : xl, $175 \mathrm{pp}, 11$ (1893)

93a The American Tertiary Aphidae, with a list of the known species and tables for their determination. U S G S, An Rp 13 pt $2: 341-366$ (1893)

93b Insect fauna of the Rhode Island coal field. U S G S, B 101:27 pp, il (1893)

94 Tertiary Tipulidae, with special reference to those of Florissant, Colo. Am $\mathrm{Ph} \mathrm{Soc}, \operatorname{Pr} 32: 163-245$, il (1894) Abst, Am Nat 28:532-533 (1894)

94a The effect of glaciation and of the glacial period on the present fauna of North America. Am J Sc (3) 48:179187 (1894)

95 Revision of the American fossil cockroaches with description of new forms. U S G S, B 124:176 pp, il (1895)

95a Canadian fossil insects; 1 , the Tertiary Hemiptera of British Columbia; 2 . The Coleoptera hitherto found fossil in Canada; 3 , Notes on myriapods and arachnids found in sigillarian stumps in the Nova Scotia coal field. Can G S, Contr Can Pal 2:1-66, il (1895)

95b The fossil cockroaches of North Amrerica, R Soc Can, $\operatorname{Pr} \operatorname{Tr} 12$, iv : 147$153(1895)$

95e A caddis fly from the Leda clays of the vicinity of Ottawa. Can Rec Sc 6: 276-277, il (1895)

98 The Pleistocene beetles of Fort River; Mass. U S G S, Mon 29: 740-746, il (1898)

00 Adephagous and clavicorn Coleoptera from the Tertiary deposits at Florissant, Colo... U S G S, Mon 40:148 pp, il (1900)

00a Canadian fossil insects; 4, Additions to the coleopterous fauna of the Interglacial clays of the Toronto district. Can G S, Contr Can Pal 2:67-90, il (1900)

See also Eastman, 00 ; Powell, 88, 89 $89 \mathrm{a}, 90,91,91 \mathrm{a}, 22$

Seupham, J. R.

98 The buried rivers of California as a source of gold. Mines and finerals 19: 150-152 (1898)

$$
28737^{\circ}-23-59
$$

Seaman, A. E.

94 A new loeality for Silurian limestone in northern Michigan. Am J Sc (3) $48: 173$ (1894)

07 (with Lane, A. C.) Notes on the geological section of Michigan; Part I, The pre-Ordovician, J G 15:680-695 (1907)

09 (with Lane, A. C.) Notes on the geological section of Michigan; Part I, The pre-Ordovician. Mich G S, Rp 1908: 21-42 (1909)

\section{Seamon, W. H.}

82 Examination of a supposed metallic meteorite found in Augusta Co., $\mathrm{Va}$. $\mathrm{Ch}$ News 46: 204-205 (1882)

82a Analysis of fergusonite from Brindletown, Burke Co., N. C. Ch News 46: 205 (1882)

82b Analysis of a niobate, which has been improperly called euxenite, from the Wisemann mica mine, Mitcheil Co., N. C. Ch News 46:205-206 (1882)

90 The zinciferous clays of southwest Missouri and a theory as to the growth of the calamine of that section. Am J Sc (3) 39: 38-42 (1890) Abst, Sch Mines Q 11: 175 (1890)

90a Tallow clays [soutbwestern Missouri]. Se Am Sup 30:12287 (1890)

94 The present condition of the earth's interior as viewed from the standpoint of the nebular hypothesis. Am G 14:20-25 (1894)

06 Observations in southwestern Chihuahua [Mexico]. M World 25:306-30s (1906)

10 Mining operations in the State of Chihuahua, Mexico. Eng M J 90:654-656 (1910)

Sears, John Henry.

s8 [Geologic notes on Essex Co., Mass.] Essex Inst, B 20: 25-26 (1888)

89 Geological and mineralogical notes, No. 1 ; sodalite. Essex Inst, B 21: 88-93 (1889)

90 The stratified rocks of Essex Co. [Mass.]. Essex Inst, B 22: 31-47 (1890)

90a On keratophyre from Marblehead Neck, Mass. Harvard Coll, Mus C Z, B 16 (g s 2) : 167-172 (1890)

91 Geological and mineralogical notes, No. 3 ; Elaeolite zircon syenites and associated granitic rocks in the vicinity of Salem, Essex Co., Mass. Essex Inst, B 23 : 145-155 (1891)

91 a Geological and mineralogical notes, No. 4 ; the extent and probable thickness of the crystalline Cambrian deposits in Essex Co., Mass. Essex Inst, B 23: 156160 (1891)

93 Geological and mineralogical notes, No. 5 [rocks of Essex Co., Mass.]. Essex Inst, B 25: 8-13 (1893) 
Sears, John Henry-Continued.

93a Geological and mineralogical notes, No. 6; on the occurrence of augite and nepheline syenites in Essex Co., Mass. Essex Inst, B 25:111-125 (1893)

94 Mineralogical and geological notes, No. 7 ; Evidences of subsidence and elevation in Essex County in recent geological time, as shown by field work at the seashore. Essex Inst, B 26:64-73 (1894)

$94 a$ Geological and mineralogical notes, No. 8 ; on a preglacial sand plain, probably of the Tertiary age, in the central part of Essex Co., Mass. Essex Inst, B 26:74-76 (1894)

94b Report on the geology of Essex Co., Mass., to accompany map. Essex Inst, B 26: 118-139 (1894)

94e Geological and mineralogical notes, No. 9 ; List of the minerals of Essex Co., Mass. Essex Inst, B 26:179-202 (1894)

95 Supplementary report on the mineralogy and geology of Essex Co. Essex Inst, B $27: 109-112$ (1895)

98 Biotite tinguaite dike rock [Manchester, Mass.]. Essex Inst, B 29:58-63 (1898)

o5 The physical geography, geology, mineralogy, and paleontology of Essex County. 418 pp, il, map, Salem, Mass., 1905

os A southern flora and fauna of postPleistocene age in Essex Co., Mass. Rhodora, J New England Bot Club, 10:42-46 (1908)

Sebbin, E. W.

04 Geology of Mexico. Lead and Zinc Ners 8: 130-131 (1904)

Seddon, William.

07 Workable coal seams of western Pennsylvaina. Eng M J 84:549-550 (1907)

Sederholm, Jakob Johannes.

13 Different types of pre-Cambrian unconformities. Int G Cong, XII, 1913, C R : 313-318 (1914: advance copy 1913)

13 a on regional granitization (or anatexis). Int G Cong, XII, 1913, C R : 319324 (1914; advance copy 1913)

13b Some proposals concerning the nomenclature of the pre-Cambrian, etc. Int $G$ Cong, XII, 1913, C R:381-385 (1914; advance copy 1913)

See, Thomas Jefferson Jackson.

06 The San Francisco earthquake of April 18. Nature 74:30 (1906)

o6a The cause of earthquakes, mountain formation, and kindred phenomena connected with the physics of the earth. Am $\mathrm{Ph}$ Soc, $\mathrm{Pr} 45: 274-414$ (1906)

06b The nature and origin of volcanic heat. Science n s 24:301-303 (1906)

06c The rigidity of the earth. Science n s $24: 558-559$ (1906)

or On the temperature, secular cooling, and contraction of the earth, and on the theory of earthquakes held by the ancients. Am Ph Soc, Pr 46:191-299 (1907)
See, Thomas Jefferson Jackson-Continod

O7a The new theory of earthquakes 2 mountain formation, as illustrated processes now at work in the depths of th sea. Am Ph Soc, Pr 46:369-415 (1907)

os Further researches on the physics the earth, and especially on the folding mountain ranges and the uplift of plater: and continents produced by movements lava beneath the crust arising from to secular leakage of the ocean bottoms. A $\mathrm{Ph}$ Soc, $\operatorname{Pr} 47: 157-275$ (1908)

Osa How the mountains were made the depths of the sea; the new theory earthquakes. Pacific Mo 20:256-? (1908)

Osb Outline of the new theory of eart quakes. Popular Astronomy 16:199-2: (1908)

09 The past history of the earth as $\mathbb{E}$ ferred from the mode of formation of th solar system. Am Ph Soc, Pr 48:119-15 (1909)

Seebach, Karl von.

65 Beobachtungen in Central Amerik Deut G Ges, Zs 17:458 (1865)

92 Ueber Vulkane Centralamerikas: Ges Wiss Gättingen, Abh 38: 251 pp (189: Seebach, M.

12 (and Paul. F. P.) Ueber Kles zinkerz von Santa Eulalia bei Chihuabu Mexico; ein Beitrag zur Kenntnis de Krystallformen dieses Mineral. Zs Kry 51: 149-206 (1912)

Seeley, Harry Govier (1839-1909).

95 The story of the earth in past agk 186 pp, N Y 1895

Seely, Henry Martyn (1828-1917).

$\mathbf{7 7}$ The original Vermont plow [glacil action]. In Vt Bd Agr, 4th Rp 1877:17181, Montpelier 1877

85 A new genus of Chazy sponge Strephochetus. Am J Sc (3) $30: 355-35 i$, il (1885)

85a The marble fields and marble to dustry of western New England. Middle bury Hist Soc, Papers and $\mathrm{Pr}-1 \mathrm{pt}$. 23-52 (1885)

86 The genus Strephochetus, distribtion and species. Am J Se (3) $32: 31$ - it (1886)

88 (with Brainerd, E.) The origins Chazy rocks. Am G $2: 323-330$ (1888)

90 (with Brainerd, E.) The Calcite: ous formation in the Champlain Valley. Soc Am, B 1: 501-513 (1890) Abst, Aml Sc (3) $39: 235-238$ (1890)

90a (with Brainerd, E.) The (at ciferous formation in the Cuamplain $\mathrm{Vat}$ ley. Am Mus N H, B 3:1-23, maps (1890)

94 Notes on the genus Stromatoceriuk Science $23: 78$ (1894)

96 (with Brainerd, E.) The Chats of Lake Champlain. Am Mus N H, B : 305-315, maps (1896) 
Seely, Henry Martyn-Continued.

01 The geology of Vermont. The Vermonter 5 [6] no $7: 53-67$ (1901)

01a Sketch of the life and work of Augustus Wing. Am G 28:1-8, port (1901) Vt, St G, Rp $3: 22-30$, port

(1902)

02 Some sponges of the Chazy formation. Vt, St G, Rp $3: 151-161$, il (1902)

03 Sketch of the life and work of Charles Baker Adams. Am G 32:1-12, port (1903) Vt, St G, Rp 4:3-15, port (1904)

04 The Stromatoceria of Isle La Motte, Vt. Vt, St G, Rp 4: 144-165, il (1904)

06 Cryptozoa of the early Champlain sea. Vt St G, 5th Rp: 156-173, il (1906)

06a Beekmantown and Chazy formations in the Champlain Valley; contributions to their geology and paleontology. Vt St G, 5th Rp, 174-187, il (1906)

08 Stellae and rhabdoliths of the genus Strephochetus. Vt St G, 6th Rp: 187-188, il (1908)

0Sa Cryptozoön; reply to the review of C. W. W. J G $16: 298$ (1908)

10 Preliminary repert of the geology of Addison Co., Vt. Vt St G, 7th Rp:257313 , map (1910)

seelye, R. W.

10 The Helen mine, Michipicoten, Ont. Can M Inst, Q B 11:189-202 (1910); J $13: 121-134$ (1911)

Segall, Julius.

15 The origin and occurrence of certain erystallegraphic intergrowths. Ec G 10 : $462-470$ (1915)

Self, Edward D.

94 A visit to the Falls of Bassasseachic [State of Chibuahua, Mexico]. N Y Ac Sc, Tr 13:148-151 (1894)

Sellards, Elias Howard.

00 Note on the Permian flora of Kansas. Kans Univ Q 9:63-64, il (1900)

00a A new genus of ferns from the Permian of Kansas. Kans Univ Q 9:179189 , il $(1900)$

01 Permian plants; Tueniopteris of the Permian of Kansas. Kans Univ Q 10:112, il (1901)

01a Fossil plants in the Permian of Kansas. Kans Ac Sc, Tr 17:208-209 (1901)

02 On the fertile fronds of Crossotheca and Myriotheca, and on the spores of other Carboniferous ferns, from Mazon Creek, III. Am J Sc (4) 14:195-202 (1902)

$02 a$ on the validity of Idiophyllum rotundifolium Lesquereux, a fossil plant from the Coal Measures at Mazon Creek, III. Am J Sc (4) 14:203-204, il (1902)

08 Some new structural characters of Paleozoic cockroaches. Am J Sc (4) 15 : $307-315$, (1903)

03a Megablattina Sellards (non Brongniart); a correction. Am J Sc (4) 15 : 488 (1903)
Sellards, Elias Howard-Continued.

03b Codonotheca, a new type of sporebearing organ from the Coal Measures. Am J Sc (4) $16: 87-95$, il (1903)

o3e Discovery of fossil insects in the Permian of Kansas. Am J Sc (4) 16:323324 (1903)

04 A study of the structure of Paleozoic cockroaches, with descriptions of new forms from the Coal Measures. Am J Sc (4) $18: 113-134,213-227$, il (1904)

o5 (with Beede, J. W.) Stratigraphy of the eastern outcrop of the Kansas Permian. Am G 36:83-111, map (1905)

06 Some sink-hole lakes of north central Florida (abst). Science n s 23:289-290 (1906) Am As, Pr 55:378-379 (1906)

06a Systematic paleontology of the Pleistocene deposits of Maryland; Insecta. Md G S, Pliocene and Pleistocene : 170-172, il (1906)

oGb Geological history of cockroaches. Pop Sci Mo 68: 244-250 (1906)

06e Types of Permian insects. Am J Sc (4) $22: 249-258$. il $(1906) ; 23: 345-355$, il $(1907) ; 27: 151-173$, il (1909)

$\mathbf{0 7}$ Occurrence and use of artesian and other underground water. Fla Agr Exp Sta, B $89: 87-113$ (1907)

07a Florida State Geological Survey, organization and plans. $11 \mathrm{pp}, 1907$

07b Venation of the wings of Paleozoic dragon-flies (abst). Science n s 25:731732 (1907)

oze Origin of sink holes. Science $\mathrm{n} \mathrm{s}$ $26: 417$ (1907)

07d Notes on the spore-bearing organ Codonotheca and its relationship with the Cycadofilices. New Phytologist $6: 175-178$, il (1907)

os Administrative report Fla G S, An Rp 1:7-16 (1908); 2:13-19 (1909); 3: $9-15$ (1910); $4:$ xi-xvi $(1912) ; 5: 7-22$ (1913) ; $6: 9-19$ (1914) ; 7:5-12 (1915); $8: 5-18$ (1916) ; 10-11:4-7, 71-76 (1918)

Osa Sketch of the geology of Florida. Fla G S, An Rp 1: 17-25 (1908)

08b Mineral industries. Fla $G$ S, An Rp 1:26-53 (1908) ; $2: 235-251$ (1909); $4: 157-168$ (1912); $6: 21-114$ (1914) ; 7 : 13-24 (1915) ; $8: 19-37$ (1916) ; $9: 9-16$ (1917) ; 10-11:103-110 (1918)

ose Geological investigations in Florida previous to the organization of the present geological survey. Fla G S, An Rp 1:5472 (1908)

osd Bibliography of Florida geology. Fla G S, An Rp 1: 73-108 (1908)

ose A preliminary report on the underground water supply of central Florida. Fla G S, B 1: 103 pp (1908)

osf Fossil plants of the upper Paleozoic of Kansas. Kans Univ G S $9: 386-480$, il (1908) 
Sellards, Elias Howard-Continued.

Osg Cockroaches of the Kansas Coal Measures and of the Kansas Permian. Kans Univ G S 9:501-541, il (1908)

09 (and Gunter, H.) The fuller's earth deposits of Gadsden Co., Fla. Fla G S, An Rp 2: 253-291 (1909)

10 A preliminary paper on the Florida phosphate deposits. Fla G S, An Rp 3:1741 (1910)

10a Some Florida lakes and lake basins. Fla G S, An Rp 3:43-76 (1910)

10b (and Gunter, H.) The artesian water supply of eastern Florida. Fla G S, An Rp 3: 77-195 (1910)

11 Two new insects from the Permian of Texas. In Case, E. C., Revision of the Amphibia and Pisces of the Permian of North America (Carnegie Inst Wash, Pub no 146) : 149-152, il (1911)

11 a An intermittent spouting well. Science n \& $33: 37-38$ (1911)

$11 b$ The Florida phosphate deposits. Am Fertilizer 35 no 10:37-47 (1911)

11e (and Gunter, H., and Cox, N. H.) Roads and road materials of Florida. Fla G S, B 2:31 pp (1911)

12 The soils and other surface residual materials of Florida, their origin, charaeter, and the formations from which derived; a study in agrogeology. Fla G $\mathrm{S}$, An Rp 4:1-79, map (1912)

12a (and Gunter, H.) The underground water supply of west central and west Florida. Fla G S, An Rp 4: 81-155 (1912)

13 Classification of the soils of Florida. Fla, Dp Agr, 12th Bien Rp: 249-300 (1913)

13a Origin of the hard rock phosphates of Florida. Fla G S, 5th An Rp: 23-80, map (1913) Abst, G Soc Am, B 24:716717 (1913)

13b (and Gunter, H.) Artesian water supply of eastern and southern Florida. Fla G S, 5th An Rp: 103-290, map (1913)

14 Some Florida lakes and lake basins. Fla G S, An Rp 6:115-159 (1914)

14a The relation between the Dunnellon formation and the Alachua clays of Florida. Fla $G$ S, An Rp $6: 161-162$ (1914)

14b The origin, mining, and preparation of phosphate rock. Am I M Eng, B $93: 2379-2395 \quad(1914)$; Tr 50:901-916 (1915)

14e The phosphate deposits of the Southern States (abst). Science n s 39 : 401 (1914)

14d The production of fuller's earth in the Southern States $(a b s t)$. Science $n \mathrm{~s}$ 39: 402-403 (1914)

14e The development of some lake beds in Florida (abst). Science n s 39:404 (1914)
Sellards, Elias Howard-Continued.

15 The pebble phosphates of Flotide Fla G S, An Rp $7: 25-116$, il (1915)

15a Natural resources survey of $y$ area in central Florida; geology and mit eral resources. Fla G S, An Rp 7:121. 133 (1915)

$15 \mathrm{~b}$ A new gavial from the late Ter tiary of Florida. [Tomistoma americans] Am J Sc (4) 40:135-138 (1915)

15e Chlamytherium septentrionalis, \& edentate from the Pleistocene of Florich Am J Sc (4) 40:139-145 (1915)

15d Stratigraphic relations of the fost vertebrate localities of Florida (abst). Soc Am, B 26:154 (1915)

16 Fossil vertebrates from Florida: new Miocene fauna; new Pliocene species the Pleistocene fauna. Fla G S, An Bp \& $77-119$, il (1916)

16a Human remains and associated for sils from the Pleistocene of Florida. F G S, An Rp 8: 121-160, il (1916)

$16 \mathrm{~b}$ On the discovery of fossil humat remains in Florida in association with es tinct vertebrates. Am J Sc (4) 42:1-18 il (1916)

16e A new tortoise and a supplementary note on the gavial, Tomistoma americam [from Florida]. Am J Sc (4) $42: 235$ 240, il (1916)

16d Human remains from the Pleiste cene of Florida. Science n s 44:615-61! (1916)

16e Dead Lake of the Chipola Rive Fla. (abst). G Soc Am, B 27:109 (1916

17 Review of the evidence on which the human remains found at Vero, Fla., art referred to the Pleistocene. Fla G S, A Rp $9: 69-82$ and supplement: 141-14 (1917)

17a Geology between the Ocklocknee ad Aucilla rivers in Florida. Fla $G \mathrm{~S}$, An $B$ $9: 85-139$, maps (1917)

17b On the association of human if mains and extinct vertebrates at Vero, Fla J G 25: 4-24 (1917)

17e Note on the deposits containing br man remains and artifacts at Vero, Fls J G 25:659-660 (1917)

17d Further notes on human remaiss from Vero, Fla. Am Anthropologist D 19:239-251 (1917)

17e Fossil vertebrates from Florids (abst). G Soc Am, B 28: 214 (1917)

18 Tenth and eleventh annual reports Fla G S : 130 pp, Tallahassee 1918

18a (and Gunter, H.) Geology be tween the Apalachicola and Ocklocknet rivers in Florida. Fla $\mathbf{G} S$, An Rp 10-11 9-56, map (1918)

18b The skull of a Pleistocene tapir it cluding description of a new species and 1 note on the associated fauna and flora. Fit G S, An Rp 10-11:57-70, il (1918 
Sellards, Elias Howard - Continued.

18e (and Gunter, H.) Geology between the Choctawhatchee and Apalachicola rivers in Florida. Fla G S, An Rp 10-11: 77-102, map (1918)

See also Berry, $17 \mathrm{~g}$

Sellier, L. M.

15 Preliminary [geologic] map of Kentucky. Scale 1 inch to 10 miles. Ky G S 1915. Another issue 1917

Selwyn, Alfred Richard Cecil (18241902).

72 Summary report of geological investigations. Can G S, Rp Prog 1870-1: $1-12$ (1872) ; ... 1871-2:11-15 (1872) ; ... 1872-3:1-7 (1873); ... 1873-4:1-9 (1874); ... 1874-5:1-23 (1876); ... $1875-6: 1-27 \quad(1877) ; \quad \ldots \quad 1876-7: 1-8$ (1878)

72a Notes and observation on the gold fields of Quebec and Nova Scotia. Can G S, Rp Prog 1870-1 : 252-282 (1872)

72b Journal and report of preliminary explorations in British Columbia. Can G S Rp Prog 1871-2: 16-72 (1872)

72e on the discovery of reptilian footprints in Nova Scotia. G Mag 9:250-251 (1872)

73 On a preliminary geological reconnaissance from Lake Superior by the English and Winnipeg rivers to Fort Garry. Can G S, Rp Prog 1872-3: 8-18 (1873)

73a Report upon the Acadia iron ore deposits of Londonderry, Colchester Co., N. S. Can G S, Rp Prog 1872-3:19-31 (1873)

$\mathbf{7 4}$ Observations in the Northwest Territory on a journey across the plains from Fort Garry to Rocky Mountain House, returning by the Saskatchewan River and Lake Winnipeg [with a memorandum on western coals, fron ore, etc., by B. J. Harrington]. Can G S, Rp Prog 1873-4:1762 (1874)

74a Notes on a journey through the Northwest Territory from Manitoba to Rocky Mountain House. Can Nat n 8 : $193-216(1874)$

75 Age of the lignitic coal formation of Vancouver Island. Am J Sc (3) $9: 318$ (1875)

76 Huronian of Canada. Am J Sc (3) $12: 461$ (1876)

77 Report on exploration in British Columbia. Can G S, Rp Prog 1875-6: 28-86, map (1877)

77a Boring made on Swan River, near Fort Pelly, in 1875 , Can G S, Rp Prog $1875-6: 292-293$ (1877)

79 Summary report of the operations of the geological corps to 31 st December 1878 . Can G S, Rp Prog 1877-8:1-9 (1879) ; ... 1879, Rp Prog 1878-9:1-6 (1880); ... 1880, Rp Prog 1879-80:1-9 (1881); .. 1881 and 1882 , Rp Prog 1880-2:1-29 (1883); ... 1883, Rp Prog 1882-4:1-28 (1885)
Selwyn, Alfred Richard Cecil-Continued.

79a Report of observations on the stratigraphy of the Quebec group and the older crystalline rocks of Canada. Can $G$ $\mathrm{S}, \mathrm{Rp}$ Prog 1877-8: $\mathrm{s} 15$ pp (1879)

79b The stratigraphy of the Quebec group and the older crystalline rocks of Canada. Can Nat n s 9:17-31 (1879)

81 Report on boring operations in the Souris River valley [Saskatchewan]. Can G S, Rp Prog 1879-80: A 1-11 (1881)

82 On the geology of the Ottawa Paleozoic basin. Ottawa Field Nat Club, $\mathrm{Tr}$ no $3: 34-39$ (1882)

83 Notes on the geology of the southeastern portion of the Province of Quebec. Can G S, Rp Prog 1880-2: A 1-7 (1883)

s3a Geological nomenclature and the coloring and notation of geological maps. Can G S, Rp Prog 1880-2: A 47-51 (1883)

s3b The Quebec group in geology. R Soc Can. Pr Tr 1, iv: 1-13 (1883)

83e On the geology of Lake Superior. R Soc Can, $\operatorname{Pr} \operatorname{Tr} 1$ iv: 117-122 (1883) Abst, Can Rec N H 1: 12 (1884)

83d Age of the rocks on the northern shore of Lake Superior. Science 1:11, 221 (1883)

St (and Dawson, G. M.) Descriptive sketch of the physical geography and geology of the Dominion of Canada. [Can G S] : $55 \mathrm{pp}$, Montreal 1884 [To accompany] Map of the Dominion of Canada, geologically colored... Scale, 40 miles to 1 inch

85 Summary report of the operations of the Geological Survey for the years 1884 and 1885. Can G S, An Rp n s 1: A 1-108 (1885) ;... for the year 1886, An Rp n s $2:$ A 1-87 (1887) ;... for the years 1887 and 1888, An Rp n s 3: A 1-117 (1888); ;... for the years 1888 and 1889 , An Rp n s 4: A $1-66(1890) ; \ldots$ for the year 1891 , An Rp n s 5: A 3-92 (1892);... for the year 1892, An Rp n s 6: A 1-95 (1893);... for the year 1893, An Rp n s 6: A 3-98 (1894) [also issued separately].

85a Notes on observations, 1883, on the geology of the north shore of Lake Superior (abst). R Soc Can, Pr Tr 2, iv : 245 (1885)

s5b On the glacial origin of lake basins (abst). Brit As, Rp 54: 721-722 (1885)

87 The Quebec group. Science $9: 267-$ 268 (1887)

88 The Huronian of Canada. Am G 2 : 61-62 (1888)

88a [The Taconic question]. Am G 2: 134-135 (1888)

s8b On new facts relating to Eozoon canadense. Science 11:146 (1888)

89 "Two systems confounded in the Huronian." Am G $3: 339-340$ (1889) 
Selwyn, Alfred Richard Cecil-Continued. S9a Canadian geological classification for the Province of Quebec, by Jules Marcou. Boston Soc N H, Pr 24:216-218 (1889)

90 Tracks of organic origin in rocks of the Animikie group. Am J Sc (3) 39: 145-147 (1890)

90a The geology of Quebec City. Science $16: 359$ (1890)

92 Geological age of the Saganaga syenite. Am J Sc (3) $43: 319-322$ (1892)

94 Volcanic rocks in the Keewatin. Science 23: 107-108 (1894)

97 Gold quartz jining in Canada and Victoria, Australia (with diseussion). Fed Can M Inst, J 2: 29-41 (1897)

See also Ami, 91 ; Canada Geol. Survey, 76 ; Frazer, $88 a$

Selwyn-Brown, Arthur.

os Mining developments in Nevada. Eng Mag 34:643-651 (1908)

OSa The Nevada copper fields. Eng Mag $34: 763-780$ (1908)

16 Fuel oil from shale. Eng Mag 50: 913-920 (1916)

Semmes, Douglas Ramsay.

16 Field work in the San Juan district, Porto Rico (abst). N Y Ac Sc, An 26 : 433-434 (1916)

17 Geology of the San Juan district, Porto Rico (abst). N Y Ae Sc, An 27 : 279-280 (1917)

Servin, Roberto.

17 Informe sobre el mineral de Sierra del Carmen de la municipalidad de Ocampo, distrito de Monclova, Estado de Coahuila [Mexico]. Bol Minero 3: 97-101 (1917)

Sewell, Henry De Q.

06 Is belief in a glacial period justifled? Can Inst, $\operatorname{Tr} 8: 279-289$ (1906)

Seybert, Henry.

30 Tennessee meteorite [analysis]. Am $J$ Sc 17:326-328 (1830)

Seymour, E.

68 List of minerals in New Jersey. N J G S, G N J : 743-750 (1868)

Seyms, George $H$.

76 On the relation of franklinite to the spinel group of minerals. Am $\mathrm{J}$ Sc (3) $12: 210-212$ (1876)

Shaaf, Albert.

01 (with Price, J. A.) Spy Run and Poinsett Lake bottoms [near Fort Wayne, Ind.]. Ind Ac Sc. Pr. $1900: 179-181$ (1901)

O1a (with Price, J. A.) Abandoned meanders of Spy Run Creek [Allen Co., Ind. ]. Ind Ac Sc, $\operatorname{Pr} 1900: 181-184$, map (1901)

Shalex, Millard King.

05 (with Tafr, J. A.) Notes on the geology of the Muscogee oil fields, Ind. T. U S G S, B 260:441-445, map (1905)

o7 Gypsum in northwestern New Mexico. U S G S, B 315: 260-265 (1907)
Shaler, Millard King-Continued.

o7a (and Gardner, J. H.) Clay a posits of the western 1 art of the Durans Gallup coal field of Colorado and Ner Mexico. U S G S, B $315: 296-302$ (190:

orb A reconnaissance survey of th western part of the Durango-Gallup col field of Colorado and New Mexico, U \& 6 S, B $316: 376-426$ (1907)

Shaler, Nathaniel Southgate (1841-1906). 62 On the geology of Antlcostl Islani in the Gulf of St. Lawrence. Boston \& N H, Pr 8: 285-287 (1862)

65 List of the Brachiopoda from the Island of Anticosti... Harvard Coll, Ifs C Z, B 1: 61-70 (1865)

66 Preliminary notice of some opinios concerning the elevation of continentil masses. Boston Soc N H, Pr 10:237-25 (1866)

66a Notes on the modiffeations of oceanic currents in successive geologial periods. Boston Soc N H, Pr 10:296-3ic (1866)

66b On the formation of the excavate lake basins of New England. Boston S $\mathrm{N} H, \operatorname{Pr} 10: 358-364$ (1866)

66e $\mathrm{On}_{\mathrm{n}}$ the formation of mountain chains. Boston Soc N H, Pr 11:8-15 (1866) G Mag 5:511-517 (1868)

66d Notes on the position and charas ter of some glacial beds containing fosdis at Gloucester, Mass. Boston Soc N B. Pr 11: 27-30 (1866)

68 On the nature of the movements in volved in the changes of level of shore lines. Boston Soc $\mathrm{N}$ H, Pr 12:128-136 (1868)

$68 \mathrm{a}$ [On the absence of distinct erf dences of glacial action in the Yukon Tatley, Alaska.] Boston Soe N H, Pr 12: 145-149 (1868)

69 Notes on the concentric structure of granitic rocks. Boston Soc N H, Pr 12: 289-293 (1869)

69a Note on the occurrence of the rtmains of Tarandus rangifer Gray at Big Bone Lick in Kentucky. Boston Soc N H, Pr 18: 167 (1869)

691 On the relations of the rocks in the vicinity of Boston [with discussion by C. T. Jackson]. Boston Soc N H, Pr 13: 172-177 (1869)

69e Earthquakes. Atlantic Monthly 2?: 676-685 (1869)

69d Earthquakes of the American continents. Atlantic Monthly 24:461-46? (1869)

69e Earthquakes of the western Unitel States. Atlantic Monthly 24:549-55. (1869)

70 On the parallel ridges of glacial dritt in eastern Massachusetts, with some re marks on the glacial period. Boston sor $\mathrm{N} H, \operatorname{Pr} 13: 196-204(1870)$ G Mag 8: $27-28$ (1871) 
Shaler, Nathaniel Southgate-Continued.

70a On the phosphate beds of South Carolina. Boston Soc N H, Pr 13:222236 (1870)

$70 \mathrm{~b}$ Note on the glacial moraines of the Charles River Valley near Watertown [Mass.] (with discussion by W. H. Niles). Boston Soc N H, Pr 13: 277-279 (1870)

70e The time of the mammoths. Am Nat 4:148-166 (1870)

70d California earthquakes. Atlantic Monthly 25:351-360 (1870)

71 On the causes which have led to the production of Cape Hatteras (with discussion by C. T. Jackson, J. B. Perry, W. H. Niles, and A. Hyatt). Boston Soc N H, Pr 14:110-121 (1871) Am Nat 5:178183 (1871) [with different title]

72 On the geology of the Island of Aquidneck and the neighboring parts of the shores of Narrangansett Bay. Am Nat 6: $518-528,611-621,751-760$ (1872)

$73 \mathrm{Cn}$ the phosphate beds of South Carolina. U. S. Coast S, Rp 1870 (U S, 41st Cong 3d sess, H Ex Doc 112) : 182-189 (1873)

$73 a$ On the geology of the region about Richmond, Va. Am Ac Arts, Pr 8:307$308(1973)$

74 General report of the geological surrey of Kentucky : plan for the conduct of the survey. 26 pp [1874]

74a Preliminary report on the recent changes of level on the coast of Maine; with reference to their origin and relation to other similar changes. Boston Soc N H, Mem 2:320-340 (1874)

75 Remarks on the geology of the coast of Maine, New Hampshire, and that part of Massachusetts north of Boston. U S Coast S, Coast Pilot for the Atlantic Seaboard, Gulf of Maine and its coast from Eastport to Boston, 1874; 883-888, Washington 1875

$75 a$ Notes on some of the phenomenn of elevation and subsidence of the continents. Boston Soc N H, Pr $17: 288-292$ (1875)

$75 b$ Some considerations on the possible means whereby a warm climate may be pro. duced within the Arctic circle. Boston Soc $\mathrm{N} \mathrm{H}, \operatorname{Pr} 17: 332-337$ (1875)

75e Propositions concerning the motion of continental glaciers. Boston soc $\mathrm{N} \mathrm{H}$, Pr 18: 126-133 (1875)

75d Notes on the cause and geological value of variation in rainfall. Boston Soc $\mathrm{N} \mathrm{H}, \operatorname{Pr} 18: 176-182$ (1875)

75e Note on some points connected with tidal erosion. Boston Soc N H, Pr 17: $465-466$ (1875)

75f Note on the geological relations of Boston and Narragansett bays. Boston Soc N H, Pr 17: 488-490 (1875)
Shaler, Nathaniel Southgate-Continued,

76 On the antiquity of the caverns and cavern life of the Ohio Valley. Ky G S, Mem 1 pt 1:13 pp (1876)

76a On the fossil brachiopods of the Ohio Valley. Ky G S, Mem 1 pt $3: 44$ pp, i] (1876)

76b A general account of the common. wealth of Kentucky; prepared by the [Kentucky] Geological Survey of the commonwealth for the Centennial Exhibition at Philadelphia, 1876. 104 pp, maps, Cambridge 1876 Also in Ky G S, Rp Prog 2 n s : 361-468, maps (1877)

76e The Harvard summer school of geology. Am Nat 10:29-31 (1876)

76d (with Carr, L.) On the prehistoric remains of Kentucky. Ky G S, Mem 1 pt 4: $31 \mathrm{pp}$, $1 \mathrm{l}$, Cambridge 1876

77 On the origin of the galena deposits of the upper Cambrian rocks of Kentucky. Ky G S, Rp Prog 2 n s: 277-329 (1877)

77a General report...[1873-1877]. Ky G S, Rp Prog 3 n s : 451 pp, maps (1877)

$\mathbf{7 7 b}$ General report of the geological survey of Kentucky. Ky G S, Rp Prog 3 n s : $1-30$ (1877)

77e History of the operations of the survey in 1874 and 1875 . Ky G S, Rp Prog 3 n s : $31-127$ (1877)

$\mathbf{7 7 d}$ Notes on the investigations of the Kentucky geological survey during the years 1873,1874 , and 1875 . Ky G S, Rp Prog 3 n s: 129-282 (1877)

77 e Annual report for the year $1876 ; \ldots$ 1877. Ky G S, Rp Prog 3 n s: $283-315$, $365-414(1877)$

77f Notes on the age and the structure of the several mountain axes in the neighborhood of Cumberland Gap. Am Nat 11: $385-392$ (1877)

$77 \mathrm{~g}$ On the existence of the Alleghany division of the Appalachian Range within the Hudson Valley. Am Nat 11:627-62s (1877)

77h On the occurrence of the genus Beatricea in Kentucky. Am Nat 11:628 (1877)

77i How to change the North American climate. Atlantic Monthly 40:724-731 (1877)

79 Petroleum. Ky G S, B 1:5-12 [1879?]

79a Notes on certain evidences of a gradual passage from sedimentary to voleanic rocks shown in the Brighton district of Boston. Boston Soc N H, Pr 20:129133 (1879)

so Summary of the work of the geological survey for the years 1878-9. Ky G S : $16 \mathrm{pp} \mathrm{[1880]}$

Son Propositions concerning the classification of lavas, considered with reference to the circumstances of their extrusion. Boston Soc N H, Anniv Mem : 15 pp (1880) 
Shaler, Nathaniel Southgate-Continued.

sob Notes on the submarine coast shelf or hundred fathom detrital fringe. Boston Soc N H, Pr 20:278-282 (1880)

soe Outline of the geology of Boston and its environs. In Winsor, Justin, The memorial history of Boston...: 1-8, Boston 1880

S1 (and Davis, W. M.) Illustrations of the earth's surface; Glaciers. $198 \mathrm{pp}$, Boston $1881 \mathrm{Rv}$, by W J McGee, Science (ed Michels) 2: 581-584, 624-630 (1881)

$81 \mathrm{a}$ On the recent advances and recessions of glaciers. Boston Soc N H, Pr 21 : 162-167 (1881)

81b Great Kanawha, W. Va., iron ores and coals. The Virginias 2:154-155 (1881)

84 A first book in geology... xvii, 255, $73 \mathrm{pp}$, Boston 1884 2d ed, - pp, Boston 1897 [not seen]

$\mathbf{8 4 a}$ General report on the building stones of Rhode Island, Massachusetts, and Maine. U S, 10th Census 10, Report on Building Stones: 107-115 (1884)

84b On the origin of kames. Boston Soc N H, Pr $23: 36-44$ (1884)

84e Physiography of North America. In Winsor, Justin, Narrative and eritical history of America, Vol. 4: i-xxx (1884)

s5 Sea coast swamps of the eastern United States. U S G S, An Rp 6:353398 (1885)

$85 a$ On the age of the Ely cave [Lee Co., Va.]. Harvard Coll, Mus C Z, Mem 10 no $2: 9-13$ (1885)

86 ...geology of the Cobscook Bay district, Me. Am J Sc (3) 32:35-60 (1886)

$86 a$ The swamps of the United States. Science $7: 232-233$ (1886)

86b Mica mines of New England. U S, 10th Census 15: 833-836 (1886)

86e (and others) A series of twentyfive colored geological models and twentyfive photographs of important geological objects, each accompanied by letter-press description. Boston 1886 [D. C. Heath \& Co.] [not seen]

87 Fluviatile swamps of New England. Am J Sc (3) $33: 210-221$ (1887)

$\mathbf{8 7 a}$ On the original connection of the eastern and western coal fields of the Ohio Valley. Harvard Coll, Mus C Z, Mem 16 no $2: 11 \mathrm{pp} \mathrm{(1887)}$

$\mathbf{8 7 b}$ The stability of the earth. Scribner's Mag 1 : 259-279 (1887)

$\mathbf{8 7 e}$ Caverns and cavern life. Scribner's Mag 2:449-472 (1887)

87d The natural-gas supply. The Forum 3: 305-312 (1887)

88 Report on the geology of Marthas Vineyard [Mass]. U S G S, An Rp 7 : 297363, maps (1888)

88a On the geology of the Cambrian district of Bristol Co., Mass. Harvard Coll, Mus C Z, B 16 ( g s 2) : 13-26, map (1888)
Shaler, Nathaniel Southgate-Continued $88 b$ (and Foerste, A. F.) Preliminer description of North Attleboro fosit [Cambrian, Massachusetts]. Harvard Col M C Z, B 16 (g \& 2) : 27-41, il (1888)

88e Origin of the divisions between th layers of stratified rocks. Boston Soe X B Pr 23: 408-419 (1888)

88d Animal agency in soil making. Pu Sc Mo 32:484-487 (1888)

88e Volcanoes. Scribner's Mag 3:201. 226 (1888)

88R Rivers and valleys. Scribner's $\frac{1}{4}$, $4: 131-155$ (1888)

$88 \mathrm{~g}$. The crenitic hypothesis and mow tain bullding. Science 11:280-281 (1889)

89 Aspects of the earth; a popular s. count of some familiar geological pbt nomena. $344 \mathrm{pp}, \mathrm{N}$ Y 1889

89a The geology of the Island of Mount Desert, Me. U S G S, An Rp 8: 987-1061, map (1889)

89b The geology of Cape Ann, Mass. S G S, An Rp 9:529-611, maps (1889)

89e The geology of Nantucket. U \& G S, B 53:55 pp, map (1889)

s9d On the occurrence of fossils of the Cretaceous age on the island of Marths vineyard, Mass. Harvard Coll, Mus C 2 B $16(\mathrm{~g} s 2): 89-97$, il (1889)

s9e The work of underground wate: Chautauquan 10:276-280 (1889)

90 General account of the fresh-wate morasses of the United States, with a de scription of the Dismal Swamp district of Virginia and North Carolina. U S \& \& An Rp 10, pt 1:255-339, map (1890)

90a The topography of Florida (with note by Alexander Agassiz). Harvat Coll, Mus C Z, B 16 (g s 2): 139-158 (1890)

90b Tertiary and Cretaceous deposits of eastern Massachusetts. $G$ Soc Am, B 1: 443-452 (1890) Abst, Science 15:10 (1890); $\Delta \mathrm{m}$ G $5: 118$ (1890); Am Nat $24: 210(1890)$

$90 \mathrm{e}$ Note on glacial climate (with dis. cussion by Warren Upham and W. 0. Crosby). Boston Soc N H 24:460-46i (1890)

90d Note on the value of saliferous de posits as evidence of former climatal con. ditions. Boston Soc N H, Pr 24:580-585 (1890)

90e The action of glaciers. Chautal. quan $10: 405-409$ (1890)

91 Origin and nature of soils. U S G \&, An Rp 12 pt 1 : 213-345 (1891)

91 The antlquity of the last glacial period. Boston Soc N $\cdot \mathrm{H}, \operatorname{Pr} 25: 258-267$ (1891)

92 The story of our continent, a readet in the geography and geology of North America... $290 \mathrm{pp}$, Boston 1892 . 2d $\mathrm{d}$, Boston 1987 
Shaler, Nathaniel Southgate Continued. 93 The geological history of harbors. U S G S, An Rp 13 pt 2:93-209 (1893)

93a The conditions of erosion beneath deep glaciers, based upon a study of the boulder train from Iron Hill, Cumberland, R. I. Harvard Coll, Mus C Z, B 16 (g s 2) : 185-225, map (1893)

93b Antiquity of man in eastern North Ameriea. Am G 11: 180-184 (1893)

93e The geology of Niagara Falls. In Howells, W. D. [and others], The Niagara book: $65-92$, Buffal, 1893

93d What is geology? Chautauquan 18 : 284-287 (1893)

94 Sea and land; features of coasts and oceans with special reference to the life of man. $252 \mathrm{pp}, \mathrm{N}$ Y 1894

94a Pleistocene distortions of the Atlantic coast. G Soc Am, B 5:199-202 (1894) Abst, Am G 13:143-144 (1894); Am J Sc (3) $47: 138$ (1894)

94b Relation of mountain growth to formation of continents. G Soc Am, B 5: 203-206 (1894) Abst, Am G 13:144 (1894); Am J Sc (3) 47:138-139 (1894)

94e Phenomena of beach and dune sands. G Soc Am, B 5:207-212 (1894) Abst, Am G 13: 144-145 (1894) ; Am J Se (3) $47: 139$ (1894)

94d On the distribution of earthquakes in the United States since the close of the glacial period. Boston Soc $\mathrm{N} \mathrm{H}, \operatorname{Pr} 26$ : 246-256 (1894)

94e The value of geological science to man. Chautauquan 20:170-174 (1894)

94f Tertiary dislocations of the Atlantic Coast of the United States (abst). Am G 13: 143-144 (1894)

95 Preliminary report on the geology of the common roads of the United States. U S G S, An Rp 15: 255-306 (1895)

95a The geology of the road-bullding stoves of Massachusetts with some consideration of similar materials from other parts of the United States. U S G S, An Rp 16 pt 2: 277-341 (1895)

$\mathbf{9 5 b}$ Origin, distribution and commercial value of peat deposits. U S G S, An Rp 16 pt $4: 305-314$ (1895)

95e Evidences as to change of sea level. G Soc Am, B $6: 141-166$ (1895)

95d Beaches and tidal marshes of the Atlantic coast. Nat Geog Soc, Nat Geog Mon 1 no 5: 137-168 (1895) Also in The physiography of the United States (Nat Geog Soc) : 137-168, N Y, American Book Co., 1896

95e On certain peculiar features in the jointing and veining of the Lower Silurian limestones near Cumberland Gap, Tenn. (abst). Science n s $1: 58$ (1895)

05f Some causes of the imperfection of the geologic record (abst). Science $n$ s 2 : 858-859 (1895)
Shaler, Nathaniel Southgate Continued.

96 (and Woodworth, J. B., and Marbut, C. F.) The glacial brick clays of Rhode Island and southeastern Massachusetts. U S G S, An Rp 17 pt 1: 951-1004 (1896)

96a Relations of geologic science to education. G Soc Am, B 7:315-326 (1896) Science n s 3:609-617 (1896)

$96 \mathbf{b}$ Conditions and effects of the expulsion of gases from the earth. Boston Soc N H, Pr 27:89-106 (1896) Abst, Am G $16: 244-245$ (1895); Science n $\mathrm{s} 2: 281$ (1895)

96e The economic aspects of soil erosion. Nat Geog Mag $7: 328-338,368-377$ (1896)

96d The share of volcanic dust and pumice in marine deposits (abst). G Soc Am, B $7: 490-492$ (1896) Am G 17:93 (1896) Science n s 3:48-49 (1896)

97 Subterranean water of southeastern New England $(a b s t)$. Science n s 5:703 (1897)

98 Outlines of the earth's history... 417 pp, N Y 1898

98a Geology of the Cape Cod district, U S G S, An Rp 18 pt 2: 497-593 (1898)

$98 b$ On the origin of drumlins (abst). Brit As, Rp 67:654 (1898)

99 (and woodworth, J. B., and Foerste, A. F.) Geology of the Narragansett Basin. U S G S, Mon 33:402 pp, maps (1899)

$99 a$ (and woodworth, J. B.) Geology of the Richmond Basin, Virginia. U S G S, An Rp 19 pt 2: 385-515, maps (1899) 99 b Loess deposits of Montana. G Soc Am, B 10:245-252 (1899)

99e Formation of dikes and veins. G Soc Am, B 10:253-262 (1899)

99d Spacing of rivers with reference to hypothesis of base-leveling. G Soc Am, B $10: 263-276$ (1899)

99e Dikes and veins $(a b s t)$. Science n s 9: 33 (1899)

01 Broad valleys of the Cordilleras. G Soc Am, B 12:271-300 (1901)

03 A comparison of the features of the earth and moon. Smiths Contr Knowl 34 art 1 (1438) : $130 \mathrm{pp} \mathrm{(1903)}$

05 Man and the earth. $240 \mathrm{pp}$, N Y 1905

09 The autobiography of Nathaniel Southgate Shaler, with a supplementary memoir by his wife. 481 pp, port, Boston 1909

See also Agassiz (L), 72; Chamberlin, 91c ; Hawes, 84 ; Hollick, 941 ; Niles, $72 \mathrm{a}$; Penrose, 88; Powell, 85, 85a, 88, 89, 89a, $90,91,91 \mathrm{a}, 92,93,95$; Russell, 90 ; Tyrrell, $90 \mathrm{a}$

Shamel, Charles $\mathrm{H}$.

or Do the geological relations of ore deposits justify the retention of the law of the apex? Ec G 2:62-77 (1907) 
Shamel, Charles H.-Continued.

o7a Mining, mineral, and geological law. $627 \mathrm{pp}, \mathrm{N}$ Y 1907

Shand, S, J

16 A recording micrometer for geometrical rock analysis. J G 24:394-404 (1916)

Shannon, Charles William.

07 The drainage area of the east fork of White River [Ind.]. Ind $\mathrm{Ac} \mathrm{Sc}, \mathrm{Pr}$ 1906 : 53-70 (1907)

07 a The iron-ore deposits of Indiana. Ind $\mathrm{Dp} \mathrm{G}, 31 \mathrm{st} \mathrm{An} \mathrm{Rp}: 299-428$ (1907)

O7b (with Beede, J. W.) [Iron ores of] Martin Co. [Ind.]. Ind D G, 31st An Rp : 383-424 (1907)

os (and others) A soll survey of seven teen counties of southern Indiana. Ind $D p$ G, 32d An Rp : 15-298, maps (1908)

09 Soll survey of Dubois, Perry, and Crawford cos., Ind. Ind $\mathrm{Dp} G, 33 d \mathrm{An} R \mathrm{R}$ : 277-342 (1909)

12 Results of glaciation in Indiana. Ind Ac Sc, Pr 1911 : 173-196 (1912)

12a The sand areas of Indiana. Ind $\mathrm{Ac}$ Sc, Pr 1911: 197-210 (1912)

12b Soll survey of Clay, Knox, Sullivan, and Vigo cos. Ind Dp G, 36th An Rp:135280, maps (1912)

14 Director's biennial report to the governor of Oklahoma, 1914; Mineral resources of Oklahoma and statistics of production from 1901 to 1914 . Oklahoma G S, B $22: 142 \mathrm{pp}$, maps (1914)

15 (and Trout, L. E.) Petroleum and natural gas in Oklahoma; Part I, General information concerning oil and gas; geology of Oklahoma. Okla G S, B 19:133 pp (1915)

16 Handbook on the natural resources of Oklahoma. Okla G S : 96 pp (1916)

17 (and others) Petroleum and natural gas in Oklahoma, Part II ; A discussion of the oil and gas fields, and undeveloped areas of the State, by counties. Okla G S, B $19: 537$ pp, maps (1917)

Shannon, Earl Victor.

13 Secondary enrichment in the Caledonia mine, Cœur d'Alene district, Idaho. Ec G 8:565-570 (1913)

13a On a supposed new occurrence of plattnerite in the Cour d'Alene. Am J Sc (4) $36: 427-428$ (1913)

17 Crystals of pyromorphite. Am J Sc (4) $43: 325-327$ (1917)

17a Famatinite from Goldfield, Nev. Am $J$ Sc (4) $44: 469-470$ (1917)

$17 \mathbf{b}$ Notes on unusual masses of plattnerite. Am Mineralogist 2:15-17 (1917)

17e Epiboulangerite from Montana. Am Mineralogist 2:131-132 (1917)

18 On mullanite, a new member of the Jamesonite group from two localities. Am $\mathrm{J} \mathrm{Sc}$ (4) 45:66-70 (1918)

$18 \mathrm{a}$ On the occurrence of llvaite in the South Mountain district, Owybee County, Idaho. Am J Sc (4) 45:118-125 (1918)
Shanuon, Earl Victor-Confinued, 1sh Some minerals from the Stanle antimony mine, Idaho. Am Mineralogist $3: 23-27$ (1918)

Shannon, W. P.

95 Wave marks on Cincinnati limestone Ind Ac Sc, $\mathrm{Pr} 1894: 53-54$ (1895)

Sharp, Benjamin.

90 An account of the Vincelonian rot eano [St. Vincent, W. I.]. Ac N Sc Pblla Pr 1890: 289-295

98 (with Pilsbry, H. A.) Seaphopods of the San Domingo Tertiary. Ac N \&e Phila, Pr 1897: 465-476, il (1898)

Sharpe, Daniel.

48 Report on the fossil remains of $\mathrm{Mnl}$ lusca from the Paleozoic formations of the United States contained in the collection of Charles Lyell, Esq., with remarks on the comparison of the North American forms. tion with those of Europe. G Soc London, Q J 4:145-181 (1848)

Sharples, B. $P$.

69 On some minerals from Newlin town. ship, Chester Co., Pa,.. Am J Sc (2) $47 ; 319-321$ (1869)

71 On some rocks and other dredgings from the Gulf stream. Am J Sc (3) 1: 168-171 (1871)

Sharpless, F, F.

91 (with Lane, A. C.) Notes on Micht gan minerals. Am J Sc (3) 42:499-508 (1891)

Sharvood, William J.

04 (with Eakle, A. S.) Luminescent zinc blende [Mariposa Co., Cal.]. Eng M J 77:1000 (1904)

07 Some associations of gold with pyrite and tellurides. M Sc Press 94:117119 (1907)

07a Gold tellurides. M Sci Press 94: 731-732 (1907)

os (with Louderback, G. D.) Cro. cidolite-bearing rocks of the Californis coast ranges $(a b s t)$. G Soc Am, B 19:659 1908.

11 Notes on tellurium-bearing gold ores Ee G 6:22-36 (1911)

11 a Analyses of some rocks and minerals from the Homestake mine, Lead, S. Dak. Ec G 6:729-789 (1911)

12 The specific gravity of mixtures (discussion). Ec G 7:588-590 (1912)

Shattuek, C. H.

o5 A fossil forest in Jackson Co. [Kans.]. Kans Ac Sc, Tr 19:107-109 (1905)

Shattuck, George Burbank.

95 Preliminary discussion of the geol. ogy of the Bordentown sheet of the geologic atlas of the United States. Johns Hopkins Univ Cire 15:14-15 (1895)

97 (with Clark, W. B.) The geology of the Sand Hills [Middlesex Co.], of New Jersey. Johns Hopkins Univ Circ 16: 13-16, map (1897) 
Shattuck, George Burbank-Continued.

98 Two excursions with geological students into the Coastal Plain of Maryland. Joln Hopkins Univ Circ 18: 15-16 (1898)

01 The Pleistocene problem of the North Atlantic Coastal Plain. Johns Hopkins Univ Circ 20:69-75 (1901) Am G 28: 87-107 (1901)

01a Apparent unconformities during periods of continuous sedimentation (abst). Science n \& $13: 99-100$ (1901)

02 Development of knowledge concerning the physical features of Cecil County, with bibliography; the physiography of Cecil County; the geology of the Coastal Plain formations. Md G S Cecil Co : 31 $62,63-82, \quad 149-194$ (1902)

02a The Miocene problem of Maryland (abst). Science n \& $15: 906$ (1902)

02b The Pleistocene problem in Maryland $(a b s t)$. Science $n \quad s \quad 15: 906-907$ (1902)

03 The Mollusca of the Buda limestone. U S G S, B 205: $94 \mathrm{pp}$, map, il (1903)

04 Meeting of section $\mathrm{E}$ of the American Association for the Advancement of Science and of the Geological Society of America. Science n \& $19: 521-533$ (1904)

04a (with Clark, W. B., and Dall, W. H.) The Miocene deposits of Maryland. Md G S, Miocene : xxi-clv, map (1904)

05 (and Miller, B. L.) Physiography and geolcgy of the Bahama Islands. In The Bahama Islands, edited by G. B. Sbattuck: 3-20, N Y 1905

06 The Pliocene and Pleistocene deposits of Maryland. Md G S, Pliocene and Pleistocene : 21-137, m (1906)

06a Description of the St. Marys quadrangle [Md.-Va.]. U S G S, G Atlas St. Marys fol (no 136) : 7 pp, maps (1906)

07 Development of knowledge concerning the principal features of Calvert Co. with biblography; the physiography and geology of Calvert Co. Md G S, Calvert Co: 25-121, maps (1907)

07a Development of knowledge concerning the physical features of St. Mary's Co., with bibliography; the physiography and geology of St. Mary's Co. Md G S, St. Mary's Co: 25-112, maps (1907)

07b Some geological rambles, near Vas. sar College, Poughkeepsie [N. Y.] 108 pp, Poughkeepsie 1907

07e (and Miller, B, L., and Bibbins, A.) Description of the Patuxent quadrangle [Md.-D, C.]. U S G S, G Atlas Patuxent fol (no 152) : 12 pp. maps (1907)

09 Concentration versus transportation : a need of accurate measurements of stream work. J Geog 7:158-163 (1909)

See also Clark (W B), 04

Shaw, A, H,

12 The Arkansas semi-anthracite field. Coal Age 2:486-488 (1912)
Shaw, E. S.

11 Structure of Goldfield ores [Nev.]. Eng M J 91:714 (1911)

Shaw, Eugene Wesley.

09 The Glenrock coal field, Wyo. U S G S, B 341: 151-164, map (1909)

10 Gravel and sand in the Pittsburg dis. trict, Pa. U S G S, B $430: 388-399$ (1910)

10a The geology and coal resources of the Murphysboro quadrangle, Ill. Ill $\mathrm{G} \mathbf{S}$, B 16:286-294, map (1910)

11 High terraces and abandoned valleys in western Pennsylvania. J G 19:140156 (1911) Abst, Science n $\mathrm{s} \quad 32: 126$ (1910)

I1a Clay resources of the Murphysboro quadrangle, III. U S G S, B 470:297-301 (1911)

$11 b$ (and Munn, M. J.) Coal, oil, and gas of the Foxburg quadrangle, Pa. U S G S. B $454: 85 \mathrm{pp}, \operatorname{map}$ (1911)

11e Preliminary statement concerning a new system of Quaternary lakes in the Mississippi basin. J G $19: 481-491$ (1911) Abst, Wash Ac Sc, J $1:$ 141-142 (1911); G Soc Am, B 22: 732-733 (1911)

$11 d$ Description of the Burgettstor: $n$ and Carnegie quadrangles, Pn. U S G S, G Atlas Burgettstown-Carnegie fol (no 177): $16 \mathrm{pp}$, maps (1911)

11e (and rines, E. F., and Munn, M. J.) Description of the Foxburg and Clarion quadrangles. Pa. U S G S, G Atlas Foxburg-Clarion fol (no 178) :17 pp, maps (1911)

$11 f$ The Murphysboro quadrangle, III. M World 34:695-696 (1911)

$11 \mathrm{~g}$ The infertility of southern Illinois (abst). As Am Geog An 1:137 (1911)

$11 \mathrm{~h}$ Geography and geology of the Dismal Swamp (abst). Science n s $33: 910$ (1911)

11 i [On the Maquoketa formation.] (abst). Wash Ac Sc, J 1:293 (1911)

$11 j$ Sketch of the local geology, City of Pittsburgh [Pa.] (discussion) (abst). G Soc Am, B 22: 721-722 (1911)

12 The Carlyle oil field and surrounding territory. III G S, B 20:45-80, map (1915) : extract: 7-37, map (1912) Abst, Wash Ac Sc, J 2: 108-109 (1912)

$12 a$ Koenigsberger on geothermic gradients and petroleum (abst). Wash $\Delta \mathrm{C}$ Sc, J $2: 393-394$ (1912)

12b (and Savage, T. E.) Description of the Murphysboro and Herrin quadrangles [III.]. U S G S, G Atlas MurphysboroHerrin fol (no 185) : 15 pp, maps (1912)

13 The mud lumps at the mouths of the Mississippi. U S G S, P P 85:27 (1913) Abst, Wash Ac Sc, J $3: 343$ (1913); by A. H. Brooks, $4: 221-222$ (1914) 
Shaw, Eugene Wesley-Continued.

13a (and Savage, 'T. E.) Description of the Tallula and Springfield quadrangles, I11. U S G S, G Atlas Tallula-Springfield fol (no 188) : 12 pp, maps (1913)

14 Gas from mud lumps at the mouths of the Mississippi. U S G S, B 541:19-22 (1914)

14a So-called water-laid loess of the central United States (abst). Wash Ac Sc, J $4: 298$ (1914)

$14 b$ New land and water areas near the mouths of the Mississippi (abst). As Am Geog, An 4:141 [1914]

14e The characteristics of the Missis. sippi Delta in the light of some observations on old World deltas (abst). Wash $\Delta c$ Sc, J 4 : 298-299 (1914) Am Geog Soc, B $46: 432-433$ (1914)

15 Newly discovered beds of extinct lakes in southern and western Illinois. III G S, B $20: 139-157$, maps (1915)

15a The rôle and fate of connate water in oil and gas sands (discussion). Am I M Eng, B 103:1449-1459 (1915); Tr 51: 597-607 (1916) [See Johnson (R H), 15]

15b On the origin of the loess of southwestern Indiana. Science n s 41: 104-108 (1915)

15e The rate of continental denudation. Science n s 41:244-245 (1915)

15d Quaternary deformation in southern Illinois and southeastern Missouri (abst). G Soc Am, B 26: 67-68 (1915)

15e A study of the Lafayette at and near the type locality (abst). Wash Ac Sc, J $5: 30$ (1915)

15f Sulphur in rocks and in river waters (abst). Wash Ac Sc, J 5:484 (1915)

15g (with Udden, J. A.) Description of the Belleville and Breese quadrangles, III. U S G S, G atlas Belleville-Breese fol (no 195) : $13 \mathrm{pp}$, maps (1915)

16 (and Trowbridge, A. C.) Description of the Galena and Elizabeth quadrangles, Ill.-Iowa. U S G S, G Atlas Galena-Elizabeth fol (no 200): 13 pp, maps (1916)

16a Gas in the area north and west of Fort Worth [Tex.]. U S G S, B 629: 1575. maps (1916)

16b Sedimentation along the Gulf coast of the United States (abst), G Soc Am, B $27: 71$ (1916)

16e (with Trowbridge, A. C.) Geology and geography of the Galena and Elizabeth quadrangles [III.]. Ill $\mathrm{G} S \mathrm{~S}, \mathrm{~B}$ $26: 13-171,11$, maps (1916)

16d (with Vaughan, T. W.) Geologic investigations of the Florida coral reef tract. Carnegie Inst Wash, Y Bk 14 (1915) : 232-238 (1916)

17 The Irvine oil fleld, Estill Co., Ky. U S G S, B 661:141-191, maps (1917) Abst, Wash Ac Sc, J $7: 514$ (1917)
Shaw, Eugene Wesley-Continued.

17a Petroleum and asphalt in the United States (with discussion). Pan American Sc Cong, 2d, $\operatorname{Pr} \sec 3$ v $3: 188-$ 200 (1917)

$\mathbf{1 7 b}$ Significance of sorting in sedimentary rocks. G Soc Am, B 28:925-932 (1917)

17e A new area of Carboniferous rocks with some coal in the north end of the Gulf embayment. Wash Ac Sc, J $7: 552-$ 560 (1917)

17d Surface tension, capillarity, and petroleum pools. Science $n$ s $45: 500-501$ (1917)

17e Possibility of using gravity anoma. lies in the search for salt-dome oil and gas pools. Science n s $46: 553-556$ (1917)

17f The absence of water in certain sandstones of the Appalachian oil fields (discussion). Ec G $12: 610-628$ (1917)

18 The Pliocene history of northern and central Mississippi. U S G S, P P 108: 125-163 (1918)

18a Ages of peneplains of the Appa. lachian Province. G Soc Am, B 29:575586 (1918) ; abst, with discussion by Frank Leverett, 28:128 (1917)

18b Principles and problems of ofl prospecting in the Gulf coast country (discussion). Am I .M Eng, B 136:829-830 (1918)

18e Crevices and cavities in oil sands (discussion). Ec G 13:207-222 (1918)

1Sd Anomalous dips. Ec G 13:598610 (1918)

18e The "lakes" of northeastern Arkansas and some features of the work of the Mississippi River (abst). Wash Ac Sc, J 8: 99-101 (1918)

18f Characteristics of the upper part of the till of southern Illinois and elsewhere (abst). G Soc Am, B 29:76 (1918)

18g Relation between occurrence and quality of petroleum and broad areas of uplift and folding (abst). G Soc Am, B $29: 87-88$ (1918)

See also Atwood, 17b; Huntley, 15a; Johnsen (R H), 15; Matteson, 18; Vaughan, $15 \mathrm{c}$.

Shaw, James.

73 Geology of northwestern Illinois; Jo Daviess Co.; Stephenson Co. ; Carroll Co.; Winnebago Co.; Boone Co. ; Ogle Co.; Lee Co.; Whiteside Co.; Bureau Co.; Henry Co.; Marshall and Putnam cos. Ill G S 5 : 1-216 (1873); Ec G 3:1-226 (1882)

73a (with Worthen, A. H.) Geology of Rock Island Co. IIl G S 5:217-234 (1873) ; Ec G 3:226-246 (1882)

Shaw, S. F.

09 Mining and milling in Tombstone district, Ariz. M World 30:589-590 (1909)

11 Some notes on Porcupine [Ont.]. Eng M J 92 : 1223-1226 (1911) 
Shea, W. S.

67 Report on recent discoveries of gold in New Brunswick $(a b s t)$. G Soc London, Q J $23: 197$ (1867)

Sheafer, Peter Wenrick (1819-?).

54 Description of the geology of Schuylkill Co., Pa. M Mag 2:626-630, map (1854)

55 The Pridevale Iron Company's property. M Mag 5:397-412, map (1855)

55 a Paleontological report for 1854 . Pottsville Sc As, B : 1-3 (1855)

58 Coals and collieries of Schuylkill Co., Pa. M Mag $11: 19-26$ (1858)

69 Boring records from the anthracite basin [Pa.]. Am Ph Soc, Pr 11: 107-110 (1869)

70 Well borings in the Wilkes-Barre coal region. $\mathrm{Am} \mathrm{Ph}$ Soc, $\mathrm{Pr} 11: 235-236$ (1870)

so Coal. Science (ed, Michels) 1:8889, 98-100 (1880)

84 The Old Dominion Coal Co.'s lands [Kanawha Co., W. Va.]. The Virginias 5: 145-147 (1884)

85 The township geology of Cameron Co. Pa G S, 2d, RR : 1-60, map (1885)

Sheak, W. H.

03 (with Blatehley, W. S.) Trenton rock petroleum. Sc Am Sup 55:22775 (1903)

shearer, Harold Kurtz.

17 A report on the bauxite and fuller's earth of the Coastal Plain of Georgia. Ga G $\mathrm{S}, \mathrm{B} 31: 340 \mathrm{pp}$, map (1917)

18 (and Hull, J. P. D.) A preliminary report on a part of the pyrites deposits of Georgia. Ga G S, B $33: 229$ pp, map (1918)

18a Report on the slate deposits of Georgia. Ga G S, B 34:192 pp, maps (1918)

18b (with Cooke, C, W.) Deposits of Claiborne and Jackson age in Georgia. U S G S, P P 120:41-81, map (1918) Abst, Wash Ac Sc, J $8: 540$ (1918)

Shedd, John C.

13 Radioactivity of the mineral springs of Manitou, Colo. Colo Sc Soc, Pr 10:233263 (1913)

Shedd, Solon.

02 The iron ores of Washington. Wash G S $1: 217-256$ (1902)

03 The building and ornamental stones cof Washington. Wash G S 2:1-163 (1903)

03a Stevens County, Wash. Mining 11: 87-91 (1903)

10 The clays of the State of Washington, their geology, mineralogy, and technology. 341 pp, Pullman, Wash. 1910

13 Cement materials and industry in the State of Washington. Wash G S, B 4:268 pp (1913)

Shedd, W. G.

81 The fault of the Yankee Hill silver deposit of Leadville, Colo. Am Nat 15 : 338-339 (1881)
Sheldon, G. L.

12 Railroad Valley potash fields [Nye Co., Nev.]. M Sc Press 105:502-503 (1912)

Sheldon, George.

03 (and Sheldon, J. M. A.) Newly exposed geologic features within the old " 8,000 acre grant." [Deerfie]d, Mass.] $21 \mathrm{pp}, \mathrm{N}$ Y 1903 [Priv pub]

Sheldon, Jennie M. Arms.

oo Concretions from the Champlain clays of the Connecticut Valley. $45 \mathrm{pp}$, Boston 1900 [Priv pub]

03 (with Sheldon, G.) Newly exposed geologic features within the old " 8,000 acre grant" [Deerfield, Mass.] 21 pp, N Y 1903 [Priv pub]

Sheldon, Pearl G.

12 Some observations and experiments on joint planes. J G 20:53-79, 164-190 (1912)

15 Mastodon tusk in glacial gravels [near Ithaca, N. Y.]. Science n $\$$ s $41: 98-99$ (1915)

17 The Atlantic slope arcas. Palaeontographica Americana 1 no 1:103 pp, il (1917)

Shelton, H. S.

10 The age of the earth and the saltness of the sea. J G 18:190-193 (1910)

Shepard, Charles Upham (1804-1886).

29 A mineralogical and chemical description of the Virginia aerolite. Am J Se $16: 191-205$ (1829)

30 Mineralogical journey in the northern parts of New England. Am J Sc 17: $353-360 ; 18: 126-136,289-303$ (1830)

$30 \mathrm{a}$ On the mineralogical and chemical characters of the deweylite ... Am J Sc 18: 81-84 (1830)

31 Notice of the mine of spathic iron (steel ore) of New Milford, and of the iron works of Salisbury in the State of Connecticut. Am J Sc 19:311-326 (1831)

32 Treatise on mineralogy. $256 \mathrm{pp}$, New Haven 1832; 2d ed, 168 pp, New Haven 1844; $3 d$ ed, 245 pp, New Haven 1852 , pt 2 , pp 241-451, New Haven 1857

$32 a$... mineralogy and geology of the counties of Orange (N. Y.) and Sussex (N. J.). Am J Sc 21:321-334, map (1832)

33 Geological observations upon Alabama, Georgia, and Florida. Am J Sc 25 : 162-173 (1833)

35 Treatise on mineralogy ; second part. 2 vols, 300, 331 pp, New Haven 1835

35a Microlite, a new mineral species. Am J Sc $27: 361-362$ (1835)

35b On the strontianite of Schoharle, New York, with a notice of the limestone cavern in the same place. Am J Sc 2: : $363-370$ (1835)

37 A report on the geological survey of Connectícut. 188 pp, New Haven 1837 Notice, Am J Sc $33: 151-175$ (1837) 
Shepard, Charles Upham-Continued.

37a Description of edwardsite, a new mineral. Am J Sc $32: 162-166$ (1837)

37b Notice of eremite, a new mineral species. Am J Sc $32: 341-342$ (1837)

38 Geology of upper Illinois. Am J Sc $34: 134-161$, il (1838)

38a Calstronbarite, a new mineral species. Am J Sc 34: 161-163 (1838)

38b Notice of warwickite, a new mineral species. Am J Sc $34: 313-315$ (1838)

38e Notice of a second locality of topaz in Connecticut and of the phenakite in Massachusetts. Am J Sc $34: 329-331$ (1838.)

38d Notice of danburite, a new mineral species. Am J Sc 35:137-139 (1838)

39 On meteoric iron from Ashville, Buncombe Co., N. C. Am J Sc 36:81-84 (1839)

39a Analysis of warwickite. Am J Sc $36: 85-87$ (1839)

40 Analysis of meteoric stone which fell near Little Piney, Mo., Feb. 13, 1889. Am J Sc 39:254-255 (1840)

40a On a supposed new mineral species [lederite]. Am J Sc 39:357-360 (1840)

$40 b$ (and Shepherd, F.) Reports respecting mineral deposits in the States of Missouri and Illinois. $12 \mathrm{pp}$, map [Boston? 1840] [Priv pub]

41 On native and meteoric iron $I N$. $Y$. and Guilford Co., N. C.], Am J Sc 40 : 366-370 (1841)

$41 a$ On two decomposed varieties of iolite. Am J Sc 41:354-358 (1841)

42 On the want of identity between microlite and pyrochlore. Am J Sc 43: 116-121 (1842)

42a Analysis of meteoric iron from Cocke Co., Tenn., with some remarks upon chlorine in meteoric iron masses. Am .J Se 43:354-363 (1842)

$42 b$ On washingtonite (a new mineral) Am J Se 43:364-366 (1842) Geologist $1843: 134-136$

45 Reply to a notice of Shepard'; Mineralogy, with various mineralogical observations. Am J Sc 48:168-180 (1845)

45a [On the occurrence of itacolumite and diamonds] (abst). As Am G, Pr $6: 41-43 \quad(1845)$

46 On three new mineral species from Arkansas and the discovery of the diamond in North Carolina. Am J Sc (2) $2: 249$ 254 (1846)

46a Report on meteorites. Am J Sc (2) 2:377-392 (1846); (2) 4:74-87 (1847); (2) $6: 402-417$ (1848)

48 On new minerals from Texas. Lancaster Co., Penn. Am J Sc (2) $6: 249-250$ (1848)

48a An account of the meteorite of Castine, Me. Am J Sc (2) 6:251-253 (1848)
Shepard, Charles Upham-Continued.

50 Account of three new America meteorites [Richland and Newberry, 8. C. and Cabarras Co., N. C.] ... Am As, Pr 3: $147-157$ (1850)

51 An account of several new mineral species. Am As, Pr 4: 311-319 (1851)

$51 \mathrm{a}$ On new localities of American mit. erals. Am As, Pr 4: 319-323 (1851

$51 b$ [Meteorites from Linn Co., Iorr, and Waterloo, Seneea Co., N. Y.] Am ss, Pr 4: 331-335 (1851)

51e On meteorites. Am J Sc (2) 11: 36-40 (1851)

52 On the meteoric stone of Deal, New Jersey, which fell August 15, 1829. Am As, Pr 6:188-189 (1852)

52a Notice of several American min. erals. Am As, Pr 6 : 230-232 (1852)

52b On chalcodite, a new mineral spe cies. Am As, Pr 6:232-233 (1852)

52e On the triplite (alluandite?) of Norwich, Mass. Am As, Pr 6:234-233 (1852)

52d Two new minerals from Monroe, Orange Co., N. Y. Am J Sc (2) $13: 39$ ? (1852)

52e On meteorites. Edinb $\mathrm{N}$ Ph J 53: 245-249 (1852)

52f [Iron Mountain, Mo.]. Western ] (St. Louis 8: 140-142 (1852)

53 Notice of the meteoric iron found near Seneca River, Cayuga Co., N. Y. Am J Sc (2) $15: 363-366$ (1853)

$53 a$ Report on the minerals collected. In Marcy, R. B., Exploration of the Red River of Louisiana in the year 1852 ; C 8, 32d Cong 2d sess, S Ex Doc 54:155-159 (1853); U S, 33d Cong 1st sess, H Er Doc : 135-139 (1854)

53b Report on the Sumner, Hipp. Ful. wood, and Lemons mines of North Carolina [Mecklenburg and Union cos.]. M Mas 1: 591-597 (1853)

54 New localities of meteoric iron. Am $J$ Sc (2) $17: 325-330$ (1854)

$54 a$ Notice of three ponderous masses of meteoric iron at Tuczon, Sonora. Am J Sc (2) $18: 369-372$ (1854)

56 Five new mineral species. Am J Sc (2) $22: 96-99 \quad$ (1856)

57 Notice of a meteoric stone which fell at Petersburg, Lincoln Co., Tenn. August 5, 1855. Am J Sc (2) 24:134137 (1857)

58 Report on the Pascoe gold mine, Cherokee Co., Ga. M Mag 11:136-143 (1858)

$58 \mathrm{a}$ New Bangor slate quarry [Polk $\mathrm{C} 0$., Ga.]. M Mag 11: 179-185 (1858)

59 On lazulite, pyrophyllite, and tetradymite in Georgia. Am J Sc (2) $27: 36-$ 40 (1859)

59a Examination of a supposed meteoric iron found near Rutherfordton, N. C. Am $\mathrm{J} \mathrm{Sc} \mathrm{(2)} \mathrm{28:259-270} \mathrm{(1859)}$ 
Shepard, Charles Upham-Continued.

59b Report on the Ducktown copper region and the mines of the Union Consolidated Mining Company of Tennessee. $8 \mathrm{pp}$, Charleston 1859 Reprinted in $\mathrm{M}$ Mag (2) 1:381-387 (1860)

59c [James Gates] Percival [17951856]. Atlantic Mo 4:59-73 (1859)

60 Notices of several American meteorites. Am J Sc (2) 30:204-208 (1860) r

64 Mineralogical notices. Am J Sc (2) $37: 405-407$ (1864); 65:110-113 (1865)

65 A description of the emery mine of Chester, Hampden Co., Mass. 16 pp, L 1865

66 On scheeletine at the Southampton lead mine, Mass., and uwarowite at Wood's chrome mine, Texas, Pa. Am J Sc (2) 41 : 215-216 (1866)

66a Hineral notices. Am J Sc (2) 42 : 246-248 (1866)

$66 \mathrm{~b}$ Brief notices of several localities of meteoric iron. Am J Sc (2) 42:249-251 (1866)

66e New locality of meteoric iron in Coahuila, northern Mexico. Am J Sc (2) 42: $347-350$ (1866)

67 New classification of meteorites with an enumeration of meteoric species. Am J Sc (2) $43: 22-28$ (1867)

67 a On the supposed tadpole nests, or imprints made by the Batrachoides nidifcans Hitchcock, in the red shale of the New Red Sandstone of South Hadley, Mass. Am J Sc (2) $43: 99-104$ (1867)

67b Additional notice of the Coahuila meteoric fron. Am J Se (2) 43:384-885 (1867)

68 On aquacreptite, a new mineral, and on corundophylite of Chester [Mass.]. Am J Sc (2) $46: 256-257$ (1868)

68 a $A$ new locality of meteoric iron in Georgia. Am J Sc (2) 46:257-258 (1868) 69 Notices of new meteoric irons in the United States. Am J Sc (2) $47: 230-234$ (1869)

69 Note upon the origin of the phosphatic formation. Am J Sc (2) $47: 338$ 340 (1869)

$69 b$ Notes on the occurrence and composition of the nodular phosphates of South Carolina. Am J Sc (2) 47: 354-357 (1869)

69 e On a mineral phosphate from the island of Redonda, W. I. Am J Sc (2) 47 : 428-429 (1869)

70 Mineralogical contributions. Am J Sc (2) $50: 90-97(1870)$

71 Phosphatic sand in South Carolina. Am J Sc (3) 2:58-59 (1871)

71 a Notice of the meteorlc stone of Searsmont, Maine. Am J Sc (3) $2: 133$ 136 (1871)

72 On a meteoric iron lately found in Eldorado Co., Cal. Am J Sc (3) $3: 438$ (1872)
Shepard, Charles Upham-Continued.

$72 a$ on the corundum region of North Carolina and Georgia with descriptions of two gigantic crystals of that species. Am J Sc (3) $4: 109-114,175-180$ (1872)

76 On hermannolite, a new species of the columbium group. Am J Sc (3) 11 : 140-141 (1876)

76a Notice of the meteoric stone of Waconda, Mitchell Co., Kans. Am J Sc (3) $11: 473-474 \quad(1876)$

76b Catalogue of minerals found within about 75 miles of Amherst College, Mass. 8 pp [Amherst 1876]

77 On the meteoric stone of Rochester, Fulton Co., Ind. Am J Sc (3) 13:207211 (1877)

78 on a new mineral, pyrophosphorite, and anhydrous pyrophosphate of lime from the West Indies. Am J Sc (3) $15: 49-51$ (1878)

79 On the Estherville, Emmet Co., Iowa, meteorite of May 10, 1879. Am J Sc (3) $18: 186-188$ (1879)

so On the Ivanpah, Cal., meteoric iron. Am J Sc (3) 19:381-382 (1880)

Soa Mineralogical notices; a pechliar mineral of the scapolite family; etc. Am $\mathrm{J}$ Sc (3) $20: 54-57$ (1880) In part, Can Nat n s $9: 437-439$ (1880)

81 On the meteoric iron of Lexington Co., S. C. Am J Sc (3) 21:117-119 (1881)

81a On a new meteoric iron of unknown locality in the Smithsonian institution. Am J Sc (3) $22: 119$ (1881)

82 On two new minerals, monetite and monite, with a notice of pyroclasite. Am J Sc (3) 23:400-405 (1882)

$\mathbf{8 3}$ On meteoric iron from near Dalton, Whitfield Co., Ga. Am J Sc (3) 26: 336338 (1883)

s5 On meteoric iron from Trinity Co., Cal. Am J Sc (3) $29: 469$ (1885)

s5a on the meteorite of Formatian, Jalisco, Mex. Am J Sc (3) 30:105-108 (1885)

See also Dana, 45a; Jackson, $45 f$

shepard, Edward Martin.

84 Systematic mineral record, with a synopsis of terms and chemical reactions used in describing minerals. $98 \mathrm{pp}, \mathrm{N} \mathbf{Y}$ 1884

98 A report on Greene Co. Mo G S 12 pt 1 , Sheet $R p$ no $5: 13-245$, iv, map (1898)

04 [Notes on water resources of] Missouri. U S G S, W-S P 102: 389-440 (1904)

04a Table of geological formations [in Missouri]. Drury Coll, Bradley G Field Sta, B 1: 41-42 (1904)

os Spring systems of the Decaturville dome, Camden Co., Mo. U S G S, W-S P 110:113-125 (1905) 
Shepard, Edward Martin-Continued.

$\mathbf{0 5 a}$ [Underground waters of] Missouri.

U S G S, W-S P 114: 209-219, map (1905) o5b The New Madrid earthquake. J

G 13:45-62, map (1905)

o5e Key to the rocks and geological horizons of Greene Co. [Mo.]. Drury Coll, Bradley G Field Sta, B 1:53-57 (190气̄)

o7 Underground waters of Missouri, their geology and utilization. U S G S, W-S P 195: 224 pp, map (1907)

15 Geology of Greene Co. [Mo.]. In Fairbanks, Jonathan, and Tuck, Clyde Edwin, Past and present of Greene County, Missouri, 1:59-119, Indianapolis, Ind., 1915

Shepard, James $H$.

95 The artesian waters of South Dakota. S Dak Agr Coll Exp Sta, B 41: 76 pp (1895)

96 The shallow artesian wells of South Dakota. S Dak Agr Coll Exp Sta B 49 : 24 pp (1896)

Shepherd, Ernest Stanley.

05 (with Day, A. L.) The phase rule and conceptions of igneous magmas (discussion of paper by T. T. Read). Ec G 1 : 286-289 (1905)

06 (with Day, A. L.) The lime-silica series of minerals. Am Chem Soc, J 28: 1089-1114 (1906). Am J Sc (4) $22: 265-$ 302 (1906)

06a (with Day, A. L.) Discussion of paper by T. T. Read; The phase rule and conception of igneous magma. Ec G 1 : 286-289 (1906)

09 [and Rankin, G. S.) The binary systems of alumina with silica, lime, and magnesia; with optical study by Fred. Eugene Wright. Am J Sc (4) 28:293-333 (1909) Zs Anorg Chem 68:370-420 (1910)

See also Hawaiian Volcano Observatory, 14 Shepherd, Forrest.

40 (with Shepard, C. U.) Reports respecting mineral deposits in the States of Missouri and Illinois. $12 \mathrm{pp}$, map [Boston? 1840] [Priv pub]

47 Remarks on a boulder mass of native copper from the southern shore of Lake Superior. Am J Sc (2) 4:115-116 (1847)

$47 a$ Observations on the drift furrows, grooves, scratches, and polished surfaces of the rocks of Lake Superior. Am J Sc (2) $4: 282-283$ (1847)

51 Observations on the Pluton geysers of Callfornia. Am J Sc (2) $12: 153-158$ (1851)

Sherborn, Charles Davies.

93 An index to the genera and species of the Foraminifera. Smiths Misc Col 37 (856 and 1031) : 485 pp (1893 and 1896) Sheridan, Jo. E.

09 The coal mines and plant of the Stag Canon Fuel Co., Dawson, N. Mex. Am I M Eng, B 30:537-564 (1909); Tr 40: 354-381 (1910)
Sherman, Paul

73 Glacial fossils in Maine. Am Nit $7: 373-374$ (1873)

Sherwin, R. S.

$\mathbf{0 3}$ Notes on the geology of the Antelope Hills [Day Co., Okla.] Kans Ac Soc, T: $18: 83-84$ (1903)

$03 a$ Notes on the theories of the origin of gypsum deposits. Kans Ac Sc, Tr 18: 85-88 (1903)

Shervood, Andrew.

78 Limits of the Catskill and Chemrung formations [in Bradford and Tioga cos.] Pa G S, 2d, G : 1-96, maps (1878)

$78 a$ Section of Devonian rocks made in the Catskill Mountain at Palenville, Kauterskill Creek, N. Y. $\Delta \mathrm{m}$ Ph Soc, $\operatorname{Pr} 17$ : 346-349 (1878)

80 (and Platt, F.) The geology of Lycoming and Sullivan cos. Pa G S, 2d, GG : ix, 268 pp, maps (1880)

SOa The geology of Potter Co. Pa G \& 2d, GGG : 1-63, map (1880)

$\mathbf{8 2}$ Geological map of Wyoming Co. $\mathrm{P}$ G S, 2d, G 6 : pocket (1882)

Sherwood, William.

90 The glaciation of Greenland. Birmingham $\mathrm{Ph}$ Soc, $\mathrm{Pr} 7: 63-67$ (1890)

Sherzer, William Hittell.

89 New characters of Diphyphyllum simeoense (Bill.) Rom. Am G 4:93-95, il (1889)

90 Some further corrections of "North American Geology and Paleontology." Am G $6: 59-61$ (1890)

91 A chart of the rugose corals. $A m G$ $7: 273-301$ (1891)

92 A revision and monograph of the genus Chonophyllum. G Soc Am, B 3: 253-282, il (1892)

95 Native sulphur in Michigan. Am J Sc (3) $50: 246-248$ (18:5)

97 Limestones of southeastern Michigan, with their associated sandstone, salt, and gypsum (abst). G Soc Am, B 9:10-11 (1897) Am G 20:195 (1897) Science ns $6: 692$ (1897)

00 Geological report on Monroe Co. Mich. Mich G S 7 pt $1: 240 \mathrm{pp}$, il, map (1900) Abst, Mich Miner 2 no $10: 9-13$ (1900)

02 Ice work in southeastern Michigan. J G 10:194-216, map (1902)

o5 Glacial studies in Canadian Rockies and Selkirks. Smiths Misc Col 47 (Q is 2) : 453-496 (1905)

06 Glacial notes from the Canadian Rockies and Selkirks. Science n 8 23: 351-354 (1906)

of Glaciers of the Canadian Rockies and Selkirks. Smiths Contr Knowl 34: xii, 135 pp (1907)

$07 \mathbf{a}$ The Lefroy, a parasitic glacier (abst). G Soc Am, B 17:707-708 (1907)

$\mathbf{0 7 b}$ Origin of the massive block moraines in the Canadian Rockies and Selkirks (abst). G Soc Am, B 17:708 (1907) 
Sherzer, William Hittell-Continued.

08 The nature and activity of Canadian glaciers. Can Alpine J 1 : 249-263 (1908) 08a (with Grabau, A. W.) Devonic elements in the late Siluric fauna of southern Michigan (abst). Science n 8 27: $157-159$ (1908)

08b (with Lane, A. C.) The nomenclature and subdivisions of the upper Siluric strata of Michigan, Ohio, and western New York (abst). Science n s 27: 409 (1908)

09 (and Grabau, A. IV.) New upper Siluric fauna from southern Michigan. G Soc Am, B 19:540-553 (1909) Abst, Science n s $27: 408$ (1908)

10 Criteria for the recognition of the various types of sand grains [and origin of the Sylvania sandstone]. G Soc Am, B 21:625-662, 775-776 (discussion) (1910) Abst, Science n s 32:190 (1910)

10a (with Grabau, A. W.) The Monroe formation of southern Michigan and adjoining regions. Mich $\mathrm{G} \mathrm{S}$ (g s 1) Pub $2: 248$ pp (1910)

13 Geological report on Wayne Co. [Mich.]. Mich G S, Pub 12 (g s 9 ): $388 \mathrm{pp}$, maps (1913)

17 Description of the Detroit district [Michigan]. U S G S, G Atlas Detroit fol, Wayne, Detroit, Grosse Point, romulus, and Wyandotte quadrangles (no 205) : 22 pp, maps (1917)

Shideler, William $\mathrm{H}$.

07 The Addison Creek exposure [near Oxford, Obio]. Miami Student, Oxford, Ohio, $26: 308-310$ (1907)

14 The upper Richmond beds of the Cincinnati group. Ohio Nat 14:229-235 (1914)

16 The Ordovician-Silurian boundary Ohio J Sc $16: 329-335$ (1916) Abst, Science n s 43:396 (1917)

18 A primitive type of Agelacrinites from the Richmond. Ohio $J$ Sc $19: 58$ (1918)

Shiltz, John H.

17 Soil survey of Whitley Co. Ind, Dp G Nat Res, An Rp 41:67-78 (1917)

Shimek, Bohumil.

88 Notes on the fossils of the loess at Iowa City, Iowa. Am G $1: 149-152$, il (1888)

90 The loess and its fossils. Iowa Univ, Lab N H, B $1: 200-214: 2: 89-98$ (1890)

92 Pyrgulopsis scalariformis (Wolf) Call and Pilsbry. Iowa, Univ, Lab N H, B 2 : $168-174$, il (1892)

94 Variation in the Succinidae of the loess. Iowa Ac Sc, Pr 1 pt 4:111 (1894)

$96 \mathrm{~A}$ theory of the loess. Iowa Ac Sc, Pr 3: 82-89 (1896)

97 Additional observations on surface deposits in Iowa. Iowa Ac Sc, Pr 4:68-72 (1897)

$$
28737^{\circ}-23-60
$$

\section{Shimek, Bohumil-Continued.}

98 Is the loess of aqueous origir? Iowa Ac Sc, Pr 5 : 32-45 (1898)

99 The distribution of loess fossils. J G $7: 122-140$ (1899) Iowa Ac Sc, $\operatorname{Pr} 6: 98$ 113 (1899)

01 Report on the loess mollusks. Iowa G S 11:261-265 (1901)

o1a Pyramidula shimekii (Pilsbry) Shimek. Iowa Univ, Lab N H, B 5:139-145 (1901)

01b The loess of Iowa City and vicinity. Iowa Univ, Lab N H, B 5: 195-212 (1901) Am G 28: 344-358 (1901)

o1e Recent decline in the level of Lake Nicaragua. Am G 28:396-398 (1901)

02 The loess of Natchez, Miss. Am G 30:279-299, map (1902) Iowa Univ, Lab N H, B $5: 299-326$ (1904)

03 The loess and the Lansing man. Am G $\quad 32: 353-369$ (1903) Iowa Univ, Lab N H, B $5: 327-346$ (1904)

03a Living plants as geological factors. Iowa Ac Sc, Pr 10:41-48 (1903)

04 Papers on the loess. Iowa Univ, Lab N H, B 5:298-381, map (1904)

04a The Lansing deposit not loess. Iowa Univ, Lab N H, B 5 : 346-352 (1904) 04b Loess and the Iowan drift. Iowa Univ, Lab N H, B 5:352-368 (1904)

04e Evidences (?) of water-deposition of loess. Iowa Univ, Lab N H, B 5:369381 (1904)

04d Helicina occulta Say. Davenport Ac Sc, Pr 9:173-180 (1904)

04e Fresh-water shells in the loess (abst). G Soc Am, B 15:576 (1904) Science n s 19:533 (1904) Sc Am Sup $57: 23447$ (1904)

o5 Additional note on Helicina occulta. J G 13:232-237 (1905)

06 The loess and associated interglacial deposits (abst). G Soc Am, B 16:589 (1906)

07 The loess of the Missouri River. Iowa Ac Se, Pr 14:237-256 (1907)

os Nebraska "loess man." G Soc Am, B $19: 243-254(1908)$

osn The loesses of the Mississippi Valley (abst). Selence $n$ \& $27: 731$ (1908)

08b Aftonian sands and gravel in western Iowa. Science n s 28:923 (1908)

ose The genesis of loess a problem in plant ecology. Iowa Ac Se, $\operatorname{Pr} 15: 57-75$ (1908)

Osa The loess of the paha and river. ridge. Iowa Ac Sc, Pr 13:117-135 (1908)

09 Aftonian sands and gravels in western Iowa. G Soc Am, B 20:399-408 (1909)

10 Geology of Harrison and Monona cos. Iowa G S $20: 271-485$, maps (1910)

10a The Pleistocene of the Missouri Valley. Science n s $31: 75-76$ (1910) 
Shimek, Bohumil-Continued.

10b Evidence that the fossiliferous gravel and sand beds of Iowa and $\mathrm{Ne}$ braska are Aftonian. G Soc $\Delta \mathrm{m}$, B 21 : 119-140 (1910)

11 The prairies. Iowa Univ, Lab $\mathrm{N} \mathrm{H}$, B $6: 169-240$ (1911)

11 a The Pleistocene of a portion of the Missouri Valley (abst). Science n s 33: 467 (1911)

$11 b$ The eolian origin of the loess (abst). Science n s $33: 467$ (1911)

11e The Nebraskan drift (abst). Science n s 34:28 (1911)

$11 d$ Pleistocene of the vicinity of Omaha, Nebraska, and Council Bluffs, Iowa (abst). G Soc Am, B 22:730 (1911)

12 Memoir of Samuel Calvin. G Soc Am, B 23:4-12, port (1912)

12 a Pleistocene of Sioux Falls, S. Dak., and vicinity. G Soc Am, B 23:125-154 (1912) ; (abst) 22:730 (1911)

12b Mingling of Pleistocene formations. G Soc Am, B 23:709-712 (1912) Abst, Science n s $35: 317$ (1912)

12e Leess a lithological term (abst). Science n s $35: 317$ (1912) ; (with discussion by F. V. Emerson, G. Frederick Wright, and Frank Leverett), G Soc Am, B 23: 738-739 (1912)

13 The significance of Pleistocene mollusks. Science n s 37:501-509 (1913)

16 The loess of Crowley's Ridge, Ark. Iowa Ac Sc, Pr 23: 147-152 (1916)

$16 a$ Types of loess in the Mississippi Valley (abst). G Soc Am, B 27:82 (1916) Science n s $43: 397$ (1916)

17 The loess and the antiquity of man. Iowa Ac Sc, Pr 24:93-98 (1917)

Shimer, Hervey Woodburn.

02 (and Grabau, A. W.) Hamilton group of Thedford, Ont. G Soc Am, B 13 : 149-186 (1902) Abst, Science n s 15:8283 (1902)

02a Petrographic description of the dikes of Grand Isle, Vt. Vt, St G, Rp 3: 174-183 (1902)

02b Columbia University summer school. Am G 30:69-71 (1902)

03 Fall excursions of the geological department, Columbia University. Am G 31 : 62-64 (1903)

03a Columbian University geological department [excursion]. Am G 32:130131 (1903)

03b Columbia University geological department excursion. Am G 32: 259-260 (1903)

o5 Upper Siluric and Lower Devonic faunas of Trilobite Mountain, Orange Co., N. Y. N Y St Mus, B $80: 173-269$, il map (1905)

06 Old age in Brachiopoda, a preliminary study. Am Nat 40:95-121 (1906) Abst, Science n s $23: 290$ (1906) ; $\Delta \mathrm{m} \mathrm{As,}$ Pr 55: 379 (1906)
Shimer, Hervey Woodburn-Continued. O6n (with Grabnu, A. W.) Nori American index fossils. Sch Mines $27: 138-243 ; 38: 20-100$ (1906)

o7 An alurost complete specimen Strenuella strenua (Billings). Am J \& (4) $23: 199-201$, il $(1907)$

07a A lower-middle Cambrian transith fauna from Braintree, Mass. Am J \& (4) $24: 176-178$, il (1907)

$\mathbf{0 7 \mathbf { b }}$ The broader features of the geolog. history of North America in diagrm Tech Q 20:287-291 (1907)

os Dwarf faunas. Am Nat $42: 472-4$ ? (1908)

osa (and Blodgett, M. E.) The strtigraphy of the Mt. Taylor region, N. Ner Am J Sc (4) $25: 53-67$, il (1908)

09 (with Grabau, A. W.) North Ame ican index fossils. Vol. I : viii, $85 \mathrm{pp}$, I N Y 1909

10 (and shimer, F. H.) The litbs logical section of Walnut Canyon, Aris. with relation to the cliff dwellings of the and other regions of northwestern Arizon Am Anthropologist 12:237-249 (1910)

10a (with Grabau, A. W.) North American index fossils, invertebrates. I 2, xv, 909 pp, il N Y 1910

11 Lake Minnewanka section (Alberts), Can G S, Sum Rp 1910: 145-149 (1911)

11 a (with Crapp, C. H.) The Suttw Jurassic of the Vancouver group, Vas couver Island, B. C. Boston Soc $\mathrm{N} \mathrm{H}, \mathrm{f}$ 34: 425-438 (1911)

13 Spiriferoids of the Lake Minnewank section, Alberta. G Soc Am, B 24:238240, 112-113 (abst), (1913)

13a (and Powers. S.) A new spong from the New Jersey Cretaceous. U 8 Nat Mus, $\operatorname{Pr} 46: 155-156$, il (1913)

14 An introduction to the study of for sils. $450 \mathrm{pp}$, il, $\mathrm{N} \times 1914$

$14 a$ Restoration of extinct reptiles. Conspectus $4: 108$, il (1914)

14b (with Powers, S.) Notes on the geology of the Sun River district, Mont J G $22: 556-559$ (1914)

15 Postglacial history of Boston. Az J Sc (4) 40": 437-442 (1915)

15 a When reptiles ruled the earth. Sc ence Conspectus 5:44-47 (1915)

16 Fossiliferous Miocene boulders frot Block Island, R. I. Am J Sc (4) $41: 255^{-}$ 256 (1916)

16a The beginnings of flight in birds Sc Conspectus 6:106-110 (1916)

16b The rôle of service in evolution. \& Mo 3: 191-195 (1916)

18 Postglacial history of Boston. Al Ac Arts 53:441-463 (1918)

See also Pirsson, 15

Shippen, John P.

os Mining coal in Big Stone Gap field, Ky. Eng M J 85:1287-1290 (1908) 
Shipton, W. D.

14 Pleistocene exposures in Cedar Rapids and vicinity. Iowa Ac Sc, Pr 21:221224 (1914)

15 The occurrence of barite in the lead snd zinc district of Iowa, Illinois, and Wisconsin. Iowa Ac Sc, Pr 22 : 237-239 (1915)

16 A note on fulgurites from Sparta, Wis. Iowa Ac Sc, Pr 23: 141 (1916)

$16 a$ A new stratigraphic horizon in the Cambrian system of Wisconsin. Iowa Ac Sc, Pr $23: 142-145$ (1916)

17 Bibliography of the Driftless Area. Iowa Ac Sc, Pr 24:67-81 (1917)

shrader, Jay.

91 Hidden treasures; the pebble phosphates of the Peace River valley of south Florida, 59 pp, Bartow, Fla., 1891

Shriver, Ellsworth $\mathrm{H}$.

17 Antimony deposits of Arkansas. M Se Press 114:920-922 (1917)

Shriver, Howard.

24 Catalogue of fossils found at Cumberland, Md. $4 \mathrm{pp}$ [1824?] [not seen]

Shufeldt, George A., jr.

65 On an oil-well boring at Chicago. Am J Sc (2) $40: 388-389$ (1865)

67 On the subterranean sources of the waters of the Great Lakes: Am J Sc (2) 43:193-197 (1867)

Shufeldt, Robert Wilson.

87 Contributions to science and bibliographical résumé of the writings of $R$. W. Shufeldt, 1881-1887. 20 pp, $\quad$ N $\quad$ Y 1887 [priv pub]

89 Remarks upon extinct mammals of Enited States. $38 \mathrm{pp}, \mathrm{il}$, reprinted from The American Field, vol. 32 , nos. 17-22, Chicago 1889

90 On the aftinities of Hesperornis. Nature $43: 176$ (1890)

91 On a collection of fossil birds from the Equis beds of Oregon. Am Nat 25: 359-362 (1891)

91n Fossil birds from the Equus beds of Oregon. Am Nat 25:818-821 (1891) $91 \mathrm{~b}$ A study of the fossil avifauna of the Silver Lake region, Oreg. (abst). Am As, Pr $40: 286$ (1892) Am G $8: 235$ (1891)

91e Fossil avifauna of the Silver Lake region, Oreg. (abst). Am G 8:235 (1891)

92 A study of the fossil avifauna of the Equus beds of the Oregon desert. Ac $\mathrm{N}$ Se Phila, J (2) $9: 389-425$, il (1892)

92a Tertiary fossils of North American birds [Silver Lake region, southwestern Oregon]. The Auk, n s $8: 365-368$ (1892)

93 Comparative osteological notes on the extinct bird Iehthyornis. J Anat Phys 27 (n 8 7) : 336-342 (1893)

97 On fossil bird bones ... from the bone caves of Tennessee. Am Nat 31:645-650 (1897)
Shufeldt, Robert Wilson-Continued.

97a On the feathers of "Hesperornis." Nature 56:30 (1897)

13 Contributions to avian paleontology ; I, The status of extinct Meleagridæ, II, Studies of the fossil birds of the Oregon desert. Auk $30: 29-39$, il (1913)

13a New and extinct birds and other species from the Pleistocene of Oregon. Science n s $37: 306-307,1913$ )

13h Extinct ostrich birds of the United States. Aquila 20:411-422, il (1913)

13e Review of the fossil fauna of the desert region of Oregon, with a description of additional material collected there. Am Mus N H, B $32: 123-178$, il (1913)

13d Further studies of fossil birds with descriptions of new and extinct specles. Am Mus N H, B 32:285-306, il (1913)

13e Fossil feathers and some heretofore undescribed fossil birds. J G 21:628652 , il (1913)

15 Fossil birds in the Marsh collection of Yale University. Conn Ac, Tr 19:1110 , il (1915)

$15 a$ On a restoration of the base of the cranium of Hesperornis regalis. B Am Pal no $25: 12 \mathrm{pp}$, il (1915)

15b A critical study of the fossil bird Gellinuloides vyomingensis Eastman. J G $23: 619-634$, il $(1915)$

15e The fossil remains, of a species of Hesperornis found in Montana. Auk 32 : 290-294, il (1915)

16 New extinct bird from South Carolina [Palaeochenoides mioceanus]. G Mag (6) $3: 343-347$, il (1916)

$16 n$ The restoration of the dinosaur Podokesaurus holyokensis (abst). Wash Ac Sc, J $6: 258-259$ (1916)

17 Fossil birds found at Vero, Fla., with descriptions of new species. Fla G S, An Rp $9: 35-42$, il (1917)

17 a Report on fossil birds from Vero, Fla. J G 25: 18-19 (1917)

17b Fossil remains of what appears to be a passerine bird from the Florissant shales of Colorado. U S Nat Mus, Pr $53: 453-455$, il (1917)

18 Notes on some bird fossils from Florida. Auk 35:357-358 (1918)

Shuler, Ellis W.

15. A new Ordovician eurypterid [Stylnnurus? alveolatus, Virginia]. Am J Sc (4) $39: 551-554$, il (1915)

17 The geology of Camp Bowle and vicinity. Tex Univ, B 1750:14 pp (1917)

$\mathbf{1 7 a}$ Dinosaur tracks in the Glen Rose limestone near Glen Rose, Tex. Am J Sc (4) $44: 294-298$, il (1917)

18 The geology of Dallas Co. Tex, Univ, B 1818: 54 pp, map (1918) 
Shnmard, Benjamin Franklin (18201869).

47 (with Yandell, L. P.) Contributions to the geology of Kentucky. $36 \mathrm{pp}$, il, Louisville 1847

50 (with Owen, D. D.) Descriptions of fifteen new species of Crinoidea from the Subcarboniferous limestone of Iowa ... Ac N Se Phila, J (2) $2: 57-70$, il $(1850)$

51 (with owen, D. D.) On the number and distribution of fossil species in the Paleozoic rocks of Iowa, Wisconsin, and Minnesota. Am As, Pr $5: 235-239$ (1851)

52 Geological report of local, detailed observations in the valleys of Minnesota, Mississippi, and Wisconsin rivers ... In Owen, D. D., Report of a geological survey of Wisconsin, Iowa, and Minnesota ...: 477531, Phila 1852

52a (with Owen, D. D.) Descriptions of one new genus and twenty-two new species of Crinoidea from the Subcarboniferous limestone of Iowa. In Owen, D. D., Report of a geological survey of Wisconsin, Iowa, and Minnesota ... : 587-598, 1l, Phila 1852

52b (with owen, D. D.) Descriptions of seven new species of Crinoidea from the Subcarboniferous limestone of Iowa and Illinois. Ac N Sc Phila, J (2) $2: 89-94$, il (1852)

53 Paleontology; description of the species of Carboniferous and Cretaceous fossils collected. In Marcy, R. B., Exploration of the Red River of Louisiana in the year 1852; U S, 32d Cong $2 \mathrm{~d}$ sess, S Ex Doc 54; 197-211, il (1853) ; U S, 33d Cong 1st sess, H Ex Doc : $173-185$, il (1854)

54 (with Evans, J.) Descriptions of new fossil species from the Cretaceous formation of Sage Creek, Nebraska Terr. Ac N Sc Phila, Pr $7: 163-164$ (1854)

54a (with Evans, J.) Descriptions of new fossil species from the fresh-water Tertiary formation of Nebraska Terr. Ac N Sc Phila, Pr 7:164-165 (1854)

55 [Geological section on the Mississippi River from St. Louis to Commerce.] Mo G S, An Rp 1-2 pt 2:139-208, maps, il (1855)

56 (and Yande11, L. P.) Notice of a new fossil genus belonging to the family Blastoidea, from the Devonian strata near Louisville, Ky. Ac N Sc Phila, Pr 8:7375 , il (1856) Am J Sc (2) $22: 120-122$ (1856)

57 Description of new fossil Crinoidea from the Paleozoic rocks of the western and southern portions of the United States. Ac Sc St L, Tr 1: 71-80, il (1857)

$\mathbf{5 7 a}$ (with Evans, J.) On some new species of fossils from the Cretaceous formation of Nebraska Territory. Ac Sc St L, $\operatorname{Tr} 1: 38-42$ (1857)
Shumard, Benjamin Franklin-Continued.

58 [On Permian rocks in the Guadalupe Mountains, N. Mex.] Ac Sc St L, Tr 1: $113-114$ (1858)

58 a Descriptions of new fossils from the Tertiary formation of Oregon and Wash. ington Territories and the Cretaceous of Vancouver Island ... Ac Sc St L, Tr 1: 120-125 (1858) U S G S, P P 59:186188 (1909)

5sb (and swallow, G. C.) descriptions of new fossils from the Coal Measures of Missouri and Kansas. Ac Sc St L, Tr 1: 198-227 (1858)

58e Descriptions of new species of Blastoidea from the Paleozoic rocks of the Western States, with some observations on the structure of the summit of the genus Pentremites. Ac Sc at L, Tr 1: 238-248, il (1858)

58d Notice of new fossils from the Permian strata of New Mexico and Texas ... Ac Sc St L, Tr 1:290-297 (1858)

58e Paleontology [of Engelmann's ex. ploration from Fort Leavenworth to Bryan's Pass-Kansas-Nebraska]. U S, 85th Cong 1st sess, H Ex Doc 2 (Rp Sec War 1857) : $517-520$ (1858)

5Sf [On Permian fossils from the Guadalupe Mountains, New Mexico.] Ac N Se Phila, Pr 1858:14

$\mathbf{5 8 g}$ Sur lexistence de la faune permienne dans ramérique du Nord (with discussion by d'Archiac). Ac Sc Paris, C R 46:897-900 (1858) Soc G irance, B (2) $15: 531-532$ (1858)

59 First report of progress of the geological and agricultural survey of Texas. 17 pp, Austin 1859

59 a Notice of fossils from the Permian strata of Texas and New Mexico... Ac Sc St L, Tr 1:387-403, il (1859)

$\mathbf{5 9 b}$ Observations on the geology of the County of Ste. Genevieve [Mo.] ... Ac Sc St L, Tr 1:404-415 (1859)

59e State house artesian well at Aus. tin. In The Texas Almanac for 1860 (Richardson \& Co.) $3: 161-162$, Galveston 1859

60 Observations upon the Cretaceous strata of Texas. Ac Sc St L, Tr 1:582$590(1860)$

60a Descriptions of new Cretaceous fossils from Texas. Ac Sc St L, Tr 1: 590$610(1860)$ Boston Soc N H, Pr $8: 188$ 205 (1861)

60b Notice of meteoric iron from Texas. Ac Sc St L, Tr 1: 622-624 (1860)

60c Descriptions of five new species of Gastropoda from the Coal Measures and a brachiopod from the Potsdam sand. stone of Texas. Ac Sc St L, Tr 1:624627 (1860)

cod [On Lower Silurian in Burnet $\mathrm{C}$., Tex.] Ac Sc St L, Tr 1:672-673 (1860) Soc G France, B (2) 18:218-219 (1861) 
Shnmard, Beniamin Franklin-Continued. 60e [Coal Measures in northern Texas.] Ac Sc St L, Tr 1:686-687 (1860)

60f Progress of the geological survey of Texas. In The Texas Almanac for 1861 (Richardson \& Co.) 4:198-203, Galveston 1860

$60 \mathrm{~g}$ Observations on the Cretaceous strata of Texas. In The Texas Almanac for 1861 (Richardson \& Co.) 4: 203-205, Galveston 1860

61 The primordial zone of Texas with descriptions of new fossils. Am J Sc (2) 32: 213-221 (1861)

63 Notice of some new and imperfectly known fossils from the Primordial zone (Potsdam sandstone and Calciferous sand group) of Wisconsin and Missouri. Ac Sc St L, Tr 2:101-107 (1863)

63a Descriptions of new Paleozoic fossils. Ac Sc St L, Tr 2: 108-113 (1863)

63b [On the discovery of dicotyledonous leaves in the Cretaceous of Texas.] Ac Sc St L, Tr 2: 140-141 (1863)

63e [On the Cretaceous formation of Texas.] Ac Sc St L, Tr 2:152 (1863)

63d Vertical section of Silurian strata of Cape Girardeau Co. [Mo.] Ac Sc St L, Tr 2: 155,156 (1863)

63e Dr. John Evans. Ac Sc St L, Tr 2:162-164 (1863)

66 [On ofl springs in Ray and Carroll counties, Mo.] Ac Sc St L, Tr 2: 263-264 (1866)

66a A catalogue of the Paleozole fossils of North America [Echinodermata]. Ac Se St L, Tr 2:334-407 (1866)

73 Ozark Co. ; Wright Co. ; Laclede Co. ; Pulaski Co.; Phelps Co.; Crawford Co.; Cape Girardeau Co. ; Perry Co. ; Ste Genevieve Co. ; Jefferson Co.; Clark Co. In Reports on the geological survey of the State of Missourl, 1855-1871:189-323, maps (1873)

Shumard, George Gettz.

53 Remarks upon the general geology of the country passed over by the exploring expedition to the sources of Red River... In Marcy, R. B., Exploration of the Red River of Louisiana in the year 1852; U S, 32d Cong 2d sess, S Ex Doc $54: 179-195$ (1853); U S, 33d Cong 1st Bess, H Ex Doc: 156-172 (1854)

58 [On coal near Fort Smith, Ark.] Ac Sc St L, Tr 1: 93 (1858)

58a Observations on the geological formations of the country between the Rio Pecos and the Rio Grande in New Mexico near the line of the $32 \mathrm{~d}$ parallel... Ac Sc St L, Tr 1:273-289 (1858)

59 The geological structure of the "Jornada del Muerto," N Mex... Ac Se St L, Tr 1:341-355 (1859)

86 A partial report on the geology of western Texas... $145 \mathrm{pp}$, Austin 1886 Notice by R. T. Hill, Am J Sc (3) $33: 73-75$ (1887)
Shumard, George Gettz-Continued.

92 Artesian water on the Llano Estacado. Tex G S, B 1:5-9 (1892)

Shumway, W. A.

81 (and others) The Marquette fron region [Mich.]. Sch Mines Q 3:35-48, $103-117, \quad 197-207,243-253$ (1881-2)

Shurick, A. T.

os The Diamondville coal field, Wyo. Eng M J 85 : 116-118 (1908)

09 The Great Falls coal field in Montana. Eng M J 87:587-590 (1909)

Shurtlefr, Nathaniel B.

46 [On Mastodon giganteum, from Newburg, Orange Co., N. Y.] Boston Soc N H, Pr 2: 96-98 (1846)

Shutt, F. T,

87 Canadian apatite. Can Inst, $\operatorname{Pr}$ (3) $5: 30-38$ (1887)

90 (with Lawson, A. C.) Petrographical differentiation of certain dikes of the Rainy Lake region (abst). Am As, $\mathrm{Pr}$ $38: 246-247$ (1890)

Sias, Solomon.

04 Summary of Schoharie Co. [N. Y.]... 154 pp, map, Middleburgh, N. Y., 1904

Sibley, R. Roy.

09 The Copper Creek mining district, Ariz. M World 30:477-480 (1909)

Siebenthal, Claude Ellsworth.

94 The geology of Dallas Co. Ark G S, An Rp 1891, 2: 279-318, map (1894)

97 (with Hopkins, T. C.) The Bedford oolitic limestone. U S G S, An Rp 18 pt $5: 1050-1057$ (1897)

$97 \mathbf{n}$ (with Hopkins, T. C.) The Bedford oolitic limestone of Indiana. Ind, Dp G N Res, An Rp 21: 291-427, maps (1897) 98 The Bedford oolitic limestone [Indiana]. U S G S, An Rp 19 pt 6 (con.) : 292-296 (1898)

99 The Bedford oolitic limestone [Indiana]. Mineral Industry 7:479-182 (1899)

o1 The Silver Creek bydraulic limestone of southeastern Indiana. Ind, Dp G N Res, An Rp 25:331-389, map (1901)

oxa The Indiana oolitic limestone industry in 1900. Ind, Dp G N Res, An Rp 25: 390-393 (1901)

01b On the use of the term Bedford limestone. J G 9:234-235 (1901)

05 Structural features of the Joplin district [Mo.]. Ec G 1: 119-128, map (1905) 06 Gypsum of the Uncompahgre region, Colo. U.S G S, B 285:401-403 (1906)

o6a Gypsum deposits of the Laramie district, Wyo. U S G S, B 285:404-405 (1906)

06b Bentonite of the Laramie Basin, Wyo. Uं S G S, B $285: 445-447$ (1906)

06e Alluvial slopes. Science n s 23 : 748-749 (1906)

07 Notes on glaciation in the Sangre de Cristo Range, Colo. J G 15:15-22 (1907)

07a Coal of Laramie Basin, Wyo. U S G S, B 316:261-263 (1907) 
Siebenthal, Claude Fllsworth-Continued. Ozb (with Smith, W, S. T.) Deseription of the Joplin district [Mo.-Kans.]. U S G S, G Atlas, fol 148: 20 pp (1907)

os General geographical and stratigraphical features of the Indiana oolitic limestone. Ind Dp G, 32d An Rp: 303 309 (1908)

08a Mineral resources of northeastern Oklahoma. U S G S, B $340: 187-228$, map (1908)

osb (and Mesler, R. D.) Tripoli deposits near Seneca, Mo. U S G S, B 340 : $429-437$ (1908)

ose Lead. U S G S, Min Res 1907 pt $1: 645-658 ; 1908$ pt $1: 227-243 ; 1909$ pt $1: 181-201 ; 1910$ pt $1: 221-259 ; 1911$ pt $1: 315-351$; 1912 pt $1: 335-372 ; 1913$ pt $1: 709-745 ; 1914$ pt $1: 799-827 ; 1915$ pt 1: 187-205 (1908-16)

0sd Zinc. U S G S, Min Res 1907 pt 1: $659-676 ; 1908$ pt $1: 245-273 ; 1909$ pt 1 : $203-220 ; 1910$ pt $1: 261-304 ; 1911$ pt 1 : $353-395 ; 1912$ pt $1: 373-416 ; 1913$ pt 1 : $621-667 ; 1914$ pt $1: 867-919$, map ; 1915 pt $1: 851-977$, map (1908-17)

ose (with Graton, L. C.) Silver, copper, lead, and zinc in central States. U S G S, Min Res 1907 pt 1:483-549 (1908)

09 Cadmium. U S G S, Min Res 1908 pt $1: 793-803 ; 1909$ pt $1: 603-604 ; 1910$ pt $1: 781-783 ; 1911$ pt $1: 399-401 ; 1912$ pt $1: 1061-1063 ; 1913$ pt $1: 669-671 ; 1914$ pt $1: 921-922: 1915$ pt $1: 979-981 ; 1916$ pt $1: 833-835 ; 1917$ pt $1: 49-53(1909-18)$

09a (with Butler, B. S.) Silver, copper, lead, and zine in the Central States. U S G S, Min Res 1908 pt 2:587-643; 1909 pt $2: 495-531$ (1909-11)

09b (with Darton, N. H.) Geology and mineral resources of the Laramie Basin, Wyo. U S G S, B 364:81 pp (1909)

10 Geology and water resources of the San Luis Valley, Colo. U S G S, W-S P $240: 128$ pp (1910)

$10 a$ The San Luis Valley, Colo. Science n $8 \quad 31: 744-746$ (1910)

10b (with Darton, N. H.) Description of the Laramie and Sherman quadrangles, Wyo. U S G S, G Atlas, fol 173 (1910)

11 [Lead and zinc], central and southeast Missouri. U S G S, Min Res 1910: 658-664 (1911)

14 Spring deposits at Sulphur Springs. Ark. Ec G 9:758-767 (1914)

15 Origin of the zinc and lead deposits of the Joplin region, Missouri, Kansas, and Oklahoma. U S G S, B 606: 283 pp, maps (1915)

16 Lead and zinc resources of the United States. M World 44:355-357 (1916)

17 Lead and zine resources of the United States. Pan American Sc Cong, 2d, Washington, $\mathrm{Pr} \sec 7$ ₹ $8: 947-954$ (1917)
Siebentha1, Claude Ellsworth-Continued,

17a Lead and zinc resources of the United States. Am M Cong, 19th An Sess, Rp Pr: 397-406 (1917)

See also Loughlin, 12

Sieplein, O, J.

18 The change of content of gasolime vapor in natural gas with age of the wells (abst). Science n 8 47:494 (1918)

Sign, Henri.

18 (with Lugeon, M.) Sur quelques roches eruptives de la Caroline du Nord. Soc Vaudoise Sc Nat, B 52: 99-112 (1918 sill, Rush T.

10 The Calabacillas mine, Chihuahua, Mexico. Eng M J $90: 359$ (1910)

Silliman, Benjamin (1779-1864).

os (and Kingsley, J. L.) Account of a remarkable fall of meteoric stones in Connecticut. Phila Medical and Physical J 3 pt 1:39-57 (1808)

O9 (and Kingsiey, J, L.) Memoir on the origin and composition of the meteoric stones which fell ... in the County of Fairfield and State of Connecticut on the 14th of December, $1807 \ldots$... Am Ph Soc, Tr 6: 323-343 (1809)

10 Sketch of the mineralogy of the town of New Haven [Conn.]. Conn dc. Mem 1: 83-96 (1810)

10a (and Fingsley, J. L.) An account of the meteor which burst over Weston in Connecticut, in December, 1807, and of the falling of stones on that occasion. Conn Ac, Mem 1:141-161 (1810) Am J Sc (2) $47: 1-8 \quad$ (1869)

14 Particulars relative to the lead mine near Northampton, Mass. Am Miner J 1: 63-69 (1814) M Mag 1:256-261 (1853)

14a Mineralogical and geological observations on New Haven and its vicinity. Am Miner J 1: 139-149 (1814)

19 Localities of minerals. Am J Sc 1: $237-243$ (1819)

$19 a$... tungsten and tellurium [Con. necticut]. Am J Sc 1:312, 405-410 (1819)

20 Remarks made on a short tour between Hartford and Quebec in the autumn of 1819 . $407 \mathrm{pp}$, New Haven 1820 2d ed, $443 \mathrm{pp}$, New Haven 1824

$20 a$ Fossil bones found in red sandstone. Am J Sc 2:147 (1820)

20b ... geology, mineralogy, and scenery. etc., of New Haven and Litchfield in Connecticut. Am J Sc 2: 201-235 (1820)

21 Notices of minerals and rocks chiefiy. in Berkshire, Mass., and contiguous to the waters of the upper Hudson and the lakes George and Champlain. Am J Sc 4: $40-55$ (1821)

26 Anthracite coal of Rhode Island... with an additional notice of the anthracites of Pennsylvania. Am J Sc 11:78100 (1826) 
Silliman, Benjamin-Continued.

28 Volcanoes. Am J Sc 13:106-145, $235-310 ; 14: 70-91$ (1828)

29 Outline of the course of geological lectures given in Yale College. See Bakewell 29

29a [On voleanic rocks from Hawaii]. Am J Sc 16:347-350 (1829)

30 Igneous origin of some trap rocks. Am J Sc $17: 119-132$ (1830)

$30 a$ Notice of the anthracite region in the valley of the Lackawanna and of Wyoming on the Susquehanna. Am J Sc $18: 308-328(1830)$

30b ... Mauch Chunk and other anthracite regions of Pennsylvania. Am J Sc 19:1-21, map (1830)

31 Hawaii (Owyhee) and its voleanic regions ... Am J Sc 20:228-229 (1831)

32 Notice of a fourtain of petroleum, called the oil spring. Am J Sc 23: 97-102 (1832)

34 Vertebral bone of a mastodon [Berlin, Conn.]. Am J Se 27:165-166 (1834)

34a Fossil tooth [from Chautauqua Co., N. Y.]. Am J Sc 27:166-168 (1834)

35 Lowell, Massachusetts; geological facts. Am J Sc $27: 340-347$ (1835)

36 [Crinoid from Schoharie, N. Y.] Am J Se 31: 165-167, il (1836)

37 Consistency of the discoveries of modern geology with the sacred ... istory of the creation and deluge. 148 pp, L 1837 $37 \mathbf{a}$ On the elevation of mountain ranges. Am J Sc 31:290-291 (1837)

$37 \mathrm{~b}$... gold region of Virginis ... Am J Se 32 : $98-130$ (1837)

37e [Gold mines in Virginia.] Am J Se 32:183-185 (1837)

39 Suggestions relative to the philosophy of geology ... $119 \mathrm{pp}$, New Haven 1839

39a Marble and serpentine in Vermont. Am J Se $35: 390$ (1839)

42 [On the science and progress of geology.] Address before the Association of American Geologists and Naturalists assembled at Boston, April 24, 1842, Am J Se $43: 217-250$ (1842) Reprint, $36 \mathrm{pp}$, N Y $(1842)$

64 Introduction to the American edition. In Mantell, G. A., The wonders of geology, 8th ed, vol 1:1-24, L 1864 (Bohn's Scientlfic Library)

See also Brongniart, 21; Scrope, 28

silliman, Benjamin, jr. (1816-1885).

41 [On joints in rocks] (abst). Am J Se $41: 173$ (1841]; As Am G, Rp : 26 (1843)

43 Abstract of proceedings of the fourth session of the Association of American Geologists and Naturalists [held at Albany, N. Y., April, 1843]. Am J Sc 45: $135-165,310-353(1843)$

44 Sillimanite and monazite. Am J Sc $46: 207-208$ (1844)
Silliman, Benjamin, fr-Continued

44a Analysis of meteoric iron from Buxlington, Otsega Co., N. Y. Am J Sc 46: 401-403 (1844)

44b Report on the intrusive trap of the New Red sandstone of Connecticut (abst). Am J Sc 47:107-108 (1844)

45 Notice of a mass of meteoric iron found at Cambria, near Lockport in the State of New York. Am J Sc $48: 388-392$ (1845)

46 (and Hunt, T. S.) On the meteoric iron of Texas and Lockport. Am J Se (2) $2: 370-376$ (1846)

47 Hydrate of nickel, a new mineral. Am J Sc (2) 3:407-409 (1847)

47a On fossil trees found at Bristol Conn., in the New Red sandstone. Am J Sc (2) 4:116-118, il (1847)

48 On emerald nickel from Texas, Lancaster Co., Pa. Am J Sc (2) 6:248-249 (1848)

49 On gibbsite and allophane from Richmond, Mass. Am J Sc (2) 7:411-417 (1849)

49a Descriptions and analyses of several American minerals. Am J Sc (2) 8 : $377-394 \quad(1849)$

50 On the new American mineral, laneasterite [Lancaster Co., Pa.]. Am J Se (2) $9: 216-217 \quad(1850)$

50a Optical examination of several American micas. Am J Se (2) 10:372$383(1850)$

50b On boltonite of Shepard and bisilieate of magnesia of Dr. Thomson. Am As, Pr 2:109-110 (1850)

51 On the Mammoth Cave of Ken tucky. Am J Sc (2) 11:332-339 (1851)

51 a On the origin of a curious spheroidal structure in certain sedimentary rocks. $\Delta \mathrm{m}$ As, $\operatorname{Pr} 4: 10-12$ (1851)

$51 b$ Notice of two American meteoric irons [Kentucky and Pen-sylvania]. Am As, Pr 4:36-38 (1851)

53 Report on the Manassas ,Fauquier Co., Va.l mining property. M Mag 1: $228-231$ (1853)

55 (and whitney, J. D.) Notice of the geological position and character of the copper mine at Bristol, Conn. Am J Se (2) $20: 361-368$ (1855)

59 Report on cannel coal lands situate in Columbiana Co., Ohio. 16 pp, Pittsburgh 1859

64 On the so-called "barrel quartz" of Nova Scotia. Am J Sc (2) 38: 104-106 (1864)

64a On glacial phenomena in Nova Scotia. Am J Sc (2) $37: 417-419$ (1864) From Report on the gold property of the New York and Nova Scotia Gold Mining Company, 56 pp, 1864

64b Notes on the New Almaden quicksilver mines. Am J Sc (2) 38: 190-194 (1864) 
Silliman, Benjamin, jr.-Continued.

64e $[O n$ supposed glacial moraines in Arizona.] Cal Ac N Sc, Pr 3: 162 (1864)

64d Remarks on the gold region of Nova Scotia. In Campbell, John, Report on the property of the Chebucto Gold Mining Company of Nova Scotia: 10-27, Boston 1864

65 Petroleum in California. Am J Sc (2) $39: 101$ (1865)

65 a On the deep placers of the south and middle Yuba, Nevada Co., Cal... Am J Sc (2) 40:1-19 (1865)

65b Report upon the oil property of the Philadelphia and California Company ... situated in Santa Barbara and Los Angeles cos.. Cal... 36 pp, maps, Phila 1865

65e A description of the recently discovered petroleum region of California; with a report on the same. $25 \mathrm{pp}, \mathrm{N}$ Y 1865

66 On some of the mining districts of Arizona near the Rio Colorado ... Am J Sc (2) $41: 289-308$ (1866)

66a On gaylussite from Nevada Territory. Am J Sc (2) $42: 220-221$ (1866)

67 Notes on the Grass Valley gold-mining district, Cal. Am J Sc (2) 44:236244 (1867)

67 a Notice of the peculiar mode of the occurrence of gold and silver in the foot hills of the Sierra Nevada, and especially at Whiskey Hill, in Placer Co., and Quail Hill, in Calaveras Co., Cal. Cal Ac N Sc, Pr 3:349-351 (1867) Am J Sc (2) 45: 92-95 (1868)

$\mathbf{6 7 b}$ Notice of new localities of diamonds in California. Cal Ac N Sc, Pr 3:354-355 (1867)

68 On the existence of the mastodon in the deep-lying gold placers of California. Am J Sc (2) 45:378-381 (1868)

68 Note on three new localities of tellurium minerals in California and on some mineralogical features of the Mother vein. Cal Ac N Sc, Pr 3:378-382 (1868)

68b On the occurrence of glauberite at Borax Lake, Cal. Cal Ac N Sc, Pr 3: 399 (1868)

72 Geological and mineralogical notes on some of the mining districts of Utah Territory and especially those of the Wasatch and Oquirrh ranges of mountains. Am J Sc (3) 3:195-201 (1872)

$72 a$ On the fossil iron ore and its associates in southern Pennsylvania. Iron and Steel Inst, J 2: 334-341 (1872)

73 On the probable existence of microscopic diamonds with zircons and topaz, in the sands of hydraulic washings in California. Am I M Eng, Tr 1:371-373 (1873) Abst, Am J Sc (3) 5:384-385 (1873)

73a On the meteoric iron found near Shingle Springs, Eldorado Co., Cal. Am J Se (3) $6: 18-22$ (1873)
Silliman, Benjamin, jr.-Continued.

73b Mineralogical notes on Utah, Call. fornia, and Nevada, with a description o! priceite, a new borate of lime. Am J \& (3) $6: 126-133$ (1873) Eng M J 16:82 98-99 (1873)

73e Remarks on the magnetites of Clif ton, in St. Lawrence Co., N. Y. Am I X Eng, $\operatorname{Tr} 1: 364-368$ (1873)

74 Tellurium ores of Colorado. Am ] Sc (3) 8:25-29 (1874) With title, The telluride ores of the Red Cloud and Cold Spring mines, Gold Hill [Colo.], U S G Geog S Terr (Hayden), An Rp [7]:680691 (1874)

77 On an association of gold with sehes. lite in Idaho. Am J Sc (3) 13:451-45? (1877)

so Report on the newly discovered aurif. erous gravels of the upper Rio.Grande del Norte in the counties of Taos and Rio Arriba, N. Mex. 34 pp, Omaha, Nebr, 1880

soa On the intimate structure of certain mineral veins $(a b s t)$. Science (ed. Michels) 1:288 (1880)

Sob The turquoise of New Mexico. Sclence (ed, Michels) 1: 289 (1880)

81 Turquoise of New Mexico. Am J Bc (3) $22: 67-71$ (1881) Am As Pr 29: 431-435 (1881) Eng M J 32: 169 (1881)

81a Mineralogical notes. Am J Sc (3) $22: 198-205$ (1881)

82 Martite of the Cerro de Mercado, of Iron Mountain, of Durango, 'Mex., and certain iron ores of Sinaloa. Am J Sc (3) 24: $375-379$ (1882)

82a The mineral regions of southetn New Mexico. Am I M Eng, Tr 10:424444 (1882) Abst, Eng M J 34:199-200, 212-213 (1882)

82b Geological age of the Lake Valley mines of New Mexico. Eng M J 34:214 (1882)

83 Sketch of the great historic mines 0 ! the Cerro de Proaño at Fresnillo, State of Zacatecas, Mexico. xxxix, $79 \mathrm{pp}$, Nef Haven 1883

86 Memroir of John Lawrence Smith, 1818-1883. Nat Ac Sc, Biog Mem 2:217248 (1886)

See also Campbell (J), 64; Conrad, 39s; Hall, 43i, j; Jackson, 40; Shepard, 45

SHiliman, Mrs. G. S.

59 On the origin of aerolites [with cata. logue]. 31 pp, N Y 1859 [priv pub]

Silver, L. P.

02 The sulphide ore bodies of the Sud bury region [Ont.]. Can $M$ Inst, J 5: 528-551 (1902) Can M Rv 21:207-211 (1902)

03 Petrography of some igneous rocks of the Kettle River mining division, B. C. Ottawa Nat 17:85-91 (1903)

06 The Animikie iron range. Ont But Mines, An Rp 15 pt 1 : 156-172, map (1906) 
Simmersbach, B.

03 Die Steinkohlengeblete ron Pennsylranien und Westvirginien. Zs prak G 11 : 413-423, map (1903)

17 Die bergbauliche Entwicklung Kana das mit besonderer Berücksichtigung der Nickelgewinnung. Zs prak G 25: 111-116 (1917)

17a Prehnit vom Adams Sund, Admiralty Inlet, Baffininsel, Franklin, Zs prak G 25: 139-141 (1917)

Simmons, Jesse,

04 Tungsten ores in the Black Hills. M Rep $50: 217-218$ (1904)

09 Tin in the Black Hills of South Dakota. M World 30: 925-926 (1909)

09a The mother lode of the Black Hills [S. Dak.]. M World 31:126 (1909)

10 Mica in the Black Hills of South Dakota. M World 33:221-223 (1910)

12. The Cambria coal field in Wyoming. Coal Age 1:766-768 (1912)

12a The Sheridan, Wyo., coal field. Coal Age 1:866-868 (1912)

Simon, A. L.

10 The Porcupine gold field, Ont. M Mag, London, 3: 348-352 (1910)

simonds, Frederic William.

77 the geology of Ithaca, N. Y., and the vicinity. Am Nat 11:49-51 (1877)

91 The geology of Washington Co. Ark G 8 , An Rp 1888, 4:1-148, map, Little Rock 1891

94 (and Hopkins, T. C.) The geology of Benton Co. Ark G S, An Rp 1891, $2: 1-75$, map (1894)

94a A reply to some statements in Professor Tarr's "Lake Cayuga a rock basin." Am G 14:58-62 (1894)

96 Floating sand; an unusual mode of river transportation. Am G $17: 29-37$ (1896) Sc Am Sup 41:16745-16746 (1896)

96a Commercial mica in North Carolina; the story of its discovery. Science n 8 4:359-361 (1896)

$96 \mathrm{~b}$ Geology in the colleges and universities of the United States. Science $n$ 8 4:497-498 (1896)

97 Professor Ch. Fred. Hartt, a tribute. Am G 19: 69-90, port. (1897)

97a The Granite Mountain area of Burnet Co., Tex, (abst). Am G 20:194 (1897) Science n s 6:691 (1897)

99 Recent publications relating to the geology of Texas. Tex Ac Sc, Tr $2 ; 86-91$ (1899)

99n A consideration of the interpretation of unusual events in geologic records, fllustrat $d$ by recent examples (abst). Am As, Pr 48:227 (1899) Science n 810 : 489 ( 1899$)$

$00 \mathrm{~A}$ record of the geology of Texas for the decade ending December 31, 1896. Tex Ac Sc, Tr 3:19-285 (1900)
Simonds, Frederic William-Continued.

$00 \mathbf{a}$ On the interpretation of unusual events in geologic records illustrated by recent examples. Am Nat 34:495-501 (1900)

00b "Floating sand," "Floating stones." Science n s 11:510-512 (1900)

01 The minerals and mineral localities of Texas (abst). Science n $\mathrm{s}$ 14:797 (1901)

02 The minerals and mineral localities of Texas. Tex Univ Min S B 5:3-95 (1902)

02a Dr. Ferdinand von Roemer, the father of the geology of Texas; his life and work. Am G 29:131-140, port (1902)

o5 The geography of Texas, physical and political. $237 \mathrm{pp}$, Boston 1905

Simonin, L.

60 Observations sur les gisements aurifères de la Californie. Ac Sc Paris, C R $50: 389-392(1860)$

Simons, M. H.

82 "Mud lumps" and mounds near New Orleans. Am Nat 16:418-420 (1882)

Simons, Theodore.

14 Dip chart (discussion). Am I M Eng, B 96:2821-2823 (1914)

$14 a$ Finding fault with the "faultess faultfinder." Eng M J 98:884-887, 11481149 (1914)

Simpson, Charles Torrey.

93 On some fossil unios and other freshwater shells from the drift at Toronto. Canada; with a review of the distribution of the Unionidae of northeastern North America. U S Nat Mus, Pr 16:591-595 (1893)

94 Distribution of land and fresh-water mollusks of the West Indian region, and their evidence with regard to past changes of land and sea. U S Nat Mus, Pr 17: $423-450$, il (1894)

96 Description of four new Triassic unios from the Staked Plains of Texas. U S Nat Mus, Pr 18:381-385, il (1896)

00 On the evidence of the Unionidae re garding the former courses of the Tennessee and other southern rivers. Science n \& $12: 133-136$ (1900)

Simpson, George Baneroft (1844-1901). s7 (with Hall, J.) Corals and Bryozon; descriptions and figures of species from the Lower Helderberg, Upper Helderberg, and Hamilton groups. N Y G S, Pal 6 : xxvi. $298 \mathrm{pp}$, il (1887)

90 Descriptions of new species of fossils from the Clinton, Lower elderberg, Chemung, and Waverly groups ... Am $\mathrm{Ph} \mathrm{Soc}$, $\operatorname{Tr} \mathrm{n}$ s $16: 435-460$, il $(1890)$

94 A discussion of the different genera of Fenestellidae. N Y St G, An Rp 13: 685-727, il (1894) N Y St Mus, An Rp $47: 879-921$, il (1894) 
Simpson, George Bancroft-Continued.

94a Glossary and explanations of specific names of Bryozoa and corals described in rol. VI, Paleontology of New York, and other reports. N Y St G, An Rp 13: 729-747 (1894) N Y St Mus, An Rp 47: $923-941$ (1894)

97 A handbook of the genera of the North American Paleozoic Bryozoa, with an introduction upon the structure of living species. N Y St G, An Rp 14:403669 , il (1895) [1897] N Y St Mus, An Rp 48 v 2:403-669, II (1895) [1897]

00 Preliminary description of new genera of Paleozoic rugose corals. N Y St Mus, B $39: 199-222$, il $(1900)$

Simpson, Howard E.

03 The accretion of flood plains by means of sand bars. Iowa Ac Sc, Pr 1902, $10: 54-56$ (1903)

12 The physiography of the DevilsStump lake region, N. Dak, N Dak G S, Bien Rp 6:101-157, maps (1912)

12a (with Norton, W. H., and others) Underground water resources of Iowa. U S G S, W-S P 293: 994 pp, maps (1912) Iowa G S 21: 29-1186, maps 1912)

Simpson, James F.

o8 The relation of copper to pyrite in the lean copper ores of Butte, Mont. Ec G $3: 628-636$ (1908)

Simpson, James $H$.

50 Journal of a military reconnaissance from Santa Fe, N. Mex., to the Navajo country ... U S 31 st Cong 1st sess, $\mathrm{S}$ Ex Doc 64: 56-138, 146-148 (1850)

76 Report of explorations across the Great Basin of the Territory of Utah ... in $1859.518 \mathrm{pp}$, maps, Washington 1876

Simpson, W. A.

10 An inquiry into the Mesozoic mystery of being. Am G As, I no $1: 7-24$ (1910)

Sinclair, Joseph H.

16 Cretaceous of Alberta, Canada. G Soc Am, B 27:85-86 (abst), 673-684 (1916)

Sinelair, R. B.

65 The contorted quartz lode at Laidlaw's "diggins," Waverly [N. S.]. N S Inst $\mathrm{N}$ Sc, $\operatorname{Pr} \operatorname{Tr} 1$ pt $3: 142-145$ (1865) Sinelair, William John.

O1 The discovery of a new fossil tapir in Oregon. J G 9:702-707 (1901)

o3 A new tortoise from the auriferous gravels of California. Cal Univ, Dp G, B $3: 243-248$, il (1903)

O3a Mylagaulodon, a new rodent from the upper John Day of Oregon. Am J Sc (4), $15: 143-144$, il (1903)

03b A preliminary account of the exploration of the Potter Creek eave, Shasta Co., Cal. Science n s 17: 705-712 (1903)

03e The Potter Creek Quaternary bone cave (abst). J G 11:96-97 (1903)
Sinelair, William John-Continued.

o3d (with Merriam, J. C.) The on relation of the John Day and the Mascal (abst). J G 11:95-96 (1903)

04 (and Furlong, E. L.) Euceratis rium, a new ungulate from the Quaternar caves of California. Cal Univ, Dp G, i $3: 411-418$, 11 (1904)

04a The exploration of the Potte Creek cave, California [geology and Q ternary vertebrates]. Cal Univ, Pub, in Arch and Eth 2:1-27 (1904)

05 New or imperfectly known rodent and ungulates from the John Day series Cal Univ, Dp G, B 4:125-143, il (1905)

o5a New Mammalia from the Quata nary caves of California. Cal Univ, Di G, B $4: 145-161$, il (1905)

o6 Some edentate-like remains from th Mascall beds of Oregon. Cal Univ, Dp G B $5: 65-66$, il (1906)

06a Volcanic ash in the Bridger bed of Wyoming. Am Mus $\mathrm{N}$ H, B 22:27\% 280 (1906)

o7 (with Merriam, J. C.) Tertiary faunas of the John Day region. Cal Dnir Dp G, B 5 : 171-205 (1907)

os Recent investigations bearing on th question of the occurrence of Neocene mu in the auriferous gravels of the Siert Nevada. Cal Univ, Pub Am Archaeolog and Ethnology 7:107-131 (1908)

09 The Washakie, a volcanic ash forms tion. Am Mus N H, B 26:25-27 (1909) Abst, Science n s 27:254 (1908)

10 Dermal bones of Paramylodon from the asphaltum deposits of Rancho La Bres. near Los Angeles, Cal. $\quad \Delta m \mathrm{Ph} S o c, \mathrm{Pr} 49:$ $191-195$, il $(1910)$

10a The restored skeleton of Lepiar chenia decora. Am Ph Soc, $\operatorname{Pr} 49: 196-$ 199, il (1910) Abst, Science n s 31: 575 (1910)

10b Interdependence of stratigraphy and paleontology. Pop Sc Mo $76: 589-$ 591 (1910)

11 Tertiary formations of northwester Wyoming (abst). Science n s $33: 96$ (1911)

11 a (and Granger, W.) Eocene ad Oligocene of the Wind River and Big Horn basins [Wyo.]. Am Mus N H, B 30:83117, maps (1911) Abst, G Soc Am, B 22: $722-723$ (1911)

12 Ten years' progress in vertebrat? paleontology ; Contributions to geologis theory and method by American workers is vertebrate paleontology. G Soc $\mathrm{Am}, \mathrm{B} 25$ : 262-266 (1912)

12a Some glacial deposits east ac Cods Wyo,, and their relation to the Pleistocese erosional history of the Rocky Mountsin region (abst). Science $\mathrm{n}$ s $35: 314-316$ (1912) ; with discussion by W. W. Atwood) G Soc Am, B 23: 731 (1912) 
Sinelair, William John-Continued. 12b (and Granger, W.) Notes on the Tertiary deposits of the Big Horn Basin. Am Mus N H, B 31:57-67, map (1912)

14 A revision of the bunodont Artiodactyla of the middle and lower Eocene of North America, Am Mus N H, B 33:267295, il (1914)

14a (and Granger, W.) Paleocene deposits of the San Juan Basin. N. Mex. Am Mus N H, B 33: 297-316, maps (1914)

14b "Laramie?," Puerco, and Torrejon in the San Juan Basin, N. Mex. (abst). G Soc Am, B 25:138 (1914)

15 additions to the fauna of the lower Pliocene Snake Creek beds (results of the Princeton University 1914 expedition to Nebraska). Am Ph Soc, Pr 54:73-95, il (1915) Abst, Science n $8 \quad 41: 839-840$ (1915)

17 A new labyrinthodont from the Triassic of Pennsylvania [Calamops paludosus]. Am J Sc (4) 43:319-321, il (1917)

17 a Labyrinthodont from the Newark series (abst, with discussion by R. P. Lull). G Soc Am, B 28: 213 (1917)

18 A large parasuchian from the Triassic of Pennsylvania. Am J Sc (4) 45:457462 (1918)

Singewald, Joseph Theophilus, jr.

09 The iron ores of Maryland. Ec G 4: $530-543$ (1909) Abst, Science n s $29: 633-$ 634 (1909): G Soe Am, B 20:671 (1910)

11 Report on the iron ores of Maryland, with an account of the iron industry. Md G S $9: 121-327$ (1911)

12 Origin of iron ores. Ee G $7: 191$ 195 (1912)

12a Some genetic relations of tin deposits. Ec G $7: 263-279$ (1912)

12b The iron ore deposits of the Cebolla distriet, Gunnison Co., Colo. Ec G 7:560573, map (1912)

13 The titaniferous iron ores in the United States. U S Bur Mines, B 64: 145 pp (1913)

13a Ein Titaneisenerzvorkommen kontaktmetamorpher Entstehung [titaniferous iron ore of contact-metamorphic origin in the Cebolla district, Colo.]. Zs Prak G 21: $279-280$ (1913)

$13 \mathrm{~b}$ The relations of limenite to magbetite in titaniferous magnetite (abst). Wash Ae Sc, J $3: 199$ (1913)

13e The microstructure of titaniferous magpetites. Ec G $8: 207-214 \quad$ (1913) dbst, G Soc Am, B 24: 704 (1913)

16 (and Miller, B. L.) The genesis and relations of the Daiquiri and Firmeza iron-ore deposits, Cuba. Am I M Eng, B $111: 671-678$ (1916) ; Tr $53: 67-74$ (1916) 16a (and Miller, B. L.) Mining in Oriente Province, Cuba. Eng M J 101: $587-592$ (1916)
Singevald, Joseph Theophilus, jr.-Con.

17 Concentration experiments with the siliceous red hematite of the Birmingham district, Ala. U S Bur Mines, B 110:91 pp, map (1917)

17a The rôle of mineralizers in ore segregations in basic igneous rocks. Johns Hopkins Univ Cire n s 1917 no $3: 24-35$ [222-233] (1917)

17b Magmatic segregation and ore genesis. M Sc Press 114: 733-736 (1917)

See also Emmons (W H), 18; Roesler, 16 ; Tolman, 16a

singley, J. A.

92 Artesian well work [Galveston]. Tex G S, Rp Prog 2 (1891) : 78-82 (1892)

93 Preliminary reports on the artesian wells of the Gulf coastal slope. Tex G S, An Rp 4 pt 1:87-113 (1893)

Sinnett, Edmund $W$.

15 (and Bailey, I. W.) The evolution of herbaceous plants and its bearing on certain problems of geology and climatology. J G 23: 289-306 (1915)

$15 a$ (with Bailey, I. W.) A botanical index of Cretaceous and Tertiary climates. Science n s 41:831-834 (1915)

16 (and Bartlett, H. H.) Coniferous woods of the Potomac formation. Am J Sc (4) $41: 276-293$, il (1916)

$16 a$ A botanical criterion of the antiquity of the angiosperms. J G 24:777782 (1916)

16h The evolution of herbs. Science n 8 44:291-298 (1916)

Sisley, L. A.

97 The porphyry dike mines of Montana. Eng M J 64: 399 (1897)

Sivyer, Leonard D.

88 The geology of the Aspen, Colo., ore deposits. Eng M J 45:195-196, 212 (1888)

09 Geology of Globe, Ariz. Los Angeles M Rv 25 no $11: 6-7$ (1909)

Six, Achille.

84 Les appendices des tribobites d'après M. Ch. D. Walcott. Soc G Nord, An 11 : 228-236 (1884)

Sjogren, Hjalmar (1856-1922).

$91 \mathrm{Om}$ jernmalmsfälten i Nordamerika [iron deposits of North America]. G Fören Stockholm, Förh 13:578-584 (1891)

os The localization of values in ore bodies and the occurrence of shoots in metalliferous deposits. Ec G $3: 637-643$ (1908)

11 Om kratern vid Canyon Diablo, Arizona, och dess samband med meteorjürnsfallet på samma plats. K Svenska Vetenskapsakad, Ärsbok 1911: 237-262

skent, Ethel $\mathrm{G}$.

04 The Jurassic rocks of East Greenland. G As, London, $\operatorname{Pr} 18: 336-350$, map (1904) 
Skeats, Ernest W.

18 The formation of dolomite and its bearing on the coral reef problem. Am J Sc (4) 45: 185-200 (1918)

skertehiy, Sydney A R.

10 Oil in Mexico. M Mag, London, 3: 283-286 (1910)

12 The Mexican oil fields. M Mag, London, $7: 199-203$ (1912)

Skewes, Edward.

95 Cripple Creek, Colo. Eng M J 59 : 103-104, 151-152 (1895)

95a Cripple Creek phonolite dikes, Raven Hill. Eng M J 59: 583 (1895)

97 The ore shoots of Cripple Creek [Colo.]. Am I M Eng, $\operatorname{Tr} 26: 553-579$ (1897) Abst, Zs Prak G 1897:98-99

skewes, Helen J.

17 Mineral resources in Illinois in 1911 and 1912. Ill G S, B $23: 25-44$ (1917) ... in 1913 and $1914 ; \mathrm{B} 30: 23-49$ (1917) ... in 1915 ; $\mathrm{B} 33: 27-70$ (1916)

skey, Joseph.

16 Some remarks upon the structure of Barbados, as connected with specimens of its rocks. G Soc London, $\operatorname{Tr} 3: 236-242$ (1816)

skilton, Dr.

58 On Equus major [Troy, N. Y.]. Boston Soc N H, Pr 6:303-304 (1858)

skinner, W. W.

03 The underground waters of Arizona ; their character and uses. Ariz Univ, Agr Exp Sta, B 46: 273-296 (1903)

slaek, Charles $G$.

87 Notes upon the artesian wells of Denver. Colo Sc Soc, Pr 2: 56-60 (1887) slichter, Charles Sumner.

98 Note on the pressure within the earth. J G 6:65-78 (1898)

99 Theoretical investigation of the motion of ground waters. U S G S, An Rp 19 pt $2: 295-384$ (1899)

02 The motions of underground waters. U S G S, W-S P 67:106 pp (1902)

05 Field measurements of the rate of movement of underground waters. U S G S, W-S P 140:122 pp (1905)

06 The underflow in Arkansas Valley in western Kansas. U S G S, W-S P 153: (1906)

06a (and Wolf, H. C.) The underflow of the South Platte Valley. U S G S, W-S P 184: 42 pp (1906)

Slipper, S. E.

15 The Sheep River map area, Alta. Can G S, Sum Rp $1914: 53-54$ (1915)

15a Calgary gas and oil field [Alta.]. Can G S, Sum Rp 1914: 143-145 (1915)

16 Boring operations in southern Alberta. Can G S, Sum Rp 1915: 116-120 (1916)

17 Oil and gas, Alberta. Can G S, Sum Rp 1916:114-134 (1917)

18 Oil production, Sheep River area [Alta.]. Can G S, Sum Rp 1917 pt C: 4-5 (1918)
Slipper, S, E.-Continued.

18a Viking gas field [central Alta.]: structure of area. Can G S, Sum Rp 1917 pt C : $6-9$ (1918)

Sloan, B. E.

82 Analysis of helvite from near Amelia Courthouse, Va. Ch News 46:195 (1882)

sloan, Earle.

04 A preliminary report on the clays of South Carolina. S C G S (4) B 1:175 pp (1904)

o5 The mineral resources of South Car olina. Am M Cong, 7 th, Pr: 129-160 (1905)

o7 Geology and mineral resources [ot South Carolina]. S C, State Dp Agr ... Handbook of South Carolina : 77-145, map, 1907

O7a A summary of the mineral resources of South Carolina. [S. C.], Dp Agr ...:66 pp, Columbia, S. C. 1907

os Catalogue of the mineral localities of South Carolina. S C G S (4) B 2: 505 pp, map (1908)

slocom, Arthur Ware.

o6 A list of Devonian fossils collected in western New York, with notes on theit stratigraphic distribution. Field Col $\mathrm{Mus}$, Pub g s 2:257-265, il (1906)

06a (with Springer, Frank) Hypsocrinus, a new genus of crineids from the Devonian. Field Col Mus, Pub g s $2: 267-$ 271 (1906)

07 New processes of taking impressions of natural molds of fossils. Science in $s$ 25: 591-592 (1907)

07a New crinoids from the Chicago area. Field Col Mus, Pub g s $2: 273-306$, il (1907)

o9 New echinoids from the I nley group of Mississippi. Field Mus N H, Pub g s 4: $1-16$, il (1909)

13 New trilobites from the Maquoketa beds of Fayette Co., Iowa. Field Mos N H, Pub g s 4:43-83, il (1913)

16 Trilobites from the Maquoketa beds of Fayette Co., Iowa. Iowa G S 25:183249, il (1916)

Slocum, Charles E.

99 The relative ages of the Maumee glacial lake and the Niagara Gorge (abst). $\mathrm{Am} \mathrm{As,} \operatorname{Pr}$ 48:227-228 (1899) Science n s 10:499 (1899)

Slosson, Edward Emery.

90 (with Bailey, E. H. S.) On barite and associated minerals in the concretionary rocks of eastern Kansas. Kans dc Sc, $\operatorname{Tr} 12: 45-46 \quad(1890)$

96 (with Knight, W. C.) The petroleum of Salt Creek, Wyo. Wyo, Univ, Sch Mines, Petroleum ser, B 1:47 pp (1896)

97 (with Knight, W. C.) The petroleum of the shoshone anticlinal. Wyo, Univ, Sch Mines, Petroleum ser, B $2: 34$ pp (1897) 
Slosson, Edward Emery-Continued.

99 (with Knight, W. C.) The oil fields of Crook and Uinta cos., Wyo. Wyo, Univ, Sch Mines, Petroleum ser, B 3:31 pp (1899)

00 (and Moudy, R. B.) The Laramie cement plaster. Published as part of the 10th An Rp of the Wyo Coll Agr and Mechanics, $18 \mathrm{pp}$, Laramie 1900 Abst, Eng M J $70: 518$ (1900)

01 (with Knight, W. C.) Alkali lakes and deposits. Wyo, Univ, Wyo Exp Sta, B $4^{r}: 71-123$, map (1901)

01a (with Knight, W. C.) The Dut ton, Rattlesnake, Arago, Oil Mountain, and Powder River oil fields. Wyo, Univ, Sch Mines, Petroleum ser, B 4:57 pp, rap (1901)

02 (with Knight, w. C.) The Neweastle oil field. Wyo, Univ, Sch Mines, Petroleum ser, B 5:24 pp (1902)

03 (with Knight, W. C.) The Bonanza, Cottonwood, and Douglas oil fields. Wyo, Univ, Sch Mines, Petroleum ser, B 6:30 pp (1903)

Small, H. B.

93 The phosphate mines of Canada (with discussion). Am I M Eng, Tr 21: $774-782,1003$ (1893)

smallwood, W. Martin.

02 (with Hopkins, T. C.) Some anti. thinal folds $(a b s t)$. Sclence $\mathrm{n}$ \& $15: 89$ (1902) G Soe Am, B 13:530 (1903)

03 (and Hopkins, T, C.) A discussion of the origin of some anticlinal folds near Meadville, Pa. Syracuse Univ, B (4) 1:18-24 (1903)

Smith, A. D. W.

95 Report on the anthracite region. Pa G S, Final Rp 3 pt 1:1916-2152, map (1895)

Smith, A. F

03 (with Ba11, S. H.) The geology of Miller $\mathrm{Co}$., with an introduction by E. R. Buckley. Mo Bur G and Mines (2) 1 : 207 pp, maps, Jefferson City, Mo., 1903

03a (with Bnckley, E. R.) Glacial boulders along the Osage River in Missouri (abst). J G 11:106-107 (1903) G Soc Am, B 14:553 (1904)

Smith, Alexander H.

05 "Los Reyes" gold mines, southern Mexico. Can M Inst, J 8:272-284 (1905) 8 mith, Alfred.

32 ...alluvial and rock formations of the Connecticut River valley. Am J Sc 22 : 205-231, map (1832)

Smith, Alva J.

99 Fusulina cylindrica shell structure. Kans Ac Sc, Tr 64-65, il (1899)

01 The Americus limestone [Kansas] Kans Ac Sc, Tr $17: 189-190$, map (1901) 02 A bulletin on Lyon County geology. 11 pp, Emporia, Kans., 1902 [Priv pub] 03 Geology of Lyon Co., Kans. Kans Ac Sc, Tr 18:99-103 (1903)
Smith, Alva J.-Continued.

os Reading blue limestone [Kans].

Kans Ac Sc, Tr 19:150-153, map (1905)

15 Deep wells at Elmdale. Kans Ac Sc, Tr $27: 50-52$ (1915)

Smith, Arthur L.

09 Delta experiments. Am Geog Soc, B 41: 729-742 (1909)

Smith, Aubrey H.

86 The railway cutting - t Gray's Ferry road [Philadelphia, Pa.]. Ac N Sc Phila, Pr 1886: 253-254

Smith, Burnett.

05 Senility among gastropods. Ac N Sc Phila, Pr 57 : 345-361 (1905)

09 Note on the Miocene drumfish, Pogonias multidentatus Cope. Am J Sc (4) $28: 275-282$, il (1909)

09a On some dinichthyid armor plates from the Marcellus shale. Am Nat 43: 588-597 il (1909)

091 Dikes in the Hamilton shale near Clintonville Onondaga Co., N. Y. Science n s $30: 724$ (1909)

10 Dikes near Clintonville, Onondaga Co., N. Y. N Y St Mus, B $140: 23-24$ (1910)

$10 a$ Notes on some little-known fishes from the New York Devonian. Ac N Sc Phila, Pr 62:656-663, il (1910)

12 Observations on the structure of some coral beds in the Hamilton shale [of New York]. Ac N Sc I'hila, Pr 64:446-454 (1912)

14 A new locality for Castoroides [Madison Co., N. Y.]. Am J Sc (4) 38:463466 (1914)

14a Notes on the fossils of the saleozoic formations within the Syracuse quadrangle [N. Y.]. N $\mathbf{Y}$ St Mus, B 171: 57-63 (1914)

14b A review of the mammalian remains from the superficial deposits in the vicinity of Onondaga Lake, N. Y. N Y St Mus, B $171: 64-72$, il (1914)

15 Morphologic sequences in the canallculate fulgurs. Ac N Sc Phila, Pr 66: $567-578$, il (1915)

16 The structural relations of some Devonian shales in central New York. Ac N Sc Phila, Pr 67:561-569 (1916)

Smith, C. D.

75 Corundum and its associated rocks. In Kerr, W. C., Report of the geological survey of North Carolina 1, App:91-97, Raleigh 1875

75a Essay on the geology of western North Carolina. In Kerr, W. C., Report of the geological survey of North Carolina 1. App: 98-120, Raleigh 1875

Smith, Carl David.

06 (with Tafr, J. A.) Ozokerite deposits in Utah. U S G S, B 285: 369-372 (1906)

09 The Washburn lignite field, N. Dak. U S G S, B 381 : 19-29, map (1909) 
Smith, Carl David-Continued.

$09 a$ The Fort Berthold Indian Reservation lignite field, N. Dak. U S G S, B 381: $30-39$, map (1909)

09b The Fort Peck Indian Reservation lignite field, Mont. U S G S, B 381 : 40-59, map (1909)

09e (with Collier, A. J.) The Miles City coal field, Mont. U S G S, B 341 : 36-61 (1909)

09d (with Leonard, A. G.) The Sentnel Butte lignite field, N. Dak. and Mont., U S G S, B 341: 15-35 (1909)

14 Structure of the Fort Smith-Poteau gas field, Arkansas and Oklahoma. U S G S, B 541: 23-33, map (1914)

$14 a$ The Glenn oil and gas pool and vicinity, Okla. U S G S, B 541:34-48, map (1914)

Smith, Charles E.

02 Work of the Cornell summer school of field geology. Am G $30: 396-397$ (1902)

Smith, Dwight Timothy.

03 A geological reconnaissance of the region of the upper main Walker River, Nevada $(\alpha b s t)$. J G 11:94-95 (1903) Eng M J $75: 154$ (1903)

04 The geology of the upper region of the main Walker River, Nev. Cal Univ, Dp G, B 4:1-32, map (1904)

12 Vein systems of the Comstock. Eng M J $94: 895-896$ (1912)

Smith, E. Eggleston.

09 The eastern part of the Great Divide Basin coal field, Wyo. U S G S, B 341: 220-242, map (1909)

11 Coals of the state of Washington. U S G S, B 474:206 pp (1911) Abst, Wash Ac Sc, J 2:161-162 (1912)

Smith, E. Percy.

04 (and Dominian, L.) Notes on a trip to White Oaks, N. Mex. Eng M J $77: 799-800$ (1904)

Smith, Edgar Fohs.

S2 (and Thomas, N. W.) Corundum and wavellite. Am Ph Soc, Pr 20:230-231 (1882)

10 Some Berks County minerals. Ac N Sc Phila, Pr 62:538-540 (1910)

Smith, Erastus Gilbert.

85 On the chrysotile from Shipton, Can.

Am J Sc (3) 29:32-33 (1885)

86 Pseudomorphs of limonite after pyrite. Am J Sc (3) 31:376-377 (1886)

94 Artesian wells as a source of water. Sc Am Sup 37: 15065-15066 (1894)

See also Hussak, 86

Smith, Essie Alma.

06 Development and variation of Pentremites conoideus. Ind Dp G, 30 th An Rp : 1219-1242, il (1906)

Smith, Ethel M.

09 A study of voleanic topography. J Geog 8 : 56-61 (1909)
Smith, Fugene Allen,

72 Remrarks on the geology of the Mic sissippi bottom. Am As, Pr 20:252-281 (1872)

73 Report on the geological and agricul. tural survey of Alabama. $8 \mathrm{pp}$, Montgor ery, Ala., 1873

75 Report of progress for 1874, Als G S : 139 pp, Montgomery 1875

76 Report of progress for 1875. Als G S : 220 pp, Montgomery 1876

76a Report of progress for 1876. Als G S : 99 pp, map, Montgomery, Ala., 1876

7s Outline of the geology of Alabams. In Berney, Saffold, Handbook of Alabama: 129-196, map, Mobile 1878

79 Report of progress for 1877 and 1878 . Ala G S: 138 pp, maps, Montgomery, Ala, 1879

79a The iron ores of Alabama, with special reference to their geological relations. Am As, Pr $27: 246-258$ (1879)

so General description of the Blact Warrior from Tuscaloosa to Sipsey Fork. U S, 46th Cong $3 d$ sess, S Ex Doc $42: j-$ $34(1880)$

81 Report of progress for 1879 and 1860. Ala G S: $158 \mathrm{pp}$, map Montgomery, Ala. 1881

$81 a$ On the geology of Florida. Am J Sc (3) 21:292-309, map (1881) Abst, Am Nat $16: 256-257$ (1882)

83 Report for the years 1881 and 1882 . embracing an account of the agricultural features of the State. Ala G S:615 pp. maps, Montgomery, Ala., 1883 In pait reprinted in A general deseription of the State of Alabama, Dept. Agriculture: 557, Montgomery, Ala., 1884

$83 a$ The Iron ores of Alabama in theit geological relations. U S G S, Min Bes [1882] : 149-161 (1883)

84 List of the ores and minerals of industrial fmportance occurring in Ala bama. 11 pp, Montgomery, Ala., 1884

84a Cretaceous phosphates in Alabama. Science $3: 586-587: 4: 78-79$ (1884)

84b Phosphatic deposits in the Cre traceous of Alabama. Am J Sc (3) 27: 492-493 (1884)

84e Physico-geographical and agricultural features of the State of Alabama. U S, 10th Census 6:17-173, map (18s4)

84d Physico-geographical and agricultural features of the State of Florida. U S, 10th Census 6:185-257, map (1884) 85 Tertiary phosphates in Alabama. Science 5:376 (1885)

85a Phosphatic rocks of Florida Science 5:395-396 (1885)

85b Remarks on a paper of Dr. Otte Meyer on "Species in the southern old Tertiary." Am J Sc (3) $30: 270-275$ (1885) 
Smith, Eugene Allen-Continued.

85e On a section of the strata of the Cretaceous and Tertiary formations of Alabama (abst). Am As, Pr 33:407-408 (1885)

s6 Summary of the lithological and stratigraphical features and subdivisions of the Tertiary of Alabama. Ala G S, B 1: 7-14 (1886)

s6a The geological formations of Alabama in their industrial and agricultural relations. In Dubose, John W. (ed.), The mineral wealth of Alabama and Birmingham illustrated: 7-15, Birmingham, Ala., 1886

87 (and Johnson, L. C.) Tertiary and Cretaceous strata of the Tuscaloosa, Tombigbee, and Alabama rivers. U S G S, B $43: 189 \mathrm{pp}$, map (1887)

8s Report of progress for the years 1884-8. Ala G S: 24 pp, map, Montgomery, Ala., 1888

88a (and others) Report of the subcommittee on the Cenozoic (marine). In International Congress of Geologists, American Committee, Reports ... F : 19 pp, Phila $1888 \Delta \mathrm{m} \mathrm{G} 2: 269-284$ (1888) Int $\mathrm{G}$ Cong, IV, London 1888, C R App $\Delta: 175$ 192 (1891)

90 Biennial report of the State geologist [of Alabama]. 18 pp, Montgomery, Ala., 1890

$90 \mathrm{a}$ on the geology of the valley regions adjacent to the Cahaba field. In Squire, Joseph, Report on the Cahaba coal field: $133-180$, Ala G S 1890

91 Preface [stratigraphic divisions of Paleozoic in Alabama]. In McCalley, Henry, Report on the coal measures of the plateau region of Alabama: 5-8, Ala G S, 1891

92 Report of geological survey of Alabama, for fiscal years ending September 30th, 1891-92. 22 pp, Montgomery, Ala., 1892

$92 \mathrm{a}$ Sketch of the geology of Alabama. $36 \mathrm{pp}$ [Birmingham, Ala.] 1892

921 On the phosphates and marls of Alabama. Ala G S, B $2: 82$ pp, Montgomery 1892

92e The clays of Alabama. Ala Ind Se Boc, Pr 2: 33-42 (1892)

92d The Lafayette gravels. Science 19 : 31 (1892)

92e The Tuscaloosa formation. Science $18: 274$ (1892)

93 Underthrust folds and faults. Am J Sc (3) 45:305-306 (1893)

93a The coal measures of Alabama. U G S, Min Res 1892: 293-300 (1893)

94 (and others) Report on the geology of the Coastal Plain of Alabama. Ala G 8: $759 \mathrm{pp}$, il, Montgomery, Ala., 1894 94a The phosphates and marls of the State. In Smith, E. A., and others, Report on ... Coastal Plain of Alabama : 447-525, Ala G S, 1894
Smith, Eugene Allen-Continued.

94b Geological map of Alabama, with explanatory chart. Ala G S, Montgomery, Ala., 1894

94e Geological surveys in Alabama. $J$ G $2: 275-287$ (1894)

94d The post-Eocene formations of the Coastal Plain of Alabama. Am J Sc (3) $47: 285-296 \quad$ (1894)

95 Alabama's resources for the manufacture of Portland cement. Ala Ind Sc Soc, Pr 5: 44-51 (1895)

96 Report of progress for the years ending September 30th, 1895, and September 30 th, 1896. Ala G S: 18 pp, Montgomery, Ala., $1896 \quad \ldots \quad 1897$ and 1898:21 pp (1898)

96a A general account of the character, distribution, and structure of the crystalline rocks of Alabama and of the mode of occurrence of the gold ores. Ala G S, B 5: 108-130 (1896)

$96 \mathrm{~b}$ Sketch of the mineral resources of Alabama. Published by direction of Isaac F. Culver, Commissioner of Agriculture. $15 \mathrm{pp}$ [n p, 1896]

96e The phosphates and marls of Alabama. Am I M Eng, Tr 25:811-822 (1896)

96d Notes on native sulphur in Texas. Science n s 3:657-659 (1896)

97 Sketch of the life of Michael Tuomey. Am G 20:205-212, port (1897)

98 The clay resources of Alabama... Eng M J $66: 369$ (1898)

98n The stone industry of Alabama. Eng M J 66:398 (1898)

98b Alabama gold mining notes. Mines and Minerals 19:129 (1898)

00 Geological relations of the clays of Alabama. Ala G S, B 6:69-113 (1900)

02 Reports of progress for the fiscal years 1898-9 and $1899-1900$ and $1900-$ 1901 and 1901-1902. Ala G S: 26 pp, Montgomery, Ala., 1902 ...1902-06:19 pp (1907) ...1906-10:19 pp (1911) ...191014:24 pp [1915]

02a (and Aldrich, T. H.) The Grand Gulf formation. Science n s 16:835-837 (1902) ; 18:20-26 (1903)

03 The Portland cement materials of central and southern Alabama. U S, 58th Cong 1st sess, S Doc 19:12-23 (1903)

03a Carboniferous fossils in "Ocoee" slates. Science n s 18: 244-246 (1903)

04 (and Mecalley, H.) Index to the mineral resources of Alabama. Ala G S: 79 pp, map, Montgomery, Ala., 1904

04a The cement resources of Alabama. Ala G S, B 8:61-93, map (1904)

04b The cement resources of Alabama. U S G S, B 225: 424-447 (1904)

o4c [Notes on water resources of] Alabama. U S G S, W-S P 102: 276-331 (1904) 
Smith, Eugene Allen-Contlnued.

o5 Revised map of the southeastern part of the Cahaba coal field, with columnar section. Ala G S, 1905

05a Portland-cement materials of Ala-

bama. U S G S, B 243:60-84, map (1905)

o5b [Underground waters of] Alabama.

U S G S, W-S P 114: 164-170, map (1905)

05e Blographical sketch of Henry Mc-

Calley. Am G 35:197-201, port (1905)

06 Memoir of Henry MeCalley. G Soc

Am, B $16: 555-558$ (1906)

06a On some post-Eocene and ether formations of the Gulf region of the United States. Science n s 23:481-491 (1906) Am As, Pr $55: 357-374$ (1906)

06b The overlap of the St. Stephens limestone on the lower Tertiary formations in Crenshaw and Pike cos, Ala. $(a b s t)$. Science n s $23: 287-288$ (1906)

o6e On the Jackson anticlinal in Clarke Co., Ala. (abst). Science n s 23:288 (1906)

O7 The underground water resources of Alabama. Ala G S : $388 \mathrm{pp}$, map (1907)

10 Memoir of Daniel- W. -Langton, jr. [1864-1909]. G Soc Am, B 21:12-16 (1910)

10a Cretaceous-Eocene contact, Tombigbee River, Ala. J G 18:430-434 (1910)

14 Pioneers in Gulf Coastal Plain geology; presidential address. G Soc Am, B $25: 157-178$ (1914)

15 Statisties of the mineral production of Alabama for 1914. Ala G S, B 16:64 pp (1915) _.. 1915; B 19:87 pp (1917) ... 1916; B 20: 102 pp (1918)

17 Concerning oil and gas in Alabama. Ala G S Circ no 3:18 pp, map (1917)

17a Memorial of Eugene Woldemar Hilgard. G Soc Am, B 28: 40-67, port (1917)

18 Memorial of Robert Hills Loughridge. G Soc Am, B 29:48-55, port (1918) See also Eckel, 13

Smith, Frank B.

02 Coal mining in the Northwest Territories and its probable future [Alberta]. Can M Inst, J 5:104-112 (1902) Can M Rv 21:79-81 (1902)

03 The Frank disaster [landslide, Frank, Alta.]. Can M Rv 22:102-103 (1903)

Smith, Frank Clemes.

98 The Potsdam gold ores of the Black Hills of South Dakota. Am I M Eng, Tr $27: 404-428$, map (1898)

oo [On the gold ores of the Black Hills.] Am I M Eng, Tr 29: 1031-1035 (1900)

08 Localization of values in ore bodies and occurrence of "shoots" in metaliferous deposits. Ec G 3:224-229 (1908)

13 Field and office methods in the preparation of geological reports. Ec $G$ : 383-386 (1913)

Smith, Franklin L.

37 ... gold of a portion of North Carolina. Am J Sc 32:130-133 (1837)
Smith, Franklin W.

10 Conditions at the Palmilla mine, Parral, Mex. Eng M J $90: 259-262(1910)$ Smith, Fred D.

96 The Bald Mountain disirict, Wro. Eng M J 62:535 (1896)

oo The Ely mining district, Nev. Fas M J $70: 217(1900)$

o2 The Osceola, Nev., tungsten deposits Eng M J 73:304-305 (1902)

Smith, Frederick H.

82 Rocks, minerals, and stocks, 234 pp, Chicago, Ill., 1882

90 Revised pocket geologist and mineral. ogist ... 214 pp, Baltimore, Md., 1890

Smith, G. F. Herbert.

02 On the remarkable problem presented by the crystalline development of cals. verite. Miner Mag 13: 122-150 (1902) 2s Kryst $37: 209-234$ (1903)

\section{Smith, George.}

62 History of Delaware County, $\mathrm{Pa}$ with a notice of the geology of the county (:403-415, map), 582 pp, maps, Phila 1862

Smith, George L.

09 The Carboniferous section of south western Iowa. Iowa G S 19:605-65i (1909)

15 The paleontology and stratigraphy of the upper Carboniferous of Iowa, Iow Ac Sc, Pr $22: 273-283$ (1915)

16 Contributions to the geology of southwestern Iowa. Iowa $\mathrm{Ac} \mathrm{Sc}, \operatorname{Pr} 23$ : $77-89$ (1916)

Smith, George Otis.

94 Notes on crystals of scapolite, gyp sum, and fayalite... Johns Hopkins Cuir Cire 13: 81-83 (1894)

95 The volcanic series of the For is lands, Me. Johns Hopkins Univ Cire 15: 12-13 (1895)

96 The geology of the Fox Islands Me. Diss, Johns Hopkins Univ. 76 p map, Skowhegan, Me., 1896

98 The rocks of Mount Rainier. I \& G S, An Rp 18 pt 2: 416-423 (1898)

98a Igneous phenomena in the Tintic Mountains, Utah $(a b s t)$. Science $n 8$ i: 502 (1898)

99 (with Tower, G. W.) Geology and mining industry of the Tintic district, Utal U S G S, An Rp 19 pt 3:601-767, maps (1899)

99a (with Willis, B.) Description of the Tacoma quadrangle [Wash.]. U S G \& G Atlas Tacoma fol (no 54) : 10 pp, maps (1899)

o0 Description of the Tintic special dis trict [Utah]. U S G S, G Atlas Tintic fol (no 65$): 1-4, \operatorname{maps}(1900)$

o0a (and Curtis, G. C.) Camasland! valley remnant [Wash.]. G Soc Am, B 11: 217-222 (1900) Abst, Science n s 11:9 (1900) 
Smith, George Otis - Continued.

oob (and Mendenhall, W. C.) Tertiary granite in the northern Cascades. G Soc Am, B $11: 223-230$ (1900) Abst, Science $n$ s $11: 144(1900)$

00e [Landslides in Mount Stuart quadrangle, Wash.]. G Soc Am, B $11: 583-584$ (1900)

ood The geology of Mount Rainier [Wash.]. Mazama 2:18-24 (1900)

01 Geology and water resources of a portion of Yakima Co., Wash. U S G S, W-S $\mathrm{P} 55: 68 \mathrm{pp}$, map (1901)

01a (and Willis, B.) The Clealum iron ores, Wash. (with discussion by W. M. Courtis). Am I M Eng, Tr 30:356-366, map (1901)

02 The coal fields of the Pacific coast. U S G S, An Rp 22 pt $3: 473-513$, maps (1902)

02a A geological study of the Fox Islands, Me. (Colby Coll., B 1 suppl); 53 pp, map [Waterville, Me., 1902]

$02 b$ The Mount Baker mining district, Washington. Eng M J 73:379-380 (1902) 02e The mineral crest (criticism of Dr. Jenney's paper). Eng M J 73:826 (1902) 03 Description of the Ellensburg quadrangle [Wash.]. U S G S, G Atlas Ellensburg fol (no 86) : 7 pp, maps (1903)

03a Geology and physiography of central Washington. U S G S, P P 19:9-89, maps (1903)

03b Gold mining in central Washington. U S G S, B 213:76-80 (1903)

03e Anticlinal mountain ridges in central Washington. J G $11: 166-177$ (1903)

03d Abandoned stream gaps in northern Washington (abst). Science n s 17:387388 (1903)

04 Description of the Mount Stuart quadrangle [Wash.]. U S G S, G Atlas Hount Stuart fol (no 106) : $10 \mathrm{pp}$, maps (1904)

04a Quartz veins in Maine and Vermont. U \& G S, B 225: 81-88 (1904)

04b (and Callins, F. C.) A geological reconnaissance across the Cascade Range near the forty-ninth parallel. U S G S, B 235: 103 pp, map (1904)

04e Stratigraphic problems in the northern Cascades (abst). Science n s 19:921 (1904)

05 (and White, D.) The geology of the Perry Basin in southeastern Maine. U S G S, P P $35: 107$ pp, map, il (1905)

05a A molybdenite deposit in eastern Maine. U S G S, B 260:197-199 (1905)

05b The granite industry of the Penobscot Bay quadrangle, Me. U S G S, B $260: 489-492$ (1905)

05e Water resources of the PortsmouthYork region, N. H, and Me. U S G S, W.S P $145: 120-128$ (1905)
Smith. George Otis Continued.

o5d Water supply from glacial gravels near Augusta, Me. U S G S, W-S P 145: 156-160 (1905)

05e Artesian water in crystalline rocks (abst). Science n s 21:224-225 (1905)

06 Graphite in Maine. U S G S, B 285: 480-483 (1906)

06a Two occurrences of graphite [in Maine] (abst). Science n s 23:915-916 (1906)

O6b (and Calkins, F. C.) Description of the Snoqualmie quadrangle [Wash.]. U S G S, G Atlas Snoqual ie fol (no 139): $14 \mathrm{pp}$, maps (1906)

06e Asbestos; mica. U S G S, Min Res 1905: 1155-1159, 1279-1283 (1906)

o6d Graphite. U S G S, Min Res 1905 : 1265-1269; 1906 : 1139-1143 (1906-7)

07 Twenty-eighth annual report of the Director of the United States Geological Survey to the Secretary of the Interior for the fiscal year ended June 30, 1907: $80 \mathrm{pp}$, map (1907) Twenty-ninth... 1908: 99 pp, maps (1908) Thirtieth...1909:128 pp, maps (1909) Thirty-first...1910:131 pp, maps (1910) Thirty-second...1911: $151 \mathrm{pp}$, maps (1911) Thirty-third...1912: $175 \mathrm{pp}$, maps (1912) Thirty-fourth...1913 : $183 \mathrm{pp}$, maps (1913) Thirty-fifth...1914: $163 \mathrm{pp}$, maps (1914) Thirty-sixth...1915 : 186 pp, maps (1915) Thirty-seventh... 1916:185 pp, maps (1916) Thirtyeighth...1917:176 pp, maps (1917) Thirty ninth...1918: $163 \mathrm{pp}$, maps (1918)

$07 \mathbf{a}$ The occurrence of granite in Maine. U S G S, B 313: 7-12 (1907)

о7b Note on a mineral prospect in Maine. U S G S, B 315:118-119 (1907) o7e Methods of igneous intrusion (abst). Science n \& 25:623 (1907)

ozd (and Bastin, E. S., and Brown, C. W.) Description of the Penobscot Bay quadrangle [Me.]. U $\mathrm{S}$ G S, G Atlas Penobscot Bay fol (no 149): 14 pp, maps (1907)

07e The possibilities and limitations of Geological Survey work as applied to mining industry. M Sc Press 95:652-654 (1907) Am M Cong, 10th An Sess, Rp Pr: 138-148 (1908) M World 27:924-926 (1907) Eng M J 84:1019-1020 (1907)

orf Geology of the Kennebec River basin [Me.]. U S G S, W-S P 198: 4-9 (1907) $\mathrm{Me}$, St Water Storage Comm, An Rp 1: 222-228 (1911)

09 Distribution of the nation's mineral wealth. Am M Cong, 11th An Sess, Papers and $\operatorname{Pr}: 247-250$ (1909)

11 Work of the United States Geological Survey. M World 34:136-137 (1911)

12 The poliey of the Geological Survey. Science n s $36: 401-403$ (1912)

$$
28737^{\circ}-23-61
$$


Smith, George Otis-Continued.

13 (and others) The classification of the public lands. U S G S, B 537:197 pp (1913)

$13 a$ The United States Geological Survey and ore deposits. M Sc Press 106:22 (1913)

13b Field and office methods in the preparation of geological reports. Ec G $8: 264-265$ (1913)

13e Contributions to general geology, Science n s 38: 78-79 (1913)

14 Our mineral reserves; how to make America industrially independent. U S G S, B $599: 48$ pp (1914)

17 (and Lesher, C. E.) The cost of coal. Science n s 44:763-772 (1916) Am M Cong, 19th An Sess, Rp Tr: 452464 (1917) Ec G 12:42-55 (1917)

$17 \mathbf{a}$ The public interest in mineral resources. Pan American Sc Cong, 2d, Washington, $\operatorname{Pr} \sec 7 v 8: 535-542$ (1917)

17b Geology and public service. Sc Mo $4: 165-173$ (1917) N Y St Mus, B $196: 135-144$ [1918]

18 The economic limits to domestic independence in minerals. U S G S, Min Res 1917 pt 1: 1a-6a (1918)

1Sa A century of government geological surveys. Am J Sc (4) 46:171-192 (1918) Reprinted in A century of science in America : 193-216, New Haven, 1918

18b Our mineral reserves. In American problems of reconstruction, edited by Elisha M. Friedman: 59-87, N Y 1918

See also Jenney, 03

Smith, Grant H.

02 State line mining district, Iron Co., Utah. M Sc Press 84: 101 (1902)

Smith, Hamilton L.

93 Diatomaceae of Minnesota interglacial peat; list of species and some notes upon them. Minn G S, An Rp 20:293-306 (1893)

Smith, Herbert W.

01 Preliminary notes on the conglomerates and amygdaloids of the Snake River valley [Minn.]. Minn Ac N Sc, B 3:312313 (1901)

Smith, Horace P.

87 Bison latifrons Leidy. Cin Soc N H, J 10:19-24, il (1887)

smith, Howard D.

13 Progress in the Cat Canyon oil field [Santa Barbara Co., Cal.]. Western Eng 3: 264-266 (1913)

Smith, J. A.

27 (with Mitehi11, S. L., and Cooper, W.) Discovery of a fossil walrus in Virginia. Lyc $\mathrm{N} H \mathrm{~N} \mathrm{Y}$, An 2:271-272 (1827)

Smith, J. Alden.

67 Metals and minerals [of Colo.]. In Hollister, Ovando J., The mines of Colorado: 396-415, Springfield, Mass., 1867

70 Catalogue of the principal minerals of Colorado... $16 \mathrm{pp}$, Central City 1870
Smith, J. Alden-Continued.

81 Biennial report of the State geologit of the State of Colorado for the term ending December 31, 1880.75 pp, Den. ver, Colo., 1881. [Includes a eatalog of the principal minerals of Colorado.]

83 Report on the development of the mineral, metallurgical, agricultural, pastoral, and other resources of Colorado for the years 1881 and 1882.151 pp, Denver, Colo., 1883

Smith, J. F., jr.

59 Note on the more characteristic fos. sils of the Hudson River group of Toronto and its environs. Can $J$ n s $4: 450-452$ (1859)

61 Note on a new species of Triarthrus from the Utica slate of Whitby, Canads West. Can J n s 6:275, il (1861)

Smith, James Hervey.

00 The Eocene of North America west of the 100th meridian (Greenwich). I $G$ $8: 444-471$, map (1900)

Smith, James Perrin.

94 The Arkansas Coal Measures in their relation to the Pacific Carboniferous propince. J G 2:187-204 (1894)

$94 \mathbf{a}$ The metamorphic series of Shasta Co., Cal. J G 2: 588-612 (1894)

$\mathbf{9 4 b}$ Age of the auriferous slates of the Sierra Nevada. G Soc Am, B $5: 243-258$ (1894) Abst, Am G 13:215 (1894)

94e Trias and Jura of Shasta Co., Cal. (abst). Am G 14:200 (1894)

94d The Carboniferous strata of Shasta Co., Cal (abst). Am G 14:203 (1894) Am As, Pr 43: 247 (1895)

95 Mesozoic changes in the faunal geog raphy of California. J G $3: 369-384$ (1895)

95a Geologic study of migration of ma. rine invertebrates. J G $3: 481-495$ (1895)

95b Supplementary notes on the meta. morphic series of the Shasta region of California (abst). Am As, Pr 44:137-138 (1896) Am G 16:249 (1895) Science ns $2: 401$ (1895) Am J Sc (3) $50: 346$ (1895)

96 Marine fossils from the Coal Meas. ures of Arkansas. Am Ph Soc, $\mathrm{Pr} 35: 213-$ 285, il (1896) Abst, J G $2: 187-204$ (1896)

96a Classification of marine Trias. I G 4:385-398 (1896)

97 Comparative study of paleontogeny and phylogeny. J G 5:507-524, il (1897)

$\mathbf{9 7 a}$ The development of Glyphioceras and the phylogeny of the Glyphioceratidae. Cal Ac Sc, $\operatorname{Pr}$ (3) G $1: 105-128$, il (1897)

98 Geographic relations of the Trias of California. J G 6:776-786 (1898)

9Sa The development of Lytoceras and Phylloceras. Cal Ac Sc, Pr (3) G 1: $129-160$, il (1898)

oo The biogenetic law from the stand. point of paleontology. J G $8: 413-425$ (1900) 
Smith, James Perrin-Continued.

00a Principles of paleontologic correlation. J G $8: 673-697(1900)$ Abst, Am As, $\operatorname{Pr} 49: 193$ (1900); Science n s 12: 995-996 (1900)

$00 \mathrm{~b}$ The development and phylogeny of Placenticeras. Cal Ac Sc, $\operatorname{Pr}$ (3) G 1: $181-240$, il (1900)

01 (and Weller, S.) Prodromites, a new ammonite genus from the Lower Carboniferous. J G $9: 255-268$, il (1901) Chicago Univ, Walker Mus, Contr 1 no 2 : 33-41, il (1901)

01a The border line between Paleozoic and Mesozoic in western America. J G 9 : 512-521 (1901)

02 Ueber Pelecypoden-Zonen in der Trias Nord-Amerikas. Centralbl Miner 1902: 689-695

03 The Carboniferous ammonoids of America. U S G S, Mon 42:211 pp, il (1903)

04 Periodic migrations between the Asiatic and the American coasts of the Pacific Ocean. Am J Sc (4) 17:217-233 (1904)

04a The comparative stratigraphy of the marine Trias of western America. Cal Ac Sc, Pr (3) G $1: 323-430$, il (1904)

05 (with Hyatt, A.) The Triassic cephalopod genera of America. U S G S, P P 40: $394 \mathrm{pp}$, il (1905)

06 The paragenesis of the minerals in the glaucophane-bearing rocks of California. Am Ph Soc, Pr 45:183-242 (1906)

07 The stratigraphy of the western American Trias. Festschrift, Adolf v. Koenen : $377-434$, Stuttgart. 1907

09 Salient events in the geologic history of California. Science $\mathrm{n} \quad \mathrm{s} \quad 30: 346-350$ (1909)

10 The geologic record of California. I G $18: 216-227 \quad(1910)$ Extract, Cal St M Bur, B 69: map folio (1915)

10a Ancient climates of the west coast. Pop Se Mo $76: 478-486$ (1910)

12 On the distribution of Lower Triassic faunas. J G 20:13-20 (1912)

12a The occurrence of coral reefs in the Triassic of North America. Am J Sc (4) 33: $92-96$ (1912)

12b Geologic range of Miocene invertebrate fossils of California. Cal Ac Se, Pr $3: 161-182$ (1912)

12e Ancient portals of the earth. Pop Sc Мo $80: 393-399$ (1912)

13 The biogenetic law illustrated in the development of fossil cephalopods (abst). G Soc Am, B 24: 129 (1913)

14 The middle Triassic marine invertebrate faunas of North America. U S G S, P P $83: 254$ pp, il (1914)

14a Acceleration of development in fossil Cephalopoda. Leland Stanford Junior Univ Pub: 30 pp, 11 (1914)
Smith, James Perrin-Continued.

15 (and others) Relations of the invertebrate faunas of the American Triassic to those of Asia and Europe (discussion). G Soc Am, B 26:412-413 (1915)

16 The geologic formations of California, with reconnaissance geologic map. Cal St M Bur, B 72:47 pp (1916)

$16 a$ Geological map of the State of California issued by State Mining Bureau, 1916. Scale 1 inch $=12$ miles.

16b Climatic zones in the Pliocene of the Pacific coast (abst). G Soc Am, B 27 : 172 (1916)

18 Tropitidae of the upper Triassic of California (abst). G Soc Am, B 29:162 (1918)

See also Eastman, 00

Smith, John Augustine (1818-1883).

46 Central cavity of the mastodon. Am Q J Agr 3: 19-22 (1846)

Smith, John Eliphalet.

14 Geology of Chapel Hill and vicinity [N. C.]. Elisha Mitchell Sc Soc, J 30 : 26-32 (1914)

14a Economic geology of Chapel Hill, $\mathrm{N}$. C., and vicinity (abst). Science $\mathrm{n} \mathrm{s}$ $40: 385-386$ (1914)

15 Some igneous rocks of Mount Collier [Orange Co., N. C.] (abst). Elisha Mitchell Sc Soc, J $81: 7-8$ (1915)

16 The diorites of the Chapel Hill stock [N. C.] (abst). Science n s 44:361-362 (1916) Elisha Mitchell Sc Soc, J 32:50 (1916)

$16 a$ Geographic causes in North Carolina (abst). Science n s $43: 400$ (1916)

$16 \mathrm{~b}$ Some structural geology of the Piedmont (abst). Science n s 43:400 (1916)

17 A laboratory guide for beginners in geology. vil, 91 pp, Chapel Hill, N. C., 1917

17a The diorites near Chapel Hill, N. C. Elisha Mitchell Sc Soc, J 33: 128-132 (1917)

17b Pliocene deposits in Orange Co. [N. C. 7 (abst). Elisha Mitchell Sc Soc, J 33 : 94-95 (1917) Science n s 46:194 (1917)

17e Structural geology of Orange Co., N. C. (abst), Elisha Mitchell Sc Soc, J $33: 96-97$ (1917) Seience n $s \quad 46: 195$ (1917)

Smith, John Lawrence (1818-1883).

44 On fossil bones from the vicinity of Charleston, S. C. (abst, with discussion). Am J Sc 47:116-117 (1844)

53 (and Brush, G. J.) Re-examination of American minerals. Am J Sc (2) 15 : $207-215 ; 16: 41-53,365-373$ (1853) ; 18 : 372-381 (1854) ; 20: 242-253 (1855)

$53 a$ Warwickite, a borotitanite. An Sc, Cleveland, 1: 251 (1853)

53b (and Brush, G. J.) Danburite, a silicoborate of lime. An Sc, Cleveland, 1: 251-252 (1853) 
Smith, John Lawrence-Continued.

55 Memoir on meteorites. Am J Sc (2)

19 : $153-163,322-343$ (1855)

56 Warwickite a borotantalite [Orange Co., N. Y.]. Am As, Pr 7:147-148 (1856)

$56 a$ Danburite, a silicoborate of lime [Danbury, Conn.]. Am As, Pr $7: 148-149$ (1856)

56b The minerals of the Wheatley mine ia Pennsylvania. Am As, Pr 9:190-204 (1856)

59 Report on Dupont's artesian well at Louisville, Ky. Am J Sc (2) 174-178 (1859)

59 a Account of several meteoric stones which fell in Harrison Co., Ind., March 28, 1859. Am J Sc (2) 28:409-411 (1859)

60 Description of three new meteoric irons, from Nelson Co., Ky., Marshall Co., Ky., and Madison Co., N. C. Am J Sc (2) $30: 240 \quad(1860)$

61 The Guernsey Co., Ohio, meteorites... Am J Sc (2) 31:87-98 (1861)

61 a Description of three new meteorites [from Kentucky and Tennessee]. Am J Sc (2) $31: 264-266$ (1861)

64 Chladnite of the Blshopville meteorle stone proved to be a magnesian pyroxene. Am J Sc (2) 38: 225-226 (1864)

$64 a$ A new meteoric iron from Wayne Co., Ohio. Am J Sc (2) $38: 385-387$ (1864)

65 A new meteorite from Newton Co., Ark. Am J Se (2) $40: 213-216$ (1865)

66 On the emery mine of Chester, Hampden Co., Mass., with remarks on the nature of emery, and its associate minerals. Am J Se (2) 42:83-93 (1866)

66a A new meteoric iron, "the Colorado meteorite," from Russel Gulch, Gilpin Co., near Central City, Colorado Territory. Am J Sc (2) 42:218-219 (1866)

67 On Colorado meteorites; Russel Gulch meteoric iron and Bear Creek meteoric iron. Am J Sc (2) $43: 66-67$ (1867)

$\mathbf{6 7 a}$ On a new locality of tetrahedrite, tennantite, and nacrite, with some account of the Kellogg mines of Arkansas. Am J Se (2) $43: 67-69$ (1867)

68 A new meteoric iron from Mexico. Am Ph Soc, Pr 10:330-331 (1867) Am J Sc (2) $45: 77$ (1868)

69 A new meteoric iron, "The Wisconsin meteorites," with some remarks on the Widmannstättian figures. $\mathrm{Am} \quad \mathrm{J} \quad \mathrm{Sc}$ (2) $47: 271-272$ (1869); (3) $3: 69$ Inote by I. A. Lapham] (1872) Ac Sc Paris, C R 68: 620-621 (1869)

69a The Coahuila meteoric irons of 1868, Mexico. Am J Sc (2) $47: 383-385$ (1869)

69b On the descloizite of the Wheatly mine, Pennsylvania. Am J Sc (2) 48: 137-138 (1869)

69e On the lesleyite of Chester Co., $\mathrm{Pa} \ldots$ Am J Sc (2) 48:254-255 (1869)
Smith, John Lawrence Continued.

70 Account of a fall of meteoric stono near Danville, Ala., with an analysis of $t$ same. Am J Sc (2) 49:90-93 (187) Cosmos, Paris, $7: 232-234$ (1870)

70a Description and analysis of th Franklin Co. meteoric iron [Ky.]... Am ? Se (2) $49: 331-335$ (1870)

70b Description and analysis of a metc oric stone that fell in Stewart $\mathrm{C}_{0}$, Ga. Am J Se (2) 50:339-341 (1870)

71 Mineralogical and chemical compes tion of the meteoric stone that fell neat Searsmont, Maine, May 21, 1871. Am : Sc (3) 2:200-201 (1871)

71a The precise geographical position the large masses of meteoric irom in Norti Mexico, with the description of a ner mass, the San Gregorio meteorite. Am ? Sc (3) 2:335-338 (1871) Am As, Pr 20: 266-270 (1872)

73 Mineralogy and chemistry; originl researches. 401 pp, Louisville, Ky, 1879

$73 n$ Notes on the corundum of Nort Carolina, Georgia, and Montana, with description of the gem variety of the corth dum from these localities. Am J Sc (\$) $6: 180-186$ (1873) Ac Sc Paris, C R 7: $356-359,439-442$ (1873)

74 On a mass of meteoric iron of Hor ard Co., Ind... Am J Sc (3) $7: 391-395$ (1874)

74a Warwickite. Am J Sc (3) 8:432434 (1874) Ae Se Paris, C R 79:695698 (1874) Abst, Ch News $30: 217-218$ (1874)

74b Curious association of garnet, it crase, and datolite. Am J Sc (3) $8: 434$ 436 (1874) Ac Sc Paris, C R 79:813-81t (1874) Abst, Ch News 30:241-242 (1874)

75 Description of the Nash County me teorite [N. C.], which fell in May, 1874 Am J Sc (3) $10: 147-148$ (1875) Ac \& Paris, C R $80: 1453-1454$ (1875)

75a A note in relation to the mass of meteoric iron that fell in Dickson 0. Tenn., in 1835. Am J Sc (3) $10: 349-35^{\circ}$. (1875) Ac Se Paris, C R 81:84-87 (1875)

75b Troilite; sa vrai place minéralo gique et chimique. Ac Se Paris, C R 81 976-978 (1875) Abst, Am J Se (3) $11:$ 68 (1876)

75e Rapport sur la chute de derr pierres météoriques dans les Êtats-Unis Ac Sc Paris, C R 80:1451-1454 (1875)

75d Sulfhydrocarbure cristallisé, rensti de l'intérieur d'une masse de fer météorique Ac Sc Paris, C R 81: 1055-1056 (1875)

76 Recherches sur les composés du cat bone pur dans les météorites. Ac Sc Paris C R $82: 1042-1043$ (1876) Am J Se (3) 11: 388-395, 433-442 (1876)

76a Sur l'aragonite observé à la sur face d'une météorite. Ac Sc Paris, C 82: 1505-1507 (1876) Am J Sc (3) 12 107-109 (1876) 
Smith, John Lawrence-Continued.

76b Nouveau minéral renfermé dans une météorite; daubréelite. Ac Sc Paris, C R $83: 74-75$ (1876) Am J Sc (3) 12:109110 (1876)

76e An account of a new meteoric stone that fell on the 25th of March, 1865, in Wisconsin, identical with the Meno meteorites. Am J Sc (3) 12: 207-209 (1876) Ac Sc Paris, C R 83: 161-163 (1876)

76d Two new minerals. Ac N Sc Phila, Pr $1876: 87$

76e Sur les combinaisons de carbone trouvées dans les météorites. Ac Sc Paris, C R $82: 1507$ (1876)

77 Examination of the Waconda meteoric stone, Bates Co. meteoric iren, and Rockingham meteoric iron. Am J Sc (3) 13:211-214 (1877)

$77 \mathbf{a}$ Note on the new localities of the columbic acid minerals and two new columbates. Am J Sc (3) $13: 234$ (1877)

$77 b$ Note of the recent fall of three meteoric stones in Indiana, Missouri, and Kentucky. Am J Sc (3) 13:243 (1877) Ac Sc Paris, C R $84: 398-399$ (1877)

77e Description of columbic acid minerals... Am J Sc (3) 13:359-369 (1877)

77d A description of the Rochester, Warrenton, and Cynthiana meteoric stones... Am J Sc (3) 14:219-229 (1877) Ac Sc Paris, C R 85:678-681 (1877)

77e Sur deux nouveaux níobates. Ac Sc Paris, C R 84:1036-1038 (1877)

78 Tantalite from Coosa Co., Ala, Am J Sc (3) $15: 203-204$ (1878)

$78 \mathrm{a}$ on the composition of the new meteoric mineral daubréelite and its frequent, if not universal, occurrence in meteoric irons. Am J Sc (3) 16:270272 (1878) Ac Sc Paris, C R $87: 338$ 340 (1878) Am As, Pr 27:147-150 (1879)

78b Sur la fer natif du Groenland et la basalte qui le renferme. Ac Sc Paris, C R $87: 674-676 \quad(1878)$

79 Mémoire sur le fer natif du Groenland et sur la dolérite qui le renferme. Ann Ch Phys (5) 16:452-505 (1879) Abst, Am J Sc (3) 18:72-73 (1879)

79a Figures de Widmannstaetten sur le fer artificiel. Ac Sc Paris, C R 88:11241125 (1879)

so Study of the Emmet Co. meteorite that fell near Estherville, Emmet Co., Iowa, May 10,1879 . Am J Sc (3) 19 : $459-463,495$ (1880)

80a A new meteoric mineral, peckhamite, and some additional facts in connection with the fall of meteorites in Iowa, May 10,1879 . Am J Sc (3) $20: 136-137$ (1880)

81 Hiddenite, an emerald-green variety of spodumene. Am J Sc (3) $21: 128-130$ (1881)
Smith, John Lawrence-Continued.

81 a Occurrence of a nodule of chromite in the interior of compact meteoric iron from Coahuila [Mexico]. Am J Sc (3) 21:461-462 (1881) Ac Sc Paris, C R $92: 991-992$ (1881)

81b Anomalie magnétique du fer météorique de Sainte-Catherine. Ac Sc Paris, C R $92: 843-844$ (1881)

83 On the peculiar concretions occurring in meteoric irons. Am J Sc (3) 25 : $417-423$ (1883)

84 Original researches in mineralogy and chemistry. 630 pp, Louisville, Ky., 1884

Smith, Leon P.

16 (with Brokaw, A. D.) Zonal weathering of a hornblende gabbro. $J$ G 24 : 200-205 (1916)

Smith, Leonard S.

06 Water powers of northern Wisconsin. U S G S, W-S P 156: 145 pp (1906)

os The water powers of Wisconsin. Wis G S, B 20:354 pp (1908)

Smith, Lloyd B.

12 A peridotite dike in Fayette and Greene cos. [Pa.]. Pa Top G S, Rp 191012: 151-155. map (1912)

Smith, Otto M.

o5 (and Standley, P. C.) The Plerson Creek mines [Greene Co., Mo.]. Drury Coll, Bradley G Field Sta, B 1:72-79 (1905)

Smith, Philip Sidney.

O4 (with Smyth, H. L.) The copper deposits of Orange Co., Vt. Eng M J 77 : $677-678$ (1904)

o7 Gold fields of the Solomon and Niukluk River basins [Alaska]. U S G S, B 314: 146-156 (1907)

o7a Geology and mineral resources of Iron Creek [Alaska]. U S G S, B 314: $157-163$ (1907)

07b The gray iron ores of Talladega Co., Ala. U S G S, B 315: 161-184 (1907)

os Investigations of the mineral deposits of Seward Peninsula, Alaska. U S G S, B 345: 206-250 (1908)

osa Notes on recent changes in the Bogoslof Islands (abst). Science n s 27 : 695 (1908)

osb (with Collier, A. J.) The gold placers of parts of Seward Peninsula, Alaska, including the Nome, Council, Kougarok, Port Clarence, and Goodhope precincts. U S G S, B 328: 343 pp (1908)

09 Recent developments in southern Seward Peninsula, Alaska. U S G S, B 379: 267-301 (1909)

09a The Iron Creek region, Alaska. U S G S, B $379: 302-354$, map (1909)

10 Geology and mineral resources of the Solomon and Casadepaga quadrangles, Seward Peninsula, Alaska. U S G S, B 433 : 234 pp, map (1910) 
Smith, Philip Sidney-Continued.

IOa (and Eakin, H. M.) Mineral re sources of the Nulato-Council region, Alaska. U S G S, B 442:316-352, map (1910)

11 (and Eakin, H. M.) The Shungnak region, Kobuk Valley [Alaska]. U S G S, B 480:271-305, maps (1911)

11 a The Squirrel River placers [Alaska]. U S G S, B 480:306-319, map (1911)

$11 \mathrm{~b}$ Notes on the geology of the Koyukuk-Kobuk region, Alaska (abst). Wash Ac Se, J 1:141 (1911) M World $36: 819$ (1912)

11e (and Eakin, H. M.) A geologic reconnaissance in southeastern Seward Peninsula and the Norton Bay-Nulato region, Alaska. U S G S, B $449: 146$ pp, map (1911) Abst, Wash Ac Sc, J 1:37-38 (1911)

12 Glaciation in northwestern Alaska. G Soc Am, B 23:563-570, map (1912). Abst, Science n s $35: 314$ (1912)

$12 a$ The Alatna-Noatak region [Alaska]. U S G S, B 520:315-338, map (1912). Abst, Wash Ac Sc, J $2: 438-439$ (1912)

12b Notes on mining in Seward Peninsula [Alaska]. U S G S, B 520:339-344 (1912)

12e Fall of volcanic ash on Seward Peninsula, Alaska. Wash Ac Sc, J $2: 406-$ 407 (1912)

13 Lode mining near Fairbanks. U S G S, B 525:153-216 (1913)

$13 a$ The Noatak-Kobuk region, Alaska. U S G S, B 536:157 pp, maps (1913) Abst, Wash Ac Sc, J 4: 161-162 (1914)

13b Lode mining near Fairbanks [Alaska]. U S G S, B 542:137-202, map (1913)

13e A sketch of the geography and geology of Seward Peninsula, Alaska. U S G S, W-S P 314 : 13-15, 32-51, map (1913)

$13 d$ The Noatak River, Alaska. As Am Geog, An 2:65-72 [1913]

13e Field and office methods in the preparation of geologieal reports (discussion). Ec G 8:392-397 (1913)

131 The fineness of gold in the Fairbanks district, Alaska. Ec G $8: 449-454$, map (1913)

14 Lode mining in the Ketchikan region, Alaska. U S G S, B 592: 75-94 (1914)

15 Notes on the geology of Gravina Island, Alaska. U S G S, P P 95: 97-105, $\operatorname{maps}$ (1915)

15a Mineral resources of the Lake Clark-Iditarod region-[Alaska]. U S G S, B $622: 247-271$, map (1915)

15b (and Maddren, A. G.) Quicksilver deposits of the Kuskokwim region [Alaska]. U S G S, B 622:272-291 (1915)

16 Geology of the Lake Iditarod region, Alaska (abst). G Soc Am, B 27:114 (1916)
Smith, Philip Sidney-Continted.

$16 a$ Notes on the geology of the lat? Clark-Iditarod region, Alaska (abs). Wash Ac Sc, J 6: 190-191 (1916)

17 The Lake Clark-central Kuskokrit region, Alaska. U S G S, B $655: 162$ / maps (1917) Abst, Wash Ac Se, J \&: 453 (1918)

18 Sulphur, pyrite, and sulphuric aci U S G S, Min Res 1916 pt 2: 403-43: 1917 pt $2: 19-62$ (1918)

18a The geologist in war times; th United States Geological Survey's war work (discussion). Ec G 13:392-399 (1918)

Smith, R. W.

14 (and Zuleh, W. G.) Solution of landslide fault. Eng M J, 97:1090-109: (1914)

Smith, Richard.

29 (with Brown, R.) Geology as mineralogy [of Nova Scotia]. In Hallburton, T. C., An historical and statistiel account of Nova Scotia, $>2: 414-4$; Halifax 1829

Smith, Richard A.

12 Michigan coal. Mich G S, Pub \& $(g$ s 6$): 257-303$ (1912)

12a Gypsum and gypsum products Mich G S, Pub 8 (g s 6) : $305-313$ (1912 13 The Saginaw ofl field. Michigan dt Sc, Rp 15: 33-38 (1913)

14 The occurrence of oil and gas it Michigan. Mich G S, Pub 14 (g s 11):28) pp, maps (1914)

$14 a$ Nonmetallic minerals. Mich 68 Pub 16 (g s 13) : 79-128 (1914)

15 Nonmetallic minerals [of Michiga] Mich G S, Pub 19: 245-329 (1915)

16 Limestones of Michigan. Mich $\mathrm{G} \&$ Pub 21 (g s 17): 103-311, map (1916)

16a (with Allen, R. C., and Barreth, L. P.) Geological map of Michigan. Mid G S, Pub 23 (1916)

Smith, Sanderson.

56 On some new localities of minerals Am As, Pr 9:188-190 (1856)

65 Notice of a post-Pliocene deposit of Gardiner's Island, Suffolk Co., N. Y. L L N H N Y. An 8: 149-151 (1865)

Smith, Sidney Irving.

71 Notice of a fossil insect from the Carboniferous formation of Indiana. Al J Sc (3) 1:44-46, il (1871)

Smith, Sumner S.

13 Lode mining in the Willow Creek dis trict [Alaska]. M Sc Press 107:335-33i (1913)

17 The mining industry in the Tert tory of Alaska during the calendar yeat 1915. U S Bur Mines, B 142:65 pP (1917)

Smith, T. Ellott.

$06 \mathrm{El}$ Oro, the premier gold camp of Mexico. M World 24:412-413 (1206) 
Smith, Thomas P.

99 Account of crystallized basalts found in Pennsylvania. Am Ph Soc, Tr 4:445446 (1799)

Smith, Titus.

34 Lecture on mineralogy. 36 pp, Halifax, N. S., 1834.

36 A lecture on the mineralogy and the geology of Nova Scotia. Mag N H (Loudon) $9: 368-375,575-593(1836)$

Smith, V. W.

57 Note on the Onondaga salt basin. N Y (State), Supt Onondaga Salt Springs, An Rp 1856:49-52 (1857)

Smith, W. H.

15 Canadian molybdenite deposits. Eng II J $99: 271-272$ (1915)

smith, W. Hampton.

93 Ancient glacial moraine and drift at the mouth of the Columbia river. Sc Am Sup 36: 14658 (1893)

smith, W. N.

05 Loon Lake iron-bearing district. Ont Bur Mines, Rp 1905,14 pt 1:254-260 (1905)

Smith, Walter B.

87 Notes on the crystal beds of Topaz Butte. Colo Sc Soc, Pr 2: 108-115 (1887) Abst, Am J Sc (3) 33: 134-135 (1887)

88 Mineralogical notes. Colo $\mathrm{Sc} \mathrm{Soc}, \mathrm{Pr}$ 2:155-160, 161-166, 175-179 (1888)

smith, Warren Du Pré.

05 The development of Scaphites. J G $13: 635-654$ il (1905)

06 Discussion of paper by Marius $R$. Campbell, Hypotbesis to account for the transformation of vegetable matter into different grades of coal. Ec $G$ 1:581583 (1906)

15 Geology as an aid to tropical engi neering. Western Eng 6:193-198 (1915)

16 Notes on radiolarian cherts in Oregon. Am J Sc (4) $42: 299-300,504$ (1916)

16a Guide to Condon Geological Museum University of Oregon. Oreg Univ, Pub n s 1 no $3: 26$ pp (1916)

$16 \mathrm{~b} \mathrm{~A}$ geologist's thoughts on returning from the Mazama outing of 1916 [to Three Sisters, Oregon]. Mazama 5:2428 (1916)

17 A summary of the salient features of the geology of the Oregon Cascades, with some correlations between the geology of the east coast of Asia and that of the west coast of America. Oreg, Univ, B In s 14 no $16: 54$ pp (1917) Abst, G Soc Am, B 29:81 (1918)

18 The Wallowa Mountains [Oreg.]; geology and economic geography. Mazama $5: 233-250$ (1918)

Smith, Warren S.

14 (with Johnson, D. W.) Recent storm effects on the northern New Jersey shore line, and their supposed relation to corstal subsidence. N J G S, B 12:2744 (1914)
Smith, Warren S.-Continued.

15 Petrology and economic geology of the Skykomish basin, Wash. Sch Mines Q 36: 154-185, map (1915)

15a (with Johnson, D. W.) Wave work on the New Jersey coast. Pop Sc Mo 86:557-567 (1915)

16 Stratigraphy of the Skykomish basin, Wash., with report upon paleontology and paleophytology, by Caroline A. Duror. J G 24:559-582, il (1916)

17 Physiography of the Skykomish Basin, Wash, N Y Ac Sc, An 37:205213 (1917)

Smith, William Henry Chatterton.

92 [Report on field work in western Ontario.] Can G S, Sum Rp 1891 (An Rp 5) : A 28-31 (1892)

92a Report on the geology of Hunter's Island and adjacent country [western Ontario]. Can G S, An Rp : $\mathbf{G} 76 \mathrm{pp}$, map (1892)

93 The Archean rocks west of Lake Superior. G Soc Am, B 4:333-348 (1893)

Smith, William S.

o5 Mineral resources of Uintah Reservation [Utah]. M World 23:491-492 (1905)

Smith, William Sidney Tangier.

97 The geology of Santa Catalina Island. Cal Ac Sc, Pr (3) G 1:1-71, map (1897)

$97 \mathbf{a}$ A note on the migration of divides. J G 5: $809-812$ (1897)

98 A geological sketch of San Clemente Island [Cal.]. U S G S, An Rp 18 pt 2 : \$59-496 (1898)

99 Some aspects of erosion in relation to the theory of the peneplain. Cal Univ, Dp G, B 2:155-178 (1899)

oo A topographic study of the islands of southern California. Cal Univ, Dp G, B $2: 179-230$, map (1900) Abst, Science n s 11: 221 (1900)

02 The submarine valleys of the California coast. Science $n$ s $15: 670-672$ (1902)

03 Description of the Hartville quadrangle [Wyo.]. U S G S, G Atlas Hartville fol (no 91):6 pp, maps (1903)

osn Lead and zinc deposits of the Joplin district, Missouri-Kansas. U S G S, B 213:197-204 (1903)

03b (with Ulrich, E. O.) Lead, zinc, and fluorspar deposits of western Kentucky. U S G S, B 213: 205-213 (1903)

04 (with Darton, N. H.) Description of the Edgemont quadrangle [S. Dak.Nebr.]. U S G S, G Atlas Edgemont fol (no 108) : $10 \mathrm{pp}$, maps (1904)

o5 Igneous rocks [of the Sundance quadrangle, Wyo.-S. Dak.]. U S G S, G Atlas Sundance fol (no 127): 4-9 (1905)

O5a Igneous rocks [of the Aladdin quadrangle, Wyo.-S. Dak.-Mont.]. U S G S, G Atlas Aladdin fol (no 128):4-5 (1905) 
Smith, William Sidney Tangier-Contd.

O5b Water resources of the Joplin district, Mo.-Kans. U S G S, W-S P 145: $74-83$ (1905)

o5e (with Ulrieh, E. O.) The lead, zinc, and fluorspar deposits of western Kentucky. U S G S, P P $36: 218$ pp, maps, il (1905)

07 Igneous rocks of the northwestern Black Hills (abst). G Soc Am, B 17: 729 (1907)

07a (and Siebenthal, C. E.) Description of the Joplin distriet [Mo.-Kans.]. U S G S, G Atlas Joplin fol (no 148) : 20 pp, maps (1907) [Rv, see Buckley, 07b]

10 Tables for the determination of crystal classes. G Soc Am, B 21:731-736 (1910) Abst, Science n s $32: 30$ (1910)

12 The teaching of economic geology (discussion). Ec G $7: 297-298$ (1912)

12a Origin of the sandstone at the State prison near Carson City, Nev. (abst). G Soc Am, B 23: 73 (1912)

14 Some graphic methods for the solution of geologic problems. Ec G $9: 25-66$ (1914)

$14 a$ Polarized skylight and the petrographic microscope (abst). G Soc Am, B $25: 120$ (1914)

\section{Smithsonian Institution.}

12 Expeditions organized or participated in by the Smithsonian Institution in 1910 and 1911. Smiths Misc Col 59 no 11:51 pp (1912)

13 Explorations and field work of the Smithsonian Institution in 1912. Smiths Misc Col 60 no $30: 76$ pp (1913) ... in $1913 ; 63$ no $8: 88$ pp (1914) $\ldots$ in 1914 ; 65 no $6: 95 \mathrm{pp}(1915) \ldots$ in $1915 ; 66$ no $3: 119$ pp (1916) $\ldots$ in $1916 ; 66$ no 17 : 134 pp (1917) $\ldots$ in $1917 ; 68$ no $12: 133$ pp (1918)

Smock, John Conover.

$\mathbf{7 4}$ The magnetic iron ores of New Jersey-their geographical and geological occurrence (with discussion by T. S. Hunt and W. P. Blake). Am I M Eng, Tr 2: 314-323 (1874) Eng M J 17:293-294, 306-307, 326-327 (1874)

74n (with Cook, G. H.) [Map of] northern New Jersey showing the iron ore and limestone districts. Scale 2 miles to 1 inch. N J G S, 1874

76 The use of the magnetic needle in searching for magnetic iron ore. Am I M Eng, Tr 4: 353-362 (1876)

78 The fire clays and associated plastic clays, kaolins, feldspars, and fire sands of New Jersey; their geographical distribution and geological occurrence (with discussion by T. S. Hunt and P. Frazer). Am I M Eng, Tr 6:177-192 (1879) Eng M J 25: 185,200 (1878)

78a (with Cook, G. H.) Report on the clay deposits of Woodbridge, South Amboy and other places in New Jersey. $N$ J G S: $381 \mathrm{pp}$, maps, Trenton 1878
Smock, John Conover-Continued.

so Thickness of the ice sheet on its southern edge (abst). Am Nat $14 ; 59-6)$ (1880)

$\mathbf{8 3}$ On the surface limit or thickness of the continental glacier in New Jersey asi adjacent States. Am J Sc (3) $25: 330$ 350 (1883)

83a The useful minerals of the Unites States; eastern" division. U S G S, Mis Res [1882] : 664-747 (1883)

84 Geologico-geographical distribution of the iron ores of the eastern United States Am I M Eng, Tr 12:130-144 (1884) Eut M J $37: 217-218,230-232$ (1884)

85 Evidences of local glaciers in the Catekill Mountain region (abst). Am As, th $33: 403-404$ (1885)

86 A geological reconnaissance in the crystalline rock region, Dutchess, Putnan, and Westchester cos., N. Y. N Y St Mus, An Rp 39: 165-185, map (1886)

88 Building stone in the State of Ner

York. N Y St Mus, B 3: 152 pp (1888)

89 First report on the iron mines and iron ore districts in the State of New York. N Y St Mus, B $\boldsymbol{\nabla}: 70 \mathrm{pp}, \operatorname{map}$ (1889)

$89 a$ A review of the iron mining industry of New York for the past decade. Am I If Eng, Tr 17: 745-750 (1889)

89b George H. Cook, late State geologist of New Jersey. Am G 4:321-326, port (1889)

90 Buflding stone in New York. $\mathrm{N}$ I St Mus, B 10:193-396, map (1890)

91 Annual report of the State geologist for the year $1890,305 \mathrm{pp}$, maps, Trentove, 1891 ; 92 For 1891,270 pp, maps (1892); 93 For 1892,367 pp, maps $(1893) ;$; For $1893,457 \mathrm{pp}$, maps $(1894) ; 95$ For 1894, 304 pp, maps (1895); 96 For 1895 $198 \mathrm{pp}$, maps (1896) ; 97 For $1896,377 \mathrm{pp}$ maps (1897) ; 98 For 1897, 368 pp, maps (1898); 99 For 1898,244 pp, maps (1899); O0 For 1899,192 pp, maps $(1900)$; 01 For $1900,231 \mathrm{pp}$, maps (1901)

$94 a$ Geological writings of George $\mathrm{B}$. Cook. G Soc Am, B 5: 569-571 (1894)

94b Minerals of New Jersey, with nots on mineral localities. N J G S, An $\mathrm{Bp}$ 1893 : 423-444 (1894)

See also Hawes, 84

Smyth, Bernard B.

85 The age of Kansas. Kans $A c$ Sc, It $9: 129-136$ (1885)

96 The Topeka coal hole [Kans.]. Kans Ac Sc, Tr 14:207-215 (1896)

$96 a$ The terminal boulder belt in Shat nee Co. [Kans.] Kans Ac Sc, Tr 14:220226, map (1896)

98 The closing of Michigan glacial lakes. Kans Ac Sc, Tr 15:23-27 (1898)

98a The buried moraine of the Shus: ganunga [Kans.]. Kans Ac Sc, $\mathrm{Tr}$ 15: 95-104 (1898) 
Smyth, Charles Henry.

$92 \mathrm{~A}$ third occurrence of peridotite in central New York. Am J Sc (3) $43: 322$ 327 (1892)

92a On the Clinton iron ore. Am J Sc (3) $43: 487-496$ (1892)

.93 Lake flling in the Adirondack region. Am G $11: 85-90$ (1893)

93a Alnoite containing an uncommon variety of melilite. Am J Sc (3) 46:104107 (1893)

93b A geological reconnaissance in the vicinity of Gouverneur, N. Y. N Y Ac $\mathrm{Sc}, \operatorname{Tr} 12: 97-108$ (1893)

93e Petrography of the gneisses of the town of Gouverneur, N. Y. N Y Ac Sc, Tr 12:203-217 (1893)

94 Report ... of the general and economic geology of four townships in St. Lawrence and Jefferson cos., N. Y. N Y St G, An Rp 13:491-515, map (1894) N Y St Mus, An Rp 47:685-709, map (1894)

94a on a basic rock derived from granite. J G $2:(37-679$ (1894) Abst, Am G 14: 195 (1894); G Soc Am, B $6: 4$ (1894)

94b On gabbros in the southwestern Adirondack region. Am J Se (3) 48:5465 (1894)

94e A group of diabase dikes among the Thousand Islands, St. Lawrence River, N Y Ac Sc, Tr 13:209-214 (1894)

94d Die Hämatite von Clinton in den östlichen Vereinigten Staaten. Zs Prak G $1894: 304-313$

95 Crystalline limestones and associated rocks of the northwestern Adirondack region. $\mathrm{G}$ Soc Am, B $6: 263-284$ (1895) Abst, Science n s 1:63-64 (1895) ; J G 4: 246 (1896)

96 Metamorphism of a gabbro occurring in St. Lawrence Co., N. Y. Am J Sc (4) 1:273-281 (1896)

96a Note on recently discovered dikes of alnoite at Manheim, N. Y. Am J Sc (4) 2:290-292 (1896)

$96 \mathrm{~b}$ The genesis of the talc deposits of St. Lawrence Co., N. Y. Sch Mines Q 17:333-341 (1896) Abst, Science n s 3 : 677 (1896) ; Zs Prak G 1897: 29-30

96e The genetic relations of certain minerals of northern New York. N Y Ac Se, Tr $15: 260-270$ (1896)

97 Report on the talc industry of St. Lawrence Co. [N. Y.]. N Y St G, An Rp 15:20,661-671 (1897) N Y St Mus, An $\operatorname{Rp} 49$ v $2: 20,661-671$ (1898)

97 a Report on the crystalline rocks of St. Lawrence Co. [N. Y.]. N Y St G, An Rp 15:20-21, 477-497 (1897) N Y St Mus, An Rp 49 v $2: 2 \mathrm{U}-21,477-497$ (1898)

97b Pseudomorphs from northern New York. Am J Sc (4) 4:309-312 (1897)
Smyth, Charles Henry-Continued.

97e Geology and geography at the American Association for the Advancement of Science [Detroit, August, 1897]. Science n s 6:688-691 (1897)

$\mathbf{9 7 d}$ Geological Society of America [ninth summer meeting, Detroit, August, 1897]. Science n s 6:691-692 (1897)

98 Weathering of alnoite in Manheim, N. Y. G Soc Am, B 9:257-268 (1898) Abst, J G $6: 331-332$ (1898)

99 Report on crystalline rocks of the western Adirondack regions. N Y St G, An Rp 17:469-497 (1899) N Y St Mus, An Rp $51 v 2: 469-497$ (1899)

99a (and Newland, D. H.) Report on progress made during 1898 in mapping the crystalline rocks of the western Adirondack region. $N$ Y St G, An Rp 18:129-135 (1899) $\mathrm{N}$ Y St Mus, An Rp 52 v $2: 129$ 135 (1900)

$99 \mathrm{~b}$ Geology of the Adirondack region. Appalachia 9:44-51 (1899)

01 Geology of the erystalline rocks in the vicinity of the St. Lawrence River. N Y St Mus, An Rp 53: r83-104, map (1901)

02 Tourmaline contact zones near Alexandria Bay, N Y. Am G 29:377-383 (1902)

02a Petrography of recently discovered dikes in Syracuse, N. Y., with note on the presence of melilite in the Green Street dike. Am J Sc (4) 14:26-30 (1902)

03 The Rossie lead veins [St. Lawrence Co., N. Y.]. Sch Mines Q 24:421-429 (1903)

04 Notes on the economic geology of Oneida Co., N. Y. N Y St Mus, An Rp 56: r115-117 (1904)

o5 The abstraction of oxygen from the atmosphere by iron. J G $13: 319-323$ (1905)

05a Replacement of quartz by pyrite and corrosion of quartz pebbles. Am J Sc (4) $19: 277-285 \quad(1905)$

10 Dikes near Clintonville, Onondaga Co., N. Y. N Y St Mus, B $140: 24-25$ (1910)

$10 n$ (with Cushing, H. P.) Geology of the Thousand Islands region, Alexandria Bay, Cape Vincent, Clayton, Grindstone. and Theresa quadrangles, N. Y. N Y St Mus, B 145: 194 pp (1910)

11 A new locality of pyrrhotite crystals and their pseudomorphs. Am J Sc (4) 32 : 156-160 (1911)

11a The Clinton type of iron-ore deposits. In Types of ore deposits (ed by H. F. Bain) : $33-52$ (1911)

12 On the genesis of the pyrite deposits of St. Lawrence Co. N Y St Mus, B $158: 143-182$ (1912)

13 The relative solubilities of the chem. ical constituents of rocks. J G 21:105120 (1913) 
Smyth, Charles Henry-Continued.

$13 a$ The chemical composition of the alkaline rocks and its significance as to their origin. Am J Sc (4) $36: 33-46$ (1913)

18 Genesis of the zinc ores of the Edwards district, St. Lawrence Co., N. Y. N Y St Mus, B 201:41 pp (1918)

18n (with Buddington, A. F.) Lake Bonaparte quadrangle. N Y St Mus, B $196: 30-32$ (1918)

Smyth, Henry Lloyd.

91 Struetural geology of Steep Rock Lake, Ont. Am J Sc (3) $42: 317-331$, map (1891)

$93 \mathrm{~A}$ contact between the lower Huronian and the underlying granite in the Republic trough, near Republic, Mich. J G $1: 268-274$ (1893)

94 The quartzite tongue at Republic, Mich. J G 2:680-691 (1894)

$94 a$ Relations of the lower Menominee and lower Marquette series in Michigan. Am J Sc (3) 47:216-223 (1894)

96 On the origin of the copper deposits of Keweenaw Point $(a b s t)$. Science $\mathrm{n} s$ $3: 251-252$ (1896)

96a (and Finlay, J. R.) The geolog ical structure of the western part of the Vermilion Range, Minn. Am I M Eng, Tr 25:595-645, map (1896)

97 The Republic trough, Mich. U S G S, Mon 28:525-553 (1897)

97a Magnetic observations in geological mapping. Am I M Eng, Tr 26:640-709, $\operatorname{map}(1897)$

99 (with Clements, J. M.) The Crystal Falls iron-bearing district of Miehigan. U S G S, Mon 36: xxxvi, 512 pp, maps (1899) Abst, U S G S, An Rp 19 pt 3: 19-151, maps (1899)

04 (and Smith, P. S.) The copper deposits of Orange Co., Vt. Eng M J 77: 677-678 (1904)

05 The origin and classification of placers. Eng M J 79:1045-1046, 1179-1180, 1228-1230 (1905)

06 The relations between gold and pyrite. M Sc Press 93:58-59 (1906)

07 Magnetic observations in geological and economic work. Ec G 2:367-379 (1907) ; 3:200-218 (1908)

See also Van Hise, 95

snedaker, J. A.

o7 Copper mines in Colorado. Eng $M$ J $83: 817-818$ (1907)

Snelling, W. $O$.

02 Titanium ores. U S G S, Min Res 1901: 271-278 (1902)

snelus, George J.

92 Notes on the iron ore districts visited by the members of the Iron and Steel Institute during the northern tour. Iron and Steel Inst. in America in 1890, special vol of $\mathrm{Pr}:$ 193-224 [1892]
Snider, Luther Crocker.

O9 Soil survey of Daviess Co., Ind. In Dp G, 33d An Rp: 343-357 (1909)

11 Preliminary report on the clays and clay industries of Oklahoma. Okla G \& B $7: 270 \mathrm{pp}, \operatorname{map}$ (1911)

11 a Preliminary report on the road as terials and road conditions of Oklabom Okla G S, B 8:191 pp (1911)

$11 b$ The Davis, Okla., zinc field. Is \& Press 103: 294-295 (1911)

11e Oklahoma lead and zinc fields. En M J 92: 1228-1230 (1911)

11d The limestones of Oklahoma. Stove $32: 589-591$, map (1911)

12 Preliminary report on the lead and zine of Oklahoma. Okla G S, B 9:97 ph map (1912)

13 Petroleum and natural gas in 0kle. homa. 196 pp, maps, Oklahoma City, Okla., 1913

$13 n$ The gypsum and salt of Oklahom. Okla G S, B 11: 214 pp, maps (1913)

13b Rock asphalts of Oklahoma ani their use in paving. Okla G S, Circ no 5: 22 pp (1913)

13e Rock asphalt deposits of Oklahoma M Eng World 38:577-580 (1913)

13d Oklahoma gypsum deposits and is dustry. Eng M J 95:931-933, mu (1913)

14 The geology of east-central Oklahont with special reference to the occurrence of petroleum and natural gas. Okla G S, B $17: 25$ pp, maps (1914)

$14 n$ The Mississippian rocks of north eastern Oklahoma. J G 22 : 613-624 (191t) 15 The geology of a portion of north eastern Oklahoma. Okla G S, B 24:7-6: maps (1915)

15a The paleontology of the Cheste group in Oklahoma. Okla G S, B 24:67122, il (1915)

17 Geography of Oklaboma. Okla G s B $27: 325 \mathrm{pp}$, maps (1917)

See also Gould, 11b

Snow, Charles H.

91 Turquoise in southwestern Ner Mexico. Am J Sc (3) 41:511-512 (1891 93 Copper crystallization at the Coppet Glance and Potosi mine, Grant Co., N. Mer Am I M Eng, Tr 21:308-313 (1893)

Snow, E. P.

95 The Fourmile placer fields of Colorado and Wyoming. Eng M J 60:102-104 (1895)

95a The Hartville iron ore deposits in Wyoming. Eng M J 60:320-321 (1895) 95b The Douglas Creek placers, Albaby Co., Wyo. Eng M J 60:539-541 (1895)

Snow, Francis Huntington.

$\mathbf{7 8}$ On the dermal covering of a mos. saurid reptlle. Kans Ac Sc, Tr 6:54-58, II (1878) ; reprint (1906) Kansas City Br Sc $2: 451-454$, il $(1878)$ 
Snow, Francis Huntington-Continued.

s7 On the discovery of a fossil bird track in the Dakota sandstone. Kans Ac Sc, Tr $10: 3-6$, il (1887)

s9 The Logan County nickel mines [Kans.]. Kans Ac Sc, Tr $11: 39-42$ (1889) 90 Kiowa Co., Kans., meteorites. Science $15: 290$ (1890)

90a A stony meteorite from Washington Co., Kans. Science 16:38-39 (1890)

90b Another meteorite from Klowa Co., Kans. Science 16,39-40 (1890)

91 A new Kansas meteorite. Science $17: 3$ (1891)

snyder, John Otterbein.

14 The fishes of the Lahontan drainage system of Nevada and their relation to the geology of the region (abst). Wash Ac Sc, J $4: 299-300$ (1914)

snyder, W. H.

96 Preliminary report on the Stamford gneiss (abst). Science n $8 \quad 3: 143-144$ (1896)

Sociedad Geológiea Mexieana.

Boletín, t. 1, 1905- México

Solano y Eulate, José María.

72 Noticia sobre un hierro meterrico ballado en el departamento oriental de la Isla de Cuba. Soc Española H N, An 1:183-186 (1872)

Sollas, Igerna B. J.

13 On Onychaster, a Carboniferous brittle-star. R Soc London, Ph Tr B 204: $51-62$, il (1913).

Sollas, W. J.

00 Evolutional geology. Nature 62 481-489 (1900) Science n \& 12:745-756, 787-796 (1900) Smiths Inst, An Rp $1900: 289-314(1901)$

Solorzano, M. M.

07 (and Hobson, B.) Plant remains in basalt, Mexico. G Mag (5) 4:217-219, I1 (1907)

Somers, Ransom Evarts.

15 Geology of the Burro Mountains copper district, N. Mex. (with discussion). Am I M Eng, B 101:957-996 (1915); Tr 52:604-644, maps (1916)

17 (with Ries, H.) The elays of the Piedmont province, Va. Va G S, B 13: 86 pp. map (1917)

Sommermeler, L.

18 Ueber einen Fossilfund aus der Unteren Krelde von Trinidad [Didymotis trinidadensis, Lower Cretaceous]. Centralbl Miner 1918:131-136, 11

Soper, Edgar Kirke.

10 Prospecting and testing of clay deposits. M Sc Press 100: 827-830 (1910)

10n Gold deposits of Georgia. M Se

Press $100:$ 923-924 (1910)

10b Iron mining in Minnesota. M Sc

Press 101: 767-769 (1910)

11 The iron ranges of Minnesota. Eng M J $91: 766-770$ (1911)

$11 \mathrm{n}$ The genesis of ore deposits. Eng M J $92: 897-900,947-949$ (1911)
Soper, Edgar Kirke-Continued,

12 The geology and mining of clay. Eng M J $93: 263-267$ (1912)

12a Modern theories of ore deposition. Mex M J 14:22-26, 38-43 (1912) Mines and Methods $3: 449-457$ (1912)

14 (with Gront, F. F.) Preliminary report on the clays and shales of Minnesota. Minn G S, B 11:175 pp, map (1914)

15 The buried rock surface and preglacial river valleys of Minneapolis and vicinity. J G 23:444-460, map (1915)

16 Peat in Minnesota. J Geog 14 : 182185 (1916)

17 The effects of cross faults on the richness of ore. Am I M Eng, B 130: 1811-1823 (1917) ; Tr 58: 372-384 (1918)

17a The peat deposits of Minnesota. Ec G $12: 526-540$ (1917)

17b Effects of faults. M Sc Press 114: 152-153 (1917)

18 Mining districts of northern Idaho. M Sc Press 116:121-127 (1918)

Sosman, Robert Browning.

11 Minerals and rocks of the composition $\mathrm{MgSiO}_{3}-\mathrm{CaSiO}_{3}-\mathrm{FeSiO}_{3}$. Wash $\mathrm{Ac} \mathrm{Sc}$, J $1: 54-58$ (1911)

13 (and Merwin, H. E.) Data on the intrusion temperature of the Palisade diabase. Wash Ac Sc, J 3:389-395 (1913)

14 (with Day, A. L.) The determination of mineral and rock densities at high temperatures. Am J Sc (4) $37: 1-39$ (1914)

15 Types of columnar structure in igneous rocks $(a b s t)$. Wash Ac Sc, J 5: 490 (1915)

15a Two subordinate types of prismatic structure (abst). Wash Ac Sc, J 5:490491 (1915)

16 Types of prismatic structure in igneous rocks. J G 24:215-234 (1916)

$16 a$ (and Hostetter, J. C.) Ferrous iron content and magnetic properties of the natural oxides of iron as an index to their origin and history (abst). G Soc Am, B 27:60-61 (1916)

17 (and Hostetter, J. C.) Zonal growth in hematite and its bearing on the origin of certain iron ores. Am I M Eng. B $126: 933-943$ (1917); Tr. 58:434-444 (1918) Abst, Wash Ac Sc, J 6:309 (1916); $8: 329$ (1918)

17 a Some problems of the oxides of iron. Wash Ac Sc, J 7:55-72 (1917)

18 The work of the geophysical laboratory of the Carnegie Institution of Washington. Am J Sc (4) $46: 255-258$ (1918) Reprinted in A century of science in America : 284-287, New Haven 1918

Souder, Harrison.

05 Mineral deposits of Santiago, Cuba (with discussion by Olof Wenstrom). Am I M Eng, Tr 35:308-321, 1008-1010 (1905) 
Southall, James Cocke.

78 Man's age in the world... University of Virginia, Opening of the Lewis Brooks Museum : 11-60, Richmond 1878

82 Pliocene man in America (with discussion by J. W. Dawson and others). Victoria Inst, $\operatorname{Tr} 15: 191-220$ (1882)

Sovereign, L. Douglas.

o5 Gems and rare minerals of southern California. S Cal Ac Sc, B 4:85-90 (1905)

05a Valuable crystals and rare minerals of San Diego Co., Cal. M World 23:521$522(1905)$

Sowerby, George B.

50 Descriptions of new species of fossil shells [San Domingo]. G Soc London, Q J $6: 44-53$, il $(1850)$

Sowter, T. W. Edwin.

87 (with Ami, H. M.) Report of the geological branch. Ottawa Nat $1: 93-97$ (1887)

87a (with Ami, H. M.) Report of the geological branch. Ottawa Field Nat Club, Tr no $7: 342-349$ (1887)

S8 Preliminary notes on the Chazy formation at Aylmer, P Q. Ottawa Nat 2: 11-15 (1888)

Spalding, E. P.

of The quicksilver mines of Brewster Co. Tex. Eng M J 71:749-750 (1901)

Spalding, William A.

09 Mine explosions as related to earthquakes. Eng M J 87:411-413, $899 ; 88$ : 562-563 (1909)

15 Seasonal periodicity in earthquakes. Seism Soc Am, B 5:30-38 (1915) S Cal Ac Sc, B 14: $38-46$ (1915)

Spande1, Erich.

o1 Die Foraminiferen des Permo-Carbon von Hooser, Kansas, Nord Amerika. Saecular-Feier der Naturhistorischen Gesellschaft in Nürnberg, 1801-1901, Festschrift : 175194 , il [1901]

Spaulding, M. B.

98 The Silver Pick, Wilson, Colo. Sch Mines Q 20:41-47 (1898)

Spear, John C.

72 Report on the geology, mineralogy... of the Isthmus of Tehuantepec. In Shufeldt, Robert W., Reports of explorations and surveys...Isthmus of Tehuantepec (U S, 42d Cong $2 d$ sess, S Ex Doc no 6) : 99139, map, Washington 1872

Spearman, Charles.

13 Ore deposits of the Kirkland Lake district [Ont.]. Can M J 34:599-601 (1913)

14 Microscopic characters of the ore deposits and rocks of the Kirkland Lake district, Ont. Can M J 35: 329-332 (1914)

15 Rocks and ore deposits at Sesekinaka, Ont. Can M J 36:69-73 (1915)

Spence, Harold C. E.

18 The oil shales of Pictou, Cape Breton. Can M Inst, B 79:928-931 (1918)
Spence, Hugh Swaine.

18 The Canadian graphite industry. Mines Br, Sum Rp 1917: 49-50 (1918)

For earlier papers see De Schmid, H. \&

spencer, Arthur Coe.

94 Occurrence in Iowa of fossiliferos concretions similar to those of Mam Creek. Iowa Ac Sc, Pr 1 pt 4:55 (1894) 95 A preliminary note on the geology d Massanutten Mountain in Virginia. Jobu Hopkins Univ Circ 15:13-14 (1895)

95a Certain minerals of Webster a Iowa. Iowa Ac Sc, Pr 2:143-145 (1805) 97 The geology of Massanutten Moo tain in Virginia. Thesis, Johns Hopkis Univ. $54 \mathrm{pp}$, map, Washington 16: [Priv pub]

98 The upper Cretaceous section in southwestern Colorado (abst). Sciencens $7: 143$ (1898)

98a (and Girty, G. H.) On the De vonian in southwestern Colorado (abst). Science n \& 7:810 (1898)

99 (with Cross, W.) Description of the La Plata quadrangle, Colo. U S G \&, 6 Atlas La Plata fol (no 60): 14 pp, mapi (1899)

00 Devonian strata in Colorado. An t Sc (4) 9:125-133 (1900) Abst, Scieos n s 11:105 (1900)

OOa A peculiar form of talus [San Jua Mountains, Colo.] (abst). Science n s 11 $188(1900)$

$00 \mathrm{~b}$ River terraces in southwestern cole rado $(a b s t)$. Science n s 11: 825 (1900) 00c (with Cross, W.) Geology of te Rico Mountains, Colo. U S G S, An B 21 pt 2: 7-165, map (1900)

01 The iron ores of Santiago, Cuth Eng M J $72: 633-634$ (1901)

O1a The physiograpby of the Coppe River basin, Alaska (abst). Seience $\mathbb{D}$; $13: 189$ (1901)

O1b (with Hayes, C. W. ad Vaughan, T. W.) Report on a logical reconnaissance of Cuba ...: 123 ph map [Havana?] 1901 Also in Civil to port of Brig.-Gen, Leonard Wood, Militarf governor of Cuba, for 1901 vol 1 Trani, with annotations by Pablo Ortega y Res Cuba, Dir Montes y Minas, Bol Minas ne 2 and $3: 132 \mathrm{pp}$, map (by Fernándes de Castro and Salterain $\mathbf{y}$ Legarra) (1917)

o1e (with schrader, F. C.) The th ology and mineral resources of a portio of the Copper River district, Alaska. If G S : 94 pp, maps (1901)

02 The manganese deposits of Santiac Province, Cuba. Eng M J 74:247-246 (1902)

02a (with Vaughan, T. W.) The of ography of Cuba. Am Geog Soc, B 34 : $105-116$ (1902)

03 Mineral resources of the Encam? ment copper region, Wyo. U S G S, B 213 : 158-162 (1903) 
Spencer, Arthur Coe-Continued.

03a Reconnaissance examination of the copper deposits at PearI, Colo. U S G S, B $213: 163-169$ (1903)

03b Manganese deposits of Santiago, Cuba. U S G S, B 213:251-255 (1903)

03e Pacific Mountain system in British Columbia and Alaska. G Soc Am, B 14: 117-132 (1903) Abst, Science n s 16 : 261-262 (1902)

04 The copper deposits of the Encampment district, Wyo. U S G S, P P 25: 107 pp, maps (1904)

04a The Juneau gold belt, Alaska. U S G S, B $225:$ 28-42 (1904)

$\mathbf{0 4} \mathbf{b}$ Genesis of the magnetite deposits in Sussex Co., N. J. M Mag $10: 377-381$ (1904)

05 The Treadwell ore deposits, Douglas Island [Alaska]. U S G S, B 259:69-87 (1905)

05a Progress of work in the pre-Cambrian rocks [of New Jersey]. N J G S, An Rp 1904: 247-252 (1905)

05b The geology of the Treadwell ore deposits, Douglas Island, Alaska. Am I M Eng. Tr 35: 473-510 (1905)

05e The magmatic origin of vein-forming waters in southeastern Alaska. Am I M Eng. Bi-Mo B 5: 971-978 (1905) ; Tr $36: 364-371$ (1906) Reprinted in Emmons, S. F., Ore deposits (pub, by Am I M Eng) : $582-589$, N Y 1913

05d The origin of vein-filled openings in southeastern Alaska. Am I M Eng, BiMo B 6:1211-1216 (1905) ; Tr 36:581$586(1905)$

05e What is a fissure vein? Ec G 1: 286 (1905)

05f Pre-Cambrian rocks of the Franklin Furnace quadrangle [N. J.] $(a b s t)$. Science n \& 21:391 (1905)

06 What is a fissure vein? Ec G $1: 286$ (1906)

06a The Juneau gold belt, Alaska. U S G S, B 287: 137 pp, maps (1906)

06b (and Arnold, Ralph) The cause of the great earthquake. The World's Work 12:7678-7681 (1906)

07 Magnetite deposits of the Cornwan types in Berks and Lebanon cos., Pa. U S G S, B 315: 185-189 (1907)

08 Three deposits of iron ore in Cuba. U S G S, B 340: $318-328$ (1908)

08a Magnetite deposits of the Cornwall type in Pennsylvania. U S G S, B 359 : 102 pp, maps (1908)

08b Review of the geology and origin of the Lapland iron ores, by O. Stutzer [notes on magnetite deposits of N. J. and N. Y.]. Ec G $3: 545-553(1908)$

08e Deposits of residual iron ore in Cuba (abst). Science n s 27:468-469 (1908)
Spencer, Arthur Coe-Continued.

osd (and Fïmmel, H, B., Wolf, J. E., Salisbury, R. D., and Palache, Charles) Description of Franklin Furace quadrangle, N. J. U S G S, G Atlas Franklin Furnace fol (no 161) : 27 pp, maps (1908)

09 The Mine Hill and Sterling Hill zine deposits of Sussex Co., N. J. N J G S, An Rp St G 1908: 23-52 (1909)

10 The Jauss iron mine, Dillisburg, $\mathrm{Pa}$, U S G S, B 430:247-249 (1910)

11 Occurrence, origin, and character of the surficial iron ores of Camaguey and Oriente provinces, Cuba. Am I M Eng, B 51:231-237 (1911); Tr 42:103-109 (1912)

13 [Notes on the] Ely [district], Nev. U S G S, B 529: 189-191 (1913)

$13 a$ Chalcocite enrichment. Ec G 8: 621-652 (1913). Wash Ac Sc, J 3:70-75 (1913)

16 The Atlantic gold district, Fremont Co., Wyo. U S G S, B 626:9-45, maps (1916)

16a Economic geology of the North Laramie Mountains, Converse and Albary cos., Wyo. U S G S, B 626:47-81 map (1916) Abst, Wash Ac Se, J 6:449 (1916)

17 The geology and ore deposits of Ely, Nev. U S G S, P P $96: 189 \mathrm{pp}$, maps (1917) Abst, by John B. Hastings, M Sc Press 116: $857-862$ (1918) ; abst, by R. W. Stone, Wash Ac Sc, J 8:455-456 (1918) Rv by C. H. Clapp, Ec G $13: 400-409$ (1918)

18 (with Hayes, C. W., and Vaughan, T. W.) Geology of Cuba ; a reprint ... from the "Report on a geological reconnaissance of Cuba,"... Cuba, Direccion de Montes y Minas: 37 pp, map, Havana 1918 See also Vaughan, 99a

Spencer, Joseph William Winthrop (18521921).

75 Geological sketches of the neighborhood of Hamilton [Ont.] Can Nat $n$ i 7 : $463-471$ (1875)

76 Report on the country between the upper Assiniboine River and lakes Winnipegosis and Manitoba. Can G S, Rp Prog $1874-5: 57-70$ (1876)

$76 \mathbf{a}$ On the Nipigon or copper-bearing rocks of Lake Superior ... Can Nat n s 8: 55-81 (1876)

78 Graptolites of the Niagara formation. Can Nat n s $8: 457-463$ (1878)

81 Discovery of the preglacial outlet of the basin of Lake Erie into that of Lake Ontario. Am Ph Soc, Pr 19:300-337, 353, maps (1881) Pa G S (2), Rp Q4:357406 , maps (1881) Can Nat n s 10:65-79 (1881) Abst, Am Nat 15:408-410 (1881)

S2 Paleozoic geology of the region about the western end of Lake Ontario. Can Nat n s 10:129-171, map (1882) 
Spencer, Joseph William Winthrop-Con. s2a Surface geology of the region about the western end of Lake Ontario. Can Nat n s $10: 213-236,265-312$ (1882)

82b A short study of the features of the region of the lower Great Lakes during the great river age; or notes on the origin of the Great Lakes of North America. Am As, Pr $30: 131-146$ (1882)

83 Terraces and beaches about Lake Ontario. Am J Sc (3) 24:409-416 (1883) Abst, Am As, Pr 31: 359-363 (1883)

s3a Occurrence of graptolites in the Nlagara formation of Canada (abst). Am As, $\operatorname{Pr} 31: 363-365$ (1883)

83b The ancient Mississippi and Its tributaries. Kansas City Rv Se 6:615-621 (1883)

84 Niagara fossils. Mo Univ Mus, B 1 : $61 \mathrm{pp}, \mathrm{il}$ (1884) Ac Sc St L, Tr 4:555$610(1886)$

85 Remarkable landslide near Brantford, Ont. Hamilton As, J Pr 1 pt 2:55-57 (1885)

85a Occurrence of boulders of decomposition at Washington, D. C., and elsewhere. Am Nat $19: 163-165$ (1885)

85b Primitive origin of solls. Mo st Bd Agr, An Rp 18:380-390 (1885)

S7 Notes upon warping of the earth's crust in its relation to the origin of the basins of the Great Lakes. Am Nat 21: $168-171$ (1887)

87a A landslide at Brantford, Ont., illustrating the effects of thrust upon yielding strata. Am Nat 21:267-269 (1887)

$\mathbf{8 7 b}$ Age of the Niagara River. Am Nat $21: 269-270$ (1887)

s7e Hummocks and boulders of decomposition in southeastern Missourl. Am Nat $21: 366-367$ (1887)

87d Sand boulders in the drift, or subaqueous origin of the drift in central Missouri. Am Nat 21:917-921 (1887) Abst, Am G 1:120-121 (1888); Am As, Pr 36:220 (1888)

s8 Glacial erosion in Norway and in high latitudes. $\mathrm{R}$ Soc $\mathrm{Can}, \operatorname{Pr} \operatorname{Tr} 5$, iv : 89-98 (1888) Am Nat 22:218-231 (1888) Abst, Can Rec Sc 2:433-434 (1887); Am As, $\operatorname{Pr} 36: 218-220$ (1888)

S8a on the theory of glacial motion. $\mathrm{R}$ Soc Can, Pr Tr 5, iv: 99-100 (1888) Am Nat $22: 53-55(1888)$

88b Notes on the drift north of Lake Ontario (abst). Am Nat 22:344-345 (1888) Science 11: 138-139 (1888)

8se Lake beaches at Ann Arbor, Mich. Am G 2:62 (1888)

s8d International Geological Congress; Report of the subcommittee on the Cenozoic; Pleistocene system. Am G 2:294297 (1888)

88e The Iroquois beach; a chapter in the history of Lake Ontario. Science 11: 49 (1888)
Spencer, Joseph William Winthrop-Con 88f Notes upon the theory of glacil motion (abst). Am As, Pr 36: 220 (1888

$\mathbf{8 8 g}$ Notes on the origin and history o. the Great Lakes of North America (abst). Am G 2:346-348 (1888) Am As, Pr 37: 197-199 (1889) Am Nat 23:491-494 (1889) Sclence 12:99-100 (1888) Cas Rec Sc (3) : 232-235 (1888)

89 Economic geological survey in Geor. gia and Alabama, throughout the betf traversed by the Macon \& Birmingtun Railway ... $86 \mathrm{pp}$, map, Athens 1889

89a Origin of soils geologically consilered. Ga, Univ, Ga Agr Exp Sta, B ? 27-31 (1889)

89b On glacial erosion. Am G 3:208212 (1889)

90 The high continental elevation prt ceding the Pleistocene period. G Soc Am, B 1:65-70 (1890) G Mag (3) $7: 200$ 213 (1890)

90a Ancient shores, boulder pavements and high-level gravel deposits in the th gion of the Great Lakes. G Soc Am, B 1: $71-86$ (1890)

9ob The deformation of Iroquois beach and birth of Lake Ontario. Am J Sc (3) $40: 443-451$ (1890)

90e The Iroquois beach; a chapter in the geological history of Lake Ontaria R Soc Can, Pr Tr 7, iv : 121-134 (1890)

90d The northeastern extension of the Iroquois bench in New York. Am G 6: 294-295 (1890)

90e Origin of the basins of the Gret Lakes of America (with discussion). Soc London, Q J 46:523-533 (1890) An G $7: 86-97$ (1891) Abst, G Mag (3) t 281-282 (1890)

9oe "Southern drift" and its agricul tural relations. Ga, Univ, Ga Agr Exp Sta B $6: 90-94$ (1890)

91 Administrative report. Ga $G \mathrm{~S}, 15$ Rp Prog 1890-1: 5-10 (1891)

$91 a$ A general or preliminary geological report on southwest Georgia and report on Polk Co. Ga G S, 1st Rp Prog 1890-1: 11-128, map (1891)

91b Post-Pleistocene subsidence versis glacial dams. G Soc Am, B $2: 465-476$ (1891) G Mag (3) $8: 262-272$ (1891)

91e Deformation of the Algonquin beach and birth of Lake Huron. Am $J$ Se (3) 41: 12-21, map (1891)

91a High level shores in the region of the Great Lakes, and their deformation Am J Sc (3) 41:201-211, map (1891)

91e Prof. W. M. Davis on the Iroquois beach. Am G $7: 68-69,266-267$ (1891)

92 The Iroquois shore north of thr Adirondacks (with discussion, pp. 492-495). G Soc Am, B 3:488-491 (1892) 
Spencer, Joseph William Winthrop-Con. 92a Channels over divides not evidence per $s e$ of glacial lakes (with discussion, pp. 492-495). G Soc Am, B 3:491-492 (1892)

92b Notes on the drift north of Lake Ontario (abst). Ph Soc Wash, B 11:506507 (1892)

93 The Paleozoic group; the geology of ten counties of northwestern Georgia. Ga G S : 406 pp, map, Atlanta, Ga., 1893

93a Terrestrial submergence southeast of the American continent (abst, with discussion by W. P. Blake and others). G Soc Am, B 5:19-22 (1893) Am G 12:168169 (1893) Am J Sc (3) 46:304 (1893)

94. Reconstruction of the Antillean continent. G Soc Am, B 6:103-140, map (1894) Abst, Am G 14:200-201 (1894); G Mag (4) 1:448-451 (1894); Am Nat 28: 881-884 (1894)

94a The rock basin of Cayuga lake [N. Y.], Am G 14:134-135 (1894)

94b The age of Niagara Falls. Am G 14: 135-136 (1894)

94e A review of the history of the Great Lakes. Am G 14:289-301 (1894)

94d Deformation of the Lundy beach and birth of Lake Erie. Am J Sc (3) 47 : 207-212, map (1894)

94e The duration of Niagara Falls. Am J Sc (3) $48: 455-472$ (1894) Abst, Am As, $\operatorname{Pr} 43: 244-246$ (1895); Am Nat 28: 859-862 (1894)

94f The drainage of the Great Lakes into the Mississippi River by way of Chicago. Am Nat 28: 884 (1894)

94g The Yumuri Valley of Cuba-a rock basin. G Mag (4) 1:499-502 (1894)

94h Niagara Falls as a chronometer of geologic time (abst). R Soc London, $\operatorname{Pr} 6$ : 145-148 (1894)

95 The duration of Niagara Falls and the history of the Great Lakes. 2d ed, 126 pp, N Y [1895] Another ed. issued with Eleventh An $\mathrm{Rp}$ of the Commissioners of the State Reservation at Niagara, $126 \mathrm{pp}$, Alban 1895

95a Geographical evolution of Cuba. G Soc Am, B $7: 67-94$ (1895) Abst, Science n s $1: 59-60$ (1895)

95b Note on Mr. Kïmmel's review of the "Reconstruction of the Antillean continent," J G 3 : 497-498 (1895)

95e The geological survey or the Great Lakes, Am As. Pr $43: 237-243$ (1895)

95d Preliminary notes on the late connection and separation of the Pacific Ocean and Gulf of Mexico. G Mag (4) 2:306308 (1895)

95e Recent elevation of New England (abst). Am As, Pr 44:139-140 (1896) Am G 16:249-250 (1895) Science n s 2: 400 (1895)
Spencer, Joseph William Winthrop-Con.

96 Niagara as a timepiece. Pop Sc Mo 49:1-19 (1896)

96a How the Great Lakes were built. Pop Sc Mo. 49:157-172 (1896)

96b Geological canals between the Atlantic and Pacific oceans (abst). Am As, Pr $44: 139$ (1896) Am G 16:248 (1895) Science n s 2:400 (1895)

96e On the geographical evolution of Jamaica (abst). G Mag (4) 3:284-285 (1896)

97 Great ehanges of level in Mexico and the interoceanic connections. G Soc $\mathrm{Am}$, B 9:13-34, map (1897) Abst, Am G 20: 195 (1897) ; Science n s 6:692 (1897)

$\mathbf{9 7 a}$ Analogy between declivities of land and submarine valleys (abst). Am G 20: 194-195 (1897) Science n s 6:691 (1897)

98 Another episode in the history of Niagara Falls. Am J Sc (4) 6:439-450, map (1898) Abst, Am As, Pr 47:299 (1898); Science n s 8:501-502 (1898); Am G 22: 259-260 (1898)

98n An account of the researches relating to the Great Lakes. Am G 21:110 123 (1898) N Y, Comm St Res Niagara, An Rp 15:139-160 (1899)

98b On Mr. Frank Leverett's "Correlation of moraines with beaches on the border of Lake Erie." Am G 21: 393-396 (1898)

9Se Late formations and great changes of level in Jamaica. Can Inst, Tr $5: 325$ 357 (1898) Abst, Am J Sc (4) 6:270272 (1898) ; G Mag (4) 5:515-517 (1898)

9sd Resemblance between the declivities of high plateaus and those of submarine Antillean valleys. Can Inst, $\mathrm{Tr} 5: 359$ 368 (1898) Abst, Am J Sc (4) 6:272273 (1898); G.Mag (4) 5:514-515, map (1898)

9Se Niagara as a timepiece. Can Inst, Pr n s 1:101-103 (1898)

98f The West Indian bridge between North and South America. Pop Sc Mo $53: 10-30$ (1898)

98 a Geological waterways across Central America. Pop Sc Mo 53:577-593 (1898)

98h On the continental elevation of the glacial epoch. G Mag (4) $5: 32-38$ (1898) Abst, Brit As, Rp 67:651-652 (1898)

9si Evidence of recent great elevation of New England (abst). Am As, $\operatorname{Pr} 47$ : 301 (1898) Am G 22:262 (1898) Science n s $8: 503$ (1898)

01 On the geological and physical development of Antigua. G Soc London, Q J 57:490-505, map (1901) Abst, G Mag (4) $8: 281$ (1901)

$01 a$ on the geological and physical development of Guadeloupe. G Soc London, Q J 57:506-519 (1901) Abst, G Mag (4) $8: 282(1901)$ 
Spencer, Joseph William Winthrop--Con. o1b On the geological and physical development of Anguilla, St. Martin, St. Bartholomew, and Sombrero. G Soc London, Q J 57:520-533 (1901) Abst, G Mag (4) $8: 282-283$ (1901)

ore on the geological and physical development of the St. Christopher chain and Saba banks. G Soc London, Q J 57 : 534-544 (1901) Abst, G Mag (4) 8:283284 (1901)

02 On the geological and physical development of Dominica; with notes on Martinique, St. Lucia, St. Vincent, and the Grenadines. G Soc London, Q J 58: 341-353, map (1902) Abst, G Mag (4) $9: 80-82$ (1902)

o2a On the geological and physical development of Barbados, with notes on Trinidad. G Soc London, Q J 58:354367 (1902) Abst, G Mag (4) $9: 82-83$ (1902)

02b The Windward Islands of the West Indies. Can Inst Tr $7: 351-370$ (1902)

03 Submarine valleys off the American coast and in the North Atlantic. G Soc Am, B 14:207-226, map (1903) Abst, Science n \& $17: 298-299$ (1903) : Sc Am Sup $55: 22647$ (1903)

o3a On the geological relationship of the volcanoes of the West Indies. Victoria inst, $\operatorname{Tr} 35: 198-207$, map (1903)

o:3b Geological age of the West Indian volcanic formations. Am G 31:48-51 (1903) J G 11: 113-116 (1903) Abst, Science n s $17: 225$ (1903)

on A rejoinder to Dr. Dall's criticism on Pr. Spencer's hypothesis concerning the late union of Cuba with Florida. Am G 34:110-119 (1904)

04a The submarine great canyon of the Hudson River. Am G 34:292-293 (1904)

05 The submarine great canyon of the Hudson River. Am J Sc (4) 19:1-15, map (1905) Geog J 25:180-190, map (1905) Abst, Science n s 21:136-137 (1905)

05a On the physiographic improbability of land at the North Pole. Am J Sc (4) $19: 333-340$, map (1905) Abst, Science n s $21: 137$ (1905)

05b Bibliography of submarine valleys off North America. Am J Sc (4) $19: 341$ 344 (1905)

05e Dr. Nansen's “Bathymetrical features of the North Polar sea, with a discussion of the continental shelves and the previous oscillations of the shore line." Am G 35: 221-235 (1905)

06 Niagara Falls and Nlagara district. Can G S, Sum Rp 1905: 87-91 (1906)

or The Falls of Niagara, their evolution and varying relations to the Great Lakes; characteristics of the power and the effect of its diversion. $490 \mathrm{pp}$, map, Can G S 1907
Spencer, Joseph William Winthrop-Con $07 \mathbf{a}$ Recession of the Niagara Falls.

Mag (5) 4:440-441 (1907)

07b The Jamaica earthquake (abst). Science n s 25:966-967 (1907)

07e Data bearing on the age of Niazan Falls. G Soc London, Abst Pr 1906-7:76 (1907)

os Soundings under Niagara Falls an/ in the gorge (abst). Science n s 27:587. 589 (1908)

OSa Revision of the age of Niagan Fall (abst). Science n s 27:925-989 (1908)

08b High-level terraces of New England (abst). Science n 8 28:382 (1908)

ose Changes in the recession of the Falls of Niagara (abst). Science n $\mathrm{s} 28: 38 \%$. 384 (1908)

08d Preglacial Erie outlet (abst). Science n s $28: 384$ (1908)

ose Side issues bearing on the age of Niagara Falls. Science n s 28:754-769 (1908)

osf Soundings in Nlagara Gorge and under the Falls. Sc Am 99:76-77 (1908)

O8g Recession of the Niagara Falls Brit As, Rp $77: 572-573$ (1908)

Osh Spoliation of the Falls of Niagar Pop Sc Mo $73: 289-305$ (1908) Am Scenit and Historic Preservation Soc, An Rp 14: 245-264 (1909)

10 Relative work of the two Falls of Niagara. G Soc Am, B 21:441-446 (1910) Abst, Science n s $32: 187-188$ (1910)

10a Interruption in the flow of the Falls of Niagara in February, 1909. G Soc At, B $21: 447-448$ (1910) Abst, Science o : 32 : 191 (1910)

10b Relationship of Niagara River to the glacial period. G Soc Am, B 21:433$440,763-764$ (discussion) (1910) Abst, Science n s $32: 191$ (1910)

10e L'évolution des chutes du Niagar. La Géog 22 : 105-118 (1910)

10d The discovery of fossil mammals it Cuba and their great geographical impor tance. Science n \& 32:564-565 (1910) La Géog 24:273-274 (1910)

10e Note on the discovery by Profesot? C. de la Torre of fossil mammals in Cubs G Mag (5) $7: 512-513$ (1910)

11 On the focus of postglacial uplift north of the Great Lakes. J G 19:57-60 (1911)

12 Postglacial erosion and oxidation (discussion). G Soc Am, B 23: 296 (1912)

12a Hanging valleys and their preglacial equivalents in New York. G Soc Am, B $23: 477-486$ (1912) Abst, Sclence n s $35: 316$ (1912)

12b Covey Hill revisited [beaches on Covey Hill, Quebec] (with discussion bf J. B. Woodworth, H. L. Fairchild, and the author). G Soc Am, B 23: 471-476, 72? (1912) Abst, Science n s $\mathbf{3 5}: 310-311$ 
Spencer, Joseph William Winthrop-lion. 13 Postglacial earth movements about Lake Ontario and the Saint Lawrence River. G Soc Am, B 24: 217-228, 714-715 (discussion), map (1913)

13a Relationship of the Great Lake basins to the Niagara limestone. G Soc Am, B $24: 229-232$, map (1913)

13b Relationship between terrestrial gravity and observed earth movements of eastern America. Am J Sc (4) 35:561573, map (1913)

13e Outline of the evolution of the Falls of Niagara ; contrast with the falls of the Zambesi. (For the Int G Cong, XII, Canada.) $8 \mathrm{pp}$, map, Washington, D. C. 1913 [Priv pub, copyright, 1913, by author.]

13d Postglacial changes of level versus recent stability of the Lake region of America $(a b s t)$. Brit As, Rp 82: 476-477 (1913)

14 Interpretations of the anomalies of gravity. Science n \& $39: 645-646$ (1914)

14a Cause of the postglacial deformation of the Ontario region (abst with discussion). G Soc Am, B 25:65-66 (1914)

15 Results of recent soundings at Niagara, and their interpretation (abst). Wash Ac Sc, J 5: 406-407 (1915)

16 Recession of Niagara Falls remeasured in 1914 (abst). G Soc Am, B 27: 78-79 (1916)

16a Terrestrial stability of the Great Lake region (abst), G Soc Am, B 27:79 (1916)

$16 \mathrm{~b}$ Scour of the $\mathrm{St}$. Lawrence River and lowering of Lake Ontario (abst). G Soc Am, B $27: 79-80$ (1916)

17 Origin and age of the Ontario shore line-birth of the modern Saint Lawrence River. Am J Sc (4) $43:$ :51-362 (1917)

See also Berkey, 13c; Dawson ( $\mathrm{G} M$ ), 91b: Fairchild, 16a ; Grabau, 13g; Hitchcock (C H), 95c; Hull, 12; Johnson (D W), 12 ; Lawson (A C), 90a ; Tarr, 05e ; Torre, 12a ; Tyrrell, 90a ; Vaughan, 15c ; Wright (G F), $90 \mathrm{a}$

spencer, Leonard James.

98 Diaphorite from Montana and Mexico. Am J Sc (4) 6:316 (1898)

16 The world's minerals, with an appendix by W. D. Hamman, 327 pp, N Y 1916

Spencer, W. K.

04 On the structure and affinities of Palaeodiscus and Agelacrinus. R Soc London, Pr 74:31-46, il (1904)

Sperr, F. W.

12 Failures of the rule of following the hanging in the development of Lake Superior copper mines (with discussion). L Sup M Inst, Pr 17 : 238-246 (1912)

Snerr, J. Dana.

16 The Tom Reed-Gold Road mining district, Ariz. Eng M J 101:1-5 (1916)

See also Schrader, 16

$28737^{\circ}-23-62$
Sperry, E. S.

87 (with Penfield, S. L.) On the chemical composition of howlite ... Am J Sc (3) $34: 220-223$ (1887)

88 (with Penfield, S. L.) Mineralogical notes. Am J Sc (3) $36: 317-331$ (1888)

Sperry, Edwin A.

12 Investigation of Feather River black sands [Cal.]. M Sc Press 105:624-626 (1912)

Sperry, F. L.

86 (with Penfield, S. L.) On pseudomorphs of garnet from Lake Superior and Salida, Colo. Am J Sc (3) $32: 307-311$ (1886)

87 (with Penfield, S. L.) Triclinic feldspars with twinning striations on the brachypinacoid. Am J Se (3) 34:390-393 (1887)

03 The eruption of Colima [Mex.]. Am J Sc (4) 15:487-488 (1903)

Sperry, L. B.

78 Report on the geology of Rice Co. Minn G S, An Rp 6: 114-125, map (1878)

Spillman, W. J.

05 Natural mounds. Science n $\mathrm{s} 21$ : 632 (1905)

Spilsbnry, E. Gybbon.

84 Gold mining in South Carolina. Am I M Eng, $\operatorname{Tr} 12: 99-106$ (1884)

10 Special problems and their study in economic geology. Ec G $5: 780-781$ (1910)

13 Geological notes on La Luz district of Guanajuato [Mexico]. Mex M J 16: 22 (1913)

18 Manganiferous iron ores of the Cuyuna district, Minnesota (discussion [manganese in Costo Rica]). Am I M Eng, B 133: 103 (1918)

Spinks, Charles $\mathrm{H}$.

04 Magnesite and its uses. Cal J Tech 4: $68-71$ (1904)

Spotswood, Alexander.

11 Occurrence and uses of Amexican tourmalines. M World $35: 280$ (1911)

Springer, Ada.

02 On some living and fossil snails of the genus Physa, found at Las Vegas, N Mex. Ac $N$ Sc Phila, Pr 54:513-516 (1902)

Springer, Frank.

77 (with Wachsmuth, C.) Revision of the genus Belemnocrinus and description of two new species. Am J Sc (3) 13: 253-260 (1877)

78 (with Wachsmuth, C.) Transition forms in crinoids, and description of five new species. Ac $\mathrm{N}$ Sc Phila, Pr 1878: $224-266$.

80 (with Wachsmuth, C.) Revision of the Palrocrinoidea. Ac $\mathrm{N}$ Sc Phila, Pr $1879: 226-378$, il $(1880) ; 1881: 177-$ 414 , il ; $1885: 225-364$, il ; $1886: 64-226$ 


\section{Springer, Frank-Continued.}

83 (with Wachsmuth, C.) Remarks on Glyptocrinus and Reteocrinus, two genera of [Lower] Silurian crinoids. Am J Sc (3) $25: 255-268$ (1883)

s3a (with Wachsmuth, C.) On $H y$ bocrinus, Hoplocrinus, and Baerocrinus. Am J Sc (3) 26:365-377, il (1883)

84 On the occurrence of the lower Burlington limestone in New Mexico. Am J Sc (3) $27: 97-103$ (1884)

87 (with Wachsmuth, C.) The summit plates in blastoids, crinoids, and cystids, and their morphological relations. Ac N Sc Phila, Pr 1887:82-114, il

89 (with Wachsmuth, C.) Discovery of the ventral strueture of Taxocrinus and Haplocrinus, and consequent modifications in the classification of the Crinoidea. Ac N Sc Phila, Pr 1888: 337-363, il (1889)

89a (with Wachsmuth, C.) Crotalocrinus; its structure and zoological position. Ac N-Se Phila, Pr 1888:364-390, il (1889)

90 (with Wachsmuth, C.) New species of crinoids and blastoids from the Kinderhook group of the Lower Carboniferous rocks at Le Grand, Iowa. III G S 8:155205, il (1890)

9on (with wachsmnth, C.) A new genus (Allocrinus) from the Niagara group of western Tennessee. Ill G S 8:206-208, il $(1890)$

91 (with Wachsmuth, C.) The perisomic plates of the crinoids. Ac N Sc Phila, Pr $1890: 345-392$, il (1891)

92 (with Wachsmuth, C.) Description of two new genera and eight species of camerate crinoids from the Niagara group. Am G 10:135-144 (1892)

97 (with wachsmuth, C.) The North American Crinoidea Camerata. Harvard Coll, Mus C Z, Mem 20 and 21:837 pp, il (1897) Rv by F. A. Bather, G Mag (4) $5: 276-283,318-329,419-428,522-527$ (1898) ; 6:32-44, 117-127 (1899) ; reprint with index (1899)

99 Notice of a new discovery concerning Uintacrinus. Am G 24: 92 (1899)

00 On the presence of pores in the ventral sac in fistulate crinoids. Am G 26 : 133-151, il (1900)

OOa Further note on Uintacrinus. Am G $26: 194$ (1900)

o1 Uintacrinus, its structure and relations. Harvard Coll, Mus C Z, Mem 25: 1-89, il (1901)

02 On the crinoid genera Sagenocrinus, Forbesiocrinus, and allied forms. Am G $30: 88-97$, il (1902)

o5 Clciocrinus. Harvard Coll, Mus C Z, Mem 25: 93-114, il (1905)

o6 Discovery of the disk of Onychoorinus, and further remarks on the Crinoidea Flexibilla. J G 14:467-523, il (1906)
Springer, Frank-Continued.

o6a (and sloeom, A. W.) Hypsocrinus a new genus of crinoids from the Deve nian. Field Col Mus, Pub g s $2: 267-271$, il (1906)

09 A new American Jurassic criboid. U S Nat Mus, Pr 36:179-190, il (1909)

11 The crinoid fauna of the Knobstone formation. U S Nat Mus, Pr 41:175-265 (1911)

11 a Some new American fossil crinoids. Harvard Coll, Mus C Z, Mem 25: 117-161, il (1911)

$11 b$ On a Trenton echinoderm fauna at Kirkfield, Ont. Can G S, Mem 15:68 pp, il (1911)

13 Crinoid genus Scyphocrinus and is bulbous root Camarocrinus (abst). G Soc Am, B 24: 110-111 (1913)

17 On the crinoid genus Scyphocrinu and its bulbous root, Camaroorinus. Smiths Inst : $74 \mathrm{pp}$, il (1917)

18 On Mysticocrinus, a new genus of Silurian Crinoidea. Am J Sc (4) 46:666668 , il (1918)

See also Eastman, 00

Springer, J. F.

13 Sulphur and iron deposits of Tir. ginia. M World $38: 528-530$ (1913)

Sproat, Ira E.

16 Refining and utilization of Georgi kaolins. U S Bur Mines, B 128:59 p (1916)

Spurr, Josiah Edward.

94 The iron-bearing rocks of the Mesali range in Minnesota. Minn G S, B 10: rili, 268 pp, map (1894)

$94 a$ Preliminary report on field work done in 1893. Minn G S, An Rp 22:115133 (1894)

94b False bedding in stratified drift de posits. Am G 13: 43-47 (1894)

94c Oscillation and single current ripple marks. Am G 13:201-206 (1894) Abot, Minn, Univ, Q B 2 : 54-55 (1894)

94d The iron ores of the Mesabl range [Minn.]. Am G 13: 335-345 (1894)

94e The stratigraphic position of the Thomson slates [Minnesota]. Am J Sc (3) 48: 159-166 (1894)

95 Economic geology of the Mercur min ing district, Utah, with introduction by S. F. Emmons. U S G S, An Rp 16 pt 2: 343-455, maps (1895)

96 Gold resources of the Yukon region of Alaska $(a b 8 t)$. Science $n$ s $4: 801$ (1896)

97 The measurement of faults. J G 5 : 723-729 (1897) Abst, Science n s 5:238 (1897)

98 Geology of the Aspen mining district. Colo. U S G S, Mon 31: xxxv, 260 pp atlas (1898)

98a Geology of the Yukon gold district Alaska. U S G S, An Rp 18 pt $3: 87-392$, maps (1898) 
Spurr, Josiah Edward-Continued.

$00 \mathrm{~A}$ reconnaissance in southwestern Alaska in 1898 . U S G S, An Rp 20 pt 7 : 31-264, maps (1900)

00a Succession and relation of lavas in the Great Basin region. J G $8: 621-646$ (1900)

00b Classification of igneous rocks according to composition. Am G 25: 210-234 (1900)

00c Scapolite rocks from Alaska. Am J Sc (4) $10: 310-315 \quad(1900)$

00d Quartz-muscovite rock from Belmont, Nev.; the equivalent of the Russian beresite. Am J Sc (4) 10:351-358 (1900) ooe Structure of the Basin ranges (abst). Science n s 11:229 (1900)

oof Ore deposits at Monte Cristo, Wash. (abst). Science n s 12:884-885 (1900)

01 The ore deposits of Monte Cristo, Washington. U S G S, An Rp 22 pt 2: 777-865, maps (1901) Rv by H. V. Winchell, Am G 30:113-118 (1902)

01a Origin and structure of the Basin ranges. G Soc Am, B 12:217-270, map (1901) Abst, Science n s 13:98 (1901)

01b Variations of texture in certain Tertiary igneous rocks of the Great Basin. J G 9:586-606 (1901)

02 The original source of the Lake Superior iron ores. Am G 29:335-349 (1902)

02a Application of geology to mining. M Sc Press 85: 145-146 (1902) Int M Cong, 5th, Pr : 80-86 (1903)

03 Descriptive geology of Nevada south of the fortieth parallel and adjacent portions of California. U S G S, B 208: 229 pp, maps (1903) ; 2d ed (1905)

03a Ore deposits of Tonopah and neighboring districts, Nev. U S G S, B 213 : 81-87 (1903)

03b The ore teposits of Tonopah, Nevada. U S G S, B 219:31 pp, map (1903) ; B 225: 89-110, map (1904)

03e A consideration of igneous rocks and their segregation or differentiation as related to the occurrence of ores (with discussion by A. N. Winchell). Am I M Eng, Tr 33: 288-340 (1903) Reprinted in Emmons, S. F., Ore deposits (pub. by Am I M Eng) : 251-304, N Y 1913 Abst, Eng M J $76: 54-55$ (1903)

03a The determination of the feldspars in thin section. Am G 31:376-383 (1903) 03e The ore deposits of Tonopah, Nev. Eng M J $76: 769-770(1903)$

03f The relation of faults to topography (abst). Science n s 17:792 (1903)

04 Geology applied to mining... $326 \mathrm{pp}$, N Y 1904

04a Ore deposits of Silver Peak quadrangle, Nev. U S G S, B 225: 111-117 (1904)

04b Notes on the geology of the Goldflelds district, Nev. U S G S, B 225:118119 (1904)
Spurr, Josiah Edward-Continued.

04e Coal deposits between Silver Peak and Candelaria, Esmeralda Co., Nev. U S G S, B 225 : 289-292 (1904)

04d Alum deposit near Silver Peak, Esmeralda Co., Ner. U S G S, B 225 : 501-502 (1904)

04e The Silver Peak region, Nev. Eng M J $77: 759-760$ (1904)

O4f Faulting at Tonopah, Nev. (abst). Science n s 19:921-922 (1904)

05 Geology of the Tonopah mining district, Nev. U S G S, P P $42: 295$ pp, maps (1905)

O5a (and Garrey, G. H.) ... ore deposits in the Georgetown, Colo., mining district. U S G S, B 260:99-120 (1905)

05b The ores of Goldfield, Nev. U S G S, B 260:132-139 (1905)

ose Developments at Tonopah, Nev., during 1904. U S G S, B 260:140-149 (1905)

o5d Genetic relations of the western Nevada ores. Am I M Eng, Bi-Mo B 5 : 939-969 (1905); Tr 36:372-402 (1906) Reprinted in Emmons, S. F., Ore deposits (pub. by Am I M Eng): $590-620$, N Y 1913

ose Tonopah mining district [western Nevada]. Franklin Inst, J $160: 1-20$, map (1905)

osf What is a fissure vein? Ee G 1: 282-285 (1905)

05g Enrichment in fissure veins. Eng M J $80: 597-598$ (1905)

06 What is a fissure vein? Ec G 1: 282-285 (1906)

O6a The southern Klondike district, Esmeralda Co., Nev.; a study in metalliferous quartz veins of magmatic origin. Ec G $1: 369-382$ (1906)

06b Ore deposits of the Silver Peak quadrangle, Nev. U S G S, P P $55: 174$ pp, map (1906)

o6c and Garrey, G. H.) The Idaho Springs mining district, Colo. U S G S, B $285: 35-40$ (1906)

07 A theory of ore deposition. Ec G 2 : 781-795 (1907) M Sc Press 96:261-265, 662-663 (1908) M World 28:489-490, $519,660(1908)$

07a How should faults be named and classified? Ec G $2: 182-184,601-602$ (1907)

07b The Goldfields district, Nev. (abst) Franklin Inst, J 164: 155-160 (1907)

os (and Garrey, G. H.) Economic geology of the Georgetown quadrangle (together with the Empire distriet), Colo., with general geology by Sydney H. Ball. U S G S, P P 63: 422 pp, maps (1908)

osn (and Garrey, G. H.) Ore deposits of the Velardeña district, Mexico. Fc G 3:688-725 (1908)

09 Scapolite rocks of America. Am J Sc (4) $25: 154$ (1909) 
Spurr, Josiah Edward-Continued.

09a Ore deposition at Aspen, Colo. Ec G $4: 301-320$ (1909) M World 31:749752 (1909)

11 Tonopah geology [Nev.]. M Sc Press 102: 560-562 (1911)

12 Theory of ore deposition. Ec G 7 : 485-492 (1912)

12a (and Garrey, G. H., and Fenner, C. N.) Study of a contact-metamorphic ore deposit; the Dolores mine, at Matehuala, S. L. P., Mexico. Ec G $7: 444-$ 484 (1912) Abst, Wash Ac Sc, J $3: 116$ (1913)

15 Origin of certain ore deposits [lead and zinc, Mississippi Valley]. Ec G 10: 472-475 (1915)

15a Geology and ore deposition at Tonopah, Nev. Ec G 10:713-769 (1915)

16 The relation of ore deposition to faulting. Ec G 11:601-622 (1916)

18 War minerals. Ec G 13:500-511 (1918)

See also Eldridge, 99; Emmons (S F), 03d; Lindgren, 03d; Rickard, 03; Weed, $03 \mathrm{~g}, \mathrm{k}$

Squier, Ephraim George (1821-1888).

50 The volcanoes of Central America ... 20 pp [N Y 1850]

51 On the volcanoes of Central America, and the geographical and topographical features, as connected with the proposed interoceanic canal. Am As, Pr $4: 101-122$ (1851)

Squier, George Hull.

83 Erratic pebbles in the Licking Valley [Ky.]. Science 2: 436 (1883)

84 The faults of southwestern Virginia. Science $3: 614-615$ (1884)

84a Depth of the glacial submergence on the upper Mississippi. Science 4:160 (1884)

97 Studies in the dxiftless region of Wisconsin. J G $5: 825-836$ (1897); 6 : 182-192 (1898); $7: 79-82$ (1899)

08 Peculiar local deposits on bluffs adfacent to the Mississippi. Wis Ac Sc, Tr $16: 258-274$ (1908)

Squire, Joseph.

90 Report on the Cahaba coal field. Ala G S: 131 pp, map, Montgomery, Ala., 1890.

Stabler, Herman.

09 (with Dole, R. B.) Denudation. U S G S, W-S P 234: 78-93 (1909)

11 Some stream waters of the western United States, with chapters on sediment carried by the Rio Grande and the industrial application of water analyses. U S G S, W-S P 274:188 pp (1911) Abst, Wash Ac Sc, J 2: 158-159 (1912)

16 (with Mendenhall, W. C., and Dole, R. B.) Ground water in San Joaquin Valley, Cal. U S G S, W-S P 398: 310 p. maps (1916)

See also Palser (C), 11
Star, Hans von.

12 Monographle der Fusulinen; Teil III, Die Fusulinen (Schellwienien) Norl. amerikas. Palaeontographica 59:157-191, il (1912)

Sta ford, O. F.

04 The mineral resources and mineral industry of Oregon for 1903. Oreg Dnir B n s 1 no $4: 112$, vili pp (1904)

Stalder, Walter.

15 Humbolat Co. [Cal.]; notes on geol ogy and oil possibilities. Cal St M Bur B $69: 444-454$, map (1915)

See also Taff, 13

Standley, Paul C.

os (with Smith, O. M.) The Pierson Creek mines [Greene Co., Mo.]. Drury Coll, Bradley G Field Sta, B 1:72-79 (1905)

Stanley, F. C.

or (with Penfield, S. L.) On the chemical composition of amphibole. Am J Sc (4) $23: 23-51$ (1907)

Stanley-Brown, Joseph.

91 Bernardinite; is it a mineral or a fungus? Am J Sc (3) $42: 46-50$ (1891)

91 a Report on auriferous sands from Yakutat Bay. Nat Geog Mag 3:196-198 (1891)

92 Geology of the Pribilof Islands. G Soc Am, B 3:496-500 (1892) Abst, Am G $9: 217$ (1892)

94 Geological writings of Richard Owen. G Soc Am, B 5:571-572 (1894)

$94 a$ (with Dall, W. H.) Cenozoic geot ogy along the Apalachicola River. G Soc Am, B 5:147-170, map (1894) Abst, Am G $13: 137-138$ (1894)

Stansbrry, Howard.

52 Exploration and survey of the valley of the Great Salt Lake of Utah, including a reconnaissance of a new route through the Rocky Mountains. U S. 32d Cong spee sess, S Ex Doc 3:487 pp, maps, Phils 1852 [another ed, with different title page, 1855]

StansfieId, Edgar.

18 (and Nicolls, J. H. H.) Analyses of Canadian fuels; in five parts. Can Dp Mines, Mines Branch, 1918. Part I, The maritime provinces, B $22: 28$ pp ; Part II, Quebec and Ontario, B 23:25 pp ; Part III, Manitoba and Saskatehewan, B 24:15 pp: Part IV, Alberta and the Northwest terrtories, B 25: 68 pp ; Part V, British Colum bia and Yukon Territory, B 26:24 pp.

\section{Stansfield, John.}

11 Microscopic examination of some typical specimens of Porcupine rocks and vein matter. Can M J 32:109-115 (1911)

12 Certain mica, graphite, and apatite deposits of the Ottawa Valley, and an oc eurrence of Eozoon canadense. Can $G \mathrm{~S}$ Sum Rp 1911 : 280-285 (1912) 
Stansfield, John-Continued.

13 Mineral deposits of the Ottawa district. Int $\mathrm{G}$ Cong, XII, Canada, Guide Book no 3: 81-115, maps (1913)

13a On the origin of graphite. Can M Inst, $\operatorname{Tr} 16: 401-411$ (1913)

14 The drift on the island of Montreal [Que.]. Can G S, Sum Rp 1913: 208-210 (1914)

14a On a new mode of occurrence of scapolite. Am J Sc (4) $38: 37-40$ (1914)

15 The Pleistocene and recent deposits of the Island of Montreal [Que.]. Can G S, Mem $73: 80 \mathrm{pp}$, maps (1915)

16 London area, Ont. Can G S, Sum Rp 1915 : 142-147; 1916 : 185-186 (191617)

17 The Petrolia oll field, Ont. Can M Inst, $\operatorname{Tr} 19: 371-398$ [1917]

18 Surface deposits of southeastern Saskatchewan. Can G S, Sum Rp 1917 pt C : 41-52 (1918)

18a Concentric ridges on naturally occurring silica. R Soc Can, Tr (3) 11 iv : 117-120 (1918)

\section{stanton, Gilman S.}

91 The occurrence of garnets and beryls on New York Island. N Y Ac Sc, Tr 10: 50-51 (1891)

17 (with Manchester, J. G.) A discovery of gem garnet in New York City. Am Mineralogist 2:85-86 (1917)

18 Louis Pope Gratacap. Am Mineralogist $3: 31-33$, port (1918)

stanton, Timothy William.

88 Paleontological notes [Fort Pierre fossils near Boulder, Colo.]. Colo Sc Soc, Pr 2:184-187 (1888)

91 Cretaceous and Tertiary strata near Wilmington, N. C. Am G $7: 333-334$ (1891)

92 The stratigraphic position of the Bear River formation. Am J Sc (3) 43: 98-115, map (1892)

93 The Colorado formation and its invertebrate fauna, U S G S, B 106:288 pp, 11 (1893)

93a The faunas of the Shasta and Chico formations. G Soc Am, B 4:245-256 (1893) Abst, Am G 11:139-140 (1893)

94 The Cretaceous faunas of the ShastaChico series (abst). Am G 13:208 (1894)

94a [Notes on Cretaceous fossils.] Am G $13: 289-290\left(189^{\prime}\right)$

94b (with Diller, J. S.) The ShastaChico series. G Soc Am, B 5:435-464 (1894) Abst, Am G 13:208 (1894)

94e (with Turner, H. W.) Notes on the geology of the coast ranges of California. Am G 14: 92-98 (1894)

95 Contributions to the Cretaceous paleontology of the Pacific coast; the fauna of the Knoxville beds. U S G S, B 133:132 pp, il (1895)
Stanton, Timothy William-Continued.

$95 a$ [Report on invertebrate fossils from southern Kansas.] Am J Sc (3) 50:215218 (1895)

96 The faunal relations of the Eocene and upper Cretaceous on the Pacific coast. U S G S, An Rp 17 pt 1:1005-1060, il (1896)

96a (and Vaughan, T. W.) Sections of the Cretaceous at El Paso, Tex. Am J Sc (4) 1:21-26 (1896)

96b The faunal relations of the Eocene and upper Cretaceous on the Pacific coast (abst). Am G 18:61 (1896) Science n s $3: 822-823$ (1896)

97 (and Knowiton, F. H.) Stratigraphy and paleontology of the Laramie and related formations in Wyoming. G Soc Am, B 8: 127-156 (1897) Abst, J G 5 : 102-103 (1897)

97 a A comparative study of the Lower Cretaceous formations and faunas of the United States, J F 5: 579-624 (1897)

$\mathbf{9 7 b}$ On the genus Remondia Gabb, a group of Cretaceous bivalve mollusks. U S Nat Mus, Pr $19: 299-301$, il (1897)

98 Memoir of Joseph Francis James. G Soc Am, B 9: 408-412 (1898)

98n Supplement to the annotated catalogue of the published writings of Charles Abiathar White, 1886-1897. U S Nat Mus, Pr 20:627-642 (1898)

98b The Mesozoic section of Sierra Blanca, Tex. (abst). Science n s $7: 429$ (1898)

99 Mesozoic fossils [of Yellowstone National Park]. U S G S, Mon 32 pt 2: $600-650$, il (1899)

01 Chondrodonta, a new genus of ostreiform mollusks from the Cretaceous, with descriptions of the genotype and a new species. U S Nat Mus, Pr 24:301307 , il (1901)

02 The stratigraphic position of the Judith River beds; a correction of $\mathrm{Mr}$. Hatcher's correction. Science $n$ s 16 : 1031-1032 (1902)

03 A new fresh-water molluscan faunule from the Cretaceous of Montana. Am Ph Soc, Pr 42:188-199, il (1903)

03a Alpheus Hyatt, 1838-1902. Wash Ac Sc, Pr 5:389-391 (1903)

03b (with Hateher, J. B.) The stratigraphic position of the Judith River beds and their correlation with the Belly River beds. Science n s 18: 211-212 (1903)

04 Note on the Cretaceous fossils [of Bisbee quadrangle, Ariz.]. U S G S, P P $21: 70-73$, il (1904)

o5 (and Hatcher, J. B.) Geology and paleontology of the Judith River beds. U S G S, B $257: 128$ pp, il (1905)

O5a Stratigraphic notes on Malone Mountain and the surrounding region near Sierra Blanca, Tex. U S G S, B 266: 23-33 (1905) 
Stanton, Timothy William-Continued.

O5b The Morrison formation and its relations with the Comanche series and the Dakota formation. J G 13:657-669 (1905) Abst, Science n s 22:755-756 (1905)

o5e (and Martin, G. C.) Mesozoic section on Cook Inlet and Alaska Peninsula, G Soc Am, B 16:391-410, map (1905)

o5d The time element in stratigraphy and correlation (abst, with discussion by W. H. Dall, E. O. Ulrich, and David White). Science n s $21: 583-584$ (1905)

ose (with sehuchert, C., and others) Catalogue of the type specimens of fossil invertebrates in the department of geology, United States National Museum. U S Nat Mus. B 53 pt 1:704 pp (1905)

o9 Succession and distribution of later Mesozoic invertebrate faunas in North America. J G 17:410-423 (1909)

$09 \mathbf{a}$ The age and stratigraphic relations of the "Ceratops beds" of Wyoming and Montana. Wash Ac Sc, Pr 11:239-293 (1909)

10 Paleontologic evidences of climate. Pop Sc Mo 77:67-70 (1910)

$10 a$ Fox Hills sandstone and Lance formation ("Ceratops beds") in South Dakota, North Dakota, and eastern Wyoming. Am J Sc (4) 30:172-188 (1910) Abst, Science n s 32:63-64 (1910)

11 Final supplement to the catalogue of the published writings of Charles Abiathar White, 1897-1908. U S Nat Mus, Pr 40: 197-199 (1911)

13 Some variations in Upper Cretaceous stratigraphy. Wash Ac Sc, J 3:55-70 (1913)

14 Boundary between Cretaceous and Tertiary in North America as indicated by stratigraphy and invertebrate faunas. $G$ Soc Am, B 25: 341-354 (1914)

15 Invertebrate fauna of the Morrison formation. $\mathrm{G}$ Soc Am. B 26:343-348 (1915)

15a Correlation of the Cretaceous (discussion). G Soc Am, B 26:414-415 (1915)

151. [The Fox Hills formation of Colorado and Wyoming.] Wash Ac Sc, J 5: 332-333 (1915)

16 Contributions to the geology and paleontology of San Juan Co., N. Mex. ; 3 , Nonmarine Cretaceous invertebrates of the San Juan Basin. U S G S, P P 98: 309 326, il (1916) Abst, by R. W. S., Wash Ac Sc, J $7: 185-186$ (1917)

17 A Cretaceous volcanie ash bed on the Great Plains in North Dakota. Wash Ac Sc, J $7: 80-81$ (1917)

18 Mesozolc history of Mexico, Central America, and the West Indies. G Soc Am, B 29: 601-606 (1918)

See also Hatcher, 04; Hyatt, 03 ; Merriam, 01a ; Powell, 93, 95
Starbird, H. B.

03 Secondary enrichment in arid regions, Eng M J 75: 702-703 (1903)

starek, Emil.

86 Line of origin of the Charleston earthquake. Sch Mines Q 8:64-73 (1886)

Statz, B. A.

12 The new placer-mining district [Sants Fe Co.] N. Mex. M Science 66:167 (1912

12a Hell Canyon mining district, Mex. M Science 66: 201 (1912)

12b Geology of the Cochita mining dis. trict, N. Mex. M Science $66: 276-277$ (1912)

12e Geology of the Magdalena district, N. Mex. M Science 66:406-407 (1912)

Stauber, I. J.

10 Burro Mountain mining district [Grant Co., N. Mex.]. Mines and Minerals $30: 380-382 \quad(1910)$

Stauffer, Clinton Raymond.

o7 The Hamilton in Ohio. J G 15: $590-596$ (1907)

07a The Devonian limestones of central Ohio and southern Indiana. Ohio Nat 7: 184-186 (1907)

08 The Devonian section on Ten Mile Creek, Lucas Co., Ohio. Ohio Nat 8:271276 (1908)

09 The middle Devonian of Ohio. Obio G S (4) B 10:204 pp, il (1909)

11 The Devonian of southwestern 0ntario. Can G S. Sum Rp 1910: 193-195 (1911)；1911 : 269-272 (1912)

11a (and Hubbard, G. D., and Bownoeker, J. A.) Geology of the Columbus quadrangle. Ohio G S (4) B 14:133 pp, maps (1911)

12 Oriskany sandstone of Ontario. G Soc Am, B $23: 371-376$ (1912)

13 Geology of the region around Hagers. ville [Ont.]. Int $G$ Cong, XII, Canads, Guide Book no 4:82-99, map (1913)

13a Geology of the region around Port Colborne [Ont.]. Int $\mathrm{G}$ Cong, XII, Canada, Guide Book no 5 : 47-55, map (1913)

14 Stratigraphy of southwestern Ontario. Can G S, Sum Rp $1912: 291-293$ (1914)

15 The Devonian of southwestern 0n. tario. Can G S, Mem 34:341 pp, map (1915)

15a Olentangy shale and associated deposits of northern Ohio (abst). G Soc Am, B $26: 95-96$ (1915)

16 Relative age of the Detroit River series (with discussion by $A$. C. Lane). G Soc Am, B 27:72-78 (1916)

16a Divisions and correlations of the Dunkard series of Ohio. G Soc Am, B 27: 86-88 (1916)

16b The relationship of the Olentangy shale and associated Devonian deposits of northern Ohio. J G 24:476-487 (1916)

18 Descriptions of some new species of Devonian fossils. J G $26: 555-560$, il (1918)

See also Hubbard (G D), 15 
Staunton, W. F.

18 Effects of an earthquake in a mine at Tombstone, Ariz. Seism Soc Am, B 8: 25-27 (1918)

stead, Geoffrey.

93 Notes on the geography and natural history of the Tobique. N H Soc N B, B [3] no $11: 19-32$ (1893)

03 Notes on surface geology of New Brunswick. N H Soc N B, B no 21 (5 pt 1) : 5-13 (1903)

06 Notes on a grindstone quarry at Stonehaven, Gloucester Co., N. B. [strain in rock]. N H Soc N B, B no 24 (5 pt 4) : $407-408$ (1906)

Stearns, C. H.

99 Some observations on the topography of Athens and vicinity [Ohio]. Ohio St Ac Sc, An Rp 7:67-70 (1899)

Stearns, Jane.

09 A physiography laboratory. J Geog 8:84-89 (1909)

Stearns, Mary R.

11 Bibliography of the scientific writings of R. E. C. Stearns, Smiths Misc Col 56 no $18: 3-15$ (1911)

Stearns, Robert Edwards Carter (1827$1909)$.

76 Descriptions of new fossil shells from the Tertiary of California. Ac $\mathrm{N}$ Se Phila, Pr 1875:463-464, il (1876)

79 Remarks on fossil shells from the Colorado Desert. Am Nat 13:141-154, il (1879)

97 Description of a new species of Actacon from the Quaternary bluffs of Spanish Bight, San Diego, Cal. Nautilus $11: 14-15$ (1897)

98 Description of a new species of Actaeon from the Quaternary blufis at Spanish Bight, San Diego, Cal. U S Nat Mus, $\operatorname{Pr} 21: 297-299$, il (1898)

00 Fossil land shells of the John Day region with notes on related living speeies. Wash Ac Sc, Pr 2:651-660, il (1900)

00a The fossil shells of the Los Angeles tunnel clays. Science n $\mathrm{s}$ 12:247-250 (1900)

00b Mollusca associated with Mastodon remains. Nautilus 13:100-101 (1900)

01 The fossil fresh-water shells of the Colorado Desert, their distribution, environment, and variation. U $\mathbf{S}$ Nat Mus, Pr 24: 271-299, il (1901)

02 Fossil shells of the John Day region. Science n s $15: 153-154,393$ (1902)

06 Fossil Mollusca from the John Day and Mascall beds of Oregon. Cal Univ, Dp G, B 5:67-70, il $(1906)$

08 Dr. John B. Trask, a pioneer of science on the west coast. Science n s 28 : $240-243(1908)$

Stebinger, Eugene.

10 (with Ball, Max W.) The eastern part of the Little Snake River coal field, Wyo. U S G S, B 381: 186-213 (1910)
Stebinger, Eugene-Continued.

12 The Sidney lignite field, Dawson Co., Mont. U S G S, B 471:284-318, map (1912)

13 Control for geologic mapping in the absence of a topographic base map. Ee G $8: 266-271$ (1913)

13a The coal fields of Montana. Am I M Eng, B $81: 2329-2359$, map (1913); Tr $46: 889-919$, map (1914)

14 The Montana group of northwestern Montana. U S G S, P P 90:61-68 (1914)

14a Titaniferous magnetite beds on the Blackfeet Indian Reservation, Mont. U S G S, B 540: 329-337, map (1914)

14b Stratigraphy of the Montana group (Upper Cretaceous) in northwestern Montana and its relation to the Belly River beds and Judith River formation ( $a b s t$ ). Wash Ac Sc, J $4: 383-384$ (1914)

16 Geology and coal resources of northern Teton Co., Mont. U S G S, B 621: 117-156, maps (1916)

$16 a$ Possibilities of oil and gas in northcentral Montana. U S G S, B 641:49-91, maps (1916) Abst, by R. W. S., Wash Ac Sc, J $7: 77 \cdot(1917)$

17 Stratigraphy of the Two Medicine formation [Mont.]. U S G S, P P 103: 1-3 (1917)

17 anticlines in the Blackfeet Indian Reservation. Mont. U S G S, B 641:281305, maps (1917) Abst by R. W. S., Wash Ac Sc, J $7: 264-265$ (1917)

171. (and Goldman, M. I.) Pleistocene deposits in the Sun River region, Mont. (abst). G Soc Am, B 28: 149 (1917)

18 Oil and gas geology of the Birch Creek-Sun River area, northwestern Mont. U S G S, B 691: 149-184, map (1918)

Steel, Alvin Arthur.

03 The ore deposits of La Cananea [Mex.]. Eng M J 76:458-460 (1903)

10 The geology, mining, and preparation of barite in Washington Co., Mo. Am I M Eng, B 38:85-117 (1910); Tr 40:711743 (1910) Can M J 31:138-143 (1910,

10a Coal mining in Arkansas, Part $I$. Ark G S : 632 pp (1910) [1912?]

Steel, John Honeywood (1780-1838).

21 New locality of chrysoberyl [Saratoga Springs, N. Y.] Am J Se 4:37-38 (1821)

23 A report of the geological structure of the County of Saratoga [N. Y.]. N.Y Bd Agr, Mem 2:44-84, 155-161 (1823)

25 Notice of Snake Hill and Saratoga Lake and its environs [N. Y.]. Am J Sc $9: 1-4$ (1825)

25a A description of the oolite formation lately discovered in the County of Saratoga and State of New York: Am J Sc 9: 16-19 (1825)

29 Description of the High Rock spring at Saratoga Springs ..., N. Y. Am J Se 16: 341-345 (1829) 
Steele, James H.

oo The Joplin zine district of southwestern Missouri. Colo Sch Mines, B 1: 43-50 (1900) M Sc Press 80:640-641 (1900)

Steele, Joel Dorman.

71 The story of the rocks; fourteen weeks in popular geology. $280 \mathrm{pp}, \mathrm{N}$ Y 1871

Steenstrup, Knud Johan Vogel (18421913).

74 Bemerkungen zu der geognostischen Uebersichtskarte des Waigattes in NordGrönland. Petermanns Mitt $20: 142-144$, map (1874)

77 On the nonmeteoric origin of the masses of metallic iron in the basalt of Disko in Greenland. Miner Mag 1:143148 (1877)

81 Bemaerkninger til et geognostisk Oversigtskaart over en Del af Julianehaabs Distrikt [observations on a geologic map of part of the Julianehaabs district, Greenland]. Med Grönland 2:27-41, map (1881)

83 Om Forekomsten af Nikkeljern med Widmannstilttenske Figurer 1 Basalten 1 Nord-Grönland [nickeliferous iron in basalt in Greenland]. Med Grönland $4:$ 133-131, 270-275 (1883; 2d ed 1893) Deut G Ges, Zs 35:695-703 (1883) Miner Mag 6:1-38 (1884)

93 Bidrag til Kjendskab til de geognos tiske og geographiske Forhold i en Del af Nord-Grönland. Med Grönland 4: 173-242, 282-289, map (1893)

93a Om Forekomsten af Forsteninger i de kulförende Dannelser i Nord-Grönland. Med Grönland 5:43-77 (1893)

93b Et par Bemaerkninger til Heers Afhandling i dette Hefte [notes on Heer's Fossil fiora of Greenland]. Med. Grönland 5 : 215-216 (1893)

10 Geologiske og antikvariske Iagttagelser 1 Julianehaab Distrikt. Med Grönland $34: 115-154$ (1910)

11 Om Jaernspaten i Kryoliten ved Ivigtut. Med Grönland $47: 381-387$ (1911)

Stefanini, G.

12 Sugli echini terziari dell' America del Nord. Soc G Italiana, B $30: 677-714$, il (1912)

Stefansson, $v$.

10 Underground ice in northern Alaska. Am Geog Soc, B 42:337-345 (1910)

Steidtmann, Edward.

08 A graphic comparison of the alteration of rocks by weathering with their alteration by hot solutions. Ec G 3:381409 (1908)

10 The secondary structures of tne eastern part of the Baraboo quartzite range, Wis. J G 18: 259-270 (1910)

11 The evolution of limestone and dolomite. J G $19: 323-345,392-428$ (1911)
Steidmann, Edward-Continued.

14 (with Hotehkiss, W. O.) Lins stone road materials of Wisconsin. G S, B 34:137 pp, maps (1914)

15 Summaries of pre-Cambrian liter: ture of North America for 1909, 191 1911, and part of 1912. J G 23:81-9. 183-188, 261-271, 461-476, 575-i난 (1915)

16 Results of a study of dolomitization Science n s 44:56-57 (1916)

17 Origin of dolomite as disclosed stains and other methods. G Soc Am, $28: 431-450,153-154$ (abst) (1917)

18 The origin of petroleum pools. Geog 16: 310-313 (1918)

Steiger, George.

oo (with Clarke, F. W.) Experimetis relative to the constitution of pectolite pyrophyllite, calamine, and analcite. Os G S, B 167 13-25 (1900)

02 (with Clarke, F. W.) The action of ammonium chloride upon silicates. U G S, B 207:57 pp (1902)

02a (with Diller, J. S.) Volcanic dus and sand from St. Vincent caught at sea and the Barbados. Science $n$ s $15: 94^{\circ}-$ 950 (1902)

05 The action of silver nitrate and that lous nitrate upon certain natural silicates U S G S, B 262:75-90 (1905)

o5a (with Clarke, F. W.) On "cal fornite." U S G S, B 262:72-74 (1905)

14 (with Clarke, F. W.) The relatil abundance of several metallic elements Wash Ac Sc, J 4:58-62 (1914)

15 Note on muscovite. U S G S, B 69: 235-236 (1915)

16 (with Larsen, E. S.) Sulphatic er crinite from Colorado. Am J Sc (4) 4.: 332-334 (1916)

17 (with Larsen, E. S.) Mineralogt notes. Wash Ac Sc, J 7:6-12 (1917)

18 (with Paige, S.) Fluorine in seth citization. Wash Ac Sc, J 8:234-2W (1918)

18a (with watsen, T. L.) Titanitu bearing corundum spinellite (rock emery): a preliminary statement of its occurresy and composition in Virginia. Wash $A c \&$ J $8: 665-676$ (1918)

Steinhart, 0 . J.

14 Production and uses of tungsten. Sc Press 109:64 (1914)

Steinhauer, Henry.

14 Notice relative to the geology of th coast of Labrador. G Soc London, Tr? 488-494 (1814)

18 On fossil reliquia of unknown vę: tables in the coal strata. $\triangle \mathrm{m} \mathrm{Ph} \mathrm{Soc,} \mathrm{It}$ n s $1: 265-297$, il (1818)

Steinmann, $G$.

99 Ueber fossile Dasycladaceen Cerro Escamela. In Felix, J., and Lenk, Beiträge zur Geologie und Paläontologie det Republik Mexico, Th 2: 187-204, 11, Leiple 1899 
Stelle, J. P.

88 An outline expose of the geological, agricultural ... characteristics of Mobile Co., Ala ... 26 pp, Mobile, Ala., 1888

stepanow, $P$.

16 (with Tsehernysehew, T.) Obercarbonfauna von König Oscars und Heibergs Land. Second Norwegian Arctic Expedition in the Fram, 1898-1902, Rp no 34: 67 pp, il, Videnskabs-Selskabet i Kristiania, 1916

Stephenson, Eugene Austin.

16 Studies in hydrothermal alteration; Part I, The action of certain alkaline solutions on feldspars and hornblende. J G 24: 180-199 (1916)

Stephenson, Lloyd William.

07 Some facts relating to the Mesozoic deposits of the Coastal Plain of North Carolina. Johns Hopkins Univ Circ n s 1907 no $7: 93-99$ [681-687]

09 Cretaceous geology of the Carolinas and Georgia $(a b s t)$. Science n s $30: 124$ 125 (1909)

11 (with Veateh, J. O.) Preliminary report on the geology of the Coastal Plain of Georgia. Ga G S, B 26:466 pp (1911)

12 (with Clark, W. B., and Miller, B. H.) The stratigraphy of the Coastal Plain of North Carolina. N C G S 3: 34-44 (1912)

12a The Coastal Plain of North Carolina; the Cretaceous, Lafayette, and Quaternary formations. N C G S 3:73-171, 258-290 (1912)

12b (and Johnson, B. L.) Water resources of the Coastal Plain of North Carolina. N C G S 3: 333-483 (1912)

14 Cretaceous deposits of the eastern Gulf region and species of Exogyra from the eastern Gulf region and the Carolinas. U S G S, P P 81: 77 pp, i1, map (1914) Abst, Wash Ac Sc, J 5 : 24-25 (1915)

14a A deep well at Charleston, S. C. U S G S, P P 90:69-90 (1914)

14b The Cretaceous-Focene contact in the Atlantic and Gulf Coastal Plain (abst). Wash Ac Sc, J 4:11-12 (1914)

15 The Cretaceous-Eocene contact in the Atlantic and Gulf Coastal Plain. U S G S, P P 90:155-182, maps (1915) Abst, G Soc Am, B 26:168 (1915)

$15 a$ (and Veateh, J. O.) Underground waters of the Coastal Plain of Georgia. U S G S, W-S P 341: 539 pp, maps (1915)

16 North American Upper Cretaceous corals of the genus Micrabacia. U S G S, P P 98: 115-131, il (1916) Abst, Wash Ac Sc, J $7: 39$ (1917)

16a (and Crider, A. F.) Geology and ground waters of northeastern Arkansas. U S G S, W-S P 399: 309 pp, maps (1916)

$16 \mathrm{~b}$ Correlation of the upper Cretaceous deposits of the Atlantic and Gulf Coastal Plain (abst). G Soc Am, B 27:154 (1916) Wash Ac Sc, J 6:156 (1916)
Stephenson, Lloyd William-Continued.

17 Tongue, a new stratigraphic term, with illustrations from the Mississippi Cretaceous. Wash Ac Sc, J $7: 243-250$ (1917)

18 A contribution to the geology of northeastern Texas and southern Oklahoma. U S G S, P P 120:129-163, map (1918)

18a Fort Monroe, Langley Field, and the adjacent country [Virginia]. [Text on back of topographic map], Virginia, Hampton quadrangle, Langley Field, U S G S, 1918

18b The camps around San Antonio [Texas]. [Text on back of topographic map], Texas, San Antonio quadrangle, Kelly Fields and Camp Travis, U S G S, 1918

18e (and Miser, H. D.) Camp Pike and the adjacent country [Ark.]. [Text on back of topographic map], Arkansas, Little Rock quadrangle, Camp Pike, U S G S, 1918

See also Clark (W B), 16b; Deussen, 14 Stephenson, M. F.

71 Geology and mineralogy of Georgia ... 244 pp, map, Atlanta, Ga., 1871

Stephenson, W. M.

11 The gypsum theory [of the origin of petroleum]. Oil and Gas J 9 no $46: 8 \div 12$ (1911)

Sterki, $\nabla$.

o7 Fossil land and fresh-water Mollusca collected in Defiance Co., Ohio. Ohio Nat $7: 110-111$ (1907)

Sternberg, Charles Hazelius.

81 The Miocene beds of the John Day River, Oreg. Kansas City Rv Sc 4:540542 (1881)

81 a The Pliocene beds of southern Oregon. Kansas City Rv Sc 4:600-601 (1881)

81b The Quaternary of Washington Territory. Kansas City Rv Sc 4:601-602

(1881)

81e The Dakota group. Kansas City Rv Sc $4: 675-677$ (1881)

81d The Judith River group. Kansas City Rv Sc 4: 730-733 (1881)

s1e The Niobrara group. Kansas City Rv Sc 5:1-4 (1881)

sif The fossil flora of the Cretaceous Dakota group of Kansas. Kansas City Rv Sc $5: 243-244$ (1881)

81. Miocene fauna of Oregon. Kansas City Rv Sc 5 : 416-417, 491 (1881)

82 The Loup Fork group of Kansas. Kansas City Rv Sc 6: 205-208 (1882)

83 Explorations in the Judith River group. Kansas City Rv Sc 7:325-330 ( 1883$)$

83n The Triassic beds of Texas. Kansas City Rv Sc $7: 455-457$ (1883)

84 The fossil fields of southern Oregon. Kansas City Rv Sc 7 : 596-599 (1884) 
Sternbera, Charles Hazelius-Continued. 84a Explorations in northeastern Oregon. Kansas City Rv Sc 7:674-678 (1884)

85 Practical studies in geology. Kansas City Rv Sc 8:481-485 (1885)

o3 Elephas columbi and other mammals in the swamps of Whitman Co., Wash. Science n 8 17: 511-512 (1903)

03a Notes on the Judith River group. Science n s 17:870-872 (1903)

03b Experiences with early man in America. Kans Ac Sc, Tr 18:89-93 (1903)

03e The Permian life of Texas. Kans Ac Sc, Tr 18:94-98 (1903)

65 Protostega gigas and other Cretaceous reptiles and fishes from the Kansas chalk. Kans Ac Sc, Tr 19:123-128 (1905)

06 The Loup Fork Miocene of western Kansas. Kans Ac Sc, Tr 20 pt 1:71-74 (1906)

67 Portheus molossus Cope and other fishes from the Kansas chalk (abst). Science $n$ \& $25: 295$ (1907)

07 a The great inferior tusked mastodon of the Loup Fork Miocene. Science $n$ s 25: 971-972 (1907)

o7b Some animals discovered in the fossil beds of Kansas. Kans Ac Sc, Tr 20 pt $2: 122-124$ (1907)

os My expedition to the Kansas chalk for 1907. Kans Ac Sc, $\operatorname{Tr} 21: 111-114$, il (1908)

69 The life of a fossil hunter [an autobiographical sketch]. $286 \mathrm{pp}$, port, il N Y 1909

09a Expedition to the Laramie beds of Converse Co., Wyo. Kans Ac Sc, Tr 22 : 113-116 (1909)

O9b An armored dinosaur from the Kansas chalk. Kans Ac Sc, Tr $22: 257-261$, il (1909)

09c A new trachodon from the Laramie beds of Converse Co., Wyo. (abst). Science n s $29: 753-754$ (1909)

11 In the Niobrara and Laramie Cretaceous. Kans Ac Sc, Tr 23-24: 70-74, il (1911)

11a Still in the Laramie country, Converse Co., Wyo. Kans Ac Sc, Tr 23-24: 219-223 (1911)

13 Expeditions to the Miocene of Wyoming and the chalk beds of Kansas. Kans Ac Sc, Tr 25: 45-49 (1913)

14 Notes on the fossil vertebrates collected on the Cope expedition to the Judith River and Cow Island beds, Ment., in 1876. Science n s 40:134-135 (1914)

15 Evidence proving that the Belly River beds of Alberta are equivalent with the Judith River beds of Montana. Science n s 42:131-133 (1915) Abst, G Soc Am, B $26: 149$ (1915)

17 Hunting dinosaurs in the badlands of the Red Deer River, Alberta, Canada ... $232 \mathrm{pp}$, il, Lawrence, Kans,, 1917
Sternberg, Charles Hazelius-Costios 18 Five years explorations in the for beds of Alberta. Kans Ac Sc, Tr : 205-211 (1918)

Sterns, F, H.

18 The Pleistocene man of Vero, Fi a summary of the evidence of man's tiquity in the New World. Sc Am s $85: 354-355$ (1918)

Sterrett, Douglas Bovard.

04 Tourmaline from San Diego Co, 0 Am J Sc (4) $17: 459-465$ (1904)

04a A new type of calcite from Joplin mining district [Kans.]. Am J (4) $18: 73-76$ (1904)

04b (with Pratt, J. H.) The tin posits of the Carolinas. N C G S, B I 64 pp, Raleigh 1904

o7 Mica deposits of western North $\mathrm{Co}$ olina. N C G S, Ec P 14:82-107 (196\% U S G S, B 315: 400-422 (1907)

07а Abrasive materials. U S G Min Res 1906: 1043-1054 (1907)

өтb Mica. U S G S, Min Res 190\% 1149-1163; 1907 pt $2: 741-750 ; 1908$; $2: 743-754 ; 1909$ pt $2: 845-856 ; 1910$; $2: 915-920 ; 1911$ pt $2: 1129-1135 ; 194$ pt 2: 1079-1091; 1913 pt 2:1-9; 19! pt $2: 67-77 \quad(1907-15)$

07e Monazite and zircon. U S G Min Res 1906:1195-1209; 1907 pt $785-794 ; 1908$ pt $2: 791-794 ; 1909$ pt ? $897-905$; 1910 pt 2 959-962; 1911 pt? 1193-1196 (1907-12)

07d Gems and precious stones. G S, Min Res 1906: 1213-1252; 1907 t $2: 795-842 ; 1808$ pt $2: 805-809 ; 1909$ / $2: 739-808 ; 1910$ pt $2: 847-900 ; 19$ pt $2: 1037-1078 ; 1912$ pt $2: 1023-106$ 1913 pt $2: 649-708 ; 1914$ pt $2: 307$-3 (1907-15)

os The discovery of meerschaum in Ner Mexico (abst). Science n s 27:892 (1906 08a Monazite deposits of the Carolini U S G S, B 340:272-285 (1908) N C G Ec P $23: 72-81$ (1911)

08b Meerschaum in New Mexico. U G S, B 340: 466-473 (1908)

oSe (with Pratt, J. H.) Monazite at monazite mining in the Carolinas. Elist Mitchell Sc Soc, J 24: 61-86 (1908)

o9 Mica deposits of South Dakota. If G S, B $380: 382-397$ (1909)

O9a (with Pratt, J. H.) Monazite at monazite mining in the Carolinas.

I M Eng, B 30:483-511 (1909)

10 Mica deposits of North Carolid U S G S, B 430: $593-638$ (1910) N C G S Ec P $23: 32-68$ (1911)

12 An occurrence of emeralds in Nort Carolina (abst). Wash Ac Sc, J $2: 36$ t $^{\circ}$ 361 (1912)

13 Mica in Idaho, New Mexico, as Colorado. U S G S, B $530: 375^{-39}$ (1913) 
Sterrett, Douglas Bovard-Continued.

14 Some deposits of mica in the United States. U S G S, B 580:65-125 (1914)

17 (with Keith, A.) Tin resources of the Kings Mountain district, N. C. and S. C. U S G S, B 660:123-146, map (1917) Abst, by R. W. Stone, Wash Ac Sc, J $8: 129$ (1918)

stevens, Blamey.

03 Geology of some copper deposits in Alaska [Latouche Island]. Eng M J 75: 782 (1903)

03a Relation of rock segregation to ore deposition. Eng M J 76:574 (1903)

04 On the differentiation of igneous magmas and formation of ores. Eng M J 77 : 71-72 (1904)

04a Magmatic segregation of ores. Eng M J $77: 311-312$ (1904)

04b Acidic magmas, their exhalations and residues. Eng M J $77: 351$ (1904)

09 The laws of fissures. Am I M Eng, B $32: 722-739$ (1909); Tr $40: 475-491$ (1910)

09a Prince William Sound, Alaska; its geology and mineralogy. Northwest M J 8 no $1: 3-6$ (1909)

11 The laws of intrusion. Am I M Eng, B $49: 1-23$ (1911) ; $\operatorname{Tr} 41: 650-676$ (1911)

12 Replacement ore bodies (discussion). Ec G $7: 195-201$ (1912)

$12 a$ The laws of igneous emanation pressure. Am I M Eng, B 64:411-427 (1912) ; $\operatorname{Tr} 43: 167-183$ (1913)

12b Physical data of igneous emanation. Am. I M Eng, B 64:429-438 (1912); Tr 43:184-193 (1913)

13 The ultimate source of metals. Am I M Eng, B 75:331-343 (1913) ; Tr 44: $683-675 \quad(1913)$

13a The nature of replacement (discussion of paper by W. Lindgren). Ec G 8: $397-398$ (1913)

13b The laws of jointing. Am I M Eng, B $79: 1285-1303$ (1913); Tr 47:91-110 (1914)

14 Nomenclature of faults. M Mag 10: 272-274 (1914)

14a Intrusive pressure of mineralizing solutions. M Mag $11: 313-314$ (1914)

18 The mechanics of vein formation (discussion). Am I M Eng, B 144:17681770 (1918) [See Taber, 18a]

Stevens, E. A.

01 An occurrence of limburgite in the Cripple Creek district [Colo.]. Am I M Eng, $\operatorname{Tr} 30: 759-764$ (1901)

03 Basaltic zones as guides to ore deposits in the Cripple Creek district, Colo. Am I M Eng, Tr 33:686-698 (1903) Reprinted in Emmons, S. F., Ore deposits (pub. by Am I M Eng) : 411-423, N Y 1913
Stevens, E. H.

15. (with Grimes, E. J.) Soil survey of Warren Co. [Ind.]. Ind $\mathrm{Dp} \mathrm{G}, \mathrm{An} \mathrm{Rp}$ $39: 145-189$, maps (1915)

Stevens, G. R.

17 Geology of the Cedar Range [Nye Co., Nev.]. M Sc Press 114: 130 (1917)

Stevens, Horace Jared (1866-1912).

oo (editor) The copper handbook; a manual of the copper industry of the world. Vols. 1(1900)-10(1910) [For continuation, see Weed, 14]

05 General information of the geology and mines of the Lake Superior copper district. Am I M Eng, Bi-Mo B 1: 208-222, map (1905)

or Mines of the Lake Superior copper district. L Sup M Inst, Pr 12:8-24 (1907)

Stevens, Neil E.

12 Notes on the structure and glaciation of Overlook Mountain [N. Y.]. N Y Ac Sc, An 22: 259-266 (1912)

12a A palm from the upper Cretaceous of New Jersey. Am J Sc (4) 34:421-436, il (1912)

Stevens, Richard $P$.

ss Description of new Carboniferous fossils from the Appalachian, Illinois, and Michigan coal fields. Am J Sc (2) 25 : $258-265$ (1858)

58a Contributions to the paleontological synchronism of the Coal Measures of Obio and Illinois. $\mathrm{Am} \mathrm{J}$ Sc (2) 26:72-79 (1858)

60 Remarks on the Taconic system. Lye N H N Y, An $7: 276-283$ (1860)

62 On the extension of the Carboniferous system of the United States so as to include all true coals. Lyc $\mathrm{N}$ H $\mathrm{N} \mathbf{Y}$, An $7: 414-419$ (1862)

63 Report on the geological and mineralogical specimens collected by Mr. C. F. Hall in Frobisher Bay. Am J Sc (2) 35 : 293-294 (1863)

65 Report upon the past and present history of the geology of New York Island. Lyc N H N Y, An 8:108-120 (1865)

72 On glacial phenomena in the vicinity of New York City. Am J Se (3) 4:88-90 (1872)

73 On glacial movements in northern New York. Am J Sc (3) 6:144-145 (1873)

$73 \mathbf{a}$ On glaciers of the glacial era in Virginia. Am J Sc (3) 6:371-373 (1873)

$\boldsymbol{7 4}$ On the fossils found in the "flag. stones" used in the cities of New York and Brooklyn. Lye N H N Y, Pr (2) [no 2] : 5-7 (1874)

74a Recent observations on drift. Lyc N H N Y, Pr (2) no $3: 71-72$ (1874)

74b On the natural coke of Richmond, Va. Lyc N H N Y, Pr (2) no $3: 73$ (1874) 
Stevens, Richard P.-Continued.

74c [On coal beds in New River valley, W. Va.] Lyc N H N Y, Pr (2) no 3:74 (1874)

74d Observations on some irregularities of the floor of the Coal Measures of eastern Kentueky. Lye $\mathrm{N}$ H N Y, An 11: 18-20 (1874)

S3 Evidences of glaciation in Kentucky. Science 1: 510-511 (1883)

86 On the San Juan Mountains of Colorado. N Y Ac Sc, Tr 5: 121-130 (1886)

Stevens, W. Le Conte.

82 The Mammoth Cave of Kentucky. N Y Ac Sc, Tr 1:58-65 (1882)

Stevens, Walter B.

oo The Ozark uplift ... zinc and lead mining industries tributary to the Frisco Line. $71 \mathrm{pp}$, maps, St. Louis 1900 [priv pub]

Stevens, William $\mathrm{H}$.

54 The prospects of the Lake Superior mining region. M Mag $2: 149-153$ (1854)

63 (and Hill, S. W., and Williams, C. P.) Geological map of the trap range of Keweenaw Point, Lake Superior. Phila [1863] [not seen]

stevenson, John James.

71 A geological examination of Monongalia Co., W. Va. W Va Univ, Rp Bd Reg 3 : 40-67 (1871)

73 The upper Coal Measures west of the Alleghany Mountains; Lyc N H N Y, An $10: 226-252$ (1873)

$73 a$ Note on the coals of the Kanawha Valley, W. Va. Lyc N H N Y, An 10:271277 (1873) The Virginlas 2:54-55 (1881)

$\mathbf{7 3 b}$ Notes on the geology of West Virginia. Am Ph Soc, Tr n s 15:15-32 (1873)

74 [On the age of the lignites of Colorađo.] Lyc $N$ H N Y, Pr 2 no 4:93-94 (1874)

75 Report on the geology of a portion of Colorado. U S Geog G S W 100th Mer (Wheeler), $3: 303-501$ (1875)

$75 a$ on the alleged parallelism of coal beds. Am Ph Soc, Pr 14:283-295 (1875)

751 Notes on the geology of West Virginia; No. II. $\mathrm{Am} \mathrm{Ph}$ Soc, $\mathrm{Pr} 14: 370$ 401, map (1875) The Virginias 2:70-71, $74-75,98-100,122-125$ (1881)

75e The geological relations of the lignitic groups. Am Ph Soc, Pr 14:447475 (1875)

76 Report of progress in the Greene and Washington district of the bituminous coal fields of western Pennsylvania. $\mathrm{Pa}$ G S, 2d, K: x, 419 pp, maps (1876)

77 Report of progress in the Fayette and Westmoreland district of the bituminous coal fields of western Pennsylvania. Pa G S, 2d, KK: vili, 437 pp, maps (1877)

$77 \mathbf{a}$ On Dr. Peale's Notes on the age of the Rocky Mountains in Colorado. Am J Sc (3) 13:297-299 (1877)
Stevenson, John James-Continued.

78 Report on the geology of Carroll Co. ; Harrison Co. ; Guernsey Co. ; Muskingum Co.; Belmont Co. Ohio G S, Rp 3 pt 1:177-287 (1878)

78a Report of progress in the Fayette and Westmoreland district of the bitumi. nous coal fields of western Pennsylvania; Part II, The Ligonier Valley. Pa G S, 2d, KKK : $x, 331$ pp, maps (1878)

$78 b$ On the surface geology of southwest Pennsylvania and adjoining portions of Maryland and West Virginia. Am J Sc (3) $15: 245-250 \quad(1878)$

78e The upper Devonian rocks of south. west Pennsylvania. Am J Sc (3) 15:423430 (1878)

79 Preliminary report of a special geological party operating in Colorado and New Mexico from Spanish Peaks to the south, field season of 1878 . In Wheeler, G. M., Annual report...surveys west of the 100th meridian... : 271-281 (1879) Also in U S [War Dp], Chief Eng, An Rp 1879 (U S, 46th Cong 2d sess, H Ex Doc 1 pt 2 ₹ 2 pt 3 ), App $00: 2249-2259$ (1879)

$79 a$ Note on the Fox Hills group of Colorado. Am J Sc (3) 17:369-373 (1879)

79b Notes on the Laramie group of sonthern Colorado and northern New Mex. ico east from the Spanish ranges. Am J Sc (3) 18:129-134 (1879)

79e Notes on the geology of Galisteo Creek, N. Mex. Am J Sc (3) 18:471-475 (1879)

80 Surface geology of southwest Pennsylvania and adjacent portions of West Virginia and Maryland. $\mathrm{Am}$ Ph Soc, $\mathrm{Pt}$ $18: 289-316$ (1880)

81 Report upon geological examinations in southern Colorado and northern Nek Mexico during the years 1878 and 1879 . U S Geog S W 100th Mer (Wheeler), 3 Sup : 420 pp, maps (atlas sheets) (1881)

81 Note on the Laramie group of southern New Mexico. Am J Sc (3) 22: 370-372 (1881)

81 b Notes respecting a re-eroded channel way [New Mexico]. Am Ph Soc, Pt 19: 84-87 (1881)

81e Notes on the geology of Wise, Lee, and Scott cos., Va. Am Ph Soc, Pr 19: 88-107 (1881) The Virginias 2:70-71, 74-75, 98-100, 122-124 (1881)

81d A geological reconnaissance of parts of Lee, Wise, Scott, and Washington cos, Va. Am Ph Soc, Pr 19:219-262, map (1881) The Virginias $2: 22-27,34-42$. map (1881)

81e The Upper Freeport coal bed along Laurel Ridge in Preston Co., W. Va. Am $\mathrm{Ph}$ Soc, $\operatorname{Pr} 19: 276-279$ (1881) The Virginias $2: 28$ (1881) 
Stevenson, John James-Continued.

sif Notes on the Quinnimont coal group in Mercer Co., W. Va., and Tazewell Co., Va. Am Ph Soc, Pr 19:498-505 (1882) The Virginias 2:181, 186-187 (1881)

82 Notes on the coal field near Canon City, Colo. Am Ph Soc, Pr 19:505-521 (1882)

82a Note on the Laramie group in the vicinity of Raton, N. Mex. Am Ph Soc, Pr 20:107-111 (1882)

82b The mineral resources of southwest Virginia. N Y Ac Sc, Tr 1:159-163 (1882)

85 The geology of Bedford and Fulton cos. $\mathrm{Pa}$ G $\mathbf{8}, 2 \mathrm{~d}, \mathrm{~T} 2: \mathbf{x v}, 382 \mathrm{pp}$, maps (1885)

85a Notes on the geological structure of Tazewell, Russell, Wise, Smyth, and Washington cos., Va. $\triangle \mathrm{m}$ Ph Soc, $\operatorname{Pr} 22$ : 114-161, map (1885) The Virginias 6: $51-52,53-55,67-74,84-91$, map (1885)

85b Some notes respecting metamorphism. Am Ph Soc, Pr 22:161-166 (1885)

87 A geological reconnaissance of Bland, Giles, Wythe, and portions of Pulaski and Montgomery cos., Va. Am Ph Soe, Pr 24: 61-108, map (1887)

87a Notes on the surface geology of southwest Virginia. Am Ph Soc, $\mathrm{Pr} 24$ : 172-178 (1887)

87b The faults of southwest Virginia. Am J Sc (3) $33: 262-270$ (1887)

87e Notes on the Lower Carboniferous groups along the easterly side of the Appalachian area in Pennsylvania and the Virginias. Am J Sc (3) 34:37-44 (1887)

88 Report of the subcommittee on the upper Paleozoic (Carbonic). In International Congress of Geologists, American Committee, Reports...D 14 pp, Phila 1888 Am G $2: 248-256$ (1888) Int G Cong, IV, London 1888, C R App A : 147-157 (1891)

89 The Mesozoic rocks of sonthern Colorado and northern New Mexico. Am G 3 : 391-397 (1889)

90 Organization of the Geological Society of America. Proceedings of the semiannual meeting held at Toronto, August 28-29, 1889. G Soc Am, B 1: 1-18 (1890)

00a Proceedings of the annual meeting held at New York December 26, 27, and 28, 1889. G Soc Am, B 1:517-586 (1890)

$90 b$ The age of the Laramie. G Soc Am, B 1:532 (1890) Am Nat 24:568$569(1890)$

91 Proceedings of the semi-annual meeting held at Indianapolis August 19, 1890. G Soc Am, B 2:1-30 (1891)

91a Proceedings of the third annual meeting, held at Washington December, 1890. G Soc Am, B 2: 607-652 (1891)

92 The Chemung and Catskill (upper Devonian) on the eastern side of the Appalachlan basin. Am As, $\operatorname{Pr} 40: 219-247$ (1892) Am G 9:6-33 (1892)
Stevenson, John James-Continued.

92a Prof. I. C. White's "Stratigraphy of the bituminous coal field of Pennsylvania, Ohio, and West Virginia." Am G 9:352355 (1892)

93 Origin of the Pennsylvania anthracite. G Soc Am, B 5:39-70, map (1893) Abst, J G 1:677-687 (1893); Am J Se (3) 46 : 302-303 (1893)

93 an the use of the name "Catskill." Am J Sc (3) $46: 330-337$ (1893) Abst, Am As, Pr 42:171 (1894)

93b John Strong Newberry. Am G 12 : 1-25, port. (1893)

95 On the New England coal fields of the United States. Manchester G Soc, Tr 23 : 117-121 (1895)

95a The origin of the Pennsylvania anthracite $(a b s t)$. Science n $\mathbf{s} 1: 391-392$. (1895)

96 Notes on the geology of Indian Territory. N Y Ac Sc, Tr 15:50-61 (1896)

96a The Cerillos coal field [N. Mex.]. N Y Ac Sc, Tr 15: 105-122 (1896) Abst, Science n s 3:392-394 (1896); Am G 17 : $94-95,128$ (1895); Am J Sc (4) 1:148 149 (1896); G Soc Am B $7: 525-527$ (1896)

97 Notes on the geology of the Bermudas. N Y Ac Sc, Tr 16:96-124 (1897) Abst, Science n \& $5: 239$ (1897)

99 Our society. G Soc Am, B 10:8398 (1899) Science n s 9:41-52 (1899) Abst, Am G 23: 88-92 (1899)

00 Memoir of James Hall. G Soc Am, B $10: 425-451$, port $(1900)$

00n Edward Orton. J G 8:205-213 (1900)

0ob (and Julien, A. A.) Oliver Payson Hubbard. Science $n$ s 11:742-74:; (1900)

01 The section at Schoharie, N. Y. N Y Ac Sc, An 13:361-380 (1901); abst, 12 : 669-670 (1900) Abst, Science n s 10: 735-736 (1899); G Soc Am, B 11:6-7 (1900)

02 Notes upon the Mauch Chunk of Pennsylvania, Am G 29:242-249 (1902)

02a Joseph Le Conte (obituary.). N Y Ac Sc, An 14: 150-15y (1902)

03 Lower Carboniferous of the Appalachian basin. G Soc Am, B 14:15-96 (1903)

03a J. Peter Lesley. Science $n$ s 18 : 1-3 (1903)

04 Carboniferous of the Appalachian basin. G Soc Am, B 15: 37-210 (1904)

04n Memoir of J. Peter Lesley. G Soc Am, B 15:532-541, port (1904)

06 Carboniferous of the Appalachian basin. G Soc Am, B $17: 65-228$ (1906); 18:29-178 (1907)

$06 n$ A bit of Quaternary geology [Vermont] (abst). Science n s 23:388 (1906) N Y Ac Sc, An 17:609 (1907) 
Stevenson, John James-Continued.

09 Darwin and geology. Pop Sc Mo $74: 349-354$ (1909)

09a Memoir of James Merrill Safford. G Soc Am, B 19:522-527, port (1909)

10 Special problems and their study in economic geology. Ec G 5:781-782 (1910)

11 The formation of coal beds. $\mathrm{Am} \mathrm{Ph}$ Soc, Pr 50:1-116, 519-643 (1911); 51: 423-553 (1912) ; 52:31-162 (1913) Reprinted in book form. Abst, Science $\mathrm{n}$ s 33 : 905-906 (1911)

14 Events leading up to the organiza. tion of the Geological Society of America. G Soc Am, B 25:15-17 (1914)

15 Geological methods in earlier days. Pop Sc Mo $86: 25-32$ (1915)

16 Interrelations of the fossil fuels. $\mathrm{Am} \mathrm{Ph} \mathrm{Soc,} \mathrm{Pr} 55: 21-203 ; 56: 53-151$; 57:1-48 (1916-8)

16a Coal formation (abst). Science $n$ s $43: 722$ (1916)

17 Origin of Formkohle. Am J Sc (4) 43: 211-222 (1917)

See also Branner, 98 ; Earle, 13 ; Emerson, 96 ; Gilbert, $90 \mathrm{~b}$.

Stevennon, Robert.

93 The persistence of ores in lodes in depth. Eng M J 55: 148 (1893)

03 The geposition of ores from an igneous magma. Eng M J 76:882; 77: $272-273,472-474(1903-4)$

stewart, A. K.

16 The geology and mining activities of northern Ontario mining fields. M World 44: 733-736 (1916)

Stewart, Alban.

96 A geological section at Providence, Mo. Kans Univ Q 4: 161-162 (1896)

97 Restoration of oreadon culbertsonii Leidy. Kans Univ Q 6:13-14, il (1897)

$\mathbf{9 7 a}$ On the osteology of Bison antiquis Leidy. Kans Univ Q 6:127-135, il (1897)

98 A contribution to the knowledge of the ichthyic fauna of the Kansas Cretaceous. Kans Univ Q $7: 21-29$, il (1898)

98a Individual variations in the genus Xiphactinus Leidy. Kans Univ Q 7:115 119, il (1898)

98b Some notes on the genus Saurodon and allied species. Kans Univ Q 7:177186, il (1898)

98e A preliminary description of seven new species of fish from the Cretaceous of Kansas. Kans Univ Q 7:191-196, il (1898)

99 Leptichthys, a new genus of fishes from the Cretaceous of Kansas. Am G $24: 78-79$ (1899)

99a A preliminary description of the opercular and other cranial bones of Xiphactinus Leidy. Kans Univ Q 8:1921. il (1899)

996 Pachyrhizodus minimus, a new species of fish from the Cretaceous of Kansas. Kans Univ Q 8:37-38, il (1899)
Stewart, Alban-Continued.

99e Notice of three new Cretaceons fishes, with remarks on the Saurodontidae Cope. Kans Univ Q 8:107-112 (1899)

99 Notes on the osteology of Anogmius polymicrodus Stewart. Kans Univ Q 8: 117-121, il (1899)

oo Cretaceous fishes; teleosts. Kans Univ G S $6: 257-403$, il (1900)

Stewart, Charles Arthur.

08 The magnetic belts of Putnam Co. N. Y. Sch Mines Q 29:283-294 (1908)

OSa Note on the occurrence of grapbite schist in Tuxedo Park, N. Y. Ec G 3: $536-538$ (1908)

09 The definition of marl. Ec G $4: 48$ 489 (1909)

10 Exploration of contact metamorphic ore deposits. Eng M J 90:513-515 (1910)

11 Note on a conglomerate pike in Arizona. Science n s $33: 434-435$ (1911)

11 a The teaching of economic geology to mining engineers (discussion). Ec G 6: $703-706$ (1911)

12 The geology and ore deposits of the Silverbell mining district, Ariz. Am I If Eng, B 65: 455-505, map (1912) : Tr 43: 240-290, map (1913) M World 36:1104$1107,1147-1150$ (1912)

$12 a$ Geology in the examination of prospects. M Sc Press 104:622-623 (1912)

$12 b$ (with Welsh, T. W. B.) Note on the effect of calcite gangue on the secondary enrichment of copper veins (discus. sion). Ec G $7: 785-787$ (1912)

13 Magmatic differentiation at Silver. bell, Ariz. Science n \& 37:338-340 (1913)

$13 a$ The formation of the secondary silicate zone in contact-metamorphic ore deposits. Ec G 8:501-507 (1913)

13b The extent of the Cordilleran ice sheet. J G 21:427-430 (1913)

14 The origin of secondary silicate zones (discussion). Ee G 9:278-281 (1914)

14a A comparison of the Coeur d'Alene monzonite with other plutonic rocks of Idaho. J G 22:684-688, map (1914)

14b A study in applied geology. I Sc Press 109:330-333 (1914)

14e (with Livingston, D. C.) The geology and ore deposits of the Dixie mining district, Idaho. Idaho Univ, B 9 no 2: 11 pp, map (1914)

Stewart, Charles S.

26 Volcano of Kilanea [Hawaii]. Am J Sc 11: 363-376 (1826)

Stevart, James Smith.

15 The foothills area, rest of the Porcupine Hills, Alta. Can G S, Sum Rp 1914: 54-55 (1915)

16 The disturbed belt of southwestern Alberta. Can G S, Sum Rp 1915: 112-115 (1916)

17 Coal mines of west central Alberta. Can G S, Sum Rp 1916:94-106, map (1917) 
Stewart, John.

88 Notes on geological work during the summer of 1887 [Ottawa region]. Ottawa Nat $1: 170-171$ (1888)

stewart, John L.

05 Ore deposits and industrial supremsey. Ec G 1:257-264 (1905) Zs Prak G $15: 225-229$ (1907)

\section{stewart, L.}

08 The Creighton mine of the Canadian Copper Co., Sudbury district, Ont. Can M Iust, J $11: 567-585$ (1908)

stewart, P. Charteris A.

15 The petroleum industry of Mexico. Inst Petroleum Techn, J 2: 7-37 (1915)

stewart, R. B.

12 West Shiningtree gold district. Ont Bur Mines, An Rp 21 pt 1:271-277, maps (1912)

13 The outlying cobalt-silver areas [0nt.]; the Shining Tree silver area. Ont Bur Mines, An Rp 19 pt 2: 187-193 (1913)

13a The West shining Tree gold area [0nt.]. Ont Bur Mines, An Rp 22 pt 1: 233-237, map (1913)

stewart, Thos. P.

28 Mammoth near Schooley's Mountain, N. J. Am J Se 14: 188-189 (1828)

Stieglitz, Julius.

09 The relations of equilibrium between the carbon dioxide of the atmosphere and the calcium sulphate, calcium carbonate, and calcium bicarbonate of water solutions in contact with it. In The tidal and other problems. (Carnegle Inst Wash, Pub no 107) : 233-264 (1909)

stiles, (Miss) M. E.

16 Bureau of economic geology and technology ; annual report for the year ending December 31, 1915. Tex Univ, B 1916 no $35: 5-16$ (1916)

\section{Stillman, J. M.}

79 Bernardinite, a new mineral resin from San Bernardino Co., Cal. Am J Sc (3) $18: 57-59(1879)$

80 Bernardinite, its nature and origin. Am J Sc (3) $20: 93-94$ (1880)

Stitson, W. B.

18 ... geology and mineralogy of a part of the State of Indiana. Am J Sc 1: 131133 (1818)

\section{Stimpson, William}

51 [A list of fossils found in the postPliocene deposit in Chelsea, Mass.] Boston Soc N H, Pr 4: 9-10 (1851)

61 ... on the occurrence of a Pleistocene deposit on the southern shore of James Bay. Ac N Sc Phila 1861:97

62 Description of a new Cardium from the Pleistocene of Hudson's Bay. Ac N Sc Phila, Pr 1862: 58-59, il

43 On the fossil crab of Gay Head [Marthas Vineyard, Mass.]. Boston J N FI 7:583-589 (1863)
Stines, Norman S.

07 The geology of the Coffee Creek mining district [Cal.]. M Se Press 95 : 25-26 (1907)

10 Hoag district [Modoc Co.], Cal. M Sc Press 100:384-386 (1910)

12 The camp of High Grade in northern California; historical facts and a description of the geology of the Hoag district in Modoc County. M Science 65:27-29 (1912) Mining Investor 66:192-193 (1912)

Stirling, James.

os The localization of values and the occurrence of shoots in metalliferous deposits. Ec G 3:534-535 (1908)

Stirrup, Mark.

86 On some fossils from the Paleozoic rocks of America, principally from the State of Indiana. Manchester G Soc, Tr 18: 331336 (1886)

stock, Chester.

13 Nothrotherium and Megalonyx from the Pleistocene of southern California. Cal Univ, Dp G, B 7:341-358 (1913)

14 Skull and dentition of the mylodont slotbs of Rancho La Brea [Cal.]. Cal Univ, Dp G, B 8:319-334, il (1914)

$14 a$ The systematic position of the mylodont sloths from Rancho La Brea [Cal.]. Science n \& $39: 761-763$ (1914) Abst with discussion, $\mathrm{G}$ Soc Am, B 25:143-144 (1914)

14b Hawver Cave; its Pleistocene fauna (abst). G Soc Am, B 25: 155 (1914)

15 Proceedings of the summer meeting of the Paleontologieal Society, held at the University of California and at Stanford University, August 3, 4, 5, and 6, 1915. G Soc Am, B 26:409-418 (1915)

16 Pleistocene mammal fauna of Hawver Cave, a fissure deposit near Auburn, Cal, (abst). G Soc Am, B 27:169 (1916)

$16 a$ (with Merriam, J. C. and Moody, C. L.) Fauna of the Rodeo Pleistocene (abst), G Soc Am, B 27:169-170 (1916)

16b (with Merriam, J. C. and Moody, C. L.) An American Pliocene bear [Rattlesnake beds, John Day region, Oreg.]. Cal Univ, Dp G, B 10:87-109, il (1916)

17 Recent studies on the skull and dentition of Nothrotherium fron Rancho La Brea [Cal.]. Cal Univ, Dp G, B 10:137164, il (1917)

17a Further observations on the skull structure of mylodont sloths from Rancho La Brea. Cal Univ, Dp G, B 10:165178, il (1917)

17b Structure of the pes in Mylodon harlani. Cal Univ, Dp G, B $10: 267-286$, il (1917) Abst, G Soc Am, B 28: 226-227 (1917)

17e Minutes of the seventh annual meeting of the Pacific coast section of the Paleontological Society. G Soc Am, B 28: 223-234 (1917) 
Stock, Chester-Continued.

17d Occurrence of Nothrotherium in Pleistocene cave deposits of Callfornia (abst). G Soc Am, B 28: 233 (1917)

17e (with Merriam, J. C.) Fauna of the Pinole tuff $(a b s t)$. G Soc Am, B 28: 230 (1917)

18 The Pleistocene fauna of Hawver Cave. Cal Univ, Dp G, B $10: 461-515$, il (1918)

18 a Minutes of the eighth annual meeting of the Pacific coast section of the Paleontological Society. G Soc Am, B 29 : 160-166 (1918)

18b Gravigrade edentates in later Tertiary deposits of North America (abst). G Soc Am, B 29:161-162 (1918)

Stoekbridge, Horace Edward.

s8 Rocks and soils; their origin, composition, and characteristics; chemical, geological, and agricultural. $239 \mathrm{pp}, \mathrm{N}$ Y $18882 d$ ed, 282 pp, N Y 1895

Stoekton, John.

45 [Mineral lands of Lake Superior region. I U S, 28th Cong spec sess, S Ex Doe $175: 2-4$ (1845)

Stoddard, Jesse C.

10 (and Callen, A. C.) Ocher deposits of eastern Pennsylvania. U S G S, B $430: 424-439$ (1910)

Stodiard, $\mathrm{O}$. N.

59 Diluvial striae on fragments in situ. Am J Sc (2) 28:227-228 (1859)

Stoddard, Wm. B.

98 (with Palmer, C. S.) The dike on the Columbia vein in Ward district, Boulder Co., Colo. Colo Sc Soc, Pr 5: 159-164 [1898] (separate ed, 6 pp 1895)

Stodder, Charles.

46 [On drift in a ridge at South Boston, Mass.] Boston Soc N H, Pr 2: 131132 (1846)

53 [On drift-filled eracks in clay at East Boston, Mass.] Boston Soc $^{-4} \mathrm{H}, \mathrm{Pr}$ $4: 286$ (1853)

57 Relations of sandstone and trap at Hadley Falls and Amherst, Mass.] Boston Soc N H, Pr 6:267 (1857)

76 A contribution to microgeology. Boston Soc N H, Pr 18:206-209 (1876) The Virginias $3: 159$ (1882)

See also Desor, $50 j$; Hayes (A A), 57 ; Perrey, 55

Stoek, Harry Harkness (1866-1923).

92 Notes on the iron ores of Danville, Pa. ... Am I M Eng, Tr 20:369-385 (1892)

96 Official geology. Min B $2: 38-52$ (1896)

02 The Pennsylvania anthracite coal field. U S G S, An Rp 22 pt $3: 55-117$, map (1902)

o9 Coal flelds of West Virginia. Mines and Minerals $29: 219-222,283-287,303-$ 307 (1909)
Stoek, Harry Harkness Continued.

09a Marquette range caving methol [Mich.]. Mines and Minerals $30: 193-2 \%$ (1909)

09b Upper Potomac coal flelds. Mins and Minerals 30:201-204 (1909)

09e Coal fields of central West Virginit Mines and Minerals 30:188-192 (1909)

10 The Illinois coal field. Mines an Minerals 31 : 54-56 (1910)

12 Geology, mining, and preparation anthracite. Western Soc Eng, J 17:70:724 (1912)

16 (with Young, L. E.) Subsidene resulting from mining. Ill Univ, B $13 \mathrm{~s}$ $49: 205$ pp (1916)

Stoess, P. C.

03 The Kayak coal and oil fields of Alaska. M Sc Press 87:65 (1903)

Stokes, Charles.

24 On a trilobite from Lake Huron [Asaphus platycephalus, St. Joseplis Island, Lake Huron]. G Soc London, I? (2) $1: 208-209$, il (1824)

38 On some species of Orthocerata [Carada]. G Soc London, $\mathrm{Pr}$ 2:688-690 (1838)

40 On some species of Orthocerata [Lak] Huron region]. G Soc London, $\operatorname{Tr}(2)$ s: $705-714$, il $(1840)$

Stokes, Henry Newlin.

00 (with Merrill, G. P.) A new stoot meteorite from Allegan, Mich., and a per iron meteorite from Mart, Tex. Wash di Sc, Pr 2: 41-68 (1900)

01 Pyrite and marcasite. U S G 8, B 186: 50 pp (1901)

06 Experiments on the solution, tran portation, and deposition of copper, silvet, and gold. Ec G 1: 644-650 (1906)

07 Experiments on the action of varloss solutions on pyrite and marcasite. Ee 6 2: 14-23 (1907)

Stokes, Ralph.

07 Mining in the Boundary copper fieli M World 27:179-182 (1907)

Oza The Cobalt silver field as an industry. M World $27: 306-309,346-349$, 427-429 (1907)

O7b. The Sudbury nickel-copper field. Ontario. M World 27:507-510, 553-555 (1907)

07c The asbestos industry of Quebec. IN World 27:637-639, 799-801 (1907)

o7d The St. Eugene silver-lead mine. B. C. M World 27:967-968 (1907)

o7e Mining in the Rossland district. B. C. M World $27: 1083-1084,1123-11:$ (1907)

Stoller, James Hough.

11 Glacial geology of the Schenectady quadrangle. N Y St Mus, B 154:44 pp. map (1911)

16 Glacial geology of the Saratoga quadrangel [N. Y.]. N Y St Mus, B 183:50 pp, maps (1916) 
Stoltz, Guy C.

08 The Forest of Dean iron mine, N. Y. Eng M J 85: 1091-1093 (1908)

11 The Cheever mines, Port Henry, N. Y. Eng M J $92: 809-812$ (1911)

stone, A. M.

98 Corundum mining in North Carolina. Eng M J $65: 490$ (1898)

Stone, C. A.

09 Milling and mining Florida phosphates. Eng M J 87:490-492 (1909).

stone, George Hapgood (1841-1917).

so The kames of Maine. Boston Soc $\mathrm{N} \mathrm{H}, \mathrm{Pr} 20: 430-469$, map (1880)

soa Note on the Androscoggin Glacier [N. H. and Me.]. Am Nat 14: 299-302 (1880)

81 Glacial deposits in eastern North America. Portland Soc N H, Pr 1880-1, 12th meeting : 1-6 (1881)

81a The kames or eskers of Maine. Am As, Pr 29:510-519, map (1881) Abst, science (ed, Michels) 1:151 (1880) s1b Apparent glacial deposits in valley drift. Am Nat $15: 251-252$ (1881)

82 Glacial erosion in Maine. Portland Soc N H, Pr 1881-2, 4th meeting: 5-15 (1882)

83 The kame rivers of Maine (abst). Am As, Pr 32:234-237 (1884) Science 2:319 (1883)

85 Local deflections of the drift scratches in Maine. Am J Se (3) 30:146$150(1885)$

86 Wind action in Maine. Am J Sc (3) $31: 133-138$ (1886)

87 Terminal moraines in Maine. Am J Sc (3) $33: 378-385$ (1887)

87a A living glacier on Hague's Peak, Colo. Science 10:153-154 (1887)

90 Classification of the glacial sediments of Maine, Am J Sc (3) $40: 122-$ $144(1890)$

91 Note on the asphaltum of Utah and Colorado, $\quad \Delta \mathrm{m}$ J Sc (3) 42:148-159 (1891)

91 a Was Lake Iroquois an arm of the sea? Selence 17:107-108 (1891)

93 The osar gravels of the coast of Maine. J G 1:246-254 (1893) Am G 12: 200-203 (1893)

93a The Las Animas Glacier [Colo.-N. Mex.]. J G 1:471-475 (1893)

93b An extinct glacier of the Salmon River Range [Idaho]. Am G 11: 406-409 (1893)

93e The Turkey Creek mining district, El Paso Co., Colo. Eng M J $56: 262$ (1893) 97 To trace an invisible dike [Cripple Creek, Colo.]. Colliery Eng 18: 151 (1897) 98 The granitic breccias of the Cripple Creek region [Colo.]. Am J Sc (4) 5:2132 (1898)

99 The glacial gravels of Maine and their associated deposits. U S G S, Mon 34 : 499 pp, maps (1899)
Stone, George IIapgood-Continued.

99a The granitic breccias of Grizzly Peak, Colo. Am J Sc (4) 7:184-186 (1899)

99b Dry gold placers of the arid regions [New Mexico]. Mines and Minerals 19: 397-399 (1899)

00 Note on the glaciation of eentral Idaho. Am J Sc (4) 9:1-12 (1900)

00a Gold placers in glaciated regions. Mines and Minerals 20:492-494 (1900)

01 Note on the minerals associated with copper in parts of Arizona and New Mexico (abst). Science n s 14:796-797 (1901) Sc Am Sup 52: 21505 (1901)

01 Note on the extinct glaciers of Arizona and New Mexico (abst). Science n s $14: 798$ (1901) Se Am Sup 52:21505 (1901)

\section{Stone, Leander.}

86 The artesian wells of Chicago [III.]. Chicago Ac Sc, B 1: 93-102 (1886)

Stone, Ralph Walter.

04 The Elders Ridge coal field, Pa. U S G S, B $225: 311-324$ (1904)

04a Oil and gas fields of eastern Greene Co., Pa. U S G S, B $225: 396-412$ (1904)

os Description of the Waynesburg quadrangle [Pa.]. U S G S, G Atlas Waynesburg fol (no 121): $12 \mathrm{pp}$, maps (1905)

o5a Description of the Elders Ridge quadrangle [Pa.]. U S G S, G Atlas Elders Ridge fol (no 123):10 pp, maps (1905)

05b Mineral resources of the Elders Ridge quadrangle, $\mathrm{Pa}, \mathrm{U}$ S G S, B 256 : 86 pp, map (1905)

o5e Coal resources of southwestern Alaska. U S G S, B 259:151-171 (1905)

o5d Water resources of the Elders Ridge quadrangle $\mathrm{Pa}$. U S G S, W-S P 110 : 164-165 (1905)

o5e Water resources of the Waynesburg quadrangle, Pa. U S G S, W-S P 110: 166-167 (1905)

06 Coal fields of the Kachemak Bay region [Alaska]. U S G S, B 277:55-73 (1906)

06a Reconnaissance from Circle to Fort Hamlin [Alaska]. U S G S, B 284:128131 (1906)

o7 The Elkhorn coal field, Ky. U S G S, B $316: 42-54$ map (1907)

07a The Russell Fork coal field, Va. U S G S, B 316:55-67, map (1907)

07b Coal mining in Dante, Va. U S G S, B $316: 68-75$ (1907)

07e (and Clapp, F. G.) Oil and gas fields of Greene Co., Pa. U S G S, B 304 : $110 \mathrm{pp}$, map (1907)

07d The Pine Mountain fault (abst). Seience n \& 25:620 (1907)

os Coal resources of the Russell Fork basin in Kentucky and Virginia. U S G S, B $348: 127$ pp, map (1908) 
Stone, Ralph Walter-Continued.

OSa Geologic work in Pennsylvania. $\mathrm{Pa}$ Top G S, Rp 1906-08: 83-108 (1908)

o8b Review of general geology [of Penn sylvania]. Pa Top G S, Rp 1906-08: 109 119, map (1908)

ose Physiography of southwestern Pennsylvania. Pa Top G S, Rp 1906-08:120127 (1908)

osd Limestone in western Pennsylvania. Pa Top G S, Rp 1906-08: 326-334 (1908)

ose Sandstones of southwestern Pennsylvania. Pa Top G S, Rp 1906-08:335339 (1908)

osf (with Ashley, G. H.) Report of progress on geologic work under the Topographic and Geologic Survey Commission of Pennsylvania. Pa Top G S, Rp 1906-8 : 81-340 (1908)

09 Coal near the Crazy Mountains, Mont. U S G S, B 341: 78-91, map (1909)

10 (and Calvert, W. R.) Stratigraphic relations of the Livingston formation of Montana. Ec G 5:551-557, 652 $669,741-764$, map (1910) Abst, Science n s $32: 218-219(1910) ; G$ Soc Am, B $21: 782$ (1910)

10a (and Lupton, C. T.) The Powder River coal field, Wyo., adjacent to the Burlington Railroad. U S G S, B 381: 115-136, map (1910)

11 Geologic relation of ore deposits in the Elkhorn Mountains, Mont. U S G S, B 470:75-98, map (1911)

12 Coal near the Black Hills, Wyo. S. Dak. U S G S, B 499:66 pp (1912) Abst, Wash Ac Sc J $2: 389-390$ (1912)

$12 a$ Coal on Dan River, N. C. U S G S, B 471: 137-169, map (1912)

12b Classification of metalliferous mineral lands $(a b s t)$. Washington Ac Sc, J 2 : 361 (1912)

13 Sand and gravel. U S G S, Min Res 1912 pt $2: 621-636$ (1913)

13a Occurrence of limestone. U S G S, Min Res 1912 pt 2:659-667 (1913)

14 (and Bonine, C. A.) The Elliston phosphate field, Mont. U S G S, B 580 : 373-383 (1914)

14a Coal on Dan River, N. C. N C G S, Ec P $34: 115-149$, map (1914)

14b Lime; sand, and gravel; gypsum. U S G S, Min Res, 1913 pt $2: 309-337$, 355-372 (1914)

14e Glacial Lake Missoula (abst).

G Soc Am, B $25: 87$ (1914)

$14 d$ (with Sanford, S.) Useful minerals of the United States. U S G S, B $585: 250 \mathrm{pp}$ (1914)

16 Gypsum. U S G S, Min Res 1915 pt $2: 151-159 ; 1916$ pt $2: 255-261 ; 1917$ pt $2: 85-95(1916-8)$

$16 a$ Sand and gravel. U S G S, Min Res 1915 pt $2: 213-225 ; 1916$ pt $2: 327$ $339(1916-7)$
Stone, Ralph Walter-Continued.

17 Gypsum products; their prepara and uses. U S Bur Mines, Tech P 155: pp (1917)

17a Phosphate. U S G S, Min o sto 1916 pt $2: 29-41 ; 1917$ pt $2:$ i (1917-8)

17b Salt, bromine, and calcium chlont U S G S, Min Res 1916 pt 2:213-2 1917 pt $2: 169-181$ (1917-8)

17 e (with Sehrader, F. C., and say ford, S.) Useful minerals of the Unit States (a revision of Bulletin 585).

G S, B 642: 412 pp (1917)

18 Magnesite deposits of Washingt Eng M J 105:665-668 (1918)

18a The development of valuable 며 nesite deposits in the State of Washingtin (abst). Wash Ac Sc, J 8:99 (1918)

18b (with Yale, C. G.) Magnesite : 1917. U S G S, Min Res 1917 pt 2 :63(1918)

See also Ashley, 08a, 17, 18; Barnet: 16 ; Bastin, 16a, 17 ; Bauer, 16; Beal, 1 . Berry, 17; Bowen (C F), 18a; Bowla 18a ; Calvert, 16 ; Capps, 17 ; Collier, 18 Condit, 16 ; Darton, 18 ; Fakin, 18; Fis lish, 18; Emerson (B K), 17 ; Fath, 17 Gilbert, 17; Gilmore, 17; Gregory (H B 17 ; Harder, 17 ; Heald, 18c; Hess, 17 Hewett, 18; Hopkins (O B), 17, 17) Jones (E L), 16; Keith, 17; Lee (W I 15 ; Loughlin, 17 ; Matson, 17, 17a, Mertie, 17, 18; Miser, 18; Pardee, 15; Reeside, 17; Robinson (H M), 16 Schrader, 18 ; Schultz, 18a ; Spencer (A C) 17 ; Stanton, 16 ; Stebinger, $17 \mathrm{a}$; Wegenas 18; Wells, 18; Winchester, 18b; Wool sey, 17

Stone, S. R.

12 Phosphate deposits and mining meth ods in the United States. M World 36: 511-512 (1912)

Stonehnm, W. J.

04 A Nevada coal field [Esmeralda Co.]. Eng M J $77: 1009-1010$ (1904)

Stoner, Reginald C.

13 Recent observations on the mode of accumulation of the Pleistocene bone deposits of Rancho La Brea. Cal Univ, Dp G, B $7: 387-396$, Il (1913) Abst, G Soc An, B 25: 156 (1914)

Stookey, S. W.

10 Geology of Iowa. Iowa G S 20: 151-198, map (1910)

10a Geology of Poweshiek Co. Iowa G S 20:237-269, map (1910)

Stopes, Marie C.

12 Paleobotany versus stratigraphy in New Brunswick. G Mag (5) 9:467-468 (1912) Abst, Brit As, Rp 82:471 (1918)

13 Excursion in eastern Quebec and the maritime provinces; Fern Ledges [at St. John, N. B.]. Int G Cong, XII, Canada, Guide Book no 1 : $390-395$, map (1913) 
Stopes, Marie C.-Continued.

14 The "Fern Ledges" Carboniferous flora of St. John, N. B. Can G S, Mem 41:142 pp, il (1914)

storch, I. B.

96 Copper deposits in Sonora, Mex. M Sc Press $73: 358$ (1896)

storm, L. W.

10 The Kennicott Bonanza copper mine, Alaska. Fng M J 90:1224-1227 (1910)

10a The Bering River coal field of Alaska. Eng M J 90:272-275 (1910)

$10 \mathrm{~b}$ Chitina copper region in southern Alaska. Eng M J 90:1011-1013 (1910)

12 The Valdez gold-mining district, Alaska. M World 36:653-655 (1912)

storms, William H. (1860-1917).

90 The mines of Calico district [San Bernardino Co.], Cal. Eng M J 49 : 382383 (1890)

90a [The Hillside mine, Yavapal Co., Ariz.] Eng M J 50:162-163 (1890)

92 Certain ore deposits [Daggett, San Bernardino Co., Cal.]. M Sc Press 64: 18 (1892)

94 Ancient channel system of Calaveras Co. Cal St M Bur, Rp 12:482-492, maps (1894)

95 The wall rocks of California gold mines. Eng M J 59:172-173 (1895)

95a The great east lode of California Mother Lode]. M Sc Press 70:100 (1895) 97 Mines of the gold belt [California]. I Sc Press $75: 96,194-195$ (1897)

98 Gold formations in California. M Sc Press 76: 110-111 (1898)

99 Amador County's mines. In California mines and minerals (pub. by California Miners' Association) : $319-329$, San Franciseo, Cal., 1899

99a Mariposa County's mineral wealth. In California mines and minerals (pub. by California Miners' Association) : 360-369, San Francisco, Cal., 1899.

99b Analogy of the ore deposits of the Black Hills and Leadville. M Sc Press 78: $234(1899)$

99e Some characteristic features of veins in granite in California. M Sc Press $78: 428$ (1899)

99d Some notes of the geology of Leadville, Colo. M Sc Press 78:536-537 (1899)

99e Peculiar effect of subterranean corrasion of rocks [Tuolumne Co., Cal.]. M Sc. Press $79: 5$ (1899)

99f Metal-bearing conglomerates. M Sc Press $79: 117$ (1899)

99g The Vanderbilt mining district, San Bernardino Co., Cal. M Se Press 79:579$580(1899)$

99h The walls of mineral veins. M Sc Press 79:609 (1899)

99i Indicator veins, M Sc Press 79 : 634 (1899)
Storms, William H.-Continued.

99j Laccolites and their relation to ore deposits. M Sc Press 79:745 (1899); $80: 5-6(1900)$

oo The Mother Lode region of California. Cal St. M Bur, B 18: 154 pp, Sacramento 1900

O0a The occurrence of gold. M Sc Press $80: 148(1900)$

OOb Mining on the California gold belt. M Sc Press $80: 578,608,644,670(1900)$

03 Some structural features of the California gold belt. M Sc Press 87 : 112, 129, $149,165,183,202,216-217$ (1903)

04 The Mother Lode in Tuolumne Co., Cal. M Sc Press 89:189, 210-211, 237. $257, \quad 271-272, \quad 306-307, \quad 326-327, \quad 343$ (1904)

04a The genesis and character of ore deposits. M Sc Press 88: 193-194 (1904)

05 Ancient gravel channels of Calaveras Co., Cal. M Sc Press 91:170-171, 192193, map (1905)

O5a The Golden West mine, Pennington Co., S. Dak. M Sc Press $91: 257$ (1905)

06 Earthquake lines. M Sc Press 92 : 289 (1906) Reprinted in After earthquake and fire: 87-90, San Francisco 1906

o6a Gold veins in grainite in California. M Sc Press $92: 348$ (1906)

06b The Black Hills of South Dakota. M World 24: 242, 272-273, 303-304 (1906)

09 Geology of the Yellow Aster mine, Kern Co., Cal. Eng M J 87:1277-1280 (1909)

O9a Great gold belt in Amador Co., Cal. M World $31: 263-266$ (1909)

09b Consolidation of Mother Lode mines [Cal.]. M Sc Press 99:597-598 (1909)

10 The Black Hills of South Dakota. M Sc Press 101: 114-117, 144-147, 264-265, 500-503, 571-573, 669-671 (1910)

10n Surface indications of ore shoots in depth. M Sc Press 101:537-538 (1910) ; $102: 109-110, \quad 449, \quad 668, \quad 763, \quad 792-793$ (1911)

11 The Helester mines of California [Placer Co.]. Eng M J 92: 858 (1911)

$11 \mathrm{a}$ Some interesting faults and vein dislocations. M World $35: 467-468$ (1911)

$11 b$ The occurrence of gold at intersections. M World 35: 1059-1060, 1112-111: (1911)

11c The auriferous ferro-dolomites of California. Can M J $32: 553-554$ (1911)

12 Mineral deposits of the Sierra Nevada, Cal. M World 36: 121-122 (1912)

12a The High Grade mining district [Modoc Co., Cal.]. M Sc Press 105:273275 (1912) Mines and Methods 4 no 1: 22-24 (1912)

12b Possibilities of the Mother Lode in depth. M Sc Press 105:459-462 (1912)

12c The California State Mining Bureau. M Sc Press 105: 821-823 (1912) 
Storms, William H.-Continued.

13 Persistence of ore in depth. M Sc Press 106: 349-351 (1913)

13a Is geology a success as guide to ore deposits? M World $38: 427-428$ (1913)

13b The Trinity-Balaklala-Vulean mines, Shasta Co., Cal. M Sc Press 107:408411 (1913)

13e Geology of the Woody copper district, Cal. Eng M J $96: 635$ (1913)

14 The eruption of Mount Lassen [Cal.]. M Sc Press 109:143-144 (1914)

16 New scheelite discovery [Greenhorn Mountains, Kern Co., Cal.]. M Sc Press $113: 768$ (1916)

17 Diamonds in California. M Sc. Press $114: 273-275$ (1917)

17 a Effects of faults on richness of ore, M Sc Press 114: 433-435 (1917)

See also Irelan. 93

Storrs, Arthur H.

05 The anthracite coal fields of Penn sylvania. M Mag 11:211-221 (1905)

Storrs, Lucius Seymour.

02 The Rocky Mountain coal field. U S G S, An Rp 22 pt 3: 415-471, maps (1902) Stose, George Willis.

94 A specimen of Ceratiocaris acuminata Hall from the water lime of Buffalo, N. Y. Boston Soc N H, Pr 26:369-371, il (1894)

03 The structure of a part of South Mountain, Pa. (abst). Science n s $17: 387$ (1903)

O4 Barite in southern Pennsylvania and pure limestone in Berkeley Co., W. Va. U S G S, B 225: 515-517 (1904)

04a Physiographic studies in southern Pennsylvania. J G $12: 473-484$, map (1904)

05 Water resources of the Chambersburg and Mercersburg quadrangles, Pa. U S G S, W-S P 110:156-158 (1905)

o5a (and Martin, G. C.) Water re sources of the Pawpaw and Hancock quadrangles, W. Va.. Md., and $\mathrm{Pa}$. U S G S, W.S P 145: 58-63 (1905)

06 The sedimentary rocks of South Mountain, Pa. J G 14:201-220, map (1906)

06a The glass-sand industry in eastern West Virginia. U S G S, B 285: 473-475 (1906)

07 White clays of South Mountain, $\mathrm{Pa}$. U S G S. B 315:322-334 (1907)

07a Phosphorus ore at Mount Holly Springs, Pa. U S G S, B 315: 474-483 (1907)

07b Phosphorus. U S G S, Min Res 1906: 1084-1090 (1907)

os The Cambro-Ordovician limestones of the Appalachian Valley in southern Pennsylvania. J G 16:698-714 (1908)

09 Description of the MercersburgChambersburg district, Pa. U S G S, G Atlas Mercersburg-Chambersburg fol (no 170) : $19 \mathrm{pp}$, maps (1909)
Stose, George Willis-Continued.

10 The copper deposits of South Mom tain in southern Pennsylvania. U S G \& 430: 122-131, map (1910)

11 Apparent sun-crack structure in di base (discussion) (abst). G Soc Am, ? $22: 718$ (1911)

12 Description of the Apishapa qui rangle [Colo.]. U S G S, G Atlas Apisbar fol (no 186) : $12 \mathrm{pp}$, maps (1912) $d$ h Wash Ac Sc, J $3: 117$ (1913)

12a The salt and gypsum deposits southwestern Virginia (abst). Wash t Sc, J $2: 361$ (1912)

12b (and Swartz, C. K.) Descriptin of the Pawpaw and Hancock quadrang [Md.-W. Va.-Pa.]. U S G S, G Atlas Par. paw-Hancock fol (no 179) :24 pp, mas (1912) Abst, Wash Ac Sc, J $2: 410$ (191:

13 Geology of the salt and gypsum of posits of southwestern Virginia. U S G \& B 530:232-255, map (1913) Va G \&. B 8: 51-73, map (1913) Abst, Wash Ac \&, J $3: 117-118$ (1913)

$13 a$ Field and office methods in the preparation of geological reports; a methol of geologic mapping and note taking. B G $8: 389-392(1913)$

14 Phosphate deposits in southwesten Virginia. U S G S, B 540:383-396, 빠 (1914)

15. The mechanics of a cross fault is the northern Appalachians (abst). Wast Ac Se, J 5:486-487 (1915)

16 (and Lewis, J. V.) Triassic igot ous rocks in the vicinity of Gettysburg, $\mathrm{PL}$. G Soc Am, B 27:55:57 (abst), 623-64: map (1916)

$16 \boldsymbol{n}$ Origin of Delaware Water Gap and of the surrounding features. Text on bad of topographic map Delaware Watergap quadrangle, Pa.-N. J., U S G S, 1916

17 Age of certain shales in Cumberland Lebanon Valley, Pa. (abst). Wash Ac \$c J $7: 82-83$ (1917)

18 (and sehrader, F. C.) Manganess deposits of east Tennessee. Tenn G S, Res Tenn 8: 153-207, 228-324, maps (1918)

18 a (with Hevett, D. F., and others) Possibflities for manganese ore on certain undeveloped tracts in Shenandoah Valles. Va. U S G S, B 660:271-296. maps (1918) Abst, by R. W. Stone, Wash Ac Sc, J $8: 450$ (1918)

See also Barrell, 12a ; Branson, 12 ; Daly (R A), 16 ; Grabau, $12 \mathrm{~b}$; Swartz, 16

Stout, Wilber.

15 Theory of the origin of clays. At Ceramic Soc, Tr $17: 557-580$ (1915)

16 Geology of southern Ohio, including Jackson and Lawrence cos. and parts of Pike, Scioto, and Gallia. Ohlo G $\mathrm{S}$ (4) B $20: 723 \mathrm{pp}$, maps (1916)

18 Geology of Muskingum Co. Ohio $A$ S (4) B 21:351 pp, maps (1918) 
Stow, Audley H.

09 Seismic disturbances and coal-mine explosions. Eng M J 88:449-450 (1909)

13 Mining in the Pocahontas [coal] field. Coal Age 3:594-600 (1913)

stowell, S. H.

83 Petroleum. U S G S, Min Res [1882] : 186-212 ; 1883-4 : 214-232 ; 1885 : $130-154 \quad(1883-6)$

strangways, H. F.

os Chrome iron mining in Canada. [Coleraine township, Que.] Can M J 29 42-47 (1908) Eng M J 85:595-597 (1908) streeruwitz, W. H. von.

88 Coal in Texas. G Sc B 1 no 2 (1888)

88a Brown coal or lignites. G Sc B 1 no 3 (1888)

s9 Report of geologist for western Texas, Tex G S, Rp Prog 1 (1888) : 3143 (1889)

S9a Mines worked in western Texas. G Se B 1 no 12 (1889)

90 Geology of trans-Pecos Texas. Tex G S, An Rp 1:217-235 (1890)

91 Report on the geology and mineral resources of trans-Pecos Texas. Tex G S, An Rp 2:665-713, map (1891)

$91 \mathrm{a}$ On the genesis of ore deposits. Seh Mines Q 12:181-186 (1891)

92 Report [on trans-Pecos Texas]. Tex G S, Rp Prog 2 (1891) : 20-26 (1892)

92a Trans-Pecos Texas. Tex G S, An Rp 3: 381-389 (1892)

92b On the precious and other valuable metals of Texas. Tex Ac Sc, Tr 1 no 1 : $19-24(1892)$

92e The nonmetallic mineral resources of the State of Texas. Tex Ac Sc, Tr 1 do $2: 97-102(1892)$

93 Trans-Pecos Texas. Tex G S, An Rp 4 pt 1:139-175 (1893)

95 Denesis of certain ore veins, with experimental verifications. Tex Ac Sc, Tr 1 no 4:61-69 (1895)

Street, Owen.

88 Geologica] explorations [in Lowell, Mass.]. Old Residents' Hist As, Lowell, Mass, Contr 4:60-86 (1888)

Stremme, H.

09 Wie ist Diplodocus richtig anfzustel len? Naturw Wochenschr N F $8: 796-799$ fi $(1909)$

Strens, A

77 (and Kloos, J. H.) Ueber die krystallinischen Gesteine von Minnesota in Nord-Amerika. N Jb $1877: 31-56,113$ 138, 225-242 Minn $G \mathrm{~S}$, An Rp 11:3085 (1884)

Streteh, Richard Harper.

67 Annual report of the State mineralogist of the State of Nevada for 1866. 151 pp, Carson City 1867

93 The Monte Cristo mining district, Washington. Eng M J 55: 343 (1893)
Streteh, Richard Harper-Continued.

oo Notes on the Whitehorse copper belt, Yukon Terr. Eng M J $70: 277-278,343$ (1900)

OOa The quartz lodes of the Atlin district, B. C. Eng M J $70: 370-372$ (1900)

01 The Silverton mining district, Snohomish Co., Wash. Eng M J $72: 105$ (1901)

02 The Independent mine at Silverton, Snohomish Co., Wash. Eng M J $73: 832$ (1902)

04 The Montezuma district, Nev. Eng M J 78: こ-6 (1904)

04a Copper ores in the Cascade Mountains [Wash.]. Eng M J 78:789-790, map (1904)

Strieby, William.

94 The origin and use of the natural gas at Manitou, Colo. Colo Coll Studies. An Pub 5:14-35 (1894)

Strong, A. M.

05 (with Arnold, R.) Some crystalline rocks of the San Gabriel Mountains, Cal. G Soc Am, B 15: 183-204 (1905)

10 Borax deposits of the United States. Am 1 M Eng, B 38:167-171 (1910) ; Tr 40:909-913 (1910)

18 (with Rolfe, F.) The earthquake of April 21, 1918, in the San Jacinto Mountains [Cal.]. Seism Soc Am, B 8: 63-67 (1918)

Strong, E. A

72 Notes upon the fossil remains of the Lower Carboniferous limestone exposed at Grand Rapids, Mich. Kent Scientific Institute, Miscellaneous Papers no $3: 6$ pp [Grand Rapids 1872]

Strong, Moses (1846-1877).

77 Geology and topography of the lead region. [Wis $\mathbf{G}$ S], $\mathbf{G}$ Wis $2: 643-752$, maps [in atlas] (1877)

so The geology of the upper St. Croix distriet. [Wis G S], G Wis $3: 363-428$, map (1880)

82 Geology of the Mississippi region north of the Wisconsin region. IWis G S], G Wis $4: 1-98$ ( 1882 )

83 Lead and zine ores. [Wis $G \quad S$ ], G Wis $1: 637-655$ (1883)

Strong, William C.

98 The sanitary chemical character of some of the artesian waters of Denver. Colo Sc Soc, Pr 5:17-23 [1898] (separate ed, 9 pp, 1894)

stroop, L. J.

7o Did a glacier flow from Lake Huron into Lake Erie? Am Nat 4:623-625 (1870)

Struthers, Joseph.

O2 Aluminum and bauxite. U S G S. Min Res 1901: 225-229; 1902: 231-238; $1903: 265-279(1902-4)$

02a Platinum. U S G S, Min Res 1901: 231-233; $1902: 239-243$ (1902-4) 
Struthers, Joseph-Continued.

02b Quicksilver. U S G S, Min Res $1901: 235-238 ; 1902: 231-238$ (1902-4)

02e Antimony. U S G S, Min Res 1901 :

$251-256 ; \quad 1902: 271-277 ; \quad 1903: 317-326$

(1902-4)

02d Arsenic. U S G S, Min Res 1901: $257-258 ; \quad 1902: 279-282 ; \quad 1902: 327-334$ (1902-4)

02e Bismuth. U S G S, Min Res 1901: $259-260$; $1902: 283-284 \quad(1902-4)$

O2f Asphaltum and bituminous rock. U S G S, Min Res $1901: 633-640 ; 1902$ : 657-664 (1902-4)

02g Phosphate rock. U S G S, Min Res 1901: 811-822; $1902: 915-920$ (1902-4)

O2h Sulphur and pyrite. U S G S, Min Res $1901: 829-842 ; 1902: 933-943$ (1902-4) 02i Gypsum. U S G S, Min Res 1901: 843-851 (1902)

02j Salt. U S G S, Min Res 1901: 853865 ; 1902 : $921-932$ (1902-4)

o2k Bromine. U S G S, Min Res 1901 : $867-868 ; 1902: 897-898$ (1902-4)

021 Borax. U S G S, Min Reg 1901:

$869-872 ; 1902: 891-896(1902-4)$

O2m Graphite. U S G S, Min Res 1901 : $897-900 ; 1902: 975-982(1902-4)$

02n Magnesite. U S G S, Min Res 1901: 959-960; $1902: 983-984$ (1902-4)

04 (and Pratt, J. H.) Tin. U S G S, Min Res $1903: 335-349$ (1904)

Struve, Heinrich von (1772-1851).

22 Belträge zur Mineralogie und Geologie des nördlichen Amerikas [chiefly translations of papers by American writers]. 124 pp, Hamburg 1822

Stuart, G. W.

oo Gold mining in Nova Scotia. Eng M J 70:309-311 (1900)

stuart, Murray.

14 The relationship of fossil wood to ofl. Ec G 9:594-597 (1914)

Stubbs, William C.

78 The soils of Alabama. In Berney, Saffold, Handbook of Alabama: 197-260, Mobile 1878

95 A handbook of Eroutsiana... [geology : 6-12]. $56 \mathrm{pp}$, map, New Orleans 1895

01 Report on the agricultural resources and capabilities of Hawali [geology : 2223]. U S, Dp Agr, Off Exp Sta, B 95:100 pp (1901)

Studley, C. K.

os On Iron Canyon. Cal Phys Geog Club, B 1:13-17 (1908)

Stubel, Alphons.

03 Martinique und St. Vincent. Sonderabdruck aus dem Werke: Ueber die genetische Verschiedenheit vulkanischer Berge... 36 pp, Leipzig 1903

04 Rüickblick auf die Ausbruchsperiode des Mont Pelé auf Martinique 1902 bis 1903 vom theoretischen Gesichtspunkte aus. Grassi-Mus Leipzig, Vulkan Abt, Veröffent : $24 \mathrm{pp} \mathrm{(1904)}$
Stuntz, G. R.

70 On some recent geological changes northeastern Wisconsin. Am As, Pt 205-210 (1870)

stuntz, S. C.

11 (and Free, E. E.) Bibliography eolian geology. U S Dp Agr, Bur Soils $68: 174-263$ (1911)

Stupart, R. F.

98 Seismological observations at Toro: [Ont.]. Can Inst, $\operatorname{Pr} \mathrm{n}$ s 1:109-1l (1898)

03 Seismology in Canada. R Soc Ca Pr $\operatorname{Tr}$ (2) 9, ili : 69-71 (1903)

o5 Canadian seismographic records. Dp Agr, Mo Weather Rv 33: 207-208 (18c Star, D.

88 Die Lunzer-Lettenkohlen-Flora in to " older Mesozoic beds of the coal field eastern Virginia." K-k G Reichsanstal, Verh 1888: 203-217

Stutzer, 0 .

os Die Nickelerzlagerstätten bei Sudbur in Kanada. Zs Prak G 16:285-287 (1906 O8a Die Kobalt-Silverlagerstätten r. Temiskaming. Zs Prak G 16:511 (1908)

o9 Die Kontaktmetamorphen Kupferem lagerstätten von White Horse in Yuku Canada. Zs Prak G 17:116-121 (1909)

12 The origin of sulphur deposit (translated by W. C. Phalen). Ec 6 ? $732-743$ (1912)

12a Amerikanisches Kalisalz. Kali 6: $294-295,432-433$ (1912)； 7:49-50 (1917)

Suess, Edward.

11 Synthesis of the paleogeography North America. Am J Sc (4) $31: 10$ 108 (1911)

Sullivan, Eugene Cornelius.

o5 The chemistry of ore depositionprecipitation of copper by natural silicate Ec G 1: $67-73$ (1905)

o7 The secondary enrichment of copper iron sulphides. Am I M Eng, B 13:14; 145 (1907)

07a The interaction between minersis and water solutions with special refe ence to geologic phenomena. U S G \& B $312: 69 \mathrm{pp} \mathrm{(1907)}$

o8 Experiments on the separation of the constituents of a solution by filtration through a mineral filter. Ec G $3: 750$ 756 (1908)

Sullivan, George $M$.

91 Report on the geology of parts of Jackson and Rockcastle cos., with map Ky G S : 20 pp, map [1891?]

12 (with Crandall, A. R.) Report of the coal field adjacent to Pineville Gap in Bell and Knox countles. Ky $G S$, B 14: 130 pp (1912)

Sullivant, $J$.

75 The discovery of the Bermuda tripol in Maryland. Boston Soc N H, Pr 17 422-423 (1875) 
Sumner, Francis B.

14 (and Louderback, G. D. and others) A report upon the physical conditions in San Francisco Bay... [sedimentation, etc.]. Cal Univ, Pub Zool 14 no 1:1-198 (1914)

Supan, A.

02 Der neue Eruptionstypus der Antillen. Petermanns Mitt 48:286-288 (1902)

sur, F. J. S.

14 Oil prospecting, drilling, and extraction. $64 \mathrm{pp}$, Calgary, 1914

surr, Gordon.

09 Tungsten deposits and surface enrichment. M World 30:19-20 (1909)

09a Distribution of metals and minerals in ore shoots. M World $30: 385-386$ (1909)

09b The association of ores and country rock, M World 30:471-473 (1909)

09e Granites. M Sc Press 99:712714 (1909)

10 Igneous rocks; their classification in the field. M World $32: 314-319$ (1910)

10a The sources of vanadium in lead rauadates. M World $33: 147$ (1910)

$10 \mathrm{~b}$ Conditions favorable for petroleum prospecting. M World 33:227-228 (1910) 10e The origin and commercial value of borates. M World 33:1137-1138 (1910)

11 Origin and importance of phosphate deposits. M World $34: 345-347$ (1911)

11a Gypsum in the Maria Mountains of California. M World 34:787-790, 891 (1911)

11b Notes on occurrence, origin, and uses of gypsum. M World $34: 1283-1284$ (1911)

12 The search for potash in western United States. M World 37:103-104 (1912)

13 Lapis lazuli in southern California. M World $39: 1153-1154$ (1913)

Suter, Charles R.

7s [On bars in the Mississippi River.] U \& [War Dp], Chief Eng, An Rp 1878 (U S, 45th Cong $3 d$ sess, H Ex Doc 1 pt 2 2 pt 2), App W: $841-847$ (1878)

Sutherland, P. C.

53 On the geological and glacial phenomena of the coasts of Davis' Strait and Baffin's Bay. G Soc London, Q J 9:296312 (1853)

sutherland, W. J.

08 Physiography of the Gulf coastal plains. J Geog 6 : $337-347$ (1908)

Sutton, George (1812-1886).

77 Glacial or lce deposits in Boone Co., $\mathrm{Ky}$, of two distinct and widely distant periods. $A \mathrm{~m} \mathrm{As}, \operatorname{Pr} 25: 225-231$ (1877) Ind $\mathrm{G}$ S, An Rp 8-9-10: 108-113 (1879)

82 The gold-bearing drift of Indiana (abst). Am As, Pr $30: 177-185$ (1882)
Sutton, W. J. (1859-1914).

04 The geology and mining of Vancouver Island. Manchester G M Soc, $\mathrm{Tr}$ 28 : 307-314 (1904)

Swallow, Ellen H.

75 Notes on the chemical composition of some of the mineral species accompanying the lead ore of Newburyport [Mass.]. Boston Soc N H, Pr 17:462-465 (1875)

Swallow, George Clinton (1817-1899).

55 The first and second annual reports of the geological survey of Missouri. 207, $239 \mathrm{pp}$, maps, Jefferson City 1855

55a Second report; geology of Missouri. Mo G S, An Rp 1-2: 59-170 (1855)

$55 b$ Geology of Marion Co. ; Cooper Co. ; of the southwest. Mo G S, An Rp 1-2: 171-207, maps (1855)

57 Third report of progress of the geological survey of Missouri [for the years 1855 and 1856]. $3 \mathrm{pp} \mathrm{[1857]}$

$57 \mathbf{n}$ Southwestern branch of the Pacific Railroad [in Missouri]. M Mag 9:220-226 (1857)

58 Explanations of the geological map of Missouri, and a section of its rocks. Am As, Pr 11 pt 2:1-21 (1858) Abst, Edinb N Ph J n s $6: 354$ (1857)

58a Quaternary deposits of Missouri. Am As, Pr 11 pt 2: 21-39 (1858)

58b On Permian strata in Kansas Territory. Am J Sc (2) 25:305 (1858)

58c [On Permian in Kansas.] Ac Sc St L, $\operatorname{Tr} 1: 111$ (1858)

58d (and Hawn, F.) The rocks of Kansas, Ac Sc St L, Tr 1: 173-197 (1858)

58e (with Shumard, B. F.) Descriptions of new fossils from the Coal Measures of Missouri and Kansas. Ac Sc St L, Tr 1: 198-227 (1858)

59 Fourth report of progress of the geological survey of Missouri [for the years 1857 and 1858]. $14 \mathrm{pp}$, Jefferson City 1859

$59 a$ Geological report of the country along the line of the southwestern branch of the Pacific Rallroad, State of Missouri. $93 \mathrm{pp}$, map, St. Louis 1859 Also published as Geological report of the country along the line of the Southwest Pacific Railroad, State of Missouri: $63-153$, N Y 1867

59b The rocks of Kansas. Am J Sc (2) $26: 182-188$ (1859) Am As, Pr 12:214221 (1859)

60 Descriptions of new fossils from the Carboniferous and Devonian rocks of Missouri. Ac Sc St L, Tr 1:635-660 (1860)

61 Fifth report of progress of the geological survey of Missouri [for the years 1859 and 1860]. $19 \mathrm{pp}$, Jefferson City 1861

63 Deseriptions of some new fossils from the Carboniferous and Devonian rocks of Missouri. Ac Sc St L, Tr 2:81-100 (1863) 